*
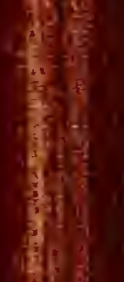

(Y)

(1)

?

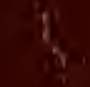





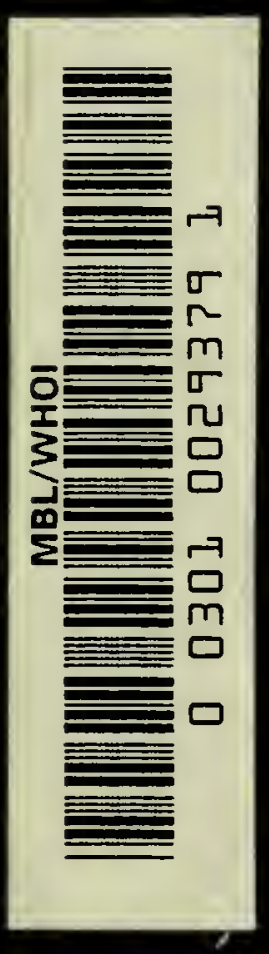





\section{A DICTIONARY OF BIRDS}





\title{
DICTIONARY OF BIRDS
}

BY

\author{
ALFRED NEWTON
}

ASSISTED BY

HANS GADOW

WITH CONTRIBUTIONS FROM

RICHARD LYDEKKER

B.A., F. R.S.
CHARLES S. ROY

M.A., F.R.S.

AND

ROBERT W. SHUFELDT, M.D.

LATF UNITED STATES' ARIY

CHEAP ISSUE, UNABRIDGED

LONDON

ADAM AND CHARLES BLACK

1893-1896 
Published originally' un four parts, $1893-96$

Cheap issue published October 1899 


\section{NOTE}

'THOSE who may look into this book are warned that they will not find a complete treatise on Ornithology, any more than an attempt to include in it all the names under which Birds, even the commonest, are known. Taking as its foundation a series of articles contributed to the ninth edition of the 'Encyclopædia Britannica,' I have tried, first, to modify them into something like continuity, so far as an alphabetical arrangement will admit; and, next, to supplement them by the intercalation of a much greater number, be they short or long, to serve the same end. Of these additions by far the most important are those furnished by my fellow-worker Dr. GADow, which bring the anatomical portion to a level hitherto unattained, I believe, in any book that has appeared. For other contributions of not less value in their respective lines, I have to thank my old pupil Mr. LydekKer, my learned colleague Professor Roy, and my esteemed correspondent Dr. SHUFELDT, formerly of the United States' Army. 'Dr. Gadow's articles are distinguished by their title being printed in Italic type: those of the other contributors bear their author's name at the end.

For my own part I have to say that, in the difficult task of choosing the subjects for additional articles, one of my main objects has been to supply information which I know, from 
enquiries often made of me, to be greatly needed. Readers who in most respects are certainly not ignorant of things in general, frequently find in works of all sorts, but especially in books of travel, mention of Birds by names which no ordinary dictionary will explain; and, on meeting with a Caracara, a Koel or a Paauw, a Leatherhead, a Mollymawk or a Tom-fool, are at a loss to know what kind of bird is intended by the author. On the other liand I have not thought it necessary to include many names, compounded (mostly of late years) by writers on ornithology, which have never come nor are likely to come into common use- such as CrowShrike, Crow-Titmouse, Shrike-Crow, Shrike-Titmouse, ThrushTitmouse, Titmouse-Thrush, Jay-Thrush and the like. Happily these clumsy inventions are seldom found but in technical works, where their meaning, if they have one that is definite, is at once made evident. Their introduction into the present volume would merely swell its bulk with little if any compensating good. On this account I have also kept out a vast number of local names even of British Birds, which could have been easily inserted, though preserving most of those that have found their way into some sort of literature, ranging from an epic poem to an act of parliament; but I confess to much regret in being compelled to exclude them, because the subject is one of great interest, and has never been properly treated. It will thus be seen that my selection of names to be inserted is quite arbitrary. I have tried to make it tend to utility, and whether I have succeeded, those who consult the volume will judge.

Thanks to the complaisance of Messrs. Longman and Company I have been able to acquire electrotypes of a considerable number of the woodcuts which illustrated Swainson's 
'Classification of Birds.' These figures were drawn by that admirable ornithological delineator, and most of them for truth of detail or beauty of design have seldom been equalled and rarely surpassed. I am also indebted to the kindness of Sir Walter Buller, K.C.M.G., F.R.S., for the use of electrotypes of woodcuts executed for his 'Birds of New Zealand,' as well as to the Publication Committee of the Zoological Society of London, to the Trustees of the British Museum, and to Dr. William Francis and Mr. Maxwell Masters, F.R.S., for their consent to the reproduction of other figures, which will be found duly acknowledged in the following pages.

Lastly, I would say that the alphabetical order has been deliberately adopted in preference to the taxonomic because I entertain grave doubt of the validity of any systematic arrangement as yet put forth, some of the later attempts being in my opinion among the most fallacious, and a good deal worse than those they are intended to supersede. That in a few directions an approach to improvement has been made is not to be denied; but how far that approach goes is uncertain. I only see that mistakes are easily made, and I have no wish to mislead others - by an assertion of knowledge which I know no one to possess; yet with all these drawbacks and shortcomings I trust that this Dictionary will aid a few who wish to study Ornithology in a scientific spirit, as well as many who merely regard its pursuit as a pastime, while I even dare indulge the hope that persons indifferent to the pleasures of Natural History, except when highly-coloured pictures are presented to them by popular writers, may find in it some corrective to the erroneous impressions commonly conveyed by sciolists posing as instructors.

A. N.

CAMmRide, March 1893. 
Where a word is introduced in small capitals, without apparent neccssity, further information concesning it may be sought for under that word in its alphabetical plece. 


\section{FRATRI EDUARDO CARISSIMIO}

PEP ANNOS PLUS QUAM QUINQUAGINTA

IN STEDIIS ORNITHOI.OGICIS

DOMI PEREGPE SUP DIO IN ANTRIS

DILIGENTISSIMO CONDISCIPULO

HOC OPUS

D.D.

AUCTOR

DIE X. NOVEMBRIB MDCCCXCVI. 



\section{PREFACE}

This Dictionary has taken me far longer to complete than, when I began it, I had any notion that it would. Yet I do not regret the delay, since it has enabled me, though very briefly, to shew (INTroduction, page 108, note) that the latest investigation has proved the newly-announced group STEREORNITHES, which seemed at first so important, to have no more claim to recognition than had that known as Odontornithes.

The articles by Dr. GADOW have fully sustained the expectation of them expressed in my initial NotE. Read with the aid of the cross-references they contain and the INDEx that follows, they cannot fail to place the enquirer, be he beginner or advanced student, in a position he could not hope to occupy through the study of any other English book, and, what is better, a position whence he may extend his researches in many directions.

It has been my object throughout to compress into the smallest compass the information intended to be conveyed. It would have been easier to double the bulk of the work, but the limits of a single volume are already strained, and to extend it to a second would in several ways destroy such usefulness as it may possess. Still I cannot but regret having te omit any special notice of several interesting subjects which bear more or less directly upon Ornithology. To name only a few of them-Insulation, Isomorphism, Reversion and the 
Struggle for Existence, as illustrated by Birds, were tempting themes for treatment, while Nomenclature, which owing to its contentious nature I have studied to avoid, and Protection, about which so much deplorable and mischievous misunderstanding exists, might well be said to demand consideration. It will be obvious to nearly every one that the number of names of Birds included in a work of this kind might be increased almost indefinitely. Whether it will ever be possible for me to supply these additions, and others, must depend on many things, and not least on the reception accorded by the public to the present volume.

A. N.

Magdalene College, Cambridge, November, 1896. 


\section{NOTANDA ET CORRIGENDA}

Page 9, line 10, for Molly-mauk read Mollymawk.

" " 23. ALECTORIDES, proposed as a Family of Grallatores by Illiger in 1811, is the same group as Temminck's of 1820 , with the addition of Cereopsis; but neither has anything in common with the Alectrides of Duméril in 1806.

Inscrt ALECTOROPODES, Huxley, P.Z.S. 1868, pp. 296, 299, and see Peristeropodes, page 707.

11, line 28. Amadavats (Anadavadra, or Anadavad, corrected in Index to Amadavad) had been brought from India to England by 1673 (Willughby, Orn. p. 194, Engl. p. 266).

"14, "11, for cases read causes.

" 21, , 39, for Hargīta read Hargilla.

" 30, after BEEF-EATER insert Pennant, Gen. B. p. 9 (1773).

", 34, line 28, for Eurinorhynchus read Eurynorhynchus.

" $38,, \quad 4$, dele his father.

45, , 27, after wintering in insert Egypt.

$58, " 1$, for OLIGOMYodr read OLIGOMYODE.

78, "25, after printed as insert "Cassawarway," Coryat, Crudities, Pref. Verses, 1611 (N. E. Dict. ii. p. 152), and then.

" 101, note 2, for LüMMERGEIER read LÄMMERGEYER.

"102, line 14, for back read beak.

" 104, "37, for Desmognathous read EGITHOgnathous.

"105, " 1, after patois-dele the comma.

" 108, "41, after known by insert Albin (N.H. Birds, ii. pl. 53, fig. 2), and subsequently by.

"118, "7, after p. 176) insert and also to the Crowned-CRane (Balearica).

"130, "26, after authors insert as Pennant in 1773 (Gen. B. p. 13).

"130, add CUT-THROAT, see WEAVER-BIRD.

" 136, "20, for Мо्тh read month.

" 139. To explanation of Fig. 1 add - L. follicle at base of villus.

"159, lime 15, for sixteen read fifteen.

"159, „17, dele De.

"162, lines 18-21. Lobivanellus and some other forms have the structure said to be peculiar to the Dotterel alone.

"165, line 3, for Mussulmans and Christians read Christians and Mlussulmans.

"166, " last. Drepanis pacifica, though nearly extinct, proves not to have been so when this sentence was written. A second species, $D$. 
funerea, has since been described from Maui (P.Z.S. 1893, p. $690)$.

Page 179, line 9 from bottom, for foramen ovale read fenestra ovalis.

"189, ,32, for ark-line read ark-like.

" 214, , 10, for 70 to 80 read 57 .

"214, lines 21-23. The statement needs correction, as the RHEA also swims rivers.

"215, line 2, after ERNE insert A.-S. Earn.

" 218, " 6, for Miserythrus read Erythromachus. (See page 764, note 1.)

" 221, „30, after In insert 1809 Tucker (Orn. Danmon. p. lix.), and in.

s

222, , 8. Examples are now known to have been killed later than 1852, see $A u k, 1894$, pp. 4-12.

$223, " 9$, for thirty-eight read forty-two or forty-three.

229, "43. The iris in Harelda is said to be straw-colour in winter, dark hazel in summer. E. A. S. Elliot, Bull. B. O. Club, 20 May 1896.

235, note 1. Falco, as a man's name, was in earlier use. Q. Sosius Falco was a Roman Consul eirca A.D. 193 ; see Capitolinus in Hist. August. Seript. VI. "Pertinax" (Lugd. Bat. : 1671, p. 558).

238, line 28, for Luggur read Luggar.

255, , 20. The statement as to nidification of Phonicopterus was confirmed by D'Orbigny, fide I. Geoffroy St.-Hilaire.

261, "20, for 45 per cent read $\frac{1}{3.43}$, and line 21 for 16 per cent read from $\frac{1}{7 \cdot 57}$ to $\frac{1}{10^{\circ} \cdot 55^{\circ}}$

269. Fig. 8 is accidentally inverted ( $f$. Marey, Vol des Ois. p. 140).

277 , line 28 , for about read in or before.

277, ,30, after and insert Dexter, and dele Subsequently.

277 "34, and note 2. Many other remains from this deposit have beeu described by Prof. Marsh, Am. Journ. Sc. (3) xxxvii. p. 331 ; xlii. p. 267 ; xliii. p. 543 ; and xlv. p. 169.

278 , , 5, for discovered read made known.

$279,{ }^{\circ}, \quad 4$, for 20 read 12.

281, note 2, for Ameyhino read Ameghino.

284, line 41, for Haliztus read Haliaetus.

289, ,26. The statement as to Gallus ferrugineus being found on the Raj-peepla hills is erroneous ( $c f$. Blanford, J.A.S.B. xxxvi. pt. 2, p. 199).

$291, \quad 26$, for 1869 read 1862.

293, , 31, for the elder Brandt read Illiger.

316, , 17, for Prosthemadura read Prosthemadera.

320, "21, for Lophophanes read Lophophaps.

$323, " 8$, for OLIgomyod read OLIGOMYode.

327, " 6, for Prionoteles read Prionotelus.

338 , note 5 , for Meado-Walde, read Meade-Waldo.

349, line 4, after Rhynchea add, Rhynchops.

370 , "10, for American read Cauadian.

371. Insert GOONEY (prov. Engl. for a stupid or awkward person), a sailors' name for an Albatros.

3`6, line 44, for Nettapus read Nettopus. 
Page 396, note 2. Mr. O. Grant (Cat. B. Br. Mus. xxii. p. 498) makes the Guan of Edwards to be Penelope cristata.

$" 406$, lines 13 et seqq. On the anatomy and affinities of Scopus, $c f$. Beddard, P.Z.S. 1884, p. 543.

" 415. HEATHER-BLEAT, a corruption of the A.-S. Hæfer-blxte, or Goatlike bleater (fide Skeat). 428, line last, for Soldier-BIRD read BLOoD-BIRD.

429, ", 12 and beneath figure, for Melithreptes read Melithreptus.

434, "38, after habits insert except what Herr Hartert has told us (J.f.O. 1889, pp. 366-368).

456 , lines 1-3, for $S$. read $I$.

,

456, line 21, after known insert, except Comatibis.

$458, " 37$, dele and best-.

459, "29, after Ambulatores insert and Scansores.

"465, lines 20, 21, transfer the latter from line 21 to line 20 after and, insert. ing also after those words.

" 482, line 4, for hiaticula read hiaticola.

" 487, "27, for SyNDACTXLISM read Syndactylism, $c f$. SyndactyLI.

" 496, note 2 (in early copies), after $A$. maxima insert (from Stewart lsland), A. haasti.

"513, "2. The derivation of Liverpool is now said to be from the A.-S. laefer, a rush or flag (cf. Britton and Holland, Dict. Engl. Plant Names, p. 304).

" 514, line 4, for Lepelaer read Lepelaar.

" 519, note 2, for Touracoo read TouRaco.

,

524 , lines 26 ct seqq. Further information on the subject is given by Mr. Ramsay, P.Z.S. 1868, pp. 49 et seqq.

525, note. The egg of M. superba has been figured by Mr. North, Nests and Eggs of Australian Birds, pl. x.

536, line 11, for CURLEw or Godwit read Godwit or to Numenius hul. sonicus (CURLEW).

. 536, , 16, for Turmbull read Trumbull.

" 553, lines 13, 14 of notes. The historic nesting-place of Parus carnteus was reoccupied in 1895.

" 562, "1-3. Mr. Clarke's Digest of the observations will be found in Rep. Brit. Association (Liverpool Meeting), 1896.

" 563, „ 7-9. Cf. Peal, Rep. Aeronaut. Soc. 16, pp. 10-17 (1881), and Nature, xxiii. pp. 10, 11. Additional observations of Birds flying at great heights are recorded by Bray, op. cit. lii. p. 415 , and West, op. cit. liii. p. 131.

- 600, line 18, for New Zealand read Western Australia. The MountainDuck of New Zealand is Hymenolemus (page 843).

"616, lines 28-35. The preparation $\mathrm{V}, \mathrm{c}$, here described, and diagrammatically figured on the opposite page, proved not to be talien from any of the Trochilide. Cf. Lucas and Gadow, 16is, 1895, pp. 298-300.

" 654, line 3, for Argusanus read Argusianus.

" 686, "29, for Cyanorhynchus read Cyanorhcimphus.

" 687, line 4. Parrots are not wanting in the Philippine Islands, as asserted. See Nature, li. p. 367. 
Page, 692, note 1, for Tita read Tito.

"698, line 8 , for laryngeal read tracheal.

"700, note 1. In the Exhibition of Venetian Art at the New Gallery in Regent Street, 1894-5, No. 63 of the Catalogue was a picture, attributed to Vittorio Carpaccio, containing a representation of a "japanned" Peacock.

„703, line 12, dele male's.

$" 703$, note 2. The first of the three derivations assigned was the suggestion "by probability" of Selden in his 'Illustrations' of Drayton's poem (p. 148). Being almost impossible, and unsupported by evidence, it is the derivation most popularly accepted.

"711, line 11, and p. 716, last line of text, for Sayornis read Empidonax.

"732, lines 16-18. The statement as to old feathers changing their colour is probably erroneous (see $A u k, 1896$, pp. 148-150; Bull. Am. MLus. $N$. H. viii. pp. 1-44).

"734, line 18 of notes, for Eurinorhynchus read Eurynorhynchus.

"743, "28, for 173,177 read $272,277$.

"744, " 8, for anterior read posterior.

"754, , 4, after Dutch insert name for the PintaIL.

"789, note 2, for Acarthidositta read Acanthidositta.

" 814, line 6, for p. cxxxix. read pp. xi. cxxxix. pl. vii.

" 814, "15. The term Ornithure is used by Fürbringer, see Introductios, page 108.

"820, "11. Chauna derbiana is the true C. chavaria (Linn.), while the species commonly so called is C. cristata ( $c f$. Salvadori, Cat. B. Brit. Nus. xxvii. pp. 4-7).

" 843, „2, after the insert Mountain- or.

" 887, "24, after for insert Myzantha garrula, M. flavigula and; for sanguinoleuta read sanguinolenta.

" 893, note 2. Local difference in Birds' notes was noticed in 1809 by Tucker (Orn. Danmon. p. lxxxiv.)

"896, „1, after designation add ; but Mr. Barrows in his able work (The English Sparrow in North America. Washington: 1889) continues the misleading name.

" 905, line 34. Clearing away the matrix of the specimen has since shewn this septum ( $f f$. InTRODUCTION, page 108, note). 


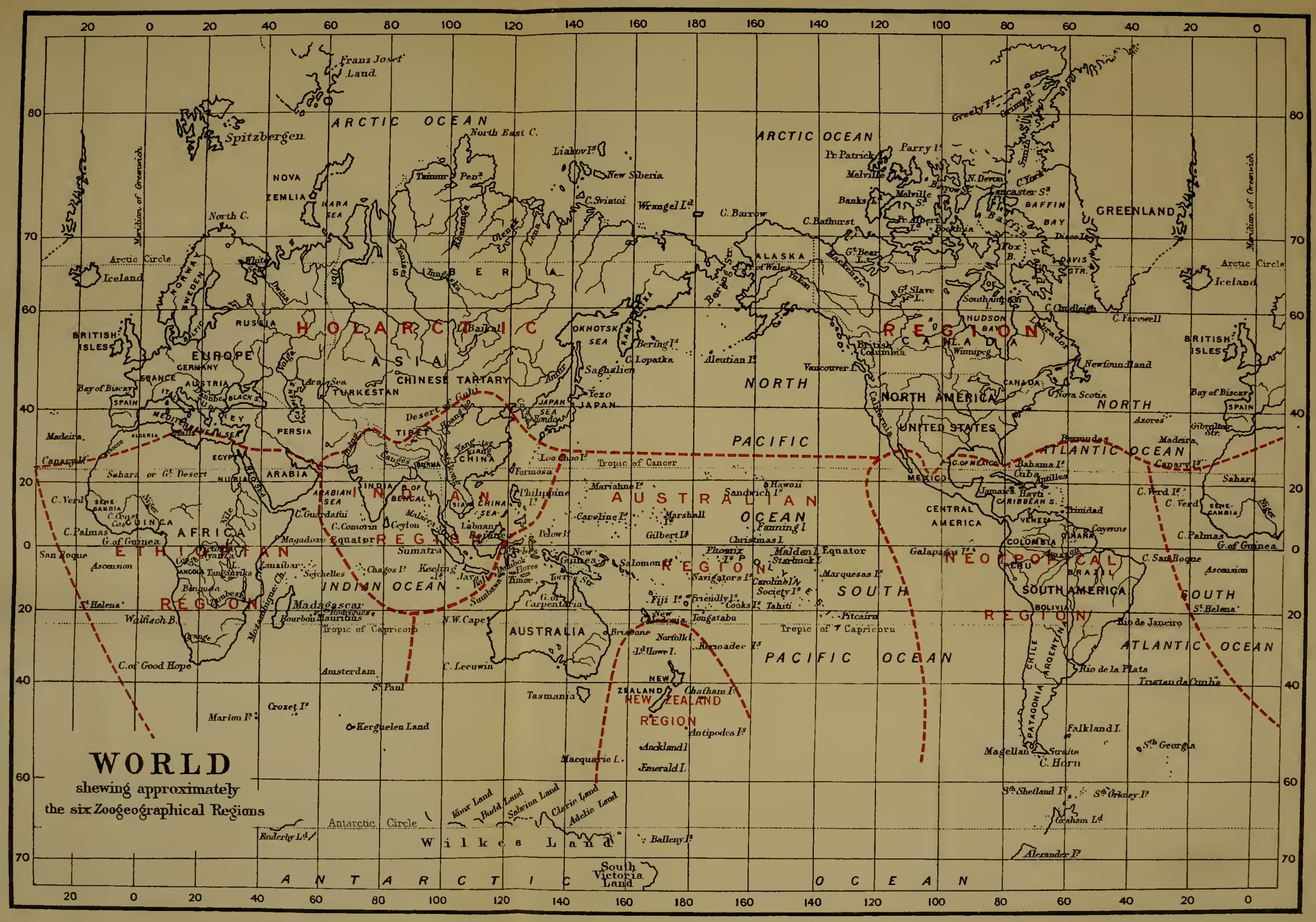





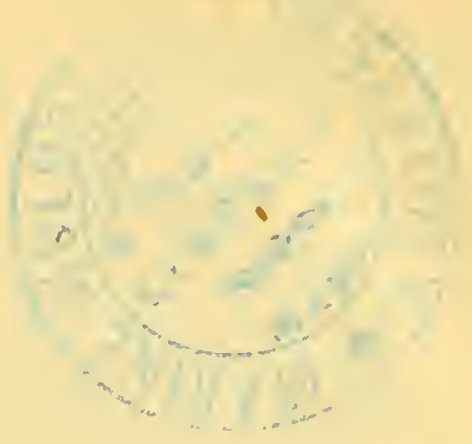

\section{INTRODUCTION}

OrNithologx in its proper sense is the methodical study and consequent knowledge of Birds with all that relates to them; but the difficulty of assigning a limit to the commencement of such study and knowledge gives the word a very vague meaning, and practically procures its application to much that does not enter the domain of Science. This elastic application renders it impossible in any sketch of the history of Ornithology to draw a sharp distinction between works that are emphatically ornithological and those to which that title can only be attached by courtesy; for, since Birds have always attracted far greater attention than any other group of animals with which in number or in importance they can be compared, there has grown up concerning them a literature of corresponding magnitude and of the widest range, extending from the recondite and laborious investigations of the morphologist and anatomist to the casual observations of the sportsman or the schoolboy. The chief cause of the disproportionate amount of attention which Birds have received plainly arises from the way in which so many of them familiarly present themselves to us, or even (it may be said) force themselves upon our notice. Trusting to the freedom from danger conferred by the power of flight, most Birds have no need to lurk hidden in dens, or to slink from place to place under shelter of the inequalities of the ground or of the vegetation which clothes it, as is the case with so many other animals of similar size. Beside this, a great number of the Birds which thus display themselves freely to our gaze are conspicuous for the beanty of their plumage; and there are very few that are not remarkable for the grace of their form. Some Birds again enchant us with their voice, and others administer to our luxuries and wants, while there is scarcely a species which has not idiosyncrasies that are found to be of engaging interest the more we know of them. Moreover, it is clear that the art of the fowler is one that must have been practised from the very earliest times, and to follow that art with success no inconsiderable amount of acquaintance with the haunts and habits of Birds is a necessity. Owing to one or another of these causes, or to the combination of more than one, it is not surprising that the observation of Birds has been from a very remote period a favourite pursuit among nearly all nations, and this observation has by degrees led to a study more or less framed on methodical principles, finally reaching the dignity of a science, and a study that has its votaries 
in almost all classes of the population of every civilized country. In the ages during which intelligence dawned on the world's ignorance, or before experience had accumulated, and even now in those districts that have not yet emerged from the twilight of a knowledge still more imperfect than is our own at present, an additional and perhaps a stronger reason for paying attention to the ways of Birds existed, or exists, in their association with the cherished beliefs handed down from generation to generation among many races of men, and not infrequently interwoven in their mythology. ${ }^{1}$

Moreover, though Birds make a not unimportant appearance in the earliest written records of the human race, the painter's brush has preserved their counterfeit presentment for a still longer period. What is asserted-and that, so far as the writer is aware, without contradictionby Egyptologists of the highest repute to be one of the oldest pictures in the world is a fragmentary fresco taken from a tomb at Maydoom, and happily deposited, though in a decaying condition, in the Museum at Boolak. This picture is said to date from the time of the third or fourth dynasty, some three thousand years before the Christian era. In it are depicted with a marvellous fidelity, and thorough appreciation of form and colouring (despite a certain conventional treatment), the figures of six Geese. Four of these figures can be unhesitatingly referred to two species (Anser erythropus and A.ruficollis) well known at the present day; and if the two remaining figures, belonging to a third and larger species, were re-examined by an expert they would very possibly be capable of determination with no less certainty. ${ }^{2}$ In later ages the representations of Birds of one sort or another in Egyptian paintings and sculptures become countless, and the bassi-rilievi of Assyrian monuments, though mostly belonging of course to a subsequent period, are not without them ; but so rudely designed as to be generally unrecognizable. ${ }^{3}$ No figures of Birds, however, seem yet to have been found on the incised stones, bones or ivories of the prehistoric races of Europe.

It is of course necessary to name Aristotle (B.c. 385-322) as the first serious author on Ornithology with whose writings we are acquainted, but even he had, as he tells us, predecessors; and, looking to that portion of his works on animals which has come down to us, one finds that, though more than 170 sorts of Birds are mentioned, ${ }^{4}$ yet what is said of them amounts on the whole to very little, and this consists more of desultory

1 For instances of this among Greeks and Romans almost any work on "Classical Antiquities" may be consulted, while as regards the superstitions of barbarous nations the authorities are far too numerous to be here named.

2 A fac-simile of the picture is, or was a few years ago, exhibited at the Museum of Science and Art in London, and the portion containing the figures of the Geese has been figured by Mr. Loftie (Ride in Egypt, p. 209). I owe to that gentleman's kindness the opportunity of examining a copy made on the spot by an accomplished artist, as well as information that it is No. 988 of Mariette's Catalogue.

$3 \mathrm{Cf}$. W. Houghton 'On the Birds of the Assyrian Monuments and Records,' Trans. Soc. Bibl. Archrol. viii. pp. 42-142, 13 pls. (1883). The author being but a poor ornithologist, his determination of the figures cannot be trusted. As to the linguistic value of his labours I am not competent to speak.

\$ This is Sundevall's estimate; Drs. Aubert and Wimmer in their excellent edition of the 'I $\sigma$ ropia $\pi \epsilon \rho i \zeta \omega ́ \omega \nu$ (Leipzig : 1868) limit the number to 126. 
observations in illustration of his general remarks (which are to a considerable extent physiological or bearing on the subject of reproduction) than of an attempt at a connected account of Birds. Some of these observations are so meagre as to have given plenty of occupation to his many commentators, who with varying success have for more than three hundred years been endeavouring to determine what were the Birds of which he wrote; and the admittedly corrupt state of the text adds to their difficulties. One of the most recent of these commentators, the late Prof. Sundevall-equally proficient in classical as in ornithological knowledge-was, in 1863, compelled to leave more than a score of the Birds unrecognized. Yet it is not to be supposed that in what survives of the great philosopher's writings we have more than a fragment of the know-

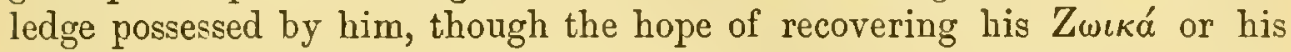
'Avarouıкá, in which he seems to have given fuller descriptions of the animals lie knew, can be hardly now entertained. A Latin translation by Gaza of Aristotle's existing zoological work was printed at Venice in 1503. Another version, by Scaliger, was subsequently published. Two wretched English translations have appeared. ${ }^{1}$

Next in order of date, though at a long interval, comes Gaius Plinius Secundus, commonly known as Pliny the Elder, who died A.D. 79, author of a general and very discursive Historia Naturalis in thirty-seven books, of which most of Book X. is devoted to Birds. A considerable portion of Pliny's work may be traced to his great predecessor, of whose information he freely and avowedly availed himself, while the additions thereto made cannot be said to be, on the whole, improvements. Neither of these authors attempted to classify the Birds known to them beyond a very rough and for the most part obvions grouping. Aristotle seems to recognize eight principal groups:-(1) Gampsonyches, approximately equivalent to the Accipitres of Linnæus ; (2) Scolecophaga, containing most of what would now be called Oscines, excepting indeed the (3) Acanthophaga, composed of the Goldfinch, Siskin and a few othors; (4) Scnipophaga, the Woodpeckers; (5) Peristeroide, or Pigeons; (6) Schizopoda, (7) Steganopoda and (8) Barea, nearly the same respectively as the Linnæan Grallæ, Anseres and Gallinæ. Pliny, relying wholly on characters taken from the feet, limits himself to three groups-without assigning names to them-those which have "hooked tallons, as Hawkes; or round long clawes, as Hennes; or else they be broad, flat, and whole-footed, as Geese and all the sort in manner of water-foule "- to use the words of Philemon Holland, who, in 1601, published a quaint and, though condensed, yet fairly faithful English translation of Pliny's work.?

About a century later came Elian, who died about A.D. 140, and compiled in Greek (though he was an Italian by birth) a number of miscellaneous observations on the peculiarities of animals. His work is a kind of commonplace book kept without scientific discrimination. A

1 By Thomas Taylor in 1809, and Cresswell in 1862.

2 The French translation by Ajasson de Grandsagne, with notes by Cnvier (Paris: 1830), is very good for the time. An English translation by Bostock and Riley appeared between 1855 and 1857. Sillig's edition of the original text (Gotha : 1851. 1853) seems to be the best. 
considerable number of Birds are mentioned, and something said of almost each of them; but that something is too often nonsense-according to modern ideas-though occasionally a fact of interest may therein be found. It contains numerous references to former or contemporary writers whose works have perished, but there is nothing to shew that they were wiser than Elian himself.

The twenty-six books De Animalibus of Albertus Magnus (Groot), who died A.D. 1282, were printed in 1478 ; but were apparently already well known from manuscript copies. They are founded on the works of Aristotle, many of whose statements are almost literally repeated, and often without acknowledgment. Occasionally Avicenna, or some other less-known author, is quoted; but it is hardly too much to say that the additional information is almost worthless. The twenty-third of these books is De Avibus, and therein a great number of Birds' names make their earliest appearance, few of which are without interest from a philologist's if not an ornithologist's point of view, but there is much difficulty in recognizing the species to which many of them apply. In 1485 was printed the first dated copy of the volume known as the Ortus Sanitatis, to the popularity of which many, editions testify. Though said by its author, Johann Wonnecke von Caub (Latinized as Johannes de Cuba), ${ }_{1}^{I}$ to have been composed from a study of the collections formed by a certain nobleman who had travelled in Eastern Europe, Western Asia and Egypt - possibly Breidenbach, ${ }^{2}$ an account of whose travels in the Levant was printed at Mentz in 1486 -it is really a medical treatise, and its zoological portion is mainly an abbreviation of the writings of Albertus Magnus, with a few interpolations from Isidorus of Seville (who flourished in the beginning of the seventh century, and was the author of many books highly esteemed in the Middle Ages), and a work known as Physiologus. ${ }^{3}$ The third tractatus of this volume deals with Birds-including among them Bats, Bees and other flying creatures; but as it is the first printed book in which figures of Birds are introduced it merits notice, though most of the illustrations, which are rude woodcuts, fail, even in the coloured copies, to give any precise indication of the species intended to be represented. The scientific degeneracy of this work is manifested as much by its title (Ortus for Hortus) as by the mode in which the several subjects are treated ; ${ }^{4}$ but the revival of learning was at hand, and

1 On this point see G. A. Pritzel, Botan. Zeitung, 1846, pp. 785-790, and Thes. Literat. Botanicæ (Lipsiæ: 1851), pp. 349-352.

2 I owe this suggestion to my late good friend, the eminent bibliographer, Henry Bradshaw.

3 See the excellent account of this curious work by Prof. Land of Leyden (Encycl. Erit. ed. 9, xix. pp. 6, 7).

4 Absurd as much that we find both in Albertus Magnus and the Ortus seems to modern eyes, if we go a step lower in the scale and consult the "Bestiaries" or treatises on animals which were common from the twelfth to the fourteenth century we shall meet with many more absurdities. See for instance that by Philippe de Thaun (Philippus Taonensis), dedicated to Adelaide or Alice, queeu of Henry I. of England, and probably written soon after 1121, as printed by the late Mr. Thomas Wright, in his Popular Treatises on Seience written during the Mirldle Ages (London: 1841). Perhaps the De Naturis Rerum libri duo of Alexander Neckam (ob. 1217), the foster-brother of Richard Cour de Lion, may be excepted, for therein (lib. I. 
William Turner, a Northumbrian, while residing abroad to avoid persecution at home, printed at Cologne in 1544 the first commentary on the Birds mentioned by Aristotle and Pliny conceived in anything like the spirit that moves modern naturalists. ${ }^{1}$ In the same year and from the same press was issued a Dialogus de Avibus by Gybertus Longolius, and in 1570 Caius brought out in London his treatise De rariorum animalium atque stirpium historia. In this last work, small though it be, ornithology has a good share; and all three may still be consulted with interest and advantage by its votaries. ${ }^{2}$ Meanwhile the study.received a great impulse from the appearance, at Zurich in 1555, of the third book of the illustrious Conrad Gesner's Historia Animalium "qvi est de Auium natura," and at Paris in the same year of Pierre Belon's (Bellonins) Histoire de la nature des Oyseaux. Gesner brought an amount of erudition, hitherto unequalled, to bear upon his subject; and, making due allowance for the time in which he wrote, his judgment must in most respects be deemed excellent. In his work, however, there is little that can be called systematic treatment. Like nearly all his predecessors since Elian, he adopted an alphabetical arrangement, ${ }^{3}$ though this was not too pedantically preserved, and did not hinder him from placing together the kinds of Birds which he supposed (and generally supposed rightly) to have the most resemblance to that one whose name, being best known, was chosen for the headpiece (as it were) of his particular theme, thus recognizing to some cxtent the principle of classification. ${ }^{4}$ Belon, with perhaps less book-learning than his contemporary, was evidently no mean scholar, and undoubtedly had more practical knowledge of Birds-their internal as well as external structure. Hence his work contains a far greater amount of original matter; and his personal observations made in many countries, from England to Egypt, enabled hin to avoid most of the puerilities which disfigure other works of his own or of a preceding age. Beside this, Belon disposed the Birds known to him according to a definite system, which (rude as we now know it to be) formed a foundation on which several of his successors were content to build, and even to this day traces of its influence may still be discerned in the arrangement followed by writers who have faintly appreciated the principles on which modern taxonomers rest the outline of their schemes. Both his work and that of Gesner were

capp. xxiii.-lxxx.) is a good deal about birds which is not altogether nonsense. This work was edited for the Rolls Series, in 1863, by the same Mr. Wright.

${ }_{1}$ This was reprinted at Cambridge in 1823 by the late Dr. George Thackeray.

2 The Seventh of Wotton's De differentiis animalium Libri Decem, published at Paris in 1552, treats of Birds; but his work is merely a compilation from Aristotle and Pliny, with references to other classical writers who have more or less incideutally mentioned Birds and other animals. The anthor in his preface states- "Veterum scriptorum sententias in unum quasi cumulum coaceruaui, de meo nilhil addidi." Nevertheless he makes some attempt at a systematic arrangement of Birds, which, according to his lights, is far from despicable.

3 Even at the present day it may be shrewdly suspected that not a few ornithologists would gladly follow Gesner's plan in their despair of seeing, in their orn time, a classification which would really deserve the epithet scientific.

"For instance, under the title of "Accipiter" we have to look, not only for the Sparrow-Hawk and Gos-Hawk, but for many other birds of the Family (as we now call it) removed comparatively far from those species by modern ornitlologists. 
illustrated with woodcuts, many of which display much spirit and regard to accuracy.

Belon, as has just been said, had a knowledge of the anatomy of Bircls, and he seems to have been the first to institute a direct comparison of their skeleton with that of Man; but in this respect he only anticipated by a few years the more precise researches of Volcher Coiter, a Frisian, who in 1573 and 1575 published at Nuremberg two treatises, in one of which the internal structure of Birds in general is very creditably described, while in the other the osteology and myology of certain forms is given in considerable detail, and illustrated by carefully-drawn figures. The first is entitled Externarum et internarum principalium humani corporis Tabulx, \&c., while the second, which is the most valuable, is merely appended to the Lectiones Gabrielis Fallopii de partibus similaribus humani corporis, \&c., and thus, the scope of each work being regarded as medical, the author's labours were wholly overlooked by the mere natural-historians who followed, thongh Coiter introduced a table, "De differentiis Auium," furnishing a key to a rough classification of such Birds as were known to him, and this, as nearly the first attempt of the kind, deserves notice here.

Contemporary with these three men was Ulysses Aldrovandus, a Bolognese, who wrote an Historia Naturalium in sixteen folio volumes, most of which were not printed till after his death in 1605 ; but the three on Birds appeared between 1599 and 1603. The work is almost wholly a compilation, and that not of the most discriminative kind, while a peculiar jealousy of Gesner is displayed throughout, though his statements are very constantly quoted-nearly always as those of "Ornithologus," his name appearing but few times in the text, and not at all in the list of authors cited. With certain modifications in principle not very important, but characterized by much more elaborate detail, Aldrovandus adopted Belon's method of arrangement, but in a few respects there is a manifest retrogression. The work of Aldrovandus was illustrated by copper plates, but none of his figures approach those of his immediate predecessors in character or accuracy. Nevertheless the book was eagerly sought, and several edition's of it appeared. ${ }^{1}$

Mention must be made of a medical treatise by Caspar Schwenckfeld, published at Liegnitz in 1603, under the title of Theriotropheum Silesix, the fourth book of which consists of an "Aviarium Silesiæ," and is the earliest of the ornithological works we now know by the name of Famna. The author was acquainted with the labours of his predecessors, as his list of over one hundred of them testifies. Most of the Birds he describes are characterized with accuracy sufficient to enable them to be identified, and his observations upon them have still some interest; but he was innocent of any methodical system, and was not exempt from most of the professional fallacies of his time. ${ }^{2}$

1 The Historia Naturalis of John Johnstone or Jonston, of Scottish desceut but by birth a Pole (Dict. Nat. Biogr. xxx. pp. 80, 81), ran throngh sereral erlitions during the seventeenth century, but is little more than an epitome of the work of Aldrovandus.

2 The IIierozoicon of Bochart-a treatise on the animals named in Holy Writ-was published in 1619 . 
Hitherto, from the nature of the case, the works aforesaid treated of scarcely any but the Birds belonging to the orbis veteribus notus; but the geographical discoveries of the sixteenth century began to bear fruit, and many animals of kinds unsuspected were, about one hundred years later, made known. Here there is only space to name Bontius, Clusius, Hernandez ${ }^{1}$ (or Fernandez), Marcgrave, Nieremberg and Piso, ${ }^{2}$ whose several works describing the natural products of both the Indies-whether the result of their own observation or compilation-together witl those of Olina and Worm, produced a marked effect, since they led up to what may be deemed the foundation of scientific Ornithology. ${ }^{3}$

This foundation was laid by the joint labours of Francis Willughby (born 1635, died 1672) and John Ray (born 1628, died 1705), for it is impossible to separate their share of work in Natural History more than to say that, while the former more especially devoted himself to zoology, botany was the favourite pursuit of the latter. Together they studied, together they travelled and together they collected. Willnghby, the younger of the two, and at first the other's pupil, seems to have gradually become the master; but dying before the promise of his life was fulfilled, his writings were given to the world by his friend Ray, who, adding to them from his own stores, published the Ornithologia in Latin in 1676, and in English with many emendations in 1678. In this work Birds generally were grouped in two great divisions-- "Land-Fowl" and "Water-Fowl," - the former being subdivided into those which have a crooked beak and talons and those which have a straighter bill and claws, while the latter was separated into those which frequent waters and watery places and those that swim in the water-each subdivision being further broken up into many sections, to the whole of which a key was given. Thus it became possible for almost any diligent reader without much chance of error to refer to its proper place nearly every bird he was likely to meet with. Ray's interest in ornithology continued, and in 1694 he completed a Synopsis Methodica Avium, which, through the fault of the booksellers to wliom it was entrusted, was not published till 1713, when Derham gave it to the world. ${ }^{4}$

Two years after Ray's death, Linnæus, the great reformer of Natural History, was born, and in 1735 appeared the first edition of the celebrated Systema Naturæ. Successive editions of this work were produced under

1 The earliest work of Hernandez, published at Mexico in 1615, copies of which are very scarce, has been reprinted and edited by Dr. León (8vo, Morelia : 1888).

2 For Lichtenstein's determination of the Birds described by Marcgrave and Piso see the Abhandlungen of the Berlin Academy for 1817 (pp. 155 et seqq.)

3 The earliest list of British Birds seems to be that in the Pinax Rerum Naturalium of Christopher Merrett, published in 1666, and to be again mentioned preseutly. In 1668 appeared the Onomasticon Zooicon of Walter Charleton, which contains some information on ornithology. An enlarged edition of the latter, under the title of Exercitationes, \&c., was published in 1677 ; but neither of these writers is of nuch authority. In 1684 Sibbald in his Scotia illustrata published the earliest Fauna of Scotland.

4 To this was added a supplement by Petiver on the Birds of Madras, taken from pictures and information sent him by one Edward Buckley of Fort St. George, being the first attempt to catalogue the Birds of any part of the British possessions in India. 
its author's supervision in $1740,1748,1758$ and 1766 . Impressed by the belief that verbosity was the bane of science, he carried terseness to an extreme which frequently created obscurity, and this in no branch of zoology more than in that which relates to Birds. Still the practice introduced by him of assigning to each species a diagnosis by which it ought in theory to be distinguishable from any other known species, and of naming it by two words-the first being the generic and the second the specific term, was so manifest an improvement upon anything which had previously obtained, that the Linnæan method of differentiation and nomenclature established itself before long in spite of all opposition, and in principle became almost universally adopted. The opposition came of course from those who were habituated to the older state of things, and saw no evil in the cumbrous, half-descriptive half-designative titles which had to be employed whenever a species was to be spoken of or written about. The supporters of the new method were the rising generation of naturalists, many of whose names have since become famous, but among them were some whose admiration of their chief carried them to a pitch of enthusiasm which now seems absurd. ${ }^{1}$ Careful as Linnæus was in drawing up his definitions of groups, it was immediately seen that they occasionally comprehended creatures whose characteristics contradicted the prescribed diagnosis. His chief glory lies in his having reduced, at least for a time, a chaos into order, and in his shewing both by precept and practice that a name was not a definition. In his classification of Birds he for the most part followed Ray, and where he departed from his model he seldom improved upon it.

In 1745 Barrere brought out at Perpignan a little book called Ornithologiæ Specimen nouum, and in 1752 Möhring published at Aurich one still smaller, his Avium Genera. Both these works (now rare) are manifestly framed on the Linnæan method, so far as it had then reached; but in their arrangement of the rarious forms of Birds they differed greatly from that which they designed to supplant, and they obtained little success. Yet as systematists their authors were no worse than Klein, whose Historix Avium Prodromus, appearing at Lübeck in 1750 , and Stemmata Avium at Leipzig in 1759, met with considerable favour in some quarters. The chief merit of the latter work lies in its forty plates, whereon the heads and feet of many Birds are indifferently figured. ${ }^{2}$

But, while the successive editions of Linnæus's great work were rerolutionizing Natural History, and lis example of precision in language was producing excellent effect on scientific writers, several other authors were advancing the study of Ornithology in a very different way-a way that pleased the eye even more than his labours were pleasing the mind. Between 1731 and 1743 Mark Catesby brought ont in London his

1 Such an one was Rafinesque, in many respects a fantastic author. Simple as. the principle of binomial nomenclature looks, its practice is not so easy, and there have not been wanting of late years quasi-scientific writers to mistake it wholly.

2 After Klein's death his Prodromus, written in Latin, had the unwonted fortune of two distinct translations into German, published in the same year, 1760, the one at Leipzig and Luibeck by Benn, the other at Danzig by Reyger-eacls of whom added more or less to the original. 
Natural History of Carolina-two large folios containing highly-coloured plates of the Birds of that colony, Florida and the Balramas-the forerunners of those numerous costly tomes which will have to be mentioned presently at greater length. ${ }^{l}$ Eleazar Albin between 1738 and 1740 produced a Natural History of Birds in three volumes of more modest dimensions, seeing that it is in quarto; but he seems to have been ignorant of Ornithology, and his coloured plates are greatly inferior to Catesby's. Far better both as draughtsman and as authority was George Edwards, who in 1743 began, under almost the same title as Albin, a series of plates with letterpress, which was continued by the name of Gleanings of Natural History, and finished in 1760 , when it had reached seven parts, forming four quarto volumes, the figures of which are nearly always quoted with approval. ${ }^{2}$

The year which saw the works of Edwards completed was still further distinguished by the appearance in France, where little had beell done since Belon's days, ${ }^{3}$ in six quarto volumes, of the Ornithologie of Mathurin

- Jacques Brisson-a work of very great merit so far as it goes, for as a descriptive ornithologist the author stands even now unsurpassed; but it must be said that his knowledge, according to internal evidence, was confined to books and to the external parts of Birds' skins. It was enough for lim to give a scrupulously exact description of such specimens as came under his eye, distinguishing these by prefixing two asterisks to their name, using a single asterisk where he had only seen a part of the Bird, and leaving unmarked those that he described from other authors. $\mathrm{He}$ also added information as to the Museum (generally Réaumur's, of which he had been in charge) containing the specimen he described, acting on a principle which would have been advantageously adopted by many of his contemporaries and successors. His attempt at classification was certainly better than that of Linnæus; and it is rather curious that the researches of the latest ornithologists point to results in some degree comparable with Brisson's systematic arrangement, for they refuse to keep the Birds-of-Prey at the head of the Class Aves, and they require the establishment of a much larger number of "Orders" than for a long while -had been thought advisable. Of such "Orders" Brisson had twenty-six, and he gave Pigeons and Poultry precedence of the Birds which are carnivorons or scavengers. But greater value lies in his generic or subgeneric divisions, which taken as a whole, are far more natural than those of Linnæus, and consequently capable of better diagnosis. More than this, he seems to be the earliest ornithologist, perhaps the earliest zoologist, to conceive the idea of each genus possessing what is now called a "type" -though such a term does not occur in his work; and, in like manner, without declaring it in so many words, he indicated unmistakably the existence of subgenera-all this being effected by the skilful use of names.

I Several Birds from Jamaica were figured in Sloane's Voyage, \&c. (1705-1725), and $a$ good many exotic species in the Thesaurus, \&c. of Seba (1734-1765), but from their faulty execution these plates had little effect upon Ornithology.

2 The works of Catesby and Edwards were afterwards reproduced at Nuremberg and Amsterdam by Seligmann, with the letterpress in German, French and Dutch.

${ }^{3}$ Birds were treated of in a worthless fashion by one D. B. in a Dictionnaire raisonné et universel des animaux, published at Paris in 1759. 
Unfortunately he was too soon in the field to avail himself, even had he been so minded, of the convenient mode of nomenclature brought into use by Linnæus, and it is only in the last two volumes of Brisson's Ornithologie that any reference is made to the tenth edition of the Systema Naturæ, in which the binomial method was introduced. It is certain that the first four volumes were written if not printed before that method was promulgated, and when the fame of Linnæus as a zoologist rested on little more than the very meagre sixth edition of the Systema Naturæ and the first edition of his Fauna Suecica. Brisson has been charged with jealousy of, if not hostility to, the great Swede, and it is true that in the preface to his Ornithologie he complains of the insufficiency of the Linnæan characters, but, when one considers his much better acquaintance with Birds, such criticism must be allowed to be pardonable if not wholly just. This work was in French, with a parallel translation in Latin, which last (edited, it is said, by Pallas) was reprinted separately at Leyden three years afterwards.

In 1767 there was issued at Paris a book entitled L'histoire naturelle éclaircie dans une de' ses parties principales, l'Ornithologie. This was the work of Salerne, published after his death, and is often spoken of as being a mere translation of Ray's Synopsis, but is thereby very inadequately described, for, though it is confessedly founded on that little book, a vast amount of fresh matter, and mostly of good quality, is added.

The success of Edwards's work seems to have provoked competition, and in 1765, at the instigation of Buffon, the younger D'Aubenton began the publication known as the Planches Enluminées d'histoire naturelle, which appearing in forty-two parts was not completed till 1780, when the plates $^{1}$ it contained reached the number of 1008 -all coloured, as its title intimates, and nearly all representing Birds. This enormous work was subsidized by the French Government; and, though the figures are devoid of artistic merit, they display the species they are intended to depict with sufficient approach to fidelity to ensure recognition in most cases without fear of error, which in the absence of any text is no small praise. ${ }^{2}$

But Buffon was not content with merely causing to be published this unparalleled set of plates. He seems to have regarded the work just named as a necessary precursor to his own labours in Ornithology. His Histoire Naturelle, générale et particulière, was begun in 1749, and in 1770 he brought out, with the assistance of Guenau de Montbeillard, ${ }^{3}$ the first volume of that grand undertaking relating to Birds, which, for the first time, became the theme of one who possessed real literary capacity. It

1 They were drawn and engraved by Martinet, who himself begau in 1787 a Histoire des Oiseaux with small coloured plates which have some merit, but the text is worthless. The work seems not to have been finished, and is rare. For the opportunity of seeing a copy I was indebted to my kind friend the late MIr. Guruey.

2 Between 1767 and 1776 there appeared at Florence a Storia Naturale degli Uccelli, in five folio volumes, containing a number of ill-drawn and ill-coloured figures from the collection of Giovanni Gerini, an ardent collector who, having died in 1751, must be acquitted of any share in the work, which, though sometimes attributed to him, is that of certain learned men who did not happen to be ornithologists ( $c f$. Savi, Ornithologia Toscana, i. Introduzione, p. v.).

3 He retired on the completion of the sixth volume, and thereupon Buffon associated Bexon with himself. 
is not too much to say that Buffon's florid fancy revelled in such a subject as was that on which he now exercised his brilliant pen; but it would be unjust to examine too closely what to many of his contemporaries seemed sound philosophical reasoning under the light that has since burst upou us. Strictly orthodox though he professed to be, there were those, both among his own countrymen and foreigners, who could not read his speculative indictments of the workings of Nature withont a shudder; and it is easy for any one in these days to frame a reply, pointed with ridicule, to such a chapter as he wrote on the wretched fate of the Woodpecker. In the nine volumes devoted to the Histoire Naturelle des Oiseaux there are passages which will for ever live in the memory of those that carefully read them, however much occasional expressions, or even the general tone of the author, may grate upon their feelings. He too was the first man who formed any theory that may be called reasonable of the Geographical Distribution of Animals, though this theory was scarcely touched in the ornithological portion of his work, and has since proved to be not in accordance with facts. He proclaimed the variability of species in opposition to the views of Linnæus as to their fixity, and moreover supposed that this variability arose in part by degradation. ${ }^{1}$ Taking his labours as a whole, there cannot be a doubt that he enormonsly enlarged the purview of naturalists, and, even if linited to Birds, that, on the completion of his work upon them in 1783, Ornithology stood in a very different position from that which it had before occupied. Because he opposed the system of Linnæus he has been said to be opposed to systems in general; but that is scarcely correct, for he had a system of his own; and, as we now see it, it appears neither much better nor mucl worse than the systems which had been hitherto invented, or perhaps than any which was propounded for many years to come. It is certain that he despised any kind of scientific phraseology - a crime in the eyes of those who consider precise nomenclature to be the end of science; but those who deem it merely a means whereby knowledge can be securely stored will take a different view-and have done so.

Great as were the services of Buffon to Ornithology in one direction, those of a wholly different kind rendered by our countryman John Latham must not be overlooked. In 1781 he began a work the practical utility of which was immediately recoguized. This was his General Synopsis of Birds, and, though formed generally on the model of Linnæus greatly diverged in some respects therefrom. The classification was modified, chiefly on the older lines of Willughby and Ray, and certainly for the better; but no scientific nomenclature was adopted, which, as the author subsequently found, was a change for the worse. His scope was co-extensive with that of Brisson, but Latham did not possess the inborn faculty of picking out the characters wherein one species differs from another. His opportunities of becoming acquainted with Birds were hardly inferior to Brisson's, for during Latham's long lifetime there poured in upon him countless new discoveries from all parts of the world, but especially fron the newly-explored shores of Australia and the islands of the Pacific Ocean.

1 See Prof. Mivart's address to the Section of Biology, Rep. Brit. Association (Sheffield Meeting), 1879, p. 356. 
The British Museum had been formed, and he had access to everything it contained in addition to the abundant materials afforded him by the private Mnseum of Sir Ashton Lever.' Latham entered, so far as the limits of his work would allow, into the history of the Birds lie described, and this with evident zest, whereby he differed from his French predecessor ; but the number of cases in which he erred as to the determination of his species must be very great, and not unfrequently the same species is described more than once. His Synopsis was finished in 1785 ; two supplements were added in 1787 and $1802,{ }^{2}$ and in 1790 he produced a Latin abstract of the work under the title of Index Ornithologicus, wherein he assigned names on the Linnæan method to all the species described. Not to recur again to his labours, it may be said here that between 1821 and 1828 he published. at Winchester, in eleven volumes, an enlarged edition of his original work, entitling it $A$ General History of Birds; but his defects as a compiler, which had been manifest before, rather increased with age, and the consequences were not happy. ${ }^{3}$

About the time that Buffon was bringing to an end his studies of Birds, Mauduyt undertook to write the Ornithologie of the Encyclopédie Methodique - a comparatively easy task, considering the recent works of his fellow-conntrymen on that subject, and finished in 1784. Here it requires no further comment, especially as a new edition was called for in 1790, the ornithological portion of which was begun by Bonnaterre, who, however, had only finished 320 pages of it when he lost his life in the French Revolution; and the work thus arrested was continued by Vieillot under the slightly changed title of Tableau encyclopédique et méthodique des trois règnes de la Nature - the Ornithologie forming volumes four to seven, and not completed till 1823. In the former edition Mauduyt had taken the subjects alphabetically; but here they are disposed according to an arrangement, with some few modifications, furnished by D'Aubenton, which is extremely shallow and unworthy of consideration.

Several other works bearing upon Ornithology in general, but of less importance than most of those just named, belong to this period. Among others may be mentioned the Genera of Birds by Thomas Pennant, first printed at Edinburgh in 1773 in octavo, and very rare, bnt well known by the quarto edition which appeared in London in 1781; the Elementa Ornithologica ${ }^{4}$ and Museum Ornithologicum of Schäffer, published at Ratisbon in 1774 and 1784 respectively; Peter Brown's New Illustrations of Zoology in London in 1776; Hermann's Tabula Affinitatum Animalium at Strasburg in 1783, followed posthmmously in 1804 by his Observationcs

1 In 1792 Shaw began the Museum Leverianum in illustration of this collection, which was finally dispersed by sale in 1806, and what is known to remain of it found its way either to the collection of the then Lord Stanley (afterwards 13th Earl of Derby), and was, at his death in 1851, bequeathed to the Liverpool MInseum, or to Vienna (Ibis, 1873, pp. 14-54, 105-124; 1874, p. 461). Of the specimens in the British Museum described by Latham not one exists. They were probably very imperfectly prepared.

2 A German translation by Bechstein subsequently appeared.

3 He also prepared for publication a second edition of his Index Ornithologicus, which was never printed, and the manuscript is now in my possession.

4 The so-called second edition (1779) of this has only a new title-page. 
Zoologicx; Jacquin's Beytrucge zur Geschichte der Voegel at Vienna in 1784, and in 1790 at the same place the larger work of Spalowsky with nearly the same title; Sparrman's Museum Carlsonianum at Stockholm from 1786 to 1789 ; and in 1794 Hayes's Portraits of rare and curious Birds from the menagery of Child the banker at Osterley near London. The same draughtsman (who had in 1775 produced a bad History of Eritish Birds) in 1822 began another series of Figures of rare and curious Birds. ${ }^{1}$

The practice of Brisson, Buffon, Latham and others of not giving names after the Linnxan fashion to the species they described gave great encouragement to compilation, and led to what has proved to be of some inconvenience to modern ornithologists. In 1773 Philip Ludvig Statius Miiller brought out at Nuremberg a German translation of the Systema Naturx, completing it in 1776 by a Supplement containing a list of animals thus described, which had hitherto been technically anonymous, with diagnoses and names on the Linnæan model. In 1783 Boddaert printed at Utrecht a Table des Planches Enluminéer, ${ }^{2}$ in which he attempted to refer every species of Bird figured in that extensive series to its proper Linnæan genus, and to assign it a scientific name if it dic not already possess one. In like manner in 1786 , Scopoli-already the author of a little book published at Leipzig in 1769 under the title of Annus $I$. Historico-naturalis, in which are described many Birds, mostly from his own collection or the Imperial vivarium at Vienna-was at the pains to print at Pavia in his miscellaneous Delicix Floræ et Faunæ Insubricx a Specimen Zoologicum ${ }^{3}$ containing diagnoses, duly named, of the Birds discovered and described by Sonnerat in his Voyage aux Indes orientales and Voyage à la Nouvelle Guinée, severally published at Paris in 1772 and 1776. But the most striking example of compilation was that exhibited by J. F. Gmelin, who in 1788 commenced what he called the Thirteenth Edition of the celebrated Systema Naturx, which obtained so wide a circulation that, in the comparative rarity of the original, the additions of this editor have been very frequently quoted, even by expert naturalists, as though they were the work of the author limself. Gmelin availed himself of every publication he could, but he perhaps found his richest booty in the labours of Latham, neatly condensing his English descriptions into Latin diagnoses, and bestowing on them binomial names. Hence it is that Gmelin appears as the authority for so much of the nomenclature now in use. He took many liberties with the details of

1 The Naturalist's Miscellany or Fivarium Naturale, in English and Latiu, of Shaw and Nodder, the former being the author, the latter the drauglitsman and engraver, was begun in 1789 and carried on till Shaw's death, forming twenty-four volumes. It contains figures of more than 280 Birds, but very poorly executed. In 1814 a sequel, The Zoological Miscellany, was begun by Leach, Nodder continuing to do the plates. This was completed in 1817, and forms three volumes with 149 plates, 27 of which represent Birds.

2 of this work only fifty copies were printed, and it is one of the rarest known to the ornithologist. Ouly two copies are believed to exist in England, one in the British Museum, the other in private hands. It was reprinted in 1874 by Mr. Tegetmeier.

3 'This was reprinted in 1852 by the Willughby Society. 
Linnaus's work, but left the classification, at least of the Birds, as it was - a few new genera excepted. ${ }^{1}$

During all this time little had been done in studying the internal structure of Birds since the works of Coiter already mentioned; ${ }^{2}$ but the foundations of the science of Embryology had been laid by the investigations into the development of the chick by the great Harvey. Between 1666 and 1669 Perrault edited at Paris eight accounts of the dissection by $\mathrm{Du}$ Verney of as many species of Birds, which, translated into English, were published by the Royal Society in 1702, under the title of The Natural History of Animals. After the death of the two anatomists just named, another series of similar descriptions of eight other species was found among their papers, and the whole were published in the Mémoires of the French sicademy of Sciences in 1733 and 1734. But in 1681 Gerard Blasius had brought out at Amsterdam an Anatome Animalium, containing the results of all the dissections of animals that he could find; and the second part of this book, treating of Volatilia, makes a respectable show of more than 120 closely-printed quarto pages, though nearly twothirds is devoted to a treatise De Ovo et Pullo, containing among other things a reprint of Harvey's researches, and the scientific rank of the whole book may be inferred from Bats being still classed with Birds. In 1720 Valentini published, at Frankfort-on-the-Main, his Amphitheatrum Zootomicum, in which again most of the existing accounts of the anatomy of Birds were reprinted. But these and many other contributions, ${ }^{3}$ made until nearly the close of the eighteenth century, though highly meritorious, were unconnected as a whole, and it is plain that no conception of what it was in the power of Comparative Anatomy to set forth had occurred to the most diligent dissectors. This privilege was reserved for Georges Cuvier, who in 1798 published at Paris his Tableau élémentaire de l'histoire naturelle des Animaux, and thus lail the foundation of a thorough and hitherto unknown mode of appreciating the value of the various groups of the Animal Kingdom. Yet his first attempt was a mere sketch. ${ }^{4}$ Though he made a perceptible advance on the classification of Linnæus, at that time predoninant, it is now easy to see in how many ways-want of sufficient material being no doubt one of the chief-Cuvier failed to produce a really natural arrangement. His principles, however, are those which must still guide taxonomers, notwithstanding that they have in so great a degree overthrown the entire scheme which he proponnded. Cuvier's arrangement of the Class Aves is now seen to be not very much

1 Dandin's unfinished Traité élémentaire et complet d'Omithologie appeared at Paris in 1800, and therefore is the last of these general works published $i$ the eighteenth century.

2 A succinct notice of the older works on Ornithotomy is given by Prof. Selenka in the introduction to that portion of Bronn's Klassen und Ordnungen des Thierreichs relating to Bircls (p1). 1-9) publislsed in 1869; and Prof. Carus's Geschichte der Zoologie, published in 1S72, may also be usefully consulted for further information on this and other heads.

3 The treatives of the two Bartholinis and Borrichius published at Copenhagen deserve mention if only to record the activity of Danish anatomists in those days.

4 It had no effect on Lacépede, who in the following year ackled a Tablcau Méthodique containing a elassification of Birds to his Discours d'Ourerture (Ném. de l'Institut, iii. pp. 454-468, 503-519). 
better than any which it superseded, though this view is gained by following the methods which Cuvier taught. In the work just mentioned few details are given; but even the more elaborate classification of Birds contained in his Lecons d'Anatomie Comparée of 1805 is based wholly on external characters, such as had been used by nearly all his predecessors; and the Règne Animal of 1817, when he was in his fullest vigour, afforded not the least evidence that he had ever dissected a couple even of Birds 1 with the object of determining their relative position in his system, which then, as before, depended wholly on the configuration of bills, wings and feet. But, thongh apparently withont such a knowledge of the anatomy of Birds as wonld enable him to apply it to the formation of that natural system which he was fully aware had yet to be sought, he seems to have been an excellent judge of the characters afforded by the bill and limbs, and the use he made of them, coupled with the extraordinary reputation he acquired on other grounds, procured for his system the adhesion for many years of the majority of ornithologists. Regret must always be felt by them that his great genius was never applied in earnest to their branch of study, especially when we consider that had it been so the perversion of energy in regard to the classification of Birds witnessed in England for nearly twenty years, and presently to be mentioned, wonld most likely have been prevented.2

Hitherto mention has chiefly been made of works on General Ornithology, but it will be understood that these were largely aided by the enterprise of travellers, and as there were many of them who published their narratives in separate forms, their contributions have to be considered. Of those travellers, then, the first to be here especially named is Marsigli, the fifth volume of whose Danubius Pannonico-Mysicus is devoted to the Birds he met with in the valley of the Danube, and appeared at the Hague in 1725, followed by a French translation in $1744 .^{3}$ Most of the many pupils whom Linnæus sent to foreign countries submitted their discoveries to him, but the respective travels of Kalm, Hasselqvist and Osbeck in North America, the Levant and China were published separately. ${ }^{4}$ The incessant journeys of Pallas and his colleagnes-Falk, Georgi, J. G. and S. G. Gmelin, Güldenstädt, Lepechin and others-in

1 So little regard did he pay to the Osteology of Birds that, according to De Blainville (Jour. de Phys. xcii. p. 187, note), the skeleton of a Fowl to which was attached the head of a Horubill was for a long time exhibited in the Museum of Comparative Anatomy at Paris! Yet, in order to determine the difference of structure in their organs of voice, Cuvier, as he says in his Leçons (iv. p. 464), dissected more than 150 species of Birds. Unfortumately for him, as will appear in the sequel, it seems not to have occurred to him to use any of the results he obtained as the basis of a classification.

2 It is unnecessary to enumerate the various editions of the Rène Animal. Of the English translations, that edited by Griffiths and Pidgeou is the most complete. The oruithological portion of it, contained iu three volumes, received many additions from John Edward Gray, and appeared in 1829, but even at that time must have been lamentably deficient.

3 Though much later in date, the Iter per Poseganam Sclavonize of Piller and Mitterpacher, published at Buda in 1783 , may perhaps be here most couveniently mentioned.

4 The results of Forskå's travels in the Levant, published after his death by Niebuhr, require mention, though the oruithology they contain is but scant. 
the exploration of the recently extended Russian empire supplied not only much material to the Commentarii and Acta of the Academy of St. Petersburg, but more that is to be found in their narratives-all of it being of the highest interest to students of Holarctic Ornithology. Nearly the whole of their results, it may here be said, were summed up in the important Zoographia Rosso-Asiatica of the first-named naturalist, two volumes of which saw the light in 1811 , — the year of its author's death,- but, owing to circumstances over which he had no control, were not generally accessible till twenty years later. Of still wider interest are the accounts of Cook's three famous voyages, though unhappily much of the information gained by the naturalists who accompanied him on one or more of them seems to be irretrievably lost: the original observations of the elder Forster were not printed till 1844, and the valuable series of zoological drawings made by the younger Forster and William Ellis still remain unpublished in the British Museum. The several accounts by John White, Collins, Phillip, Hunter and others, of the colonization of New South Wales at the end of the last century, ought not to be overlooked by any Australian ornithologist. The only information belonging to this period on the Ornithology of Sonth America is contained in the two works on Chili by Molina, published at Bologna in 1776 and 1782. The travels of Le Vaillant in Sonth Africa having ended in 1785, his great Oiseaux d'Afrique began to appear in Paris in $1797 ;^{1}$ but it is hard to speak patiently of this work, for several of the species described in it are certainly not, and never were inhabitants of that country-admittedly so in some cases, though in others he gives a long account of the circumstances in which he observed them.2

From travellers who employ themselves in collecting the animals of any distant country the zoologists who stay at home and study those of their own district, be it great or small, are really not so much divided as at first might appear. Both may well be named "Faunists," and of the latter there were not a few who having turned their attention more or less to Ornithology should here be mentioned, and first among them Rzaczynski, who in 1721 brought ont at Sandomirsk the Historia naturalis curiosa regni Polonix, to which an Auctuarium was posthumously published at Danzig in 1742 . This also may be perhaps the most proper place to notice the Historia Avium Hungaria of Grossinger, published at Posen in 1793. In $1734 \mathrm{~J}$. L. Frisch began the long series of works on the Birds of Germany with which the literature of Ornithology is enriched, by his Vorstellung der Vögel Teutschlands, which was only completed in 1763 , and, its coloured plates proving very attractive, was again issued at Berlin in 1817. The little fly-sheet of Zorn ${ }^{3}$-for it is scarcely more-on the

1 In 1798 he issned a duodecimo edition of this work, which seems to be little known. Two volumes, exteuding to No. 117 of the folio edition, are in my possession, but I cannot say whether more appeared. His large work failed to obtain support, and finished with its sixth volume in 1808.

2 It has been charitably suggested that, his collection and notes having suffered shipwreck, he was induced to supply the latter from his memory and the former by the nearest approach to his lost specimens that he could obtain. This explanatiou, poor as it is, fails, however, in regard to some species.

3 His earlier work under the title of P'etinotheologie can hardly be deemed scientific. 
Birds of the Hercynian Forest made its appearance at Pappenheim in 1745. In 1756 Kramer published at Vienna a modest Elenchus of the plants and animals of Lower Austria, and J. D. Petersen producer at Altona in 1766 a Verzeichniss balthischer Vögcl; while in $1791 \mathrm{~J}$. B. Fischer's Vcrsuch einer Naturgeschichte von Livland appeared at Königsberg. Next year Beseke brought ont at Mitan his Beytrag zur Naturgeschichte der Vögel Kurlands, and in 1794 Siemssen's Handbuch of the Birds of Mecklenburg was published at Rostock. But these works, locally useful as they may have been, did not occupy the whole attention of German ornithologists, for in 1791, Bechstein reached the second volume of his Gemeinnütige Naturgeschichte Deutschlands, treating of the Birds of that country, which ended with the fourth in 1795. Of this an abridged edition by the name of Ornithologischcs Taschenbuch appeared in 1802 and 1803, with a supplement in 1812 ; while between 1805 and 1809 a fuller edition of the original was issued. Moreover in 1795 J. A. Naumann humbly began at Cöthen a treatise on the Birds of the principality of Anhalt, which on its completion in 1804 was found to have swollen into an ornithology of Northern Germany and the neighbouring countries. Eight supplements were successively published between 1805 and 1817 , and in 1822 a new edition was required. This Naturgeschichte der Vögel Deutschlands, being almost wholly re-written by his son J. F. Naumann, is by far the best thing of the kind as yet produced in any country. The fulness and accuracy of the text combined with the neat beauty of its coloured plates, have gone far to promote the study of Ornithology in Germany, and while essentially a popular work, since it is suited to the comprehension of all readers, it is throughout written with a simple dignity that commends it to the serious and scientific. Its twelfth and last volume was published in 1844-by no means too long a period for so arduous and honest a performance, -and a supplement was begun in 1847 ; but, the author dying in 1857, this continuation was finished in 1860 by the joint efforts of J. H. Blasins and Baldamus. In 1800 Borkhansen with others commenced at Darmstadt a Teutsche Ornithologie in folio which appeared at intervals till 1812, and rcmains unfinished, though a reissue of the portion published took place between 1837 and 1841 .

Other countries on the Continent, though not quite so prolific as Germany, bore some ornithological fruit at this period; but in all Southern Europe only four faunal products can be named :-the Saggio di Storia Naturale Bresciana of Pilati, published at Brescia in 1769; the Ornitologia dell' Europa Meridionule of Bernini, published at Parma between 1772 and 1776 ; the Uccolli di Sardegna of Cetti, published at Sassari in 1776; and the Romana Ornithologia of Gilius, published at Rome in 1781 - the last being in great part devoted to Pigeons and Poultry. More appeared in the North, for in 1770 Amsterdam sent forth the beginning of Nozeman's Nedcrlandsche Vogelen, a fairly-illustrated work in folio, but only completed by Houttuyn in 1829, and in Scandinavia most of all was done. In 1746 the great Linnæus had produced a Faunc Svecica, of which a second edition appeared in 1761 , and a thirc revised by Retzius in 1800. In 1764 Brünnich published at Copenhagen 
his Ornithologia Borcalis, a compendious sketch of the Birds of all the countries then subject to the Danish crown. At the same place appeared in 1767 Leem's work De Lapponibus Finmarchix, to which Gunnerus contributed some good notes on the Ornithology of Northern Norway, and at Copenhagen and Leipzig was published in 1780 the Faunu Groenlandica of Otho Fabricius.

Of strictly American origin can here be cited only Bartram's Travels through North and South Carolina and Barton's Fragments of the Natural History of Pennsylvania, ${ }^{1}$ botl printed at Philadelphia, one in 1791, the other in 1799 ; but J. R. Forster published a Catalogue of the Animals of North America in London in 1771, and the following year described in the Philosophical Transactions a few Birds from Hudson's Bay. ${ }^{2}$ A greater undertaking was Pennant's Arctic Zoology, published in 1785, with a supplement in 1787. The scope of this work was originally intended to be limited to North America, but circumstances induced him to include all the species of Northern Europe and Northern Asia, and though not free from errors, it is a praiseworthy performance. A second edition appeared in 1792. The Ornithology of Britain naturally demands greater attention. The earliest list of British Birds we possess is, as already stated, that in Merrett's Pinax Rerum Naturalium Britannicarum, printed in Jondon in 1666.3. In 1677 Plot published his Natural History of Oxfordshire, which reached a second edition in 1705, and in 1686 that of Staffordshire. A similar work on Lancashire, Cheshire and the Peak was sent out in 1700 by Leigh, and one on Cormwall by Borlase in 1758all these four being printed at Oxford. In 1766 appeared Pennant's British Zoology, a well-illustrated folio, of which a second edition in octavo was published in 1768, and considerable additions (forming the nominally third edition) in 1770 , while in 1777 there were two issues, one in octavo the other in quarto, each called the fourth edition. In 1812, long after the author's death, another edition was printed, of which his son-in-law Hanmer was the reputed editor, but he received much assistance from Latham, and through carelessness many of the additions herein made have often been ascribed to Pennant himself. In 1769 Berkenhout gave to the world his Outlines of the Natural History of Great Britain and Ireland, which reappeared under the title of Synopsis of the same in 1795. Tunstall's Ornithologia Britannica, which was issued in 1771 , is little more than a list of names. ${ }^{4}$ Hayes's Natural History of British Birds, a folio of forty plates and corresponding text, shewing much ignorance of them on the part of the author, appeared between 1771 and 1775. In 1781 Nash's

1 This rare book has been repriuted by the Willughby Society.

2 Both of these treatises have also been reprinted by the Willughby Society.

3 In 1667 there were two issues of a reprint of this book ; one, nominally a second edition, only differs from the other in having a new title-page. In auticipation of a revised edition Sir Thomas Browue prepared in or about 1671 (?) his "Account of Birds found in Norfolk," of which the draught, now in the British Museum, was printed in his collected works by Wilkin in 1S35. If a fair copy was ever made its resting-place is nuknown.

4 It has been republished by the Willughby Society. Of similar character is Fothergill's Ornithologia Britannica, a mere list of names, Latiu and English, printed in small folio at York in 1799. 
Worcestershire included a few ornithological notices ; and Walcott in 1789 published an illustrated Synopsis of British Birds, coloured copies of which are rare. Simultaneously Willian Lewin commenced his Birds of Great Britain, in 7 quarto volumes, the last of which appeared in 1794, a re-issue of the whole in 8 volumes following between 1795 and 1801 . In $1791 \mathrm{~J}$. Heysham added to Hutchins's Cumberland a list of birds of that county, while in the same year began Thomas Lord's Entire New System of Ornithology, or Ecumenical History of British Birds, the ungrammatical text professedly written, or corrected, by Dr. Dupree, a pretentious and worthless work of which 38 parts were published in the course of the next five years. In 1794 Donovan commenced a History of British Birds which was only finished in 1819-the earlier portion being reissued about the same'time. Bolton's Harmonia Ruralis, au account of British Song-Birds, first appeared between 1794 and 1796. Other editions followed, one even 50 years later. ${ }^{1}$

All the foregoing British publications yield in importance to two that remain to be mentioned. In 1767 Pennant, several of whose works have already been named, entered into correspondence with Gilbert White, receiving from him much information, almost wholly drawn from his own observation, for the succeeding editions of the British Zoology. In 1769 White began exchanging letters of a similar character with Barrington. The epistolary intercourse with the former continued until 1780, and with the latter until 1787. In 1789 White's sliare of the correspondence, together with some miscellaneous matter, was published as The Natural History of Selborne-from the name of the village in which he lived. Observations on Birds form the principal though by no means the whole theme of this book, which may be safely said to have done more to promote a love of Omithology in this country than any other work that has been written, nay more than all the other works (except one next to be mentioned) put together. It has passed through a far greater number of editions than any other work on Natural History in the whole world, and has become emphatically an English classic-the graceful simplicity of its style, the elevating tone of its spirit and the sympathetic chords it strikes recommending it to every lover of nature, while the severely scientific reader can find few errors in the statements it contains, whether of matter-of-fact or opinion. It is almost certain that more than half the zoologists of the British Islands for the past eighty years or more lave been infected with their love of the study by Gilbert White; and it can hardly be supposed that his influence will cease. ${ }^{2}$

I I cannot vouch for the complete accuracy of some of the dates given above. They have puzzled even that accomplished bibliographer Dr. Cones. It was nobody's business in those days to record the precise time of appearance of a work published in parts, and the date, when given at the foot of the plates, cannot always be trusted.

2 Next to the original edition, that known as Bennett's, published in 1837, which was reissued in 1875 by Mr. Harting, was long deemed the best; but it must give place to that of Bell, which appeared in 187\%, and contains much additional information of great interest. But the editions of Markwick, Herbert, Blyth and Jardine all possess features of merit. An elaborately prepared edition, issued in 1875 by one who gained great reputation as a naturalist, only shews his ignorance and his vulgarity. Since that time several popular writers have essayed other editions, though their labour may have been limited to the production of a preface in which 
The other work to the importance of which on Ornithology in this country allusion has been made is Bewick's History of British Birds. The first volume of this, containing the Land-Birds, appeared in 17971 the text being, it is understood, by Beilby-the second, containing the Water-Birds, in 1804. The woodcuts illustrating this work are generally of surpassing excellence, and it takes rank in the category of artistic publications. Fully admitting the extraordinary execution of the engravings, every ornithologist may perceive that as portraits of the Birds represented they are of very unequal merit. Some of the figures were drawn from stuffed specimens, and accordingly perpetuate all the imperfections of the original; others delineate species with the appearance of which the artist was not familiar, and these are either wanting in expression or are caricatures ; ${ }^{2}$ but those that were drawn from live Birds, or represent species which he knew in life, are worthy of all praise. It is well known that the earlier editions of this work, especially if they be upon large paper, command extravagant prices ; but in reality the copies on smaller paper are now the rarer, for the stock of them has been consumed in nurseries and schoolrooms, where they have been torn up or wor'l out with incessant use. Moreover, whatever the lovers of the fine arts may say, it is nearly certain that the "Bewick Collector" is mistaken in attaching so high a value to these old editions, for owing to the want of skill in printing-indifferent ink being especially assigned as one cause - many of the earlier issues fail to shew the most delicate touches of the engraver, which the increased care hestowed upon the edition of 1847 (published under the supervision of the late John Hancock) has revealed, -though it must be admitted that certain blocks have suffered from wear of the press so as to be incapable of any more producing the effect intended. Of the text it may be said that it is respectable, but no more. It has given satisfaction to thousands of readers in time past, and will, it may be hoped, give satisfaction to thousands in time to come.

The existence of these two works explains the widely-spread taste for Oruithology in this country, which is to foreigners so puzzling, and the

they generally contrive to display their incompetence. A more remarkable feature is the publication of a fairly printed edition at the price of sixpence! A curiously compressed German translation by F. A. A. Meyer appeared at Berlin in 1792, under the title of Eeyträge aur Naturgeschichte von England; and more than one reprint, apparently of Lady Dover's "Bowdlerized" edition of 1833 , has been issued in America (cf. Cones, Proc. U. S. Nat. Nfus. ii. p. 429). For information as to different editious published prior to and including that of Bell, see Notes and Queries, ser. 5, vii. pp. $241,264,296,338,471$, viii. p. 304 , and ix. p. 150.

The imitators of Gilbert White are countless. More than one has admittedly produced a very pretty book; but on essaying a second the falling off is manifest. Others at once shew their shallowness, aud good as may be their intention, their observations, however pleasant to read, are utterly valueless. Such writers can seldom rid themselves of the cousciousness of their own personality, the absence of which is so charming in the author they more or less unconsciously mimic.

1 There were two issues-virtually two editions-of this with the same date on the title-page, though one of them is said not to have been published till the following year. Among several other indicia this may be recognized by the woodcut of the "Sea Eagle" at page 11 bearing at its base the inscription "Wycliffe, 1791," and by the additional misprint on page 145 of Sahaniclus for Schaniclus.

2 This is especially observable in the figures of the Birds-of-Prey. 
zeal-not always according to knowledge, but occasionally reaching to serious study - with which that taste is pursued.

Having thus noticed, and it is to be hoped pretty thoroughly, the chief ornithological works begun if not completed prior to the commencement of the present century, together with their immediate sequels, those which follow will require a very different mode of treatment, for their number is so great that it would be impossible for want of space to deal with them in the same extended fashion, though the attempt will finally be made to enter into details in the case of works constituting the foundation upon which apparently the superstructure of the future science has to be built. It ought not to need stating that much of what was, comparatively speaking, only a few years ago regarded as scientific labour is now no longer to be so considered. The mere fact that the principle of Evolution, and all its admission carries with it, has been accepted in some form or other by almost all naturalists, has rendered obsolete nearly every theory that had hitherto been broached, and in scarcely any branch of zoological research was theory more rife than in Ornithology. One of these theories must presently be noticed at some length on account of the historical importance which attaches to its malefic effects in impeding the progress of true Ornithology in Britain ; but charity enjoins us to consign all the rest as much as possible to oblivion.

On reviewing the progress of Ornithology since the end of the last century, the first thing that will strike us is the fact that general works, though still undertaken, have become proportionally fewer, and such as exist are apt to consist of mere explanations of systematic methods that had already been more or less fully propounded, while special works, whether relating to the ornithic portion of the Fauna of any particular country, or limited to certain groups of Birds-works to which of late years the name of "Monograph" has become wholly restricted-have become far more numerous. But this seems to be the natural law in all sciences, and its cause is not far to seek. As the knowledge of any branch of study extends, it outgrows the opportunities and capabilities of most men to follow it as a whole; and, since the true maturalist, by reason of the irresistible impulse which drives him to work, cannot be idle, he is compelled to confine his energies to narrower fields of investigation. That in a general way this is for some reason to be regretted is true; but, like all natural operations, it carries with it some recompense, and the excellent work done by so-called "specialists" has over and over again proved of the greatest use to advancement in different departments of science, and in none more than in Ornithology. ${ }^{1}$

Another change has come over the condition of Ornithology, as of kindred sciences, induced by the multiplication of learned societies which issue publications, as well as of periodicals of greater or less scientific pretension-the latter generally enjoying a circulation far wider than the

1 The truth of the preceding remarks may be so obvious to most men who have acquaintance with the subject that their introduction here may seem unnecessary; but it is certain that the facts they state have been very little appreciaterl by many writers who profess to give an account of the progress of Natural History during the present century. 
former. Both kinds increase yearly, and the desponding mind may fear the possibility of its favourite study expiring through being smothered by its own literature. Without anticipating such a future disaster, and looking merely to what has gone before, it is necessary here to premise that, in the observations which immediately follow, treatises which have appeared in the publications of learned bodies or in other scientific periodicals must, except they be of prime importance, be hereinafter passed unnoticed; but their omission will be the less felt because the more recent of those of a "faunal" character are generally mentioned in the text (Geographical Distribution) under the different countries with which they deal, while reference to the older of these treatises is usually given by the writers of the newer. Still it seems advisable here to furnish some connected account of the progress made in the ornithological knowledge of those countries in which the readers of the present volume may be supposed to take the most lively interest-namely, the British Islands and those parts of the European continent which lie nearest to them or are most commonly sought by travellers, the Dominion of Canada and the United States of America, the British West Indies, Sonth Africa, India, together with Australia and New Zealand. The more important Monographs, again, will usually be found cited in the series of special articles contained in this work, though, as will be immediately perceived, there are some so-styled Monographs, which by reason of the changed views of classification that at present obtain, have lost their restricted character, and for all practical purposes have now to be regarded as general works.

It will perhaps be most convenient to begin by mentioning some of these last, and in particular a number of them which appeared at Paris early in this century. First in order of them is the Histoire Naturelle d'une partie d'Oiseaux nouveaux et rares de l'Amérique et des Indes, a folio volume ${ }^{I}$ published in 1801 by Le Vaillant. This is devoted to the very distinct and not nearly-allied groups of Hornbilis and of Birds which for want of a better name we call "Chatterers", and is illustrated, like those works of which a notice immediately follows, by coloured plates, done in what was then considered to be the highest style of art and by the best draughtsmen procurable. The first volume of a Histoire Naturelle des Perroquets, a companion work by the same author, appeared in the same year, and is truly a Monograph, since the Parrots constitute a Family of Birds so naturally severed from all others, that there has rarely been anything else confonnded with them. The second volume came out in 1805, and a third was issued in 1837-38 long after the death of its predecessor's author, by Bourjot St.-Hilaire. Between 1803 and 1806 Le Vaillant also published in just the same style two volumes with the title of Histoire Naturelle des Oiseaux de Paradis et des Rolliers, suivie de celle des Toucans et des Barbus, an assemblage of forms, which, miscellaneous as it is, was surpassed in incongruity by a fourth work on the same scale, the Histoire Naturelle des Promerops et des Guêpiers, des Couroucous et des Touracos, for herein are found Jays, Wax-

1 There is also an issue of this, as of the same author's other works, on large quarto paper. 
wings, the Cock-of-the-Rock (Rupicola) and what not besicles. The plates in this last are by Barraband, for many years regarded as the perfection of ornithological artists, and indeed the figures, when they happen to have been drawn from the life, are not bad; but his skill was quite unable to vivify the preserved specimens contained in Museums, and when he had only these as subjects he simply copied the distortions of the "bircl-stuffer." The following year, 1808, being aided by Temminck of Amsterdam, of whose son we shall presently hear more, Le Vaillant brought out the sixth volume of his Oiseaux d'Afrique, already mentioned. Four more volumes of this work were promised; but the means of executing them were denied to him, and, though he lived until 1824, his publications ceased.

A similar series of works was projected and begun about the same time as that of Le Vaillant by Audebert and Vieillot, though the former, who was by profession a painter and illustrated the work, had died more than a year before the appearance of the two volumes, bearing date 1802 , and entitled Oiseaux dorés ou a reflets métalliques, the effect of the plates in which he sought to heighten by the use of gilding. The first volume contains the "Colibris, Oiseaux-mouches, Jacamars et Promerops," the second the "Grimpereaux" and "Oiseanx de Paradis"associations which set all the laws of systematic method at defiance. His colleague, Vieillot, brought out in 1805 a Histoire Naturelle des plus beaux Chanteurs de la Zone Torride with figures by Langlois of tropical Finches, Grosbeaks, Buntings aud other hard-billed Birds; and in 1807 two volumes of a Histoire Naturelle des Oiseaux de l'Amérique Septentrionale, without, however, paying much attention to the limits commonly assigned by geographers to that part of the world. In 1805 Anselme Desmarest published a Histoire Naturelle des Tangaras, des Manakins et des Todiers, which, though belonging to the same category as all the former, differs from them in its more scientific treatment of the subjects to which it refers; and, in 1808, Temminck, whose father's aid to Le Vaillant has already been noticed, brought out at Paris a Histoire Naturelle des Pigeons, illustrated by Madame Knip, who had drawn the plates for Desmarest's volume. ${ }^{1}$

Since we have begun by considering these large illustrated works in which the text is made subservient to the coloured plates, it may be convenient to continue our notice of such others of similar character as it may be expedient to mention here, though thereby we shall be led somewhat far afield. Nost of them are but luxuries, and there is some degree of truth in the remark of Andreas Wagner in his Report on the Progress of Zoology for 1843, drawn up for the Ray Society (p. 60), that they "are not adapted for the extension and promotion of science, but must inevitably, on account of their unnecessary costliness, constantly tend to reduce the number of naturalists who are able to avail themselves of them, and they thus enrich ornithology only to its ultimate

1 Temminck subsequently reproduced, with many additions, the text of this volume in his Histoire Naturelle des Pigeons et des Gallinacées, published at Amsterdam iu 1813-15, in 3 vols. 8vo. Between 1838 and 1848 Florent-Provost brought out at Paris a further set of illustrations of Pigeons by Mdme. Knip. 
injury." Earliest in date, as it is greatest in bulk, stands Audubon's egregious Birds of America, in four volumes, containing 435 plates, of which the first part appeared in London in 1827 and the last in 1838.1 It seems not to have been the author's original intention to publish any letterpress to this enormous work, but to let the plates tell their own story, though finally, with the assistance, as is now known, of William Macgillivray, a text, on the whole more than respectable, was produced in five large octavos under the title of Ornithological Biography, of which more will be said in the sequel. Audubon has been greatly extolled as an ornithological artist; but he was far too much addicted to representing his subjects in violent action and in postures that outrage nature, while his drawing is very frequently defective. ${ }^{2}$ In 1866 Mr. D. G. Elliot began, and in 1869 finished, a sequel to Audubon's great work in two volumes, on the same scale-The New and hitherto Unfigured Species of the Birds of North America, containing life-size figures of all those which had been added to its fauna since the completion of the former.

In 1830 John Edward Gray commenced the Illustrations of Indiun Zoology, a series of plates, mostly of Birds, from drawings by native artists in the collection of General Hardwicke, whose name is therefore associated with the work. - Scientific names are assigned to the species figured; but no text was ever supplied. In 1832 Lear, well known as a painter, brought out his Illustrations of the Family of Psittacidx, a volume which deserves especial notice from the fidelity to nature and the artistic skill with which the figures were executed.

This same year (1832) saw the beginning of the marrellous series of works by which the name of Jobn Gould is likely to be always remembered. A Century of Birds from the Himalaya Mountains was followed by The Birds of Europe, in five volumes, published between 1832 and 1837, while in 1834 appeared $A$ Monograph of the Ramphastidx, of which a second edition was sone years later called for ; and then the Icones Avium, of which only two parts were published (1837-38), while $A$ Monograph of the Trogonidx (1838), also reached a second edition (1858-75). In 1837-38 he also brought out the first two parts of his Birds of Australia, but speedily perceiving that he conld not do justice to the oruithology of the vast island-continent without visiting it, he suspended the publication, and in 1838 sailed for New South Wales. Returning thence in 1840, he at once cancelled the portion he bad issued and commenced anew this, the greatest of all his works, which was

I In contrast to this, the largest of ornithological works, I may mention a Histoire Naturelle en Miniature de de [sic] 48 Oiseanx (96 pp. Paris: 1816). The only copy I have seen appears to be in the original calf binling, and measures $2 \cdot 6$ by $2 \cdot 15$ inches. I am indebted for the loan of it to Mr. Robert Service.

2 On the completion of these two works, for they must be regarded as distinct, an octavo edition in seven volunes under the title of The Birds of America was published in 1840-44. In this the large plates were reduced by means of the "camera lucida," the text was revised, and the whole systematically arranged. other reprints have since been issued, but they are vastly inferior both in execution and value. A sequel to the octaro Birds of America, corresponding witl it in form, was brought out in 1853-55 by Cassin as Illustrations of the Birds of California, Texas, Oregon, British and Russian America. 
finished in 1848 in seven volumes, to which five supplementary parts, forming another volume, were subsequently (1851-69) added. In 1849 he began $A$ Monograph of the Trochilidx or Humming-birds, extending to five volumes, the last of which appeared in 1861, and has since been followed by a supplement by Dr. Sharpe, who since the author's death in 1881 las completed The Birds of Asia, in seven volumes (1850-83), and The Birds of New Guinea, begun in 1875. A Monograph of the Odontophorine or Partridges of America (1844-50), and The Birds of Great Britain, in five volumes (1862-73) make up the wonderful tale consisting of more than forty folio volumes, and containing more than 3000 coloured plates. ${ }^{1}$ The earlier of these works were illustrated by Mrs. Gould, and the figures in them are fairly good; but those in the later, except when (as he occasionally did) he secured the services of Mr. Wolf, are not so much to be commended. There is, it is true, a smoothness and finish about them not often seen elsewhere; but, as though to avoid the exaggerations of Audubon, Gould usually adopted the tamest of attitudes in which to represent his subjects, whereby expression as well as vivacity is wanting. Moreover, both in drawing and in colouring there is frequently much that is untrue to nature, so that it has not uncommonly happened for them to fail in the chief object of all zoological plates, that of affording sure means of recognizing specimens on comparison. In estimating the letterpress, which was avowedly held to be of secondary importance to the plates, we must bear in mind that, to ensure the success of his works, it had to be written to suit a very peculiarly composed body of subscribers. Nevertheless a scientific character was so adroitly assumed that scientific men-some of them even ornithologistshave thence been led to believe the text had a scientific value, and that of a high class. However it must also be remembered that, throughout the whole of his career, Gould consulted the convenience of working ornithologists by almost invariably refraining from including in lis folio works the technical description of any new species without first publishing it in some journal of comparatively easy access.

An ambitious attempt to produce in England a general series of coloured plates on a large scale was Fraser's Zoologia Typica, the first part of which bears date 1841-42. Others appeared at irregular intervals until 1849 , when the work, which never received the support it deserved, was discontinued. The 70 plates (46 of which represent Birds) composing, with some explanatory letterpress, the volume are by $\mathrm{C}$. Cousens and H. N. Turner,-the latter (as his publications prove) a zoologist of much promise, who in 1851 died of a wound received in dissecting. The chief object of the author, who had been naturalist to the Niger Expedition, and curator to the Museum of the Zoological Society of London, was to figure the animals contained in its gardens or described in its Proceedings, which until the year 1848 were not illustrated.

The publication of the Zoological Sketches of Mr. Wolf, from aninals

1 In $1850 \mathrm{Mr}$. F. H. Waterhouse brought out a careful pamphlet shewing The Dates of Publication of some of Gould's works, and in 1893 Dr. Sharpe an Analytical Index to them. It is books of this kind that place the literature of ornithology so far in advance of that relating to any other branch of zoology. 
in the gardens of the Zoological Society, was begun about 1855, with a brief text by Mitchell, at that time the Society's secretary, in illustration of them. After his death in 1859, the explanatory letterpress was rewritten by Mr. Sclater, his successor in that office, and a volume was completed in 1861. Upon this a second series was commenced, and brought to an end in 1868 . Thongh a comparatively small number of species of Birds are figured in this magnificent work (17 only in the first series, and 22 in the second), it must be mentioned here, for their likenesses are so admirably executed as to place it in regard to ornithological portraiture at the head of all others. There is not a plate that is unwortly of the greatest of all animal painters.

Proceeding to illustrated works generally of less pretentious size but of greater ornithological utility than the books last mentioned, which are fitter for the drawing-room than the study, we next have to consider some in which the text is not wholly subordinated to the plates, though the latter still form a conspicuous feature of the publication. First of these in point of time as well as in importance is the Nouveau Recueil des Planches Coloriées d'Oiseaux of Temminck and Laugier, intended as a sequel to the Planches Enluminées of D'Aubenton before noticed, and like that work issued both in folio and quarto size. The first portion of this was published at Paris in 1820, and of its 102 livraisons, which appeared with great irregularity (Ibis, 1868, p. 500), the last was issued in 1839 , containing the titles of the five rolumes that the whole forms, together with a "Tableau Méthodique," which but indifferently serves the purpose of an index. There are 600 plates, but the exact number of species figured (which has been computed at 661 ) is not so easily ascertained. Generally the subject of each plate has letterpress to correspond, but in some cases this is wanting, while on the other hand descriptions of species not figured are occasionally introduced, and usually observations on the distribution and construction of each genus or group are added. The plates, which shew no inprovement on those of Martinet, are after drawings by Huet and Prêtre, the former being perhaps the less bad draughtsman of the two, for he seems to have had an idea of what a bird when alive looks like, though lie was not able to give his figures any vitality, while the latter simply delinented the stiff and dishevelled specimens from museum shelves. Still the colouring is pretty well done, and experience has proved that generally speaking there is not much difficulty in recognizing the species represented. The letterpress is commonly limited to technical details, and is not always accurate ; but it is of its kind useful, for in general knowledge of the outside of Birds Temminck probably surpassed any of his contemporaries. The "Tableau Méthodique" offers a convenient concordance of the old Planches Enluminées and its successor, and is arranged after the system set forth by Temminck in the first volume of the second edition of his Manuel d'Ornithologie, of which more presently.

The Galérie des Oisecux, a rival work, with plates by Oudart, seems to have been begun immediately after the former. The original project was apparently to give a figure and description of every species of Bird; but that was soon found to be impossible; and, when six parts had been issued, 
with text by some unnamed author, the scheme was brought within practicable limits, and the writing of the letterpress was entrusted to Vieillot, who, proceeding on a systematic plan, performed his task very creditably, completing the work, which forms two quarto volumes, in 1825, the original text and 57 plates being relegated to the end of the second volume as a supplement. His portion is illustrated by 299 coloured plates that, wretched as they are, have been continnally reproduced in various text-books-a fact possibly due to their subjects having been judiciously selected. It is a tradition that, this work not being favourably regarded by the authorities of the Paris Museum, its draughtsman and anthor were refused closer access to the specimens required, and had to draw and describe them through the glass as they stood on the shelves of the cases.

In 1827 Jardine and Selby began a series of Illustrations of Ornithology, the several parts of which appeared at long and irregular intervals, so that it was not until 1835 that three volumes containing 150 plates were completed. Then they set about a Second Series, which, forming a single volume with 53 plates, was finished in 1843. ${ }^{1}$ These authors, being zealous amateur artists, were for the most part their own draughtsmen and engravers. In 1828 James Wilson began, under the title of Illustrations of Zoology, the publication of a series of his own drawings (which he did not, however, himself engrave) with corresponding letterpress. Of the 36 plates illustrating this volume, a small folio, 20 are devoted to Ornithology, and contain figures, not very successful, of several species rare at the time.

Though the three works last mentioned fairly come under the same category as the Planches Enluminés and the Planches Coloriés, no one of them can be properly deemer their rightful heir. The claim to that succession was made in 1845 by Des Murs for his Iconographie Ornithologique, which, containing 72 plates by Prévot and Oudart ${ }^{2}$ (the latter of whom had marvellonsly improved in his drawings since he worked with Vieillot), was completer in 1849. Simultaneously with this Du Bus began a work on a plan precisely similar, the Esquisses Ornithologiqucs, illustrated by Severeyns, which, however, stopped short in 1849 with its 37 th plate, while the letterpress unfortunately does not go beyond that belonging to the 20th. In 1866 the succession was again taken up by the Exotic Ornithology of Messrs. Sclater and Salvin, containing 100 plates, representing 104 species, all from Central or South America, which are neatly executed by Mr. Smit. The accompanying letterpress is in some places copious, and useful lists of the species of various genera are occasionally subjoined, adding to the definite value of the work, which, forming one volume, was completed in 1869 .

Lastly here must be mentioned Rowley's Ornithological Miscellany, in three quarto volumes, profusely illustrated, which appeared between 1875 and 1878. The contents are as varied as the authorship, and, most of the leading English ornithologists laving contributed to the work, some of the papers are extremely good, while in the plates, which are in Mr.

1 Cf. Sherborn, Ibis, 1894, p. 326.

${ }^{2}$ On the title-page credit is given to the latter alone, but only two-thirds of the plates (from pl. 25 to the end) bear his name. 
Keulemans's best manner, many rare species of Bircls are figured, some of them for the first time.

All the works lately named have been purposely treated at some lencth, since being costly they are not easily accessible. The few next to be mentioned, being of smaller size (octavo), may be within reaeh of more persons, and therefore can be passed over in a briefer fashion without detriment. In many ways, however, they are nearly as important. Swainson's Zoological Illustrations, in three volumes, containing 182 plates, whereof 70 represent Birds, appeared between 1820 and 1821, and in 1829 a Second Series of the same was begun by him, which, extending to another three volumes, eontained 48 more plates of Birds out of 136, and was completed in 1833. All the figures were drawn by the author, who as an ornithological artist had no rival in his time. Every plate is not beyond criticism, but his worst drawings shew more knowledge of bird-life than do the best of his English or French contemporaries. A work of somewhat similar eharaeter, but one in which the letterpress is of greater valne, is the Centurie Zoologique of Lesson, a single volume that though bearing the clate 1830 on its title-page, is believed to have been begun in $1829,{ }^{1}$ and was certainly not finished until 1831. It received the benefit of Isidore Geoffroy St.-Hilaire's assistance. Notwithstanding its name it only contains 80 plates, but of them 42, all by Prêtre and in his usual stiff style, represent Birds. Concurrently with this volume appeared Lesson's Traité d'Ornithologie, which is dated 1831 , and may perhaps be. here most conveniently mentioned. Its professedly systematic form strietly relegates it to another group of works, but the presence of an "Atlas" (also in oetavo) of 119 plates to some extent justifies its notice in this place. Between 1831 and 1834 the same author brought out, in continuation of his Centurie, his Illustrations de Zoologie with 60 plates, 20 of whieh represent Birds. In 1832 Kittlitz began to publish some Kupfertafeln zur Naturgeschichte der Vögel, in whieh many new speeies are figured; but the work came to an end with its 36 th plate in the following year. In 1815 Reichenbach commenced with his Pralctische Naturgeschichte der Vögel the extraordinary series of illustrated publications which, under titles far too numerous here to repeat, ended in or about 1855, and are commonly known collectively as his Vollstïndigste Naturgeschichte der Vögel. ${ }^{2}$ Herein are contained more than 900 coloured and more than 100 uncoloured plates, which are crowded with the figures of Birds, a large proportion of them reduced eopies from other works, and espeeially those of Gould.

It now behoves us to turn to general and partieularly systematic works in which plates, if they exist at all, form but an accessory to the text. These need not detain us for long, since, however well some of them may have been exeeuted, regarl being had to their epoch, and whatever repute some of them may have achieved, they are, so far as general information and especially elassification is concerned, wholly

I In 1928 he hall brought ont, under the title of Manuel d' Ornithologie, two handy duodecimos which are very good of their kind.

2 Technieally speaking they are in quarto, but their size is so small that they may be well spoken of here. In 1879 Dr. A. B. Meyer brought out an Index to them. 
obsolete, and most of them almost useless except as matters of antiquarian interest. It will be enough merely to name Duméril's Zoologie Analytique (1806) and Gravenhorst's Vergleichende Uebersicht des linneischen und einiger neuern zoologischen Systeme (1807); nor need we linger over Shaw's General Zoology, a pretentious compilation continued by Stephens. The last seven of its fourteen volumes include the Class $A v e s$, and the first part of them appeared in 1809 , but, the original author dying in 1815 , when only two volumes of Birds were published, the remainder was brought to an end in 1826 by his successor, who afterwards became well known as an entomologist. The engravings which these volumes contain are mostly bad copies, often of bad figures, though many are piracies from Bewick, and the whole is a most unsatisfactory performance. Of a very different kind is the next we have to notice, the Prodromus Systematis Mammalium et Avium of Illiger, published at Berlin in 1811, which must in its day have been a valuable little manual, and on many points it may now be consulted to advantage-the characters of the genera being admirably given, and good explanatory lists of the technical terms of Ornithology furnished. The classification was quite new, and made a step distinctly in advance of anything that had before appeared. ${ }^{1}$ In 1816 Vieillot published at Paris an Analyse d'une nouvelle Ornithologie elémentaire, containing a method of classification which he had tried in vain to get printed before, both in Turin and in London. ${ }^{2}$ Some of the ideas in this are said to have been taken from Illiger; but the two systems seem to be wholly distinct. Vieillot's was afterwards nore fully expounded in the series of articles which he contributed between 1816 and 1819 to the Second Edition of the Nouveau Dictionnaire d'Histoire "Naturelle, containing much valuable information. The views of neither of these systematizers pleased Temminck, who in 1817 replied rather sharply to Vieillot in some Observations sur la Classification méthodique des Oiseaux, a pamphlet published at Ansterdam, and prefixed to the second edition of his Manuel d'Ornithologie, which appeared in 1820, an Analyse du Système Général d'Ornithologie. This proved a great success, and his arrangement, though by no means simple, ${ }^{3}$ was not only adopted by many ornithologists of almost every country, but still has some adherents. The following year Ranzani of Bologna, in his Elementi di

1 Illiger may be considered the founcler of the school of nomenclatural purists. He would not tolerate auy of the "barbarous" geueric terms adopted by other writers, though some had been in use for many years.

2 The method was communicated to the Turin Academy, 10th January 1814, and was ordered to be printed (Mém. Ac. Sc. Turin, 1813-14, p. xxviii.); but, through the derangements of that stormy period, the order was never carried out ( $\mathrm{ACH}$. Accad. Sc. Torino, xxiii. p. xcvii.). The minute-book of the Linnean Society of London shews that his Prolusio was read at meetings of that Society between 15th November 1814 and 21st February 1815. Why it was not at once accepted is not told, but the entry respecting it, which must be of much later date, in the "Register of Papers" is "Published already." It is due to Vieillot to mention these facts, as he has been accused of publishing his method in haste to anticipate some of Cuvier's views, but he might well complain of the delay in London. Some reparation has been made to his memory by the reprinting of his Analyse by the Willughby Society.

3 He recognized sixteen Orders of Birds, while Vieillot had been content with five. and Illiger with seven. 
Zoologia-a very respectable compilation-came to treat of Birds, and then followed to some extent the plan of De Blainville and Merrem (concerning which much more has to be said by and by) placing the "Struthious" Birds in an Order by themselves. ${ }^{1}$ In 1827 Wagler brought out the first part of a Systema Avium, in this form never completed, consisting of 49 detaclied monographs of as many genera, the species of which are most elaborately described. The arrangement he subsequently adopted for them and for other groups is to be found in his Natürliches System der Amphibien (pp. 77-128), published in 1830, and is too fanciful to require any further attention. The several attempts at system-making by Kaup, from his Allgemeine Zoologie in 1829 to his Ueber Classification der Vögel in 1849, were equally arbitrary and abortive ; but his Skizzirte Entwiclelungs-Geschichte in 1829 must be here named, as it is so often quoted on account of the number of new genera which the peculiar views he had embraced compelled him to invent. These views he shared more or less with Vigors and Swainson, and to them attention will be immediately especially invited, while consideration of the scheme gradually developed from 1831 onward by Charles Lucien Bonaparte, and still not without its influence, is deferred until we come to treat of the rise and progress of what we may term the reformed school of Ornithology. Yet injustice would be done to one of the ablest of those now to be called the old masters of the science if mention were not here made of the Conspectus Generum Avium, begun in 1850 by the naturalist last named, with the help of Schlegel, and unfortunately interrupted by its author's death six years later. ${ }^{2}$ The systematic publications of George Robert Gray, so long in charge of the ornithological collection of the British Museum, began with A List of the Genera of Birds published in 1840. This, having been closely, though by no means in a hostile spirit, criticized by Strickland (Ann. Nat. Hist. vi. p. 410 ; vii. pp. 26 and 159), was followed by a Second Edition in 1841, in which nearly all the corrections of the reviewer were adopted, and in 1844 began the publication of The Genera of Birds, beantifully illustrated-first by Mitchell and afterwards by Mr. Wolf-wlich will always keep Gray's name in remembrance. The enornous labour required for this work seems scarcely to have been appreciated, though it remains to this day one of the most useful books in an ornithologist's library. Yet it must be confessed that its author was hardly an ornithologist but for the accident of his calling. He was a thoroughly conscientious clerk, devoted to his duty and unsparing of trouble. However, to have conceived the idea of executing a work on so grand a scale as this-it forms three folio volumes, and contains 185 coloured and 148 uncoloured plates, with references to upwards of 2400 generic names-was in itself a mark of genius, and it was brought to a successful conclusion in $1849 .^{3}$. Costly as it necessarily

1 The classification of Latreille in 1825 (Familles Naturelles du Règne Animal, pp. 67-88) needs naming only, for the author, great as an entomologist, had no special knowledge of Birds, and his greatest merit, that of placing Opisthocomus next to the Gallinæ, was perhaps a happy accident.

2 To this indispensable work a good index was supplied in 1865 by Dr. Finsch.

3 Capt. Thomas Browne's Illustration of the Genera of Birds, begmn in 1845 in imitation of Gray's work, is discleditable to all concerned with it. It soon ceased to 
was, it has been of great service to working ornithologists. In 1855 Gray brought out, as one of the Museum publications, A Catalogue of the Genera and Subgenera of Birds, a handy little volume, naturally founded on the larger works. Its chief drawback is that it does not give any more reference to the authority for a generic term than the name of its inventor and the year of its application, though of course more precise information would have at least doubled the size of the book. The same deficiency became still more apparent when, between 1869 and 1871 , he published bis Hand-List of Genera and Species of Birds in three octavo volumes (or parts, as they are called). Never was a book better named, for the working ornithologist must almost live with it in his hand, and though he bas constantly to deplore its shortcomings, one of which especially is the wrong principle on which its index is constructed, he should be thankful that such a work exists. Many of its defects are, or perhaps it were better said ought to be, supplied by Giebel's Thesaurus Ornithologix, also in three volumes (1872-77), a work admirably planned, but the execution of which, whether through the author's carelessness or the printer's fault, or a combination of both, is lamentably disappointing. Again and again it will afford the enquirer who consults it valuable lints, but he must be mindful never to trust a single reference in it until it has been verified. It remains to warn the reader also that, useful as are both this work and those of Gray, their utility is almost solely confined to experts.

With the exception to which reference has just been made, scarcely any of the ornithologists litherto named indulged their imagination in theories or speculations. Nearly all were content to prosecute their labours in a plain fashion consistent with common sense, plodding steadily. onwards in their efforts to describe and group the various species, as one after another they were made known. But this was not always to be, and now a few words must be said respecting a theory which was promulgated with great zeal by its upholders during the end of the first and early part of the second quarter of the present century, and for some years seemed likely to carry all before it. The success it gained was doubtless due in some degree to the difficulty which most men had in comprehending it, for it was enwrapped in alluring mystery, but more to the confidence with which it was announced as being the long lookedfor key to the wonders of creation, since its promoters did not hesitate to term it the discovery of "the Natural System," though they condescended, by way of explanation to less exalted intellects than their own, to allow it the more moderate appellation of the Circular or Quinary System.

A comparison of the relation of created beings to a number of intersecting circles is as old as the days of Nieremberg, who in 1635 wrote (Historia Naturæ, lib. iii. cap. 3)-_" Nullus hiatus est, nulla fractio, nulla dispersio formarum, invicem connexa sunt velut anmulus annulo"; but it is almost clear that he was thinking only of a chain. In 1806 Fischer de Waldheim, in his Tableaux Synoptiques de Zoognosie (p. 181), quoting

appear and remains incomplete. Had it been finished it would have been useless. The author had before (1831) attempted a similar act of piracy upon Wilson's American Ornithology. 
Nieremberg, extended his figure of speech, and, while justly deprecating the notion that the series of forms belonging to any particular group of creatures-the Mammalia was that whence he took his instance-could be placed in a straight line, imagined the various genera to be arrayed in a series of contiguous circles around Man as a centre. Though there is nothing to shew that Fischer intended, by what is here said, to do anything else than illustrate more fully the marvellous interconnexion of different animals, or that he attached any realistic meaning to his metaphor, his words were eagerly caught up by the prophet of the new faith. This was William Sharpe Macleay, a man of education and real genius, who in 1819 and 1821 bronght ont a work under the title of Horæ Entomologicæ, which was soon after hailed by Vigors as containing a new revelation, and applied by him to Ornithology in some "Observations on the Natural Affinities that connect the Orders and Families of Birds," read before the Linnean Society of London in 1823, and afterwards published in its Transactions (xiv. pp. 395-517). In the following year Vigors returned to the subject in some papers published in the recently established Zoological Journal, and found an energetic condisciple and coadjutor in Swainson, who, for more than a dozen years-to the end, in fact, of his career as an ornithological writer-was instant in season and out of season in pressing on all his readers the views he had, through Vigors, adopted from Macleay, though not without some modification of detail if not of principle. What these views were it would be manifestly improper for a sceptic to state except in the terms of a believer. Their enunciation must, therefore, be given in Swainson's own words, though it must be adnitted that space cannot be found here for the diagrams, which it was alleged were necessary for the right understanding of the theory. This theory, as originally propounded by Macleay, was said by Swainson in 1835 (Geogr. and Classific. of Animals, p. 202) to have consisted of the following propositions : ${ }^{1}$

"1. That the series of natural animals is continuous, forming, as it were, a circle ; so that, upon commencing at any one given point, and thence tracing all the modifications of structure, we shall be imperceptibly led, after passing through numerous forms, again to the point from which we started.

"2. That no groups are natural which do not exhibit, or shew an evident tendency to exhibit, such a circular series.

" 3 . That the primary divisions of every large group are ten, five of which are composed of comparatively large circles, and five of smaller: these latter being termed osculant, and being intermediate between the former, which they serve to connect.

"4. That there is a tendency in such groups as are placed at the opposite points of a circle of affinity 'to meet each other."

" 5 . That one of the five larger groups into which every natural circle is divided 'bears a resemblance to all the rest, or, more strictly speaking, consists of types which represent those of each of the four other groups, together with a type peculiar to itself."

As subsequently modified by Swainson (tom. cit. pp. 224, 225), the foregoing propositions take the following form :-

I I prefer giving them here in Swainson's version, because he seems to have set them forth more clearly and concisely than Macleay ever did, and, moreover, Swainson's application of them to Ornithology-a branch of science that lay outside of Macleay's proper studies-appears to be more suitable to the present occasion. 
"I. That every natural series of beings, in its progress from a given point, either actually returus, or evinces a tendency to return, again to shat point, thereby forming a circle.

"II. The primary circular divisions of every group are three actually, or five apparently.

"III. The contents of such a circular group are symbolically (or analogically) represented by the contents of all other circles in the animal kingdom.

"IV. That these primary divisions of every group are characterized by definite peculiarities of form, strueture and economy, which, under diversified modifications, are nniform throughout the animal kingdom, and are therefore to be regarded as the PRIMARY TYPES OF NATURE.

"V. That the different ranks or degrees of circular groups exhibited in the animal kingdom are NINE in number, each being involved within the other."

Though, as above stated, the theory thus promulgated owed its temporary success chiefly to the extraordinary assurance and pertinacity with which it was urged upon a public generally incapable of understanding what it meant, that it received some support from men of science must be admitted. A "circular system" was advocated by the eminent botanist Fries, and the views of Macleay met with the partial approbation of the celebrated entomologist Kirby, while at least as much may be said of the imaginative Oken, whose mysticism far surpassed that of the Quinarians. But it is obvious to every one who nowadays indulges in the profitless pastime of studying their writings that, as a whole, they failed in grasping the essential difference between homology (or "affinity," as they generally termed it) and analogy (which is only a learned name for an uncertain kind of resemblance)-though this difference had been fully understood and set forth by Aristotle himself-and, moreover, that in seeking for analogies on which to base their foregone conclusions they were often put to hard shifts. Another singular fact is that they often seemed to be totally unaware of the tendency if not the meaning of some of their own expressions; thus Macleay could write, and doubtless in perfect good faith (Trans. Linn. Soc. xvi. p. 9, note), "Naturalists have nothing to do with mysticism, and but little with a priori reasoning." Yet his followers, if not he himself, were ever making use of language in the highest degree metaphorical, and were always explaining facts in accordance with preconceived opinions. Fleming, already the author of a harmless and extremely orthodox Philosophy of Zoology, pointed out in 1829 in the Quarterly Review (xli. pp. 302-327) some of the fallacies of Macleay's method, and in return provoked from him a reply, in the form of a letter addressed to Vigors On the Dying Struggle of the Dichotomous System, couched in language the force of which no one even at the present day can deny, though to the modern naturalist its invective power contrasts ludicrously with the strength of its ratiocination. But, confining ourselves to what is here our special business, it is to be remarked that perhaps the heaviest blow dealt at these strange doctrines was that delivered by Rennie, who, in an edition of Montagu's Ornithological Dictionary (pp. xxxiii.-lv.), published in 1831 and again issued in 1833, attacked the Quinary System, and especially its application to Ornithology by Vigors and Swainson, in a way that might perhaps have demolished it, had not the author mingled with his undoubtedly sound reasoning much that is 
foreign to any question with which a naturalist, as such, ought to dealthough that herein he was only following the example of one of his opponents, who had constantly treated the subject in like manner, is to be allowed. This did not hinder Swainson, who had succeeded in getting the ornithological portion of the first zoological work ever published at the expense of the British Government (namely, the Fauna Boreali-Americana) executed in accordance with his own opinions, from maintaining them more strongly than ever in several of the volumes treating of Natural History which he contributed to the Cabinet Cycloprdiaamong others that from which we have just given some extracts-and in what may be deemed the culmination in England of the Quinary System, the volume of the "Natnralist's Library" on The Natural Arrangement and History of Flycatchers (1838), an unhappy performance mentioned in the body of the present work (p. 274, note). 'This seems to have been his last attempt; for, two years later, his Bibliography of Zoology shews little trace of his favourite theory, though nothing he had uttered in its support was retracted. Appearing almost simultaneously with that work, an article by Strickland (Mag. Nat. Hist., ser. 2, iv. pp. 219-226), entitled Observations upon the Affinities and Analogies of Organized Beings, administered to the theory a shock from which it never recovered, though attempts were now and then made by its adherents to revive it; and, even ten years or more later, Kaup, one of the few foreign ornithologists who had embraced Quinary principles, was by mistaken kindness allowed to publish Monographs of the Birds-of-Prey (Jardine's Contr. Orn. 1849 , pp. 68-75, 96-121; 1850, pp. 51-80 ; 1851, pp. 119-130; 1852, pp. 103-122; and Trans. Zool. Soc. iv. pp. 201-260), in which its absurdity reached the climax.

The mischief caused by this theory of a Quinary System was very great, but was chiefly confined to Britain, for (as already stated) the extraordinary views of its adherents found little favour on the continent of Europe. The purely artificial character of the System of Linnæus and his successors had been perceived, and men were at a loss to find a substitute for it. The new doctrine, loudly proclaiming the discovery of a "Natural" System, led away many from the steadly practice which should have followed the teaching of Cuvier (though he in Ornithology had not been able to act up to the principles he had laid down) and from the extended stucly of Comparative Anatomy. Moreover, it veiled the honest attempts that were making both in France and Germany to find real grounds for establishing an improved, state of things, and consequently the labours of De Blainville, Étienne Geoffroy St.-Hilaire, and L'Herminier, of Merrem, Johannes Müller and Nitzsch-to say nothing of others-were almost wholly unknown on this side of the Channel, and even the value of the investigations of British ornithotomists of high merit, such as Macartney and Macgillivray, was almost completely overlooked. True it is that there were not wanting other Inen in these islands whose common sense refused to accept the metaphorical doctrine and the mystical jargon of the Quinarians, but so strenuously and persistently had the latter asserted their infallibility, and so vigorously had they assailed any who ventured to doubt it, that 
most peaceable ornithologists found it best to bend to the furious blast, and in some sort to acquiesce at least in the phraseology of the selfstyled interpreters of Creative Will. But, while thus lamenting this unfortunate perversion into a mistaken channel of ornithological energy, we must not over-blame those who cansed it. Macleay indeed never pretended to a high position in this branch of science, his tastes lying in the direction of Entomology; but few of their conntrymen knew more of Birds than did Swainson and Vigors; and, while the latter, as editor for many years of the Zoological Journal, and the first Secretary of the Zoological Society, has especial claims to the regard of all zoologists, so the former's indefatigable pursuit of Natural History, and conscientions labour in its behalf_-among other ways by means of his graceful pencil - deserve to be remembered as a set-off against the injury he unwittingly caused.

It is now incumbent upon us to take a rapid survey of the ornithological works which come more or less under the designation of "Faunæ" ; ${ }^{1}$ but these are so numerous that it will be necessary to limit this survey, as before indicated, to those countries alone which form the homes of English people, or are commonly visited by them in ordinary travel.

Beginning with our Antipodes, it is hardly needful to go further back than Sir Walter Buller's beautiful Birds of New Zealand (4to, 1872-73 ; ed. 2, 2 vols. 1888), with coloured plates by Mr. Keulemans, and the same author's Manual of the Birds of New Zealand (8vo, 1882), founded on the former; but justice requires that mention be made of the labours of G. R. Gray, first in the Appendix to Dieffenbach's Travels in New Zealand (1843) and then in the ornithological portion of the Zoology of the Voyage of H.M.S. 'Erebus' and 'Terror,' begun in 1844, but left unfinished from the following year until completed by Dr. Sharpe in 1876. A considerable number of valuable papers on the Ornithology of the country by Sir James Hector and Sir Julius Von Haast, Prof. Hutton, Mr. Potts and others are to be found in the Transactions and Proceedings of the New Zealand Institute.

Passing to Australia, we have the first good description of some of its Birds in the several old voyages and in Latham's works before mentioned. Shaw's Zoology of New Holland (4to, 1794), though unfinished, added that of a few more, as did J. W. Lewin's Birds of New Holland (4to, London : 1808), of which, under the title of A Natural History of the Birds of New South Wales, a second edition, with 26 instead of 18 plates, appeared in 1822, the year after the author's death, and a third with additions by Eyton, Gould and others in 1838. Gould's great Birds of Australia has been already named, and he subsequently reproduced with some additions the text of that work under the title of Handbook to the Birds of Australia (2 vols. 8vo, 1865). In $1866 \mathrm{Mr}$. Diggles commenced a similar publication, The Ornithology of Australia, but the coloured plates are not comparable with those of his predecessor. This is still incomplete, though the parts that appeared were collected to

1 A very useful list of more general scope is given as the Appendix to an Address by Mr. Sclater to the British Association in 1875 (Report, pt. ii. pp. 114-133). 
form two volumes and issued (Brisbane : 1877) with title-pages. Many notices of Australian Birds by Dr. Ramsay, Messrs. A. J. North, K. H. Bennett and others are to be found in the Records of the Australian Museum, the Proceedings of the Linnean Society of New South Wales, of the Royal Society of Victoria and of that of Tasmania. ${ }^{1}$ Papers by Mr. Devis on the ornithology of British New Guinea have appeared in the Annual Reports on that Dependency presented to the parliament of Queensland, and in their original form are hardly accessible to the ordinary ornithologist.

Coming to our Indian possessions, and beginning with Ceylon, we have Kelaart's Prodromus Faunx Zeylanicæ (8vo, 1852), and the admirable Birds of Ceylon by Col. Legge (4to, 1878-80), with coloured plates by Mr. Keulemans of all the peculiar species. One can hardly name a book that has been more conscientiously executed than this. In regard to continental India many of the more important publications have been named in the body of this work (pages 356, 357), but Blyth's Mammals and Birds of Burma (8vo, 1875) ${ }^{2}$ should be especially noticed, as well as the fact that since the return of Mr. Oates to the East, the ornithological part of the Fauna of British India is being continued by Mr. Blanford, though Jerdon's classical work will always remain of value, notwithstanding that it no longer reigns supreme as the sole comprehensive work on the Ornithology of the Peninsula. ${ }^{3}$

In regard to South Africa there is little to be added to the works mentioned (pages $347,351,352$ ); but in 1896 Capt. Shelley brought out a List of African Birds, which, it is hoped, may be the forerunner of a series of volumes on Ethiopian Ornithology. It is much to be regretted that of the numerous sporting books that treat of this part of the world so few give any important information respecting the Birds.

Of special works relating to the British West Indies, Waterton's well-known $W$ anderings has passed through several editions since its first appearance in 1825, and must be mentioned here, though, strictly speaking, much of the country he traversed was not British territory. To Dr. Cabanis we are indebited for the ornithological results of Richard Schomburgk's researches given in the third volume (pp. 662-765) of the latter's Reisen im Britisch-Guiana (8vo, 1848), and then to Léotaud's Oiseaux de l'île de la Trinidad (8vo, 1866). Of the Antilles there is to be named Gosse's excellent Birds of Jamaica (12mo, 1847), together with its Illustrations (sm. fol. 1849) beantifully executed by him. A nominal

1 Dr. Ramsay has a Tabular List of Australian Birds (ed. 2, Sydney: 1888). Mr. North's contributions have been chiefly on Nidification and Oology, though the ornithology of the recent "Horn Expedition" has fallen to his share. Mr. Archibald J. Campbell's Nests and Eggs of Austratian Birds (Melbourne: 1883) deserves especial mention. A convenient Manual of Australian Ornithology is still a great want, aud, if supplied, would undoubtedly advance the knowledge of the wonderful bird-population of that country, and induce the inhabitants to take greater interest in it. But the work to be well done must be by Australian hands.

2 This is a posthumous publication, nomiually forming au extra number of the Journal of the Asiatic Society.

3 A multitude of papers, some very important, on Indian Ornithology, appeared in Stray Feathers, a periodical edited between 1877 and 1882 by Mr. A. O. Hume, of which the eleventh and last volume remains unfinished. 
list, with references, of the Birds of the island is contained in the Handbook of Jamaica for 1881 (pp. 103-117) ; while in 1885 Mr. Cory, ${ }^{1}$ who in 1880 had brought out, at Boston (ed. 2, 1890), a work on the Birds of the Bahama Islands (not strictly Antillean), published a List of the Birds of the West Indies, with a revised edition in the following year, and one still more elaborate, so that the words "List of" were dropped from the title, in 1889.

So admirable a "List of Faunal Publications relating to North American Ornithology" up to the year 1878 has been given by Dr. Coues as an appendix to his Birds of the Colorado Valley (pp. 567-784) that nothing more of the kind is wanted except to notice some of the chief separate works which have since appeared, for so prolific are our American relatious that it would be impossible to mention many. Among those that cannot be overlooked are Mr. Stearns's New England Bird Life (2 vols. 8vo, 1881-83), revised by Dr. Coues, and the several editions of his own Check List of North American Birds (1882), and Key to North American Birds. ${ }^{2}$ Then there is the great North American Birds of the late Prof. Baird, Dr. Brewer and Mr. Ridgway (1874-84), aud the Manual of North American Birds (1887; ed. 2, 1896) by the last of these authors; beside Capt. Bendire's Life Histories of North American Birds (4to, Washington: 1892), beautifully illustrated by figures of their eggs. Yet some of the older works are still of sufficient importance to be especially recorded here, and especially that of Alexander Wilson, whose American Ornithology, origiually published between 1808 and 1814, has gone through many editions, of which mention should be made of those issued in Great Britain by Jameson (4 vols. 16mo, 1831), and Jardine (3 vols. 8 vo, 1832). The former of these has the entire text, but no plates; the latter reproduces the plates, but the text is in places much condensed, though excellent notes are added. A continuation of Wilson's work, under the same title aud on the same plan, was issued by Bonaparte between 1825 and 1833, and most of the later editions include the work of both authors. The works of Audubon, with their continuations by Cassin and Mr. Elliot, and the Fauna Boreali-Americana

1 In the same year Mr. Cory also produced the Birds of Haiti and St. Domingo, supplying a want that had been long felt, since nothing had really been known of the ornithology of Hispaniola for nearly a century. Gundlach, Lembeye and Poey are the chief authorities on that of Cuba, while the first has also treated of the Birds of Porto Rico.

2 The second and revised edition (the first having appeared in 1872, while a fifth is now in preparation) of this useful work was published in 1884, and contains (pp. 234,235 ) a classification of North-American Birds, though being limited to them will not need detailed notice hereafter; but I may remark that the author very justly points out (p. 227) the difference, overlooked by many writers of to-day, between "natural aualysis" and the "artificial keys" now so much in vogue, the latter being merely "an attempt to take the student by a "short cut' to the name and position in the ornithological system of any specimen" he may wish to determine. Under the title of Handbook of Field and General Ornithology, the two portions of this work most valuable to the non-American reader were republished in London in 1890, and deserve to be far better known among the ornithologists of all countries than they seem to be, for they give much excellent information not to be found elsewhere. Many writers on Birds in newspapers and magazines would be often spared some silly mistakes were they to make acquaintance with Dr. Coues's little book. 
of Richardson and Swainson have already been noticed; but they need naming here, as also cloes Nuttall's Manual of the Ornithology of the United States and of Canada (2 vols. 1832-34; vol. i. ed. 2, 1840); the Birds of Long Island (8vo, 1844) by Giraud, remarkable for its excellent account of the habits of shore-birds; and of course the Birds of North America (4to, 1858) by Baird, with the co-operation of Cassin and Lawrence, which originally formed a volume (ix.) of what are known as the "Pacific Railroad Reports." Apart from these special works the scientific journals of Boston, New York, Philadelphia and Washington contain innumerable papers on the Ornithology of the country, while in 1876 the Bulletin of the Nuttall Ornithological Club began to appear, and continned until 1884, when it was superseded by The Auk, established solely for the promotion of Ornithology in America, and numbering among its supporters almost every American ornithologist of repute, its present editors being Dr. Allen and Mr. F. M. Chapman.

Of Canada, unfortmnately, not much is to be said. It is hard to understand why zoological studies have never found such favour there as further to the southward, but this is undombtedly the fact, and no ornithological work can be cited of which the Dominion as a whole can be proud, though Mr. M'Ilwraithe's Birds of Ontario, of which an enlarged edition appeared in 1894 , is a fair piece of local work.

Returning to the Old World, among the countries whose Ornithology will most interest British readers we have first Iceland, the fullestindeed the only full-account of the Birds of which is Faber's Prodromus der isländischen Ornithologie (8vo, 1822), though the island has since been visited by several good ornithologists, - Proctor, Krüper and Wolley among them. A list of its Birds, with some notes, bibliographical and biological, has been given as an Appendix to Mr. Baring-Gould's Iceland, its Scenes and Sagas (8vo, 1862); and Mr. Shepherd's North-west Peninsula of Iceland (8vo, 1867) recounts a somewhat profitless expedition made thither expressly for ornithological objects. ${ }^{1}$ For the Birds of the Færoes there is Herr H. C. Müller's Færöernes Fuglefauna (8vo, 1862), of which a German translation has appeared. ${ }^{2}$ The Ornithology of Norway has been treated in a great many papers by Herr Collett, some of which may be said to have been separately published as Norges Fugle (8vo, 1868; with a supplement, 1871), and The Ornithology of Northern Norway (8vo, 1872)-this last in English, while an English translation by Mr. A. H. Cocks (London: 1894) has been published of one of the author's latest works, a popular account of Bird-Life in Arctic Norway, communicated to the Second International Congress of Ornithology in 1892. For Scandinavia generally the latest work is Herr Collin's Skandinaviens Fugle (8vo,

1 Two papers by Messrs. Backhouse and W. E. Clarke, and Carter and Slater (Ibis, 1885 , p. $364 ; 1886$, p. 45) should be consulted, as well as one by Messrs. $\mathrm{H}$. J. and C. E. Pearson (op. cit. 1895, pp. 237-249), which gives a list of the species hitherto recorded there. Herr Gröndal has also a list and an ornithological report on Iceland (Ornis, 1886, pp. 355, 601), with a dissertation on birds' names (op.cit. 1887, p. 587).

2 Journ. für Orn. 1869, pp. 107,341,381. One may almost say an English translation also, for Col. Feilden's contribution to the Zoologist for 1872 on the same subject gives the most essential part of Herr Müller's information. 
1873), being a greatly bettered edition of the very moderate Danmarts Fugle of Kjærbölling; but the ornithological portion of Nilsson's Skandi navisk Fauna, Foglarna (3rd ed. 2 vols. 8 vo, 1858) is of great merit while the text of Sunderall's Svenska Foglarna (obl. fol. 1856-73), unfortunately unfinished at his death, but completed in 1886 by Prof. Kinberg, and Herr Holmgren's Slandinaviens Foglar (2 vols. 8vo, 186675) deserve naming.

Works on the Birds of Germany are far too numerous to be recounted. That of the two Naumanns, already mentioned, and yet again to be spoken of, stands at the head of all, and perhaps at the head of the "Faunal" works of all countries. For want of space it must here suffice simply to name some of the ornithologists who in this century have elaborated, to an extent elsewhere unknown, the science as regards their own country: -Altum, Baldamus, Bechstein, Berlepsch, Blasius (father and two sons), Bolle, Borggreve, whose Vogel-Fauna von Norddeutschland (8vo, 1869) contains what is practically a bibliographical index to the subject, Brehm (father and sons), Von Droste, Gätke, Gloger, Hintz, Holtz, Alexander and Eugen von Homeyer, Jäckel, Koch, König-IVarthausen, Krüper, Kutter, Landbeck, Landois, Leisler, Leverkühn, Von Maltzan, Matschie, Bernard Meyer, Von der Mühle, Neumann, Tobias, Johann Wolf and Zander. ${ }^{1}$ Were we to extend the list beyond the boundaries of the German empire, and include the ornithologists of Austria, Bohemia and the other states subject to the same monarch, the number would be nearly doubled; but that would overpass our proposed limits, though Von Pelzeln must be named. ${ }^{2}$ Passing onward to Switzerland, we must content ourselves by referring to the list of works, forming a Bibliographia Ornithologica Helvetica, drawn up by Dr. Stölker for Dr. Fatio's Bulletin de la Societé Ornithologique Suisse (ii. pp. 90-119); but the latter has already published a Catclogue Distributif of Swiss Birds, of which a third edition appeared in 1892, and in conjunction with Dr. Studer is bringing out a more elaborate work on the ornithology of the country, of which two parts have appeared. As to Italy, we have to name here the Faunc d'Italia, of which the second part, Uccelli (8vo, 1872), by Count T. Salvadori, contained an excellent bibliography of Italian works on the subject, while his Elenco degli Uccelli Italiani (Genova: 1887) is drawn up with his characteristic thoroughness. Then there is the posthumously published Ornitologia Italiana of Savi (3 vols, 8vo, 1873-77). But the country rejoices in what may be called an official Ornithology. This is the Avifauna Italica of Prof. Giglioli, and consists of four volumes pub-

1 This is of course no complete list of German ornithologists. Some of the most eminent of them have written scarcely a line on the Birds of their own country, as Cabanis (editor from 1853 to 1893 of the Journal für Ornithologie), Finsch, Hartlaub, Hartert, Heine, A. König, Prince Max of Wied, A. B. Meyer, Nathusius, Nehrkorn, Reichenbach and Schalow among others. In 1889 Dr. Reichenow, of whom more hereafter, published a convenient Systematisches Verweichniss der Vögel Dcutschlands und des angrenzenden Nittel-Europas.

2 An ornithological bibliography of the Austrian-Hungarian dominions was printed in the Verhandlungen of the Zoological and Botanical Society of Vienna for 1878, by Victor Ritter von T'schusi zu Schmidhofen. A similar bibliography of Russian Ornithology by Alexander Brandt was printed at St. Petersburg in 1877 or 1878. 
lished at Florence between 1886 and 1891, in which the subject is treated in the greatest detail, owing to the multitude of observers by whom the author was assisted, with the result that Ornithology stands in Italy on a footing different from that which it occupies in any other nation. But it is pleasing to observe that this official recognition has not checked independent work, and the number of local Italian faunas is far too great to be here particularized. ${ }^{1}$ Coming to the Iberian peninsula, we must in default of separate works depart from our rule of not mentioning contributions to journals, for of the former there are only Col. Irby's Omithology of the Straits of Gibraltar (8vo, 1875 ; ed. 2, 1895) ${ }^{2}$ and Mr. A. C. Smith's Spring Tour in Portugal ${ }^{3}$ to be named, and these but partially cover the ground. However, Dr. A. E. Brehm has pulblished a list of Spanish Birds (Allgem. deutsche Naturhist. Zeitung, iii. p. 431), and The Ibis contains several excellent papers by Lord Lilford and by Mr. Saunders, the latter of whom there records (1871, p. 55) the few works on Oruithology by Spanish authors, and in the Bulletin de la Societé Zoologique de France (i. p. 315 ; ii. pp. $11,89,185)$ has given a list of the Spanish Birds known to him. ${ }^{4}$

Returning northwards, we have of the Birds of the whole of France, apart from Western Europe, nothing of real importance more recent than the Oiseaux in Vieillot's Faune Francaise (8vo, 1822-29); but there is a great number of local publications of which Mr. Saunders has furnished (Zoologist, 1878, pp. 95-99) a catalogue. Some of these have appeared in journals, but many have been issued separately. Those of most interest to English ornithologists naturally refer to Britanny, Normandy and Picardy, and are by Baillon, Benoist, Blandin, Bureau, Canivet, Chesnon, Degland, Demarle, De Norguet, Gentil, Hardy, Lemetteil, Lemonnicier, Lesauvage, Maignon, Marcotte, Nourry and Taslé, while perhaps the Ornithologie Parisienne of M. René Paquet, under the pseudonym of Nérée Quépat, should also be named. Of the rest the most important are the Ornithologie Provençale of Roux (2 vols. 4to, 1825-29); Risso's Histoire naturelle... des environs de Nice (5 vols. 8vo, 1826-27); the Ornithologie du Dauphiné of Bouteille, and Labatie (2 vols. 8vo, 1843-44); the Ornithologie du Gard (8vo, 1840) and Faune Meridionale of Crespon (2 vols. 8vo, 1844); the Ornithologie de la Savoie of Bailly (4 vols. 8vo, 1853-54), and Les Richesses ornithologiques du midi de la France (4to, 1859-61) of MM. Jaubert and Barthélemy-Lapommeraye. For Belgium the Faune Belge of Baron De Selys-Longchamps (8vo, 1842) long remained the

I A compendium of Greek and Turkish Ornithology by Drs. Krüper and Hartlaub is contained in Mommsen's Griechische Jahrzeiten for 1875 (Heft III.). For other countries in the Levant there are Canon Tristram's Fauna and Flora of Palestine (4to, 1884) and Capt. Shelley's Handbook to the Birds of Egypt (8vo, 1872).

2 Mr. Abel Chapman's Wild Spain (London: 1893) contains a considerable quantity of ornithological information, chiefly from the sportsman's point of view.

3 In the final chapter of this work the author gives a list of Portuguese Birds, including beside those observed by him those recorded by Prof. Barboza du Bocage in the Gazeta Medica de Lisboa, 1861, pp. 17-21.

4 Certain papers published at Corunna by a Galician ornithologist require an explanation (cf. Sherborn, Ann. \& Mag. Nat. Hist. ser. 6, xiv. p. 154), which has not and probably never will be given. 
classical work, though the Planches coloriées des Oiseanx de la Belgique of the late M. Ch. F. Dubois (8vo, 1851-60) was so nutuch more recent. To this followed, in 1861-64, a supplementary volume, which, by including species not found in Belgium, justified an extension of the title of the whole to Planches coloriées des Oiseaux de l'Europe; while between 1876 and 1887, his son, Dr. Alphonse Dubois, devoted to Birds four volumes of his Faune illustrée des Vertébrés de la Belgique (gr. 8vo), a work remarkable for the introduction of small maps shewing the author's view of the geographical range of the several species. In regard to Holland we have Schlegel's De Vogels van Nederland (3 vols. 8vo, 1854-58; ed. 2, 2 vols. 1878), besides his De Dieren van Nederland: Vogels (8vo, 1861). ${ }^{1}$

Here it may be well to cast a glance on a few of the works that refer to Europe in general, the more so since most of them are of Continental origin. First we have the already-mentioned Manuel d'Ornithologie of Temminck, which originally appeared as a single volume in $1815^{2}$; but was speedily superseded by the second edition of 1820 , in two volumes. Two supplementary parts were issued in 1835 and 1840 respectively, and the work for many years deservedly maintained the highest position as the authority on European Ornithology-indeed in England it may almost without exaggeration be said to have been nearly the only foreigu ornithological work known; but, as may well be expected, grave defects are now to be discovered in it. Some of them were already manifest when one of its author's colleagues, Schlegel (who had been employed to write the text for Susemihl's plates, originally intended to illustrate Temminck's work), brought out his bilingual Revue critique des Oiseaux. d'Europe (8vo, 1844), a very remarkable volume, since it correlated and consolidated the labours of French and German, to say nothing of Russian, ornithologists. Of Gould's Birds of Europe (5 vols. fol. 1832-37) nothing need be added to what has been already said. The year 1849 saw the publication of Degland's Ornithologie Europénne (2 vols. 8vo), a work fully intended to take the place of Temminck's; but of which Bonaparte, in a caustic but well-deserved Revue Critique (12mo, 1850), said that the author bad performed a miracle since he had worked without a collection of specimens and without a library. A second edition, revised by $\mathbf{M}$. Gerbe ( 2 vols. 8 vo, 1867), strove to remedy, and to some extent did remedy, the grosser errors of the first, but enough still remain to make few statements in the work trustworthy unless corroborated by other evidence. Meanwhile in England the late Dr. Bree in 1858 began the publication of The Birds of Europe not observed in the British Isles (4 vols. $8 \mathrm{vo}$ ), which was completed in 1863 , and in 1875 reached a second and improved edition (5 vols.). In 1870-1 Dr. Anton Fritsch brought out his Naturgeschichte der Vögel Europas (8vo, with atlas in folio); and in 1871 Messrs. Sharpe and Dresser began the publication of their Birds of Europe, which was finished by the latter alone in 1879 ( 8 vols. 4 to), and is unquestionably the most complete work of its kind, both for fulness of information and beauty of illustration-the coloured plates being nearly all by Mr.

1 There are several important papers on Dutch Oruithology by Albarda, Blaauw, Büttikofer, Crommelin, Jentink and others.

2 Copies are said to exist bearing the date 1814 . 
Keulemans or Mr. Neale. In so huge an undertaking mistakes and omissions are of course to be found if any one likes the invidious task of seeking for them; but many of the error's imputed to this work prove on investigation to refer to matters of opinion rather than of fact, while many more are explicable if we remember that while the work was in progress Ornithology was being prosecuted with umprecedented activity, and thus statements which were in accordance with the best information at the beginning of the period were found to need modification before it was ended. As a whole European ornithologists have been all but unanimously grateful to Mr. Dresser for the way in which he brought this enormous labour to a successful end. A Supplement to his work is now nearly finished. The late M. des Murs in 1886 completed his Description des Oiseaux d'Europe (4 vols. gr. 8 vo), with coloured figures of the Birds and of their egrs, but it is rather a popular than a scientific work. The Contributions à la Faune ornithologique de l'Europe Occidentale of the late M. Olphe-Galliard, contained in 41 fascicules between 1884 and 1892 , is an important work, involving a vast amount of research, and composed in a highly original way. The author was well read in ornithological literature, for he had the accomplishment, rare among his countrymen, of a good acquaintance with modern languages not his own, and was especially observant of the doings of foreign naturalists. Yet the work cannot be called wholly successful, and this chiefly, it would seem, through the want of autoptical acquaintance with many of the species treated, or at least with a sufficient series of specimens, whereby he has been led to rely too much on the descriptions of others, with the usual unsatisfactory result. Still the work fully deserves attention, and nothing need be said of the author's fanciful classification, for no one is likely to follow it. In 1890 Mr. Backhouse brought out a convenient little Handbook of European Birds. ${ }^{1}$

Coming now to works on British Birds only, the first of the present century that requires remark is Montagu's Ornithological Dictionary (2 vols. 8vo, 1802 ; supplement 1813), the merits of which have been so long and so fully acknowledged. both abroad and at home that no further comment is here wanted. In 1831 Rennie brought out a modified edition of it (reissued in 1833), and Newman another in 1866 (reissued in 1883); but those who wish to know the author's views should consult the original. Next in order come the very inferior British Ornithology of Graves (3 vols. 8vo, 1811-21; ed. 2, 1821), and a better work with the same title by Hunt ${ }^{2}$ (3 vols. 8vo, 1815-22), published at Norwich, but never finished. Then we have Selby's Illustrations of British Ornithology, two folio volumes of coloured plates engraved by himself, between 1821 and 1833, with letterpress also in two volumes (8vo, 1825-33), a second

1 Herr Gätke's remarkable Fogeluarte IIelgoland (Braunschweig: 1891), which treats of much more than European ornithology, has been elsewhere (MIGRATION, p. 562) mentioned. It remains to say that a fair English translation by Mr. Rosenstock, with a preface by Mr. Harvie-Brown, has appeared under the title of Heligoland as an Oinithological Observatory (Edinburgh: 1895).

2 The text was written, I was told by the late Mr. Joseph Clarke, by $\mathrm{P}$. C. Coxe, who was a schoolboy when it was begun, but died in 1863 Archdeacon of Lindisfarne. 
edition of the first volume being also issued (1833), for the author, having yielded to the pressure of the "Quinarian" doctrines then in vogue, thought it necessary to adjust his classification accordingly, and it must be admitted that for information the second edition is best. In 1828 Fleming brought out his History of British Animals (8vo), in which the Birds are treated at considerable length (pp. 41-146), though not with great success. In 1835 Jenyns (afterwards Blomefield) produced an excellent Manual of British Vertebrate Animals, a volume (8vo) executed with great scientific skill, the Birds again receiving due attention (pp. 49-286), and the descriptions of the various species being as accurate as they are "terse. ${ }^{1}$ In the same year began the Coloured Illustrations of British Birds and their Eggs of H. L. Meyer (4to), which was completed in 1843, whereof a second edition (7 vols. 8 vo, 1842-50) was bronght out, and subsequently (1852-57) a reissue of the latter. In 1836 appeared Eyton's History of the rarer British Birds, intended as a sequel to Bewick's well-known volumes, to which no important additions had been made since the issue of 1821. The year 1837 saw the beginning of two remarkable works by Macgillivray and Yarrell respectively, and each entituled A History of British Birds. Of the first, undoubtedly the more original and in many respects the more minutely accurate, mention will again have to be made, and, save to state that its five volumes were not completed till 1852, nothing more needs now to be added. The second unquestionably became the standard work on British Ornithology, a fact due in part to its numerous illustrations, many of them indeed ill drawn, though all carefully engraved, but much more to the breadth of the author's views and the judgment with which they were set forth. In practical acquaintance with the internal structure of Birds, and in the perception of its inıportance in classification, he was certainly not behind his rival; but he well knew that his public in a Book of Birds not only did not want a series of anatomical treatises, but would even resent their introduction. He had the art to conceal his art, and his work was therefore a success, while the other was unhappily a failure. Yet with all his knowledge he was deficient in some of the qualities which a great naturalist ought to possess. His conception of what his work should be seems to have been perfect, his execution was not equal to the conception. However, he was not the first nor will he be the last to fall short in this respect. For him it must be said that, whatever may have been done by the generation of British ornithologists now becoming adranced in life, he educated them to do it; nay, his influence even extends to a younger generation still, though they may hardly be aware of it. Of Yarrell's work in three volumes, a second edition was published in 1845, a third in 1856, and a fourth, begun in 1871, and almost wholly rewritten, was finished in 1885 by Mr. Saunders, who in 1888 and 1889, carrying out the suggestion of a brother ornithologist, skilfully condensed the whole into a single volume, forming a useful Manual of British Birds, illustrated by the same figures as the larger work. Of other compilations based upon it, without which they could not have been composed, there is no need to

1 A series of MS. notes which he gave to the Cambridge Museum shews that he was largely aided by his brother-in-law Henslow, the botanist. 
speak. ${ }^{1}$ One of the few appearing since, with the same scope, that are not borrowed is Jardine's Birds of Great Britain and Ireland ( 4 vols. 8vo, 1838-43), forming part of his Naturalist's Library; and Gould's Birds of Great Britain has been already mentioned. ${ }^{2}$ Two imposing folios, with very good plates by Mr. Keulemans, were issued with the title of Rough Notes on Birds in the British Islands during 1881 to 1887 , by the late Mr. Booth (whose "Museum" is one of the popular sights of Brighton), and contain a great number of personal observations, though few of any novelty or value, while as a record of butchery the work fortunately stands alone. Lord Lilford's Coloured Figures of the Birds of the British Islands, begun in 1885 and now nearly completed, has given great pleasure to many lovers of Birds, by whom such a series of plates was strongly desired, for they are generally good, and some of the latest, by Mr. Thorburn, are exquisite. ${ }^{3}$

The good effects of "Faunal" works such as those named in the foregoing rapid survey none can doubt. "Every kingdom, every province, should have its own monographer," wrote Gilbert White, and experience has proved the truth of his assertion. It is from the labours of nono-

1 Yet two of them have attained great popularity, and have exerted such an influence in this country, that as a matter of history their authors, both deceased, must here be named, though I would willingly pass them over, for I have not a word to say in favour of either. By every well-informed ornithologist the History of British Birds of Mr. Morris has long been known to possess no authority; but about Mr. Seebohm's volumes with the same title there is much difference of opinion, some holding them in high esteem. The greater part of their text, when it is correct, will be found on examination to be a paraphrase of what others had already written, for even the information given on the author's personal experience, which was doubtless considerable, extends little or no further. But all this is kept studiously out of sight, and the whole is so skilfully dressed as to make the stalest observations seem novel - a merit, I am assured, in some eyes. Of downright errors and wild conjectures there are enough, and they are confidently asserted with the misuse of language and absence of reasoning power that mark all the author's writings, though the air of scientific treatment assumed throughout has deluded many an unwary reader.

2 Though contravening our plan, we must for its great merits notice here the late Mr. More's series of papers in The Ibis for 1865, "On the Distribution of Birds in Great Britain during the Nesting Season."

3 Local ornithologies are far too numerous to be named at length. Fortunately Mr. Christy has published a Catalogue of them (Zool. 1890, pp. 247-267, and separately, London: 1891), and only a few of the most remarkable and the most recent need here be mentioned. The first three volumes of Thompson's Natural History of Ireland (1849-51) cannot be passed over, as containing an excellent account, to equal which no approach has since been made, of the Birds of that country, though there are many important papers by later Irish ornithologists, as Messrs. Barrett-Hamilton, Blake-Knox, H. L. Jameson, P. Paterson, Ussher and Warren, and conspicuously by Mr. Barringtou. For North Britain, Robert Gray's Birds of the West of Scotland (1871), and the series of district Vertebrate Faunas, begun by Messrs. Harvie-Brown and T. E. Buckley, of which 7 volumes have now appearedtreating of (1) Sutherland, Caithness and West Cromarty, (2) Outer Hebrides, (3) Argyll and Inner Hebrides, (4) Iona and Mill (this by Graham), (5) Orkney and (6 and 7) Moray - while others, as Dee and Shetland, are in progress, calls for especial remark, as does Mr. MIuirhead's Birds of Berwickshire (2 vols. 1889-96); but for want of space many meritorious papers in journals, by Alston, Dalgleish, W. Evans, Lumsden and others must here be unnoticel. The local works on English Birds are still more numerous, but among them may be especially named the oldest of all, Tucker's unfinished Ornithologia Danmoniensis (4to, 1809 ), au ambitions work of which not even the whole of 
graphers of this kind, but on a more extended scale, when brouglit together, that the valuable results follow which inform us as to GEOGRAPHICAL Distribdtion. Important as they are, they do not of themselves constitute Ornithology as a science; and an enquiry, no less wide and far more recondite, still remains-that having for its object the discovery of the natural groups of Birds, and the mutual relations of those groups, which, has always been of the deepest interest, and to it we must now recur.

But nearly all the authors abore named, it will have been seen, trod the same ancient paths, and in the works of scarcely one of them had any new spark of intelligence been struck out to enlighten the gloom which surrounded the investigator. It is now for us to trace the rise of the present more advanced school of ornithologists whose labours, preliminary as we must still regard them to be, yet give signs of far greater promise. It would probably be unsafe to place its origin further back than a few scattered hints contained in the 'Pterographische Fragmente' of Christian Ludwig Nitzsch, published in the Magazin für den neuesten Zustand der Naturlunde (edited by Voigt) for May 1806 (xi. pp. 393-417), and even these might be left to pass unnoticed, were it not that we recognize in them the germ of the great work which the same admirable zoologist subsequently accomplished. In these "Fragments," apparently his earliest productions, we find him engaged on the subject with which his name will always be especially identified, the structure and arrangement of the feathers that form the proverbial characteristic of Birds. But, though the observations set forth in this essay were sufficiently novel, there is not much in them that at the time would have attracted attention, for perhaps no one-not even the author himself-could have then foreseen to what important end they rould, in conjunction with other investigations, lead future naturalists; but they are marked by the close and patient determination that eminently distinguishes all the work of their author; and, since it will be necessary for us to return to this

the somewhat turgid Introduction was published; but the two parts printed shew the author to have been a physiologist, anatomist and outdoor-observer far beyoud most meu of his time, beside being of a philosophical turn, well acquainted with literature, and an agreeable writer. At a long interval follow Dillwyn's Fauna and Flora of Swansea (1848); Knox's Ornithological Rambles in Sussex (1849) ; Mr. Harting's Birds of Middlesex (1866) ; Stevenson's Birds of Norfolk (3 vols. 1866-90, completed by Mr. Southwell) ; Cecil Smith's Birds of Somersct (1869) and of Guernsey (1879); Mr. Cordeaux's Birds of the Humber District (1872) ; Hancock's Birds of Northumber. land and Durham (1874); The Birds of Nottinghamshire by Messrs. Sterland and Whitaker (1879); Rodd's Birds of Cornwall, edited by Mr. Harting (1850); the Vertebrate Fauna of Yorkshire (1881), in which the Birds are by Mr. W. E. Clarke ; Churchill Babington's Birds of Suffolk (18S4-6); aud Mr. A. C. Smith's Birds of Wiltshire (1887). Since the publication of Mr. Cliristy's Catalogue a few more bave to be briefly mentioned, and first his own volume ou the Birds of Essex (1890), while those of Sussex were treated in 1891 by Mr. Borrer; Worcestershire (1891) by Mr. Willis Bund; Devonshire (1891) by Mr. Pidsley and (1892) by Messrs. D'Urban and Mathew (Suppl. and (ed. 2, 1895) ; Lakcland (1892) by Mr. H. A. Macphersou ; Lancashire (ed. 2, 1893) by Mr. F. S. Mitchell ; London (1893) by Mr. Swann; Derbyshire (1893) by Mr. Whitlock, and finally Northamptonshire (2 vols. 1895) by Lord Lilford. The papers in journals are countless, but almost all up to the time of compilation are contained in the excellent List of Faunal Publications relating to British Birds, published in 1880 by Dr. Coues (Proc. U. S. Nat. Mus. ii. pI. 359-482). 
part of the subject later, there is here no need to say more of them. In the following year another set of hints - of a kind so different that probably no one then living would have thought it possible that they should ever be brought in correlation with those of Nitzsch-are contained in a memoir on Fishes contributed to the tenth volume of the Annales du Muséum d'histoire naturelle of Paris by Étienne Geoffroy St.Hilaire in 1807.l Here we have it stated as a general truth (p. 100) that young birds have the sternum formed of five separate pieces-one in the middle, being its keel, and two "annexes" on each side to which the ribs are articulated-all, however, finally uniting to form the single "breast-bone." Further on (pp. 101, 102) we find observations as to the number of ribs which are attached to each of the "annexes"- - there being sometimes more of them articulated to the anterior than to the posterior, and in certain forms no ribs belonging to "one, all being applied to the other. Moreover, the author goes on to remark that in adult birds trace of the origin of the sternum from five centres of ossification is always more or less indicated by sutures, and that, though these sutures had been generally regarded as ridges for the attachment of the sternal muscles, they indeed mark the extreme points of the five primary bony pieces of the sternum.

In 1810 appeared at Heidclberg the first volume of Tiedemann's carefully-wrought Anatomie und Naturgeschichte der Vögel-which shews a remarkable advance upon the work which Cuvier did in 1805, and in some respects is superior to his later production of 1817. It is, however, only noticed here on account of the numerous references made to it by succeeding writers, for neither in this nor in the author's second rolume (not published until 1814) did he propound any systematic arrangement of the Class. More germane to our present subject are the Osteographische Beiträge zur Naturgeschichte der Vögel of Nitzsch, printed at Leipzig in 1811-a miscellaneons set of detached essays on some peculiarities of the skeleton or portions of the skeleton of certain Birds-one of the most remarkable of which is that on the component parts of the foot (pp. 101-105) pointing out the aberration from the ordinary structure exhibited by Caprimulgus (NIGHTJAR) and Cypselus (SwIFT) - an aberration which, if rightly understood, would have conveyed a warning to these ornithological systematists who put their trust in Birds' toes for characters on which to erect a classification, that there was in them much more of importance, hidden beneath the integument, than had hitherto been suspected; but the warning was of little avail, if any, till many years had elapsed. However, Nitzsch had not as yet seen his way to proposing any methodical arrangement of the various groups of Birds, and it was not until some eighteen months later that a sclieme of classification in the main anatomical was attempted.

This scheme was the work of Blasius Merrem, who, in a communication to the Academy of Sciences of Berlin on the 10th December 1812, and published in its Abhandlungen for the following year (pp. 237-259),

I In the Philosophie Anatomique (i. pp. 69-101, and especially pp. 135, 136), which appeared in 1818, Geoffroy St.-Hilaire explained the views he had adopted at greater length. 
set forth a Tentamen Systematis naturalis Avium, no less "modestly entitled than modestly executed. The attempt of Merrem must be regarded as the virtual starting-point of the more recent efforts in Systematic Ornithology, and in that view its proposals deserve to be stated at length. Some of its details, as is only natural, cannot be sustained with our present knowledge, resulting from the information accumulated by various investigators throughont more than eighty years; but it is certainly not too much to say that Merrem's merits are incomparably superior to those of any of his predecessors as well as to those of the majority of his successors for a long time to come; while the neglect of his treatise by many (until of late it wonld not be erroneous to say by most) of those who liave since written on the subject seems inexcusable save on the score of inadvertence. Premising then that the chief characters assigned by this ill-appreciated systematist to his several groups are drawn from almost all parts of the structure of Birds, and are supplemented by some others of their more prominent peculiarities, we present the following abstract of his scheme: ${ }^{1}$

I. Aves carinate.

1. Aves aereæ.

A. Rapaces.-a. Accipitres-Vultur, Falco, Sagittarius.

b. Strix.

B. Hymenopodes, - $a$. Chelidones :

a. C. nocturnæ-Caprimulgus.

B. C. diurnæ-Hirundo.

b. Oscines :

a. O. conirostres-Loxia, Fringilla, Emberizl, Tangara.

B. O. tenuirostres - Alauda, Motacilla, Muscicapa, Todus, Lanius, Ampelis, Turdus, Paradisea, Buphaga, Sturnus, Oriolus, Gracula, Coracias, Corvus, Pipra?, Parus, Sitta, Certhix quædam.

C. Mellisugæ. - Trochilus, Certhiæ et Upupæ plurimæ.

D. Dendrocolaptæ.-Picus, I unx.

E. Brevilingues. - $\alpha$. Upupa; b. Ispida.

F. Levirostres. - a. Ramphastus, Scythrops?; b. Psittacus.

G. Coccyges. - Cuculus, Trogon, Bucco, Crotophagu.

2. Aves terrestres.
A. Columba.
B. Gallinx.

3. Aves aquaticæ.

A. Odontorhynchi : $a$. Boscades-Anas; $b$. Mergus; e. Phonicopterus.

B. Platyrhynchi.-Pelicanus, Phaeton, Plotus.

C. Aptenodytes.

D. Urinatrices: $a$. Cepphi-Alca, Colymbi pedibus palmatis; b. Podiceps, Colymbi pedibus lobatis.

E. Stenorhynchi._Procellaria, Diomedea, Larus, Stcrna, Rhynchops.

4. Aves palustres.

A. Rusticolæ : a. Phalarides-Rallus, Fulica, Parra; b. Limosugæ-Áumenius, Scolopax, Tringa, Charadrius, Recurvirostra.

B. Grallæ: $a$. Erodii-Arder ungue intermedio serrato, Cancroma; b. Pelargi -Ciconia, Mycteria, Tantali quidam, Seopus, Platalea; c. Geraui-C. Otis. Arder cristati, Grues, Psophia

II. Aves RATITE. - Struthio.

1 The names of the genera are, he tells us, for the most part those of Linnæus, as being the best-known, though not the best. To some of the Linnæan genera he 
The most novel feature, and one the importance of which most ornithologists of the present day are fully prepared to admit, is of course the separation of the Class Ares into two great Divisions, which from one of the most obvious distinctions they present were called by its author Carinatix ${ }^{1}$ and Ratitx, ${ }^{2}$ according as the sternum possesses a keel or not. But Merrem, who subsequently communicated to the Academy of Berlin a more detailed memoir on the "flat-breasted" Birds, ${ }^{3}$ was careful not here to rest his Divisions on the presence or absence of their sternal character alone. He concisely cites (p. 238) no fewer than eight other characters of more or less value as peculiar to the Carinate Division, the first of which is that the feathers have their barbs furnished with hooks, in consequence of which the barbs, including those of the wing-quills, cling closely together; while among the rest may be mentioned the position of the furcula and coracoids, ${ }^{4}$ which keep the wing-bones apart; the limitation of the number of the lumbar vertebræ to fifteen, and of the carpals to two; as well as the divergent direction of the iliac bones, - the corresponding characters peculiar to the Ratite Division being (p. 259) the disconnected condition of the barbs of the feathers, through the absence of any hooks whereby they might cohere; the non-existence of the furcula, and the coalescence of the coracoids with the scapulæ (or, as he expressed it, the extension of the scapulie to supply the place of the coracoids, which he thought were wanting); the lumbar vertebræ being twenty and the carpals three in number; and the parallelism of the iliac bones.

As for Merrem's partitioning of the inferior groups there is less to be said in its praise as a whole, though credit must be given to his anatomical knowledge for leading him to the perception of several affinities, as well as differences, that had never before been suggested by superficial systematists. But it must be confessed that (chiefly, no doubt, from paucity of accessible material) he overlooked many points, both of alliance and the opposite, which since his time have gradually come to be aclmitted. For instance, he seems not to have been aware of the distinction, already shewn by Nitzsch (as above mentioned) to exist, between the Srallows and the Swifts; and, by putting the genus Coracias among his Oscines Tenuirostres ${ }^{5}$ withont any remark, prored that lie was not in all respects greatly in advance of his age; but on the other hand he most righteously juilged that some species hitherto referred to the genera Certhic and Upupa required removal to other positions, and it is much to dare not, howerer, assign a place, for instance, Buceros, Hamutopus, Merops, Glareola (Brisson's genus, by the way) and Palamedea.

1 From carina, a lieel.

2 From ratis, a raft or flat-bottomed barge.

3 "Beschreibung der Gerippes eines Casuars nebst einigen beiläufigen Bemerkungen über die fiachbriistigen Vögel." - Abhandl. der Berlin. Aliadcmie, Phys. Klasse, 1817, pp. 179-19s, tabb. i.-iii.

"Merrem, as did many others in his time, calls the coracorns "claviculie"; but it is now well understood that in Birds the real elavicula form the FURCOLA.

5 He also placed the genus Todus in the same group, but it must be borne in mind that in his time a great many Birds were referred to that genus which certainly do not belong to it, and it may well have been that he never had the opportunity of examining a specimen of the genus as nowadays restricted. 
be regretted that the very concise terms in which his decisions were given to the world make it impossible to determine with any degree of certainty the extent of the changes in this respect which he would have introdnced. Had Merrem published his scheme on an enlarged scale, it seems likely that he would have obtained for it far more attention, and possibly some portion of acceptance. He had deservedly attained no little reputation as a descriptive anatomist, and his claims to be regarded as a systematic reformer would probably lave been admitted in his lifetime. As it was his scheme apparently fell flat, and not until many years had elapsed were its merits at all generally recognized.

Notice has next to be taken of a Memoir on the Employment of Sternal Characters in establishing Natural Families among Birds, which was read by De Blainville before the Academy of Sciences of Paris in $1815,{ }^{1}$ but not published in full for more than five years later (Journ. de Physique, xcii. pp. 185-215), though an abstract forming part of a Prodrome d'une nouvelle distribution du Règne Animal, appeared earlier (op. cit. Ixxxiii. pp. 252, 253, 258, 259; and Bull. Soc. Philomat. Paris, 1816, p. 110). This is a very disappointing performance, since the author observes that, notwithstanding his new classification of Birds is based on a study of the sternal apparatus, yet, because that lies wholly within the body, he is compelled to have recourse to such ontward characters as are afforded by the proportion of the limbs and the disposition of the toeseven as had been the practice of most ornithologists before him! It is evident that the features of the sternum on which De Blainville chiefly relied, though he states the contrary, were those drawn from its posterior margin, which no very extensive experience of specimens is needed to shew are of comparatively slight value; for the number of "échancrures" -notches as they have sometimes been called in English-when they exist, goes but a very short way as a guide, and is so variable in some very natural groups as to be even in that short way occasionally misleading.? There is no appearance of his having taken into consideration the far more trustworthy characters furnished by the anterior part of the sternum, as well as by the coracoids and the furcula. Still De Blainville made some advance in a right direction, as for instance by elevating the Parrots ${ }^{3}$ and the Pigeons as "Ordres," equal in rank to that of the Birds-of-Prey and some others. According to the testimony of L'Herminier (for whom see later) he divided the "Passereaux" into two sections, the "faux" and the "vrais"; but, while the latter were very correctly defined, the former were most arbitrarily separated from the "Grimpeurs." He also split his Grallatores and Natatores (practically identical with the Gralla and Anseres of Linnæus) each into four sections; but he failed to see-as on his own principles he ought to have seen-that each of these sections was at least equivalent to almost any one of his other "Ordres." He had, however, the courage to act up to his own professions in collocating the Rollers

1 Not 1812, as has sometimes been stated, probably on his own authority (loc. cit. p. 110), but this seems to be a misprint for 1815 .

2 Cf. Philos. Trans. $1869, \mathrm{p}$. 337 , note.
3 This view had been long before taken authors.

This view had been long before taken by Willughby, but abandoned by later 
(Coracias) with the Bee-eaters (Merops), and had the sagacity to surmise that Menura was not a Gallinaceous Bird. The greatest benefit conferred by this memoir probably is that it stimulated the efforts, presently to be mentioned, of one of his pupils, and that it brought more distinctly into sight that other feature (page 48), originally discovered by Merrem, of which it now clearly became the duty of systematizers to take cognizance.

Following the order of time we next have to recur to the labours of Nitzsch, who, in 1820, in a treatise on the Nasal Glands of Birds-a subject that had already attracted the attention of Jacobson (Nouv. Bull. Soc. Philomat. Paris, iii. pp. 267-269)-first prtt forth in Meckel's Deutsches Archiv fiur die Physiologie (vi. pp. 251-269) a statement of lis general views on ornithological classification which were based on a comparative examination of those bodies in various forms. It seems unnecessary here to occupy space by giving an abstract of his plan, ${ }^{1}$ which hardly includes any but European species, because it was subsequently elaborated with no inconsiderable modifications in a way that must presently be mentioned at greater length. But the scheme, crude as it was, possesses some interest. It is not only a key to much of his later work - to nearly all indeed that was published in his lifetime_-but in it are founded several definite groups (for example, Passerinæ and Picariæ) that subsequent experience has shewn to be inore or less natural; and it furtber serves as additional evidence of the breadth of his views, and his trust in the teachings of anatomy; for it is clear that, if organs so apparently insignificant as these nasal glands were found worthy of being taken into account, and capable of forming a base of operations, in drawing up a system, it would almost follow that there can be no part of a Bird's organization that by proper study would not help to supply some means of solving the great question of its affinities. This seems to be one of the most certain general truths in Zoology, and it is probably admitted in theory to be so by most zoologists, but their practice is opposed to it ; for, whatever group of animals be studied, it is found that one set or another of characters is the chief favourite of the authors consulted-each generally taking a separate set, and that to the exclusion of all others, instead of effecting a combination of all the sets and taking the aggregate. ${ }^{2}$

That Nitzsch took this extended view is abundantly proved by the valuable series of ornithotomical observations which he must have been for some time accumulating, and almost immediately afterwards began to contribute to the younger Naumann's excellent Naturgeschichte der Vögel Deutschlands, already noticed. Beside a concise general treatise on the Organization of Birds to be found in the introduction to that work (i. pp.

1 This plan, having been repeated by Schöpss in 1829 (op. cit. xii. p. 73), became known to Owen in 1835 , who then drew to it the attention of Kirby (Seventh Bridgewater Treatise, ii. pp. 444,445), and in the next year referred to it in his own article "Aves" (Todd's Cyclop. Anat. i. p. 226), so that Englishmen need no excuse for not being aware of one of Nitzsch's labonrs, though his more advanced work of 1829 , presently to be mentioned, was not cited by Owen.

2 A remarkable instance of this may be seen in the Systema Avium, promulgated in 1830 by Wagler (a man with great knowledge of Birds) in his Natürliches System der Amphibien (pp. 77-128). He took the tongue as his chief. guide, and found it indeerl an vnruly member. 
23-52), a brief description from Nitzsch's pen of the peculiarities of the internal structure of nearly every genus is incorporated with the author's prefatory remarks, as each passed under consideration, and these descriptions being almost without exception so drawn up as to be comparative are accordingly of great utility to the student of classification, though they have been greatly neglected. Upon these descriptions he was still engaged till death, in 1837, put an end to his labours, when his place as Nanmann's assistant for the remainder of the work was taken by Rudolph Wagner; but, from time to time, a few more, which he had alrearly completed, made their posthumous appearance in it, and, even in recent years, some selections from his unpublished papers have through the care of Giebel been presented to the public. Throughout the whole of this series the same marvellous industry and scrupulous accuracy are manifested, and attentive study of it will shew how many times Nitzsch anticipated the conclusions at which it took some modern taxonomers fifty years to arrive. Yet over and over again his determination of the affinities of several groups even of European Birds was disregarded ; and his labours, being contained in a bulky and costly work, were hardly known at all outside of his own country, and within it by no means appreciated so much as they deserved ${ }^{1}$ - for even Nammann himself, who gave them publication, and was doubtless in some degree influenced by them, utterly failed to perceive the importance of the characters offered by the song-muscles of certain groups, though their peculiarities were all duly described and recorded by his coadjutor, as some indeed had been long before by Cuvier in his famous dissertation ${ }^{2}$ on the organs of voice in Birds (Legons d'anat. comp. iv. pp. 450-491). Nitzsch's name was subsequently dismissed by Cuvier withont a word of praise, and in terms which would have been applicable to many another and inferior anthor, while Temminck, terming Naumann's work an "ouvrage de luxe," -it being in truth one of the cheapest for its contents ever published,-effectually shnt it out from the realms of science. In Britain it seems to have been positively unknown until quoted some years after its completion by a catalogue-compiler on account of some peculiarities of nomenclature which it presented. ${ }^{3}$

Now we must return to France, where, in 1827, L'Herminier, a creole of Guadeloupe and a pupil of De Blainville's, contributed to the Actes of the Linnæan Society of Paris for that year' (vi. pp. 3-93) the 'Recherches sur l'appareil sternal des Oiseanx,' which the precept and example of his master had prompted him to undertake, and Cuvier had found for him the means of executing. A second and considerably enlarged edition of this very remarkable treatise was published as a separate work in the following year. We have already seen that De Blainville, though fully persuaded of the great value of sternal features as a method of classification, had been compelled to fall back upon the old pedal characters so often

1 Their value was, however, understood by Gloger, who in 1834, as will presently be seen, expressed his regret at not being able to use them.

2 Cuvier's first observations on the subject seem to have appeared in the Magazin Encyclopéclique for 1795 (ii. pp. 330, 358).

3 However, to this catalogne-compiler my gratitude is due, for thereby I became acquainted with the work and its merits. 
employed before; but now the scholar had learnt to excel his teacher, and not only to form an at least provisional arrangement of the various nembers of the Class, based on sternal characters, but to describe these characters at some length, and so give a reason for the faith that was in him. There is no evidence, so far as we can see, of his having been aware of Merrem's views; but like that anatomist he without hesitation divided the Class into two great "coupes," to which he gave, however, no other names than "Oiseaux Normaux" and "Oiseaux Anomaux,"-exactly corresponding with his predecessor's Carinatx and Ratitx-and, moreover, he had a great advantage in founding these groups, since he had discovered, apparently from his own investigations, that the mode of ossification in each was distinct; for hitherto the statement of there being five centres of ossification in every Bird's sternum seems to have been accepted as a general truth, without contradiction, whereas in the Ostrich and the Rhea, at any rate, L'Herminier found that there were but two such primitive points, ${ }^{1}$ and from analogy he judged that the same would be the case with the Cassowary and the Emeu, which, with the two forms mentioned above, made up the whole of the "Oiseaux Anomaux" whose existence was then generally acknowledged." These are the forms which composed the Family previously termed Cursores by De Blainville; but L'Herminier was able to distinguish no fewer than thirty-four Families of "Oiseaux Normaux," and the judgment with which their separation and definition were cffected must be deemed on the whole to be most creditable to him. It is to be remarked, however, that the wealth of the Paris Museum, which he enjoyed to the full, placed him in a situation incomparably more favourable for arriving at results than that which was occupied by Merrem, to whorn many of the most remarkable forms were inaccessible, while L'Herminier had at his disposal examples of nearly every type then discovered. But the latter used this privilege wisely and well-not, after the manner of De Blainville and others subsequent to him, relying solely or even chicfly on the character afforded by the posterior portion of the sternum, but taking also into consideration those of the anterior, as well as of the in some cases still more important characters presented by the presternal bones, such as the furcula, coracoids and scapulæ. L'Herminier thus separated the families of "Normal Birds":-

1. "Accipitres"-Accipitres, Linn.

2. "Serpentaires" - Gypogeranus, Illiger.

3. "Chonettes"-Strix, Linn.

4. "Touracos"-Opaetus, Vieillot.

5. "Perroquets"-Psittacus, Linn.

6. "Colibris"-Trochilus, Linn.

7. "Martinets"-Cypselus, Illiger.

8. "Engoulevents" - Caprimulgus, Linn.

9. "Concous"-Cuculus, Linn.
10. "Couroucous"-Trogon, Linn.

11. "Rolliers"-Galgulus, Brisson.

12. "Gnêpiers" - Iferops, Linn.

13. "Martins-Pêcheurs" - -Alcedo, Linn.

14. "Calaos"-Buceros, Linn.

15. "Toucans"-Ramphastos, Linn.

16. "Pies"-Picus, Linn.

17. "Épopsides" -Epopsides, Vieillot.

18. "Passereaux" - Passeres, Linn.

19. "Pigeons"-Columba, Linn.

20. "Gallinacés"-Gallinacea.

1 This fact in the Ostrich appears to have been known already to Geoffroy St. Hilaire from his own observation in Egypt, but does not seem to have been published by him.

2 Considerable doubts were at that time, as said elsewhere (KIwI), entertained in Paris as to the existence of the Apteryx. 
21. "Tinamous"-Tinamus, Latham.

22. "Foulques ou Poules d'eau" Fulica, Linn.

23. "Grues"-Grus, Pallas.

24. "Hérodions"-Herodii, Illiger.

25. No name given, but said to include "les ibis et les spatules."

26. "Gralles ou Échassiers"-Grallx.
27. "Monettes"-Larus, Linn.

28. "Pétrels"-Procellaria, Linn.

29. "Pélicans"-Pelecanus, Limn.

30. "Canards"-Ancıs, Linn.

31. "Grèbes"-Podiceps, Latham.

32. "Plongeons"-Colymbus, Latham.

33. "Pingouins" - Alca, Latham.

34. "Manchots"-Aptenodytes, Forster.

The preceding list is given to shew the very marked agreement of L'Herminier's results compared witl those obtained fifty years later by another investigator, who approached the subject from an entirely different, though still osteological, basis. The sequence of the Families adopted is of course open to much criticism; but that wonld be wasted upon it at the present day; and the cautious naturalist will remember that it is generally difficult and in most cases absolutely impossible to deploy even a small section of the Animal Kingdom into line. So far as a linear arrangement will permit, the above list is very creditable, and will not only pass muster, but camnot easily be surpassed for convenience even at this moment. Experience has shewn that a few of the Families are composite, and therefore require further splitting ; but examples of actually false grouping cannot be said to occur. The most serious fault perhaps to be found is the intercalation of the Ducks (No. 30) between the Pelicans and the Grebes-but every systematist must recognize the difficulty there is in finding a place for the Ducks in any arrangement we can at present contrive that shall be regarded as satisfactory. Many of the excellences of L'Herminier's method could not be pointed out without too great a sacrifice of space, because of the details into which it would be necessary to enter ; but the trenchant way in which he shewed that the "Passereanx" -a gromp of which Cuvier had said "Son caractere semble d'abord purement négatif," and had failed to define the limits-differed so completely from every other assemblage, while maintaining among its own innumerable members an almost perfect essential homogeneity, is very striking, and shews how admirably he could grasp his subject. Not less conspicuous are his merits in disposing of the groups of what are ordinarily known as Water-birds, his indicating the affinity of the Rails (No. 22) to the Cranes (No. 23), and the severing of the latter from the Herons (No. 24). His union of the Snipes, Sandpipers and Plovers into one group (No. 26) and the alliance, especially dwelt upon, of that group with the Gulls (No. 27) are steps which, though indicated by Merrem, are here for the first time clearly laid down; and the separation of the Gulls from the Petrels (No. 28) - a step in advance already taken, it is true, by Illiger-is here placed on indefeasible ground. With all this, perhaps on account of all this, L'Herminier's efforts did not find favour with his scientific superiors, and for the time things remained as though his investigations had never been carried on. ${ }^{1}$

Two years later Nitzsch, who was indefatigable in his endeavour to

1 With the exception of a brief and wholly inadequate notice in the Edinburgh Journal of Natural History (i. p. 90), I am not aware of attention having been directed to L'Herminier's labours by British ornithologists for several years after; but considering how they were employing themselves at the time (as is shewn in another place) this is not surprising. 
discover the Natural Families of Birds, and had been pursuing a series of researclies into their vascular system, published the result, at Halle in Saxony, in his Observationes de Avium arteria carotide communi, in which is included a classification drawn up in accordance with the variation of structure which that important vessel presented in the several groups that he had opportunities of examining. By this time he had visited several of the principal museums on the Continent, among others Leyden (where Temminck lived) and Paris (where he had frequent intercourse with Cuvier), thus becoming acquainted with a considerable number of exotic forms that had hitherto been inaccessible to him. Consequently his labours had attained to a certain degree of completeness in this direction, and it may therefore be expedient here to name the different groups which he thus thought himself entitled to consider established. They are as follows :-

\section{Aves Carinate [I'H. "Oiseanx Normaux"].}

A. Aves Cariuatæ aereæ.

1. Accipitrinx [L'H. 1, 2 partim, 3] ; 2. Passerinx [L'H. 18] ; 3. Macrochires [L'H. $6,7]$; 4. Cuculinæ [L'H. 8, 9, 10 (qu. 11, 12 ?)]; 5. Picinæ [I,H. 15, 16]; 6. Psittacinx [L'H. 5]; 7. Lipoglosse [L'H. 13, 14, 17] ; 8. Amphibolæ [L'H. 4].

B. Aves Carinatæ terrestres.

1. Columbinæ [L'H. 19] ; 2. Gallinacex [L'H. 20].

C. Aves Carinatæ aquaticæ.

Gralle.

1. Alectorides (=Dicholophus + Otis) [L'H. 2 partim, 26 partim] ; 2. Gruinæ [L'H. 23] ; 3. Fulicariz [L'H. 22] ; 4. Herodiæ [L'H. 24 partim] ; 5. Pelargi [L'H. 24 partim, 25]; 6. Odontoglossi (=Phoenicopterus) [L'H. 26 partim]; 7. Limicolæ [I'H. 26 pæne omnes].

\section{Palmatr.}

8. Longipennes [L'H. 27];9. Nasuta [L'H. 28]; 10. Unguirostres [L'H. 30]; 11, Steganopodes [L'H. 29]; 12. Pygopodes [L'H. 31, 32, 33, 34].

II. Aves Ratit死 [L'H. "Oiseaux Anomaux"].

To enable the reader to compare the several groups of Nitzsch with the Families of L'Herminier, the numbers applied by the latter to his Families are suffixed in square brackets to the names of the former ; and, disregarding the order of sequence, which is here immaterial, the essential correspondence of the two systems is worthy of all attention, for it obviously means that these two investigators, starting from different points, must have been on the right track, when they so often coincided as to the limits of what they considered to be, and what we are now almost justified in calling, Natural Groups. ${ }^{1}$ But it must be observed that the classification of Nitzsch, just given, rests much more on characters furnished by

1 Whether Nitzsch was cognizaut of L'Herminier's views is in no way apparent. The latter's name seems not to be even mentioned by him, but Nitzsch was in Paris in the summer of 1827 , and it is almost impossible that he should not have heard of L'Herminier's labours, unless the relations between the followers of Cuvier, to whom Nitzscli attached himself, and those of De Blainville, whose pupil L'Herminier was, were such as to forbid any conmunication between the rival schools. Yet we have L'Herminier's evidence that Cuvier gave him every assistance. Nitzsch's silence, both on this occasiou and afterwards, is very curious ; but he cannot be accused of plagiarism, for the scheme given above is only an amplification of that foreshadowed by him (as already mentioned) in 1820-a scheme which seems to have been equally unknowu to L'Herminier, perhaps through linguistic difficulty. 
the general structure than those furnished by the CARotid artery only. Among all the species (188, he tells us, in number) of which he examined specimens, he found only four variations in the structure of that vessel, but so much has since been done in this way that there is no need to dwell on his particular researches, and the reader may be referred to Dr. Gadow's article in the text of this work (pp. 76, 77).

Considering the enormous stride in advance made by L'Herminier, it is very disappointing for the historian to have to record that the next inquirer into the osteology of Birds achieved a disastrous failure in his attempt to throw light on their arrangement by means of a comparison of their sternum. This was Berthold, who devoted a long chapter of his Beiträge zur Anatomie, published at Göttingen in 1831, to a consideration of the subject. So far as his introductory chapter went- the development of the sternum - he was, for his time, right enough and somewhat instructive. It was only when, after a close examination of the sternal apparatus of 130 species, which he carefully described, that he arrived (pp. 177-183) at the conclusion-astonishing to us who know of L'Herminier's previous results - that the sternum of Birds cannot be used as a help to their classification on account of the egregious anomalies that would follow the proceeding-such anomalies, for instance, as the separation of Cypselus from Hirundo and its alliance with Trochilus, and the grouping of Firundo and Fringilla together. He seems to have been persuaded that the method of Linnæus and his disciples was indisputably right, and that any method which contradicted it must therefore be wrong. Moreover, he appears to have regarded the sternal structure as a mere function of the Bird's habit, especially in regard to its power of flight, and to have wholly overlooked the converse position that this power of flight must depend entirely on the structure. Good descriptive anatomist as he certainly was, he was false to the anatomist's creed; but it is plain, from reading his careful descriptions of sternums, that he could not grasp the essential characters he had before him, and, attracted only by the more salient and obvious features, had not capacity to interpret the meaning of the whole. Yet he did not amiss by giving many figures of sternums hitherto unrepresented. We pass from him to a more lively theme.

At the very beginning of the year 1832 Cuvier laid before the Academy of Sciences of Paris a memoir on the progress of ossification in the sternum of Birds, of which menoir an abstract will be found in the Annales des Sciences Naturelles (xxv. pp. 260-272). Herein he treated of several subjects with which we are not particularly concerned at present, and his remarks thronghout were chiefly directed against certain theories which Étienne Geoffroy St.-Hilaire had propounded in his Philosophie Anatomique, published a good many years before, and need not trouble us here; but what does signify to us now is that Cuvier traced in detail, illustrating his statements by the preparations he exhibited, the progress of ossification in the sternum of the Fowl and of the Duck, pointing out how it differed in each, and giving his interpretation of the differences. It had hitherto been generally believed that the mode of ossification in the Fowl was that which obtained in all 
Birds-the Ostrich and its allies (as L'Herminier, we have seen, had already shewn) excepted. But it was now made to appear that the Struthious Birds in this respect resembled not only the Duck, but a great many other groups-Waders, Birds-of-Prey, Pigeons, Passerines and perhaps all Birds not Gallinaceous, - so that, according to Cuvier's view, the five points of ossification observed in the Gallinx, instead of exhibiting the normal process, exhibited one quite exceptional, and that in all other Birds, so far as he had been enabled to investigate the matter, ossification of the sternum began at two points only, situated near the anterior upper margin of the side of the sternum, and gradually crept towards the keel, into which it presently extended; and, though he allowed the appearance of detached portions of calcareous matter at the base of the still cartilaginous keel in Ducks at a certain age, he seemed to consider this an individual peculiarity. This fact was fastened upon by Geoffroy in his reply, which was a week later presented to the Academy, but was not published in full until the following year, when it appeared in the Annales du Museum (ser. 3, ii. pp. 1-22). Geoffroy here maintained that the five centres of ossification existed in the Duck just as in the Fowl, and that the real difference of the process lay in the period at which they made their appearance, a circumstance, which, though virtually proved by the preparations Cuvier had used, had been by him overlooked or misinterpreted. The Fowl possesses all five ossifications at birth, and for a long while the middle piece forming the keel is by far the largest. They all grow slowly, and it is not until the animal is about six months old that they are united into one firm bone. The Duck on the other hand, when newly liatched, and for nearly a month after, has the sternum wholly cartilaginons. Then, it is true, two lateral points of ossification appear at the margin, but subsequently the remaining three are developed, and when once formed they grow with much greater rapidity than in the Fowl, so that by the time the young Duck is quite independent of its parents, and can shift for itself, the whole sternum is completely bony. Nor, argued Geoffroy, was it true to say, as Cuvier had said, that the like occurred in the Pigeons and true Passerines. In their case the sternum begins to ossify from three very distinct points-one of which is the centre of ossification of the keel. As regards the Struthicus Birds, they could not be likened to the Duck, for in them at no age was there any indication of a single median centre of ossification, as Geoffroy had satisfied himself by his own observations made in Egypt many years before. Cuvier seems to have acquiesced in the corrections of his views made by Geoffroy, and attempted no rejoinder; but the attentive and impartial student of the discussion will see that a good deal was really wanting to make the latter's reply effective, though, as events have shewn, the former was hasty in the conclusions at which he arrived, having trusted too much to the first appearance of centres of ossification, for, had his observations in regard to other Birds been carried on with the same attention to detail as in.regard to the Fowl, le would certainly have reached some very different results.

In 1834 Gloger brought out at Breslau the first (and unfortunately 
the only) part of a Vollständiges Handbuch der Naturgeschichte der Vögel Europa's, treating of the Land-birds. In the Introduction to this book (p. xxxviii. note) he expressed his regret at not being able to use as fully as he could wish the excellent researches of Nitzsch which were then appearing (as has been above said) in the successive parts of Naumann's great work. Notwithstanding this, to Gloger seems to belong the credit of being the first anthor to avail himself, in a book intended for practical ornithologists, of the new light that had already been shed on Systematic Ornithology; and accordingly we have the second Order of his arrangement, the Aves Passerinx, divided into two Suborder's:Singing Passerines (melodusx), and Passerines without an apparatus of Song-muscles (anomalx) - the latter including what some later writers called Picariz. For the rest his classification demands no particular remark; but that in a work of this kind he had the courage to recognize, for instance, such a fact as the essential difference between Swallows and Swifts, lifts him considerably above the crowd of other ornithological writers of his time.

An improvement on the old method of classification by purely external characters was introduced to the Academy of Sciences of Stockholm by Sundevall in 1835, and was published the following year in its Handlingar (pp. 43-130). This was the foundation of a more extensive work of which, from the influence it still exerts, it will be necessary to treat later, and there will be no need now to enter much into details respecting the earlier performance. It is sufficient here to remark that the author, even then a man of great erudition, must have been aware of the turn which taxonomy was taking; but, not being able to divest himself of the older notion that external characters were superior to those furnished by the study of internal structure, and that Comparative Anatomy, instead of being a part of Zoology, was something distinct from it, he seems to have endeavoured to form a scheme which, while not running wholly counter to the teachings of Comparative Anatonists, should yet rest ostensibly on external characters. With this view he studied the latter most laboriously, and certainly not without success, for he brought into prominence several points that had hitherto escaped the notice of his predecessors. He also admitted among his characteristics a physiological consideration (apparently derived from Oken ${ }^{1}$ ) dividing the class Aves into two sections Altrices and Pracoces, according as the young were fed by their parents, or, from the first, fed themselves. Eut at this time he was encumbered with the hazy doctrine of analogies, which, if it did not act to his detriment, was assuredly of no service to him. He prefixed an 'Idea Systematis' to his 'Expositio'; and the former, which appears to represent his real opinion, differs in arrangement very considerably from the latter. Like Gloger, Sundevall in his ideal system separated the true Passerines from all other Birds, calling them Volucres; but he took a step further, for he assigned to them the highest rank, wherein nearly every recent

${ }^{1}$ He says from Oken's Naturgeschichte fiir Schulen, published in 1821, but the division is to be found in that author's earlier Lehrbuch der Zoologie (ii. p. 371), which appeared in 1816. 
authority agrees with him; out of them, however, he chose the Thrushes and Warblers to stand first as his ideal "Centrum"-a selection which, though in the opinion of the present writer erroneous, is still widely followed.

The points at issue between Cuvier and Étienne Geoffroy St.Hilaire before mentioned naturally attracted the attention of L'Herminier, who in 1836 presented to the French Academy the results of his researches into the mode of growth of that bone which in the adult Bird he had already studied to such good purpose. Unfortunately the full account of his diligent investigations was never published. We can only judge of his labours from an abstract (Comptes Rendus, iii. pp. 12-20, and Ann. Sci. Nat. ser. 2, vi. pp. 107-115), and from the report upon them by Isidore Geoffroy St.-Hilaire (Comptes Rendus, iv. pp. 565-574), to whom with others they were referred, and which is very critical in its character. It were useless to conjecture why the whole memoir never appeared, as the reporter recommended that it should; but, whether, as he suggested, the author's observations failed to establish the theories he advanced or not, the loss of his observations in an extended form is greatly to be regretted, for no one seems-to have continued the investigations he began and to some extent carried out; while, from his residence in Guadeloupe, he had peculiar advantages in studying certain types of Birds not generally available, his remarks on them could not fail to be valuable, quite irrespective of the interpretation he was led to put upon them. L'Herminier arrived at the conclusion that, so far from there being only two or three different modes by which the process of ossification in the sternum is carried out, the number of different modes is very considerable-almost each natural group of Birds having its own. The principal theory which he hence conceived himself justified in propounding was that instead of five being (as had been stated) the naximum number of centres of ossification in the sternum, there are no fewer than nine entering into the composition of the perfect sternum of Birds in general, though in every species some of these nine are wanting, whatever be the condition of development at the time of examination. These nine theoretical centres or "pieces" L'Herminier deemed to be disposed in three transverse ranks (rangés), namely the anterior or "prosternal," the middle or "mesosternal," and the posterior "metasternal" - -each rank consisting of three portions, one median piece and two side-pieces. At the same time he seems, according to the abstract of his memoir, to have made the somewhat contradictory assertion that sometimes there are more than three pieces in each rank, and in certain groups of Birds as many as six. ${ }^{1}$

1 We shall perliaps be justified in assuming that this apparent inconsistency, and others which present themselves, would be explicable if the whole memoir with the necessary illustrations had been published. It wonld occupy more space than can here be allowed to give even the briefest abstract of the numerous observations which follow the statement of his theory and on which it professedly rests. They extend to more than a score of natural groups of Birds, and nearly each of them presents some peculiar characters. Thus of the first rank of pieces he says that when all exist they may be developed simultancously, or that the two side-pieces may precede the median, or again that the median may precede the side-pieces-according to the 
Hitherto it will have been seen that our present business las lain wholly in Germany and France, for, as is elsewhere explained, the chief ornithologists of Britain were occupying themselves at this time in a very useless way - not but that there were several distinguished men in this country who were paying due heed at this time to the internal structure of Birds, and some excellent descriptive memoirs on special forms had appeared from their pens, to say nothing of nore than one general treatise on ornithic anatomy. ${ }^{1}$ Yet no one in Britain seems to have attempted to found any scientific arrangement of Birds on other than external characters until, in 1837, William Macgillivray issued the first volume of his History of British Birds, wherein, though professing (p. 19) "not to add a new system to the many already in partial use, or" that have passed away like their authors," he propounded (pp. 16-18) a scheme for classifying the Birds of Europe at least founded on a "consideration of the digestive organs, which merit special attention, on account, not so much of their great importance in the economy of birds, as the nervous, vascular and other systems are not behind them in this respect; but because, exhibiting great diversity of form and structure, in accordance with the nature of the food, they are more obviously qualified to afford a basis for the classification of the numerous species of birds" (p. 52). Experience has again and again exposed the fallacy of this last conclusion, but it is no disparagement of its author to say,

group of Birds, but that the second mode is much the commonest. The same variations are observable in the second or middle rank, but its side-pieces are said to exist in all groups of Birds without exception. As to the third or posterior rank, when it is complete the three constituent pieces are dereloped almost simultaneously; but its median piece is said often to originate in two, which soon unite, especially when the side-pieces are wanting. By way of examples of L'Herminier's observations, what he says of the two groups that had been the subject of Cuvier's and the elder Geoffroy's contest may be mentioned. In the Gallina the five welllinown pieces or centres of ossification are said to consist of the two side-pieces of the second or middle rank, and the three of the posterior. On two occasions, how. ever, there was found in addition, what may be taken for a representation of the first series, a little "noyau" situated between the coracoids-forming the only instance of all three ranks being present in the same Bird. As regards the Ducks, L'Herminier agreed with Cuvier that there are commonly only two centres of ossitication-the side-pieces of the middle rank; but as these grow to meet one another a distinct median "noyau," also of the same rank, sometimes appears, which soon forms a connexion with each of them. In the Ostrich and its allies no trace of this median centre of ossification ever occurs; but its existence seems to be invariable in all other Birds.

1 Owen's celebrated article 'Aves,' in Todd's Cyclopactic of Anatomy and Physiology (i. pp. 265-358), appeared in 1836, and, as giving a general view of the structure of Birds, needs no praise here; but its object was not to establish a classification, or throw light especially on systematic arrangement. So far from that being the case, its distinguished author was content to adopt, as he tells us, the arrangement proposed by Kirby in the Seventh Bridgewater Treatise (ii. pp. 445474 ), being that, it is true, of an estimable zoologist, but of one who had no special knowledge of Ornithology. Indeed it is, as the latter says, that of Linnæus, improved by Cuvier, with an additional modification of Illiger's-all tliese three authors having totally ignored any but external characters. Yet it was regarded " as being the one which facilitates the expression of the leading anatomical differences which obtain in the class of Birds, and which therefore may be considered as the most natural" ! 
that in this passage, as well as in others that might be quoted, he was greater as an anatomist than as a logician. He was indeed thoroughly grounded in anatomy, and though undoubtedly the digestive organs of Birds have a claim to the fullest consideration, yet Macgillivray himself subsequently becanie aware of the fact that there were several other parts of their structure as important from the point of view of classification. He it was, apparently, who first detected the essential difference of the organs of voice presented by some of the New-World Passeres (subsequently known as Clamatores), and the earliest intimation of this seems to be given in his anatomical description of the Arkansas Flycatcher, Tyrannus verticalis, which was published in 1838 (Ornithol. Biog. iv. p. 425), though it must be admitted that he did not-because he then could not-perceive the bearing of their difference, which was reserved to be shewn by the investigation of a still greater anatomist, and of one who had fuller facilities for research, and thereby almost revolutionized, as will presently be mentioned, the views of systematists as to this Order of Birds. There is only space here to say that the second volume of Macgillivray's work was published in 1839 , and the third in 1840 ; but it was not until 1852 that the anthor, in broken health, found an opportunity of issuing the fourth and fifth. His scheme of classification, being as before stated partial, need not be given in detail. Its great merit is that it proved the necessity of combining another and hitherto much-neglected factor in any natural arrangement, though vitiated as so many other schemes have been by being based wholly on one class of characters. ${ }^{1}$

But a bolder attempt at classification was that made in 1838 by Blyth (Mag. Nat. Hist. New Ser. ii. pp. 256-268, 314-319, 351-361, 420-426, 589-601; iii. pp. 76-84). It was limited, however, to what he called Insessores, being the group upon which that name had been conferred by Vigors (Trans. Iinn. Soc. xiv. p. 405) in 1823, with the addition, moreover, of his Raptores, and it will be unnecessary to enter into particulars concerning it, though it is equally as remarkable for the insight shewn by the author into the structure of Birds as for the breadth of his view, which conıprehends almost every kind of character that had been at that time bronght forward. It is plain that Blyth saw, and perhaps he was the first to see it, that Geographical Distribution was not unimportant in suggesting the affinities and differences of natural groups (pp. 258, 259); and, undeterred by the precepts and practice of the hitherto dominant English school of Ornithologists, he declared that "anatomy, when aided by every character which the manner of propagation, the progressive

1 This is not the place to dwell on Macgillivray's merits; but I may perhaps be excused for repeating my opinion that, after Willugliby, Macgillivray was the greatest and most original ornithological genius save one (who did not live long enough to nake his powers widely known) that this island has produced. The exact amount of assistance he afforded to Andubon in his Ornithological Biography will probably never be ascertained; but, setting aside "all the anatomical descriptions, as well as the slietches by which they are sometimes illustrated," that on the latter's own statement ( $p$. cit. iv. Introduction, p. xxiii.) are the work of Macgillivray, no impartial reader call compare the style in which the History of British Birds is written with that of the Ornithological Biography withont recognizing the similarity of the two. On this subject some remarlis of Prof. Coues (Bull. Nutt. Ornithol. Club, 1880, p. 201) may well be consulted. 
changes and other physiological data supply, is the only sure basis of classification." He was quite aware of the taxonomic value of the vocal organs of some groups of Birds, presently to be especially mentioned, and he had himself ascertained the presence and absence of cxca in a not inconsiderable number of groups, drawing thence very justifiable inferences. He knew at least the earlier investigations of L'Herminier, and, though the work of Nitzsch, even if he had ever heard of it, must (through ignorance of the language in which it was written) have been to him a sealed book, he had followed out and extended the hints already given by Temminck as to the differences which various groups of Birds display in their moult. With all this it is not surprising to find, though the fact has been generally overlooked, that Blyth's proposed arrangement in many points anticipated conclusions that were subsequently reached, and were then regarded as fresh discoveries. It is proper to add that at this time the grenter part of his work was carried on in conjunction with Mr. Bartlett, the present Superintendent of the Zoological Society's Gardens, and that, without his assistance, Blyth's opportunities, slender as they were compared with those which others have enjoyed, must have been still smaller. Considering the extent of their materials, which was limited to the bodies of such animals as they could obtain from dealers and the several menageries that then existed in or near London, the progress made in what has since proved to be the right direction is very wonderful. It is obvious that both these investigators had the genius for recognizing and interpreting the value of characters; but their labours do not seem to have met with much encouragement; and a general arrangement of the Class laid by Blyth before the Zoological Society at this time ${ }^{1}$ does not appear in its publications, possibly through his neglect to reduce his scheme to writing and deliver it within the prescribed period. But even if this were not the case, no one need be surprised at the result. The scheme could hardly fail to be a crude performance-a fact which nobody would know better than its author; but it must have presented much that was objectionable to the opinions then generally prevalent. Its line to some extent may be partly made out-very clearly; for the matter of that, so far as its details have been published in the series of papers to which reference has been given-and some traces of its features are probably preserved in his Catalogue of the specimens of Birds in the Museum of the Asiatic Society of Bengal, which, after several years of severe labour, made its appearance at Calcutta in 1849 ; but, from the time of his arrival in India, the onerous duties imposed upon Blyth, together with the want of sufficient books of reference, seem to have hindered him from seriously continuing his former researches, which, interrupted as they were, and born out of due time, had no appreciable effect on the views of systematizers generally.

Next must be noticed a series of short treatises communicated by Johann Friedrich Brandt, between the years 1836 and 1839 , to the Academy of Sciences of St. Petersburg, and published in its Mémoires.

1 An abstract is contained in the Minute-book of the Scientific Meetings of the Zoological Society, 26th June and 10th July 1838. The Class was to contain fifteen Orders, but only three were dealt with in any detail. 
In the year last mentioned the greater part of these was separately issued under the title of Beiträge zur Kenntniss der Naturgeschichte der Vögel. Herein the author first assigned anatomical reasons for rearranging the Order Anseres of Linnæus, the Natatores of Illiger, who, so long before as 1811, had proposed a new distribution of it into six Families, the definitions of which, as was his wont, he had drawn from external characters only. Brandt now retained very nearly the same arrangement as his predecessor; but, notwithstanding that he could trust to the firmer foundation of internal framework, he took at least two retrograde steps. First he failed to see the great structural difference between the Penguins (which Illiger had placed as a group, Impennes, of equal rank to his other Families) and the Auks, Divers and Grebes, Pygopodes-combining all of them to form a "Typus" (to use his term) Urinatores; and secondly he admitted among the Natatores, though as a distinct "Typus" Podoidx, the genera Podoa (Finfoot), and Fulica (Соoт), which are now known to be allied to the Rallidx. At the same time he corrected the error made by Illiger in associating the Phalaropes with these forms, rightly declaring their relationship to Tringa, a point of order which other systematists were long in admitting. On the whole Braudt's labours were of no small service in asserting the principle that consideration must be paid to osteology ; for owing to his position he was able to gain more attention to his views than some of his less favourably placed brethren had succeeded in doing.

In the same year (1839) another slight advance was made in the classification of the true Passeres. Keyserling and Blasius briefly pointed out (Arch.f. Naturgesch. v. pp. 332-334) that, while all the other Birds provided with perfect song-muscles had the "planta" or hind part of the "tarsus" covered with two long and undivided horny plates, the Larks had this part divided by many transverse sutures, so as to be scutellated behind as well as in front; just as is the case in many of the Passerines which have not the singing-apparatus, and also in the HoopoE. The importance of this singular but superficial departure from the normal structure has been so needlessly exaggerated as a character that at the present time its value is apt to be unduly depreciated. In so large and so homogeneous a group as that of the true Passeres, a constant character of this kind is not to be despised as a practical mode of separating the Birds which possess it; and, more than this, it would appear that the discovery thus announced was the immediate means of leading to a series of investigations of a much more important and lasting nature-those of Johannes Müller to be presently mentioned.

Again we must recur to that indefatigable and most original investigator Nitzsch, who, having never intermitted his study of the particular subject of his first contribution to science, in 1833 brought out at Halle, where he was Professor of Zoology, an essay with the title Pterylographix Avium Pars prior. It seems that this was issued as much with the object of inviting assistance from others in view of future labours, since the materials at his disposal were scanty, as with that of making known the results to which his researches had already led him. Indeed he only communicated copies of this essay to a few friends, and 
examples of it are comparatively scarce. Moreover, he stated subsequently that he thereby hoped to excite other naturalists to share with him the investigations he was making on a subject which had hitherto escaped notice or had been wholly neglected, since he considered that he had proved the disposition of the feathered tracts in the plumage of Birds to be the means of furnishing characters for the discrimination of the various natural groups as significant and important as they were new and unexpected. 1 There was no need for us hore to quote this essay in its chronological place, since it dealt only with the generalities of the subject, and did not enter upon any systematic details. These the author reserved for a second treatise which he was destined never to complete. He kept on diligently collecting materials, and as he did so was constrained to modify some of the statements he had published. He consequently fell into a state of doubt, and before he could make up his mind on some questions which he deemed important he was overtaken by death.' 'Then his papers were handed over to his friend and successor, Burmeister, afterwards and for many years of Buenos Aires, who, with much skill elaborated from them the excellent work known as Nitzsch's Pterylographie, which was published at Halle in 1840 . There can be no doubt that the editor's duty was discharged with the most conscientious scrupulosity; but, from what has been just said, it is certain that there were important points on which Nitzsch was as yet undecided-some of them perhaps of which no trace appeared in his manuscripts, and therefore as in every case of works posthumously published, unless (as rarely happens) they have received their author's "imprimatur," they cannot be implicitly trusted as the expression of his final views. It would consequently be unsafe to ascribe positively all that appears in this volume to the result of Nitzsch's mature consideration. Moreover, as Burmeister states in his preface, Nitzsch by no means regarded the natural sequence of groups

1 It is still a prevalent belief that feathers grow almost uniformly over the whole surface of a Bird's body; some indeed are longer and some are shorter, but that is about all the difference perceptible to most people. It is the easiest thing for anybody to satisfy himself that this, except in a few cases, is altogether an erroneous supposition (see PtErylosis). Before Nitzsch's time the only men who seem to have noticed this fact were the great John Hunter and the accurate Macartney. But the observations of the former on the subject were not given to the world until 1836, when Owen introduced them into his Catalogue of the Museum of the College of Surgeons in London (vol. iii. pt. ii. p. 311), and therein is no indication of the fact having a taxonomical bearing. The same may be said of Macartney's remarks, which, though subsequent in point of time, were published earlier, namely, in 1819 (Rees's Cyclopædia, xiv. art. 'Feathers'). Ignorance of this simple fact has led astray many celebrated painters, among them Landseer, whose pictures of Birds uearly always shew an unnatural representation of the plnmage that at once betrays itself to the trained eye, though of course it is not perceived by spectators generally, who regard only the correctness of attitucle and force of expression, which in that artist's work commonly leave little to be desired. Every draughtsman of Birds to be successful should study as did Mr. Wolf, the plan on which their feathers are disposed.

2 Though not relating exactly to our present theme, it would be improper to dismiss Nitzsch's name without reference to his extraordinary labours in investigating the insect and other external parasites of Birds, a subject which as regards British species was subsequently elaborated by Denny in his MFonographica Anoplurorum Britannix (1842) and in his list of the specimens of British Anophura in the collection of the British Museum. 
as the highest problem of the systematist, but rather their correct limitation. Again the arrangement followed in the Pterylographie was of course based on pterylographical considerations, and we have its author's own word for it that he was persuaded that the limitation of natural groups could only be attained by the most assiduous research into the species of which they are composed from every point of view. The combination of these three facts will of itself explain some defects, or even retrogressions, observable in Nitzsch's later systematic work when compared with that which he had formerly done. On the other hand some manifest improvements are introduced, and the abundance of details into which lie enters in his Pterylographie renders it far more instructive and valuable than the older performance. As an abstract of that has already been given, it may be sufficient here to point out the chief changes made in his newer arrangement. To begin with, the three great sections of Aerial, Terrestrial and Aquatic Birds are abolished. The "Accipitres" are divided into two groups, Diurnal and Nocturnal ; but the first of these divisions is separated into three sections:-(1) the Vultures of the New World, (2) those of the Old World and (3) the genus Falco of Linnæus. The "Passerinx," that is to say, the true Passeres, are split into eight Families, not wholly with judgment; ${ }^{1}$ but of their taxonomy more is to be said presently. Then a new Order "Picaria" is instituted for the reception of the Macrochires, Cuculinx, Picinx, Psittacinæ and Amphibolæ of his old arrangement, to which are added three 2 others-Caprimulginæ, Todidæ and Lipoglossæ-the last consisting of the genera Buceros, Upupa and Alcedo. The association of Alcedo with the other two is no doubt a misplacement, but the alliance of Buceros to Upupa, already suggested by Gould and Blyth in $1838^{3}$ (Mag. Nat. Hist. ser. 2, ii. pp. 422 and 589), though at first sight unnatural, has been corroborated by many later systematizers; and taken as a whole the establishment of the Picarix was certainly a commendable proceeding. For the rest there is only one considerable change, and that forms the greatest blot on the whole scheme. Instead of the Ratita of Merrem being recognized as before as a Subclass, they were now reduced to the rank of an Order under the name "Platystemx", and placed between the "Gallinacex" and "Grallx," though it was admitted that in their pterylosis they differ from all other Birds, in ways that the antlior is at great pains

1 A short essay by Nitzsch on the general structure of the Passerines, writteu, it is said, in 1836, was published in 1862 (Zeitschr. Ges. Naturwissensch. xix. pp. 389408). It is probably to this essay that Burmeister refers in the Pterylographie (p. 102, note; English translation, p. 72 , note) as forming the basis of the article "Passerinæ" which he contributed to Ersch and Gruber's Encyllopädie (sect. iii. bd. xiii. pp. 139-144), and published before the Pterylographie.

2 By the numbers prefixed it would look as if there should be four new members of this Order'; but that seems to be due rather to a slip of the pen or to a priuter's error.

3 This association is one of the most remarkable in the whole series of Blyth's remarkable papers on classification in the volume cited above. He states that Gould suspected the alliance of these two forms "from extermal structure and habits alone;" otherwise one might suppose that he had obtained an intimatiou to that effect on one of his Continental journeys. Blyth "arrived at the same conclnsion, however, by a different train of investigation," and this is beyond doubt. 
to describe, in each of the four genera examined by him-Struthio, Rhea, Dromxus and Casuarius. ${ }^{1}$ It is significant that notwithstanding this he did not figure the pterylosis of any one of them, and the thought suggests itself that, though his editor assures us he had convinced himself that the group must be here shoved in (eingeschoben), the intrusion is rather due to the necessity which Nitzsch, in common with most men of his time (the Quinarians excepted), felt for deploying the whole series of Birds into line, in which case the proceeding may be defensible on the score of convenience. The extraordinary merits of this book, and the admirable fidelity to his principles which Burmeister shewed in the difficult task of editing it, were unfortunately overlooked for many years, and perhaps are not sufficiently recognized now. Even in Germany, the author's own country, there were few to notice seriously what is certainly one of the most remarkable works ever published on the science, much less to pursue the investigations that had been so laboriously begun. ${ }^{2}$ Andreas Wagner, in his report on the progress of Ornithology (Arch. $f$. Naturgesch. vii. 2, pp. 60,61), as miglit be expected from such a man as he was, placed the Pterylographie at the summit of those publications the appearance of which he had to record for the years 1839 and 1840 , stating that for "Systematik" it was of the greatest importance. On the other hand Oken (Isis, 1842, pp. 391-394), though giving a summary of Nitzsch's results and classification, was more sparing of his praise, and prefaced his remarks by asserting that he could not refrain from laughter when he looked at the plates in Nitzsch's work, since they reminded him of the plucked fowls in a poulterer's shop-it might as well be urged as an objection to the plates in many an anatomical book that they called to mind a butcher's - and goes on to say that, as the author always had the luck to engage in researches of which nobody thought, so had he the luck. to print them where nobody sought them. In Sweden Sundevall, without accepting Nitzsch's views, accorded them a far more appreciative greeting in his anmual reports for 1840-42 (i. pp. 152-160); but of course in England and France ${ }^{3}$ nothing was known of them beyond the scantiest notice, generally taken at second hand, in two or three publications. 4

1 He does not mention Apteryx, at that time so little known on the Continent.

2 Some excuse is to be made for this neglect. Nitzsch had of course exhausted all the forms of Birds commonly to be obtained, and specimens of the less common forms were too valuable from the curator's or collector's point of view to be subjected to a treatment that might end in their destruction. Yet it is said, on good authority, that Nitzsch had the patience so to manipulate the skins of many rare species that he was able to ascertain the cliaracters of their pterylosis by the inspection of their inside only, without in any way damaging them for the ordinary purpose of a museum. Nor is this surprising when we consider the marvellous skill of Continental and especially German taxilermists, inany of whom have elevated their profession to a height of art inconceivable to most Enghishmen, who are only acquainted with the miserable mockery of Nature which is the most sublime result of all but a few "birlstuffers."

3 In 1836 Jacquemin communicated to the French Academy (Comptes Rendus, ii. pp. 374, 375 and 472) some observations on the order in which feathers are disposed on the body of Birds; but, however general may have been the scope of his investigations, the portion of them pnblished refers only to the Crow, and there is no mention made of Nitzscli's former work.

4 Thanks to Mr. Sclater, the Ray Society was induced to publish, in 1867, an 
The treatise of Kessler on the osteology of Birds' feet, published in the Bulletin of the Moscow Society of Naturalists for 1841, next claims a few words, though its scope is rather to shew differences than affinities; but treatment of that kind is undonbtedly useful at times in indicating that alliances generally admitted are unuatural ; and this is the case here, for, following Cuvier's method, the author's researches prove the artificial character of some of its associations. While furnishing-almost unconsciously, however-additional evidence for overthrowing that classification, there is, nevertheless, no attempt made to construct a better one ; and the elaborate tables of dimensions, both absolute and proportional, suggestive as is the whole tendency of the author's observations, seem not to learl to any very practical result, though the systematist's need to look beneath the integument, even in parts that are so comparatively little bidden as Birds' feet, is once more made beyond all question apparent.

It has already been mentioned that Macgillivray furnished Audubon with a series of descriptions of some parts of the anatomy of American Birds, from subjects supplied to him by that enthusiastic naturalist, whose zeal and prescience, it may be called, in this respect merits all praise. Thus he (prompted very likely by Macgillivray) wrote:-"I believe the time to be approaching when much of the results obtained from the inspection of the exterior alone will be laid aside; when museums filled with stuffed skins will be considered insufficient to afford a knowledge of birds; and when the student will go forth, not only to observe the habits and haunts of animals, but to preserve specimens of them to be carefully dissected" (Orn. Biogr. iv. Introduction, p. xxiv.) As has been stated, the first of this series of anatomical descriptions appeared in the fourth volume of his work, published in 1838 , but they were continued until its completion with the fifth volume in the following year, and the whole was incorporated into what may be termed its second edition, The Birds of America, which appeared between 1840 and 1844. Among the many species whose anatony Macgillivray thus partly described from autopsy were at least half a dozen of those now referred to the Family TrRaNT-BIRDs, but then included, with many others, according to the vague and rudimentary notions of classification of the time, in what was termed the Family "Muscicapinx." In all these species he found the vocal organs to differ essentially in structure from those of other Birds of the Old World, which we now call Passerine, or, to be still more precise, Oscinine. But by him these last were most arbitrarily severed, dissociated from their allies, and wrongly combined with othel forms by no means nearly related to them (Brit. Birds, i. pp. $17,18)$ which he also examined; and he practically, though not literally, 1

excellent translation by Dallas of Nitzsch's Pterylography, and thereby, however tardily, justice was at length rendered by British ornithologists to one of their greatest foreign brethren. The Society had the good fortune to obtain the ten original copper-plates, all but one drawn by the author himself, wherewith the work was illustrated. It is only to be regretted that the quarto size in which it appeared was not retained, for the folio form of the English version puts a needless impediment in the way of its common and convenient use. On the important subject of the pterylography of Birds' wings see the works cited under ReMIges (page 781, note).

1 Not literally, because a few other forms such as the genera Polioptila and 
asserted the truth, when he said that the general structure, but especially the muscular appendages, of the lower larynx was "similarly formed in all other birds of this family" described in Audubon's work. Macgillivray did not, however, assign to this essential difference any systematic value. Indeed he was so much prepossessed in favour of a classification based on the structure of the digestive organs that he could not bring himself to consider vocal muscles to be of much taxonomic use, and it was reserved to Johannes Miiller to point out that the contrary was the fact. This the great German comparative anatomist did in two communications to the Academy of Sciences of Berlin, one on the 26th June 1845 and the other on the 14th May 1846, which, having been first briefly published in the Academy's Monatsbericht, were afterwards printed in full, and illustrated by numerous figures, in its Abhandlungen, though in this latter and complete form they did not appear in public until 1847. I This very remarkable treatise forms the groundwork of almost all later or recent researches in the comparative anatomy and consequent arrangement of the Passeres, and, though it is certainly not free from imperfections, many of them, it must be said, arose from want of material, notwithstanding that its author had command of a much more abundant supply than was at the disposal of Nitzsch. Carrying on the work from the anatomical point at which lie had left it, correcting his errors, and utilizing to the fullest extent the observations of Keyserling and Blasius, to which reference has already been made, Müller, though hampered by mistaken notions of which he seems to have been unable to rid himself, propounded a scheme for the classification of this group, the general truth of which has been admitted by all his successors, based, as the title of his treatise expressed, on the hitherto unknown different types of the rocal organs in the Passerines. He freely recognized the prior discoveries of, as he thought, Audubon, though really, as has since been ascertained, of Macgillivray; but Müller was able to perceive their systematic value, which Macgillivray did not, and taught others to know it. At the same time Müller shewed himself, his power of discrimination notwithstanding, to fall behind Nitzsch in one very crucial point, for he refused to the latter's PICARI\& the rank that had been claimed for them, and imagined that the groups associated under that name formed but a third "Tribe" -PrCarII- of a great Order Insessores, the others being (1) the Oscines or Polymyodi-the Singing Birds by emphasis, whose inferior larynx was endowed with the full number of five pairs of song-muscles, and (2) the Tracheophones, composed of some South-American Families. Looking on Müller's labours as we now can, we see that such errors as he committed are chiefly due to his want of special knowledge of Ornithology, combined with the absence in several instances of sufficient materials for investigation. Nothing whatever is to be said against the composition of Ptilogonys, now known to have no relation to the Tyrannidr, were included, though these forms, it would seem, had never been dissected by him. On the other hand he declared that the American Redstart, Muscicapa, or, as it now stands, Setophaga muticilla, when young, has its vocal organs like the rest-a statement corrected by Müller in a Nachtrag (p. 405) to his paper next to be mentioned.

1 Also printed separately as Ueber die bisher unbekannten typischen Verschieden. heiten der Stimmorgane der Passcrinen, 4to, Bcrlin : 1847. 
his first and second "Tribes"; but the third is an assemblage still more heterogeneous than that which Nitzsch brought together under a name so like that of Müller-for the fact must never be allowed to go out of sight that the extent of the Picarii of the latter is not at all that of the Picarix of the former. I For instance, Miiller places in his third "Tribe" the group which he called Ampelidx, meaning thereby the peculiar forms of South America that are now considered to be more properly named Cotingidx (Chatterer), and herein he was clearly right, while Nitzsch, who, misled by their supposed affinity to the genus Ampelis (WAxwING)peculiar to the Northern Hemisphere, and a purely Passerine form, had kept them among his Passerinx, was as clearly wrong. But again Miiller made his third "Tribe" Picarii also to contain the Tyrannidx, of which mention has just been made, though it is so obvious as now to be generally admitted that they have no very intimate relationship to the other Families with which they are there associated. There is no need here to criticize more minutely his projected arrangement, and it must be said that, notwithstanding his researches, he seems to have had some misgivings that, after all, the separation of the Insessores into those "Tribes" might not be justifiable. At any rate he wavered in his estinate of their taxonomic value, for he gave an alternative proposal, arranging all the genera in a single series, a proceeding in those days thought not only defensible and possible, but desirable or even requisite, though now utterly abandoned. Just as Nitzsch had laboured under the disadvantage of never having any example of the abnormal Passeres of the New World to dissect, and therefore was wholly ignorant of their abnormality, so Müller never succeeded in getting hold of an example of the genus Pitta for the same purpose, and yet, acting on the clew furnished by Keyserling and Blasius, he did not hesitate to predict that it would be found to fill one of the gaps he had to leave, and this to some extent it has been since proved to do. The result of all this is that the Oscines or true Passeres are found to be a group in which the vocal organs not only attain the greatest perfection, but are nearly if not quite as uniform in their structure as in the sternal apparatus; while at the same time each set of characters is wholly unlike that which exists in any other group of Birds, as is set forth in Dr. Gadow's article SyRINx in the text.

It must not be supposed that the muscles just defined were first discovered by Müller; on the contrary they had been described long before, and by many writers on the anatomy of Birds. To say nothing of foreigners, or the authors of general works on the subject, an excellent account of them had been given by Yarrell in 1829 (Trans. Linn. Soc. xvi. pp. 305-321, pls. 17, 18), an abstract of which was subsequently given in the article "Raven" in his History of British Birds, and Macgillivray also described and figured them with the greatest accuracy ten years later in his work with the same title (ii. pp. 21-37, pls. x.-xii.), while Blyth and Nitzsch had (as already mentioned) seen some of their value in classification. But Müller has the merit of clearly outstriding his predecessors, and with lis accustomed perspicacity made the way even

1 It is not needless to point ont this fine distinction, for more than one modern author would seem to lave overlooked it. 
plainer for his successors to see than he himself was able to see it. What remains to acld is that the celebrity of its anthor actually procured for the first portion of his researches notice in England (Ann. Nat. Hist. xvii. p. 499), though it must be confessed not then to any practical purpose. ${ }^{1}$

It is now necessary to revert to the year 1842, in which Dr. Cornay of Rochefort communicated to the French Academy of Sciences a memoir on a new Classification of Birds, of which, however, nothing but a notice has been preserved (Comptes Rendus, xiv. p. 164). Two years later this was followed by a second contribution from him on the same subject, and of this only an extract appeared in the official organ of the Academy (op. cit. xvi. pp. 94, 95), though an abstract was inserted in one scientific journal (L'Institut, xii. p. 21), and its first portion in another (Journal des Découvertes, i. p. 250). The Revue Zoologique for 1847 (pp. 360-369) contained the whole, and enabled naturalists to consider the merits of the author's project, which was to found a new Classification of Birds on the form of the anterior palatal bones, which he declared to be subjected more evidently than any other to certain fixed laws. These laws, as formulated by him, are that (1) there is a coincidence of form of the anterior palatal bones and of the cranium in Birds of the same Order ; (2) there is a likeness between the anterior palatal bones in Birds of the same Order ; (3) there are relations of likeness between the anterior palatal bones in groups of Birds which are near to one mother. These laws, he added, exist in regard to all parts that offer characters fit for the methodical arrangement of Birds, but it is in regard to the anterior palatal bones that they unquestionably offer the most evidence. In the evolution of these laws Dr. Cornay had most laudably studied, as his observations prove, a vast number of different types, and the upshot of his whole labours, though not very clearly stated, was such as wholly to subvert the classification at that time generally adopted by French ornithologists. He of course knew the investigations of L'Herminier and De Blainville on sternal formation, and he also seems to have been aware of some pterylological differences exhibited in Birds-whether those disclosed by Nitzsch or those by Jacque min is not stated. Trne it is the latter were never published in full, but it is conceivable that $\mathrm{Dr}$. Cornay may have known their drift. Be that as it may, he declares that characters drawn from the sternum or the pelvis-hitherto deemed to be, next to the bones of the head, the most important portions of the bird's framework-are scarcely worth more, from a classificatory point of view, than characters drawn from the bill or the legs; while pterylological considerations, together with many others to which some systematists had attached more or less importance, can only assist, and apparently must never be taken to control, the force of evidence furnished by this bone of all bones-the anterior palatal.

1 More than 30 years after proper tribute was rendered to one who by his investigations had so materially advanced the study of Ornithology, since in 1878 Mr. Sclater procured the publication at Oxford of an English version of this treatise under the title of Johannes Müller on Certain Variations in the Vocal Organs of the Passeres that have hitherto escaped notice. It was translated by Prof. Jeffrey Bell, and Garrod added an appendix containing a summary of his own continuation of the same line of research. By some unaccountable accident, the date of the originai com. munication to the Academy of Berlin is wrongly printed. It is rightly given above. 
That Dr. Cornay was on the brink of making a discovery of considerable merit will by and by appear ; but, with every disposition to regard his investigations favourably, it cannot be said that he accomplished it. No account need be taken of the criticism which denominated his attempt " mnphilosophical and one-sided," nor does it signify that his proposals either attracted no attention or were generally received with indifference. Such is commonly the fate of any deep-seated reform of classification proposed by a comparatively unknown man, unless it happen to possess some extraordinarily taking qualities, or be explained with an abundance of pictorial illustration. This was not the case here. Whatever proofs Dr. Cornay may have had to satisfy himself of his being on the right track, these proofs were not adduced in sufficient number nor arranged with sufficient skill to persuade a somewhat stiff-necked generation of the truth of his views-for it was a generation whose leaders, in France at any late, looked with suspicion upon any one who professed to go beyond the bounds which the genius of Cuvier had been unable to overpass, and regarded the notion of upsetting any of the positions maintained by him as verging upon profanity. Moreover, Dr. Cornay's scheme was not given to the world with any of those adjuncts that not merely please the eye but are in many cases necessary, for, though on a subject which required for its proper comprehension. a series of plates, it made even its final appearance nnadorned by a single explanatory figure, and in a journal, respectable and well-known indeed, but one not of the highest scientific rank. Add to all this that its anthor, in his summary of the practical results of his investigations, committed a grave $\sin$ in the eyes of rigid systematists by ostentationsly arranging the names of the forty types which he selected to prove his case wholly without order, and without any intimation of the greater or less affinity any one of them might bear to the rest. That success should attend a scheme so inconclusively elaborated could not be expected.

The same year which saw the promulgation of the crude scheme just described, as well as the publication of the final researches of Miiller, witnessed also another attempt at the classification of Birds, much more limited indeed in scope, but, so far as it went, regarded by most ormithologists of the time as almost final in its operation. Under the vague title of 'Ornithologische Notizen' Prof. Cabanis of Berlin contributed to the Archiv für Naturgeschichte (xiii. 1, pp. 186-256, 308-352) an essay in two parts, wherein, following the researches of Müller ${ }^{1}$ on the syrinx, in the course of which a correlation had been shewn to exist between the whole or divided condition of the planta or hind part of the "tarsus" (first noticed, as has been said, by Keyserling and Blasius) and the presence or absence of the perfect song-apparatus, the younger author found an agreement which seemed almost invariable in this respect, and he also pointed out that the planta of the different groups of Birds in which it is divided, is divided in different morles, the mode of division being generally characteristic of the group. Such a coincidence of the internal

1 On the other hand, Miiller makes several references to the labours of Prof. Cabanis. The investigatious of both authors must have been proceeding simultaneously, and it matters little which actually appeared first. 
and external features of Birds was naturally cleemed a discovery of great value by those ornithologists who thought most highly of the latter, and it was unquestionably of no little practical utility. Further examination also revealecl the fact ${ }^{1}$ that in certain groups the number of "primaries," or quill-feathers growing from the manus of the wing, formed another characteristic easy of observation. In the Oscines or Polymyodi of Müller the number was either nine or ten-and if the latter the ontermost of them was generally very small. In two of the other groups of which Prof. Cabanis especially treated - groups which had been hitherto more or less confounded with the Oscines-the number of primaries was invariably ten, and the outermost of them was comparatively large. This observation was also hailed as the discovery of a fact of extraordinary importance ; and, from the results of these investigations taken altogether, Ornithology was declared by Sundevall, undoubtedly a man who had a right to speak with authority, to have made greater progress than had been achieved since the days of Cuvier. The final disposition of the "Subclass Insessores"-all the perching birds, that is to say, which are neither Birds-of-Prey nor Pigeons-proposed by Prof. Cabanis, was into four "Orders," as follows:-

1. Oscines, equal to Müller's group of the same name.

2. Clamatores, being a majority of that division of the Picarix of Nitzsch, so called by Andreas Wagner, in $1841,2^{2}$ which have their feet normally constructed.

3. Strisores, a group now separated from the Clamatores of Wagner, and containing those forms which have their feet abnormally constructed; and

4. Scansores, being the Grimpeurs of Cuvier, the Zygodactyli of several other systematists.

The first of these four "Orders" had been already indefeasibly established as one perfectly natural, but respecting its details more must presently be said. The remaining three are now seen to be artificial associations, and the second of them, Clamatores, in particular, containing a very heterogeneous assemblage of forms; but it must be borne in mind that the internal structure of some of them was at that time still more imperfectly known than now. Yet even then, enough had been ascertained to have saved what are now recognized as the Families Todidx and Tyrannid $x$ from being placed as "Subfamilies" in the same "Family Colopterid $x$ "; and several other instances of unharmonious combination in this "Order" might be adduced were it worth while to particularize them. More than that, it would not be difficult to shew, only the present is not exactly the

1 This seems to have been made known by Prof. Cabanis the preceding year to the 'Gesellschaft der Naturforschender Freunde' (cf. Miiller, Stimmorgane der Passerinen, p. 65). Of course the variation to which the number of primaries was subject had not escaped the observation of Nitzsch, but he had scarcely used it as a classificatory character.

${ }^{2}$ Archiv für Naturgeschichte, vii. 2, pp. 93, 94. The divisiou seems to have been instituted by this author a couple of years earlier in the second edition of his Handbuch der Naturgeschichte (which I have not seen), but not then to have received a scientific name. It included all Picarix which had not "zygodactylous" feet, that is to say, toes placed in pairs, two before and two behind. 
place for it, that some groups or Families which in reality are not far distant from one another are distributed, owing to the dissimilarity of their external characters, throughout these three Orders.

But to return to the Oscines, the arrangement of which in the classification now under notice has been deemed its greatest merit, and consequently has been very generally followed. That by virtue of the perfection of their vocal organs, and certain other properties-though some of these last have perhaps never yet been made clear enough-they should stand at the head of the whole Class, may be freely admitted, but the respective rank assigned to the various component Families of the group is certainly open to question, and to the present writer seems, in the methods of several systematists, to be based upon a fallacy. This respective rank of the different Families appears to have been assigned on the principle that, since by reason of one character (namely, the more complicated structure of their syrinx) the Oscines form a higher group than the Clamatores, therefore all the concomitant features which the former possess and the latter do not must be equally indicative of superiority. Now one of the features in which most of the Oscines differ from the lower "Order" is the having a more or less undivided planta, and accordingly it has been assumed that the Family of Oscines in which this modification of the planta is carried to its extreme point must be the highest point of that "Order." Since, therefore, this extreme modification of the planta is exhibited by the Thrushes and their allies, it is alleged that they must be placed first, and indeed at the head of all Birds. The groundlessness of this reasoning ought to be apparent to everybody. In the present state of anatomy at any rate, it is impossible to prove that there is more than a coincidence in the facts just stated, and in the association of two characters-one deeply seated and affecting the whole life of the Bird, the other superficially, and so far as we can perceive without effect upon its organism. Because the Clamatores, having no song-muscles, have a divided planta, it cannot be logical to assume that among the Oscines, which possess song-muscles, such of them as have an undivided planta must be higher than those that have it divided. The argument, if it can be called an argument, is hardly one of analogy; and yet no stronger ground has been occupied by those who invest the Thrushes, as do the majority of modern systematists, with the most dignified position in the whole Class. But passing from general to particular considerations, so soon as a practical application of the principle is made its inefficacy is manifest. The test of perfection of the vocal organs must be the perfection of the notes they enable their possessor to utter. There cannot be a question that, sing admirably as do some of the Birds included among the Thrushes, ${ }^{1}$ the Larks, as a Family, infinitely surpass them. Yet the Larks form the very group which, as elsewhere

1 Prof. Cabanis would have strengthened his position had he included in the same Family with the Thrushes, which he called Rhacnemidx, the birds commonly known as Warblers, Sylviid $x$, which the more advanced of recent systematists are inclined with much reason to unite with the Thrushes, Turdidx; but instead of that he, trusting to the plantar character, segregated the Warblers, including of course the Nightingale, and did not even allow them the second place in his methocl, putting 
shewn (LiRk, page 511), have the plantu more divided than any other among the Oscines. It seems hardly possible to adduce anything that would more conclusively demonstrate the independent nature of each of these characters--the complicated structure of the syrinx and the asserted inferior formation of the planta-which are in the Alaudidx associated. ${ }^{1}$ Moreover, this same Family affords a very valid protest against the extreme value attached to the presence or absence of the outermost quillfeather of the wings, and in this work it is also shewn (loc. cit.) that almost every stage of magnitude in this feather is exhibited by the Larks from its almost abortive condition in Alauda to its very considerable development in Mirafra. Indeed there are many genera of Oscines in which the proportion that the outermost "primary" bears to the rest is at best but a specific character, and certain exceptions are allowed by Prof. Cabanis (p. 313) to exist. ${ }^{2}$ Some of them it is now easy to explain, inasmuch as in a few cases the apparently aberrant genera have elsewhere found a more natural position, a contingency to which he himself was fully awake. ${ }^{3}$ But as a rule the allocation and ranking of the different Families of Oscines by this author must be deemed arbitrary. Yet the value of his Ornithologische Notizen is great, not only as evidence of his extensive acquaintance with different forms, which is proclaimed in every page, but in leading to a far fuller appreciation of characters that certainly should on no account be neglected, though too much importance may easily be, and already has been, assigned to them. ${ }^{4}$

This will perhaps be the most convenient place to mention another kind of classification of Birds, which, based on a principle wholly different from those that have just been explained, requires a few words, though it has not been productive, nor is it likely, from all that appears, to be productive of any great effect. So long ago as 1831, Bonaparte, in his Saggio di una distribuzione metodica degli Animali Vertebrati, published at Rome, and in 1837 communicated to the Linnean Society of London, 'A new Systematic Arrangement of Vertebrated Animals,' which was subsequently printed in that Society's Transactions (xviii. pp. 247-304), though before it appeared there was issued at Bologna, under the title of Synopsis Vertcbratorum Systematis, a Latin translation of it. Herein he

them below the Family called by him Sylvicolidx, consisting chiefly of the American forms now known as Mniotiltidx, none of which as songsters approach those of the old World.

I It must be observed that Prof. Cabanis does not place the Alaudida lowest of the seventeen Families of which he makes the Oscines to be composed. They stand eleventh in order, while the Corvidæ are last-a matter on which something may be said in the sequel.

2 The American Fanily Vireonida (V1REo) presents some notable examples, though there it is stated that the tenth primary is always present, but often concealed by the ninth (cf. Coues, Key $N$. Am. Birds, ed. 2, p. 391).

3 By a curious error, probably of the press, the number of primaries assigned to the Paradiseida and Corvidx is wrong (pp. 334, 335). In each case 10 should be substituted for 19 and 14 .

4 A more extensive and detailed application of his method was begun by Prof. Cabanis in the Museum Heineanum, a useful catalogue of specimens in the collection of the late Oberamtmann Heine, of which the first part appeared at Halberstadt in 1850, and the last, the work being still unfinished, in 1863. A Nomenclator of the same collection was printed at Berlin $1882-90$ by its owner's son and Dr. Reichellow. 
divided the Class Aves into two Subclasses, to which he applied the names of Insessores and Grallatores (hitherto used by their inventors Vigors and Illiger in a different sense), in the latter work relying chiefly for this division on characters which had not before been used by any systematist, namely, that in the former group Monogamy generally prevailed and the helpless nestlings were fed by their parents, while the latter group were mostly Polygamous, and the chicks at birth were active and capable of feeding themselves. This method, which in process of time was dignified by the title of a Physiological Arrangement, was insisted upon with more or less pertinacity by the author throughout a long series of publications, some of them separate books, some of them contributed to the memoirs issued by many scientific bodies of various European countries, ceasing only at his death, which in July 1857 found him occupied upon the unfinished Conspectus Generum Avium before mentioned. In the course of this series, however, he saw fit to alter the name of his two Subclasses, since those which he at first adopted were open to a variety of meanings, and in a communication to the French Academy of Sciences in 1853 (Comptes Rendus, xxxvii. pp. 641-647) the denomination Insessores was changed to Altrices, and Grallatores to Prxcoces-the terms now preferred by him being taken from Sundevall's treatise of 1835 already mentioned. The views of Bonaparte were, it appears, also shared by an ornithological amateur of some distinction, Hogg, who propounded a scheme which, as he subsequently stated (Zool. 1850, p. 2797), was founded strictly in accordance with them; but it would seem that, allowing his convictions to be warped by other considerations, he abandoned the original "physiological" basis of his system, so that this, when published in 1846 (Edinb. N. Philos. Journ. xli. pp. 50-71) was found to be established on a single character of the feet only, whereon he defined his Subclasses Constrictipedes and Inconstrictipedes. The numerous errors made in his assertion hardly need pointing out. Yet the idea of a "physiological" arrangement on the same kind of principle found another follower, or, as he thought, inventor, in Newman, who published (Proc. Zool. Soc. 1850, pp. 46-48, and Zool. pp. 2780-2782) a plan based on exactly the same considerations, dividing Birds into two groups, "Hesthogenous"- -a word so vicious in formation as to be incapable of amendment, but intended to signify those that were hatched with a clothing of down-and "Gymnogenous," or those that were hatched naked. These three systems are essentially identical ; but, plausible as they may be at the first aspect, they have been found to be practically useless, though such of their characters as their upholders have advanced with truth deserve attention, and, as will be seen in the present work, Dr. Gadow's terms Nidicolæ and Nidifugx, used in no systematic sense, express with greater accuracy what is needed. Physiology may one day very likely assist the systematist; but it must be real physiology and not a sham.

In 1856 Prof. Gervais, who had already contributed to the Zoologie of M. de Castelnau's Expédition dans les parties ccntrales de l'Amérique du Sud some important memoirs describing the anatomy of the HoActzin (page 421) and certain other Birds of doubtful or anomalous position, published some remarks on the characters which could be drawn from the 
sternum of Birds (Ann. Sc. Nat. Zoologie, ser. 4, vi. pp. 5-15). The considerations are not very striking from a general point of view; but the author adds to the weight of evidence which some of his predecessors had brought to bear on certain matters, particularly in aiding to abolish the artificial groups "Déodactyls," "Syndactyls" and "Zygodactyls," on which so much reliance had been placed by many of his countrymen; and it is with him a great merit that he was the first apparently to recognize publicly that characters drawn from the posterior part of the sternum, and particularly from the "échancrures," commonly called in English "notches" or "emarginations," are of comparatively little importance, since their nunlber is apt to vary in forms that are most closely allied, and even in species that are usually associated in the same genus or unquestionably belong to the same Family, ${ }^{1}$ while these "notches," sometines become simple foramina, as in certain Pigeons, or on the other hand foramina may exceptionally change to "notches," and not unfrequently disappear wholly. Among his chief systematic determinations we may mention that he refers the Tinamous to the Rails, because apparently of their deep "notches," but otherwise takes a view of that group more correct according to modern notions than did most of his contemporaries. The Bustards he would place with the "Limicoles," as also Dromas (Crab-Plover) and Chionis, (Sheathitli). Phaethon (TropicBIRD) he would place with the "Laridés" and not with the "Pelécanidés," which it only resembles in its feet having all the toes connected by a web. Finally Divers, Auks and Penguins, according to him, form the last term in the series, and it seems fit to him that they should be regarded as forming a separate Order. It is a curious fact that even at a date so late as this, and by an investigator so well informed, doubt should still have existed whether Apteryx should be referred to the group containing the Cassowary and the Ostrich. On the whole the remarks of this esteemed author do not go much beyond such as might occur to any one who had made a study of a good series of specimens; but many of them are published for the first time, and the author is careful to insist on the necessity of not resting solely on sternal characters, but associating with them those drawn from other parts of the body.

Three years later in the same journal (xi. pl. 11-145, pls. 2-4) M. Blanchard published some Recherches sur les caractères ostéologiques des Oiseaux appliquées à la Classification naturelle de ces animaux, strongly urging the superiority of such characters over those drawn from the bill or feet, which, he remarks, though they may have sometimes given correct notions, have mostly led to mistakes, and, if observations of habits and food have sometimes afforded happy results, they have often been deceptive; so that, should more be wanted than to draw up a mere inventory of creation or trace the distinctive outline of each species, zoology without anatomy would remain a barren study. At the same time he states that authors who have occupied themselves with the sternum alone have often

1 Thus he cites the cases of Machetes pugnax and Scolopax misticula among the "Limicoles," and Larus cataractes among the "Laridés," as differing from their nearest allies by the possession of only one "notch" on either side of the keel (cf. suprà, page 49). 
produced uncertain results, especially when they have neglected its anterior for its posterior part; for in truth every bone of the skeleton ought to be studied in all its details. Yet this distinguished zoologist selects the sternum as furnishing the key to his primary groups or "Orders" of the Class, adopting, as Merrem had done long before, the same two divisions Carinatæ and Ratitx, naming, however, the former Tropidosternii and the latter Homalosternii. ${ }^{1}$ Some unkind fate has hitherto hindered him from making known to the world the rest of his researches in regard to the other bones of the skeleton till he reached the head, and in the memoir cited he treats of the sternum of only a portion of his first "Order." This is the more to be regretted by all ornithologists since he intended to conclude with what to them would have been a very great boon-the shewing in what way external characters coincided with those presented by Osteology. It was also within the scope of his plan to have continned on a more extended scale the researches on ossification begun by L'Herminier, and thus M. Blanchard's investigations, if completed, would obviously have taken extraordinarily high rank among the highest contributions to ornithology. As it is, the 32 pages we have of them are of considerable importance; for, in this unfortunately unfinished meinoir, he describes in some detail the several differences which the sternum in a great many different groups of his Tropidosternii presents, and to some extent makes a methodical disposition of them accordingly. Thus he separates the Birds-of-Prey into three great groups-(1) the ordinary Diurnal forms, including the Falconidx and Vulturidx of the systematist of his time, but distinguishing the American VuLTuRES from those of the Old World; (2) Gypogeranus (SECRETARY-BIRD); and (3) the Owls. Next he places the Parrots, and then the vast assemblage of "Passereaux" - which he declares to be all of one type, even genera like Pipra (Manakin) and Pitta-and concludes with the somewhat heterogeneous conglomeration of forms, beginning with Cypselus (SWIFT), that so many systematists have been accustomed to call Picariæ, though to them as a group he assigns no name.2

Important as are the characters afforded by the sternum, that bone even with the whole sternal apparatus should obviously not be considered alone. To aid ornithologists in their studies in this respect, Eyton, who for many years had been forming a collection of Bird's skeletons, began the publication of a series of plates representing them. The first part of this work, Osteologia Avium, appeared early in 1859, and a volume was completed in 1867. A supplement was issued in 1869, and a Second Supplement, in three parts, between 1873 and 1875. The whole work contains a great number of figures of Birds' skeletons and detached bones; but they are not so drawn as to be of much practical use, and the

1 These terms were explained in his great work L'Organisation du Règne Animal, Oiseaux (p. 16), begun in 1855 , and unhappily unfinished, to mean exactly the same as those applied by Merrem to his two primary divisions.

2 M. Blaichard's animadversions on the employment of external characters, and on trusting to observations on the habits of Birds, called forth a rejoinder from Mr. Wallace (Ibis, 1864, pp. 36-41), who successfully shewed that they are not altogether to be despised. 
accompanying letterpress is too brief to be satisfactory. A somewhat similar work, Abbildungen von Vogel-Skeletten, was begun in 1879 by Dr. A. B. Meyer, and is still in progress, 210 plates of Birds' skeletons having already appeared. Some of these are excellent, but photography, by means of which they are all represented, is an unintelligent art, and as the sun shines alike on the evil and the good, so minor characters are as faithfully portrayed as those which are of importance, and indeed the latter are often, from the nature of the case, obscure or even indistinguishable. Yet we may be sure that every possible care was taken to avoid the disappointment thus caused.'

That the eggs laid by Birds should offer to some extent characters of utility to systematists is only to be expected, when it is considered that those from the same nest generally bear an extraordinary family-likeness to one another, and also that in certain gromps the essential peculiarities of the egg-shell are constantly and distinctively characteristic. Thus no one who has ever examined the egg of a Duck or of a Tinamou would ever be in danger of not referring another Tinamou's egg or another Duck's that he might see to its proper Family, and so on with many others. Yet, as is stated in the text (p. 182), the expectation held out to oologists, and by them, of the benefits to be conferred upon Systematic Ornithology from the study of Birds' eggs, so far from being fulfilled, has not unfrequently led to disappointment. But at the same time many of the shortcomings of Oology in this respect must be set down to the defective information and observation of its votaries, among whom some have been very lax, not to say incautious, in not ascertaining on due evidence the parentage of their specimens, and the author next to be named is open to this charge. After several minor notices that appeared in journals at various times, Des Murs in 1860 brought out at Paris his ambitious Traité général d'Oologie Ornithologique au point de vue de la Classification, elsewhere mentioned (EGGS, page 191, note), which contains (pp. 529-538) a 'Systema Oologicum' as the final result of his labours. In this scheme Birds are arranged according to what the author considered to be their natural method and sequence; but the result exhibits some unions as ill-assorted as can well be met with in the whole range of tentative arrangements of the Class, together with some very unjustifiable divorces. This being the case, it would seem useless to take up further space by analysing the several proposed modifications of Cuvier's arrangement which the author takes as his basis. The great merit of the work is that the author shews the necessity of taking Oology into account when investigating the classification of Birds, but it also proves that in so doing the paramount consideration lies in the thorough sifting of evidence as to the parentage of the eggs which are to serve as the building stones of the fabric to be erected (Ibis, 1860, pp. 331-335). The attempt of Des Murs was praiseworthy; but in effect it has utterly failed, notwithstand-

1 A countless number of osteological papers have appeared in journals, and to name them would here be impossible. The more important have generally been mentioned in the body of this work in connexion with the species or group of species they illustrate; but many that are good are necessarily passed over. 
ing the encomiums passed upon it by friendly critics (Rev. de Zoologie, 1860 , pp. 176-183, 313-325, 370-373). ${ }^{\mathrm{I}}$

Until about this time systematists, almost without exception, may be said to have been wandering with no definite purpose. At least their purpose was indefinite compared with that which they now have before them. No doubt they all agreed in saying that they were prosecuting a search for what they called the True System of Nature; but that was nearly the end of their agreement, for in what that True System consisted the opinions of scarcely any two would coincide, unless to own that it was some shadowy idea beyond the present power of mortals to reach or even comprehend. The Quinarians, who boldly asserted that they had fathomed the mystery of Creation, had been shewn to be no wiser than other men, if indeed they had not utterly befooled themselves; for their theory at best could give no other explanation of things than that they were because they were. The conception of such a process as lias now come to be called by the name of Evolution was certainly not novel; but except to two men the way in which that process was or could be possible had not been revealed. ${ }^{2}$ Here there is no need to enter into details of the history of Evolutionary theories; but the annalist in every branch of Biology must record the eventful First of July 1858, when the now celebrated views of Darwin and Mr. Wallace were first laid before the scientific world, ${ }^{3}$ and must also notice the appearance towards the end of the following year of the former's Origin of Species, which has effected one of the greatest revolutions of thought in this or perhaps in any century. The majority of biologists who had schooled themselves on other principles were of course slow to embrace the new doctrine; but their hesitation was only the natural consequence of the caution which their scientific training enjoined. A few there were who felt as though scales had suddenly dropped from their eyes, when greeted by the idea conveyed in the now familiar phrase "Natural Selection"; but even those who had hitherto believed, and still continued to believe, in the sanctity of "Species" at once perceived that their life-long study had undergone a change, that their old position was seriously threatened by a perilous siege, and that to make it good they must find new means of defence. Many bravely maintained their posts, and for them not a word of blame ought to be expressed. Some few pretended, though the contrary was notorious, that they had always been on the side of the new philosopliy, so far as they allowed it to be philosophy at all, and for then liardly a word of blame is too severe. Others after due deliberation, as became men who honestly desired the truth and nothing but the truth, yielded wholly or almost wholly to arguments which they gradually found to be irresistible. But,

1 In this historical sketch of the progress of Ornithology it has not been thought necessary to mention other oological works, since they have not a taxonomic bearing and the chief of them are named elsewhere (p. 188, note), but to them must be added Mr. Poynting's Eggs of British Birds (at present confined to the Limicola), the figures of which are excellent, and Capt. Bendire's work mentioned above (page 37).

2 Neither Lamarck nor Robert Chambers (the now acknowledged author of Vestiges of Creation), though thorongh evolutionists, rationally indicated any means whereby, to usc the old phrase, "the transmutation of species" conld be effected.

${ }^{3}$ Journal of the Proccedings of the Linnean Society, iii. Zoology, pp. 45-62. 
leaving generalities apart, and restricting ourselves to what is here our proper business, there was possibly no branch of Zoology in which so many of the best informed and consequently the most advanced of its worker's sooner accepted the principles of Evolution than Ornithology, and of course the effect upon its study was very marked. New spirit was given to it. Ornithologists now felt they had something before them that was really worth investigating. Questions of Affinity, and the details of Geographical Distribution, were endowed with a real interest, in comparison with which any interest that had hitherto been taken was a trifling pastime. Classification assumed a wholly different aspect. It had up to this time been little more than the shufling of cards, the ingenious arrangement of counters in a pretty pattern. Henceforward it was to be the serious study of the workings of Nature in producing the beings we see around us from beings more or less unlike them, that had existed in bygone ages and had been the parents of a varied and varying offspring-our fellow-creatures of to-day. Classification for the first time was something more than the expression of a fancy, not that it had not also its imaginative side. Men began to figure to themselves the original type of some well-marked genus or Family of Birds. They could even discern dimly some generalized stock whence had descended whole groups that now differed strangely in habits and appearance-their discernment aided, may be, by some isolated form which yet retained undeniable traces of a primitive structure. More dimly still visions of what the first Bird may have been like conld be reasonably entertained; and, passing even to a higher antiquity, the Reptilian parent whence all Birds have sprung was brought within reach of man's consciousness. But relieved as it may be by reflexions of this kind-dreams some may perhaps still call them-the study of Ornithology has unquestionably become harder and more serious; and a corresponding change in the style of investigation, followed in the works that remain to be considered, will be immediately perceptible.

That this was the case is undeniably shewn by some remarks of Canon Tristram, who, in treating of the Alaudidæ and Saxicolinæ of Algeria (whence he had recently brought a large collection of specimens of his own making), stated (Ibis, 1859, pp. 429-433) that he could "not lielp feeling convinced of the truth of the views set forth by Messrs. Darwin and Wallace," adding that it was "hardly possible, I should think, to illustrate this theory better than by the Larks and Chats of North Africa." It is unnecessary to continue the quotation; the few words just cited are enough to assure to their author the credit of being (so far as is known) the first ornithological specialist who had the courage publicly to recognize and receive the new and at the time unpopular philosophy. ${ }^{1}$ But greater work was at hand. In June 1860 the late Prof. W. K. Parker broke, as most will allow, entirely fresh ground, and ground that during his life he continued to till more deeply perhaps than any other man by communicating to the Zoological Society a memoir ' On the Osteology of Balæniceps' (SHOEBILI), subsequently published in that Society's Transactions (iv. pp. 269-351). Of this contribution to science, as of all the rest which

1 Whether Canon Tristram was anticipated in any other, and if so in what, branch of Zoology will be a pleasing enquiry for the historian of the future. 
have since proceeded from him, may be said in the words he himself has applied (tom. cit. p. 271) to the work of another labourer in a not distant field:- "This is a model paper for mbiassed observation, and freedom from that pleasant mode of supposing instead of ascertaining what is the true nature of an anatomical element." I Indeed the study of this memoir, limited though it be in scope, could not fail to convince any one that it proceeded from the mind of one who taught with the authority derived directly from original knowledge, and not from association with the scribes-a conviction that has become strengthened as, in a series of successive memoirs, the stores of more than twenty years' silent abservation and unremitting research were unfoldecl, and more than that, the hidden forces of the science of Morphology were gradually brought to bear upon almost each subject that came under discussion. These different memoirs, being technically monographs, have strictly no right to be mentioned in this place; but there is scarcely one of them, if one indeed there be, that does not deal with the generalities of the study; and the influence they have had upon contemporary investigation is so strong that it is impossible to refrain from noticing them here, though want of space forbids us from enlarging on their contents. ${ }^{2}$ Moreover, the doctrine of Descent with variation is preached in all-seldom, if ever, conspicuously, but perhaps, all the more effectively on that account. There is no reflective thinker but nust perceive that Morphology is one of the lamps destined to throw light on the obscurity that still shrouds the genealogy of Birds as of other animals ; and, though as yet its illuminating power is admittedly far from what is desired, it has perhaps never shone more brightly than in Parker's

1 It is fair to state that some of Parker's conclusions respecting Balaniceps were contested by J. T. Reinhardt (Overs. K. D. Vid. Selsk. Forhandlinger, 1861, pp. 135154 ; Ibis, 1862, pp. 158-175), and it seems to the present writer not ineffectually. Parker replied to his critic (1bis, 1862, pp. 297-299).

2 It may be convenient that a list of Parker's principal works which treat of ornithological subjects, in addition to the two above mentioned, should here be giveu. They are as follows:-In the Zoological Society's Transactions-On the Osteology of the Gallinaceous Birds and Tinamous, v. pp. 149-241; On some Fossil Birds from the Zebbug Cave, vi. pp. 119-124; On the Osteology of the Kagu, vi. pp. 501-521 ; On the Egithognathous Birds, Pt. I. ix. pp. 289-352, Pt. II. x. pp. 251-314. In the Proceedings of the same Society-1863, On the systematic position of the Crested Screamer, pp. 511-518; 1865, On the Osteology of Microglossa alecto, pp. 235-238. In the Philosophical Transactions of the Royal Society-1865, On the Structure and Development of the Skull in the Ostrich Tribe, pp. 113-183; 1869, On the Structure and Development of the Skull of the Common Fowl, pp. $755-807 ; 1888$, On the Structure and Development of the Wing of the Common Fowl, pp. 385-398. In the Linnean Society's Transactions-On the Morphology of the Skull in the Woodpeckers and Wrynecks, ser. 2, Zoology, i. pp.1-22 ; On the Structure and Development of the Bird's Skull, tom. cit. pp. $99.154 ; 1891$, On the Morphology of the Gallinacex. In the Monthy Microscopical Journal for $1872,-$ On the Structure and Development of the Crow's Skull, pp. 217-226, 253 ; for 1873, On the Development of the Skull in the genus Turdus, pp. 102-107, and On the Development of the Skull in the Tit and Sparrow Hawk, parts i. and ii., pp. 6-11, 45-50. In the Cunningham Memoirs of the Royal Irish Academy, No. vi. (Dublin: 1890), On the Morphology of the Duck and Auk Tribes. There is beside the great work published by the Ray Society in 1868, A Monograph on the Structure and Development of the Shouldcr-girdle and Sternum, of which pp. 142-191 treat of these parts in the Class Aves; and the first portion of the article 'Birds' in the Encycl. Brit. ed. 9, iii. pp. 699-728. Nearly each of this marvellous series is copiously illustrated by figures from drawings made by the author. 
hands. The great fault of his series of memoirs, if it may be allowed the present writer to criticize them, is the indifference of their author to fornulating his views, so as to enable the ordinary taxonomer to perceive how far he has got, if not to present him with a fair scheme. But this fault is possibly one of those that are "to merit near allied," since it would seem to spring from the author's hesitation to pass from observation to theory, for to theory at present belong, and must for some time belong, all attempts at Classification. Still it is not the less annoying and disappointing to the systematist to find that the man whose life-long application would have enabled him, better than any one else, to declare the effect of the alliances and differences shewn to exist among various members of the Class, should yet have been so reticent, or that when he spoke he should rather use the language of Morphology, which those who are not morphologists find difficult of correct interpretation, and wholly inadequate to allow of zoological deductions. ${ }^{1}$

For some time past rumours of a discovery of the highest interest had been agitating the minds of zoologists, for in 1861 Andreas Wagner had sent to the Academy of Sciences of Munich (Sitzungsber. pp. 146-154; Ann. Nat. Hist. ser. 3, ix. pp. 261-267) an account of what he conceived to be a feathered Reptile (assigning to it the name Griphosaurus), the remains of which had been found in the lithographic beds of Solenhofen; but he himself, through failing health, had been unable to see the fossil. In 1862 the slabs containing the remains were acquired by the British Museum, and towards the end of that year Owen communicated a detailed description of them to the Royal Society (Philos. Trans. 1863, pp. 33-47), proving their Bird-like nature, and referring them to the genus Archropteryx of Hermann von Meyer, hitherto known only by the impression of a single feather from the same geological beds. Wagner foresaw the use that would be made of this discovery by the adherents of the new Philosophy, and, in the usual language of its opponents at the time, strove to ward off the "misinterpretations" that they would put upon it. His protest, it is needless to say, was unavailing, and all who respect his memory must regret that the sunset of life failed to give him that insight into the future which is poetically ascribed to it. To Darwin and those who believed with him scarcely any discovery could have been more welcome; but that is beside our present business. It was quickly seen -even by those who held Archxopteryx to be a Reptile-that it was a form intermediate between existing Birds and existing Reptiles-while those who were convinced by Owen's researches of its ornithic affinity saw that it must belong to a type of Birds wholly unknown before, and one that in any future arrangement of the Class must have a special rank reserved for it. ${ }^{2}$ It is elsewhere briefly described and figured in this work (Fossil Birds, pages 278-280). ${ }^{3}$

${ }^{1}$ As an instance, take the passages in which Turnix and Thinocorys are apparently referred (Trans. Zool. Soc. ix. pp. 291 et seqq.; and Encycl. Brit. ed. 9, iii. p. 700) to the Agithognathre, a view which, as shewn by the author (Trans. x. p. 310), is not that really intended by him.

2 This was done in 1866 by Prof. Häckel, who (Gen. Morphol. ii. pp. xi., cxxxix.cxli.) proposed the name SAURIURe for the group containing it.

${ }^{3}$ It behoves us to mention the 'Outlines of a Systematic Review of the Class of 
In the spring of the year 1867 the late Prof. Huxley, to the delight of an appreciative audience, delivered at the Royal College of Surgeons of England a course of lectures on Birds, and it is much to be regretted that his many engagements hindered him from publishing in its entirety his elucidation of the anatomy of the Class, and the results which he drew from his investigations of it; for never assuredly had the subject been attacked with greater skill and power, or, since the days of Buffon, had Ornithology been set forth with greater eloquence. To remedy, in some degree, this unavoidable loss, and to preserve at least a portion of the fruits of his labours, Huxley, a few weeks after, presented an abstract of his researches to the Zoological Society, in whose Proceedings for the same year it will be found printed ( $\mathrm{pp} .415-472$ ) as a paper ' On the Classification of Birds, and on the taxonomic value of the modifications of certain of the cranial bones observable in that Class.' Starting from the basis (which, undeniably true as it is, not a little shocked many of his ornithological hearers) "that the phrase "Birds are greatly modified Reptiles' wonld hardly be an exaggerated expression of the closeness" of the resemblance between the two Classes, which he had previously brigaded under the name of Sauropsida (as he had brigaded the Pisces and Amphibia as Ichthyopsida), he drew in bold outline both their likenesses and their differences, and then proceeded to enquire how the Aves could be most appropriately subdivided into Orders, Suborders and Families. In this course of lectures he had already dwelt at some length on the insufficiency of the characters on which such gromps as had hitherto been thought to be established were founded; but for the consideration of this part of his subject there was no room in the present paper, and the reasons why he arrived at the conclusion that new means of philosophically and successfully separating the class must be sought were herein left to be inferred. The upshot, however, admits of no uncertainty : the Class Aves was held to be composed of three "Orders"-SaURURA (p. 814); RATite

Birds,' communicated by Prof. Lilljeborg to the Zoological Society in 1866, and published in its Proceedings for that year (pp. 5-20), since it was immediately after reprinted by the Smithsonian Institution, and with that authorization has exercised a great influence on the opinions of American ornithologists. Otherwise the scheme would hardly need notice here. This paper is indeed little more than an English trauslation of one published by the author in the annual volume (Arsskrift) of the Scientific Society of Upsala for 1860 ; and, belonging to the pre-Darwinian epoch, should perhaps have been more properly treated before, but that at the time of its original appearance it failed to attract attention. The chief merit of the scheme perhaps is that, contrary to nearly every precedent, it begins with the lower and rises to the higher groups of Birds, which is of course the natural mode of proceeding, and one therefore to be commended. Otherwise the "principles" on which it is founded are not clear to the ordinary zoologist. One of them is said to be "irritability," which is explained to mean, not "muscular strength alone, but vivacity and activity generally," aud on this ground it is stated that the Passeres should be placed highest in the Class. But those who know the habits and demeanour of many of the Limicole would no doubt rightly claim for them much more "vivacity and activity" than is possessed by most Passcres. " Irritability" does not seem to form a character that can be easily appreciated either as to quantity or quality ; in fact most persons would deem it quite immeasurable, and, as such, removed from practical consideration. Moreover, Prof. Lilljeborg's scheme, being actnally an adaptation of that of Sundevall, of which we shall have to speak almost immediately, may possibly be left for the present with these remarlis. 
(p. 766) and Carinatæ (p. 76). The Saururæ have the metacarpals well developed and not ancylosed, and the caudal vertebræ are numerous and large, so that the candal region of the spine is longer than the body. The furcula is complete and strong, the feet are very Passerine in appearance. The skull and sternum were at the time unknown, and indeed the whole Order, without doubt entirely extinct, rested exclusively on the celebrated fossil, then unique, Archropteryx just mentioned. The Ratita comprehend the "Struthious" Birds, which differ from all others now extant in the combination of several peculiarities, some of which have been mentioned in the preceding pages. The sternum has no keel, and ossifies from lateral and paired centres only; the axes of the scapula and coracoid have the same general direction; certain of the cranial bones have characters very mnlike those possessed by the next Order-the vomer, for example, being broad posteriorly and generally intervening between the basisphenoidal rostrum and the palatals and pterygoids ; the barbs of the feathers are disconnected; there is no syrinx or inferior larynx; and the diaphragm is better developed than in other Birds. ${ }^{1}$ The Ratitx are divided into five groups, separated by very trenchant characters, principally osteological, and many of them afforded by the cranial bones. These groups consist of (i.) Struthio (Ostrich), (ii.) Rhea, (iii.) Casuarius Cassowary, and Dromæus (Ened), (iv.) Dinornis (MOA) and (v.) Apteryx (KIwI); but no names are here given to them. The Carinata comprise all other existing Birds. The sternum has more or less of a keel, and is said to ossify, with the possible exception of Stringops (KAKAPO), from a median centre as well as from paired and lateral centres. The axes of the scapula and coracoid meet at an acute, or, as in Didus (DoDo) and Ocydromus (WEKA), at a slightly obtuse angle, while the vomer is comparatively narrow and allows the pterygoids and palatals to articulate directly with the basisphenoidal rostrum. The Carinatæ are divided, according to the formation of the palate, into four "Suborders," and named (i.) Drommognathe, (ii.) Schizognathe, (iii.) Desmognathe and (iv.) Egithognatha. ${ }^{2}$ The Dromæognathx resemble the Ratitx, and especially Dromæus, in their palatal structure, and are composed of the Tinasous. The Schizognathx include a great many of the forms belonging to the Linnæan Orders Gallinx, Grallx and Anseres. In them the voner, however variable, always tapers to a point anteriorly, while behind it includes the basisphenoidal rostrum between the palatals; but neither these nor the pterygoids are borne by its posterior divergent ends. The maxillopalatals are usually elongated and lamellar, uniting with the palatals, and, bending backward along their inner edge, leave a cleft (whence the name given to the "Suborder") between the vomer and themselves. Six groups of Schizognathæ are distinguished with considerable minuteness:- (1) Charadriomorphe ; (2) Geranomorphae ; (3) Cecomorphe;

1 This peculiarity had led some zoologists to cousider the "Struthious" Birds more nearly allied to the Mammalia than any others.

2 These names are compounded respectively of Dromæus, the generic name applied to the Emeu, $\sigma \chi i \xi a$, a split or cleft, $\delta \epsilon \sigma \mu a$, a bond or tying, al $\gamma \iota \theta 0 s$, a Finch, and, in each case, $\gamma \nu a \dot{\theta} \theta$ s, a jaw. The constitution of the several groups is explained in the body of this work under nąmes here printed in small capitals, but is repeated for the convenience of the reader. 
Spheniscomorphe; ; (5) Alectoromiorphe; and finally (6) PeristeroMORPH $巴$. In the third of these "Suborders," the Desmognathx, the vomer is either abortive or so small as to disappear from the skeleton. When it exists it is always slender, and tapers to a point anteriorly. The maxillo-palatals are bound together (whence the name of the "Suborder") across the middle line, either directly or by the ossification of the nasal septum. The posterior ends of the palatals and anterior of the pterygoids articulate directly with the rostrum. The groups of Desmognathæ are characterized as carefully as are those of the preceding "Suborder," and are as follows:-(1) Chenomorpha ; (2) Amphimorphe; ; (3) PelargoMorpha ; (4) Drsporomorpha ; (5) Aetomorphe ; (6) Psittacomorpha; and lastly (7) CoccrgosorPh $\&$, containing four groups, to which, however, names were not given. Next in order come the Celeosionph $Æ$, a group respecting the exact position of which Prof. Huxley was uncertain, ${ }^{1}$ though he inclined to think its relations were with the next group, EgithogNathe, the fourth and last of his "Suborders," characterized by a form of palate in some respects intermediate between the two preceding. The vomer is broad, abruptly truncated in front, and deeply cleft behind, so as to embrace the rostrum of the sphenoid; the palatals have produced postero-external angles; the maxillo-palatals are slender at their origin, and extend obliquely inwards and forwards over the palatals, ending beneath the vomer in expanded extremities, not united either with one another or with the vomer, nor does the latter unite with the nasal septum, though that is frequentIy ossified. Of the Egithognathre two divisions are made-(1) CYPSELOMORPHE, and (2) CORACOMORPH r $^{2}$ which last are separable into two groups, one (a) formed of the genus Ienura (LYRE-BIRD), which then seemed to stand alone, and the other $(b)$ made up of PolymYode, TracheOPHONe and OLIgOMrode, sections founded on the syringeal structure, but declared to be not natural.

The above abstract ${ }^{3}$ shews the general drift of this very remarkable contribution to Ornitlology, and it has to be added that for by far the greater number of his minor groups Huxley relied solely on the form of the palatal structure, the importance. of which Cornay, as already stated (page 69), had before urged, though to so little purpose. That the palatal structure must be taken into consideration by taxonomers as affording hints of some utility there could no longer be a doubt; but the present writer is inclined to think that the characters drawn thence owe more of their worth to the extraordinary perspicuity with which they were presented by Huxley than to their own intrinsic value, and that if the same power had been employed to elucidate in the same way other parts of the skeleton-say the bones of the sternal apparatus or even of the pelvic girdle-either set could have been made to appear quite as instructive and perhaps more so. Adventitious value would therefore seem

1 Prof. Parker subsequently advanced the Woodpeckers to a higher rank under the name of SAUROGNatHe (Microscop. Journ. 1872, p. 219, and Tr. Limn. Sac. ser. 2, Zoology, i. p. 2).

2 By mistake this group was referred (page 104) to the Desmognathous Birds.

3 This is adapted from one (Record of Zool. Lit. iv. pp. 46.49) which was sub. mitted to the author's approval. 
to have been acquired by the bones of the palate through the fact that so great a master of the art of exposition selected them as fitting examples upon which to exercise his skill. ${ }^{I}$ At the same time it must be stated this selection was not premeditated by him, but forced itself upon him as his investigations proceeded. ${ }^{2}$ In reply to some critical remarks ( $I b i$, 1868 , pp. 85-96), chiefly aimed at shewing the inexpediency of relying solely on one set of characters, especially when those afforded by the palatal bones were not, even within the limits of Families, wholly diagnostic, the author (Ibis, 1868, pp. 357-362) announced a slight modification of his original scheme, by introducing three more groups into it, and concluded by indicating how its bearings upon the great question of "Genetic Classification" might be represented so far as the different groups of Carinatæ are concerned:-

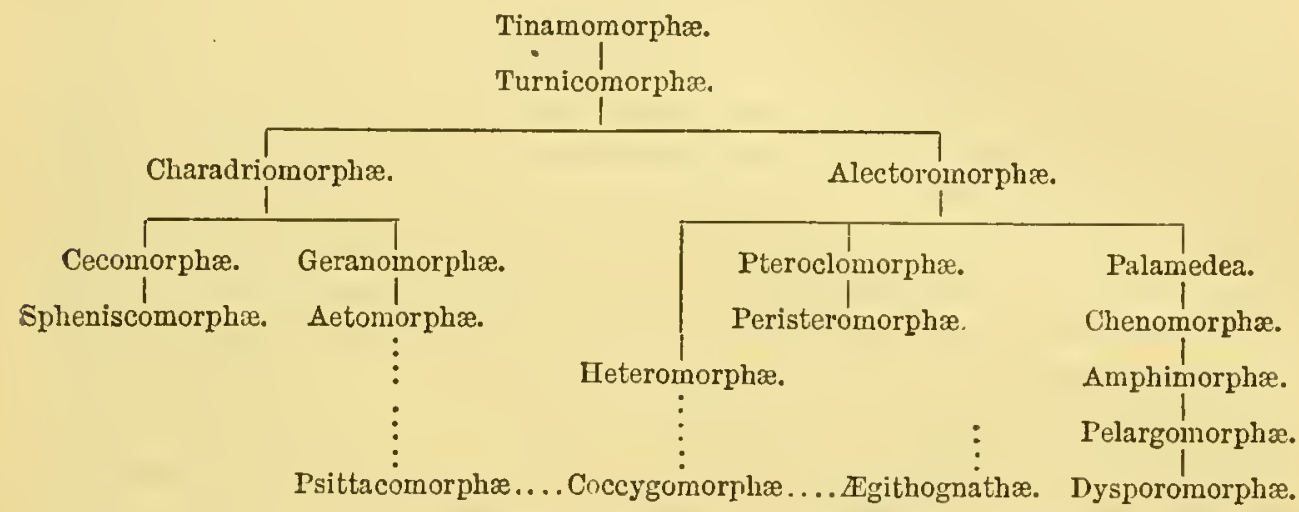

The above scheme, in Huxley's opinion, nearly represents the affinities of the various carinate groups,- - the great difficulty being to determine the relations to the rest of the Coccygomorph, Psittacomorph $x$ and Agithognath which he indicated "only in the most doubtful and hypothetic fashion." Almost simultaneously with this he expounded more particularly (Proc. Zool. Soc. 1868, pp. 294-319) the groups of which he believed the Alectoromorphr to be composed and the relations to them of some outlying forms usually regarded as Gallinaceous, the Turnicidx (HEMIPODE) and Pteroclidx (SAND-Grodse), as well as the singular HoACTzIN, for all three of which he had to institute new groups-the last forming the sole representative of his HeteromorpHe. More than this, he entered upon their Geographical Distribution, the facts of which important subject were,

1 The notion of the superiority of the palatal bones to all others for purposes of classification has pleased many persons, from the fact that these bones are not unfrequently retained in the dried skins of Birds sent home by collectors in foreign countries, and are therefore available for study, while such bolles as the sternum and pelvis are rarely preserved. The common practice of ordinary collectors, until at least very recently, has been tersely described as being to "shoot a bird, take off its skin and throw away its characters."

2 Perhaps this may be partially explained by the fact that the Museum of the College of Surgeons, in which these investigations were chiefly carried on, like most other museums, contained a much larger series of the heads of Birds than of their entire skeletons or of any other portion of the skeleton. Consequently the materials avaidable for the comparison of different forms consisted in great part of heads only. 
almost for the first time, since the attempt of Blyth already mentioned, ${ }^{1}$ brought to bear practically on Classification, as has been previously hinted (Geographical Distribution, page 313 ); but, the subject being treated elsewhere at some length, there is no need to enter upon it here.

Nevertheless it is necessary to mention here the intimate connexion between Classification and Geographical Distribution as revealed by the palæontological researches of Prof. Alphonse Milne-Edwards, whose magnificent Oiseaux Fossiles de la France began to appear in 1867, and was completed in 1871 - the more so, since the exigencies of his undertaking compelled him to use materials that had been almost wholly neglected by other investigators. A large proportion of the fossil remains the determination and description of which were his object were what are commonly called the "long bones", that is to say, those of the limbs. The recognition of these, minute and fragmentary as many were, and the referring them to their proper place, rendered necessary an attentive study of the comparative osteology and myology of Birds in general, that of the "long bones," whose sole characters were often a few muscular ridges or depressions, being especially obligatory. Hence it became manifest that a very respectable Classification can be found in which characters drawn from these bones play a rather important part. Limited by circumstances as is that followed by M. Milne-Edwards, the details of his arrangement do not require setting forth here. It is enough to point out that we have in his work another proof of the multiplicity of the factors which nust be taken into consideration by the systematist, and another proof of the fallacy of trusting to one set of characters alone. But this is not the only way in which the author has rendered service to the advanced student of Ornithology. The unlooked-for discovery in France of remains which he has referred to forms now existing it is true, but existing only in countries far removed from Europe, forms such as Collocalia, Leptosomus, Psittacus, Serpentarius and Trogon, is perhaps even more suggestive than the finding that France was once inhabited by forms that are wholly extinct, of which, as is elsewhere mentioned (Fossir BrRDs, pages 284, 288), there is abundance in the older formations. Unfortunately none of these, for none is old enough, can be compared for singularity with Archæopteryx or with some American fossil forms next to be noticed, for their particular bearing on our knowledge of Ornithology will be most conveniently treated here.

In November 1870 Prof. Marsh, by finding the imperfect fossilized tibia of a Bird in the Middle Cretaceous shale of Kansas, began a series of wonderful discoveries which will ever be associated with his name, ${ }^{2}$ and, making us acquainted with a great number of forms long since vanished

1 It is true that from the time of Buffon, though he scorned any regular Classification, Geographical Distribution had been occasionally held to have something to do with systematic arrangement; but the way in which the two were relatel was never clearly put forth, though people who could read between the lines might have guessed the secret from Darwin's Journal of Researches, as well as from his introduction to the Zoology of the 'Beagle' Voyage.

2 It will of course be needless to remind the general zoologist of Prof. Marsh's no less wonderful discoveries of wholly unlooked-for types of Reptiles and Mammals. 
from among the earth's inhabitants, has thrown a coinparatively broad beam of light through the darkness that, broken only by the solitary spark emitted on the recognition of Archropteryx, had hitherto brooded over our knowledge of the genealogy of Birds, and is even now for the most part palpable. Subsequent visits to the same part of North America, often performed in circumstances of discomfort and occasionally of danger, brought to this intrepid and energetic explorer the reward he had so fully earned. Brief notices of his spoils appeared from time to time in various volumes of the American Journal of Science and Arts (Silliman's), but it is unnecessary here to refer to more than a few of them. In that Journal for May 1872 (ser. 3, iii. p. 360) the remains of a large swimming Bird (nearly 6 feet in length, as afterwards appeared) having some affinity, it was thought, to the Colymbidx were described under the name of Hesperornis regalis, and a few months later (iv. p. 344) a second fossil Bird from the same locality was indicated as Ichthyornis dispar-from the Fish-like, biconcave form of its vertebre. Further examination of the enormous collections gathered by the author, and preserved in the Museum of Yale College at New Haven in Connecticut, shewed him that this last Bird, and another to which he gave the name of Apatornis, had possessed well-developed teeth implanted in sockets in both jaws, and induced him to establish for their reception a "Subclass" Odontornithes (page 649) and an Order Ichthyornithes. Two years more and the originally found Hesperornis was discovered also to have teeth, but these were inserted in a groove. It was accordingly regarded as the type of a distinct Order ODONTOLCA (loc. cit.), to which were assigned as other characters vertebræ of a saddle-shape and not biconcave, a keelless sternum and wings consisting only of the humerus. In 1880 Prof. Marsh brought out a grand volume, Odontornithes, being a monograph of the extinct toothed Birds of North America. Herein remains, attributed to no fewer than a score of species, which were referred to eight different genera, are fully described and sufficiently illustrated, and, instead of the ordinal name Ichthyornithes previously used, that of ODONTOTORMe (loc. cit.) was proposed. In the author's concluding summary he remarks on the fact that, while the Odontolcr, as exhibited in Hesperornis, had teeth inserted in a continuous groove-a low and generalized character as shewn by Reptiles, they had, however, the strongly differentiated saddle-shaped vertebræ such as all modern Birds possess. On the other hand the Odontotorma, as exemplified in Ichthyornis, having the primitive biconcave vertebræ, yet possessed the highly specialized feature of teeth in distinct sockets. Hesperornis too, with its keelless sternum, had aborted wings but strong legs and feet adapted for swimming, while Ichthyornis had a keeled sternum and powerful wings, but diminutive legs and feet. These and other characters separate the two forms so widely as quite to justify their assignment to distinct Orders, and the opposite nature of the evidence they afford illustrates one fundamental principle of Evolution, namely, that an animal may attain to great development of one set of characters and at the same time retain other features of a low ancestral type. Prof. Marsh states that he had fully satisfied himself that Arch opteryx belonged to the Odontornithes, which be thought it advisable for 
the present to regard as a Subclass, separated into three Orders-Odontolcx, Odontotormæ and Saururx-all well marked, but evidently not of equal rank, the last being clearly much more widely distinguished from the first two than they are from one another. But that these three oldestknown forms of Birds should differ so greatly from each other unmistakably points to a great antiquity for the Class. All are true Birds; but the Reptilian characters they possess converge towards a more generalized type. He then proceeds to treat of the characters which may be expected to have occurred in their common ancestor, whose remains may yet be hoped for from the Palæozoic rocks, or at least from the Permian beds that in North America are so rich in the fossils of a terrestrial fauna. Birds, he believes, branched off by a single stem, which gradually lost its Reptilian as it assumed the Ornithic type ; and in the existing Ratitx we have the survivors of this direct line. The lineal descendants of this primal stock doubtless at an early time attained feathers and warm blood, but, in his opinion, never, acquired the power of flight, which probably originated among the sulall arboreal forms of Reptilian Birds. In them even rudimentary feathers on the fore-limbs would be an advantage, as they would tend to lengthen a leap from branch to branch, or break the force of a fall in leaping to the ground. As the feathers increased, the body would become warmer and the blood more active. With still more feathers would come increased power of flight as we see in the young Birds of to-day. A greater activity would result in a more perfect circulation. A true Bird would doubtless require warm blood, but would not necessarily be hot-blooded, like the Birds now living. Whether Archropteryx was on the Carinate line cannot as jet be determined, and this is also to be said of Ichthyornis; but the biconcave vertebræ of the latter suggest its being an early offshoot, while it is probable that Hesperornis came off from the main "Struthious" stem and has left no descendants.

From this bright vision of the poetic past-a glimpse, some may call it, into the land of dreans - we must relapse into a sober contemplation of the prosaic present-a subject quite as difficult to understand. The former efforts at classification made by Sundevall have already several times been mentioned, and a return to their consideration was promised. In 1872 and 1873 he brought out at Stockholm a Methodi Naturalis Avium Disponendarum Tentamen, two portions of which (those relating to the Diurnal Birds-of-Prey and the "Cichlomorphx," or forms related to the Thrushes) he found himself under the necessity of revising and modifying in the course of 1874 , in as many communications to the Swedish Academy of Sciences (K. V.-Ak. Förhandl. 1874, No. 2,-pp. 21-30; No. 3, pp. 27-30). This Tentamen, containing a complete method of classifying Biràs in general, naturally received much attention, the more so perhaps, since, with its appendices, it was nearly the last labour of its respected author, whose industrious life came to an end in the course of the following year. From what has before been said of his works it may have been gathered that, while professedly basing his systematic arrangement of the groups of Birds on their external features, he had hitherto striven to make his schemes harmonize if possible with the dictates of internal structure as evinced by the science of anatomy, though he 
uniformly and persistently protested against the inside being better than the outside. In thus acting he proved himself a true follower of his great countryman Linnæus ; but, without disparagement of his efforts in this respect, it must be said that when internal and external characters appeared to be in conflict he gave, perhaps with unconscious bias, a preference to the latter, for he belonged to a school of zoologists whose natural instinct was to believe that such a conflict always existed. Hence his efforts, praiseworthy as they were from several points of view, and particularly so in regard to some details, failed to satisfy the philosophic taxonomer when generalizations and deeper principles were concerned, and in his practice in respect to certain technicalities of classification he was, in the eyes of the orthodox, a transgressor. Thus instead of contenting himself with terms that had met with pretty general approval, such as Class, Subclass, Order, Suborder, Family, Subfamily and so on, he introduced into his final scheme other designations, "Agmen," "Cohors," "Phalanx" and the like, which to the ordinary student of Ornithology convey an indefinite meaning, if any meaning at all. He also carried to a very extreme limit his views of nomenclature, which were certainly not in accordance with those held by most zoologists, though this is a matter so trifling as to need no details in illustration. It is by no means easy to set forth briefly, and at the same time intelligibly, to any but experts, the final scheme of Sundevall, owing to the number of new names introduced by him, and there is no need here to make the attempt, for experts would rather consult the work itself or the English version of it. ${ }^{l}$ Praised in various quarters as Sundevall's perfected System was on its appearance, the present writer felt from the first that it would speedily be seen to what little purpose so many able men had laboured if arrangement and grouping so manifestly artificial-the latter often of forms possessing no real affinity - could pass as a natural method. He was not so sanguine as to hope that it might be the last of its kind, though any one accustomed to look deeper than the surface must have seen its numerous defects, and almost every one, whether so accustomed or not, ought by its means to be brought to the conclusion that, when a man of Sundevall's knowledge and experience could not, by trusting only to external characters, do better than this, the most convincing proof is afforded of the inability of external characters alone to produce anything save ataxy. The principal merits it possesses are confined to the minor arrangement of some of the Oscines; but even here many of the alliances, such, for instance, as that of Pitta with the true Thrushes, are indefensible on any rational grounds, and some, as that of Accentor with the Weaver-birds, verge upon the ridiculous, while on the other hand the interpolation of the American Warblers, Mniotiltidx, between the normal Warblers of the Old World and the Thrushes is as bad-especially when the genus Mniotilta is placed, notwithstanding its differentwing-formula, with the Tree-creepers, Certhiidx. The whole work unfortunately betrays throughout an utter want of the sense of proportion. In many of the large groups very slight differences are allowed to keep the forms exhibiting them widely apart, while in

1 Sundevall's Tentamen. Translated into English with Notes, by Francis Nicholson. London : 1889. 
most of the smaller groups differences of far greater kind are overlooked, so that the forms which present them are linked together in more or less close union. Thus, regarding only external characters, great as is the structural distinction between the Gannets, Cormorants, Frigate-birds and Pelicans, it is not held to remove them from the limits of a single Family ; and yet the Thrushes and the Chats, whose distinctions are barely sensible, are placed in separate Families. Again, even in one and the same group, the equalization of characters indicative of Families is wholly neglected Thus among the Pigeons the genera Didus and Didunculus, which differ, so far as we know it, in every external character of their structure, are placed in one Family, and yet on very slight pretext the genus Goura, which in all respects so intimately resembles ordinary Pigeons, is set apart as the representative of a distinct Family. The only use of dwelling upon these imperfections here is the lope that thereby students of Ornithology may be induced to abandon the belief in the eflicacy of external characters as a sole means of classification, and, seeing how unmanageable they become unless checked by internal characters, be persuaded of the futility of any attempt to form an arrangement without that solid foundation which can only be obtained by a knowledge of anatomy. Where Sundevall failed no one else is likely to succeed; for he was a man gifted with intelligence of a rare order, a man of cultivation and learning, one who liad devoted his whole life to science, who had travelled much, studied much and reflected much, a man whose acquaintance with the literature of his subject probably exceeded that of any of his contemporaries, and a man whose linguistic attainments rendered him the envy of his many friends. Yet what should have been the crowning work of his long life is one that all who respected him, and that comprehends all who knew him, must regret, though apart from his systematic treatment his handiwork is adnirable.

Of the very opposite kind was the work of the two men next to be mentioned-Garrod and Forbes-both cut short in a career of promise ${ }^{2}$

1 In 1882 Dr. Reichemow prefixed to his Iögel der Zoologischen Garten another scheme of Classification, which, though out of order, may here be mentioned, from its treatment being in several respects similar to Sundevall's. Its author gave (I. p. viii.) the representation of a genealogical tree (Stammbaum) shewing the descent of existing Birds from those which were furnished with teeth (of which more presently) by four principal stems-1. "Kurzfiugler", Brevipennes; 2. speedily dividing into "Schwimmvögel", Natatores and "Stelzvögel", Grallatores ; 3. "Girrvögel", Gyrantes ; and 4. "Fänger", Captatores, "Paarzeher", Fibulatores and "Baumvögel", Arboricolæ, which succeed one another in the order named. These all form 7 Series (Reine) and are split into 17 Orders. The sense of proportion seems here more lamentably wanting than iu Sundevall's Tentamen. All the "Struthious" Birds form one Family, and the Oscines contain 21! While Series 5, Gyrantes, cousists only of the Columbx, Series 6, Captatores, includes Crypturi, Rasores (all Galline aud Opisthocomus), and Raptatores-containing Vulturide (Sarcorhamphine, Vulturinæ aud Gypastinæ), Falconide and Strigide. This will shew that no account is taken of any structural characters except those which are superficial; but the author's tree of ornithic genealogy may be regarded as an important feature, laving been auticipated, so far as I know, ouly by that of Prof. Häckel (Gen. Morphol. ii. Taf. vii.) which went but a short way.

2 Alfred Henry Garrod, Prosector to the Zoological Society of London, died of consumption in 1879, aged thirty-three. His successor in that office, William Alexauder Forbes, fell a victim to the cleadly climate of the Niger in 1883, and in his tweuty-eighth year. 
that among students of Ornithology has rarely been equalled and perhaps never surpassed. The present writer finds it difficult to treat of the labours of two pupils and friends, for while fully recognizing the brilliant nature of some of their researches, he is compelled very frequently to dissent from the conclusions at which they arrived, deeming them to have often been of a kind that, had their authors survived to a maturer age, they would have greatly modified. Still he well knows that learners are mostly wiser than their teachers; and, making due allowance for the haste with which, from the exigencies of the post they successively held, their investigations had usually to be published, he believes that much of the highest value underlies even the crudest conjectures contained in their several contributions to Ornithology. Putting aside the monographical papers by which each of them followed the excellent example set by their predecessor in the office they filled-Dr. Murie ${ }^{1}$ - and beginning with Garrod's, ${ }^{2}$ those having a more general scope, all published in the Zoological Society's Proceedings, may be briefly considered. Starting from the level reached by Huxley, the first attempt made by the younger investigator was in 1873 , "On the value in Classification of a Peculiarity in the anterior margin of the Nasal Bones in certain Birds." Herein he strove to prove that Birds ought to be divided into two Subclasses-one, called "Holorhinal," in which a straight line drawn transversely across the hindmost points of the external narial apertures passes in front of the posterior ends of the nasal processes of the præmaxillæ, and the other, called "Schizorhinal," in which such a line passes behind those processes. If this be used as a criterion, the validity of Huxley's group Schizognatha is shaken; but there is no need to enlarge upon the proposal, for it was virtually abandoned by its author within little more than a twelvemonth. The next subject in connexion with Systematic Ornithology to which Garrod applied himself was an investigation of the CAROTID Arteries, and here, in the same year, he made a considerable advance upon the labours of Nitzsch, as might well be expected, for the opportunities of the latter were very limited, and he was only able, as we have seen (page 55), to adduce four types of structure in them, while Garrod, with the superior advantages of his situation, raised the number to six. Nevertheless he remarks that their "disposition has not much significance among Birds, there being many Families in which, whilst the majority of the species have two, some have only one carotid." The exceptional cases cited by lim are quite sufficient to prove that the condition of this artery has nearly no value from the point of view of general classification $(c f$. pages 76, 77). If relied upon it would split up the Families Bucerotidx and

${ }^{1}$ Dr. Murie's chief papers having a direct bearing on Systematic Ornithology are:-in the Zoological Society's Transactions (vii. p. 465), 'On the Dermal and Visceral Structures of the Kagu, Sun-Bittern and Boatbill '; in the same Society's Proceedings-(1871, p. 647) 'Additional Notice concerning the Powder-Downs of Rhinochetus jubatus', (1872, p. 664) 'On the Skeleton of Todus with remarks as to its Allies', (1879, p. 552) 'On the Skeleton and Lineage of Fregilupus varius' ; in The 1bis-(1872, p. 262) 'On the genus Colius', (1872, p. 383) 'Motmots and their affinities', (1873, p. 181) 'Relationships of the Upupid\&.'

${ }^{2}$ Garrod's Scientific Papers were collected and published in a memorial volumo edited by Forbes in 1881. There is therefore no need to give a list of them here. Forbes's papers were similarly edited by Mr. Beddard in 1885 . 
Cypselidx, which no sane person would doubt to be homogeneous and natural. The femoral vessels formed another subject of investigation, and were found to exhibit as much exceptional conformation as those of the neck-for instance in Centropus phasianus, one of the Birds known as Codcals, the femoral artery accompanies the femoral vein, though it does not do so in another species of the genus, C. rufipennis, nor in any other of the Cuculidx (to which Family the genus Centropus has been always assigned) examined by Garrod. Nor are the results of the very great labour which he bestowed upon the muscular conformation of the thigh in Birds any more conclusive when they come to be impartially and carefully considered. Myology was with him always a favourite study, and he may be not unreasonably supposed to have had a strong feeling as to its efficacy for systematic ends. It was in favour of an arrangement based upon the muscles of the thigh, and elaborated by him in 1874, that he gave up the arrangement he had published barely more than a year before based upon the conformation of the nostrils. Nevertheless it appears that even the later of the two methods did not eventually content him, and this was only to be expected, though he is said by Forbes (Ibis, 1881, p. 28) to have remained "satisfied to the last as to the naturalness of the two main groups into which he there divided birds"-Homalogonate and Anomalogonate. The key to this arrangement lay in the presence or absence of the AMBIENs muscle, "not because of its own intrinsic importance, but because its presence is always associated with peculiarities in other parts never found in any Anomalogonatous bird." Garrod thought that so great was the improbability of the same combination of three or four different characters (such as an accessory femoro-caudal muscle, a tufted oil-gland and $\mathrm{C} \triangle \mathrm{CA}$ ) arising independently in different Birds that similar combinations of cilaracters could only be due to blood-relationship. The ingenuity with which he found and expressed these combinations of characters is worthy of all praise; the regret is that time was wanting for him to think out all their consequences, and that he did not take also into account other and especially osteological characters. Every osteologist must recognize that the neglect of these makes Garrod's proposed classification as unnatural as any that had been previously drawn up, and more unnatural than many. So much is this the case that, with the knowledge we have that ere his death he had already seen the need of introducing some modifications into it, its reproduction here, even in the briefest abstract possible, would not be advisable. Two instances, however, of its failure to shew natural affinities or differences may be cited. The first Order Galliformes of his Subclass Homalogonatæe is made to consist of three "Cohorts"-Struthiones, Gallinacex and Psittaci-a somewhat astonishing alliance; but even if that be allowed to pass, we find the second "Cohort" composed of the Families Palamcdeidæ, Gallinæ, Rallidr, Otididæ (containing two Subfamilies, the Bustards and the Flamingoes), Musophagidæ and Cuculidæ. Again the Subclass Anomalogonatæ includes three Orders-Piciformes, Passeriformes, Cypseliformes-a preliminary to which at first sight no exception need be taken; but immediately we look into details we find the Alcedinida placed in the first Order and the Meropidx in the second, together with the Passeres and a collection of 
Families almost every feature in the skeleton of which points to a separation. Common sense revolts at the acceptance of any scheme which involves so many manifest incongruities. With far greater pleasure we would leave these investigations, and those on certain other muscles, as well as on the Disposition of the deep plantar Tendons, and dwell upon his researches into the anatomy of the Passerine Birds with the view to their systematic arrangement. Here he was on much safer ground, and it can hardly be doubted that his labours will stand the test of future experience, for, though it may be that all his views will not meet with ultimate approval, he certainly made the greatest advance since the days of Müller, to the English translation of whose classical work he added (as before mentioned) an excellent appendix, besides having alrearly contributed to the Zoological Proceedings between 1876 and 1878 four memoirs replete with observed facts which no one can gainsay. As his labours were continued exactly on the same lines by Forbes, who between 1880 and 1882 published in the same journal six more memoirs on the subject, it will be convenient here to state generally, and in a combined form, the results arrived at by these two investigators.

Instead of the divisions of Passerine Birds instituted by Müller, Garrod and Forbes having a wider range of experience considered that they had shewn that the Passeres consist of two primary sections, which the latter named respectively DeSMODACTYII and ElEUTHERODACTYLI, from the facts discovered by the former that in the Eurylæmidæ (BROADBILL), a small Family peculiar to some parts of the Indian Region, and consisting of some ten or twelve species only, there is a strong band joining the muscles of the hind toe exactly in the same way as in many Families that are not Passerine, and hence the name Desmodactyli, while in all other Passerines the hind toe is free. This point settled, the Eleutherodactyli form two great divisions, according to the structure of their vocal organs; one of them, roughly agreeing with the Clamatores of some writers, is called Mesomrod, and the other, corresponding in the main, if not absolutely, with the Oscines, Polymyodi, or true Passeres of various authors, is named ACROMYODI- "an Acromyodian bird being one in which the muscles of the syrinx are attached to the extremities of the bronchial semi-rings, a Mesomyodian bird being one in which the muscles of the syrinx join the semi-rings in their middle." Furthermore, each of these groups is subdivided into two : the Acromyodi into "normal " and "abnormal," of which more presently; the Mesomyodi into HoMœOMERI and Heteromeri, according as the sciatic or the femoral artery of the thigh is developedthe former being the usual arrangement among Birds and the latter the exceptional. Under the head Heteromeri come only two Families, but these Garrod was inclined to think should not be considered distinct. The Homoomeri form a larger group, and are at once separable, on account of the structure of their vocal organs, into Tracheophonæ (practically equivalent to the Tracheophones of Muiller) and Haploophone (as Garrod named them) - the last being those Passeres which were by Müller erroneously included among his Picarii, namely, the Tyrannidæ (TrRaNt) with Rupicola (Cock-OF-THE-Rock) and PITTA. To these are now added Families not examined by him,-_but subsequently ascertained by Forbes 
to belong to the same group,_-Philepittidæ and Xenicidæ, more properly Acanthidosittidx (XENICOS), and it is remarkable that these last three Families are the only members of the Mesomyodi which are not peculiar to the New World-nay more, if we except the Tyrannida, which in North America occur chiefly as migrants, - not peculiar to the Neotropical Region. The Tracheophonæ are held to contain five Families-Furnariid $x$ (Oven-BIRD), Pteroptochidx (TAPACUlo), Dendrocolaptidæ (PICUCUlE), Conopophagidær and Formicariidæ (ANT-THRUSH). Returning now to the Acromyodi, which include, it has just been said, a normal and an abnormal section, the latter consists of Birds agreeing in the main, though not absolutely, as to the structure of the syrinx with that of the former, yet differing so considerably in their osteology as to be most justifiably separated. At that time only two types of these abnormal Acromyodi were knownMenura (LYRE-BIRD) and Atrichornis (SCRUB-BIRD), both from Australia, while all the remaining Passeres, that is to say, incomparably the greater number of Birds in general, belong to the normal section. Thus the whole scheme of the Passeres, ${ }_{1}^{1}$ as worked out by Garrod and Forbes, can be briefly expressed as below; and this expression, so far as it goes, is probably near the truth, though for simplicity's sake some of the intermediate group-names might perhaps be omitted :-

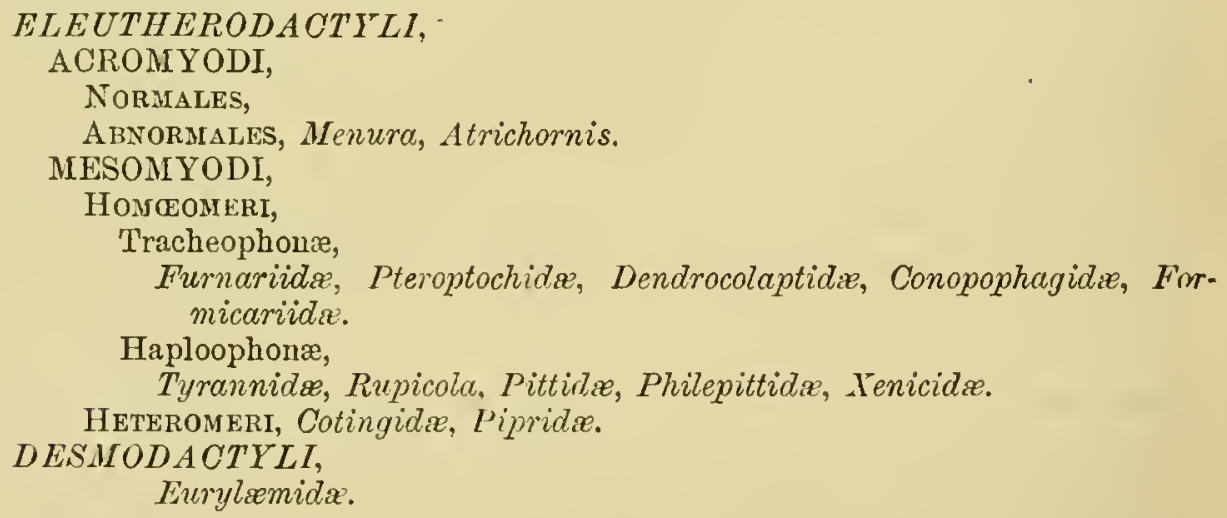
micariida.

Haploophonæ,

Tyrannidæ, Rupicola. Pittille, Philepittidæ, Nenicidæ.

Heteromeri, Cotingid $x$, Pipridie.

DESMODACTYLI,

Eurylamidx.

It will be seen that no attempt was made to separate the Normal Acromyodians into Families. Already, in The Ibis for 1874 (pp. 406416), Mr. Wallace liad published a plan, ${ }^{2}$ which, with two slight modifications that there were manifestly improvements, he employed two years later in his great work on The Geographical Distribution of Animals, and this included a method of arranging the Families of this division. Being based, however, wholly on alar characters, it has of course a great similarity to the schemes of Prof. Cabanis and of Sundevall, and, though simpler than either of those, there is no need here to enter much into its details. The Birds which would fall under the category of Garrod's Acromyodi normales are grouped in three series:- A. "Typical or

I It is right to observe that this scheme was not a little aided by a consideration of palatal characters, as well as regard to the disposition of some of the tendons of the wing-muscles.

2 Presenting some analogy to the work of Garrod and Forbes, though mainly based on external characters, is that carried on in regard to the feathering of Birds' wings, as quoted elsewhere (REMlges, p. 781, note), and deserving much attention. 
Turdoid Passeres," having a wing with ten primaries, the first of which is always more or less markedly reduced in size, and to this 21 Families are allotted; B. "Tanagroid Passercs," having a wing with nine primaries, the first of which is fully developed and usually very long, and containing 10 Families; and C. "Sturnoid Passeres," having a wing with ten primaries, the first of which is "rudimentary," with only 4 Families. The remaining Families, 10 in number, which are not normally acromyodian are grouped as Series D. and called "Formicaroid Passeres."

In The Ibis for 1880 (pp. 340-350, 399-411) Mr. Sclater made a laudable attempt at a general arrangement of Birds, ${ }^{1}$ trying to harmonize the views of ornithotomists with those taken by the ornithologists who only study the exterior; but, as he explained, his scheme is really that of Huxley reversed, ${ }^{2}$ with some slight modifications mostly consequent on the recent researches of Parker and of Garrod, and (here may be added) a few details derived from the author's own extensive knowledge of the Class. Adopting the two Subclasses Carinatx and Ratitx, he recognized 3 "Orders" as forming the latter and 23 the formera number far exceeding any that had of late years met with the approval of ornithologists. First of them comes the Passeres, of which IIr. Sclater wonld make four Suborders:--(1) the Acromyodi normales of Garrod under the older name of Oscines, to the further subdivision of which we must immediately return ; (2) under Huxley's term Oligomyodi, all the Haploophonx, Heteromeri and Desmodactyli of Garrod, comprehending 8 Families-Oxyrhamphidx, ${ }^{3}$ Tyrannidx, Pipridx, Cotingidx, Phytotomidx, Pittidx, ${ }^{3}$ Philepittidx and Eurylæmidx; ${ }^{4}$ (3) Tracheophonx, containing the same groups as in the older scheme, but here combined into 3 Families only-Dendrocolaptidx, Formicariidx and Pteroptochidæ; ${ }^{5}$ and (4) the Acromyodi abnormales of Garrod, now elevated to the rank of a Suborder and unhappily called Pseudoscines. With regard to the Acromyodi normales or Oscines, Mr. Sclater takes what seems to be the only reasonable view, when he states that they "are all very closely related to one another, and, in reality, form little more than one group, equivalent to other so-called families of birds," going on to remark that as there are some 4700 known species of them "it is absolutely necessary to subdivide them," and finally proceeding to do this nearly on the method of Sundevall's Tentamen, merely changing the names and position of the groups in accordance with a plan of his own set forth in the Nomenclator Avium Neotropicalium, which he and Mr. Salvin printed in 1873, making, as did Sundevall, two divisions (according as the hind part of the "tarsus" is plated or scaled), A. Laminiplantares and B. Scutiplantares-but confining the latter to the Alaudidx alone, since the other Families forming Sundevall's Scutelliplantares are not Oscinine, nor

1 An abstract of this was read to the British Association at Swansea in the same year, and may be found in its Report (pp. 606-609).

2 A matter of no moment whatever, provided that the ascending or descending order be preserved throughout, and not intermixed as slovenly writers are wont.

3 Not recognized by Garrod.

4 To these Mr. Sclater has now (Cat. B. Br. Mfus. xiv. p. 2) added Forbes's Yenicidre.

5 Mr. Sclater has since admitted (op. cit. xv. p. 2) the Conopophagida of Garrod (Proc. Zool. Soc. 1877, p. 452). 
all even Passerine. The following table shews the result of a comparison of the two modes as regards the Laminiplantares, and may be found convenient by the reader :-

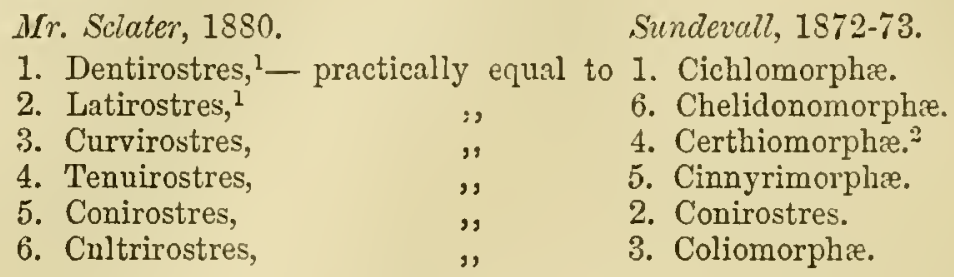

These six groups Mr. Sclater thinks may be separated without much difficulty, thongh on that point the proceedings of some later writers a notable instance of which he himself cites) shew that doubt may still be entertained; but he rightly remarks that, "when we come to attempt to subdivide them, there is room for endless varieties of opinion as to the nearest allies of many of the forms," and into further details he does not go. It will be perceived that, like so many of his predecessors, he accords the highest rank to the Dentirostres, which, as has before been hinted, seems to be a mistaken view that must be considered in the sequel.

Leaving the Passeres, the next "Order" is Picurix, of which Mr. Sclater proposes to make six Suborders:-(1) Pici, with 2 Families; (2) Cypseli, with 3 Families, ${ }^{3}$ practically equal to the Macrochires of Nitzsch ; (3) Anisoductylx, with 12 Families-Colizdx, Alcedinidæ, Bucerotidæ, Upupidæ, Irrisoridæ, Meropidæ, Momotidæ, Todidx, Coraciidæx, Leptosomidx, Podargidx and Steutornithida; (4) Heterodactylx, consisting only of the Trogoss; (5) Zygodactylæ, with 5 Families, Galbulidx, Bucconidx, Rhamphastidæ, Capitonidæ and Indicatoridæ; and (6) Coccyges, composed of the two Families Cuculidx and Musophagidæ. That all these may be most conveniently associated under the name Picariæ seems likely enough, and the first two "Suborders" are probably natural groups, though possibly groups of different value. In regard to the rest comment is for the present deferrerl. The Psittaci, Striges and Accipitres, containing respectively the PARRoTS, OwLS and diurnal Birds-of-Prev, form the next three "Orders" - the last being held to include 3 Families, Falconidx, Cathartidx and Serpentariidx (SECRETARY-BIRD), which is perhaps the best that can be done with them. We have then the Steganopodes to make the Sixth "Order," consisting of the 5 Families usually grouped together as by Brandt (supri, page 62) and others, and these are followed naturally enough by the HERoss under the name of Herodiones, to which the three Families Ardeidx, Ciconiidx (STORK) and Plataleida (SPOonbiLL) are referred; but the Flamingoes, under Nitzsch's title Odontoglossæ, form a distinct "Order." The Ninth "Order" is now erected for the Palamedex (SCREAMER), which precede the Anseres-a group

1 These are not equivalent to Sunclevall's groups of the same names.

2 Mr. Sclater (p. 348) inadvertently states that no species of Sundevall's Certhiomorph $x$ is found in the New World, having omitted to notice that in the Tentamen (pp. 46, 47) the genera Mniotilta (peculiar to America) as well as Certhice and Sittc are therein placed.

3 Or 2 only, the position of the Caprimulgidæe being left undecided, but in 1 SS3 (see next note) put here. 
that, disencumbered from both the last two, is eminently natural, and easily dealt with. A great break then occurs, and the new series is opened by the Eleventh "Order," Columbx, with 3 Families, Carpophagidx, Columbidx and Gouridx, "or perhaps a fourth," Didunculidæ, 1-the DoDos being "held to belong to quite a separate section of the order." The Twelfth "Order" is formed by the Pterocletes [!] (SAND-Grouse); and then we have the very natural group Gallinæ ranking as the Thirteenth. The next two are the Opisthocomi and Hemipodii for the HoACTzIN and the Tunicide (HeMIPODE) respectively, to which follow as Sixteenth and Seventeenth the Frllicarix and Alectorides-the former consisting of the Families Rallidx (RAIL) and Heliornithidx (Finfoot), and the latter of what seems to be a very heterogeneous compound of 6 Families-Aramida (Limprin), Eurypygida (Sun-Bitrern), Gruidæ (Crane), Psophiidæ (TrudPeter), Cariamide (Seriens) and Otididx ${ }^{2}$ (Bustard). It is confessedly very puzzling to know how these varied types, or some of them at least, should be classed; but the need for the establishment of this group, and especially the insertion in it of certain forms, is not explained by the author. Then we have "Orders" Eighteen and Nineteen, the Limicola, with 6 Families, and Gavix, consisting only of Lavidx (GULL), which taken in their simplest condition do not present much difficulty. The last are followed by Tubinares (Petrels), and these by Pygopodes, to which only 2 Fanilies Colymbida (DIVER) and Alcidx (AUK) are allowedthe GreBEs being included in the former. The Impennes (PENGUIN) form the Twenty-second, and Crypturi (Tinamou) complete the Carinate Subclass. For the Ratitx only three "Orders" are allotted-Apteryges, Casuarii and Struthiones.

As a whole it is impossible not to speak well of the scheme thus sketched out, so far as materials for it existed; and, in 1884, an attempt was made (Encycl. Brit. ed. 9, xviii. pp. 43-49) to indicate those points in recent Classifications which then seemed to have been established on a pretty sure footing, though therein the writer had no intention, any more than he now has, of inventing (as has sometimes been supposed) a new arrangement of Birds. He did, however, try to shew that some positions which had been taken up could not be maintained, and among other things that the "Subclass" Odontornithes, founded as above mentioned (page 87) by Prof. Marsh, was artificial, for, while Birds yet retained the teeth they had inherited from their Reptilian ancestors, two remarkable and, in the opinion of many, distinct groups of the Class had already made their appearance, which two gromps persist at the present day in the Aves Ratitx and Aves Carinatx long ago recognized by Merrem. Furthermore, while the Ratite type (Hesperornis) presents the kind of teeth which indicate (in Reptiles at least) a low morphological rank, the Carinate type (Ichthyornis) is furnished with teeth set in sockets and shewing a ligher development. On the other hand this early Carinate type has vertebræ whose comparatively simple, biconcave form is equally evidence of a rank unquestionably low; but the saddle-shaped vertebræ of the

I In the eighth edition of the List of Vertebrated Animals in the Zoological Gardens, which, being published in 1883, may be taken as expressing Mr. Sclater's later views, the first two Families only are recognized, the last two being placed under Columbidæ.

2 Wrongly spelt Otidæ. 
contemporary Ratite type as surely testify to a more exalted position. The explanation of this complicated if not contradictory state of things seemed then out of reach; but one, as will directly be shewn, has since been offered by Prof. Fürbringer. Moreover, the uncertainty which then prevailed, even if it has now wholly ceased, among the best-informed ornithologists as to the respective origin of Patitx and Carinatr, was at that time considered with a decided leaning to the view that the last were evolved from the first. The labours of the distinguished zoologist just named have now shewn the strong probability, if one may not say the certainty, of that view being wrong and of the Ratite being a degraded type descended from the Carinate. ${ }^{1}$ Still further, it may here be remarked that there is now no need to presume (as was then presumed) the former existence of Ratitx with biconcave vertebre, since all Birds had most likely acquired saddle-shaped vertebræ before any forms began to retrograde in the direction of Ratitx, while the ancestors of the modern Carinate possibly lost their teeth as their liconcave vertebre were improving into the higher form. ${ }^{2}$.

Seldom does it happen that in a professedly popular work any novelty is shewn unless it be of a kind essentially unscientific; but the Fourth Volume of the Standard Natural History, which treats of Birds and was published at Boston in Massachusetts in 1885, is a notable exception. Even if some of its originality may be said to lie in its eclecticism, ${ }^{3}$ no one will refuse Dr. Stejneger's labour a conspicuous place in a historical sketch of Systematic Ornithology. Though not sole author of the book, incleed his name does not appear on the title-page, he has admittedly written most of the descriptive portion, ${ }^{4}$ while there is no question of the taxonomy being all his own and its basis is anatomical. The whole volume compares most favourably with anything of the kind that has appeared, whether before or since, and open as it may be on many points to criticism, ${ }^{5}$ all who have used it must regret that it is not better known in this comntry. Here, however, we have but its Classification to deal with; and, considering the many new ideas and terms put

1 It now seems to me curious that, having then suggested (tom. cit. p. 44) that A pteryx and Dinornis were degraded descendants of earlier Ratiti, I did not perceive the possibility of those very Ratita being degenerate forms.

2 Prof. Marsh (Am. Journ. Sc. April 1879, and Odontornithes, pp. 180, 181) stated that in the third cervical vertebra of Ichthyornis "we catch nature in the act as it were" of modifying one form of vertebla into another, for this single vertebra in Ichthyornis is in vertical section "moderately convex, while transversely it is strongly concave ; thus presenting a near approach to the saddle-like articulation." He proceeded to point out that this specialized featnre occurs at the first bend of the neck, and, greatly facilitating motion in a vertical plane, is "mainly due originally to its predominance." The form of the vertebre would accordingly seem to be as much correlated with the molility of the neck as is the form of the sternum with the faculty of flight.

3 Cf. Gadow, Thier-reich, Vögel, ii. p. 48.

4 His fellow-workers were Messrs. Barrows and Elliot, the former taking the Accipitres, and the latter Opisthocomi, Gullina, Pterocletes[!], Columbre and Trochilide, while Dr. J. S. Kingsley, the editor of the whole series, supplied the account of the Psittaci.

5 Especially on matters of Nomenclature, a trifling but highly-contentious subject, which throughout the present work I have studiously tried to avoid. 
forth, an abstract ${ }^{1}$ of Dr. Stejneger's scheme, the peculiarities of spelling being observed, seems advisable:-

\begin{tabular}{|c|c|c|c|c|c|c|}
\hline 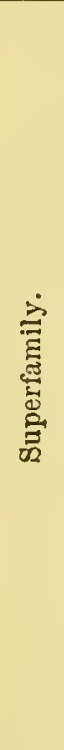 & 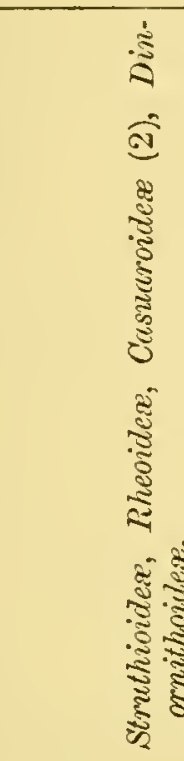 & 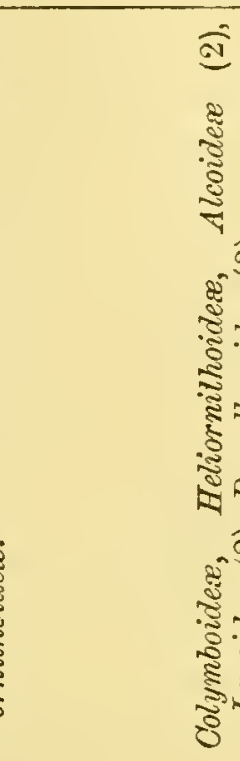 & 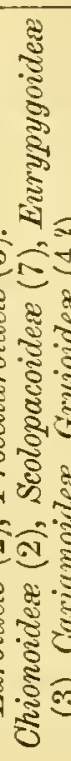 & 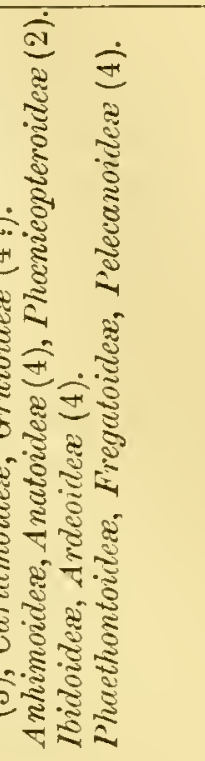 & 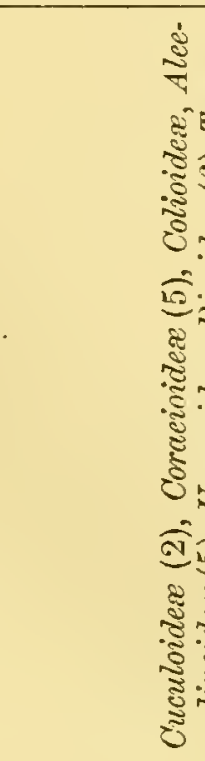 & 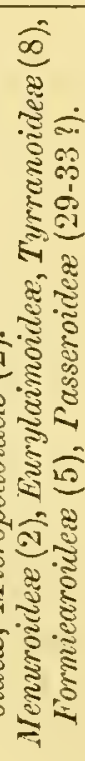 \\
\hline 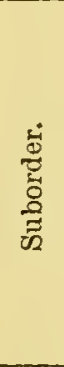 & \multicolumn{6}{|c|}{ 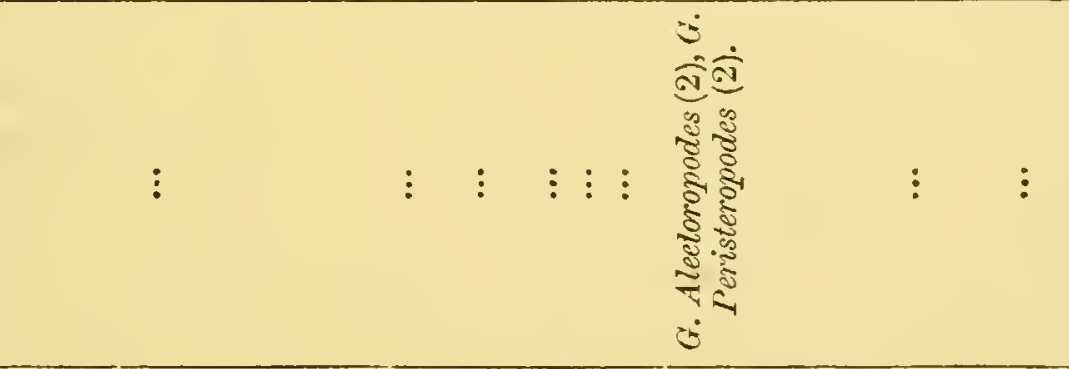 } \\
\hline 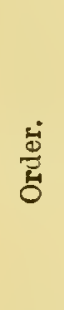 & 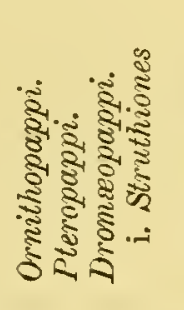 & 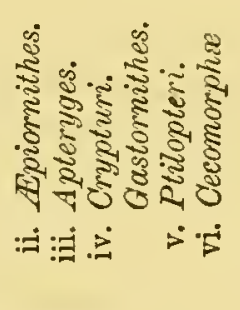 & 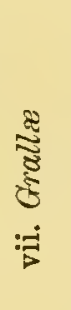 & 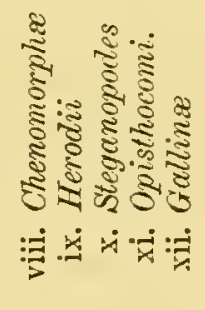 & 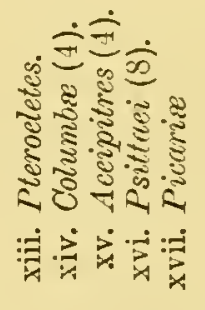 & 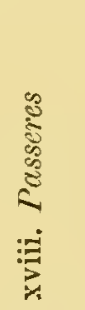 \\
\hline 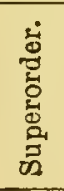 & $\vdots: \vdots: \stackrel{\overbrace{}}{s}$ & 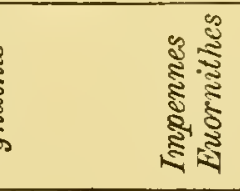 & & & & \\
\hline 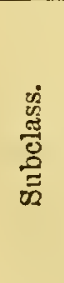 & 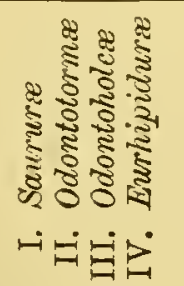 & & & & & \\
\hline
\end{tabular}

I I have thought it needless to occupy space by adding the name of the Families, which in nearly every case will be readily supplied, though where there is more than one referred to any higher division, I have inserted the number. The Family-names are given by Mr. A. H. Evans (Zool. Rec. xxii. Aves, pp. 14-18), by Dr. Sharpe (Attempts to classify Birds, pp. 24-29) and Dr. Gadow (ut suprd, pp. 46-48). 
Even now ornithologists might easily invent or follow worse schemes than that of which the outline has just been given. It looks far more complicated at first sight than it will be found to be on closer inspection, and close inspection it thoroughly deserves; while, granting the impossibility of forming a linear series, the result is remarkably successful. This is owing to the attention paid to anatomical facts, shewing to what good purpose Dr. Stejneger, in addition to his own investigations, has studied the works of ornithotomists, and also the good judgment he has, in most cases, exercised as to the respective value of characters, whether internal or external-and these last are not forgotten. Had he published his classification in a technical form, concisely stating the characters on which it was based, instead of leaving all to be collected by the reader as he goes, Dr. Stejneger would have simplified matters very much, and perhaps have saved some useless labour on the part of others ; but it will assuredly be counted to him for righteousness that in theory at least, if not always in practice, he has held to morphological principles so far as they had been made known.

Unquestionably the most remarkable recent contribution to Systematic Ornithology is that of Prof. Fürbringer, in the Second Volume of his magnificent Untersuchungen zur Morphologie und Systematik der Vögel, published in 1888 as a jubilee work by the well-known 'Natura Artis Magistra' Society of Amsterdam. It is impossible to exaggerate either the importance or the amount of the labour bestowed on these researches, of which the systematic results are but a comparatively small part, though the part that here requires most notice, for they render doubtful much that had before been deemed fairly-well established, and put the Reptilian pedigree of Birds and the position of the Ratitx in a wholly new light, incidentally proving the latter to be derived from ancestors fully endowed with wings. This last position, however, does not upset Prof. Marsh's contention that the first Birds had not the faculty of flight. It only makes evident that between the volant forefathers of the modern Ratitx and the very first Birds, there intervened an indefinite but great number of forms of which few if any traces are known to us, and that the origin of Birds is far more remote than we had been inclined to suppose.

Birds, considers Prof. Fürbringer (op. cit. p. 1563), since they, spring from Reptiles, must have begun with toothed forms of small or moderate size, with long tails and four Lizard-like feet, having distinct metacarpals and metatarsals, beside well-formed claws, while their bodies were clothed with a very primitive kind of down. These forms he terms Protoherpornithes - old Reptilian Birds (Ur7riechvögel). To them, succeeded forms wherein the down developed into feathers, and the fore and hind limbs differed in build-the former becoming organs of prehension, and the latter the chief instruments of progression. There was a Dinosaurlike transformation of the legs and pelvis, with by-and-by a coalescence of the metatarsals, enabling the creature to become bipedal. These were the Protorthornithes or Prot-Aptenornithes-the first Birds that stood erect, or the first flightless Birds - many of considerable size, but flightless, and they may have left their footprints (ORNITHIChNITES, page 277) on Triassic rocks, and to them may have belonged (p. 1518) Laopteryx (page 280, note 
1). Hitherto all these ancient animals, whether having four feet or two, moved on the ground or, at most, and this especially in the case of the smaller forms, climbed trees. Among those that possessed this habit, the befeathering (which as yet had, like the hair of Mammals, served only for warmth) presumably entered upon a ligher step, the feathers becoming larger on certain parts of the body, particularly on the fore limbs and tail, so as to begin to act as a parachute, and allow of a safe gliding descent from a height. By successive increase in stiffness and size of the feathers, and corresponding modification and strengthening of the skeleton and muscles, the possibility of incipient but real flight was afforded to these Birds, the Proto-Ptenornithes-the first flying Birds (Urflugvögel), of which, in all likelihood, there were many varied forms, though Archæopteryx (page 278) is the single type known to us. The faculty of flight, thus acquired, went on improving. The remiges grew stronger and stronger, and, in correlation therewith, the distal wing-bones (the metacarpals coalescing) gained greater rigidity, and the muscles connected with them, as well as the processes giving origin and insertion thereto, increased in size. In proportion as the fore limbs specialized into highlydeveloped wings, and the pectoral arch approached the Carinate type, the original faculty of the former as grasping organs was lost. Simultaneously as the remiges acquired strength, the tail shortened and was consolidated, the posterior vertebræ becoming united as a pygostyle (page 753). Thus originated those forms which may be denominated Deutero-Ptenornithes or Euptenornithes-the higher or better Birds of Flight (höhere Flugvögel). This type was already established in the Cretaceous Ichthyornis (page 652), and includes the rast majority of existing Birds commonly grouped as Carinatr; but these only in later times developed their various higher modifications, which were rendered possible by the saving of material and weight, - more elaborate vertebre; the loss of teeth; the gain in pneumacity of the body-especially in larger forms; the suitable configuration of parts of the skeleton, and the greater importance of smooth muscle compensating for the diminished performance of striped muscle (page 602).

During the period in which the Protoptenornithes and Deuteroptenornithes were differentiated, there came about, as almost everywhere in Nature, retrograde movement. All Birds did not reach the highest degree of faculty of flight. Many stopped, as it were, half way, when a retrogression of the power already attained took place; or, if the power were reached, it could not be maintained-an easy life and absence of rivalry inducing an increased bulk of the body, until the utmost exertion of muscular strength could no longer sustain it in the air. Thus when this retrograde development began, occasion was afforded for the dwindling away of the volant power, and hence arose the different types which are commonly grouped as Ratitæ, and may be called Deuter-Aptenornithes, or secondary Flightless Birds (secundür fluglos Vögel). Again, says the author, if the retrogression extended only to a limited degree, as in recent cases like the Impennes, Alca impennis, certain Rallidæ, the Dididæ, Stringops and others, in whose structure this or that Carinate character is very apparent, these form the Trit-Aptenornithes or Flightless Carinates (fluglose Carinaten). But in Nature no sharp boundary exists between the Deuter-and TritAptenornithes; Cnemiornis and still more likely Gastornis and Aptornis 
might stand midway. Future discoveries, which one nay in all probability expect, will still more efface this artificial boundary (p. 1564). ${ }^{1}$

The great novelty of Prof. Fürbringer's treatment of the Ratita is not merely denying their existence as a distinct Subclass, for that had been done before ${ }^{2}$; but his demonstration, for it amounts to that, of their being the retrogracle descenclants of volant ancestors, and moreover his opinion that they diverged at different epochs, so that the several groups which now exist are not homogeneous but each had an independent pedigree. This not only carries to an extreme the views first enunciated by Huxley, who pointed out that each of the existing Ratite groups was equivalent in rank to what is commonly deemed an "Order" among Birds (though he himself refused them the title), but it also involves an acceptance of the doctrine of Isomorphism, to consider which would lead us quite beyond our present limits, and therefore must be here let alone. ${ }^{3}$ It should be said, however, that this conclusion seems to have been slowly and almost reluctantly adopted by Prof. Fürbringer, who in the fairest way states the objections that may be taken to it, though finally overriding them with the result given above. ${ }^{4}$ Among the great merits of this great work are the representations of a genealogical "tree" shewing the descent of Birds not only vertically, and that on two sides, but also horizontally at three different epochs. It is unfortunately impossible here to reproduce these designs, and as without their aid no correct impression of his Classification could be conveyed, it seems better to abstain from any attempt to set it forth imperfectly in a linear form, ${ }^{5}$

1 The expectation expressed by Prof. Fürbringer in this last sentence is a truism and need not alarm any true believer in Evolution, since as elsewhere observed (Geographical Distribution, page 344 ) it is obvious that if all creation, past and present, stood before us no lines of demarcation could be drawn. The taxonomer has to judge by the comparatively small number of forms left to us, and between them are gaps, sometimes (so to speak) narrow cracks at others wide chasms, to fill up which is often beyond the power of imagination, though we know that filled they once were. Those gaps form not only convenient but the sole means of marking off groups of beings, whether we call them species or sub-kingdoms. Experience teaches us to expect that in time we shall partially know how some of these gaps were filled.

2 It has been likened to Owen's treatment of them, but is really very different. Owen, having formerly recognized an Order CỦRSOREs (by no means equivalent to that of Illiger), in 1866 declared (Anat. Vertebr. ii. p. 12) it not to be natural, which is quite true if in it are placed the heterogeneons forms he then assigned to itNotornis, Struthio, Didus, Apteryx, Dinornis and Palapteryx, which last three lie said "bear affinity to the Megapodial family of Gallina," while he considered that "the Ostrich bears the same relation to the Bustards" as Notornis to the Coots!

3 This doctrine, like that of the Correlation of Growth, is one that may he made to account so easily for many clifficulties, otherwise apparently insuperable, that one is inclined always to view its application with suspicion, and to be loth to invoke its aid except on the greatest emergency.

${ }^{4}$ Quite recently Prof. Milne-Edwards (Ann. Sc. Nat. ser. 7, ii. p. 134) declarcs against the homogeneity of the "Brévipennes," and consequently admits the isomorl'hism of some New-Zealand and Mascarene types.

5 It is much to be regretted that while so many works of trifling importance are continually being reviewed in our scientific journals, Prof. Fiirbringer's has obtained but little notice in this country. An excellent abstract by Dr. Gadow was published in Nature (xxxix.pp. 150-152, 177-181) for the 13th and 20th December 1888, and its republication in an accessible form would be most useful, since no translation of the original could be hoped for. A more condensed summary, with the anthor's own paradigm, was given by Mr. A. H. Evans (Zool. Rec. xxv. Ares, pp. 14-16), while Dr. Sliarpe (Attempts at Classif. B. pp. 39-43) has reproduced the original plates as well 
and merely to copy his diagrammatic expression of the relationships between different groups taken in horizontal section across the tree's main branches, as shewn on the next page. ${ }^{1}$

While toiling at his gigantic task Prof. Fïrbringer was in frequent communication with his friend Dr. Gadow, at that time engaged in completing the Ornithology of what is known as Bronn's Thier-Reich. This harmonious intercourse naturally had an effect on the opinions of each. On the termination of the former's labours the latter, profiting of course by them, continued his own investigations in order to work ont the systematic part of his subject, and they led to conclnsions which, though for the most part agreeing with those of his predecessor, as might be expected when both were the results of morphological research, differed from them in several rather important particulars. In 1892 Dr. Gadow contributed to the Proceedings of the Zoological Society (pp. 229-256) a highly condensed summary of his views ' On the Classification of Birds,' which in the following year he elaborately set forth, with some slight modifications, in the Systematic portion of the work above named (pp. 61-282). This Classification is based on the examination, mostly autoptic, of a far greater number of characters than any that had preceded it, and, moreover, they were chosen in a different way, discernment being exercised in sifting and weighing them, so as to determine, so far as possible, the relative value of each, according as that value may vary in different groups, and not to produce a mere mechanical "key" after the fashion become of late years so common. Whether the upshot of it all has been to establish a Natural Classification, one indicating the true descent and the real affinities of the several groups known, time alone will shew; but that this latest attempt has been made according to the best method few will doubt. Dr. Gadow recognizes two Sub-

as the paradigm, and the whole has been preyed upon by one of the most successful of modern plagiarists.

1 It is difficult to take as seriously as they were intended the two alternative methods simultaneously presented in 1890 , by the late Mr. Seebohm (Classification of Birds. London: 8vo), while a somewhat modified arrangement of certain groups was offered in his Birds of the Japanese Empire, which appeared a few months later; but hesitation on that score was removed by his publication in 1895 of a fourth scheme called a Supplement, though really subverting its predecessors. In each of these works the language of science is professed, but the author's natural inability to express himself with precision, or to appreciate the value of differences, is everywhere apparent, even when exercising his wonted receptivity of the work of others, and especially of Dr. Stejneger and Prof. Fürbringer. Nevertheless the first of these works formed the basis of Dr. Sharpe's arrangement (Review of Recent Attempts to Classify Birds, pp. 55-90) propounded in 1891 to the International Ornithological Congress held that year at Buda-Pest, and shortly after followed, with some slight alteration, in his Catalogue of the osteological specimens of Bircts in the Museum of the Royal College of Surgeons of England. Dr. Sharpe, however, is not the only disciple of Mr. Seebohm, whose method commanded the admiration of Prof. Mivart in his handy volume (Birds: The Elernonts of Ornithology. London : [1892] p. 255), which is pronounced by Mr. Headley (The Structure and Life of Birds. London: 1895, p. 390) to be "The best book for beginners."

The year 1891 saw also the Nouvelle Classification proposte pour les Oiseaux by Dr. Alphonse Dubois (Mém. Soc. Zool. de la France, iv. pp. 96-116), grounded mainly on the work of Sundevall, though modified by Huxley's views. The author had the advantage of knowing Prof. Fürbringer's scheme; but hardly of appreciating the morphological considerations on which it was based. The chief peculiarity of Dr. Dubois's plan is a revival of Bonaparte's notion as to the primacy of the Psittaci. 

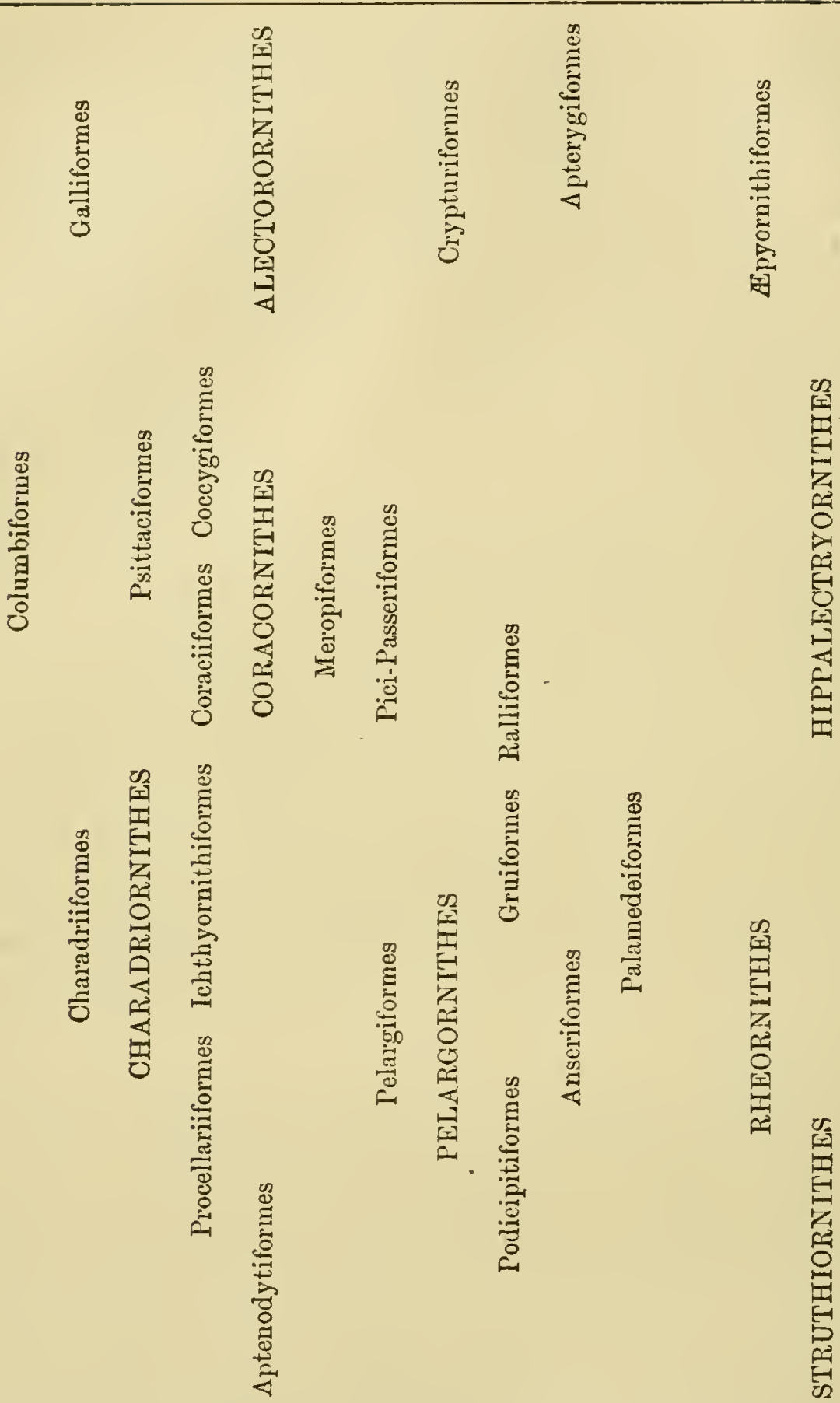

国

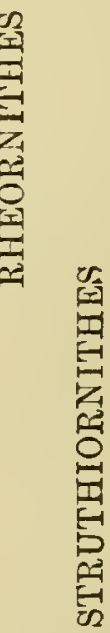

Horizontal Projection ${ }^{1}$ of the Genealogical Tree of the Subclass Aves Ornithuræ. After Fürbringer (op. cit. 1. 1568.)

1 Sir William Flower (Proc: Zool. Soc. 1869, p. 37) seems to have been the first Zoologist to use this conveuient way of expressing relationships by thus representing a transverse section of the diverging genetic lines or branches of a genealogical tree. In practice, however, it comes to much the same thing as the Maps of Classification, described by Strickland to the British Association in 1810 (Ann. Nat. Hist. vi. pp: 190, 191, pl. viii.), of which a large one designed by him is now in the Cambridgo Museum; but his trees were of course only metaphorically genealogical, and so differed in principle. 
classes-Archaornithes, of which Archropteryx alone can be said to be known, and Neornithes, his Classification of which, according to the paradigm given by himself (pp. 299-302) is as follows:-

1. RATITæ.

Ratitx: Struthiones; Rhex; Casuarii ; Apteryges; Dinornithes; Apyornithes.

Stereornithes: Phororhacos, Brontornis, Stereornis, \&c. ; Diatryma; Remiornis, Dasornis ; Gastornis.

2. Opontolc.27: Hesperornithes; Enalionithes.

3. Garinate: : [Orders.] [Suborders.]

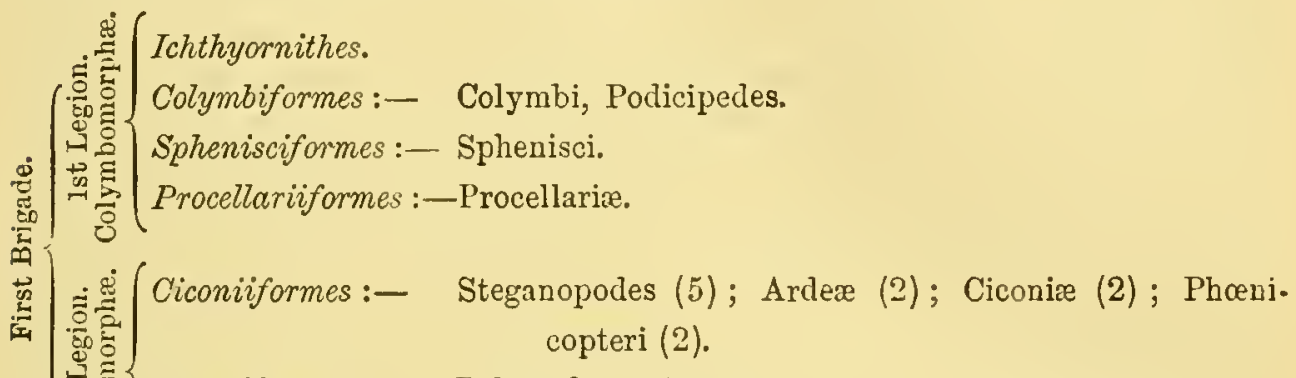

Anseriformes:- Palameder ; Anseres.

Falconiformes:- Cathartæ; Accipitres (4).

(Tinamiformes:- Tinami.

( Galliformes:- Mesites ; Turnices (2); Galli (3); Opisthocomi.

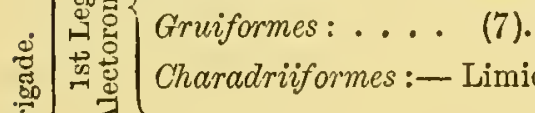

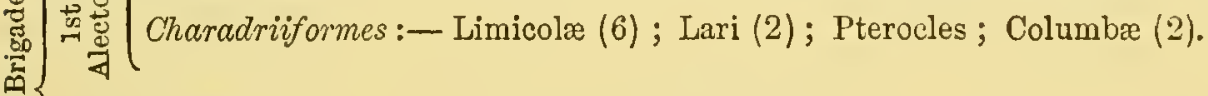

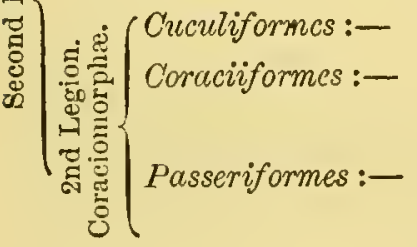

Cuculi (4); Psittaci (6).

Coraciæ (9) ; Striges (2) ; Caprimulgi (3) ; Cypseli (2) ;

Colii ; Trogones ; Pici (7).

P. anisomyodi :-Subclamatores; Clamatores (5).

P. diacromyodi :--Suboscines (2) ; Oscines (?).

[The number suffixed to the name of the Order or Suborder indicates the number of Families and Subfamilies recognized, when there is more than one.]

Dr. Gadow's Phylogeny arranged in ordinary fashion, for comparison with those used before, would be thus-

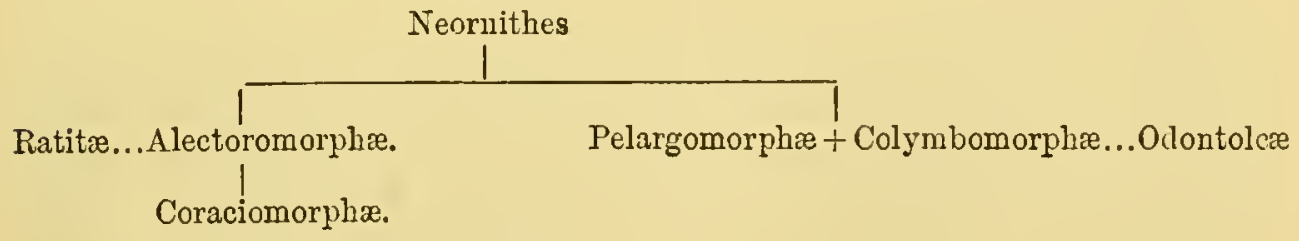

From the preceding pages, recounting the efforts of many systemmakers-good, bad and indifferent-it will have been seen what a very great number and variety of characters need to be had in remembrance while planning any scheme that will at all adequately represent the results of the knowledge hitherto attained, and the best lesson to be learnt from them is that our present knowledge goes 
but a very little way in comparison with what we, or our successors, may hope to reach in years to come. Still we may feel pretty confident that we are on the right track, and, moreover, that here and there we can plant our feet on firm ground, however uncertain, not to say treacherous, may be the spaces that intervene. Now that geographical exploration has left so small a portion of the earth's surface unvisited, we cannot reasonably look for the encountering of new forms of extant ornithic life that, by revealing hitherto unknown stepping stones, will quicken our course or effectively point out our path. Indeed, as a matter of fact, the two most important and singular types of existing BirdsBalæniceps and Rhinochetus - that in the latter half of this century rewarded the exertions of travelling naturalists, have proved rather sources of perplexity than founts of inspiration. Should fortune favour ornithologists in the discovery of fossil remains, they will unquestionably form the surest guide to our faltering steps; but experience forbids us to expect much aid from this quarter, warmly as we may wish for it, and the pleasure of any discovery of the kind would be enhanced equally by its rarity as by its intrinsic worth. Even the startling revelation of the group named Stereornithes has as yet done little except to add to our knowledge a number of ancient types. ${ }^{I}$ However, it is now a well-accepted maxim in Zoology that immature forms of the present repeat mature forms of the past, and that, where Palæontology fails to instruct us, Embryology may be trusted to no small extent to supply the deficiency. Unhappily the embryology of Birds has been till lately very insufficiently studied. We had indeed embryological memoirs of a high value, but almost all were of a monographic cliaracter, and were only oases in a desert of ignorance. The same may be said of Morphology, so that a really connected and continuous series of investigations, such as was instituted by Prof. Fürbringer, marked a new starting-point; for it seems clear that henceforth schemes for the Classification of Birds, as of other groups, will be divided into those which are based on Morphology, and those which are not-the latter falling year by year into disrepute. At the same time, with the greatest respect to Morphologists, it must be held that they, like other men, are bound by the rules of evidence and the exercise of common sense. Moreover, as the discrepancies between the schemes of different Morphologists shew, individual opinion will have to be reckoned with for solne time to come.

Birds are animals so similiar to Reptiles in all the most essential features of their organization that they may be said to be merely an extremely modified and aberrant Reptilian type. These are almost the very words of Huxley in $1866,{ }^{2}$ and there are now but few zoologists to dissent from his statement, which by another man of science has been expressed in a phrase even more pithy_- "Birds are only glorified Reptiles." It is not intended here to enter upon their points of resemblance and differences. These may be found summarized with more

1 Cf. Andrews, Rep. Brit. Association (Ipswich Meeting) 1895, pp. 714, 715 ; and Ibis, 1896, pp. 1-12.

2 Lectures on the Elements of Comparative Anatomy p. 69; see also Carus, Irandbuch der Zoologie, i. p. 192. 
or less accuracy in any text-book of zoology, ${ }^{1}$ and it is enough to remark that by the naturalist just named Birds and Reptiles have been brigaded together under the name of Sauropsida as forming one of the three primary divisions of the Vertebrata-the other two being Ichthyopsida and Mammalia. Yet Birds have a rinht to be considered a Class, and as a Class they have become so wholly differentiated from every other group of the Animal Kingdom that, among recent and even the comparatively few fossil forms known to us, there is not one about the assignation of which any doubt ought now to exist, though some naturalists liave refused a place anong Aves to Archxopteryx, of which, as elsewhere stated (pages 278-280), the remains of only two individuals-most probably belonging to as many distinct forms ${ }^{2}$ - have been discovered. Yet one of them was referred, without much hesitation, by Vogt to the Class Reptilia on grounds which seem to be mistaken, since it was evidently in great part if not entirely clothed with feathers, ${ }^{3}$ and scarcely any one now doubts that its Bird-like characters predominate over those which are obviously Reptilian, while most authorities leave the genus as the sole representative as yet known of the Subclass SAURURe, established for its reception by Prof. Häckel. The great use of the discovery of Archropteryx to naturalists in general was the convincing testimony it afforded as to what is well called "the imperfection of the Geological Record." To ornithologists in particular its chief attraction is the evidence it furnishes in proof of the evolution of Birds from Reptiles ; though, as to the group of the latter from which the former may have sprung, it tells us little that is not negative. It throws, for instance, the Pterodactyls ${ }^{4}$ - so often imagined to be nearly related to Birds, if not to be their direct ancestors - completely out of the line of descent. Next to this its principal

1 The various schemes for classifying Bircls set forth by the authors of general text-books of Zoology do not call for any particular review here, as almost without exception they are so drawn up as to be rather of the nature of a compromise than of a harmony. The best and most notalule is that by Prof. Carus in 1868 (tom. cit. i. pp. 191-368); but it is of course now antiquated. Among the worst schemes is that by Prof. Claus in 1882 (Grundzügc der Zoologie, ii. pp. 318-388); but Dr. R. Hertwig's Lehrbuch der Zoologie (Jena: 1892, pp. 538-544) is quite as bad. Of most other similar text-books that have come under my notice, the less said the better.

2 See Prof. Seeley's remarks on the differences between the two specimens (Geol. Mag. 1881, p. 454).

3 Vogt laid much stress on the absence of feathers from certain parts of the body of the second example of Archropteryx now, thanks to Dr. Werner Siemens, in the museum: of Berlin. But Vogt himself shewed that the parts of the body devoid of feathers are also devoid of skin. Now it is well known that among most existing Birds the ordinary "contour-feathers" have their origin no deeper than the skin, and thus if that decayed and were washed away the feathers growing upon it would equally be lost. This has evidently happened (to judge from photographs) to the Berlin specimen just as to that which is in London. In each case, as Owen rightly suggested of the latter, the remains exactly call to mind the very familiar relics of Birds found on a seashore, exposed perhaps for wceks or even months to the wash of the tides so as to lose all but the deeply-seated feathers, and finally to be embedded in the soft soil. Vogt's paper is in the Revue Scientifique, ser. 2, ix. p. 241, and an English translation of it in The Ibis for 1880, p. 434.

"In 1866 Owen (Anatomy of V'ertebrates, ii. p. 13) maintained that "Derivatively the class of Birds is most elosely connected with the Pterasaurian order," i.e. the Pterodactyls; and the view is probably still held by many persons. 
advantage is to reveal the existence, at so early an epoch, of Birds with some portion of their structure as highly organized as the highest of the present day, a fact witnessed by its foot, which, so far as can be judged by its petrified relics, might well be that of a modern Crow. The fossil remains of most other Birds are too imperfect to help the systematist much; but the grand discoveries of Prof. Marsh, spoken of above, afford further hints as to the taxonomy of the Class, and their bearing deserves the closest consideration.

And now to review as briefly as possible the present position of the taxonomy of Birds. It is allowed by almost all that Archæopteryx and its allies, with some of which we may reasonably hope time will make us acquainted, must stand alone whether by the name of Saururæ or Archæornithes. For the rest we may, with Prof. Fürbringer, revive Prof. Häckel's designation of Ornithuræ, or adopt the Neornithes of Dr. Gadow; but the next steps of the latter cannot be followed without misgivings. We should be content to wait further discoveries before assigning a definite place to very many fossil forms of which our knowledge is as fragmentary as are the specimens on which it is based. It appears impossible yet to correlate the Stereornithes, Diatryma, Gastornis and the rest ${ }^{1}$ with recent forms, some of which though extinct essentially resembled many that now exist, and confusion can only arise from any attempt to do so. Perhaps it would be better if these last could be spoken of as constituting a separate division, for which Dr. Stejneger has somewhat unhappily appropriated Dr. Gill's name Eurhipiduræ (page 99); but this division would have to be immediately subdivided into Carinatæ and Ratitx, for, fully admitting that Prof. Fürbringer has shewn the latter to be degenerate descendants of the former (page 101), it seems impossible not to recognize each as a distinct group. His argument in favour of the multiple origin of the Ratitz is hardly convincing. We can well believe that the examples he cites of Didus, Stringops, Cnemiornis and other modern flightless Birds are highly instructive as to the way in which the Ratitx have been brought into their present condition ; but the characters possessed by all of them in common, as first adduced by Huxley, and to those characters others have been added by Dr. Gadow, point indubitably to a single or common descent.

Seeing that we have no knowledge of the presumed Carinate ancestors of the Ratitx, it might be thought an open question which of the two existing branches should be first considered; but it is eviclent that those ancestors, being the collaterals of the ancestors of the modern Carinatæ,

1 While these pages are under revision for the press, a renewed investigation of the famous Sonth-American fossils, most of which are now in the British Mnseum, more than justifies the view taken when I wrote the above. The results arrived at by Mr. Andrews and Dr. Gadow, as briefly announced by the latter (Ibis, 1896, pp. 586, 587) are that Stereornithes are abolished as a taxonomic group. Phororhacos, of which Stereornis seems to be a synonym, is declared to belong to the "Gruiformes," and Pelecyornis and Liornis are likely to stand near it. Dryornis appears to belong to the "Falconiformes," though Mesembryornis is perhaps a forerunner of the Rheidx, and therefore probably Ratite. More important is the fact that the fossils are not even Upper Oligocene, but Milocene, and none of the forms has any relation to Gustornis. Recent excavation of the matrix, as Mr. Andrews has been so good as to shew me, proves that Phororhacos had an ossified interorbital septum, which had before been thought to be wanting (page 905). 
must have been morphologically inferior to these descendants, which on evolutionary principles have gone on improving, while the Ratite branch retrograded. That this last branch also may have improved and undergone specialization is true, but not to the point, for it can hardly have improved up to the level at which was the parting of the ways, and thus we are quite justified in contiuuing to regard the Ratitx as the lower branch, and in beginning witl them. They were shewn beyond doubt by Huxley to form five separate groups, which we shall here, as before, ${ }^{1}$ dignify by the name of Orders, adding to them a sixth, though little has as yet been made known of its characteristics. Of this, which contains the great extinct Birds of Madagascar, he did not take cognizance, as it is here necessary to do. In the absence of any certain means of arranging all these orders according to their affinities, it will be best to place their names alphabetically thus-

Epyorithes. Fam. Epyomithida (Roc).

Apteryges. Fam. Apterygidæ (KIwt).

ImMaves. Probably two Families ${ }^{2}$-Dinornithida (MOA).

Megrstanes. Fam. i. Casuariidæ (Cassowary); Fam. ii. Dromæidæ (EмE⿺)..$^{3}$

RHew. Fam. Rheidæ (RнeA).

Strothiones. Fam. Struthionidx (Ostrich).

Some systematists think there can be little question of the Struthiones being the most specialized and therefore probably the highest type of these Orders. Nevertheless the formation of the bill in the Apteryges is quite unique in the whole Class, and indicates therefore an extraordinary amount of specialization. Their functionless wings, however, point to their being a degraded form, though in this matter they are not much worse than the Megistanes, ${ }^{4}$ and are far above the Immanes-some of which at least appear to have been absolutely wingless, and were thus the only members of the Class possessing but a single pair of limbs.

Turning then to the Carinatx, their subdivision into Orders is attended with a considerable amount of difficulty; and still greater difficulty is presented if we make any attempt to arrange these Orders so as in some way or other to shew their respective relations-in other words, their genealogy. In regard to the first of these tasks, a few groups can no doubt be at once separated without fear of going wrong. For instance, the Crypturi or Tinamous, the Impennes or Penguins, the Striges or Owls, the Psittaci or Parrots, and the Passeres, or at least the Oscines, seem to stand as groups each quite by itself, and, since none of them contains any

1 See Ann. Nat. Hist. ser. 4, xx. pp. 499, 500. 1t nust, however, be borne in mind that what here is meant by an "Order" of Aves is a rery different thing from an "Order" of Reptilia.

2 On this see Prof. T. Jeffery Parker's most instructive paper (Trans. Zool. Soc. xiii. pp. 373-431, pls. lvi.-lxii.), in which, though admitting only a single Fanily, be recognizes three Subfanilies-Dinornithinæ, Anomalopteryginæ and Emeinæ.

3 Since this was in type Dr. Stirling has announced (Trans. Roy. Soc. S. Austrol. xx. pp. 171-190) that fossil remains of a gigantic bird, Genyornis, found at Callabonna in South Australia, prove it to have been allied to the Emeus, in which case a third Family of Megistanes will probably be required.

4 Nor, possibly, than the Apyornithes (cf. Andrews, Ibis, 1896, 1). 376-389, pls. viii. ix.). 
hangers-on about the charactel of which there can any longer be room to hesitate, there can be little risk in setting them apart. Next comes a category of groups in which differentiation appears not to have been carried so far, and, though there may be as little doubt as to the association in one Order of the greater number of forms commonly assigned to each, yet there are in every case more or fewer outliers that do not well harmonize with the rest. Here we have such groups as those called Pygopodes, Gavix, Limicolx, Gallinx, Columbx, Anseres, Hcrodiones, Steganopodes and Accipitres. Finally it has been sought to establish two groups of types presenting characteristics so diverse as to defy almost any definition, and, if it were not almost nonsense to say so, agreeing in little more than in the differences. These two groups are those known as Picarix and Alectorides; but, while the majority of Families or genera usually referred to the former plainly have some features in common, the few Families or genera that have been clubbed together in the latter make an assemblage that is quite artificial, though it may be freely owned that with our present knowledge it is impossible to determine the natural alliances of all of them. ${ }^{1}$

That our knowledge is also too imperfect to enable systematists successfully to compose a phylogeny of Carinate Birds, and draw ont their pedigree, ought to be sufficiently evident. We can point to some forms which seem to be collaterally ancestral, and among them perhaps some of those which have been referred to the group "Alectorides" just mentioned; and, from a consideration of their Geographical Distribution and especially Isolation, it will be obvious that they are the remnants of a very ancient and more generalized stock which in various parts of the world have become more or less specialized. The very case of the NewCaledonian Rhinochetus (KAGJ), combining features which occasionally recall the Eurypyga (Sux-BITTERN), and again present an unmistakable likeness to the Limicolæ or the Rallidx, shews that it is without any very near relation on the earth, and, if convenience permitted, would almost justify us in placing it in a group apart from any other, though possessing some characteristics in common with several.

If we trust to the results at which Huxley arrived, there can be little doubt as to the propriety of beginning the Carinate Subclass with his Dromxognathx, the Crypturi of Illiger and others, or Tinasious, for their resemblance to the Ratitæ is not to be disputed; though it must be borne in mind that their mode of development is not known, and that this may, when made out, seriously modify their position; but of the sufficient standing of the Crypturi as an Order there can hardly be a question. ${ }^{2}$

1 It should have been stated (page 9) that this heterogeneous assemblage called au "Order" by Temmincl, was adapted from Illiger's Family of the same name founded in 1811, and then including in aldition Cereopsis; but in neither group was there a single Cock-like bird. The Alectrides of Dumeril in 1806 consisted of the Bustards and Gallina.

2 We have seen that Huxley would derive all other existing Carinate Birds from the Dromzognathæ; but of course it must be understood in this, as in every other similar case, that it is not thereby implied that the modern representatives of the Dromæognathous type (namely, the Tinamous) stand in the line of aucestry. 
Under the name Impennes we have a group of Birds, the Pengoins, smaller even than the last, and one over which until lately systematists have been sadly at fault; for, though we as yet know little definite as tc their embryology, no one, free from bias, can examine any member of the group, either externally or internally, without perceiving how completely different it is from any others of the Carinate division. There is perhaps scarcely a feather or a bone which is not diagnostic, and nearly every character hitherto observed points to a low morphological rank. The title of an Order can scarcely be refused to the Impennes.

The group known as Pygopodes has been often asserted to be closely akin to the Impennes, and we have seen that Brandt combined the two under the name of Urinatores, but of their essential difference there can now be no doubt, and indeed it is hard to look upon Pygopodes as a natural group, so many are the differences between the Podicipedidx or GreBEs and Colymbidx ${ }^{1}$ or Divers, though recent molphologists agree to unite them, while the affinity of the Divers to the Auks seems to be still more uncertain, and there appears to be ground for considering the Alcidx to be much modified relatives of the Laridie. These are points deserving of still more attention on the part of embryologists than they have hitherto received. Under the improperly applied name of Gavia the Gulls and their close allies form a very natural section, but it probably hardly merits the rank of an Order more than the Pygopodes, for its relations to the large and somewhat multiform though very natural group Limicolæ have to be taken into consideration. ${ }^{2}$ The Limicoline genera Dromas and Chionis have many points of resemblance to the Laridx; and on the whole the proper inference would seem to be that the Limicolæ, or something very like them, form the parent-stock whence have descended the Gavix, from which or from their ancestral forms the Alcidre have proceeded as a degenerate branch. If this hypothesis be correct, the association of these three groups would constitute an Order, of which the highest Family would perhaps be Otididx, the Bustard, associated with the foregoing by Prof. Fiirbringer, but regarded by Dr. Gadow as allied to CRANes, Gruidx, and until further research shews which view can be maintained the matter must remain in doubt. On the other hand the Petrels, which form the group Tubinares, seem for several reasons to be perfectly distinct from the Gulls and their allies, and may be taken to rank as an Order.

Considerable doubt had long been expressed as to the existence of an "Order" Alectorides, and it has just been stated that no one can now regard it as a natural group. One of the Families included in it by its founder is Cariamidx (SERIEMA), the true place of which has been a puzzle to many systematizers. There is nothing, however, here to add to

I American ornithologists have lately used this term for the GREBES, to the great disturbance of nomenclature. It is apparently from the ancestors of the Colymbida, before they lost their teeth, that Hesperornis branched off as a degenerate, bulky and flightless form.

2 The late Prof. Parker long ago observed (Trans. Zool. Soc. v. p. 150) that characters exhibited by Gulls when young, but lost by them when adult, are found in certain Plovers at all ages, and hence it would appear that the "Gavix" are but more advanced Limicolie. 
what is elsewhere said in this book (pages 828, 829). It is doubtless a generalized form, ' the survival of a very ancient type, whence several groups may have sprung; and, whenever the secret it has to tell shall be revealed, a considerable step in the phylogeny of Birds ought to follow. Allusion has also been made to the peculiarities of two other forms placed with the last among the Alectorides-Eurypyga and Rhinochetus-each being the sole type of a separate Family. It seems that they might be brought with the Gruidx, Psophiidæ (Trumpeter), and Aramidx (LIMPKIx) into a group or Suborder Grues, - which, with the Fulicariæ2 ${ }^{2}$ of Nitzsch and Mr. Sclater as another Suborder, would constitute an Order that might continue to bear the old Linnæan name Grallæ. It must be borne in mind, however, that some members of both these Suborders exhibit many points of resemblance to certain other forms that it is at present necessary to place in different groups-thus some Rallidx to the Gallinx, Grus to Otis, and so forth; and it is as yet doubtful whether further investigation may not shew the resemblance to be one of affinity, and therefore of taxonomic value, instead of mere analogy, and therefore of no worth in that respect.

We have next to deal with a group nearly as complicated. The true Gallinæ are indeed as well marked a section as any to be found; but round and near them cluster some forms very troublesome to allocate. The strange Opisthocomus (HoACTZIN) is one of these, and what seems to be in some degree its arrested development makes its position almost unique. ${ }^{3}$ It must for the present at least stand alone, the sole occupant of a single Order. Then there are the Hemipones, which have been raised to equal rank by Huxley as Turnicomorphx; but, though no doubt the osteological differences between them and the normal Gallinæx, pointed out by him as well as by the late Prof. Parker, are great, they do not seem to be more essential than are found in different members of some other Orders, nor to offer an insuperable objection to their being classed under the designation Gallinx. If this be so there will be no necessity for removing them from that Order, which may then be portioned into three Suborders-Hemipodii standing somewhat apart, and Alectoropodes and Peristeropodes, which are more nearly allied-the latter comprehending the Megapodiidx (MEgapodes) and Cracidx (CURAssows), and the former consisting of the normal Gallinx, of which it is difficult to justify the recognition of more than a single Fanily, though in that two types of structure are discernible.

The Family of SAND-Grouse, Pteroclidie, is perhaps one of the most instructive in the whole range of Ornithology. In Huxley's words (Proc. Zool. Soc. 1868, p. 303), they are "completely intermediate between

I Cariama is the oldest name for the genus, but being a word of "barbarons" origin it was set aside by Illiger and the purists in favour of Dicholophus, under which name it is several times mentioned in the present work ( $c f$. INDEx, page 1066).

2 This group wonld contain three families-Rallida, Helion mithida (the FixFOOTS of Eastern India, Africa and South America) and the Mesitide of Madagascar - for which an at least approximate place has been found by MI. A. Milne-Elwards (Ann. Sc. Nat. ser. 6, vii. No.6).

${ }^{3}$ Mesites, just mentioned, presents a case which may, however, be very similar. 
the Alectoromorphx [Gallinx] and the Peristeromorphx [Columba]. They cannot be included within either of these groups without destroying its definition, while they are perfectly definable themselves." Hence he would make them an independent group of equal value with the other two. Both Prof. Fürbringer and Dr. Gadow consider the Pigeonallance the strongest, and indeed the general resemblance of most parts of the osteology of the two gromps, so well shewn by M. Milne-Edwards, combined with the Pigeon-like pterylosis of the Sand-Grouse, leaves no room for doubt; but the many important points in which they differ from the more normal Pigeons, especially in the matter of their young being clother with lown, and their coloured and speckled eggs, ${ }^{1}$ must be freely admitted. Young Sand-Grouse are not only "Dasypædes" but even "Prrecoces" or Nidifuga at birth, while of course every one knows the helpless condition of "Pipers"-that is, Pigeons newly-hatched from their white eggs. Thus the opposite condition of the young of these two admittedly very near gromps inflicts a severe blow on the so-called "physiological" method of dividing Birds before mentioned (page \% 4), and renders the Pteroclidx so instructive a form. The Columbx considered in the wide sense suggested, possessed another and degenerate subdivision in the DoDo and its kindred, thongh the extirpation of those strange and monstrous forms will most likely leave their precise relations a matter of some doubt; while the third and last subdivision, the true Columbre, is much more homogeneous, and can hardly be said to contain more than two Families, Columbidæ and Didunculidx-the latter consisting of a single species (the absurdly-named "DoDLET"), and having no direct connexion with the Dididx, ${ }^{2}$ though possibly it may be found that the Papuan genus Otidiphaps presents a form linking it with the Columbidx.

The Gallinx would seem to hold a somewhat central position among existing members of the Carinate division, ${ }^{3}$ whence many gromps diverge, and one of them, the Opisthocomi or Heteromorpha of Huxley, indicates, he hinted, the existence of an old line of descent, now almost obliterated, in the direction of the Musophagidx and thence, it has been inferred, to the Coccygomorphax of the same authority. But these "Coccygomorphs" would also appear to reach a higher rank than some other groups that we have to notice, and therefore, leaving the first, we must attempt to trace the fortunes of a more remote and less exalted line.

It is impossible with our present knowledge to thread the maze in which the taxonomer now finds himself. The Pelargomorph of Huxley will be seen to differ much from Dr. Gadow's group of the same name; and, though it has been shewn that "Desmognathism" must be abandoned as a bond of union, just as "Schizognathism" has to be relinquished as a broken alliance, the difficulty of finding a place for the Anseres seemis as hard as ever. That ancient form, Palamcdea (Screamer), which is

1 This fact tells in favour of the views of those who hold the Sand-Grouse to be allied to the Plovers; but the eggs of the Pigeons tell as strongly the other way, as do the young.

2 Phil. Trans. 1867, p. 349.

3 Cf. Parker (Phit. Trans. 1850, p. 755). 
doubtless rightly attached to them does not help us, though perhaps the Flajingos may. From fossil remains we know that they are not of yesterday; and both to Huxley and to Dr. Gadow they seem intermediate between the Geese and the Storks and Herons. These last may well be considered to be akin to the STEGANOPODEs, which in their turn indicate some relation to the Accipitres.

Whatever may be the alliances of the genealogy of the Accipitres, the Diurnal Birds-of-Prey, their main body must stand alone, hardly divisible into more than two principal groups-(1) containing the Sarcorhamphidx or the Vultures of the New World (page 1016), and (2) all the rest, though no doubt the latter may be easily subdivided into two Families, Vulturid $x$ and Falconidx, and the last into many smaller sections, as has commonly been done; but then we have the outliers left. The African Serpentariidæ (SECRETARY-BIRD), though now represented only by a single species, ${ }^{1}$ are fully allowed to form a type equivalent to the true Accipities composing the main body, and in it we may possibly see a trace of the link connecting the Accipitres with the Heriodiones.

It was so long the custom to place the OwLs next to the Diurnal Birdsof-Prey that any attempt to remove them from that position could not fail to incur criticism. Yet it is now admitted by almost every investigator that when we disregard their carnivorous habits, and certain modifications which may possibly be thereby induced, we find almost nothing of value to indicate relationship between the two groups. That the Striges stand quite independently of the Accipitres as above limited can hardly be doubted, and, while the Psittaci (PARROT) form a very distinct group, and may on some grounds appear to be the nearest allies of the Accipitres, the nearest relations of the Owls must be looked for in the multifarious group PICARIæ. Here we have the singular Steatornis (Guacharo), which, long confounded with the Caprimulgidx (NIGHTJAR), has at last been recognized as an independent form, and it may possibly have branched off from a common ancestor with the Owls. The Nightjars may have done the like, ${ }^{2}$ for there is really not much to ally them to the Cypseti (SWIFT) and Trochili (Homming-BIRD), the Macrochires proper, as has often been recommended. However, it should not be supposed that the place of the Striges is under the Picarix; and the last are already a sufficiently heterogeneous assemblage. Whether the Pici (Woodpecken) should be separated from the rest is a matter on which Prof. Fürbringer and Dr. Gadow are at variance. That they constitute a very natural and easily defined group is indisputable; more than that, they are perhaps the most differentiated group of all those that are retained in the "Order" Picarix; but it does not seem advisable at present to deliver them from that chaos when so many other groups have to be left in it.

I It was long suspected that that the genus Polyboroides of South Africa and Madagascar, from its general resemblance in plumage and outward form. might come into this group, but that idea has now been fully dispelled by M. A. Milne-Edwards in M. Grandidier's magnificent Oiseaux de Madagascar (i. pp. 50-66).

2 The great resemblance in coloration between Nightjars and Owls is of course obvious, so obvious indeed as to make one suspicious of their being akin; but in reality the existence of the likeness is no bar to the affinity of the groups ; it merely has to be wholly disregarded. 
Lastly we arrive at the PAsseres, and here, as already mentioned, the researches of Garrod and Forbes prove to be of immense service. It was of course not to be supposed that they had exhausted the subject even as regards their Mesomyodi, while their Acromyodi were left almost untouched so far as concerns details of arrangement; but later investigations have produced a much more manageable scheme, and so far as it is goes Dr. Gadow seems to have gooct reason for the groups he has made, even though exception be takeu to part of his nomenclature.

Thus we reach the true Oscines, the last and highest group of Birds, and one which, as before hinted, it is very hard to subdivide. Some two or three natural, because well-differentiated, Families are to be found in it-such, for instance, as the Hirundinidx (Swallow), which have no near relations; the Alaudidx (LARK), that can be unfailingly distinguished at a glance by their scutellated planta, as has been before mentioned ; or the Meliphagidæ (HoNEY-EATER), with their curionsly constructed tongue. But the great mass, comprehending incomparably the greatest number of genera and species of Birds, defies any sure means of separation. Here and there a good many individual genera may be picked out capable of the most accurate definition; but genera like these are in the minority, and most of the remainder present several apparent alliances, from which we are at a loss to choose that which is nearest. Four of the six groups of Mr. Sclater's "Laminiplantar" Oscines seem to pass almost imperceptibly into one another. We may take examples in which what we may call the Thrush-form, the Tree-creeper-form, the Finch-form, or the Crow-form is pushed to the most extreme point of differentiation, but we shall find that between the outposts thus established there exists 'a regular chain of intermediate stations so intimately connected that no precise lines of demarcation can be drawn cutting off one from the other.

Still one thing is possible. Hard though it be to find definitions for the several groups of Oscines, whether we make them more or fewer, it is by no means so hard, if we go the right way to work, to determine which of them is the highest, and, possibly, which of them is the lowest. It has already been shewn (page 79 ) how, by a woeful want of the logical apprehension of facts, the Turdidr came to be accounterl the highest, and the position accorded to them has been generally acquiesced in by those who have followed in the footsteps of Keyserling and Blasius, of Prof. Cabanis and of Sundevall. Now the order thus prescribed seems to be almost the very reverse of that which the doctrine of Evolution requires, and, so far from the Turdide being at the head of the Oscines, they are among its lower members. There is no doubt whatever as to the intimate relationship of the Thrushes (Turdidx) to the Chats (Sacicolinx), for that is admitted by nearly every systematizer. Now most authorities on classification are agreed in associating with the latter group the Birds of the Australian genus Petroca and its allies (Wheatear, pp. 1035, 1036)the so-called "Robins" of the English-speaking part of the great southern communities. But it so happens that, from the inferior type of the osteological characters of this very group of Birds, the late Prof. Parker called them (Trans. Zool. Soc. v. p. 152) "Struthious Warblers." Now if the Petroca-group be, as most allow, allied to the Saxicolina, they must also 
be allied, only rather more remotely, to the Turdidx-for Thrushes and Chats are inseparable, and therefore this connexion must drag down the Thrushes in the scale. Let it be granted that the more highly-developed Thrushes have got rid of the low "Struthious" featnres which characterize their Australian relatives, the unbroken series of connecting forms chains them to the inferior position, and of itself disqualifies them from the rank so fallaciously assigned to them. Nor does this consideration stand alone. By submitting the Thrushes and allied groups of Chats and Warblers to other tests we may try still more completely their claim to the position to which they have been advanced.

Without attaching too much importance, to the systenatic value whicl the characters of the nervous system afford, there can be little doubt that, thronghout the Animal Kingdom, where the nervous system is sufficiently developed to produce a brain, the creatures possessing one are considerably superior to those which have none. Consequently we may reasonably infer that those which are the best furnished with a brain are superior to those which are less well endowed in that respect, and that this inference is reasonable is in accordance with the experience of every Physiologist, Comparative Anatomist and Palæontologist, who are agreed that, within limits, the proportion which the brain bears to the spinal marrow in a Vertebrate is a measure of that animal's morphological condition. These preliminaries being beyond contradiction, it is clear that, if we had a series of accurate weights and measurements of Birds' brains, it would go far to help us in deciding many cases of disputed precedency, and especially such a case as we now have under discussion. To the dispraise of Ornithotomists this subject has never been properly investigated, and of late years seems to have been wholly neglected. The lists given by Tiedemann (Anat. und Naturgesch. der Vögel, i. pp. 18-22), based for the most part on very ancient observations, are extremely meagre, and the practical difficulties of carrying on further research, though not insuperable, are considered to be great ; ${ }^{1}$ but, so far as those observations go, their result is conclusive, for we find that in the Blackbird, Turdus merula, the proportion which the brain bears to the body is lower than in any of the eight species of Oscines there named, being as 1 is to 67. In the Redbreast, Erithacus rubecula, certainly an ally of the Turdidx, it is as 1 to 32 ; while it is highest in two of the Finches-the Siskin, Carduelis spinus, and the Canary-bird, Serinus canarius, being in each as 1 to 14 . The signification of these numbers needs no comment to be understood.

Evidence of another kind may also be adduced in proof that the high place hitherto commonly accorded to the Turdidx is undeserved. Throughout the Class Aves it is observable that the young when first fledged generally assume a spotted plumage of a peculiar character ${ }^{2}$-nearly each of the body-feathers having a light-coloured spot at its tip-and this is

1 One of the latest writers on the brain of Birds (Zeitschr. für wissensch. Zoolog. xxxviii. pp. 430-467, pls. xxiv. xxv.), though giving tables of the proportion of its several parts in various genera, unfortunately gives none of the proportion of the whole to the body.

2 Blyth in 1833 seems to have indicated this well-known fact as affording a character in classification (Field Nat. i. pp. 199, 200). Nearly 50 years after it was clained as the discovery of another writer. 
particularly to be remarked in many groups of Oscincs, so much so indeed, that a bird thus marked may, in the majority of cases, be set down without fear of mistake as being immature. All the teachings of morphology go to establish the fact that any characters, not specially adaptive, which are peculiar to the immature condition of an animal, and are lost in its progress to maturity, are those which its less advanced progenitors bore while adult, and that in proportion as it gets rid of them it shews its superiority over its ancestry. This being the case, it would follow that an animal which at no time in its life exhibits such, marks of immaturity or inferiority must be of a rank, compared with its allies, superior to those which do exhibit these marks. The same may be said of external and secondary sexual characters. Those of the female are almost invariably to be deemed the survival of ancestral characters, while those peculiar to the male are in advance of the older fashion, generally and perhaps always the result of sexual selection. ${ }^{1}$ When both sexes agree in appearance it may mean one of two things-either that the male has not lifted himself much above the condition of his mate, or that, he having raised himself, the female has successfully followed his example. In the former alternative, as regards Birds, we shall find that neitlier sex departs very much from the coloration of its fellow-species; in the latter the departure may be very considerable. Now, applying these principles to the Thrushes, we shall find that without exception, so far as is known, the young have their first plumage more or less spotted; and, except in some three or four species at most, ${ }^{2}$ both sexes, if they agree in phumage, do not differ greatly from their fellow-species.

Therefore as regards capacity of brain and coloration of plumage priority ought not to be given to the Turdidx. It remains for us to see if we can find the group which is entitled to that eminence. Among Ornithologists of the highest rank there have been few whose opinion is more worthy of attention than Macgillivray, a trained anatomist and a man of thoroughly independent mind. Through the insufficiency of his opportunities, his views on general classification were confessedly imperfect, but on certain special points, where the materials were present for him to form a judgment, one may generally depend upon it. Such is the case here, for lis work shews him to have diligently exercised his genius in regard to the Birds which we now call Oscines. He belonged to a period anterior to that in which questions that have been brought uppermost by the doctrine of Evolution existed, and yet he seems not to have been without perception that such questions might arise. In treating of what he termed the Order Vagatores, ${ }^{3}$ including among others the Family Corvida -the Crows, lue tells us (Brit. Birds, i. pp. 485, 486) that they "are to be accounted among the most perfectly organized birds," justifying the opinion by stating the reasons, which are of a very varied kind, that led

I See Darwin, Descent of Man, chaps. xv. xvi.

2 According to Seebohm (Cat. B. Brit. Mus. v. p. 232) these are in his nomenclature Merula nigrescens, $\boldsymbol{M}$. fuscatra, $\boldsymbol{M}$. gigas and $\boldsymbol{M}$. gigantodes.

3 In this order he included several groups of Birds which we now know to be but slightly if at all allied; but his intimate acquaintance was derived from the Corvida and the allied Family we now call Sturnidix. 
him to it. In one of the earlier treatises of the late Prof. Parker, he has expressed (Trans. Zool. Soc. v. p. 150) his approval of Macgillivray's views, adding that, "as that speaking, singing, mocking animal, Man, is the culmination of the Mammalian series, so that bird in whec the gifts of speech, song and mockery are combined must be considered as the top and crown of the bird-class." Any doubt as to which Bird is here intended is dispelled by another passage, written ten years later, wherein ( $M$. Microscop. Journ. 1872, p. 217) he says, "The Crow is the great subrational chief of the whole kingdom of the Birds; he has the largest brain ; the most wit and wisdom ;" and again, in the Zoological Society's Transactions (ix. p. 300), "In all respects, physiological, morphological and ornithological, the Crow may be placed at the head, not only of its own great series (birds of the Crow-form), but also as the unchallenged chief of the whole of the "Carinatie." I

It is to be supposed that the opinion so strongly expressed in the passage last cited has escaped the observation of many systematizers; for he would be a bold man who would venture to gainsay it. Still Parker has left untonched or only obscurely alluded to one other consideration that has been here brought forward in opposing the claim of the Turdidx, and therefore a few words may not be ont of place on that point-the evidence afforded by the coloration of plumage in young and old. Now the Corvidæx fulfil as completely as is possible for any gromp of Birds to do the obligations required by exalted rank. ${ }^{2}$ To the magnitude of their brain beyond that of all other Birds Parker has already testified, and it is the rule for their young at once to be clothed in a plumage which is essentially that of the adult. This plumage may lack the lustrous reflexions that are only assumed when it is necessary for the welfare of the race that the wearer should don the best apparel, but then they are speedily acquired, and the original difference between old and young is of the slightest. Moreover, this obtains even in what we may fairly consider to be the weaker forms of the Corvidx-the Pies and Jays. In one species of Corvus, and that (as might be expected) the most abundant, namely, the Rook, C. frugilegus, very interesting cases of what would seem to be explicable on the theory of Reversion occasionally though rarely occur. In ther the young are more or less spotted with a lighter shade, and these exceptional cases, if rightly understood, do but confirm the rule. ${ }^{3}$

1 Dr. Stejneger (Stand. Nat. Hist. iv. p. 482) considers that Parker liimself has "partly nentralized, not to say gainsaid" this opiuion, citing a passage from the same paper (tom. cit. p. 304) wherein is the assertion that the Redstart, Phonicura ruticilla, and its allies, which of course come near the Thrushes, "are of the bighest and purest blool," with more to like effect. But Dr. Stejneger has overlooker the qualifying words "of the small Passerines" at the beginning of the paragraph, which makes all the difference, seeing that the Corvide are the largest of them. Moreover, the drift of the whole passage shews that Parker was thereiu using the word " "Oscines," or songsters," in its literal and not its technical sense. No one knows better than Dr. Stejneger that Crows are not exactly song-birds.

2 It is curious to remark, not that it can aflect my argument, that this was also the opinion of the Quinarians ( $c f$. Swainson, in 1834, Discourse on the Study of Nat. Tist. p. 262, and in 1835, Trcatise on the Geogr. and Classific. of Animals, p. 243).

3 One of these specimens has been figured by Hancock (N. H. Trans. Northumb. and Dicrham, vi. pl. 3) ; see also Yarrell's British Birds, eil. 4. ii. pp. 302, 303. 
It may be conceded that even among Oscines ${ }^{1}$ there are some other groups or sections of gromps in which the transformation in appearance from youth to full age is as slight. This is so among the Paridx; and there are a few groups in which the young, prior to the first moult, may be more brightly tinted than afterwards, as in the genera Phylloscopus and Anthus. These anomalies cannot be explained as yet, but we see that they do not extend to more than a portion, and generally a small portion, of the groups in which they occur; whereas in the Crows the likeness between young and old is, so far as is known, common to almost every member of the Family." It is therefore confidently that the present writer asserts, as Prof. Parker, with far more right to speak on the subject, las already done, that at the head of the Class Aves must stand the Family Corvida, of which Family no one will dispute the superiority of the genus Corvus, nor in that genus the pre-eminence of Corvus corax-the widely-ranging Raven of the Northern Hemisphere, the Bird perhaps best known from the most ancient times, and, as it happens, that to which belongs the earliest historical association with man. There are of course innumerable points in regard to the Classification of Birds which are, and for a long time will continue to be, hypothetical as matters of opinion, but this one seems to stand a fact on the firm ground of proof. ${ }^{3}$

A perusal of the foregoing can hardly fail to confirm the doubts already expressed in the initial 'Note' (page vii.) as to the validity of any Systematic Arrangement of Birds as yet put forth. Still the history of Ornithology, as here sketcher, gives hope of the ultimate attainment of the object sought by so many earnest students of the Science, though a long time may yet elapse before that end is reached. As in all branches of Zoology accession of knowledge, be it the making of a new discovery or the solution of an old difficulty, is followed by, or may almost be said to produce, a fresh series of questions of a kind that it is absolntely impossible to anticipate, and it needs only the application of experience to foresee that this is likely to continue. But slow as is the process of eliminating error, it is certain that, notwithstanding occasional relapses, considerable advance has been made in the right direction. It is even possible that progress will be accelerater by some nnexpected turn of

1 In other Orders there are many, for instance some Humming-birds and Kingfishers; but this only seems to shew the excellence in those Orders attained by the forms which enjoy the privilege.

2 The Canada JAY, Dysornithia canadensis, as rightly notel by Dr. Stejneger (tom. cit. p. 483), is apparently the only exception, and I do not attempt to acconnt for it.

3 Dr. Stejneger (loc. cit.) would prefer with Sundevall, who certainly was not affected by morphological considerations, placing the Finches, Fringillida, at the head of the Passeres, and selects as his example the Evening Grosbeak, Hesperiphona vespertina, of North America to demonstrate his position. That the Finches stand high I readily admit, but $I$ fail to appreciate the force of the argument he adduces. Among other things le declares that in them "the plumage of the young is essentially like that of the adults" - a statement which will hardly be accepted by most ornithologists, and especially not so far as $\mathbf{I}$ can judge ( $c f$. Audubon, $\mathscr{B}$. $A m$. iii. pl. 207) in the example of his clioice, which seems to be rather an unhappy one, seeing that in its inmatule plumage it differs so much from the adult as to have been clescribed by a fairly good authority (Lesson, Illustr. Zool. pl, xxxi.) as n distinct species under tho name of Coccothraustes bonapartii. 
research. To that, however, we inust not trust, but our dnty is to proceed steadily along the path that seems the straightest, making sure of every step as we go. In this way we may be confident that the end, however distant, will eventually arrive. The triple alliance of Morphology, Palæontology and Geographical Distribution-when this last is rightly understood-can be trusted to keep our steps from wandering and to guide us to the goal we seek so far as the genealogy and relations of the several groups of Birds are concerned, for that is what their true Classification means. But Ornithology consists of much more than even a perfect Taxonomy, the field of investigation is much wider, and includes subjects that unfortunately have been too little considered by the higher intellects, especially of late years. Thongh there is no fear of Morphology or Palæontology failing to be attractive, the real lessons conveyed by the facts of Geographical Distribution liave been greatly neglected, while to name only two other subjects of which our ignorance immeasurably exceeds our knowledge, Migration and Variation still afford mysteries that have scarcely been penetrated. Hybridism too, which will probably lead to very important results, has never been investigated by a scientific Ornithologist. There is therefore plenty of room for research, observation and experiment, so that no honest enquirer in any branch of the study need feel discouraged by the prospect before him, unless indeed he be dismayed by the very vastness of the unknown regions lie has to explore. 


\section{INDEX TO INTRODUCTION}

ELIAN, 3, 5

Albarda, 41

Albertus Mraguus, 4

Albin, 9

Aldrovandus, 6

Allen, 38

Alston, 44

Altum, 39

Andrews, 106, 108, 109

Aristotle, 2, 5

Aubert, 2

Audebert, 23

Audubon, 24, 25, 37 $60,66,67,119$

Avicemna, 4

BABINGTON, 45

Backhouse, 38

Baillon, 40

Bailly, 40

Baird, 37, 38

Baldamus, 17,39

Baring-Gould, 35

Barraband, 23

Barrere, 8

Barrett-Hamilton, 44

Barrington, 19, 44

Barrows, 98

Barthélemy-Lapom meraye, 40

Bartholini, 14

Bartlett, 61

Bartram, $1 S$

Bechstein, 12, 1\%, 39

Beddard, 91

Behn, 8

Beilby, 20

Bell, Jeffrey, 69

Bell, Thomas, 19, 20

Belon, 5, 6, 9

Bendire, 3\%, 78

Bennett, 19, 36

Benoist, 40 $\mid$\begin{tabular}{|l|} 
Berkenhout, 18 \\
Berlepsch, 39 \\
Bernini, 17 \\
Berthold, 55 \\
Beseke, 17 \\
Bewick, 20, 29, 43 \\
Bexou, 10 \\
Blainville, 15, 30,34, \\
49, 51, 52, 54, 69 \\
Blake-Kuox, 44 \\
Blauchard, 75, 76 \\
Blandin, 40 \\
Blanford, 36 \\
Blasius, G. 14 \\
Blasius, J. H. 17, 39, \\
62, 67, 68, 70, 115 \\
Blasius, R. 39 \\
Blasius, W. 39 \\
Blauw, 41 \\
Blomefield, 43 \\
Blyth, 19, 36, 60,61,
\end{tabular} $64,68,116$

Bocage, Barboza du, 40

Bochart, 6

Boddaert, 13

Bolle, 39

Bolton, 19

Bonaparte, 30, 37, $41,73,74,103$

Bonnaterre, 12

Boutius, 7

Booth, 44

Borggreve, 39

Borkhausen, $1^{\text {ry }}$

Borlase, 18

Borrer, 45

Borrichins, 14

Bostock, 3

Bourjot St. Hilaire, 22

Bouteille, 40

Bradshaw, 4

Brandt, A. 39

Brandt, J. F. 61, $62,96,111$

\author{
Bree, 41 \\ Brehm, A. E. 39, 40 Cocks, 38 \\ Brehm, C. L. 39 \\ Breidenbach, 4 \\ Brewer, 37 \\ Brisson, 9, 10, 11, 13 . Collins, 16 \\ Broun, $14 \quad$ Cook, 16 \\ Brown, Peter, 12 Cordeaux, 40 \\ Browne, Capt. T. 30 Cornay, 69, 70, 84 \\ Browne, Sir T. 18 Cory, 37 \\ Brünnich, $17 \quad$ Coues, 19, 37, 45, 60 \\ Buckley, E. 7 Cousens, 25 \\ Buckley, T. E. 44 Coxe, 42 \\ Büttikofer, 41 Crespou, 40 \\ Buffon, 10 11, 12, Cresswell, 3 \\ 13,86 \\ Buller, 35 \\ Bumm, 116 \\ Bund, 45 \\ Bureau, 40 \\ Crommelin, 41 \\ Cuba, 4 \\ Cuvier, 3, 14, 15, 29, \\ $46,51,53,54,55$, \\ $56,58,59,66,70$, \\ 71
}

Burmeister, 63, 64, 65

\section{DALGLEISH, 44}

Cabanis, 36, 39, 70, Dallas, 66

71,72, 73, 94, 115 Darwin, $78,81,86$, Caius, 5

Campbell, 36

Canivet, 40

Carter, 38

Carus, 14, 106, 107

Cassiu, 24, 37, 38

Castelnau, $7 / 4$

Catesby, 8

Canb, 4

Cetti, 17

Chambers, 78

Chapman, Abel, 40

Chapman, F. M. 38

Charleton, 7

Chesnon, 40

Child, 13

Christy, 44, 45

Clarke, Joseph, 48 117

Daudin, 14

D. B., 9

D'Aubenton, 10, 12, 26

Degland, 40, 41

Demarle, 40

Denny, 63

Derby, Lord, 12

Derham, $y$

Desmarest, 23

Des Murs, 27, 49, 77

D'Urbau, 45

Devis, 36

Dieffenbach, 35

Diggles, 35

Dillwyn, 45

Donovan, 19

Dover, Lady, 20

Dresser, 41 
Droste, 39
Dubois, Alph. 41,
103

Dubois, C. F. 41

Du Bus, 27

Duméril, 29, 110

Dupree, 19

Du Verney, 14

EDWARDS, 9. 10

Elliot, 24, 37, 98

Ellis, 16

Ersch, 64

Evans, A. H. 99, 102

Evans, IV. 44

Eyton, $35,43,76$

Faber, $3 S$

Fabricius, 18

Falk, 15

Fallopius, 6

Fatio, 39

Feilden, 38

Fernandez, 7

Finsch, 30, 39

Fischer de Waldheim, 31

Fischer, J. B. 17

Fleming, 33,43

Florent-Provost, 23

Flower, 104

Forbes, 90, 91, 92, $93,94,95,115$

Forskål, 15

Forster, G. 16

Forster, J. R. 16, $1 S$

Fothergill, $1 S$

Fraser, 25

Frisch, .J. L. 16

Fritsch, A. 41

Fiurbringer, 98, 100, 102, 103, 104, 108, $111,113,114$

GADow, 55, 6S, 74, 98, 99, 102, 103, $104,105,108,111$. 113,114

Gätke, 39, 4\%

Garrod, 90, 91, 92, $93,94,95,115$,

Gaza, 3

Gentil, 40

Geofiroy St. - Hilaire, E. $34,46,52,55$, $56,5 S, 59$

Geoffroy St. - Hilaire, I. $2 \mathcal{S}, 5 S$
Georgi, 15

Gerini, 10

Gervais, 74

Gesner, $\overline{5}, 6$

Giebel, 31

Giglioli, 39

Gilius, 17

Giil, 108

Giraud, $3 \mathcal{S}$

Gloger, 39, 51, 56, 57

Gmelin, J. F. 13

Gmelin, J. G. 15

Gmelin, S. G. 15

Gosse, 36

Gonld, 24, 25, 2S, $35,41,44,64$

Graudilier, 114

Grandsagne, 3

Graves, 42

Gray, G. R. 30, 31, 35

Gray, J. E. 15,24

Gray, R. 44

Griffiths, 15

Groot, 4

Grossinger, 16

Gruber, 64

Güldenstädt, 15

Gundlach, 37

Gunnerus, 18

Gurney, sen. 10

HAAST, 35

Häckel, 81, 90, 10\%, 108

Hancock, 20, 45, 118

Haumer, 18

Hard wicke, 2.

Hardy, 40

Harting, 19, 45

Hartlaub, 39, 40

Hal'vey, 14

Harrie-Brown, 49, 44

Hasselqvist, 15

Hayes, 13,18

Headley, 103

Hector, 35

Heine, jun. 73

Heine, sen. 73

Henslow, 43

Herbert, 19

Hermann, 12

Hernandez, 7

Hertwig, $10 \%$

Heysham, 19

Hintz, 39

Hogg, 74
Holland, 3

Holmgren, 39

Homeyer, A. ron, 39

Homeyer, E. von, Labatie, 40 39

Houghton, 2

Honttuyn, 17

Huet, 26

Hume, 36

Hunt 49

Hunter, 16, 63

Hutchins, 19

Huxley, 82, S4, S5, $95,102,103,106$, 108, 109, 110,112, 113,114

ILLIGER, 99, 53, 59, 62,7 多 102, 110, 112

Irby, 40

Isidorus, 4

JACOBSON, 50

Jacquemin, 65, 69

Jacquin, 13

Jäckel, 39

Jameson, H. I. 44

Jameson, R. 37

Jardine, 19, 27, 37, 44

Jaubert, 40

Jentink, 41

Jenyns, 43

Jerdon, 36

Jonston, 6

KALM, 15

Kaup, 30, 34

Kelaart, 36

Kessler, 66

Keulemans, 2S, 35 $36,49,44$

Kevserling, 62, 67, $68,70,115$

Kinberg, 39

Kingsley, 98

Kirby, 33, 50, 59

Kittlitz, 28

Kjærbölling, 39

Klein, 8

Knip, 23

Knox, 45

Koch, 39

König - Warthausen, 39

Kramer, 17

Leigh, 18
Krïper, 38, 39, 40

Kutter, 39

Lacépède, 14

Lamarck, 78

Land, 4

Landbeck, 39

Landois, 39

Landseer, 63

Langlois, 23

Latham, 11, 12, 13 18,35

Latreille, 30

Langier, 26

Lawrence, 38

Leach, 13

Lear, 24

Leem, 18

Legge, 36

L'Herminier, 34,49 $51,52,53,54,55$, $56,58,59,61,69$, $\approx 6$

Leisler, 39

Lembeye, 37

Lemetteil, 40

Iemonnicier, 40

Léon, 7

Léotaud, 36

Lepechin, 15

Lesauvage, 40

Lesson, $\mathscr{S}, 119$

Le Vaillant, 16, 22 2.3

Lever, 12

Leverkühn, 39

Lewin, J. IV. 35

Lewin, W. 19

Lichtenstein, 7

Lilford, 40, 44, 45

Lilljeborg, $\mathcal{S} 2$

Linneus, 3, 7, \&, 9, $10,11,14,15,1 \%$, $34,47,59,62$

Loftie, 2

Longolius, 5

Lord, 19

Lumsden, 44

MACARTNEY, 34, 63

Macgillivray, 24, 34, $43,59,60,66,5 \%$, 117

V'Tlwraithe, 38

Macleay, 32, 33, 34 35

Macpherson, 45 
Naiguon, 40

Maltzan, 39

Marcgrave, 7

Marcotte, 40

Nariette, ?

Markwick, 19

Marsh, S6, 87, 97, $9 \mathcal{S}, 10 \mathrm{~s}$

Marsigli, 15

Martinet, 10, 26

Mathew, 45

Mauduyt, 12

Max zu Wied, 39

Neckel, 50

Nerrem, 30, 34, 46, $47,48,49,50,52$, 64,76

Merrett, 7, 18

Meyer, A. B. 2S, 39, ry

Meyer, Bern. 39

Meyer, F. A. A. 20

Meyer, H. L. 43

Meyer, H. von, 81

Milne-Edwards, 86 , 10\%, 11\%, 113, 114

Mitchell, F. S. 45

Mitchell, W. D. 26, 30

Mitterpacher, 15

Mivart, 11, 103

Möhring, 8

Moliua, 16

Mommsen, 40

Montagu, 33, 4\%

Iontbeillard, 10

Nore, 44

Molris, 44

Mühle, Von der, 39

Niiller, H. C. 38

Iüller, Johannes, $34,62,67,68,69$, $70,71,93$

Miiller, P. L. S. 18

Muirhead, 44

Murie, 91

NASH, 18

Nathusius, 39

Naumann, J. A. 17, 39

Naumann, J. F. 1\%, $39,50,51,57$

Neale, 42

Neckam, 4

Nehrliorn, 39

Neumann, 39

Newman, 49, 74

Nicholson, 89
Niebuhr, 15

Nieremberg, 7,31

Nilsson, 39

Nitzscl, $34,45,46$, $4 S, 50,51,54,57$, $61,62,63,04,65$ $66,67,68,69,71$, 96,112

Nodder, 13

Norguet, 40

North, 36

Nourly, 40

Nozeman, 17

Nuttall, 38

\section{OATES, 36}

Oken, 33, 57

Olphe-Galliard, 42

Ortus Sanitatis, 4

Osbeck, 15

Oudart, 26,27

Owen, $50,59,63,81$, 102,107

\section{Pallas, 15}

Paquet, 40

Parker, 'T. J. 109

Parker, W. K. 79, So, S4, 111, 112, $113,115,118,119$

Paterson, 44

Pearson, C. E. 38

Pearsols, H. J. 38

Pelzeln, 39

Penuant, 19, 18, 19

Perrault, 14

Petersen, 17

Petiver, 7

Phillip, 16

Physiologus, 4

Pidgeon, 15

Pidsley, 45

Pilati, 17

Piller, 15

Piso, 7

Pliny, 3, 5

Plot. 18

Poey, 37

Potts, 35

Poynting, 78

Prêtre, 26, 2S

Prérot, 27

"QUÉPAT," 40

RafinesquF, 8

Ramsay, 36
Ranzani, 29

Ray, \%, 11

Réaumur, 9

Reichenbach, 2S, 39

Reichenow, 39, 73, 90

Reinhardt, 80

Reunie, 33, 42

Retzius, 17

Reyger, $\mathcal{S}$

Richardson, 38

Riligway, 37

Riley, 3

Risso, 40

Rodd, 45

Rosenstock, 4?

Poux, 40

Rowley, 27

Rzaczrnski, 16

St. - Hilaire, see Bourjot, all Geofiroy

Salerne, 10

Salvadori, 39

Salvin, 27, 95

Saunders, 40, 43

Savi, 10, 39

Scaliger, 3

Schäffer, 12

Schalow, 39

Schlegel, 30, 41

Schöpss, 50

Schomburgh, 36

Schwenckfeld, 6

Sclater, 26, 27, 35, $65,69,95,96,9 \%$, 119.115

Scopoli, 13

Seba, 9

Seebohm, 44, 103, 117

Seeley, 107

Selby, 27, 43

Selenka, 1/4

Selys - Longchamps, 40

Service, 24, 44

Sharpe, 25, 35, 41, $99,109,109$

Shaw, 12, 13, 99,35

Shelley, 36, 40

Shepherd, 88

Sherborn, 2\%, 40

Siemssen, 17

Sillig, 3

Slater, 38

Sloane, 9

Smit, 27

Smith, A. C. 40. 45 $\mid$ Voigt, 45
Smith, Cecil, 45

Southwell, 45

Spalowsky, 13

Sparrman, 13

Stanley, Lord, 12

Stearus, 37

Stejneger, 98, 99, $100,103,108$, 118,119

Stephens, 29

Sterland, 45

Stevenson, 45

Stirling, 109

Stölker, 39

Stricklaud, 30, 34, 104

Studer, 39

Sundevall, 2, 39, 5\%, $65,82,88,89,90$, $94,96,115,119$

Susemihl, 41

Swainson, 28, 30, 32, 34, 35, 38, 118

Swann, 45

TASLÉ, 40

Taylor, 3

Tegetmeier, 13

Temminck, A. J. 23

Temminck, C. J. 23, $26,99,41,51,54$ 110

Thackeray, 5

Thaun, 4

Thompson, 44

Thorburn, 44

Tiedemaun, 46, 116

Tobias, 39

Todd, 50, 59

Tristram, 40, 79

Tschusi von Schmid. hofen, 39

Tucher, 44

Tunstall, 18

Turner, F. N. 25

Turner, W. 5

UsSHer, 44

VALENTINI, 14

Vieillot, 23, 27, 29 40

Vigors, 30, 39, 39 $35,60,74$

Vogt, 107 


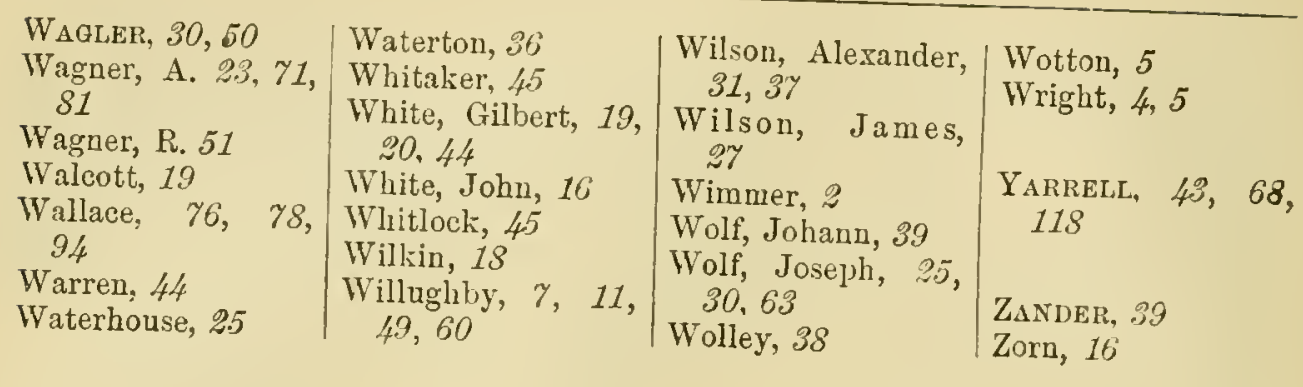




\section{DICTIONARY OF BIRDS}

\section{A}

AASVOGEL (Carrion-bird), the name given to some of the larger Vuitures by the Dutch colonists in South Africa, and generally adopted by English residents (Layard, B. S. Africa, pp. 5, 6).

ABADAVINE or ABERDUVINE (etymology and spelling doubtful), a name applied in 1735 by Albin (S'uppl. Nat. Hist. B. p. 71) to the Siskis, but perhaps hardly ever in use, though often quoted as if it were.

ACANTHIZA, the scientific name given in 1826 by Vigors and Horsfield to a genus of birds commonly ranked with the Sylviida (WARbler), and used as English since Gould's time for the eight or more species which inhabit Australia.

ACCENTOR, Bechstein's name for a genus of Sylviidze (including the Hedge-Sparrow and its allies) which some British anthors have tried with small success to add to the English language.

ACCIPITRES, the name given by Linnæus to his first Order of the Class Ares, consisting of what are commonly known as Birds-ofPrey, namely, the Vultures, the Eagles and Hawks, and the Owls; the last being by many recent authors, whose example is followed in the present work, separated from the first two.

ACORN-DUCK, a name given in some parts of North America to the Carolina or Wood-Duck, AEx sponsa.

ACROMYODI, Garrod's name (Proc. Zool. Soc. 1876, p. 507) for a group of birds practically the same as the Oscines, POLYMYODI or true PASSERES of various authors, "an acromyodian bird, being one in which the muscles of the SYRINX are attached to the extremities of the bronchial semi-rings." The Acromyodi are further divided into two groups, one (abnormales or Pseudoscines) consisting of, so far as is known, only the genera Atrichia (SCRUB- 
BIRD) and Menura (LYrE-BIRD), the other (normales) containing all the rest of the Oscines.

ADJUTANT, a large lind of STORK, so called by the English in India and elsewhere "from its comical resemblance to a human figure in a stiff dress pacing slowly on a parade-ground" (Yule \& Burnell, Hobson-Jobson, sub roce). It belongs to the genus Leptoptilus, of which the members are distinguished by their sad-coloured plumage, their black, scabrous head, and their enormous tawny pouch, which depends, occasionally some 16 inches or more in length, from the lower part of the neck, and is not connected as commonly believed with the digestive system (see ArR-SACKS). In many parts of India $L$. dubius, or $L$. argala of some authors, the largest of these birds, the Hargila as Hindus call it, is a most efficient scavenger, sailing aloft at a vast height and descending on the discovery of offal, though frogs and fishes also form part of its diet. It familiarly enters the large towns, in many of which on account of its services it is strictly protected from injury, and, having satisfied its appetite, seeks the repose it has earned, sitting with its feet extended in front in a most grotesque attitude. A second and smaller species, L. javanicus, has a more southern and eastern range; while a third, $L$. crumenifer, of African origin, and often known as the Marabou-Stork, gives its name to the beautifully soft feathers so called, though our markets are mostly supplied with them by the Indian species (in which they form the lower tailcoverts), if not, as some suppose, by VuLTuREs. Related to the Adjutants are the birds known as JABIRUS.

AGITHOGNATH无, the fourth and last Suborder of CARINATA, according to Prof. Huxley's arrangement (Proc. Zool. Soc. 1S67, pp. 450-456,467-472), founded chiefly on palatal characters, containing two groups, the CYPSELOMORPHAs and CoraCOMORPHA, and possibly a third, the CELEOnIoRPII (or Gecinomorpha). In the true ægithognathous structure the vomer is broad, abruptly truncated in front and deeply cleft behind, so as to embrace the rostrum of the sphenoid; the palatals have produced posteroexternal angles, the maxillo-palatals are slender at their origin, and extend obliquely inwards and backwards over the palatals, ending beneath the vomer in expanded extremities, not united either with one anotler or with the vomer, nor is the last united with the ossification of the anterior part of the nasal septum-a not uncommon condition. As a whole the Agithognathe correspond pretty well with the INsEssores of Vigors.

AETOMORPHA, Prof. Huxley's name (Proc. Zool. Soc. 1S67, pp. 462-465) for that group of his Suborder DesmogNaTHe, which inclucles the Birds-of-Prey, commonly so called, and therefore practically equivalent to the ACCIPITRES of Linnæus and the RAP- 
TOREs of many authors. Prof. Huxley makes four divisions of the Aetomorphic birds, namely, Strigidx (Owls), Cathartida (VuLtures of the New World), Gypaetidx (Vultures of the old World, EAGLes and HAwKS), and Gypogeranila (formed by the SECRETARYBIRD alone).

AFTERSHAFT or hyporhachis is the generally small counterpart of a typical feather which springs from the inner surface of the quill common to both. The aftershaft is of the same size as the shaft in the Cassowary, Emeu, and in the Moa: it is well developed, but forms an unimportant part of the whole feather in Parrots, most Birds-of-Prey, Herons, Gulls : it is very small and feeble in most Pusseres, Grallax, and many Gallina; and absent or extremely small in the Ostrich, Rhea, Kiwi, Pigeons, Owls, Woodpeckers, Steganopodes, Anseres, and others. As a rule, the aftershaft is best developed in downs, and in the smaller contour-feathers, while it is wanting or minute in the remiges and rectrices. While the absence of an aftershaft is certainly due to its subsequent reduction or loss, it is probable that its great size in the Emen is not a primitive but a secondary acquired feature, becanse the feathers of the first or nestling plumage of this bird consist of two very unequal halves (see also Feathers).

$A I R-S A C K S$ (or SACS) are membranaceous receptacles which communicate with the cavities of the respiratory organs or passages, and can through them be filled with air. According to their connexions we distinguish between a (I) pulmonary and (II) a nasopharyngeal system of air-sacs.

I. The pulmonary system has the widest distribution in the bird's body. The sacs, of which there are generally five large pairs, begin in the embryo of about eleven days to grow ont as small vesicles from the surface of the lungs, as dilatations of branches of the bronchial tubes, pushing the peritoneal membranes before them, and gradually extending as enlarged sacs into the body cavity between the various intestines. Each sac has an inner layer, the continuation of the lining membrane of the bronchial tubes, and an outer layer or serous membrane, which is the bulged-out pleura or peritoneal covering of the lung. The pulmonary openings are beset with vibrating cilia like the bronchi. The outside of the sacs frequently possesses a covering of involuntary or of voluntary muscles; for instance, in Vultures, Gannets, and Flamingos a thin fan-shaped muscle extends from the furcula over the interclavicular air-sac. Through contraction of these muscles the cells can be emptied of air. The five principal pairs of air-sacs are :-

1. A prebronchial or cervical pair, situated in front of or "headwards" from the lungs and the pulmonary system. They are sub. jected to many modifications. They form on each side a single sac 
in the Duck, which in the Fowls, Gulls, Gannets, and some others, communicates with the next pair. In the Stork, Flamingo, and Screamer each sac is elongated and divided into numerous smaller cells. Frequently these sacs extend far up the neck, even into the head, and small side branches may enter any of the neighbouring organs, such as the inside of the vertebræ, the carotid and vertebral canals, the cervical muscles, the cranial cavities, and others. Sometimes they form large inflatable sacs on the throat, as, for instance, in the Prairie-fowls.

2. A pair of subbronchial or interclavicular sacs. They are united into one sac in Storks, communicate with each other in Ducks, ale subdivided into a number of smaller sacs in the Swan and in the Screamer: in Vultures they talie the large crop between them. Lateral extensions accompany the large blood-vessels and form axillary cells penetrating ultimately the humerus and other bones of the wing; other secondary cells penetrate the large pectoral muscles (e.g. in Mycteria) or enter the body and the keel of the sternum.

3, 4. A pair of anterior and posterior intermediate sacs, extending more or less far into the abdominal cavity, covering chiefly the lower portions of the lungs and the liver, occasionally subdivided, being filled through several openings at the external edge of the lungs, and sometimes continued into the lateral parts of the sternum.

5. A pair of abdominal sacs. These are the largest, extending with irregular subdivisions between the intestines into the pelvis, and penetrating the femur together with the rest of the bones of the sacrum, and the legs.

Besides these principal air-sacs, there exist numerous smaller cells, which enter more or less directly from the lungs into the vertebrie and ribs, between the muscles, underneath the skin and other parts, thus making the skeleton, and sometimes the greater part of the body, pneumatic. The air-sacs do not enter the bones before a considerable portion of the marrow has been absorbed, an extremely small hole in the bone is sufficient for their entrance; the cavity of hollow bones is ultimately lined with the thin membrane of the air-sac. Generally the skeleton is most pneumatic in large birds that fly well, like Vultures, Storks, Swans, Pelicans; less so in small birds, and least in heavy or little-flying water-birds. However, there are many exceptions. While, for instance, most of the bones of many Passeres, of Swifts, Divers, Rails, the Kiwi, and of Terns, are solid, and air-cells are restricted chiefly to the cranium, many parts of the skeleton of the large latita are very pneumatic.

The greatest development of pneumatic cells exists in the Screamers and Hornbills, in which even the fingers and toes, in fact, any part of the skeleton, are hollow, and large subcutaneous air-sacs 
are present in great numbers between the muscles and the roots of the feathers. These birds when inflated and pricked emit a peculiar hissing noise through the skin. It is well known that a bird which has its humerus shattered by shot can for some time breathe, although its beak and nostrils be tightly closed, and thus be submitted to unnecessary excruciating pain. Compression of the thorax and abdomen suffocates a wounded bird better than strangulation.

II. The naso-pharyngeal or tympanic system of air-sacs is restricted to the head, extending chiefly into the occipital, frontal, parietal, quadrate, and mandibular bones. To this system belong the Eustachian tubes (see EAR and SkULL), the tympanic, and other cavities which communicate with the nose. The most curious dilatation belonging to this system is the crop-like pouch of the ADJuTant. This sac communicates in Leptoptilus crumenifer with a large cavity below the orbit and the pterygoid bone on the left side of the basis cranii, opening directly into the nasal cavity and extending like a hernia into a loose fold of integument, the pouch being divided into two by a vertical membrane which descends to the level of the eighth cervical vertebra.

Another inflatable sac is the gular pouch of Bustards. It seems to be developed only in adult males, reaching its greatest size during the breeding season, and again shrivelling up during the rest of the year. Its opening is a 1 -shaped slit in front of the frenulum of the tongue and below this organ; the opening can be closed by muscles, and leads into a large, glandless blind sac (about 8-10 inches long, with half the width), which is a dilatation of the frenulum and hangs down between the throat and the skin of the front of the neck. It seems to be an entirely sexual ornament, inflating the skin, and containing neither water nor food.

A similar homologous structure exists in the male of Bizinra lobata, as a little pouch between the two halves of the frenulum, with a roundish opening, but apparently not extending into or inflating the outer cutaneous wattle or fold underneath the mandibles.

Lastly, the tracheal pouch of the EMEU may be mentioned. It is a large unpaired hernia-like sac of the tracheal walls, conmunicating with the trachea through a longitudinal slit on the ventral side, an individually-varying number of from five to fourteen cartilaginous rings being known to be deficient in the middle line. In the embryos this deficiency is already shewn, but the pouch is developed much later, and attains its full size in the adults of both sexes. This organ seems to act as a resounding bag to the peculiar drumming noise made by the adult birds.

The function of all these air-sacs has been the subject of many controversies. Some are undoubtedly subservient to sexual orna- 
mental purposes, by inflating the slin, rustling the feathers, or acting as resounding bags in the Prairie-fowls and in the Emeu. The suggestion that the warm air in these sacs makes the bird lighter, and assists, balloon-like, the flight, is void of practical value, because the few grains of weight lifted up by the whole amount of air-sacs of even a large bird would be more than counterbalanced by a few grains of food or better-nourished condition of the bird. Nor would this view be applicable to the Ratitæ, with their well-developed air-sacs. The newer researches of Sappcy, Campana, ${ }^{2}$ and Strasser ${ }^{3}$ make it probable that one of the principal functions of the air-sacs consists in the ventilation of the lungs, the latter being only capable of very limited expansion and contraction in birds. No exchange of gas seems to take place in the sacs themselves, they being poor in blood-vessels; but they seem to be directly connected with the regulation of the exhalation of aqueous vapour, there being besides no perspiration through the slrin. Frequently they serve also as reservoirs for air, in order to increase the voice; for instance, in the long-continued song of the Nightingale, or still more so, in the Lark when warbling.

ALBATROS, a corruption of the Spanish and Portugnese Alcatraz or Alcaduz ${ }^{4}$ by which name the Pelican is known in some parts of the Iberiau peninsula and the Spanish colonies in the West Indies; but it is also applied vaguely to other large sea-birds. By English navigators its use was formerly quite as indiscriminate, and its spelling no less so, the forms Alcatraza, Alcatraze, Algatross, and Albitross, occurring in various authors-the last being that found in Shelvocke's Voyage (London: 1726), wherein (pp. 72, 73) is recorded the incident that, on Wordsworth's suggestion, Coleridge immortalized in his Ancient Mariner. In process of time the name has become definitely limited to the larger species of Diomedeida, ${ }^{5}$ a family of the group Tubinares, and especially to the largest species of the genus, Diomedea exulans, the "Man-of-war bird" or Wandering

${ }^{1}$ Compt. Fiend. de l'Acad. des Seiences, xxii. pp. 250, 508.

- Physiologie de la respiration ehez les Oiseaux. Paris : 1875.

3 Jenaische Zeitschrift, xix. pp. 174-327, 330-429.

4 The word is Arabic, al-eâdous, adopted from the Greek rádos, watcr-pot or bucket (ef. Dozy \& Engelmann, Glossaire des mots espagn. et portug. derivés de l'Arabe, ed. 2, p. 79), and especially signifying the leathern bucket of an irrigating machine. Thence it was applied to the Pelican, from the resemblance of that bird's pouch, in which it was believed to carry water to its young in the wilderness.

5 The Avcs Diomedca of Pliny (lib. x. cap. 44), whence the word has been preserved in Ornithology, inhabiting the islands of the same name, generally identified with Tremiti off the Adriatic coast of Italy (cf. Lachmund, De Ave Diomedea dissertatio. Amstelodami: 1672, 1. 23), seem to have been SHFarWATERS of some sort. 
Albatros of many authors. Of this, though it has been so long the observed of all observers among voyagers to the Southern Ocean, no one seems to have given, from the life, its finished portrait on the wing, and hardly such a description as would enable those who have not seen it to form an idea of its look. The diagrammatic sketch by Captain (now Professor) Hutton, here introduced, is prob-

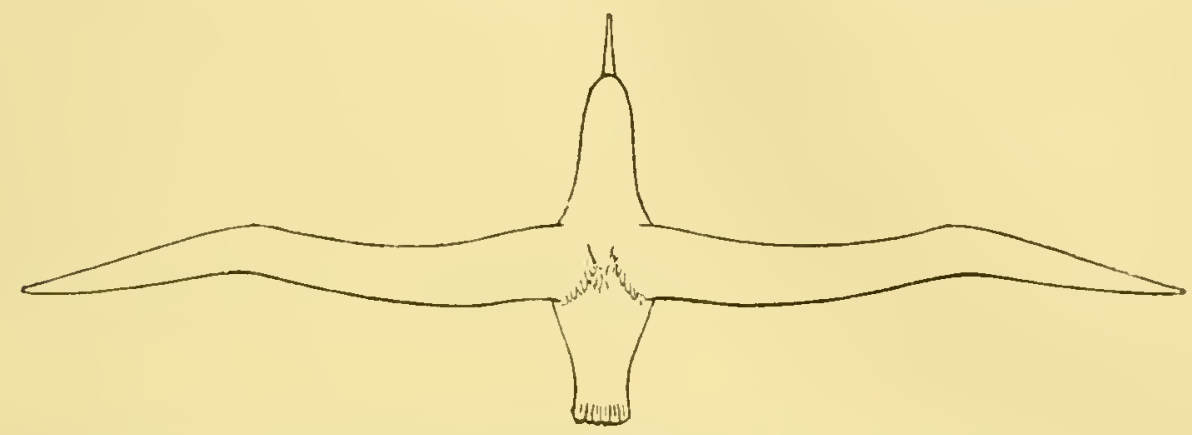

Albatros. (After Hutton. From the Philos. Mag. Aus. 1869, with the Editor's permission.)

ablyamore correet representation of it than ean be found in the conventional figures which abound in books. Writers who apply to its FLTGHT the epithets graceful, grand, majestie, and the like, convey thereby 110 definite meaning, and yet by all aceounts its appearance must be extremely characteristic. The ease with which it maintains itself in the air, "sailing" for" a long while withont any pereeptible motion of its wings, whether gliding over the billows, or boldly shooting aloft again to descend and possibly alight on the surface, has been dwelt "pon often enongh, ${ }^{1}$ as has its eapacity to perform these feats equally in a seeming calm or in the fice of a gale; but more than this is wanted, and one must hope that a series of instantaneous photographs may soon be obtained which will shew the feathered aeronaut with becoming dignity. The mode in which the "sailing" of the Albatros is efiected has been much discussed, but there can be little doubt that Professor Hutton is right in declaring (Ibis, 1865, p. 296) that it is only "by combining, according to the laws of mechanies,

1 The most vivid description is perhaps that of $\mathrm{Mr}$. Froude (Oceana, pp. 65, 66), and, as it is eited with approval by Sir W. Buller (B. New Zeal. ed. 2, ii. 1. 195), a part may here be cquoted. The Albatros "wheels in cireles round and round, and for ever round the ship--now far behind, now sweeping past in a long rapid enrve, like a perfect skater on an mntonehed field of ice. There is no effort; watel as closely as yon will, yon rarely or never see a stroke of the mighty pinion. The flight is generally near the water, often close to it. You lose sight of the bird as he disippears in the hollow between the waves, and eatch him again as he rises over the crest; but low he rises and whence eomes the propellingr force is to the eye inexplicable; he alters merely the angle at which the wings are inclined; nsually they are parallel to the water and horizontal; but when he turns to ascend or makes a change in his direction the wings then point at an angle, one to the sky, the other to the water." 
this pressure of the air against his wings with the force of gravity, and by using his head and tail as bow and stern rudders, that the Albatros is enabled to sail in any direction he pleases, so long as his momentum lasts." Much discrepancy, at present inexplicable, exists in the accounts given by various writers of the expanse of wing in this species. We may set aside as a gross exaggeration the assertion that examples have been obtained measuring 20 feet, but Dr. George Bennett of Sydney (Wanderings, \&c., ii. p. 363) states that he has "never seen the spread of the wings greater than fourteen feet." Recently Mr. J. F. Green (Ocean Birds, p. 5) says that, out of more than one hundred which he had caught and measured, the largest was 11 feet 4 inches from tip to tip, a statement exactly confirmed, he adds, by the forty years' experience of a ship-captain who had always made a point of measuring these birds, and had never found one over that length.

This Albatros is too well known by description in countless books, or by specimens to be seen in almost any museum, to need many words as to its chief features. In the adult the plumage of the body is white, more or less mottled above by fine wavy bars, and the quill-feathers of the wings are brownish-black. The young are suffused with slaty-brown, the tint becoming lighter as the bird grows older. It is found throughout the Sonthern Ocean, seldom occurring northward of lat. $30^{\circ} \mathrm{S},{ }^{1}$ and is invariably met with by ships that round the Cape of Good Hope or pass the Strait of Magellan. As a species it is said to be less numerous than most of its smaller congeners, and one cannot but fear that it will become rarer still, if not extinct, partly because of the senseless slaughter to which it is subjected by the occupants of almost every ship, but especially because of the ravages inflicted upon it at its not too many breeding-places, which are on islands mostly small and remote, where disastrous havoc can be, and continually is, wrought by a boat's crew in a few hours.

In the North-Pacific Ocean are found two other large species of Albatros, regarded for a long time by ornithologists as identical with $D$. exulans, but now recognized as being distinct species. They have also been confounded with one another by some anthors, while the young have been described as if different from their parents, so that their nomenclature presents a tangled puzzle which it would be impossible here to unravel. Enough to say, that the one of them which is most like $D$. exulans, and has over and over again been so termed by authors, is the $D$. albatrus of Pallas, its young being the $D$. derogate of Swinhoe. This secms to be always

1 Instanees are recorded of its oeenrrence in Europe and North America, and no doubt examples of some speeies of Albatros have wandered so far from their usnal range; hut whether $D$. cxulans is one of them seems to await proof. Fossil remains of Diomedca liave been found in Suffolk (?. J. Geol. Soc. 1886, p. 367). 
distinguishable by its ycllow or light-coloured legs, while the other, the $D$. brachynura of Temminck, its young being the $D$. nigripes of Audubon, has those limbs dark or black. Both of them seem to occur in summer in Bering Sea, while they occasionally appear along the shores of China and California ; but nothing can yet be said as to their precise range. It remains to mention the smaller species of the genus, one of which, $D$. cauta, described by Gould, is not much inferior in size to the preceding, and owing to its wary disposition, indicated by the trivial name it bears, is extrencly rare in collections. These are all known to seafaring men as Molly$W$ manks-a corruption of Mathanuck-and chiefly frequent the Southern Ocean, as does also the Sooty Albatros, which, from its wedge-shaped tail, has been placed in a genus of its own, and passes as Phobetria fuliginosa.

ALBINO (coll. n. albinism). A case of HeTERochrosis, produced by the partial or total absence of the normally-present black pigment in the feathers and other parts. In complete albinos the pupil and iris are red, owing to the blood-vessels shining through these otherwise strongly pigmented parts. A lesion of the pulp of a growing feather not unfrequently prevents the deposition of pigment therein, but the pulp recovers as a rule after one or more moults (see CoLOUR).

ALECTORIDES, an Order proposed by Temminck in 1820 (ITan. d'Orn. ed. 2, i. p. xev.) to contain the genera Psophia (TruurpEter), Dicholophus (Seriema), Glareola (Pratincole), Palamedea, and Chauna (Screanier). Sundevall subsequently (K. Vet. Acad. Handlingar, 1836, p. 120) substituted Otis (BustaRD) for Glareola, but wholly dropped the group in his Tentamen (1872-73) wherein these for'ms are differently disposed. The Order has, however, been admitted by several other systematists, and among them by Mr. Sclater, who, in 1880, made it include six Families (see INTroduction).

ALECTOROMORPHAE, according to Prof. Huxley's arrangement (Proc. Zool. Soc. 1867, pp. 456, 459), the fifth group of Schizognathas, corresponding practically with the GALLINA of Linnæus; and, omitting the genera Opisthocomus (HoACTzIN) and Memura (LyRE-BIRD), with the section Gallinacei of Illiger's RAsores.

7 ALK, the old and apparently the more correct form of AUK.

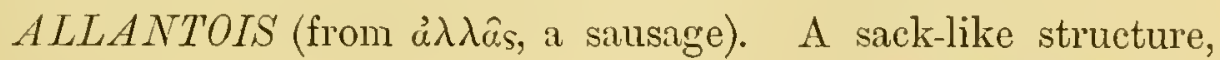
which during the very early development of the embryo grows out from the posterior gut into the body cavity, and extends rapidly all round the embryo in the space enclosed by the false amnion, forming then with the latter a highly vascular inner lining of the eggshell. This bag receives urine, and takes on respiratory functions in embryonic Birds and Reptiles. Towards the end of incubation the

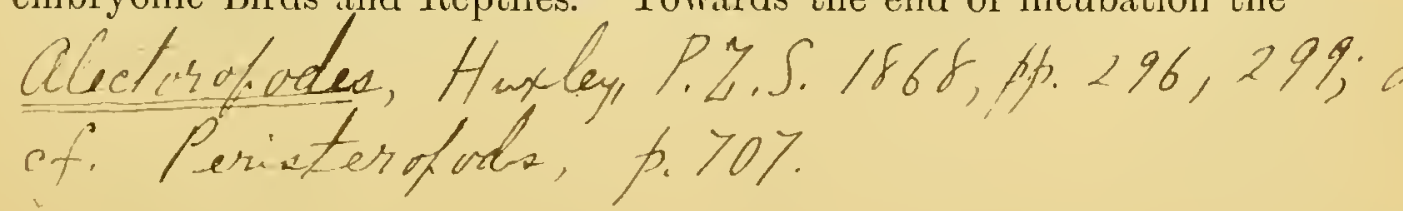


allantois shrivels up, and is cast off with the shell; its stalk or urachus, from the cloaca to the navel, is gradually absorbed, there being no urinary bladder in Birds (see EMBRyology).

ALP, otherwise ALPH, AWBE, or OLPH, a word of unknown origin, but of long standing (see Chaucer, Romaunt of the Rose, circa 1400), and still locally used in one or other of its forms, e.g. "BloodOlph" and "Green-Olph" for the Bullafinch and Greenfinch respectively.

ALTRICES, the name given by Sundevall (K. Vet. Acad. Handl. 1836, p. 64) to his first section of the Class Aves, comprehending those which "alunt pullulos" (feed their young); founded on the scheme of Oken (Lehrb. d. Zoologie, p. 371), in opposition to Pracoces, the birds which at birth are more or less able to feed themselves, but subsequently abandoned by its inventor (Tentamen, p. xx., Nicholson's transl. p 26).

The division of the Class thus indicated has under various names been advocated by several authorities, and at first sight has a plausible appearance; but investigation shews that it cannot be adopted. Doubtless the original Birds, like Reptiles, were Præcoces, and the Altrices are of later date. The existence of the numerous intermediate forms may thus be explained; but it follows that we cannot use as absolutely valid differentiating characters such as are afforded by the open or closed eyes of the young at birth, by their being clothed in down or naked, by their remaining in the nest or not, by their way of feeding themselves or being fed. It is possible that the transition from Pracoces to Altrices has been governed by purely external circumstances, which may still be in action-such, for instance, as the nest being built high above the ground or water. There are many Altrices whose whole anatomical structure proves them to be more nearly related to certain groups of typical Præcoces than they are to other Altrices. These circumstances as fully explained (Jenaisch. Zeitschrift, 1879, p. 385, and Bronn, Thierveich, Aves. p. 701) lead to the following divisions of birds in regard to their development :-

1. PRECOCES or Nidifugæ-hatched with eyes open; thickly clad in down; able to run at once, or almost at once; and having such an amount of yolk stored in the abdomen as to render them for some time more or less independent of other food:-Ratita, Crypturi, Gallinx, Laridx, Limicole, Pteroclide, Gralle, Anseres, Pygopodes.

¿. A tTRICES or Nidicola-

a. Lower Nidicola-some hatched with their eyes open, others blind ; covered or not with down ; unable to leave the nest ; fel by the parents ; amount of food-yolk very limited:Spheniscidx, Steganopodes, Tubinares, Herodii, Pelargi. 
b. Higher Nidicolx-hatched in a helpless condition, blind; mostly naked, and for a long time nursed in the nest, the food-yolk having been used up at birth:-Columbr, Striges, Accipitres, Psittaci, Coccyges, Epopes, Halcyones, Cypselomorphx, Pici, Passcres.

The two series $a$ and $b$ stand phylogenetically parallel to each other.

AMAZON, a bird-fanciers' name for a certain group of PARRoTs belonging chiefly to the genus Chrysotis.

AIIBIENS is a muscle (so called by Sundevall, Förhandl. Sliand. Naturf. 1851, pp. 259-269: abstract in Rep. Brit. Assoc. 1855, 'Trans. of Sect. p. 137) which, arising from the pectineal process of the pelvis, runs along the inner surface of the thigh, passes the linee as a string-like tendon, and then forms one of the heads of the deep flexor muscle of the second and third toe. 'The taxonomic value of this muscle has been much over-estimated since Garrod ( $P . Z$. S'. 1874, pp. 111-123) divided the Class into Honalogonate, birds possessing an ambiens nuscle, and Aromalogonate, or birds without such a muscle. The muscle is typically developed in Crypturi, Gallinæ, Pteroclidæ, Grallæ, Laridæ, Colymbidæ, Steganopodes, Impennes, Anseres, Accipitres, Coccyges; it is absent in all Striges, Cypselomorphr, Halcyones, Epopes, 'Trogonidæ, Pici, Passeres, Herodii, Alcidx, Podicipedidx; it is very variable in Ratitr, Pelargi, Tubinares, Columbæ, Psittaci (see also Muscular Systeir and INTRODUCTION).

AMIDAVAD, otherwise AMADAVAT, or AVADUVAT, the name given to a well-known favourite cage-bird, Estrilda amandava (see WFAVER-BIRD), being a corruption of Ahmadabad, the name of a town in Goojerat whence, more than 200 years ago, according to Fryer (New Account of East India, \&c., London: 1698), examples were brought to Surat. In his peculiar style he tells us (p. 116) that "they are spotted with White and Red, no bigger than Measles, the principal Chorister begiming, the rest in Concert, Fifty in a cage, make an admirable Chorus."

AMNION (a Greek word of doubtful derivation, used already by Aristotle). From either end of the body of the very early embryo grows out a fold which passes dorsally over the embryo, and unites above it with its fellow from the other end; between the two layers of this double fold, which is the amnion, extends the body-cavity, and receives the rapidly-growing Altantois; the outer membrane of the allantois fuses with the outer double fold of the ammion, and forms the chorion, lining the eggshell (see EnBryoLOGY). The amnion affords one of the principal differentiating characters in the vertebrata; Reptiles, Birds, and Mammals are as Amniota (Hreckel, Anthropogenie, 1874) opposed to Amphibians and Fishes or Anamnia.

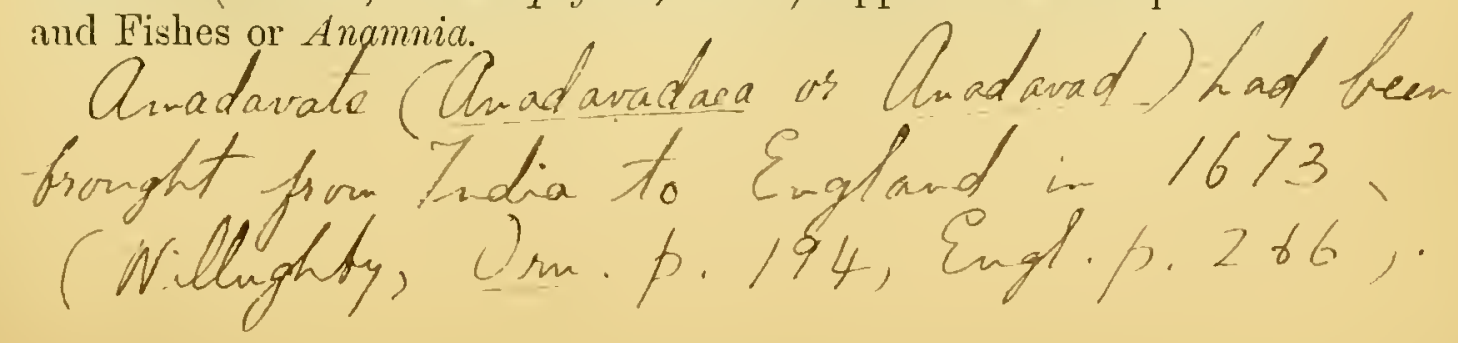


AMPHIBOL $\mathrm{E}$, a group of birds so ealled by Nitzsch in 1829 (Observationes de Avium Carotide communi, p. 16) comprising the genera, as then understood, Musophaga (Touraco), Colius (MouseBIRD), and Opisthocomus (HoACTZIN); but by no means to be eonfounded with the

AMPHIBOLI, one of Illiger's groups, defined in 1811 (Prodromus Systematis Mammalium et Avium, p. 203), and composed of the genera Crotophaga, Scythrops, Bucco, Cuculus and Centropus - the third of which is treated of under the titles of BARBET and PUFFBIRD, while the rest will be found under those of ANI, ChasvetBILL, and CUCKOW.

AMPHIBOLIC is a toe which ean be reversed at will either backwards or forwards. The outer or fourth toe is amphibolic, and can be turned backwards in Pandion, the Striges, Musophagidæ, Leptosomatidæe, and Coliidæ. This feature, when retained, forms the true zygodactyle foot. The Mouse-BIRDs can turn the first toe forwards, being thus enabled temporarily to assume the condition of some of the SwiFTs, or that of zygodactyle birds. Reversion of the second toe backwards has produced the psendo-zygodactyle or heterodactyle foot of the Trogons (see Skeleton).

AMPHINORPH E, the name given by Prof. Huxley (Proc. Zool. Soc. 1867, p. 460) to his second group of Desmograthe, which consists of the genus Phoenicopterus (Flaningo), as being "so completely intermediate between the Anserine birds on the one side, and the Storks and Herons on the other, that it ean be rangerl with neither of these. groups, but must stand as the type of a division by itself."

ANATOMY ('́varopia, dissection) is that branch of zoology which deals with the deseription of the organic structure of animals; a branch of this zootomy is IIistology, the knowledge of the eomposition of the tissues of the various organs. The object of Comparative Anatomy is the explanation of the features exhibited by the animal organization. The comparative method examines numbers of different animals (or plants) with reference to the anatomical structure of their varions organs, putting similar conditions together, and scparating or excluding those which are dissimilar. By observing in such organs their size, number, shape, structure, relative position to other organs, and their development, we ultimately acquire a knowledge of such a series of conditions or features, exhibited by one and the same organ, which in their extremes may appear totally different, but are connected with each other by numerous intermediate stages. By proceeding in such a way, we are, for instance, enabled to understand the ankle-joint of Birds, by comparing the bones of their hind limbs with those of Mammals 
and Reptiles, and by concluding that the avine ankle-joint is produced by the fusion of the proximal tarsal bones with the tibia, and of the distal tarsals with the metatarsals, that consequently this joint in Birds is not the same as the ankle-joint of Mammals. If moreover, as is the case here, the study of the embryonic development of Birds shews that this fusion actnally does take place, Ontogeny corroborates the correctness of the conclusions which we had arrived at by the strictly comparative or phylogenetic method.

Phylogeny, then, is the study of the relationship and the descent of the various animals, often with the help of fossil species, which are generally in some ways intermediate between other recent forms. For instance, through comparison of the skeleton of Birds with that of other Vertebrates, we find that Birds resemble Reptiles much more than they do Fishes or Amphibia or Mammals; this we express by saying that Birds are rather nearly related to Reptiles; the extraordinary resemblance of recent Birds with the fossil Archaopteryx, which at the same time has still many truly Reptilian characters, links the two classes still more together. We conclude that Reptiles and Birds are descendants of one common Reptilian stock. Since most Reptiles possess teeth, and the more than half avine Aichropteryx also has teeth, we again conclude that the earliest Birds likewise possessed such organs, and that their descendants have lost them. In this belief we are not shaken, although the most careful examination of embryonic birds has failed to reveal even the smallest traces of dental germs. The subsequent discovery in American cretaceous deposits of 'Toothed bircls, like Enalionis and Hesperornis, is a beantiful corroboration of the soundness of the method.

Ontogeny, on the other hand, includes the study of the development of the individual, and hence is often called EMBryoLogy. Thatever organic modifications the parents have acquired during their life, subjected to the struggle for existence, be it through natural or sexual selection, or be it through spontaneous variation, will be inherited, at least partly, by their offspring. Ontogeny is therefore the recapitulation by the growing individual of the sum total of the erer-changing stages and conditions througl which the whole chain of its ancestors has passed: it is a condensed repetition of Phylogeny. This repetition is often so much condensed that many previous stages are rapidly passed throngh, or may even be apparently left out, or they have become modified beyond recognition through the development of organs necessitated by, and restricted to, the embryonic stages. Such strictly embryonic organs (for instance the Amnion and the Allantors, or the placenta) are featmes which have originally nothing whatever to do with the adult, because we know of no Tertebrates which in their adult 
condition live within such bags. Another imperfection of the ontogenetic record lies in the fact that the sequence in which the various organs are developed in the embryo does not always correspond with the temporary succession in which we know them to have been acquired during the phylogenetic development of the animal in question; thus feathers begin to bud while the skeleton of the embryo is still cartilaginous. Such discrepancies between the ontogenetic and phylogenetic development have been termed "cænogenetic" by Prof. Hæckel (from kaı̀ò, new). The fact of their frequent occurrence without our being aware of the various cases, warns us to be extremely careful in interpreting the various features exhibited by the embryo. In the present state of our knowledge it is often impossible to decide the taxonomic value of a given feature.

Descriptive Anatomy requires a number of technical terms which shall not be ambiguous, or permit of doubt as to their intended meaning. For instance, terms like upper and lower, anterior and posterior, inner and outer, are often liable to be misunderstood. In ordinary parlance anterior corresponds with ventral in Man (with reference to whom many of our technical terms have been invented), but the head though at the anterior end of the animal is not ventral, and yet the anterior surface of a vertebra may mean its ventral surface. In fact, these vernacular names change their meaning according to the starting-point which happens to be used.

It seems therefore advisable to enumerate, and give a definition of, those terms which it is useful to apply throughout in the description of the various organs of a Bird.

The longitudinal axis of every bird corresponds with its rertebral column : one end is marked by the head, the other by the tail, thus giving the terms cephalic and caudal ; and concerning the neck, trunk, and tail, together with their constituent parts, anterior and posterior: On one side of the vertebral column or axis are situated the heart, lungs, and digestive organs; this is the ventral, in opposition to the dorsal side. These give, combined with anterior and posterior, right and left. An axis at right angles with the longitudinal one, and at the same time running right and left, is a transverse axis; beginning with the vertebral axis as the starting-point, the terms proximal and distal are applied to any organ or part which is referable to the longitudinal axis. These two terms are chiefly applicable to parts like ribs and limbs with their various elements. The proximal end of the tibia articulates with the distal end of the femur; the proximal end of a rib articulates with a vertebra, and so on. The tip of the wing marks its distal, the AxILLA its proximal end.

With reference to an ideal plane through the longitudinal axis, and at right angles to the transverse axis, are applied the terms 
median or inner, lateral or outer. Lastly, since it is not almays obvious to which axis or plane a given organ is to be referred, its parts can be described with reference to its neighbours. Hence we speak of the tibial and fibular, radial and ulnar side of the bones and other parts of the extremities; the fourth toe is on the fibular, outer, or lateral side of the foot, the first, which is ordinarily the hind toe, on the tibial, inner, and posterior sicle.

The basal part of an organ is generally also its proximal part or root, while the apex corresponds with its free or distal end, the latter being the portion most removed or distant from the region whence it grew. Thus we speak of the distal tracheal rings as joining the bronchi, while proximally the trachea is attached to the larynx.

In comparing the various parts of one animal with each other, or with those of another animal, we call the organs which are morphologically or structurally similar homologous, the parts which physiologically or functionally correspond are analogous. When the comparison is restrieted to one individual, the homologies are general. The different vertebræ, or the ribs, or the anterior and posterior extremities of any particular Bird are serially homologous or homodynamous organs, because they are to a certain extent repetitions of each other, although not necessarily exactly alike. If the eomparison refers to similar organs in various individuals, no matter if these belong to the same speeies, genus, family, or class, the homologies are special, and these again may be complete or incomplete. For instance, the humerus of a Bird is completely homologous with that of a Mammal, Reptile, or Amphibiain; the atlas or first vertebra of a Crow is completely homologous with the same part of a Dog. On the other hand, the wing of a Crow is only incompletely homologous with the arm of Man; nor is the two-toed foot of the Ostrich eompletely homologous with the four-toed foot of a Fowl, although the various bones which compose the feet in both are complete homologues.

Homologous organs are consequently developed from the same parts of the embryos of the creatures which are under comparison. Hence the number of existing homologies in given animals indicates their further or closer relationship, and is used for assigning these animals to their places in the system. It follows from this consideration, that the animal's place in the system depends greatly, or entirely, upon the characters or organs selected for this purpose. Unless all the organs and all their characters are carefully considered, not only in the few Birds which happen to occupy our attention at the time, but also in Birds of as many different groups as it is possible to examine, our attempts to produce a classification of Birds must invariably end in the production of arbitrary "keys." It is extremely difficult, often hopeless, with the present state of our 
knowledge of the anatomy of Birds, to decide which characters and which organs are of extrinsic taxonomic value, and which are not. Nor is it always possible to see why certain organs, fully developed, and exhibiting striking and constant features in one group of Birds, are extremely variable in another otherwise very circumscribed and apparently natural group. Supposing such a character to be absent in a given group, is it absent because it has not yet been developed, or is it because it has been lost? Has it been lost by the ancestors of this group, or has it been abolished within this group? In the former case the absence of this character would probably help to decide the relative position of the group; in the latter case this very same character would be reduced to a cliagnostic point within the group, and not throw any light upon its relationship or systematic position. It may be very easy to diagnose genera or even large groups of birds, but this ability to determine them by the help of mechanically arranged "keys" does not necessarily afford us more than an occasional glimpse of the sunk avine tree, at the reconstruction of which we all aim, as the true representation of the natural affinities of Birds.

It is occasionally insisted upon that "tact" will leelp us to select and to reject characters, and thus prevent us from falling into glaring errors; but tact is a personal feeling, often bias, and it is proof, not inclination, that settles scientific questions. The importance of these considerations, often expressed before in abler words, is gaining more and more ground among ornithologists, and will therefore permit the following illustrations of the ways in which we may or may not apply the study of comparative anatomy to classification.

The presence of the Ambiess Muscle is a Reptilian feature; among Birds it exists in the majority of the lower groups, and is absent in most of the higher members of the Class. We conclude that the latter have lost this muscle, and not that it has not yet been developed in them. Its reduction or loss is still going on within some groups, such as Parrots and Pigeons. This loss takes place independently in widely different groups. It follows, first, that absence of this muscle does not always indicate relationship; secondly, that we can derive forms that are without it from a group which still possess it; but that the reversed conclusion is not possible. We know of no organ which has been redeveloped after it has once disappeared in the ancestors of the animals under consideration. Therefore the absence of the ambiens muscle in all Owls, which apparently use their hinder extremities in the same way as the Falconida (which possess this muscle), indicates that the Owls are not developed from the Falconidx, but from a group which, like the Hacrochires, had alrcady lost this organ.

Similar arguments apply to the CECA. It is generally admitted 
that the ancestral bird-stock did possess well-developed cæca, therefore all those birds which are now found without creca must have lost them either phylogenetically or even during their embryonic development. In fact, we find in embryos of such birds as have, when adult, only very small or rudimentary cæca, that the germs of these organs are, in the embryo, just as well developed as in birds with long creca; but these organs, in a Pigeon for instance, do not grow any further. They are in early life stopped in their development, and thus remain in a rudimentary state. Again, in all those birds which are completely devoid of creca, their suppression is simply carried out to the extreme. We cannot therefore, as has been done sometimes, separate Birds into those with and those without cæca : this is especially wrong, as there exist many forms, which, although undoubtedly allied to each other, differ greatly in the presence or absenee of these organs. If we want to use the cæca as a differentiating character, we must consider their quality, and enquire whether those organs are functional and well cleveloped, or are they now without function? Consequently birds with rudimentary cæca have to be grouped together with those which have no creca, althongh the ancestors of both had functional cæca; and since we know that these organs stand in close correlation with the nature of the food, we are enabled to weigh their taxonomic value. Hence it is probable that the Owls are related to the creapossessing Nightjars, and that the crecaless Macrochires (like Swifts) are a recent offshoot of the latter, while it is impossible to assume that the Owls are descendants of the Diurnal Birds-of-Prey.

The modifications of the Carotid Arteries have enabled Prof. Fuerbringer to draw a very ingenious and valic conclusion as to the probable original centre of the Parrots. While the Australian, Oriental, and African Parrots exhibit almost every possible modification of these arteries, from the most primitive to the most specialised conditions, the American Parrots possess only the right deep carotis and a left superficial carotis, an arrangement which is a decidedly recent, not primary feature. Hence the conelusion that the American Parrots are a branch of the Palæotropical stem; but however fascinating such speculations are, we must not forget that they hardly ever amount to definite proofs.

Supposing we divide Birds into two classes (A and B), according to the presenee or absence of the AmBinss muscle. As a second differentiating character let us take the functional or fully developed $(a)$ and the absent or functionless state of the $\mathrm{CACA}(b)$; and as a third character the presence $(\alpha)$ or absence $(\beta)$ of an AFTERSHAFT. 'Then using the ambiens as the principal, and the aftershaft as the tertiary differentiating feature, and indieating presence or absence by the signs + and - respectively, we get the following eight divisions :- 
A. Ambiens +

a. Cæca +

a. Aftershaft + e.g. Gallinæ, Impennes, Phœnicopterus, Musophaga, etc.

B. Aftershaft - e.g. Anseres, etc.

b. Creca -

a. Aftershaft + e.g. Accipitres, Psittaci partim.

$\beta$. Aftershaft - e.g. Columbæ partim.

B. Ambiens -

a. Cæca +

a. Aftershaft + e.g. Alca, Podicipes.

$\beta$. Aftershaft - e.g. Striges.

b. Cæca -

a. Aftershaft +e.g. Psittaci pt., Cypseli, Trochili, etc.

$\beta$. Aftershaft - e.g. Passeres, Columbæ pt., Herodii, etc.

Thus the Owls in this arrangement approach nearest to the Auks and Grebes, while the Parrots, owing to their variable ambiens muscle, are grouped either with the Accipitres, or with the Swifts and Humming-birds. This is obviously unsatisfactory, perhaps owing to the value of the ambiens muscle being overrated. Let us next use the aftershaft as the principal, the ambiens as the secondary determining character, and the cæca as the third. Then the Psittaci approach the Gallinaceous birds and also the Anks and Grebes, while the Owls verge into the neighbourhood of Pigeons, Herons, and Passerine birds. Again, by using the cæca as the principal, and the ambiens as the secondary feature, Psittaci, Accipitres, and Columbæ, Owls, Auks, and Grebes are once more thrown together. The same or very similar arrangements result from a combination of the creca with the oil-gland, or of the ambiens and cieca with the conditions of the palatal bones. But these persistent coincidences will never induce us to look upon them as indicating relationship between Owls, Auks, and Grebes, because this conclusion would be obviously wrong! How does the question stand with regard to other combinations, when we cannot at a glance discern a glaring error? When, e.g. according to the muscles of the thigh, leaving out the ambiens, Striges, Accipitres, and Cypselidæ stand closely together? Is this a mere coincidence or does a deeper meaning underlie this Trias? It is obviously not due to a superior taxonomic value of Garrod's myological formulæ, because application of the same principle throws Nightjars, Storks, and Parrots together.

It is hopeless to attempt to arrive at a natural classification of Birds by a mechanical arrangement of even a great number of alleged leading characters. More may be expected from the combination of various taxonomic arrangements, each of which has been based upon a single organic system without reference to other 
organs. Of course every one of such one-sided attempts will occasionally shew a rather perplexing face, but each of them will bring to light some unexpected points of resemblance between certain groups; and, while restricting ourselves to one organic system, we are more likely to understand which points are given to modifications through mode of life, food, habit, and surroundings, and which remain least affected, and therefore are indicative of relationship. Let us then combine the several one-sided arrangements. They will each of them contribute something good or certain, and thus help to settle the great question. Reasoning from a broad basis of facts will do the rest.

ANHIMA o! ANHINGA, see SNAKE-BIRD.

ANI, according to Marcgrave (Hist. Per. Nat. Brasilia, p. 193), the Brazilian name of what is the Crotophaga major of modern ornithologists, who have ignorantly misapplied Linnæus's designation, $C$. ani, to its smaller congener, an inhabitant of the Antilles and part of the Spanish Main. This latter is known to most of the English-speaking people of the IVest Indies as the Plack Witch or Savanna Blackbird. The genus Crotophaga is one of the most remarkable forms of the Cuculida (Cuckow) of the New World.

ANISODACTYLI, Vieillot's name, in 1816 (Analyse, p. 29), for the second tribe of his second Order, comprehending all the PASSERES of Linneus and such of the latter's PICE as had not two toes before and two behind. By some later authors the name has been restricted to the genera which are not ZYGODACTYLI and are yet placed among the ScANSORES.

ANKLE-JOINT. The true ankle-joint is a Mammalian feature, being the articulation of the tibia with the astragalus, and therefore a tibio-tarsal joint. In Birds the so-called ankle-joint is an intertarsal joint, because the proximal tarsal bones, of which the astragalus is one, are fused with the end of the tibia, and the distal tarsal are fused with the metatarsal bones (see Skeleton).

ANOMALOGONATA, the second of the two subclasses, the other being called Homalogonate, into which Garrod at one time divided Birds, according as they possessed an AnIBIENs muscle or not (Proc. Zool. Soc. 1874, pp. 116-118). In the Homalogonatous or "typically-kneed" birds "the ambiens runs in the tendon of the knee," though there are some of them in which it is absent; but "there cannot be any Anomalogonatous birds in which it is present." For the groups which are contained in these categories, see INTRODUCTION.

ANSERES, the third Order of the Class Aves according to the system of Linnæus, comprising all the Web-footed Birds known to 
him except Phonicopterus (Flamingo) and Recurvirostra (Avoset). If the term be used at the present day, it must be limited to the Geese and their allies.

ANT-THRUSH, Latham's rendering in 1783 (Gen. Synops. ii. p. 87) of Bufton's Foumilier proprement dit (Hist. Nat. Ois. ir. p. 473), a bird figured by Daubenton ( $P l$. enl. 700 , fig. 1) as the Fourmillier de Cayenne, the Formicarius torquatus of Boddaert in 1783, the Turdus formicarius of Gmelin in 1788, and the Phopotrope torquate of modern systematists; for, though it should be logically recognized as the type of the genus Formicarius, Prof. Cabanis in 1847 (Orn. Notiz. p. 227), misled probably by G. R. Gray, removed it to one of his own making. This little bird, not so big as a Skylark, is very beautiful, notwithstanding its curious figure, with a disproportionately long bill, short tail, and strong legs, and absence of bright coloration, for the black, rich brown, sienna, buff, grey and white which its plumage presents, are most harmoniously contrasted or blended. It is a native of the northerm parts of South America, and Buffon received it from Cayenne through Manoncour, the little we know of its habits being due to the latter. It is a mark of Buffon's insight that he at once recognized in this species, and several other's allied to it, obtained from the same source, a perfectly distinct group of birds which he designated Fourmiliers from their feeding (as he was told) chiefly on Ants. ${ }^{1}$ 'The systematists of his day, Boddaert and Hermann excepted, were not so perceptive, and referred these birds to the Thrushes or some of them to the Shrikes. Their distinctness was at last recognized, and they were duly regarded as forming a Family, Formicurida, which is now known to contain more than 250 species, and by Mr. Sclater (Cat. B. Br. Mus. xv. pp. 176-328) in 1890 has been divided into 3 subfamilies - Thamnophilina, often known as "Bush-Shrikes," containing 10 genera and at least 80 species; Formicariina, the true Ant-Thrushes, including in them the Formicivorina, by Swainson ${ }^{2}$ called "Ant-Wrens" (Zool. Journ. ii. p. 146), that Mr. Sclater had formerly (P. Z. S. 1858, pp. 232-254) recognized, and thus enlarging the Formicariina so as to comprise 18 genera and more than 130 species; while the third subfamily Grallariinx includes 5 genera and over 30 species. In

${ }^{1}$ Mr. Bates (Nat. Ama:on, ii. p. 357) says that the first signal given to the pedestrian of meeting with a train of Foraging Ants (Eciton) is the twittering and restless movement of small flocks of Ant-Thrushes in the forest, and that if he disregards their warning he is sure to be attacked by the ferocious insects.

2 Swainson did not know that his genus Formicivora had been anticipated by Temminck, who in 1807 (Cat. du Cab. p. 92) used the name Formicivorus, in a sense equivalent to Boddaert's Formicarius. The group separated by Swainson was in 1827 called by Gloger Eriodora, which name therefore apparently ought to be used for it. 
reality but few of these birds have an outward resemblance to Shrikes, Thrushes, or Wrens, and all belong to quite a different division of PAssfres. In 1847 Johannes Müller and Prof. Cabanis justly placerl them among their CLAmatores, and subsequently Garrod shewed their Mesomyodian structure. The Formicariida are one of the most characteristic Families of the Neotropical Region, abounding in the forest-districts of its middle portion, becoming less numerous in Central America, and still scarcer in the southern parts, only just reaching the plains of La Plata. They are mostly small bircls of sober hue, some not bigger than Wrens; but members of the Genera Batara and Grallaria attain the stature of a Jay. The last named of them has much the appearance of a PITTA - a distinct group to which the name "Ant-Thrush" has also been applied. As is the case with most South-American birds, scarcely anything is known of their habits. The large genus Thamnophilus, containing upwards of 50 species, is one of the most important of the so-called "Bush-Shrikes," and many of its members are remarkable for the sexual diversity in plumage, that of the cocks being black or black banded with white, while that of the hens is rufous; but in some other groups the black or black-and-white plumage is common to both sexes. Of this genus several species inhabit British Guiana, at

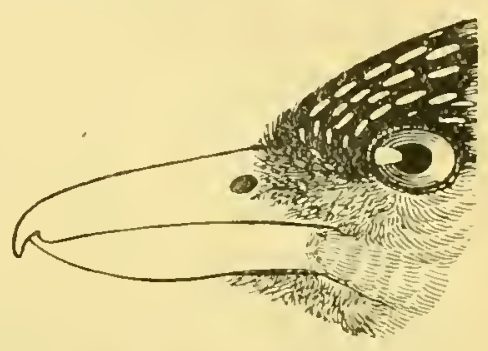

AvT-Thrush (Thamnophilus). (After Swainson.) least three occur in Trinidad, and one is found in Tobago, where it is known as the Qua-qua or Cata-bird (Ann. N. H. xx. p. 331), their presence in these two islands offering one of the many strong proofs of their fauna belonging to that of continental South America, since no member of the Family is found in the Antilles proper.

AORTA (adj. aortic), the principal ARTERY from which arise the blood-vessels supplying the trunk, hind limbs, and viscera below or behind the heart (see VASCULAR SYSTEM).

\section{APTERYX, see KIwI.}

\section{ARCHAOPTERYX, see Fossil BIRDs.}

AREND, the Dutch for Eagle, but used by the colonists in South Africa for the Bearded Vulture or Lämnergeyer.

ARGALA, Hindoo Hargiza-said by Yule to be the rinda of Alian (xvi. 4) - a name of the AdJutant.

ARGUS or ARGUS-PHEASANT, the name originally applied in ornithology to the extraordinary and beautiful birds of the Malay Peninsula, Siam, and Borneo, which are not distantly related to the PEACOCK; but by English sportsmen in India commonly 
used for the species of the genus Ceriomis, also known as Tragopans, which are supposed to have more affinity to the true PHEAsAnts. In each case the ocellated phumage has suggested the allusion to the well-known personage in classical mythology.

APTAMUS, a genus of true Passerine bircts founded by Vieillot, and of late use as an English word. They are the "WoodSwallows" or "Swallow-Shrikes" of some authors, and by many are considered to be the nearest neighbours of the Hirundinida (Swallow), making some approach to them in their long wings, and habit of catching insects in continuous flights. If it be granted from their possessing patches of PowDER-Down that they should form a separate Family Artamidx', its true alliance must still be guessed at. Some 15 species have been described, more than half of them being found in Australia, while one inhabits India.

ARTERY (adj. arterial). Arteries are the vessels through which the blood leaves the heart; no matter if this blood be arterial or venous, as, for instance, is that which flows through the pulmonary arteries (see TASCULAR SYSTEM).

ATTEAL, ATTEILE or ATTILE, a word, presumably a bird's name, occurring with variations of spelling in many old Scottish records (as, for example, in 1600, Act. Jac. VI. cap. 23), and apparently used in Orkney for some kind of Duck so lately as 1848 according to Baikie and Heddle (Hist. Nat. Orcad. p. 79), who, possibly by mistake, apply it to the POCHARD. The same was done in 1886 by Mr. Thomas Edmondston (Etymolog. Glossary of the Shetland and Orkney Dialect), who associates it with the old Norsk Tjaldr, which he calls "Turdus marinus," but is properly the OYsTER-CATCHER. Of unknown etymology, it may be connected with the Scandinavian Atteling-And or Atling, which again may be cognate with Taling, the Dutch for TEAL.

AUK (Teutonic Alk), the old English name for the RAzor-BILL, and perhaps the Guillewor, of modern writers; but as applied to

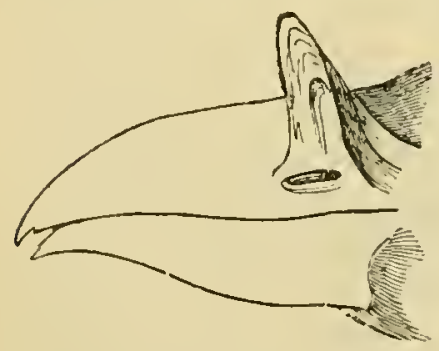

HORN-BILLED AUK. (After Swainson.) the former now only in provincial use, though maintained in a collective sense for members of the Family Alcidrt. With the prefix "Great" ol "Little," it signifies respectively the GARE-FOwL and the bird so well known to Arctic seamen as the RoTCHE.

The greatest number of forms belonging to this Family inhabit the North Pacific, and have been separated into various genera.

Some of them exhibit the seasonal shedding of the outgrowths on the sheath of the bill and on the head that, as in the PUFFin, are 
only assumed in spring. Among them is the curious Cerorhynche (or Ceratorhina) monocerata which by shedding the horn-like protuberance rising between the nostrils, and here figured, led to no few nistakes until the peculiarity was known.

AVADUVAT, a corruption of AMADAVAT.

AVIS, the ordinary Latin word for Brid, and in its plural form, Aves, the scientific name of the Class of Vertebrate Animals which comprises every kind of Bird.

The want of an adjective derived from Avis and Bird is one much felt both in Latin ${ }^{1}$ and English. In the latter language remedy is hopeless, for "bird-like is not enough; and "birdy" can only be regarded as jocose. From the former an attempt has been made to supply this defect by the invention and use by some writers of "avian" - a form which scholars cleclare to be unclassical, though they allow that "avine" might perhaps be admitted. Of Greek origin "ornithic" is quite justifiable.

AVOSET, from the Ferrarese Avosetta, ${ }^{2}$ the Recurvirostra avocetta

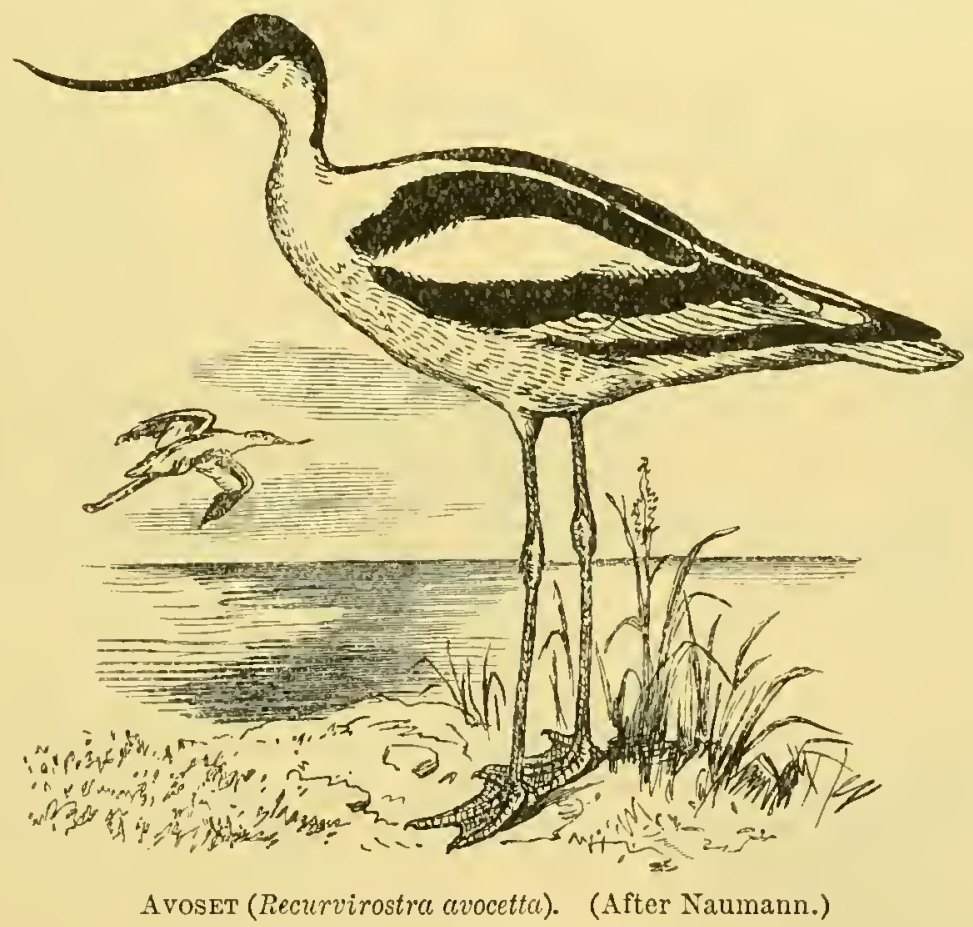

of ornithology, a bird remarkable for its bill, which is perhaps the most slender to be scen in the whole Class, and curving upward towards the end, has given it two names which it formerly bore in

1 Aviarius exists as a Latin adjective, but its precise meaning is somewhat indefinite, and its use can hardly be recommended.

2 This word is considered to be derived from the Latin avis-the termination expressing a diminutive of a graceful or delicate kind, as donnetta from donna (Prof. Salvadori in epist.); but it is spelt Avocetta by Prof. Giglioli. 
England,_- "Cobbler's-awl," from its likeness to the tool so called, and "Scooper," because it resembled the scoop with which boatmen threw water on their sails. The legs, though long, are not extraordinarily so, and the feet, which are webbed, bear a small hind toe.

This species was of old time plentiful in England, though doubtless always restricted to certain localities. Charleton in 1668 says that when a boy he had shot not a few on the Severn, and Plot mentions it so as to lead one to suppose that in his time (1686) it bred in Staffordshire, while Willughby (1676) knew of it as being in winter on the eastern coast, and Pennant in 1769 found it in great numbers opposite to Fossdyke Wash in Lincolnshire, and described the birds as hovering over the sportsman's head like Lapwings. In this district they were called "Yelpers" from their cry ${ }^{1}$ but whether that name was elsewhere applied is uncertain. At the end of the last century they frequented Romney Marsh in Kent, and in the first quarter of the present century they bred in various suitable spots in Suffolk and Norfolk, — the last place known to have been inhabited by them being Salthouse, where the people made puddings of their eggs, while the birds were killed for the sake of their feathers, which were used in making artificial flies for fishing. The extirpation of this settlement took place between 1822 and 1825 (cf. Stevenson, Birds of Norfolk, ii. pp. 240, 241). ${ }^{2}$ There is some evidence of their having bred so lately as about 1840 at the mouth of the Trent (cf. Clarke and Roebuck, Vert. Fauna of Yorkshire, p. 72). The Avoset's mode of nesting is much like that of the STILT, and the eggs are hardly to be distinguished from those of the latter but by their larger size, the bird being about as big as a LAPwING, white, with the exception of its crown, the back of the neck, the inner scapulars, some of the wing-coverts and the primaries, which are black, while the legs are of a fine light blue. It seems to get its food by working its bill from side to side in shallow pools, and catching the small crustaceans or larvæ of insects that may be swimming therein, but not, as has been stated, by sweeping the surface of the mud or sand-a process that would speedily destroy the delicate bill by friction. Two species of Avoset, $R$. americana and $R$. andina, are found in the New World; the former, which ranges so far to the northward as the Saskatchewan, is distinguished by its light cinnamon-coloured head, neck, and breast, and the latter, confined so far as known to the mountain lakes of Chili, has no white on the upper parts except the head and neck. Australia produces a

I $C f$. "Yarwhelp" (Gonwit) and "Yaup" or "Whaup" (CurLew). "Barker" and "Clinker" seem to have been names used in Norfolk.

2 The same kind of lamentable destruction has of late been carried on in Holland and Denmark, to the extirpation probably of the species in each country. 
fourth species, $R$. nor: hollandia or rubricollis, with a chestnut head and neck; but the European $R$. arocetta extends over nearly the whole of middle and southern Asia as well as Africa.

The proposal (Ibis, 1886, pp. 224-237) to unite the Arosets and Stilts in a single genus seems to have little to recommend it but its novelty, and will hardly meet with acceptance by systematists.

AXILLA (adj. axillary), the arm-pit, whence, or from the adjoining part of the arm, arise in many birds some elongated feathers (axillaries or lower humeral coverts), constituting the hypopteron. In most water-birds, especially in Numenius, and Grus, but also in a few others, as Coracias, some of these feathers are very long, straight, and slender.

\section{B}

BABBLER, apparently first used in ornithology in 1837, by Swainson (Classif. B. ii. 233), for the birds, assigned by him to the subfamily Crateropodina, belonging to the genera Pellorneum, Crateropus, Grallina, Malacocercus (including as a subgenus Timalia of Horsfield) and Pteroptochus (TAPACULO). With the exception of the third and the last these forms are now commonly re-

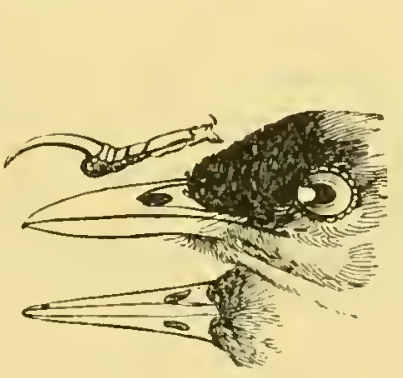

Pellorneum.

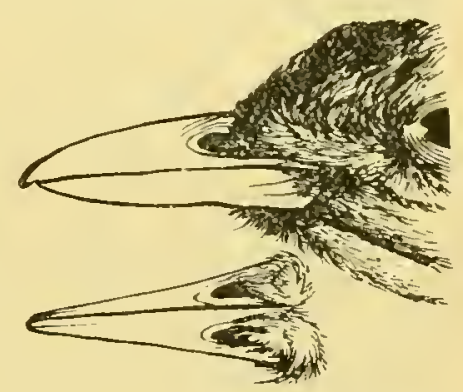

Crateropus. garded as forming part of the Family Timeliida (often but less accurately written Timaliida), which no systematist has yet been able to define satisfactorily, while many have not unjustly regarded it as a "refuge for the destitute" - thrusting into it a great number of forms, chiefly Oscinine, that, with a bill resembling a SHRIkE's, a Thrush's, or a WAR-

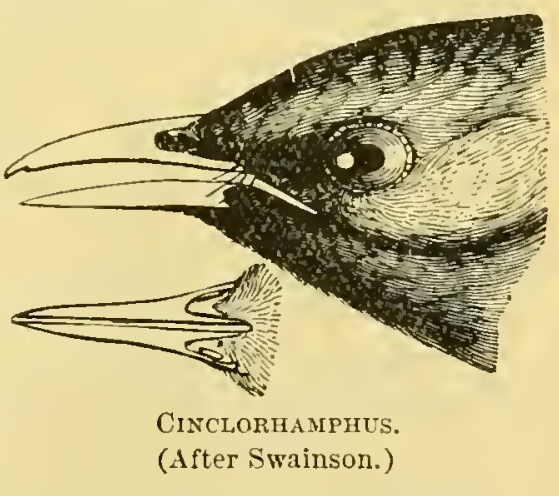
BLER's, mostly possess very short and incurved wings, and cannot, in the opinion of some, be conveniently stowed elsewhere. Two volumes (vi. and vii.) of the Catalogue of Birds in the British 
Mruseum ${ }^{1}$ are devoted to this mixed multitude, which is therein made to inelude, beside the groups usually assigned to the Family, others more or less well defined, such as BowEr-BIrds, Mocking-Birds, and Wrens, with certain Bulbuls, Shrikes, Thrushes, and Warblers. Some of these, such as the first three, to say nothing of Water-OusELs, Hedge-SPARrows, and some American forms, are obviously not allied to the rest; but, after their withdrawal, there is still a fine field left for a systematic ornithologist who would take in hand what remains of this heterogeneons assemblage, and introduce even the semblance of orcler

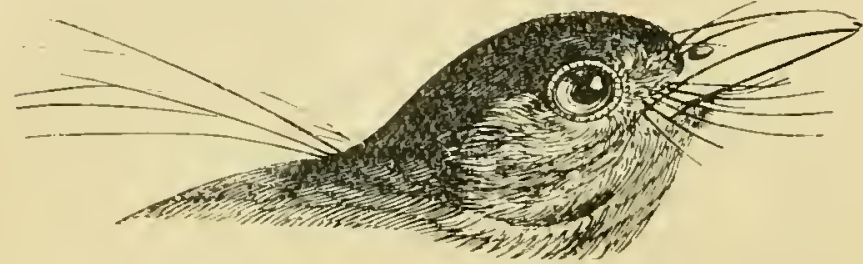

Criniger. (After Swainson.) where all is at present confusion. The bircls more particularly called Babblers, often with a prefix such as Bush-Babbler, Shrike-Babbler, Tit-Babbler, and so

forth, belong chiefly to the Ethiopian and Indian Regions, and many of the last are well treated, under the name of Crateropodicla, by Mr. IT. E. Oates (Fuun. Brit. India, Birck, i. pp. 70-297), though eren he has perhaps been too generous in receiving some forms. Many of these Birds originally described under the genus Criniger of Temminck, but since subdivided as Tricholestes, Xenocichlu, and so forth, are remarkable for the long fine bristles that spring from the nape or middle of the back, as shewn in the annexed figure; but traces of this feature may be seen in many other forms, and even in one so familiar as the common Song-Thrush.

BABILLARD, a Freneh name, Anglified in 1831 by Rennie in his edition of Montagu's Onithological Dictionary (p. 15), for the bird already known as the Lesser WHITETHRoAT; but one that has fortunately not taken real hold in our langnage. Had he attempted to revive the old English "Babelard," he probably would not have been more suceessful.

BACBAKIRI, one of the short-winged SHRIKEs, the Telephonus bacbativi of South-African ornithology, and so named of the colonists from its call-note (Layard, B. S. Africa, p. 161).

BALDPATE, the name eommonly given by the English-speaking residents of the West Indies to a Dove, the Columbe leucoceppulu, from its white head-thongh most inacenrately, for that part is well clothed with feathers. It may here be observed that

1 The second of these volumes possesses one great merit: it does not pretend to assign an English name to birds which by hardly any conceivable cliance will need one. 
the epithet "Bald" is applied just as inaccurately in North America to an EAGLE, the Hatiaetus lencocephalus, and in England, thongh more appositely, to the Coot.

BANTAM, a small breed of domestic ponltry, so-called under the belief that it came from the part of Java which hears that name; but apparently it originated in Japan (cf. Darwin, Anim. \& Plonts under Domest. chap. vii.) Birds of this breed were mentioned in 1698 by Fryer (New Accont of Eust Imtia, p. 116) as "Champore cocks," coming from Siam. Remarkable for their diminutive size, they were characterized also by their feathered feet. In modem times Sebright established a sub-breed, known by his name, in which not only is this last feature wanting, but there is comparatively little external difference between the cocks and hens.

BARBET, Pennant's equivalent in 1773 (Gen. Birds, pp. 13, 14) of Brisson's and subsequently Linnæus's genus Bucco (a word coined ${ }^{1}$ in 1752 by Wœhring; though applied by him to the TOUCANS); but Brisson ealled it in French Burbu, "from its bristles, a sort of beard "with which the beak is beset, as will be seen in the figure, and hence Pennant formed his word. ${ }^{2}$ The type of Brisson's genus, on which that of Linnæus was founded, was called

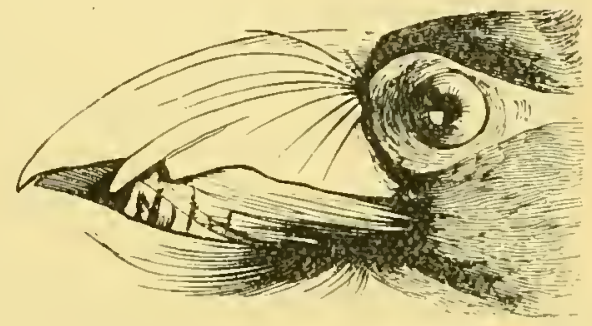

Pogonorhymenus. (After Swainson.) by the latter in $1766, \mathcal{B}$. capensis-most unliappily in all respects, for the former had expressly given Cayenne as its habitat. ${ }^{3}$ The birds originally included in the genus are now recognized as belouging to two distinct Fanilies, commonly known as Bucconida and Cupitonidx, and it is to the latter of these that the name "Barbet" is restricted by molern ornithologists, the former being known as PUFF-BIRDs. The Capitonida, ${ }^{4}$ or "Scansorial" Barbets as some authors designate them, though their climbing power is disputed, form the subjeet of a beantifully illnstrated Monograph by Messrs. C. H. T. and G. F. L.

1 From the Latin bucce; and, as explained by Pennant, referring to "tho fniness of the cheeks."

2 Barbet hat long existed in French in the sense of a shaggy log--a proodle or water-spaniel.

${ }^{3}$ In this case of the use of the extraordinary and ungrammatical adjective which has unfortunately been so frequently adopted, one can hardly doubt that Linnæus meant to write, and very likely did write (in an abbreviated form, as was his habit), caycnsis for cayennensis, which he afterwards misread, and unluckily elenched the mistake by adding, "Hab. ad Cap. b. Spei."

${ }^{4}$ Garrod (Proc. Zool. Soc. 1879, p. 935) and Forbes (op. cit. 1882, p. 94) nsed this term to inelude the Toucans and Honer-guides as well as the Barbets. Of course if these Families, Indicatoridx, Capitonidæ, and Rhamphastidx, be united in one, the last is the name it should bear. 
Marshall (London: 1870-71, 4to), who divide the Family into three subfamilies:--Pogonorhynchine, with 3 genera and 15 species; Megalamina, with 6 genera and 44 species; and Capitonina, with 4 genera and 18 species. Since the appearance of that work one new genus and some thirty new species have been described. Supposing that the subfamilies above named be truly established, it would seem that the Capitonina, of which members are now to be found in the New World as well as in Africa and Asia, may from its wide distribution be regarded as the most ancient, and next the Pogonorhynchine, inhabiting both America and Africa, while the Megalamine, restricted to Africa and Asia, appears to be the most modern subfamily, and two genera belonging to it, Megalama and Xantholama are found in India and Ceylon. They are birds mostly of a bright green plumage, some of them variegated, especially on the head, with scarlet, violet, blue, or yellow-though others are plainly coloured. All of them seem to live chiefly on fruit, but insects occasionally form part of their food, and in captivity they become carnivorous. They breed in holes of trees, laying white eggs, and most, if not all of them, utter a clear ringing note, so lond as to attract general attention. The cry of Xantholama indica is especially resonant; and, being accompanied by a peculiar motion of the head, has obtained for the bird in some of the native languages a name signifying Coppersuith, by which English rendering it is also known to Anglo-Indians.

BARGANDER or BERGANDER, a local name, of uncertain origin and spelling, of the SHeLd-Drake.

BARKER, a name locally applied, from their cry, to the Blacktailed Godwit and the Avoset in the days when they inhabited England. Albin, a very poor anthority, figured under this name what was certainly a GreEnshank, though Montagu took it to be Totanus fuscus, and hence an error has found its way (sub voce) into Dr. Murray's New English Dictionary.

BARLEY-BIRD, a name given in some parts to the Yellow WAGTAIL, in others to the WRYNECK-but in both cases from their appearing at the time of barley-sowing. By some authors it is said, but obviously in error, to be applied to the Siskin.

BARWING, the Anglo-Indian name for birds of the genus Actinodura, from the black bar or bars which the wings of most of them present. The genus is usually placed in the ill-defined Fanily Timeliidx.

BASIPTERYGOID PROCESSES are a pair of bony outgrowths on the right and left side of the body of the basisphenoid, forming the principal articulation of the pterygoids with the basis cranii. Such processes are well developed in all the Ratite, Crypturi, 
Turnices, and Striges. Similar processes spring from the basisphenoidal rostrum in many other Carinatie, e.g. Anseres, Gallina, Columbæ, Pteroclidi, Catharticke, and Serpentarius; while in many birds these processes are developed in the embryo but are resorbed finally, or they are never developed, the anterior ends of the pterygoicls in either case articulating with the palatine bones alone, or, resting directly upon the basisphenoidal rostrum, as in Phonicopterus, Grallæ, Laridæ, Dicholoplius, Pygopodes, Impennes, Steganopodes, Falconidæ, Psittaci, Cuculidæ, Opisthocomus, Macrochires, Pici, and Passeres. In the Limicolæ and Tubinares these processes are very variable. For illustrations see SkUtJ.

BAYA (Hindoo Baia), often used by English writers for the common WEAVEr-BIRD of India, Ploceus baya, the builder of the wellknown retort-shaped nests.

$\mathrm{BAY}$-BIRD, and

BEACH-BIRD, common names on the Atlantic coasis of North America for several of the Limicola, as the SANDERLing, TurNsToNe, and others. (Cf. Trumbull, Names and Portraits of Birds, pp. 186, 191 note.)

\section{BEAK, see BILL.}

BEAMI-BIRD, said to be the name used in some parts of England for the Spotted FLYCATCHER.

BEE-EATER, a name apparently first used in 1668 by Charleton (Onomasticon, p. S7) as a translation of the Latin and Greek Merops, though he said that the bird was rarely or never found in England - the Merops apiaster of ornithology. The term being appropriate (as is shewn by its equivalent in cognate tongues-Danish, Biader; German, Bicnenfresser) has been continued to this species, and subsequently extended to others more or less elosely allied to it, forming a small but natural Family, Meropida, admirably monographed by Mr. Dresser (London: 1884-1886, imp. 4to), who recognizes five genera, and thirty-one species. They belong to the group in this work termed Picaria, and are distinguished for their brilliant coloration, their graceful form, and their active habits, since every species seems to obtain its living by catching insects as they fly. The Beeeaters are birds of the Old World, and the majority (1S) of the species are peculiar to the Ethiopian Region, two more also occurring within its limits, while only four inhabit the Palæarctic area, one of them being the $M$. apiaster named above, which appears irregularly in Northern Europe in summer, and has more than thirty times visited Great Britain since its first recorded occurrence in June 1793, when a flight of about twenty was observed in Norfolk, and a specimen obtained at that time is still preserved in the Derby Museum at Liverpool. 
It is certainly one of the most beautifully-colouled birds ever found in these islands, and no one who has once seen a specimen will forget its rich chestnut crown and mantle passing lower down into primrose, its white frontal band, the black patch extending from the bill to the ear-coverts, the saffron throat bordered with black, while most of the rest of the plumage is of a vivid greenishblue or bluish-green, and the middle pair of tail feathers are elongated and attenuated in a way that is not seen in any other British land-bird. This formation of the tail characterizes also the single species of the genus Meropogon, while Dicrocercus has the tail deeply forked, and in Melittophagus and Nyctiornis it is nearly even, but the last, containing two species-one ranging from Burma to Borneo, and the other (the largest of the whole Family) inhabiting India as well as Burma and Cochin China_is readily distinguishable by the remarkable elongated feathers of the gular tract. Six species of the Family shew themselves in the Cape Colony or parts immediately adjacent, and one, Merops ornatus, occurs over almost the whole of Australia.

The Meropidx have much in common with the Coraciidx (Roller), Alcedinidæx (Kingfisher), Momotidæx (Мотмот), and especially with the Galbulidx (JACAMAR), for not only are there many anatomical resemblances between the birds of these Families, but nearly all of them, so far as is known-the Rollers perhaps being the chief exceptions-breed in holes made by themselves in a bank of earth, and the Bee-eaters, or at least the species of the genis Merops, it would seem, nearly always in society.

BEEE-EATER, see Ox-PECkER. (Penant, fen. B. p.9,1473).

BELL-BIRD is the English name given in various parts of the world to very different species; but always from the resemblance of the sound of the note they utter to that of a bell. In Guiana, it is applied to the Campanero of the Spanish settlers, Chasmorhynchus niveus, belonging to the Family Cotingidæ (CHATTERER), of which Waterton wrote (Wanderings, 2nd Journey): "He is about the size of the jay. His plumage is white as snow. On his forehead rises a spiral tube nearly three inches long. It is jet black, dotted all over with small white feathers. It has a communication with the palate, and when filled with air, looks like a spire; when empty it becomes pendulous. $^{1}$ His note is loud and clear, like the sound of a bell, and may be heard at the distance of three miles. . . You hear

1 In the allied species from Costa Rica, C. tricarunculatus-so called from its three elongated appendages, which in appearance call to mind the long pendants of an orchid (Cypripedium caudatum)-Mr. Salvin records his impression (Ibis, 1865, p. 93) that "no inflation takes place, and that the bird possesses little or no voluntary muscular control over these excrescences." The fact that the Brazilian species, C. mudicollis, utters a note which, if not actually "bell-like" in 
his toll, and then a pause for a minute, then another toll, and then a pause again, and then a toll, and again a pause. Then he is silent for six or eight minutes, and then another toll, and so on." In New Zealand the name is given to the Anthornis melanure of the Family Meliphagida (HoNEY-SUCKER), whose melody struck the companions of Cook, when on his second voyage the ship was lying in Queen Charlotte's Sound, as being "like small bells most exquisitely tuned"-_a bird which owing to the destruction of the forests no longer exists in most parts of that country, and will speedily become extinct. In Australia, according to Gould, two speeies of birds-one of them, Manorhina melanophrys, belonging to a different genus of the Family last-named, and the other, Oreoce cristata, possibly to the Laniida (SHRIKE) - are called by the same name for the same reason.

BENGALI, the dealer's' name for the beautiful little African bird, Fringilla bengalus of Linnæus, and some of its allies, belonging to the Ploceida (WEAVER-BIRD), and referred by liter miters to the genus Estrilda, Pytelic or Uragnathus. The name originated with Brisson (Ornithol. iii. p. 203), who believed these birds came from Bengal.

BERGHAAN (Mountain-cock) the name given to some of the larger EAGLES, and especially to the beautiful Helotarsus ecaudutus (sometimes known as the "Bateleur"), by the Dutch colonists in Sioutl Africa, and often adopted by English residents (Layard, B. S. Africu, pp. 11, 18).

BERNACLE, apparently the right way of spelling the word often written, in accordance with its pronunciation, "Barnacle" or "Barnicle." Its derivation is as puzzling to the etymologist as is to the ornithologist the discovery of the breeding-grounds of the bird it denominates. Dr. Murray, under the word "Barnacle" in the New English Dictionary, gives as the oldest known English form the Bernekke (Latinized Bernaca) of Giraldus Cambrensis about

tone, has a clear metallic ring, though the bird, as may be seen by the figure, has no caruncle, shews that this feature is not likely to he conuected with the power of producing the peeuliar sound. A fourth species, C. variegatus, inhabits
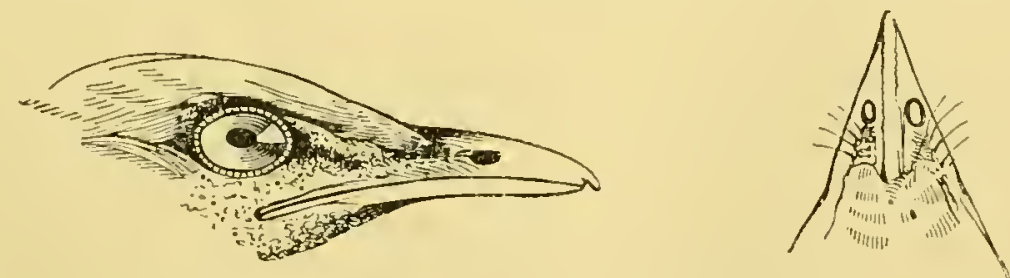

Chashorhynchus nudicollis. (After Swainson.)

Trinidad and the neighbonring part of Sonth America. Its loud note is likened by Léotaud (Ois. Trinidad, p. 260) to the sound of a cracked bell. 
1175 ; and states that the Cirriped (Lepas anatifera), also so-called, took its name from the Birl, a kind of Goose, and not the Bird from the Cirriped.

BILCOCK, said to be a local name for the Water-RAIL.

BILL or BEAK, in Latin Rostrum. This consists of an upper, chiefly premaxillary and maxillary, and of a lower, or mandibular. half. The horny covering is to a certain extent moulded after the shape of the supporting bones. The soft cutaneous portion of the skin is frequently restricted to a thin layer between the periosteum and the Malpighian layer of the epiderm; in it run numerous bloodvessels and nerves, the latter occasionally penetrating the horny layer, and ending in tactile or sensory corpuscles.

On the other hand, in very stout beaks, the cutaneous layer forms conical elongations which project into the thick horny parts, especially into the ends of the upper and lower bill. In the broad edge of the mandible of Parrots such projections are particularly numerous and long; when they calcify, as cutaneous structures are liable to do, they bear in horizontal sections a superficial resemblance to the germs of teeth, and have been mistaken as such by various anatomists (see TEETH).

The horny sheath, or thamphotheca, is produced by the outer layers of the Malpighian cells, and resembles in structure othel horny parts, as CLAws, nails, and spurs. Sometimes, as in the Anseres, the greater portion of the outer sheath of the bill is soft, and only the tip of the bill is transformed into a thick horny "neb," which contains numerous tactile organs. In some birds, especially in the diurnal Birds-of-Prey and in the Parrots, the greater portion of the distal end of the upper beak is hard, while the basal portion is thick and soft-the so-called cere. It is generally very sensitive, and encloses the nostrils. Though mostly bare, it is in some Parrots thickly covered with feathers, and then approaches in structure the ordinary skin. The neighbourhood of the nostrils is often soft, and produces an operculum by which, in some cases, the external nares can apparently be closed, although no muscles seem to exist there. Such a soft and swollen operculum is a prominent feature in Pigeons, and is very large and curled in Rhinochetus (KAGU). In the Petrels each operculum forms a more or less complete tube, which may or may not fuse with its counterpart in the middle line, and thus produce an apparently single tube with a longitudinal vertical septum, whence the name "Tubinares."

A leathery operculum or valve also occurs in Plovers, in Podargus, many Passeres (especially shewn in Meliphagiclæ), and in the Humming-birds, in the last being covered with feathers. In Caprimulgus each nostril is produced into a short, narrow, and quite soft tube.

Another differentiating feature in comnexion with the nostrils 
and the rostrum is the presence or absence of a complete vertical internasal septum. If the septum is complete, which seems to be the primary condition, the right and left nasal cavities are completely separated from each other, and birds having this structure are said to possess nares impervix. The septum either remains cartilaginous, or it ossifies to a variable extent. Consequently in macerated skeletons, where only the bony parts remain, this character camnot be determined. In comparatively few birds is the ossification complete, but this occurs in the Owls, in Podargus, in some Accipitres, Parrots, and others. When the septum is incomplete, the right and left nostrils communicate with each other, forming nares pervix, as in Phaethon, among the Steganopodes, in the Herons, Grebes, Divers, Grallæ (except Rhinochetus), Gaviæe, Limicolæ, Storks, Flamingos, Anseres, Cathartidæ (but not in the Vuituridre and Falconidx), and in many Passeres, especially in the Meliphagidx. In some Steganopodes, for instance in the Cormorants, the nostrils are rednced to narrow slits, and this condition is carried to an extreme in the Gannets, the external nostrils being absolutely closed, and the greater portion of the nasal cavity obliterated or filled with cancellated bony tissue; however, the olfactory apparatus is well developed, the inner nostrils or' CHOANA being very wide, and in open communication with the mouth, enabling the Gannet to smell its food when in the mouth.

Valious parts of the lostrum have receivech special names: culmen, the dorsal ridge of the upper bill; apex or tip; dertrum, in which it often terminates; gonys, or more correctly genys, the prominent ridge formed by the united halves of the under jaw, e.g. in Gulls; tomiu, the cutting edges of the bill.

The form of the bill exhibits almost infinite rariations in sizc, shape, and structure, of which only the most striling modifications can here be dealt with. Generally shape and size stand in obvious correlation with the mode of feeding, but sexual selection seems also to play a great part, and leads to formations which it is often impossible to nuderstand.

The horny sheath of the bill sometimes consists of a number of pieces more or less separate. In the Ostriches and Tinamous there is a lateral pair and an unpaired piece for each jaw; in the Tubinares on the upper jaw at least one pair of lateral or maxillary pieces, an unpaired piece which covers the culmen and is continued into the prolonged nasal tubes, and an apical hook, strongly curved and pointed: each half of the under jaw is covered by one ventral, one dorsal, and one terminal piece, the latter partly fusing with that of the other side into a strong scoop. Indications of such a compound rhamphotheca are, however, found in other birds, especially in the Steganopodes, in some Herons, like Nycticorax and Scopus, and in Penguins; the culminar or dorsal

YNOL. I. 
unpaired piece being more or less separated from the lateral pieces. In the majority of birds the horny covering forms one coherent sheath.

Frequently the edges of the mandibles and of the maxillæ are serrated to secure a firmer hold upon the food, for instance in Toucans. In the Anseres these tooth-like serrations are arranged in the shape of numerous transverse lamellæ, and hence the name "Lamellirostres," which, especially in the Shoveler, form an elaborate sifting apparatus.

The bill of the Flamingos is likewise furnished with such sifting lamellæ; the two halves of the under jaw are considerably enlarged, so that the comparatively narrow upper jaw closes upon a wide cavity. In addition to this the whole bill is bent downwards, in some species rather abruptly; these long-necked birds being thus enabled to sift the soft mud oí lagoons with their bill in an inverted position, the dorsal surface of the bill being turned towards the bottom. Undoubtedly this most peculiar bill is a secondarily acquired character, referable to the mode of feeding, which again is connected with the long neck and legs. This view is strengthened by the fact that very young Flamingos still have straight and short bills, which very gradually and only comparatively late assume the final shape.

Fine sifting lamellæ occur also in Prion (WHALEBIRD), and as a dense brushlike mass on the inside of the premaxillary region in Anastomus. The jaws of this genus have the further peculiarity that they do not shut completely, being slightly curved in opposite directions.

In the Spoonbilled Sandpiper, Eurinorhynchus pygmæus, the end of the upper and lower bill is of a peculiar spatulate and heartshaped form.

The broad and flattened spatulate bill of the Spoonbills, the boat or shoe-shaped bill of the Whale-headed STork, Balzniceps, and of the Cancroma (BOATBILL), the long bills of the Ibis and the Whimbrel, curved downwards, and upwards in the Avoset, need no further comment but that they all are illustrations of the adaptation to a special mode of life, and therefore not necessarily indicative of relationship, as rather analogous than homologous structures.

The beak of Parrots is extremely strong, and well adapted to the breaking open of nuts by sheer force. The mandible ends in a transverse blunt edge, which presses against a corresponding horny prominence of the upper beak. In the large Microglossa (CockATOO), which lives on the stone-hard fruit of the kanari-tree (Canarium commune), the beak bears a striking resemblance to a sledgc-hammer. Transverse ridges, like those of a file, are common in front of the prominence of the upper jaw, the bird using them as a rasp-no Parrot swallowing anything but absolutely com- 
minuted particles of hard substance, or pulpy and soft food-and also for filing or sharpening its mandible.

In the SkImufe, Phynchops, the bill forms two sharp vertical blades, which somewhat gape asunder, with the further peculiarity that the mandibular sheath and the supporting bone itself is considerably larger than the upper portion. A vertically compressed bill is also common in the Alcidr, and is often vividly coloured during the summer. In the Puffrns the outermost bright layers of the horny sheaths, and the horny excrescences at the gape of the mouth and above the eyes are cast off periodically, these parts being developed for the breeding season (Burean, Bull. Soc. Zool. France, 1877, p. $377 \mathrm{ff}$.)

In many birds the covering of the bill, especially near the base of the culmen and the forehead, is swollen, and forms various protuberances, horns, knobs, and other apparently ornamental excrescences. In the Coots and in Musophaga (Plantain-eater) the coating of the culmen is produced backwards over the forehead, overlapping the latter as a conspicuous white or yellow soft plate. Often the underlying bones, especially the nasals and the adjoining premaxillary parts, are also swollen, and form a light and extremely spongy meshwork of cancellated bony tissue, a peculiarity which attains its highest development in the Hornbills and in the Toucans. Similar swellings are the knobs on the bill or on the forehead of the SCOTER and Mute SwAN, of Globicera among Pigeons, of certain Cracidæ, and of Macrocephalon (MEGAPODE). In most of these cases the swellings are very light; rarely, as in the Helmet-HoRNBILL, the bones of the forehead are greatly enlarged, and, although much cancellated, of great weight and strength; moreover, the horny epidermal covering of the forehead is three quarters of an inch thick, and of the hardness and weight of ivory.

Another deviation is constantly found in the CrossbruL's beak, the sharply-pointed and hooked ends of the upper and lower jaws crossing each other in an individually varying way, there being an equal number of right and left-billed specimens. This crossing begins to shew itself before the young birds are fledged, increases with age, and ultimately leads to an asymmetrical development of the masticatory muscles and of the bones of the occipito-quadrate region.

In Anarhynchus frontalis (WRYBILL) the terminal half of the bill is turned towards the right side, an abnormality which exists in a marked degree even in the very young birds. The right edges of the premaxilla and of the mandible are thin and strongly turned inwards, so that the right and left sides are asymmetrical in section. The left nostril and the groove which is continued towards the terminal third of the bill remain in their original 
position, but the right nostril, and still more the groove, are perceptibly slanting towards the right, as can be ascertained by viewing the bill from the dorsal side.

Sexual Dimorphisu is mostly restricted to peculiarly shaped bills; for instance, the horn of the male Hornbills is often larger, and differs in shape from that of the female. In the males of Pelicans several unpaired excrescences are formed entirely by the horny coating of the premaxilla; they sometimes reach a height of three to four inches, and are again cast off after the breeding season, resembling in the latter feature the Auks, as described above.

The most striking example of dimorphic bills is that of the NewZealand HurA, Heterolocha, the bill of the female being slender, about four inches long, and much curved, while that of the male is nearly straight, stont, and scarcely half that length. The knobs or swellings in the Gallini are mostly restricted to the males; the same applies to (Edemia (Scoter). Sexual differences in colour are common. For instance, in the male scoter the bill is black and orauge, in the young and in the female it is simply grey, and without the knob. The bill of the adult male BuACKBIRD is orangeyellow; that of the young of both sexes and of the adult males of Buceros malayanus (HorNBILL) is white, but becomes black in the adult Iemale, forming thus an interesting exception to the general rule that the young agree with the females, and that aberrant coloration is confined to the males. The colour of the bill is deposited as a diffused pigment in the horny cells of the epidermal coat, but is occasionally restricted to the deeper layer's, or even to the Malpighian layer itself, then shining through the outer tramsparent layer's.

In connexion with the bill is to be mentioned the "egg-tooth," which is developed in the embryos of all birds as a small whitish protuberance $\mathrm{Or}^{\circ}$ conglomerition of salts of calcareons matter, deposited in the middle layers of the epidermis of the tip of the npper bill, without being connected with the premaxilla itself. 'The sharp point of this "tooth" soon perforates the upper layel's of the horny sheath, and then files through the eggshell, a slight crack in the latter being sufficient to enable the young bird to free itself. A similar egg-tooth exists in Reptiles, and is, as in Birds, cast off after liatching. The wearing away of the growing and constantly renewed horny layers of the bill can be easily observed in the pealing beak of a Par'ot.

BIPD (etymology unknown; but in Old English Lrid), originally the general name for the young of animals; ${ }^{1}$ then, as the

1 As in Wyclif"s translation of Matth. xxiii. 33 " "eddris, and eddris bridilis" (A.V. "serpents" and "generation of vipers"); Trevisa, Barth de P. R. xii. v. 
ancient work Fow became specialized in meaning, taking its place to signify what cannot be more tersely expressed than by the saying that "A bird is known by its feathers." This proverb is, according to our present knowledge, also a scientific definition, for no other group in the Animal Kingdom has the same kind of clothing (sec FEATHERS), though, regarding as almost certain the evolution of Birds from Reptiles, it must be that at one time there existed creatures intermediate between them, and it may be that remains of some of them will yet be discovered, shewing that plumage was worn by animals which had not yet dropped all the characters that now distinguish Reptiles from Birds. The two Classes (Reptitic and Aves) have been brigaded together by Prof. Huxley under the name of Sauropsida, and there can be no doubt that they are essentially much more closely allied to each other than either is to the rest of the Vertebrates. It has of late years become manifest that among Reptiles the forms which approach most nearly to Birds are those known as the Dinosauria; but of them there is not one yet discorered respecting the rank of which any reasonable doubt may be entertained, though certain parts of the skeleton, and particnlarly of the pelvic arch, present a remarkable resemblance to the corresponding parts of certain Birds, of the RATITe especially. On the other hand, the earliest known Bird, Archaropteryx, is less like the Dinosaurs than are the modern Rutitic. The gulf between Birds and Mammals is much wider than between the former and Reptiles, notwithstanding that the lowest of existing Nammals, the Monotremata, possess several bird-like characters in their structure, and, as is now proved, lay eggs (see Anatony, Fossil Birds, and INTRODUCTION).

BIRD-OF-PARADISE, a phrase used in many European languages since the return (6 Sept. 1522) of the first expedition for circumnavigating the globe, commonly known as Magellan's. In December 1521 the voyagers, then at Tidore, one of the Moluccas, were offered by the ruler of Batchian, as a gift to the King of Spain, two very beautiful dead birds, as we are told by Antonio Pigafetta the chronicler of the voyage (Primo Tiaggio intorno al Globo, ed. Amoretti, Milano: 1 S00, p. 156), who is generally believed to have been the first to introduce these birds to the notice of Europeans ; ${ }^{1}$

415, "In temperat yeres ben fewe byrdes of been" [= bees], and op. cit. xiii. xxvi. 458 "All fysshe ... fede and kepe theyr byrdes"; Scots Acts, 7 Jac. I. "The Woolfe and Woolfe-birdes [i.e. cubs] suld be slaine." The comnexion formerly thought to exist between bird and breed or brood is now denied (Aew English Dictionary, sub roce), but no approach to the derivation of the first has been marle.

1 Pigafetta's account contains some details worthy of attention. It describes the birds as being as big as Thrushes, with a small head, a long bill, and slender legs like pens used for writing, about as long as a palm. They had no wings 
but it is now certain that he was anticipated by Maximilianus Transylvanus, a young man who was residing in the Spanish court on the arrival of the survivors of Magellan's company, and promptly wrote to his father, the Archbishop of Salzburg, an account of their discoveries and spoils, sending moreover to him one of the wonderful birds they had obtained. This account ( $D e$ Moluccis insulis \&c.) ${ }^{1}$ was published at Cologne in the January following, and the native name of the birds, of which it seems that five examples were brought home, is given as Mamuco-Diata, a variant of Manucodiata, meaning the Bird of the Gods, a name which seems to be still in use (cf. Crawfurd, Malay and Engl. Dict. p. 97). But it may well be that even before this Birds-of-Paradise were known to Europeans, for the Portıguese reached the Moluccas in 1510 , to say nothing of the possibility of skins being imported by Eastern traders at a much earlier period. Belon, who travelled in the Levant between 1546 and 1549, mentions (Observations de plusieurs singularitez \&c. liv. iii. chap. 25), among the feathery adornments of the Janissaries, plumes which could hardly be other than those of these birds; and expressly states that they were obtained from the Arabs. ${ }^{2}$ His statement was first published in 1553, and in the same year appeared the work of Cardanus, De Subtilitate, wherein (lib. x.) the Manucodiata, as the Bird-of-Paradise now began to be called (the adoption of its Malay name shewing that knowledge of it was derived from Spanish or Portuguese navigators), is made to support the author's argument. In 1555 it was again treated of by Belon, as well as by Gesner, who figured (p. 612) what seems to have been a specimen of Paradisea minor, both of them expressing doubt as to the truth of the stories which were already rife on the subject. Some of these were touched upon in 1557 by J. C. Scaliger in his reply (Exotericarum exercitationum Liber XV. ccxxviii. 2) to Cardanus, while in 1599 Aldrovandus (Ornithol.

(which were doubtless cut off) but in their place long feather's of different colours like great plumes (pennacchi), the tail like a Thrush's, and all the rest of the feathers, the wings excepted, of a dull colour. Much of this description fits the only species of Bird-of-Paradise that inhabits Batchian, the ruler of which island, as above stated, gave the birds; but that species remained unknown to naturalists until Mr. Wallace procured examples in October 1858 (Malay Archipelago, ii. pp. 40, 41), and it was subsequently described as Semioptera wallacii.

1 I have not seen the original, but a fac-simile reprint, together with a translatiou of it, is given by the late Mr. Henry Stevens of Vermont in his Johann Schöner \&c., edited by Mr. C. H. Coote (London: 1888).

$2 \mathrm{He}$ said that they belonged to birds called Rhintaces, which some modern writers identified with the Apus of classical authors, though he himself thonght they were the feathers of the Phonix. A plausible case might indeed be made out for connecting the legend of the bird last-named with that of the gods and of paradise. 
lib. xii.), rejoicing of course in these absurd fables, severely took to task some of those who doubted them-among them Pigafetta himself, who is rated for declaring that Birds-of-Paradise had legs, for it was clear from the authorities cited that they had or ought to have none. Aldrovandus professedly figured five species, but only three of them can be referred with any certainty to the genus Paradisea.

There would be little use in dwelling mpon the many false assertions made by some of the older writers concerning these gorgeous and singular birds, nor is space here available to recount the way in which species after species has been discovered. The first naturalist who was able to observe anything of them in their own haunts seems to have been Lesson, who in July and August 1824 passed a fortnight at Dorey in New Guinea ( $V_{0 y}$. Coquille, Zoologie, ii. p. 436); but, though his remarks have interest, his opportunities are not worthy to be named with those enjoyed by Mr. Wallace, who in the course of his long sojourn and wanderings in the Moluccas and neighbouring islands made the personal acquaintance of nearly every species then known, and indeed first brought to the notice of naturalists one most curious form, Semioptera wallacii. His admirable account of their habits may be read in one of the most accessible of books, his Malay Archipelago. Varied as is the appearance of the several forms of Paradiseidx, most of them are sufficiently well known to require no description here. In $1873 \mathrm{Mr}$. Elliot completed a fine Monograph of the Family, which he divided into 3 subfamiliesParadiseinx, with 10 genera and 17 species ; Epimachinx, with 4 genera and S species; and Tectonarchina-the last comprising the BowER-BIRDs, and including in all 36 species, of which 22 inhabit New Guinea. In 1SS1 Prof. Salvadori enumerated 39 species, which he disposed of in 21 genera, as occurring within the scope of his elaborate Ornitologia della Papuasia e delle Molucche. Recent explorations, mostly by German naturalists, and especially by Dr. Hunstein, have considerably increased this number, and the representatives of two very distinct and beautiful new forms Astrarchia stephanix and Paradisornis rudolphi, to say nothing of two fine species of the old genus Paradisea, $P$. gulielmi-ii., and $P$. augusta-victorix, by their names testify to the loyalty of Drs. Finsch, A. B. Meyer, and Cabanis, who have described them (Zeitschr. ges. Oin. 18S5, pp. 369-391, pls. xv.-xxii. ; transl. Tois, 18S6, pp. 237-258, pl. vii. ; and Journ. f. Orn. 1888, p. 119, 1889, pls. i. ii.)

The Paradiseida are admittedly true PAsseres, but their exact position cannot be said to have been absolutely determined, though there can be little doubt of their forming part of the group indefinitely known as "Austrocoraces" I to which so many forms

1 The Noto-Coracomorph of Parker (Trans. Zool. Soc. ix. p. 327). 
of the Anstralian Region belong - and the precise limits of the Family must still be regarded as uncertain (see BowER-BIRD, Manucode, and Rifleman-bird).

BIRD-OF-PREI, a phrase in common use, signifying any member of the Order Accipitres of Linnæus (the SHRikes being generally excepted) or of the RAPTORES of many later systematists.

BISHOP-BIRD, or Bishop-Tanager, Latham's rendering (Gen. Synops. ii. p. 226) of the French l'Erêque, by which a species inhabiting Louisiana was, according to Dupratz (Hist. de le Louisiane, ii. p. 140), originally called, as stated by Buffon (Hist. Nat. Ois. iv. p. 291). Dupratz's bird was probably the Spiza cyanea of modern ornithology; the Indigo-bird or Indigo-Bunting of the English in North America; but Buffom confounded it with his Organiste of Santo Domingoa very different species figured by D'Aubenton $(P l$. enl. 809, fig. 1); while Brisson (Orn. iii. p. 40) had already applied the French name (l'Evesque, as he wrote it) to a third species from Brazil, which subsequently became the Tanagra episcopus of Linnæus, and this seems to be the only one now known (and that to few but "fanciers") as the "Bishop-Bird" or "Bishop-Tanager" - the colour of its plumage suggesting, as in the original case, the appellation. Audubon, himself a Louisianian, makes no mention of the name "Bishop-Bird"; but says (B. Amer. iii. p. 96) that it was known to his countrymen as the Petit Papebleu. He adds that the first settlers called all the Buntings, Finches and "Orioles" Papes.

BITTERN (in older English "Bittour," "Botor," and "Buttour") cognate with the French Butor, and of obscure origin says Dr. Murray, ${ }^{1}$ though Belon's suggestion, made in 1555 , connecting it with a bird described by Pliny (lib. $x$. cap. xlii.), which imitates the lowing of oxen (boum), and hence was called taurus in the district of Arelate $^{2}$ (Arles), may be correct; for the bird is the Botaurus of some mediæval writers, and their name is still kept by systematists as that of the genus to which the Bittern belongs. Turner, in 1544, gave as an English synonym "Miredromble"; while "Butter-bump" (corrupted into "Botley-bump") and perhaps other uncouth forms have reference to the booming or bellowing sound for which this species was famous.

1 It seems, howerer, not to be connected, as he thinks, with the medieval Latin Bitorius for that is gencrally glossed Wranna (WrEx) or sometimes as "Earthlinger" or "Yr'aling." It may not signify a bird at all, lnt a ShrewMouse-Araneus, in English a "[w]ranner:" Butio seems also to be meant by medieval writers in some cases, and a hopeless confusion has been established between that word and Buteo, a Buzzain.

2 According to Rolland (Faun. Pop. Franee, p. 376) it is known in sonse parts of France as Bouf d'eau, Taureau d'etcung, and other names of similar import. 
The Bittern is the Botums stelluris of ornithology, belonging to the Family Ardcida (Heros), but to a genus fainly separable, more perhaps on account of its almost wholly nocturnal habits and correspondingly-adiapted coloration, than on strictly structural gromils, though some differences of proportion are observable. It was formerly an abundant birl in many parts of Britain; but, since the reclamation of the bogs and fens it nsed to inhabit, it is become only an irregular visitant, - though not a winter passes

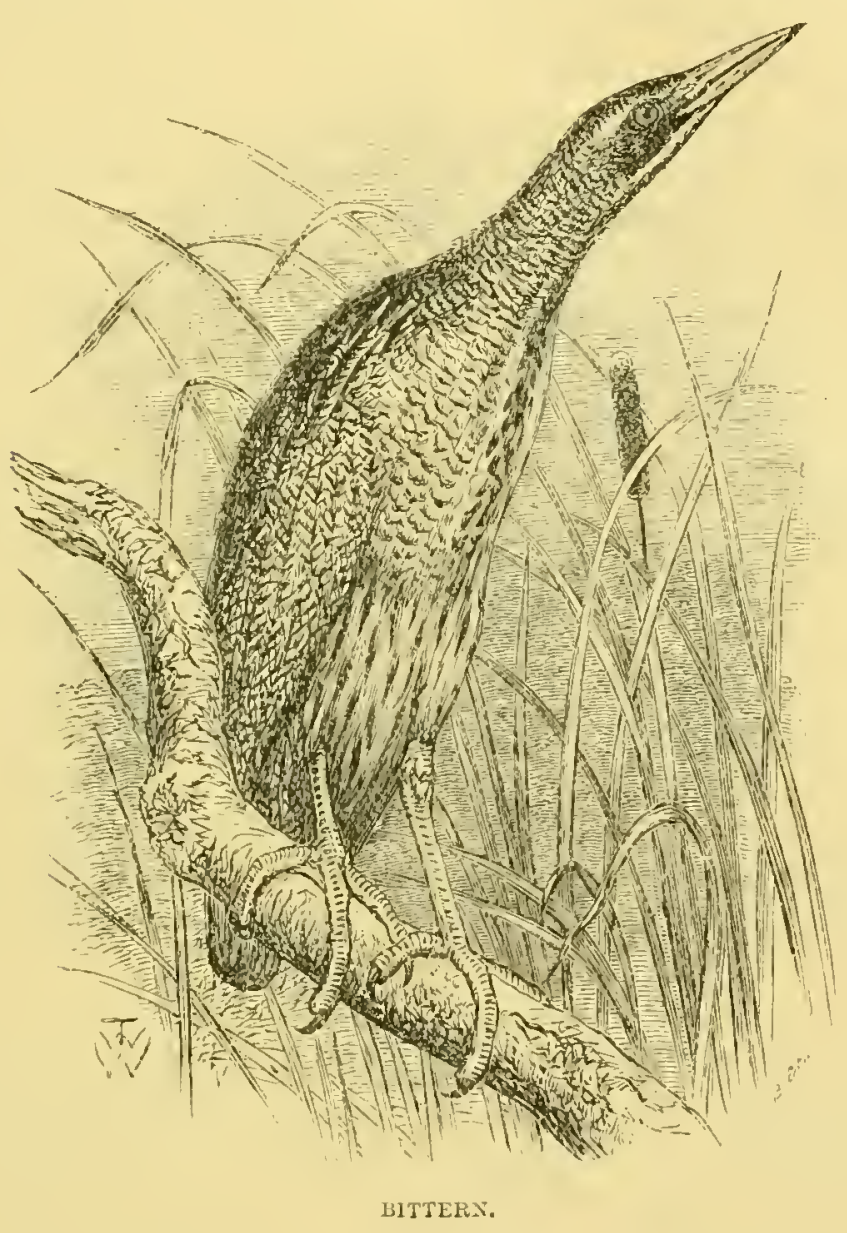

without its appearing in some numbers, when its meommon aspect, its large size, and beantifully-pencilled plumage cause it to be regarded as a great prize by the lucky gun-bearer to whom it falls a victim. Its value as a delicacy for the table, once so highly esteemed, has long vanished. The old fable of this bird inserting its beak into a reed or plunging it into the ground, and so causing the booming sound with which its name will be always associated, is also exploded, and nowadays indeed so few people in Britain have ever heard its lond and awful roice, which seems to be uttered only in the breeding-season, and is therefore mnknown in a 
country where it no longer breeds, ${ }^{1}$ that incredulity as to its booming at all has in some quarters succeeded the old belief in this as in other reputed peculiarities of the species. The Bittern is found from Ireland to Japan, in India, and throughout the whole of Africa-suitable localities being, of course, understood. Australia and New Zealand have a kindred species, $B$. pociloptilus, and North America a third, $B$. mugitans or $B$. lentiginosus. The former is said to bellow like a bull, but authorities differ as to the vocal powers of the latter, ${ }^{2}$ which has several times wandered to Europe, and is distinguishable by its smaller size and uniform greyish-brown primaries, which want the tawny bars that characterize $B$. stellaris. Nine other species of Bitterns from various parts of the world are admitted by Schlegel (MIus. P.-B. Ardeæ, pp. 47-56), but some of them should perhaps be excluded from the genus Botaurus; on the other hand, Dr. Reichenow (Journ. f. Orn. 1877, pp. 241-251), by comprehending the birds of the Group Ardetta,-commonly known as "Little Bitterns," and differing a good deal from the true Bitterns-makes the whole number of species twenty-two.

BLACKBIRD, the common, but not the most ancient ${ }^{3}$ name of the Ouser, the Turdus merula ${ }^{4}$ of Linnæus and most ornithologists, one of the best known of British birds; but since conferred in distant countries on others whose only resemblance to the original bearer lies in their colour, as in North America to several members of the Icterida (GRACKLE and ICTERUS), in the West Indies to the species of Crotophaga (ANi), and perhaps to more in other lands. Occasionally too in translations of Scandinavian works it is used to render Svartfugl-the general name for the Alcida (AUK)-of which indeed it is an equivalent, but its use in that capacity tends to mistakes.

BLACKCAP, the Sylvia atricupilla of ornithology, one of the most delicate songsters of the British Islands, and fortunately of general distribution in summer. To quote the praise bestowed upon it in more than one passage by Gilbert White would be

1 The last recorded instance of the Bittern breeding in England was in 1868, as mentioned by Stevenson (Birds of Norfolk, ii. p. 164). All the true Bitterns, so far as is known, lay eggs of a light olive-brown colour.

2 Richardson, a most accurate observer, positively asserts (Fauna BorealiAmcricana, ii. p. 374) that its booming exactly resembles that of its European congener, but few American ornithologists, MIr. Torrey (Auk, 1889, pp. 1-S) excepted, seem to have heard it in perfection.

3 Its earliest use seems to be in the Book of St. Albans in 1486, where it occurs as "blacke bride."

4 By some unhappy accident the order of these words is reversed in Dr. MIurray's New English Dictionary. The bird has been named Merula atra, but never Merula turdus (as therein stated) by Linnæus or any one else. 
superfluous. Enough to say that its tones always brought to his mind the lines in As You Like It (Act ii. sc. 5):

"And turn his merry note

Unto the sweet bird's throat."

The name, however, is only applicable to the cock bird of this species, who further differs from his browncapped mate by the pure ashygrey of his upper plumage; but notwithstanding the marked sexual difference in appearance, he shares with her the duty of incubation, and has been declared by more than one writer to sing while so employed-a statement that seems hardly credible. Closely allied to the Blackcap, which, it may be said, is a regular summer visitant, though examples have sometimes occurred in winter in England, are the so-called Garden-WARBLer, Sylvia salicaria (S. or Curruca hortensis of some authors), and the WHITE-THROAT.

But the name Blackcap is also applied to some other birds, and both in this country and in North America especially to certain species of TITMOUSE and GULL which have the top of the head black, as well as locally to the SToNeCHAT and Reed-BunTING.

BLACKCOCK, the male of the bird to which the name Grows or Grouse seems to have been originally given.

BLEATER, a name for the SNIPE, from the noise it makes in its love-flights, the cause of which has given rise to much discussion.

\section{BLIGHT-BIRD, see Zosterops.}

$B L O O D$ is the fluid which circulates through the heart, arteries, and veins. It is mixed with lymph, its corpuscles being suspended in a fluid called blood-plasm. The arterial blood is of a lighter red than the venous, which is more purple blood. Blood shews the following composition :-

1. Red blood-corpuscles, oval, flat disks, with rounded-off margins and a central nucleus which forms a slight swelling: they contain a substance known as hæmoglobin, which, combining with the oxygen of the blood, causes the latter's red colour. These red corpuscles are present even in a small drop of blood in innumerable numbers ; they are largest in the Cassowary, smallest in Hummingbirds, their smallest axis measuring about $\mathrm{mm}$. $\frac{1}{110}$ or $\frac{1}{1 \frac{1}{5}}$, their larger axis from mm. $\frac{1}{59}$ to $\frac{1}{105}$.

2. White-blood or lymph-corpuscles; by far less numerous, colourless, and of very variable size (from $\mathrm{mm} . \frac{1}{50}$ to $\frac{1}{100}$ ), shewing lively amœboid motions.

3. The blood-plasm, consisting of fibrin and serum. The latter is a fluid, frequently yellowish, and is composed of water, albumen, and various salts. 
The function of the blood is this: 'The arterial blood in the capillaries of the body gives off its oxygen to the tissues of the body; the lymph, charged with the nutritive elements derived through the process of digestion, bathes the same tissnes by leaving the capillaries, and is collected again into lymphatic ressels, being ultimately emptied into the big veins of the body, to be mixed again with the deoxydized blood returning likewise through the veins from the capiliaries of the whole body. All this exhansted blood is, together with the lymph, received into the right auricle of the heart, thence pumped through the right ventricle and the pulmonary arteries into the capillaries of the lungs, there to give up its carbonic acid, and to be charged again with oxygen. Returning through the pulmonary veins into the left auricle, and thence into the left ventricle, it is forced by the contraction of the latter into the arteries of the body to commence its circulation anew.

The lymph is a fluid like the blood-plasm, slightly yellowish or colourless and containing only wlite, but no red, bloodcorpuscles.

BLOOD-BIRD, one of the species of the genus Myzomela, belonging to the Meliphagida (HoNEY-sucker), so called in New South Tales - M. sanguinolenta (Latham). (Gould, Handb. B. Australia, i. p. 555.)

BLOOD-OLPH, a not uncommon loca! name of the BuLr FINCH.

BLOOD-PHEASANT, the Anglo-Indian name for the Ithaginis cruentus of ornithologists, one of the most beautiful game-birds of the mormtains of Eastern Nepal and Sikkim, so called from the blood-red blotches with which its otherwise green plumage is diversified. A second species of the genus, I. geoffroyi, has been described from Northern China. By some systematists they are referred to the subfamily Perdicina, by others to the Phasianina. (Jerdon, B. India, iii. p. 522.)

BLUEBIRD, in North America the appropriate name of the no less familiar than favonite Sialia wilsoni, or sialis of ornithology, and of its congeners S. mexicana or occidentalis ${ }^{1}$ and S. aretica:the first, with a chestnut throat and breast, being an abundant bird on the eastem side of the continent, appearing also in Bermuda; the second, with the midcle of the back and breast chestnut, taking

'By some writers S. mexicence is reçarded as distinct from S. occidentalis, and there seems little doubt that S. azurea of Central America may be considered a good sprecies. Mr. Seebohm (Cat. B. Brit. Mus. v. p. 328) places in this genus the Grandala cælicolor of the Himalaya and other mountain-ranges in Asia. 
its place further to the south and westward; and the third, of a lighter hue and with no chestnut, being the north-western form. The genus Sialia is one of those that are midway between the reputed Families Sylviide (WARbler) and Turdida (THrush), and with Monticola and some others shew how hard it is to maintain any valid distinction between them. The Bhuebirds of North America breed in holes of trees, and seem all to lay pale blue spotless egors. In IVestern India, Ceylon, and Burma, the name Bluebird is equally well bestowed on the Irena puella of modern ornithologists, which is commonly referred to the chaotic groups Timeliida or Crateropodida (Oates, Fauna of British India, Birds, i. pp. 239, 240), and has several representatives in the Indian Region (Jerdon, $E$. India, ii. p. 106); but the precise place of the genus must be regarded as uncertain. According to $\operatorname{Mr}$. Layard (B.S.Afr. p. 365), in the seas of the Cape of Good Hope, the name is applied to a wholly different kind of bird, Diomedea fuliginosa (Albatros).

BLUECAP, a common name of the Blue 'IImouse Parus caruleus.

BLUETHROAT, the Euglish name by which the beautiful Motacilla suecica of Linneus is now generally known. By some systematists it has been referred to the genus Puticilla (REDSTART) or to Evithacus (REDBREAST), and by others regarded as the type of a distinct genus Cyanecula-the last view being perhaps justifiable. There are two, if not three, forms of Bluethroat in which the male is quite distinguishable:-(1) the true C. suecica, with a bright bay spot in the middle of its elear blue throat, breeding in Scandinavia, Northern Russia, and Siberia, and wintering in Abyssinia and India, though rarely appearing in the intermediate countries, to the wonder of all who have studied the mystery of the migration of birts ; next there is (2) C. lencocyanea, with a white instead of a red gular spot, a more western form, ranging from Barbary to Germany and Holland; and lastly (3) C. wolfi, thought by some authorities (and not withont reason) to be but an accidental variety of the preeding (2), with its throat wholly blue,-a form of comparatively rare occurrence. The first of these is a not infrequent, though very irregular visitant, to England, while the second has appeared there but seldom, and the third never, so far as is known. The affinity of the Bluethroat to the Redstart is undeniable; but it is not much further removed from the Nightingale, and forms a nember of that group which eomnects the so-called Families Sylviula (IVARBLER) and Turdida (THRUSH).

BOAT-BILL, the Cancromu cochlearia of most ormithologists, a native of Tropical Ameriea, and the only species of its genus. It seems to be merely a Night-Heron (Nycticorax) with an exaggerated bill, so much widened as to suggest its English name, and its habits, 
so far as they are known, confirm the inference derived from its structure. The wonderful "Shoe-bird" or Whale-headed STORK

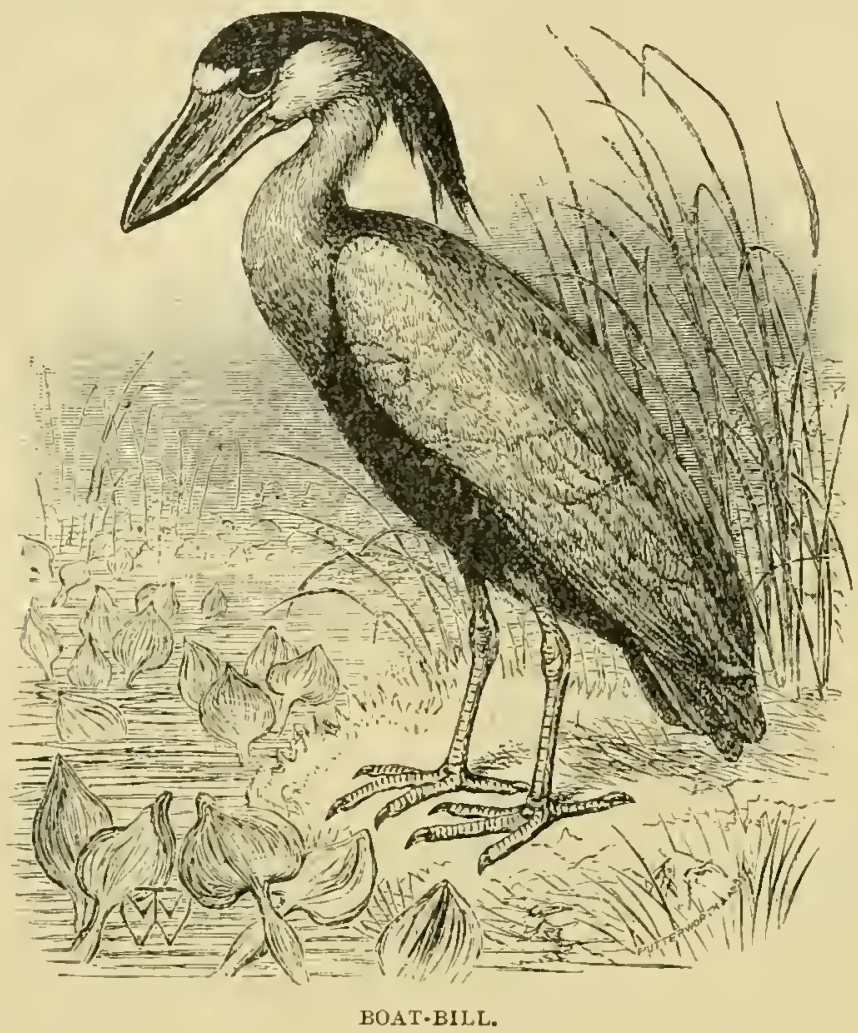

(Balaniceps) is regarded by some authorities as allied to Cancroma; but the present writer cannot recognize in it any close affinity to the Ardeidx.

BOATSIVAIN, in scamen's ornithology, is a name applied to several kinds of birds, and was perliaps first given to some of the genus Stercorarius (SKUA), though, nowadays most commonly used for the species of Placthon (Troprc-BIRD), the projecting middle feathers of the tail in each being generally likened to the marlinespike that is identified with the business of that functionary, but probably the anthoritative character assumed by both Skua and officer originally suggested the appellation.

BOAT-TAIL, a common name applied to certain North-American birds of the genus Quiscalus, belonging to the Family Icterida (see Grackle and ICterus), from the power they have of holding the tail in the shape of a boat with the concavity uppermost.

BOB-LINCOLN, BOBLINK, and BOBOLINK, names given by the English in North America to what is commonly called in boolis the Rice-Bunting, Dolichonyx orywivore, one of the best-known birds of that continent-valued for its song and still more for its sapidity, in which last respect it equals if it does not surpass the famed 
Ortolan. Its good qualities have been described at length by Alexander Wilson, Nuttall, and Audubon, to say nothing of more recent writers on North-American ornithology, and to those author's must reference be made for its description and an account of its habits. From the purely scientific point of view the form is one of considerable interest, as it seems to connect the Emberizida (BunTing) with the Icteridx (GRACKLE, ICTERUs); and, though generally considered to belong to the latter, is rather a divergent member of that Family. It is a bird that performs vast migrations, breeding as high as lat. $54^{\circ} \mathrm{N}$, and in winter visiting the Antilles and Central and South America as far as Paraguay.

BOB-WHITE, a nickname of the Virginian QUAIL, Ortyx virginianus, aptly bestowed from the call-note of the cock.

$B O N E$ or osscous tissue consists of phosphate and carbonate of lime, salt, and a few other earthy substances. Hollow bones contain marrow, a fatty substance with delicate connective tissue, except where it has been driven out by the penetrating AIR-SAcS. On the surface of a bone, covered by a fibrous membrane, the periosteum, there open small, often microscopic, holes, which as "Haversian Canals" are continued through the walls of the bone into larger spaces or cancelli, and ultimately into the marrow cavity. These render possible the entrance of blood-vessels, air-cells, and nerves. Bones which have their entire substance or diploe between the outer and the inner lamella filled with cavities and cancelli are called cancellated or spongy; this is especially the case in the bones of the head of Owls, and to an enormous extent in the "horn" of the Hornbills. The bony substance forms consecutive layers around the Haversian canals. The layers themselves contain numerous irregular lacunæe, formerly but wrongly called bone-corpuscles, from which radiate numerous extremely fine canaliculi; these communicate with those of neighbouring lacunæ and with the Haversian canals, securing thus access of blood and lymph to any part of the bone.

Bone is never directly formed out of the indiflerent embryonic tissue, it always passes through a stage of connective tissue. If this tissue ossifies directly, it becomes a primary or membrane bone; if the tissue is cartilage and finally supplanted by bony tissue, the latter forms a secondary or curtiluge bone. Most of the bones of a bird's skeleton pass during their development through such a cartilaginous stage. Membrane bones are principally some of those forming the cranium, as the parietal, frontal, maxillie, and vomer. Bones which are developed in tendons by direct ossification are termed sesamoid bones, as the brachial and the crural patella. Either kind of bone can ossify from various centres, but these "centres of ossification" do not necessarily indicate that the bone in question is composed of a number of originally separate bones. 
In long bones especially the shaft ossifies first, while the ends remain for" a long time cartilaginous as "epiphyses" and eventually ossify often from a centre of their orrn, and are only in the adult completely fused with the shaft, forming the articulating facets, or projecting "processes" for the attachment and leverage of muscles.

BONXIE, the name by which the Great SkUA, Stercorarius catarhactes, is known in some of the Shetland Islands, its only British habitat.

BOOBI, said by Prof. Skeat (Etymol. Dict.) to be derived from the Spanish or Portugnese bobo-a fool, and that from the Latin balbus-stuttering or inarticulate, a name applied, most likely by our seamen originally, to certain birds from their stupidity in alighting upon ships and allowing themselves to be easily taken by the hitud. ${ }^{1}$ The Boobies are closely allied to the GANNET, and indeed can hardly be separated from the genus Sula, though they differ in having no median stripe of bare skin down the front of the throat, and they almost invariably breed upon trees instead of rocks, and are inhabitants of warmer climates. One of them, $S^{\prime}$. cyanops, when adult has much of the aspect of a Gannet, but S. piscator is readily distinguishable by its red legs, and $S$. lencogaster by its upper plumage and neck of deep brown. These three are widely distributed within the tropies, and are in some places exceedingly abundant. A fourth, $S$. variegata, which seems to preserve throughout its life the spotted suit characteristic of the immature $S$. bassuna, has a much more limited range, being as yet only lnown from the coast of Pern, where it is one of the binds which contribute to the formation of guano.

BOWER-BIRD, Gonld's rather poetical name for some inlubitants of Australia which, while he was in that comntry he ascertained, ${ }^{2}$ as on his return he ammounced (25 August, 18+0) to the Zoological Society, to have the extraordinary habit of building what the colonists commonly called "runs." "These constructions", he rightly said (Proc. Zool. Soc. 1840, p. 94), "are perfectly anomalous in the architecture of birds, and consist in a collection of pieces of stick or grass, formed into a bower; or one of them (that of the Chlamy(era) might be called an avenue, being about three feet in length, and seven or eight inches broad inside; a transverse section giving the figure of a horse-shoe, the round part downwards. They

1 Thus Purchas in his account of Davis's Second Voyage to India, in 1604-5, tells (Pilgrimes, 1. bk. iii. p. 132) of "fowles called Pashara boues"-which correctly spelt would be Pararos bobos-at the island of Fernando Norhona. Later examples are too numerous to cite.

2 The discovery seems to have been mainly due to the late Mr. C. Coxen of Brisbane. 
are used by the birds as a playing-house or ' 'run,' as it is termed, and are used by the males to attract the females. The 'r'un' of the Satin-bird is much smaller, being less than one foot in length, and moreover differs from that just described in being decorated with the highly-coloured feathers of the Parrot-tribe; the Chlamydera, on the other' hand, collects around its 'run' a quantity of stones, shells, bleached bones, etc. ; they are also strewed down the centre within."

This statement, marvellous as it seemed, has been proved by many subsequent observers to be strictly true, and it must be borne in mind that these structures, ${ }^{1}$ each of which as above described he next year (1 Sept. 1841) figured (B. Austral. iv. pls. 8, 10), have nothing to do with nests of the birds-indeed, their mode of nidification, which was not made known until some years later, presents no extraordinary feature. Moreover, the birds will build their "bowers" in confinement, and therein disport themselves, as has been repeatedly shewn in the Zoological Gardens ${ }^{2}$ by the Satin-bird last mentioned, Ptilorhynchus violaceus. Subsequently it was found that the Regent-bird, Sericulus melinus, a species long before known, had the habit of making a "bower" of similar kind, though built, so to speak, in another style of architecture, and having for its chief decoration the shells of a small species of Hetix.

The account of these curious birds which may be most conveniently consulted is that in Gould's Handbook to the Birds of Australia (i. pp. 441-461), published in 1865; but since that time discoveries still more wonderful have been made. A bird of New Guinea, originally referred to the genus Ptilorhynchus, but now recognized as Ambiyornis inornatus, has been found by Sign. Beccari to present not only a modification of bower-building, but an appreciation of beauty perhaps unparalleled in the animal world. His interesting observations (Annali del Mus. Civ. de Storia Nat. di Genova, ix. pp. 382-400, tav. viii.) shew that this species, which he not inaptly calls the "Gardener" (Gjardiniere), builds at the foot of a small tree a lind of hut or cabin (capanna) some two feet in height, roofed with orchid-stems that slope to the ground, regularly

${ }^{1}$ Gould brought home with him at least two examples, whrch he gave to the British Museum. There is no reason to suppose that this extraordinary habit had been described before the date above given, or that the name "Bower-bird" had been previously used, and yet we find Trelawny in liis Memoirs of Shelley, published in 1878, referring to himself (i. p. 136) as saying, in a conversation not later than 1822, "Yon two have built your nest after the fashion of the Anstralian bower-birds"!

2 The ordinary visitor to these gardens seems to regard the structures of the Bower-birds withont any intelligent interest. He perhaps supposes that they are the handiwork of one or other of the keepers. From my own long comnexion with the Zoological Society, I think I am able to state that neither in this nor anything else of the kind is any deception practised. The Bower-birds are supplied with matcrials, and that is all. 
radiating from the central support, which is covered with a conical mass of moss, and sheltering a gallery round it. One side of this hut is left open, and in front of it is arranged a bed of verdant moss, bedecked with blossoms and berries of the brightest colours. As these ornaments wither they are removed to a heap behind the lnut, and replaced by others that are fresh. The lint is circular, and some three feet in diameter, and the mossy lawn in

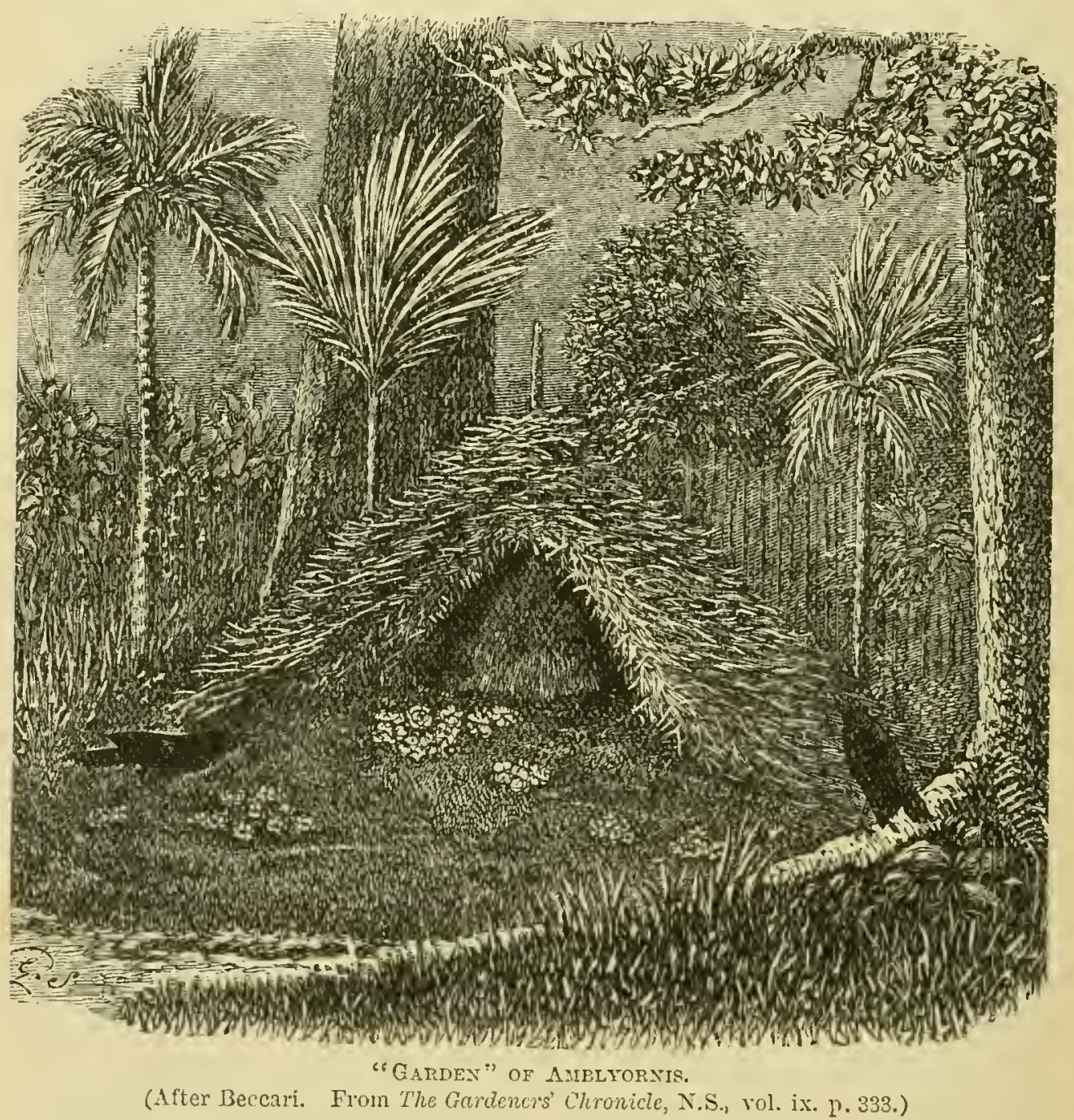

front of it of nearly twice that expanse. Each hut aud garden are, it is believed, though not known, the work of a single pair of birds, or perhaps of the male only; and it may be observed that this species, as its trivial name implies, is wholly inornate in plumage. ${ }^{1}$ Not less remarkable is the more recently described

1 Another species referred to the same genus, A. subalaris, the female of which was originally lescribed by Mr. Sharpe (Journ. Linn. Soc. xvii, p. 40) as being still more dingy, tumed out to have the male embellished with a wonderful crest of reddish-orauge (Finsch and Meyer, Zcitschr. f. ges. Orn. 1885, p. 390 , tab. xxii.). 
"bower" of Prionolura, a genus of which the nale, like the Regentbird, is conspicuous for his bright orange coloration. This structure is said by Mr. Devis (Truns. Roy. Soc. Queenshund, 1 t June 1889) to be piled up almost horizontally round the base of a tree to the height of from 4 to 6 feet, and around it are a number of hut-like fabrics, having the look of a dwarfed native camp. Allied to the forms already named are two others, Scenopaus and Aituroulus, which, though not apparently building "bowers," yet clear a space of ground some 8 or 9 feet in diameter, on which to display themselves, ornamenting it "with tufts and little heaps of gaily tinted leaves and young shoots" (Ramsay, Proc. Zool. Soc. 1875, p. 592). The former of them, which, according to Mr. Lumholtz (Among Cannibals, pp. 139, 140), covers a space of about a square yard with large fresh leaves neatly laid, and removes them as they decay, inhabits Queensland, and to the latter belongs the "Cat-bird," so well known to Australians from its loud, harsh, and extraordinary cries.

By most systematists these birds are placed anong the Paradiseida (BIRD-OF-PARADIse); but in the British Museum Catalogue of Birds (vi. pp. 380-396) they are to be found in the "limbo larce and broad" of Timetiulix-thongh allowed the rank of a subfamily "Ptilonorlynchinx," the name being taken from the feathered and not the bare (as might from its etymology have been expected) condi-

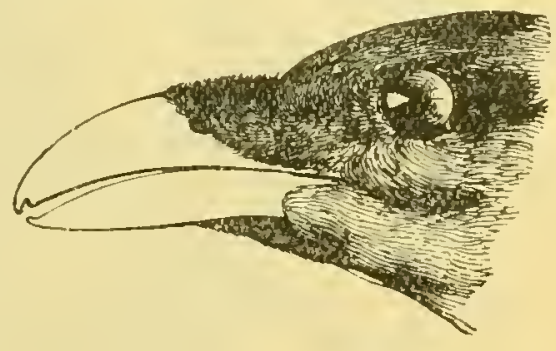

PtLORHYNCHUS VIOLACEUS.

(After Swainson.) tion of the base of the bill shewn in the figure of that part in the Satin-bird.

BRACHIAL, ARTERY, see VAsCULAR SYsTEM: BRACHIAL PLEXUS, see Nervous SYsTEM.

BRAIN, the part of the Central Nervous System which is enclosed by the cranium, and in Birds consists of three principal divisions, named after their position-Hind- Mid- and Forebrain. The hindbrain is composed of the medulla oblongata, the direct and comparatively little modified continuation of the spinal cord, and of the cerebellum, these two parts being connected with each other by the pedunculi or crura cerebelli. The midbrain contains the peduncles of the great or forebrain, and the cortex or rind of the optic lobes. The forebrain is subdivided into the thalamencephalon and into the cerebral hemispheres. The ventral parts of the thalamencephalon form the hypophysis and the chiasma or crossing of the optic nerves, the lateral parts contain the immer portions of the optic lobes, which are partly lomologous with 
the corpora bigemina of Mammals, and the optic thalami; the dorsal roof forms the epiphysis or pineal gland, the corpus callosum and the anterior commissure, both of which consist of bundles of white nerve fibres and conneet the right with the left hemisphere. The ventral portion of the hemispheres consists of the corpora striata, which are masses of grey brain-substance, and of the olfactory lobes, which mark the anterior end of the brain.

The central camal, which runs through the spinal cord, is continned into the brain, and forms the fourth ventricle in the hindbrain, extending dorsally into the cerebellum; and is then contimued as "aquaductus Sylvii" through the midbrain, with lateral extensions into the optic lobes. The dilatation of this canal in the thalimencephalon is the third ventricle: it extends ventrally towards the hypophysis as the infundibulum, in a similar way

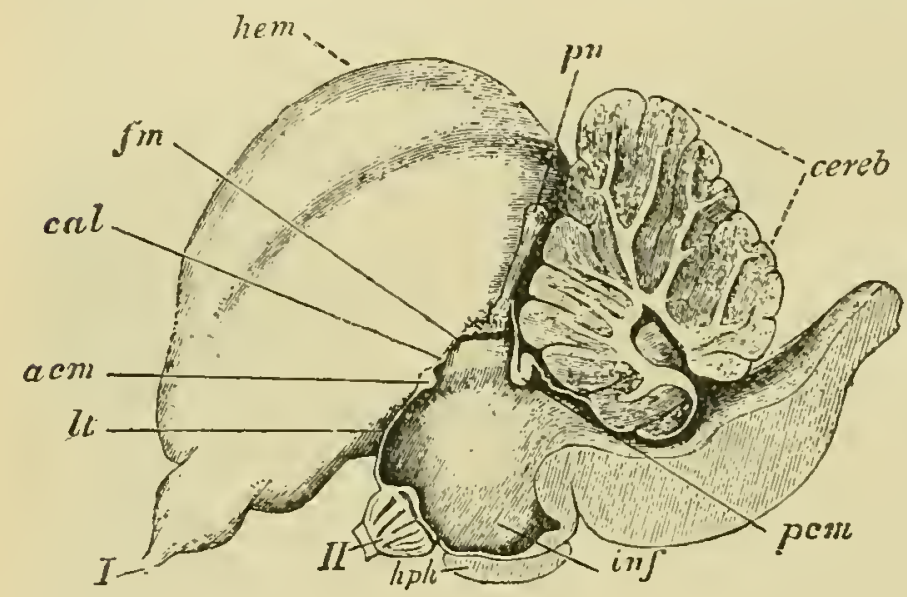

VERTICAL SECTION IN THE MIDDLE LINE THROUGH THE BRAIN OF A DUCK. Enlarged. (After $\mathbf{H}$. F. Osborne.)

$I$, Rightolfactory nerve ; $I I$, Riglit optic nerve and chiasma: acm, Anterior commissure ; cal, Corpus callosum; ccreb, CerebelIum; lt, Lamina terminalis; fm, Forameu Monroi; hem, night hemisphere; $h p h, H y p o p l_{y}$ sis ; inf. Infundibulum; pom, Posterior commissure ; $p n$, Epiplysis or pineal gland.

dorsally towards the epiphysis, and communicates through the formen of Monro with the second and first ventricles; these being the cavities of the two hemispheres.

The hypophysis cerebri or pituitary body is lodged in the "sella turcica," a niche or reeess formed by the anterior and posterior basisphenoid bones. This peculiar body is probably the degenerated remnant of a special sense-organ in the mouth of early Vertelsata, it being developed partly as an outgrowtl from the roof of the mouth which fuses with a corresponding growth from the brain and then loses its comnexion with the month.

The epiphysis cerebri or pineal body is the remnant of a sense-organ, possibly visual, as it is still funetional in many Lizards possessing a lens, a retina-like accumulation of black pigment and a nerve, but quite degenerated in all Birds and Mammals.

The cerebellum of Birds is homologons only with the "worm" or middle portion of the cerebellum of Mammals, the lateral lobes being absent, although a pair of flocculi are present. Externally it exhibits a number of transvers furrows, which divide it into 
lamellæ. On a vertically longitudinal, or "sagittal," section, it has a beautiful tree-like appearance. From the walls of the contral cavity branch-like white medullary fibres spread ont, surrounded by a layer of reddish ginglionic cells, followed by larger ganglia (Purkinje's layer), and externally covered by a grey mantle of smaller ganglionic cells. Such a thin section, especially when stained with carmine, for'ms a fascinating object for the microscope, and is easily made.

The surface of the cerebral hemispheres in Birds exhiljits no convolutions or gyrations as in the higher Nammals. In the Ratitie and in many Passeres the surface is entirely smooth, but in Swimmers, TTaders, Pigeons, Fowls, and Birelsof-Prey, there is a very slight furrow which might be

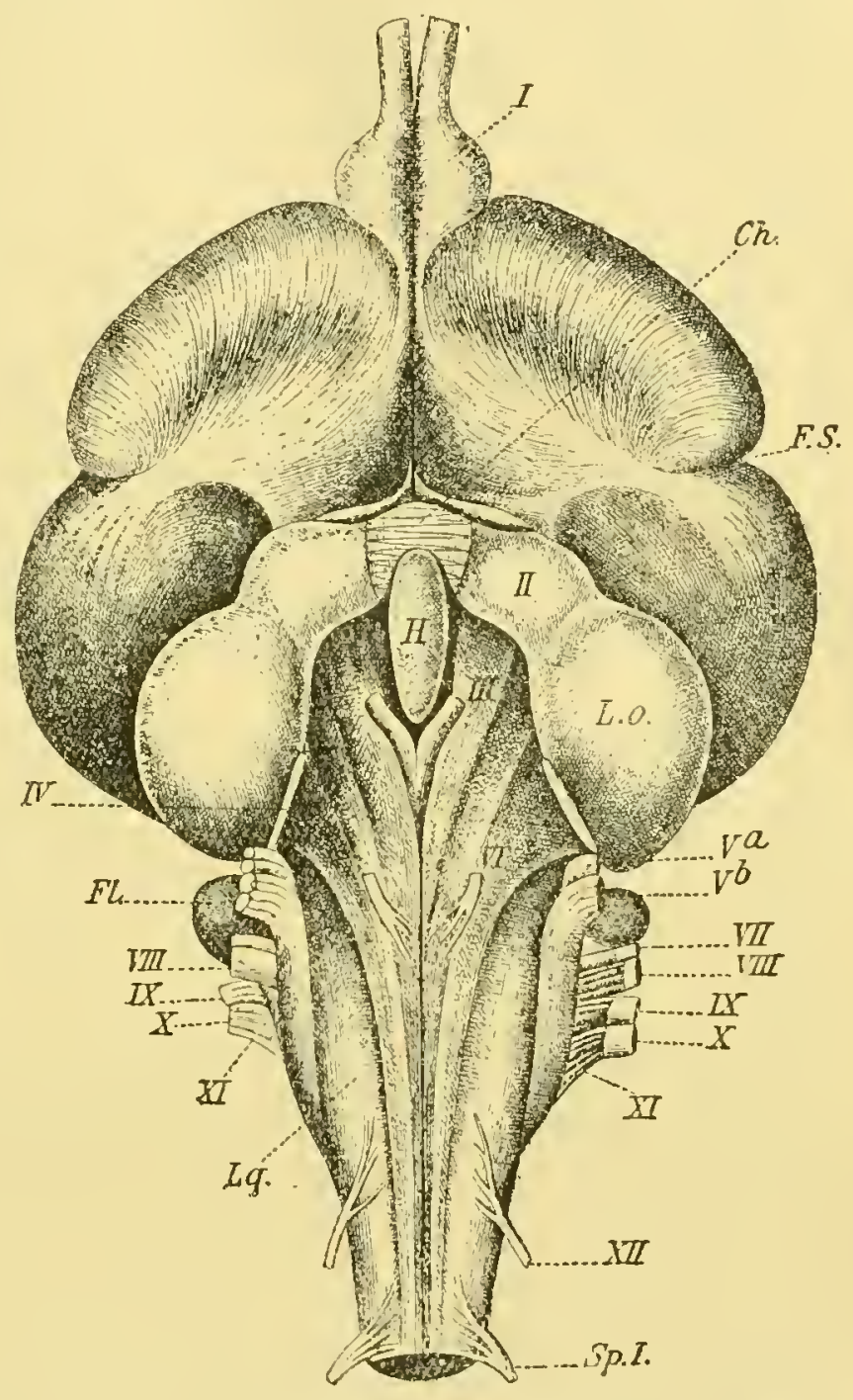

VeyTRAL VIEW OF TIE BRAIN of A GuOSE. Twice matural size. (After A. Heckel.)

$I$-XII, the twelve pairs of cranial nerves; $C h$. Chiasma of the optic nerves cut across; Fl. Flocculus; II. IIypophysis ; L.o. Optic lobe; Lq. Laqueus; F.S. Sy.lvian fissure; Sp.I. First spinal nerve.

compared with the Sylvian fissmre. There is also very little grey substance in the surface layers of the hemispheres. Tarions attempts have been made, by Tiedemann, ${ }^{1}$ Serres, ${ }^{2}$ Leuret, ${ }^{3}$ and Bumm, ${ }^{4}$ to compare the weight of the whole brain with that of the body, or

1 Anatomie und Naturgcschichte der Vögel. Heilelherg : 1810.

2 Anatomie comparée du ccrecau. Paris : IS24.

3 Anatomie comparic du système nerveux. Paris : 1839-5\%.

* Das Grosshirn der Vügel. Zeitschr. für wisscnsch. Zool. xxxviii. (1883) pp. $430-466$, tabb. xxiv.-xxv. 
the weight of the hemispheres with that of other parts of the central nervous system, in order to draw conclusions as to the intelligence of various Birds. When Birds are arranged according to the preponderance of the hemispheres over the rest of the brain, the first place is taken by the Passeres and Parrots $(2 \cdot 7$ or $2 \cdot 0$ to 1$)$, then follow Geese, Ducks, Waders, and Birds-of-Prey, lastly Fowls and Pigeons, the proportions in the Common Domestic Pigeon being 0.95 to 1 , i.c. the forebrain weighs less than the rest, while in many Oscines it weighs nearly three times as much. The attempts to sort Birds according to the proportion of brain to body have led to no practical results, chiefly because the variable conditions of fat and lean subjects have not been considered. The absolute weight or mass alone of the brain is not a safe guide.

There are twelve pairs of cranial or brain-nerves which arise from the brain and leave the cranium through special holes. These pairs, as in other Classes of Vertebrates, are frequently spoken of by their number, counting from the nasal region backwards to the occiput.

I. $N$. olfactorius forms the anterior and ventral continuation of the hemisphere of its side, but arises in reality from ganglionic cells in the thalamencephalon and the midbrain. It leaves the cranial cavity through a canal in the dorsal and median part of the orbit and ends in the ganglionic cells of the olfactory membrane of the nose.

II. $N$. opticus arises from the ganglionic cells of the mantle of the optic lobes. Immediately in front of the hypophysis is the optic chiasma, produced by the complete crossing of the fibres which compose the two optic nerves, those from the right optic lobe passing over the left, and those from the left lobe to the right side. From the chiasma start the right and left optic nerves, each leaving the cranium by the large optic foramen between the orbitosphenoid and alisphenoid, entering the orbit near the posterior and ventral corner of the orbital septum and ultimately forming the retina of the eye.

III. $N$. oculomotorius arises close behind the hypophysis, near the medio-ventral line, from the midbrain, enters the orbit behind or together with the optic nerve (II), and supplies most of the external muscles of the eye, namely the n. rectus superior, inferior; internus, and obliquus inferior. A ciliary, partly sympathetic, branch supplies the eyeball and the internal muscles (see EYE).

IV. N. trochlearis or patheticus is the only one which leaves the brain on its dorsal surface, namely as a thin thread winding its way from the midbrain upwards between the cerebellum and the optic lobes, and entering the orbit through a fine opening close to the optic nerve (II) in order to supply the m. obliquus superior of the eyeball. 
V. $N$. trigeminus is next to the optic the thickest nerve, and of a complex nature, being motory and sensory. It arises from the sides of the micl- and hindbrain, forms the large Gasserian ganglion in the wall of the cranium, and leaves the latter in the form of three branches. The first or ophthalmic branch comes directly out of the ganglion through a foramen behind the optic (II), runs along the dorsal corner of the orbital septum, and leaves the orbit at its inner anterior corner in order to supply the palate, the bill, forehead, and the lacrymal gland. It is chiefly sensory, and consequently strongest in birds with tactile bills, like Ducks and Snipes. The second or upper maxillary branch runs along the ventral edge of the orbital septum, and besides the palatine and maxillary regions supplies the eyelids and Harder's gland. The third or inferior maxillary branch is the strongest of the three; it leaves the cranium together with the second through a foramen between the basi-alisphenoid and petrosal bones and innervates all the masticatory muscles, the parotid gland, and the whole of the under jaw.

VI. $N$. abducens is a very thin nerve arising from the hindbrain near the medio-ventral line, entering the orbit through a special foramen latero-ventrally from the optic foramen, and supplying the m. rectus externus and the two muscles of the nictitating membrane. It is entirely motory.

VII. $N$. facialis arises from the side of the hindbrain, possesses a ganglion (g: geniculatum), passes through the petrosal bone into the Fallopian canal, and sends the sympathetic sphenopalatine branch to the second branch of the trigeminal nerve $(V)$. The facial nerve leaves the tympanic cavity behind the quadrate bone, supplies the digastric muscle or depressor of the mandible, the little stapedius muscle of the ear-bones, the mylo- and stylohyoid muscles of the tongue, and further on connects itself with branches from the first four cervical nerves and occasionally with branches from the glossopharyngeal nerve (IX), ultimately supplying the skin on the front of the neck. There are no branches, as in Mammals, to supply the face, nor is there in Birds a chorda tympani, i.e. a branch of the facial nerve joining the mandibular branch of the trigeminal nerve (V).

VIII. $N$. acusticus arises dorsally from the facial nerve (VII), of which it is the sensory portion. It is very short and thick, possesses a little ganglion, and spreads out in the cochlea of the EAR as the nerve of hearing.

IX. $N$. glossopharyngeus takes its origin from the dorso-lateral sides of the medulla oblongata, near the rhomboid fossa. It leaves the cranium through the foramen jugulare, which lies between the petrosal and the lateral occipital bones, and also serves as exit for the vagus nerve $(X)$ and the jugular vein. Here the ninth nerve forms a big swelling, the ganglion jugulare, and is connected with the 
ganglion of the vagus and with the large sympathetic g. cervicale supremum, receiving a strong branch from the stem of the vagus, and dividing into two branches:-One, the pharyngeal branch, supplying the upper portion of the pharynx and the gustatory papillæ of the palate; the other, or lingual branch, supplying the glottis, larynx, and the tongue, and acting chiefly as the nerve of taste.

$\mathrm{X}$. N. vagus or pneumogastricus arises behind the glossopharyngeal (IX), and passes likewise through the jugular foramen. Its ganglion is connected with that of the glossopharyngeal and with that of the sympathetic system. The stem of this nerve receives a branch from the hypoglossal (XII) and takes up the accessory (XI). It runs down the side of the oesophagus, enters the thoracic cavity between the brachial nerve plexus and the carotid artery, then passes between the bronchus and the subclavian artery to the ventral side of the proventriculus, and joining its fellow from the other side, spreads out to supply the stomach. Other branches leave the principal stem of each vagus at the level of the bronchi to supply the liver, heart, and lungs, and as the recurrent laryngeal branch also supply the distal portion of the trachea and oesophagus. Some fibres of the vagus often extend beyond the stomach, and are conneeted with the sympathetic nerves of the trunk, supplying part of the intestinal canal.

XI. $N$. accessorius, a little nerve taking its origin between the dorsal and ventral roots of the third cervical nerve, runs upwards through the occipital foramen into the cranium, and joins the ganglion of the vagus $(\mathrm{X})$, to leave the eranium with the lattel and to supply the cucullaris musele or constrictor colli.

XII. N. hypoglossus arises ventro-laterally from the medulla oblongata, and leaves the cranium by two foramina in the lateral occipital bone, in front of and sidewards from the occipital condyle. It supplies the m. complexus, forms a connecting loop with the first cervical nerve, innervates some of the cervical muscles, and divides into two branches-one of which supplies most of the muscles of the tongue and communicates with its fellow on the undersurface of the tongue, while the other innervates the muscles of the larynx, and then descends along the side of the trachea to the syrinx in order to supply the vocal museles and membranes.

BRAMBLE-FINCH or BRAMBLING (Germ. Brämling), names of one of the most beautiful of our annual visitors, Fringilla montifringilla, which has its home in the birch-forests of Northern Enrope and Asia, whence it yearly proceeds, often in flocks of thousands, to pass the winter in more southern comntries. It is congenerie with the CHAFFINCH, but is still more brightly coloured, especially in summer, when the brown edges of the feathers being shed, it presents a rich combination of black, white, and orange. 
Even in winter, however, its diversified plumage is sufficiently striking.

BRANT or BRENT, words of doubtful etymology: the former spelling is most usually adopted by American, the latter by English anthor's, and in Britain the word Goose is generally added.

\section{BREASTBONE, see STtERNU.}

BRISTLE-BIRD, the name given by the colonists to three species of the genus Splemura of Lichtenstein (as now restricted) which inhabit Australia, from the two or three pairs of strong recurved bristles which project laterally from the gape. They were formerly considered to belong to the Sylviida; but latterly, like many others, have been referred (chiefly on account of their short wings) to the Timelivare by Mr. Sharpe (Cat. B. Br. Mus. vii. p. 104). Their true position seems yet to be determined. They mostly conceal themselves in thickets, especially in marshy places, flying very little, but rumning very quickly, and carrying the tail erect. The nest is built of dry grass, globnlar in form, and is of large size. S. brachyptera, the type of the genus, inhabits New South Wales, and the two others, S. longirostris and $S$. broudbenti, are found in Western Australia and the interior of South Anstralia respectively. Allied to Sphenura is Amytis, with 3 or 4 species, also Australian, somewhat Wren-like in form, and having the gape beset with five pairs of bristles, which, hoverer, are directed more forwardly, and are weaker.

BROADBILL, Swainson's name, appropriate as will be seen by the figure, in 1837 (Classif. Ji. ii. p. 80), for a remarkable group of birds comprehending the genus Eurylixmus of Horsfield (Trans. Limn. Soc. xiii. p. 170) and some allied forms, all inhabiting the Indian Region, and especially developed in Malacca, Java, Sumatra, and Borneo; but found also in the elevated part of India, and extending to the

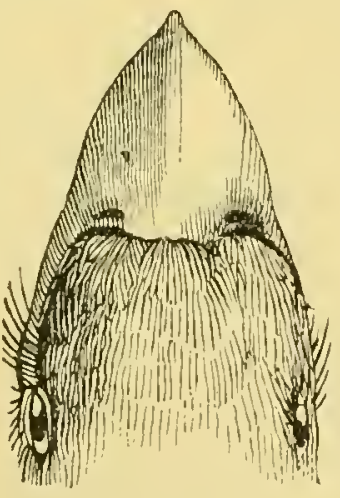

EUPYLAMUS.

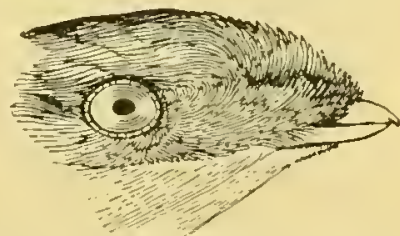

CALYPTOMENA. (After Swainson.)

Philippines. The position of this group, which was in 1842 recognized by Baron de Selys-Longehamps as forming a good Family, Eurylamida, had long been doubtful, some authors regarding it as allied to the Muscicapida (FLY-CATCHER), others to the Coraciida (Roller), and so forth. By degrees what seems to 
be its true place as belonging to the OLIGOMYoD, as that term is used in this work; but the Eurylamidx, so far as they have been examined, differ from all other PAsseres in "their retention of a plantar vinculum," as first noticed by Garrod (Proc. Zool. Soc. 1877, p. 449), which fact led W. A. Forbes to propose for them furtlier separation as Desirodactyli (op. cit. 1880, p. 390). But what seems to be a stronger reason for separating them is that, as Mr. Sclater had already shewn (Ibis, 1872, p. 179), the manubrium, or anterior projection of the sternum, is not forked as in other Passeres. According to him in 1888 (Cat. B. Br. Mus. xiv. pp. 454-470) the Eurylamidx comprehend two subfamilies, Calyptomeninx, consisting of the genus Calyptomena only, and Eurylaminx, containing six genera, two of which, Psarisomus and Serilophus, ${ }^{1}$ are found in India, while examples of all the rest, the Philippine Sarcophanops excepted, occur in British territory further to the eastward. They are nearly all birds of great beauty, and the two species of Calyptomena are remarkable for their rich green plumage, and the way in which the frontal feathers project upwards and forwards, so as almost to conceal the bill, and being adpressed form a disk-like prominence. They are frugivorous, but the Eurylaminx seem to be insectivorous. Not much is recorded of their habits, but they are said to be stupid, songless birds, and usually keep in small flocks. (Cf. Oates, B. Br. Burmah, i. pp. 422-431.)

$B R O N C H I$, adj. bronchial, from $\beta$ póy $\chi^{\circ}$, the windpipe. The thoracic end of the TRACHEA is divided into a right and a left bronchus. Each bronchus enters the lung of its side and passes through its whole length as mesobronchium, from which go off about 10 secondary bronchi towards the surface of the LUNG. In almost all birds-the exceptions being the Cathartidæ, true Storks, and Steatornis - the bronchi are strengthened by cartilaginous semirings ; the ends of these rings point towards the median line, and are closed by the inner tympaniform membrane. The right and left membranes are connected with each other by an elastic band, called bronchidesmus. All the rings which partake of the formation of the pessulus of the trachea belong to the latter, the pessulus thus marking the beginning of the bronchi (see also TrACHEA and SYRINX).

BRONZE-WING, the name given in Australia to several species of PIGEON belonging to the genera or so-called genera Phaps, Geophaps, Lophophaps, and Ocyphaps, from the lustrous coppery or bronze-like spots they display on their wings.

BRUBRU, the name (apparently originating with Levaillant) of a conspicuously-coloured SHRIKE, the Nilaus brubru or $N$. capensis of modern ornithology.

1 The style of plumage in this genus recalls that of Ampelis (WAXWING), but no affinity thereto can be thought to exist. 
BRUSH-TURKEY, the Australian name for one of the largest of the MEgapodis, Talegallus lathami, which has frequently made its mound, laid its eggs, and reared its young in the Zoological Gardens, after the manner described many years ago by Mr. Bartlett (Proc. Zool. Soc. 1860, pp. 426,427 ). In earlier days the position of this bird was a great puzzle to some ornithologists, who thought from the form of

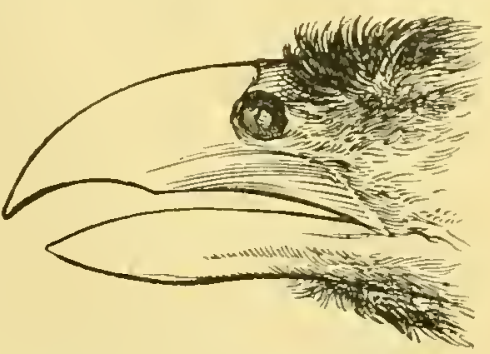

TAlegallus. (After Swainson.) its bill that it was a Bird-of-Prey, and called it the "Nerr-Holland Vulture."

BUDJERIGAR (spelling doubtful) a corruption of Betcherrygah, given by Gould as the native name of the pretty little Australian Parrakeet, Melopsittacus undulatus, that is now so favourite a cage-bircl. Its name has of late been still further corrupted into Beauregard!

BUFFLE-HEAD (i.e. Buffalo-head) a North-American species of Duck, Clangula albeola, allied to the GoLDEN-EYE.

BULBUL, from the Arabic through the Persian, in the poetry of which langnage it plays a great part, and is generally rendered "Nightingale" by translators, and rightly so according to Blyth (Culcuttc lieview, No. lv. March 1857, p. 153), who says that it "is a species of true Nightingale." In this case it is probably that named Duulius hafizi, in hononr of the great Persian poet. ${ }^{\text {I }}$ But whatever may have been originally intended, and Tule says

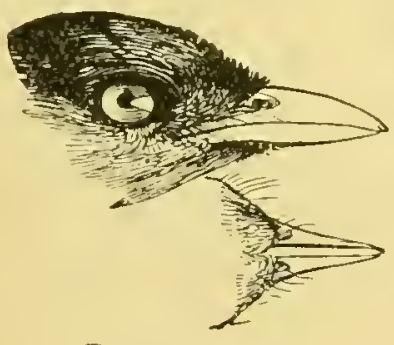

Prcionotus.

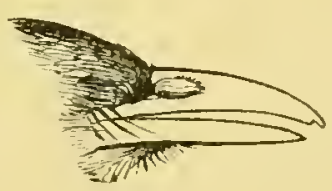

Molpastes.

(After Swainson.)

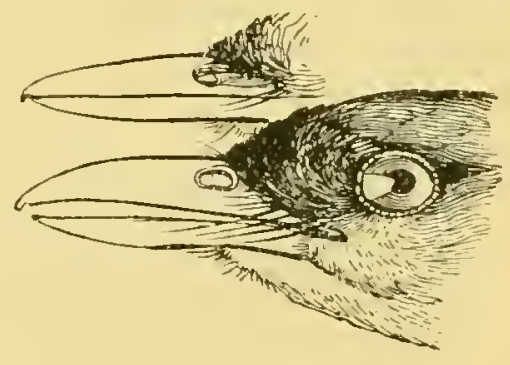

Phyllostrephis.

(Holson-Jobson) that the name is derived from the bird's note, the word has for a good many years been applied by AngloIndians to varions species, all or nearly all of which belong to a group Ixida (otherwise Brachypodida, so-called from their short legs), and usually referred to the ill-defined "Family" Timelidex. Of this group the latest anthority, Mr. Oates (Funn. Br. India, Birds,

${ }^{1} C_{f}$. Blanford, Zool. and Geol. Persia, p. 169, pl. x. fig. 2 ; and Dresser, Ibis, 1875, p. 338 . 
i. pp. 253,254), makes sixteen genera, one of them, Molpastes, being that which he considers to contain what may be called the genuine Bulbuls, formerly included in the genus Pycnonotus, but since separated therefrom, on characters, however, which seem to be of the slightest. No fewer than nine species are now recognized as inhabiting varions parts of the Indian Empire and Ceylon, that found in Bengal and to the northward, $M$. pygaus or bengalensis, being perhaps the best known, but Madras, the Punjab, Burma, and Tenasserin have each its own form or species. They are said to be familiar garden-birds, and are usually common, going about in pairs with a melodions chirping.

BULLFINCH, doubtless so called from the thickness of its head and neck, when compared with other members of the Family Fringillida (FINCH), to which it belongs-the familiar bird, Pyrrhula europara, which hardly needs description. The varied plumage of the cock-his bright red breast and his grey back, set off by his coalblack head and quills-is naturally attractive; while the facility with which he is tamed, and his engaging disposition in confinement, make him a popular cage-bird,-to say nothing of the fact (which in the opinion of so many adds to his charms) of his readily learning to "pipe" a tune, or some bars of one, though this perversion of his natural notes is hardly agreeable to the ormithologist. By gardeners the Bullfinch has long been regarded as a deadly enemy, from its undoubted destruction of the buds of fruit-trees in spring-time, though whether the destruction is really so much of a detriment is by no means undoubted. Northern and Eastern Europe is inhabited by a larger form, $P$. major, which differs in nothing but size and more vivid tints from that which is common in the British Isles and Western Europe. A very distinct species, $P$. murina, remarkable for its dull coloration, is peculiar to the Azores, and several others are found in Asia from the Himalayas to Japan. More recently a Bullfinch, P. cassini, has been discovered in Alaska, being the first recognition of this genus in the New World. (Cf. Stejneger, Proc. U.S. Nat. Mus. 18s7, pp. 103-110.)

BULLHEAD and BULLSEYE, names applied chiefly in Ireland and North America to the Golden and Grey PLovers; but the former also given locally to the GOLDEN-EYE.

BUNTING, Old English "Buntyle," Scottish "Buntlin," a word of uncertain origin, ${ }^{1}$ properly the common English name of the bird

1 Prof. Skeat (Etymol. Dict.) has suggested a connexion with the old verb, still extant as a dialectic form, bunten $=$ to butt; but this is not very apparent. He has also cited the Scottish word buntin = short and thick, or plump, which, however, seems as likely to have been derived from the bird, for the clumsy 
called by Linnseus Emberiza miliaria, but now used in a general sense for all members of the Family Emberizida, which are closely allied to the Fringillida (FINCH). The Buntings generally may be outwardly distinguished from the Finches by their angular gape, the posterior portion of which is greatly deflected; and most of the Old-World forms, together with some of those of the New World, have a bony knob on the palate-a swollen out growtl of the dentary edges of the bill. Correlated with this peculiarity the maxilla usually has the tomia sinuated, and is generally concave, and smaller and narrower than the mandible, which is also concave to receive the palatal knob. In most other respects the Buntings greatly resemble the Finches, but their eggs are generally distinguishable by the irregular hair-like markings on the shell. In the British Islands by far the commonest species of Bunting is the Yellow HAaner, E. citrinella, but the true Bunting (or Corn-Bunting, or Bunting-Lark, as it is called in some districts) is a very well known bird, while the Reed-Bunting, E. schoniclus, frequents marshy soils almost to the exclusion of the two former. In certain localities in the south of England the Cirl-Bunting, $E$. cirlus, is also a resident; and in winter vast Hocks of the SnowBunting, Plectrophanes nivalis, at once recognizable by its pointed wings and elongated hind-claws, resort to our shores and open grounds. This last breeds sparingly on the highest mountains of Scotland, the fact being placed beyond doubt by the discovery of a nest and young in 1886 by Messrs. B. N. Peach and L. N. Hinxman, as briefly recorded soon after by Mr. Harvie-Brown (Zoologist, 1886, p. 336), and with full details in the Vertebrate Fauna of Sutherland by that gentleman and Mr. Buckley (pp. $138-143$, pl.); but the flocks which visit us come from northern regions, for it is a species which in summer inhabits the whole circumpolar area. The OrTolas, E. hortulana, so highly prized for its delicate flavour, occasionally appears in England, but this island lies outside its proper range. On the continent of Europe, in Africa, and throughout Asia, many other species are found, while in America the number belonging to the Family cannot at present be computed. As already stated, the beautiful and melodious Cardinal, Cardinatis virginianus, often called the Virginian Nightingale, probably has to be included in this Family, but doubts exist as to the BoBOLINK, though it is commonly known as the RiceBunting. Whether any species of Emberizida inhabit the Australian Region is yet to be proved; but it would seem possible that several genera of Australian birds hitherto classed with the Fringillidx may have to be assigned to the Emberizidx.

figure of the true Bunting is very evident to any observer. Any connexion with the German bunt or the Dutch bonte (= pied or variegated) is said to be most uniikely. 
BURROW-DUCK, a common local name of the SHELD-DRAKE.

BUSTARD (corrupted from the Latin Avis tarda, though the application of the epithet ${ }^{1}$ is not easily understood), the largest British land-fowl, and the Otis tarda of Linnæus, which formerly frequented the champaign parts of Great Britain from East Lothian to Dorset, but of which the native race is now extirpated. Its existence in the northern locality just named rests upon Sibbald's authority (circa 1684), and though Hector Boethius (1526) unmistakably described it as an inhabitant of the Merse, no later writer than the former has adduced any evidence in favour of its Scottish domicile. The last examples of the native race were probably two killed in 1838 near Swaffham, in Norfolk, a district in which for some years previously a few hen-birds of the species, the remnant of a plentiful stock, had maintained their existence, though no cock-bird had latterly been known to bear them company. In Suffolk, where the neighbourhood of Icklingham formed its chief hannt, an end came to the race in 1832; on the wolds of Yorkshire about 1826, or perhaps a little later; and on those of Lincolnshire about the same time. Of Wiltshire, Montagu, writing in 1813, says that none had been seen in their favourite haunts on Salisbury Plain for the last two or three years. In Dorset there is no evidence of an indigenous example having occurred since that date, nor in Hampshire nor Sussex within the present century. From other English counties, as Cambridgeshire, Hertfordshire, and Berkshire, it disappeared without note being taken of the event, and the direct cause or causes of its extermination can only be inferred from what, on testimony cited by Mr. Stevenson (Birds of Norfolk, ii. pp. 1-42), is known to have led to the same result in Norfolk and Suffolk. In the latter the extension of plantations rendered the country unfitted for a bird whose shy nature could not brook the growth of covert that might shelter a foe, and in the former the introduction of improved agricultural implements, notably the corn-drill and the horse-hoe, led to the discovery and generally the destruction of every nest, for the bird's chosen breeding-place was in wide fields- "brecks," as they are locally called,- - of winter-corn. Since the extirpation of the native race the Bustard is known to Great Britain only by occasional wanderers, straying most likely from the open country of Champagne or Saxony, and occurring in one part or another of the United Kingdom some two or three times every three or four years, and chiefly in midwinter.

An adult male will measure nearly four feet from the tip of the bill to the end of the tail, and its wings have an expanse of

1 It may be open to doubt whether tarda is here an adjective. Several of the medirval naturalists used it as a substantive. 
eight feet or more-its weight varying (possibly through age) from 22 to 32 pounds. This last was that of one which occurred

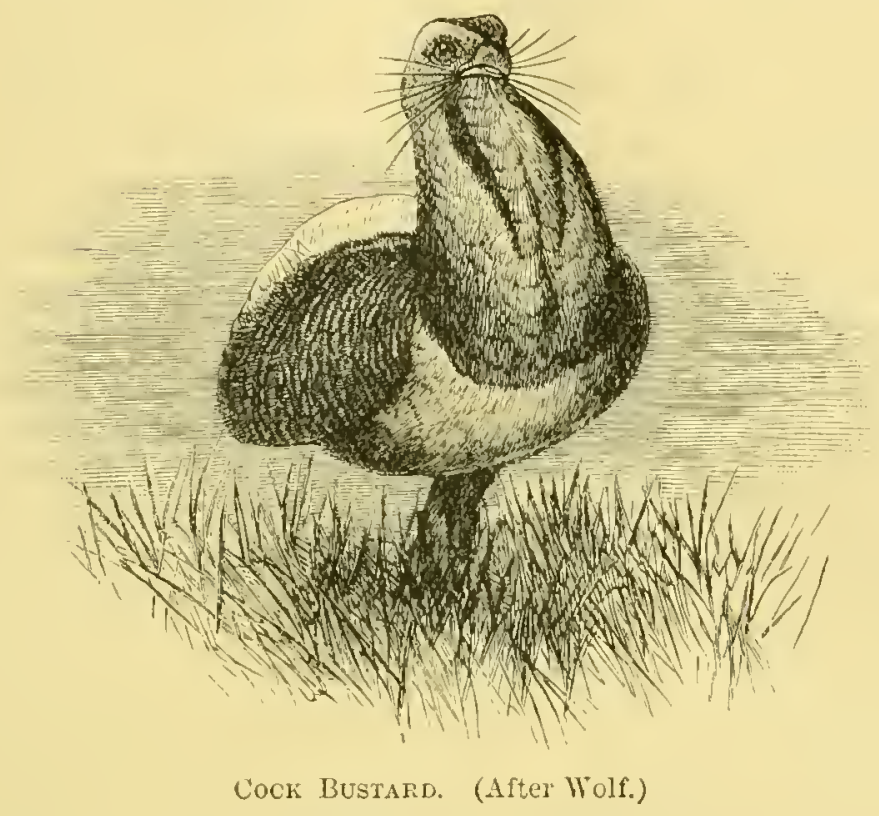

to the younger Naumann, the best biographer of the bird (Fogel Deutschlands, vii. pp. 12-51), who, however, stated in $183 t$ that

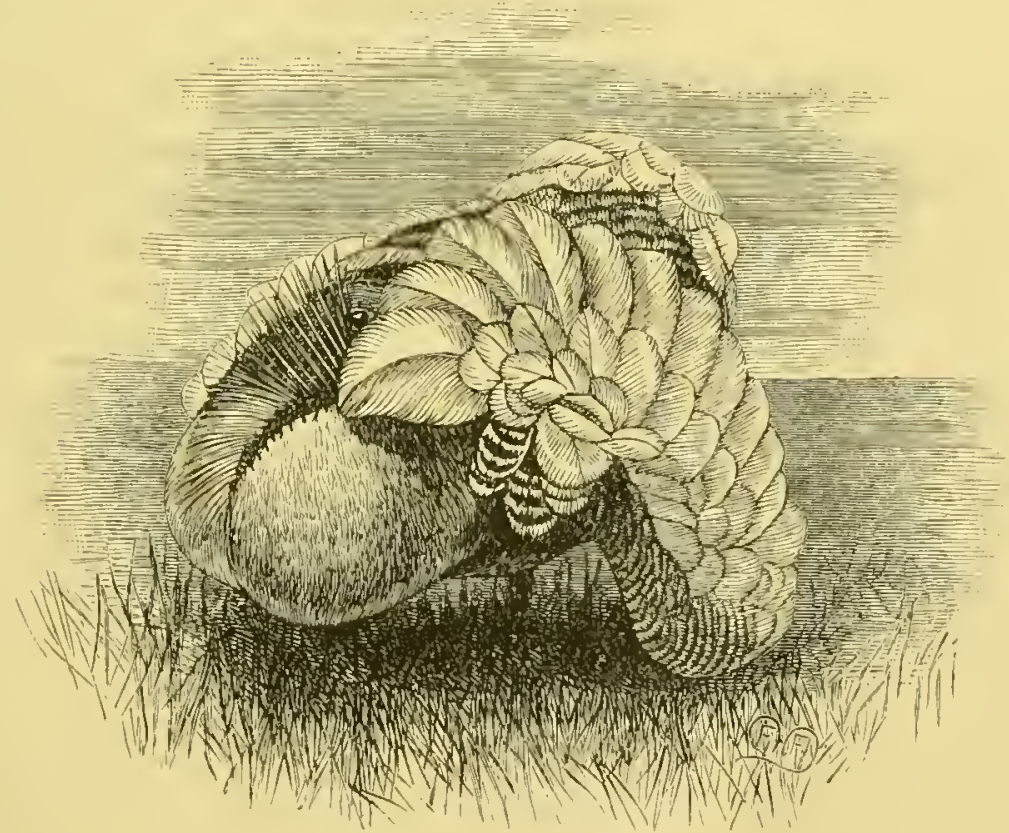

Cock Bustard. (After Wolf.)

he was assured of the former existence of examples which had weighed from 35 to $3 S$ pounds. The female is considerably smaller. Compared with most other birds frequenting open places 
the Bustard has disproportionately short legs, yet the bulk of its body renders it a conspicuous and stately object, and when on the wing, to which it readily takes, its flight is not inferior in majesty to that of an Eagle. The bill is of moderate length, but, owing to the exceedingly flat head of the bird, appears longer than it really is. The neck, especially of the male in the breeding-season, is thick, as shewn in the first figure, and the tail, in the same sex at that time of year, is generally carried in an upright position, being, however, in the paroxysms of courtship turned forwards, while the head and neck are simultaneously retracted along the back, the wings are lowered, and their slorter feathers erected. In this posture, which has been admirably portrayed by Mr. Wolf (Zool. Sketches, pl. 45), the bird presents, as will be seen by the second figure, a very strange appearance, for the tail, head, and neck are almost buried amid the upstanding feathers before named, and the breasts are protruded to a remarkable extent. The Bustard is of a pale grey on the neck and white beneath, but the back is beautifully barred with russet and black, while in the male, at the height of the breeding-season, a band of deep tawny-brown-in some examples approaching a claret-colour-descends from either shoulder and forms a broad gorget on the breast. The secondaries and greater wing-coverts are white, contrasting vividly, as the bird flies, with the black primaries. Both sexes have the ear-coverts somewhat elongated - whence doubtless is derived the name Otis (Gr. $\omega * i s$ ) - and the male is adorned with a tuft of long, white, bristly plumes, springing from each side of the base of the mandible. The food of the Bustard consists of almost any of the plants natural to the open country it loves, but in winter it will readily forage on those which are grown by man, and especially coleseed and similar green crops. To this vegetable diet much animal matter is added when occasion offers, and from an eartliworm to a field-mouse little that lives and moves seems to come amiss to its appetite.

Though not many birds have had more written about them than the Bustard, much remains to be determined with regard to its economy. A moot point, which will most likely always remain undecided, is whether the British race was migratory or not, though that such is the habit of the species in most parts of the European continent is beyond dispute. Equally uncertain as yet is the question whether it is polygamous or not-the evidence being perhaps in favour of its having that nature. But one of the most singular properties of the bird is the presence in somie of the fully-grown males of a pouch or gular sack, opening under the tongue. This extraordinary feature, first discovered by James Douglas, a Scotch physician, and made known by Albin 
in 1740 , though its existence was hinted by Sir Thomas Browne sixty years before, if not by the Emperor Frederick II, has been found wanting in examples that, from the exhibition of all the outward marks of virility, were believed to be thoroughly mature; and as to its function and mode of development judgment had best be suspended, with the understanding that the old supposition of its serving as a receptacle whence the bird might supply itself or its companions with water in dry places must be deemed to be wholly untenable. The structure of this pouch - the existence of which in some examples has been well established-is, however, variable; and though there is reason to believe that in one form or another it is common in the breeding-season to several species of the Family Otidide, it would seem to be as inconstant in its occurrence as in its capacity. As might be expected, this remarkable feature has attracted a good deal of attention (Journ. für Ornith. 1861, p. 153; 1862, p. 135 ; Ilis, 1862, p. 107 ; 1865, p. 143 ; Proc. Zool. Soc. 1865 , p. 747 ; 1868, p. 471 ; 1869, p. 140 ; 1874 , p. 471), and the researches of Garrod, the latest investigator of the matter, shew that in an example of the Australian Bustard, Otis australis, examined by him there was, instead of a pouch or sack, simply a highly dilated oesophagus - the distention of which, at the bird's will, produced much the same appearance and effect as that of the undoubted sack found at times in the o. tarda.

The distribution of the Bustards is confined to the Old World - the bird so-called in the Fur-Countries of North America, and thus giving its name to a lake, river, and cape, being the Camada Goose, Bernicla canadensis. In the Palearctic area we have the 0 . tarda already mentioned, extending from Spain to Mesopotamia at least, and from Scania to Morocco, as well as a smaller species, O. tetrax, which often occur's as a straggler in, but was never an inhabitant of, the British Islands. Two species, known indifferently by the name of Houbara (derived from the Arabic), frequent the nuore southern portions of the area. One of them, 0 . houbara, inhabits Mauritania and even some of the Canary Islands, while the other, 0 . macqueeni, though having the more eastern range and reaching India, has several times occurred in North-western Europe, and once even in England. In the east of Siberia the place of 0 . tarda is taken by the nearly-allied, but apparently distinct, O. dyborstivi, which would seem to occur also in Northern China. Africa is the chief stronghold of the Family, nearly a score of wellmarked species being peculiar to that continent, all of which have been by later systematists separated from the gemus Otis. India, too, has three peculiar species, the smaller of which are there known as Floricans, and, like some of their African and one if not both of their European cousins, are remarkable for the ornamental 
plumage they assume at the breeding-season. Neither in Madagascar nor in the Malay Archipelago is there any form of this Family, but Australia possesses one large species already named. From Xenophon's days (Anab. i. 5) to our own, the flesh of Bustards has been esteemed as of the highest flavour. The Bustard has long been protected by the game-laws in Great Britain, but, as will have been seen, to little purpose. A fow attempts have been made to reinstate it as a lenizen of this country, but none on any scale that would ensure success. Many of the older authors considered the Bustards allied to the OsTrich, a most mistaken view, their affinity pointing apparently towards the Cranes in one direction and the Plovers in another. The so called Thick-kneed Bustard is the Stone-CurLew.

BUTCHER-BIRD, a name that seems at one time to have been in general use, though latterly usurped, except locally, by SHrike, which last was probably applied by mistake. The former takes its origin from the bird's habit of impaling its prey on a thorn while eating it, and leaving the remains there to decay. A place suitable for this purpose is often used many times, and, reminding people of a butcher's shambles, induced the English name, as well as the Latin Lanius, conferred, it would appear, by Gesner. The habit is carried out when the bird is liept in confinement, for j.t will then fix its food to the wires of its cage. One species, $L$. excubitor, derives its trivial designation from the use made of it as a sentinel by falconers when catching wild Hawks. The mode employed is well described by Hoy (Mag. Nat. Hist. iv. p. 342), but can be only briefly mentioned here. The Hawk-catcher lies hidden in a hut, watching through a small hole the Butcher-bird, which is tethered some yards off, and by its actions not only gives him notice of the approach of a Birdof-Prey, but also indicates of what lind the stranger is. Thus the sentinel is but slightly troubled at a passing Kite, Eagle, or Buzzard; but beats itself on its perch with screams at the sight of a Harrier, while on the appearance of a Falcon or Sparrow-Hawk it drops with cries of distress into a retreat that has been considerately prepared for it. On this the falconer, by pulling long strings, displays first one and then a second tethered Pigeon, and the instant the Hawk clutches this last, draws a bow-net over both, thus securing his prize.

BUTTON-QUAIL, the Anglo-Indian name for a little bird, Turnix sykesi, and one if not more of its congeners, which, though for a long while confounded with the true QUAILS, really belong to a very distinct group, Turnicidx, and may be more conveniently treated under the title of HEMIPODE.

BUZZARD, a word derived from the Latin Buteo, through the French Busard, and used in a general sense for a large group of 
Diurnal Birds-of-Prey, which contains, anong many others, the species usually known as the Common Buzzard, Buteo vulgaris, of Leach, though the English epithet is nowadays hardly applicable. The name Buzzard, however, belongs quite as rightfully to the biris called in books "HARriers," and by it one of them, the Moor-Buzzard, Circus aruginosus, is still known in such places as it inhabits. "Puttock" is also another name used in some parts of the comutry, but perhaps is rather a synonym of the lite, Mileus ictinus. Though ornithological writers are almost unanimous in distinguishing the Buzzards as a group from the EAGLEs, the grounds usually assigned for

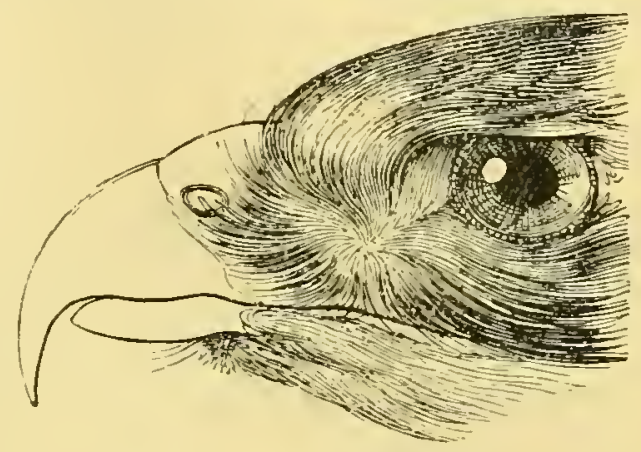

Buzzari! (After Swainson.) their separation are but slight, and the diagnostic character that can be best trusted is probably that in the former, as the figure shews, the bill is decurved from the base, while in the latter it is for about a third of its length straight. The head, too, in the Buzzards is short and round, while in the Eagles it is elongated. In a general way Buzzards are smaller than Eagles, though there are sereral exceptions to this statement, and have their plumage more mottled. Furthermore, most if not all of the Buzzards, about which anything of the kind is with certainty known, assume their adult dress at the first moult, while the Eagles take a longer time to reach maturity. The Buzzards are fine-looking birds, but are slow and heavy of Hight, so that in the old days of falconry they were regarded with infinite scorn, and hence in common English to call a man a "buzzard" is to denounce him as stupid. Their food consists of small mammals, young birds, reptiles, amphibians, and insects-particularly bectles-and thms they never could have been very injurious to the game-preserver, though they have fallen under his ban, if indeed they were not really his friends; but at the present day they are so scarce that in this country their effect, whatever it may be, is inappreciable. Buzzards are found over the whole world with the exception of the Australian Region, and have been split into many genera by systematists. In the British Islands we have two species, one (the H. milguris already mentioned) resident, and now almost confined to a few of the wilder districts; the other the Rough-legged Buzzard, Archibuteo lagopus, an irregular winter-visitant, sometimes arriving in large bands from the north of Europe, and readily distinguishable from the former by being feathered down to the toes. The Hoxer-Buzzard, Pernis apiroms, a summer-visitor from the south, and breeding, or attempting to 
breed, yearly in the New Forest, does not come into the subfamily Buteonina, but is probably the type of a distinct group, Perninx, 1 of which there are other examples in Africa and Asia. The so-called "Turkey-Buzzard" is one of the American Vultures.

\section{C}

$C A E C A$, a pair of blindsacs or lateral dilatations of the gut, marking the beginning of the rectum. When the cxea are large the rectum is shut off from the ilem or small intestine by a valvular sphincter, which allows the frecal matter to ascend from the rectum into the caca, but prevents it from passing back into the ileum. The cæca vary extremely in size in the different groups of Birds; they attain their greatest size in those that are herbivorous, are small or hardly functional in most that live on animal food, and are altogether absent in fruit- and grain-eaters. There are, however, so many exceptions to this broad generalisation, that an enumeration is advisable, especially since a certain taxonomic value cannot be denied to these organs.

It is highly probable that originally all Birds possessed cæca, and that, according to the diet, these were either further developed or reduced in size or even lost ultimately. Hence the mere presence of crea in a bird is of less taxonomic value than their state of development; they are either functional, or without function; their absence is only the last step of their degeneration.

1. The cæca are large and of great functional importance in Struthio, Rhea, Apteryx, Crypturi, Gallinæ, Pteroclidæ, Grallæ, and Anseres, i.e. in birds which are chiefly herbivorous; also in many worm-eating Limicoli, for instance in the Avoset, Lapwing, Ringed Plover, Edicnemus, Thinocorys, Attagis, and the Cornclake ; lastly in the Owls, Nightjars, Rollers, Bee-eaters, and Cuckoos, i.e. birds which, with the exception of the first group, are strictly insectivorons.

2. The cæea are distinctly functional, but comparatively short, in Casuarius, Dromæus, Grus, Tumix, many Anatida (vegetableeaters with a great predilection for animal food), Limicolse and Rallidx, like the Golden Plover, Numenius, Totanus, Gallinago, Chionis, Porphyrio, Porzana; the piscivorous Spheniscidre, Pelicanus, Podicipes, Uria, Colymbus; Merops, and Phœnicopterus.

3. The cæca are quite degenerated and functionless, being either (a) reduced to small wartlike or vermiform appendages, as in some Spheniscidx, Herodii, Pelargi, Steganopodes, Laridæ, Strep-

1 The name Pernis was given in 1817 by Cuvier (Rigne Anim. i. p. 322), who said it was used by Aristotle; but the latter lias only rtépv's (Hist. Anim. ix. 36). 
silas, Limosa, Scolopax, Parla, Rhinochetus, many Columbr, Accipitres, and Passeres; or (b) they are entirely absent, as in many Columbe, Psittaci, Musophaga, Corythaix, Pici, Alcedinidæ, Bucerotidæ, Upupidie, Colius, Cypselidæe, and Trochilidæ.

4. Sometimes one crecum remains in a rudimentary condition and the other one has disappeared; this is the rule in almost all Herodii and in Procellaria, but occasionally met with in Steganopodes, Podicipes, Strepsilas, and in Atrichia.

The greatest development of the crea occurs in Struthio, Rhea, Tinamus, and Meleagris, their aggregate volume equalling or even surpassing that of the rest of the intestinal canal, the creca in these cases, especially in Ratitr, shewing numerous transverse constrictions and sacculations, which increase the absorbing surface.

A certain correlation exists between the ceca and the length and width of the rectum.

The examples enumerated above seem to shew that crea are not required for the cligestion of meat, fruit, and grain. Fish-eating Ducks have considerably shorter crea than their strictly regetarian relations; the same remark applies to those Waders which live upon mollusks and other soft-bodied invertebrates. On the other hand, the well-developed creca of Coracias, Caprimulgus, Merops, Cuculus, and those of the likewise inseetivorous Todies and Bee-eaters, make it not improbable that in the crea not only cellulosis (as in Mammalia) but also chitine is digested.

Lastly, the presence or absence of the caca being thus explained by the food, a clew will occasionally be afforded to the systematic position of birds in whicl they appear against reasonable expectation. It is clear that change of diet may be accomplished in a much shorter time than it takes to modify the various digestive organs. For instance, the exclusive meat-diet of the Birds-of-Prey has reduced their ciea to mere rudiments, and it is more than improbable that the insectivorous habits of many of the smaller Filconidse will ever redevelop these organs, especially since these birds throw out the indigestible parts in pellets. Owls now cannot be distinguished from Diurnal Birds-of-Prey by their diet; they possess large cæca, and cannot therefore be derived from the Accipitres, which have lost them, nor is it probable that Owls and Accipitres came from one common stock and are collateral branches, because in this case both would be of equal age, and we should have to assume that the meatdiet had in one branch suppressed and in the other branch preserved or even increased the crea. We can only conclude that the Owls are descendants of a stock of birds which, like the Nightjars, lived on chitinous insects (Beetles, Moths), and that they, like Podargus, as shown by its predilection for mice, comparatively recently took to the flesh of vertebrates.

As might be expected, the members of any large and much 
diversified group of birds, like Waders, Pigeons, Spheniscidie, and others, have cxea in varions stages of development, but it would be a hopeless attempt to explain this dirersity in particular instances by reference to the preponderance of animal over vegetable diet, of which in wild birds we know so rery little.

CALANDER ("Chalaundre" and "Chelaundre," Chancer, Romant of the Rose), Fr. Culduedre, and Ital. Cutumlice, both from the Latin culiemdm (a head-dress of false hair), a speeies of LARK, the Aloude culantro of Linnens, and the Hetenuroryphes cutendice of later writers, described by Willughlyy after Olina, and figured by Edwards (Gloenings, pl. 268) as coming from Carolina, a curions mistake, for the birk is not Ameriean, but a well-known inhabitant of Europe, though no proof of its oceurrence in Britain las been given. It may easily be recognized by its Jarge size, thick bill, and interrupted black collar.

CALAO, the name under which some old writers wrote of the Horsillas; generally adopted for them in Freneh, and found also in scientifie nomenclature.

CALAW or CALLOO-generally followed by "Duek" - a shetland name of the Long-tailed Durci.

CALICO-BIRD, one of the many names given to the TurxsTONE on the east eoast of North Ameriea (Trumbull, Trmes and Porti. of B. p. 186).

CAMPEPHAGA (Citerpillar-eater), the seientific name of a genus of birds bestowerl by Vieillot, and anglified by Gonld for

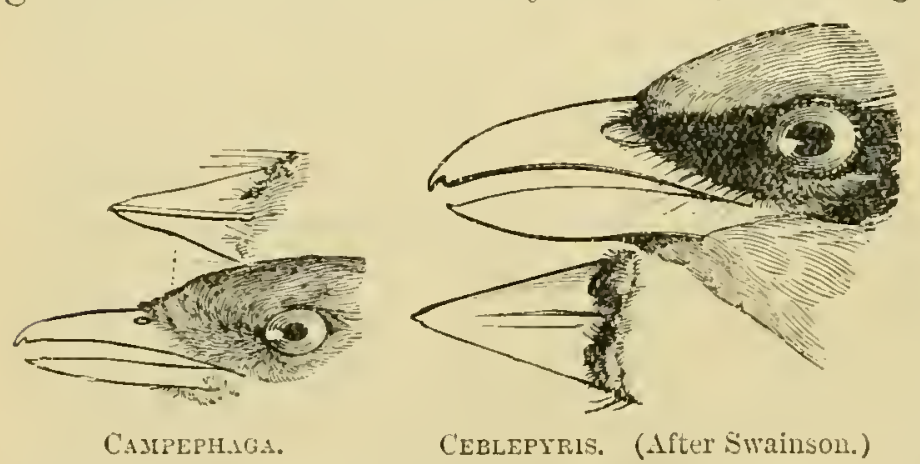
certain Australian forms, which, if notbelonging to the Luniidex (SHRLKE), are aplarently intermediate between that Family and the Contidie (Crow). By some whiters they are regarded as a separate group, Cumpephagillax, to which are attached several other forms that inhabit not only Anstralia, but the Indian and Ethiopian Regions. This view will very likely prove eorrect; but it wonld be at present premature to trace the limits of the gronp, of which celdepyris may be an extreme eximple. One of their tharacteristies is the stiffened shaft of the rump-feathers, so as to feel spinons to the tonch ( $f$. also Oxrsotus).

CANARI-BIRD, a FINCH so-called from the islands whenee it was alparentiy first brought, the Fringille cancria of Linneus, and 
Serinus camarius of modern writers, which has long been the commonest of cage-birds throughout the rorld. It abounds not only in the islands whence it has its name, but in the neighbouring groups of the Madeiras and Azores. It seems to have been imported into Europe very early in the sixteenth century. Turner in 1.544 speaks of the birds "quas Anglia aues canarias nocat"; a statement confirmed by the poet Gascoigne, who died in 157\%, and speals (Complaint of Philomene, 1. 33) of "Canara byrds." Gesner had not seen one in 1555, but he gave an account of it (Omithol. p. 234), communicated to him by Raphael Seiler of Augsburg, monder the name of Suckeruögele. The wild stock is of an olive-green, mottled with dark brown, above, and greenish-yellow beneath. All the bright-hned examples we now see in captivity have been induced by carefully breeding from any chance varieties that have shewn themselves; and not only the colour, but the build and stature of the bird have in this manner been greatly molified. The change miust have begun early, for Hermandez, who died in 158\%, described the bird (Hist. Anim. Nor. Hisp. cap. xxviii. p. 20) as being wholly yellow (tota lutea) except the end of its wings. ${ }^{1}$ Of late the ingenuity of "the fancy," which might seem to have exhausted itself in the production of topknots, feathered feet, and so forth, has brought about a still further change from the original type. It has been found that by a particular treatment, in which the mixing of large quantities of carenne-pepper with the food plays an important part, the ordinary "canary yellow" may be intensified so as to verge upon a more or less brilliant flame culour. Birds which have successfully undergone this forcing process, and are hence called "hot canaries," command a rery high price, for a large proportion die under the discipline, though it is said that they soon become exceedingly fond of the exciting condiment. But it is impossible here to treat of this species in its domesticated state. A small library of books has been written on the subject."

Very nearly resembling the Canary-bird, but smaller in size, is the SERIN, Serimus hortulanus, a species which not long since was very local in Europe, and chiefly known to inhabit the countries bordering on the Nediterranean. It has of iate years pushed its way towards the north, and has even been serelal times taken in England (Yarrell's Brit. Birds, ed. 4, ii. pp. 111-116). A closely allied species, $S$. cunonicus, is peculiar to Palestine.

In many different parts of the world the word "Canary" is

1 This book was not published till 1631, and of course there is a possibility of the passage being an interpolation, but I know no reason to suspect it.

2 Those most to be commended are perhaps The Canary Book by Robert L. Wallace, Canaries and Cayc Birds by W. A. Blackston, and of course Darwin's Animals and Plants under Domestication (i. P. 295). An excellent monograph of the wild bird is that by Dr. Carl Bolle (Joum. für Om. 185s, pl. 125-151). 
applied to almost any small bird that is yellow, and not mufrequently to some that are not. Thus in the Antilles the name is given to certain species of Dendrece (Warbler), in the Cape Colony to Serimus canicollis, the "Cape Canary," and some of the Ploceida (WEAver-BIRD), ${ }^{1}$ in New Zealand to the Clitonyx achrocephala, while in some districts of Australia the BUDJERIGAR is known as the "Canary-Parrot."

CANVAS.BACK, generally with the addition of "Duck," the Anas vallisneria of Wilson, Fuligula or Ethyia vallisneriana of modern ornithology, the North-American bird so famous for its delicate flavour-nearly allied to the PocHARD.

CAPERCALLY or CAPERCAILLIE, a word commonly derived from the Gaelic Capull, a horse (or, more properly, a mare), and Coille, the genitive of coll, a wood; but with greater likelihood, according to the opinion with which I was favoured by Dr. M'Lauchlan, from Cabher, an old man (and, by metaphor, an old bird), and Coille-the name of the largest species of Tetraonida (Grouse), Tetrao urogallus, which was formerly indigenous to the north of England, to Scotland, and to Ireland. The word is frequently spelt otherwise, as Capercalze and Capercailzie (the $z$, a letter unknown in Gaelic, being pronounced like $y$ ), and the English name of Wood-Grouse or Cock-of-the-wood has been often applied to the same bird. The earliest notice of it as an inhabitant of North Britain seems to be by Hector Boetlius, whose works were published in 1526, and it can then be traced through various Scottish writers, though to them it was evidently but little known, for about 200 years, or may be more. ${ }^{2}$ However, Bishop Lesly, in 1578, assigned a clefinite habitat to it:-_In Rossia quoque Louquhabria [Lochaber], atque aliis montanis locis" (De Origine Moribus et rebus gestis Scotorum. Romæ: ed. 1675, p. 24). Taylor, the water-poet, in his Visit to the Brea of Marr (Works, London: 1630, p. 135) mentions, "caperkellies" among the meats provided for the guests of Lord Erskine in 1618; and The Black Book of Taymouth tells (pp. 433, 434) of one that was sent in 1651 by the laird of Glenorchy to King Charles II, who, being then at Perth, "accepted it weel as a raretie, for he had never seen any of them." Pennant, during his first tour in Scotland, found that it was then (1769) still to be met with in Glen Moriston and in the Chisholm's country, whence he saw a cock-bird. We may infer that it became extinct about that time, since Robert Gray (Birds of the West of Scotland, p. 229) quotes the Rev. John Grant

1 A species of Laniarius, one of the SHrikes, credited with preying upon some of these little birds, is known as Canaricbyter (Layard, E. S. Afr. p. 164).

2 For particulars the reader is referred to $\mathrm{Mr}$. Harvic-Brown's careful volume The Capercaillic in Scotland (Edinburgh : 1879). 
as writing in $1794:-$ "The last seen in Scotland was in the woods of Strathglass about thirty-two years ago." I Of its existence in Ireland we have scarcely more details. If we may credit the Pavones syluestres of Giraldus Cambrensis with being of this species, it was once abundant there, and Willughby (1678) was told that it was known in that kingdom as the "Cock-of-the-wood." A few other writers mention it by the same name, and Rutty, in 1772, says (Nat. Hist. Dublin, i. p. 302) that "one was seen in the county of Leitrim about the year 1710, but they have entirely disappeared of late, by reason of the destruction of our woods." Pennant also states that about 1760 a few were to be found about Thomastown in Tipperary, but no later evidence is forthcoming, and thus it would seem that the species was exterminated at nearly the same period both in Ireland and Scotland.

That the Cock-of-the-wood once inhabited England is a discovery of recent date. It is stated in The Zoologist for 1879 (p. 468) that its bones had been found among Roman remains at Settle in Yorkshire, though the authority for their determination is not given; but the present writer had the pleasure of receiving from Mr. James Backhouse a considerable number of its bones, some of them unmistakable, found by him in caves that he was investigating in Teesdale, and of confirming the conclusion at which he had already arrived. The remains were those of both sexes, and were sufficiently numerous to shew that the species had been common in the neighbourhood, and had contributed not a little to the food of the people who in a prehistoric age nsed the caves as dwellings.

When the practice of planting was introdnced, the restoration of this fine bird to both countries was attempted. In Ireland the trial, of which some particulars are given by Thompson (B. Freland, ii. p. 32), was made at Glengariff, but it seems to have utterly failed, whereas in Scotland, where it was begun in earnest at Taymonth in 1838, it finally succeeded, and the species is now not only firmly established, but has vastly increased in numbers and range. Lloyd, the well-known author of several excellent works on the wild sports and natural history of Scandinavia, supplied the stock from Sweden, but it must be always borne in mind that the original British race was wholly extinct, and no recent remains of it are lknown to exist in any museum.

This species is widely, though intermittently, distributed on the continent of Europe, from Lapland to the northern parts of Spain, Italy, and Greece, but is always restricted to pine-forests, which

I Yet Stephens in his continuation of Shaw's Genercl Zoology (ix. p. 268), writing in 1819, says that Montagu was present "when one was killed near the upper end of Loch Lomond about thirty-five years since." This would mean that the species survived until about 1784, bnt the incident is not mentioned by Montagu in his own work, and the assertion may be cloubted. 
alone afford it food in winter. Its bones have been found in the kitchen-middens of Demmark, proving that country to have once been clothed with woods of that kind. More lately its remains have been recognized from the cares of Aquitaine. Its eastern or southern limits in Asia cannot be precisely giren, but it certainly inhabits the forests of a great part of Siberia. On the Stannovoi Nountains, however, it is replaced by a distinct though nearly allied species, the $T$. urogalloides of Dr. von Middendorff ${ }^{1}$ which is smaller with a slenderer bill but longer tail.

The Cock-of-the-wood is remarkable for his large size and glossy-black plumage. He is polygamous, and in spring mounts to the topmost bough of a tall tree, whence he challenges all comers by extraordinary sounds and gestures; while the hens, which are much smaller and mottled in colour, timidly abide below the result of the frequent duels, patiently submitting themselves to the victor. While this is going on it is the practice in many countries, though senerally in defiance of the law, for the so-called sportsman stealthily to draw nigh, and with well-aimed rifle to murder the principai performer in the scene. The hen makes an artless nest on the ground, and lays therein from seren to nine or even more eggs. The young are able to fly soon after they are hatched, and towards the end of summer and beginning of autumn, from feeding on the fruit and leaves of the bilberries and other similar plants, which form the undercovert of the forests, get into excellent condition and become good eating. With the first heavy falls of snow they betalie themselves to the trees, and then, feeding on the pine-leaves, their flesh speedily acquires so strong a flarour of turpentine as to be distasteful to most palates. The usual method of pursuing this species on the Continent is by encouraging a trained dog to range the forest and spring the birds, which then perch on the trees: while he is baying at the foot their attention is so much attracted by him that they permit the near approach of his master, who thus obtains a more or less easy shot. A considerable number, howerer, are also snared. Hybrids are very frequently produced between the Capercally and the Black Grouse, T. tetirix, and the offspring has been described by some authors under the name of $T$. medius, as though a clistinct species.

CAPE-SHEEP, a name absurdly given by sailors to the Albatros (Layard, B. S. Afi. p. 363).

CARACARA, a South-American bird, so called by the natives of Brazil, first clescribed and figured by Maregrave (Hist. Nat. Brazil, p. 211). In 1782 it became the Fulco tharus of Molina (Sagg. Stor. Nat. Chiti, 1). 264), and is the Polyborus tharus of

1 Not to be confounded with the bird so mamed previously by Nilsson, which is an hybrid. 
modern ornithologr,- the representative of a small group of birds, which from their Falconine structure and Tulturine habit, to say nothing of certain peculiarities, might be not unfitly regarded as forming a distinct Family. Three genera, Ryyter which is arboreal, Miliago which is not, ant Polyborus proper are usually admitted: but Mr. Sharpe (Cut. Li. Br. Mus. i. p. 3t) mites the first two, though as the figures here giren shew, their bills are rery differently formed, while he places as of equal rank in the same sub-

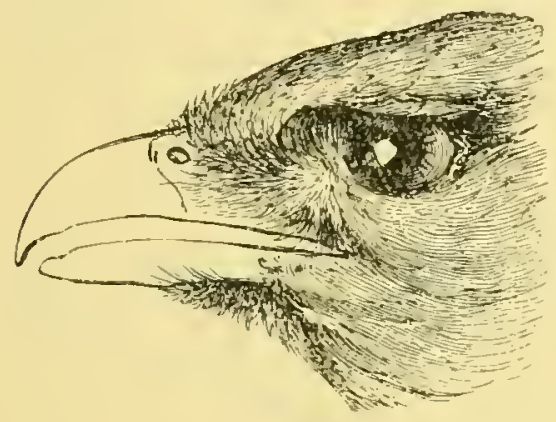

MiLVAGo.

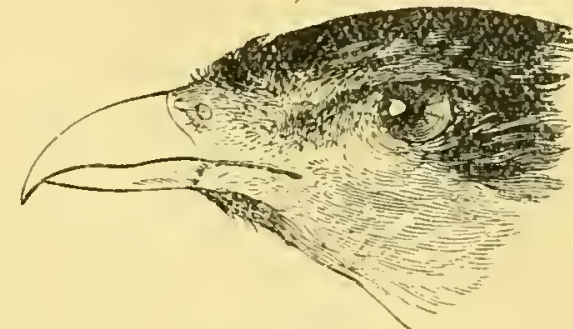

IBTCTER.

(After Swainson,)

family Curiame (SEREaA) and Serpenturius (SECRETARY-BirD) Mr. Ridgway in a careful monograph of the group) (Bull. Geol. Geort. Sure. Temit. No. 6, pp. 451-473, pls. 22-26) regards a fourth genus, Phalcobems, as necessary, and Guney (List. Dium. B. of l'rey, pp. 11-1!) wonld have six genera. These birds, with some others, are the "Carrion-hawks" so frequently mentioned in Darwin's Foyage; but the fullest description of the hatits of those frequenting the southern part of Sonth America is by Mr. W. H. Hudson (Argent. Omithotory, ii. pp, $74-88$ ) under the names of "Chimango" and "Carancho"- - the former belonging to Milvag" and the latter being the species which more to the northward is called "Caracara," namely Polyborns thums. Still further northward, extending thronghout Guiana and thence to Ecuador, as well as to Central America, California, and the Crulf States of North America, besides Cuba, a form is found now recognized by many as a distinct species under the name of $P$. cheriway or $P$. auduboni-the last being applied especially to examples from the norther'n sicle of the Gulf of Mexico; while the Guadelupe Islands on the coast of Lower California possess what is deemed by Mr. Fidgway (ut suprit) to be a third species, $P$, lutosus. All the members of this group are said to walk or lun on the grounda peculiarity not possessed in perfection by any of the other Falconine birds with which they are generally associated. It is worthy of remark that, according to Mr. Hudson (ut suprit), since the introduction of large herds of cattle to the plains of Sonth America the abundance of food supplied by their carcases has produced a great increase in the numbers of these birds. 
CARDINAL, the name given in different parts of the world to various birds from their scarlet plumage, but perhaps originally to the North-American Loxia cardinalis of Linnæus, the Cardinalis virginianus of modern authors, a beautiful and favourite cage-bird, which, according to Parker, is one of the Emberizida (Bunting). It is also known as the "Virginian Nightingale" and "Red Bird." In the United States it does not usually occur to the northward of lat. $40^{\circ}$; but it is common in and one of the most characteristic birds of Bermuda. Other birds on which the name "Cardinal" has been bestowed belong to the Finches, TANAGERS, and WEAverBIRDS.

\section{CARIAMA, see SERIEMA.}

CARINAT $F$, that division of the Class Aves possessing a "keel" (carina) to the sternum, and accordingly so named by Merrem in 1812 (Ablandl. Akad. Wissensch. Berlin, 1812-13, Physil. Kil. p. 238); but generally orerlooked by systematists until prominently brought forward by Prof. Huxley (Proc. Zool. Soc. 1867, p. 418) as one of the three "Order's" recognized by him, and in the present work regarded as forming a Subclass (see INTRODUCTION). It may here be observed, however, that among the Carinatx are to be included a few forms such as Cnemionis (CEREOPSIS), Didus (DODO), and Strigops (KAKAPO), in which the keel of the sternum is nearly or wholly wanting, presumably through disuse of their volant powers.

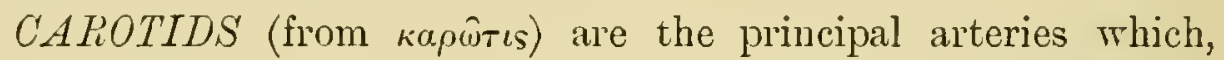
arising from the brachiocephalic arteries, ascend the neck and supply the head. They exhibit several modifications which have been investigated chiefly by Nitzsch and by Garrod; but their taxonomic value is limited. They shew the following seven arrangements :-

1. The right and the left carotids converge towards the middle line and run side by side (or the left covering the right) in a furrow along the ventral surface of the cervical vertebrs. This is their normal and original condition, and is found in the majority of Birds.

2. The two carotids fuse into one, for the greater length of the neck; this "carotis conjuncta" is generally imbedded in a special median osseous canal formed by the rertebrr; the right and left root or basal portions are both functional, although one of them is sometimes weaker, as in.Herodii, Phœnicopterus, and some OldWorld Parrots.

3. There is one carotis conjuncta, but the right root, i.e. the basal portion of the original right carotis, has been obliterated. The artery is a so-called "carotis primaria sinistra." Such "Aves lov" carotidina" (Garrod) are very frequent, e.g. Rhea and Apteryx among 
the Ratitx, Podicipes, several Steganopodes, Alca, Otis, Turnix, Megapodiida, some Old-IVorld Psittaci, Merops, Buceros, Upupa, Trogronidie, Cypselidie, Colius, all the Pici and Passeres.

4. One carotis conjuncta, but the right root alone is present, the left being obliterated. "This carotis primaria dextra" is likewise deeply lodged, as in the 2nd and 3rd cases, and has hitherto been observed only in Eupodotis.

In the following three cases, one or two collateral and superficially-placed arteries take the place of one or both deep carotids.

5. A carotis primaria s. profunda dextra coexists with a carotis superficialis s. collateralis sinistra. All the American and a few Old-World Parrots are such "Aves bicurotidina abnormales" (Garrod).

6. Two superficial carotids, a right and left, are present, the deep or primary ressels being entirely obliterated. Hitherto only

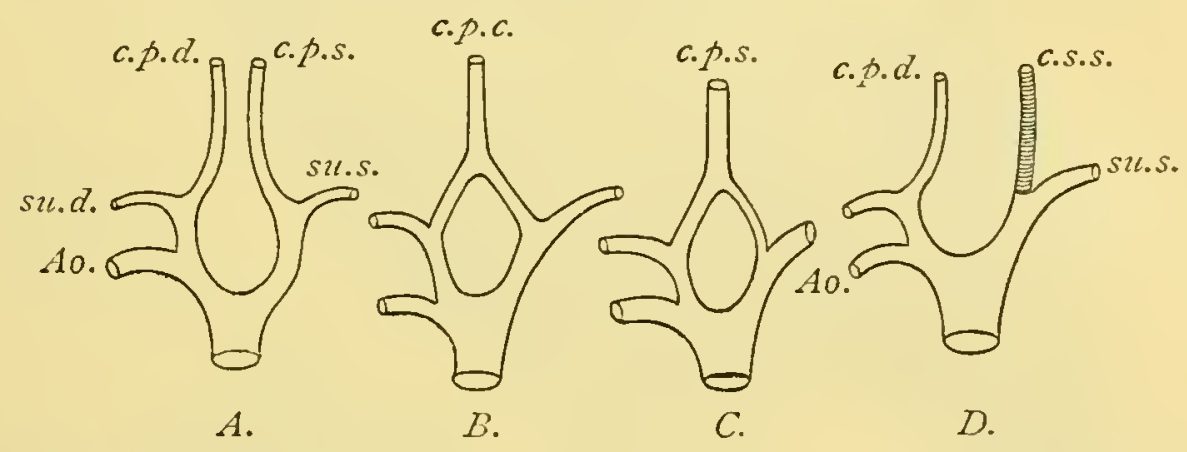

Diaoramatic Representation of some of the Vapiations of the Carotid Arteries.

Aa. Aorta; su.d. A. subclavia lextra; su.s. A. subclavia sinistia; c.n.d. A. carotis profunda dextra; c.p.s. A. carotis profumda sinistra; c.p.c. A. carotis profunda conjuncta; c.s.s. A. carotis superficialis sinistra.

$A$. normal condition, two separate decp caroticls ; $B$. the two deep carotids fused into one, e.g. Ardea; $C$. the same as $B$, but the root of the left carotid is reducer, c.g. Phonicopterus; $D$. the left deep carotid is lost, but supplanted by a superficial vessel, c.g. certain Psittaci.

observed by Ottley (P.Z.S. 1879, p. 461), as an individual variation of Bucorvus abyssinicus.

7. The only carotis is a c. superficialis sinistra, all the other vessels being lost, observed by Forbes in Orthonyx spinicauda (not in 0 . ochrocephala), this being the only exceptional case of all the Passeres hitherto examined.

It is clear that the 2 nd case is directly referable to the 1 st, that the 3rd and 4th are each independently developed from the 2nd, and that the 5th. 6th, and 7 th cases are recent and very qualified modifications. The undoubtedly independent acquisition of these carotid characters renders them valueless for taxonomic purposes, except within smaller and well-defined groups, e.g. the Parrots (see also Vascular Systen).

CARPUS (adj. carpal), kaptós; the wrist or articulating region between the forearm, or ulna and radius, and the hand. In adult 
birds there are only two separate carpal bones, one radial, on the convex or anterior bend of the wrist, and one nlnar, on the posterior or inner angle. Originally the carpus is composer, as in Reptiles and Mammals, of a greater number of bones, which are also present in the embryos of Birds, but most of them fuse either with each other or with the arljoining metacarpal bones (see SKELETON).

CAPR-CROW or CARR-STALLOW, the mame used in Lincolnshire and perhaps other parts of England for the Black Terix in the days when it inhabited this conntry. The former was written by rillughby-on the authority of his correspondent Johnson-"Scare-crow"

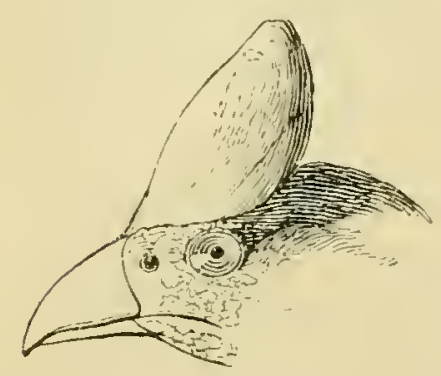

CASHEW-BIRI). (After Swainson.)

CARR-GOOSE, an old name for the Great Crested Greme (Podicipes cristutus).

CASHEW OP CUSHEW-BIRD, so called, according to Edwards (Gleanings, ii. p. I81, pl. 295), from the likeness of the blue knob on its forehead to the cushew or cashew-mut, which is an appendage to the fruit of Anucurdiun occidentule, Limn. The bird is the Paucis guleutu of modern ornithology, one of the Curassows.

CASSOTARY, a corrupted form of the Malayan Suxari (Crawfurd, Grumm. und Dict. Ifalay Language, ii. pp. 1 is and 25), apparently first printed as Casomis by Bontius in 1658 (ITist. nat. et med. Ind. Orient. p. T1).

The Cassowaries (Cusutivida) and Eureus (Dromaida) - as the latter name is now used-have much structural resemblance, and form the Order Megistunes, ${ }^{1}$ whieh is peenliar to the Australian Region. Prof. Huxley has shewn (Proc. Zool. Soc. 1867, pp. 422, 423) that they agree in differing from the other RatiTs in many important characters, into the details of which it is now impossible to enter; but one of the most obvions of them is that each contonrfeather appear's to be double, its lyporhuclis, or AFTERshAFT, being as long as the main shaft-a feature noticed in the case of either form so soon as eximples were bronght to Enrope. The external distinctions of the two families are, however, equally plain. The Cassowaries, when adult, bear a horny helmet on their head, they have some part of the neck bare, generally more or less ornamented with caruncles, and the claw of the inner toe is remarkably elongated. The Emeus have no helmet, their head is feathered, their neck has no carmeles, and their inner toes bear a claw of no singular character. 
The type of the Casucriald is the species named by Linnaus Struthio casuarius and by Lathan Cusuurus emen. Tieillot subsequently called it $C$. quleatus, and his epithet has been very commonly adopted by writers, to the exclusion of the older specific appellation. It seems to be peculiar to the island of Ceram, and was made known to naturalists, as we learn from Clusius, in 1597 ,

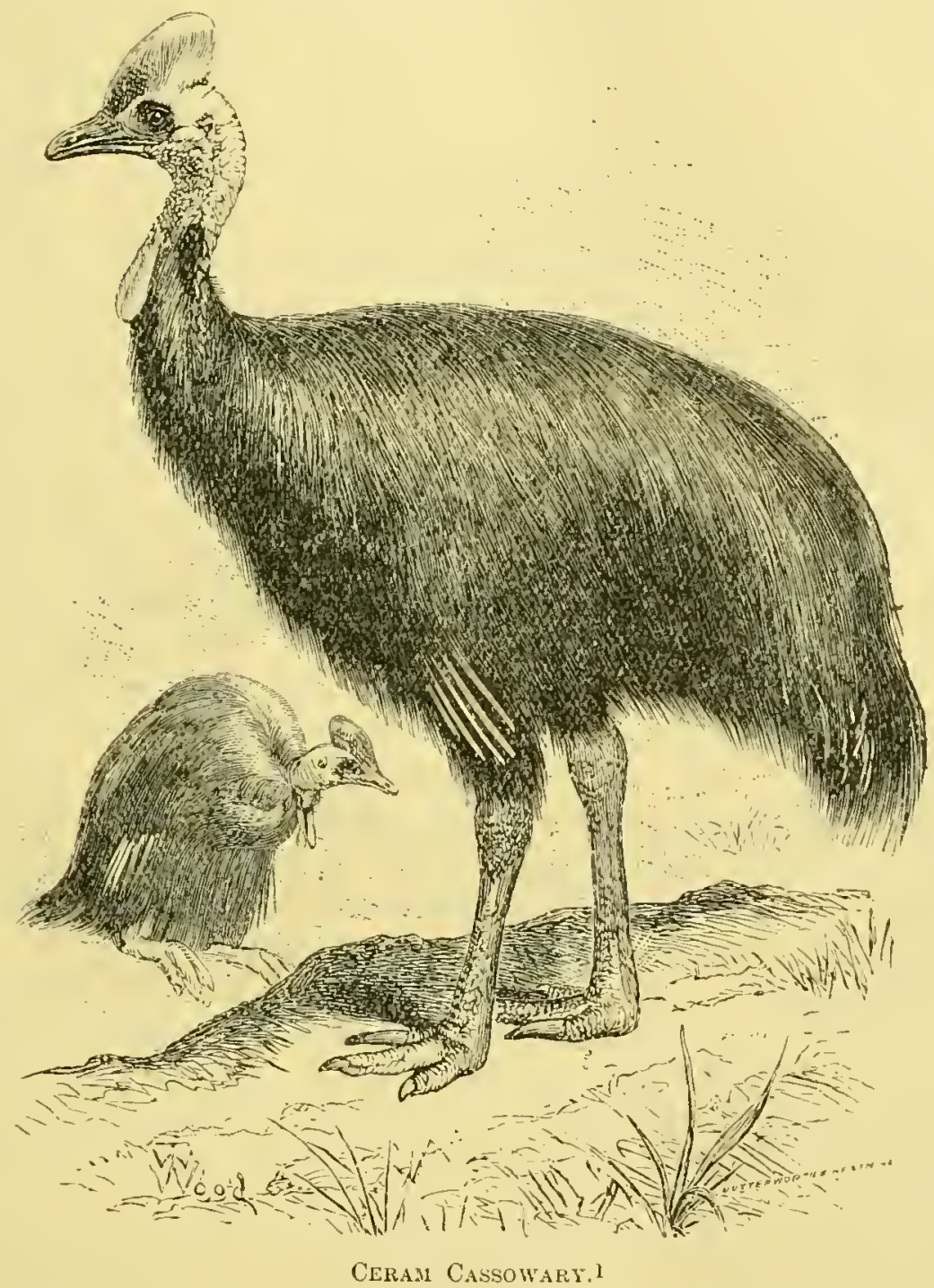

by the first Dutch expedition to the East Indies, when an example was brought from Banda, whither it had doubtless been eonveyed from its native island. It was said to have been called by the inhabitants "Emeu," or "Ema," but this name they must have had from the earlier Portuguese navigators. ${ }^{2}$ Since that time examples

1 The figure is taken, by permission, from Messi's. Mosenthal and Harting's Ostriches and Ostrich Farming (London : 187i).

2 It is known that the Portuguese preceded the Duteh in their voyagres to the East, and it is almost certain that the latter were assisted by pilots of the 
have been continually imported into Europe, so that it has become one of the best-known members of the subclass Patita, and a description of it seems hardly necessary. For a long time its glossy, but coarse and hair-like, black plumage, its lofty helmet, the gaudily-coloured caruncles of its neck, and the four or fire barbless quills which represent its wing-feathers, made it appear unique among birds. But in 1857 Dr. George Bennett certified the existence of a second and perfectly distinct species of Cassowary, an inhabitant of New Britain, where it was known to the natives as the Moorul; and in his honour it was named by Gould $C$. bernetti. Several examples were soon after received in this country, and these confirmed the view of it already taken. Nine good species, with the possibility of a tenth, are recognized by Prof. Salvadori in his great work, Ornithologia della Papuasia e delle Molucche (iii. pp. 473-503), the heads of all of them having been previously figured by him in an excellent monograph of the genus (Mem. Accud. Sc. Torino, 1882), from various localities in the same Subregion. Conspicuous among them from its large size and lofty helmet is the $C$. custralis, from the northern parts of Queensland. Its existence indeed had been ascertained, by the late $\mathrm{Mr}$. T. S. Wall, in 1854, but the specimen obtained by that unfortunate explorer was lost, and it was not until 1866 that an example was submitted to competent naturalists (Proc. Zool. Soc. 1S67, p. 241).

Not much seems to be linown of the habits of any of the Cassowaries in a state of nature; bur Prof. Salvadori (ut suprì) has collected, with his usual assiduity, almost everything that can be said on the subject. Though the old species occurs rather plentifully over the whole of the interior of Ceram, Mr. Wallace was unable to obtain or even to see an example. They all appeal. to bear captivity well, and the hens in confinement frequently lay their dark green and rough-shelled eggs, which, according to the custom of the liatitx, are incubated by the cocks. The nestling plumage is mottled (Proc. Zool. Soc. 1S63, pl. xlii.), and when about half-grown they are clothed in dishevelled feathers of a deep tawny colour.

CAT-BIRD in North America is the name of a common and familiar summer-visitant, Mimus carolinensis, one of the Mocking-BIRds, which in addition to the mewing and liarsh cry for which it is notorious, is also a remarkably good songster; in Australia the birds of the gemus Ailuradus (Bower-BIRD), and especially A. crassirostris, or smithi of some authors, are so called for the same reason.

CECONIORPHA, the third group of Prof. Huxley's Suborder Schizognathe (Proc. Zool. Soc. 1867, pp. 457, 458), composed of

former nation, whose names for places and various natural objects would be imparted to their employers (see AlEatros, Boobr, and Dodo). 
the Families Larida (GULL), Procellariida (PETREL), Colymbidae (Drver), and Alcida (AUK).

CEDAR-BIRD, a name given in North America to a delicatelycoloured and rather common bird Ampelis cedrorum, or carolinensis of some authors, for a long while confounded with its larger congener A. garrulus (IVAXIVING), which it much resembles in appearance and characters - among them the dilatation at the tip of the secondary wing-quills looking like red sealing-wax; but it is much smaller and plainer in plumage.

CELEOMIORPH 玉, Prof. Huxley's name (Proc. Zool. Soc. 1S67, p. 467) for the group containing the Picide (WOODPECKEr) and Iyngide (WRYNECK), to which he found it difficult to assign a place. Parker subsequently (Trans. R. Microsc. Soc. 1872, p. 219) raised them to a higher rank as SAUROGNATHE.

CERE or CEROMA (from cera, wax), the soft, generally somewhat swollen skin which covers the base of the upper bill, especially well defined in Parrots and Diurnal Birds-of-Prey (see BILL).

CEREOPSIS, a genus founded by Latham in 1801 (Suppl. Ind. Orn. p. Ixvii.) on a single specimen of a bird received from Australia apparently in poor condition, and placed by him in the Order Gralle. A truer view of its position was, however, taken by those who had observed it in its own comntry, where it became known as the "Cape-Barren Goose" from its ocemring at that spot." However abnormal in appearance this bird may be with its short bill thickened at the base, its rather long legs and semipalmated feet, and its grey plumage spotted with black on the wing-coverts

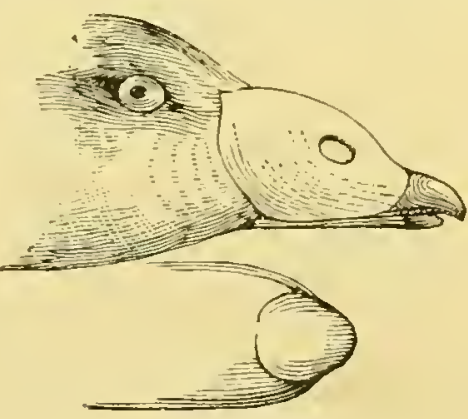

Cereopsis. (After Swainson.) and scapulars; in its internal structure, as described by Tarrell (Proc. Zool. Soc. 1S31, pp. 25, 26), it does not differ in the least important character from other Geese, and in its habits, whether at large or in confinement, is a thorough Goose. It has been introduced into England for more than 60 years, examples having been transferred from Windsor, where it had bred freely in the menagerie of King

1 According to Somnini, who calls it "Le Cygne cendré" (N. Dict. d"hist. nat. vii. 1. 68), it was first noticed by Labillardière in Espérance Bay on the south coast of New Holland, during the search by D'Entrecasteaux for La Pérouse in 1792. Collins in 1802 (New South Wales, ii. p. 94) ascribes its discovery by the English settlers to one of the company of the 'Sydney Cove,' who took it for a Swan ; and Flinders, who was there in February 1798, accordingly named from it two islands on the north coast of Van Dieman's Land. Bass gave the first intelligible description, stating that it "was either a Brent or a Baruacle Goose or between the two." 
George IV, to the Gardens of the Zoological Society at its foundation. Indeed, it is not at all improbable that there are more living examples at this time in Europe than in Australia, where even when Gould was there he found it to have been extirpated in places where a few years before it had been abundant.

Additional interest is imparted to this by the discovery in New Zealand of remains originally attributed by Sir R. Owen (Proc. Zool. Soc. 1865, p. 438) to the Dinornithine group (MOA) under the name of Cnemiornis calcitrans, and subsequently fully described by him (Trans. Zool. Soc. v. pp. 395-404, pls. Ixiii.-lxvii.). The acquisition in 1872 of a further collection of bones of this extinct bird enabled Sin James Hector to recognize in it a large Goose, probably allied to Cereopsis and of similar habits, but in which the power of flight had become obsolete, and as such he described it before the Wellington Philosophical Society, 18th August 1873 (Trans. N. Zeal. Inst. vi. pp. 76-84, pls. x.-xiv.A), communicating his results also to the Zoological Society of London, in whose Proceedings for the same year they will be found (pp. 763-771, pls. lxv.-lxviii.), as well as to Sir R. Owen, who lost no time in preparing an additional memoir on the subject, subsequently published in that Society's Transactions (ix. pp. 253-272, pls. xxxv.-xxxix.), and acquiescing in Sir James's determination of the position and relations of this remarkable form. A good many more of its bones have since been obtained, and no doubt can exist on the subject, though the precise epoch at which it became extinct camnot be regarded as settled.

CHACHALACA or CHIACALACCA, so called in Texas from its cry (Coues, Key N.Am. B. p. 573), Ortalis maccalli (see GUAN).

CHAFEINCH, a well-known bird, the Fringilla ccelebs ${ }^{1}$ of olnithology, which may be regarded as the type-form of the Fringillida (FINCH). This handsome and sprightly species, which is so common throughout the whole of Europe, requires no description. Conspicuous by his variegated plumage, his peculiar call-note 2 , and his glad song, the cock is almost everywhere a favourite. In Algeria our Chaffinch is replaced by a closely-allied species, $F$. spodogenia, while in the Atlantic Islands it is represented by two others, $F$. tintillon and $F$. teydea - all of which, while possessing

1 This fanciful trivial name was given by Linnæus on the supposition (which later observations do not entirely confirm) that in Sweden the hens of the species migrated southward in antumn, leaving the cocks to lead a celibate life till spring. It is eertain, however, that in some Jocalities the sexes live apart during the winter.

2 This eall-note, which to many ears sounds like "pink" or "spink," not only gives the bird a name in many parts of Britain, but is also obviously the origin of the German Fints and our Finch. The similar Celtie form Pinc is said to lave given rise to the Low Latin Pincio, and thence come the ltalian Pincione, the Spanish Pinzon, and the French Pinson. 
the general appearance of the European bird, are clothed in soberer tints. Another species of true Fringilla is the Brandble-Finch.

CHAMFA, ${ }^{1}$ a genus instituted by Gambel (Proc. Ac. N.S. Philad. 1847, p. 154) for a curious little bird from the coast-district of California which he had previously described (op. cit. 1845, p. 265) as Parus fasciatus but found to require separation. In the difficulty of assigning a position to this and a more recently discovered congeneric form, $C$. henshawi, from the interior of the same country, systematists have resorted to considering the genus as the type and sole member of a distinct Family Chamaidce, which, if its validity be allowed, proves to be the only Family of Land-birds that is peculiar to the Nearctic area. Thus it becomes a factor of some importance in determining the question whether that area should rank as a Zoogeographical or at least as an Ornithogeographical Region. It is impossible here to give details of a matter which has agitated the best ornithologists of North America, and reference can only be made to Dr. Shufeldt's paper "On the position of Chamaa in the System," published in 1889 at Boston in Massachusetts (Journ. Morphol. iii. pp. 475-502), wherein the evidence is very carefully weighed, and the conclusion reached is to the effect that it is more nearly related to the Colombian Cinnicerthic than to any other, but the author abstains from declaring the value of Chamaidx as a Family, though of the two, to one or other of which it has generally been referred-namely the Paridx (Titmouse) and Troglodytida (WREN) - he sees most resemblance to the former. So far as one can judge from the habits of the birds as described by observers, they are more those of a Wren than of a Titmouse; while the blue egg's which it is said to lay removes it really from the category of either. In the absence then of any very strong reason for disputing what has been asserted by no mean authorities, it would seem better for the present to let the Family Chamæida stand.

CHANNEL-BILL, Latham's name in 1802, and since generally used, for a bird described and figured by Phillips in 1789 (Voy. Botany Bay, p. 165, pl.) as the "Psittaceous Hornbill," and by John White in 1790 (Journ. Voy. N. S. Wules, p. 142, pl.) as the "Anomalous Hornbill," which was apparently first obtained 16th April $^{2}$ 1788, and therefore not long after the foundation of the colony. Latham seeing the need of a new genus for it, made one,

1 This word not having been accepted as English has strictly no right to head an article, but the only names applied to the birds to which it refers, "BushTit" and "Ground-Wren," have not enongh special meaning to justify their insertion, while the form, as will be seen in the text, is important enough to require particular notice.

2 But aceording to other accounts this speeies leaves New South Wales in January, only returning in October to breed. 
Scythrops, and as S. nove-hollandix it has been almost always recognized ever since, though its systematic position has often been disputed - its large and cmiously grooved bill inducing some to refer it to the Bucerotida (HoRNBILL), while its zygodactyl feet caused other's to place it among the Rliamphastida (ToUCAN). It is now generally allowed to belong to the Cuculidx (Cuckow).

CHAPARRAL-COCK, so called from the chaparral or dwarf forest which it frequents, the name commonly given by English-

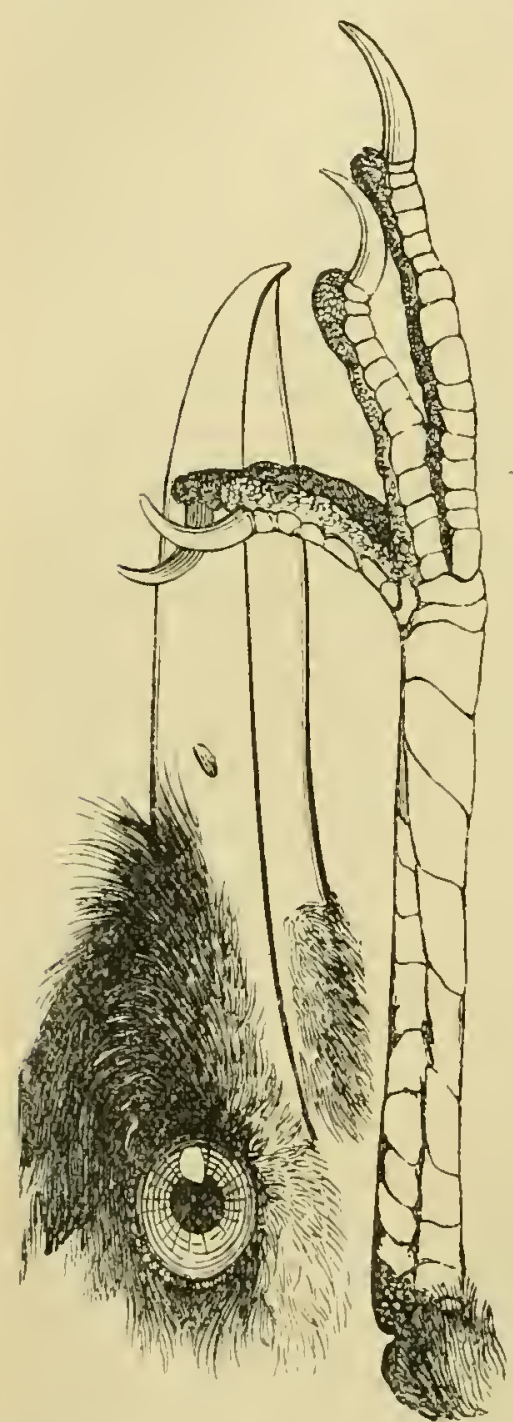

Chaparral-Coch. (After Swainson.) speaking settlers in the south-western districts of North America to a curious form of Cuckow, Geacoccyx, of which there are two species. The first, described by Hernandez (Hist. Anim. Nov. Hispan. p. 25 , cap. lii.) under the name of Hoitlallotl, and then identified by Buffon with the Paralia of Barrere (France Equinox. p. 140), was mistaken by Latham for the Parraqua figured by Bajon in 1777 (Mem. pour l'hist de Cuyenne, i. p. 374, pl. i.), and became the Phasianus mexicanus of Gmelin. This, being the southern form, is presumably that which is usually called $G$. affinis. The second, a larger bird, inhabits New Mexico and the adjacent part of the United States of America, and, nunder the name of Saurothera culiforniana, was described by Lesson (Compl. Buffon, vi. p. 420) as one of the most interesting discoveries of modern times. The habits of both seem to be very similar and very remarkable. They have short wings, and seldom fly unless suddenly surprised, but l'un with great speed, bearing their long tail erect. Like others of their Fanily in the New World they build their own nests, though clumsily, and lay therein from two to four white eggs. When tamed, as these birds often are, they become expert mousers, but are so mischicvous, says Mr. Dresser (Ihis, 1865, p. 467), as hardly to be suffered in a house. The name Paisano (countryman) by which this species is known in some districts is said to be a corruption of Faisan (Pheasant). "Road-rumner" is another name frequently given to it. The osteology of the species has been minutely deseribed by 
J). Shnfeldt (Journ. Anat. and Physiol. xx. pp. 246-266, pls. vii.-ix., and xxi. pp. 101, 102).

CHARADRIOMORPHAE, the first group of Prof. Huxley's Suborder Schizognutha (Proc. Zool. Soc. 1867, p. 457), nearly corresponding with the Pressirostres and Longirostres of Cuvier, and the Limicola or Scolopaces of Nitzsch-or in other words inchnding almost all the Scolopacida (SNIPE) and Charadriidie (PLOVER) of other systematists.

CHAT, in England generally usech with a prefix as STONEcHAT, Whinchat, but in the valley of the Thames said of itself to signify the Sedge-IVARELER. In North America it is applied to the two forms of the genus Icteria (I. virens and I. longicanda), which is generally referred to the Family Mniotiltidx, or American ITARDLERS, but may possibly not belong to them, its stont bill being very unlike that possessed by the rest.

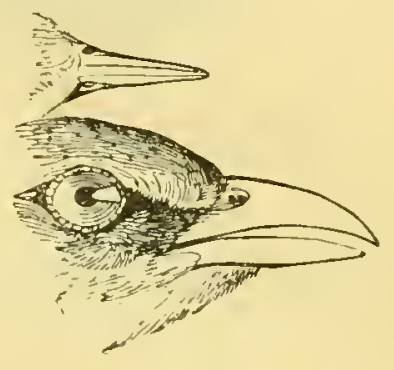

CHATTERER, a word that has been used by ornithologists in a very widle sense, and wholly irrespective of its meaning. Gesner's name for the WAxwing, Garrulus Bohemicus (i.e. Bohemian Jay), having been erroneously rendered by Ray, in his translation of Willughby's Ornithology (p. 133), "Bohemian Chatterer"; and that bird being also the Ampelis of Aldrovandus, subsequent writers, Pennant and Latham, used "Chatterer" as the equivalent of Ampelis, when Linmens had founded a genus with that name, quite regardless of its inapplicability. This genus being very composite

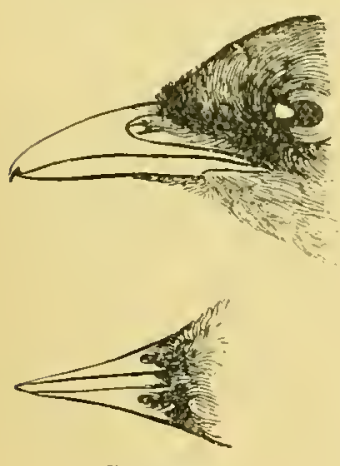

COTINGA.
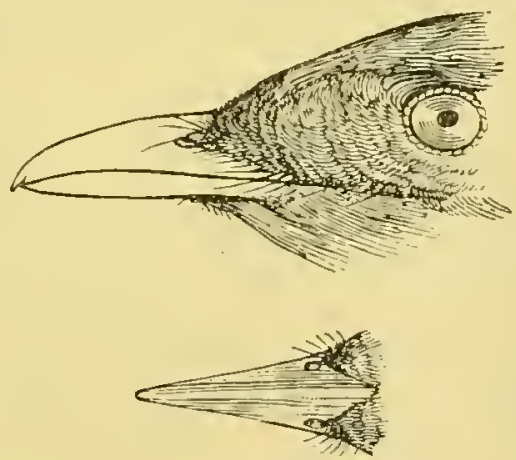

TIJUCA.

(After Swainsou.)

in its character was naturally broken up, and the name Ampelis having been retained by the more accurate writers in its original sense for the Waxwing and its congeners, the name Chatterer lias been generally conferred, for want of a better, on a group of birds, one of the most beautiful of which Brisson had termed Cotinga. This gromp, all the members of which inhabit the Neotropical Region, is a very natural one, and has long been regarderl as a separate Family, properly called Cotingide, though it is closely allied to the Piprida (Manakin), and together they form the divi- 
sion Heteroneri of the Mesoniyodi of Garrod and Forbes (see Introduction). Mr. Sclater, who adds thereto Piupicola (Cock-OFTHE-Rock) and an allied genus, which Garrod had put among his Honconeri, divides the Cotingida into five subfamilies (Cat. B. Br.

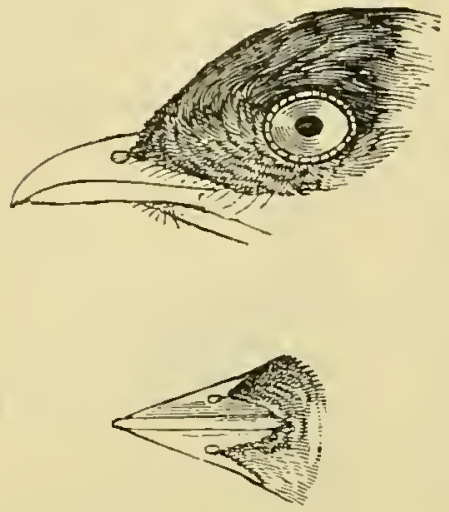

Aypelion.
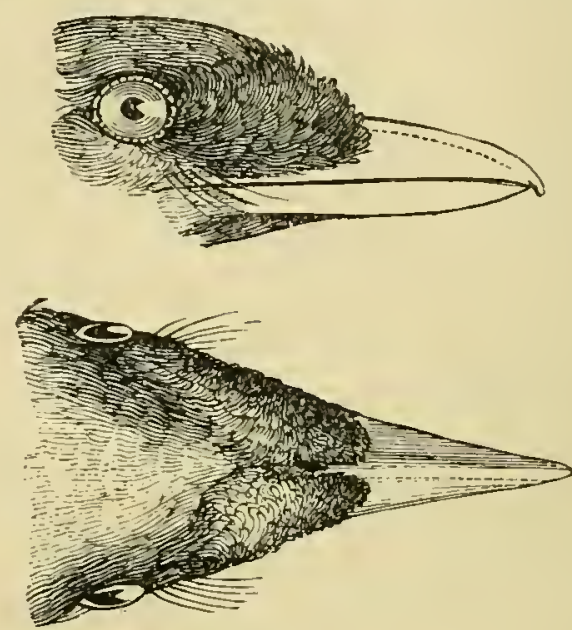

Pyroderus.

(After Swainson.)

Mus. xiv. pp. 326-405), Tityrinæe with 3 genera, Lipangine with 4, Attilina and Rupicolina each with 2, Cotingina with 11, and Gymnoderinæ with 7 (see BeLt-BIRd, partim, and UnbredLA-BIRD). A considerable number of these birds are remarkable for the extraordinarily abnornal form of some of their wing-quills, and occasionally of their wing-coverts-a feature in the former case observable also among the Pipridx, and, where existing, generally confined to the male sex. Many of them also are brilliantly coloured, and at least one, Xipholena pompadora-known as the Pompadour ${ }^{1}$ Chatterer, is of a hue scarcely to be seen in any other bird.

CHEEPER, the young of any kind of bird that cheeps or utters a low plaintive note, especially used of game-birds, Grouss, Partridges, or Pheasants ; but also a name of the Tit Lark, though mostly with a prefix, as Moss-Cheeper or the like.

CHEER or CHIR, the Anglo-Indian name of Phasianus wallichi, it fine but plainly-coloured Pheasant, a native of the Western Himalayas.

CHENOMORPH E, the first group of Prof. Huxley's Suborder Desmognathe (Proc. Zool. Soc. 1867, p. 460), composed of the Anatida of most authors-the Ducks and their allies, among which he includes Pulamedea (Screaner).

1 So named by Edwards (Gleanings, ii. p. 275, pl. 341) after the celebrated Madame de Pompadour, to whom it and other birds were being sent, when the ship that bore them from Cayenne fell a prize to a British cruiser. 
CHEPSTER, possibly a corruption of Shepster, a StaRling.

CHERRY-BIRD, a name of the CEDAR-BIRD.

CHERRY-PICKER, the Tasmanian name, according to Gould (Handb. B. Austral, i. p. 565), of a species of Melithreptus (HoNeYSUCKER.

CHERRY-SUCKER, a name absurdly given in some parts of England to the Spotted Flycatcher.

CHICKADEE, a North American name for various species of Tituouse-no doubt from their call-note.

CHICKEN, abbreviated CHICK, the young of any bird, but generally signifying that of the domestic FowL.

CHIFFCHAFF, occasionally CHIPCHOP, Phylloscopus collybita, or rufus of some authors, the smallest of the three native species of the genus, which are often called collectively Willow-Wrens. The name is doubtless an attempt to syllable the bird's ordinary cry (see SoNG), and seems to be first found in Gilbert White's Observations (p. 77) published in 1795 after his death by Aiken.

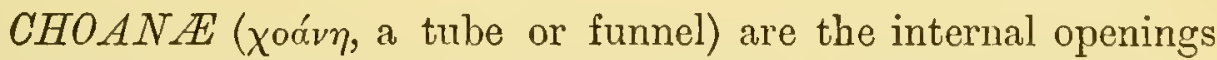
of the nasal cavities into the month, situated on the palate or roof of the mouth, generally between the maxillo-palatine and pterygoid bones.

CHOK, a name used in the Cape Colony for one of the EAGLES, Aquila rapax (Layard, B. S. Afr. p. 10).

CHOUGH, a bird much better known, generally with the prefix "Cornish," by name than by observation, the Pyrrhocorax or Fregilus graculus of ornithology, one of the Corrida (CROw), and formerly a denizen of the precipitous cliffs of the south coast of England, of Wales, of the west and north coast of Ireland, of the south of Scotland, and some of the Hebrides, but now greatly reduced in numbers, and only found in such places as are most free from the intrusion of man or of the DAw, Corvus monedula, which last seems to be gradually dispossessing it of its sea-girt strongholds, and its present scarcity is probably in the main due to its persecution by its kindred. In Britain, indeed, it would appear to be only one of the survivors of a more ancient fauna, for in other countries where it is found it has been driven inland, and inhabits the higher mountains of Europe and North Africa. In the Himalayas a larger form occurs, which has been specifically distinguished, $P$. himalayanus, but whether justifiably. so may be doubted. The general colour is a glossy black with steel-blue reflections, and it has the bill and legs bright red. ${ }^{1}$ Another species, $P$. alpinus, is altogether

I Shakespear's expression, "russet-pated choughs" (Mids. -Night's Dream, act iii. sc. ii.) has mnch exercised his commentators. Some see in it that "pated" 
a mountaineer, and does not affect a sea-shore life: A single example has occurred in England, and is figured in Mr. Aplin's Birds of Oxfordshire, but the possibility of its having escaped from captivity is not to be overlooked, though the species has reached a spot so distant from its home as Heligoland. The Alpine Chough is somewhat smaller than its congener, and is easily distinguished by its shorter and bright yellow bill. Remains of both have been found in French caverns, the deposits in which were formed during the "Reindeer Age." Commonly placed by systematists next to Pyrrhocorax is the Australian genus Corcorax, represented by a single species, C. melanorhamphus, but osteologists must be further consulted before this assignment of the bird, which is chiefiy a frequenter of woodlands, can be admitted without hesitation.

CHUCK-WILL'S-WIDOTV, so syllabled in North America from the bird's cry. One of the Caprimulgida (GoATSUCKer), Antrostomus carolinus, much larger than but congeneric with the WHIP-POORwILL, A. vociferus.

CHURN-OWL, one of the many names of the common NIGHTJAR of Europe.

CIRCULATION, or circulatory system, signifies motion of the blood, which is pumped by the heart through the blood-vessels. Birds, like Mammals, possess a complete double circulation, namely (1) that of the body, from the left ventricle of the heart into the aortic arch, thence through the arteries of the body, returning by the veins into the right auricle, and (2) the pulmonary circulation, from the right ventricle into and through the lungs, returning by the pulmonary veins into the left auricle, and thence into the left ventricle (see VAScular System).

CITRIL, the name under which Ray and Willughby in 1663 became acquainted at Vienna with a Finch, and now occasionally used for it in German, though it is more commonly known as Citronenfink, the allusion in each case being to the colour of its plumage, which some consider to be of a citron hue, but is mostly of a yellowish-green. The bird is the Venturon of the French, the Chrysomitris citrinella of modern ornithology - a common species in southern and parts of central Europe, but seldom occurring much further northward than the Black Forest. It usually frequents mountainous districts, keeping to the neighbourhood of fir-trees, though chiefly feeding on the seeds of grasses and other lowlygrowing plants.

meant "patted" or footed ( $c f$. the heraldic croix patée), and that therefore it refers to this bird with its red feet. Others maintain that "russet" did not necessarily mean red, but was frequently used for grey, and accordingly that the DAw with its grey head was intended. 
CLAKIS, a Scottish name for the BerNacle.

CLAMATORES, the third Order of Birds according to the arrangement of Andreas Wagner (Arch. für Naturgesch. 1841, ii. p. 93), in which he included all the PICARIæ of Nitzsch which were not ZygodaCTYL or Amphibolic. Subsequently Prof. Cabanis (op. cit. 1847, i. pp. 209-256, and ii. pp. 336-345) gave in greater detail the Families, subfamilies, and genera which he believed the "Order" should comprise, and his are the views which have been adopted by most of the systematic writers who have recognized it.

CLAVICLES (Lat. claricula, the collar-bone). Each clavicle articulates by its dorsal end with a process on the median side of the dorsal end of the coracoid, or with the scapula, or with both; the ventral ends of the two clavicles generally fuse with each other, forming the FURCULA, and approach the anterior end of the crest of the sternum. Between them the Esophagus and the TracheA pass from the neck into the thoracic cavity (see SkELEToN).

CLAWS or NAILS are the horny sheaths of the terminal phalanges of the toes and fingers, generally curved, and often sharply pointed. They are produced by a thickening of the Malpighian layer, which forms the "nailbed" out of which the corneous cells grow. The toes of most birds are protected by claws or flat nails, only in the Ostrich the outer toe has no nail, or hardly any, but the often reduced hallux is frequently unprotected. The inner side of the nail of the third toe is ofter serrated like a fine comb, as in Colmorants, Herons (including Scopus), Ibis, Dromas, Cursorius, Glareola, also in many Nightjars ; in Podicipes the clistal margin of the third nail is serrated.

Nilsson, Meves, Stejneger, Collett, and Malmgren ( $c f$. Dresser, B. Eur. vii. p. 189 , pl. 485 ) have described the periodical shedding of the claws in Lagopus, which grow to a considerable length during winter, the seasonal extension dropping off in spring as do the horny fringes on the toes in the Black Grouse, Capercally, and allied birds.

Claws on the tips of the fingers are much rarer. Archropteryx had a well-developed hooklike claw on each of its three fingers. In recent birds such claws are restricted, when occurring at all, to the pollex and index, being sometimes surprisingly well developed, although hardly functional. They occur more or less regularly on the first two fingers in Struthio and Rhea (occasionally as embryonic traces even on the third finger), also in Anseres and Birds-ofPrey (e.g. Milvus and Cathartes). A pollex claw alone has been found in various Anseres, in Gallus, Birds-of-Prey (especially well developed in the Kestrel), and individually in the Whitethroat and in the Blackbird. ${ }^{1}$ An index claw alone occurs in Casuarius,

I Such an example of the Whitetluroat is in Mr. Seebohm's collection, and 
Dromæus, and Apteryx. Probably many more birds will be found in which such fingernails have remained dormant as latent germs and have individually been revived; but the taxonomic value of these ancestral vestigial structures is nil.

Spurs are claws and nails in a different sense. They are generally conical, consisting of a horny sheath which surrounds a bony core produced by the supporting bone. Hereto belong those on the metatarsus of many Phasianidæ. Similar structures occur on the bones of the wrist and hand, namely a long and sharp spur with strong bony core on the radial side of the first and one on the second metacarpal bone in Chauna derbiana; on the first metacarpal in Parra and in Hydrophasianus ; and on the radial carpal bone in Plectropterus. The large exostoses of the size of a walnut on the wrist of the male Pezophaps were probably likewise covered with a thickened horny layer, and were, like all these structures, used as weapons. Young spurs can be easily grafted on various parts of other animals.

$C L O A C A$, the dilated terminal portion of the alimentary canal, which opens through the vent, and besides the fæces, discharges the urine and the genital products. The whole cloaca of most birds is divided by transverse folds into a vestibulum, a urino-genital or middle, and a rectal or innermost chamber.

The urino-genital chamber or "urodæum" is small, and receives in its dorso-lateral walls the ureters and the genital ducts, which are protected by papillæ. Above their orifices is a circular fold, most prominent on the ventral side; below them, towards the vent, is another well-marked circular fold, which, towards the ventral aspect, passes into the coating of the copulatory organ, when such is present. The space between this fold and the outer anal opening, which is closed by a strong sphincter muscle, lodges the copulatory organ, and on its dorsal wall leads through a wide opening into the bursa Fabricii. This organ is peculiar to birds, is most developed in the young of both sexes, and often becomes more or less obliterated in the adult; its function is still unknown; it certainly is not a lymphatic gland, and the occurrence of sperma in it is accidental.

The innermost chamber, or "coprodæum," is situated above the urodxum, is mostly an oval dilatation of the rectum, and is of considerable size in those birds whose fæces are very fluid, as Accipitres, Herodii, and Steganopodes. In Casuarius and Rhea it passes gradually into the rectum above, but in many Carinate, as well as in Struthio, the upper end is marked by a strong circular fold, and the inner surface of the walls is smooth and different from

one of the Blackbird, from Syria, was described by Bonaparte (Comptes rendus, 1856, xliii. p. 412) as a new species under the name of Merula dactyloptera. 
that of the rectum proper. In Struthio this chamber is followed by another, which is smaller and less defined, resembling in this respect some Samrians.

It follows from the arrangement described above, that in Birds the urine is not retained in the small urodreum, but that, as in Saurians, it passes into the next chamber above. Through this the fæces pass; if they are very fluid, they collect in the then very capacious space, together with the urine, and transform the chamber into a physiologieal cloaca. If the freces are more solid, as for instance in Geese, they are retained in the rectum proper, and simply pass through the cloaca. In the Ostriches defrecation and micturition are mostly separate acts, especially when the largely-developed and persistent bursa Fabricii acts as a physiological bladder. A true urinary bladder, i.e. a ventral dilatation of the urodreum, is absent in Birds.

The copulatory organ in the male, and the corresponding part in the female, are developed from the ventral wall of the vestibnlum or" "proctodæum." It is present in two different

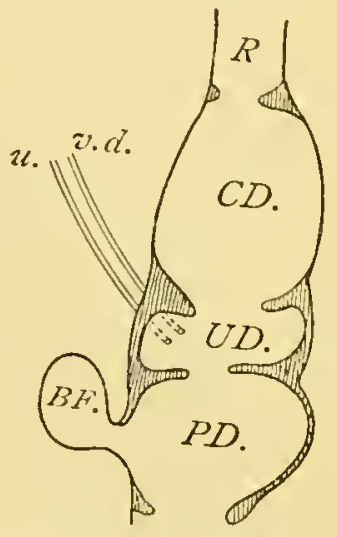

DIAGRAM OF THE Cloaca of a Bird.

BF. Bursa Fabricii ; C.D. Coprodxum; U.D. Urodrum; $P . D$. Proctodæum; $R$. Rectum; $u$. ureter; $v . d$. vas deferens. forms. In the Ratitre, exeept Rhea, it consists of a right and left united half, with a deep longitudinal furrow on the dorsal side, and strongly resembles the same organ in Crocodiles and Tortoises; it can be protruded and retracted by special muscles which in the Ratitie are partly attached to the pelvic bones. In Rhea, and among the Carinatre in the Anseres only, the copulatory organ consists likewise of two halves with a longitudinal furrow, but is greatly specialized by being spirally twisted and being reversible like the finger of a glove; its muscles are derived solely from the sphincter muscle of the vent. In other Carinatre, for instance in the Timamidre, Cracida, in Platalea, Ciconia, and Phonicopterus, the penis is much smaller and simpler in strueture, with all the appearance of a degraded organ. In the majority of Birds, especially in the highest, it has disappeared, and the primitive way of everting the cloaca is resorted to during copulation (H. Gadow, Phil. Trans. 1ss7, p. 32).

COACHWHIP-BIRD, so called in eastern Australia from its lond full note, ending sharply like the crack of a whip, the Psophodes crepitans of ornithologists, while a second form, $P$. nigrigularis takes its place further westward. Beside this curious ntterance it has a low, inward, melodious song. It inhabits the thickest brushwood, seldom exposing itself to view; but when seen is very animated in 
all its actions, raising its crest and spreading its tail. Originally described by Latham as a Flycatcher, Muscicapa, Vigors and Horsfield saw the need of founding a new genus for it, though they admitted their ignorance of its position. Its short rounded wings induced G. R. Gray to place it among his Crateropodinx, and until its internal structure has been examined there it must remain. If, however, the eggs be so curiously marlied as they are described by Gould (Hundb. B. Austral. i. p. 314), it would seem unlikely to belong to that group, and that ornithologist placed the genus next to Menura (LYRE-BIRD) - not that any affinity thereto follows in consequence.

COALMOUSE (sometimes wrongly spelt "Colemouse"), Germ. Kohlmeise, the Coal-Timiouse, Parus ater, or as some would have it $P$. Uritannicus.

COB, Dutch Kaap and Kobbe, according to Montagu a name for the Great Black-backed Gulu, Larus marinus, but applied in the present writer's knowledge to almost any of the larger species of Sea-Gull. Yarrell says (Br. B. ed. 1; iii. p. 130):-"In the language of swanherds, the male Swan is called a Cob, the female a Pen: these terms refer to the comparative size and grade of the two sexes"; but corroboration of the first statement has been sought in vain, while the second is hardly intelligible.

COBBLER'S-AWL, a fanciful name given to the Avoser until its extermination in the country; and, according to Gould (Handb. B. Austral. i. p. 551), now used by the colonists of Tasmania for the Acanthorhynchus tenuirostris one of the Meliphagidx (HoNEY-SUCKER), known in eastern Australia as the SPINE-BILL. The shape of the bill has in both cases suggested the name, but it is far less appropriate in the latter than in the former.

COCCYGOMORPHA, the seventh section of DEsiognathe according to Prof. Huxley's scheme (Proc. Zool. Soc. 1867, pp. 466, 467), comprehending 14 Families which are arranged in four groups, viz. a, Coliidx (Mouse-BIRd); b, Musophagida (Plantain-eater and Touraco), Cuculidx (Cuckow), Bucconidx (Puff-BIRD), Rhamphastidx (ToucaN), Capitonidæe (BARBET), Galbulidx (JACAMLAR) ; c, Alcedinida (KINGFIsHer), Bucerotidce (Horndill), Upupida (Hoopoe), Meropida (BeE-Eater), Momotida (Motмot), Coraciida (Roller): and drogonida (Trogor) - all of which are in the present work regarded as PICARIE.

COCKATEEL, a bird-fancier's name lately invented by Mr. Jamrach, and now in common use, being an English adaptation of Kakatielje, which in its turn is supposed to be a Dutch sailor's rendering of a Portuguese word, Cacatilho or Cacatelho, meaning a little Cockstoo, and applied to the Australian Cockatoo-Parrakeet, Calopsitta norw-hollandix, a favourite cage-bird. 
COCKATOO, Malay Kakutía, a name used in England and, with some modification of spelling, in other European countries for more than 200 years, and undoubtedly taken from the cry of one or other of the well-known birds so called, though it would be impossible to say which of them. With the exception of one species which inhabits the Philippine Islands, the Cockatoos are peculiar to the Australian Region, and are especially abundant in that portion of the Malay Archipelago which is included in it, but they do not go farther eastward than the Solomon Islands. They seem to be a very natural group of the Order Psittaci (PARRoT), and some writers would regard them as forming a Family Cacatuida or Plictolophida, while others consider the lower rank of a subfamily sufficient for them. Six genera are pretty generally admitted, Cacatua, Callocephalon, Calopsittacus (CockATEeL), Calyptorhynchus, Licmetis, and Microglossa - the first containing all the species ordinarily called Cockatoos and kept in confinement, which are commonly white with yellow, or pink crests. The second genus has only one species, an iron-grey bird with a bright red head. The fourth contains the large black species of Australia, with a long tail banded with scarlet, yellow or cream-colour. The fifth has a considerable resemblance to the first, but the birds have a slender bill, while the sixth comprises the largest forms to be found in the Order, birds whose wholly black plumage is relieved by their bare cheeks of bright red. In striking contrast to these last some systematists would place among the Cockatoos the smallest of the Parrot-tribe, members of the genus Nusiterna, from New Guinea and the Solomon Islands, but that as Dr. Murie has shewn (Proc. Zool. Soc. 1865, p. 622), really presents no sort of resemblance to them.

COCK-OF-THE-PLAINS, one of the American Tetraonida (Grouse), Centrocercus urophasianus.

COCK-OE-THE-ROCK, a "familiar name," according to Swainson in 1837 (Classif. B. ii. p. 76), "lung bestowed" on a bird from the northern parts of Sonth America; but his seems to be the first rendering into English of the old French Coq-de-roche, or Coc-des-roches as Barrere (Fr. Equinox. p. 132) has it. The flat-sided crest borne by the bird was likened by the colonists to that of the HoopoE, and accordingly he in 1745 (Ornithol. p. 46) placed it in the genus Upupa, while Edwards a few years after figured its head (Gleanings, pl. 264) as that of the "Hoopoe Hen," having received it from Surinam under the name of Widdehop (Hoopce), and thus Limneus was originally induced to follow their example, though finally he referred it to the genus Pipra (MLANakin); but in the meanwhile Brisson, who first gave a good description and figure of it, made it in 1760 the representative of a new genus Pupicola. In 1769 Vosmaer again figured it, expressing his surprise that the 
Dutch authors, who had clescribed so many beautiful creatures from their possessions in South America, had never mentioned this remarkable bird. It his now for many years been recognized as Pupicolit croceu, the type of the genus, and is common enongh in museums, where its almost wholly orange-coloured plumage, as well as its disk-like crest, render it conspicuous. It inhabits Guiana, and the lower countries of the Amazons; but further to the westward it is replaced by the more deeply-tinted $R$. perwiana, and a third species, the blood-red $R$. sunguinolenta occupies still higher elevations in Ecuador. The gemus is now generally placed in the Family Cotingidas (ChatTerke), though Gariod, on account of certain differences in the formation of the crural arteries, which seem to be of 110 great taxonomic value (see INTRODICTION), had separated it from them; but it may well be regarded, as by $\mathrm{M}_{\mathrm{r}}$.
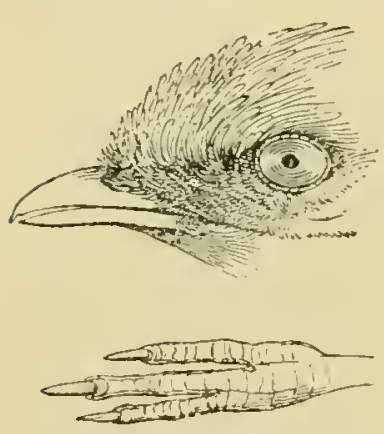

Piranicocercus. (Aiter Swainson.) Sclater (Cut. B. Br. Mus. xiv. p. 366) as forming a distinct subfamily, Rupicolina, the only question being whether it is not as much allied to the Pipridle. Next to Rupicola he places Phanicocercùs, containing two species, $P$. curnifex from Guiana and the lower Amazons, and $P$. nigricollis from the upper portion of the same valley. Each of these genera exhibits a curious modification of the primary quills, which in both the Families just named are subject to so much abnormality. In the males of Phanicocercus the fourth quill is much shortened, and terminates in a thickened horny process, while in Rupicala the first quill is suddenly attenuated towards the tip.

COCK-OF-THE-WOOD, see CAPERCALLY.

CODDY-MODDY (etymology mknown), a local name of considerable antiquity, and still in "use for the Black-headed GuLL (Lurus ridibundus).

COLDFINCH, a name for which no explanation can be ofiered, unless it may have been intended for Coalfinch, but used so long ago as Willughby's time for the Pied Flycatcher.

COLIN, the Mexican word ${ }^{1}$ which practically signifies QUAIL, though the Quails of the New World have long been held to form a group distinct from any of those of the Old. The name seems to have been first printed in 1635 by Nieremberg (Hist. Nat. p. 232, cap. lxxii.); but he says he took it from Hernandez, whose work was not published until 1651, where it duly occurs (Hist. Anim. Nov. Hispan. p. 22, cap. xxxix.). Willughby (Ornithol. Lat. p. 304 ,

1 The French Cotin, an old nick-name for a GuLb, given in 1555 by Belon (Ois. 1. 167), has no connexion with the Mlexican word. 
Angl. p. 393) quoted from both, and thus the word came into English use, even to finding its way into an Act of Parliament (43 and 44 Vict. cap. 35). In the Mexican language it was variously compounded, as Ococolin (Mountain-Partridge), Acolin (Water-Quail), and Cacacolin (cf. Hernandez, op. cit. pp. 32, 42). These have not all been determined; but it is generally agreed that Colin alone meant some species of the genus Ortyx.

COLOUP, as perceived in the various parts of Birds, is produced by pigment or by structure or by a combination of the two. Three classes of colours can therefore be distinguished.

I. 'The so-called chemical or absorption colours are always due to colouring matter, which may exist in the form of a solution diffused in the coloured parts, or in the form of pigmented corpuscles, distributed in and between the cells of the various organs. Such colours do not vary or change under any position of the light or eye; and even under transmitted light a red, yellow, brown, or black feather will always appear the same. Black, red, and brown always belong hereto, orange and yellow mostly, but rarely green, and never blue.

The principal colour pigments are:-

Zoomelanin, the black animal colouring matter, distributed in amorphous little corpuscles, insoluble in Water, Alcohol, Acids, or Ether, but dissolved and destroyed when boiled in Canstic Potash and then treated with Chlor; it consists of about $53.5 \%$ of Carbon, $4 \cdot 6$ of Hydrogen, 8.2 of Nitrogen, and $33 \cdot 7$ of Oxygen.

Zoonerythrin, red, hitherto found in the red feathers of Cotinga, Phœenicopterus, Ibis, Cacatua, Cardinalis, and others, and in the "rose" round the eyes of the Tetraonidx. It is soluble in Ether, Alcohol, and Chloroform, but not in Acids or in Potash ; the varialle amount of fat or oil in the feathers of the Flamingo causes them to be more or less intensely coloured.

Zooxanthin, yellow, can be extracted by boiling in absolute Alcohol, and is a diffused pigment which tinges the shafts, rami, and radii of the feathers, and is possibly the same in the yellow feet and bills of Birds-of-Prey and Anseres. Like Zoonerythin it is a coloured fatty oil.

Turacin is a most peculiar pigment, discovered by Church in 1867 (Phil. Trans. 1869, pp. 627-636) in the red feathers of the Musophagidre, and seems to be restricted to these birds. It consists of the same elements as Zoomelanin with the addition of from 5 to $8 \%$ of copper. It can easily be extracted by weak alkaline solutions, such as Ammonia, and with the addition of Acetic Acid, it can be filtered of as a metallic red or blue powder. The presence of metallic copper is indicated by the green flame of the red feathers when burnt. These birds lose the red colour when washed by the rain, but regain 
it when dry. When bathing they colour the water red, and the red feathers, when wet, are distinctly shot with blue.

Turucoverdin is the only instance of a green pigment, and is only found in the Musophagidæ; it contains comparatively much iron, but no copper.

Brown is the result of a mixture of red and black colouring matter.

White is never due to pigment; in every white object its colour is clue to there being an innumerable number of interstices between its molecules, or the air-cells in its substance. The whole substance of a white feather, the "ceratine," is colourless, but its texture forms a fine network which diffracts and reflects the light.

The gloss of feathers, independent of the colour itself, is the result of their horny surface being smooth and polished, when rough they appear more or less dull.

II. Objective structural colours are those which are produced by the combination of a certain pigment with a special structure of the superimposed colourless parts. Hereto always belong violet and blue, green almost always, and occasionally yellow. Such a feather, when examined under transmitted light, i.e. held against the light, appears only in the colour of its pigment. For instance, the deep blue or green feathers of a Parrot will then appear only grey or yellowish. The same happens when their polished surface is scratched or crushed, the blue colour instantly disappears, shewing only the blackish underlying pigment, or yellow pigment in green feathers. When thoroughly wetted in a bath, the feathers of the back of an Amazon Parrot appear brown without a trace of green.

Microscopical examination of such colours reveals the following structures :-

Yellow. The radii and rami of many yellow feathers are in reality without pigment, but their surface shews a number of longitudinal ridges and furrows, as for instance in Ara, Rhamphastus, Coereba, Icterus, Xanthomelas, and Picus. Some of the radii of the yellow fluffy pectoral tufts of Arachnothera have a diameter of $0.007 \mathrm{~mm}$; their surface exhibits irregular ridges, separated by as many furrows; the width of one ridge is less than $0.0007 \mathrm{~mm}$, and the distance from ridge to ridge about 0.002 , so that the theory of colours of a system of narrow gratings can well be applied to explain these colours.

Orange is occasionally produced by red pigment with a yellow superstructure.

Green, except in the case of the Musophagida mentioned above, is always due to yellow, orange, or greyish-brown pigment with a special superstructure, which consists either of narrow longitudinal ridges, as in Psittacula and in Pitta, or else, as in Chrysotis, Pitta, 
and Megaloprepia, the surface of the rami and radii is smootl and quite transparent, while between it and the pigment exists a layer of small polygonal bodies, similar to those of blue feathers.

Blue has not yet been discovered as a pigment. Blue feathers contain only orange or brownish pigment; the blue appears only on the shafts of the rami and larger radii. The structure of blue feather's seems to be always the same: (1) a transparent, colourless layer of ceratine, fiom 0.004 to $0.007 \mathrm{~mm}$. in thickness; (2) a layer of polygonal, more or less pyramidal, and often hexagonal columnar cells, each of which is colourless itself, and its walls are highly refractory and not unfrequently striated and ridged ; ${ }^{1}$ (3) the horny narrow cells of the inside of the radius, with brown, black, or orange pigment corpuscles.

The blue naked parts of the skin of Cassowaries contain yellow or black pigment covered by peculiarly modified epidermal layer's.

III. Subjective structural, prismatic, or metallic colours. - These colours change according to the position of the light and the eye of the observer, and they always change in the order of those in the rainbow. They are restricted, as a rule, to the radii without cilia, and moreover to those parts of the feather's which are not covered by others. The metallic portions of the radii are composed of one row of compartments, which often partly overlap each other like curved tiles. In the inside black or blackish-brown pigment is collected; and each compartment is covered with a transparent colourless layer of extreme thinness, e.g. $0.0008 \mathrm{~mm}$. in Sturnus. The surface of this coat is either smooth and polished as in Nectarinia, or exhibits very fine longitudinal wavy ridges when the feather is violet, or numerous small dot-like irregularities as in Galbula. The coating seems to act like a number of prisms, as indicated in the first figure. All metallic feathers appear black when their surface is parallel to the rays of the light in the same level with the eye and the light. To the eye of the observer at $A$, in the lower part of the first figure, the metallic collar of Ptilorhis magnifica will appear absolutely black; the eye at B will see it bright coppery red, and at $\mathrm{C}$ rich green; the metallic feathers of the sides of the breast in the same bird will change from black to green at $B$, and to blue at $\mathrm{C}$. The beautiful Pharomacrus mocimno changes from greenish bronze through golden green, green, and indigo to violet. Oreotrochilus chimborazo in position $\mathrm{B}$ exhibits the whole solar spectrum, namely, violet and red on the head, followed by orange and green on the back, blue, violet, and lastly purple on the

1 In Pitta moluccensis I calculated the following measurements: width of une polygon $0.001 \mathrm{~mm}$, height of same $0.015 \mathrm{~mm}$., thickness of its transparent coating abont 0.0012 ; distance between two of the longitudinal ridges on the surface of the polygon 0.0005 , thickness of the transparent outer layer of the radins about $0.005 \mathrm{~mm}$. 
long tail feathers. The red colours of the spectrum lie nearer towards the position A, the blue colours towards C. The colours always appear in the same order: no feathers are known, which

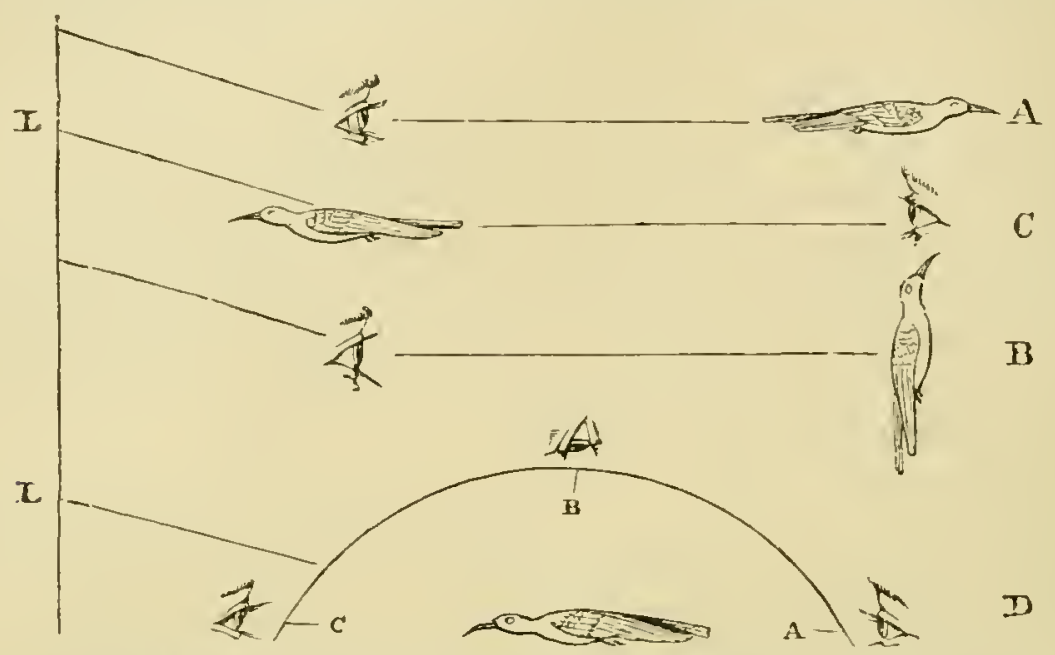

POSITIONS For OBSERVING the COLOUR OF "MIETallic" Feathers.

(From the Proccedings of the Zoological Socicty, 1Ss:.)

when looked at from $B$ towards $A$, ehange from the red towards the blue end of the spectrum. In case two or more of these spectrat (of which we imagine the horny coating to be composed) overlap each other, only a limited number of colours are able to reach the eye of the observer. Thus in the theoretical case figured red only will be visible besides black.

A peculiar case is that of Artamia bicolor; the pure white feathers

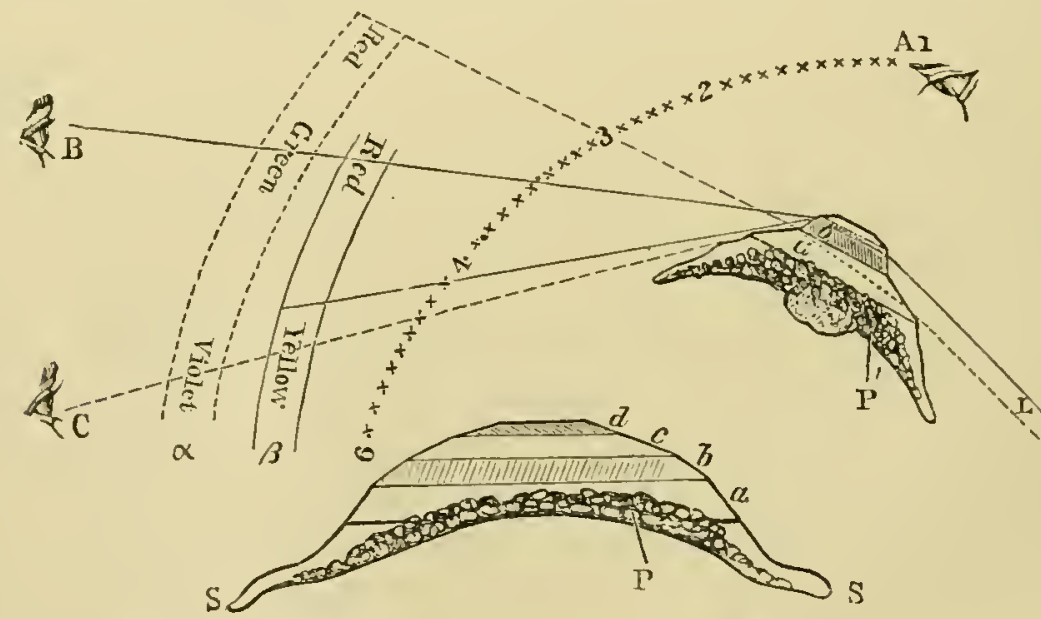

Diagramatic Section thrnugil the Barb of a "Metallic" Feather.

(From the I'roccedings of the Zoological Socicty, 1s\$2.)

of the underparts have no metallie gloss, but nevertheless they seem to be prismatic, because in position $A$ the mnderparts appear bluishwhite, in $\mathrm{B}$ delicately pale blue, and in position $\mathrm{C}$ pale grey.

Deviation from the normal coloration is more or less patho- 
logical, and can be conveniently expressed by the term Heterochrosis (from the Greek є̈ $\tau \epsilon \rho o s$ and $\chi \rho \hat{\omega} \sigma \iota s$, colouring). The following are the chief cases :-

Albinism, caused by the pathological absence of the black pigment, and often locally produced by a lesion of the pulp of the growing feather; extreme instances are white Ravens and Blackbirds.

Melanism, produced by the superabundance of black pigment, mostly causing the feathers to assume a clarker or more sooty colour. Melanistic specimens have been described of many birds, such as Bullfinch, Skylark, and in particular of the common Snipe, which in this phase has by some been regarded as a rlistinct species, Scolopax sabinii.

Xanthochroism, mostly in originally red or orange feathers; when the feathers are yellow instead of green, this may possibly be a reversional step or a case of arrested development because of the absence of the green-making superstructure.

Erythrism, the abnormal occurrence of red, mostly confined to originally yellow or orange feather's, occasionally produced by abnormal food, like cayenne pepper, or directly by the colouring matter of Rutia tinctoria, one of the madder-worts. A certain correlation between green and red is exhibited by the intensely green adult males of Eclectus polychlorus, the females being bright red and the young of both sexes being reddish, without any indication of green in the young male.

In Brazil "contrafeitos" of the various species of Chrysotis are fashionable. These are produced by the rubbing in of the cutaneous secretion of a Toad, Bufo tinctorius, into the budding feathers of the head, which then turn out yellow instead of green.

Concerning the literature of Albinism and Melanism the reader may consult Toppan, Bull. Ridgway Club, 1887, pp. 61-77, and Deane, Bull. Nuttall Orn. Club, 1876, pp. 20-24; "Xanthochroism" in Parrots: Meyer, Sitzber. k. Akcd. Wissensch. Berlin, 1852,.pp. 517-524; and a general account by Pelzeln in Verhandt. zool.-bot. Gesellsch. Wien, 1865, pp. 911-946. For further information concerning colours see (Bronn's) Klassen und Ordn. des Thier-Reichs, Vögel, pp. 575-5S8, and P. Z. S. 1SS2, pp. 409-421, pls. $27,28$.

The distribution of colour in the feathers and the colour-pattern of the plumage require some notice.

It is a hitherto unsettled question if the longitudinally striated or the crossbarred feathers are the older style of coloration. The general impression of the coloration of a bird is the sum total of the coloration of all the uncovered parts of the feathers. This sounds like a truism, but means that crossbarred feathers can never give the general impression of a striated plumage and vice versâ. Kerschner believes (Zeitschr. wiss. Zool. 18\$6, p. 681) that 
the distribution of colouring matter in transverse lines or bars is the phylogenetically older method, because natural and sexual selection camnot well have affected the hidden parts of the feathers. On the other hand, the striated downy or first plumage of the Gallinæ and Ratite has been already, by Darwin, taken to be a very old stage. This appearance, however, as in Struthio, is not due to striation of the single feathers, but to juxtaposition of colourless and deeply pigmented downs. To judge from the growth of a fcather, the production of crossbars seems to be the older stage, since they will result from the intermittent deposition of pigment, while, on the other hand, the production of shaft-streaks is not yet satisfactorily explained. At any rate, it must be borne in mind that possibly various groups of birds have gone independently through sucl stages, and that what is primitive or archaic in one need not be so in all. But a strong proof of the soundness of Darwin's views is that we are able to trace the pattern of the most beautifully-adorned feathers of the Argus-Pheasant or of the Peacock step by step backwards to longitudinal stripes, spots, crossbars, and lastly to insignificant and simple irregular little dots.

Natural and sexual selection, whether combining or striving against each other, have worked marvels in plumage. Significant colours, as for instance total blackuess or whiteness, could be developed only when higher intellectual qualities, bodily size and strength, or occasionally even special smalluess, gruaranteed the safety of the bird. The females and the young mostly retain a more sombre garb, and thus remain on a phylogenetically lower level. It takes the large Gulls several years to change from a mottled brownish and grey appearance into the beautifully dark and white colours. The same applies to the white shoulders of certain Eagles; and many other instances, too well known to be repeated here, shew clearly how.the changes of bygone ages of the ancestors are recapitulated in the yearly moult of the growing individual until with maturity its present stage of perfection is reached-but only its present stage, because its descendants in turn will be different, either still more beautiful or still better adapted to the ever-changing conditions of life. This consideration implies that whole-coloured birds, like Swans and Ravens, have reached their limit so far as coloration is concerned; since both black and white are very conspicuous and are correlated with a considerable amount of intellectual development. The very early assumption of the black plumage by the nestlings of Ravens and Crows is a strong argument for their relatively highest position on the hypothetical avine tree. Albinos are notoriously shy. The females of birds which breed in holes, as Rollers, Kingfishers, and Parrots, are frequently as beautifully coloured as the males, because they need no protection through colour while sitting on the nest. In the 
green Amazons beauty, intelligence, and safety by protection are combined. The often surprising adaptation of the coloration of the plumage to the surroundings is well known. Frequently the conspicuously coloured parts are hidden when the bird is at rest, and are only exposed or shewn-occasionally as "danger signals," to use Mr. Wallace's excellent term - when the bird is on the wing. It cannot be doubted that the sense of colour is highly developed in birds, perhaps most so in the female when choosing a mate; the result of this sexual selection being constantly regulated by natural selection is exhibited most by the male, but enjoyed by both sexes, and for the benefit of the whole race.

COLY, Pennant's rendering of the French Coliou, adapted by Brisson from Möhring's Colins; which, according to Cuvier, is the Greek kodoiòs (see Mouse-BIRD).

CONDOR, the Spanish way of writing the Peruvian Cuntur; the Vultur gryphus of Linnæus and Sarcorhamphus gryphus of recent authors, one of the largest of volant birds. The accounts given by early travellers of its size and ferocity were so obviously exaggerated that the cautious Ray would not admit it into Willughby's Ornithology, and only included it in his own Synopsis Avium (p. 11) after proof that such a bird existed had reached him in the shape of one of its wing-quills brought by Capt. Strong to Sir Hans Sloane from the coast of Chili. Nearly a century passed before European ornithologists saw a complete specimen. This was a female which Capt. Middleton brought from the Strait of Magellan and deposited in the Leverian Museum, where it was figured in 1791 by Shaw (Mus. Lev. No. 1, p. 4, pl.) Shortly after, a second specimen, this time an adult male, found its way from the same quarter to the same Museum, and was also figured in 1793 by the same author (op. cit. No. 6, p. 4, pl.) $)^{1}$ But the species was little known on the continent, until in 1806 when Humboldt communicated his classical Mémoire on the bird to the French Institute, and as he was certainly the first scientific man who had made its personal acquaintance in life, ${ }^{2}$ his account of it deserves the attention with which it has met, and the voracity, stupidity, and tenacity of life of this huge Vulture have through him been long known to the world. Its liabits have perhaps been since more fully described by Darwin in his Journal, though that account of them seems to have been unknown to the latest writer on the subject, Taczanowski (Ornithol. Pérou, i. pp. 75-80), who quotes only from D'Orbigny and Stolzmann. Yet a good many

1 Both these specimens passed into the II sseum of Vienna, where they are now preserved (Von Pelzeln, Ibis, 1873, p. 16).

2 As Broderip well remarks Molina can hardly have seen the bird, which he, like Buffon, took to be the same as the LÄMMERG HyER. 
years passed before examples became at all common in museums, and Temminck writing in 1823 (Rec. l'Ois. livr. 23) was only able to refer to a single one at Paris, beside the two originally received in England. Seven years afterwards he figured a male which was alive at Paris, and says there was another in Holland. But at or about the same time the species was exhibited in London (Bennett, Gard. and Menag. Zool. Soc. ii. p. 8), where it has even bred, though the only young bird that, after an incubation lasting from 7 th May to 30 th June 1846 , or 54 days, was hatehed lived but six weeks (Broderip, Learez fiom the Note-Book of a Nuturalist, pp. 14-16).

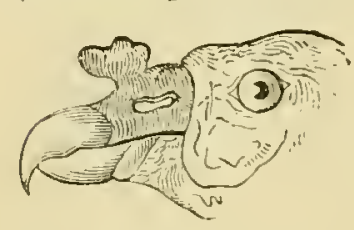

Condor.

(After Swainson.) The male Condor is remarkable among birds for the large caruncle which crowns his head, like an exaggerated cock's comb, and falling down on the culmen of the back often leaves an open space in front of the base. This and his bare head and neck of a dull reddish colour, wrinkled into many folds; give him a very peculiar expression, and the hard dry appearance of the latter contrasts with the ruff of white down that separates it from the glossy black of the rest of the plumage, except the edges of the wing-coverts and the secondary wing-quills which are white. The range of the Condor extends from near the month of the Rio Negro on the east coast of Patagonia, through the Strait of Magellan and along the Cordilleras of the Andes to about lat. $8^{\circ} \mathrm{N}$. It is possible that some of the older Spanish accounts usually taken to refer to the Condor were based upon the equally-large Vulture of North America, Cathartes ol Pseudogryphus califomionus, a species which seems to be rapidly becoming extinct.

CONIROSTRES, the fourth Family of PAsseres in Duméril's arrangement (Znologie anulytique, p. 43), containing STARLINGs, FincHes, and several other groips; but, though admitted by him to be a wholly artifieial assemblage, it is one that has been for a long while recognized by systematic writers.

COOT, a well-known British water-fowl, the Fulica atra of Linnæus, belonging to the Family liallidx (RAIL). The word Coot, in some parts of England pronounced Cute, or Scute, is of uncertain origin, lout perhaps eognate with Scout and Scotwr-both names of aquatic birds-a possibility which seems to be more likely since the nime Macreuse, by which the Coot is known in the south of France, boing in the north of that country applied to the Scoter (Eilemia nigre) shews that, thongh belonging to very different Families, there is in popular estimation some comexion between the bircls. " The

1 It is owing to this interchange of their names that Yarrell in his British Birds refers a description, assigned to Vietor Hugo (who, I hare the best 
Listin Fulica (in polite Freneh, Foulque) is probably allied to fuligo, anrl has reference to the bird's dark colour. ${ }^{1}$ The Coot breeds abundantly in many of the larger inlind waters of the northern pirts of the Old World, in winter commonly resorting, and often in great numbers, to the montl of rivers ol shallow bays of the sca, where it becomes a general object of pursuit by gumners whether for sport or gain. At other times of the year it is comparatively ummolested, and being rery prohifie its abmulance is easily understood. The nest is a large mass of flags, reeds, or serge, piled together among rushes in the water or on the margin, and not unfrequently contains as many as ten eggss. The young, when first hatched, are beautiful little ereatures, clother in jetblack down, with their heads of a bright orange-scarlet, varied with purplish-blue. This brilliant colouring is soon lost, and they begin to assume the almost nniform sooty-black plumage which is worn for the rest of their life; but a characteristic of the aclult is a bare pateh or callosity on the forehead, which being nearly white gives rise to the epithet "bald" often prefixed to the bird's name. The Coot

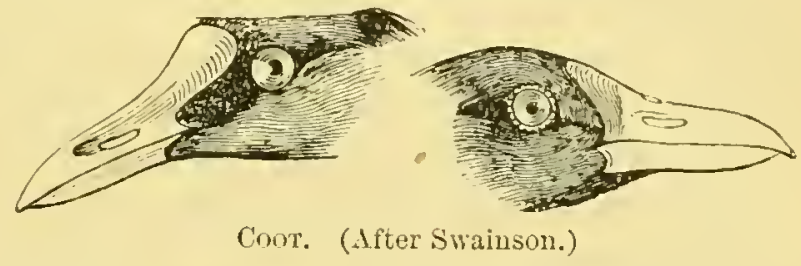
is abont 18 inches in length, and will sometimes weigh orer 2 lb. Though its wings appear to be short in proportion to its size, and it seems to rise with diffieulty from the water, it is capable of long-sustained and rather rapid flight, which is performed with the legs stretehed ont behind the stumpy tail. It swims buoyantly, and looks a much larger bird in the water than it really is. It dives with ease, and when wounded is said frequently to clutch the weeds at the bottom with a grasp so firm as not even to be loosened by death. It does not often come on dry land, hut when there, marches leisurely and not withont a certain degree of grace. The feet of the Coot are very remarkable, the toes being fringed by a lobed membrane, which must be of considerable assistance in swimming as well as in walking orer the ooze-aeting as they do like mud-boards.

In England the sport of Coot-shooting is pursued to some extent on the broads and back-waters of the eastern counties, and in Southampton Water, Christehurch Bay, and at Slapton Lay, and is often conclueted battue-fashion by a number of gmms. But even in these eases the numbers killed in a day seldom reach more than a few hundreds, and come very short of those that fall in the officiallyauthority for stating, never wrote it), of the "chasse anx Macrenses" to the Scoter instead of the Coot.

${ }^{1}$ Hence also we have Fulix or Fuligute applied to a Duck of dingy aprearance, and thus forming another parallel case. 
organized chasses of the lakes near the coast of Languedoc and Provence, of which an excellent description is given by the Vicomte Louis de Dax. ${ }^{1}$ The flesh of the Coot is very variously regarded as food. To prepare the bird for the table, the feathers should be stripped, and the down, which is very close, thick, and hard to pluck, be rubbed with powdered resin; the body is then to be dipped in boiling water, which melting the resin causes it to mix with the down, and then both can be removed together with tolerable ease. After this the bircl should be left to soak for the night in cold spring-water, which will make it look as white and delicate as a chicken. Without this process the skin after roasting is found to be very oily, with a fishy flavour, and if the skin be taken off the flesh becomes dry and good for nothing (Hawker's Instructions to Young Sportsmen; Hele's Notes about Aldeburgh).

The Coot is found throughout the Palæarctic area from Iceland to Japan, and in most other parts of the world is represented by nearly allied species, having almost the same habits. An African species ( $F$. cristata), easily distinguished by a red caruncle on its forehead, is of rare appearance in the south of Europe. The Australian and North American species ( $F$. australis and $F$. ameri. cana) have very great resemblance to our own bird; but in South America half a dozen or more additional species are found which range to Patagonia, and vary much in size, one ( $F$. gigantea) being of considerable magnitude. The remains of another large species have been described by Prof. A. Milne-Edwards (Ann. Sc. Nat. ser. 5, Zool. viii. pp. 194-220, pls. 10-13) from Mauritius, where it must have been a contemporary of the Dodo, but like that bird is now extinct.

\section{COPPERSMITH, see BARBET.}

COPACOID (named after the coracoid process on the human shoulder-blade, which was likened in shape by medirval anatomists to a Raven's bill) one of a pair of strong bones which connect the anterior or basal margin of the sternum with the scapula and clavicle, and form the chief articulation of the humerus with the shoulder-girdle (see SKELEToN).

CORACOMORPH王, Prof. Huxley's name for the large group of Desmognathous-birds-incomparably the largest of those that now exist, and for the most part equivalent to the PAsseres of Linnæus and Cuvier, and wholly to the VouUcres of Sundevall (Proc. Zool. Soc. 1867, pp. 468-472). (See Introduction.)

CORMORANT ${ }^{2}$ - from the Latin corvus marinus, through the

1 "La Volée aux Macrenses." Nouveaur Sonvenirs de Chasse et de la Pêche dans le midi de la France, pp. 53-65. Paris: 1860.

2 Some anthors, following Cains, derive the word from corvus vorans and spell it Corvorant, but doubtless wrongly. 
French (in some patois, of which it is still "cor marin," and in certain Italian dialects" "corvo mariu" or "corvo marino")large sea-fowl belomging to the genus Phalacrocorax ${ }^{1}$ (Curbo, Haliens, and Graculus of some ornithologists), and that group of the Linnæan Order Anseres, now pretty generally recognized by Illiger's tem STEqANopones, of which it with its allies forms a Family Phalucrocorucila.

The Cormolant, $P$. curlon, frequents almost all the sea-const of Europe, and breeds in societies at varions stations most generally on steep cliffs, but occasionally on rocky islands as well as on trees. The nest consists of a large mass of seaweed, and, with the ground immediately surrounding it, generally looks as though bespattered with whitewash, from the excrement

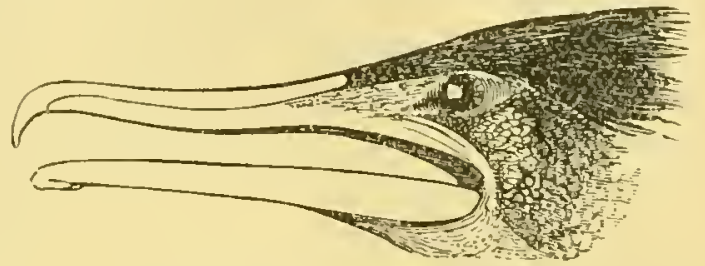

Cormoravt. (After Swainson.) of the bird, which lives entirely on fish. The eggs, from four to six in number, are small, and liave a thick, soft, calcareous shell, bluishwhite when first linid, but soon becoming discoloured. The young are latched blind, and covered with an inky-black skin. They remain for some time in the squab-condition, and are then highly esteemed for food by the northern islanders, their flesh being said to taste as well as a roasted hare's. Their first plumage is of a sombre brownish-black above, and more or less white beneath. They take two or three years to assume the fully adult dress, which is deep black, glossed above with bronze, and varied in the breeding-season with white on the cheeks and flanks, besides being adorned by filamentary feathers on the head, and further set off by a bright yellow gipe. The old Cormorant looks as big as a Goose, but is really much smaller: its flesh is quite mueatahle.

Taken when young from the nest, this bird is casily tamed, and can be trained to fish for its keeper, as was of old time commonly done in England, where the Master of the Cormorants was one of the officers of the royal houschold. Nowadays the practice is nearly disused, though a few gentlemen still follow it for their diversion. When taken ont to fumish sport, a strap is fastened round the bird's neck so as, without impeding its breath, to hinder it from swallowing its captures. ${ }^{2}$ Arrived at the waterside, it is cast off. It at once dives and darts aloug the bottom as swiftly as

1 So spelt since the days of Gesner ; but possibly Phalarocorax would be more correct.

2 It was formerly the custom, as we learn from Wilhughby, to carry the Cormorant hooded till its services were required, by which means it was kept quiet. At the present time its bearer wears a wire-mask to protect his eyes and face from the bird's beak. 
an arrow in quest of its prey, rapidly scanning every hole or pool. A fish is generally seized within a few seconds of its being sighted, and as each is taken the bird rises to the surface with its capture in its bill. It does not take much longer to dispose of the prize in the dilatable skin of its throat so far as the strap will allow, and the pursuit is recommenced until the bird's gular pouch, capacious as it is, will hold no more. It then returns to its keeper, who has been anxiously watching and encouraging its movements, and a little manipulation of its neck effects the delivery of the booty. It may then be let loose again, or, if considered to have done its work, it is fed and restored to its perch. The activity the bird displays under water is almost incredible to those who have not seen its performances, and in a shallow river scarcely a fish escapes its keen eyes and sudden turus, except by taking refuge under a stone or root, or in the mud that may be stired up during the operation, and so avoiding observation. ${ }^{1}$

Nearly allied to the Cormorant, and having much the same habits, is the Shag, or Green Cormorant of some writers, P. graculus. The Shag (which name in many parts of the world is used in a generic sense) is, however, about one-fourth smaller in lineal dimensions, is much more glossy in plumage, and its nuptial embellishment is a nodding plume instead of the white patches of the Cormorant. The easiest diagnostic on examination will be found to be the number of tail-feathers, which in the former are fom teen and in the Shag twelve. The latter, too, is more marinc in the localities it frequents, seldom entering fresh or indeed inland waters.

In the south of Europe a still smaller species, $P$. pygmaus, is found. This is almost entirely a fresh-water bird, and is not uncommon on the lower Danube. Other species, to the number perhaps of thirty or more, have been discriminated from other parts of the world, but all have a great general similarity to one another. A large and very richly-coloured species, $P$. perspicillatus, which formerly frequented Bering Island off the coast of Kamchatka, was in 1882 ascertained by Dr. Stejneger to have been extirpated some thirty years before (Proc. U. S. Nat. Mus. 18s3, p. 65). A specimen now in the British Museum was figured by Gould (Voy. 'Sulphur;' pl. 32) and two others (in the Musenms of Leyden and St. Petersburg respectively), with a few bones, brought to Washington by Dr. Stejneger, are all the remains of it known to exist. New Zealand and the west coast of Northern America are particularly rich in birds of this genus, and the species found there are the most beautifully decorated of any. All, however, are remarkable for their curiously-formed feet, the four toes of each being con-

1 See Capt. Salvin's chapters on "Fishing with Cormorants," appended to his aud MIr. Freeman's Falconry (London : 1859). 
nected by a web, for their long stiff tails, and for the absence, in the adnlt, of any exterior nostrils. When gorged, or when the state of the tide precludes fishing, they are fond of sitting on an elevated perch, often with extended wings, and in this attitude they will remain motionless for a considerable time, as though hanging themselves out to dry, but hardly, as the fishermen report, sleeping the while. It was perhaps this pecnliarity that struck the observation of Milton, and prompted his well-known similitude of Satan to a Cormorant (Parad. Lost, iv. 194); but when not thus behaving they themselves provoke the more homely comparison of a row of black bottles. Their voracity is proverbial.

CORRIRA, a bird so named and described by Aldrovandus, as occurring in Italy; but never, so far as is known, seen since, and apparently fictitions.

COTINGA, see ChatTErer.

COUCAL, Levaillant's name, compounded, says Cuvier (Riegne Alim. 1. 425, note), of coucon and alouette, adopted by several English ornithologists, ${ }^{1}$ and especially by Gould (Handb. B. Austral. i. Pl. 634, 636), as the equivalent of Illiger's Centropus, a widely spread group of Cuculidx (Cuckow), chiefly of terrestrial habit, and having the hallux terminated by a straight spine-like claw, whence the name and that of "Lark-heeled" Cuckows applied to them absurdly by some writers. The Coucals may be taken to form a very distinct subfamily, Centropodina, and have been divided into half-a-dozen genera or more. They inhabit almost all parts of the Ethiopian Region from Egypt to the Cape Colony, as well as Madagascar: one species ocen's in India, where it is known as the "Crow-Pheasant," and other's range to the eastward as far as China and thronghont the Archipelago to New Guinea and Australia. They build their own nests, and lay eggs with white, chalky shell.

COULTERAEB, a common name of the PuFrix, from the likeness of its bill to the conlter of a plongh.

COURSER, apparently Lewin's rendering (B. Gr. Brit. vi. p. 4S) of Latham's word Cursorius, a genus established by him in 1790 for the Coure-tite of Buffon (H. $\Lambda$. Ois. viii. p. 128), who had already seen that, though allierl to the Plovers, it required separation. It was first known from an example taken in France (whence Gmelin called it Churadius gallicus), and Button in

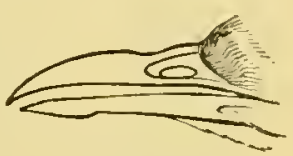

CuRsoriús. (After swainson.) 1781 had seen only one other, though that was from Coromandel and was of a distinct species. The third specimen, which was of the

I Mr. Sharpe (B.S. Afr. ed. 2, p. 161, pl. v. fig. 1), however, has bestowed the name on a sprecies, Ceuthmocheres australis (P. Z. S. 1873, 1. 609), which apparently does not possess the Lark-like claw whence the name is derived. 
same species as the first, was killed in Kent, not later, according to Mr. Saunders (Yarrell, Br. B. ed. 4, iii. p. 239), than 1785, and is now in the British Museum. The Coursers form a small group of some nine or ten species, belonging to the Charadriidx (Plover), but differing from all except the PrATincoles by their thick and clecurved bill. One species is peculiar to the Indian Region, the rest belong to the Ethiopian, though that which accidentally visits Europe breeds in Mauritania and the Canary Islands, as well as in India.

COW-BIRD, in England the yellow WAGTaIL, Motacilla raii; but in North America the name applied to two very distinct birds. First to one of the Cuckows (Coccyzus carolinenis), next and far more commonly as an abbreviation of Cowpen-bird, according to Catesby (N. H. Carotina, i. p. 34), who says :-- "They delight much to feed in the pens of cattle, which has given them their name," to a species which is also spoken of as Cow-Blackbird, Cow-Bunting, and Cow-Troopial, and is the Molotmes pecoris, ${ }^{1}$ one of the Icterida, and particular interest attaches to it from its parasitic habits, first recorded in 1810 by Alexander Wilson (Amer. Orn. ii. pp. 145160), though, as he was careful to say, they had "long been known to people of observation resident in the country,".and indeed he cites an instructive series of observations by Dr. Potter of Baltimore, shewing that that gentleman had for some time made the bird his study. The species which are the victims of the Cowbird's intruding its eggs into their nests are hardly less numerous than the dupes of orw own Cuckow, but no one seems to have witnessed the actual displacement of their rightful owner's progeny. Further particulars, which it would be impossible to reproduce here, may be found in the works of Nuttall and Audubon, as well as in the North American Birds of Messrs. Baird, Brewer, and Riclgway, besides Dr. Cones's Birds of the North-West (pp. 1S1-185). In the South American species of Molobrus, Mr. W. H. Hudson, whose remarks (Argent. Ornithol. i. pp. 72-97) upon them deserve the best attention, has observed that the old Cow-birds, both male and female, destroy many of the eggs in the nests which they visit; but extraordinary as it seems, one of the species, $M$. rufaxillaris, is parasitic upon another, $M$. badius, which makes a nest for itself, though he believes that this last will not foster the offspring of a third and eminently parasitical species, M. bonariensis.

COWRY-BIRD, the Fingilla punctulata of Linnæus, the Amadina or Munia punctulata of modern writers. It was apparently first made known by Edwards (N. H. Birds, i. p. 40), who figured it

1 The word was originally misprinted Molothrus, and thougli Swainson (Faun. Bor.-Am. ii. p. 27\%) was at the pains to explain this meaning of it, "qui non vocatus alienas res intrat," shewing that Molobrus must hare been intended, the majority of writers prefer following the error. 
from an example which he was told had come from the East Indies, where it "was called a Goury or Cowry Bird, they being sold for a small shell apiece, called a Gowry." It is a common cage-bird belonging to the Ploceidx (WEAVER-EIRD), and is found throughout India, Ceylon, and Burma.

CRAB-PLOVER, the Anglo-Indian name for a curious bird of wide range, frequenting the east coast of Africa from the Red Sea to Natal, as well as the northern and western shores of the Indian Ocean, the Bay of Bengal, and many of the intervening islands. It was described and figured by Payliull in 1805 (K. Vet.-Acal. $N$. Handl. xxvi. pp. 182-190, pl. viii.), from a specimen bought by him at Amsterdam, and said to have come from the East Indies, under the name of Dromas ardeola, which it has since generally borne. Several systematists have urged that it should be regarded as an aberrant form of TerN; but there can be little doubt, especially after the researches of Van der Hoeven $(N$. Acta Acad. L.-C. Nat. Cur. xxxiii.; French Transl. Arch. Néerl. 1S6S, pp. 2S1295 ), that it properly belongs to that polymorphic group of LIMICOLE, which comprises the genera Hrmatopus (OYsTER-CATCHER), IImantopus (STILT), and Recurvirostra (AvOSET) - the last of which it closely resembles in general coloration and in its webbed toes, while its bill is as hard and trenchant as in any member of the first, though of a different form. The possibility of its being with Chionis (SHEATHBILL) a surviving link between the Churadriide and the Larida is very great. For its habit of breeding in burrows in sandhills, see Hume, Nests and Eggs of Indian Birds, ed. 2, iii. pp. 327-330.

CRACKER, a name of the PINTAIL, Dufile acuta.

CRAKE (Lat. Crex), generally with a prefix, as Corm-Crake, a common name of the Land-RAIL, and often used for other's of the Rallida, in which the bill is comparatively short.

CRANE (in Dutch, Kraan; Old German, Iran; cognate, as also the Latin Grus, and consequently the French Grue and Spanish Grulla, with the Greek y'fovos), the Grus communis or G. cinerea of ornithologists, one of the largest Wading-birds, and formerly a native of England, where Turner, in 1544, said that he had very often seen its young ("earum pipiones sapissime vidi"). Notwithstanding the protection afforded it by sundry Acts of Parliament, it has long since ceased from breeding in this country. Sir $\mathrm{T}$. Browne (ob. 16S2) speaks of it as being found in the open parts of Norfolk in winter. In Ray's time it was only known as occurring at the same season in large flocks in the fens of Lincolnshire and Cambridgeshire; and though mention is made of Cranes' eggs and young in the fen-laws passed at a court held at Revesby in 1780 , this was most likely but the formal repetition of an older edict; 
for in 1768 Pennant wrote that after the strictest enquiry he found the inhabitants of those counties to be wholly unacquainted with the bird, and hence concluded that it had forsaken our island. The Crane, however, no doubt then appeared in Britain, as it does now, at uncertain intervals and in unwonted places, shewing that the examples occurring here (which usually meet the hostile reception commonly accorded to strange visitors) have strayed from the migrating bands whose movements have been remarked from almost the earliest ages. Indeed, the Crane's aerial journeys are of a very extended kind; and on its ray from beyond the borders of the Tropic of Cancer to within the Arctic Circle, or on the returnvoyage, its flocks may be descried passing overhead at a marvellous height, or halting for rest and refreshment on the wide meadows that border some great river, ${ }^{1}$ while the seeming order with which its ranks are marshalled during flight has long attracted attention. The Crane takes up its winter-quarters under the burning sun of Central Africa and India, but early in spring returns northward. Not a few examples reach the chill polar soils of Lapland and Siberia, but some tarry in the south of Europe and breed in Spain, and, it is supposed, in Turkey. The greater number, however, occupy the intermediate zone and pass the summer in Russia, North Germany, and Scandinavia. Soon after their arrival in these countries the flocks break up into pairs, whose nuptial ceremonies are accompanied by loud and frequent trumpetings, and the respective breeding-places of each are chosen.

The nest is formed with little art on the ground in large open marshes, where the herbage is not very high - a tolerably dry spot being selected and used apparently year after year. Here the eggs, which are of a rich brown colour with dark spots, and always two in number, are laid. The young are able to run soon after they are hatched, and are at first clothed with tawny down. ${ }^{2}$ In the course of the summer they assume nearly the same grey plumage that their parents wear, except that the elongated plumes, which in the adults form a graceful covering of the hinder parts of the body, are comparatively undeveloped. and the clear black, white, and red (the last being due to a patch of papillose slin of that colour) of the head and neck are as yet indistinct. During this time they keep in the marshes, but as autumn approaches the different families unite by the rivers and lakes, and ultimately form the enormous bands which after much more trumpeting set out on their southward journey.

1 A beantiful picture, representing a flock of Cranes resting by the Rhine, is to be seen in Mr. Wolf's Zoological Sketches.

"A paper "On the Breeding of the Crane in Lapland" (Ibis, 1859, pp. 191-198), by the late Mr. John Wolley, is one of the most pleasing contributions to Natural History ever written. 
The Crane's power of uttering the sonorous and peculiar trumpet-like notes, of which mention has been made, is commonly and perhaps correctly ascribed to the formation of its trachea, which on quitting the lower end of the neck passes backward betwcen the branches of the furcula and is received into a hollow space formed by the bony walls of the carina or keel of the sternum. Herein it makes three turns, and then runs upwards and backwards to the lungs. The apparatus on the whole much resembles that found in the Whooping Swaxs, Cygnus musicus, C. Zuccinator, and others, though differing in some not unimportant details; but at the same time somewhat similar convolutions of the trachea occur in other birds which do not possess, so far as is known, the faculty of trumpeting. The Crane emits its notes both during flight and while on the ground. In the latter case the neck and bill are uplifted and the mouth kept open during the utterance of the blast, which may be often heard from birds in confinement, especially at the beginning of the year.

As usually happens in similar cases, the name of the once familiar British species is now used in a general sense, and applied to all others which are allied to it. Though by many systematists placed near or even among the Herons, there is no doubt that the Cranes have only a superficial resemblance and no real affinity to the Ardeidx. In fact the Gruida folm a somewhat isolated group. Prof. Huxley has included then together with the Pallida in his GERANOMORPHe; but a more extended view of their various characters would probably assign them rather as relatives of the Bustards--not that it must be thought that the two Families have not been for a very long time distinct. Grus, indeed, is a very ancient form, its remains appearing in the Miocene of France and Greece, as well as in the Pliocene and Post-pliocene of North America. In France, too, during the "Reindeer Period" there existed a huge species--the G. primigenia of M. Alphonse Milne-Edwards-which has doubtless been long extinct. At the present time Cranes inhabit all the great zoogeographical Regions of the earth, except New Zealand and the Neotropical, and some sixteen or seventeen species are discriminated. In Europe, besides the $G$. communis already mentioned, we have as an inhabitant that which is generally known as the Numidian Crane or Deworseule. G. virgo, distinguished from every other by its long white ear-tufts. This bird is also widely distributed throughout Asia and Africa, and is said to have occurred in Orkney as a straggler. The eastern part of the Palæarctic area is inhabited by six other species that do not frequent Europe, $G$. antigone, $G$. viridirostris or japonensis, $G$. monachus, $G$. leucauchen, $G$. nigricollis, and $G$. leucogeranus, of which the last is perhaps the finest of the Family, with nearly the whole plumage of a snowy white. The Indian Region, besides 
being visited in winter by four of the species already named, has two that are peculiar to it, $G$. collaris and $G$. antigone. The Australian Region possesses a large species known to the colonists as the "Native Companion," G. australasiana; while the Nearctic area is tenanted by two species, $G$. americana and $G$. canadensis, to say nothing of the possibility of a fourth, $G$. schlegeli, a little-known and somewhat obscure bird, finding its habitat here. In the Ethiopian Region we have two species, G. paradisea and $G$. camnculatr, which do not occur out of Africa, as well as two others forming the group known as "Crowned Cranes"-differing much from other members of the family, and justifiably placed in a separate genus, Balearica. One of these, $B$. paronina, inhabits Northern and Western Africa, while the other, $B$. chrysopelargus or regulorum, is confined to the eastern and southern parts of that continent. $^{1}$

CRANIUM (latinized from kpaviov, a skull) anatomically applied to the bony and cartilaginous parts of the skull without the jaws and the palato-pterygo-quadrate bones, and therefore practically equivalent to those parts which enclose the clanial cavity and the three principal sense-organs (see SKELETON).

CREEPER (Dutch Kruiper, Swedish Krypare, Norsk Kryber), a term employed by ornithologists in a very vague sense, but chiefly to render Certhia as used by Linnæus and his immediate successors, and thus including forms belonging to more perfectly distinct Families than can here be named; for it was customary to thrust therein almost every outlandish Passerine bird which could not be conveniently assigned to any other of the then recognized genera, provided only that it had a somewhat attenuated and decurved bill. Taken by itself, "Creeper" signifies nothing in modern ornithology, and provincially it is very frequently used for the NuTHATcH. With a prefix, as TreE-CrEePEr, it has a much more definite meaning, and in England is the Certhic famitiaris of Linnæus.

CREST. Feathery crests need no further comment than that they seem to be entirely ornamental, favourite objects of sexua! selection, and therefore mostly developed in the male sex; they are generally erectile by the aid of cutaneous and subcutaneous muscles, notably by the musculus cucullaris. Horny crests, often supported by swollen cancellous outgrowths of the maxillary, nasal, and frontal bones (as in Hornbills and Cassowaries), have been described in connexion with the Bill. Very peculiar are the entirely

1 An admirably snceinet account of all the diflerent species was communicated by the late Mr. Blyth to The Field newspaper in 1873 (vol. xl. p. 631 ; vol. xli. pp. $7,61,136,189,218,384,408,418)$, which has since been published in a separate form with additions by the editor, Mr. Tegetmeier, as The Natural History of the Cranes (London: 1881). 
horny, slender, and erectile outgrowths on the forehead of Palamedea comuta; and the similar erectile, long process of Chasmorhynchus, which is partly covered with very small feathers. The soft crest or comb of many Phasianidre consists, like the wattles of other birds, entirely of the bare skin, and, being very rich in nerves and blood-vessels, is, as swelling organs, erectile in a different sense. Prominent ridges of bones, serving then for the attachment of powerful muscles, are likewise called "crests,"-for instance the crista sterni.

CROCKER in England, according to Montagu, a name for the Black-headed GuLL, Larus riditundus; but in North America (and perhaps also in some parts of Britain) used for the BRAnt-Goose (Trumbull, Portr. and Names of Birds, p. 6).

CROP, or ingluvies, the dilatation of the oesophagus before its entrance into the thorax. The walls of the crop seem to contain no other glands than the ordinary mucous glands of the oesophagus; the crop is used as a receptacle for the food, which therein is softened and acted upon by water and the saliva and warmth of the bird. Between a narrow, temporarily-dilated oesophagus and a permanent crop-like dilatation many intermediate stages exist. A distinct sac-like crop is present in most seed-eating birds, as in the Gallinæ, Columbæ, Pteroclidx, in Opisthocomus, Thinocorys, Attagis, Psittaci, and, among the Passeres, many of the Fringillidx and the Drepanididx. The crop is less marked or only temporary in the Birds-of-Prey, the Cassowary, the Humming-birds, in Mormon, Pedionomus, and Panurus; and is represented by a slight but permanent dilatation in the Cormorant, various Ducks and Storks, and in the Flamingo. It is absent in all other birds. It reaches its highest development in the Pigeons, consisting of a right and a left globular half which are united by an unpaired portion; the inner walls possess numerous irregular ridges, and shew during the breeding-season an extraordinary activity, the cells of the mucous membrane proliferating and peeling off as a cheesy natter, with which both sexes feed their nestlings for a considerable time.

The most peculiarly constructed crop is that of Opisthocomus ; the oesophagus is much widened and forms a long doubled loop, which rests upon the great pectoral muscles, and almost suppresses the anterior part of the keel of the breastbone. The walls are extremely muscular, and are inside furnished with numerous furrows and ridges, to enable the HoACTzIN to squeeze out the juicy leaves of the tree, Arum arborescens, upon which it feeds.

CROSSBILL (Fr. Bec-croisé, Germ. Kreuzschnabel), the name given to a genus of birds, belonging to the Family Fringillida (FINCH), from the unique peculiarity they possess among the whole Class of having the horny sheaths of the bill crossing one 
another obliquely, ${ }^{\mathrm{I}}$ whence the appellation Loxia ( $\lambda$ o $\xi^{\prime}$ s, obliquus), conferred by Gesner on the group and continued by Linnæus. At first sight this singular structure appears so like a deformity that writers have not been wanting to account it such, ${ }^{2}$ ignorant of its being a piece of mechanism most beautifully adapted to the habits of the bird, enabling it to extract with the greatest ease, from fir-cones or fleshy fruits, the seeds which form its usual and almost invariable food. Its mode of using this unique instrument seems to have been first described by Townson (Tracts on Nat. Hist. p. 116, London: 1799), but only partially, and it was Yarrell who, in 1829 (Zool. Journ. iv. pp. 459-465, pl. xiv. figs. 1-7), explained fully the means whereby the jaws and the muscles which direct their movements become so effective in riving asunder cones or apples, while at the proper moment the scoop-like tongue is instantaneously thrust out and withdrawn, conveying the hitherto protected seed to the bird's mouth. Without going into details it may be observed that in the Crossbills the articulation of the mandible to the quadrate-bone is such as to allow of a very considerable amount of lateral play, and, by a particular arrangement of the muscles which more the former, it comes to pass that so soon as the bird opens its mouth the point of the mandible is brought immediately opposite to that of the maxilla (which itself is movable vertically) instead of crossing or overlapping it - the usual position when the mouth is closed. The two points thus meeting, the bill is inserted between the scales or into the pome, but on opening the mouth still more widely, the lateral motion of the mandible is once more brought to bear with great force to wrench aside the portion of the fruit attacked, and then the action of the tongue completes the operation, which is so rapidly performed as to defy scrutiny, except on very close inspection. Fortunately the birds soon become tame in confinement, and a little patience will enable an attentive observer to satisfy himself as to the process, the result of which at first seems almost as unaccountable as that of a clever conjuring trick.

1 As an accidental malformation, however, the peculiarity has been many times observed in other groups of birds, and especially in the Crows (Corvidx). Such cases may be well compared to the monstrosity often seen in Rabbits and other members of the Order Glires, wherein the incisor teeth grow to inordinate length:

2 The special animosity of De Buffon on this point may perhaps be explained by the existence of a mediæval legend (of which, however, be it said, he takes no notice), best known to English readers by Longfellow's pretty version of Mosen's poem, to the effect that the bird acquired its peculiar conformation of bill and coloration of plumage in recognition of the pity it bestowed on the suffering Saviour at the crucifixion. Schwenckfeld in 1603 (Theriotropheum Silesia, pp. 253, 254) gave the fable in the Latin verses of Johamnes Major, which have been reprinted in Notes and Queries (ser. 5, vii. p. 505). 
The Common Crossbill of the Palæarctic area, Loxia curvirostra, is about the size of a Skylark, but more stoutly built. The young (which on leaving the nest have not the tips of the bill crossed) are of a dull olive colour with indistinct dark stripes on the lower parts, and the quills of the wings and tail dusky. After the first moult the difference between the sexes is shewn by the hens inclining to yellowish-green, while the cocks become diversified by orange-yellow and red, their plumage finally deepening into a rich crimson-red, varied in places by a flame-colour. Their glowing hues are, however, speedily lost by examples which may be kept in confinement, and are replaced by a dull orange, or in some cases by a bright golden-yellow, and specimens have, though rarely, occurred in a wild state exhibiting the same tints. The cause of these changes is at present obscure, if not unknown, and it must be admitted that their sequence has been disputed by some excellent authorities, but the balance of evidence is certainly in favour of the above statement. Depending mainly for food on the seeds of conifers, the movements of Crossbills are irregular beyond those of most birds, and they would seem to rove in any direction and at any season in quest of their staple sustenance. But the pips of apples are also a favourite dainty, and it stands recorded by the old chronicler Matthew Paris (Hist. Angl. MS. fol. 252), that in 1251 the orchards of England were ravaged by birds, "pomorum grana, \& non-aliud de eisdem pomis comedentes"; which, from his description, "Habebant autem partes rostri cancellatas, per quas poma quasi forcipi vel cultello dividebant," could be none other but Crossbills. Notice of a like visitation in 1593 was published by Wats (Vit. 2 Offar. \&c. 1640, p. 263), but of late it has become evident that hardly a year passes without Crossbills being observed in some part or other of England, while in certain localities in Scotland they seem to breed annually. The nest is rather rudely constructed, and the eggs, generally four in number, resemble those of the Greenfinch, but are larger in size. This species ranges throughout the continent of Europe, ${ }^{1}$ and, besides occurring in the islands of the Mediterranean, is permanently resident in Mauritania and in the fir-woods of the Atlas. In Asia it would seem to extend to Kamchatka and Japan, keeping mainly to the forest-tracts.

Three other forms of the genus also inhabit the Old Worldtwo of them so closely resembling the common bird that their specific ralidity has been often questioned. The first of these, of large stature, the Parrot-Crossbill, L. pityopsittacus, comes occasionally to Great Britain, presumably from Scandinavia, where it is

1 It was obtained by Dr. Malmgren on the desolate Bear Island (lat. $741_{2}^{\circ} \mathrm{N}$.), and in the autumn of 1889 enormons flocks were observed migrating southward along the coast of Portugal by the present Fing of that country. 
known to breed. The second, L. himalayana, which is a good deal smaller, is only known from the Himalaya Mountains. The third, the Two-barred Crossbill, L. tanioptera, is very distinct, and its proper home seems to be the most northern forests of the Russian empire, but it has occasionally occurred in Western Europe and even in England.

The New World has two birds of the genus. The first, $L$. anericana, representing our common species, but with a smaller bill, and the males easily recognizable by their more scarlet plumage, ranges from the northern limit of coniferous trees to the highlands of Mexico, or even further. The other, L. leucoptera, is the equivalent of the Two-barred Crossbill, but smaller. It has occurred in England at least thrice.

CROW (Holland. Kraai, Germ. Krähe, Fr. Corbeau, Lat. Corvus), a name most commonly applied in Britain to the bird properly called a Rook, Corvus frugilegus, but perhaps originally peculiar to its congener, nowadays usually distinguished as the Black or Carrion-Crow, C. corone. By ornithologists it is also used in a far wider sense, as under the title Crows, or Corvida, is included a vast number of birds from almost all parts of the world, and this family is probably the most highly developed of the whole Class Aves. Leaving out of account the best known of these, as the CHOUGH, DAw, JAY, NuTCRACKER, PIE, RAven, and Rook, it will be enough to consider here the species of the Family to which the appellation is strictly applicable, for of the limits and subdivisions of this Family it is at present desirable to speak with great caution, if not doubt. All authorities admit that it is very extensive, and is capable of being parted into several groups, but scarcely any two agree on either head. Especially must reserve be exercised as regards the group Streperina, or Piping Crows, belonging to the Australian Region, and referred by some writers to the SHRIkEs, Laniida: since it is highly probable that Parker's suggestion (Trans. Zool. Soc. ix. p. 327) as to the recognition of these "Austro-Coraces" as a distinct Family will prove to be correct. On the other hand, it seems hardly possible to admit, as some have done, that the Jays require raising to that rank or even to separate them as a subfamily from the Pies, Pica and its neighbours, which lead almost insensibly to the typical Crows, Corvinx. Dismissing then these subjects, we may turn to what may be literally considered Crows, and attention must be mainly directed to the Black or Carrion-Crow, Corivs coronc, and the Grey, Hooded, or Royston Crow, C. cornix. Both these inhabit Europe, but their range and the time of their appearance are very different. Without going into minute details, it will suffice to say that the former is, speaking generally, a summervisitant to the south-western part of this quarter of the globe, and 
that the latter occupies the north-eastern portion-an irregular line drawn diagonally from about the Firth of Clyde to the head of the Adriatic roughly marking their respective distribution. But both are essentially migrants, and hence it follows than when the Black Crow, as summer comes to an end, retires southward, the Grey Crow moves downward, and in many districts replaces it during the winter. Further than this, it has now been incontestably proved that along or near the boundary where these two birds march, they not infrequently interbreed, and it is believed that the hybrids, which sometimes wholly resemble one or other of the parents and at other times assume an intermediate plumage, pair indiscriminately among themselves, or with the pure stock. Hence it has seemed to some ornithologists who have studied the subject, that these two birds, so long unhesitatingly regarded as distinct species, are only local races of one and the same dimolphic species. No structural difference-or indeed any difference except that of range (already spoken of) and colour-can be detected, and the problem they offer is one of which the solution is exceedingly interesting if not important to zoologists in general. ${ }^{1}$

The views here briefly expressed have been set forth much more fully in the fourth edition of Yarrell's British Birds (ii. pp. 274-288); but they seem to be highly distasteful to some writers, whose remarks, however, shew a curious inability to appreciate the admitted facts of the question. The mode of life of the Crows needs not to be described. Almost omnivorous in their diet, there is little edible that comes amiss to them, and, except in South America and New Zealand, they are mostly ommipresent. The number of species described is considerable, but doubtless should and will be ruthlessly curtailed when a revision of the group is undertaken by any ornithologist working with proper materials. The Fish-Crow of North America, C. ossifragus, demands a few words, since it betrays a taste for maritime habits beyond that of other species, but our own Crows of Europe are not averse on occasion from prey cast up by the waters, though they will hardly draw it thence for themselves. The so-called "Hooded Crow" of India, C. splendens, is not very nearly allied to its European namesake, from which it can be readily distinguished by its smaller size and the lustrous tints of its darkest feathers, while its confidence in the human race has been so long encouraged by its intercourse with an unarmed and inoffensive population, that it becomes a plague to the European abiding or travelling where it is abundant. Hardly a station or camp in British India is free from a crowd of feathered followers

1 As bearing upon this question may be mentioned the fact that the Crow of $\Delta$ ustralia, C. australis, is divisible into two forms or races, one having the irides white, the other of a dark colour. It is stated that they keep apart and do not intermix. 
of this species, ready to dispute with the Kites and the cooks the very meat at the fire; and when any lengthened settlement is established the Crows will build their nests of the wire from the Englishman's soda-water bottles.

CROWN-BIRD, the name given by some old African travellers to one or more species of Touraco (cf. Latham, Gen. Hist. B. v. p. 176). 2

CUBITALS (or Secondaries) are those REMIGES which are supported by the upper surface of the ulna or cubitus of the anterior extremity. The rational way of counting them is to begin with the quill nearest to the wrist-joint, because reduction and addition in numbers takes place at the proximal end of the ulna. The number of the cubitals is reduced to 6 in the Trochilidx and is increased to 30 and more in some Tubinares; it stands in direct correlation with the length of the wing bones. Archæopteryx seems to have possessed 10 cubitals, which probably approaches closely the original number in true Birds. Of perhaps some slight taxonomic value is the presence or absence of the original fifth cubital quill. This peculiarity was discovered by Gerbe (Bull. Soc. Zool. France, 1877, p. 289), and followed up by Wray, Gadow, and Sclater (P.Z.S. 1887, p. 343 ; 1888, p. 655 ; and Ibis, 1890, p. 77). Contrary to expectation, the missing fifth quill shews no trace of its former existence in embryos, there being a distinct gap between the fourth and sixth quill, while the upper and lower fifth coverts remain. This peculiarity is still unexplained. Wray proposed to call the birds with the fifth quill normally developed quincubital, those without it aquincubital!

Among the Ratitæ with well-developed cubitals, are Struthio, Rhea, and Apteryx; and among the Carinatæ, Psophia, Dicholophus, and Rhinochetus; the Gallinæ except the Megapodes; the Turnices and Crypturi ; Opisthocomus, all the Picariæ after exclusion of the Psittaci ; all the Passeres, Colius, Trochilidæ, and Caprimulginæ possess the fifth cubital. In the Alcedinidæ and some Cypselidæ it is variable.

The groups with typically-developed remiges that have no fifth cubital are Anseres (including Palamedea), Colymbidæ, Podicipedidæ, Steganopodes, Tubinares, Herodii, Pelargi, Laro-Limicolæ, Grus, Aramus, Eurypyga, all the Fulicaria (except Psophia, Dicholophus, and Rhinochetus), the Pteroclidæ, Columbidæ, Accipitres, Psittaci, and Striges (also see Pterylosis).

CUCKOW, or CUCKoo, as the word is now generally speltthough without any apparent warrant for the change except that accorded by custom, while some of the more scholarly English ornithologists, as Montagu and Jenyns, have kept the older formthe common name of a well-known and often-heard bird, the Cuculus 
canorus of Linnrus. In some parts of the United Kingdom it is more frequently called Gowk, and it is the Greek ко́кvg, the Italian Cuculo or Cucco, the French Coucou, the German Kuckuk, the Dutch Koekkock, the Danish Kukker or Gjög, and the Swedish Gök. The oldest English spelling of the name seems to have been Cuccu.

No single bird has perhaps so much occupied the attention both of naturalists and of those who are not naturalists, or has had so much written about it, as this, and of no bird perhaps have more idle tales been told. Its strange and, according to the experience of most people, its singular habit of entrusting its offspring to foster-parents is enough to account for much of the interest which has been so long felt in its history; but this habit is shared probably by many of its Old-World relatives, as well as in the New World by birds which are not in any near degree related to it ( $c f$. Cow-BIRD). In giving here a short account of this species, there will be no need to refute much of the nonsense about it which has found access to works even of respectable authority; but, besides the known facts of its economy, there are certain suppositions in regard to parts of its history that are unknown, which suppositions are apparently probable enough to deserve notice.

To begin with the known facts. The Cuckow is a summervisitant to the whole of Europe, reaching even far within the Arctic circle, and crossing the Mediterranean from its winter-quarters in Africa at the end of March or beginning of April. Its arrival is at once proclaimed by the peculiar and in nearly all languages onomatopoetic cry of the cock-a true song in the technical sense of the word, since it is confined to the male sex and to the season of love. In a few days the cock is followed by the hen, and amorous contests between keen and loud-voiced suitors are to be commonly noticed, until the respective pretensions of the rivals are decided. Even by night they are not silent; but as the season advances the song is less frequently heard, and the Cuckow seems rather to avoid observation as much as possible, the more so since whenever it shews itself it is a signal for all the small birds of the neighbourhood to be up in its pursuit, just as though it were a Hawk, to which indeed its mode of flight and general appearance give it an undoubted resemblance-a resemblance that misleads some beings, who ought to know better, into confounding it with the Bircls-ofprey, instead of recognizing it as a harmless if not a beneficial destroyer of hairy caterpillars. Thus pass away some weeks. Towards the middle or end of June its "plain-song" cry alters; it becomes rather hoarser in tone, and its first syllable or note is doubled. Soon after it is no longer heard at all, and by the middle of July an old Cuckow is seldom to be found in these islands, though a stray example, or even, but very rarely, two or three in 
company, may occasionally be seen for a month longer. This is about as much as is apparent to most people of the life of the Cuckow with us. Of its breeding comparatively few have any personal experience. Yet there are those who know that diligent search for and peering into the nests of several of our commonest little birds-more especially the Pied Wagtail (Motacilla lugubris), the Titlark (Anthus pratensis), the Reed-Wren (Acrocephalus streperus), and the Hedge-Sparrow (Accentor modularis) - will be rewarded by the discovery of the egg of the mysterious stranger which has been surreptitiously introduced therein, and waiting till this egg is hatched they may be witnesses (as was the famous Jenner in the last century ${ }^{1}$ ) of the murderous eviction of the rightful tenants of the nest by the intruder, who, hoisting them one after another on his broad back, heaves them over to die neglected by their own parents, of whose solicitous care he thus becomes the only object. In this manner he thrives, and, so long as he remains in the country of his birth, his wants are anxiously supplied by the victims of his mother's dupery. The actions of his foster-parents become, when he is full grown, almost ludicrous, for they often have to perch between his shoulders to place in his gaping mouth the delicate morsels he is too indolent or too stupid to take from their bill. Early in September he begins to shift for himself, and then follows the elders of his kin to more southern climes.

Of the way in which it seems possible that this curious habit of the Cuckow may have originated something will be found elsewhere (NIDIFICATION). But in connexion with its successful practice a good deal yet remains to be determined, most of which, however probable, is still to be proved. So much caution is used by the hen Cuckow in choosing a nest in which to deposit her egg that the act of insertion has been-but seldom witnessed. The nest selected is moreover often so situated, or so built, that it would be an absolute impossibility for a bird of her size to lay her egg therein by sitting upon the fabric as birds commonly do; and there have been a few fortunate observers who have actually seen the deposition of the egg upon the ground by the Cuckow, who, then taking it in her bill, introduces it into the nest. Of these, so far at least as this country is concerned, the earliest seem to be two Scottish lads, sons of Mr. Tripeny, a farmer in Coxmuir, who informed Weir, as recorded by Macgillivray (Brit. Birds, iii. pp. $130,131)$, that they saw most part of the operation performed, 24 th June 1838. But perhaps the most positive evidence on the point is that of Herr Adolf Müller, a forester at Gladenbach in Darm-

1 A wholly unjustifiable attempt has lately been made to impugu Jenner's accuracy. His observations as printed in the Philosophical Transactions for 1788 (pp. 227 et seqq.), have been corroborated by others in the most minute detail. 
stadt, who says (Zoolog. Garten, 1866, pp. 374, 375) that through a telescope he watched a Cuckow as she laid her egg on a bank, and then conveyed the egg in her bill to a Wagtail's nest. Cuckows too have been not unfrequently shot as they were carrying a Cuckow's egg, presumably their own, in their bill, ${ }^{1}$ and this has probably given rise to the vulgar, but seemingly groundless, belief that they suck the eggs of other kinds of birds. More than this, Rowley, who had much experience of Cuckows, declared (Ibis, 1865 , p. 186) his opinion to be that traces of violence and of a scuffle between the intruder and the owners of the nest at the time of introducing the egg often appear, whence we are led to suppose that the Cuckow ordinarily, when inserting her egg, excites the fury (already stimulated by her Hawk-like appearance) of the owners of the nest by turning out one or more of the eggs that may be already laid therein, and thus induces the dupe to brood all the more readily and more strongly what is left to her. Of the assertion that the Cuckow herself takes any interest in the future welfare of the egg she has foisted on her victim, or of its product, there is no evidence worth a moment's attention.

But a much more curious assertion has also been made, and one that at first sight appears so incomprehensible as to cause little surprise at the neglect it long encountered. Elian, who flourished in the second century, declared (De Nat. Anim. III. xxx.) that the Cuckow laid eggs in the nests of those birds only that produced eggs like her own-a statement which is of course far too general; but in 1767 currency was given to it by Salerne (L'hist. Nat. Ois. p. 42), who was, however, hardly a believer in it; and it is to the effect, as he was told by an inhabitant of Sologne, that the egg of a Cuckow resembles in colour that of the eggs normally laid by the kind of bird in whose nest it is placed. In 1853 the same notion was prominently and independently brought forward by Dr. Baldamus (Naumannia, 1853, pp. 307-325), and in time became known to English ornithologists, most of whom were sceptical as to its truth, as well they might be, since no likeness whatever is ordinarily apparent in the very familiar case of the blue-green egg of the Hedge-Sparrow and that of the Cuckow, which is so often found beside it. ${ }^{2}$ Dr. Baldamus based his motion on a series of eggs in his cabinet, ${ }^{3}$ a selection from which he figured (op. cit. 1854, pl. v.)

I The earliest instance of this in the British Islands seems to be that reported by Thompson ( $B$. Irel. iii. p. 472); another was recorded in 1851 (Z0ol. p. 3145); but Le Vaillant seems to have been the first to discover the fact in a South African species (Ois. d'Afr. v. pp. 47, 48), and untrustworthy witness as he was, in this case he seems to have spoken truly.

2 An instance to the contrary was recorded by Mr. A. C. Smith (Zoologist, 1873, p. 3516) on Mr. Brine's authority, and a few others have since been observed.

3 This series was seen in 1861 by the writer. 
in illustration of his paper, and, however the thing may be accounted for, it seems impossible to resist, save on one supposition, the force of the testimony these specimens afford. This one supposition is that the eggs liave been wrongly ascribed to the Cuckow, and that they are only exceptionally large examples of the eggs of the birds in the nests of which they were found, for it cannot be gainsaid that some such abnormal examples are occasionally to be met with. But it is well known that abnormally-large eggs are not only often deficient in depth of colour, but still more often in stoutness of shell. Applying these rough criteria to Dr. Baldamus's series, most of the specimens stand the test very well, and, though no doubt more precise and delicate examination, than any to which they seem to have been submitted, were desirable, there are some other considerations to be urged. For instance, Herr Braune, a forester at Greiz in the principality of Reuss (Naumannia, 1853, pp. 307,313), shot a hen Cuckow as she was leaving the nest of an Icterine Warbler (Hypolais icterina). In the oviduct of this Cuckow he found an egg coloured very like that of the Warbler, and on looking into the nest he found there an exactly similar egg, which there can be no reasonable doubt had just been laid by that very Cuckow. Moreover, Herr Grunack (Jour. für Orn. 1873, p. 454) has since found one of the most abnormally-coloured specimens, quite unlike the ordinary egg of the Cuckow, to contain an embryo so fully formed as to shew the characteristic zygodactyl feet of the bird, thus proving unquestionably its parentage. Now these being both of them extreme cases, Dr. Baldamus may fairly claim attention to his assertion; for short of absolutely disbelieving his word we must admit that he has ground for it. On the other hand, we must bear in mind the numerous instances in which not the least similarity can be traced-as in the not uncommon case of the HedgeSparrow already mentioned, and if we attempt any explanatory hypothesis it must be one that will fit all round. Such a one then seems to be this. We know that certain kinds of birds resent interference with their nests much less than others, and among them it may be asserted that the Hedge-Sparrow will patiently submit to various experiments. She will brood with complacency the egg of a Redbreast (Erithacus rubecula), so unlike her own, and for aught we know to the contrary may even be colour-blind. In the case of such a species there would be no need of anything further to insure success-the terror of the nest-owner at seeing her home invaded by a Hawk-like giant, and some of her treasures tossed out, would be enough to stir her motherly feelings so deeply that she would without misgiving, if not with joy that something had been spared to her, resume the duty of incubation so soon as the danger was past. But with other species it may be, nay doubtless it is, different. Here assimilation of the introduced egg to 
those of the rightful owner may be necessary, for there can hardly be a doubt as to the truth of Dr. Baldamus's theory (the only theory, by the way, he has put forth), as to the object of the assimilation being to render the Cuckow's egg "less easily recognized by the foster-parents as a substituted one." But in this place it is especially desirable to point out that there is not the slightest ground for imagining that the Cuckow, or any other bird, can voluntarily influence the colour of the egg she is about to lay. Over that she can have no control, but its destination she can determine. It is also impossible that a Cuckow having laid an egg, should look at it, and then decide from its appearance in what bird's nest she should put it. That the colour of an egg-shell can be in some mysterious way affected by the action of external objects on the perceptive faculties of the mother is a notion too wild to be seriously entertained. ${ }^{1}$ Consequently, only one explanation of the facts can here be suggested. Every one who has sufficiently studied the habits of animals will admit the tendency of some of those habits to become hereditary. That there is a reasonable probability of each Cuckow most commonly putting her eggs in the nest of the same species of bird, and of this habit being transmitted to her posterity, does not seem to be a very violent supposition. Without attributing any wonderful sagacity to her, it does not seem unlikely that the Cuckow which had once successfully foisted her egg on a Reed-Wren or a Titlark should again seek for another Reed-Wren's or another Titlark's nest (as the case may be), when she had another egg to dispose of, and that she should continue her practice from one season to another. It stands on record (Zoologist, 1873, p. 3648) that a pair of Wagtails built their nest for eight or nine years running in almost exactly the same spot, and that in each of those years they fostered a young Cuckow, while many other cases of like kind, though not perhaps established on authority so good, are believed to have happened. Such a habit could hardly fail to become hereditary, so that the daughter of a Cuckow which always put her egg into a Reed-Wren's, Titlark's, or Wagtail's nest would do as did her mother. Furthermore it is unquestionable that, whatever variation there may be among the eggs laid by different individuals of the same species, there is a strong family likeness between the eggs laid by the same individual, even at the interval of many years, and it can hardly be questioned that the eggs of the daughter would more or less resemble those of her mother. Hence the supposition may be fairly regarded that the habit of laying a particular style of egg is also likely to become hereditary. Combining this supposition with that as to the Cuckow's habit of using the nest of the same species

1 The misconception of the unreasoning mind on all these points is almost incredible. 
becoming hereditary, it will be seen that it requires but an application of the principle of "Natural Selection" to shew the probability of this principle operating in the course of time to produce the facts asserted by Alian, by the anonymous Solognot of the last century, and by Dr. Baldamus and others since. The particular gens of Cuckow which inherited and transmitted the habit of depositing in the nest of any particular species of bird eggs having more or less resemblance to the eggs of that species would prosper most in those nembers of the gens where the likeness was strongest, and the other members would (cxteris paribus) in time be eliminated. As already shewn, it is not to be supposed that all species, or even all individuals of a species, are duped with equal ease. The operation of this kind of natural selection would be most needed in those cases where the species are not easily duped,-that is, in those cases which occur the least frequently. Here it is we find it, for observation shews that eggs of the Cuckow deposited in nests of the Red-Backed Shrike (Lanius collurio), of the Bunting (Emberiza miliaria), of the Redstart (Ruticilla phonicura), and of the Icterine Warbler approximate in their colouring to eggs of those speciesspecies in whose nests the Cuckow rarely (in comparison with others) deposits eggs. Of species which are more easily duped, such as the Hedge-Sparrow, mention has already been made.

More or less nearly allied to our Cucliow are many other forms of the genus from various parts of Africa, Asia, and their islands, while one even reaches Australia. How many of these deserve specific recognition will long be a question among ornithologists which need not be discussed here. In some cases the chief difference is said to lie in the diversity of voice-a character only to be appreciated by those acquainted with the living birds, and though of course some regard should be paid to this distinction, the possibility of birds using different "dialects" according to the locality they inhabit (see SoNG) must make it a slender specific diagnostic. All these forms are believed to have essentially the same habits as our Cuckow, and, as regards parasitism, the same is to be said of the large Cuckow of Southern Europe and North Africa, Coccystes glandarius, which victimizes Pies (Pica mauritanica and Cyanopica. cooliz) and Crows (Corvus cornix). True it is that an instance of this species, commonly known as the Great Spotted Cnckow, having built a nest and hatched its young is on record, but this is a manifest error ( $c f$. Salvadori, Uccelli d'Italia, pl. 42); the later observations of Dr. A. E. Brehm, Canon Tristram, Stafford Allen, and others leave no doubt on the subject. It is worthy of remark that the eggs of this bird so clasely resemble those of one of the Pies in whose nest they have been found, that even expert oologists have been deceived by them, only to discover the truth when the Cuckow's embryo had been extracted from the supposed Pie's egg. 
This species of Cuckow, easily distinguishable by its large size, long crest, and the primrose tinge of its throat, has more than once made its appear'ance as a straggler in the British Isles. Equally parasitic are many other Cuckows, belonging chiefly genera which have been more or less clearly defined as Cucomuntis, Chrysococeyx, Eudynamis,

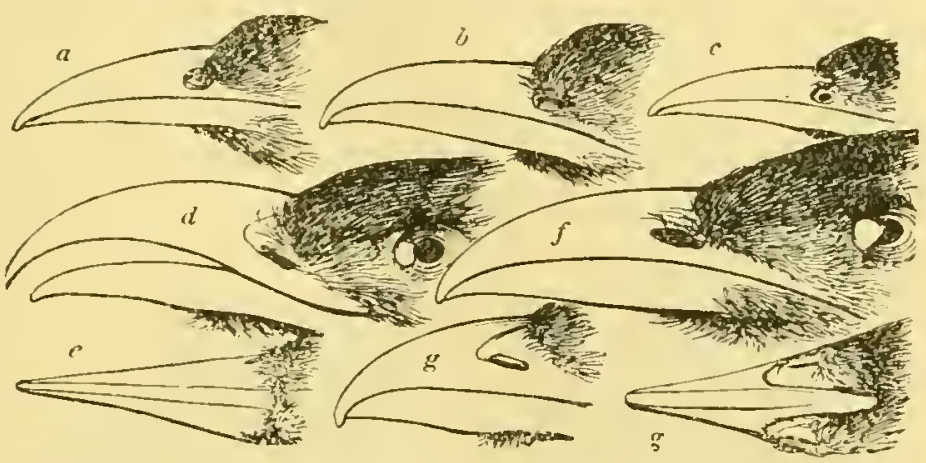

e, Cuculus ; $b$, Orylophus ; $e$, Chaleites ; $d, c$, Zaxclostoma, $f$, Piata; $g$, Centropus. (After Swainsun.) Oxylophus, Phoenicophaes, Pulypleasia, Surniculus, and Zunclostomu, and inlabiting parts of the Ethiopian, Indian, and Australian Regions ; ${ }^{1}$

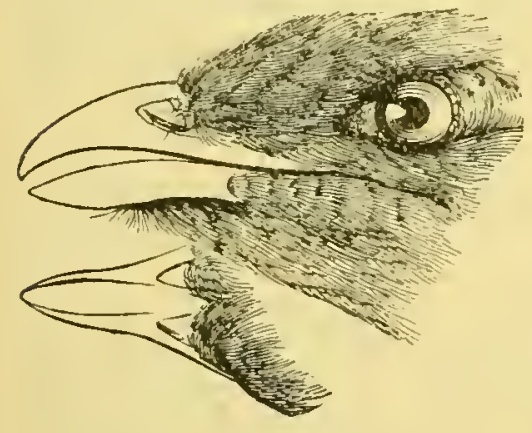

Covi. (After Swainson.)

but there are certain aberrant forms of Old-World Cuckows which unquestionably do not shirk parental lesponsibilities. Among these especially ane the birds placed in or allied to the genera Centropus (CoucaL) and Conuthe latter bearing no English name, and limited to the island of Madagascar. These build a nest, not perhaps in a highly-finished style of architecture, but one that serves its end.?

Respeeting the Cuckows of America, the evirlence, though it has been impugned, is nearly enough to clear them from the calumny which attaches to so many of their brethren of the Old World. There are two species very well known in parts of the United States and some of the Mest-Indian Islands, Coccyzus americums and C. crythrophthelmus, and each of them has

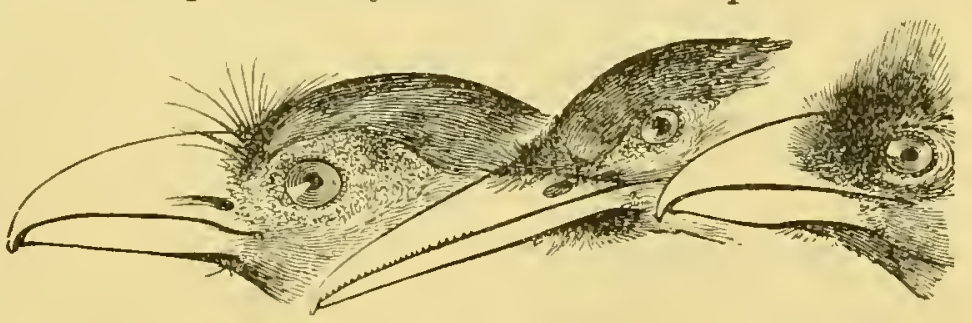

Phonicophaes. Salrothera, Dastlophls, (After Swainson.) occasionally visited Europe. They both build nests-remarkably small structures when compared with those of other birds of their size-and faithfully incubate their delicate sea-green eggs. In the sonth-western States of the Union and thence into Central America

1 Evidence tends to shew that the same is to be said of the curious CHANNELBiLL, S'ythrops nor:-Tollandix, but absolute proof seems to be wantinc.

- See Grandidier and Milne-Edwards Oiseaux de Madagascar (1. 140). 
is found the curious form, Geococcyx (Chapparal-COCK). The genera Neomorphus, Diplopterus, Saurothera, and Piaya (the last two commonly called Rain-birds, from the belief that their cry portends rain) may be noticed-all of them belonging to the Neotropical Region; but perhaps the most curious form of American Cuckows is Crotophaga (ANI), of which three species inhabit the same Region. The best-known species (C. ani) is found throughout the Antilles and on the opposite continent. In most of the British colonies it is known as the Black Witch, and is accused of various malpractices -it being, in truth, a perfectly harmless if not a beneficial bird. As regards its propagation this aberrant form of Cuckow departs as much in one direction from the normal habit of birds as do so many of our familiar friends of the Old World in the other, for several females unite to lay their eggs in one nest. Full details of its economy are wanting, but it is evident that incubation is carried on socially, since an intruder on approaching the rude nest will disturb perhaps half a dozen of its sable proprietors, who, loudly complaining, seek safety either in the leafy branches of the tree that holds it, or in the nearest available covert, with all the speed that their feeble powers of flight permit.

CUCKOW'S-LEADER and CUCKOW'S-MATE, common names for the WRYNECK.

CURASSOW, ${ }^{1}$ the ordinary corruption of Curaçoa-bird, as the name was spelt in 1756 by Browne (Civ. and Nat. Hist. Jamaica, p. 470), and doubtless due to the belief that the birds of this kind first known to English voyagers came from the island so called. They form the Linnæan genus Crax, and the Family Cracida, which is held by Messrs. Sclater and Salvin (Proc. Zool. Soc. 1870, pp. 504-544) to include three subfamilies - Cracinæ the Curassows proper, Penelopina (GUAN), and Oreophasina-the last consisting of but a single species, the beautiful Oreophasis derbianus of the Volcan de Fuego in Guatemala, of whose haunts and habits Mr. Salvin has given an excellent account (Ibis, 1860, pp. 248-253). Prof. Huxley has shewn (Proc. Zool. Soc. 1868, pp. 294-319) that the Cracida with the Megapodiida (MEgapodE) form a distinct group of Alectoronorphes or Galina, to which he applied the name Peristeropodes, and thereon based some riews of GeographICaL

1 Dampier, a good authority on many things but not on orthography, in 1699 and 1703, used Corresso and Curreso (Voy. ii. pt. 2, p. 67, and iii. jt. 1, p. 74); Albin in 1738 wrote (N. H. Birds, ii. p. 29) of birds of this kind (he having figured both male and female), "They are generally brought from Carassow, from whence they take their name." Sloane in 1707 (Voy. p. 302) used Quirizao for both island and bird; and Linnæus in 1758 (Syst. Nat. ed. 10, i. p. 157) used Gallus curassivicus, which he professedly got from Aldrorandus, in whose work, however, I have failed to find it. He figures a species of Crax as Gallus Indicus (lib. xiv. cap. 10). 
Distribution which are considered elsewhere. But at present to treat of the Cracina, the two anthors above mentioned recognize 4 good genera:- Cira, with a soft cere, and the nostrils pluced in the middle of the maxilla, while the remaining three have the whole of the bill horny and the nostrils at its base, the lores being bare in Nothocrar, but feathered in Pauxis (CASHEW-BIRD) and Mitu, the former of which bears the eurious frontal knob alreaty mentioned, while the latter has the enlmen of its short and greatly compressed bill elerated and swollen. Miny further par-

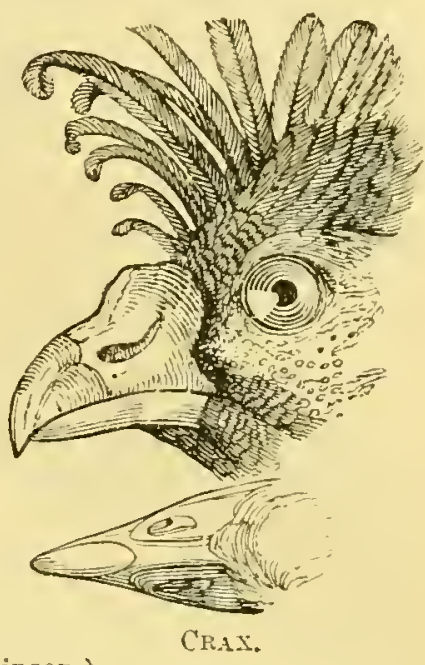
(After Swainson.)

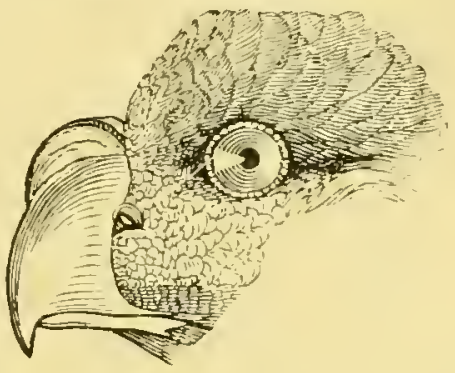

MITU'A. ticular's of the Curassows may be gathered from two other papers by Mr. Sclater (Trans. Zool. Soc. ix. pp. 273-288, pls. 40-53, and x. pp. 543-546, pls. 89-95), which are illustrated copionsly and mostly from living examples, for these birds thrive well in continement, though the hopes once entertained of their eapacity for domestication have been disappointed. 'The Cracida are one of the most characteristic Families of the Neotropical Region, ontsicle of which but few of them and none of the Cracine go, and are especially abundant in Central and the north parts of Sonth America, few being found in Paraguay, and none in Patagonia or Chili.

CURLEW, in French Courtis or Corlieu, a name given to two birds, of whose cry it is an imitation, both belonging to the group Limicola, but possessing very difierent habits and features.

1. The Long-Billed Cunlew, or simply Curlew of most British writers, the Numenius arquatu ${ }^{2}$ of ornithologists, is one of the largest of the Family Scolopucida, or Sinipes and allied forms. It is common on the shores of the United Kingrlom and most parts of Europe, seeking the heaths and moors of the interior and more northern eountries in the breeding-season, where it lays its four brownish-green eggs, suffused with cinnamon markings, in an artless nest on the ground. In England it has been ascertained to breed in Cornwall and in the counties of Deron, Dorset, Salop, and

1 On this see E. S. Dixon, The Dovecote and the Aviary, p1). 223-279 (London: 1851).

2 Some authors have tried to improve on this word by writing arquatus, which is nonsense, though arcuatus might be right. As a matter of fact, arquata is a substantive and the name of the bird in medixval Latin, which of course Linuæus knew. 
Derby-though sparingly. In Forkshire it is more numerous, and thence to the extreme north of Scotland, as well as throughout Ireland, it is, under the name of WHAUP, familiar to those who have occasion to traverse the wild and desolate tracts that best suit its habits. So soon as the young are able to shift for themselves, both they and their parents resort to the sea-shore or mouths of rivers, from the muddy flats of which they at low tide obtain their living, and, though almost beyond any other birds wary of approach, form an object of pursuit to numerous gunners. While leading this littoral life the food of the Curlew seems to consist of almost anything edible that presents itself. It industriously probes the mud or sand in quest of the worms that lurk therein, and is also active in seeking for such crustaceans and mollusks as can be picked up on the surface, while vegetable matter as well has been found in its stomach. During its summer-sojourn on the moorlands insects and berries, when they are ripe, enter largely into its diet. In bulk the Curlew is not less than a Crow, but it looks larger still from its long legs, wings, and neck. Its bill, from 5 to 7 inches in length, and terminating in the delicate nervous apparatus common to all birds of its Family, is especially its most remarkable feature. Its plumage above is of a drab colour streaked and mottled with very dark brown; beneath it is white, while the flight-quills are of a brownish black.

Nearly allied to the Curlew, but smaller and with a more northern range, is the WhInBres, $N$. phroopus, called in some parts Jack-Curlew, from its small size-May-fowl, from the month in which it usually arrives - and Titterel from one of its cries. ${ }^{1}$ This so much rescmbles the former in habit and appearance that no further details need be given of it. In the countries bordering on the Mediterranean occurs a third species, $N$. tenuirostris, the home of which has yet to be ascertained. Some 15 other species, or more, have been described, but Mrr. Seebohm (Geogr. Distrib. Charadriille, p. 321) admits but 11 in all with 2 "subspecies." The genus Numenius is almost cosmopolitan. In North America three very easily recognized species are found-the first, $N$. longirostris, closely agreeing with the European Curlew, but larger and with a longer bill; the second, N. hudsonicus, representing our Whimbrel; and the third, $N$. borectis, which has several times found its way to Britain, very much less in size. All these essentially agree with the species of the Old World in habit; but it is remarkable that the American birds can be easily distinguished by the rufous colouring of their axillary feathers - a feature which is also presented by the American Godwirs (Limosa). A very singular peculiarity is afforded by $N$. tahitiensis or femoralis, a species which seems to have

1 The name Sprowe ( $c f$. Icelandic Spói) also seems to have been anciently given to this birl (see Stevenson's Birds of Forfolk, ii. p. 201). 
its home in Alaska and winters in the islands of the Pacific. In this bird the shaft of most of the feathers clothing its legs is produced into a long glistening bristle.

2. The Curlew of inlanders, or STONE-CurLew-ealled also, by some writers, from its stronghold in this conntry, the Torfolk Plover, and most wrongly and absiudly the Thick-Knee or Thick-Kneed Bustard-is usually classed among the Charalriida, but it offer's several remarkable differences from the more normal Plovers. It is the Charadrius acticnemus of Linneus, the C. scolopux of Sam. Gottl. Gmelin, and the Eidicnemus

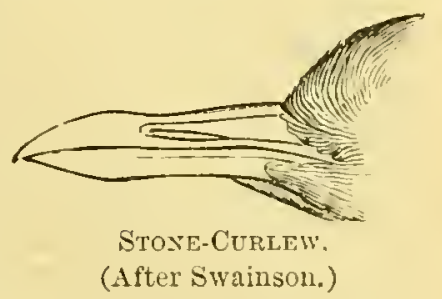
crepituns of Temminck. With much the same ery as that of the Nimenii, only uttered in a far sweeter tone, it is as fully entitled to the name of Curlew as the bird most commonly so called. In England it is ahnost solely a summer-visitor, though an example will occasionally linger thronghont a mild winter: and is one of the few birds whose distribution with us is affected by geological formation, since it is nearly limited to the chalk-conntry-the open spaces of which it haments, and its numbers have of late years been sensibly diminished by their enclosure. The most barren spots in these districts, even where but a superficial coating of light sand and a thing growth of turf scarcely hide the chalk below, supply its needs; though at night (and it chiefly feeds by night) it resorts to moister and more fertile places. Its food consists of snails, coleopterous insects, and eurthworms, but larger prey, as a mouse or a frog, is not rejected. Withont making the slightest attempt at a nest, it lays its two eggs on a level spot, a bare fallow being often chosen. These are not very large, and in colour so closely resemble the sandy, flintstrewn surface that their detection except by a practised eye is difficult. The bird, too, trusts much to its own drab colouring to elude observation, and, on being disturbed, will frequently run for' a considerable distance and then squat with outstretched neck so as to become almost invisible. In such a case it may be closely approached, and its large golden eye, if it do not pass for a tuft of yellow lichen, is perhaps the first thing that strikes the searcher. As autumn advances the Stone-Curlew gathers in large flocks, and then is as wary as its namesake. Towards October these take their departure, and their survivors return, often with wonderful constancy, to their beloved haunts (see Migration). In size this species exceeds any other European Plover, and looks even still larger than it is. The bill is short, blunt, and stout; the head large, broad, and flat at the top. The wings and legs long-the latter presenting a singular enlargement of the tibio-tarsal joint, whence the name Edicnemus has been conferrer. The toes are short and fleshy, 
and the hind-toe, as in most Charadriuda, is wanting. This Curlew seems to have been an especial favourite with Gilbert White, in whose classical writings mention of it is often made. Its range extends to North Africa and India, though examples from the latter country have been regarded as requiring specific distinctions. Four other species of Edicnomus from Africa are recognized by Mr. Seebohm (op. cit. p. 71). Australia possesses a very distinct species, E. grallarius, which some writers have raised to a genus Burhinus, and there are 3 species in the Neotropical Region, $\mathscr{E}$. bistriatus, $E$. dominicensis, and $E$. superciliaris. The analogy of all these birds to the Otididix (BUsTARD), is manifest, but that they have any really close affinity to that Family is questionable. An exaggerated form of Edicnemus is found in Asacus, of which two species have been described, one $A$. recurvirostris, from the Indian, and the other, $A E$. magnirostris, from the northern parts of the Australian Region.

CURSORES, an Order of Birds proposed by Illiger in 1811 (Prodrom. Syst. Mammal. et Avium, pp. 246-250) to contain the genera Casuarius (CAssowary), Struthio (Ostrich), Rhea, Otis (Bustard), Charadrius (Plover), Calidris (SAnderling), Himantopus (STILT), Hamatopus (Orster-CATCHER), Tachydromus (= Cursorius, Courser), and Burhinus (Stone-Curlew). Notwithstanding the obviously artificial nature of this group, several authors have accepted it, some entirely, but others with so many modifications that the meaning of the term has become quite indefinite.

CURUCUI, a Brazilian word adopted, through the French, by

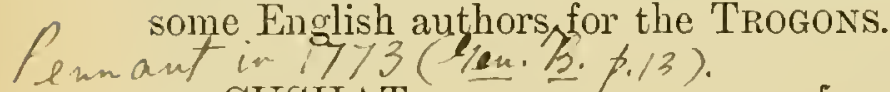

CUSHAT, a common name for the Ring-Dove or WoodPigeon.

CYPSELOMORPHA, Prof. Huxley's name (Proc. Zool. Soc. 1867, p. 468) for the group of EGiTHognaTH 2 containing the Families Caprimulgidx (GOATsucker), Cypsclidx (SWIFT), and Trochilidx (HUMmING-BIRD), which he considers to be "ammectent forms between the CORACOMORPHA and the CocCrgonorPHæ."

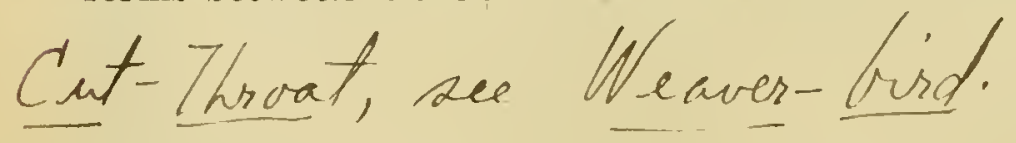




\section{D}

DABCHICK or DOBCHICK, the smallest and most common European species of Podicipes, which has also a wide range in the Old World. It is the Little GREBE of books, and the Podicipes Aluciatilis or minur of modern ornithology. In most parts of Britain it resorts in spring to lakes or even small ponds, building there a nest of aquatic plants, collected in the pool it frequents, and either piled up from the bottom near the margin or resting on the growing water-weeds themselves, while use is occasionally marle of any branch of a tree that may have fallen into the water. In every case the mass of materials brought together is large compared with the size of the bird, and is always in a moist condition, even to the upper part, which is slightly hollowed out in the form of a cup to reeeive the seven or eight eggs that are therein laid. These, as is generally the ease with those of other members of the Family, are symmetrical in form, there being little or no difference between the two ends, and have a chalky shell, which from being at first of a pure white are soon stained by the damp weeds forming the nest, some of which are carefully drawn over it by the parent whenever it is left, and even if she be too snddenly disturbed to make this possible, she will stealthily return at the first opportunity and cover them.

Few birds have a greater faculty of escaping observation than this, and it often happens that a pair will frequent a smill weedy pond, nigh unto a human habitation, and rear their young there, without their existence being detected, though they stay for the whole of a summer. In winter the greater part emigrate, and those that remain betake themselves to rivers, brooks, and ditches near the sea, which exeept in very hard frost are free from icensing, as a last resort, the tidal waters.

DACNIS, a genus established by Cuvier, with the conspicuous bhe and black Motacille ceryenu of Limens as its type, belonging to the Carebirla. Fourteen species are recognized by Mr. Sclater (Cut. B. Br. Hus. xi. pp. 18-27), and the skins of two or three of them, remarkable for their beautiful blue or bluish-green coloration, are

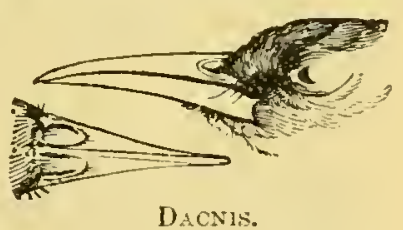

(After swainson.) among the commonest of those sent from South Ameriea.

DAKER-HEN, an old and widely-spread name of the LandRaIL, referring, it is thonght, to the unsteady flight of the bird, for" to "dacker" (Frisian, dukkern, M. Dutch, dueckeren), signifying to stagger, totter, or hesitate, is a well-known word in Lincolnshire, 
and perhaps in other districts (cf. Cordeaux, Zoologist, 1883, pp. 22s, 229).

DARR, a local name applied to some species of TERx.

DARTER, see SNAKE-BIRD.

DASSIE-VANGER (Coney-catcher), the Dutch name for an EAGLE in South Africa, adopted by English residents - the "Dassie" being Hyrax capensis (Layard, B. S. Africa, p. 11).

DAW (Old Low Germ. Daha), doubtless from the bird's cry, as seems also to be the nickname "Jack" commonly prefixed." The Jackdaw, to use its vulgar and redundant name, is the smallest as it is, perhaps, the best known in Britain of the Corvida (Crow); for, though much less numerous than the Rook, it inhabits the outslirts of even large towns as well as the country; and, from its diverting manners, and its aptitude for imitating the sounds it hears, is often kept in captivity more or less modified. In its natural state it differs from most of the Corvida in the choice it makes of breeding-quarters, nearly always placing its nest in some hollow tree or convenient corner in a building-a church-tower (from its being seldom ascended) especially affording a secure position. It will equally make itself a home in a rabbit-burrow, a seagirt cliff, or contrive to find a suitable receptacle for its progeny among the sticks that form the base of some huge Rook's nest which has been accummlating for years. Gamekeepers view it in great despite, for it is undoubtedly ready to rob the eggs of other birds when occasion offers; but it is as omnivorous as a Rook in feeding, and there is scarcely a flock of that species that is not attended by more or fewer Daws, who act as the light company of the heavier regiment. The normal glossy black plumage of the Corviax is in the Daw, when adult, diversified by its having the hinder part of the head of a delicate ashy-grey colour, ${ }^{2}$ while examples from Sonth-Eastern Europe and Asia Minor, having the nape of a silvery white, have been called $C$. collaris, and further to the eastward the birds have not only the collar broader and of a pure white, but the lower parts of the body white also. These belong to the species called by Pallas $C$. duuuricus.

1 Perhaps the earliest instance of nicknaming birds is to be found in Langland's Piers the Plowman, written soon after 1400, where the Sparrow is called "Philip"; but the practice, as all know, extended, and Swift in his Description of a Salamander thus mentions it :-

"As mastiff-logs in moderu phrase are

Call'd Pompey, Scipio, and Cesar ;

As pyes and daws are often stil'd

With Christian nicknames like a child."

2 It is only the hinder part of the head that wears this light tint, a fact which renders improbable that the "russet-pated choughs" of Shakespear" (Mids.Night's Dream, Act iii. Sc. 2) were birds of this species (see CHovgri). 
DAYAL, or more correctly, it would seem, DHYAL (corrupted into Dial-bird ${ }^{1}$ ), the Hindostani name commonly adopted by Anglo-Indians for one of the londest-voiced of their songsters, the Gracula saularis of Linnæus, and Copsychus saularis of modern ornithology, whose plumage, black and white in the male, made Edwards call it the "Little Indian Pye." In Nepal it is kept to exhibit its pugnacity, and a bird that will fight well is highly prized. Its other habits have been recognized by the best ornithologists as pointing to an alliance with the Saxicoline group of Turdidx ('Thrush) or Sylviida (W ARbler), nevertheless a recent writer (Cat. B. Br. -Mus. vii. p. 60) has phunged the genus Copsychus into the cesspool which he calls Timelizda, with the true members of which it has little in common. The number of species of the genus is doubtful; but one is certainly peculiar to the Philippine Islands, and another to the Seychelles, while two are found (to say nothing of the barely separable Gervaisia) in Madagascar. Other forms are also very nearly allied to Copsychus, and among them may be mentioned the African Cercotrichas, and Cittocincla of the Indian Region, of which C. tricolor, known throughout India by its Hindostani name of Sháma, is a favourite song-bird, and deserves mention.

DEMOISELLE, a name fancifully given by the French to several kinds of birds ${ }^{2}$; but the only sense in which it has been used (and that for nearly 200 years $^{3}$ ) by English writers is as applied to the Grus or Anthropoides ${ }^{4}$ virgo, otherwise called the Numidian CRANe, though it is only a winter visitant to any part of Africa; the range of its breeding-haunts extending from the valley of the Lower Danube eastward through Southern Russia, Turkestan, and Siberia to China. Examples occasionally stray from its proper home and have occurred in Germany, Heligoland, and Sweden; while two were seen, and one of them shot, in Orlnney in May 1863

1 This phonetic spelling has naturally given rise to a series of mistakes. First used by Albin in 1737 (Suppl. N. H. Birds, i. p. 17, pls."xvii. xviii.), it was sup. poser by Levaillant (Ois. d'Afr. iii. p. 50) to refer to the ordinary instrument for' ascertaining the time of day, and by him was accordingly rendered Cadran. Subsequently Jerdon asserted ( $B$. India, ii.p. 116), that Linnæus, thinking it had some connexion with a sun-dial, called it "solaris, by lapsus pennæ, saularis." Herein Jerdon was misled, for the epithet applied by Linnæus is but the Latinized form of "Saulary," the name under which a cock and hen were sent from Madras by E. Buckley to Petiver, who first described the species (Ray, Synops. Aeth. Avium, p. 197).

- Bufiou, Hist. Nat. Oiseaux, iii. p. 247; v. p. 437, note, and vii. pp. 313-316.

3 The Natural History of Animals . . . dissected by the Royal Aeademy of Sciences at Paris (London : 1702, pp. 205 et seqq.)

4 This name was given by Vieillot, following a misapprehension of the French Academicians, Du Vemay and Perranlt, whose observations were translated in the work mentioned in the last note. On the questions arising out of the various names assigned to this species, see Bennett, Gordens and Menagerie of the Zoological Society, ii. pp. 231, 232. 
(Zoologist, p. 8692). It is considerably smaller than the ordinary Crane, G. communis, and has a long tuft of white feather's reaching backward behind each eye, while the black plumes of its breast and the grey inner secondaries are greatly elongated-the last especially.

DENTIROSTRES, a group of Birds discriminated by Dìméril in 1806 (Zool. Anulyt. p. 41), composed of the genera (as then regarded) Buceros (Honnillu), Mlomotus (Motnot), and Pluytotoma (PlANT-CUTTER), as having their bills scored with at least three notches (dentelures); but in 1817 used in it wholly different sense by Curier (Riegn. Animal, p. 336), so as to contain Laniëda, T'enagridx, Inscicapida, Ampclida [ = Cotingidex], Edolines, Turdita, Pyrrhocorar, Oriolida, Myiotheru, Cinchus, Philedon, Gracula, Memura, Pipra, and Alotucille; and subsequently adopted with more or less modification by a great number of systematists.

DERTRUM, the hook of the BILL.

DESMODACTYLI, the name proposed by Forbes (Proc. Zool. Soc. 1880, p. 390) for a group of PAssertis, consisting of the Eurylitmilda (BROADEILL).

DESMOGNATHA, Prof. Huxley's third Suborder of Carivate, composed of seven groups - CHENOMORPHe, AMPHIMORYHe, Pelargonorpha, Dysporomorphe Aetomonpha, Psittaconor. PHÆ, and COCCYGOMORPHE-in all of which the vomer is often abortive or so small as to disippear; but, when existing, it is slender, and tapers anteriorly to a point, while the maxillo-palatals are united (whence the name of the Suborder) across the middle linc, either directly or by the ossification of the nasal septum, and the posterior ends of the palatals and anterior of the pterygoids articulate directly with the rostrum. Moreorer, the lower larynx in these birds is never formed on the plan of the Passeres. It may be observed that nothing approaching to this association of the groups above named had ever before been proposed by any taxonomer (Proc. Zool. Soc. 1867, pp. 435-448, 460-466).

DEVIL-BIRD, a name applied by the English in Ceylon to a species of Owh, Strix or Symium indrani, as well as to a GodTsUCKER, Caprimulgus kelaurti (Legge, B. Ceyl. 11). 155, 33i).

DEVILING, a common local name for the SwIFT.

DHYAL or DIAL-BIRD, see DAYAL.

DIAMIOND-BIRD, the name bestowed in Australia on the mem-

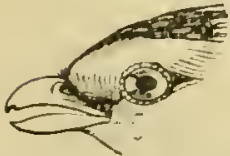

DLAMOND-BIRL, (After Swainson.) bers of the genus Pordulotus founded in 1816 by Vieillot (Anulyse, p. 31), with Pipra punctute of Latham as its type, for which in our present ignorance it is hard to find a place. Gould (Handl. B. Austrul. i. p. 156) put it with a mark of donbt uncler Ampeliclix, in whatever 
sense (and that is mucertain) he used the word. Dr. Sharpe (Cat. B. Mr. Mus. x. pp. 3, 5t et seqq.) refers it to the Dicaida-a groul' which, he says, "cannot be defined in exact terms" (tom. cit. p. 2), and the genns Purdalotus is made to consist of 9 species. If this assignment be correct, the name of the Family should be changed, as the gemus Purdalotus anterlates DICÆUn, and, according to usage, the Family is called after the oldest genus it contains.

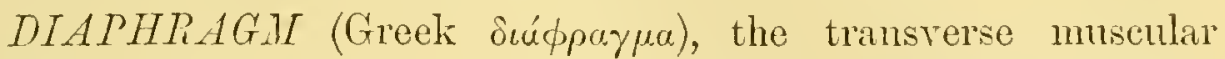
partition below the heart and lungs and above the liver, stomach, and rest of the intestinal canal, fully developer in Mammals only. In Birds it is incomplete and rather differently arranged, consisting (1) of the pulmonary or transverse, and (2) of the abdominal or oblique portion. The first arises from the second to the sixth pairs of ribs near the lateral edge of the lungs, and spreads over their ventral surface as an aponeurotic membrane, while it is connected with the vertebral column as the median vertical septum; completely separating the lungs and the cervical air-sacs from the rest of the thoraco-abdominal carity. Small roluntary muscles arising from the ribs and from the stermm extend over part of the aponeurosis. The second or oblique half is entirely membranous withont muscular fibres: it forms the continuation of the ventral margin of the vertical median septum, and is comnected with the pericardium and with the medio-ventral portion of the sternum, while the rest extends obliquely through the abdominal cavity to the posterior and ventral margins of the sternum. The space thus enclosed is the subpumonary chamber, divided into a right and a left half by the vertical septum. Three transverse septa divide again either half into four loculi, into each of which one of the three or four post-bronchial ArR-sAcs extends from the lungs. Consequently the whole of the diaphragmatic membranes divide the entire thoraco-abdominal carity into three chambers: (1) the Pulmonary chamber, anteriorly and doreally from the pumonary septum, containing the lungs and cervical air-sacs; $(2)$ the Subpulmonary chamber, anteriorly and ventrally from the oblique septum, and ventrally from the pulmonary septum, containing most of the air-sacs; and (3) the Cardio-abdominal chamber, posteriorly from or below the oblique septum, containing the heart and the rest of the intestines.

DIC EUN, a group differentiated by Cuvier in 1817 (Piegne Anim. i. p. 410) for the Certhice cruentute of Linnæus and its allies, several of which inhabit India, and one of them-D. hirundinacem-Australia, in which country the scientific name has been accepted as English (Gould, Handb. B. Austral. i. p. 581). The (After Swainson.) group has since been recognized as entitled not only to goneric rank, 
and subdivided into several sections or genera, but has been of late advanced to the dignity of a Family, Dicxidx, for which much might be said; but several forms have at the same time been erroneously referred to it (Sharpe, Cat. B. Br. Mus. x. pp. 9-84)-among them the Dramond-BIRDs above mentioned. The Dicaida range from Nepal through India (where they have been called, but seemingly without reason, Flower-pickers) and the Malay Archipelago to China and Australia; but to this Family have been referred a goorl many forms which Dr. Gadow's researches prove to have no near relationship to Dicam proper.

DICK-CISSEL, the nickname familiarly applied to the Blackthroated Bunting of witers, Spi:a or Euspiza americana, a species whose recent disappearance from localities which it formerly frequented has not yet been explained by North-American ornithologists (cf. H. M. Smith, Proc. U.S. Nat. Mus. xiii. p. 171).

DIDAPPER or DIVEDAPPER, an old name ( $\mathrm{f}$. Shakespear, $V$ enus and Adonis, line 86) for the DABGHICK or Little GrEBE.

DIGESTIVE SYSTENI. This consists chiefly of the Alimentary Canal and its glandular appendages, the former, beginning with the Mouth, is successively made up of the CEsophagus, the STOMACH, the small intestine or "ileum," and the large intestine or "rectum" (with the CACA when present), which last opens into the CloACA. The glandular appendages are either proventriculal' and other mucous glands, imbedded in the walls of the Canal, or salivary glands, Liver, and PANCREAs, communicating with it through special ducts. The function of the System is of two separate kinds: first the preparation of the food, which is effected in part mechanically and in part by chemically-acting secretions of the accessory glands; and secondly the absorption of the "chyle," or prepared nutritive fluid, by means of the LrmpHatic SYSTEM.

The digestive process is as follows:- The food taken into the mouth is swallowed and passes through the asophagus into the stomach, assisted in its descent by the secretions of the salivary and mucous glands. When there is a CROP, it is therein mixed with saliva and water, and assisted by the heat of the body is softened and acted upon in a preliminary way. It then enters the stomach, where it meets with the secretions of the proventricular or gastric glands. But beside being acted upon chemically it is crushed and triturated in the gizzard, especially in graminivorous and granivorous birds, which possess a strong musenlar stomach. Thus comminuted it is linown as "chyme," and passes through the pylorus into the small intestine, in the first loop of which, the "duodenum," it is mixed with the bile and pancreatic juice, these 
two fiuids being the secretions of the liver and the pancreas. Their principal action is to convert its soluble parts into "peptones," which are to be conveyed into the Lymphatic System, and so into the BLOOD. Their absorption as chyle is effected by numerous "villi" or projections which line the walls of the whole Canal from the pylorus to the cloaca. At the beginning of the rectum the caca, when such are functional, receive the remaining chyme, and it is probable that in them certain hitherto undissolved matter, as cellulose and possibly chitin, is acted upon by marshgas, so as to extract as much nutrition as possible from the food. After remaining a due time in the creca, their contents return into the rectum, and are finally ejected through the cloaca as freces.

The walls of the Alimentary Canal are composed of five layers, of which the innermost only is of "endodermal" origin, the rest being "mesodermal" (see Embryology). These layers are: (1) the tunica serusa or adventitia, which is outermost and consists of partly elastic connective tissue; (2) a layer of smooth muscular fibres, transversely or circularly arranged; (3) one of smooth muscular fibres, longitudinally arranged; (4) the tunica submucosa of loose connective tissue, which contains nerves, blood, and lymphatic vesscls; and (5) the tunica mucosa or innermost lining, composed of epithelial cells, which give rise to mucous and various specific digestive glands. It is noteworthy that Birds and Reptiles differ from Mammals in the succession of the two muscular layers (2 and 3 ), since in the last the circular fibres are placed on the inside, next to the submucosa (4), while the longitudinal fibres together with the serosa (1) form the outer wall. These layers vary considerably in the different parts of the Alimentary Canal; thus the thickening of the walls of the gizzard is due to the excessive development of the muscular layers, while in the csophagus the mucosa is represented chiefly by ordinary epithelial cells, comparatively few of which form simple mucous glands, though in the region of the proventriculus its cells are transformed into large glands, often closely packed and compressed, constituting the greater part of the thickened walls. Again, in the gizzard no such specific, but only mucous glands oecur, the hardened secretion of which invests its cavity with an additional cuticular lining. Both the small and large intestines are characterized by numerous villi, protruding into the canal as excrescences of the two innermost layers, and absorbing the prepared nutritive fluid. Beside the ordinary mucous glands the mucosa gives rise to two masses of specific nature which as LIVER and PANCREAS grow out of the walls of the duodenum, and thus indicate their point of origin only by their respective ducts.

The intestine, or gut proper, begins at the pyloric end of the 
stomach and ends at the cloaca. It may be conveniently divided into (1) the dundenum or first loop, (2) the ileum or narrowest and longest portion, equivalent to both the jejunum and ileum of man, and lastly (3) the rectum, corresponding with his large intestine. The transition from the ilenm to the rectum is marked by a more or less circular valve (the "ileo-crecal"), so placed as to permit its coutents to pass into the crea and rectum, but to hinder their return - their passage throughout the whole intestine being aided by the peristaltic contractions of the muscular layers of its walls. An epithelium of cylindrical cells, forming a colourless, structureless and soft cuticle, lines nearly the whole of the intestine, and is

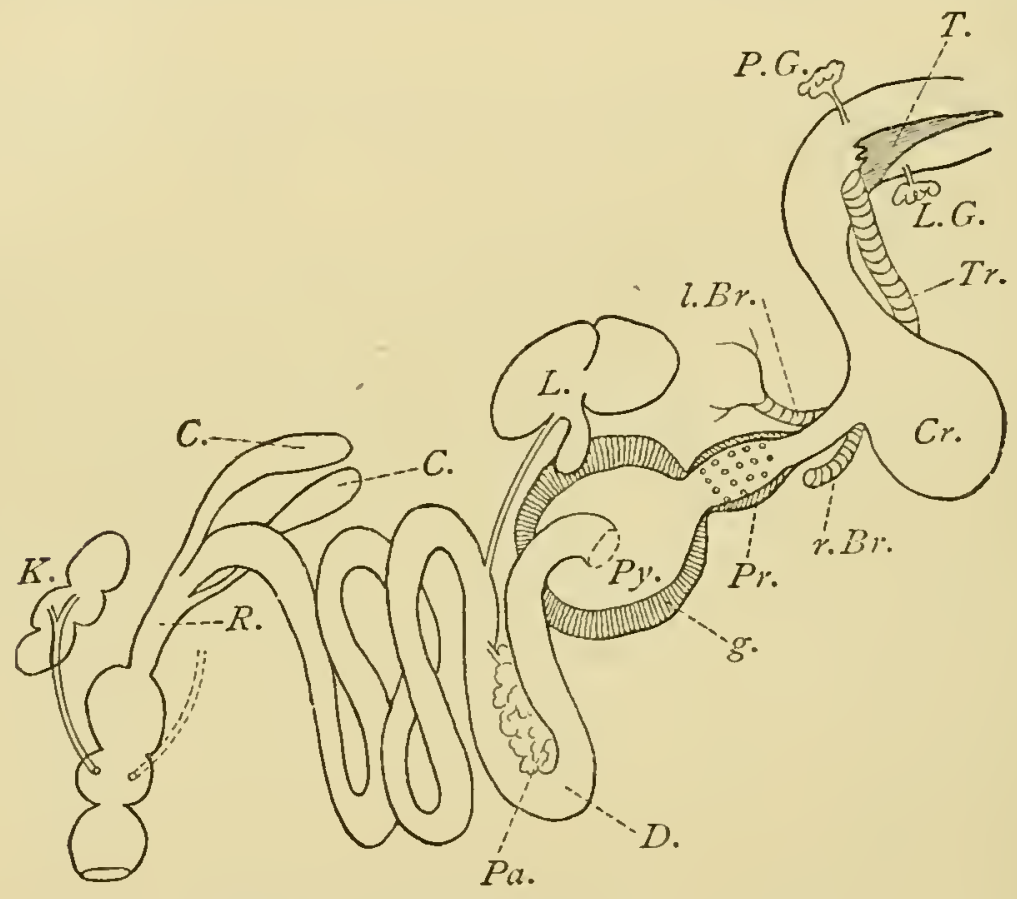

Diagrai of the Digestite Orgaxs of a Bird.

T. Tongue; P.G. L.G. Parutid and salivary glands; Tr. Trachea; l.Dr. r.Br. left and right bronchus ; $\mathrm{Cr}$. Crop ; $\mathrm{Pr}$. Proventriculus or glandular stomach ; g. Gizzarl or muscular stomach ; Py. Pylorus; D. Duodenum; L. Liver with gall-blaluler and duct; $P a$. Pancreas with duct; $C$. Ceca ; $R$. Rectum ; $K$. Kidney with Ureter opening into the middle cloacal elamber.

perforated by numerous small pores, opening upon their interstices. In many parts these cells form rery simple and sometimes tubular glands ("Lieberkïhn's"), and the greater portion of the walls is beset with the villi mentioned above. These are very numerous, and are arranged in various ways-being either uniformly and thickly spread over the surface, giving it a velvety appearance, or are longer and more sparingly distributed in lines, which may be straight or zigzag, transverse or longitudinal. Their arrangement is occasionally characteristic of different gronps of birds; but it varies also in different parts of the gut. As a rule they are largest and most numerous in the duodenum, but sometimes in the rectum 
as well. The structure of these small but important organs will be best understood by reference to the accompanying figure. Fach villus consists of a finger-shaped prolongation of the tissue of the submucosa, which contains a ramified central canal conveying the collected chyle into the lymphatic vessels, which are frequently comnected with a lymphatic follicle for the production of white BLOnD-corpuscles or lymph-cells. A pair of small arteries and veins enter the villus, forming a capillary network, while fine unstriped museles in its walls contract it and force the chyle into the lymphatic vessels. In the figure, on one side of the villus is shewn a Lieberkühn's gland, since such are generally associated with the villi.

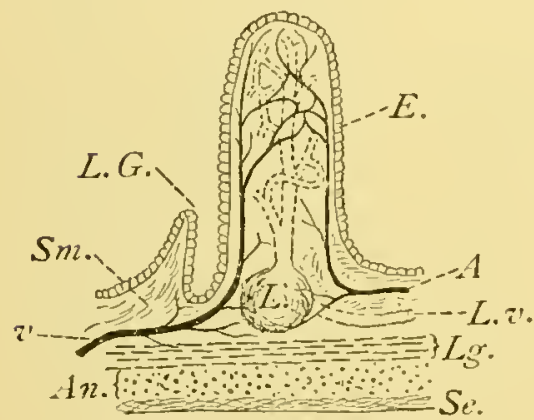

FIG. 1.

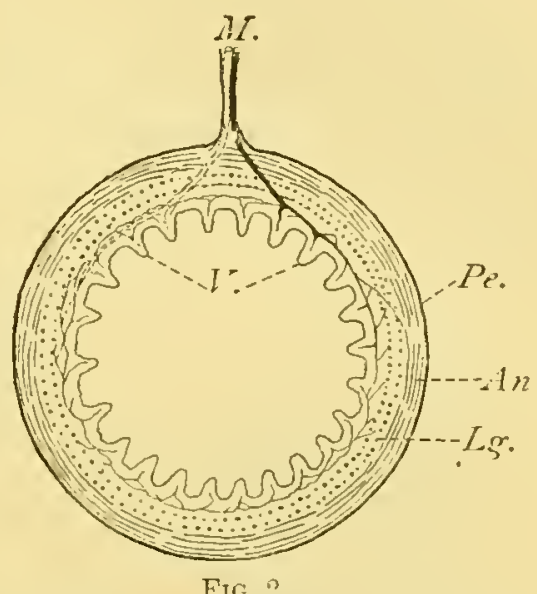

Fig. 1.-Diagray of an Ixtestixal Villus with the Cextral Absorbent, Ramified Canal.

$L . v$. its duct; $A$ and $v$, Artery and vein ascenuling in $S m$. the subuncons lay,a ; $E$. Cylindrical cells of the epitheliun of the mucous layer, which at $\mathrm{L}$. f . forms a Lieberkiiln glanl: $\mathrm{Lg}$. and An. Longitudinal and annular or circular nuscular fibres; Se. Serosa or onter layer of connective tissue, together with the investing peritoneal lamella $P^{2}$., which forms the mesentery $M$. in Fig. 2.

Fic. 2.-Diagram of a Transverse Section throvgit the Intristine.

I. Villi ; M. Mesentely with blood-and lymphatic vessels.

The eapacity of the Intestinal Canal depends upon the nature of the bird's food. In order to compare its length in different forms we require a unit by which to arrive at its relative proportions. The length of the whole vertebral column, or even the distance from the tip of the bill to that of the tail, has been frequently used; but this gives only faulty results, since the length of the neck is obviously not correlated with that of the intestine. Numerons measurements and comparisons have led me to adopt as the mint the distance from the first thoracie vertebra (i.e. from the root of the neck) to the anus, and thus the quotient of the absolute length of the intestine from the pylorus to the anus is the relative length of the gut. This relative length is very constant in a species, and often gives results of considerable taxonomic value. Of course "short-gutted" and "long-gutted" are 
arbitrary expressions; but, if we assume that a relative length not exceeding 5 indicates a short, and one of more than 8 a long gut, we find that the Intestinal Canal is very short in all purely frugivorous and insectivorous birds, while it is very long in those which live upon fishes, carrion, grain, and grass. It must, however, be remarked that, aceording to the nature of the food, a short intestinal canal is often compensated by its width either wholly or in part, as of the rectum, or by the presence of large crca. Consequently all these points have to be eonsidered in using the features of the intestine for taxonomic purposes. Cateris paribus, the relative length of the eanal is as good a character as many others, and occasionally by it alone closely-allied species can be determined. The subjoined table shews the measurements of the intestine in a few forms; but for fuller information the reader may be referred to (Bronn's) Kl.\& Ordn. Thier-P. Vögel, pp. 590-661 and 700, where the respective measurements of nearly 400 birds will be found.

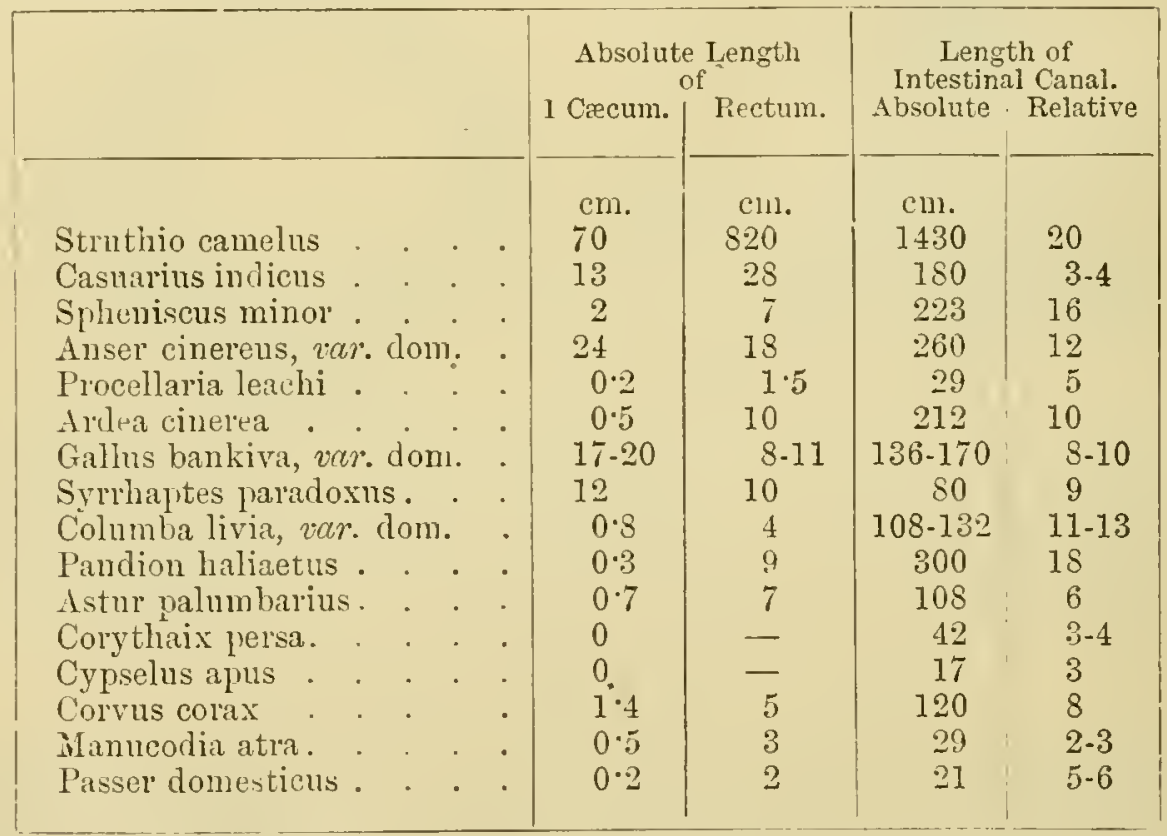

In early embryonic stages the Intestinal Canal is a straight tube; but, as its growth proceeds far more rapidly than that of the body-cavity, it is necessarily thrown into folds or loops. Moreover, since it is suspended from the vertebral column by the mesentery, or lining of the body-cavity, its several folds are thereby connected with one another in various ways, and their number and shape depend to a great extent upon the space available in the cavity, as well as upon the shape, size, and position of the stomach and neighbouring organs; but the various ways in whieh the small intestine is stowed away in different birds exhibit types so definite and constant that they camnot be considered accidental or meaningless features. On the contrary, a somewhat exhaustive study of its 
convolutions reveals their taxonomic value, and enables me to say that the Digestive System, taken in its entirety-that is to say, the crop, glandular and muscular stomach, liver, gall-bladder with its ducts, creca, and the relative length and convolutions of the intestinal canal-affords more diagnostic features than any other organic system-the osseous excepted. Moreover, it has the great advantage that through reference to the food we can in many cases account for the aberrant features of the digestive organs displayed by birds otherwise closely allied. So much cannot be said for character's furnished by PTERYLosis, and attempts to explain taxonomically the more important differences observable in the Muscular System have hitherto been futile because of the complex problems involved. At any rate, we ought not to treat recent birds as if they were fossil and had left us nothing but their bones, unless, indeed, the specimens be skinned and all their other important characters throwi away.

It is hoped therefore that a brief general account, condensed from a paper in the Zoological Proceedings for 1889 (pp. 303-316), of the chief types of intestinal structure in birds may here have interest, especially as, with the exception of Cuvier, British Anatomists only ${ }^{l}$ have treated the subject, and since the days of Macgillivray, who alone attempted it systematically, this branch of Ornithotomy has been neglected, perhaps from the apparent but not leal difficulty of studying these easily-putrefying organs.

In a typical loop of the intestines of a bird we distinguish between a descending and an ascending branch; both meet at the distal end or apex of the loop, and this forms its turning-point. The starting-point is the pylorus, the goal the cloaca. Each loop is either closed or open. It is closed when both the descending and the ascending branches are throughout the length of the loop closely bound together by an extension of the mesentery and its vessels. Of these vessels, as a rule, each principal loop receives one bigger branch from the middle mesenteric artery. A loop is open when its two branches are not closely connected by mesentery and vessels; the mesentery is wider, and the two branches of the loop may receive another loop or intestinal fold between them, the latter then resting upon the mesentery of the former open loop.

The cluodenum is always a typically-closed loop. Its first or

1 E. Home, The course of the intestine with the varieties in the form of the cæca in carnivorous, piscivorous, and granivorous birds, Phil. Trans, 1814. G. Cuvier, Leçons d'anatomie comparée, ed. 2, 1835. R. Owen, Todd's Cyctopædic of Anatomy and Physiology, article "Aves," 1836. W. Macgillivray, "Observations on the Digestive Organs of Birds," Mag. Zool. and Bot. 1837. Occasional notes on the intestinal canal are extremely numerous, among others by Burton, Crisp, Duvernay, Forbes, Garrod, Jobert, Leuckart, L'Herminier, Martin, Nitzsch, Pavesi, Perrin, and Yarrell. 
descending branch lies, when viewed from the ventral side, to the light of the second or ascending branch; both invariably enclose the PANCREAS.

A loop which runs in the same way as the dnodenum may be termed right-handed, and one running in the opposite way is lefthouded, i.e. its descending branch lies to the left of the aseending branch. Again, if the intestine forms a number of (mostly closed) loops, which run parallel with each other in the long axis of the body, we term this arrangement orthocalous, or straight-grutted.
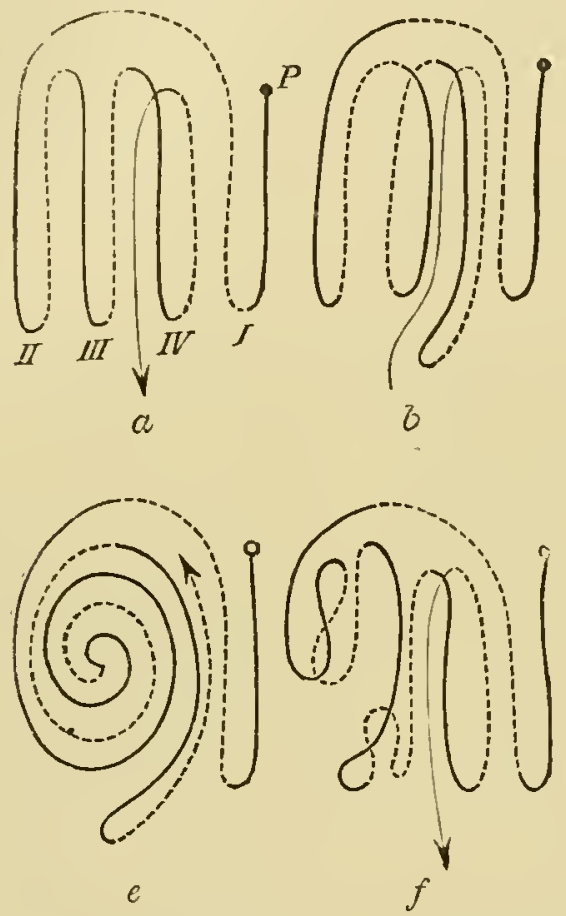

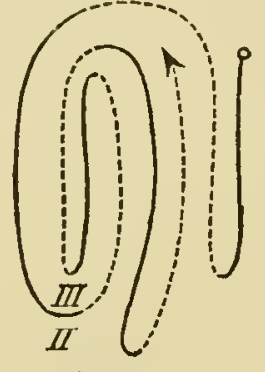

$c$

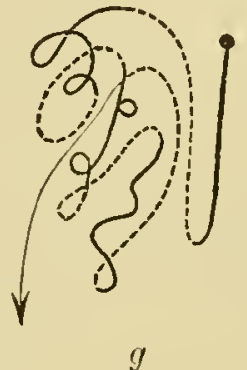

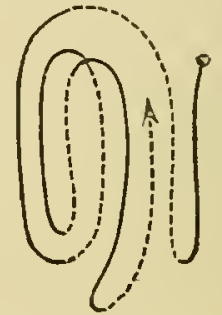

$d$

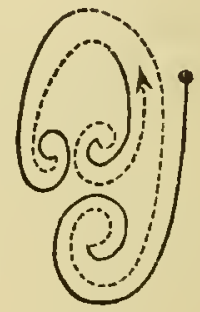

$h$

DIALRAHMATIC REPRESENTATION OF THE PRINCIPAL RELATIVE POSITIONS OF THE INTESTINAL LOOPS WHEN SEEN FROM THE RIGHT SIDE.

a. Isoculuus.

b. Anticalons.

c. Anti-Pericuelous.

c. Cyclucomous.

$f, g$. Plagiucuelous.

h. Telogyrous.

d. Iso-Periccelous

The descending branches of the longs are markell by black lines, the ascending or returning branches are dutterl.

The first and third loops in fig. $b$ are "right-landed," the second is "left-lianded"; in tig. $c$ the second is "left-," the third "right-handed," etc.

(Fron the Procedings of the Zoological society, 1859.)

If, on the other hand, some of the loops form a spirul, we distinguish this formation as cyclurelous.

Of the orthocolous type the following modificitions deserve especial remark with reference to the second and third loops; the fir'st, or duodenal, loop is invariably right-handed, and therefore needs no further comment.

I. Istucrelous. - The second and third, and, if present, also the fourth loop are all closed and left-handed. The second is most dorsally sitnated, the third to the right of it, the fourth to the 
right of the latter, between it and the duodenum. The ascending branch of one loop runs side by side with the descending branch of the next following one.

II. Anticolous.-The second and third loops are closed and sharply alternating; the second is left-, the third is right-handed; the second lies dorsally, consequently its ascending braneh runs side by side with that of the third.

III. Plagiocolous. - The second and often more loops are doubled or turned over with the apices like a horseshoe, giving the loops, which are generally open, an irregular or convoluted appearanee.

IV. Periccelous. - The second loop is left-handed, open, and encloses the third which is generally straight and closed. This formation is of especial interest, because it leads quite gradually to the

V. Cyclocolous formation by the conversion of the second and third loops into one left-handed spiral. Such a conversion of the second and third loops into a spiral occurs in tle Limicolx, Laridx, and Columbx. Each of these families possesses some genera in which the spiral is still represented by long, oval, concentric turns, and even some genera which still exhibit the pericolous type with the two loops in question still separate, distinct, and more or less straight.

Not every spiral, however, is formed by the concentration of two loops. In many instances a spiral is produced by one loop being curled upon itself, its apex then forming the centre of the spiral. To the apex is attached the diverticulum crecum vitelli; this shews that this spiral is produced by the primitive fold of the embryonic mid-gut.

Such is the ease in all the Passeres, and since there are only three folds formed by the whole gut, the spiral represents the middle or seeond fold; hence this arrangement may be distinguished as mesogyrous. The number of turns in such a spiral depends directly upon the length of the intestine; while in the short-gutted Sylvix the spiral is just indicated, there are in the Sparrow (with an intestinal length of $21 \mathrm{~cm}$.) $1 \frac{1}{2}$ direct and 1 retrograde turn, and in Pinicola enucleator (which possesses an intestine of 99 $\mathrm{cm}$. in length) there are many direct turns.

It is clear that with an original number of only four loops, the conversion of the two middle ones into a single spiral will eause such birds as certain Limicola, Laridx, and Columba likewise to assume the mesogyrous feature; but the position of the diverticle on the original third loop, and the relations of these birds, e.g. Charadrius and Sterna, shew that this mesogyrous formation has been brought about in a way different from that of the Passeres.

Lastly, the distal portion of any loop originally straight may be coiled up into a spiral, while the rest of the loop remains straight. 
This feature may be termed telogyrous. With the duodenum this is very rare, it then invariably forms a right-handed spiral, e.g. in Buceros, Ciconia, and Milvus; the duodenum is more irregularly twisted in certain Pelargi and Accipitres. The ends of the second, third, and fourth loops are never coiled into a regular spiral, but rather form irregularly coiled masses, in many Pelargi, Accipitres, and in the Psittaci.

We see, then, that the cyclocœlous (meso- or telogyrous) feature by itself cannot be taken as a character which indicates the affinity of the larger groups or Orders of Birds, unless we take the mode of development of these concentric convolutions into consideration. In fact, the cyclocolus formation is the highest mode of stowing in the smallest compass that portion of the gut which had to be increased in length, the relative length of the mid-gut being dependent upon the nature and composition of the food. In strictly orthocœlous birds the increased length of the gut causes the formation of secondary folds anywhere between the previously existing loops, whereby frequently a very irregular arrangement of all the convolutions is caused. A similar process has produced the plagiocalous feature (fig. f), which was probably derived from an orthocœlous basis.

The highest and perhaps newest mode of stowing an increased amount of intestinal length is that in which one of the folds already existing is lengthened and, owing to its interstitial growth, turns into a spiral; in this way the other loops will undergo the least possible disturbance.

It is not necessary to give here a long and detailed enumeration and description of the intestinal convolutions as they occur in the numerous Orders and Families of birds, because this has been done elsewhere. ${ }^{1}$

Secondary shortening and widening of the gut (owing to the assumption of frugivorous habits) may reduce the number of loops, and may render the original arrangement quite untraceable, as in Carpophaga, Rhamphastus, and Manucodia. When a bird has acquired strictly piscivorous habits, the gut is considerably lengthened and narrowed and may, as in Pandion and in Haliaetus, render the old formation quite unrecognizable. These are, however, exceptions, which are not numerous; as a rule the lengthening of the preexisting loops and the additional intercalation of new ones does not disturb the typical formation, but rather throws interesting lights upon the lines of new departure along which certain birds hare become developed, e.g. the Alcedinida from a Coraciine stock, now modified through the acquisition of carnivorous and piscivorous habits.

1 Jenaische Zeitschrift f. Naturwiss, xiii. pp. 92-117, 339-403, pls. iv.-ix. and xvi. ; P.Z. S. 1889, pp. 303-316, pl. xxxii. ; Bronn's Thierreich. 
All the Patita agree in having the second loop right-handed, and the third left-handed; this is a feature which occurs again only in the Crypturi, Gallina, Opisthocomus, and in the Cuculida. Moreover, as with the exception of the duodenum none of the loops are closed and well defined, the Ratitie represent in this respect the lowest avine type.

The Gallina form a well-defined group; lowest among them stand the Neotropical Cracida, through which they lead towards the Crypturi. The Gallinx have also an unmistakable resemblance to Opisthocomus and thence to the Cuculidx.

The Turnices, to which belongs undoubtedly Pedionomus, are traceable to a Ralline or low Gralline stock, with assumed plagiocoelous characters of the second loop.

The pericolous assemblage is large. It is typically represented by the Waders, of which the Limicola and the Rallidx form the principal groups.

The Rallidx with Otis and Grus are connected with the Innices, more distantly with the Crypturi, and still more so with Apteryx. Dicholophus is in all points a Gruine form, like Psoplia, and cannot be separated from them. Rhinochetus contains Ralline, Limicoline, and Ibis-like features; the only bird which it resembles somewhat closely in its very peculiar intestinal convolutions is Podica.

The Limicolx agree with the Laridx, and also with the Columba in all essential points. Each of these three groups contains a number of forms which lead in an unbroken series from the typically pericolous birds with four alternating loops to the typically mesogyrous birds. Most Columba and Laridre are mesogyrous, but Sternce and its allies represent pericolous or lower forms. Neither granivorous, nor insectivorous, nor piscivorous habits have exerted any appreciable influence upon their intestinal convolutions, although of course the stomach and the cæca are affected. The presence of the crop of the Columbx is repeated in the granivorous Limicoline genera Attagis and Thinocorys.

Numenius approaches in various ways the Ibises, whence a continuous line can be traced into Platalea and Phonicopterns on the one hand and into the Pelargi proper. on the other.

Rather different from the Limicola are the Pteroclida. They have four loops, which are all closed, left-handed, i.e. isocolous, and straight ; the second and fourth loops have their apices turned back, and especially the terminal end of the second resembles somewhat a plagiocolous formation. The Pteroclidie have consequently various points in common with the Pallida, Limicola, and Columbx.

The Alcida are pericolous and strictly orthocœlous; they agree with the Laro-Limicola in the configuration of their first three loops, but they differ from them in the number of loops, which is at least six, the last three of which are left-handed. They approach in this 
respect the Pygopodes. These (Colymbidx and Podicipedidx) shew unmistakable affinities with what may be called generalized or low Gralline forms ; their four or five loops are closed, orthocolous, and alternating. The Pygopodes connect the large assemblage of the Waders with the following congregation, of which the Herodii, Steganopodes, Tubinares, and Spheniscidx are all divergent types. A very close connexion exists between the Herodii and the Steganopodes, and this is supported by numerous other characters. The Tubinares are in more than one respect the most specialized outcome of this great collective Order, and reach in the typically mesogyrous Procellariinæ their highest development.

The Spheniscida are very specialized. They possess undeniable characters in common with the Pygopodes, Steganopodes, and Tubinares; they are on the whole orthocoelous, but the extreme length of their gut thrown into numerous straight and oblique, or quite irregular, convolutions renders comparison very difficult.

The Anseres, to which belongs Palamedea as a probably very old member, are all orthocœlous and combine peri- and plagiocolous characters in their second loop. The five or six principal loops are alternating; the last four are closed and straight. As typically orthocolous, aquatic birds, and as Pracoces they agree with the Pygopodes, and the root of the stock of the Anseres has to be looked for in this direction alone.

The Pelargi, containing the Hemiglottides (Ibis and Platalea), Phoenicopterus, and the Ciconia, are rather diverging forms, which can be characterized as possessing four very long and mostly closed loops (with occasional secondary loops intercalated), of which the first three have a tendency to coil their apical ends into more or less irregular spirals : this leads sometimes to an almost mesogyrous formation.

The Hemiglottides approach nearest to the Limicola, although their points of resemblance with Numenius may possibly be cases of convergence only. Very closely allied to, in fact inseparable from the Hemiglottides, and connecting them with Tantalus, and thus with the Ciconia proper, is Phonicopterus; there is not one single feature in the whole of the Digestive System in which this bird differs from the Pclargi or resembles the Anseres except in the presence of small but functional crea, which are nearly lost in the Pelargi. But these cæca stand in direct relation to the food of the Flamingoes, which consists of the conferva in the mud of the lagoons. The zoophagous Pelargi have lost them, the phytophagous Flamingoes have preserved them.

The Ciconiina proper, represented by Ciconia, and connected with the former genera by Tantalus, are essentially telogyrous; their second loop is right-handed, and accompanies the duodenum; this is a rare feature, and is of taxonomic value for the diagnosis of the subfamilies of the Pelargi. 
The Pelargi are often classed with the Herodii, but these two Families differ from each other in almost every point of primary importance.

There are also certain resemblances between the Pelargi and the Accipitres, the chief connexion is formed by the telogyrous character, the mode in which additional loops of the lengthened gut are stowed away, and the tendency to convert some or one of the principal loops into regular spirals. Among the Accipitres, the Old-World Vultures especially exhibit striking Ciconiine similarities. As regards the Cathartida, I have to deplore want of material.

The Psittaci are distinctly telogyrous; all their five principal loops are closed and alternating; this, with the presence of a crop, and the absence of functional cæca, are features which occur again together only in the Accipitres. The absolutely vegetable food of the Parrots would sufficiently account for the differences which exist between them and the entirely zoophagous Accipitres. However, this indication of a possible relationship between the Birds-of-Prey and Parrots is as little binding or satisfactory as other suggestions based upon other organic systems.

Of the Coccyges the Cuculida possess four intestinal loops, of which the first and second are right-handed. The loops are on the whole orthocœlous, but the apices of the two middle ones are often turned up, or the second loop is plagiocolous. Moreover, they possess fully-developed cæca. In all these respects they resemble to a great extent the Gallinas; and this hint is considerably strengthened by Opisthocomus, which is, barring special features, exactly intermediate between the Cuculidx and the Gallinx. The Musophagida seem to possess but three loops, the original second loop having been suppressed in connexion with the frugivorous habits of these birds. The isocolous feature of the Musophagidz is therefore reduced to a secondarily acquired one, and to a case of convergence towards the typically isocolous birds.

The Pici (Picidx, Capitonidx, and Rhamphastidx) differ, like tho Epopes (Bucerotidx, and Upupidx), from all the remaining birds in the alternating position of their four loops, which in the frugivorous Rhamphastidx, as well as in the extremely short-gutted genus Upupa, are reduced to three by the suppression of the original second loop. Xantholsma, one of the Capitonidx, has this second loop still indicated. The total absence of crea in all these birds is a coincidence, while there are no obvious characters, besides the anticolous convolutions, which point to a close relationship between the Pici and the Epopes.

The remaining birds are all isocolous. Of them the Coraciidæ stand nearest to the hypothetical ancestral or central stock, because they are the most generalized group, from which all others can be derived. The Alcedinida, which have reached a truly mesogyrous formation, started in one direction from or out of the Coraciidæ. 
The lengthened gut of the Kingfishers in conformity with their generally piscivorous habits, forms a left-handed spiral by its second loop, while the fourth loop is long, and in the more piscivorous members widely open and irregularly placed. The affinity between the Coraciidix and the Alcedinidx in opposition to other groups may be expressed by the term Halcyones.

The Striges verge towards the plagiocoelous type, but all their affinities rest with the Coraciida and Caprimulgidx combined. These three Families possess long cæca; the Alcedinidx, Cypselidx, and Trochilida, have lost them, the first of these because of their piscivorous and cancrivorous habits.

The Cypselomorpha (Caprimulgidx, Cypselidx, and Trochilida) agree very much with each other. They all have only three intestinal loops, which are short, in agreement with their principally insectivorous habits. The Trochilidx differ in the possession of a crop. The Cypselidx and Caprimulgidx are somewhat more closely related to each other, and the latter (including Podargus) turn towards the Owls. The Cypselidae are sometimes supposed to be somewhat nearly allied to the Passeres. Their alimentary system does not altogether favour such a view; but perhaps the ancestors of Colius once filled this gap, leaving their existing descendants now in a solitary position.

The Trogonidx stand on a lower level than the Cypselidx, Trochilidx, and Coliidx, on the same level as the Caprimulgidx and Coraciidx, and connect them all with each other. The Trogons still possess well-developed cæca like the Coraciidæ, Caprimulgidæ, and Striges, while all the other isocolous birds have lost them, or have only functionless remnants of them.

The Passeres are a very uniform group. They all possess only three loops, without indications of more ; the second and third are left-handed; the second becomes. a left-handed spiral, the turns of which depend upon the length of the gut; the third loop is always open, and invariably encloses the duodenum between its descending and ascending branches, the latter branch being situated on the ventral and left side of the descending branch of the duodenum. This arrangement is invariably the same, even in the Mesomyodians, and in such otherwise aberrant forms as Rupicola and Pitta. There is a special line which leads from the Laniine forms through the Austrocoraces (Gymnorhina, Graucalus, Strepera, and Paradiseida) into the Coraces nroper, which latter have produced some special modifications of the intestinal convolutions, and may be looked upon as the last and highest blossom of the avine tree.

DIKKOP (Thick-head), the Dutch name for the Stone-CurLEW of South Africa, Edicnemus capensis, used also by the English in that part of the world (Layard, B.S. Afr. p. 288). 
DINORPHISM, a term originally used by botanists to express the fact that in certain plants a difference, whether in form or colour, more or less considerable, exists between individuals belonging to the same species, this difference not being attributed to local influence or of the kind called accidental, but yet one that is constantly exhibited. As analogous cases are observable in animals, the term has been adopted by zoologists, and, disregarding other classes, it will be at once perceived that among Birds there are two kinds of Dimorphism - one depending upon sex, in which the secondary sexual characters of the male and female may differ in very many ways, and the other which is apparently quite independent of sexual distinction. Of this last kind, which seems to approach most nearly to the Dimorphism of botanists, there are not many undisputed instances. The best known is that of some species of SkUA, in which a parti-coloured bird may be frequently found mated with one that is (so to speak) whole-coloured-in some cases the former being the male, the latter the female, and in others just the contrary, it rarely happening that both partners are alike in plumage. A similar state of things occurs on the confines of the districts respectively occupied by the Black and Grey Crows of the Old World, but here we are met by the difficulty that some ornithologists consider these two forms to be distinct species, and the produce of their union to be hybrids. The White-eyed and Dark-eyed Crows of Australia present a phase intermediate between that last mentioned and the first; for, though some writers have regarded them as distinct species, locality seems to have no influence on the difference, comparatively slight as it is, observable between them. Another case more resembling the first is that afforded by the GuILlisiot, for at nearly every one of its breedingresorts a portion of the tenants (perhaps one in a score) will be formd to have a white circle round the eye and a white line stretching backward from it-these Ringed or Bridled Guillemots being of either sex and apparently paired with birds of normal plumage, while no example is known which shews any intermediate conclition. ${ }^{1}$ All these are instances in which Dimorphism is confined to colour, but it may well be regarded as extending also to size, thongh here we again meet with the objection that numerous writers regard the smaller or larger forms as constituting two local races if not species. The DUNLIN furnishes us with an instance of this kind. Ranging throughout the Old World, but in far fewer

1 At one time these Ringed or Bridled Guillemots were looked upon as a distinct species, called Uria lacrymans, but that view has of late been wholly abandoned. Similarly the dark, whole-coloured examples of the common species of SKUA were originally described as forming a separate species, Lestris richardsoni, but though the name has by many writers been mistakenly retained none now believe the birds to be distinct. 
numbers than the ordinary form, Tringa alpina, is a smaller one which has received the specific name of $T$. schinzi, while in the New World our common T. alpina is comparatively scarce, and a larger form, the T. americana of some authors, is the more abundant. It is difficult to determine at present whether this is a case of local races or one of Dimorphism-though here Trimorphism might be the more proper word.

Among birds examples of sexual Dimorphism are so numerous as to make it almost the rule. Yet, as already stated and as is widely known, this kind of Dimorphism manifests itself in very many ways - the commonest being that of general coloration, instances of which will occur to every one; but apart from that the coloration of particular parts is scarcely less often divergent in the two sexes, while differences of the form or development of certain portions of the plumage are also very abundant, as witness the occipital plumes in the male of many birds, while the extraordinary elongation of the feathers of the lower back in the PEACOCK, of those on the side of the breast in the BIRD OF PARAdISE, or of the tail in the BLACKCOCK are notorious. Passing to characters which may be of greater signifrcance, we have spurs on the metatarsus or near the wrist, the former only among the Gallinx, but the latter found in birds of several groups that are not nearly allied. These are generally and justly admitted to be weapons, and hardly less effective are the knobs which occupy the like position in other forms, those of the male Pezophaps being perhaps the most remarkable. Sexual Dimorphism of the BILL has been already noticed, and it extends in various ways to the head, wattles, frontal plates, protuberances that are permanent or only temporarily erectile, which are far too numerous to mention; but other much more special peculiarities are the sublingual bag of Biziura lobata, the seasonal pouch of the BUSTARD, and the inflatable sacs of the Prairie-fowls (GROUSE), while the convolutions and enlargements of the trachea in many birds (e.g. MavUCODE) though not externally visible produce an audible sexual Dimorphism.

Sexual Dimorphism in size is also manifested among birdsand this in both directions. To ourselves it may seem natural that the male should be the stronger and therefore the bigger sex, and among Mammals he generally is; but in Birds this is by no means su much the rule, the cock being very considerably larger than the hen only in certain Gallinaceous and Ratite groups, most of which are polygamous, and hence a possible explanation may be afforded. On the other hand, though a case in which the female is larger than the male is hardly to be found among Mammals, instances occur among Reptiles (notably in Tortoises and Snakes) and very frequently among Amphibians and Fishes. Among Birds it is almost universal with the ACCIPITREs, and obtains in several of the 
Limicolix, as the Dotterel, Godwit, Phalarope, and Phynchac or Painted SNIPE, as well as in some of the Turnicida (HEMIPODE). No single explanation that will fit all these cases seems possible; but in those of the Limicolax just mentioned, it is to be remarked that the females are not only larger but are more conspicuously coloured than the males, which latter are believed to perform exclusively the duty of incubation. In the lower classes of Vertebrates the production of the often numerous eggs may be the original cause of the greater size of the females.

DINORNIS, see MOA.

DIPPER, a name now in general use for the Water-OuseL, but apparently invented in 1804 by the author of Bewick's British Birds (ed. 1, ii. p. 17) because "it may be seen perched on the top of a stone in the midst of the torrent, in a continual dipping motion, or short courtesy often repeated," and not (as commonly is supposed) from its habit of entering the water in search of its food.

DISHWASHER, a common name in many parts of England, especially in the south, by which the Pied WAGTaIL, Motacilla lugubris, is known; and given also in Australia to Sisura inquieta (FLYCATCHER).

DIVER, a name that when applied to a bird is commonly used in a sense even more vague than that of Loom, several of the SeaDucks or Fuligulinx and MERgansers being frequently so called, to say nothing of certain of the Auks or Alcida and Grebes; but in English ornithological works the term Diver is generally restricted to the Family known as Colymbida, a very well-marked group of aquatic birds, possessing great, though not exceptional, powers of submergence, and consisting of a single genus Colymbus (or Eudytes of some writers) ${ }^{1}$ which is composed of three or four species, all confined to the northern hemisphere. This Family belongs to the CECOnORPHA of Prof. Huxley, and is usually supposed to occupy a place between the Alcidx and Podicipedidx; but to which of those groups it is most closely related is at present undecided. Brandt in 1837 (Beitr. Naturgesch. Vögel, pp. 124-132) pointed out the osteological differences of the Grebes and the Divers, urging the affinity of the latter to the Aulss; while, thirty years later, Prof. Alphonse Milne-Edwards (Ois. foss. France, i. pp. 279-283) inclined to the opposite view, chiefly relying on the similarity of a peculiar formation of the tibia in the Grebes and Divers, ${ }^{2}$ which indeed is very remarkable, and, in the latter group,

1 By these writers the name Colymbus is generally used for what others term Podiceps, more correctly written Podieipes. Americans of late prefer Urinator.

2 The remains of Colymboides minutus, from the Miocene of Langy, described by this naturalist in the work just cited, seem to shew it to lave been a generalized form. Unfortunately its tibic is unknown. 
attracted the attention of Willughby more than two hundred years since. On the other hand, Brandt, and Rudolph Wagner shortly after (Naumann's Fögel Deutschlands, ix. p. 683, xii. p. 395), had already shewn that the structure of the knee-joint in the Grebes and Divers differs in that the former have a distinct and singularlyformed patella (which is undeveloped in the latter) in addition to the prolonged, pyramidally-formed, procnemial process-which last may, from its exaggeration, be regarded as a character almost peculiar to these two groups. ${ }^{1}$ The evidence furnished by oology and the newly-hatched young would seem to favour Brandt's views; and, without according too much weight to such evidence, it certainly ought to be considered before a decision is reached. The abortion of the rectrices in the Grebes, while these feathers are fairly developed in the Divers, is another point that helps to separate the two Fanilies; but until their morphology has been worked out nothing can be safely averred on the subject.

The commonest species of Colymbus is C. septentrionalis, known as the Red-throated Diver from an elongated patch of dark bay colour which distinguishes the throat of the adult in summer-dress. Notwithstanding this ornament, it is the least conspicnous, as it is also the smallest, species of the genus, the back and upper plumage being of a blackish-brown with a few insignificant white spots, while the head and sides of the neck are ash-coloured, bounded by a long nuchal band, which lower down advances towards the breast, of feathers marked with black, grey, and white, to form regular stripes. Immature birds want the bay patch, and have the back so much more spotted that they are commonly known as "Speckled Divers." Next in size is the Black-throated Diver, C. arcticus, having a light grey head and a gular patch of purplishblack, above which is a semi-collar of white striped vertically with black, while two patches on the black back, between the shoulders, as well as the scapulars, are conspicuously marked with large subquadrangular white spots. Still bigger is the Great Northern Diver, C. glacialis or torquatus, with a glossy black head and neck, two semi-collar's of white and black vertical stripes, and nearly the whole of the black back and upper surface of the wings beautifully marked with white spots, varying in size and arranged in belts. ${ }^{2}$ Closely resembling this bird, so as to be most easily distinguished from it by its ivory-white or yellow bill, is $C$. adamsi, the specific

1 Garrod, in lis tentative and chiefly myological arrangement of Birds (Proc. Zool. Soc. 1874, p. 117), placed the Colymbidx and Podicipcdidx in one Order (Anseriformes) and the Alcidx in another (Charadriformes); but the artificial nature of this assignment may be realized by the fact of his considering the other Families of the former Order to be Anatida and Spheniscidx.

2 The osteology and myology of this species are described by Dr. Coues (Mem. Boston Soc. Nat. History, i. pp. 131-172, 11. 5). 
validity of which is not yet fully recognized. The Divers live chiefly on fish, and are of eminently marine habit, though invariably resorting for the purpose of breeding to freshwater-lakes, where they lay their two dark-brown eggs on the rery brink; but they are not unfrequently found far from the sea, being either driven inland by stress of weather, or exhausted in their migrations. Like most birds of their build, they chiefly trust to swimming, whether submerged or on the surface, as a means of progress, but once on the wing their flight is strong and they can mount to a great height, whence on occasion they will rush downward with a velocity that must be seen to be appreciated, and this sudden descent is accompanied by a noise for which those who have witnessed it will agree in thinking that thundering is too weak an epithet. In winter their range is too extensive and varied to be here defined, though it is believed never to pass, and in few directions to approach, the northern tropic; but the geographical distribution of the several forms in summer requires mention. While C. septentrionalis inhabits the north temperate zone of both hemispheres, C. arcticus breeds in suitable places from the Hebrides to Scandinavia, and across the Russian empire, it would seem, to Japan, reappearing in the north-west of North America, ${ }^{1}$ though its eastern limit on that continent cannot yet be laid down; but it is not found in Greenland, Iceland, Shetland, or Orkney. $C$. glacialis, on the contrary, breeds throughont the north-eastern part of Canada, in Greenland, and in Iceland. It has been said to do so in Scotland as well as in Norway, but the assertion seems to await positive proof, and it may be doubted whether, with the exception of Iceland, it is indigenous to the Old World, ${ }^{2}$ since the form observed in Nerth-eastern Asia is evidently that which has been called C. adamsi, and is also found in North-western America; but it may be remarked that three examples of this form have been taken in England, and two in Norway (Proc. Zool. Soc. 1859, p. 206, Nyt Mag. for Naturvidenskaberne, 1877, p. 218, and Stevenson's Birds of Norfolk, iii. pp. 268, 269).

DIVERTICULUM (d. cxcum vitelli). After the yolk-sac has been withdrawn into the body-cavity its stalk remains in connection with the small intestine, and forms an appendix to it like a little cæcum, which often persists throughout life in the NIDIFUGæ, and

1 Mr. Lawrence's C. pacificus seems hardly to deserve specific recognition.

${ }^{2}$ In this connexion should be mentioned the remarkable occurrence in Europe of two birds of this species which had been previonsly wounded by a weapon presumably of transatlantic origin. One had "an arrow headed with copper sticking through its neck," and was shot on the Irish coast, as recorded by Thompson (Nat. Hist. Ireland, iii. p. 201); the other, says Herr H. C. Mïller ( $V i d$. Medd. nat. Forening, 1862, p. 35), was found dead in Kalbaksfjord in the Færoes, with an iron-tipped bone dart fast under its wing. 
occasionally, as in the RATIT瓜, retains a small quantity of degenerated yolk, while in the NIDICOLE or ALTRICES it is generally absorbed before maturity.

DODLET, Sir R. Owen's name, intended to be a diminutive of DoDo (as its scientific appellation Didunculus is of Didus), for the Tooth-billed PIGEoN of the Samoan or Navigators' Islands, the hooked bill of which presents an outward resemblance to that of the celebrated inhabitant of Mauritius; but Didunculus, though by many writers placed in the Family Dididx, differs remarkably from them, and is really much more allied to the true Columbida (Dove, PIGEON), though entitled to form a separate Family, Didunculidxe (Phil. Trans. 1869, p. 349).

The name given by Sir $R$. Owen has fortunately not been adopted, but for convenience sake this curious bird is here treated under it. The species must have been first observed in October or November 1839, when the Samoan Islands were visited by the United States' Exploring Expedition under Commander Wilkes (Narrative, etc. pp. 87-116. London: 1845), and Strickland seems to have first publicly announced the discovery at the meeting of the British Association held at York in September 1844, when he stated (Report, etc. p. 189) that "among other rarities" obtained on the voyage by Mr. Titian Peale, the naturalist of the expedition, was "a new bird allied to the Dodo, which he proposes to name Didunculus." The earliest description of it that appeared was accompanied by a figure, and was published by Jardine (Ann. Nat. Hist. xvi. p. 175, pl. 9), just a year after, under the name of Gnathodon I strigirostris, from a specimen which had been sent home, probably by some missionary, and was bought in a sale at Edinburgh. This, and those brought by the American explorers, were for a long while the only specimens known to have reached any civilized country. In 1847 Reichenbach conferred on this bird a new generic name, Plioclus, for an invalid reason (see his Vög. Neuholl, ii. p. 158, note), but courtesy required what custom has acceded, and the oldest generic name applied to it has been commonly adopted, though the full title of the Tooth-billed Pigeion, Didunculus strigirostris, was not bestowed until 1848, when Peale's work on the zoology of the Expedition to which he was attached put matters so far straight enough. Of late many specimens have been brought to Europe, and they may be seen in many museums. Much has been written of the habits of Didunculus in its native condition, but little that is to the purpose, while some seem to have confounded it with the Carpophaga pacifica or oceanica, which also is peculiar to the Samoan Islancls. The interest taken in this species, chiefly because of its

1 J. E. Gray had already, in 1836, forestalled the use of this name for a genus of Mollusca. 
supposed-but really very slight-affinity to the DoDo, and of the belief that it would speedily undergo the same fate, has already caused legends about it to spring up, and statements are made to the effect that it has changed its habits so as to ensure its safety from the numerous enemies which civilization has introduced. I have no means of contradicting such assertions, but according to my own experience they are very mlikely to be true, and they should be verified by particular observation and not left to general impression. Living examples have several times been taken to Sydney, and 3 have been exhibited in the Zoological Gardens in London. The first of them, obtained through the care of Dr. George Bennett (Proc. Zool. Soc. 1864, p. 158), laid an egg (Proc. Zool. Soc. 1867, p. 164, pl. xv. fig. 6) which was of the normal Columbine form and nearly of the normal Columbine colour. It must be confessed that the species, the speedy extinction of which seems probable, was not lively or attractive as a cage-bird.

DODO, from the Portuguese Doudo (a simpleton ${ }^{1}$ ), a large bird formerly inhabiting Mauritius, but now extinct-the Didus ineptus of Limmeus. The precise year in which that island was discovered by the Portuguese is undetermined; but M. Codine shews (Mém. Géogr. sur la Mer des Indes, chap. vii. Paris : 1868) that it was probably in 1507 , and it was by them called Cerne, after one of their ships so named from an island mentioned by Pliny (Hist. Nat. vi. $36 ;$ x. 9), though many authors have insisted that it was known to the seamen of that nation as Ilha do Cisneperhaps but a corruption of Cerne, and brought about by their finding it stocked with large fowls, which, though not aquatic, they likened to Swans, the most familiar to them of bulky birds. However, that early experience is unfortunately lost to us, no clirect evidence having come to light, and nothing positive can be asserted of the island or its inhabitants (none of whom, it should be observed, were human) until 1598, when the Dutch, under Van Neck, arrived there and renamed it Mauritius. A narrative of this voyage was published in 1601, if not sooner, and has been often reprinted. Here we have birds spoken of as big as Swans or bigger, with large heads, no wings, and a tail consisting of a few curly feathers. The Dutch called them Walghrogels (the word is variously spelt), i.e. "nauseous birds," because, as is said, no cooking made them palatable; but another and perhaps better l'eason, for it was admitted that their breast was tender, is also assigned, namely, that this island-paradise afforded an abundance of superior fare. De Bry gives two admirably quaint prints of the doings of the Hollanders, and in one of them the Walchrogel

1 Alewyn and Collé, in their Woordenschat der twee Taalen Portugcesch en Nederduitsch (Amsterdam: 1714, p. 362), render it "Een sot, dwaas, dol, of uitzinnig mensch." 
appears, being the earliest published representation of its unwieldy form, with a footnote stating that the voyagel's brought an example alive to Holland. Among the company there was a draughtsman, and from a sketch of his Clusius, a few years after, gave a figure of the bird, which he vaguely called "Gallinaceus Gallus peregrinus," but deseribed rather fully. Meanwhile two other Duteh fleets had visited Mamritius. One of them lad a draughtsman on board, and his original sketches fortunately still exist in a library at Utrecht. Three or four of them represent the Dodo, and one of them is here

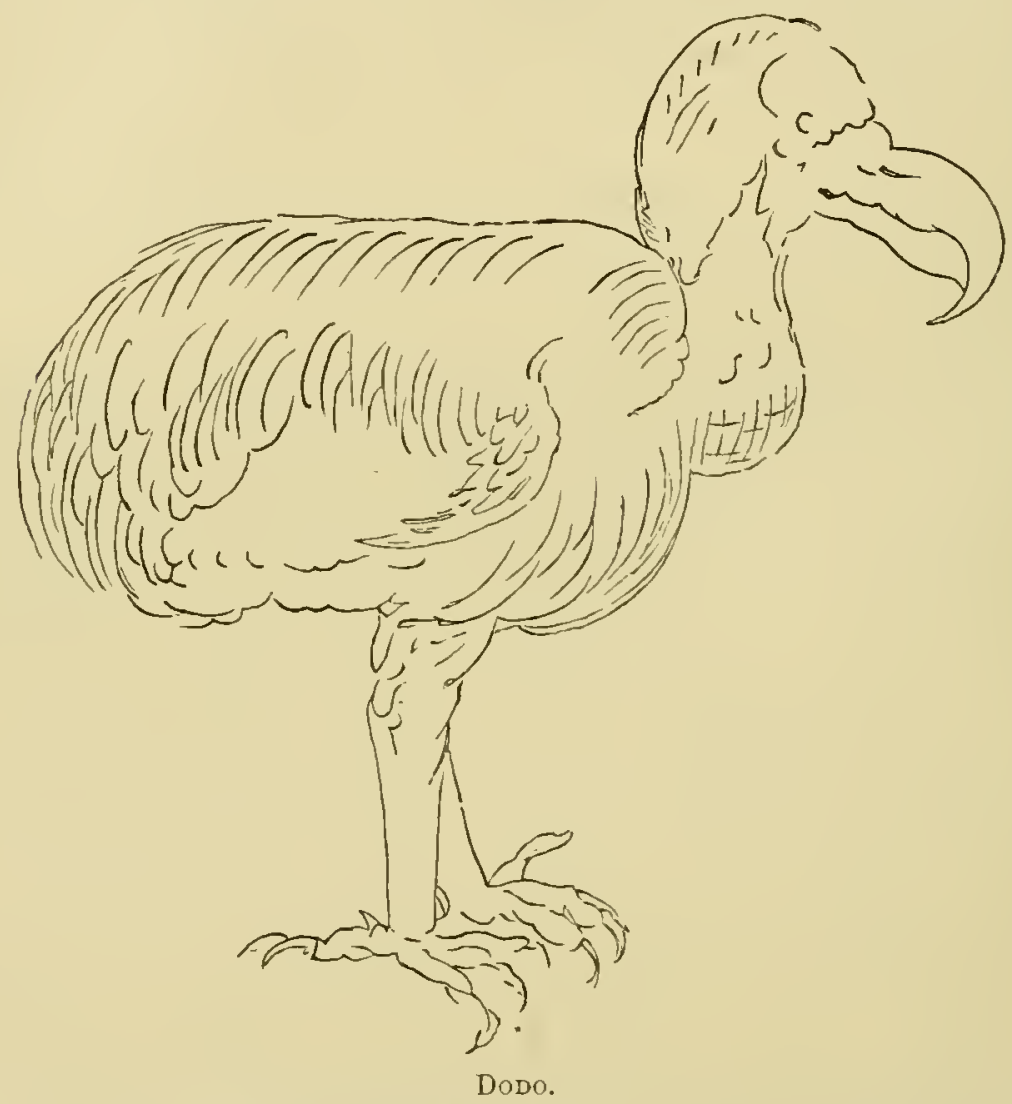

Reduced from a tracing by Prof. Schlegel of the original drawing in a MS. jotrnal kept during Wolphart Harmanszoon's voyage to Mauritius (A.D. 1601-1602).

reproduced, for the first time, but on a smaller seale. ${ }^{1}$ Of the other fleet, a journal kept by one of the skippers was subsequently publisher. This in the main eorroborates what has been before said of the birds, but adds the emions fact that they were now called by some Doduarsen and by others Dronten. ${ }^{2}$

1 On the death of Prof. Schlegel, who announced his intention of publishing these sketches in fac-simile, I became possessed of his collection of drawings of the Dodo and other extinct birds of Mauritius, which includes tracings by him of these curious and interesting sketches ( $f$. Extermixitiox).

2 The etymology of these names has been much discussed. The former has been shewn by Prof. Schlegel (Vcrsl. en Mededeel. K. Akad. Wetensch. ii. pp. 255 et seqq.) to be the homely name of the Dabchick or Little Grebe, Podicipes 
Henceforth Dutch narrators, though several times mentioning the bird, fail to supply any important fact in its history. Their navigators, however, were not idle, and found work for their naturalists and painters. Clusius says that in 1605 he saw at Pauw's House in Leyden a Dodo's foot, ${ }^{1}$ which he minutely describes. Of late years a copy of Clusius's work has been discovered in the high school of Utrecht, in which is pasted an original drawing by Van de Venne, reproduced in fac-simile by Herr H. C. Millies in 1868, and superscribed "Vera effigies huius avis W $\mathrm{Valgh-}$ vogel (quæ \& a nautis Dodaers propter foedam posterioris partis crassitiem nuncupatur) qualis viua Amsterodamum perlata est ex Insula Mauritii. Anno M.DC.XXVI." Now a good many paintings of the Dodo by a celebrated artist named Roelandt Savery, who was born at Courtray in 1576 and died in 1639, have long been known, and it has always been understood that these were drawn from the life. Proof, however, of the limning of a living Dodo in Holland at that period had hitherto been wanting. There can now be no longer any doubt of the fact; and the paintings by this artist of the Dodo at Berlin and Vienna-dated respectively 1626 and 1628 - as well as the picture by Goiemare, belonging to the Duke of Northumberland, at Sion House, dated 1627, may be with greater plausibility than ever considered portraits of a captive bird. It is even probable that this was not the first example which had sat to a painter in Europe. In the private library of the late Emperor Francis of Austria is a series of pictures of various animals, supposed to be by the Dutch artist Hoefnagel, who was born about 1545. One of these represents a Dodo, and, if there be no mistake in Von Frauenfeld's ascription, it must almost certainly have been painted before 1626, while there is reason to think that the original may have been kept in the vivarium of the then Emperor Rudolf II, and that the portion of a Dodo's head, which was found in the Museum at Prague abont 1850 , belonged to this example. The other pictures by Roelandt Savery, of which may be mentioned that at the Hagne, that in the minor, of which the Dutchmen were reminded by the round steru and tail dimimished to a tuft that characterized the Dodo. The same learned anthority suggests that Dodo is a corruption of Dodaars, but, as will presently be seen, we herein think him mistaken. The latter of the two names, which has been naturalized in France as Dronte, as Dr. Jentink has kindly suggested to me, may be from the obsolete Dutch verb dronten (cognate with drenten and drinten), to be swollen ( $c f$. Verwijs and Verdam, Middelnederlandsch Woordenbuek, ii. col. 435), and would inlicate the Dodo's figure as represented by some draughtsmen, and as described by Herbert.

1 What became of the specimen (which may have been a relic of the bird brought home by Van Neck's squadron) is not known. Broderip and the late Dr. Gray suggested its identity with that now in the British Museum, but ou what grounds is not apparent. 
possession of the Zoological Society of London (formerly Broderip's), that in the Schönborn collection at Pommersfelden near Bamberg, and that belonging to Dr. Seyffery at Stuttgart are undated, but were probably all painted about the same time (viz. 1626 to 1628). The large picture in the British Museum, once belonging to Sir Hans Sloane, by an unknown artist, but supposed to be by Roelandt Savery, is also undated; while the still larger one at Oxford (considered to be by the younger Savery) bears a much later date, 1651. Undated also is a picture said to be by Pieter Holsteyn, and in the possession of Dr. A. van der Willige at Haarlem in Holland.

In 1628 we have the evidence of the first English observer of the bird-one Emanuel Altham, who mentions it in two letters written on the same day from Mauritius to his brother at home. These, through the intervention of the late Dr. J. B. Wilmot, were brought to light. I In one the writer says: "You shall receue... a strange fowle: which I had at the Iland Mauritius called by ye portingalls a Do Do: which for the rareness thereof I hope wilbe welcome to you." The passage in the other letter is to the same effect, with the addition of the words "if it liue." Nothing more is known of this valuable consignment. In the same fleet with Altham sailed Herbert, whose Travels ran through several editions and have been long quoted. It is plain that he could not have reached Mauritius till 1629, though 1627 has been usually assigned as the date of his visit. The fullest account he gives of the bird is in his edition of 1638 , and in the curiously affected style of many writers of the period. It will be enough to quote the beginning: "The Dodo comes first to a description: here, and in Dygarrois ${ }^{2}$ (and no where else, that ever I could see or heare of) is generated the Dodo (a Portuguize name it is, and has reference to her simpleness), a Bird which for shape and rareness might be call'd a Phœnix (wer't in Arabia:) "- the rest of the passage is entertaining, but the whole has been often reprinted. Herbert, it may be remarked, when he could see a possible Cymric similarity, was weak as an etymologist, but his positive statement, corroborated as it is by Altham, cannot be set aside, and hence we do not hesitate to assign a Portnguese derivation for the word. ${ }^{3}$ Herbert also gave a figure of the bird.

1 Proc. Zool. Soc. 1574, pp. 447-449. I am informed that on the death of Dr. Wilmot these interesting papers (which, had they been his own property, he would have willingly made over to some public library) were burnt. I had, however, taken the precaution to have them accurately transcribed while they were entrusted to my keeping.

2 1.e. Rodriguez; an error, as we shall see.

3 Hence we venture to dispute Schlegel's supposed origin of "Dodo." The Portuguese must have been the prior nomenclators, and if, as is most likely, some of 
Proceeding chronologically, we next come upon a curious bit of evidence. This is contained in a MS. diary kept between 1626 and 1640 by Thomas Crossfield of Queen's College, Oxford, where, under the year 1634, mention is casually made of one Mr. Gosling, "who bestowed the Dodar (a blacke Indian bird) vpon ye Anatomy school." Nothing more is known of it. About 1635, Sir Hamon Lestrange tells $n \mathrm{~s}$, as he walked London streets he saw the picture of a strange fowl hung out on a cloth canvas, and going in to see it, found a great bird kept in a chamber "somewhat bigger than the largest Turliey cock, and so legged and footed, but shorter and thicker." The keeper called it a Dodo and shewed the visitors how his captive would swallow "large peble stones . . as bigge as nutmegs."

In 1651 Morisot published an account of a royage made by François Cauche, who professed to have passed sixteen days in Mauritius, or "l'isle de Saincte Apollonie" as he called it, in 1638. According to De Flacourt the narrative is not very trustworthy, and indeed certain statements are obviously inaccurate. Cauche says he saw there birds bigger than Swans, which he describes so as to leave no doubt of his meaning Dodos; but perhaps the most important facts (if they be facts) that he relates are that they had a cry like a Gosling ("il a un cry comme l'oison"), and that they laid a single white egg, "gros comme un pain d'un sol," on a mass of grass in the forests. He calls them "oiseaux de Nazaret," perhaps, as a marginal note informs us, from an island of that name which was then supposed to lie more to the northward, but is now known to have no existence.

In the catalogue of 'Tradescant's Collection of Parities, preserved at South Lambeth, published in 1656, we have entered among the "Whole Birds" a "Dodar from the island Nauritius; it is not able to flie being so big." This specimen may well have been the embalmed body of the bird seen by Lestrange some eighteen years before, but any how we are able to trace the specimen through Willughby, Lhwyd, and Hyde, till it passed in or before 1684 to the Ashmolean collection at Oxford. In 1755 it was ordered to be destroyed, but, in accordance with the original orders of Ashmole, its head and right foot were preserved, and still ornament the Musenm of that University. In the second edition of a Catalogue of many Natural Parities, \&c., to berseen at the place formerly called the Music House, near the West End of St. Paul's Church, collected by one Hubert alias Forbes, and published in 1665, mention is made of a "legge

their nation, or men acquainted with their language, were employed to pilot the Hollanders, we see at once how the first Dutch name Walghvogel would give way. The meaning of Doudo not being plain to the Dutch, they would, as is the habit of sailors, convert it into something they did understand. Then Dodaers would easily suggest itself ( $c f$. Albatros and Booby). 
of a Dodo, a great heavy bird that cannot fly; it is a Bird of the Mauricius Island." This is supposed to have subsequently passed into the possession of the Royal Society. At all erents such a specimen is included in Grew's list of their treasures which was published in 1681, and it was afterwards transferred to the British Museum, where it still reposes. As may be seen, it is a left foot, without the integuments, but it differs sufficiently in size from the Oxford specimen to forbid its having been part of the same individual. In 1666 Olearius brought out the Gottorfisches Kunst Kammer, wherein he describes the head of a Walghvogel, which some sixty years later was removed to the Museum at Copenhagen, and is now preserved there, having been the means of first leading zoologists, under the guidance of the late Prof. Johannes Theodor Reinhardt in 1843 , to recognize the true affinities of the bird.

Little more remains to be told. For brevity's sake we have passed over all but the principal narratives of voyagers or other notices of the bird. A compendious bibliography, up to the year 1848 , will be found in Strickland's classical work, ${ }^{1}$ and the list was continued by Von Frauenfeld ${ }^{2}$ for twenty year's later. The last evidence we have of the Dodo's existence is furnished by a journal kept by Benj. Harry, and now in the British Museum (IISS. Addit. $3668,11 . D)$. This shews its survival till 1681, but the writer's sole remark upon it is that its "fflesh is very hard." The successive occupation of the island by different masters seems to have destroyed every tradition relating to the bird, and cloubts began to arise whether such a creature had ever existed. Duncan, in 1828, proved how ill-founded these doubts were, and some ten years later Broderip with much diligence collected all the available evidence into an admirable essay, which in its turn was succeeded by Strickland's monograph just mentioned. But in the meanwhile little was done towards obtaining any material advance in our knowledge, Reinhardt's determination of its affinity to the Pigeons (Columba) excepted; and it was hardly until the late Mr. George Clark's discovery in 1865 (Ilis, 1866, pp. 141-146) of a large number of Dodos' remains, that zoologists generally were prepared to accept that affinity without question. The examination of bone after bone by Sir R. Owen (Truns. Zool. Soc. vi. p. 49) and other's confirmed the judgment of the Danish naturalist, and no different view can now be successfully maintained. In 1889, at the instance of M. Sauzier, researches on the scene of Mr. Clark's successes were renewed, this time by the Mauritian Government, and a vast number of Dodos' and other bones were recovered from the Mare aux Songes. Some

I The Dodo and its Kindred. By H. E. Striekland and A. G. Melville. London : 1848, 4 to.

- Neu aufgefundem Abbildung des Dronte, u. s. w. Von Georg Ritter voll Frauenfeld. Wien : 1868, fol. 
of these specimens, having been sent by M. Sauzier to Sir Edward Newton, are now in process of being worked out, and it is clear that they will add not a little to a better knowledge of the osteo$\log y$ of the species.

The causes which led to the extipation of this ponderous Pigeon are elsewhere discussed (ExTERMINATION), and it will be remembered that the Dodo does not stand alone in its fate, but that two more or less nearly allied birds inhabiting the sister islands of Réunion and Rodriguez (SolitaIRE) have in like manner disappeared from the face of the earth.

DOE-BIRD or DOUGH-BIRD, the name given, according to Nuttall (Man. Orn. U.S. and Canada, ii. p. 102), indiscriminately by the English in eastern North America to some species of CURLEw and Godwit ; but, says Mr. Trumbull (Names and Portr. B. p. 203), rightly applied to the small species of the former, Numenius borealis, commonly called the Esquimaux Curlew.

DOLLAR-BIRD, the Australian name for Eurystomus pacificus, from the silvery white spot in the middle of the wing, which is distinctly shewn in flight (Gould, Handb. B. Austral. i. p. 120). The genus Eurystomus, which is one of the Coraciida (RoLLER), contains about half a dozen species, belonging to the Indian or Ethiopian Regions.

DORR-HAIVK, a name of the NIGHTJAR, from its feeding on the mischievous "Dorr-Beetle" (Melolontha solstitialis).

DOTTEREL (variously spelt), the diminutive of Dolt, a bird so called from its alleged stupidity; for, as asserted by many old writers, if the fowler stretched out his arm or his leg, so did the Dotterel with its homologous limb. So prone is mankind to believe any silly story of what it is the custom to call "Animal Instinct," that this foolish notion prevails to the present day among many who pass for zoologists. Yet the true meaning was told to Willughby in or before 1676: one Peter Dent, a Cambridge apothecary, having written to him the information supplied by a gentleman of Norfolk well acquainted with the "sport" of catching these birds, to the effect that instead of their aping the gestures .of the men, it was the men who aped those of the birds, as the latter were being driven into the nets; for, as every one who has watched the actions of Limicola must know, it is their common habit as they run to extend a wing and often simultaneously a leg. This belief in the foolishness of the species has been fostered also by its name morinellus, bestowed by Caius with a double meaning -being a diminutive of morus, a fool, and having reference to Morini, the ancient name of the people of Flanders, where he had 
found the bird common (De rar. Anim. atque Stirp. Hist. Londini : 1570, fol. 21).

The Dotterel, Charadrius or Eudromias morinellus, is one of the most beautiful of the PLover-kind, and its gradual extinction in Great Britain is a fact much to be regretted. It has long had the credit of being a delicacy for the table, and has moreover lain under the disadvantage of being thought to be in better condition in spring, or early summer, when it arrives in this island on its way to its breeding-quarters than when it is returning southward in autumn. Consequently it has been for years ruthlessly shot down at the time when its life was most precious for the continuance of its species, and with the result that always attends such brutal practice. It used formerly to breed on the Cumberland and Westmoreland fells, but scems to have ceased from doing so for some years, the birds resorting thither having been destroyed, and its haunts on the Scottish mountains appear to be devastated by the "collector" so soon as they are discovered. So far as is at present known, the Dotterel stands alone among the Charadriida, in the facts that the posterior processes of the sternum extend backward nearly as far as the keel does, the outer pair being somewhat everted, and that the hen birds are larger and more brightly coloured than the cocks. Furthermore, the Dotterel lays only three eggs, four being the usual number in the Limicolx. The name Dotterel is often applied, with or without a prefix, to the Ringed Plover, Agialitis hiaticola, and some of its relations, to all of which it is wholly inappropriate.

DOUCKER or DUCKER (Germ. Taucher), a word used by many old writers for any bird that "ducks" or dives, and wholly without special meaning.

DOVE (Dutch, Duyve; Danish, Due; Icelandic, Dufa; German, Taube), a name which seems to be most commonly applied to the smaller members of the group of birds by ornithologists usualiy called Pigeons, Columba; but no sharp distinction can be drawn between Pigeons and Doves, and in general literature the two words are used almost indifferently, while no one species can be pointed out to which the word Dove, taken alone, seems to be absolutely proper. The largest of the group to which the name is applicable is perhaps the Ring-Dove, or Wood-Pigeon, also called in many parts of Britain Cushat and Queest, Columba palumbus, a very common bird throughout these islands and most parts of Europe. It associates in winter in large flocks, the numbers of which (owing partly to the destruction of predacious animals, but still more to the modern system of agriculture, and the growth of plantations in many districts that were before treeless) have of late years increased enormously, so that their depredations are at times very serious. 
In former days, when the breadtl of land in Britain under green crops was comparatively small, these birds found little food in the dead season, and this scarcity was a natural check on their superabundance. ${ }^{1}$ But since the extended cultivation of turnips and plants of similar use the case is altered, and perhaps at no time of the year has provender become more plentiful than in winter. The Ring-Dove may be easily distinguished from other European species by its larger size, and especially by the white spot on either side of its neck, forming a nearly continuous "ling," whence the bird takes its name, and the large white patches in its wings, which are very conspicuous in flight. It breeds several times in the year, making for its nest a slight platform of sticks on the horizontal bough of a tree, and laying therein two eggs-which, as in all the Columbida, are white.

The Stock-Dove ( $C$. cenas of most authors) is a smaller species, with many of the habits of the former, but breeding by preference in the stocks of hollow trees or in rabbit-holes. It is darker in colour than the Ring-Dove, without any white on its neck or wings, and is much less common and more locally distributed. Formerly scarce or unknown in the north of England, it has of late years been found to extend over almost the whole of Scotland.

The Rock-Dove (C. livia, Temm.) much resembles the StockDove, but is of a lighter colour, with two black bars on its wings, and a white rump. In its wild state it haunts most of the rocky parts of the coast of Europe, from the Færoes to the Cyclades, and, seldom going inland, is comparatively rare. Yet, as it is without contradiction the parent-stem of all our domestic Pigeons, its numbers must far exceed those of both the former put together. In Egypt and various parts of Asia it is represented by what Mr. Darwin has called "Wild Races," which are commonly accounted good "species" (C. schimperi, C. affinis, C. intermedia, C. leuconota, and so forth), though they differ from one another far less than do nearly all the domestic forms, of which more than 150 kinds that "breed true," and have been separately named, are known to exist. Very many of these, if found wild, would have unquestionably been ranked by the best ornithologists as distinct "species," and

1 Yet one curious fact in connexion herewith has never been satisfactorily explained. It not unfrequently happens that after Wood-Pigeons have abounded in a district for some two or three years, so as to be a perfect plague, their numbers have suddenly dwindled without any assignable cause, for the ordinary modes of destruction prove wholly futile in checking their multiplication. Another fact, perhaps worth recording, is the curious increase of late years-say from 1885, or possibly a little earlier-of this species in St. James's Park, where it is now as nunerous, if not as familiar, as in what used to be the Gardens of the Tuileries in Paris. I had long known that it inhabited the singular paradise afforded by the gardens of Buckingham Palace, but that it should establish itself even nearer to the centre of London I had not expected. 
several of them would as undoubtedly have been placed in different genera. These various breeds are classified by Mr. Darwin ${ }^{1}$ in four groups as follows :-

Group I. composed of a single Race, that of the "Pouters," having the gullet of great size, barely separated from the crop, and often inflated, the body and legs elongated, and a moderate bill. The most strongly marked subrace, the Improved English Pouter, is considered to be the most distinct of all domesticated pigeons.

Group II. includes three Races:-(1) "Carriers," with a long pointed bill, the eyes surrounded by much bare skin, and the neck and body much elongated; (2) "Runts," with a long massive bill, and the body of great size ; and (3) "Barbs," with a short broad bill, much bare skin round the eyes, and the skin over the nostrils swollen. Of the first four and of the second five subraces are distinguished.

Group III. is confessedly artificial, and to it are assigned five Races:-(1) "Fan-tails," remarkable for the extraordinary development of their tails, which may consist of as many as forty-two rectrices in place of the ordinary twelve; (2) "Turbits" and "Owls," with the feathers of the throat diverging, and a short thick bill ; (3) "Tumblers," possessing the marvellous habit of tumbling backwards during flight or, in some breeds, even on the ground, and having a short, conical bill; (4) "Frill-backs," in which the feathers are reversed; and (5) "Jacobins," with the feathers of the neck forming a hood, and the wings and tail long.

Group IV. greatly resembles the normal form, and comprises two Races:- (1) "Trumpeters," with a tuft of feathers at the base of the neck curling forward, the face much feathered, and a very peculiar voice; and (2) Pigeons scarcely differing in structure from the wild stock.

Beside these, some three or four other little-known breeds exist, and the whole number of breeds and sub-breeds almost defies computation. The difference between them is in many cases far from being superficial, for Mr. Darwin has shewn that there is scarcely any part of the skeleton which is constant, and the modifications that have been effected in the proportions of the head and sternal apparatus are very remarkable. Yet the proof that all these different birds have descended from one common stock is nearly certain. Here there is no need to point out its bearing upon the doctrine of "Natural Selection" which that eminent naturalist and Mr. Wallace have rendered so well known. The antiquity of some of these breeds is not the least interesting part of the subject, nor is the use to which one at least of them has long been applied. The Dove from the earliest period in history has been associated

1 The Variation of Animals and Plants under Domestication. London : 1868. Vol. i. pp. 131-224. 
with the idca of a messenger (Genesis viii. 8-12), and its employment in that capacity, developed successively by Greeks, Romans, Mussulmans, and Christians, has never been more fully made available than in our own day, as witness the "Pigeon-post" established during the sicge of Paris in 1870-71.

Leaving, then, this interesting subject, space does not permit our here dwelling on various foreign species, which, if not truly belonging to the genus Columba, are barely separable therefrom. Of these examples may be found in the Indian, Ethiopian, and Neotropical Regions. Still less can we here enter upon the innumerable other forms, though they may be entitled to the name of "Dove," which are to be found in almost every part of the world, and nowhere more abundantly than in the Australian Region. Mr. Wallace (Ibis, 1865, pp. 365-400) considers that they attain their maximum development in the Papuan Subregion, where, though the land-area is less than one-sixth that of Europe, more than a quarter of all the species (some 300 in number) known to exist are found-owing, he suggests, to the absence of foresthaunting and fruit-eating Mammals.

It would, however, be impossible to conclude this article without noticing a small group of birds to which in some minds the name Dove will seem especially applicable. This is the group containing the Turtle-Doves - the time-honoured emblem of tenderness and conjugal love. The common Turtle-Dove of Europe, Turtur communis or auritus, is one of those species which is gradually extending its area. In England, not much more than a century ago, it seems to have been chiefly, if not solely, known in the southern and western counties. Though in the character of a straggler only, it now reaches the extreme north of Scotland, and is perhaps nowhere more abundant than in many of the midland and eastern counties of England. On the continent the same thing has been observed, though indeed not so definitely; and this species has within the last forty years or so appeared as a casual visitor within the Arctic Circle. The probable causes of its extension cannot here be discussed; and there is no need to dwell upon its graceful form and the delicate harmony of its modest colouring, for they are proverbial. The species is migratory, reaching Europe late in April and retiring in September. Another species, and one perhaps better known from being commonly kept in confinement, is that called by many the Collared or Barbary Dove, T. risoriusthe second English name possibly indicating that it was by way of that country that it was brought to us, for it is not an African bird. This is distinguished by its cream-coloured plumage and black necklace. Some uncertainty seems to exist about its original home, but it is found from Constantinople to India, and is abundant in the Holy Land, though there a third species, T. senegalensis, also 
occurs, which Canon Tristram thinks is the Turtle-Dove of Scripture.

The "Greenland Dove" of Arctic seamen and of some writers in the last century is the

DOVEKEE or DOVEKEY (often written affectedly Dovekie), the whalers' name for what is called in most books the Black GuILlemot, Uria grylle; but sometimes misapplied to the Little AUK or Rotche.

DRAW-TTATER, a common name given to the GoLDFINCH, which in captivity learns the trick of pulling a small bucket or cup of water from a reservoir placed below its cage, the cup being suspended by a string or light chain.

DREPANIS, the scientific name given by Temminck (Man. d'Orn. ed. 2, i. p. Ixxxvi.) to certain birds of the Sandwich Islands,

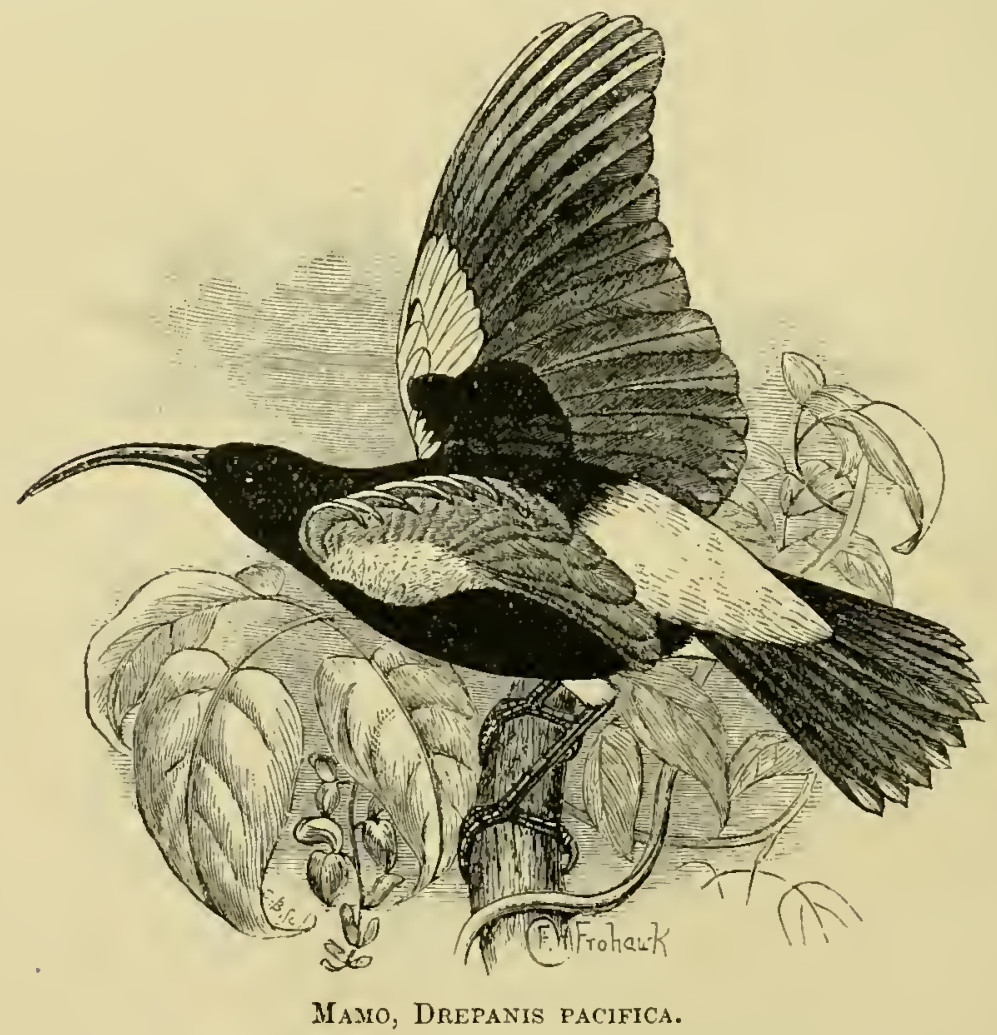

originally referred to the genus Certhiu, and subsequently regarded as belonging to the Family Meliphagida (HonkY-SUCKER), but lately ascertained by Dr. Gadow to differ from the latter by possessing a tongue of a very distinct structure, and to be probably more nearly allied to the Carebida, so that their recognition as a separate Family, Drepanidida, is justifiable. The genus Drepanis, as latterly restricted, includes but a single species, $D$. pucifica, now according to all accounts cxtinct, owing, it is believed, to the way in 
which it was destroyed for the sake of its rich yellow feathers, used in former days to decorate the state robes of the chiefs. ${ }^{1}$ Specimens were brought to England by the companions of Cook on his last voyage, when the Sandwich Islands were discovered, and one of them exists in the Museum of Vienna, while other examples are to be seen in Honolulu, Paris, Leyden, and Cambridge; but probably not more than half a dozen have been preserved. Nearly allied to this species is the beantiful Scarlet Creeper of Latham, Vestiaria cocinea, which also provided feathers for the adornment of the natives, but has escaped the fate of its relative, being still one of the most characteristic birds of the islands; and to the same Family belong several other genera, among which Hemignathus, with its

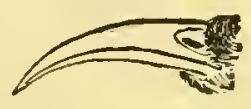

Testiaria. (After Swainson.) upper mandible in some species monstrously prolonged beyoud the lower, is very remarkable (see Wilson and Evans, Birds of the sundwich Islands).

DROM FOGNATHE, the first Suborder of Cavinata, according to Prof. Huxley's taxonomy (Proc. Zool. Soc. 1867, pp. 425, 456), consisting of the Family Tinamida (Tinanou), or Order Crypturi as some would have it. These birds have a completely Struthions palate, with a very broad vomer meeting in front with the broad maxillo-palatal plates as in Dromaus (EuEU), while, behind, it receives the posterior extremities of the palatals and the anterior ends of the pterygoids, which thus have a Ratite conformation.

DRONGO, a native name of the Eldolius forficatus of Madagasear which has been not only adopted into varions Emopean languages, but also used generally for the allied species, several of which are referred to distinct genera, as Bhringe, Chuptia, Chibia, Dicnu'us, Dissemuns, Melanornis, and so forth, and inhabit Africa, Asia, the

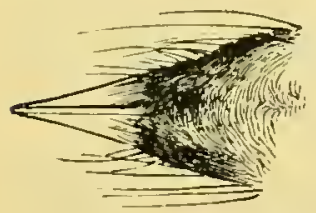

DicruRus. (After Swainson.) Fastern Archipelago, and Australia. The Drongos, known as "King-Crows" to Anglo-Indians, are commonly placed as a subfamily among the Laniüla (SHrIkE); but are fully entitled, so far as the groups of Pusseres are concerned, to rank as a Family, Dicruida. Their colour when adult is almost

I Its native name seems to have been Mromo, which was thence applied to the gorgeons mantles beset with its golden feathers. As the species became rare, recourse was had for this purpose to the yellow feathers of a very different birt, the O-o, the Acrulocercus nobilis of modern ornithologists, lelonging, as Dr. Gadow has shewn, to the wholly-distinct Family Mcliphagida (Honey-stcrer). $C f$. Wilson and Evans, op. cit. 
invariably black, ${ }^{1}$ and they have but 10 feathers in their tail, the outer reetrices being in several forms mueh prolonged and often more or less involuted, while in some eases the outermost pair are enlarged at the end in a raequet-like form. Many are erested, and all have the base of the bill beset by more or fewer strong bristles.

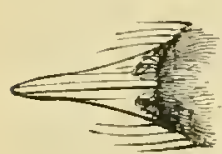

MELANORNIS

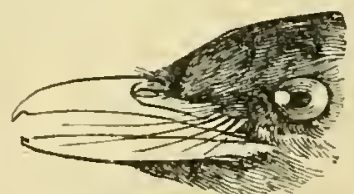

(After Swainson.) The Drongos seem to be wholly insectivorous, and are usually re. markable for the courage with which they will attack and drive off lar'ger birds, such as Kites or Crows. Considerable difficulty is found in discriminating the specifie and generic forms of this Family; but two, Dicmurus (or Buchangw) assimitis and D. ludwigi, inhabit the Cape Colony, while no fewer than 15, referred by Mr. Oates (Faun. Br. Ind. Birds, i. pp. 308-326) to 7 genera, inhabit various parts of our Indian possessions, among which $D$. ater or macrocercus is the King-Crow proper, ranging from Affghanistan to China, though apparently not found in the Malay Peninsula. Australia is graced, so far as is known, with a single species, Chibia bracteata, but many are found in Malasia and the islands of the Malay Arehipelago.

DUCK, a word cognate with the Dutch Duycker (Germ. Tauchente-and in Bavaria Duck-antl), the general English name for a large number of birds forming the greater part of the Family Anatida of modern ornithologists. Technically the term Duck is restricted to the female, the male being ealled Drake, and in one speeies Mallard (Fr. Mulart).

The Anatida may be at once divided into six more or less well-marked subfamilies - (1) the Cygnina (Swas), (2) the Anserine (Goose) - which are each very distinet, (3) the Anatina or Freshwater Ducks, (4) those commonly called Fuligulina or SeaDucks (Pochard), (5) the Erismaturine or Spiny-tailed Ducks, and (6) the Mergina (Merganser). Of the Anatina, which may be considered the typical group, we propose to treat here only, and especially of the Anas boscas of Linnaus, the common Wild Duck, which from every point of view is by far the most important species, as it is the most plentiful, the most widely distributed, and the best known-being, without a doubt, the origin of all our domestic breeds. It inhabits the greater part of the northern hemisphere, reaching in winter so far as the Isthmus of Panama in the New World, and in the Old being abundant at the same season in Egypt and India, while in summer it ranges throughont the Fur-

1 G. R. Gray placed in this group the genus Trene (see Bluebulid), "most mnfortunately," as Jerdon states (B. Ind. ii. p. 104), and herein all who have any knowledge of the subject agree. The position of the genus may be uncertain, but among Passeres one less suitable than this can hardly be found. 
Countries, Greenland, Iceland, Lapland, and Siberia. Most of those which fill our markets are no doubt bred in more northern climes, but a considerable proportion of them are yet produced in the British Islands, though not in anything like the numbers that used to be supplied before the draining of the great Fen-country and other marshy places. The Wild Duck pairs very early in the year - the period being somewhat delayed by hard weather, and the ceremonies of courtship, which require some little time. Soon after these are performed, the respective couples separate in search of suitable nesting-places, which are generally found, by those that remain with us, about the middle of March. The spot chosen is sometimes near a river or pond, but often very far removed from water, and it may be under a furze-bush, on a dry heath, at the bottom of a thick hedge-row, or even in any convenient hole in a tree. A little dry grass is generally collected, and on it the eggs, from 9 to 11 in number, are laid. So soon as incubation commences the mother begins to divest herself of the down which grows thickly beneath her breast-feathers, and adds it to the nestfurniture, so that the eggs are deeply imbedded in this heat-retaining substance-a portion of which she is always careful to pull, as a coverlet, over her treasures when she quits them for food. She is seldom absent from the nest, however, but once, or at most twice a day, and then she dare not leave it until her mate after several circling flights of observation has assured her she may do so unobserved. Joining him, the pair betalie themselves to some quiet spot where she may bathe and otherwise refresh herself. Then they return to the nest, and after cautiously reconnoitring the neighbourhood, she loses no time in reseating herself on her eggs, while he, when she is settled, repairs again to the waters, and passes his day listlessly in the company of his brethren, who have the same duties, hopes, and cares. Slort and infrequent as are the absences of the Duck when incubation begins, they become shorter and more infrequent torvards its close, and for the last day or two of the 28 necessary to develop the young it is probable that she will not stir from the nest at all. When all the fertile eggs are hatched her next care is to get the brood safely to the water. This, when the distance is great, necessarily demands great caution, and so cunningly is it done that but few persons have encountered the mother and offspring as they make the dangerous journey. I If disturbed, the young instantly hide as they best can, while the mother quacks loudly, feigns lameness, and flutters off to divert the attention of the intruder from her brood, who lie motion-

1 When Ducks breed in trees, the precise way in which the young get to the ground is still a matter of uncertainty. The mother is supposed to convey them in her bill, and very likely does so, but further observation on this point is required. 
less at her warning notes. Once arrived at the water they are comparatively free from harm, though other perils present themselves from its inmates in the form of Pike and other voracious fishes, which seize the Ducklings as they disport in quest of insects on the surface or dive beneath it. Throughout the summer the Duck continues her care unremittingly, until the young are full grown and feathered; but it is no part of the Mallard's duty to look after his offspring, and indeed he speedily becomes incapable of helping them, for towards the end of May he begins to undergo an additional Moult, loses the power of flight, and does not regain his full plumage till autumn. About harvest-time the young are well able to shift for themselves, and then resort to the corn-fields at evening, where they fatten on the scattered grain. Towards the end of September or beginning of October both old and young unite in large flocks and betake themselves to the larger waters, many of which are fitted with the ingenious appliances for catching them known as decoys. ${ }^{1}$ These are worked on all favourable occasions during the winter, but the numbers taken vary greatlysuccess depending so much on the state of the weather. If longcontinued frost prevail, most of the Ducks resort to the estuaries and tidal rivers, or even leave these islands almost entirely. Soon after Christmas the return-flight commences, and then begins anew the course of life already described.

The domestication of the Duck is doubtless very ancient, but evidence on this head is exceedingly imperfect. Several distinct breeds have been established, of which the most esteemed from an economical point of view are those known as the Rouen and Aylesbury; but perhaps the most singular deviation from the normal form is the so-called Penguin-Duck, in which the bird assumes an upright attitude and its wings are much diminished in size. A remarkable breed also is that often named (though quite fancifully) the "Buenos-Ayres" Duck, wherein the whole plumage is of a deep black, beautifully glossed or bronzed. But this saturation, so to speak, of colour only lasts in the individual for a few years, and as the birds grow older they become mottled with

1 The origin of this word has given rise to a good deal of speculation, but it seems to be simply an abbreviation of the Dutch "cende-coy"-that is to say, duckcage or netted enclosure-and it is admitted that the use of Decoys was introduced into this country from Holland (Spelman's Posthumous Works, ed. Gibson, ii. p. 153). If this view be correct, we may justifiably speak of a Decoy-Duck, but the expression Duck-Decoy is an intolerable pleonasm. Those who are curious as to the mode of using Decoys should consult Mr. Sonthwell's edition of Lubbock's Fauna of Norfolk (1879), and Sir R. Payne-Gallway's Book of DuckDecoys (1886), which last is an almost exhaustive treatise on the subject. The ordinary descriptions and even figures of a Decoy met with in popular works are almost invariably misleading-the writers having no knowledge of the practice followed, and misrepresenting it accordingly. 
white, though as long as their reproductive power lasts they "breed true." The amount of variation in domestic Ducks, howcver, is not comparable to that found among Pigeons, no doubt from the absence of the competition which Pigeon-fanciers have so long exercised. One of the most curions effects of domestication in the Duck, however, is, that whereas the wild Mallard is not only strictly monogamous, but, as Waterton believed, a most faithful husband-remaining paired for life, the civilized Drake is notoriously polygamous.

Very nearly allied to the common Wild Duck are a considerable number of species found in various parts of the world in which there is little difference of plumage between the scxes-both being of a dusky hue--such as Anas olscura of North America, $A$. superciliose of Australia, A. pecilorluyncha of India, A. melleri of Madagasear, A. xanthorhyncha of South Africa, and some others.

It would be impossible here to enter mpon the other senera of Anctinx. We must content ourselves by saying that both in Europe and in North America there are the gromps represented by the Shovelefr, Garganit, Gadwall, Teal, Pintail, and WIGEON-each of which, according to some systematists, is the type of a distinct genus. Then there is the group Ex with its beantiful representatives the Wood-Duck (At. sponsa) in America and the Mandarin-Duck (A. galericuluta) in Eastern Asia. Besides there are the SHewd-Drakis (Tudorma), confined to the Old World, ${ }^{1}$ and remarkably developed in the Australian Region; the MuskDuck (Cuivina) of South America, which is often domesticated, and

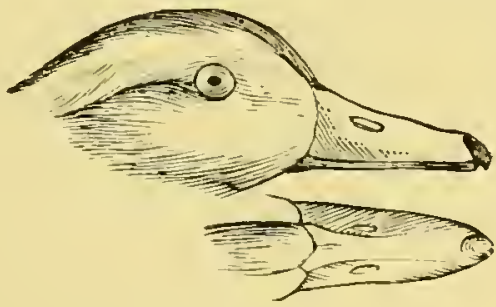

EX SPONSA.

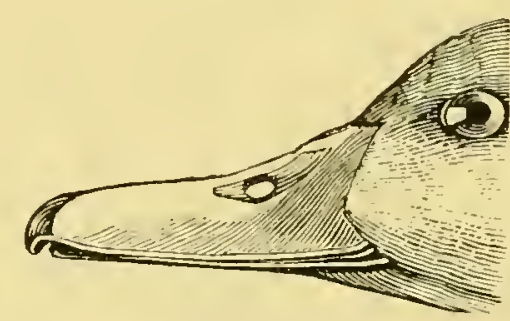

DENDROCYGNA.

(After Swainson.)

in that condition will produce fertile hybrids with the common Duck; and finally the Tree-Ducks (Dendrocyma), which are almost limited to the Tropies.

\section{DUCKER, sce DOUCKER.}

DULWILLY, said to be a local name of the Ringed Plover, Egialitis hiaticola; and, according to Prof. Skeat, signifying dull of will or stupid, though the application of such a name is not obvious. (See, however, DotTEREL.)

1 To these belong apparently the genera Chenalopex and Plectropterus, though from their size the species of each bears in English the name of Goose. 
DUNBIRD, DUNCUR or DUNKER, names of the PochaRd.

DUNLIN, the common name of the commonest of shore-birds, the Tringa alpina and $T$. cinclus of Linnæus, who, not knowing the great seasonal change of plumage it undergoes, took examples in their summer dress to be specifically distinct from those in that which it wears in winter-an error, long shared by many writers, which Montagu in 1813 (Orn. Dict. Appendix) was perhaps the first to suspect, though it could hardly be said to have been dispelled until Temminck in 1815 (Man. d'Orn., pp. 395-398) boldly united them, calling the species T. variabilis. ${ }^{1}$ In its breeding-attire the Dunlin is a beautiful bird, of a rich reddish-orange above, each feather having a dark brown median stripe, with a broad black gorget contrasting with the white of the lower plumage. In this condition it is generally lnown to professional gunners as the Purre or Stint, though the last name is by authors restricted to two or three smaller species. The Dunlin breeds sparingly on the higher hills of the western, midland, and northern counties of England, and far more abundantly and at lower levels in Scotland, as well as on the continent from Holland northwards. The ordinary form of Dunlin from the New World has been described as distinct under the name of T. americana, and examples of it are constantly larger than those of Europe, though there is no other difference between them. A smaller form of Dunlin, by some writers accounted a species, the T. schinzi of Brehm, ${ }^{2}$ also occurs not very rarely on our coasts, and generally in flocks by itself. It is said to breed on the Cimbric peninsula, but nothing is known of the limits of its range, and at present it cannot be deemed with certainty to be even a local race. In the pairing-season the cock Dunlin, like most of his allies, exercises himself in peculiar flights, and in the course of them utters a singular whistle, which sounds like the for-a-time continuous ringing of a small bell with a shrill note, and notwithstanding its high pitch is pleasing to the ear. 'The nest is a simple depression in the ground, to some extent furnished or enclosed by grass, leaves, or the like, as incubation proceeds ; and therein are laid four eggs, generally of great beauty, with varied spots or blotches, but presenting so many differences that description of them is here impossible. Towards winter Dunlins flock in thousands to our shores, especially those which are fringed by extensive mud-flats, and are thus exposed to much persecution on the part of fowlers, both by the gun and the net. In an aviary they bear confinement well, and at the proper season will assume their nuptial plumage.

1 This was already a synonym of T. alpina, for in 1810 Bernhard Meyer had so applied it (Taschenb. deutsch. Vögel, ii. p. 397).

2 Not to be confounded with the T. schinzi of Bonaparte, now known as $T$. bonapartii, a North-American species belonging to a different group of the genus. 
DUNNOCK, a local name of the Hedge-SPARRow.

DUNTER, generally with the addition of "Goose," a name of the EIDER-DUCK.

DYSPOROMORPHA, the third "Family" of Desmognathous birds according to Prof. Huxley's classification (Proc. Zool. Soc. 1867, pp. 438-440,461,462) answering to the STEGanopodes of Illiger, and including two groups, the Pelicanidx in a restricted sense, and then all the rest-Cormorants, SNake-BIRDs, Frigate-BIRds and Tropic Birds. Whatever be the shape of the bill in all these, and it varies much, the exterior nares are very small, there are no basipterygoid processes; while, behind the posterior nares, the palatals unite for a considerable distance; and other characters are recognizable.

\section{$\mathrm{E}$}

EAGLE (French Aigle, from the Latin Aquila), the name generally given to the larger diurnal Birds-of-Prey which are not Vultures; but the limits of the subfamily Aquilinæ have been very variously assigned by different writers on systematic ornithology, and, as elsewhere observed (BuzzaRD), there are Eagles smaller than certain Buzzards. By some authorities the LEMMERGEIER of the Alps, and other high mountains of Europe, North Africa, and Asia, is accounted an Eagle, but by others the genus Gypactus is placed with the Vulluridx, as its common English name (Bearded Vulture) shews. There are also other forms, such as the SouthAmerican HARPY and its allies, which though generally called Eagles have been ranked as Buzzards. In the absence of any truly scientific definition of the Aquilinx, ${ }^{\mathbf{1}}$ it is best to leave these and many other more or less questionable members of the groupsuch as the genera Spizaetus, Circaetus, Spilornis, Helotarsus, and so forth-and, so far as space will allow, to treat here of those whose position cannot be gainsaid.

Eagles inhabit all the Regions of the world except New Zealand, and some seven or more species are found in Europe, of which two are resident in the British Islands. In England and in the Lowlands of Scotland Eagles only exist as stragglers; but in the Hebrides and some parts of the Highlands a good many may yet be found; and, though one species is verging upon extermination as a native, the numbers of the other appear to have rather

1 The nearest approach to a characteristic is perhaps that afforded by the elongated head, and bill straight at the base, as before remarked (supro, p. 67); but this is possibly not unfailing. 
increased of late years than diminished ; for the foresters and shepherds, finding that a high price can be got for their eggs, take care to protect the owners of the eyries, which are nearly all well known, and to keep up the stock by allowing them at times to rear their young. There are also now not a few occupiers of Scottish forests who interfere so far as they can to protect the "king of birds." But hardly thirty years ago resort was had without stint to trapping, poisoning, and other destructive devices, and there

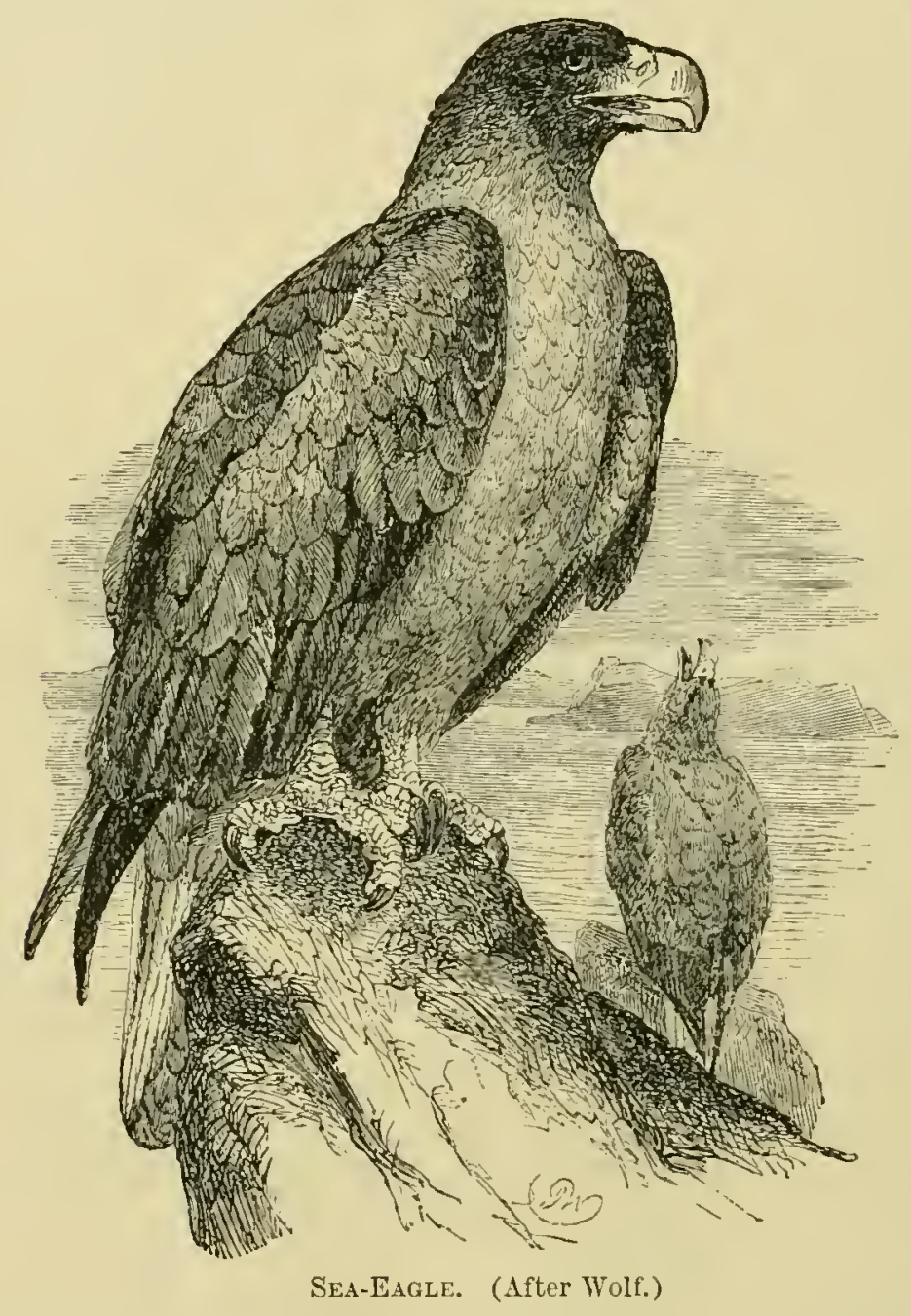

was then every probability that before long not an Eagle of any kind would be left to add the wild majesty of its appearance to the associations of the momtain, the cliff, or the lake. ${ }^{1}$ In Ireland

1 The late Lord Breadalbane (John, 2nd Marquess of the first creation, and 5th Earl) who died in 1862, was perhaps the first large landowner who set the example that has been since followed by others. On his univaliect forest of Black Mlount, Eagles-clsewhere persecnted to the death-were by him ordered to be unmolested so long as they were not numerous enough to cause considerable depredations on the farmers' flocks. He thonght, and all who have an eye for the harmonies of nature will agree with him, that the spectacle of a soaring 
the extirpation of Eagles seems to have been carried on almost unaffected by the prudent considerations which in the northern lingdom have operated so favourably for the race, and except in the wildest parts of Donegal, Mayo, and Kerry, Eagles in the sister-island are said to be birds of the past.

Of the two British species the Erne (Icel. $60^{\circ} n$ ) or Sea-Eagle (by some called also the White-tailed and Cinereous Eagle), Halicetus albicilla, has of late years suffered severe persecution, so that at the present time there is probably not a single pair left on the mainland of Scotland, while not fifty years ago it frequented almost every steep headland on our northern shores. Affecting chiefly the coast, mostly building its nest on sea-cliff's, it has been at the mercy of any adventurer, and in the absence of the protection which the practice of deer-stalling has afforded the other native species, it has been ruthlessly destroyed, and apparently to the benefit of nobody in particular, for the species lives in great part on the fish and refuse that is thrown up on the shore, though it not unfrequently takes living prey, such as lambs, hares, and rabbits. On these last, indeed, young examples mostly feed when they wander southward in autumn, as they yearly do, and appear in England. The adults are distinguished by their prevalent greyish-brown colour, their pale head, yellow beak, and white tail -characters, however, wanting in the immature, which do not assume the perfect plumage for some three or four years. The eyry is commonly placed in a high cliff or on an island in a lakesometimes on the ground, at others in a tree-and consists of a vast mass of sticks, in the midst of which is formed a hollow lined with Luzula syluatica (as first observed by the late Mr. John Wolley) or some similar grass, and here are laid the two or three white eggs. In former days the Sea-Eagle seems to have bred in several parts of England-as the Lake district, and possibly even in the Isle of Wight and on Dartmoor. This species inhabits all the northern part of the Old World from Iceland to Kamchatka, and breeds in Europe so far to the sonthward as Albania. It is also found in Greenland; but is replaced in the New World by the White-headed or Bald Eagle, $H$. leucocephalus, a bird of similar habits, and the chosen emblem of the United States of America. In the far east of Asia occurs a still larger and finer Sea-Eagle, H. pelagicus, remarkable for its white thighs and upper wing-coverts. South-eastern Europe and India furnish a much smaller species, $H$. leucoryphus, which has its representative, $H$.

Eagle was a fitting adjunct to the grandeur of his Argyllshire mountain-scenery, and a good equivalent for the occasional loss of a lamb, or the slight deduction from the rent paid by his tenantry in consequence. How faithfully his wishes were carried out by his head-forester, the late Peter Robertson, the present writer has abundant means of knowing. 
leucogaster, in the Malay Archipelago and Australia, and, as allies in South Africa and Madagascar, $H$. vocifer and $H$. vociferoides respectively. All these Eagles ${ }^{1}$ may be distinguished by their scaly tarsi, while the group next to be treated of have the tarsi feathered to the toes.

The Golden or Mountain-Eagle, Aquilu chrysuetus, is the seeond British species. This also formerly inhabited England, and a nest, found in 1668 in the Peak of Derbyshire, is well deseribed by

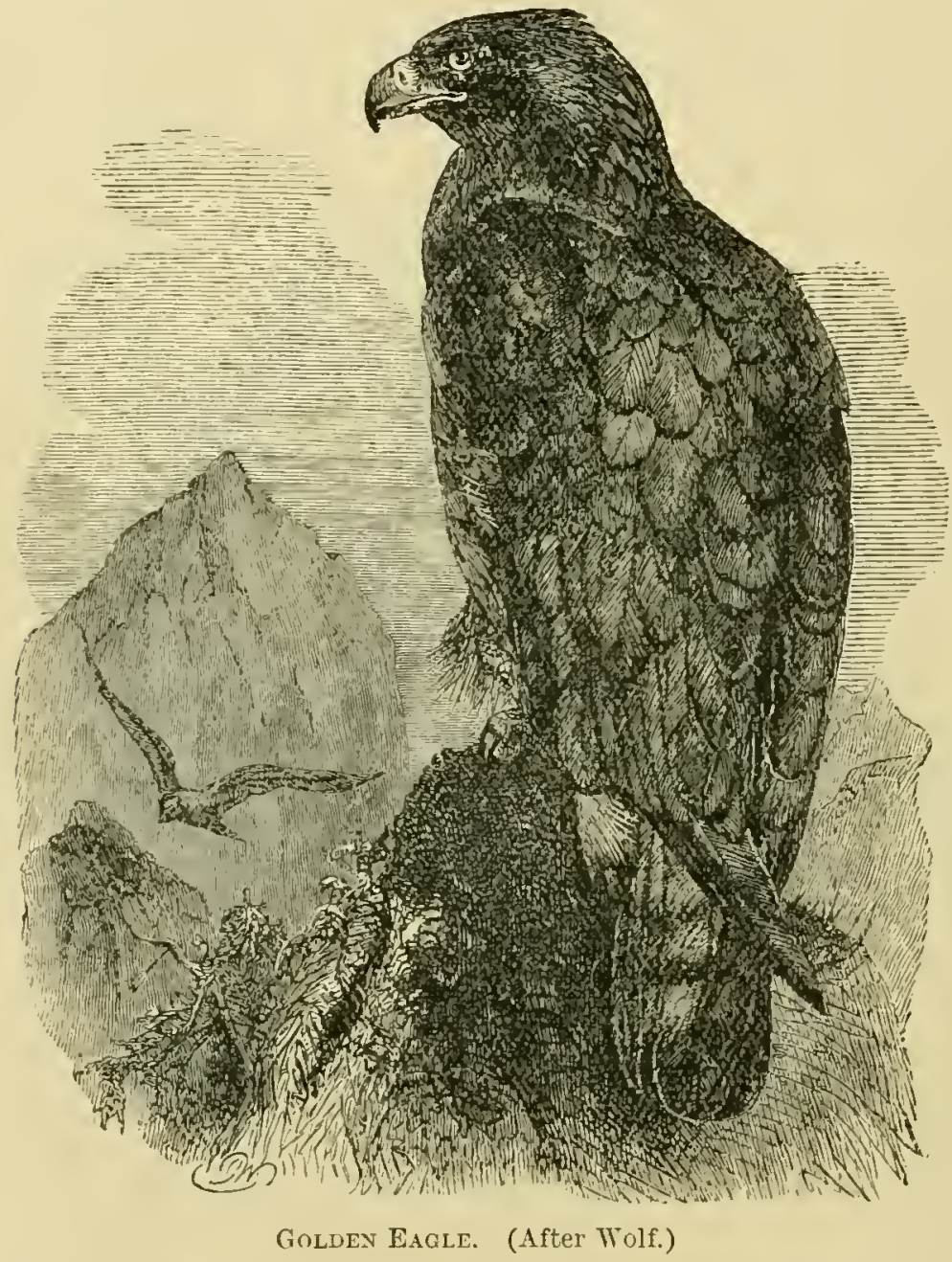

Willughby, in whose time it was said to breed also in the Snowdon range. It seldom if ever frequents the coast, and is more active on the wing than the Sea-Eagle, being able to take some birds as they fly, but a large part of its sustenance is the flesh of animals that die a natmal death. Its eyry is generally placed and built like that of the other British species," but the neighbourhood of

I Much resembling them are the species separated to form the genus Haliastur, which some anthorities regard as more nearly allied to the Fites.

2 As already stated, the site chosen varies greatly. Oceasionally placed in a. 
water is not requisite. The eggs, from two to four in number, vary from a pure white to a mottled, and often highly-coloured, surface, on which appear different shades of red and purple. The adult bird is of a rich, dark brown, with the elongated feathers of the neck, especially on the nape, light tawny, in which imagination sees a "golden" hue, and the tail marbled with brown and ashygrey. In the young the tail is white at the base, whence in this stage it has been often called the Ring-tailed Eagle, and the neck has scarcely any tawny tint. The Golden Eagle does not occur in Iceland, but occupies suitable situations over the rest of the Palæarctic area and a considerable portion of the Nearctic-thongh the American bird has been, by some, considered a distinct species. Domesticated, it has many times been trained to take prey for its master in Europe, and to this species is thought to belong an Eagle habitually used by the Kirgiz Tartars, who call it Bergut or Bearcoot, ${ }^{1}$ for the capture of antelopes, foxes, and wolves. It is carried hooded on horseback or on a perch between two men, and released when the quarry is in sight. Such a bird, when well trained, is valued, says Pallas, at the price of two camels. It is quite possible, however, that more than one kind of Eagle is thus used, and the services of $A$. heliaca (which is the Imperial Eagle of some writers ${ }^{2}$ ) and of $A$. mogitnit-both of which are found in Central Asia, as well as in South-eastern Europe-may also be employed.

Of the other more or less nearly allied species or races want of room forbids the consideration, but there is a smaller form on which a few words may be said. This has usually gone under the name of $A$. navia or Spotted Eagle, but is now thought by the best authorities to include three local races, or, in the eyes of some, species. They inhabit Europe, North Africa, and Western Asia to India, and five examples of one of them- $A$. clunga, the form which is somewhat plentiful in North-eastern Germany-have occurred in England. The smallest true Eagle is A. pennata, which inhabits Southern Europe, Africa, and India. Differing from other Eagles of this genus by its wedge-shaped tail, though otherwise greatly resembling them, is the $A$. audax of Australia. Lastly may be

niche in what passes for a perpendicular cliff to which access could only be gained by a skilful eragsman with a rope, the writer has known a nest to within ten or fifteen yards of which he rode on a pony. Two beautifui views of as many Golden Eagles' nests, drawil on the spot by M[r. Wolf, are given in the Oothece Wrolleyane, and a fine series of eggs is also figured in the same work.

I The similarity between this name and the Welsh Barcud, said by Pennant (Brit. Zool. Ed. 4, ii. pp. 620, 621) to be Kite or Harrier, but, as Lord Lilford informs me, really equivalent to Buzzard, is worth noting.

2 Which species may have been the traditional emblem of Roman power, and the Ales Jovis, is very uncertain. 
noticed here a small group of Eagles, characterized by their long legs, forming the genus Nisaetus, of which one species, $N$. fasciatus or bonellii, is found in Europe. The OsPrey (Pandion), though placed by many among the Aquilina, certainly does not belong to that subfamily.

$E A R$. The whole auditory apparatus is divided into the outer, middle, and inner ear.

The outer ear or "audlitory meatus" is a short, membranous, and sometimes partly cartilaginous tube. The outer opening is generally covered by feathers, and rarely naked as in Vultures and Ostriches. The feathers which surround the ear are often more or less reduced, and occasionally assume the shape of bristles. There is no external ear or "concha auris," but a more or less prominent fold projects from the outer margin into the meatus, and seems to be used as a sort of imperfect valve, especially since it possesses several little muscles. Such a valvular fold attains its largest development in Owls. Many of these birds present the peculiar anomaly of having the outer ears very asymmetrically developed, an asymmetry which often affects also the whole of the temporal region together with the squamosal, quadrate, and neighbouring bones, so that the whole skull assumes a lop-sided shape. Collett (Christiania Videnskabs. Forhandl. 1881, No. 3, pp. 1-38, pls. i.-iii.) has examined this point in all the North-European species of Owl. According to him there are three different formations: 1. Skull and auditory meatus symmetrical, ear-valve absent: Surnia funerea, Glaucidium passerinum, Nyctea scandiaca, Bubo ignavus. 2. Skull symmetrical, meatus asymmetrical, ear-valve present: Asio accipitrinus, A. otus, Strix aluco. 3. Skull and meatus asymmetrical, ear-valve present: Strix uralensis, S. lapponica, and Nyctala tengmalmi. Of other, not North-European, Owls, Aluco flammeus belongs to the first group. ${ }^{1}$

Another peculiar modification is exhibited by the CAPERCALLY. It is well known that the cock for several seconds towards the end of his rutting ecstasy is completely deaf to any external sounds. This deafness is produced by an erectile fold of the posterior wall of the auditory meatus; this fold or flap becomes turgid with blood during the excitement of the bird, and seems moreover to be assisted in pressing upon the opposite margin of the quadrate bone, and in thus effectively closing the ear-passage, by the action of the digastric or depressor muscle of the mandible which is always widely opened during this stage. The harsh and loud sounds emitted by the cock, and the blocked ear-passage render him absolutely indifferent to any other sounds. (See Graff and

1 A large number of fignres of North-American species in illustration of this point is given by Ridgway (North American Birds, iii. pp. 97-102). 
Wurm, Zeitschr. f. uiss. Zoologie, 1885, pl. 107-115, Taf. vii., and pp. 728-730.)

The middle ear consists of the tympanic cavity, its communication with the cavity of the month throngh the "Enstachian tube," and the sound-conducting apparatus-the "tympanic membrane" and the "columella amris."

The tympanic membrane or drum is thin and stretched across the ralls of the inner end of the auditory meatus, and shnts off the latter from the tympanic carity. This cavity communicates with the mouth throngh a canal-the Eustachian tube, which passes between the basisphenoid and basioccipital bones, and opens upon the ventral side of the sphenoid a little belind the latter's anticulation with the pterygoid bone. The right and left

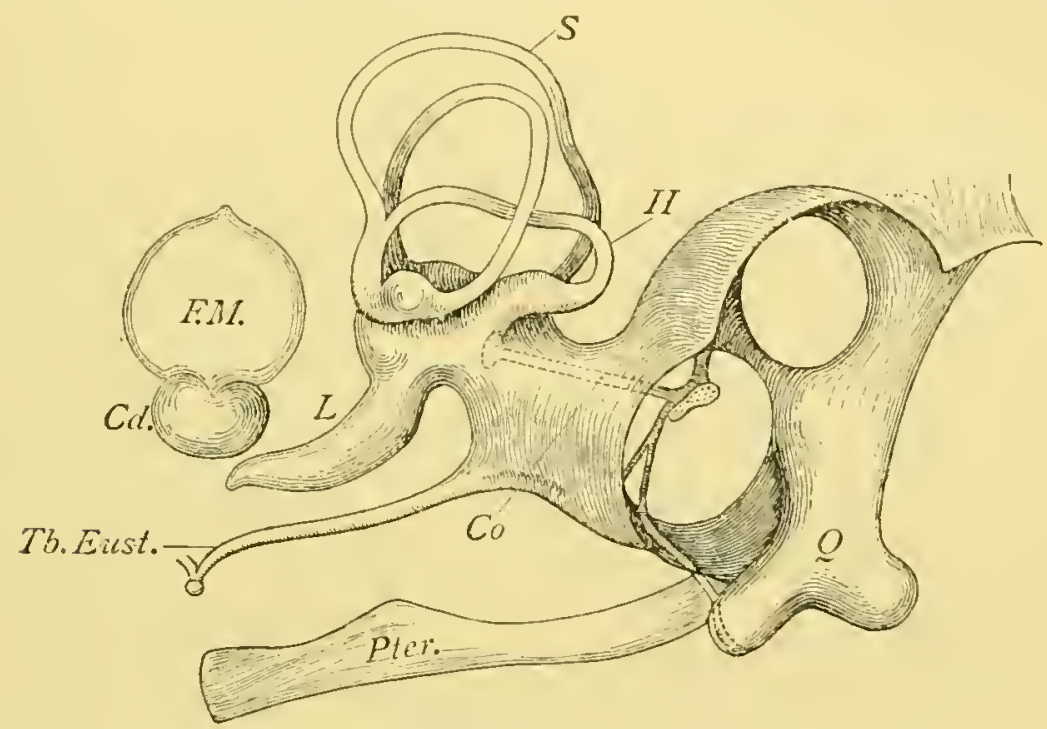

Hind View of the Osseous Auditory Organ of an OwL (Bubo indranec). About twice the natural size.

Cl. Occipital condyle: F.M. Foramen magnum; L, Lagena; Pter. Right pterygoid bone; Q, Quadrate bone; $I H, S$, llorizontal and Sagittal semieircular canals; Co, Columella anris, its extra-columellar portion continued towards the hasis of the quadrate; Tb. Fust. Eustachian tube.

canals unite in the middle line into one short membranous dnct, which opens in the roof of the posterior part of the mouth cavity.

The columella is a cartilaginous and partly osseous jointed rod, which fits with its inner slightly-swollen and disk-like end into the "foramen ovale" of the capsule of the inner ear. "The outer end of this rod sends out three cartilaginous processes; the dorsal one is attached to the upper wall of the tympanic cavity close to the drum; the ontermost process leans against the middle of the drum, and consequently conveys the vibrations of the latter through the whole rod into the imner ear ; the ventral process is directed downwards, and lums out into a thin thread which can be traced between pterygoid and quadrate into the inner comer of the articular portion of the mandible. 
Birds possess one muscle belonging to the middle ear; this muscle acts as a tensor tympani; it arises near the occipital conldyle, passes through a hole into the tympanic cavity, attaches its tendon to the ends of the columellar processes, and also spreads over the tympanum itself.

The whole columella of Birds is equivalent to the chain of earossicles of Nammals, the inner end of the columellar rod representing the stapes, while the outer and lower processes of the tympanic end correspond with the manubrium and the long process of the Mammalian malleus. The quadrate bone, so well developed, and functional as the hinge of the masticatory apparatus in Reptiles and Birds, has in Mammals lost this function, and in them is reduced and modified into the comparatively insignificant tympanic ring, acting only as a frame for the tympanic membrane.

The inner ear is the most important portion of the whole ear, because it contains the sound-perceiving apparatus. It consists of the labyrinth or membranous capsule which encloses the end-organs of the auditory nerve, and of the cartilaginous or osseous capsule which surrounds and protects the membranous organs. The outer capsule is consequently more or less a cast of the other, and repeats all its principal complicated configurations.

The membranous ear is a system of hollow tubes which form various labyrinthic dilatations and canals, all of which communicate with each other. The whole is divided into-I. pars superior, consisting of an utriculus, two sinus, three ampullæ, and three semicircular canals; each canal connects one ampulla with one of the two sinus; the anterior canal runs in a vertical and longitudinal plane, the posterior canal lies in a transverse vertical plane, extending from right to left, while the external canal stretches out in a nearly horizontal direction; II. pars inferior, consisting of the cochlea and the sacculus with the endolymphatic duct. The sacculus is a small dilatation or appendix of the utriculus; its walls are continued as the endolymphatic duct straight into the cranial cavity, ending in the dura mater in the shape of a flattened sac. This peculiar arrangement is an imperfect remnant of previous conditions; because in Selachians the endolymphatic duct of each ear opens upon the top of the head, through the skin, and indicates the way by which the primitive ear-capsule (itself, like all the higher sense-organs, a modification of epidermal and neural cells) has gradually become transferred into the depth of the skull.

The cochlea ends blindly, "with its apex towards the occipital condyle; instead of being curled into several turns as in Mammals, it forms in Birds never more than, and often much less than, half a twist. Its internal structure is most complicated and intimately connected with the perception of sound, through the possession of "Reissner's membrane" and the "organ of Corti." 
The position of these parts is shewn in the adjoining figure. The basal portion of the membranons cochlea, the "ductus cochlearis," communicates with the sacculus by a canal, the dorsal wall of which is contimued into the tegmentum vasculosum or membrane of Reissner, while the ventral wall contains the basilar membrane, with its acoustic papilla or organ of Corti. The space between the periosteum of the bony wall of the cochlea and the tegmentum is called "scala vestibuli"; that between the bone and the basilar membrane is the "scala tympani."

The scalre are part of the perilymphatic space between the membranous and the bony inmer ear, and are filled with the perilymphatic fluid.

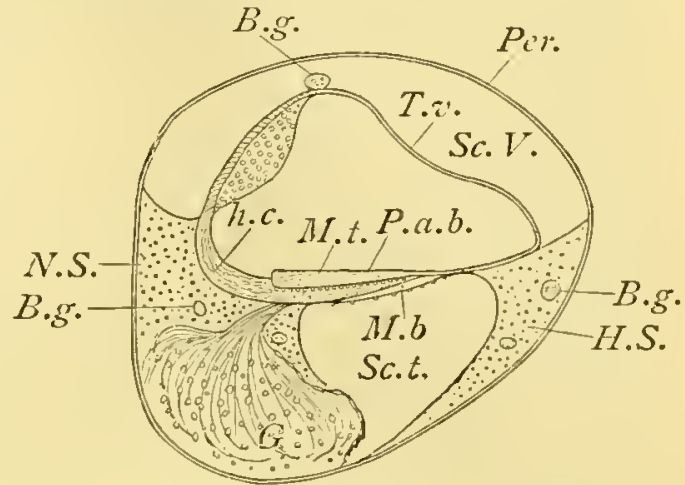

Vertical Mediar Section of the Cochlea of a Pigeos, nagnified $30^{\circ}$ times. (After Retzius.)

D.g. Blonrl-ressels; $G$. Ganglia in the ramus basilaris of the cochlear portion of the acoustic nerve; H.S.N.S. Cartilaginous fiame of the cochlea; M.b. Membrana basilaris; M.t. Membrana tectoria ; l.a.b. Papilla acustica basilaris; l'er. Periost of the cochlea; Sc.I. Scala restibuli; Sc.t. Scala tympani ; T.v. Tegmentum rasculosum.

The acoustic nerve enters the membranous ear near the base of the cochlea, and terminates by eight macula, papilla, and crista acustice in the ampulle and various other dilatations. The cells of these terminating nervous spots are cylindrical, and end in one or more extremely fine filaments or hairs; they extend into the endolymphatic fluid, which fills the whole membranous ear, and contains, especially in the sacculus, mmerous small otolithic crystals of carbonate of lime. The filamentous and hairy cells take up the vibrations or waves of sound which are transmitted from the typanum through the columella to the endolymphatic fluid, and convey them through the acoustic nerve to the brain.

The whole inner ear is subject to comparatively few and unimportant variations, and does not throw much light upon the affinities of the varions gromps of Birds, the differences being restricted chiefly to the relative size of the cochlea and the position and size of the semicircular canals. It cannot be doubted that the faculty of hearing is highly developed in Birds, not only the mere perception of sound, but also the power of distinguishing or understanding pitch, notes and melodies, or music.

For further information concerning the minute structure of the eir, see the monumental work of G. Retzins (Das Gehïrorgan der Wribeltiicre, Stockholm: 1884, ii. pp. 139-198, pls. 15-20).

EASTERLING, according to Latham, a local name for the IVIGEON. 
$\mathrm{EBB}$, said to be a local name of the Great Bunring.

EBB-SLEEPER, a name given by shore-gunners to various liinds of LINICOLA, though, except on the principle of lucus a non lucendo, the reason why cannot be explained, for these birds at ebbtide are especially active, while they take their rest as high water approaches; but so it is.

EDOLIER, Levaillant's name for a South-African SHRIKe which some writers have tried to Anglify.

EEE-EVE, in modern spelling Iivi, the English rendering by many voyagers of the native name of the beantiful scarlet Vestiaria coccinea, whose feathers were largely used by the Sandwich-islanders in the making of their magnificent mantles ( $c f$. Drepanis).

EGG-BIRD, the name given by many voyagers to the Sooty TeRn, Sterna fuliginosa, but perhaps occasionally used for other species whose eggs afforded them supplies.

EGGS. The pains bestowed by such Birds (incomparably the most numerous of the Class), as build elaborate nests (see NidificATION), and the devices employed by those that, not doing so, display no little skill in providing for the preservation of their produce, invite some attention to the eggs which they lay. This attention will perhaps be more cheerfully given when we think how many naturalists, not merely ornithologists, have been first directed to the study of the animal kingdom by the spoils they have won in their early days of birds'-nesting. With some such men the fascination of this boyish pursuit has maintained its full force even in old age - a fact not so much to be wondered at when it is considered that hardly any branch of the practical stndy of Natural History brings the enquirer so closely in contact with many of its secrets. It is therefore eminently pardonable for the victions of this devotion to dignify their passion by the learned name of "Oology," and to bespeak for it the claims of a science. Yet the present writer-once an ardent follower of the practice of birds'nesting, and still on occasion warming to its pleasures-must confess to a certain amount of disappointment as to the benefits it was expected to confer on Systematic Ornithology, though he yields to none in his high estimate of its utility in acquainting the learner with the most interesting details of bird-life-without a knowledge of which nearly all systematic study is but work that may as well be done in a library, a museum, or a dissecting-room, and is incapable of conveying information to the learner concerning the why and the wherefore of such or such modifications and adaptations of structure. To some-and especially to those who are only anatomists - this statement may seem preposterous, but it 
is in truth no such thing. What engineer can be said to understand his business if he knows not the purpose to which the machines he makes are to be applied and is unacquainted with their mode of working? We may investigate thoroughly the organs of any animal, we may trace them from the earliest moment in which they become defined, and watch them as they develop to maturity, we may comprehend the way in which every part of a complicated structure is successively built up; but, if we take not the trouble to know their effect on the economy of the creature, we as naturalists have done but half our task, and abandon our labour when the fulness of reward is coming upon us. The field-naturalist, properly instructed, crowns the work of the comparative anatomist and the physiologist, though without the necessary education he is little niore than an empiric, even should he possess the trained cunning of the savage on whose knowledge of the habits of wild animals depends his chance of procuring a meal.

Perhaps the greatest scientific triumph of oologists lies in their having fully appreciated the intimate alliance of the LIMICOLA (the great group of Snipes and Plovers) with the GAvis (the Gulls, Terns, and other birds more distantly connected with them) before it was recognized by any professed taxonomer-L'Herminier, whose researches have been much overlooked, excepted; though to such an one was given the privilege of placing that affinity beyond cavil (Huxley, Proc. Zool. Soc. 1867, pp. 426, 456-45s; cf. Ibis, 1868, p. 92). In like manner it is believed that oologists first saw the need of separating from the true PAsseres several groups of birds that had for many years been unhesitatingly associated with that very uniform assemblage. Diffidence as to their own capacity for meddling with matters of systematic arrangement may possibly have been the cause which deterred the men who were content to brood over birds' eggs from sooner asserting the validity of the views they held. Following the example furnished by the objects of their study, they seem to have chiefly sought to hide their offspring from the curious eye-and if such was their design it must be allowed to have been admirably successful. In enthusiastic zeal for the prosecution of their favourite researches, however, they have never yielded to, if they have not surpassed, any other class of naturalists. If a storm-swept island, only to be reached at the risk of life, held out the hope of some oological novelty there was the egg-collector (Faber, Isis, xx. pp. 633-688; Proctor, Naturalist, 1838, pp. 411, 412). Did another treasure demand his traversing a burning desert (Tristram, Itis, 1859, p. 79) or sojourning for several winters within the wildest wastes of the Arctic Circle (Wolley, Ibis, 1859, pp. 69-76 ; 1861, pp. 92-106 ; Kennicott, Rep. Smithson. Inst. 1862, pp. 39, 40), he endured the necessary hardships to accomplish his end, and the possession to him of an 
empty shell of carbonate of lime, ${ }^{1}$ stained or not (as the case might be) by a secretion of the villous membrane of the parent's uterus, was to him a sufficient reward. Taxonomer's, however, have probably been right in not attaching too great an importance to such systematic characters as can be decluced from the eggs of birds, but it would have been better had they not insisted so strongly as they have done on the infallibility of one or another set of characters, chosen by themselves. Oology taken alone proves to be a guide as misleading as any other arbitrary method of classification, but combined with the evidence afforded by dne study of other particularities, whether superficial or deep-seated, it can scarcely fail in time to conduct us to an ornithological arrangement as nearly true to Nature as we may expect to achieve.

The first man of science who seems to have given any special thought to oology, was the celebrated Sir Thomas Browne, of Norwich, who already in 1671, when visited by John Evelyn (from whose diary we learn the fact), had assigned a place in his cabinet of rarities to a collection of birds' eggs. The next we hear of is that Comnt of Marsigli who early in the eighteenth century explored, chiefly for this kind of investigation, the valley of the Danube - a region at that time, it is almost unnecessary to remark, ntterly unknown to naturalists. But there is no need to catalogue the worthies of this study. As they approach our own day their number becomes far too great to tell, and if very recently it has seemed to dwindle the reason is probably at hand in the reflexion that most of the greatest prizes have been won, while those that remain to reward the aspiring appear to be just now from one cause or another almost out of reach. Perhaps at the present time the Birds-of-Paradise and the Fin-foots form the only groups of any recognized distinctiveness and extent of whose eggs we know absolutely nothing-though there are important isolated forms, such as Atrichia, Heteralocha, and, others, concerning the eggs as well as the breeding-habits of which our ignorance is absolute, and the species of many Families that have hitherto defied the zeal of oologists are very numerous. These last, however, though including some common and some not very uncommon British birds, possess in a general way comparatively little interest, since, the eggs of their nearest allies being well known, we cannot expect much to follow from the discovery of the recluses, and it is only to the impassioned collector that the obtaining of such desiderata will afford much satisfaction.

The first thing which strikes the eye of one who beholds a large collection of egg-shells is the varied hues of the specimens. Hardly a shade known to the colourist is not exhibited by one or more,

1 A sull proportion of carbonate of magnesia and phosphate of lime and maguesia also enters into its composition. 
and some of these tints have their beauty enhaneed by the glossy surface on which they are displayed, by their harmonious blending, or by the pleasing contrast of the pigments which form markings as often of the most irregular as of regular shape. But it would seem as though such markings, which a very small amount of observation will shew to have been deposited on the shell a short time before its exclusion, are primarily and normally circular, for hardly any egg that bears markings at all does not exhibit some spots of that form, but that in the progress of the egg, through that part of the oviduct in which the colomring matter is laid on, many of them become smeared, blotched, or protraeted in some particular direction. The circular spots thus betoken the deposition of the pigment while the egg is at rest, the blurred markings shew its deposition while the egg is in motion, and this motion would seem often to be at once onward and rotatory, as indicated by the spiral markings not uncommonly observable in the eggs of some Birds-ofPrey and others - the larger end of the egrs (when the ends differ in form) making way for the smaller. ${ }^{1}$ At tha same time the eggs of a great number of birds bear, beside these last and superimposed markings, more cleeply-seated stains, generally of a paler and often of an altogether different hue, and these are evidently due to some earlier dyeing process. The peenliar tint of the ground-colour, though commonly superficial, when not actually congenital with the formation of the shell, would appear to be suffused soon after. The depth of colouring whether original or supervening is obviously dependent in a great measure on the constitution or bodily condition of the parent. If a bird, bearing in its oviduct a fully-formed egg, be captured, that egg will speedily be laid under any circumstances of inconvenience to which its producer shall be subjected. but such an egg is usually deficient in coloration-fright and captivity having arrested the natural secretions. In like manner over excitement or debility of the organs, the consequence of ill health, give rise to much and often very curious abnormality. It is commonly believed that the older a bird is the more intensely coloured will be its eggs, and to some extent this belief appears to be true. Certain Falconida, which ordinarily lay very brilliantlytinted eggs, and are therefore good tests, seem when young not to secrete so much coloming-matter as they do when older, and season after season the dyes become deeper, but there is reason to think

1 That the larger end is protruded first was fond on actual experiment by Ir. Bartlett, Superintendent of the Gardens of the Zoologieal Society, to be the case commonly, but as an accident the position may be sometimes reversed, and this will most likely account for the occasional deposition of markings on the smaller instead of the larger end as not unfrequently shewn in eggs of the Sparrow-Hawk, Accipiter nisus. The head of the chick is always formed at the larger end (see Embryology). 
that when the bird has attained her full vigour improvement stops, and a few years later the intensity of hue begins to decline. It would be well if we had more evidence, however, in support of this opinion, which is chiefly based on a series of eggs of one speciesthe Golden EAGLE, Aquila chrysaetus, in the writer's possession, among which are some believed on good grounds to have been the produce in the course of about twelve years of one and the same female. The amount of colouring-inatter secreted and deposited seems notwithstanding to be generally a pretty constant quantityallowance being made for individual constitution; but it often lrappens-especially in birds that lay only two eggs-that nearly all the dye will be deposited on one of these, leaving the other colourless; it seems, however, to be a matter of inconstancy which of the two is first developed. Thus of two pairs of Golden Eagles' eggs also in the possession of the writer, one specimen of each pair is nearly white while the other is deeply coloured, and it is known that in one case the white egg was laid first and in the other the coloured one. When birds lay many mottled, and $\dot{a}$ fortiori plain, eggs, there is generally less difierence in their colouring, and though no two can hardly ever be said to be really alike, yet the familyresemblance between them all is obvious to the practised eye. It would seem, however, to be a peculiarity with some species-and the Tree-Sparrow, Passer montanus, which lays five or six eggs, may be taken as a striking example-that one egg should always differ remarkably from the rest of the clutch. In addition to what has been said above as to the deposition of colour in circular spots indicating a pause in the progress of the egg through one part of the oviduct, it may be observed that the cessation of motion at that time is equally shewn by the clearly defined hair-lines or vermiculations seen in many eggs, and in none more commonly met with than in those of most BunTINGs, Emberizidis. Such markings must not only have been deposited while the egg was at rest, but it must have remained motionless until the pigment was ompletely set, or blurred instead of sharp edges would have been the result. .

1 The principal oological works with coloured figures are the following: Thienemann, Fortpflanzungsgeschiehte der gesammten Vögel (4to, Leipzig: 1845); Lefèvre, Atlas des cerfs des oiseaux d' Europe (8vo, Paris: 1845); Hewitson, Coloured Illustrations of the Eggs of British Birds (8vo, Ld. 3, London: 1856); Brewer, North Ameriean Oology (4to, Washington : 1859); Taczanowski, Oologia Ptaków Polskieh (8vo, Warszawa: 1862); Bädeker, Die Eier der Europäischen Vögel (fol. Leipzig : 1863); Wolley, Ootheea Wolleyana (8vo, London : 1864)some of which have never been completed. The above is not, and does not profess to be, an exhaustive list, and perhaps some others deserve inclusion in it; but there are works, ehiefly on. British oology, which have unfortunately attained considerable notoriety, though really unworthy of serious notice, either from the recklessly inaccurate statements to be found in the text which accomfranies the plates, or the misleading tendencies of the plates. I prefer passing 
The composition of this pigment long excited much curiosity; and it was commonly and rather crudely ascribed to secretions of the blood or bile, ${ }^{1}$ but unexpected light was shed upon the subject by the researches of Mr. Sorby (Proc. Zool. Soc. 1875, pp. 351-365), who, using the method of spectrmm-analysis, ascertained the existence of seven well-marked substances in the colouring-matter of eggs, to the admixture of which in certain proportions all their tints are due. These he named Oorhodeine, Oocyan, Banded Oocyan, Yellow Ooxanthine, Rufous Ooxanthine, a sixth substance, giving narrow absorption-bands in the red-the true colour of which is not yet decided, and lastly Lichenoxanthine. It would be out of place here to particularize their chemical properties, and it is enough to say that they are closely connected either with hæmoglobin or bile-pigments, and in many respects resemble the latter more than do any other group of colouring-matters, but do not actually agree with them. The first is perhaps the most important of all the seven, because it occurs more or less in the shells of so great a number of eggs that its entire absence is exceptional, and it is of a very permanent character, its general colour being of a peculiar brown-red. The second and third seem when pure to be of a very fine blue, but the spectrum of the former shews no detached bands, while that of the latter has a well-marked detached absorbent-band near the red end, though the two are closely related since they yield the same product when oxidized. The fourth and fifth substances supply a bright yellow or reddish-yellow hue, and the former is particularly characteristic of eggs of the EniEus, Dromaus, giving rise when mixed with Oocyan to the fine malachitegreen which they possess, while the latter has only been met with in those of the Tinamous, Tinamidx, in which it should be mentioned that oorhodeine has not been found, or perhaps in those of a CASSOWARY, Caswarius, and when mixed with Oocyan produces a peculiar lead-colour. The sixth substance, as before stated, has not yet been sufficiently determined, but it would seem in combination with others to give them an abnormally browner tint; and the seventh appears to be identical with one which occurs in greater or less amount in almost all classes of plants, but is more especially abundant in and characteristic of lichens and fungi. There is a possibility, however, of this last being in part if not wholly due to the growth of minute fungi, though Mr. Sorby. believed that some such substance really is a normal constituent of the shell of eggs having a peculiar brick-red colour. He was further inclined to

over them in silence to exposing their inefficiency. A great number of rare eggs are also figured in various journals, as the Proceedings of the Zoological Society, Naumannia, the Journal für Ornithologie, and The Ibis.

1 Cf. Wilke, Naumannia, 1858, p1. 393-397, and C. Leconte, Revue el Magasin de Zoologie, 1860, pp. 199-205. 
think that Oorhodeine is in some way or other closely related to Cruentine, being probably derived from the red colouring-matter of the blood by some unknown process of secretion, and likewisc that there is some chemical relation between the Oocyans and the bile.

It was remarked by Hewitson in 1838 (Brit. Oology, Introd. p. 8), and perhaps he was not the first to make the observation, that the eggs of many if not of most birds which breed in holes, or even in covered nests, are of an uniform white; but the number of exceptions is so great, that no general rule can be laid down to this effect. Conversely, the number of birds which lay purely white eggs in open nests-the multitudinous species of PIGEON being notorious instances of the fact ${ }^{1}$-is also large, and in some respects quite independent of their taxonomic relations, as, for example, the Little BITTERN among the Ardeida, the Virginian QUAIL among the so-called "Odontophorinx," and again among the Gallinx even the Common Fowl, though some of its breeds, perhaps acted upon by what is known as "reversion," lay coloured eggs. The eggs of OwLS are always white, whether the species be one that breeds in holes, on the bare ground, or in an open nest in a tree. The egg of the Gos-HAwk is white, but that of its small relative the SparrowHAWK is always blotched, and sometimes richly, with pigment, the nest of both being built precisely in the same kind of position,but it would be almost endless to cite similar cases. To account for some, at least, of these anomalies, an ingenious hypothesis has been set forth by Dr. M'Aldowie, ${ }^{2}$ starting on the assumption "that the pigmentary coat on birds' eggs came into existence at a very early period in their life-history, and existed in the eggs of the progenitors of all the extant species." It is further taken as proved that the pigments being "unstable and variable" makes "the process of change and decolorization a simple one; and that its primary use is for protection from the solar rays, but that it afterwards becomes modified for concealment." Finally, it is maintained "that eggs acquire a highly developed pigmentary layer, or lose their pigment entirely, according to whether they are exposed to the full glare of the sun or laid in situations inaccessible to its rays, and that the intermediate degrees of coloration are in direct ratio to the amount of light to which the eggs are exposed. ${ }^{3}$

1 Of course, Columbe livia, and its allies C. schimperi and C. intermedia, usually breed in cares, and $C$. cenas generally though not always places its nest under cover, but these seem to be the only exceptions in a Family comprising some 350 species.

2 Observations on the Development and the Decay of the Pigment Layer in Birds' Eggs, Journ. Anat. and Physiol. xx. (1886), pp. 225-237.

${ }^{3}$ It is to be observed that the author bases his lyypothesis on a study of the egrs of British birds only. Considering that in most respects the most instructive forms of the Class do not belong to our own limited fama, allowance must be made for the imperfect information whence his results are drawn. 
In regard to the almost comntless cases of spotted eggs in holes or covered nests, of which so many groups of birds furnish examples either wholly or in part, the only supposition that could apparently justify the last statement would be that the species in question have taken to hiding their treasures in times comparatively recent, and have not yet got rid of the ancestral labit of secreting and depositing pigment. In support of such an argument might be alleged, among some other cases, the generally pale colouring of eggs of the Daw, Corvus monedula, compared with those of its kindred, as indicating a step in this direction, while a more conclusiveone has been taken by those members of the Hirundinida as the Sand-Martin, Cotile riparia, and House-Martin, Chelidon urbica, which breed in holes or build close nests-their relative the Swallow, Himndo rustica, though its nest is rarely exposed to direct light, continuing to lay eggs that are conspicuously spotted with two or three tints. But if this supposition be valid some other one, on (it wonld seem) a wholly different principle, must be found to explain why perhaps the eggs that are at once the most delicately and most richly coloured laid by any bird are those of the Snow-Bunting, Plectrophanes nivalis, which except in rare instances are so sedulously concealed as to be almost beyond the reach of reflected light; and again, why the several species of NuTHaTcH, Sitta, which must have been ages in learning the art of masonry they so skilfully practise, lay eggs more deeply dyed than those of their felt-making brethren the Parida (TITuIOUse), or their feather-bed cousins the WRENS and the TreECrEEPERS. But the supposition would seem to break down wholly as an explanation of the variable colouring offered by eggs of the Fantail-WARELER, Cisticola cursitans or schonicola-whether the observations of M. Lunel (Bull. Soc. Ornithol. Suisse, 1865, pp. 9-30, pl. 7), referring the marvellous differences they present to the season of the year at which they were laid, be correct or not, for the ark-like structure of the nest remains constant. No more can here be added on this matter, interesting as it is, and worthy of much more investigation than it las received. ${ }^{1}$

The grain of the egg-shell offers characters that deserve far more consideration than they have received until the attention of Herr von Nathusius having been directed to the subject by some

1 Having introdnced Hewitson's name in this comexion, and having presently to refer to him again, I may say at once that his remarks on the coloration of eggs, and some other subjects, hare been frequently repeated, of course with more or less modification and verbose actlition, by various plagiarists who have sometimes forgotten to mention the source of their information. With the greatest regard for my old friend, I am bound to say that the princilles on which he wrote, more than fifty years since, are such as no man of science can accept now ; but they were those of his time, and the more recent adaptors of them are behind theirs. 
investigations carried on by Drs. Landois ${ }^{1}$ and Rudolf Blasius, ${ }^{2}$ he brought out a series of remarkable papers ${ }^{3}$ in which he arrived at the conclusion that a well-defined type of shell-structure belongs to certain Families of birds, and is easily recognized under the microscope. In some cases, as in the eggs of certain SwANs and GEESE (Cygnus olor and C. musicus, Anser cinereus and A. segetum) even specific differences are apparent; but more than this, differences of the same kind are observable in the eggs of the Grey and Black Crows (Corvus cornix and C. corone), which, in the present writer's opinion, are only forms of the same dimorphic species, and, what is still more wonderful, the eggs of the hybrids or mongrels between these two forms are recognizable under the microscope by the structure of the shell, while yet most extraordinary is the general conclusion that the egg laid by a bird mated with a male of a different species is recognizable from one laid by the same bird when paired with a male of her own. The bearing of these researches on classification generally is of considerable importance and must be taken into account by all future taxonomers. Here we cannot enter into details, it must suffice to remark that the grain of the shell is sometimes so fine that the surface is glossy, and this is the case with a large number of PICARIE, where it is also quite colourless and the contents of their eggs seen through the semi-transparent shell give an opalescence of great beauty; but among the Tinamous, Tinamidx, colour is invariably present and their opaque eggs present the appearance of more or less globular balls of highly-burnished metal or glazed porcelain. Most birds lay eggs with a smooth shell, such as nearly all the Gavix, Limicola, and Passeres, and in some groups, as with the normal Gallinx, this seems to be enamelled or much polished, but it is still very different from the brilliant surface of those just mentioned, and nothing like a definite line can be drawn between their structure and that in which the substance is dull and uniform, as among the Alcidas and the Accipitres. In many of the Patito the surface is granulated and pitted in an extraordinary manner, ${ }^{4}$ and in a less degree the same feature is

1 Zeitschr. für wissensch. Zoologic, xv. pp. 1-31.

2 Op. cit. xvii. pp. 480-524.

: Op. cit. xviii. pp. 19-21, pp. 225-270, xix. pp. 322-348, xx. pp. 106-130, xxi. pl. 380-335, xxx. pp. 69-77. A summary of these will be found in Joum. fïr Omith. 1871, pl. 241-260, and the subject has been continued in the same periodical for 1872, pp. 321-832, 1874, pp. 1-26, 1879, pp. 525-761, 1880, pp. 341-346, 1881, pp. 334-336, 1882, pp. 129-161, 225-315, 1885, pp. 165-178; as well as in Zool. Anzeiger, 1885, pp. 413-415, 1886, pp. 555-569, 1887, pp. 292-296, 311-316. Sone critical remarks by Dr. Kutter are contained in Jouri. für Orn. 1877, pp. 396-423, 1878, pp. 300-348, 1880, 1p. 157-187; and Orn. Certralbl. 1881 , p. $6 \mathrm{~s}$.

'It is cnrious that Ostriches' eggs from North Africa are to be readily ilistinguished from those from the Cape of Good Hope by their smooth ivory-like 
observable in the eggs of some other birds, as the STORKS, Ciconiida. Many Watel-fowls, and particularly the Ducks, Anatidx, lay eggs with a greasy or oleaginous exterior, as the collector who wishes to inscribe his specimens with marks of their identity often finds to his inconvenience; but there are other eggs, as those of the ANIS, Crotophaga, the GREBEs, Podicipcdidix, and all of the Steganopodes, except Phacthon, which are more or less covered with a cretaceous film, often of considerable thickness and varied by calcareous protuberances.

In form egors vary very much, and this is sometimes observable in examples not only of the same species but even from the same mother, yet a certain amount of resemblance is usually to be traced according to the natural group to which the parents belong. Those of the OwLs, Strigida, and some of the Picaria-especially those which lay the glossy eggs above spoken of-are often apparently spherical, though it is probable that if tested mathematically none would be found truly so-indeed it may be asserted thit few eggs are strictly symmetrical, however nearly they may seem so, one side bulging out, though very slightly, more than the other. The really oval form, with which we are most familiar, needs no remark, but this is capable of infinite variety caused by the relative position and proportion of the major and minor axis. In nearly all the Limicola and some of the Alcide the egg attenuates very rapidly towards the smaller end, sometimes in a slightly convex curve, sometimes without perceptible curvature, and occasionally in a sensibly concave curve. The eggs having this pyriform shape are mostly those of birds which invariably lay four in a nest, and therein they lie with their points almost meeting in the centre and thus occupying as little space as possible and more easily covered by the brooding parent. Other eggs as those of the SAND-Grouse, Pterocleidx, are elongated and almost cylindrical for a considerable part of their length, terminating at each end obtusely, while eggs of the Grebes, Podicipedidx, which also have both ends nearly alike but pointed, are so wide in the middle as to present a biconical appearance. $^{1}$

The size of eggs is generally but not at all constantly in proportion to that of the parent. The GuILLEIIOT, Alca troile, and the RAver, Corvus corax, are themselves of about equal size; their eggs vary as ten to one. The Siripe, Scolopax gallinago, and the Blackbird, Turdus merula, differ but slightly in weight, their eggs remarkably. The eggs of the Guillemot are as big as those of an Eagle;

surface, without any punctures, whereas southern specimens are rough as though pock-marked (Ibis, 1860, p. 74), yet no other difference that can be deemed specifio has as yet been established between the birds of the north and of the sonth.

1 A great deal of valuable information on this and other kindred subjects is given by Des Murs, Traité général d'Oologie ornithologique (8ro, Paris : 1860). 
and those of the Snipe equal in size the eggs of a PARTridge, Perdix cincrea. Hewitson, from whom these instances are taken, renarks: "The reason of this great disparity is, however, obvious; the eggs of all those birds which quit the nest soon after they are hatched, and which are consequently more fully developed at their birth, are very large." 1 It must be added, though, that the number of eggs to be covered at one time seems also to have some relation to their size, and this offers a further explanation of the fact just mentioned with regard to the Snipe and the Partridge-the former" being one of those birds which are constant in producing four, and the latter often laying as many as a dozen-for the chicks of each run as soon as they release themselves from the shell (see EMBRYOLOGY, INCUBATION).

EGRET (French Aigrette, cognate with Italian Aghirone, and Provençal Aigron-Latinized Egretta), a white HFron, remarkable for the tufts of long filiform feathers ${ }^{2}$ which spring from the middle and lower part of its back, and take their name from the bird which produces them. A small bundle of these feathers has long been used among eastern nations as all ornament, and worn in front of the turban, caftan, or other head-dress by personages of high rank, being occasionally mounted with, or its form imitated by, precious stones; and the gift of an "egret" so bejewelled has been one of the most distinguished marks of honour that could be bestowed by an oriental ruler upon a favourite minister or successful leader. ${ }^{3}$ The fashion has spread among western nations, and in the "plume" that surmounts or until lately surmounted the "busby" or "bearskin" of our artillery, hussars, and certain select regiments of foot, it verges on the ridiculous, all the grace of the original being lost in the horsehair that counterfeits its form.

In Europe we have two species to which the name Egret properly belongs. One is of large size, the Ardea alba, the other much smaller, A. garzettu. The "Egrittes" of Archbishop Neville's Inthronization feast at York (temp. Edw. IV.) were no donbt LAPWINGS.

EIDER (Icelandic, Exurr), a large marine Duck, the Somateria mollissima of ornithologists, famous for its down, which, from its

1 Hewitson, op. cit. Introul. p. x.

2 These feathers consist of fine barbs alone, without barbules, and though soft as silk keep their stiffness. They are assumed only just before the breedingseason, and hence the procuring of them destroys the birds at a most critical moment (see Extermination). In the "plume trade" they bear the name of "Ospreys"!

3 The "egret" sent by the Sultan to Nelson after the battle of the Nile is almost historieal, and was apparently more valued by the hero than any other gift he got. 
extreme lightness and elasticity, is in great request for filling bedcoverlets. This bird generally frequents low rocky islets near the coast, and in Iceland and Norway has long been afforded every encouragement and protection, a fine being inflicted for killing it during the breeding-season, or even for firing a gun near its haunts, while artificial nesting-places are in many localities contrived for its further accommodation. From the care thus taken of it in those countries it has become exceedingly tame at its chief resorts, which are strictly regarded as property, and the taking of eggs or down from them, except by authorized persons, is severely punished by law. In appearance the Eider is somewhat clumsy, though it flies fast and dives admirably. The female is of a dark reddish-brown colour barred with brownish-black. The adult male in spring is conspicuous by his pied plumage of sable beneath, and creamywhite above; a patch of shining sea-green on his head is only seen on close inspection. This plumage he is considered not to acquire until his third year, being when young almost exactly like the female, and it is certain that the birds which have not attained their full clress remain in flocks by themselves without going to the breeding-stations. The nest is generally in some convenient corner among large stones, hollowed in the soil, and furnished with a few bits of dry grass, seaweed, or heather. By the time that the full number of eggs (which rarely if ever exceeds five) is laid the down is added. Generally the eggs and down are taken at intervals of a few days by the owners of the "Eider-fold," and the birds are thus kept depositing both during the whole season; but some experience is needed to insure the greatest profit from each commodity. Every Duck is ultimately allowed to hatch an egg or two to keep up the stock, and the down of the last nest is gathered after the birds have left the spot. The story of the Drake's furnishing down, after the Duck's supply is exhausted, is a fiction. ${ }^{1}$ He never goes near the nest. The eggs have a strong flivour, but are much relished by both Icelander's and Norwegians. In the Old World the Eider breeds in suitable localities from Spitsbergen to the Farn Islands off the coast of Northumberland-where it is known as St. Cuthbert's Duck. Its food consists of marine animals (mollusks and crustaceans), and hence the young are not easily reared in captivity. The Eider of the New World differs somewhat from our own, and has been described as a distinct species, S. dresseri. Though much diminished in numbers by persecution, it still inhabits the coast of Newfoundland and thence northward. In Greenland Eiders are very plentiful, and it is supposed that three-fourths of the supply of down sent to Copenhagen come from that country. The limits of the Eider's northern range are not known, but the last British

1 Equally fictitious is the often-repeated statement that Eider-down is white. Mouse-colour would perhaps best deseribe its hue. 
Arctic Expedition does not seem to have met with it after leaving the Danish settlements, and its place is taken by an allied species, the King-Duck, S. spectabilis, a very beautiful bird which sometimes appears on the British coasts. The female greatly resembles that of the Eider, but the male has a black chevron on his chin and a

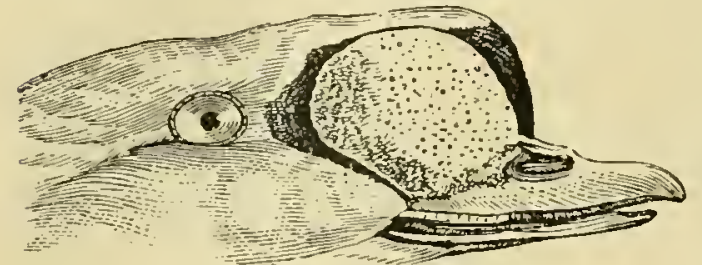

KING-Duck, \& (After Swainson.) bright orange prominence on his forehead, which last seems to have given the species its English name. On the west coast of North America the Eider is represented by a species, $S$. $t$-nigrum, with a like chevron, but otherwise resembling the Atlantic bird. In the same waters two other fine species are also found, S. fischeri and S. stelleri, the latter of which also inhabits the Arctic coast of Russia and East Finmark, and has twice reached England. The Labrador Duck, S. labradoriu, which is now believed to be extinct (see ExTERMINATION), also belongs to this group.

ELEUTHERODACTYLI, Forbes's name (Proc. Zool. Soc. 1s80, p. 390) for all the PAsseres except the Desmodactyl or Eurylamidax (BROADBILL), but

ELEUTHERODACTYLOUS is sometimes said of any bird which has its toes free and not connected by a web, or otherwise bound together ; equivalent to Fissipedal of some older authors.

ELK (Icelandic Alft), a name formerly used, but perhaps now obsolete, for the ordinary Wild or Whooper-Swas.

EMBER (otherwise IMMER) GOOSE-Dan. Imber ; Sw. Immer, and Emmer ; Icel. Himbrim--a name applied in the northern Islands of Britain to the Great Northern Drver.

EMBRYOLOGY, from $\epsilon_{\mu} \beta$ pvov, a growth within. Tery few types of Birds have been studied embryologically, and for obvious reasons the common Fowl has always been the favourite; but recently the early development of the Duck, Goose, Pigeon, Starling, Melopsittacus, and Apteryx has also been investigated. ${ }^{1}$ Later embryonic stages being more easily procured and preserved by field-ornithologists have been studied in a greater number of species, such as the Ostrich, Gulls, Guillemots, and the Rook, besides the forms mentioned above. These investigations have, however, shewn that the variations in the early development of different Birds are only of general importance. Until about the fifth or sixth day of

1 M. Braun, "Die Entwicklung des Wellenpapageis," Arbeit. der zool.-bot. Inst. Würalurg (1879), v. pts. ii. and iii. 
incubation the cmbryos of the most different Birds still so much resemble each other that the want of extensive examination need not be so much deplored. Towards the end of the first week internal and external differences appear, characteristic of the Order and Family to which the bird belongs, while, with exceptions, the generic differences make their appearance during the second week: specific difference can hardly be expected in the embryos. Of course the seven days' embryo of a Sparrow is more advanced than that of a Duck, which requires four times as many days, or than that of an Ostrich, which requires more than seven weeks of incubation, but their several characteristic features can be discerned at the end of the first third of the whole period of incubation. A comparative treatise on avine embryology which is to render valuable taxonomic results will have to restrict itself to the latter half of the embryonic stages. Such a treatise is still a desideratum, and cannot be undertaken until a large, well-preserved, well-named, and well-timed material of embryos of a great number of any birds is at hand. Prof. Fuirbringer has incidentally drawn attention to the probably considerable help which may be derived from the resemblances between middle-aged embryos of certain Families, before their specialized forms of bill and feet are fixed, and then rather obscure the affinities of the Birds in question. He mentions the striking similarity between Laridæ and Limicolæe (the affinities of which two groups it took Ornithologists a long time to find out), between Picidæ and Passeres, Striges and Caprimulgidæ, and so on. Tery young nestlings of Humming-birds, kindly sent to me by Col. Feilden are scarcely distinguishable in general appearance from young Swifts, because their bills are still quite short and broad.

Formation of the Ovum in the Ovary. - Each ovum is a globular yellow body, consisting mainly of yellow and white yolk, and surrounded by the follicular membrane, which is the bulged-out continuation of the stroma of the ovary. This membrane contains numerous blood-vessels, through which the ovum is nourished and enabled to grow. Gradually the growing ovum draws the follicular capsule out into a stalk, surrounds itself with the vitelline membrane, and ultimately bursts the capsule, whereupon it falls into the body-cavity, or rather into the wide fumnel-shaped mouth of the oviduct. The stalk and rest of the burst capsule shrivel up, and are gradually absorbed without forming a corpus luteum, as is the case in Mammals. The ovum is now ripe and ready for fertilization. It shews the following composition: A small amount of white yolk, consisting of small vesicles with albuminous matter, and a number of globular highly-refractive bodies, forming a small mass at the centre of the ovum, and continued to the surface by a stalk expanding into a funnel-shaped disk, the edges of which are continued over the surface of the ovum as a delicate 
layer. Upon the top of the funnel-shaped disk of white yolk lies the germinal vesicle, which, like the white yolk, consists of numerous protoplasmatic spherules; part of the contents of this vesicle shrivels $u p$, and causes the resicle to assume the shape of a disk, the "germinal disk." The rest, the greater portion of the ovum, so far as it is surrounded by the vitelline membrane, consists of yellow yolk, composed of numerous granular globules of albuminous and fatty matter.

The Ovum in the Oviduct.-The ovum, while still in the upper portion of the oviduct, is surrounded by the spermatozoa which have worked themselves through the oviduct from the cloaca. They swarm round the surface of the vitelline membrane, and one or more spermatozon find their way into the germinal vesicle, and fuse with the contents of the latter. Upon this impregnation follows,

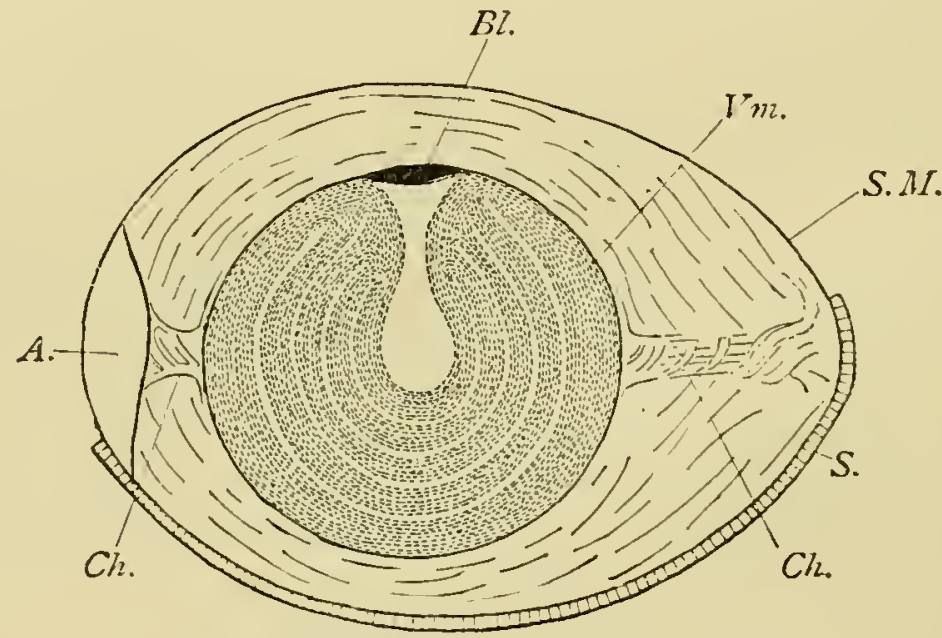

Diagramatic Section of a Fertilized Egg.

A. Air-chamber at the blunt pole; Bl. Blastoderm; Ch. Chalaze; S. Shell;

S.M. Shell nembrue; $r m$. Titelline menbrane.

while the ovum is still within the oviduct, the remarkable process of "segmentation." This process consists of the division of the germinal disk by successive cleavages into a number of cells, which step by step build up the complex mechinism of the embryo. This segmentation being restricted to the germinal disk is called "meroblastic," in opposition to "holoblastic" segmentation, where, as in the ova of the higher Mammals, the whole material of the egg becomes segmented.

The egg, having been received into the oviduct, is propelled in a spiral course by the peristaltic contractions of its walls, and receives from the glands of its lining membrane an accessory mantle of albumen, or the "white" of the egg. The arerage composition of this albumen is $12 \%$ of proteid matter, 1.5 fat, 0.5 saline matter, and $86 \%$ witer. The albumen is lapidly added, and owing to alteruating denser and more watery layers, has a spiral 
arrangement, as may be seen in hard-boiled eggrs. Some of the layers of denser albumen, surrounding the fluid layer next the vitelline membrane, extend as twisted cords or "chalaze" towards the two poles of the egg. They do not quite reach the outer layer of the white, although the cord next the pointed pole of the egg ultimately becomes somewhat superficially attached to the lining membrane of the eggshell. The chalaze serve to suspend the yolk by acting as elastic pads, and thus keeping it in position. The interior of each cord presents the appearance of a succession of opaque white knots, hence the name of chalaza or hailstones.

When the egg has arrived at the narrow constriction of the oviduct (which seems to take place in the common Fowl in from four to six hours after its entrance into the infundibular upper end of the oviduct), the mucous membrane of the latter produces a denser layer of albumen mixed with several laminæ of felted fibres, which approach the nature of connective tissue. This is the shell-membrane which gives the egg its final size and shape, and consists of an inner and an outer layer, both of which remain permanently in close apposition over the greater part of the egg, and adhere to the shell, but at the broad end they tend to separate, and develop an air-chamber between them. This chamber does not exist in perfectly fresh eggs, but makes its appearance and increases in size as the white of the egg loses in bull from evaporation.

From the narrow isthmus the egg passes into the uterine or shell-forming dilatation; here it remains from twelve to twenty lours. The whole shell is deposited as an accessory sheath by the thickish white excretions of the glandular walls of the uterus. This excretion forms an organic basis or matrix, impregnated with calcareous matter, which coagulates and crystallizes partly in the shape of felted strands. The shell rests with so-called mammillary processes upon and partly in the shell-membrane; the mammillæe themselves are comparatively poor in inorganic matter. The interstices between them and the shell-membrane are continued through the calcareous layer of the hard shell as vertical canals. These canals are branched only in the Ostrich, and converge towards the bottom of the little pits on the surface of the egg; in the Rhea only two canals seem to open into each pit; in all other birds each pit leads only into one vertical canal. Besides this mammillary and the porous layer, the shell of most birds possesses a cuticular layer. This outermost layer is the most variable part of the shell; it is apparently structureless, either very poor in calcine salts, and in this case smooth and shiny, or considerably infiltrated with calcareous matter, and then exhibiting the well-known chalky and often rough appearance of the eggrs of the Ani, Cormorants, Grebes, and Flamingos. Even when well developed, this cuticular layer is always extremely thin. In the Ostrich and in Rhea it is very 
hard and brittle, like the glaze of pottery; in the common Fowl and Turkey it is parchment-like; in Auks, and apparently in Gulls, it is absent. The cuticle is spread over the whole surface of the egg, extending unbroken over and into the pits or surface ends of the air-canals, which are therefore closed when such a cuticle is present. The latter, however, readily admits the passage of air when dry, but when wet or moist is impermeable to air.

The colour of the shell is produced by pigment-corpuscles, which may be deposited in various levels of the shell. Sometimes the pigment is restricted to the cuticular membrane, or when the latter is absent it is deposited on the surface of the porous or calcareous layer. In most eggs pigment exists also in the deeper strata of the calcareous layer; interrupted deposition produces the spots, those which are deepest being naturally modified in appearance through the superimposed surface-colour, or they may not be visible at all. The Gallina seem to be the only birds in which the spots, when such occur at all, are restricted to one stratum, while the spots of other birds' eggs are both deep and superficial. In many eggs, whether spotted or plain, the deepest strata of the porous layer of the shell are uniformly coloured. As a rule spots are more frequent and larger towards the blunt pole of the egg, and there exists a distinct resemblance between the eggs, even between those of successive clutches, laid by the same bird (see EGGs).

Abnormal eggs, occasionally of the most perplexing shape, are of common occurrence in domesticated birds where, especially in Fowls, the artificial overproduction of eggs tends to overstrain and to exhaust the oviduct. Want of calcareous food may explain the soft-shelled or "wind" eggs. Sometimes eggs with two yolks, but otherwise normal, are met with, and that twins have been hatched out of such an egg has been observed beyond doubt (see also Monstrosities). Eggs which conțin intestinal worms, blood clots, inorganic concretions, and similar strange enclosures are quite abnormal. Such substances, when once inside the oviduct, seem to stimulate its walls like an ovarian egg and receive the ordinary albuminous and calcareous supplementary coatings.

When the eggshell is completed, the egg is protruded into the cloaca and out through the vent, by the violent contractions of the uterine and cloacal walls, head foremost, i.e. the blunt pole appears first ( $c f$. p. 185, note), and not the pointed end, as some have stated. Controversies have often arisen on this point. Mechanical reasons plainly indicate, not the impossibility, but the greater difficulty of an egg moving with its pointed end forwards. A wedge or a cone enclosed within or driven into an elastic substance slips out towards its broad basis, not in the direction of its apex. ${ }^{1}$

1 Direct observations of hens when in the act of laying are rare and not free 
The production of eggs does not necessarily depend upon previous fertilization by the male, as shewn by numerous instances of birds which have laid eggs although they had been kept in absolute celibacy.

A most important, but still unexplained, allegation is that eggs, containing hybrids, are not exactly like the eggs of the race or species of the female, but more or less resemble also the eggs of the race or species to which the fertilizing male belongs. Instances of such mongrel eggs are mentioned by Nathusius (Zeitschrift $f$. wissensch. Zoologie, xviii. p. 229); and other well-authenticated instances would form valuable contributions to any of our scientific periodicals.

During the descent of the fecundated egg along the oviduct, where it is exposed to the temperature of the bird (about $40^{\circ} \mathrm{C} .=104^{\circ} \mathrm{F}$.) the germinal disk has already undergone important changes; repeated divisions, or segmentation having transformed the disk into a large number of small rounded masses of protoplasm, or cells. Between this segmented disk or "blastoderm" and the bed of white yolk on which it rests, a space containing fluid makes its appearance. The central, greater part of the disk, so far as it overlies the fluid-containing space, is transparent and distinguished as the area pellucida from the area opaca or opaque rim of the disk, which rests immediately upon the white yolk within the vitelline membrane.

When the egg is laid and becomes cold these changes all but entirely cease, and the blastoderm remains inactive until, under the influence of the higher temperature of incubation, the vital activities of the germ are again brought into play, ushering in the series of events by means of which the development of the individual bird is accomplished. No better description of them, as they occur in the Common Fowl, can be found than that given in Foster and Balfour's Elements of Embryology, of which the following is a condensed account, and to that admirable book ${ }^{1}$ the student may be referred for further detailed information.

It is convenient to begin with a preliminary general sketch of the development of the embryo. The embryo itself is formed entirely in the area pellucida; the structures to which the area opaca gives

from deception, but the ingenious and simple experiment made by Mrs. A. Ernst (cf. Zoologischer Anzeiger, viii. 1885, p. 718) could easily be repeated. The birds were kept upon moist sand and charcoal, and when the cackling of a hen indicated her safe dclivery, the egg was inspected and invariably found to be blackened at the blunt cnd. Unless it be assumed for argument's sake that the egg while dropping had time to turn round with its heavier pole downwards, this test scems to be conclusive, but of course it does not exclude wrong presentations.

I Chaps. ii.-ix. Second edition, revised by A. Sedgwick and W. Heape, London : 1883. 
rise are to be regarded as appendages which sooner or later disappear or are ultimately cast off.

The blastoderm, consisting originally of two layers, is soon transformed into three fundamental germinal layers; the upper, middle, and lower layers, or epiblast, mesoblast, and hypoblast. Three similar germinal layers are found in the embryos of all animals with the exception of the lowest invertebrate forms, and their history is one of the most important subjects of comparative Embryology.

The epiblast gives rise to the epidermis with its derivatives, to the whole of the nervous system, and to the most important parts of the special sense-organs. The hypoblast furnishes the whole secretory layer and epithelial lining of the alimentary canal and its glands, with the exception of part of the month and anus, which as invaginations of the onter layer are lined by the epiblast. Ont of the mesoblast the whole of the vascular, muscular, and skeletal systems, and the connective tissue of all parts of the body are developed, as well as the excretory organs and the generative glands. The blastoderm gradually and uniformly expands as a thin circular sheet over the yolk immediately beneath the vitelline membrane. At last by the end of the seventh day of incubation, the whole mass of the yellow yolk becomes enclosed in a bag formed by the blastoderm. This bag is formed chiefly by the area opaca, the mesoblast of which produces numerous blood-vessels and becomes transformed into the area vasculosa.

The embryo itself is formed by a folding-off of the central portion of the area pellucida from the rest of the blastoderm; a semilunar groove or tucking-in of the blastoderm appearing at the head end of the future embryo is spoken of as the "headfold." In an egg placed before us with its blunt end towards the right-hand side, the head-

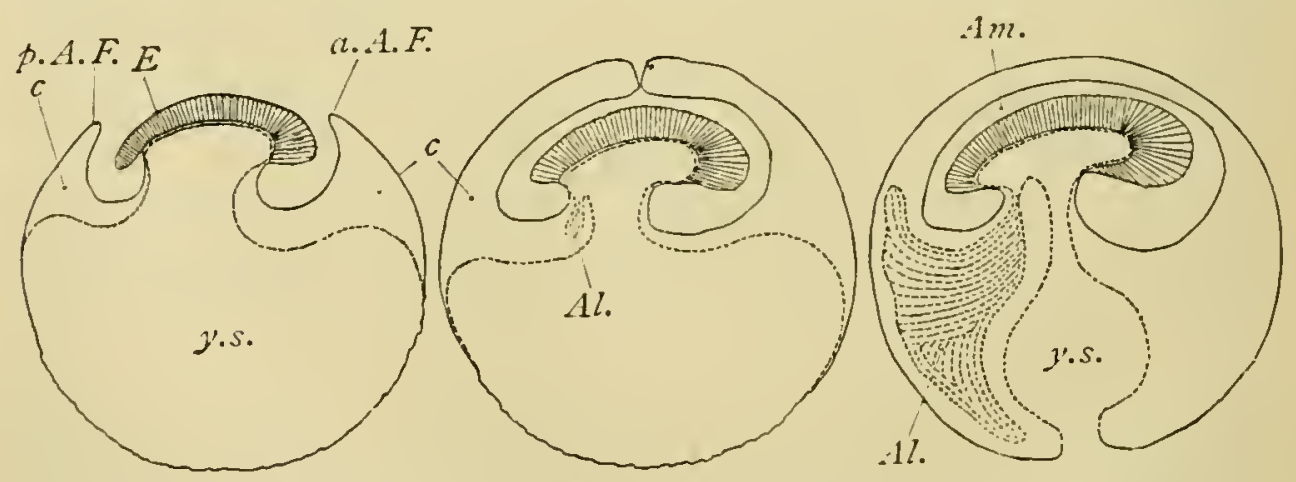

Longitudinal and Vertical Sections through Truxh of ax Embryo, $E$ (shaeled), on the Second, Fourtil, axd Sixth Days.

a.A.F. Anterior amniotic fold; p.A.F. Posterior amniotic fold ; $c$, Pleurn-peritoneal cavity; y.s. Yolk-sac; Al. Allantois.

fold invariably looks away from us, and the longitudinal axis of the future embryo stands at right angles to the long axis of the 
egg. In a rertical section along a line which will afterwards become the axis of the embryo, the whole headfold is in the shape of an 2. The authors named above ingeniously suggest the making of a rough model in order to render the somewhat complicated matter easier to comprehend. Spread a cloth ont flat to represent the blastoderm, and by placing the left hand underneath it mark the axis of the embryo, and then tuck in the cloth from above under the tips of the fingers. The fingers, covered with the cloth and slightly projecting from the level of the rest of the cloth, will represent the head, in front of which will be the semicircular or horseshoe-shaped groove of the headfold.

A similar, but shallower fold, appears at the hind end of the embryo. This, the "tailfold," travelling forwards and the "headfold" gradually extending backwards, and a pair of literal folds miting the two and moving inwards, ultimately suceeed in forming a

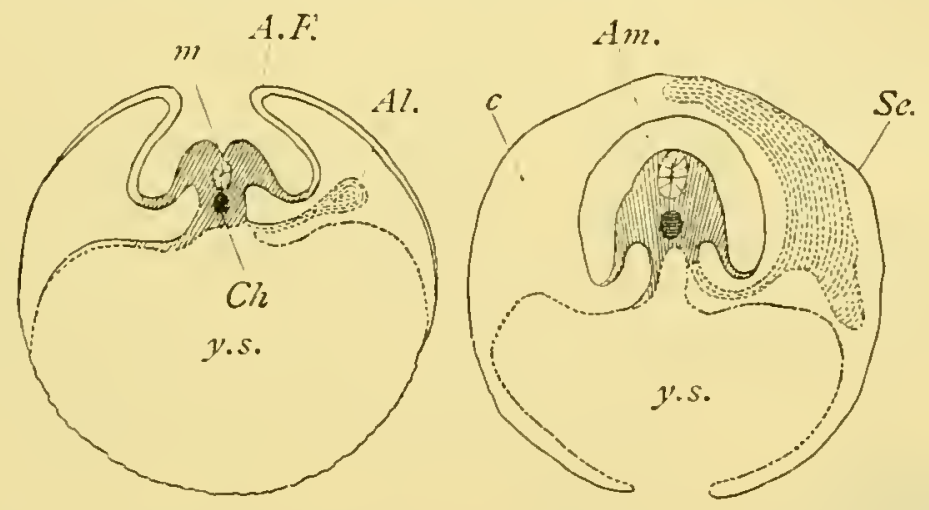

Transverse Sections throvgh the Trunk of an EMbryo on the Third and Sistu Days. A.F. Anterion anniotic fold; -47 . Allantois ; $-4 \mathrm{~m}$. Amniotic eavity; $C h$, Chorda dorsalis ; m, Spinal marrow; Se. Membrana serosa.

tubular sac seated upon and connected by a continually-narrowing hollow stalk, with that larger sac which is formed by the extension of the rest of the blastoderm over the whole yellow yolk. The smaller or upper sac contains, or rather forms the embryo, the larger or lower sac is the yolk-sac. As incubation proceeds the contents of the yolk-sac are gradually assimilated by nutritive processes into the tissues forming the growing walls of the embryonic sac. Consequently the latter becomes larger and larger at the expense of the former. Within a few days of the hatching of the chick, when the embryo is nearly complete, the yolk-sac is still of some considerable size, and is slipped into the body of the embryo through the umbilicus or navel. In the article Altrices it has been pointed out that in the Nidifugie a considerable amount of this yolk still exists when the embryo is hatehed, while in the Nidicolæ this food-yolk has been eompletely, or nearly so, used up by the time the embryo is ripe.

The whole mass of the white of the egg, between the shell and 
the vitelline membrane, has soon after the beginning of incubation become very fluid and its albumen is like the contents of the yolksac assimilated into the tissues of the growing embryo. Already a few days before hatching it is used up completely, so that by this time the embryonic sac and its enclosing membranes fill up the whole egg.

The embryo, as explained above, is formed by a folding-off of the portion of the blastoderm from the yolk-sac. The tubular sac of the embryo, while everywhere acquiring thicker walls, undergoes many modifications through local thickening, buclding, and folding, and is gradually monlded into the proper shape of the body of the chick.

First there appears, on the upper side, a longitudinal canal, the neural tube, the walls of which become transformed into the brain and spinal cord. Below and parallel with this tube appears an axis represented by the vertebrie. Underneath this, again, is another tube, closed in above by the axis, and on the sides and below by the body-walls. Enclosed in this second tube, and suspended from the axis, is a third tube, consisting of the alimentary canal with its diverticular appendages, the liver, pancreas, lungs, etc. The cavity of the outer tube is the body-or pleuro-peritoneal cavity; it also contains the heart and other parts of the vascular system, together with the genital glands and

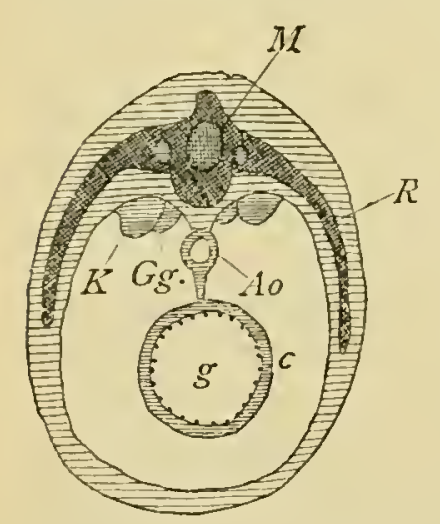

Diagramatic, Transverse
SECTION DF THE BODY OF ANY

Diagamatic, Transverse
Secton of the BOdY OF ANy VERTEERATE.

Ao, Aorta; $c$, Peritoneal cavity ; g, Cut-cavity; lig. Genital glands; $K$, Kidneys; $M$, Spinal marrow contained in the vertebral column, the vertebre and ribs being sluaded. eventually meet and coalesce dorsally in the middle line, thus converting the groove into a canal which becomes closed at either encl. The cavity of the tube becomes the cerebro-spinal canal, its walls are transformed into the spinal cord and through thickenings the kidneys, which are all folded or buddedoff portions of the inmer walls of the bodycavity.

Thus a transverse section of a chick, or in fact of any vertebrate animal, always shews the same fundamental structure; above a single tube, below a clouble tube, the latter consisting of one tube enclosed within another, the inner being the alimentary canal, the outer the general cavity of the body. Into such a triple tube the simple tubular embryonic sac of the chick is converted by a series of changes of a remarkable character.

The upper or neural tube begins at a very early period by the raising up of the epiblast of the blastoderm into two ridges, which run parallel to the long axis of the future embryo and enclose a shallow longitudinal groove. These medullary folds coalesce dorsally in the middle line, thus

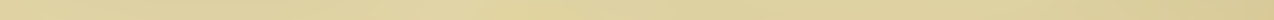


and swellings at the head-end into the BraIN. Its walls are entirely formed of epiblast.

The tube of the alimentary canal and that of the general bodycavity are formed in a totally different way. They are, broadly speaking, the result of the junction and coalescence of the fundamental embryonic folds, the head-, tail-, and lateral folds. It is obvious that the folding in of a single sheet of tissue, such as we hitherto considered the blastoderm tube, can only result in the production of a sac with a single cavity, and would not explain the formation of the double tube. The blastoderm, however, soon splits throughout its greater part into a double sheet, an upper and a lower leaf. In the neighbourhood of the axis or future vertebral column, beneath the neural tube, this cleavage is absent. In fact the cleavage begins at some little distance on either side of the axis, and thence spreads through the mesoblast horizontally to the margin. The upper leaf or half of the mesoblast remains united with the epiblast, and from its forming the body-walls, is called the somatopleure; the lower half of the mesoblast, together with the hypoblast, forms the alimentary canal and its tributary viscera, and is therefore called the splanchnopleure. The space between the two pleura or flaps is the general body-or pleuro-peritoneal cavity.

This cleavage of the mesoblast into a somato- and splanchnoplenre is not confined to the region of the embryo, but extends in time over the whole of the yolk-sac. Hence the yolk-sac comes ultimately to have an inner splanchnopleuric and an outer somatopleuric coat, and since, as we have seen above, the embryonic sac is connected with the yolk-sac by a continually narrowing hollow stalk, this stalk must be likewise double, consisting of a smaller inner stalk within a larger and outer one. The narrow space between these two investments of the yolk-sac is continuous with the pleuroperitoneal cavity. Long before hatching the inner stalk becomes obliterated, so that the material of the yolk can no longer pass directly into the alimentary canal (the walls of which were continuous with the walls of the inner stalk), but has to find its way into the body of the chick by absorption through the blood-vessels, which by this time have spread over the yolk-sac. The outer or somatic stalk remains widely open for a long time as a thin and insignificant continuation of the somatopleure. When in the last days of incubation the greatly diminished yolk-sac, with its splanchnic investment, is withdrawn into the rapidly enlarging abdominal cavity of the embryo, the walls of the abdomen (themselves somatopleuric) close in and unite without regard to the shrivelled, emptied, somatopleuric investment of the yolk-sac, which is cast off as no longer of any use. The place where this has happened is the outer umbilicus or navel, long visible on the middle of the belly of the young bird. Remnants of the stalk between the 
inside of the navel and the alimentary canal, sometimes with a little degenerated yolk, persist in many, chiefly nidifugous, birds as the DIVERTICULUM crecum vitelli; it is attached somewhere to the middle of the small intestine, and, especially when still hollow, rather closely resembles in shape, size, and colour the degraded cæca of Crows, Storks, and diurnal Birds-of-Prey.

All Birds, Reptiles, and Mammals possess in their embryonic state an Amion and an Allantois. The Amnion is a peculiar membrane enveloping the embryo and taking its origin from the somatopleure only. Its development is closely connected with the cleavage of the mesoblast. At an early period the somatopleure forms a semilunar fold in front of the headfold; it consists of a very thin membrane (epiblast and somatic mesoblast), which increases in height, and is gradually drawn backwards over the developing head of the embryo. At the same time a similar fold starts behind the tail and extends with its arms sidewards from the embryo, meeting the corresponding lateral continuations of the anterior fold. All are drawn over the body of the embryo, or rather the embryo seems to sink into these folds, which ultimately meet above it, and completely coalesce with each other, all traces of their junction becoming absorbed. Thus the united folds form a sac, within which the embryo lies. The sac is the amnion; the cavity between the embryo and the inner wall of the amnion is the cavity of the amnion. As will be seen from the diagram (p. 200), each fold of the amnion consists of two lamellie or flaps, but in one the epiblast looks towards the embryo, while in the other it looks away from it. The space between the two flaps or walls of the folds is, according to their mode of formation, part of the cleft between the somato- and splanchnopleure, and consequently continuous with the future pleuro-peritoneal cavity. When the several folds coalesce above the embryo, the double septum of their junction becomes absorbed, so that the inner flaps of each fold form a continuous inner membrane or sac round the body of the embryo; this is the amniotic sac, or amnion proper; while the fluid which collects in it, and in which the embryo lies, is the liquor amnii. The space between this inner and the outer sac is, of course, part of the general mesoblastic cleft. The wall of the outer sac, above the embryo, lies closely under, and fuses with, the vitelline membrane, while marginally it is continued into the somatopleuric investment of the yolk-sac, as has been described above. As the white of the egg is gradually used up, the outer sac or false amnion gradually approaches the inner shell membrane, and ultimately lines it.

The Allantois is a diverticulum of the alimentary canal, and opens immediately in front of the anus. It forms a flattened sac or bulging out of the splanchnopleure of the ventral wall of the 
alimentary canal, and is consequently lined inside by hypoblast. The sac extends forwards into the peritoneal cavity, until it reaches the stalk connecting the embryo with the yoll-sac, whereupon it grows rapidly, and pushes its way into the space between the true and false amniotic sacs. Curving over the embryo, the allantois comes to lie partly above the embryo, separated from the shell by nothing more than the thin false amnion. Being thus situated most superficially, and in close proximity to the air which penetrates the porous shell, the allantois, besides acting as a receptacle for the urine, becomes highly vascular, and performs the functions of a respiratory organ. Towards the end of incubation, when the embryo is already able to breathe through its lungs, the allantois shrivels up and is cast off; together with the shell, but its narrowed and elongated stalk, from the gut to the navel, remains for some time as the urachus upon the inside of the abdominal wall.

\section{Chronological and Special Account of the Derelopment of the Embryo of the Common Fowl.}

First doy. 1st to sth hour of incubation.- Scattered cells appear between the epiblast and hypoblast, as the beginning of the middle layer or mesoblast; they are confined to the posterior part of the area pellucida, and cause this part, called now the embryonic shield, to become somewhat opaque.

Sth to 12th hour:- The three embryonic fundamental layers are more distinctly established; thẻ embryonic shield grows fainter, and vanishes after there has appeared within it, through a thickening of the median portion of the blastoderm, the primitive streak, which is a structure of significance still little understood. The hitherto pellucid area becomes oval, its narrow end corresponding with the future hind end of the embryo. If an egg be placed with its broad end to the right hand of the observer, the head of the embryo will in nearly all cases be found pointing away from him.

12 th to 16 th hour.--The pellucid area becomes pear-shaped; the primitive streak is marked by a shallow median longitudinal furrow, known as the primitive groove.

16 th to 20 th hour.-An important structure, the notochord, found in all vertebrate animals, makes its appearance in the meclian line in front of the primitive streak. The axial part of the epiblast, above the notochord, and in front of the streak, forms two longitudinal folds, which enclose the medullary groove. In front of this groove appears the semilunar headfold, and in front of this again the amniotic fold begins to make its appearance.

20 th to 24 th hour. - The semilunar headfold enlarges rapidly, and rises above the level of the blastoderm; the medullary folds come into contact with each other on the dorsal side, and tend to 
transform the groove into a tube, beginning at the head end, while the posterior arms of the medullary folds remain asunder, and take the front end of the primitive streak between them. In the meantime the cleavage of the lateral or more marginal portions of the

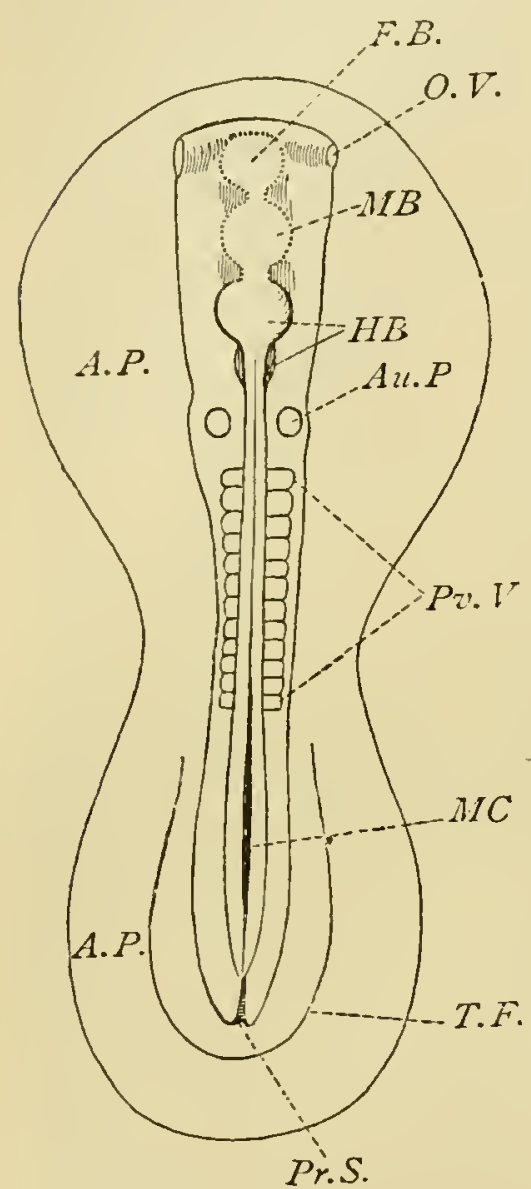

EMBRYo OF THE Comion Fow L, FROM THIETY TO THIRTY-SIX HOURS OF InCUBATION, From ABOVE. Magnified tifteen times. (After Balfour.)

F.R. $M L, I L D$, Vesicles of the fore-, mid-, and hind-brain; $O . V$, optic vesicle; Au.P, Auditory Pit; A.P. Area pellucida; $P v . V$, Protovertebrx (mesoblastic somites); $M C$, Medullary canal in region of sacral rhanboid sinus: Pr.S. Rest of the primitive streak; T.F. Tail-fold of the amnion. mesoblast into an outer and an inner layer has taken place, the cleft being the future pleuro-peritoneal cavity (cf. p. 203). This clearage does not extend throughout the whole of the mesoblast, but stops at some little distance to the right and left from the medullary groove and the notochord. These uncleft mesoblastic portions are called the vertebral plates, in opposition to the lateral plates or split portions of the mesoblast. At first the right and left vertebral plates remain unbroken along their length, but soon transverse constrictions appear in them, and cut them up into a series of cubical masses. These cubes are called the mesoblastic somites or protovertebræ; they are the basis out of which the voluntary muscles of the trunk and limbs, and the bodies of the vertebræ are formed. The first pair of somites rises in level of the anterior end of the primitive streak, the next pairs are added on between the first and the streak, so that the latter seems continually carried back, the lengthening of the embryo always taking place between the front end of the streak and the last somite. All that part of the embryo which is in front of the first somite corresponds to the future head, and the rest to the neck, body, and tail. During all these changes the area opaca has been spreading over the surface of the yolk, so far that the whole blastoderm at the end of the first day of incubation, has attained the size of a sixpence. Vessels appear in the area opaca in the immediate neighbourhood of the embryo.

Changes during the 2 nd day.-During the first half of this the medullary folds are closing rapidly; the groove is converted into the neural canal, closed in front, but still open behind. The portion 
of the tube in front of the first somite forms four successive swellings, the cerebral vesicles, from the foremost of which (the forebrain) a pair of lateral processes (the optic vesicles) grows out; near the end of the future head a pair of shallow pits (the anditory pits) is visible. The number of somites increases from four or five to as many as fifteen during the sccond day. Eventually about fifty are present.

Another most important feature of the first half of the second day is the formation of the heart and of the principal blood-vessels. The whole heart is developed out of the inner or splanchnic layer of the mesoblast on the rentral side of the future throat. To understand this complicated developmental feature, we have to remember the 2 -shaped headfold, with the sinus below the head (cf. p. 201), and have also to resort to transverse sections. The right and left splanchnopleuric layers bulge inwards, and meet each other in the medio-ventral line, thus shutting off a space, the foregut or anterior end of the alimentary canal, lined with hypoblast. The mesoblastic portion of the walls of the right and left recesses, below the foregut and above the splanchnopleuric extension over the yolksac, bulge out, thicken, and become hollow; each tube being continued forwards as an aorta, and backwards, at right angles to the axis of the embryo, as the vitelline vein. 'Thus the heart consists originally of a right and a left tube; the median septum, which separates the two, becomes absorbed, and the now single heart begins to beat, first with slow and rare pulsations. In front the two primitive aortæ, into which the contractions of the heart pump the fluid, bend upwards round the sides of the foregut, and then run backwards towards the tail; each of these aorta gives off a vitelline artery, which is distributed over the pellucid and vascular areas of the blastoderm. Round the margin of the vascular area of the blastoderm runs a red line, the vena terminalis, through which and other vessels spread over the blastodermic layer of the yolk-sac the blood is collected into the two vitelline veins, and by them conveyed into the hinder or venous end of the heart.

During the second half of the second day all the changes initiated during the first half become more advanced or completed. Besides the headfold, the tailfold appears; in addition, the amnion grows rapidly, and the allantois begins to be formed (cf. p. 204).

Changes during the $3 \mathrm{rd}$ day.-This is the most eventful day of the embryonic chick, because the rudiments of so many important organs now first make their appearance. The blastoderm spreads over about half the yolk. The white of the egg decreases considerably, consequently the vessels of the vascular area are brought near the shell, and act as the chief organ of respiration. The blood leaving the body by the vitelline arteries is carried to the small vessels of the vascular area, where it is exposed to the influence 
of the atmosphere; it returns through the vena terminalis into the heart as oxidized or arterialized blood. Besides this complete circulation of the yolk-sac, the body of the embryo itself has received a circulation. A pair of anterior and posterior cardinal veins collect the blood from the body, and convey it through a right and a left Cuvierian duct into the heart. The two primitive aortæ are united into one median dor'sal aorta, but in the region of the neck, instead of the single right and left aortic stems, several aortic arches appear-six on each side, although not more than three or four are present at the same time. From them are sent off the carotid arteries into the head; these and other subsequent important modifications of the aortic arches will perhaps best be understood by reference to the accompanying diagrams. The first, second, and fifth transverse arches obliterate very early; the third pair is continued along the neck and into the head as the internal and external CARotios and also sends off the subclavian arteries for the anterior extremities. The fourth arch of the right side is transformed into the ascending arch of the big aorta, while the corresponding parts of the left side disappear. The last or sixth pair is transformed into the pulmonary arteries; the connexion of the right pilmonary with the aortic trumk remains for some time as the "ductus Botalli." Simultaneously with these changes goes the transformation of the simple tubular heart into a four-chambered organ. The heart-tube assumes an S-shaped twist; a septum begins to grow out from the inner wall, and indicates the division of the bulged-out middle portion of the heart into a right and left ventricle; and to complete this part of the subject it may be added that this division is completed on the fifth day, when a similar septum separates the posterior or venous portion of the heart into a right and left atrinm, each with a lateral dilatation or auricle. This atrial septum is not completed before the twelfth day, the right and left atrium communicating with each other" until this time by the "foramen ovale." On the fifth day a longitudinal continuation of the ventricular septum into the anterior or arterial portion of the heart and into the root of the ventral aorta divides this bulbus arteriosus into a truncus arteriosus and a truncus pulmonalis. As the lungs are being formed, pulmonary veins also make their appearance, and become connected with the left atrium of the heart. By the end of the fifth day most of the principal arteries and veins of the body hare likewise been developed.

The remaining changes on the $3 r d$ duy are as follows:-

The appearance of the vesicles of the cerebral hemispheres; the separation of the hindbrain into cerebellum and medulla oblongata.

The lens of the eye is formed by involution of the optic vesicle, and the eyeball appears as the secondary optic vesicle.

First appearance of the nasal pits. 
Cranial and spinal nerves appear as lateral outgrowths of the central nervous system.

The foregut and the hindgut are completed; the former is divided into oesophagns, stomach, and duodenum, the hindgut into large intestine and cloaca.

The formation of the lungs from a ventral diverticulum of the alimentary canal immediately in front of the stomach.

The diverticular outgrowths from the duodenum form the liver and the pancreas, the ducts of these glands being the lengthened stalks of the outgrowths.

A pair of primitive excretory organs appears in the proximal corners of the walls of the pleuroperitoneal-cavity, as the "Wolffian" duets and bodies. side.

The embryo itself has turned over so that it now lies on its left

Changes during the $4 t h$ day.-Owing to the still further diminution of the white of the egg, the embryo lies almost in immediate contact with the shell membrane. The vascular area is about as large as a halfpenny, and the whole blastoderm embraces more than half of the yolk. The amnion completely encloses the embryo, which by this time has been so much folded-off from the yolk-sac, that the connecting stalk is much constricted. The inner or splanchnic stalk is now called the vitelline duct.

The head of the embryo is bent ventralwards at more than a right angle, forming the cranial flexure. The tail is curved inwards and forms a conspicuous feature, the whole embryo being somewhat spirally curled up on itself.

The anterior and posterior extremities make their appearance as flattened conical buds.

The cerebral hemispheres and the optic vesicles have enormously increased in size.

The nose, ears, and jaws become more distinct. The ovary, kidneys, and ureters are formed. The allantois projects as a small pear-shaped bag and receives allantoic vessels from the vitelline veins and from the dorsal aorta.

Changes during the 5th day.-

The blastoderm has spread over the whole of the yolk-sac, and the yolk is thus completely enclosed in a bag, whose walls, however, are excessively delicate and easily torn. The vascular area extends over about two-thirds of the yolk. The splanchnic stalk or vitelline duct has been reduced to a narrow solid cord. The allantois serves already as the chief organ of respiration, and stretches far over the right side of the embryo in the cavity between the two amniotic layers. The embryo, lying on its left side, remains extremely curved, so much that the head and tail are nearly in contact. The fore- and hindlimbs have become lengthened, elbow 
and knee are formed, but all the limbs are still cxceedingly alike in shape. Most of the skeletal parts make their appearance as cartilages; especially the cartilaginous cranium, the visceral arches like the jaws and hyoids, the vertebra with the ribs, and the framework of the limbs. The changes affecting the vascular system have already been mentioned.

Changes from the 6th day onwards.-.

The sixth day marks a new epoch in the development of the chick, for distinctly avine characters then first make their appearance, the embryo of a Bird being until this period strikingly like that of any other amniotic vertebrate, for instance, that of a Mammal or still more like that of a four-footed Reptile. The avine specialization begins of course very gradually. But on the sixth day for the

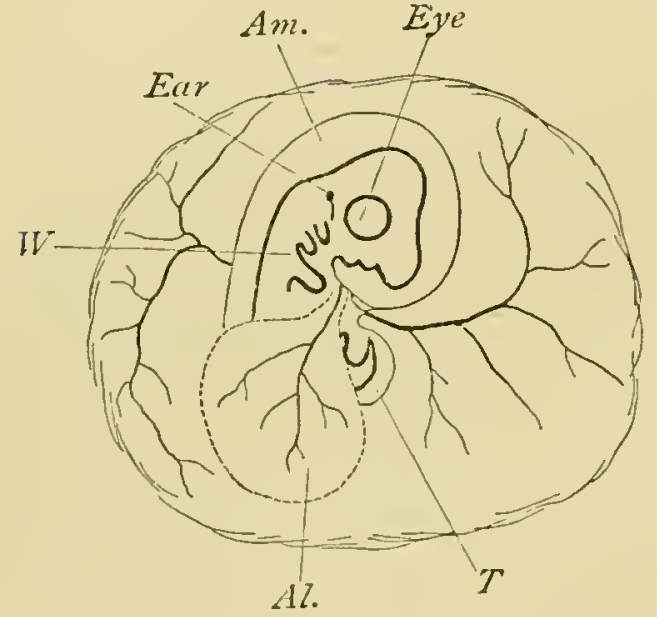

Embryo of Fow on the Sixth Day. Natural size and position.

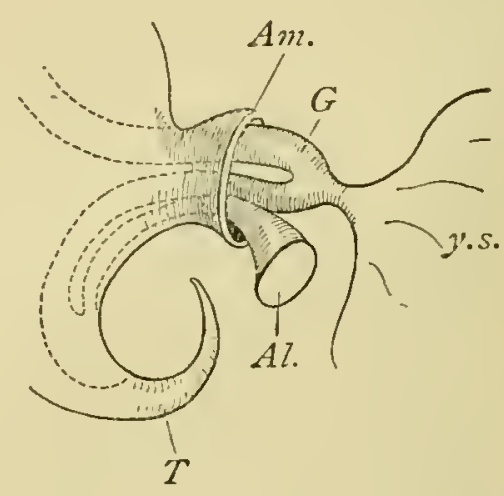

Umbilical Region of the Same. Magnified.

$A m$. Amnion; $A l$. Allantois; $G$, Gut; $T$, Tail; $W$, Wing; y.s. Yolk-sac.

first time become visible the main features of the characteristically avine wing and foot; the crop and the intestinal creca make their appearance, the stomach is differentiated into a proventriculus and a gizzard; the nose begins to develop into a beak; and the commencing bones of the skull arrange themselves after an arine type.

During the seventh day the amniotic cavity has assumed considerable dimensions, the fluid increasing within it; obvious movements begin to appear in the amnion itself as slow rermicular contractions which creep rhythmically over it. The amnion in fact begins to pulsate slowly and rhythmically, and by its pulsations the embryo is rocked to and fro in the egrs. The allantois, which at a later period shews similar movements, has spread ont rapidly in all directions and is filled with fluid. The vascular area loses its terminal simus; both vitelline arteries and veins now pass to and from the body of the chick as single trunks, assuming more 
and more the appearance of mere branches of the by this time advanced mesenteric vessels. The yellow yolk has become quite fluid, and its bulk has increased owing to its having absorbed much of the rapidly-diminishing white of the egg. During the next days the yolk diminishes rapidly in bulk, it being taken up by the abundantly-developed blood-vessels; the yolk-sac becomes flaccid, and by the eleventh day is thrown into a series of internal folds. The intestine has by elongation formed a number of convolutions and loops, some of which are hanging down into the somatic stalk, but by the fifteenth day these loops are gradually withdrawn into the cavity of the abdomen, the walls of which have by this time been definitely established like the walls of the chest. The allantois now fills most of the amniotic cavity and lies close under the shell, being separated from the shell membrane only by the thin false amnion and the remains of the vitelline membrane, with which it fuses. When the egg is opened the pulsations of the allantoic arteries at once attract attention. By the nineteenth day the white of the egg has entirely disappeared, and the yolk-sac is withdrawn into the abdomen.

Concerning the changes of the embryo itself it is to be observed, that by the seventh day the head, which is still disproportionately large, ceases to grow more rapidly than the body. The tongue appears on the floor of the mouth; the visceral clefts on the sides of the now more distinctly-marked neck are closed. On the eighth day a white patch of calcareous matter appears on the tip of the nose; the latter is by the twelfth day transformed into a horny but still soft beak. On the following day nails are visible at the ends of the toes and some of the fingers, and scales on the anterior surface of the feet and toes. Beak, claws, and scales become harder and more horny by the sixteenth day. Feathers begin to protrude as early as the ninth day from the surface of the skin as papillæ, especially prominent on the middle line of the back and on the thighs. By the thirtcenth day the feathers are distributed over most parts of the body, and acquiring the length of a quarter of an inch appear to the naked eye as feathers, their thin horny sheaths allowing their pigmented contents to shew through. The sheaths are not pierced until a day or two before hatching, when some of them are nearly an inch in length. The cartilaginous skeleton is completed by the thirteenth day, and the muscles can be made out with tolerable clearness. Ossification begins already much earlier in various parts of the bones of the limbs, but much of the skeleton remains cartilaginous or imperfectly ossified long after the bird has been hatched. The whole embryo changes its position on the fourteenth day so as to lie lengthways in the egg, with its beak touching the shell-membrane where this forms the inner wall of the rapidly-increasing air-chamber at the broad end. On about the 
twentieth day the beak, furnished with the hard "egg-tooth," is thrust through the inner shell membrane, and the bird begins to breath the air contained in the chamber. Thereupon the pulmonary circulation becomes functionally active and blood ceases to flow through the umbilical vessels from and to the allantois. The latter shrivels up, the navel becomes completely closed, and the chick by repeated filing motions pierces the shell at the broad end of the egg with its egg-tooth. A small crack in the shell is sufficient to destroy the surprising strength of the intact egg, the chick casts off the dried, now no longer useful, remains of allantois and amnion, and steps out into the world.

The length of the period of incubation seems to depend upon, first, the state of perfection in which the young bird leaves the cgg, the Nidifugæ requiring a much longer time than the Nidicolæ; secondly, the size of the bird,-large birds requiring more days than small birds; thirdly, climate and season, because an occasional slight cooling of the eggs retards the development of the embryo. The amount of cooling will naturally be greater in cold than in hot climates, while the temperature of the sitting bird varies within small limits only. However, there seem to be no observations made on the question if there is a difference in the length of incubation between polar and tropical individuals of the same species. Experience with artificial incubators has shewn that during the earliest days of incubation the growth of the embryo can be much retarded or even be stopped temporarily by a temperature below the normal point; on the other hand, a higher than normal temperature does not shorten the time of incubation but is rather detrimental to the embryo's life ( $c f$. W. Evans, Ibis, 1S91, pp. 52-93).

EMEU, evidently from the Portuguese $E$ ma ${ }^{1}$ a name which has in turn been applied to each of the earlier-known forms of Ratite Birds, but has in all likelihood finally settled upon that which inhabits Australia, though, until less than a century ago, it was given by most authors to the bird now commonly called CASsowary.

1 By Moraes (1796) and Sousa (1830) the word is said to be from the Arabic Nciáma or Naiema, an Ostrich (Struttio camelus); but no additional evidence in support of the assertion is given by Dozy in 1869 (Glossaire des mots espagnols et portugais dérivés de l'arabe. Ed. 2, p. 260). According to Gesner in 1555 (lib. iii. p. 709), it was the Portuguese name of the Crane, Grus communis, and had been transferrel with the qualifying addition of " $d i$ Gei" (i.e. Ground-Crane) to the Ostrich. This statement is confirmed by Aldrovandus (lib. ix. cap. 2). Subsequently, but in what order can seareely now be determined, the name was naturally enough used for the Ostrich-like birds inhabiting the lands discovered by the Portuguese, both in the Old and in the New World. The last of these are now known as Rheas, and the preceding as Cassowaries. 
Of the Emeus (as the word is now restricted) the best-known is the Casuarius notix-hollandix of Latham, made by Vieillot the type of his genus Dromaus, whence the name of the Family, Dromaida, is taken. This bird immediately after the colonization of New South Wales (in 1788) was found to inhabit the southeastern portion of Australia, where, according to Hunter (Hist. Journ. etc. p1. 409, 413), the natives called it Maracry, Marryang,

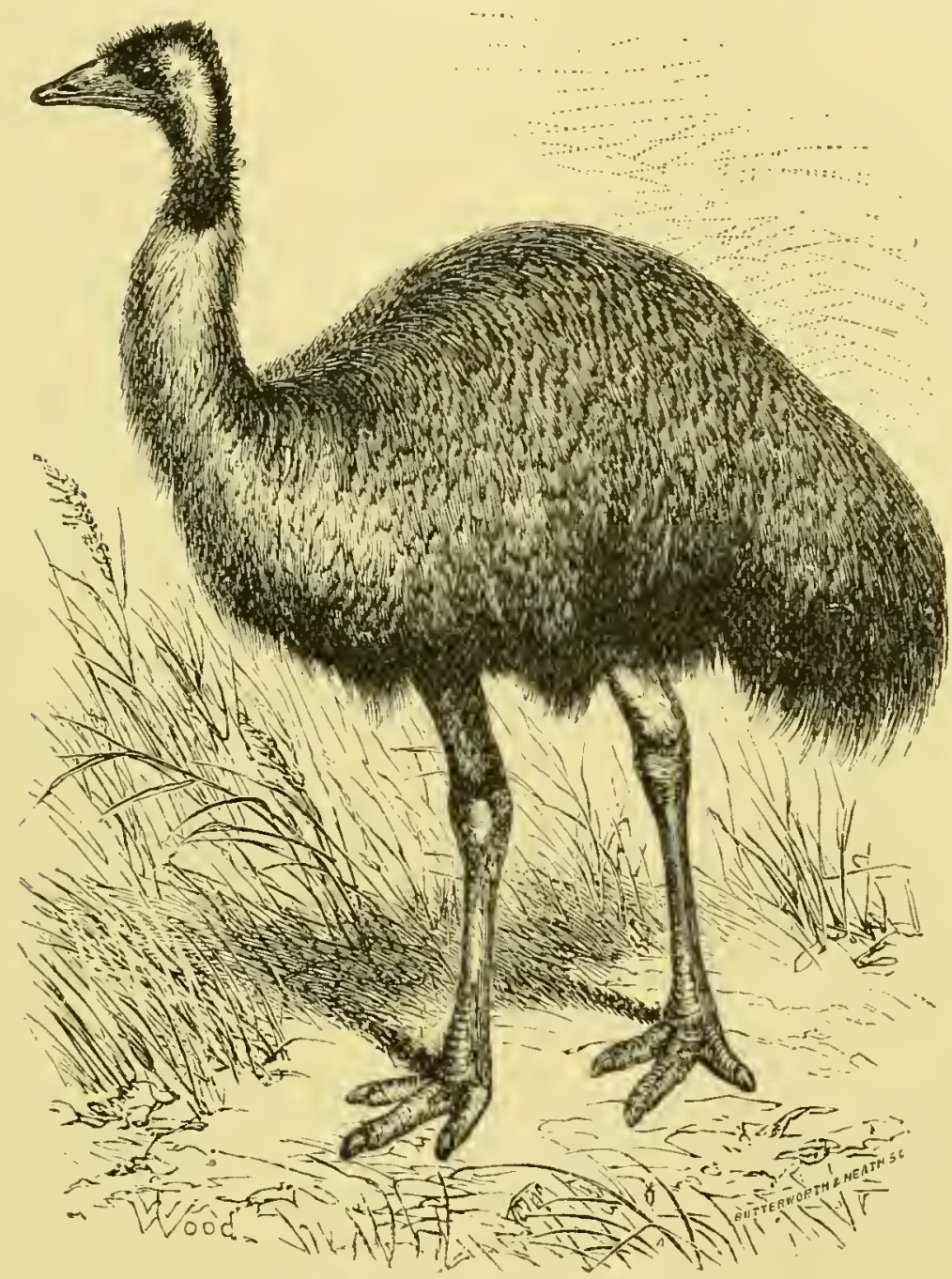

Eveu. (From MIosenthal and Harting's Ostriches, etc.)

or Maroang; but it has now been so hunted down that not an example remains at large in the districts that have been fully settled. It is said to have existed also on the islands of Bass's Straits and in Tasmania, but it has been extirpated in both,

1 The obvious misprint of Dromeicus in this author's work (Analyse de., p. 54) has been foolishly followed by many naturalists, forgetful that he corrected it a few pages further on (p. 70) to Dromains-the properly latinized form of which is Dromæus. 
without, so far as is known, any ornithologist having had the opportunity of determining whether the race inhabiting those localities was specifically identical with that of the mainland or distinct. ${ }^{1}$ Next to the OsTRICH the largest of existing birds, the Emeu is an inhabitant of the more open country, feeding on fruits, roots, and herbage, and generally keeping in small companies. The nest is a shallow pit scraped in the ground, and from nine to thirteen eggs, in colour varying from a light bluish-green to a dark bottle-green, are laid therein. These are hatched by the cock-bird, the period of incubation lasting from 70 to 80 days. The young at birth are striped longitudinally with dark markings on a light ground. A remarkable structure in Dromaus is a singular opening in the front of the windpipe, communicating with a tracheal pouch. This has attracted the attention of several anatomists, and has been well described by Dr. Murie (Proc. Zool. Soc. 1867, pp. 405-415). ${ }^{2}$ Various conjectures have been made as to its function, the most probable of which seems to be that it is an organ of sound in the breeding-season, at which time the henbird has long been known to utter a remarkably loud booming note. Due convenience being afforded to it, the Emeu thrives well, and readily propagates its kind in Europe. Like the South American RHEA it will take naturally to the watel, and examples have been seen voluntarily swimming a wide river.*

The existence in Australia of a second species of Dromaus had long been suspected, and Broderip in 1842 stated (Penny Cyclop. xxiii. p. 145) that Mr. Gould had even supplied a name (D. parvulus) for it; but there can be little doubt that this suggestion was founded on a mistake. However, in $1859 \mathrm{Mr}$. Bartlett described, under the name of $D$. irroratus, what has since been generally admitted to be a good species, and it now seems certain that this fills in Western Australia the place occupied by the olderknown form in the eastern part. . It is a more slender bird, and when adult has the feathers barred with white and dark-grey ending in a black spot which has a rufous margin, while those of D. novx-hollandix are of a uniform blackish grey from the base to near the tip, which is black with a broad subterminal rufous band. Both species have been figured from admirable drawings by $\mathrm{Mr}$. Wolf (Trans. Zool. Soc. iv. pls. 75, 76), and interesting particulars as to their domestication in England are given by Mr. Harting (Ostriches and Ostrich Farming, pp. 131-174).

1 Latham (Gen. Hist. B. viii. p. 384, pl. 138) in 1823 described and absurdly figured what he called "Van Diemen's Cassowary" from one of two young birds exhibited alive in London; but there is nothing to shew that they really came from Tasmania, and as they were apparently the only Emeus he had ever seen, he had no means of determining whether they differed from the Australian form.

2 See also Gadow (Zoolog. Jahrb. v. pp. 636-638), and above, AIr-sacs. 
EMMET-HUNTER, a common local name of the WRYNECK.

ERN or ERNE, Scandin. Orn, the Sea-EAGLE; but hardly used now except in poetry or as the name of a pleasure-yacht.

ERODY (corrupted from Herodias, a Heron) Latham's name (Gen. Hist. B. ix. p. 139) for Dromas ardeola (Crab-Plover).

EROLIA, a genus proposed by Vieillot (Nouv. Anab. p. 55), and the name Englished by Stephens in 1819 (Shaw's Zoology, xi. p. 497), but believed to be founded on a specimen of Tringa subarquata (SANDPIPER) which had lost its hind toes.

ERYTHRISM, the abnormal replacement of other colours, generally green or yellow, by red (see Colour and Heterochrosis).

ESTRIDGER, an old word signifying a Falconer.

EXTERMINATION, literally a driving out of bounds or banishment, is a process which, intentionally or not, has been and still is being carried on in regard to many more species of Birds than most people - not excepting professed ornithologists - seem to recognize, and one that has frequently led to the Extinction, ${ }^{1}$ or dying out, of the species affected. The inhabitants of islands are especially subject to this fate. In them each species has long been brought into harmony with its circumstances, and relations with its fellow-creatures have so far become mutually adjusted that in the long run the balance between them is preserved, and the stock of each remains the same one year with another. But the appearance on the scene of man, and especially of civilized man, upsets the equilibrium. Even if he do not immediately begin to bring the virgin soil under cultivation by felling the primæval forest or burning the brushwood, he almost always introduces certain animals which make war on the aboriginal population-directly in the case of Cats and Rats, indirectly in that of Goats and Rabbits, or both ways in that of Hogs. Against such enemies, whether forcibly attacking them or insidiously robbing them of food, the most part of the indigenous species are unprepared and absolutely helpless. In the majority of instances each of the islands so colonized has its own peculiar Fauna, largely consisting, that is, of species not found elsewhere, and if the island be small it is soon overrun by the newcomers, and its ancient inhabitants with difficulty preserve their existence, or wholly succumb.

The best known if not the most remarkable case of this kind is that of the DoDo, Didus ineptus, which, on the rediscovery of Cerne,

1 In some instances the still stronger word, Extirpation, or rooting out, might be appropriately used; but this would be most applicable in those where destruction of the species is purposely intended, and attempts of that kind have rarely proved to be successful, unless carried on for a long period of time, or by poison. 
or Mauritius, by the Dutch under Tan Neck at the end of the 16th century, was found to inhabit that island. Toyagers have vied with each other in describing or depicting its uncouth appearance, and its name has almost passed into a byword expressive of all that is effete. Clumsy, flightless, and defenceless, it soon succumbed, not so much to the hmman invaders of its lealm as to the domestic beasts-especially Hogs ${ }^{1}$-which accompanied them, and there gaining their liberty, mnchecked by much of the wholesome discipline of natme, ran riot, to the utter destruction (as will be seen) of no inconsiderable portion of the Mauritian famna.

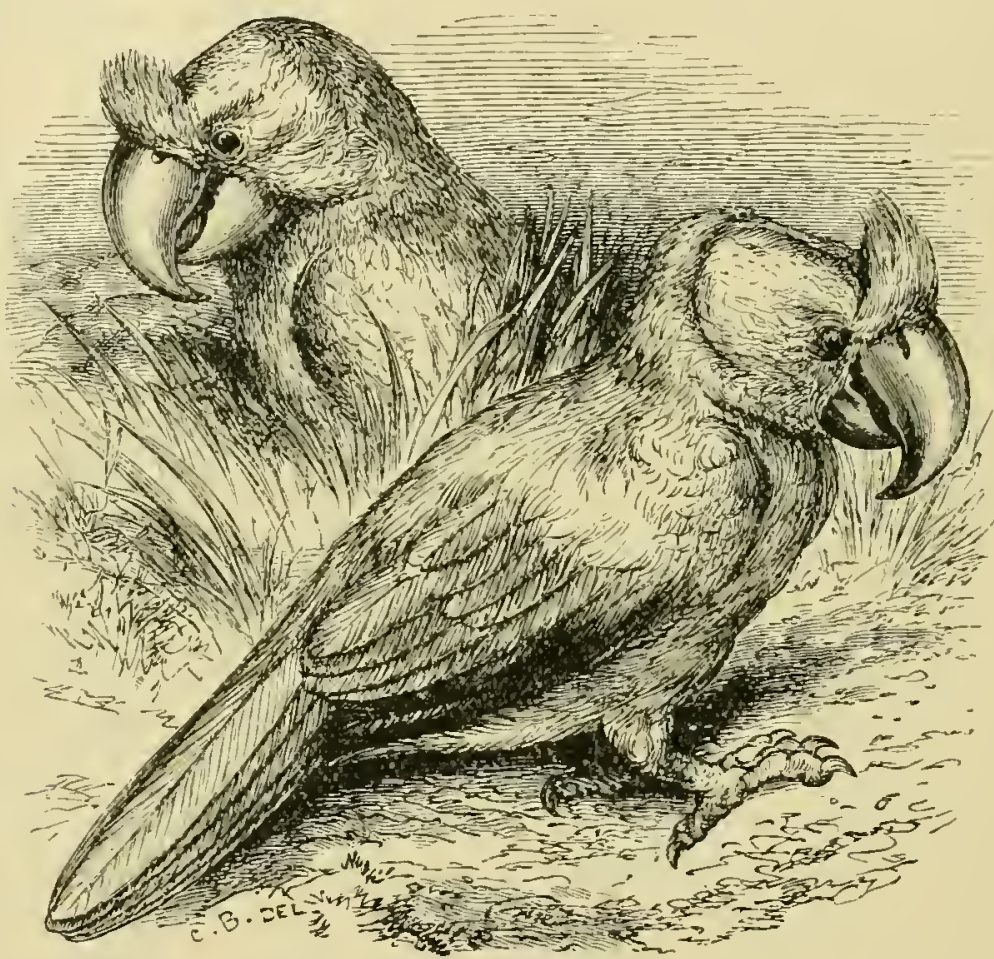

Extinct Crested Parrot of Mauritius, Lophopsittacus mauritianus. Ailapted from a tracing by M. A. Milne-Edwards of the original drawing in a MS. Journal kept during Wolphart Harmanszoon's royage to Mauritius, A.D. 1601-1602 (cf. Proc. Zool. Soc. 1S75, p. 350).

But the Dodo is not the only member of its Family that has vanished. The little island which has successively borne the name of Mascaregnas, England's Forest, Bombon, and Rémion, and lies to the southward of Mauritius, had also an allied Bird, now dead

1 In La Roque's aceount of the Voyage de l'Arabie Heureuse (Paris: 1715) in 1708-10 (the first made by the Freneh) it is stated that the ships tonched at Mauritius in September 1709 and that "rle l'antre eôté de l'isle andelà des montagnes on trouvoir force sangliers, qui faisoient un tel dégât, qu'on avoit depuis peu ordonné une chasse générale pour les détruire, \& que les habitans s'étant assemblez, on en tua en un jour plus de quinze cens" (p. 175). A few days after he writes: "en me promenant dans leur jardin, j'eus le plaisir de voir de derriere la haye plus de quatre mille singes dans le champ voisin" (p. 183). In regard to 
and gone. Of this not a relic has been handled by any naturalist. The latest description of it, by Du Bois, ${ }^{1}$ is meagre in the extreme, and though two figures-one by Bontekoe (civec 1646) and another by Pierre Witthoos (ob. 1693) have been thought to represent it (Trans. Zool. Soc. vi. p. 373, pl. 62), their identification is but conjectural. Yet the existence of such a bird is indubitable.

Far to the eastward of these two sister islands lies a third -Rodriguez. Here there formerly lived another Didine bird, sufficiently distinct from the Dodo of Mauritius to form a genus of its own-Pezophaps solitarius, the SolitaIre of Leguat, a Huguenot exile who, passing some time in 1691-93 on that island, has left, with a very inferior figure, a charmingly naive account of its appearance and habits, the general truth of which has been amply substantiated by Sir Edward Newton's discovery in large numbers of its bones (Phil. Trans. 1869, p. 327). These have since been supplemented by those collected by Mr. H. H. Slater in 1874 (op. cit. vol. 168 , p. 438 ), and now nearly complete specimens may be seen in several of the principal Museums of this country, the most perfect being one of each sex in that of the University of Cambridge.

Nor does this group of Didine birds contain all the lost forms of the Mascarene islands. From Mauritius have disappeared at least two species of Parrot, a Dove, ${ }^{2}$ a large Coot, and a second Ralline bird, abnormal, flightless, and long-billed-Aphanapteryx. A painting of this last was found by Von Franenfeld in the emperor's library at Vienna, and some of its bones rescued by Sir Edward Newton from the peat of the Mare alx Songes, have been fully described by Prof. A. Milne-Edwards. Remains of the Coot and one of the extinct Parrots were found also in the same spot, while skins of the other Parrot and of the Dove still exist in a few museums. Réunion, also, once had other birds now lost, and so had Rodriguez. In the former, a somewhat abnormal STARLING, Fregilupus, existed until some forty years ago, and its skin and skeleton are among the treasures of three or four museums. ${ }^{3}$

this last statement allowance may perhaps be made for some exaggeration, but a Monkey, the Macacus piteatus, still inhabits Mauritins, and though I know no record of its introduction, introduced it must have been from Ceylon, to which island the species is peculiar. We may be certain that there were no Monkeys in Mauritius or any of the Mascarene Islands at the time of their discovery.

1 Les Voyages faits par le Sicur D. D. aux Isles Dauphine ou Madagascar, \& Bourbon, ou MFascarenne, és années 1669.70. 71. \& 72. p. 170. (Paris: 1674.)

2 Alcetorcenas nitidissima. For a notice of the specimen in the Mnseum of Science and Art in Edinburgh, and the only one known to exist in the United Kingdom, see Proc. Zool. Soe. 1879, pp. 2-4.

3 The only known skeleton is in the Mnseum of the University of Cambridge, and has been minutely described by Dr. Murie (Proc. Zool. Soc. 1874, pp. 474488). In 1889 the British Museum obtained, at the dispersal of the Riocour 
Perhaps, also, there were other Ralline birds, but the evidence on this head is inconclusive. From Rodriguez, the greater part of its original Arifanne has vanished. There was a small but peculiar Ows, Athene murivora, a big PARrot, Necropsittacus rodericanus, a Dove, Erythrana (? sp. ign.), a large brevipennate HErox, Ardea megacephala, and a singular RaIL, described as Miserythrus leguati, but perhaps not generically distinct from the Mauritian Aphanapteryx, -besides other birds of which we know from old voyagers, ${ }^{1}$ though their lemains, from the mumerous caverns of the island, have not

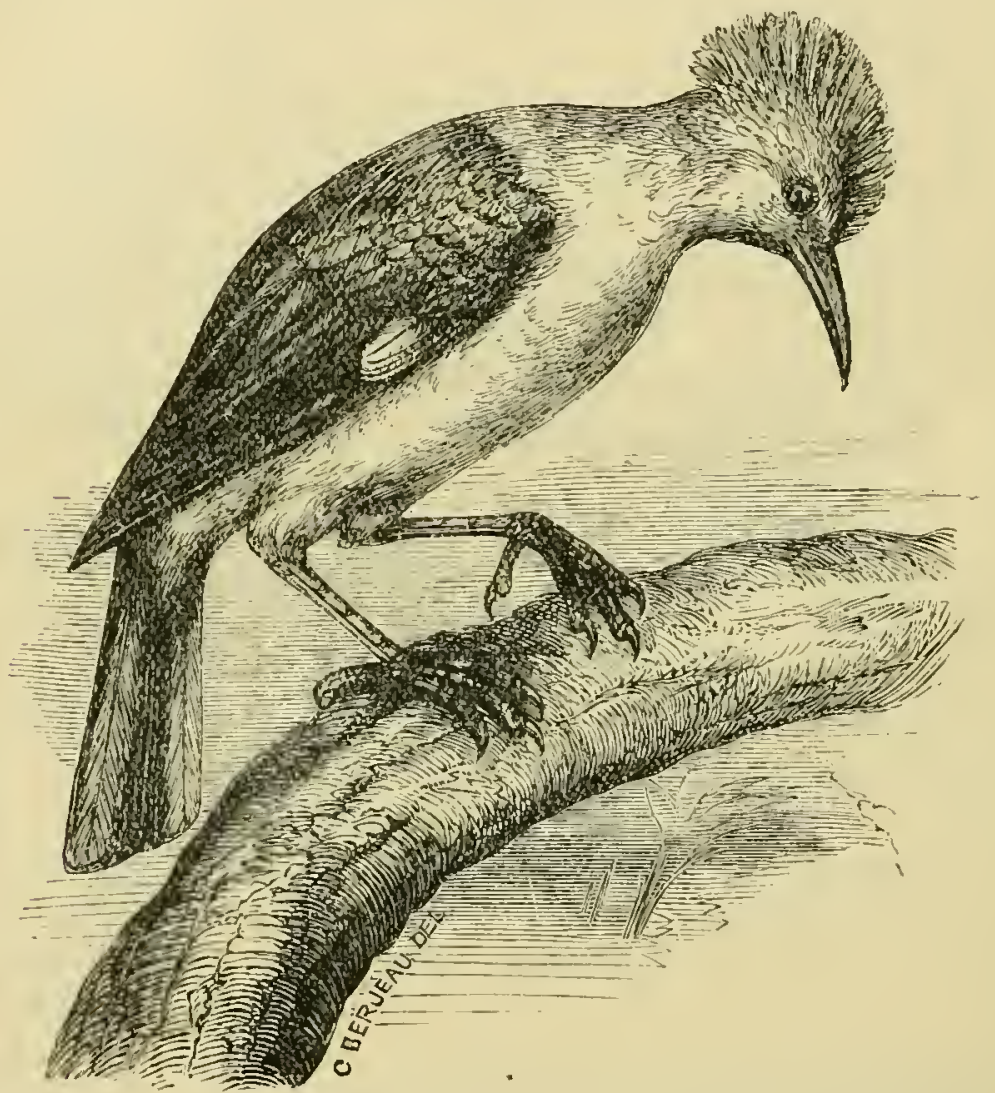

Extinct Starlixg of Rídnios, Fregilupus varius, adapted from figures by Daubenton, Levaillaut, and others. Reduced.

yet been determined, as those of the species above mentioned have been. A second Parrot, or rather Parrakeet, Palaomis exsul, still exists, but in very small numbers, and the only two specinens known to have been obtained are in the Museum at Cambridge. (Ilis, 1872, p. $31 ; 1875$, p. 342, pl. vii.)

With the examples of these Mascarene Islands before us, it is not without reason that we supjose a like fate to have befallen many of the feathered inhabitants of other places exposed to similar collection, the only skin believed to be in the British Islands. For a notice of other specimens see Salvadori, Atti Soc. Torino, xi. I'], 481-488.

1 Proc. Zool. Soc. 1875, 1'1. 39-42. 
lavages. We cannot read the accounts not merely of the carliest voyages to the Antilles, but even of those performed within the last hundred years, without being aware that the writers met with many birds which are not now known to inhabit them. These lost species, there is some ground for believing, were mainly, if not wholly, peculiar to the locality, and after having made good their existence, maybe, for ages, fell easy and helpless victims to the forces which European civilization brought into play. Chief among these forces was fire. In all countries and at all times it has been the habit of colonists, as before hinted, to burn the woods surrounding their settlements-partly to clear the ground for future crops, and partly (in tropical climates especially) to promote the salubrity of their stations. When fire was set to the forest and bush of a small island, the whole of which conld be burned at once, the disastrous effect on its Fauna can easily be conceived. Even the animals which happened to escape the conflagration itself would speedily starve, owing to the at least temporary destruction of the native Flora whence, either directly or indirectly, they derived their wonted sustenance. Thus in certain of the Virgin Islands the "dead" shells of many species of terrestrial Gasteropods are everywhere found in astounding numbers, while not a living individual of several of the species has ever been met with by the conchologists of our day. The only assignable cause of the extinction of these creatures lies in the fact that these islands are known to have been laid waste by fire. The shells have resisted destruction, but how many more animals have perished without leaving a trace of their existence? Even at the present time, few parts of the world so overrun by people of European descent are from a naturalist's point of view so little known as the West-India Islands. Still less is known of their state a century ago; and it would be a long and wearisome task to collect from old voyages the meagre, scattered, and often inaccurate information they contain as to the zoology of these islands. One example may, perhaps, be sufficient. Ledru accompanied an expedition sent out in 1796 by the French Government to the West Indies. In his work he gives a list of the birds he found in the islands of St. Thomas and St. Croix (Foyage aux Isles de Teneriffe, \&c., Paris : 1810, ii. p. 29). He enumerates fourteen kinds of birds as having occurred to him there. Of these there is now no trace of eight of the number; and, if he is to be believed, it must be supposed that within fifty or sixty years of his having been assured of their existence, they have become extinct. ${ }^{1}$ And yet the period just

1 One of the survivors (a Parrakeet), now regarded by Count T. Salvadori as the true Conurus pertinax, is or was a few years ago restricted to a single hill-top in St. Thomas, and so reduced in numbers that the present writer was ridiculed by many of the inhabitants for believing that such a bird ever existed in the island. Found, however, it was, but it must be regarded as verging upon extinction. 
mentioned was long subsequent to that in which the primæval woods of the islands were burnt. What, then, must not have been the changes which the forest-fires produced?

If this be not enough we may cite the case of the French islands of Guadeloupe and Martinique, in which, according to M. Guyon (Comptes Pendus, lxiii. p. 589), there were once found six species of Psittaci, all now exterminated; and it may possibly be that the Maccaws stated by Gosse (B. Jamaica, p. 260) and Mr. March (Proc. Acad. N. S. Philad. 1863, p. 283) to have formerly frequented certain parts of Jamaica, but not apparently noticed there for many years, have fallen victims to colonization and its consequences. ${ }^{1}$

But from the North Atlantic seas two species have disappeared within the lifetime of men who are not yet very old, and one of them was a truly British bird. This was the GARE-FowL, or Great Auk, Alca impennis, whose bones have been found in the kitchen-middens of Denmark, and afterwards in similar deposits in Caithness and Oronsay, and in a cave on the coast of Durham. This species seems to have become extinct since 1844, in which year the last two examples known to have lived were taken on a rocky islet-one of a group called Fuglaskér, or Fowl-skerries, off the south-west point of Iceland. Ten years before, one had been caught alive at the entrance of Waterford harbour; and in 1821 one was taken on the west side of St. Kilda, ${ }^{2}$ to which lonely island, as appears from old authors, the bird had been accustomed to resort in the breeding season. In 1811 and 1812 a pair were killed at Papa-IVestray, and the stuffed skin of the last of them is preserved in the British Museum, while that of the Waterford specimen may be seen in the museum of Trinity College, Dublin. In the Færoes the species was formerly common, but it certainly ceased from appearing there about the beginning of the present century. In the Iceland seas there are three localities called after the bird's name, but on only one of them has it been observed for many years, having probably been as long extirpated in the others as in the Froes. On the locality where it continued latest, there is ample evidence to shew that it once was plentiful. There was a large skerry-the Geirfuglaskér proper-on which, in 1813, the crew of a Froese vessel made a descent and slaughtered a large number of Gare-fowls; but this, like the rest of the group, was a place very difficult of access, and in 1821, Faber, the well-known faunist of Iceland, failed to land upon it, though some of his companions reached the Geirfugladrángr, a smaller islet lying further

1 For other instances of extermination, effected or threatened, in the Antilles, see note at p. $22 \pi$, infrù.

2 Another one seems to have been caught and killed on Stack an Armin, about 1840 , but the year is uncertain. In 1887 I saw the man who said he killed it. 
to seaward. In 1830 the large skerry, through a submarine volcanic eluption, disappeared beneath the waves, and immediately after a colony of Gare-fowls was discovered on another rock lying nearer the mainland, and known as Eldey. ${ }^{1}$ In the course of the next fourteen years, not fewer probably than sixty birds were killed on this newly-chosen station, and a nearly corresponding number of eggs were brought off ; but the colony gradually dwindled until, as above said, in 1844 the last two were taken (Ibis, 1861, p. 374).

In Greenland, for the last three hundred years, the Gare-fowl has only been known as an occasional straggler, but it would appear that in 1574 a party of Icelanders found it so plentiful at a spot on the east coast-since identified with Danell's or Graah's Islandsthat they loaded their boats with their captives. All recent explorations of this inhospitable coast prove the utter vanity of the notion that the Gare-fowl is able there to find an asylum.

But it was in the seas of Newfoundland that this species, known to the settlers and fishermen as the "Penguin," - a colruption of the words "pin-wing," - was most abundant, as a reference to Hakluyt's and similar collections of voyages will prove. In 1536 , or forty years after the discovery of the country, we find an island taking its name from the bird, and other's are even now so called. English and French mariners alike resorted to these spots, driving the helpless and hapless birds on sails or planls into a boat, "as many as shall lade her," and salting them for provision. The French crews, indeed, trusted so much to this supply of victual, as to take, it is said, but "small store of flesh with them." This practice, we learn from Cartwright (Joum. Labrad. iii. p. 55), was carried on even in 1785, and he then foresaw the speedy extippation of the birds, which at that time had only one island left to breed upon. In ${ }^{*}$ 819, Anspach reported their entire disappearance, but it is possible that some few yet lingered. On Funk Island, their last resort, rude inclosures of stones are, or recently were, still to be seen, in which the "Pin-wings" were impounded before slaughter; and a large quantity of their bones, and even natural mummies, preserved partly by the antiseptic property of the peat and partly by the icy subsoil, have been discovered. One of the last has furnished the chief materials from which the osteology of the species las been described (Trans. Zool. Soc. v. p. 317). ${ }^{2}$

Far less commonly known, but apparently quite as certain, is the doom of a large Duck which until 1842 or thereabouts was commonly found in summer about the mouth of the St. Lawrence

1 Whether on the subsidence of the large skerry another portion of the birds which frequented it colonized the outermost islet is not known, for this spot does not seem to have been visited by any naturalist since Faber's time.

2 The latest account of this locality and of the deposit of Penguins' bones thereon found is by Mr. Lucas (Rep. U.S. Nat. Mus. 1887-88, pp. 493-529). 
and the coast of Labrador, migrating in winter to the shores of Nova Scotia, New Brunswick, New England, and perhaps further southward. There is no proof, according to the best-informed American ornithologists, of a single example being met with for many years past in any of the markets of the United States, where formerly it was not at all uncommon at the proper season, and the last known to the present writer to have lived was killed by Col. Nedderburn in Halifax harbour in the autumn of $1852.1 \times$ This bird, the Anas labradoria of the older ornithologists, was nearly allied to the EIDERDuck, and like that species used to breed on rocky islets, where it

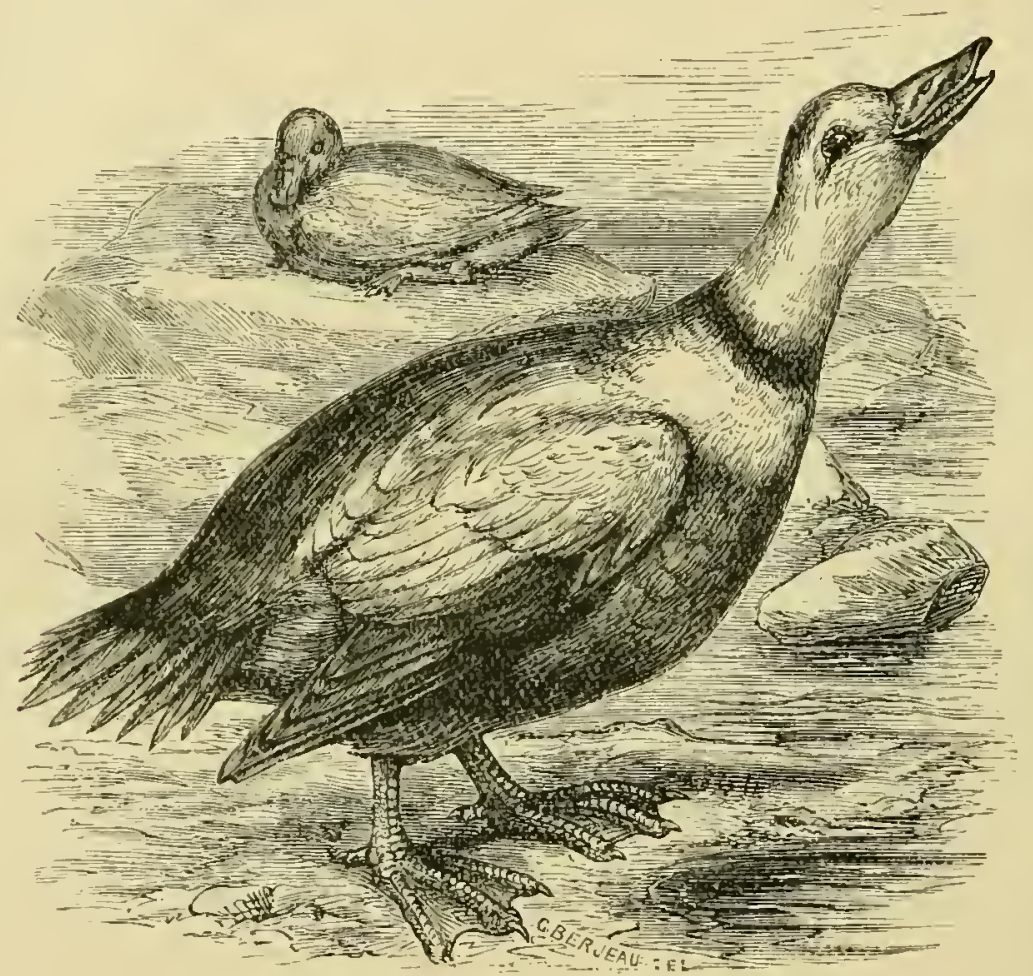

PLED Duch, Somateria Lubradoria, Male and Female.

${ }^{3}$ It is needless to observe that no one at that time had any notion of its approaching extinction. The skin of this example is in Canon Tristram's collection, its stermm, which was figured by Rowley (Orn. Miscell. p1. 205-223), is in the Cambridge Musenm. Mr. Dutcher (Auk, 1891, Pl. 208, 211) reports three specimens supposed to have been obtained between 1857 and 1861 ; but the information of the former owner of two of them points to an earlier time, and that respecting the third is somewhat vagne. Still more meertain are the rumours, though properly printed by him (p1.214, 215), of examples said to have been obtained in 1871 and 1878, but since lost. If they conld be recovered, a mistake wonld probalbly be found to have been made. Modern American authors profess their inability to explain the extirpation of this species. I have little doubt that the cause mentioned in the text and published by me in 1875 is the true one. The shooting down of nesting-birds, witnessed by Andubon when he was among the islands of the Labrador coast, and year by year carried on with increasing intensity, could jroduce no other result. 
was safe from the depredations of foxes and other carnivorous quaclrupeds. This safety was, however, unavailing when man begau yearly to visit its breeding-haunts, and, not content with plundering its nests, mercilessly to shoot the birds. Most of such islets are, of course, easily ransacked and depopulated. Having no asylum to turn to, for the shores of the mainland were infested by the fourfooted enemies just mentioned, and (unlike some of its congeners) it had not a high northern range, its fate is easily understood. Some thirty-eight specimens are computed to exist in museums.

A very similar case is that of the largest known species of

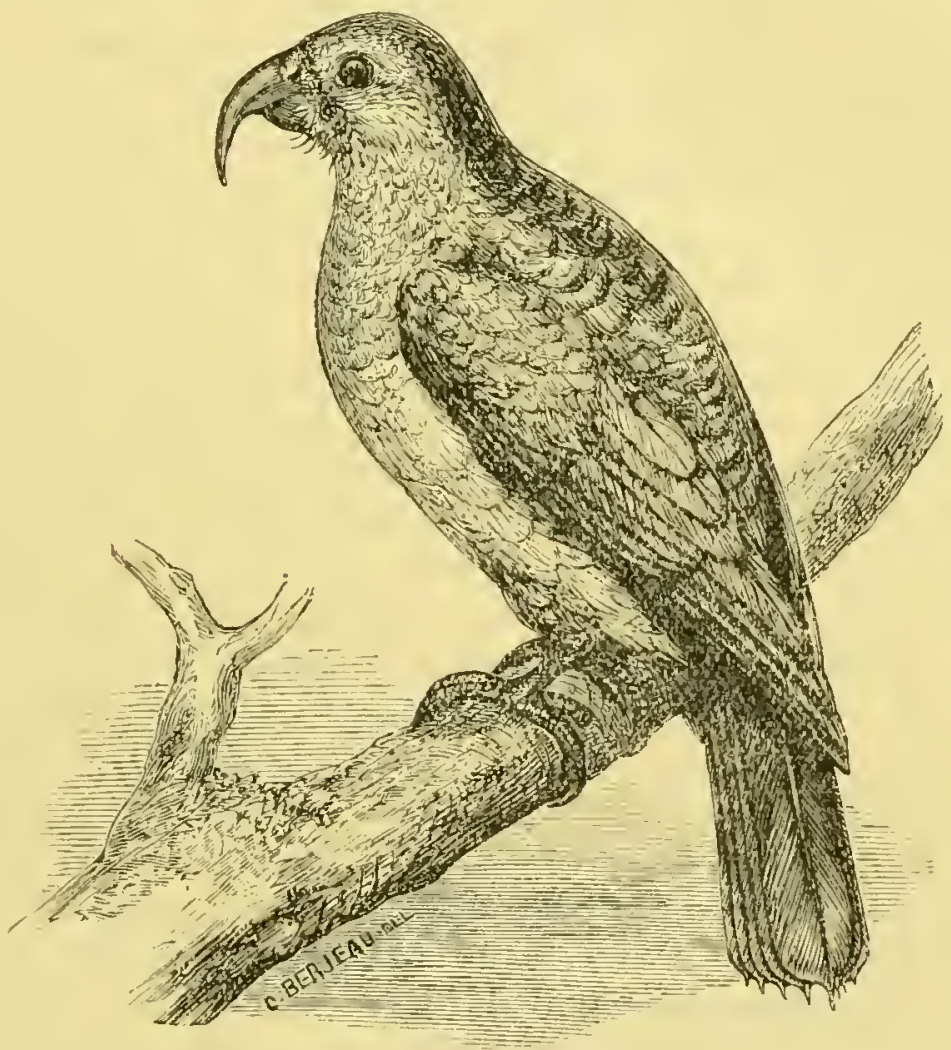

Phillip-Island Parrot, Nestor productus.

Conmonane, Phalacrocorar perspicillutus, which in 1882 Dr. Stejneger learned from the natives of Bering Island in the North Pacific had become extinct some thirty year's before, having previously been abundant there. It is said to have been killed for food, and thus its fate is identical with that of its better known countryman, Steller's Manatee, Phytina gigas. Four skins and a few bones are all that remain of this fine birct. (Proc. U.S. Nat. MTus. vi. p. 65, xii. pp. 83-94; Bull. U.S. Nat. Mrus. No. 29, pp. 180, 181.)

Another bird which became extinct about the middle of this century is one of a group of Parrots (Nestor) peculiar to the NewZealand Region, and though some of its congeners still exist in the less-frequented and alpine parts of that country, this species, 
N. productus, seems to have been confined to Phillip Island. 'The last known to have lived, according to information supplied to the present writer by Gould, was seen by that gentleman in a cage in London about the year 1851. Not many more than a dozen specimens are believed to exist in collections.

In respect of Extermination leading immediately to Extinction, the present condition of the New-Zealand Fauna is one that must grieve to the utmost every ornithologist who cares for more than the stuffed skin of a bird on a shelf. In the Fauna of that Region the Class Ares holds the lighest rank ${ }^{2}$ (GEOGRAPHICAL Distribution), and though its mightiest members (MOA) had passed away before the settlement of white men, what was left of its Avifanna had features of interest unsurpassed by any others. It was indeed long before these features were appreciated, and then by but few ornithologists, yet no sooner was their value recognized than it was found that nearly all of their possessors were rapidly expiring, and the destruction of the original Avifauma of this important colony, so thriving and so intellectual, is being attended by circumstances of extraordinary atrocity. Under the evil influence of what was some thirty" years ago called "Acclimatization," not only were all sorts of birds introduced, which being of strong species speedily established themselves ${ }^{2}$ with the usual effect on the weal aboriginals, but in an evil day Rabbits were liberated. These, as was anticipated by zoologists, soon became numerous beyond measure and devoured the pasture destined for the Sheep, on which so much of the prosperity of the country depended. Allowing for a considerable amount of exaggeration on the part of the Sheep-owners, no one can doubt that the Rabbit-plague has inflicted a serious loss on the colony. Yet a remedy may be worse than a disease, and the so-called remedy applied in this case has been of a kind that every true naturalist knew to be most foolish, namely the importation from England and elsewhere and liberation of divers carnivorous Mammals ${ }^{3}$ - Polecats or Ferrets, Stoats, and Weasels! Two wrongs do not make a right even at the Antipodes, and from the most authentic reports it seems, as any zoologist of common sense would have

1 The various reports of an indigenous Mammal, to which some writers have attached importance, seem to be all due to misconception on the part of persons who did not know how very like a quadruped a Krwi or a WEKA can look when thick herbage or broken ground hinders a clear view.

2 Sir Walter Buller has told me that within some miles of the larger towns not a single native species of bird is now to be seen, while foreigners abound.

${ }^{3}$ Unhappily when the idea of sending out these predacious creatures was first promulgated, it was encouraged by one who passed in England for a great naturalist. Well-informed persons knew better, but their warnings wero sliglited. 
expected, that the bloodthirsty beasts make no greater impression upon the stock of Rabbits in New Zealand than they do in the mother-country, while they find an easy prey in the heedless and harmless members of the aboriginal Fauna, many of whom are incapable of flight, so that their days are assuredly numbered. Wrere these indigenous forms of an ordinary kind, their extirpation might be regarded with some degree of indifference; but unfortunately many of them are extraordinary forms-the relics of perhaps the oldest Fauna now living. Opportunities for learning the lesson they teach have been but scant, and they are vanishing before our eyes ere that lesson can be learnt. Assuredly the scientific naturalist of another generation, especially if he be of Ner-Zealand birth, will brand with infamy the short-sighted folly, begotten of greed, which will have deprived him of interpreting some of the great secrets of Nature, while utterly failing to put an end to the nuisance-admittedly a great one. ${ }^{1}$

Another noticeable case though free from the culpable blindness just recounted is that which is offered by the Sandwich Islands, where it appears that several of the land-birds are actually extinct, while many more are doomed to disappear within a very few years. In this instance the reasons assigned are the destruction of the indigenous Flora, effected directly on the lowlands by cultivation of sugar-canes and other plants, and on the forestcovered hills by the large stock of horned cattle which not only destroy the existing brushwood but check the growth of young trees to replace the elders that yet stand. Of the species of birds known to be extinct one, however, has met its fate from a different cause. This is the Mamo (DrkPanis), whose beautiful feathers, as elsewhere stated, have led to its extirpation; but no such cause can be assigned for the extinction (of which the writer is assured) of a plain-coloured bird like Chatoptila angustipluma, of which perhaps not more than three or four specimens have been preserved, or some other species that a recent collector has been unable to find.

An instance of apparent extinction more unaccountable than the last named is that of the bird described and figured by Latham (Gen. Synops. Birds, iii. p. 172, pl. 82) under the name of Whitewinged Sandpiper, as having been found on Cook's last voyage on the islands of Tahiti and Eimeo, where it seems to have been not uncommon. Though it has been often sought no specimen seems to have been obtained since, and indeed the only one known is in the Museum at Leyden. Placed by Bonaparte in a separate genus Prosobonia, it was supposed by him to belong to the Ralliclix; but

1 The provoking part of the thing is that as shewn by Mr. Sclater (Nature xxxix. p. 493) there exists a way, the discovery of Mr. Rodier, at once simple, natural, and efficacious of reducing the Rabbit-pest. 
more recent writers refer it as Latham did to the Scolopacidx. Its rediscovery, should it still survive, would therefore be of some interest, and it is just possible that the localities for it are erroneously given.

From birds which have recently become altogether extinct we naturally turn to those that have of late been exterminated in certain countries though still surviving elsewhere. Several such instances are furnished by the British Islands. First there is the Crave which in Turner's time (1544) was described as breeding in om fens. Then the Spoonbill, said by Sir Thomas Browne (1688) to breed in Suffolk, as it formerly had done in Norfolk and shewn by Mr. Harting (Zoologist, 1877, p. $425 ; 1886$, p. 811) to have inciently had breeding-stations in Sussex and in Middlesex. The CAPERCalLy, we know to have frequented the indigenous pineforests of Ireland and Scotland. In the former it had most likely become extinct soon after 1760 , and in the latter not much later. Not a single specimen of the British stock of this bird is known to exist in any museum, but the species has been successfully introduced from Sweden into Scotland during the last forty years, and is now certainly increasing in numbers. The BustarD, which ouce tenanted the downs and open country of England from Dorset to the East Riding of Yorkshire, vanished from Norfolk, its last stronghold as a British Bird, in 1838. From other counties it had before disappeared. It is worthy of note that three of the four species just mentioned were protected to a certain degree by Acts of Parliament, but these laws only gave immunity to their eggs and zone to the parent-birds during the breeding-season, thus shewing how futile is protection to the former when compared with the safety of the latter, since there are very many species whose nests from time ont of mind have been and are yearly pillaged without any disastrous consequences arising from the practice. ${ }^{1}$

It would be impossible here to name the many Birds which, once numerous in the British Islands, have now so much diminished as to be rightly considered scarce, or to recount the various canses to which their diminution is due. The persecution of Birds-of-Prey seems to have begun with the keepers of poultry, to whom the KITE, and the Hen-HARrIEr, Circus cyaneus, were a sore trouble, ${ }^{2}$ but it has been actively followed up by game-

1 The singular wisdom of the old command (Dent. xxii. 6)-the most ancient "game-law" (using the term in its widest sense) in existence-has here a curious exemplification.

2 Schaschelr, a Bohemian who visited England about 1161, says he had nowhere seen so many Kites as around London Bridge (Bibl. Lit. Ver. Stuttgart, vii. p. 40). And the statement is confirmed by Belon, who in the later editions of his Obserrationes (book ii. chap. xxxri. note) says that they were scarcely more numerons in Cairo than in London, feeling on the garbage of the streets 
preservers, and this to their own cost, as the ravages of the Grouse-disease testify. ${ }^{1}$ To the reclaining of waste lands, the enclosure of open spaces, and the greater care bestowed on timber trees (by removing those that being decayed are much infested with insects) must, however, be attributed the extermination or rarification of far more species than the direct action of man has been able to effect. ${ }^{2}$ Still what we lose in one direction we gain in another, and while Birds-of-Prey and Wild-fowl are being banished, the smaller denizens of the woodlands, gardens, and arable fields are unquestionably more numerous than ever. ${ }^{3}$ The change is, of course, not satisfactory to the naturalist or to the lover of wild scenery, but to some extent it seems inevitable; yet well-directed laws for the protection of those birds which suffer worst in the unequal contest may delay their impending fate, and preserve to our posterity the most pleasing features of many a landscape and the grateful opportunities of studying many a curious and interesting species. Thanks, perhaps, to the stronger constitution of most Palaarctic birds, the votaries of "acclimatization" have obtained little success in these islands, for the exotic species which it has been attempting to introduce have, almost without exception, failed to establish themselves. The efforts made in some British colonies ${ }^{4}$ - especially in Australasia, apart from the sinfulness already mentioned in regard to the Rabbitplague-are unfortunately too likely not to be successful; and, when their own peculiar Fanna has been half extirpated, our fellowsubjects at the Antipodes will probably have good reason to lament and even of the Thames. From the same writer (Hist. Nat. Oyseaux, p. 131) it would seem that at that time (1555) they, and Ravens also, were protected by law in the City! The Hen-Harrier's name is enough to shew what was thought of it in days when it abounded.

1 In Transbaikalia, the Bearded Vulture, Gypaetus burbatus, which was formerly common, has of late been completely exterminated, through persecution prompted by the desire to obtain its feathers, which are highly valued. - Von ILiddendorfi, Sibir. Reise, iv. p. 851.

2 The extermination from Europe of the Franconin, Francolinus vulycris, has been treated at some length by Lord Lilford (Ibis, 1862, p. 352) without his being able to assign any cause for the fact.

3 Report from the Select Committee on Wild Birds' Protection, de. (House of Commons), 1878. Appendix, pp. 188-193.

${ }^{4}$ Unintentionally, it would seem, a carnivorous Mirsupial has been introduced into the island of Dominica and there appears to have extirpated one of the PETRELs which formerly bred numeronsly in the mountains, where it was called the "Diablotin" and is known to have been Estrelata hresitata (cf. Feillen, Trans. Norf. Norw. Nat. Soc. v. Pp. 24-39). The intentional introduction of the Mongoose is said to be likely to effect the destruction there of the allied species $\mathscr{E}$. jamaicensis. It has already greatly diminished the numbers of "John-Crow" VuLtures, by the destruction of their eggs ol young, for the nests are placed on the ground. 
the extraordinary sentiment that has led them to introduce from other countries birds which, in the absence of their natural checks, will be nothing else than a positive nuisance; for so reckless is the manner in which they have been imported, that species possessing few or exceedingly doubtful recommendations to begin with have been carried over in abundance, and some of these cannot fail to become permanent settlers equally with those for the transportation of which the would-be "acclimatizers" might find themselves excused. All, however, in the battle of life will contribute first to the subdual and by degrees to the disappearance of the original inhabitants, which had hitherto constituted a Fauna, from a scientific point of view, perhaps the most interesting on the face of the globe.

One other cause which threatens the existence of many species of birds, if it has not already produced the extermination of some, is the rage for wearing their feathers that now and again seizes civilized women who take their ideas of dress from interested milliners of both sexes-persons who, having bought a large stock of what are known as "plumes," proceed to make a profit by declaring them to be "in fashion." The tender-hearted ladies who buy them little suspect that some of the large supplies required by the "plume-trade" are chiefly got by laying waste the homes of birds that breed in society, and that at their very breedingtime. The slaughter which formerly took place at many of the chief resorts of sea-birds on the British coasts was fortunately checked by Act of Parliament in 1869 ; but the infamous practice is still to some extent surreptitiously followed in secluded places (and they are not so few in number) where it can be pursued with impunity. However, no havoc in these islands approaches that which is perpetrated in some other countries, especially, it is surmised, in India - though there now contrary to law; and the account of the ravages of a party of "bird-plumers" at the breeding-stations on the coast of Florida, given by Mr. W. E. D. Scott, ${ }^{1}$ who in former years had seen them thronged by a peaceful population, is simply sickening. All efforts to awaken the conscience of those who tacitly encourage this detestable devastation, and thereby share in its guilt, have hitherto failed, and unless laws to stop it be not only passed but enforced it will go on till it ceases for want of victims-which indeed may happen very shortly. Then milliners

1 Auk, 1887, pp. 135-144, 213-222, 273-284; 1888, p. 128. This series of papers is the more valuable because Mr. Scott records what he saw and learnt on the spot in the calmest language. Did we not know what his feelings were, one might, in reading lis terrible narrative, lose patience with him for not expressing more strongly his detestation of the barbarities he recounts. But his abstention is doubtless attributable to the fact that his narrative appears in a strictly scientific journal, where sentimental expressions would be out of place. 
will doubtless find that artificial feathers can be made, even as artificial flowers now are, and there will be a fine opening for the ingenious inventor. The pity is that he does not at once begin.

EYE. The eyeball of Birds is far less globular than that of Mammals, resembling rather the tube of a short and thick operaglass. It consists externally of three successive portions. A basal or posterior, an intermediate, and an anterior portion. The wall of the anterior portion is formed by the transparent cornea, and is more strongly curved than that of the basal portion, which like the intermediate portion is formed by the white and opaque sclera. Within the walls of the sclera exists cartilage with occasional ossifications. Such an ossification, the posterior sclerotic ling, surrounds in many birds, especially in the Pici and in the Passeres, the entrance of the optic nerve. Nearly all birds possess an anterior sclerotic ring which is composed of from 10 to 17 , generally from 13 to 15 , bony scales which overlap each other in varions ways, and form the somewhat conical intermediate or connecting portion of the walls of the eye.

The onter surface of the cornea is covered by the likewise quite transparent conjunctiva, a continuation of the mucous membrane lining the inside of the eyelids. The inner surface of the cornea is covered by the "membrana Descemeti," a structureless film which seems to be the continuation of the chorioid membrane.

The inner surface of the sclerotic wall is covered by the chorioid membrane, a thin membrane, which is rich in blood-vessels and is dark or black owing to the number of pigment-cells. It is morphologically the continuation of the pia mater or innermost sheath of the optic nerve, which enters the middle of the posterior segment of the eye and then spreads itself out as the retina upon the inner surface of the chorioid membrane. The latter is consequently situated between the sclera and the retina. Level with the junction of the cornea and the sclera, i.e. at the anterior margin of the intermediate portion of the eye, the chorioid membrane leaves the wall of the eye by turning away at a right angle and hanging like a circular curtain, the iris, over the anterior surface of the lens, into the anterior chamber of the eye. The central hole in this diaphragma-like curtain is the pupil. The iris is a thin plate of connective tissue; its hinder surface is covered like the chorioid with a layer of black pigment, while its anterior side is coloured in various ways, either by pigment corpuscles or by coloured drops of fat. Often beautifully bright, it adds much to the expression of birds; it is, for instance, vividly yellow in Lamprocolius, Botaurus, and Picus martius; red in Chrysotis and in Nycticorax; green in the Cormorant; white in the Grey Parrot and in Harelda; grey in Balearica paronina and in Fratercula; bluish in Cypselus; black in Cacatua, and so on. In most young birds the colour of the iris is, 
however, brown, and attains brighter tints with maturity occasionally in the male only : for instance, yellow in the males of Ploceus, but

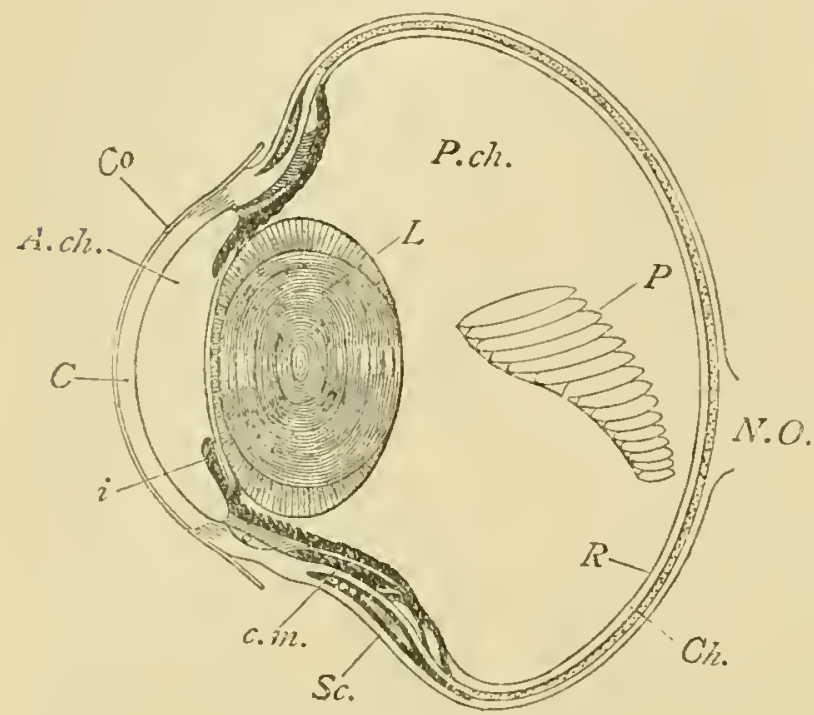

Horizontal Section throvgh the Eye of a Biri-of-

Prey. About twice the natural size. (After H. Müller.)

A.ch. Anterior chamber; P.ch. Posterior cliamber; $C$, Cornea; Ch. Chorioid; Co, Conjunetiva; c.m. Crampton's muscle; $i$, Iris: $L$, Lens; P, Pecten; N.O. Optic nerve ; $R$, Retina; Sc. Sclerotic, witl embedded osseous ring. brown in the females: greyish-brown in the females and young of the Golden Oriole, and carmine-red in the old males. ${ }^{1}$

The iris contains a sphincter and a dilator muscle. The sphincter' consists of concentrical fibres which constitute a considerable portion of the whole iris, while the fibres of the dilator are arranged in a radiating way. Those of the former are supplied by branches from the oculomotory or third pair of clanial nerves, and are in Birds, in opposition to the Nammalia, under the control of the will. The dilator muscle is supplied by sympathetic nerve fibres. Both sorts of nerve fibres enter the posterior wall of the eye, ascend between the chorioid and sclera, and supply these parts together with the iris and the ciliary muscle. The shape of the pupil, when fully dilated, is round in all birds; when partly contracted it is either likewise round in most birds, or obliquely oval as in some Gallinæi.

The corpus ciliare is that part of the chorioid wlich covers the

1 Tumerous notes concerning the colour of the iris in reference to age and sex have been published by Th. A. Bruhin in Zoolog. Garten, 1870, 11. 290-295. A curious observation by the late Mr. J. H. Gurney is recorded in Mr. Southwell's continuation of Stevenson's Birds of Norfolk. (iii. 1\%. 20T). On removing a living male Pochard (Fuligula ferina) from one pond to another, while the bird was lield in the hand the ordinary cherry-colour of its irides was seen to be replaced by yellow, hardly, if at all, tinged with red. When this bird was released, the normal colour was gradually but speedily resumed. In this speeies it will be remembered the red iris is peculiar to the male, that of the female being of a dark brown.

The four nearly-allied species of the genus Hypsipetes inhaliting Madagasear and the Mascarene Islands differ, according to the observation of Sir Edward Newton (Orn. Misecll. ii. 11.52, pl. xlii.), in the colour of their irides, which in $H$. madagascaricnsis are bright red, in $H$. Zorbonicus whitish, in $H$. otivaceus (of Mauritins) orange, and in $H$. crassirostris (from the Seychelles) dark red. 
anterior sclerotic ring; it is thrown into numerous radiating folds, and immediately behind the base of the iris surrounds the margin of the lens, which it connects through the ligamentum pectinatum with the anterior margin of the sclerotic ring, and thus holds the lens in position.

The ciliary muscle is of importance for the accommodation of the eye to varying distances. It consists of numerous striated or voluntary muscular fibres, which are situated partly within the corpus ciliare. The whole muscle consists of several portions. The anterior" one, "Crampton's muscle," arises from the anterior maron of the sclerotic ring and is inserted upon a small circular ridge of the cornea. The chief portion, "Müller's muscle," extends from the same ridge backwards into the chorioid; other fibres likewise arising from this ridge pass into the ligamentum pectinatum. The mechanism of the accommodation of the eye is very complicated; it amounts to this that it can be most rapidly adjusted to different distances, not through a change in the convexity of the cornea or through a forward or backward motion of the lens, but through a change in the convexity of the lens itself.

The pecten, comb or fan of the eye, is a peculiar lamclla of the chorioid which projects from the entrance of the optic nerve far into the posterior chamber of the eye. It is present, so far as known, in all birds except Apteryx, and is a wedge-like or rhomboid, deeply-pigmented black lamella, which is thrown into a variable number of folds. The number of these folds ( 3 in Caprimulgus, 4 in Dromæus, 14 to 20 in Struthio, 20-30 in Crows) varies in closely-allied birds, and is of no systematic value. The use of this organ, which is absent in Mammals and most Reptiles, is not the screening off of light, but the vascular supply or alimentation of the vitreous humor.

The lens is a biconvex absolutely colourless and transparent body of considerable refractory power. Its broad diameter amounts to about $1 \cdot 3$ of its axis; the anterior surface is more convex than the posterior; the lens is composed of numerous mostly concentrically-arranged layers.

The lens, being held in position by the ligamentum pectinatum of the corpus ciliare, divides the whole of the inner space of the eye into an anterior and a posterior chamber. The anterior chamber is filled with the colourless aqueous humor, while the vitreous humor, which fills the posterior larger chamber, is of a more gelatinous but likewise colourless consistency.

The retina is a thin expansion of the optic nerve over the inner surface of the chorioid membrane, and extends over the posterior or basal portion of the eye, ending at the beginning of the cilia:'y body. The retinal membrane is scarcely 0.3 of a millimetre in thickness, and is, as continuation of the optic nerve, composed of 
nerve fibres, with the addition of intercalated ganglionic cells, each fibre ending either as a "cone" or as a "rod." Both, cones and rods, look, however, ontwards, i.e. away from the inside of the eye, being inserted into the pigment layer of the chorioidea.

The retina is transparent, devoid of blood-vessels, and, except certain cones, colourless. It consists of the following nine layers:-

1. Membrana limitans interna, an extremely thin colourless

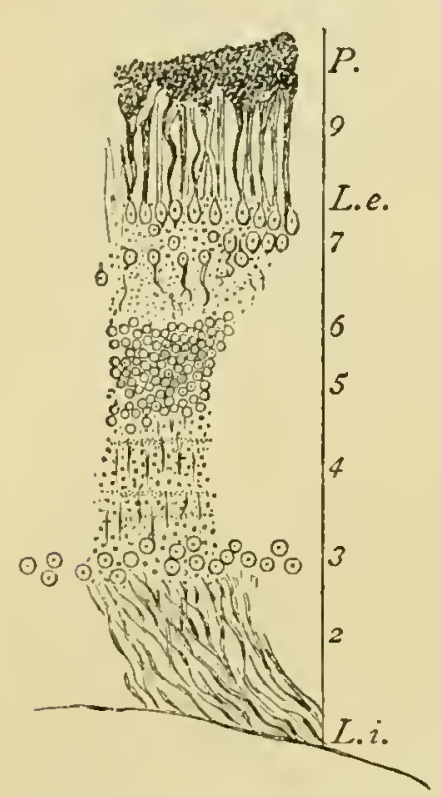

Vertical Section throvgh THE RETINA OF A SPARROW. Highly magnified.

L.e. Membrana limitans externa, perforated at its base by the rods and cones; $L . i$. Membrana limitans interna; $P$. Black pigment on the top of the rods and cones (9); 9 , Layer of the fibres of the optic nerve; $3,5,7$, Inner, midrle, and outer ganglionic layers; 4, 6 , Inner and outer molecular layers. membrane, which separates the retina from the corpus vitreum, and sends out fine radial fibres between the retinal fibres.

2. Layer of the optic fibres; they enter the eye at the fovea crea, or blind spot, indicated by a small funnel-shaped depression in the middle of the optic nerve, whence they spread out at right angles; the fibres nearly lose their myelin sheaths, and consist chiefly of thin axial cylinders.

3. Layer of inner ganglionic cells, intercalated into the axial cylinder's.

4. Inner molecular or gramular layer, a molecular substance, penetrated by the nerve fibres.

5. Middle ganglionic layer, consisting of small cells which comnect the 3rd with the Tth layer.

6. Outer molecular or gramular layer.

7. Outer ganglionic layer, consisting of bipolar cells, contimed through

8. Membrana limitans externa, a colourless membrane, into

9. A layer of cones and rods; these elongated cylindrical bodies are the real light-perceiving end-organs of the optic nerve fibres. Into each of the bodies is intercalated a small lens-like body which possesses a higher refractory power than the surrounding parts. The cones contain drops of fat, mostly red or yellow in colom.

Near the posterior pole of the eye, but somewhat cxcentrically placed, is the foved centralis (the "yellow spot" of Mammals), a slight depression in the retina, and composed chiefly of cones; it is the spot of most acute visuality. Many birds possess a second fovea more towards the outer or temporal side of the eye. One pair of these fovere seems to be used for monocular the other for binocular sight, so that the whole field of vision of birds possesses three points where vision is most acute. 
The muscles of the eyeball and of the third eyelid are 8 in number, of which 6 serve to move the eyeball. Four recti, viz. superior, inferior, internus, and externus arise from the orbit in the vicinity of the optic nerve; the first three are innervated by the
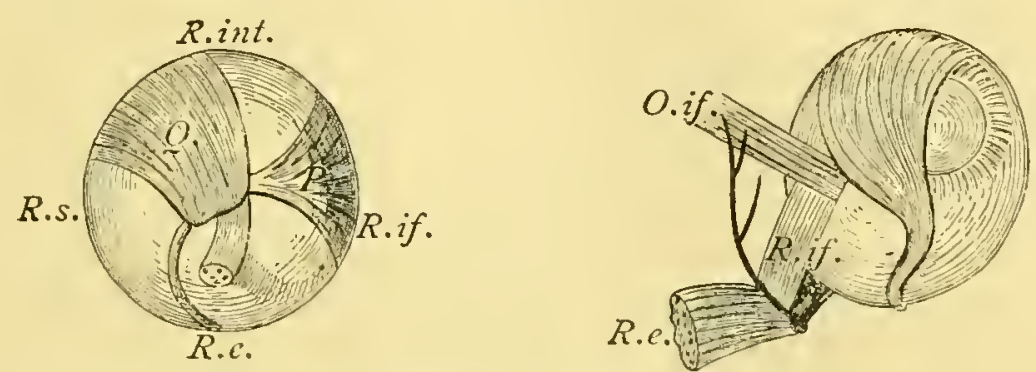

Left Eye of the Conjon Fow from Front and BeHind.

O.if. Musculus obliquus inferior; R.if. R.int. R.s. R.e. M. rectus inferior, internns, superior, and externus; $Q$. M. quadratus ; $P$. M. pyramiclalis.

1. oculomotorius or 3rd cranial nerve, and the externus by the $n$. abducens, or 6 th cranial nerve.

The m. obliquus superior arises from the ethmoidal margin of the orbit, passes between the olfactory and the first branch of the trigeminal nerve, is supplied by the $n$. trochlearis or 4 th cranial nerve, and is inserted upon the upper and inner side of the eyeball.

The m. obliquus inferior arises below the optic nerve, and is inserted laterally from the inferior' rectus; it is supplied by the $3 \mathrm{rd}$ cranial nerve.

The nictitating membrane is moved by two muscles, both of which are innervated by the 6 th cranial nerve. The m. quadratus is a trapezoid muscle, arising with a broad base from the hinder surface of the eyeball, and forming with its narrow margin, which is clirected towards the optic nerve, a pulley for the long tendon of the m. pyramidalis. The latter arises from the nasal or median surface of the eyeball, passes into a tendon, which runs above the optic nerve through the pulley and groes over on the anterior side of the eye into the nictitating mem-

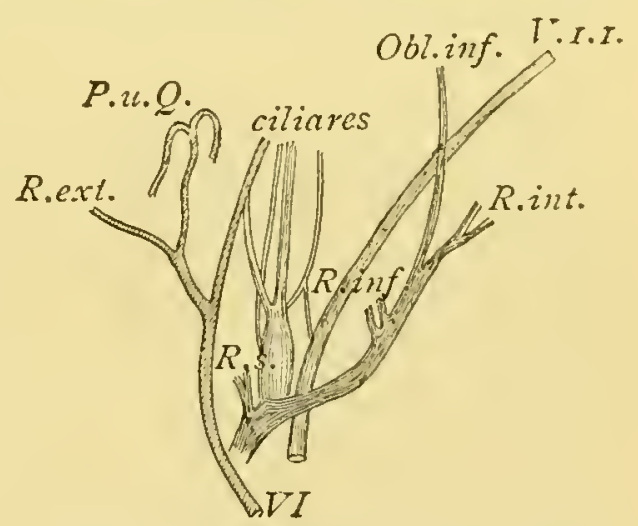

Vextral View of the Nerves of the Left Exeball of Rhea ainericana.

$V .1 .1$. First braneh of nervus trigeminus: IT, Nervus abulucens, innervating the musculus rectus externus, m. pyramiclalis, and in. quadratus; R.s. R.inf. R.int. Oul. inf. Branches of the nervus oculomotorius (see Brain); ciliares, Ciliary nerves supplying the internal muscles of the eye, e.g. Crampton's muscle:-the swelling at the ront of these nerves is the eiliary ganglion.

brane. The latter is a transparent, slightly whitish membrane, which arises with a broad base from the upper onter margin of the eye as a duplication of the conjunctiva. Contraction of the pyra- 
midal muscle pulls the nictitating membrane obliquely over the anterior surface of the eye, from the outer lower towards the upper inner angle. Contraction of the quadrate muscle adjusts this motion, and at the same time prevents pressure of the optic nerve. During relaxation of the muscles the nictitating membrane withdraws through its own elasticity.

The upper and lower eyelids are simply folds of the skin, being attached to the orbital margins and hanging over the eye. The outer surface of these lids is sometimes covered with fine down-like feathers, as in Sula, more frequently, however, it is naked. The margins of the lids carry sometimes rudimentary feathers without barbs; such eyelashes being especially well developed in the Ostrich, the Amazon Parrots, in the Hornbills, and Crotophaga. The inner' surface of the lids is transformed into a sort of mucous membrane, and is continuous with the conjunctiva. In most birds only the lower eyelid is movable, and contains frequently a rather large saucel-shaped cartilage, the so-called "tarsus palpebralis"; the latter" is large in Ratitæ, Birds-of-Prey, and Gallinæ; but is absent in Parrots. The eyelids are moved by a circular sphincter, a levator, and a depressor muscle, which partly arise from the walls of the orbit, and are supplied by the oculomotor and trigeminal nerves. In all birds the margins of the upper and lower eyelids are fused together during the greater part of their embryonic stage. The lids become separated either shortly before the bird is hatched, as is the case in most Nidifugæ, or the blind condition prevails during a longer or shorter time in the young Nidicolæ.

Glands of the eye. The surface of the cornea is kept moist and bathed by the secretions of two glands situated within the orbit.

The lacrymal gland rests as a mostly small roundish and reddish body upon each eyeball near the outer or hinder corner of the eye, and opens upon the inmer wall of the eyelids through a small slit; the secretion, the tears spread over the cornea, and are collected near the inner corner of the eye through two slits into the wide naso-lacrymal canal, which, situated below the skin and between the lacrymal and nasal bones, opens into the nasal cavity immediately above the choanæ or inmer nares.

Besides these lacrymal and the NAsAL glands (q.v.) birds possess a pair of so-called Harderian glands, which produce a slimy fluid, which escapes below the nictitating membrane at the inner corner of the eyc. This gland is yellowish white, always placed within the orbit upon the median and upper surface of the eyeball, and is of an irregular, often considerable size. 


\section{F}

FALCON (Latin, Falco; ${ }^{1}$ French, Faucon; Teutonic, Falk or Valken), a word now restricted to the high-couraged and long-winged Birds-of-Prey which take their quarry as it moves; but formerly it had a very different meaning, being by the naturalists of the last and even of the present century extended to a great number of birds comprised in the genus Falco of Linnæus and writers of his day, ${ }^{2}$ while, on the other hand, by falconers, it was, and still is, technically limited to the female of the birds employed by them in their rocation, whether "long-winged" and therefore "noble," or" "short-winged" and "ignoble."

According to modern usage, the majority of the Falcons, in the sense first given, may be separated into five very distinct groups: -(1) the Falcons pure and simple (Falco proper); (2) the large northern Falcons (Hierofalco, Cuvier); (3) the "Desert Falcons" (Gennea, Kaup); (4) the MerLins (AEsalon, Kaup); and (5) the HoBBIEs (Hypotrionchis, Boie). The precise order in which these should be ranked need not concern us here, but it must be mentioned that a sixth group, the KEsTreLs (Tinnunculus, Vieillot), is often added to them. This, however, appears to be justifiably reckoned a distinct genus, and its consideration may for the present be deferred.

The typical Falcon is by common consent allowed to be that cosmopolitan species to which unfortunately the English epithet "peregrine" (i.e. strange or wandering) has been attached. It is the Fulco peregrinus of Tunstall (1771) and of most recent ornithologists, though some ${ }^{3}$ prefer the specific name communis applied by J. F. Gmelin a few years later (1788) to a bird which, if his diagnosis be correct, could not have been a true Falcon at all, since it had yellow irides - a colour never met with in the eyes of any bird now 1 The earliest use of this word, which is unknown to classical writers, is $\mathrm{Cf}$. Corrigen
said to be by Servius Honoratus (circa $390-480$ A.D.) in his notes on E En. lib. $x$. vers. 145. It seems possibly to be the Latinized form of the Teutonic Falk, though falx is commonly accounted its root.

2 The nomenclature of nearly all the older writers on this point is extremely confused, and the attempt to unravel it would hardly repay the trouble, and would undonbtedly occupy more space than could here be allowed. What many of them, even so lately as Pennant's time, termed the "Gentle Falcon" is certainly the bird we now call the Gos-Hawn (i.c. Goose-Hawk), which name itself may have been transferred to the Astur patumbarius of modern ornithologists, from one of the long-winged Birds-of-Prey.

${ }^{3}$ Among them Dr. Sharpe, who, in the first volume of the Catalogue of the Birds in the British Mrseum, has besides rejected much of the evidence that the experience of those who have devoted years of study to the Falcons has supplied. 
called by naturalists a "Falcon." This species inhabits suitable localities thronghout the greater part of the globe, though examples from North America have by some received specific recognition as F. anatum-the "Duck-Hawk," and those from Australia have been described as distinct under the name of $F$. melanogenys. Here, as

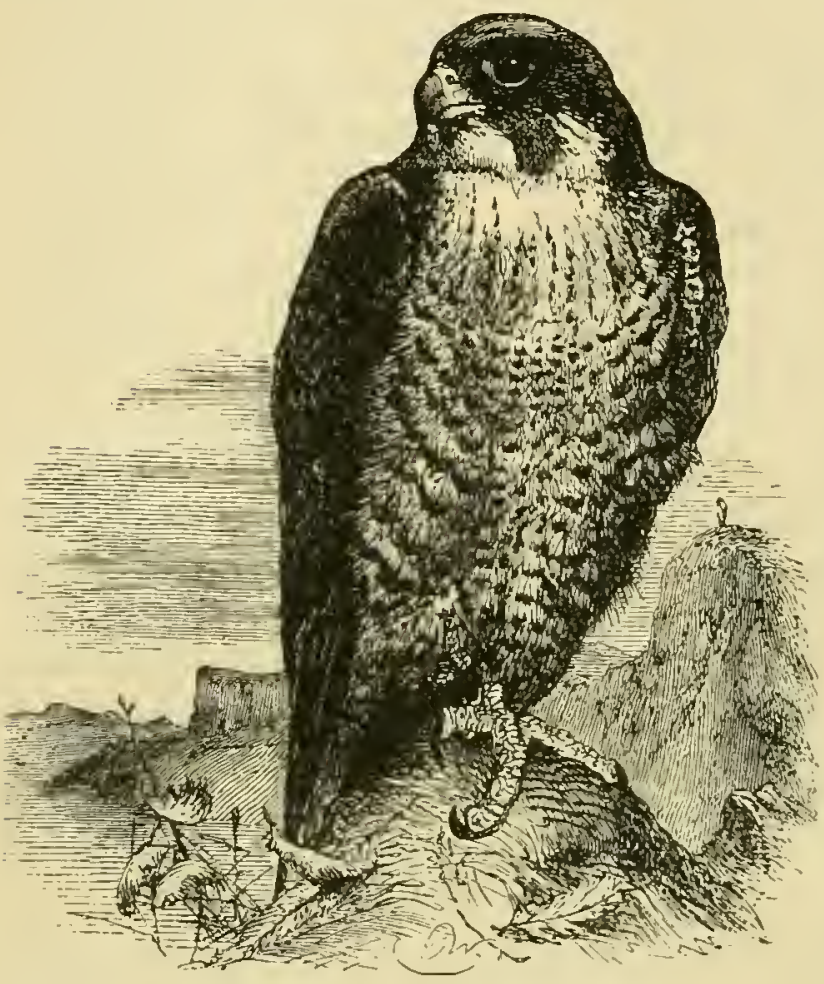

Peregrine Falcos. (After Wolf.) in so many other cases, it is almost impossible to decide as to which forms should, and which should not, be accounted merely local races. In size not surpassing a Raven, this Falcon is perhaps the most powerful Bird-ofPrey for its bulk that flies, and its comrage is not less than its power. It is the species, in Europe, most commonly trained for the sport of hawking. Volumes have been written upon it, and to attempt a complete account of it is, within the limits now available, impossible. The plumage of the adult is generally blackish-blue above, and white, with a more or less deep cream-coloured tinge, beneath-the lower parts, except the chin and throat, being barred transversely with black, while a black patch extends from the bill to the ear-coverts, and descends on either side beneath the mandible. The young have the upper parts deep blackish-brown, and the lower white, more or less strongly tinged with ochraceous-brown, and striped longitudinally with blackish-brown. From Port Kennedy, the most northern part of the American continent, to Tasmania, and from the shores of the Sea of Ochotsk to Mendoza in the Argentine territory, there is scarcely a country in which this Falcon has not been found. Specimens have been received from the Cape of Good Hope, and it is only a question of the technical differentiation of species, whether it does not extend to Cape Horn. Fearless as it is, and adapting itself to almost every circumstance, it will place its eyry as equally on sea-washed cliffs, craggy mountains, or (though more rarely) the drier spots of a marsh in the northern hemispliere, as on trees (says Schlegel) in the forests of Java, or in the waterless ravines of Aus- 
tralia. In the United Kingdom it was formerly very common, and hardly a high rock from the Shetlands to the Isle of Wight but had a pair as its tenants. But the British gamelieeper has long held the mistaken faith that it is his worst foe, and the number of pairs which are now allowed to rear their brood ummolested in these islands must be small indeed. Yet its utility to the gamepreserver, by destroying those of his precious wards that shew any sign of infirmity, can hardly be questioned by reason, and no one has more earnestly urged its claims to protection than Mr. G. E. Freeman (Falconry \&c. p. 10). ' Nearly allied to this Falcon are several species of which it is impossible here to treat at length, such as $F$. barbarus of Mauritania, $F$. minor of South Africa, the Asiatic F. babylonicus, F. peregrinator of India-the "Shaheen," and perhaps $F$. cassini of South America, with some others.

Next to the typical Falcon comes a group known as the "great northern" Falcons (Hierofalco). Of these the most remarliable is the Gyrfalcon, $F$. gyrfalco, whose lome is in the Scandinavian mountains, though the young are yearly visitants to the plains of Holland and Germany. In plumage it very much resembles $F$. peregrinus, but its flanks have generally a bluer tinge, and its superiority in size is at once manifest. Nearly allied to it is the Icelander, $F$. islandus, which externally differs in its paler colouring, and in almost entirely wanting the black mandibular patch. Its proportions, however, differ a good deal, its body being elongated. Its country is shewn by its name, but it also inhabits South Greenland, and not unfrequently makes its way to the British Islands. Very close to this comes the Greenland Falcon, $F$. candicans, a native of North Greenland, and perhaps of other countries within the Arctic circle. Like the last, the Greenland Falcon from time to time occurs in the United Kingdom, but it is always to be distinguished by wearing a plumage in which at every age the prevailing colour is pure white. In North-Eastern America these birds are replaced by a kindred form, $F$. labradorus, first detected by Audubon, ${ }^{2}$ and lately recognized by $\mathrm{Mr}$. Dresser (Orn. Miscell. i. p.

I It is not to be inferred, however, as many writers have done, that Falcons habitually prey upon birds in which disease has made any serious progress. Such birds meet their fate from the less noble Accipitrcs, or predatory animals of many kinds, their death being often caused by the parasites which infest them, for no sooner is the condition of their " host" lowered than they gain an increased power and multiply in numbers. But when a bird is first affected by any disorder, its power of taking care of itself is at once impaired, and hence in the majority of cases it may become an easy victim under circumstances which would enable a perfectly sound bird to escape from the attack even of a Falcon.

2 Recent American authors call this form $F$. sacer, identifying it with the "Speckled Partridge-Hawk" of J. R. Forster (Phil. Trans. 1xii. p. 383) which he wrongly referred to the "Sacre" of Brisson (Orn. i. p. 337), though stating that its "irides are yellow", a fact which shews it to have been a Gos-hawk! 
135). It is at once distinguished by its very dark colouring, the lower parts being occasionally almost as deeply tinted at all ages as the upper.

All the birds hitherto named possess one character in common. The darker markings of their plumage are longitudinal before the first real moult takes place, and for ever afterwards are transverse. In other words, when young the markings are in the form of stripes, when old in that of bars. The variation of tint is very great, especially in $F$. peregrinus; but the experience of falconers, whose business it is to keep their birds in the very highest condition, shews that a Falcon of either of these groups if light-coloured in youth is light-coloured when adult, and if clark when young is also lark when old-age, after the first moult, making no difference in the complexion of the bird. The next group is that of the socalled "Desert-Falcons" (Gennxa), wherein the difference just indicated does not obtain, for long as the bird may live and often as it may moult, the original style of markings never gives way to any other. Foremost among these are to be considered the LANNER and the SAKEr (commonly termed $F$. lanarius and $F$. sacer), both well known in the palmy days of Falconry, but only within the last fifty years or so re-admitted to full recognition. Both of these birds belong properly to South-eastern Europe, North Africa, and South-western Asia. They are, for their bulk, less powerful than the members of the preceding group, and though they may be trained to high flights are naturally captors of humbler game. The precise number of species belonging here is very doubtful, but among the many candidates for recognition are especially to be named the Lugger, $F$. jugger, of India, and the Prairie-Falcon, $F$. mexicanus, of the western plains of North America.

The systematist finds it hard to decide in what group he should place two somewhat large Australian species, $F$. hypoleucus and $F$. subniger, both of which are rare in collections-the latter especially; and, until more is known about them, their position must remain doubtful.

FALLOW-CHAT, a local name of the WHEATEAR.

FANTAIL, the name of a well-known breed of domestic Doves, but also given by the English in India, Australia, and New Zealand to several species of the genus Phipidura of Vigors and Horsfield, supposed to belong to the Family Muscicapida (FLYCATCHER), and containing more than thirty species which have the habit of expanding their tail, generally a much-developed feature, by a sidelong flirt. By some the Indian and Malayan forms are separated as a genus Leucocerca ( $c f$. Jerdon, B. Ind. i. pp. 450-454; Gould, Handb. B. Austral. i. pp. 237-246). ${ }^{1}$

${ }^{1}$ Fantail-WArbLer is a name that has been given to the Cisticola schnenicola 
FASCEDDAR (Gaelic Fasgadair, a squeezer), the bird first described in English as the Arctic Gull, for which the name of Richardson's SKUA has been commonly but wrongly appropriated.

FAUVETTE, a French word especially applied by Buffon (Hist. Nat. Ois. v. p. 117) to what is now known to be the female of the Orphean WARBLER, Sylvia orphea, and with some qualification to several other allied species. In 1831 Rennie in his edition of Montagu's Ornithological Dictionary (p. 176) tried to make it the English name of what had hitherto and since been known as the Garden-Warbler, S. salicaria or hortensis.

FEATHER-POKE (i.e. pocket or bag of feathers) a common and not inappropriate name of the nest of the Long-tailed TITMouse, whence it has been transferred to the builder.

FEATHERS, like Claws, spurs, and hairs, are horny products of the epidermal cells of the skin, and may consist of the following parts:-(1) a Barrel or culamus; (2) a principal Shaft or rhachis; (3) an Aftershaft or hyporhachis; (4) Barbs or rami; (5) Barbules or radii ; and (6) Barbicels or cilia, some of which last may end in Hooklets or hamuli. The calamus, together with the rhachis, is often called the main stem, quill, or scapus, while the ranil, radii, and cilia compose the inner and outer web, vane, or vexillum of the feather.

(1) The calamus is hollow and transparent: its base is the umbilicus inferior, whence a series of colourless horny "caps" I extends to the umbiliciform pit or umbilicus superior; which marks the point of junction with the rhachis and hyporhachis.

(2) The rhachis is opaque, filled with a pithy substance, and roughly quadrangular in transverse section, with a longitudinal furrow along its inner surface, or that which is towards the body.

(3) The hyporhachis is, according to its development and position, the "ventral" counterpart of the rhachis, and may bear rami and radii, though no cilia; but it varies considerably in different birds. For reasons presently to be given, it is probably not a primitive feature but one acquired secondarily; while its absence in many forms is certainly due to reduction.

(4) The rami or barbs consist each of a slender lamella, the thin end of which is turned toward the body, while its upper margin is thicker and rounded. The lamellie of the outer web though shorter are higher and stronger than those of the inner web. Their number of course depends chiefly on the length of the whole feather: on

of the Mediterranean basin, a little bird that builds one of the most remarkable nests known.

1 This series of "caps" has no name in English. In German it is known as die Seele, that is, the "soul" of the feather. 
the inner web of one of the primaries of a Crane $(G r u s), 38 \mathrm{~cm}$. long, I found about 650 .

(5) The radii or barlules are attached in two opposite rows to the

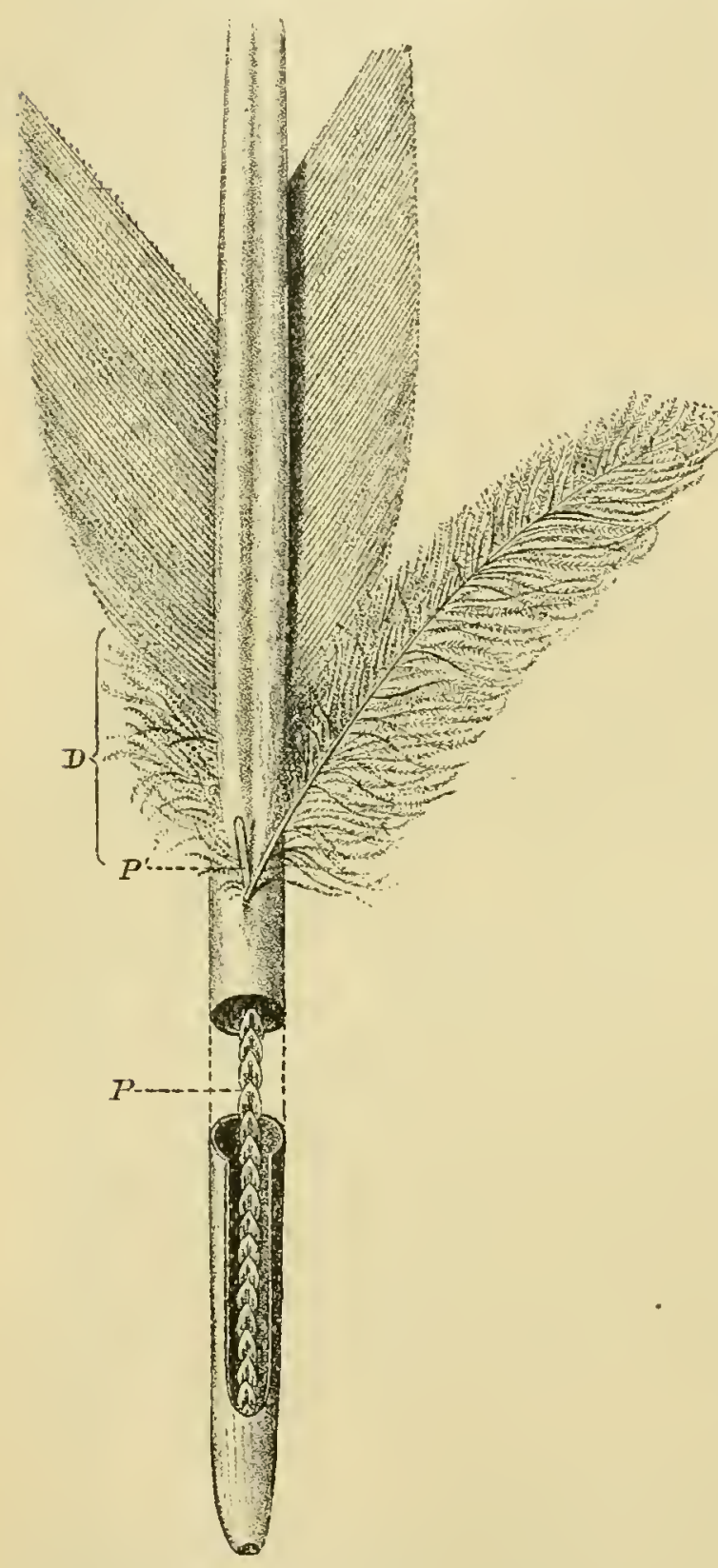

Contour-Feather, witn Aftershaft.

Part of the barrel has been cut away to shew the series of horny cups $(p)$ eontinued (as $p^{\prime}$ ) throughl the unbilieiform pit, whence arises the Aftershaft. $D$, downy portion of the web. thick upper rim of the rami, and like them point toward the tip of the feather. Each radius is a thin lamella, about $1 \mathrm{~mm}$. in length, the upper surface of which is not, however, thickened like that of the rami, but doubled up. Their number is enormous: every ramus of the Crane's feather just mentioned bore about 600 pairs-making nearly 800,000 radii for the inner web alone, and certainly more than a million for the whole feather.

(6) The citia or barticels with their hamuli or hooks are outgrowths of the radii. The hamuli are of the greatest importance in regard to the faculty of Flight, because by their means alone the radii, and consequently the rami, are connected to form a coherent almost air-tight surface. The hamuli grow only on the distal rows of the radii, that is, the rows which look toward the tip of the feather, and those of one radius reach over and hook on to the doubledup margin of the radii (themselves hookless) of the proximal row of the next ramus, as shewn in the opposite figures. Cilia which are not furnished with hooks frequently have shapes which may possibly prove to be characteristic of different groups of birds.

From their varying forms feathers are usually divided into 
"contour feathers" (penna or pluma), "downs" (plumula), "halfdowns" (semiplumx) and "liairlike feathers" (filopluma), but numerous intermediate stages connect these principal forms; and there must also be added as a special feature the nestling feathers.

The "Contour-feathers," as their name implies, are those which appear on the surface of the bird. As a rule they have a com-

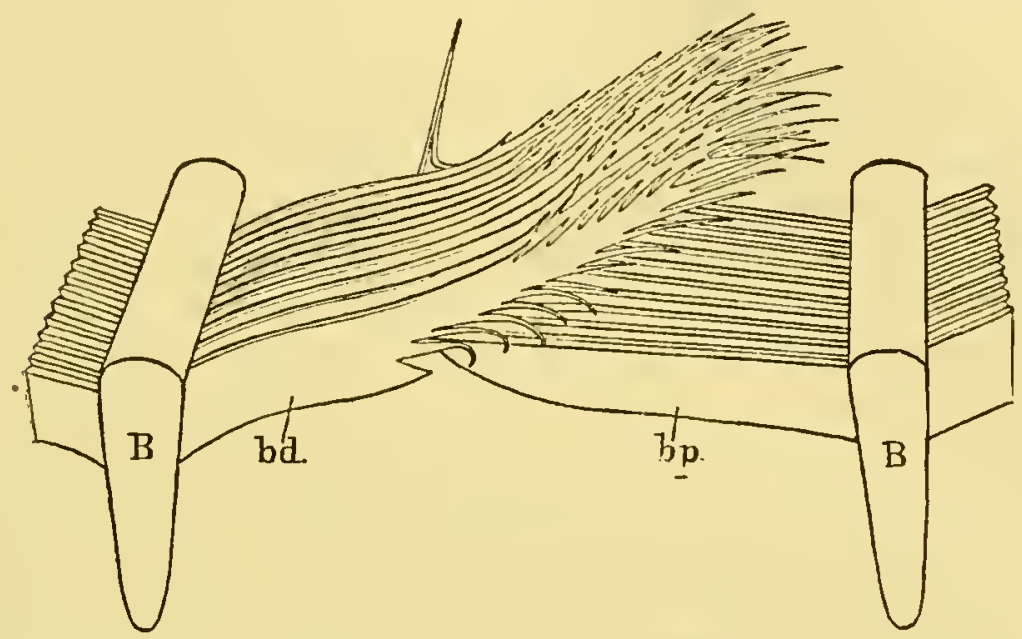

Perspective View of a portion of two adjacest Barbs $(B, B)$ looking from the Shaft TOWARDS THE LDGE OF THE FEATHER.

$b d$, distal barbules; $b p$, proximal barbules.

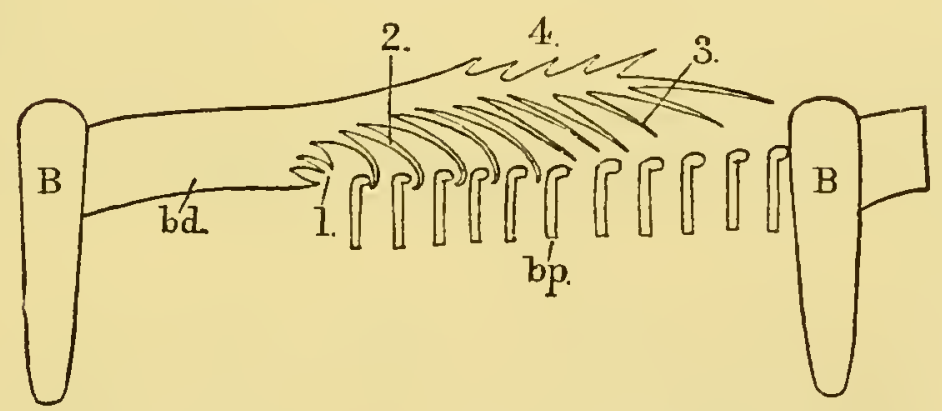

Oblique Section throvgh the Proximal Barbules in a plane parallel to the Distal Barbules of the last Figure.

Letters as before; 1,2,3, Barbicels and hamuli of the ventral side of the distal barbule; 4 , Barbicels of the dorsal side of the same, without hammi.

From The Ibis, 1587, plate xii.

paratively strong shaft, with both inmer and outer webs complete, and they attain their fullest development as rectrices and remiges. Many Contour-feathers, especially those which are ornamental, have no cilia, and therefore no hamuli, while occasionally the radii are rare, so that their webs are disconnected and have a more or less "fluffy" appearance, such as is shewn by the pectoral tufts of the Birds-OF-PARADise, the dorsal plumes of the EGRETs, and the crest of the PEacocks and Crowned Cranks. The cilia of "metallic" 
feathers consist of a series of flattened and comparatively thick compartments (see CoLOUR). The distal part of the rami is often broadened and modified into a blue-producing structure, bearing no cilia. The rhachis of some of the median rectrices of certain Birds-of-PARAdise, the Lyre-BIRD, and others, has no web, and consists of the shaft alone, while the same applies to the rictal bristles of most birds and the eyelashes of those that possess them, and to the peculiar strong and black quills of the Cassowaries' wings. The expanded tip of the shaft of some feathers which gives the IVAXWING its well-known name, and the similar structure of the neck-hackles of some Gallinx, are special modifications. Nitzsch having stated (Pterylographie, p. 17; Engl. ed. p. 13) that the Contour-feathers of Struthio and Rhen have no cilia or hamuli, and that radii ${ }^{1}$ are wanting on some of the rami in Casuarius and Dromaus, the assertion has been often repeated as shewing an important differential character between Carinatx and Patitx, and assigning a more primitive stage to the plumage of the latter. But Fürbringer has pointed out (Beiträge, p. 1482) that the statement needs considerable qualification. In fact, the remiges of Plcea have numerous though small cilia, some of them even ending in hooklike nodules, while the nestling-feathers are abundantly furnished with well-developed cilia. The double shafts of Dromæus and Casuarius carry rami only on their distal portion, but the more basal rami of both webs bear numerous radii. The same applies to the plumage of the Penguins. We have therefore to conclude that the feathers of the Ratitx and Spheniscidx have undergone a. degenerating process through the loss of hamuli, cilia, and occasionally of radii-a reduction that is most apparent on the remiges, but finding a parallel in numerous instances of reduced Contourfeathers.

The "Downs" are almost always concealed by the Contourfeathers, and are smaller, more fluffy, and more numerous. They may be characterized by the absence of hamuli, though generally possessing all the other parts of a typical feather, except that they frequently have no rhachis, in which case all their long rami start at the same level from a short calamus. They thus approach the condition of the so-called nestling-feathers of many birds, and it can hardly be doubted that Downs represent a lower or more primitive stage than Contour-feathers, although of course many Downs are elaborate, and highly specialized. A peculiarly modified kind are the PowDER-DOWNS.

The "Filoplumes" consist of a short calamus and a rery thin hairlike rhachis with few or no rami. Such feathers are always associated with Contour-feathers, close to the base of which one or

1 There is an accidental misprint in the English rersion of the passage (loc. cit.) of "barbicels" for barbules. 
more Filoplumes arise. Their development shews them to be degenerate and not primitive feathers. In most cases they are concealed, but not unfrequently a few elongated Filoplumes project beyond the feathers of the neck, as in Fringilla, Sylvia, Turdus, and above all in Criniger. According to Nitzsch, the delicate white feathers on the neck and thighs of the CoRIIORANT in breedingplumage are comparatively little degenerated and rather specialized Filoplumes.

The first clothing of the newly-hatched bird consists of more or fewer soft feathers, on the whole resembling the Downs of adult birds; but possessing several characters which make it advisable to distinguish them, by the name of "Neossoptiles" ( $v \epsilon \circ \sigma \sigma o ̀ s, ~ a ~ c h i c k)$, from those feathers which subsequently appear, and may be called

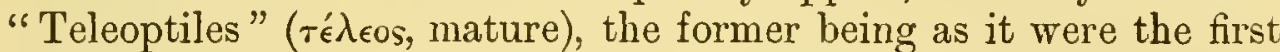
generation to which others follow in constant succession (MOULT), so long as the bird lives.

Neossoptiles are characterized by (1) a very short calamus, (2) an insignificant or ill-defined rhachis-if there be one at all, (3) the almost universal absence of cilia, (4) long and slender rami, and (5) absence of an aftershaft, except in Dromaus. To the combination of these characters is due the soft or downy structure of these feathers.

Teleoptiles, whether Contour-feathers or Downs, are each originally preceded by a Neossoptile, the base of which is in direct continuity with the tips of the rami of its succeeding final feather; but, owing to a shortened process of development or cænogenetic conditions (as before described, p. 14), many, or even all Neossoptiles may occasionally be suppressed, so that the tips of the first feathers which appear are actually those of the second generation. This is

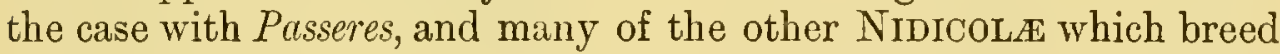
in holes, and thus seem not to need a nestling plumage. In these (Passeres and Psittaci especially) the Neossoptiles, complicated structures as they are, grow on but a few parts-notably on the top of the head, the humeral and spinal tracts. Subsequently they appear on the extremity of the future wing and tail-quills, but they are very sparse on the ventral surface. In the Kingfishers and Woodpeckers, and probably in other PICARIE, the Neossoptiles are almost wholly suppressed. On the whole, this plumage is best developed in the NIDIFUGE, and is naturally thickest in those of them which early take to an aquatic life; but it is thick at the time of hatching in Patitæ, Gallina, Spheniscida, Anseres, Phoenicopterus, Colymbo-Podicipedes, Laro-Limicolx, Pterocleidx and Grallæ, as well as in Accipitres and Striges among the Nidicola, while on the other hand in the majority of the last-even in the Pelargi, Herodii, and Steganopodes-it is at birth very scanty or even absent. Lastly, in the Megapodiidx the Neossoptiles are cast off before the 
birds are hatched, so that they are born clothed in a plumage of the second generation.

There can be no doubt that the nesting habits and various other circumstances are closely correlated with the condition of the first plumage, and that this, taken as a whole, can only be used as a taxonomic character with great caution, while its constituent parts, the Neossoptiles themselves, are far less adaptive and therefore afford surer characters.

The following types of Neossoptiles may be distinguished:-

(1) The lowest and most prinitive type is that of the Columba, and probably of various Limicola. A newly-hatched Pigeon looks

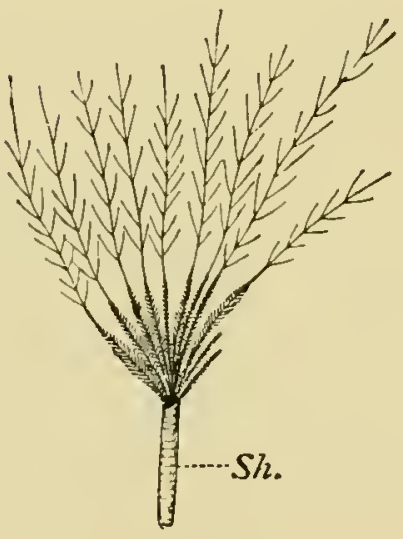

1

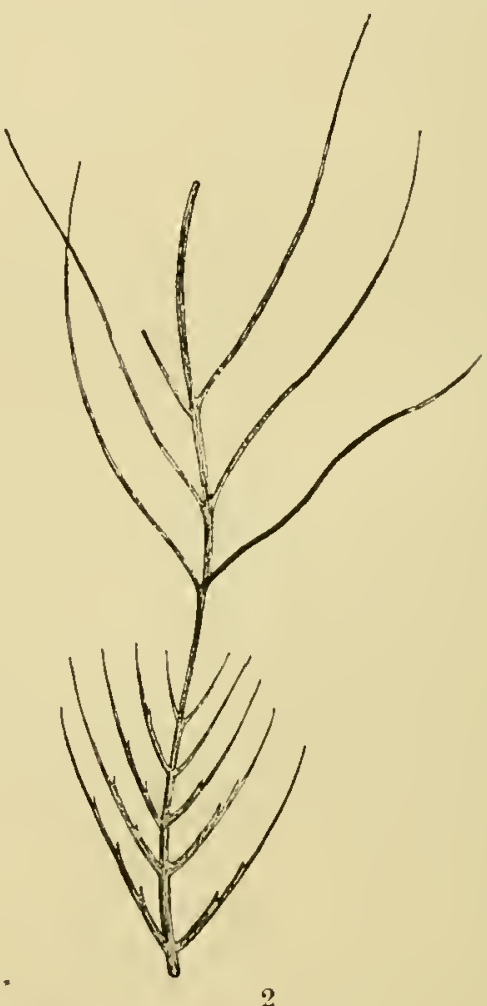

2

Feather of Nestling (Nycticorax). Mlagnitied.

1. Sh. Horny sheath, not wholly shed, enclosing the base of eleven rami. Natural size. 2. Single ramus of the same, supported by a ramus of the Teleoptile.

very naked because each of its long feathers has a bristle-like appearance, being still enclosed in its sheath. When this is shed the feather spreads out in form of a brush, composed of about seven long and thin uniform branches, beset with very few lateral rays, and all springing without any rhachis from a short cylindrical portion, representing the calamus, which passes into the tips of the as yet hardly begun Teleoptile.

(2) In Ciconia, Colymbus, Nycticorax, Phonicopterns, the Spheniscida, and in Sula, the Neossoptile consists of a very short calamus, whence spring about a dozen long and delicate rami, each of which 
is beset with two series of unmerous radii, forming a fluffy plumage which is still more characteristic of the young in Accipitres, Pusseres, I'sittuci, and Striges.

(3) In Gulline there are from 10 to 12 somewhat stiff radiusbearing rami, springing from a slender rhachis.

(4) In Anseres a feeble rhachis bears all the biserially radiated lami, forming feathers which closely resemble the Downs of mature hirds, and are devoid of an Aftershaft.

The Neossoptiles differ much in the various groups of lictita. In Struthio they attain a length of $10 \mathrm{~cm}$., and consist of a calamus $1 \mathrm{~cm}$. long, which may carry as many as 30 rami, each biserially beset with radii, and these again are furnished with eilia. The distal part of some of the rami is flattened and bears no radii. In the absence of any trace of rhachis these feathers agree with our second type. In liher the Neossoptiles measure $6 \mathrm{~cm}$. in length and are composed of a feeble shaft carrying numerous rami with their radii - the tips of the former being split into two or three thickened ends. In Cusucrivs each primitive feather consists of a long and slender rhachis bearing two series of rami, and consequently resembling exactly one-half of the double Final feather. In Dromaus each Neossoptile, which may be $4 \mathrm{~cm}$. long, has a short ealamus earrying a long dorsal rhachis and a mueh shorter ventral Aftershaft-each of them furnished with from 5 to 9 rami neasuring from 1 to $2 \mathrm{em}$. in length, and these again beset with numerons radii withont cilia. This is the only known instance of a Neossoptile with an appendage, and it is significant that the latter is smaller than the principal shaft, and only in its final stage equals the rhaehis in size.

If we consider the condition of the various types of Neossoptiles, above described, with reference to the presence or absence of an Aftershaft in the Teleoptiles, we are led to conclude that this appendage, and consequently also the double feather's of certain Ratita, are seeondarily acquired and not primitive features.

The first indieations of feather's appear about the fifth or sixth day of incubation as slight pimples on the still semi-transparent skin of the embryo. Each pimple is produced by a cluster of dermal cells, covered by a few layers of epiclermal cells, the outermost of

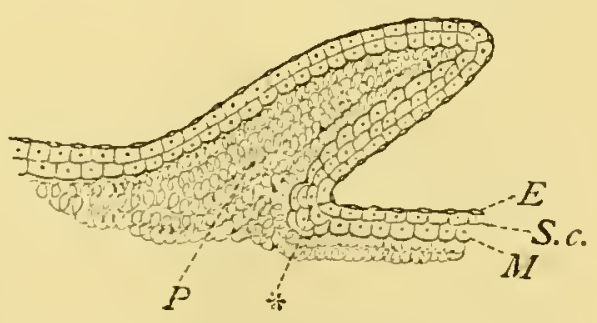

Longitudinal Section of an EARLy Feather-papilla. Magnified.

$E$, Epitrichium; $M$, Malpighian cells ; P, Pulp ; S.c. Stratum corneum; *, Place where the Malpiglian cells grow dowuward to form the follicle.

which forms a single layer of flattened eells, the epitrichium, while the rest, the stratum Malpighii proper, are cylindrical and soon increase to form several layers. All the cells of the whole 
pimple or "feather-papilla" multiply rapidly and cause it to take

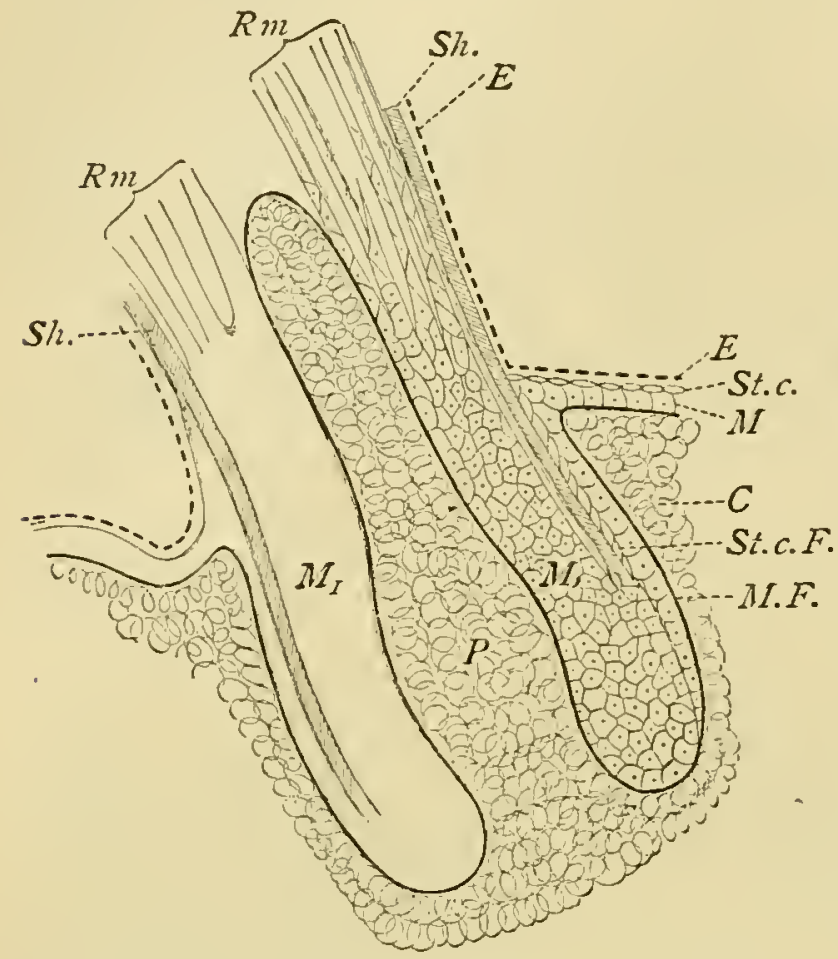

Longitudinal Section of a very young Teleoptile of a PIgeon. Magnified.

$C$, Cutis ; $E$, Epitrichium ; $M$, Malpighian cells ; $M_{1} M_{1}$, Middle stratum of inner half of the Malpighian mass of cells; $M . F$. Outer half of Malpighian cells forming the follicie: $P$, Pulp ; Rm, Rami ; Sh. Sheath; St.c.F.Stratum corneum of the follicle continued into St.c. at the surface of the shin. the shape of a cone, the apex of which is directed backward. The base of the papilla then sinksmore deeply into the skin, chiefly owing to the downward growth of the mass of Malpighian cells, which arrange themselves into two halves_an (1) outer one, lining the invaginated mass of cells of the "feather-follicle" and directly continuous with the Malpighian stratum at the surface; and (2) an inner one which, like a mantle, surrounds the whole central mass. This mass or "pulp" is wholly a product of the cutis, and therefore of mesodermal origin, and its upper portion is gradually transformed into a delicate meshwork which is filled with blood-the plasma necessary for the nutrition of the epidermal parts. In fact, the pulp is the nutritive organ of the whole feather.

The mantle of Malpighian cells which surrounds the pulp differentiates itself into three strata of unequal thickness. The innermost and thinnest stratum forms a transparent sheath for the pulp, and persists ultimately as the series of "caps" or "soul" before mentioned. The midlle stratum is the thickest and becomes the feather itself, while the outermost forms a transparent and coherent cylindrical sheath, which encloses the growing

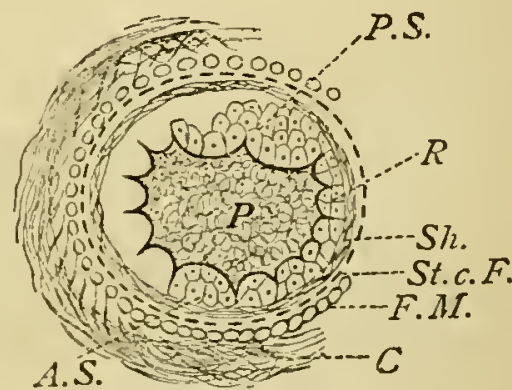

Trassverse Section of the same Feather throvgir $M_{1} M_{1}$. Magnified.

A.S. Cells forming the future Aftershaft; C, Cutis ; F.M. Malpighian cells of the follicle; P.S. Cells of the principal shaft; $R$, Rami; Sh. Sheath; St.c.F. Stratnon corneum of the follicle. feather, giving it its well-known spine-like appearance, until, peeling 
off as scurf, it sets free the rami of the young product. While the papilla grows to the length the young feather is to reach, the cells of the middle stratum arrange themselves in longitudinal rows, causing the pulp to assume in transverse section a somewhat starshaped appearance. These rows are transformed into the hair-like rami of which most Neossoptiles consist, and their formation proceeds from the apex downwards, while the radii seem to be produced by secondary splitting. Ultimately all the rami meet at the base of the feather and there form, with the basal portion of the sheath, a very short cylindrical tube, which is the calamus of the Neossoptile, while the pulp having fulfilled its function has withdrawn towards the base of the follicle, leaving only its horny sheath in the form just above stated, its projecting portion.

The development of the feathers of adults is merely a continuation of the process now described, because each Teleoptile is produced by the same pulp and Malpighian cells as gave rise to its predecessor of the first generation. "The short calamus of a Neossoptile is not closed at its base, but is again split into a number of columns of cells, which though not yet horny are the tips of the rami of its successor. As a rule the whole follicle sinks deeper into the skin, and thus comes to lie in a sort of pocket, which, occasionally reaching the periosteum of underlying bones, produces on the ulna the well-known roughnesses that correspond with the number of cubital quills.

Those papillæ which give rise to the larger feathers, such as the rectrices, become much thickened and greatly elongated, each being surrounded by a horny sheath which peals off as the feather attains maturity. A transverse section shews nearly the same conditions as those of the growing Neossoptiles, but both on the dorsal and ventral side are two columns longer than the rest, and especially the two on the former which are transformed into the rhachis, while the two on the latter give rise to the hyporhachis. The intermediate columns and their secondarily-split parts form the rami. A transverse section of the growing feathers shews that both rhachis and hyporhachis pass into the calamus, but that the former occupies by far the greater part of the ring, or the whole of it when there is no hyporhachis. It is moreover observable in an entire quill that the rami of both outer and inner webs converge toward the ventral side and ultimately surround the umbiliciform pit. In fact, the rhachis is only a vast elongation and thickening of more than the dorsal half of the growing calamus which during its rapid increase carries with it most of the rami, while only those nearest the ventral median line of the quill remain in their original position, unless an hyporhachis be developed as a ventral elongation of the calamis. The pulp 
extends through the umbiliciform pit along the ventral side of the rhachis to its tip, but the part within the calamus being expanded shrivels in the way before described. When the apex of the feather is finished, and its elements have become horny and firm, the outer follicular sheath bursts from the tip backward, so as to liberate the rami, but these continue to carry the Neossoptile until after a longer or shorter time it is rubbed off. Part of the withdrawn follicle, consisting of the pulp and the mantle of Malpighian cells, remains in a dormant condition until the time of Mouli awakens it to renewed action, when the old feather is pushed out and a new one produced in its place. These feathers from the second generation onward are not in direct continuity with their successors, for the base of the calamus or umbilicus inferior becomes more or less constricted and is closed by a plug formed by the lowest eaps of the now retired pulp; though in Dromaus and Casuarius the tip of each new feather extends into the short ealamus of its predecessor, which as it is being pushed out still adheres to its successor, so that these birds for a long time wear their old coat over their new one. The reproductive power of this follicle seems to be unlimited unless it be mechanically injured. It is hardly diminished by age, but is affected at once by want of food or wrong diet. It is well known that the action of the follicle is generally revived by the accidental loss of a feather, so that, regardless of its being in the season of Moult or not, the missing feather is speedily replaced-a matter of great importance to a bird when its life may depend upon its undiminished power of flight. On the other hand, it is not so generally known that the ellormously-developed rectrices of the Cocks of some Japanese poultry are artificially produced by the Moult being checked, in some way at present unknown to Europeans, so that the feathers instead of being shed go on continuously growing and reach the length of ten or twelve feet.

FEDOA, the Latinized form of some English name of the Goowit, now lost apparently beyond recovery, but so written by Turner in 1544. From him the word got into ornithology, where it has been several times misapplied, and misunderstood. The only suggestion as to its origin that presents itself is in connexion with the fact that Godwits used to be caught alive and fed to fatten them for the table.

$F E M I U R$, the thigh-bone made up of the globular Head articulating with the acetabulum of the pelvis, and connected by the Nech with the Shaft, which terminates in an outer and inner Condyle for articulation with the Tibia. Between these condyles, on the anterior side, and partly imbedded in the tendon of the great extensor muscle lies the Patella. On the median side of the proximal end 
of the Shaft there is often a small pneumatic foramen for the entrance of an AIR-SAC into its then hollow and cancellated interior.

FERN-BIRD, the name in New Zealand of Sphenceacus punctatus.

FERN-OWL, one of the many local names of the NightJar.

FIBULA, the bone on the outer side of the TrBIA, thick at its proximal end, but very slender and pointed towards the ankle-joint, which, however, is never normally reached, the distal portion of the Fibula being already deficient in the Embryo. The Fibula and Tibia are frequently more or less coalescent.

FIELDFARE, Anglo-Saxon Fealo-for (= Fallow-farer), a large species of Thrush, the Turdus pilaris of Linnæus-well known as a regular and common autumnal visitor throughout the British Islands and a great part of Europe, besides Western Asia, and even reaching Northern Africa. It is the Veldjakker and Veld-lyster of the Dutch, the Wachholderdrossel and Kramtsrogel of Germans, the Litorne of the French, and the Cesena of Italians. This bird is of all Thrushes the most gregarious in habit, not only migrating in large bands and keeping in flocks during the winter, but even commonly breeding in society-200 nests or more having been seen within a very small space. The birch-forests of Norway, Sweden, and Russia are its chief resorts in summer, but it is known also to breed sparingly in some districts of Germany. Though its nest has been many times reported to have been found in Scotland, there is perhaps no record of such an incident that is not open to doubt; and unquestionably the Mistletoe-Thrush, T. viscivorus, has been often mistaken for the Fieldfare by indifferent observers. The head, neck, upper part of the back, and the rump are grey; the wings, wing-coverts, and middle of the back are rich hazelbrown; the throat is ochraceous, and the breast reddish-brownboth being streaked or spotted with black, while the belly and lower wing-coverts are white, and the legs and toes very dark brown. The nest and eggs resemble those of the BLACKBIRD, T. merula, but the former is usually built ligh up in a tree. The Fieldfare's call-note is harsh and loud, sounding like t'chat-t'chat: its song is low, twittering, and poor. It usually arrives in Britain about the middle or end of October, but sometimes earlier, and often remains till the middle of May before departing for its northern breeding-places. In hard weather it throngs to the berrybearing bushes which then afford it sustenance, but in open winters the flocks spread over the fields in search of animal food-worms, mollusks, and the larvæ of insects. In very severe seasons it will altogether leave the country, and then return for a shorter or longer time as spring approaches. From the author of William of Palerne to the writers of our own day the Fieldfare has occasionally 
been noticed by British poets with varying propriety. Thus Chancer's association of its name with frost is as happy as true, while Scott was more than unlucky in his well-known reference to its "lowly nest" in the Highlands.

Structurally very like the Fieldfare, but differing greatly in many other respects, is the bird known in North America as the "RoBIN"—its ruddy breast and familiar habits reminding the early British settlers in the New World of the household favourite of their former homes. This bird, the Turdus migratorius of Linnæus, has a wide geographical range, extending from the Atlantic to the Pacific, and from Greenland to Guatemala, and, except at its extreme limits, is almost everywhere a very abundant species. ${ }^{1} \quad$ As its scientific name imports, it is essentially a migrant, and gathers in flocks to pass the winter in the south, though a few remain in New England throughout the year. Yet its social instincts point rather in the direction of man than of its own kind, and it is not known to breed in companies, while it affects the homesteads, villages, and even the parks and gardens of the large cities, where its fine song, its attractive plumage, and its services as a destroyer of noxious insects, combine to make it justly popular.

FIG-EATER, Ray's rendering in 1678 of the Italian Beccafico, a name commonly and almost indiscriminately given to any of the little birds which towards autumn resort to gardens, whether to eat figs or not, and are themselves caught by various devices, to be eaten as delicacies. According to the best recent authorities the true Beccafico is our Garden-Warbler, Sylvia salicaria or hortensis; but the bird which Buffon calls by the corresponding French term, Bec-figue, is the female Pied Flycatcher, Muscicapa or Ficedula atricapilla -one that may be safely said never to eat a fig.

FINCH (German Fink, Latin Fringilla), a name applied (but almost always in composition-as Bullfinch, Chaffinch, GoldFINCH, HAWFINCH, and so forth) to a great many small birds of the Order Passeres, and now pretty generally accepted as that of a group or Family - the Fringillide of most ornithologists. Yet it is one the extent of which must be regarded as being uncertain. Many writers have included in it the Buntings (Emberizidx), though these seem to be quite distinct, and the grounds of their separation have been before assigned, as well as the LARKs (Alaudida), the TANAGERS (Tanagrida), and the WEAYER-BIrDS (Ploceidæ) - the mode in which these last three differ having in due time to be shewn in these pages. Others have separated from it the Crosseills, under the title of Loxiidæ, but without due cause,

1 It is recorded as having occurred a few times in Europe, and once even in England (Zool. 1877, p. 14); but whether in any case it has been a voluntary visitor is doubtful. 
while again some systematists have placed among the Finches the MousE-BIRDs (Coliida) — an allocation which a very slight study of osteological characters would have proved to be unsound; and a group which has no English name, including probably the genera Panurus (the so-called Bearded Tituouse), Paradoxomis, and, perhaps, a few others, has also been occasionally referred to the Finches, but to all appearance erroneously. The difficulty which at this time presents itself in regard to the limits of the Fringillidar arises from our ignorance of the anatomical features, especially those of the head, possessed by many exotic forms.

Taken as a whole, the Finches, concerning which no reasonable doubt can exist, are not only little birds with a hard bill, adapted in most cases for shelling and eating the various seeds that form the chief portion of their diet when ndult, but they appear to be mainly forms which predominate in and are highly characteristic of the Palæarctic Subregion; moreover, though some are found elsewhere on the globe, the existence of but very few in the Notogxan area can as yet be regarded as certain.

But even with this limitation, the separation of the undoubted Fringillida ${ }^{l}$ into groups is a difficult task. Were we merely to consider the superficial character of the form of the bill, the genus Loxia (in its modern sense) would be easily divided not only from the other Finches, but from all other birds. The birds of this genus - the Crossbills - when their other characters are taken into account, prove to be intimately allied on the one hand to the Grosbeaks (Pinicola) and on the other through the ReDpolus (Agiothus) to the Linnets (Linota) - if indeed these two can be properly separated. The Linnets, through the genus Leucosticte, lead to the Mountain-Finches (Montifringilla), and the Redpolls through the Siskins (Chrysomitris) to the Goldfinches (Carduclis); and these last again to the Hawfinches, one group of which (Coccothraustes) is apparently not far distant from the Chaffinches (Fringilla proper), and the other (Hesperiphona) seems to be allied to the Greenfinches (Ligurinus). Then there is the group of SErins (Serinus), to which the CANARY-BIRD belongs, that one is in doubt whether to refer to the vicinity of the Greenfinches or that of the Redpolls. The Mountain-Finches (before named) may be regarded as pointing first to the Rock-Sparrows (Petronia) and then to the true Sparrows (Passer); while, returning to the Grosbeaks, we find them passing into many varied forms which regard to space forbids our here naming, and throwing out a very well marked form - the Bullfinches (Pyrhula). But the reader must be prepared to take all this as problematical. Some of the modifications of the Family are very gradual, and therefore conclusions founded

\footnotetext{
I About 200 species of these have been described, and perhaps 150 may really
} exist. 
on them are likely to be correct; others are further apart, and the links which connect them, if not altogether missing, can but be surmised.

FINFOOT, Latham's name in 18.4 (Gen. Hist. B. x. p. 10) for two birds which he then rightly associated. One of them from America, the size of a small Teal, had been long known, and formerly referred by him to the genus Plotus (SNAKE-BIRD), while Pennant in 1776, in Peter Brown's Illustrations of Zoology (pl. 39, p. 98), had described it as the "Surinam Tern," and it was figured by Daubenton (Pl.enl. 893) and described in 1781 by Buffon as the

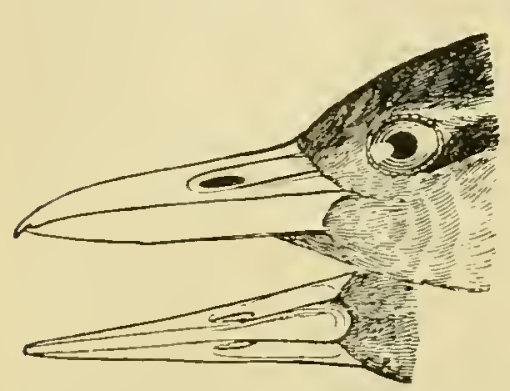

Helioris. (After Swainson.) Gièbe-Foulyue. In 1790 the ill-fated Bonnaterre established the genus Heliornis ${ }^{1}$ for it. Its affinities remained uncertain until the publication in 1839 of Brandt's Beitrüge zur Kenntniss der Nuturgeschichte der Tögel, communicated to the Academy of St. Petersburg, wherein he shewed (pp. 117-122) that they were rather towards the RAILs; but people have been slow to admit the force of his osteological evidence, though it has since been confirmed in the case of another species of the group by Jerdon (B. Iml. iii. p. 721). In the meanwhile Prince Maximilian of Wied had in 1832 published his observations on the bird's habits (Beitr. zur Naturgesch. Brasilien, iv. pp. 827, 828), and very curious some of them are, for he says that he himself had shot a cock-bird, under the wings of which were two newly-hatched, naked young. The old birds swim and dive adroitly, but their flight is heavy, though they run swiftly on land, and they are addicted to perching on trees. The proper name of this species is Heliomis fulicu, though it appears in some works as Podoc surimamensis. It has an extensive range in the Neotropical Region from Guatemali to Paraguay (Proc. Zool. Soc. 1868, p. 469); but it is not found in the Patagonian Subregion.

The second species described, as above stated, by Latham, and as he thought for the first time, is a much larger bird from Western Africa, made known by Tieillot in 1817 ( $N$. Dict. N' Hist. Nut. ed. 2, xiv. p. 277) as Heliomis senegalensis, but in 1831 Lesson put it in a genus by itself which he called Podica. The differences between them, though of no real importance, are yet sufficient to warrant the separation; and this $P$. senequlensis is said to be represented on the opposite side of the African continent by a yet bigger species, P. petersi or mosambicana, ranging from Natal north-

1 This name seems to have arisen from a mistake of Latham's (Synops. B. iii. p. 626) who in 1785 supposed the "Oiscun cle Soleil," so translated by Fermin in 1769 (Deser. Surinam, ii. p. 192) from the Duteh Sonne-vogel, to be the present bird, whereas it is obviously the Eurypyga (Stی-BitTEnx). 
ward. ${ }^{1}$ In 1848 another species, wholly distinct, was described as P. personata by G. R. Gray, from a specimen obtained in Malacca, and it has since been found to inhabit Tenasserim, Burma, and Assam, though not yet recognized in India properly so called.

These birds are certainly entitled to form a distinct Family Heliornithida, allied to the Rails, but probably, as their geographical distribution suggests, a more ancient and therefore more generalized group, which would well repay further anatomical examination. ${ }^{2}$ Examples are by no means common in museums, though it can hardly be that the birds are not in their own haunts sufficiently numerous; and their seeming scarcity may be attributed to their shyness and means of escaping observation ( $c f$. W. Darison, Stray Feathers, vi. p. 465). Nothing is known of their nidification or eggs.

FIRECREST, a colloquial abbreviation of Fire-crested Wren, Regulus ignicapillus (see GoLdCREST).

FIRETAIL, a common English name of the REDSTART; and, according to Gould (Hand-b. B. Austral. i. p. 406), given in Tasmania to Zonaginthus bellus, a small Finch-like or WEAver-BIRD.

FISCAL, the name given in the Cape Colony to a SHrike, Lanius collaris, from its rapacity, which no revenue-officer could exceed ( $c f$. Latham, Gen. Hist. B. ii. p. 22 ; Layard, B. S. Afr: p. 157).

FISH-HAWK, a name for the OsPREY, especially given to it in North America.

FLAMINGO (Portuguese Flamingo, Spanish Flamenco), a bird conspicuous for the bright flame-coloured or scarlet patch upon its wings, and long known by its classic name Phonicopterus as an inhabitant of most of the countries bordering the Mediterranean Sea, in some of which it is still far from uncommon. ${ }^{3}$ Other species have since been discovered, and both its common and

1 Dr. Büttikofer's evidence (Notes Leyd. Mrus. x. P). 103-105) is to the effect that there is only one species in Africa.

${ }^{2}$ Brandt's investigations above mentioned were confined to the head and feet of Heliornis; Jerdon had apparently seen the whole skcleton of $P$. personata. I myself have the sternum of a male and female of $P$. petersi, sent to me by $\mathrm{Mr}$. Layard from Natal. The characters of this part of the skeleton are certainly Rail-like in a general way, but yet offer a good many pecnliarities. The result of Mr. Beddard's examination (Proe. Zool. Soe. 1890, pp. 441, 442) of P. senegalensis is to shew that the osteological and myological characters are almost in antagonism: but he concludes that the Heliornithidx form a distinct Family "which has traversed for a certain distance the branch leading from the Rails to the Colymbidæ and has then diverged rather widely in a direction of its own."

3 In Greece and Asia Minor, however, it is rare, and to this cause is most likely to be attributed Aristotle's silence conccrning it, though it was known, by name at least, to Aristophanes. 
scientific names are now used in a general sense. The true position of the Flamingos (Phonicopterida) has been much debated, and ornithologists are as yet by no means agreed upon it. Prof. Huxley (Proc. Zool. Soc. 1867, p. 460) considered the form "so completely intermediate between the Anserine birds on the one

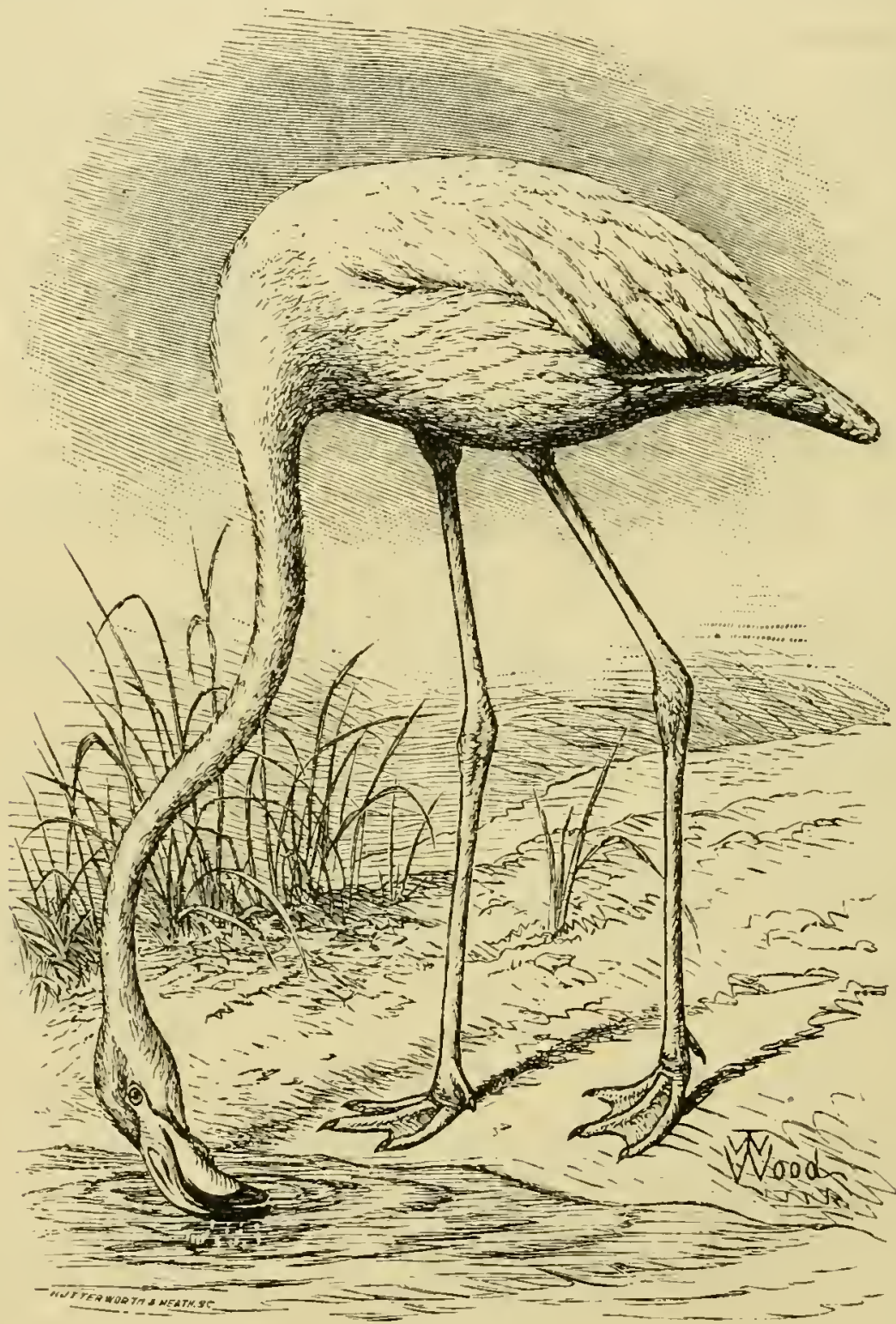

Flaingigo.

side, and the Storks and Herons on the other, that it can be ranged with neither." I And he put it by itself as the type of a group Amphinorphe under the larger assemblage of DesmogNathe. To Prof. Fürbringer and Dr. Gadow its affinity to the Spoonbills,

1 Thus confirming the opinion of Linnæus a century old (Syst. Nat. ed. 12, i. p. 230):- "Medium inter Anscres et Grallas, si quis ad precedentem ordinem referat, forte non errat." He limself places it among the latter. 
Ibises and Storks seems to be the strongest ; but that it should stand as a distinct Family is manifest.

Though not a few birds have in proportion to the size of their body very long legs and a very long neck, yet the way in which both are employed by the Flamingo seems to be absolutely singular. In taking its food this bird reverses the ordinary position of its head so as to hold the crown downwards and to look backwards. The peculiar formation of the bill, which to the ordinary observer looks as if broken, is of course correlated with this habit of feeding, as well as the fact that the maxilla is (contrary to what obtains in most birds) not only highly movable, but is much smaller than the mandibula - while the latter is practically fixed. Both jaws are, however, beset with lamelli, as in most of the Duck-tribe, and the food is thereby sifted out of the mud as the Flamingo wades with its long neck stretching to the bottom of the shallow waters it frequents. Still more extraordinary is one of the alleged uses of its long legs. Dampier asserts as of his own observation near Querisao (i.e. Curaçăo) prior to $1683^{1}$ that the hen stands upon them while performing that duty which in other birds is rightly called "sitting," and the statement, being confirmed by other writers," remained unquestioned for a century and a half. Crespon in 1844 (orrigenat. (Fauna Mérid. ii. p. 69) was one of the first to raise a doubt on the subject, though he had before (Ornithol. du Gord, p. 397) accepted what was and still is the prevalent belief in Southern France (Ibis, 1870, p. 441); but he now went so far as to declare that Flamingos did not build a nest at all, and only laid their eggs on a

1 The passage is too quaint and interesting not to be quoted:- "They build their Nests in shallow Ponds, where there is much Mud, which they scrape together, making little Hillocks, like small Islands, appearing out of the Water, a foot and a half high from the bottom. They make the foundation of these Hillocks broad, bringing them up tapering to the top, where they leave a small hollow pit to lay their Eggs in ; and when they either lay their Eggs, or hatch them, they stand all the while, not on the Hillock, but close by it with their Legs on the ground and in the water, resting themselves against the Hillock, and covering the hollow Nest upon it with their Rumps: For their Legs are very long; and building thus, as they do, upon the ground, they could neither draw their legs conveniently into their Nests, nor sit down upon them otherwise than by resting their whole bodies there, to the prejudice of their Eggs or their young, were it not for this admirable contrivance, which they have by natural instinct. They never lay more than two Egrgs, and seldom fewer. The young ones cannot fly till they are almost full grown; but will run prodigiously fast; yet we have taken many of them."-Dampier, New Voyage round the World, ed. 2, corrected, i. p. 71 , London : 1699.

2 Thus Catesby (Nat. Hist. Carol. i. p. 73), though apparently got from the information of others; but Pallas (Zoogr. Ross.-Asiat. ii. p. 208), obviously from his own observation, says :- "Vera est Dampieri observatio, eos in stagnis marinis vadosis corradere colles sesquipedali altitudine, quorum summitati cavatae imponunt ova vulgo bina, quæ colli adstantes pectore fovent." 
slight elevation so as to be out of the water, sitting upon them with their legs doubled under the belly. Part of this assertion was proved to be false by Lord Lilford (Proc. Zool. Soc. 1880, pp. 446450), who obtained from Andalusia one of the mud-built nests (just as they were described by Dampier) and gave it to the British Museum, where it may be seen; but he was unable to offer personal evidence as to the position of the bird during incubation, though he doubted the probability of its being with the legs "stretched out behind," as had in the meanwhile been stated (Ibis, 1871, p. 394). Of late the old story has been absolutely contradicted both in regard to the Mediterranean species and that of North America. Mr. Abel Chapman described and figured (op. cit. 1884, p. 88, pl. iv.) a breeding-place of the former seen by him in Andalusia, and then Sir Henry Blake gave an account (op. cit. 1888, pp. 151, 152) of a visit paid by him to one of the latter on Abaco in the Bahamas. Both of these observers knew of the prevalent belief, and seem to have expected to find it borne out; but one of them writes of the birds as sitting on the nests with their "long red legs doubled under the body," while the other states that "in every instance the legs were folded under the bird in the usual manner." Most of the nests seen by Mr. Chapman, and all apparently that Sir Henry saw, were on mud, -and in the latter case they were only eight inches high, so that it would be impossible for the birds to sit on them in the way described-moreover, none of Mr. Chapman's contained eggs, and therefore he did not see a bird actually incubating. The question cannot be regarded as settled, and further observation must be awaited. ${ }^{1}$

It is of course only under very favourable circumstances that such nests as these can be built. When time or place is wanting, the hens seem to drop their eggs at random, and in the south of both France and Spain years seem to pass when, from want of sufficient water, or the persecution of the people, no Flamingos are able to breed, so that more than one beholder of the magnificent sight afforded by them as they flock has wondered in vain concerning their birthplace. Late in the summer the adults shed all their quill-feathers, and being thus rendered flightless, are easily captured. Under these circumstances, both the European and the North-American species may be expected to become rare, if not extinct. Flamingos are eminently gregarious. Their farourite resorts are salt-lakes-indeed these may be said to be a prime necessity; and when, as often happens, they are diminished by drought, the birds have to take long flights in quest of new haunts. Thus some of the wanderers occasionally get separated from the

1 Sinee the above was in type, Mr. Saunders has shewn me Mr. Maynard's account (Nat. in Florida, 1884, No. 1) of a breeding-place in the Bahamas, where among hundreds of sitting birds none had its legs "hanging down." 
main body, and appear in various unwonted spots. ${ }^{1}$ On the wing the Flamingo is described as presenting a singular appearance, its neck and legs being stretched out in a continuous straight line. Then feeding or at rest, a flock of these birds, owing to their red plumage, has often been likened to a body of British soldiers. The young appear to be a long time in arriving at the full beauty of their plumage, and as the sexes are said to differ greatly in size, some of the difficulties which the determination of species in this genus presents may be excused. No fewer than four species of Phonicopterus have been described as inhabiting the old World. There is the large bird known to the ancients, Temminck's $P$. untiquorum, which certainly ranges from the Cape Verd Islands to the Caspian and to India, if not further. The P. erythraxs of Jules Verreaux has been described as differing in its brighter plumage, and is supposed to be a native of Southern and Western Africa, but it is also said to have strayed to Europe. Then two smaller species (P. minor, Geoffroy, and P. vubidus, Feilden)-the one from Africa the other from India-have also been described, but whether their existence can be substantiated remains to be seen. Fon species have likewise been indicated as belonging to the New World. There is first a large and very brilliantly-coloured bird to which the Linnæan name $P$. ruber ${ }^{2}$ has been continued, inhabiting suitable localities from Florida southwards to an undetermined latitude. To this species Mr. Salvin (Trans. Zool. Soc. ix. p. 49S) refers the $P$. glyphorhynchus of G. R. Gray, founded on a specimen from the Galapagos. Then there is the $P$. chilensis of Gmelin ( $P$. imnipalliatus of later writers), in colouring more like the European species, and found in various parts of Sonth America. Lastly comes the $P$. andinus of Philippi, easily distinguished from all others through the want of a back-toe, and regarded by Bonaparte as meriting generic separation under the name of Phonicoparrus. This appear's to have its home on the salt-lakes of the elevated desert of Atacama.

The fossil remains of a Flamingo have been recognized from Lower and Middle Tertiary heds in France, and the species, which appears to have been very close to that commonly called $P$. antiquorum, has received the name of $P$. croizeti from Prof. Gervais. But a more interesting discovery is that by Prof. A. MilneEdwards of no fewer than five species of an extinct form of Phcenicopterida, named by him Palalodus (Ois. Foss. de la France, ii. p. 58). These are from lacustrine deposits of the Miocene epoch.

1 The Flamingo has been added by Mir. Samders to the "British" list (Yarrell, Br. B. ed. 4, iv. p. 244) from examples observed at several places in England ; but the evidence to shew that these were voluntary visitors is weak.

${ }^{2}$ Linnæus referred all the accounts of Flamingos known to him to a single species, under this name, wherein he was decidedly wrong, but the reason for assigning it to an American species has yet to be explained by ornithologists. 
The same distinguished zoologist also refers to this Family remains designated by him Agnopterus, and those of the "Elonnis" (properly Helomis) of M. Aymard ( $c f$. Fossil Birds).

FLAX-BIRD, the North-American Goldfinch or "Yellow Bird," Chrysomitris tristis (congeneric with our SISKIN), so "called in the back parts of Carolina" as Latham (Gen. Hist. B. vi. p. 120) was informed by Abbot; but the name seems to have dropped out of use.

FLICKER, one of the most characteristic, common, and conspicuous birds of the greater part of North America, the Goldenwinged WooDPECkER of books, the Picus auratus of Linnæus, and

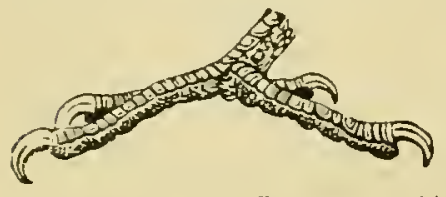

Colaptes. (After Swainson.)

Colaptes auratus of modern ornithology.

Its habits have been well described by Wilson, Audubon, and other writers,

but there is no space here to dwell upon them, engaging as the topic is, for the mention of this bird suggests a more important theme. Widely distributed as it is from the Atlantic coast, so far southward as Louisiana, to Canada, and thence across the Rocky Mountains, and still further northward to Alaska, its place is taken on the greater part of the Pacific side by a species which, avoiding Southern California, reaches the tablelands of Mexico-a species more brilliantly tinted, for ruby appears in its plumage instead of gold, the C. mexicanus or rubricatus ${ }^{1}$ of authors. But in an intervening broad belt runuing north-westward from Texas to British Columbia there occur birds presenting almost every combination of the distinctive coloration of the two species just named, ${ }^{2}$ and though one of these intermediate specimens had been long before figured and described as $C$. ayresi by Audubon (B. Amer. vii. p. 348, pl. 494), yet Baira was so much persuaded that all these puzzling birds were hybrids, that he used (Expl. dic. Railroad Route, ix. p. 122) the name C. hybridus to cover the whole of them. ${ }^{3}$ It must be admitted that

1 By some writers identified with the $P$. cafer of Gmelin, founded on Latham's description of a specimen said to have come from South America; but most likely the locality assigned is wrong.

2 The series contained in the Museum of the Smithsonian Institution in 1857 was in that year shewn to me and descanted upon by my highly esteemed friend the late Prof. S. F. Baird. He did not convince me of the truth of his views, and I afterwarls saw greater reason to doubt their correctness; but they were probably the only views in those days consonant with philosophy to any one not in the confidence of Mr. Darwin, whose secret was not revealed till the next year.

3 Cassin at that time was inclined to beliere that they could be broken up into several distinct "species"; but I do not know that lie ever published this opinion. 
this is a view which cannot at present be disproved; but it also must be admitted that neither has it been proved. Mr. J. A. Allen was supposed to explain the difficulty (Bull. Mus. Harvard, iii. p. 118) as arising from climatic influences, while Dr. Coues was formerly (B. North-West, p. 294) inclined to support that view, but subsequently (Key N.-Am. B. p. 492) followed Mr. Ridgway's suggestion (Orn. Forticth Parallel, p. 556, note) that these birds might be "remnants of a generalized form." If so, a case would be found analogous to that presented by certain forms of Coracias (RoLLER), and a good many of the Phasianidx, to say nothing of other groupsthough strictly intermediate forms are not often met with. So much has been written on what is called the "interbreeding" of species by persons who seem ignorant of the fact that all specialized forms must have sprung from more generalized ancestors, that the careful zoologist will abstain from invoking a theory of "interbreeding" to account for every difficulty that presents itself in the differentiation of species. Granted that most of these generalized forms are by this time become extinct, there is no reason, even allowing for the going on of specialization, why some of them should not still exist, and thus such forms of Colaptes, Coracias, Euplocamus, and Phasianus survive to this time. Against this view, however, may be set the fact that examples of $C$. ayresi or hybridus offer some characters so very pronounced $^{1}$ that those who favour the hybrid origin have apparently a strongish case. ${ }^{2}$ But then it may be reasonably alleged that zoologists, to their shame, are so absolutely ignorant of the laws that govern hybridity in animals, that no argument can be founded on a presumption that has positively no foundation-for no zoologist has as yet carried out any such series of experiments as has again and again been done by botanists to the very great advancement of their study. Consequently the phænomena of hybridity in animals can only be interpreted - and possibly wrongly interpreted-by those observed in plants. Among the few experiments hitherto made in regard to Birds, some unmistakably shew how strongly the principle of Reversion works.

Another interesting fact relating to the genus is that at least one of the South-American members of it, $C$. agricola, inhabiting the treeless plains of La Plata and Patagonia, has succeeded in accommodating itself to circumstances, —as recorded among others by Darwin (Origin of Species, chap. vi.) under the name of $C$. campestris, which seems rightfully to belong to a more northern form. Since Azara's time it has been known to frequent the open country, seek-

${ }^{1}$ For instance, an example may be all mexicanus on one side and all auratus on the other!

2 Since this was in type, Mr. Allen has published (Bull. Am. Mus. N. H. iv. pp. 21-44) the results of an elaborate investigation which he says "tend strongly to confirm Baird's startling hypotheses of hybridization on a grand scale." 
ing its food on the ground, and to breed in holes which it excavates in cliffs, the banks of streams, or in old walls; but latterly, according to Mr. Hudson (Argent. Ornithol. ii. p. 25), it has taken to make its nest in trees, reverting presumably to the habit of its ancestors. The fact rests on the best of evidence, but any inference is open to criticism. Curiously enough, a very similar state of things is presented by an apparently cognate bird from South Africa, Geocolaptes olivaceus or arator, which bears a strong superficial resemblance and possibly (though this has not yet been ascertained) a deepseated affinity to the American forms. This Woodpecker, as Mr. Layard remarks (B. S. Afr. p. 239), " never pecks wood, but bores its way into the banks of rivers, sides of hills, or the walls of mudbuildings, in search of its prey, and for a home for its young." Mr. Buckley states (Ibis, 1874, p. 369) that in Natal he never noticed it among trees; but found it on the open hills and sitting among stones. Considering how few Woodpeckers there are in the Ethiopian Region, the occurrence at its southern extremity of this simulacrum of a New-World type raises more than one question of the deepest interest.

FLIGHT. ${ }^{1}$ Birds have three chicf modes of flight, each differing from the others in certain important particulars. These are-

I. By gliding or skimming, supported on the extended wings, which do not flap up and down. Most probably all birds that fly can move in this manner. It requires a certain velocity of motion of the bird through the air (relative velocity), which is acquired (1) by previous strokes of the wings, (2) by descending from a higher to a lower level, or (3) by commencing flight in a wind of sufficient velocity.

II. By active strokes of the wings. The manner in which this mode of progression is carried out varies in detail in different birds, and in the same bird at different times, but its main features appear to be the same for all.

III. By sailing or soaring with motionless extended wings. This appears to be only possible for certain birds, and is not described as taking place except in a wind of a certain minimum velocity, and differs from ordinary gliding in the fact that the bird does not necessarily lose either in velocity or in vertical position, as a result of the resistance of the air to the bird's passage through it.

1 I an indebted for this article to my colleague Prof. Roy, who remarks that, in it, he has "sought to avoid inaccuracy of fact or method of statement, the main objeet being to put the matter in as simple a form as possible, so as not to confuse the non-scientific reader. The references given to the most important authorities on the subject will enable those who wish to pursue it further to do so "-A. N. 
Before analyzing these morles of aerial locomotion, it is desirable to refer to some of the conditions under which birds are placed, since these must be taken into account if it be desired to understand the problems of flight. What, in the first place, is known about the relation between the weight of birds and the area of their wings, and how do birds differ from one another in this respect? This subject has been carefully studied by Müllenhoff ${ }^{1}$ and others. It has been found that the relation of the wing-or rather sail-area to the weight of the bird varies greatly. As might be expected, the greater the sail-area, the more powerful, other things being equal, is the flight.

Another matter in which birds differ greatly is the strength of the muscles which move the wings. It may be assumed that the strength of these muscles corresponds with their weight. The relation between the weight of the pectoral muscles and that of the whole bird has been investigated among others by Legal and Reichel, ${ }^{2}$ who found that the pectoral muscles weigh on an average about one-sixth of the whole bird; but that in different types of birds there may be considerable difference in this respect. For instance, in a House-Pigeon the proportion was 45 per cent, while in a Herring-Gull it was only 16 per cent. Some birds therefore have much more powerful wing-muscles than others.

The shape of the wing, moreover, varies considerably also in different birds. Some, like the Swallow, have long and narrow wings, while others, like the Quail, have short and broad wings. The wings of some soaring birds, as Eagles and Vultures, are rounded at the points, and the primary feathers are separated from one another at their tips, giving a notched appearance to the end of the extended wings. A typically flying bird, such as a Falcon, on the other hand, has pointed wings with little separation of the tips of the primary feathers. These differences correspond to differences in the power and mode of flight.

Birds, as well as all other animals that fly, may be divided into categories according $(a)$ to the ratio between the sail-area and the weight, $(b)$ to the strength of the pectoral muscles, and $(c)$ to the shape of the wings. Of these categories or "types" Müllenhoff

1 "Die Grösse der Flugflächen." Archiv für die gesammte Physiologie (Pfliuger's), xxxv. (1885) pp. 407 et seqq. Müllenhoff follows Harting, Legal and Reichel, Marey, and others in estimating the ratio between the sail-area of Birds and their weight by the formula $\mathrm{A}^{\frac{2}{2}} / \mathrm{P}^{\frac{1}{3}}=\sigma$, in which $\mathrm{A}$ is the area (in square centimetres) of the out-stretched wings and tail as well as of the body, spread out on a flat surface, while $P$ is the weight of the bird (in grammes). The values found for $\sigma$ in different birds range from 2.85 (Golden-Eye) to 6.735 (Barn-Owl).

2Verhandlungen der Schlesischen Gesellschaft für vaterländ-Cultur. Breslau : 1882. 
distinguishes six,-namely the Quail, Pheasant, Sparrow, Swallow, Vulture, and Gull.

In considering birds from the point of view of their flying capacities, it should be kept in mind that their anatomical structure is such as to give them great stability in the air. The wings are attached to the highest part of the thorax, so that the centre of gravity of the bird is as low as passible beneath the centre of suspension on the wings, and also that the same object is assisted by the light organs, viz. the lungs and air-sacs, being placed high, while the heavy organs of digestion, and above all the heavy pectoral muscles, are placed as low as possible. The shape of a bird's body, moreover, is such that it offers little resistance to its passage through the air.

We must here say something about the resistance offered by the air to the passage of a body through it. As Newton first shewed, this resistance increases with the square of the velocity of the body. It increases also directly with the sectional area at right angles with the axis of motion (the geometrical form of the body being similar), and this velocity and area multiplied by one another and by a numerical coefficient gives the resistance. ${ }^{1}$

Of the greatest importance for the flight of birds is the fact that the resistance offered to the motion of a flat body in a direction at right angles to the plane of its surface is very greatly increased if it be made to move at the same time through the air rapidly in a direction parallel with its surface.

As a clear comprehension of this matter is important, an illustration may be given from Sir George Cayley. ${ }^{2}$ Supposing a flat surface, such as a piece of cardboard, with a superficial area of one foot and inclined at an angle of six degrees to the line of movement, be carried forwards horizontally, as in the case of the wings of a gliding bird, it is found that with a rapidity of 23.6 feet per second the pressure perpendicular to its surface is 4 of a pound, while if the speed be increased to $27 \cdot 3$ feet per second, it is equal to one pound. A Rook, whose weight and wing-area were found by Cayley to be, roughly speaking, in the ratio of one pound to the square foot, would therefore be able to glide horizontally whenever it had a velocity of $27 \cdot 3$ feet. But a Rook usually flies

1 Expressed more exactly, the resistance, $\mathrm{R}$, offered by the air to the passage of a flat surface through it may be stated as $\mathrm{R}=\mathrm{K} \mathrm{S} \mathrm{V} 2 \frac{\rho \pi \sin ^{2} a}{4+\pi \sin a} ; \mathrm{K}$ being the numerical coefficient, $\mathrm{S}$ the surface, $\mathrm{V}$ the velocity, $\rho$ the density of the air, and $a$ the angle of the surface with the line of motion. It must be understood here that the resistance is to the forward movement of the surface, i.e. the resistance in the line of motion.

2 "On Aërial Navigation." Journal of Natural Philosophy, Chemistry, and the Arts (Nicholson's), xxiv. p. 164 (1809). 
faster than this, about 35 fect per second according to Cayley, and can glide horizontally for a short distance whencver it likes. ${ }^{1}$

We can now proceed to consider the different moles of aerial locomotion employed by birds, and in doing this it will be convenient to take first (I.) gliding flight, as this is the simplest. Its commonest form is when a bird, having acquired a certain velocity, intermits the flapping of its wings, and, with them and its tail extended, floats or skims forward in the air. This is especially common with such birds as Herons, Storks, Buzzards, Gulls, and others with a relatively large sail-area. The required velocity of movement may be obtained by descending; as for example, when a Pigeon flies from the roof of a house to the ground below it usually glides or skims down. The movement is, from its nature, a temporary one, involving as it does a loss either in vertical height or in relative vclocity, i.e. in motion through the air. The direction of the trajectory may be up as well as down. In the case of a Falcon, which swoops down on its quarry, the altitude which is lost may, in case of its missing its prey, be in great part recovered by gliding upwards on extended wings. As was long ago known by falconers, these swoops involve little exertion on the part of the birds, which do not pant as they do after severe effort. Here the velocity acquired by descending with the wings close to the body is used to raise the bird again. If a bird moving in a horizontal line seeks to glide upwards, the height to which it will be able to rise will correspond with the square of the initial velocity.

We can get some idea of the efficacy of this mode of flight by observations on the rapidity of motion of birds which descend in gliding for some distance obliquely in a straight line. This has been done by Bretonnière, ${ }^{2}$ who found that Storks were in the habit

1 This illustration is given becanse, besides being of historical interest, it is clear and easily comprehensible. It was accurate enough for the time when written, but is now open to criticism from several points. For instance, the sail-area of the Rook ought to include an allowance for the area of the body measured in the plane of flight as well as the area of the wings. The supporting force, i.e. the thrust upwards on the Rook's wings and body, can be suffciently accurately expressed by the formula

$$
\mathrm{M}=\mathrm{KS} \mathrm{V} \frac{2 \rho \pi \sin a \cos a}{4+\pi \sin a}
$$

where $\mathrm{M}$ is the force on the plane at right angles to the direction of motion, and the other letters are as before.

By some curious oversight, Cayley stated that an increase of speed from 23.6 $\mathrm{ft}$. to $27 \cdot 3 \mathrm{ft}$. per second will give an increase in the supporting force sufficient to raise it from 4 of a pound to one pound. It ought to be 37.3 instead of $27 \cdot 3$.

2 "Étndes sur le vol plané," L'Aéronaute, juillet 1889. Reproduced by Marey, Vol des Oiseaux, p. 296. 
of descending obliquely from the high rock on which the town of Constantine is built by a gliding flight; that they usually followed a straight line, and, with a constant velocity, progressed thus more than a kilometre before reaching the ground. The rate of motion was found to be about 20 metres per second, and the trajectory was at an angle of 10 degrees with the horizon, which gives a descent of about 1 in 5 . This corresponds with other observations.

We now come to the question how a bird guides its motion during the act of gliding, and here we must refer to the Law of Avanzini, ${ }^{1}$ illustrated by the aunexed diagrams, shewing that a plate $(\mathrm{AB})$

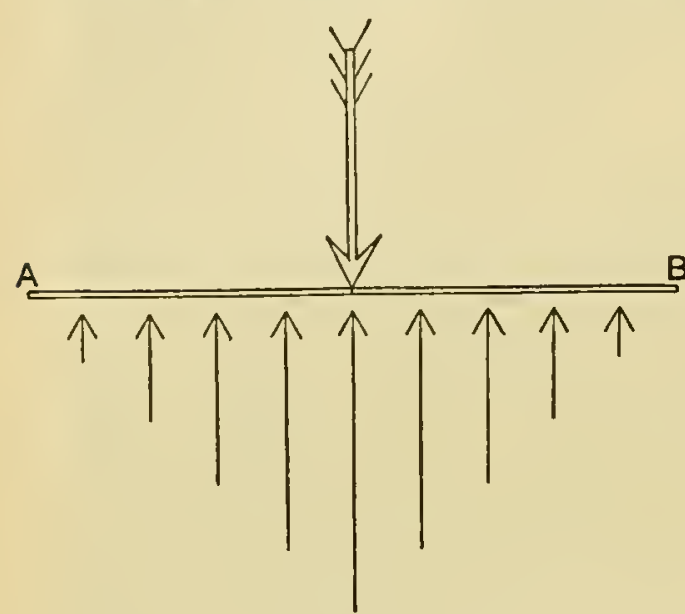

Fir. 1.

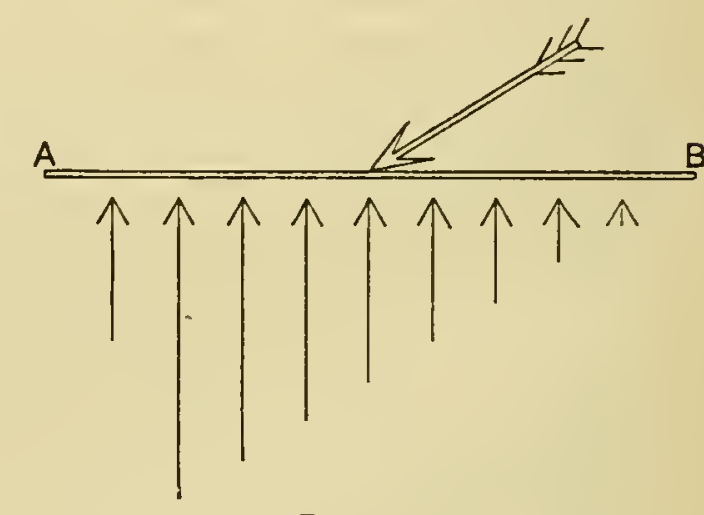

FIG. 2.

falling vertically through the air (as in Fig. 1) encounters the maximum of resistance (indicated by the greater length of the lower series of arrow-heads) at the centre, the resistance decreasing toward the margin, whereas if the direction in which the plate falls be oblique (as in Fig. 2), the maximum of resistance is no longer at the centre but the fore end of the plate, which therefore has a tendency to tilt up. In the case of a bird which has no horizontal motion, but is falling slowly with extended wings, it is known that the point of maximum upward pressure by the air on the lower surface of each wing will correspond with the centre of its area; and the same is the case when a bird gives a downward stroke of the wing, if the bird has no forward motion through the air. If, however, the bird be gliding forward, the point of maximum upward pressure is changed and is placed nearer the anterior niargin of the extended wing, and the faster the bird is moving the further forward is the position of maximum upward thrust. The result of this is that any increase of velocity tends to thrust up the front part of a gliding bird's wings; and in the same way and

1 "Resistenza dei fluidi," Mem. Istit. Naz. Itat. Bologna, i. p. 199. A more recent account of the same subject is that by Lord Rayleigh "On the Resistance of Fluids," Phitos. Mag. ser. 5, ii. p. 430 (1876). 
for the same reason as a sheet of paper which is allowed to fall tends to describe curves with their concavities upwards, so also does a gliding bird tend to rise in the air whenever its velocity is increased. This tendency the bird can counteract in various ways. It can, in the first place, change the position of its centre of gravity forwards in relation to the position of its centre of support by the outstretched wings. It can do this in the case of such a bird as a Heron by extending its neck, which is usually bent with the head retracted, but which, when the bird strives to fly fast, is stretched out forward to the full extent. In the case of most birds, however, the short neck does not allow of this means of moving forward or backward of the centre of gravity, and what the bird does is to move forward or backward the extended wings. As a matter of fact, it had been noted long before the true reason

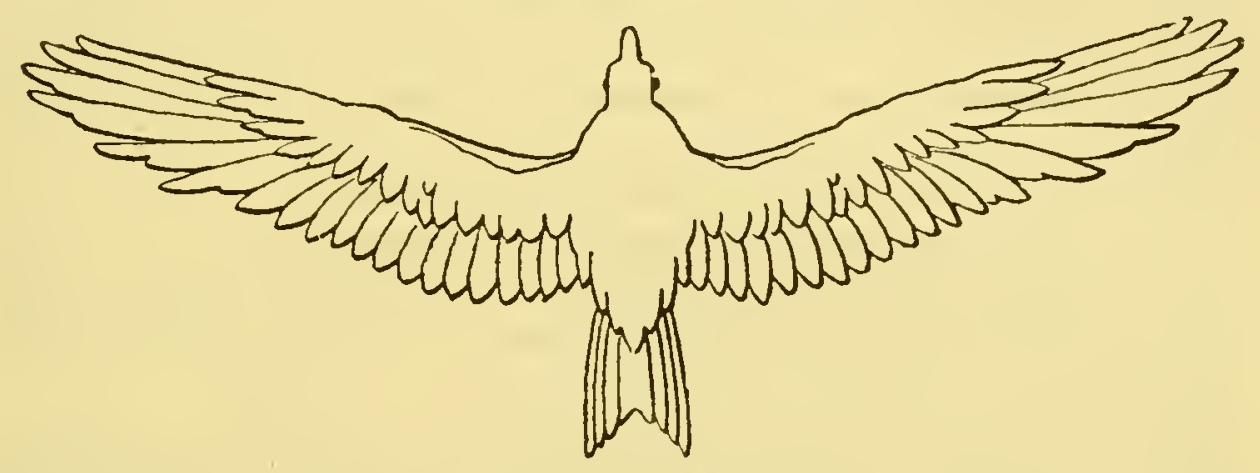

FIG. 3. (From Marey.)

was understood that birds which glide slowly (Fig. 3) had their wings much further forward than the partially flexed wings of birds which glide rapidly (Fig. 4) through the air. ${ }^{1}$

A similar effect is obtained by spreading out the tailfeathers, which moves back the centre of the plane of suspension formed by the wings, body, and tail, thereby

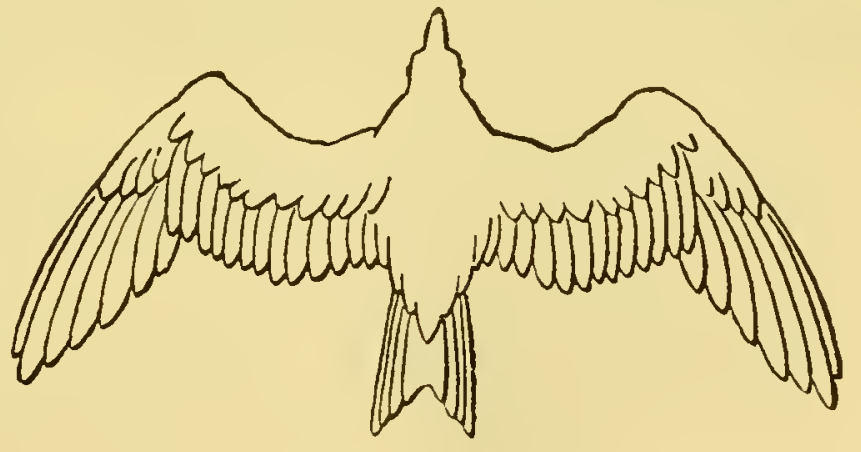

Fig. 4. (From Marey.) relatively advancing the centre of gravity of the bird. Change of direction, upward or downward, can in this way be obtained

1 This fact (that the point of maximum resistance is moved forward when a flat surface strikes a fluid, with at the same time a movement parallel with the plane of the surface) seems to us well fitted to explain why it is that the shafts of the primary wing-feathers, which during extension of the wing make a great angle 
by moving backwards or forwards the centre of gravity in relation to the centre of suspension, and this does not involve any change in the angle which the under surface of the wings or tail makes with the line of flight. It involves, moreover, only slight muscular exertion, and therefore comparatively little expenditure of energy on the part of the bird in guiding its motion. By raising or lowering the expanded tail the direction can also be changed, but either of these movements tends to destroy equilibrium, and they do not seem to be used in ordinary gliding. In order to turn to the right or left a gliding bird has only to move its centre of gravity to one or other side of its centre of suspension. This it can do in a variety of ways; for instance, by turning its head to one side, when, as was observed by Leonardo da Vinci, the course of the gliding turus in the same direction. A still more effective way is to change the centre of suspension by partially flexing one wing, which causes the bird to turn towards the same side. A similar effect is produced by raising one side of the extended tail and lowering the other. Any or all of these movements give the bird power to turn to either side.

We should not have considered it necessary to say so much about the gliding flight of birds had it not been that what we have said on this mode of aerial locomotion is equally true when the bird moves by active strokes of the wings or by sailing.

with the line of flight, are placed so much nearer the anterior margin of the feathers than is the case with the secondary feathers, which lie in a line more

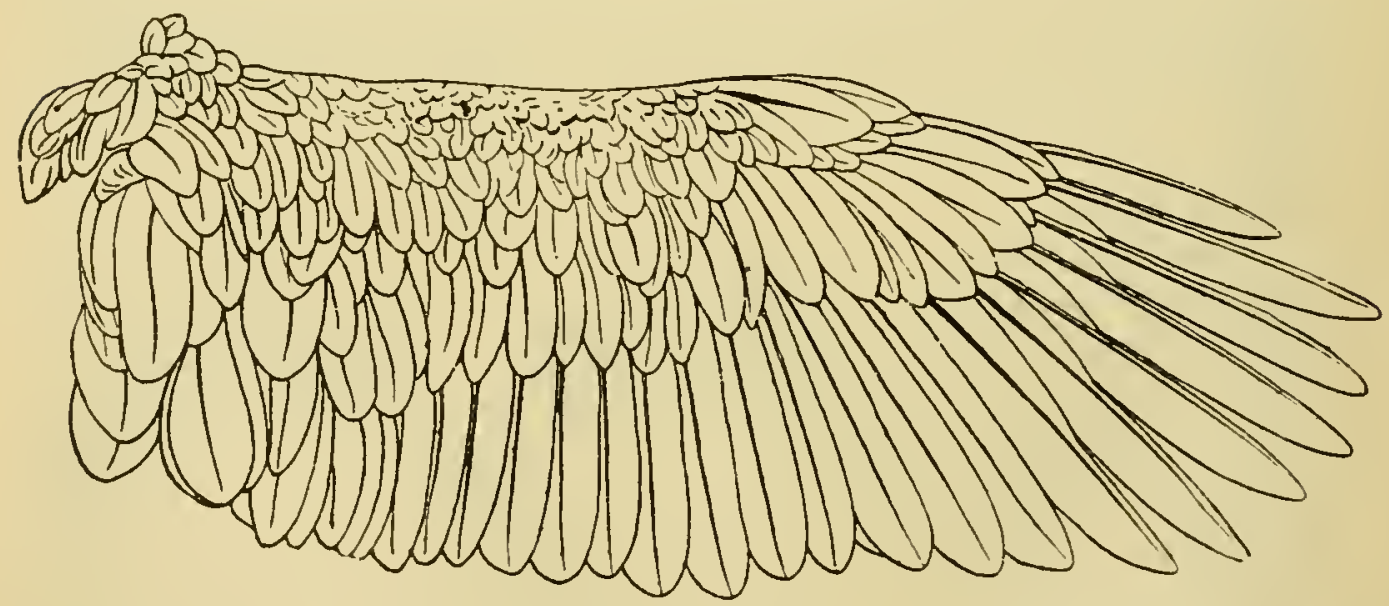

FIG. 5. (From Marey.)

nearly parallel with the axis of flight, as is shewn in the amexed figure (Fig. 5) of a fully extended eagle's wing. Were it otherwise, the outer or anterior vane would bend upwards more than the posterior vane and make forward movement, as a result either of the passive extension in gliding or the active down stroke, an impossibility. This explanation of the different shape of the primary and secondary feathers of the wing scems to have been hitherto overlooked. 
II. Flight by active strokes of the wings. It is very much easier for a bird to sustain itself in the air by active flight, if it have a certain initial relative velocity, than if it seek to begin flying from a position of relative rest or want of motion. This leads all birds to rise from the ground with their heads towards the wind. If there be not wind enough, the bird seeks to gain initial velocity by running or springing, or both. In the case of aquatic birds the velocity is obtained in part by striking the water with their wing-tips during the first few strokes. In "hovering," which is only possible for very powerful flyers, the great exertion call be seen from the rapidity with which the wing-strokes follow one another. Birds with short legs and long wings, as the Condor and Albatros, cannot, in the absence of wind, rise at all from the ground unless they have room to run, and Condors can be easily caught by tempting them with food within a narrow enclosure. Even the strong-flying Pigeon, after being made to rise from the ground and fly a short distance for five or six times in succession, refuses to rise again, and remains on the ground panting with open beak. Marey, who observed this in his own Pigeons, calculates that the energy expended per second in a Pigeon when taking flight is five times as great as when it has acquired a certain velocity. The bird at starting makes rapid strokes with its wings, which move through a large angle, -in the case of the Pigeon striking one another above the back at the end of the up stroke, and nearly touching with their tips at the end of the down stroke. When velocity has been acquired, the flaps are slower, and the angle which they describe round the shoulder-joint is a very much smaller one. The reason why so much more energy is required to fly when they have little or no initial velocity relative to the air is due to the increased support afforded by the air if the wing-surface which strikes it be at the same time travelling through the air in a line more or less parallel to its surface. This gain in resistance to the wing-stroke increases, as we have already pointed out, with the square of the velocity of the wing in a direction parallel with the axis of flight.

With regard to the manner in which a bird uses its wings during flight we are indebted chiefly to Marey, who employed much more exact methods of observation than had previously been made use of. As can be seen from the annexed figure (Fig. 6), which shews a Gull photographed at successive intervals of onefiftieth of a second, the wings during the down stroke move forward as well as downward. It can be shewn that the outer end of the humerus describes a kind of ellipse(Fig. 7 ) round a straight line passing through the shoulder-joints, the long axis of which ellipse is inclined slightly downwards from the horizontal. During the down stroke, which is made along the front half of the ellipse, the surface of the 
remiges, shewn by the short lines in the figure, taken in a line parallel to the trajectory of the bird, is inclined at an angle with

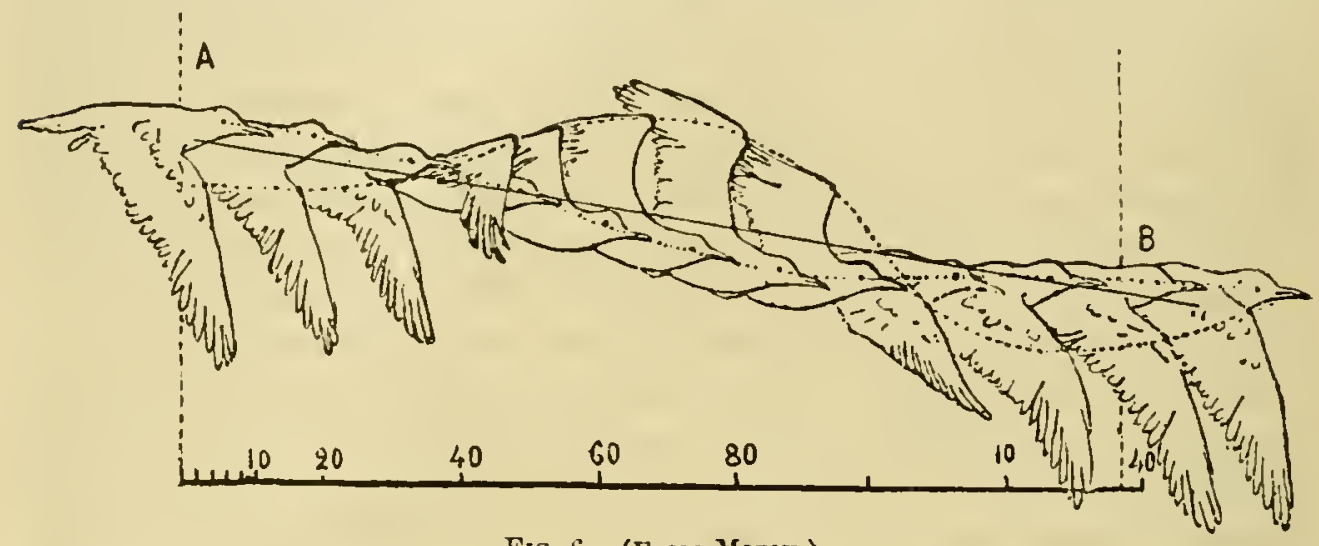

Fig. 6. (Froin Marey.)

the line of flight, so that their under surface looks downwards and backwards. The exact angle is not known, but it is certainly a

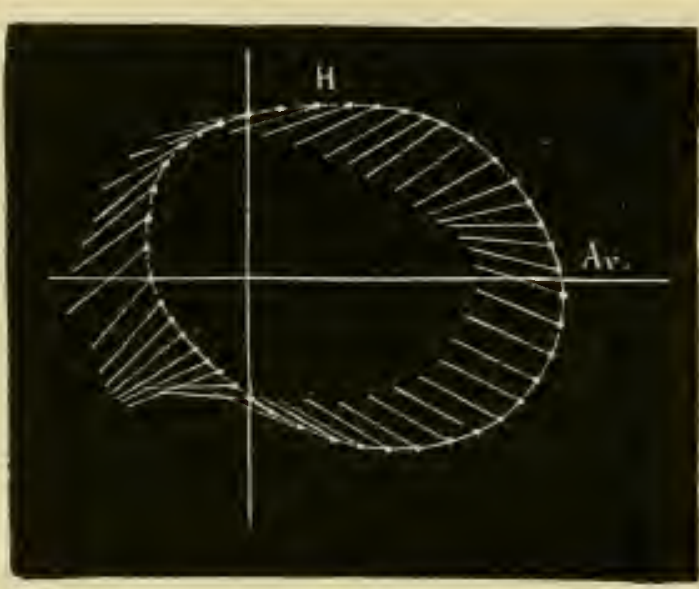

FIG. 7. (Froin Marey.) small one, and probably varies with the velocity of the bird's motion. Having made the down and forward stroke, the wing moves backward, being still extended, and still inclined slightly backwards. The diagram indicating a bird flying from left to right, though not to be taken as more than approximately exact, gives an idea of what is known regarding the trajectory of the wing and the inclinations of its plane with the axis of flight. The down stroke, it should be added, takes a longer time than the up stroke. In making the latter, as can be seen from the figure (Fig. 8), the wing passes at first backwards, and then, becoming partially flexed with a whiplike action, it rises upwards, the plane of the wing being altered during the up stroke, so that it looks down and forward. If the bird be flying fairly rapidly through the air, the up stroke is mainly a passive movement, the bird continuing to rest on the wings, and the velocity of the forward motion of its body diminishing, to be increased again with the next down stroke. At starting, and before the bird has acquired velocity, the up stroke is an active one, and the primary feathers can be proved to separate from one another, facilitating thereby the movement by redneing the resistance offered by the air to the back of the wing. The above description applies mainly to the Pigeon and 
Gull, on which the observations have for the most part been made, but there is at present $n 0$ reason for supposing that the active flight of other birds differs from that described in any essential
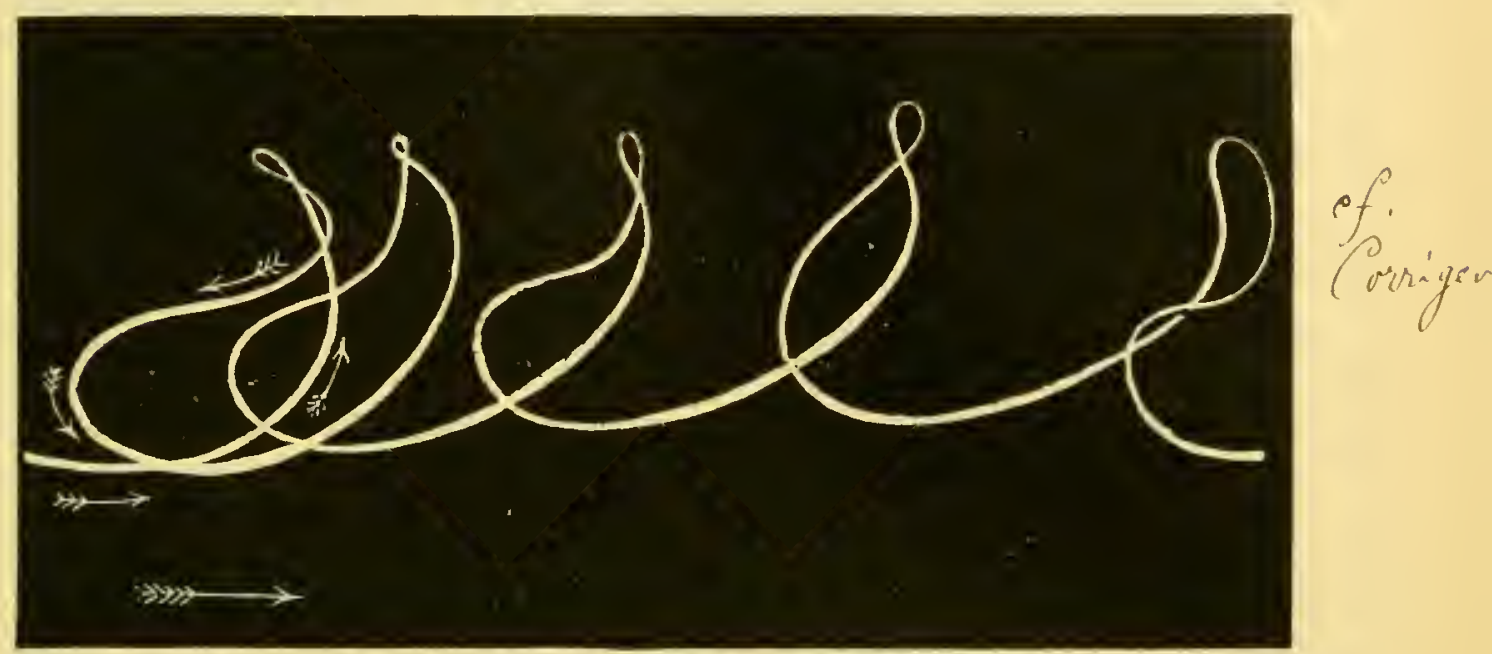

Fig. E. - Photooral'hic trajectory of tile tip of a Crow's Wing. The little arrows shew the direction of the tip's movement. (From Marey.)

particulars, though there is still a good deal to be learned about the mechanics of active flight, and data sufficient, for example, to enable us to calculate the work done by a bird in flying through the air are still wanting. We have, however, in the above given only a very incomplete sketch of what has already been learned on the subject.

III. We now come to the interesting subject of soaring or saiting. The typical soaring birds come under Müllenhoff"s ' "Vulture-type," whose sail-area in relation to the total weight of the bird is a large one. In this category come such birds as the larger Corvidx, viz. the Raven and Crow, the Falcons and Vultures, the Owls, 'Pelicans, and Storks. Those of them which can soar are mostly large birds, with a relatirely large wing-area, and few of them are commonly visible in this conntry, which'is possibly one reason why the whole subject of soaring flight is still so obscure.

The main characteristics of the soaring flight of such birds have, however, been recorded by a number of trustworthy observers, and are no longer seriously disputed. A certain amount of wind appears to be essential, soaring flight not being observed in a dead calm. Observers seem to agree also in this, that the soaring bird, with motionless outstretched wings (having raised itself some distance from the ground or sea by active wingstrokes), describes in its flight, curves or circles which lead it to alternately sail up the wind and down the wind. It describes wide curves, and loses in vertical position while it is directed down

\footnotetext{
1 Tom. cit. p. 425.
} 
the wind, while in going up into the wind it rises higher in the air. The bird may, in describing these curves or circles, rise as high or higher than the point from which it started, and may be as far or further to windward, and this without any very evident expenditure of mechanical work on the part of the bird. This at first sight looks sufficiently startling, and one's first impulse would naturally be to question the facts. There appears, however, to be no sutficient reason for doubting the main points above stated. Other modes of soaring have, indeed, been described, but it is unnecessary to go into these latter, since any explanation of how it is that a bird, with what may be described as little or no mechanical work ${ }^{1}$ on its part, can not only keep itself up in the air but can actually rise higher, or, keeping about the same level, can progress to windward, will presumably cover all the varieties of soaring.

Now the theories with which we are acquainted as to the mechanics of soaring may be divided into two categories-those, in the first place, evolved by observers who have noted certain prominent facts and have sought to explain these by reasonings which have been in some cases wildly disregardful of the elements of dynamics. Such theories may, indeed must, be put to one side, although the facts on which they are based cannot be left out of consideration. The second category of theories are those made by physicists and mathematicians, and which are characterized by being in harmony with what is known of the laws of nature, and also, with certain important exceptions (to be presently considered), by being inadequate to explain facts which had been noted by a consensus of trustworthy observers. We cannot go over these two series of theories in detail, and can only find room to consider two, drawn from our second category. These are, first, the theory of upvard currents of air ${ }^{2}{ }^{2}$ and, secondly, the theory of varying velocity of the wind at different heights from the land or water. There is a good deal to be said for both of these possible explanations-which, of course, involves the conclusion that the data required to decide the matter are still wanting. Nevertheless, the subject is too interesting and important to justify us in seeking to evade the difficulties of the problem before us, and we will try to put seriatim the reason for and against these two (so far as we know only) possibilities.

1 While resting on its motionless extended wings a bird may be doing no mechanical work, but it is nevertheless expending energy in keeping up a certain legree of contraction of its pectoral muscles. This work, which is real enough of its kind, is expended in the muscles themselves, and concerns the physiologist rather than the mechanician. It is called internal work by physiologists.

2 W. Fronde, Proc. R. Soc. Edinb. xr. pp. 256-25s (19 March 1888). [A continuation of this note has since appeared (op. cit. xviii. pl. 65-72, 5 January 1891).-A. N.] 
Upward currents of air are to be met with, when there is a wind, on the windward side of a sloping mountain, or a house, or the sail of a ship, or as a result of the inequalities of surface produced by waves on the sea. For example, Gulls may be seen to soar for a prolonged period of time in front of or above clifis on the shore when the wind comes from the sea. This, however, cannot be taken as an example of soaring proper, seeing that Gulls can only remain suspended in the air without loss of relative horizontal motion under special conditions which do not apply in the case of the typical soaring birds. Gulls are not seen to soar except under conditions which point toward upward currents, being a very obvious explanation of the phenomenon. In the case, on the other hand, of typical soaring birds, such as those named above, soaring is observable under conditions and at heights where there is no sufficient reason to assume that upward currents exist. For example, Eagles and Adjutants are seen to rise continuously by soaring for miles above the surface of the ground ol sea. To explain such cases as being due to upward currents would, we are of opinion, require a good deal more evidence of continuous upward currents of air from the plains or seas than is at present available. That the direction of the wind even at great heights, and above a comparatively smooth sea or plain, is by no means always parallel with the surface of the globe is more than probable; but we know of no reason for assuming that the upward currents are sufficiently predominant over the downward currents to justify us in looking on the former as capable of explaining observed facts as to soaring. In other words, the theory of upward currents of the air as an explanation of sailing or soaring flight requires more support in the way of facts than have been so far produced.

The theory of unequal velocity of the air at different heights as an explanation of soaring is based on the fact that the motion of a wind is retarded by the surface of the earth, so that considerable variations in velocity may and do occur at different heights above the ground. The matter is put very clearly by Hubert Airy, ${ }^{1}$ although we are indebted, in this country at all events, to Lord Rayleigh for having first formulated it. Airy says: "Suppose a bird at the highest point of one of its gyrations, when it has mounted against the wind and is wheeling to one or other side preparatory to the descent with the wind. . . Let us regard the air at the level of the bird, at this turuing-point, as still. Then, relative to this point, the lower strata of air have a horizontal velocity in the opposite direction to the wind (as perceived on earth); and the bird in falling apparently down the wind will really be meeting stronger and stronger adverse currents, and when it has reached

$$
1 \text { Nature, xxvii. pp. } 534 \text { and } 591 .
$$


the lowest point of the 'circle' it will have a greater horizontal velocity relative to the air at that level than if the whole air through which it had fallen had been still. . . . Suppose the bird as it rises wheels gradually round and faces the wind. Then in rising it will enter successive strata of air, having successively greater and greater velocity relative to itself (the bird) than if the air had no internal movement, and therefore the air-resistance, which is the lifting force, will ever be greater than that due to (or corresponding with) the height gained by the bird if in still air." As Rayleigh noted, the gain to the bird corresponds, not with the increments in velocity, but with the increments in the square of velocity.

This theory fits in very well with most of the facts noted by different observers in soaring birds. It especially agrees with the fact that soaring birds appear always in making their horizontal curves to alternately rise and descend in the manner above described. Against this theory, on the other hand, is the fact that birds may be seen to soar a great height above the surface of the globe-too high to justify us in assuming that different strata of the wind travel with such differences in velocity as have been observed nearer the earth. This is a matter, however, on which we have as yet insufficient information; and it is worth noting that any local variations in the velocity of neighbouring currents of air will be capable of being of use to a soaring bird in a manner analogous to that described by Airy.

In the meantime we are inclined to accejt Rayleigh's theory; but the facts, it appears to us, want investigation with more exact methods than have hitherto been employed. What is needed is to learn exactly the course of a soaring bird both in the vertical and horizontal dimensions in each part of its course, as well as the exact velocity and direction of the wind in the strata of air through which the bird progresses.

Much has been written on size as influencing the power of flight in different birds, but this is a subject into which we cannot here enter. Two opposite views regarding it will be found stated at length by Müllenhoff (op. cit.) and Strasser. ${ }^{1}$

Finally, it is important to note that frictional resistance, which, as the late Mr. W. Froude has shewn, plays so great a part in obstructing the movement of a ship through water, seems, from recent observations by Langley ${ }^{2}$ and Maxim, $^{3}$ to have very slight influence in hindering the passage of a bird through the air.

Charless S. Roy.

-* Ueber den Flug der Vögel, pl. $404-417$ (Jena : 1885).

2 Comptes Rendus de l'Aead. Se. cxiii. pp. 59.63 (1891).

3 Century Magazine, xlii. pp. 829-836 (Oct. 1891). 
FLORICAN or FLORIKEN, ${ }^{1}$ the Anglo-Indian name for the smaller BustaRDs, the origin of which neither Jerdon (B. Ind. ii. p. 625) nor Yule (Hobson Jobson, p. 270) can trace. The latter shews that it was used in 1780 (Munro, Narrative, p. 199), and says "it looks like Dutch"; but from analogy a Portuguese derivation would seem more likely.

FLOWER-PECKER, the name given by Indian ornithologists to species of the genus DICEUM and others supposed to be allied to it (cf. Jerdon, B. Ind. i. pp. 373-378; Oates, Fauna Br. Ind. Birds, ii. pp. 376-386).

FLUSHER, said by Ray in 1674 (Coll. Engl. Words, p. 83) to be a name given in Yorkshire to the BUTCHER-BIRD or Red-backed SHRIKE; but he probably should have written "Flesher"-that being a common North-country word for butcher.

FLYCATCHER, a name introduced in ornithology by Ray, being a translation of the Muscicapa of older authors, and applied by Penmant to an extremely common English bird, the MI. grisola of Linnæus. It has since been used in a general and very vague way for a great many small birds from all parts of the world, which have the habit of catching flies on the wing, and thus ornithologists who have trusted too much to this characteristic and to certain merely superficial correlations of structure, especially those exhibited by a broad and rather flat bill and a gape beset by strong hairs or bristles, have associated under the title of Muscicapidæ an exceedingly heterogeneous assemblage of forms that, though much reduced in number by later systematists, has scarcely yet been sufficiently revised. Great advance has been made, however, in establishing as independent Families the Todide (Tony) and Eurylamida (BROADBILL), as well as in excluding from it various members of the Cotingida (ChatTerer), Tyrannida, Vireonida, Mniotiltida (American WARBLER), and perliaps others, which had been placed within its limits. These steps have left the Muscicapida a purely Old-World Family of the Order Passeres, and the chief difficulty now seems to lie in separating it from CAMPEPIfAGA, with its relations, and from the Laniida (SHRIKE). Every ornithologist must own that its precise definition is at present almost impossible, and must await that truer knowledge which comes of investigating structural characters more deeply seated than any afforded by the epidermis. But here want of space forbids the pursuit of this kind of enquiry,

1 Some form of this word, variously spelt by authors, doubtless gave rise to "Flercher," which Latham in 1787 said (Syn. B. Suppl. p. 229) was used in India "by some of the English," and is probably due to a misprint or wrong reading. Jerdon says that he was once informed that the Little Bustard was "sometimes called Flanderkin"; but I am not able to find such a nane for it. May Florican, after all, arise from a mispronunciation of Francolis? 
and for the same reason only a very few of the forms of Flycatchers (which, after all the deductions above mentioned, may be reckoned to include some 60 genera or subgenera, and perhaps 250 species) can be even named. ${ }^{1}$

The best known bird of this Family is that which also happens to be the type of the Linnæan genus Muscicapa-the Spotted or Grey Flycatcher, M. grisola, already mentioned. It is a common summer-visitant to nearly the whole of Europe, and is found throughout Great Britain, though less abundant in Scotland than in England, as well as in many parts of Ireland, where, however, it seems to be but locally and sparingly distributed. It is one of the latest of our migrants to arrive, and seldom reaches these islands till the latter part of May, when it may be seen, a small dustcoloured hird, sitting on the posts or railings of our gardens and fields, ever and anon springing into the air, seizing with an audible snap of its bill some passing insect as it flies, and returning to the spot it has quitted, or taking up some similar station to keep watch as before. It has no song, but merely a plaintive or peevish callnote, uttered from time to time with a jerking gesture of the wings. It makes a neat nest, built among the small twigs which sprout from the bole of a large tree, or fixed in the branches of some plant trained against a wall, or placed in any hole of the wall itself that may be left by the falling of a brick or stone. The eggs are from four to six in number, of a pale greenish-blue, closely blotched or freckled with rust-colour. Silent and inconspicuous as is this bird, its constant pursuit of flies in the closest vicinity of our houses makes it a familiar object to almost everybody. A second Britisl species is the Pied Flycatcher, M. atricapilla,-called by some writers the Coldfinch - a much rarer bird, and in England not often seen except in the hilly country extending from the Peak of Derbyshire to Cumberland, and more numerous in the Lake district than elsewhere. It is not common in Scotland, and has only once been observed in Irelancl. More of a woodland bird than the former, the brightly-contrasted black and white plumage of the cock, together with his agreeable song, readily attracts attention where it occurs. It is a summer visitant to all Western Europe, but further eastward its place is taken by a nearly allied species, II. collaris, in which the white of the throat and breast extends

1 Of the 30 senera or subgenera whieh Swainson ineluded in his Natural Arrangement and Relations of the Family of Flycatchers (published in 1838), at least 19 do not belong to the Mruscicapidx at all, and one of them, Todus, not even to the Order Passeres. It is perhaps impossible to name any ornitho. logical work whose substance so fully belies its title as loes this treatise. Swain. son wrote it filled with faith in the so-called "Quinary System" (see IxtropucTrox), and, unconsciously swayed by that bias, his judgment was warped to fit his hypothesis. 
like a collar round the neck. A fourth European species, M. parva, distinguished by its very small size and red breast, has also strayed several times to the British Islands. This last belongs to a group of more eastern range, which has received generic recognition (possibly well deserved) under the name of Erythrosternu, and it has several relations in Asia and particularly in India, while the allies of the Pied Flycatchers (Ficedula of Brisson) are chiefly of African origin, and those of the Grey or Spotted Flycatcher (MIuscicopu proper $^{1}$ ) are common to almost the whole Paliearctic area.

One of the most remarkable groups of Muscicapida is that known as the Paradise Flycatchers, forming the genus Terpsiphone of Gloger (Tchitrea of Lesson). In nearly all the species the males are distinguished by the growth of exceedingly long feathers in their tail, and by their putting on, for some part of the year at least, a plumage generally white, but almost always quite different from that worn by the females, which is of a more or less deep chestnut or bay colour, though in both sexes the crown is of a glossy steelblue. They are found pretty well throughout Africa and tropical Asia to Japan, and seem to affect the deep shade of forests rather than the open country. The best-known species is perhaps the Indian T. paradisi; but the Chinese $T$. incii, and the Japanese T. princeps, from being very commonly represented by the artists of those nations on screens, fans, and the like, are hardly less so; and the cock of the last named, with his bill of a pale greenishblue and eyes surrounded by bare skin of the same colour-though these are characters possessed in some degree by all the speciesseems to be the most beautiful of the genus. T. bourbonnensis, which is peculiar to the islands of Mauritius and Réunion, appears to be the only species in which the outward difference of the sexes is but slight. In T. corvina of the Seychelles, the adult male is wholly black, and his middle tail-feathers are not only very long but very broad. In T. mutata of Madagascar, some of the males are found in a blackish plumage, though with the elongated median rectrices white, while in others white predominates over the whole body; but whether this sex is here actually dimorphic, or whether the one dress is a passing phase of the other, is at present undetermined. Some of the Aflican species, of which many have been described, seem always to retain the rufous plumage, but the long tail-feathers serve to mark the males; and the whole group deserves more investigation than it has yet received, as it is likely to reveal facts of importance in regard to the theory of "Sexual Selection."

On the other groups of the Family there is not room to descant. A few are distinguished by the brilliant blue they exhibit, as Myiugra azurea, and others, as Piezorhynchus chrysomelas, by their

${ }^{1}$ By some writers this section is distinguished as Butalis of Boie, but to do so seems contrary to rule. 
golden-yellow. Arses has the skin round the eyes bare and of some bright colour. The Australian forms assigned to the Muscicapida

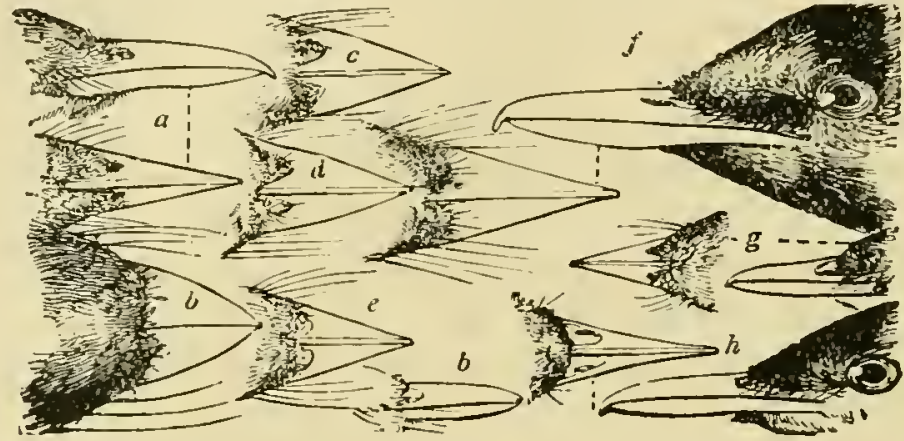

$a$, Cryptolopha $; b, e, d$, $e$, Mriafira $f$, Terpsiphone; $g$, Muscicapa ; $h$, Hyliota.

(After Swainson.)

are very varied, and probably require much further scrutiny. Sisura inquieta, for instance, has some of the habits of a WaterWAGTAI, Motacilla, and hence has received from the colonists the

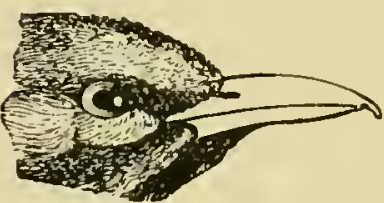

Piezorimtehus chrysomelas.

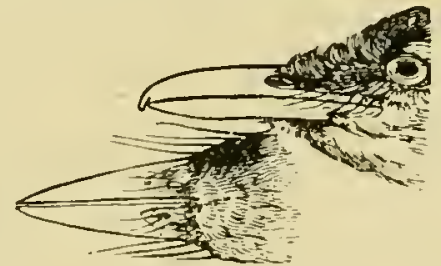

Platýstira.

Alter Swainson.)

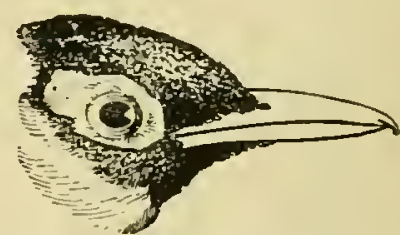

ARSES TELESCOPHTHALMUS.

name of "Dishwasher," bestowed in many parts of England on its analogue; ${ }^{1}$ and the many species of Rhipidura or Fantailed Flycatchers, which occur in various parts of the Australian Region, have manners still more singular-turning over in the air, it is said, like a Tumbler Pigeon, as they catch their prey; but concerning the mode of life of the majority of the Muscicapida, and especially of the numerous African forms, hardly anything is known.

FOOL'S-COAT, according to Sir Thomas Browne (IF orks, ed. Wilkin, iv. p. 323), a name of the GoLdFINCH, referring of comse to its gandy and particoloured plumage.

FORKTAIL, of old time used in England for the KITE, but now applied in India to the birds of the genus Henicurus, ${ }^{2}$ a small group, the position of which has long been doubtful, several systematists referring it to the Motacillidie (WAGTAIL), to some members of which there is undoubtedly a strong outward resemblance, while other methodists, as Blyth (Cut. B. MIus. Asiat. Soc. p. 159), Cabanis (Ius. Mein. i. p. 11), and Sundevall (Tentam. p. 5) placed it next to

1 Another mame for it is Grixder.

2 Originally and even now sometimes written Enicurus, but incorrectly. 
Cinclus (Tater-Ousel), and Dr. Sharpe, as usual in similar cases of difficulty, has put it (C'at. B. Br. Nus. vii. p. 312 ) among the Timeliidx, making two other senera, Hydrocichla and Microcichla. These are adopted by Mr. Oates, who (Faun. Br. Ind. Birds, ii. p. 81) refers all to the Ruticilline group (REDSTART) of Turdida. With but few exceptions their plumage is wholly black and white;

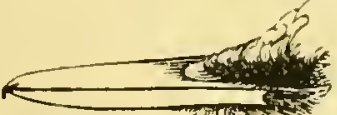
and, save in Microcichla, the forked tail which is constantly in motion is a marked characteristic. These birds are found along the whole of the Himalayan range and its eastward extensions to China in the north, and further south in the mountains of the Malay Peninsula, Java, Sumatra, and Borneo. They form, says Mr. Elwes (Ibis, 1872, p. 251) "a conspicuous feature in Himalayan scenery, being usually found either singly or in pairs flitting from rock to rock by the side of the most rapid torrents." They are said to build a large nest, placed under a stone or fallen tree close to the water, and their eggs are of a dull greenish-white freckled with rusty brown.

FORTY-SPOT, the name in Tasmania, to which the species is peculiar, of Pardalotus qualraginta (DIANOND-BIRD).

FOSSIL BIRDS. ${ }^{1}$ Footprints or casts of footprints, at the time of their discoveryand long afterwards, supposed to be those of Birds, were found about the year 1835 in the Triassic sandstone of the valley of the Connecticut in New England, and were described by Messis. Deane and Marsh. Subsequently Prof. Hitchcock and Mr. Tarren contributed to the elucidation of these tracks, which were ascribed to various genera of the Class that received the names of Amblonyr, Argosoum, Brontozonm, Grullator, Ornithopus, Platypternu, Tridentipes, and others. No portion of any of the animals to which these traces c f. (ring are due seems to have been met with, ${ }^{2}$ and most American paleontologists are now inclined to attribute them rather to Dinosaurian Reptiles than to Birds. Whatever may be thought of the rest, it appears that the creatures designated as Platypternce and Tridentipes were certainly not ornithic. Bronto:oum must have been a colossal

I I am obliged to my friend Mr. Lyclekker for this article, which, though founded upon one that appeared in the Encyctopadia Britannica, has been hy him so entirely remodelled, that he may he considered its sole anthor. $\mathrm{A}$. X.

2 The only known bones from this deposit were exhibited by Prof. W. B. Rogers at the first meeting of the British Association in Bath (Rep. Br. Ass. 1864, Trans. Sect. 1, 66). 
animal, its footprint measuring nearly 17 inches in length and its stricle some 8 feet.

An enormous space of time separates these reputed Ornithichnites, as they are called, from the first undoubted fossil Bird. This was discovered in 1861 by Andreas Wagner in the lithographic slate of Solenhofen in Bavaria, belonging to the Jurassie system, and is commonly known by the name of Archxopteryx, ${ }^{\mathrm{I}}$ thongh that of Crmphosumus was given by him to the original specimen now in the

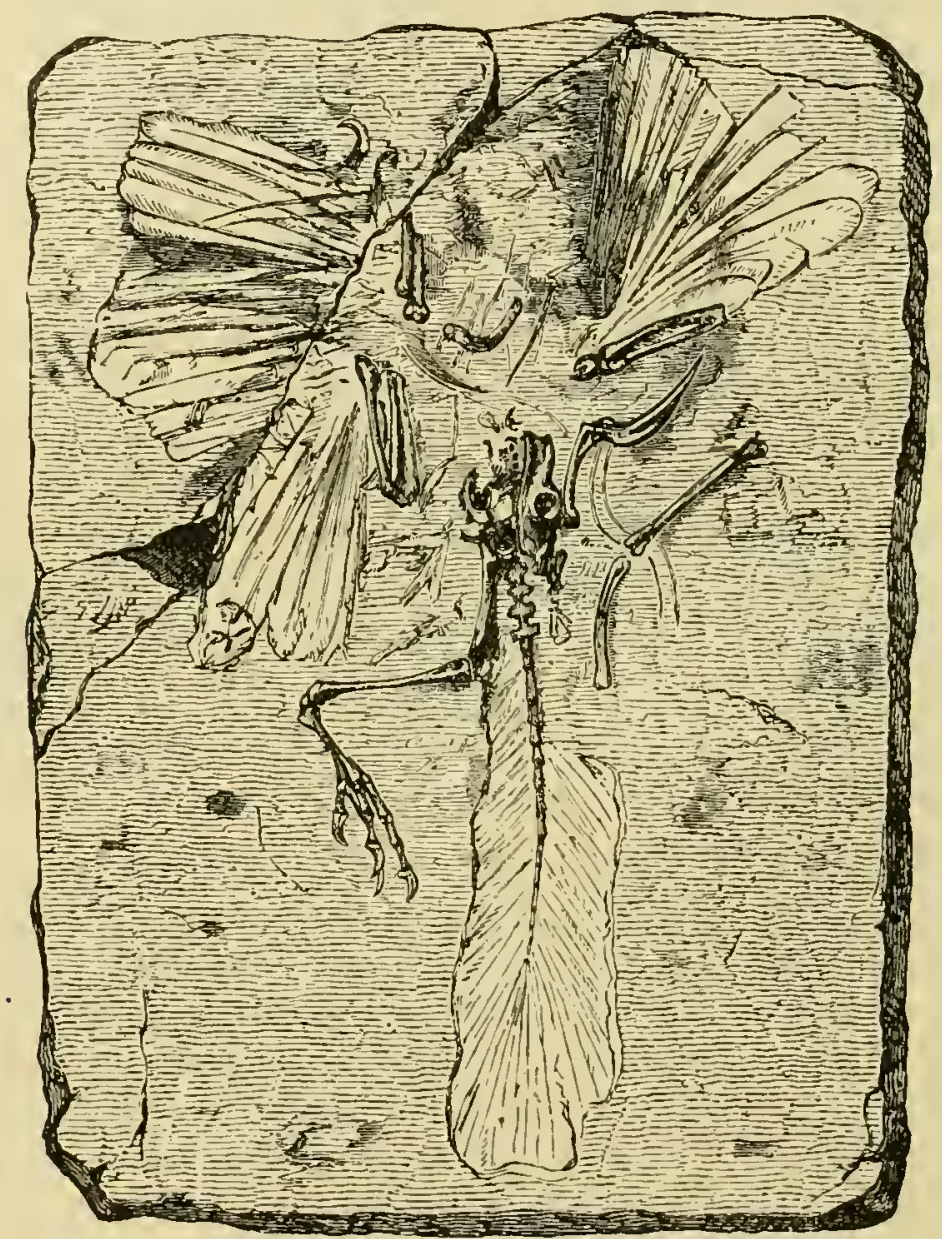

Slab witre REMains of ARCheopteryx, from the original in the British Museum. Reduced.

British Museum, which remained unique until 187T, when a second, now in the Museum of Berlin, ${ }^{2}$ was found in the same locality. ${ }^{3}$ Since

1 Hermann von Neyer had previously described a fossil feather from the same formation, to the owner of whieh he gave this name. Its specific, generie, not to say ordinal, identity with the ereature whose remains were subsequently found is of course problematical, but the reeeived laws of nomenelature fully justify the eommon usage.

2 W. Dames, Ueber Arehacopteryx (Pal. Abhandl. Band. ii. Heft 3), Berlin : 1884; and Gcol. Mag. 1884, 1). 410.

${ }^{3}$ Future investigations may shew that the two specimens belong to distinet species if not genera (cf. Seeley, Geol. Mag. 1881, P. 454). 
these two specimens supplement one another in the parts that are exposed, we can form a fair notion of what the animal was like.

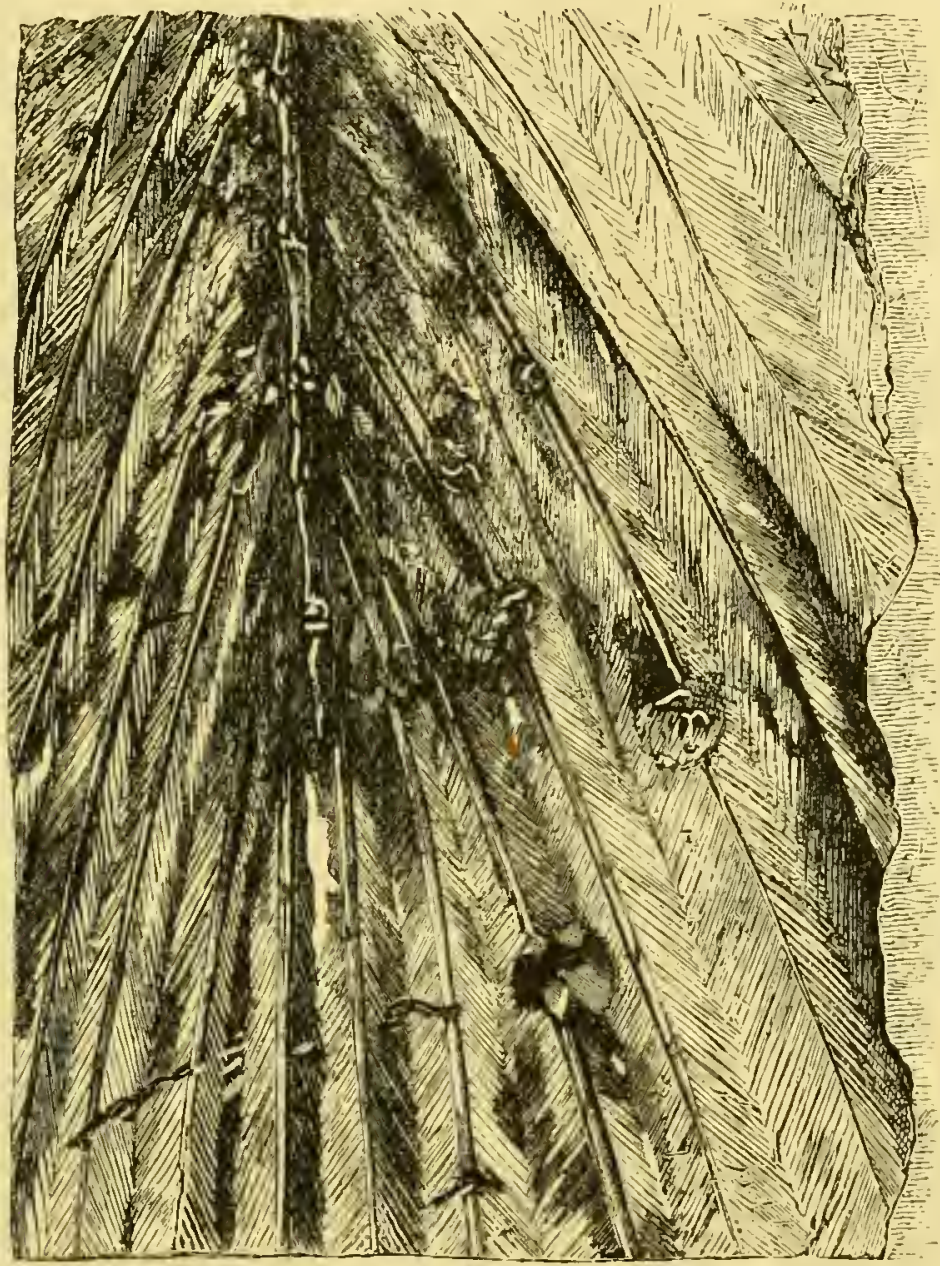

Portion of the same Slab, suewna the lixtremity of the Bird's Tail. Natural size.

About the size of a Rook, its most obvious peculiarity is a long Lizard-like tail of 20 vertebre, from each of which springs a pair of $\mathrm{c} f$. Cothy well-developed rectrices. The bill was short and blunt; the upper jaw being furnished with 13 , and the lower with 3 teeth on each side, all implanted in distinct sockets. 'The vertebræ of the neck and back were biconcave, the sternum seems to have been keeled, and the manus had 3 free digits. The tibia and fibula do not coal-

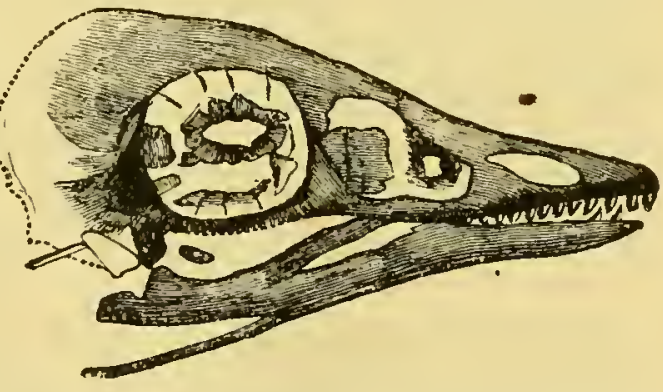

HEAD of ArCheopterrx, from the specimen in the Museum of Berlin. Natural size. (After Dames.) esce, and the former was furnished with a series of feathers very similar to those of the tail. ${ }^{1}$ Though presenting many ${ }^{1}$ J. Evans, On Portions... of the Archæopteryx. London: 1881. 
Reptilian features which cannot be here noticed, few zoologists since Sir R. Owen's description of the original specimen (Phil. Trans.

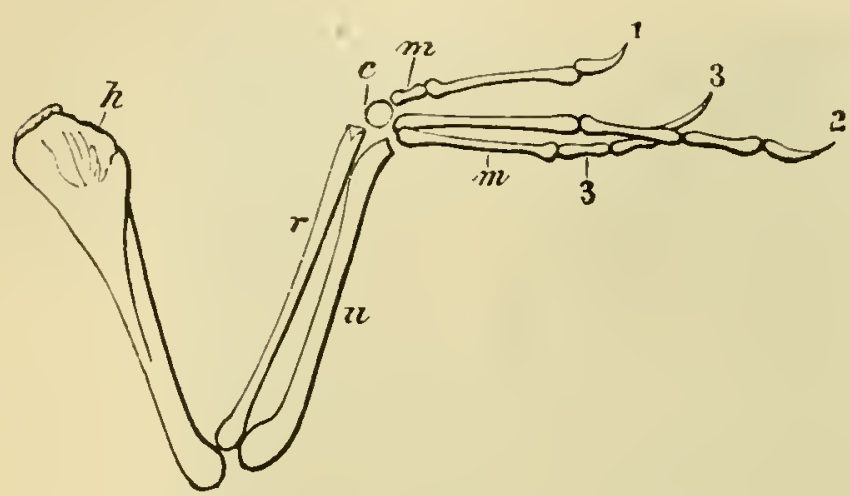

Wing-bones of Arch.£opteryx. (After Vogt.)

$c$, Carpus ; $h$, Humerus ; $m, m$, Metacarpals ; $r$, Radius ;

$u$, Ulna; $1,2,3$, first, second, and third Digits. 1863 , p. 33) have hesitated to accept Archrenptery.r as a Bird; but to suggest anything of its more immediate affinities or habits were vain, except that the form of its fect indicates a more or less arboreal mode of life. It is not easy to understand the use of the singular tail, which appears a clumsy appendage - a notion which is perhaps justified by the certainty that such tails had disappeared in the birds next known to have existed. ${ }^{1}$

These belong to the Cretaceous epoch, and since (with the exception of the Wealden) freshwater deposits of that age are rare in Europe, true ornithic remains are there nncommon. Many bones formerly referred to Birds have since proved to belong to Pterodactyls, and among them Cimoliomis from the English Chalk, Cretornis from that of Bohemia, and the so-called Pularmis ${ }^{2}$ of the Sussex Wealden. But in 1858 Barrett discovered in the Upper Greensand of Cambridgeshire remains described by Professor Seeley in 1866 (Anu. and Mag. Nut. Hist. ser. 3, xviii. p. 100) under the preoccupied name Pelagornis, ${ }^{3}$ but in 1867 renamed Enalionis (Index to Ares and Rep. Camb. Mus.; Q. Journ. Geol. Soc. xxxii. p. 509). These indicate a bird apparently allied to Colymbus, and not improbably to Hesperornis, of which more presently. Prof. Dames (K. Se. Vet.-Akud. Handl. Bihang, xvi. pt. 4, No. 1) has described some remains from the Chalk of Southern Sweden under the name of Scaniornis, resembling those of Pulalodus, to be again mentioned. From the Cretaceous rocks of North America, a much larger number of Bircl-fossils have been described by Prof. Marsh, by whom they are referred to seven genera-Apatoinis, Baptornis,

1 Certain remains from the Upper Jurassie of Wyoming being regarded as ornithic have received the name Laopteryx from Prof. Marsh (Am. Joum. Sci. ser. 3, xxi. p. 341), but in the absence of full description and figures our judgment may be suspended.

2 Mantell, Mcdals of Crcation, ed. 2, p. 804 (1S44)-not to be confounded with Palarnis, Vigors, a Parrakeet-and = Pterodactylus clifti, Brom, Ind. Pal. p. 895.

3 This name had already been given by Lartet (Comptes Rendus, 1857, p. 740) to a different fossil noticed below. 
Graculavus, Palaotringa, Telmatornis, Hesperornis, and Ichthyornis. The last two-occurring in the Cretaceous Shales of Kansas - are placed by him in a distinct "Subclass" of Birds, Odontornithes." The affinities of the others can scarcely yet be determined. Baptornis seems to be allied to Enaliornis; Graculavus in the first notice was referred to the STEGanopodes; and Palaotringa and Telmatornis respectively to the LIMICOL $\mathbf{E}$ and Rallida ; it is, however, highly probable that all were toothed. Laornis, from the Cretaceous Marls of New Jersey, was as large as a Swan.

The Lower Eocene furnishes still more Ornitholites. First in point of size are those of Gastornis, found by M. Gaston Planté and soon after by $M$. Herbert in a conglomerate below the Plastic Clay (Woolwich beds) of Bas-Meudon. It has lately been recognized by Dr. V. Lemoine in beds of nearly the same age at Rheims, and by Mr. E. T. Newton in England near Croydon (Trans. Zool. Soc. xii. p. 143). Much difference of opinion has obtained as to the affinities of this bird, which was far larger than an Ostrich, but it was certainly incapable of flight, and was probably one of the Ratita. The owner of an imperfect cranium from the London Clay, for which Sir R. Owen (Trans. Zool. Soc. vii. p. 145) proposed the name Dasornis, as well as Prof. Cope's Diatryma (Proc. Ac. N. S. Philad. 1876, p. 11) seem to have been other members of the same group. Phororhacos and Brontornis, giant-birds, ${ }^{2}$ from the Lower Tertiary of South America should also be named here. The London Clay of Sheppey has likewise supplied some long but broken humeri, described by Sir R. Owen (Q. Journ. Geol. Soc. xxxiv. p. 129) as Argillornis, whose nearest affinities seem to lie with the Steganopodes, and not, as had been supposed, with the Diomedeida (Albatros), especially if a skull from the same deposits be rightly referred. To the same bird belong, apparently, remains described under the preoccupied names of Lithornis and Megalomis; and from the same locality the zoologist last-named has also added (op. cit. xxix. p. 511) a yet more remarkable bird in the Odontopteryx toliapica, the edges of whose jaws were serrated like those of certain Tortoises, but the general character was Steganopodous, with a similar division of the horny sheath of the mandible into several pieces. A small skull, also from Sheppey, was described by him as Halcyornis, and regarded as allied to the KINGFISHER, but it seems more nearly related to the Gulis, further evidence to this effect being afforded by an undoubtedly Larine humerus probably belonging to the genus described. The equivalent beds at Highgate have supplied the steruum of a HERoN-like bird, for which the name Proherodius has been suggested by the writer; a tarso-

1 Am. Journ. Sci. ser. 3, x. p. 403.

2 See Mercerat and Moreno, An. Nus. La Plata, i. (1891), and Ameyhino, Revist. Argent. Hist. Nat. i. pp. 441-453. 
metatarsus from the London Clay near St. James's Park confirming its Ardeine relationship. Several associated bones of a bird from Sheppey were described by Sir R. Owen as Lithornis and provision-

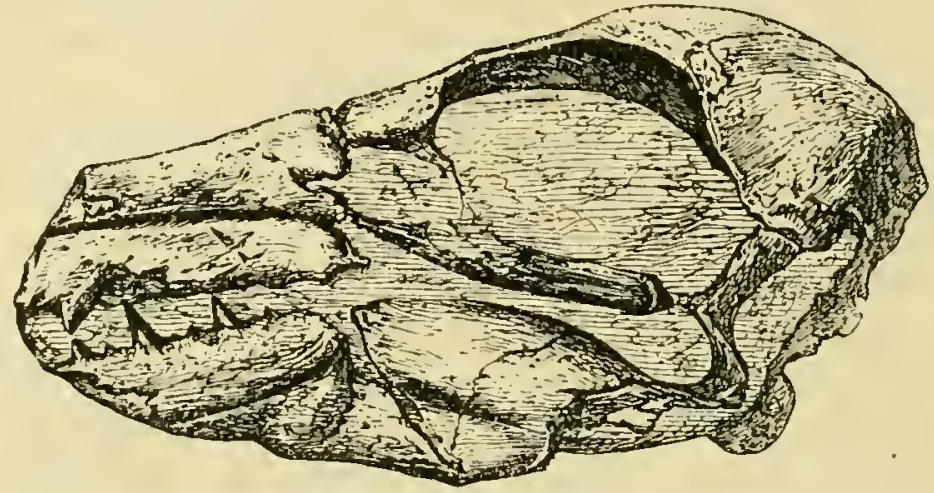

REMAINS of HEAD of Odontopteryx, from the original in the British Museum. Side view. $\frac{5}{3}$ natural size.

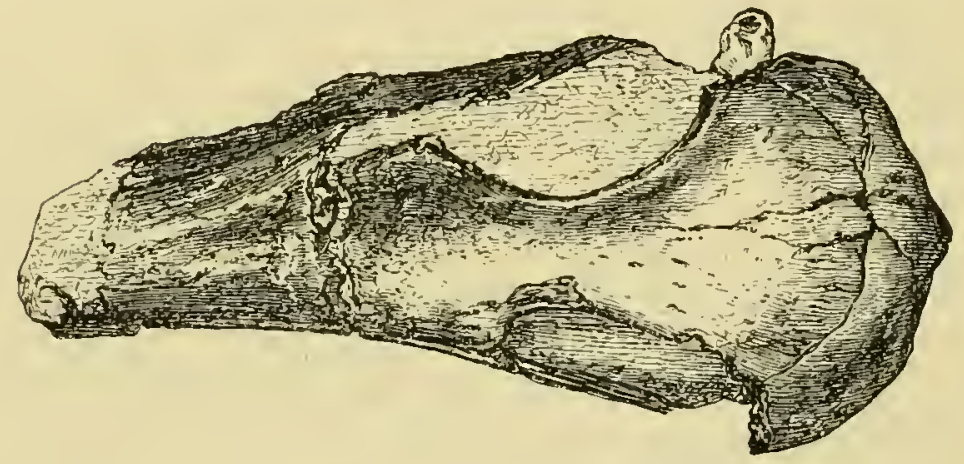

The SAME, seen from above.

ally referred to the Accipitres. The shale of Plattenberg at Glarus has produced the skeleton of a bird probably belonging to the

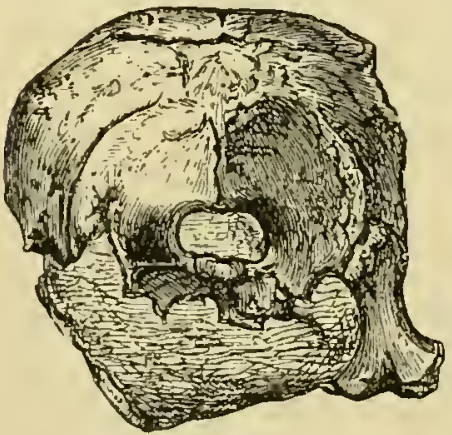

THс SAME, seen from behind. Passeres, and called by Vou Meyer P'rotornis, but since renamed Osteornis by $\mathrm{M}$. Gervais.

The bird-bones of the Upper Eocene of the Paris Basin deserve fuller notice. First bronght to light towards the end of the last century, many of the remains fell under the notice of Cuvier, by whom they were more or less exactly determined. Following his investigations, the labours of MM. Gervais, Blanchard, and Desnoyers added considerably to our knowledge of these ornitholites, till finally Prof. A. Milne-Edwards, ${ }^{1}$ having compared all the specimens,

1 I cannot let the name of this distinguished naturalist pass without acknowledging the very many tokens of friendship received at his hands in connection witl the present subject. His magnificent work on the Fossil Birds of France is known to all, and together with his article on Fossil Ornithology, in the second edition of D'Orbigny's Dictionnaire universelle d'histoire naturelle, has been of 
referred them to the genera Agnopterus, Coturnix, Cryptornis, Falco, Gypsornis, Laurillardia, Limosa, Palægithalus, Palaocircus, Palæortyx, Pelidna, Phalacrocorar, Rallus, and (?) Tringa. Of these the extinct genera are the first, which was probably distantly allied to the Flamingos; the third, believed to be a Hornbill (A. MilueEdwards, Ois. Foss. Fr: ii. p. 547); the fifth a Ralline form; the sixth now shewn to be allied to Hartlaubia of Madagascar ; ${ }^{1}$ the eighth (originally identified with Sitta) probably connecting Parus (TITMOUSE) and Sylvia (WARBLER); and the ninth and tentl respectively referable to the Accipitres and the Gallinx. The equivalent beds of Hordwell in Hampshire have yielded remains of several birds, ${ }^{2}$ including an Accipitrine, Actiornis, Agnopterus (?), Colymboides, Elornis (?), Geranopsis, Grus, Ibidopsis, of which the second being allied to the Cormorants, the fifth to the Cranes, and the last to the Ibises, are peculiar to these deposits. The third, fourth, and fifth, are mentioned below. Nothing can be said as to the affinities of the bone from the same beds described as Macrornis by Prof. Seeley. Grus (Palxogrus) also occurs in the Italian Eocene. The Marl beds of Aix in Provence, belonging to this epoch, have yielded fossil eggs and feathers, but as yet no bones of Birds; and to the same period must probably also be assigned the lacustrine calcareous deposits of Armissan, in Languedoc, whence M. Gervais recovered remains originally roferred to Tetrao (Grouse), but subsequently to a distinct though allied genus Taoperdix. The bird-bones of the Upper Eocene Phosphorites of Central France, although numerous, have as yet been only partially described. They include remains of Passeres, Picaria, and Accipitres, together with Palaortyx, the Stork-like Propelargus, and Asgialornis, the last being apparently allied to the Gulls, but with a shorter wing. From the Eocene of Wyoming Prof. Marsh (Am. Journ. Sci. ser. 3, iv. p. 256) has described five birds varying in size from a Flamingo to a Woodcock, all of which ar'e refer'ed to an extinct genus Aletornis, presumably allied to the Gruidre (CRANE). Remains referred to Bubo and Charadrius, as well as the extinct Uintornis, referred to the Picidr (WoODPECKER) and Palaospiza, have likewise been obtained from the Eocene of the United States. Our list of birds of this epoch closes with Palwertdyptes, a giant Penguin from New Zealand described by Prof. Huxley (Q. Journ. Geol. Soc. xv. p. 670).

The freshwater beds of Hempstead in the Isle of Wight, as well as those of Ronzon near Puy-en-Velay, form a transition from

the greatest use in preparing the present summary. To Prof. Seeley also I have owed much assistance. - A. N.

${ }^{1}$ See Flot, Mém. Soc. Geol. France, Pal. i. fasc. 6.

2 These, together with some of the ornitholites of the Phosphorites, are described in the Cat. Foss. Birds Brit. MIus. I891. 
the Upper Eocene to the Lower Miocene. The coracoid from the former described by Prof. Seeley (Ann. and Mag. $N$. H. ser. 3, xviii. p. 109) as Ptenornis cannot be definitely placed. From the Marls of Ronzon several ornitholites have been recognized by M. Aymard, who refers them to the genera Camascelus, Dolichopterus, Elomis (3 spp.), and Teracus. Of these the first was declared to be allied to the Plovers (Charculriidx), the second to the Gulls, the third to the Flamingos, and the fourth to be a Falconine; but Prof. Milne-Edwards considers the first and second to be probably identical. From the same beds M. Gervais has described eggs and imprints of feathers, as well as a pelvis, referred by him to Mergus, but regarded by M. Milne-Edwards as a Sula. This naturalist has also described from the typical Lower Miocene beds of Allier and Puy-de-Dôme an enormous number of ornitholites (loc. cit.), referring them to nearly 50 species. Besides the already-mentioned Palxortyx (3 spp.), Limnatornis, Palaohierax, Pelargopsis, ${ }^{1}$ Ibidopodia, Elornis, Palxlodus, Hydromis, and Colymboides, are the extinct genera described by him; to which the writer (Cat. Foss. B. Br. Mus. p. 169) has added Milnea. Of these the second is referred to the Upupidx (Hoopos); Palæohierax was allied to Aquila; Pelargopsis ${ }^{1}$ was SToRK-like; while Ibidopodia connects the Storks and Ibises; Iilnea being allied to Edicnemus (Stone-CuRLEw) and Elornis to Limicola. The remarkable Palalodus (5 spp.) was a generalized form to which the FLAMINGo is allied, but having shorter legs. Hydrornis was an aquatic bird of uncertain affinity; while Colymboides may be placed in the Colymbidx. The existing genera include Anas, Aquila, Bubo, Collocalia, Columba, Cypselus, Fuligula, Ibis, Lanius, Larus, Milvus, Motacilla, Pelecanus, Phalacrocorax, Phonicopterus, Picus, Psittacus, Pterocles, Pullus, Serpentarius, Strix, Sula, Totanus, Tringa, and above all Trogon. In addition to these, remains (as yet undescribed) referable to Himantopus, Leptoptilus, Otis, and Puffinus, are also said to occur in these beds. Several of the birds of the Allier are represented in equivalent deposits of the basin of Mainz. From the Middle Miocene of Bordeaux and other parts of the south of France humeri of an elongated type, described as Pelagornis, indicate a bird closely allied to the Eocene Argillornis. From that of Sansan in the Gers we have as extinct forms Homolopus, allied to the Picidx, Necrornis, which seems to belong to the Musophagidx-a Family now limited to Africa-and Palaoperdix ( 3 spp.) a Gallinacean; while among existing genera we have represented Aquila, Halixtus, Strix, Corrus, Phasianus (2 spp.)-a genus generally supposed to have been introduced into Europe in historic times-Rallus, Numenius, Ardea, and Anas. The same Phasianus and a species of Palaortyx have been recorded by Dr. Depéret from the equivalent beds of Grive-St.-Alban in the Isère ;

: This name being preoccupied, the writer has proposed Pelargodes in its place. 
while from Steinheim and other places in Bavaria we have several kinds of birds recorded by Dr. Osear Fraas, ${ }^{1}$ and the writer (loc. cit.) These include Anas, Ardea, Elonis, Ilis, Larus, Otis, Palxloulus, and Pelecanus. Anas apparently has also been recorded by Count T. Salvadori (Mem. Acc. Torino, ser. 2, xxiv. p. 225) from the Middle Miocene of Monte Bamboli in Italy; while Chenornis described by Prof. Portis (op. cit. xxxvi. art. 3, p. 6) from other Miocene beds of Ceva, in the same country, may belong to the Anseres. From the Miocene of Radaboj, in Croatia, the foot of a bird has been assigmed by Helmann von Meyer to Fringilla; while a humerus from that of Germany has been made the type of the genus Ardeacites by Haushalter, being apparently allied to the Herons. From the Upper Miocene of Eningen, on the border of Baden and Switzerland, we have remains of Anas, Anser, Phasianus, and Totanus. In the Miocene of Colorado and New Jersey Prof. Marsh has detected bones of Meleagris, Puffinus, Sula, and Uria, all existing genera; but the first being especially suggestive, since it is one of the most characteristic forms of the New World.

The Pliocene ornitholites, possibly from less favourable conditions for their preservation, are less numerous than those of the Miocene. From Pikermi in Attica Prof. Gaudry has described a Gallus, somewhat larger than $G$. sommerati (the grey Jungle-FowL of India), a Phasianus, a large Grus, and an undetermined Stork. Amphipelargus of the present writer (Cat. Foss. B. Br. Mus. p. 68) is a large Stork from the equivalent beds of Samos. From the Sivalik Hills, on the southern flanks of the Himalayas, we have a Struthio (OsTRICH) and a Ratite with three toes, to which he has given (op. cit. p. 354) the name of Hypselornis, as well as Leptoptilus, Pelecamus and Phalacrocorax. The fossil egg of a bird, called Struthiolithus by Prof. Alexander Brandt (Bull. Ac. Sc. Petersb. xviii. pp. 158-161; Ibis, 1874, p. 4), and found near Cherson, possibly belongs also to Struthio. Very noteworthy is the discovery of Diomerlea (Albatros) in the Suffolk Crag (Q. Journ. Geol. Sor. xliii. p. 366). From the Upper Pliocene of the Val d'Arno Prof. Portis has recorded Fuligula, Totanus, and Uriu; but from that of France the only well-determined form is a Gallus from Auvergne, though traces of other birds have been noticed. From the Pliocene of North America Prof. Marsh has described remains of Aquila, Grus, and Phalacrocorax; while others, among them a Grouse, Palsetetrix, are reported by Dr. Shufeldt.

By far the greater portion of the remains of Birds from the Plistocene seem to be generically if not specifically identical with those now inhabiting the district in which they occur, and it must suffice here to mention those which shew a former range more extensive than at present, or have become extinct, presumably with-

${ }^{1}$ Die Fauna von Steinheim. Stuttgart: 1870. 
out human intervention - those that are known to have met their fate at the hand of man having been before treated (ExTERIINATION).

At an uncertain but (geologically speaking) recent epoch there flourished in Madagascar huge birds referable to the Ratita. The first positive evidence of their former existence was made known in 1851 by Isidore Geoffroy St.-Hilaire, who gave the name of Epyornis maximus to a species represented by an enormous egg sent a short time before to Paris, and the discovery soon after of some bones of corresponding magnitude proved to all but the prejudiced the kinship of the producer of this wonderful specimen, which not unnaturally recalls the Roc of Arabian romance. ${ }^{1}$ Three species of the genus have now been characterized from remains found in the drifted sands of the southern part of that island.

Next we may turn to our antipodes. In New Zealand Birds' bones of gigantic size seem to have been first made known in 1838 by Polack, who resided there between 1831 and 1837 , and in 1839 the fragment of one was placed by Mr. Rule in the hands of Sir R. Owen, by whom it was described under the name of Dinornis, as will be elsewhere found mentioned (MOA). In the same formations as those which hold the relics of this wonderful bird and its allies, have been found, but less abundantly, remains of other's scarcely less remarkable, Pseudapteryx, near akin to the KIwI; and, belonging to the Carinata, there is Harpagornis, a Bird-of-Prey of stature sufficient to make the largest Dinomis its quarry, then Cnemiornis, a bigr Goose, flightless, and allied to Cereopsis, together with Aptornis and Notornis, both also incapable of flight and belonging to the Rallidx (RAIL), and the latter still maintaining its existence in the mountainous tract at the south-west of the South Island. Here also must be mentioned the Australian Dromornis, which indicates a distinct group of Ratita (C'at. Foss. B. Br. Mus. p. 35), and Progoura, allied to the Crowned Pigeons (GourA).

A great number of Birds' bones have been discovered in caves. Those of Minas Gerães in Brazil yielded to the laborious explorations of Iund a vast collection now in Copenhagen, which has been lescribed by the late Dr. O. Winge (Fugle fra Knoglehuler i Brasilien, Kjöbenhavn: 1887, 4to), who determined at least 126 species, of which all but three (and those of existing genera) survive, though some two dozen 110 longer inhabit the district. Results more important follow the investigation of cave-bones in Europe. From France we liave a large and extinct species of Crane, Grus mimi-

1 Sir Henry Yule well remarked of the story of the Roc, Ruc, or Rukh, as told ly Marco Polo, that the circumstance which for the time localized it in Madagascar-the fable being widely spread-was perhaps some rumour of these great fossil egrgs. Some of the Malagasy are reputed to believe that the bird still exists, but as they also attribute to it great power of flight, the belief must be an invention (cf. The Look of Ser MLarco Polo, ii. p. 350).-A. N. 
genia, with which the Italian $G$. turfa is probably identical; but more interesting than that are the very numerous relics of two species, the concomitants even now of the Reindeer, which were abundant in that country when this beast flourished there and have followed it in its northward retreat. There are the Willow-Grouse, Lagopus albus, ${ }^{1}$ and the Snowy Owl, Nyctea scandiaca-a single bone of the latter, found in the historic deposits of Kent's Hole near Torquay, giving indication that a similar state of things once existed in our island, while yet another fact quite as suggestive is afforded by the recognition of many bones of the CAPERCALLY, Tetrao urogallus, from caves explored by the late Messrs. Backhouse in Teesdale, as well as from Kent's Hole by the present writer. ${ }^{2}$

It is not a little singular that remains of the species last mentioned have also been found in another country which it now no longer inhabits and under circumstances very different; for the next ancient Birds' bones that have to be mentioned are those from the kitchen-middens of Denmark, among which occur those of this bird, shewing the co-existence with it of pine-forests in that country, though on other evidence it is plain that such forests cannot have existed there for many centuries. Bones of the GARE-FowL, Alca impennis, found in the same deposits perhaps do not prove more than that the surrounding seas, though cold, were free from ice in the summer-time. The Birds' remains hitherto recovered from the ruins of the Swiss lake-dwellings are all of species which now occur more or less commonly in the same neighbourhoods, and are therefore of comparatively little interest.

On the other hand, the Fens of East Anglia have yielded proofs of a form now extinct not only in England but even in Northern Europe. This is the Pelican, of which two humeri, one from Norfolk and the other most likely from the Isle of Ely, are preserved in the Museums of Cambridge. Whether the species be identical with either of those now inhabiting the South of Europe, it was undoubtedly a true Pelecanus, and apparently only differed from $P$. onocrotalus by its larger size. The immature condition of one of the specimens leads to the inference that the bird was a native of the locality.

Io sum up this brief survey of our present imperfect knowledge of Fossil Birds, it may suffice to state that nearly all the Plistocene species still survive, at least on continents, for the exceptions lie

1 I am not aware of any difference between the bones of $L$. albus and $L$. scoticus. It nay well be that those from the cares of 'Teesdale, and naturally ascribed to the latter, may be those of the former, in which case the identity of conditions once obtaining in England and Fuance could be more clearly made out; but Reindeer remains are rare in this country.-A. N.

${ }^{2} \mathrm{~A}$ bone from the Forest-bed of Norfolk is provisionally referred to a young example of this species (Cat. Foss. B. Br. Mus. p. 183). 
chiefly in forms confined to islands; and this is a result in full accordance with that already attained in the foregoing treatise on Exteruination. In Europe a not very remote glacial epoch has left its indubitable trace in the former southerly extension of some forms whose home is now in more northern districts. The comparatively-few known Pliocene Birds are mostly referable to existing genera, though the majority of the species are extinct; but in the Lower Miocene we meet with a considerable number of extinct genera; while, both here and in the Upper Eocene, the occurrence in Europe of genera either identical with or nearly allied to those which now inhabit only the tropies or lands lying even further to the southward is particularly instructive. Some of them are at present peculiar to the Ethiopian Region, and among these are especially to be noted Laurillardia, Psittacus (PArRot), and Serpentarius (SECRETARY-BIRD), with perhaps Cryptornis-a supposed Hornbili, and Necromis-referred to the Plantain-EatiR. Others have their modern representatives in Asia, as Gallus and Phasianus; while others again have now a still wider range, though no longer occurring anywhere in the temperate zones, as Collocalic (SwIFT), Leptoptilus (ADJUTANT), and, perhaps most suggestive of all, 'Trogon, for the Family to which it belongs, though inlabiting both the Ethiopian and Indian Regions, is now more largely developed in the Neotropical Regions than elsewhere. This last case is in some measure analogous to that of the Tapirida among Mammals, though no African Tapir is known. But in a general way all the lessons which Fossil Ornithology so far teaches seem to be in perfect harmony with what we learn from a study of Fossil Mammals; and, when palreontologists generally come to admit the fact, which some of their leaders have long since recognized, ${ }^{1}$ that their study, though one of infinitely great meaning to the geologist, is but a branch of Zoology, no one can doubt of the valuable results that will follow from their co-operation. But letting this pass, it is important to notice that already in the Lower Miocene, if not in the Upper Eocene periods, there is sufficient evidence to shew that many of the chief groups of Birds as we now know them had been already established, and

I The views of the elder Agassiz on this point are notorious; those of Prof. Alphonse Nilne-Edwards were declared prior to the publication of his great work, which itself is a perpetnal witness of their truth. Prof. Huxley many years ago in a speech, which tlough never fully reported is well remembered by some of those who heard it, most rightly asserted that "Palæontology is simply the biology of the past; and a fossil animal differ's only in this regard from a stuffed one, that the one has been dead longer than the other, for ages instead of for days" (Ibis, 1866, p. 413). The present petrified condition of some geologists requires a life-imparting impulse, and they-be it said with all due respect-need bringingr into touch with those who would gladly accejt their assistance or even their guidance.-A. N. 
perhaps it will eventually shew that nearly all were. ${ }^{1}$ It is also worth remembering that it was during these epochs that the Ratite (just as the Marsupials among Mammals) were represented in the European Fauna. In the Cretaceous period we come to Birds differing very widely from existing forms, and apparently indicating distinct Ordinal groups, while the two known Jurassic specimens clearly belong to a distinct Subclass-SAURURA.

\section{RICHARD LYDEKKER.}

FOUR-O'CLOCK, one of several names given in Australia to Philemon corniculatus (FRIAR-BIRD).

FOWL (Danish Fugl, German Vogel), originally used in the sense that BIRD now is, but, except in composition-as Sea-Fowl, Wild-Fowl, and the like-practically almost confined ${ }^{2}$ at present to designate the otherwise nameless species which struts on our dunghills, gathers round our barn-doors, and stocks our poultryyards-the type of the genus Gallus of ornithologists, of which four well-marked species are known. The first of these is the Red Jungle-Fowl of the greater part of India, $G$. ferrugineus - called by many writers $G$. bankiva - which is almost undoubtedly the parent stock of all the domestic races ( $c f$. Darwin, Animals and Plants under Domestication, i. pp. 233-246). It inhabits Northern India from Sindh to Burma and Cochin China, as well as the Malay Peninsula and many of the islands as far as Timor, besides the Philippines. It occurs on the Himalayas up to the height of 4000 feet, and its southern limits in the west of India proper are, according to Jerdon, found on the Raj-peepla hills to the south of the Nerbudda, and in the east near the left bank of the Godavery, or perhaps even further, as he had heard of its being killed at Cummum. This species greatly resembles in plumage what is commonly known among poultry-fanciers as the "Black-breasted Game" breed, and this is said to be especially the case with examples from the Malay countries, between which and examples from India some differences are observable-the latter having the plumage less red, the ear-lappets almost invariably white, and slate-coloured legs, while in the former the ear-lappets are crimson, like the comb and wattles, and the legs yellowisl. If the Malayan birds be considered distinct, it is to them that the name $G$. bankiva properly applies. This species is said to be found in lofty forests and in dense thickets, as well as in ordinary bamboo-jungles, and when cultivated land is near its haunts, it may be seen in the fields

1 The graphic representations given by Professor Fuirbringer in his great work, Untersuchungen zur Morphologie und Systematik der Vögel (plates xxix. A and $\mathrm{E}, \mathrm{xxx}$.), make this very clear to the eye.-A. N.

${ }^{2}$ Like Deer (Danish Dyr, German Thier). Beast, too, with some men has almost attained as much specialization. 
after the crops are cut in straggling parties of from 10 to 20 . The crow to which the cock gives utterance morning and evening is described as being just like that of a BANTAM, but never prolonged as in some domestic birds. The hen breeds from Jamary to July, according to the locality; and lays from 8 to 12 creamy-white eggs, occasionally scraping together a few leaves or a little dry grass by way of a nest. The so-called $G$. giganteus, formerly taken by some ornithologists for a distinct species, is now regarded as a tame breed of $G$. ferrugineus or bankiva. The second good species is the Grey Jungle-Fowl, G. sonnerati, whose range begins a little to the northward of the limits of the preceding, and it occupies the southern part of the Indian peninsula, without being found elsewhere. The cock has the shaft of the neck-hackles dilated, forming a horny plate, the terminal portion of which is like a drop of yellow sealing-wax. His call is said to be very peculiar, being a broken and imperfect kind of crow, quite unlike that of G. ferrugineus, and impossiblè, says Jerdon, to describe. The two species, where their respective ranges overlap, occasionally interbreed in a wild state, and the present readily crosses in confinement with domestic poultry, but the hybrids are nearly always sterile. The third species is the Cingalese Jungle-Fowl, G. stanleyi (the G. lufayrttii of some authors), peculiar to Ceylon. This also greatly resembles in plumage some domestic birds, but the cock is red beneath, and has a yellow comb with a red edge, and purplish-red cheeks and wattles. He has also a singularly different voice, his crow being dissyllabic. This bird crosses readily with tame hens, but the hybrids are said to be infertile. The fourth species,

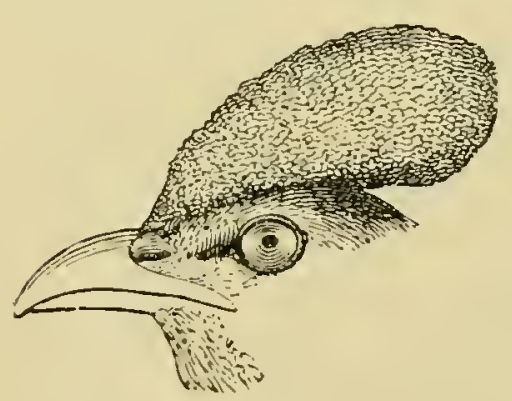

Gallus varius. (After Swainson.) $G$. varius (the G. furcutus of some authors), inhabits Java and the islands eastwards as far as Flores. This differs remarkably from the others in not possessing hackles, and in having a large unserrated comb of red and blue, and only a single chinwattle. The predominance of green in its plumage is another easy mark of distinction. Hybrids between this species and domestic birds are often produced, but they are most commonly sterile. Some of them have been mistaken for distinct species, as those which have received the names of $G$. arneus and $G$. temmincli.

Several circumstances seem to render it likely that Fowls were first domesticated in Burma or the countries adjacent thereto, and it is the tradition of the Chinese that they received their poultry from the WTest about the year 1400 B.C. By the Institutes of Manu, the date of which is variously assigned from 1200 to 800 B.C., the tame Fowl is forbidden, though the wild is allowed 
to be eaten-shewing that its domestication was accomplished when they were written. The bird is not mentioned in the Old

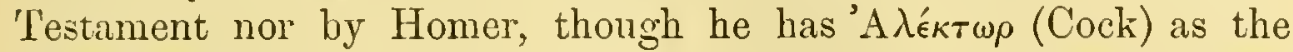
name of a man, nor is it figured on ancient Egyptian monuments. Pindar mentions it, and Aristophanes calls it the Persian bird, thus indicating it to have been introduced to Greece through Persia, and it is figured on Babylonian cylinders between the 6 th and 7 th centuries B.C. It is sculptured on the Lycian marbles in the British Museum (circa 600 B.c.), and Blyth remarks (Ibis, 1867, p. 157) that it is there represented with the appearance of a true Jungle-Fowl, for none of the wild Galli have the upright bearing of the tame breeds, but carry their tail in a drooping position.

FRANCOLIN, from the French, and that, says Littre, from the Italian Francolino, which others think is cognate with the Portuguese Frango or Frangão, a cockerel; but according to Olina, ${ }^{1}$ in 1622 (Uccelliera, p. 33), whose opinion is confirmed by Count T. Salvadori in 1887 (Elenco Ucc. Ital. p. 19S), signifying, as Willughby's translator indeed has it (Ornithol. ed. Angl. p. 174), a "Free Fowl", because princes granted it freedom of living, common people being forbidden to take it. This explanation, had not the accomplished Italian author last named given his adhesion to it, might be justly set aside; but he has suggested that the species was not improbably introduced in the time of the Crusades from Cyprus into Sicily, an opinion not shared by Prof. Giglioli (Avifaun. Ital. p. 515). However this may be matters little now, for by all accounts, as first shewn. by Lord Lilford (Ibis, 1869, pp. 352-356), the species is, and has been for some time past, extinct in every part of Italy, though the canse of its extinction may be inexplicable. The word Francolin seems to have been first used as English in 1757 by Edwards (Glean. N. H. i. p. 75, pl. 246), who figured a male from Cyprus. The species is the Tetrao francolinus of Linnæus, and Francolinus vulgaris of Stephens. The evidence adduced by Lord Lilford shews that it was once numerous in Spain, and in Barbary, from Tangier to Tunis, as well as in Sardinia, Sicily, Italy, and Greece, but its most western limit must now be Cyprus, and even there, he thinks (Ibis, 18s9, p. 335), it is probably "doomed to extinction." Mr. Danford also states (Dresser, B. Eur. vii. p. 124) that it seems "to be fast disappearing in Asia Minor." It, however, ranges thence through Armenia, Persia, and Beluchistan to Northern India, where it is well known to the English as the "Black Partridge," from the colour of the throat and breast of the rock. In Southern India it is replaced by an allied species,

a His words are: "Credesi con l'allusione alla franchezza de viuer, che ha rispetto alle bandite, e rigorosi editti, che per conto di quello da Prencipi si fanno." 
$F$. pictus. Specimens from Assam are said to be specifically identical with those from Cyprus. More than forty species of the genus (the several subdivisions of which may be questioned) have been described, a number probably far in excess of those that exist; but still there are undeniably a good many-most of them belonging to the Ethiopian Region, and no fewer than ten being found within the limits of the Cape Colony, $F$. levaillanti, the "Redwing" of English settlers, being especially numerous. They are all attractive to sportsmen.

FRENCH PIE, given by Montagu in 1802 (Om. Dict.) as a local name of Lanius excubitor (SHRIKE), but much more commonly applied to one or other of the Pied WooDPeckens, Dendrocopus major especially.

FRIAR-BIRD, an Australian species, so called from early colonial days, and not inaptly, considering its bare head, the semblance of a hood abont its shoulders, formed by a ruff of soft recurved feathers, and the sad hue of its plumage. According to Latham (Synops. B. Suppl. ii. p. 15l) it was first brought to England by Banks, who returned with Cook in 1771, but it was not described until 1790, when it received the name of Merops cormiculatus from Latham (Ind. Orn. i. p. 276), and "Knob-fronted BeeEater" from John White (Voy. N. South Wales, p. 190), who also figured it. That it was no BeE-EATER, but one of the Meliphagidie (HoNEY-EATER), became in time apparent, and Vigors and Horsfield (Trans. Linn. Soc. xv. p. 323) founded for it a new genus, Tropidorhynchus, not knowing that Vieillot had anticipated them in 1816 (Nour. Anal. p. 47) by the establishment of Philemon with a species strictly congeneric as its type. This is the "Polochion" of Montbeillard (Hist. Nat. Ois. vi. p. 477) found by Commerson ${ }^{1}$ in Bouru, one of the Moluccas, and hence named by Gmelin Merops moluccensis. It was subsequently redescribed by Mr. Wallace (Proc. Zool. Soc. 1863, p. 31, and Malay Archipelago, ii. p. 151) as a new species, Tropidorhynchus bourouensis, and mention of it must be elsewhere made (Mnnicry). Dr. Gadow in 1884 (Cat. B. Br. Mus. ix. pp. 269-281) recognized 16 species, with two subspecies, of the gennis Philemon, to which another has since been added by Mr. E. P. Ramsay, making, according to the latter's views, six ${ }^{2}$ which inhabit

1 Commerson had said that the word Polochion, which expressed the cry and was the name of the bird, signified "baisons-nous," and hence proposed to call it Philemon or Philedon. Vieillot, as above stated, adopted the one, Cuvier, a year later, the other.

2 In this number is not included the Merops monachus of Latham (Ind. Orn. Suppl. p. 34), for that is the young of Philemon corniculatus; but it is in connexion with this supposed species that the name "Friar" first appears (Synops. B. Suppl. ii. p. 155). 
Australia, while the rest are natives of various islands from Lombock to New Caledonia. With their stout bill, mostly surmounted by a horny excrescence, and their head and neck frequently bare of feathers and black, these birds seem to be the most abnormal forms of the Family Metipharida. The commonest species in Australia, which is found from Rockingham Bay to Victoria, is, according to Gould (Handb. B. Austral. i. p. 546),

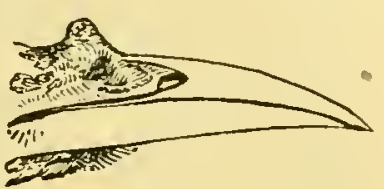

Philemon.

(After Swainson.) generally dispersed, and may be seen perching on the top of high trees, or clinging to their branches in every variety of attitude, being also of powerful flight, and attacking boldly every predatory bird that may approach. Its lond cries have given it the additional names of "Poor Soldier," "Pimlico," and "Four-o'clock," which words they are thought to resemble, while its naked head and neck have also suggested those of "Monk" and "Leather-head." The other species seem to have similar habits, and the plumage of all is of an almost uniform drab colour, though the young exhibit mole or less of a yellow tinge on some parts of it. Several of them, however, have the head feathered.

FRIGATE-BIRD, the name apparently first printed by Albin in 1739-40 (Nat. Hist. B. iii. p. 75), but now commonly given by our sailors, on account of the swiftness of its flight, its habit of cruising about near other species and of claringly pursuing them, to a large Sea-bird ${ }^{1}$ - the Fregute aquila of most ornithologists-the Fregute of French and the Pabitioncudo of Spanish mariners. It was placed by Linneus in the genus Pelecamus, and its assignment to the Family Pelecunidx was never doubted until Prof. Mivart declared (Trans. Zool. Soc. x. p. 364) that, as regards the postcranial part of its axial skeleton, he camnot detect sufficiently good characters to unite it with that Family in the group named by the elder Brandt STEGANOPODks. There seems to be 10 ground for disputing this decision so far as separating the genus Fregatu from the I'elecanida goes; but systematists will probably pause before they proceed to abolish the Steganopodes, and no doulst the Frigate-Birds form a distinct Family, Fregatila, in that group. In one very remarkable way the osteology of Frequta differs from that of all other birds known. The furcula coalesces firmly at its symphysis with the carina of the sternum, and also with the coracoids at the upper extremity of each of its rami, the anterior end of each coracoid coalescing also with the proximal end of the scapula. Thus the only articulations in the whole sternal apparatus are where the

1 "Man-of-war-Birl" is also sometimes applied to it, and though an older it is a less distinctive name, some of the larger kinds of Albatros being so called, while, in books at least, it has generally passed out of use. 
coracoids meet the stermum, and the consequence is a bony framework which would be perfectly rigid did not the flexibility of the rami of the furcula permit a limited amount of motion. That this mechanism is closely related to the faculty which the bird possesses of soaring for a considerable time in the air with scarcely a perceptible movement of the wings can hardly be doubted, but the particular way in which it works has yet to be explained.

Two species of Fregata are considered to exist, though they differ in little but size and geographical distribution. The larger, $F$. aquila, has a wide range all round the world within the tropics, and at times passes their limits. The smaller, $F$. minor, appears to be confined to the eastern seas, from Madagascar to the Moluccas, and southward to Australia, being particularly abundant in Torres Strait, - the other species, however, being found there as well. Having a spread of wing equal to a Swan's and a comparatively small body, the buoyancy of this bird is very great. It is a beautiful sight to watch one or more of them floating overhead against the deep blue sky, the long forked tail alternately opening and shutting like a pair of scissors, and the head, which is of course kept to windward, inclined from side to side, while the wings are to all appearance fixedly extended, though the breeze may be constantly varying in strength and direction. Equally fine is the contrast afforded by these birds when engaged in fishing, or, as seems more often to happen, in robbing other birds, especially BoobIEs, as they are fishing. Then the speed of their flight is indeed seen to advantage, as well as the marvellous suddenuess with which they can change their rapid course as their victim tries to escape from their attack. Before gales Frigate-Birds are said often to fly low, and their appearance near or over land, except at their breeding-time, is supposed to portend a hurricane. ${ }^{1}$ Generally seen singly or in pairs, except when the prospect of prey induces them to congregate, they breed in. large companies, and Mr. Salvin has graphically described (Ibis, 1864, p. 375) one of their settlements off the coast of British Honduras, which he visited in May 1862. Here they chose the highest mangrove-trees ${ }^{2}$ on which to build their frail nests, and seemed to prefer the leeward side. The single egg laid in each nest has a white and chalky shell very like that of a Cormorant's. The nestlings are clothed in pure white down, and so thickly as to resemble puff-balls. When fledged, the beak, head, neck, and belly are white, the legs and feet bluish-white, but the body is dark above. The adult females retain the white beneath, but the adult males lose it, and in both sexes at maturity

1 Hence another of the names- 'Hurricane-Bird ' - by which this species is occasionally known.

2 Capt. Taylor, however, found their nests as well on low bushes of the same tree in the Bay of Fonseca (Ibis, 1889, pp. 150-152). 
the upper plumage is of a rery dark chocolate brown, nearly black, with a bright metallic gloss, while the feet in the females are pink, and black in the males - the last also acquiring a bright scarlet pouch, capable of inflation, and being perceptible when on the wing. The habits of $F$. minor seem wholly to resemble those of F. aquila. According to Bechstein (Orn. Taschenb. pp. 393, 394), an example of this last species was obtained at the mouth of the Weser in the winter of 1792, and it has hence been included by some ornithologists among European birds!

FROG-MOUTH, Jerdon's rendering (B. Ind. i. p. 189), since adopted by Anglo-Indian writers, of Gould's Batrachostomus, a genus which he instituted in 1838 (Icones Avium, pt. ii.) for some NIGHTJARs, apparently allied to Podargus (MOREPoRK), and found in India and some parts of the Malay Archipelago.

FULFER, a corrupt form of FIELDFARE.

FULMAR, from the Gaelic Falmair or Fulmaire, the Fulmarus glacialis of modern ornithologists, one of the largest of the Procellariidæ (PETRELS) of the northern hemisphere, being about the size of the Common Gull (Larus canus) and not unlike it in general coloration, except that its primaries are grey instead of black. This bird, which ranges over the North Atlantic, is seldom seen on the European sicle below lat. $53^{\circ} \mathrm{N}$., but on the American side comes habitually to lat. $45^{\circ}$, or even lower. It has been commonly believed to have two breeding-places in the British Islands, namely, the group of islands collectively known as St. Kilda, and South Barra; but, according to the late Mr. Robert Gray (B. W. Scotl. p. 499), it has abandoned the latter since 1844 , while he was assured of its now breeding in Skye. ${ }^{1}$ Northward it established itself about 1838 on Myggenæs Holm, one of the Færoes, while it has several stations off the coast of Iceland and Spitsbergen, as well as at Bear Island. Its range towards the pole seems to be only bounded by open water, and it is the constant attendant upon all who are employed in the whale- and seal-fisheries, shewing the greatest boldness in approaching boats and ships, and feeding on the offal obtained from them. By our seamen it is commonly called the "Molly Mawk" 2 (corrupted from the Dutch Mallemugge), and is extremely well known to them, its flight, as it skims over the waves first with a few beats of the wings and then gliding for a long way, being very peculiar. It only visits the land to deposit its single white egg, which is laid on a rocky ledge, where a

1 Messrs. Harvie-Brown and Buckley (Vert. Faun. Out. Hebrid. p. 157) mention a report of a settlement of the species having been effected in the Flannan Islands, but proof of it is wanting. There is, however, reason to believe that it breeds in North Rona.

2 A name misapplied in the southern hemisphere to some of the smaller species of Albatros (see Mallemuck). 
shallow nest is made in the turf and lined with a little dried grass. Many of its breeding-places are a most valuable property to those who live near them and take the eggs and young, which, from the nature of the locality, are only to be had at a hazardous risk of life. In St. Kilda it is said that from 18,000 to 20,000 young are killed in one week of August, the only time when, by the custom of the community, they are allowed to be taken. These, after the oil is extracted from them, serve the islanders with food for the winter. This oil, says Mr. Gray, having been chemically examined by Mr. E. C. C. Stanford, was found to be a fish-oil and to possess nearly all the qualities of that obtained from the liver of the cod, with a lighter specific gravity. It, however, has an extremely strong scent, which is said by some who have visited St. Kilda to pervade every thing and person on the island, and is certainly retained by an egg or skin of the bird for many years. Whenever a live example is seized in the hand it ejects a considerable quantity of this oil from its mouth. Though abounding in certain seasons on the banks of Newfoundland, where, according to Montagu (Suppl. Orn. Dict.), it was called by the fishermen "John Down," it seems to have no breeding-place on the east coast of America, but it has several, which are thronged, on either side of Baffin's Bay. The Fulmar is said by Mr. Darwin (Origin of Species, ed. 4, p. 78 ) to be the most numerous bird in the world; but on whose authority the statement is made does not appear, and to render it probable we shonld have to unite specifically with the Atlantic bird, not only its Pacific representative, $F$. pacificus, which some ornithologists deem distinct, but also that which replaces it in the Antarctic seas and is considered by most authorities to be a perfectly good species, $F$. glacialioides. The differences between them are, however, exceedingly slight, and for Mr. Darwin's purpose on this particular occasion it matters little how they are regarded. It is a more interesting question whether the statement is any how true, but one that can hardly be decided yet.

FURCULA, a name for the two Chaviches when coalescent, as generally is the case among Birds; in English commonly known as the Merrythought or Wishbone. ${ }^{1}$ Some very peculiar forms of the Furcula are presented in certain species of Crank, GuINEA-FOWL, and Swan, chiefly adaptations to convolutions taken by the TrACHEA, as well as in the Frigate-BIRD, HoACtzin, and some others.

\section{FURZE-CHA'T, a name often given to the STONE-CHAT.}

1 Cotgrave, in his Dictionary (1660), explains the former name as "the forked craw-bone of a bird which we use in sport to put on our noses." The latter comes from the practice of two persons, mostly children, each holding one prong of the furcula and expressing a wish before breaking it asunder. The one who carries off the greater portion expects the fulfilment of his or her wish. 


\section{G}

GABBLE-RATCHET. In many parts of England, but especially in Yorkshire, the cries of some kind of Wild Goose, ${ }^{1}$ when flying by night, are heard with dismay by those who do not know the cause of them, and are attributed to "Gabriel's Hounds," an expression equivalent to "Gabble-ratchet," a term often used for them, as in this sense gabble is said to be a corruption of Gabriel, and that, according to some mediæval glossaries, is connected with gabbarca or gabares, a word meaning a corpse (cf. Way, Promptorium Parvulorum, p. 302, sub voce "Lyche"); while ratchet is undoubtedly the same as the Anglo-Saxon racc and Middle English racche or rache, a dog that hunts by scent and gives tongue. Hence the expression would originally mean "corpse-hounds," and possibly has to do with legends, such as that of the Wild Huntsman, on which it would be out of place here to dwell. The sounds are at times very marvellous, not to say impressive, when heard, as they almost invariably are, on a pitch-dark night, and it has more than once happened within the writer's knowledge that a flock of Geese, giving utterance to them, has continued for some hours to circle over a town or village in such a way as to attract the attention of the most unobservant of its inhabitants, and inspire with terror those among them who are prone to superstition ( $c f$. Atkinson, Notes and Queries, ser. 4, vii. pp. 439, 440, and Cleveland Glossary, p. 203 ; Herrtage, Catholicon Anglicum, p. 147 ; Robinson, Glossary Whitby (Engl. Dial. Soc.), p. 74 ; and Addy, Glossary Shefficld (Engl. Dial. Soc.), p. 83). Mr. Charles Swainson (Prov. Names Br. B. p. 98), gives "Gabble-Ratchet" as a name of the NighTJAR; but satisfactory proof of that statement seems to be wanting.

GADWALL, a word of obscure origin, ${ }^{2}$ the common English name of the Duck, called by Linnæus Anas strepera; but, from

I Presumably the Brant, on the rare occasions when, losing its way, it comes inland, for the call-notes procecding from a flock of this species curiously resemble the sound of hounds in full cry (Thompson, $B$. Irel. iii. p. 59), though some hearers liken them to the yelping of puppies. The discrepancy may to some extent depend on distance.

2 Webster gives the etymology gad well="go about well "-which is nonsense. The late Dr. R. G. Latham suggested that it is taken from the syllables quedul, of the Latin querquedulc, a Teal. The spelling "Gadwall" seems to be first found in Willughby in 1676, and has been generally adopted by later writers ; but in 1667 Merrett (Pinax Rerum naturalium Britannicamum, p. 180), had "Gaddel," saying that it was so called by bird-dealers. The synonym "Gray," given by Willughby and Ray, is doubtless derived from the general colour of the species, and has its analogue in the Icelandic Grisnd, applied 
the fine comb-like "teeth" with which its maxillæ are furnished, considered by many modern ornithologists to require removal from the genus Anas to that of Chaulelasmus or Ctenorhynchus, of which

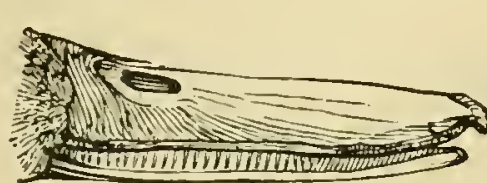

GADWALL. (After Swainson.) it is the typical species. Its geographical distribution is almost identical with that of the common Wild Duck or Mallard, since it is found over the greater part of the Northern Hemisphere; but, save in India, where it is said to be perhaps the most plentiful species of Duck during the cold weather, it is hardly anywhere so numerous; and both in the eastern parts of North America and in the British Islands it is rather rare than otherwise. Its habits also, so far as they have been observed, greatly resemble those of the Wild Duck; but its appearance on the water is very different, its small head, fiat back, elongated form, and elevated stern rendering it recognizable by the fowler even at such a distance as hinders him from seeing its very distinct plumage. In coloration the two sexes agree much more than is the case with any of the European Freshwater-Ducks, Anatina-one only, the Anas marmorata, excepted; but on closer inspection the drake exhibits a delicate ash-coloured breast, and upper wing-coverts of a deep chestnut, which are wholly wanting in his soberly clad partner. She, however, has, in common with him, a pure white patch on the wings, which forms one of the most readily-perceived distinctive characters of the species. The Gadwall is a bird of some interest, since it is one of the few that have been induced, by the protection afforded them in certain localities, to resume the indigenous position they once filled, but had, through the draining and reclaiming of marshy lands, long since abandoned. In regard to the present species, this fact is due to the efforts of the late Mr. Andrew Fountaine, on whose property, in West Norfolk, and its immediate neighbourhood, the Gadwall has, since 1850, annually bred in constantly increasing numbers, so that it may again be accounted, in the fullest sense of the word, an inhabitant of England; and, as it has been always esteemed one of the best of wild fowl for the table, the satisfactory result of its encouragement by this gentleman is not to be despised. A second species, C. couesi, from Washington Island, one of the Fanning group, has been described (Bull. Nutt. Orn. Club, i. p. 46).

GALL-BLADDER, the receptacle of the bile secreted by the LIVER, on the right lobe of which it is situated, between that and the proventriculus. When large it hangs down on the right side of

almost indifferently, or with some distinguishing enithet, to the female of any of the Freshwater-Ducks, and especially to the present.

1 Stevenson and Southwell, Birds of Norfolk, iii. pp. 160-162. 
the stomach into the beginning of the two arms of the duodenal loop. It is present in most Birds, but generally absent in the Columbida, Psittaci, and Trochilida, as also in Cuculus, Numida, Struthio, and Phea. Its absence has also been noted as an individual peculiarity in Grus, Mergus, Numenius, Tringa, and others; while as a like individual peculiarity it has, on the other hand, been known to occur in Cockatoos, Cuculus, Pigeons (despite the almost proverbial belief to the contrary), and Phea-a fact which shews it to be of minor importance. Its shape is very variable, and in the Capitonida, Picide, and Phamphastidie it is very peculiar, being a long narrow blind sac, accompanying the duodenum far down. The bile, on leaving the liver, enters the duodenal loop of the intestine by two "hepatoenteric" ducts (of which that coming from its left lobe most frequently opens into the middle of the loop or its ascending branch, and but rarely-as in Struthio and the Columbida-near the pyloric end); while the right duct forms by its dilatation the gall-bladder, and consists therefore of a cysto-hepatic and a cysto-enteric duct. When the gall-bladder is absent the right lobe of the liver is emptied by a simple hepato-enteric duct. Sometimes one of these ducts is obliterated, as the right one is in Struthio, or one of them is double, as in certain Cracida, so that three ducts enter the duodenum (see Digestive S.ysteir).

GALLEY-BIRD, given as a Sussex name for a WooDPECKER by Mr. Charles Swainson (Prov. Names Br. B., pp. 99, 100), but not mentioned as such by Mr. Borrer or Mr. Knox.

GALLIN $A$, the fifth Order of the Class Aves in the arrangement of Linnæus, and taken as a whole a very natural one, comprehending all that are commonly known as Gallinaceous Birds, or those allied to the common Fowl (Gallus). Other systematists have varied its title to Gallinacex or Gallinacei, and it is practically equivalent to the Alectoromorphe of Prof. Huxley. By adding to the Order, as defined by Linnæus, the Columbr (Dove) and Crypturi (TINamou), Illiger in 1811 formed an Order which he called Rasokes, a name adopted by many writers for more than half a century, but now generally admitted to be inadmissible.

GALLINEY, a local name for the domestic GUINEA-FowL.

GALLINULE, a name given in books to the Moor-Hes, and thence occasionally, with qualification, to others of the Pallidx (RAIL).

GAMBET, Fr. Gambette, Ital. Gambetta (Lat. gamba), which last is said by modern Italian writers to be the common name of the RuFF. The word was anglified by Pennant, and applied to what, in Montagu's opinion (Orn. Dict. Suppl.), was a bird of that species 
in one of its varied stages of plumage; but it has since been used, especially by American writers, indiscriminately for several SANDPIPERS.

GANDER (Anglo-Saxon, Gandra), the male Goose.

GANNET (Anglo-Saxon, Ganot) or Solan Goose, ${ }^{1}$ the Pelecanus bassanus of Linnæus and the Sula bassana of modern ornithologists, a large sea-fowl long known as a numerous visitor, for the purpose of breeding, to the Bass Rock at the entrance of the Firth of Forth, and to certain other islands off the coast of Britain, of which four are in Scottish waters-namely, Ailsa Craig, at the mouth of the Firth of Clyde; the group known collectively as St. Kilda; ${ }^{2}$ North Barra or Sulisgeir (otherwise Suleskerry), some 40 miles north of the Butt of Lewis; and the Stack, ${ }^{3}$ about the same distance westward of Stromness. It appears also to have two Irish stations, the Skellig Islands off the coast of Kerry, and the Bull Rock off that of Cork, ${ }^{4}$ and it resorts besides to Lundy Island in the Bristol Channel -its only English breeding-place, though in Wales a considerable settlement occupies Grassholm, off the coast of Pembrokeshire. ${ }^{5}$

1 The phrase ganotes bæð (Gannet's bath), a periphrasis for the sea, occurs in the Anglo-Saxon Chronicle, in reference to events which took place 975 A.D., as pointed out by Prof. R. O. Cunningham, whose learned treatise on this bird (Ibis, 1866, pp. 1-23) nearly exhausts all that could then be said of its history and habits. The name, like Gander and Goose in English and German Gans, is from an old base gan, which also supplied the Greek $\chi \grave{\eta} \nu$, and the Latin anser. Solan is no doubt from the Scandinavian Sula, whatever that may mean.

Prof. Cunninghain (ut supr. p. 15) noticed the wonderful mistake of Robert Browning, which surpasses the licence ordinarily taken on any subject, save natural history, by poets. In Paracelsus (part iii.) "we find Festus referring to his son Aureole's glee when some stray Gannet builds amid the birch trees by the lake of Geneva!"

2. Gannets frequent Rockall in the breeding-season, as Basil Hall, in his wellknown account of that distant rock, states, and as the late Mr. Gwyn Jeffrey told me, but whether they breed there is not known.

${ }^{3}$ Cruising round this place in June 1890, my companions and I remarked the large proportion (compared with what we had seen elsewhere) the birds which had not attained their full plumage bore to those perfectly adult. The most likely explanation of the fact seems to be that, the station being so rarely visited and its inhabitants so free from molestation, a greater number of young would yearly grow up; and I was glad to find afterwards that this way of accounting for it is thought to be right by Mr. Harvie-Brown, whose experience is far greater than that of any one else ( $c f$. Buckley and Harvie-Brown, Vertcbr. Fauna of Orkney, p. 160).

4 This last seems to have been but recently colonized. Whether it ever bred upon the Stags of Broadhaven, off the coast of Mayo, as has been stated, is doubtful ( $c f$. Barrington and Ussher, Zool. 1884, pp. 473-481).

5 The history of this settlement is very obscure. Its existence was practically unknown to ornithologists until 1890 , when a wanton massacre of its inluabitants 
Further to the northward its settlements are Myggenæs, the most westerly of the Freroes, and various small islands off the coast of Iceland, of which the Vestmannaeyjar, the Reykjanes Fuglaskér, and Grimsey are the chief. On the western side of the Atlantic it appears to have now but three stations, and on them the population is so reduced in numbers that there is every chance of the species ceasing to exist in those parts unless proper steps are taken to protect it. In old times the birds existed in extraordinary numbers, and even in 1860 the late Dr. Bryant reckoned the population of Gannets on the Great Bird Rock at 50,000 pairs. In 1887 not more than 10,000 birds were said to be there, and the numbers, according to Mr. Lucas (Auk, 1888, pp. 129-135), are yearly decreasing both there and on Bonaventure Island, the only other considerable settlement, owing to the brutality of the fishermen in the Gulf of St. Lawrence. There seems to be no recent account of the settlement in the Bay of Fundy. On all these places the bird arrives about the end of March or in April, and departs in autumn when its young are ready to $\mathrm{fly}$; but even during the breeding-season many of the adults may be seen on their fishing excursions at a vast distance from their home, while at other times of the year their range is greater still, for they not only frequent the North Sea and the English Channel, but stray to the Baltic, and, in winter, extend their flight to Madeira, while the members of the species of American birth traverse the ocean from the shores of Greenland to the Gulf of Mexico.

Apparently as bulky as a Goose, and with longer wings and tail, the Gannet weighs considerably less. The plumage of the adult is white, tinged on the head and neck with butf, while the outer edge and principal quills of the wing are black, and some bare spaces round the eyes and on the throat reveal a dark blue skin. The first plumage of the young is of a deep brown above, but paler beneath, and each feather is tipped with a triangular white spot. 'The nest is a shallow depression, either on the ground itself or on a pile of turf, grass, and seaweed-which last is often conveyed from a great distance. The single egg it contains has a white shell of the same chalky character as a Cormorant's. The young are hatched blind and naked, but the slate-coloured slin with which their borly is covered is soon covered with white down, replaced in due time by true feathers of the dark colour already mentioned. The mature plumage is beliered not to be attained for some three years. Towards the end of summer the majority of Gannets, both old and young, leave the neighbourhood of their breeding-place, and, betaking themselves to the open sea, follow the shoals of herrings and other fishes (the presence of which they areattracted attention. Its discovery was made only a short time before by lír. Jo J. Neale (cf. T. H. Thomas, Trans. Cardiff Nat. Soc. xxii. part 2). 
most useful in indicating to fishermen) to a great distance from land. Their prey is almost invariably captured by plunging upon it from a height, and a company of Gannets fishing presents a curious and interesting spectacle. Flying in single file, each bird, when it comes over the shoal, closes its wings and dashes perpendicularly, and

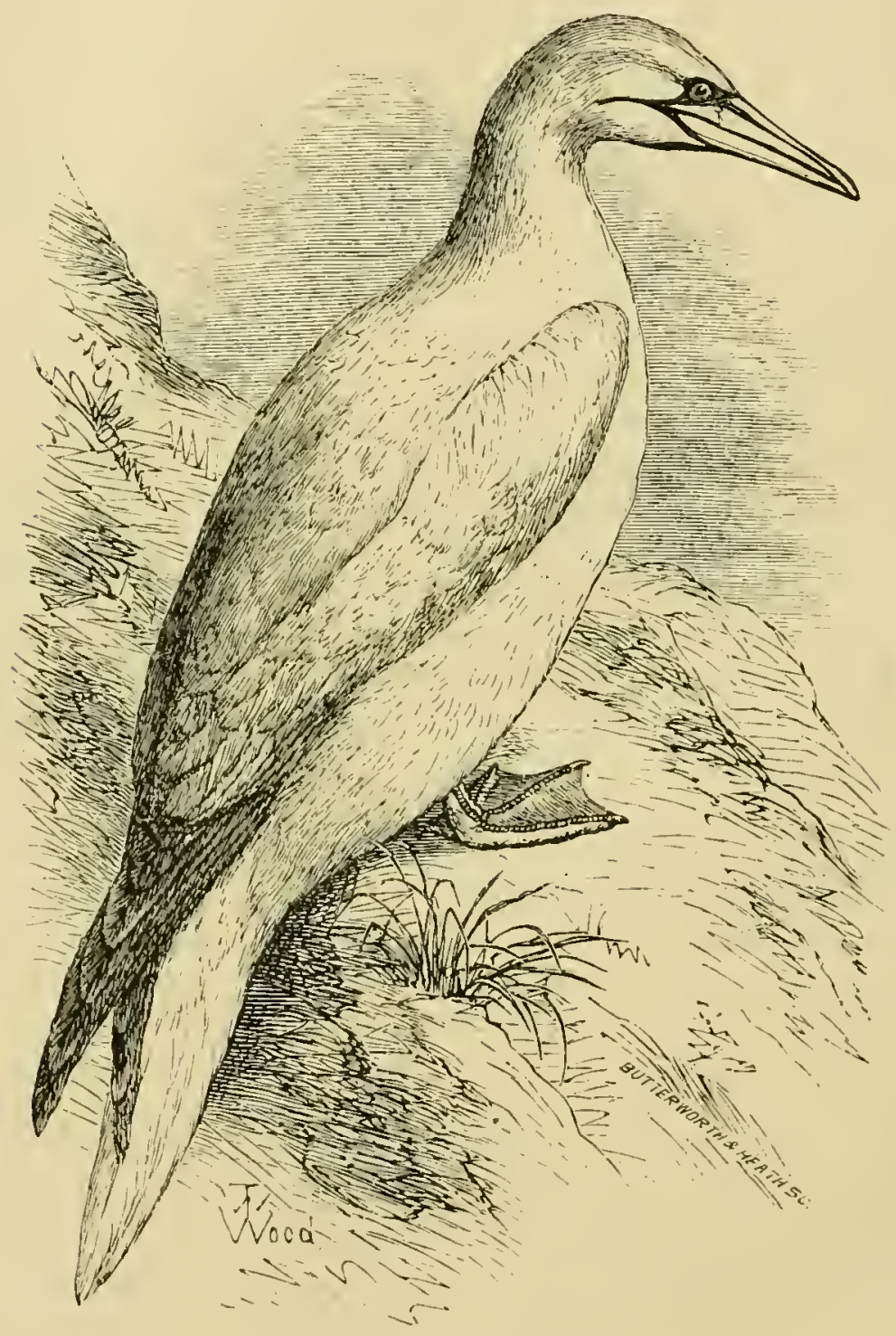

Gaxiet, or Solax Goose.

with a velocity that must be seen to be appreciated, into the waves, whence it emerges after a few seconds, and, shaking the water from its feathers, mounts in a widle curve, orderly taking its place in the rear of the string, to repeit its headlong plunge so soon as it again finds itself above its prey. ${ }^{1}$

1 The large number of Gannets, and the vast quantity of fish they take, have been frequently animadverted upon, but the computations on this last point are 
Structurally the Gannet presents many points worthy of note, such as its closed nostrils, its aborted tongue, and its toes all connected by a web-characters which it possesses in common with most of the other members of the group of birds (STEGANoPODES) to which it belongs. But more remarkable still is the system of subcutaneous air-cells, some of large size, pervading almost the whole surface of the body, communicating with the lungs, and capable of being inflated or emptied at the will of the bird. This peculiarity has attracted the attention of several writers-Montagu, Sir R. Owen (Proc. Zool. Soc. 1831, p. 90), and Míacgillivray; but a full and particular account of the anatomy of the Gannet is still to be desired.

In the southern hemisphere the Gannet is represented by two nearly allied but somewhat smaller forms-one Sula capensis, inhabiting the coast of South Africa, and the other, S. serrator, the Australian seas. Both much resemble the northern bird, but the former seems to have a permanently black tail, and the latter a tail the four middle feathers of which are blackish-brown with white shafts.

Apparently inseparable from the Gannets generically are the smaller birds well known to sailors by the name of BOOBY, which has passed into an English byword, though few know its Por tuguese origin.

\section{GARDENER-BIRD, see Bower-BIRD.}

GARE-FOWL ${ }^{1}$ (Icelandic, Geirfugl; Gaelic, Gearbhul!: the anglicized form of the Hebridean name of a large sea-bira, for-

perhaps fallacious. It seems to be certain that in former days fishes, and herrings in particular, were at least as plentiful as now, if not more so, notwithstanding that Gannets were more numerous. Those frequenting the Bass were reckoned by Macgillivray at 20,000 in 1831, while in 1869 they were computed at 12,000, showing a decrease of two-fifths in 38 years. On Ailsa in 1869 there were supposed to be as many as on the Bass, but their number was estimated at 10,000 in 1877 (Report on the Herring Fisheries of Scotland, 1878, pp. xxv. and 171), - being a diminution of one-sixth in eight years, or nearly twice as great as on the Bass. The falling-off has since been still greater, but I have no means of computing it.

1 "Avis Gare dicta, Corvo Marino Similis, Ovo maximo" is included in Sibbald's treatise De Animalibus Scotiæ (p. 22), published in 1684, being the frst printed notice of this bird as British, and apparently on information berived from a MS. description of the Western Islands by Dean Munro, drawn up about 1549 (cf. J. A. Smith, Proc. Soc. Antiq. Scotl. xiii. p. 84, and xiv. p. 436). A modified, not to say corrupt, version of a transcript of this MS., nuw in the Advocates' Library at Edinburgh, was printed in 1809 by Pinkerton (Coll. Voy. "nd Trav. iii. p. 730), who used the same spelling. In 1698 Martin (Voy. to St. Kilda, p. 48) had the name "Gairfowl." Sir R. Owen, in 1864, adopted the form "Garfowl," without, as would seem, any precedent authority. Mr. Alexander Carmichael (Harvie-Brown and Bnckley, Vertebr. Faun. Outer 
merly a native of certain remote Scottish islands, the GREAT AUK of most English book-writers, and the Alca impennis of Linnæus. Of this remarkable creature mention has been alrcady made (Extermination), but since the species has a mournful history and several egregious misconceptions prevail concerning it, a few more details may not be unacceptable. In size it was hardly less than a tame Goose, and in appearance it much resembled its smaller and surviving relative the RAzor-Brr., $A$. torda; but the

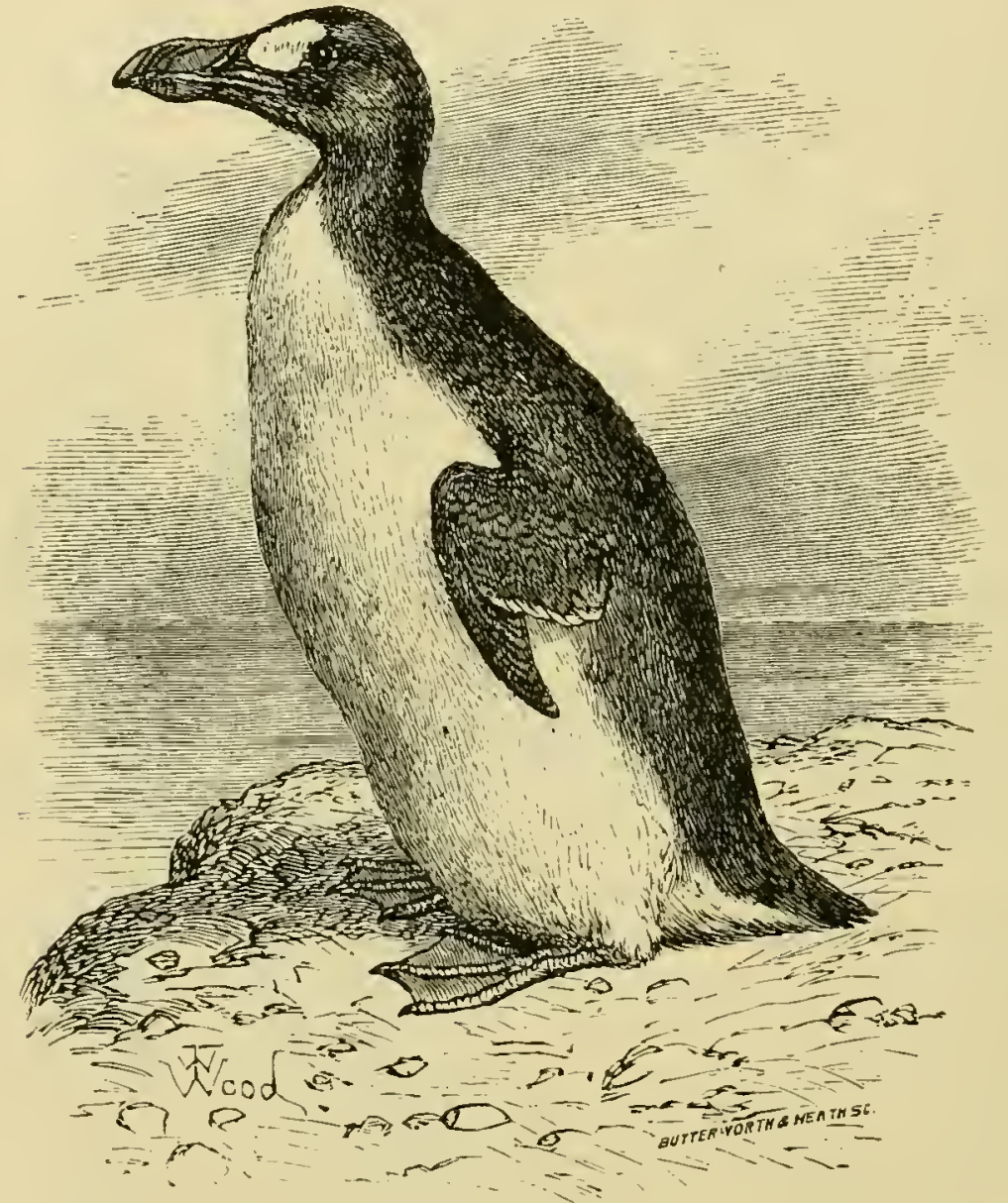

Gare-Fowl, or Great AuK.

glossy black of its head was varied by a large patch of white occupying nearly all the space between the eye and the bill, in

Hebrides, 1. 158) gives the correct Gaelic spelling as Gearr bhul or An Gearrabhul, meaning "the strong, stout bird with the spot"; but others may think the word to be a rendering of the old Norsk name. According to Pennant, Carfil is the generic word in Welsh for any of the Alcidæ. It may be observed that just as "Penguin" (or Pin-wing), being the first English name applied to this species, on its discovery in America, has been transferred to birds of a very different Order, so also has Gorfou, the Freneh corruption of Geirfugl, been applied to some of the same. 
plice of the hazol-bill's thin white line, while the. bill itself bore eight or more deep trinsverse grooves instead of the smaller number and the ivory-like mark possessed by the species last named. Otherwise the coloration was similar in both, and there is satisfactory evidence that the Gare-fowl's winter-plumage differed from that of the breeding-season just as is ordinarily the case in other members of the Family Alcilie to which it belongs. The most striking characteristic of the Gare-fowl, however, was the comparatively abortive condition of its wings, the distal portions of which, though the bird was just about twice the linear dimensions of the Razor-bill, were almost exaetly of the same size as in that species-proving, if more direct evidence were wanting, its inability to fiy.

The most prevalent misconception concerning the Gare-fow is one which has been repeated so often, and in books of such generally good repute and wide dispersal, that a successful refutation seems almost hopeless. This is the notion that it was a bird possessing a very high northern range, and consequently to be looked for by Arctic explorers. How this error arose would take too long to tell, but the fact remains indisputable that, setting aside general assertions resting on no evidence worthy of attention, there is but a single record deserving any credit at all ${ }^{1}$ of a single example of the speeies having been observerl within the Arctic Circle, and this, according to the late Prof. J. T. Reinhardt, who had the best means of ascertaining the truth, is open to grave doubt. ${ }^{2}$ It is clear that the older ornithologists let their imagination get the better of their knowledge or their judgment, and their statements have been blindly repeated by most of their successors. Another error which, if not so widely spread, is at least as serious, since Sir R. Owen (Encycl. Brit. ed. S, xvii. p. 176 ; Palrontology, p. 400) unhappily gave it comntenance, is that thibird "has not been specially hunted down like the dodo and linornis, but by degrees his become more scarce." Now, if any reliance ean be placed upon the testimony of former observers, the first part of this statement is absolutely untrue. Of the DoDo we know that the mode of its extinction is open to conjecture, a strong suspicion existing that though indirectly due to man's acts it was accomplished by his thoughtless agents. The extinction of the Dinornis (MOA) lies beyond the range of recorded history, and evidence that the whole population of Moas was done to death by

1 I cannot attach importance to the later statements of Herr L. Brodtkorb (Mitth. Orn. Ver. Wien, 1884, pp.67-69). His story was sifted nearly 30 years before by the late Mr. Wolley.

2 The specimen is in the Museum of Copenhagen; the donkt lies as to the locality where it was obtained, whether at Diseo, which is withiu, or at Fiskernäs, which is without, the Arctic Circle. 
man, however likely it may seem, is wholly wanting. The contrary is the case with the Gare-fowl. In Iceland there is the testimony of a score of witnesses, taken down from their lips by one of the most careful naturalists who ever lived, the late John Wolley, that the latest survivors of the species were caught and killed by expeditions expressly organized with the view of supplying the demands of caterers to the various museums of Europe. In like manner the fact is incontestable that its breeding-stations in the western part of the Atlantic were for three centuries regularly visited and devastated with the combined objects of furnishing food or bait to the fishermen from very early days, and its final extinction, foretold in 1792 by Cartwright (Labrador, iii. p. 55), was due, according to Sir Richard Bonnycastle (Newfoundland in $1 \$ 42$, i. p. 232 ), to "the ruthless trade in its eggs and skin." No doubt that one of the chief stations of this species in Icelandic waters disappeared, as has been before said (pp. 220, 221), through rolcanic action-

"A land, of old upheaven from the abyss

By fire, to sink into the abyss again "-

and that the destruction of the old Geirfuglaskér drove some at least of the birds which frequented it to a rock nearer the mainland, where they were exposed to danger from which they had in their former abode been comparatively free; yet on this rock (Eldey = fire-island) they were "specially hunted down" whenever opportunity offered, until the stock there was wholly extirpated in 1844 , and whether any remained elsewhere must be deemed most doubtful.

A third misapprehension was that entertained by Gould who, in his Birds of Great Britain, said that "formerly this bird was plentiful in all the northern parts of the British Islands, particularly the Orkneys and the Hebrides. At the commencement of the present century, however, its fate appears to have been sealed; for though it doubtless existed, and probably bred, up to the year 1830 , its numbers annually diminished until they became so few that the species could not hold its own."

Now of the Orkneys, we know that Low, who died in 1795 , says in his posthumously-published Fauna Orcadensis (p. 107) that he could not find it was ever seen there $;^{1}$ and on Bullock's visit in 1812 he was told, says Montagu (Orn. Dict. App.), that one male only had made its appearance for a long time. This bird he saw and unsuccessfully hunted, but it was killed in the following year, and its

I However, from lis more recently published (Kirkwall : 1579) Tour, made in 1774 at the instance of Pennant, we learn that he clid not visit Papa Westray, the only locality assigned for the bird. His negative evidence is therefore not to be talien as conclusive. 
stutfed slin is $110 \mathrm{w}$ in the British Museum, ${ }^{1}$ while its mate had been killed before his arrival. None have been seen there since. As to the Hebrides, St. Kilda is the only locality recorded for it, and there but two examples are believed to have been taken during the present century, one being a living bird given in 1821 by Mr. Maclellan of Glass to Fleming, who not being aware of the particulars of its capture, erroneously recorded them (Edind. Plitl. Journ. x. p. 96). These have now been ascertained. The second was lilled about $1840 .^{2}$ That the Gare-fowl was not plentiful in either group of islands is sufficiently obvious, as also is the impossibility of its continuing to breed "up to the year 1830."

But mistakes like these are not confined to British authors. As on the death of an ancient hero myths gathered round his memory as quickly as clouds round the setting sun, so have stories, probable as well as impossible, accumulated over the true history of this species, and it behoves the conscientious naturalist to exercise more than common caution in sifting the truth from the large mass of error. Americans at one time asserted that the specimen which belonged to Audubon (now at Vassar College) was obtained by him on the banks of Newfoundland, thongh there was Macgillivray's distinct statement (Brit. Birds, v. p. 359) that Audubon procured it in London. The account given by Degland (Orn. Europ. ii. p. 529) in 1849, and repeated in the last edition of his work by M. Gerbe, of its extinction in Orkney, is so manifestly absurd that it deserves to be quoted in full:- "Il se trouvait en assez grand nombre il y a une quinzaine d'années aux Orcades; mais le ministre presbytérien dans le Mainland, en ofirant une forte prime aux personnes qui lui apportaient cet oiscau, a été cause de sa destruction sur ces îles." The same author claims the species as a visitor to the shores of France on the testimony of Hardy (Annuaire Normand, 1841, p. 298), which he grievously misquotes both in his own work and in another place (Naumannia,

${ }_{1}$ Bullock's own account, all he ever published on the subject, appeared in 1814 (Companion to the London Mruseum, ed. 16, pp. 75, 76), and is as follows: "Of this rare and noble bird, we have no account of any having been killed on the shores of Britain, except this specimen, for upwards of one humdred years. It was taken at Papa Westra in Orkney, to the rocks of which it had resorted for several years, in the summer of 1813 , and was fincly preserved and sent to me by Miss Trail of that island. . . . I had the pleasure of exanining this curious bird in its native element; it is wholly incapable of flight, but so expert a diver that every effort to shoot it was ineffeetual." Fuller details will be found in Messrs. Buckley and Harvie-Brown's Vertebrate Fauna of Orkney (pp. 245-257). I have reason to believe that the breeding-place of this last pair was on the Holm of Papa Westray, though the survivor was killed on the main island of that name.

$\because$ For the whole story see Messrs. Harvie-Brown and Buckley's Vertebrute Fauna of the Outer Hebrides (pp. 158-160). 
1855, p. 423), thereby misleading an English writer (Nat. Hist. Rev. 1865, p. 475 ) and numerous German readers.

In further addition to this account already given it may be here mentioned that in 1874 Prof. Milne visited Funk Island, the famous resort in old times of this bird, in the Newfoundland seas, a place where bones had before been obtained by Stuvitz, and natural mummies so lately as 1863 and 1864, and landing there at the risk of his life, he brought off a rich cargo of its remains, belonging to no fewer than fifty birds, some of them in size exceeding any that had before been known. His collection, since dispersed, most of the specimens finding their way into various public museums in this country, has, however, been far exceeded by that made in 1887 by Mr. Lizcas. ${ }^{1}$

I A literature by no means inconsiderable has grown up respecting the Gare-fowl. Neglecting works of general bearing, few of which are without many inaccuracies, and omitting some to which reference has been already made, the following treatises may be especially mentioned:-J. J. S. Steenstrup, "Et Bidrag til Geirfuglens Naturhistorie og særligt til Kundskaben om dens tidligere Udbrerlningskreds," Naturh. Foren. Vidensk. Mecldelelser [Copenlagen], 1855 , p. 33 ; E. Charlton, "On the Great Auk," Trans. Tyncside Nat. Ficld Club, iv. p. 111 ; "Abstract of Mr. J. Wolley"s Researches in Iceland respecting the Gare-fowl," Ibis, 1861, p. 374; W. Preyer, "Ueber Plautus impennis," Journ. für Orn. 1S62, pp. 110, 337 ; K. E. von Baer, "Ueber das Aussterben der Thierarten in physiologischer und nicht physiologischer Hinsicht," Bull. de l'Acad. Imp. de St. Pétersb. ri. p. 513 ; R. Oren, "Description of the Skeleton of the Great Auk," Trans. Zool. Soc. v. p. 317; "The Garefowl and its Historians," Nat. Hist. Rev. r. p. 467 ; J. H. Gurncy, jun., "On the Great Auk," Zoologist, 2nd ser. pp. 1442, 1639 ; H. Reeks, "Great Auk in Newfoundland," \&.c., op. cit., p. 1S54; V. Fatio, "Sur l'Alca impennis," Bull. Soc. Orn. Suisse, ii. Pp. 1, 80, 147 ; "On existing Remains of the Gare-fowl," Ibis, 1870, p. 256 ; J. Milne, "Relics of the Great Ank," Ficld, 27 March, 3 and 10 April 1875 ; J. A. Allen, "The Extinction of the Great Auk at the Funk Islands," Am. Nat. 1876, p. 4\$; Robert Gray, "On the Great Auk," Proe. Roy. Soc. Edinb. x. pp. 685-682; Synnington Grieve, "Discovery of Remains of the Great Auk . . . on . . Oronsay," Journ. Linn. Soc. (Zoology) xvi. pp. 479-487, The Great Auk or Garefowl (Edinburgh : 1885, 4to) [Reviews, Nature, xxxii. p. 545, Auk, 1986, p. 262], "Recent Notes on the Great Auk," Trans. Edinb. Field Nat. and Nieroscop. Soc. 18SS, pp. 93-119; W. Blasius, "Ueber die letzten Vorkomnisse des Riesen-Alks," Ver. f. Naturw. zu Braunschueig, iii. pp. 89-115, "Zur Geschichte der Ueberreste von Alca impennis," Journ. für Oru. 1884, pp. 58-176, "Neue Thatsachen in Betrefl" der Ueberreste ron Alca impennis," Tagebl. Naturf. Vers. Nagdeburg, 18\$4, pp. 321-323; I. Collett, "Ueber Alca impenuis in Norwegreu," Mitth. Orn. Ver. Wien, 18S4, pp. 65-69, 85-\$9; F. A. Lucas, "Great Auk Notes," Aul; 18s8, pp. 278-283, "Expedition to the Funk Island, with Obserrations upon the History and Anatomy of the Great Auk," Iiep. U. S. Nat. Heus. 18S7-SS, P1. 493-529; F. Hardy, "Testimony of Some Larly Voyagers on the Great Allk, Auk, 1SSs, pp. 3S0-3S4; P. Leverkiihn, "Wanu starb der Grosse Alk aus?" Monatsschr. Deutsch. Ver. Schutse Vogelwelt, 1888, pp. 3\$8-390; Baron d'Hamonville, "Note 
GARGAXEL' (North-Italian, Garguncllo), or Summer-Test, the Anas querquedula and A. circia of Linnæus (who made, as did Millughby and Ray, two species out of one), and the type of Stephens's genus Querquedulu. This is one of the smallest of the Anatida, and has gained its common English name from being almost exclusively a summer-risitant to this country, where nowadays it only regularly resorts to breed in some parts of Norfolk, though probably at one time found at the same season throughout the great Fen-district. About the same size as the common TeaL, A. crecca, the male is readily distinguished therefrom by its peculiarly-coloured head, the sides of which are nutmeg-brown, closely freckled with short whitish streaks, while a conspicuous white curved line descends backwards from the eyes. The upper wing-coverts are bluish-grey, the scapulars black with a white shaftstripe, and the wing-spot (speculum) greyish-green bordered above anu below by white. The female closely resembles the hen Teal, but possesses nearly the same wing-spot as her mate. In Ireland or Scotland the Garganey is rery rare, and though it is recorded from Iceland, more satisfactory evidence of its occurrence there is needed. It has not a high northern range, and its appearance in Norway and Sweden is castual. Though it breeds in many parts of Europe, in none can it be said to be common; but it langes far to the eastwald in Asia-even to Formosa, according to Swinhoeand yearly visits India in winter. Those that breed in Norfolli arrive somewhat late in spring; and mostly make their nests in the vast reed-beds which border the Broads - a situation rarely or never chosen by the Teal. The labyrinth or bony enlargement of the trachea in the male Garganey differs in form from that described in any other drake, ${ }^{2}$ being more oval and placed nearly in the median line of the windpipe, instead of on one side, as is usually the case.

GARROT, a French name of the GOLDEN-EYE, which some writers, beginning in 1829 with Griffith (Anim. Kingd. viii. p. 609) sur les quatre cufs d'Alca impeunis appartenant à notre collection," MIém. Soc. Zool. France, 1889, pp. 224-227, "Addition à une Note," Sc. Bull. Soc. Zool. France, 1591, pp. 105-109. Lastly, reference cannot be omitted to the happy exercise of poetic fancy with which Charles Kingsley was enabled to introduce the chief facts of the Gare-fowl's extinction (derived from one of the abovenamed papers) into his charning Woter Babies.

1 The word was introduced by Willughby from Gesner (Orn. lib. iii. p. 12 7 ), but, though generally adopted by authors, seems never to have become other than a book-name in English, the bird being invariably lnown in the parts of this island where it is indigenous as "Summer-'Teal."

2 I have found no mention of this part in the Bine-winged Teal of North America, $A$. discors, which in plumage lias some resemblance to the Garganey ; but did its labyrinth differ from the ordinary form, I think some one would have noticed the fact. 
have tried to make an English word. The origin of the French word was unknown to Littré; but its application to this bird is probably due to its rapid flight, one meaning of garrot being a crossbow-bolt.

GAULDING or GAULIN, a word rarionsly spelt, of unknown etymology and originally of doubtful meaning. What seems to be the same word appears as "Goldeine," "Goldynis" (plur.), and "Goldynhis" in an Act of the Scottish Parliament in 1555, according to Langmuir and Donaldson (Jamieson's Scott. Dict. ed. 2), but without explanation, though a connexion is suggested witl the Icelandic Gulфnd, which is the GoosAnder. In an Act of 1600 (16 Jac. VI. cap. xxiii.) it stands as "Golding," and there at present it must be left; but "Gaulding," most generally pronounced "Gaulin", is used in the Antilles, and perhaps elsewhere, for any of the smaller Ardeidx, be they BitTerss or Herors.

GAUNT, said to be applied in some parts of England to the Great Crested GREBe, and possibly corrupted from GANNET.

GAVIA, an Order of the Class Aves, proposed by Bonaparte in a Conspectus Systematis Ornithologia, which appeared in a tabular form in 1850 , and in 1853 was published in a more convenient shape in the Comptes Rendus (xxxvii. pp. 643, 647), as well as in the Amales des Sciences Naturelles (ser. 4, i. pp. 107, 142). At first it was made to include two tribes, Totipalmi (STEGANopodes) and Longipennes, consisting of Procellariidre, Laridre, and "Chionida" (SHEATHBILL), but to these was afterwards added a third, Urinatores, formed of Alcida, Colymbida, and "Podicipida." By some recent writers the term Gariz has been restricted to the Gulls and Terss, or these together with the Auks; but its original signification should be always borne in mind; and liere it may be remarked that, almost from the beginning of Systematic Ornithology, the woird Gavia ${ }^{1}$ has been used in several senses-for instance, in 1752 , by Möhring (Av. Gen. p. 66), as equivalent to the Linnæan Larus; in 1760 by Brisson (though not generically) for the middle-sized and smaller Gulls, together with the Noddy; in 1788 by J. R. Forster (Enchirid. Hist. Nat. p. 38) for a genus of Water-birds of which he did not specify the type ${ }^{2}$ by Boie (Isis, 1822, p. 563) as the generic name of the short-legged Gulls, Larus cburneus and L. rissa; 3 and by Gloger in 1842 (Handund Hilfsb. f. Naturgsch. p. 433) for the LAPIring (Fanellus) and

2 Gavia seems to be still an Italian word signifying Gull, though the derivative Gabbiano is more commonly used.

2 His diagnosis indicates that he meant what is most commonly called Colymbus (DIVER).

${ }^{3}$ Boie subsequently (Isis, 1822, p. $876 ; 1826$; n. 980 ; and 1844, p. 191) lised the word in other senses. 
its allies, while in 1834 Naumann ( $/ 0 ̈ g$. Deutschl. vii. p. 248) chose Gavia as the name of a group consisting of the Grey PLover.

GEELBEC (Yellow beak), the Dutch name used by Englishmen in the Cape Colony for Anas flavirostris, the common Wild DUCK of South Africa.

GELINOTTE, diminutive of the old French Geline (Lat. Gallina, ^ Hen), often used in English for what is otherwise called the Hazel-hen or Hazel-Grouse - the one species, perhaps, whose introduction, were it possible, to this country might be desirable.

GEMITORES, Macgillivray's name (Br. B. i. pp. 97, 2 49 ) for the Order of Birds consisting of PIGEONs.

GEOGRAPHICAL DISTRIBUTION. In regard to no group of animals did the desire to know the details of what is commonly styled Geographical Distribution become earlier manifest than the Class Aves. One probable reason of this is the obvious fact that no group as a whole possesses such faculties for extensive locomotion, and the appearance, disappearance, and reappearance of species after species, whether accolding to orderly MigRATion or as casual stragglers to any particular spot or country, naturally led men of enquiring mind to wonder where the resort for the rest of the vear of these visitants might be. By degrees this wonder gave way to scientific investigation; and, after the futile attempts (which may here be passed over) of students or quasi-students of other branches of Zoology, it was with lively satisfaction that ornithologists found the first reasonable and philosophical explanation of the subject furnished by one of their own body, Mr. Sclater. ${ }^{1}$ Though here and there in the writings of his predecessors truths are doubtless apparent, it is certain that no one had hitherto taken the question seriously in hand, and that such truths as had been reached were rather by favour of fortune than by application of knowledge; and this is markedly shewn even in the brilliant speculations of Buffon, the first writer who seems to have formed any general ideas on the subject.

Now Mr. Sclater's success is to be attributed to the method in which his investigations were carried on. Instead of looking at the earth's surface from the point of view hitherto adopted by most writers, mapping out the world according to degrees of latitude and longitude, determining its respective portions of land and water regardless of their products, or adhering to its political divisions, he endeavoured to solve the problem simply as a zoologist

1 Journ. Proc. Linn. Soc. (Zoology) ii. pp. 130-145. Mr. Sclater's latest views on the subject may be read in The Ibis for 1891 (pp. 514-557), being a modification of an Address communicated by him to the International Ornithological Congress held at Budapest; and, like an Address delivered by him at Bristol in 1875 to the Biological Section of the British Association for the Advancement of Science, it has an Appendix giving a very useful list of works on Geographical Ornithology. 
should. He took up the branch of the subject with which he was best acquainted, and pointed out and defined the Regions of the globe in conformity with the various aspects of ornithic life as known to him. But herein there was at once a great diliculty to be met. Birds constituting the most vagrant Class of animals in existence, it was necessary for him to eliminate from consideration those groups of then, be they large or small, which are of more or less universal occurrence, ${ }^{1}$ and to ground his result: on what was at that time commonly known as the Order Insessores, comprehending those birds that are now generally differentiated as the groups or Orders, Passeres, Picarice, and Psittaci.

On this basis, then, Mr. Sclater, after dwelling on the great distinction he thought observable between the Fauna of the Old World and of the New, was enabled to set forth that the surface of the globe exhibited six great Regions, each in a marked manner differing from all the rest, though the difference was not always equally important. These Regions lie termed respectively the Palacarctic, Ethiopian, Indian, Australian, Nearctic, and Neotropicalnames which, so far as may be possible, it is convenient to preserveand proof that the method he followed was the true one is afforded by the fact that these Regions liave met with very general acceptance at the hands of those who study other groups of animals. ${ }^{2}$ Without.

1 Not but that even in the most widely-spread grroups are contained otherssubfamilies, genera, or species-strictly limited to certain localities. Some of them will be noticed further on.

2 This is a thing on which few writers seem to have dwelt sufficiently. What. ever be the causes, and it would be out of place here to discuss them, it must be admitted that what may be taken as a "law" of Geographical Distribution for one group of beings is not necessarily applicable to other groups. Botanists have shewn no disposition to accept the territorial divisions of their zoological brethren. It seems difficult to defend the position so often assumed that the boundaries set up for one group of animals are true for anotler, or still less that they are universally true. This fact has inleed had to be recognized in the case of some marine forms-for instance, Fishes, which, it is confessed, cannot be made subject to the limitations of terrestrial forms (cf. Günther, Introduction to the s'tudy of Fishes, pp. 259, 260), thuugh Dr. Gill (Ann. and May. Nat. Hist. ser. 4, xv. pp. 254, 255) recognizes for this Class what are practically the same divisions as those of Prof. Huxley-New Zealand, however, being placed with Australia. As regards the Land-slullusks, malacologists demur to the general principles of Distribution which students of most Classes of Vertebrates accept, while even anong Vertebrates themselves, and exchding Fishes, whit is the best division of the Earth's surface into Regions, Subregions, Provinces and so on, for Birds nay not be the best for Miammals, Reptiles, or Amphibians. It would appear Irefurable to consider the case of each of these Classes on its owu merits, and thus in what follows the territorial divisious alopted are in accordance with what it is supposed we know or seem to know of the Class Ares, and it may even he opcn to question whether the best division for one Subclass or Order of birts is the best for another. 
lowever, troubling ourselves on that score, or attempting a complete listory of the subject since his treatment of it, it is proper to remark that Prof. Huxley pointed out (Proc. Zool. Soc. 1s6s, pp. $313-319)$ that there was reason to divide the earth's surface latitudinally, rather than longitudinally as Mr. Sclater had done, and that four primary Regions were better than six-these four being: I. Aretogar, comprising Mr. Sclater's Indian, Ethiopian, Palæarctic, and Nearctic Fegions: II. Austro-Columbia, corresponding with the Neotropical Region; III. Australcsia; and IV. New Zeuland-this last being eut off from that gentleman's Australian Region. Eight rears later, Mr. Wallace in his gleat work, for which zoologists can never be too thankful, disregarding Prof. Huxley's scheme, adopted with some very slight modifications the plans of $\mathrm{Mr}$. Sclater, which had been alreadr followed in the main by many others, and among them by the present witer in a contribution to the Encyclopadia Britannica. In the course, however, of compiling that contribution a considerable number of doubts arose in his mind. Some of them he at the time intimated; but it was not until several years after that he saw how the chiefest of them should be dispelled. The full force of Prof. Huxley's reasoning is now evident to him, and he has to urge the reeognition of New Zealanc? as a primary division, while the recent ornithological investigation of Aliska, shewing that it is peopled in summer by so many Passeres hitherto supposed to be of purely Palrarctic type, has convinced him that Prof. Huxley's statement of the Nearctic area being far more nearly allied to the Paliearctic than to the Neotropical Region is not only true but has a still deeper meaning, for that it is impossible justifiably to separate the Palrearctic and Nearctic areas as "Regions," though we may keep the epithets as conveniently indicating geographical portions of one enormous but continuous Region, to which the name Holurctic may be fitly applied." Some rectification of the hitherto-aceepted frontier of the Neotropical Region may thereby be required, but that is a comparatively unimportant consideration, and it is not proposed

1 The Geographical Distribution of Animals. 2 vols. Londons : 1876. My own gratitude to the author for allowing me at a critical time to see the manuscript of this work prior to its publication has been before expressed (Encycloy. Prit. ed. 9, iii. p. 737); but wili never be forgotten.

I I have to thank Prof. Heilurin, who lad originally (Proc. Ac. Philed. 1882, 1. 334) bestowed the name "Triaretic" on this combination, for so readily adopting (Nature, xxvii. p. 606) my suggestion to call it "Holaretic," under which name it appears in the excellent defence of his pasition (Proc. Ac. Philad. 1853, pp. 266-275) as well as in his work (The Geographical and Geological Distritution of Animals. New York: 18s7). The objections raised to this combination by Mr. Wallace and Dr. Gill will be found in Vature (xxrii. p. 482, xxviii. 1. 124!. 
here ¿o go much into details. ${ }^{1}$ The question, often mooted, of recognizing a distinct Circumpolar Region need not be discussed, for it has not become practical; and whatever may be the case as regards other Classes, it seems almost impossible for the ornithologist reasonably to refuse recognition, as regards Birds, of the six Geographical Regions-New-Zealand, Australian, Neotropical, Holarctic, Ethiopian, and Indian, brigading, if he so please, the first three as Notogxa, and the last three as Arctogad, but always bearing in mind that the differences between each of the component parts of the former, and especially the differences between New Zealand and all the rest of the world, are not only more striking, but far more essential than those presented by the component parts of the latter.

It is admitted by nearly all naturalists that the study of the extinct organisms of any country leads the investigator to a proper appreciation of its existing Flora or Fauna; while on the other hand a due consideration of the plants or animals which predominate within its bounds cannot fail to throw more or less light on the changes it has in the course of ages undergone. That is to say, the Distribution of living creatures in Time is so much connected with their Distribution in Space that the one can harlly be considered without the other. Granting this as a general truth, it must yet be acknowlerged as a special fact already foreshadowed when treating of FossiL Birds, that we at present have in them but scanty means of arriving at precise results which would justify bold generalization as regards the Distribution of the Class. Compared with other Vertebrates, fossil remains of Birds are exceedingly scarce, and have been until lately little investigated. However suggestive be the discovery in France of somewhat early remains of Birds allied to those which we at present only know as living denizens of tropical countries, and the recognition of far later remains of species identical with those that now flourish in arctic lands, these facts merely corroborate what is from other sources within the cognoscence of every geologist-the vicissitudes, namely, to which that part of Europe has been subjected. Even the former existence of RATITA in England and other countries where they are not now found only proves that they were once not confined to their present limits, and possibly pervaded the greatest part of the earth. Almost the same is to be said of every other case, and perhaps in the whole range of zoology there is no Class from the fossil remains of which we learn less as regards the physical history of our planet than we do from the Birds. We therefore have to turn to the other side of the question and try to find whether the

1 Prof. Heilprin has stated (loc. primo cit.) the probability that "portions of California, Texas, and Florida will have to be relegated to the Neotropical realm." Mexico wouk naturally follow; but hereon more will be said hereafter. 
evidence which is from one point of view so evidently deficient may not be supplied by enquiry into existing Avifauna, and this signifies that a knowledge of the GeographicalDistribution of living or recently extinct Birds becomes a matter of prime importance to every one who would exercise intelligently the calling of an Ornithologist.

Of the six Regions above adopted it seems fitting to begin with that in the Fauna of which Birds play the principal part, since of indigenous terrestrial Mammals it has none, ${ }^{1}$ and that Class is represented only by Bats or Seals.

I. The New-Zealand Pegion presents, in Mr. Wallace's words (Island Life, p. 442), "the most remarkable and interesting of insular Famnas," and leads to the inference that this portion of the globe shews a longer period of isolation than any other of equal magnitude-an isolation possibly anterior to the time when ter'restrial Mammals first appeared, or at least appeared in any land which could have been then connected with it. Beside the two large islands and one of moderate size (Stewart's), known in the aggregate as New Zealand, numerous satellites belong to the Region, as Lord Howe's, Norfolk and Kermadoc Islands, with the Chatham, Auckland, and Macquarrie groups, as well as Antipodes Island. It possessed until recently two perfectly distinct Orders ( $\mathrm{Ol}^{1}$, as some rank them, Families) of Patitix-the Immanes 2 (MoA) and Apteryges (Kirvi), of which the latter still exists, while the former, now extinct, contained, according to the latest revision by Mr. Lydekker (Cat. Foss. B. Br. Mus. pp. 219-351), about a score of species that may require 5 genera for their reception, and certainly exhibit no inconsiderable modification of a tolerably uniform structure, while some of their members reached a stature that may be almost caller colossal. Moreover, these two Orders seem to be absolutely peculiar to the Region. ${ }^{3}$

Turning to the Carinata, we have a very remarkable genus in Ocydromus (WEKA) which, Ralline as it is, afiords in the loss of its power of flight and corresponding structural modification evidence of considerable antiquity. The Limicola present a quite unique form in the highly specialized Anarhynchus (WRYBILL), and the Anseres in Cnemiornis, a large flightless Goose, now extinct and apparently allied to the Australian CEREopsis, while the Accipities shew Harpagornis, a bird half as big again as an Eagle, and stout enough to make Moas its prey-indeed it possibly owes its extinction to their disappearance, finding no fit quarry when they and Cnemiornis were gone. Sceloglaux is a very peculiar genus of Striges

1 See above (p. 224, note 1).

- Ann. and Mag. Nat. Hist. ser. 4, xx. 1. 400.

3 Positive assertion to this effect cannot be male, since a portion of a fossil femur from Queensland, said to appear indistinguishable from Dinornis, has been described and figured (Proc. R. Soc. Qucensi. i. D. 27, Yì.s. ii. iv.) 
(OWr), and the Psittaci have in NEsTor and Stringops (KAKApo) two others that may fairly be regarded as types of as many Families. Very noteworthy also is the presence of the Family Acanthidosittince (SPINE-BILL), represented by two genera, Acanthirosittu and Tenicus, proved by W. A. Forbes to belong to the Mesomyodian (IxTRODUCTION) section or suborder of Passeres, which is most largely developed in the Neotropical Pegion. Of the higher. Passeres, or what appear to be such, there is a proportionate allowance, but some of them are of a character so generalized that systematists strain their principles when bringing them under Families that exist elsewhere. Turnagra, a very generalized Thish, has been permitted to stand as the type of a separate Family, though Glaucopis has been referred to the Corvidx; Creadion and Heteralocha (HUIA), not without violence, to the Sturnida (STARLING); Miro, Myiomoiru, and Gerrgone to Muscicapidx or Sylzidia; Certhiparus to Paridix (TrTuouse) ; Clitonyx to Timeliidx, and so on. With less hesitation can Prosthemadyra, Anthonis (BelL-BIRD), and Pogonornis (STITCHBIRD) be placed under Meliphayida, so largely dispersed throughout the Australian Region. Alongside of these we have the cosmopolitan genus Anthrs (PIPIT), almost certainly a settler of comparatively recent days, since it has undergone so little modification; while it species of Zosterops has, within the recollection of men still living, made its way over from Australia, and shews that the tendency to colonize is not confined to the human race. Another and apparently modern immigrant is offered by the genus Coturuir, (QUAIL), but its representative has been long enough in the country to become specifically differentiated. Though abundant not many years ago, it has lately suffered so much from the practice of firing the grassy plains it frequented, that some believe it to be now extinct. Notormis, an exaggerated form of Porphyrio, is probably another, but a more ancient settler, since it has lost the use of its wings, thongh it possesses the purple plumage of its relatives. It is remarkable for being a bird which was originally described from fossil remains, and only some years later was found to exist, though in very small numbers and in certain restricted localities. A second species which inhabited Norfolk Island seems to have become extinct since the early years of this century. Its white plumage is likely to have hastened its doom. Of other forms there is not space here to treat, but it will be noticed that many which are most characteristic of the Australian Region are wholly wanting, a fact that helps to justify the separation of New Zealand as a primary Region on the ground of its completc isolation from a very remote time. Mention has been already made (ExTERMINATION) of the unhappy fate which awaits the surviring members of the New-Zealand Fauna, and its ineritable end camnot but excite a lively regret in the minds of all ornithologists who care to know how things have grown. This 
regret is quite apart from all questions of sentiment; but just as we lament our ignorance of the species which in rarious lands have been extirpated by our predecessors, so our posterity will want to know much more of the present avifauma of New Zealand than we can possibly record, for no one can pretend to predict the scope of investigation which mill be required, and required in vain, by naturalists in that future when New Zealand may be one of the great nations of the earth. ${ }^{1}$

II. The Australian Region has but little intimate connexion with $\mathrm{New}$ Zealand, and is as trenchantly divided from the Indian. which geographically, and possibly geologically, seems to be conterminous with it, by the narrow but deep channel that separates the small islands of Bali and Lombok, and will be found to determine the boundary between these two distinct Regions. Midway along this channel we may draw an imaginary line, and produce it in a north-north-easterly direction through the Strait of Macassar, dividing Borneo from Celebes. An interchange of animal forms in the two islands last named is indeed to be observed, and even a slight intermingling of the productions of the two former seems to be now going on, but to a much less degree than obtains between any other two Regions, while the characteristic, not to say peculiar, zoological types which occupy either side of this line, are so divergent that it raay be fairly deemed more definite than any to be found elsewhere. Between Bali and Lombok, as above stated, it has been shewn by Mr. Wallace to be all but perfect, and in his honour this boundary was most justly named by Prof. Huxley (Proc. Zool. Soc. 1S68, p. 313) "Wallace's Line." As it proceeds northward it becomes less definite, though we know it to run between the Philippine Islands and Sanguir, and again between the former and the Palau (Pelew) group, its further progress in that direction being to the westward of the Ladrones. But hereabouts we lose it, until we reach the Sandwich Islands, the Fauna of which, in deference to usage, may perhaps be still accounted Australian, though apparently Neogrean at bottom, and subsequently overlaid by Holarctic forms. ${ }^{3}$ Thence the line must be drawn so as to include all of what is

I See Sir Walter Buller's Birds of New Zealand. London: 1873, 4to (witl beautifully colonred plates): ed. 2, London : 1888, 2 vols. fol. ; and Mranual of the Birds of Now Zealand. New Zealand: 1882, 8vo, as well as many papers by various authors in the Transactions of the New Zcaland Institute from $186 \mathrm{~S}$ onward.

2 Its existence was first indicated by Mr. Wallace in The Ibis for 1859 (p. 450). He subsequently (Proc. Zool. Soc. 1863, p. 481) insisted on its importance, which was fully shewn in his Malay Archipelago.

${ }^{3}$ Cf. Dr. Gadow's "Remarks on the Structure of certain Hawaiian Birds" in Wilson's Birds of the S'andwich Islands. A similar conclusion had been before reached by Messrs. Sharp and Blackburn in their memoir on Hawaiian Coleoptera (Trans. R. Dubl. Sac. ser. 2, iii. part 6, pp. 119-300). 
commonly called Polynesia, avoiding, however, the northern outlier's of the New-Zealand Region, and so return to encompass Australia proper and Tasmania.

Though the characteristic Mammals of the Australian Region are highly remarkable, comprenending as they do the whole of the most peculial (Ornithodelphia) of the three Subclasses and nearly all of a second (Didelphia), by far the lar'gest portion of the area it cover's is weak if not wanting in Mammalian life, and its zoological features are nearly as well exhibited by its Birds. Nor can mention be here omitted of the remarkable Ganoid Fish, Ceratodus, a genus which has come down to us unaltered from Mesozoic times,-all facts selving to shew that the isolation of Australia is probably the next oldest in the world to that of New Zealand, having possibly existed sinee the time when no Mammals higher than Marsupials had appeared on the face of the earth. ${ }^{1}$

The prevalent zoologieal features of any Region are of two kinds -negative and positive. It is therefore just as mueh the business of the zoogeographer to ascertain what groups of animals are wanting in any particular locality (altogether independently of its extent) as to determine those which are forthcoming there. Of course, in the former case, it would be idle to regard as a valuable physical feature of a district the absence of groups which do not occur exeept in its immediate neighoourhood; but when we find that certain groups, though abounding in some part of the vicinity, either suddenly eease from appearing or appear only in very reduced numbers, and occasionally in abnormal forms, the fact obviously has an important bearing. Now, as has been above stated, mere geographical considerations, taken from the situation and configuration of the islands of the Indian or Malay Archipelago, would indicate that they extended in an unbroken series from the Strait of Malacea to New Guinea, or even further to the eastward. Indeed, the very name Australasia, often applied to this part of the world, would induce the belief that all those countless islands were but a southern prolongation of the mainland of Asia-broken up, it is true. But so far from this being the case a very definite barrier is interposed. A strait, some 15 or 20 miles wide, dividing, as just stated, the two otherwise insignificant islands (Bali and Lombok), makes such a frontier as can hardly be shewn to exist elsewhere. The former belongs to the Indian Region, the latter to the Australian, and between them there is absolutely no true transition-that is, no species are common to both which cannot be easily accounted for by the various accidents and nigrations that in the course of time

1 It will ve borne in mind that fossil remains shew that Marsupials once inhabited Europe. They are now restricted to Australia with the exception of one group, which inhabits the Neotropical Region, a single species ranging also over the temperate parts of North America. 
must have tended to mingle the productions of islands so close to one another. The Faunas of the two are as distinct as those of South America and Africa, and it is only because they are separated by a narrow strait instead of a wide sea that they have become slightly connected by the interchange of a few speeies and genera. This narrow strait, it scarcely needs to say, must be of uncommon antiquity.

Space does not permit our dwelling at any length on the gromps of Birds which prevail throughout the Indian Region, but are wholly wanting in the Australian. It must here be enough to mention that among them are the Ixida (Ixus), Phyllonithina," Megalamina (Barbet), Fulturida (Vulture), and Phasianidre (Pheasant). Some would add Fringillide, but the real position of the so-called "Finches" of Australia must still be considered doubtful, and it may prove that they are the less-modified descendants of the generalized group whence sprung both the true Fringillidx and the Ploceida(TVAVER-BIRD), if indeed these can be justifiably separated. Then of forms weakly represented are the otherwise abundant Turdidx ${ }^{2}$ (Thrush), and above all the Picidx (WoOdPecker), of which some 4 or 5 species out of more than 350 just cross the boundary and oceur in Lombok, Celebes, or the Moluceas, but are unknown elsewhere in the Region.

Turning to the Families, which are most characteristic of the Region, we find among those that are almost but not absolutely peculiar ${ }^{3}$ to it, first the Meliphagida (HoNEY-SUCKEn), one that, though not so polymorphic as has often been alleged, abounds in genera and species of diverse aspect, while only 3 of the former belong to the New-Zealand Region, and but a single speciesPtilotis limbata, which is common from 'Timor to Lombok-crosses the sea to Bali and trespasses upon the Indian Regrion. To this may be added the Pachycephalida (THICkInAD), Cumpephagida (Campephaga), Artamida and Cucatzida (Cockatoo), of which last but a single species ever passes the line by appearing in the Philippines, and the Megapodiidx (MEGAPODE), though they have a representative in the group last named, as well as in Borneo, and another in the Andaman Islands ; but are otherwise peculiar to the Australian

"In this and other like cases such forms have been called "lipotypes" by Mr. Sclater (Proc. Zool. Soc. 1SS2, pp. 311, 312).

2 It is almost certain that no satisfactory limits can be laid down butween this so-called Family and Sylviidæ (WARBLER), but as the latter have few if any members in the Region now under notice, the lesult would hardly be affected. indubitable Thrushes are, howerer, scattered among many of the chief groups of islands thronghout the Pacific Ocean.

3 It may be proper to state that herc, and wherever the subject of Geographical Distribution is concerned, this word "peculiar" has the technical meaniug of " not occurring elsewhere." 
Region; while the Kingfishers and Doves exhibit a wonderful variety of form that is only equalled by the beauty of their coloration. Of the Families which are absolutely peculiar may first be cited the Casuarida (CAssowary) and Dromzidre (ENEU), both Ratite, and together forming the Order Megistanes, and then the Rhinochetida (KAGU), a very generalized type, consisting of a single genus and species inhabiting New Caledonia, and having apparently its nearest living ally in the Eurypyga (SUx-BITTERs) of South America. The Order Columber furnishes a very distinct and monotypic Family in Didunculide (DODLET) and the Psittaci, the gorgeous brush-tongued Parrots, known as Loriida or Trichoglossida (LORY). The Families of true Passeres are at present so ill-defined that in many cases to cite them is only to mislead, but one is pretty safe in relying upon the Drepanidida (Drepanis) and Paradiseida (Bird-of-Paradise) as good examples of peculiar groups, while Australia itself furnishes the only known members of the section of Passeres called "Pseudoscines" in Atrichiidx (SCRUB-BIRI), and Menuride (Lyre-BIRD). ${ }^{1}$ However, the number of peculiar groups of Passeres proper is too numerous to be here told, and there are many beautiful and singular forms of Columbe, such as Gonera, Lencosarcia (WoNGA-WoNGA), Lophophathes, Chryscena, and others, while among the most curious Land-birds, beside those already named, may be specially recorded Megacephulon, Lipou, and Talegallus among the MEg.LPoDEs; Tribonyx, Pareudiastes, and Habroptila - the two last brevipennate PaILs; while Pedionomus, the position of which has long been disputed, proves (Proc. Zool. Soc. 1889, p. 310) to be one of the Turnicidr. The existence of a BUstaRd (Eupodotis) in Australia presents a suggestive example of interrupted distribution, since none of the Otidide is found nearer than the Continent of India.

The Australian Region may. be taken to include 3, if not 4, Subregions, to which the names of Papua, Australia proper, and Polynesia may be attached, but the boundaries of the first and second are not yet to be clearly defined, and the Peninsula of Cape York, though a part of Australia, is by many included in the Papuan Subregion. To this Subregion may be assigned, though with doubt, the wonderful island of Celebes, presenting perhaps more anomalies than any other in the world, and yet anomalies which, by the use of strictly scientific inference (as Mr. Wallace has shewn us), may possibly tell a story that sounds so romantic and yet will satisfy those who would judge it most severely."

1 'The precise relation of these two forms is rery' doubtful, and their connexion with others, Graldist for example, is, as i write, equally uncertain.

$\because \Lambda$ modern work on the Birds of Australia is much needed, Gonld's IIandbook, frood for the time it appeared (1865), being in many respects obsolete, and IIr. Diggles's Ornitholog! of Austratia leaving much to be desired. Dr. E. P. 
III. The Neotropical Region completes the great division (Notogax proposed by Prof. Huxley. It presents certain alliances to the Australian, and some to New Zealand; but these are of a different kind, and there is no community between them. Looking to the extreme remoteness of the time when this Region could even by the most roundabout route have been connected with either (if such a connexion ever existed), it is perhaps wonderful that any resemblance remains. As a matter of fact the resemblance lies rather in the comparatively low rank (morphologically speaking) that is indicated by some of its most peculiar and at the same time characteristic forms than in any positive affinity that they display, for it must be eviclent that in the course of ages the ancient types -at that epoch, may be, the most highly developed of their kind on the earth-if they survive at all to the present day must have become more and more specialized as various influences came to bear upon them. Enough, however, remains to point with certainty to the fact that South America, that is to say, the most important part of the Neotropical Region, retains a greater proportion of these less-modified descendants of generalized ormithic types than does any other portion of the globe-the two Regions before mentioned only excepted. The hint afforded by the contimed existence of an Order (or, as some would have it, only a Family) of Marsupialsthe Pedimanu, comprehending the animals to which the name Opossum was first applied, onght to suffice for this. It has before been suggested that there seems to have once been a period in which the Didelphia formed the highest group of Manmalian and therefore of animal life on the globe, and pervaded all parts of it that were accessible. New Zealand, as has been indieated, was at that time already cut ofi, and the Marsupials had no means of reaching it; but they spread over what is now represented by Australia and also arrived in Sonth America. It is reasonable to suppose that in each of these countries they differentiated, and in Australia, from its subsequent isolation, flourished in the way that has there produced the

Ramsay's Tabular List of the species known to him in 1888 is useful in shewing their distribution, but gives little more information. The Records of the Australian Museum as weli as some other journals contain, however, many valuable papers by him, laying the foundation of future work, and Mr. A. J. North's Descriptive Catalogue of the Nests and Eggs of Australian and Tasmanian Birds (Sydney : 1889) cannot be passed over in silence.

For other parts of the Region must be mentioned the Beitrag zur Fauna Centralpolynesiens by Drs. Hartlaub and Finsch (Halle: 1867), treating of the ornithology of Fiji, Samoa, and Tonga, but very much has since been done in these and other groups of islands which cannot be here particularized, while the Omitologia della Papuasia e delle Molucche by Count T. Salvadori (Torino: 1880-82), with its Agginnte (1889-91), is a most carefully executed work. A complete list of Polynesian Birds by Mr. L. W. Wiglesworth appeared in 1891 at Dresden. 
numerous forms of which we are cognizant. But in South America a direct connexion with the northern soil must have been perpetuated, and when Monodelphians appeared in what we now call Arctogac they must have made their way further south, and thus checked the efflorescence of the older stock, restricting it in the New World to the one Order which we now find there. Without calling in, as so many are apt to do, the aid of a Glacial Epoch, it seems that, granting the general continyity of land between North and Sonth America, ${ }^{1}$ the older and weaker Marsupial population would give way before the newer and stronger Placental population that had become developed in the North. Part of the latter established itself in the South, but of the feebler population which it dispossessed only a scant remnant exists. Now we may not unfairly suppose that the same kind of process went on as regards the Birds. It is justifiable to conceive that at one time the whole of America was occupied by the ancestors of those forms that we now find chiefly displayed in its southern portion, no inconsiderable proportion of which still yearly seek their ancient home, migrating northward every spring, and returning at the end of summer or towards the fall of the year, their original seat being occupied by the higher and comparatively recent forms that constitute part of the Holarctic Fauma-of whose invasion more must presently be said. The consequence of all this is that each of the Americas presents a mixed population, puzzling to account for until the way in which it has been brought about is perceptible. On the hypothesis here given, however, the chief difficulties should disappear, and no evolutionist will regard it as unlikely, forced, or impossible-though we may freely grant that its proof requires further evidence, but that evidence is of a kind that the marvellous success which has attended palæontological research in North America induces one to hope may be forthcoming.

It has just been stated that the general character of the Neotropical Fauna is morphologically low. In regard to the Class Aves this is shewn by the presence of an Order of Ratita, consisting of 3 species of RHEA, and next by the fact that among the Carinata the Region claims all the Tinamida (TINAMOU)-the Dromezognathe of Prof. Huxley, which, if we carry out his principles, ought to be regarded as the equivalent of an Order in the usually-accepted sense-and also a unique, very remarkable, and generalized form Opisthocomus (HoACTzIN), which he has satisfactorily shewn to be so unlike every other that it can only be conveniently classed by itself as the sole representative of HETERO-

1 There can be hardly any assumption here. The existence of corals on the Atlantic side of the Isthmus of Panama and their absence on the Pacific Coast shews the antiquity of that bridge between the continents, even though it may have been sometimes broken down. 
IIORPHÆ. Both the Dromzognathx and Heteromorphx are indubitably of low developmental rank; in that respect, though in no other, resembling certain Australian and New-Zealand groups; but the similarity between the Avifaunas of the three Regions composing his Notogara seems to be further borne out by the same fact being observable in other South-American Families forming the lower sections or suborders of Passeres, to which the names of OLIGOMYODI and TRACHEOPHON玉 have been applied-the Neotropical Region having a complete monopoly of the latter and a large proportion of the former, ${ }^{1}$ according to our present knowledge. Of the species of Passeres, belonging to the Region, we find that a little more than one-half have to be classed under the lighest sections of that Order, while nearly one-half must be ranked under its two lowest sections. $^{2}$ This is a state of things that exists nowhere else, and it is believed that much the same result would appear from a close scrutiny of other Orders, especially of the Picarix. But more than this, if we examine the true Passeres we find similar indications. Their highest group, the Corvidar, is only just represented in the northern portion by its highest genus Corvus, and even its lower forms, belonging to the subfamily Garrulinx (JAY), only occur in parts of the rest: the Fringillidæe though inhabiting the Region are vastly outnumbered by the Tanagrida, and the Mniotiltidx occupy the position clsewhere taken by the Sylviidx.

Leaving, however, this question as in some degree hypothetical, though its probability can hardly be denied, we have as genera, Families, or even larger groups, a great many remarkable forms that are characteristic of or peculiar to the Neotropical Region in part if not as a whole. Of Families there are more than a score absolutely restricted to it, beside some half-dozen which, being peculiar to the New World, extend their range into the Nearctic area, but are there so feebly developed that wherever they may have originated in bygone ages, they may be safely ascribed now to South America. First in point of numbers come the Trochilida (Humming-BIRD) with, according to some systematists, nearly 150 genera, of which perhaps only 3 occur in the Nearctic area. Then the Tyrannida (KING-BIRD) with above 70 genera, yet scarcely more than 10 ranging into the Holarctic Region. To these follow the Tanagridx (TANAGER) with 40 genera, only 1 of which crosses the border; and, in addition to those before mentioned the various Families of Conopophagida, Cotingidx, Dendrocolaptida, Formicariidx, Furnariida (Oven-BIRd), Pipridx (Manakin), and Pteroptochida

1 The exceptions are Tyrannidx, which occur in comparatively small proportion in North America, Pittidx, Philepittidx, Acanthidosittidx, and Eurylæmidx.

2 'The section which for want of a better name we have to call "Pseudoscines" has hitherto been found peculiar to Australia. 
(TAPACUlo) - all of them low Passeres, which are absolutely peculiar, and of Picaria, in the like condition, Gulbulida (JACAMAR), Momotida (Мотпгот), Rhamphastide (TouCAN), Steatornithida (Guacharo), and Todida (ToDY); while still more significant are the Palamedeida (Screamer), Psophiida (Trunpeter), certain generalized Limicole as Attagis and Thinocorys, and above all isolated folms like Cariama (Serienia) and Eurypyga (Sun-Bittern). Te can searcely be wrong also in attributing to the Neotropical Region the Order of Impennes (Penguin) and the singularly generalized form Chionis (Sheathbill), though both have a wide distribution in the South-polar seas.

Taking the Neotropical Region to extend from Cape Horn over the whole continent of South and Central America, but leaving its northern frontier, if it can be defined at all, to be delimited by the zoologists of the Nearetic area, ${ }^{1}$ there is hardly one that exhibits more variety of physical features, and the Subregions into which it may be divided cannot be easily traced. The six divisions suggested to the present writer in 1875 (Encycl. Brit. ed. 9, iii. p. 744) by Mr. Salvin seem to be better thin the four laid down by Mr. Wallace; and, subject to some uncertain modification, as just hinted, on the northern boundary, are here again adopted; but the confines of all, except one, are of the vaguest. That one is the Antillean, composed of what are generally known as the West-India Islands, with the omission of Trinidad and Tobago, whose Fauna is distinctly continental. Beginning, however, at the sonthern point of the Region, we seem to have a Subregion extending on the east coast to somewhere north of Bahia Blanca, whence its boundary runs in a north-westerly direction, passing to the easi of Mendoza, and then northward along the eastern and higher slopes of the Andes, and after trifurcating on either side of the valleys of the Magdalena and its confluent the Cauca, returns along the western slope of the Cordillera until it trends seaward and reaches the Pacific coast about Truxillo. As the peculiarities of this Subregion are mainly developed in Patagonia, the name "Patagonian" has been applied to it, though its northern extremity is so far distant from its eponymons territory. Next we have what may be called the "Brazilian" Subregion, marehing with the foregoing to somewhere near Potosi, whenee it turns to the north-east, and, avoiding the basin of the Amazons, strikes the Paranahyba, thence making its way to the Atlantic. Then comes the "Amazonian," consisting of the enormous basin of the

1 As already stated, Prof. Heilprin proposes to annex to the Neotropical Region a not inconsiderable portion of what has generally been referred to the so-ealled "Nearctic Region," as, for instance, the lowlands (tierras calientes) on either site of the Mexican tableland, Southern California, and some more of the territory of the United States of America. 
liver whence it has its name, but the peculiarities of the lower portion not being observable in the higher tributaries of that inighty flood, its upper waters must be regarded as draining land that belongs to another Subregion, which, intervening between the Patagonian and first the Brazilian and next the Amazonian, ineludes all that is left of South America, and has been named the "Subandean." To this also belong on the one side the Galapagos - ever memorable as the place where, as Darwin has told us, there first clawned on him, from a consicleration of their Birds, the doctrine of Natural Selection, which has led to such fruitful and stupendous results - and on the other side Trinidad and Tobago, beside the islands on the northern coast of South America. This Subregion reaches the "Central American" in the Isthmus of Panama, and of the limits of this last none can yet speak with eertainty.

The difficulty of distinguishing these Subregions is very great, and the close alliance between all but the Patagonian and Antillean will be plain to any one who analyzes the differences as shewn by the prevalence in them of the various Families of Birds peeuliar to the whole Region. ${ }^{2}$ That the most characteristic features are exhibited by the Patagonian none can doubt, and indeed therein we find, as might be expected, the nearest resemblance to the Fauna of New Zealand or the Australian Region, and some of the best eviclence of the antiquity of its population. These are the

1 Messrs. Godman and Salvin, and there can be no better authorities, suggest (Ibis, 1889, p. 242) that the northern limit of certain species of Psittaci "may be almost said to define the boundary between the Nearetic [Holarctic] and Neotropical Regions." They also point ont that the same limit is practically that of the Trogonidx, and on the eastern side that of the Momotida. It is also the termination of the Cracida, with the exception of an Ortalis, and of the Tinamida, while among the Passcres the same boundary confines Pachyrhamphus, one of the Cotingidær, an essentially Neotropical Family, on both sides. "From this it will be seen that the line of demarcation between the two regions, so far as the birds are concerned, is capable of being defined with some precision, and will be found to coincide with the northern limits of the forests. These on the eastern sile leave the coast a little north of Tampico, and continne in a narrow belt along the eastern flank of the mountains in a nearly northern direction almost to Monterey. On the western side a similar state of things is found, and we meet with a number of southern forms extending along the western slope of the mountains as far as Alimos" in Sonora.

" It is only in deference to Mr. Salvin's views that I do not rank the Subandean, Brazilian, Amazonian, and Central American areas as Provinces, and group them to form a single Subregion. Recognizing of conrse the Antillean Subregion, I hold the existence of a Patagonian Fauna to be unquestionable, whatever be its geographical limits; but as regards the rest I an prepared to find that future consideration will justify the suggestion just made, so that the Neotropical Region will be deemed to be composed of three Subregions only, the Antillean, the Patagonian, and one which (comprehending the four areas above named), for want of a better epithet, might perhaps be called the "Colmmbian." 
Patitx (RHEA) which wander over its solitudes, ${ }^{1}$ and the Impennes (PENGUrN), which haunt its shores and those of the Falkland Islands, besides the generalized Attagis, Chionis, and Thinocorys, the Cariamida, Palamedeida, Phytotomidx, Pteroptochida, and other forms which are wholly or nearly peculiar, while some of the most characteristic Neotropical Families, Carebidx, Mniotiltidx, Tanagridx, and Vireonidx, are but poorly represented or do not appear at all. The Antillean being the only Subregion whose precise boundaries can be definitely laid down, its Fauma, small as it is, is very interesting. The unbroken chain of islands, to which in common speech the name "West Indies" is wrongly limited, forms geographically a second connecting line between the two halves of the American continent, and at once suggests a former communication by land with Yucatan at one end and Venezuela at the other, to say nothing of a possible junction with Florida. Yet omitting other considerations, ${ }^{2}$ the peculiar forms of Bird-life manifested throughout the chain shew that any such communication, if it ever existed, must have been exceedingly remote in point of time; for narrow as are the channels between Cuba and Central America, between the Bahamas and the south-western peninsula of North America, and between Grenada and Tobago (the latter, as already stated, belonging zoologically to South America) the Fauna of the Antilles, instead of being a mixture of that of the almost contiguous countries, differs much from all, and in some groups exhibits a speciality which may be not unfitly compared with that of Oceanic Islands. One might have expected here to find an cxtremely varied animal population; but no instance perhaps can be cited to show more strikingly the difference between a continental and an insular Fauna; since, making every allowance for extinction since Europeans settled on the soil, possibly no area of land so highly favoured by nature is so poorly furnished with the higher forms of animal life, and here once more we have Birds constituting the supreme Class-the scarcity of Mammals being the normal effect of insularity. There is no Family of Birds common to the Nearctic area and the Antillean Subregion without occurring also in other parts of the Neotropical Region, a fact which proves its affinity to the latter. Out of about 140 genera found in the Subregion about 30 are peculiar to it, and these are all Land-birds, being a ratio very nearly approaching that found in Madagascar, but in no other subregional district; and the distribution of some of the peculiar genera is very limited, for 19 out of the 30 are confined each to a single island or nearly connected

1 Rhea macrorhyncha, however, occupies an isolated station much further to the north, in the province of Parahyba (16is, 1881, p. 361).

2 For these see "Three Cruises of the "Blake," by Alexander Agassiz, Bull. NIus. Comp. Zoöl. Harvar’d Coll. xiv, xv. (Cambridge [Mass.] : 1888). 
group of islands. There is one peculiar Family, Todidx, already mentioned, and that consists of but a single genus with 4 or perhaps 5 species-one limited to each of the large islands, Cuba, Jamaica, Hispaniola, and Porto Rico-the fifth (if it exists) being from an unknown locality. ${ }^{1}$ Especially worthy of record is the plesence of 2 species or even genera of TroGoN-Prionotelks peculiar to Cuba, and T'emnotrogon (which exhibits a remarkable similarity to the African Hapaloderma) peculiar to Hispaniola. Another of many singular facts that might be noticed did space admit is that while Jamaica has no KEsTres at all (its place there being taken, in winter at least, by the American form of MerLin) Cuba possesses in addition to one widely-ranging species of the genus Tinnunculus, ${ }^{2}$ a second that is peculiar to it, and this last, T. sparverioides, offers a great resemblance to the species, $T$. aracitis, which is peculiar to the Seychelles, almost at its antipodes. ${ }^{3}$ Speculation as to the former history of the Antilles would be at present vain. There is no portion of the world that has been so Jong colonized by Europeans, of which the existing Fauna is so little known, and though of late as regards the British possessions something more than ever had been done has been attempted, the results do not justify more than the belief, which the facts already given may indicate, that there must have been no ordinary amount of geological disturbance to account for the present distribution of the Fauna. ${ }^{4}$

With this must end the account here to be given of the several Notogran Regions, since at present we have few means of determining the northern limits of the Neotropical Avifauna, nor $\mathbf{k}$ 'ow

I A bird of this group, or name at any rate, was one of those asserted by Ledru (Voyage \&c. ii. p. 39. Paris : 1810) to have formerly inhabited St. Thomas in the Antilles ( $f$. Exteraination, p. 219).

${ }^{2}$ I am unable to agree with the view taken (Cat. B. Br. Mus. i. pp. 437-442) as to splitting up the $T$. sparverius into several local species or forms, though it was approved by so good an authority as the late Mr. Gurney.

${ }^{3}$ This fact is worth consideration relatively to the similarity or asserted affinity between the two Mammalian genera, Solenodon of the Antilles and Centetes, with its allies, of Madagascar, while a splendid genus of Lepidoptera, Uranidia or Urania, which has two species peculiar to Cuba and one to Jamaica, is said to have its nearest ally in Chrysiridia of the grand African island and of Zanzibar.

4 The Neotropical Avifanna is said to be the richest in the world, and the literature relating to it is no less abundant. While the papers in journals are ahnost countless, it would be impossible here to give the titles of even the separately-published works. The following list contains the names of the chief author's of the latter:-Azara, Burmeister, Castelnau, Cory, d'Orbigny, Gay, Godman, Gosse, Gundlach, Hernandez, Hudson, Lembeye, Léotaud, Marcgrave, Martius, (Prince) Maximilian (of Wied), Molina, Nierenberg, Oustalet, von Pelzeln, de Philippi, Poey, de la Sagra, Salvin, Sclater, Sloane, Spix, Taczawowski, Tschudi. 
whether it melts insensibly into that of the Nearetic area of the Holaretic Region. It will be most convenient to consider that Region next, though strong doubts may be entertained as to the logical propriety of such a course, for this Holarctic Region seems to have the most highly developed Fauna, in that it is one from which the weakest types have generally been eliminated, though that result is chiefly seen in its Palrearctic area, and perhaps especially in the western part of this, shewing the truth of the poet's line happily applied by Mr. Sclater in his classical essay-

"Better fifty years of Europe than a cycle of Cathay."

IV. The Holarctic Region.-As has been stated in the introductory portion of this article, the combination intimated by this phrase, though sanctioned in spirit by Prof. Huxley, wholly contravenes the opinion expressed by two of the leading authorities on the subject-Messrs. Sclater and Wallace. The arguments of the former being based on positive facts, or at least on what seemed at the time to be such, must be met by corresponding facts. Those of the latter having a more hypothetical foundation-the notion that each of the primary divisions of the earth's surface should comprehend about the same extent-require less consideration. The natural philosopher regards quality rather than quantity, and things must be weighed as well as measured, analyzed as well as surveyed. Scarcely any systematist nowadays doubts that among Nammals the Monotremes, of which only two living Families are known, form a Subclass at least as important as the Monodelphians, the existing members of which may number nearly fourscore Families, even if there be not an opinion that Monotremes are of equal rank (in one sense of the word) with the Monodelphians and Didelphians thereto added. But, not to wander from our present business, no one who will investigate the Avifauna of that part of North America lying outside the boundary (if it can ever be traced) of the Neotropical Region, will find in the Nearctic area more than a single Family of Birds that is peculiar to it, and that is a Family of position so doubtful that some of those who have most closely studied it refer it to one or another of well-known FamiliesPuridx or Troglodytida-both of which are widely dispersed and admittedly contain genera that differ considerably. If by way of accommodating these dissentient views we recognize Chamad as the type of a distinct Family_and in our present state of imperfect linowledge no other course seems open-the existence of such a Family, Chamæidx, still seems precarious. Every other Nearetic Family is common to the Neotropical Region or to the Palicarctic area, or to both. Of the Passeres common to the Neotropical Region and the Nearctic area 4 Families are admittedly better represented in the latter-namely, Mniotiltida by some 13 genera and about 50 
species, Virconida by 1 genus and 14 species, Icteridx by 8 genera and 21 species, and Tyzmnidx by 10 genera and 26 species. The first of these, howerer, can alone be regarded as eminently characteristic of the area, since that affords a home to all but 3 of the genera, but at the same time only about half of the described species occur there. None of the rest can compare with it in this respect, $\mathrm{Vir}_{i}$ conidx having some 5 genera and 50 species, Icteridx more than 20 genera and more than 100 species, and Tyrannida some 70 genera and over 300 species in the Neotropical Region.

If we extend our investigation from the Families to the genera, we shall come to results which point the same way. It is confessedly difficult to make any accurate comparison owing to the tendency (not wholly modern) of ornithologists to propose the foundation of genera on very slight excuse; but, taking the number of Nearctic genera at 330, which was a very liberal estimate toward the end of the period signalized by the labours of the late Prof. S. F. Baird, not more than two dozen of them seem to be peculiar to the Nearctic area, ${ }^{1}$ while this has about 128 genera in common with the Palrarctic area and 178 which are also Neotropical. The genera peculiar to the New World, occurring both in the Nearctic area and in the Neotropical Region, without appearing in the Palæaretic area, must be divided into two categories in order to obtain a just estimate of the relations of the first two districts. These categories consist of (1) those genera which being only winter visitants to the Southern Region are not natives of it, and (2) those which breeding in both districts may fairly be called common to both. The former, some 27 in all, must of course be considered characteristic of the Nearctic area, and might indeed be appropriately added to the 23 or 24 genera which are peculiar thereto; but if this be done, the number of peculiar and characteristic genera taken together reaches only $51-$ a smaller number than that of the genera of Land-birds alone (57) which are common to the Nearctic and Paliearctic areas, and considerably less than half the number of all genera which are found on botll, while that of the remaining generiu which are common to the Nearctic area and the Neotropical Region is much larger again, being 151. Again, the total of peculiar and characteristic Nearctic genera being (as just said) 51, cannot compare with the 264 (or perhaps more) genera which are peculiar to the Neotropical Region; while $n o$ one can pretend that among the former are there any types of such significance as the latter abundantly afford. Thus regarded from every ornithological aspect, what has been called the Nearctic "Region" has no right to be so accounted, since its

1 Of these 2 belong to Turclidx, 1 to Chamaidx, Paridæ, Troglodytidæ respectively, 5 to Emberizida, 2 to Corvide, 1 to each of Picida, Falconida, and Columbidx, 5 to Tetraonidx, and 1 to Scolopacidx, Anatidx, and Laridx respectively. 
peculiarity is numerically of less importance than some of the Subregions of the Neotropical Region, as the following table will shew more plainly :-

\begin{tabular}{|c|c|c|c|c|c|c|}
\hline & & & & $\begin{array}{l}\text { Whole No. } \\
\text { of Genera. }\end{array}$ & $\begin{array}{l}\text { Peculiar } \\
\text { Gentera. }\end{array}$ & $\begin{array}{l}\text { Percentage of } \\
\text { Peculiarity. }\end{array}$ \\
\hline Patagonian. & . & . & . & 290 & 46 & $15 \cdot 862$ \\
\hline Brazilian . & . & . & . & 396 & 43 & $10 \cdot 85 \overline{7}$ \\
\hline Amazonian . & . & . & & 373 & 27 & $7 \cdot 238$ \\
\hline Subandean & . & & & 469 & 72 & $15 \cdot 33$ \\
\hline Central American & & . & . & 464 & 46 & $9 \cdot 913$ \\
\hline Antillean & . & . & • & 140 & 30 & $21 \cdot 444$ \\
\hline Nearctic & . & . & . & $330^{*}$ & $24^{*}$ & $7 \cdot 272$ \\
\hline
\end{tabular}

* These numbers, calculated according to the formerly received boundaries of the Nearctic "Region," are certainly overstated, but means of arriving at a more accurate computation are not now forthcoming.

A considerable majority of the Nearctic Families and genera seem to be generally distributed throughout the whole area, which we may fairly call a Subregion, and consequently its division into Provinces is not easily effected, their delimitations resting rather on differences of species than of higher groups. Of the many attempts to subdivide the Subregion, that of Baird ${ }^{1}$ seems to be the most successful. ${ }^{2}$ He long ago pointed out the existence of three Provinces in its southern portion, the most easterly of which may be termed the "Alleghanian," since it extends from the Atlantic across the mountains whence it is named, and over the valley of the Mississippi and its prairies to about long. $100^{\circ} \mathrm{W}$. where the sterile plains begin. Then its boundary turns northward, crossing the Platte and intersecting the Missouri about Fort Lookout.

1 "The Distribution and Migrations of North American Birds," Am. Journ. Sc. and Arts, ser. 2, xli. pp. 78-90, 1\$4-192, 337-347 (January, March, and May, 1866). Reprinted Tbis, 1867, pp. 257-293. German translation, Journ. f. Orn. 1866, pp. 244-269, 338-352.

2 I make this assertion though aware of the views to the contrary expressed by Dr. Merriam in his "Results of a Biological Survey of the San Francisco Mountain Region and Desert of the Little Colorado, Arizona" (North American Fauna, No. 3. Washington: 1890). He arrives (p. 24) at the conclusions " that the whole of extratropical North America consists of but two primary life regions, a Boreal region, which is circumpolar; and a Sonoran or Mexicantable-land region, which is unique." The first of these, it will be seen, supports my contention of the essential unity of the Nearctic and Palrarctic areas. The second is one the probability of which I will not dispute; but I think that at present the facts adduced in its support are hardly sufficient to warrant its adoption by naturalists, who, not being Americans, must necessarily be acquainted with them only at second hand, especially as I am disposed to consider that Dr. Merriam's enumeration (pp. 26-28) of the "canses which determine distribution," however well they may fit the area of which he treats, may not be of nuiversal application. 
Reaching the eastern frontier of Canada, it rapidly inclines westward and loses itself in the Arctic wilds. But this Province melts away also on its north-eastern border, and cannot there be sharply distinguished from what may be named the "Canadian," which occupies the north-easter'n portion of the continent, including the eastern half of the Dominion, and it must be held to extend across Davis Strait to Greenland, though it only fringes the shore of that ice-bound country, while here and there on the continent it follows the higher ranges southward, even to Fort Burgwyn near lat. $37^{\circ} \mathrm{N}$. if not further. Then on the west we have a "Californian" Province, the longitudinal extent of which is very indefinite. Prof. Heilprin would cut off the southern portion, annexing it to the Neotropical Region, and its eastern boundary would seem to proceed along the Sierra Nevada and the Cascade Mountains, so that it is restricted to a mere strip of coast territory, extending, however, beyond British Columbia. Between this Californian and the Alleghanian Province is interposed a considerable tract of country called by many American writers the "Middle Province," a name so vague that it would seem allowable to distinguish it as the "Missourian" since its characteristic vertebrates culminate (so to speak) in the wide basin of that greatest of tributaries to the Mississippi. ${ }^{1}$ Occupying the extreme north-west of the continent, a fifth Province, the "Alaskan," must be recognized, and this from a zoogeographical point of view is the most important of all, since it is characterized by the presence of Mammals and Land-birds, which are not only specifically identical with those of Asia, but among them some individually have an Asiatic resort. The list of Birds observed in this Province, which may be taken as beginning about Cape St. Elias, and thence extending northward to the Icy Sea, seems (after such revision as can at present be made) to number $227,{ }^{2}$ of which 112 , or very nearly one-half, are also Asiatic. Dividing the whole into Water-birds and Land-birds, we find that of the former (127) more than 66 and of the latter (100) exactly 27 per cent. are found on both sides of the Pacific. Moreover no fewer than 11 of the 100 species of Land-birds, belonging

1 Indication of its being the focus (if such a thing can now exist) of purely Nearctic types is not wanting, since here we find at least one generalized or undifferentiated genus, Colaptes (FLickER), which both to the north and to the south separates itself into specific forms.

2 The gross number given in 1887 by Messrs. Nelson and Henshaw in their Report upon Natural History Collections made in Alaska (pp. 19-226) is 255, but 28 of these should be deducted as not being known to occur to the northward of Cape St. Elias or the Alaska Mountains, where apparently a very natural frontier exists. 'This Report contains a useful bibliography of Alaskan ornithology. In making the estimates given in the text above, all the subspecies or conspecies recognized by the authors have been treated as true species. Were it otherwise the results would still more favour the views here expressed. 
to 3 if not 4 genera of Passeres, are found nowhere else in the New World, ${ }^{1}$ and their occurrence there does not preclude us from setting them down as essentially Palæarctic forms. Indeed they all belong to genera widely distributed throughout the greater part of Europe and Asia, while if the species be not identical they are represented by others that are closely cognate-as in the case of the IVAGTAILS ${ }^{2}$ and the BuLLFinch. Some are summer immigrants, and therefore must yearly cross and recross Bering's Sea, since they assuredly do not winter upon the American side. To these last may even be added the WHEATEAR, Saxicola ananthe, for though that species is known as a regnlar anmual visitant to Greenland ${ }^{3}$ and Labrador (where it breeds), and almost annually appears as a straggler in the maritime provinces of Canada, in Maine, and in New England, the flocks which throng the stony hill-tops of Alaska in spring are not likely to have performed a north-west passage from Europe, and indeed it is stated that specimens from Norton Sound differ considerably from those obtained in Greenland. All these birds are unseen in British Columbia, ${ }^{4}$ and as all are migratory, the inference that they make some part of Asia their winter quarters is almost irresistible: ${ }^{5}$ but the point to be observed is that an ornithologist passing in summer from Kamchatlia or the eastern extremity of Siberia would on landing in Northern Alaska find himself in the midst of an Avifauna of which nearly one-half, namely 112 out of 227 species, was identical with that which he had left on the other side of the Pacific. ${ }^{6}$

1 These are Pyrrhula cassini, Lencosticte griscinucha, Anthus cervinus, Budytcs lcucostriatus, Motacilla ocularis, Parus obtectus, Phylloscopus borealis, Cyanceula suecica, Surnia funerea, Strix Irpponica, and Archibuteo lagopus. The purely American species which occur accidentally in Europe are of course left out of consideration. It is to be remarked that at present there is no trace of the acciclental occurrence of any purely American species in Northern Asia, though such are quite likely to come ander the notice of future observers.

a "Several small birds of the water-wagtail genus" came on board one of Cook's ships, 16 Angust 1778, when in lat. $69.57 \mathrm{~N}$. and long. 166.19 W., being then off Cape Lisburn on the northern coast of Alaska (WV. lillis, Narrative of a Voyage \&c. i. p. 340).

3 Though Messis. Nelson and Henshaw (op. cit. p. 222) state that the present writer "assumes that the bird reaches North-west America by the way of Greenland," he does not remember having entertained or expressed any such opinion. On the contrary, he used the very words above printel in his article "Birds" published in the Encyclopadia Britannica (ed. 9, iii. p. 753) in 1875.

+ They seem not to occur to the southward of Cape St. Elias, the presumed limit of the Province.

5 This remark must be taken as not influencing the argument, or the example of Egypt presently to be cited wonld thereby be affected.

6 It may be observed that in order to avoid the least appearance of overstating the case, forms like the TrEE-CrEEPEl and Osprex have been countel as though distinct. If these and some others were regarded as specifically identical, and 
Perhaps there is nothing very surprising in this, when we consider the narrowness of the channel which here divides America from Asia, and furthermore the fact that the water of Bering's Strait is shallow suggests a still eloser connexion in bygone times of the two continents. The Aleutian Islands, though they look like a series of stepping-stones from one to the other, do not seem to furnish a route of communication, for Mr. Dall (Proc. Californ. Acad. Sc. 14 March 1874) ealls special attention to the fact that no intrusion of Asiatic forms occurs towards the western end of the chain, while observing that its Avifauna is reinforced beyond Oumalaska by several Aretic species not possessed by the more eastern islands. The other islands belonging to the Nearetic Subregion, the Prybilof in the Northern Pacific, and the Bermudas nearly in the middle of the Northern Atlantic Ocean, do not need any particular remark here. Greenland may be regarded as coming almost into the same category, and thongh there, as might be expected, the influence of the Old Trorld is strong, that of the New World just prevails, since of the 45 genera to which belong the feathered demizens of the fringe of habitable soil on its western coast (which is all that is offered by that land of desolation) none is especially characteristic of the former, while one, Zonotrichicu, is peculiar to the latter, and a similar result follows from an investigation of the species-a bare majority being Nearctic. ${ }^{1}$

It has been already stated that more than one-third of the genera of Nearctic birds are common also to the Palsearctic Subregion. If we take the number of Nearetic species at 700 , which is perhaps an exaggeration, and that of Palnarctic at 850 , we find that, exclusive of stragglers, there are about 120 common to the two areas. Nearly 20 more are properly Paliearctic, but oceasionally occur in America, and about 50 are Nearctic, which from time to time stray to Europe or Asia." This, however, is by no means the only point of resemblance. Of many genera, the socalled species found in the New World are represented in the Old by forms so like them that often none but an expert can distinguish them, and of such representative "species" about 80 might be enumerated.

this the writer fully believes them to be, more than one-half the Avifauna of these portions of the two continents would be the same.

1 Any one at all curious in these questions should consult Prof. Palmén's tables at the end of his contribution to the ornitholory of the Siberian coast, printed in the fifth volume of the Seientific Results of the Voyage of the 'Vega.'

2 Baird, in the essay before cited, has reasonably accounted for this disproportionate reciprocity between Europe and America; but perhaps more than he has alloweil for nust be set down to the comparative want until lately of records in the newer country. This want is being speedily supplied by the increased study of Ornitliology of recent years in Canada and the United States. 
Since, as above indicated, the avifamna of the Nearctic Subregion shews its intimate connexion with that of the Palrearetie by the yearly interchange that obtains between Alaska and the northeastern portion of Asia, it would seem most fitting to begin the consideration of the Palæarctic Subregion at that part of it. As in the Nearctic Subregion difficulty was found in defining the limits of its several Provinees, so there is difficulty here, and perhaps it is even greater in this far vaster area. The very fulness of details we possess in regard to some of the countries of our own Subregion, those of its western or European portion especially, makes the scarcity of information in respect of others all the more conspicuous, and renders comparison useless. In the eastern portion, its southern frontier cannot be as yet determined. Granting that it includes the whole of Japan, the line of demarcation on the continent is open to much doubt: Mr. Wallace would place its commencement about Ningpo, just to the southward of Chusan, whence it would have to enclose the basin of the Yang-tse-Kiang, and then turn suddenly northward to skirt the valleys of the rivers which drain Cochin China, Siam, and Burma, as they undoubtedly belong to the Indian Region. Thence it would make for the eastern end of the Himalayas, on reaching which its course becomes fairly plain so far as the Hindoo Koosh; here it trends to the southward to inelude Afghanistan and the greater part if not the whole of Beloochistan. Skirting the northern shore of the Persian Gulf, it continues westward, passing to the north of Arabia, but comprising Mesopotamia and Palestine, with a remarkable exception to be presently noticed, and reaching the south-eastern corner of the Mediterranean Sea. Here its land-boundary is interrupted, but it may be taken up again in Tunis, if not in Tripoli, and, including all the ancient Mauritania-that is, the portion of Africa north of the Great Desert-meets the Atlantic Ocean about Mogador. The Subregion includes the Atlantic Islands (Canaries, Madeiras, and Azores), as well as Iceland, but otherwise its western and northern limits are those of Europe and Asia, with the more or less explored Arctic lands lying to the northward of them.

Of the Provinees into which this vast area may be separated, there is first the "Siberian," beginning on Bering's Strait, and extending across the northerumost part of Asia to the confines of Europe, where what passes for the Ural Mountains may be found a convenient though probably an arbitrary boundary. Guided by the investigations of the late Capt. Blakiston and Mr. H. Pryer, ${ }^{1}$ we find that the Strait of Tsugaru, between Yezo and Nipon (oecasionally called Hondo), constitutes a boundary between two Provinces, the more northern being that first named, while the more

1 Trans. Asiat. Soc. Japan, x. pp. 84-186 (1882), and Amended List of the Birds of Japan (London: 1884). 
southern has been termed the "Mongolian." Where the line just indicated may reach the continent of Asia is as yet very doubtful. Some would make it round the Corean peninsula; but a careful scrutiny of all that is known of the ornithology of that country, as stated by Professors Giglioli and Salvadori, and the late Dr. Taczanowski, ${ }^{1}$ forbids it being so drawn, and there seems a probability of the Stannovoi first, and then the Altai Mountains marking their respective limits, while further inland the great deserts can scarcely fail to interpose a barrier almost impassable for resident birds. The "Mongolian" Province may be taken to extend between the frontier's thus vaguely sketched until it reaches the eastern coast of the Caspian Sea, but the chain of mountains that forms the western continuation of the Himalayas, separates it from a third Province, which, beginning on the shores of the Gulf of Oman, includes the rest of Asia, all the portion of Africa that lies in the Paliearctic Subregion, as well as the three great European peninsulas, so that the northern boundaries of its western part would be the Pyrenees, the Alps, and the Balkan range. Looking to the importance of the sea which perretrates this Province more than half way from west to east, the name "Mediterranean " may not inaptly be conferred upon it. The rest of Europe, having an Avifauna, as all will admit, differing enough from the "Mediterranean," will form another Province, and though on its eastern side it might well have a more decided boundary, we must accept the Ural Mountains for want of a better, and the Kirghiz Desert, while the Caspian Sea, the Caucasus, and the Euxine complete its circuit on the south.

That a desert should form, as just hinted, a proper boundary to a Fauna will not be gainsaid by any one who takes the tromble to consider what is thereby meant. It will be enough to point out that the southern border of the western portion of the Palæarctic Subregion has, in the Great Desert of Africa, commonly known as the Sahara, a boundary hardly inferior to a coast-line in the precision with which it may be laid down, and in the influence which it exerts. That indeed may be an extreme instance, but the existence of many others more or less nearly approaching it is certain. Moreover, some of these are likely to lead to a misapprehension, against which it is advisable to guard the unwary, and in no part of the world more so than in relation to that now under consideration. It is well

1 The list of Corean birds by the first two anthorities (Proc. Zool. Soc. 1887, pp. 580-596) consists wholly of species, chiefly Water-birds, obtained at a season when the migrants from the north would predominate over the actual natives; and hence, though of valne in some other respects, fails to shew the real character" of the Avifauna of Corea. If the lists of the third writer (op. cit. 1887, pp. 596-611; 1888, pp. 450-469) be closely examined, it will be seen that, though he aseribes a Siberian character to the avifauna, the species obtained by the collector in spring or summer, and these are of course the natives, belong to the Chinese Fauna. 
known that wherever there are deserts they are inhabited by what is called a "Desert Fauna" consisting of animals belonging to many Classes_-Vertebrates and Invertebrates-which are especiallyadapted to their surroundings; but hitherto there has been no need to notice this fact in the present work. However, in the Palæarctic Subregion, and especially in its eastern portion, as well as in the Ethiopian Region, next to be treated, deserts are so extensive that some zoologists have been inclined to deem them guides in the matter of Geographical Distribution. For very limited districts there is perhaps no great harm in so doing, though there is always the risk of thereby confounding what botanists have long since seen to be essentially different, namely station and habitat; but a wholly wrong notion would be conveyed were deserts to be accounted factors in determining the value of geographical areas. These, as $\mathrm{Mr}$. Wallace has laid down (Geogr. Distr. Anim. i. pp. 3 and 4), do not depend on physical features, though physical features may affect them. Furthermore, it is observable of Desert Famas that most of the mimals composing them are very nearly related to those which inhabit the country bordering on the desert-in some cases the difference between the two is only that of tint and must again be mentioned (VARIATION), in others it is greater and may extend to stature or the proportional size of various organs, as in Birds in the length and thickncss of the BruL. Again, it may be greater still, and instead of regarding the animal as a local race, we have to recognize its specific or generic validity as, among Birds, several LARKs, Sparrows, Starlings, and Wheatears, or even as a well-marked form like the CoURSERs, a Family like the SAND-GrousE, or an Order such as the Ostrich represents. But it scems clear that the right way to regard these and other inhabiters of the desert is to view them as we do the denizens of the great oceans. We do not determine the Avifanma of Polynesia by the oceanic birds which sweep over its watels or even lodge upon its coral-reefs; but by the birds which inhabit its islands. Now oases are to deserts what islands are to oceans, and it is therefore by the dwellers in the oases that the characteristic fauna of a tract ${ }^{1}$ which includes desert must be judged, while that of the wastes which surround them is but the result of local causes. Were it otherwise we should have to recognize a Desert Province (or rather a Region, even) in the Old World, which starting from the nountain range lying to the westward of Pekin would stretch in a wide belt over Asia, and crossing Arabia, as well as Africa at its wiclest part, be terminated only by

1 Canon Tristram seems to be the first who drew the special attention of omithologists to Desert Forms, the precise value of which he set forth admirably in his famons remarks (Ibis, 1859, pp. 429-433) - too long to be here quotedon their bearing on the then half-revealed Darwinian hypothesis of Natural Selection. 
the shores of the Atlantic, for throughout that immense tract species of Passeres are found that wear the Desert uniform and scarcely differ from one end to the other.

Having already indicated the component parts of the Subregion, it is time to say somewhat of its ornithic characters. Like the Nearctic, it seems to produce but a single peculiar Family of Birds - the Panuridx, the type of which is the beautiful species known to most Englishmen as the Bearded Titmonse, Panurus biarmicus ${ }^{1}$; but this fact need excite no surprise when we remember that along almost the whole of its southern frontier, extending from long. $120^{\circ}$ E. to $10^{\circ} \mathrm{W}$., it is conterminous with the Indian or the Ethiopian Region, whereas the Nearctic Subregion presents not more than $20^{\circ}$ of latitude to the Neotropical Region. ${ }^{2}$ Indeed, the wonder rather is that the Palrearctic Subregion should have even a single peculiar Family, for we ought to bear in mind that all the Families of the Holarctic Region consist of stronger forms than those inhabiting the Regions which abut upon it, so that the faculty of extending their range is possessed in a greater degree by the former. The whole number of Palrearctic Families may be taken to be 67 , and of the genera 323, about which there can be little doubt, or if any exist, it is that the number is understated. Of these, as before stated, 128 are common to the Nearctic Subregion. Species of 51 more seem to occur as true natives within the Ethiopian and Indian Regions, and besides these, 18 appear to be common to the Ethiopian, without being found in the Indian, and no fewer than 71 to the Indian without occurring in the Ethiopian-a result that might be expected from geographical considerations, since the latter Region is cut off by a wide desert, constituting (as above stated) a barrier as hard to pass as a sea, while the former Region, though in fact separated by one of the highest mountain-ranges in the world, is in almost its whole length conterminous.

Taking the Provinces separately, we find that the Siberian has but one genus peculiar to it-Eurynorhynchus, the Spoon-billed Sandpiper, a bird of wide wanderings, whose home was finally discovered by the companions of Baron Nordenskjöld on the mainland opposite to Burney Island (long. $174^{\circ} \mathrm{W}$.) during the memorable voyage of the 'Vega.' 3 The Mongolian seems to have the largest number of peculiar genera of any Palrarctic Province, there being no fewer than 13, which may be assigned as follows-Fringillida,

1 This bird is most unhappy in its names. It has nothing whatever to do with the Titmouse-Family, Paridx, and its specific title, signifying of or belong. ing to Biarmia, the district of Perm in Russia, is just as inapt.

${ }^{2}$ As the southern boundary of both Subregions lies in much the same latitude (say roughly $30^{\circ} \mathrm{N}$.), the degrees of longitude are practically equal in either case.

3 Palmén, Bidrag till Kännedomen om Sibiriska Ishafskustens Fogelfauna. Vega-Expeditionens vetenskapliga Iakttagelser, v. pp. 326, 327. 
3 ; Sturnidx, Panuridx, Ixidx and Sylviidx, 1 each; Timeliidx and Phasianidx, 2 each; and "Pterocleidx" 1 and Anatidx, 1 apiece." The Mediterranean Province appears to have peculiar to it 4 genera of Sylviidx, and 1 genus of Laridx; but some 23 more belong to it and to no other part of the Subregion, though having a wider range outside of the latter. Of these, 8 are common to the Ethiopian and Indian Regions, while confined to the former and the Province are 11, and having the same relation to the latter 2. Finally, it has a genus of Anatidx, Erismatura, which is represented in Australia and America, as well as in Africa.

The Atlantic Islands, ${ }^{3}$ which must be regarded as belonging to the Mediterranean Province, offer some peculiarities of great interest. First we have the Azores, the subject of an excellent monograph by Mr. Frederick Godman, ${ }^{4}$ who shews that there is a general tendency among their birds to vary more or less from their continental representatives, especially in having almost always a darker plumage, a stouter bill and stronger legs, and in one instance, a BULLFINCH, Pyrrhula murina, the variation justifies its specific distinction. The same tendency is not so observable in the Madeiras, but these have at least two peculiar species, and recent researches in the Canaries ${ }^{5}$ prove that there differentiation is carried on to a still greater extent, and that certain local forms are often confined to a particular island, while again there are some species that occur in all the islands with little or no sensible variation. It is almost indukitably proved that all those groups have been colonized from the mainland of the Mediterranean Province, and the changes which the colonists have undergone may be in some cases a measure of the period that has elapsed since one species after another has settled upon them. In no case does the colonization of Land-birds seem to be very ancient,

1 By strict rule, this Family should be called Syrrhaptidx, Syrrhaptes being the earliest-named genus belonging to it. But one species of this genus overran Europe in astonishing numbers in 1863 and again in 1888, both times breeding in its new-found quarters (see SAND-GrousE).

2 Information on the ornithology of this Province gathered by recent Russian travellers has been mostly published in their own language. Nevertheless, Dr. Severzov's notes on the Birds of Turkestan have been rendered into English by Messrs. Crämers and Dresser (Tbis, 1875, pp. 96, 236, 332 ; and 1876, pp. 77, 171, 319, 410), and an English translation by the former of those gentlemen of the ornithological portion of Prjevalsky's travels was given by the late MIr. Rowley in lis Ornithological Miscellany, vols. ii. and iii.

3 Among these Mr. Wallace groups the Cape-Verd Islands; but whatever may be the case with other Classes of auimals, their Birds shew a preponderance of Ethiopian forms, and here they must be referred to that Region.

4 Natural History of the Azores or Western Istands. London : 1870.

5 E. G. Meadp-Waldp, Iois, 1889, 1p. 1-13, 503-520; 1890, pp. 429-438; H. B. Tristram, op. cit. 1889, pp. 13-32; and A. König, Journ. für Or’n. 1889, pp. 199, $263 ; 1890$, pl. 257-488, tabb. i.-viii. 
as no indication of loss of wing-power, which is one of the effects of protracted isolation, has been observed among them, though, as is well known, many of the Insects are said to shew it remarkably. Moreover, the colonization seems to be going on still, and it happens not unfrequently that when an island has a well-established local race it is yet more or less regularly visited by individuals of the normal and parental form.

The European Province does not seem to possess a single genus that can be accounted peculiar to it, but it has one consisting of a single species, Mergulus alle (RотснE), which does not elsewhere occur in the Paliearctic Subregion, though it inhabits the northern parts of the Canadian Province of the Nearctic. It would, however, extend too far for the present article to dwell upon more than a very few of the curiosities of distribution revealed by the continued observation of birds in Europe. 'There is no need to travel out of our own island to meet with some of the most remarkable among them, and we may take the case of the NigH'TINGALE as an example. In England the western limit of this incomparable songster's range seems to be formed by the valley of the Exe, which is only overstepped on rare occasions. But even in the east of Devon it is local and rare, as it also is in the north of Somerset, though plentiful in other parts of that county. Crossing the Bristol Channel, it is said to be not uncommon at times near Cowbridge in Glamorganshire; but this seems to be an isolated spot, or at any late there is no evidence of its being found elsewhere in Wales, or between that place and 'Tintern on the Wye, where it has been reported to be plentiful. Thence there is more or less good testimony of its occurrence in Herefordshire, Shropshire, Staffordshire, Derbyshire, and so on, to about 5 miles north of York, but not further, that is to say in the ordinary course of things, for Mr. Wolley-Dod, an unquestionable authority, recorded one that he heard singing at Malpas in Cheshire in May 1859.1 Along the line thus sketched out, and immediately to the south and east of it, the appearance of the Nightingale, even if regular, which may be doubted, is rare, and the bird is very local; but in many parts of the midland, eastern, and southern counties it is abundant, and the woods, coppices, and gardens ring with that thrilling song which has been the theme of writers in all ages. There are many assertions of its occurrence in England further to the northward, but some of them rest on anonymous authority only, and all must be regarded with the greatest suspicion. Still more open to doubt are the statements which have been made as to its visits to Scotland, while in Ireland there is no pretence even of its appearance. No reasonable mode of accounting for the

I Others were reported to have been heard about the same time in Flintshire and near Rhyl. 
partial distribution of the Nightingale has hithcrto been propounded; there is no peculiar kind of soil which it especially affects, or none, so far as we know, that it especially avoids; and the same may be said of its relations to the Flora of this country. It is not so entirely adscriptus glebre that it will not readily betake itself to new localities suited to its liking, when these have been formed within its natural limits, though they may be miles away from its ancient haunts. On the contrary, it is often one of the first birds to establish itself when a heath has been broken up, and plantations of trees thereon made have grown sufficiently to afford it the sheltering covert that it loves. This instance taken from a bird whose habits have been so closely studied both in captivity and at large, and one which is so familiar and in many places so numerous, that abundant opportunities are given for observing all that can be observed about it, shews how futile would be the expectation that in most cases we could at present, even if ever, satisfactorily account for the existing causes which limit the distribution of species. A vast majority of them, we know, have each its bounds, which virtually it cannot pass, and the case of the Nightingale in England, beyond the fact that its distribution is extremely well marked, and therefore has long attracted especial attention, has really nothing out of the common way in it. ${ }^{1}$ In Europe, the neighbourhood of Copenhagen is the most northern point which our Nightingale is asserted to reach; but on the continent its range is less extended, and though abundant in Mecklenburg, it is not found in that part of Pomerania which lies to the north of the Peene valley, nor does it stretch so far eastward as Danzig. ${ }^{2}$ It occurs, however, sparingly on the Polish frontier, near Thorn, and is observed in Austria, Upper Hungary, and Galizia. In Russia its distribution cannot be laid down with any degree of accuracy, but it does not reach the Governments near the Ural, though it is said to be plentiful in that of Kharkov, and it is known to visit the Crimea. Records of its occurrence still further to the eastward are probably incorrect, as it seems to be

1 When the history of the earth shall be really well and minutely under. stood, it seems quite possible that as much light will be shed on this and other particular cases of the same kind by a knowledge of the various changes and displacements which sea and land have undergone as has already been done by the same means in regard to many of the general facts of Distribution. The results of the labour of the geologist are doubtless just as necessary to and closely connected with the work of the biologist, as those of the investigation of the historian are to and with the efficiency of the statesman; while, in return, the researches of the biologist are, or ought to be, of the greatest use to the geologist. 'The history of the earth is for a long period of time that of its inhabitants.

2 From the Rhine valley eastward the range of the other European species overlaps that of the present. 
replaced in Circassia and Persia by another form; but southward of this imperfectly-drawn line our Nightingale may be found as a winter-visitant in Nubia and Abyssinia, as well as in Algeria, where it is reported as breeding, and it would seem to migrate thence so far as the Gold Coast. It is abundant in Spain and Portugal; but it is a stranger to Britanny, the western peninsula of France, just as it is to the western peninsula of England. ${ }^{1}$

One other example we may take, and this, though much less familiar, is equally instructive as exhibiting some of the as yet unexplained peculiarities of Distribution. It shall be that of a bird belonging to a very different Order from the last, having habits entirely dissimilar, and presenting in most ways a great contrast. The Kentish Plover, Aggialitis cantiana, a species first determined from specimens obtained on the coast of that English county whence it takes its specific name, has its breeding-place in Britain limited to the pebbly beach between Sandwich and Hastings, and in other parts of this kingdom only occurs as a chance straggler. Yet this species has a very wide range, breeding not only abundantly along the greater part of the coasts of the temperate and warmer portions of the old World north of the Equator, but also occasionally in the interior, as at the base of the Caucasus and in the chotts of the North-African plains; while in its regular migration it wanders to the Malay Archipelago and South Africa, and is hardly to be specifically separated from a Plover which inhabits the coast of China, or from another which is found on the west coast of America from California southward, though the former has been described as distinct under the name of $A E$. dealbata, and the latter under that of $A$. nivosa.

A remarkable case of restricted range is that of the Red Grouse, Lagopus scoticus, found-and in certain districts, as every one knows, numerously - in each of the three kingdoms, as well as in Wales. The details of its local distribution, as of that of all other birds which breed in Great Britain, were carefully and concisely given by Mr. More (Ibis, 1865, pp. 1-27, 119-142, 425-458), and there is no need to dwell upon them here; but what is worthy of remark is that this particular species differs in no other essential character save coloration from the Willow-GRouse, L. albus, which is an abundant bird throughout the whole of the northern parts of the Holarctic Region, from Norway to Kamchatka, and again from Alaska to Newfoundland. Its remains, as before stated (Fossil Birds), have been found in the south of France associated with those of the Snowy Owl and the Reindeer; and, deferring for the present any hypothetical discussion, it is impossible to resist the inference that our own bird, though fully entitled to the rank of a "species," is a local form of the widely-spread Willow-Grouse.

${ }^{1}$ Cf. Yarrell, British Birds, ed. 4, i. pp. 315-318. 
Other instances there are in which British-born examples of species common to the Continent are, though in a less degree, distinguishable from those of neighbouring countries. The CoalTitnouse of England is to be recognized from that of Europe, Parus ater, and accordingly by some ornithologists it is regarded as a distinct species, $P$. britannicus; but the scanty remnants of the ancient pine-forests of Scotland are inhabited by birds between which and continental specimens no difference can be established. The homebred Bottle-Trumouse of Britain, too, has, from its darker coloration, been accorded specific rank; but it is now known that birds of this species, Acredula canduta, from southern and central Europe vary in this respect, and the specific validity of the British form, A. rosea, can hardly be with consistency maintained. Indeed, as a matter of fact, nearly all of our smaller birds can be distinguished by an expert from their continental brethren, and this mainly through the duller or darker plumage of the former. ${ }^{1}$ The difference is by no means so great as obtains in the birds of the Atlantic Islands above mentioned, but it exists to a greater or less degree, and it is certain that an malogous state of things is observable in regard to some of the birds of Japan, a country which is subject to many of the same climatic conditions as the British Islands. It will be for future investigators to determine the cause of this similarity, it is enough here to record the fact; but another remarkable instance of the forms of the western portion of the Subregion being repeated in the far east is found in the range of the two kindred species of the genus Cyanopicathe Blue Pre of Portugal and Spain, C. cooki, being replaced in Amoorland and Japan by one, C. cyana, so closely allied that some authorities have refused to acknowledge their distinctness, and yet throughout $130^{\circ}$ of longitude no representative of either is found. ${ }^{2}$

Here it would be convenient to refer to the subject of local variation, which is, however, of general application, though it has naturally received most notice in regard to the Birds of the Holarctic Region. The questions it involves were treated many years

1 The difference is of course most striking if specimens of brightly-coloured species be compared-for example, the Chaffinch or the Yellow-Hammer.

"A well-known writer has declared the "obvious" explanation of "this anomalous fact" to be "that the Chinese Blue Magpie was brought from China to Spain, precisely in the same manner as the Chinese Ringed Pheasant was introduced into England." No evidence in support of this assertion being adduced, charity forbids my here naming the author or his work. Should he ever turn his attention to Mammals he will perhaps account for the interrupted distribution of the genus Tapirus by suggesting that the Portuguese carried $T$. indicus from the Malay countries to Brazil, where "in consequence of the greater rainfall " it may have "become browner" and the adult indeed have lost its piebald coloration "by protective selection." 
since by Gloger, 1 and perhaps as satisfactorily as the evidence at his command would permit. In North America the late Prof. Baird seems to have been the first to turn his attention to this topic, the importance of which gradually impressed itself upon him as the several collections of specimens made during the exploratious for a railway-route to the Pacific Ocean came under his eyes. He was content to register the results, and, so far as the writer knows, abstained from theorizing upon them. His example was followed by many of the enthusiastic and painstaking ornithologists who sprang up around him, ${ }^{2}$ and they, rejoicing in a wealth of specimens such as had never before been amassed, have undeniably shewn that it was not lost upon them. With scarcely an exception they too have exhibited as much caution in regard to speculations as did their venerated leader. The great fact was established that, given a species, especially of a Land-bird, which had a wide range on a continent, the variation exhibited by individuals from different localities is generally so considerable that it is hardly possible to predicate its amount, while almost every intermediate form may be found if the series of specimens be large enough. ${ }^{3}$ One of the first results which naturally followed was the abolition of a great number of what had hitherto passed as distinet "species," and the recognizing them as local forms, any two or more of which should be united under one heading. It is of course true that to some extent naturalists were already aware of the fact that "missing links" were from time to time found between what had borne an unsullied reputation as good "species"; but this had happened in a comparatively small number of eases, whereas it now became plain that it was of very common occurrence. Moreover, some "laws" were more or less manifest-for instance, examples of a set

1 Das Abündern der Vögel durch Einfluss des Klimas. Bresla11 : 1833.

2 These are too numerous to name; but the labours of MIr. J. A. Allen cannot be passed withont recognition. His essay "On the Mammals and Wiuter Birds of East Florila," published in 1871 (Bull. Mus. Comp. Zoöl. ii. No. 3), entered into details of part of this question more thoroughly than had been before attempted; and the views therein expressed have been confirmed on additional evidence in his "Notes of an Ornithological Reconnaissance of portions of Kansas, Colorado, Wyoming, and Utah" (op. cit. iii. No. 6), as well as in his "Geographical Variation in North American Birds" (Proc. Boston Soc. Nat. Hist. xv. pp. 212-219). He also notices the fact, since observed in regard to the Red Grouse in Great Britain, that considerable variation may exist independently of locality.

3 It conld be wished, however, that the North-American ornithologists had not latterly, by many innovations in the establislied theory and practice of scientific nomenclature, rendered so nucl of their excellent work unintelligible to all but the expert, and not readily understood by lim. This proceeding was the more extraordinary as it is so contrary to the practical claracter of citizens of the United States. 
of several species of different genera from, say, a locality in the north varied in the same way from examples of a set of the same species from the south, and so with eastern and western examples. In principle this was not novel or unexpected. Indeed it had been noticed in some instances in Europe, particularly, as the writer can testify, by the late Mr. Gould many years ago; but the small size of our own quarter of the globe compared with that of North America, and still more the short series of specimens which existed even in the largest of our collections, forbade the generalizations that at once became possible and almost suggested themselves when the vast aggregations obtained by Baird and the elder Agassiz were studied and compared. In the meanwhile, however, European, and especially English, ornithologists had been growing dissatisfied with the shortcomings of their collections, and took pains to enlarge them, but there were special difficulties in the way of obtaining specimens from the eastern portion of the Palæarctic area, and Central Asia was practically an unknown country. That their efforts were more or less successful may be seen by Mr. Dresser's Birds of Europe, the publication of which marked an enormous forward stride, but still the dearth of sufficient series of specimens from Eastern Europe, and particularly from the Asiatic portion of the Russian Empire, continues to be keenly felt. The zeal shewn by Mr. Seebohm to meet this want deserves high commendation, and of late Russian ornithologists have turned their attention to the question of local races. The immediate effect has been no little confusion, but that is unavoidable, and none can doubt that much of it will disappear, so that we may hope our knowledge of the ornithology of the Palæarctic area will in a few years be on a level with that which Americans possess as regards the Nearctic. But a word of warning may be uttered in respect of both. Many writers on natural history find it hard to realize the fact, undeniable according to the principles of the doctrine of Evolution, that if all the individuals of any genus that ever existed could be set before a naturalist, he would be unable, even though gifted with the most critical eye, to separate them into species, for, however unlike the extremes might be, the means would shew an unbroken series between them. It must be obvious that these intermediate individuals are the ancestral, generalized forms, while the rest shew a greater and greater tendency to specialization in one way or another. In the course of ages many of these intermediate forms disappear, and then it is right to regard those that survive without near relations as good species. But others there may or will be that, however they may vary locally, are still unmistakably linked. The forms that connect them continue the nearest heirs of the ancestral stock, and present its more generalized features. Thus to assume, as some do, that, these comnecting 
forms are the result of interbreeding between the extremes is to begin at the wrong end, and virtually to mistake cause for effect. $^{1}$ In reality there is no need to make any assumption whatever. It is far better, certainly at the present time, to stick to the plain facts of each case, so far as we can acquaint ourselves with them, and there is every appcarance of each case having to be treated upon its own merits. But opportunities for generalization will, of course, come at last, and meanwhile we shall possibly not be far wrong in expecting, as one result of the facts already known and undoubtedly to be multiplied by increased observation, an elucidation of what has seemed to so many an insoluble puzzle-the repetition, so to speak, of similar forms in Western Europe and in Eastern Asia without their appearance in the intermediate territory, or cases of, to use another expression, "interrupted distribution "-be the interruption as in that of Cyanopica, already mentioned, absolute, or modified more or less as in so many other instances.

V. The Ethiopian Region is by no means easily divided. In treating of it in 1875 (Encyclop. Brit. ed. 9, iii. pp. 757-760), the present writer followed in the main the guidance kindly afforded him by Dr. Sharpe, whose knowledge of its Avifauna is hardly, if at all, exceeded by that of any other ornithologist, and recognized five Subregions. The progress of geographical discovery, which has of late years laid open so much of the wilds of Central Africa, has shewn a much greater homogeneity than was before expected in the Fauna of the several parts of that continent, though it is true that the explorers of its interior have in few cases had any zoological knowledge or even taste, and that to at least one of the most celebrated of them scientific research of any kind is repellent. It must also be remembered that nearly all of those few zoological explorers have forfeited their life ${ }^{2}$ in their zeal for investigation, and, with the notable exception of Emin Pasha, scarcely one has survived to carly on his observations or to malie collections for any length of time. Consequently the vast area of EquatoriaI Africa, and the districts immediately conterminous, are ornithologically almost mknown. Meanwhile we do know that nearly all the most

1 The seeming inability to grasp this position detracts greatly from the value of nearly all that Mr. Seebohm has written on the geographical distribution of birds in the Palæarctic Subregion and elsewhere, leading him to conclusions of the most erroneous kind, which have been uncritically accepted by several other writers.

${ }^{2}$ It would be impossible here to name even the naturalists who from Mungo Park downwards have fallen victims to African exploration; yet, in an ornithological work, William Alexander Forbes must be especially mentioned, as it was the pure love of ornithology that led him up the Niger, where he succumbed to fever in the very prime of life. 
characteristic types of the continental portion of the Ethiopian Region shew themselves, and (so far as we can judge) dwell alike in the southern as well as the northern parts, the eastern as well as the western-the chief differences observable being not even generic, but mostly specific. The OsTRICH, for example, extends, or extended, from the Karroo to the Belki, and still further to the eastward, ${ }^{1}$ and no more essentially characteristic form of the continental portion of the Ethiopian Region can be found than this highly specialized bird, the sole representative of one Order of the subclass Ratita, for whether we accept the difference exhibited by the Ostrich of the north and that of the south as specific, or admit the validity of a third alleged species in Somaliland, all will agree that these differences are in quality of the slightest. When this is to be said of a bird having the peculiarity of habit and structure possessed by Struthio, it seems vain to talk of regarding its range as extending over Subregions. The highest term we are justified in applying to these portions of its continental area, which for one reason or another it may be convenient to speak of separately, is Province. And thus it seems better to merge the whole of Africa and that part of Asia which belongs to the Ethiopian Region into one Subregion, which may be called the "African," unless some better name be suggested, instead of breaking it up into four as was done formerly by the author, or into three as has been done by Mr. Wallace. These districts, be they four or three in number, may perhaps be termed Provinces, and thus we may recognize a "Libyan" 2 Province extending from the easternmost border of the Ethiopian Region, wherever we may place that, comprehending the whole of Arabia, Egypt, and all Africa from Cape Guardafui in the east to Cape Verd in the west, reaching northward to the Mediterranean Province of the Palaarctic Subregion, while scarcely an approximation can be made to tracing its southern limits. For the rest of Africa, seeing that we have a fair knowledge of the birds of the seaboard, and for some distance up a few of its more considerable rivers, we may justifiably divide that portion which lies immediately to the southward of this indefinite area, and comprehending the greater part of its equatorial tract, into two Provinces, a "Guinean" on the west, and a "Mosambican" on the east, though it is quite possible that these two may with the progress of discovery have to be united, and even now there seems nothing to indicate any boundary between the belt they would form if combined and the territory

1 For all that ean be said as to the former extent of the Ostrich's range in Asia see the Vögel Ost-Afrikas (pp. 597-607) of Drs. Finsch and Hartlaub, forming the fourth volume of Von der Decken's Teise in Ost-Afrika (Leipzig and Heidelberg : 1870). Remains of Struthio not to be distinguished from S. camelus have been reeognized from the Sivalik Hills in India (cf. Fossin Birds).

2 In using this name I follow Blyth (Nature, iii. p. 428, 30 March 1871). 
lying still further south and extending to the Cape of Good Hope. However, of the species which inhabit part of this territory, the Cape Colony and some of its adjoining lands, we may say that our acquaintance is as good as we have with the Avifauna of almost any country outside of Europe and North America, and though it has some clear characteristics at its extremity, these melt away gradually towards the north and seem finally to be lost. Still their existence ought to be taken into account, and therefore we may recognize a "Caffrarian" I Province. In 1884 Dr. Sharpe, when writing the preface to the second edition of Mr. Layard's Birds of South Africa, considered the "natural limits" of what he termed the "South African Subregion" (which is practically equal to the Caffiarian Province just mentioned) to be the Zambesi River on the east and the Quanza or Coanza on the west. Now it ought to be obvions that no river (however wide) can form the "natural limit" of any zoological area, ${ }^{2}$ and indeed the cases are rare in which a river limits the range of any species of land-animal. 'This proposed boundary, therefore, however convenient for some purposes, is as artificial and arbitrary as that of the 28 th parallel of south latitude adopted by Mr. Layard in 1867 for the first edition of his work, and indeed it is pretty evident that no boundary is yet to be laid down, even if one is ever to be found. ${ }^{3}$

So large a portion of the Ethiopian Region lies between the Tropics that no surprise need be expressed at the richness of its Fauna relatively to that of the Holarctic last considered. Between 50 and 60 Families of Land-birds alone are found within its limits, and of them at least 9-Buphagida, Eurycerotidx, Philepittidx, Musophagidæ, Rhinopomastidæ, Leptosomidx, Coliidæ, Serpentariidæ, and Struthionida-are peculiar; but it is a singular fact that only the first three of them belong to the Order Passeres, a proportion which is not maintained in any other Tropical Region. The number of peculiar genera is too great for them to be named here; some of the most remarkable, however, especially of those belonging to the insular or Madagascarian Subregion, where Bird-life has been differentiated to a degree that is very extraordinary, will presently be mentioned.

1 Again following Blyth (loc. cit.)

2 Unless indeed the river be a channel left by the silting up of an inland sea, as is said to be the case with the lower Amazon.

3 Should its delimitation be ever effected, it will probably be done by taking cognizance of other Classes than that of Birds. The extraordinary diversity of forms shewn by certain groups of Mammals, and especially of the hollow-horned Ruminants, generally known as Antelopes, towards the southern extremity of the African continent can hardly fail to be of use in this investigation, conpled also with the absence of so well-marked and apparently so ancient a Family of Edentates as the Manidx, and the non-occurrence of any representative of the Ganoids among Fishes in the more southern rivers of Africa. 
Further subdivision seems only possible in the case of the first of these four Provinces above named-the Libyan, which may perhaps be broken up into four subprovinces-an Arabian, an Egyptian, an Abyssiniall, and a Gambian; but no boundaries can be assigned for any but the first, and that has precisely the fewest possible characteristics, so that the propriety of its recognition, except on purely geographical grounds, is most questionable. We may doubt whether it has more than half a dozen peculiar species if we exclude from the number those of the Ghor, or the valley of the Jordan and the depressed basin of the Dead Sea, which we must regard as an outlier of the Province; but then we know very little of the zoology of any part of Arabia, save the peninsula of Sinai, the desert of the Tîl, and a few places on the sea-coast. ${ }^{1}$ The species of Birds which seem to be peculiar to the Jordan basin are said to be eleven in number, ${ }^{2}$ many of them showing Indian consanguinity, though the Ethiopian element on the whole predominates, and especially in Amydrus tristrami, the name of which commemorates the naturalist to whom we owe most of our information as to the Fauna of this singular district.

The Egyptian subprovince, so far as regards the valley of the Lower Nile, is remarkable for being overrun by migrants from the north during the winter, and since it is chiefly from the observations of travellers at this season that most of our knowledge is derived, it is perhaps not very wonderful that some zoogeographers have included this district within the Palæarctic area. But a little reflexion will shew that to obtain a right estimate of the Fauna of any country we should take count of the animals which are its natives and have their home there rather than of those which resort to it as visitors, without remaining to breed within its limits. Now the number of species of Birds which appear in Egypt and Nubia, as given by Captain Shelley, ${ }^{3}$ who is still the latest and best authority, is 352 , though many of them, he says, are of doubtful occurrence. Of these more than 230 are natives of the Palæarctic Subregion, but only between 50 and 60 , or about one-quarter of them, remain to breed in Egypt, and of this number a considerable proportion do not breed in Europe, but only in the Barbary States. The Palæarctic species, which are only winter-visitors, to the number say of 180 , should therefore be left out of the reckoning. On the other hand, more than 70 species, which are not Palæarctic, are true

${ }^{1}$ Considering our ignorance of the Fauna of Arabia, I have not been able to see why Mr. Wallace assigned the northern extratropical portion of it to the Palearctic area. With our present want of information, any line of demarcation drawn across the country must be purely arbitrary, for I am not aware of any evidence favouring such a division.

"Tristrain, Fauna and Flora of Palestine (pref. pp. ix. x.) London : 1884.

3 Handbook to the Birds of Egypt. London: 1872. 
natives of Egypt, ${ }^{1}$ and among them members of some 8 or 10 good genera, not a species of which rightly belongs to the northeru area-such as Nectarinia, Chrysococcyx, C'entropus, Otogyps, Tantalus, Ibis, Chenalopex, Eupodotis, Pluvianus, and Rhynchaa. The Ethiopian character of the truly Egyptian Avifauna seems to be thus fully established.

Respecting the Abyssinian subprovince very full particulars are included in the work of Von Heuglin, ${ }^{2}$ supplemented as regards Shoa, by the labours of Count 'T. Salvadori, ${ }^{3}$ based upon the explorations of Antinori and Dr. Ragazzi, but the precise features of its Avifauna are not easily ascertained from the former, since he has not discriminated between it and the Egyptian. Still it would seem that nearly 220 species may be peculiar to this part of the subprovince, and among them that most wonderful form Balaniceps (SHOE-BILL). A remarkable feature in the Abyssinian Avifuuna is the occurrence there, not as migrants but as actual natives of its mountains, of several birds which would otherwise be deened purely Palrarctic, as, for example, both the Cornish and the Alpine CHough (Fregilus). The presence of these northern forms in the Abyssinian highlands induced a hope that some of them might extend to the still loftier lands of Kilima-njaro and its neighbouring heights, which would therefore have to be included in the subprovince, but that hope has been disappointed by the zoological survey of Mr. Johnston (Proc. Zool. Soc. 1885, pp. 219-239), which unfortunately produced nothing of the kind. Indeed, it seems as if we might suspect that the Fauna of this district, which reaches the highest elevation in Africa, may have greater affinity to, if it be not practically identical with that of the Caffrarian Province far away to the southward. To the Abyssinian subprovince, however, must probably be assigned the island of Socotra, whereon out of two dozen species that have been observed, one-third-and all of them Passeres - seem to be peculiar, two of them belonging to a peculiar genus Rhynchostruthus.

Of the Gambian subprovince not much is to be said. M. de Rochbrune ${ }^{4}$ has enumerated 686 species of Birds as occurring in the French portion of it, but none of them are peculiar, while 423 , or more than sixty per cent., seem to be common to the north-east of Africa, 112 to the Gaboon district, and 274 to Angola, thus leading directly to the Province next to be mentioned. But to the Gambian subprovince belong the Cape Verd Islands, which out of

1 There can be haruly a donbt that this number would be increased were further researches carried on during the breeding-season.

2 Ornithologie Nordost Afrika's. Cassel : 1859-1875.

3 Uccelli dello Scioa. Genova: 1884 ; and Catalogo di una collezione di Uccelli dello Sciors. Genova : 1888.

4 Fanne de la Sénégambic, Oiseaux. Paris: 1884.

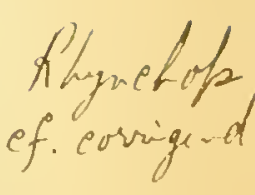


17 or 18 Land-birds enumerated by Dr. Dohrn (Journ. für Orn. 1871, pp. 1-10) seem to have 2 peculiar species, both of the Order Passeres.

The "Guinean" Province occupies what is commonly called the "West Coast" of Africa, and may extend from Sierra Leone to the south of the Congo valley. Hitherto no catalogue of its Birds has been published, for the work of Dr. Hartlaub ${ }^{1}$ comprehends also those of the subprovince just treated, while admirably executed as it was at the time of its appearance, so much has since been done by collectors in this part of Africa, and by those who in Europe have examined their collections, especially Prof. Barboza du Bocage, Dr. Büttikofer, and Dr. Sharpe, that its results must be regarded as out of date. Yet no good and much harm would follow from any attempt to generalize on the facts thus recorded, at various times and in various publications, except it were made by one thoroughly conversant with the details of African ornithology. Here we must be content to notice as very characteristic forms of this district, Agelastes and Phasidus, both allied to Numida (GuinetFowL), that very characteristic form of the whole Ethiopian Region. However, the first of the three naturalists last named has published an excellent ornithology of Angola and Loango, ${ }^{2}$ whence it appears that out of $69 \mathrm{~S}$ species about 220 are peculiar, but he states that it would be premature to establish any divisions. The Avifauna of Loango leans to that of Gaboon, while Angola in like manner shews an affinity to South Africa-a result which was only to be expected. Something may be said with more confidence of the islands which pertain to the Province. Of them, Fernando Po was once believed to possess a very remarkable Avifauna, but further investigation seems to prove that it has no peculiar species whatever. Prince's Island has been declared to have 6 peculiar species, and it is asserted that it is not inhabited by any Diurnal Bird-ofPrey, every one being driven off by the Grey Parrots (Psittacus erithacus) which there abound. The island of St. Thomas, lying just under the Equator, is also said to have 6 peculiar species besides one found on Prince's Island as well, but nowhere else.

The "Caffiarian" Province, as before stated, has no more definite inland boundary than either of the preceding, yet its distinctive features are more marked-a fact doubtless due to so large a portion of it lying without the Tropic. Though this part of Africa has for more than a century received attention from ornithologists, ${ }^{3}$ their several labours in its various districts require careful

1 System der Omithologic West Africa's. Bremen : 1857.

- Ornithologic d'Angola. Lisbonne: 1881.

3 Levaillant's Oiscaux d'Afrique (Paris : 1799-1808) is notorious for its untrustworthiness, as manifested by Sundevall's critical review of it in the Handlingar of the Academy of Stockholm (ii. No. 3, pp. 16-60). MIr. Salvin 
collation and comparison before their bearings can be understood. Such results as have been obtained are quite out of proportion to the extent of country whence they have been gathered. As it is, there cannot have been fewer than 800 species observed in what may be deemed to be this Province, but we must bear in mind that the number, even at the very extremity of Africa, is swollen by the inclusion of many which have their home in the Palrearctic Subregion, and should be by no means reckoned as belonging to the Ethiopian Region. These are not limited to birds of well-known wandering habit like the TuRnstone, the WHIMBREx, and numerous Limicolx, or those possessing powers of endurance like the Cuckow or the NightJar, or of strong and speedy flight as the SwIFT and the Swallow, but they include many of the more weaklywinged (as commonly considered) of our summer-visitants, the SEDGE-BIRD, the Willow-WREN, the Garden-WARBLER, and others. Nor is this seasomal influx confined to birds of European birth, which need not greatly diverge from their meridian in their journey; the most eastern part of Asia sends its representatives, of which Erythropus amurensis is a remarkable example. A revised list of South-African Birds has yet to be made out before we can state with any accuracy what are to be deemed members of the Caffrarian Avifauna.

Only one island can with certainty be affiliated to this Province, and that is St. Helena, where the indigenous Land-birds, if any there were, have probably been extirpated with most of its original and peculiar flora. Yet it seems to be a curious fact that this isolated spot possesses a peculiar Water-bird, albeit of a group that greatly affects dry places. This is the so-called WIRE-BIRD, a Ringed Plover, AEgialitis sancta-thelenx; and, though belonging to a genus the members of which are remarkable for very wide distribution, it is not known to have occurred off the island. Tristan da Cunha, commonly assigned to this Region, and therefore to this Province, seems to have at least as much affinity to the Neotropical, and Ascension appears to have no indigenous Land-birds whatever, so that its appropriation must remain in doubt.

collected the ornithological papers contributed by the late Sir Andrew Smith to The South African Journal between 1830 and 1834, and they were reprinted in 1880 by the Willughby Society, but neither these nor the rolume containing the Birds in the Illustrations of the Zoology of South Africa, published by that excellent naturalist (London: 1838-1849) give a connected account of the ornithology of this Province. The most comprehensive work is that by Mr. Layard before mentioned, and next to it Andersson's Notes on the Birds of Damara Land (London: 1872), edited by the late Mr. Gurney, who also communicated to The Ibis a long series of valuable articles on the Birds of Natal based on the observations and collections of Mr. Ayres. Finally may be montioned the Beiträge zur Ornithologie Suclafricas, by HH. Holub and von Pelzeln (Wien : 1882). 
The "Mosambican" Province next follows; but its claims for recognition are perhaps more shadowy than any of those of the preceding. The general uniformity of distribution which obtains among the Birds of all Tropical Africa, especially noticed by Sir John Kirk (Ibis, 1864, p. 307) in treating of those of Zambesia, requires more geographical details than are as yet available to entitle us to form any decided opinion, though the work of Drs. Finsch and Hurtlaub (ut suprà) gives ample information as to the literature and description of the 448 species, which, according to them, constitute its Avifauna. Considerable additions have been made by Dr. Reichenow (Orn. Centralbl. 1879, pp. 107, 114, 138, 155). Lying off its coast are three considerable islands, Pemba, Zanzibar, and Monfia, but there is no reason to expect that they are of any very great importance from a zoogeographical point of view. Zanzibar is the best known, and that seems to have but one species peculiar to it, Francolinus kirki, but further observation may prove that it also occurs on the mainland.

There remains for consideration the Subregion formed by Madagascar and its satellite islands, the remarkable peculiarities of which fully deserve the attention that has been paid to them. Except New Zealand, there is no part of the earth's surface of like dimensions that can compare with Madagascar for interest, and the latter far surpasses the former in the wealth and multifariousness of its ornithic population. More than one high authority has regarded Madagascar as forming a distinct primary Region, but of that something must be said hereafter. It once possessed, in Epyornis, a form of Ratitz which, if not actually gigantic, greatly exceeded the Ostrich in size, and, though some writers would fain see in the fossil remains of this bird a realization of the fabulous Roc, not a vestige has been recovered which seems to belong to any period that history or even legend can reach ${ }^{1}$ (see Fossil Birds).

This Subregion is easily divided into two Provinces, Madagascar itself, to which the Comoros must be attached, and the Mascarene Islands, of which more presently. Long studied as the Birds of Madagascar have been, the island has until quite recently produced one novelty after another, and some of them of the most unexpected lind. It would perhaps be premature to say that the supply is exhausted, but since the completion of the ornithological portion of M. Grandidier's magnificent work ${ }^{2}$ little or nothing of importance has come to light. Herein the authors enumerate 238 species as belonging to the island, of which 129 are peculiar to it, and among

1 Bianconi, Memorie delle Accai. delle Seienze dell' Istituto di Bologna, 1862. 1874.

2 Histoire physique, naturelle et politique de Madagascar, vol, xii. Histoire naturelle des Oiseaux par HM. Alphonse Milne-Edwards et Alfred Grandidier. Paris : $1875-84$. 
these there are no fewer than 35 peculiar genera. Great as is this amount of peculiarity, the present writer believes it to be rather understated than exaggerated; but it is sufficient to shew all that is here needed, though he would add that, in his opinion, at least 3 of the genera, Euryceros, Philepittu, and Mesites, must be regarded as forming the types of as many distinct Families, the first belonging to the normal Acromyodian Passeres, the second to the Oligomyodian section of the same Order, and the third, though of kin to the Pallidx (RAIL), can hardly be kept in that Family. It is quite possible too that Falculia, which apparently had allies in Fregilupus and Necropsar (both recently extinct) of the Mascarene Islands, though commonly referred to the Sturnide (STARLING), and Brachypteracias, with Atelornis and Geobiastes, which are generally included among the Coraciidx (RoLLER), should be removed from those Families, and recognized as forming distinct Families, which would have to take the names of Fregilupida and Brachypteraciidax respectively, while Helioditus is an OwL, belonging to the Strigine Family, Aluconidx, which hitherto had but one known representative, the widely-spread Aluco flammens. But the Avifauna of Madagascar is not entirely composed of such singularities as these. We have homely genera, even among the true Passeres, occurring there-such as Alauda, Acrocephalus, Motacilla, and Praticola, while the Cisticola madagascariensis is only distinguishable from the well-known Fan-tailed Warbler, C. schoenicola, of Europe, Africa and India, by its rather darker coloration. But there are also species, though not Passerine, which are absolutely identical with those of Britain-Aluco flammeus, Coturnix communis, Porzana pygmaa, and Podicipes fluviatilis-all of them common and apparently resident in the island.

The Comoros, as might be expected, are influenced by their proximity to the African continent. The latest list of their Fauna, by Messrs. A. Milne-Edwards and Oustalet ${ }^{1}$ in 1888 accords them 79 species or local races, of which 59 are Land-birds - but at least 5 of these have certainly been imported, and one is included by mistake. Of the remainder 2 are common to South Africa, 22 to Madagascar, and 29 seem to be peculiar, one forming a peculiar genus, but nearly all have their nearest allies in Madagascar, and with them have doubtless a common ancestry, and indeed the Comoro Islands furnish one of the best examples in the world where species may be seen in the process, so to speak, of specification.

${ }^{1}$ Nouv. Arch. du Mnuséum, ser. 2, x. pp. 219-298, pls. iv.-ix. Earlier notices by the same naturalists are in Comptes Rendus, ci. Ip. 218-222, and Ann. Sce. Nat. ser. 7, ii. pl. 213-238; and still earlier, by other hands, are Sclater, Ibis, 1864, p. 292 ; E. Newton, Proc. Zool. Soc. 1877, pp. 295.302, pls. xxxiii. xxxiv.; and Shelley, op. cit. $1879, \mathrm{pp} .673 \cdot 679$. 
The three chief Mascarene Islands have had their original Fauna so largely destroyed by colonization (see ExTERMINATION) that its peculiarities can hardly yet be accurately judged, and that chiefly from remains which, if not strictly fossil, have been recovered from the earth. Mauritius and Réunion, better known by its older name Bourbon, lying within sight of each other, and possessing about the same number of existing species, seem to have not more than three Land-birds in common, and there is one genus, OxyNoTus, peculiar to these two islands and represented in each by a distinct species. Réunion had also, within the memory of men yet living; two peculiar genera, a Parrot, Mascarinus, and Fregilupus, perhaps allied to Falculia of Madagascar, and still more nearly to Necropsar of Rodriguez. The Avifauna of this last and remote island has been so reduced that it has left only 3 species of native Land-birds; these are all peculiar, one being the Parrakeet, Palxornis exsul before mentioned (p. 218) as being on the verge of extinction, and another an aberrant form of Drymoca, pointing possibly to a common origin with Indian species. The Land-birds of Seychelles which have not been introduced are 16 in number, and of these 14, according to Sir Edward Newton, ${ }^{1}$ are peculiar, but there is perhaps not one good genus that may be so termed. Taken as a whole, we cannot but be struck with the force of the evidence as to the land-connexion which seems to have once existed-though not necessarily all at once-between the various units forming the whole Subregion. Even the scanty remnant that is left shews how the denizens of its most distant parts represent one another, a clear tolsen of their long-continued isolation and the working of a differentiating force.

But before leaving this area reference must be made to an hypothesis which has obtained considerable support in various quarters, and has been accepted as an easy solution of a difficult problem. By dwelling on the peculiarities of the Fauna of Madagascar, regarding it as perfectly distinct from that of Africa, and looking to the fact that in that island are collected in great abundance the chief forms of those Mammals known as Lemurs, belonging to the Suborder Prosimia, while another group of the same Suborder occupies the Indo-Malay Islands, the idea was conceived of there having once been not only a land-connexion between those countries, but that they must be the relics of a vast continent now submerged, to which the name of "Lemuria" was assigned, and it has been counted as one of the primary Regions of the earth's surface. The fallacy of the argument on behalf of this conjecture has been exposed by Mr. Wallace, who lias not only shewn that the hypothesis of a Lemmrian continent was alike unnecessary to

1 "List of the Birds of the Mascarene Islands, including the Seychelles," Trans. Norf. and Norw. Nat. Soc. iv. pp. 548-554. 
explain one portion of the facts presented by the Fauna of Madagascar, and inadequate to explain the rest; but he has demonstrated, so far as can be, that the existence of such a continent was impossible. Here there is only room to indicate the line he has taken (Island Life, pp. 390-399). He incontestably shews (1) that Madagascar must have been united to Africa in very ancient days, (2) that it must have received its stock of Lemurs thence at a time when Lemurs inhabited not only Africa but Emrope (for Lemurian remains have been found fossil in France--if not in England), and probably Asia, (3) that Lemurs made their way to the Indo-Malay Islands by passing through Asia, just as they passed through Africa to Madagascar, (4) that Madagascar must have been separated from Africa before the now prevailing African types overran that continent, and (5) finally, that the Indian facies of the Fauna of Madagascar, which is chiefly shewn by certain Birds, and is of comrse very striking to an ornithologist, is caused by forms of existing Indian genera, and by species very closely allied to those of India, this last fact shewing their comparatively recent arrival in the Mascarene Islands and Madagascar, where they must be regarded as colonists. The hypothesis of a "Lemuria" is in fact exuctly like that of an "Atlantis," which was for a long while thought requisite for the explanation of the Famna of the Atlantic Islands, but has proved to be untenable in the face of more complete knowledge.

VI. The Indian Region ${ }^{1}$ completes our survey of the globe; and its boundaries, so far as they can be defined, have been already sketched out when treating of the adjoining areas. Large as is its extent and varied as are its physical features, it would seem to have but 2 peculiar Families of Birds, Phyllornithida and Eurylanida, out of upwards of 70 which occur within its limits. There is peculiar difficulty in settling the Subregions and Provinces into which it should be separated. While the Fauna of some districts has been studied so that we possess a very fair knowledge of them, the greater part is no better known zoologically than the centre of Africa. Yet we cannot treat this Indian Region with the same audacity of ignorance that we did the Ethiopian, for our acquaintance with it is such as to shew that there are in it districts, large or small, which have an unmistakable affinity to one another and

1 It must be mentioned that objection has been taken, and not without show of reason, to the name "Indian" applied to this Region, since what is correctly called "India" forms but a small and perhaps not the most characteristic part of it. Mr. Wallace has used the name "Oriental," against which it may be urged that it errs on the side of vagueness, just as "Indian" does on the side of particularity. Though in this use he has had several followers, it seems on the whole that "Indian," being the distinguishing term first applied to this Region, had better be retained for it. 
yet seem to be cut off from all communication with their neighbours. We may indeed account for this on the ground that the similarity observed is due to corresponding elevation above the sea-level, and that throughout the whole Region the hill-countries are as a rule disconnected; but such an explanation does not make the task easier. We find the characteristics of the Himalayan Avifauna shewing themselves not only on the highlands of Southern India and Ceylon, but far away to the eastward also in Formosa, Hainan, and Cochin China, and again repeated in a lesser but still perceptible degree to the southward in the mountains of Malacca and Sumatra. This being the case, it seems better to follow for the primary divisions a scheme set forth by Mr. Elwes (Proc. Zool. Soc. 1873, pp. 645-682), especially as in the main it has the approval of Mr. W. T. Blanford, ${ }^{1}$ whose further subdivisions, so far as they go, it would be wise to adopt. In this way we have three Subregions-the "Himalo-Chinese," the "Indian" (proper), and the "Malayan." 2

The Himalo-Chinese Subregion, according to this view, includes the southern slopes of the Himalayas from their base to the limit of the growth of trees; and, beginning with Cashmere, extends through Nepal and Blotan, thence marching with the as yet undetermined frontier of the Mongolian Province of the Palaarctic Subregion until it reaches the coast of China. It includes all Burma so far as the middle of Tenasserim, and for the rest its southern and eastern boundaries are those of the Asiatic continent, while to its Chinese portion also belong the islands of

I The Faunce of British India. Mammalia. London : 1858. Introduction, pp. iv. $v$.

2 Here it may be stated that since want of space forbids the enumeration of the many publications on the ornithology of the British possessions and protectorates in India, it wonld be still less possible to attempt a summary of the results which they produce. No oue wishing to study the Avifama of any portion of India can do so successfully without consulting the original records, mostly published in that country. The Joumal of the Asiatic Socicty of Bengal (generally quoted as J. A. S. B.), the Calcutta Journal of Natural History, the Madras Journal of Literature and Science have each contained many valuable papers on Indian ornithology, while Stray Feathers, entirely devoted to that subject, and edited by Mr. Allan Hume, is a magazine of which ten volumes and a halt have appeared since 1873. That gentleman also published in 1873-75 Nests and Eggs of Indian Birds, of which a second and enlarged edition was brought out in 1859-90 by Mr. Oates. Jerdon's Birds of India, the appearance of which, in 1862-64, gave new life to the study of ornithology in that comtry, by consolidating the scattered work that had becn before done, is never to be mentioned but with respect, thongh in many ways it will be superseded by the portion, begun by Mr. Oates, of The Fauna of British India, mentioned in the preceding note. While mentioning all these, tho important contributions to Indian ornithology by Mr. Hodson and Blyth must not pass mnoticed. 
Hainan and Formosa. In its western part it is a mere strip of territory, and this alone can at present be recognized as a Province-the "Himalayan" - but as already remarked its influence is felt in widely-separated upland districts, though here it is impossible to give details of them. Few countries seem to have a richer Avifauna than those which compose this Himalayan Province. Cashmere, the most westerly of them, is said to produce nore than 170 species of Land-birds, of which 70 are peculiar to the district. Nepal, which is the next of which any satisfactory account can be given, has more than 550 species of Land-birds, 80 of which are peculiar to or characteristic of the Himalayan Province, a number that in Sikkim rises to 270 . Further to the eastward our information is less, for though Mr. Hume has published (Stray Feathers, xi. pp. 1-353) a list of the Birds of Manipur, Assam, Sylhet, and Cachar, which shews that these countries have in the aggregate a rich population, his results have unfortunately not been tabulated, and none that were trustworthy could be educed but by some one possessed of local knowledge. Burma nust be taken next, but its highlands may be said to be ornithologically unexplored, for Blyth's catalogue (J.A.S.B. 1875, part ii. pp. 54-167), edited after his death by the late Mr. Arthur Grote, with notes by the late Lord Tweeddale, and Mr. Oates's Birds of British Burmah (London : 1883), good as they are, only treat of the lower part of that country. Still they furnish a very fair account of the valley of the Irrawadi so far as the British frontier then reached, that is to say to the limits of Pegu, together with the adjoining state of Karennee, and Tenasserim, to the isthmus of Krau. All this district is especially rich in species of the peculiarly Indian Family, Eurylamidre (BroAdBILL) possessing a majority of the known forms.

We ought now to retrace our steps northward and notice China, but this is a branch of the subject on which it is as yet impossible to form an opinion. The late Mr. Swinhoe was unquestionably one of the chief authorities on Chinese ornithology, but his duties confined him almost entirely to the coast, so that he had only the opportunity of becoming acquainted with the outskirts of that interesting country. Mioreover, death prematurely cut short his labours, and the results of his multitudinous contributions to our knowledge have never been tabulated. It would be impossible to eliminate from his latest Catalogue of the Birds of China (Proc. Zool. Soc. 1871, pp. 337-343) those of the 675 species therein enumerated which do not strictly belong to the part of the Celestial Empire lying within our present bounds, to say nothing of the difficulty, which he himself seems to have felt, of separating the Birds-of-passage from the natives. A more successful attempt has been made by the Abbé David, who had much better 
opportunities of bccoming acquainted with the interior of the country. In fiually publishing the observations which a residence of twelve years in central and western China enabled him to make, he had the advantage of M. Oustalet's co-operation, and their joint work, Les Oiseaux de la Chine (Paris: 1877), with its many illustrations, is naturally a most valuable addition to our knowledge of the subject. By these gentlemen the number of species observed in China is raised to 807 , of which 158 are said to be found in Europe, 148 in Palæarctic Asia, and 248 in Southern Asia. More important than this is the statement that 249 species are peculiar to China, which for the occasion is trisected into a Northern with 92, a Tibetan with 58, and a Southern district with 169 peculiar species. It seems as if these last only would come within our Indian Region, the rest or most of them belonging truly to the Palæarctic area; but unfortunately the author's do not trace their geographical boundaries, and indeed, as has been more than once hinted in the preceding paragraphs, our existing lnowledge seems not to admit of this being done.

The two principal islands off the Chinese coast are happily in a different position. In Formosa Swinhioe found 144 species referable to 102 genera, of which 98 occur in the continental part of this Subregion and 70 in the Indo-Malayan, while Hainan has 130 species belonging to 96 genera, of which 93 are common to the Himalo-Chinese Subregion and 86 to the Malayan, thus shewing in each case a decided predominance. Formosa has no fewer than 34, and Hainan 16 species believed to be peculiar, but it is needless to say that they are more or less nearly allied to those of the mainland.

The truly Indian Subregion, according to $\mathrm{Mr}$. Blanford's latest determination, consists of the whole Peniusula from the base of the Himalayas, and of the island of Ceylon. It contains two districts which we may call Provinces-the first, the "Indian," 1 excepts the Malabar coast but includes the northern part of Ceylon, while the second, called by him "Malabar or Ceylonese," takes in what is left of both peninsula and island. But he also remarks that further subdivision may be required, for the Fauna of what are politically called the "North-IVestern Provinces" and of the Punjab differs considerably from that of Southern India, and both areas exhibit zoological distinction from the forest-clad tracts of South-western Bengal. Since the publication of Jerdon's never-to-

1 It is of course inconvenient having to apply this epithet to a Region, a Subregion, and a Province. But that is not the fault of those who regard its prior application to the first by MIr. Sclater. Practically the inconvenience is not so great as it might seem, for the word being an adjectire, requires a substantive in apposition, and that shonld always signify which of the three is meant. 
be-forgotten work, so much has been announced by the many labourers, both at home and in the Empire, whom he inspired, that there are parts of both Subregions as well known ornithologically as are most of the countries of Europe, while on the other hand there are some districts wholly or almost wholly uninvestigated. The enormous collection of Mr. Hume, now in the British Museum, would, if examined by an expert, no doubt yield results as profitable in their way as those which Baird educed from the examination of the North-American collections before mentioned; but that process has yet to be gone through, and in the meanwhile little has been extracted from them to advance in a wide senso the study of Geographical Distribution, though their importance as to details of what is commonly and irreverently called "speciesmongering" by those who are incapable of appreciating its utility, cannot be called in question. At present the lesson which this collection, notwithstanding all the expense and care bestowed on its formation, has to teach is yet to be learnt, ${ }^{1}$ and there is no help for it but to regard the literature of Indian ornithology as a collection of local monographs containing-some of them admirable - materials which awaits a master hand to work into a scientific and serviceable fabric.

Under these circumstances it would serve no useful purpose here to enter into details of the various local Faunas which have appeared, nearly all in journals of one kind or another, ${ }^{2}$ and indeed mischief could hardly be avoided were those details treated by any one who had not especially devoted himself to the elucidation of the subject, and was therefore competent to treat it in a reasonable fashion.

Ceylon has profited by the residence, by no means continuous, of a series of naturalists who make as respectable a show as can be said for those of any other exotic country. Beginning with Loten, who was governor for the Dutch while they held possession in the island, and formed a collection of zoological drawings, some of

1 It is greatly to be regretted that on the acquisition by the British Museum of this collection, which of its kind can never have been surpassed, a catalogue of it was not immediately made and published; for thereby such encouragement to the study of Indian ornithology would have been given, as can hardly occur again. But the opportunity was missed. If the exigencies of the Government service in which he is employed have not permitted Mr. Oates to finish the work he so well began, some recompense is to be found in the thought that $\mathrm{Mr}$ Blanford will complete it.

2 See, as before mentioned, the Journal of the Asiatic Society of Bengal, and especially Blyth's contributions to it, from 1841 to 1874 . When Stray Feathers began to appear, it, as might be expected, carried off much of the ornithological contributions which had enriched the older publication. Many excellent papers are contained in the Proceedings of the Zoological Society and The Ibis; but the whole are ton numerous to specify here. 
which were published by Pennant in $1769,{ }^{1}$ we have had in our own time Mr. Layard, Mr. Holdsworth, and finally Colonel Legge, whose Birds of Ceylon (London : 1878-80) is one of the best books of its class. He has traced in considerable detail the curious distribution of its Avifauna in the four districts into which he divides the island. He recognizes 233 species of Land-birds as certainly belonging to it, 47 of which seem to be peculiar, though there is a possibility that 2 may occur on the mainland. A genus Elaphrornis and a subgenus Sturnornis are considered by him to be restricted to the island.

Two groups of islands in the Bay of Bengal require notice. A very full account of their ornithology was given by Mr. Hume (Stray Feathers, ii. pp. 29-324), who visited them in 1873 , and furnished a valuable analysis of their Avifauna as he then found it, subsequently publishing some additional information about it (op. cit. iv. pp. 279-294), which does not seem, however, to affect materially his earlier conclusions. About one-fourth of the species observed seem to be peculiar; but he maintains that the character of the whole is essentially "Indian" as distinct alike from "IndoBurmese" and "Indo-Malayan." About 20 species (letting alone races) appear to be peculiar to the Andaman Islands, and about 12 to the Nicobars, while 9 are peculiar to the two groups in common. The Birds of the Andamans need have no peculiar remark, but the Nicobars have a very singular PIGEON, Calcenas nicobarica (of wide range, however), and what is still more worthy of notice, a MEGAPODE, Megapodius nicobariensis, said to be distinct from any species found elsewhere, and certainly the most western member of that curious Family. ${ }^{2}$

The Indo-Malayan Subregion remains for consideration, with a rich Fauna of great interest. On geographical grounds alone we may here easily recognize at least 5 Provinces, formed by the peninsula of Malacca, the great islands of Sumatra, Java, and Borneo, and the Philippine Archipelago. The difficulty is to choose the order in which they should be treated; but it may be most convenient to begin with the first, though we know little ornithologically about it except in its western half, which the efforts of $\mathrm{Mr}_{\mathrm{r}}$. Hume ${ }^{3}$ (Stray

1 The 12 plates and 14 pages of letterpress which then appeared form the basis of the Zoologia Indica Selecta published by J. R. Forster at Halle in 1781, a modified English translation of which, with great additions, is the Indian Zoology of Pennant (London: 1790-91). A Latin version of that by Forster was bronght out as Faunula Indica at Halle in 1795.

2 Mr. Wallace (Geogr. Distrib. Anim. ii. p. 342) thinks that it must have been introduced by the Malays.

3 An older list of the Birds of the Wellesley Province (J.A.S.B. 18i0, pp. 277-334), by Stoliczka, may be usefully consulted, but the remarks upon it of Lord Walden (16is, 1871, pp. 158.17\%) should also be read. 
Feathers, viii. pp. 37-72, 151-163; ix. pp. 107-132) and the personal experience of Captain Kelham (Itis, 1881, pp. 362-395, 501-532; 1882, pp. 1-18, 185-204) have investigated. Of Perak and the adjoining district Dr. Sharpe has rendered an account of some collections made there (Proc. Zool. Soc. 1886, pp. 350-353; 1887, pp. 431-443), and Herr Hartert has recorded his impressions (Journ. fiir Orn. 1889, pp. 379-407); while Herr August Müller has very fully recounted researches in the island of Salanga (op. cit. 1882, pp. 354-448). The result arrived at by the first of these gentlemen shews a considerable amount of peculiarity in the Avifauna, since of the 459 species which he finally accepted, 115 (or just over one-fourth) had not been observed elsewhere in British India or its dependencies, but it is doubtless true, as the second of them remarks, that the rest of it has much in common with Inclia and Ceylon, though the eastern slopes of the peninsula shew a strong relationship to Borneo, the Malay Archipelago, and even China.

The Philippine Islands for more than a century have supplied ornithologists with materials for study, but the first attempt to compile a list of their Birds, made by Prof. von Martens (Journ. für Orn. 1866, pp. 5-31) was manifestly imperfect. In 1875 appeared what was for the time a careful account of their Avifauna by the late Lord Tweeddale, then known as Lord Walden (Trans. Zool. Soc. ix. pp. 125-252), which he shewed to have a great amount of peculiarity. Yet so much has since been done that his resuits camnot be now accepted, especially as Palawan and the Sooloosislands which connect the Philippines with Borneo-were then unexplored. To him is probably due the interest in the subject almost ever since kept up, and indeed he contributed a long series of papers upon it, ${ }^{1}$ which after his death was continued by his nephew and ornithological heir, Captain Wardlaw-Ramsay, ${ }^{2}$ while Dr. Sharpe has contributed nearly as many more, ${ }^{3}$ and the recent investigations in Palawan of Dr. Platen recorded by Prof. W. Blasius, ${ }^{4}$ and of Dr. Steere, the final results of which last have not yet appeared, shew that the subject is not exhausted. Until this mass of information has been digested by a competent ornithologist it will be obvious that no useful end can be attained by attempting a summary here. Perhaps the chief thing to note is the presence here of a Megapode, Megapodius cumingi, as it is the most northern locality for any member of the Family, and indeed it was in the

${ }^{1}$ Proc. Zool. Soc. 1878, pp. 106-114, 280-288, 339-346, 379-381, 429, 430, 611-624, 708-712, 936-954; 1879, pp. 68-73.

2 Ibis, 1884, pp. 330-335; 1886, pp. 155-162.

3 Trans. Linn. Soc. (2) i. pp. 307-355; Itis, 1884, pp. 316-322; 1888, pp. 193-204, 383-396 ; Proc. Zool. Soc. 1888, p1. 268-2S1.

4 Ornis, 1888, pp. 301-320. 
Philippine Islands that this interesting form was first brought to the knowledge of Europeans.

Much the same has to be said of Borneo, that magnificent island, larger than Great Britain and Ireland. Though its Avifauna was carefully investigated by Count T. Salvadori, who published his results in 1874,1 so much has since been done both abroad and at home ${ }^{2}$ that the number of species observed there was raised from 392, of which 325 were Land-birds, to 472 , including 386 Land-birds, in 1886 by Dr. Vorderman, ${ }^{3}$ and 570 in 1889 by Mr. A. H. Everett, ${ }^{4}$ the two last having alone among the various writers of recent memoirs visited the island. Yet there seem to be only four unquestionable peculiar genera, Pityriasis, a singular form generally referred to the Laniida, Schuaneria belonging to Muscicapidx, Heterococcyx to Cuculidx, and Lobrophasis to Phasianida. ${ }^{5}$ A species of MEcapode, $M$. lowi, is said to be peculiar to Borneo and the adjacent island of Labuan. On the whole the character of the Avifauna is much what would be expected from its geographical position, but a resemblance to that of Malacca and Sumatra preponderates, though to that of Java there is considerable affinity, yet a remarkable feature of Borneo is presented by the number of species of Pittidx, a Family of wide range throughout the Old World, but therein exhibiting its maximum, and the comparatively little-known island of Banca, lying between Borneo and Sumatra produces 2 species of the same Family, one representing a form which inhabits the whole Subregion and extends to China and Siam, the other allied to 2 species, the first ranging from Nepal to Malacca, and the second inhabiting the Philippines, Borneo, and Sumatra. ${ }^{6}$

Sumatra must be considered next, and perhaps it ought to have

1 Annali del Museo Civico di Storia Naturale di Genora, v. pp. 1-430.

2 It is perhaps needless here to specify all the papers on this subject. Dr. Sharpe has communicated more than a dozen to The Ibis and Zoological Proceedings, beginning with the year 1576 ; Herr von Pelzeln three to the publication of the Zoologico-botanical Society of Vienna, in which also appeared in 1883 an excellent list by Prof. W. Blasius; while in conjunction witl Herr Nehrkorn and the late Dr. Kutter others will be found in the Journal für Omithologie and Yearbook of the Natural History Society of Brunswick; and in that of the similar Society of Bremen for 1876, 1877, and 1878 Dr. Brüggemann has published three more.

${ }^{3}$ NatunuFundig Tijdschrift von Nederlandsch-Indië. Deel xlvi. Aflev. 3. This is a mere list of names: for a more critical catalogue see that of Prof. Blasius.

4 "A List of the Birds of the Bornean Group of Islands," Journ. R. Asiat. Soc. Straits Branch, No. 20, pp. 91-212, and map (1889).

5 A reputed fifth, Anais, referred to Artamidx, is suspected to be founded on a manufactured specimen :

${ }^{6}$ On this point compare Mr. Hume's remark (Stray Feathers, ii. p. 475). 
been taken after Malacca, from which it is divided by so narrow a channel. The northern part of this island is still little known, but the ornithology of some districts at each of its ends has of late been more or less examined, ${ }^{1}$ with the effect of setting aside details formerly accepted though not of announcing new results. All that can be said here is that its Avifauna is much allied to that both of Malacca and Borneo, but it seems to have less peculiarity than the latter's. No Megapode has yet been found in the island, and but three species of Pitta.

We then have Java, the best-explored, the most thickly-peopled, and, proportionately to its Avifauna, the most peculiar, perhaps, of the Indo-Malay Islands. According to Dr. Vorderman, who in 1884 summarized a long series of valuable papers published by him in the Natural-history Journal of Netherlandish India by issuing a List of the Birds from Java, ${ }^{2}$ which are 404 in number, whereof 307 are Land-birds. He simultaneously put forth an alphabetical index to the species which have been recorded from Batavia, and has since produced two other papers ${ }^{3}$ on Birds obtained at as many stations in Western Java. Still a comparison of the Avifauna with that of the neighbouring islands is yet to be made, and it is to be hoped that this naturalist from his intimate acquaintance with this part of the Subregion will in due time accomplish it. General remarks from a compiler would here be futile, but it may be mentioned that several Burmese species which have been said not to occur in the Malay Peninsula south of Penang reappear in Javaamong them a beautiful PEACOCK, Paro muticus.

Of Bali, so interesting as the southern limit of the Indian Region, we only know from Mr. Wallace that he saw there several Birds highly characteristic of Javan ornithology, but whether the island has any peculiar species nowhere appears; it will be soen, however, from the preceding statements that Bali stands not alone in the Indo-Malay Archipelago as requiring further investigation, and a comparative view of the Avifauna of its component parts is still greatly needed. We are now brought to the brink of that remarkable Strait through which runs "Wallace's Line," and crossing it we find ourselves in the Australian Region, of which we have already treated.

GERANOMORPH $\nexists$, the second group of Prof. Huxley's Suborder Schizognathes (Proc. Zool. Soc. 1S67, p. 457), of which he

1 Cf. Tweeddale, Ibis, 1877, pp. 283-323; Wardlaw-Ramsay, Proc. Zool. Soc. 1880, pp. 13-16 (Mr. Carl Bock's collection); Niclolson, Ibis, 18s2, pp. 51-65 (IIr. H. O. Forbes's collection); Salvadori, Ann. AIus. Genova, xiv. pp. 169-253, (2) iv. pp. 514-563 ; Biittikofer, Notes Leyden Mrus. ix. pp. 1-96.

2 Cf. Natuurk. Tijdschr. Nederlandsch-Indië, xliv. Aflev. 3.

3 op. cit. xlv. Aflev. 3 ; rlvi. Aflev. 1. 
considered the Cranes and RaILS the typical forms. Whether the Bustards and SERIEMa should be also added seemed questionable; but the former connect it with the CharadrionorPHe and the latter with the AETOMORPHж.

GERFALCON, see Gyrfalcon.

GERYGONE, Gould's name, now used as English, for a genus of uncertain position, generally placed among the Muscicapida (FLYCATCHER), but shewing great resemblance to some Sylviidre (WARBLER), and especially to the Hypolais-group. Six species were recognized by him as inhabiting Australia, and nearly two dozen more, from the Philippines, Borneo, New Guinea, Norfolk Island, New Zealand, and other islands, have been referred to this genus, most of which Dr. Sharpe has since separated (Notes Leyd. AIus. 1879, p. 29) under the name of Pseudogerygone. The Australian and New-Zealand forms are inconspicuous little birds, building a pensile domed nest, and are among the commonest foster-parents of the Cuckows of their respective countries (cf. North, Descr. Cat. Nests \& Eggs of B. Austral. pp. 97-100; Buller, B. New Zeal. ed. 2, i. pp. $45-48$ ).

GIER-EAGLE (Dutch Geier, Vulture), the rendering by English translators of the Bible of the Hebrew Racham (Levit. xi. 18; Deut. xiv. 17), said by Canon Tristram to be the equivalent of the Arabic Rachmah, the vernacular name of the Egyptian Vulture, Nephron percnopterus.

GILLY-HOWLET, a Scottish nickname for the Barn-OwL, Aluco flammeus, "Gilly" being an abbreviation of Gillian (= Juliana), comparable with Jack-Daw, Mag-PiE, Robin-Renbreast, Tom-Tit, and others.

GLASOOGJE (= Glass-eye), the name given by the inhabitants of the Cape Colony to the common species of Zosterops, Z. capensis, found in that country (Layard, B.S.Afr. p. 116); but the

GLASS-EYE of Jamaica is a THRUsh, Turdus jamaicensis (see Gosse, B. Jamaica, p. 142). In the former case the name is given from the ring of white feathers surrounding the eye, in the latter from the colour of the iris.

GLEAD or GLED (A.S. Glida; Sw. Glada), an old English name not wholly obsolete for the KITE, referring to its gliding flight.

GNAT, the same as KNot, ${ }^{1}$ according to Sir Thomas Browne

1 In this connexion Mr. Charles Srainson (Prov. Names Br. B. p. 194) unhappily quotes the line

"The little Gnat-snap, worthy princes' boords,"

to be found in the translation by Josuah Sylvester, who died in 1618 (Works, ed. 
(Works, ed. Wilkin, iv. p. 319). The similar double use of the French Maringouin, for a gnat or mosquito and a small shorebird (Descourtilz, Voyage d'un Natural. ii. p. 249), is an analogous case, and would tend to shew that the supposed derivation of Knot. from Cnut or Canute may be dismissed as a fable; but

GNAT-CATCHER was the name applied by Richardson in 1831 (Faun. Bor.-Am. ii. p. 223) to birds of the genus Setophaga, commonly called in North America ReDstarts, though belonging to a very different Fanily (Mniotiltida) from the rightful owner of the name. It has been revived of recent years in a wholly different sense for members of the genus Polioptila, so called (Proc. Zool. Soc. 1S55, p. 11) from their characteristic hoary-grcy colouring, whereof three species are found in the United States, while some half-dozen others, or perhaps more, are natives of the Neotropical Region. The genus Polioptila is referred to the Family Sylviidre (WARELER), and the birds belonging to it were in 1837 called by Swainson (Classif. B. i. p. 37)

GNAT-SNAPPER, but the name has not become current in England.

GOATSUCKER, one of the most common names of the NIGHT$J_{A R}$, having an equivalent in almost every European language, and thereby testifying to the widespread belief in the malpractice it attributes to its unfortunate bearer.

GODWIT, a word of unknown origin, ${ }^{1}$ the name commonly applied to a marsh-bird in great repute, when fattened, for the table, and formerly abundant in the fens of Norfolk, the Isle of Ely, and Lincolnshire. In 'Turner's days (1544) it was worth three times as much as a Snipe (see FEDOA), and at the same period Belon

Grosart, The Divine Workes and IVeakes, 5th day, 1st week, i. p. 67, line 714) of a poem by Du Bartas; but the word thus rendered, is in the original (line 657) Bennaric, explained by French editors or commentators to mean a Becquefiguc or Ficedula (Fig-Eater), and by Bulfon and Polland, who spell it Bennevie, referred to the Ortolan; but in neither case has it anything to do with the bird called Guat or Knot in English.

1 In the absence of any plausible derivation of this word or explanation of its meaning it may be allowable to point out that the Greek Airorétoinos, Latin Egocephalus, signifying Goathead, was long ago the name of some bird, and that Belon, who knew the Greek of his day, believed some species of Limosa to be thereby understood. Philologists, on whose province I have no wish to intrude, may perhaps shew that the word Goathead, if ever used in this country, was capable of being corrupted into Godwit. At the same time it may be remarked that the original Egocephalus was possibly the Sripe, whose Goat-like bleating song has obtained for it in many countries such names as BLEATER, Chèvre-rolant, and

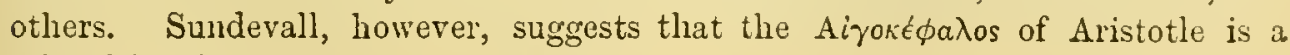

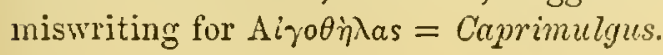


said of it- "C'est vn Oyseau es delices des Françoys." Casaubon, who Latinized its name "Dei ingenium" (Ephemerides, 19th September 1611), was told by the "ornithotrophaus" he visited at Wisbech that in London it fetched twenty pence. Its fame as a delicacy is perpetuated by many later writers, Ben Jonson among them, and Pennant says that in his time (1766) it sold for half-a-crown or five shillings. Under the name Godwit two distinct species of British birds are included, but that which seems to have been especially prized is known to modern ornithologists as the Black-tailed Godwit, the Scolopax limosa of Linnæus, the Limosa belgica, agocephala, or melanura of other authors, formerly called, from its loud cry, a Yarwhelp, ${ }^{1}$ Shrieker, or Barker, in the districts it inhabited. The practice of netting this bird in large numbers during the spring and summer, coupled with the gradual reclamation of the fens, to which it resorted, has now rendered it but a visitor; and it probably ceased from breeding regularly in England in 1824 or thereabouts, though under favourable conditions it may have occasionally laid its eggs for some thirty years later or more (Stevenson, B. Norf. ii. p. 250). This Godwit is a species of wide range, reaching Iceland, where it is called Jardrakc (= earth-raker), in summer, and occurring numerously, it is said, in India in winter. Its chief breeding-quarter's seem to extend from Holland eastwards to the south of Russia. The second British species is that which is known as the Bar-tailed Godwit, the Scotopax lapponica of Linnæus, the L. lapponica or rufa of modern authors, ${ }^{2}$ and this seems to have never been more than a bird of double passage in the United Kingdom, arriving in large flocks on the south coast about the 12 th of May (hence known as Godwit-day), and, after staying a few days, proceeding to the north-eastward. It is kuown to breed in Lapland, but its eggs are of great rarity. Towards autumn the young visit our coasts, and a few of them remain, together with some of the other species, in fayourable situations, throughout the winter. One of the local names by which the Bar-tailed Godwit is known to the Norfolk gunners is Scamell, a word which, in the mouth of Caliban (Tempest, act ii. scene 2), has been the cause of much perplexity to Shakespearian critics.

The Godwits belong to the group Limicole, and are about as big as a tame Pigeon, but possess long legs, and a long bill with a slight upward turn. In the genus Limosa the female is larger and more conspicuously coloured than the male, who is believed to talie the chief duty of incubation on himself. While the winter plumage is of a sober greyish brown, the breeding-dress is marked by a pre-

1 This name seems to have survived in Whelp Mloor, as part of the fen between Ely and Brandon used to be called.

$2 L$. meyeri of some authors seems to be the male of this species in his incubating plumage. 
dominance of bright bay or chestnut, rendering the wearer a very beautiful object. The Black-tailed Godwit, though varying a good deal in size, is constantly larger than the Bar-tailed, and especially

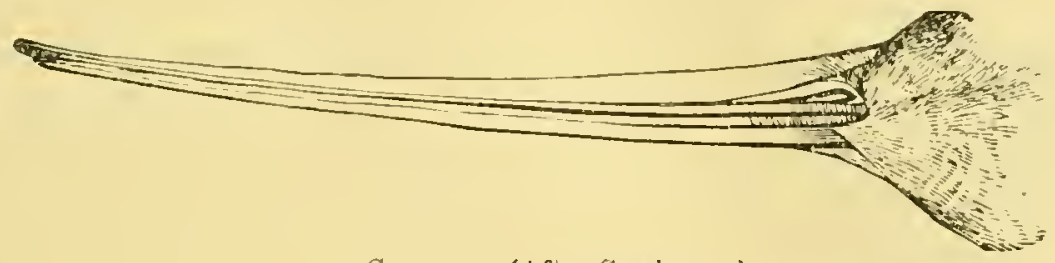

Godwir. (After Swainson.)

longer in the legs. The speeies may be further distinguished by the former having the proximal third of the tail-quills pure white, and the distal two-thirds black, with a narrow white margin, while the latter has the same feathers barred with black and white alternately for nearly their whole length.

America possesses two species of the genus, the rery large Marbled Godwit or Marhin, L. fedoa, easily recognized by its size and the butf colour of its axillaries, and the smaller Hudsonian Godwit, L. hudsonica, which has its axillaries of a deep black. This last, though less numerous than its congener, seems to range over the whole of the continent, breeding in the extreme north, while it has been obtained also in the Strait of Magellan and the Falkland Islands. 'The first seems not to go further' southward than the Antilles and the Isthmus of Panama.

From Asia, or at least its eastern part, two speeies have been described. One of them, L. melunuroides, differs only from L. bclgica in its smaller size, and is believed to breed in Amurland, wintering in the islands of the Pacific, New Zealand, and Australia. The other, L. uropygralis, is closely allied to and often mistaken for $L$. lapponica, from which it chiefly differs by having the lump barred like the tail. This was found breeding in the extreme north of Siberia by Dr, von Middendorff; and ranges to Australia, whence it was first described by Mr. Gould.

GOLDCREST, a commonly used abbreviation of Golden-crested (also called Golden-crowned) Wren, the Motacilla regulus of Linneus, and Regulus cristatus of most modern ornithologists. This species is the type of a small gemus ${ }^{3}$ generally placed among the Syluida or true WARbLers, but by certain witer's it is referred to the Paridie (Titrouse). That the Requli possess many of the haljits and actions of the latter is undeniable, but on the other hand they are not known to differ in any important points of organization or apperance from the former-the chief distinction being that the

1 The name Kinglet, a literal rendering of Regulus, has been applied to the birds of this group in many books, but cannot be said to lave become in this sense an English word. 
nostril is covered by a single bristly feather directed forwards. The Golden-erested Wren is the smallest of British birds, its whole length being about 3 inches and a half, and its wing measuring only 2 inches from the carpal joint. Generally of an olive-green colour, the top of its head is bright yellow, deepening into orange, and bounded on either side by a black line, while the wing-coverts are dull black, and some of them tipped with white, forming a somewhat conspicuous bar. The cock has a pleasant but weak song. The nest is a beautiful object, thickly felted of the softest moss, wool, and spiders' webs, lined with feathers, and usually built under and near the end of the branch of a yew, fir, or cedar, supported by the interweaving of two or three laterally diverging and pendent twigs, and sheltered by the rest. The eggs are from six to ten in number, of a dull white sometimes finely freckled with reddish-brown. The species is particularly social, living for the most of the year in family-parties, and often joining bands of any species of Titmouse in a common search for food. Though to be met with in Britain at all seasons, the bird in autumn visits the east coast in enormous flocks, apparently emigrants from Scandinavia, while hundreds perish in crossing the North Sea, where they are well known to the fishermen as "Woodcock's Pilots," from their genelally preeeding by a few days the advent of those regular" immigrants. A second and more local European species is the Fire-crested Wren, $P_{\text {. }}$ ignicapillus, easily recognizable by the black streak on each side of the head, before and belind the eye, and conspicuous white streak above it, as well as by the deeper colour of its crown. A third and fourth species, $R$. maderensis and R. teneriffa, inhabit Madeira and the Canary Islands, being peculiar to each group respectively; and examples from the Himalayas and Japan have been differentiated as $R$. himalayensis and $R$. japonicus. North America has two well-known species, $R$. satrapa, very like the European $P_{i}$. ignicapillus, and the Ruby-crowned Wren, $R$. calendula, which is remarkable for $\dot{a}$ loud song that has been compared to that of a Canary-bird or a Sliy-lark, and for having the characteristic nasal feather in a rudimentary or aborted condition. ${ }^{1}$

GOLDEN-EYE, a name indiscriminately given in many parts of Britain to two very distinct species of DUCKs, from the rich yellow colour of their irides. The commonest of them-the Anas fuligula of Linnæus and Fuligula cristata of most modern ornitholo-

1 Under the name of $I_{i}$. modestus, or "Dalmatian Regulus" of some English anthors, two very distinct species are now known to have been confounded, both belonging really to the group of WILLOW-Wrexs, and having nothing to do with Regulus. One, which has occurred in Britain, is the Motacilla supercitiosa of old or Phylloscopus supercitiosus of modern authors, and is a native of northern Asia, visiting Europe nearly every year, and the other, also of Asiatic origin, is the Motacilla or Phylloscopnes proregulus. 
gists-is, howerer, usually called by English writers the Tufted Duck, while "Golden-eye" is reserved in books for the A. clangula and A. glaucion of Linnæus, who did not know that the birds he so named were but examples of the same species, differing only in age or sex; and to this day many fowlers perpetuate a like mistake, deeming the "Morillon," which is the female or young male, distinct from the "Goldencye" or "Rattlewings" (as from its noisy flight they oftener call it), which is the adult male. This species belongs to the group

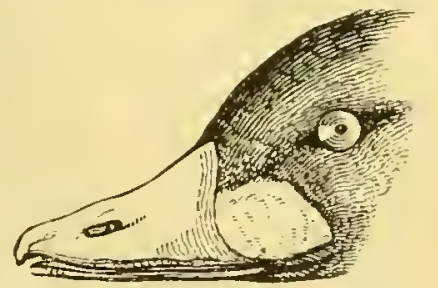

GOLDEN•ErE. (After Swainson.) known as Diving Ducks, and is the type of the very well-marked genus Clangula of later systematists, which, among other differences, has the posterior end of the sternum prolonged so as to extend considerably over, and, we may not unreasonably suppose, protect the belly - a character possessed in a still greater degree by the Mergina (Mergaxser), while the males also exhibit in the extraordinarily developed bony labyrinth of their trachea and its midway enlargement another resemblance to the members of the same subfamily. The Golden-eye, C. glaucion of modern writers, has its home in the northern parts of both hemispheres, whence in winter it migrates sonthward ; but as it is one of the Ducks that constantly resorts to hollow trees for the purpose of breeding, it hardly transcends the limit of the Aretic forests on either continent. ${ }^{1}$

The adult male is mostly black above, but with the head, which is slightly crested, reffecting lich green lights, a large oval white patch under each eye, and elongated white scapulars; the lower parts are wholly white and the feet bright orange, except the webs, which are dusky. In the female and young male, dark brown replaces the black, the cheek-spots are indistinct, and the elongated white scapulars wanting. The Golden-eye of North America has been by some authors deemed to differ, and has been named $C$. americana, but apparently on insufficient grounds. That country, however, has in common with Greenland and Iceland a very distinct species, C. islandica, often called Barrow's Duck, which is but a rare straggler to the continent of Europe, and not, so far as known, to Britain. ${ }^{2}$ In Iceland and Greenland it is the only

${ }^{1}$ So well known is this habit to the people of the northern districts of Scandinavia that they very commonly devise artificial nest-boxes for its accommodation and their own profit. Hollow logs of wood are prepared, the top and bottom closed, and a hole cut in the side. These are affixed to the trunks of living trees in suitable places, at a convenient distance from the gromd, and, being readily ocenpied by the birds in the breeding-season, are regularly robbed, first of the numerous eggs, and finally of the down they contain, by those who have set them up.

2 The recorded instance (Zool. p. 9038) is on worthless anthority. 
habitual representative of the genus, and it occurs from thence to the Rocky Mountains. In breeding-habits it differs from the commoner species, not placing its eggs in tree-holes; but how far this difference is voluntary may be doubted, for in the countries it frequents trees are wanting. It is a larger and stouter bird, and in the male the white cheek-patches take a more crescentic form, while the head is glossed with purple rather than green, and the white scapulars are not elongated. The New World also possesses a third and still more beautiful species of the genus in C. albeola, known in books as the Buffle-headed Duck, and to American fowlers as the "Spirit-Duck" and "Butter-ball"-the former name being applied from its rapidity in diving, and the latter from its exceeding fatness in autumn. This is of small size, but the lustre of the feathers in the male is brilliant, and exhibits a deep plumcoloured gloss on the head. It breeds in trees, and is supposed to have occurred more than once in Britain.

GOLDFINCH (German Goldfink ${ }^{1}$ ) the Fringilla carduelis of Linnæus and the Carduelis elegans of later authors, an extremely wellknown bird found over the greater parts of Europe and North Africa, and eastwards to Persia and Turkestan. Its gay plumage is matched by its sprightly nature; and together they make it one of the most favourite cage-birds among all classes. As a songster it is indeed surpassed by many other species, but its docility and ready attachment to its master or mistress make up for any defect in its vocal powers. In some parts of England the trade in Goldfinches is very considerable. In $1860 \mathrm{Mr}$. Hussey reported (Zool. p. 7144) the average annual captures near Worthing to exceed 11,000 dozensnearly all being cock-birds; and a witness before a committee of the House of Commons in 1873 stated that, when a boy, he could take forty dozens in a morning near Brighton. In these districts and others the number has of late years become much reduced, owing doubtless in part to the fatal practice of catching the birds just before or during the breeding season; but perhaps the strongest cause of their growing scarcity throughout the kingdom has been the constant breaking-up of waste lands, and the extirpation of weeds (particularly of the Order Composita) essential to the improved system of agriculture ; for in many parts of Scotland, East Lothian for instance, where Goldfinches were once more plentiful than Sparrows, they are now only rare stragglers, and yet there they have not been thinned by netting. Though Goldfinches may occasionally be observed in the coldest weather, incomparably the largest number leave Britain in autumn, returning in spring, and resorting to our gardens and orchards to breed, when the lively

1 'The more common German name, however, is Distelfink (Thistle-Finch) or Sticgliti. 
song of the cock, and the bright yellow wings of both sexes, quickly attract the notice of even the unobservant. 'The nest is a beautifully neat structure, often placed at no great height from the ground, but generally so well hidden by the leafy bough on which it is built as not to be easily found, until, the young being hatehed, the constant visits of the parents reveal its site. When the broods leave the nest they move into the more open country, and frequenting pastures, commons, heaths, and downs, assemble in large flocks towards the end of summer. Eastward of the range of the present species its place is taken by its congener $C$. caniceps, which is easily recognized by wanting the black hood and white ear-coverts of our own bird. Its home seems to be in Central Asia, but it moves southward in winter, being common at that season in Cashmere, and it is not unfrequently brought for sale to Calcutta. The position of the genus Carduelis in the Family Fringillida (FINCH) is not very clear. Structurally it would seem to have some relation to Chrysomitris (SISKIN), though the members of the two groups nave very different habits, and perhaps its nearest kinship lies with Coccothraustes (HawFinCH).

\section{GOLDING, see GAULDING.}

GOM-PAAUW (Gum-Peafowl) the colonial name for Otis cristata or kori, the largest species of BUSTARD inhabiting South Africa (Layard, B. S. Africa, p. 283), so called because it is believed to feed largely on the gum of the Mimosa-bushes growing

\section{on the plains which it affects.}

GOOSANDER, or, as formerly spelt, ${ }^{2}$ GOSSANDER, probably from old Norsk Gas (A.S. Gós) and $\not n d$, pl. Andir (Dan. And), meaning therefore "Goose-Duck," the ordinary name of the largest species of Mergus (MERGanser), apparently applied first in Lincolnshire, where so many words of Seandinavian origin have lingered; but now in general use.

GOOSE (A.S. Gos), the general English name for a considerable number of birds, belonging to the Family Anatida of modern ornithologists, which are mostly larger than Ducks and less than Swans. Technically the word Goose is reserved for the female, the male being called GANDER, while the young is a Gosling.

The most important species of Goose, and the type of the genus Anser, is undoubtedly that which is the origin of our well-known domestic race, the Anser ferus or $A$. cinereus of most naturalists, commonly called in English the Grey or Grey Lag ${ }^{2}$ Goose, a bird

1 Drayton (1622) Polyolbion, Song xxv. ; Merrett (1667) Pinax, p. 184.

2 The meaning and derivation of this'word Lag had long been a puzzle until Prof. Skeat suggested (Ibis, 1870, p. 301) that it signified late, last, or slow, 
of exceedingly wide range in the Old World, apparently breeding where suitable localities are to be found in most European countries from Lapland to Spain and Bulgaria. Eastwards it extends to China, but does not seem to be known in Japan. It is the only species indigenous to the British Islands, and in former days bred abundantly in the English Fen-country, where the young were caught in large numbers and kept in a more or less reclaimed condition with the vast flocks of tame-bred Geese that at one time formed so valuable a property to the dwellers in and around the Fens. It is impossible to determine when the wild Grey Lag Goose ceased from breeding in England, but it certainly did so towards the end of the last century, for Daniel, in or about 1802, mentions (Rural Sports, iii. p. 242) his having once obtained two broods in a season. In Scotland this Goose continues to breed sparingly in several parts of the Highlands and on certain of the Hebrides, the nests being generally placed in long heather and the eggs seldom exceeding five or six in number. It is most likely the birds reared here that are from time to time obtained in England, for at the present day the Grey Lag Goose, though once so numerous, is, and for many years has been, the rarest species of those that habitually resort to the British Islands. The domestication of this species, as Mr. Darwin remarks (Animals and Plants under Domestication, i. p. 287), is doubtless of very ancient date, and yet scarcely any other animal that has been tamed for so long a period, and bred so largely in captivity, has varied so little. It has increased greatly in size and fecundity, but almost the only change in plumage is that tame Geese lose the browner and darker tints of the wild bird, and are invariably more or less marked with white-being often indeed wholly of that colour. ${ }^{1}$ The most generally recognized breeds of domestic Geese are those to which the distinctive names of Emden and Toulouse are applied; but a singular breed, said to have come from Sevastopol, was introduced

as in laggard, a loiterer, lagman, the last man, lagteeth, the posterior molar or "wisdom" teeth (as the latest to appear), and lagclock, a clock that is behind time. Thus the Grey Lag Goose is the Grey Goose which in England when the name was given was not migratory but lagged behind the other wild species at the season when they betook themselves to their northern breeding-quarters. In comnexion with this word, however, nust be noticed the curious fact mentioned by the late Mr. Rowley (Orn. Mriscell. iii. p. 213), that to this day the flocks of tame Geese in Lincolnshire are urged on by their drivers with the cry of "Lag'em, Lag'em."

1 From the time of the Romans white Geese have been held in great estimation, and hence, doubtless, they have been preferred as breeding stock; but the detestable practice of plucking Geese alive, continued for so many centuries, has not improbably also helped to perpetnate this variation, for it is well known to bird-keepers that a white feather is often produced in place of one of the natural colour that has been pulled out. 
into Western Europe about the year 1856. In this the scapulars are elongated, curled, and spirally twisted, having their shaft transparent, and so thin that it often splits into fine filaments, which, remaining free for an inch or more, often coalesce again. ${ }^{1}$

The other British species of typical Geese are the Bean-Goose, A. segetum, the Pink-footed, $A$. brachyrhynchus, and the Whitefronted, $A$. albifrons. On the continent of Europe, but not yet recognized as occurring in Britain, is a small form of the last, $A$. erythropus, which is known to breed in Lapland. All these, for the sake of discrimination, may be divided into two groups-(1) those laving the "nail" at the tip of the bill white, or of a very pale flesh colour, and (2) those in which this "nail" is black. To the former belong the Grey Lag Goose, as well as $A$. albifrons and $A$. erythropus, and to the latter the other two. $A$. albifrons and $A$. erythropus, which hardly differ but in size, - the last being not much bigger than a MALLARD, - may be readily distinguished from the Grey Lag Goose by their bright orange bill and legs, and their mouse-colomred upper wing-coverts, to say nothing of their very conspicuous white face and the broad black bars which cross the belly, though the two last characters are occasionally observable to some extent in the Grey Lag Goose, which has the bill and legs flesh-coloured, and the upper-wing coverts of a bluish-grey. Of the second group, with the black "nail," $A$. segetum has the bill long, black at the base and orange in the middle; the feet are also orange, and the upper wing-coverts mouse-coloured, while $A$. brachyrhynchus has the bill short, bright pink in the middle, and the feet also pink, the upper wing-coverts being nearly of the same bluish-grey as in the Grey Lag Goose. Eastern Asia possesses in A. grandis a third species of this group, which chiefly differs from A. segetum in its larger size. In North America there is only one species of typical Goose, and that belongs to the white-" nailed" group. It very nearly resembles $A$. albifrons, but is larger, and has been described as distinct under the name of $A$. gambeli. Central Asia and India possess in the Bar-headed Goose, $A$. indicus,

1 Want of space forbids our entering on the breeding of tame Geesc, which was formerly so largely practised in some English counties, especially Norfolk and Lincoln. It was no uncommon thing for a man to keep a stock of a thousand, each of which might be reckoned to rear on an average seven Goslings. The flocks were regnlarly taken to pasture and water, just as sheep are, and the man who tended them was called the Gooseherd, corrupted into Gozzerd. The birds were plucked five times in the year, and in antumn the flocks were driven to Londou or other large markets. They travelled at the rate of about a mile an hour, and would get over nearly ten miles in the day. For further particulars the reader may be referred to Pennant's British Zoology; Montagu's Ornithological Dictionary; Latham's General History of Birds; Stevenson's Birds of Norfolk; and Rowley's Ornithologienl Miscellany (iii. pp. 206-215), where some account also may be found of the Goose-fatting at Strassburg. 
a bird easily distinguished from any of the foregoing by the character implied by its English name; but it is certainly somewhat abnormal, and, indeed, nuder the name of Eulabia, has been separated from the genus Anser, which has no other member indigenous to the Indian Region, nor any at all to the Ethiopian, Australian, or Neotropical Regions.

But the New World possesses by far the greatest wealth of Anserine forms. Beside others, presently to be mentioned, its northern portions are the home of all the species of Snow-Geese belonging to the genus Chen. It is true that two of these are reported as having appeared, and that not unfrequently, in Europe and Asia; but they possibly have been but stragglers from Americi. The first of these is C. hyperloreus, the Snow-Goose proper, a bird of large size, and when adult of a pure white, except the primaries, which are black. This has long been deemed a visitor, and sometimes in considerable numbers, to the Old IVorld; but the later

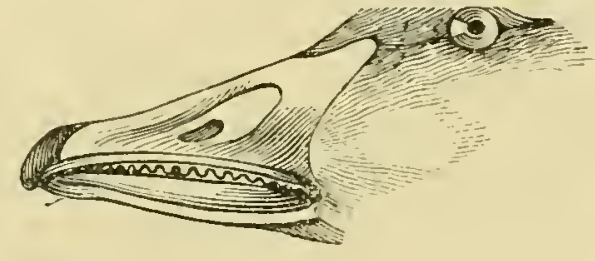

SNOW-GoOsE.

(After Swainson.)

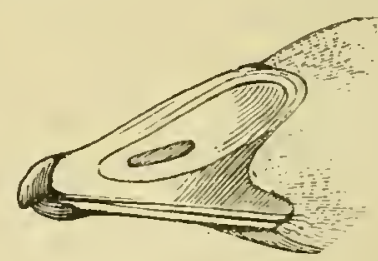

BRANT GOOSE.

diseovery of a smaller form, $C$. albatus, searcely differing except in size, throws some doubt on the older records, especially since examples which have recently been obtained in the British Islands undoubtedly belong to this lesser bird, and it wonld be satisfactory to have the occurrence in the Old World of the true C'. hyperboreus placed on a surer footing. So nearly allied to the species last named as to have been often confounded with it, is the Blue winged Goose, C. camlescens, which is said never to attain a snowy plumage. 'Then we have a very small species, long ago described as distinet by Hearue, the Arctic traveller, but until 1861 discredited by ornithologists. Its distinctness has now been fully recognized, and it has received, somewhat unjustly, the name of C. rossi. Its face is adorned with numerous papille, whence it has been removed by Mr. Elliot to a separate genus, Excunthemops, and for the same reason it has, for more than a century, been known to the Emropean residents in the Fur Countries as the "Horned Wavey" - the last word being a rendering of a native name, IV awa, which signifies Goose. Finally, there appenrs to belong to this section (though it has been frequently referred to another, Chloephogu, and has also been made the type of a distinct gemus, Philacte) the beantiful Painted or Emperor Goose, C. canagica, which is almost peculiar to 
the Aleutian Islands, though straying to the continent in winter, and may be recognized by the white edging of its remiges.

The southern portions of the New World are inhabited by about half-a-dozen species of Geese, akin to the foregoing, but separated as the genus Chloephaga. The most noticeable of them are the Rock- or Kelp-Goose, C. antarctica, and the Upland-Goose, $C$. magellanica. In both of these the sexes are totally unlike in colour, the male being nearly white, while the female is of a mottled brown, but in others a greater similarity obtains. ${ }^{1}$ Very nearly allied to the birds of this group, if indeed that can be justifiably separated, comes one which belongs to the northern hemisphere, and is common to the Old World as well as the New. It contains the Geese which have received the common names of BERNACLE or BrANT, and the scientific appellations of Bernicla and Branta-for the use of either of which much may be said by nomenclaturists. All the species of this section are distinguished by their general dark sooty colour, relieved in some by white of greater or less purity, and by way of distinction from the members of the genus Anser, which are known as Grey Geese, are frequently called by fowlers Black Geese. Of these, the best known both in Europe and North America is the Brant-Goose-the Anas bernicla of Linnæus, and the $B$. torquata of many modern writers-a truly marine bird, seldom (in Europe at least) quitting salt water, and coming southward in vast flocks towards autumn, frequenting bays and estuaries on our coasts, where it lives chiefly on sea-grass (Zostera maritima). It is known to breed in Spitsbergen and in Greenland. A form which is by some ornithologists deemed a good species, and called by them $B$. nigricans, occurs chiefly on the Pacific coast of North America. In it the black of the neck, which in the common Brant terminates just above the breast, extends over most of the lower parts. The true Bernacle-Goose, ${ }^{2}$ the B. leucopsis of most authors, is only a casual visitor to North America, but is said to breed in Iceland, and occasionally in Norway. Its usual incunabula, how: ever, still form one of the puzzles of the ornithologist, and the difficulty is not lessened by the fact that it will breed freely in semi-captivity, while the Brant-Goose will not. From the latter

${ }^{1}$ See Sclater and Salvin, Proc. Zool. Society, 1876, pp. 361-369.

2 The old fable, perhaps still believed by the uneducated in some parts of the world, of Bernacle-Geese being produced from the Bernacles (Lepadida) that grow on timber exposed to salt-water, is not more absurd than many that in darker ages had a great hold of the popular mind, and far less contemptible than the conceited spirit in which many modern zoologists and botanists often treat it. They forget that there are still adherents to the doctrine of spontaneous generation, which seems to be hardly less extravagant than the notion of birds growing from "worms," as they were then called. The mistake of our forefathers is of course evident, but that is no reason for deriding their innocent ignorance as some writers are fond of doing. 
the Bernacle-Goose is easily distinguished by its larger size and white cheeks. Hutchins's Goose, B. hutchinsi, seems to be its true representative in the New World. In this the face is dark, but a white crescentic or triangular patch extends from the throat on either side upwards behind the eye. Almost exactly similar in coloration to the last, but greatly superior in size, and possessing 18 rectrices, while all the foregoing have but 16 , is the common wild Goose of America, B. canadensis, which, for some two centuries or more, has been introduced into Europe, where it propagates so freely that it has been included by nearly all the ornithologists of this quarter of the globe as a member of its fauna. An allied form, by some deemed a species, is $B$. leucopareia, which ranges over the western part of North America, and, though having 18 rectrices, is distinguished by a white collar round the lower part of the neck. The most diverse species of this group of Geese are the beautiful B. ruficollis, a native of North-eastern Asia, which has occasionally strayed to Egypt ${ }^{1}$ and Western Europe, and has been obtained more than once in Britain, and that which is peculiar to the Hawaiian archipelago, B. sandvicensis.

The largest living Goose is that called the Chinese, Guinea, or Swan-Goose, Cygnopsis cygnoides, and it seems to be the stock whence the domestic Geese of several Eastern countries have sprung. It may not unfrequently be seen in English farmyards, and it is found to cross readily with our common tame Goose, the offspring being fertile, and Blyth has said that these crosses are very abundant in India. The true home of the species is in Eastern Siberia or Mongolia. It is distinguished by its upright bearing, which has been well rendered by Bewick's figure. The Ganders of the reclaimed form are distinguished by the knob at the base of the bill, but the evidence of many observers shews that this is not found in the wild race. Of this bird there is a perfectly white breed.

Lastly must be mentioned the curious form CEREOPSIS, with its apparently exaggerated ally the extinct Cnemiornis of New Zealand, a bird of great size and, as said before (p. 82), unable from the shortness of its wings to fly. In connexion with this loss of power may also be noted the dwindling of the keel of the sternum.

Birds of the genera Chenalopex (the Egyptian and Orinoco Geese), Plectropterus, Sarcidiornis, Chlamydochen, and some others, are commonly called Geese. To the writer it seems almost certain that they are allied to the SHELD-DRAKE. The males of all appear to have that curious enlargement at the junction of the bronchial tubes and the trachea which is so characteristic of the Ducks or Anatina and is wanting in the Anserina or true Geese. As much may be said for the genus Nettapks.

${ }^{2}$ Its portraits are recognizable in what is said to be one of the oldest pictures in the world see (InTronuction). 
GORCOCK, a Seottish name for the male of the Red Grousk.

GOS-HAWK, i.e. Goose-Hawk, the Astur palumbarius of ornithologists, and the largest of the short-winged Hawks used in Falconry. Its English name, however, has possibly been transferred to this species from one of the long-winged Hawks, or true Falcons, since there is no tradition of the Gos-Hawk, now so called, having ever been used in Europe to take Geese or other large and powerful birds. The genus Astur may be readily distinguished from Falco by the smooth edges of its beak, its short wings (not reaching beyond about the middle of the tail), and its long legs and toes-

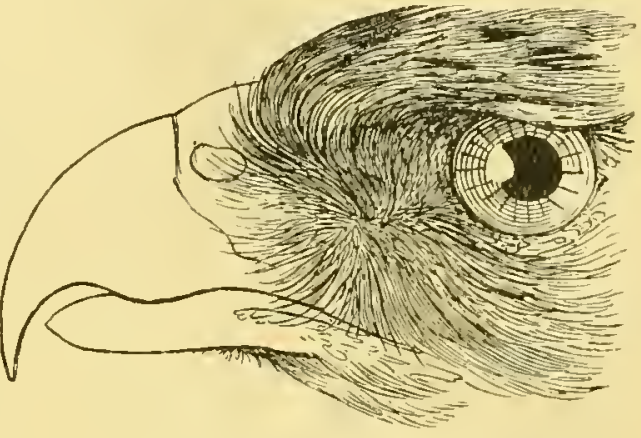

Gos.HAWk. (After Swainson.) thongh these last are stout and comparatively shorter than in the Sparrow-Hawks, Accipiter. In plumage the Gos-Hawk has a general resemblance to the Peregrine FALCON, and it undergoes a corresponding change as it advances from youth to maturity-the young being longitudinally streaked beneath, while the adnlts are transversely barred. The irides, however, are always yellow, or in old bircls orange, while those of the Falcons are dark brown. The sexes differ greatly in size. There can be little doubt that the Gos-Hawk, nowadays very rare in Britain, was once common in England, and even towards the end of the last century Thornton obtained a nestling in Scotland, while Irisli Gos-Hawks were of old highly celebrated. Being strictly a woodland-bird, its disappearance may be safely connected with the disappearance of our ancient forests, though its destructiveness to Poultry and Pigeons has cloubtless contributed to its present seareity. In many parts of the continent of Enrope it still abounds. It ranges eastward to China, and is much valued in India. In North America it is represented by a very nearly allied species, A. atricapillus, chiefly distinguished by the closer barring of the breast. Three or four examples corresponding with this form have been obtained in Britain. A good many other species of Astur (some of them passing into Accipiter) are found in various parts of the world, but the only one that need here be mentioned is the A. nova-hollandia of Australia, which is remarkable for its dimorphism-one form possessing the normal dark-coloured plumage of the genus, and the other being perfectly white, with yellow or red irides. It must be stated, however, that some writers hold these two forms to be distinet species, and call the dark-coloured one $A$. cinereus or $A$. raii.

GOURA, the name (apparently of Eastern origin) applied in 
1776 by Sonnerat (Foy. Nouv. Guince, pl. 104) to the GreatCrowned Pigeon, Columba coronata of Limnæus, given by Stephens in 1819 (Gen. Zool. xi. p. 119) to a genus, and by him and others used also as an English word. The speeies inhabits New Guinea and some of the neighbouring islands, whence it has been frequently brought alive to Europe, and though it has even bred in eaptivity, it has as yet evineed no readiness to domestication, which is to be regretted when we consider its large size and the becoming appearance it makes with its erect crest, its eolouring of lavender-grey with a ehestnut mantle and white wing-pateh, to say nothing of its stately gait. A second and even finer species, $G$. victoria, now known to come from the islands of Jobie and Missorie, was deseribed by Fraser (Proc. Zool. Soc. 1846, p. 136), and since then three, or perhaps four, others, all from the Papuan Subregion, if not from New Guinea itself, have been discovered (Salvadori, Ornitul. Papucs. iii. pp. 191-209). The species of Goura are the largest of the existing Columba.

GOWK (Dan. Gjфg; Norsk. Gjфki; Swed. Göli), a common name of the Ccckow in the northem part of Britain.

GRACKLE (Latin, Gracculus or Graculus, a $\mathrm{DAW}^{\mathrm{l}}$ ), a word which has been much used in ornithology, but generally in a vague sense, though restrieted to members of the Families Sturnida (STARLING) belonging to the Old World, and Icteridx belonging to the New. Of the former those to which it has been most commonly applied are the speeies variously known as Mynas, Mainas, and Minors of India and the adjacent countries, and especially the Gracula religiosa of Limmens, who, aceording to Jerdon and others, was very probably led to confer this epithet upon it by confound-

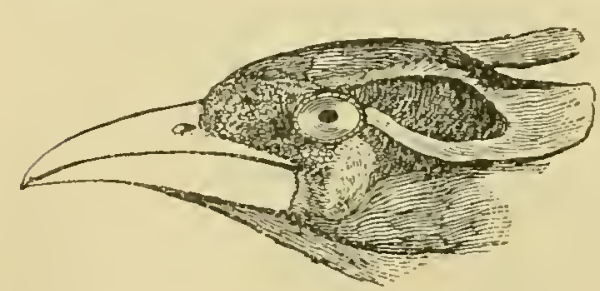

Gracula REligiosa. (After Swainson.) ing it with the Sturnus or Acridotheres tristis, ${ }^{2}$ which is regarded by the Hindus as saered to Ram Deo, one of their deities, while the true Gracula religiosa does not seem to be anywhere held in veneration. This last is about 10 inches in length, elothed in a plumage of glossy black, with purple and green reflexions, and a conspicuous patch of white on the quill-feathers of the wings. The bill is

${ }^{1}$ Some old writers translated Water-Clow, or its equivalent in their own language, by Graculus marinus, whereby Linneus was originally led to make Graculus the name of a genms eontaining the Cormorsit and its like; and tlough he afterwards eorrected the mistake, eertain systematists continued to use the name in its erroneous sense.

2 By some writers the birts of the genera Acridotheres and Temenuchus are considered to be the true Mynas, and the species of Graeula are called "Hill Mynas" by way of distinction. 
orange and the legs yellow, but the bird's most characteristic feature is afforded by the curious caruncles of bright yellow, which, beginning behind the eyes, rm backward in form of a lappet on each side, and then return in a narow stripe to the top of the head. Beneath each eye also is a bare pateh of the same colour. This speeies is common in southern India, and is represented further to the north, in Ceylon, Burma and some of the Malay Islands by cognate forms. They are all frugivorous, and, being easily tamed and learning to pronounce words very distinctly, are favourite eage-birds. In Africa they are perhaps represented by a somewhat similar genus, which anthors generally continue to call Dilophus,

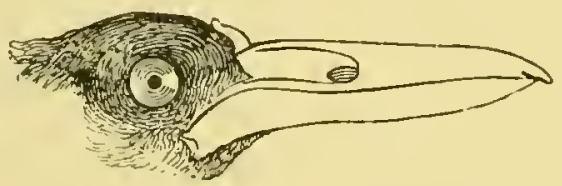

Creatopliora carunculata.

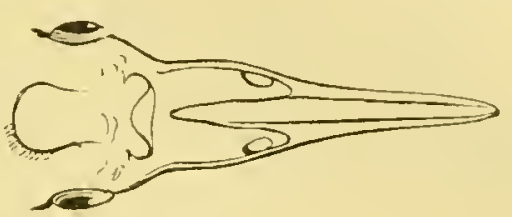

(After swainson.)

though that name has long been preoccupied." There is but one species, the Creatophora carmenlata of Lesson (Descr. Mammif. et Ois. p. 308), the common Locus'r-Bird of South Africa.

In the New World the name Grackle has been applied to several speeies of the genera Scolecophagus and Quiscalus, though these are more commonly called in Canada and the United States "Blackbirds," or Maize-birds, and some of them "Boat-tails." They all belong to the Family Icterida. The best known of these are the Rusty Grackle, S. ferrugineus, which pervacles almost the whole of North America, and Q. purpureus, the Purple Grackle or Crow-Blackbird, of more limited range, for though abundant enough in most parts to the east of the Rocky Mountains, it seems not to appear on the Pacific side. There is also Brewer's or the Blue-headed Grackle, S. cyanocephalus, which has a more western range, not occurring to the eastward of Kansas and Minnesota, while a fourth species, Q. major, is found to inhabit the Atlantic States as far as North Carolina. All these birds are of exceedingly omnivorous habit, and though nndoubtedly destroying large numbers of pernicious insects are in many places held in bad repute from the mischief they do to the corn-crops (see ICTERUs).

GRALL Æ, the fourth Order of Birds in the Linnaean system, composed of the genera Phenicopterus (Flaungo), Platalea (SPoonBILL), Palamedea (SCREAner), Mycteriu (JABiru), Tantalus (IBIS), Ardea (Heron), Recurvirostru (Avosti), Scolopax (Woodock ),

1 Ditophus was used for a genus of Dipterce in 1803 by Meigen (Mag. $f$. Insektenk. ii. p. 264). The bird was originally described by Walch in 1777 (Naturf. xi. 1.9) as a Tringa! It is the Cockscomb Stare of Latham (Synops. ii. p. 8). 
Tringa (SANdpiper), Fulica (Coot), Parra (JaCANa), Rallus (Rail), Psophia (Trumpeter), Cancroma (BoAt-Bill), Hæmatopus (OYsterCatcher), Charadrius (Plover), Otis (Bustard), and Struthio (OSTRICH).

GRALLATORES, Illiger's modification (in 1811) of the preceding, dividing it into 8 Families and 32 genera. For some fifty years this arrangement met in its main points with pretty general acceptance, but systematists at last came to the conclusion that the Order was an unnatural assemblage, and the name Grallatores is now scarcely used by any writers of authority.

GRALLINA, a genus founded by Vieillot in 1816 (Analyse, p. 42), for what he thought was a new form of bird from New Holland, G. melanoleuca; but it had been already twice described in 1802 by Latham (Gen. Synops. Suppl. ii. pp. 117 and 130, and Ind. Orn. Suppl. pp. 25, 29) as Corrus cyanoleucus and Gracula picata, and again in 1811 by Oppel, who also figured it (Dentischr. Akad. bayer. Wissensch. iii. pp. 156-166, pl. viii.) as a new genus and species, Tanypus australis. This generic term being preoccupied, Vieillot's has to be adopted, and it has been accepted as an English word. Placed as it had been among Crows, Grackles, and Thrushes, Gould shewed great discrimination (Handb. B. Austral. i. 187) in not referring it to any group; but Dr. Sharpe (Cat. B. Br. Mus. iii. p. 272) assigned it to Prionopida, even then a doubtful position and a doubtful Family; and Dr. Gadow has since ascertained that its vocal organs are not those of the normal Oscines.

Grallina picata is generally dispersed over Australia, where it is known as the Magpie-Lark, frequenting the alluvial plains and sides of rivers, but being of a familiar disposition and constantly visiting homesteads, when it is said to run along the roofs like a Wagtail. Gould describes its flight as unlike that of any other bird known to him, being "in a straight line with a heavy flapping motion of the wings." It builds a large cup-like nest of mud or earth, more or less mixed with grass, so as to look like a massive clay vessel, and this is generally placed on a bare horizontal branch, without attempt at concealment, though sometimes a few twigs or leaves partially hide the structure. The eggs, 3 or 4 in number, vary considerably in tint and markings (North, Cat. Nests and Eggs, B. Austral. p. 79). This bird seems to be purely insectivorous. A second species, G. bruijni, has been described from New Guinea (Salvadori, Ann. Genov. vii. p. 929).

GRAPE-EATER, a name given in Australia to one or more of the species of ZOSTEROPS.

GRASS-BIRD, a general name in America, from Canada to the Antilles, for the smaller SANDPIPERS, or some of them at least; but 
applied by Gould (Handb. B. Austral. i. pp. 399, 400) to two. species of Australian birds which he referred to the genus Sphenocacus of Strickland (Proc. Zool. Soc. 1841, p. 28), the type of which is the Motacilla africana of Gmelin and bird known in the Cape Colony as "Idle Jack" and "Lazy Dick" (Layard, B. S. Afr. p. 96). Other species from various localities, and especially one: from New Zealand, where it is known as the Fern-bird, have been assigned to the same genus, but whether rightly or not remains to be shewn. One of the Australian species, $S$. gramineus, has been generically separated by Prof. Cabanis as Poodytes. Dr. Sharpe (Cat. B. Br. Mus. vii. p. 93) includes Sphencacus among the Timeliidæ, but any attempt to arrange these birds must at present be guesswork, and it is quite likely that their association is due only to their outward resemblance. They mostly have their tailfeathers stiff in the shaft and the webs not connected; the plumage above is striated, and they skulk in thick grass so as to be seldom seen, flying but a short way when forced to take wing.

GRASS-QUIT, applied in Jamaica to some species of the genus Phonipava, or, as some have it, Euethia, apparently belonging to the Family Emberizida, one of which, $P$. bicolor, of wide range in the Antilles, shews itself in Florida.

GRAUCALUS, Cuvier's name for a genus of birds, to which have been assigned a score of species, found from West Africa eastward to the coast of China in the north and Tasmania in the south, while one occasionally strays to New Zealand, and for those inhabiting Australia the name has been Anglified by Gould. The genus is generally referred to the Campephayidx; but its position must be regarded as uncertain. The Australian species are said to be subject to several changes of plumage, that of the young, assumed after leaving the nest, differing as much from that of the nestling as from that of the adult; but as a rule the plumage is mostly grey, diversified by black and white.

GRAY (Icelandic Graind), a name of the GaDwall (Willughby, Orn. (Lat.) p. 287) now perhaps obsolete.

GREBE (French Grebe), the generally accepted name for all the birds of the Family Podicipedidx, ${ }^{1}$ belonging to the group Pygopodes of Illiger, members of which inhabit almost all parts of the world. Some systematic writers have distributed them into several so-called genera, but, with one exception, these seem to be insufficiently defined, and here it will be enough to allow but two-Podicipes and

1 Often, but erroneously, written Podicipidx. The word Podiceps, as commonly spelt, being a contracted form of the original Podicipes ( $c f$. Gloger, Journai fü Ornithologie, 1854, p. 430, note), a combination of podex, podicis, and pes. pedis, its further compounds must be in accordance with its derivation. 
the Centropelmo of Messi's. Sclater and Salvin. Grebes are at once distinguishable from all other Water-birds by their very short body, and the peculiar structure of their feet, which are not only pliced far behind, but have the tarsi flattened and elongated toes furnished with broad lobes of skin.

In Enrope we have five well-marked species of Podicipes, the commonest and smallest of which is the very well-known DABCHICK of our ponds, P. Anviatilis or minor, found throughont the British Islands, and with a wide range in the Old World. Next in size are

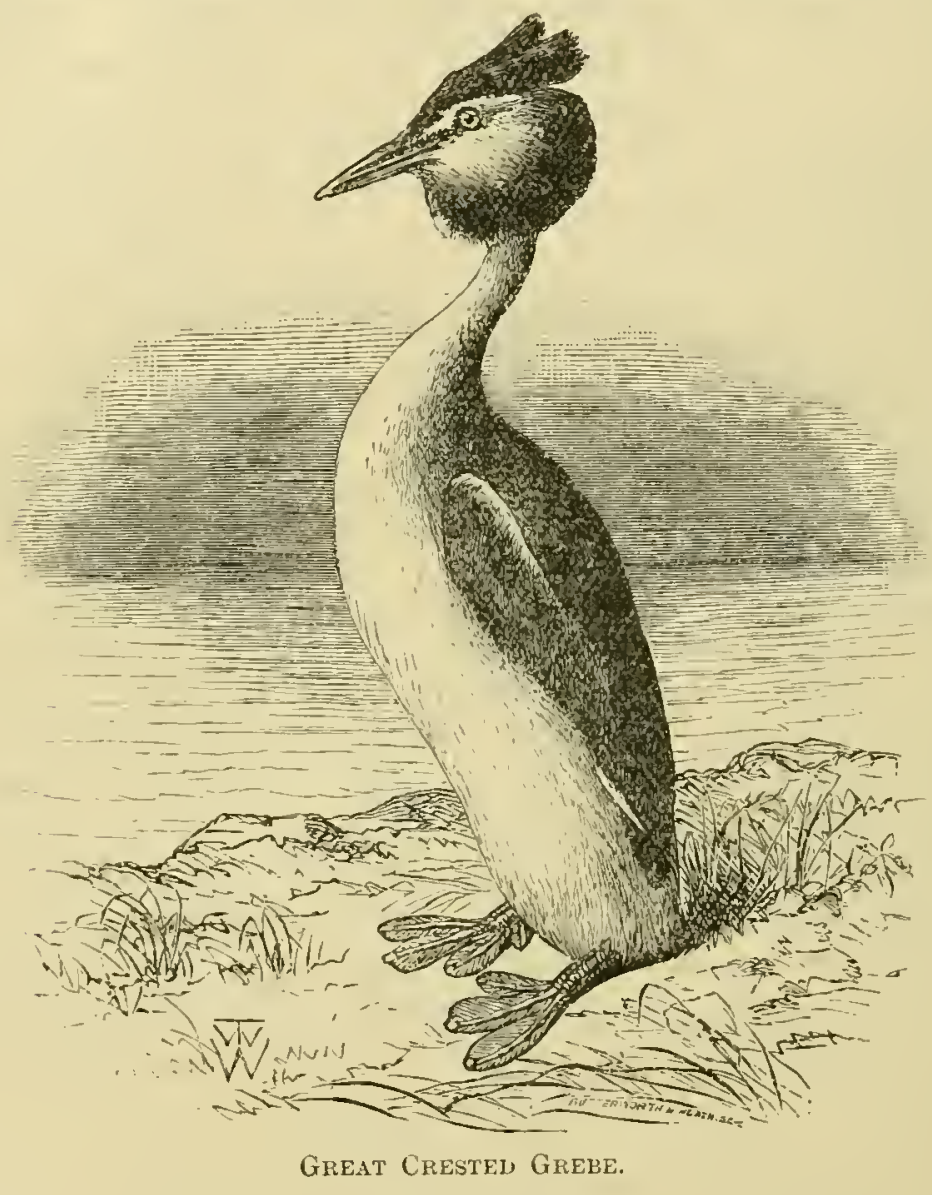

two species known as the Eared and Horned Grebes, the former of which, $P$. nigricollis, is a visitor from the south, only occasionally shewing itself in Britain, while the latter, $P$. unitus, has a more northern lange, breeding plentifully in Iceland, and is a not uncommon winter-visitant. Then there is the larger Red-necked Grebe, P. griseigena, also a northern bird, and a native of the subaretic parts of both Europe and America, while lastly the Great Crested Grebe, P. cristatus, or Gannt-known as the Loon on the meres and broads of East Anglia, ${ }^{1}$ and some other parts of England, is also widely spread over both Worlds; and, though apparently

${ }^{1} \mathrm{Cf}$. Stevenson and Southwell, Birds of Norfoll, iii. pp. 233-254. 
not found within the tropics, is known in the extreme sonth as a native of Australia and New Zealand. North America is credited with seven species of Grebes, of which three ( $P$. cristatus, $P$. griseigena, and $P$. auritus) are admitted to be specifically inseparable from those already named, and two ( $P$. occidentalis and $P$. californicus) appear to be but local forms; the remaining two, $P$. dominicus and $P$. ludovicianus, may, however, be accounted good species, and the last differs so much from other Grebes that many systematists make it the type of a distinct genus, Podilymbus. South America seems to possess four or five more species, one of which, the $P$. micropterus of Gould (Proc. Zool. Soc. 1858, p. 220), has been separated from the genus Podicipes by Messrs. Sclater and Salvin (Exot. Ornithology, p. 189 , pl. xcv.), owing to the form of its bill, and the aborted condition of its wings, which seem to render it absolutely flightless. Lake Titicaca in Bolivia is, so far as is known at present, its only habitat. Grebes in general, though averse from taling wing, have much greater power of flight than would seem possible on examination of their alar organs, and are capable of prolonged aerial journeys. Their plumage is short and close. Abore it is commonly of some shade of brown, but beneath it is invariably white, and so glossy as to be in much request for muffs and the trimming of ladies' dresses. Some species are remarkable for the crests or tippets, generally of a golden-chestnut colour, they assume in the breeding season. $P$. auritus is particularly remarkable in this lespect, and when in its full nuptial attire presents an extraordinary aspect, the head (being surrounded, as it were, by a nimbus or aureole, such as that with which painters adorn saintly characters), reflecting the rays of light, and glittering with a glory that passes description. All the species seem to have similar habits of nidification. Water-weeds are pulled from the bottom of the pool, and piled on a convenient foundation, often a seminatant growth of bogbean (Menyanthes), till they form a large mass, with a shallow cup in the centre, wherein the eggs, with a chalky white shell almost equally pointed at each end, are laid-the parent covering them, whenever she has time to do so, before leaving the nest. Young Grebes are beautiful objects, clothed with black, white, and brown hair, disposed in streaks, and their bill is often brilliantly tinted with orange or yellow. When taken from the nest and placed on dry ground, it is curious to observe the way in which they progressnsing the wings almost as fore-feet, and suggesting the notion that they must be quadrupeds instead of birds (Ibis, 1889, p. 577). In water, however, they equal if not surpass their parents in the power of diving, which is a special accomplishment of all Grebes.

GREENFINCH (German Grünfint) or Green Linnet, as it is very often called, a common European bird, the Fringilla chloris of 
Limnæus, ranked by many systematists with one section of HAwFINCHES, Coccothrustes, but apparently more nearly allied to the other section Hesperiphona, and perhaps justifiably deemed the type

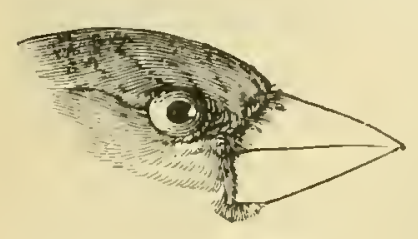

GREENFINCH. (After Swainson.) of a distinct genus, to which the name Ligurinus or Chloris has been applied. The cock, in his plumage of green and gold, is among the most finely coloured of onr common birds, but he is rather heavily built, and his song is hardly to be praised. The hen is much less brightly tinted. Throughont Britain, as a rule, this species is one of the most plentiful, and is found at all seasons of the year. It pervades almost the whole of Europe, and in Asia reaches the river Ob. It visits Palestine, but is unknown in Egypt. It is, however, abundant in Mauritania, whence specimens are so brightly coloured that they have been deemed to form a distinct species, the Ligurinus aurcutiventris of Dr. Cabanis, bnt that view is now generally abandoned. In the north-east of Asia and its adjacent islands occur two allied species-the Fringilla sinica of Linnwens, and the F. kuwarahiba of Temminck. No species of Greenfinch is found in America; but what seems to be an exaggerated form, differentiated as a distinct genus, Chloridops, has been described from Hawaii in the Sandwich Islands (Proc. Zool. Soc. 1S88, p. 21S).

GREENLEEK, according to Gould, the local name in New Sontl Wales of Palaornis or Polytelis barrabandi, the scarlet-breasted ParRakeEt.

GREENLET, a word originating apparently with Swainson in 1831 (Faun. Bor.-Am. ii. p. 233) as an English rendering of VIREo, and not uncommonly used in America for birds of that genus and its allies.

GREENSHANK, one of the largest of the birds commonly known as Sandpipers, the Totamus glottis ${ }^{1}$ of most ornithological writers. Some exercise of the imagination is, however, needed to see in the dingy olive-coloured legs of this species a justification of the English name by which it goes, and the application of that name, which seems to be due to Pennant, was probably by way of distinguishing it from two allied but perfectly distinct species of Totonus (T. catidris and T. fuscus), having red legs and usually called Redshanks. The Greenshank is a native of the northern parts of the Old World, but in winter it wanders far to the sontl, and occurs regularly at the Cape of Good Hope, in India, and thence

1 There scems no reason to dispute the applieation of this specifie name by Limnæus, who may be pardoned for recognizing the well-known Glutt of lis own country in the Glottis of elassical anthors, since Belon and Gesner saw in the latter some kind of aquatic bird. Sundevall has, however, shewn that the $\gamma \lambda \omega r$ ris of Aristotle was a Wrineck. 
throughout the Indo-Malay Archipelago to Australia. It has also been recorded from North America, but its appearance there must be considered accidental. Almost as bulky as a Woodcock, it is of a much more slender build, and its long legs and neck give it a graceful appearance, which is enhanced by the activity of its actions. Disturbed from the moor or marsh, where it has its nest, it rises swiftly into the air, conspicuous by its white back and rump, and uttering shrill cries flies round the intruder. It will perch on the topmost bough of a tree, if a tree be near, to watch his proceedings, and the cock exhibits all the astounding gesticulations in which the males of so many other Limicola indulge during the breeding-season - with certain variations, however, that are peculiarly its own. It breeds in no small numbers in the Hebrides, and parts of the Scottish Highlands from Argyllshire to Sutherland, as well as in the more elevated or more northern districts of Norway, Sweden, and Finland, and probably also from thence to Kamchatka. In North America it is represented by two species, Totanus semipalmatus and 'T' melanoleucus, there called Willets, Telltales, or Tattlers, which in general habits resemble the Greenshank of the old World.

GREYBACK, in England a common name of the Grey form of Crow, Corvus cornix; but in North America applied by gunners to the KNoт.

GREYHEN, the female of the Blackcock or Black GrousE.

GRIFFON (Fr. Griffon, Lat. Gryphus, Gr. ypú -a fabulous monster with a hooked beak, an Eagle's wings, and a Lion's body) the name applied in 1666 by certain French academicians to a VULTURE, which they dissected, and continued by Buffon for what is now known as Gyps fulvus, being finally adopted as its English distinctive name by Bemett in 1831 (Gard. and Menag. Zool. Soc. ii. p. 97$){ }^{1}$

GRINDER, one of the names given in Australia to Sisura inquieta, a form very similar to Rhipidura (FANTAIL) and like that generally assignied to the Muscicapidx (FLYCATCHER). Caley noticed (Trans. Linn. Soc. xv. p. 250), the resemblance of the noise made by this bird, though how it is produced is not said, to that caused by a razor-grinder at work, and Gould adds (Handb. B. Austral. i. p. 247), on Gilbert's authority, that its general note is a loud harsh cry, several times repeated, but it also utters a clear whistle. Its flight is very remarkable, and its habit of hovering, at which time is cansed the sound that gives it this name, very peculiar.

GROSBEAK (French, Grosbec), a name very indefinitely applied

I The Griffin of heraldry is the same word, but that is represented with Batlike wings. 
to many birds belonging to the Families Fringillida and Ploceida of modern ornithologists, and perhaps to some members of the Emberizidx and Tanagride, but always to birds distinguished by the great size of their bill. Taken alone it is commonly a synonym of HAwFinch, but a prefix is most usually added to indicate the species, as Pine-Grosbeak, Cardinal-Grosbeak, and the like. By earlier writers the word was generally given as an equivalent of the Linnæan Loxia, but that genus, as first established, has been found to include many forms which, according to more recent notions, cannot possibly be placed in the same Family.

The Pine-Grosbeak, Pinicola enucleator, is, with the exception of the Hawfinch just mentioned, the best known species to which the name is applied. It inhabits the conifer-zone of both the Old and the New Worlds, seeking, in Europe and probably elsewhere, a lower latitude as winter approaches - often journeying in large flocks; and stragglers are said to have occasionally reached the British Islands, though the records of not more than four or five such occurrences can be trusted (Yarrell, Br. Birds, ed. 4, ii. pp. 177-179). In structure and some of its habits much resembling a Bullfinch, but much exceeding that bird in size, it has the plumage of a Crossbicl, and appears to undergo exactly the same changes as do the members of the restricted genus Loxia,-the young being of a dull greenish-grey streaked with brownish-black, the adult hens tinged with golden-green, and the cocks glowing with crimson-red on nearly all the body-feathers, this last colour being replaced after moulting in confinement by bright yellow. Nests of this species were found in 1821 by Zetterstedt near Juckasjärvi in Swedish Lapland, but little was really known with certainty concerning its nidification until 1855 , when the late $\mathrm{Mr}$. Wolley, after two years' ineffectual search, succeeded in obtaining in the not very distant district of Muonioniska well-authenticated specimens with the eggs, both of which are like exaggerated Bullfinches' (Hewitson, Eggs Br. B. ed. iii. p. 210*, pl. liii.*). The food of this species seems to consist of the seeds and buds of many sorts of trees, though the staple may very possibly be those of some kind of pine. The cock has a clear and pleasing song, which makes him in many countries a favourite cage-bird; and the notes of the hen may even be deemed to qualify her as a musician of no small merit.

Allied to the Pine-Grosbeak are a number of species of smaller size, but its equals in beauty of plumage. ${ }^{1}$ These have been referred to several genera, such as Carpodacus, Propasser, Bycanetes,

1 Many of them are described and beautifully figured in the Monographie des Loxiens of Bonaparte and Schlegel (Leyden and Disseldorf : 1850), a work which includes, however, all the Crossbills, Redpolls, and Linnets then known to the authors, while it excludes many birds that an English writer would have to call "Grosbeaks." 
Uragus, and others; but possibly Carpodacus is sufficient to contain all. Most of them are natives of the Old World, and chiefly of its eastern division, but several inhabit the western portion of North America, and one, C. githagineus (of which there seem to be at least two local races), is an especial native of the deserts, or their borders, of Arabia and North Africa, extending even to some of the Canary Islands - a singular modification in the habitat of a form which one would be apt to associate exclusively with forest trees, and especially conifers. Other species of the Old World, though commonly called "Grosbeaks," certainly belong to the Ploceida (WEAVER-BIRD).

The CardiNal Grosbeak, or Virginian Nightingale of many writers, Cardinalis virginianus, claims notice here, though doubts may be entertained as to the Family to which it really belongs. No less remarkable for its bright carmine attire, and the additional embellishment of an elongated crest of the same colour, than for its fine song, it has been an object of attraction almost ever since the settlement of its native country by Europeans. All American ornithologists speak of its easy capture and its ready adaptation to confinement, which for nearly three centuries have helped to make it a popular cage-bird on both sides of the Atlantic. The rocal powers possessed by the cock are to some extent shared by the hen, though she is denied the vivid hues of her partner, and her plumage, with exception of the wings and tail, which are of a dull red, is light olive above and brownish-yellow beneath. It is represented in the south-west of North America by other forms that by some writers are deemed species, and in the northern parts of South America by the C.phoniceus, which would really seem entitled to distinction. Another kindred bird, placed from its short and broad bill in a different genus, and known as Pyrrhuloxic sinuata or the Texan Cardinal, is found on the southern borders of the United States and in Mexico; while among North-American "Grosbeaks" must also be named the birds belonging to the genera Guiraca and Hedymeles-the former especially exemplified by the beautiful blue $G$. crerulea, and the latter by the brilliant rosebreasted $H$. ludovicianus, which last extends its range into Canada.

This may be the fittest place to mention a small but interesting group of birds containing the genera Geospiza, Comarhynchus and Cactornis, some of which are truly Grosbeaks in the literal meaning of the name. They are peculiar to the Galapagos, where they were discovered by Mr. Darwin, who in his Joumal of Researcles (chap. xvii.) dwelt on the "perfect gradation in the size of the beak" in the different species of Geospiza, shewn here by the figures inserted. It is indeed curious to find the beak, generally considered to be the most useful and important feature of a bird's organization, subject to so much variation in closely-allied species, living, so far as we 
know, under very similar conditions. Nine species of Geospiza have been described, five of Camarhynchus and four of Cactornis. All these birds have a sombre coloration, in many deepening to a pitch-black. Further particulars respecting them are to be found in the Zoology of the Voyage of the 'Beagle," and in Mr. Salvin's paper "On the Avifamia of the Galapagos Archipelago" (Trans. Zool. Soc. ix. pp. $447-510$ ), from which last the accompanying illustrations are borrowed.

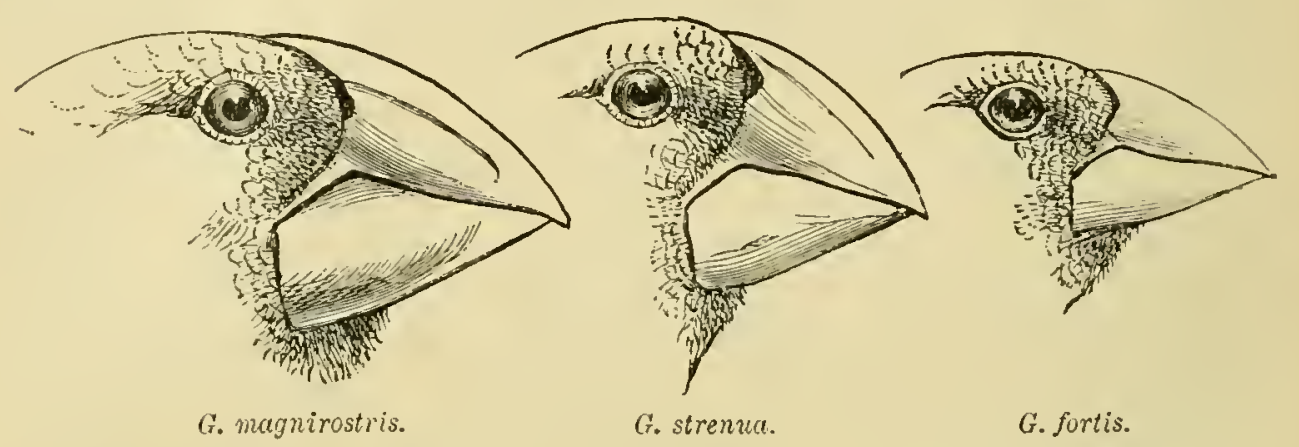

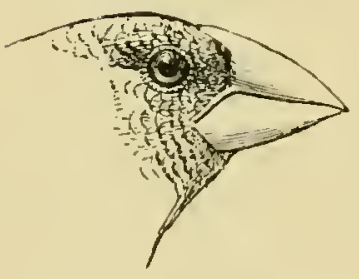

G. fortis.

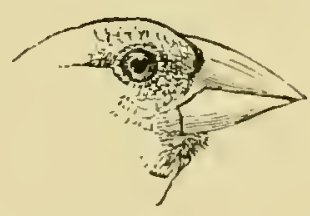

G. fuliginosu.

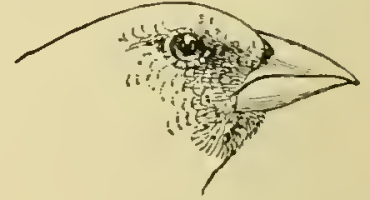

G. parvula.

SERIES OF ForMS of GeospizA.

(From the Transactions of the Zoological Society.)

GROUND-THRUSH, a name long ago used for birds of the genus Pirta and its allies (Jerdon, B. Ind. i. p. 502); but latterly an attempt has been made (Cat. B. Br. Mus. v. p. 147) to foist it on a composite group of some 40 species of THRUsHes which have been referred to a ghost-like genus Geocichla, the characters and type of which contime to defy discovery. ${ }^{1}$

GROUSE, a word of uncertain origin, ${ }^{2}$ now used generally by ornithologists to include all the "rough-footed" Gallinaceous birds,

1 The assertion (loc. cit.) that Kuhl, to whom the establishment of this supposed genus is attributed, founded it "in some popular Dutch periodical," is unconfirmed by evidence, and is contradicted by all we know of his strictly scientific practice.

${ }^{2}$ It seems first to occur ( fide O. Salusbury Brereton, Archaologia, iii. p. 157) as "Grows" in an ordinance for the regulation of the royal household dated "apud Eltham, mens. Jan. 22 Hen. VIII." (i.c. 1531), and considering the locality must refer to Black game. It is found in an Act of Parliament 1 Jac. I. cap. $27, \S 2$ (i.e. 1603), and, as reprinted in the Statutes at Large, stands as now 
but in common speech applied almost exclusively, when used alone, to the Tetrao scoticus of Linnæus, the Lagopus scoticus of modern systematists-more particularly called in English the Red Grouse, but not a century ago almost invariably spoken of as the Moor-fowl or Moor-game. The effect which this species is supposed to have on the British legislature, and therefore on history, is well known, for it is the common though mistaken belief that parliament in these days always rises when the season for Grouse-shooting begins ; but even of old time it seems to have excited on one occasion a curious kind of influence, for we may read in the Orkneyinga Saga (ed. Jonæus, p. 356 ; ed. Anderson, p. 168) that events of some importance in the annals of North Britain followed from its pursuit in Caithness in the year 1157. The Red Grouse is found on moors from Monmouthshire and Derbyshire northward to the Orkneys, as well as in most of the Hebrides. It likewise inhabits similar situations throughout Wales and Ireland, but it does not naturally occur beyond the limits of the British Islands, ${ }^{1}$ and is the only species among birds absolutely peculiar to them. The word "species" may in this case be used advisedly; since the Red Grouse invariably "breeds true," it admits of an easy diagnosis, and it has a definite geographical range; but scarcely any zoologist who looks further into the matter can doubt of its common origin with the Willow-Grouse, Lagopus albus (L. subalpinus or L. saliceti of some authors), ${ }^{2}$ that inhabits a subarctic zone from Norway across the whole continent of Europe and Asia, as well as North America from the Aleutian Islands to Newfoundland. ${ }^{3}$ The Red Grouse indeed is rarely or never found away from the heather on which chiefly it subsists, and with which it is in most men's minds associated; while the Willow-Grouse in many parts of the Old World seems to prefer the shrubby growth of berry-bearing plants

commonly spelt, but by many writers or printers the final $e$ is now omitted. In 1611 Cotgrave had "Poule griesche. A Moore-henne; the henne of the Grice [in ed. 1673 "Griece"] or Mooregame" (Dictionarie of the French and English Tongucs, sub voce Poule). The most likely derivation seems to be from the old French word Griesche, Greoche, or Griais (meaning speckled, and cognate witl griseus, grisly or grey), which was applied to some kind of Partridge, or according to Brunetto Latini (Trés. p. 211) to a Quail, "porce que ele fu premiers trovée en Grece" !

1 It was successfully, though with much trouble, introduced by Baron Dickson, on a tract of land near Gottenburg in Sweden (Svenska Jägarförbundets Nya Tidskrift, 1868, p. 64 et alibi), and seemed likely to maintain itself there, so long at least as the care hitherto bestowed upon it is continued; but of its present condition I know nothing.

3 It is to this species that belong, almost without exception, the thousands of birds sold in our markets as "Ptarmigan."

${ }^{3}$ Examples from Newfoundland have been described (Auk, 1884, p. 369) as forming a "subspecies," L. alleni. 
(Vuccinium and others) that, often thickly interspersed with willows and birches, elothes the higher levels or the lower mountain-slopes, and it contrives to flourish in the New World where heather scarcely exists, and a "heath" in its strict sense is unknown. It is true likewise that the Willow-Gronse always becomes white in winter, which the Red Grouse never does; but then we find that in summer there is a considerable resemblance between the two species, the cock Willow-Grouse having his head, neck, and breast of the same rich chestnut-brown as his British representative, and, though his back be lighter in colour, as is also the whole plumage of his mate, than is found in the Red Gronse, in other

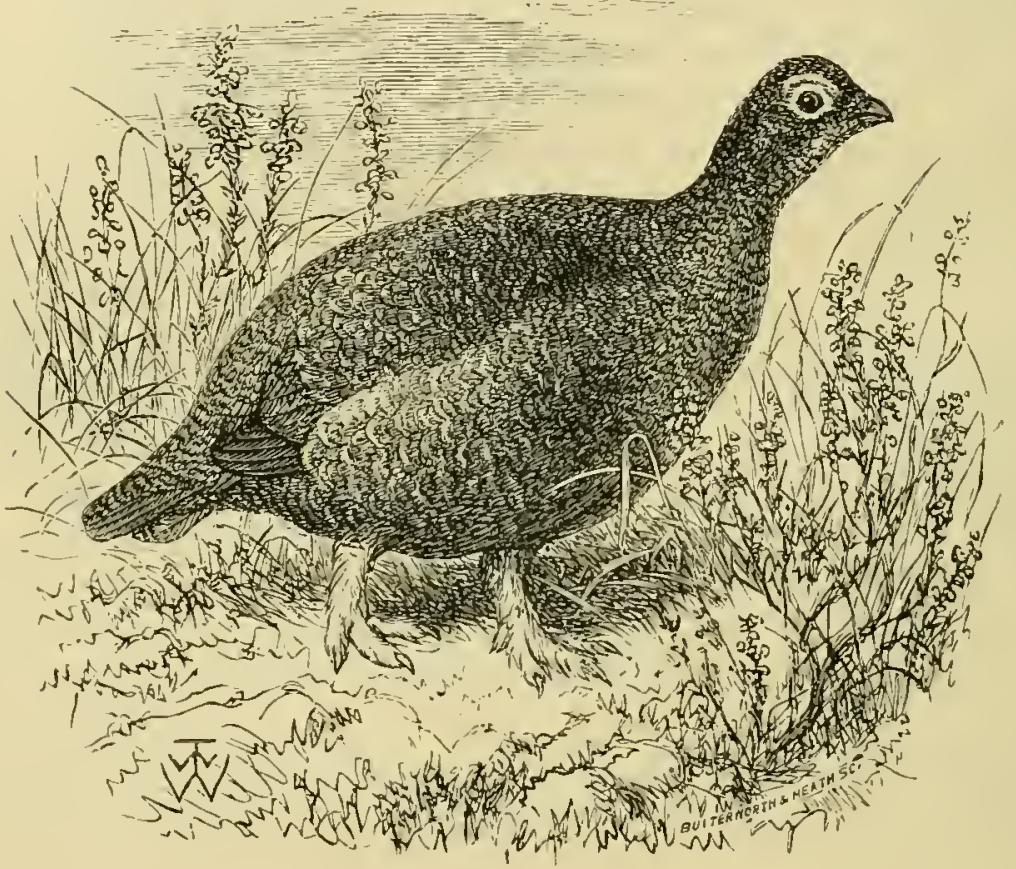

REy Groust.

respects than those named above the two species are precisely alike. No distinction can be discovered in their voice, their eggs, their build, nor in their anatomical details, so far as these have been investigated and compared. In comnexion too with this matter it should not be overlooked that the Red Gronse, restricted as is its range, varies in colour not inconsiderably, and game-dealers of experience assert that they are able to pronounce at sight the native district of almost any bird that comes to their hands. ${ }^{1}$

1 A very interesting subject for discussion would be whether Lagopus scoticus or $L$. albus has varied most from the common stock of both. I can here but briefly indicate the more salient points that might arise. Looking to the fact that the former is the only species of the genus which does not assume white clothing in winter, an evolutionist might at first deem the variation greatest in its case; but then it must be borne in mind that the species of Lagopus which 
Other peculiarities of the Red Grouse-the excellence of its flesh, and its economic importance, which is perhaps greater than that of any other wild bird in the world-hardly need notice here, and there is not space to dwell upon that dire malady to which it is from time to time subject, primarily induced, in the opinion of many, by the overstocking of its haunts and the propagation of diseased offspring by depauperized parents. ${ }^{1}$

turn white differ in that respect from all other groups of the Family Tetraonidx. Furthermore it must be remembered that every species of Lagopus (even $L$. leucurus, the whitest of all) has its first set of remiges coloured brown. These are dropped when the bird is about half-grown, and in all the specics but $L$. scoticus white remiges are then produced. If therefore, as is generally held, the successive phases assumed by any individual animal in the course of its progress to maturity indicate the phases through which the species has passed, there may have been a time when all the species of Lagopus wore a brown livery even when adult, and the white dress clonned in winter has been imposed upon the wearers by causes that can be easily suggested, for it has been freely admitted by naturalists of all schools that the white plumage of the birds of this group protects them from danger during the snows of a protracted winter. On the other liand, it is not at all inconceivable that the Red Grouse, instead of perpetuating directly the more ancient properties of an original Lagopus that underwent no great seasonal change of plumage, may derive its ancestry from the widelyranging Willow-Grouse, which in an epoch comparatively recent (in the geological sense) may have stocked Britain, and left descendants that, under conditions in which the assumption of a white garb would be almost fatal to the preservation of the species, have reverted (hough doubtless with some modifications) to a comparative immutability essentially the same as that of the primal Lagopus.

That Red Grouse, especially when in full winter-plumage-a fact of import in regard to what has just been said-are subject to greater variability than most species of birds has been proved by Mr. Buckley (Proc. Zool. Soc. 1882, pp. 112. 116), and moreover that this variability does not wholly depend on locality as bad been frequently surmised, for he found that birds differing most remarkably from each other occurred on the same ground or were at least near neighbours. Having seen his series of specimens, I can state that he has not exaggerated the variations they present, which are far greater than between those offered by some of the so-called local forms of Lagopus. On the other hand, a general uniformity seems to pervade Irish examples, as a large number submitted to me by Mr. A. G. More shews. Indeed Irish specimens could be picked out by the practised eye ahmost withont fail from their plnmage being duller and more snuff-colonred (if the phrase be allowable). This hue is occasionally seen in English birds, but not to my knowledge in Scottish, thongh I shonld not be surprised if it were to occur. Whether the fact, as I take it to be, can be correlated with the more equable climate which the sister-island enjoys, I do not pretend to say, but the consideration seems worthy of attention. Several varieties and hybrids are figured in Mr. Millais's Game Birds and Shooting Sketches (London : 1892).

${ }^{1}$ On the Gronse-disease the papers of Prof. Young in Proc. Nat. Hist. Soc. Glasgow, i. p. 225, and Dr. Farquharson, Edinb. Med. Journal, No. 263, p. 222, may be consulted; but especially Dr. Klein's Reports in The Ficld (23 July 1887 and 15 June 1889, and his work on the subject (London : 1892). 
Though the Red Grouse does not, after the manner of other members of the genus Lagopus, become white in winter, Scotland possesses a species of the genus which does. This is the PTarMIGAN, ${ }^{1}$ L. mutus or $L$. alpinus, which differs far more in structure, station, and habits from the Red Gronse than that does from the Willow-Grouse, and in Scotland is far less abundant, haunting only the highest and most barren mountains. It is said to have formerly inhabited both Wales and England, but there is no evidence of its appearance in Ireland. On the continent of Europe it is found most numerously in Norway, but at an elevation far above

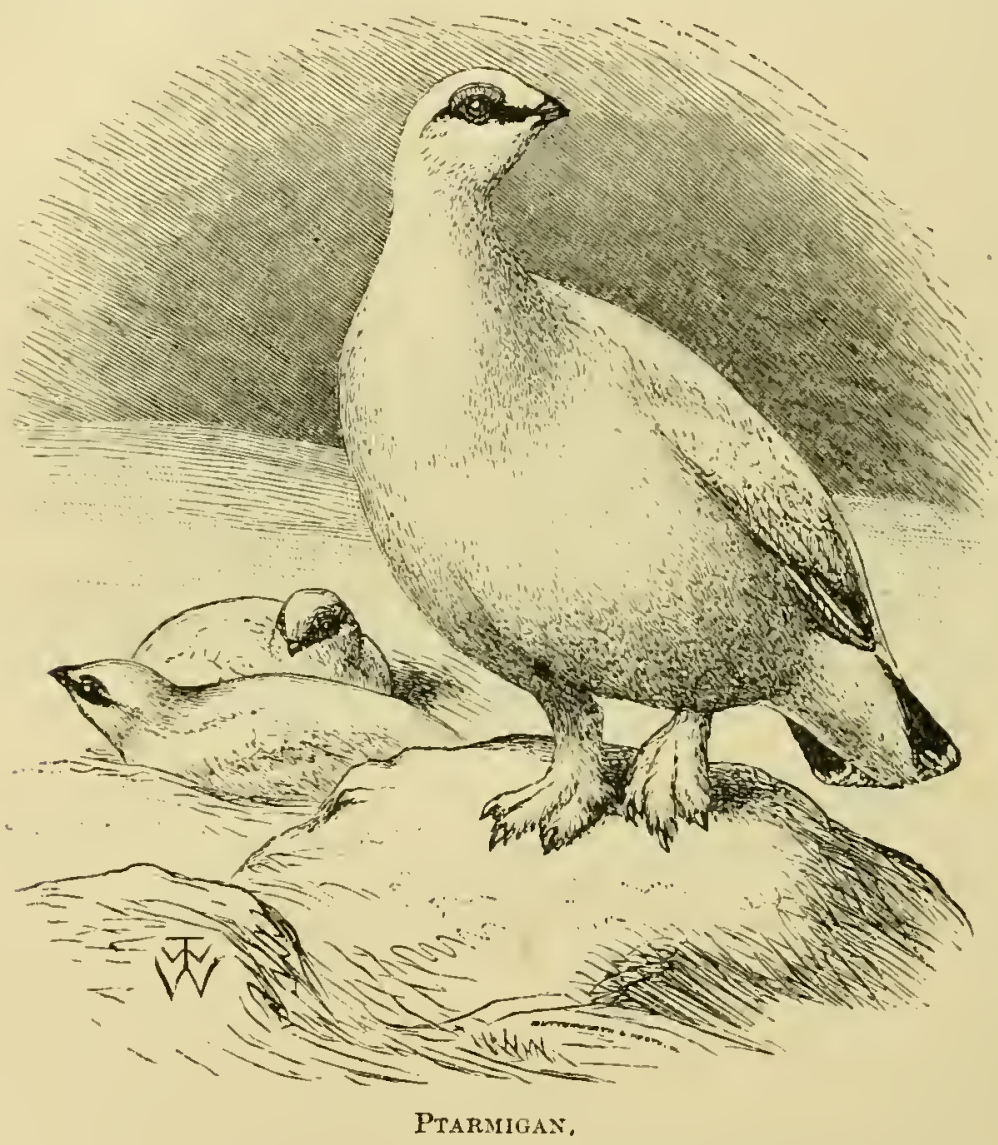

the growth of trees, and it occurs on the Pyrenees, and on the Alps. It also inhabits northern Russia, but its eastern limit is

${ }^{1}$ James I. (as quoted by Mr. Gray, $B . W$. Scotland, p. 230) writing from Whitehall in 1617 spelt the word "Termigant," and in this form it appears in one of the Scots Acts in 1621. Taylor the "water poet," who (in 1630) seems to have been the first Englishman to use the word, has "Termagant." How the unnecessary initial letter has crept into the name is more than is known to me. I can only trace it to Sibbald in 1684. The word is adnittedly from the Gaelic Tarmachan, meaning, according to some, "a dweller" upon heights," but thought by Dr. T. M'Lauchlan to refer possibly to the noise made by the bird's wings in taking flight. It has of course really nothing to do with the name of the idol which early medixval writers supposed to be worshipped by Pagans. 
unknown. In North America, Greenland, ${ }^{1}$ and Iceland it is represented by a very nearly allied form-so much so indeed that it is only at certain seasons that the slight difference between them can be detected. This form is the L. rupestris of anthors, and it would appear to be found also in Siberia (Ibis, 1879, p. 148). ${ }^{2}$ Spitsbergen is inhabited by a large form which has received recognition as $L_{\text {. }}$ hemileucurus, and the northern end of the chain of the Rocky Mountains is tenanted by a very distinct species, the smallest and perhaps the most beautiful of the genus, L. leucurus, which has all the feathers of the tail white. 'The very curious and still hardly under-

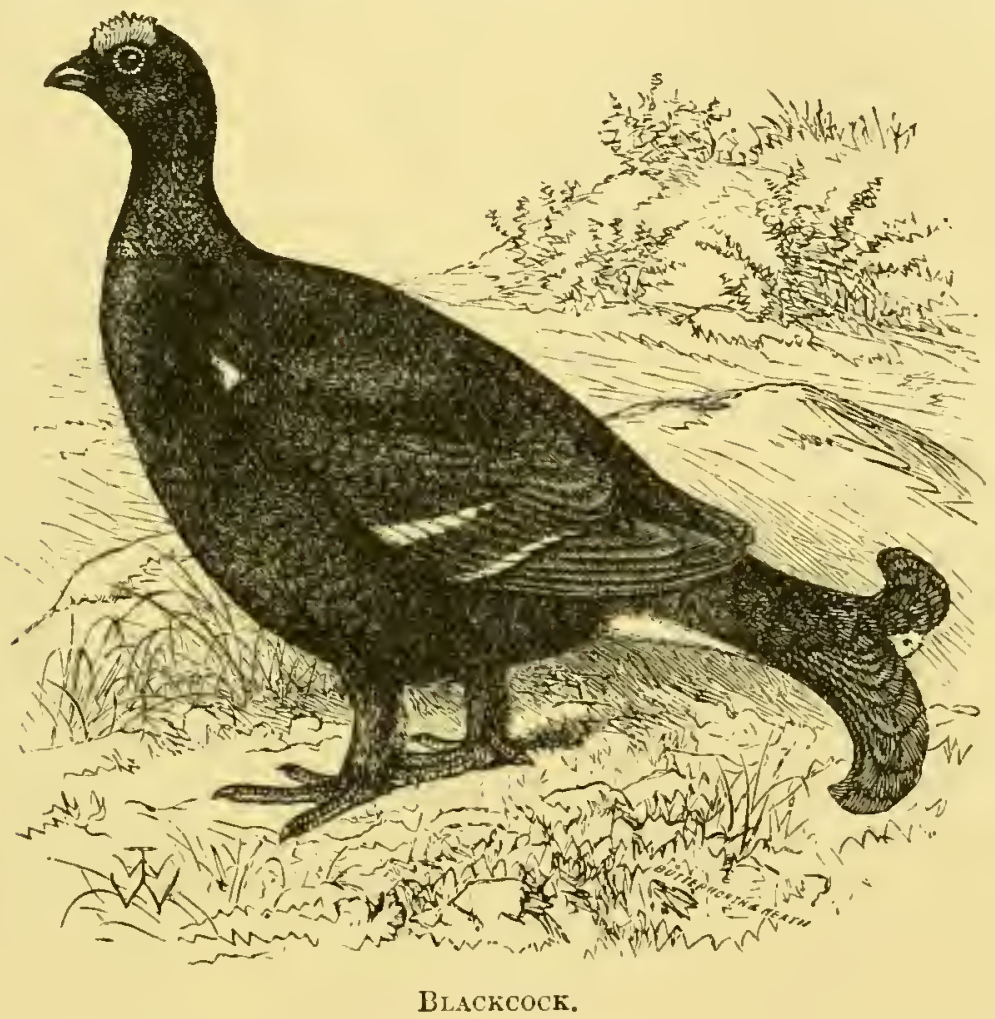

stood question of the MoulT of the Ptarmigan could not be discussed here, and reference can only be made to the shedding of its CLAws.

The bird, however, to which the name of Grouse in all strictness belongs (see p. 388, footnote 2) is Tetrao tetrix-the Blackcock and Greyhen, as the sexes are with us respectively called. It is distributed over most of the heath-country of England, except in East Anglia, where attempts to introduce it have becn only partially successful. It also occurs in North Wales, and very generally

1 Examples from Greenland have borne the name of L. reinhardti, others from Newfoundland $L$. velchi, and the islands of Unalaska and Atka are said to present local forms distinguishable as nelsoni and atkhensis respectively (cf. Ridgway, Man. N. Am. B. p. 201).

${ }_{2}^{2}$ I am indebted to Prof. Mitsukuri for specimens from Japan; but I dare not yet characterize them. 
throughout Scotland, though not in Orkney, Shetland, or the Outer Hebrides, nor in Ireland. On the continent of Europe it has a very wide range, and it extends into Siberia. In Georgia its place is taken by a distinct species, on which a Polish naturalist (Proc. Zool. Soc. 1875, p. 267) has unhappily conferred the name of $T$. mlokosiewiczi. Both these birds have much in common with their larger congeners the CAPERCALLY and its eastern representative.

We must then notice the species of the genus Bonasa, of which the European B. sylvestris, the Hazel-hen, is the type. This does not inhabit the British Islands; unfortunately so, for it is perhaps the most delicate game-bird that comes to table. It is the Gelinotte of the French, the Haselhathn of Germans, and Hjerpe of Scandinavians. Like its transatlantic congener $B$. umbellus, the Ruffed Grouse or Birch-Partridge (of which there are three other local forms, B. togata, B. umbelloides, and B. sabinii), it is purely a forestbird. The same may be said of the species of Canachites, of which two forms are found in America, C. canadensis, the Spruce-Partridge, and $C$. franklini, and also of the Siberian C. falcipennis. Nearly allied to these birds is the group known as Dendragapus, containing three large and fine forms, $D$. obscurus, $D$. fuliginosus, and $D$. richardsoni-all peculiar to North America. Then we have Centrocercus urophasianus, the Sage-cock of the plains of Columbia and California, and Pediocates, the Sharp-tailed Grouse, with its three forms, $P$. phasianellus, $P$. columbianus, and $P$. campestris, while finally Tympanuchus, the Prairie-hen, also with three local forms, T. cupido, now nearly extinct, $T$. americanus, and $T$. pallidicinctus, is a bird that in the United States of America possesses considerable economic value, as witness the enormous numbers that are not only consumed there, but exported to Europe. It will be seen that the great majority of Grouse belong to the northern part of the New World, and it is to be regretted that space here fails to do justice to these beautiful and important birds, by enlarging on their interesting distinctions. They are nearly all figured in Mr. Elliot's Monograph of the Tetraoninx, and an excellent account of the American species, so far as then known, is given in Baird, Brewer, and Ridgway's North American Birds (iii. pp. 414-465), while the Manual of the last of these authors concisely notices the forms lately recognized.

GUACHARO, ${ }^{1}$ the Spanish-American name of what English writers have lately taken to calling the OIL-BIRD, the Steatornis caripensis of ornithologists, a very remarkable bird, first described by Alexander von Humboldt (Journ. de Physique, liii. p. 57 ; Voy. aux Rég. équinoxiales, i. p. 413, Engl. transl. iii. p. 119 ; Obs. Zoologie, ii. p. 141, pl. xliv.) from his own observation and from

1 This is said to be an obsolete Spanish word signifying one that cries, moans, or laments loudly. 
examples obtained by Bompland, on the visit of those two traveller's, in September 1799, to a cave near Caripé (at that time a monastery of Aragonese Capuchins) in the Venezuelan province of Cumana on the northern coast of South America. A few years later it was discovered, says Latham (Gen. Hist. Birds, 1823, vii. p. 365), to inhabit 'Trinidad, where it appear's to bear the name of Diublotin; ${ }^{1}$ and much more recently, by the receipt of specimens procured at Sarayacu in Ecuador, Caxamarca in the Peruvian Andes, and Antioquia in New Grenada (Proc. Zool. Soc. 1878, pp. 139, 140 ; 1879, p. 532), its range has been shewn to be much greater than had been supposed. The singularity of its structure, its curious habits, and its peculiar economical value have naturally attracted no little attention, and it has formed the subject of investigation by a considerable number of zoologists both British and foreign. First referring it to the genus Caprimulgus, its original describer soon saw that it was no true NiGHTJAP. It was subsequently separated as forming a subfamily, and has at last been regarded as the type of a distinct Family, Steatornithida-a view which, though not put forth till 1870 (Zool. Record, vi. p. 67), scems now to be generally accepted. Its systematic position, however, can scarcely be considered settled, for though on the whole its predominating alliance may be with the Caprimulgida, nearly as much affinity may be traced to the Striges, while it possesses some characters in which it differs from both (Proc. Zool. Soc. 1873, pp. 526-535). About as big as a Crow, its plumage exhibits the blended tints of chocolate-colour and grey, barred and pencilled with dark brown or black, and spotted in places with white, that prevail in the two groups just named. The beak is hard, strong, and deeply notched, the nostrils are prominent, and the gape is fulnished with twelve long hairs on each side. The legs and toes are comparatively feeble, but the wings are large. In habits the Guacharo is wholly nocturnal, slumbering by day in deep and dark caverns which it frequents in vast numbers. Towards evening it arouses itself, and, with croaking and clattering that has been likened to that of castanets, it approaches the exit of its retreat, whence at nightfall it issues in search of its food, which, so far as is known, consists entirely of oily nuts or fruits, belonging especially to the genera Achras, Aiphanas, Laurus, and Psichotric, some of them sought, it would seem, at a very great distance, for M. Funck (Bull. Acad. Sc. Bruxelles, xi. pt. 2, pp. 371-377) states that in the stomach of one he obtained at Caripé he found the seed of a tree which he believed did not grow nearer than 80 leagues. The hard, indigestible seeds swallowed by the Guacharo are found in quantities on the floor and the ledges of the caverns it frequents, where many

1 Not to be confounded with the bird so called in the French Antilles, which is a Perrel, Estrelata hrsitata (see Extermination, p. 227, note 4). 
of them for a time vegetate, the plants thus growing being etiolated from want of light, and, according to travellers, forming a singular feature of the gloomy scene which these places present. The Guacharo is said to build a bowl-like nest of clay, in which it lays from two to four white eggs, with a smooth but lustreless surface, resembling those of some Owls. The young soon after they are hatched become a perfect mass of fat, and while yet in the nest are songht by the Indians, who at Caripé, and perhaps elsewhere, make a special business of taking them and extracting the oil they contain. This is done abont midsummer, when by the aid of torches and long poles many thousands of the young birds are slanghtered, while their parents in alarm and rage hover over the destroyers' heads, uttering harsh and deafening cries. The grease is melted over fires kindled at the cavern's mouth, run into earthen pots, and preserved for nse in cooking as well as for the lighting of lamps. It is said to be pure and limpid, free from any disagreeable taste or smell, and capable of being kept for a year without turning rancid. In Trinidad the young are esteemed a great delicacy for the table by many, though some persons object to their peculiar scent, which, says Léotand (Ois. de la Trinidad, p. 68), resembles that of a cockroach (Blatta), and consequently refuse to eat them. The old birds also, according to Mr. E. C. Taylor (Ilis, 1864, p. 90) have a strong Crow-like odour. But one species of the genus Steatornis is known. ${ }^{1}$

GUAN, a word apparently first introduced into the ornithologist's

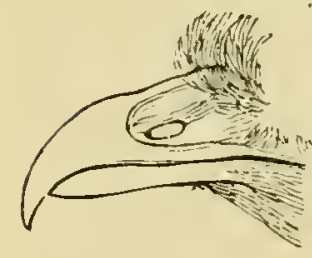

PENELOPE.

(After Swainson.) vocabulary about, 1743 by Edwards, ${ }^{2}$ who said that a bird he figured (Nat. Hist. pl. xiii.) was "so called in the West Indies," and the name has hence been generally applied to all the members of the subfamily Penelopina, which are distinguished from the kindred subfamily Cracina or Curassows by the broad postacetabular area of the pelvis, as pointed out by Prof. Huxley (Proc. Zool. Soc. 1868, p. 297), as well as by their maxilla being wider than

${ }^{1}$ In addition to the rorks above quoted valuable information about this curious bird may be fonnd under the following references:-L'Herminier; A A n. Sc. Nat. 1836, 1. 60, and Nouv. Anu. Mus. 1838, 1. 321 ; Hautessier, Rev. Zool. 1838, p. 164 ; J. Miiller, Monatsb. Berl. Acad. 1841, 1. 172, and Archiv für Ancut. 1862, p1. 1.11; Des Murs, Rev. Zool. 1843, p. 32, and Ool. Orn. pp. 260-263 ; Blanchard, Ann. Mus. 1859, xi. pl. 4, fig. 30 ; König-Warthansen, Journ. für Orn. 1868, 11). 384-387 ; Goering, Vargasia, 1869, 11. 124-128; Miurie, Ibis, 1873, pp. 81-86 ; Sclater, Ibis, 1890, pp. 335-339.

"Edwards also gires "Quan" as an alternative spelling, and this may be nearer the original form, since we find Dampier in 1676 writing (Voy. ii. pt. 2, p. 66) of what was doubtless an allied if not the same bird as the "Quam." The species represented by Edwards does not seem to have heen identified by the latest authorities. $f f$. corrigenda 
it is high, with its culmen depressed, the crown feathered, and the nostrils bare - the last two characters separating the Penelopina from the Oreophasinx, which form the third subfamily of the Cracida, ${ }^{1}$ a Family belonging to that taxonomer's division Peristeropodes $^{2}$ of the group ALECTOROMORPHe.

The Penelopina have been separated into seven genera, of which Penelope and Ortalis (erroneously Ortalida), containing respectively about sixteen and nineteen species, are the largest, the others numbering from one to three only. Into their minute differences it would be useless to enter; nearly all have the throat bare of feathers, and from that of many of them hangs a wattle; but one form, Chamapetes, has neither of these features, and Stegnolama, though wattled, has the throat clothed. With few exceptions the Guans are confined to the South American continent; one species of Penelope is, however, found in Mexico and at Mazatlan, Pipile cumanensis inhabits Trinidad as well as the mainland, while three species of Ortalis occur in Mexico or Texas, and one, which is also common to Venezuela, in Tobago. Like Curassows, Guans are in great measure of arboreal habit. They also readily become tame, but all attempts to domesticate them in the full sense of the word have wholly failed, and the cases in which they have even been induced to breed and the young have been reared in confinement are very few. ${ }^{3}$ Yet it would seem that Guans and Curassows will interbreed with poultry (Ibis, 1866, p. 24 ; Bull. Soc. Imp. d'Acclimatation, 1868 , p. 559 ; 1869, p. 357), and there is the more extraordinary statement that in Texas the hybrids between the Chiacalacca, Ortalis vetula, and the domestic Fowl are asserted to be far superior to ordinary Game-cocks for fighting purposes. More information on this subject is very desirable.

GUILLEMOT (French, Guillemot ${ }^{4}$ ), the name accepted by

1 See the Synopsis, extensively laid under contribution for this article, by Messrs. Sclater and Salvin (Proc. Zool. Soc. 1S70, pp. 504-544), while further information on the Cracinæ has since been given by the former of those gentlemen (Trans. Zool. Soc. ix. pp. 273-2Ss, pls. xl.-liii.) Some additions have since been made to the knowledge of the Family, but none of very great importance.

2 It wonld be here out of place to dwell upon the important bearings on the question of GEOGRAPHICAL Distribution (p. 313) which the establishment of this division has tended to shew. For this reference must be made to Prof. Hnxiey's original paper (ut suprò), or to the epitome of it given in the Zoological Record (v. pp. 34 and 99).

${ }^{3}$ Cf. E. S. Dixon (The Dovecote and the Aviary, pp. 223-273. London : 1551), who argues that the reported success of the Dutch towards the end of the last century in domesticating these birds was an exaggeration or altogether a mistake. His two chapter's are well worth reading.

* The word, however, seems to be cognate with or derived from the Welsh and Manx Guiltem, or Gwilym as Pennant spells it. The association may have no real meaning, but one cannot help comparing the resemblance between the 
nearly all modern authors for a Sea-bird, the Colymbus troile of Linnæus, and the Uria or better Alca troile of later writers, which nowadays it seems seldom if ever to bear among those who, from their vocation, are most conversant with it, though, according to Willughby and Ray his translator, it was in their time so called "by those of Northumberland and Durham." Around the coasts of Britain it is variously known as the Frowl, Kiddaw or Skiddaw, Langy ( $c f$. Icelandic, Langvia), Lavy, Marrock, Murre, Scout ( $c f$. Coot and SCOTER), Scuttock, Strany, Tinker or Tinkershire, and Willock. The number of local names testifies to the abundance of this bird, at least of old time, in different places, but it should be observed that in certain districts some of them are the common property of this species and the RAzOR-BILL. In former days the Guillemot yearly frequented the cliffs on many parts of the British coasts in countless multitudes, and this is still the case in the northern parts of the United Kingdom; but more to the southward nearly all its smaller settlements have been rendered utterly desolate by the wanton and cruel destruction of their tenants during the breeding-season, and even the inhabitants of those which were more crowded had become so thinned that, but for the intervention of the Sea Birds Preservation Act (32 and 33 Vict. cap. 17), which provided under penalty for the safety of this and certain other species at the time of year when they were most exposed to danger, they would unquestionably by this time have been exterminated so far as England is concerned. The slaughter, which, before the passing of that Act, took place annually on the cliffs of the Isle of Wight, near Flamborough Head, and at such other stations frequented by this species and its allies the Razor-bill and Puffin, and the Kittiwake-Gull, as could be easily reached by excursionists from London and the large manufacturing towns, was in the highest degree brutal. No use whatever could be made of the bodies of the victims, which indeed those who indulged in their massacre were rarely at the trouble to pick out of the water; the birds shot were all engaged in breeding; and most of them had young, which of course starved througl the destruction of their parents, intercepted in the performance of the most sacred duty of nature, and butchered to gratify the murderous lust of those who sheltered themselves under the name of "sportsmen."

Part of the Guillemot's history is still little understood. We know that it arrives at its wonted breeding-stations on its accustomed day in spring, that it remains there till, towards the end of sunmer, its young are hatched and able, as they soon are, to encounter the perils of a scafaring life, when away go all, parents

French Guillemot-though that appears to have been originally applied to the young of the Golden PLover (Belon, Hist. d'Oys. 1. 262)-and Guillaume with that between the English Willock, another name for the bird, and William. 
and progeny. After that time it commonly happens that a few examples are occasionally met with in bays and shallow waters. Tempestuous weather will drive ashore a large number in a state of utter destitution-many of them indeed are not unfrequently washed up dead-but what becomes of the bulk of the birds, not merely the comparatively few thousands that are natives of Britain, but the hundreds of thousands, not to say millions, that are in summer denizens of more northern latitudes, no one can yet say. This mystery is not peculiar to the Guillemot, but is shared by all the Alcida that inhabit the Atlantic Ocean. Examples stray every season across the Bay of Biscay, are found off the coasts of Spain and Portugal, enter the Mediterranean and reach Italian waters, or, keeping further south, may even touch the Madeiras, Canaries, or Azores; but these bear no proportion whatever to the mighty hosts whose position and movements they no more reveal than do the vedettes of a well-appointed army. The common or Foolish (as it is often named) Guillemot of both sides of the Atlantic is replaced further northward by a species of a stouter build, the $A$. arra or A. bruennichi of ornithologists, and on the west coast of Nortl America by the $A$. californica. These have essentially the same habits, and the structural resemblance between all of them and the Auks is so great that of late several systematists hare relegated them to the genus Alca, confining the genus Uria to the Guillemots of a very distinct group, of which the type is the $U$. grylle, the Black Guillemot of British authors, the Dovekey or Greenlind Dove of sailors, the Tysty of Shetlanders. This bird assumes in summer an entirely black plumage with the exception of a white patch on each wing, while in winter it is beautifully marbled with white and black. Allied to it as species or geographical races are the $U$. mandti, $U$. columba, and $U$. carbo. All these differ from the larger Guillemots and other members of the genus, $A l c a$, as here used, by laying two or three eggs, which are generally placed in some secure niche, while the latter lay but a single egg, which is invariably exposed on a bare ledge.

GUINEA FOWL, a well-known domestic gallinaceous bird, so called from the country whence in modern times it was brought to Europe, the Meleagris and Avis or Gallina Numidica of ancient authors. ${ }^{1}$ Little can be positively stated of the wild stock to which we owe our tame birds, nor can the period of its reintroduction

1 Columella (De Re Rustica, viii. cap. 2) distinguishes the Meleagris from the Gallina Africana or Numidica, the latter having, he says, a red wattle (palea, a reading obviously preferable to galea), while it was blue in the former. This would look as if the Meleagris had sprung from what is now called Numide ptilorhyncha, while the Gallina Africana originated in the $N$. meleagris, - species which, as will be seen by the text, have a different range, and if so the fact would point to two distinct introductions-one by Greeks, the other by Latins. 
(for there is apparently no evidence of its domestication being continuous from the time of the Romans) be assigned more than roughly to that of the African discoveries of the Portuguese. ${ }^{1}$ It does not seem to have been commonly known till the middle of the 16 th century, when Caius sent a description and figure, with the name of Gallus Mauritanus, to Gesner, who published both in his Paralipomena in 1555, and in the same year Belon also gave a notice and woodcut under the name of Poulle de la Guinée; but while the former authors properly referred their bird to the ancient Meleagris, the latter confounded the Meleagris and the TuRkwY.

The ordinary Guinea Fowl of our poultry-yards is the Numida meleagris of ornithologists, and is too common a bird to need description. The chief or only changes which domestication seems to have induced in its appearance are a tendency to albinism generally shewn in the plumage of its lower parts, and frequently, though not always, the conversion of the colour of its legs and feet from dark greyish-brown to bright orange. That the home of this species is West Africa from the Gambia ${ }^{2}$ to the Gaboon is certain, but its range in the interior is quite unknown. It appears to have been imported early into the Cape Verd Islands, where, as also in some of the Greater Antilles and in Ascension, it has run wild. Representing the species in South Africa we have $N$. coronata, which is very numerous from the Cape Colony to Ovampoland, and $N$. cornuta of Drs. Finsch and Hartlaub, which replaces it in the west as far as the Zambesi. Madagascar also has its peculiar species, distinguishable by its red crown, the $N$. mitrata of Pallas, a name which has often been misapplied to the last. This bird has been introduced to Rodriguez, where it is now found wild. Abyssinia is inhabited by another species, the $N$. ptilorhyncha, ${ }^{3}$ which differs from all the foregoing by the absence of any red colouring about the head. Very different from all of them, and the finest species known, is the $N$. vulturina of Zanzibar, conspicuous by the bright bhe in its plumage, the hackles that adorn the lower part of its neck, and its long tail. By some writers it is thought to form a separate genus, Acryllium. All these Guinea Fowls are characterized by having the crown bare of feathers and elevated into a bony "helmet," but there is another group (to which the name

1 Edwards, writing about 1760 (Gleanings, ii. p. 269), says that "Guiney Hens, which were shewn as rarities when I was a boy, are now become a common domestick Fowl in England."

2 Specimens from the Gambia are said to be smaller, and have been described as distinct under the name of $N$. rendalli.

3 Mr. Darwin (Anim. and Pl. under Domestication, i. p. 294) gives this as the original stock of our modern domestic birds, but herein I venture to think he has been misled. As before observed, it may possibly have been the true $\mu \epsilon \lambda \epsilon a \gamma p i s$ of the Greeks. 
Guttera has been given) in which a thick tuft of feather's ormaments the top of the head. This contains four or five species, all inhabiting some part or other of Africa, the best known being the $N$. cristata from Sierra Leone and other places on the western coast. This bird, apparently mentioned by Maregrave more than 200 years ago, but first described by Pallas, is remarkable for the structure-mique, if not possessed by its representative forms - of its FURCULA, where the head, instead of being the thin

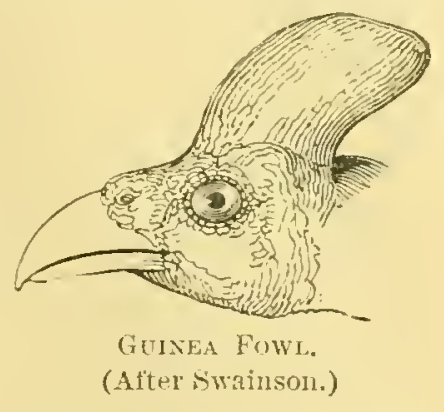
plate found in all other Gallina, is a hollow eip opening upwards, into which the trachea dips, and then emerges on its way to the lings. Allied to the genus Numula, but readily distinguished therefrom among other characters by the possession of spurs, are two rare forms, Agelastes and Phasidus, both from IVestern Africa. Of their habits nothing is known. All these birds are beantifully figured in Mr. Elliot's Monogruph of the Phasianida, from drawings by Mr. Wolf.

GUIRA, a Spanish-American name, oceasionally to be found since Willughby's time in English books, but applied to so many birds of different kinds as to convey no definite meaning unless with a qualification, and then possibly not always.

GUIT-GUIT, a name, presumably in imitation of the cry of a bird, used almost indefinitely for any species of the Neotropical genera Careba, DACNIs and their allies (cf. QUIT).

GULL (Welsh, Gwylan; Breton, Goulen: French, Goeland) the name now commonly used, to the almost, entire exclusion of the old English Mrw (Icelandic, Múfur; Damish, Muuge; Swedish, Måse; German, Meve; Dutch, Meeuw; French, Mouette), for a group of Sea-birds widely and commonly known, all belonging to the genus Larus of Linnæus, which subsequent systematists have broken up in a very arbitrary and often absurd fashion. The Family Laride is composed of two chief groups, Larinx and Sternina-the Gulls and the TERNs, though two other subfamilies are frequently counted, the SkUAS (Stercoruriure), and tlat formed by the single genus Rlunnchops, the SkImmers'; but there seems no strong reason why the former should not be referred to the Larina, and the latter to the Sterninar.

Taking the Gulls in their restricted sense, Mr. Howard Siunders, who subjected the group) to a rigorous revision ( $P^{\prime}$ oc. Zool. Soc. 1878, pp. 152-211), admitted forty-nine species of them, which he placed in five genera instead of the many which some prior investigators had sought to establish. Two or three more species might now be added. Of the genera recognized by him, 
Pagophila and Phodostethia have but one species each, Rissa and Xema two, while the rest belong to Larus. The Pagophila is the so-called Ivory-Gull, $P$. eburnea, ${ }^{1}$ names which hardly do justice to the extreme whiteness of its plumage, to which its jet-black legs offer a strong contrast. The young, however, are spotted with black. An inhabitant of the most northern seas, examples find their way in winter to more temperate shores. Its breeding-places have seldom been discovered, and the first of its eggs seen by ornithologists was brought home by Sir L. M'Clintock in 1853 from Cape Krabbe (Journ. R. Dubl. Soc. i. p. 60, pl. 1); two other's ${ }^{2}$ were obtained by Dr. Malmgren in Spitsbergen in 1868, and, in August 1887, the captain of a Norwegian ship found from 100 to 150 nests on Storö, an islet on the extreme north-east of that country ${ }^{3}$ (Ibis, 1888, pp. $440-443$, pl. xiii.) Of the species of Pissa, one is the abundant and well-known KITTIwake, $R$. tridactyla, of circumpolar range, breeding, however, also in comparatively low latitudes, as on the coasts of Britain, and in winter frequenting sonthern waters. The other is R. brevirostris, limited to the North Pacific, between Alaska and Kamchatka. The singular fact requires to be noticed that in the former of these species the hind toe is generally deficient, but that examples, and especially those from Bering's Sea, are occasionally found in which this functionless member has not wholly disappeared. We have then the genus Larus, which ornithologists have hitherto attempted most unsuccessfully to subdivide. It contains the largest as well as the smallest of Gulls. In some species the adults assume a dark-coloured head every breeding-season, in others any trace of dark colour is the mark of immaturity. The larger species prey on eggs and weakly birds, while the smaller content themselves with a diet of insects and worms. But however diverse be the appearance, structure, or habits of the extremities of the series of species, they are so closely connected by intermediate forms that it is hard to find a gap between them that would justify a generic division. Of the forty-five species of this genus now recognized by Mr. Saunders it would be here impossible to attempt to point out the peculiarities. About seventeen belong

1 The white Gulls reported to Gunner (Leen1, De Lapp. Comment. p. 285), and called by him Larus albus, may have been as he thought identical with the Rathsherr of Marten (Spitsb. Reiu. p. 56), which undoubtedly was the IvoryGull; but there is nothing to prove that they were. Hence I cannot adopt that specific name, as recent American writers do. From what has been before said as to Gavia, they seem to be also wrong in using that word as a generic name in place of Pagophita.

2 One of these has longr been in my possession.

: The Norwegian pilot of the yacht in which I visited Spitsbergen told me that the crew of a boat which visited Giles's Land in 1859 found many IvoryGulls' nests on its shore (Ibis, 1864, p. 508). 
to Europe and fourteen to North America, of which (excluding stragglers) some five only are common to both countries. Our knowledge of the geographical distribution of several of them is still incomplete. Some have a very wide range, others very much the reverse: as witness $L$. fuliginosus, believed to be confined to the Galapagos, and L. scopulinus and L. bulleri to New Zealand-the last indeed perhaps only to the South Island. The largest species of the group are the Glaucous and Greater Black-backed Gulls, L. glaucus and $L$. marinus, of which the former is cireumpolar, and the latter nearly so-not having been bitherto found between Labrador and Japan. The smallest species is the European L. minutus, though the North-American L. philadelphia does not much exceed it in size. Many of the Gulls congregate in vast numbers to oreed, whether on rocky cliffs of the sea-coast or on heathy islands in inland waters. Some of the settlements of the Black-headed or "PLEWIT" Gull, L. riditundus, are a somrce of no small profit to their proprietors, - the eggs, which are accounted a delicacy, being often taken on an orderly system up to a certain day, and the birds carefully protected. Ross's or the Roseate Gull, Rhodostethia rosea, forms a well-marked genus, distinguished not so much by the pink tint of its plumage (for that is found in other species) but by its small Dore-like bill and wedge-shaped tail. It used to be an exceedingly scalce bird in collections; but it was met with abundantly in the autumn of 1881 off Point Barrow by Mr. Murdoch of the United States' Polar Expedition (Report, \&c., p. 123, pls. i. ii.), and a large series of specimens was obtained. Its Arctic home, however, has not yet been found, but it has been seen, if not procured, in summer in Boothia Felix, and off the coast of Spitsbergen and on Franz Josef Land. More rare still is one of the species of Tema, X. furcatum, of which only fire specimens, all but one believed to have come from the Galapagos, have been seen. Its smaller congener Sabine's Gull, X. sabinii, is more common, and has been found breeding both in Aretic America and in Siberia, and many examples, chiefly immature birds, have been obtained in the British Islands. Both species of Xema are readily distinguished from all other Gulls by their forked tail.

\section{GULLET, see CEsophagus.}

\section{GWILLEM, see GUILLEMO'T.}

GYMNORHINA, G. R. Gray's name in 1840 (List Gen. B. p. 37) for a genus apparently allied to Strepera and belonging to the "Austro-Coraces" of Parker (Thans. Zool. Soc. ix. p. 327), a group of birds that has not yet been properly defined. They have frequently been called "Crow-Shrikes," or, from their loud voice, "Piping Crows," while dealers know them as "Australian Magpies," 
their plumage being black and white.

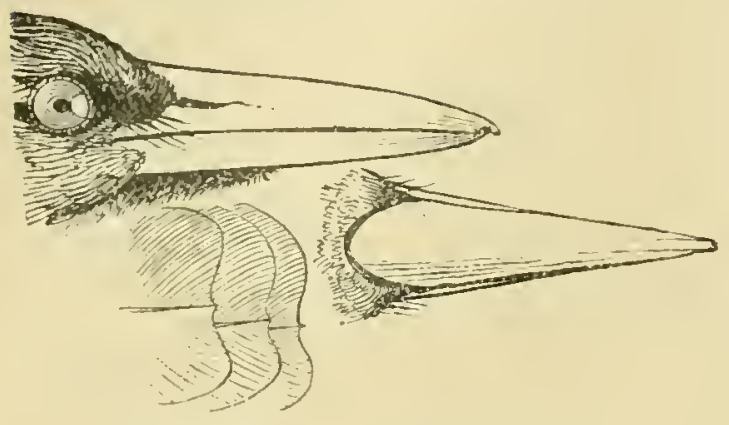

Grisophina. (After Swainson.)
G. tibicen has a wide range in Anstralia, while G. lenconota is restricted to its southern and western parts. Tasmania has a smaller race of the former, or distinct species, as some regard it: the Organ-bird of the colonists, G. hyperleuca, to correct the name originally bestowed on it by Gonld (Proc. Zonl. Soc. 1836, p. 106), or organice.

GYPAETE, intended as an Anglified form of Gypactus (LïriMERGEYER).

GYREALCON, from the Low Latin Gyrofulco, but the etymology of that is doubtful, the best anthorities differing concerning it. Some wonld have it from the verb gyrare, to circle, others from Geier, a Vulture, and this from the Old High German givi, greedy, while others again say that Geier is allied to gyrare. All agree, however, in denying that there can be any derivation from Hierofalco, which is a hybrid word of modern invention (see FALCON).

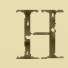

HACKBOLT, HAGBOLT, and HAGDOWN, names said to be given by the people of Scilly and Man to the larger of the species of Shearwater with which they meet, if indeed they recognize any distinction, and in one form or. other used, it would appear, also on the east coast of North America.

HALCYON, Greek à $\lambda \kappa^{\prime} v^{\prime \prime}$ (the $h$ being redundant), a poetical name for the KINGFisher.

HALF-BIRD, a common fowler's name for the smaller kinds of Duck, especially the TEAL, which bring only half-price, or something like it, when sold.

IHALLUX, the first digit of the foot, commonly known as the "hind toe" from its backward direction in most birds. When fully developed it consists of only two phalanges, its metatarsal is reduced to the distal portion, and is only loosely attached to the inner and hinder surface of the other three coalesced metatarsals. As regards position, structure and size, the Hallux is the most 
variable of all the toes, and its taxonomic value is very limited. In Hesperomis (ODOntornithes), the Spheniscidie (PENGUIN) and STEGANOPODEs it is turned forward, and joined to the second digit by a web, as is also the case to a certain extent in the Colymbidx (DIVER). In some of the cypselidx (SWIFT) all four toes are directed forward, but they are free at the base; and in certain of the Caprimulgild (NIGHTJAR) and in the Coliulde (MOUSEBIRD) the Hallux is reversible. In the Tubinares and the "threetoed" Woodpeckeps (Picoides, Susia and "Tiga) it is reduced to a small subcutaneous nodule; and in most LIMICOL ж, though visible, it is in a scarcely functional condition, while in some of them, as Calidris (SANDERLING) and many Charadriide (Plover), it is wholly absent, as it is also in the Alcida (AUK), Otididx (Bustard) and all the existing Ratita except Apteryx (KIWI). In Risse (KITTIWAKE) its condition varies almost individually from being nearly functional to absence (see Toks).

IIAMMER-HEAD or HAMMER-KOP, names given in the Cape Colony to the Scopus umbrettr of ornithology, called by

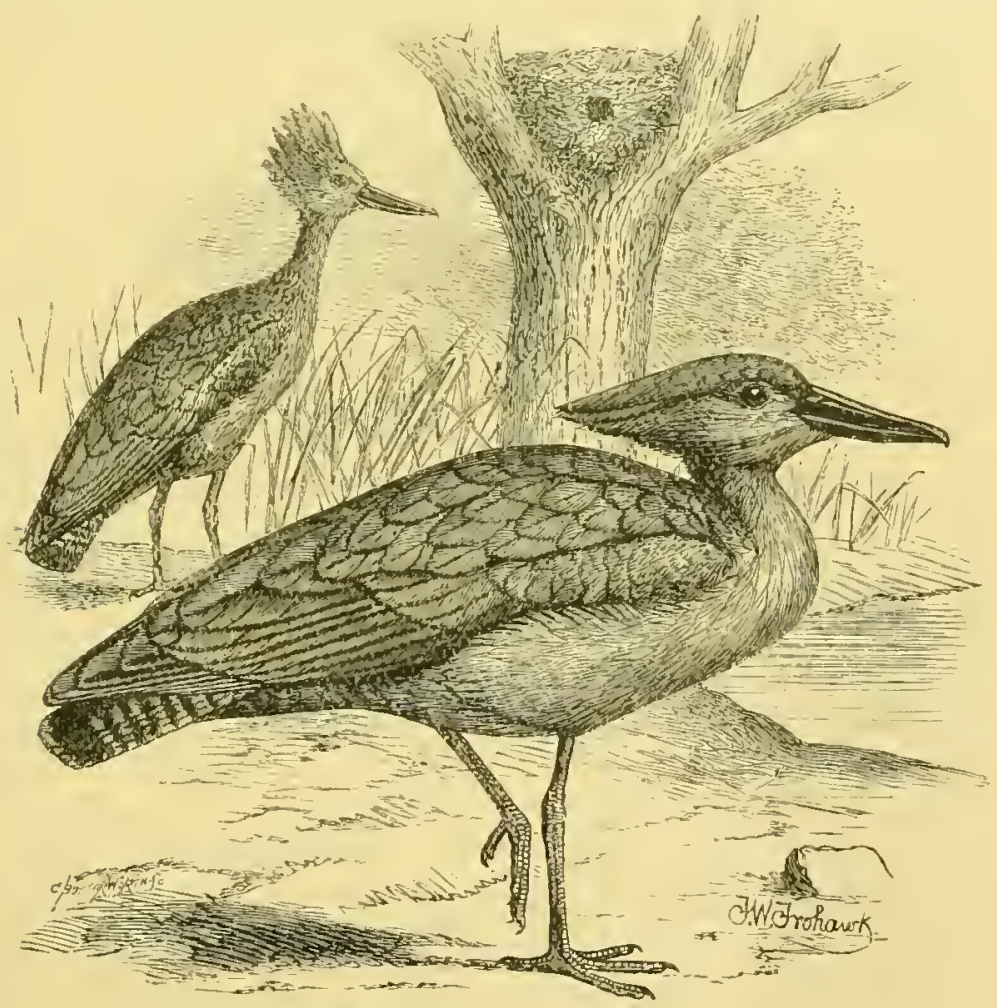

HavMGR-HEAD, Scopus umbrette.

Pennant and some writers the "Umbre." This was discovered by Adanson, the French traveller in Senegal, about the middle of the eighteenth century, and was described by Brisson in 1760. It has since been found to inhabit nearly the whole of Africa and 
Marlagascar. Though not larger than a Raven, it builds an enormous nest, occasionally some six feet in diameter, and placed either in a tree or on a rocky ledge. ${ }^{1}$ The structure is a mass of sticks, roots, grass and rushes, compactly piled together, with a flat-topped roof, the interior being neatly lined with clay, and a hole for entrance and exit. The bird, of an almost uniform earthy-brown colour (umber), whence the French Ombrette, slightly glossed with purple, and its tail barred with black, has a long occipital crest, generally borne horizontally, so as to give rise to its expressive colonial name, for the likeness of its head to that of a hammer is obvious. It is somewhat sluggish by day, but displays much activity at dusk, when it will go through a series of strange per-

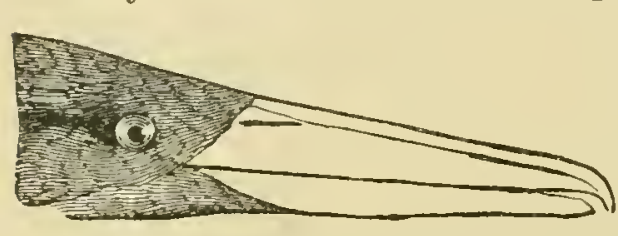

Bill of Scopis. (After Swainson.) formances. * Scopus has hitherto been generally referred to the group Pelargi (SтоRк), but recent investigations point ont that its affinity is rather to the Herodiones (Heron), though it can hardly enter into the Family Ardeitax, and its flight is described as not being Heron-like (Ibis, 1863, p. 170). The late Prof. Reinhardt (op. cit. 1862, pp. 158-175) thought that Balaniceps (SHOE-BLLL) was its nearest ally.

HANG-BIRD ol HANG-NEST, common names in North America for the beautiful Baltimore Oriole and its allies (see ICTERUs), from the pensile nests they build.

HANNA, the usual name in British Guiana for the HoActzis.

HAPLOOPHON E, Garrod's name (Proc. Zool. Soc. 1876, pp. 517,518 ) for a division of the Pusseres Mesomyoni, containing the Families Tyrannida (KInG-BIrd), Pupicotide and Pittide, to which Forbes subsequently added (op. cit. 1880, pp. 389-391, and 1882, pp. 569-571) the Philepittida of Madagascar and the Xenicidie (or more correetly Acanthidosittida) of New Zealand. Together with the Tracheophone, they form the gromp Honceneri as opposed to the Heteroneri.

HARELD (corruptly HERALD), apparently the invention in 1824 of Stephens, who (Gen. Zool. xii. pt. 2, p. 174) so rendered the generic name Harelda which he bestowed upon the Long-tailed DUCK, Anas glacialis of Linnæus, misspelling (whether purposely or not), the Havelda of Ray (Synop. Av. p. 145) which was nearly Worm's (Mus. Worm. p. 302) Latinized form of Hicrelle (pronounced Hauvadla) the common Icclandic name for the bird, having

1 Holnb and Von Pelzeln (Beitr. Orn. Sudafrikas, 1. 279) give two figures of the nest, one of which is reprodueed in the aceompanying illustration. 
reference to the trilling sound of its musical notes. The name is current in Orkney; but with it must be noticed

HARLE, the name given, both there and in Shetland, to one of the Mergansers, and probably cognate if not identical with the French Harle or Herle (Belon, Hist. Oys. p. 164) which has the same meaning, though how a French word should reach and come into use among a Scandinavian population is not easily explained, except on the supposition that Harle is a contracted form of Havelle (as above), and the name has been transferred from one species to another.

HARLEQUIN (with the suffix) DUCK was Forster's rendering in 1791 (Cat. Anim. N. Am. p. 16) of Anas histrionica of Linnæus, and since maintained as the common English name of that beautiful species, which inhabits the norther'n part of the Holarctic Region from Iceland westward to some undetermined limit in Siberia ; but is unknown, except as a rare wanderer, to the British Islands $01^{\circ}$ Continental Europe. It belongs to the subfamily Fuligulina (POCHARD), and has been often placed in the genus Clangula (GOLDEN-EYE), from which, however, it differs sufficiently to deserve separation as Cosmonetta or Histrionicus. The epithet Harlequin has been applied by Gould to one of the Australian Bronze-wing Pigeons, Phaps histrionica, and by Gurney to an African QuaIL, Coturnix delegorguii.

HARPY, a large diurnal Bird-of-Prey, so named after the mythological monster of the classical poets, ${ }^{1}$ - the Thrasaetus harpyia of modern ornithologists, - an inhabitant of the warmer parts of America from Southern Mexico to Brazil. Though known for more than two centuries, its habits have come very little under the notice of naturalists, and what is said of them by the older writers must be received with some suspicion. A cursory inspection of the bird, which is not unfrequently brought alive to Europe, its size, and its enormous bill and talons, at once suggest the vast powers of destruction imputed to it, and are enough to account for the stories told of its ravages on mammals, - sloths, fawns, peccaries, and spider-monkeys. It has even been asserted to attack the human race. How much of this is fabulous there seems no means at present of determining, but some of the statements are made by veracious travellers-D'Orbigny and Tschudi. It is not uncommon in the forests of the isthmus of Panama, and Mr. Salvin says (Proc. Zool. Soc. 1864, p. 368) that its flight is slow and heavy. Indeed its Owl-like visage, its short wings and soft plumage, do not indicate a bird of very active habits, but the weapons of offence with which,

1 But the åp $\eta \eta$ or harpa of their prose-writers seems to have been the LÄMMERGEYER. 
as above stated, it is armed, shew that it must be able to cope with vigorous prey. Its appearance is sufficiently striking - the head and

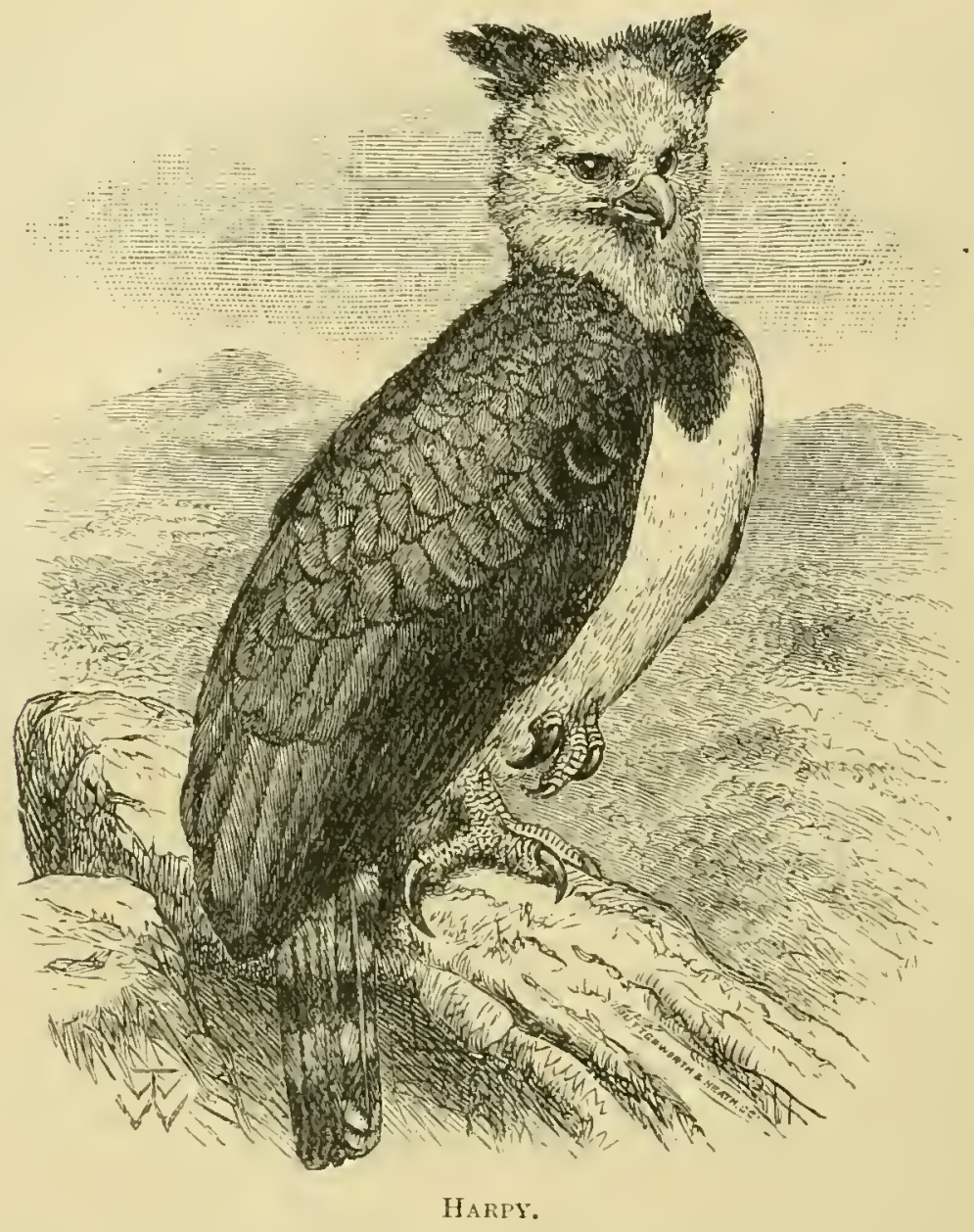

lower parts, except a pectoral band, white, the former adorned with an erectile crest, the upper parts dark grey banded with black, the

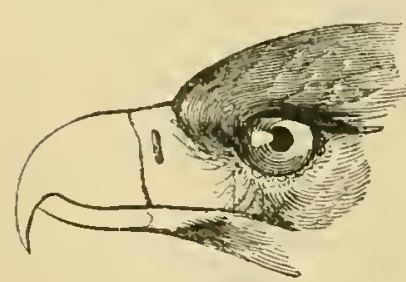

BLL OF HARPY.

(After Swainson.) wings dusky, and the tail barred; but the huge bill and powerful scutellated legs most of all impress the beholder. The precise affinities of the Harpy cannot be said to have been determined. By some authors it is referred to the EAGLES, by others to the Buzzards, and by others again to the Hawks; but possibly the first of these alliances is the most likely to be true.

HARRIER or HEN-HARRIER, from their habit of harrying poultry, names given to certain Birds-of-Prey which were formerly' very abundant in parts of the British Islands. The first of these names has now become used in a generic sense for all the species ranked under the genus Circus of Lacépède, and the second confined 
to the particular species which is the Falco cyaneus of Linnæus and the Circus cyaners of modern ornithologists.

On the wing Harriers have much resemblance to Buzzards, using the same flapping stroke of the pinions, and wheeling or sailing aloft as they fly. One European species indeed, C. seruginosus, though called in books the Marsh-Harrier, is far more commonly known in England and Ireland as the Moor-Buzzard. But Harriers are not, like Buzzards, arboreal in their habits, and always affect open country, generally, though not invariably, preferring marshy or fenny districts, for snakes and frogs form a great part of their ordinary food. On the ground their carriage is utterly unlike that of a Buzzard, and their long wings and legs render it easy to

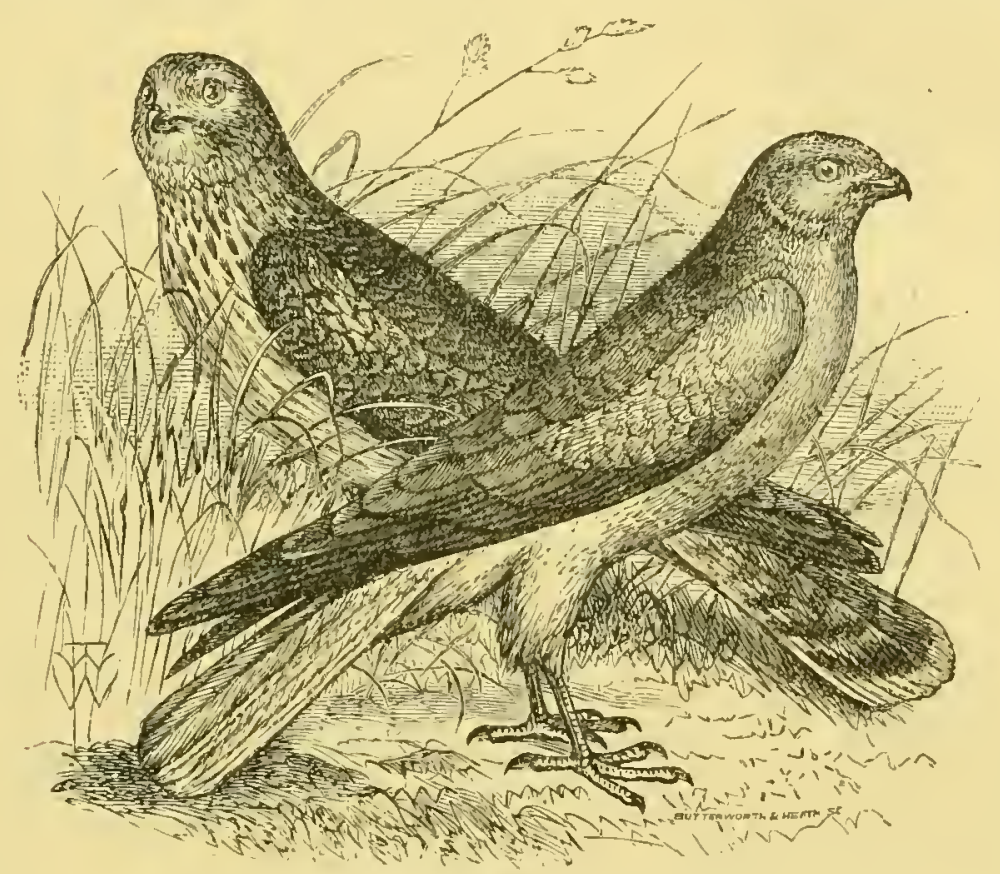

HEN-HARRIEP (Male and Female).

distinguish the two groups when taken in the hand. All the species also have a more or less well-developed ruff or frill of small thick-set feathers surrounding the lower part of the head, nearly like that seen in OwLS, and accordingly many systematists consider that the genus Circus, though undoubtedly belonging to the Falconidx, connects that Family with the Striges. No osteological affinity, however, can be established between the Harriers and any section of the Owls, and the superficial resemblance will have to be explained in some other way. Harriers are found almost all over the world, ${ }^{1}$ and fifteen species are recognized by Dr. Sharpe (Cat. B. Br. Mus. i. pp. 50-73). In most if not all the Harriers the sexes

1 The distribution of the various speeies is remarkable, while the range of some is exceedingly wide, that of others is very limited-C. maillardi, for instance, seems to be confined to the island of Réunion (Bourbon). 
differ greatly in colour, so much so that for a long while the males and females of one of the commonest and best known, the C. cyaneus

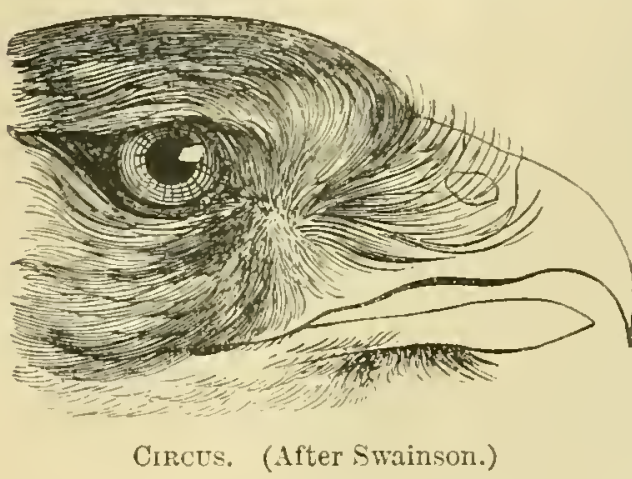
above mentioned, were thought to be distinct species, and were or still are called in various European languages by different names. The error was maintained with the greater persistency since the young males, far more abundant than the adults, wear much the same plumage as their mother, and it was not until after Montagu's observations were published at the beginning of the present century that the "Ringtail," as she was called (the Falco pygargus of Linnæus), was generally admitted to be the female of the "HenHarrier." But this was not Montagu's only good service as regards this gemus. He proved the hitherto unexpected existence of a second species, ${ }^{1}$ subject to the same diversity of plumage. This was called by him the Ash-coloured Falcon, but it now generally bears his name, and is known as Montagu's Harrier, C. cineraceus. In habits it is very similar to the Hen-Harrier, but it has longer wings, and its range is not so northerly, for while the Hen-Harrier extends to Lapland, Montagu's is but very rare in Scotland, though in the south of England it is the most common species. Harriers indeed in the British Islands are rapidly becoming things of the past. Their nests are easily found, and the birds when nesting are easily destroyed. In the south-east of Europe, reaching also to the Cape of Good Hope and to India, there is a fourth species, the $C$. swainsoni of some writers, the C. pallidus of others. In North America $C$. cyaneus is represented by a kindred form, $C$. hudsonius, usually regarded as a good species, the adult male of which is always to be recognized by its rufous markings beneath, in which character it rather resembles $O$. cineraceus, but it has not the long wings of that species. South America has in $C$. cinereus another representative form, while China, India, and Australia possess more of this type. Then there is a section in which the males have a strongly contrasted black and grey plumage, and finally there is a group of larger forms allied to the European C. aruginosus, wherein a grey dress is less often attained, of which the South African $C$. ranivorus and the New Zealand C. gouldi are examples.

HAWFINCH, a bird so called from the belief that the fruit of

1 A singular mistake, which has been productive of further error (Cat. B. Br. IIus. i. p. 64), was made by Albin, who drew his figure (Hist. B. ii. 11. 5) from a specimen of one species and colourel it from a specimen of the other. 
the hawthorn (Cratagus oxyacanthe) forms its chief food, the Loxia coccothraustes of Linnæus, and the Coccothraustes vulgaris of modern ornithologists, one of the largest of the FINCH Family (Eringillida), and found over nearly the whole of Europe, in Africa north of the Atlas, and in Asia from Palestine to Japan. It was formerly thought to be only an autumnal or winter-visitor to Britain, but later experience has proved that, though there may very likely be an immigration in the fall of the year, it breeds in nearly all the English counties to Yorkshire, and abundantly in those nearest to London. There

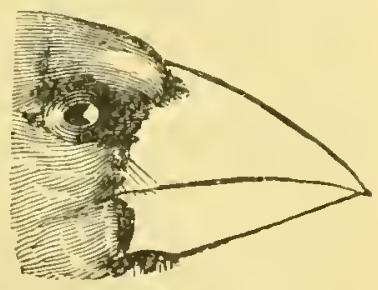

HAWTINCH. (After Swainson.) is also good reason for supposing that it is yearly extending its range in the British Islands. In coloration it bears some resemblance to a CHAFFINCH, but its much larger size and enormous beak make it easily recognizable, while on closer inspection the singular bill-hook form of some of its wing-feathers will be found to be very remarkable. Though not uncommonly frequenting gardens and orchards, in which as well as in woods it builds its nest, it is exceedingly shy in its habits, so as seldom to afford opportunities for observation. As the genus Coccothrumstes is now commonly restricted, it inchudes only two species,- the Japanese form, at one time regarded as distinct, being considered by later authorities to be inseparable from that of the continent-but examples from North-Western India have been described by Dr. Sharpe (Proc. Zool. Soc. 1886, p. 97) as forming a second.

HAWK (Anglo-Saxon, Hufoc), a word of indefinite meaning, being often used to signify all dinmal Birds-of-Prey which are neithei Vultures nor EAGLes, and again more exclusively for those of the remainder which are not Buzzards, Falcons, HARRIERs, or KITFS. Even with this restriction it is comprehensive enougl (for the definition of these groups is incertain), and will include more than a hundred species, which have been arrayed in genera varying in number from a dozen to above a score, according to the fancy of the systematizer. Speaking generally, Hawks have been characterized by possessing comparatively short wings and long legs, a bill which begins to decurve directly from the cere (or soft bare skin that covers its base), and has the cutting edges of its maxilla (or upper mandible) sinuated ${ }^{1}$ but never notched. If the word be taken with the limitation of signifying only the groups to which the Gos-Hawk and Sparrow-Hawk with their immediate allies belong, this is true enough, and then to these characters may be added others, structurally perhaps of less

I In one form, Nisoides, which on that account has been generically separated, they are said to be perfectly straight. 
value, but in other respects quite as important, that the sexes differ very greatly in size, that in most species the irides are yellow, deepening with age into orange or even red, and that the immature plumage is almost invariably more or less striped or mottled with heart-shaped spots beneath, while that of the adults is generally much barred, though the old males have in many instances the breast and belly quite free from markings. Nearly all wle of small or moderate size-the largest among them being the Gos-Hawk and its immediate allies, and the male of the smallest, Accipiter timus, is not bigger than a Song-THrusi. They are all birds of great boldness in attacking a quarry, but if foiled in the first attempt they are apt to leave the pursuit. Thoronghly arboreal in their habits, they seek their prey, chiefly consisting of birds (though reptiles and smill mammals are also taken), among trees or bushes, patiently waiting for an unwary victim to shew itself, and, when it appears, glicling upon it with a rapid swoop, clutching it in their talons, and bearing it away to eat it in some convenient spot.

It is impossible to enter into details of the mumerous forms which, notwithstanding the limitation above adopted, are to be called Hawks, or to describe the distinguishing characters, so far as any have been given, of the different groups or sections into which it has pleased systematic ornithologists to break them up, since hardly any two are agreed in the latter respect. There is at the outset a difference of opinion as to the scientific name which the most numerous and best known of these sections should bear-some authors terming it Nisus, and others, who seem to have the most justice on their side, Accipiter.

In a wider sense the word, Hawk, includes a considerable number of forms which cannot be positively assigned to any of the

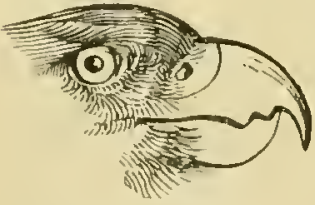

IIARPACtis.

(Alter swainson.) groups already named, one instance of which, out of several that could be cited, is seen in the Neotropical genus Hurpagus, whose deeply and doubly-notched bill 1 has caused it to be often put in the subfamily Falconina. But there its short and rounded wings, and the style of its successive phumages make it strangely out of place, so that its true position must be regarded as undetermined. The same characters, added to that afforded by its "amber" irides (Proc. Zool. Soc. 1882, 1. 623), indicates that the rare form which had the misfortune to be named Spiziupterye (Ilis, 1862, pl. ii.) is a near ally of Harpagus, notwitlistanding all that has been saicl to the contrary. One species of Harpagus is subject to Mrmicry.

1 'The "denticulations" are not merely superticial, as is the case with many birds possessing them, but exist, as Mr. Ridgway has shewn (Bull. U. S. Frool. and Googr. Survey, ser. 2, no. 4, pl. xii. fig. 8), in the bone of the premaxilla. 
HAY-BIRD and HAY-JACK, common local names in many parts of England for species of the restricted genus Sylvic (or Curruce as some would have it)-especially the BLACKCAP and Garden-WARBLER, on account of the beautiful nests like open basket-work they build, chiefly of bents, but having a portion of other plant-stems, and hairs interwoven. The first name is also often given to the WILLOW-WREN; but apparently by confounding it with the birds to which it properly applies.

HEART, a muscular tube interposed between the central ends of the reins and arteries, forming the pump that forces all the blood through every part of the body, by its contractions, which are much quicker in Birds than in any other animals, numbering abont 120 in the minute when the bird is at rest, and, when it is flying or has just alighted, beyond count by the ear-even the first strolie of the wings nearly doubles the rate of pulsation, and in accordance with this rapid metabolism of the avine organism the Heart is comparatively larger than in other Vertebrates. In shape it is conical, with the apex directed towards the tail, its long axis being parallel to that of the trunk, and it lies in the middle line of the body in the thoracic cavity, partly surrounded by the lobes of the Liver.

The walls of the Heart consist of three layers, of which the principal (1), forming the greater part of the whole, is composed of striped muscular fibres, differing from voluntary muscular fibres, and peculiar in so far that they are individually ramified and connected with each other like network-most of them describing a figure of 8 , starting at the base of the Heart and passing the apex with a spiral twist. The next layer (2) is the endocardium, lining the cavities of the organ, and composed of endothelial cells, elastic tissue and unstriped muscular fibre. Lastly (3) is the pericardium riscerale, a continuation of the peritonxum, and covering the Heart like any other viscus (cf. Digestrve Systen, p. 139, fig. 2). This visceral layer is prolonged from the base of the organ to the pericardium parietale or externum, forming a closed bag filled with a little serous fluid in which the Heart lies. This is the pericardium proper and is part of the cardio-abdominal chamber, severally connected with the membranes of the DrapHragar. Owing to this arrangement the whole ventral surface of the pericardinm is exposed when the sternum is removed.

The Heart of Birds like that of Mammals consists of two completely divided halves, each of which again is composed of an atrium and a ventricle. The right half receives and discharges only venous, the left only arterial blood ( $c f$. Circulation, p. SS). The two atria form the basal division of the Heart-thin-walled and darklycoloured. The two ventricles, lighter in colour and with thicker walls, form the greater part of the cone. These two divisions are 
marked externally by a transverse girdle of fat, indicating the course of the coronary vessels, or those arteries and veins which, as vasa vasorum, supply the Heart itself.

The right atrium occupies the upper right quarter of the organ, its thin walls having numerous muscular ridges (musculi pectinati) projecting into its cavity and presenting a honeycombed appearance. It receives the 3 great venous trunks of the body-namely (I) the vena cava superior dextra to the right and above, (2) the v. c. sup. sinistra more dorsally, and (3) the v. c. inferior more to the right and below. The entrance of the last is guarded by two prominent valves, corresponding functionally with the valvula Eustachii of Mammals. The orifices of the other veins are in many Birds without a valve, and are subject to many modifications.

The right ventricle occupies the ventral portion of the organ from the coronary sulcus to near the apex, and its walls are smooth internally, except in the distal corner, where the ventral wall passes into the septum ventriculorum, and sends out retiform muscular and tendinous projections. This ventricle communicates with the right atrium through the ostium atrio-ventriculare dextrum, which is furnished with a peculiar valve that hinders the return of the blood. This valve, valvula cardiaca dextra, represents the tricuspid valve of Mammals in function but not in shape or structure, since it consists chiefly of an oblique prominent reduplication of the muscles with the endocardiac lining of the right ventricle, while the opposite dividing wall is convex, and forms no velum, papillary muscles, or chorda tendinex. The right anterior corner of the right ventricle passes into the two pulmonary arteries, the short and still undivided stem of which is guarded by three semilunar valves.

The left atrium is less capacious but more muscular than the right. From its dorsal wall, a membranaceous and partly muscular projection partially divides its cavity into two portions-that on the right having smooth walls and receiving through one orifice the two pulmonary veins, and that on the left with numerous pectinate muscles-this projection directs the arterialized pulmonary blood towards the left ventricle.

The left ventricle extends to the apex of the Heart and is covered ventrally by the right ventricle, and anteriorly by the left atrium. Its cavity is larger and its walls three or four times thicker than those of the right ventricle. Two or three elaborate membranaceous flaps, held by numerous chordx tendinea, form a true mitral valve and allow the blood to pass througl the left ostium atrio-ventriculare and enter the root of the aorta through three semilunar valves.

The interventricular septum is always very thick, smooth and complete. In the corner which it forms with the ventral walls of the ventricles, trabecula carnea are often numerously developed. 
The interatrial septum is likewise complete, and is generally wholly membranaceous, though in the Ratitx and some others partly muscular. In the middle it is thinner and more transparent, but there is no depression or fossa ovalis as in Mammals.

HEATH-COCK and HEATH-HEN, originally names by which what we now know as the Blackcock and Greyhen were called; but on the North-American continent, though there no heather grows, applied to one or more species of Grouse inhabiting the open country.

HEATHER-BLEAT or HEATHER-BLITE, names given to the SNIPE in the breeding season, from the sound made by the corrigs wed cock-bird when performing his love-flight.

HEMIPODE, a recognized English rendering of Temminck's generic name Hemipodius (1815), which was anticipated by Bonnaterre's Turnix (1790), for a small group of birds some of which Anglo-Indians often call "Bustard-Quails" or "Button-Quails." Their complete distinction from the true QUAILS, and therefore from the Gallinde (or Rasores of some systematists), which had already been asserted, was proved by Prof. Hnxley (Proc. Zool. Soc. 1868 , pp. 303, 304), who established for them an independent group, TURNICOMORPHe, differing in his opinion "nruch more from the Alectoromorpha, Pteroclomorphx, and Peristeromorphax than these groups do from one another." This view is no doubt in the main correct; but most systematists have not gone so far, and deem the Turnicida to be but a Family of Gallinx. The genns Turnix is the subject of a very special monograph by Mr. Ogilvie-Grant (Ibis, 1889, pp. 446-475; 1892, p. 346), in which 23 species are admitted, but some points of great interest are therein but lightly treated. This being one of the few groups of birds in which the females are generally more finely colonred than the males--the sex supposed, and probably with truth, to perform the duty of incubation-the author's chief conclusions are that specific distinctions are afforded rather by the females than by the males, which generally so much resemble the young of the other sex as to furnish few specific characters, while the former when adult often differ widely; then, that the variegated markings (in some species very notable) tend to disappear with age; next, that the males seem to retain the characters of youth longer than the females; and, lastly, that the characteristic adornnents of the adult females denote maturity, and are permanent. Members of this genus are found from Spain and Sicily throughout Africa and Madagascar, southern Asia to China, the Indian Archipelago and Australia. The species from the western part of the Mediterranean Province is $T$. sylvatica, known in the Iberian peninsula by the 
name of Torillo, from the note it utters, which is like the subdued bellowing of a Bull.1

HERN, HERNSER, HERNSHAW, names of the

HERON 2 -French, Héron; Italian, Aghirone, Airone; Latin, Ardea; Greek, épwồós; Anglo-Saxon, Hragra; Icelandic, Hegre; Swedish, Häger ; Danish, Heire ; German, Heiger, Reiher, Heergans ; Dutch, Reiger - a long-necked, long-winged, and long-legged bird, the representative of a very natural group, the Ardeidx, which through the neglect or ignorance of ornithologists has been for many years encumbered by a considerable number of alien forms, belonging truly to the Gruidre (CRANE) and Ciconiddx (STORK), whose structure and characteristics are wholly distinct, however much external resemblance some of them may possess to the Herons. Eliminating these intruders, it is difficult or even impossible to estimate with any accuracy the number of species of Ardeidla which exist. Schlegel in 1863 enumerated 61 , besides 5 of what he termed "conspecies," as contained in the collection at Leyden (Mus. des Pays-Bas, Ardex, 64 pp.), - on the other hand, G. R. Gray in 1871 (Hand-list, iii. pp. 26-34) admitted above 90, while Dr. Reichenow (Journ. f. Orn. 1877, pp. 232-275) recognizes 67 as known, besides 15 "sub-species" and 3 varieties, arranging them in 3 genera, Nycticorax, Botaurus, and Ardea, with 17 subgenera. But it is difficult to separate the Family, with any satisfactory result, into genera, if structural characters have to be found for these groups, for in many cases they run almost insensibly into each other-though in common language it is easy to speak of Herons, EGRETS, BiTTterns, Night-Hhrons, and BoATbiLls. With the exception of the last, Schlegel retained all in the genus Ardea, dividing it into eight sections, the names of which may perhaps be Englished-Great Herons, Small Herons, Egrets, Semi-egrets, Rail-like Herons, Little Bitterns, Bitterns, and Night-Herons. It may be expedient here to adopt this arrangement, thongh the present writer would give it only partial and provisional assent.

The common Heron of Europe, Ardea cinerea of Linnæus, is the type of the Family, and it may also be regarded as that of Schlegel's first section. The species inhabits suitable localities

1 Three examples of it are said to have occurred in England (Ann. Nat. Itist. xiv. pp. 459, 460; Proc. Zool. Soc. 1868, p. 210), and easily-satisfied persons have admitted the speeies as a "British Bird."

"Generally pronounced "Hern," and in many parts of Engrland called "Hernser"-being a corruption of "Heronsewe," which, as Prof. Skeat states (Etymol. Dict. p. 264), is properly a distinct word from "Heronshaw" (a shaw or wood in which Herons breed), commonly confounded with it. The further corruption of "Hernser" into "handsaw," as in the well-known proverb, was easy in the mouth of men to whom hawking the Heronsewe was unfamiliar. 
throughout the whole of Europe, Africa, and Asia, reaching Japan, many of the islands of the Indian Archipelago, and even Australia. Though not so numerous as formerly in Britain, it is still common enough to render a description of it almost unnecessary, and there must be few persons who have not seen it rising slowly from some river-side or marshy flat, or passing overhead in its lofty and leisurely flight on its way to or from its daily haunts; while they are many who have been entertained by watching it as it sought its food, consisting chiefly of fishes (especially eels and flounder's)

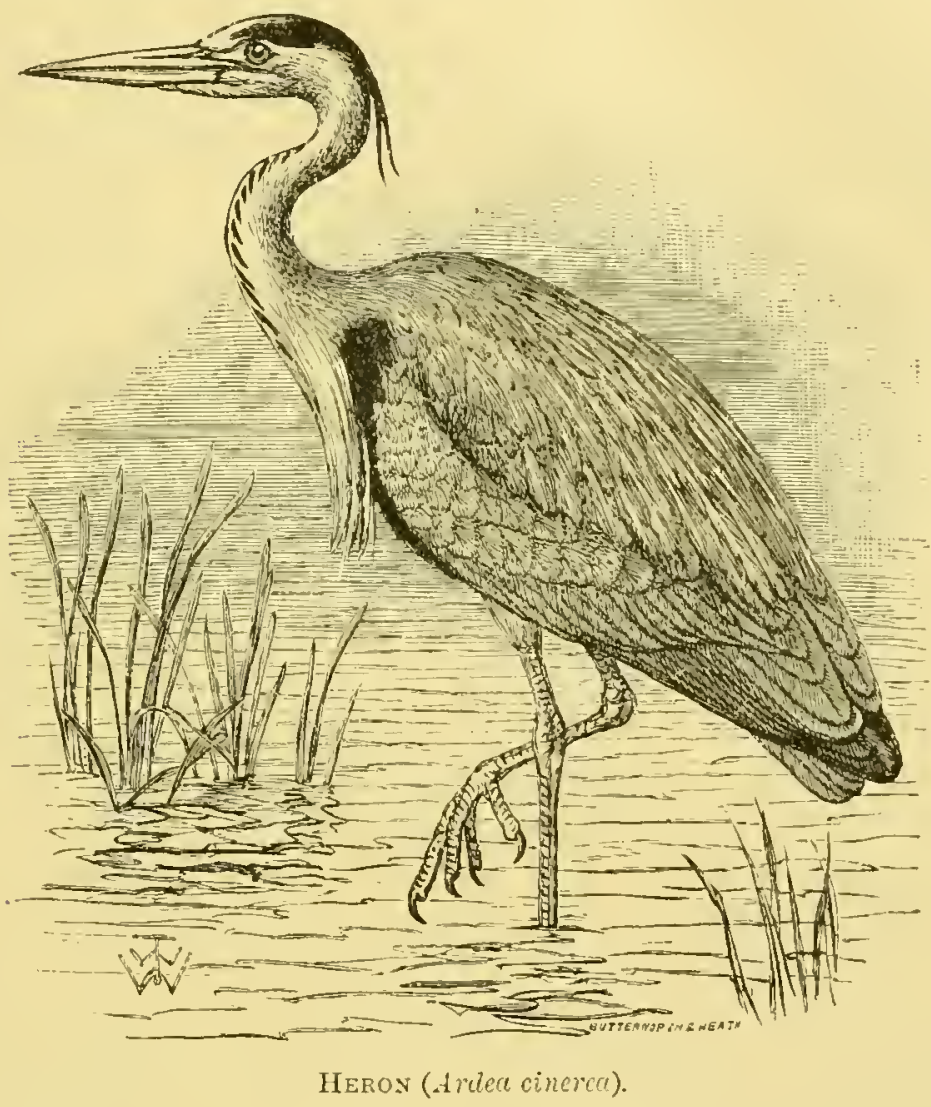

and amphibians-though young birds and small mammals come not amiss-wading midleg in the shallows, swimming ${ }^{\mathrm{I}}$ occasionally when out of its depth, or standing motionless to strike its prey with its formidable and sure beak. When sufficiently numerous it breeds in societies, known as Heronries, which of old time were protected both by law and custom in nearly all European countries, on account of the sport their tenants afforded to the falconer. Of late years, partly owing to the withdrawal of the protection they

I The medireval belief, expressed in the line, quoted by Folland (Foune pop. Fr. ii. p. 373),

Ardea culpat aquas quia nescit nare per illas,

is unfounced, as many observers can testify. 
had enjoyed, and still more, it would seem, from agricultural improvement, which, by draining meres, fens and marshes, has abolished the feeding-places of a great population of Herons, many of the larger Heronries have broken up-the birds composing them dispersing to neighbouring places and forming smaller settlements, most of which are hardly to be dignified by the name of Heronry, though commonly aceounted such. Thus the number of so-called Heronries in the United Kingdom, and especially in England and Wales, has become far greater than formerly, but no one can doubt that the number of Herons has dwindled. Mr. Harting gave, in 1872 (Zoologist, s.s. pp. 3261-3272 ; with additions and corrections, pp. 3404-3407), a list of those existing in the three kingdoms, more than 200 in number, of which a little orer one-half are in England and Wales, more than 50 in Scotland, and nearly 50 in Ireland. The sites chosen by the Heron for its nest rary greatly. It is generally built in the top of a lofty tree, but not unfrequently (and this seems to have been much more nsual in former days) near or on the ground among rough vegretation, on an island in a lake, or again on a rocky cliff of the coast. It commonly consists of a huge mass of sticks, often the accumulation of years, lined with twigs, and in it are-laid from four to six sea-green eggs. The young are clothed in soft flax-coloured down, and remain in the nest (NIDICOL. 2 ) for a considerable time, therein differing remarkably from the "pipel's" of the Crane, which are able to run almost as soon as they are hatched. The first feathers assimed by young Herons in a general way resemble those of the adult,

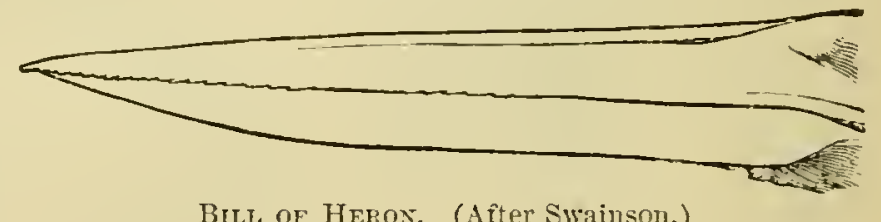

Brll of Herox. (After Swainson.) but the fine leaden-grey back, the pure white breast, the black throat-streaks, and espeeially the long pendent plnmes, which characterize only the very old birds, and are most beantiful in the cocks, are subsequently acquired. The Heron measures about 3 feet from the bill to the tail, and the expanse of its wings is sometimes not less than 6 feet, yet it weighs only between 3 and 4 it.

Large as is the common Heron of Europe, it is exceeded in size by the Great Blne Heron of America, Ardea herodias, which generally resembles it in appearance and habits, and both are smaller than the $A$. sumatrance or $A$. typhon of India and the Malay Archipelago, while the $A$. goliath, of wide distribntion in Africa and Asia, is the largest of all. The Purple Heron, A. purpurea, as a well-known Enropean species having a great range orer the Old World, also deserves mention here. Of the speeies included in Schlegel's second section, little need now be said. They inhabit the tropical parts of Africa, Australia and Ameriea. The Egrets, 
forming his third group, require more notice, distinguished as they are by a more slender bill, their pure white plumage, and, when in breeding-dress, by the beautiful dorsal tufts of decomposed feathers that ordinarily droop over the tail, and are in such request as ornaments by eastern magnates and western milliners, the latterand their customers causing some of the most abominable cruelty

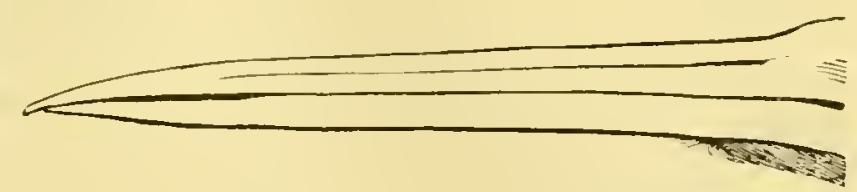

BILl of EGRET. (After Swaiuson.) practised in the animal world (see above, pp. 192, 225). The largest species is $A$. occidentulis, chiefly known from Lonisiana, Florida and Cuba; but one not much less, the Great Egret, A. ulbu, belongs to the OHd World, breeding regularly in south-eastern Europe, and occasionally straying to Britain. A third, A. egrette, represents it in America, while much the same may be said of two smaller species, $A$. gurwetta, the Little Egret of English anthors, and A. candidissime; and a sixth, A. intermedia, is common in India, China and Japan, besides occurring in Australia. The group of Semi-egrets, containing some nine or ten forms, among which the Buff-backed Heron, A. bubulcus, is the only species that is known to have occurred in Europe, is hardly to be distinguished from the last section except by their plumage being at certain seasons raried in some species witl slaty-blue and in others with rufous. The Rail-like Herons for'm Schlegel's next section, but it can scarcely be satisfactorily difterentiated, and the epithet is misleading, for its member's have no Rail-like affinities, though the typical species, which inhabits the south of Europe, and occasionally finds its way to England, has long been known as A. ralloides. ${ }^{1}$ Nearly all these birds are tropical or subtropical. Then there is the somewhat better defined group of Little Bitterns (Ardetta) containing about a dozen species - the smallest of the whole Family. One of them, $A$. minutu, though very local in its distribution, is a native of the greater part of Europe, and formerly bred in England. It has a close counterpart in the A. cxilis of North America, and is represented by three or four forms in other parts of the world, the $A$. pusilla of Australia especially differing very slightly from it. Ranged by Schlegel with these birds, which are all remarkiable for thoir skulking habits, but more resembling the true Herons in their nature, are the common Green Bittern of America, A. virescens, and its very near ally the African $A$. atricapilla, from which last it is almost impossible to distinguish the $A$. juranicu, of wide range thoughout Asia and its islands, while other species, less closely related, occur

I It is the "Squacco-Heron" of modern British authors-the distinctive name, given "Sguacen" by Willughby and Ray from Aldrovandus, having been misspelt by Latham. 
elsewhere as $A$. flavicollis, - one form of which, $A$. gouldi, inhabits Australia.

The true Bitterns, forming the genus Botaurus, have been already noticed (pp. 40-42); and of the Night-Herons Sehlegel recognized six species, all to be reasonably placed in the genus Nycticorax, characterized by a shorter beak and a few other peculiarities, among which the large eyes deserve mention. The first is $N$. griseus, a bird widely spread over the Old World, and not unfrequently visiting England, where it would undoubtedly breed if permitted. The same author united with it the common Night-Heron of America; but this, though very closely allied, is generally deemed distinct, and is the $N$. nxivis or $N$.gardeni of most writers. A clearly different American species, with a more southern habitat, is the $N$. violaceus or $N$. cayennensis, while others are found in South America, Australia, some of the Asiatic Islands, and in West Africa. The Galapagos have a peculiar species, $N$. pauper, and another, brevipennate and no doubt peculiar, $N$. megacephalus, existed in Rodriguez at the time of its being first colonized, but is now extinct. To this section undoubtedly belongs the BoAT$\operatorname{BILL}(\mathrm{p} .45)$, though it deserves generic distinction as Cancroma. ${ }^{1}$

Bones of the common Heron and Bittern are not uncommon in the peat of the East-Anglian fens. Remains from Sansan and Langy in France have been referred by M. Alphonse Milne-Edwards to Herons under the names of Ardea perplexa and A. formosa; a tibia from the Miocene of Steinheim by Dr. Fraas to an $A$. similis, while Sir R. Owen recognized a portion of a sternum from the London Clay (see above, 1p. 281, 282) as approaching this Family.

It remains to say that the Herons form part of Prof. Huxley's section Pelargomorpha, belonging to his larger group Desmognatha, and to draw attention to the singular development of the patches of "powder-down" which in the Family Ardeidxattain a magnitude liardly to be found elsewhere. .Their use is utterly unknown.

HETEROCHROSIS, the collective term sionifying the occurrence of abnormal coloration which may be due to one or other of various causes, such as

1. The partial or total absence of pigment producing a paler hue or even a complete AlBino.

2. The overproduction of pigment resulting in a more intense tint or the introduction of a new colour.

3. The absence of or change in the surface overlying the pigment.

There seems to be a certain correlation of colours in most cases of Heterochrosis: for instance, feathers with a yellow pigment have a tendency toward orange and red; green feathers exhibit

1 The Sun-BitTelis (Eurypyga), by some systematists considered to belong to the Ardeidx, certainly forms a Family by itself. 
xanthochroism; while blue, in the absence of the colour-producing surface, may appear brownish or grey. The pale coloration of "Desert-forms" (suprà, p. 336), and the seasonal and sexual changes of colour in many species, though perhaps ultimately reforable to acts of Heterochrosis, are not covered by this term since they are now become normal features (see CoLOuR, p. 99).

HETEROMERI, Garrod's name (Proc. Zool. Soc. 1S76, pp. 517, 518) for a group composed of Cotingide (CHATTERER) and Piprida (MANAKIN) which differ from most other birds in having the femoral artery developed instead of the sciatic, wherein they are opposed to the HomatomerI, but both combined form his MESOMYodr.

HETEROMORPHA, Prof. Huxley's name (Proc. Zool. Soc. 1865 , p. 311) for an ormithological section consisting, so far as known, of a single genus, Opisthocomus (HoACTZIN).

HEWEL, ${ }^{1}$ HEWHOLE, HICKWALL and HIGH-HOLDER, names given in various places to a WoODPECKER of one lind or another. The first two are said to be corrupted from the third," the older form of which, "Hickwaw" (Hollyband) and "Hickway," "Heigh-hawe" and "Highawe" (Cotgrave), can hardly have come - from anything but the Anglo-Saxon Higera or Higere (T. Wright's Tocabularies, pp. 29, 62, 281) meaning a laugher, and doubtless referring to the cry of the Green Woodpecker, Gecinus viridis. Hewhole was, however, in use in 1544, as shewn by Turner, who Latinized it Huhola; and in North America it has taken the further modifications of High-holc and High-holder for the FuICKER (Audubon, Orn. Biogr. i. p. 191 ; Ingersoll, Bull. Nuttall Club, 1881, p. 1S4). For further information on these and other English synonyms of Woodpecker see Yarrell (Br. B. ed. 4, ii. pp. 461-463). ${ }^{3}$

HOACTZIN or HOATZIN, a bird of tropical South America, thought by Buffon to be that indicated by Hernandez under these names, the Opisthocomus hoazin or 0 . cristatus of modern ornithologists-a very curious and remarkable form, which has long exercised the ingenuity of classifiers. Placed by Buffon among his "Hoccos" (Curassow), and then by P. L. S. Müller and Gmelin in

${ }^{1}$ For this Andrew Marvell on ( Nun) Appleton House (lines 557 et seqq.) may be cited.

2 If Hewhole be a corruption of Hickwall it has been obviously brought in by the bird's habits ; but we must not forget that Holzhauer is a German equivalent (Bechstein, Gemeinn. Naturgesch. Deutscht. ii. p. 1007).

3 The derivations of the many names of the Woodpecker in the earlier editions of Yarrell's work are extremely erroneous, being the work of some anonymous authority in days before the study of.words was placed on a sure basis. 
the Linnean genus Phasiams, some of its many peculiarities were recognized by Illiger in 1,811 as sufficient to establish it as a distinct genus, Opisthocoms ; but varions positions were assigned to it hy subsequent systematists, whose views, not being based on any information respecting its intemal structure, do not here require particular attention. L'Herminier, in 1837, was the first to give any account of its anatomy (Comptes liendus, v. p. 433), and from his time our knowledge of it has been successively increased by many authors. ${ }^{1}$

After a minute description of the skeleton of Opisthocomus, with the especial object of determining its affinities, Prof. Huxley (loc.

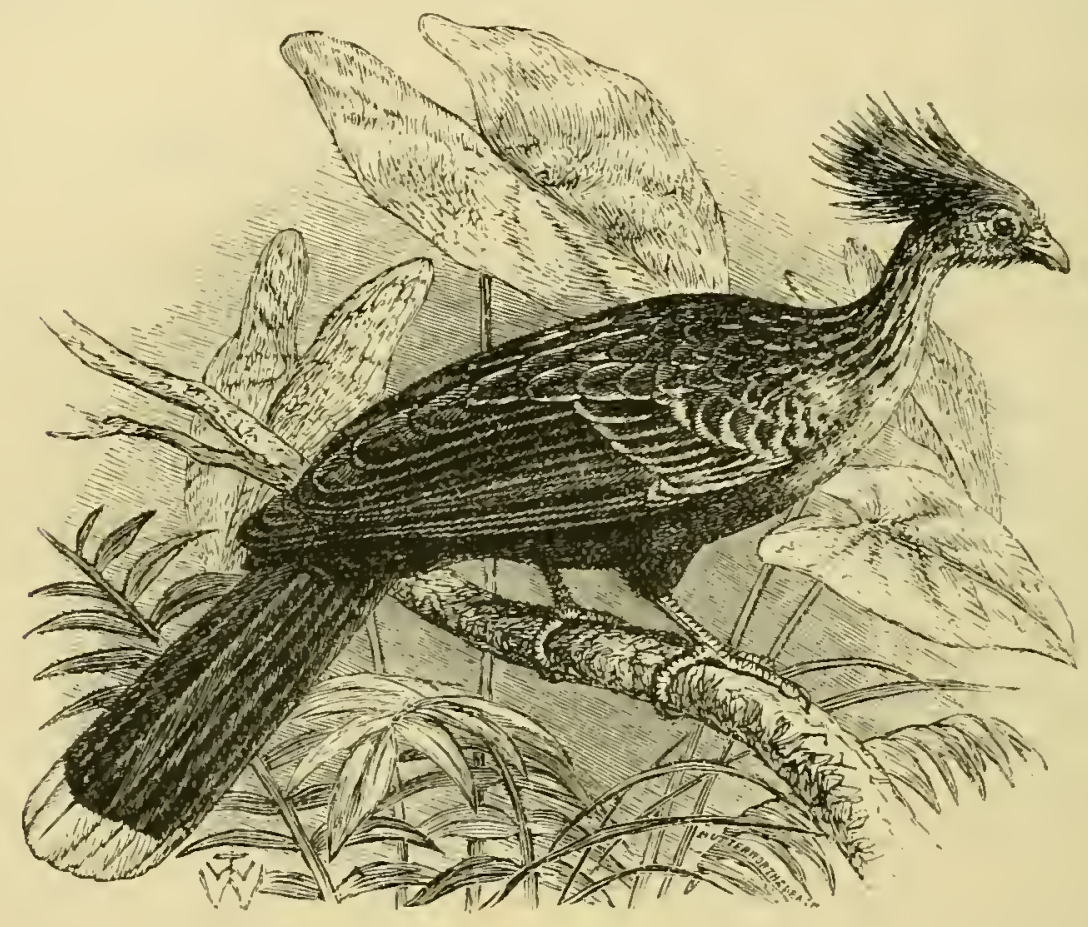

HOACTZLN.

cit.) declared that it "resembles the ordinary Gallinaceous birds and Pigeons more than it does any others, and that when it diverges from them it is either sui generis or approaches the Musophugida." He accordingly regarded it as the type and sole nember of a group, named by him HeTERonorpHe, which sprang from the great Carinate stem later than the Timumomorphar, Turnicomorphar, or Charudriomorpha, but before the Peristeromorphax, Pteroclomoriha, or Alectoromorpha'. This conchusion is substantially the same as that

1 Johannes Miiller, Ber. Akad. Missensch. Bertin, 1841, p. 17T; Deville, liev. Zool. 1852, p. 217; Gervais, Expél. Amérique du Sud, Zool. Anot. (Castelnau), p. 66 ; Huxley, Proc. Zool. Soc. 1868, 1) 304 ; Garrod, op. cit. 1879, p. 109 ; Perrin, Trans. Zool. Soc. ix. 1'. 53.3; Parker, op. cit. xiii. pp. 43-85; C. G. Young, Notes Leyd. Mus. x. Pl. 169-174, [1. S; Duclch, Ibis, 1S90, pp. 327.335 ; Gadow, Trans. Fr. Irish Acad. ser. 3, ii. PP. 147-151, pls. vii. viii. 
at which Garrod subsequently aruived after closely examining and dissecting specimens preserved in spirit; but the latter has gone further and endeavoured to trice more particularly the descent of this peculiar form and some others, remarking that the ancestor of Opisthocomus must have left the parent stem very shortly before the true Gallina first appeared, and at about the same time as the independent pedigree of the Cuculida and Musophagida commencedthese two groups being, he believed, very closely related, and Opisthocomus serving to fill the gap between them. Still more recently Dr. Gadow has shewn that the very singular modification of the sternal structure in this form is chiefly due to the extravagant enlargement of its crop.

It wonld be impossible here to state at length the facts on which these views are grounded, and equally impossible to give more than a very few details of the anatomy of this singular form. The first thing that strikes the spectator of its skeleton is the extraordinary structure of the sternal apparatus, which is wholly unlike that of any other bird known. The keel is only developed on the posterior part of the sternum-the fore part being aborted, or, as it were, cut away, while the short furcula at its symphysis meets the manubrium, with which it is firmly consolidated by means of a prolonged and straight hypocleidium, and anteriorly ossifies with the coracoids. This unique arrangement seems to be correlated with the enormously capacious crop, which rests upon the furcula and fore part of the sternum, and is also received in a cavity formed on the surface of each of the great pectoral muscles. Furthermore this crop is extremely muscular, so as more to resemble a gizzard, and consists of two portions divided by a partial constriction, after a fashion of which no other example is known among birds.

The Hoactzin appears to be about the size of a small Pheasant, but is really a much smaller bird. The beak is strong, curiously denticulated along the margin of the maxilla near the base, and is beset by diverging bristles. The eyes, placed in the middle of a patch of bare skin, are furnished with bristly lashes, resembling those of Hornbills and some few other birds. The head bears a long pendent crest of loose yellowish feathers. The body is olivecoloured, varied with white above, and beneath is of a dull bay. The wings are short and rounded. The tail is long, and tipped with yellow. The legs are long, the feet stout, the tarsi reticulated, and the toes scutellated; the claws long and slightly curved. According to all who have observed the habits of this bird, it lives in bands on the lower trees and bushes bordering the streams and lagoons, seldom taking wing, and then flying weakly, feeding on leaves and various wild fruits, especially, says the late Mr. Bates (Nat. Amaz. i. p. 120), on those of a species of Psidium, and it is 
also credited with eating those of an aroid (Montrichardia arborescens), which grows plentifully in its haunts. "Its voice is a harsh, grating liss," continues the same traveller, and "it makes the noise when alarmed, all the individuals sibilating as they fly heavily away from tree to tree, when disturbed by passing canoes." It exhales a very strong odour - wherefore it is known in British Guiana as the "Stink-bird" I_compared by him to "musk combined with wet hides," and by Deville to that of a cow-house. The species is said to be polygamous; the nest is built on trees, of sticks loosely placed above one another, and softer materials atop. Therein the hen lays her eggs to the number of three or four, of a dull yellowishwhite, somewhat profusely marked with reddish blotches and spots, so as to resemble those of some of the Pallidx (Proc. Zool. Soc. 1867, pl. xv. fig. 7, p. 164). The nestling has a claw on the index as well as the pollex, sufficiently developed to be functional, and enable the bird to creep about, and even raise itself by their aid, which is more than a young GREBE is able to do. In the valley of the Amazon it is called the "Cigano" or Gipsy, and in no part of the country where it occurs does it seem to be regarded with much favomr. Only one species of the genus is known to have existed, for Mr. Wallace's statement (Geogr. Distrib. Animals, i. p. 164) that remains of a second have been found in Brazilian caves originated in a mistake.

HOBBY (Fr. ${ }^{2}$ Hobreau and Hobereau, Old Fr. Hobé, Hoberel, Aubreau, Aubrier, Oubrier, and other forms; Provençal, Alban; Italian, Albanella $^{3}$ ) one of the smallest and most graceful of the British Falcons, the Falco or Hypotriorchis subbuteo of ornithology, the type of a very distinct group of Falconidx comprising a considerable number of forms, in life at once recognizable by their bold upstanding posture, and at any time by their long wings. The Hobby is a bird of great power of flight, chiefly used in the capture of insects, which form its ordinary food. It is a summer-visitant to most parts of Europe, including these islanils, frequenting woodland districts, and is most wantonly and needlessly destroyed by ignorant gamekeepers. A second European species of the group is the beantiful $F$. eleonoræ, which hardly comes further north than the countries

1 According to Mr. Quelch, whose notes (loc. cit.) on the havits of the bird are very valuable, the name most commonly used is "Hanna."

2 According to Littré, the French names are derived from the English, which, as Prof. Skeat kindly informs me, is allied to hober (whence, hover), to stir or ruove from place to place, and from the same root also come hobby, a small (active) horse, hobcler, a light horseman, and some other words.

3 This name seems to belong properly to birds of the genus Circus (HARRIEr), but has been misappropriated in the same way as the German Weissbäcklcin, to say nothing of Subbuteo and Hypotriorchis (which Gesner says should be Gypotriorchis). Seeing how very distinct Hobbies and Harriers are in behaviour, haunts and appearance, the confusion or change of name is inexplicable. 
bordering the Mediterranean, and, though in some places abundant, is an extremely local bird. There is no member of this section in

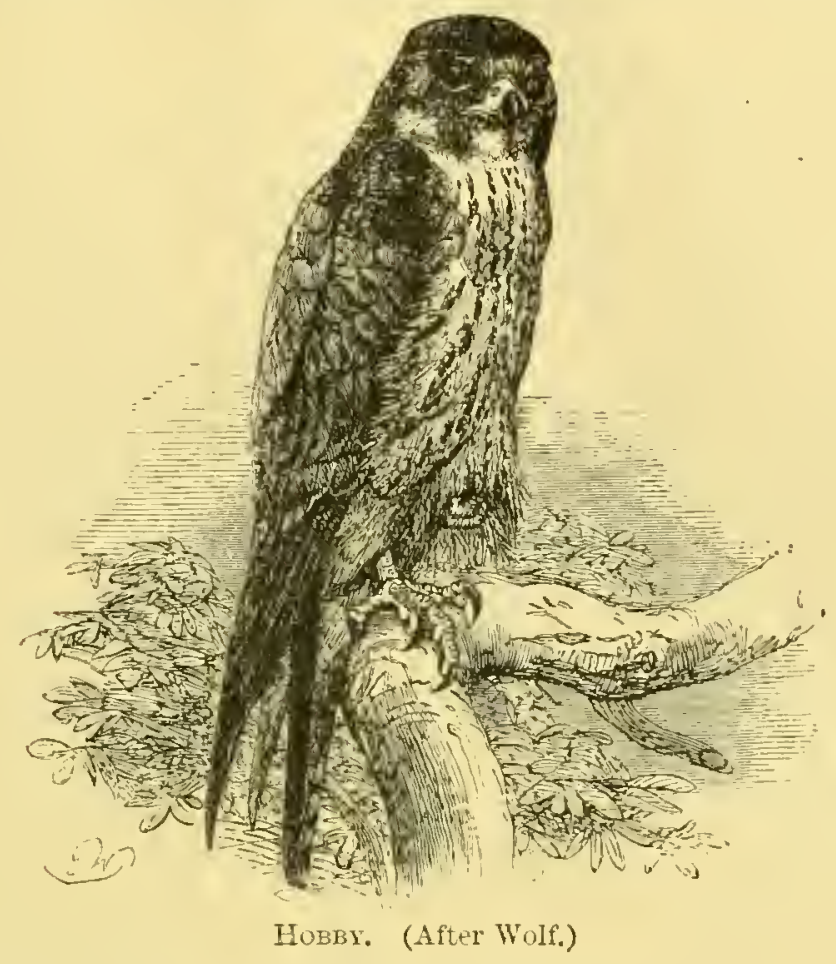

Torth America, but the largest species belonging to it seems to he the Neotropical H. femoralis, for $H$. diroleucus, thongh often assigned here is now supposed to be one of the group of typical Falcons.

HOLMCOCK, HOLM-THRUSH, names of the MistletoeTirnush from its seeking the berries of the Holm ol Holly-tree.

HOLORHINAL, the epithet bestowed by Garrod (Proc. Zool. Soc. 1873, p. 33) in his first taxonomical paper, on what seemed to him a "Subclass" of Birds; and, although given up hy him very soon aftel (op. cit. 1874, pp. 111-123), it has been absurdly used since by some systematizers, who have thereby made the introduction of the word here necessary.

HOMALOGONATA, the first of the two Subclasses, the other being called Anonalogonate, into which Garrod at one time divided Birds, according as they possessed an Ambiens muscle or not (Proc. Zool. Soc. 1S74, pp. 116-118), though he admitted that "there are a few undoubtedly homalogonatous birds in which the ambiens muscle is absent." For the groups contained in these categories see INTRODUCTION.

HOMCEOMERI, Garrod's name (Proc. Zool. Soc. 1ST6, pr. 517, 518 ) for a group of Birds consisting of the HAPLOOPHON Tracheophone, and differing from the Heteromeri in that the 
sciatic is the artery of the thigh, but with the last named forming the combination Mesonyodi, as opposed to the Acromyodr, the other great section of PASSERES.

HOMRAI, the Nepalese name, often used by Anglo-Indians, of the Great Indian HopNBILL.

HONEY-BIRD, an expression of respectable antiquity, since it was used by Sylvester early in the seventeenth century (Du Bartas, Weeke II.), but with no attempt at precision, and since applied indiscriminately to birds of varions sorts (see Honey-EATER).

HONEY-BUZZARD, the English name in Willughby's day of a bird which he thought he was describing for the first time; but herein he was wrong, for it was the Boudree ${ }^{1}$ of Belon (1555). It is the Falco apivorus of Linnæus, generically separated in 1817 by Cuvier, together with the crested eastern species from Java, as Pernis, which word, as before stated (p. 68, note) should be written Pternis. ${ }^{2} \quad$ Willughby spoke of it as being not unfrequent in this country, and the statement need not be doubted, but the destruction of our old forests, and the depredations of gamekeepers, who foolishly look upon this innocent bird as an enemy, have almost extirpated it in England, though a few pairs return every summer with the intent (generally frustrated) to breed in some of our larger woods, while towards the fall of the year young birds of the season visit this island on the way to their winter-quarters; and, through ignorance or wantonness, are generally killed. The home of these autimual visitants can be only vaguely surmised to exist in some northeastern country, for the species is not ordinarily common in Scandinavia; but its yearly passage, often in great numbers, over Heligoland in Angust and September is one of the most remarkable ornithological features of that.remarkable ornithological spot. ${ }^{3}$

1 In modern French Bondrée, which, according to Littré, is from the old word bondir, to cry out; but he takes no notice of the more ancient form, and that may perliaps be supposed to be related to bouder, to be alone or withdraw from company (ef. the French boudoir and the English "withdrawing-room")-in a secondary sense to sulk.

2 The mistaken spelling is much older than Cuvier, for Gaza the first translator of Aristotle has Pernix (Hist. Anim. ix. 36, Venetiis: 1525, fol. 34). Gloger in 1842 (Hand- und Hilfsbuch der Nuturgesch. p. 215) noticed this error, but seems himself to have been the victin of a misprint. The eastern species was not technically denominatel by Cuvier in his work, but was donbtless, after his custom, named in the Paris Museum, whence Vieillot in 1823 (Encyclop. Héthoul. p. 1225) described it as Buteo eristatus. In the same year it wis described and figured by Temminck anıl Laugier ( $P l$. col. 44) as Faleo ptilorhyju. chus, a specific name so bad, that unless its priority be clearly established it should be given up for cristatus.

3 Herr Gätke (Vogelw. Helgolend, p. 190) records one extraordinary instance. During the forenoon of the 19th of September 1858 parties of from 5 to 10 wrere 
The name Honey-Buzzard is admittedly misleading, for honey forms no part of its food, though the immature stages of Wasps and Humble-bees have a particular attraction for it ; and it may be seen on the ground, where it runs swiftly like a Barndoor-Fowl, scratching out their nests, and feeling on the living contents of the combs, regardless of the stings of the infuriated owners, against which the short, rounded and closely-adpressed feathers covering its face are said to form a protective vizor. The species is still further remarkable for the great difference of coloration exhibited by individuals belonging to it, which have hitherto defied all attempts at reduction to what passes for "law" $;$ " but the widest variation is obserrable in young birds of the year, while the assumption of an ashy-grey head is held to indicate maturity. Whether these cases can be justifiably attributed to what is called POLYMORPHISM remains to be proved; but that obviously could only be done after a series of attentive observations which can hardly be carried out in England on a scarce species that is dwindling in numbers, as this is. The HoneyBuzzard occupies a nest in a high tree, and therein lays 3 richlycoloured eggs. When the young are hatched the parents surround it with leafy boughs, renewed as they wither, but whether intended as a screen or a barrier is unknown; though the former is believer to be the object of this habit, and may possibly have given rise to the old French name of the species.

Two other species of the genus beside those mentioned are recognized by Mr. Gumey (List Diurn. B. of Prey, p. ST) - one from Burma and the adjacent countries, $P$. bruchypterus or tuceddulii, and

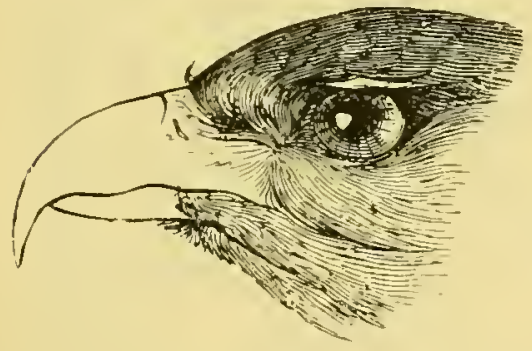

CYMINDIS.

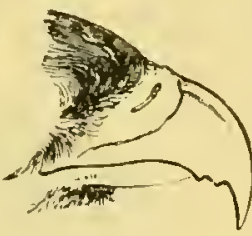

B. $\%$ A.

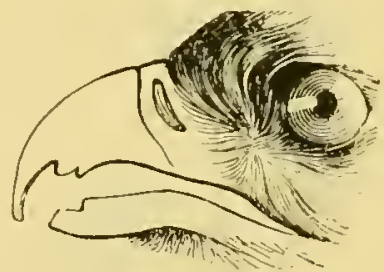

AVICIDA.

(After Swainson.)

one from Celebes, $P$. celebensis; but it is asserted to have also several other allies, some of which lead off to the IItrina (KiTw),

seen on jassage, constantly increasing in numbers and with greater frequeney; while from 3 to 6 o'clock in the afternoon a continuous stream of greater and greater fiocks from 50 to 80 or even more was maintained. All came from the cast and passed westward ( $f f$. Cordeaux, T6is, 1875, pp. 175, 176). Similar flocks lave been observed erossing the strait of Gibraltar by Favier and Lord Lilford (Ibis, 1865, p. 177; Irby, Orn. Sti. Gibralt. p. 49).

1 Herein see the late Mr. Gurney's notes (Ibis, 1880, 11. 195-204), wherein are references to many other anthorities. 
and others to the true FALCONs. Yet it may he doubted whether further observation of such forms as Leptodon or Cymindis, and Baza or Avicidu will admit of their being placed very near to the present genus. The last named inhabits the south-eastern portion of the Old World; while the first belongs to the Neotropical Region.

HONEY-EATER or HONET-SUCKER, names applied by many writers in a very loose way to a large number of birds, some of which have no intimate affinity; but here to be used for the Family Meliphagida in a restricted sense-excluding therefrom the Carpbida (DaCnis), Dicrida (Dicæum), Drepanididæ (Drepanis), and Nectarinizda (SUN-BIRD), as well as the genera Promerops and Zosterops with whatever allies they may possess. Even with this restriction, the extent of the Family must be regarded as indefinite, owing to the absence of materials sufficient for arriving at a satisfactory conclusion, though the existence of such a Family may be indisputable. Making allowance then for the imperfect light in which they must at present be viewed, it includes some of the most characteristic forms of the ornithology of the New-Zealand and Australian Regions - but a single species only, Ptilotis limbata (which just crosses "Wallace's Line" to Bali), being said to occur ontside their limits. They all possess, or are supposed to possess, a long protrusible tongue with a frayed, brush-like tip, differing in its quadruple or multiple structure, and laciniated outer border (cf. Gadow, Proc. Zool. Soc. 1883, p. 66) from that found in any other bird, and capable of being formed into a suctorial tube, by means of which honey is absorbed from the nectary of flowers, though it would seem that insects attracted by the honey furnish the chief nourishment of many species, while others undoubtedly feed to a greater or less extent on fruits. The Meliphugida, as now considered, are for the most part small birds, none exceeding a Jay in

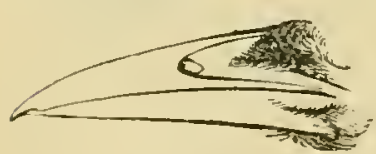

ExTonyza.

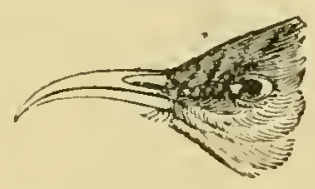

MYZONELA.

(After Swainson.) size-Entomyat cyanotis, the "Blue-eye" of Australian colonists, being one of the largest. They hare been divided into some 24 genera, containing about 150 species, of which only a few can here be particularized. Most of the forms have a very confined range, being found perhaps only on a single island or group of islands, but there are a few which are more widely distributed. In plumage they vary much. The species of Ptilotis are senerally characterized by a tuft of white, or in others of yellow, feathers springing from behind the ear. In the greater number of the genus Myzomela the males are recognizable by a gorgeous display of crimson or scarlet, which has caused one species, MI. sangminolenta, to be known as the SomfrEr-BIRD to Australian colonists; but in others 
no brilliant colour appears, and those of several genera have 10 special ornamentation, while some have a particularly plain appearance. One of the most curions forms is Prosthemadera-the Tui or PARson-BIRD of New Zealand. The Bell-BIRD of the same comntry (supric, p. 31), Anthornis melanum, is another member of this Family, and unfortmutely seems to be fast becoming extinet, a fate

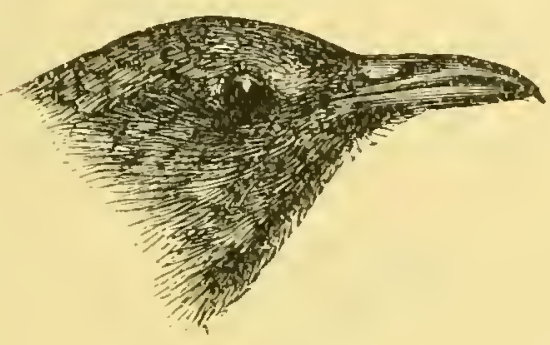

ANTHORis.

(From Buller:)

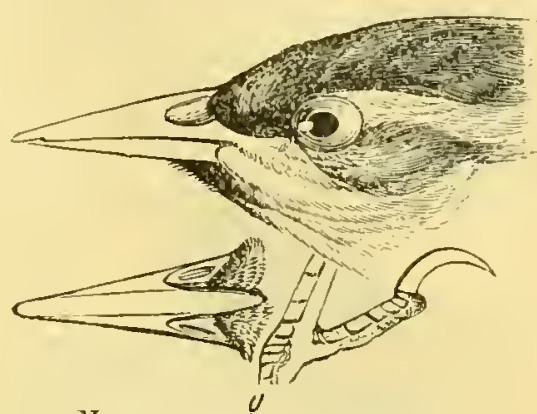

MELITHREPT F VALIDIROSTRIS. (After swainson.)

that is said to have already befallen the STITCh-BIRD, Poyononis, of the same country. But it would be impossible here to entel' much further into detail, thorgh the Watrue-ErRds, Anthocharu, of Anstralia have at least to be named, and the Friar-BIRDs, Philemon, already mentioned (supiù, pp. 292, 293), must again be noticel (Mnncri ). Melithreptes, with 5 or 6 species, all but one peculiar to Australia or Tasmania, considered by some writers to be allied to Zosterops, probably belongs here.

HONEY-GUIDE, a bird so called from its habit or supposed habit of pointing out to man and to the ratel (Mellivore capensis) the nests of bees. Stories to this effect have often been told, and may be found in the narratives of many Africin travellers, from Brice to Livingstone. Yet Mr. Layard says (B. S. Africa, p. 24.2) that the birds will not unfrequently lead any one to a leopard or a snake, and will follow a dog with vociferations, ${ }^{1}$ so that at present judgment may perhaps be suspended on the matter, though its antics and noisy cry unquestionably have in many cases the effect signified by its English name. If not its first discoverer, Sparrman, in 1777 , was the first who described and figured this bird, which he met with in the Cape Colony (Phil. Tians. lxvii. pp. 42-47, pl. i.), giving it the name of Cuculus inclicator; its feet with the toes placed in pairs-two before and two behind-inducing the belief that it must be referred to that genus. Vieillot in 1816 elevated it to the rank of a genus, Indicator; but it was still considered to belong to the Family Cuculida (its asserted parasitical habits lending force to that belief) by all systematists except Blyth and Jerdon, until it was shewn by Mr. Blanford (Obs. Geol. and Zool. Abyssiniu,

1 'This is alsn a well-known habit with some Corvida-the Jays ancl Pies for example. 
pp. 308, 309) and Mr. Sclater (Ibis, 1870, Ip. 176-180) that it was more allied to the C'upitonida (BARBET), and, in consequence, was then made the type of a distinct Fimily, Indicutorida. The correctness of this view was proved by Garrod (Proc. Zool. Soc. 1S78, pp. 930935). In the meanwhile other speeies had been discovered, some of them differing sufficiently to warant Sundevall's foundation of a second genus, Prodotiscus, of the gromp. The Honey-Guides are small birds, the largest hardly exceeding a Lark in size, and of plain plumage, with what appears to be a very Sparrow-like bill. Captain Shelley in 1891 (Cut. B. Br. Mus. xix. pl. 1-12) recognized nine

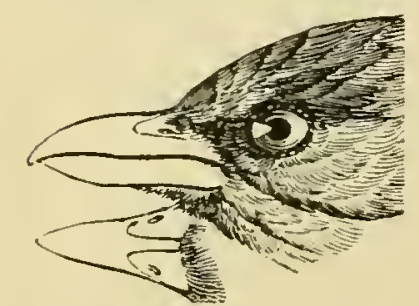

IvDicATor. (After Swainson.) species and one subspecies of the genus Indicutor, and two of Prodotiscus. Four of the former, including $I$. sparmani, which was the first made known, are found in South Africa, and one of Prolotiscus. The rest inhabit other parts of the same continent, except $I$. archipelagicus, which belongs to Bomeo and Malacea, and I. xanthonotus, which oceurs on the Himalayas from the borders of Afghanistan to Bhotan. The interrupted geographical distribution of this genus is an instructive fact.

HOODIE, properly the Scottish name for the Grey or Hooded Crow, but occasionally used also for the Black form.

HOOPOE (French Huppe, Latin Upupu, Greek " bestowed apparently from its cry), a bird long celebrated in literature, and conspicuous by its variegated plumage and its large erectile erest, ${ }^{1}$ the Upupa epops of naturalists, which is the type of the very peculiar Family Upupida, placed by Prof. Huxley in his group Coccygomorpha, but considered by Dr. Murie (Ilis, 1873, p. 208) to deserve separate rank as Epmomompha. This speeies has an exceedingly wide range in the Old World, being a regular summervisitant to the whole of Europe, in some parts of which it is abundint, as well as to Siberia, mostly retiring southwards in autumn to winter in equatorial Africa and India, though it would seem to be resident throughout the year in North-Eastern Africa and in China. Its power of wing ordinarily seems to be feeble; but it is capable of very extended flight, as is testified by its wandering habits (for it oceasionally makes its appearance in places very far removed from its usual haunts), and also by the fict that when pursued by a Falcon it will rapidly mount to an extreme height and frequently effect its escape from the enemy. About the size of a Thrusl, with a long, pointed, and slightly arched bill, its head and

1 Hence the secondary meaning of the French word huphe-a crest or tuft (cf. Littré, Dict. Françuisc, i. 2067). 
neck are of a golden-buff-the former adorned by the crest already mentioned, which begins to rise from the forehead and consists of broad feathers, gradually increasing in length, tipped with black, and having a subterminal bar of yellowish-white. The upper part of the back is of a rinous-grey, and the scapulars and flight-feathers are black, broadly barred with white, tinged in the former with buff. The tail is black with a white chevron, marking off about the distal third part of its length. The legs and feet are as well alapted for ruming or walking as for perching, and the scutellations are contimued round the whole of the tarsi. Chiefly on account of this character, which is also possessed by the Larks, Sundevall

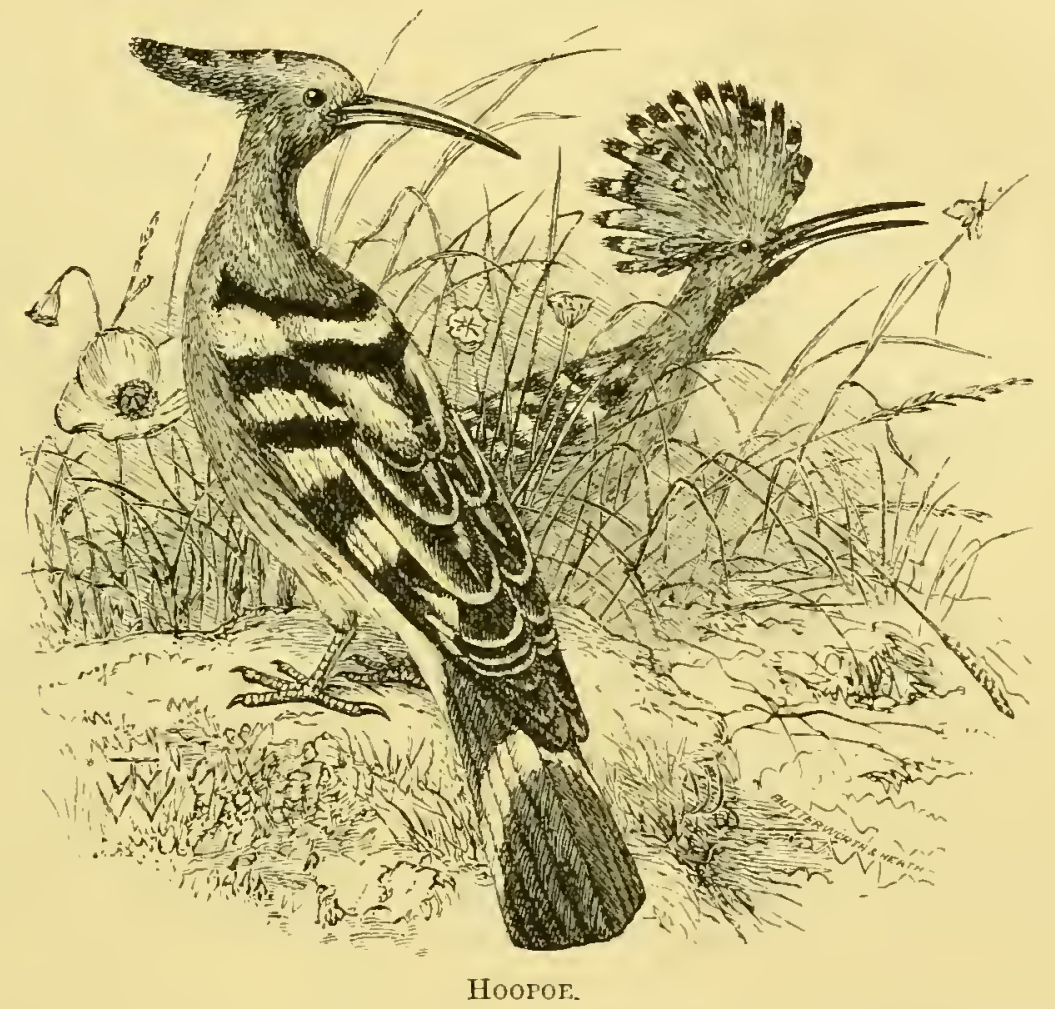

(Tentamen, pp. 53-55) united the Upupida and Alaudida in the same "cohors," Holaspidea. Comparative anatomy, however, forbids its being taken to signify any real affinity between these groups, and the resemblance on this point, which is by no means so striling as that displayed by the form of the bill and the coloration in certain LARKs (of the genus Certhilauda, for instance), must be ascribed to analogy merely, though at present no explanation of the why and the wherefore can be offered.

Pleasing as is the appearance of the Hoopoe as it fearlessly parades its showy plumage, its habits are much the reverse. All observers agree in stating that it delights to find its food among filth of the most abominable description, and this especially in its winter-quarters. But where it breeds, its nest, usually in the hole 
of a tree or of a wall, is not only partly composed of the foulest material, but its condition becomes wurse as incubation proceeds, for the hen scarcely ever leaves her eggs, being assiduously fed by the cock as she sits; and when the young are hatched, their fæces are not removed by their parents, ${ }^{1}$ as is the case with most bircls, but are discharged in the immediate neighbourhoad of the nest, the unsanitary condition of which can readily be imagined. Worms, grubs, and insects generally, form the Hoopoes' food, and upon it they get so fat in autumn that they are esteemed a delicate morsel in some of the countries of Southern Europe, and especially by the Christian population of Constantinople. ${ }^{2}$

Not a year passes but the Hoopoe makes its appearance in some part or other of Britain, most often in spring, and if unmolested would doubtless stop to breed here, for a few instances are known in which it has done so. But its remarkable plumage always attracts attention: it is generally shot so soon as it is seen, and before it has time to begin a nest, which there is reason to think would not in a temperate climate become so offensive a nuisance as it is in more southern latitudes. Eight or nine so-called species of the genus have been described, but the existence of five only can be established (Dresser; B. Eur. v. p. 184). Beside the Upupa epops above treated, these are $U$. indica, resident in India and Ceylon; $U$. longirostris, which seems to be the form of the IndoChinese countries; U. marginata, peculiar to Madagascar; and $U$. africance or minor, which inhabits South Africa to the Zambesi on the east and Benguela on the west coast. In habits and appearance they all resemble the best-known and most widely-spread species, and their particular differences need not be here pointed ont. ${ }^{3}$

HORNBILL, the English name long ago given to all the birds of the Family Bucerotida of modern ornithologists, from the extraordinary horn-like excrescence (epithema) developed on the bill of most of the species, though to.which of them it was first applied seems doubtful. Among classical authors Pliny had heard of such animais, and mentions them (Hist. Nat. lib. x. cap. xlix.) under the name of Tragopan; but he deemed their existence fabulous, comparing them with Pegasi and Gryphones-in the words of Holland,

1 This indeed is denied by Naumamn, but by him alone; and the statement. in the text is confirmed by many eye-witnesses.

2 Under the name of Dukipath, in the anthorized version of the Bible translated "Lapwing" (Lev. xi. 19, Deut. xiv. 18), the Hoopoe was accounted unclean by the "Jewish law." Arabs have a great reverence for the bird, imputing to it marvellons medicinal and other qualities, and making use of its head in their charms (cf. Tristram, Nat. Hist. of the Bible, pp. 208, 209).

3 The genera Ihinopomustus and IrRIsor are generally placed in the Family Upupide, but Dr. Murie (l.c.), after an exhaustive examination of their osteology, regards them as forming a group of equal value. 
his translator (i. p. 296)_- I thinke the same of the Tragropanades, which many men affirme to bee greater than the Egle; having crooked hornes like a Ram on either side of the head, of the colour of yron, and the head onely red." Yet this is but an exiggerated description of some of the species with which doubtless his informants had an imperfect acquaintance. Mediæval writers ${ }^{1}$ found Pliny's bird to be no fable, for specimens of the beak of one species or another seem occasionally to have been brought to Europe, where they were preserved in the cabinets of the curious, and thus Aldrovandus was able in 1599 to describe and figure (Ornithologia, lib. xii. cap. xx.) under the name of "Phinoceros Avis," the head of what is now called Buceros rhinoceros, though the lest of the bird was unknown to him. When the exploration of the East Indies had extended further, more examples reached Europe, and the "Cortus Indicus cornutus" of Bontius became fully recognized by Willughby and Ray, under the title of the "Horned Indian Raven or Topar called the Rhinocerot Bird." Since their time our knowledge of the Hornbills has been steadily increasing, but on many points there is still great lack of precise information, though the completion in 1882 of Mr. Elliot's Monograph of the Bucerotidx supplied a great want, for much diversity of opinion long prevailed as to how many real genera the Family comprises, or how many species. The group, though no doubt can be entertained as to its limits, ${ }^{2}$ contains many bulky birds, and has never been attractive to private collectors, while several of the species were, and still are, rare even in public museums. Some authors appeared to despair of dividing it satisfactorily, and left all the described species in the Limnæan genus Buceros, others split that genus into more than a score, while Sundevall (Tentamen, pp. 96, 97) recognized only three genera; but it is unquestionable that more should reasonably be admitted, and the present writer, though here adopting Mr. Elliot's determinations, is not prepared to state how many are required.

That gentleman divides them into two subfamilies, Bucorvina, with one genus Bucorvus, and Bucerotina with 18 genera, 8 of which belong wholly to the Indian Region, 4 to the Ethiopian and 2 to the Australian, while 3 have members in both the Ethiopian and Indian Regions, and one genus occurs in both the Indian and the Australian, though no species is common to any two Regions. The genus Bucorvus (or Bucorax as some write it), and consequently the subfamily Bucorvina, is confined to Africa, and contains 3 species distinguishable among other characters by their longer legs and shorter toes-the Ground-Hornbills of English writers. From the

1 E.g. Cardanus, De Subtil. lib. x. (ed. 1611, p. 601), Scaliger, Exercit. 231, 3.

2 Such genera as Euryceros, Scythrops, and others, together with the whole Family Momotidre, which had been at times placed by systematists among the Buceroticlix, have no affinity to them. 
days of Bruce there are few travellers in that country who have not met with and in their narratives said more or less of one or other of these bilds, whose large size and fearless habits render them conspicuous as they walk or run on the ground, or when disturbed perch on trees. The precise range of the several forms is not known, but the genus is found from Abyssinia to Natal, and from the Gold Coast to Zambesia. The northern forms differ from the southern, B. cafer-the "Brom-vogel" of European colonists in South Africa-in having the epithema open in front, and thereby presenting an appearance quite unique among birds.

Of the Bucerotinx, all of which are thoroughly arboreal in habit, Mr. Elliot recognizes only two species of Buceros, one B. rhinoceros (being, as already said, that whose head, with its unique up-turned epithema, was known to Aldrovandus) from Malacca, Sumatra, and Borneo, and the other, $B$. silvestris (with the epithema straight) peculiar to Java. Hardly less extraordinary than the first of these is the single species separated to form the genus Dichoceros, in which the epithema is a broad plate, slightly convex in the middle and rising on either side in a prominent ridge ending in two projecting points. This is D. bicornis, the "Homrai " of Anglo-Indian writers, found not only in the hilly forests of India but throughout the Malay Peninsula and reaching Sumatra. The genus Hydrocorax seems hardly separable from the last, but, with its 3 species, is peculiar to the Philippine Islands, and thus these genera contain the largest species of the Bucerotinx. Then comes Rhinoplax, which seems properly to contain but one species, the Buceros vigil, $B$. scutatus, or $B$. galeatus of authors, commonly known as the HelmetHornbill, a native of Sumatra and Borneo. This is easily distinguished by having the front of its nearly vertical and slightly convex epithema composed of a solid mass of horn ${ }^{\text {I }}$ instead of a thin coating of the light and cellular structure found in the others. So dense and hard is this portion of the "helmet" that Chinese and Malay artists carve figures on its surface, or cut it transversely into plates, which from their agreeable colouring, bright yellow with a scarlet rim, are worn as brooches or other ornaments. This bird, which is larger than a Raven, is also remarkable for its bare neck and long graduated tail, having the two middle feathers nearly twice the length of the rest. Nothing is known of its habits. $*$ Its head was figured by Edwards in 1755 , but little else was known

${ }^{1}$ Apparently correlated with this structure is the curious thickening of the "prosencephalic median septum" of the cranium as also of that which divides the "prosencephalic" from the "mesencephalic chamber," noticed by Sir R. Owen (Cat. Osteol. Ser. NIus. Coll. Surg. Engl. i. 1. 287); while the solid horny mass is further strengthened by a backing of bony props, directed forwards, and mecting its base at right angles. This last singular arrangement, not perceptible in the skull of any other species, does not seem to have been described. 
of it until 1801, when Latham described the plumage from a specimen in the British Musemm, and the first figure of the whole bird, from an example in the Museum at Calcutta, was published by Hardwicke in 1823 (Trans. Linn. Soc. xiv. pl. 23). Yet over twenty year's elapsed before French naturalists had seen more than its head. Under Rhinoplax Sundevall places the Buceros comatus of Raffles; but this would seem to be a wrong position for that species, the type of Bonaparte's genus Berenicomis, since it does not appear to possess a frontlet of solid horn, and Mr. Elliot puts it in the genus Anorrhinus.

Of other forms of Hornbill there is not room here to treat at length. In some, as the Indian Anthracoceros and the Ethiopian Bycanistes, the epithema grows out in such wise as to make the bird seem as if it had two beaks, one superimposed upon the other. Great as is the wonder which this arouses among stay-at-home ornithologists, it has failed, as in other cases, to excite enough curiosity among those that have opportunities of observation to enable them to provide the least hint as to the use it serves in the bird's economy. In other forms the epithema is hardly developed, and indeed a fairly complete series may be traced from (setting aside Bucorvus) Buceros to certain species of Toccus in which it may be said not to appear. In some of the intermediate forms it is curiously corrugated, and the ridge and furrow surface extends in Cranorhinus to the mandible. The development, however, of this most characteristic feature of the Family depends in some species, as might be expected, more or less on age and sex; and, important as it undoubtedly is, too much weight should not be assigned to it or other means of diagnosis neglected on its account. That excellent observer Tickell in his manuscript Birds of India (in the library of the Zoological Society of London) divides the Hornbills of that country into two genera only, Buceros and Aceros, remarking that the birds of the former fly by alternately flapping their wings and sailing, while those of the latter fly by regular flapping only. ${ }^{1}$ Several differences of structure are presented by the sternal apparatus of the various Bucerotidx, and it is quite possible that these differences may be correlated with Tickell's observations so as to furnish, when more is known about these birds, a better mode of classing them, and the same may be said of those of the African group containing the genus Toccus and its allies.

As a whole the Hornbills, of which more than 60 species have been described, form a very natural and in some respects an isolated group, placed by Prof. Huxley among his Coccygomorpha. It has

1 The noise made by the wings of some of the large species in their flight is compared by $\mathrm{Nr}$. Wallace, in an admirable article on the Family (Intellectual Observer, 1863, pp. 310 et seqq.), to the puffing of a locomotive steam-engine when starting with a train, and can be heard a mile off. 
been snggested that they have some affinity with the Upupida (Hoopoe), but even if that view be good the affinity cannot be very near. Their supposed alliance to the Rhamphastida (Toucan) rests only on the apparent similarity presented by the enormons beak, and is contradicted by important structural characters. In many of their habits, so far as these are known, all Hombills scem to be much alike, and though the modification in the form of the beak,

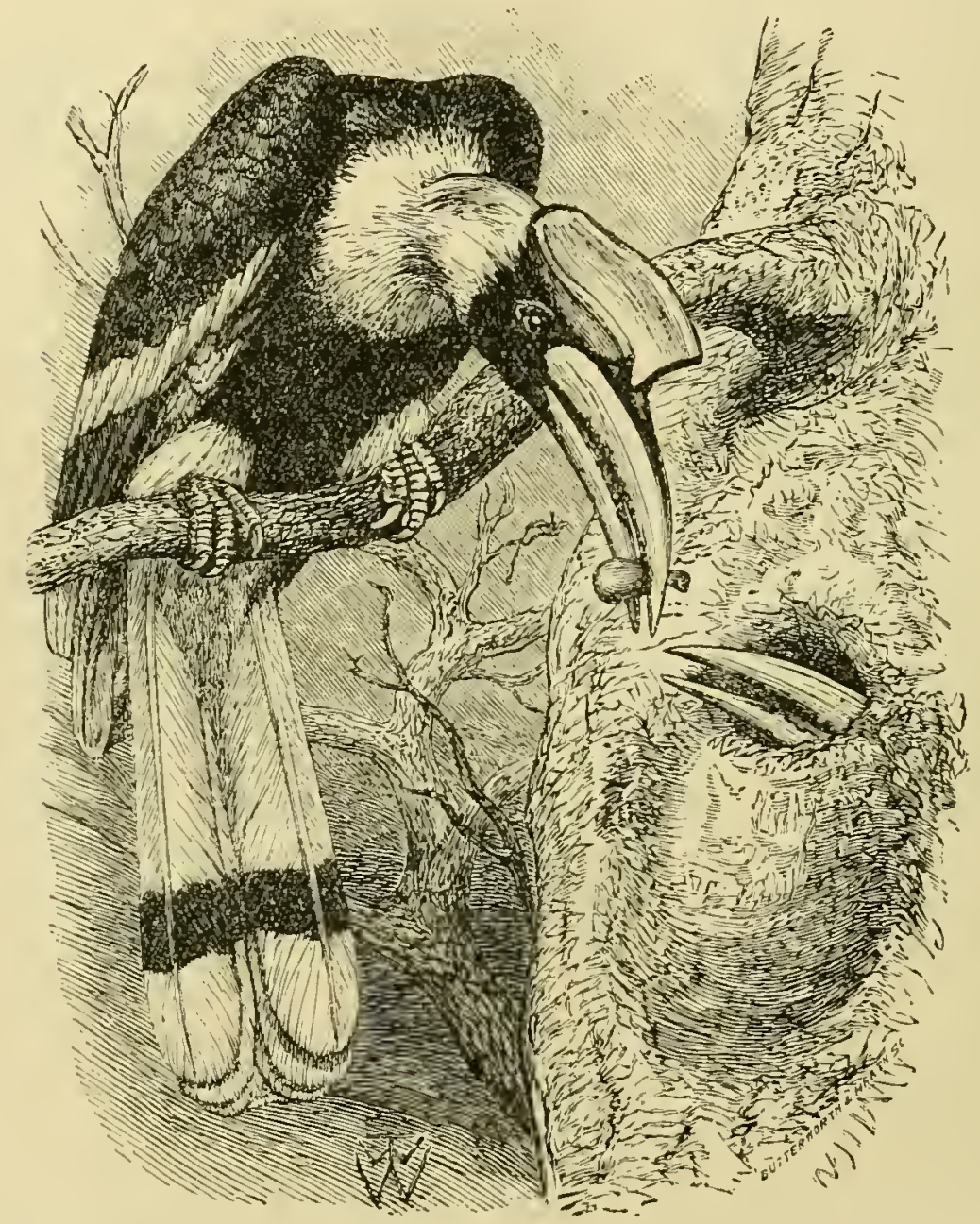

Homral or Great Indiax Horneill (Dichoceros bicorni 9 ). After Tickell's drawing in the Zoological Society's library.

and the presence or absence of the extraordinary excrescence, ${ }^{1}$ whenee their name is derived, canses great diversity of aspect among them, the possession of prominent eyelashes (not a common

1 Buffon, as was his mamer, enlarges on the cruel injustice done to these birls by Nature in eneumbering them with this deformity, which he deelares must hinder them from getting their food with ease. The only corroboration lits lervertel view receives is afforded by the olserved faet that Hombills, in captivity at any rate, never have any fat about them. 
feature in Birds) procluces a uniformity of expression which makes it impossible to mistake any member of the Family. Horubills are social birds, lieeping in companies, not to say flocks, and living chiefly on fruits and seeds; but the bigger species also capture and devour a large number of snakes, while the smaller are great destroyers of insects. The older writers say that they eat earrion, but further evidence to that effect is required before the statement can be believed. Almost every morsel of food that is picked up is tossed into the air, and then caught in the bill before it is swallowed. They breed in holes of trees, laying large white eggs, and when the hen begins to sit the coek plasters up the entrance with mud or elay, leaving ouly a small window through which she reeeives the food he brings her during her voluntary imprisonment.

This remarkable habit, almost simultaneously noticed by Dr. Mason in Burma, Tickell in India, and Livingstone in Africa, but since confirmed by other observer's, especially Mr. Wallace ${ }^{1}$ in the Malay Arehipelago, has been connected by Mr. Bartlett (Proc. Zool. Soc. 1869 , p. 142) with a peculiarity as remarkable, which he was the first to notice. This is the fact that Hornbills at intervals of time, whether periodical or irregular is not yet known, east the epithelial layer of their gizzard, that layer being formed by a secretion derived from the glands of the proventrieulus or some other upper part of the alimentary eanal. The epithelium is ejected in the form of a sack or bag, the mouth of which is closely folded, and is filled with the fruit that the bird has been eating. The announeement of a cireumstance so extraordinary naturally caused some hesitation in its acceptance, but the essential truth of $\mathrm{Mr}$. Bartlett's obserrations has been abundantly confirmed by Professor Flower (tom. cit. p. 150), and especially by Dr. Murie (op. cit. 1874, p. 420), and what seems now to be most wanted is to know whether these castings are really intended to form the henbird's food during her confinement.

HORN-PIE, a local name for the LAPWING, the first syllable referring to its erest which the bird in fullest vigour sets up on high, and the last to its plumage that on the wing appears to be black and white.

HOWLET, a form of Owlet, the diminutive of Owt, which has preserved the prefixed aspirate in some way that etymologists find hard to explain.

HUIA, the Maori name, adopted by the English in New Zealand, of a bird of that comntry, the only member of its genus,

1 In his interesting work (i. I. 213), he describes a mestling, of the species above figured, which he obtained as " a most curious object, as large as a pigeon, but without a particle of plumage on any part of it. It was exceedingly plump and soft, and with a semi-transparent skin, so that it looked more like a bag of jelly, with head and feet stuck on, than like a real bird." 
Heteralocha, ${ }^{1}$ and very remarkable for the sexual difference in the bill, which is so great as to have led Gould to describe the male and female as distinct species (Proc. Zool. Soc. 1836, pp. 144, 145). First referred, like so many other curve-billed birds, to the Upupida (Hoopoe), it was placed by Prof. Cabanis in 1850 (Mus. Hein. i. p. 218 ) among the Corvida, but Garrod after dissection (Proc. Zool. Soc. 1872, pp. 643-647) found its relation to the Stumida (STARLing) to be very intimate, and its structure clearly not allied to the Corvide, among which, however, Dr. Sharpe included it in 1877 (Cut. B. Br. MIus. iii. p. 143) though the year before (Voy. 'Evebus' and 'Terror,' App. 1. 27) he had followed Garrod. Probably the

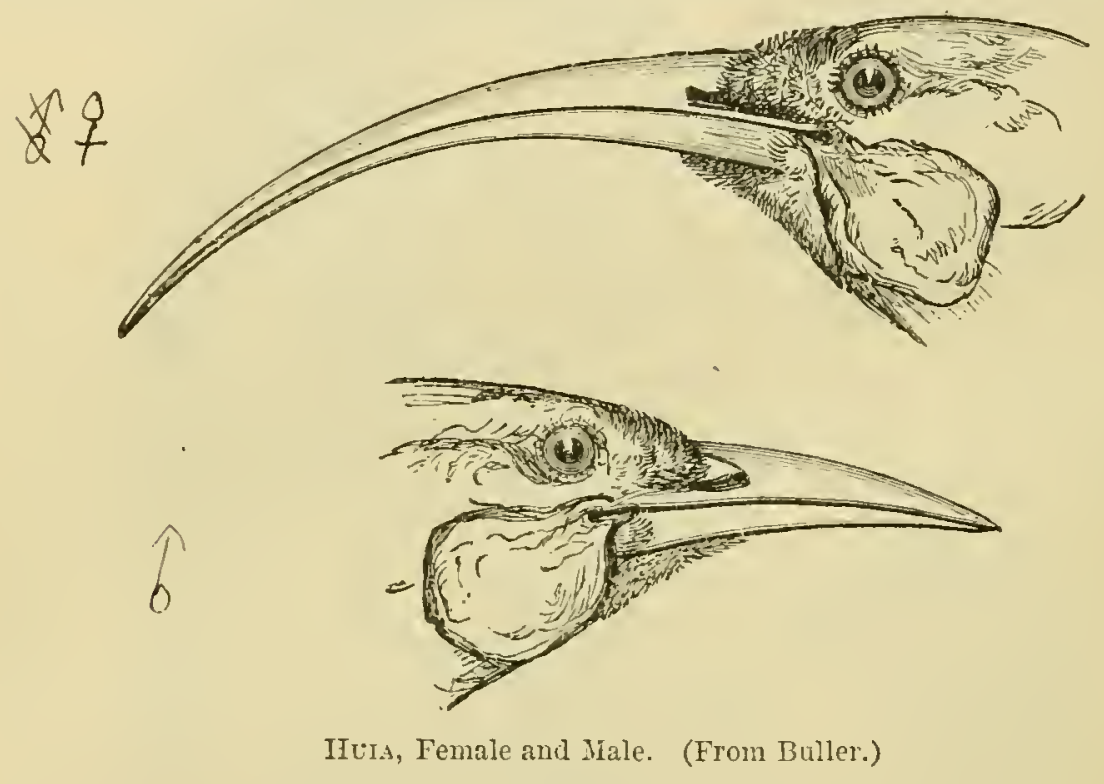

right view, as indicated by Prof. Cabanis's remarks on this very subject (loc. cit.), is that it is an ancient and generalized form, which cannot really be assigned to any of the more differentiated Families. According to the personal observation of Sir W. Buller, who enters at length on the natural history of the Huia (B. N. Zeal. ed. 2 , i. pp. $7-17$ ), its favourite food is the grub of a timber-boring beetle, and the male bird with his short stout bill attacks the more decayed portions of the wood, and chisels ont his prey, while the fomale with her long slender bill probes the holes in the sounder part, the hardness of which resists his weapon ; or, when he, having removed the decayed portion, is unable to reach the grub, the female comes to his aid and accomplishes what he has failed to do. The Huia is entirely a forest-bird, and is doubtless one of those doomed to extinction, though at present it seems to maintain its existence. Except a white terminal band on the tail, the whole plumage is in both sexes black, with a green metallic gloss: the bill is ivorywhite, and the large rounded wattles at the gape are of a rich orange.

${ }^{1}$ Originally named by Gould Neomorpha, a term which was preocenpied. 
HUMERUS, the upper arm-bone in Birds, articulating by its head with the coracoid and scapula at the glenoid cavity, and by

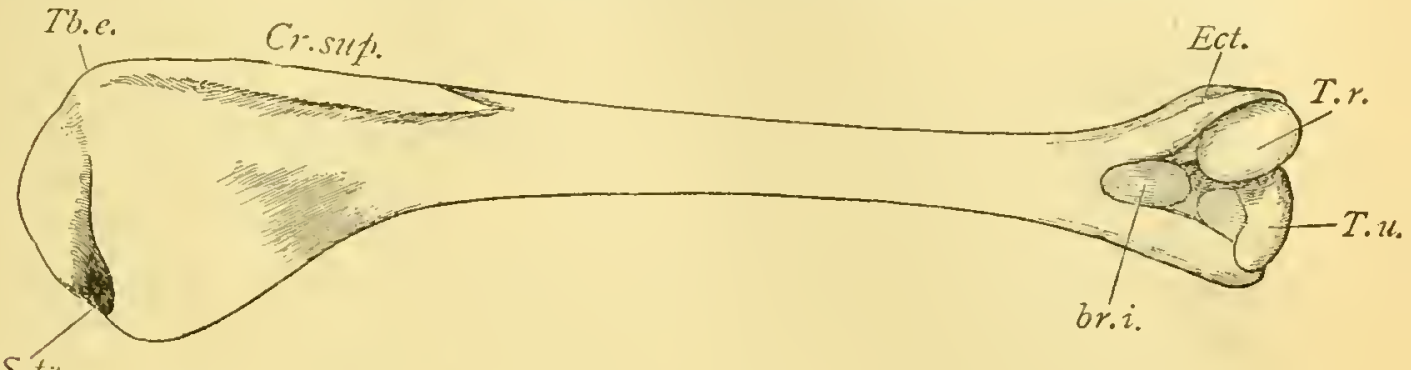

S.tr.
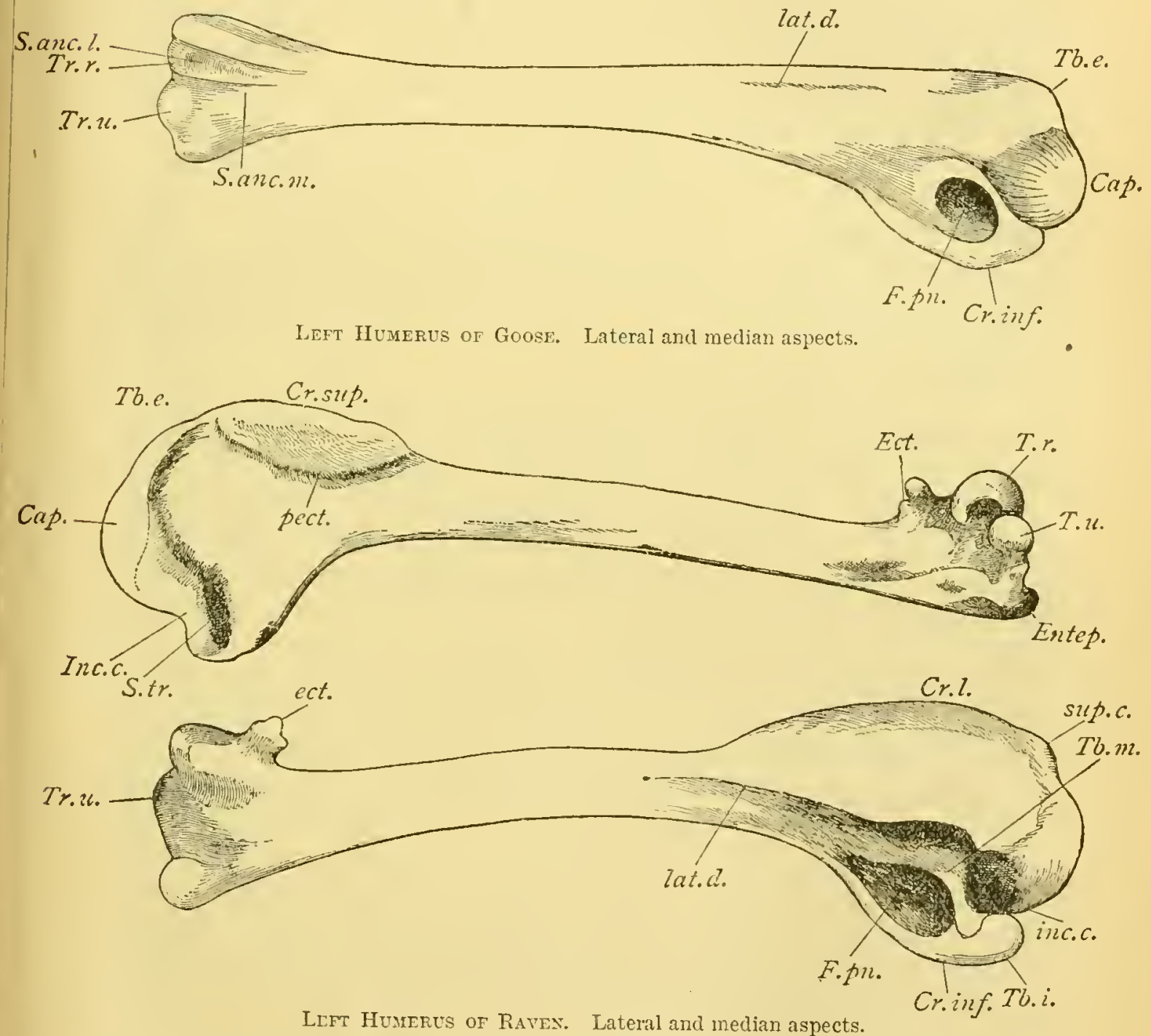

br. $i$. Insertion of M. brachialis inferior; Cup. Caput lumeri ; $C r$. inf., Cr. $l$. and $C r$. sup. Crista inferior, lateralis and superior; Ect. and Entep. Eetepicondylar anrl Entepicondylar process; $F$. $1^{n}$. Foramen puemnaticum; Inc. c. Incisura capitis ; lat. $d$. Insertion of M. latissimus lor'si ; pect. Insertion of M. pectoralis; $S$. anc. $l ., S$ anc. $m$, and $S . t r$. Sulcus anconci lateralis, inedius and transversus ; sup. c. Insertion of $\mathrm{M}$. supracoracoicleus; Tb. C., Tb. $i$. ancl Tb. m. Tuve1. culum exterum, internum, and medium ; $T$. or $T r$. $r$. and $T$. or $T r$. $u$. Trnchlea rarlicalis am ninaris. 
its inner and outer condyle at the distal end with the radius and ulna. Its crests, ridges and processes present so many obvious modifications, characteristic of various groups, that its configuration appears to be of considerable taxonomic value. Assuming it to be in its natural position when the wing is folded, the glenoid surface of its head is bordered above by the tubercutum superius (insertion of the musculus supracoracoidus), and in the middle and below by the tuberculum inferius (insertion of musc. coraco-brachialis posterior). From the former extends the large crista superior (insertion of musc. pectoralis major on its outward dorsal edge, and of musc. deltoides major on its median surface). The ventral portion of the neck of the Humerus is formed by the strong crista inferior, on the median side of which, between the lower tubercle there is mostly a deep depression (fossa subtrochanterica) at the bottom of which air is admitted to the bone ( $c f$. AIR-SACKS, p. 4) by means of a hole or holes. Among Anseres and Striges there is a rery large orifice; in Accipitres and Otidida the foramina are so numerous as to be cribriform; but in the Sphenisci (Penguin), Colymbidx, Alcida, Laridx, many Tubinares and occasionally in Phonicopterus (Flaningo) foramina pneumatica are either very sniall or do not exist, while in Columba and Galline the depression is very shallow and the foramen is almost on a plane surface.

On the outer side of the Humerus, between the head and the crista inferior, is a groove lodging one of the coraco-humeral ligaments. This groove is very deep in Steganopodes, Ardeida, Ciconiidx, Plicnicopterus, Rallidx, Laridæ, Columbidx, Striges, Cypseli and Parrots, but very shallow in Gruidx, Otididx, Tubinares, Sphenisci, Coracias (Roller), Buceros (Horsaill) and Caprimulgus, and scarcely marked in Gallina, Anseres and Accipitres. Distally the humerus ends in a trochlea, composed of a larger roundish condyle for the articulation of the Ulna, and a smaller and more elongated knob for that of the Radius. A little above this knob) there is frequently present an ectepicondylar process, serving for the origin of the tendons of some of the radiai and ulnar flexors. This process is best developed in Larida, most Limicolx, Turnicida, Tubinares, Passeres, Pici and Cypselidx: it is small in Striges, most Accipitres and Columbidx, and minute or absent in Pteroclidx, Edicnemus, Otis, Dicholophus, Grus, Phinochetus, Eurypyga, Rallidx, Tinamida, Gallina, Colymbida, Podicipedida, Alcida, Sphenisci, Steganopodes, Ardeidx, Ciconiidre, Phonicopterus and Anseres. It is variable in the Picariæ (see Skeleton).

HUMMING-BIRD, a name in use for more than two centuries, and possibly ever since English explorers first knew of the beautiful little animals to which, from the sound occasionally made by the rapid vibrations of their wings, it is applied. Among books that are 
ordinarily in naturalists' hands, the name seems to be first found in the Musaum Tradescantianum, published in 1656, but it therein occurs (p. 3) so as to suggest its having already been accepted and commonly understood $:^{1}$ and its earliest nse, as yet discovered, is said to be by Thomas Morton in the New English Camucn, printed in 1632-a rare work reproduced by Peter Force in his Historical Tracts (rol. ii. Washington: 1S3S). Thevet, in his Singularitez de la France antarctique (Paris: 155s, fol. $94^{2}$ ), has been more than once cited as the earliest author to mention Humming-birds, which he did under the name of Gonabuch or Gonambuch; but it is quite certain that Oriedo, whose Hystoria general de las Indias was published at 'Toledo in 1525 , preceded him by more than thirty years, with an account of the "paxaro mosquito" of Hispaniola, of which island "the first chromicler of the Indies" was governor." This name, though now apparently disused in Spanish, must have been current about that time, for we find Gesner in 1555 (De avium natura, iii. p. 629) translating it literally into Latin as Passer muscatus, owing, as he says, his knowledge of the bird to Cardan, who (De Subtil. lib. x.) had called it by the same name, and tells us (Comment. in Ptolem. de astr. judiciis, Basilix: 1554, p. 472 ) that, on his return to Milan from professionally attending Archbishop Hamilton at Edinburgh, he visited Gesner at Zurich,

1 Sir Thomas Browne in 1646 wrote (Pseudodoxia Epidemica, Bk. 6, chap. viii.): "So have all Ages conceaved, and most are still ready to sweare, the Wren is the least of birds, yet the discoveries of America, and even of our own Plantations shewed us one farre lesse, that is, the Hum-birl, not much exceeding a Beetle." The name Hmm-bird was in nse fifty years later. Mr. Benjamin Buttivant, writing from Boston in New England to Pettiver on 15 January 1697/8, says (Phil. Trans. xx. p. 168): "The Hum-bird I have shot with sand, and had one some Weeks in my keeping. I put a Straw for a Perch into a Venice Glass Tumbler, ty'd over the Mouth with a Paper in which I cut holes for the Bird's Bill (about as long and as small as a Taylor's Needle), and laying the Glass on one side, set a Drachm of Honey by it, which it sonn scentel, and with its long Tongue put forth beyond its Bill, fed daily ; it mutecl the Honey pure, and was a Prospect to many Comers; it flew away at last."

2 Not having seen a copy of this first edition, I take the reference from the reprint of MI. Gaffarel (Paris: 187S, T. 249).

3 In the edition of Oviedo's work, published at Salamanca in 1547, the earliest I hare seen, the account (lib. xiv. cap. 4) runs thus:- "Ay assi mismo enesta ysla vnos paxaricos tan negros como rn terciopelo negro muy bneno \& son tan pequeños que ningunos he yo visto en Indias menores/ excepto el que aca se llana paxaro mosquito. El qual es tan peqneño que el bulto del es menor harto o assaz que le cabeça del declo pulgar de la nano. Este no le he visto enesta Ysla pero dizen me que aqui los ay : \& por esso dexo de hablar enel pa lo dezir dõde los he visto que es en la tierra frme quãdo della se trate." A modern Spanish version of this passage will be found in the beantiful edition of Oviedo's works published by the Academy of Madrid in 1851 (i. p. 444). 
about the end of the year 1552.1 The name still survives in the French Oiseau-mouche; but the ordinary Spanish appellation is, and long has been, Tominejo, from tomin, signifying a weight equal to the third part of an adarme or drachm, and used metaphorically for anything very small. Humming-birds, however, have been called by a variety of other names, many of them derived from American languages, such as Guainumbi, Ourissia and Colibri, to say nothing of others bestowed upon them (chiefly from some peculiarity of habit) by Europeans, like Picaflores, Chuparosa and Froufrou. Barrere, in 1745 , conceiving that Humming-birds were allied to the Wren, the Trochilus, ${ }^{2}$ in part, of Pliny, applied that name in a generic sense (Ornith. Spec. novum, pp. 47, 48) to both. Taking the hint thus afforded, Linnæus very soon after went further, and, excluding the Wrens, founded his genus Trochilus for the reception of such Humming-birds as were known to him. The unfortunate act of the great nomenclator cannot be set aside; and, since his time, ornithologists with but few exceptions have followed his example, so that nowadays Humming-birds are universally recognized as forming the Family Trochilida.

The relations of the Trochilida to other birds were for a long while very imperfectly understood. Nitzsch first drew attention to their agreement in many essential characters with the Cypselidax (SwifTs), and placed the two Families in one group, which he called Macrochires, from the great length of their manual bones, or those forming the extremity of the wing. The name was perhaps not very happily chosen, for it is not the distal portion that is so much out of ordinary proportion to the size of the bird, but the proximal and median portions, that in both Families are curiously

${ }^{1}$ See also Prof. Morley's Life of Girolamo Cardano (ii. pp. 152, 153).

2 Under this name Pliny perpetuated (Hist. Nat. viii. 25) the confusion that had doubtless arisen before his time of two very distinct birds. As Sundevall

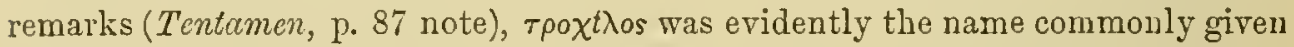
by the ancient Greeks to the smaller Plovers, and was not improperly applied by Herodotus (ii. 68) to the species that feeds in the open mouth of the Crocodilethe Pluvianus xgyptius of modern ornithologists-in which sense Aristotle (Hist. Anim. ix. 6) also uses it. But the received text of Aristotle has two other passages (ix. 1 and 11) wherein the word appears in a wholly different connexion, and can there be only taken to mean the Wren-the usual Greek name of which would seem to be op $p$ i none of his editors or commentators have suggested the possibility of such a thing, one can hardly help suspecting that in these passages some early copyist

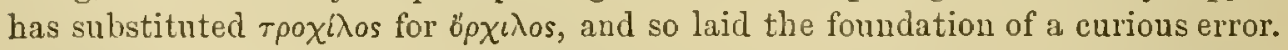
It may be here remarked that the Crocodile of St. Domingo is said to have the like office done for it by some kind of bird, which is called by Descourtilz (Voyage, iii. p. 26) a "Todier," but, as Geoffr. St. Hilaire observes (Deser. de l'Égypte, ed. 2, xxiv. p. 440), is more probably a Plover. Unfortunately the fauna of Hispaniola is not much better known now than in Oviedo's days. 
dwarfed. Still the manus, in comparison with the other parts of the wing, is so long that the term Macrochires is not wholly inaccurate. The affinity of the Trochilida and Cypselida, once pointed out, became obvious to most careful and mprejudiced investigators, though there are a few systematists who refuse to admit its validity. $^{\text {I }}$ More than this, it is confirmed by an examination of other osteological characters. The "lines," as a boat-builder would say, upon which the skeleton of each for'm is constructed are precisely similar, only that whereas the bill is very short and the head wide in the Swifts, in the Humming-birds the head is narrow and the bill long-the latter developed to an extraordinary degree in some of the Trochitidx, rendering them the longest-billed birds known. $^{2}$ Prof. Huxley considers these two Families, together with the Caprimulgidx (NIGHTJAR), to form the division Cypselomorpha-one of the two into which he separated his larger group Agithognathx. However, the most noticeable portion of the Humming-bird's skeleton is the sternum, which in proportion to the size of the bird is enormously developed both longitudinally and vertically, its deep keel and posterior protraction affording abundant space for the powerful muscles which drive the wings in their rapid vibrations as the little creature poises itself over the flowers where it finds its food. ${ }^{3}$

So far as is known, all Humming-birds possess a protrusible tongue, in conformation peculiar among the Class Aves, though to some extent similar to that member in the Picidx (WoODPECKER) ${ }^{4}$ - the "hor"ns" of the HYOID apparatus mpon which it is seated being greatly elongated, passing round and over the back part of the head, near the top of which they meet, and thence proceed forward, lodged in a broad and deep groove, till they terminate in front of the eyes. But, unlike the tongue of the Woodpeckers, that of the Humming-birds consists of two cylindrical tubes, tapering towards the point, and forming two sheaths which contain the extensile portion, and are capable of separation, thereby facilitating the extraction of honey from the nectaries of flowers, and with it, what is of far greater importance for the bird's sustenance, the

1 Especially Dr. Shufeldt (Proc. Zool. Soc. 1885, pp. 886-915, pls. Iviii.-1xi., and Journ. Linn. Soc. xx. pp. 299-394, pls. xxi.-xxiv.) On the other side may be cited the views of Mr. Lucas (Auk, 1S\$6, pp. 444-451).

2 Thus Docimastes cnsifer, in which the bill is longer than both head and body together.

3 This is especially the case with the smaller species of the group, for the larger, though shooting with equal celerity from place to place, seem to flap their wings with comparatively slow but not less powerful strokes. The difference was especially observed with respect to the largest of all Humming-birds, Patagona gigas, by $\mathrm{Mr}$. Darwin.

* The resemblance, so far as it exists, must be merely the result of analogical function, and certainly indicates no affinity between the Families. 
small insects that have been attracted to feed upon the honey. ${ }^{1}$ These, on the tongue being withdrawn into the bill, are caught by the mandibles (furnished in the males of many species with fine, horny, saw-like teeth ${ }^{2}$ ), and swallowed in the nsual way. The stomach is small, moderately muscular, and with the inner coat slightly hardened. There seem to be no creca. The trachea is remarkably short, the bronchi beginning high up on the throat, and song-muscles are wholly wanting, as in all other Cypselomorpha. ${ }^{3}$

Humming-birds, as is well known, comprehend the smallest members of the Class Aies. The largest among them measures no more than $S$ inches and a half, ${ }^{4}$ and the least 2 inches and three. eighths in length, for it is now admitted generally that Sloane must lave been in error when he described (Voyage, ii. p. 30s) the "Least Humming-bird of Jamaica" as "about $1 \frac{1}{4}$ inch long from the end of the bill to that of the tail"-unless, indeed, he meant the proximal end of each, an interpretation, however, that will not save Edwards and Latham from the charge of careless misstatement, when they declare that they had received such a bird from that island. Next to their generally small size, the best known characteristic of the Trochitida is the wonderful brilliancy of the plumage of nearly all their forms, in which respect they are surpassed by no other birds, and are only equalled by a few, as, for instance, by the Nectariniidx (SUN-BIRD) of the tropical parts of the Old World, in popular belief so often confounded with them, and even by some mistaken naturalists thought to be their allies.

The number of species of Humming-birds now known to exist considerably exceeds 400 ; and, though none depart very widely from what a morphologist would deem the typical structure of the Family, the amount of modification, within certain limits, presented by the various forms is surprising and even bewildering to the uninitiated. But the features that are ordinarily chosen by systematic ornithologists in drawing $u p$. their schemes of classification are

1 It is probable that in various members of the Trochilide the structure of the tongue, and other parts correlated therewith, will be found subject to several and perhaps considerable modifications, as is the case in various members of the Picidx. At present there are scarcely more than half a dozen species of Hummingbirds of which it can be said that any part of their anatomy is known.

2 These are very plain in Thamphodon nævius and Androdon squatorialis.

${ }^{3}$ Gosse (B. Jamaica, p. 130) says that Mcllisuga minima, the smallest species of the Family, has "a real song"- -but the like is not recorded of any other.

4 There are several species in which the tail is rery much elongated, such as the well-known Aithurus polytmus of Jamaica, and the remarkable Loddigesia mirabilis of Chachapoyas in Peru, which last was for many years only known from a unique specimen (Iois, 1880, p. 152 ; Proc. Zool. Soc. 1881, pp. 827-834, fig.); but "trochilidists" in giving their measurements clo not take these extraordinary derelopments into account. 
found by the "trochilidists," or special students of the Trochilida, insufficient for the purpose of arranging these birds in groups, and characters on which genera can be fomnded have to be sought in the style and coloration of plumage, as well as in the form and proportions of those parts which are most generally deemed sufficient to furnish them. Looking to the large number of species to be taken into account, convenience has demanded what science would withhold, and the genera established by the ornithologists of a preceding generation have been broken up by their successors into multitudinous sections-the more adventurous making from 150 to 180 of such groups, the madest being content with 120 or thereabouts, but the last dignifying each of them by the title of genus. It is of course obvious that these small divisions cannot be here considered in detail, nor would much advantage accrue by giving statistics from the works of the latest trochilidists, Messrs. Gonld, ${ }^{1}$ Mulsant, ${ }^{2}$ and Elliot. ${ }^{3}$ It would be as umprofitable here to trace the successive steps by which the original genus Trochitus of Linnaus, or the two genera Polytmus and Mellisuga of Brisson, have been split into others, or have been added to, by modern writers, for not one of these professes to have arrived at any final, but only a provisional, arrangement; it seems, however, expedient to motice the fact that some of the anthors of the last century $y^{4}$ supposed themselves to lave seen the way to dividing what we now lnow as the Family Trochilidie into two groups, the distinction between which was that in the one the bill was arched and in the other straight, since that difference has been insisted on in many works. This was especially the view taken by Brisson and Buffon, who termed the birds having the arched bill "Colibris," and those having it straight "Oiseaux-mouches." The distinction wholly breaks down, not merely because there are Trochilida which possess almost every gradation of decurvation of the bill, but some which have the bill upturned after the mamner of an Avoskt, ${ }^{5}$ while it may be remarked that several of the species placed by those anthorities among the "Colibris" are not Humming-birds at all. ${ }^{6}$

1 A Monograph of the Trockitidis or Humming-birds, 5 vols. imp. fol. London: 1861 (with Introlnction in 8ro).

2 Histoire naturelle des Oiscanx-Mouches ou Colibris, 4 vols. with supllement, imp. 4to, Lyon-Genève-Bale : 1874-77.

${ }^{3}$ Smithsonian Contributions to Knoulcige, No. 317, A Classification and Synopsis of the Trochilida, 1 vol. imp. 4to, Washington: 1879.

* Salerne must be excepter, especially as he was rebuked by Buffon for doing what we now deem right.

${ }^{5}$ For example Arocettula recurvirostris of Guiana and A. curypterce of Colombia.

${ }^{6}$ Mr. Salvin's list (Cat. D. Br. Mus. xvi. pl). 27-433), and Mr. Ridgway's work (Tep. U. S. Nat. MIus. 1890, pp. 253-380) can only be named here, as neither appeared in time for the results to be utilized in this article. 
The extraordinarily brilliant plumage which most of the Trochilida exhibit has been already mentioned, and in describing it ornithologists have been compelled to adopt the vocabulary of the jeweller in order to give an idea of the indescribable radiance that so often breaks forth from some part or other of the investments of these feathered gems. In all save a few of other birds, the most imaginative writer sees gleams which he may adequately designate metallic, from their resemblance to burnished gold, bronze, copper, or steel, but such similitudes wholly fail when he has to do with the Trochitidx, and there is hardly a precious stone-ruby, amethyst, sapphire, emerald, or topaz-the name of which may not fitly, and without exaggeration, be employed in regard to Humming-birds. In some cases this radiance beams from the brow, in some it glows from the throat, in others it shines from the tailcoverts, in others it sparkles from the tip only of elongated feathers that crest the head or surround the neck as with a frill, while again in others it may appear as a luminous streak across the cheek or auriculars. The feathers that cover the upper parts of the body very frequently have a metallic lustre of golden-green, which in other birds would be thought sufficiently beautiful, but in the Trochitide its sheen is overpowered by the almost dazzling splendour that radiates from the spots where Nature's lapidary las set her jewels. The flight-feathers are almost invariably dusky-the rapidity of their movement would, perhaps, render any display of colour ineffective; while, on the contrary, the feathers of the tail, which, as the bird hovers over its food-bearing flowers, is almost always expanded, and is therefore comparatively motionless, often exhibit a rich translucency, as of stained glass, but iridescent in a manner that no stained glass ever is-cinnamon merging into crimson, crimsou changing to purple, purple to violet, and so to indigo and bottle-green. But this part of the Humming-bird is subject to quite as much modification in form as in colour, though always consisting of ten rectrices. It may be nearly square, or at least but slightly rounded, or wedge-shaped with the middle quills prolonged beyond the rest; or, again, it may be deeply forked, sometimes by the overgrowth of one or more of the intermediate pairs, but most generally by the development of the outer pair. In the last case the lateral feathers may be either broadly webbed to their tip, ol acuminate, or again, in some forms, may lessen to the filiform shaft, and suddenly eularge into a termiual spatulation as in the forms known as "Racquet-tails." The wings do not offer so much variation; still there are a few groups in which occur diversities that require notice. The primaries are invariably ten in number, the outermost being the longest, except in the single instance of Aithume, where it is shorter than the next. The group known as "Sabre-wings," comprising the genera Campylopterus, 
Eupetomena and Sphenoproctus, present a most curious sexual peculiarity, for while the female has nothing remarkable in the form of the wing, in the male the shaft of two or three of the onter primaries is dilated proximally, and bowed near the middle in a mannel almost unique among birds. The feet again, diminutive as they are, are very diversified in form. In most the tarsus is bare, but in some groups, as Eriocnemis, it is clothed with tufts of the most delicate down, sometimes black, sometimes buff, but more often of a snowy whiteness. In some the toes are weak, nearly equal in length, and furnished with small rounded nails; in others they are largely developed, and armed with long and sharp claws.

Apart from the well-known brilliancy of plumage, of which enough has been here said, many Humming-birds display a large amount of ornamentation in the addition to their attire of crests of various shape and size, elongated ear-tufts, projecting neck-frills, and pendent beards-forked or forming a single point. But it would be impossible here to dwell on a tenth of these beautiful modifications, each of which as it comes to our knowledge excites fresh surprise and exemplifies the ancient adage-maxime miranda in minimis Nutura. It must be remarked, however, that there are certain forms which possess little or no brilliant colouring at all, but, as most tropical birds go, are very soberly clad. These are known to trochilidists as "Hermits," and by Mr. Gould have been separated as a subfamily under the name of Phacthornithina, though Mr. Elliot says he cannot find any characters to distinguish it from the Trochitida proper. But sight is not the only sense that is affected by Humming-birds. The large species known as Pterophanes temminclii has a strong musky odour, very similar to that given off by the Petrels, though, so far as appears to be known, that is the only one of them that possesses this property. ${ }^{1}$

All well-informed pcople are aware that the Trochilida are a Family peculiar to America and its islands, but one of the commonest of common errors is the belief that Humming-birds are found in Africa and India-to say nothing even of England. In the first two cases the mistake arises from confounding them with some of the brightly-colomed Nectariniida (SUN-BIRD), to which British colonists or residents are apt to apply the better-known name; but in the last it can be only due to the want of perception which disables the observer from distinguishing between a bird and an insect

1 The specific name of a species of Chrysolampis, commonly spelt by many writers moschitus, would lead to the belief that it was a mistake for moschatus, i.e. "musky," but in truth it originates with their carelessness, for thougln they quote Linnæus as their authority they can never have referred to his works, or they would have found the word to be mosquitus, the "mosquito" of Oviedo, awkwardly, it is true, Latinized. If emendation be needed, muscatus, after Gesner's example, is undoubtedly preferable. 
- the object seen being a Hawk-Moth (Mucroglossu), whose mode of feeding and rapid flight certainly bears some resemblance to that of the Trochilidx, and hence one of the species ( $I$. stellurum) is very generally called the "Humming-bird Hawk-Moth." But though confined to the New World, the Trochilida pervade almost every part of it. In the south Eusteplanus galeritus has been seen flitting about the fuchsias of Tierra del Fuego in a snowstorm, and in the north-west Selatophorus ${ }^{1}$ rufus in summer visits the ribes-blossoms of Sitka, while in the north-east Trochilus culubris charms the vision of

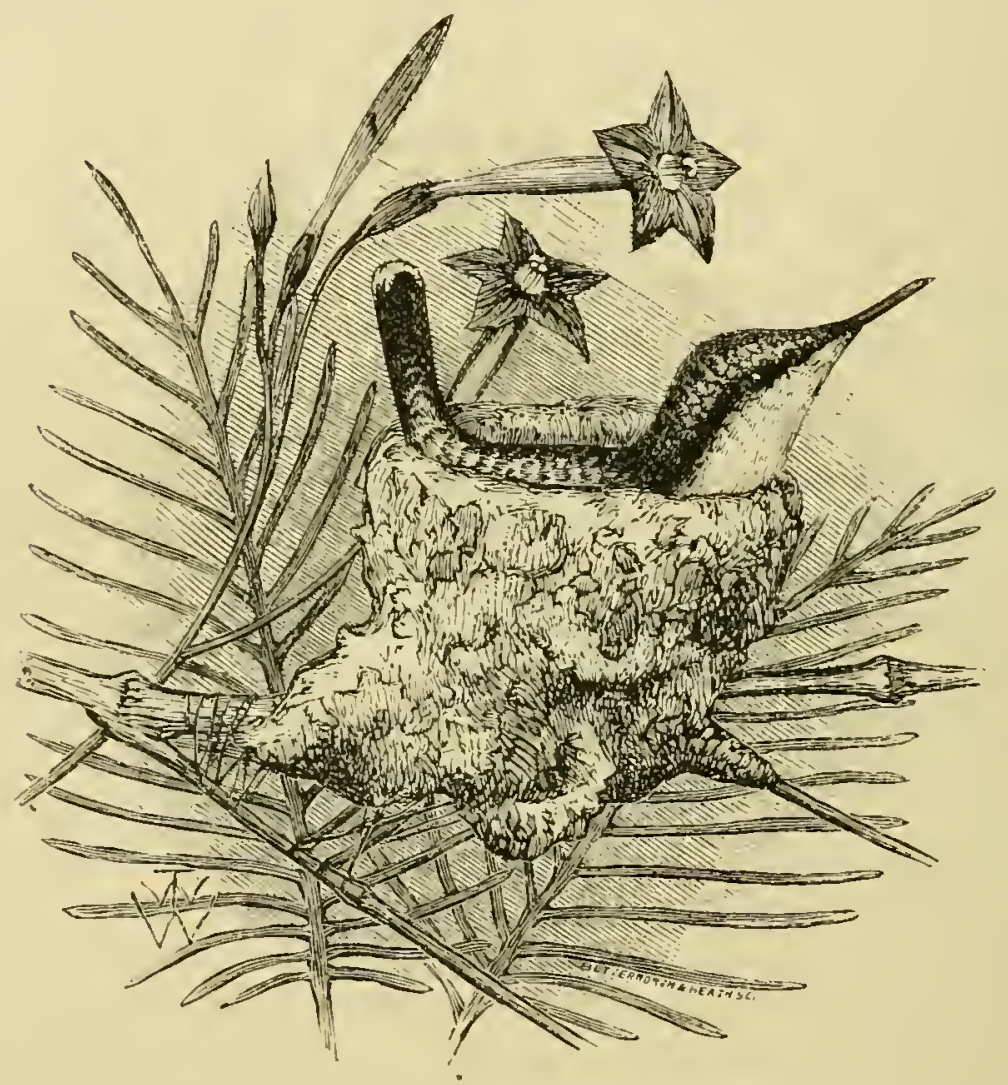

MELLISUGa MINIMA ON NEST, natural size. (Aifter Gosse.)

Canadians as it poises itself over the althæa-bushes in their gardens, and extends its range at least so far as lat. $57^{\circ} \mathrm{N}$. Nor is the distribution of Humming-birds limited to a horizontal direction only, it rises also vertically. Oreotrochilus chimboraro and 0 . pichincha live on the lofty mountains whence each takes its trivial name, but just beneath the line of perpetual snow, at an elevation of some 16,000 feet, dwelling in a world of almost constant hail, sleet and rain, and feeding on the insects which resort to the indigenous flowering plants, while other peaks, only inferior to these in lieight, are no less frequented by one or more species. Peru and Bolivia produce some of the most splendid of the Fanily-the genera

1 Coumonly but in error written Sclasphorus. 
Cometes, Diphlogana and Thummastura, whose very names indicate the glories of their bearers. The comparatively gigantic Patagona inhabits the west coast of South America, while the isolated rocks of Juan Fernandez not only afford a lome to the Eustephanns before mentioned, but also to two other species of the same genus which are not found elsewhere. The slopes of the Northern Andes and the hill country of Colombia furnish perhaps the greatest number of forms, and some of the most beautiful, but leaving that great range, we part company with the largest and most gorgeously arrayed

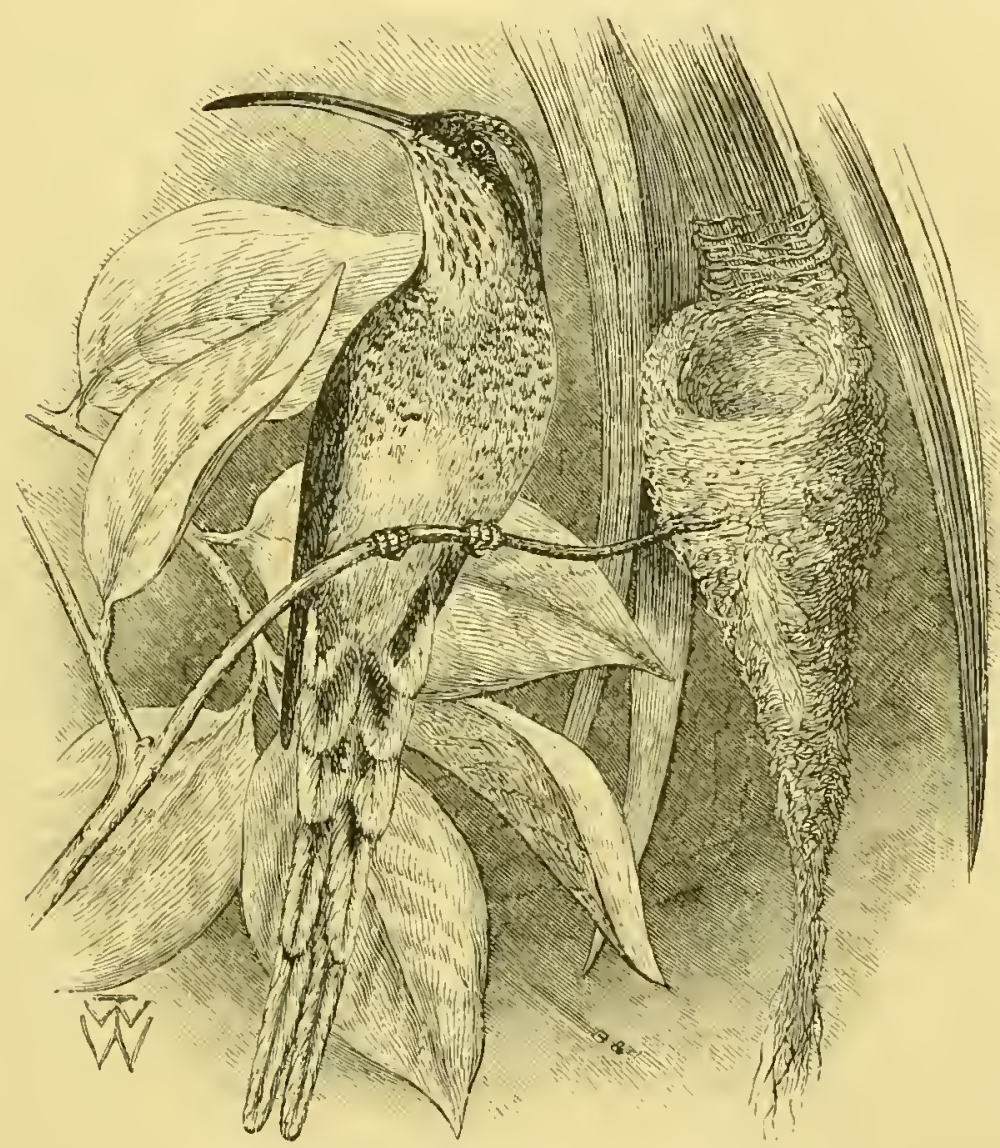

Phathornis euryome, and vest. (After Gould.)

species, and their number dwindles as we approach the eastern coast. Still there are many brilliant Humming-birds common enough in the Brazils, Guiana and Venezuela. The Chrysolampis mosquitus is perhaps the most plentiful. Thousands of its skins are annually sent to Europe to be used in the manufacture of ornaments, its rich ruby-and-topaz glow renclering it one of the most beantiful objects imaginable. In the darkest depths of the Brazilian forests dwell the russet-clothed brotherhood of the genus Phacthornis - the "Hermits"; but the great wooded basin of the Amazons seems to be particularly unfavourable to the 1rochilida', and from Pará to Ega there are scarcely a dozen species to be met with. There is 
no island of the Antilles but is inhabited by one or more Hummingbirds, and there are some very remarkable singularities of geographical distribution to be found. Northwards from Panama, the highlands present many genera, whose names it would be useless here to insert, few or none of which are found in South Americathough that must unquestionably be deemed the metropolis of the Family, and advancing towards Mexico the numbers gradually fall off. Seventeen species have been enrolled in the fauna of the United States, but some perhaps on slender evidence, while others only just cross the frontier line.

But little room is left to speak of the habits of Humming-birds, which is perhaps of the less consequence since the subject, as regards most of the species which in life have come under the observation of ornithologists, has been so ably treated by writers like Waterton, IVilson, and Audubon, to say nothing of Gosse, Bates, Mr. Wallace, and some others, while, whatever novelty further investigation may supply, it is certain that at present we lack. information that will explain the origin or the function of the many modifications of external structure of which mention has been made. But there is no one appreciative of the beauties of nature who will not recall to memory with delight the time when a live Humming-bird first met his gaze. The suddenness of the apparition, even when expected, and its brief duration, are alone enough to fix the fluttering vision on the mind's eye. The wings of the bird, if flying, are only visible as a thin grey film, bounded above and below by fine black threads, in form of a St. Andrew's cross, - the effect on the observer's retina of the instantaneous reversal of the motion of the wing at each beat-the strokes being so rapid as to leave no more distinct image. Consequently an adequate representation of the bird on the wing cannot be produced by the draughtsman. Humming-birds shew to the greatest advantage when engaged in contest with another, for rival cocks fight fiercely, and, as may be expected, it is then that their plumage flashes with the most glowing tints. But these are quite invisible to the ordinary spectator except when very near at hand, though doubtless efficient enough for their object, whether that be to inflame their mate or to irritate or daunt their opponent, or something that we cannot compass. Humming-birds, however, will also often sit still for a while, chiefly in an exposed position, on a dead twig, occasionally darting into the air, either to catch a passing insect or to encounter an adversary; and so pugnacious are they that they will frequently attack birds many times bigger than themselves, without, as would seem, any provocation.

The food of Humming-birds consists mainly of insects, mostly gathered in the manner already described from the flowers they visit; but, according to Mr. Wallace, there are many species which 
he has never seen so occupied, and the "Hermits" especially seem to live almost entirely upon the insects which are found on the lower surface of leaves, over which they will closely pass their bill, balancing themselves the while vertically in the air. The same excellent observer also remarks that even among the common flowerfrequenting species he has found the alimentary canal entirely filled with insects, and very rarely a trace of honey. It is this fact doubtless that has hindered almost all attempts at keeping them in confinement for any length of time-nearly every one making the experiment having fed his captives only with syrup, which is wholly insufficient as sustenance, and seeing therefore the wretched creatures gradually sink into inanition and die of hunger.

The beautiful nests of Humming-birds, than which the work of fairies could not be conceived more delicate, are to be seen in most museums, and will be found on examination to be very solidly and tenaciously built, though the materials are generally of the slightest - cotton-wool or some vegetable down and spiders' webs. They vary greatly in form and ornamentation-for it would seem that the portions of lichen which frequently bestud them are affixed to their exterior with that object, though probably concealment was the original intention. They are mostly cup-shaped, and the singular fact is on record (Zool. Journal, v. p. 1) that in one instance as the young grew in size the walls were heightened by the parents, until at last the nest was more than twice as big as when the eggs were laid and hatched. Some species, however, suspend their nests from the stem or tendril of a climbing plant, and more than one case has been known in which it has been attached to a hanging rope. These pensile nests are said to have been found loaded on one side with a small stone or bits of earth to ensure their safe balance, though how the compensatory process is applied no one can say. Other species, and especially those belonging to the "Hermit" group, weave a frail structure round the side of a drooping palmleaf. The eggs are never more than two in number, quite white, and having both ends nearly equal. The solicitude for her offspring displayed by the mother is not exceeded by that of any other birds, but it seems doubtful whether the male takes any interest in the brood.

HURGILA, Hind. Hargĩla, see Adjutant.

HURRICANE-BIRD, see FrIGATE-BIRD.

HYLACOLA, Gould's name (Proc. Zool. Soc. 1842, p. 135) for a genus of Australian birds, and subsequently used by him and others as English. It has been placed near Atrichia (ScRun-BIRD); but its true position is unknown. There are two species, one, H. cauta, confined to South Australia and Victoria, the other, H. erythropygia, of wider range. Gould saw in them some resemblance to the 
Hedge-SparRow as they rapidly trip on the ground or along the horizontal branches of fallen trees; but unlike that bird they carry the tail erect. Mr. Ramsay has described (Proc. Linn. Soc. N. S. Wales, ii. p. 109) their nest and eggs: the former has a dome, and the latter, like those of so many Australian small birds, are salmon-coloured with light chocolate-brown markings. The males have an agreeable song.

IIYOID (Greek iociớs, shaped like Y) Apparatus, the collective
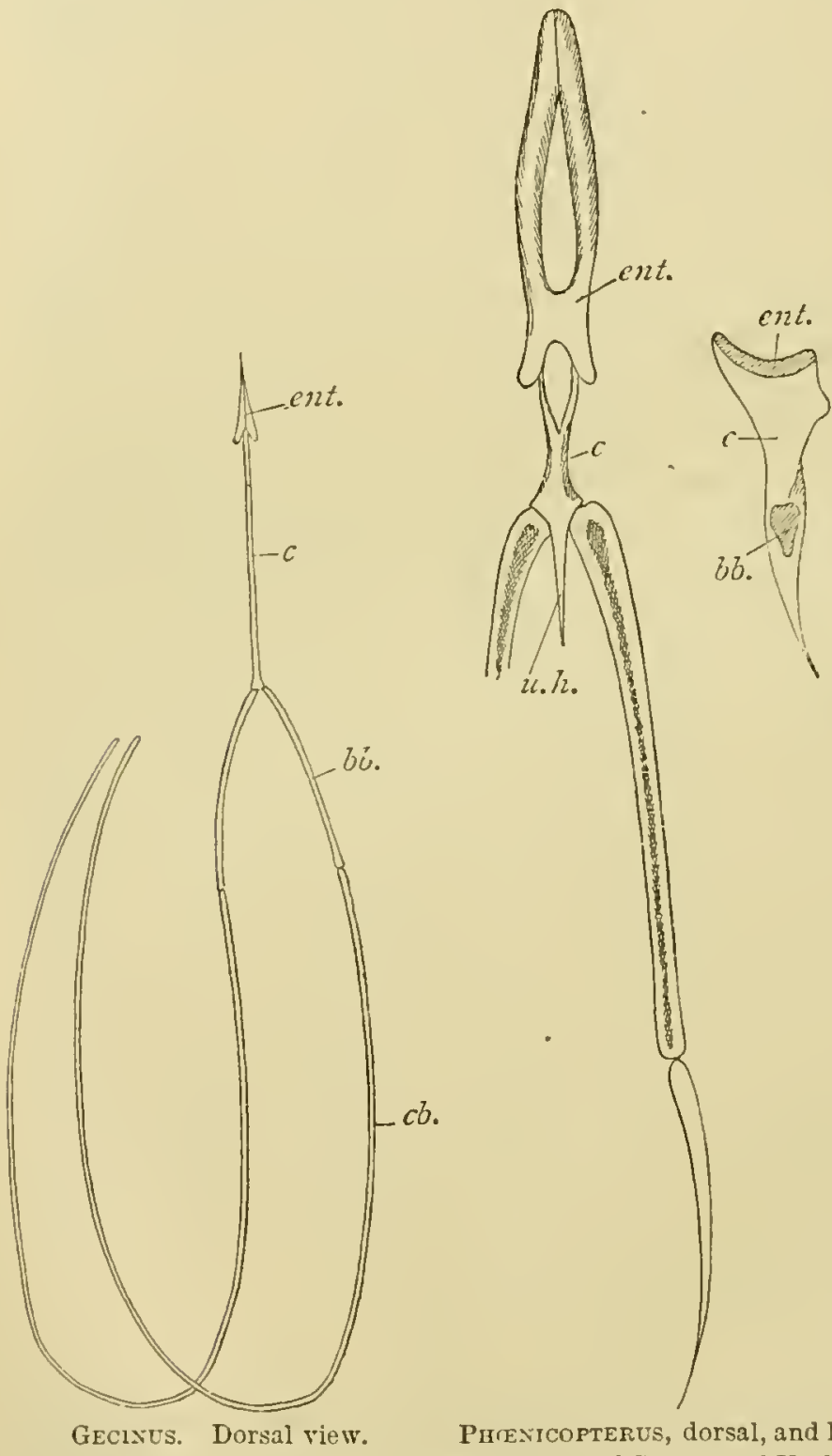

Phexicopterus, dorsal, and left lateral view of Corpus and Urohyal.

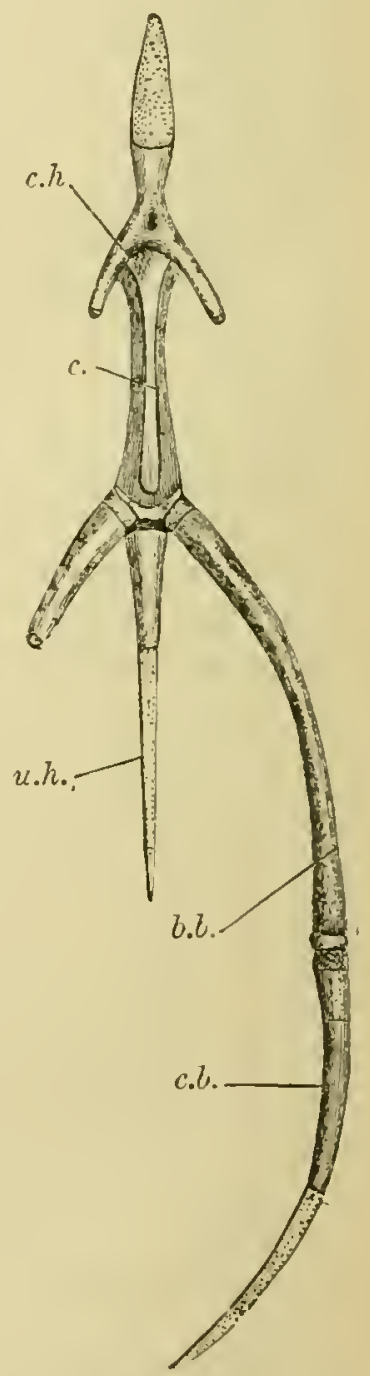

Commos Fowr.

ub. Basibranchial; c. Corpus linguæ or Basihyal ; cb. Ceratobranchial; ent. Os entoglossum; $u . h$. Urohyal.

name of the cartilaginous and bony framework of the tongue, consisting of 
(1) the "Basihyal" (comula or corpus lingure) or unpaired middle portion, forming the basis of the framework;

(2) the "Urohyal," likewise umpaired, applied to the posterior" end of the former, often wholly cartilaginous, and resting ventrally on the laryux, to which it is attached by muscles or ordinary connective tissue. In a few forms as Phea, Sula and the Picida, it is absent;

(3) the "Os entoglossum," originally paired, but coalescing into an arrow-headed piece, attached to the anterior end of the basihyal, and lodged in the tongue proper. Equivalent to the ceratohyals, or anterior hyoid horns of Mammals;

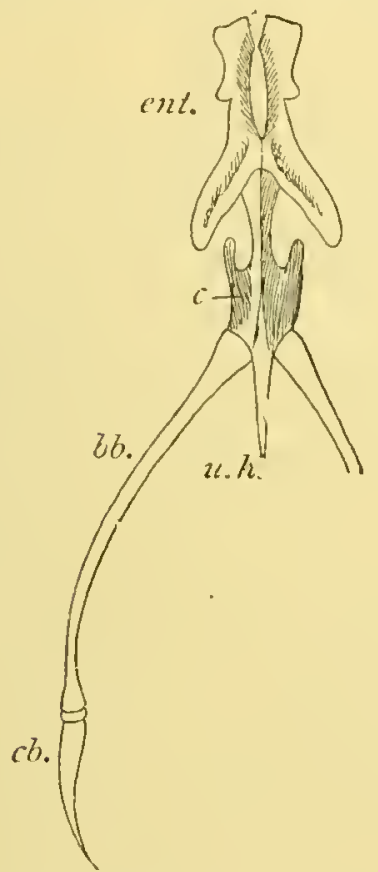

Strixgors. Tental view.

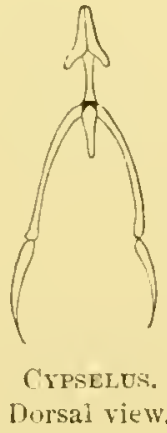

Dorsal view.

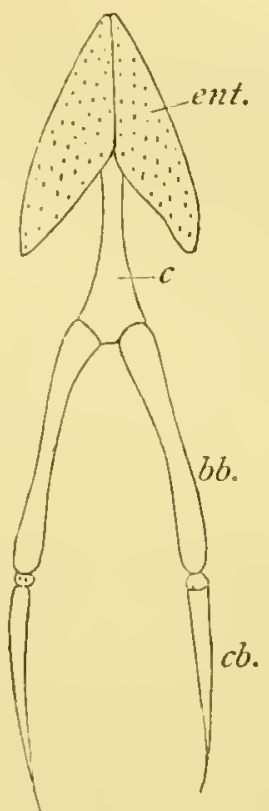

RHEA. Dorsal view.

bl. Basibranchial ; c. Corpus liugure or Basihyal; cb. Ceratobranchial ; ent. Os entoglossum; u.h. Uroliyal.

(4) a pair of "Thyrohyals," homologous with the posterior hyoid horns of Mammals ; and, as the most developed pair in Bircls, commonly called the "Hyoid Horns." Each of them consists of two or three pieces, placed end to end, of which the basal one articnlates upon a facet of the posterior lateral corner of the basihyal.

From the unpublished papers of Nitzsch, Giebel in 1858 described and figured (Zeitschr. ges. Nuturwissensch. xi. pp. 19-51, tabb. i.-viii.) the Hyoid bones of a great many birds, drawing attention to the taxonomic value of the modifications they present. Thus is shewn an unmistakable resemblance between Steganopodes and Tulinares, between Gulls, Guillemots and Divers, between Glareola and Edicnemus, Menura and the true Oscines, while on the other hand it is easy to distinguish the Hyoid apparatus of Panurus from those of the Purida, and occasionally even closely allied species, as 
the Martin and the Swallow, exhibit marked differences, and some of those observed in the Picidx are described by Macgillivray (Audubon, Orn. Biogr. v. pp. 542, 543, and B. Am. iv. pp. 223, 224, 289).

IIYPOPTERON, Sundevall's name for the lower humeral coverts (see AxILLA).

\section{I}

IBIS, one of the most sacred birds of the ancient Egyptians, which in moderu times was identified by Bruce (Travels, v. p. 173, pl.) with the Abou-Hannes or "Father John" of the Abyssinians, and in 1790 received from Latham (Ind. Orn. p. 706) the name of Tantalus athiopicus. This determination was placed beyond all question by Cuvier (Ann. du Muséum, iv. pp. 116-135) and Savigny (Hist. Nat. et Mythol. de l' Ibis) in 1805. They, however, shewed the removal of the bird from the Linnæan genus Tantalus to be necessary, and, Lacépède having some years before founded a genus Ibis, it was transferred thither, and is now generally known as $I$. rethiopica, though some speak of it as I. religiosa. No useful purpose would be served by dwelling on the vain attempts of older writers to discover what the much venerated bird was, as on that score all loubt has long ceased, or on the other synonyms applied to it by later ornithologists, some of whom (and among them not the most remote) have shewn little acquaintance with the literature of the subject. Nor can the Ibis be here treated from a mythological or antiquarian point of view. Savigny's memoir (above noticed) contains much interesting matter on the subject. Wilkinson (Ancient Egyptians, ser. 2, ii. pp. 217-224) has thereto added some of the results of modern research, and latest of all Mr. Renouf in the Hibbert Lectures for 1879 (pp. 116 and 237) concisely explains how the bird came to be regarded as representing Thoth or Tehuti, the moon-deity.

The Ibis is chiefly an inhabitant of the Nile basin in Nubia, from Dongola southward, as well as of Kordofan and Sennaar; whence (according to Savigny, whose opportunities for observation seem to have been greater than those enjoyed by any European since his time) about midsummer, as the river rises, it moves northwards to Egypt, and reaches the delta, ${ }^{1}$ passing over the inter-

1 It has been said to occur occasionally in Europe (Greece and southern Russia), but further evidence is needed before the assertion can be taken as proved. 
mediate districts, in a way not unknown elsewhere among migratory birds. In Lower Egypt it bears the name of Aboumengel, or "Father of the Sickle," from the form of its bill, but it does not stay long in that country, disappearing by all accounts when the inundation has subsided. Hence doubtless arises the fact that almost all European travellers have failed to meet with it there, ${ }^{1}$ since their acquaintance with the birds of Egypt is mostly limited to those which frequent the country in winter, and consequently writers have not been wanting to deny to this species a place in its modern fauna ( $c f$. Shelley, B. Egypt, p. 261); but, in December 1S64, Von Heuglin (Journ. für Orn. 1S65, p. 100) saw a young bird which had been shot at Gata in the delta, and subsequently Mr. E. C. Taylor (Ibis, 1878, p. 372) saw an adult which had been killed near Lake Menzaleh in November 1S77. The old story told to Herodotus of its destroying snakes is, according to Savigny, devoid of truth, ${ }^{2}$ and that naturalist found, from dissection of the examples he obtained, that its usual food was fresh-water univalve mollusks; but Cuvier asserts that he discovered partly-digested remains of a snake in the stomach of a mummied Ibis which he examined, and there can be little doubt that insects and crustaceans, to say nothing of other living creatures, enter on occasion into the bird's diet.

The Ibis is somewhat larger than a Curlew, Numenius arquata, which bird it in appearance calls to mind, with a much stouter bill and stouter legs. The head and greater part of the neck are bare and black. The plumage is white, except the primaries which are black, and a black plume, richly glossed with bronze, blue and green, which curves gracefully over the hind-quarters. The bill and feet are also black. The young lack the ornamental plume, and in them the head and neck are clothed with short black feathers, while the bill is yellow. The nest is placed in bushes or high trees, the bird generally building in companies, and in the middle of August Von Heuglin (Orn. Nordost-Afrika's, p. 1138) found that it had from two to four young or much incubated eggs. ${ }^{3}$ These are of a dingy white, splashed, spotted, and speckled with reddish-brown.

Congeneric with the typical Ibis are two or three other species,

1 Mr. E. C. Taylor remarked some years ago (Ibis, 1859, p. 51), that the Buff-backed Heron, Ardea bubulcus, was made by the tourists' dragomans to do duty for the "Sacred Ibis," and this seems to be no novel practice, since by it, or something like it, Hasselqvist was misled, and through him Linnæus.

2 The suggestion that the "flying serpents" whose remains were seen by Herodotus (Eut. 75) were locusts is perhaps plausible, but there is considerable difficulty in accepting it.

3 The Ibis has more than once nested in the gardens of the Zoological Society, and even reared its young there (Ibis, 1878, pp. 449-451, pl. xii.) 
the 8. melanocephala of India, the 8. molucca, or \$. strictipennis, of Australia, and the S.t.bernieri of Madagascar, all of which closely resemble S. Frathiopica; while many other forms not very far removed from it, though placed by authors in distinct genera, ${ }^{1}$ are also known. Among these are several beautiful species such as the Japanese Geronticus nippon, the Lophotibis cristata of Madagascar, and the Scarlet Ibis, ${ }^{2}$ Eudocimus ruber, of America; but here there is only room to mention more particularly the Glossy Ibis, Plegadis falcinellus, a species of very wide distribution in both hemispheres, being found throughout the Antilles, Central and the south-eastern part of North America, as well as in many parts of Europe (whence it not unfrequently strays to the British Islands), Africa, Asia and Australia. This bird, which is no doubt the second kind of Ibis spoken of by Herodotus, is rather smaller than the Sacred Ibis, and mostly of a dark chestnut or deep bay colour with brilliant green and purple reflexions on the upper parts, exhibiting, however, when young little of this glossiness. One of the most remarkable things about this species is that it lays eggs of a deep sea-green colour, having wholly the character of Herons' eggs, and it is to be noticed that it often breeds in company with Herons, while the eggs of all other Ibises whose eggs are known resemble those of the Sacred Ibis. Congeneric with the Glossy Ibis, some three or four other species, all from South America, have been described; but the propriety of deeming them distinct is questioned by some authorities.

Much as the Ibises resemble the Curlews externally, there is no real affinity between them. The lbidida are more nearly related to the Ciconiida (STork), and still more to the Plutaleida (Spoonbill), with which latter many systematists consider them to form one group, the Hemiglottides of Nitzsch. They belong to the Pelargomorpha of Prof. Huxley, one of the divisions of his Desmognatha, while the Curlews are Schizognatlious. The true Ibises above spoken of are also to be clearly separated from the Wood-Ibises, Tantalide, of which there are four or five species, by several not unimportant structural characters, which cannot here be particularized for want of space. Fossil remains of a true Ibis, I. pagane, have been found in considerable numbers in the middle Tertiary beds of France.

1 For some account of these may be consulted Dr. Reichenow's paper in Joum. für Orn. 1877, pp. 143-156; Mr. Elliot's in Proc. Zool. Society, 187t, pp. 47\%-510; and that of M. Oustalet in Nouv. Arch. du Mruséum, ser. 2, i. pp. 167-184.

2 It is a popular error-especially among painters, as almost every aunual exhibition of the Royal Academy witnesses - that this bird was the Sacred Ibis of the Egyptians. It was of course utterly unknown in the Old World until the discovery of the New. 
IBTCTER, SEe CARACARA.

\section{ICTERIA, see CHAT.}

ICTERUS, a bird so called by classical authors, and supposed by Pliny to be the same as the Galgulus, which nearly all writers agree in considering to be what we now know as Oriolus galbuld (OrIOLE). At any rate it signified one in the plumage of which yellow or green predominated, and hence Brisson did not take an unhappy liberty when he applied it in a scientific sense to some birds of the New World of which the same could be said. These are now held to constitute a distinct Family, Icteridas ; and, while many of them bear the vulgar name of Troopials (the English equivalent of the French Troupiales, first used by Brisson), others are known as the American (irackles. The typical species of Icterus is the Oriolus icterus of Linnæus, the Icterus vulguris of Daudin and modern ornithologists, an inhabitant of northern Brazil, Guiana, Venezuela, which seems to have been introduced into some of the Antilles, and occasionally, it is said, visits the United States.

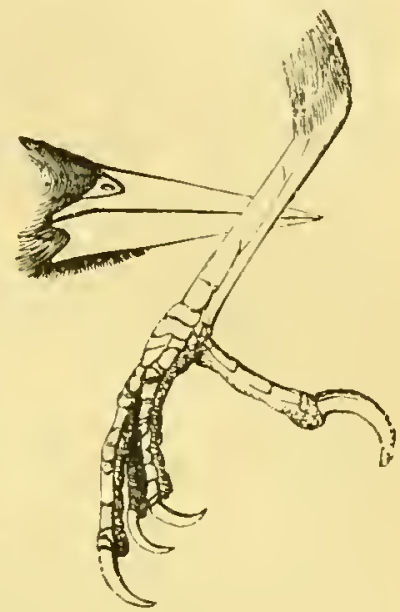

Icterus. (After swainson.) Thirty-eight species of the genus Icterus alone, and ninety others belonging to 28 genera, are recognized by Mr. Sclater (Cat. B. Br. Mus. xi. pp. 308-405), most of them belonging to the Neotropical Region, though a few have their home to the northward, whither they repair to breed in summer. It would be impossible here to dwell upon them, but Eucorystes, Cussicus and Agela'us may perhaps be named as the most remarkable. They are nearly all gregarious birds, many of them with lond and melodious notes, rendering them

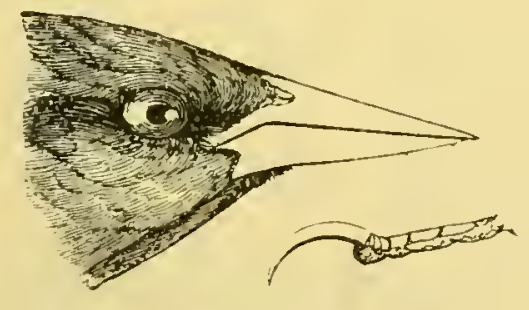

AGELEUS,

(After Swainson.)

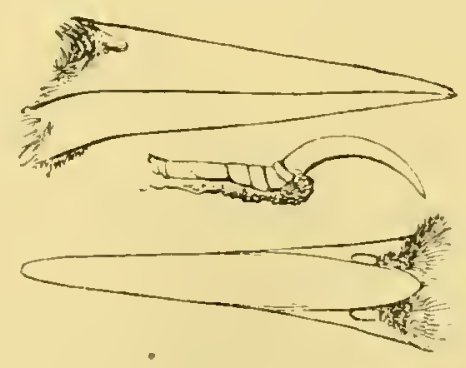

Sturnella.

favourites in captivity, for they readily learn to whistle simple tunes, which are admirably reproduced by their clear voice. Some have a plumage wholly black, others are richly clad, as is the well-known Baltimore Oriole, Golden Robin, or Hangnest of the United States, 
Icterus baltimore, whose brightly contrasted black and orange have conferred upon it the name it most commonly bears in North America, those colours being, says Catesby (B. Carol. i. p. 48), the tinctures of the armorial bearings of the Calverts, Lords Baltimore, the original grantees of Maryland, but probably more correctly those of their liveries. The most divergent form of Icteridæ seems to be Sturnella ${ }^{1}$ (though Leistes comes near it in that respect), containing some four or five species or local races, of which the Meadow-Lark, S. magna or ludoviciana of North America, and its western ally S. neglecta are the best known. These are birds which in aspect and habits have considerable resemblance to the Alaudidx (LARK) of the Old World, and a still greater outward likeness to the members of the African and especially Caffrarian genus Macronyx (KALKoENTJE), usually referred to the Motacillida (WAGTAIL), though there can be no affinity between them. ${ }^{2}$ Dolichonyx oryzivorus, the BoBolink or Rice-bird, with its very Bunting-like bill, is not much less aberrant. The genus Molobrus containing, among other species of parasitic habits, the well-known Cowpen-bird (Cow-BIRD) of North America, also belongs to this Family. The Icteridæx are commonly supposed to represent in the New WorId the Sturnida (Starling) of the Old; but no clear affinity between them seems to have been proved, while by several character's the former are clearly allied to the Emberizida (BunTING).

ICTINIA, see KITE.

IDLE JACK, a local name in the Cape Colony for Sphenoacus africanus (GRASS-BIRD). but

ILEUM, part of the intestine (see Digestive System, p. 138);

ILIUM, or os ilei, the most dorsal and largest of the three bones on each side of the PeLvis, which it connects with the sacral vertebri.

\section{IMBER- or IMMER-GOOSE, see EMBER GOOSE.}

IMPENNES, Illiger's name in 1811 for a "Family" of Birds consisting of the genus Aptenodytes, and since often employed as that of the group containing the Penguins.

IMPEYAN, mistakenly used by the ignorant, as though a substantive, for any species of Lophophorus, the first bot-known of

1 Trupialis has been separated from Sturnella on very slight grounds.

2 It is impossible not to remark on the coincidence of this resemblance (so striking that did the birds occur in the same area it would be set down to MIMICRY) with that afforded by the American genus Colaptes (FLICKER) and the South-African Geocolaptes already mentioned (suprè, p. 260). 
which, L. impeianus (MoNAL) was brought into notice by Sir Elijah and Lady Impey (cf. Latham, Gen. Synops. B. Suppl. p. 209).

$I N D E X$, the second finger, in Birds always the best developed of the digits of the fore-limb. It frequently possesses the original number of three phalanges, and often bears a horny CLAw, especially in Ratites and in the embryos of Accipitres and Anseres (see Skeleton).

INDIGO-BIRD, so called from its deep blue colour, in part tinged with green, a well-known North-American species, the Cyanospiza, Spiza or Passerina of modern authors, ${ }^{1}$ belonging to a small group of Finches or Buntings (for anatomy has not decided which), mostly of great beauty, rivalling some of the Tanagers in their bright plumage. American ornithologists give full accounts of the habits of this bird, together with those of its equally gay congener the Lazuli Finch, C. amona, and the still more gaudy Painted Bunting or NonPareil, C. ciris.

INEPTI, Illiger's name in 1811 for a "Family" of Birds consisting of the genus Didus (DODo).

INERTES, an "Order" proposed by Temminck in 1820 to contain the genera Apteryx (KIwI) and Didus (DoDo).

INSECTIVORES, Temminck's third "Order" of Birds in $1820^{2}$ (Man. d'On. ed. 2, i. pp. Ivi.-lxix. and 139), a name that has been used by a few other writers, but long since disregarded, not only as containing a very unnatural congeries of Birds, but as having been anticipated in 1817 by Cuvier's Order of Mammals, Insectivora.

INSESSORES, $^{3}$ the name given by Vigors in 1823 (Trans. Linn. Soc. xiv. p. 405) to the second Order of Birds in his classification containing nearly all the Picæ and PAsseres of Linnæus, and practically equal to the Ambulatores of Illiger. Though long accepted without hesitation by most British and many foreign authors, the composite nature of the group has now been recognized, and the use of the name is generally abandoned.

INTESTINES originally signified all the soft parts within the

${ }^{1}$ Cyanospiza seems to be the right name, since Bonaparte in 1827 expressly stated (Specchio Comp. Orn. di Roma e di Filadelfia, p. 47) that the type of his Spiza was the Emberiza americana of Gmelin, which is not congeneric with the present species, though afterwards (Comp. List B. Eur. \& N.Am. p. 35) retaining Spiza for this group. Passerina though older than either is by ancient practice wholly inadmissible, having been long before used in Botany.

2 Often stated to have been given by him in 1815 (Man. d'Orn. ed. 1, p. xx.), but lie then used Canori for what is practically the same group.

${ }^{3}$ From the Latin insiderre to perch, not incedere to walk, as is often supposed. 
body, but generally now restricted to the organs of the DiGestive SYSTEM,

IRIS (plural Irides), the coloured ring surrounding the pupil of the EYE.

IRRISOR, the generic name, since adopted as Enghish, proposed by Lesson in 1831 (Traité d'Orn. p. 239) for an African bird, the Upupa erythrorhynchus of Latham, which had hitherto been so variously assigned that its affinities were uncertain, and so they remained until Dr. Murie (Itis, 1873, pp. 181-211, pls. v.-vii.) proved that the surmise of its original describer and of Strickland (Ann. Nat. Hist. xii. pp. 238-243) in referring it to the Upupidae (HoOpoE) was not far wrong, though, along with Pininopomastus an allied genus named by Andrew Smith and established by Jardine in 1828 (Zool. Joum. iv. p. 2, pl. i.), it might be justifiably placed in a separate Family. No fewer than 10 species of Irrisor, one of which has been further generically distinguished as Scoptelus, have been described, and 3 of Rhinoponustus; but perhaps there are not really so many. All are African, recognizable by their more or less curved bill, glossy purple or steel-blue plumage, with a white patch on the wing, and white on at least the outer feathers of the tail, which is commonly clongated. They are wholly arboreal in their habits, thereby differing from the Upudida, and unceasingly seek their food in the insects that frequent the bark of trees. The commonest species of the Cape Colony, I. erythrorlunnchus has, according to Mr. Layard (B. S. Africu, p. 73), a harsh cry, and is called by the Dutch Kackelu, meaning "chatterer." Another, $l_{i}$. cycnomelus, also occurs in Sonth Africa.

ISCHILM, or Os ischii, the posterior and ventral, or middle bone of the three that form each half of the PeLris, and meet at the acetabulum or cup which receives the head of the Feulr.

IVORY-BILL, an abbreviation of Ivory-billed WoODPECKER, so called from the colour of its beak, Picus or Campephilus mincipalis, the largest species of the Family inhabiting the United States of America, and except its more

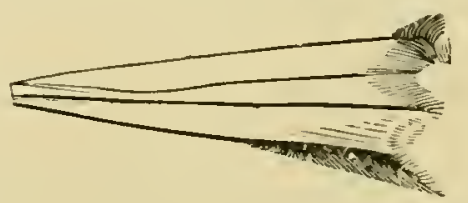

CaMpephllés PRINCIPALIs. (After Swainson.)

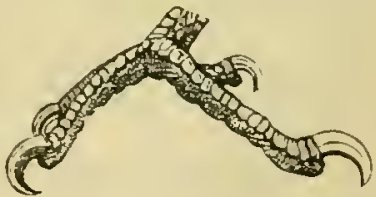
sontherm relative $P$. or $C$. imperialis the largest of the Picida. Though said to have been met with in Maryland, North Carolina seems to be the northern limit of its ordinary range in the east, and

1 In this case the name of the Family should be Family Rhinnpomastidix from the oldest genus in it, not Jrrisorida as often given. 
Ohio in the west. It affects the most thickly wooded districts and especially the cyprus-swamps. The male has a crest of fine scarlet, but otherwise his plumage is black and white, as is also that of the female. Beside the two species just named Mr. Hargitt (Cut. B. Br. Mus. xviii. pp. 460-480) includes 12 others in the genus, all of smaller size.

IXUS, incorrectly written Ixos by Temminck, who proposed it in 1825 (Rec. de Pl. col. d'Ois. livr. 64) as a generic term for a section of Thrush-like ("Turdoüde") birds which he had indicated two years before (op. cit. livr. 12), and a word used occasionally in English, particularly in regard to a species which he in 1840 (Man. d'Orn. iv. p. 608) called I. obscurus, believing it to be new and to be found in Europe. Some writers have been so much puzzled as to the precise application of the term that they have clropped its use, for Temminck made it include forms that are not congeneric, and did not define it until le described the species just mentioned, which has since been identified with the Turdus barbatus of Desfontaines (1Tém. Acad. Poy. Sc. 1787, p. 500) discovered by him in Algeria, and not known to occur to the north of the Mediterranean, while it certainly cannot be placed in the same genus as the bird of Java to which the term was first applied. This last, which has been referred to a genus Hemixus by Dr. Sharpe (Cat. B. Er. Mus. vi. p. 53), should still retain Temminck's title of I. virescens, while his $I$. obscurus has been rightly referred to the genus Pycnonotus (BULBuL) and now stands as P. barbatus. Though the section "Turdoide" was no doubt meant to be equivalent to the grenus which Kuhl called Pycnonotus, ${ }^{1}$ as Boie witnesses (Isis, 1826, p. 973), Temminck expressly states that his genus Ixus contained birds which had not a thickly-feathered back, the eponymic character of Pycnonotus, and therefore the two genera are not identical as some have thought. The so-called "Dusky Ixus," $P$.barbatus of English anthors, is a common bird in parts of Algeria and Morocco where its habits have been observed by several competent ornithologists whose accounts have been conveniently collected by Mr. Dresser (B. Eur. iii. pp. 353-355). A nearly allied species, $P$. xanthopygius, inhabits Palestine, and a single example of one from the Cape of Good Hope, $P$. capensis, is said to have strayed to Ireland (Yarrell, Br. B. ed. 4, i. p. 247).

1 Kull did not live to publish this name, and Boie is the authority for its bestowal. In their days it was not uncommon for naturalists to ticket a specimen in a museum with a name that, though accessible to a visitor, might not find its way into print for many years. The assertion, unsupported by any evidence, and contradicted by all we know of Kuhl's severely scientific method, that a generic name given by him was published "in some popular Dutch periodical" can only raise a smile. 


\section{J}

JABIRU, according to Marcgrave ${ }^{1}$ the Brazilian name of a bird, subsequently called by Linnæus Mycteria americana, one of the largest of the Ciconiida (SToRK), which occurs from Mexico

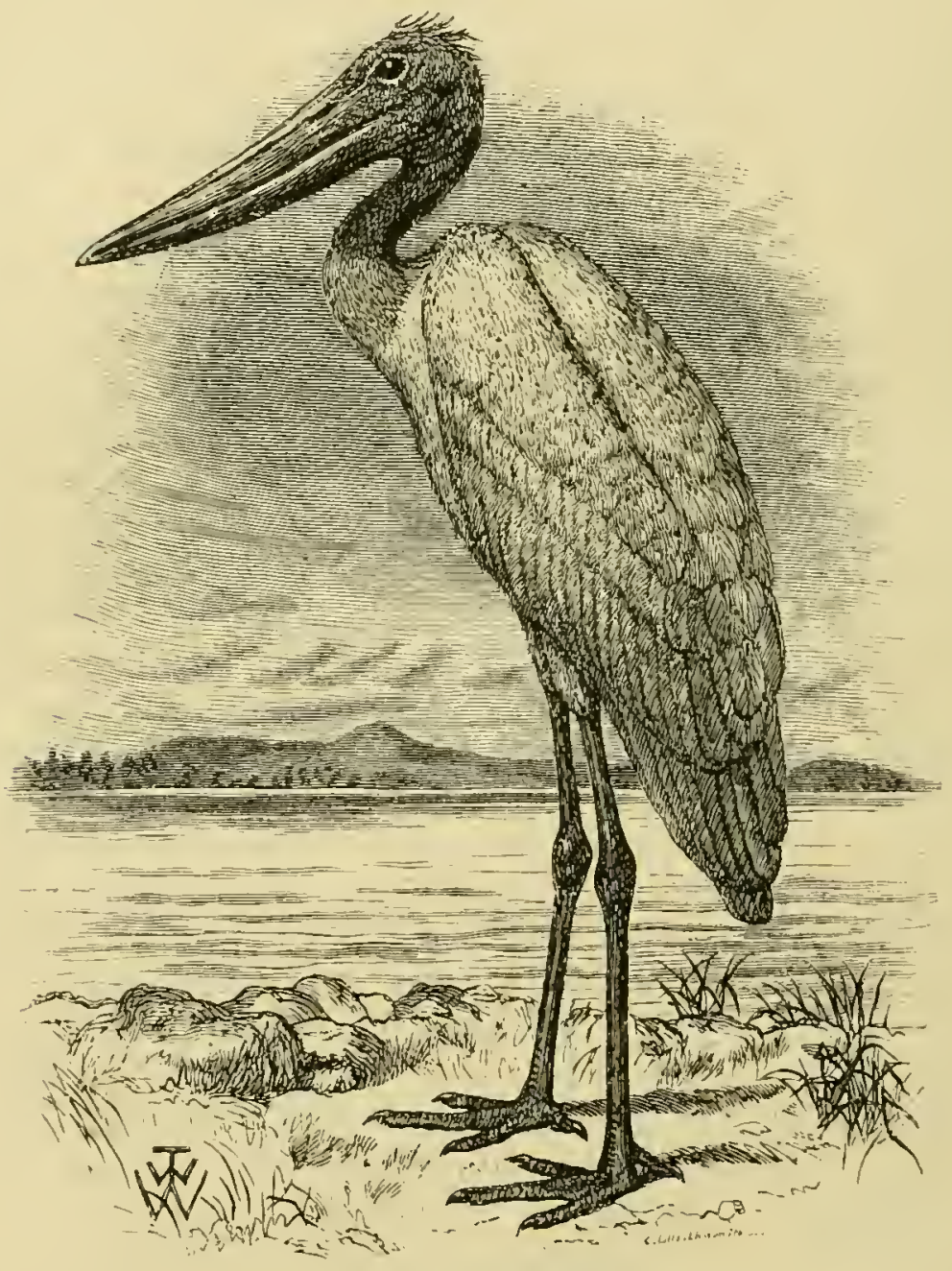

JAEIRU, Mycteria americana.

southwards to the territory of the Argentine Republic. It stands between 4 and 5 feet in height, and is conspicuous for its massive bill, slightly upturned, and its entirely white plumage; but the head and neck are bare and black, except for about the lower third

1 An apparently accidental transposal of two of the figures given by this author (Hist. Nat. Brasilix, pl. 200, 201) misled several of lis successors from Piso to Brisson, until noticed by Buffon (Hist. Nat. Ois. vii. pp. 280-286). 
part of the latter, which is bright red in the living bird. Very nearly allied to Mycteria, and also commonly called Jabirus, are the birds of the genera Xenorhynchus and Ephippiorhynchus-the former containing one or (in the opinion of some) two species, X. australis and $X$. indicus, and the latter one only, E. senegalensis. These belong to the countries indicated by their names, and differ chiefly by their feathered bead and neck, while the last is sometimes termed the Saddle-billed Stork from the very singular shape of its beak. Somewhat more distantly related are the large birds belonging to the genus Leptoptilus (ADJUTANT).

JACAMAR, ${ }^{1}$ a word formed by Brisson from Jacameri, the Brazilian name of a bird, as given by Marcgrave, and since adopted in most European tongues for the species to which it was first applied and others allied to it, forming the Family Galbutidx ${ }^{2}$ of ornithologists, the precise position of which is uncertain. All will agree that the Jacamars belong to the great heterogeneous group called by Nitzsch PICARI e, but further into detail it is hardly safe to go. The Galbulida have zygodactylous feet, like the Cuculidx (Cuckow), Bucconidx (Puff-BIRd), and Picidx (Woodpecker), they also resemble both the latter in laying glossy white eggs, but in this respect they bear the same resemblance to the Momotida (Мотмот), Alcedinidæ (KIngfisher), Meropidæ (BeE-Eater), and some other groups, to which affinity has been claimed for them. In the opinion of Mr. Sclater, ${ }^{3}$ the Jacamars form two groups-one consisting of the single genus and species Jacamerops aureus ( $J$. grandis of most authors), and the other including all the rest, namely, Urogalba with two species, Galbula with ten, Brachygalba with six, and Jacamaralcyon and Galbalcyrhynchus with one each. They are all rather small birds (the largest known being little over 10 inches in length), with a sharply pointed bill, and the plumage in every case more or less resplendent with golden or bronze reflexions, but at the same time comparatively soft. Jacamaralcyor tridactyla differs from all the rest in possessing but three toes (as its name indicates) on each foot, the hallux being deficient. With the exception of Galbula melanogenia, which is found also in Central America and southern Mexico, all the Jacamars inhabit the tropical portions of South America eastward of the Andes, Galbula ruficauda, however, extending its range to the islands of Trinidad and Tobago. ${ }^{4}$

1 In this word the $c$ should be sounded soft, as $s$.

2 Galbula was first applied to Marcgrave's bird by Moehring. It is another form of Galgulus, and seems to have been one of the many names of the Golden ORIOLE.

'A Monograph of the Jacamars and Puff-birds (London: 1879-82); and Cat. B. Br. Mus. xix. pp. 161-177.

4 The singular appearance, recorded in 1853 by Canon Tristram (Zoologist, 
Very little is known of the habits of any of the species. They are seen sitting motionless on trees, sometimes solitarily, at other times in companies, whence they suddenly dart off at any passing insect, catch it on the wing, and return to their perch. Of their nidification almost nothing has been recorded, but the species abovementioned as occurring in Tobago is said by Mr. Kirk (Ann. and, Mug. Nat. Hist. xix. p. 80)-apparently the only European observer of the mode of propagation in these birds-to make its nest in marl-banks, digging a hole about an inch and a half in diameter and some 18 inches deep. From the accounts received by other travellers we may possibly infer that more of the Family possess the same habit.

JACANA, ${ }^{1}$ the Brazilian name, according to Marcgrave, of certain birds, since found to have allies in other parts of the world, which are also very generally called by the same appellation. They hare been most frequently classed with the Pallidie (RAIL), but are now admitted to form a separate Family, Parrida, ${ }^{2}$ whose leaning is towards the Limicola, as apparently first suggested by Blyth, a view supported by the osteological observations of Parker (Proc. Zool. Soc. 1863, p. 513), though denied by Prof. A. Milne-Edwards (Ois. Foss. France, ii. p. 110). The most obvious characteristic of this group of birds is the extraordinary length of their toes and claws (the latter being turned upwards), whereby they are enabled

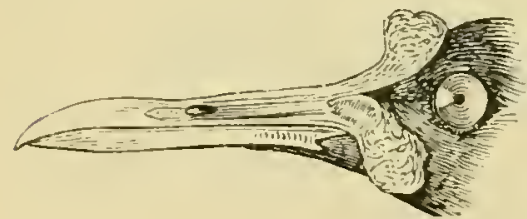

Pirra. (After Swainson.) to walk with ease over water-lilies and other aquatic plants growing in river's and lakes. It is also remarkable for the carpal spurs with which its members are armed. The Family has been divided into four genera, — of which Parra, as now restricted, inhabits South America; Metopidius, hardly differing from it, has representatives in Africa, Madagascar and the Indian Region; Hydralector, also very nearly allied to Parra, belongs to the northern portion of the Australian Region; ${ }^{3}$ and Hydrophasianus, the most extravagant form of the whole, is found in India, Ceylon and China - the

p. 3906), of a bird of this species in Lincolnshire requires notice. No instance secins to be known of any Jacamar having been kept in confinement or brought to this country alive.

In pronunciation the $c$ is soft, and the accent placed on the last syllable.

2 The classic Parra is by some authors thought to have been the Golden Or:rouE, while others suppose it was a Jay or Pie. The word seems to have been imported into Ornithology by Aldrovandus, but the reason which prompted Linnæus to apply it, as he seems first to have done, to a bird of this group, cannot be satisfactorily stated.

3 The species inhabiting Queensland, $H$. cristatus or gallinuceus, is said to be there known as the "Lotus-bird" (Lumholtz, Among Cannibals, 1). 22). 
draughtsmen of the comntry last named making it a favourite subject of their pictures, in which its flowing tail and the very peculiar filamentous appendages to the tip of its first and fourth primaries are generally faithfully represented. In habits the Jacanas have much in common with the Water-hens, but that fact is insufficient to warrant the affinity asserted to exist between the two groups; for in their osteological structure, as already implied, there is much difference, and the resemblance seems to be only that of analogy. The Parrida, or at least such of them as have been sufficiently observed, lay very peculiar eggs, of a rich olive-brown

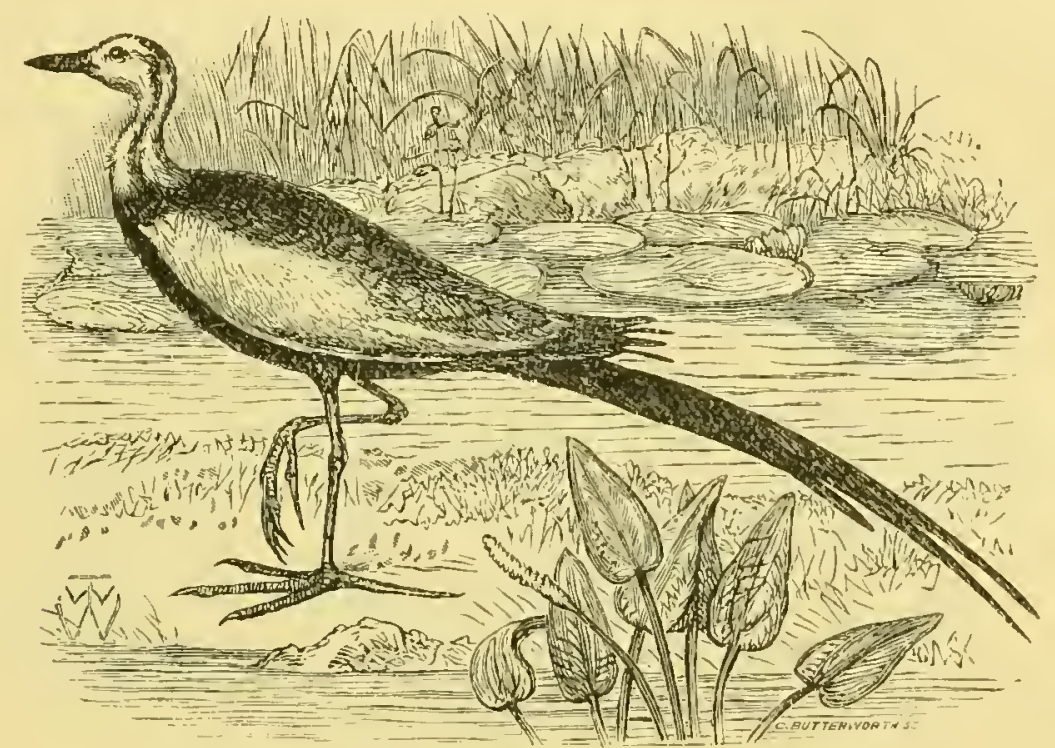

Indan JaCana, Hydrophasianus chirurgus.

colour, in most cases closely marked with dark lines, thus presenting an appearance by which they may be readily known from those of any other birds, though an approach to it is occasionally to be noticed in those of cortain Limicola, and especially of certain Charadriadx. The genus Palamedea (SCREAnER) was at one time thought to be allied to this Family, but is now, by almost common consent, allowed to have nothing to do with it.

JACKASS, two species of PENGUIN (resembling one another so nearly as to have been long confounded) Spheniscus demersus and $S$. magellanicus, so called by sailor's and by the people of the cfleverigenda
Falkland Islands 1 - the latter "from its habit, while on shore, of throwing its head backwards, and making a loud strange noise, very like the braying of an ass." (Darwin, Journal of Researches, chap. ix.) With the prefix "Laughing," the name is commonly applied to a large Anstralian KingFisher, Dacelo gigas, which makes, says Caley

I An older name there was Jumping Jack (Clayton, Phil. Trans. 1xvi. p. 103). 
(Trans. Linn. Soc. xv. p. 204), "a loud noise somewhat like laughing," whence, together with its uncouth appearance, it probably received its extraordinary appellation from the settlers on their first arrival in the country.

JACKDAW, the common nickname of the DAw, Corvus monedula.

JACK-SNIPE, so called either from its small size, or from being accounted the male of the common SNIPE.

JAVA SPARROW, one of the best-known of exotic cage-birds, Padda or Munia oryzivora, belonging to the Family Ploceidix (IVEAverBIRD) and a species which has been naturalized in many countries, where it is often very injurious to crops of rice or other grain. It is said to have been brought to Europe from China, whither it was conveyed from Java many year's before, and a living bird possessed by Sloane in 1740 was described and figured by Edwards (Nat. Hist. Uncom. B. pl. 41). It is easily recognized by its pink bill, red orbits, slate-coloured body, and black crown, beneath which is generally a pure white patch on the cheek, but according to the observation of Mr. Bartlett as recorded by his son (Monogr. Weaver-B. pt. 1) these white patches will change to black, and then again to white, irrespective of age, sex, or season. Examples without white patches are often sold as females, but Mr. Edward Bartlett says he has dissected many and found that both sexes are alike in plumage, nor has the male any song by which he may be distinguished.

JAY (French, Geai), a well-known and very beautiful European bird, the Corvus glandarius of Linnens, the Garrulus glandarius of modern ornithologists. To this species are more or less closely allied numerous birds inhabiting, both areas of the Holarctic Region, the Indian and the Neotropical, except the southern portion of the last two. All these birds are commonly called Jays, and form a group of the Corvida (Crow), which may be considered a subfamily, Garrulinz. Indeed there are, or have been, systematists who would, unnecessarily as it seems, elevate the Jays to the rank of a Family, Garrulida. Some of them have an unquestionable resemblance to the PIEs, if the group now known by that name can be satisfactorily severed from the true Corvinx. In structure the Jays are not readily differentiated from the Pies; but in habit, so far as is known of them, they are much more arboreal, delighting in thick coverts, seldom appearing in the open, and seeking their food on or under trees. They seem also never to walk or run when on the ground, but always to hop. The body-feathers are commonly loose and soft; and, gaily coloured as are most of the species, in 
few of them has the plumage the metallic glossiness it generally presents in the Pies, while the proverbial beauty of the "Jay's wing" is due to the vivid tints of blue-turquoise and cobalt, heightened by bars of jet-black, an indication of the same style of ornament being observable in the greater number of the other forms of the group, and in some predominating over nearly the whole surface. Of the many genera that have been proposed by ornithologists, perhaps about nine may be deemed sufficiently well established.

The ordinary European Jay, Garrulus glandarius, has of late years suffered so much persecution in the British Islands as to have become in many districts a rare bird. In Ireland it seems now to

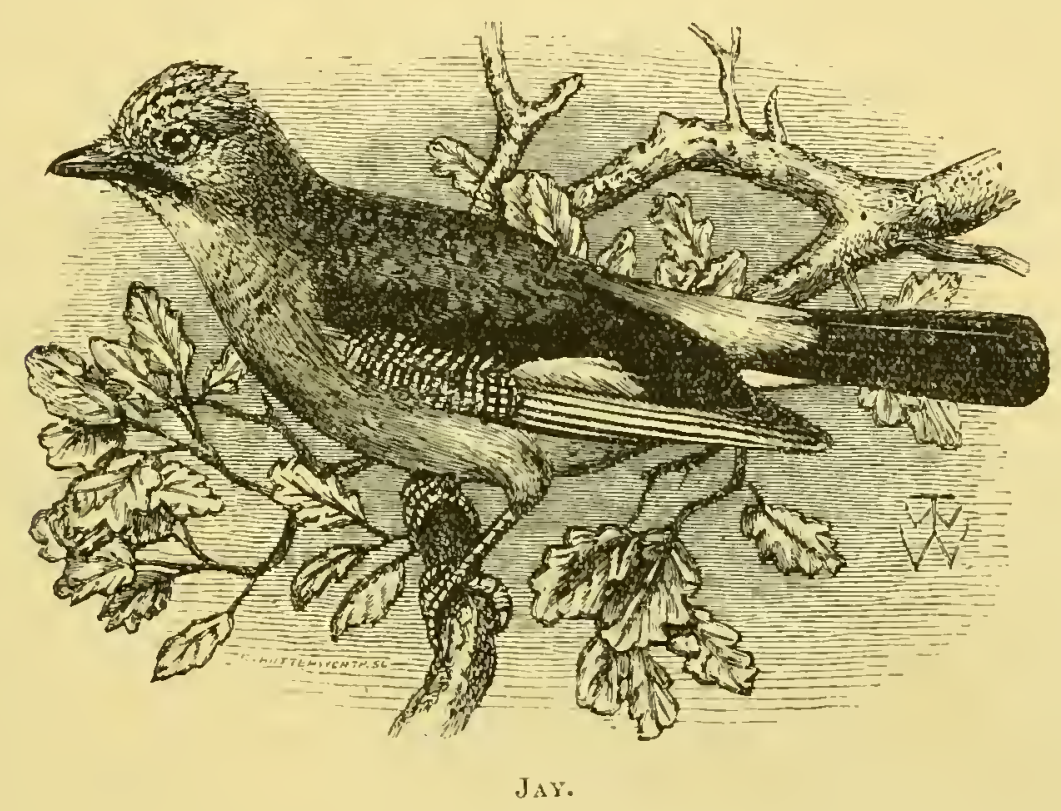

be indigenous to the southern half of the island only; in England generally, it is far less numerous than formerly; and $\mathrm{Mr}$. Lumsden (Scott. Nat. iii. pp. 230-240) has shewn that in Scotland its numbers have decreased with still greater rapidity. It would possibly have been exterminated by this time but for its stock being supplied in autumn by immigration, and for its shy and wary behaviour, especially in the breeding-season, when it becomes almost, wholly muie, and thereby often escapes detection. No truthful man, however much he may love the bird, will gainsay the depredations on fruit and eggs that it at times commits; but the gardeners and gamekeepers of Britain fall into the usual error of persons imperfectly acquainted with the ways of Nature, and, instead of taking a few simple steps to guard their charge from injury, or at most of killing the individual birds from which they suffer, deliberately adopt methods of wholesale destruction- 
methods that in the case of this species are only too easy and too effectual-by proffering temptation to trespass which it is not in Jay-nature to resist, and accordingly the bird runs great chance of total extirpation. Notwithstanding the war carried on against the Jay, its varied cries and active gesticulations shew it to be a sprightly bird, and at a distance that renders its beauty-spots invisible, it is yet conspicuous by its cinnamon-coloured body and pure white tail-coverts, which contrast with the deep black and rich chestnut that otherwise mark its plumage, and even the young at once assume a dress closely resembling that of the adult. The nest, generally concealed in a leafy tree or bush, is carefully built, with a lining formed of fine roots neatly interwoven. Herein from four to seven eggs, of a greenish-white closely freckled so as to seem suffused with light olive, are laid in March or April, and the young on quitting it accompany their parents for some weeks.

Though the common Jay of Europe inhabits nearly the whole of this quarter of the globe south of $64^{\circ} \mathrm{N}$. lat., its territory in the east of Russia is also occupied by $G$. brandti, a kindred form, which replaces it on the other side of the Ural, and ranges thence across Siberia to Japan; and again on the Lower Damube and thence to Constantinople the nearly-allied G. Irynicki (which alone is found in southern Russia, Caucasia, and Asia Minor) shares its haunts with it. It also crosses the Mediterranean to Algeria and Morocco; but there, as in southern Spain, it is probably but a winter immigrant. The three forms just named have the widest range of any of the genus. Next to them come $G$. atricapillus, reaching from Syria to Beloochistan, G. japonicus, the ordinary Jay of southern Japan, and $G$. sinensis, the Chinese bird. Other forms have a much more limited area, as $G$. cervicalis, the local and resident Jay of Algeria, $G$. hyrcanus, found on the southern shores of the Caspian Sea, and $G$. taivanus confined to the island of Formosa. The most aberrant species referred to the true Jays is the $G$. lidthi of Bonaparte (Proc. Zool. Soc. 1850, p. 80, Aves, pl. xvii.), which, though said to come from some part of Japan (Salvadori, Atti Accad. Torino, vii. p. 474), seems not to have been met with there, and its proper country is not known.

Leaving the true Jays of the genus Garrulus, we may next consider those of a group, named, in 1831, Dysornithia by Swainson (F. Bor.-Am. ii. p. 495) and Perisoreus by Bonaparte (Saggio \&c. Anim. Vertebr. p. 43), ${ }^{2}$ containing two species-one the Lanius

${ }^{1}$ Further information will possibly shew that these districts are not occupied at the same season of the year by the two forms.

2 Recent writers have preferred the latter term, though it was only used subgenerically by its author, who assigned to it no characters, which the inventor of the former was careful to do, regarding it at the same time as a genus. 
infaustus of Linnæus and the Siberian Jay of English writers, which ranges throughout the pine-forests of the north of Europe and Asia, and the second the Corvus canadensis of the same author, or Canala Jay, occupying a similar station in America. The first is one of the inost entertaining birds in the world. Its versatile cries and actions, as seen and heard by those who penetrate the solitude of the northern forests it inhabits, can never be forgotten by one who las had experience of them, any mole than the pleasing sight of its rust-coloured tail, which an occasional gleam of sunshine will light u1) into a brilliancy quite unexpected by those who have only surveyed the bird's otherwise gloomy appearance in the glass-case of a museum. It seems scarcely to know fear, obtruding itself on the notice of any passenger who invades its haunts, and shonld he halt, making itself at once a denizen of his bironac. In confinement it speedily becomes friendly, but suitable food for it is not easily found. Linnæus seems to have been under a misapprehension when he applied to it the trivial epithet it bears; for by none of his countrymen is it deemed an mnlucky bird, but rather the leverse. In fact, no one can listen to the cheery sound of its ordinary calls with any but a hopeful feeling. 'The Canada Jay, or "WhiskeyJack" (the corruption probably of it Cree name), seems to be of a similar nature, but it presents a still more sombre coloration, its nestling plumage, ${ }^{1}$ indecd, being thoronghly Corvine in appearance and suggestive of its being a pristine form.

As though to make amends for the dull plumage of the species last mentioned, North America offers some of the most brilliantly coloured of the subfamily, and the com-

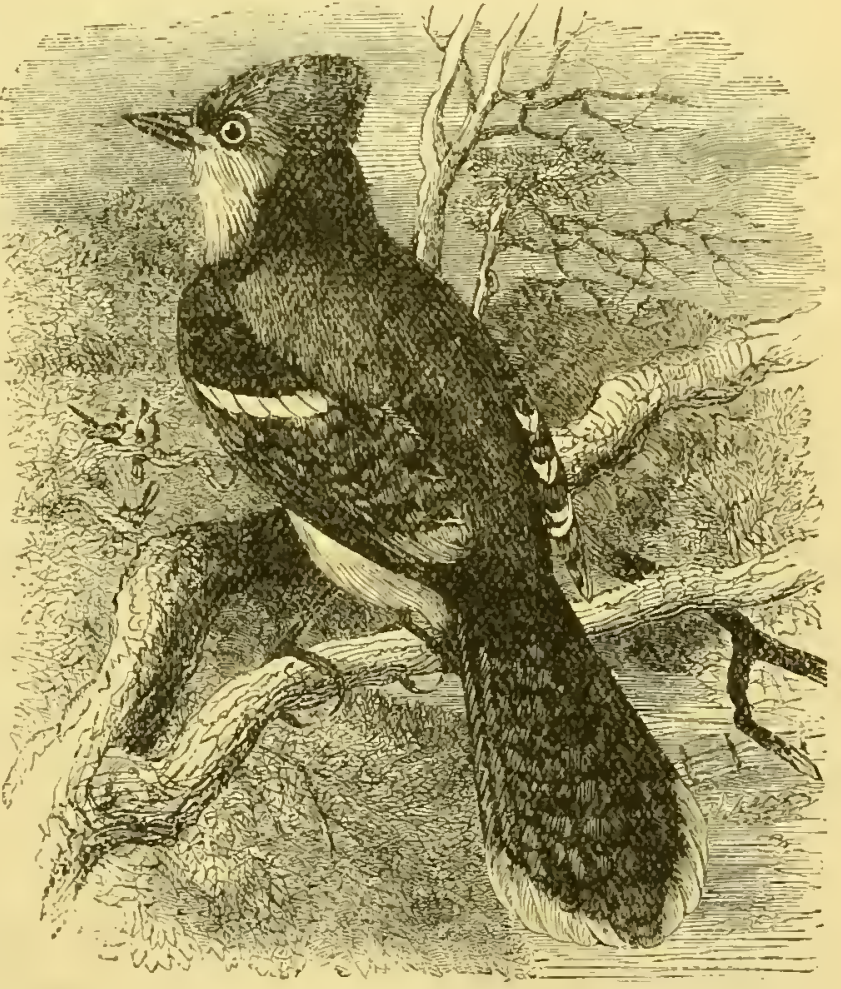

BLUE JAT. mon Blue Jay of eastern Canada and the older States of the Union, Cyanurus cristatus, is one of the most conspicuous bircls of the trans-

1 In this it was lescribed and figured (F. Bor.-Am. ii. p. 296, pl. 55) as a distinct species, G. brachyrhynchus. 
atlantic woods. The account of its habits by Alexander Wilson is known to every student of ornithology, and Wilson's followers have had little to do but supplement his history with unimportant details. ${ }^{1}$ In this bird and its many allied forms, coloration, though almost confined to various tints of blue, seems to reach its climax, but want of space forbids more particular notice of them, or of the members of the other genera Cyanocitta, Cyanocorax, Xanthura, Psilorhinus, and more, which inhabit various parts of the Western continent. It remains, however, to mention the genus Cissa, including many beautiful forms belonging to the Indian Region, and among them the C. speciosa and C. sinensis, so often represented in Oriental drawings, though doubts may be expressed whether these birds are not more nearly related to the Pies than to the Jays.

JENNY, a child's nickname of the WREN, in the character of Robin Redbreast's wife.

JERFALCON, a vulgar corruption of Gerfalcon, that is GYRFALCON.

JOHN-CROW, the local name in Jamaica for what is elsewhere in the New World called the Turkey-Buzzard, the Vultur aura of

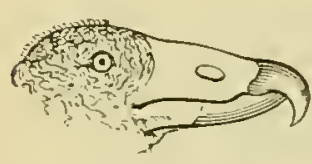

Cathartes atra. (After Swainson.) Linnzeus, and Cathartes or Catharista ance of most writers ; to which, in $1874, \mathrm{Mr}$. Ridgway $(N .-A m$. B. iii. p. 337) applied the generic term of Phinogryphus, and Dr. Sharpe (Cat. B. Br. Mus. i. p. 25) that of Enops. It is the most widely spread of American Vultures, ranging from the Saskatchewan valley in Canada, under $55^{\circ}$ of northern latitude, to Tierra del Fuego, which is about as far south. This fact shews its success in the struggle for existence; but the zoologist should not neglect the lesson tanght by another fact. In Jamaica, within a few years, the John-Crow, though there protected by human law, has been nearly extirpated by the introduction of the Mongoose (Extermination, p. 227, note 4), shewing how inadequately a successful animal can compete with conditions for which it has not been prepared, and to which it is suddenly exposed-the result of thus upsetting a natural law being fatal. No notice of this bird, however brief, should omit allusion to the controversy that once raged around it, in regard to the supposed olfactory powers ascribed to it and other members of the Sarcorhamphida as well as to those of the analogous Family Tulturida. Happily the whole mystery was dispelled by the simple "conjecture" (is he modestly called it) of Canon Tristram (Ilis, 1859, p. 280),

1 The "Bhe Jay" of a recent American humourist woull, however, from the locality assigned to his inimitable story, appear to be, not this species, but one of its western kindred- $\Lambda$ merican ornithologists must determine which. 
and never need again occupy the attention of the ornithologist. It remains to say that the present species has its common name from the outward resemblance to a TuRkEY afforded by its bare, reel head and neck, and its generally black plumage. In its near ally C. burrovianus, of Eastern Brazil, the nape is clothed nearly to the occiput, and in $C$. atratus the naked skin of head and neck is black.

JOHN-DOWN, the name given to the FULmar by Newfoundland fishermen.

JOHNNY, the Sonth-Sea sealer's' name ${ }^{1}$ for a Penguix, Pygoscelis papua or taniata, one of the widely-distributed species; but rapidly decreasing in numbers, owing to the destruction to which it is subjected at its breeding-places. It is disgusting to read (Phil. Trans. vol. 168, p. 155) that, on the occasion of the observation of the Transit of Tenus in 1874-5 on Kerguelen Land, where this species had many settlements, a naturalist should have to write of one of them- "The whole of this community of Penguins was subsequently boiled down into 'hare soup' for the officers of H.M.S. "Volage.'" It is obvious that officers of this lind should not be sent on scientific expeditions.

JUMBY-BIRD, a Negro name for almost any kind that is of bad omen, but especially for an OwL.

JUNGLE-FOWL, generally accepted as the wild original of the domestic FowL.

\section{K}

KAE, the common Scottish name of the DAw.

KAGU, the native name, since Anglified, of an extremely curious bird, found, after the French occupation of New Caledonia in 1852 , to be an inhabitant of that island, to which it is peculiar. It is the Phinochetus jubutus of ornithology, and the first specimen brought to the notice of naturalists was sent to the Colonial Exhibition in Paris in 1860 by Mons. Latour. Its original describers, Jules Verreanx and Des Murs, regarded it first as a HERon and then as a Crane (Rev. Zool. 1S60, pp. 439441, pl. 21; 1862, pp. 142-144); but, on Dr. George Bennett sending two live examples to the Zoological Gardens, Mr. Bartlett (Proc. Zool. Soc. 1862, pp. 218, 219, pl. xxx.) quickly detected in

1 Modern sailors' names are hard to trace. Perhaps this may be connected with "Gentoo," which, Capt. Abbot says (Ibis, 1S60, p. 337), is the name given to the species in the Falkland Islands, and may snggest a Portuguese origin. 
them an affinity to Eurypyga (SUN-BitTFres), and in due time anatomical investigation shewed him to be right. The Kagu, however, would not strike the ordinary observer as having much outward resemblance to the Sun-Bittern, of which it has neither the figure nor posture. It is rather a long-legged bird, about as large as an ordinary Fowl, walking quickly and then standing almost motionless, with bright red bill and legs, large eyes, a full pendent crest, and is generally of a light slate-colour, paler beneath, and obscurely barred on its longer wing-coverts and tail with a darker shade. It is only when it spreads its wings that these are seen to be marked and spotted with white, rust-colour, and black,

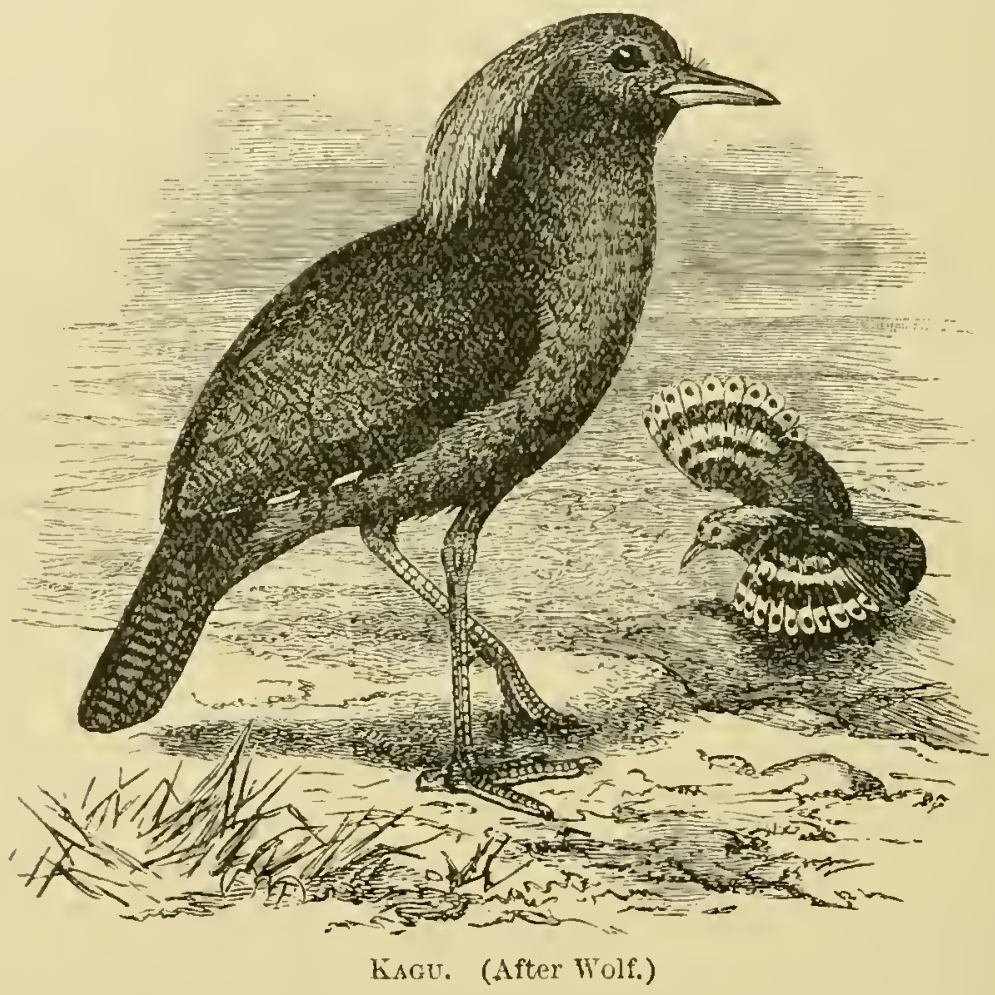

somewhat after the pattern of those of the Sun-Bittern. Like that bird too, the Kagu will, in moments of excitement, give up its ordinary placid behaviour and execute a variety of violent gesticulations, some of them even of a more extraordinary kind, for it will dance round, holding by the bill the tip of its tail or of one of its wings in a way that no other bird is known to do. Its habits in its own country were described at some length in 1863 by $M$. Jouan (Mém. Soc. Sc. Nat. Cherbourg, ix. pp. 97 and 235), and in 1870 by M. Marie (Actes Soc. Linn. Bordeaux, xxvii. pp. 323-326), the last of whom predicts the speedy extinction of this interesting form, a fate foreboded also by the statement of Messrs. Layard (Ibis, 1882, pp. 534, 535) that it has nearly disappeared from the neighbourhood of the more settled and inhabited parts. 
The internal and extermal structure of both these remarkable forms, Phinochetus and Eurypyga, has been treated in much detail by Parker in the Zoological Proceedings (1864, pp. 70-72) and Transactions (vi. pp. 501-521, pls. 91, 92: x. pp. 307-310, pl. 54, figs. 7-9), as also by Dr. Murie in the latter work (vii. pp. 465-492, pls. 56,57 ), and the result of their researches shews that though separable as distinct Families, Eurypygidx and Phinochetidx, they belong to Prof. Huxley's Geranomorpize, of which they must be deemed the relics of very ancient and generalized types. Their inter-relations to the Pullida (RAIL), Psophiidie (Trumpeter), and other groups need not to be here considered; but it may be remarked that the eggs of both Eurypyga and Rhinochetus have a very strong Ralline appearance-stronger even than the figures pnblished (Proc. Zool. Soc. 1868, pl. xii.) would indicate.

\section{KAKA, see NEsTor.}

KAKAPO, the Maori name, signifying "Night-Parrot," and frequently adopted by English writers, of a bird, commonly called by British colonists in New Zealand the "Ground-Parrot" or" "OwlParrot." The existence of this singular form was first made known in 1843 by Dieffenbach (Travels in $N$. Zealand, ii. p. 194), from some of its tail-feathers obtained by him in the interior of that country, and he suggested that it was one of the Cuculidx, possibly belonging to the genus Centropus, adding that it was becoming scarce, and that no example had been seen for many years. The late Mr. G. R. Gray, noticing it in June 1845 (Zool. Voy. 'Erebus' and 'Terror', part ix. p. 9), was able to say little more of it; but very soon after a skin was received at the British Museum, of which, in the following September, he published a figure (Gen. Birds, part xvii.), naming it Strigops ${ }^{1}$ habroptilus, and rightly placing it among the Parrots, though he did not describe it technically for another eighteen mon'ths (Proc. Zool. Soc. 1847, p. 61), by which time some further information concerning it had been furnished by Sir George Grey (Ann. Nat. Hist. xviii. p. 427) and Strange (Proc. Zool. Soc. 1847 , p. 50); while in the same year Jules Verreaux sent an example, with an account of its habits, to the museum of Paris, which was published by Pucheran (Rev. Zool. 1847, p. 385). Various observers, among whom must be especially named Dr. Lyall (Proc. Zool. Soc. 1852 , p. 31), who was the first to recond the breeding habits and obtain the egg of the bird, and Von Haast (Verh.zool.-bot. Gesellsch. Wien, 1863, p. 1115) supplied other particulars, and so many specimens have been received in Europe that it is now represented in most museums, and more than half a dozen examples have

I This generic term was subsequently altered by Van der Hoeven to Stringopsis, but Stringops is the spelling now generally adopted. 
reached England alive. Yet, thongh much has been written about it, there is 10 detailed description of its internal structure, a fact the more to be regretted since the bird is obviously doomed to early extinction, and the opportunity of solving several problems of interest, which a minute examination of its anatomy might afford, will be lost if the matter be not speedily taken in hand. Few existing birds offer a better subject for a monographer, and it is to be hoped that, if perish the genus and species must, posterity will not have to lament the want of an exhaustive treatise on the many and wonderful characteristics of what Prof. Fürbringer considers (Journ. für Orn. 1889, pp. 239-241) to be one of the primitive forms of Psittaci.

In habits the Kakapo is almost wholly nocturnal, ${ }^{1}$ hiding during the daytime in holes (made in some instances it would seem by itself) under the roots of trees or rocks, and only issuing forth about sunset to seek for food, which is solely vegetable in kind, and consists of the roots, twigs, leaves, seeds, and fruits of trees, grasses, or ferns-some observers say mosses also. It sometimes climbs trees, but generally remains on the ground, only using its comparatively short wings to balance itself in rumning, or to break its fall when it drops from a tree-though not always then -being apparently quite incapable of real flight. It thus becomes an easy prey to the marauders which the colonists have let loose in New Zealand, so disastrously for its indigenous inhabitants. Sir G. Grey, writing in 1854, said it had been, within the memory of old people, abundant in every part of that country; but was then found oniy in the unsettled districts, and thus little hope can be entertained of its surviving much longer.

The Kakapo is about the size of a Raven, of a green or brownishgreen colour, thickly freckled and irregularly barred with dark brown, and dashed here and there with longitudinal stripes of light yellow. Examples are subject. to much variation in colour ${ }^{2}$ and shade, and in some the lower parts are deeply tinged with yellow. Externally the most striking feature of the bird is its head, armed with a powerful beak, that it well knows how to use, and its face clothed with hairs and elongated feathers that sufficiently resemble

1 It has, however, been occasionally observed abroad by day ; and, in captivity, one example at least is said to have been just as active by day as by night.

2 A specimen in the British Museum (Zool. Voy. 'Erebus' and 'Terror,' pl. 7) has the prevailing green tint replaced by blne of several shades, and has been described as a distinct species, S. greyi ; but it is obviously in an abnormal condition, and its specific distinctness, though admitted by Count T. Salvadori (Cat. B. Br. Mus. xx. p. 601), cannot be maintained withont further eridence. Sir W. Buller (loc. cit.) describes several varieties of the Kakapo, and Mr. Reischek states (T'rans. I. Zcal. Inst. xvii. p. 196) that examples from the high moun. tains are larger and brighter in colour than those from the lower grounds. 
the physiognomy of an Owl to justify the generic name bestowed upon it. Of its internal structure little has been described, and that not always correctly. Its furcula has been said (Proc. Zool. Soc. 1874, p. 594) to be "lost," whereas the clavicles, which in most birds unite to for'm that bone, are present, though they do not meet, while in like manner the bird has been declared (op. cit. $1867, \mathrm{p}$. 624 , note) to furnish among the Curinatie "the only apparent exception to the presence of a keel" to the sternum.

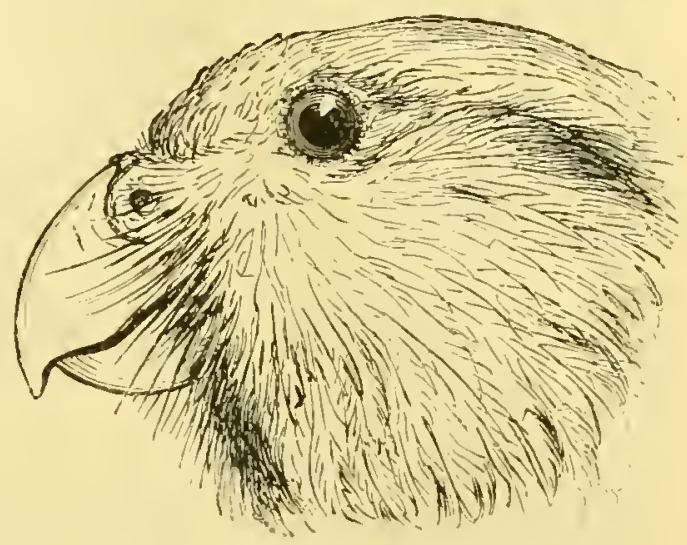

KaKapo. (From Buller.) The keel, however, is undoubtedly there, as remarker by MM. Blanchard (Amn. Nat. Sc. Zoologie, ser. 4, xi. p. 83) and A. MilneFdwards (Ois. Foss. de la France, ii. p. 516), and, though much redneed in size, is nearly as much developed as in the DoDo and the W'EKA. The aborted condition of this process can hardly be regarded but in connexion with the incapacity of the bird for flight, and may very likely be, as some have supposed, the result of disuse. There can be scarcely any doubt as to the propriety of considering this genus the type of a separate Family of Psittaci; but whether it stands alone, or some other forms (Pezoporus or Geopsittucus, for example, ${ }^{1}$ which in coloration and habits present some curious analogies) should be placed with it, must await future determination. In captivity the Kakapo is said to shew much intelligence, as well as an affectionate and playful disposition, soon attaching itself to its master and taking pleasure in caressing him and being caressed in turn. Unfortunately it does not seem to share the longevity characteristic of most Parrots, and none that have been held in confinement appear to have long survived, while many succumb speedily. For further details the reader may be referred to Gould's Birds of Australiu (ii. 1. 247) and Handbook (ii. p. 539), Dr. Finsch's Die Papageien (i. p. 241), but especially to Sir W. Buller's Birds of New Zealand (p. 26, ed. 2, i. p. 176), in which last work nearly all the information hitherto recorded is to be found.

KALKOENTJE (Little Turkey), the Dutch name in South Africa for the Alauda capensis of Linnsus, the type of Swainson's genus Mucronyx, which recent authors suppose to be allied to Anthus (PIPIT), and refer to the Family Motucillida, a position that may be open to doubt. It is common throughout the open country, and

1 Dr. Reichenow (Journ. für Orn. 1881, pl). 13-16) boldly unites them in a single Family, but in that case it should bear the name of Peroporidat. 
has much of the habits of a LARK, except that it does not soar and has no song, uttering a cry which Levaillant syllabled "qui vive?"
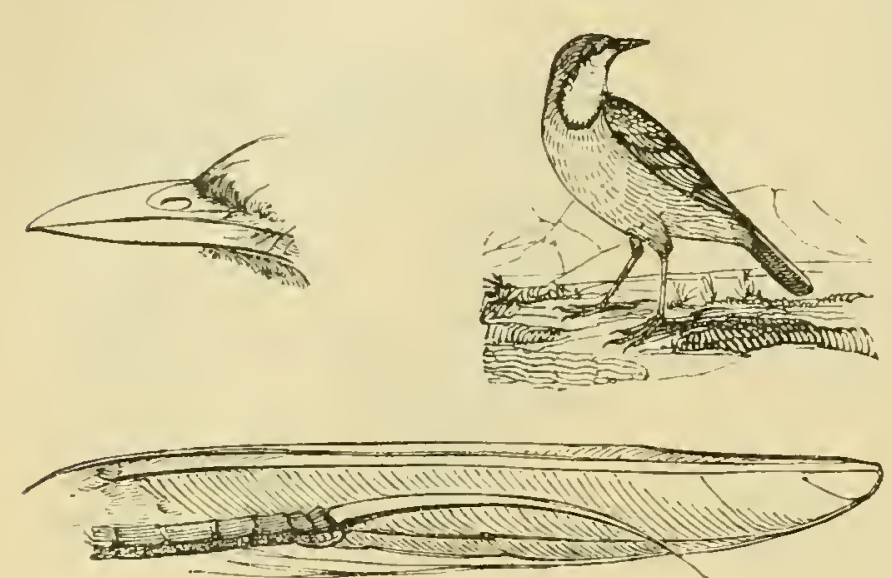

MACRONYX. (After Swainson.) and Mr. Layard terms "mewing." The eurious similarity in coloration, which obtains between this form and the Ameriean Sturnella, has been already noticed (ICTERUS); but it must be understood that whatever be the true position of Macronyx, the tro

genera are not allied. Several English names have been suggested for this bird. and one by which it is said to be called in the Cape Colony is "Cnt-throat Lark," from the deep orange colour of its throat. Three other species of Hucronyx are known-one, Mr. crocea, having a yellow throat, and therefore still more closely resembling Sturnella magna, being widely spread throughout Africa; another, MI. flavicollis, inhabiting Abyssinia and the neighbouring countries; and the fourth, MI. amelix, with a red throat, confined to the southeastern part of the continent.

KALLEGE ${ }^{1}$ or KALIJ, the Anglo-Indian name, applied to about a dozen forms of Pheasant, constituting the genus Euplocamus (Gullophasis of some authors), among which the E. albicristatus of the north-western Himalaya and the nearly-allied E. melanonotus of Sikhim are those to which it properly belongs. Passing eastwards they are represented by other forms, as E. horsfieldi in Assam, $E$. lineatus in Burma and so on; and, where the range of almost any two of them is conterminous, so-called "hybrids" are observed. Others which may be regarded as thoroughly good species inhabit islands, as Sumatra, Borneo and even Formosa, while parts of China produce the best-known of all, E. nycthemerus, the Silver Pheasant of our aviaries, which was introduced to England in the first lalf of the 18th century.

KEA, see Nestor.

KEEL, carina, or crista sterni, a medio-ventral outgrowth from the two coaleseent parts of the sternal cartiliginous plate. Itself originally cartilaginous, it subsequently ossifies from the basal region and from the anterior margin hackwards, so as to form a

1 Corrupted into "College Pheasant" (Yule and Burnell, Hobson-Jobson). 
vertical bony septum between the great pectoral muscles, which mainly rise from it. Its size, and especially its depth, stand in direct correlation with these, the chief motor muscles of the wing. Great power of flight, as in Gannets, Petrels, Swifts and Hummingbirds is associated with a deep Keel, while disuse of the wingmuscles tends to reduce it, as is strikingly illustrated by the thin and inconspicuous ridge which it takes in Stringops (KAKAPo). In the Ratito the Keel is altogether absent, without even the least trace of it in the embryo, and there is no sign of it in the fossil Hesperornis (OdonToritiHes). In this last, its absence is in keeping with the very slender humerus, indicating that the welldeveloped paddle-like feet were the only organs of locomotion. On the other hand, its great size in the Penguins is easily explained by the use they make of their wings, with a semi-rotatory or screwlike action, as the means of propulsion under water. The configuration of the anterior margin of the Keel is of some taxonomic value (see STERNUM).

KEEL-BILL, Shaw's name (Gen. Zool. viii. p. 380) for the ANI.

KESTREL (French Cresserelle or Crécerelle, Old French Quercerelle and Quercelle, in Burgundy Cristel), the Euglish name ${ }^{1}$ of one of the smaller FALCONS, originating probably from its peevish and languid cry. This bird, though in the form of its bill and length of its wings one of the true Falcons, and by many ornithologists placed among them under its Linnæan name of Falco tinnunculus, is by others referred to a distinct genus Tinnunculus as T. alaudarius - the last being an epithet wholly inappropriate. We have here a case in which the propriety of the custom that requires the establishment of a genus on structural characters may seem open to question. The differences of structure which separate Tinnunculus from Falco are slight, and, if insisted upon, in the way some systematists have done, must lead to including in the former genus birds which obviously differ from Kestrels in all but a few characters arbitrarily chosen; and yet, if structural characters be not required, the Kestrels form a group readily distinguishable by several peculiarities from all other Falconida, and a group that the instinct of real ornithologists (though this is treading upon dangerous ground) does not hesitate to separate from the true Falcons of the genus Falco, with its subsidiary sections or genera, Esalon (Merlin), Hypotriorchis (HoBby), and the rest. Scarcely ally one outside the walls of a museum or library would doubt for a moment whether any bird shewn to him were a Kestrel or not; and the late Mr. Gurney believed (Ibis, 1881, p. 277) that the aggregation

1 Other English names are Windhover and Staniel of which Stannell is a corrup. tion, and often by mistaken etymology written Standgale ( $c f$. Skeat, Trans. Etymol. Soc. 1888-90, p. 21). 
of species placed by Dr. Sharpe (Cat. B. Br. Mus. i. pp. 423-448) under the generic designation of C'ercheis (which should properly be Tinnumulus) inclucled "three natural gromps sufficiently distinct to be treated as at least separate subgenera, bearing the name of Dissodectes, Tinnunculus, and Eiythropus." Of these we may say that the first and last are not at all Kestrels, but are perhaps rather related to Hypotriorchis. Mr. Gmrney's latest views as shewn in 1884 (List of the Diumal Birds of Prey, pp. 96-100) recognized 15 species of Timmunculus, with 5 subspecies.

The ordinary Kestrel of Europe, T. alaudarius, is by far the commonest Bird-of-Prey in the British Islands, and is too common and rell known to need any description. It is almost entirely a

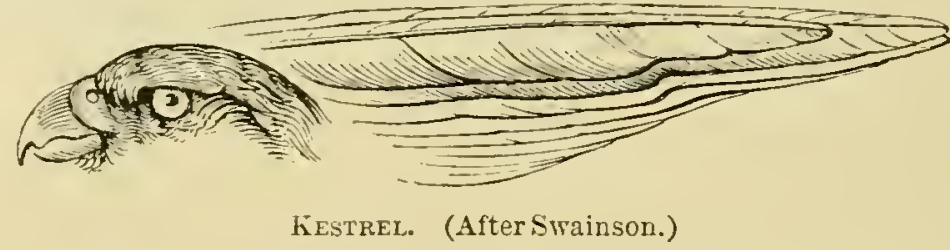

summer migrant, coming from the south in early spring and departing in autumn, though examples (which are nearly always found to be birds of the year) occasionally occur in winter, some arriving on the eastern coast in autumm. It is most often observed while practising its habit of hanging in the air for a minute or two in the same spot, by rapid beats of its wings, as, with head pointing to windward and expanded tail, it looks out for prey-consisting chiefly of mice, but it will at times take a small bird, and the remains of frogs, insects, and even earth-worms have been found in its crop. It generally breeds in the deserted nest of a Crow or Pie, but frequently in rocks, ruins, or even in hollow trees-laying four or five esgs, mottled all over with dark brownish red, sometimes tinged with orange and at other times with purple. Though it may occasionally snatch a young Partridge or Pheasant, ${ }^{1}$ the Kestrel is quite the most harmless of the Accipitres, if it be not, from its destruction of mice and cockchafers, the most beneficial. It is a species of very wide range, extending over nearly the whole of Enrope from $68^{\circ} \mathrm{N}$. lat., and the greater part of Asia-though the form which inhabits Japan and is abundant in north-eastern China has been by some writers deemed distinct and called 1 . japonicus - and it also pervades the greater part of Africa, becon-

1 Where what are called "tame" Pheasants are bred, a liestrel will often contract the bad habit of infesting the coops and carrying off the young birds. This evil may easily be stopped; but it should not lead to the relentless persecution of the species, especially when it is remembered that the Festrel is in the first place attracted to the spot by the presence of the mice which come to eat the Pheasants' food. 
ing, however, scarce in souther'n latitudes, and unknown beyond Fantee on the west and Mombasa on the east coast (Ibis, 1881, p. 45i). The southern countries of Europe have also another and smaller species of Kestrel, T. tinnunculoides (the T. cenchris and $T$. naumanni of some writers), which is widely spread in Africa and Asia, while examples from India and China are distinguished as T. pekinensis.

Three $^{1}$ other species are found in Africa as well-T. rupicola, T. rupicoloides, and T. alopex-the first of which is a common bird in the Cape Colony, while the others occur in the interior. Some of the islands of the Ethiopian Region have peculiar species of Kestrel, as the T. newtoni of Madagascar, T. punctatus of Mauritius, and T. gracilis of the Seychelles; while, on the opposite side of the continent, the Kestrel of the Cape Verd Islands has been separated as T. neglectus, and that of the Canaries indulged with subsidiary lecognition (König, Journ. für Orn. 1890, p. 285, pl. i.) as Cerchneis tinnunculus canariensis.

The next species deserving of notice is that of America, $T$. sparverius, commonly known in Canada and the United States as the "Sparrow-Hawk" - a beautiful little bird, though not more courageous than the rest of its relations. Various attempts have been made to recognize several species, more or less in accordance with locality, but the majority of ornithologists seem unable to accept the distinctions elaborated, chiefly by $\mathrm{Dl}^{2}$. Sharpe (ut suprà) and Mr. Ridgway (N.-Am. Birds, iii. pp. 159-175), the former of whom in 1874 recognized six species, while the latter, in the same year, and since, has admitted but three, T. sparverius, T. leucophrys, and T. sparverioides, with five geographical races of the first, viz. the typical $T$. sparverius from the continent of North America, except the coast of the Gulf of Mexico; $T$. australis from the continent of South America, except the North Atlantic and Caribbean coasts; T. isabellinus, inhabiting continental America from Florida to Cayenne; T. dominicensis from the Lesser Antilles as far northwards as St. Thomas; and lastly $T$. cinnamominus from Chili and western Brizil. T. lexcophrys is said to be from Hispaniola and Cuba; and T. sparverioides peculiar to Cuba only. This last has been generally allowed to be a good species, though Dr. Gundlach, the best authority on the birds of that island, in his latest work, published in 1876 (Contribucion á la Ornitologia Cubana, p. 48) would not allow its validity. More recently it was found (Ibis, 1881, pp. 547-564) that $T$. australis and $T$. cinnamominus calnot be separated, that Mr. Ridgway's T. leucophrys should properly be called T. dominicensis, and his T. dominicensis T. antillarum, while that gentleman has recorded the supposed occurrence of $T$. spar-

1 Mr. Gurney's T. arthuri (op. cit. pp. 98 and 156) rests on a single specimen, and therefore requires confirmation. 
verioides in Florida. ${ }^{1}$ Of other Festrels it remains to say that $T$. moluccensis is widely spread throughout the islands of the Malay archipelago, while $T$. cenchroides seems to inhabit the whole of Australia, and has occurred in Tasmania (Proc. Poy. Soc. Tasmania, 1875$, pp. 7,8$)$. No Kestrel is found in New Zealand, but an approach to the form is made by the very peculiar Harpe novazelandix (of which a second race or species has been described, $H$. brunnea or H. ferox) the "Sparrow-Hawk," "QUAIL-HAwk," and "Bush-Hawk" of the colonists - a bird of much higher courage than any Kestrel, and perhaps exhibiting the more generalized and ancestral type from which both Kestrels and Falcons may have descended.

KIDDA IV, one of the many local names of the GUILLENoT.

KIDNEYS, renes, the organs of the Excretory System for the discharge as urine of the nitrogenous waste-matter of the blood. In Birds they are comparatively large, weighing about onehundredth part of the whole body, and extend from the posterior margin of the lungs to nearly the end of the pelvis, filling the cavities between the iliac bones and the sacral vertebræ, the transverse processes of which.produce deep impressions upon the dorsal surface of the Kidneys, and divide them into a number of irregular lobes; but their rentral surface is almost smooth. Near their anterior end, and close to the vertebral column, lie the genital glands (ovaries or testes), the ducts of which (oviduct or vas deferens as the case may be), run, together with the ureter, upon the ventral surface of the Kidneys. Resting against these glands, there is on each side a reddish or yellowish-brown body of irregular shape, the supra-renal or adrenal capsule, an organ of still problematic significance. In most Birds each Kidney is more or less divided into three lobes, of which the anterior is gencrally the largest, and the middle one the smallest. Sometimes the two Kidneys partly coalesce across the vertebral column, so that the unpaired dorsal aorta and the inferior rena cara are enclosed in their substance; but their shape, size and the number of their principal lobes depend much on the configuration of the sacrum and pelvis, and are scarcely of practical taxonomic value. The Kidneys are shut off from the body-cavity by a peritoneal lamella, and their minute structure as well as their vascular system is very complicated. Each possesses a transparent sheath of comnective tissue, on the removal of which the dark brown substance of the organ is seen to consist of an enormous number of convoluted and tightly-packed lobules, and each of these lobules is pervaded by renal arteries and veins with their capillaries, and contains the uriniferous tubules that

1 The absence of any Kestrel from Jamaica is a most curious fact, considering the abundance of the form in other parts of the West Indies. 
ultimately open into the ureter. These tubules begin near the surface of the lobule, as small invaginated capsules, each surrounding a glomerulus of fine arterial blood-vessels, through the walls of which the urinary matter exudes from the blood into the tubule. The rest of the arterial blood entering the Kidneys through the renal arteries (which are branches from the dorsal aorta and from the sciatic artery) passes through a capillary network, and is thence conducted through the efferent renal veins into the system of the inferior vena cava (see VASCULAR SYSTEMr).

KILLDEER, a common and well-known American Plover, so called in imitation of its whistling cry, the Charadrius vociferus of Linnæus, and the AEgialitis vocifera of modern ornithologists. About the size of a Snipe, it is mostly sooty-brown above, but shewing a bright buff on the tail coverts, and in flight a white bar on the wings; beneath it is pure white except two pectoral bands of deep black. It is one of the finest as well as the largest of the group commonly known as Ringed Plovers or "Ring Dotterels," I forming the genus Egialitis of Boie. Mostly wintering in the south or only on the sea-shore of the more northern States, in spring it spreads widely over the interior, breeding on the newlyploughed lands or on open grass-fields. The nest is made in a slight hollow of the ground, and is often surrounded with small pebbles and fragments of shells. Here the hen lays her pearshaped, stone-coloured eggs, four in number, and always arranged with their pointed ends touching each other, as is indeed the custom of most Limicoline birds. The parents exhibit the greatest anxiety for their offspring on the approach of an intruder: the hen runs off with drooping wings and plaintive cries, while the cock sweeps around, gesticulating with loud and angry vociferations. It is the best-known bird of its Family in the United States, throughout which it is found in all suitable districts, but less abundantly in the morth-orst than further south or west. In Canada it does not range further to the northward than $56^{\circ} \mathrm{N}$. lat., and it is not known to occur in Greenland, or hardly in Labrador, though it is a passenger in Newfoundland every spring and autumn. ${ }^{2}$ In winter it finds its way to Bermuda and to some of the Antilles, but it is not recorded from any of the islands to the windward of Porto Rico. However, in the other direction it goes very much further south, travelling down the Isthmus of Panama and the west coast of South America to Peru.

1 The word Dotrenel is properly applicable to a single species only (see above, pp. 161, 162).

2 A single example is said to have been shot near Christchurch, in Hampshire, in April 1857 (Lbis, 1862, p. 276), and a female was undoubtedly shot on Tresco, one of the Scilly Isles in January 1Ss5 by Mr. F. Jenkinson (Proc. Zool. Soc. 1885, p. \$35). 
This may be the most convenient place to speak of the congeners of the Killdeer, of which there are several in America, and among them may be noticed $E$. semipalmata, curiously resembling the ordinary Ringed Plover of the Old World, EE. hiatickla, except that it has its toes connected by a web at the base; and $E$. nirosa, a bird inhabiting the western parts of both the American contiments, which in the opinion of some authors is only a local form of the widely-spread E. alexandrina or cantiana, best known as the Kentish Plover, from its discovery near Sandwich, though it is far more abundant in many other parts of the Old World (GEographical Distribution, p. 341). The common Ringed Plover, E. liaticola, has many of the habits of the Killdeer, but is much less often found away from the sea-shore, though it has stations on dry warrens in certain parts of England many miles from the coast, and in Lapland at a still greater distance. In such localities it has the habit of paving its nest with small stones, whence it is locally known as the "Stone-hatch," a habit almost muaccountable unless regarded as an inherited instinct from shingle-haunting ancestors.

About thirty species all apparently referable with propriety to the genus Egialitis have been described, but probably so many do not exist. Some, as the Kentish Plover above named, have a very extended distribution, for that, letting alone its supposed American habitat, certainly occurs in greater or less numbers on the

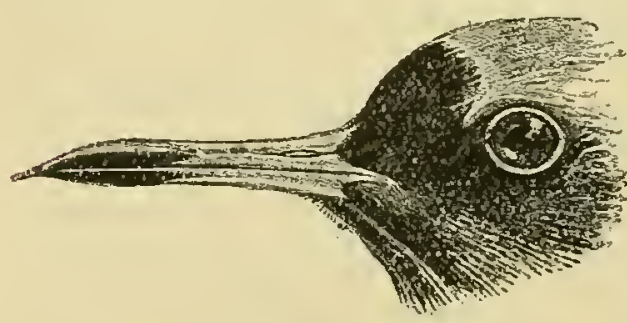

Thisornis. (From Buller.) coasts of China, India and Africa generally. On the other hand there is one, the $A$. sanctio-helenx, which seems to be restricted to the island whence it takes its scientific name, and is there called the "Wire-bird" (Ilis, 1873, p. 260). Nearly allied to Egialitis are two genera peculiar to the New-Zealand Region-Thinornis, which, having been separated on the slightest grounds, does not call for any particular remark, and the extraordinary Anarhynchus (WrybiLL).

\section{KILLIGREN, an old name for the CHOUGH.}

$\mathrm{KING}^{\top} \mathrm{BIRD}{ }^{1}$ is the epithet almost mniversally applied in the United States to the best-known representative of the Tyrannida, or the "Tyrant Flycatchers." In some of the rural districts,

1 For this article I have to thank the well-known American ornithologist, Dr. Shufeldt; but I have to add that more than one species of TEnx is called "IKing-bird" by sailors, and the name may be often met with in the narratives of whaling or sealing royages to the Southern Ocean.-1. K. 
in those quarters of the country where he is a regular migrant, he is familiarly known as the "Bee-Martin," a name he has earned from his fondness for the denizens of the bee-hive. It is only occasionally that naturalists refer to him as the TrRANT, while to ornithologists generally he is known as Tyranmus carolinensis, belonging to the group of songless Passeres called Clamatores. Some recent taxonomists, including the present writer, however, are inclined to regard the group as a superfamily of the PASSERES, to be designated the Tyrannoidea. ${ }^{1}$ Dr. Coues has said of the Tyrannida that "Only a small fragment of the family is represented within our limits, giving but a vague idea of the numerous and singularly diversified forms abounding in tropical America. Some of these grade so closely toward other families, that a strict definition of the Tyrannidx becomes extremely difficult; and I am not prepared to offer a satisfactory diagnosis of the whole group" (Key N. Amer: Birds, ed. 2, p. 42S). With respect to our United States species, however, they are more or less closely affined, and have usually been all restricted to subfamily grouping-the Tyrannina. Of the genus Tyrannus, to which the King-bird belongs, there are some three or four other species or subspecies inhabiting various geographical areas in the United States, while some range southward into Mexico. Other North-American genera are Iilvulus, including the handsome fork-tailed Flycatchers; Pitangus, the elegant Derby Flycatcher; Myiarchus, the Crested Flycatchers; the genera Myiozetetes and Myiodynastes are also represented, as well as Sayornis (PHCEEE). The still smaller forms are abundantly present in the genera Contopus, Empidonax, Pyrocephalus and Ornithion."

Many of the Tyrannida have habits in common, while the King-birds have others that are essentially peculiar to the genus. To present an account of the most characteristic of these we may choose the eastern form as an example, and the extraordinary behaviour of this bird during the entire breeding season is the most remarkable trait to be noted. From the very day the building of the nest is first started, until the time when the young finally shift for themselves, the male of this species gives constant battle, without discrimination, to every bird that passes within range of his

1 See Dr. Stejneger in The Standard Natural History and elsewhere; also Prof. Cope in The American Naturalist (Oct. 1859, p. 873).

2 For the comparative osteology of several of the genera of the N. American Tyrannidæ see the present writer's "Contributions to the Comparative Osteology of the Families of North American Passeres" (Journ. Morpholog. iii. PI. 81-112). In that memoir sorne of the striking resemblances in the skulls of certain Laniidæ and Tyrannidæe are set forth, which are quite significant; while for other points in the anatomy of these birds see Macgillivray in Audubon's Orn. Biography, v. pp. 421, 422, and also the classical work of J. Miuller (Abhandl. K. Akad. Wissensch. Berlin, 1845, pp. 321-495). 
sitting mate and the precious contents of his nest. These sallies are almost invariably successful, and Wilson wites that "Hawks and crows, the Bald Eagle, and the great Black Eagle, all equally dread a rencontre with this dauntless little champion, who, as soon as he pereeives one of these last approaching, launches into the air to meet him, mounts to a considerable height above him, and darts down on his back, sometimes fixing there to the great annoyance of his sovereign, who, if no convenient retreat or resting place be near,

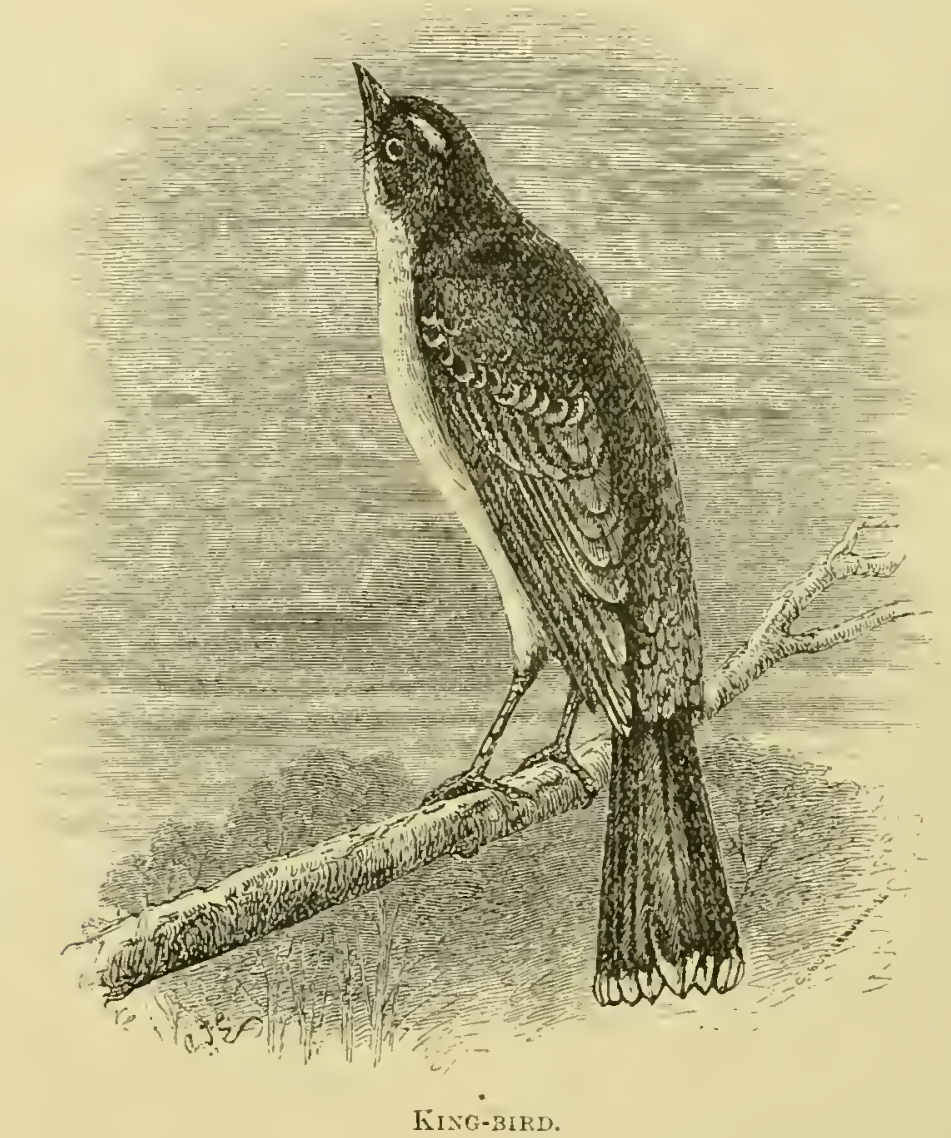

endeavours by various evolutions to rid himself of his mereiless adversary. But the King-bird is not so easily dismounted. He teases the Eagle incessantly, sweeps upon him from right to left, remounts, that he may descend on his back with the greater violence; all the while keeping up a shrill and rapid twittering; and continuing the attack sometimes for more than a mile, till he is relieved by some other of his tribe equally cager for the contest." Other birds meet with a similar fate, but the Purple Martin (Progne) and the Red-headed Woodpecker are exceptions, the former eseaping by superior flight, the latter by being able to dodge the little tyrant around the perch where he has taken refuge. During other times of the year the King-bird entirely 
loses all these belligerent habits, and becomes comparatively quite a quiet bird. His diet seems to be confined entirely to various kinds of insects, of which he destroys vast quantities, that would otherwise be destructive to the products of the farm. ${ }^{1}$ Indeed, he is one of the husbandman's best friends, and in his tastes for bees at a certain season of the year it is not yet proven to the contrary that he selects only the drones upon which to regale himself.

In appearance the King-bird is a species of plain plumage, and the sexes are nearly alike. Above he is black, most intense on the crown, where we also find a semiconcealed, longitudinal, median dash of flame-coloured feathers, capable of erection, as a crest, with the rest of the capital plumage. Below he is nearly white, and his black tail is strongly tipped with the same. Laterally, the white of the breast is shaded with plumbeous, and his wings are dusky, bordered with whitish. He has a peculiar wavering flight, something after the manner of certain small Hawks; while song he has none, possessing only the twittering note to which allusion has already been made, and which at times is very shrill, being heard at some considerable distance. This bird builds a large, compact nest of twigs, lined with fine grass, and other materials interspersed throughout, as tow and fine roots. The place chosen may be quite conspicuous, as in a low tree near the wayside, or without regard to concealment in the middle of the orchard, as in an apple-tree. Usually from four to six, the eggs are of a creamy white, boldly dashed with elegant blotches of various shades of brown, which chiefly encircle the larger end.

It may with great truth be said, then, that on the whole the King-bird is not only an interesting and handsome species, but thoroughly deserving of our protection and encouragement, as he is likewise useful and brave.

R. W. SHUFELDT.

KINGFISHER-Königsfischer, Germ. ${ }^{2}$; Roi-péheux (=pêcheur), Walloon-the Alcedo ispida of ornithologists, one of the most beautiful and well-known of European birds, being found, though nowhere very abundantly, in every country of this quarter of the globe, as well as in North Africa and South-Western Asia as far as Sindh. Its blue-green back and rich chestnut breast render it conspicuous as it frequents the streams and ponds whence it procures its food, by plunging almost perpendicularly into the water, and emerging a moment after with the prey-whether a small fish, a crustacean, or an aquatic insect-it has captured. In hard frosts

1 Other authorities state that at times the King-bird is very fond of certain berries, especially blackberries, but I have not been able to personally verify this.

2 But more commonly called Eisvogel, which finds its counterpart in the Anglo-Saxon Isern or Isen. 
it resorts to the sea-shore, but a severe winter is sure to occasion a great mortality in the species, for many of its individuals seem unable to reach the tidal waters where only in such a season they could obtain sustenance; and to this cause rather than any other (though, on account of its beauty and the utility of its feathers in making artificial flies, it. is shot and netted in great numbers) is perhaps to be ascribed its general scarcity. Very early in the year it prepares its nest, which is at the end of a tunnel bored by itself in a bank, and therein the six or eight white, glossy, translucent eggs are laid, sometimes on the bare soil, but often on the fishbones. which, being indigestible, are thrown up in pellets by the birds; and, in any case, before incubation is completed these rejectamenta accumulate so as to form a pretty cup-shaped structure that increases in bulk after the young are hatched, but, mixed with their fluid excretions and with decaying fishes brought for their support, soon becomes a dripping fotid mass.

The Kingfisher is the subject of a variety of legends and superstitions, both classical and mediceval. Of the latter one of the most curious is that having been originally a plain grey bird it acquired its present bright colours by flying towards the sun on its liberation from Noah's ark, when its upper surface assumed the hue of the sky above it and its lower plumage was scorched by the heat of the setting orb to the tint it now bears. ${ }^{1}$ More than this, the Kingfisher was supposed to possess many virtues. Its dried body would avert thunderbolts, and if kept in a wardrobe would preserve from moths the woollen stuffs therein laid, or hung by a thread to the ceiling of a chamber would point with its bill to the quarter whence the wind blew. All readers of Ovid (Metam. bk. xi.) know how the faithful but unfortunate Ceyx and Alcyone were changed into Kingfishers-birds which bred at the winter solstice, when through the influence of Eolus, the wind-god and father of the fond wife, all gales were hushed and the sea calmed so that their floating nest might ride uninjured over the waves during the seven proverbial "Halcyon Days"; while a variant or further development of the fable assigned to the Halcyon itself the power of quelling storms. ${ }^{2}$

The common Kingfisher of Europe is the representative of a well-marked Family of birds, the Alcedinidx or Halcyonidx of ornithologists, which is considered by some authorities ${ }^{3}$ to be closely related to the Bucerotidx (HorNbILL); but the affinity can scarcely be said as yet to be proved; and to the present writer

I Rolland, Faune populaire de la France, ii. p. 74.

2 In many of the islands of the Pacific Ocean the prevalent Kingfisher is the object of much veneration.

3 Cf. Eyton, Contrib. Orn. 1850, p. 80 ; Wallace, Ann. Nat. Hist. ser. 2, xviii. pp. 201, 205 ; and Huxley, Proc. Zool. Soc. 1867, p. 467. 
there seems to be at least some gromnd for believing that a nearer * alliance is to be found in the Gallulidx (JACAMAR), Momotidx (Мотnот), Meropide (BeE-EATER), and perhaps some other Families -though all may possibly be discovered to belong to one and the same larger group. Be that as it may, the present Family forms the subject of a work by Dr. Sharpe, ${ }^{1}$ which, though wholly incomplete as regards their anatomy, ${ }^{2}$ is certainly one of the best of its class, and reflects infinite credit on its then youthful author, whose treatment of his subject was most successful. Herein are described 125 species, nearly all of them being beantifully figmed by Mr. Keulemans, and that number may be taken even now as approximately correct; for, while the validity of a few has been denied, nearly as many have since been made known, and it seens likely that two or three more described by older writers may yet be rediscovered. These 125 species Dr. Sharpe groups in 19 senera, and divides into 2 subfamilies, Alcedininx and Dacelonina, 3 the one containing 5 and the other 14 genera, the largest being Hulcyon with 36 species ranging from Asia Minor to Tapan, and from

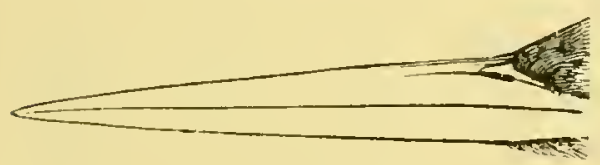

$\triangle$ LCEDO.

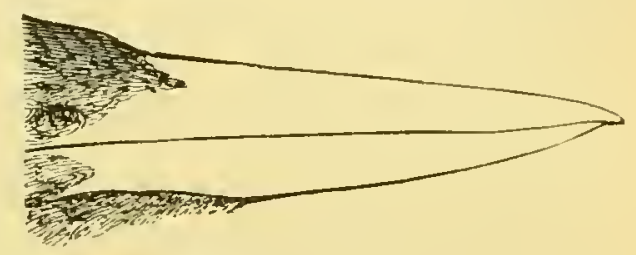

HALCYON.

the Cape Verd Islands to New Zealand. With the then existing materials perhaps no better arrangement could have been made, but in the absence of anatomical knowledge it is certainly not to be deemed conclusive, and indeed the method since published by Sunderall (Tentamen, pp. 95, 96) differs from it not inconsiderably. Here, however, it will be convenient to follow that of Dr. Sharpe. Externally, which is almost all we can at present say, Kingfishers present a great uniformity of structure. One of their most remarlable features is the feebleness of their feet, and the union (SYNDACTYLISM) of the third and fourth digits for the greater part of their length; while, as if still further to shew the comparatively functionless character of these members, in two of the genera, Alcyone and

1 A Honograph of the Alcedinidie or Family of the Kingfishers, by R. B. Sharpe, 4to. London : 1868- $\uparrow 1$.

2 Some important anatomical points are briefly noticed by Prof. Cunningham (Proc. Zool. Soc. 1870, p. 280).

3 The name of this latter subfamily as constituted by Dr. Sharpe would seen to be more correctly Ceycina-the genus Ceyx, founded in 1801 by Lacépede, being the oldest included in it. The word Dacclo, invented by Leach in 1815 , is simply an anagram of Alccdo, and, though of course without any etymological meaning, has been very generally adopted. 
Ceyx, the second digit is aborted, and the birds have but three toes. In most forms the bill does not differ much from that of the common Alcedo ispida, but in Syma its edges are serrated, while in Carcineutes, Dacelo, and Melidora the maxilla is prolonged, becoming in the last a very pronounced hook. Generally the wings are short and rounded, and the tail is in many forms inconspicuous; but in Tanysiptera, one of the most beautiful groups, the middle pair of feathers is greatly elongated and spatulate, while this genus possesses only ten rectrices, all the rest having twelve. Sundevall relies on a character not noticed by Dr. Sharpe, and makes its principal divisions depend on the size of the scapulars, which in one form a mantle, and in the other are so small as not to cover the back. The Alcedinidax are a cosmopolitan Family, but only one genus, Ceryle, is found in America, and that extends as well over a great part of the Old World, though not into the Australian Region, which affords by far the greater number both of genera and species, having no fewer than 10 of the former and 59 of the latter peculiar to it. ${ }^{1}$

In habits Kingfishers display considerable diversity, though all, it would seem, have it in common to sit at times motionless on the watch for their prey, and on its appearance to dart upon it, seize it as they fly or dive, and return to a perch where it may be conveniently swallowed. But some species, and especially that which is the type of the Family, are not always content to await at rest their victim's showing itself. They will hover like a Hawk over the waters that conceal it, and, in the manner already described, precipitate themselves upon it. This is particularly the way with those that are fishers in fact as well as in name; but no inconsiderable number live almost entirely in forests, feeding on insects, while reptiles furnish the chief sustenance of others. The last is characteristic of at least one Australian form, which manages to thrive in the driest districts of that country, where not a drop of water is to be found for miles, and the air is at times heated to a degree that is insupportable by most animals. The limits of this article forbid an entrance upon details of much interest, but the Belted Kingfisher of North America, Ceryle alcyon, is too characteristic a bird of that country to be passed in silence, though its habits greatly resemble those of the European species before described; and the so-called "Laughing JACKASS" of New South Wales and South Australia, Dacelo gigas-with its kindred forms, D. leachi, D. cervina, and $D$. occidentalis, from other parts of the country-likewise requires special notice. Attention must also be called to the speculations of Dr. Sharpe (op. cit. pp. xliv.-xlvii.) on the genetic affinity of the various forms of Alcedinidx, and it is to be regretted that hitherto no light has been shed by palæontologists on this ${ }^{1}$ Cf. Wallace, Geogr. Distr. Animals, ii. r. 315. 
interesting subject, for the only fossil referred to the neighbourhood of the Family is the Halcyornis toliapicus of Sir R. Oren (Br. Foss. Mamm. and Birds, p. 554) from the Eocene of Sheppey-the very specimen said to have been previously placed by König (Icon. foss. sectiles, fig. 153) in the genus Lavus (Fossil-BIrds, p. 281).

KING HARRY, a local name for the GoldFinch.

KINGLET, see GordcrEst.

KIRR-MEW, a local name for the common TERN, the first syllable having reference to its cry.

KITE, ${ }^{1}$ Anglo-Saxon Cyta, the Falco milvus of Linnæus and Milvus ictinus of modern ornithologists, once perhaps the most familiar Bird-of-Prey in Great Britain, and now one of the rarest. Three or four hundred years ago foreigners were struck with its abundance in the streets of London, and the evidence of two of them, one being the eminent naturalist Belon, has been already given (EXTERMINATION, p. 226, note 2). ${ }^{2}$ It was doubtless the scavenger in ordinary of that and other large towns (as a kindred species now is in Eastern lands), except where its place was taken by the Raven; for Sir Thomas Browne wrote (circa 1662) of the latter at Norwich-.." in good plentie about the citty which makes so few Kites to be seen hereabout." Wolley has well remarked of the modern Londoners that few "who see the paper toys hovering over the parks in fine days of summer, have any idea that the bird from which they derive their name used to float all day in hot weather high over the heads of their ancestors." Even at the beginning of the present century the

\section{"Kites that swim sublime}

In still repeated circles, screaming loud,"

formed a feature of many a rural landscape in England, as they had done in the days of Cowper. But an evil time soon came upon the species. It must have been always hated by the henwife, but the resources of civilization in the shape of the gun and the gin were denied to her. They were, however, employed with fatal zeal by the gamekeeper; for the Kite, which had long afforded the supremest sport to the falconer, was now left friendless, ${ }^{3}$ and in a very'

1 Glead or Gled, cognate with glide, is also auother English name.

2 Its abundance was almost simultaneously testified by Turner, who added that it was so rapacions as to snatch meat from the hands of children in our towns and cities.

3 George, third Earl of Orford, died in 1791, and Col. Thornton, who with him had been the latest follower of this lighest branch of falconry, broke up his hawking establishment not many years after (ef. Lubbock, Faun. Norf. ed. 2, pp. 227231). There is no evidence that the pursuit of the Kite was anywhere reserved to kings or privileged persons, but the taking of it was quite beyond the powers of the 
few years it seems to have been exterminated throughout the greater part of England, certain woods in Huntingdonshire and Lincolnshire and in the Western Midlands, as well as Wales, exceptecl. ${ }^{1}$ In these last a small remnant still exists; but the well-wishers of this beautiful species are naturally chary of giving information that might lead to its further persecution. In Scotland there is no reason to suppose that its numbers suffered much diminution until about 1835 or even later, when the systematic destruction of "vermin" on so many moors was begun. In that kingdom, however, it is now as much restricted to certain districts as in England or Wales, and those districts it would be equally inexpedient to indicate.

The Kite is, according to its sex, from 25 to 27 inches in length, about one half of which is made up by its deeply-forked tail, capable of great expansion, and therefore a powerful rudder, enabling the bird while soaring on its wide wings, more than 5 feet in extent, to direct its circling course with scarcely a movement that is apparent to the spectator below. Its general colour is pale reddish-brown or cinnamon, the head being greyish-white, but almost each feather has the shaft dark. The tail-feathers are broad, of a light red, barred with deep brown, and furnish the salmon-fisher with one of the choicest materials of his "flies." The nest, nearly always built in the crotch of a large tree, is formed of sticks intermixed with many strange substances collected as chance may offer, but among them rags ${ }^{2}$ seem always to have a place. The eggs, three or four in number, are of a dull white, spotted and blotched with several shades of brown, and often lilac. It is especially mentioned by old ordinary trained Falcons, and in older days practically became limited to those of the sorereign. Hence the Kite had attached to it, especially in France, the epithet of "royal," which has still survived in the specific appellation of regalis applied to it by many ornithologists. The scandalous work of Sir Antony Weldon (Court and Character of King James, p. 104) bears witness to the excellence of the Kite as a quarry in an amusing story of the "British Solomon," whose Master-Falconer, Sir Thomas Monson, being determined to outdo the performance of the French king's falconer, who, when sent to England to shew sport, "could not kill one Kite, ours being more magnanimous than the French Kite," at last succeeded after an outlay of $£ 1000$, in getting a cast of Hawks that took nine Kites running-" "never missed one." On the strength of this, James was induced to witness a flight at Royston, "but the Kite went to such a mountee as all the field lost sight of Kite and Hawke and all, and neither Kite nor Hawke were either seen or heard of to this present."

1 One most fatal way of destroying Iites is described in the curious book publisherl in 1814 by Col. George Hanger ardressed To all Sportsmen and particularly to Farmers and Gamekeepers (p. 80).

2 Thus justifying the advice of Autolycus (Vinter's Tale, act iv. sc. 3) "When the Kite builds, look to lesser linen"-very necessary no doubt to the laundresses of former days when the bird conmonly frequented their drying grounds. 
anthors that in Great Britain the Kite ras resident throughout the year; whereas on the Continent it is one of the most regular and marked migrants, stretching its wings toward the sonth in autumn, wintering in Africa, and returning in spring to the land of its birth.

There is a second European species, not distantly related, the Milvus migruns or $M$. uter of most authors, ${ }^{1}$ smaller in size, with a general dnll blackish-brown plumage and a less forked tail. In some districts this is much commoner than the red Kite, and on one occasion it has appeared in England. Its habits are very like those of the species already described, but it seems to be more addicted to fishing. Nearly allied to this Black Kite are the $M$. aryptius of Africa, the $M$. govinda (the Pariah Kite of India), the M. melanotis of Eastern Asia, and the M. affuis and $M$. isurus; the last is by some authors removed to another genus or subgenus as Lophoictinia, and is peculiar to Australia, while $M$. affinis also oceur's in Ceylon, Burma and some of the Malay countries as well. All these may be considered true Kites, while those next to be mentioned are more aberrant forms. First there is Huliastur containing the well-known Brahminy Kite of Anglo-Indians, 11 . indus, which the late Mr. Gurney retained in this group, though it seems to be rather a

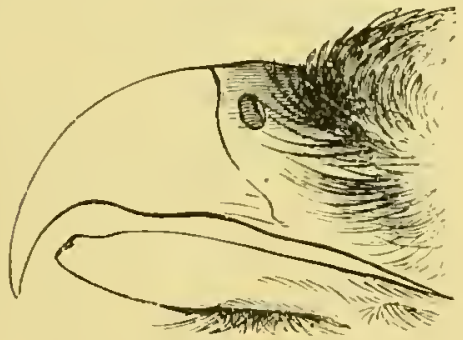

HALIASTUR.

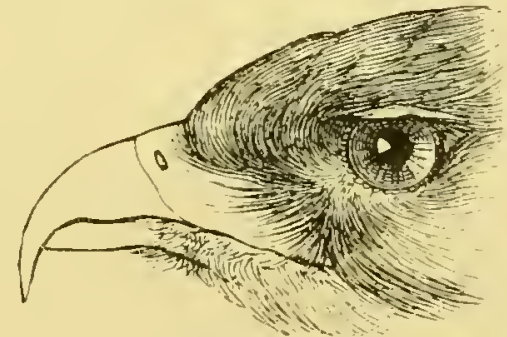

El.ANOIDES.

(After Swainson.)

fishing Eagle. Less doubtful is the place of Elanus, the type of which is $E$. creruleus, a beautiful little bird, the Black-winged Kite of English authors, that comes to the south of Europe from Africa, and has several congeners-E. axillaris and $E$. scriptus of Australia being most worthy of notice. An extreme development of this form is found in the African Nauclerus rioconri, as well as in Elanoides furcatus, the Swallow-tailed Kite, a widely-ranging bird in America, and remarkable for its length of wing and tiil, which gives it a marvellous power of flight, and serves to explain the unquestionable fact of its having twice appeared in Great Britain. To Elanus also Ictinia, another American form, is allied, though perhaps mcre

I Dr. Sharpe (Cat. B. Brit. Nus. i. 1. 322) calls it Ar. korschun ; but the figure of S. G. Gmelin's Accipiter korschun, whence the name is taken, unquestionably represents the Moor-Buzzard, Circus zeruginosus. 
remotely, and it is represented by $I$. mississippicnsis, the Mississippi Kite, which is by some considered to be but the northern race of

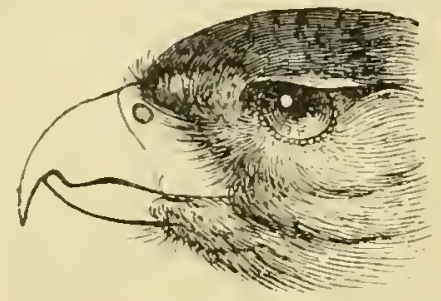

ICTINIA.

(After Swainson.)

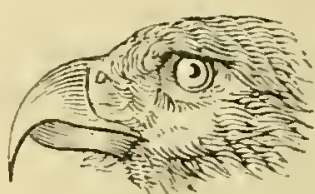

GampSONYA.

the Neotropical I.plumbea. Gampsonyx, Rostrhams, and Cymindis, all belonging to the Neotropical Region, complete the series of forms that seem to compose the subfamily Milvina, though there may be doubt about the last, and some systematists would thereto add the Honey-Buzzards, "Peruina."

KITTIWAKE, ${ }^{1}$ so called from the plaintive cry that is heard almost incessantly from its thronged breeding-places, to visit one of which is among the greatest delights of the real ornithologist-the Larus rissu and L. tridactylus, the Pissa tridactyla of most authorsthe smallest of the strictly marine GULLs, ${ }^{2}$ and a species that yet abounds on many of the northern parts of the British coasts, where the rocks afford it a home, for it seems never to breed but on the side of a cliff, and there shelf-room is all it needs, though preference to a niche that is overhung may sometimes be .noticed, and the entry of a cave is almost always a favourite spot. Space is here wanting to enter into particulars of these resorts, possessing a char'm almost indescribable; but notwithstanding that, they were for a long while, and, did not the law interpose, again would be scenes of sickening slaughter, carried on at first for "sport," but latterly, and far more fatally, to obtain "plumes" for women's dress. The Kittiwake among other distinguishing characters differs from all Gulls in that its hind toe (functionless among them) is generally reduced to a mere tubercle, and it differs from the other marine Gulls in that the young bear for the first year a dark semi-collar at the base of the neck, dark patches on the wings and a black tip to the tail-markings that make the wearer easily recognizable. In this condition they are very generally called Tarrocks. The adults on the wing very closely resemble those of the Common Gull, Larus cumus, but under favourable circumstances can he distinguished by

1 This spelling of the word, which has long been established, seems to hare been first published by Sibbald in 1684 (Scot. Illustr. pars 2, lib. iii. p. 26). In Ray's Itinerary of 1671 it appears as "Cattiwike" in reference to the Farne Islands. It might just as well be written "Pick-1we-up."

2 Excepting perhaps Rhodostethia, of whose breeding habits we know nothing. 
their primaries not being tipped with white. The species occurs on both sides of the Atlantic, breeding in great numbers in Spitsbergen and Greenland, but in Baffin's Sea not groing so far to the northward as some of the other Gulls. It inhabits also the North Pacific, and among those which frequent Bering's Sea, not a few examples have the hind toe considerably developed, though not enough to be functional. These have been named $R$. lotzebuii, but cannot be regarded as forming a good species. The $P$. brevirostris, with red legs and feet, from the same waters, seems to be distinct, but whether it is justifiably placed in the genus is another matter.

KITTY, a local nickname of the WREx.

KIVI, or Krwr-Kiw, the Maori name-first apparently introduced to zoological literature by Lesson in 1828 (Man. d'Orn. ii. p. 210, or Voy. 'Coquille,' Zool. p. 418), and now very generally adopted in English - of one of the most characteristic forms of New-Zealand birds, the Apteryx of scientific writers. This remarkable creature was unknown till Shaw, as almost his latest labour, very fairly described and figured it in 1813 (Nat. Miscellany, pls. 1057, 1058) from a specimen brought to him from the southern coast of that country by Capt. Barcley of the ship 'Providence.' At Shaw's death, in the same year, it passed into the possession of the then Lord Stanley, afterwards thirteenth Lord Derby, and is now with the rest of his collection in the Liverpool Museum. Considering the state of systematic ornithology at the time, Shaw's assigmment of a position to this new and strange bird, of which he had but the skin, does him great credit, for he said it seemed "to approach more nearly to the Struthious and Gallinaceous tribes than to any other" 1 And his credit is still greater when we find the venerable Latham, who is said to have examined the specimen with Shaw, placing it sume year's later among the Penguins (Gen. Hist. B.x. p. 394), beins apparently led to that conclusion through its functionless wings and the backward situation of its legs. In this false allocation Stephens also in 1826 acquiesced (Gen. Zool. xiii. p. 70). Meanwhile in 1820, Temminck, who had never seen a specimen, assorted it with the DoDo in an Order to which he applied the name of INERTES (Man. d'Orn. i. p. cxiv.) In 1831 Lessoll, who had previously (locc. citt.) made some blunders about it, ${ }^{2}$ placed it (Traité d'Orn. p. 12), though only, as he says, "par analogie et a priori," in his first division of Birds "Oiseaux Anomaux," which is equivalent to what we now call Ratitx, making of it a separate Family "Nullipennes." At that time no second example was known, and some doubt was felt especially on

1 Before Merrem nearly all had held the "Struthious" birds to be "Gallinaceous," and his views were not published till 1813 (see Intronuctios).

2 Mruch may be forgiven to Lesson for declaring that the stermu of Apteryx would be "indubitablement" fonnd to have no keel! 
the Continent, as to the rery existence of such a bird ${ }^{1}$ - though Lesson had himself when in the Bay of Islands in April 1824 (Voy. 'Coquille,' ut sumic) heard of it ${ }^{2}$ and a few years later Dumont d'Urville had seen its skin, which the maturalists of his expedition procured, worn as a tippet by a Maori chief at Tolaga Bay (Houahoua), ${ }^{3}$ and in 1830 gave what proves to be on the whole rery accurate information concerning it (Voy. 'Astrulabe, ii. p. 107). To put all suspicion at rest, Lord Derby sent his unique specimen for exhibition at a meeting of the Zoological Society, 12 th February 1833 (Proc. Zool. Soc. 1833, p. 24), and a few months later (tom. cit. p. 80) Yarrell communicated to that body a complete descrip)-

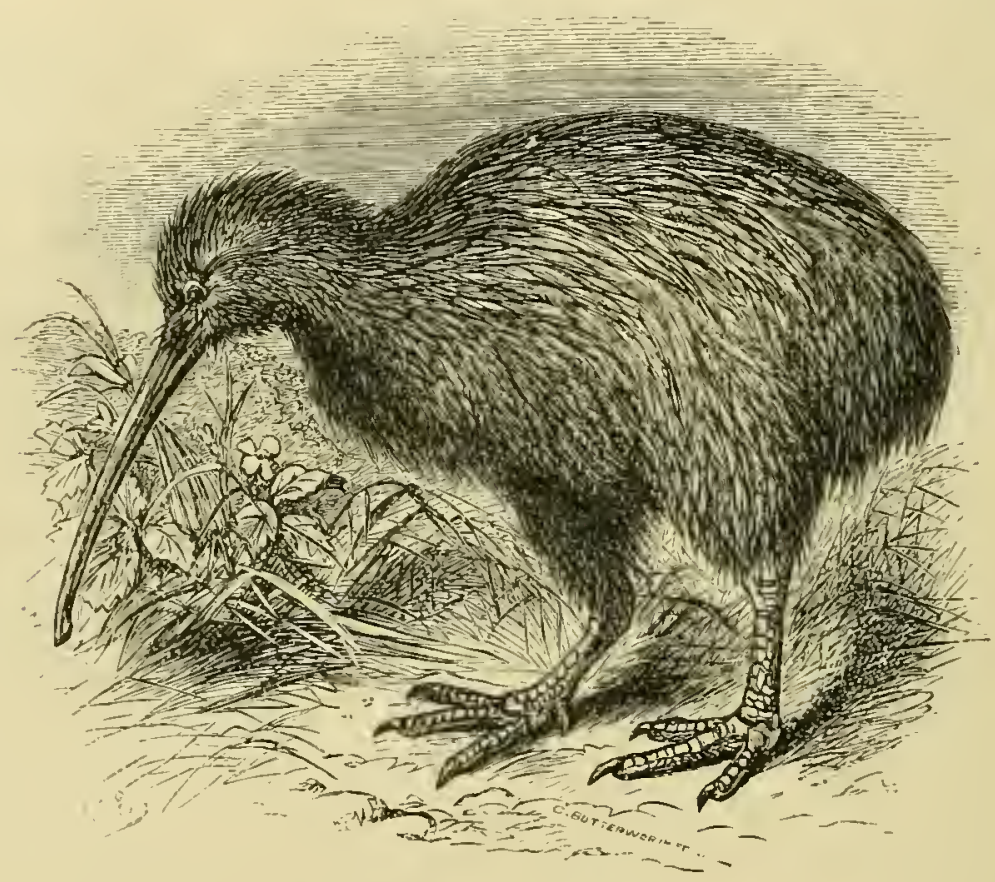

Nurthers Kini, Apteryx mantelli.

tion of it which was afterwards published in full with an excellent portrait (Trans. Zool. Soc. i. p. 71, pl. 10). Herein the systematic place of the species, as akin to the Struthious birds, was placed beyond cavil, and the author called upon all interested in " zoology to aid in further research as to this singular form. In consequence of this appeal a legless skin was within two years sent to the Society (Proc. 1835, p. 61) obtained by Mr. $\mathbb{T}^{r}$. Yate of Waimate, who said it was the second he had seen, and that he had liept the

1 Cuvier in the seeond edition of lis liegne Animal (15:2) only referred to it in a footmote (i. 1). 49s).

2 From what he says in his Vnyage untour elu .Honde (ii. 1. 348), not published till 1839, he evidently only knew the hird hy Shaw's description.

${ }^{3}$ Cruise in 1522 (Journ. Liesidence in New Zealand, 1). 313) liad spoken of an "Eneu" found in that island, which must of course have been an Apteryx. 
bird alive for nearly a fortnight, while in less than another two years additional information (op. cit. 1837, p. 24) came from Mr. T. K. Short to the effect that he had seen two living, and that all Yarrell had said was substantially correct, except underrating its progressive powers. Not long afterwards Lord Derby received and in March 1838 transmitted to the same Society the trunk and viscera of an Apteryx, which, being entrusted to Prof. Owen, furnished lim, in conjunction with other specimens of the same kind received from Drs. Lyon and George Bennett, with the materials of the masterly monograph laid before the Society in instalments, and ultimately printed in its Transactions (ii. p. 257, iii. p. 277). From this time the whole structure of the Kiwi has certainly been far better linown than that of nearly any other bird, and by degrees other examples found their way to England, some of which were distributed to the various museums of the Continent and of America. ${ }^{1}$

In 1847 much interest was excited by the reported discovery of another species of the genus (Proc. Zool. Soc. 1847, p. 51), and though the story was not confirmed, a second species was really soon after made known by Gould (tom. cit. p. 93 ; Trans. Zool. Soc. iii. p. 379, pl. 57) under the name of Apteryx oweni-a just tribute to the great master who had so minutely explained the anatomy of the group. Three years later Mr. Bartlett drew attention to the manifest difference existing among certain examples, all of which had hitherto been regarded as specimens of $A$. australis, and the examination of a large series led him to conclude that under that name two distinct species were confounded. To the second of these, the third of the genus (according to his views) he gave the name of $A$. mantelli (Proc. 1850, p. 274), ${ }^{2}$ and it soon turned out that to this new form the majority of the specimens already obtained belonged. In 1851 the first Kiwi known to have reached Europe alive was presented to the Zoological Society by Mr. Eyre, then Lieutenant-Governor of New Zealand. This was found to

${ }^{1}$ In 1842, according to Broderip (Penny Cyclopædia, xxiii. p. 146), two skins had been presented to the Zoological Society by the New-Zealand Company, and two more obtained by Lord Derby, one of which he had given to Gould. In 1844 the British MIuseum possessed three, and the sale catalogue of the Rivoli Collection, which passed in 1846 to the Academy of Natural Sciences at Philadelphia, included a single specimen-probably the first taken to America.

2 For a wholly insufficient reason, and iguorant of the circumstances of the case, Dr. Sharpe has attempted, in the Procecdings of the IVcllington Philosophical Society for 1888 (p. 6), to abolish this name, and to substitute one of his own conferring. I myself can testify to the fact that Mr. Bartlett gave the name $A$. mantelli to the form from the North Island, of which examples were then comparatively common in England, leaving the name $A$. australis to that of the South Island, of which only two specimens were at the time known. The difference between the two forms was at that time as clear to him as it is to any of us now. 
belong to the newly described $A$. mantelli, and some careful observations on its habits in captivity were published by Wolley and amother (Zoologist, pp. 3409, 3605). ${ }^{1} \quad$ Subsequently the Society has receired several other live examples of this form, besides one of the real A. australis (Proc. 1872, p. 861), some of $A$. oweni, and one of a supposed fourth species, $A$. huasti, characterized in 1871 by the late Mr. Potts (Ibis, 1872, p. 35 ; Trans. N. Zecel. Inst. iv. p. 204, v. p. 195$).^{2}$

The Kiwis form a group of the Subclass Ratite, to which the rank of an Order has been fitly assigned, as they differ in many important particulars from any of the other existing forms of Ratite birds. The most obvions feature the Apteryges afford is the presence of a back toe, while the extremely aborted condition of the wings, the position of the nostrils-almost at the tip of the billand the absence of an aftershaft in the feathers, are characters nearly as manifest, and others not less determinative though more

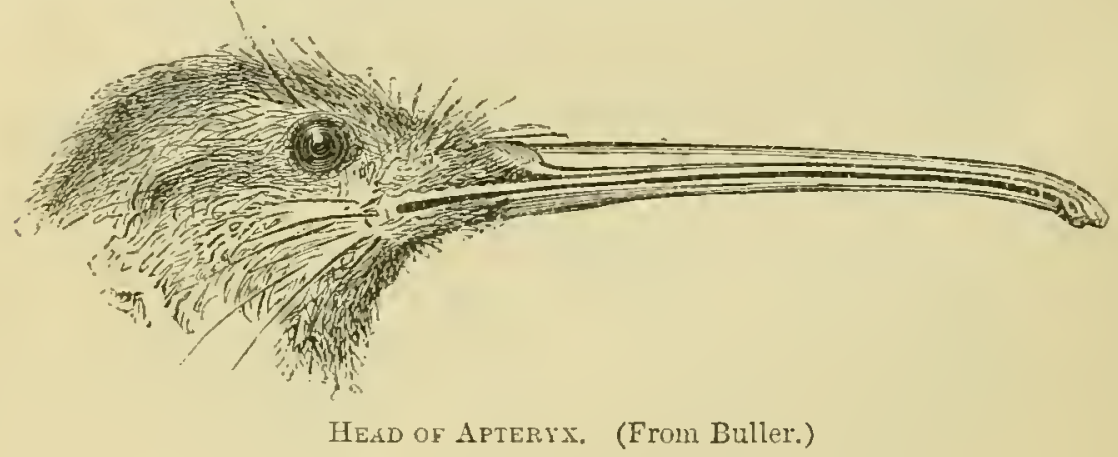

recondite will be found on examination. The Fiwis are peculiar to New Zealand, and it is believed that $A$. mantelli is the representative in the North Island of the southern $A$. uustralis, both being of a dark reddish-brown, longitudinally striped with light yellowish-brown, while $A$. oweni, of a light greyish brown transverscly barred with black, is said to occul in both islands. About the size of a large domestic Fowl, they are birds of nocturmal habit, sleeping, or at least inactive, by day, feeding mostly on earthworms, but occasionally swallowing berries, though in captivity they will eat flesh suitably minced. Sir W. Buller writes ( $B$. New Zeal. p. 362 ; ed. 2, ii. p. 313):-

I This bird in 1859 laid an egg, and afterwards continued to lay one or two more evcry year. In 1865 a male of the same species was introduced, but though a strong disposition to breed was shewn on the part of both, and the eggs, after the enstom of the Ratita, were incubated by him, no progeny was hatehed (Proc. Zool. Soc. 1868, p. 329).

: A fine series of figures of all these supposed species is given by Rowley (Om. Miscell. i. pls. 1-6). Some others, as A. maxima (from Stewart Island), A. hausti, A. mollis and A. fusca, have also been indicated, but proof of their validity has yet to be addueed. 
"The Kiwi is in some measure compensated for the absence of wings by its swiftness of foot. When running it makes wide strides and carries the body in an oblique position, with the neck stretched to its full extent and inclined forwards. In the twilight it moves about cautiously and as noiselessly as a rat, to which, indeed, at this time it bears some outward resemblance. In a quiescent posture, the body generally assumes a perfectly rotund appearance; and it sometimes, but only rarely, supports itself by resting the point of its bill on the ground. It often yawns when disturbed in the daytime, gaping its mandibles in a very grotesque manner. When provolied it erects the body, and, raising the foot to the breast, strikes downwards with considerable force and rapidity, thus using its sharp and powerful claws as weapons of defence. . . While hunting for its food the bird makes a continual sniffing sound through the nostrils, which are placed at the extremity of the upper mandible. Whether it is guided as much by touch as by smell I cannot safely say; but it appears to me that both senses are used in the action. That the sense of touch is highly developed seems quite certain, because the bird, although it may not be audibly sniffing, will always first touch an object with the point of its bill, whether in the act of feeding or of surveying the ground; and when shut up in a cage or confined in a room it may be heard, all through the night, tapping softly at the walls. . . . It is interesting to watch the bird, in a state of freedom, foraging for worms, which constitute its principal food: it moves about with a slow action of the body; and the long, flexible bill is driven into the soft ground, generally home to the very root, and is either immediately withdrawn with a worm held at the extreme tip of the mandibles, or it is gently moved to and fro, by an action of the head and neck, the body of the bird being perfectly steady. It is amusing to observe the extreme care and deliberation with which the bird draws the worm from its hiding-place, coaxing it out as it were by degrees, instead of pulling roughly or breaking it. On getting the worm fairly out of the ground, it throws up its head with a jerk, and swallows it whole."

The foregoing extract refers to $A$. mantelli, but there is little doubt of the remarks being equally applicable to $A$. australis, and probably also to $A$. oweni, though the different proportion of the bill in the last points to some diversity in the mode of feeding. Did space allow much more should be said of the Kiwis-perhaps to ornithologists the most interesting group of birds now existing, and the more interesting in regard to the melancholy doom of extinction which almost inevitably awaits them; but there is some consolation in the thought that their anatomy and development have been admirably studied and described in the light of existing scientific methods by Prof. T. Jeffrey Parker (Phil. Trans. 1891, pp. 25-134, pls. $3-19$; 1892, pp. 73-84, pls. 7, 8). 
KNEE, a term commonly misapplied by many ornithological writers to the intertarsal (often called tibio-tarsal) joint, hence the absurd name of THICK-KNEE; but correctly used as in Mammals for the femoro-tibial joint, which is not usually visible in the living Bird, owing to the shortness of the thigh and its being hidden by the flank-feathers.

KNORHAAN (Scolding Cock), the colonial name in South Africa for several species of BUSTARD, of the genus Eupodotis and especially E. afra.

KNOT, a Limicoline bird very abundant at certain seasons on the shores of Britain and many countries of the northern hemisphere. Camden in the edition of his Britannia published in 1607 (p. 408) inserted a passage not found in the earlier issues of that work, connecting the name with that of King Canute, and this account of its origin has been usually received. But no other evidence in its favour is forthcoming, and Camden's statement is merely the expression of an opinion, ${ }^{1}$ so that there is perhaps ground for believing him to have been mistaken, and that the clue afforded by Sir Thomas Browne, who (circa 1672) wrote the name "Gnatts or Knots," may be the true one. ${ }^{2}$ Still the statement was so positively repeated by successive authors that Linnæus followed them in calling the species Tringa canutus, and so it remains with nearly all modern ornithologists. ${ }^{3}$ Rather larger than a SNIPE, but with a short bill and legs, the Knot visits the coasts of some parts of Europe, Asia and North America at times in vast flocks; and, though in temperate climates a good many remain throughout the winter, these are nothing compared with the numbers that arrive towards the end of spring, in England generally about the 15th of May, and after staying a few days pass northward to their summer quarters, while early in autumn the young of the year throng to the same places in still greater plenty, being followed a little later by their parents. In winter the

1 His words are simply "Knotts, i. Canuti aues, vt opinor e Dania enim adnolare creduntur." In the margin the name is spelt "Cnotts," and he possibly thonght it had to do with a well-known story of that king. Knots undoubtedly frequent the sea-shore, where Canute is said on one occasion to have taken up his station, but they generally retreat, and that nimbly, before the advancing surf, which he is said in the story not to have done.

2 In this connexion we may compare the French maringouin, ordinarily a gnat or mosquito, but also, among the French Crcoles of America, a small shore-bird, either a Tringa or an Egialitis, according to Descourtilz (Voyagc, ii. p. 249). See also Littrés Dictionnaire, sub voce.

3 There are few of the Limicolæ, to which group the Enot belongs, that present greater changes of plumage aecording to age or season, and hence before these phases were understood the species bccame encumbered with many synonyms, as Tringa cincrea, ferruginea, grisea, islandica, nævia, and so forth. The confusion thus caused was mainly eleared away by Montagu and Temminck. 
plumage is ashy-grey above (save the rump, which is white) and white beneath. In summer the feathers of the back are black, broadly margined with light orange-red, mixed with white, those of the rump white, more or less tinged with red, and the lower parts are of a nearly uniform deep bay or chestnut. The birds which winter in temperate climates seldom attain the brilliancy of colour exhibited by those which arrive from the south; the luxuriance generated by the heat of a tropical sun seems needed to develop the full richness of hue. The young when they come from their birthplace are clothed in ashy-grey above, each feather banded with dull black and ochreous, while the breast is more or less deeply tinged with warm buff. Much curiosity has long existed among zoologists as to the egg of the Knot, of which not a single identified or authenticated specimen is known to exist in collections. Yet more than sixty years ago the species was found breeding abundantly on the North Georgian (now commonly called the Parry) Islands by Parry's memorable expedition, as well as soon after on Melville Peninsula by Capt. Lyons, and agnin, during the voyage of Sir George Nares, on the northern coast of Grinnell Land and the shores of Smith Sound, where Col. Feilden obtained examples of the newly-hatched young (Ibis, 1877, p. 407), and observed that the parents fed largely on the buds of Saxifraga oppositifolia. Gen. Greely subsequently found that Knots bred in small numbers near Discovery Harbour, on the northern shore of Lady Franklin Bay, and obtained from the ovary of an example shot there "a completely formed hard-shelled egg ready to be laid" (Three Years of Arctic Serrice, ii. p. 37t) - a specimen, however, which had to be abandoned in the dire distress to which he and his comrades were subjected. These are the only localities in which this species is known to breed, for on none of the arctic lands lying to the north of Europe or Asia has it been unquestionably observed. ${ }^{1}$ In winter its wanderings are very extensive, as it is recorded from Surinam, Brazil, Walvisch Bay in South Africa, China, Queensland and New Zealand. Formerly this species was extensively netted in England, and the birds fattened for the table, where they were esteemed a great delicacy, as witness the entries in the Northumberland and Le Strange Household Books; and the British Museum contains an old treatise on the subject"The maner of kepyng of knotts, after Sir William Askew and my Lady, given to my Lord Darcy, 25 Hen. VIII." (MSS. Sloane, 1592, 8 cat. 663).

KOEL, the Hindi name of a well-known Indian Cuckow, the use of which has been extended to other allied species forming the

1 The Tringa canutus of Payer's expedition seems more likely to have been $T$. maritima, which species is not named among the birds of Franz Josef Land, though it can hardly fail to occur there. 
genus Eudynamis, a peculiarity of which is that the adult males have a uniform glossy black plumage while the females and young present a very different aspect, being of some brownish tint, variously mottled, barred or spotted. Hence in several Indian languages the two sexes bear different names. The true Koel was long thought to be the Cuculus orientalis of Linnæus, but the late Lord Tweeddale shewed (Ibis, 1869 , p. 338) that that name applied to a cognate form, and it has since been used for the species of the Moluccas (Salvadori, Ornitol. Papuas. i. p. 359), and the Indian bird, which also inhabits Ceylon, and stretches across Burma to China (where it has been called $E$. maculata) and the Malay Archipelago to Timor, is now recognized as Eudynamis honorata or nigra-the latter epithet being especially suited to the male. Australia and New Guinea produce another species, $E$. cyanocephala or flindersi, and some three more inhabit other eastern localities. The Koel is parasitic, the hens laying their eggs in Crows' nests (Hume, Nest \& Eggs Ind. B. ed. 2, ii. p. 392).

KRAAI, Dutch for CRow, applied to several species in South Africa.

LADY-FOWL said to be a name of the WIGEON.

LÄMMERGEYER (i.e. Lamb-Vulture), or Bearded Vulture, the Falco barbatus of Linnæus and the Gypaetus barbatus of modern ornithologists, one of the grandest Birds-of-Prey of the Old World -inhabiting lofty mountain chains from Portugal to the borders of China, though within historic times, if not within living memory, it has been exterminated from several of its ancient haunts. Its northern range in Europe does not seem to have extended further than the southern frontier of Bavaria, or the neighbourhood of Salzburg; but in Asia it formerly reached a higher latitude, having been found even so lately as 1830 in Dauuria (ExTERMination, p. 227 , note 1), where according to Dr. Radde (Beitr. Kenntn. Russ. Reichs, xxiii. p. 467) it has now left but its name. It is not uncommon on many parts of the Himalayas, where it breeds, and on the mountains of Kumaon and the Punjab, and is the "Golden Eagle" of most Anglo-Indians. Returning westward, it is found also in Persia, Palestine, Crete, and Greece, the Italian Alps, Sicily, Sardinia and Mauritania; but can scarcely be said to exist any longer in Carinthia ${ }^{1}$ or in Switzerland. ${ }^{2}$

$1 C f$. Keller, Jahrb. nat.-hist. Landesmus. Klagenfurt, 1886, pp. 285-232.

2 Dr. Girtanner has a valuable paper on this bird in Switzerland (Verhandl. 
In some external characters the Lämmergeyer is obviously intermediate between the Families Vulturidx and Falconidx, and the opinion of systematists has from time to time varied as to its proper position; but as this ought to depend on the decision of anatomists, who have not yet delivered their verdict, it must be still left in doubt; and there rould be little advantage in recounting how one author has referred it to the former group and another to the latter, since nobody seems to have applied the only sure testthat afforded by characters which are not superficial. ${ }^{1}$ It will suffice to say that most writers have deemed its Vulturine affinity the strongest (relying apparently on the form of the beak, which can scarcely be said to be either Aquiline or Falconine), in spite of its well-feathered head and tarsi. The whole length of the bird is from 43 to 46 inches, of which, however, about 20 are due to the long cuneiform tail, while the pointed wings measure more than 30 inches from the carpal joint to the tip. The coloration of the plumage is very peculiar; the top of the head is white, bounded by black, which, beginning in stiff bristly feathers turned forwards over the base of the beak, proceeds on either side of the face in a well-defined band to the eye, where it bifurcates into two narrow stripes, of which the upper one passes above and beyond that feature till just in front of the scalp it suddenly turns ipwards across the liead and meets the corresponding stripe from the opposite side, enclosing the white forehead already mentioned, while the lower stripe extends beneath the eye about as far backwards and then suddenly stops. A tuft of black, bristly feathers projects beardlike from the base of the mandible, and gives the bird one of its commonest epithets in many languages, as well as an appearance almost unique among the whole Class Aves. The rest of the

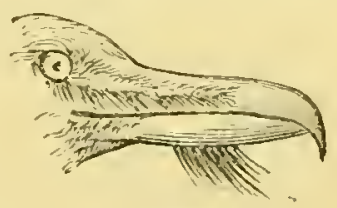

LÄMMERGEYER. (After Swainson.) head, the neck, throat, and lower parts generally are clothed with lanceolate feathers of a pale tawny colour-sometimes so pale as to be nearly white beneath ${ }^{2}$ while the scapulars, back, and

St.-Gall. naturw. Gesellschaft, 1869-70, pp. 147-244). The last lilled, by poison, was near Viège in the Canton Talais in February 1586, since when very few have been seen, but it is possible that it may yet exist in the Haute Engadine. See the mournful but interesting aceount by MII. Fatio and Studer, Cat. Ois. de la Suisse, 1p. 25-46 (Genève: 1859), and their more recent Cat. distrib. Ois. de la Suisse, 1. 7 (Genève: 1892).

1 Prof. Huxley's labours unfortunately were not directed to this particular point, and therefore throw little or no light on it. He puts the Vulturidx and Futconida together under the name of Gypcetida, very properly separating from them the American Vultures as Cathartidx, of which the right name is Sarcorhamphide.

2 IIeves (Offers. Vct. Akad. Forrhandl. 1860, 1. 4S7) asserts that in some cases, as proved by chemical tests, the red colouring is due to a superficial deposit 
wing-coverts generally, are of a glossy greyish-black, most of the feathers having a white shaft and a median tawny line. The quill-feathers, both of the wings and tail, are of a dark blackishgrey. The irides are of a light orange, and the sclerotic tunics,equivalent to the "white of the eye" in most animals, - which in few birds are visible, are in this very conspicuous and of a deep crimson, giving it an air of great ferocity. In the young of the year the whole head, neck, and throat are clothed in dull black, and most of the feathers of the mantle and wing-coverts are broadly tipped and mesially streaked with tawny or lightish grey.

The Lämmergeyer breeds early in the year. The nest is of large size, built of sticks, lined with soft material, and placed on a ledge of rock-a spot being chosen, and often occupied for many years, which is nearly always difficult of access, and not unfrequently quite inaccessible, to man, from the precipitous or overhanging configuration of the cliffs. Here in the month of February a single egg is usually laid. This is more than 3 inches in length by nearly $2 \frac{1}{2}$ in breadth, of a pale but lively brownishorange. The young when in the nest are clad in down of a dirty white, varied with grey on the head and neck, and with ochraceous in the iliac region. How long the eggs take in hatching, or how long the young remain nestlings, seems to be unknown. Equally unknown is the length of time that elapses before the latter assume the adult plumage, but it is probable that this period must at least exceed a twelvemonth.

There is much discrepancy as to the ordinary food of the Lämmergeyer, some observers maintaining that it lives almost entirely on carrion, offal, and the most disgusting garbage; but there is no question of its frequently taking living prey, and it is reasonable to suppose that this bird, like so many others, is not everywhere uniform in its habits. Its very name shews it to be the reputed enemy of shepherds, and it is in some measure owing to their hostility that it has been extirpated in so many parts of its European range. Its usual mode of proceeding is said to be by suddenly rushing at the animal, especially if it be young, when in a somewhat dangerous position, so startling it as to make it lose its foothold and fall down the precipice. ${ }^{1}$ But the Lämmergeyer has of oxide of iron on the feathers, and that the colonring-natter on the eggs (to be presently described) also arises from the same cause. This opinion has, however, been denied by several other naturalists, though none of them seem to have tried the experiment; while Mr. Hume, who has (Scrap Book, p. 46), confirms Meves's statement. In confinement, moreover, the bird has been observed always to lose or not to acquire its tawny tint.

${ }^{1}$ Stories are told of its attacking human beings under such circumstances, and the present writer is not disinclined to believe that some of such stories may be true, though he is unable to refer to any that rest on testimony sufficient to dispel all doubt. 
also a great partiality for bones, which when small enough it swallows and slowly digests. When they are too large, it is said to soar with them to a great height and drop them on a rock or stone that they may be broken into pieces of convenient size. Hence its name Ossifrage, ${ }^{1}$ by which the Hebrew Peres is rightly translated in the Authorized Version of the Bible (Lev. xi. 13; Deut. xiv. 12)-a word corrupted into OsPrey and misapplied to a bird which has no habit of the kind.

The Lämmergeyer of north-eastern and south Africa is deemed by systematists to be specifically distinct, and is known as Gypaetus meridionalis or $G$. nudipes. In habits it seems closely to resemble the northel'n bird, from which it differs in little more than wanting the black stripe below the eye and having the lower part of the tarsus bare of feathers. It is the "Golden Eagle" of Bruce's Travels, and has been beautifully figured by Mr. Wolf in Rüppell's Syst. Ueber's. der Vögel Nord-Ost-Afrilia's (Taf. 1).

LAMELLIROS'TRES, Cuvier's name in $1817^{2}$ (Riène Anim. i. p. 527) for the group composed of the Linnæan genera Anas (Duck) and Mergus (Merganser), the Anatidie of modern ornithologists.

LANNER (Fr. Lanier, Lat. Laniarius, from laniare to dissever ${ }^{3}$ ), a species of FALCON about which great confusion or ignorance existed for many years. The older writers on Falconry, to say nothing of so good a naturalist as Belon, were well acquainted with it; but, as the sport fell into disuse, knowledge of the different kinds of birds therein employed was gradually obscured and lost, so that the Falco lanarius of Linnzus (and therefore of precise scientific nomenclature), whatever it may have been, ${ }^{4}$ was, as he in 1761 admitted (Faunc Suec. ed. 2, p. 22) "distinctissimus a Lanario Italico," and therefore certainly not the Lanner, Lanier, or Lanarius of falconers. In the same way doubt may exist as to the "Lanner" of some old English authors, though it is not to be questioned that true Lanners were brought to England and used for Falconry. Schlegel has the credit of having restored the ancient Lanner to a

1 Among other crimes attributed to the species is that, according to Pliny (Hist. Nat. lib. x. can. 3), of having caused the death of the poet Eschylus, by dropping a tortoise on his bald head, mistaking it for a stone! In the Atlas range this bird is said to prey chiefly on the Tcstudo mauritanica, which "it carries to some height in the air, and lets fall on a stone to break the shell" (Ibis, 1859 , p. 177). It seems to be the äp $\eta$ and $\phi \dot{\eta} \nu \eta$ of Greek classical writers.

${ }^{2}$ In 1805 he (Lee. d'Anat. comp. tabl. 2) had called this gronp Serrirostres; but whether the worl was intended as Latin is donbtful.

3 Some derive the word from lana (wool), in allusion to the soft character of the plumage; but Littré rejected this etymology.

${ }^{4}$ Schlegel thought it was an immature Grrfalcon; but that seems beyond proof. 
recognized and recognizable position, which he did in 1841, then calling it (Abhandl. Geb. Zool. \& vergl. Anat. ii. p. 3, pls. x. xi.) Falco feldeggi, it having been brought to his notice from examples obtained by the Baron of that name in Dalmatia. In the same year, however, Sir Gardiner Wilkinson (Mann. \& Cust. Anc. Egypt, ser. 2, ii. pp. 121,210) conferred the name of Falco aroeris ${ }^{1}$ on the sacred Falcon of the ancient Egyptians, which we now know to be the true Lanner. It is found locally throughout the countries bordering the Mediterranean, from Spain eastward, and is known to breed on the Egyptian Pyramids. Further to the southward it is replaced by the allied $F$. tanypterus (which the late Mr. Gurney regarded as a local race), and in Western Asia by $F$. babylonicus.

LAPWING, Anglo-Saxon Hleápewince ( = "one who turns about in running or flight," see Skeat's Etymol. Dict. p. 321), ${ }^{2}$ a wellknown bird, the Tringa vanellus of Linnæus and the Vanellus vulgaris or $V$. cristatus of most modern ornithologists. In the temperate parts of the Old World this species is perhaps the most abundant of the Charadriida (PLovER), breeding in greater or fewer numbers in almost every suitable place from Ireland to Japan, - the majority migrating towards winter to southern countries, as the Punjab, Egypt, and Barbary,-though in the British Islands some are always found at that season, chiefly about estuaries. As a straggler it has occurred within the Arctic Circle (as on the Varanger Fjord in Norway), as well as in Iceland and even Greenland; while it not unfrequently appears in Madeira and the Azores. Conspicuous as the strongly contrasted colours of its plumage and its very peculiar flight make it, one may well wonder at its success in maintaining its ground when so many of its allies have been almost exterminated, for the Lapwing is the object perhaps of greater persecution than any other European bird that is not a plunderer. Its eggs — the well-known "Plovers' Eggs" of commerce ${ }^{3}$ _are taken by

I It may be doubted whether either of these names can stand, since Gmelin's F. griseus in 1788 (Syst. Nat. i. p. 275) is founded on tlie "Grey Falcon" of Latham and Pennant, the description of which was transmitted to the last by Thomas Bolton, who subsequently communicated a drawing of the bird to Lewin, by whom it was reproduced (B. Gr. Brit. ed. 2, i. pl. 17). The figure seems intended for an adult of the true Lanner, though coloured somewhat to resemble $F$. chicquera. The question is intricate, and could not be here discussed. Confusion began early, since Lewin in the first edition of his work figured (No. 15) a very different bird, and one not agreeing with the description.

2 Caxton in 1481 has "lapwynches" (Reynard the Fox, cap. 27).

3 There is a prevalent belief that many of the eggs sold as "Plovers" are those of Rooks, but no notion can be more absurd, since the appearance of the two is wholly unlike. Those of the Redshank, of the Golden Plover (to a small extent), and enormous numbers of those of the Black-headed Gnll, and in certain places of some of the Terns, are, however, undoubtedly sold as Lapwings', having 
thousands or ten-thousands; and worse than this, the bird, wary and wild at other times of the year, in the breeding-season becomes easily approachable, and is (or used to be) shot down in enormous numbers to be sold in the markets for "Golden Plover." Its growing scarcity as a species was consequently very perceptible in this country until an Act of Parliament in 1872 frightened people into letting it alone, when its numbers immediately increased, to the manifest advantage of many classes of the community - those who would eat its eggs, those who would eat its flesh (at the right time of year), as well as the agriculturists whose lands it frequented, for it is admitted on all hands that no bird is more completely the farmer's friend. What seems to be the secret of the Lapwing holding its position in spite of slaughter and rapine is the adaptability of its nature to various kinds of localities. It will find sustenance for itself and its progeny equally on the driest soils as on the fattest pastures; upland and fen, arable and moorland, are alike to it, provided only the ground be open enough. The wailing $\mathrm{cry}^{1}$ and the frantic gestures of the cock-bird in the breeding-season will tell any passer-by that a nest or brood is near; but, unless he knows how to look for it, little save mere chance will enable him to find it. Yet by practice those who are acquainted with the bird's habits will accurately mark the spot whence the hen silently rises from her treasure, and, disregarding the behaviour of the cock, which is intended to delude the intruder, will walk straight to one nest after another as knowing beforehand the exact position of each. In many cases they will know, from the hen's behaviour, the number of eggs they will find, and whether she has begun to sit. The nest is a slight hollow in the ground, wonderfully inconspicuous even a little similarity of shell to the latter, and a difference of flavour only to be detected by a fine palate. It is estimated that 800,000 Lapwings' eggs are yearly sent to England from the one province of Friesland in Holland (see Ornith. Centralbl. 1877, p. 108).

${ }^{1}$ This sounds like pee-weet, with some rariety of intonation. Hence the names Peewit, Peaseweep, and Teuchit, commonly applied in some parts of Britain to this bird; - thongh the first is that by which one of the smaller Gulls, Larus ridibundus, is known in some of the districts it frequents. In Sweden Vipa, in Germany Kiebitz, in Holland Kiewiet, and in France Dixhuit, are names of the Lapwing, given to it from its usual cry. Other English names are Green Plover and Horn-pie-the latter from its long lornlike crest and pied plumage. The Lapwing's conspicuons crest seems to have been the canse of a common blunder among our writers of the Middle $\Lambda$ ges, who translated the Latin word Upupa, properly Hoopoe, by Lapwing, as being the crested bird with which they were best acquainted. In like manner other writers of the same or an earlier period Latinized Lapwing by Egrettides (plural), and rendered that again into English as Egrets-the tuft of feathers misleading them also. A common Italian name is Pavoncella (Little Peahen), and that has led to some amusing mistakes. The word Vanellus is said to be from vannus, the fan used for winnowing corn, and refers to the audible beating of the bird's wings. 
when deepened and its margin heightened by the accumulation of vegetable matter, as is usually the case while incubation continues, and the black-spotted olive eggs (four in number) are almost invisible to the careless or untrained eye unless it should happen to glance directly upon them. The young when first hatched are clothed with mottled down so as closely to resemble a stone and to be thus overlooked as they squat motionless on the approach of danger. At a distance the plumage of the adult appears to be white and black in about equal proportions, the latter prerlominating above; but on closer examination nearly all the seeming black is found to be a bottle-green gleaming with purple and copper ; and the tail-coverts, both above and below, are seen to be of a bright bay colour that is seldom visible in flight. The crest consists of six or eight narrow and elongated feathers, turned slightly upwards at the end, and is usually carried in a horizontal position, extending in the cock beyond the middle of the back; but it is capable of being erected so as to become nearly vertical. Frequenting (as has been said) parts of the open country so very divergent in character, and as remarkable for the peculiarity of its flight as for that of its cry, the Lapwing is far more often observed in nearly all parts of the British Islands than any other of the LInJCol 2. The peculiarity of its flight seems due to the wide and rounded wings it possesses, the steady and ordinarily somewhat slow flapping of which impels the body at each stroke with a manifest though easy jerk. Yet on occasion, as when performing its migrations, or even its almost daily transits from one feeding-ground to another, and still more when being pursued by a Falcon, the speed with which it moves through the air is very considerable; and the passage of a flock of Lapwings, twinkling aloft or in the distance, as the dark and light surfaces of the plumage are alternately presented, is always an agreeable spectacle to those who love a landscape enlivened by its wild creatures. On the ground this bird runs nimbly, and is nearly always engaged in searehing for its food, which is wholly animal.

Allied to the Lapwing are several forms that have been placed by ormithologists in the genera Hoplopterus, Chettusiu, Lobiranellus, Sarciophorus, and so forth; but the respective degree of affinity they bear to one another is not rightly understood, and space would

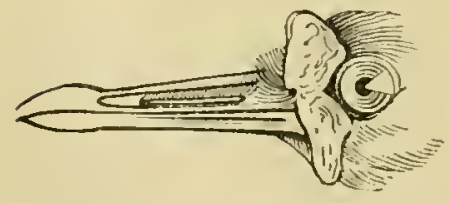

Bill axd Carpat SPLR OF Hoplopthrus. (After Swainson.) prohibit any attempt at here expressing it. In some of them the hind toe, which has already ceased to have any function in the Lapwing, is wholly wanting. In others the wings are armed with a tubercle or even a sharp spur on the carpus. Few have any occipital crest, but several have the face ornamented by the 
outgrowth of a fleshy lobe or lobes. With the exception of North America, they are found in most parts of the world, but perhaps the greater number in Africa. Three species occur in Europe-Hoplopterus spinosus, the Spur-winged Plover, and Chettusia gregaria and C. leucura; but the first and last are only stragglers from Africa or Asia.

LARK, Anglo-Saxon Láwerce, German Lerche, Danish Larke, Dutch Leeuwerik, a name (perhaps always, but now certainly) used in a rather general sense, any special meaning being signified by a prefix, as Skylark, Tithark, WoODlark, and so forth; though custom ordains that the first of these, the Alauda arvensis of ornithology, is intended if no qualification be expressed, since it is the best known and most widely-spread species throughout Europe. It scarcely needs description. Of all birds it holds unquestionably the foremost place in our literature, and there is hardly a poet or poetaster who has not made it his theme, to say nothing of the many writers of prose who have celebrated its qualities in passages that will be remembered so long as our language lasts. It is also one of the most favourite cage-birds, as it will live for many years in captivity, and, except in the season of moult, will pour forth its thrilling song many times in an hour for weeks and months together, while its affection for its owner is generally of the most marked kind. Difficult as it is to estimate the comparative abundance of different species of birds, there would probably be no error in accounting the Skylark the most plentiful of the Class in Western Europe. Not only does it frequent almost all unwooded districts in this quarter of the globe, making known its presence throughout spring and summer, everywhere that it occurs, by its gladsome and heart-lifting notes, but, unlike most birds, its numbers increase with the spread of agricultural improvement, and since the beginning of the century the extended breadth of arable land in Great Britain must have multiplied manifold the Larkpopulation of the country. Nesting chiefly in the growing corn, its eggs and young are protected in a great measure from all molestation; and, as each pair of birds will rear several broods in the season, their produce on the average may be set down as at least quadrupling the original stock-the eggs in each nest varying from three to five. The majority of young Larks seem to leave their birthplace as soon as they can shift for themselves, but what immediately becomes of them is one of the many mysteries of bird-life that has not been penetrated. When the stubbles are cleared, old and young congregate in flocks; but the young then seen appear to be those only of the later broods. In the course of the autumn they give place to other's coming from more northerly districts, and then, as winter succeeds, in great part vanish, leaving 
not a tithe of the numbers previously present. On the approach of severe weather, in one part of the country or another, flocks arrive, undoubtedly from the Continent, which in magnitude cast into insignificance all those that have hitherto inhabited the district. On the east coast of both Scotland and England this immigration has been several times noticed as occurring in a constant stream for as many as three days in succession. Further inland the birds are observed "in numbers simply incalculable," and "in colmtless hundreds." On such occasions the bird-catchers are busily at work with their nets or snares, so that 20,000 or 30,000 Larks are often sent together to the London market, and at the lowest estimate $£ 2000$ worth are anmually sold there. During the winter of $1867-68,1,255,500$ Larks, valued at $£ 2260$, were taken into the town of Dieppe. ${ }^{1}$ The same thing happens in various places almost every year, and many persons are apt to believe that thereby the species is threatened with extinction. When, however, it is considered that, if these birds were left to continue their wanderings, a large proportion would die of hunger before reaching a place that would supply them with food, and that of the remainder an enormous proportion would perish at sea in their vain attempt to find a settlement, it must be acknowledged that man by his wholesale massacres, which at first seem so brutal, is but anticipating the act of Nature, and on the whole probably the fate of the Larks at his hands is not worse than that which they would encounter did not his devices intervene.

The Skylark's range extends across the Old World from the Fieroes to the Kurile Islands. In winter it occurs in North China, Nepal, the Punjab, Persia, Palestine, Lower Egypt, and Barbary.

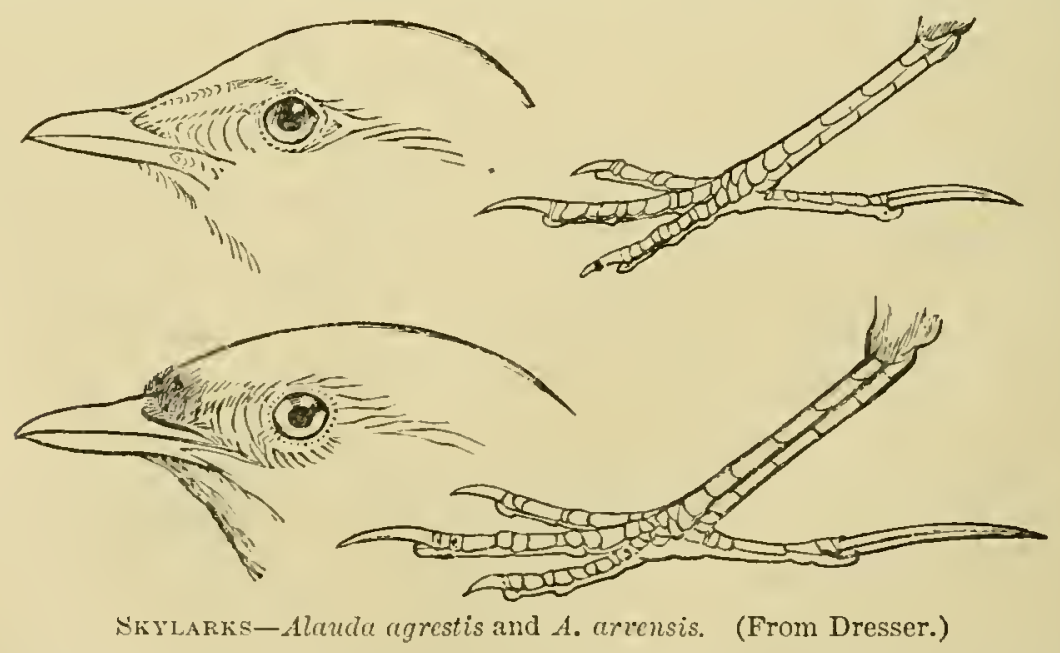

It sometimes strays to Madeira, and has been killer in Bermuda, though its unassisted appearance there is doubtful. It has been

I See Yarrell (Hist. Br. Birds, ed. 4, i. pp. 618-621), where partieular references to the above statements, and some others, are given. 
successfully introduced on Long Island in the State of New York, and into New Zealand-where it may possibly become as troublesome a denizen as are other subjects upon which Acclimatization Societies have exercised their meddling activity. Allied to the Skylark a considerable number of species have been described, of which Dr. Sharpe (Cat. B. Br. Mus. xiii. pp. 566-579) deems only two to be valid, besides a supposed local race, Alauda agrestis, not recognized by him, the difference between which and the normal bird (stated at length in Mr. Dresser's Birds of Europe, iv. pp. 310,311$)$ is shewn above.

The WOODLARK, the Alauda arborea of most systematists, has been by some generically separated as Lullula. It is a much more local and therefore a far less numerous bird than the Skylark, from which it may be easily distinguished by its finer bill, shorter tail, more spotted breast, and light superciliary stripe. Though not actually inhabiting woods, as its common name might imply, it is seldom found far from trees. Its song wants the variety and power of the Skylark's, but has a resonant sweetness peculiarly its own. The bird, however, requires much care in captivity, and is far less often caged than its congener. It has by no means so wide a range as the Skylark, and perhaps the most eastern locality recorded for it is Tiflis, while its appearance in Egypt and even in Algeria must be accounted rare.

Not far removed from the foregoing is a group of Larks characterized by a larger crest, a stronger and more curved bill, a rufous lining to the wings, and some other minor features. This group has been generally termed Galerita, ${ }^{1}$ and has for its type the Crested Lark, the Alauda cristata of Linnæus, a bird common enough in parts of France and some other countries of the European Continent, and said to have been obtained several times in the British Islands. Many of the birds of this group frequent the borders if not the interior of deserts, and such as do so exhibit a more or less pale coloration, whereby they are assimilated in hue to that of their haunts ( $c f$. Geographical Distribution, p. 336). The same characteristic may be observed in several other groups - especially those known as belonging to the genera Calandrella, Ammomanes, and Certhilauda or Alamon, some species of which are of a light sandy or cream colour. The genus last named is of very peculiar appearance, presenting in some respects an extraordinary resemblance to the HOOPOE, so much so that the first specimen

1 The name, however, is inadmissible, owing to its prior use in Entomology, just as is Heterops, conferred without any definition in 1844 by Hodgson or J. E. Gray (Zool. Miscell. p. 84). Aristotle's old name, Corydus, was ntilized by Cnvier, in a slightly different form, for a very different bird, or it would have come in appropriately. Any one coveting the privilege of bestowing a generic name has here an easy opportunity of distinguishing himself. 
described was referred to the genus $U p u p a$, and named $U$. alandipes. The resemblance, however, is merely one of analogy. The Hoopoe belongs to a totally distinct Order of birds, widely differing anatomically and physiologically, and we can hardly yet assume that this resemblance is the effect of what is commonly called Mimicry, though that may ultimately prove to be the case.

There is, however, abundant evidence of the susceptibility of the Alaudine structure to modification from external circumstances,

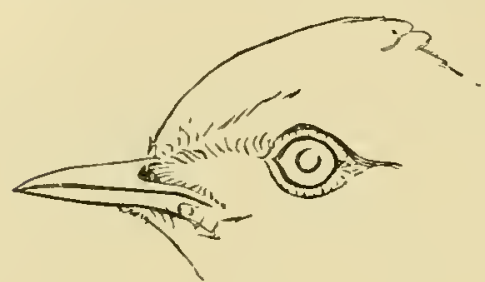

IULLULA.

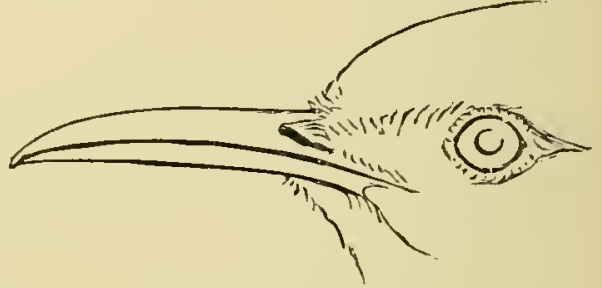

Certhilauda.

-in other words, of its "plasticity"; and perhaps no homogeneous group of Pusseres could be found which better displays the working of "Natural Selection." This fact was. recognized many years ago by Canon 'Tristram (Ibis, 1859, pp. 429-433), and his remarlis deserve all attention, going, as they go, to the root of the matter. A monograph of the Family executed by a competent ornithologist could not fail to be a weapon of force in the hands of all evolutionists. Almost every character that among Passerine birds is accounted most sure is in the Larks found subject to modification. The for'm of the bill varies in an extraordinary degree. In the Woodlark, Lullula, already noticed, it is almost as slender as a Warbler's ;

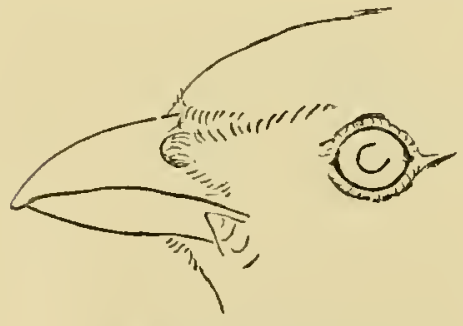

MIELANOCORYPHA.

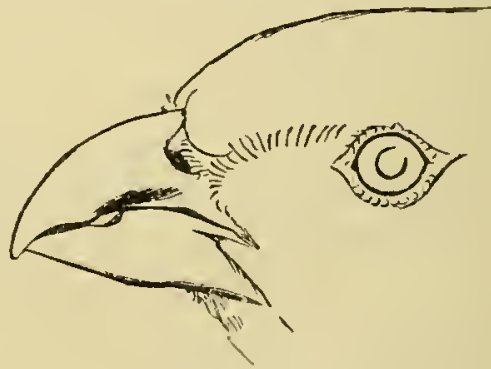

RHAMPHOCORY'S

in Ammomanes it is short; in Certhilauda and Alamon it is elongated and curved; in Pyrrhulauda and Mclanocoryphe it is stout and Finchlike; while in Phamphocorys it is exaggerated to an extent that equals almost any Fringilline form (cf. GROSBEAK), exceeding in its development that found in some members of the perplexing genus l'arudoxornis, and even presenting a resemblance to the same feature in the far-distant Anastomus (OPEN-BILI) - the tomia of the maxilla not meeting those of the mandibula along their whole length, but 
leaving an open space between them. The hind elaw, generally greatly elongated in Larks, as exemplified in Alaucla and Calendula,
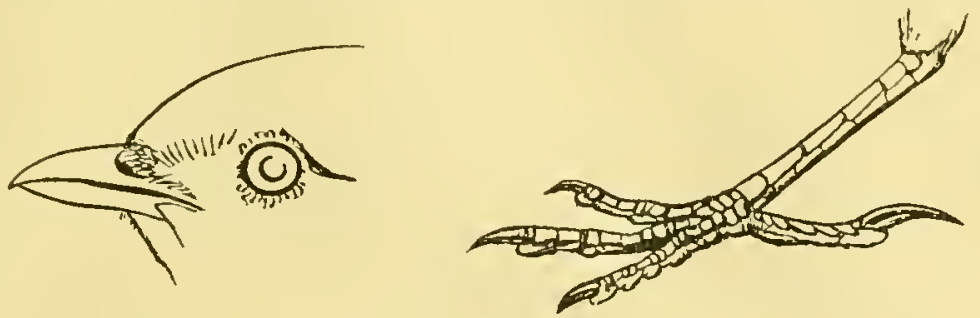

CALANDRELLA BRACHYDACTYLA.

is in Calandrella and some other genera redneed to a rery moderate size. The wings exhibit almost every modification, from the almost
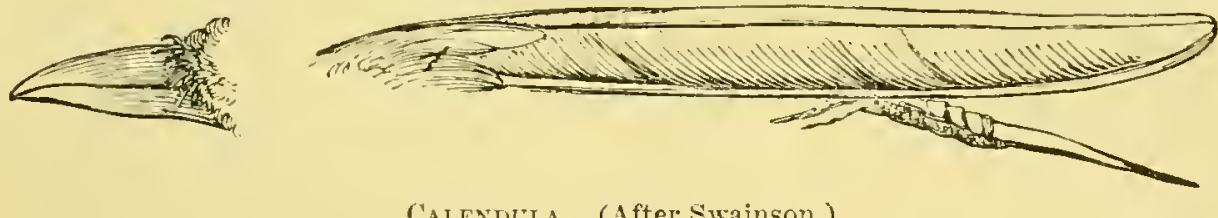

CalendeI.A. (After Swainson.)

entire abortion of the so-called "first" primary in Alaulu to its considerable development in Mirafia, and from tertials and scapulars of ordinary length to the extreme elongation found in the Motacillida
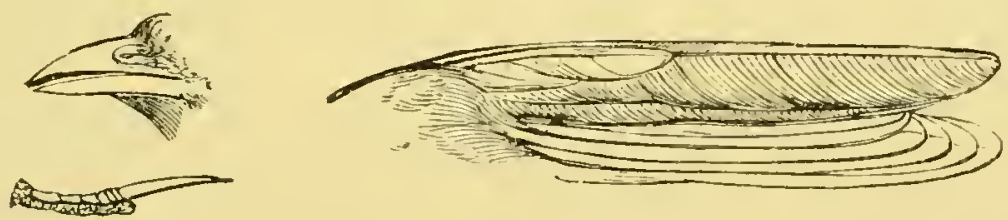

Mirafra. (After Swainson.)

and almost in certain Limicola. The most constant character indeed of the Alaudida would seem to be that afforded by the podotheca or eovering of the tarsus, which is scutellate behind as well as in front, but a character easily overlooked.'

In the Old World Larks are found in most parts of the Paliearctic area as well as in the Ethiopian and Indian Regions; but only one species, Mirafro horsfieldi, inhabits Australia, and thare is no true Lark indigenous to New Zealand. In the New World there is also only one genus, Otocorys, ${ }^{2}$ one species of which, found over nearly the whole of North America, is eertainly not distinguishable from the Shore-Lark of Europe and Asia, O. alpestris;

1 By assigning far too great an importance to this superfieial character (in comparison with others), Sundevall (Tentamen, pp. 53-63) was induced to array the Larks, Hoopoes, and several other heterogeneons groups in one "Series," to which he applied the name of Scutelliplantares (see Istronuctios).

2 By American writers it is usually ealled Eremophila, but that name is preoccupier in natural history. Its osteology is minutely deseribed by Dr. Shufeldt (Bull. U.S. Geol. Survey, vi. pp. 119-147). 
while how many others should be recognized is a question far from being settled. The Shore-Lark is in Europe a native of only the extreme north, but is very common near the shores of the Varanger Fjord, and likewise breeds on mountain-tops further south-west, though still well within the Arctic Circle. The mellow tone of its call-note has obtained for it in Lapland a name signifying "Bellbird," and the song of the cock is lively, though not very loud. The bird trustfully resorts to the neighbourhood of houses, and even enters the villages of East Finmark in search of its food. It produces at least two broods in the season, and towards autumn migrates to lower latitudes in large flocks. Of late years these have been observed almost every winter on the east coast of Great Britain, and the species, instead of being regarded, as it once was, in the light of an accidental visitor to the United KRingdom, must now be deemed an almost regular visitor, though in very varying numbers. Several other congeneric forms originally described as distinct species, but the validity of which has been more than once denied and reasserted, inhabit south-eastern Europe, Palestine, and Central Asia; but an admittedly good species is the O. bilopha of Arabia and Mauritania. All these birds, which have been termed Horned Larks, from the tuft of elongated black feathers growing on each side of the head, form a little group easily recognized by their peculiar coloration, which calls to mind some of the Ringed Plovers, Egialitis.

The name Lark is also frequently applied to many birds which do not belong to the Alaudidx as now understood. The Mud-Lark, Rock-Lark, Titlark, and Tree-Lark are PIPITS. The GrasshopperLark is one of the aquatic WARBLERs, while the Meadow-Lark of America, as has been already said, is an Icterus. Sand-Lark and Sea-Lark are likewise names often given to some of the smaller members of the Limicolx. Of the true Larks, Alaudida, Dr. Sharpe (ut suprà) makes over 70 species, and more than 40 local races or subspecies. It is believed to be a physiological character of the Family that they moult but once in the year, while the Pipits, which in general appearance so much resemble them, undergo a double moult, as do others of the Motacillida, to which they are most nearly allied.

LARYNX, the upper end of the trachea, into which the air enters from the mouth through a longitudinal, slit-like opening, the rima glottidis. It lies behind the tongue, between the two Hyord horns, connected in front by a strong band with the cartilaginous or bony urohyal, the sides of its dorsal margin being also attached loosely by connective tissue to the walls of the upper end of the œesophagus. The cartilaginous or bony part of the Larynx consists of several pieces, of which the principal or cricoid cartilage forms 
the anterior and lateral boundary, and runs out in a point towards the urohyal. To this is attached an unpaired procricoid which articulates with the right and left arytænoid cartilages, that close the top of the Larynx, and between them encompass the rima glottidis. The Larynx possesses only two muscles of its own, an apertor and a sphincter; but other tracheal and hyoid muscles are attached to it, while the rima glottidis in Birds is devoid of vocal chords, and hence no voice is produced bere, though sounds can be modulated by the approximation or separation of its rigid margins, which are protected by pads of fatty tissue with horny, wart-like hooks upon their surface. An epiglottis, or soft process springing from the anterior corner of the glottis and capable of shutting down upon the latter, such as is found in Mammals, is scarcely developed in Birds, or indicated only by a tranverse fold, which may, as in Anseres, be supported by a little cartilage. In Birds the voice is produced by the Syrinx, sometimes called the Lower Larynx, which is situated at the pectoral end of the TrachEA.

LATIROSTRES, Cuvier's name in 1805 for a section consisting of the SPOONBILL.

LAVEROCK or LAVROCK, a Scottish name for LARK.

LAVY, one of the many local names of the Guillemot.

LEATHER-HEAD, a name for one or more species of FrIARBIRD.

LEVER, or LIVER. Interest has been roused by a statement which Montagu made in 1813 (Suppl. Orn. Dict.) to the effect that the present city of Liverpool took its name from a bird called "Liver" killed on the verge of a "pool," and said by him to be an IBrs (Falcinellus igneus). Several writers have uncritically repeated this story, one part of which is very old, but the identification of the bird with an Ibis was new. ${ }^{1}$ No one can suppose that this was his invention, but he unfortunately did not give the source of his information. The question of the origin of the name Liverpool ${ }^{2}$ has been often discussed, and occasionally so warmly (Notes and Queries, ser. 6, ix. pp. 350, 414) that it must here be avoided. The mysterious bird that figured on the ancient corporation seal seems to have been an Eagle, the well-known symbol of St. John the Evangelist ( $c f$. Picton, Memorials of Liverpool, i. p. 18); but that a bird called Liver or Lever was known to heralds is

1 By most writers it had been said to be a Cormorant, for which there is no authority.

2 Camden gives an Anglo-Saxon form, "Lyferpole vulg. Lerpole," for which there is said to be no real authority, the oldest form known being temp. Hen. II. "Lirpul" or "Litherpul" (Baines, Hist. County Palat. Lancaster, iv. p. 55).

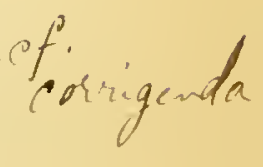


shewn by Randle Holme's Academy of Armory published at Chester in 1688, wherein he stated (p. 266) that three heads of the Lever "couped" were borne by the family of that name, ${ }^{\text {I }}$ and identified the bird with the Lepelakr, Leplar, and Lefler (or Löflar) of Low and High Dutch, which last, he remarks, "we more finely pronounce Lever." Now all these are well-known names of what we now call the SPoonbili, a bird which on incontestable evidence had several breeding-stations in England, so that places may well have taken their name from it; but on the other hand, Holme's assertion that this bird was ever called Lever or Liver in English wants confirmation, and is said to contravene all etymological laws.

LIGAMENT, a tis of connective tissue, binding several parts or organs to one another. Ligaments form an important feature in all joints where the bones are held together by bands of little variability, and are especially strong in the region of the shoulder and the knee. Skeletal Ligaments mostly consist of modified periosteum and fibrous cartilage, and hence they occasionally ossify, causing bones that were originally distinct to unite. Sometimes tendons which have lost their muscles are converted into Ligaments, or obliterated vessels act as bands betwèen intestinal organs.

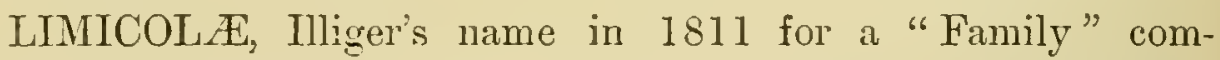
posed of the genera Numenius, Scolopax, Ereunetes, Actitis, Strepsilas and Tringa, practically that is the Scolopacida of later authors; but since his time used in a general sense for all the Scolopacidx and Chasadriida, the latter of which he had placed in a separate Family, Littorales.

LIMPKIN, a bird so called in Florida, because, though swift of foot, some of its movements resemble those of a limping man. It is the Aramus pictus of moderu American ornithologists, ${ }^{2}$ and together with its southern congener $A$. scolopaceus, with which it was long confounded (if indeed they be distinct), is considered to hold a place midway between the Gruidx (Craxe) and the Rallida (RAIL), its osteological (Eyton, Osteol. Av. p. 200, pl. xiv. K) and pterylographical characters being those of the former, while its digestive organs (as described by Macgillivray for Audubon) are those of the latter. Beside Florida it inhabits the coast-districts of Central America, and the Greater Antilles, being known in Jamaica as the "Clucking Hen," but the French name "Courlan,"

1 A Lancashire family interesting to ornithologists, since from it sprang Sir Ashton Lever, famous for his Museum.

2 In the belief that it is the species mentioned by Willian Bartram as being called by the Indians Ephouskyka (signifying "Crying Bird") and by him Tantalus pictus; but neither his description of it nor his drawing, as afterwards given by Barton (T'rans. Linn. Soc. xii. pl. 1), is very accurate. 
bestowed by Buffon on the South-Anerican form, is often given to it in books.

LINNET, Anglo-Saxon Limete aud Linet-wige, whence seens to have been corrupted the old Scottish "Lintquhit," and the modern northern English "Lintwhite,"-originally a somewhat generalized bird's name, but latterly specialized for the Fringilla cannabina of Limnens, the Linota cannebine of ormithology. ${ }^{\mathrm{I}}$ This is a common and well-known song-bird, frequenting almost the whole of Europe south of lat. 64, and in Asia extendiug to Turkestan. In Africa it is known as a winter visitant to Egypt and Abyssinia, and is abundant at all seasons in Barbary, as well as in the Canaries and Madeira. Thongh the fondness of this species for the seets of Hax (Linum) and hemp (Cunnabis) has given it its common

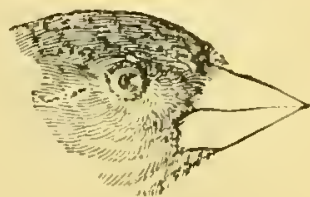

LINNET.

(After Swainson.) name in so many European langruages, 2 it feeds largely, if not chietly, in Britain on the seeds of plants of the order Composita, especially those growing on lieaths and commons. As these waste places have been gradually brought under the plough, and improved methods of cultivation have been applied to all arable land, in England and Scotland particularly, the haunts and means of subsistence of the Linnet have been slowly but surely curtailed, and lrence of late years its numbers have undergone a very visible diminution throughont Great Britain, and its diminution has also been aided by the detestable practice of netting it in spring-for it is a popular cage-bird-so popular indeed as to require no special deseription. According to its sex, or the season of the year, it is known as the Red, Grey or Brown Linnet, and by the earlier English writers, as well as in many places now, these names have been held to distinguish at least two species; but there is no question on this point, though the conditions under which the bright crimson-red colouring of the breast and crown of the cock's spring and summer plumage is dommed and doffed may still be open to disenssion. Its intensity seems due, however, in some degree at least, to the weathering of the brown fringes of the feathers which hide the more brilliant hue, and it is to be remarked that in the Atlantic Islands examples are said to retain their gay tints all the year round, while throughont Europe there is scarcely

1 Dr. Sharpe (Cot. B. Br. Ifus. xii. 1. 235) puts the Limets and Redpolls in a genns Acanthis which he assigns to Bechstein (Orn. Taschenb. 1\% 125), but the latter founded no sueh genus, keeping all his snecies in the Linnean Fringillu, while the Linnets are not even in the section Acunthis, as is evident to any one who will consult his work, that portion of which is dated 1802 and not 1803 as Dr. Sharpe states (cp. Sclater, Ibis, 1892, pr. 555-557).

2 E.g. French, Linotte; German, Hänfling; Swedish, Hämpling. 
a trace of them visible in autumn and winter; but, beginning to appear in spring, they reach their greatest brilliancy towards midsummer; and it is also to be remarked that they are never assumed by birds in confinement. The Linnet begins to breed in April, the nest being generally placed in a bush at no great distance from the ground. It is nearly always a neat structure composed of fine twigs, loots, or bents, and lined with wool or hair. The eggs, often six in number, are of a very pale blue marked with reddish or purplish-brown. Two broods seem to be commonly brought off in the course of the season, and towards the end of the summer the birds-the young of course greatly preponderating in numbercollect in large flocks and move to the sea-coast, whence a large proportion depart for more southern latitudes. Of these emigrants some return the following spring, and are invariably recognizable by the more advanced state of their plumage, the effect presumably of having wintered in countries enjoying a brighter and hotter sun.

Nearly allied to the foregoing species is the Twite, so named from its ordinary call-note, or Mountain-Linnet, the Linota flavirostris, or $L$. montium of ornithologists, which can be at once distinguished by its yellow bill, longer tail, and reddish-tawny throat. This bird never assumes any crimson on the crown or breast, but the male has the rump at all times tinged more or less with that colour. In the breeding-season it seems to affect exclusively hilly and moorland districts from Herefordshire northward, in which it partly or wholly replaces the common Linnet, but is very much more local in its distribution, and, except in the British Islands and some parts of Scandinavia, it only appears as an irregular visitant in winter. At that season it may, however, be found in large flocks in the low-lying countries, and as regards England even on the sea-shore. In Asia it seems to be represented by a kindred form, L. brevirostris.

The REDPOLLS form a little group placed by many authorities in the genus Linota, to which they are unquestionably allied, and, as before stated (FINCH, p. 251), the Linnets seem to be related to the birds of the genus Leucosticte, the species of which, in number uncertain, inhabit the northern parts of North-West America and of Asia. There is need here to mention only twoL. tephrocotis, which is generally of a chocolate colour, tinged on some parts with pale crimson or pink, and has the crown of the head silvery-grey; and $L$. arctoa, which was formerly said to have occurred in North America, but its proper home is in the Kurile Islands or Kamchatka. This has no red in its plumage. The birds of the genus Leucosticte seem to be more terrestrial in their habit than those of Linota, perhaps from their having been chiefly observed where trees are scarce; but it is possible that the mutual relationship of the two groups is more apparent than real. Allied 
to Leucosticte is Montifingilla, to which belongs the SNow-FrNCH of the Alps, M. nivalis, so often mistaken by travellers for the SNowBunting, Plectrophanes niralis.

\section{LIRA, see LYRA.}

LITTORALES, Illiger's name in 1811 for a "Family" composed of the genera Charadrius, Calidris, Himantopus, Hæmatopus, Cursorius and Burhinus.

LIVER, hepar, a large dark reddish or yellowish-brown gland, consisting of two lobes connected by a commissure of variable thickness, and resting upon the dorsal side of the sternum so as to enclose the HEART and Lungs. Bile, the secretion of this gland, passes through two ducts-that on the right side being, in most Birds, dilated into the GALL-BLADDER-into the duodenal loop of the small intestine (Digestive System). The relative size of the two lobes, which varies much in different groups of Birds, might be used for taxonomic purposes, were it not for the numerous exceptions that occur. Thus an equality in this respect is characteristic of Accipitres, Pelargi and Tubinares; but among the last Puffinus anglorum (SHEARWATER) has the right lobe about six times as large as the left; and the right lobe is generally by far the largest in Columbx, Herodii, Steganopodes, Pici and Passeres, while the opposite proportion is rare. Of greater and often of considerable importance is the shape of the two principal lobes, and especially that of the left: thus the right lobe is deeply cleft in most Cypselomorphx and Passeres, while the left is much divided only in Struthio, in the Gallinæ and in the Turnices-the Australian Pediononus agreeing with the group last named in having the left lobe doubled, as well as in being twice as large as the right. Livers of many kinds of Birds are described in (Bronn's) Klassen und Ordnungen des Thier-Reichs (Vögel, pp. 680-684).

LOBIPEDES, Illiger's name in 1811 for a "Family" made up of the genera Fulica (СоOT), Podica (Finfoot) and Phalaropus (Phalarope), which as we now know are not nearly allied.

LOCUST-BIRD, a name given in South Africa to three very different species. Without qualification it signifies Creatophora carnnculata (GRACKLE); with the prefix "Great" Ciconia alba (STORK) is meant; and with the prefix "Little," Glareola nordmanni (Pratincole) (cf. Layard, B.S. Afr. pp. 177, 291, 314 ; and Holub and Von Pelzeln, Beitr. Orn. Südafr. p. 243).

LOGCOCK, one of the many local names in North America of Picus pileatus (WOODPECKER).

LOGGER-HEAD, a name applied to several kinds of Birds, -for instance (1) to a SHRIKE, Lanius or Collyrio ludovicianus or 
carolinensis (Wilson, Am. Orn. iii. p. 5i), well known in the eastern part of North America, as well as to its western representative $L$. excubitoroides, Baird; (2) in Jamaica to two species of TyRant-BIrD inhabiting that island, Pitangus candifasciatus in the Windward portion, and Myjurchus ralidus or crinitus in the Leeward (Gosse, $B$. Jam. pp. 177, 186); but perhaps originally to (3) a very large Duck, the Tachyeres ${ }^{1}$ or Micropterus cinereus or brachypterus, on which have since been bestowed the names of Race-Horse (Byron, Norrative de. p. 50) and Steamer-Duck (P. P. King, Voy. 'Adrenture,' i. p. 36), inhabiting the Falkland Islands and the Strait of Magellan, where its peculiar habit of rowing itself with its wings along the top of the water at great speed has been noticed by seamen for more than three centuries, and accounts of it may be read in many narratives. A second species, $T$. patachonicus has been described (Zool. Joum. iv. p. 100) and said to be capable of flight; but Prof. R. O. Cunningham is of opinion (Nat. Hist. Strait Magell. pp. 91-9S) that the rolant birds are the young of those which do not $\mathrm{fly}$, and growing heavier with age lose the power of raising themselves in the air. This view he ably maintains (Trans. Zool. Soc. vii. pp. 493-501, pls. 58-62), and if it be as correct as it seems its bearing on the flightlessness of Birds is of great importance. Doubts, however, have been expressed on the subject, and $M$. Oustalet has declared (Miss. Scientif. du Cup ILom, Oisenux, pp. B. $212-232$, pls. 4,5$)$ his belief in the validity of two species.

LONGIPEN IES, Duméril's name in 1806 (Zool. Analyt.p. 71) for a "Family" of birds containing the Skmmer, Tern, Avoset, Petrel, AlBatros and Gull, which having been adopted by Cuvier, who had before called (Lec. d'Anat. Comp. tabl. ii.) this group, the Avoset excepted, "Macroptères," has been very often used, though mostly by French authors.

LONGIROSTRES, Cuvier's name in 1805 (Leç. d'Anat. Comp. tabl. ii.) for a group containing all the Limicole of modern authors then known to him except Hamatopus (OxSTkr-CATCHER).

LOOM, or LOON (Icelandic, Lom ), a name applied to waterbirds of three distinct Families, all remarkable for their clumsy gait on land. ${ }^{2}$ The first of them is the Colymbida, to which tho ter'm Drver is nowadays usually restricted in books; the second the Podicipedidx, or Grebss; and the third the Alcida. The form Loon is most commonly used both in the British Islands and in

1 This name was given to it by Sir R. Owen (Trans. Zool. Soc. ix. p. 254), Micropterus being preoccupied.

"The word also takes the form "Lumme" (fide Montagu), and, as Prof. Skeat observes, is probably connected with lame. The signification of loon, a clumsy fellow, and metaphorically a simpleton, is obvious to any one who has secn the attempt of the birds to which the name is giren to walk. 
Fiorth America for all the species of the genus Colymbus, or Eudytes according to some ornithologists, frequently with the prefix Sprat, indicating the kind of fish on which they are supposed to prey; though it is the local name of the Great Crested Grebe, Podicipes cristatus, wherever that bird is sufficiently well known to have one; and, as appears from Grew (Mus. Reg. Soc. p. 69), it was formerly given to the little Grebe or DABCHICK, $P$. fluviatitis or minor, as well. The other form, Loom, seems more confined in its application to the north, and is said by Mr. T. Edmondston (Etym. Gloss. Shetl. and Orkn. Dialect, p. 67) to be the proper name in Shetland of Colymbus septentrionalis ; 1 but it has come into common use among Aretic seamen as the name of the species of Guillemo't, Alca an or bruennichi, which in thousands throngs the cliffs of far northern lands, from whose (hence called) "loomeries" they obtain a considerable stock of wholesome food, while the writer believes he has heard the word locally applied to the RAzorBiLL.

LORD, the Newfoundland name for what is now commonly called the HArlequin-Duck (Edwards, Nat. Hist. B. i. p. 99).

LORIKEET, the diminutive of

LORY, a word of Malayan origin signifying PARrot, ${ }^{2}$ which is in general use with slight variation of form in many European languages, and is the name of certain birds of the Order Psittaci, mostly from the Moluccas and New Guinea, and remarkable for their bright scarlet or crimson colouring, though also, and perhaps subsequently, applied to some others in which the plumage is chiefly green. Among the birds so called are some that have

1 Dunn and Saxby, however, agree in giving "Rain-Goose" as the name of this bird in Shetland.

2 The anonymous anthor of a Vocabulary of the English and Malay Languages, published at Batavia in 1879, in which the words are professedly spelt according to their pronunciation, gives it Looree. Buffon (Hist. Nat. Ois. vi. p. 125) states that it comes from the bird's cry, which is likely enongh in the case of captive examples taught to utter a sound resembling that of the nane by which they are commonly called. Nieuhoff (Voyages par mer et par terre it differents lieux des Indes. Amsterdam: 1682-92) seems to have first made the word "Lory" known (ef. Ray, Synops. Avium, p. 151). Crawfurd (Dict. Engl. and MfaTay Languages, p. 127) spells it nori or nuri; and in the first of these forms it is used, says Dr. Finsch (Die Papageien, ii. p. 732), by Pigafetta. Aldrovandus (Ornith. lib. xi. cap. 1) noticed a Parrot called in Java nor, and Clusius (Exotica, p. 364) has the same word. This will account for the name noyre or noira applied by the Portuguese, according to Buffon (ut suprì, pl). 125-127); but the modern Portuguese seem to call a Parrot generally Louro, and in the same language that word is used as an adjective, signifying bright in colour. The French write the word Loury (ef. Littré, sub voce). The Lory of colonists in South Africa is a Touracop; and King Lory is a name applied by dealers in birds to the Australian Parrots of the genus Aprosmictus.

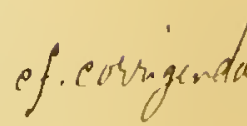


been referred to a considerable number of genera, of which Eclectus, Lorius (the Domicella of some authors), Eos, and Chalcopsittacus may be here particularized, while under the equally vague name of LoRIKEeTs may be comprehended the genera Charmosyna, Loriculus, and Coriplitus. By most systematists some of these forms have been placed far apart, even in different Families of Psittaci, but Garrod shewed (Proc. Zool. Soc. 1874, pp. 586-598, and 1876, p. 692) the many common characters they possess, which thus goes some way to justify the relationship implied by their popular designation. Perhaps the most complete account of these birds is that of Count T. Salvadori (Ornitol. Papuas. parte i. Torino : 1880 ; Aggiunte, 1889), who has subsequently treated of them technically (Cat. B. Br. Mus. xx. London: 1891). Of the genus Eclectus the Italian naturalist admits six species, namely, $E$. pectoralis and E. roratus (which are respectively the polychlorus and grandis of most authors), $E$. cardinalis (otherwise intermedius), E. westermani, and $E$. cornelia - all no doubt from the Papuan Subregion, though the precise habitat of the last two is unknown-as well as E. ricdeli, from Cera or Seirah, one of the Tenimber group, of which Timor Laut is the chief, to the south-ivest of New Guinea, first described by Dr. A. B. Meyer (Proc. Zool. Soc. 1881, p. 917). ${ }^{1}$ Much interest was excited by the discovery in 1873 , by the traveller and naturalist last named, that the birds of this genus possessing a red plumage were the females of those wearing green feathers. So unexpected a disclosure announced by him on the 4th of March $1874,{ }^{2}$ naturally provoked not a little controversy, for the difference of coloration is so marked that it had even been proposed to separate the Green from the Red Lories generically ; ${ }^{3}$ but now the truth of his assertion is generally admitted, and the story is very fully told by him in a note contributed to Gould's Birds of New Guinea (part viii. 1st October, 1878), though several interesting matters therewith connected are still undetermined. Among these is the question of the colour of the first plumage of the young, a point not without important signification to the student of phylogeny. ${ }^{4}$

Though the name Lory has long been used for the species of Eclectus, and other genera related thereto, some writers would restrict its application to the birds of the genera Lorius, Eos,

1 There seems just a possibility of this, however, proving identical with either $E$. westermani or $E$. cornelia - both of which are very rare in collections.

${ }^{2}$ Verhandl. z.-b. Gesellsch. Wien, 1874, p. 179; and Zool. Garten, 1874, p. 161 .

3 Proc. Zool. Soc. 1857, p. 226.

4 The chemical constitution of the colouring matter of the feathers in Eclectus has been treated by Dr. Krukenberg of Heidelberg (Vergl. physiol. Stud. Reihe ii. Abth. i. p. 161 reprinted in Mittheil. Orn. Vor. Wein, 1881, p. 83). 
Chalcopsittacus, and their near allies belonging to the so-called Family of Trichoglossida, or "Brush-tongued" Parrots, more correctly termed, as by Count T. Salvadori, Loriidx. Garrod, however, in the course of his investigations on the anatomy of the Psittaci was led to attach little importance to the structure indicated by the epithet "brush-tongued," stating (Proc. Zool. Soc. 1874, p. 597) that it "is only an excessive development of the papillæ which are always found on the lingual surface." The birds of this group are very characteristic of the Papuan Subregion, ${ }^{1}$ in which occur, according to Count T. Salvadori, ten species of Lorius, twelve of Eos, and seven of Chalcopsittacus; but none scem here to require any further notice, ${ }^{2}$ though among them, and particularly in the genus Eos, are included some of the most richly-coloured birds to be found in the whole world; nor does it appear that more need be said of the so-called Lorikeets.

LOTUS-BIRD, the name given in Queensland to the Australian JACANA or Parra, Hydralector cristatus.

LOVE-BIPD, a name indefinitely bestowed, chiefly by dealers in live animals and their customers, on some of the smaller short-tailed PARRoTs, from the remarkable affection which examples of opposite sexes exhibit towards each other, an affection popularly believed to be so great that of a pair that have been kept together in captivity neither can long survive the loss of its partner. By many systematic ornithologists the little birds thus named, brought almost entirely from Africa and South America, have been retained in a single genus, Psittacula, though those belonging to the former country were by others separated as Agapornis. This separation, however, was by no means generally approved, and indeed it was not easily justified, mntil Garrod (Proc. Zool. Soc. 1874, p. 593) assigned good anatomical ground, afforded by the structure of the carotid artery, for regarding the two groups as distinct, and thus removed what had seemed to be the almost unintelligible puzzle presented by the geographical distribution of the species of Psittacula in a large sense, though Prof. Huxley (op. cit. 1868, p. 319) had indeed already suggested one way of meeting the difficulty. Nine species of Psittacula are recognized by Count T. Salvadori (Cat. B. Br. Mus. xx. pp. 240252), who places them in his subfamily Conurina, while he assigns Urochroma, often considered to be nearly allied, to another subfamily Pioninx-but all these inhabit the New World. On the other hand, all the seven species of Agapornis, which he admits, belong to the Ethiopian Region, and all but one, $A$. cana (which

1 They extend, however, to Fiji, Tahiti, and Fanning Island.

2 Unless it be Oreopsittacus arfaki, of New Guinea, remarkable as the only Parrot known as yet to have fourteen instead of twelve rectrices. 
is indigenous to Madagascar, and thence has been widely dis. seminated), are natives of Africa. These Old-World forms are the "Love-birds" proper; the others scarcely deserve that designation.

LOTWAN, see MEGAPOdE.

LUGGAR (Hind. Laggur or Lhagar, the female; Jaggar or Jhagar, the nale), the Falco juggur of ornithology, and well known to Indian sportsmen as tine most common of the large FALCONs of that country. It belongs to the group containing the SAKER and others, which have been called "Desert Falcons," 1 as they prefer the plains or open country to the hills or forest districts. The number of species is uncertain; but, except the Australian $F$. hypoleucus (if that be rightly included among them) they may be recognized by the dull brown colouring of their plumage above, which does not display the light bluish-grey or rufous tints assumed by the LANNErs or the Falcons allied to $F$. peregrinus, while it is doubtful whether the adults assume the bars or horizontal markings which are generally so characteristic of maternity in the Fulconidx. The $F$. mexicanus or polyagrus of the southern parts of North America, and the rare $F$. subniger of Australia have been referred to this group.

LUMME, see Loom.

LUNDA (Skandin. Lunde), one of the many local names of the Puffin, and doubtless that from which Lundy, the island in the Bristol Channel, is called.

LUNGS, pumones, in Birds are symmetrical and comparatively small. They occupy the dorsal portion of the thoracic cavity, above the HEART, Stomach and Liver, and in front of the KIDNEYs, from the vertebral column to the beginning of the sternal portion of the ribs, which impress themselves deeply upon the dorsal surface of the Lungs, while they are covered ventrally with a serous membrane (pleur a). Secondary Bronchi (page 58), besides opening into AIR-SACS, send off a number of radially-arranged parabronchin, all of which extend to and end blindly near the surface of the Lungs. The walls of these (tertiary) tubes, which form the chief mass of the ordinary tissue of the organs, are perforated in all directions by minute tubules (canaliculi aeriferi), which' end in slight swellings, and so far resemble the alveoli of the Mammalian Lung. With these very fine respiratory passages are felted together the capillaries of the pulmonary vessels, so that blood and air, being separated from each other only by the extremely thin

1 Separated by some systematists as a subgenus or genus Gennaia, properly written Gennæa, and a term inadmissible in nomenclature owing to the prior application of Gennæus to a group of Pheasants. 
walls of these canaliculi and capillaries, exchunge their gases by osmosis. 'The Lumgs, being small, scarcely elastic, and moreover fixed to the thoracic walls, are capable of very limited expansion, and the necessury rentilation is secured by the extremely welldeveluped Ail'sacs.

\section{LYMPHATIC VESSEL, see VASCULA: SYstga.}

LYRA or LYRIE (Skandin. Liru, Live or Liri), the Oreadian name for SHEARWATER.

LIRE-BIPD, one of the most remarkable feathered inhabitants of Australia, the Memme supertu or M. nover-hollamila of ornithologists. First discovered, January 24, 1798. on the other side of the river Nepean in New South Wales by an exploring party from Paramatta, under the leadership of one Wilson, a single example was brought into the settlement a few days after, aurl though called by its finders a "Pheasant"-from its long tail-the more learned of the colony seem to have regarted it as a Bircl-ofParadise. ${ }^{1}$ A specimen having reached England in the following year, it was described by Gen. Davies as forming a new genus of birds, in a paper read before the Linnean Society of London, November 4, 1800, and subsequently published in that Society's Transuctions (vi. p. 20 7 , pl. xxii.), no attempt, however, being made to fix its systematic place. Other eximples were soon after received, bnt Latham, who considered it a Gallinaceous bird, in 1801 knew of only five having arrived. The temporary cessation of hostilities permitted Vieillot in 1802 to become acquainted with this form, though not apparently wath any published notice of it, and he figured and described it in a supplement to his Oisenux: Dorés as a Bird-of-Paradise (ii. pp. 39-42, pls. 14-16), from drawings by Sydenham Edwards, sent him by Parkinson, the then owner of the Leverian Mnsenm."

It would be needless here to enter at any length on the various positions which have been assigned to this singular form by different

${ }^{1}$ Collins, Account of New South Wretes, ii. pp. 87-92 (London: 1802).

2 Vieillot called the bird "Le Parkinson"! and hence Bechstein, who seems to have been equally ignorant of what had been publisherl in England concerning it, in 1811 (Kurze Uebersicht, p. 134), designated it Purlinsonizes mirabitis!! Shaw also, prior to 1813, figmred it (Nat. Hiscel. xir. 1. 577) under the name of Paradised parkinsoniand. The name "Nenura lyre, Shaw," was quoterl by Lesson in 1831 ( $\mathrm{Tr}$. d' Orn. p. 473), and has been repeated by many colyists of synonymy, lnt I cannot find that snch a name was ever applied by Shaw. Vieillot's principal figure, which has a common origin with that given by Collins, has been extensively copied, in spite of its inartistie not to say inaccurate dhawing. It is decidedly inferior to that of Davies, the first describer and delineator. 
systematizers - who had to judge merely from its superficial characters. The first to describe any portion of its anatomy was Eyton, who in 1841 (Ann. \& Mag. Nat. Hist. vii. pp. 49-53) perceived that it was truly a member of the Order then called Insessores, and that it presented some points of affinity to the South American genus Pteroptochus ; ${ }^{I}$ but still there were many who could not take advantage of this step in the right direction. In 1867 Prof. Huxley stated that he was disposed to divide his very natural assemblage the Coracomorphx (essentially identical with Eyton's Insessores) into two groups, "one containing Menura, and the other all the other genera which have yet been examined" (Proc. Zool. Soc. 1867, p. 472) - a still further step in advance. ${ }^{2}$ In 1875 the present writer put forth the opinion (Encycl. Brit. ed. 9, iii. p. 741) that Menura had an ally in another Australian form, Atrichia or Atrichornis (SCRUB-BIPD), which presented peculiarities hitherto unsuspected, and accordingly regarded them as standing by themselves, though each constituting a distinct Family. This opinion was partially adopted in the following year by Garrod, who (Proc. Zool. Soc. 1S76, p. 518) formally placed these two genera together in his group of Abnormal Acromyodian Oscines under the name of Menurinx; but the author sees no reason to change his mind, and herein he is corroborated by Mr. Sclater, who at once recognized (Ibis, 1850, p. 345) the alliance and distinctness of the Families Menuride and Airichiidx, forming of them a group which he unluckily called Pseudoscines.

Since the appearance in 1865 of Gould's Handbook to the Birds of Australia, little if any fresh information has been published concerning the habits of this form, and the account therein given must be drawn upon for what here follows. Of all birds, says that author, the Menura is the most shy and hard to procure. He has becn among the rocky and thick "brushes"-its usual hauntshearing its loud and liquid call-notes for days together without getting sight of one. Those who wish to see it must advance only while it is occupied in singing or scratching up the earth and leaves; and to watch its actions they must keep perfectly stillthough where roads have been made through the bush it may be more often observed and even approached on horseback. The best way of procuring an example seems to be by hunting it with dogs, when it will spring upon a branch to the height of ten feet and afford an easy shot ere it has time to ascend further or escape

${ }^{1}$ He subsequently (Ostcol. Avium, pp. 97, 98, pl. 3, F and pl. 14) described and figured the skeleton.

2 Owing to the imperfection of the specimen at his disposal, Prof. Huxley's brief description of the bones of the head in Mcnura is not absolutely correct. A full description of them, with elaborate figures, is given by Parker in the same Society's Transactions (ix. pp. 306-309, pl. lvi. figs. 1-5). 
as it does by leaps. Another method of stealing upon it is said to be practised by the natives, and is attained by the hunter fixing on his head the erected tail of a cock-bird, which alone is allowed to be seen above the brushwood. The greater part of its time is said to be passed upon the ground, and seldom are more than a pair to be found in company. One of the habits of the cock is to form small round hillocks, which he constantly visits during the day, mounting upon them and displaying his tail by erecting it over his head, drooping his wings, scratching and pecking at the soil, and uttering various cries-some his own natural notes, others an imitation of those of other animals. The wonderful tail, his most characteristic feature, only attains perfection in the bird's third or fourth year, and then not until the month of June, remaining until October, when the feathers are shed to be renewed the following season. The food consists of insects, especially beetles and myriapods, as well as snails. The nest is generally placed near to or on the ground, at the base of a rock or foot of a tree, and is closely woven of fine but strong roots or other fibres, and lined with feathers, around all which is heaped a mass, in shape of an oven, of sticks, grass, moss, and leaves, so as to project over and shelter the interior structure, while an opening in the side affords entrance and exit. Only one egg is laid, and this of rather large size in proportion to the bird, of a purplish-grey colour, suffused and blotched with dark purplish. brown. ${ }^{1}$

Incubation is believed to begin in July or August, and the young is hatched about a month later. It is at first covered with white down, and appears to remain for some weeks in the nest. How much more is needed to be known for a biography of this peculiar and beautiful creature may be inferred by those who are aware of the diligence with which the habits of the much more easily observed birds of the northern hemisphere have been recorded, and of the many interesting points which they present. It is greatly to be hoped that so remarkable a form as the Lyrebird, the nearly sole survivor apparently of a very ancient race of beings, will not be allowed to become extinct-its almost certain fate so far as can be judged-without many more observations of its manners being made and fuller details of them placed on record. The zoologists of Australia alone can do this, and the zoologists of other countries expect that they will.

Several examples of Menura have been brought alive to Europe, but none have long survived in captivity. Indeed a bird of such

1 A nest and egg of Menurc alberti, now in the British Museum, are figured in Proc. Zool. Soc. 1853, Aves, pl. 53. The egg of $M$. victoriæ is represented in Journ. für Orn. 1856, pl. ii. fig. 18, under the name of $M$. superba, but the real egg of that species does not seem to have been figured at all. 
active habits, and dombtless requiring facilities for taking violent excreise, conld not possibly be kept long in confinement until the method of menageries is vastly improved, as doubtless will be the case some day, and, we may hope, before the disappearance from the face of the earth of forms of vertebrate life most instructive to the zoologist.

'Three species of Menure have been indicated-the old $I$. superba, the Lyre-bird proper, now known for neirly a century, which inhabits New South Wales, the sonthern part of Queensland, and perhaps some parts of the colony of Victoria; $M$. victoria, separated from the former by Gould (Proc. Zonl. Soc. 1S62, p. 23), and said to take its place near Melbourne; and $M$. alberti, first described by C. L. Bonaparte (Consp. Avium, i. p. 215) on Gould's authority; and, though discovered on the Richmond river in New South Wales, having appirently a more northern range than the other two. All those have the appirent bulk of a hen Pheasant, but are really much smaller, and their general plumage is of a sooty brown, lelieved by minous on the chin, throat, some of the wing-feathers, and the tail-coverts. The wings, containing twenty-

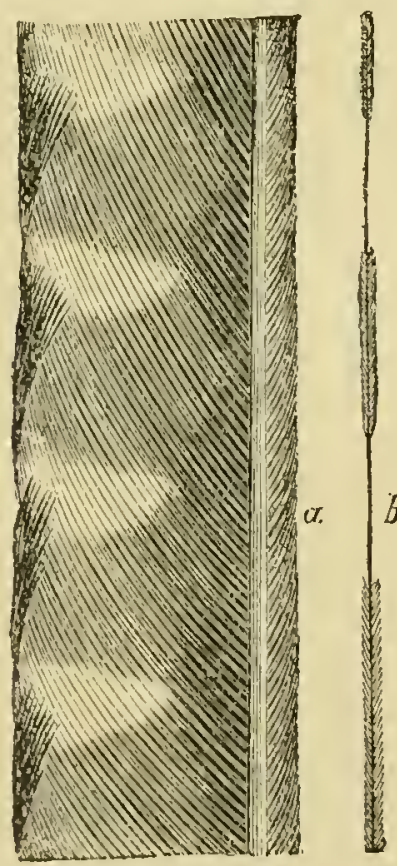

Fing. 1.

polition of Outer tailFEATITLi.

(u. in ordinary position.

b. seen edgeways.)

Menura supeiba.

one remiges, are rather short and rounded; the $\operatorname{legs}^{1}$ and feet very strong, with long, nearly straight claws. In the immature and female the tail is somewhat long, though affording no very remarkible character, except the possession of sixteen rectrices; but in the fully-plumaged male of $M$. superbu and $M$. victorise it is developed in the extraordinary fashion that gives the bird its common English name. 'The two exterior feathers (Fig. 1, a, b) have the onter web very narrow, the imer very broad, and they curve at first outwards, then sonewhat inwards, and neal the tip ontwirds again, bending round forwards so as to present a lyre-like form. But this is not all; their broad inner web, which is of a lively chestnut colour, is apparently notched at regular intervals by spaces that, according to the angle at which they are viewed, seem either black or transparent; and this effect is, on examination, found to be dne to the barbs at those spaces being destitute of barbules.

'The middle pair of feithers (Fig. 2,,,$b$ ) is nearly as abnormal. These have no onter web, and the inner web very narrow; near

1 The metatirsals are very remarkable in form, as already noticed by F.yton (loc. cit.), and their tendons strongly ossified. 
their base they cross cach other, and then diverge, beuding round forwards near their tip. The remaining twelve feathers (Fig. 3) except near the base are very thinly furnished with barbs, about a cruarter of an inch apart, and those they possess, on their greater

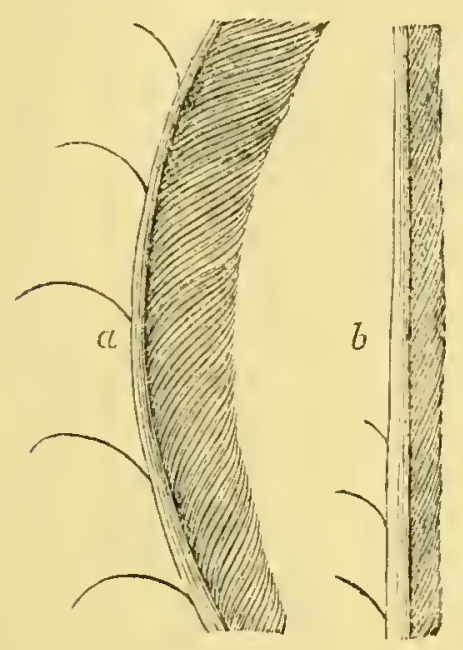

Fig. 2.

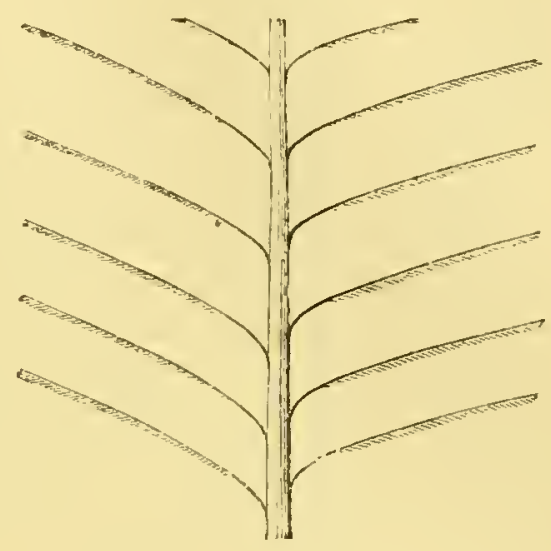

Fig. 3.

Portion of Midde Tail-feather.

Portion of Interiediate Tall-feather.

MENURA SUPERBA.

part, though long and flowing, bear no barbules, and hence have a hair-like appearance. The shafts of all are exceedingly strong. In the male of $M$. alberti the tail is not only not lyriform, but the exterior rectrices are shorter than the rest.

\section{M}

MACAT, or, as formerly spelt, MaC'CAW, the name given to about a score of species of large, long-tailed birds of the Order Psittaci (PARrot), natives of the Neotropical Region, and forming a very well-known and in some respects easily recognized group to which the generic designation Aru is usually applied by ornithologists, though some prefer for it Macrocercus or Sittece, while

1 Thus Willughby (1676), Onnithologia, p. 73; but an earhier form of the word is found in the "great blew and yellow Parrat called the Machao, or Cockatoon" of Cliarleton, Onomasticon, p. 66 (1668). Its derivation is shewn by De Laet, who, in his deseription of certain Brazilian birds (Novus Orbis, ed. 1633, 1. 556), has "inter alios [sc. Psittacos] excellunt magnitudine \& pulchritudine, quos barbar'i Arcicts \& Maceos vocant," and again (loe. cit.) "Tertium locm meretur Araruna rel Ifuchao." Webster, in his dictionary, says that Macaw, "written also Maccao," is "the native name in the Antilles," but gives no anthority for his statement, 
others break it up into three or four genera as is done by Count $T$. Salvadori (Cat. B. Br. Mus. xx. pp. 145-169). Most of the Macaws are remarkable for their gaudy plumage, which exhibits the brightest scarlet, yellow, blue and green in varying proportion and often in violent contrast, while a white visage often adds a very peculiar and expressive character. ${ }^{1}$ With one exception the known species inhabit the mainland of America from Paraguay to Mexico, being especially abundant in Bolivia, where no fewer than seven of them (or nearly one-half) have been found (Proc. Zool. Soc. 1879, p. 634). The single extra-continental species, $A$. tricolor, is one of the most brilliantly coloured, and is peculiar to Cuba, where, according to Dr. Gundlach (Ornitologia Cubana, p. 126), its numbers are rapidly decreasing, so that there is every chance of its becoming extinct. ${ }^{2}$

It will be enough here to dwell on the best-known species of the group, and first the Blue-and-yellow Macaw, $A$. ararauna, which has an extensive range in South America from Guiana in the east to Colombia in the west. Southwards it is replaced in Paraguay by the nearly allied $A$. caninde. Of large size, it is to be seen in almost every zoological garden, and is frequently kept alive in private houses, for its temper is pretty good, and it will become strongly attached to those who tend it. Its richly-coloured plumage, sufficiently indicated by its common English name, has the additional recommendation of supplying feathers which are eagerly sought by salmon-fishers for the making of "flies." Next may be mentioned the Red-and-blue Macaw, $A$. macao, which is even larger and more gorgeously clothed, for, beside the colours expressed in its ordinary appellation, yellow and green enter into its adornment. It inhabits Central as well as South America as far as Bolivia, and is also a

which, considering that now one West Indian island only is known to possess a Macaw (and that in that island the bird is known as Guacamayo), is very unlikely. Some of the older writers, Buffon (Oiseaux, vi. p. 278) for instance, say that Makavouanne was the name given by natives of Guiana to one species of Macaw found in that country; but the Antillean origin of the name cannot at present be accepted.

1 This serves to separate the Macaws from the long-tailed Parrakeets of the New World, Conurus, to which they are very nearly allied; and Count T. Salvadori (ut suprä) places them indeed in the same subfamily, which in that case should bear the name of Arinæ instead of Conurinx.

2 There is good reason to think that Jamaica formerly possessed a Macaw (though no example is known to exist), and if so it was most likely a peculiar species. Sloane (Voyage, ii. p. 297), after describing what he calls the "Great Maccaw" (A. ararauna, to be spoken of in the text), which he had seen in captivity in that island, mentions the "Small MIaccaw" as being very common in the woods there, and Gosse (B. Jamaiea, p. 260) gives, on the authority of Robinson, a local naturalist of the last century, the description of a bird which cannot be reconciled with any species now known, though it evidently must have been allied to the Cuban $A$. tricolor (see Extermination, p. 220). 
common bird in captivity, though perhaps less often seen than the foregoing. The Red-and-yellow species, $A$. chloroptera, ranging from Guatemala to Brazil, is smaller, or at least has a shorter tail, and is not quite so usually met with in menageries. The Red-and-green, A. militaris, smaller again than the last, is unfrequent in confinement, and presents the colours of the name it bears. This has the most northerly extension of habitat, occurring in Mexico and thence southwards to Bolivia. All the other species are comparatively rare in a reclaimed condition. Four of them, $A$. hyacinthina, $A$. leari, $A$. glauca, and $A$. spixi, are almost entirely blue, while in $A$. manilate and $A$. nobilis the prevailing colour is green, and $A$. severce is green and blue.

As is the case with most Neotropical birds, very little is known of the habits of Macaws in a state of nature. They are said to possess consiclerable power of flight, rising high in the air and travelling long distances in search of their food, which consists of various kinds of fruits; but of any special differences of behaviour we are wholly ignorant. The sexes appear in all cases to be alike in colouring, and the birds, though constantly paired, are said to live in companies. Like other Psittaci, they nest in hollow trees, and the eggs, asserted to be two in number, are white without any lustre. Of the habits of these birds in confinement it is needless to speak, as they are so extremely well known. If caged, their long tail-feathers are sure to suffer, but chained by the leg to a perch, Macaws seem to enjoy themselves as well as any captive can, and will live for many years.

MACCARONI, a seaman's name for one of the crested PENGUINs, Eudyptes chrysolophus, so-called probably at the time (circu 1769) when the word was a cant term for a fop or exquisite, with his hair dressed in extravagant fashion, this bird having its head more conspicuously attired than its congener $E$. chrysocome, the RockHOPPER, with which it often consorts (Ibis, 1860, p. 327).

MACKEREL-BIRD, -COCK, -GULL or -DIVER, local namesthe first for the Wryneck (Cecil Smith, B. Guernsey, p. 94), the second for the Manx SHEarwaTER, the third one of the numerous appellations of the RAzOR-BILL, and the last used on the coast of North America for a TERn ; but all referring to the appearance of their respective bearers being coincident with that of the wellknown Fish.

MACROCHIRES, Nitzsch's name in 1829 for a "Family" of Birds composed of the Trochili (Humaing-BIRD) and Cypseti (Swift).

MADGE, short for Margaret, a nickname of the Barn OwL, and also of the PIE; but 
MAGPIE is far more commonly applied to the latter, beside being used in combination as MAGPIE-LARK (GRALLINA), -ROBIN, -SHRIKE, and so on for many birds whose plumage is characterized by black and white.

\section{MAINA (Hindi), MINOR and MYNAH, see Grackle.}

MAIZE-BIRD, a local name for Agelæus phoniceus, often called the Red-winged Blackbird, and in Canada the Field-officer, one of the commonest and best known of the Icteride (ICTERUS).

MALEO, see MEgapode.

MALKOHA, according to J. R. Forster (Zool. Ind. 1781, p. 16) the Cingalese name of the Cuckow now known as Phonicophaes pyrhocephalus (see page 125), a species peculiar to Ceylon; but a name used by Jerdon (B. Ind. i. pp. 345, 346) and other AngloIndian ornithologists for birds belonging to allied forms such as Zanclostoma, Rhopodytes (cf. Shelley, Cat. B. Br. Mus. xix. 384) and others.

MALLARD, French Malart, the male of the common Wild Duck and its domesticated races.

\section{MALLEE-BIRD, a name given to Lipoa ocellata (MEGAPODE).}

MALLEMUCK, from the German rendering of the Dutch Mallemugge (which originally meant small flies or midges that madly whirl round a light), a name given by the early Dutch Arctic voyagers to the Fulmar, ${ }^{1}$ of which the English form is nowadays most commonly applied by our sailors to the smaller kinds of AlBatros, about as big as a Goose, met with in the Southern Ocean - corrupted into "Molly-mawk," or otherwise modified. ${ }^{2}$ There is some difference of opinion as to the number of species, and it is unfortunate that the results of the royage of the 'Challenger' do not clear up the doubts that have been expressed. Three have been described and figured, the Diomedea melanophrys and D. chlororhynchus for a long while, while the third, D. culminata, was discriminated by Gould (Proc. Zool. Soc. 1843, p. 107), who

1 The correct German form, as originally given by Friderich Martens (Spitzbergische oder Groentandische Reise Beschreibung, Hamburg: 1675, 4to, p. 68), is Mfallemucke. The anonymous translation of this voyage, under the title of An Account of several late Voyages and Discoveries to the South and North, published in London in 1694 (p. 93), was probably the means of the name becoming known to Ray, in whose Synopsis methodica Avium, published in 1713, it appears (p. 130) as Mallemuck, and thereafter kept its place in English ornithological works.

2 The application is of some standing and not confined to our own country. men, for it was mentioned in 1764 by Brïnnich (Orn. Boreal. p. 31, note). 
stated that the difference between it and the second is so apparent that he had no difficulty in distinguishing them on the wing. Capt. Hutton, on the other hand (Ibis, 1865, p. 283), considers all thrce to be specifically identical. Others, as appears by the Report on the Birds of the 'Challenger' voyage (pp. 148, 149), while regarding $D$. melanophrys as distinct, would seem to unite $D$. culminata with D. chlororhynchus. The first of these, says Gould, is the commonest species of Albatros inhabiting the Sonthern Ocean, and its gregarious habits and familiar disposition make it well known to every voyager to or from Australia, for it is equally common in the Atlantic and the Pacific. The back, wings and tail are of a blackish-grey, but all the rest of the plumage is white, except a dusky superciliary streak, whence its name of Black-browed Albatros, as also its scientific epithet, are taken. The bill of the adult is of an ochreous-yellow, while that of the young is dark. This species (supposing it to be one) is said to breed on the Falliland Islands and on Tristan da Cunha, but the latter locality seems questionable, for, according to Carmichael (Trans. Linn. Soc. xii. p. 490), D. chlororhynchus is the bird of this group there found; while the late Prof. Moseley (Notes of a Naturalist, p. 130) calls it D. culminata. ${ }^{1}$ Whatever it may be, the excellent observer just named describes it as making a cylindrical nest of grass, sedge and clay, with a shallow basin atop and an overhanging rim-the whole being about 14 inches in diameter and 10 in height. The bird lays a single white egg, which is held in a sort of pouch formed by the skin of the abdomen, while she is incubating. A few other details are given by him, but his visit was too hurried to enable him to ascertain the more important and interesting points in the economy of this Albatros which were neglected by his predecessor, Carmichael, during his four months' sojourn in 1816-17. D. culminata is said by Gould to be more plentiful in the Australian seas than elsewhere, numbers coming under his notice between Launceston and Adelaide, and being also frequently observed by him between Sydney and the northern extremity of New Zealand, as well as in the same latitude of the Indian Ocean. He describes its bill as having the greyish-yellow ridge broad and flat, while that of $D$. chlororhynchus is laterally compressed and the ridge round. All these birds seem to have much the same habits.

MANAKIN, from the Dutch word Manneken, applied to certain small birds, a name apparently introduced into English by Edwards (Nat. Hist. Birds, i. p. 21) in or about 1743 , since which time it has been accepted generally, and is now used for those which form the

$1 \mathrm{Mr}$. Sclater with commendable caution assigns no specific name to the eggs of the Diomedea found breeding on this island and its neighbour (Report, ut suprà, p. 151). 
Family Pipritie of modern ornithologists. The Manakins are peculiar to the Neotropical Region, and are said to have many of the habits of the Parida (Titmouse), living, says Swainson, in deep forests, associating in small bands, and keeping contimually in motion, but feeding almost wholly on the large soft berries of the different kinds of Melastoma. However, as with most other SonthAmerican Passerine birds, little is really known of their mode of life; and it is certain that the Piprida have no affinity to the Purida, but belong to the other great division of the Order Passeres, to which Garrod assigned the name Mesomyodr, and in that division, aecording to the same anthority, eonstitute, with the Cotingida (Chatterer), ${ }^{1}$ the group Heteroneri (Proc. Zool. Soc. 1876, p. 518). The Manakins are nearly all birds of gay appearance, generally exhibiting rich tints of blue, crimson, scarlet, orange, or yellow in combination with chestnut, deep black, black and white, or olive-green; and among their most obvious characteristics are their short bill and feeble feet, of which the onter toe is united to

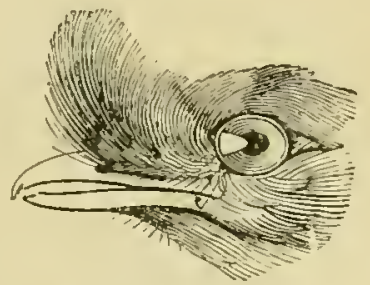

METOPIA GALEATA.

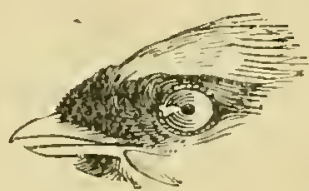

MACHEROPTERUS PEGULUS.

(After Swainson.)

the middle toe for a good part of its length. Some few, as IIetopiu, are crested. The tail, in most species very short, has in others the middle feathers much elongated, and in one, Helicura, the outer rectrices are attenuated and produced into threads. They have been divided by various authors into upwards of 20 genera, but Mr. Sclater (Cat. B. Br. Mrus. xiv. pp. 282-325) recognizes only 19, though admitting 70 species, of which 18 belong to the genus Pipra as now restricted, the $P$. leucocilla of Linnæus being its type." This species has a wide distribution from the isthnus of Panama to Guiana and the valley of the Amazon ; but it is one of the most plainly coloured of the Family, being black with a white head. The genus Macharopterus, consisting of 4 species, is very remarkable for the extraordinary form of some of the secondary wing-feathers in the males, in which the shaft is thickened and the webs changed in shape, as described and illustrated by Mr. Sclater (Proc. Zool. Soc. 1860, 1. 90 ; Tbis, 1862 , p. 175), and shewn in the accompanying figures, in the case of the beautiful $M$. deticiosus, and it has been observed that the

1 Excluding, however, the genus Rupicola (Cock-oF-THE-Rock), which has usually been placed among the Cotingidx. 
wing-bones of these birds are also much thickened, no doubt in correlation with this abnormal strncture. A like deviation from the ordinary character is found in the allied genus Manacus or Chiromacharis, comprehending 7 species, and that gentleman believes it enables them to make the singular noise for which they have for long been noted ( $c f$. SoNG), described by Mr. Salvin (Ilis, 1860, p. 37) in the case of one of them, M. candxi, as beginning "with a sharp note not unlike the crack of a whip, which is "followed by a rattling sound not mulike the call of a landrail "; and it is a similar" habit that has obtained for another species, $M$. edwurdsi, the name
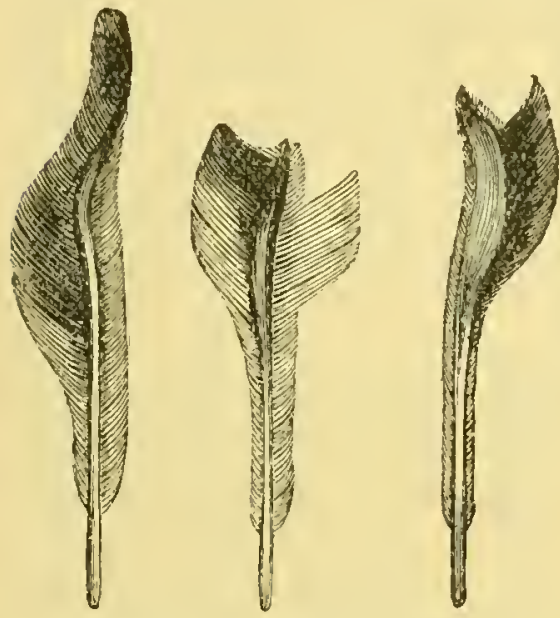

Fifth, Sixth, and Seventh Secondaries of THE Male MaCh 玉ropterUS DeLicioSUS: THE FIRST TWO FROM ABOVE, THE LAST FROM RENEATH.

(From the Procecdings of the Zoolarical Society, 1860, p. 90.)

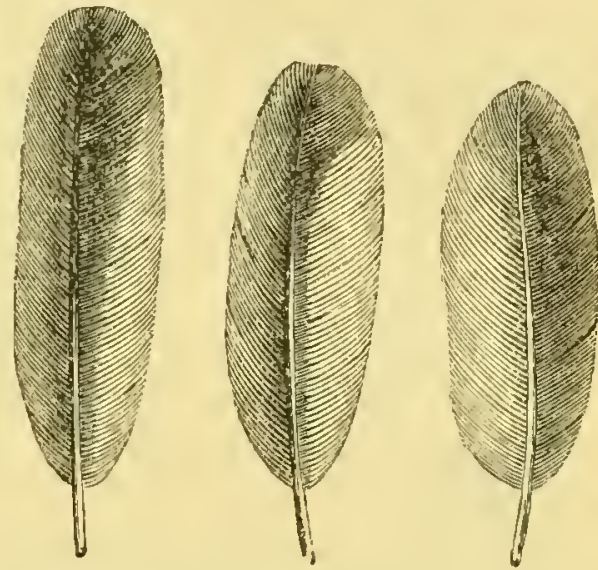

Corresponding Feathers of the Female, SHEWING THE SAME ASPECT.

in Cayenne, according to Buffon (Hist. Nat. Oiseaux, iv. p. 413), of C'assenoisette. This view is supported by Mr. Layard, who, writing of the last species, says (Ibis, 1873, p. 384)—"They make a curious rattling noise (I suspect, by some movement of the oddly shaped wing-feathers), which constantly betrays their presence in the forests," while of the congeneric $M$. gutturosus, Mr. J. F. Hamilton remarks (Ilis, 1871, p. 305) — "The first intimation given of the presence of one of these birds is a sharp whiring sound very like that of a child's small wooden rattle, followed by two or three sharp smaps." The same observer adds (loc. cit.) of a member of the kindred genus Chiroxiphic, containing 5 species, that $C$. caudata is known to the Brazilians as the Fandango-bird from its "habit of performing a dance." They say that "one perches upon a branch and the others arrange themselves in a circle round it, dancing up and down on their perches to the music sung [?] by the centre one." Exception must be taken to this story so far as regards the mode in which the "music" is produced, for these birds have no true song- 
muscles; but the effect is doubtless as described by Mr. Hamilton's informant.

MANDARIN DUCK, the name given, says Latham (Synops. ii. p. 549), by the English in China, to the beautiful species of that country, Ex galericulata of modern ornithology, figured by Edwards (Nat. Hist. Uncomm. B. pl. 102) in 1746, from a live bird in England; but it was clearly known to Aldrovandus (Orn. lib. xix. cap. 31) from a drawing of one brought to Rome in his time by Japanese envoys.

MANDIBLE (Lat. Mandibula) the lower jaw in Birds, consisting of an unpaired $V$-shaped piece which forms the tip, and some four or five paired pieces, one of which (os articulare) articulates with the quadrate bone, and another (os dentale) forms the upper margin of the side of the jaw. In such birds as the Parrots and Falcons which need a strong beak, all these pieces coalesce in one mass, in others as Ducks there remain sutures, or again as in Owls and Gulls, foramina (see Maxilla).

MANGO-BIRD, in Jamaica Lampornis mango, one of the Trochilidx (Hummng-BIRD); but in India an OrIole, Oriolus kundoo. but

MANGROVE-CUCKOIV, Coccyzus minor or seniculus of some;

MANGROVE-HEN is in Jamaica, and perhaps in other parts of the New World, Rallus longirostris or some other species of RAIL.

MAN-OF-IVAR BIRD, apparently the oldest English name of what is now called a FRIGATE-BIRD; but also occasionally applied to one or more of the smaller species of $S_{K U A}$, and not unfrequently to an Albatros.

MANUCODE, from the French, an abbreviation of Manucodiata, the Latinized form of the Malay Manuldewata, meaning, says Crawfurd (Malay and Engl. Dictionary, p. 97), the "bird of the gods," and a name applied for more than two hundred years apparently to BIRDS-OF-PARADISE in general. In the original sense of its inventor, Montbeillard (Hist. Nat. Oiseaux, iii. p. 163), Manucode was restricted to the King Bird-of-Paradise and three allied species; but in English it has curiously been transferred ${ }^{1}$ to

1 Manucodiata was used by Brisson (Omithologie, ii. p. 130) as a generic term equivalent to the Linnæan Paradisea. In 1783 Boddaert, when assigning scientific names to the birds figured by Daubenton, called the subject of one of them (Pl. entum. 634) DIanucodia chalybca, the first word being apparently an accidental curtailment of the name of Brisson's genus to which he referred it. Nevertheless some writers have taken it as evidence of an intention to found a new genus by that name, and hence the importation of Manucodia into scientific nomenclature, and the English form to correspond. 
a small group of species whose relationship to the Paradiseidic has been fiequently doubted, and must be considered uncertain. These Manucodes have a glossy steel-blue plumage of much beanty, but are casily distinguished from other birds of similar coloration by the outer and middle toes being united for some distance, and they are very remarkable for the extraordinary convolution of the trachea, in the males at least, with which singular structure is correlated their loud and clear voice. The convoluted portion of the trachea lies on the breast, between the skin and the muscles, much as is found in the females of the genus Pllynchau (SNIPE), in the males of the Cracida (Curassow), and in a few other birds, but wholly unknown elsewhere among the Passeres. The Manucodes are peculiar to the Papuan Subregion (including therein the peninsula of Cape York), and comprehend, according to Dr. Sharpe (Cat. b. Brit. Hus. iii. p. 164), two genera, for the first of which, distinguished by the elongated tufts on the head, he adopts Lesson's name Plonygoma, and for the second, having no tufts, but the feathers of the head crisped, that of Manucollia; and the late Mr. W. A. Forbes (Proc. Zoul. Soc. 1852, p. 349) observes that the validity of the separation (which has not yet been generally acknowledged) is confirmed by what is now known of their tracheal formation. Of Phonygama Dr. Sharpe recognizes three species, $P$. keraudreni (the type) and $P$. jamesi, both from New Guinea, and $P$. gouldi, the Australian representative species ; but the first two are considered by Mr. Elliot

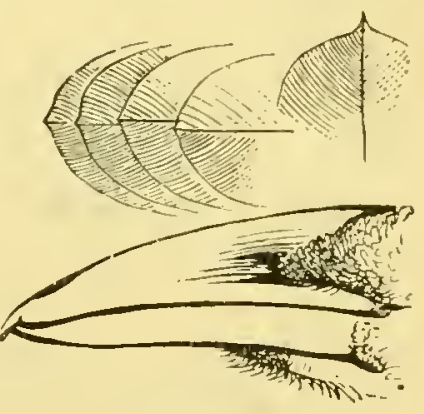

TAIL-FEATHERS AND BILL OF PhongGama.

(After Swainson.) (Tlis, 1878, p. 56) and Count T. Salvadori (Om. Papuces. ii. p. 510) to be inseparable. There is a greater unanimity in regard to the species of the so-called genus Manucodia proper, of which four are admitted-M. chalybeata or chalybea from northwestern New Guinea, M. comrii from the south-eastern part of the same country, $M$. atra of wide distribution within the Papuan area, and $M$. jobiensis peculiar to the island which gives it a name. Little is known of the habits of these birds, except that they are as already mentioned remarkable for their vocal powers, which, in P. Kerandreni, Lesson describes (Voy. 'Coquille,' Zool. i. p. 638) as enabling them to pass through every note of the gamut. Mr. Wallace (Anu. \& Mag. N. H. ser. 2, xx. p. 476) remarked that $M I$. atrce was very powerful and active, clinging suspended to the smaller branches of trees, on the fruits of which alone it appears to feed. $I$. gouldi, according to an informant quoted by Forbes (ut suprit), frequents in pairs the dense palm-forests, perching high up, uttering a very deep and lond guttural note ; it is graceful in its 
movements, evincing more curiosity than timidity on being approached. As with members of the Paradiseida generally, the nidification of the Mallucodes had been shrouded in mystery, until, as recorded by Mr. North (Rec. Austral. Mus. ii. p. 32, pl. vii.), the nest and eggs of $M$. comrii were found, in July 1891, by Mr. Rickard on Fergusson Island, one of the D'Entrecasteaux group, off the south-eastern coast of New Guinea.

\section{MARABOU-STORK, Leptoptilus crumenifer, see ADJUTANT.}

MARLIN, apparently a corrupt spelling of MERLIN, of which it is an ancient form, but applied in the east coast of North America with qualification to any species of CURLEW or GODWIT.

MARROCK or MARROT, one of the many local names of the Guillemot and Razor-BIll, perhaps also of the Puffin.

MARSH-HEN, used in North America for various species of RAIL; but especially, it would seem, for Rallus elegans and $R_{\text {. }}$. crepitans (Turnbull, Names \& Portr. B. pp. 125, 127).

MARTIN formerly MARTLET ${ }^{1}$ (French, Martinet and Martelet), the Hirundo urbica of Linnæus and Chelidon urbica of most modern ornithologists, ${ }^{2}$ a bird very well known throughout Europe, including even Lapland, where it is abundant, retiring in winter to the south of Africa. ${ }^{3}$ It also inhabits the western part of Asia, and appears from time to time in large flocks in India; but the boundaries of its range and those of some of its Eastern congeners cannot as yet be laid down. The Martin (or House-Mantin, as it is often called, to distinguish it from the Sand-Martin presently to be mentioned) commonly reaches its summer-quarters a few days later than the SWALLOW, whose habits its own so much resemble that heedless persons often disregard the very perceptible differences

1 Thus Shakespear-

" "Like the martlet,

Builds in the weather on the outward wall."

Merchant of Venice, Act ii. sc. 9.

But the older English form is, except in heralds' language, almost obsolete, and when used is now applied in some places to the SwIFT. The forms Martyn, Mertyn, and Morton are found printed in some Scottish Acts of Parliament, and from the context may be inferred to mean a Bird, but of what kind it is hard to guess.

2 Of late North-American writers have taken the words Chelidon and Hirundo in the opposite sense, which is puzzling to readers in the rest of the world.

3 After the publication of the account of this species in Yarrell's British Birds (ed. 4, ii. p. 354), the late Mr. Gurney informed me of a specimen obtained out of a migratory flock flying very high on the Qua'qua' river, lat. $19^{\circ} \mathrm{I} 0^{\prime} \mathrm{S}$., by the expedition of Messrs. Jameson and Ayres, 23rd October IS80, and the fact has since been recorded by Capt. Shelley (Ibis, 1882, p. 259). Mr. Fairbridge believes that he has lately found the species breeding in Cape Town. 
between them, the Martin's white rump and lower parts being conspicuous as it flies or clings to its "loved mansionry" attached to our houses, for, as Shakespear wrote-

"No jutty, frieze,

Buttress, nor coign of vantage, but this bird

Hath made his pendent bed and procreant cradle."

Macbeth, Act $\vdots$ sc. 6 .

This nest, made of the same material as the Swallow's, is, however, a far more difficult structure to rear, and a week or more is often occupied in laying its foundations - the builders clinging to the wall while depositing the mud of which it is composed. But, the base once securely fixed, the superstructure is often quickly added till the whole takes the shape of the half or quarter of a hemisphere, and a lining of soft feathers, mixed with a few bents or straws, fits it for its purpose. The Martin sets about building very soon after its return, and a nest that has outlasted the winter's storms is almost at once reoccupied; though if a new nest be needed its construction often involves great delay, for any excess of wet or drought retards the operation, and the work is often placed in such an exposed situation that heavy driving rains will wash away the half-dried walls. However, the bird mostly perseveres against these and other untowardnesses, contriving in the course of the summer to raise a second or even, though rarely, a third brood of offspring-but it is certain that the latest broods often die in the nest-apparently through failure of food. Yet examples of this species are observed in England every year so late as November, and there are several instances of their appearance within a few days of the winter solstice; but it is to be remarked that these late birds are almost certainly strangers, and not natives of the locality in which they are seen. ${ }^{1}$

The SAND-MARTIN, Hirundo riparia of Linnæus and Cotile riparia of modern writers, differs much in appearance and habits from the former. Its smaller size, mouse-coloured upper surface, and jerking flight ought to render it easily recognizable from the other British Hirundinidx; but through carelessness it is seldom discriminated, and, being the first of the Family to return to its northern home, the "early Swallow" of newspaper-writers would seem to be nearly always of this species. Instead of using a clay-built nest like the HouseMartin, this bird bores, with a degree of regularity and an amount

1 This is inferred from their not shewing themselves until some time after the departure of the regular inhabitants. Prof. Giglioli has recorded the appearance of C. cashmirensis in Italy (Avif. Ital. p. 187), though Count T. Salvadori (Uccell. Ital. p. 81) has expressed his doubt as to the determination of the specimen. It behoves all ornithologists to examine very critically examples of Martins obtained in Europe late in the year. 
of labour rarely excelled in its Class, horizontal galleries in a natural or artificial escarpment. When beginning its excavation, it clings to the face of the bank, and with its bill loosens the earth, working from the centre outwards, assuming all sorts of positions-as often as not hanging head downwards. The form of the boring and its length depend much on the nature of the soil ; but the tunnel may extend to 4, 6, or even 9 feet. The gallery seems intended to be straight, but inequalities of the ground, and especially the meeting with stones, often cause it to take a sinuous course. At the end is formed a convenient chamber lined with a few grass stalks and feathers, the latter always beautifully arranged, and upon them the eggs are laid. The Sand-Martin has several broods in the year, and is much more regular than other Hirundinidx in its departure for the south. The lind of soil needed for its nesting-habits makes it a somewhat local bird; but no species of the Order Passeres has a geographical range that can compare with this. In Europe it is found nearly to the North Cape, and thence to the Sea of Okhotsk. In winter it visits many parts of India, and South Africa to the Transvaal territory. In America its range is even still further, extending (due regard being of course had to the season of the year) from Melville Island to Caiçara in Brazil, and from Newfoundland to Alaska.

The Purple Martin of America, ${ }^{1}$ Progne sutis or purpurea, requires some remarks as being such a favourite bird in Canada and in the United States. Naturally breeding in hollow trees, it readily adapts itself to the nest-boxes which are very commonly set up for its accommodation; but its numbers are in some years and places subject to diminution in a manner which has not yet been satisfactorily explained. The limits of its range in winter are not determined, chiefly owing to the differences of opinion as to the validity of certain supposed kindred species found in South America; but according to some authorities it reaches the border of Patagonia, while in summer it is known to inhabit lands within the Arctic Circle. The male is almost wholly of a glossy steelblne, while the female is much duller in colour above, and beneath of a brownish-grey.

Birds that may be called Martins ${ }^{2}$ occur almost all over the world except in New Zealand, which is not regularly inhabited by any member of the Family. The ordinary Martin of Australia is the Hirundo or Hylochelidon nigricans of most ornithologists, and another and more beautiful form is the Ariel or Fairy-Martin of the same country, Hirundo or Lagenoplastes ariel. This last builds of mud a

1 In 1840 an example is said to have been killed at Kingstown in Ireland, the skin of which is in the Dublin Museum of Science and Art.

2 The Martin of the French colonists (in the Old World) is an Acridotheres (GRACKLE). 
bottle-shaped nest, as does also the Rock-Martin of Europe, Hirundo or Biblis rupestris; but space fails wherein to tell more of these interesting birds, which are treated of in the beautifully-illustrated monograph of Hirundinidx now in course of publication by Messrs. Sharpe and Wyatt.

MAVIS, Fr. Mauvis, ${ }^{1}$ a common local name of the Song-Thrush.

MAXILLA, a rather slender bone on each side of the anterior part of the head connecting the jugal with the premaxilla, and forming part of the lateral margin of what is often called the Upper Mandible, though the word Maxilla is frequently used to express the whole of the upper jaw. Its palatal processes are of considerable taxonomic value (see SKULL).

MAY-BIRD and MAY-FOWL, common names of the WHIMBREL in England, and the former given on the east coast of North America to the KNoT as well as to the BoBolink, while

MAY-COCK is, in places, applied to the Grey Prover, Squatarola helvetica; and

MAY-CHICK, according to Sir T. Browne, was used in Norfolk for some bird "a little bigger than a Stint, of fatness beyond any." This last seems to be obsolete; but all doubtless refer to the month in which the birds bearing the names appeared.

MEADOW-CHICKEN and MEADOW-HEN, names given in North America to more than one species of RaIL or Coot ; but the

MEADOW-LARK of the same country is Sturnella magna (see ICTERUS).

MEGAPODE, the name given generally to a small but remarkable Fanily of birds highly characteristic of some parts of the Australian Region, to which it is almost peculiar. The Megapodiida with the Cracidx form that division of Gallinx named by Prof. Huxley Peristeropodes (Proc. Zool. Soc. 1868, p. 296), and morphologically seem to be the lowest of the Order, with which apparent fact may perhaps be correlated their singular habit of leaving their eggs to be hatched without incubation, either burying them in the ground (as many Reptiles do) or heaping over them a mound of earth, leaves,

1 Now applied chiefly to the REDwING, Turdus iliacus, but also to the Crested LARK, and the Mauviette of French cookery is always a Lark. The old Norman form, whence we probably get our word, is said to be Maulvis (Gasté apud Rolland, Furune Pop. Fr. p. 243). According to Littré its origin is uncertain; some supposing it to be the Low Latin Malvitius (= malum vitis, or scourge of the vine, the Neapolitan Marvizzo), others allege the Low Breton Milvid (a Gull) or Mithuez (a Lark). The Walloon Mavi or Maiwi, according to Baron de SelysLongchamps a BLACKBIRD, is evidently the same word. 
and rotten wood. ${ }^{1}$ This habit attracted attention more than three hundred years ago, ${ }^{2}$ but the accounts given of it by various travellers were generally discredited by naturalists, ${ }^{3}$ and as examples of the birds, probably from their unattractive plumage, appear not to have been brought to Europe, no one of them was seen by any ornithologist or scientifically described until near the end of the first

1 Hence the name of Mound-BIRDs given to them by some writers.

$\because$ Antonio Pigafetta, one of the survivors of Magellan's glorious but disastrous voyage, records in his journal, under date of April 1521, among the peculiarities of the Philippine Islands, then first discovered by Europeans, the existence of a bird there, abont the size of a Fowl, which laid its eggs, as big as a Duck's, in the sand, and left them to be hatched by the heat of the sun (Primo Viaggio intorno al Globo, ed. Amoretti, Milano: 1800, p. 72 ; Fr. transl. Premier Voyage autour du Monde, Paris: A.R. ix. p. 88). More than one hundred years later the Jesuit Nieremberg, in his Historia Natura, published at Antwerp in 1635, described (p. 207) a bird called "Daie," and by the natives named "Tapun," not larger than a Dove, which, with its tail (!) and feet, excavated a nest in sandy places and laid therein eggs bigger than those of a Goose. The publication at Rome in 1651 of Hernandez's Hist. Avium Noræ Hispaniæ shews that his papers must have been accessible to Nieremberg, who took from them the passage just mentioned, but, as not unusual with him, misprinted the names which stand in Hernandez's work (p. 56, cap. 220) "Daic," and "Tapum" respectively, and omitted his predecessor"s important addition "Viuit in Philippicis." Not long after, the Dominican Navarrete, a missionary to China, made a considerable stay in the Philippines, and returning to Europe in 1673 wrote an account of the Chinese empire, of which Churchill (Collection of Voyages and Travels, vol. i.) gave an English translation in 1704. It is therein stated (p. 45) that in many of the islands of the Malay Archipelago "there is a very singular bird call'd Tabon," and that "What I and many more admire is, that it being no bigger in Body than an ordinary Chicken, tho' long legg'd, yet it lays an egg larger than a Gooses, so that the egg is bigger than the bird itself. . . . In order to lay its Eggs, it digs in the Sand above a yard in depth; after laying, it fills up the hole and makes it even with the rest; there the Eggs hatch with the heat of the Snn and Sand." He adds further information which need not be quoted here. Gemelli Careri, who travelled from 1663 to 1699, and in the latter year published an account of his voyage round the world, gives similar evidence respecting this remarkable bird, which he calls "Tavon," in the Philippine Islands (Voy. du tour du Monde, ed. Paris: 1727, v. pp. 157, 158). The Megapode of Luzon is fairly described by Camel or Camelli in his observations on the Birds of the Philippines communicated by Petiver to the Royal Society in 1703 (Phil. Trans. xxiii. p. 1398). In 1726 Valentyn published his elaborate work on the East Indies, wherein (deel iii. bk. v. chap. ii. p. 320) he very correctly describes the Megapode of Amboina under the name of Moelcoe or Malleoe, and also a larger kind found in Celebes, so as to shew he had in the course of his long residence in the Dutch settlements become personally acquainted with both.

3 This Willughby (Ornithologia, p. 297), or Ray for him, who had, however only Nieremberg's evidence to cite, and they can scarcely be blamed for their hesitation, considering the number of other marvels narrated by the same worthy father. Buffon also (Oiscaux, ix. p. 436) was just as sceptical in regard to the relation of Careri. 
quarter of the present century. The first member of the Family to receive authoritative recognition was one of the largest, inhabiting the continent of Australia, where it is known as the BRUsH-TURKEY, and was originally described by Latham in 1821 under the name of the New-Holland Vulture, a misleading designation which he subsequently tried to correct on perceiving its Galline character. It is the Talegallus lathami of modern ornithologists, and is nearly the size of a hen Turkey. Six smaller species of the same genus have since been described, all from New Guinea or the neighbouring islands, but two of them, T. pyrrhopygius and T. bruyni, have been separated to form a group Apypodius. The Australian bird is of a sooty-brown colour, relieved beneath by the lighter edging of some of the feathers, but the head and neck are nearly bare, beset with fine bristles, the skin being of a deep pinkisk-red, passing above the breast into a large wattle of bright yellow. The tail is commonly carried upright and partly folded, something like that of a domestic Fowl.

The next form of which we may speak is another inhabitant of Australia, commonly known in England as the MALLEE-BIRD, but to the colonists as Lowan and "Native Pheasant"- - the Lipoa ocellata first described by Gould (Proc. Zool. Soc. 1840, p. 126), which has much shorter tarsi and toes, the head entirely clothed, and the tail expanded. Its plumage presents a pleasing combination of greys and browns of various tints, interspersed with black, white, and buff, the wing-coverts and feathers of the back bearing each near the tip an oval or subcircular patch, whence the trivial scientific name of the bird is given, while a stripe of black feathers with a median line of white extends down the front of the throat, from the chin to the breast. There is but one species of this genus known, as is also the case with the next to be mentioned, which is a singular bird long known to inhabit Celebes, but not fully described until $1846,{ }^{1}$ when it received from Salomon Müller (Arch. f. Naturgesch. xii. pt. 1, p. 116) the name of Macrocephalon maleo, but, being shortly afterwards figured by Gray and Mitchell (Gen. Birds, iii. pl. 123) under the generic term of Megacephalon, has since commonly borne the latter appellation. This is a very remarkable form, bearing a helmet-like protuberance on the back of its head, all of which as well as the neck is bare and of a bright red colour; the plumage of the body is glossy black above, and beneath roseate-white.

Of the Megapodes proper, constituting the genus Megapodius, many species have been described, but authorities are greatly at variance as to the validity of several, and here it would be impossible to name all that have been supposed to exist. Some are only

1 As we have seen, it was mentioned in 1726 by Valentyn, and a young example was in 1830 described and figured by Quoy and Gaimard (Voy. 'Astrolabe': Oiseaux, p. 239, pl. 25) as the Megapodius rubripes of Temminck, a wholly different bird. 
known from very young examples-mere chickens; and some have even been described from their eggs alone. In $1870 \mathrm{Mr}$. G. R. Gray enumerated 20 species, of which 16

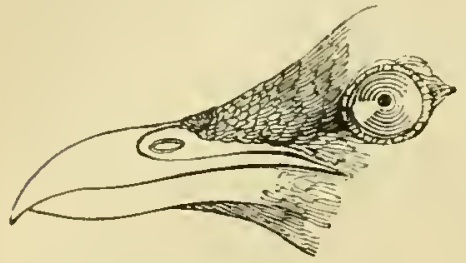

BILL OF MEgapoDIUS. (After Swainson.) were represented in the British Museum, and several have, been described since; but ten years later Schlegel recognized only 17 species, of which examples of 12 were contained in the Leyden Mnsenm (Mus. des Pays-Bas, viii. Monogr. 41, pp. 56-86), while M. Oustalet, in his elaborate monograph of the Family ( $1 \mathrm{nn}$. Sc. Nat., Zool. ser. 6, x. and xi.), admits 19 species. The birds of this genus range from the Samoa Islands in the east, through the Tonga group, to the New Hebrides, the northern part of Australia, New Guinea and its neighbouring islands, Celebes, the Pelew Islands, and the Ladrones, and have also outliers in detached portions of the Indian. Region, as the Philippines (where indeed they were first discovered by Europeans), Labuan, and even the Nicobars-though none are known from the intervening islands of Borneo, ${ }^{1}$ Java, or Sumatra. Within what may be deemed their pioper area they are found, says Mr. Wallace (Geogr. Distr. Anim. ii. p. 341) " on the smallest islands and sand-banks, and can evidently pass over a few miles of sea with ease." Indeed proof of their roaming disposition is afforded by the fact that the bird described by Lesson ( Voy. 'Coquille,' Zool. p. 703) as Alecthelic urvillii, but now considered to be the young of $M$. freycineti, flew on board his ship when more than two miles from the nearest land (Guebé), in all exhausted state, it is true, but that may be attributed to its extreme youth. The species of Megupodius are about the size of small Fowls, the head generally crested, the tail

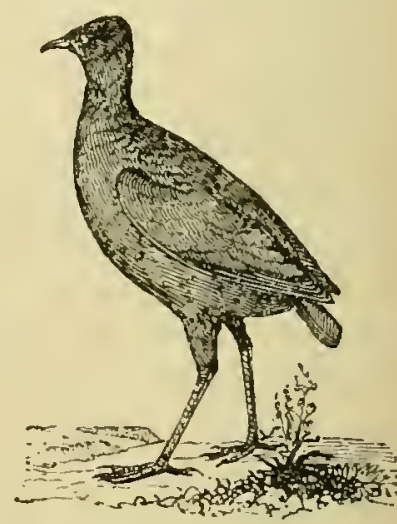

MEgapodius FRETCINETI. (After Swainson.) very short, the feet enomonsly large, and, with the exception of MI. wullacii (Proc. Zool. Soc. 1860, Aves, pl. 171) from the Moluceas, all have a sombre plumage.

The extraordinary habit possessed by the Megapodes generally of relieving themselves of the duty of incubation, as before mentioned, -a habit which originally attracted the attention of travellers, whose stories were on that very account discredited, - as well as the highly developed condition of the young at birth, has been so fully

1. 1T. cumingi occurs on Labnan and other islands off the north coast of Borneo, and it is recorded (Proc. Zool. Soc. 1881, p. 800) from Sandakan, but confirmation of the statement is desirable. 
described, ${ }^{1}$ and so often repeated by other writers, as to be very commonly known, and here there seems no necessity to enter into further details concerning it.

MEGGY, properly an abbreviation of Margaret, a nickname of the WhIteTHRoat ; but perhaps a corruption of MUGGY.

MEGISTANES, Vieillot's name in 1816 (Analyse, p. 53) for a group containing the four genera of Ratite birds then known, Struttio, Rhea, Casuarius, and Dromaus, and since applied (Ann. \& Mag. N. H. ser. 4, xx. p. 500) to the Order composed of the two last (Cassowary, EmeU).

MELANISII (adj. melanistic) the abnormal occurrence of black or very dark coloured plumige (see Colour, p. 99, and Heterochrosis, p. 420).

MERGANSER, a word originating with Gesner (Hist. Anim. iii. p. 129) in 1555, and for a long while used in English as the general name of a group of fish-eating Ducks which possess great diving powers, and form the genus Mergus of Linnæeus, now regirded by ornithologists as a subfamily, Mergina, of the Family Anutidx. They have a long, narrow bill, with a small but evident hook at the tip, and the edges of both mandibles beset by numerous horny denticulations, whence the name of "Saw-bill" is

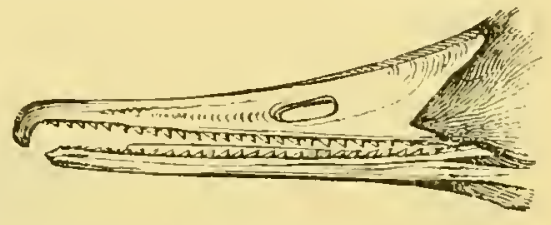

Bill ow Mergus. (After Swaiuson.) frequently applied to them. Otherwise their structure does not much depart from the Anatine or rather Fuliguline type. All the species bear a more or less developed crest or tuft on the head. Three of them, Mergus mergunser or custor, $M$. serrator; and $M$. albellus, are found over the northern parts of the Old World, and of these the first two also inhabit North America, which has besicles a fourth speeies, $M$. cucullatus, said to have occasionally visited Britain. M. merganser, the GoOSANDFR, is the largest species, being nearly as big as the smaller Geese, and the adult male in breeding-attire is a very beautiful bird, conspicuous with his dark glossy-green head, rich salmoncoloured breast, and the upper part of the body and wings black and white. This full plumage is not assumed till the second year, and in the meantime, as well as in the postnuptial dress, he much lesembles the female, having, like her, a reddish-brown head, the upper parts greyish-brown, and the lower dull white. In this condition the bird is often known as the "Dun Diver." This species

1 See Gould, Handb. B. Austral. ii. Pl. 152-175; G. R. Gray, Proc. Zool. Soc. 1S61, pp. 292-296 ; Wallace, Malay Archipelago, i. PT. 415-419; ii. I1). 147-149; Guillemard, Cruise of the 'Marchesa,' ii. pp. 193-197 with fig. ; Hichson, Naturalist in North Celebes, pp. 94, 95. 
breeds abundantly in many parts of Scandinavia, Russia, Siberia and North America, and of late years has been found to do so in Scotland, usually making its nest in the stump of a hollow tree or under a slab of rock. M. serrator, commonly called the Red-breasted Merganser, is a somewhat smaller bird; and, while the fully-dressed male wants the delicate hue of the lower parts, he has a gorget of rufous mottled with black, below which is a patch. of white feathers, broadly edged with black. The male at other times and the female always much resemble the preceding. It is more numerous than the Goosander, with a somewhat more southern range, and is not so particular in selecting a sheltered site for its nest. Both these species have the bill and feet of a bright reddish-orange, while $M$. albellus; known as the SMEw, has these parts of a lead colour, and the breeding-plumage of the adult male is white, with quaint crescentic markings of black, and the flanks most beautifully vermiculated - the female and male in undress having a general resemblance to the other two already described-but the Smew is very much smaller in size, and, so far as is known, it invariably makes its nest in a hollow tree, as ascertained first by Wolley (Ibis, 1859, pp. 69 et seq.) This last habit is shared by $M$. cucullatus, the Hooded Merganser of North America, in size intermediate between $M$. albellus and $M$. serrator, the male of which is easily recognizable by his broad semicircular crest, bearing a fan-shaped patch of white, and his elongated subscapulars of white edged with black. The conformation of the trachea in the male of $M$. merganser, $M$. serrator, and $M$. cucullatus is very like that of the Ducks of the genus Clangula, but $M$. albellus has a less exaggerated development more resembling that of the ordinary Fuligula. ${ }^{1}$ From the southern hemisphere two species of Mergus have been described, $M$. octosetaceus or brasilianus, Vieillot ( $N$. Dict. d'Hist. Nat. ed. 2, xiv. p. 222 ; Gal. des Ois. ii. p. 209, pl. 283), inhabiting South America, of which but few specimens have been obtained, having some general resemblance

1 Four hybrids between, as is presumed, M. albellus and Clangula glaucion, the GoLDFY-EYE, have been described and figured (Eimbeck, Isis, 1831, 300; tab. iii. ; Brehm, Naturgesch. aller Vög. Dentschlands, p. 930 ; Naumann, Vög. Deutschlands, xii. p. 194, frontispiece ; Kjærbölling, Jour. für Ornithologie, 1853, Extraheft, p. 29, Naumannia, 1853, p. 327, Ornithol. Danica, tab. Iv. suppl. tab. 29; F. Schmidt, Arch. Naturgeseh. Neeklenb. 1875, p. 145 ; Wolschke, VII. Jehresher. Annab.-Buchholz. Ver. für Naturk. ; Kolthoff, Afvers. K. Vet.Al. Förh. 1884, p. 185, pls. xxxi. xxxii.) sometimes under the names of Hergus anatarius, Clangula angustirostris, and Anas (Clangula) mergoides, as though they were a distinet species; but the remarks of Baron de SelysLongchamps (Bull. Ac. Sc. Brux. 1S45, pt. ii. p. 354, and 1856, pt. ii. p. 21), and Prof. R. Blasius (Monatsschr. Ver. zu Schutz. der Vogelwelt, 18s7) leave little room for doubt as to their origin, which, when the cryptogamic habit and common range of their putative parents, the former unknown to the author named last but one, is considered, will seem to be still more likely. 
to $M$. serrator, but much more darkly coloured; and $M$. australis, Hombron and Jacquemont (Amn. Sc. Nat. Zoologie, ser. 2, xvi. p. 320 ; Voy. an Pol Sul, Oiseuur, pl. 31, fig. 2), long known only by the unique example in the Museum of Paris procured by the French Antaretic expedition in the Anckland Islands; but of which Baron A. von Higel (Itis, 1875 , p. 392), obtained two other specimens, and gave one to the British Museum (Proc. Zoul. Soc. 1881, p. 1), and the other to that of the University of Cambridge. This last species may perhaps be found to visit New Zealand.

Often associated with the Mergansers is the genus Merganetta, the so-called Torrent-Ducks of South America, of which three species are said to exist; but they possess spiny tails and have their wings armed with a spur. Whether they should be referred to the Mergina or the Erismaturina-the Spiny-tailed Ducks proper-is a question that further investigation must decide.

MERLE, the French name of the Blackbirs (Lat. Merula), perhaps introduced by the Normans, but scarcely used now as English except in fiction.

MERLiN, Old Eng. Marlin and Marlion; Old Fr. Esmerillon

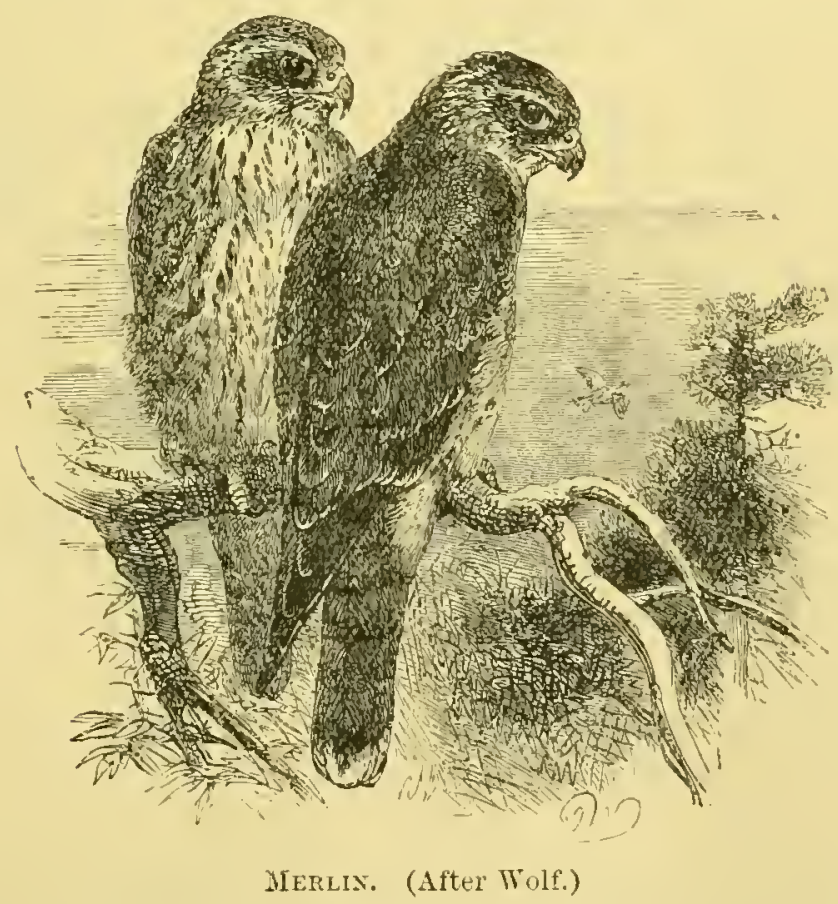

and Smirlon, Mod. Fr. Émerillon, ${ }^{1}$ the Falco asalon of Tunstall,

1 The Icelandic Smirill (a comparatively modern word, as Mr. Eiríkr Magnússon tells me), the German Schmerl and corresponding words in Italian, Spanish and Portuguese are all evidently cognate with the French, the root being the Latin Merula as in Mericl: 
in 1771 , and ornithologists generally, ${ }^{1}$ but the $F$. lithofalco ${ }^{2}$ of some-one of the most beautiful of the Falconida (FALCON) and perhaps the boldest of the Accipitres, not hesitating to attack birds of twice its own size, and even on occasion threatening human beings. Yet it readily becomes tame, if not affectionate, when reclaimed, as it often is for Falconry, and its ordinary prey consists of the smaller Passeres. Its "pinion of glossy blue" has become almost proverbial, and a deep ruddy blush suffuses its lower parts; but these are characteristic only of the male-the female maintaining very nearly the sober brown plumage she wore when as a nestling she left her lowly cradle in the heather. It breeds or used to breed commonly on the moors of the northern parts of England and on those of Scotland, as well as on the mountainous districts of Ireland; but of late years has been much reduced in numbers. In winter the young frequent the lower levels in all three kingdoms, and strike terror into the small birds that congregate at that season. Very close to this bird comes the PigeonHawk, $F$. columbarius, of North America-so close, indeed, that none but an expert ornithologist can detect the difference. The Turumti of Anglo-Indians, $F$. chicquera, and its representative from Southern Africa, $F$.ruficollis, also belong to this group, but they are considerably larger than either of the former.

MEPOBLASTIC, the term applied to the ova of certain Vertebrates, including Birds, in which the process of segmentation is confined to the germinal disk (see Embryology, p. 196).

MERPY-IVING, a North-American fowler's name for the GOLDEN-EYE.

MERTYN, an old Scottish spelling of MARTIN.

MESENTERY, the thin trinsparent membrane composed of layers of connective tissue that holds together the various loops of the intestine and other viscera, attaching them to the vertebral column where it is continuous with the peritoneal lining of the body cavity.

MESOBLAST, the middle layer of the three into which the blastoderm subdivides (see Embriologr, p. 200).

MESOMYODI, Garrod's name (Proc. Zool. Soc. 1876, p. 507), for a division of Passerine birds the peculiarities of which were first to some extent though not fully appreciated by Johannes Müller (see Introduction) — "a mesomyodian bird being one in which the muscles of the SrRINx join the semi-rings in their

1 Modern American authors eall it Falco (or - Esalon) regulus, a name given in 1773 by Pallas (Reise, u.s.u. ii. p. 707).

2 This from the common German name Steinfalk. 
middles," while in the other division, Acromyod, the syringeal museles are attached to their extremities. Garrod further divided the Mesomyodi into Homoroneri, comprehending TracheoPHONE and HAPLOOPHONe, and HeTEROMERI. Mesomyodian Families are most eharacteristic of the Neotropical Region, all but three, Pittidx, Philepittidx and Acanthidosittidx, being, so far as is known, peculiar to the New World.

MET ACARPUS, generally used in Ornithology for the portion of the wing from the wrist (CARPUS) to the root of the fingers, but since the distal carpal bones coalesce with the proximal end of the metacarpals, this part should strictly be called carpo-metacarpus (see Hand under Skeletor).

METATARSUS, by Onnithologists often applied to that part of the foot which reaches from the ankle-joint to the root of the toes and is commonly but wrongly ealled the TARSUs; the distal tarsal bones coalescing with the proximal end of the metatarsals (see Foot under Skeleton).

MEIT, Angl.-Sax. Maw, see Gull.

MIGRATION. Strangely confounded by many writers with the subject of Geographical Distribuizon is that of Migration. True it is that owing to the vast powers of locomotion possessed by nearly all Birds, we have individuals belonging in the main to certain groups, but by no means always eonfined to them, straying from their proper quarters and occurring in places far remored, not only from the land of their birth, but from the eountry whither they are ordinarily bound in their journeys, to reach which is the object wherefore such journeys are undertaken. It may be that in some measure this erraticism is governed by fixed laws, and indeed indication is not wanting that such laws exist, though as yet we know much too little to lay them down with any approach to confidence. But it is obvious on reflection that granting the existence of most rigorous laws of this kind-determining the flight of every winged vagabond - they must be very different from those which are obeyed by Birds commonly called "Nigratory," and year after year moving, according to a more or less fixed rule, from one locality to another with the seasons as they roll. The former laws would seem to be created or controlled by purely external circumstances, which if they possess any periodicity at all possess a periodicity of cycles, and are most likely dependent in the main on cycles of the weather, but on this point observation has not yet supplied us with the means of avoiding speculation. We may indeed say almost without much risk of error that so many individuals of a foreign species-whether North-American or Asiatic -will occur in Great Britain so many times in the course of a 
term of years; but, though we may safely predict that if they appear at all they will do so at a certain season, it is impossible to make a forecast as to the year in which an example will arrive, or whether in one year some half-dozen may or may not occur. The matter thus becomes a matter of averages, and like all such is open to the influence of many perturbants, not that such may not well be subject to some law of which we are ignorant. Beside this, the average is hard to strike, depending as it must on the existence of farourably-placed and watchful observers. Moreover if we consicler that the number of competent observers, though possibly as great in England as anywhere, has been at all times small, it is not surprising that little has been effected towards the compassing of any definite notion on this head. At present we can but attribute the appearance of some foreign stragglers on our shores, and no doubt the same may be said of other countries, to the influence of storms which have driven the wanderers from their course, and though other more remote causes may possibly be assigned, there seems to be none but this on which we can safely rely. Consequently until the periodicity of storms is brought within our knowledge we must be content to abide in our ignorance of the laws which govern the appearance of the strangers. Still confining our remarks to the British Islands, the effect of these laws is in some degree constant. Singular as it may appear, the greatest number of North-American Birds - and especially of the Limicolx, which are recorded as having occurred in this country have been met with in the eastern part of England or Scotland. There are two ways of accounting for this fact, the first of which is the comparative scarcity of observers in Ireland and on its western coast especially, and this is by no means to be overlooked; but it may be remarked that in no part of the United Kingdom is the profession of the gunner more enthusiastically followed than in the sister-island, and the men who pursue that vocation are all alive to the mercantile value of any strange bircl which may fall in their way. Of course they have no means of knowing what it is, yet as their spoils are sent for sale to the nearest market, it cannot but happen that if many examples of North-American species were procured by them, some proportion of these would find their way to the notice of the amateur naturalist and by him be recorded in the public prints. ${ }^{1}$ Now, as compared with Great Britain, this so rarely occurs in Ireland that it is by no means unfair to draw the inference that Transatlantic Birds are there far less frequently met with. The second mode of accomnt-

1 It seems also not unlikely that the very scarcity of rare birds in Ireland is one reason why there are so few ornithologists in that country, for here it is not uncommon for a man to have his attention first called to zoology by meeting with some strange animal-be it beast, bird, beetle, or butterfly, and for such a man afterwards to become no mean field-naturalist. 
ing for the fact above stated is that the majority of North-American Birds which occasionally visit Europe are of species which breed in somewhat high northern latitudes. On their way thence to their winter-quarters, some are driven out to sea by violent westerly gales-the strongest winds, be it remembered, that prevail in the North Atlantic, and thus strike the coast of Norway. ${ }^{1}$ In that country observer's may be said to be practically absent, and fowler's as a rule unknown. Such storm-beaten wanderers there consort with the allied species to be found at that season in abundance on its shores, and in their company pursue the same southerly course. With them they cross to the east of Great Britain, and once arrived here are speedily picked out and secured by the practised gumner. But should they even escape his notice, they with their comracles follow the shore-line, where they obtain the best supply of food, until passing round the south coast they find themselves at the western extremity of England-the district of the Land's End, in which, next to Norfolk and Suffolk, the greatest number of these Transatlantic stragglers have been obtained. This suggestion may serve to shew what most likely goes on in other parts of the world, though the materials for establishing its general truth are not forthcoming.

But returning to the subject of Migration proper, distinguished as it ought to be from that of the more or less accidental occurrence of stray visitors from afar, we have here more than enough to excite our wonder, and indeed are brought face to face with perhaps the greatest mystery which the whole animal kingdom presents-a mystery which attracted the attention of the earliest writers, and can in its chief point be no more explained by the modern man of science than by the simple-minded savage or the poet or prophet of antiquity. Some facts are almost universally known and have been the theme of comment in all ages and in all lands. The Hawk that stretches her wings toward the south is as familiar to the latest Nile-boat traveller or dweller on the Bosphorus as of old to the author of the book of Job. The autumnal thronging of myriads of Waterfowl by the rivers of Asia is witnessed by the modern sportsman as it was of old by Homer. Anacreon welcomed the returning Swallow in numbers which his imitators of the colder north, to whom the associations connected with it are doubly strong, have tried in vain to excel. The Indian of the FurCountries in forming his rude calendar names the recurring moons after the Birds-of-passage whose arrival is coincident with their changes. But there is no need to multiply instances. The flow and ebb of the feathered tide has been sung by poets and discussed by philosophers, has given rise to proverbs and entered into popular

1 Prof. Baird's remarks on this subject are much to the point ( $A$ n. Journ. So. ser. 2, xli. pp. 344,345$)$. 
superstitions, and yet we must say of it still that our "ignorance is inmense."

On one point and one only in connexion with this subject can we boast ourselves to be clearly wiser than our ancestors. Some of them fully believed that the seasonal disappearance of the Swallow, the Nightingale, the Cuckow, and the Corncrake was due to what is commonly called "hibernation," that is to say, passing the winter in a torpid condition, while others indeed doubted whether or not this was the true explanation of the fact. It is not so long since this belief and these doubts were in vogue, but now assuredly they have no hold upon the mind of any one capable of appreciating evidence, and this absurd fancy being exploded need not again trouble us. Yet it recurs again and again to those who will not take the trouble to reason, and even to some thinling persons who cannot rid themselves of prejudice. Scarcely a year passes but an instance of this credulity presents itself to the writer, either in some public print or in a private communication. Of the same kind is the equally ancient belief that little birds get themselves conveyed from one country to another by their bigger brethren. Storks and Cranes on their Migration are manifest tô beholders, but the transit of lesser birds of feebler flight is seldom evident, and when, as often happens, large and small birds disappear or arrive simultaneously, what is more natural than that the ignorant should suppose that the latter avail themselves of the former as a vehicle? Thus in 1740 the Tartars of Krasnojarsk and the Assanians assured J. G. Gmelin (Pieise durch Sibirien, iii. pp. 393, 394) that when autumn came each Crane took a Corncrake on its back and transported it to a warmer land, ${ }^{1}$ while the well-known belief of the Egyptian peasant that Cranes and Storks bring a living load was not long since gravely promulgated in this country as a truth!

In considering the phrnomena of Migration it will be best first to take the facts, and then try to account for their cause or causes. That a very large number of Birds all over the world change their abode according to the season is well known, and we find that in all temperate countries there are some species which arrive in spring, remain to breed, and depart in autumu; others which arrive in autumn, stop for the winter, and depart in spring; and other's again - and these are strictly speaking the "Birds of Passage"which shew themselves but twice a year, passing through the country without staying long in it, and their transient visits take place about spring and autumn. People who have given but little thought to the subject are apt to suppose that these migrants, which may thus easily be classed in three categories, are acted upon by influences of different kinds, whereas very little reflection

1 This passage has been adverted to by Buffon (Hist. Nat. Ois. viii. p. 150) and Pallas (Zoogr. Toss. -Asiat. ii. p. 153). 
will shew that all are really affected by the same impulse, what ever that may be, and that the nature of their movements at first sight so dissimilar is in truth almost uniform. The species which resort to this and to other temperate countries in winter are simply those which have their breeding-quarters much nearer the poles, and in returning to them on the approach of spring are but doing exactly as do those species which, having their winter abode nearer the equator, come to us with the spring. The Birds-of-passage proper, like our winter-visitants, have their breeding-quarters nearer the poles, but, like our summer-visitants, they seek their winter-abode nearer the equator, and thus perform a somewhat longer Nigration. So far there is no difficulty and no hypothesis-the bringing together of these three apparently different categories is the result of simple observation. ${ }^{1}$

This, however, is not the only fact which is evident on the most cursory examination. To take the birds of the British Islands as an example (though exactly similar cases are presented in other countries), we find that while there are some species, such as the Swallow or the FieldFARE, of which every individual disappears at one period of the year or another, there are other species, such as the Pied WAGTAIL or the WoODCOCK, of which only the majority of individuals vanish-a few being always present?-and these species form the so-called "Partial Migrants." If we extend our view and look to birds on the continent of Europe, we find that many species are there notoriously migrant which are not generally suspected to be so in this country-such as the Song-THrusH and the REDBREAST, both of which species eloser observation has proved to be with us subject to the migratory impulse. In respect of the former it is known that towards the end of summer or in autumn our native Song-Thrushes receive a considerable accession in numbers from the birds which arrive from the north, though the immigration is by no means so well marked as it is in Belgitum, Franee, or Germany, where the arrival of the strangers sets all the fowlers to. work, and the beginning of the Chasse "un Grives or

1 One of the first, at least in this country, to set forth the mity of the migratory movement seems to have been the author of a Discourse on the Emigration of British Birds, published anonymonsly at Salisbury in 1780, and generally attributed to "George Edwards," though eertainly not written by the celebrated ornithologist of that name. Mr. A. C. Smith has discovered that the author-a man in many respects before his time-was John Legg, hitherto unknown as a naturalist. Bnt the real George Edwards also held opinions on the subject that are mostly sound, and his remarks gathered from varions parts of his greater works, where they appeared "in a detached and unconnected form," were repnblished. with a few modifications, in the third of his Essays upon Natural History (London: 17\%0) and may yet be read to advantage.

2 Whether these few be not migrants from another distriet is a point that would require further consideration. 
Drosselzug is regarded in many places nearly as the Twelfth of August or the First of September is with us. In most localities in Britain the new comers depart after a short sojourn, and are accompanied by so many of the home-bred birds that in some parts of the island it may be safely declared that not a single Song-Thrush can be found from the end of November to the end of January, while in other districts examples can always be seen. Much the same may be said of the Redbreast. Undeniably resident as a species, attentive scrutiny will reveal the fact that its numbers are subject to very considerable variation according to the season of the year. At no time do our Redbreasts collect in bands, but towards the end of summer they may be seen in the south of England successively passing onward, the travellers being mostly if not wholly young birds of the year; and so the majority disappear, departing it may be safely presumed for more southeru countries, since a few weeks later the rnarkets of most towns first in France and then in Italy are well supplied with this species. But the migratory influence affects, though in a less degree, many if not most of the Redbreasts that remain with us. Content during the autumn to ocempy their usual haunts, the first sharp frost has a decided effect upon their distribution, and a heavy fall of snow drives them towards the homesteads for the larger supply of food they find there, while should severe and long-continued hard weather follow even these birds vanish, leaving only the few which have become almost domesticated.

These two species have been here chosen as illustrative cases because they are at once plentiful and familiar, and want of space only forbicls us from citing others, but we shall find on inquiry that there is scarcely a Bird of the Holarctic Region, whose habits are at all well known, of which much the same may not be said, or in other words, that every Bird of the northern hemisphere is to a greater or less degree migratory in some part or other of its range. Such a conclusion brings us to a still more general inference-namely, that Migration instead of being the exceptional characteristic it used formerly to be thought, may really be almost universal, and though the lack of observations in other, and especially tropical, countries does not allow us to declare that such is the case, it seems probable to be so. Before proceeding, however, to any further conclusions it is necessary to examine another class of facts which may passibly throw some light on the matter.

It must be within the experience of every one who has ever been a birds'-nesting boy that the most sedentary of Birds year after year occupy the same quarters in the breeding-season. ${ }^{1}$ In some instances this may be ascribed, it is true, to the old haunt

1 Two remarkable instances of this persistency may be noticed. The nest of a Falcon (Falco peregrimus) on Avasaxa-a hill in Finland somewhat celebrated 
affording the sole or the most convenient site for the nest in the neighbourhood, but in so many instances such is not the case that we are led to believe in the existence of a real partiality, while there are quite enough exceptions to shew that a choice is frequently exercised. The same may equally be said of the most migrant of Birds, and perhaps the strongest instance that has ever come to the knowledge of the writer refers to one of the latter. A pair of Stonc-Curlews (Edicnemus crepitans) - a very migratory species, affecting almost exclusively the most open country-were in the habit of breeding for many years on the same spot ${ }^{l}$ though its character had undergone a complete change. It had been part of an extensive and barren rabbit-warren, and was become the centre of a large and flourishing plantation.

With these two sets of facts before us we may begin to try and account for the cause or causes of Migration. In some cases want of food would seem to be enough, as it is undoubtedly the most obvious cause that presents itself to our mind. ${ }^{2}$ The need which all animals have of finding for themselves proper and sufficient sustenance is all-powerful, and the difficulties they have to encounter in obtaining it are so great that none can wonder that those which possess the power of removing themselves from a place of scarcity should avail themselves of it, while it is unquestionable that no Class of animals has this facility in a greater degree than Birds. ${ }^{3}$ Even among many of those species which we commonly speak of as sedentary, it is only the adults which maintain their ground

as one of the most southern points whence the midnight sun may be seen-is mentioned by the French astronomer Maupertuis as having been observed by him in the year 1736. In 1799 the nest was rediscovered by Skjöldebrand and Acerbi. In 1853 Wolley found it tenanted, and from enquiries he made of the neighbours it was evident that such had yearly been the case so far as any one could remember, and so it was in 1855 as I myself can testify. In 1779 according to one account, in 1785 according to another, a pair of the Blue Titmouse (Parus coeruleus) built their nest in a large earthenware bottle placed in the branches of a tree in a garden at Oxbridge near Stockton-on-Tees. With two exceptions only, this bottle, or a second which had been placed close to it, was tenanted by a pair of birds of this species from the year in which it was first occupied until 1873, when I saw it (see Yarrell's British Birds, ed. 4, i. pp. $58,486)$; but I regret to add that I learnt through Canon Tristram in 1892 that the occupancy had ceased for four years.

1 At Elveden in Suffolk.

2 Far more so than variation of the tempcrature, though in popular belief that probably holds the first place. But Birds generally, as compared with other Vertebrates, are but slightly affected by extremes of heat or cold, and indeed (so far as we can judge) by most climatic influences, provided only their supply of food is not affected thereby ( $c f$. Max Schmidt, Zoolog. Garten, 1865, pp. 330-340).

3 The only animals which approach Birds in the extent and character of their migrations aje Fishes, of which there is no need here to say anything. 
throughout the year. It has long been known that Birds-of-Prey customarily drive away their offspring from their own haunts so soon as the young are able to shift for themselves. The reason generally, and no doubt truly, given for this behaviour, which at first sight appears so unnatural, is the impossibility of both parents and progeny getting a livelihood in the same vicinity. ${ }^{1}$ The practice, however, is not limited to the Birds-of-Prey alone, but is much more universal. We find it to obtain with the Redbreast, and if we watch our feathered neighbours closely we shall perceive that most of them indulge in it. The period of expulsion, it is true, is in some Birds deferred from the end of summer or the autumn, in which it is usually performed, until the following spring, when indeed from the maturity of the young it must be regarded as much in the light of a voluntary secession on their part as in that of an act of parental compulsion, but the effect is ultimately the same. These cases, however, which make certainly the exception rather than the rule, we can account for in another manner. It is to be observed that they are confined to species having a peculiar mode of life, the individuals associating in familyparties to form small bands. The members of the TrTMouseFamily (Paridæ) offer a good instance of this peculiarity, but it requires no very abstruse reflection to perceive that the adoption of this habit is one eminently conducive to the easy attainment of their food, which is collected, as it were, into particular spots often far apart, but where it does occur occurring plentifully. Thus a single Titmouse searching alone might hunt for a whole day without meeting with a sufficiency, while if a dozen are united by the same motive it is hardly possible for the place in which the food is lodged to escape their detection, and when discovered a few callnotes from the lucky finder are enough to assemble the whole company to share the feast. It is impossible to watch a band of any species of Titmouse, even for a few minutes, without arriving at this conclusion. One tree after another is visited by the active little rovers, and its branches examined: if nothing be forthcoming away goes the explorer to the next that presents itself, merely giving utterance to the usual twitter that serves to keep the body together. But if the object of search be found, another kind of chirp is emitted, and the next moment the several members of the band are flitting in succession to the tree and eagerly engaged with the spoil. ${ }^{2}$

I It is a very ancient remark about young Ravens that "they wander for leck of meat."

2 The case is altogether diffcrent with those spccies which in winter form themselves into large flocks, as most of the Finches (Fringillidle) and Buntings (Emberizida). The discoverer of a favourite morsel perhaps hy his actions betrays what he has obtained, and accordingly his fellows mav repair to the 
The mode in which the want of sustenance produces Migration may best be illustrated by confining ourselves to some of the unquestionably migrant Birds of our own northern hemisphere. As food grows scarce toward the end of summer in the most northern limits of the range of a species, the individuals affecter thereby seek it elsewhere; in this way they press upon the haunt of other individuals: these in like manner upon that of yet others, and thus

$$
\text { "The waves behind impel the waves before," I }
$$

until the movement which began in the far north is communicated to the individuals occupying the extreme southern range of the species at that season; though, but for such an intrusion, these last might be content to stay some time longer in the enjoyment of their existing quarters.

This seems satisfactorily to explain the southward movement of many migrating Birds in the northern hemisphere ; but when we consider the return movement which takes place some six months later, doubt may be entertained whether scarcity of food can be assigned as its sole or sufficient cause, and perhaps it would be safest not to come to any decision on this point. On one side it may be urgerl that the more equatorial regions which in winter are crowded with emigrants from the north, though well fitted for the resort of so great a population at that season are deficient in certain necessaries for the nursery. Nor does it seem too violent an assumption to suppose that even if such necessaries are not absolutely wanting, yet that the regions in question would not supply sufficient food for both parents and offspring-- the latter being, at the lowest computation, twice as numerous as the former-muless the numbers of both were diminished by the casualties of travel. ${ }^{2}$ But on the

place, but it is without invitation on his part, and the only particular bond of ninion not entirely selfish which keeps them together is the cry of alarm witl which a stranger is greeted.

"In regard to Migration the word "wave" is only allowable as a poetical figure of speech, since the particles composing a real wave do not necessarily move onward.

2 If the relative proportion of land to water in the southern hemisphere were at all such as it is in the northern, we shonld no doubt find the birds of southern continents beginning to press upon the tropical and equatorial regions of the globe at the season when they were thronged with the emigrants from the north, and in such a case it wonld be only reasonable that the latter should be acted upon by the force of the former, according to the explanation given of the sonthward morement of northern migrants. But, thongh we know almost nothing of the Jigration of birds of the other hemisphere, yet, when we regard the comparative deficiency of the land in south latitudes all round the world, it is obvions that the feathered population of such as nowadays exists can excrt but little influence. and its effect may be practically disregarded. 
other hand we must remember what has above been advanced in regard to the pertinacity with which Birds return to their accustomed breeding-places, and the force of this passionate fondness for the old home cannot but be taken into account, even if we do not allow that in it lies the whole stimulus to undertake the perilous rovage.

Mr. Wallace in some remarks on the subject (Nature, x. p. 459) ingeniously suggests the manner in which the habit of Migration has come to be adopted : ${ }^{1}$

"It appear's to me probable that here, as in so many other cases, 'surrival of the fittest' will be found to have had a powerful influence. Let us suppose that in any species of migratory bird, breeding can as a rule be only safely accomplished in a given area; and further, that during a great part of the rest of the year sufficient food cannot be obtained in that area. It will follow that those birds which do not leave the breeding area at the proper season will suffer, and ultimately become extinct; which will also be the fate of those which do not leave the feeding area at the proper time. Now, if we suppose that the two areas were (for some remote ancestor of the existing species) coincident, but by geological and climatic changes gradnally diverged from each other, we can easily understand how the habit of incipient and partial migration at the proper seasons would at last become liereditary, and so fixed as to be what we term an instinct. It will probably be found, that every gradation still exists in various parts of the world, from a complete coincidence to a complete separation of the breeding and the subsistence areas; and when the natural history of a sufficient number of species is thoroughly worked out, we may find every link between species which never leave a restricted area in which they breed and live the whole year round, to those other cases in which the two areas are absolutely separated."

A few more particulars respecting migration are all that can here be given, and it is doubtful whether much call be built upon then. It has been ascertained by repeated observation that in the spring-movement of most species of the northern hemisphere the cock-birds are always in the van of the advancing army, and that they appear some days, or perhaps weeks, before the hens. ${ }^{2}$ It is not difficult to imagine that, in the course of a journey prolonged throughout some $50^{\circ}$ or $60^{\circ}$ of latitude, the stronger individuals should outstrip the weaker by a very perceptible distance, and it can hardly be doubted that in most species the males are stouter, as they are bigger than the females. Some observers assert that the same thing takes place in the return-journey in autumn, but on this point others are not so sure, which is not surprising when we

1 ln principle Capt. Hutton (Trans. New Zeal. Inst. 1872, p. 235) had already foreshadlowed the same theory, which some writers have called that of "land-bridges."

2 This fact, often regarded as a very recent discovery, was made known by Iontagu in 1802 (Orn. Dict. Introd. pp. xxviii., xxx. note), and had also been observed by Sheppard in 1819 (Trans. Norf. \& Nork. Nat. Soc. iii. p. 391). 
consider that the majority of observations have been made towards what is the northern limit of the range of the Passeres, to which the remark is especially applicable - in the British Islands, France, North Germany, and the Russian Empire-for it is plain that at the beginning of the journey any inequality in the speed of travelling will not have become so very manifest. There is also another matter to be noticed. It has been suspected that where there is any difference in the size of birds of the same species, particularly in the dimensions of their wings, the individuals that perform the most extensive journeys are naturally those with the longest and broadest remiges, and in support of this view it certainly appears that in some of the smaller migrants-such as the WHEATEAR (Saxicold cenanthe) and WILLOW-WREN (Phylloscopus trochilus)-the examples which reach the extreme north of Europe and there pass the summer possess greater mechanical power's of flight than those of the same species which stop short on the shores of the Mediterranean. It may perhaps be also inferred, though precise evidence is wanting, that these same individuals push further to the southward in winter than do those which are less favoured in this respect. It is pretty nearly certain that such is the case with some species, and it may well be so with individuals. Canon 'Tristram has remarked (1lis, 1865 , p. 77) that, in many genera of birds, "those species which have the most extended northerly have also the most extended southerly range; and that those which resort to the highest latitudes for nidification also pass further than others to the southward in winter," fortifying his opinion by examples adduced from the genera Turdus, Fringilla, Cypselus, and Turtur. But supposing this to be true for many Birds, it may fairly be doubted whether it is so for all, and whether in some species certain individuals do not always occupy the most northern portion of the range and others always keep to the most southern, no matter what the season of the year may be, or over what countries the range may extend. On this point therefore it will be advisable to await further investigation.

For many years past a large number of persons in different countries have occupied and amused themselves by carefully registering the dates on which various migratory Birds first make their appearance, and certain publications abound with the records so compiled. ${ }^{1}$ Some of the observers have been men of high scientific repute, others of less note but of not inferior capabilities for this especial object. Still it does not seem that they have been able to determine what connexion, if any, exists between the arrival of birds and the state

1 These are far too numerous to mention here. Perhaps the most remarkable series of them is that carried on from 1736 to 1810 and again from 1836 to 1874 by four generations of the Marsham family at Stratton-Strawless and Rippon near Norwich, of which an account is given by Mr. Southwell (Trans. Norf. \& Noru. Nat. Soc. ii. p. 31). 
of the weather. ' This is not very wonderful, for the movements of the migrants, if governed at all by meteorological forces, must be influenced by their action in the places whence the travellers have come, and therefore to establish any direct relation of cause and effect corresponding observations ought equally to be made in such places, which has seldom been done. ${ }^{2}$ As a rule it would seem as though Birds were not dependent on the weather to any great degree. Occasionally the return of the Swallow or the Nightingale may be somewhat delayed, but most Sea-fowls may be trusted, it is said, as the almanack itself. Were they satellites revolving around this earth, their arrival could hardly be more surely calculated by an astronomer. Foul weather or fair, heat or cold, the PUFFINS (Fratercula arctica) repair to some of their stations punctually on a given day as if their movements were regulated by clock-work. Whether they have come from far or from near we know not, but other Birds certainly come from a great distance, and yet make their appearance with scarcely less exactness. Nor is the regularity with which certain species disappear much inferior; every observer knows how abundant the Swift (Cypselus apus) is up to the time of its leaving its summer-home-in most parts of England, the first days of August - and how rarely it is seen after that time is past.

It must be allowed, however, that, with few cxceptions, the mass of statistics above spoken of has never been worked up and digested so as to allow proper inferences to be made from them, and therefore it would be premature to say that little would come of it, but the result of those few exceptions is not very cncouraging. The most important is due to Dr. von Middendorff who carcfully

1 Herr Gätke in the valuable work presently to be particularly noticed, attaches much more importance to the effects of weather than I aln inclined to do, though I an far from saying that his opinion may not be borne out by his experience on Heligoland, where his observations were made. That is a spot so snall that, though exceptionally faroured as a resort for Birds-of-passage, it might easily be missed (as indeed it frequently is) owing to the wind lying in such a quarter as would turn them from their usual course. He certainly gives (p. 85) a remarkable instance of a temporarily reversed movemeut in March 1879, doubtless caused by the setting in of bad weather; but in nearly all cases Birds on their northward Migration do not retrace their flight but persevere in the eflorts to get forward, even though when they reach their goal they may succumb and perish for want of food throngh the severity of the season.

2 To a limited extent it must be admitted that the popular belief as to certain Birds being the harbingers of severe weatler is justifiable. Cold comes ont of the north, and when it is accomplanied, as is most generally the case, by heavy falls of snow, sueh Birds are of course driven southwards to seek their living. But as often as not the Birds arrive with the kind of weather they are commonly held to prognosticate, while sometimes this does not follow their appearance. 
collated the records of the arrival of migratory Birds throughout the Russian Empire, but the insight into the question afforded by his published labours ${ }^{1}$ is not very great. His chief object was to

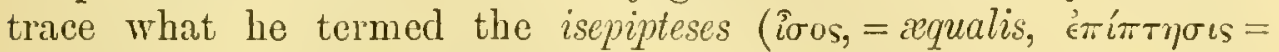
advolatus) or the lines of simultaneous arrival, and in the case of 7 species ${ }^{2}$ these are laid down on the maps which accompany his treatise. The lines are found by taking the average date of arrival of each species at each place in the Russian dominions where observations have been regularly made, and connecting those places where the dates are the same for each species by lines on the map. The curves thus drawn indicate the inequality of progress made by the species in different longitudes, and assuming that the advance is directly across the isepiptesial lines, or rather the belts defined by each pair of them, the whole comrse of the Migration is thus most accurately made known. In the case of his seven sample species the maps shew their progressive advance at intervals of a few days, and the issue of the whole investigation, according to him (op. cit. p. 8) proves that in the middle of Siberia the general direction of the usual migrants is almost due north, in the east of Siberia from south-east to nortl-west, and in European Russia from south-west to north-east. Thus nearly all the migrants of the Russian Empire tend to converge upon the most northern part of the continent, the Taimyr Peninsula, but it is almost needless to say that few of them reach anything like so far, since the country in those high latitudes is utterly unfit to support the majority. With the exception of some details, which thongh possessing a certain special interest, need not here be mentioned, this treatise fails to shew more; for the fact that there are places that notwithstanding their higher latitude are reached by Birds on their spring migrations sooner than others in a lower latitude was already knowll, and indeed may be to some small extent observed even in England.

The routes followed by migratory Birds have been the subject of enquiry by many naturalists, among whom must be especially named Prof. Palmén, of whose work, ${ }^{3}$ originally published in

I Die Isepiptesen Riusslands. Grundlaycn zur Evforschung der Zugzeitcn und Zugrichtungen der Vögel Russlands. St. Petersburg : 1855.

${ }^{2}$ Hirundo rustica, Motacilla alba, Alauda arvensis, Oriolus galbula, Cuculus canorus, Ciconia alba and Grus communis.

${ }^{3}$ Om Foglarnes Ayttningsvägar (Helsingfors: 1874). In this and the work of Dr. von Middendorff, already cited, reference is made to almost every im. portant publication on the subject of Migration, which renders a notice of its very extensive literature needless lere, and a pretty full bibliographical list is given in Giebel's Thesaurus Ornithologia (i. pp. 146-155). Yet mention may be made of Schlegel's Over het trelken der Vogels (Harlem : 1828), Mr. Hodgson's "On the Migration of the Natatores and Grallatores as observed at Katlimandu" in 
Swedish, some of the chief results ${ }^{1}$ were briefly given in 1875 in the Encyclopadia Britannica (ed. 9, iii. p. 768), but until its appearance in a German translation ${ }^{2}$ it attracted little notice. The author's views were at first approved by the late Hel'r Eugen von Homeyer, an ornithologist of great experience (Journ. für Orn. 1876, pp. 387-391; 187s, p. 113$)$, but then challenged on several points by him in a separate work, ${ }^{3}$ which called forth a spirited reply from Prof. Palmén. ${ }^{4}$ Similar researches have been continued in greater detail by two Russian zoologists, as regards Central Asia

Asiatic Researches (xviii. pp. 122-128), and Marcel de Scrres's Des causes des Migrations des Animaux et particulièrement des Oiseaux et des Poissons (Harlem : 1842). This last though one of the largest publications on the subjeet is one of the least satisfactory. Baird's excellent treatise On the Distribution and Mfigrations of North American Birds has been before adverted to (supric, p. 330).

1 'They may be here repeated: The main routes taken by the most migratory Birds of the Palæarctic area on their return antumnal journey are, aecording to Prof. Palmén, nine in number. The first (A-to use his notation), leaving the Siberian shores of the Polar Sea, Nova Zembla, and the North of Rnssia, passes down the west coast of Norway to the North Sea and the British Islands. The second $(\mathrm{B})$, proceeding from Spitsbergen and the adjoining islands, follows much the same course, but is prolonged past France, Spain, and Portugal to the west coast of Africa. The third (C) starts from Northern Russia, and, threading the White Sea, and the great Lakes of Onega and Ladoga, skirts the Gulf of Finland and the southern part of the Baltie to Holstein and so to Holland, where it divides-one branch uniting with the second main route (B), while the other, running up the valley of the Rhine and crossing to that of the Pinone, splits up on reaching the Mediterranean, where one path passes down the western coast of Italy and Sicily, a seeond takes the line by Corsica and Sardinia, and a third follows the sonth coast of France and eastern eoast of Spain-all three paths ending in North Africa. The fourth (D), fifth (E), and sixth (F) main rontes depart from the extreme north of Siberia. The fourth (D), aseending the river Obi, branches out near Tobolsk-one track, diverging to the Volga, deseends that river and so passes to the Sea of Azov, the Black Sea, and thence, by the Bosphorus and Egean, to Egypt; another track makes for the Caspian by way of the Ural River and so leads to the Persian Gulf, while two more are lost sight of on the steppes. The fifth (E) mounts the Jennesei to Lake Baikal and so passes into Mongolia. The sixth (F) ascends the Lena and striking the Upper Amoor reaches the Sea of Japan, where it coalesces with the serenth $(G)$ and eighth $(0)$ which run from the eastern portion of Siberia and Kamchatka. Besides these the ninth $(\mathrm{X})$, starting from Greenland and Iceland, passes by the Froes to the British Islands and so joining the second (B) and third (C) runs down the French coast. These being the main routes it must be added that, in Prof. Palmén's opinion and that of many others, nearly all river-courses form minor routes. In giving this abstract I wish to state that I do not thereby express my agreement with all that it contains.

2 Ueber die Zugstrassen der Vöget. Leipzig: 1876.

3 Dic Wanderungen der Vögel. Leipzig: 1881.

4 Antwort an Herrn E. F. von Homeyer', bezüglich der 'Zugstrassen der Vögel.' Helsingfors \& Leipzig: 1882. 
by the late Dr. Sererzoff, 1 and as regards Eastern Europe by Dr. Menzbier," while other contributions to the subject, too numerous to be here named, have also appeared. ${ }^{3}$ It seems even now premature to criticize minutely the results of these works-conjectural many of them confessedly are, while some of the details on which they are founded rest on observations that cannot be regarded as wholly trustworthy and are doubtless open to correction, but nearly all is put forward in a way that deserves the fullest attention. On the part of some writers, we will not say it of Prof. Palmén, there seems to be a disposition to attach an almost superstitious importance to the phrase Migration-route. Such persons should bear in mind Dr. Menzbier's very true remark that every species on Migration goes its own way, and what is called a Migration-route is only the coincidence of the way taken by more or fewer of them. One of the routes (" $\mathrm{X}$ ") described by Prof. Palmén, and one of considerable interest to dwellers in the United Kingdom, is extremely questionable. Indeed the data to establish its existence were not forthcoming when he wrote, and probably are not forthcoming now, though in the interim much has been done toward the collection of facts at light-houses and light-ships around our coasts by the "Migration Committee" appointed by the British Association in 1880, which continued its exertions for nine years, ${ }^{4}$ with the result of accumulating a mass of statistics,

1 Études sur le passage des Oiseaux dans l'Asie Centrale particulièrement par le Ferghanah et le Pamir (Bull. Soc. Imp. Nat. Moscou, 1880, i. pp. 234-287).

2 Die Zugstrassern der Vögel im europäischen Russland (op. cit. 1886, ii. pp. 291-369). Herein four chief routes of European origin are laid down-(1) a via norvegica rounding the North Cape, skirting the coast of the Kola Peninsnla and continued along the aretic shores of Russia to Waigats and Nova Zembla: (2) a via baltica which splits into three lines, one passing up the Gulf of Bothnia to Tornea where it bifurcates, one stream ascending the river of that name, the other proceeding overland to Fola ; a second line passes along the Gulf of Finland to Viborg, and thence along the northern shore of the Ladoga and Onega Lakes over the White Sea to Nova Zembla; while a third, occasionally anastomosing with the second, crosses the Gulf of Riga and, passing to the southward of the two lakes just named, finally arrives also in Nova Zembla: (3) a via pontica which, leaving the Black Sea, spreads over the whole of Russia, becoming fainter as it proceeds northward though perceptible within the Arctic Circle in the MInonio basin, and reaching nearly as far north in the valleys of the Mezen and Petchora: lastly (4) a via caspia ascending the Yolga on the west so far as Jaroslar, and to the eastward reaching by many anastomosing streams the valley of the Obi.

${ }^{3}$ A good summary of them is given in the Report (Referat über den Stand der Kenntniss des Vogelauges) drawn up by Prof. Palmén for the International Ornithological Congress held at Budapest in 1891.

${ }_{4}$ When I say the exertions of the Committee I mean chiefly those of its secretary, MIr. Cordeaux, whose enthusiasm prompted the men at the several stations to make observations, while his energy in carrying on the laborions 
the reduction of which to intelligible order is still taxing the ingenuity and patience of $\mathrm{Mr}$. W. E. Clarke, who has undertaken the onerous duty. Similar observations have also been organized since 1883, at stations in Denmark, and the results published by Prof. Lütken and HH. Oluf and Herluf Winge; while, since 1885, the example has been followed both in Germany and Russia by Prof. Rudolf Blasius and Herr E. von Middendorff. In North America a very praiseworthy piece of work was performed by Prof. W. W. Cooke, whose Report on Bird Migration in the Mississippi Valley in 1884 and 1885, based on the records furnished by 170 observers, of whom Mr. Otto Widman is especially to be named, was edited by Dr. C. Hart Merriam. ${ }^{1}$ Some of the facts herein adduced are highly suggestive, but it must be remarked that on several points there is a difference of opinion between the author and the editor. For instance, Prof. Cooke confirms the statements of European observers as to the young birds of many species preceding their parents in the autumnal movements, while Dr. Merriam, trusting to some evidence which appears not yet to have been published, and to the testimony of Mr. W. Brewster, ${ }^{2}$ declares to the contrary. effect. As the European experience on this point is indisputable, and a good deal depends upon it, we trust that the matter will eventually be cleared up.

But the result of all these efforts, good as they are, may be said to pale before the stupendous amount of information amassed during more than fifty years by the venerable Herr Gätke of Heligoland, a place which through his watchfulness has attained celebrity as a post of observation quite beyond any other in the world, so that ornithologists may at times wonder whether the man made the station or the station the man-so fitted have they been for one another. It is to be hoped that his work ${ }^{3}$ will one day appear in an English version, for until then its contents will remain unknown to most British-and North-American ornithologists. On the author's theories we would offer but few remarks. It is his conviction that of effective and successful Migration we see but little, as it is for the most part carried on at such a height in the air as to be beyond our ken, and what comes to our perception

correspondence deserves the thanks of every ornithologist. Beside this it was he and Mr. Harvie-Brown who in 1879 initiated the light-house enquiry, afterwards adopted by the British Association, and obtained for it the countenance of the official authorities.

1 U. S. Department of Agriculture. Division of Economic Ornithology, Bulletin No. 2. Washington: 1888.

2 Memoirs of the Nuttall Ornithological Club, No. 1. Cambriage, Mass.: 1886.

3 Die Vogelwarte Helgoland. Braunschweig: 1891. A brief summary of the least interesting part of this volume, being hardly more than a list of the species that have been observed on the island, is printed in The Ibis for 1892, pp. 1-32. 
consists chiefly of the abortive or unsuccessful attempts at its accomplishment, when birds are checked in their course, and being unable to proceed present themselves to our sight and hearing. If this be so, the aid of "land-bridges" and river-valleys, the importance of which is so strongly pressed by certain writers (mostly theorizers) becomes insignificant.

Now that birds can and do fly at elevations far beyond those which most people are accustomed to think possible, we have some indication. Mr. J. Tennant states (Stray Feathers, iii. p. 419) that at Roorkee on the 23rd Sept. 1875, while looking throngh a telescope at the sun, he saw birds, apparently Kites, frequently pass over its face, some of which were in focus with the sun itself and must therefore have been several miles high, while the nearest must have been quite a mile above the earth's surface. These birds indeed were only soaring, on the look-out for prey, and not migrating; but a stronger case in point is the curious and valuable observation recorded by Mr. W. E. D. Scott (Bull. Nuttall Orn. $C l u b$, vi. pp. 97-100) when on the night of the 19th Oct. 1880, he saw through an astronomical telescope, at Princeton, in New Jersey, great numbers of birds passing across the face of the moon. ${ }^{1}$ Computation shewed that these birds, which were on their autumual Migration, must have been travelling at heights varying from a mile to two miles. Some time later, 16th April 1881, the same gentleman, in company with Mr. Allen, made some further observations (tom. cit. p. 188) at the same place; but on this occasion the birds seen-Swallows, and on their northward journey-were flying comparatively low. They were also much less numerous, for only 13 passed in three-quarters of an hour, whereas on the former occasion the average was 4.5 per minute. Again Mr. F. MI. Chapman (Auk, 1888, pp. 37-39), also in New Jersey, watching for nearly three hours on the evening of the 3rd Sept. 1887, saw in like manner 262 birds cross the moon's face. Of these 233 were computed to be at a height of from 1500 to 15,100 feet; but an especially remarkable thing is that the lowest birds were "flying upward," as if they had risen from the immediate neighbourhood and "were seeking the proper elevation at which to continue their flight." 2

1 "Most of the birds were the smaller land-birds, among which were plainly recognized Warblers, Finches, Woodpeckers and Blackbirds [Icteridx]... Among the Finches I would particularly mention Chrysomitris tristis, which has a very characteristic flight; and the Blackbirds were conspicuous by the peculiar shape of the tail, from which characteristic I feel most positive in my identification of Quiscalus purpureus."

2 Among the birds recognized on this occasion were 5 Carolina RaILs, of which 3 are computed to have been between the limits of 1900 and 10,200 feet, one between 2000 and 11,000 , and one between 2600 and 13,500 . 
It has been objected that owing to the extreme cold known to prevail at great elevations birds would be unable to travel or even exist at some of the heights suggested; but on this point we have not yet enough information, any more than as regards the limit of cold that birds can endure, which ( $c f$. page 553 , note 2 ) is much lower than most people imagine. ${ }^{1}$ The mere exertion of flight would certainly for a time keep the body warm, and it is beyond all doubt, as Mr. Glaisher's observations (Rep. Brit. Assoc. 1862, pp. $422,423)$ shew, that the older estimate as to temperature regularly decreasing by a degree of Fahrenheit in about every 300 feet of elevation must be given up, that the decrease is by no means constant, and moreover that the atmosphere is traversed by currents of various degrees of heat, so that it would often be in the power of any bird by raising or lowering its flight to avoid the most chilly stratum. ${ }^{2}$ Then again, as every one knows, feathers and down form the best non-conducting clothing that exists, and so clad almost every part of the bird is not "servile to all the skyey influences." It must be admitted that birds in confinement suffer in their feet and legs from frost, but it is not known that birds at liberty, and especially in the act of taking violent exercise, are so affected.

It has long been remarked that on clear and bright nights birds are rarely heard passing over head, while on nights that are overcast, misty and dark, especially if slight rain be falling, flocks may often be heard almost continuously. It is in such weather that birds while migrating are most vociferous, doubtless with the result that thereby the company of fellow-travellers is kept together, and in such weather that they fly to and often dash themselves against the glasses of light-houses, ${ }^{3}$ occasionally in astonishing numbers. These "rushes," as our light-keepers call them, have been so often recorded and described that little need here be said concerning them; and

1 It is unfortunate that no definite deductions can be made from the behaviour of birds taken up in balloons. Biot and Gay-Lussac, in their celebrated ascent of the 24th August 1804, at the height of 11,000 feet, or rather above 2 miles, liberated a Greenfinch and a Pigeon, each of which after a few turns disappeared downwards through the clouds (Journ. de Phys. lix. p. 318). A similar experience was that of Mr. Glaisher in his still loftier ascent of 5th Sept. 1862. A Pigeon thrown out at the height of 3 miles "extended its wings and dropped as a piece of paper." A second at 4 miles "flew vigorously round and round." A third between 4 and 5 miles "fell downwards as a stone." A fourth at 4 miles "flew in a circle" and then alighted on the balloon (Tiep. Brit. Assoc. 1862, pp. 385, 386'; see also Nature, xix. p. 434, 13 March, 1879).

2 The quickness with which animals lower in the scale than Birds will avail themselves of variation of temperature may be appreciated by any one who has studied the habits of the common House-Fly.

3 Why Birds or Insects fly at times to a light has never been explained. Birds are often indifferent to it, as MIr. G. H. Mackay remarks (Auk, 1891, pp. 340-343). 
Heligoland, so far as is known, is the place where they recur with the greatest frequency and intensity. Two instances given by Herr Gätke may here suffice. From 10 o'clock on the night of the 28th of October 1882, to the next morming, GoLDCrEsTs eddied, thick as flakes in a heary snow-fall, round the light-house there, on the morrow literally swarming on every square foot of the island; and twelve months later Larks in myriads I thronged to its bright beams for four nights in succession, accompanied by Starlings in hardly fewer numbers. These great hosts consist usually of many kinds of birds, congruous only in their congress-Larks and Lapwings, Starlings and Sandpipers, Fieldfares and Curlews, Golden-crested Wrens and Golden Plovers, Oyster-catchers and Owls_-while the air is filled with their cries, among which are several that are wholly unrecognizable, for it would seem that some birds have a language that they use only while migrating. Otherwise is it with the return of the wanderers in spring, and then the exciting scenes of autumn are seldom if ever presented, yet under a moonless and clouded sky the wakeful ear may often catch positive evidence of what is going on aloft, though owing to the smaller numbers (for at that season it is only the birds which are about to breed that pass) and the shorter nights, the movement attracts far less attention. ${ }^{2}$ Generally troop after troop of the traveller's succeeds in orderly, and what has been called "wavelike", fashion, ${ }^{3}$ varying indeed in rapidity according to the species, but taken as a whole in comparatively little else. With some birds the progress is very leisurely made, while others, there is reason to think, project themselves northward with a haste that would seem incredible. But on this as on so many other points we must be content to await the results of further observation and experiment ${ }^{4}$

1 "Milliarden" is the anthor's word, but that seems hardly credible.

2 So much less indeed that a writer has flippantly remarked (Contemporary Review, July 1880, p. 1) that the return of birds in spring is "like the Kingdom of Heaven which cometh not with observation," forgetful of the fact that all we know of Migration is due to observation, and nearly all we do not know to want of it.

3 Such a "wave," though it was more like a stream, in Nova Scotia has been described by Mr. Philip Cox (Auk, 1889, pp. 241-243) and a succession of "waves" in Pennsylvania and New Jersey with a diagrammatic representation of them by Mr. Whitmer Stone (op. cit. 1891, pp. 194-198).

${ }^{4}$ It is with no little diffidence that I demur to the acceptance of Herr Gätke's estimate of the speed at which Birds travel. Against the evidence adduced by him must be set that collected by others; and from my own experience I am persuaded that there is much exaggeration-nnintentional of course-in many observations that have been made on this subject. It is very well to believe that in autumn Grey Crows travelling across Heligoland from east to west, pass over the island from $80^{\prime}$ clock A.M. to 2 P.M. ; and it is equally well to believe that Grey Crows arrive on the coast of Lincolnshire (for which it may be allowed that the Crows first mentioned are making) from the eastward between 11 A.M. and 
- the latter especially, ${ }^{1}$ for as yet little has been effected of the kind.

But lay down the paths of migratory Birds, observe their comings and goings, or strive to account for the impulse which urges them forward as we will, there still remains for consideration the most marvellous thing of all-How do the birds find their way so unerringly from such immense distances? This seems to be by far the most inexplicable part of the matter. Year after year the migratory Wagtail will build her nest in the accustomed spot, and year after year the migratory Cuckow will deposit her eggs in that nest, and yet in each interval of time the former may have passed some months on the shores of the Mediterranean, and the latter, absent for a still longer period, may have wandered into the heart of Africa. ${ }^{2}$ There was a time when the writer had hopes that

5 P.M. ; but it is not proved that they are the same birds. If they are, the distance being about 360 miles they must have flown at the rate of 120 miles an hour-a speed few will believe it possible for a bird of the Crow-kind to attain. But Herr Gätke would have even this speed exceeded by the Bluethroat (of which more presently), believing that it travels from the Delta to Heligoland in 9 hours, while he has ascertained that Curlews, Godwits, and Plovers cross from Heligoland to the oyster-beds lying to the eastward, a known distance of 22,000 feet, or rather more than 4 English miles, in one minute, or at the rate of over 240 miles an hour! On the other hand, Mr. Tegetmeier declares (Field, 22 Jan. 1887 , p. 114) that the average speed of Carrier Pigeons in 18 matches is 36 English miles an hour, thougl in two of them a rapidity of about 55 miles was maintained for 4 hours in succession. If I might cite my own experience, it is to the effect that the Swallow does not ordinarily fly so fast as the express train from which one may view it, and a train going at no great speed completely outstrips the Partridges which rise in front of it and fly for a few hundred yards alongside of it, as I have observed again and again. Yet to do Herr Gätke justice I must admit his general contention to be sustained by a good observer, Mr. Oswald Crawfurd, who states (Round the Calendar in Portugal, pp. 154-156) in regard to the wonderful speed with which Turtle-Doves fly on Migration in antumn, that he once made a calculation to arrive at the pace of their travelling; "but the result came out in such surprising figures" that he would not set them down. He convinced himself, however, that, if the flight were continuous, Turtle. Doves leaving "Kent or Surrey at dawn, might easily be the very birds that a few hours later were skimming over the Portuguese pine-forests on their way to Central A frica."

1 At the request of the editor of The Field Mr. Griffith made some trials which are reported in that journal (19 Feb. 1887, pp. 242, 243), but most of them cannot be regarded as satisfactory, having been made in a covered gallery, for it proved that "Blue rock" Pigeons and Partridges flew faster in this gallery of limited length than in the open, so far as the experiments went. The greatest rapidity, in the 40 yards' range, was Pigeons and Pheasants 33.8 miles an hour, Partridges 28.4 ; in the open, Pigeons 27.9 , Pheasants 38.1 , Partridges 32.1 . It is much to be wished that experiments of this kind could be repeated on a more extended scale; but of course the difficulty attending such trials is very great.

" Absolute proof of the identity of the particular birds is indeed wanting, 
what is called the "homing" faculty in Pigeons might furnish a clue, but Mr. Tegetmeier and all the best authorities on that subject declare that a knowledge of landmarks obtained by sight, and sight only, is the sense which directs these Birds, while sight alone can hardly be regarded as affording much aid to Birds-and there is reason to think that there are several such-which at one stretch transport themselves across the breadth of Europe, or even traverse more than a thousand miles of open ocean, to say nothing of those -and of them there are certainly many-which perform their migrations mainly by night. That particular form of BLUETHROAT which yearly repairs to breed upon the mosses of the Subalpine and Northern parts of Scandinavia (Cyanecula suecica) is hardly ever seen in Europe south of the Baltic. ${ }^{1}$ Throughout Germany it may be said to be practically absent, being replaced by a conspicuously different form (C. leucocyana), and as it is a Bird in which the collectors of that country, a numerous and well-instructed body, have long taken great interest, we are in a position to declare that save in Heligoland, it is hardly known to stop in its transit from its winter haunts, which we know to be Egypt and the valley of the Upper Nile, to its breeding-quarters. Other instances, though none so crucial as this, could be cited from among European Birds were there room here for them. In New Zealand there are two Cuckows which are annual visitors: one, a species of Chrysococcyx, probably has its winter quarters in New Guinea, though commonly supposed to come from Australia, the other, Eudynamis taitensis, is widely spread throughout Polynesia, yet both these birds yearly make two voyages over the enormous waste of waters that surrounds the country to which they resort to breed. But space would utterly fail us were we to attempt to recount all the examples of these wonderful flights. Yet it seems impossible that the sense of sight should be the faculty whereby they are so guided to their destination, any more than in the case of those which travel in the dark.

Dr. von Middendorff (Isepipt. Russl. p. 9), from the conclusions he has drawn, as before mentioned, as to the spring-movement of all birds in the Russian Empire being towards the Taimyr Peninsula, the seat of one of the magnetic poles, has suggested that the migrating Bird is always aware (he does not exactly explain by

but if that objection be raised the circumstance becomes still more puzzling, for then we have to account for some mode of communicating precise information by one bird to another.

1 It has occurred indeed as a straggler in spring about a dozen times in England, and it arrives twice a year in greater or less numbers in Heligoland as reported by Herr Gätke. Its autumnal visits to this country, occasionally in considerable numbers, seem to be almost annual, though of course they are not always observed. 
what means) of the situation of this point, and thus knows how to steer its course. Not only is this hypothesis unsupported by any considerations known to the writer, but it is not at all borne out by the observed facts of Migration in North America, where Birds, as has been shewn by Prof. Baird (op. cit. p. 347), do not migrate in the direction of the magnetic pole.

Another and assuredly a more valuable hint was thrown out by Dr. von Middendorff ${ }^{1}$ (Sibirische Reise, Band iv. Th. 2, pp. 1168, 1169), and it has been accepted by several who have become acquainted with it, and are competent to express an opinion on the subject. In principle it is identical with the idea that had long ago suggested itself to the present writer when he fancied that the "homing" faculty of Pigeons was akin to that by which migratory Birds directed their voyages, and he believes that it has been independently entertained by several others who have considered the subject; but, so far as he knows, the merit of first stating it clearly belongs to the eminent Russian naturalist just named.

That the sense of direction unconsciously exercised by human beings varies greatly with individuals is a matter of common experience, and that it is possessed in a high degree of excellence by certain races of men is notorious, for travellers without end have noticed the fact, and no one can deny that this excellence is attained by those races who have the greatest need to employ it in their daily vocation - whether they be Samojeds (as in the case cited by Dr. von Middendorff), American Indians, Bushmen or Aus-

1 The passages containing it have been quoted by both Von Homeyer (op. cit. p. 304) and Herr Gätke (op. cit. p. 13j), and since they do not seem to have been laid before English readers, a rendering may here be attempted :-

"In Nammals the remarkable memory for places they enjoy may be of essential use in finding their way correctly; bnt it is not to be doubted that they must also be conscious of general direction, for they know how to reach their goal, and that by the shortest route, through places which are wholly strange to them. In the course of my life I have met with the most decided examples of this sense of direction in dogs and horses; but never did experience of this kind strike me so much as when on the boundless wastes (Tundrcn) of the high north I perceived the same incomprehensible animal faculty, almost unweakened, among rude uncivilized men. What Samojeds can do in this way often surpasses all our comprehension.

"Highly pleased with having found among these people my interpreter of the natural mystery of animals finding their way, I tried to extract from them their magic art, and pressed them as opportunity afforded. They, horrever, looked at me confusedly, wondered at my wondering, and thought a thing of such everyday occurrence to be self-evident, while our incapacity to direct ourselves was to them quite unintelligible. At last they wholly disarmed me with the question 'How, now, does the little Arctic Fox find its way aright on the great Tundra and it never goes astray?' That was all! I was thrown back on the unconscious performance of an inherited animal faculty." 
tralians, while among those races who have little or no need to exercise it, such as people in the highest state of civilization, and of them especially dwellers in towns, the faculty - comparatively weak to begin with and undeveloped by practice-perishes through disuse. If this variability in possessing the sense of direction ${ }^{1}$ in the human species be thus admitted, there can be no impropriety in inferring that the lower animals may have the faculty in a degree out of all proportion with even those people that have it most. Just as some men surpass others in powers of hearing, sight or smell, and many animals excel all men in these respects, of all animals the sense of direction would naturally attain the greatest perfection in Birds, for they are endowed with and exercise the greatest power of locomotion. In urging this opinion there would seem to be no theorizing : it is merely arguing from the known to the unknown.

Nevertheless it is right to take cognizance of all suggestions that seem to be reasonable, and among them is one put forth by Prof. Möbius (Das Ausland, No. 33, pp. 648, 649, 14 Aug. $1882)$ to the effect that Birds performing long migrations over sea may be guided by observing the roll of the waves. The possibility of this cannot be denied if the roll be constantly in one direction as seems likely to be in that part of the Pacific Ocean to which his remarks especially refer; but obviously it will not hold good for the stormy waters of the North Atlantic, where a swell may be set up from any point of the compass, and the American Golden Plovers that yearly resort with sucl punctnality to "the still-vext Bermoothes" would assuredly get but little help on their passage thither, or in its continuation to the Antilles, from the set of the billows over which they pass-ever varying with the inconstant winds.

Other authors there are who rely on what they call "instinct" as an explanation of this wonderful faculty. This with them is simply a way of evading the difficulty before us, if it does not indeed remove the question altogether from the domain of scientific enquiry. Rejecting such a mode of treatment, Prof. Palmén meets it in a fairer spirit. He asserts (Fogl. Flyttn. p. 195), that migrants are led by the older and stronger individuals among them, and, observing that most of those which stray from their right course are yearlings that have never before taken the journey, he ascribes the due performance of the flight to "experience." But, granting

1 I have no wish to urge this sense of direction as a "sixth sense," as has been imputed to me by Dr. Weismann (Nature, xix. pp. 579, 580, 24 April 1879). What it may be called does not concern me in the least. I know that it exists, and is wholly independent of intellectual forces, as in myself I had proof of the fact in my younger days, but rant of exercise has impaired its efficacy so as to render it almost obsolete. Some would perhaps attribute the effect to "unconscious cerebration," and I do not object to the phrase if it seems more explanatory. 
the undisputed truth of his observation, his assertion seems to be only partially proved. That the birds which lead the flock are the strongest is on all accounts most likely, but what is there to shew that these are also the oldest of the concourse? Beside this, there are many Birds which cannot be said to migrate in flocks. While Swallows, to take a sufficiently evident example, conspicuously congregate in vast flocks and so leave our shores in large companies, the majority of our summer-visitors slip away almost unobserved, each apparently without concert with others. It is also pretty nearly certain that the same species of Bird does not migrate in the same manner at all times. When Skylarks arrive on our north-eastern coast in autumn they come flitting over in a constant, but intermittent stream, not in compact flocks; yet a little later these same birds collect in enormous assemblages which prosecute their voyage in company. It is indeed possible that each bird of the stream intentionally follows that which goes before it, though in a long sea-passage it must be hard to keep the precursor in sight, and it may perhaps be granted that the leader of the whole is a bird of experience. But then we must consider not these cases only, but also those of Birds which do not migrate in company, and we must also have regard to what is implied in the word "experience." Here it can only signify the result of knowledge acquired on former occasions, and obtained by sight. Now it was stated by Temminck $^{1}$ many years ago, and the statement has been abundantly confirmed by Herr Gätke and others, that among migrants the young and the old always journey apart and most generally by different routes. The former can have no "experience," and yet the greater number of them safely arrive at the haven where they would be. The sense of sight, essential to a knowledge of landmarks, as we have above attempted to demonstrate, is utterly insufficient to account for the success that attends Birds which travel by night, or in a single flight span oceans or continents. Yet without it the idea of "experience" cannot be substantiated. We may admit that inherited but unconscious experience is a factor in the whole matter-certainly, as Mr. Wallace seems to have proved, in originating the migratory impulse, but yet every aspect of the question is fraught with difficulty, and we must leave to time the discovery of this mystery of mysteries.

There yet remain a few words to be said on what may be termed Exceptional Migration, that is when from some cause or other the ordinary practice is broken through. This differs from the chance occurrence of the waifs and strays with which we began to consider the question in that the Birds subject to it keep in a great measure their customary habit of migrating, and yet are compelled to indulge it in an irregular, or perhaps an altogether novel,

1 Manuel d'Ornithologie, iii. Introd. p. xliii. note. 
mauner, though they are not entirely the sport of circumstances. The erratic movements of the various species of Crossbill (Loxia) and some allied forms afford perhaps the best-known examples. In England no one can say in what part of the country or at what season of the year he may not fall in with a company of the common Crossbill ( $L$. curvirostra), and the like may be said of many other lands. The food of these Birds consists mainly of the seeds of conifers, and as its supply in any one locality is intermittent or precarious, we may not unreasonably guess that they shift fron place to place in its quest, and may thus find an easy way of accounting for their uncertain appearance. The great band of NuTCRACKERs (Nucifraga caryocatactes) which in the autumn of 1844 pervaded Western and Central Europe 1 may also have been actuated by the same motive, but we can hardly explain the roaming of all other Birds so plausibly. The inroads of the WAXWING (Ampelis garrulus) have been the subject of interest for more than 300 years, and by persons prone to superstitious anguries were regarded as the forerunners of dire calamity. Sometimes years have passed without its being seen at all in Central, Western or Southern Europe, and then perhaps for two or three seasons in succession vast flocks have suddenly appeared. Later observation has shewn that this species is as inconstant in the choice of its summer-as of its winter-quarters, and though the cause of the irregularity may possibly be of much the same kind as that just suggested in the case of the Crossbill, the truth awaits further investigation. ${ }^{2}$ One of the most extraordinary events known to ornithologists was the irruption into Europe in 1863 of Pallas's SAND-Grouse, Syrrhaptes paradoxus. Yet this was thrown into insignificance by the appearance in 1888 of a still vaster horde which followed on the whole the lines of its predecessor. Speculation has amused itself by assigning causes to these movements, but the real reason remains in doubt.

We cannot quit the subject of Migration, however, without remarking that the "rushes" to light-houses and light-ships already mentioned are not confined to marine stations or to places possessing the fascination of a Pharos. Toward the close of summer, and well on into autumn, in dark, cloudy, and still weather, it not unfrequently happens that a vast and, to judge from their cries, heterogeneous concourse of Birds may be heard hovering over our large inland towns. The practical ornithologist will recognize the notes of Plover, Sandpiper, Tern and Gull, now faint with distance and then apparently close overhead, while occasionally the stroke of a wing may catch his ear, but nothing is visible in the surrounding gloom. Sometimes but a few fitful wails are heard, of which

1 Bull. de l'Acad. de Bruxelles, xi. p. 298.

2 Cf. Yarrell, Brit. Birds, ed. 4, i. pp. 524-532. 
only an expert listener will know the meaning. At others the continuous Babel of sounds will ensure the attention of the most incurious ( $c f$. GABBLE-RATCHET). It is now well known that these noises proceed from migrating birds, which, it is supposed, having lost their way, are attracted by the glare of the street-lamps; but far too little has been observed to remove the obscurity that in a double sense surrounds them and to enable us to come to further definite conclusion. It must be added also that such a concourse has been noticed where the attraction of light did not exist, for Lord Lilford has recorded (Ibis, 1865, p. 176) how that once at Corfu he was startled by an uproar as if all the feathered inhabitants of the great Acherusian Marsh had met in conflict overhead, but he could form no conception of what birds produced the greater part of it.

MILLER, a name given to the grey males of Circus cyaneus and C. cineraceus (HARRIER) in days when both were common; and also locally to the Whiтeтнroat (cf. Germ. Müllerchen and Dutch Molenaartje).

MIMICRY, with the prefix UNCONSCIOUs, which in every department of Zoology should be always expressed or understood, ${ }^{1}$ signifies the more or less complete likeness, in colouring or form or in both, which one creature bears to another, so that in some cases one may easily be mistaken for the other, though the affinity between them may be very remote. It is probably among Birds that the earliest example of this kind of Mimicry was recognized, for Aristotle (Hist. An. vi. 7) noticed the resemblance of a Cuckow to a Hawk, ${ }^{2}$ while among insects many cases have long been known, ${ }^{3}$ and generally spoken of as instances of "mimetic analogy," whatever that phrase might mean; but, as Mr. Wallace has said (Darwinism, p. 240), "the subject was looked upon as one of the inexplicable curiosities of nature, till Mr. Bates studied the phenomenon among the butterflies of the Amazon, and on his return home gave the first rational explanation of it,"

I Except perhaps in relation to Sorg, but this is uncertain.

2 Hence sprang the belief, as old as his time (though discountenanced by him) and hardly yet given $11 \mathrm{p}$ in some places, that the Cuckow became a Hawk in winter, resuming its more harmless character in summer; and of course all observers know that this belief is still shared by little birds, who on that account "mob" the Cuckow whenever it appears.

${ }^{3}$ These are far too numerous to be cited here, but reference may be given to a few of the older examples, as so many people think the discovery to be recent: Linnæus included the Homopterous Aleyrodes proletella in the Lepidopterous subgenus Tinea; some remarkable instances are given by Kirby and Spence (Introd. Entomol. ii. p. 223), who did not hesitate to assign deception as the motive of the counterfeit presentment, though of course accounting for it in a way very different from that now generally accepted; and Prof. Westwood mentions (Trans. Linn. Soc. xviii. pp. 410, 411) others. 
in a paper that will always be classical (Trons. Linn. Soc. xxiii. pp. 495-566, pls. 55, 56). The explanation is simply that the weaker animal, or that which exists under less farourable conditions, "mimics" the stronger, or that which is more flourishing, the Mimicry being presumably effected by means of Natural Selection; but the difficulties which attend the investigation of the way in which this result is brought about, so as to render the explanation in all cases acceptable, are often extrenely great, and one ought not to be surprised that some zoologists are unable to accept this explanation at all. Indeed it is only by fully appreciating the enormous advantage which protective coloration confers upon certain forms of animal life that any zoologist can bring himself to believe that changes so great, and deviation from the usual appearance of kindred forms so extensive, can be produced in the manner indicated. The difficulties seem also to be increased by the fact that instances of Mimicry, though not unfrequent, and found in many widely differing groups, do not occur oftener!

Cases strictly analogous to those so admirably treated by the late Mr. Bates were immediately after described by Mr. Wallace (Proc. Zool. Soc. 1863, pp. 26-28) as existing in Birds, and especially in certain species of the genus or subgenus known as Nimeta ${ }^{1}$ (OrIoLE) which inhabit many of the islands of the Malay Archipelago, and so nearly resemble those of the genus Philemon ${ }^{2}$ (FrIAR-BIPD) inhabiting the same islands as to deceive even some of the most expert ornithologists. ${ }^{3}$ The details have since been more or less fully given by him in several accessible works (Malay Archipelago, ii. chap. xxvii. ; Contrib. Theory Nat. Selection, pp. 103106 ; Darwinism, pp. 262-264), so that there is no need here to dwell upon them. It will be enougl to state that the two species of Mimetc, $M$. bouronensis and $M$. forsteni, respectively inhabiting the islands of Bouru and Ceram, are on superficial examination identical in appearance with two species of Philemon, $P$. moluccensis or bourouensis and $P$. subcornutus, natives of the same islands, the Oriole and Friar-bird of each island respectively presenting exactly the same tints - the black patch of bare skin round the eyes of the latter, for instance, being counterfeited in the former by a patch

1 It is a curious fact that this genus was, in 1827, named Mimetes (that is, Nimic) by Capt. Philip King (Survey de. of Australia, ii. pp. 417, 418) under the belief that the birds composing it belonged to the Family MLeliphagida, which had assumed the appearance of Orioles, whereas the imitation, as will be seen by the text, is just the other way!

2 Tropidorhynehus Mr. Wallace calls it, but Philemon is the older name.

3 These of course have judged from external appearance only. By any one. with the opportunity of examining the tongue no mistake should be possible, for that member in the Meliphagida (Hover-EATER) to which Philemon or Tropidorhynchus belongs, is most characteristic. 
of black feathers, and even the protuberance on the bill of the Philemon being imitated by a similar enlargement of that of the Mimeta. In the same way Mr. H. O. Forbes in Timor Laut found a corresponding species of Philemon and one of Mimeta so closely alike that Mr. Sclater did not at first distinguish one from the other (Proc. Zool. Soc. 1883, p. 199). In these cases it is pretty clear that the Mimeta, which retains the dull coloration now characteristic only of the immature among the Oriolidx, ${ }^{1}$ is rightly named the mimic, since it is a comparatively weak bird, and must benefit by being mistaken for the strong, pugnacious and noisy Philemon, two or three of which will drive away Crows and even Hawks that venture to perch on a tree they have occupied. ${ }^{2}$

On the information of Mr. Salvin, Mr. Wallace has cited (Contrib. Nat. Select. p. 107) another very curious case of Mimicry in Birds. This is furnished by Accipiter pileatus, a widely-ranging species of Sparrow-Hawk which near Rio Janeiro departs from the plumage it wears in other places to assume that of Harpagus diodon (HAWK), ${ }^{3}$ a local species of insectivorous habit, with the object, as suggested, of deluding small birds into the belief that it is harmless in character. The similarity here extends to both immature and adult plumages, which are very different.

The most perfect case of resemblance between two Birds of different groups seems to be one that, though announced a good many years ago (Proc. Zool. Soc. 1870, p. 386), has been overlooked by most writers on the subject. This is exhibited in the genera Tylas and Xenopirostris, peculiar to Madagascar, ${ }^{4}$ the former being indeed of doubtful alliance, but generally admitted to be very near to Hypsipetes, which is placed either among the Turdidx (Thrush) or Pycnonotidre 5 (BabBLER), while Xenopirostris is one of the Laniidz (SHRIKE), of which Family it wears the regular livery - though apparently dimorphically, for examples of $X$. polleni may be either white or buff beneath. But in either plumage this species is counterfeited, feather for feather, by Tylas eduardi, so exactly that but for a slight difference in size, and a marked distinction in the bill and feet-both of which are in Xenopirostris

1 Mr. Wallace speaks of Mimela "having lost the gay colouring" of Oriolus : but I think the better way of stating the probability is as above.

2 Mr. Wallace finding a peculiar Mimeta in Gilolo, hazarded the prediction that a corresponding Friar-bird would be found there, which subsequently proved to be correct ( $c f$. Salvadori, Orn. Papuas. ii. p. 354).

${ }^{3}$ These species are rudely but recognizably figured, $P l$. col. 205 and 198.

${ }_{4}$ Dr. Sharpe, it is true (Cat. B. Br. Mus. viii. p. 109), merges Mr. Elliot's genus Clytorhynchus in Xenopirostris, making the range of the latter extend to New Caledonia. I venture to doubt the wisdom of this step.

5 By Dr. Sharpe (op. cit. vi. pp. 163-166) it is thrust into the bottomless pit, which he terms "Timeliidx." He recognizes 5 species of Tylas, M. Grandidier (Hist. Madag. Oiseaux, pp. 376-381) but one-with 3 local races. 
very stout - the difficulty of telling one from the other would be exceedingly great, ${ }^{1}$ and according to the canon laid down by Mr. Wallace Tylas must be the mimic, because if it be allied to Hypsipetes, it has wholly thrown off the sombre and inconspicuous coloration of that genus to assume one that is of a very normal Shrike-like character.

It must be borne in mind, however, that all cases of close similarity of plumage are not necessarily cases of Mimicry. Of this the genera Sturnella (MEADow-LARK) and Macronyx (KALKOENTJE) are examples, for these, the latter being a peculiarly African and the former a peculiarly American form, have no points of contact, any more than have the Snowy Petrel of the Antarctic and the equally white Ivory-Gull of the Arctic Seas. In these cases Mimicry is impossible, but even where it is not only possible but even probable, we must always remember that the Mimicry, however produced, is unconscions.

\section{MINA or MINOR, see GrackLE.}

MINIVET, Blyth's name, since adopted by Anglo-Indian writers, for birds of the genus Pericrocotus, a beautiful group of some 20 species or more, wherein the males are generally black and rosecolour and the females grey and saffron, the tints differing in the several forms, while a few have no bright colouring at all. 'The range of the genus extends from Affghanistan through India, Burma and China to Manchuria and Japan on the north, and to Java and Lombock on the south, and some of the islands, as Loochoo and Hainan, seem to have peculiar species. Pericrocotus appears to belong to the group containing CAMPEPHAGA, if that be regarded as distinct from the Laniida, as it probably is. BITTERN.

MIRE-DROMBLE and MIRE-DRUM, local names of the

MISSEL-BIRD or MISSEL-THRUSH, vulgar corruptions of Mistletoe-bird or Mistletoe-THRUsh.

MOA, supposed to be the Maori name for the extinct Ratite birds comprehending the genus Dinornis and its allies; ${ }^{2}$ and now

1 Xenopirostris polleni and all the forms of Tylas are describer and well figured in M. Grandidier's great work just cited (1p. 432-434, pls. 169, 170 A. fig. 2, 170 B. fig. 2 ; pp. 376,379 , pls. 141, fig. 2, 141 A. fig. 2, 143, 144, 144 A.)

2 The word, however, has several other meanings, and Sir James Hector has kindly communicated to this work the suggestion that applied to a Bird it was probably sounded more like $\mathrm{Mor}_{\mathrm{ah}}$, as latterly pronounced by the natives of the South Island, for it had dropped out of nse among the northern tribes, from whom the vocabulary was collected by the early missionaries, one of whom (Bishop Hadfield) said that not conceiving, when so engaged, the former existence of so large a bird, he had never been able to obtain the precise meaning of the word, and it is impossible now to be certain as to its sound. 
generally accepted in that sense. The earliest published notice of the Moa seems to be that of Polack, whose New Zealand, a narrative of his travels and adventures in that country between 1831 and 1837 , appeared in 1838 , the preface to the work being dated from London in the month of July of that year. Herein he observes (i. p. 303) "that a species of the emu, or a bird of the genus Str'uthio, formerly existed in the latter [North] island I feel well assured, as several fossil ossifications were shewn to me when I was residing in the vicinity of the East Cape, said to have been found at the base of the inland mountain of Ikorangi "; stating also that "the natives added that, in times long past they leceived the tradition, that very large birds had existed, but the scarcity of animal food, as well as the easy method of entrapping them, had caused their extermination." 1 In another passage Polack writes (i. p. 345), "Petrifactions of the bones of large birds supposed to be wholly extinct, have often been presented to me by the natives." And again (i. p. 346), "Many of the petrifactions had been the ossified parts of birds, that are at present (as far as is known) extinct in these islands, whose probable tameness, or want of volitary powers, caused them to be early extirpated by a pèople, driven by both hunger and superstition (either reason is quite sufficient in its way) to rid themselves of their presence."

There can be little doubt that the first Moa-bone seen in Europe was the shaft of a femur brought by Mr. Rule to Sir Richard Owen, who exhibited it to the Zoological Society on the 12th of Novembe: 1839 ; but, though indicating its Struthious affinities, neither in the abstract of the memoir he read (Proc. Zool. Soc. 1839, pp. 169-171), nor in the memoir itself as published in 1842 , when the fragment was beautifully lithographed by Mr. Scharf (Trans. Zool. Soc. iii. pp. 29-32, pl. 3), was any scientific name assigned to the bird of which it had formed part. At two meetings of the same Society in January 1843, Sir Richard having received further information from Messrs. Cotton and Williams, well-known missionaries in New Zealand, returned to the subject and exhibited various bones transmitted by the latter to Buckland, proposing for the bird to which they belonged the name of Megalornis now -zeulandix; though, finding this generic name to have been already used in another sense, that of Dinomis

1 The amount of traditional evidence as to Moas which has come down to modern times has been varionsly stated by different investigators, and some of it is not milikely to have been supplied to mect the demands of zealous enquirers. Still none can doubt that there is enough to prove the survival of the birds until after the conntry was peopled by man, and the legends describing them contain little that can be deemed fabulous. Nevertheless all are agreed that one of the most ancient of the Maori poems contains a saying which may be rendered "Lost as the Moa is lost," shewing that its extirpation was accomplished when that composition was made. 
was promptly (14th Feb. 1843) substituted for it and has ever since lield ground (Proc. Zool. Soc. 1843, pp. 1, 2, 8-10, 19). In due time these specimens with others, subsequently received from the same quarter (tom. cit. pp. 144-146), and referred to five, or rather six, distinct species of the genus ${ }^{1}$ were fully described and figured (Trans. Zool. Soc. iii. pp. 235-275, pls. 18-30), forming the first of that incomparable series of memoirs continued over nearly forty years which will always be associated with the author's name, ${ }^{2}$ but cannot be here further particularized, though mention must be made of the assistance rendered by Mr. Percy Earl and by Mr. Walter Mantell.

The Moas inhabited both the North and South Islands of New Zealand, where they were represented by a considerable number of species, of which the smallest was scarcely larger than a Turkey, while the largest had a tibia of more than a yard in length. We are inclined to estimate the number of species at about 20; Capt. Hutton (N. Zeal. Journ. i. pp. 247-249; Trans. N. Zeal. Inst. xxiv. pp. 93 - 172) admits, indeed, 26 species, but some of these we should prefer regarding merely as varieties or sexes. Certain species were peculiar to the North, and others to the South Island, while some were common to both. A femur described under the name of $D$. queenslandix ${ }^{3}$ appears to belong to a Moa, and if its reputed place of origin be correct, shews that the Family extended to Australia; - a fact in distribution which, if true, is of extreme importance.

When New Zealand was first systematically explored by Europeans, Moa-bones were found lying on the surface of the ground in many districts in great profusion, being especially abundant near the old cooking-places of the natives, and often shewing traces of the action of fire. They also occur in the most superficial and recent deposits, such as blown sands, as well as in caves and swamps. Many of the latter, such as that of Glenmark, near Canterbury, when drained have been found to be full of Moa-bones, frequently in all conceivable positions. In one particular district of the South Island, where climatic conditions appear to be peculiarly favourable, skeletons have been found with the bones connected by dried muscles, ligaments, and integument with the cuticle and feathers. Fragments of egg-shells, as well as pebbles swallowed by the birds and contained in their stomachs at their death, together with impressions of footprints, have likewise been discovered. The discovery of

1 Namely D. giganteus, ingens, struthioides, dromæoides, didiformis and otidiformis. The original specific name novæ-zealandire was tacitly dropped.

${ }^{2}$ This series was issued in 1879 in a separate form under the title of the Extinet Birds of New Zealand.

${ }^{3}$ De Vis, Proc. R. Soc. Queensl. i. p. 27, pls. iii. ir. (1884). Etheridge, Rec. Gcol. Surv. N. S.W. i. p. 128 (188:). 
remains of a Moa (Anomalopteryx antiqua) in clay on Timaru Downs seems, however, to carry back the group to the Pliocene, or possibly the upper part of the Miocene period; but the age of the beds has been called in question by Mr. H. O. Forbes. That Moas lived down to a comparatively recent epoch is abundantly evident, and it is practically certain that they formed a considerable portion of the food of the human race by whom New Zealand was first peopled, and by whom they were in great part or wholly extirpated. Capt. Hutton considers that in the North Island Moas were exterminated not less than 400 or 500 years ago, while in the South Island they might have lingered a century later. The larger species (Dinornis) were always comparatively rare, but many of the smaller forms were very numerous. How so many became entombed in the swamps is a question not yet solved; although it is suggested that débâcles during a glacial period may have been the chief agents.

As a rule, Moas were destitute of wings, although Capt. Hutton states that a rudimentary pair existed in Anomalopteryx (Palapteryx) dromaoides. The nearest allies of the Moas being apparently the KIwis, it seems a fair inference that the females were larger than the males; and this is confirmed by bones differing only slightly, but constantly, in size. ${ }^{1}$ The feathers differ from those of the Kiwis in having an aftershaft.

Moas are distinguished from all existing Patita in having a bony bridge on the anterior surface of the lower end of the tibia above the condyles (fig. 1). The tarso-metatarsus (fig. 2) has three distal trochleæ, and in most cases (according to Capt. Hutton probably all) carried a hallux. The beak (unlike that of the Kiwis) is short and stout; the form of the lower jaw being either U-like or V-like. The general form of the pelvis is very like that of the Kiwis; but the sternum (fig. 3) differs by the absence of the superior notch, the more divergent lateral processes, and the abortion or disappearance of the grooves for the coracoids.

The most remarkable features which the birds present are the gigantic dimensions attained by some of them, and the great number of species occurring in such a limited area as New Zealand. The absence of Mammals in those islands has doubtless been the chief cause which has led to this great development, both as regards species and individuals, of Moas (as well as of other flightless birds); and it has generally been considered that this development has taken place entirely within the limits of these islands ${ }^{2}$ while Capt. Hutton suggests that the genera may have been differentiated on separate islets by subsidence during the Pliocene period. As regards their introduction into New Zealand, Mr. Wallace (Island Life, pp. 446,447 ) is of opinion that Cassowaries, Emeus, Dromornis, Kiwis

1 Capt. Hutton does not admit this sexual difference in size.

${ }^{2}$ If $D$. queenslandiæ be truly Australian, this view will need modification. 
and Moas were derived from an Asiatic stock of Ratite birds; bnt Capt. Hutton objects to this view, and suggests that the Moas are descended from rolant birds, allied to the TiNanous, which inhabiter New Zealand during the Eocene. The Moas are thus regarded as the ancestral stock of all the Australasian Ratita, while those of Asia and Ameriea are supposed to have had a totally independent origin. There are, however, many objections to this view; one of the most obvious being the absence of any evidence of the presumed Tinamoulike Eocene birds. ${ }^{1}$

Althongh, as already mentioned, there is some uncertainty as to the aetual mumber of speeies of Moas, yet there is no doubt that the

A
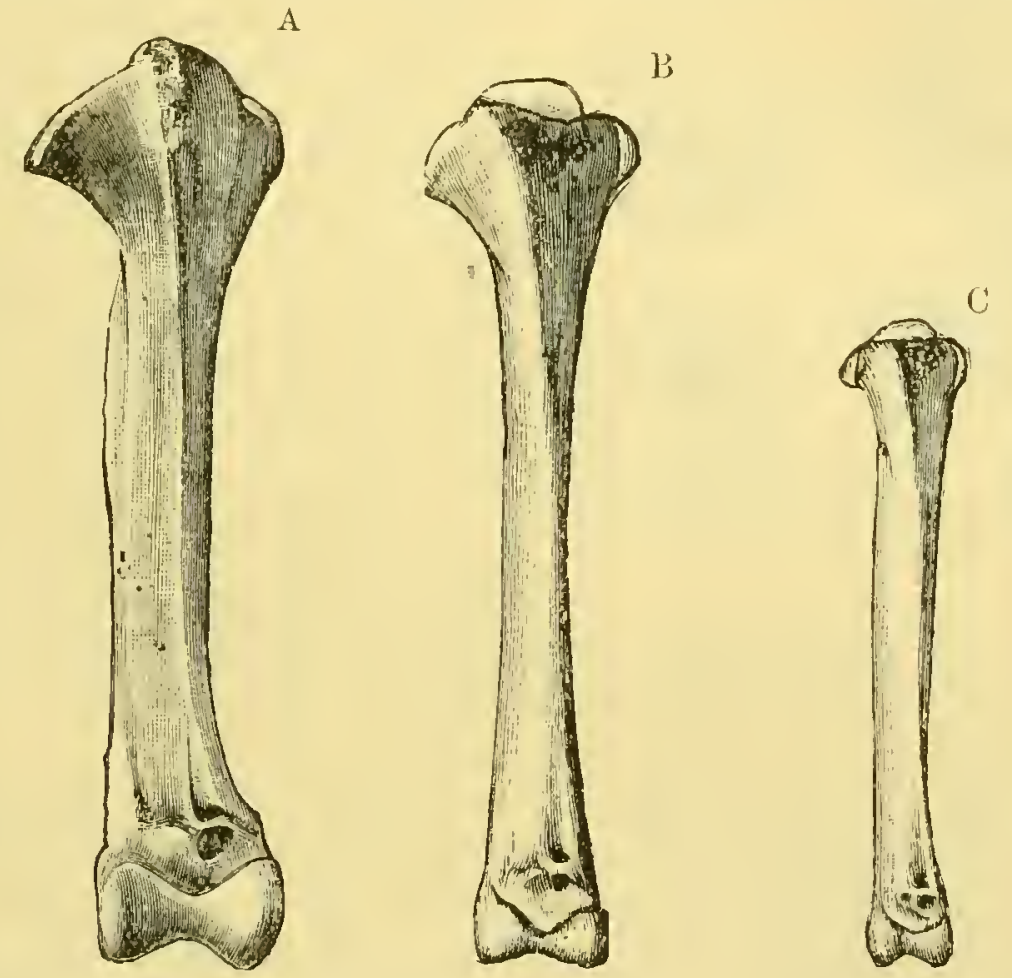

Fig. 1. RIFH TiBiA of Euryapteryx gravis (A), 1/6, of Dinornis gracilis (B), 1/s, and Megal-nteryx temuipes (C), 1/8. Anterior view.

(From Lydekker's 'Catalogue of Fossil Birds in the British Museum.')

number was large. The Family may be divided into at least 5 genera, of which the first and last are very widely separated, althongh connected to a eertain extent by the intermediate forms."

The typical genus Dinornis, Owen, includes the tallest of the Moas, and is characterized by the length and slenderness of the

1 It is not easy to reconcile Capt. Hutton's views as to the impossibility of an immigration of flightless birds having taken place into New Zealand, while he admits that emigrations must lave happened.

2 Capt. Hutton adopts 7 genera (one of which he subdivides into two subsenera), exchnsive of one of those noticed below. 
tibia (fig. 1, B) and tarso-metatinsus (fig. 2, B), and also by the broad and flattened beak, the apparent absence of the hallux, and the width and convexity of the sternum. The typical $D$. nowa-
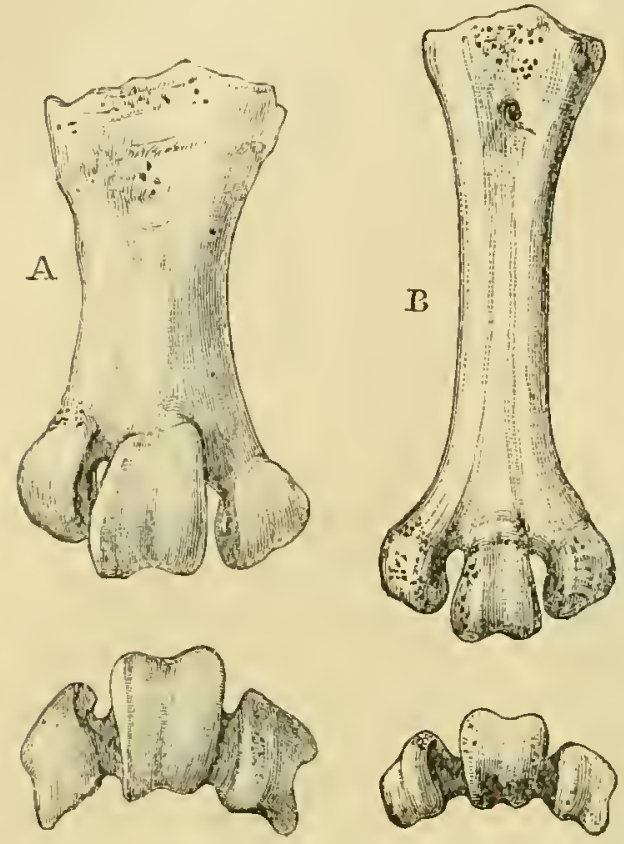

Fig. :2. Right Tarso-metatarsus of Pachiomis elephuntopus (A), and Dinornis struthioides (B), 1/0. Anterior aspect. (From the same work.)

smaller and imperfectly-known forms from the Sonth Island, characterized by the extreme slenclerness and length of the femul and tibia (fig. 1, C), and the shorter tarso-metatarsus.

Anomalopteryx, Reichenbach (= Meionornis, Haast) is typically replesented by the small D. didiformis, Owen, and, in our opinion, may be conveniently taken to inchnde all the smallel species of the group, although Capt. Hutton prefers to separate Owen's D. diumaoides as Palapteryx, D. curtus as Celu, and D. diclimus as Mesopteryx. On the other hand, Owen's D. casucuinus, which Von Haast included in Meionoruis, is placed by Capt. Hutton with Emeus crussus. Whether included under one or more generic headings, all these forms are characterized by having the tibia and tarso-metatarsus considerably shorter and stonter than in Dinomis, while the beak is narrow and more or less pointed, the hallux present (as in the following genera), and the stermm (fig. 3, A) very long and narrow. There is great difficulty in correctly identifying the various members of this group with the species named by Owen on the evidence of detached bones. A. cusucurina, with a tibia measuring 19 inches in length, is the largest form, and $A$. (Cela)

1 If these forms be regarded as distinet, the name novie-zealandir should be adopted for the latter. 
oucni, in which the tibia measures only $9 \cdot 2$, the smallest. A. parie is the only member of the Family of which there is a perfect skeleton in English collections. It is identified by Capt. Hutton with the trpical A. didiformis; but a skeleton transmitted by Ton Harst to the British Museum and assigned to the latter has a relatively smaller skull. In the type of $A$. (Mesopteryx) didince the integuments of the head and feet are still preserved.

Emeus, Reichenbach, was established on D. cressus, Owen. It is a rather large species, to which Owen and Ton Haast assigned a broadbilled skull, and although Capt. Hutton states that the skull is really of the narrow-beaked type of Anomulopteryx, we have reason to believe that the original view is correct. This Moa was confined to the South Island.
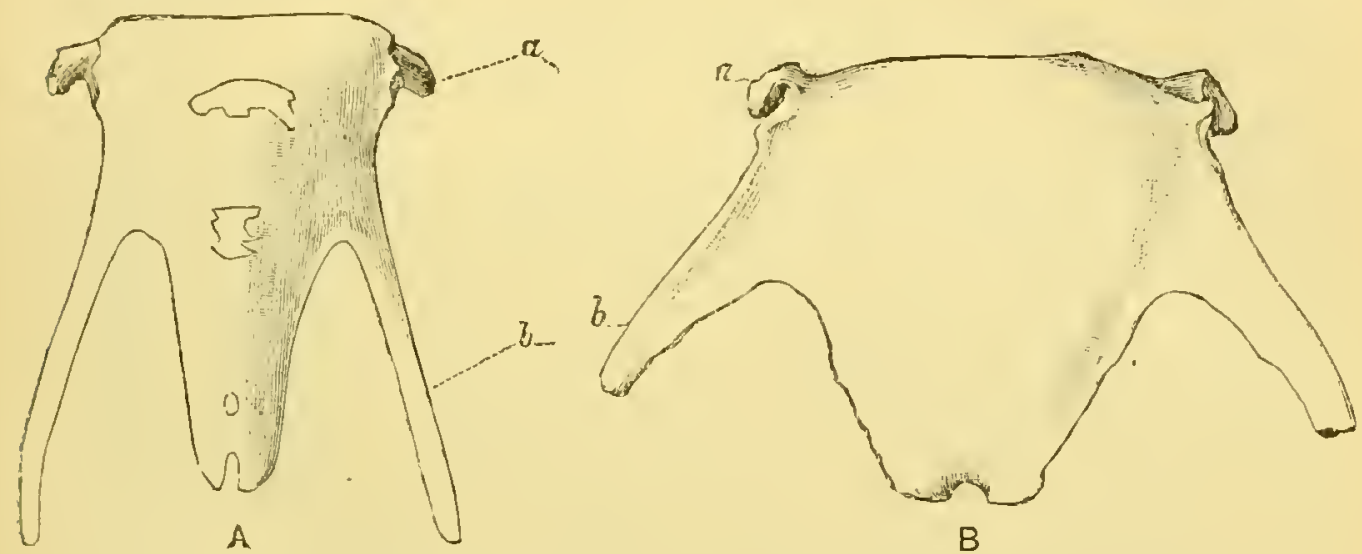

Fig. 3. STERvis of Anomatopleryx casurerina (1), and Puchyornis elcphanlopus (B), $1 / 6$. $a$, Custal process; $b$, Lateral process. (From the same work.)

Ton Haast proposed the name Euryaptery.r. for the small and broad-beaker D. gravis, Owen. This species, which is confined to the South Island, is distinguished from those that follow by the absence of any inflection of the lower end of the tibia, and the relative Jength and straightness of that bone. It therefore seens to be cutitled to generic distinction. ${ }^{2}$ If, therefore, the so-called $I$. rrassus really have a broad-beaked skull, both that and the present species may be inclucled under the title of Emeus.

Lastly we have the genus Puchyornis, Lydekker, likewise typically confined to the South Jsland, and inchuding some three or four species of large size, characterized by the extraordinary massiveness and sharpness of their limb-bones. The tarsometatarsus (fig. 2, A) presents a remarkable contrast to the corresponding bone of Dinornis (fig. 2, B); and a similar contrast is

1 It is doubtful if this skeleton is altogether authentic.

2 Aceording to Ton Haast it is further distinguished by laving a sternum of the tyle of Anomalopterys, but Capt. Hutton throws some doubt on the correctness of the restoration of the skeleton ly Von Haast. 
exhibited by the tibir of the two genera, that of Pachyornis being further distinguished from the corresponding bone of all the preceding members of the Family by the inflection of its distal end. The sternum (fig. 3, B) is likewise very different from that of the other forms, being very wide and flat, with broad and divergent lateral processes. The skulls found with the limb-bones of $P$. clephantopus near Oamaru Point, and transmitted with them to the British Museum, have pointed beaks, and there is much probability of their reference to this species by Owen being correct. $P$. elephantopus, of which the remains, often charred by fire, are extremely abundant near Oamaru Point, was a large species, the tibia measuring 24 inches in length; but $P$. immanis was still larger, with a remarkably wide tarso-metatarsus.

R. LYDEKKER.

\section{MIOAT-HEN, an old name for the Moor-HEN.}

MOCKING-BIRD ${ }^{1}$ is the name given by naturalists and other's to a number of birds that possess the power of imitating the notes of other species of the Class. Comparatively speaking, however, it almost exclusively applies to the Mocking-bird of America, the Mimus polyglottus of recent ornithologists. This remarkable bird is regarded by those who have investigated its structure as belonging to the Family Troglodytidx, a group containing the Wrens, Thrashers (Harporhynchus), and their allies; a subfamily, Mimina, within this Family having been created to contain such birds as are represented in the United States by the lastnamed genus, as well as the genera Oreoscoptes, Mimus and Galeoscoptes. ${ }^{2}$

The most THRUsH-like forms among the Troglodytidæx are more or less closely related to the Turdidx, the Family containing the typical Thrushes, and none more so than are the several genera above named. Indeed, many ornithologists regard the Niminx as being

1 For this article on a subject which can only be fitly treated by an American ornithologist I am again indebted to Dr. Shufeldt. The earlier English naturalists, Charleton, Ray and Catesby wrote the name "Mock-bird"; and in England either form, or more often "Mock-Nightingale," is occasionally given to the BLACKCAP, Sylvia atricapilla, and the SEDGE-BIRD. In India and Australia the name is sometimes applied to other species, and eveu in North America two Wrens, Thryothorus ludovicianus and $T$. bewicki seem to be widely known as "Mocking-birds."-A. N.

2 In this connexion see the paper by Mr. F. A. Lucas entitled Notes on the Osteology of the Thrushes, Miminx, and Wrens (Proc. U. S. Nat. Mus. vol. xi. 1888), and two papers by the present writer, viz. On the Position of Chamac in the System (Jour. Morph. vol. iii. No. 3, 1889, pp. 475-502), also Contributions to the Comparative Osteology of the Families of North American Passeres (Jour. Ilorph. vol. iii. No. 1, 1889, pp. \$1-114). 
aberrant Turdidx, the former possessing tarsi anteriorly scutellate, while the latter are characterized by having the tarsal theca fused into one solid, smooth sheath in front. It is as well to observe here, however, that in Galeoscoptes the scutella of the tarsus are sometimes quite obsolete. Osteologically the Mimina, Thrushes and Wrens possess apparently distinguishing characters of about equal rank and strength, wlile in some particulars the several genera almost seem to intergrade where the affinities are most closely drawn. From some cause or another, not yet fully determined, adult Mockingbirds vary considerably in size, especially in length, several apparently full-grown males ranging from $9 \frac{1}{2}$ to 11 inches; and it is also a well-known fact that they likewise vary greatly in their powers of song.

Althongh exceedingly plain in the coloration of his plumage, the Mocking-bird is a strikingly handsome and graceful bird. This is largely due to the ease and elegance of his every movement, his neat appearance, and a certain decisive dignity in all his actions. His eye is full of animation, and his constant bearing full of energy. The sexes differ but little in colour or size, the female being rather browner and at the same time smaller, while young birds are speckled below with dusky, as is the case in the majority of young Turdida. An adult male is of an ashy-grey above, and a dingy white below. A large white space marks the blackish-brown wing, and the outer tail-feathers are also white, the remainder of the tail being black, the feathers tipped with white, the same being graduated from without towards the middle pair of usually wholly black feathers. The bill and feet are likewise black, and the irides of a fine golden cream-colour. In form, the bird is trim and Thrush-like, the tail being rather long and cuneiform.

The habitat of this species may be said to extend across the entire breadth of the United States, and south into Mexico; but north of the 38 th parallel the bird becomes rare. Over this wide range the food of the Mocking-bird varies somewhat, although it may be broadly said that it everywhere consists largely of many of the smaller fruits, insects and some seeds. In some respects its nidification agrees with the typical Thrushes, the nest being placed without much regard to concealment in some bush or low tree; being bulky, and built of twigs, dried leaves, fine fibrous roots, and sometimes to these are added wool or tow when procurable. The eggs are from four to six, bluish-green in colour, freckled with blotches of various shades of yellowish-brown. Two broods may be reared in the season, and in the southern States sometimes even three. Very often the nest of the Mocking-bird is attacked by various species of snakes, more especially the black-snake (Bascanium constrictor), which is very partial to the eggs and young of this and other birds. These attacks are met by Mimus with 
conspicuous courage, and the intruder is frequently compelled to withdraw, while the victorious bird announces the result of the encounter with a perfect medley of his richest vocalizations, which are usually poured forth from the top of the tree or bush containing his nest.

Were what we have given in the foregoing account of the Mocking-bird all that goes to make up his life-history, he would pass among his Class as a very ordinary representative of it indeed; it is not, however, for any of the traits or habits thus far enumerated that he has become one of the most famous of his tribe. He is, as every student of nature lnows, one of the most extraordinary songsters of the entire world's avifauna. As an imitator of the songs or cries of every other species of bird he has ever listened to, the Mocking-bird probably stands without a rival in the entire Class, but in addition to this power he possesses native notes of great purity, strength, energy, and sweetness. To some degree these latter resemble the notes of the Brown Thrasher, Harporhynchus rufus, but are of greater variety and far richer.

For thorough appreciation, one should catch him upon a dewy morning just as the sun rises, and he flits to the top of some low tree to pour forth his medley of carols in sonl-felt welcoming. This may be in some quarter of the sunny south, perhaps near the manor-house of some broad plantation, where not only can he imitate any individual of the host of native songsters about him, but vary the strain with any of those familiar sounds heard about the house and barn-yard. To see that little feathered being so brimful of ecstasy, replete with action and animation, drooping his wings, spreading his tail, so buoyant as hardly to be able to retain his perch, while the air is actually filled with his inimitable musical performances, is a sight not likely to be forgotten. Clearly, and with the greatest possible accuracy and rapidity, and with a mellow strength even exceeding the originals, he utters the notes and calls of twenty or more birds in succession, ranging all the way from the plaintive air of the Blue-Bird to the harsh, discordant cries of Jays, Sparrow-Hawks, and even with equal compass the vociferations of an Eagle. Catching breath, and tossing himself lightly into the air above his perch, he alarms the entire feathered community assembled by his imitating the cries of a wounded birdling in the talons of a Hawk; this is followed perhaps by the crowing of a Cock or the vociferous note of the Whip-poor-will, and the very incongruity appears to put his feathered listeners to shame at the hoax.

Caging seems hardly to diminish his powers, and he will sing with the greatest energy the best part of a moonlit night, as lustily as though he were free in his native haunts. But enough: to have one appreciate the Mocking-bird he must be heard, and he 
must be heard under all circumstances where he best loves to dwell. To compare him with his only rival, the European Nightingale, seems to me quite out of place, though I will say that my faith in the powers of the Mocling-bird is so firm, that I believe were he successfully introduced into those countries where the Nightingale flourishes, that princely performer might some day wince as he was obliged to listen to his own most powerful strains poured forth with all their native purity by this king of feathered mockers, the subject of the present notice.

In America there are no other birds that at all deserve the name of a Mocking-bird. The Magpie often imitates bits of human speech with great accuracy, while the CAT-BIRD sometimes makes a feeble effort to bring out the notes of some of the smaller birds, but they are not to be thought of in connexion with the powerful productions of Mimus polyglottus, while the cat-like mewing note of the former is not in imitation of that animal at all, but only an accidental vocal resemblance. ${ }^{1}$

R. W. SHUFFLd.

MOLLY and MOLLY-MAWK, corruptions of MALLEMUCK, applied by modern seamen to the smaller kinds of ALBATRos.

MONAL or MOONAUL (Hind. Munál), ${ }^{2}$ the Anglo-Indian name for birds of the genus Lophophorus, some of the largest of the

1 Some twelve or fourteen other species of Mimus have been recognized, mostly from South America, where the name of "Calandria" (Lark) is often applied to them, and MIr. Hudson's account (Argent. Orn. i. pp. 5-11) of the three inhabiting the portion of that continent treated of by him is well worth attention; but $M$. orpheus seems to be common to some of the Greater Antilles, and $M$. hilli is peculiar to Jamaica, while the Bahamas have a local race in $M$. bahamensis. The so-called Mountain Mocking-bird, Oreoscoptes montanus, is a form not very distant from Nimus; but, according to Mr. Ridgway, it inhabits exchnsively the plains (overgrown with Artemisia) of the interior tableland of North America, and is not at all imitative in its notes, so that it is an instance of a misnomer. Of the other genera allied to Mimus, those known in the United States as THrashers, and belonging to the genus Harporhynchus - of which six or eight species are found in North America, and are very Thrnsh-like in their habits-have been mentioned abore; but there is only room here to dwell on the CAT-BIRD, Galeoscoptes or Mimus carolinensis, which is an imitator of many sounds, with at the same time peculiar notes of its own, from one of which it has gained its popular name. The sooty-grey colour that, deepening into blackish-brown on the crown and quills, pervades the whole of its plumage - the lower tail-coverts, which are of a deep chestnut, excepted-renders it a conspicuous object; aud though, for some reason or other, far from being a favourite, it is always willing when undisturbed to become intimate with men's abodes. Besides its range on the American continent it is one of the few species that are resident in Bermuda, while on more than one occasion it is said to have appeared in Europe, thongh whether as an unaided risitor may be doubted. $-\Lambda$. N.

- See Intc and Burnell, Hobson.Jobson, pp. 443, 444. 
Plocianilat, the Impeyan PHEAsAsts of many writers, so ealled because one of them was introdueed to notice by Sir Elijall and Lady Impey on returning from India in $1784 .^{1}$ But the speeies thus made known, the true $L$. impeianus, seems to have a re-

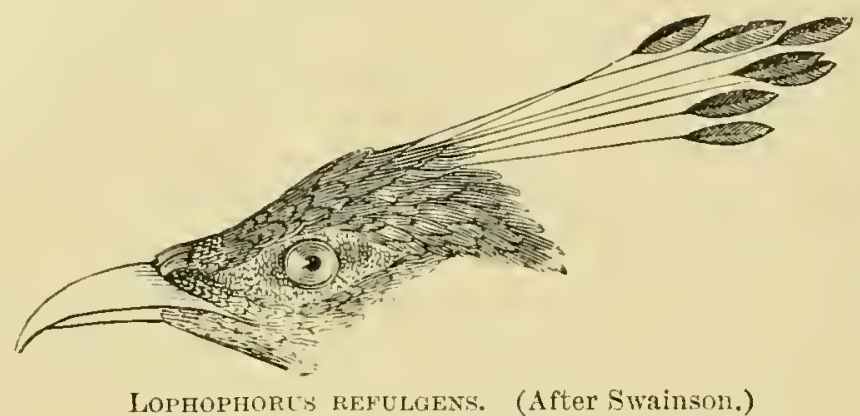

strieted range in southern Cashmere (Chamba), and is not common in collections, a nearly allied one, L. refulgens, which frequents the forests of the southern slopes of the Himalayas, from eastern Affghanistan to western Bhotan, being generally mistaken for it." Its habits, described by Mr. Frederic Wilson, writing in 1848, as "Mountaineer" in The India Sporting Reriew (viii. pp. 143-148), and quoted by. Jerdon (B. Ind. iii. pp. 511-515), are completely those of an ordinary Pheasant, though it often shews a greater partiality for perching upon a tree when made to take wing. In some districts it seems to have been extremely numerous not so many year's ago, but there is reason to fear that, in spite of the well-intended action of the Indian Government, this is not so now; fol the cocks have been killed by thousands to meet the "phme" market, and their refulgent feathers are not only largely used by women to bedizen their persons, but also in the construetion of fans, sereens and the like. The liens are fortunately without special adormment, and carry on their maternal duties comparatively ummolested in a modest attire admirably adapted to concealment, and in strong cortrist to the brilliant hues of their mates, whose plumage of shining green and blue over nearly the

1 Cuvier in 1829 (Riene Animal, ed. 2, i. p. 474), and after him Tule (Marco Polo, i. 1. 248), believe that it was described by Ælian (Nat. Anim. xvi. 2), but what the last says of his "Great Indian Cock," though in several respects fitting the Monaul, seems too vagne to make this certain. Some suppose that Flian took lis information from Ctesias, but the fragments of the latter speak only (Indica, (a). 3) of very birg Indian Cocks, a IIS. at Ifmich reading, according to P. J. C.

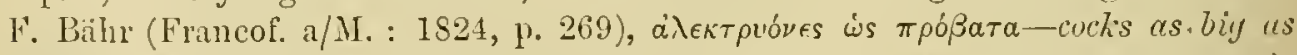
sheep! Mr. II'Crindle, in his edition of Ctesias (Bombay: 1852, 1. 36, note), also thinks he had this bird in view, but woefully misspells its scientifie name.

- L. impeionus has the lower part of the hack and body generally of a goldengreen, while in $L$. rrfulgens the former is white and the latter black. The correction of the common mistake is dne to Mr. Ogilvie-Grant (Cut. B. Br. Mus. xxii. 1). $278)$, and is the more welcome since the original species had bcen redeseribed (Ilis, 1884, p. 421, 11. x.) under the new name of $L$. chambann: 
whole body, with a gleam of gilded purple on the nape, a snowywhite rump and rufous tail, ofter a marvellously bright combination of colours. Another striking feature is the crest of feather's formed almost like those of the common Peacock, and this erest is possessed also by the true L. impeimus. In Assam a third species, L. scluteri, is fomd (Proc. Zool. Soc. 1870, pl. xiv. ; 1879, pl. li.) crestless, and having the tail white with a broad reddish bar near the tip; while a fourth, L. l'huysi, having a erest of ordinary feathers, and a dark glossy green tail (op. cit. 1868 , pl. i.), inhabits Moupin. Other species may not unlikely reveal themselves as the

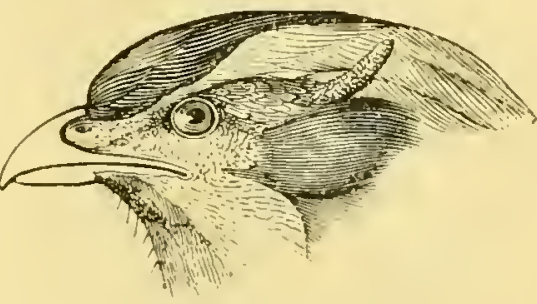

Tragopax SATYRCs. (After Swainson.) North-eastern portion of the Indian Region is explored. According to Jerclon (op) cit.), one of the Horned Pheasants, Trugopen or Ceriomis sutyrus, is also called "Monaul" ly Europeans at Darjiling.

MONK, a name in some parts of England for the cock BuLLFINCH, and in Anstralia one of many applied to the Friar-BLRD.

DIONSTLOSTTIES' are naturally more observed in domesticated than in wild Birds, and are more commonly eases of excessive than of arrested development. The former may be restricted to overgrowth of otherwise small parts, such as donble feathers, or may amount to the addition of a whole limb, or even still greater portion of the body. Frequently such supernumerary parts seem clue to an early splitting of the affected nember in the embryo, but whether caused by mechanical injury or due to an unusual activity of the growing and multiplying cells it is of course in most cases impossible to say. As a rule, such abnormalities are purely pathological, and not indicative of ancestral conditions, though vases are known in which latent germs have certainly been awakened and given rise to organs or parts of organs that in normal individnals of the species are either absent or rudimentary.

Supernumerary toes, as in the Dorking Fowl, are of common occurrence. In these cases the additional toe is generally the result of the HALLUX being split into two, and not the real fifth toe, which was long ago completely lost by the Reptilian ancestor's of Birds.

Three legs are very frequent; the third limb, which is generally smaller and with crippled toes, being attached to the caudal vertebre, to the pelvis, or even to the femur of one of the proper legs. Such cases have been many times recorded in the Duck, Fowl, Sparrow and other common birds, while Lidbeck long ago described (K. Tetensk. Acud. Hundl. 1762, p. 164) in adult Eagle with three feet, of which the superfluous foot was placed between the other two and bore seven toes. A more recent ind somewhat similar 
instance is described by Mr. H. K. Coale (Auk, 1887, p. 332), in which a superfluous toe was loosely attached to the muscles of the thigh of a Buteo latissimus. ${ }^{1}$ Monstrous examples with four legs are known in Fowls, Pigeons, Geese, Sparrows and the Goldfinch, the supernumerary pair being sometimes correlated with a double vent. A Chick preserved in the Cambridge Museum has the additional pair of limbs attached to the end of the stunted tail.

Supernumerary wings, articulating below the normal wings, likewise occur, but very rarely except the legs be also doubled, so that the monster possesses eight limbs (Tiedemann, Anat. und Naturgesch. Vögel, ii. p. 273).

Many other malformations may be seen in various Museums, but only a few need be here mentioned-such as Chicks with two bills, three wings and four legs; Geese, Pigeons, and Pheasants with two or three bills; Chicks, Ducklings and Pigeons with two heads. Occasionally considerable portions of the trunk are affected by duplicity, producing not only two heads and necks, but two vertebral columns and two bellies. Two hearts, within otherwise normal bodies, have also been described in adult Fowls, Turkeys and Geese. The Cambridge Museum possesses a nearly adult example of a Duck which beside the two normal and functional legs has an extra right leg of the same size as the others, but ending in five complete toes. Another immature Duck has a cleft in the middle line of the sternum, separating it together with the lieel into a right half and a left, in this respect continuing the embryonic condition. Similar cases of arrested development are common, and one, of a Pigeon, has been figured (Phil. Trans. 1869, pl. xxiii. fig. 172). In the same Museum is an adult male Turnstone (Strepsilas interpres), which was in perfect plumage when killed, with only one leg, and not the least trace, as ascertained on dissection, of the other. Fowls may have their toes more or less united by a web, and Ducks be without any web between their toes; the last case is of some curiosity, insomuch as such birds, as they swim, close their toes during the back stroke, thus adapting themselves to their abnormal condition.

Questions relating to abnormal excess of structure form what is called Teratology, on which the works of M. Camille Dareste ${ }^{2}$ and Mr. Bateson ${ }^{3}$ may be profitably studied. The former comes to the following conclusions:-Abnormalities are always due to modifications of the early embryonic development. Multiple heads are the

1 The same gentleman also records a Dolichonyx oryzivorus having a horny spur, of which he gives a figure (tom. cit. p. 333), "growing from the thumb tip" of each wing. This may be compared with the examples already cited (CLAws, pp. 89, 90), but they scarcely belong to the category of Monstrosities. -A. N.

2 Recherches sur la production artificielle des monstruosités, ou essai de Tératogénic expérimentale. Paris : 187\%.

${ }^{3}$ Materials for the Study of T'ariation. London: 1894. 
result of arrested derelopment of the anterior cranial resicle. Irregular glowth of the Axsion frequently has a disturbing influence upon rarions parts of the embryo, and thus abnormalities of the tailfold (EMBryologr, p. 201) produce hind limbs abnormal in shape and position, a crooked vertebral column and so on. Double or treble monsters, partial or even perfect twins, or triplets, may be due to any one of three causes:- - two or three yolks, each with its own blastodem (p. 200) in one common shell; two blastoderms with one yolk; or one blastoderm upon a single yolk, split by a subsequent injury, each portion of it producing a more or less complete counterpart of an embryo or portion of it. M. Dareste las been able to shew beyond doubt that portions of the blastoderm artificially split off, or even parts of more advanced embryos will occasionally continue growing into a part at least of that organ, of which the respective embryonic cells were the normal substratum; in the case of two blastoderms mpon a single yolk, complete though more or less united embryos will be the result. According to the present state of our knowledge it is not justifiable to explain partly multiple monstrosities by the assumption of a fusing of originally separate embryos, but by a splitting of the blastoderm, and if that takes place very early and is complete, each of its halves, which in Mammals have little or no yolk, may produce an independent embryo, so that in such a case the flippant saying that "A twin is only the other half" happens to be true.

MOOR-BUZZARD, the common name in England, in days when the bird was not scarce, for what is called in books the Marsh-Harrier.

MOOR-COCK, MOOR-FOWL and MOOR-POULT, old English names of the bird now well known as the Ped Grouse; but

MOOR-HEN is the commonest name of a common bird, often called $W^{\top}$ ater-hen, and in books sometimes Gallimnle. An earlier English name was Moat-hen, which was appropriate in the days when a moat was the ordinary adjunct of most considerable houses in the country, and this species its ordinary denizen. It is the Gullinulu. chloropus of ornithologists, and so well known as hardly to need description.

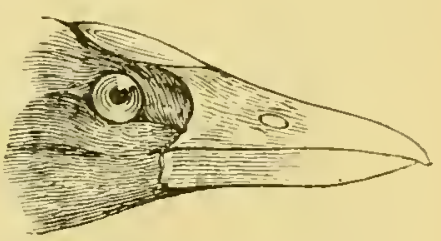

Moor-heN. (After Swainson.) About the size of a small Bantam-hen, but with the body much compressed, as is usual with members of the Family Rallide (RAIL) to which it belongs, its plumage above is of at deep olive-brown, so dark as to appear black at a short distance, and beneath iron-grey, relieved by some white stripes on the flanks, with the lower tail-coverts of pure white-these last being very conspicuous as the bird swims. A scurlet frontlet, especially 
bright in the spring of the year, and a red garter on the tibia of the male render him very showy. Though often frequenting the neighbourhood of man, the Moor-hen seems unable to orercome the inherent stealthy habits of the Rallida, and hastens to hide itself on the least alarm; but under exceptional circumstances it may be induced to feed, yet always suspiciously, with tame ducks and poultry. It appears to take wing with difficulty, and may be often canght by an active dog; but, in reality, it is capable of sustained flight, its longer excursions being chiefly performed by night, when the peculiar call-note it utters is frequently heard as the bird, itself invisible in the darkness, passes overhead. The nest is a mass of flags, reeds, or other aquatic plants, often arranged with much neatness, almost always near the water's edge, where a clump of rushes is generally chosen; but should a mill-dam, sluicegate, or boat-house afford a favourable site, advantage will be taken of it, and not unfrequently the bough of a tree at some height from the ground will furnish the place for a cradle. The eggs, from seven to eleven in number, resemble those of the Coor, but are smaller, lighter, and brighter in colour, with spots or blotches of reddish-brown. In winter, when the inland waters are frozen, the majority of Moor-hens betake themselves to the tidal rivers, and many must leave the country entirely, though a few seem always able to maintain their existence however hard be the frost. The common Moor-hen is widely spread throughout the Old World, being found also at the Cape of Good Hope, in India, and in Japan. In America it is represented by a very closelyallied form, G. galeata, so called from its rather larger frontal helm, and in Australia by another, G. tenebrosa, which generally wants the white flank-markings. Both closely resemble $G$. chloropus in general habits, as does also the G. pyrthorrhoa of Madagascar, which has the lower tail-coverts buff instead of white. Celebes and Amboyna possess a smaller cognate species, G. hrmatopus, with red legs; tropical Africa has the smallest of all, G. angulata; and some more that have been recognized as distinct are also found in other. more or less isolated localities. One of the most remarkable of these is G. nesiotis, the "Island Hen" of Tristan da Cunha (Proc. Zool. Soc. 1861, p. 260, pl. xxx.), which has wholly lost the power of flight concomitantly with the shortening of its wings and a considerable modification of its external apparatus, as well as a strengthening of its pelvic arch and legs. ${ }^{1}$ The same is to be said of the "Mountain Cock" of Gough Island, the Porphyriornis comeri of Mr. Allen (Bull. Am. Mus. N. H. iv. pp. 57, 58), who

$1 \Lambda$ somewhat intermediate form seems to be presented by the Moor-hen of the Island of St. Denys, to the north of Seychelles (Proc. Zool. Soc. 1867, 1. 1036 ; Trans. Norf. \& Norw. Nat. Soc. iv. p. 552, note), hitherto undescribed, and accordingly now named by me Gallinula dionysiana. 
has institnted for it a new genus, to which he also refers the preceling bind. A more extreme development in this direction appears to be exhibited by the singular Habroptila wallacii of Gilolo (Proc. Zool. Soc. 1860, p. 365, pl. clxiii.), and to some extent by the Purcudiustes pacificus of Samoa (opr. cit. 1871, p. 25, pl. ii.), but at present little is known of either. Of other forms, such as the common Gallinulu (Einthro) phenicura and Gallivex cinerea of India, as well as the Sonth-American species classed in the genus Porphyriops, there is not room to speak; bnt mention must be made of the remarkable Australian genus Tribonyx, containing three species (Amn. \& May. $N$. H. ser. 3, xx. p. 123), called by the colonists "Moor-hen" and "Native Hen," which seem to be more terrestrial than aquatic in their hamts and habits.

Allied to all these is the genus Porpluyrio, including the bird so named by classical writers, and perhaps a dozen other species often called Sultunas and Purple Water-hens, for they all have a plumage of deep blue-some becoming violet, green, or black in parts, but preserving the white lower tail-coverts so generally characteristic of the gromp; and their beanty is enhanced by their scarlet

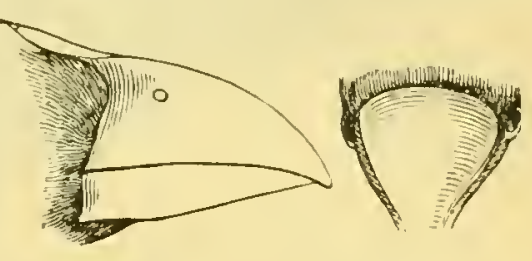

Porphyro. (After Swainson.) bill and legs. Two, $P$. alleni of the Ethiopian Region and the Sonth-American P. parna, are of small size. Of the larger species, $P$. carulcus seems to be the "Porphyrio" of the ancients, and inhaloits certain localities on both sides of the Mediterramean, while the rest are widely dispersed within the tropics, and even berond them, as in Australia and New Zealand. But this last comntry has produced a more exaggerated form, Notonis, which has an interesting and perhaps unique history. First described from an imperfect fossil skull by Oren (Proc.Zool.Soc. 1848, pp. 2, 7; Trens. iii. p. 366, pl. lvi.), and at that time thought to be extinct, an example was soon after taken alive (Proc. 1850, pp. 209-214, pl. xxi.; Trans. iv. pp. 69-74, pl. xxv.), the skin of which (with that of another procured like the first by Mr. Walter Mantell) may be seen in the British Musenm. Other fossil remains were from time to time noted by Prof. Owen ; but it began to be feared that the bird had ceased to exist, ${ }^{2}$ until a third example was taken about the year 1879 , the skin and most

1 Thus the leg-bones and what appeared to be the stermm were described and figured by him (Trans. iv. pp. 12,17, pls. ii. iv.), and the pelvis and another femmr (vii. p1. 369, 373, pls. xlii. xliii.); bnt the supposed sternum subseqnently proved not to be that of Notomis, and the anthor's attention being called to the fact (Proc. 1852, p. 97) he rectified the error (tom. cit. p. 689) which he had previously been "inclined to believe" (Trans. viii. p. 120) he had made.

"Notwithstanding the statement, which certainly presented some incongrruities, made by Mr. Mackay (Ibis, 1867, p. 114). 
of the bones of which, after undergoing examination by Sir W. Buller and Prof. T. J. Parker (Truns. N. Zeal. Inst. xiv. pp. 238-25S), are now in the museum of Dresden, where Dr. A. B. Meyer deelared the recent remains to be specifically distinct from the fossil, and while

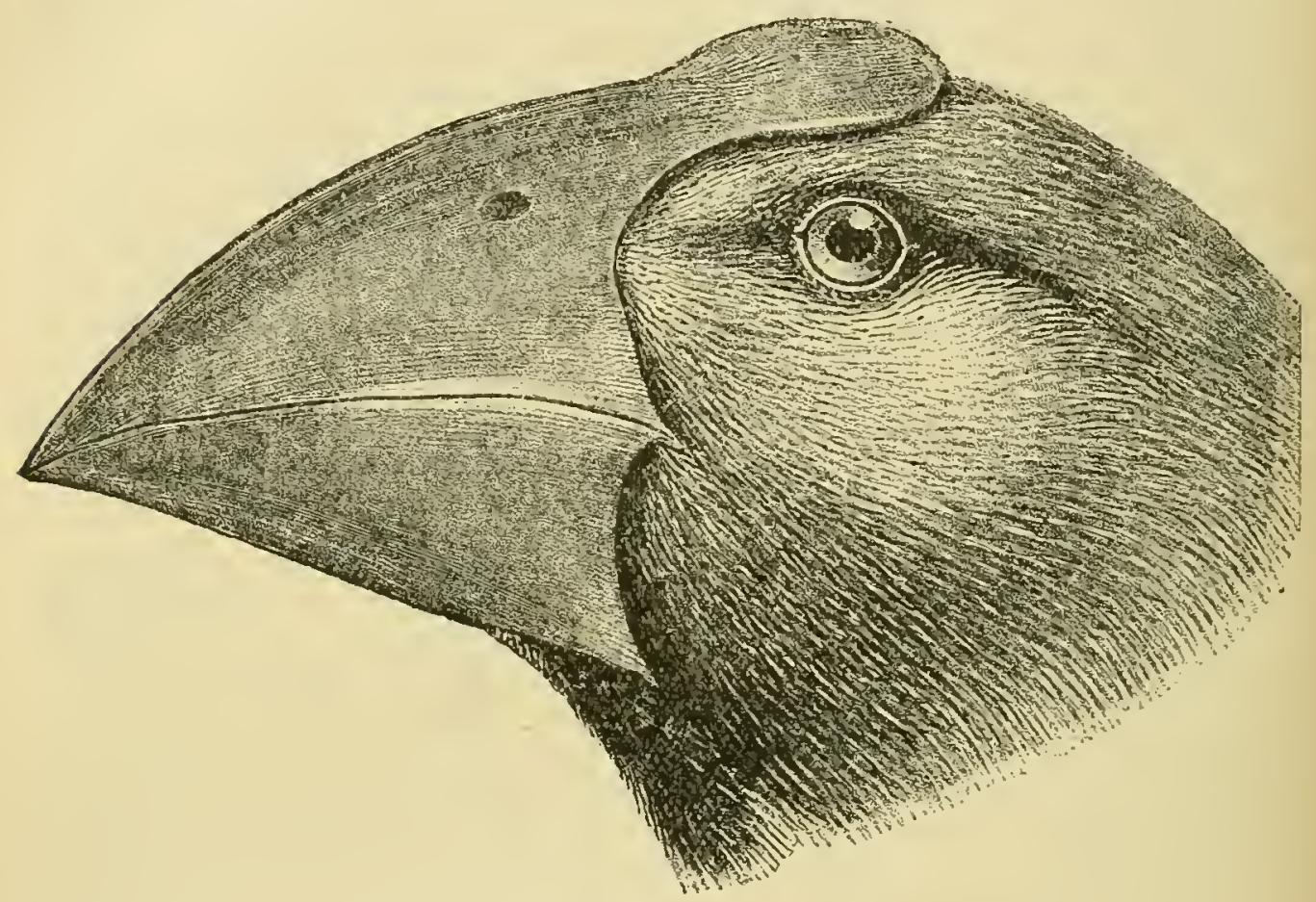

Totonsis. Natural size. (From Buller.)

keeping for the latter the name $N$. mantelli gave the former that of $N$. hochstetteri. A third suecies ascribed to the genus, $N$. allue, is said to hare once inhabited Lord Howe's and Norfolk Islands, but is now extinct, a specimen at Viema (Itis, 1873, p. 295, pl. x.) being its sole remains. ${ }^{1}$

MOOR-TITLING, a common local name in Scotland and the North of England for the Tituark.

MOORUK, the native name of the speeies of CASSOWARY peculiar to New Britain, and adopted as an English word.

MIOOSE-BIRD, a name for the Camada JAY.

MOREPORK, in New Zealand the name of an Owt, Śpiloglan, notw-zedlundix, but in Tasmania that of Podurgus cuvieri (NIGHTJAR), in each case from the ery of the bird.

MORILLON, a name eommonly given by fowlers to the female and immature male of the GOLDES-EYE, the Clungulu gluncion of

1 The genus Aptornis, of which Prof. Owen deseribed the remains from New Zealand as nearly allied to Notornis and Porphyrio, is considered by Prof. 'T. J. Parker" (loc. cit.) to lie a "development by legeneration of an ocydromine type," and Mr. Lydekker (Cut. Foss. D. Dr. Mus. p. 147) speaks of it as "allied to ocydromus" (WEKa). 
modern ornithology, under the belief which still very generally obtains among them, as it once did among naturalists, that they formed a distinct species of Duck. The mistake no doubt originated in, and is partly excused by, the facts that the birds called Morillons were often of opposite sexes, and differed greatly from the adult male Golden-Eye, whose full and beautiful plumage is not assumed until the second year. The word is used in French in precisely the same form, but is in that language applied to the Tufted Duck, Fuligulu cristata, and is derived, according to Littré, from more, signifying black.

MOSQUITO-HAWK, a name in America for the species of Chordiles (NightJAR).

MOSS-CHEEPER, a north-country name of the TrTLARK.

MOTHER CAREY'S CHICKEN, GOOSE and HEN-sailor's' names, the first of any of the small black or black and white PETRELs, the second of the Giant Petrel, Ossifraga gigantea, and the third seems to be applied without much discrimination to any Petrel of middle size.

MOTH-HAWK, MOTH-HUNTER, names of the NightJAR.

MOTMOT, according to Hernandez in his Historia Avium Nova Hispania (p. 52), published at Rome in 1651, was the Mexican name of a bird which he described well enough to leave no doubt. as to what he meant; but the word being soon after printed Momot by Nieremberg and others gave rise to the Latinized Momotus, invented by Brisson as a generic term, which has since beeu generally adopted by ornithologists, ${ }^{1}$ though Motmot has been retained as the English form. Linnæus knew of only one species of Motmot, and referred it to his genus Ramphastos (ToucaN) under the name of $R$. momota. This is the Momotus brasiliensis of modern ornithologists, and from its geographical range camnot be the original Motmot of Hernandez, but is most likely the "Guira guaimumbi" of Maregrave.

The Motmots have been for many years recognized as forming a distinct family, Momotidæ or Prionitidæe, of the heterogeneous assemblage known as Picarix or Coccygomorpha; and the only question among systematists has been as to their position in that group. This has been discussed and illustrated with his usual assiduity by Dr. Nurie (Ibis, 1872, pp. 383-412, pls. xiii.-xv.), who conclusively shewed that Todus (ToDy) was the Motmot's nearest existing relative, while he believed that both Momotidx and Todida might be placed in one section (Serratirostres) with the Coraciida (RoLLER), Meropida (BeE-eater), and Alcedinida (Kingfisher). To the latter

1 Its barbarous origin induced Illiger to substitute for it the word Prionites, and his example has been followed by some nomenclatural purists. 
allocation Garrod (Proc. Zool. Soc. 1878, pp. 100-102) partly demurred, though admitting the Kingfisher affinity, while upholding the former, and even declaring that Motmots and Todies form but a single Family. As the conclusions of both these investigators are based on the sure ground of anatomical structure, they are of incomparably greater value than most of those arrived at by prior systematists who judged from external characters alone.

In outward appearance the Motmots have an undoubted resemblance to the Meropidæx, but, though beautiful birds, various shades of blue and green predominating in their plumage, they do not exhibit such decided and brilliant colours; and while the Beeeaters are only found in the Old World, the Motmots are a purely Neotropical form, extending from southern Mexico to Paraguay, and the majority of species inhabit Central America. They are said to be solitary birds, or at most living in pairs, among the gloomy forests, where they sit on the underwood nearly motionless, or only jerking their long tail as the cry "houtou" (or something like it) is uttered. Their ordinary food is small reptiles, insects, and fruits. The nest of one species, as observed by Mr. Robert Owen, is at the end of a hole bored in the bank of a watercourse, and the eggs are pure white and glossy (Ibis, 1861, p. 65). Little else has been recorded of their ways.

The Momotidx form but a small group, containing, according to the enumeration of them in 1873 by Messrs. Sclater and Salvin (Nomenclator, pp. 102, 103), but 17 species, ${ }^{1}$ distributed into 6 genera, of which last, however, Dr. Murie (l.c.) would only recognize four-Momotus, Baryphthengus, Hylomanes, and Eumomota-the second including Urospatha, and the last Prionorhynchus, while Dr. Sharpe in 1892 (Cat. B. Br. Mus. xvii. pp. 313-332) made an additional genus, raising the number of genera to 7 and of species to 18 . The distinctions between Dr. Murie's, and still more Dr. Sharpe's groups would require more space to indicate than can here be allowed; but it may be stated that, while all have a general resemblance in the serrated edges of the bill and many other characters, Momotus has the normal number of 12 rectrices, while the rest have only $10,{ }^{2}$ which in Hylomanes have the ordinary configuration, but in adult examples of all the other's the shaft of the median pair is devoid of barbs for the space of about an inch a little above the extremity, so as to produce a spatulate appearance, such as is afforded by certain Huming-BIRDs known as "Racquet-

1 The same number was recognized by the first-named of these gentlemen in his review of the Family (Proc. Zool. Soc. 1857, pp. 248-260), where they are all diagnosed, a species, subsequently described by Dr. Cabanis (Mnss. Hein. ii. p. 115), not being admitted.

2 Dr. Sharpe (l.c.) makes a different statement, but I believe Dr. Murie, whose reckoning is here followed, to be right. 
tails," Kingfishers of the genus Tanysiptera, and Parnots of the group Prioniturus. Waterton (Wanderings, Journey 2, chap. iii.), mentioning the species $M$. brasiliensis by its native name "Houtou," long ago asserted that this peculiarity was produced by the Motmot itself nibbling off the barbs, and this extraordinary statement, though for a while doubted, has since been shewn by Mr. Salvin (Proc. Zool. Soc. 1873, pp. 429-433), on Mr. Bartlett's authority, to be perfectly true. The object with which the operation is performed is wholly unknown. It is sometimes incompletely executed, and the tail has then an asymmetrical form. This must have been the case with the example that Hernandez described (l.c.), and brought on himself the criticism of Willughby (Ornithologia, p. 29s) for so doing. Much of the bibliography of the family is given in Dr. Murie's paper already quoted; and it may be remarked that in 1734 Seba, probably misled by wrong information, figured (Rerum Nat. Thesaur. tab. 67, fig. 2) under the name of "Motmot" a bird which has been identified with a species of GUAN, and is the Ortulis motmot of modern ornithology.

MOULT, ${ }^{1}$ the change of plumage, or shedding of its old and often weather-beaten feathers to be replaced by an entirely new suit, to which almost every individual bird is subject at least once a year, and a process of the most vital consequence, being possibly the severest strain to which the life of each is exposed, for to judge by its effects on those we domesticate, it produces a greater mortality than temporary want of food may do. Important then as is all that relates to the subject, it is yet one that has been sadly neglected by ornithologists, among whom that careful observer the late Herr IW. Meves seems alone to have published any extensive series of observations, ${ }^{2}$ and it is certainly not to the credit of ornithologists in general, and especially of those who are afforded facilities by Zoological Gardens, that so much ignorance of the process should prevail as undoubtedly is the case, for since his time little advance has been made in our knowledge, so that questions arising out of investigations made by him more than forty years ago remain unanswered and disregarded; and, apart from general works, in which the subject is usually but lightly touched, the literature relating to this branch of ornithology is very small. The structure and mode of growth of FEATHERs has already been sufficiently treated, and

1 In Middle English the word (originally a verb) is mout, the modern $l$ being redundant, and it is derived from the Latin mutare, to change.

2 His valuable paper is in the Efversigt of the Academy of Sciences of Stockholm for 1854 (No. 8), and an English translation of it has been published by Mr. Dresser (Zoologist, 1879, pp. 81-89), while a German version containing some modifications and additional matter appears in the Journal für Ornithologie for 1855 (pp. 230-238). But the essay treats also of change of colour in feathers apart from moult. 
here we have briefly to consider the different phases which the act of Moulting offers.

As a general rule all kinds of Birds are subject to an annual Moult, and this commonly begins immediately on the close of the breeding-season, but, as will be presently explained, there are some which undergo in addition a second or even a third partial change of plumage, and it is possible that there may be others still more exceptional : our information respecting these, however, is too meagre to make it worth while saying anything here about them. It must be acknowledged that with regard to the greatest number of forms we can only judge by analogy, and though it may well be that some interesting deviations from the general rule exist of which we are altogether ignorant, yet when we consider that the Ratita, so far as observed, moult exactly in the same manner as most other birds, ${ }^{1}$ the uniformity of the annual ehange may be almost taken for granted.

It is not intended here to say more ( $c f$. p. 248) of the way in which a feather dies and a new one suceeds it, nor need we compare the process of moulting with the analogous shedding of the hair in Mammals or of the skin in Reptiles, though the latter, in the case of the flipper-like wings of the PENGUIN-the scaly feathers of which come off in flakes-Mr. Bartlett (Proc. Zool. Soc. 1879, p. 6) has shewn to be remarkably elose. Enough for our present purpose to see that such renovation is required in Birds, nearly all of which have to depend upon their quills for the means of loco. motion and hence of livelihood. It is easy to understand that durable as are the flight-feathers, they do not last for ever, and are beside very subject to accidental breakage, the consequence of which rrould be the crippling of the bird. ${ }^{2}$ It is obviously to provide against what in most cases would be such a disaster as this last that we find the remiges, or quill-feathers of the wings, to be nearly always shed in pairs. They drop out not indeed absolutely at the same moment, though this sometimes seems to happen, but within a few days of each other, and, equilibrium being thus preserved, the power of flight is but slightly deteriorated by their temporary loss. The same may be observed in a less degree, since there is less need of regularity, with the rest of the plumage, as a little attention to any tame bird will shew, and the new feathers grow at an almost equal rate. In the young of most speeies the original quills are not shed during the first year, nor in the young of many does there seem to be an entire moult during that time, but in the

1 For the knowledge of this fact I am indebted to the vast experience of Mr. Bartlett.

2 By an ingenious but simple process known as "imping," which properly means engrafting, and is described in almost every book on hawking, falconers repair any broken flight-feather, and so restore the bird to its full power. 
typical Gallinx, ${ }^{1}$ which are able to fly at a very early age, often before they are one-third grown, the original quills, being proportioned to the duties required of them, are shed before the bird has attained its full size and are succeeded by others that serve it when it has reached maturity. In the Anatida and some other groups, however, we have a singular exception to what has been above stated. Most of the former, Ducks, Geese and Swans, shed their quill-feathers all at once, and become absolutely incapable of flight for a season, ${ }^{2}$ during which time they generally seek the shelter of thick aquatic herbage, ${ }^{3}$ and it is further to be particularly remarked that the males of most of the Family Anatidx at the same period lose the brilliantly-coloured plumage which commonly distinguishes them and "go into eclipse," as Waterton happily said, putting on for several weeks a dingy garb much resembling that of the other sex, to resume their gay attire only when, their new quills being grown, it can be safely flaunted in the open air. Here we have the first instances of Additional Moult to be mentioned. Another is not less interesting, though ornithologists must confess with shame that they have not sufficiently investigated it. This is that of the Ptarmigan, Lagopus mutus (p. 392), both sexes of which not

1 Nothing seems to be known about the monlting of the young Megapodiidie, and information thereon would be very acceptable.

2 A Patagonian form, the Loggen-Head (p. 518, No. 3) Tachycres cinereus, seems never to regain the power of flight thus lost (ef. Cunningliam, Proc. Zool. Soc. 1871, p. 262).

3 It is amusing to find from comments on a paper by the Baron d'Hamonville (Bull. Soc. Zool. Fr. 1881, pp. 101-106), that the observation of this fact has been regarded by reviewers and other's as a recent discovery. The fact may liave been neglected by some writers; but it was well known to a monk of the 12 th century (Liber Elicnsis, ii. cap. 105), and it is hard to imagine the time when it was not familiar to "divers persons next inhabiting in the countries and places within this realm, where the substance of the same wild-fowl hath been accustomed to breed," for they-to continue the words of an Act of Parliament $(25 \mathrm{Hen}$. viii. cap. 11) passed in 1533-" in the summer season, at such time as the said old fowl be moulted, and not replenished with feathers to fly . . . have by certain nets, engines and other policies yearly taken great numbers of the same fowl, in such wise that the brood of wild-fowl is almost thereby wasted and consumed." It was accordingly declared mlawful to take Wild Ducks or Wild Geese in this manner between the last day of May and the last day of August. Another Act in 1710 (9 Anne, cap. 25, §4) reinforced this provision for any "Fowl commonly reputed Waterfowl, in any place of resort for wild fowl in the moulting season," and in 1737 (10 Geo. ii. cap. 32, §10), the close time for monlting waterfowl was extended to the 1st of October.

A similar state of things in the Fuamisgo came under the notice of Palias (Zoogr. Ross.-Asiat. ii. p. 207) who therein is corroborated by Crespon (Orn. duc Gard, 1. 396); and, more recently, it has been asserted by M. Gerbe (Rev. Zoot. 1875, pp. 271-277, pl. vi.) to obtain in the PuFFix, Fratercula arctica, and in the Black-throated Diver, Colymbus arcticus. 
only moult after the breeding-season is over into a grey suit, and then again as autumn passes away into their snowy winter-clothing, but, divesting themselves of this last in spring, at that time put on each a third and most distinctive dress-these changes, however, do not extend to the quills either of the wings or tail. ${ }^{1}$

The number of Birds which undergo a more or less entire Double Moult is very considerable, and the peculiarity is not always characteristic of Families or even, unless in a very restricted sense, of genera. Thus while the Garden-WARELER, Sylvia salicaria, and the Whitethroats, S. rufa and S. curruca, are said to moult twice in the year the BlACKCAP, $S$. atricapilla, does so but once. The same may be said of the Emberizida (BUNTING), in which Family both practices seem to obtain, but on the other hand, the distinction in this respect between the Alaudidre (LARK) and the Anthina (PIPIT), belonging to the Family Motacillidie (WAGTaIL), appears, so far as our knowledge goes, to be invariable, though the habits and general appearance of both groups are so much alike-the Alaudidx moulting but once and the Anthina, conforming to the practice of the normal Motacillida (Motacillinx), twice a year-the quills, be it understood, excepted. But it would be impossible here to give more than these few examples, and indeed we scarcely know anything of the subject outside of some groups belonging to the Northern hemisphere.2

In a large number of species the Additional Moult is very partial, being often limited to certain portions of the plumage, and it is yet an unsolved problem how far some of the changes to be observed are due to actual Moult and how far to the alteration of colour in the feathers themselves, as also the way by which this alteration of colour is produced, whether, as certainly happens in many instances, by the dropping off of the "barbicels" - the fine filaments that fringe the "barbules," which are arranged on the upper surface of each "barb" composing the web of the featheror in some other manner. With either of these last considerations we need not now concern ourselves. It is unquestionable that there are innumerable species of birds, the males at least of which put forth in spring decorative plumes unknown at any other season, and it would appear that in some of them the feathers which before clothed the parts whence the newly-donned ornaments grow are doffed to make room for these paraphernalia of marriage.

1 Macgillivay (Brit. Birds, i. p. 196 ; and Nat. Hist. of Deeside, p. 405) thought there were four moults in this spccies, but that seems to be one too many. Meves (loc. cit.) and the Abbé Caire (Ror. Zool. 1854, p. 494) independently made the discovery of the Triple Moult, and almost simultaneonsly aunounced it ( $c f$. Gloger, Journ. für Orn. 1S56, p. 461).

2 The fullest list as yet published is that of Meves (Journ. f. Orn., loc. cit.), but it is not entirely free from error. 
The subject of Additional Moult is thus intimately conmected with the seasonal adornment of Birds, and as that properly belongs to a branch of the great question of Natural Selection it could not be suitably entered upon here. 'The reader is accordingly referred to those excellent chapters in which Mr. Darwin ${ }^{1}$ has treated the matter with his usual perspicuity, though even he has far from exhausted its varied points of interest.

It remains to be remarked that though the annual Moult commonly takes place so soon as the breeding-season is over, there are plenty of cases in which the change is delayed to a later period. This is so with the Swallow, Hirundo rusticu, which has long been known to moult in our mid-winter or even later, and it is generally the way with the Diumal Birds-of-Prey. But unquestionably most birds accomplish the change much earlier, and before they leave their breeding-quarters for their winter haunts, thereby starting on one of their great annual journeys with all the external machinery of flight renewed and in the best condition for escaping its actendant perils.

But the plumage is not the only part of the Bird's integument that undergoes regularly periodical change. Many years ago Nilsson made known by a communication to the annual report of the Academy of Sciences of Stockholm on Zoology for 1828 (pp. 104-106) that in certain species of Tetraonidx (Grouse) the CuAws grow to an inordinate length in winter and are partly shed or worn off as spring comes on, and the fact has since received further attention ( $c f$. Dresser, B. Eur. vii. p. 189, pl. 485). The seasonal elongation of the bill of REDPOLIS during summer, first announced as a conjecture by Gloger (Journ. für Orn. 1856, pp. 433-440), had been previously made known to the present writer by Wolley, who first observed it in 1853-4 ( $c f$. Yarrell, Br. B. ed. 4, ii. p. 139). In both these cases, however, the getting rid of the extraneous growth is to a great extent a mechanical process, and therefore in some measure comparable with the shedding of the fringes of the featliers before mentioned. Not so does it seem to be with others, and a far stranger state of things was revealed by the observation, originally made by $\mathrm{Mr}$. H. G. Palmer about 1865 , according to $\mathrm{Mr}$. Pidgway (U. S. Geol. Explor. 40th Parall. iv. p. 634), who himself confirmed it in countless instances, that irrespective of sex the White PelicaN of North America, during the breeding-season, bears on the ridge of its bill a curious horny projection, flattened at the sides and roughly-triangular in shape, which is worn for about two months only, and then dropping off may be "gathered by the bushel" on the nesting-grounds of the species, as recorded by Baird (Ibis, 1869, p. 350). Still more extraordinary was the

1 The Descent of Man and Selection in relation to Sex, chaps. xiii.-xvi. London : 1871. 
discovery by Dr. Burean of the Puffin moulting the horny sheath of its BrLL, together with the outgrowths over the eyes, while the fleshy rosette at the corner of the mouth shrinks to insignificance, completely changing the bird's physiognomy, and he has since described the same astonishing metamorphosis as existing in other allied forms, inchinding the genera Chimerina, Ombria, and Simorhynchus (Bull. Soc. Zool. Fr. 1877, pp. 377-399, pl. v. and 1879, pp. 1-63, pls. i.-vi.) Mr. Harting has given a translation of the first of these papers, with a reproduction of the remarkable plate (Zool. 1878, pp. 233-240), and Dr. Coues has published an abstract of both (Bull. Nutt. Orn. Club, iii. pp. 87-91, and v. pp. 127, 128).

MOUND-BIRD, a name sometimes given to the MEGAPODES in general, from their mode of nidification, but not applicable to all.

MOUNTAIN-, a prefix to the name of many birds, but often inappropriate, and seldom used except in books, or by persons whose knowledge is thereto limited-thus Mountain-Bunting is the Snow-Bunting; Mountain-Cock the Capercally; Mountain-Duck several species of Anatidx-and in New Zealand apparently applied colloquially to Tadorna tadornoides (SHELD-DRAKE); Mountain-Finch the Brambling; Mountain-Parrot the Kea (see Nestor); Mountain-Sparrow the Tree-SPARRow, and so on.

MOUSE-BIRD (Dutch Muisrogel), the name by which in Cape Colony, Natal, and other parts of British Africa, the members of Brisson's genus Colius, ${ }^{1}$ Englished CoLY in 1773 by Pennant (Gen. $B$. p. 31), are known-partly, it would seem, from their general coloration, but probably more from their singular habit of creeping along the bonghs of trees with the whole tarsus applied to the branch. By the earlier systematists, who had few opportunities of examining the internal structure of exotic forms, Colius was usually placed among the Fringillidx; but nearly all travellers who had seen one or another species of it in life demurred to that view. Still its position was doubtful till $\mathrm{Dr}$. Murie, in an elaborate treatise on its osteology and systematic place (Ibis, 1872, pp. 262-280, pl. x.) showed that it was no Passerine, and subsequently (Ibis, 1873, p. 190 , note) proposed to regard the Family Coliid $\mathscr{x}$ as the sole representative of a distinct group (PAMPRODACTYLE) - this word being coined to indicate the obvious character of all the toes being ordinarily directed forwards, though it is by no means the only peculiar character these birds possess. A few years later most of Dr. Murie's views were confirmed by Garrod (Proc. Zool. Soc. 1876, pp. 416-419), who added considerably to our knowledge of the general anatomy of the Family, which he considered to be relatcd on the one hand to the Picidx (WoODPECkER), and on the other to

1 Some other generic divisions have been suggested, but on grounds so siender as hardly to merit consideration. 
the Alcedinila (Kingfisher), and Bucerotida (Honsbitu). The Coliuda are small birds, with a rather Finch-like bill, a more or less crested head, a rery long tail, and are generally of a dun or slatecoloured plumage that sometimes hrightens into blue or is pleasingly diversified with white or chestmut. They feed almost wholly on fruits, but occasionally take insects, in quest of which they pass in bands of fifteen or twenty from tree to tree, and hang in all

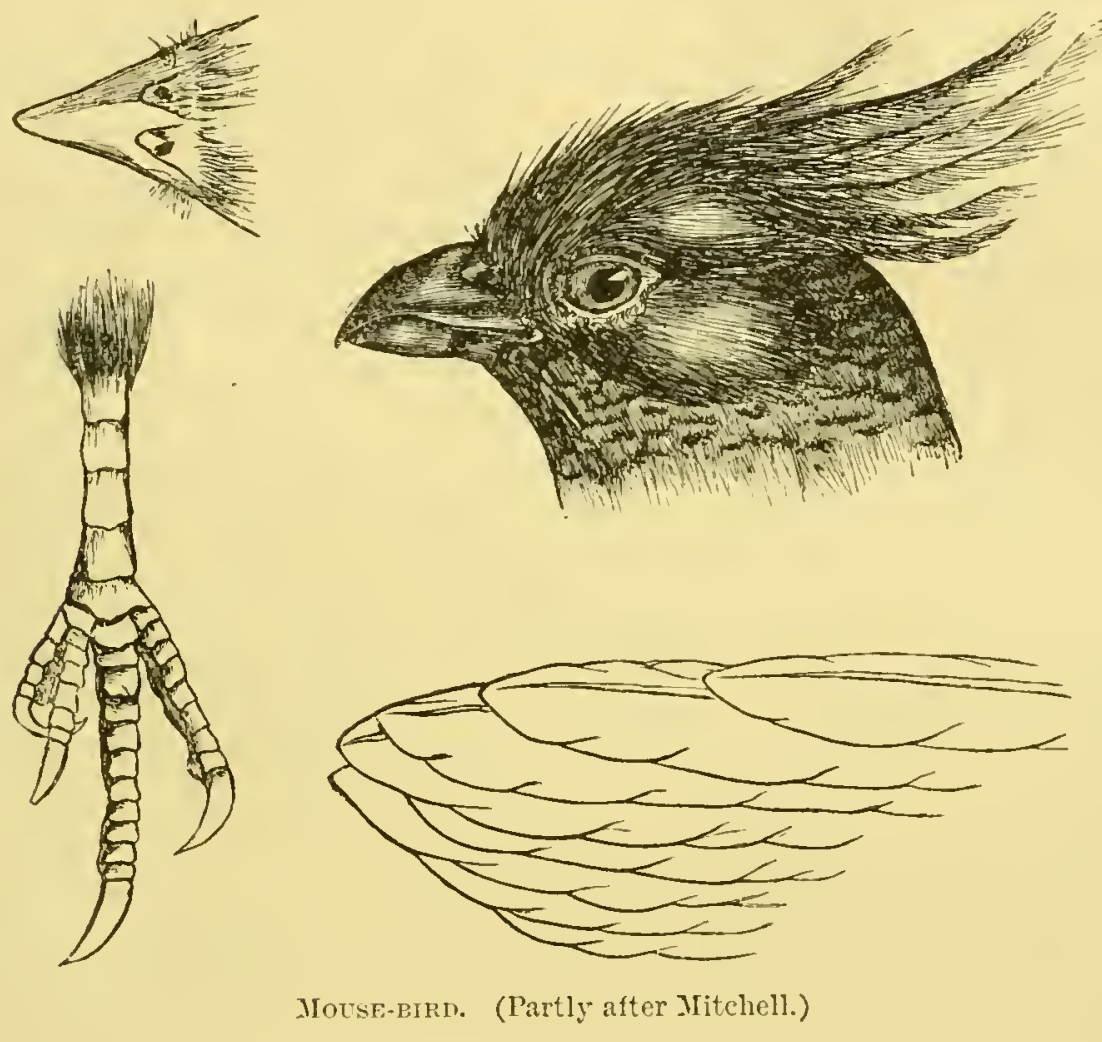

attitudes from the branches as they feed. It is even said that they sleep suspended by their powerful and rersatile toes. Ten species are recognized by Dr. Sharpe (Cut. B. Br. Mus. xvii. pp. 338-346, and 500), all belonging to the Ethiopian Region (of which the Family is one of the most characteristic), and ranging from Abyssinia soutlivards. Three species inhabit the Cape Colony.

MUGGY, possibly cognate with the latter part of Grasmiclie (Grass-Midge), the common German name of the Whitethro.'T, and allied birds; but perhaps only a corruption of MEGGr.

MULLET-HAWK, a name for the OsPREY.

MUMRUFFIN, said to be a local name of the Long-tailed TITMOUSE.

MUNIA, the general name in many parts of India for several kinds of small sced-eating birds, commonly placed in the Family 
Ploceidx (WEAVER-BIRD), which are distinguished for their familiarity with man, their gregarious habits, their depredations on the ricecrops, and their ingenious Nests, to quote Mr. Hodgson (Asiat. Piesearches, xix. p. 155), who not only Anglified the word but Latinized it, making it the title of a genus to which he assigned three species, while Dr. Sharpe in 1890 (Cat. B. Br. MIus. xiii. p. 326) referred to it no fewer than twenty-six. Many of them are among the commonest of exotic cage-birds.

MURRE, a name applied by fishermen indifferently to GUILLEMOT and RAZOR-BILL.

MIUSCULAR SYSTEM. Muscles constitute what is generally called "flesh," and are composed of fibres, each of which is an elongated cell of contractile tissue surrounded by a thin sheath of connective tissue, the whole being held together by an outer sheath of connective, and frequently elastic, tendinous tissue. The fibres are arranged with their long axes in the direction of the action or pull of the muscle, and each is intimately connected with a nervecell, stimulation of which causes contraction, and consequently draws together the parts to which the whole muscle is attached. In the Muscles of the Skieleton the attachment nearest to the axis of the body is called the "Head" or "origin"; the attachment furthest from the same is the "Tail" or "insertion "-no matter which extremity is the punctum fixum: the intermediate portion is the "Belly" or "Body."

In Birds, as in other Vertebrates, there are two fundamentally different kinds of Muscles:-

1. Involuntary or unstriped Muscles, which are generally of slow or rhythmical action, such as all those of the viscera, and the true cutaneous Muscles, such as those attached to the root of the feathers.

2. Voluntary or striped Muscles, in which each fibre under a microscope secms to consist of a great number of alternate dark and light disks, which cause a transverse striation.

The Muscle of the HEART is in some degree intermediate between those two kinds.

The nomenclature of Muscles has always been difficult. Names like Musculus deltoides or M. gracilis afford no information, and the physiological method of naming a muscle from its function permits only a limited application. The most preferable way is to use a compound word, of which the first portion should indicate the origin, and the second the insertion, further distinction, when needed, being secured by an additional adjective-as M. ilio-tibialis internus. Where the old names of human anatomy can be used without mistaken homology, they may be well applied to Birds, as with M. latissimus dorsi or M. biceps, even though the words M. 
spini-humeralis and M. coraco-humero-brachialis would also fix and, moleover, in a measure describe the muscle; but the application of these old names is not always easy, as shewn by the M. supracoracoideus of Birds which really is the modified M. supraspinatus of Man, and has been called the M. pectoralis minor, M. p. secundus, M. p. medius and M. subclavicus; while the M. caudilio-femoralis figures as M. adductor femoris, M. gemellus, M. pyriformis and $M$. femoro-caudalis-the last being wrong and inappropriate in more than one way-that is to say, it has been mistaken for at least three distinct muscles, and since the nervesupply has not been ascertained by the writers who employ those names, it is gencrally doubtful which piece of flesh is intended to be described. Our knowledge of the homologies of avine Muscles may now be regarded as fairly settled by the present writer in Bronn's Thier-reich (Vögel, pp. 91-325), thanlss to the previous labours of Alix, De Man, Fürbringer, Retzius, Rolleston and Rüdinger, and it is based upon their nerve-supply and a study of their origin and insertion in a great number of different Birds.

The taxonomic value of Muscles is theoretically great, but very limited when put to a practical test. Most of them cannot be understood unless the whole group to which they belong be examined, and the study of their correlations is a very complicated problem. To pick out a few of the most variable muscles of the leg, and to arrange Birds according to their mere presence or absence, without regarding intermediate stages, is an easy but scarcely serious mode of investigation, and there is no wonder that systems built on such simple notions broke down. There is no reason why a dozen different kinds of Birds should not have lost the same muscle at different times and independently of each other, and that other kinds may not lose it in future if its function be no longer required or can be fulfilled by some other combination. Similar conditions may possibly have abolished 3 out of the 4 famous thigh-muscles in Cypselus, Trochilus, Striges, Fregata and Accipitres, and identical circumstances have caused Dicholophus and Serpentarius to assume the same "myological formula," which in this case means only the loss of the caudal portion of the M. caud-ilio-femoralis! It is certain that similar muscular combinations in two or more Birds do not necessarily mean relationship, while on the contrary similar requirements are often met in similar ways, that is to say the respective organs are "isomolphous" if in two Birds they are modifications of one and the same substratum of the same previous condition, but if identical requirements were in both Birds reached after they had already differed in their substratum, the later requirement would be differently met, and the results would be no longer isomorphous. Thus if in a descendant of the Passeres the hallux became reduced 
and ultimately lost, its so-called "long flexor" muscle would in all likelihood disappear also, because in existing Passeres its tendon is unconnected with that of the M. flexor perforans digitorum, while Birds which lost the hallux before these two tendons were disconnected have kept both these muscles.

Prof. Fürbringer, who with enormous labour has exhaustively studied the muscles of the shoulder-girdle, has tabulated the chief characters of 14 muscles selected with a view to taxonomic application, but the results are very small and far less obvious than those afforded by the muscles of hind limbs. The former, as the apparatus of Flight, seen to be more uniformly constructed than the latter, which are more diversified according to the varied uses of the legs and feet. Fluttering, skimming, sailing, soaring are motions much more akin to one another, than climbing, grasping, running, scratching, swimming and wading. The only really aberrant modifications of the wings and their muscles are found in the Ratita, where they are all easily explained by reduction, and in the Spheniscida, where bones and muscles are greatly specialized. The modifications of the hind limbs are many times greater-such as extremely long legs, with four, three or only two toes-short or long: very short legs, almost incapable of running or walking, with all four toes directed forwards, or two or one backwards, and two or more connected in various ways.

Most Muscles leave an impression upon the bones to which they are attached, in the shape of ridges, furrows, crests and processes. These marks, small as they often are, are mostly significant, and of greater assistance in the recognition of a bone than its general configuration, as any one will find on trying to determine the kind of bird to which a given bone belongs. The muscles are not as a rule attached to such crests and ridges because these happen to be there, but on the contrary they shape the bone which serves as their passive framework: what is bred in the flesh comes out in the bone, not vice versâ. It is the quality not the quantity of an organ that determines its taxonomic value, and adhesion to this principle precludes us from classifying Birds by trim myological formulæ which seem to afford easy keys, but rather obscure than elucidate natural affinities.

Without entering upon genetic and therefore fundamental differences, the voluntary skeletal muscles may be conveniently grouped thus :-

A. Muscles supplied by spinal nerves.

a. Muscles of the Stem (neck, trunk and tail).

1. Dorso-spinal Muscles, supplied by dorsal branches.

2. Ventri-spinal Muscles, supplied by ventral branches.

$\beta$. Muscles of the extremities (limbs) supplied by ventral branches. 
B. Muscles supplied by cranial nerves.

a. Muscles of the Visceral Skeleton.

1. Muscles of the Jaws.

2. Muscles of the Hroid apparatus (page 452).

$\beta$. Muscles of the Srrinx.

$\gamma$. Muscles of the EAl (page 178) and Ere (page 229).

A. The Muscles of the Stem (A.a) and of the Extrcmities (A.B) not only exhibit many varieties in different Birds, but they are also very numerous, about one hundred pairs being recognized. To describe them all adequately would go far beyond the scope of this work, while simply to name them and devote a few lines to the general condition of each would, considering their great variability, be of no practical use, for the dissection and recognition of Muscles is not easy. In what follows, therefore, only some of those will be dealt with which, rightly or wrongly, bear the reputation of being of taxonomic value.

Musculus pectoralis, consisting of a thoracic, propatagial and abdominal portion-the first forming the chief muscular mass of the breast and arising from the sternum in the shape of a $\mathrm{U}$ - the two arms of which surround the $m$. supracoracoideus, the longer formed by the clavicle, sterno-clavicular membrane and the side of the keel, the shorter by the body and lateral margin and membranes, filling the sterual notches, and adjoining parts of the sternal ribs. All the fibres of this great muscle, which occupies most of the ventral surface of the sternum, converge toward the shoulder into one or two tendons, the principal of which is inserted on the greater tubercle and the upper crest of the humerus, and the muscle is the chief depressor of the upper arm during the down stroke, while it also rotates it forwards. 'This last is especially its effect in the Spheniscidx, giving their wings the screw-like motion, and is in conformity with the peculiar fact that the tendon of the clavicular portion of the muscle is attached to the whole length of the radial surface of the humerus between its inferior crest and the head. The weight of both the pectoral muscles together is said to amount to about 1/14 in Birds-of-Prey and 1/11 in Wild Geese of that of the whole body.

II. supracoracoideus, arising chiefly from the sides of the angle formed by the keel and body of the sternum, and from part of the coraco-clavicular membrane, and covered by the $m$. pectoratis, ascending from the sternum along the inner and anterior surface of the coracoid, passing by a strong tendon through the foramen triosseum and the region over the joint, and inserted on the upper tubercle of the crest of the humerus, which it rotates and abducts. This muscle is generally described as a second pectoral or as the $m$. subclavius; but Alix and Fürbringer have shewn that its 
Mammalian equivalent is the $m$. supraspinatus. In Ratita it arises almost wholly from the coracoid, and scarcely from the sternum: in Carinatx the lateral margin of its sternal origin is marked by a ridge beginning near the coracoid and running parallel to the keel, or converging towards or diverging posteriorly from the latter. The direction and extent of this ridge afford some taxonomic help, as shewn thus:-

\begin{tabular}{|c|c|c|c|}
\hline \multirow{2}{*}{$\begin{array}{l}\text { ORIOIN OF } \\
\text { MIUSCLE. }\end{array}$} & \multicolumn{3}{|c|}{ Sternat Ridge. } \\
\hline & Converging. & Parallel. & Diverging. \\
\hline $\begin{array}{l}\text { From the whole } \\
\text { length of the } \\
\text { keel. }\end{array}$ & $\begin{array}{l}\text { Spheniscidæ, Tinami- } \\
\text { dæ, Gallinæ, Limicolæ } \\
(p t .)\end{array}$ & $\begin{array}{l}\text { Anseres (pt.), Grues, } \\
\text { Columbæ, Opistho- } \\
\text { comus, Psittaci. }\end{array}$ & $\begin{array}{l}\text { Cypseli, Tro- } \\
\text { chili, Capri- } \\
\text { mulgidr. }\end{array}$ \\
\hline $\begin{array}{l}\text { From half to } \\
\text { two-thirds. }\end{array}$ & $\begin{array}{l}\text { Limicolæ (pt.), Lari, } \\
\text { Auseres (pt.). Phœni- } \\
\text { copterus, Pelargi, } \\
\text { Herodii, Stegano- } \\
\text { podes, Cathartidæ, } \\
\text { Neophron, Striges, } \\
\text { Steatornis. }\end{array}$ & & \\
\hline $\begin{array}{l}\text { From the an- } \\
\text { terior third. }\end{array}$ & $\begin{array}{l}\text { Acciptres } \quad \text { (plurimi), } \\
\text { Colymbidæ, } \quad \text { Tubi. } \\
\text { uares. }\end{array}$ & Passeres $(p t)$. & $\begin{array}{l}\text { Picariæ (plur- } \\
\text { ima), Pici, } \\
\text { Passeres (plur- } \\
\text { imi). }\end{array}$ \\
\hline
\end{tabular}

M. propatagialis longus, always present, composed of slips from the $m m$. deltoides, pectoralis, biceps and cucullaris. Its strong belly originates near the shoulder-joint from the clavicle, scapula and coracoid. Its tendon runs directly to the carpus, forming the outer margin of the patagium or fold of skin between the anterior surfaces of the upper and forearm, which it with the m. propatag. brevis serves to extend, and consists of yellow elastic and blue non-elastic fibres, the latter radiating into and being attached to various portions of the patagium. When the wing is extended the elastic portion is stretched to about three times its ordinary length, to which it returns when the wing is folded.

M. propatagialis brevis, composed like the last, absent only in Apteryx, Casuarius, Dromæus and the Spheniscida. In other Birds it is often very complicated-the simplest condition being in the Pici, where it consists of a belly and a strong tendon, running down the anterior and outer side of the upper arm, and attached to the proximal tendon of the $m$. extensor metacarpi radialis longus, a little below the outer condyle of the humerus. In Cuculus its tendon is attached simply to the ulnar fascia, below the elbowjoint. In most other Birds the tendon is split into sereral portions, and is further complicated by receiving slips from, and by connexion 
with the $m$. propretug. longus. Frequently one or more sesamoid bones are intercalated with these tendons, which shew the most complicated arrangement in the Tubinures.

Garrod devoted nuch labour to the elucidation of these patagial muscles, regarding them as of taxonomic value. An obvious and
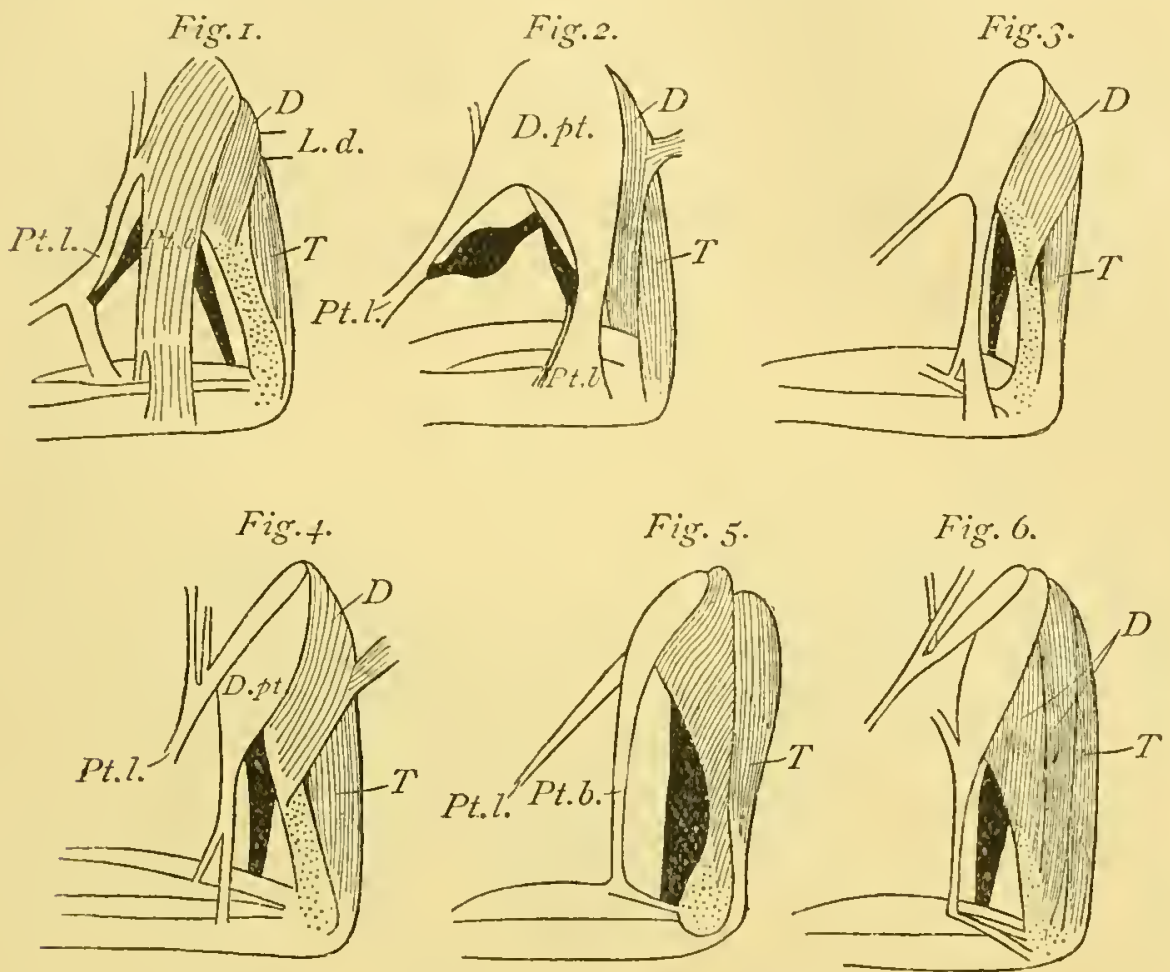

MUSCles of LEFT ARy. Lateral View. (After Fürbringer.)

Fig. 1.. Anes; 2, Columba; 3, Phanicophacs; 4, Umuje; 5, Nenure; 6, cyenocorax. $D$, m. reltoides major; D.pt. deItojd portion of $\mathrm{m}$. propatagialis; L.d. 1n. latissimus dorsi (jortion); Pt.b. and Pt.l. mun. propatagialis brevis and m. Iongus ; $T$, m. triceps.

(The m. biceps with its slip to the 1m. prolutagialis is black.)

constant character is the presence or absence of a slip from the $m$. liceps to the tendon of the m. propatag. longus, and its value may be jutged from the following lists :-

Present-Gallina (excl. Cracida), Columbar Limicola, Larida, Alcida, Rallidin, Grues, Tubinares, Colymbidx, Podicipedida, Phalacrocorax, Plotus, Sulu, Anseres, Phonicopterus, Plutuleu, Caprimulgida, Colius.

Absent-Ratita, Tinumida, Tunices, Cracida, Otis, Cariama, Spheniscidr, Phuethon, Fregatu, Pelicanus, Palamedea, Herodii, Pelargi, -tccipitres, Psittaci, Striges, Picaria (excl. Caprimulgila), Steutornis, I'ici, Passeres.

M. metapatagialis, formed by slips from the $m$. serratus super. ficialis and $m$. latissinus dorsi, and with the addition of the m. expansor secundarion extending by its tendons the posterior patiagium or fold of skin between the trunk and the inner surface of the upper arm. The serratus-portion comes from the ribs and is 
inserted on the patagium and the last eubital quills, the other splits off from the posterior portion of the lutissimus dorsi and acts indirectly on the patagimm by joining the m. anconaus longus.

1. expunsor secundariontm or of the eubital quills, arises as a long tendon from the sterno-scapular ligament, passes the axilla, often by a fibrous pulley, accompanies the axillary vessels and nerves along the humerus, and is inserted by a few fleshy fibres on the base of the last two or three cubital quills. It is, however, more complicated in many birds, especially Gallina and Anseres; but it is searcely of taxonomie value, being weak or absent in Columber, absent in Spheniscida, Tubinures, Stegunopodes, some Herodii, Alcida, some Accipitres, in Striges, Psittuci, Cypselomorpha, Pici and Passert:.

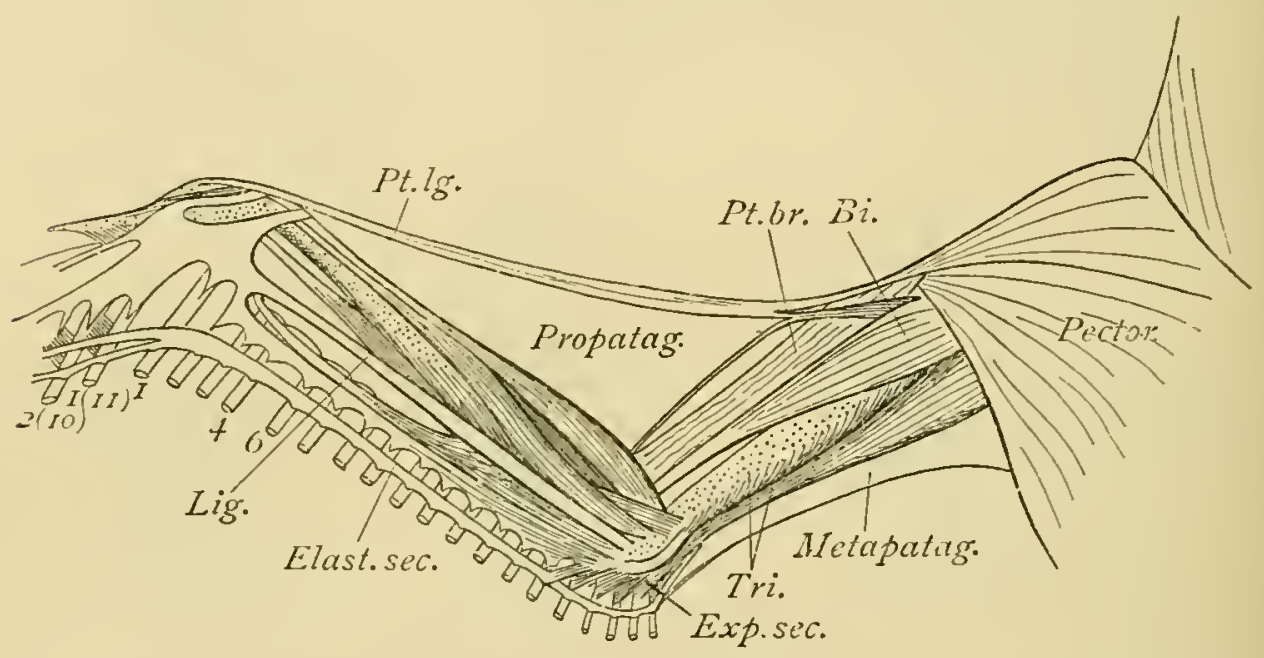

Wing Muscles of a Goose.

Li. ın. biceps; Elast. sec. vinculum elasticum and Exp. scc. m. expansor secundartorum; Lig. ligament; Metapatag. metapatagium ; Pcctor. m. pectoralis; Propatug. propatagiun; Pt. br. and $P t . l \mathrm{~g}$. mm. propatagialis brevis and longus; Tri. m. triceps.

M. Alexor digitorum sublimis, arising fleshy from the inner face of the long subcutaneous elastie band that extends from the inner condyle of the humerus along the ventral surface of the ulua to the ulnar earpal, over which the tendon runs and is inserted on the radial anterior side of the first phalanx of the seeond digit. Owing to the elastieity of the humero-carpal band the wing remains elosed without any speeial muscular exertion, while, when the wing is extended, this band assists considerably in keeping it tant. ${ }^{1}$

M. Aubiens (page 11), long and spindle-shaped, lying immediately beneath the skin as the most nedian or internal of all the

1 From its position immediately under the skin, this band may be easily cut, and thongh that operation wonld canse a lrooping of the wing, it wonld suficiently hinder its being firmly extended, and thus would be the neatest substitute for the clunsy and barbaric method commonly employed for pinioning Birds. The power of flight is more effectively destroyed if one wing only be operated mon than if both are treated. 
muscles extending from the pro-acetabular ilium to the knee. When typically developed, it arises with a short tendon from the outer face and the apex of the pectineal process or ilio-pubic spine and runs as a long tendon between the insertion of the $m$. sartorius and the patella over the outer surface of the knee-joint, where it is covered by the origins of the $m$. flexor perforans and perforatus dig. iii., and the $m$. perforutus dig. ii., then perforating the lateral head of the $m$. peroneus superficialis, it lastly forms one of the heads of $m$. flex. perforat. $\ddot{i i}$. or $i i i$. Its nerve-supply comes from the last branch but one of the middle crural plexus. This muscle is subject to many modifications, and upon their extremes were founded the two groups Anomalogona're and Homalogonate (see also Anatomy, page 16). One of the functions of this peculiar muscle, which is similarly developed in Crocodiles, but absent or not differentiated from the ilio-tibial and ilio-femoral mass in other Vertebrates, is that its contraction closes the second and third toes. ${ }^{1}$

M. caud-ilio-femoralis, when fully developed, consists of two parts, inserted by a single strong and ribbon-like tendon near the end of the first third of the hind face of the femur. The caudal part is longer than the other, and arises from the transverse processes of one or more caudal vertebræ passing externally over the distal half of the ischium and pubis. The iliac part, which is the "accessory femoro-caudal " of some writers, is more or less triangular and arises in most cases from the outer face of the distal half or mid-third of the pro-acetabular ilium. This double-headed condition is the most primitive and obtains in most NIDIfUG \&, but in many of them as well as in many of the NIDICOLA either the caudal or the iliac head is absent, though in very few is the whole wanting. The absence of the caudal head may possibly be correlated with the strength of the

1 Owen, in 1835, described (Cyclop. Anat. Physiol. i. p. 296) the disposition of this muscle, which he called the gracilis, as passing "first, over the convexity of the knee-joint, and afterwards over the projection of the heel, [so] that from its connection with a flexor of the toes, these must necessarily be bent simultaneously with every inflection of the joints of the knee and ankle. As these inflections naturally take place when the lower extremities yield to the superincumbent weight of the body, birds are thus enabled to grasp the twigs on which they rest whilst sleeping, without making any muscular exertion." This ingenious explanation of the perching and roosting of Birds was apparently first given by Borelli (De motu animalium, Romæ: 1680-82), and has been copied and made nuch of by many subsequent writers, though Sundevall in $1851 \mathrm{drew}$ attention to the faultiness of the idea, since the ambicns muscle is absent in such typical perching Birds as the Coccygomorpha and Passeres, while it is present in the Anseres. Elsewhere I have pointed out (Thier-reich, Vögcl, p. 148) that Birds possessing it can spread and stretch their toes freely while the leg is also extended becanse then only it is not interfered with, and accordingly it is fully developed in running, wading, swimming and rapacious Birds, but absent in those which hop and climb. 
leg; but these four principal modifications are linked to each other by intermediate stages, which moreover frequently occur in closelyallied genera or even species. Thus the caudal head is very weak in Edicnemus superciliaris and E. bistriatus and, as Garrod found, does not exist in $E$. grallarius. Dicholophus cristatus, like Otis, has lost it, but $D$. burmeisteri the iliac head as well. In Ciconia, the Striges and Cathartida the whole muscle is represented only by the feebly-developed caudal head, and in Leptoptilus this also is lost. In some of the Limicolx, for instance Charadrius pluvialis and Vanellus cristatus, the presence of the iliac head is an individual variation. In Pedionomus the iliac head is very large, while the caudal is reduced to a very thin and feeble slip that does not even reach the femur, but merges into the iliac: if this reduction were continued Pedionomus would agree with Pavo and Meleagris and not with Turnix, in which the iliac head is absent. Thus the taxonomic value of this muscle may be judged from the following table, shewing its four principal modifications :-

\begin{tabular}{|c|c|c|c|}
\hline $\begin{array}{l}\text { Candal and Iliac Head } \\
\text { present. }\end{array}$ & $\begin{array}{l}\text { Caudal Head alone } \\
\text { present. }\end{array}$ & $\begin{array}{l}\text { Iliac Head alone } \\
\text { present. }\end{array}$ & $\begin{array}{l}\text { Both Heads } \\
\text { absent. }\end{array}$ \\
\hline $\begin{array}{l}\text { Ratitæ } \\
\text { Tinamidæ } \\
\text { Pedionomus } \\
\text { Gallinæ (most) } \\
\text { Pterocles } \\
\text { Columbæ (most) } \\
\text { Glareola } \\
\text { Numenius } \\
\text { Hæmatopus } \\
\text { Himantopus } \\
\text { CEdicnemus super- } \\
\text { ciliaris, E. bistri- } \\
\text { atus } \\
\text { Charadrius } \\
\text { Vanellus } \\
\text { Crex } \\
\text { Parra } \\
\text { Sterninæ } \\
\text { Ibididæ } \\
\text { Platalea } \\
\text { Tubinares } \\
\text { Colymbus } \\
\text { Spheniscidæ } \\
\text { Auatidæ } \\
\end{array}$ & $\begin{array}{l}\text { Larinæ } \\
\text { Alcidæ } \\
\text { Ciconiinæ } \\
\text { Herodii } \\
\text { Steganopodes } \\
\\
\text { Accipitres } \\
\text { Striges } \\
\text { Psittaci } \\
\text { Pici } \\
\text { Cypselomorphæ } \\
\text { Passeres }\end{array}$ & $\begin{array}{l}\text { Pavo, Meleagris } \\
\text { Lopholæmus } \\
\text { E. grallarins } \\
\text { Otis } \\
\text { Eupodotis } \\
\text { Grus } \\
\text { Dicholophus cris- } \\
\text { tatus } \\
\text { Phœnicopterus } \\
\text { Podicipes } \\
\text { Serpentarius }\end{array}$ & $\begin{array}{l}\text { D. burmeisteri } \\
\text { Leptoptilns }\end{array}$ \\
\hline
\end{tabular}


M. cuud-ilio-flerorins or semitendinosus, subject to many modifications, but when fully developed, as in Gullina, arising from the transverse processes of the first three caudal vertebre and the lateral margin of the posterior half of the post-acetabular ilium, and thence extending, as a broad ribbon, mesially from the ischiadic nerve towards the popliteal region, where it splits into two portions, one of which, being broad and fleshy, is inserted on the posterior face of the clistal third of the femur, while the other starting at a right

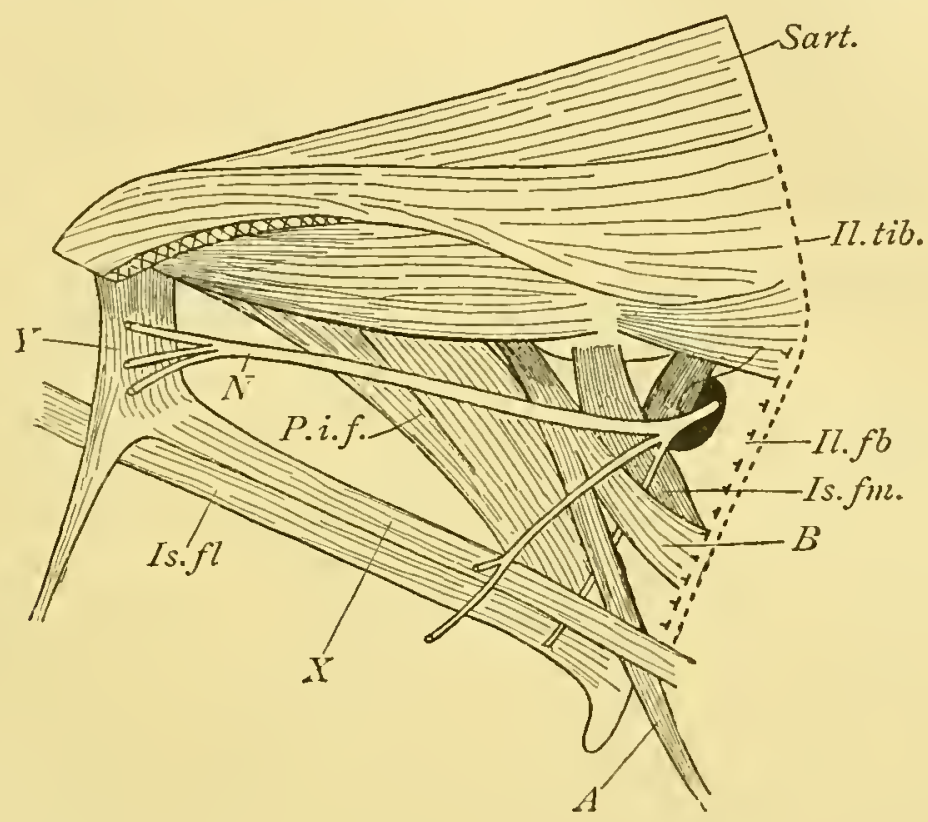

Left Thigh-11uscles (Grus or Fullus). Outer view after removal of the superficial 11. iliotibularis and $\mathrm{m}$. ilio-tibialis.

$A$, caudal, $B$, iliac portion of $m$. cand-ilio-femoralis ; $X$, m. caud-ilio-flexorius ; $r$, accessory or femoral portion of the same; $I l . f b$. m. ilio-fibularis (cut away); Il. tib. nn. ilio-tibialis (cut away) ; Is. $f$. 11 . ischio-flexorius ; Is. fm. m. ischio-femoralis; P.i.f. m. pub-iscliofemoralis; Surt. In. sartorius; $N$, nerve.

angle joins the fascia of the inner femoral head of the m. gustrocnemius. The divergence of these two portions is marked by a tendinous intersection, which rumining in the direction of the gastrocnemial insertion has caused the femoral portion of the whole to be wrongly described as the "accessory semitendinosus." The cxtent of the insertion on the femur varies nuch, occupying more than its distal half in Phew or confined to the intercondyloid region. In almost all swimming Birds as well as in some of the Picarie, there is a complete split between the femoral and crural portions, the crural tendon being then inserted on the neck of the tibia, and the original femoral portion forming part of the median femoral head of the m. gastrocnemius, in which case the "accessory head" is generally stated to be absent. The origin of this muscle likewise varies, arising either from the tail and ilium as in Gallina, Pterocles, 
Numenius and Rhamphastus, or from the ilium only as in Larus, Ardea, Grus, Corythaix and Podargus. It is frequently connected aponeurotically with the $m$. ischio-flexorius, and when its "accessory" is absent, both are inserted on the tibia by one common tendon.

M. ischioflexorius or semimembranaceus, ribbon-shaped, running parallel to the posterior margin of the preceding, present in all Birds, though sometimes much reduced, as in Podicipes, Columbx and Pterocles, arising chiefly from the outer face of the middle or distal third of the ischium and inserted by a flat tendon on the neck of the tibia, whether on its anterior crest or the posterior or inner face. A slip from the principal tendon frequently descends the leg and is inserted either separately or jointly with a similar tendon of the $m$. caud-ilio-flexorius, being often connected with it in various ways.

M. ilio-fibularis or biceps cruris, arising from a great portion of the lateral and dorsal margin of the post-acetabular ilium, changing near the knee to a round and strong tendon that, accompanied by one of the principal stems of the ischiadic nerve, runs over a tendinous pulley ${ }^{1}$ and passing between the outer and middle head of the m. gastrocnemius is inserted on the tuberosity of the fibula at about the level of the first fifth of the tibia.

M. extensor digitorum communis, arising from the outer and anterior face of the crest and proximal half of the tibia, its roundish tendon passes mesially from that of the $m$. tibialis anticus through the transverse ligament along the anterior metatarsal groove and, arrived at its distal end, splits into several tendons, according to the number of front toes, to be inserted on the dorsal surface of the base of their several phalanges. In Striges and Pandion, where the fourth toe is reversible, the principal tendon first splits into two, one for the second toe, the other soon subdividing for the third and fourth. In the Rhamphastidx and Cuculidx, the main stem goes to the third toe, and sends a short slip to each of the others. In the Picidæ the tendon for the fourth toe passes through an ossified loop and over a furrow at the end of the fourth metatarsal, so as to ensure the extension of this digit with the others notwithstanding its backward position. In the Psittaci alone the principal tendon sends a slip to the hallux also, the rest being divided into an inner and outer half, each of which splits again to be inserted on the other toes, the third of which therefore receives two such tendons.

$M$. extensor hallucis, arising from the anterior and inner face of the proximal part of the second tarso-metatarsal and inserted

1 This pulley or loop on the outer side of the knee is composed of three arms, two arising from the outer face of the external femoral condyle, the third from the inner head of the $m$. perforat. dig. iv. and supporting the outer of two principal branches. Owing to the pulley the contraction of this muscle does not merely draw the leg towards the trmk, but also lifts it towards the thigh. 
on the dorsal face of the base of the first phalanx of the hallux. Generally best developed in Birds with a large hallux, as Apteryx, Gallina, Accipitres, Steganopodes and Herodii, but yet very small in Picus and absent in Psittaci. When the hallux is very small, as in Pterocles and many Limicolx, this muscle still exists, and though slender is rather long.

Mm. flexores longi digitorum consist of three principal sets, each of which is again divided into several muscles, the hallux having one, the fourth toe two, and the third and second toe three each, which are conveniently distinguished by the relation to one another of their respective tendons. Those that are inserted on the base of the first phalanges are perforated immediately above the insertion by the tendons of those that are inserted on the second and third phalanges, which in their turn are perforated by those that are attached to the terminal phalanges-hence there are perforati, perforantes et perforati, and perforantes.

Nm. flexores perforati digitorum ii. iii. $i v$. These three, of which each anterior toe has one, arise in a variable way, either separately or partly blended, from almost any part of the region of the knee, but especially from the posterior intercondylar space of the femur, from its outer condyle, from the ligaments of the knee and patella, the proximal part of the tibia and fibula, and lastly from the tendon of the $m$. ambiens (page 11), of which in most cases the $m$. perforatus iii. partly forms the continuation. Each of them becomes a distinct tendon which passes posteriorly over the intertarsal joint, and piercing the pad above mentioned, runs along the plantar groove of the metatarse to be inserted ventri-laterally on the base of the first phalanx of the second, third or fourth toe as the case may be-their insertion being perforated as before stated. The tendon of the $m$. perforatus iii. may be easily recognized, first by its passing the intertarsal joint and the pad the most superficially, and next by its receiving below that joint the lateral distal tendon of the $m$. peronens superficialis. The tendon of $m$. perforatus $i$. often passes the pad through a special canal, but in Struthio is wholly absent, in conformity with the loss of the corresponding toe. The tendon of $m$. perforatus iv. passes the intertarsal joint as superficially as that of the third toe, and is often inserted on all the four proximal phalanges of the fourth toe.

IIm. flexores perforantes et perforati digitorum ii. et iii., with a similar origin to the last group, except as regards the $m$. ambiens (page 11). The tendon of the second toe pierces the pad by a special canal, and is inserted on the plantar and lateral faces of the base of its first or second phalanx, after having perforated that of the foregoing and being perforated by that of the following muscle. It is absent in Struthio. The tendon of the third toe in many Birds receives a vinculum or slip from that of the m. perforatus iii., 
then passes the pad and is inserted like that of the second toe on the base of its own second and third phalanges.

In conformity with the separate position of the hallux, the mass of deep flexors is divided into two principal portions, each becoming a strong tendon which passes through or posteriorly over the metatarsal pad and tubercle, then along the metatarsal groove for insertion in various ways on the plantar face of the last or two last phalanges, having in its course perforated the more superficial tendons. It is convenient to distinguish these two portions, the one as $m$. flexor perforans, the other as $m$. hallucis longus.

$M$. flexor perforans s. profundus, arising from the greater part of the hind face of the fibula and tibia, and rarely also from the outer femoral condyle, runs covered by all the other flexors straight to the intertarsal joint, which it passes more deeply than any of the rest, entering between the pad and the tibio-tarsus, piercing the former and immediately after the metatarsal tubercle as well. In most Birds its tendon divides just above the distal end of the metatarse, sending a slip to each front toe.

$M$. flexor hallucis longus, regarded as the posterior portion of the whole mass mentioned above, arises mostly from the intercondylar space, with its belly resting upon that of the preceding, but slightly towards the outer or fibular side, and its tendon in most cases accompanying that of the preceding, there to pass either through the tarsal pad and hypotarsus, resting in this case on the posterior surface of the other tendon, or lying a little towards its outer side, superficially over the pad and tubercle, after which both run down the metatarsal groove, that of the present resting on the plantar and fibular side of the other. About half-way down the middle of the metatarse the tendon of the $m$. flex. hallucis splits into two parts, one, continued as the so-called vinculum to the front tendon, the other, which is generally the weaker, to be inserted on the last phalanx of the hallux. It is obvious that the tendon of the $m$. flex. hallucis, after passing over the outer part of the ankle, must cross the deeper tendon obliquely to reach the hallux, a crossing which is correlated with its reversed position, and is really double, because the $m$. flex. hallucis arising more inwardly than the $m$. flex. perforans, and thus crossing it laterally, crosses it once above the joint and then again upon the metatarse, since its tendon goes to the hallux. It is also clear that, owing to the vinculum, contraction of the $m$. flex. hallucis bends not only the hallux but the other toes as well, while the $m$. flex. perforans acts on the front toes only. This $m$. flex. hallucis is therefore, properly speaking, a $m$. flexor communis, and the so-called $m$. flex. perforans is the anterior portion of the whole mass of deep flexors, a view which is justified by the fact that the $m$. flex. hallucis is present regardless of the absence of the hallux. 
According to the variable configuration of the toes, whether two, three or four in number, whether the Bird be anisodactyl, syndactyl, zygodactyl, heterodactyl, eleutherodactyl or what, the connexion between the two principal deep flexors and their distribution to the toes exhibits many modifications, almost any combination conceivable occurring in some Bird or other. There can be no doubt that the various uses of the toes-running, climbing, grasping, rowing and so on, are the chief determining causes of the manifold arrangements of these tendons. It is easy to understand the action of a single muscle by itself, but of the action of a group of muscles, of their mutual play, and how they partially counteract, supplant or support one another, we know next to nothing. One point, however, is certain, and that is that coincidence does not necessarily indicate affinity. The misconception concerning these plantar tendons has exaggerated their taxonomic value, culminating in the separation of the Trochilidx from the other Cypselomorphx, and in the association of the Cathartidx with the Alcedinidx, C'oraciidx, Caprimulgidx and Bucerotidx to the exclusion of Upupa.

Sundevall ${ }^{1}$ and Garrod ${ }^{2}$ have done most to describe the modifications of the deep plantar tendons, which are reducible to seven chief types, most of them connected by intermediate stages. ${ }^{3}$ In the following enumeration, the muscle and tendon of the flexor perforans are called $\mathrm{A}$ (anterior portion), those of the flexor hallucis $\mathrm{P}$ (posterior portion).

I. Vinculum from $\mathrm{P}$ to $\mathrm{A}$. Tendon $\mathrm{A}$ splits into 3, going to toes ii. iii. and iv. Tendon $P$ goes to $i$, and by the vinculum acts also on ii. iii. and iv.-i.e. upon all the toes. - The arrangement most commonly found in 4 -toed birds, no matter whether the toes be normally placed, paired or reversible: Ardex, Ciconia, Platalea, Gallinx, Ralli, Grues, Rhinochetus, Eurypyga, Otis, Limicola, Pterocles, Columbr, Laridx, Alcidx, Opisthocomus, Cuculidx, Musophagidx, Psittaci, Striges, Eurylæmidx. In Herodii the vinculum is either very weak or wholly lost, thus leading to type VII.

II. Vinculum very strong and broad, forming the direct and principal continuation of tendon $\mathrm{P}$, of which the hallux receives but a slender portion. Tendon $\mathrm{P}$ goes to $\mathrm{i}$. by vinculum to $\mathrm{ii}$. iii. and iv.-i.e. it acts on all. Tendon $A$ goes to ii. iii. and iv. Muscles $\mathrm{A}$ and $\mathrm{P}$ of equal strength. This is the case in Apteryx, Tinamidx (Nothura), Spheniscidx, Steganopodes, Anseres, Colymbi, Podicipedes and also in Podica.

III. Tendons $\mathrm{A}$ and $\mathrm{P}$ more or less fused throughout the greater extent of the metatarse. The vinculum and the level of the actual crossing are shifted to the distal portion of the meta-

1 Förhandl. Skandinav. Naturforsk. 1851, pp. 259-269.

2 Proc. Zool. Soc. 1875, pp. 339-348.

3 Thier-reich, Vögel, p. 195. 
tarse. Tendon $\mathrm{A}$ goes to ii. iii. and iv. Tendon $\mathrm{P}$ to i. and by vinculum to ii. also, consequently, owing to the vinculum's distal position, its action is confined to two toes. This type, to a certain extent intermediate between I. and II., is characteristic of Accipitres, except Cathartidx (see V.), and Pandion, in which last, perhaps owing to its reversible outer toe, $A$ goes to ii. iii. and iv., but tendon $\mathrm{P}$ splits into 4, sending a slip to each toe directly, and in this case is therefore a complete flexor communis.

IV. The prevalent type where the hallux is absent or very small. Both muscles are strong and almost equally developed, their tendons unite about the middle of the metatarse, the joint tendon $\mathrm{A}+\mathrm{P}$ going to the front toes, the hallux receiving no tendon, and consequently there is no crossing. This type, genetically connected with II., occurs in Casuarius, Dromaus, Rhea, Struthio, Tumix: Pterocles and Phonicopterus, Palamedea, Dicholophus, Tubinares, Colymbi.

$\mathrm{V}$. Tendons $\mathrm{A}$ and $\mathrm{P}$ unite at a variable distance below the ankle joint, passing it in the ordinary way, and there is no crossing behind the metatarse, tendon $\mathrm{P}$ running directly into $\mathrm{A}$ from its fibular side. Muscle A generally much stronger than muscle P. In the simplest case $(\mathrm{V}, \mathrm{a})$ the united tendons $\mathrm{A}+\mathrm{P}$ split into 4 equally strong tendons, either just above the base of the toes, or successively first to the hallux and lastly to iv.-as in Buceros, Cypselus and Colius. Secondly an exaggerated condition of this $(\mathrm{V}, \mathrm{a})$ prevails (as $\mathrm{V}, \mathrm{b}$ ) in Momotidx, Todidx, Meropidx and in some Alcedinidx, where the tendon of the hallux is split off directly from the tibial and ventral side of $A$ above its fusion with $P$. Thirdly there is a condition $(\mathrm{V}, \mathrm{c})$, hitherto known in the Trochilidx only, where $A$ and $P$ are completely divided from each other into a deep mass $(A)$ which goes to ii. and iii., and into a plantar mass supplying i. and iv. Careful and, from their small size, difficult preparations of this have been made by Prof. Stewart and Mr. Bourne for the Museum of the College of Surgeons in London, and any other description and figures of these Trochiline tendons are either incorrect or misleading. Lastly comes the modification found in the Cathartida, where the fusion of the two principal tendons (as in $\mathrm{V}, \mathrm{a}$ and $\mathrm{V}, \mathrm{b}$ ) is followed by a splitting into a ventral mass $(\mathrm{P})$ to ii. iii. and iv., and into a deep mass (A) to i. ii. and iii. This arrangement can be easily derived from type $V$, a, but almost equally well from the variable type III., as indicated by Pandion (fig. XI.) In the latter case the Cathartidx would appear as a peculiar departure from primitive Accipitrine conditions.

VI. Vinculum present, going from $\mathrm{P}$ to A. Tendon A single, going only to iii. Tendon $P$ going to $i$. ii. and iv., and by the vinculum to iii. also, i.e. to all the toes. This most peculiar typo prevails in all the anomalogonatous zygodactyl Birds, Picida, Rham- 
phestida, Indicatoridie, Buccomidae, Capitonida and Galbulidie. The fourth toe being turned backwards behaves like a hallux and receives a tendon from the flex. hallucis, but this cannot be the only reason, since the Cuculidie and Psittaci are also zygodactyl, but possess an ambiens, and belong to type I.

VII. Tendons $\mathrm{A}$ and $\mathrm{P}$ are entirely disconnected, owing to the

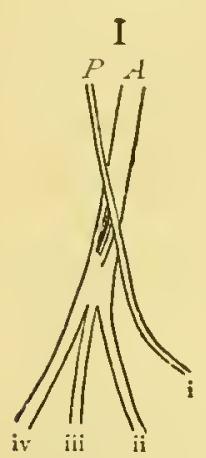

II

III

IV

$\mathrm{V}^{\mathrm{a}}$
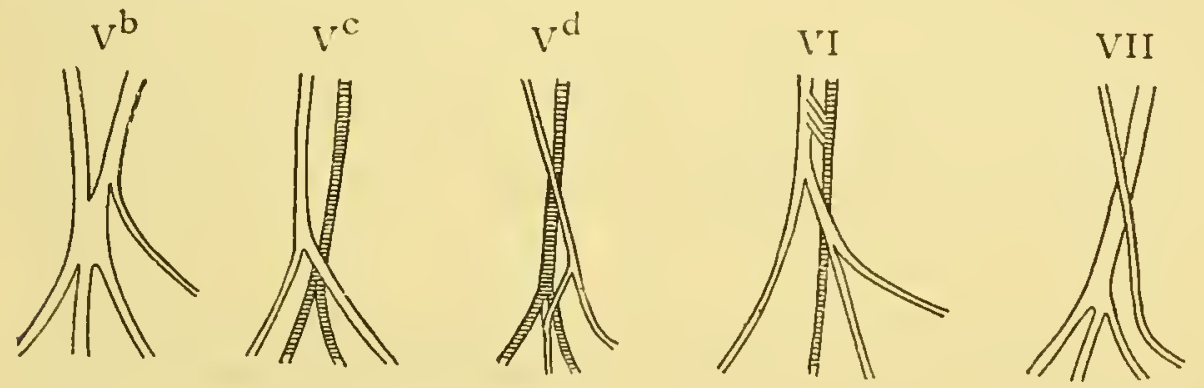

VIII

IX

$x$

XI
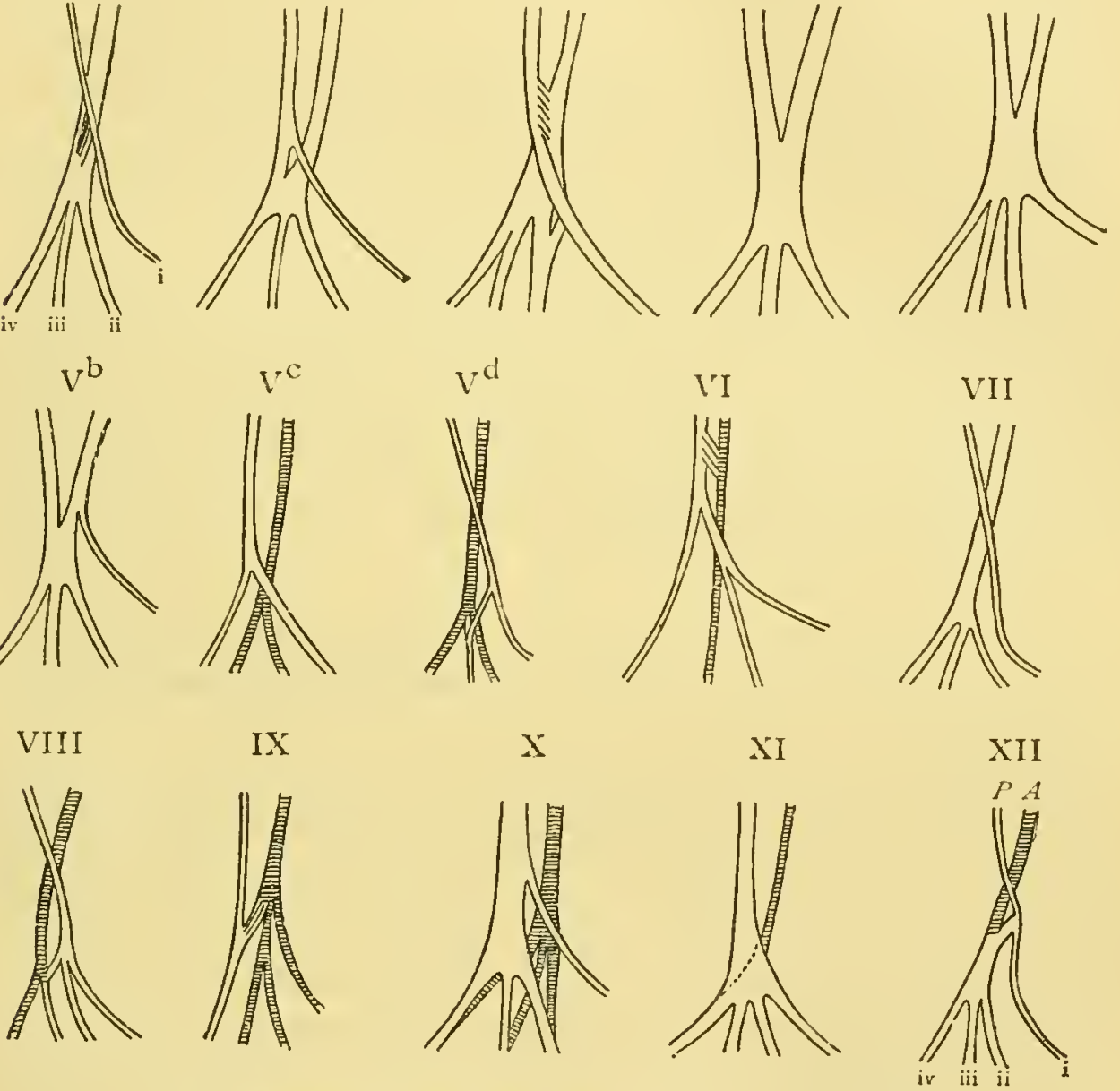

Diaframs shewing arrangement of TendoNs of the Foot.

$A$, Tenrlon of the anterior portion (m. flexor perforans). $P$, Tendon of the posterior portion ( $m$. flexor hallucis. The toes are mumbered i. ii. iii. iv.

1-Yill, The types numbered according to Garrod, Gadow and Fürbringer. I, Gallus; II, A pteryx ; III, Falconicle; IV, Rlıea ; Va, Cy]sselus ; Vb, Momotus ; Vc, Trochilus; Vu, Upupa and Irrisor; VI, Picus; VII, Oscines ; VII Harpactes uluvauceli ; IX, Dacelo gigas ; $\mathrm{X}$, Helionis surinamensis; XI, Pandion; XII, Cuculi.

(Vc, VIlI, IX, after preparations in Mus. R. Coll. Surg. ; $\mathrm{X}$, after Beddard.)

loss of the vineulum. Tendon A goes to ii. iii. and iv.; Tendon $\mathrm{P}$ only to the hallux, which is always well developed and the only posterior toe. This type is the most differentiated and also the simplest. Morphologieally therefore it is the highest. It exists in all the Passeres, except Eurylamida, and in some Herodii. 
Hitherto it has always been stated that Upupa has free tendons (as in type VII.) and this has been used as an argument for placing it among the Passeres; but, as a matter of fact, in Upupa and Irrisor, tendon $\mathrm{P}$ sends a vinculum to the slips of tendon $\mathrm{A}$ which goes to iii., and this vinculum joins $\mathrm{A}$ below, not above, the root of the toes (see fig. V,d).

VIII. This type is peculiar to the Trogonida. These Birds are heterodactyl, the hallux and second toe being reversed, while the third and fourth are front toes, and their deep flexor tendons likewise anomalous. Tendon $\mathrm{A}$ goes to the two hind toes $i$. and ii., and by the vinculum together with tendon $\mathrm{P}$ to iii. and iv. Analysis of this case means:- fusion of $P$ with $A$, without any crossing; proximal splitting-off of the tendons for $i$. and ii. from the tibial side of $\mathrm{A}$; and consequently direct derivation from type $\mathrm{V}$, a, analogous to, but more exaggerated than, $\mathrm{V}, \mathrm{b}$.

These eight types are to be genetically grouped as follows :I. II. III. IV. and VII. are closely allied to each other; I. and IV. to be derived from II. and VII. from I., while III. is a comparatively primary condition; $\mathrm{V}$, a shews a primitive stage, whence are developed in diverging directions $\mathrm{V}, \mathrm{b}, \mathrm{V}, \mathrm{c}, \mathrm{V}, \mathrm{d}, \mathrm{VI}$. and VII. Any derivation of VI. from VIII. or vice versa is impossible; and the same applies to $\mathrm{V}, \mathrm{c}$ and $\mathrm{VI}$.

B.a. Muscles of the Visceral Skeleton, which according to their innervation, derivation and function fall naturally into three groups.

1. Group of the m. mylohyoideus, formed by the most anterior continuation of the $m$. cucullaris and $m$. constrictor colli and consisting of two portions:-(1) m. mylohyoid. anterior, lying between the branches of the mandible from the inner face of which its transversely-directed fibres arise to meet in the middle line, and by their contraction press the tongue and larynx against the palate, and supplied from the third ramus of the nervus trigeminus, and (2) m. mylohyoid. posterior, arising from the outer face of the posterior end of the mandible and sometimes also from the adjoining part of the occiput, and inserted in the corner formed by the hyoid horn and the corpus lingux, being supplied by a branch of the nervus facialis, and drawing the tongue with the larynx upward and backward. When the tongue is very protractile or very thick this portion consists of two parts, one, $m$. serpi-hyoideus, arising from the serpiform process of the mandible, the other, $m$. stylohyoideus, from the occiput.

2. Group of the masticatory muscles, supplied by nervus trigeminus and $n$. facialis.

M. digastricus or depressor mandibula, large and often compound, generally arising from the lateral occipital bone, and inserted on the 
inner angular process of the mandible, acting on the jaw behind the articulation so as to open the mouth.

M. temporalis, consisting of a variable number of parts, the chief of which, arising from the postorbital process and the quadrate, pass beneath the jugal arch and are inserted on the mandible in front of the joint, acting mostly as masseters. Two or three smaller muscles, arising from the deeper region of the orbit and the interorbital septum to be inserted on the palatal and pterygoid bones, are much less constant.

M. pterygoideus, arising chiefly from the ventral face of the pterygoid, palatal and, sometimes, from the maxillary bones, and inserted on the inner face of the mandibular articulation, close the bill or, when the mouth is open, flex the upper mandible, as seen in Psittaci, Anatidze and others.

3. Group of the Hyoid muscles, supplied solely by nervus hypoglossus often very numerous and always attached to the HyoID apparatus (page 452), whence they reach backward to the sternum or to the furcula as $m m$. sterno-hyoidei or $m m$. cleido-hyoidei, to the larynx and trachea as mm. thyreo-hyoidei or $m m$. tracheo-hyoidei, while others extend forward to the mandible as $m m$. genio-hyoidei and genioglossus, or lastly they connect the various portions of the Hyoid apparatus. In most cases their position is indicated by their name.

System of the m. sterno-hyoideus, a long pair of muscles, presenting its least differentiated condition in Apteryx (where no other sterno-hyoid or sterno-tracheal exists). The broader and more superficial portion arises from the ventral face of the thyroid cartilage and the hyoid bones, meeting its fellow without being attached to the trachea, and is inserted aponeurotically on the lateral and posterior margin of the sternum, partly covering the muscles of the shoulder and breast. The deeper portion likewise begins at the thyroid cartilage, passes down the side of the trachea, to which it is firmly attached until just above the bronchial fork, where it leaves it to be inserted near the coraco-sternal articulation. From the conditions just described are differentiated the more complex arrangements found in other Birds. By reduction of the muscular mass about the middle of the neck an upper and lower portion are formed, the upper then appearing as tracheo-laryngeal or thyrohyoid muscles-the lower as sterno- or cleido-tracheal, and through further extension to the bronchi as muscles of the SYRINX. In many Birds the superficial portion of the whole system remains as one or two ribbons, $m$. cleido-hyoidens, rumning along the side of the neck and connecting the tongue with the furcula, or other parts of the scapular arch. The chief retractor of the tongue, $M$. tracheohyoideus reaches its highest development in some of the Picidx, where it takes several spiral turns round the trachea.

M. genio-liyoideus, arising. from about the middle of the mandi- 
bular bar, extends as a ribbon to the hyoid bone, round which it twists loosely ; and, being attached to its dorsal extremity, the contraction of the spiral surrounding the hyoid horns protrudes them with great force, the extent of protrusion depending on their length. This is greatest in Trochilide and Picidx, in some of which they pass round the head and reach forward to the nostrils.

M. genio-glossus, a small protractor of the tongue, connecting the os entoglossum with the chin, but often absent.

M. ceratoglossus, arising from the dorsal face of the ceratohyal, inserted by a tendon laterally on the os entoglossum, which it draws sideways or bends when acting jointly with its fellow.

$M$. cerato-luyoideus, extending from the inner face of the ceratohyal to the urohyal, but often absent.

M. hypoglossus, extending from the ventral face of the body of the tongue to the ventral or lateral face of the os enioglossum.

MUSKET- or MUSQUET-HAWK (O. Fr. mousquet or mouchet), an old name for the cock Sparrow-HAwk, seemingly given from its comparatively small size (Fr. mouche, Lat. musca - a fly), and hence, on the invention of fire-arms, applied to one which was smaller and handier than the older match-lock.

MUTTON-BIRD, a sailors' name for at least one species of Shearwater, but especially for Puffinus brevicauda, presumably because "the young are literally one mass of fat, which has a tallowy appearance" (Gould, Handb. B. Austral. iii. p. 462). Mr. Robert Elwes has given (Ibis, 1859, pp. 397-399) a remarkable account of one of the most frequented breeding-places of this bird on an island in Bass's Strait, which, it is to be feared, no longer exists as such owing to the devastation wickedly carried on-nearly 60,000 breeding birds having been taken in a single season.

\section{$\mathrm{N}$}

NANDU, from Nhandu-guaçu, given by Marcgrave and Piso as the Brazilian name of the RHEA, and occasionally used for that bird by some English writers.

NASAL GLANDS exist pairwise in almost all Birds, and their tear-like secretion serves to moisten and cleanse the mucous lining of the nasal cavities. Each gland has a duct opening into the vestibulum of the nares below the nasal bone, and passing beneath the lacrymal bone. Those glands vary much in shape, size, position and colour, in the last respect ranging from bluish-red to red and 
pale yellow. They are very large in Limicola, except Scolopur, and are occasionally absent in S. rusticola, Larida, Colymbida and Tubinures, resting subcutaneously on the frontals between the eyes, or above the orbital margin and producing on these bones deep depressions, the configuration of which, together with lateral notches, or canals between the nasals, lacrymals and frontals can, with care, be used for taxonomic purposes. In most Auseres the glands are small and placed on the upper orbital margin. When they are small they extend to the orbital cavity only or are restricted to the maxillary cavity, as in Putita, Gallina, Columbx, Otis, Sulu, Pelargi, Accipitres, Picarix and Passeres.

NASUT E, Nitzsch's name in 1840 for the group which Illiger had called Tubinares in 1811.

NATATORES, Illiger's name in 1811 for an Order of Birds (including 6 Families and 22 genera), equivalent to the Linnean ANsErEs. Holding its place, to the exclusion of the older term, for about fifty years, ornithologists at last perceived that the group contained many forms which have no affinity, and the word is now hardly used but by writers who know little of the principle of Taxollomy.

NATIVE-COMPANION, Grus anstralasianus (CRANE); -HEN, any species of Tribonyx (RAIL); -PHEASANT, Lipoa ocellata (MEGAPODE); -SPARROW, Zonaginthus oculeus, one of the WEAVERBIRDs ; -THRUSH, Pachycephale olivacea (THIckHFAD); -TURKET, Otis austratis, a BusTARD - all names used, according to Gould, by the English in Australia or Tasmania.

$N E C K$, or cervix, that part of the body which extends from the head to the thorax, the last cervical vertebra being the one which carries a pair of ribs that do not join the STEliNUu.

NEOPHRON, the generic term given to the Vultur percnopterus of Linnæus by Savigny ${ }^{1}$ when separating it from the other VuLTuREs, and sometimes used as an English word.

NEOSSOPTILE, see FEATHERs (p. 243).

NERVOUS SYSTEM. This consists of two parts, (1) a Central portion, composed of

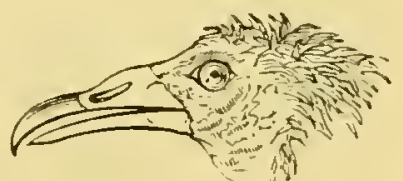

Nemphrox.

(After swainson.) the Spinal Cord and Brain, and (2) Peripheral, containing the Cranial and Spinal Nerves, together with all that pertains to what is called the Sympathetic.

I He took the word from the pseudomythological Mctamorphoses (or Tiansformationum congeries, Fab. 5) of Antoninns Liberalis, a writer who flourished abont the middle of the second century, Neophron bcing the name of a man changed, for a base trick he played, into a V'ulture by Zeus. 
I: The Spinal Cord or "Marrow" is the continuation of the medulla oblongata, extending throughout the vertebral canal to the tail, being swollen at the level of the shoulders by an accumulation of ganglionic cells to serve the Brachial Nerve Plexus governing the fore-limbs, and again in the lumbar region where the nerves of the hind-limbs have their origin. On the dorsal side of this lumbar swelling, there is a lozenge-shaped slit, the sacro-rhomboidal sinus, filled with a colourless gelatinous substance, behind which the cord lessens gradually, ending as a thin thread in the last free caudal vertebræ. The whole of this System is encased in a strong, fibrous sheath of connective tissue, the dura mater, the outer layer of which is closely attached to and forms the lining of the central vertebral canal, while its inner layer forms a looser and more meshy tissue. A much thinner membrane, the pia mater, is immediately attached to the surface of this System, penetrating its various furrows or sulci, and containing blood-vessels which nourish the nervous matter. Between the dura and the pia mater, but partly separated from each by lymphatic spaces, lies the Arachnoid Membrane.

The composition of the Spinal Cord is best studied in transverse section:-in the midst is the central canal, on the medio-ventral and medio-dorsal lines are the anterior and posterior sulci, forming more or less deep vertical slits which thus divide the cord into a right and left side. The central portion of the cord, distinctly grey in colour, being composed of grey nerve-fibres, without axial cylinders, and interspersed with numerous ganglionic nerve-cells, arranged in the form of a saltire or St. Andrew's cross, of which the ventral pair of limbs contain the ganglia and send out the motory roots of the spinal nerves, while the dorsal pair contain the ganglia and send out the sensory bundles of nerve-fibres. This grey matter is surrounded by a thick mantle of white nerve-fibres, most of them conducting threads composed of an axial cylinder with a sheath, and running longitudinally parallel to each other, though at the so-called commissures a crossing from one side to the other occurs with many of both white and grey fibres.

II. The Spinal Nerves arise from the medulla by a number of rootlets, which leave its surface in the form of a dorsal and i ventral root-the former (with a small swelling, the spinal ganglion, at its base) containing the sensory, the latter the motory fibres; but all the fibres of each issue as a single bundle either between two vertebrie or pass through a hole at the anterior end of a vertebra. The first spinal or cervical nerve issues between the occiput and the atlas, and each that follows from the anterior end of its vertebra-all on leaving the vertebral column separating into three branches-a dorsal, ventral and visceral. The first two contain sensory and motory nerves mixed; but the dorsal branches 
are small and innervate the skin and muscles of the dorsal spinal tract, while the ventral branches are much larger, and, depending on the muscles they have to supply, are strongest in the region of the limbs. The visceral branches, or "sympathetic nerves," supply chiefly the digestive, vascular and generative organs.

Four or five of the lowest cervical nerves join to form the Brachial Plexus, whence diverge those that serve the wings and shoulders; but the composition of this plexus varies considerably not only in different species but even individually. The serial number of the nerves entering into its formation depends chiefly on the length of the neck, the extremes being found in Cypselus (10th to the 14 th cervical pair), and Cygnus (22nd to $24 \mathrm{th}$ ), intermediate cases occurring in Columba (11th to 15th), Gallus (13th to 17 th), Anas (15th to 18th) and in many Passeres (12th to 15th). The last nerve of this plexus often marks off the boundary of the cervical and thoracic regions, by issuing just above the first thoracic vertebra.

The nerves arising from this plexus are divided into (A) small dorsal branches supplying the scapular muscles, and (B) thoracic branches forming a system for the sterno-coracoid and all the wingmuscles. The thoracic branches (B) send off a group $(a)$ to the superior and another $(b)$ to the inferior brachial muscles. Among the former $(a)$, the chief are (1) nervus subcoraco-scapularis for the m. subcoracoideus, m. subscapularis and $\mathrm{m}$. subcoraco-scapularis, (2) n. musculi latissimi dorsi, (3) n. axillaris, a strong nerve passing the humero-scapular joint, running between the humerus and the $m$. triceps, and innervating the deltoid muscles, as well as the skin of the shoulder, upper arm and propatagium, and (4) the n. radialis, the strongest nerve of all, running spirally round the dorsal side of the humerus, supplying the $\mathrm{m}$. triceps, and, dividing at the elbow into a superficial and a deep branch, innervating all the numerous exterior muscles beside the skin and feathers of the forehead. Among the latter group (b) are three strong nerves (1) the n. supracoracoideus, covered by a membranaceous ligament, crossing the coracoid and supplying the m. supracoracoideus, ${ }^{1}(2)$ the $n$. pectoralis for the large pectoral muscle, and (3) the $n$. brachialis inferior, which accompanies the last so far as the axilla, and then passing along the humerus divides into a $n$. medianus, supplying the $\mathrm{m}$. biceps and the radial side of the forearm and hand, and a $n$. ulnaris, sending several branches to the ulnar side.

The spinal nerves succeeding to the Brachial Plexus are those of the intercostal region, their short dorsal branches supply the

1 In many birds the median side of the coracoid has a notch (bridged by a tendinons ligament) for the passage of the nerve, which in other cases may pass through a foramen near the inner side of that bone; but these differences have little taxonomic importance. 
624

NERVOUS SYSTEM

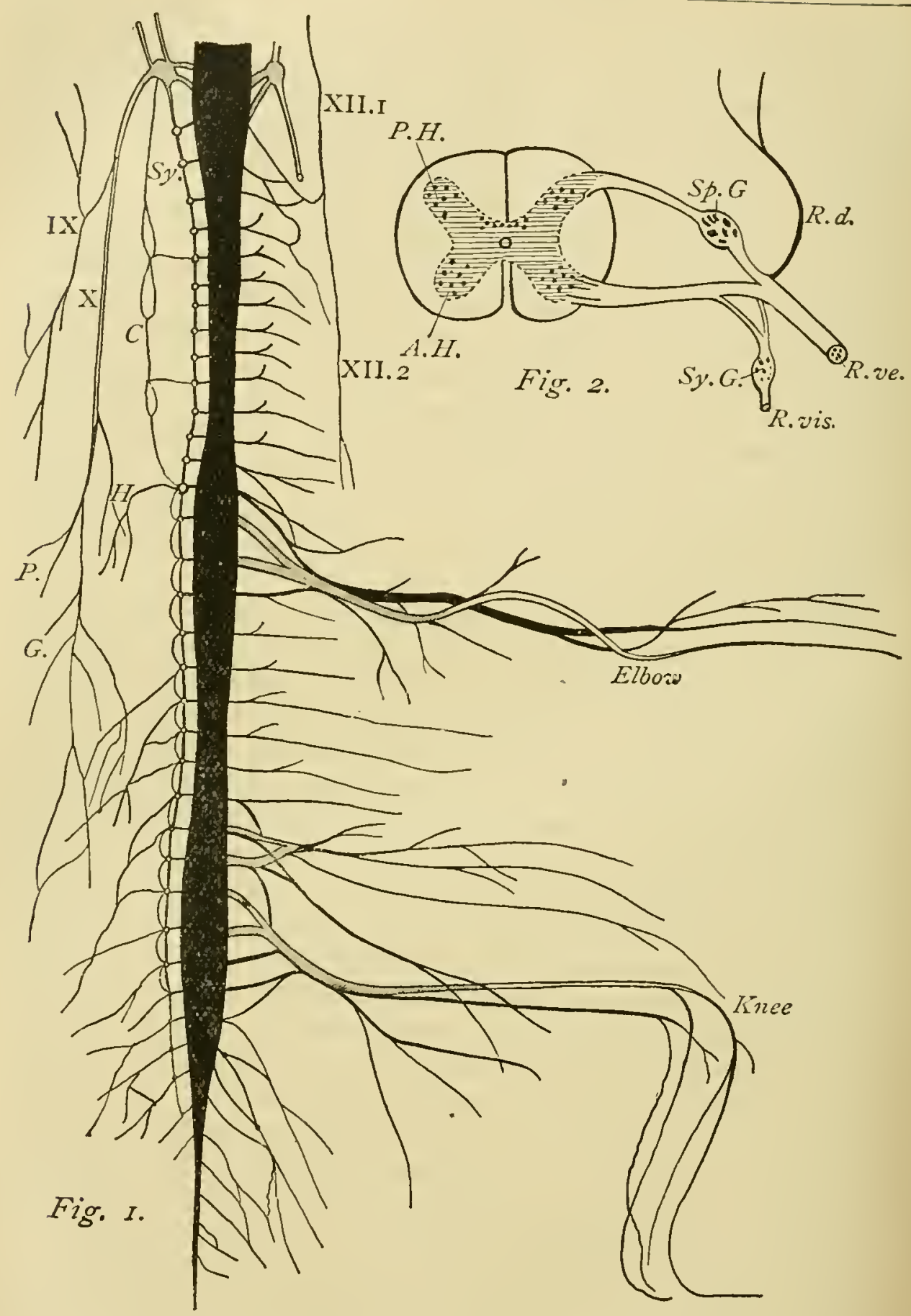

Fig. 1. -Diagrammatic Representation of the peripheral Nervous System of a Birl. Ventral view. Left side showing the Somatic, right side showing the Visceral Nerves.

IX. N. glossopharyngeus ; X. X. vagus, C. G. H. P. its distribution to the Carotid, the Heart, Lings, Stomach and Gut; XII.1, Lingual branch and XII.2, Syringeal branch of N. hypoglossus ; Ny. Sympathetic ganglion of the first spinal nerve.

Fig. 2.-Diagranmatic view of a transverse section through the spinal cord on the level of the exit of a typical spinal nerve.

$A . H$. and $Y$ 'H. Anterior or ventral and Posterior or dorsal Horns with ganglia, of the grey sub. stance; in the inildle of which is seen the central canal ; Sp.G. the Spinal Ganglion of the dorsal root of the spinal nerve; Sy.G. the Sympathetic Ganglion; Rod., Rove., R.vis. Dorsal, Ventral and Visceral (or sympathetic) branches of the spinal nerve. 
dorsal muscles of the spine, and their long ventral branches run between the ribs, supplying the intercostal and, further back, the abdominal muscles.

The Sacral Plexus is formed by the Spinal Nerves in the pelvic region, and may be conveniently divided into (A) a Crural or Lumbar, (B) a Sciatic, and (C) a Pudic portion. The first (A) is composed of from 2 to 4, but generally of 3 nerves, the foremost of which sends a long branch to the abdominal muscles, while the hindmost, $n$. furcalis, leaving the spinal column, as a rule, between the 2 last lumbo-sacral vertebræ, divides-one-half going to the Sciatic portion. From the Crural portion spring several branches forming 3 groups-(1) those that serve the $\mathrm{m}$. sartorius, m. ambiens and some other muscles of the leg; (2) the $n$. obturatorius, supplying the $\mathrm{m}$. obturator and its accessories, as well as the $\mathrm{m}$. adductor magnus; and (3) a long nerve which runs down the median side of the thigh to the inner side of the knee, supplying the latter and passing subcutaneously down the median side of the leg. This nerve is almost peculiar to Birds, occurring beside only in Crocodiles and Monotremes.

The Sciatic portion (B) generally consists of 5 or 6 nerves, which leave the pelvis as a thick stem, passing close behind the antitrochanter through the ischio-iliac foramen, where a strong branch separates itself from the hinder side of the common stem to supply most of the adductor muscles of the thigh and leg. From the main stem branches are given off to the ilio-femoral, ilio-tibial, iliofibular and ischio-femoral muscles. The rest of the stem continues as the Sciatic nerve, accompanied by the great arteries and veins on the posterior side of the thigh, and below the knee invariably divides into 3 branches, the first of which (1) is the strongest, and passes with the tendon of the ilio-fibular muscle through the peculiar tendinous pulley on the side of the fibula, whereupon it splits into the superficial and deep peroneal nerves, to supply the extensor and peroneal muscles of the foot and toes; the median branch (2) soon breaks up into a number of nerves for the deep flexor muscles of the toes and the inner and middle portion of the $\mathrm{m}$. gastrocnemius; while the third (3) innervates the outer head of the gastrocnemius and the rest of the flexor muscles of the toes. As before stated, the Sciatic portion (B) receives one-half of the $n$. furcalis from the Crural (A), while its hindmost spinal stem, leaving the spinal column, in most birds, between or just below the hindmost of the 2 primary sacral vertebræ (see Pelvis under SkELEToN), sends a branch to the Pudic portion (C), which is composed of the post-ischiadic spinal nerves. These are partly imbedded in the substance of the KIDNEYs, and run obliquely outwards, forming many anastomoses with one another, especially on the hinder parts of the ischium and pubic bone. This portion chiefly innervates the 
ventral muscles between the pelvis and tail, together with those of the cloacal region and the copulatory organs.

The dorsal branches of all the spinal nerves in the whole pelvic region are restricted to small, cutaneous branches in conformity with the reduction of the dorso-spinal muscles. The caudal nerves are also small, their dorsal branches supply the levator and their ventral the depressor muscle of the tail.

III. 'The Cranial or Cerebral Nerves have been already described (BRAIN).

IV. The Sympathetic System consists of the visceral branches of the Cerebro-Spinal Nerves, and supplies chiefly the alimentary and genital organs and the circulation. The Nerves composing it have no axial cylinder: they are paler than the white fibres, and are characterized by the presence of ganglia in their course, each branch containing one near its base which beside sending off other ramifications is connected with the corresponding ganglion of the next metamere, so as to form a "Sympathetic" chain running along each side of the ventral surface of the vertebral column. The two chains by means of these comnexions somewhat resemble a ladder, the cross-bars of which are called rami communicantes, from a mistaken notion that they join the longitudinal "strand" or n. sympathicus of their side with the medulla, the fact being that the cross-bars are the true "rests," the lateral strands rather making the connexion between the successive ganglia. In the region of the NECK each of these strands runs, accompanied by the vertebral artery of its side, through the transverse foramen of each of the cervical vertebræ. In the thoracic region each strand is double, and the basal ganglia are successively connected with the next by a nervous branch which runs over the head of the rib, and by another which passes directly through the space between the head of the rib and its tubercle. In the pelvic region each strand again becomes single; but, conversely to the single strand of the cervical region, each is composed of ventral branches only, while lastly in the caudal region the right and left branches approach and coalesce in the middle line. From the first thoracic ganglion there issues a cardiac branch supplying the HEART, while other branches starting from neighbouring ganglia form a sort of plexus which, accompanying the coliac artery, innervate the stomach, LIVER and other viscera. Similar branches from the basal ganglia of the lumbar and sacral regions form a plexus with ganglia numerously interspersed, and serve the rest of the Alimentary Canal, the Kidneys (page 480), genital organs and CloACA (page 90), where they partly anastomose with the branches of the Pudic portion of the Sacral Plexus.

From the first pair of cervical ganglia the Sympathetic strands are continued on either side to the ganglia of the $n$. hypoglossus, 
and thence to the ganglion supremum of the combined $n$. ragus and glossopharyngers. From this last, which sends ont long sympathetic branches to the carotids and the throat generally, the Sympathetic chain extends to the head by complicated connexions with the ganglia of the 7 th, 5 th and 3rd pairs of cranial nerves (see Brarr), its numerous branches serving chiefly the blood-vessels of the head, the lacrymal glands and the Eyes.

NESTOR, the name applied to a small but remarkable group of Parrots peculiar to the New-Zealand Region, of which the type is the Psittacus meridionalis of Gmelin, founded on a species described by Latham (Gen. Synops. i. p. 264), and subsequently termed by him $P$. nestor, in allusion to its hoary head, but now usually known as Nestor meridionalis, the "Kata" of the Maories and English settlers in New Zealand, in some parts of which it was, and even yet may be, very abundant, though its numbers are fast decreasing. Forster, who accompanied Cook in his second voyage, described it in his

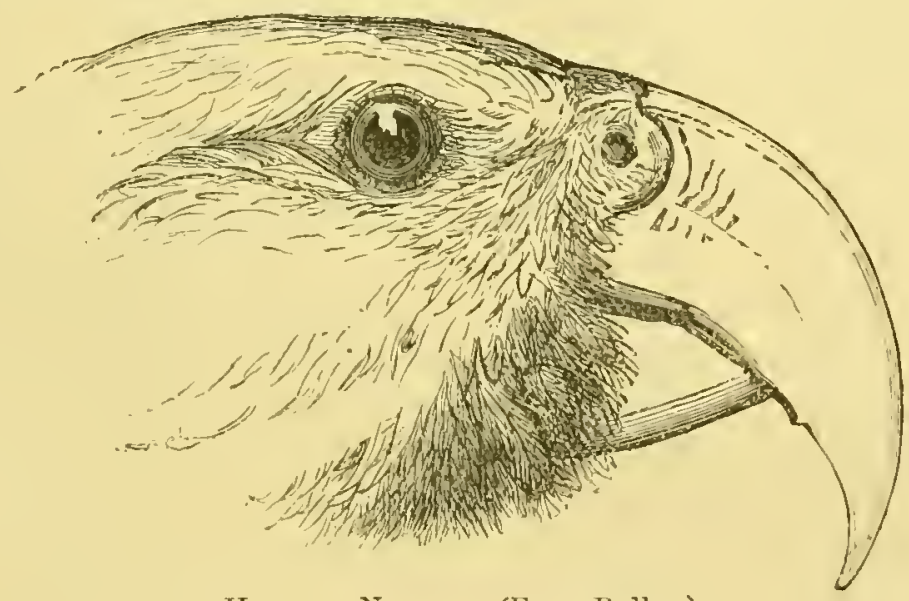

HeAd of Nestor. (From Buller.)

MS. in 1773, naming it $P$. hypopotius, and found it in both the principal islands. The general colour of the Kaka is olive-brown, nearly all the feathers being tipped with a darker shade, so as to give a scaly appearance to the body. The crown is light grey, the ear-coverts and nape purplish-bronze, and the rump and abdomen of a more or less deep crimson-red; but much variation is presented in the extent and tinge of the last colour, which often becomes orange and sometimes bright yellow. The Kalia is about the size of a Crow; but a larger species, generally resembling it, though having its plumage varied with blue and green, the Nestor notubilis of Gould, was discovered in 1856 by Mr. Walter Mantell, in the higher mountain-ranges of the South Island. This is the "Kea" of the Maories, and has of late incurred the enmity of colonists by developing, when pressed by hunger in winter, an extraordinary habit of assaulting sheep, picking holes with its powerful beak in 
their side, wounding the intestines, and so causing the animals' death. The lacerations are said to be made so uniformly in one place as to suggest deliberate design ; but the bird's intent has yet to be investigated, though it is admittedly an eater of carrion in addition to its ordinary food, which, like that of the Kaka, consists of fruits, seeds, and the grubs of wood-destroying insects, the last being obtained by stripping the bark from trees infested by them. The amount of injury the Kea inflicts on flock-masters has doubtless, as always happens in similar cases, been much exaggerated, for Dr. Menzies states (Trans. N. Zeal. Inst. xi. p. 377) that on one "run," where the loss was unusually large, the proportion of sheep attacked was about one in three hundred, and that those pasturing below the elevation of 2000 feet are seldom disturbed. ${ }^{1}$

On the discovery of Norfolk Island (10th October 1774) a Parrot, thought by Forster to be specifically identical with the "Kagháá" (as he wrote the name) of New Zealand,-though his son (Voyage, ii. p. 446) remarked that it was "infinitely brighter coloured,"-was found in its hitherto untrodden woods. Among the drawings of Bauer, the artist who accompanied Robert Brown and Flinders, is one of a Nestor marked "Norfolk Isl. 19 Jan. 1805," on which Von Pelzeln in 1860 founded his $N$. norfolcensis. Meanwhile Latham, in 1822, had described, as distinct species, two specimens evidently of the genus Nestor, one, from the collection of Mr. Thomas Wilson of Maidenhead, said, but doubtless erroneously, to inhabit New South Wales, and the other brought by Col. Hunter from Norfolk Island. In 1836 Gould described an example, without any locality, in the museum of the Zoological Society, as Plyctolopluus productus, and when some time after he was in Australia, he found that the home of this species, which he then recognized as a Nestor, was Phillip Island, a very small adjunct of Norfolk Island, and not more than five miles distant from it. Whether the birds of the two islands were specifically distinct or not we shall perhaps never know, since they are all extinct (Exterinination, pp. 223, 224), and no specimen undoubtedly from Norfolk Island seems to have been preserved ${ }^{2}$ while, now that we are aware of the great diversity in colour, size, and particularly in the form of the beak, to which the New-Zealand members of the genus are subject, it would be unsafe to regard as specific the differences pointed out by Von Pelzeln

1 A third form, from an nnknown locality, has been distinguished as $N$. esslingi (Rev. Zool. 1856, p. 223), and has been regarded by several whiters, and among them Count T. Salvadori (Cat. B. Brit. Mrus. xx. p. 8), as a good species, though Sir W. Buller (B. N. Zeal. ed. 2, i. pp. 150-175) believes it to be, like his own $N$. occidentalis and $N$. superbus, as well as the so-called $N$. montanus of Haast, founded on individual variation.

$\because$ Canon Tristram (Ibis, 1892, p. 557) believes that one in his possession had this origin, and so it may prove. 
from Baner's drawing. The Phillip-Island Nestor may be distinguished from both of the New-Zealand species by its somerhat smaller size, orange throat, straw-coloured breast, and the generally lighter shade of its tints.

The position of the genus Nestor in the Order Psittaci must be regarded as uncertain. Garrod removed it altogether from the neighbourliood of the Lories (Proc. Zool. Society, 1874, p. 597), to which indeed the structure of its tongue, as previously shewn by him (op. cit. 1872 , p. 789), indicates only a superficial resemblance. Like so many other New-Zealand forms, Nestor seems to be isolated, and may fairly be deemed to represent a separate Family-Nestoridae -a view adopted by Count T. Salvadori (Cat. B. Brit. NIus. xx. Introd. p. viii.), and fully justified by a cursory examination of its osteology, though this has hitherto been only imperfectly described and figured (Eyton, Osteol. Avium, p. 72 ; A. B. Meyer, Abrild. von Vogel-Skeletten, p. 18, pl. 23).

Further knowledge of this very interesting form may be facilitated by the following references to the Transactions and Proceedings of the New Zealand Institute, ii. pp. 64, 65, 387; iii. pp. 45-52, 81 90 ; v. p. 207 ; vi. pp. 114,128 ; ix. p. 340 ; x. p. 192 ; xi. p. 377 ; and of course to Sir Walter Buller's Birds of New Zealand, especially the second edition.

\section{NESTS, see NidifICATION.}

NIAS (Fr. Niais, and that from the Low Latin Nidax, a nestling), corruptly "Eyas" or "Eyess," a falconer's term for a Hawk that has been brought up from the nest, in contradistinction to a "Haggard" or Hawk that has been caught wild.

NIDICOLAE, a word used in this work in no systematic sense, but as a convenient term to indicate those Birds, the young of which remain in the nest for a shorter or longer time as opposed to NIDIFUGA, or those whose chicks are hatched in a condition enabling them to leave their birthplace at once. The Nidicola, all of which have their eyes closed at coming into the world, may be divided into four categories, according to their initial state and the way in which they subsequently develop :-

(1) Those born with a clothing of "Neossoptiles" (see Feathers, p. 243), as Accipitres, Alcidx (partly), Caprimulgi, Columbida, Eurypyga, Helionis (excl. Podica), Sphenisci, Striges, Tubinares.

(2) Those born naked or nearly so, but soon acquiring a thick clothing of neossoptiles, often of complicated structure, as Ardex ( + Scopus), Cathartx, Ciconia ( + Platalea), Podica, Steganopodes.

(3) Those born naked, but with a few neossoptiles growing out of the tip of the "Teleoptiles" (see Feathers, p. 243) as Passeres, Upupidx.

(4) Those born naked and never acquiring neossoptiles, nearly 
all being birds that breed in holes, as Alcedines, Bucerotida, Coraciida, Cuculida, Cypseli, Meropidx, Momotidx, Musophagidx, Pici, Todida, Trochitida.

The Bucconida, Cotiidx, Eurylamida, Galbulida and Trogonida are probably all naked.

Menura is said to have downy nestlings.

Opisthocomus is born with open eyes, but is fed by its parents, and has an imperfect nestling plumage.

The interesting correlation between Neossoptiles and permanent Downs (see Feathers, p. 242) is shewn (Thicr-reich, Vögel, Systemat. Theil, pp. 76-85).

NIDIFICATION, or the building of the nest in which the EGGS are to be incubated and hatched, is with most Birds the beginning of the real work of the breeding-season, to which SoNG and its concomitant actions are but the prelude or the accompaniment; but with many it is a labour that is scamped if not shirked. Some of the AUK tribe place their single egg on a bare ledge of rock, where its peculiar conical shape is but a precarious safeguard when rocked by the wind or stirred by the thronging crowd of its parents' fellows. The Stone-CURLEw and the. NIGHTJAR deposit their eggs without the slightest preparation of the soil on which they rest; yet this is not done at haphazard, for no birds can be more constant in selecting, almost to an inch, the very same spot which year after year they choose for their procreant cradle. ${ }^{1}$ In marked contrast to such artless care stand the wonderful structures which others build for the comfort or safety of their young. But every variety of disposition may be found in the Class. The Apteryx (KIWI) seems to entrust its abnormally big egg to an excavation among the roots of a tree-fern; while a band of female OsTRICHES scrape holes in the desert-sand, and therein promiscuously dropping their eggs cover them with earth, and leave the task of incubation to the male, who discharges the duty thus imposed upon him by night only, and trusts by day to the sun's rays for keeping up the needful, fostering warmth. Some MEgApodes bury their eggs in sand, leaving them, as many Reptiles do, to come to maturity by the mere warmth of the ground, while others raise a huge hotbed of dead leaves wherein they deposit theirs; but in either case the young are hatched without further care on the part of either parent. The GREBES and some RAILS seem to avail themselves in a less degree of the heat generated by vegetable decay (B. Norf. iii. p. 240), ${ }^{2}$ and dragging from the bottom or sides of the waters they frequent fragments of aquatic

${ }^{1}$ I make this statement literally on the experience of my brother Edward and myself, but I believe it will be abundantly confirmed by the evidence of other observers.

2 Mr. Sonthwell found the temperature of an unincubated nest of Podicipes cristatus to be $67^{\circ}$, that of two incubated nests to be $72^{\circ}$ and $73^{\circ}$ respectively, 
plants form of them a rude half-floating mass which is piled on some growing water-weed-but these birds do not spurn the duties of maternity. Many of the Gulus, SANDPIPERs, and Plovers lay their eggs in a shallow pit which they hollow out in the soil, and then as incubation proceeds add thereto a low breastwork of haulm. 'The Ringed Plover commonly places its eggs on shingle, which they so much resemble in colour; but when breeding on grassy uplands it paves the nest-hollow with small stones. PIGEONs mostly make an artless platform of sticks so loosely laid together that their pearly treasures may be perceived from beneath by the inquisitive observer. The PIE, as though conscious that its own thieving habits may be imitated by its neighbours, surrounds its nest with a hedge of thorns. Very many birds of very different groups bore holes in some sandy cliff, and at the end of their tunnel deposit their eggs with or without bedding. Such bedding, too, is very various in character; thus, while the SHELD-DRAKE and the Sand-MARTIN supply the softest of materials, - the one of down from her own body, the other of feathers collected by dint of diligent search,-- the KInGFIsHer forms in the course of incubation a couch of the undigested spiny fish-bones which she ejects in pellets from her own stomach. Other birds, as the WOODPECKERS, hew holes in living trees, even when the timber is of considerable hardness, and therein establish their nursery. Some of the SwIFTs secrete from their salivary glands a fluid which rapidly hardens as it dries on exposure to the air into a substance resembling isinglass, and thus furnish the "edible birds" nests" that are the delight of Chinese epicures. In the architecture of nearly all the PASSERES, too, some salivary secretion seems to play an important part. By its aid they are enabled to moisten and bend the otherwise refractory twigs and straws and glue them to their place. Spiders' webs also are employed with great advantage for the purpose last mentioned, but perhaps chiefly to attach fragments of moss and lichen so as to render the whole structure less obvious to the eye of the spoiler. The TAILOR-BIRD deliberately spins a thread, and therewith sews together the edges of a pair of leaves to make a receptacle for its nest; while the Fantail WARBLer, by a similar process of stitching-even making a knot at the end of the thread-unites as a sheltering canopy above its nest the upper ends of the grass stems amid which it is built. Beautiful too is the felt fabricated of fur or hairs by the various species of TITiouse, while many birds ingeniously weave into a compact mass both animal and vegetable fibres, forming an admirable non-conducting medium which guards the eggs from the extremes of temperature outside. Such a structure may be open and cup-shaped, supported from below as that of the CHAFFincr and and that of a nest of Fulica atro to be $61^{\circ}$, while the maximum temperature of the air that day was $58^{\circ}$ Fahr. 
GoLdFINCH, domed like that of the WrEN and Bottle-Titmouse, slung hammock-wise as in the case of the Golden-crested Wren and the ORIOLES, or suspended by a single cord as with certain GrosBeAKS and HuMning-BIRDs. Under such circumstances it is even sometimes needful to balance the nest lest the weight of the growing young should destroy the equipoise, and, precipitating them on the ground, dash the hopes of the parents, and compensation in such cases is applied by loading the opposite side of the structure with lumps of earth. Certain WarbLers (Aedon and Thamnobia) for some unascertained reason invariably lay a piece of snake's slough in their nests - to repel, it has been suggested, marauding lizards who may thereby fear the neighbourhood of a deadly enemy. The clay-built edifices of the SwALLOW and MARTIN are known to everybody, and the NuthatcH plasters up the gaping mouth of its nesthole till only a postern large enough for entrance and exit, but easy of defence, is left. In South America we have the subfamily Furnariinx (OVEN-BIRD), which construct of mud on the arching roots of the mangrove or the branches of other trees globular "ovens," so to speak, wherein the eggs are laid and the young hatched. The FLAMINGo erects in the marshes it frequents a mound of earth some two feet in height, with a cavity atop, on which the hen, having oviposited, is said to sit astride with dangling legs, and in that remarkable attitude perform the duty of incubation. ${ }^{1}$ The females of the HoRNBILLs, and perhaps of the Hoopozs, submit to incarceration during this interesting period, the males immuring them by a barrier of mud, leaving only a small window to admit air and food, which latter is assiduously brought to the prisoners.

But though in a general way the dictates of hereditary instinct are rigidly observed by Birds, in many species a remarkable degree of elasticity is exhibited or the rule of habit is rudely broken. Thus the noble FALCON, whose ordinary eyry is on the beetling cliff, will for the convenience of procuring prey condescend to lay its eggs on the ground in a marsh, or appropriate the nest of some other bird in a tree. The Golden EAGLE, too, remarkably adapts itself to circumstances, now rearing its young on a precipitous ledge, now on the arm of an ancient monarch of the forest, and again on a treeless plain, making a humble home amid grass and herbage. Herons also shew the same versatility, and will breed according to circumstances in an open fen, on sea-banks or (as is most usual) on lofty trees. Such changes are easy to understand. The instinct of finding food for the family is predominant, and where most food is there will the feeders be gathered together. This explains, in all likelihood, the associated bands of Ospreys or Fish-Hawks, which in North America breed (or used to breed) in large companies where sustenance is plentiful, though in the Old World the same

I As before noticed (pp. 255, 256), this statement has been impugned. 
species brooks not the society of aught but its mate. Birds there are of eminently social predilections. In Europe, excepting Seafowls - whose congregations are universal and known to all-we have perhaps but the Herons, the FieldFare, and the Roor, which habitually flock during the breeding-season; but in other parts of the world many birds unite in company at that time, and in none possibly is this habit so strongly developed as in the ANIS of the Neotropical Region, the Republican Swallow of North America, and the Sociable Grosbeak (WEaVER-BIRD) of South Africa, which last joins nest to nest until the tree is said to break down under the accumulated weight of the common edifice. ${ }^{1}$

In the strongest contrast to these amiable qualities is the parasitic nature of the Cuckows of the Old World and the Cow-BIRDs of the New, but this peculiarity of theirs has been alieady dwelt upoll. Enough to say here that the egg of the parasite is introduced into the nest of the dupe, and after the necessary ineubation by the fond fool of a fostel'-mother the interloper successfully counterfeits the heirs, who perish miserably, victims of lis superior strength. The whole process has been often watched, but the reflective naturalist will pause to ask how such a state of things came about, and there is not much to satisfy his enquiry. Certain it is that some birds whether by mistake or stupidity do not unfrequently lay their eggs in the nests of others. It is within the knowledge of many that Pheasants' eggs and Partridges' eggs are often laid in the same nest, and it is within the knowledge of the writer that Gulls' eggs have been found in the nests of EIDER-Ducks, and vice versâ; that a ReDSTART and a Pied FLyCATCHER, or the latter and a Trtmouse, will lay theil eggs in the same convenient hole-the forest being rather deficient in such accommodation; that an OWr and a GOLDEN-EYE will resort to the same nest-box, set up by a scheming woodsman for his own advantage; and that the STARLING, which constantly dispossesses the Green Woodpecker, sometimes discovers that the rightful heir of the domicile has to be brought up by the intruding tenant. In all such cases it is not possible to say which species is so constituted as to obtain the mastery; but just as it is conceivable that in the course of ages that which was

1 There are not many works on nidification, for "Caliology" or the study of nests has hardly been deemed a distinct branch of ornithological study. A good deal of instructive matter (not altogether free from error) will be found in Rennie's Arehitecture of Birds (London : 1831), and there is Mr. Wallace's most interesting dissertation, "A Theory of Birds' Nests," originally published in the Journal of Travel and Natural History (1868, p. 73), and reprinted in his Contributions to the Theory of Natural Selection (London: 1870). Andrew Murray's and the Duke of Argyll's remarks on this essay are contained in the same volume of the Journal named (pp. 137 and 276). The late Hr. J. G. Wood's Homes without Hands, perhajs the best of his books, contains a popular account of many Birds' nests, but is devoid of scientific treatment and disfigured by some glaring errors. 
driven from its home might thrive through the fostering of its young ly the invader, and thus the abandonment of domestic duties would become a direct gain to the evicted householder; so the bird which, through inadvertence or any other cause adopted the habit of casially dropping her eggs in a neighbour's nest, might thereby ensure a profitable inheritance for endless generations of her offispring. This much granted, all the rest will follow easily enough, but it must be confessed that this is only a presumption, though a presumption which seems plausible if not likely.

Incubation is performed, as is well known, by the female of nearly all Birds, but with most of the Passeres and many others the male seems to share her tedious duties, and among the RatTTæ, apparently without exception, the cock ordinarily takes that office on himself. There are a few groups or perhaps species in which the same practice is suspected to obtain-certain of the Limicola for instance, the Godwits (Limosa), the Phalaropes (Phalaropus), and the DotTerel (Eudromias morinellus) - and in these it is to be remarked that the hen is larger and more brightly coloured than her mate. Owing to the unfortunate neglect of those who have the best opportunities of making the needful observations, ${ }^{1}$ the period of incubation has been ascertained in comparatively few birds, and it is here possible to deal with that subject only in the most vague and general language. It may be asserted that most of the smaller Passeres of Europe hatch their young in from 13 to 15 days, but in a few species the term is believed to be shortened to 10 or 11 days, while in the largest of that Order, the Raven, it may be lengthened to some 18 or 19 days. The Barndoorfowl ordinarily takes 21 days, but the Pheasant, though so very nearly allied, takes two or three days longer. Most Waterbirds, so far as is known, and the smaller Birds-of-Prey seem to require as long a time, but the Tubinares are said (Ibis, 1892, p. 581) to take 35 days, while the Gannet needs at least 39 ; and in the Swan incubation lasts from 35 to 40 days, and in the Condor, according to Broderip (Notebook of a Naturalist, p. 14), 54 days. The temperature of the air is commonly credited with having something to do either in hastening or retarding exclusion from the egg, but to what extent, or even whether justly so or not, seems in the absence of precise experiments to be doubtful. Certain birds occasionally begin brooding so soon is the first egg is laid, ${ }^{2}$ and this practice unquestionably has its advantages, since the offspring being of different ages thereby become less of a burthen on the parents which have to minister

1 The most valuable papers on the subjeet are by Mr. William Erans (Ibis, 1891, pp. 52-93; and 1892, pp. 55-58).

2 This seems to be very often the ense with the Owls; but, if my observation is not mistaken, the habit is not constant even with the same individual bird. 
to their wants, while the fostering warmth of the earlier chicks can hardly fail to aid the development of those which are unhatched, during the absence of father and mother in search of food; but most birds, and it need scarcely be said, all those the young of which run from their birth, await the completion of the clutch before sitting is begun. The care bestowed, by almost every species, on the infant-brood, is proverbial, and there is hardly any extremity of danger which one at least of the anxious parents will not incur to ward off injury from their progeny.

NIDIFUGLE, a word used in this work in contradistinction to Nidicole (p. 629) to signify those Birds which are able, at latching or immediately after, to leave the nest. They are all born with their eyes open and are thickly clothed with Neossoptiles (Feathers, p. 243) of simple structure, as Alcidx (portion), Anatidx, Colymbi, Dicholophus, Gallinx, Grues, Larida, Limicola, Otididx, Palameder, Phonicopteri, Podicipelida, Pterocles, Ralli, Ratita, Tinami, Turnices.

Opisthocomus, though born with open eyes, and able to creep about on the branches, has but few Neossoptiles and is fed by its parents.

As previously remarked (page 244) the condition of the first plumage is of little taxonomic value. This applies with still more force to the difference between Nidicola and Nidifugæ. Taken as a whole the latter comprise most of the phylogenetically older groups ; but any of them may include some closely-allied members which have reached the developmental level of the former-the Alcida, Pigeons, Plovers and Fowls for example. Most if not all Nidicola feed their young, but there are also many Nidifuga which prefer being fed by their parents though they can feed themselvesfor instance the Gulls.

In order to shew the utterly useless nature of these characters in the hands of various systematists it will be enough to state that Newman considered Gulls and Birds-of-Prey to be "gymnogenous" or born naked: Bonaparte held all the Alcida and the Sphenisci to be "Pracoces" but the Laridx to be AlTRICES: Sundevall classed Herons and Storks, Sphenisci and Tubinares among the Pracoces; while Mr. Seebohm informs us (Classif. B. p. 9) that Pigeons do not pass through a downy stage.

NIGHT-HAWK, locally applied in parts of England to the NightJar, and in North America to species of the genus Chordiles.

NIGHT-HERON, see HERon, page 120.

NIGHTINGALE (Anglo-Saxon, Nihtegale, literally "singel" of the night"), the bird justly celebrated beyond all others by European writers for the admirable vocal powers which, during some weeks after its return from its winter-quarters in the south, it 
exercises at all hours of the day and night. The song itself is indescribable, though several attempts, from the time of Aristophanes to the present, have been made to express in syllables the sound of its many notes; and its effects on those that hear it depend so much on their personal disposition as to be as varied as are its tones. To some they suggest melancholy; and many poets have discanted on the bird (which they nearly always make of the feminine gender) leaning its breast against a thorn and pouring forth its melody in anguish. It is accordingly to be observed that the cock alone sings, and that there is no reason to suppose that the cause and intent of his SoNG, unsurpassed though it be, differ in any respect from that of other birds. Sadness, therefore, is certainly the last impelling sentiment that can be properly assigned in this case. In great contrast to the Nightingale's pre-eminent voice is the inconspicuous coloration of its plumage, which is alike in both sexes, and is of a reddish-brown above and dull greyish-white beneath, the breast being rather darker, and the rufous tail shewing the only bright tint. The range of this bird in Europe has already been so fully described (GEographical Distribution, pp. 339-341) as to render a further account of it needless. The Nightingale reaches its English home about the middle of April, ${ }^{1}$ the males (as is usual among migratory birds) arriving some days before the females; and, often stopping on their way, letting their song be heard in places they do not habitually frequent, pass to their proper breedingquarters. At this time they run very great danger from birdcatchers, for their capture is effected with facility, and it is painful to add that of those then caught nine-tenths are said to die within a month. Fortunately for the species, it receives great protection from the practice of game-preserving, which guards from intrusion so many of the localities it affects, and there is probably no country in which the Nightingale breeds more abundantly and in greater security than in England. On the cocks being joined by their partners, the work for which the long and hazardous journey of both has been undertaken is speedily begun, and before long the nest is completed. This is of a rather uncommon kind, being placed on or near the ground, the outworks consisting chiefly of a great number of

1 Poets and novelists are apt to command at will the song of this bird, irrespective of season. If the appearance of truth is to be regarded, it is dangerous to introduce a Nightingale as singing in England before the 15th of April or after the 15th of June. The "Early Nightingale" of newspaper paragraphs is generally a Song-Thrush. Mr. Harting has pointed out to me that the well-known and beautiful passage in which Izaak Walton speaks of this bird's song is an adaptation of one in D'Ar'cussia's Lettres de Philoierax à Philofalco (No. 24); but the way in which Walton turns the idea expressed shews great superiority over the original, the words of which are "O quel doit estre le concert des Anges du Ciel, puis que ces Anges terrestres nous extasient par leurs chants?" 
dead leaves ingeniously applied together so that the plane of most is nearly vertical. The mass is wrought so as to contain in the middle a deep cup-like hollow, neatly lined with fibrous roots, but the whole is so loosely constructed, and depends for lateral support so much on the stems of the plants among which it is generally built, that a very slight touch disturbs its beautiful arrangement. Herein from four to six eggs of a deep olive colour are duly laid, and the young hatched. If the latter, when nearly fit to fly, be taken from the nest, they can with proper care be reared by hand, and this is the only justifiable mode of proceeding for those who wish to keep this fine songster in confinement, as, if the birds survive their first moult, they may live for some years in a cage, and the cocks will in due time exercise their full vocal powers. The nestling plumage of the Nightingale differs much from that of the adult, the feathers above being tipped with a buff spot, just as in the young of the Redbreast, Redstart and Hedge-Sparrow, thereby pointing to the affinity of all these forms. Towards the end of summer the Nightingale disappears, and but little has been observed of it in its winter-retreats, which are presumably in the interior of Africa. One of the few records of it at that season proves that it visits the Gold Coast (Ibis, 1872, p. 291).

The Nightingale is the Motacilla luscinia in part of Linnæus, and the Dutias luscinia of some modern ornithologists. In the east of Europe a second species occurs which was not discriminated by Linnæus, though long known to German bird-fanciers as the Sprosser. This, the Sylvic philomela or Daulias plitomela of many scientific writers, is a somewhat larger bird, which fact, and the presence of some faint spots on its breast, have caused it to receive the English name of Thrush-Nightingale. Its westward range appears to be limited to the valley of the Rhine, and the statement that it has occurred in England is erroneous. Its song is louder than that of the true Nightingale, but not so sweet in tone or so varied in note. Still further to the eastward, extending from the Caucasus through Persia to Turkestan, and occasionally occurring in winter in India, is a third species, almost simultaneously described in Berlin and Moscow as Luscinia golzi and L. hafizi (see Radde, Orn. Caucas. p. 247, pl. xv. and Oates, Faun. Br. Ind. Birds, ii. p. 101). The name Nightingale has been vaguely applied to several other birds. The so-called "Virginian Nightingale" is a species of GroseEAK (p. 387), and the REDwing, strangely enough, has been often spoken of as the "Swedish Nightingale." 1

1 The Nightingale holds a place in classical mythology. Proene and Philomela were the daughters of Pandion, king of Attica, who in return for warlike aid rendered him by Tereus, king of Daulis in Thrace, gave him the first-named in marriage. 'lereus, however, being enamoured of her sister, feigned that his wife was dead, and induced Philomela to take her place. On her discovering the 
NIGHTJAR or GOATSUCKER, a bird from very ancient times absurdly believed to have the habit implied by one of the common names it bears in many European tongues besides our own-as

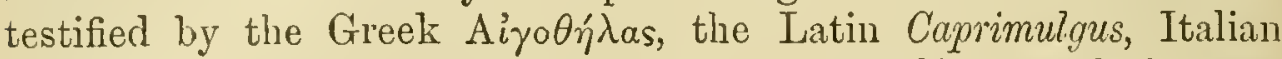
Succiacapre, Spanish Chotacabras, French Tettecherre, and German Ziegenmelker. It is admittedly the type of a very peculiar and distinct Family, Caprimulgidx, a group remarkable for the flat head, enormously wide mouth, large eyes, and soft, pencilled plumage of its members, which vary in size from that of a Lark to that of a Jay. Its position has been variously assigned by systematists. Prof. Huxley considered it to form, with two other Families-the Cypsetidx (SwIFT) and Trochilidx (Hunmmg-BIRD)-the division Cypselomorphe. The same view was taken in 1884 by Dr. Reichenow; but in $1885 \mathrm{Dr}$. Stejneger proposed to place it in a "Superorder" Coracoidex along with Steatornis (GuACHARo), Coraciida (Roller) and Leptosomatida; while in 1888, Prof. Fürbringer put it between the Rollers and OwLs, with which it forms in his opinion a group Coraciiformes. There are two ways of regarding the Caprimulgida-one including the genus Podargus (Morepork) and its allies, the other recognizing them as a distinct Family, Podargidx, as is done among others by $\mathrm{Mr}$. Hartert (Cat. B. Brit. Mus. xvi. pp. 519-654). As a matter of convenience the last are here comprehended in the Caprimulgida, which will then contain two subfamilies, Caprimulginx and Podarginx; for what, according to older authors, constitutes a third, though represented only by Steatornis, the singular GUACHARO or Oil-bird, certainly requires separation as an independent Family.

Some of the differences between the Caprimulgina and Podargina were pointed out by Mr. Sclater (Proc. Zool. Soc. 1866, p. 123), and are very obvious. In the former, the outer toes have four phalanges only, thus presenting a very uncommon character among Birds, and the middle claws are pectinated; while in the latter the normal number of five phalanges is found, the claws are smooth, and other distinctions more recondite have also been indicated by him (tom. cit. p. 582). The Caprimulginx may be further divided into those having the gape thickly beset by strong bristles, and those in which there are few such bristles or none-the former containing the

truth, he eut out her tongue to hinder her from revealing his deceit; but she depicted her sad story on a robe which she sent to Procne; and the two sisters then contrived a horrible revenge for the infidelity of Tereus, by killing and serving to him at tahle his son Itys. Thereupou the gods interposed, changing Terens into a Hoopoe, Procne into a Swallow, and Philomela into a Nightingale, while Itys was restored to life as a Pheasant, and Pandion (who had died of grief at his daughter's' dishonour) as a Bird-of-Prey (see OsPrex). The fable has several variants. Ovid's version may be seen in the 6 th Book of his Meta. morphoses (lines 412-676). 
genera Caprimulgus, Antrostomus, Nyctidromus, and other's, and the latter Podager, Chordilcs, Lyncomis, and a few more.

The common Nightjar of Europe, C. curopeus, arrives late in spring from its winter retreat in Africa, and its presence is soon made known to us by its lubit of chasing its prey, consisting chiefly of moths and cockchafers, in the evening-twilight. As the season advances the song of the cock, from its singularity, attracts attention amid all rural sounds. It seems to be always uttered when the bird is at rest, though the contrary has been asserted, and is the continuous repetition of a single burling note, as of a thin lath fixed at one end and in a state of vibration at the other, loud enough to reach in still weather a distance of half-a-mile or more. On the

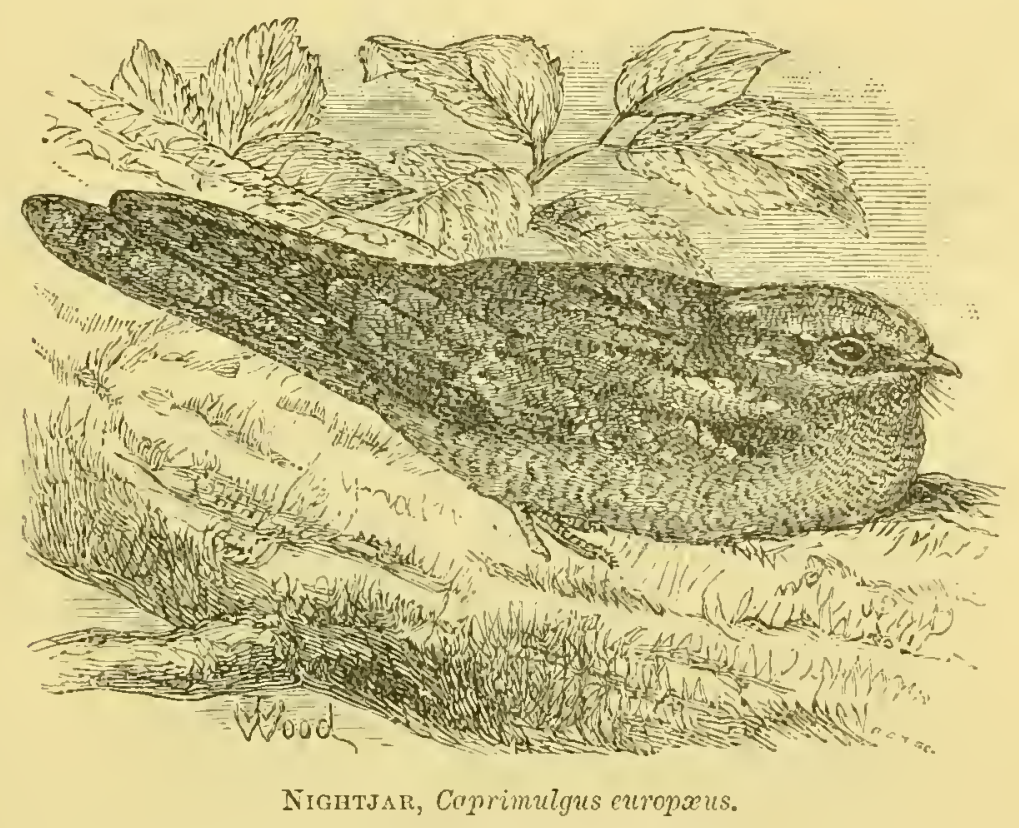

wing, while toying with its mate, or performing its rapid evolutions round the trees where it finds its food, the bird has the habit of occasionally producing another and equally extraordinary sound, sudden and short, but somewhat resembling that made by swinging a thong in the air, though in what way this noise is produced is not ascertained. In general its flight is silent, but at times when disturbed from its repose, its wings may be heard to smite together. The Nightjar or, to use perhaps its commoner English name, Goatsucker, ${ }^{1}$ passes the day in slumber, crouching on the gromnd ol perching on a tree-in the latter case sitting not across the branch but lengthways, with its head lower than its body. In hot weather, however, its song may sometimes be heard by day and even at noontide, but it is then uttered, as it were, drowsily, and without the

I Other English names of the bird are Churn-Owl, Evejar, Fern-Owl, NightHawk, Puckeridge and Wheel-bird-the last from the bird's song resembling the noise made by a spinning-wheel in motion. 
vigour that characterizes its crepuscular or nocturnal performance. Towards evening the bird becomes active, and it seems to pursue its prey throughout the night uninterruptedly, or only occasionally pausing for a few seconds to alight on a bare spot-a pathway or road-and then resuming its career. It is one of the few birds that absolutely make no nest, but lays its pair of beautifully-marbled eggs on the ground, generally where the herbage is short, and often actually on the soil. So light is it that the act of brooding, even where there is some vegetable growth, produces no visible depression of the grass, moss, or lichens on which the eggs rest, and the finest sand almost equally fails to exhibit a trace of the parental act. Yet scarcely any bird shows greater local attachment, and the precise site chosen one year is almost certain to be occupied the next (Nidification, p. 630). The young, covered when hatched with dark-spotted down, are not easily found, nor are they more easily discovered on becoming fledged, for their plumage almost entirely resembles that of the adults, being a mixture of reddish-brown, grey, and black, blended and mottled in a manner that passes description. They soon attain their full size and power of flight, and then take to the same manner of life as their parents. In autumn all leave their summer haunts for the south, but the exact time of their departure has hardly been ascertained. The liabits of the Nightjar, as thus described, seem to be more or less essentially those of the whole subfamily - the differences observable being apparently less than are found in other groups of birds of similar extent.

A second species of Nightjar, C. ruficollis, which is somewhat larger, and has the neck distinctly marked with rufous, is a summer visitant to the south-western parts of Europe, and especially to Spain and Portugal. Hancock recorded (Ibis, 1862, p. 39) the occurrence of a single example of this bird at Killingworth, near Newcastle-onTyne, in October 1856 ; but the season of its appearance argues the likelihood of its being but a casual straggler from its proper home. ${ }^{1}$ Many other species of Caprimulgus inbabit Africa, Asia and their islands, while one, C. macrurus, ranges very widely and is found in Australia. Very closely allied to this genus is Antrostomus, ${ }^{2}$ an American group containing several species, of which the Chuck-will'swidow, A. carolinensis, and the Whip-poor-will, A. vociferus, of the eastern United States (the latter also reacling Canada) are familiar examples. Both these birds take their common name from the cry they utter, and their habits scem to be almost identical with those of the Old-IVorld Nightjars. Passing over some other forms which need

I A third species, C. $x$ gyptius, recognizable by its pale coloration, has occurred about half a dozen times in Europe, and once even in England (Zool. 1853, pp. 374,375$)$.

2 Mr. Hartert (op. cit. 1). 521) denies its generic validity, and not unjustifiably. 
not here be mentioned, the genus $N$ yctidromus, though consisting of only one species ( $N$. albicollis) which, though varying somewhat in size and coloration, ranges from Texas to Southern Brazil, requires remark, since it has tarsi of sufficient length to enable it to run swiftly on the ground, while the legs of most birds of the Family are so short that they can make but a shuffling progress. The South-American Heleothreptes, with the peculiar form of wing (counting from the wrist, in which the $2 \mathrm{nd}, 3 \mathrm{rd}$, and 4 th primaries are greatly elongated) possessed by the male, needs mention; but a still more exaggerated condition exists in two African species, referred by some ornithologists

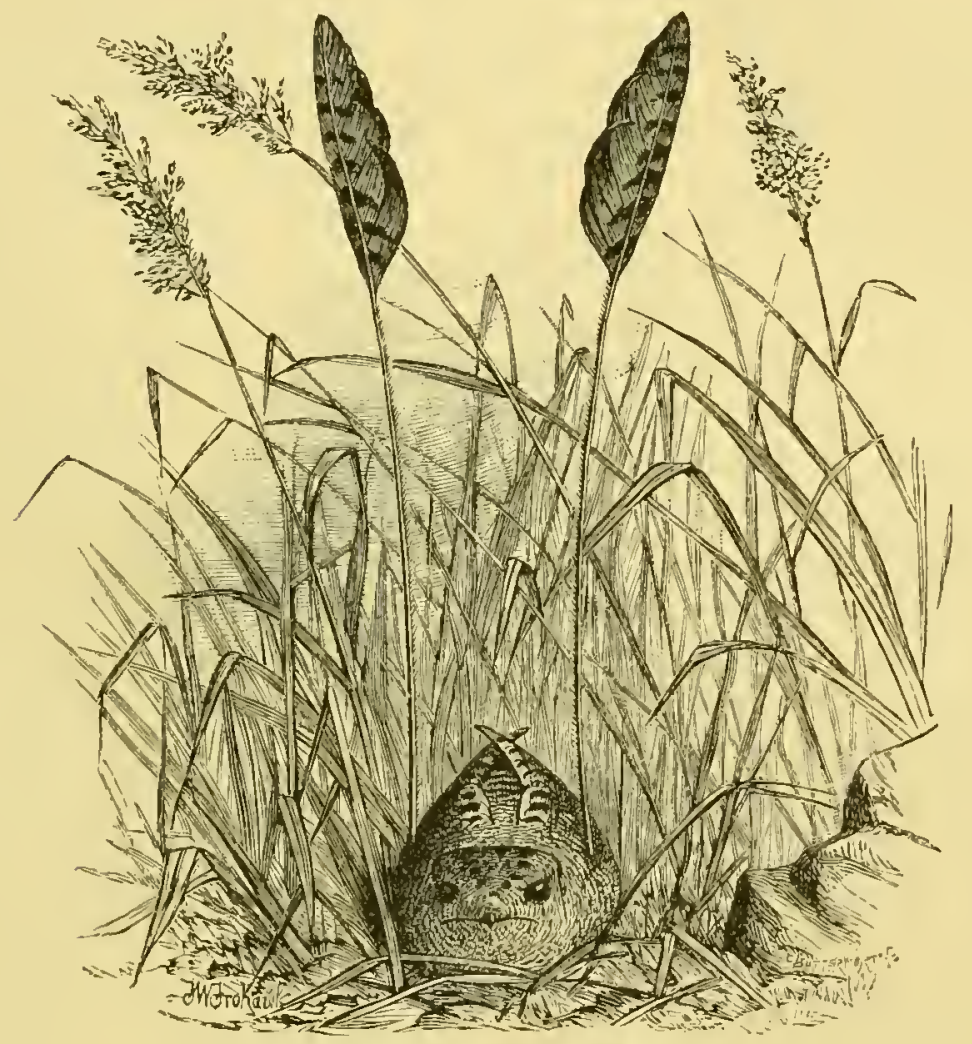

Pennant-winged Nightuar, Macrodipteryx.

(After sketch from life by J. Gedge.)

to as many genera (Macrodipteryx and Cosmetornis) though probably one genus would suffice for both. The males of each of them are characterized by the wonderful development of the 2nd primary, which reaches in adult specimens the extraordinary length of 17 inches or more. The formel of these, the Caprimulgus macrodipterus of Afzelius, seems to have the more northern range, occurring across the continent from Abyssinia to the West Coast, and the shaft of the elongated remiges is bare for the greater part of its length, retaining the web, in a spatulate form, only near the tip. The latter, to which the specific name of vexillarius was given by $\mathrm{Mr}$. Gould, inhabits equatorial Africa, and thence to Damaraland on 
the east and Fernando Po on the west, and is reported to have occurred in Madagascar and Socotra. In this the remigial streamers do not lose their barbs, and as a few of the next quills are also to some extent elongated, the bird, when flying, is said to look as though it had four wings. Specimens of both are rare in collections, and no traveller seems to have had the opportunity of studying the habits of either so as to suggest a reason for this marvellous sexual development, though the late Mr. Joseph Gedge, who accompanied Sir Samuel Baker's expedition to the Soudan, on one occasion observed a Macrodipteryx squatting on the ground with its long remiges erected perpendicularly, and the accompanying figure is from a sketch sent by him to his friend Mr. Marlborough Pryor.

The second group of Caprimulginx, those which are but poorly or not at all furnished with rictal bristles, contains about five genera, of which there is here only room to particularize Lyncornis of the Old World and Chordiles of the New. The species of the former are remarkable for the tuft of feathers which springs from each side of the head, above and behind the ears, so as to give the bird an appearance like some of the "Horned" OwLs-those of the genus Scops, for example; and remarkable as it is to find certain forms of two Families, so distinct as are the Strigidx and the Caprimulgidx, resembling each other in this singular external feature, it is yet more remarkable to note that in some groups of the latter, as in some of the former, a very curious kind of DimorPHIsur takes place. In either case this has been frequently asserted to be sexual, but on that point doubt may be fairly entertained. Certain it is that in some groups of Nightjars, as in some groups of Owls, individuals of the same species are found in plumage of two entirely different huesrufous and grey. The only explanation as yet offered of this fact is that the difference is sexual, but, as just hinted, evidence to that effect is conflicting. It must not, however, be supposed that this common feature, any more than that of the existence of tufted forms in each group, indicates any close relationship between them. The resemblances may be due to the same causes, concerning which futurc observers may possibly enlighten us, but at present we must regard them as analogies, not homologies. The species of Lyncornis inhabit the Malay countries, one, however, occurring in Burma and India. Of Chordiles the best-known species is the Night-hawk of North America, C. virginianus or popetue, which has a wide range from Canada to Brazil. Others are found in the Antilles and in South America.

We have next to consider the birds forming the genus Podargus and those allied to it, whether they be regarded as a distinct Family, or as a subfamily of Caprimulgida. As above stated, they have feet constructed as those of Birds normally are, and their sternum seems to present the constant though comparatively trivial difference 
of having its posterior margin elongated into two pairs of processes, while only one pair is found in the Caprimulgina. Podargus includes the bird, $P$. cuvieri, known from its cry as Morepork to Tasmanian colonists, and several other species, the number of which is doubtful, from Australia and New Guinea. They have comparatively powerful bills, and, it would seem, feed to some extent on fruits and berries, though they mainly subsist on insects, chiefly Cicadx and Phasmidx. They also differ from the true Nightjars in having the outer toes partially reversible, and they are said to build a flat nest on the horizontal branch of a tree for the reception of their eggs, which are of a spotless white. Apparently allied to Podargus, but differing among other respects in its mode of nidification, is AEgotheles, which belongs also to the Australian Region; and further to the northward, extending throughout the Malay Archipelago and into India, comes Batrachostomus, wherein we again meet with species having "ear"-tufts somewhat like Lyncornis. The Podargina are thought by some to be represented in the New World by the genus Nyctibius, of which several species occur from the Antilles and Central America to Brazil. Finally, it may be stated that none of the Caprimulgida seem to occur in Polynesia or in New Zealand, though there is scarcely any other part of the world suited to their habits in which members of the family are not found.

NIGHT-RAVEN, a bird frequently met with in fiction, but apparently nowhere else.

NINE-KILLER or NINE-MURDER, old and obsolete renderings of the German Neuntödter or Neunmörder, names applied to more than one species of Lanius (SHRIKE) and due to the belief that each of the shambles of one of these birds displays the remains of nine victims ("Nimmurder" by misprint, Cotgrave, 1611, sub roce "Escriere").

NODDY, the name applied, originally by sailors, to a sea-bird from its shewing so little fear of man as to be accounted stupid. ${ }^{1}$ It is the Sterna stolida of Linnæus, and the Anous stolidus of modern ornithology, having the figure of a TERN, and belonging to the subfamily Sterninx, but is heavier in flight, with shorter wings and the tail less deeply forked. The plumage is of a uniform sooty hue, excepting the crown of the head, which is light grey. The Noddy is very generally distributed throughout the tropical or nearly tropical oceans, but occasionally wander's into colder climates, and has been met with even in the Irish Sea. It breeds often in astounding numbers, on islands, even low cays and coral-islets, commonly making

1 Nodden, used by Chaueer, the old form of nod, is to drop the head suddenly as in falling asleep, and hence eomes Sir Thomas Browne's nodipol-a sleepy head, a simpleton-the modern noodle. Noddle, a joeular word for the head, is possibly allied, as I am told by Prof. Skeat. 
a shallow nest of sea-weed or small twigs, which may be placed on the ground, on a tuft of grass, or in the fork of a tree, while sometimes it lays its egggs on a bare rock. Mr. Saunders (Proc. Zool. Soc. 1876, pp. 669-672) admitted four other species of the genus:-Anous tenuirostris, supposed to be confined to the southern part of the Indian Ocean, from Madagascar to West Australia; $A$. melanogemys, often confonnded with the last, but having nearly as wide a range as the first ; ${ }^{1}$ and $A$. leucocapillus, hitherto known only from Torres Strait and the Southern Pacific. These three have much resemblance to $A$. stolidus, but are smaller in size, and the two latter, which have the crown white instead of grey, are now considered to be identical. The fourth species, $A$. caruleus, with which he then included the $A$. cinereus of some authors, but subsequently (op. cit. 1878, pp. 211, 212) recognized the last as distinct, differs not inconsiderably, being of a dove-colour, lighter on the head and darker on the back, the wings bearing a narrow white bar, with their quill-feathers blackish-brown, while the feet are reddish and the webs yellow. Three more species-A. superciliosus from the Caribbean Sea and Gulf of Mexico, A. plumbeigularis from the Red Sea, and $A$. galapagensis from the Galapagos-were added by Dr. Sharpe (Philos. Trans. clxviii. pp. 468, 469); while Mr. Rothschild has described and figured (Avifauna of Laysan, p. 43, pl.) the birds which frequent the Sandwich Islands as forming a tenth- $A$. hawaiiensis.

NONPAREIL, the name under which, from its supposed matchless beauty, a little cage-bird, chiefly imported from New Orleans, has long been known to English dealers ( $c f$. Edwards, Gleanings, i. p. 132). It is the Emberiza ciris of Linnæus and the Cyanospiza, Spiza or Passerina ciris of recent ornithologists, belonging to a small group, which, in the present state of knowledge, cannot with certainty be referred either to the Buntings or to the Finches, while some authors have regarded it as a TANAGER. The cock has the head, neck, and lesser wing-coverts bright blue, the upper part of the back yellow, deepening into green, and the lower parts generally, together with the rump, bright scarlet, tinged on the latter with purple. This gorgeous colouring is not assumed until the bird is at least two years old. The hen is green above and yellow beneath; and the younger cocks present an appearance intermediate between the adults of either sex. The species, often called also the Painted Bunting, after wintering in Central America or Mexico, arrives in the southern States of the American Union in April, but does not ordinarily proceed to the northward of South Carolina. In

1 Aceording to information supplied to Dr. F. Penrose (Ibis, 1879, p. 280) this species took up a station in 1878 on the Island of Aseension in large numbers, it having been hitherto unknown there. 
Louisiana, where it is especially the Pape of the French-speaking inhabitants (see BISHOP-BIRD, page 40) it is said to be very abundant; and on its appearance in spring advantage is, or was, taken of the pugnacious disposition of the males (which so often accompanies a brilliant sexually-distinct plumage) to capture them alive in great numbers by means of the stuffed skin of one so placed in connexion with a cage-trap that they instantly fall into the latter on attacking what they conceive to be a rival. In this way many thousands are said to have been taken formerly. The prisoner usually reconciles himself to his fate, and in a few days will utter his sprightly though not very powerful song; and, if provided with a mate and proper accommodation, will breed and rear a family in confinement. Belonging to the same genus as the Nonpareil is the INDIGo-BIRD, Cyanospiza cyanea, which, as a summer risitant, is widely diffused from the Missouri to the Atlantic, and extends into the provinces of Ontario and New Brunswick, being everywhere regarded with favour. Though wanting most of the bright hues of its congener, the Indigo-bird has yet much beauty, the adult cock being nearly all over of a deep blue, changing, according to the light, to green. The hen is brown above and ochreous-white beneath. This species is represented in the western part of the continent by the Lazuli-Finch, C. amcena, the male of which has the upper parts greenish-blue, the wings barred with white, a pectoral band of light chestnut extending to the flanks on each side, and the lower parts white. Of the three remaining species of the genus, $C$. versicolor shews in the male a plumage beautifully varied with brownish-red, violet, and blue; C. leclancheri is bluish-green above and yellow beneath, with an orange breast; while C. rositx, though quite distinct, comes nearest in coloration to C. ciris. These three have a more southern range than the other three; but the first of them is believed occasionally to cross the Mexican frontier into the United States. None of the species of Cyanospiza are thought to occur further south than the isthmus of Panama; but the wonderful Ciridops anna of Hawaii (Wilson and Evans, Birds of the Sandwich Islands) is possibly allied to this genus.

NOPE, a name of the BuLLFINCH, said to be an old corruption of ALP or some other form of that word (see page 10) which has taken on an initial $n$ borrowed from the indefinite article $a n .^{1}$

NORFOLK PLOVER, a needless book-name for the StoneCurlew (see page 129), apparently invented by Pennant in 1766.

1 Like a newt for "an ewt" (or eft), a nickname for "an ekename," a noke for "an oak," and several other words (cf. Skeat, Etymol. Dict. sub litt. N); but the only case among English birds' names where the converse process, or loss of a real initial $n$, has happened as in aclder for "nadder," auger for " nanger," seems to be that of eyas for "NIAs." 
NULLIPENNES, Lesson's name in 1831 (Tr. d'Orn. p. 11) for a group of birds to consist of the genus Apteryx (KrwI) ; but lately applied in error (Century Dictionary, sub voce) to the PENGuins.

NUN (printed "Non" in Merrett's Pinax, p. 183), the adult male Sinew, from his delicate white and black plumage, and also said to be a local name of the Blue Titmouse, Parus cxruleus, according to Charleton (Onomast. p. 90), from its banded head; but the French Nonnette and the German Nonnenmeise are names of the Marsh-Titmouse, P. palustris.

NUTCRACKER, the name given in 1758 by Edwards (Gleanings, i. p. 63, pl. 240) to a bird which had hitherto none in English, though described in 1544 by Turner, who, meeting with it in the Rhætic Alps, where it was called "Nousbrecher" (hodie "Nussbrecher"), translated that word into Latin as Nucifraga. In 1555 Gesner figured it and conferred upon it another designation, Caryocatactes. Willughby and Ray obtained it on the road from Vienna to Venice as they crossed what must have been the Sömmerring Pass, 26th September 1663; and it has a wide range in the northern parts of the Palrarctic area, chiefly keeping to subalpine or subarctic pine-forests, and apparently nowhere numerous, though roving bands of seventy or one hundred have occasionally been observed in autumn, at which season it can be often seen in suitable localities in several European countries. It is the Corvus caryocatactes of Linnæus, the Nucifraga caryocatactes of modern ornithology. ${ }^{1}$ The first known to have occurred in Britain was, according to Pennant, shot at Mostyn in Flintshire, 5th October 1753, while about fifteen more examples have since been procured, and others seen, in this island. For many years nothing was known of this bird during the breeding-season, when it seemed to disappear from sight, and this notwithstanding the interest taken in the search for its nest and eggs. It is now pretty clear that the discovery was due to the Abbé Caire of Sanières in the Lower Alps, but though he obtained an egg in 1846, he was unable to produce proof of the fact, and the truth was not ascertained until some sixteen years later by the Danish oologists HH. Fischer and Erichsen, who after much labour found and took nests and eggs in the island of Bornholm. ${ }^{2}$ The Nutcracker breeds very early in the year, long before the

1 A monograph of the species by the Ritter Victor von Tschusi-Schmid. hoflen was printed at Dresden in 1874 with the title of Der Tannenheher, one of its many German names.

2 Many other claimants appeared in the meanwhile without making good their pretensions. The story of the discovery is told with some details in Yarrell's British Birds (ed. 4, ii. pp. 332-33i). The egg of the Nutcracker seens to have been first figurell by Bädeker (Journ. fiir Orn. 1S56, pl. i. fig. 1), but the first specimen with an undeniable history, being from Bornholm as above stated, in the Proceedings of the Zoological Society (1867, pl. xv. fig. 2). 
snows are melted, and this fact coupled with that of its becoming, like a $\mathrm{JAY}_{\mathrm{AY}}$, silent in the breeding-season, when at other times it is rather noisy than not, will account for the mystery which so long enwrapped its domestic arrangements; but, now that the secret has been divulged, nests and eggs have been found without much difficulty in various parts of Europe, and contrary to what was for many years believed, the nest seems to be invariably built on the bough of a tree, some 20 feet from the ground, and is a comparatively large structure of sticks lined with grass. The eggs are of a very pale bluish-green, sometimes nearly spotless, but usually more or less freckled with pale olive or ash-colour. The chief food of the Nutcracker, though it at times searches for insects on the ground, appears to be the seeds of fir-trees, which it extracts as it holds the cones in its foot, and it has been questioned whether the bird has the faculty of cracking nuts-properly so called-with its bill, though that can be used with much force and, at least in confinement, with no little ingenuity. Considerable difference has been observed in the form and size of the bill of examples of this species, but as in the case of the HuIA (page 437) this is now supposed to depend on the sex-that of the cock being stout and short, while in the hen it is long and thin. The bird is about the size of a Jay, and of a dark sooty-brown colour spangled with white, nearly each body-feather ending in a tear-shaped patch of that colour. Beside the European species, which also extends into Northern or Central Asia, three others, very nearly akin to it, have been described from the Himalayas. Of their American cousin, Clark's Crow, as it is called (Picicorvus columbianus), inhabiting only the western slopes of the Rocky Mountains, and discovered during the famous expedition of Lewis and Clark to the mouth of the Columbia River in 1804-6, an excellent account has been given by Dr. Coues (Ibis, 1872, pp. 52-59).

The old supposition that the Nut-crackers had any affinity to the Picida (WOODPECKER) or were intermediate in position between them and the Corvida (CROw) is now known to be wholly erroneous, for they undoubtedly belong to the latter Family.

NUTHATCH, in older English NuTHACK, and locally NUTJOBBER, from its habit of hacking or chipping nuts, which it cleverly fixes, as though in a vice, in a chink or crevice of the bark of a tree, and then hammers them with the sharp point of its bill till the shell is broken. This bird was long thought to be the Sitta europra of Linnæus; but that is now admitted to be the northern form, with the lower parts white, and its buff-breasted representative in central, southern, and western Europe, including England, is knowil as Sitta cxsia. It is not found in Ireland, and in Scotland its appearance is merely accidental. Without being 
very plentiful anywhere, it is generally distributed in suitable localities throughout its range-those localities being such as afford it a sufficient supply of food, consisting during the greater part of the year of insects, which it diligently seeks on the boles and larger limbs of old trees; but in autumn and winter it feeds on nuts, beech-mast, the stones of yew-berries and hard seeds. Being of a bold disposition, and the trees favouring its mode of life often growing near houses, it will become on slight encouragement familiar with men; and its neat attire of ash-grey and warm buff, together with its sprightly gestures, render it an attractive visitor. It generally makes its nest in a hollow branch, plastering up the opening with clay, leaving only a circular hole just large enough to afford entrance and exit; and the interior contains a bed of dry leaves or the filmy flakes of the inner bark of a fir or cedar, on which the eggs are laid. Corsica has a Nuthatch peculiar to itself and remarkable for its black crown, the $S$. whiteheadi of Dr. Sharpe, and in the Levant occurs a third species, $S$. syriaca, with somewhat different habits, as it haunts rocks rather than trees; while four or five representatives of the European arboreal species have their respective ranges from Asia Minor to the Himalayas and Northein China. North America possesses nearly as many; but, curiously enough, the geographical difference of coloration is just the reverse of what it is in Europethe species with a deep rufous breast, $S$. canadensis, being that which has the most northern range, while the white-bellied $S$. carolinensis, with its western form, $S$. aculeata, inhabits more southern latitudes. The Ethiopian Region seems to have no representative of the group, unless it be the Hypositta corallirostris of Madagascar. Callisitta and Dendrophila are nearly allied genera, inhabiting the Indian Region, and remarkable for their beautiful blue plumage; but some doubt may for the present be entertained as to the affinity of the Australian Sittella, with four or five species, found in one or another part of that continent, which doubt is increased by the late $\mathrm{Mr}$. W. A. Forbes's discovery (Proc. Zool. Soc. 1882, pp. 569-571) that the genera Acanthidositta (SPINEBILL) and Xenicus, peculiar to New Zealand, and hitherto generally placed in the Family Sittida, belong really to the Mesomyodian group and are therefore far removed from it. The true Sittidx seem to be intermediate between the Parida (Timmouse) and the Certhiidx (Trencresper), and some authors comprehend them in either one or the other of those groups.

NUTMEG-BIRD, the dealers' name in common use for Mrunia punctulata (CowRY-BIRD, page 108), but apparently of somewhat recent origin. 
OAT-FOWL, a local name for the Snow-Buntixg; OATSEEDBIRD for the Yellow WAGTAIL.

OCCIPUT, properly the hinder part of a bird's head, from the crown backward, as opposed to SINCIPUT, but often used vaguely for the whole cap.

OCTOBER BIRD, in the Antilles used for the BoBOLINK, from its arriving there in that month (B. Edwards, Hist. $W$. Ind. i. p. 99, note).

OCYDROME, see WEKA.

ODONTOGLOSSA, Nitzsch's name in 1840 (Pterylographie, p. 191) for a group consisting of the genus P'henicopterus (Flamingo).

ODONTOLCA, see ODONTORNITHES.

ODONTOPHORINA, the supposed subfamily containing the American Quails ( $f$. Colin), upon the distinctness of which from those of the Old World some systematists have laid unnecessary importance. Dr. Coues (Key N.-Am. Birds, ed. 1884, p. 594) says that he knows no characters to distinguish the true Quails from the so-called Odontophorina.

ODONTORNITHES, ${ }^{1}$ a term proposed in 1873 by Prof. Marsh (Am. Journ. Sci. ser. 3, v. pp. 161, 162) to designate a so-called Subelass of birds, consisting of the genera Hesperomis and Ichthyormis (both of which had been named in the previons year) from the cretaceous deposits of Kansas, and characterized by the presence of teeth (Fig. 1). Its founder afterwards subdivided this group (op. cit. $\mathrm{x}$. pp. 403-408) into the two Orders ODONTOLCE and ODOnTOTORNe; the former, represented by Hesperornis and characterized by having the teeth (Fig. 2) placed in grooves, heterocoelons vertebræ, and the abortion of the carina sterni with a generally Ratite conformation of the seapular arch (Fig. 3); while the latter, typified by Ichthyornis, was distinguished by the presence of distinct sockets for the teeth (Fig. 5), amphicoelous vertebra (Fig. 6), and the Carinate modification of the sternal apparatus. Subsequent writers have disputed the expediency of this proposal, for Prof. Cope in 1875 (Vert. Cretac.

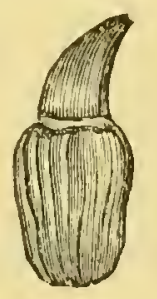

Fig. 1.

TOOTH OF HesperorNis. (From Nicholson and Lydekker's Palaontology, after Marsh.) Form. of the IVest, pt. iii. p. 245) and Prof. Seeley in 1876 (Q. Jouru.

1 Again indebted to Mr. Lydekker's kindness for an article worthy of the closest attention, I wish to guard myself against its being taken as the expression of my own views on one of the hardest subjects that the ornithologist has to consider, and one still open to various interpretations.-A. N. 
Geol. Soc. xxxii. p. 496) referred Hesperornis to the "Nutatores." In 1S81, M. Dollo (Bull. sc. Dépurt. du Norel, ser. 2, iv. p. 300) pro-

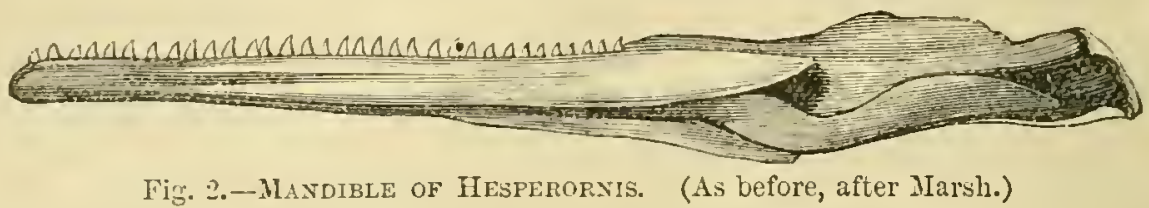

nounced it to be "une autruche carnivore aquatique." This notion was popularized in 1884 by Prof. Wiedersheim (Biolog. Centralbl. ii. p. 690), while Prof. Dames in the same year (Palaontol. Abhandl. ii. pt. 3) took much the same view, as did also (though in a different

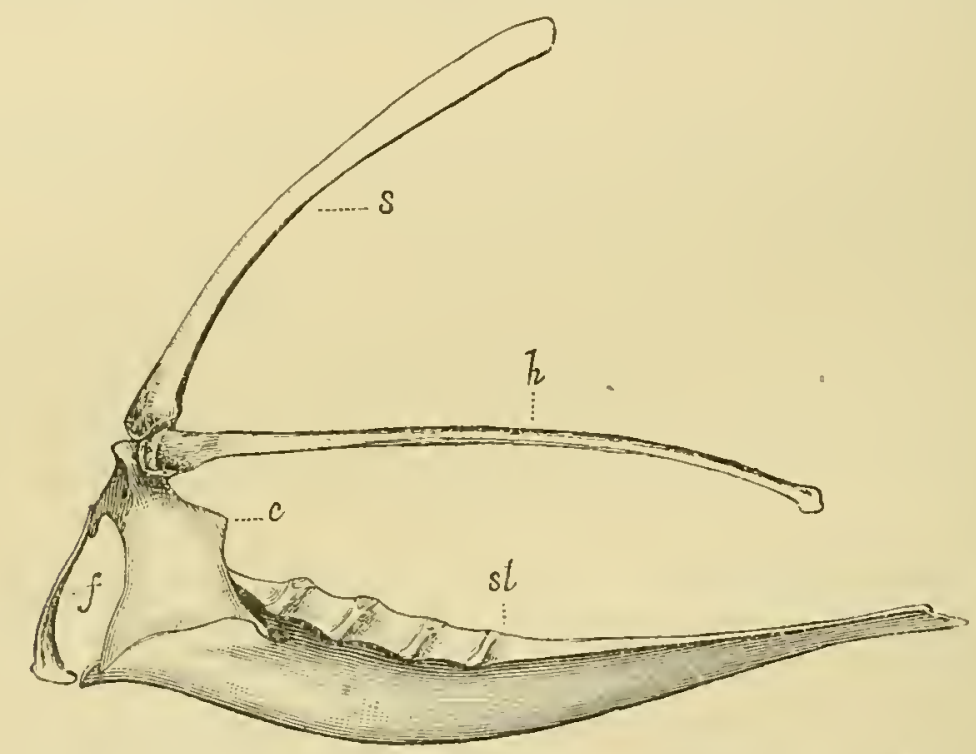

Fig. 3.-Sterval Apparatus of Hesperornis. (As before, after Marsh.) c coracoid; $f$, furcula; $h$, humerus; s, scaptula; st. sternum.

fashion) an anthor in the Encyclopadia Britannica (ed. 9, xviii. pp. 43, 44), and Prof. von Zittel (Handb. Palaozool. Abth. 1. iii. pp. \$26, 834). Almost simultaneously, however, Prof. Vetter (Festschr. der Ges. Isis in Dresden, 1885, p. 109) explained Hesper-

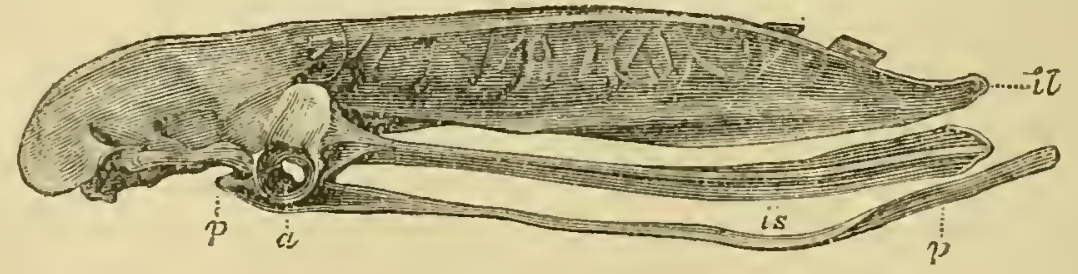

Fis. 4.-PELIIS of HeSPERORNIS. (As before, after Marsh.) u, acetabulum; $i l$. ilium; is. ischium; $p$, pectineal process ; $\mu^{\prime}$, os jubis.

mis as a Cirinate Bird, exclusively adapted to aquatic life, and having no affinity to the Ratita', though since he regarded these last as reduced Carinate its mutual relation to the Ratita was obvious, and people began to confound them, speaking almost in M. Dollo's 
phrase of it as a "Swimming Ostrich." About the same time it was found that the presence of teeth was a character apparently common to all "Cretaceous" Birds. The opinions expressed by Prof. Fürbringer in the earlier portion of his great work need not be here adduced, since they were modified in the course of its progress; but he finally declared (Untersuchungen, u. s. W. pp. 1543, 1565,1580 ) that the Odontolce were the ancestral relations of his "Colymbo-Podicipites," with which they formed his Suborder "Podicipitiformes," while a similar view was taken in 1890 by Prof. D'Arcy Thompson (Stud. Mus. Dundee, No. 10).

As to the Odontotorma Prof. Marsh has displayed commendable caution. On account of some similarity, the significance of which may or may not be important, he based his restoration of Ichthyornis on Sterna (TERN), a fact which has led to exaggerated if not mistaken views, for he was careful to state that Ichthyornis seemed to have points of resemblance to Ardea, Ciconia, Colymbus, Phalacrocorax and even to the Accipitres, while its posterior extremities alone indicated a structure similar to that of the Laridx and Alcidx. In 1893 Dr. Gadow (Thier-reich, Vögel, ii. p. 119) suggested that the low characters of Ichthyornis shew it to be the beginning of the Carinata.

In 1891 the present writer (Cat. Foss. B. Br. Mus. pp. 200 et seqq.), while fully admitting both the Colymbine affinities of Hesperornis and the Larine resemblances of Ichthyornis, proposed to retain the term Odontornithes for a series of Birds ancestral to the modern series of toothless Carinatx, adopting (op. cit. p. 2) for the latter, but in a wider sense, Dr. Stejneger's name (Stand. Nat. Hist. iv. p. 64) of Euornithes. In addition to the presence of teeth, the extinct series differs from the Euornithes by the absence of union between the rami of the mandible, and between the distal ends of the ilium and ischium.

Whatever may be the ultimate verdict on these points of classification, it would seem probable that Hesperornis should be regarded as an offshoot from the same ancestral stock as the one from which the modern Colymbidx have originated; such ancestral stock being characterized by the presence of teeth, absence of ancylosis between the mandibular rami, and want of union between the spike-like patella and the upwardly-produced cnemial crest of the tibia. On the other hand, the abortion of the keel of the sternum, as well as the general Ratite modification of the scapular arch, are features peculiar to Hesperornis, and not common to the ancestral type; being; in fact, nearly analogous to those presented by Didus among the Columbr. The typical species of Hesperornis (H. regalis) was of large size, attaining a length of about six feet; while a second species (II. crassipes) was still more gigantic. Both were aquatic, and probably very similar in their general habits to the Divers. Probably more or less closely allied to this genus was the much smaller Colymbiform bird from the Cambridge 
Greensand, named by Prof. Seeley in 1869 Enalionis, and the closely allied Baptornis from the North American Cretaceous (see Fossin Brrds). While possessing heterocolous cervicals, it is believed that Enalionis had its dorsal rertebræ amphicolous.

Retaining in their amphicolous vertebra evidence of their reptilian ancestry which is lost in the more specialized Hesperornis,

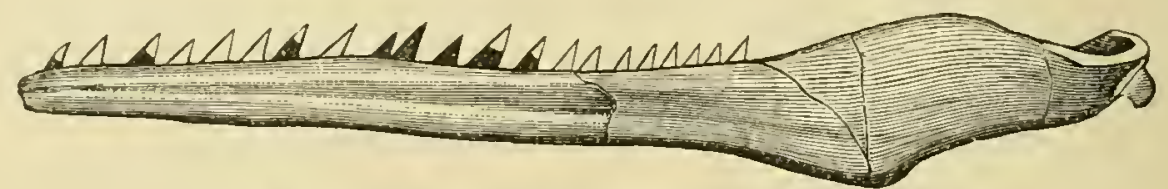

Fig. 5. MAandible of Ichthyoris. (As before after Mars'i.)

the small Gull-like birds known as Ichthyornis may probably be regarded as holding a somewhat more intimate relationship to the modern LnIICOL.æ and GAVIæ than is presented by the former to the Pygopodsis, the specialization connected with the absence of

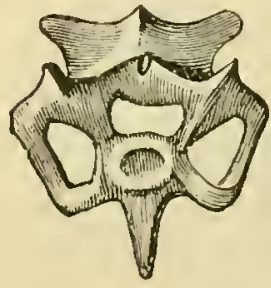

Fig. 6.

C'ERVICAL TERTEBRA OF ICHTHYORNis, FROM FRONT AND SIDE. (As before, after Marsl.) flight in the former genus being wanting. Traces of aftinity with Ichthyornis are, indeed, indicated by the more or less markedly opisthocœelous dorsal vertebre of the Limicola and Gavia; but whereas both these groups have an ectepicondylar process to the humeris, and an extensor bony bridgo to the tibio-tarsus, neither of these features are present in the cretaceons genus. The fenestration of the metacarpus characteristic of the Gavia is, moreover, wanting in Ichthyornis. Hence it would appear that we must regard all the above-mentioned features characterizing the existing groups named as of comparatively late origin; while the differences between the extinct and living forms appear to the writer far too important to admit, as has been proposed, of their inclusion in a single ordinal group. Although Aprtornis, from the Yellow Chalk of Kansas, and as yet imperfectly known, was apparently an allied type, distinguished by the great development of the acromial process of the scapula, and the stouter hind limbs, the remaining genera of (? toothed) birds from the same horizon referred to the Odontomithes are named on the evidence of such incomplete remains, that it is impossible to speak of their affinities with certainty; all that can be said for them will be found in their lescriber's magnificent work forming the first volume of the Memoirs of the Peabody Muscum of Yale College. ${ }^{1}$

\section{RICHARD LTDEKKER.}

1 Odontornithes: "Nonograph on the Extinct Thothed Birds of North America. By Othniel Charles Marsh. Fol. New Haven, Conn. : 1880. 


\section{ODONTOTORMA, see ODONTORNITHES.}

ESOPHAGUS (Greek oiøoфáyos), so named by Aristotle, the gullet or "swallow" of plain English ( $c f$. Digestive Syster, page 136), the part of the alimentary canal from the LARYNX (page $512)$ to the STOMACH. It passes down the right and dorsal side of the TrACHEA, with which and other adjoining parts it is connected by loose tissue, entering the thoracic cavity dorsally from the Bronchi (page 58), and when not distended it forms numerous longitudinal folds owing to the yielding nature of the tunica mucosa (page 137). Deglutition is aided by simple mucous glands, but in many birds the middle portion of the Esophagus forms a permanent dilatation, the Crop (page 113), to the outer surface of which thin but broad bands of striped or voluntary muscle are generally attached. These may arise from the Furcula (page 296) as in Pigeons, or from the skin of the neck as in the Gallinx, and their action assists the conveyance of the food from the crop to the stomach. During this process, especially if only little and dry food be left, Birds, Parrots for instance, may be occasionally observed to stretch their neck and gape widely with their mouth.

\section{OIL-BIRD, see Guacharo.}

$O I L-G L A N D$ (glandula uropygialis), in Birds the only cutaneous gland except some small organs in the external ear-passages. Consisting of two symmetrical portions, more or less united posteriorly in shape of a heart-since each half is broad and rounded in front and pointed behind-it is seated upon the levator muscles at the root of the tail. Internally it is formed of numerous secretory tubules which gradually unite in a common cavity opening on the surface through a variable number of orifices-there being from 3 to 5 of them in many Water-birds, though only one to each lialf in Anseres-frequently prolonged in form of a nipple and occasionally united in a single tube, the double origin of which is, however, shewn by a median septum. In the HoOPOE alone, according to Nitzsch, there is but one orifice to the common cavity, wherein the stinking secretion of the gland, for which the female during incubation and the young while they stay in the nest are notorious, is stored. The whole structure, which is surrounded by connective tissue and unstriped muscular fibres, is innervated by the first caudo-spinal nerves, and its blood-supply is in connexion with the caudal arteries and veins.

In the majority of Birds this gland is well developed, being largest in those of aquatic habit, and especially in the TUBINARES and Steganopodes, as well as in Pandion (Osprex); but it is also large in Steatornis (GUACHARO). It exists, though hardly in a functional condition, in certain PIgeons (Ptilopus), Cacatua cristata (COCKATOO), and most Caprimulgi (NightJAR), while in other 
Pigeons as Didunculus (DoDleT), Goura and Treron; in other Cockatoos, in several Parrots (Chrysotis and Pionus), in Podargus (Nightjar), Otis, Argusianus and the Ratita it is absent. This irregularity shews that it has not much value as a taxonomic character; but attention to other peculiarities in its form or structure has been drawn by Nitzsch and Garrod, and especially to the presence or absence of a circlet of feathers surrounding the nipple-like orifice, and when that occurs the skin covering the gland is naked, while when the circlet is wanting the whole is covered with down interspersed with stiff feathers. Among the birds to which the last condition applies are the Bucconidx, Caprimulgi (excl. Podargus), Cariama, Coraciidæ, Cuculidx, Cypseli, Galbulidæ, Leptosomus, Meropidx, Momotidx, Steatornis and Trogonidæ, while by far the greater number of birds possess the tuft.

Analysis of the secretion of the Oil-gland shews that its composition closely resembles that of the sebaceous product of Mammals ; but that it differs from milk through the absence of sugar. Its use is probably the anointing of the plumage, and the presence of Powder-Downs in Cacatua, Chrysotis and Podargus may possibly indicate some correlation between these organs and the oil-gland. ${ }^{1}$

OLD MAN, the name in Jamaica for Hyetornis pluvialis, one of the Cuckows which is also called Rain-bird, as are others of the Family.

OLD SQUAW and OLD WIFE are two of the many names of the Long-tailed DUCK, the former necessarily of transatlantic origin.

OLECRANON, the proximal end of the ULNA, projecting backward from and beyond its articulation with the Hunierus, being practically equivalent to the point of the elbow. It serves as a lever during the extension of the wings, the tendons of the triceps muscle being inserted on the Olecranon.

OLIGOMYOD王, Prof. Huxley's name (Proc. Zool. Soc. 1867, p. 471) for the group of Passerine Birds having but few songmuscles (Syrinx) which Johannes Müller had previously called PICARII.

1 It seems that it would be improper here to overlook a controversy on this still unsettled question which, though now wholly forgotten, was carried on, to the amusement of our predecessors, in the later volumes of Loudon's Magazine of Natural History, and in the early years of The Zoologist. Waterton, with the mistaken zeal he so frequently exhibited, maintained that the gland had no lubricating function, chiefly because he had observed that the so-called "rumpless" breed of Fowls, in which the gland is wanting, kept their feathers as glossy as other Fowls which possessed it. He was easily victorious so long as he had to deal only with the late Mr. F. O. Morris, but when he met with an adversary like the late Mr. C. A. Bury, who knew something about birds, was a good observer and conld write rationally, Waterton's mistaken position seems to have become plain to him, and he retired from the contest.-A. N. 
OLIVE, a locil name of the Oyster-CATCHER, and apparently a corruption of OLAF, which is said also to be nsed (Christy, B. Essex, p. 23S), and if so the word should be more properly spelt Olave, that being the English form of the sainted Danish king's name. (Cf. Krot, said to be from Cnut.)

OLPH (see AlP and Nope), with the prefix "Blood" a local mame of the Bullfinch, with that of "Green" of the Grienfinch.

OMBRE or OMBRETTE, see HAMMER-HEAD.

$\mathrm{O}-\mathrm{O}$ (varionsly spelt), the name given in the Sandwich Islands to birds of the genus Acrulocercus (Mohoa of some writers), one of the Meliphagidie (HoNkY-SUCKER), of which 4 species, inhabiting as many islands, have been described. The yellow axillary tufts of one of them, A. notilis, peculiar to Hawaii, have been greatly sought for the beantiful featherwork of the natives since the Mamo ${ }^{1}$ (DREPANIS) became rare.

OPEN-BILL (French Bec-ouvert), one of the names ${ }^{2}$ given to birds of the gemus Anastomus, allied if not actually belonging to the Ciconiidie (STORK), but by some $^{3}$ regarded as constituting a distinct Family. Two species have long been known--one Indian, parti-coloured, A. oscituns,

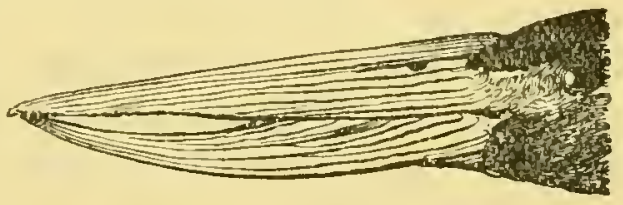

Bill of Anastonus, (After Swainson.) pondicerianus or coromandelianus; the other African and dark coloured, A. lamelligerus, so called from the curious flattening and broadening into shining horny-plates of its feather-shafts, especially on the lower parts. In 1880, Prof. Alphonse MilneEdwards described the form inhabiting Madagascal as distinct, A. malagascariensis. It differs chiefly from the African in its smaller size, and the deeper grooving of the bill.

\section{OPISTHOCOMUS, see HoACTZIN.}

ORANGE-BIRD, a name in Jamaica for Spindalis (properly Spindasis) nigricephala, wrongly identified by Gosse (B.Jam. p. 231) with the Fringilla aence of Limmaus (which proves to be peculiar to Bahama), one of the TANAGERS, and so-called, says the former, "from the resemblance of its plump and glowing breast to that

1 At pages 166 and 225 this species was mentioned as extinct: an example, however, was obtained in 1892, and its remains are in Mr. Rothschild's collection.

2 Others, and more recent, are Shell-eater, Shell-Ibis, and Snail-eater, of which the first two are incorrect, and the latter far from distinctive, though these birds feed chiefly on molhusks of the genera Ampullarice and Unio.

${ }^{3}$ Cf. G:urney in Andersson's B. Damere Land, p. 283 ; Oates in Hume's Nests and Eggs Ind. B. ed. 2, iii. p. 224. 
beautiful fruit." He assigns to it also the name of Cashew-bird; but it is not the CASHEW-BIRD of older authors.

ORGAN-BIRD, the name in Tasmania for the species of Grinorhina there found (Gould, Handb. B. Austral. i. p. 178).

ORGANIST, the English rendering of the Organiste of Buffon (Hist. Nat. Ois. iv. p. 290), though it may be questionable whether all the information he cites really refers to this species, which is the Pipra musica of Gmelin, and Euphonia musica of modern ornithology, an inhabitant of Hispaniola. Other congeneric species inhabit Jamaica, Porto Rico and some of the Lesser Antilles, though none is found in Cuba, while many more occur from Mexico throughout Central and most parts of South America. Mr. Sclater recognizes 33 species in all (Cat. B. Br. Mus. xi. pp. 58-83).

ORIOLE, from the Old French Oriol and that from the Latin aureolus, the name once applied, from its golden colouring, to the bird generally admitted to be the Vireo or ICTERus (page 457) of classical authors-the Oriolus galbula of Linnæus-but now commonly used in a much wider sense. The Golden Oriole, which is the type of the Family Oriolidie of modern ornithologists, is a far from uncommon spring-visitor to the British Islands; but the conspicuous plumage of the male-bright yellow contrasted with black, chiefly on the wings and tail-always attracts attention, and usually brings about its death. Yet a few instances are known in which it is supposed to have bred in England. The nest is a beautifully interwoven fabric, suspended under the horizontal fork of a bough, to both branches of which it is firmly attached, and the eggs are of a shining white sometimes tinged with pink, and sparsely spotted with dark purple. On the Continent it is a well-known though not an abundant bird, and its range in summer extends so far to the east as Irkutsk, while in winter it is found in Natal and Damaraland. In India it is replaced by a closely allied form, $O$. Kundoo, chiefly distinguishable by the male possessing a black streak behind as well as in front of the eye; and both in Asia and Africa are sevoral other species more or less resembling 0. galbula, but some depart considerably from that type, assuming a black head, or even a glowing crimson instead of the ordinary yellow colouring, while others again remain constant to the dingy type of plumage which characterizes the female of the more normal form. Among these last are the aberrant species of the group Mimetes or Mimeta, belonging to the Australian Region, respecting which Mr. Wallace pointed out the very curious facts-as yet only explicable on the theory of "unconscious MIMicRY" - of which mention has already been made (pages 573,574 ). The external similarity of the Mimeta and the Philemon or Tropidorhynchus (FriArBIRD) of the island of Bouru is perfectly wonderful, and has again 
and again deceived some of the best ornithologists, though the birds are structurally far apart. Another genus which has been referred to the Oriolida, and may here be mentioned, is Sphecotheres, peculiar to the Australian Region, and distinguishable from the more normal Orioles by a bare space round the eye.

The Baltimore Oriole, Orchard Oriole, and other North-American birds to which the name has been applied, belong to the wholly distinct Family Icterida (ICTERUs).

ORNITHICHNITES, a word compounded from the Greek by Hitcheock in 1832 (Am. Journ. Sc. xxix. p. 315) to signify the fossil footprints of Birds, and hence taken as the generic name of the animals which had left those marks, but are now generally believed to have been Dinosaurs (Fossil Birds, page 277).

OPNITHOLITE, a stone containing the remains or impression of the remains of a Bird.

ORNITHOLOGY, from the Greek o $\rho v \iota \theta$, crude form of öpvı, a bird (cognate with Scandiu. Ørn and A.S. Earn, whence our ERNE),

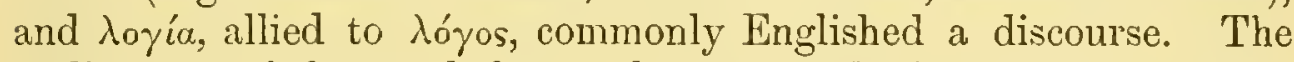
earliest use of the word thus spelt seems to be in the third edition of Blount's Glossographia (1670), where it is explained as "the speaking of birds: the title of a late Book"1 (cf. Skeat, Etymol. Dict. p. 407).

ORNITHOTOMY, the dissection of Birds, and hence the science thereon founded.

ORTHONYX, the scientific name given in 1820 , by Temminck, to a little bird, which, from the straightness of its claws, - a character somewhat exaggerated by him,-its large feet and spiny tail, he judged to be generically distinct from any other form. Concerning' its affinities much doubt long prevailed. The typical species, 0. maculatus or spinicauda, is from eastern Australia, where it is said to be very local in its distribution, and strictly terrestrial in its habits. In the course of time two other small birds from New Zealand, where they are known as the "WHITEHEAD" and

I This book was doubtless 'Ornitho-lorgie, | or | The Speech of | Birds. | London, | Printed for John Stafford, and are to | be sold at his House, at the George at | Fleet-bridge. 1655.' The authorship of the book, of which there are several later editions, is ascribed by Lowndes (p. 848) to Thomas Fuller; but whether he was the celebrated writer of that name is doubtful. MIr. J. E. Bailey in his Life of that worthy (London: 1874, pp. 761, 762) includes it anong his "spurious works," though a later biographer, M1. Morris Fuller (London : 1884, ii. p. 525) accepts it as genuine. Whoever may have been the author, the word "Ornithologie" is used in a sense very different from the meaning applied to it a few years after, for this treatise is a fable, perhaps, like the agnate "Anthologia" published with it, "Partly Morall, Partly Misticall," and possibly has also a political significance. 
"YelLowheAD," were referred to the genus, under the names of 0. albicilla ${ }^{1}$ and 0 . ochrocephala, and then the question of its affinity became more interesting. By some systematists it was supposed to belong to the otherwise purely Neotropical Dendrocolaptida (PICUCULE), and in that case would have been the sole representative of the Tracheophone Passeres in the Australian Region. Others considered it one of the nearest relatives of Menura, and if that view had been correct it would have added a third form to the small section of "Pseudoscines"; while Sundevall, in 1872, placed it not far from Timelia, among a group the proper sorting of which will probably for years tax the ingenuity of ornithologists. ${ }^{2}$ The late Mr. W. A. Forbes shewed (Proc. Zool. Soc. 1882, p. 544) that this last position was the more correct, as Orthonyx proved on dissection to be one of the true Oscines, but yet to stand, so far as is known, alone among birds of that group, or any other group of Passeres, in consequence of the superficial course taken by the (left) carotid artery, which is nowhere contained in the subvertebral canal. Whether this discovery will require the segregation of the genus as the representative of a separate Family Orthonycida- which has been proposed by Mr. Salvin (Catal. Coll. Strickland, p. 294)-remains to be seen. ${ }^{3}$

The typical species of Orthonyx-for the scientific name has been adopted in English-is rather larger than a Skylark, coloured above not unlike a Hedge-Sparrow. The wings are, however, barred with white, and the chin, throat and breast are in the male pure white, but of a bright reddish-orange in the female. The remiges are very short, rounded and much incurved, shewing a bird of weak flight. The rectrices are very broad, the shafts stiff, and towards the tip divested of barbs. Two other species that seem rightly to belong to the genus have been described-0. spaldingi from Queensland, of much greater size than the type, and with a jet-black plumage, and 0 ; nowe-guinex, from the great island of that name.

ORTOLAN (Old Fr. Hortolan, mod. Fr. Ortolan), the Emberiza

1 It may be charitably conjectured that the nomenclator intended to write albicapilla.

2 Dr. Sharpe naturally extended his generous hospitality to Orthonyx and placed it in his Timeliida (Cat. B. Br. Mrus. vii. p. 329), but refused entrance to Clitonyx, which Dr. Gadow had therefore to inclnde (op. cit. viii. p. 75) among the Parida-a wrong position, according to Sir W. Buller.

${ }^{3}$ Forbes also demonstrated that one at least of the two New-Zealand species above mentioned, 0 . ochrocephala, had been wrongly referred to this genus, and they therefore at present stand as Clitonyx. This is a point of some little importance in its bearing on the relationship of the fauna of the two countries, for Orthonyx was supposed to be one of the few genera of Land-birds common to both. 
hortulana of Linnæus, a bird so celebrated for the delicate flavour of its flesh as to have become proverbial, and to have given its name to others, not all of them nearly related, which are supposed to be as well-tasted. A native of most European countries-the British Islands (in which it occurs but rarely) excepted-as well as of western Asia, it emigrates in autumn presumably to the southward of the Mediterranean, though its winter-quarters cannot be said to be accurately known, and returns about the end of April or beginning of May. Its distribution throughout its breeding-range seems to be very local, and for this no reason can be assigned. It was long ago said in France, and apparently with truth, to prefer wine-growing districts; but it certainly does not feed upon grapes, and is found equally in countries where vineyards are unknownreaching in Scandinavia even beyond the arctic circle-and there it generally frequents corn-fields and their neighbourhood. In appearance and habits it much resembles its congener the YELLOWHAMMER, but wants the bright colouring of that species, its head for instance being of a greenish-grey instead of a lively yellow. The somewhat monotonous song of the cock is also much of the same kind; and, where the bird is a familiar object to the country people, who usually associate its arrival with the return of fair weather, they commonly apply various syllabic interpretations to its notes, just as our boys do to those of the Yellow-hammer. The nest is placed on or near the ground, but the eggs seldom shew the hair-like markings so characteristic of those of most Emberizida (Bunting). Ortolans are netted alive in great numbers, kept from the light of day, and fed with millet, oats and other seeds. In a shor't time they become enormously fat, and are then killed for the table. If, as is supposed, the Ortolan be the Miliaria of Tarro, the practice of artificially fattening birds of this species is very ancient. ${ }^{1}$

In Europe the "Beccafico" (FIG-EATER), whatever that may be, shares with the Ortolan the highest honours of the dish, but the former is not artificially fattened, and on this account is preferred by some sensitive tastes to the latter.

OSCINES, the third Order of Birds according to the arrangement in 1840 of Keyserling and Blasius (Wirbelth. Europ. pp. xxxvi. and S0), consisting of forms which, among other less important characters, are distinguished by the possession of true song-muscles ( $c f$. SxRINX and InTroduction).

1 In France the word is used so as to be almost synonymous with our "Bunting" ; but in some of the Antilles, where French is spoken, the Ortolan is a little Ground-Dove of the genus Chamapelia. In North America the name is one of the many applied to the BoBournk, so justly celebrated for its excellent flavour, as well as to the SorA or Carolina RAIL; while by Anglo.Indians two species of LA RK (Calandrella brachydactyla and Pyrrhulauda grisca) are commonly called Ortolans (Jerdon, B. Ind. ii. p. 373). 
OSPRAY or OSPREY, 1 a word said to be corrupted from "Ossifrage," in Latin Ossifragn or bone-breaker. The Ossifraga of Pliny (Hist. Nat. x. 3) and some other classical writer's seems, as already said, to have been the Lämergeyer (page 503); but the name, not inapplicable in that case, has been transferred-through a not uncommon but inexplicable confusion - to another bird which is no breaker of bones, save incidentally those of the fishes it devours. ${ }^{2}$ The Osprey is a rapacious bird, of middling size and of conspicuously-marked plumage, the white of its lower parts, and often of its head, contrasting sharply with the dark brown of the back and most of its upper parts when the bird is seen on the wing. It is the Fulco haliaetus of Linnæus, but unquestionably deserving generic separation was, in 1810, established by Savigny (Ois. de l'Egypte, p. 35) as the type of a new genus which he was pleased to term Pandion-a name since pretty generally accepted. It has commonly been kept in the Family Falconilix, but of late regarded as the representative of a separate Family, Puntionida, for which view not a little can be said. ${ }^{3}$ Pandion differs from

1 In the so - called "plume-trade" the worl is applied to the feather's taken from the back of certain Egrets (ef. ExTERiINATION, P. 228).

2 Another supposel old form of the namo is "Orfraie" ; but that is said by M. Rolland (Fraune popul. Fronce, ii. 1. 9, note) quoting M. Suchicr (Zeitschr. Rüm. Philol. i. p. 432), to arise from a mingling of two wholly different sources:-(1) Oripelargues, Oriperagnes, Orpreis, and (2) Ossifraga. "Orfraie" again is occasionally interchanged with Effraic (which, through such dialectical forms as Fresaic, Fressaice, is sail to come from the Latin prasaga), the ordinary French name for the Barn-Owl, Alueo flemmeus (seo OwL, infra, p. 679, note 2); but tho subject is too complex for any but an expert philologist to treat. According to Prof. Skeat (Etymol. Dict. p. 408), "Asprey" is tho oldest English form; but "Osprey" dates from Cotgrave at least.

"Dr. Sharpe goes further, and makes a "Suborder" Pandiones; but the 
the Fulconidx not only pterylologically, as long ago observed by Nitzsch, but also osteologically; as pointed out by M. Alphonse Milne-Edwards (Ois. Foss. France, ii. pp. 413,419), and it is a curious fact that in some of the characters in which it differs structurally from the Falconidx, it agrees with certain of the Owls, especially in possessing a bony bridge or loop ( $a$, in fig.) on the upper part of the anterior face of the tarsometatarse, through which passes the common extensor tendon of the toes $;^{1}$ and in having the exterior toe partly reversible; but the most important parts of its internal structure, as well as of its ptilosis, quite forbid a belief that there is any near alliance of the two groups.

The Osprey is one of the most cosmopolitan Birds-of-Prey. From Alaska to Brazil, from Lapland to Natal, from Japan to Tasmania, and in some of the islands of the Pacific, it occurs as a winter-visitant or as a native. The countries which it does not frequent would be more easily named than those in which it is found - and among the former are Ireland, Iceland and New Zealand. Though migratory in Europe at least, it is generally independent of climate. It breeds equally on the half-thawed shores of Hudson's Bay and on the cays of Honduras, in the dense forests of Finlind and on the barren rocks of the Red Sea, in Kamchatka and in West Australia. Where, through abundance of food, it is numerous - as in former days was the case in the eastern part of the United States - the nests of the Fish-Hawk (to use its American name) may be placed on trees to the number of three hundred close together. Where food is scarcer and the species accordingly less plentiful, a single pair will occupy an isolated rock, and jealously expel all intruders of their kind, as happens in Scotland. ${ }^{2}$ The lover of birds cannot see many more enjoyable spectacles than an Osprey engaged in fishing-poising itself aloft, with upright body, and wings beating horizontally, ore it plunges like a plummet beneath the water, and immediately after reappears shaking a shower of drops from its plumage. The feat of carrying off an Osprey's eggs is often difficult, and attended with some risk, but has more than once tempted the most daring of birds' nesters. Apart from the dangerous situation not unfrequently chosen by the birds for their eyry, - a steep rock in a lonely lake, only to be reached after a long swim through chilly water, or the summit of a

characters on which he founds such an important division are obviously inadequate. The other genus associated with Pandion by him has been shewn by $\mathrm{Mr}$. Gurney (Ibis, 1878 , p. 455) to be nearly allied to the ordinary Sea-EAGLES (Haliactus), and therefore one of the true Falconida.

1 This character is possessed by the group of Orls of the subfamily Strigina, according to the nomenclature of this work, but not by those of the Alucinæ.

2 Two good examples of the different localities chosen by this bird for its nest are ilhstrated in Ootheca Wolleyana, pls. B. \& H. 
very tall tree,- - their fierceness in defence of their eggs and young is not to be despised. Men and boys have had their head gashed by the sharp claw of the angry parent, and this, happening when the robber is already in a precarious predicament and unable to use any defensive weapon, renders the enterprise formidable. But the prize is worthy of the danger. Few birds lay eggs so beautiful or so rich in colouring: their white or pale ground is spotted, blotched or marbled with almost every shade of purple, orange and red - passing from the most delicate lilac, buff and peachblossom, through violet, chestnut and crimson, to a nearly absolute black. A few years ago some of the best-informed ornithologists were led to think that persecution had extirpated the Osprey in Great Britain, except as a chance visitant. This opinion proved to be incorrect, and at the present time the bird is believed still to breed in at least two counties of Scotland, but the secret of its resorts should be carefully guarded by those who wish to retain it as a member of the country's fauna, for indiscreet publication would endanger its occupancy.

\section{OSSIFRAGE, see OSPREY.}

OSTRICH (Old English, Estridge; French, Autruche; Spanish, Avestruz; Latin, Avis struthio). Among exotic birds there can be hardly one better known by report than the strange, majestic and fleet-footed creature that "scorneth the horse and his rider," or one that from the eurliest times to the present has been oftener more or less fully described; and there must be few persons in any civilized country unacquainted with the appearance of this, the largest of living birds, whose size is not insignificant in comparison even with the mightiest of the plumed giants that of old existed upon the earth, since an adult male will stand nearly 8 feet in height, and weigh 300 pounds.

As to the ways of the Ostrich in a state of nature, not much has been added of late years to the knowledge acquired and imparted by former travellers and naturalists, many of whom enjoyed opportunities that will never again occur of discovering its peculiarities, for even the most favourably-placed of their successors in recent years seem to content themselves with repeating the older observations, and to want either leisure or patience to make additions thereto, their personal acquaintance with the bird not amounting to more than such casual meetings with it as must inevitably fall to the lot of those who traverse its haunts. Thus there are still several dubious points in its natural history. On the other hand we unquestionably know far more than our predecessors respecting its geographical distribution, which has been traced with great minuteness in the Vögel Ost-Afrikas of Drs. Finsch and Hartlaub, who have therein given (pp. 597-607) the most comprehensive account of the 
bird that is to be found in the literature of ornithology. ${ }^{1}$ As are many conspicuous forms, the Ostrich is disappearing before the persecution of man, and this fact it is which gives the advantage to older travellers, for there are several districts, some of wide extent, known to have been frequented by the Ostrich within the present century,

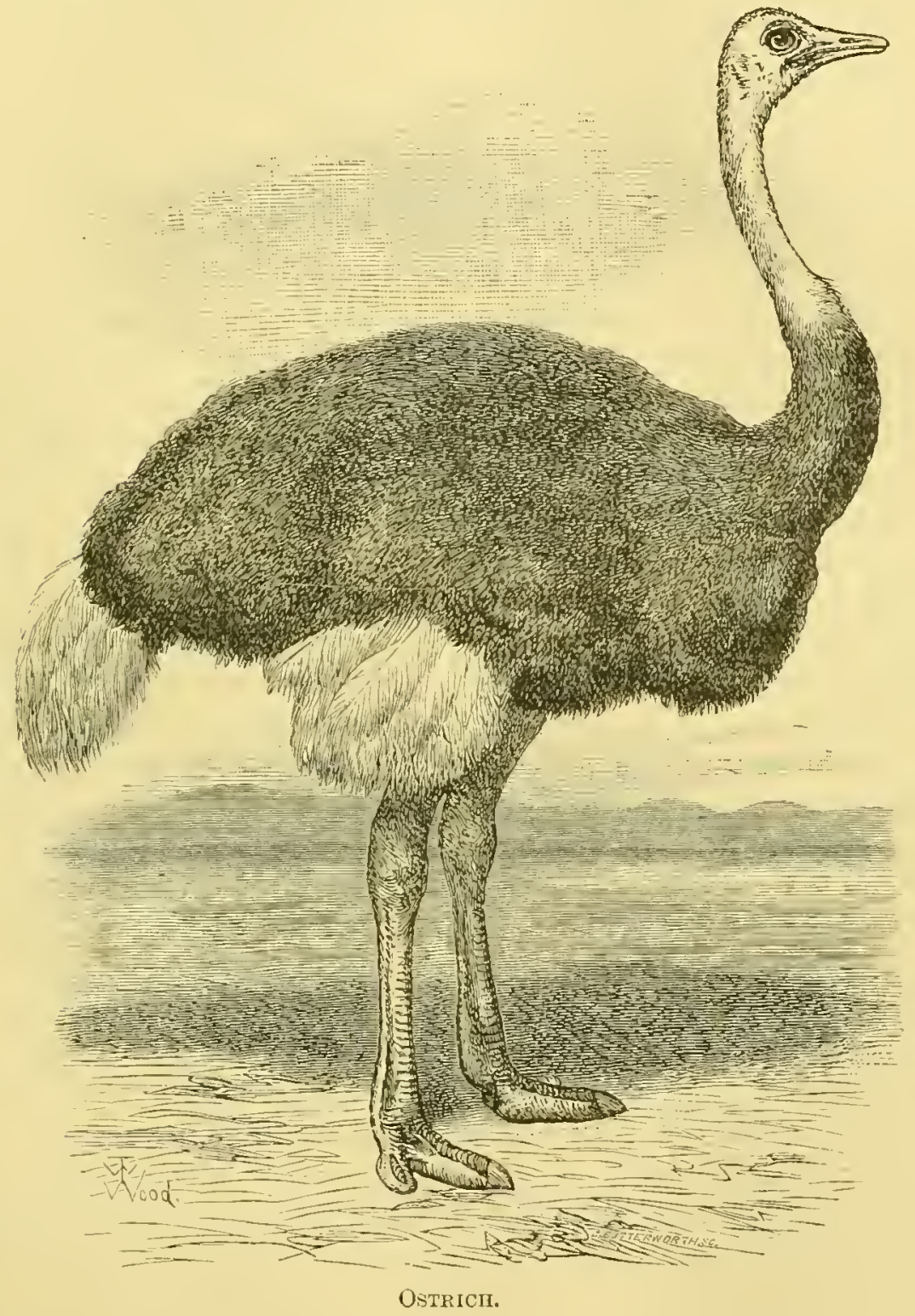

especially towards the extremities of its African range-as on the borders of Egypt and the Cape Colony-in which it no longer occurs, while in Asia there is evidence, more or less trustworthy, of its

1 A good summary of it is contained in the Ostriches and Ostrich Farming of Messrs. De Mosenthal and Harting, from which the accompanying figlue is, with permission, taken. Von Henglin, in his Ornithologie Nordost-Afrike's (pp. 925935), has given more particular details of the Ostrich's distribution in Africa. 
former existence in most parts of the south-western desert-tracts, in few of which it is now to be found. Xenophon's notice of its abundance in Assyria (Anabasis, i. 5) is well known. It probably still lingers in the wastes of Kirwan in eastern Persia, whence examples may occasionally stray northward to those of Turkestan, ${ }^{1}$ even near the Lower Oxus; but the assertion, often repeated, as to its former occurrence in Baloochistan or Sindh, though not incredible, seems to rest on testimony as yet too slender for acceptance. Apparently the most northerly limit of the Ostrich's ordinary range at the present day cannot be further than that portion of the Syrian Desert lying directly to the eastward of Damascus; and, within the limits of what may be called Palestine, Canon Tristram (Fauna and Flora of Palestine, p. 139) regards it as but a straggler from central Arabia, though we have little information as to its appearance and distribution in that country. Africa, however, is still, as in ancient days, the continent in which the Ostrich most flourishes, and from the confines of Barbary to those of the European settlements in the south it appears to inhabit every waste sufficiently extensive to afford it the solitude it loves, and in many wide districts, where the influence of the markets of civilization is feebly felt, to be still almost as abundant as ever. Yet even there it has to contend with deadly foes in the many species of wild beasts which frequent the same tracts and prey upon its eggs and young-the latter especially ; and Lichtenstein long ago remarked that if it were not for its numerous enemies "the multiplication of Ostriches would be quite unexampled." The account given of the habits of the species by this naturalist, who had excellent opportunities of observing it during his three years' travels in South Africa, is perhaps one of the best we have, and since his narrative ${ }^{2}$ has been neglected by most of its more recent historians we may do well by calling attention thereto. Though sometimes assembling in troops of from thirty to fifty, and then generally associating with zebras or with some of the larger antelopes, Ostriches commonly, and especially in the breedingseason, live in companies of not more than four or five, one of which is a cock and the rest are hens. All the latter lay their eggs in one and the same nest, a shallow pit scraped out by their feet, with the earth heaped around to form a kind of wall against which the ontermost circle of eggs rest. As soon as ten or a dozen eggs are laid, the cock begins to brood, always taking his place on them at nightfall surrounded by his wives, while by day they relieve one another,

1 Drs. Finsch and Hartlaub quote a passage from Renusat's Remarques sur i'extension de l'Empire Chinoise, stating that in about the seventh century of our era a live "camel-bird" was sent as a present with an embassy from Turkestan to China.

2 M. H. K. Lichtenstein, Reise im südlichon Africa, ii. pp. 42.45 (Berlin • 1812). 
more it would seem to guard their common treasure from jackals and small beasts-of-prey than directly to forward the process of hatching, for that is often left wholly to the sun. ${ }^{1}$ Some thirty eggs are laid in the nest, and round it are scattered perhaps as many more. These last are said to be broken by the old birds to serve as nourishment for the newly-hatched chicks, whose stomachs cannot bear the hard food on which their parents thrive. The greatest care is taken by them not only to place the nest where it may not be discovered, but to avoid being seen when going to or from it, and their solicitude for their tender young is no less. Andersson in his Lake N'gami (pp. 253-269) has given a lively account of the pursuit by himself and Mr. Francis Galton of a brood of Ostriches, in the course of which the father of the family flung himself on the ground and feigned being wounded to distract their attention from his offspring. Though the Ostrich ordinarily inhabits the most arid districts, it needs water to drink; and, moreover, it will frequently bathe, sometimes even, according to Von Heuglin, in the sea.

The question whether to recognize more than one species of Ostrich, the Struthio camelus of Linnæus, has been for some years agitated without leading to a satisfactory solution.2 It has long been known that, while eggs from North Africa present a perfectly smooth surface, those from South Africa are pitted (see page 190, note 4 ). It has also been observed that northern birds have the skin of the parts not covered with feathers flesh-coloured, while this skin is bluish in southern birds, and hence the latter have been thought to need specific designation as $S$. australis. More recently examples from the Somali country have been described as forming a distinct species under the name of $S$. molybdophanes, ${ }^{3}$ from the leaden colour of their naked parts.

The genus Struthio forms the type of one group of the Subclass RATITA, which differs so widely from the rest, in points that have been concisely set forth by Prof. Huxley (Proc. Zool. Soc. 1867, p. 419), as to justify us in regarding it as an Order, to which the name Struthiones may be applied; but that term, as well as

1 By those whose experience is derived from the observation of captive Ostriches this fact has been disputed. But, to say nothing of the effects of the enforced monogamy in which such birds live, the difference of the circumstances in which they find themselves, and in particular their removal from the heatretaining sands of the desert and its burning sunshine, is enough to account for the change of habit. Von Heuglin also (p. 933) is explicit on this point. That hen Ostriches while on duty crouch to avoid detection is only natural, and this habit seems to have led hasty observers to suppose they were really brooding.

2 Dr. Gadow tells me that the discrepancy of several accounts of the Ostrich's anatomy is such as to suggest the possibility of more than one species.

3 Apparently first noticed in a Berlin newspaper (Sonntagsb. d. Norddeutsch. Allgem. Zeitung) by Dr. Reichenow, 16th Sept. 1883, and later, Mitth. Orn. Ver. Wien, 1883, tab., and Journ. f. Orn. 1883, p. 399. 
Struthionidx, has been often used in a more general sense by systematists, even to signify the whole of the RATITA. ${ }^{1}$ The most obvious distinctive character presented by the Ostrich is the presence of two toes only, the third and fourth, on each foot, - a character absolutely peculiar to the genus Struthio. ${ }^{2}$

The great mercantile value of Ostrich-feathers, and the increasing difficulty, due to the causes already mentioned, of procuring them from wild birds, has led to the formation in the Cape Colony and elsewhere of numerous "Ostrich-farms," on which these birds are kept in confinement, and at regular times deprived of their plumes. In favourable localities and with judicious management these establishments are understood to yield very considerable profit; while, as the ancient taste for wearing Ostrich-feathers shews no sign of falling off, but seems rather to be growing, it is probable that the practice will yet be largely extended. ${ }^{3}$

OUSEL or OUZEL, Anglo-Saxon Ósle, equivalent of the German Amset (a form of the word found in several old English books, and perhaps yet surviving in some parts of the country), apparently the ancient name for what is now more commonly known as the BLAC $\mathrm{K}$ BIRD, the Turdus merula of ornithologists, but at the present day not often applied to that species, though, as will immediately be seen, used in a compound form for two others. The adult male of this beautiful and well-known bird scarcely needs any other description than that of the poet:-

"The Ousel-cock, so black of hue, With orange-tawny bill."

—Midsummer Night's Dream, act iii. sc. 1.

But the female is of an uniform umber-brown above, has the chin, throat and upper part of the breast orange-brown, with a few dark streaks, and the rest of the plumage beneath of a hair-brown. The

a At one time it was not uncommon to include the Bustarids among the Struthionidæ!

2 Remains of a true Ostrich have been recognized from the Sivalik formation in India, and the petrified egg of an apparently allied form, Struthiolithus, has been found in the south of Russia (see Fossir Brrds, p. 285).

3 Among the more important treatises on this bird may be mentioned:-E. D'Alton, Die Skelete der Straussartigen Vögel abgebildet und beschrieben, folio, Bonn: 1827 ; P. L. Sclater, "On the Struthions Birds living in the Zoological Society's Menagerie," Trans. Zool. Soc. iv. p. 353, containing the finest representation (pl. 67), by Mr. Wolf, ever published of the male Struthio eamelus; Prof. Mivart, "On the Axial Skeleton of the Ostrich," op. cit. viii. p. 385 ; Prof. Haughton, "On the Muscular Mechanism of the Leg of the Ostrich, Ann. Nat. Hist. ser. 3, xv. pp. 262-272-a subject more fully treated by M. Alix in his Essai sur l'appareil locomoteur des Oiseaux (Paris : 1874); and Prof. Macalister, "On the Anatomy of the Ostrich," Proc. R. Irish Acad. ix. pp. 1-24. 
young of both sexes resemble the mother. The Blackbird is found in every country of Lurope, even breeding-though rarely-beyond the arctic circle, and in eastern Asia, as well as in Barbary and the Atlantic islands. Resident in Britain as a species, its numbers yet receive considerable accession of passing visitors in autumn, and in most parts of its range it is very migratory. The song of the cock has a peculiarly liquid tone, which makes it much admired, but it is too discontinuous to lank the bird very high as a musician. The species is very prolific, having sometimes as many as four broods in the course of the spring and summer. The nest, generally placed in a thick bush, is made of coarse roots or grass, strongly put together with earth, and is lined with fine grass. Herein are laid from four to six eggs of a light greenish-blue closely mottled with reddish-brown. Generally vermivorous, the Blackbird will, when pressed for food, eat grains and seeds, while berries and fruits in their season are eagerly sought by it, thus earning the enmity of gardeners. More or less allied to and resembling the Blackbird are many other species which inhabit most parts of the world, except. ing the Ethiopian Region, New Zealand and Australia proper, and North America. Some of them have the legs as well as the bill yellow or orange; and, in a few of them, both sexes alike display a uniformly glossy black. The only one that need here be particularized is the Ring-Ouser, Turdus torquatus, which is at once distinguishable from the Blackbird by its conspicuous white gorgetwhence its name. It has also very different habits, frequenting wild and open tracts of country, shumning woods, groves and plantations, and preferring the shelter of rocks to that of trees. Its distribution is accordingly much more local, and in most parts of England it is only known as a transitory migrant in spring and autumn - from and to its bardly as yet ascertained winter quarters. ${ }^{1}$

The WATER-OUSEL, or Water-Crow-now commonly named the "DIPPER" - is the Cinclus aquaticus of most ornithologists, and the type of a small but remarkable group of birds, the position of which many taxonomers have been at their wits' end to determine. It would be useless here to recount the various suppositions that have been expressed; suffice it to say that most ornithologists are now agreed in regarding the genus Cinclus ${ }^{2}$ as differing so much

1 The Ring-Ousel of central and southern Europe presents several differences, having most of its feathers edged with white, and is regarded hy some authorities (Stejneger, Proc. U.S. Nat. Mus. 1886, pp. 365-372; Salvadori, Boll. Mus. Zool. Torino, viii. No. 152 ) as a distinct species, T. alpestris (Brehm); but Mr. Seebohm says (Ibis, 1888, pp. 310,311) that intermediate forms occur, and that further to the eastward, as in Caucasia and Persia, examples shew a still greater divergence, forming a local race to which he applies the name orientalis.

2 Some writers have used for this genus the name Hydrobata. 
from other birds that, though essentially one of the true PAsseris (i.e. Oscrnes), it forms a distinct Family, Cinclida, which has no rery near allies. That some of its peculiarities (for instance, the sternum in adult examples having the posterior margin generally entire, and the close covering of down that clothes the whole body - a character fully recognized by Nitzsch) are correlated with its aquatic habit is probably not to be questioned; but this fact furnishes no argument for associating it, as has often been done, with the Turdida (THRUsH), the Troglodytida (WREN), or much less with other groups to which it has undoubtedly no affinity. The Dipper haunts rocky streams, into which it boldly enters, generally by deliberately wading, and then by the strenuous combined action of its wings and feet makes its way along the bottom in quest of its living prey-freshwater mollusks, and aquatic insects in their larval, pupal or mature condition. By the careless and ignorant it is accused of feeding on the spawn of fishes, and it has been on that account subjected to much persecution. Innumerable examinations of the contents of its stomach have not only proved that the charge is baseless, but that the bird clears off many of the worst enemies of the precious product. Short and squat of stature, active and restless in its movements, silky black above, with a pure white throat and upper part of the breast, to which succeeds a broad band of dark bay, it is a familiar figure to most fishermen on the streams it frequents, while the cheerful song of the cock, often heard in the hardest frost, helps to make it a favomite with

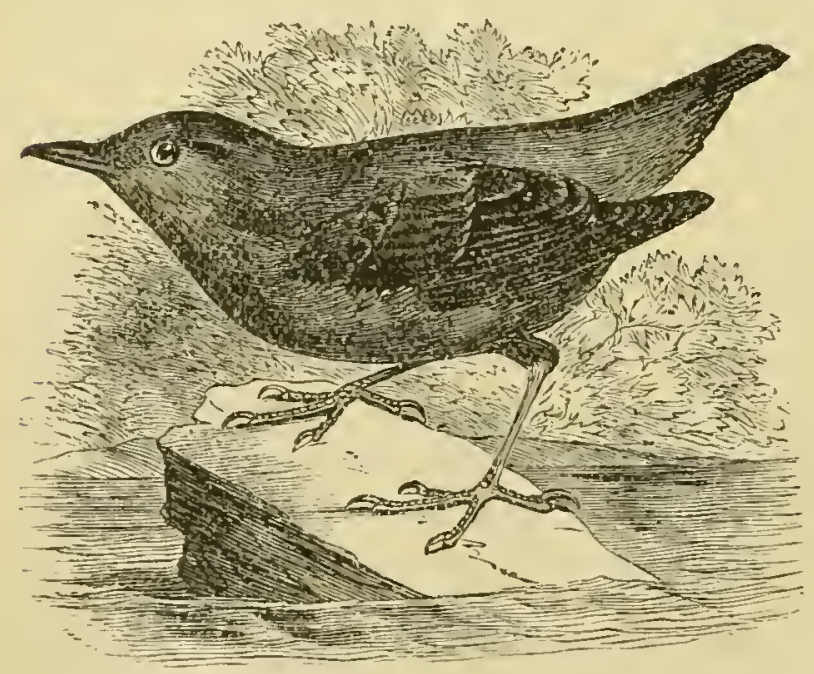

Criclus mexicanus. them in spite of the obloquy under which it labours. The WaterOusel's nest is a very curious structure,-outwardly resembling a Tren's, but built on a wholly different principle,-an ordinary cupshaped nest of grass lined with dearl leaves, placed in some conrenient niche, but encased with moss so as to form a large mass that covers it completely except only a small hole for the bird's passage. The eggs laid within are from four to six in number, and are of a pure white. These remarks refer to the Water-Ousel of central and western Europe, including the British Islands; but, except as regards plumage, it is be- 
lieved that they will apply to all the other species, about a dozen in number, which have been described. These inhabit suitable places throughout the whole Palwarctic area as well as the southern slopes of the Himalaya and the hill-country of Formosa, besides the Rocky Mountains and a great part of the Andes. Mr. Salvin, in a very philosophical paper on the genus (Ilic, 1867, pp. 109-122), refers these species-some of them wholly black and one slate-coloured-to five well-marked forms, of which the other members are either "representative species" or" merely "local races"; but all seem to oceupy distinct geographical areas, - the C. mexicanus repiesented in the accompanying figure having a wide range along the mountainous parts of North America to Mexico; and it is quite possible that their number may yet be increased, for the general habits of the birds preclude much invasion of territory, and thus produce practical isolation.

OVARY, OVIDUCT, see ReProductive OrGans.

OVEN-BIRI), a name locally given to several species that build domed nests in England, especially to the Willow-IVREx, and in

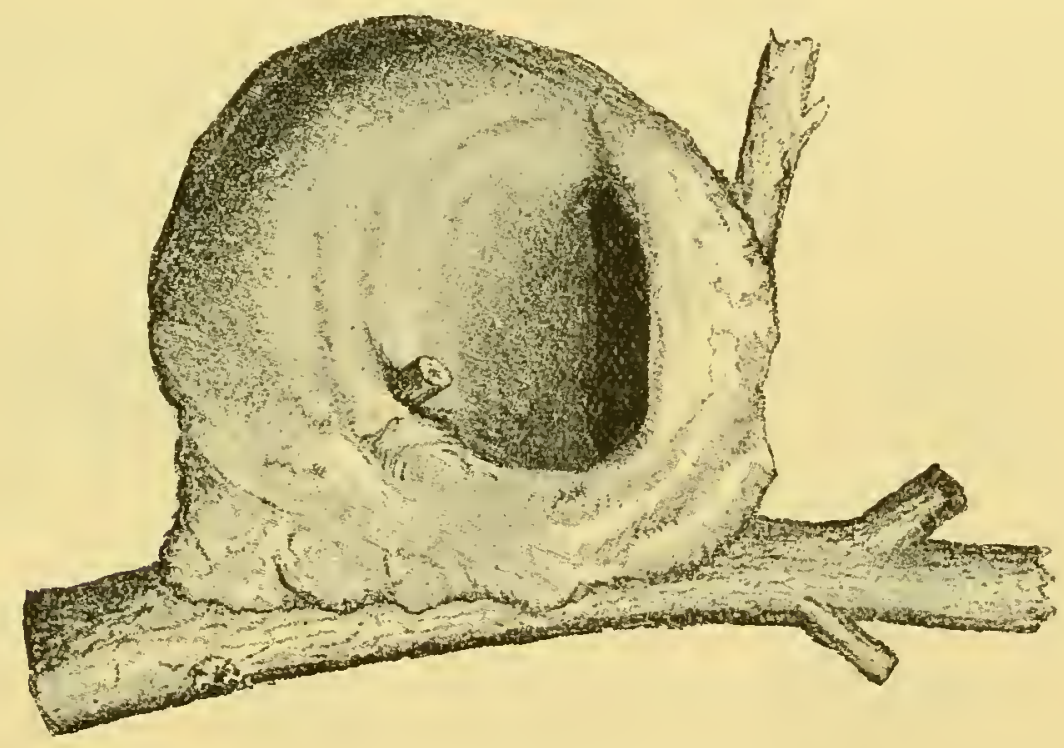

NEST OF OVEN-BIRD (Furnarius).

(From specimen given to the Cambridge MIstim by Mr. J. Young.)

North America to Siurus auricapillus, otherwise known as the Golden-crowned Thrush; but by most ornithologists applied to birds of the genus Furnarius, belonging to the Neotropical Family Dendrocolaptidix (PICUCULE), the best known of which is $F$. rufus, the Hornero (Baker) or Casera of the Spanish-speaking population. 


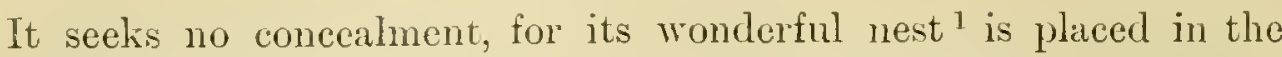
most conspicuous situations, on the top of a post, a bare rock or a leafless branch, being a massive structure with strong thick walls, composed of mud mixed with bits of straw or fibres, roughly

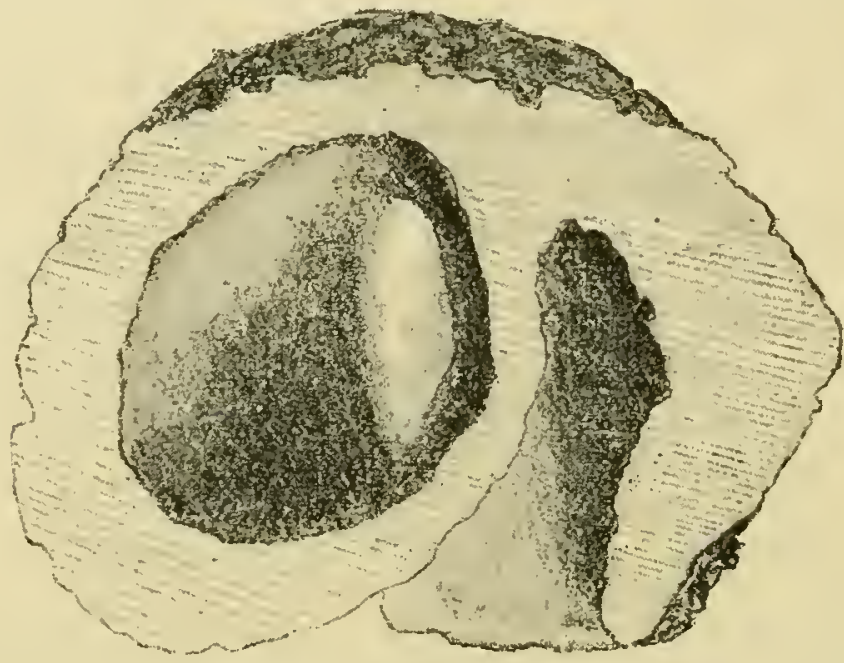

SECTION OF OVEN-BIRD'S NEST.

globular in form with an upright opening in front whence a partition extends nearly to the back, forming an ante-chamber to the portion which contains the 4 or 5 white eggs, laid on a bed of soft dry grass. The habits of this species have been mentioned by Mr. Darwin (Nut. Vo\%. chap. v.) and described at some length by Mr. Hudson (Argent. Orn. i. pp. 167-170), beside Durnford (Itis,

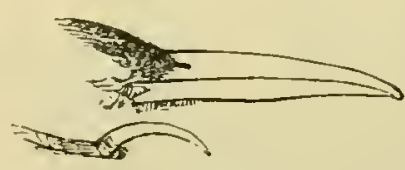

Furnarius.

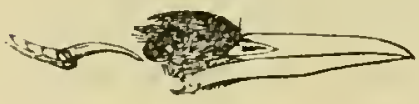

GEOBATES.

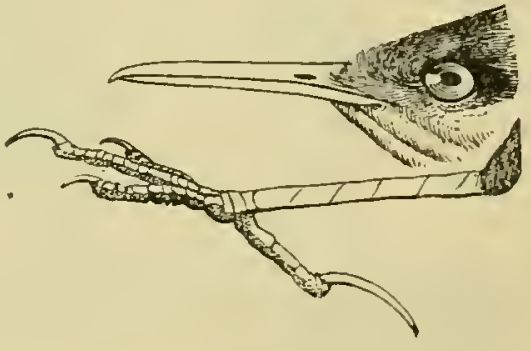

Geositra.

(After Swainson.)

1877 , p. 179) and Mr. E. Gibson (op. cit. 1880, pp. 16-18), to say nothing of Burmeister (Syst. Uebers. Th. Brasil. Vügel, iii. pp. 3, 4) and Dorbigny (Voy. Amér. Mérid. Ois. p. 250).

Allied to Furnarius are the genera Geobates and Geosittu, of which

1 Not many figures of this have been given. There is one, sueh as a elild might draw, in Molina's Cumpendio (tav. 2, Bologna: 1776), and that in a Nuturul History (iv. 1). 113) edited by Duncan is hardly more instruetive: D1: Göldi's figures (Zool. Gart. 1586, pp. 268, 271) are fair. 
last one species, $G$. cuniculariu, with many of the habits of a WHEATEAR, bores a hole from 3 to 6 feet long in a bank or the side of a biscacha's burrow, placing its nest at the end; but. Geobates, which is peculiar to the grassy plains (campos) of Southeastern Brazil, has much the habits of a LARK or PIPIT, together with the elongated cubital feathers characteristic of those forms, while another, Upucerthia, inhabits the most sterile of the upland deserts. None of these birds is of any particular beauty, but to the ornithologist they form a most interesting group, the position of which was for a long while wholly mistaken, and it was only when their anatomical structure came to be known that their place was determined among the TRACHEOPHONA.

OWL, the Anglo-Saxon Úle, Swedish Uggla, and German Euleall allied to the Latin Ulula, and evidently of imitative origin-the general English name for every nocturnal Bird-of-Prey, ${ }^{1}$ of which group nearly two hundred species have been recognized. The Owls form a very natural assemblage, and one about the limits of which no doubt has for a long while existed. Placed by nearly all systematists for many years as a Family of the Order Accipitres (or whatever may have been the equivalent term used by the particular taxonomer), there has been of late a disposition to regard thein as forming a group of higher rank. On many accounts it is plain that they differ from the ordinary diurnal Birds-of-Prey, more than the latter do among themselves; and, though in some respects Owls have a superficial likeness to the NightJAIs, ${ }^{2}$ and a resemblance more deeply seated to the GuACHARO, even the last has not been made out to have any strong affinity to them. A good deal is therefore to be said for the opinion which would rank the Owls as an independent Order, or at any rate Suborder, Striges. Whatever be the position assigned to the group, its subdivision has always been a fruitful matter of discussion, owing to the great resemblance obtaining among all its members, and the existence of safe characters for its division has only lately been at all generally recognized. By the older naturalists, it is true, Owls were divided, as was first

1 The poverty of the English language-generally so rich in synonyms-is here very remarkable. Though four well-known if not eommon species of Owls are native to Britain, to say nothing of half a dozen others which occur with greater or less frequency, none of them has ever acquired an absolutely individual name, and various prefixes have to be used to distinguish them. It is almost the same in other countries where English is spoken, though North America has its "Saw-whet" and New Zealand its "Morepork"-each name from the bird's call-note. In Greece and Italy, Germany and France, almost eacli indigenous species has liad its own particular designation in the vulgar tongue. The English Owlet or Howlet is of course a simple diminutive only.

- In many parts of England the Nightjar is known as the Churn.Owl or Fern-Owl. 
done by Willughby, into two sections-one in which all the species exhibit tufts of feathers on the head, the so-called "ears" or "horns," and the second in which the liead is not tufted. The artificial and therefore untrustworthy nature of this distinction was shewn by Isidore Geoffroy-St. Hilaire (Ann. Sc. Nat. xxi. pp. 194203 ) in 1S30; but he did not do much good in the arrangement of the Owls which he then proposed; and it was hardly until the publication, ten years later, of Nitzsch's Pterylographie that rational grounds on which to base a division of the Owls were adduced. It then became manifest that two very distinct types of pterylosis existed in the gromp, and further it appeared that certain differences, already partly shewn by Berthold (Beitr. Anat. pp. 166, 167), of sternal structure coincided with the pterylological distinctions. By degrees other significant differences were pointed out, till, as summed up by Prof. Alphonse Milne-Edwards (Ois. foss. de la France, ii. pp. 474-492), there could no longer be any doubt that the bird known in England as the Screech-Owl or Barn-Owl, ${ }^{1}$ with its allies, formed a section which should be most justifiably separated from all the others of the group then known. Space is here wanting to state particularly the pterylological distinctions which will be found described at length in Nitzsch's classical work (Eng. trans. pp. 70, 71), and even the chief osteological distinctions must be only briefly mentioned. ${ }^{2}$ These consist in the Screech-Owl section wanting any manubrial process in front of the sternum, which has its broad keel joined to the clavicles united as a furcula, while posteriorly it presents an unbroken ontline. In the other section, of which the bird known in England as the Tawny or Brown Owl is the type, there is a manubrial process; the furcula, far from being joined to the keel of the sternum, often consists but of two stylets which do not even meet one another; and the posterior margin of the sternum presents two pairs of projections, one pair on each side, with corresponding fissures between them. Furthermore the Owls of the same section shew another peculiarity in the bone usually called the tarsus. This is a bony ring or loop bridging the channel holding the common extensor tendon of the toes-which, as already noticed, is possessed by the OsPREY, but does not appear in the Screech-Owl section any more than in the majority of birds. The subsequent examination by M. Milne-Edwards (Nour. Arch. Mus. Mém. se1. 2, i. pp. 185-200, pls. 4, 5) of the skeleton of an Owl known as Phodilus (more correctly Photodilus) badius, hitherto attached to the Screech-Owl section, shewed that, though in most of its osteological characters it must be referled to the Tawny-Owl

1 The Owl, however, which commonly breeds in barns in Sweden and perhaps some other parts of Europe is our Tawny Owl, Strix stridule.

- A few more distinctive characters are shewn by Mr. Beddard in his paper on the classification of this group (Ibis, 1888, pp. 335-344). 
section, in several of the particulars mentioned above it resembles the Screech-Owls, and therefore we are bound to deem it a connecting link between them. The pterylological characters of Photodilus seem not to have been fully investigated, ${ }^{1}$ but it is found on the one hand to want the singular bony tarsal loop, as well as the manubrial process, while on the other its clavicles are not united into a furcula to meet the keel, and the posterior margin of the sternum has processes and fissures like those of the TawnyOwl section. Photodilus having thus to be removed from the Screech-Owl section, Prof. Milne-Edwards has replaced it by a new form, Heliodilus, from Madagascar (Comptes Rendus, 1887, p. 1282), described at length by him in M. Grandidier's great work on the natural history of that island (Oiseaux, i. pp. 113-118, pls. xxxvi. a-c). The unexpected results thus obtained preach caution in regard to the classification of other Owls, and add to the misgivings that every honest ornithologist must feel as to former attempts to methodize the whole group-misgivings that had already arisen from the great diversity of opinion displayed by previous classifiers, hardly two of whom seem able to agree. Moreover, the difficulties which beset the study of the Owls are not limited to their respective relations, but extend to their scientific terminology, which has long been in a state so bewildering that nothing but the strictest adherence to the very letter of the laws of nomenclature, which until lately have been approved in principle by all but an insignificant number of zoologists, can clear up the confusion into which the matter has been thrown by heedless or ignorant writers-some of those who are in general most careful to avoid error being not wholly free from blame in this respect.

A few words are therefore here needed on this most unprofitable subject. ${ }^{2}$ Under the generic term Strix, Linnæus placed all the Owls known to him; but Brisson most justifiably divided that genus, and in so doing fixed upon Strix stridula-the aforesaid Tawny Owl-as its type, while under the name of Asio he established a second genus, of which his contemporary's $S$. otus, presently to be mentioned, is the type. Some years later Savigny, who had very peculiar notions on nomenclature, disregarding the act of Brisson, chose to recognize the Linnæan S. flammea-the Screech-Owl before spoken of - as the type of the genus Strix, which genus he further dissevered, and his example was largely followed until Fleming gave to the Screech-Owl the generic name of $A$ luco, ${ }^{3}$ by which it had been known for more than three hundred years, and reserved Strix for the Tawny Owl. He thus anticipated Nitzsch, whose editor (Bur-

1 Mr. Beddard has noticed a few points (Ibis, 1890, pp. 293-294).

2 It was dealt with at greater length in The Tois for 1876 (pp. 94-105).

3 The word seems to have been the invention of Gaza, the translator of Aristotle, in 1503, and is the Latinized form of the Italian Allocco. 
meister) was probably unacquainted with this fact when he allowed the name Hybris to be conferred on the Screech-Owl. No doubt inconvenience is caused by changing any general practice; but, as

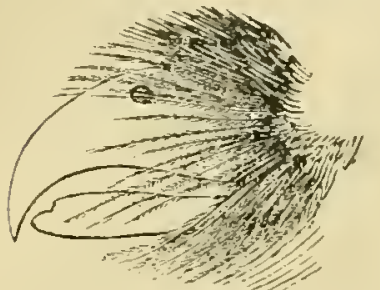

Bill of Aluco flamieus.

(After Swainson.) will have been seen, the practice was not universal, and such inconvenience as may arise is not chargeable on those who abide by the law, as it is intended in this article to do. The reader is therefore warned that the word Strix will be here used in what is believed to be the legitimate way, for the genus containing the Strix stridula of Linnæus, while Aluco is retained for that including the $S$. flammea of the same naturalist.

Except the two main divisions just mentioned-Strigina and Alucina-any further arrangement of the Owls must at present be deemed tentative, for the ordinary external characters, to which most systematists trust, are useless if not misleading. ${ }^{1}$ Several systematizers have tried to draw characters from the orifice of the ear, and the parts about it; but hitherto these have not been sufficiently studied to make the attempts very successful. If it be true that the predominant organ in any group of animals furnishes for that group the best distinctive characters, we may have some hope of future attempts in this direction, ${ }^{2}$ for we know that few birds have the sense of hearing so highly developed as the Owls, and also that the external ear varies considerably in form in several of the genera which have been examined. Thus in Surnia, the HawkOwl, and in Nyctea, the Snowy Owl, the external ear is simple in form, and, though proportionally larger than in most birds, it possesses no very remarkable peculiarities,-a fact which may be colrelated with the diurnal habits of these Owls-natives of the far north, where the summer is a season of constant daylight, and to effect the capture of prey the eyes, are perhaps more employed than the ears. ${ }^{3}$ In Bubo, the Eagle-Owl, though certainly more nocturnal in habit, the external ear, however, has no very remarkable develop-

1 It is much to be regretted that an interesting form of Owl, Sceloglaux albifacies, peculiar to New Zealand, the Whekan of the Maories, should be rapidly becoming extinct, without any effort, so far as is known, being nuade to ascertain its affinities. It would seem to belong to the Strigine section, and is remarkable for its rery massive clavicles, that unite by a kind of false joint, which in some examples may possibly be wholly ancylosed, in the median line.

2 'This hope is strengthened by the very praiseworthy essay on the Owls of Norway by Herr Collett in the Forhandlinger of Christiania for 1881.

3 But this hypothesis must not be too strongrly urged; for in Carine, a more southern form of nocturnal (or at least crepuscular) habits, the external ear is perliajs even more normal. Of course by the ear the real organ of hearing is here ineant, not the tuft of feathers often so called in speaking of Owls. 
ment of conch, which may perhaps be accounted for by the ordinary prey of the bird being the larger rodents, that from their size are more readily seen, and hence the growth of the bird's auditory orgaus has not been much stimulated. In Strix (as the name is here used), a form depending greatly on its sense of hearing for the capture of its prey, the ear-conch is much enlarged, and it has, moreover, an elevated flap or

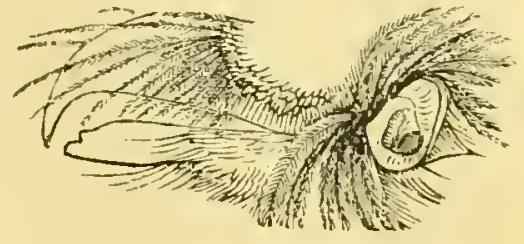

BHLL AND EAR OF BUBO.

(After Swainson.) opereulum. In Asio, containing the Long-eared and Short-eared Owls of Emrope, Asia and America, the conch is enormonsly exaggerated, extending in a semicireular direction from the base of the lower mandible to above the middle of the eye, and is furnished in its whole length with an opereulum. ${ }^{1}$ But what is more extraordinary in this genus is that the entrance to the ear is asymmetrical-the orifice on one side opening downwards and on the other upwards. This eurious adaptation is carried still further in the genus Nyctala, containing two or three small species of the Northern hemisphere, in which the asymmetry that in Asio is only skin-deep extends, in a manner very surprising, to several of the bones of the head, as may be seen in the Zoological Soeiety's Proceedings (1871, pp. 739 743), and in the large series of figures given by Messrs. Baird, Brewer and Ridgway (N.-Am. Bivds, iii. pp. 97-102).

Among Owls are found birds which vary in length from 5 inches-as Glaucidium cobanense, which is therefore much smaller than a Skylark-to more than 2 feet, a size that is attained by many species. Their plumage, none of the feathers of which possesses an aftershaft, is of the softest kind, rendering their flight almost noiseless. But one of the most characteristic features of this whole group is the ruff, consisting of several rows of small and much-curved feather's with stiff shafts-originating from a fold of the skin, which begins on each side of the base of the beak, runs above the eyes, and passing downwards round and behind the ear's turns forward, and ends at the chin-and serving to support the longer feathers of the "disk" or space immediately around the eyes, which extend over it. A considerable number of speeies of Owls, belonging to various genera, and natives of countries most widely separated, are remarkable for exhibiting two phases of coloration-one in which the prevalent browns have a more or less rustyred tinge, and the other in which they incline to grey. Another characteristic of nearly all Owls is the reversible property of their onter toes, which are not unfrequently turned at the bird's pleasure

${ }_{1}$ Figures of these different forms are given by Maegillivray (Brit. Birds, iii. pp. 396, 403, and 427), and of Asio otus in the Fourth Edition of Yarrell's British Bircls (i. 1. 162). 
quite backwards. Many forms have the legs and toes thickly clothed to the very claws; others have the toes, and even the tarsi, bare, or only sparsely beset by bristles. Among the bare-legged Owls those of the Indian genus Ketupa are conspicnous, and this feature is usually correlated with their fish-catching habits; but certainly other Owls that are not known to catch fish present much the same character.

From the multitude of Owls there is only room here to make further mention of a few of the more interesting. First must be noticed the Tawny Owl-the Strix stridula of Linnæus, the type, as has been above said, of the whole group, and especially of the Strigine section as here understood. This is the Syrnium aluco of many authors, the Chat-huant of the French, the species whose tremulous hooting "tu-whit, to-who," has been celebrated by Shakespear, and, as well as the plaintive call, "keewick," of the young after leaving the nest, will be familiar sounds to many readers, for the bird is very generally distributed thronghout most parts of Europe, extending its range through Asia Minor to Palestine, and also to Barbary - but not belonging to the Ethiopian Region or to the eastern half of the Paliearctic area. It is the largest of the Owls indigenous to Britain, and chiefly affects woodlands, only occasionally choosing any other place for its nest than a hollow tree. Its food consists almost entirely of small mammals, especially rats; but, though on this account most deserving of protection from all classes, it is subject to the stupid persecution of the ignorant, and is rapidly declining in numbers. ${ }^{1}$ Its nearest allies in North America are the $S$. nebulosa, with some kindred forms, one of which, the S. occidentalis of California and Arizona, is here figured; but none of them seems to have the "merry note" that is uttered by the European species. Common to the most northerly forest-tracts of both continents (for, though a slight difference of coloration is observable between American examples and those from the Old World, it is impossible to consider it specific) is the much larger S. cinerea or S. lapponica, whose small eyes, with their yellow iris, iron-grey plumage, delicately mottled with dark brown, and the concentric circles of its facial disks make it one of the most remarkable of the group. Then may be noticed the genus Bubo-containing several species which from their size are usually known as Eagle-Owls. Here the Nearctic and Palearctic forms are sufficiently distinct-

1 All Owls have the habit of casting up the indigestible parts of the food swallowed in the form of pellets, which may often be found in abundance under the Owl-roost, and reveal without any manner of doubt what the prey of the bird has been. The result in nearly every case shews the enormous service they render to man in destroying rats and mice. Details of many observations to this effect are recorded in the Bericht über dic XIV. Versammlung der Deutschen Ornithologen-Gesellsehaft (pp. 30-34). 
the latter, B. ignawns, ${ }^{1}$ the Duc or Giand Duc of the French, ranging over the whole of Europe and Asia north of the Himalayas, while the former, B. virginianus, extends over the whole of North Ameriea. A contrast to the generally sombre colonr of these birds is shewn by the Snowy Owl, Nycter scandiaca, a cirenmpolar speeies, and the only one of its genus, which disdains the shelter of forests and braves the most rigorous aretic elimate, though eompelled to migrate southward in winter when no sustenance is left for it. Its large size and white plumage, more or less mottled with black, distinguish this

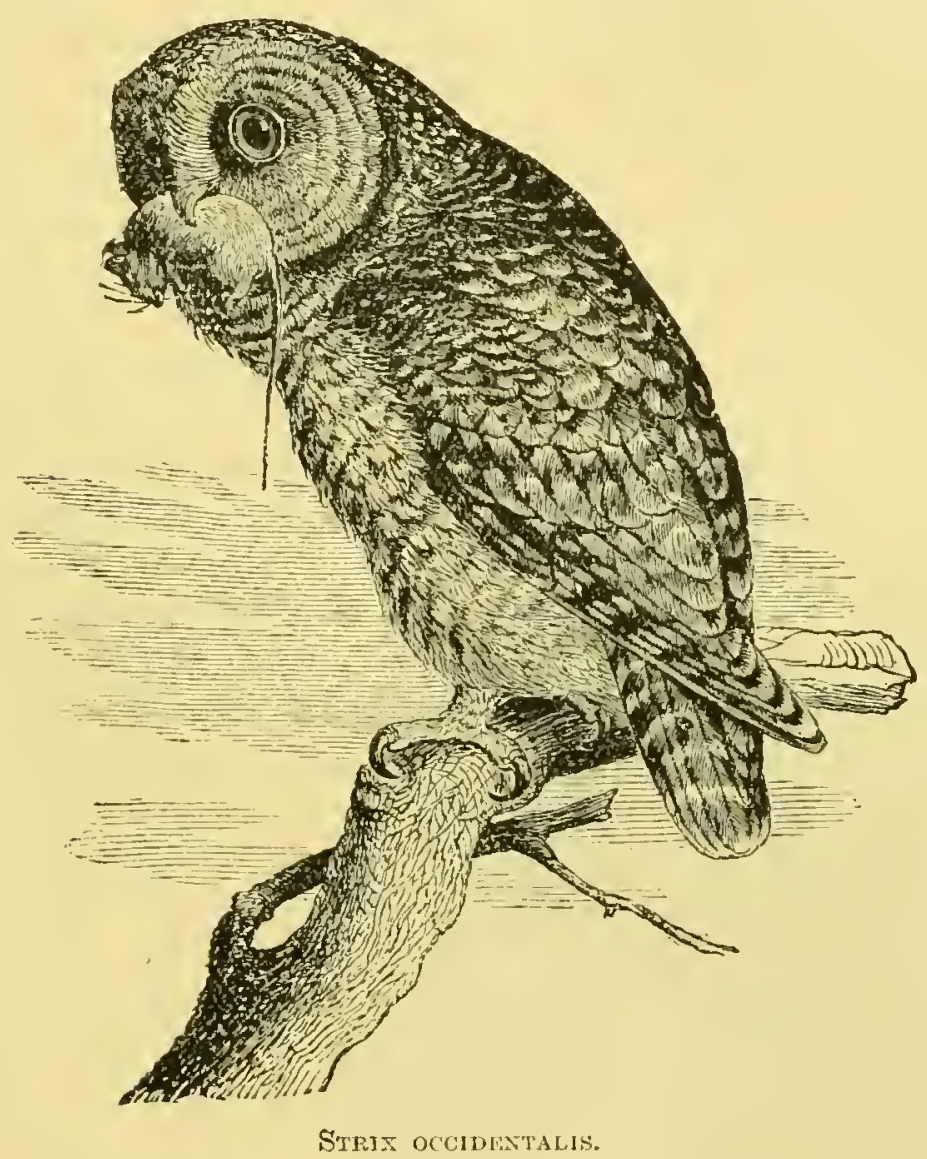

from evely other Owl. Then may be mentioned the birds eommonly known in English as "Horned" Owls-the Hibous of the Freneh, belonging to the genus Asin. One, A. otus (the Otus vulgaris of some authors), inhabits woods, and, distinguished by its long tufts, usually borne ereeted, would seem to be common to both America and Europe-though experts profess their ability to distinguish between examples from each eountry. Another species, $A$.

1 This species bears confinement very well, and propagates freely therein. The Owls so well known as formerly kept at Arundel Castle were always referred to it, until MIr. Borrer (B. Sussex, Introd. p. xvii.) shewed that they belonged to the kindred $B$. virginianus. 
accipitrinus (the Otus brachyotus of many author's), has much shorter tufts on its head, and they are frequently carried depressed so as to escape observation. This is the "Woodcock-Owl" of English sportsmen, for, though a good many are bred in Great Britain, the majority arrive in autumn from Scandinavia, just about the time that the immigration of Woodcocks occurs. This species frequents heaths, moors, and the open country generally, to the exclusion of woods, and has an enormous geographical range, including not only all Europe, North Africa, and northern Asia, but the whole of America,-reaching also to the Falklands, the Galapagos and the Sandwich Islands, - for the attempt to separate specifically examples from those localities only shews that they possess more or less illdefined local races. Commonly placed near Asio, but whether really akin to it cannot be stated, is the genus Scops, of which nearly forty species, coming from different parts of the world, have been described; but this number should probably be reduced by one half. The type of the genus, S. giu, the Petit Duc of the French, is a well-known bird in the south of Europe, about as big as a Thrush, with very delicately-pencilled plumage, occasionally visiting Britain, emigrating in autumn across the Mediterianean, and ranging very far to the eastward. Further southward, both in Asia and Africa, it is represented by other species of very similar size, and in the eastern part of North America by $S$. asio, of which there is a tolerably distinct western form, $S$. kennicotti, besides several local races. S. asio is one of the Owls that especially exhibits the dimorphism of coloration above mentioned, and it was long before the true state of the case was understood. At first the two forms were thought to be distinct, and then for some time the belief obtained that the ruddy birds were the young of the greyer form which was called S. novic; but now the "Red Owl" and the "Mottled Owl" of the older American ornithologists are known to be one species. ${ }^{1}$ One of the most remarkable of American Owls is Speotyto cunicularia, the bird that in the northern part of the continent inhabits the burrows of the prairie-dog, and in the southern those of the biscacha, where the latter occurs-making holes for itself, says Darwin, where that is not the case, - rattlesnakes being often also joint tenants of the same abodes. The odd association of these animals, interesting as it is, cannot here be more than noticed, for a few words must be said, ere we leave the Owls of this section, on the species which has associations of a very different kind-the bird of Pallas Athene, the emblem of the city to which science and art were so welcome. There can be no doubt, from the

1 See the remarks of Mr. Ridgway in the work before quoted ( $B . N$. America, iii. pp. 9, 10), where also response is made to the observations of $\mathrm{Mr}$. Allen in the Harvard Bullctin (ii. pp. 338, 339), as well as the former's elaborate review of the American species of the genus (Proc. U.S. Nat. Mus. i. pp. 85-11\%.) 
many representations on coins and sculptures, as to their subject being the Carine noctua of moder'n ornithologists, but those who

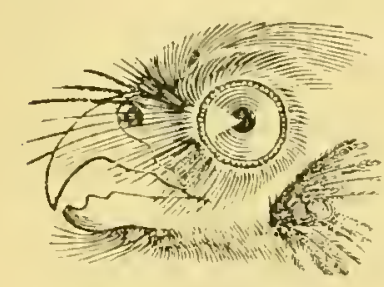

HEAD OF CARINE.

(After Swainson.) know the grotesque actions and ludicrous expression of this veritable buffoon of birds can never cease to wonder at its liaving been seriously selected as the symbol of learning, and can hardly divest themselves of a suspicion that the choice must have been made in the spirit of sarcasm. This Little Owl (for that is its only English name-though it is not even the smallest that appears in England), the Chevêche of the French, is spread throughout the greater part of Europe, but it is not a native of Britain. ${ }^{1}$ It has a congener in C. brama, a bird well known to all residents in India.

Finally, we have Owls of the second section, those allied to the Screech-Owl, Aluco flammens, the Effrcie ${ }^{2}$ of the French. This, with its discordant screan, its snoring, and its hissing, is far too well known to need description, for it is one of the most widelyspread of birds, and is the Owl that has the greatest geographical range, inhabiting almost every country in the world, - Sweden and Norway, America north of lat. $45^{\circ}$, and New Zealand being the principal exceptions. It, varies, however, not inconsiderably, both in size and intensity of colour, and several ornithologists have tried to found on these variations more than half a dozen distinct species. Some, if not most of them, seem, however,

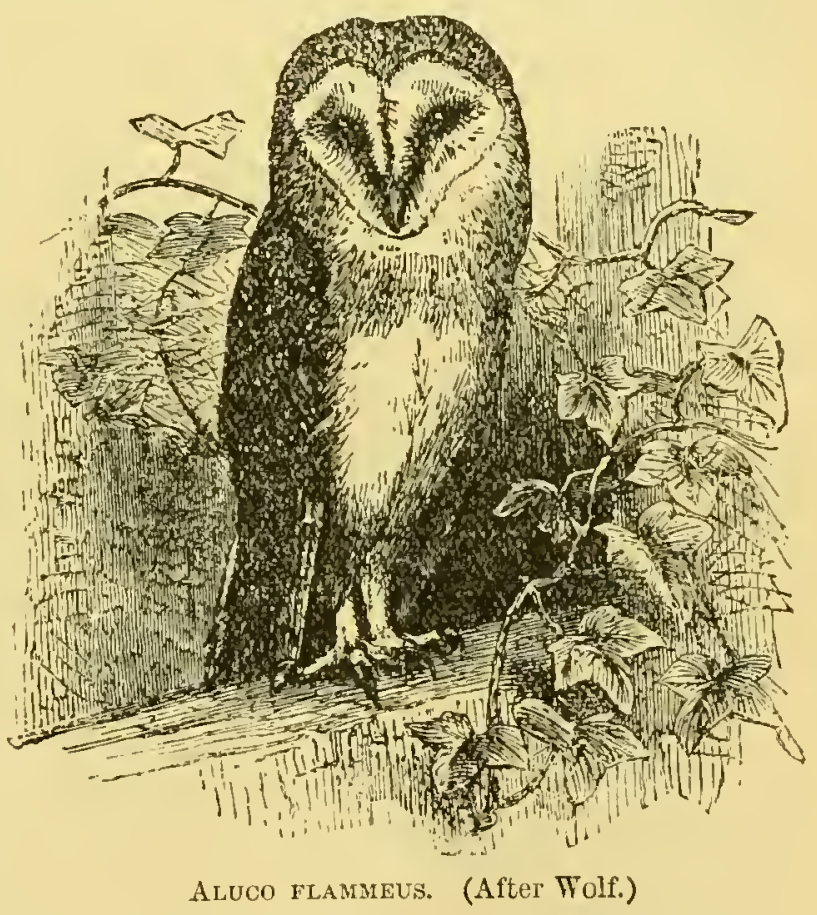
hardly worthy to be considered geographical races, for their differences do not always depend on locality. Dr. Sharpe, with much labour and

I A very large number have first and last been liberated in this conntry by Lord Lilford and Mr. Meade-Waldo; but thongh they have been known to breed in their feral state, they ean hardly be said to have established themselves.

2 Through the dialectic forms Fresaie and Presaie, the origin of the word is easily traced to the Latin masaga -a bird of bad omen; but it has also been confounded with Orfraic, a name of the OsPrey. 
in great detail, has given his reasons (Cat. B. Brit. NIus. ii. pp. 291-309; and Ornith. Miscell. i. pp. 269-298; ii. pp. 1-21) for acknowledging four "subspecies" of $A$. flammeus, as well as five other species. Of these last, $A$. tenebricosus is peculiar to Australia, while $A$. nor $x$ hollandix inhabits also New Guinea, and has a "subspecies," $A$. castanops, found only in Tasmania; a third, A. cundidus, has a wide range from Fiji and northern Australia through the Philippines and Formosa to China, Burma and India; a fourth, A. copensis, is peculiar to South Africa; while $A$. thomensis is said to be confined to the African island of St. Thomas. There is also the extinct $A$. sauzieri of Mauritius (Trans. Zool. Soc. xiii. p. 286), and to these will perhaps liave to be added a species from New Britain, described by Count T. Salvadori as Strix aurantia, though it may prove on further investigation not to be an Alucine Owl at all.

OX-BIRD, a common name for the DUNLIN, and in connexion therewith Mr. Harting, in the Introduction (p. xvii.) to Rodd's Birds of Cornuall, reasonably refers OXEN-AND-KINE, by which name some apparently small wildfowl were of old times known in the west country (cf. Carew, Survey of Cornwall, fol. 35, and a curious paper printed in the Camden Miscellany, ${ }^{1}$ iv. pp. 10,26 ).

OX-EYE seems once to have been synonymous with OX-BIRD, but is now only known as a local name for the Great Tituouse (cf. Sw. Talgoxe = fat ox)..$^{2}$

OX-PECKFR, a rendering of the French Pique-bouf, bestowed on a small, dull-coloured bird discovered by Adanson in Senegal,

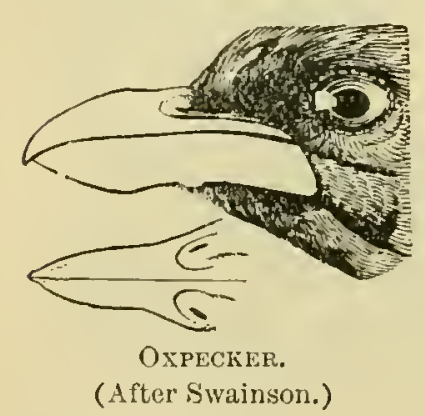
the Buphaga africana of Linnæus, which has been almost invariably referred to the Family Sturidic (Starling), chiefly, it would seem, because it flies in flocks, and settles on the back of cattle in search of the bots or ticks with which they are infested. Though the animals are at first alarmed at the visitation, they soon get over the fright, regarding, it is said, with evident pleasure the way in which the birds creep about them and rid them of the pests. A second

1 The Editor of this, Mr. W. D. Cooper, suggests that the birds were Ruffs and Reeves, but there is no evidence that those birds were ever to be had in Devon or Cornwall; however, Mr. C. Swainson (Prov. Names Br. B. p. 195) accepts the suggestion as if it were a fact. Mr. Sclater (List Vert. Anim. Gardens of the Zool. Soe. 1883, p. 246) applies "Ox-bird" to Textor albirostris or alceto, one of the WEAVEL-BIRDS.

${ }^{2}$ A copy of Belon's Portraits d'Oyscaux (1557) in the Public Library of the University of Cambridge (M. 15. 43) has the English names of anany of the birds written in an ancient hand. To the figure of Himantopus (STILT) the name Ox-eye is applierl. 
species, $B$. erythrorhyncha, with a wholly red instead of a yellow bill was afterwards fornd in Abyssinia, and thought for some time to be peculiar to the more northern part of Africa, but it is now known to occur so far south as Natal, while the first has been observed in Damaraland and the Transvaal. Very little more seems to be known of the habits of either, and the systematic position of the genus must be held uncertain.

OXYNOTUS, the name of a genus of birds now ascertained to be peculiar to two of the Mascarene Islands-Mauritius and Rémion (Bourbon) - where the name of Cuisinier is applied to them, and remarkable for the fact, nearly if not quite mique in Ornithology, that, while the males of both species are almost identical in appearance, the females are wholly mlike each other. Though the habits of the Mauritian species, $O$. mufinenter, have been very fairly observed, there seems to be nothing in them that might account for the peculiarity. The genus Oxynotus is generally placed in the group known as Campephagida, most or all of which are distinguished from the Laniidx (to which they seem nearly allied) by the feathers on the lower part of the back and on the rump having the basal portion of the shaft very stiff and the distal portion soft-a structure which makes that part of the body, on being touched by the finger, feel as though it were beset with blunt prickles. Hence the name of the genus conferred by Swainson, and intended to signify "prickly back." The males, which look rather like miniature Grey Shrikes (Lanius excubitor and others), are -except on close examination, when some slight differences of build and shade become discernible-quite indistinguishable; but the female of the one species has a reddish-brown back, and is bright ferruginous beneath, while the female of the other species is dull white beneath, transversely barred, as are the females of some Shrikes, with brown. Both sexes of each species, and the young of one of them, are described and figured in The Ibis for 1866 (pp. 275-280, pls. vii. and viii.)

OYSTER-CATCHER, a bird's name which does not seem to occur in books until 1731, when Catesby (Nat. Hist. Carolina, i. p. 85) used it for a species which he observed to be abundant on the oyster-banks left bare at low water in the rivers of Carolina, and believed to feed prineipally upon those mollusks. In 1773 Pennant applied the name generically, though he and for nearly two hundred years other British writers had called the allied British species the "Sea-Pie." The change, in spite of the misnomer-for, whatever may be the case elsewhere, in England the bird does not

1 The only other instance cited by Darwin (Descent of MFan, ii. pp. 192, 193) is that of two species of Paradisea; but therein the males differ from one another to a far greater degree than do those of Oxynotus. 
feed upon oysters-met with general approval, and the new name has, at least in books, almost wholly replaced what seems to have been the older one. ${ }^{1}$ The Oyster-catcher of Europe is the Hæmatopus ${ }^{2}$ ostralegus of Linnæus, belonging to the group now called Limicola, and is generally included in the Family Charadriidx; though some writers have placed it in one of its own, Hamatopodidx, chiefly on account of its peculiar bill-a long thin wedge, ending in a vertical edge. Its fect also are much more fleshy than are generally seen in the Plover Family. In its strongly-contrasted plumage of black and white, with a coral-coloured bill, the Oyster-catcher is one of the most conspicuous birds of the European coasts, and in many parts is still very common. It is nearly always seen paired, though the pairs collect in prodigious flocks; and, when these are broken up, its shrill but musical cry of "tu-lup," "tu-lup," somewhat pettishly repeated, helps to draw attention to it. Its wariness, however, is very marvellous, and even at the breeding-season, when most birds throw off their shyness, it is not easily approached within ordinary gunshot distance. The hen-bird commonly lays three clay-coloured eggs, blotched with black, in a very slight hollow on the ground, not far from the sea. As incubation goes on the hollow is somewhat deepened, and perhaps some haulm is added to its edge, so that at last a very fair nest is the result. The young, as in all Limicolx, are at first clothed in down, so mottled in colour as closely to resemble the shingle to which, if they be not hatched upon it, they are almost immediately taken by their parents, and there, on the slightest alarm, they squat close to elude observation. This species occurs on the British coasts (very seldom shewing itself inland) all the year round; but there is some reason to think that those we have in winter are natives of more northern latitudes, while our home-bred birds leave us. It ranges from Iceland to the shores of the Red Sea, and lives chiefly on marine worms, crustacea, and skch mollusks as it is able to obtain. It is commonly supposed to be capable of prizing limpets from their rock, and of opening the shells of mussels; but, though undoubtedly it feeds on both, further evidence as to the way in which it

I It seems however very possible, judging from its equivalents in other European languages, such as the Frisian Oestervisscher, the German Austcrmann, Austernfischer, and the like, that the name "Oyster-catcher" may have been not a colonial invention but indigenous to the mother-country, thongh it had not found its way into print before. The French Huîtrier, however, appears to be a word coined by Brisson. "Sea-Pie" has its analognes in the French Pie-de-Mer, the German Mccrelster, Secelster, and so forth.

2 Whether it be the Hæmatopus whose name is found in some editions of Pliny (lib. x. cap. 47) is at best doubtful. Other editions have Himantopus; but Hardouin prefers the former reading. Both words have passed into modern ornithology, the latter as the generic uame of the STuLT ; and some writers have blended the two in the strange and impossible compound Hæmantopus. 
procures them is desirable. Mr. Harting inforns us that the bird seems to lay its head sideways on the ground, and then, grasping the limpet's shell close to the rock between the mandibles, use them as scissor-blades to cut off the mollusk from its sticking-place. The Oyster-catcher is not highly esteemed as a bird for the table.

Differing from this species in the possession of a longer bill, in having much less white on its back, in the paler colour of its mantle, and in a few other points, is the ordinary American species, already mentioned, $H$. palliatus. Except that its call-note, judging from description, is unlike that of the European bird, the habits of the two seem to be perfectly similar; and the same may be said indeed of all the other species. The Falliland Islands are frequented by a third, $H$. leucopus, very similar to the first, but with a black wing-lining and paler legs, and Mr. Ridgway (Auk, 18s6, p. 331) thinks the Galapagos have a distinct species, $H$. galapagensis, while the Australian Region possesses another, H. longirostris, with a very long bill as its name intimates, and no white on its primaries. China, Japan and possibly eastern Asia in general have an Oystercatcher which seems to be intermediate between the last and the first. This has received the name of $H$. osculans; but doubts have been expressed as to its deserving specific recognition. Then we have a group of species in which the plumage is wholly or almost wholly black, and among them only do we find birds that fulfil the implication of the scientific name of the genus by having feet that may be called blood-red. $H$. niger, which frequents both coasts of the northern Pacific, has, it is true, yellow legs, but towards the extremity of South America its place is taken by $H$. ater, in which they are bright red, and this bird is further remarkable for its laterally compressed and much upturned bill. The South-African $H$. capensis has also scarlet legs; but in the otherwise very similar bird of Australia and New Zealand, $H$. unicolor, these members are of a pale brick-colour:

\section{$\mathrm{P}$}

PAAUW (Peafowl), the Dutch name applied generally in South Africa to some of the Bustards.

PADDA, see JAVA SPARrow.

PADDY-BIRD, the Anglo-Indian name for any of the smaller EGRETS, from their frequenting the rice-fields (padda).

PALAMEDEA, see ScREAMER.

$P A L A T E$, the roof of the mouth, whence PALATAL (commonly Palatine) Bones, being the pair of bones which commect the Maxilua 
with the Pterygoids, and rest by articulating facets on the ventral side of the sphenoidal rostrum of the SkULL. They have considerable taxonomic importance.

PAMPRODACTYL E, Dr. Murie's name (Ibis, 1873, p. 190, note) for the group consisting of the Coliid $x$ (Mouse-BIRD).

PANCREAS, a conglomeration of glands, forming one or more lobes, and placed between the two branches of the duodenal loop (Digestive Systeir, pages 141-143). Its secretion, the Pancreatic Juice, contains a ferment important for digestion and enters the duodenum through from one to three short ducts, which in most birds open into its ascending branch between the hepato-enteric and cystico-enteric ducts. The size and position of the Pancreas are very variable and of little general interest.

PARADISE-BIRD, see BIRD-of-PARAdise; -DUCK, see SHELdDRAKE.

PARAKEET, variously spelt, see PARRoT.

PARAPTERON, Sundevall's name for the row or rows of feathers commonly known as upper wing-coverts.

PARDALOTE, see DIAMIOND-BIRD.

PARRA, see JACANA.

PARROT, according to Prof. Skeat (Etym. Dict. p. 422), from the French Perrot or Pierrot, a proper name and the diminutive of Pierre, ${ }^{1}$ the name given generally to a large and very natural group of Birds, which for more than a score of centuries have attracted attention, not only from their gaudy plumage, but, at first and chiefly it would seem, from the readiness with which many of them learn to imitate the sounds they hear, repeating the words and even phrases of human speech with a fidelity that is often astonishing. It is said that no representation of any Parrot appears in Egyptian art, nor does any reference to a.bird of the kind occur in the Bible, whence it has been concluded that neither the painters nor the writers

1 "Parakeet" (in Shakespear, 1 Hen. IV. ii. 3, 88, "Paraquito") is said by the same authority to be from the Spanish Periquito or Pcrroqueto, a small Parrot, diminutive of Perico, a Parrot, which again may be a diminutive from Pcdro, the proper name. Parakeet (spelt in various ways in English) is usnally applied to the smaller kinds of Parrots, especially those which have long tails, not as Perroquet in French, which is used as a general term for all Parrots, Pcrruche, or sometimes Perriche, being the ordinary name for what we call Parakeet. The old English "Popinjay" and the old French Papegaut have almost passed ont of use, but the German Papagci and Italian Papagaio still continue in vogue. Some trace these names to the Arabic Babagha; but others think that word a corruption of the Spanish Papagayo. The Anglo-Saxon name of the Parret, a river in Somerset, is Pedreda or Pedrida, which at first sight looks as if it had to do with the proper name, Petrns ; but Prof. Skeat believes there is no connexion between them-the latter portion of the word being rid, a stream. 
concerned had any knowledge of it. Aristotle is commonly supposed to be the first author who mentions a Parrot; but this is an error, for nearly a century earlier Ctesias in his Indica (cap. 3), ${ }^{1}$ under the name of ßírтакоs (Bittacus), so neatly described a bird which could speak an "Indian" language-naturally, as he seems to have thought-or Greek-if it had been taught so to do,_-about as big as a Sparrow-Hawk (Hierax), with a purple face and a black beard, otherwise blue-green (cyaneus) and vermilion in colour, so that there cannot be much risk in declaring that he must have had before him a male example of what is now commonly known as the Blossonheaded Parakeet, and to ornithologists as Palxornis cyanocephalus, an inhabitant of many parts of India. Much ingenuity has been exercised in the endeavour to find the word whence this, and the later form of the Greek name, was derived, but to little or no purpose.

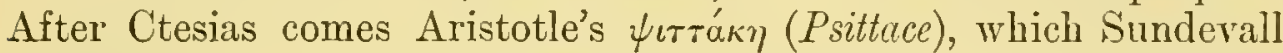
supposes him to have described only from hearsay; but this matters little, for there can be no doubt that the Indian conquests of Alexander were the means of making the Parrot better known in Europe, and it is in reference to this fact that another Eastern species of Palaxomis now bears the name of $P$. alexandri, though from the localities it inhabits it could not have had anything to do with the Macedonian king. That Africa had Parrots does not seem to have been discovered by the ancients till long after, as Pliny tells us (vi. 29) that they were first met with by explorers employed by Nero beyond the limits of Upper Egypt. These birds, highly prized from the first, reprobated by the moralist, and celebrated by more than one classical poet, as time went on were brought in great numbers to Rome, and ministered in various ways to the luxury of the age. Not only were they lodged in cages of tortoisc-shell and ivory, with silver wires, but they were professedly esteemed as delicacies for the table, and one emperor is said to have fecl his lions upon them! But there would be little use in dwelling longer on these topics. With the decline of the Roman empire the demand for Parrots in Europe lessened, and so the supply dwindled, yet all knowledge of them was not wholly lost, and they are occasionally mentioned by one writer or another until in the fifteenth century began that career of geographical discovery which has since proceeded uninterruptedly. This immediately brought with it the knowledge of many more forms of these birds than had ever before been seen, for whatever races of men were visited by European navigators-whether in the East Indies or the West, whether in Africa or in the islands of the Pacific-it was almost invariably found that even the most savage tribes had tamed some kind of Parrot; and, moreover, experience soon shewed that no bird was

1 The passage seems to have escaped the notice of all naturalists until Broderip mentioned it in his article "Psittacidæ" in the Penny Cyclopædia (xix. p. 83). 
more easily kept alive on board ship and brought home, while, if it had not the merit of "speech," it was almost certain to be of beautiful plumage. Yet so numerous is the group that even now new species of Parrots are not uncommonly recognized, though, looking to the way in which the most secluded parts of the world are being ransacked, we must soon come to an end of this.

The home of the vast majority of Parrot-forms is unquestionably within the tropics, but the popular belief that Parrots are tropical birds only is a great mistake. In North America the Carolina Parakeet, Conurus carotinensis, at the beginning of the present century used to range in summer as high as the shores of Lakes Erie and Ontario - a latitude equal to that of the south of France; and even within the last forty years it reached, according to trustworthy information, the junction of the Ohio and the Mississippi, though now its limits have been so much curtailed that its occurrence in any but the Gulf States is doubtful, and its extirpation as a species seems to be only a question of time. ${ }^{1}$ In Sonth America, at least four species of Parrots are found in Chili or La Plata, and one, Conurus or Cyanolyseus patagonus, is pretty common on the bleak coast of the Strait of Magellan. In Africa, it is true that no species is known to extend to within some ten degrees of the tropic of Cancer; but Pcecephalus robustus inhabits territories lying quite as far to the southward of the tropic of Capricorn. In India the northern range of the group is only bounded by the slopes of the Himalaya, and further to the eastward Parrots are not only abundant over the whole of the Malay Archipelago, as well as Australia and Tasmania, but two very well-defined Families are peculiar to New Zealand and its adjacent islands (KAKAPO and NESTOR), while the genus Platycercus, or that section of it called Cyanorhynchus, has several representatives in the Region last named, one species, $P$. erythrotis, reaching the Macquarrie Islands in lat. $55^{\circ} \mathrm{S}$., the highest attained by any of the Order. No Parrot has recently inhabited the Palæarctic area, ${ }^{2}$ nor are Parrots represented by many different forms in either the Ethiopian or the Indian Region. In continental Asia the distribution of Parrots is rather remarkable. None extend further to the westward than the valley of the Indus, ${ }^{3}$ which, con-

${ }^{2}$ Cf. inter alios, W. W. Cooke, Rep. Bird MFigr. Mississippi, p. 124 (1888); W. Brewster, Auk, 1889, p. 337 ; A. W. Butler, op. cit. 1892, pp. 49-56.

2 A few remains of a Parrot have been recognized from the Miocene of the Allier in France, by Prof. A. Milne-Edwards (Ois. Foss. France, ii. p. 525, pl. cc.), and are said by him to shew the greatest resemblauce to the common Grey Parrot of Africa, Psittacus erithacus, though having also some affinity to the Ring-necked Parakeet of the same country, Pataornis torquatus. He refers them, however, to the same genus as the former, under the name of Psittacus verreauxi.

3 The statements that have been made, and even repeated by writers of authority, as to the occurrence of "a green parrot" in Syria (Chesney, Exped. 
sidering the nature of the country in Baloochistan and Affghanistan, is perhaps intelligible enough; but it is not so easy to understand why none are found either in Cochin China or China proper; and they are also wanting in the Philippine Islands, which is the more remarkable and instructive when we find how abundant they are in the groups a little further to the southward. Indeed Mr. Wallace has well remarked that the portion of the earth's surface which contains the largest number of Parrots, in proportion to its area, is undoubtedly that covered by the islands extending from Celebes to the Solomon group. "The area of these islands is probably not one-fifteenth of that of the four tropical regions, yet they contain from one-fifth to one-fourth of all the known Parrots" (Geogr. Distr. Anim. ii. p. 330). He goes on to observe also that in this area are found many of the most remarkable forms - all the red Lories, the great black Cockatoos, the pigmy Nasiternæ, and other singularities. In South America the species of Parrots, though numerically nearly as abundant, are far less diversified in form, and all of them seem capable of being referred to two or, at most, three sections. The species that has the widest range, and that by far, is the common Ring-necked Parakeet, Palaornis torquatus, a well-known cage-bird which is found from the mouth of the Gambia across Africa to the coast of the Red Sea, as well as throughout the whole of India, Ceylon and Burma to Tenasserim. ${ }^{1}$ On the other hand there are plenty of cases of Parrots which are restricted to an extremely small area-often an island of insignificant size, as Conurus pertinax, confined to the island of St. Thomas in the Antilles, and Palrornis exsul, to that of Rodriguez in the Indian Ocean (Ibis, 1872, pp. 3134,1875 , p. 342 , pl. vii.) - to say nothing of the remarkable instance afforded by Nestor productus ${ }^{2}$ (see pp. 223, 224 and 628).

Survey Euphrates and Tigris, i. pp. 443, 537) and of a Parrot in Turkestan (Jour. As. Soc. Bengal, viii. p. 1007) originated with gentlemen who had no ornithological kuowledge, and are evidently erroneous. Some species of RoLlER possibly gave rise to the assertions.

1 It is right to state, howerer, that the African examples of this bird are said to be distinguishable from the Asiatic by their somewhat shorter wings and weaker bill, and hence they are considered by some authorities to form a distinct species, $P$. docilis; but in thus regarding them the difference of locality seems to have influenced opinion, and without that difference they would scarcely have been separated, for in many other groups of birds distinetions so slight are regarded as barely evidence of local races. Even West-African examples are said by Count T. Salvadori (Cat. B. Brit. NIus. xx. p. 448) to have larger bills than those from the eastern side, which have been further distinguished as $P$. parvirostris.

2 A case very like that of Nestor productus (pp. 223, 628) is presented by the "Mascarin" ( $P l$. Enl. 35) a Parrot which formerly inhabited the island of Bourbon (Rémnion). The last known living example was in the royal menagerie at Munich and was figured in 1835 by Hahn (Orn. Atlas, Papegeien, p. 54, pl. 39) ; 
The systematic treatment of this very natural group has long been a difficult subject, and almost the only approach to unanimity among those who have made it their study, lies in the somerhat general belief which has grown up within the last half of this century that the Parrots should be regarded as forming a distinct Order. A few systematists, among whom Bonaparte was chief, placed them at the top of the Class, conceiving that they were the analogues of the Primates among Mammals. Prof. Huxley has recognized the Psittacomorphax as forming one of the principal groups of Carinata, and, by whatever name we call them, that much seems to be evident. It will here, however, be umecessary to discuss the rank which the Parrots should hold, and it is quite enough of a task to consider the most natural or-if we cannot hope at present to reach that-at least the most expedient way of subdividing them. It is a reproach to ornithologists that so little satisfactory progress has been made in this direction, and the result is all the more disheartening, seeing that there is no group of exotic birds that affords equal opportunities for anatomical examination, since almost every genus extant, and more than two-thirds of the species, have within recent times been kept in confinement in one or another of our zoological gardens, and at their death have furnished subjects for dissection. Yet the laudable attempt of M. Blanchard (Compt. Pend. xliii. 1097-1100 and xliv. 518-521) was not successful, and it cannot be affirmed that the latest arrangement of the Psittaci is really much more natural than that planned by Buffon in 1779.' He was of course unaware of the existence of some of the most remarkable forms of the group, in particular of Stringops and Nestor; but he began by making two great divisions of those that he did know, separating the Parrots of the Old World from the Parrots of the New, and subdividing each of these divisions into various sections somewhat in accordance with the names they had received in popular language-a practice he followed on many other occasions, for he seems to have held a belief that there is more truth in the discrimination of the unlearned than the scientific are apt to allow. The end was that he produced a plan which is comparatively simple and certainly practical, while as just stated it cannot be confidently declared to be imnatural. However, not to go very

but all trace of it has since been lost, and the only two specimens that exist in Mnseums are at Paris and Vienna respectively-the latter having been obtained on the dispersal of the Leverian Museum in 1806, when it formed lot 5828 in the sale catalogue, and was there said to be from America! (Cf. Von Pelzelu, Ibis, 1873 , p. 32 ; A. Milne-Edwards, Ann. Sc. Nat. ser. 5, vi. pl. ii. fig. 4, pl. iii. fig. 8 ; the same and Onstalet in the centenary volume of the Museum of Natnral History at Paris, pp. 7-21, pl. i. ; and W. A. Forbes, Ibis, 1879, pp. 303-307.)

1 This is virtually admitted by Count T. Salvadori (tom. cit. Introd. p. viii.), the latest reviser of the Order: 
far back: in 1867-68 Dr. Finsch published an excellent monograph of the Parrots, ${ }^{1}$ regarding them as a Family, in which he admitted 26 genera, forming 5 subfamilies; but only in the single group NESTOR did he recognize characters that were not external. In 1874 Garrod communicated to the Zoological Society the result of his dissection of examples of 82 species of Parrots, which had lived in its gardens, and these results were published in its Proceedings for that year (pp. 586 598 , pls. lxx. lxxi.) The principal points to which he attended were the arrangement of the CAROTID artery, and the presence or absence of an AMIBIENs muscle, an OIl-GLAND and a Furcula; but except as regards the last character he unfortunately almost wholly neglected the rest of the skeleton, looking upon such osteological features as the formation of an orbital ring and peculiarities of the atlas as "of minor importance" - an estimate to which nearly every anatomist will demur. Indeed the investigations of Prof. A. Milne-Edwards (Ann. Sc. Nat. Zoologie, ser. 5, vi. pp. 91-111; viii. pp. 145-156) on the bones of the head in Parrots make it clear that these alone, and especially the maxilla, present features of much significance, and if his investigations had not been carried on for a special object, but had been extended to other parts of the skeleton, there is little doubt that they would have removed some of the greatest difficulties. The one osteological character to which Garrod trusted, namely, the condition of the furcula, contributes little towards a safe basis of classification. That it is wholly absent in some genera of Parrots had long been known, but its imperfect ossification, it appears, is not attended in some cases by any diminution of volant powers, which tends to shew that it is an unimportant character, an inference confilmed by the fact that it was found wanting in genera placed geographically so far apart that the loss must have had in some of them an independent origin. Thus grounded, his scheme was so manifestly artificial that further criticism would here be useless; the greatest merit of his method is that, as before mentioned (LOVE-BIRD), he gave sufficient reasons for distinguishing between the genera Agapornis and Psittacula. In the Journal fï Ornithologie for 1881 Dr. Reichenow published a Conspectus Psittacorum, founded, as so many others ${ }^{2}$ have been, on external characters only. He made 9 Families of the group, and recognized 45 genera, and 442 species, besides subspecies. In 1883 he brought to completion a work, ${ }^{3}$ finely illustrated by Herr G. Miitzel, which forms a concise monograph. His grouping is generally very different from Garrod's, but

1 Die Papageien monographisch bearbeitet. Leiden : 1867-68. 2 vols. 8vo.

2 Such, for instance, as Kuhl's treatise with the same title, which appeared in 1820, and Wagler's Monographia Psittacorum, published in 1832-both good of their kind and time.

3 Vogelbilder aus fernen Zonen. Abbildungen und Besehreibungen der Papageien. Fiassel : 1878-83. 
displays as much artificiality ; for instance, Nestor is refcrred to the Family which is otherwise composed of the Cockatoos. Almost simultaneously with the last came the arrangement followed by Mr. Sclater in the List of those exhibited of late years in the gardens of the Zoological Society, and published in 1883. This seemed to be a manifest improvement on anything before proposed; but more recently we have Count $T$. Salvadori, who, while cataloguing the collection of specimens in the British Museum (Cat. B. Brit. Mus. xr.), came to the conclusion that 6 Families are needed. These are Nestorida (Nestor); Loriida (Lory), ${ }^{1}$ with 14 genera and 71 species; Cyclopsittacida (2 genera, 18 species); Cacatuida (Cockatoo), with 2 subfamilies-Cucatuinx (5 or 6 genera, 26 or 27 species) and the other consisting of the well-known Calopsitta (COCKATEEL); Psittacida, with 6 subfamilies - Nasiternina (1 genus, 9 species), Conurina, including the MACCAws (15 genera, 102 species), Pionina (10 genera, 91 species), Psittucinæ (3 genera, 8 species) Palaornithina (16 genera, 114 species) and Platycercina (11 genera, 50 species); while Stringopida (KAKAPO) completes the group. That this scheme is worthy of its author's name none can doubt, but he himself remarks that materials are not yet "sufficient-for" a complete study of Parrots." The separation of the first and last of these Families is unquestionably required, since they stand on a very different and much firmer footing than the other four, and the recognition of Cucatuida and Loriidx is probably justifiable, as they can be without much difficulty defined, but exception may be taken to Cyclopsittacida as a Family, and the grouping of the genera of Psittacida proper is open to objection. Pionus and Psittacus certainly seem to furnish two different types, to the former of which, rather than to Conurus, Psittacula appears to be attached, bearing much the same relation thereto that Agapornis, placed by the Count near Palaroris, does to the latter. Details of this kind, however, must be expected to produce some divergence of opinion. Among the genera Chrysotis, Palaornis and Psittucus are probably to be found the most highly organized forms, and it is these birds in which the faculty of socalled "speech" reaches its maximum development. But too much importance must not be assigned to that fact; since, while Psittacus erithacus-the well-known Grey Parrot ${ }^{2}$ with a red tail-is the most accomplished spokesman of the whole group, it is fairly

- I I take this opportunity of correcting an error (p. 520) as to the plumage of the young of Eclectus, which has been proved by Dr. A. B. Neyer (Zcitschr. f. gesanmte Zool. 188:, i. pp. 146-162, 1884, i. p. 274, pl. xvi. and Ibis, 1890, pp. 26-29, pl. i.) to resemble that of the adult.

2 In many foreign works this species is said to be called in English "The Jacko," but no such practice is known to me, and the assertion probably originated in the general application of the name of some particular captive. Bishop Stanley hacl a bird so called (Prothero, Life of Dean Stanley, 1. 18). 
approached by some species of Chrysotis-usually styled Amazonsand yet its congener $P$. timneh is not known to be talkative. ${ }^{1}$

Considering the abundance of Parrots both as species and individuals, and their wide extent over the globe, it is surprising how little is known of their habits in a wild state. Even the species with which Englishmen and their descendants have been more in contact than any other has an almost unwritten history, compared with that of many other birds ; and, seeing how many are oppressed by and yielding to man's occupation of their ancient haunts, the extirpation of some is certain, and will probably be accomplished before several interesting and some disputed points in their economy have been decided. The experience of small islands only foreshadows what will happen in tracts of greater extent, though there more time is required to produce the same result; but, the result being inevitable, those who are favourably placed for observations should neglect no opportunities of making them ere it be too late.

PARSON-BIRD (so-called by the English in New Zealand from the two tufts of curled and filamentary white feathers hanging beneath its chin, which were supposed to resemble the bands worn until lately by clerics), the Prosthematodera nor:-zealandix of modern ornithology. Made known on the publication of Cook's First Voyage (i. p. 98), where it is figured as the Poe or Poy-bird, ${ }^{2}$ in 1776 it was technically described by Pennant and figured by Peter Brown (Illustr. Zool. p. 18, pl. ix.) from a specimen in Tunstall's collection still existing in the Museum at Newcastle-on-Tyne (Fox, Synops. Newc. MIus. p. 138). The bird belongs to the Meliphagida (HONEY-EATER), and is in many ways one of the most remarkable of them, being generally of glossy black with vivid green or blue reflexions, while in addition to the white gular tufts, the feathers on the sides of the neck are curved forwards and white-shafted, the greater wing-coverts also being white. It is a fine songster, and a great favourite in captivity, learning to mimic various noises,

1 In connexion with the "speaking" of Parrots, one of the most curious circumstances is that recorded by Humboldt, who states (Ansichten der Natur, ed. 3, i. p. 285, Engl. transl. p. 172) that in Sonth America he met with a venerable bird which remained the sole possessor of a literally dead language, the whole tribe of Indians, Atures by name, who alone had spoken it, having become extiuct. This inciclent was the theme of a poem by Curtius, printed in Hum. boldt's volume, and how cleverly it has been worked into a romance by a recent novelist all well know; but unfortunately there are people who will have it that the romance of the story did not begin with Mrr. Grant Allen.

2 This name, for a long while used in the books, was given by Cook's people, who compared the bircl's remarkable gular tufts to the earrings worn by the Tahitians, and called Poies, as the word was then written. But Kago is given as the native name of the bird, and in the form Koko is still used, though Tui is the commoner appellation. 
including the human voice. ${ }^{1}$ In fine weather, as remarked by Mr. Layard (Ibis, 1863, p. 243), this species has the habit of mounting aloft in parties of half a dozen or more and indulging in various aerial evolutions. Another merit it possesses is that of being an excellent bird for the table, but probably few in future will have the opportunity of tasting its good qualities. Dr. Gadow has de-

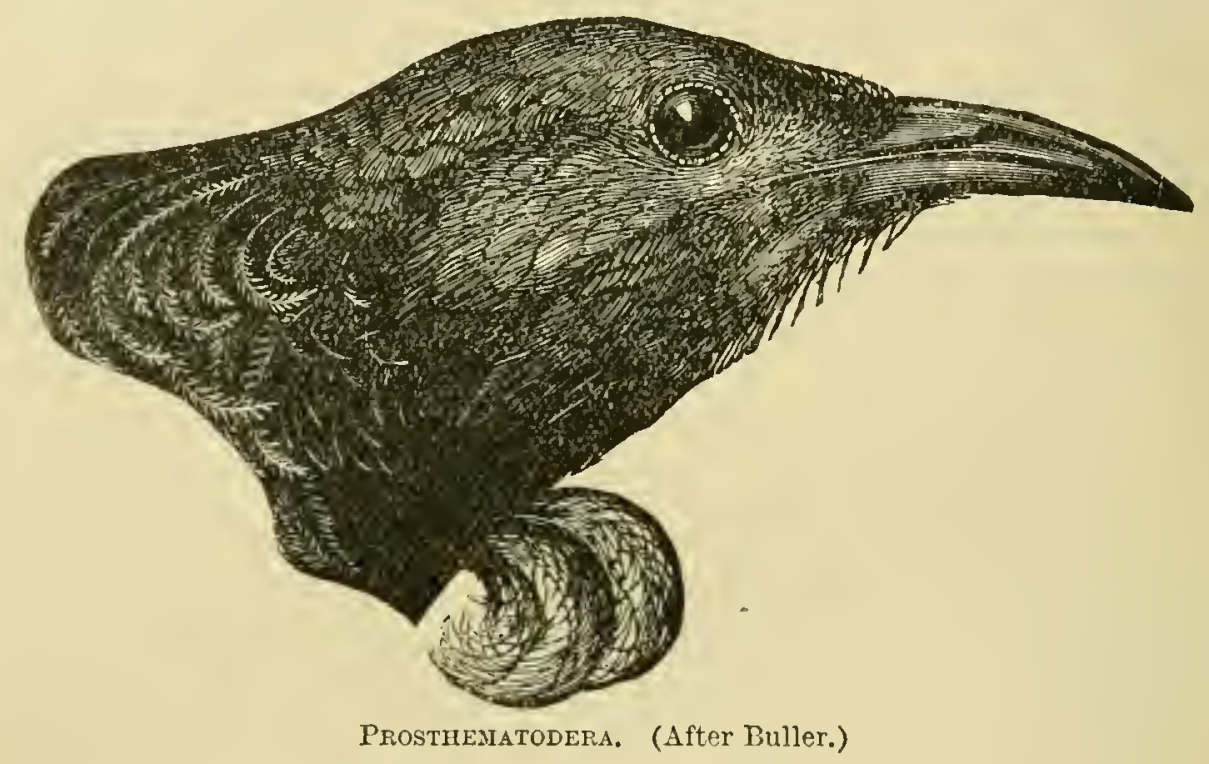

scribed (Proc. Zool. Soc. 1883, pp. 67-69, pl. xvi. figs. 6, 7 ) the peculiar lingual apparatus and mode of feeding of this bird.

PARSON-GULL, a common name for the adult of either of the Black-backed GuLLS, Larus marinus and fuscus.

PARTRIDGE, in older English Pertriche, Scottish Patrick, Dutch Patrijs, French Perdrix, all from the Latin Perdix, which word in sound does not imitate badly the eall-note of this bird, so well known throughout the British Islands and the greater part of Europe $^{2}$ as to need no description or account of its liabits here. The English name properly denotes the only species indigenous to Britain, often nowadays called the Grey Partridge ${ }^{3}$ (to distinguish it from others, of which more presently), the Perdix cinerea of

I Sir W. Buller tells us how that having addressed a Mraori assemblage in the course of a negotiation, at the end of his speech the chief's tame Tui exclaimed "Tita" (false), whereupon the dignitary remarked that the arguments were no doubt good, but they had failed to convince his bird.

2 More than one local form has been said to exist on the continent if not in Britain. One such, inhabiting the north-west of Spain, seems worthy of notice. It was described by Dr. Reichenow (Journ. für Orn. 1892, p. 226) as P. Tispaniensis, which Dr. Sharpe (Zool. Ree. xxix. Aves, 1. 27) has rendered P. hispaniolensis.

3 In India the name Grey Partridge is used for Ortygornis ponticcrianus, which is perhaps a Fraxcolix (cf. Jerdon, B. Ind. iii. 1. 569). 
ornithologists, a species which may be regarded as the model gamebird-whether from the excellence of the sport it affords in the field, or the no less excellence of its flesh at table, which has been esteemed from the time of Martial to our own-while it is on all hands admitted to be wholly innocuous, and at times beneficial to the agriculturist. It is an undoubted fact that the Partridge thrives with the highest system of cultivation; and the lands that are the most carefully tilled, and bear the greatest quantity of grain and green crops, generally produce the greatest number of Partridges. Yielding perhaps in economic importance to the Red Grouse, what may be called the social influence of the Partridge is greater than that excited by any other wild bird, for there must be few rural parishes in the three kingdoms of which the inhabitants are not more or less directly affected in their movements and business by the coming in of Partridge-shooting, and therefore a few words on this theme may not be out of place.

From the days when men learned to "shoot flying" until the latter half of this century, dogs were generally if not invariably used to point out where the "covey," as a family-party of Partridges is called, was lodged, and the greatest pains were taken to break in the "pointers" or "setters" to their duty. In this way marvellous success was attained, and the delight lay nearly as much in seeing the dogs quarter the ground, wind and draw up to the game, helping them at times (for a thorough understanding between man and beast was necessary for the perfection of the sport) by word or gesture, as in bringing down the bird after it had been finally sprung. There are many who lament that the old-fashioned practice of shooting Partridges to dogs has, with rare exceptions, fallen into desuetude, and it is commonly believed that this result has followed wholly from the desire to make larger and larger bags of game. The opinion has a certain amount of truth for its base; but those who hold it omit to notice the wholly changed circumstances in which Partridge-shooters now find themselves. In the old days there were plenty of broad, tangled hedgerows which afforded permanent harbour for the birds, and at the beginning of the shooting-season admirable shelter or "lying" (to use the sportsman's word) was found in the rough stubbles, often reaped knee-high, foul with weeds and left to stand some six or eight weeks before being ploughed, as well as in the turnips that were sown broadcast. Throughout the greater part of England now the fences are reduced to the narrowest of boundaries and are mostly trimly kept; the stubbles-mown, to begin with, as closely as possible to the ground-are ploughed within a short time of the corn being carried, and the turnips are drilled in regular lines, ofiering inviting alleys between them along which Partridges take foot at any unusual noise. Pointers in such a district-and to this 
state of things all the arable part of England is tending-are simply useless, except at the beginning of the season, when the young birds are not as yet strong on the wing, and the old birds are still feeble from moulting their quill-feathers. Of late years therefore other modes of shooting Partridges have had to be employed, of which methods the most popular is that known as "driving"-the "guns" being stationed in more or less concealment at one end of the field, or series of fields, which is entered from the other by men or boys who deploy into line and walk across it making a noise. It is the custom with many to speak depreciatingly of this proceeding, but it is a fact that as much knowledge of the ways of Partridges is needed to ensure a successful day's "driving" as was required of old when nearly everything was left to the intelligence of the dogs, for the course of the birds' flight depends not only on the position of the line of beaters, but almost on the station of each person composing it, in relation to the force and direction of the wind and to the points on which it is lesired that the Partridges should converge. Again, the skill and alacrity needed for bringing down birds flying at their utmost velocity, and often at a considerable height, is enormously greater than that which sufficed to stop those that had barely gone 20 yards from the dog's nose, though admittedly Partridges rise very quickly and immediately attain great speed. Moreover, the shooting of Partridges to pointers came to an end in little more than six weeks, whereas "driving" may be continued for the whole season, and is never more successful than when the birds, both young and old, have completed their moult, and are strongest upon the wing. But, whether the new fashion be objectionable or not, it cannot be doubted that the old one could not be successfully restored without a reversion to the slovenly methods of agriculture followed in former years, and therefore is as impossible as would be a return to the still older practice of taking Partridges in a setting-net, described by Gervase Markham or Willughby.

The Partridge has doubtless largely increased in numbers in Great Britain since the beginning of the present century, when so much down, heath and moorland was first brought under the plough, for its partiality to an arable country is very evident. It has been observed that the birds which live on grass lands or heather only are apt to be smaller and darker in colour than the average; but in truth the species when adult is subject to a much greater variation in plumage than is commonly supposed, and the well-known chestnut horse-shoe mark, generally considered distinctive of the cock, is very often absent. ${ }^{1}$ In Asia our Partridge seems

1 Mr. W. R. Ogilvie Grant has indicated certain claracters in the plumage of the two sexes of this species whereby they may be unfailingly distinguished. In the adult cock the sides of the neck are grey, but in the hen olive-brown, while 
to be unknown, but in the temperate parts of Eastern Siberia its place is taken by a very nearly allied form, $P$. barbata, and in Tibet there is a bird, $P$. hodgsonia, which can hardly with justice be generically separated from it. The relations of some other forms inhabiting the Indian Region are at present too obscure to make any notice of them expedient here.

The common Red-legged Partridge of Europe, generally called the French Partridge, Caccabis rufa, seems to be justifiably considered the type of a separate group. ${ }^{1}$ This bird was introduced into England toward the end of the eighteenth century, and has established itself in various parts of the country, notwithstanding a widely-spread, and in some respects unreasonable prejudice against it. It has certainly the habit of trusting nearly as much to its legs as to its wings, and it thus incurred the obloquy of old-fashioned sportsmen, whose dogs it vexatiously kept at a running-point; but when it was also accused of driving away the grey Partridge, the charge only shewed the ignorance of those that brought it, for as a matter of fact the French Partridge rather prefers ground which the common species avoids - such as the heaviest clay-soils, or the most infertile heaths. But even where the two species meet, the present writer can declare from the personal observation of many years that the alleged antipathy between them is imaginary, and unquestionably in certain parts of the country the "head of game" has been increased by the introduction of the foreigner. ${ }^{2}$ The French nearly each feather shews a buff shaft-stripe. Again the median upper wingaoverts in the cock are of a sandy-brown blotched with chestnut and black transverse lines, while in the hen the corresponding feathers are blackish-brown with conspicuons buff crossbars. I am much indebted to Lord Lilford and Mr. Beilby Oakes for kindly informing me that, after examining a great many Partridges, they can wholly confirm Mr. Grant's observations, which having been originally published in a newspaper (Field, 21 Nov. 1891 and 9 April 1892), and only incidentally mentioned by him in a scientific work (Cat. B. Br. Muss. xxii. p. 185) will be new to many persons.

I The late Prof. Parker first (Trans. Zool. Soc. v. p. 155) and, after him, Prof. Huxley (Proc. Zool. Soc. 1868, pp. 299-302) pointed out that the true Galline offer two types of structure, "one of which may be called Galline, and the other Tetraonine," to use the latter's words, though he is "by no means clear that they do not graduate into one another" ; and, according to the characters assigned by him, Caccabis lies "on the Galline side of the boundary," while Perdix belongs to the Tetraonine group. Further investigation of this matter is very desirable, and, with the abundant means possessed by those who have access to zoological gardens, it might easily be carried ont.

2 It is a singular fact that the game-preservers who object most strongly to the Red-legged Partridge are not agreed on the exact grounds of their objection. One party will declare that it vanquishes the Grey Partridge, while the other holds that, though the latter, the "English" Partridge, is much vered by the introdnced species, it invariably beats off the "Frenchman" ! 
Partridge has several congeners, all with red legs and plumage of similar character. In Africa north of the Atlas there is the Barbary Partridge, C. petrosa; in southern Europe another, C. saxatilis, which extends eastward till it is replaced by $C$. chukar, which reaches India, where it is a well-known bird. Two very interesting desert-forms, supposed to be allied to Caccabis, are the Ammoperdix heyi of North Africa and Palestine and the $A$. bonhami of Persia; but the absence of the metatarsal knob, or incipient spur, suggests (in our ignorance of their other osteological characters) an alliance rather to the genus Perdix. On the other hand the groups of birds known as Francolins and Snow-Partridges are generally furnished with strong but blunt spurs, and therefore probably belong to the Caccabine group. Of the former, containing many species, there is only room here to mention, in addition to what has been before (page 291) said of that which used to occur in Europe, the possibility, as some think, of its having been the Attagas or Attagen of classical authors, ${ }^{1}$ a bird celebrated for its exquisite flavour. Of the latter it is only to be said here that those of the genus Tetraogallus, often called Snow-Pheasant, are the giants of their kin, and that nearly every considerable range of mountains in Asia seems to possess its specific form; while the genus Lerwa contains but a single species, L. niricola, which is emphatically the Snow-Partridge of Himalayan sportsmen.

By English colonists the name Partridge has been very loosely applied, and especially so in North America. Where a qualifying word is prefixed no confusion is caused, but without it there is sometimes a difficulty at first to know whether the Ruffed Grouse (Bonasa umbellus) or the Virginian CoLIN (Ortyx virginianus) is intended, while the "Partridge-Hawk" of the same country is Astur atricapillus (GoshawK), and the "Partridge-Pigeon" of Australia is a species of Geophaps (BRONZE-WING).

PASSAGE-HAWK, in modern falconers' language, is one taken on its passage or migration, generally in Holland. It is therefore always what in old time was called a "Haggard," and when trained is more valued than a Nras.

PASSENGER-PIGEON, so-called in books, but in North America commonly known as the "Wild Pigeon," the Ectopistes migratorius of ornithology, the bird so famous in former days for its multitude, and still occasionally to be found plentifully in some parts of Canada and the United States, though no longer appearing in the countless numbers that it did of old, when a flock seen by Wilson was estimated to consist of more than 2230 millions. The

1 However, many naturalists have maintained a different opinion-some making it a WooDCock, a Godwit, or even the Hazel-hen (Grouse). The question has been well discussed by Lord Lilford (Ibis, 1862, pp. 352-356). 
often-quoted descriptions given by him and Audubon of Pigeonhaunts in the then "back-woods" of Kentucky, Ohio and Indiana need not here be reproduced. That of the latter was declared by Waterton to be a gross exaggeration if not an entire fabrication; but the critic would certainly have changed his tone had he known that, some hundred and fifty years earlier, Wild Pigeons so swarmed and ravaged the colonists' crops near Montreal that a bishop of his own Church was constrained to exorcise them with holy water as if they had been demons. ${ }^{1}$ The rapid and sustained flight of these Pigeons is also as well-established as their former overwhelming abundance-birds having been killed in the State of New York whose crops contained undigested grains of rice that must have been not long before plncked and swallowed in South Carolina or Georgia. The Passenger-Pigeon is about the size of a common Turtle-Dove, but with a long, wedge-shaped tail. The male is of a dark slate-colour above, and purplish-bay beneath, the sides of the neck being enlivened by gleaming violet, green and gold. The female is drab-coloured above and dull white beneath, with only a slight trace of the brilliant neck-markings ${ }^{2}$ (see PIGEON).

PASSERES, the name given by Linnæus to his Sixth Order of Birds, which though for a time set aside in favour of other designations, InSESSORES and the like, or modified into such a form as PASSERIN.${ }^{3}$, has been restored to use of late years, and approximately in its author's sense-the genera Certhia, Sitta, Oriolus, Gracula, Corvus and Paradisca, which he had placed in his PICA, being added, while Caprimulgus, the portion of Hirundo containing the SwIFTs, and Columba have been removed. For further subdivision of the Order, which, though offering comparatively little variation of essential importance, comprehends far more genera and species than all the others put together, see INTRODUCTION.

PASSERINA, a group so named of Nitzsch in 1820 (Deutsche Archiv für Physiol. vi. p. 253) to include the genera Sturnus, Oriolus, Lanius, Muscicapa, Ampelis, Hirundo, Turdus, Accentor, Sylvia, Motacilla, Anthus, Alauda, Parus, Sitta, Certlica (with Tichodroma),

1 Voyages du Baron de la Hontan dans l'Amerique septentrionale, ed. 2, Amsterdam: 1705, vol. i. pp. 93, 94. In the first edition, published at The Hague in 1703 , the passage, less explicit in details but to the same effect, is at p. 80. The author's letter, describing the circumstance, is dated May 1687.

2 There are several records of the occurrence in Britain of this Pigeon, but in most cases the birds noticed cannot be supposed to have found their own way hither. One, which was shot in Fife in 1825 , may, however, have crossed the Atlantic unassisted by man.

${ }_{3}$ The names Passeriformes and lately even Passeridx(!) have been in some instances employed; with very slight or no modification they signify the same thing as Passerinz: 
Limberiza, Fringille, Loria, Cinclus(?) and Corus-thus differing somewhat from Johannes Müller's application of the cognate term

PASSERINI (AThandl. K. Akar. Berlin, Phys. T5\% 184i, p. $366)$, which he regarded as equiralent to the Order InsEssones (as it was then called), separating its members into Passerini Polmayodi (or Oscines), Tracheophones and Picarit, though cantionsly declaring these to be not so much the names of groups, but as merely indicating different laryngeat, formations.

PASTOR, Temminck's generic name in 1815 for a beautiful bird, the Turdus roseus of Linnæus, very commonly known in English as the Rose-coloured Pastor, one of the Stumida (STARLING), which is not an infrequent visitor to the British Islands. It is a

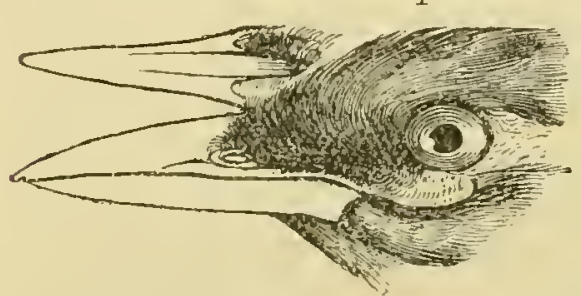

PAston. (After Swainson.) bird of most irregular and erratic habits-a vast horde suddenly arriving at some place to which it may have hitherto been a stranger, and at once making a settlement there, leaving it wholly deserted so soon as the young are reared. This happened in the summer of 1875 at Tillafranca, in the province of Terona, the castle of which was occupied in a single day by some 12,000 or 14,000 birds of this species, as has been graphically told by Sig. de Betta (Atit del R. Ist. Veneto, ser. 5, vol. di.); but similar instances have been before recorded,_as in Bulgaria in 186 7 , near Smyrna in 1856, and near Odessa in 1844, to mention only some of which particulars lave been published, ${ }^{2}$ and a concise account of them will be found in the Fourth Edition of Yarrell's British Birds (ii. pp. 245-250). The Rose-coloured Starling hardly ever occurs in Africa, but is a well-known bird in India, over nearly the whole of which it regularly appears, and generally in the cold weather.

PASTURE-BIRD, a name indiscriminately given in parts of North America and the West Indies to any of the STINTS and smaller SANDPIPERs met with on their antumnal migration, and then mostly resorting to the cattle-pastures.

PATELLA, a sesamoid bone interposed in the tendon of the cotensor-cruris muscle, and connected with the npper end of the TIEIA by the Patellar Ligament, which in old birds is often ossified. The most remarkable variations of condition are shewn in Colymlnis,

1 It is remarkable that on almost all of these occasions the locality pitched mpon has been, either at the time or soon after, ravaged by locusts, which the birds greedily devour. Another fact worthy of attention is that they are often observer to affect trees or shruhs bearing rose-colonred flowers, as Nerium olcander and Robinia viscosa, among the blossoms of which they themselves may easily eseape notice, for their llumage is rose-pink and black shot with blue. 
where the Patella is reduced to a small ossicle within the tendon, its fuuction being taken by the greatly-developed pyramidal processus tibialis anterior, and in Podicipes and Hesperornis, where it is almost as large as the cnemial process with which it freely articulates.

PEACOCK (the first syllable from the Latin Pavo, in AngloSaxon Pawe, Dutch Paauw, German Pfan, French Paon), the bird so well known from the splendid plumage of the male, and as the proverbial personification of pride. A native of the Indian peninsula and Ceylon, in some parts of which it is very abundant, its domestication dates from times so remote that nothing can be positively stated on that seore. Setting aside its importation to Palestine by Solomon (1 Kings x. 22; 2 Chron. ix. 21), its assignment in classical mythology as the favourite bird of Hera or Juno testifies to the early acquaintance the Greeks must have had with it; but, though it is mentioned by Aristophanes and other older writers, their knowledge of it was probably very slight until after the conquests of Alexander. Throughout all succeeding time, however, it has never very willingly rendered itself to domestication, and, retaining much of its wild character, can hardly be accounted an inhabitant of the poultry-yard, but rather an ornamental denizen of the pleasure-ground or shrubbery; while, even in this condition, it is seldom kept in large numbers, for it has a bad reputation for doing mischief in gardens, it is not very prolific, and, though in earlier days highly esteemed for the table, ${ }^{1}$ it is no longer considered the delicacy it was once thought.

As in most cases of domestic animals, pied or white varieties of the ordinary Peacock, Pavo cristatus, are not unfrequently to be seen; and, though lacking the gorgeous resplendence for which the common bird stands unsurpassed, they are valued as curiosities. Greater interest, however, attends what is known as the "japanned" Peacock, often erroneously named the Japanese or Japan Peacock, a form which has received the name of $P$. nigripennis, as though it were a distinct species. In this form the cock, beside other less conspicuous differenees, has all the upper wing-coverts of a deep lustrous blue instead of being mottled with brown and white, while the hen is of a more or less greyish-white, deeply tinged with dull yellowish-brown near the base of the neek and shoulders. It "breeds true"; but occasionally a presumably pure stock of birds of the usual coloration throws out one or more having the

a Classical anthors contain many allusions to its high appreciation at the most sumptuous banquets; and mediæval bills of fare on state occasions nearly always include it. In the days of chivairy one of the most solemn oaths was taken "on the Peacock," which seems to have been served up garnished with its gaudy .)lumage. 
"japanned" plumage, leading to the conchision that the latter may be due to "reversion to a primordial and otherwise extinct condition of the species," and it is to be observed that the "japanned" male has in the coloration of the parts mentioned no little resemblance to that of the second indubitably good species, the P. muticus (or P. spicifer of some writers) of Burma and Java, though the character of the latter's crest-the feathers of which are barbed along their whole length instead of at the tip only-and

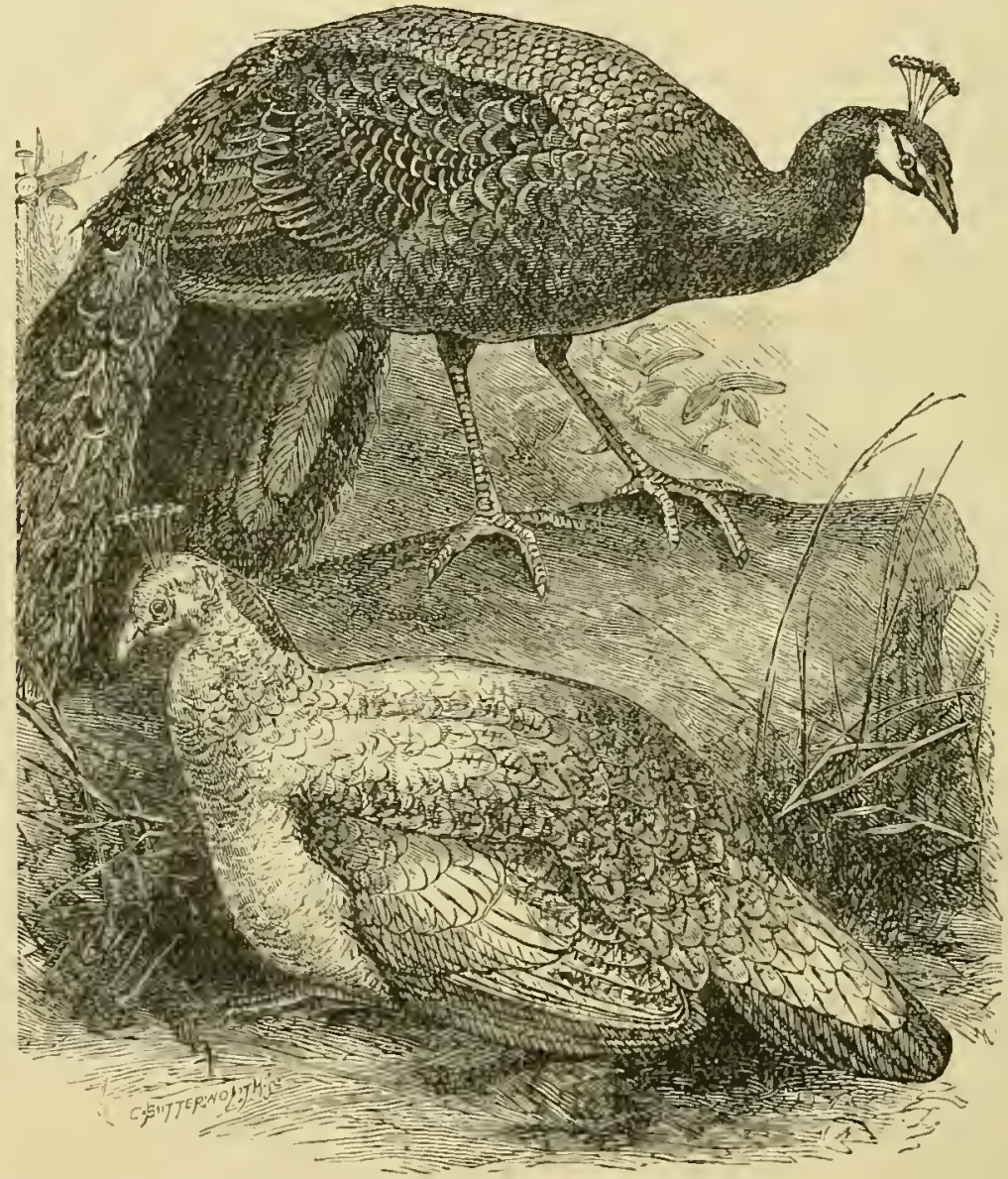

"J.APANNED" Peafowls. (After Wolf in Elliot's 'Phasienida'.)

its golden-green neck and breast furnish a ready means of distinction. The late Sir R. Heron was confident that the "japanned" breed had arisen in England within his memory, ${ }^{1}$ and Darwin (Anim. und Plants under Domestic. i. pp. 290-292) was inclined to believe it only a varicty; but its abrupt appearance, which rests on indisputible evidence, is most suggestive in the light that it may

I This may have been the case as regards England; but I have a distinct recollection of having seen a bird of this form represented in an old Dutch picture, though when or where I cannot state. An instance of its sudden prodnction from the ordinary stock occurred to my own knowledge as mentioned by Mr: Darwin. cf. corrigenda. 
one day throw on the question of evolution as exhibited in the origin of "species." It should be stated that the "japamned" bird is not known to exist anywhere as a wild race.

The Peafowls belong to the Gullina, from the normal members of which they do not materially differ in structure; and, though by some systematists they are raised to the rank of a Family, I'aconida, most are content to regard them as a subfamily of Phasianida (Pheasant). ${ }^{1}$ Akin to the genus Puio is Polyplectrum, of which the males are armed with two or more spurs on each leg,

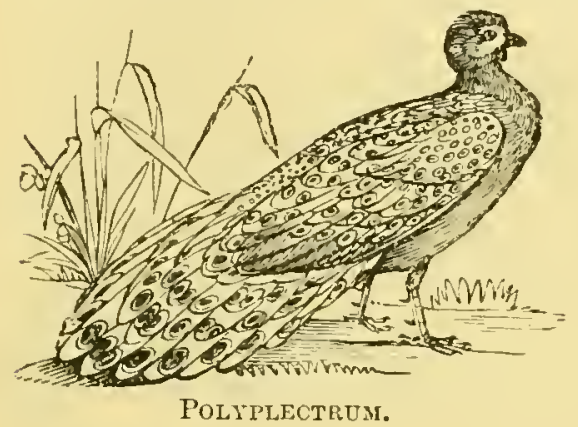

(After Swainson.)

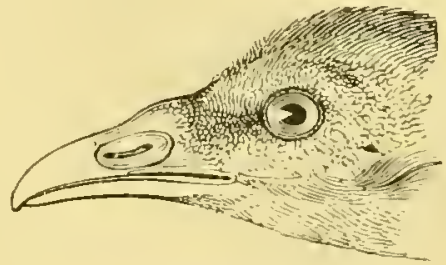

Argus-Preasant,

and near them is generally placed the genus Argusiams, containing the ARGUs-Pheasants, remarkable for their wonderfully ocellated plumage, and the extraordinary length of the secondary quills of their wings, as well as of the tail-feathers. It must always be remembered that the so-called "tail" of the Peacock is formed not by the rectrices or true tail-feathers, but by the singular development of the tail-coverts, a fact of which any one may be satisfied by looking at the bird when these magnificent plumes are erected and expanded in disk-like form, as is his habit when displaying his beauty to his mates.

PEASEWEEP (spelling uncertain), the Scottish form of PEWIT, but applied to the LAPWING only.

PECTEN, a fan-like lamella which projects into the posterior chamber of the EYE, near the entrance of the optic nerve, and is found in all Birds except Apteryx.

PECTINEAL PROCESS (so called from the attachment to it of the Pectineal muscle), a process, near the anterior margin of the acetabulum (see OdonToritites, fig. $4 a$, page 650), and is in Birds formed by the os pubis alone, by the os pubis and ilium jointly, or occasionally by the ilium alone. Then formed wholly by the pubic bone and well developed, as in Apteryx and Centrococcyx, it strongly resembles the so-called "prepubis" of Dinosaurs and other Reptiles.

1 As Mrr. Elliot does in his magnificent Monograph of the Phasianida. 
PEEP, used chiefly in North America for any of the STINTs or small SANDPIPERS from their cry.

PEGGY, a common name of the WhiteTHRoAT.

PELARGOMORPH Ee, Prof. Huxley's name (Proc. Zool. Soc. 1867, p. 461) for that group of DeSMOGNATHe which contains the Storks, Herons, Ibises and Spoonbills.

PELICAN (Fr. Pélican, Lat. Pelecanus or Pelicanus), a large fisheating water-fowl, remarkable for the enormous pouch formed by the extensible skin between the lower jaws of its long, and apparently formidable but in reality very weak, bill. The ordinary Pelican, the Onocrotalus of the ancients, to whom it was well known, and the Pelecanus onocrotalus of ornithologists, is a very abundant bird in some districts of South-eastern Europe, South-western Asia, and North-eastern Africa, occasionally straying, it is believed, into the northern parts of Germany and France; but the possibility of such wanderers having escaped from confinement is always to be regarded, ${ }^{1}$ since few zoological gardens are without examples which are often in the finest condition. Its usual haunts are the shallow margins of the larger lakes and rivers, where fishes are plentiful, since it requires for its sustenance a vast supply of them, pursuing them under water, and rising to the surface to swallow those that it has captured in its capacious pouch. The nest is formed among the reeds that border the water's it frequents, placed on the ground and lined with grass. Therein two eggs, with white, chalky shells, are commonly laid. The young during the first twelvemonth are of a greyish-brown, but this dress is slowly superseded by the growth of white feathers, until when mature almost the whole plumage, except the black primaries, is white, deeply suffused by a rich blush of rose or salmon-colour, passing into yellow on the crest and lower part of the neck in front. A second and somewhat larger species, P. crispus, also inhabits Europe, but in smaller numbers. This, when adult, is readily distinguishable from the ordinary bird by the absence of the blush from its plumage, and by the curled feathers that project from and overhang each side of the head, which with some differences of coloration of the bill, pouch, bare skin round the eyes, and irides give it a wholly distinct expression. ${ }^{2}$ Two specimens of the humerus of as many Pelicans have been found in the English fens (Ibis, 1868, p. 363; Proc. Zool. Soc. 1871, p. 702),

1 This caution was not neglected by the prudent, cven so long ago as Sir Thomas Browne's days; for he, recording the occurrence of a Pelican in Norfolk, was careful to notice that about the same time one of the Pelicans kept by the king (Charles II.) in St. James's Park had been lost. Char'eton says (Onomast. p. 94) they came from the Czar.

2 It is also said to have twenty-two rectrices, while the ordinary species has only eighteen. 
thus proving the former existence of the bird in England at no very distant period, and one of them being that of a young example points to its having been bred in this country. It is possible from their large size that they belonged to $P$. crispus. Ornithologists have been much divided in opinion as to the number of living species of the genus Pelecanus (cf. op. cit. 1868, p. 264; 1869, p. 571; 1871, p. 631) - the estimate varying from six to ten or eleven; but the former is the number recognized by M. Dubois (Bull. Mus. Belg. 1883). North America has one, P. erythrorhynchus, very similar to $P$. onocrotalus both in appearance and habits, but remarkable for a triangular, compressed, horny excrescence which is developed on the ridge of the male's bill in the breeding-season, and, as ascertained by Mr. Ridgway (Tois, 1869, p. 350), falls off without leaving trace of its existence when that is over ( $c f$. Moult, page 599). Australia has $P$. conspicillatus, easily distinguished by its black tail and wingcoverts. Of more marine habit are $P$. philippensis and $P$. fuscus, the former having a wide range in Southern Asia, and, it is said, reaching Madagascar, and the latter being common on the coasts of the warmer parts of both North and South America. ${ }^{1}$

PELVIS, that part of the trunk to which are attached the hind limbs, and consisting of a number of fused vertebræ, beside three coalescent portions on either side of the Median line-the Ilium, Ischiun and Os Pubis (see Skeletor).

PEN, said by Yarrell to be the technical name of the hen Mute Swar, the cock being called CoB.

PENELOPE, the generic name most inappropriately given by Merren to the GuANS and occasionally used as English.

PENGUIN, the name of a flightless sea-bird, ${ }^{2}$ but, so far as is

1 The genus Pelecanus as instituted by Linnæus included the Cormorant and Ganset as well as the true Pelicans, and for a long while these and some other distinet groups, as the SNAKE-BIRDS, Frigate-BIrDS, and TropiC-BIRDS, which have all the four toes of the foot connected by a web, were regarded as forming a single Family, Pelecanidæ; but this name has now been restricted to the Pelicans only, though all are still usually associated under the name STEganopodes. It may be necessary to state that there is no foundation for the renerable legend of the Pelican feeding her young with blood from her own breast, which has given her an important place in ecclesiastical heraldry, except that, as Mr. Bartlett has suggested (Proc. Zool. Soc. 1869, p. 146), the curious bloody secretion ejected from the mouth of the Fla irivgo may have given rise to the belief, through that bird having been mistaken for the "Pelican of the wilderness."

2 Of the three derivations assigned to this name, the first is by Drayton in 1613 (Polyolbion, Song 9), where it is said to be the Welsh pen gwyn, or "white head" ; the second, which seems to meet with Littré's approval, deduces it from the Latin pinguis (fat) ; the third supposes it to be a corruption of "pin-wing" (Ann. Nat. Hist. ser. 4, iv. p. 133), meaning a bird that has undergone the operation of pinioning or, as in one part at least of England it is commonly calleci

\section{ef.errig.}


known, first given, as in Hore's "Voyage to Cape Breton," 1536 (Hackluyt, Researches, iii. pp. 168-170), to one inhabiting the seas of Newfoundland, which subsequently became known as the Great Auk or GARE-FowL; and, though the French equivalent Pingouin ${ }^{1}$ preserves its old application, at the present day, the word Penguin is by English ornithologists always used in a general sense for certain Birds inhabiting the Southern Ocean, called by the French Manchots, the Spheniscida of ornithologists, which in some respects form perhaps the most singular group of the whole Class, or at least we may say of the Carinatz. For a long while their position was very much misunderstood, some of the best of recent or even living systematists having placed them in close company with the Alcida (AUKS), to which they bear only a relationship of analogy, as indeed had been perceived by a few ornithologists, who recognized in the Penguins a very distinct Order, InPennes. The view of the latter is hardly likely to be disputed in future, now that the anatomical researches of MM. Paul Gervais and Alix (Journ. de Zool. 1877, pp. 424-470), M. Filhol (Bull. Soc. Philomath. ser. 7, vi. pp. 226-248), and above all of Prof. Watson (Zoology, Voy. Challenger, part xviii.) have put the independent position of the Spheniscidx in the clearest light. ${ }^{2}$ The most conspicuous outward character presented by the Penguins is the total want of quills in their wings, which are beside

"pill-winging." In opposition to the first of these hypotheses it has been urged (1) that there is no real evidence of any Welsh discovery of the bird, (2) that it is very unlikely for the Welsh, if they did discover it, to have been able to pass on their name to English navigators, and (3) that it had not a white head, but only a patch of white thereon. To the second hypothesis Prof. Skeat (Etymol. Dict. p. 433) objects that it "will not account for the suffix -in, and is therefore wrong; besides which the 'Dutchmen' [who were asserted to be the authors of the name] turn ont to be Sir Francis Drake" and his men. In support of the third hypothesis MIr. Reeks wrote (Zoologist, ser. 2, p. 1854) that the people in Newfoundland who used to meet with this bird always prononnced its name "Pin-wing." Prof. Skeat's enquiry (loc. cit.), whether the uame may not after all be South-American, is to be answered in the negative, since, so far as evidence goes, it was given to the North-American bird before the South-American was known in Enrope.

I Gorfou has also been used by some French writers, being a corruption of Geirfugl or Gare-fowl.

2 Though I cannot wholly agree with Prof. Watson's conclusions, his remarks (pp. 230-232) on the "Origin of the Penguins" are worthy of all attention. He considers that they are the surviving members of a gronp that branched off early from the primitive "avian" sten, but that at the time of their separation the stem had diverged so far from Reptiles as to possess true wings, though the metatarsal bones had not lost their distinctness and become fused into the single bone so characteristic of existing Birds. The ancestral Penguin, he argues, must have had functional wings, the museles of which, through atrophy, have been converted into non-contractile tendinons bands, and this view agrees practieally with that taken by Prof. Fürbringer and Dr. Gadow. 
as incapable of flexure as the flippers of a Cetacean, though they move freely at the shoulder-joint, and some at least of the species occasionally make use of them for progressing on land. In the water they are most efficient paddles, and are usually, if not always, worked, as birds' wings commonly are ( $c f$. FLIGHT, pp. 267-269), with a rotatory action. The plumage which clothes the whole body, leaving no bare spaces, generally consists of small scale-like feather's, many of them consisting only of a simple shaft without the development of barbs; but several of the species have the head decorated with long cirrhous tufts (MACCARONI), and in some the tail-quills, which are very numerous, are also long. ${ }^{1}$ In standing these birds preserve an upright position, generally resting on the "tarsus" 2 alone, but in walking or running on land this is kept nearly vertical, and their weight is supported by the toes as well.

The most northerly limit of the Penguins' range in the Atlantic is Tristan da Cunha, and in the Indian Ocean Amsterdam Island, but they also occur off the Cape of Good Hope and along the south coast of Australia, as well as on the south and east of New Zealand, while in the Pacific one species at least extends along the west coast of South America and to the Galapagos; but north of the equator none are found. In the breeding-season they resort to the most desolate lands in higher southern latitudes, and indeed have been net with as far to the southward as navigators have penetrated. Possibly the Falliland Islands may still be regarded as the locality richest in species, ${ }^{3}$ though, whatever may have been the case once, their abundance there as individuals does not now nearly approach what it is in many other places, owing to the ravages of man, whose advent is always accompanied by massacre and devastation on an enormous scale-the habit of the helpless birds, when breeding, to congregate by hundreds and thousands in what are called "Penguinrookeries" contributing to the ease with which their slaughter can

1 The pterylographical characters of the Penguins are well described by Mr. Hyatt (Proc. Boston Soc. Nat. Hist. 1871). Mr. Bartlett has observed (Proc. Zool. Soc. 1S 7 , pp. 6-9) that, instead of monlting in the way that birds ordinarily do, Penguins, at least in passing from the immature to the adult dress, cast off the short scale-like feathers from their wings in a manner that he compares to "the shedding of the skin in a serpent."

2 The three metatarsals in the Penguins are not, as in other Birds, united for the whole of their length, but only at the extremities, thus preserving a portion of their originally distinct existence, a fact probably attributable to arrest of clevelopment, since the researches of Prof. Gegenbaur shew that the embryos of all Birds, so far as is known, possess these bones in an independent condition. More recently Prof. Marsh has found that in the Dinosaurian genus Ceratosanerus the metatarsals acquire a condition very similar to that which they present in the Penguins (Am. Journ. Sc. Aug. 18S4).

${ }^{3}$ An interesting account of the Penguins of these islands is given by Capt. Abbott (Tois, 1860, P. 336). 
be effected. Incapable of escape by flight, they are yet able to make enough resistance or retaliation (for they bite hard when they get the chance) to excite the wrath of their murderers, and this only brings upon them greater destruction, so that the interest of nearly

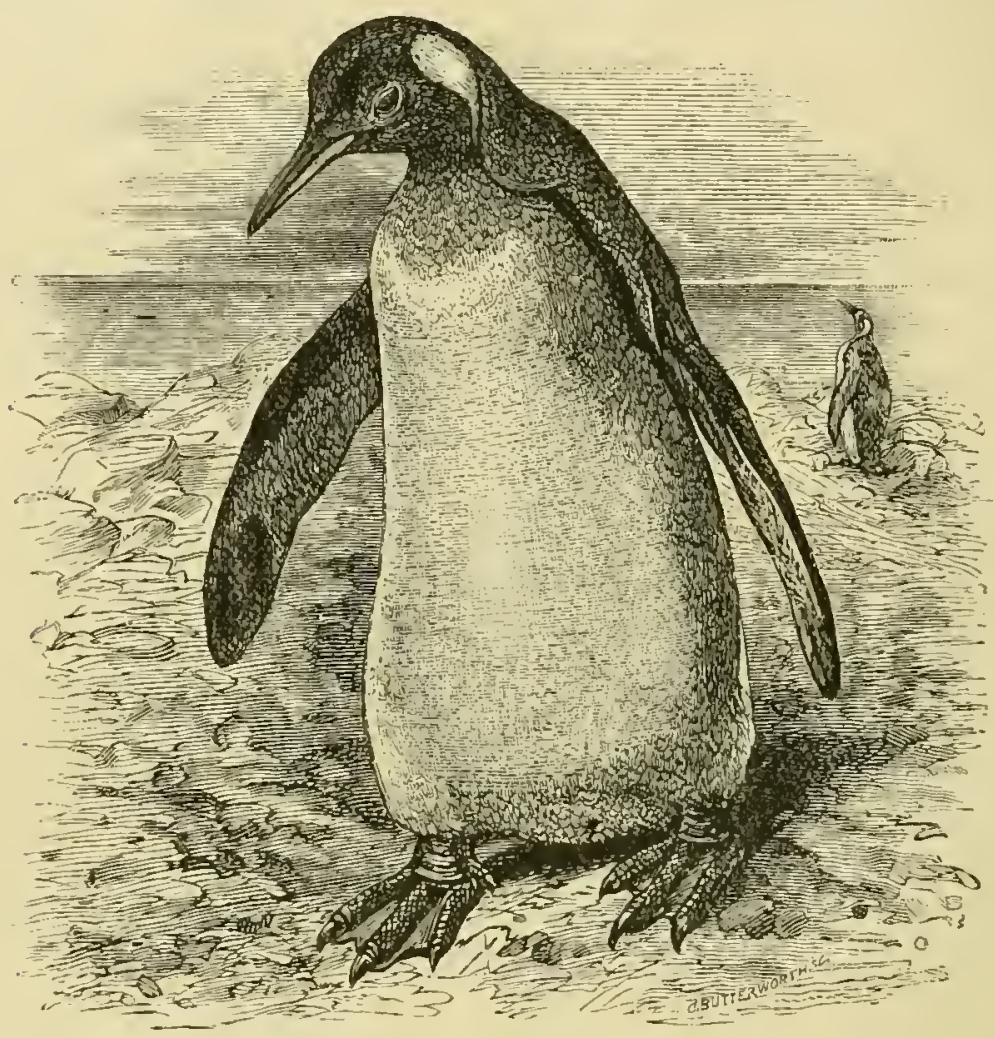

Ining-Penguin. (From living example in the Zoological Gardens.)

all the numerous accounts of these "rookeries" is spoilt by the disgusting details of the brutal havoc perpetrated upon them (cf. JoHNNY).

The Spheniscida have been divided into at least eight genera, but three, or at most four, seem to be all that are needed, and three can be well distinguished, as pointed out by Dr. Cones (Proc. Ac. $N$. Sc. Philad. 1872, pp. 170-212), by anatomical as well as by external characters. They are (1) Aptenodytes, easily recognized by its long and thin bill, slightly decurved, from which Pygoscelis, as Prof. Watson has shewn, is hardly distinguishable ; (2) Eudyptes, in which the bill is much shorter and somewhat broad; and (3) Spheniscus, in which the shortish bill is compressed and the maxilla ends in a conspicuous hook. Aptenodytes contains the largest species, among them those known as the "Emperor" and "King" Penguins, $A$. patagonica and $A$. longirostris. ${ }^{1}$ Three others belong also to this

1 Some authorities (ef. Sclater, Ibis, 1888, pp. 325-334) prefer calling these species $A$. forsteri and $A$. pennanti. An example of the former, weighing is pounds, was, according to Dr. MrCormick (Voyages of Discovery, i. P. 259), obtained by the 'Terror' in January 1842. 
genus, if Pygoscelis (JoHnNy) be not recognized, but they seem no further to require remark. Eudyptes, containing the crested Penguius (known to sailors as Rock-hoppers or MACCARonis), would appear to have five species, and Spheniscus (JACKASS) four, among which $S$. demersus, the well-known "Cape Penguin," and S. mendiculus, which occurs in the Galapagos, and therefore has the most northerly range of the whole group, alone need notice here. ${ }^{1}$

PERCHERS, the rendering by popular writers of the word INSESSORES, now almost wholly abandoned by systematists.

PEREGRINE (Lat. peregrinus, wandering) an adjective often mistaken for a substantive, and used as an abbreviation of Peregrine FALCON, an expression that originally meant one of foreign origin, regardless of the species.

PERISTEROMORPH $\not E$, according to Prof. Huxley's taxonomy (Proc. Zool. Soc. 1867, pp. 459, 460), the sixth group of ScHizoGNATH $\approx$, consisting of the Columbre (Dove, Pigeon), but not to be confounded with his

PERISTEROPODES, a section of ALECTOROMORPH $\approx$ established the year after (op. cit. 1868, p. 296), composed of the CuRAssows and Megapodes, being so called from the Pigeon-like structure of their feet, in which the hallux is long and on a level with the other toes, instead of being short and raised as in the other section, Alectoropodes, and it was a consideration of this difference that led to his important conclusions in regard to the GEOGRAPHICAL Distribution of Mammals and Birds before mentioned (page 313).

PERITONEUM, a thin layer of connective tissue lining the whole of the body-cavity, and enveloping the viscera, as well as attaching the intestinal folds to each other and to the vertebral column as MESENTERY.

PETREL, the name applied in a general way to a group of Birds (of which more than 100 species are recognized) from the habit which some of them possess of apparently walking on the surface of the water as the apostle St. Peter (of whose name the word is a diminutive form) is recorded (Matt. xiv. 29) to have done. For a long while the Petrels were ranked as a Family, under the name of Procellariidx, ${ }^{2}$ and thought to be either very nearly allied to the Laridx (GULL), or intermediate between that Fanily and the STEGANOPODES; but this opinion has gradually given way,

1 The generic and specific distribution of the Penguins is the subject of an excellent essay by Prof. Alphonse Milne-Edwards in the Annales des Sciences Naturelles for 1880 (vol. ix. art. 9, pp. 23-81), of which there is a German trans. lation in the Mitthcilungen of the Ornithological Union of Vienna for 1883 (pp. $179-186,210-222,238-241$ ).

2 Most commonly but erroneously spelt Procellaridæ. 
and it is now hard to resist the conclusion that they have to be regarded as an "Order," to which the name Tubinares has been applied from the tubular form of their nostrils, a feature possessed in greater or less degree by all of them, and one by which each may at a glance be recognized. They had been variously subdivided; but to little purpose until the anatomy of the group was subjected to comparative examination by Garrod and $\mathrm{IV}$. A. Forbes, the latter of whom summed up the results obtained by limself and his predecessor in an elaborate essay (forming part ix. of the Zoology of the voyage of the 'Challenger') which shewed determinations that differed greatly from any that had been reached by prior systematists. According to these investigators, the Tubinares are composed of two Families,

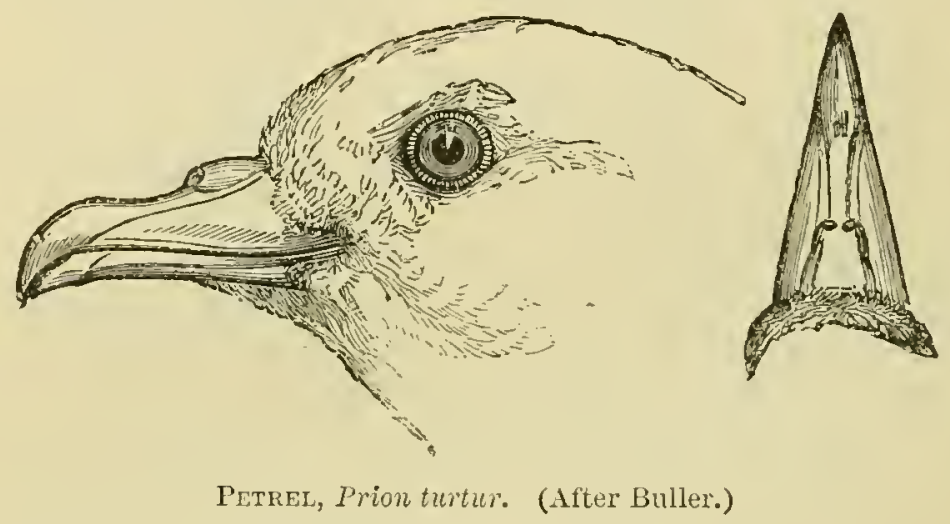

Procellariula and Oceanitida, whose distinctness had hardly before been suspected ${ }^{1}$ - the latter consisting of four genera not very much differing in appearance from many others, while the former includes as subfamilies Diomedeina (Albatros), witl three genera, Diomedec, Thalassiarche and Phobetriu, and the true Petrels, Procellariina, in which last are combined forms so different externally and in habit as the Diving-Petrels, Pelecanoides or Hulodrona, the Storm-Petrels, Procellaria, the Flat-billed Petréls, Prion, the Fulmar, the SHzalWATERs and others. Want of space forbids us here dwelling on the character's assigned to these different groups, or the means which have led to this elassification of it, set forth at great length in the essay cited where also will be found copious references to previous studies of the Petrels. ${ }^{2}$

1 It is due to Prof. Coues to state that in 1864 he had deelared the gentis Occanites, of which he only linew the external eharacters, to be "the most distinct and remarkable" of the "Procllarica," though he never thought of making it the type of a separate Family.

2 Among these may here be espeeially mentioned those of Quoy and Gaimard (Ann. Sc. Nat. v. pp. 123-155, and Voy. de l'Uranie et la Physicienne, Zool. pp. 142-169) ; Jaequinot (Comptes Renchus, 1844, pp. 353-358, and Zool. Voy. au, Pol Sud, iii. pp. 128-152) ; Prof. Coues (Proc. Acut. Philad. 1864, pp. 72-91, 116144, and 1866, pp. 25-33, 134-197); Mr. Salvin (On. Miscell. ii. 1p. 223-238, 
Petrels are dispersed throughout all the scas and oceans of the world, and some species apparently never resort to land except for the purpose of nidification, though nearly all are liable at times to be driven ashore, and often very far inland, by gales of wind. ${ }^{1}$

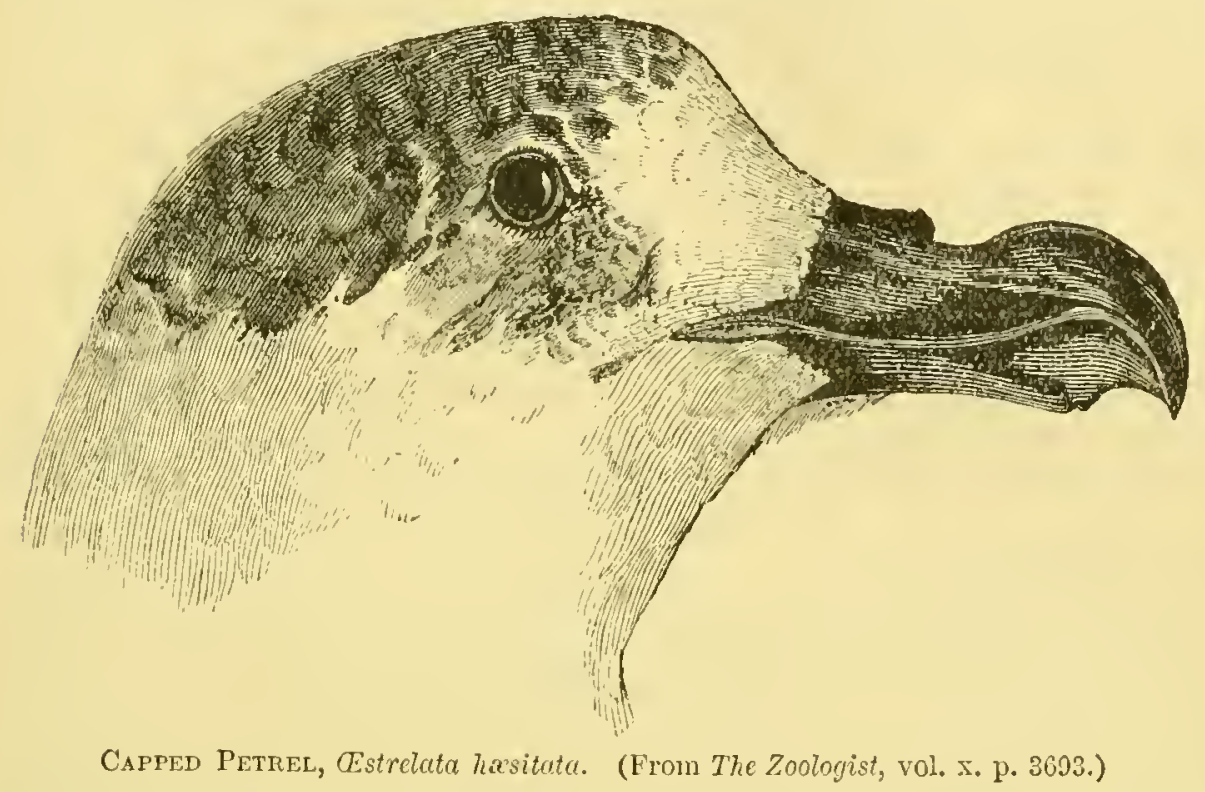

Wanderers as they may be, there is reason to think that attachment to their home is a feeling as strong with them as with other birds, and it is only now beginning to be clear that until we know the breeding-place or places of each species-and some seem to be extremely restrieted in this respect-we shall know very little to the point about their geographical distribution. But this knowledge is not easily obtained, for during the breeding-season many of these bircls are almost wholly nocturnal in their habits, passing the day in holes of the ground, or in clefts of the rocks, in which they generally nestle, the hen of each pair laying a single white egg, sparsely speckled in a few species with fine reddish dots. Of those species that frequent the North Atlantic, the common Storm-Petrel, Procellaric pelagica, a little bird which has to the ordinary eye rather" the look of a Swift or Swallow, is the "Mother Carey's chicken" of 249-257; and Zoology, Foy. 'Challenger,' pt. viii. pp. 140-149); and the distribution of the group in the Southern Ocean is treated by Prof. A. MilneEdwards (Ann. Sc. Nct. 1882, Zool. ser. 6, xiii. art. 4; Germanicè, Mitth. Ornith. Ter. in Wien, 1884).

1 Thus CEstreluta hasitata, the Capped Petrel, a species whose proper home seems to have been in Guadeloupe and Dominica (where it was known as the "Diablotin"), has even occurred in the State of New York, near Boulogne, in Norfolk and in Hnugary (Ibis, 1884, p. 202)! But there is reason to fear that this species is nearly extinct, though an example is recorded (Auk, 1893, P. 361) in Virginia, some 200 miles from the sea, in August 1893, two days after a great storm, while its congener, $\mathscr{E}$. jumaiccnsis, luns a risk of the same fate (see ExTErMisation, p. 227, note 4). 
sailors, and is widely believed to be the harbinger of bad weather; but seamen hardly discriminate between this and others nearly resembling it in appearance, such as Leach's or the Fork-tailed Petrel, Cymochorea leucorrhoa, a rather larger but less common bird, and Wilson's Petrel, Oceanites oceanicus, the type of the Family Oceanitidx mentioned above, which is more common on the American side. But it is in the Southern Ocean that Petrels most abound, both as species and as individuals. The Cape-Pigeon or Pintado Petrel, Daption capensis, is one that has long been well known, while those who voyage to or from Australia, whatever be the route they take, are certain to meet with many more species, some, as Ossifraga gigantea, as large as Albatroses, and several of them called by sailors by a variety of choice names, generally having reference to the strong smell of musk emitted by the birds, among which that of "Stink-pot" is not the most opprobrious. None of the Petrels are endowed with any brilliant colouring--sooty-black, grey of various tints (one of which approaches to and is often called "blue"), and white being the only hues their plumage exhibits; but their graceful flight, and their companionship when no other life is visible around a lonely vessel on the widest of oceans, give them an interest to beholders, though this is too often marred by the wanton destruction dealt out by brutal or thoughtless persons who thus seek to break the tediousness of a long voyage.

PETTICHAPS, the name under which a bird, supposed to be that now commonly known as the Garden-WARBLER, Sylvia salicaria or hortensis, was sent from Yorkshire by Jessop to Willughby (Ornithologia, p. 158), and hence more or less frequently applied to that species; or, with the qualification of "Lesser," to the CHIFFCHAFF. The name was known in Lancashire a century later (Latham, Gen. Synops. ii. p. 413), but seems never to have been in general use in England. In 1873 the present writer obtained evidence (Yarrell, Br: B. ed. 4, i. p. 415) that it had not become obsolete near Sheffield where Jessop lived. It is also given as the name of a bird by Clare the Northamptonshire poet.

PEWEE, so called from its drawling note, ${ }^{1}$ a well-known North-American bird, Contopus virens, one of the Tyrannida (TrranTBIRD), extremely abundant in the eastern side of the continent, and represented by other species in the remainder of it.

PEIVIT, anciently Puet, the ordinary name of what is called in books the Black-headed GuLL, Larus ridibundus, in the inland localities affected by it for breeding. The great Pewit-pool at Norbury in Staffordshire visited by Ray and Willughby, 14th May 1662,

1 This is said to be in sharp contrist with that of its relative called in North America the PewrT. 
and well known from Plot's description (Hist. Staffordsh. pl. xix. pp. 231-233) had ceased to be occupied by the end of the last century, and most of the other stations throughout the country have been destroyed, some through drainage, but often by carelessness and occasionally by greediness-for the eggs are a valuable commodity, even as the young in old days were accounted ${ }^{1}$ - but there are still two of considerable size in England, Scoulton in Norfolk, and Twigmoor in Lincolnshire. The name Pewit, in Scotland Peaseweep, is now more commonly applied to the LAPWING, but in each case it was given from the bird's cry, as it is in North America to one of the TYRANT-BIRDs, Sayornis fusca, which is a general favourite there as a recognized harbinger of summer. ${ }^{2}$ To some ears its note sounds like "phebe," and as the "PHaEBE-bird" 3 it was first described by Pennant. In certain districts it bears the name of "Bee-eater," to which it is very likely entitled, and there it is not very popular with the owners of hives.

PHALANGES, the several bones composing the digits. In those of the hind limb (or Toes) the original and almost universal number is 2 for the HALLUX, and 3,4 and 5 for the second, third and fourth digits respectively. Exceptions are found in Cypselus and Panyptila (SwIFT), where the second, third and fourth toes have each 3 phalanges, in some of the Caprimulgi (NIGHTJAR), and in the singular genus Cholornis from Western China and of doubtful affinity, where the fourth digit is reduced to a mere stump. Of the wing-digits the Pollex has 2 phalanges, the index 2 or 3 , and the third 1 or 2 -the terminal phalanges being often very small or represented by cartilage only.

PHALAROPE, Brisson's maladroit rendering 4 of the "Cootfooted Tringa" of Edwards who, in 1741, shewed himself a better judge of its affinities than many others both before and after him, since for a long while some of the best authorities thought the Phalaropes allied to the COOT, whereas they are unquestionably Limicola, only somewhat modified in accordance with their habit of swimming. There are three species, each possessing a peculiarity of structure sufficient to warrant its being regarded as generic were the doing so convenient. The type is Phalaropus fulicarius, commonly known in England as the Grey Phalarope, from the prevalent colour of its winter-plumage, which it has generally donned when

1 They were netted before they could fly, and kept in pens to be killed for the table as wanted, selling in Ray's time for five shillings the dozen.

2 Not to be confounded with the PEwes.

3 This name is usually so spelt, but it has nothing to do with the moongoddess or any one named after her.

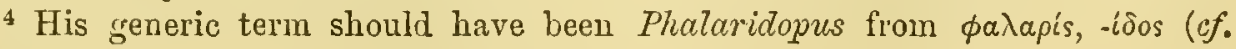
Murdoch, Bull. Nutt. Orn. Club, iii. p. 150). 
it visits this country, as it does almost every year. ${ }^{1}$ It wears a very different aspect in summer, when the whole of the lower parts are bright bay, while the feathers above are dark brown broadly edged with light rusty, and hence it has in this condition been called the Red Phalarope. It is known to breed in Spitsbergen, in one part at least of Iceland, in Greenland, and presumably throughout Arctic America and Asia, but not on the continent of Europe. Its wanderings in winter seem to be boundless, since its appearance is recorded in Chili and in New Zealand. The next species, known as the Red-necked Phalarope, $P$. or Lobipes hyperboreus, is truly a British bird, breeding in a few spots (which are best not named) in Scotland and its islands. Of more slender form, its plumage is comparatively plain, but the bay patch on the side of the neck contrasts with the white chin to give it a conspicuous appearance. It does not range northward so far as the last, but it is found breeding in Scandinavia, Russia, Siberia and America-from Alaska to Labrador, as well as in Greenland, while in winter it would seem not to stray quite so far to the south. The third species, $P$. or Steganopus tricolor or wilsoni, of still more slender form, has a very restricted breeding-range in North America, not being recorded from the Pacific slope and being rare on the Atlantic coast. In winter, however, it reaches Patagonia. Did space allow, the various qualities of this beautiful group of birds would be willingly dwelt upon here. A more entrancing sight to the ornithologist can hardly be presented than by either of the two species first named. Their graceful form, their lively coloration, and the confidence with which both are familiarly displayed in their breeding-quarters can hardly be exaggerated, and it is equally a delightful sight to watch these birds gathering their food in the highrumning surf, or when that is done peacefully floating outside the breakers. The nest, which the male-for in the Phalaropes, as in the DotTerel and the Godwits, that sex undertakes the duty of incubation-leaves only to escape being trodden upon, is in itself a picture that the finder will recall with rapture, while the tameness of the birds tempts the observer to watch their ways by the hour, be the weather never so bad ${ }^{2}$ (see SANDPIPER).

1 In numbers it is very variable. In the autumn of 1866 , more than 5 co were recorded as observed and mostly shot in Britain, according to the Summary which Mr. J. H. Gurney, junior, was at the pains to compile and publish in 1867.

2 Here may be noticed the "Barred Phalarope," described in 1785 by Latham (Gen. Synops. iii. p. 274) from a specimen in Banks's collection obtained at Christmas Island on Cook's Third Voyage, the Tringa cancellata of Gmelin. It seems not to have been a Phalarope at all, and in $1859 \mathrm{G}$. R. Gray (Cat. B. Isl. Pacif. p. 51) referred to it the T. parvirostris described and figured by Peale as fonnd in July 1839, by the United States' Expedition under Wilkes, abundantly on some of the Paumotu Islands, where it was breeding and exceedingly tame. In 1874 Prof. Coues (B. North-Wcst, p. 506) established for it the genus AEch- 
PHEASANT, Mid.-Eng. Fesant and Fesaun, Germ. Fusan and anciently Fasant, Fr. Faisan-all from the Latin P'husiun or P'hasiuna (sc. aris), the Bird brought from the banks of the river Phasis, now the Rioni, in Colchis, where it is still abundant, and introduced by the Argonauts, it is said in what passes for history, into Europe. As a matter of faet nothing is known on this point; and, judging from the recognition of the remains of several species referred to the genus Phasiamus both in Greece and in France, ${ }^{1}$ it seems not impossible that the ordinary Pheasant, the $P$. colchicus of ornithologists, may have been indigenons to this quarter of the globe. If it was introdnced into England, it must almost certainly have been brought lither by the Romans; for, setting aside several earlier records of doubtful authority, ${ }^{2}$ Bishop Stublos has shewn that by the regulations of King Harold in 1059 "unus phasianus" is preseribed as the alternative of two Partridges or other birds among the "pitantice" (rations or commons, as we might now say) of the canons of Waltham Abbey, and, as Prof. Dawkins has remarked (Jbis, 1869, p. 358), neither Anglo-Saxons nor Danes were likely to have introduced it

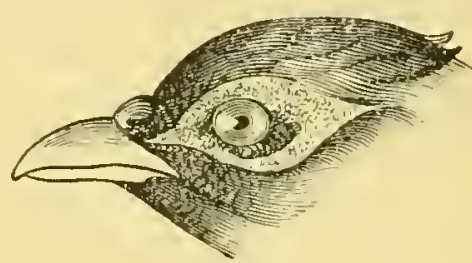

Pheasaxt. (After Swainson.) into England. It seems to have been early under legal protection, for, according to Dugdale, a lieence was granted in the reign of

morkynchus. Mr. Seebohm (Charadriida, p. 451, pl. xvii.) refers it to the gemus Phegornis, with which it seems to have little in eommon; but makes some anends by giving a good figure of it. The only specimens now known to exist appear to be those at Washington, and there is good reason to fear that the species may be extinet-the victim, most likely, of rats or other predacions animals that have found their way to its very confined haunt-a case parallel perhaps to that of Prosobonia lencoptere of Tahiti (see SaNiptipres).

1 These are $P$. archiaci from Pikermi, $P$. altus and $P$. modius from the laeustrine beds of Sansan, and $P$. desnoyersi from Touraine (A. Milue-Elwards, Ois. foss. de la France, ii. pp. 229, 239-243).

2 Among these perhaps the most worthy of attention is in Probert's translation of The Ancient Lawes of Cambria (ed. 1823, pp. 367, 368), wherein extracts are given from Weish triads, presumably of the age of Howel the Good, who died in 948. One of them is "There are three barking hmuts: a bear, a squirrel, and a pheasant." The explanation is "A pheasant is called a barking lunnt, becanse when the pointers come upon it, and ehase it, it takes to a tree, where it is hunted by baiting." I have not been able to traee the manuseript containing these remarkable statements so as to find out what is the original word rendered "Pheasant" by the transiator"; but a referenee to what is probably the same passage with the same meaning is given by Ray (Synops. Meth. Animed. pp. 213, 214) on the anthority of Llwyd or Lloyd, thongh there is no mention of it in Wotton and Clarke's Leges Wallica (1730). A eharter (Kemble, Cod. Diplom. iv. p. 236), mrofessedly of Edward the Confessor, granting the wardenship of eertain forests in Essex to Ralyh Peperking, speaks of "fesant hen " and "fesant cocke," but is now known to be spurious. 
Henry I. to the Abbot of Amesbury to kill Hares and Pheasants, and from the price at which the latter are reckoned, in various documents that have come down to us, we may conclude that they were not very abundant for some centuries, and also that they were occasionally artificially reared and fattened, as appears from Upton, ${ }^{1}$ who wrote about the middle of the 15th century, while Henry VIII. seems from his privy purse expenses to have had in his household in 1532 a French priest as a regular "fesaunt breder," and in the accounts of the Kytsons of Hengrave in Suffolk for 1607 mention is made of wheat to feed Pheasants, Partridges and Quails.

Within recent years the practice of bringing up Pheasants by hand has been extensively followed, and the numbers so reared vastly exceed those that are bred at large. The eggs are collected from birds that are either running wild or kept in a mew, ${ }^{2}$ and are placed under domestic Hens; but, though these prove most attentive foster-mothers, much additional care on the part of their kecpers is needed to ensure the arrival at maturity of the poults; for, being necessarily crowded in a comparatively small space, they are subject to several diseases which often carry off a large proportion, to say nothing of the risk they run by not being provided with proper food, or by meeting an early death from various predatory animals attracted by the assemblage of so many helpless victims. As they advance in age the young Pheasants readily take to a wild life, and indeed can only be kept from wandering in every direction by being plentifully supplied with food, which has to be scattered for them in the coverts in which it is desired that they should stay. Of the proportion of Pheasants artificially bred that "come to the gun "when the shooting-season arrives it is impossible to form any estimate, for it would seem to vary enormously, not only irregularly according to the weather, but regularly according to the district. In the eastern counties of England, and some other favourable localities, perhaps three-fourths of those that are hatched may be satisfactorily accounted for ; but in many of the western counties, though they are the objects of equally unremitting or even greater care, it would seem that more than half of the number that live to grow their feather's disappear inexplicably before the coverts are beaten. The various effects of the modern system of Pheasantbreeding and Pheasant-shooting need here be treated but briefly. It is commonly condemned as giving encouragement to poaching, and, especially under ignorant management, as substituting slaughter for sport. Undoubtedly there is much to be said on this score; but in reply to the first objection it has been urged that as a rule

${ }^{1}$ In his De studio militari (not printed till 1654) he states (p. 195) that the Pleasant was brought from the East by "Palladius ancorista."

2 In 1883, 134,000 Pheasants' eggs were sold from one estate in Suffolk, and 101,000 in 1893, while 9700 birds were killed upon it. 
the poacher does not like visiting coverts that he knows to be effectively preserved, and that coverts containing a great stock of Pheasants, whose rearing has cost a considerable sum of money, are probably the most effectively preserved. As to the second objection, it is to be observed that what constitutes sport is in great measure a matter of individual taste, and that the reasonable limit of a sportsman's "bag" is practically an unknown quantity. One man likes shooting a Pheasant rising at his feet or sprung by his spaniels, as it flies away from him through the trees and is still labouring to attain its full speed; another prefers shooting one that has mounted to its greatest height, and, assisted perhaps by the wind, is traversing the sky at a pace that almost passes calculation. If skill has to be considered in the definition of sport, there can be no doubt as to which of these cases most requires it. In regard to cruelty-that is, the proportion of birds wounded to those killed-there seems to be little difference, for the temptation to take "long shots" is about equal in either case. The Pheasant whose wing is broken by the charge, if at a great height, is often killed outright by the fall, whereas, if nearer the ground, it will often make good its escape by running, possibly to recover, or more possibly to die after lingering in pain for a longer or shorter time. On the other hand, highflying Pheasants, having their vital parts more exposed, are often hit in the body, but not hard enough to bring them down, though the wound they have received proves mortal, and the velocity at which they are travelling takes them beyond reach of retrieval.

Formerly Phcasants were taken in snares or nets, and by hawking; but the crossbow was also used, and the better to obtain a "sitting shot," for with that weapon men had not learnt to "shoot flying"; dogs appear to have been employed in the way indicated by the lines under an engraving by Hollar;, who died in 1677 :-

"The Feasant Cocke the woods doth most frequent, Where Spanie'ls spring and pearche him by the sent." I

The use of firearms has put an end to the older practices, and the gun is now the only mode of taking Pheasants recognized as legitimate.

Of the many other species or local races of Phasianus, two only can be dwelt upon here. These are the Ring-necked Pheasant of China, $P$. torquatus, easily known by the broad white collar, whence it has its name, as well as by the pale greyish-blue of its upper wing-coverts and the light buff of its flanks, and the P.versicolor of Japan, often called the Green Pheasant from the beautiful tinge of

1 Quoted by the writer (Broderip?) of the article "Spaniel" in the Penny Cyclopxdia. The lines throw light on the asserted Welsh practice mentioned in a former note. 
that colour that in certain lights pervades almost the whole of its plumage, and, deepening into dark emerald, occupies all the breast and lower surface that in the common and Chinese birds is bay barred with glossy black scallops. Both of these species have been to a considerable extent introduced into England, and cross freely with $P$. colchicus, while the hybrids of each with the older inhabitants of the woods are not only perfectly fertile inter se, but cross as freely with the other hybrids, so that birds are frequently found in which the blood of the three species is mingled. The hybrids of the first cross are generally larger than either of their parents, but the superiority of size does not seem to be maintained by their descendants. White and pied varietics of the common Pheasant, as of most birds, often occur, and with a little care a race or breed of each can be perpetuated. A much rarer variety is sometimes seen; this is known as the Bohemian Plieasant, not that there is the least reason to suppose it has any right to such an epithet, for it appear's, as it were, accidentally among a stock of the pure $P$. colchicus, and offers an example analogous to that of the "japanned" PEACOCK already noticed, being, like that breed, capable of perpetuation by selection. To a small extent two other species of Pheasant have been introduced to the coverts of England - $P$. reevesi from China, remarkable for its very long tail, white with black bars, ${ }^{\perp}$ and the Copper Pheasant, $P$. sammerringi, from Japan. The well-known Gold and Silver Pheasants, Thaumalea picta and Euplocamus nycthemerus, are both from China and have long been introduced into Europe, but are only fitted for the aviary. To the. former is allied the still more beautiful $T$. amherstia and to the latter about a dozen more species, most of them known to Indian sportsmen by the general name of KALLEGE. These with the comparatively plain Pukras, Pucrasia, the magnificent Monals, Lophophorus, are elsewhere treated, but the fine Snow-Pheasants, Crossoptilum, of which there are several species, must, for want of space, be only mentioned here. All the species known at the time were beautifully figured from drawings by Mr. Wolf in Mr. Elliot's grand Monograph of the Phasianida (2 vols. fol. 1870-72)-the last term being used in a somewhat general sense. With a more precise scope Mr. Tegetmeier's Pheasants : their Natural History and Practical Management (4to, ed. 2, 1881) is to be commended as a very useful work.

PHILIP and PHILP, old nicknames for the SPARrow (see page 132 , note 1 ).

PHCEBE, in parts of North America a name for what is there called also the PEwit, Sayornis fusca, one of the Tyrant-Birds.

I The introduction of this species by the first Lord Tweedmouth near Guisachan in Inverness-shire is said to have been remarkably successful. 
PHCENIX, said by Hesiod (apud Plin. H. $N$. vii. 49) to be a bird that lived nine times as long as a Crow; and, in a passage too often quoted to need repetition, described by Herodotus (Euterpe, 73) from a picture which he saw in Egypt. To doubt the existence of this bird was for ages evidence of depravity, for it had been so entwined by Classical, Rabbinical, Christian and Mahomedan legend, and so used to illustrate the sublimest doctrine, that we may almost wonder at belief in it not being enjoined by some confession of faith or imported into some religious formulary. Moreover though no Greek, Latin or Arabic author ${ }^{1}$ could vouch for having himself seen a specimen, and its last appearance on earth was said to be in the consulship of Paulus Fabius and Lucius Vitellius (i.e. A.D. 34), as stated by Tacitus (Ann. vi. 2S), 'yet according to Camden (Britannia, p. 783 , ed. 1607) one of its feathers was sent in 1599 by Pope Clement VIII. to the celebrated Hugh O'Neal, Earl of Tyrone, then leader of the Irish opposition; and the writer of the article "Phøenix" in the Penny Cyclopxdia (xviii. pp. 101-103) declared that even in June 1840, a very learned scholar at Oxford, subsequently stated (Notes and Queries, ser. T, vi. pp. 481, 4S2) to have been Mr. J. B. Morris of Exeter College, still seriously believed in the existence of the bird. It was long ago suggested by Sir Thomas Browne (Vulgar Errors, book III. chap. xii.) that the Phonix-story had its origin in a BIRD-of-PARAdISE (p. 38, note 3 ), and unless the whole was a lie from the beginning this still seems possible; but the late Mr. Gurney used to consider that a "Bateleur" Eagle (Helotarsus ecaudatus) was the cause of it."

PICA, the second Order of Birds in the Linnæan system, composed of the genera Psittacus (PArrot), Pamphastos (Toucan), Buceros (Horneill), Buphaga (Oxpecker), Crotophaga (ANi), Corvus (Crow), Coracias (Roller), Oriolus (OrIole), Gracula (Grackle), Paradisea (Bird-of-Paradise), Trogon (Trogon), Bucco (BArbet), Cuculus (Cuckow), Yunx ${ }^{3}$ (TrRyneck), Picus (Woodpecker),

1 It was defined by Arabic writers to be a creature "whose name was known, its body unknown."

2 The literature of the subject is not without interest and very large, though (possibly through the lack of specimens) it has fallen off of late years. Among separate works the following may be named:-Danderstarlius, Disput. de Phonice (Lipsiæ: 1665); Kirschmaier and Oheimb, De Phonice (Wittemberge: 1660); Kirschmaier, Disputt. zooll. de Basilisco, Unicornu, Phanice \&e. (WVittemb.

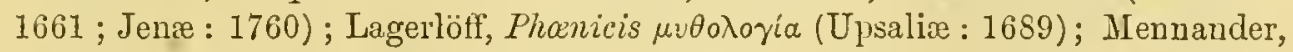
Dissert. de Phonice Ave (Abor: 1748); Pfeiffer, Dissert. de Phanice Ave (Regiomonti : 1673) ; Seuberlich, De Phonice (Regiom. 1696); Wendler, Disscrt. de Phanice (Gere: 1687); but the above-named article in the Penny Cyclopxdia, by the late Dr. Greenhill, is especially good.

${ }^{3}$ In the preceding edition of the Systema Naturæ more correctly spelt Jynx, which is the continental way of printing our Iynx. 
Sitta (Nuthatch), Todus (Tody), Alcedo (Kingfisher), Merops (BeE-Eater), Upupa (Hoopoe), Certhia (Tree-Creeper), Trochilus (Humming-BIRD). Of this multifarious assembly the 4th, 6th, Sth, 9th, 10th, 16th and 21st are now almost unanimously referred to the Order Passeres, while the disposition of the rest cannot be accounted fixed, though, except the 1st, they are referred in this book to

PICARI Æ, a group of Birds, so named by Nitzsch in 1820 (Deutsches Arch. für Physiol. vi. p. 255) to include the genera Coracias, Upupa, Alcedo, Cuculus, Psittacus, Picus, Yunx, Caprimulgus and Cypselus: opposed to his Passerine, but not to be confounded with

PICARII, Johannes Müller's name (Abhandl. Akad. Berlin, 1845 , p. 383) for what he separated as the third Tribe of his great Order Insessores or Passerini (the other two being Oscines and TraCHEOPHONES) comprehending the Ampelid $x^{1}$ and Tyrannidx in addition to those included, actually or consequentially, in Nitzsch's PiCARIA.

PICI, the name of an Order of Birds proposed in 1810 by Meyer and Wolf (Taschenb. deutsch. Vögelkunde, i. p. 115) to include the genera Picus, Yunx, Sitta, Certhia, Merops and Alcedo, the 3rd and 4th of which are truly Passerine. Such modern systematists as retain the term limit it to the WOODPECKERS and WRYNECKS.

PICKCHEESE, a common local name of the Blue TITMOUSE.

PICKET and PICKTARN, local names for the Common TERs.

PICKMIRE, a local name for the Pewit or Black-headed GulL.

PICUCULE, ${ }^{2}$ a name given, without reason says Buffon $(H . N$. Ois. vii. p. 82 , note), to a bird figured by D'Aubenton (Pl. cnl. 621) - the Dendrocolaptes certhia or cayennensis of later writerscontinued by Vieillot in 1816 (Analyse, p. 45), and retained in 1820 by Temminck (Man. d'Orn. ed. 2, i. p. lxxxi.) in a generic sense, while it was used as English in Griffith's translation of Cuvier's Animal Kingdom in 1829 (ii. p. 350), and is here adopted for want of a better, ${ }^{3}$ as that of the large Family of TracheopHON $A$,

1 Mcaning what are more correctly called Cotingidæ (ChatTerer).

2 Accidentally misspelt (Encyclop. Brit. ed. 9, iii. p. 743 and perhaps elsewhere) "Piculule." It would seem that the inventor coined the word as a combination of Picus and Cuculus. Buffon used "Pic-grimpereau," which is just as mislcading.

${ }^{3}$ Mr. Hndson, who (Argent. Orn. i. pp. 165-202) tells more of the habits of the birds of this Family than perhaps any other writer, uses for them collectively the name "Woodhewer," which seems unhappily applied, as no species appcars able to hew wood, and the word is hardly an accurate renclering of Dendrocolaptcs. 
Dendrocoluptida', which is so highly characteristic of the Neotropical Region. Not one of them was known to Linmæus, and for many years very erroneous notions were entertained as to their systematic position. They are mostly small birds of dull appearance, brown being their prevalent huc, with stiff and often sharply-pointed rectrices - a character which led the earlier writers to associate them with the PICI or the Certhiida (Trike-Cresper), and their entire difference from both those groups was not admitted until shewn by Johannes Müller. Mr. Sclater (Cat. B. Br. Mus. xv. pp. 2-175) groups them in 5 subfamilies, the first of which, Fumariina, has been already mentioned in these pages (OVEN-BHRD), while the

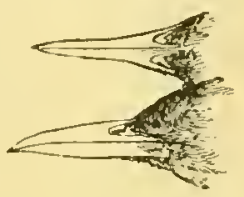

SYNALLAXIS.

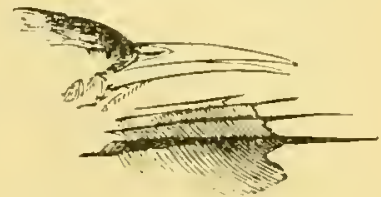

OXYCRTS.

(After Srainson.) next three, Synallaxine (with 8 genera, inchnding Symallaris and the curions form Oxyurus), Philydorine (with 17 genera, including

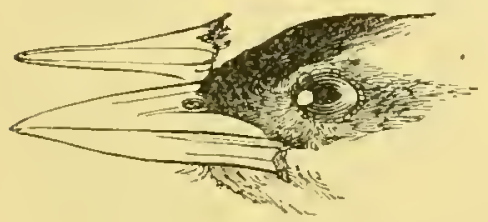

ANABATOIDES.

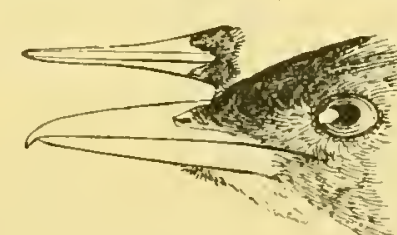

PHILIDOR.

(After Swainson.) Anubatoides and Philydor) and S'clerurina call for no particular remark here. The last and most typical subfamily Dendiocolaptine has, according to the authority just named, 15 genera (among which are Dendrocolaptes proper and its section Dendrocops,
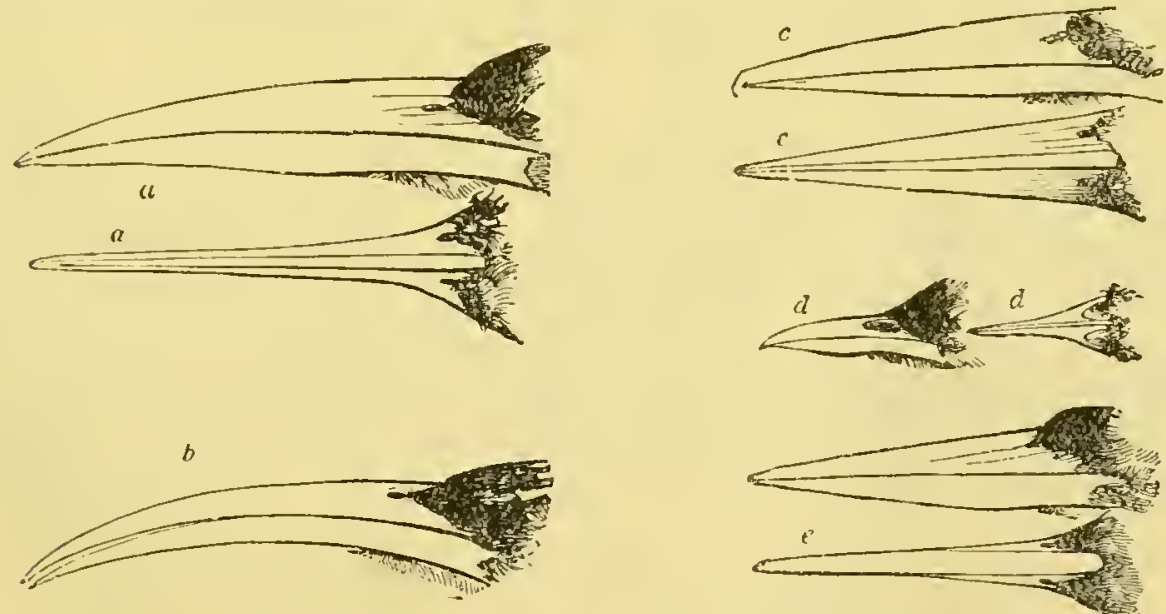

$a$, Dendrocolaptes ; $b$, Xiphorhyschus ; $c$, Dendrocops ; $d$, SitTasonus ; $c$, Dexidopiex. (After swainson.)

Tiphorhynchus, Sittesomus and Dendroplex) and some 80 species. Indeed there is no need here to dwell upon them more than to point out their importance in the Fauna of Southern tropical America. Though now ranging all over the Neotropical Region, 
the Antillean Subregion excepted, and even extending into Mexico, which according to most zoo-geographers is "Nearetic,"-while the number of forms inhabiting the tropical portion is vastly greater than that of those now existing within "Patagonian" limits, however liberally the last may be regarded,-this Family will very likely prove eventually to belong to the more ancient population of the continent. These forms are essentially of identical nature, but exhibit many and some extreme modifications of structure, a fact which furmishes a strong argument in favour of the antiquity of the original stock. As might be expected, their differences correspond with much diversity of habit, some of the forms living on the most sterile uplands, others in the thickest forests, others in reed-beds and others again on the sea-shore.

PICULET, the name apparently first assigned in 1845 by $\mathrm{G}$. R. Gray ${ }^{1}$ (Gen. B. ii. p. 432) to birds of the subfamily Picumninx, composed according to Mr. Hargitt (Cat. B. Br. MIus. xviii. pp. 8, 521-559) of 4 genera-Picumnus with 33 species, of which 31 are Neotropical and 2 Indian; Nesoctites with a single species peculiar to Hispaniola; Verreauxia, also with one species, confined to the Gaboon country; and Sasia, with 3 species, ranging from Nepal through the Malay peninsula to Borneo. They are all of small size and thorough WoODPECKERs in habit and appearance, but having the tail short, soft and rounded. The geographical distribution of the whole subfamily, and especially of Picumms proper, as above stated, points to its antiquity, and interest in the group is enhanced by the fact that Sasia has got rid of its hallux, thus affording a case parallel to that of Picoides among the Picina or true Woodpeckers.

PIE (French, Pie, ${ }^{2}$ in Scotland Piet) or more commonly Magpie, the prefix being the abbreviated form of a human name (Margaret ${ }^{*}$ ) applied as in so many other instances to familiar animals, as this bird once was throughout Great Britain, though of late years almost extirpated in many parts, and now nearly everywhere scarce. Its pilfering habits have led to this result, yet the injuries it causes are unquestionably exaggerated by common report; and in many countries of Europe it is still the tolerated or even the cherished

1 Possibly adapted from the "Picule" of Isid. Geoffroy-St. Hilaire (N.Am. Nus. 1832, 1. 396). Before him Temminck had used the word "Picumne."

2 The "French Pie" of many parts of England is the Great-Spotted or Pied WoopPEcier of authors. When the Liminan system came to be known in this country the word "Pie" was often used in a general sense as a rendering of PICæ, the name of one of his Orders of Birds.

" "IIagot" and "MIadge," with the same origiu, are names frequently given in England to the Pie; while in France it is commonly known as Margot, if not termed, as it is in some districts, Jaquette. 
neighbour of every farmer, as it formerly was in England if not in Scotland also. Though now common enough in Ireland, there is ample evidence ${ }^{1}$ to prove that it did not exist in that country in 1617, when Fynes Morison ${ }^{2}$ wrote his Itinerary, and that adduced by Mr. Barrett-Hamilton (Zool. 1891, pp. 247-249) shews that it first appeared about 1676 , when "a parcel," supposed to have been driven from Wales by stormy weather, landed in Wexford. It is a species that when not molested is extending its range, as Wolley ascertained in Lapland, where within the last century it has been gradually pushing its way along the coast and into the interior from one fishing-station or settler's house to the next, as the country has been peopled.

Since the persecution to which the Pie has been subjected in Great Britain, its habits have undoubtedly altered greatly in eharacter. It is no longer the merry, saucy hanger-on of the homestead, as it was to writers of former days, who were constantly alluding to its disposition, but is become the suspicious thief, shunning the gaze of man, and knowing that danger may lurk in every bush. Hence opportunities of observing it fall to the lot of few, and most persons know it only as a curtailed captive in a wicker eage, where its vivacity and natural beauty are lessened or wholly lost. At large few European birds possess greater beauty, the pure white of its scapulars and inner web of the flight-feather's contrasting vividly with the deep glossy black of the rest of its body and wings, while its long tail is lustrous with green, bronze and purple reflexions. 'The Pie's nest is a wonderfully ingenious structure, whether placed in high trees or low bushes, and is so massively built that it will stand for years. Its foundation consists of stout sticks, turf and clay, wrought into a deep, hollow cup, plastered with earth, and lined with fibres; but around this is erected a firmly-interwoven, basket-like outwork of thorny twigs, forming a dome over the nest, and leaving but a single hole in the side for entrance and exit, so that the whole structure is rendered almost impregnable. Herein are laid from six to nine eggs, of a pale bluish-green freckled with brown and blotched with ash-colour. Superstition as to the appearance of the Pie still survives even among many educated persons, and there are several versions of a riming adage as to the various turns of luck which its presenting itself, either alone or in company with others, is supposed to

1 A compendious summary of this will be found in Yarrell's British Birds, ed. 4 , ii. pp. $318-320$.

2 His predecessor Derricke, in 1578, said :-

"No Pies to plucke the Thatch from house, are breed iu lrishe grounde:

But worse then Pies, the same to burne,

a thousande maie be founde."-The Inage of Irelande, London : 1581. 
betoken, for some of these versions contradict one another in details, though all agree in this that the sight of a single Pie unquestionably forebodes sorrow.

The Pie belongs to the Corvidx (Crow), and is the Corms pica of Linnæus, the Pica caudata, P. melanoleuca or P. rustica of modern ornithologists, who have recognized it as forming a distinct genus, but the number of species thereto belonging has been a fruitful source of discussion. Examples from the south of Spain differ slightly from those inhabiting the rest of Europe, and in some points more resemble the $P$. manritanica of north-western Africa; but that species has a patch of bare skin of a fine blue colour behind the eye, and much shorter wings. No fewer than five species have been discriminated from various parts of Asia, extending to Japan; but only one of them, the $P$. lewcoptera of Turkestan and Tibet, has of late been admitted as valid. In the west of North America, from Alaska to New Mexico, as well as in some of its islands, a Pie is found which extends to the upper valleys of the Missouri and the Yellowstone, even appearing so far to the eastward as Cumberland House, in the Province of Winnipeg, and in the State of Michigan, and was long thought entitled to specific distinction as $P$. hudsonia; but its clain thereto is now disallowed by most Ameriean ornithologists, and it can hardly be deemed even a geographical variety of the Old-IVorld form. In California, however, there is a permanent race if not a good species, $P$. nuttalli, easily distinguishable by its yellow bill and the bare yellow skin round its eyes; and it is a curious fact that on two occasions in the year 1867 a bird apparently similar was observed in Great Britain (Zoologist, ser. 2, pp. 706, 1016). ${ }^{1}$

Nore or less allied to the genus Pica are some forms that can

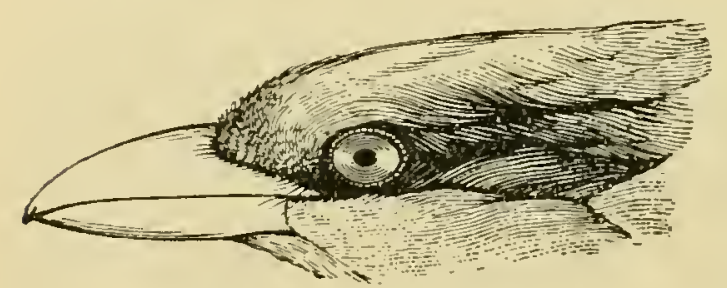

Cissa. (After Swainson.) hardly be separated from IAYs, as for instance the species of Cissa, before mentioned (page 470), concerning the affinity of which opinions have differed much, but Mr. Oates (Founa Br. Ind. Birds, i. 1. 28), declares in favour of its Pic-like position. On the other hand Dendrocitta with several kindred genera, all belonging to the Indian Region, are with less doubt referred to the neighbourhood of Pica, as also is Cyanopica, ${ }^{2}$

1 Dr. Diederich (Ornis, 1889, pp. 280-332, tab. iv.) has treated at length and illustrated hy a map the geographical distribution of the genus Pica.

2 Dr. Sharpe (Cut. B. Er. Mus. iii. p. 67), calls this genus Cyanopolius, citing as his anthority a passage wherein that name does not occur. Bonapirte seems to have used it only in manuseript (see his Consp. Av. i. p. 282 : and Waterhouse, Index Generum Avium, p. 59, note). 
so remarkable for its discontinuous distribution, already noticed (p. 342) - one of its two species, C. cooki, being the Blue Pie of the Iberian Peninsula, and the other, C. cyanu, that of Eastern Asia with Japal.

PIGEON, French Pigcon, Itilian Piccione and Pipione, Latin Pipio, literally a nestling-bird that pipes or eries ont, a "Piper"the very llame now in use among Pigeon-fanciers. The word Pigeon, doubtless of Norman introduction as a polite term, seems to bear much the same relation to Dork, the word of Anglo-Saxon origin, that mutton has to sheep, beef to ox, veal to calf, and pork to bacon; but, as before stated (p. 162), no sharp distinction can be drawn between the two, and the collective members of the group Columba are by ornithologists ordinarily called Pigeons. Perhaps the best known species to which the latter name is exclusively given in common speech ${ }^{1}$ is the Wild or PAssengerPIGEON of North Aneriea, Ectopistes, already mentioned; but among the multitudinous

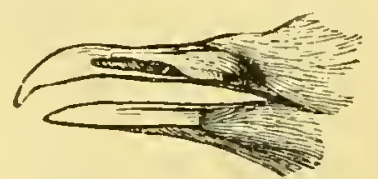

Ectopistes. (After Swainson.) forms very few ean here be noticed. A species which seems worthy of attention as being one that might possibly repay the trouble of domestication, if any enterprising person would give it the ehance, is the Wonga-wonga or White-fleshed Pigeon of Australia, Leucosarcia picuta, a bird larger than the Ring-Dove, of a slaty-blue colour above and white beneath, streaked on the flanks with black. It is known to breed, though not very freely, in eaptivity, and is said to be excellent for the table. As regards flavour, however, those who have been so fortunate as to eat them declare that the green Fruit-Pigeons of the genera Treron and Finago and their allies surpass all birds. These inhabit tropical Africa, India, and especially the Malay Arehipelago; but the probability of domesticating any of them is very remote. Hardly less esteemed are the Pigeons

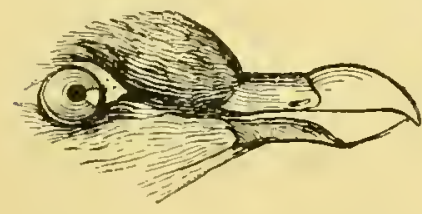

VINAGO.

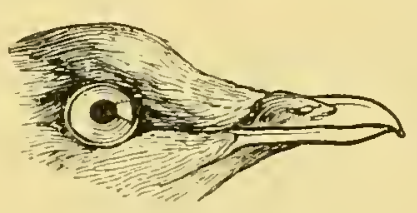

PTilopus.

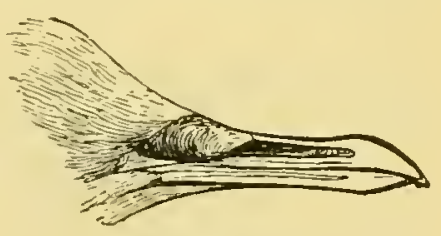

PHAPS.

(After Swainson.)

of the feather-legged genus Ptilopus and its kindred forms, which have their headquarters in the Pacific Islands, though some occur far to the westward, and also in Australia. Among them are found the most exquisitely-coloured of the whole Family, and the Fijian Chryscenas victor with its glorious orange plumage especially

1 It may be observed that the "Rock-Pigeons" of Anglo-Indians are SANDGrouse, and the "Cape Pigeon" of sailors is a Petrel. 
deserves attention, but the beautiful "Bronze-wings" of Australia, belonging to the genus Phaps, and some others are in their way hardly inferior. Then may be mentioned the strange Nicobar Pigeon, Calenus, an inhabitant of the Indian arehipelago, not less remarkable for the long lustrous hackles that clothe its neek than for the structure of its gizzard, which has been described by Sir W. Flower (Proc. Zool. Soc. 1860, p. 330), though this peculiarity is matched or even surpassed by that of the same organ in the Phonorrtina goliath of New Caledonia (Rev. Zool. 1862, p. 138) and in the Carpophaga latrans of Fiji, wherein the surface of the epithelial lining is beset by holny conical processes, adapted, it is believed, for crushing the very hard fruits of Onocarpus ritiensis on which the bird feeds (Proc. Zool. Soc. 1878, p. 102). The 'modern giants of
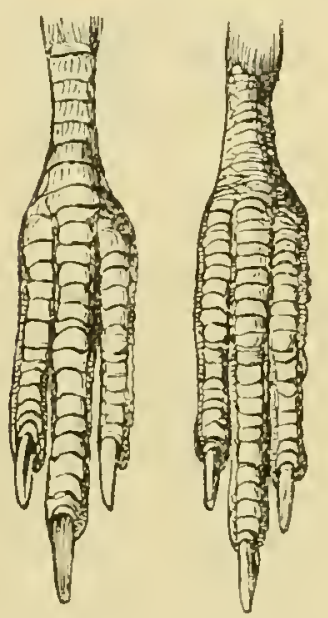

PIGEONS' FEET

shewing amount of feathering of the "tarsus."

(After Swainson.)
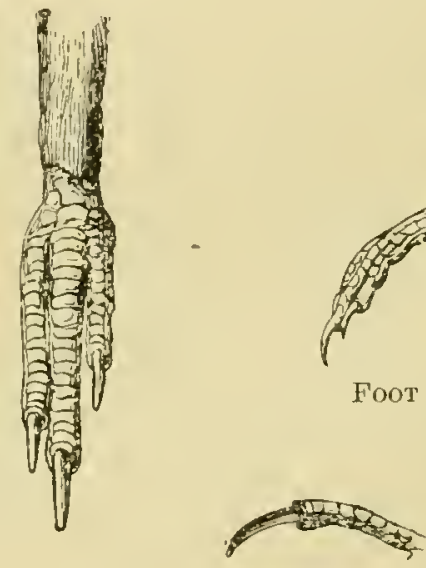

HALLUX OF

ENgrptila and Ptilopus.

(After Swainson.)

the group, consisting of about half a dozen speeies of the genus Gound and known as Crowned Pigeons have been already noticed, and all that need be added here is to mention the reticulated instead of seutellated covering of their "tarsi." In contrast to them may be mentioned the Afriean Ginc capensis, the "Namaqua Duif " of the Dutch colonists, which if not the smallest is one of the most graceful in form of all the Columbx.

A very distinct type of Pigeon is that represented by Didunculus striqirostris, the "Manu-mea" of Samoa, absurdly ealled the DoDLE'1, and still believed by some to be the next of kin to the DoDo, though really presenting only a superficial resemblance in the shape of its bill to that effete form, from which it differs osteologically quite as much as do other Pigeons (P/til. Trans. 1869, p. 349). It remains to be seen whether the Papuan genus Otidiphaps, of which several species are now known, may not belong rather to the Didunculida. than to the true Columbidia. 
At least 500 species of Pigeons have been described, and many methods of arranging them suggested. The most recent is that by Count T. Salvaidori (Cat. B. Brit. Mus. xxi. London: 1893), but though elaborated with the usual skill of that careful worker, it cannot be deemed satisfactory since it is based only on some external characters, and of these the amount of feathering of the "tarsus," which is relied upon by a good many authors, receives but little notice. Perhaps, however, no other method is at present possible, for certainly the partial attempt of Garrod (Proc. Zool. Soc. 1874, pp. 249-259) was not very successful. The Count, rightly premising that " the Pigeons constitute a very homogeneous Order," divides it into two Suborders, Columbx and Didi, asserting that the former of them "does not admit of division into easily definable or sharply defined groups" (but to this statement Didunculus proves a striking exception), recognizing it as composed of 5 Families, Treronidx and Columbida with 3 subfamilies each ; Peristeridx with 7, and Gourida and Didunculidx, each consisting of a single genus, and the last of a single species. Of genera he admits on the whole upwards of 60 , to say nothing of subgenera, and it wonld be nseless here to give even their names, since want of space forbids anything useful being said of them. The older works on the group, such as Temminck's folio (Paris: 1808-11), with its continuation (in 1838-43) by Florent Prévost, and Selby's more modest Natural History of the Columbidx (1835) are of course out of date, and a new monograph of the Pigeons, containing all the recent dis- coveries, would be a desirable acquisition.

PILWILLET, one of the many names of the WILLET, Symphemic semipalmata, but also applied, according to Mr. Dresser (Ibis, 1886, p. 34), in Galveston Bay to the North-American Oyster-CATCHER, Hrmatopus palliatus.

PIMLICO, one of the names given to the Australian FriarBIRD.

PINC-PINC (or rather "Tinc-tinc"), the name which a SouthAfrican bird, Drymoca or Cisticola textrix, has given itself from its ringing metallic cry, often uttered as it hovers in the air (Layard, B. S. Afr. p. S5), and a species chiefiy known to English readers from the often-repeated copy of Le Vaillant's figure (Ois. d'Afr. pl. 131) of a beautiful nest, which he wrongly assigned to it as its fabricator, the real builder of the wonderful structure being (Layard, op. cit. pp. 86, 114) the Kapok vogel (Cotton-bird), AEgithatus capensis, a near ally of $A$. pendulinus, the so-called Penduline Titmouse of Europe.

PINK, otherwise Spink, a well-known name of the CHAFFinCH. PINTADO, a Portuguese word, meaning painted or mottled, 
commonly applied in some parts of England, and especially by some English writers, to the GurNEA-Fown, but also by sailors to the so-called Cape-Pigeon, Daption capensis (PETPEL).

PINTAIL, properly the well-known Duck, the male of which has the two middle tail-coverts very much elongated and pointed, the I nas acutu of Linneus and Dufilu acute of moderu writers, one

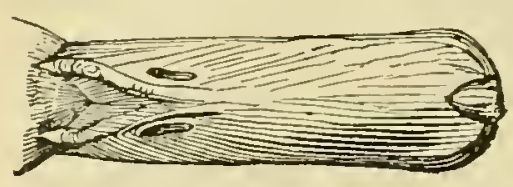

BrLl, of PrNtall. (After Swainson.) of the most graceful and beautiful of the Anutinx or" so-called "fresh-water" Ducks, though not distinguished by the brilliance of its plumage. The drake lias a brown head, whence a dark stripe runs down the nape, contrasting with the pure white of the throat and breast, which is continued upward along the side of the neck almost to the base of the skull. The upper parts generally are clothed with feathers marked with fine undulating bars of black and very light grey, so as to look as of a lavender-colour at a distance, against which the long and pointed scapulars, of a deep black with a broad elging of greyish-white, shew conspicuously: the bluegreen speculum of the wing is bordered above by a rust-coloured and below by a white bar. The female is still more modestly clad, but the characteristic speculum and a somewhat elongated tail easily serve to her recognition. The Pintail is common to botll areas of the Holarctic Region, and thongh not reaching its extreme circumpolar lands, breeds over most of the northern parts of both New and Old Worlds; but few unquestionable instances of its doing so in the British Islands, except as a captive, are known. Three other species of the genus Dafila exist, and they resemble $D$. acuta in the slenderness of their form, which extends even to the bill, and their pointed tail. Two belong to South America (Proc. Zool. Soc. 1876, pp. 392, 393), and the third is the "Red-billed Teal" of South Africa.

The name Pintail is applied in the colonies and elsewhere by English-speaking sportsmen to sereral other birds, as to one of the Grouse of North America, Pediocates, and to one of the SANuGrouse, Pterocles setarius.

\section{PIPING CROIV, see Grmnorhina.}

PIPIRI, one of several local names of Tyranmus grisens or dominicensis, a TYRANT that is wiclely spread throughout most parts of the West Indies.

PIPIT, French Pipit, cognate with the Latin Pipro (see Prgkon, p. 723), the name applied by ornithologists to a group of birds having a great resemblance both in habits and appearance to the LARks, with which they were formerly confounded by systematists as they are at the present day in popular speech, but differing from them in several important characters; and, laving been first separ- 
ated to form the genus Anthus, which has since been much broken up, are now generally associated with the WAGTAILs in the Family Motacillide. ${ }^{1}$ Pipits, of which over 30 speeies have been described (cf. Sharpe, Cat. B. Br. Mus. x. pp. 534-623), occur in almost all parts of the world, even New Zealand having its peculiar species, but in North America are represented by only two forms - Neocon'ys spraguii, the Prairie-Lark of the north-western plains, and Anthus ludovicianis, the American Titlark, which last is very nearly allied to the so-called Water-Pipit of Europe, A. spipolettu. To most English readers the best-known species of Pipit is the TITLARK or MeadowPipit, A. pratensis, a bird too common to need deseription, and abundant on pastures, moors and unenltivated districts generally; but in some localities the Tree-Pipit (to which the name Pipit seems properly to belong), the $A$. trivialis, or $A$. arboreus of some authors, takes its place, and where it does so it generally attracts attention by its loud song, which is not unlike that of a Canary-bird, but usually delivered (as is the habit of most or all the Pipits) on the wing and during a short circuitous flight. Another species, the Rock-Lark, $A$. obscurus, scarcely ever leaves the sea-coast and is found almost all round the British Islands. The South African genus Macronyx (KALKonNTJE), remarkable for the extreme length of its hind claw, is generally placed among the Pipits, but differs from all the rest in its brighter coloration, which has a curious resemblance to the American genus Sturnella (ICTERUs), though the bird is certainly not allied thereto.

PIRAMIDIG, a Creole name, according to Gosse (B. Jamaica, p. 33), of Chordiles virginianus, or more properly C. minor (NightJAR), being an imitation of its cry uttered during its remarkable flight, which was minutely described by Osburn (Zool. 1860, pp. 6837-6841).

PIRENET, said to be a local name of the SHELD-DRAKE.

PIRREE, a name often given, from its cry, to a TERN.

PITTA, from the Telugu Pitta, meaning a small Bird, latinized by Vieillot in 1816 (Analyse, p. 42) as the name of a genus, and since adopted by English ornithologists as the general name for a group of Birds, ealled by the French Biêves, and remarkable for their great beauty. 2 For a long while the Pittas were commonly sup-

2 Pipits can be distinguished from Larks by laving the hind part of the "tarsus" undivided, while the Larks have it scutellated.

2 In Ornithology the word is first found as part of the native name, "Ponnunky pitta" of a Bird, given in 1713 by Petiver, on the authority of Buckley, in the "Mantissa" to Ray's Synopsis (1. 195). This bird is the Pitta bengalensis of modern ornithologists, and is said by Jerdon (B. Ind. i. p. 503) now to bear the Telugu name of Pona-inki. 
posed to be allied to the Turdidx, and some English writers applied to them the names of "Ground-Thrushes" (page 388), "WaterThrushes" and "Ant-Thrushes" (page 20), to the first of which the group has some prescriptive right; but the second and third are misapplied since there is no evidence of their having aquatic habits, or of their preying especially upon ants. The fact that they had nothing to do with THrushes, but formed a separate Family, was gradually admitted. In 1847 Prof. Cabanis (Arch. f. Naturg. xiii. 2, i. p. 216) placed them under the Clamatores, and their position was at last determined by Garrod, who, having obtained examples for dissection, proved (Proc. Zool. Soc. 1876, pp. 512, 513) that the Pittidæ belonged to that section of Passerine Birds which he named Mesomyodr. This in itself was an unexpected determination, for all the other birds of the group, as then known, inhabit the New World, where no Pittas occur. But it is borne out by, and may even serve to explain, the sporadic distribution of the latter, which seems to indicate them to be survivors of a somewhat ancient and lower type of Passeres. Indeed except on some theory of this lind the distribution of the Pittas is almost inexplicable. They form a very homogeneous Family, most of its members bearing an unmistakable resemblance to each otherthough the species inhabit countries so far apart as Angola and China, India and Australia; and, to judge from the little that has been recorded, they are all of terrestrial habit, while their power of flight, owing to their short wings, is feeble. In $1888 \mathrm{Mr}$. Sclater (Cat. B. Br. Mus. xiv. pp. 411-449) recognized 4 genera. They are Anthocincla with a single species from Tenasserim, remarkable for the tuft of elongated feathers on each side of its nape; Pitta with 43 species (to which by now more than one has to be added) of wide distribution; Eucichla with 5 species, all from the Indo-Malay countries; and "Melampitta" (Schlegel), ${ }^{1}$ with a single species from New Guinea, which after all may not belong to the Family. Most of the true Pittas are from the Malay archipelago, between the eastern and western divisions of which they are pretty equally divided; and, in Mr. Wallace's opinion, they attain their maximum of beanty and variety in Borneo and Sumatra, from the latter of which islands comes the species, Pitta elegans, here represented. Few Birds can vie with the Pittas in brightly-contrasted coloration. Deep velvety black, pure white, and intensely vivid scarlet, turquoise-blue and beryl-green - mostly occupying a considerable extent of surface-are found in a great many of the species,- to say nothing of other composite or intermediate hues; and, though

1 Objcction has been taken to this name, which is quite correct in form (witness Melampus), and Mellopitta (Stejneger, Stand. Nat. Hist. iv. p. 466), Coracopitta (Sclater, ut supr. p. 449) and Coracocichla (Sharpe, op. cit. xvii. p. 7) have been proposed in its stead. 
in some a modification of these tints is observible, there is scarcely a trace of any blending of shade, each patch of colour standing out distinctly. This is perhaps the more remarkable as the feathers

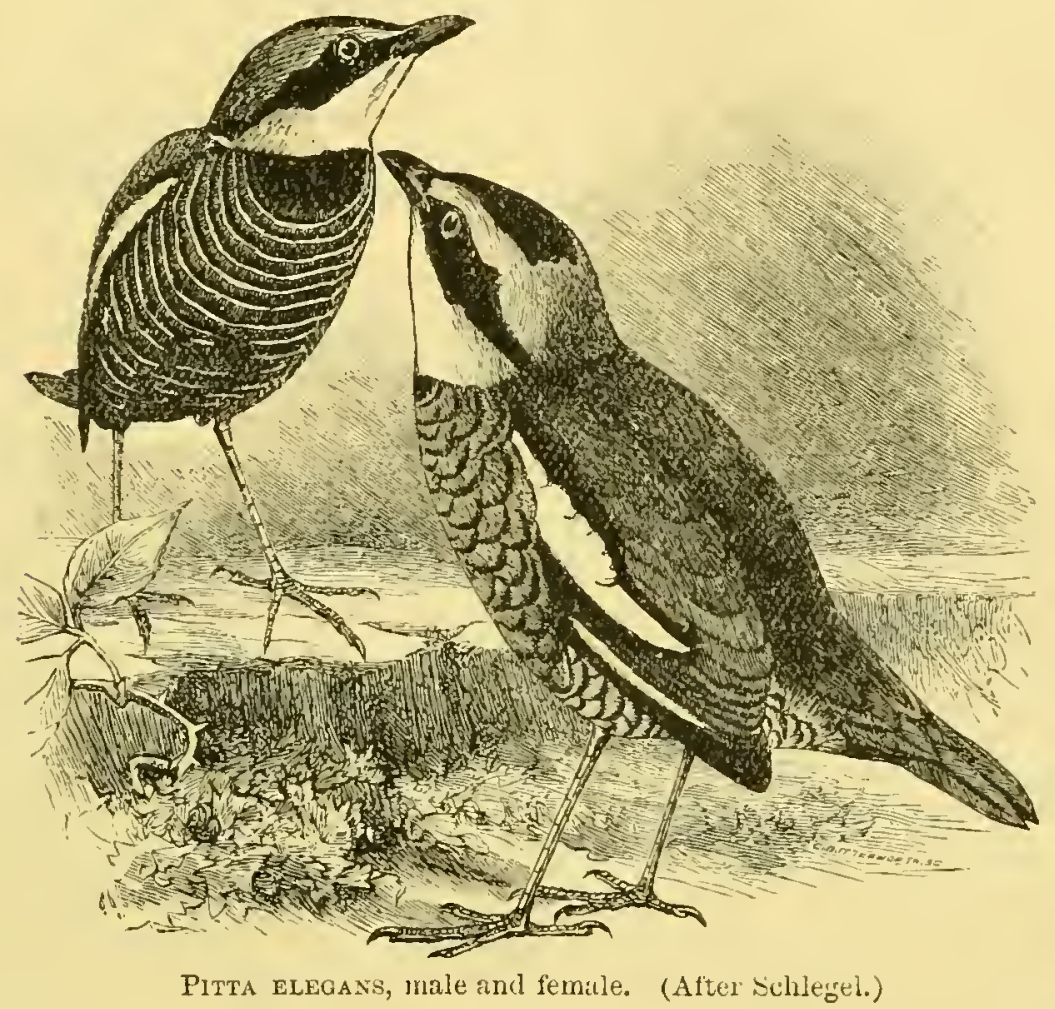

have hardly any lustre to heighten the effect produced, and in some species the brightest colonrs are exhibited by the plumage of the lower parts of the body. Pittas vary in size from that of a Jay to that of a Lark, and generally have a strong bill, a thickset form, which is mounted on rather high legs with scutellated "tarsi," and a very short tail. In many of the forms there is little or no external difference between the sexes. ${ }^{1}$

Placed by some authorities among the Pittidx is the genus Philepittu, consisting of two species peculiar to Madagascar, while other systematists would consider it to form a distinct Family. This last was the conclusion, the propriety of which can hardly be questioned, arrived at by W. A. Forbes (Proc. Zool. Soc. 1880, pp. 387-391), from its syringeal characters, which, though shewing it to be allied to the Pittas, are yet sufficiently different to justify its separation as the type of a Family Philepittida. The two species which conpose it have little outward resemblance to the Pittas, not having

1 All the species then known were figured in Mr. Elliot's Monograph of the Pittidx, completed in 1863 ; but so many have since been described, that lie is now bringing out a revised and enlarged edition of this work, as several of those lately discovered are figured only in Gould's Birds of Asia and Birds of New Guinea. Mr. Sclater's Catalogne above quoted will be found very useful. 
the same style of coloration and being apparently of more arboreal habits. The sexes differ greatly in plumage, and the males have the skin round the eyes bare of feathers and carunculated. ${ }^{1}$

PLANTAIN-EATER, Latham's translation (Suppl. ii. Gen. Symops. p. 104) in 1802 of Isert's generic name Musophaga (Musa being the botanical name of the genus which contains the Plantains and Bananas) in 1788 (Beobucht. Gesellsch. naturf. Freunde, iii. pp. 16-20, pl. 1), see Touraco.

PLANT-CU'T'TER, Latham's rendering in 1802 (Suppl. ii. Gen. Synops. p. 212) of Phytotoma, the generic name given by Molina in 1782 (Sagg. Stor. Nat. Chili, p. 254 ; Eng. transl. 1809, i. p. 210) to a bird called, from its harsh and broken cry, "Rara" by the people of Chili, who bear it no goodwill from its habit of cutting off growing plants close to the ground with its strongly-serrated bill, often, says the latter, from sheer wantonness, without eating a single leaf, and it is said to be also very destructive to the buds of trees. For a long while classed among the Fringillida, Musophagida or Tanagrida, its complete difference from any one of these Families became at last evident, and, chiefly from the position of the songmuscles, ${ }^{2}$ it is now regarded as forming a Family of its own, Phytotomila, one of the undeveloped or lower forms of PASsEREs so abundant in and so characteristic of South America-not to say Patagonia. Mr. Sclater (Cat. B. Br. MIus. xiv. pp. 406-408) recognizes 3 more species- $P$. angustirostris from Bolivia, $P$. raimondii from the west coast of northern Peru, and $P$. rutila of the Argentine territory and Patagonia, where it is common, according to Mr. Hudson, who gives (Argent. Orn. p. 164, pl. viii.) a brief but lively account of its habits, and pretty figures of both sexes.

PLATYSTERNA, Nitzsch's name, first published in 1840 (Pterylographia, p. 170), for what Merrem had already termed RATITA.

PLOVER, French Pluvier, Old French Plovier, which doubtless has its origin in the Latin pluvia, rain (as witness the German equivalent Regenpfeifer, Rain-fifer); but the connexion of ideas between the words therein involved, so that the former should have become a bird's name, is doubtful. Belon (1555) says that the name Pluvier is bestowed "pour ce qu'on le prend mieux en temps pluvieux qu'en nulle autre saison," which is not in accord-

1 It may be remarked that nomenclatnral purists, objecting to the names Pitta and Philepitta as "barbarons," call the former Coloburis and the latter Paictes. Brachynurus also has frequently been used for Pitta; but is inadnissible, having been previously applied in another sense.

2 This fact was ascertained and published by Eyton (Zool. Voy. Beagle, Birds p. 153), from a specimen brought lome by Mr. Darwin. 
ance with modern observation, for in lainy weather Plovers are wilder and harder to approach than in fine. Others have thought it is from the spotted (as though with rain-drops) upper plumage of two of the commoncst species of Plovers, to which the name especially belongs - the Charadrius plurialis of Linnæus, or Golden

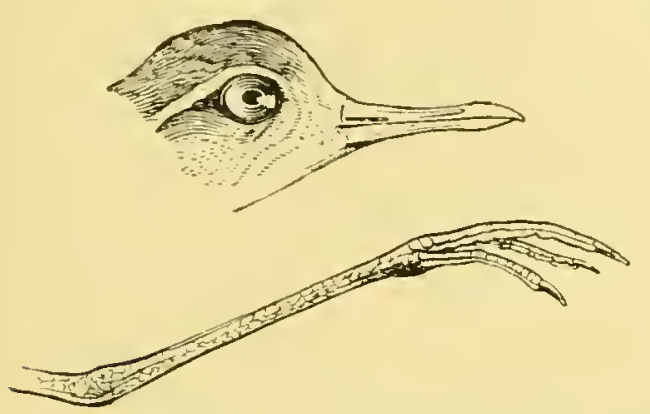

Charadrius (hear? and foot).

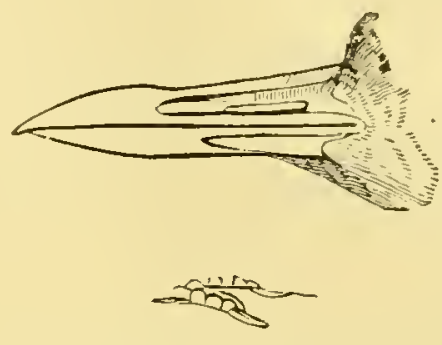

Squata Rola (bill and hind toe).

(After Swainson.)

Plover, and the Squatarola helvetica of recent ornithologists, or Grey Plover. Both these birds are very similar in general appearance, but the latter is the larger and has an aborted hind-toe on each foot, ${ }^{1}$ while its axillary feathers, which in the Golden Plover are purc white, are black, and this difference often affords a ready means of distinguishing the two species when on the wing, even at a considerable distance. The Grey Plover is a lird of almost circumpolar range, breeding in the far north of America, Asia and eastern Europe, ${ }^{2}$ frequenting in spring and antumn the coasts of the more temperate parts of each continent, and generally retiring further southward in winter-examples not unfrequently reaching the Cape Colony, Ceylon, Australia and even Tasmania. Charadrius pluvialis has a much narrower distribution, thongh where it occurs it is much more numerous as a speeies. Its breeding-quarters do not extend further than from Iceland to western Siberia, but include the more elevated tracts in the British Islands, whence in autumn it spreads itself, often in immense flocks, over the cultivated districts if the fields be sufficiently open. Here some will remain so long as the absence of frost or snow permits, but the majority make for the Mediterranean basin, or the countries beyond, in which to winter; and, as with the Grey Plover, stragglers find their way to the

${ }^{1}$ But for this really unimportant distinction both wonld doubtless have been kept in the same genus, for they agree in most other structural characters. As it is they have long been sundered.

2 The earliest account of its breeding in America was no doubt mistaken, but it was found there by Mr. MacFarlane in 1864. The first discovery of its eggs was by Von Middendorft in 1843, who described them (Sib. Reise, ii. p. 209, pl. xix. fig. 1), while another obtained by him has since been figured (Proc. Zool. Soc. 1861, p. 398, pl. xxxix. fig. 2). Subsequently it was found breeding in Europe by Messrs. Harvie-Brown and Seebohm (Ibis, 1876, pp. 222-230, pl. v.). 
southern extremity of Africa. The same may be said, mutatis mutanclis, of two other cognate forms, $C$. virginicus and $C . f$ fulus, which respectively represent C. pluvialis in America and Eastern Asia, where they also are known by the same English name. The discrimination of these two birds from one another requires a very acute eye, and room is here wanting in which to specify the minute points in which they differ ; ${ }^{1}$ but both are easily distinguished from their European ally by their smaller size, their greyish-brown axillary feathers, and their proportionally longer and more slender legs. All, however,-and it is the same with the Grey Plover,-minderga precisely the same scasonal change of colour, greatly altering their appearance and equally affecting both sexes. In the course of spring or early summer nearly the whole of the lower plumage from the chin to the vent, the greater part of which during winter has been white, becomes deep black. This is partly due to the growth of new feathers, but partly to some of the old feather's actually changing their colour, though the way in which the alteration is bronght about is still uncertain. ${ }^{2}$ A corresponding alteration is at the same season observable in the upper plumage; but this seems chiefly due (as in many other birds) to the shedding of the lighter-coloured margins of the feathers, and does not produce so complete a transformation of appearance, though the beauty of the wearer is thereby greatly increased.

The birds just spoken of are those most emphatically entitled to be called Plovers; lut the DotTerel, the group of Ringed Plovers before mentioned (KiLLDEER) and the LAPwING, with

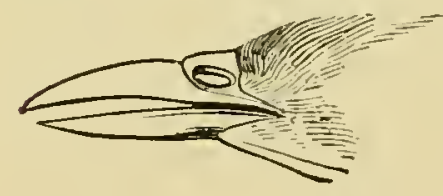

Pluvianus. (After Swainson.) their allies, have, according to usage, hardly less claim to the name, which is also extended to some other more distant forms that can here have only the briefest notice. Among them one of the most remarkable is the Pluvianus or Hyas agyptius of ornithologists, celebrated for the services it is said to render to the crocodile - a small bird whose plumage of delicate lavender and cream-

${ }^{1}$ Sehlegel (Mus. Pays-Bas, Cursores, p. 53) states that in some examples it seems impossible to determine the form to which they belong; but ordinarily American specimens are rather larger and stouter, and have shorter toes than those from Asia.

2 It is mueh to be regretted that ornithologists favomrably situated in regard to zoological gardens liave not used more extensively opportunities whieh might there be enjoyerl of condurcting useful observations on this subject and others of the kind. Elsewhere it wonld be hardly possible to earry on sueh an investigation, and even in the best cireumstances it would not be easy and would require unremitting attention. The results of some partial observations superintended hy Yarrell in the gardens of the Zoological Society of London are given in its Transactions (i. l]. 13-19). Little of this nature has been done there since. 
colour is relieved by markings of black and white. ${ }^{1}$ This probably belongs to the small section generally known as Counsers, Cursorius, allied to which are the curious Pratincoles, also peculiar to the old World, while the genera I'hinocorys and Attagis form an outlying group peculiar to South America, that is by some systematists regarded as a separate Family "Thinocoridx," near which are often placed the singular Sheathbills. By most authorities the StoneCurlews, the Oyster-Catchers and Turnstones are also regarded as belonging to the Fanily Charadriidx, and some would add the Avosets and Strlts, among which the Crab-Plover or "Cavalier," Dromas ardeola-a form that has been bandied about from one Family and even Order to another-should possibly find its place.

Though the various forms here spoken of as Plovers are closely allied, they must be regarded as constituting a somewhat indefinite group, for no very strong line of demarcation can be drawn between them and the SANDPIPERs and SNipes. United, however, with both of the latter, under the name of Limicol $A$, after the method approved by recent systematists, the whole folm an assemblage the compactness of which no observant ornithologist can hesitate to admit, even if he be not inclined to treat as its nearest relations the Bustards on the one hand and the "Gaviæ." on the other."

1 The elder Geofliroy-St. Hilaire (Mém. du Mus. xv. pp. 466, 467) in 1827 was apparently the first to identify this bird with the rpoxi inos of Herodotus (cf. Huming-Bik., p. 442, note 2), and lid so from having actually seen it enter the Crocodile's mouth, while his testimony is confirmed by the experience of Dr. A. E. Brehm, who says (Thierleben, Vögcl, ed. 2, iii. p. 216) that he had repeatedly seen it thus act. In the face of the positive assurance of two such competent wituesses it wonld be rash to conclude that another observer, who seems to be no ornithologist, is right in attributing ( $I b i 3,1893$, p. 277) the part of the "Crocodile-bird" to Hoploptcrus spinosus (Lapwing), though Dr. A. L. Adans (Ibis, 1864, p. 29) and Mr. A. C. Smith (Attractions of the Nite, ii. pp. 255, 256)-neither of whom had witnessed the feat-liad already maile the same suggestion. However, other ornithological observers of equal, if not yreater repute, such as $\mathrm{Mr}_{1}$. E. C. Taylor (Ibis, 1859 , p. $52 ; 1867$, p. 68), Von Heuglin (Orn. Nord-ost Afrika's, pp. 978, 979), and M. d'Aubusson (Echassier's d'Egypte, pp. 16-18), without professing personal experience, hold to Pluvianus rather than Hoplopterus being the reptile's benefactor, and so the matter must be left, though the balance of scientific opinion is sufficiently declared.

2 In this connexion it is necessary to mention Mr. Seebohm's lavishly illnstrated Geographical Distribution of the Family Charadriida (4 to, London: without date, but published in 188i), under which tcrm le comprises all the ordinary Plovers, Sandpipers and Snipes, but exclndes Attagis, Chionis, Dromas and Thinocorys. It would be out of place here to dwell upon his speculations, and it is enough to state his arrangement of the forms he iucludes. Professing to despise "structural characters," upon them he yet chiefly grounds nearly all his groups, but chooses characters which most taxonomers regard as of minor 
PLOVER'S PAGE, a local name for the DUNLIN from its curious habit of flying in company with a Golden PLorer, as though waiting upon it, when both species are breeding on the same part of a moor. The common Icelanclic name Lónprell (anciently Lóarprall) has a like origin, Lón being a Plover and prall (Anglice thrall) a servant.

POCHARD, POCKARD or POKER, ${ }^{1}$ names properly belonging to the male of a species of Duck (the female of which is known as the Dunbird), the Anes ferinu of Linnæus, and Nyroce, Ethigia or Fuligula ferinu of later ornithologists - but names very often applied

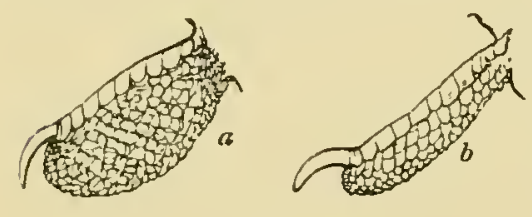

a, HALLUX OF "SEA-" :

b, OF "FRESHWATER" -DUCK. (After Swainson.) by writers in a general way to most of the subfamily "Fuligulina," commonly called Diving or Sca-Ducks, the member's of which can be readily distinguished by the greater development of the lobe of the hallux from those of the Anatine or Freshwater-Ducks. The Pochard in full plumage is a very handsome bird, with a coppery-red head, on the sides of which

importance, while those which seem far more signifieant are entirely negleeted, so that his remark that lis subdivisions are "very probably artificial" will not provoke dissent. In diagnosing his three subfamilies (p. 66), his "Scolopecina" are distinguished by having the "toes all eleft to the base"-his other two, "Totanine" and "Charadrizina," by laving the "middle and outer toes connected by a web at the base." Yet having assigned so much value to the presence or absence of the interdigital web, which seldom exists but in a rudimentary state, when it becomes most developed he proceeds to disregard it wholly by miting in one genus the Avosets and the Srilts, and no reason is given for this ineonsisteney. What to most ornithologists seems a character of some significanee, as directly affecting the bird's economy, is by him wholly disregarderl. This is the structure of the bill - whether it be a hard and horny chisel as in an Orster-catcher or a Turnstone, or a sensitive organ of pereeption as in a Sxipe or a Gonwit. Thus we find Hæmatopus grouped with Limose, and Strepsilas with Seolopax, while Tringa and Ereunetes are severed. It would not be so very great an exaggeration of Mr. Secbohm's practice to say that when two species have very different bills it is expedient to put them in the same subfamily, if not (as in the cases of Anarhynchus and Egialitis, and of Eurrinorhynchus and Tringa) in the same genus. If results like these legitimately follow-though this I take leave to doubt-from the teaching of "tlie new sehool of modern ornithologists" ( $p$. iv.), a nuan who has any regard for common sense, not to say for science, may congratulate himself on not being imputed a member of it. Tet the many beantiful figures given by $\mathrm{Mr}$. Seebohm will always make his work acceptable to ornithologists of all schools, despite his numerons vagaries.

1 The derivation of these words, in the first of which the $c h$ is pronounced hard, and the $o$ in all of them generally long, is very mncertain. Cotgrave has Pocheculier, whieh he renders "Shoneler," nowadays the name of a kind of Dnek, but in his time meaning the bird we commonly call Spoosnil.. Littré gives Pochard as a popular French word signifying drunkard. 'That this word 
sparkle the ruby irides of his eyes, relieved by the greyish-blue of the basal half of his broad bill, and the deep black of his gorget, while his back and flanks appear of a light grey, being really of a dull white closely barred by fine undulating black lines. The tail-coverts both above and below are black, the quill feathers brownish-black, and the lower surface of a dull white. The Dumbird has the head and neck reddish-brown, with ill-defined whitish patches on the cheeks and chin, brown irides, the back and upper tailcoverts dull brown, and the rest of the plumage, except tlie lower tail-coverts, which are brownish-grey, much as in the Pochard. This species is very abundant in many parts of Europe, northern Asia, and North America, generally frequenting in winter the larger open waters, and extending its migrations to Barbary and Egypt, but in summer retiring northward and inland to breed, and is one that has certainly profited by the legislative protection lately afforded to it in Britain, for, whereas during many year's it had but a single habitual breeding-place left in England, it is now known to have several, to some of which it resorts in no inconsiderable numbers. American examples seem to be slightly larger and somewhat darker in colour, and hence by some writers have been regarded as specifically distinct under the name of $N$. or $F$. americana; but America has a perfeetly distinct though allied species in the celebrated Canvas-back Duck, $N$. vallisneriana, a mnch larger bird, with a longer, higher and narrower bill, which has no blue at the base, and, though the plumage of both, especially in the females, is very similar, the male Canvas-back has a darker head, and the black lines on the back and flanks are much broken up and further asunder, so that the effect is to give these parts a much ligliter colour, and from this has arisen the bird's common though fanciful name. Its scientific epithet is derived from the freshwater plant, a species of Tallisneria, usually known as "wild celery," from feeding on which its flesh is believed to acquire the delicate flavomr that is held in so great a repute. The Pochard and Dunbird, however, in Europe are in much request for the table (as the German name of the species, Tafelente, testifies), though their quality in this respect depends almost wholly on the food they have been eating, for bircls killed on the sea-coast are so rank as to be almost worthless, while those that have been frequenting fresh water are generally well-tasted. ${ }^{1}$

wonld in the ordinary way become the English Pochard or Poker may be regarded as certain; but then it is not known to be used in French as a bird's name.

1 The plantknown in some parts of England as "willow-weed"- -not to be confounded, as is done by some writers, with the willow-wort (Epilobium)-one of the many species of Polygonum, is especially a favourite food with most kinds of Ducks, and to its effects is attributed much of the fine flavour' which distinguishes the birds that have had access to it. 
Among other species nearly allied to the Pochard that frequent the northern hemisphere may be mentioned the ScAUP-Duck, $N$. marila, with its American representative $N$. affinis, in both of which the male has the head black, glossed with blue or green; but these are nearly always uneatable from the nature of their food, which is mostly gathered at low tide on the "scaups" or "scalps" "-as the banks on which mussels and other marine mollusks grow are in many places termed. Then there are the Tufted Duck, $N$. cristata -black with a crest and white Hanks-and its American equivalent $N$. collaris, and the White-eyed or Castaneous Duck, $N$. castanea or $F$. nyroca, and the Red-crested Duck, N. rufina-both peculiar to the Old World, and the last, conspicuous for its red bill and legs, well known in India. In the southern hemisphere the genus is represented by three species, $N$. capensis, $N$. australis and $N$. novæ-zealandix, whose respective names indicate the country each inhabits, and in South America exists a somewhat divergent form which has been placed in a distinct genus as Metopiana peposaca.

Leaving the Scoters for further consideration, a few words may be here added to what has been already said of the small group known as the ErDERs, which, though generally classed with the "Fuligulinx," differ from them in several respects: the bulb at the base of the trachea in the male, so largely developed in the members of the genus Nyroca, and of conformation so similar in all of them, is here much smaller and wholly of bone; the males take a much longer time, two or even three years, to attain their full plumage, and some of the feathers on the head, when that plumage is completed, are always stiff, glistening and of a peculiar pale-green colour. This little group of hardly more than half a dozen species may be fairly considered to form a separate genus under the name of Somateria. Many authors indeed have-unjustifiably, as it seens to the present writer-broken it up into three or four genera. The well-known Eider, S. mollissima, is the largest of this group, and, beautiful as it is, is excelled in beauty by the King-Duck, S. spectabilis, and the little S. stelleri. Space fails here to treat of the rest, but the sad fate which has overtaken one of them, S. labradoria, has been before mentioned (ExTERuINATION, pp. 221-223) ${ }^{2}$ and only the briefest notice can be taken of

\section{Cognate with scallop, and the Dutch schelp, a shell.}

2 The statements made at this reference have been criticized by Mr. Dutcher (Auk, 1894, pp. 4-12). In the main they are confirmed by what he says, though he adduces evidence, which it is not for me to dispute, as to examples of the species, subsequently adding (tom. cit. p. 176) one more, having been obtained since 1852 , the latest year that. had been known to me as a certainty for its existence. Whether it survived (as is now, to use the American idiom, "claimed") until 1875 signifies little. That it is extinct I think no one will justifiably deny, thongh no one would be better pleased than myself to learn that 
that most interesting form generally, but obviously in error, placed among them, the LOGGER-HEAD (p. 518), Racehorse or SteamerDuck, Tachyeres or Micropteius cinereus of the Falkland Islands and Straits of Magellan-nearly as large as a tame Goose, and subject, as is asserted, to the, so far as known, unique peculiarity of losing its power of flight after reaching maturity.

PODARGUS, a genus of birds so named by Vieillot in 1819 , being based on the Podarge of Cuvier, and used by Gould and other writers as an English word (see MorEPork, p. 592, and NightJaR, p. 638).

POE-BIRD, another name for the PARSON-BIRD.

POLLEX, the thumb or first digit of the wing, never consisting of more than two phalanges, of which the terminal one is often aborted or absent; but, when fully developed, it often bears a horny CLAw. From the basal phalanx grows the so-called "bastard wing."

POLYMYODI (or POLYMYOD正 if a feminine ternination be needed), Johannes Müller's name (Abhandl. k. Akad. Berlin, Phys. Kl. 1847 , p. 366) for the first of his three groups of PAssErinI, from the many song-muscles they possess, equivalent to the Oscines of Keyserling and Blasius.

POMPADOUR, ${ }^{1}$ the name given by Edwards in 1759 (Gleanings, ii. p. 275, pl. 341) to one of the most beautiful of the Cotingidx (CHATTERER), and since generally adopted, though prior to his publication of the species it had been already described and figured by Brisson (Ornithol. ii. p. 347, pl. xxxv. fig. 1). It is the Ampelis pompadora of Linnæus, referred now to the genus Xipholena, a native of Guiana, Surinam and Cayenne, and easily recognized by the shining crimson-purple of its plumage, set off by its white wings. Two other allied species, $X$. atripurpurea and X. lamellipennis, inhabit Brazil (cf. Sclater, Cat. B. Br. Mus. xir. pp. 387-389).

POOL-SNIPE, said to be a local name of the REDSHANK.

POOR SOLDIER, a name for the Australian FRIAR-BIRD.

POPE, one of the many local names of the PUFFIn, Fratercula arctica, as well as of the BuLLFincH.

POPELER, an old name for the SPOONBILL, Platalea leucorodia,

it is not so; but anybody who has taken the trouble to investigate the history of an exterminated species will find that to determine the time when it ceased from appearing is no easy thing.

1 As a bird's name in French, Pompadour signifies a breed of domestic poultry, apparently that which we call the Polish. 
possibly a mispronunciation of the Dutch Lepelaar, which means the same bird.

POPINJAY, a word of respectable antiquity since it is used in some manuscript copies of Chaucer (Canterb. Tales, 13,299), while the French Papegai, written "Papejay," is used in others. Prof. Skeat, whose remarks (Etymol. Dict. p. 456) deserve all attention, concludes "that F. papegai, a talking jay, was modified from the older O. F. papegau, a talking cock," akin to the Italian Papagallo - the first half of all these words being cognate with "babble." Originally the name signified PARROT, but since most of the best-known Parrots are green, it has in this country been transferred to the Green WOODPECKER. It was also the wooden figure of a bird set up as a mark to be shot at. The Arabic babaghó (a Parrot), from which some derive Papagau and other forms, seems itself to be a corruption of the Spanish Papagayo.

PORT-EGMONT HEN, the Southern Great SkUA, so called by seamen in the last century from its familiarity about the place of that name in the Falkland Islands (cf. Latham, Gen. Synops. iii. p. 386).

POST-BIRD, a local name of the Spotted Flycatcher, Muscicapa grisola, from its habit of sitting on posts when looking out for prey (see p. 274).

POTOO, the Creole name for one of the NightJars, Nyctibius jamaicensis (Gosse, B. Jamaica, p. 41).

POIVDER-DOWNS are so called from the powder produced by the continuous disintegration of the numerous brush-like barbs and barbules, into which the barrel is constantly splitting as it grows without forming a principal shaft. In size, form and situation they vary much. In the Psittaci they are very short tufts, the barrel hardly projecting from the skin, while in Botaurus the barrel is nearly half an inch long, and bear's a short tuft of very fine filaments. In Podargus they attain their extreme size and complexity, being about two inches long. In some cases Powder-downs occur over the greater part of the body, among the contour-feathers as well as on the featherless spaces, in others they grow in more or less distinct tracts or in compact patches. The appearance of these peculiar organs, scattered as it were throughout various groups - Tinamous, Herons, Diurnal Birds-of-Prey, Parrots and in a few members of other groups - seems to be rather an illustration of isomorphism than an indication of affinity. Hitherto they have been found to exist as follows :-

Crypturi-interspersed among the contonr-feathers of the large dorsal tract. 
Ardeida-all the Herons and Bitterns possess them in pairs, forming large thick patches on the breast, the lower back and frequently on the abdomen. These patches are greasy and yellow at the base, but the tufts are very fine, grey or blackish, and produce a bluish powder. back.

Bulizniceps-a pair of large patches on the middle of the lower

Rhinochetus and Eurypyga-numerons, forming tracts as well as detached spots.

Mesites-five pairs of patches, the arrangement of which somewhat resembles the distribution of the powder-downs in the two genera last named.

Accipitres-at present only found in Elanus, Cymindis and Circus, as a large united patch on the lower back or as a pair on the same part. Nitzsch states that Gypactus has scattered powderdowns during its immaturity, and probably many other Accipitres, especially of the Vulturidx, will on further examination have to be included.

Psittaci-numerous scattered tracts and separate tufts on the neck, shoulders and sides of the trunk, in the Cacatuinz, in Chrysotis and in Psittacus. back.

Podargus - a pair of extremely developed patches on the lower

Leptosoma-resembles the last in the distribution of the patches, but Coracias has only seattered powder-downs.

Passeres - in this enormons group Artamus is the only genus known to possess them. They occur in all the species, in patches on the sides of the breast, the thighs and lower back, and have a strong barrel, one-third of an inch long.

(See Feathers, Pterylosis.)

POWEE, commonly applied in the West Indies to Crax alector, if not to the Curassows generally, and said in 1769, by Bancroft, who spells the word "Powese" (Nat. Hist. Guyuna, pp. 193-195), to be so called "by the natives from their cry, which is similar to that name." Frisch in 1763 (Vorstell. Vög. Deutschl. u. s. w. HauptArt. ix. Abth. 2, No. iv.) has the word Poes, which Buffon (Hist. Nut. Ois. ii. p. 374) misprinted Pocs, while P. L. S. Mïller (Nutursyst. ii. p. 465) spells it Panwis. It seems possible that the Dutch Paanu (Peacock) may be the origin of the word.

PRACOCES, the name given by Sundevall (K. Vet.-Acad. Handl. 1836, p. 70), to his second section of the Class Aves, in contradistinction to Altrices, but subsequently abandoned loy him.

PRAIRIE-CHICKEN, PRAIRIE-HEN, names given by the 
English in North America to what is lnown in books as the Pinnated Grouse, the Tympanuchus americanus of recent authors; or, where that does not occur, to forms of the allied genus Pediocates - the Sharp-tailed Grouse; but, according to Mr. Trumbull (Names and Portr. of Birds, Index, p. 21S), the term "Prairie" is prefixed by American sportsmen to many more kinds of birds than there is need here to specify.

PRATINCOLE, a word invented in 1773 by Pennant (Gen. B. p. 48), being an English adaptation of Pratincola, applied in 1756 by Kramer (Elenchus, p. 381) to a bird which had hitherto received no definite name, though it had long before been described and even recognizably figured by Aldrovandus (Ornithologia, xvii. 9) under the vague designation of "hirundo marina." It is the Glareola pratincola of modern ornithologists, forming the type of a genus Glareola, founded by Brisson in 1760, and unquestionably belonging (as is now generally admitted) to the group LiMICOLE, being either placed among the Charadriidx (PLOVER,) or regarded as constitutinga separate Family Glareolidx. The Pratincoles, of which Mr. Seebohm (Charadriidx, pp. 252-269) recognizes ten species-the last resting on a single specimen procured by the late Emin Pasha and described by Captain Shelley (Proc. Zool. Soc. 1888, p. 49)-are all small birds, slenderly built and mostly delicately coloured, with a short stout bill, a wide gape, long pointed wings and a tail more or less forked. In some of their habits they are thoroughly Plover-like, running very swiftly and breeding on the ground, but on the wing they have much the appearance of Swallows, and like them feed, at least partly, while flying. ${ }^{1}$ The ordinary Pratincole of Europe, G. pratincola, breeds abundantly in many parts of Spain, Barbary and Sicily, along the valley of the Danube, and in Southeru Russia, while

1 This combination of characters for nany years led systematists astray, though some of them were from the first correct in their notions as to the Pratineole's position. Linneus, even in his latest publication, placed it in the genus Hirundo ; but the interleaved and annotated copies of his Systema Natura in the Linnean Society's library shew the species marked for separation and insertion in the Order Gralla-Pratincola trachelia being the name by which he had meant to designate it in any future edition. He seerns to have been induced to this change of view mainly through a specimen of the bird sent to him by John the brother of Gilbert White; but the opinion published in 1769 by Scopoli (Ann. I. hist. naturalis, p. 110) had doubtless eontributed thereto, though the earlier judgment to the same effect of Brisson, as mentioned above, had been disregarded. Want of space here forbids a notice of the different erroneous assignments of the form, some of them made even by recent authors, who negleeted the clear evidence afforded by the internal strueture of the Pratincole. It must suffice to state that Sundevall in 1873 (Tentamen, p. 86) placed Glareola among the Caprimulgid $x$, a position which its ostcology shews camot be maintained for a moment. 
owing to its great powers of flight it frequently wanders far from its home, and more than a score of examples have been recorded as occurring in the British Islands. In the south-east of Europe a second and closely-allied species, $G$. nordmanni or $G$. melanoptera, which has black instead of chestnut inner wing-coverts, accompanies or, further to the eastward, replaces it; and in its turn it is replaced in India, China and Australia by $G$. orientalis. Australia also possesses another species, $G$. grallaria, remarkable for the great length of its wings and much longer legs, while its tail is scarcely forked-peculiarities that have led to its being considered the type of a distinct genus or subgenus Stiltia. Two species, G. lactea and G. cinerea, from India and Africa respectively, seem by their pale coloration to be desert-forms, and they are the smallest of this curious little group. The species whose mode of nidification is known lay either two or three eggs, stone-coloured, blotched, spotted and streaked with hlack or brownish-grey. The young when hatched are clothed in down and are able to run at once-just as are young Plovers.

PRIMARIES, the larger quill-feathers of the wing growing from the manus, the rational mode of counting which is to begin, as with the Cubitals, at the wrist, but to proceed ontwards, so that the distal quill is the last, and not the first as in the popular way of enumeration. ${ }^{1}$ The number of Primaries varies little. Most Birds possess 10 or 11 ; but 12 are found in Podicipes, Phonicopterus and some of the Ciconiidx, as Anastomus, Leptoptilus, Mycteria and Tantalus. As a rule the first 6 quills rest upon the united metacarpal bones ii. and iii., and when there are 12 Primaries 7 of them so originate, but the following Primary is always borne by the first phalanx of digit iii., while the next two quills are attached in all Carinate to the first phalanx of digit ii., its second phalanx carrying the rest- 3 in Struthio, 2 in birds with 11, and only 1 in those with 10 Primaries; but here are to be mentioned certain special conditions. Struthio has as many as 16 Primaries, $\delta$ of which belong to the metacarpals, while Rhea has the normal 12, and in Casuarius only 2 or 3 are attached to the manus, the rest of its barbless quills being really Cubitals. Archropteryx apparently had only 6 or 7 Primaries, but it is doubtful whether they proceeded from the index and its metacarpal alone, or chiefly from the third digit and its metacarpal. ${ }^{2}$ Peculiar conditions, hitherto mexplained, prevail also in the Sphenisci,

1 In a wider sense the stiff feathers, from 2 to 4 in number, which grow from the Pollex, and form the alula or "bastard wing," may also be accounted Primaries.

2 As before stated (p. 279) the manus of Archxopteryx had 3 free digits; but I conceive the figure from Vogt (p. 280) to be fanciful and erroneous. The main point is the regnlarly-inereasing number of the phalanges-the pollex having 2 , the index 3 and the third digit 4. 
which seem to have no true remiges, the posterior edge of their Hipper-like wings being formed of a greatly increased number of little stiff feathers.

The number of Primaries indicates a gradual reduction beginning at the distal end. Omitting the few birds with 7 metacarpal quills, we fiud that the 11 th or terminal quill is never fully developed and often scarcely functional. It is always much shortened and concealer between its upper and lower covert, being not unfrequently shorter and weaker than its covert, which in that case is sometimes stiff. In some Rails and in many P'asseres the 11 th quill is very small indeed, or may be wholly absent. In this case, however, the upper covert is present as an apparently supernumerary feather, provided that the 10th quill is not much reduced. This last shews every intermediate stage between the largest development possible as in Larus and Cypselus, and a degenerate condition as in many of the so-called "Oscines norempennata," "where the 10th primary is supposed to be absent or at least extremely small and concealed. In reality it is always present, even in the Dicrida, while in some Hirundinida it is more than half an inch, and in Icterida may be more than an inch long. In fact there are few birds in which this "absent" quill does not measure the third of an inch in length (see Remiges).

PRION, a genus of PeTrels established by Lacépède (Mém. de l'Inst. iii. p. 514), on account of the denticulated or serrated edges

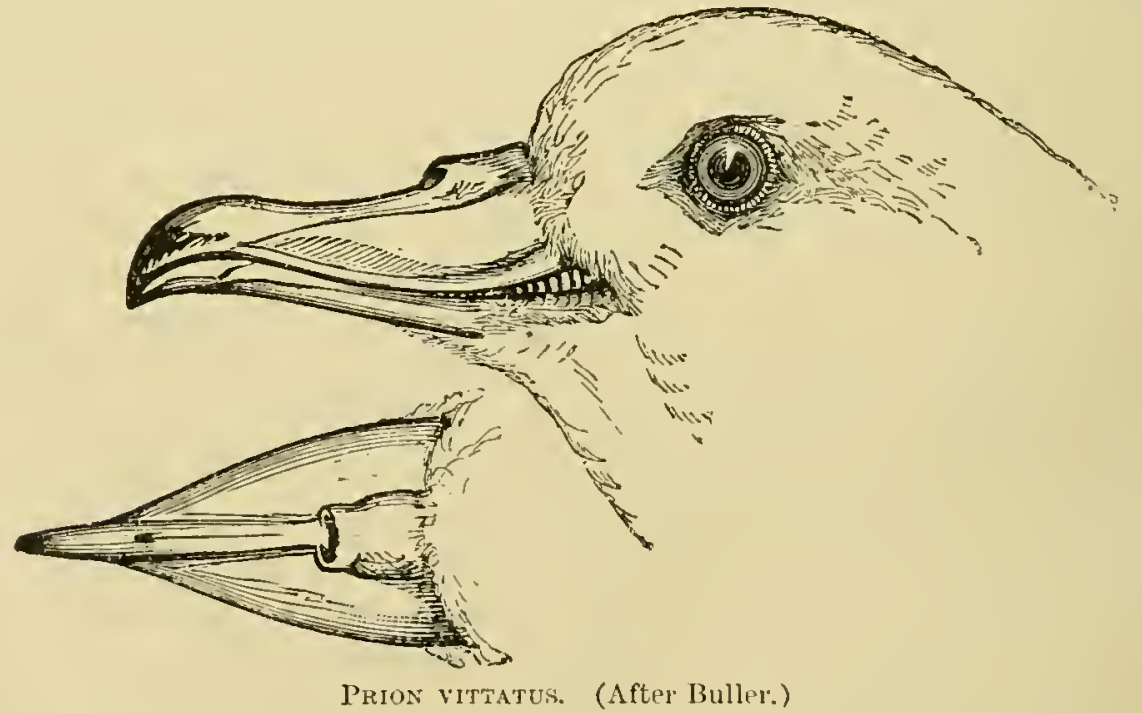

of their mandibles, and used as an English word by many writers. To it are referred the Procelluric rittuta of Gnelin and several other

1 Equivalent to the "Tanagroid Passeres" of Mr. Wallace (IVis, 1874, P. 410), or the "Passeres Fringilliformes" of the Catalogue of the Birds in the British Museum, vols. x.-xii. 
species, all-with perhaps one exception, the $P$. brevirostris of Gould (Proc. Zool. Soc. 1855, p. 88, pl. xciii.), if indeed that be distinct, as seems very doubtful, from his $P$. ariel-belonging to the southern hemisphere. They are remarkable also for the breadth of their bill at the base.

PROMEROPS, a name, long since Anglicized, invented by Réaumur, says Brisson (Ormithol. ii. p. 460, pl. xliii. fig. 2), who used it in a generie sense for a small South-African bird with plain plumage and a remarkably long tail. Without having seen a specimen Linnæus referred it to the genus Upupa (Hoopoe), but also described the same species, from a drawing sent to him by Burmann, as a Merops (BeE-LATER). Promerops, however, has nothing to do with either, though perhaps its true affinity is not yet correctly determined. Most modern systematists think it allied to the Sux-BIrds ${ }^{1}$ (cf. Layard, B.S. Afr. pp. 74, 75, and Shelley, Monogr: Nectariniidx, p. 37\%, pl. 121), though it has none of the brilliant hues that distinguish most of that group, its yellow vent being all that enlivens the soberly-mottled white of its lower parts, while above it is of a uniform greyish-brown. A considerable number of birds, having apparently no affinity at all to it, have been referred to the genus Promerops, which probably should be regarded as the type of a Family. Natal furnishes a second species, P. gurneyi, described and figured by Verreaux (Proc. Zool. Soc. 1871, p. 135 , pl. viii.)

PROUD 'TAILOR, a local name for the GOLDFINCH.

PSEUDOSCINES, Mr. Selater's name (Ibis, 1880, p. 345) for the abnormal AcRonryon of Garrod; but, being of hybrid derivation, Dr. Gadow (Thier-reich, Vögel, System. Th. pp. 173, 177) substituted Suboscines in its stead, correlative with his Subclamatores.

PSILOP ADDES, a name proposed in 1872 by Sundevall (Tentamen, p. 1) for his first division (agmen) of the Class Aves, being the Birds whose young are naked before their feathers grow: in 1873 changed (tom. cit. p. 158) to Gymnopxdes, to prevent confusion with PTILOPADES.

PSITTACI, given in 1826-8 as the name of a Family or group consisting of the PArrots, by Ritgen (N. Act. Acad. L.-C. Nat. Cur. xiv. part i. pp. 231, 243), and afterwards adopted as that of an Order by Bonaparte and other authors, equivalent therefore to the

PSITTACOMORPH无 of Prof. Huxley (Proc. Zool. Soc. 1867, pp. 465,466$)$, by whom it was regarded as the sixth group of his DESMOGNATHA.

1 In the Catalogue of the Birds in the British MIuseum (vol. ix.) Promerops is placed among the Meliphaginx; but apparently not with the approval of the author (tom. cit. p. 209). 
PTARMIGAN, Gael. Turmachan, see Grouse (p. 392, note).

PTEROCLETES, ${ }^{1}$ Mr. Sclater's name (Ibis, 1880, p. 407) for the Order composed of the SAND-GRoust, equivalent to the

PTEROCLOMORPH Æ of Prof. Huxley (Proc. Zool. Soc. 1868, p. 303), which itself was anticipated as a group by Bonaparte's Pectiophiti in 1831 (Saggio \&c. p. 54).

PTERYGOIDS, a pair of bones in the roof of the mouth of every firm bird, articulating with the QUADRATES and the anterior-end of the Palatals, as well as, directly or indirectly, with the Basi-sphenoid and other parts of the SKULL.

PTERYLOSIS signifies plumage considered in regard to the
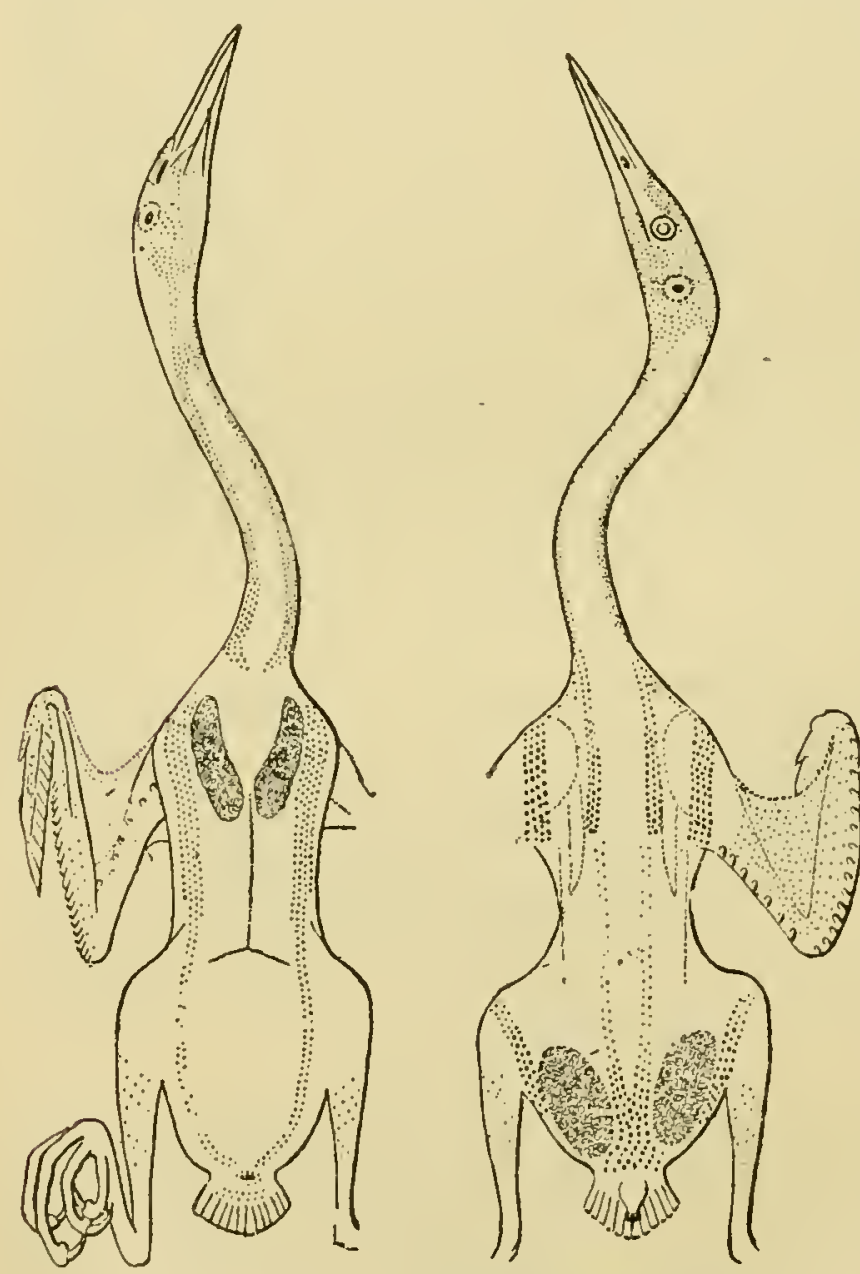

Botaunus stellaris. Ventral anil dorsal aspect. The dirk flatehes shew tle "Powder-lowns."

(After Nitzsch.) distribution of its growth. In only a few Birds do the FEATHERS grow over the whole body, but they are generally restricted to welldefined patches or tracts, which in 1833 received from Nitzsch (Pterylographia Avium pars prior, p. 11) the

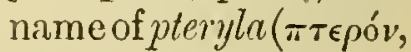
pluma; $v i \eta$, sylva) or "feather-forests," in opposition to the apteria, or featherless spaces, which intervene. Presumably the first bird-like creatures had their skin uniformly clothed; but the Ratita, Sphenisci and Palamedea are almost the only existing forms having the "Contour - feathers" (p. 241) evenly disposed over the body. It would be, however,

1 It is no more easy to find a plural for the worl Pterocles than for Patrocles, Themistocles or many others, but we may be quite sure that it would not take this form. Sundevall many years ago (K. Vet.-Ae. Handl. 1836, p. 119) had Fteroctides, which is perhaps possible. 
a fallacy to look on this feature as proof of an archaic condition in then, since fully-developed embryos of both Struthio and Apteryx have well-defined pteryla. If treated skilfully, Pterylosis is of prime taxonomic importance in Ornithology, though more in the investigation of small than of large groups. Unfortunately it can seldom be described in a few words, and hence it is chiefly or only those among its characters which can be. expressed in terse and trim formulæ that appeal most to the mechanical constructor of elassifications. ${ }^{1}$

The principal pteryla or feathered tracts are as follows :-

(1) Spinal tract ( $p t$. spinalis), extending along the vertebral column from neck to tail, bordered by the lateral, cervical and trunk apteria or featherless spaces. This tract is one of the most variable, its modifications, of which Nitzsch enumerated 17, being practically countless. It is rarely of the same width throughout, and is most frequently dilated on the back or between the shoulders,

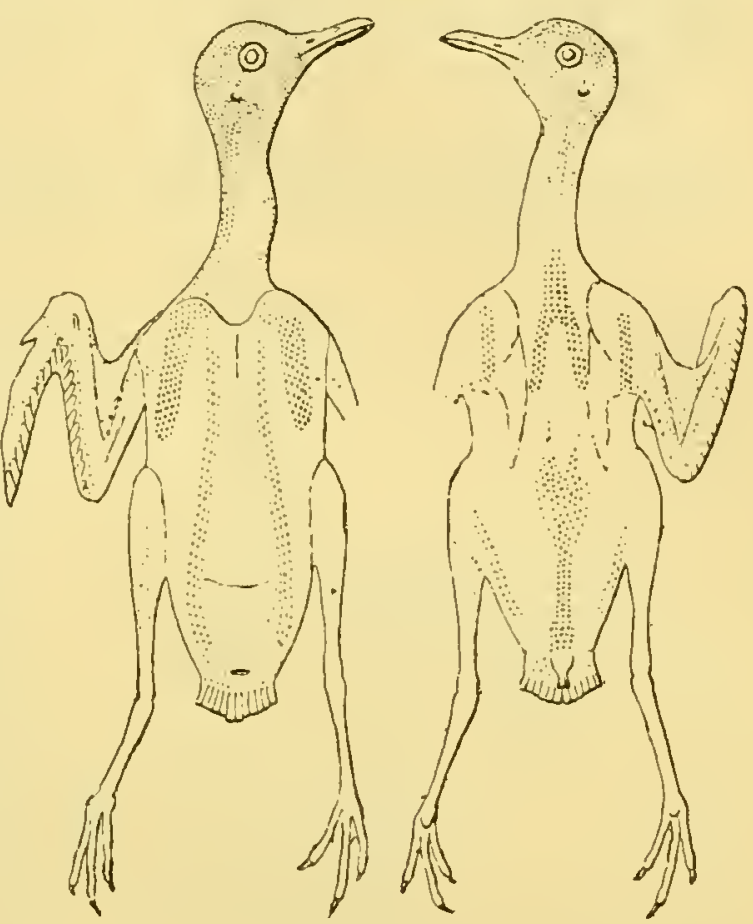

Charadrius pluviazis. Ventral and dorsal aspect.

(After Nitzsch.) with or without a featherless space in the midst, the position and size of which varies much. In Pelecunus, Fregatu, Phacthon and Ardea the space is narrow, and extends from the neck to the tail, in others as Podicipes, Cuculi, Cypselus, Coracias and Opisthocomus it is restricted to the back, in Sula to the interscapular region, in Colymbus to the neck. In some birds this apterium, whether interscapular, dorsal or lumbar, is rhomboidal, and it may become so large as to interrupt the spinal pteryla, which may end in an interseapular fork and begin again with a sacral bifurcation, or as a single streak; but there is no apterium in the spinal pteryle of the following:- Ratita, Splenisci, Phalacrocorax, Plotus, Palamedea, Tinami, Gallinx (pt.),

I Even this lias taken place within comparatively few years, for Nitzsch's great work on the subject Pterylogruphic (Halle: 1810, 4to), which after his deatly was edited by Burmeister, excited but little and mostly unfavourable notice for ncarly a quarter of a century after its publication. An English translation by the late MIr. Dallas was brought out in folio by Mr. Sclater for the Ray Society in 1867 . 
Grues (pt.), Pterocles, Alcedinida, Momotida, Todidix, Colii, Trogones, Menura, Atrichic and most Oscines.

(2) Tentral tract ( $p$ t. ventratis). This is nearly as diverse as the foregoing, and is next to it in taxonomic value. It always has a longitudinal median apterium of variable extent, but in Steganopodes this is only a narrow space extending from the furcula to the vent, while in Ardea each half of the pteryla is but a narrow band. The presence and shape of a lateral pectoral branch is also an important feature.

(3) Neck-tract ( $p t$. colli). This is mbroken in Ratita, Sphenisci, Colymbus, Podicipes, Steganopodes, Ciconiida, Plataleidx, Phonicopterus,

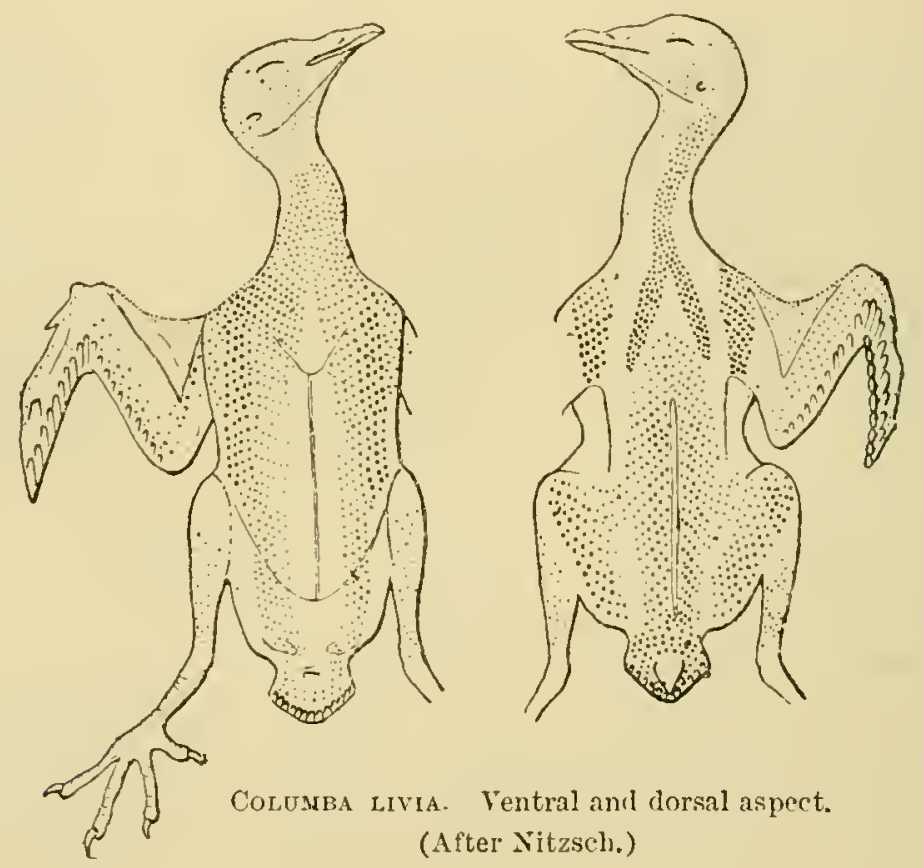

Anseres, Palamedea, Dicholoplens, Otis tarda (not O. tetrax), Enpodotis, Eurypyga, Podica, Rhynchaca, Opisthocomus and Buceros. All other birds have lateral cervical apteria of variable length, sometimes in addition to the median cervical apteria which, whether dorsal or ventral, are often long. What Nitzsch called pteryla colli luterules, divided by a very broad dorsal and a ventral cervical apterium, occur only in the Herons and in Otis tetrax.

4. Wing-tract (pt. alaris), composed of the Rumigks with their coverts, and hence of great importance.

5. Tail-tract ( $p t$. candalis), composed chiefly of the RECTRICES with their upper and lower coverts.

6. Shoulder-tract (pt. humeralis), always well marked, consisting of the feather's, often called tertials, which grow from the 
humerus, and with the SCAPULARs forming a narrow band across the upper arm parallel to the shoulder-blade.

7. Femoral or Lumbar tract (pt. femorulis s. lumbulis), forming an oblique band on the onter side of the thigh.

s. Crural tract (pt. cruralis), clothing the legs so far as they are featheled.

9. Head-tract ( $p t$. capitis), that which covers the head. Remarkable and of rare occurrence is a well-defined occipital apterium as is seen in Colius and Trochitidie.

10. Tract of the OIL-GLAND (pt. uropygii).

The description of the Pterylosis of any bird is not exhausted by an enumeration of the pteryla and apteriu, but should also inchude the disposition of Downs, other than PownerDowns, both in the young and the old. The distribution of Downs on the featherless spaces as well as among the contour-feather's is a prinary feature, and is characteristic of the following - Accipitres, Alcilla, Alseres, Cuthartidia, Ciconivida, Colymbida, Dicholophus, Eurypyga, Grvida, Lurilax, Opisthocomus, Palamedea, Phanicopterus, Platuleida, Podica, Podicipedidx, Psittaci, Rullida, Rihinochetus, Sphenisci, Steganopodes, Tutinares-curiously also in Cinclus and in the aquatic members of the Alredinitix. Restriction of Downs to the apteria is found in the adults of

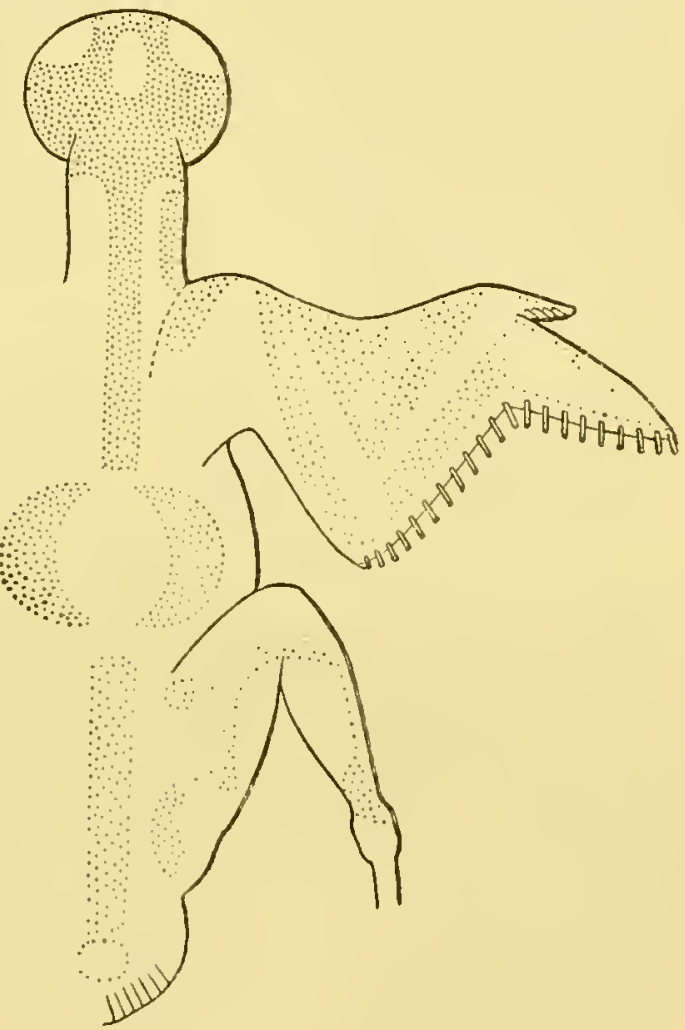

Gecinus viridis. Dorsal aspect. Ardeida, Cuprimulgida, Cypselida, Cuculidx, Gallina, Otilidix, Passeres (except Cinclus), Pteroclidix, Scopus, Striges and Turnicida. In the Tinami only are Downs confined to the pteryla; but in them they are sparsely and frequently thinly developed, as is also the case with the Cuculida, Dicholophus, Gallina, Limicola, Opisthocomus, Pteroctidx, Turnicida and some Passeres, while they are wholly absent in Atrichia, Buceroticla, Capitonidx, Colivda, Colunbidx, Coruciuda, Eurylamida, Galbulida, Menurw, Meropidida, Momotida, Picida, Ratita, Rhamphastida, Todide, Trochilida, Trogonida, Upupida and in most Passeres. 
The figures here inserted serve to shew some of the differences of Pterylosis presented by various birds; but it will be obvious

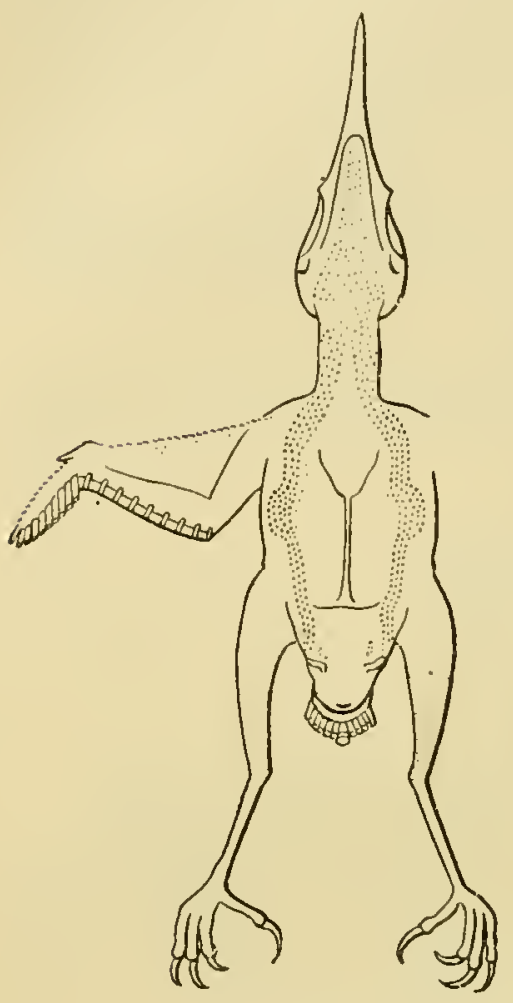

Civvreis chloroprais.

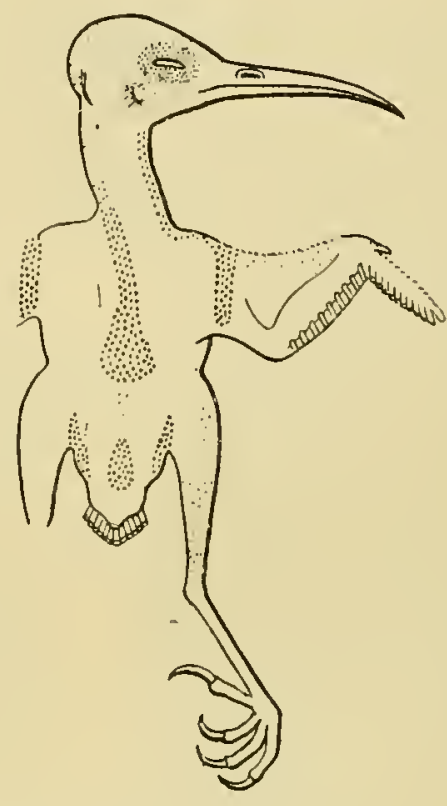

Ventral and clorsal aspect.

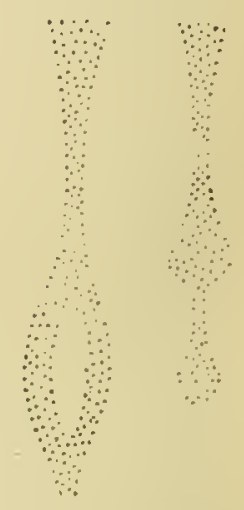

ARACHNECIITHRA and Cinnyis oBscura. Dorsal tract.

that a very long series would be required to exhibit even the principal types observable in the whole Class. ${ }^{1}$

PTILOP $\mathbb{E D E S}$, a name proposed in 1872 by Sundevall (Tentamen, p. 102) for his second division (agmen) of the Class Aves, being the Birds whose young are thickly covered with down before their feathers grow: in 1873 changed (tom. cit. p. 158) to Dasypedes, to prevent confusion'with PSILOP EDES.

PTILOSIS, the learned word for Plumage.

PUBIS (properly Os pubis) or PUBIC Bones, the anterior, most ventral and slenderest of the three component parts of the Pelvis.

PUCKERIGE (possibly connected with the A.S. pucu, a goblin

I Since the time of Nitzsch additional descriptions of the Pterylosis of ecrtain birds have appeared, but no special work on the subject, though it has by no neans been exhansted, and such a work would be of eonsiderable taxonomic utility if it were amply illustrated (little text being needed) and special attention paid to the numerous transitional forms that eomnect the chief types. A great and revised mass of information is to be found, lowever, in Prof. Fürbringer's Untersuchungen der Morphologie und Systematik der Vügel. 
or demon), a name of the NightJAR, and also of the disorder in the udders of cattle that it has been said to eause.

PUDDING-POKE, i.e. Pudding-bag, properly the nest of the Long-tailed Trtmouse; but in common use transferred to the bird itself.

PUFF-BIRD, the name first given, according to Swainson (Zool. Illustr. ser. 1, ii. text to pl. 99), by English residents in Brazil to a group known to ornithologists as forming the restricted Family Bucconidx, but for a long time confounded, under the general name of BARBETs, with the Capitonida of modern systematists, who regard the two Families as differing very considerably from one another. Some authors have used the generic name Capito in a sense precisely opposite to that which is now commonly accorded to it, and the natural result has been to produce one of the most complex of the rany nomenclatural puzzles that beset Ornithology. Fortunately there is no need here to enter upon this matter, for each group has formed the subject of an elaborate work-the Capitonidx being treated as before stated (p. 27) by the Messrs. Marshall, and the Bucconida by Mr. Sclater ${ }^{1}$--in each of which volumes the origin of the confusion has been explained, and to either of them the more curious reader may be confidently referred. The Bucconidx are zygodactylous Birds belonging to the large heterogeneous assemblage in the present work called PICARIE, and are commonly considered nowadays to be most nearly allied to the Galbulida (JACAMAR). Like them they are confined to the Neotropical Region, in the middle parts of which, and especially in its Sub-Andean Subregion, the Puff-birds are, as regards species, abundant; while only two seem to reach Guatemala and but one Paraguay. As with most South-American Birds, the habits and natural history of the Bucconida have been but little studied, and of only one species, which happens to belong to a rather abnormal genus, has the nidification been described. This is the Chelidopteru tenebrosa, which is said to breed in holes in banks, and to lay white eggs much like those of the Kingfisher and consequently those of the Jacamars. From his own observation Swainson writes (loc. cit.) that Puff-birds are very grotesque in appearance. They will sit nearly motionless for hours on the dead bough of a tree, and while so sitting "the disproportionate size of the head is rendered more conspicuous by the bird raising its feathers so as to appear not unlike a puff ball. . . When frightened their form is suddenly changed by the feathers lying quite flat." They are very confiding birds and will often station themselves a few yards only from a window. The Bucconida almost without ex-

1 A Monograph of the Jacamars and Puff-birds, or Families Galbulidse and Bucconidie. London : 1879-82, 4 to. 
ception are very plainly coloured, and the majority have a spotted or mottled plumage suggestive of immatmrity. The first Puff-bird known to Europeans seems to have been that described by Marcgrave under the name of "Tamutia," by which it is said to have been called in Brazil, and there is good reason to think that his description and figure-the last, comic as it is in ontline and expression, having been copied by Willughby and many of the older authors - apply to the Bucco muculutus of modern Ornithology -a bird placed by Brisson (Ornithologie, iv. p. 524) among the Kingfishers. But if so, Marcgrave described and figured the same

a
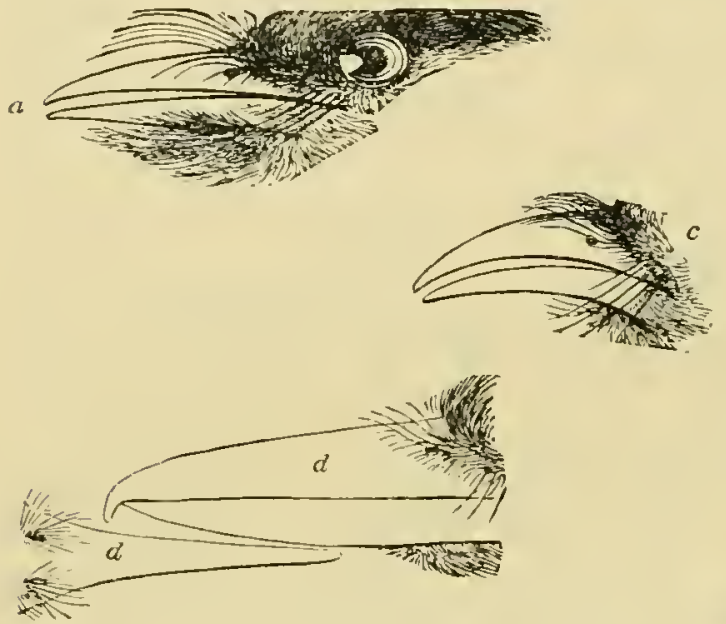

a, Malacoptila ; $b$, Monacha ; $c$, Chelinoftera ; $l$, Bucco Maculata; $c$, B. tamatia.

(After Swainsor.)
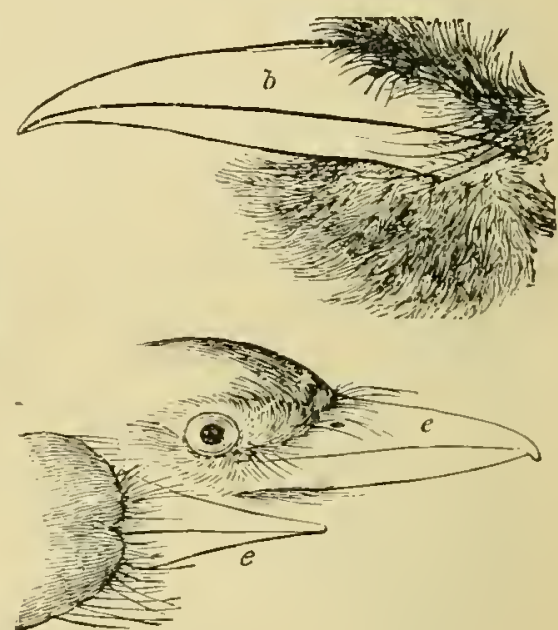

species twice, since his "Mutuitui" is also Brisson's "Martin pescheur tacheté du Biésil."

Mr. Sclater in his Monograph divided the Family into 7 genera, of which Bucco is the largest and contains 20 species. The others are Mulucoptila and Monacha each with 7, Nommle with 5, Chelidopterce with 2, and Micromonacha and Hapaloptila with 1 species each, treating them precisely in the same way in 1891 (Cat. B. Br. Mus. xix. pp. 17S-20S). The most showy Puff-bircls are those of the gemus Monuchu with an inky-black plumage, nsually diversified by white about the head, and a red or yellow bill. 'The rest call for no particular remark.

PUFFIN, the common English name of a sea-bird, the Fraterculc arctica of most ornithologists, known, however, on various parts of the British coasts as the Bottlenose, Coulterneb, Pope, Sea-Parrot, and Tammy-Nolie, to say nothing of other still more local designations, some (as Marrott and Willock) shared also with allied species of Alcidix, to which Family it has, until very lately, been invariably deemed to belong. Of old time Puffins were a valuable commodity to the owners of their breeding-places, for the young 
were taken from the holes in which they were hatched, and "being exceeding fat," as Carew wrote in 1602 (Survey of Cornwall, fol. 35), were "kept salted, and reputed for fish as coming neerest thereto in their taste." In 1345, according to a document from which an extract is given in Heath's Islands of Scilly (p. 190) those islands were held of the crown at a yearly rent of 300 Puftins $^{1}$ or 6 s. 8d., being one-sixth of their estimated annual value. Some years later (1484), either through the birds having grown scarcer or money cheaper, only 50 Puffins are said (op. cit. p. 196) to have been demanded. It is stated by both Gesner and Caius that they were allowed to be eaten in Lent. Ligon, who in 1673 speaks (Hist. Barbadoes, p. 37) of the ill taste of Puffins "which we have from the isles of Scilly," and adds, "this kind of food is only for servants." Puffins used to resort in vast numbers to certain stations on the coast, and are still plentiful on some, ${ }^{2}$ reaching them in spring with remarkable punctuality on a certain day, which naturally varies with the locality, and after passing the summer there, leaving their homes with similar precision. They differ from most other Alcida in laying their single egg (which is white, with a few grey markings, when first produced but speedily begrimed by the soil) in a shallow burrow, which they either dig for themselves or appropriate from a rabbit, for on many of their haunts rabbits have been introduced. Their plumage is of a glossy black above-the cheeks grey, encircled by a black band-and pure white beneatl ; their feet are of a bright reddish-orange, but the most remarkable feature of these birds, and one that gives them a very comical expression, is their huge bill. This is very deep and laterally flattened, so as, indeed, to resemble a coulter, as one of the bird's common names expresses; but moreover it is parti-coloured-blue, yellow and red-curiously grooved and still more curiously embossed in places, that is to say, during the breeding-season, when the birds are most frequently

1 There can not be much doubt that the name Puffin given to these young birds, salted and dried, was appliecl on account of their downy clothing, for an English informant of Gesner's described one to him (Hist. Avium, 1). 110) as wanting true feathers, and being covered only with a sort of woolly black: plumage. It is right, however, to state that Caius expressly declares (Rarior. animal. libellus, fol. 21) that the name is derived "a naturali voce pupin." Prof. Skeat states that the word is a dimimutive, which favours the view that it was originally used for these young birds. The parents were probably known by one or other of their many local names.

2 In 1893 I took some trouble to make an estimate, though from the nature of the case a very rough one, of the number of Puffins which had their home in one locality among the Hebrides. The calculation worked out to be three millions, and my friend Mr. Henry Evans, to whose kindness I was indebted for the opportunity of visiting the place, considered that number not to be excessive. In 1894 I was again at the same spot and was inclined to think that I had before underrated the number: 
seen. But it had long been knowl to some observers that such Puffins as occasionally occur in winter (most often dead and washed up on the shore) presented a beak very different in shape and size, and to account for the difference was a standing puzzle. Many years ago Bingley (North Wales, i. p. 354) stated that Puffins "are said to change their bills annually." The remark seems to have been generally overlooked; but it has proved to be very near the truth, for after investigations carefully pursued during some years by Dr. Bureau of Nantes he was in 1877 enabled to shew (Bull. Soc. Zool. France, ii. pp. 377-399) ${ }^{1}$ that the Puffin's bill undergoes an annual MoULT, some of its most remarkable appendages, as well as certain horny outgrowths above and beneath the eyes, dropping off at the end of the breeding-season, and being reproduced the following year. Not long after the same naturalist announced (op. cit. iv. pp. 1-68) that he had followed the similar changes which he found to take place, not only in other species of Puffins, as the Fratercula corniculata and $F$. cirrhata of the Northern Pacific, but in several birds of the lindred genera Cerorhyncha, the Horn-billed AUk, and Simorhynchus inhabiting the same waters, and consequently proposed to regard all of them as forming a Family distinct from the Alcidix-a view which has since found favour with Dr. Dybowski (op. cit. vii. pp. 270-300 and viii. pp. 348-350), though there is apparently insufficient reason for accepting it.

The name Puffin has also been given in books to one of the Shearwaters, and its Latinized form Puffinus is still used in that sense in scientific nomenclature. This fact seems to have arisen from a mistake of Ray's, who, seeing in Tradescant's Museum and that of the Royal Society some young Shearwaters from the Isle of Man, prepared in like manner to young Puffins, thought they were the birds mentioned by Gesner (loc. cit.), as the remarks inserted in Willughby's Omithologia (p. 251) prove; for the specimens described by Ray were as clearly Shearwaters as Gesner's were Puffins.

PUKRAS, from its name in one of the dialects in the Northwestern Himalaya, a species of Pheasant (well-known to AngloIndian sportsmen, by whom it is also called the "Koklas"), the Pucrasia macrolopha of most ornithologists. The cock is remarkable for his very long ear-tufts of glossy black, which contrast with the large spot of pure white on each side of the neck; but the rest of his plumage is comparatively unobtrusive, while the hen, as usual among the Pheasants, is very plainly coloured. Beside a local form which seems to be peculiar to Cashmere and Gilgit, Mr.

1 A translated abstract of this paper--containing an account of what is perhaps the most interesting discovery of the kind made in Ornithology for many years-is given in the Zoologist for 1878 (pp. 233-240) and another' in the Bulletin of the Nuttall Ornithological Club for the same year (iii. pp. 87-91). 
Ogilvie Grant (Cat. B. Br. Mus. xxii. pp. 310-316) recognizes 5 other species, one inhabiting Affghanistan, a second Nepal and the rest Tibet or China.

PULLASTR. E, an Order proposed by Sundevall (K. Vet.-Acad. IIandl. 1836, pp. 69, 116) to contain the CuRassows, LYre-BIRD, Plantain-Eaters and Pigeons; subsequently abandoned by him; but in the meanwhile brought forward by Prof. Lilljeborg (Proc. Zool. Soc. 1866, pp. 11, 15), with the addition of the MEGAPODES and omission of Menura and Musophagidx.

PURRE (A.S. Pur, Wright's Vocabularies, i. p. 21), a common name for the DUNLIN in its winter-dress, especially among professional gunners, who are apt to believe, as did ornithologists for a long while, that the Purre and the Dunlin are distinct species.

PUTTOCK, an old name for the Kite and BuzZARD, suggested by Prof. Skeat (Etymol. Dict. p. 480) to signify Poot- or Poult-Hawk, that is to say the Hawk that especially preys on the young of Gallinaceous birds.

PYGOPODES, Illiger's name in 1811 for a group consisting of the genera Colymbus (= Podicipes, GrEBE), Eudytes (=Colymbus, Drver), Uria (Guillemot), Mormon (Puffin), and Alca (Auk), and by many writers regarded as a reasonably natural group or Order.

PYGOSTYLE is the terminal bony expansion of the last 6 or 7 caudal vertebræ which in almost all Carinatæ coalesce into a subtriangular upright plate or blade carrying the RECTRICES. Archxopteryx (pp. 278-279) shews the most primitive condition by possessing about 21 free post-sacral vertebræ, of which each, from the 9 th to the 20 th, supports a pair of welldeveloped rectrices. In all other Birds, as yet known, the number of post-sacral vertebra is considerably diminished, partly by the fusion of about 6 of them with the Pelvis, and partly by reduction at the distal end, so that not more than some 13 caudal vertebræ are left, of which about one-half are free while the rest form the Pygostyle - a result possibly due to the greater use and development of the rectrices. However, Hesperornis (pp. 649-650), the Ratitre and Tinamida retain, even when adult, 13 free vertebræ, which diminish in size towards the tip of the tail, and thus these birds present in that respect an embryonic condition, though it is more probable that in them the absence of a Pygostyle has been brought about in a secondary way by the gradual loss or reduction of once strongly-developed rectrices, than that it should be the retention of a primitive feature. A Pygostyle has been occasionally observed in Apteryx, and the specimen of an old Ostrich in the Cambridge Musemm has one, some 2 inches high and nearly an inch and a half long. In Ichthyornis (p. 651) it is very 
small. All this tends to shew that the distinction expressed by the term SAURURe, in opposition to "Ornithurx," is based on an erroneous supposition.

PYLSTAART, from the Dutch, signifying a tail like the shaft of an arrow, and apparently applied originally to the long-tailed SkUAs, but now more frequently to the Tropic-BIrds.

\section{Q}

QUA-BIRD, so-called from its cry, one of the names given to the North-American Night-Heron, Nycticorax navius (page 420).

QUADRATE BONES form in Birds, as in Reptiles, Amphibians and Fishes, the suspensorial apparatus of the mandibles, while in Mammals they are transformed into the tympanic ring and lose their jaw-bearing function. The dorsal or proximal end of the Quadrate invariably articulates with the squamosal, and often with the lateral occipital bone also. In Hesperornis, Ichthyornis, Ratitæ and Tinamidx the articulation is formed by a single convexity, while in all other birds it consists of an outel and an inner linob, though the existence of an inner knob, small and sometimes indistinct, is indicated in Hesperomis, Phea and the Peristeropodes. The ventral or distal end of the Quadrate has two oblong knobs for articulation with the mandible, as well as two small facets, one on the lateral side for the jugal bone, and the other, which is prominent, on the median side for articulation with the posterior end of the PTERYGOID. From the anterior surface of the shaft of the Quadrate projects the orbital process serving for the attachment of one of the masseter muscles. This process differs greatly in various birds, being large and strong in most aquatic forms, pointed in the Birds-of-Prey and scarcely developed in the Nightjars. Since, as in Lizards and Snalies, the whole Quadrate is movable, protrusion of its distal end helps, by means of the jugal bone, to raise the upper jaw ( $c f$. Skull). That the general shape of the Quadrate can be advantageously used for taxonomic purposes has been shewn by the excellent figures of Miss M. Walker (Stud. Mus. Dundee, 1885).

QUAIL (Old Scottish Quailzie, Old French Quaille, Mod. French Caille, Italian Quaglia, Low Latin Quaquila, Dutch Kwakkel and Kwartel, German Wachtel, Danish Vagtel), a very well-known bird thronghout almost all countries of Europe, Asia and Africa,-in modern ornithology the Coturnix communis or $C$. dactylisonans. 
This last epithet was given from the peculiar three-syllabled callnote of the cock, which has been grotesquely rendered in several European languages, and in some parts of Great Britain the species is popularly known by the nickname of "Wet-my-lips" or "Wetmy-feet." The Quail varies somewhat in colour, and the variation is rather individual than attributable to local causes; but generally the plumage may be described as reddish-brown above, almost each feather being transversely patched with dark brown interrupted by a longitudinal stripe of light buff; the head is dark brown above, with three longitudinal streaks of ochreous-white; the sides of the breast and flanks are reddish-brown, distinctly striped with ochreous-white; the rest of the lower parts are pale buff, clouded with a darker shade, and passing into white on the belly. The cock, besides being generally brighter in tint, not unfrequently has the chin and a double throat-band of reddish or blackish-brown, which marks are wanting in the hen, whose breast is usually spotted. Quails breed on the ground, without making much of a nest, and lay from nine to fifteen eggs of a yellowishwhite, blotched and spotted with dark brown. Essentially migratory by nature, ${ }^{1}$ in March and April they cross the Mediterranean from the south on the way to their breeding-homes in large bands, but these are said to be as nothing compared with the enormous flights that emigrate from Europe towards the end of September. During both migrations immense numbers are netted for the market, since they ale almost universally esteemed as delicate meat. On capture they are placed in long, narrow and low cages, darkened to prevent the prisoners from fighting, and, though they are often so much crowded as to be hardly able to stir, the loss by death that ensues is but trifling. Food, usually millet or hempseed, and water are supplied in troughs hung in front, and thus these little birds are transported by tens of thousands from the shores of the Mediterranean for consumption in the most opulent and populous cities of Europe. The flesh of Quails caught in spring commonly proves $d r y$ and indifferent, but that of those taken in autumn, especially when they have been kept long enough to grow fat, as they quickly do, is excellent. In no part of the British Islands at present do Quails exist in sufficient numbers to be the especial object of sport, though there are many places in which a few, and in some seasons more than a few, yearly fall to the gun. When made to take wing, which is not always easily done, they rise with great speed, but on such occasions they seldom fly far, and no one seeing them only thus would be inclined to credit them with the power of extensive migration that they possess, though this is often overtaxed, and the birds in their

1 Yet not a few Quails pass the winter in the northern hemisphere and eveu in Britain, and many more in southeru Europe. 
transmarine voyages frequently drop exhausted into the sea or on any vessel that may be in their way. In old days they were taken in England in a net, attracted thereto by means of a Quail-call, - a simple instrument, ${ }^{1}$ the use of which is now wholly neglected,-on which their notes are easily imitated.

Five or six other species of the restricted genus Coturnix are now recognized; but the subject of the preceding remarks is generally admitted to be that intended by the author of the book of Exodus (xvi. 13) as having supplied food to the Israelites in the wilderness, though a few writers have thought that bird to have been a SAND-Grouse. In South Africa and India allied species, $C$. delegorguii and $C$. coromandelica, the latter known as the Rain-Quail, respectively occur, as well as the commoner one, which in Australia and Tasmania is wholly replaced by C. pectoralis, the Stubble-Quail of the colonists. In New Zealand another species, $C$. novx-zealandix, was formerly very abundant in some districts, but is considered to have been nearly if not quite extirpated within the last thirty years by bush-fires. Some fifteen or perhaps more species of Quails, inhabiting the Indian and Australian Regions, have been separated, perhaps unnecessarily, to form the genera Synocus, Perdicula, Excalphatoria and so forth; but they call for no particular remark.

America has some forty species of birds which are commonly deemed Quails, though by some authors placed in a distinct Family or subfamily Odontophorinæ. ${ }^{2}$ The best known is the Virginian Quail, or CoLrN, as it is frequently called-that being, according to Hernandez, its old Mexican name. It is the Ortyx virginianus of modern ornithology, and has a wide distribution in North America, in some parts of which it is known as the "Partridge," as well as by the nickname of "Bob-White," 3 aptly bestowed upon it from the call-note of the cock. Many attempts have been made to introduce this bird to England (as indeed similar trials have been made in the United States with Quails from Europe); but, though it has been turned out by hundreds, and has been frequently known to breed after liberation, its numbers rapidly diminish until it wholly disappears. The beautiful tufted Quail of California, Lophortyx californicus, has also been tried in Europe without success; but is well established in New Zealand and the Sandwich Islands. All these American Quails or Colins seem to have the habit of perching on trees, which none of the Old-TVorld forms possess.

Interesting from many points of view as is the group of Birds

1 One is figured in Rowley's Ornithological Miscellany (ii. p. 363).

2 They form the subject of a monograph in folio by Gould, published between 1844 and 1850 .

${ }^{3}$ I learn from a kindly critic $(A u k, 1893$, p. 358) that this name has lately been adopted as generic. 
last mentioned, there is another which, containing a score of species (or perhaps more) often termed Quails, is of still greater importance in the eyes of the systematist. This is that comprehended by the genus Tumix (HemroDE). It is characteristic of this genus to want the hind toe; but the African Ortyxelus and the Anstralian Pedionomus which have been referred to its neighbomrhood have four toes on each foot, and, though nothing is known of the anatomy or habits of the first, the second, after much discussion, has been decisively shewn by Dr. Gadow (Rec. Austral. Nus. 1891, pp. 205-211) to be closely allied to Turnir.

QUAIL-DOVE and QUAIL-SNIPE, both book-names-the former for Starncenas cyanocephala a Cuban species which occasionally strays to the Florida Cays, and the latter for species of the

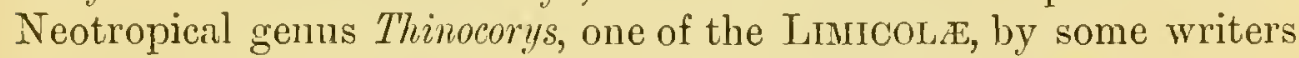
referred to the Charadrizde" (PLOVER, p. 733), and by other's regarded as forming with Attugis a self-standing Family.

QUAIL-HATVK, the name given by colonists to the Fulco norx-zealandia of Gmelin, by later writers referred to the genus Hieracidea or even placed apart as Harpe, ${ }^{1}$ a fine Falconine bird,

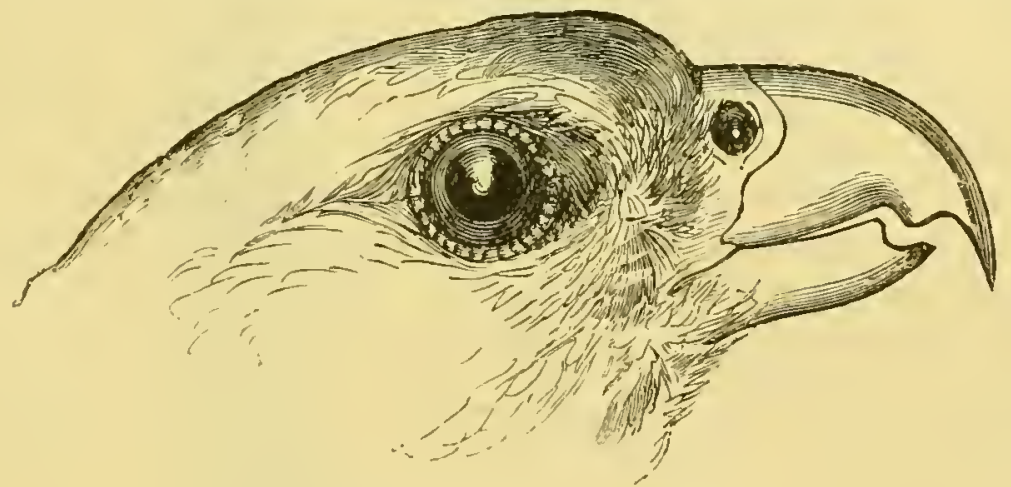

QUAIt-HAWK. (From Buller.)

the precise affinities of which it would he very interesting to know, and one must hope that they may be determined before the cxtirpation of the form, since there seems to be a chance of its proving to be a less modified descendant of an ancient stock whence the true genus Falco and others have sprung, while on the other hand it may turn out to be only an early settler from Australia or elsewhere. Several authorities, and among them Sir Walter Buller, recognize a second species, the Falco ferox of Peale or brumeus of Gould, which seems scarcely to differ from the first but in its smaller size, its habit of frequenting the bush rather than the open, and its comparative abundance in the North Island, where the

1 This name has long been preoccupied by conchologists, and that in the very form, Herpa, to which Dr. Sharpe (Cat. B. Br. Mus. i. p. 372) changed it. 
larger one is seldom if ever seen. Both appear to be equally courageous, and their thoroughly Falconine aspect is shewn by the annexed figure. fuliginosa.

QUAKER, a sailors' name for the Dusky Albatros, Phobetria

QUAKETAIL, a book-name invented for the Yellow WAGTAIL and its allies, after they had been generically separated from Motacilla as Budytes. GUAN.

QUAM or QUAN, old ways of spelling what is now written

QUA-QUA, the Creole name in Tobago, for a species of Thamnophilus (ANT-Thrush, p. 21) there found.

QUEEST or QUIST, an abbreviated corruption of CUSHAT.

QUESAL or QUEZAL the Spanish-American name for one of the most beautiful of birds, abbreviated from the Aztec or Maya Quetzal-tototl, the last part of the compound word meaning fowl, and the first, also written Cuetzal, the long feathers of rich green with which it is adorned. ${ }^{1}$ The Quezal is one of the Trogons, and was originally described by Hernandez (Historia, p. 13), whose account was faithfully copied by Willughby. Yet the bird remained practically unknown to ornithologists until figured in 1825 , from a specimen belonging to Leadbeater, ${ }^{2}$ by Temminck ( $P l$. col. 372) who, however, mistakenly thought it was the same as the Trogon pavoninus, a congeneric but quite distinct species from Brazil, that had just been described by Spix (Av. Bras. i. p. 47, pl. xxxv.) In 1832 the Registro Trimestre, a literaly and scientific journal printed at Mexico, of which few copies can exist in Europe, contained a communication (pp. 43-49) by Dr. Pablo de la Llave, describing this

1 Dr. Tylor informs me that the Mexican deity Quetzal-coatl had his name, generally translated "Feathered Snake," from the quetzal, feather" or bird, and coatl, snake, as also certain kings or chiefs, and many places, e.g. Quetzalapan, Quetzaltepec, and Quezaltenango, though perhaps some of the last were named directly from the personages ( $c f$. Bancroft, Native Races of the Pacific States, vol. v. Index). Qnetzal-itzli is said to be the emerald.

2 This specimen had been given to Mr. Camning (a tribute, perhaps, to the statesman who afterwards boasted that he had "called a New World into existence to redress the balance of the Old") by Mr. Schenley, a diplomatist, and was then thought to be unique in Europe; but, apart from those which had reached Spain, where they lay neglected and undescribed, James Wilson says (Illustr. Zool. pl. vi. text) that others were brought with it, and that one of them was given to the Edinburgh Mnseum. On the 21st day of the sale of Bullock's Museum in 1819, Lot 38 is entered in the Catalogne as "The Tail Feather of a magnificent undescribed Trogon," and very likely belonged to this speeies. It was bought for nineteen shillings by Warwick, a well-known London dealc1. 


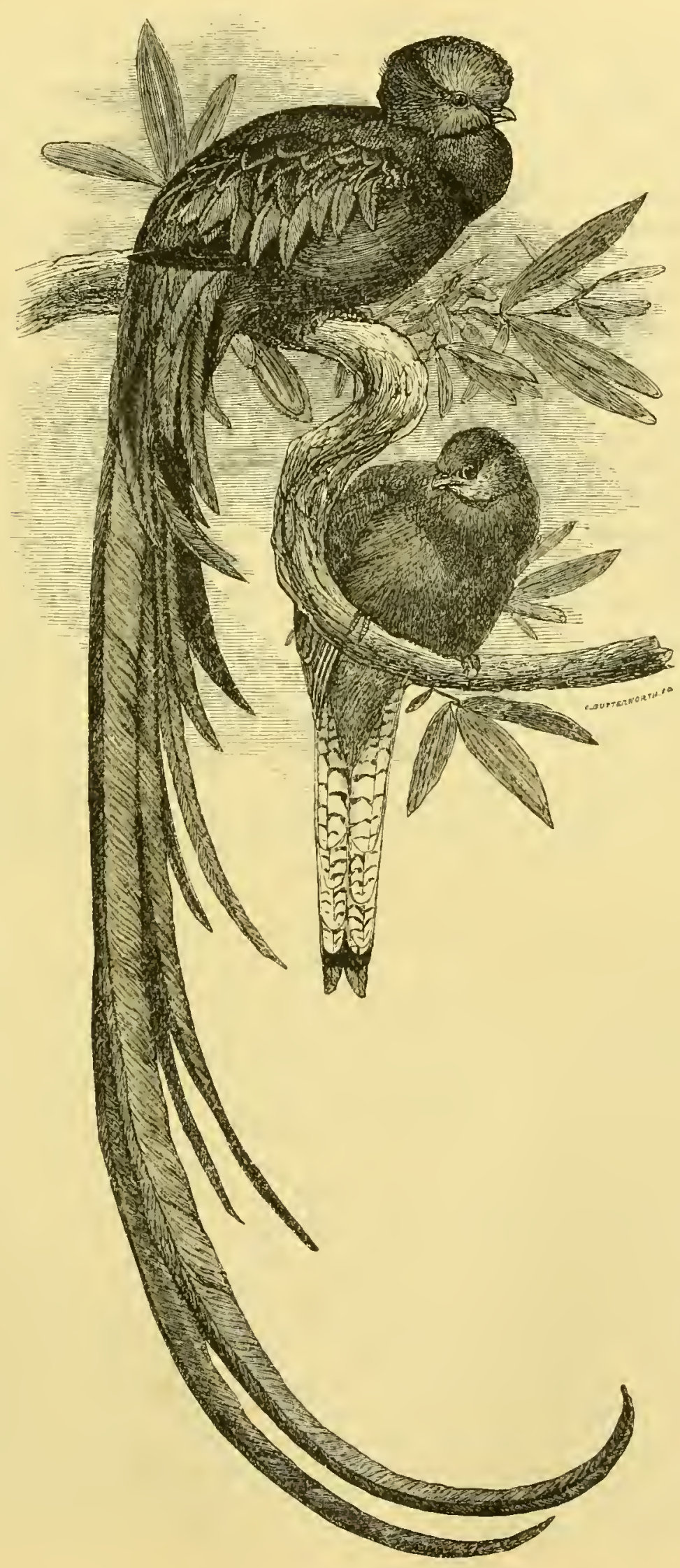

Quezal, male and female. 
species (with which he first became acquainted prior to 1810 , from examining more than a dozen specimens obtained by the naturalhistory expedition to New Spain and kept in the palace of the Retiro near Madrid) under the name by which it is now commonly known, Pharomacrus mocinno, ${ }^{1}$ in memory of a Mexican naturalist, Dr. Mociño. This fact, however, being almost unknown to the rest of the world, Gould, while pointing out Temminck's error (Proc. Zool. Soc. 1835, p. 29), gave the species the name of Trogon resplendens, which it bore for some time. Yet little or nothing was generally known about the bird until Delattre sent an account of his meeting with it to the Echo du Monde Savant for 1843 (reprinted Rev. Zool. for that year, pp. 163-165). In 1860 the nidification of the species, about which strange stories had been told to the naturalist last named, was determined, and its eggs, of a pale bluish-green, were procured by Mr. Robert Owen (Proc. Zool. Soc. 1860 , p. 374 ; Ibis, 1861, p. 66, pl. ii. fig. 1); while further and fuller details of its habits (of which want of space forbids even an abstract here) were made known by Mr. Salvin (Ibis, 1861, pp. 138-149) from his own observation of this very local and remarkable species. Its chief home is in the-mountains near Coban in Vera Paz, but it also inhabits forests in other parts of Guatemala at an elevation of from 6000 to 9000 feet.

The Quezal is hardly so big as a Turtle-Dove. The cock has a fine yellow bill and a head bearing a rounded crest of filamentous feathers; lanceolate scapulars overhang the wings, and from the rump spring the long flowing plumes which are so characteristic of

1 M. Sallé translated De la Llave's very rare and interesting memoir (Rev. et Mag. de Zool. 1861, pp. 23-33). Bonaparte stated (Proc. Zool. Soc. 1837, p. 101) that in 1826 he had proposed the name paradiseus for this species, and had communicated a notice of it to an American journal. There seems no reason to doubt his statement, and the journal was most likcly the Contributions of the Maclurian Lyeeum, pnblished at Philadelphia (1827-29), to which, as he says in his Sulla seconda cdizione del Iicgno Animale del Barone Cuvier Osservazioni (Bologna: 1830, p. 80), he sent some remarks on Swainson's Synopsis of the Birds of Mexico, and believed they had been printed there. But these Contributions minfortunately came to an end with the third number, and the only article by Bonaparte they contain is a Catalogue of the Birds of the United States (pp. 8-34), so that his criticism of Swainson's paper (which had appeared in the Philosophical MFagazine for 1827), though doubtless accepted for publication, has never seen the light. Dr. Hartlaub has printed (Naumannia, 1852, Hft. 2, p. 51) part of a letter from Duke Paul of Würtemberg, in which the writer says that in 1831 he communicated a description of $P$. mocinno to Cuvier, who thought that its long train-feathers liad been put together artificially. He possibly had in mind the celebrated feather treasured in the Escurial as having come from the wing of the Archangel Gabriel. This might be thought to have been a Quezal's, but the author of Vathek who saw it in 1787, says (Italy with Sketches of Spain, i. p. 325) it was rose-coloured. 
the species, and were so highly prized by the natives prior to the Spanish conquest that no one was allowed to kill the bird when taken, but only to divest it of its feathers, which were to be worn by the chiefs alone. These plumes, the middle and longest of which may measure from three feet to three feet and a half, are with the upper surface, the throat and chest, of a resplendent goldengreen, ${ }^{1}$ while the lower parts are of a vivid scarlet. The middle feathers of the tail, ordinarily concealed, as are those of the Peacock, by the uropygials, are black, and the outer white with a black base. In the hen the bill is black, the crest more round and not filamentous, the uropygials scarcely elongated and the vent only scarlet. The eyes are of a yellowish-brown. Southern examples from Costa Rica and Veragua have the tail-coverts much narrower, and have been needlessly considered to form a distinct species under the name of $P$. costaricensis. There are, however, three good congeneric species, $P$. antisianus, $P$. auriceps and $P$. pavoninus, from various parts of South America, and, though all are beautiful birds, none possesses the wonderful singularity of the Quezal.

QUILL, properly that part of FEATHER which is often called the "barrel"; but in common use applied to any feather that has a barrel of considerable size, and especially to the large feathers of the tail and wing (see Rectrices, Remiges).

QUILL-TAIL COOT, a local name in North America for Erismatura rubida, one of the Spiny-tailed Ducks (p. 168). $57,375)$.

QUINCK-GOOSE, a fowlers' name of the Brant-Goose (pp.

QUISCALUS, said to be from the Low Latin Quiscula or Quisquilla, which like Quaquila are supposed to be renderings of Quagila or some such word, and to mean QUAIL, but the first is used as the scientific name of the genus to which belong the BOAT-TAIL GrACKtes, and also occasionally as an English word.

QUIT, a name applied in Jamaica, and perhaps some others of the British Antilles, to several very different kinds of birds, probably from the note they utter ( $c f$. GUIT-GUIT). Thus the Banana Quit is the SUgar-BIRD, the Blue Quit is Euphonia jamaica, one of the TANAGERS, the Grass-Quits are species of Phonipara allied if not belonging to the Emberizida (Bunting), and the Orange-Quit is Glossoptila ruficollis, one of the Carebida.

1 Preserved specimens, if exposed to the light, lose mucls of their beanty in a few years, the original glorious colour becoming a dingy greenish-blue. 


\section{$\mathrm{R}$}

RACE-HORSE, a name applied by seamen to the LOGGERHEAD Duck (p. 518) for more than a century, but of late years superseded by that of Steamer-Duck.

RACQUET-TAIL, a name given to several of the MotMots, and by Gould to Humming-Bipds of the genus Spathura.

RADIUS, the straighter and more slender of the two bones of the forearm (the other being the ULNA). Its proximal end forms a shallow cup for articulation with the outer condyle of the HUNERUS, while the distal end bears a knob which fits into the radial bone of the CARPUS.

\section{PAFTER-BIRD, a local name of the Spotted Flycatcher.}

RAIL (German Ralle, French Râle, Low Latin Rallus), originally the English name of two birds, distinguished from one another by a prefix as Land-Rail and Water-Rail, but latterly applied in a much wider sense to all the species which are included in the Family Rallicix.

The LAND-RAIL, also very commonly known as the Corn-Crake, and sometimes as the Daker-Hen, is the Rallus crex of Linnæus and Crex pratensis of later authors. Its monotonous grating cry, which has given it its common name in several languages, is a familiar solind throughout the summer-nights in many parts of the British Islands; but the bird at that season very seldom shews itself, except when the mower lays bare its nest, the owner of which, if it escape beheading by the scythe, may be seen for an instant before it disappears into the friendly covert of the stillstanding grass. In early autimn the partridge-shooter not unfrequently flushes it from a clover-field or tangled hedgerow; and, as it rises with apparent labour and slowly flies away to drop into the next place of concealment, if it fall not to his gum, he wonders how so weak-winged a creature can ever make its way to the shores if not to the interior of Africa, whither it is almost certainly bound; for, with comparatively few individual exceptions, the Land-Rail is essentially migratory-nay more than that, it is the Ortygometra of classical authors - supposed by them to lead the QUAIL on its voyages-and in the course of its wanderings has now been known to reach the coast of Greenland, and several times that of North America, to say nothing of Bermuda, in every instance we may believe as a straggler from Europe or Barbary. An example has even been recorded from New South Wales (Rec. Austral. Mus. ii. 
p. 8\%). The Land-Rail needs but a brief description. It looks about as big as a Partridge, but on examination its appearance is found to be very deceptive, and it will hardly ever weigh more than half as much. The plumage above is of a tawny brown, the feathers being longitudinally streaked with blackish-brown; beneath it is of a yellowish-white; but the flanks are of a light chestnut. The species is very locally distributed, and in a way for which there is at present no accounting. In some dry upland and corn-growing districts it is plentiful ; in others, of apparently the same character, it but rarely occurs; and the same may be said in regard to lowlying marshy meadows, in most of which it is in season always to be heard, while in others having a close resemblance to them it is never met with. The nest is on the ground, generally in long grass, and therein from nine to eleven eggs are commonly laid. These are of a cream-colour, spotted and blotched with light red and grey. The young when hatched are thickiy elothed with black down, as is the ease in nearly all species of the Family.

The WATER-KAIL, locally known by several names as Bilcock or Skiddy, is the Rallus aquaticus of Ornithology, and seems to be less abundant than the preceding, though that is in some measure due to its frequenting places into which from their swampy nature men do not often intrude. Having a general

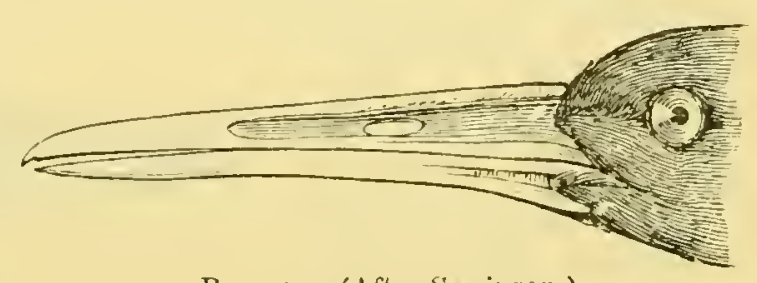

RALLus. (After Swainson.) resemblance to the Land-Rail, ${ }^{1}$ it can be in a moment distinguished by its partly red and much longer bill, and the darker coloration of its plumage-the upper parts being of an olive-brown with black streaks, the breast and belly of a sooty-grey, and the flanks dull black barred with white. Its geographical distribution is very wide, extending from Iceland (where it is said to preserve its existence during winter by resorting to the hot springs) to China ; and though it inhabits Northern India, Lower Egypt and Barbary, it seems not to pass beyond the tropical line. It never affects upland districts as does the Land-Rail, but always haunts wet marshes or the close vicinity of water. Its love-note is a loud and harsh cry, not continually repeated as is that of the Land-Rail, but uttered at considerable intervals and so suddenly as to have been termed "explosive." Besicles this, which is peculiar to the cock-bird, it has a croaking call that is frog-like. The eggs resemble those of the preceding, but are more brightly and delieately tinted.

1 Formerly it seems to have been a popular belief in England that the Land-Rail in antumn transformed itself into a Water-Kail, resuming its own character in spring. I lave met with several persons of general intelligence who had serious doubts on the sulject. 
The various species of Rails, whether allied to the former or latter of those just mentioned, are far too numerous to be here noticed. Hardly any part of the world is without a representative of the genera Crex or Rallus, and every considerable country has one or perhaps more of each-though it has been the habit of systematists to refer them to many other genera, the characters of which are with difficulty found. Thus in Europe alone three other species allied to Crex pratensis occur more or less abundantly; but one of them, the Spotted Rail or Crake, has been made the

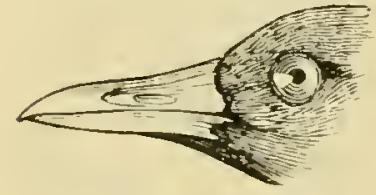

PORZANA.

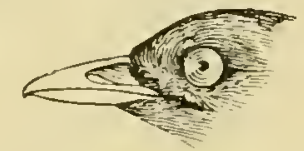

ZAPORNIA.
(After Swainson.) type of a so-called genus Poralna, and the other two, little birds not much bigger than Larks, are considered to form a genus Zapornia. The first of these, which used not to be uncommon in the eastern part of England, has a very near representative in the Carolina Rail or Sora, Crex curolina, of North America, often there miscalled the Ortolan, just as its European analogue, $C$. poratena, is in England often termed the Dotterel. Then there is the widely-ranging Hypotanidia, having a representative almost everywhere from India to China, and far away among the islands to the

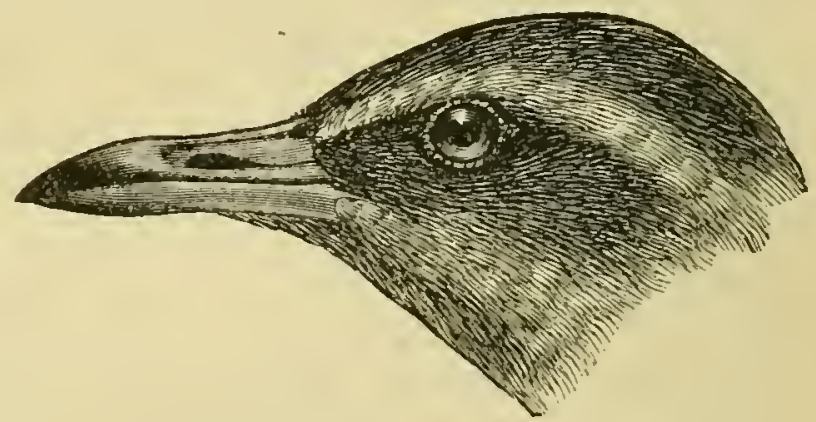

ITrpot.æanidia. (From Buller.)

south-east, even to New Zealand, while at least one example has been known to reach Mauritius. But, passing over these as well as some belonging to genern that can be much better defined, as the Coot and Moor-Hen, to say nothing of other still more interesting forms of the Family, as the already extinct Aphanapternx and Erythromachus ${ }^{1}$ (ExTenMnNATION, pp. 217, 218), Ocyelromus (WEkA) and certain other members of the Family which there is reason to think are doomed to extirpation, brief notice must he taken of the curious genus Blesites of Madagascar, which his been referred by Prof. Alphonse Mine-Edwards (Ann. Sce. Nut. ser. 6, vii. art. 2) to the neighbourhood of the Rails, though offering some points of resemblance to the Herons. ${ }^{2}$ On the

1 By an oversight this genms was ealled Miserytleres in the passage ruoted. (For it see Proc. Zool. Soc. 1875, p. 41.)

2 The Finfoots and JacAsis, hy some systematists formerly placed witl the Rallide, to which the former certainly have some affinity, should he regarded as forming distinet Families, Hcliornithida and Parrida. The 
whole the Rallida constitute a group of birds which, particularly as regards their relations to some other remarkable forms, of which the Sun-BitTern, Eurypyga, and KAgu, Rhinochetus, may especially be named, well deserve greater attention from the systematist, and any ornithologist in want of a subject could hardly find one more likely to reward his labours if he were only to carry them out in a judicious way. Based on the safe ground of anatomy, but due regard being also had to the external characters, habits and other peculiarities of this multifarious group, a monograph might be produced of surpassing interest, and one that in its bearings on the doctrine of evolution would be likely to prove a telling record. ${ }^{1}$

RAIN-BIRD, RAIN-GOOSE and RAIN-QUAIL, the first. applied in England locally to the Green WooDPECKER, but in Jamaica to Cuckows of the genera Piaya and Saurothera; the second in Orkney to the Divers, and preferably to Colymbus septentrionalis; the third in India to Coturnix coromandelica, because of its abundance in some parts of the country during the rainy season; but the others seem to be used because the birds in question are supposed to predict rain by their frequent cries.

RAPACES, RAPTATORES, RAPTORES, names proposed for the Order containing the Birds-of-Prey (both diurnal and nocturnal), and therefore nearly equivalent to the ACCIPITRES of Linnæus. The first was conferred in 1777 by Scopoli (Introd. IIist. Nat. p. 478), and included the genera Strix, Falco, Vultur, Buceros and Rhamphastos. Temminck adopted it, properly excluding the last two, and gave it currency. The second name was invented in 1811 by Illiger (Prodr. System. p. 194), who so termed his Third Order, consisting of the genera Strix, Falco, Gypogeranus, Gypaetus, Vultur and Cathartes; and the third, being only a grammatical alteration of the second, by Vigors in 1823 (Trans. Linn. Soc. xiv. p. 405 , note). No one of the three is used by the latest taxonomers of repute.

RASORES, Illiger's name in 1811 (Prodr. System. p. 195) for his Fourth Order, made to contain 5 Families:-(1) Gallinacei, with the genera Numida, Meleagris, Penelope, Crax, Opisthocomus, Pavo, Phasianus, Gallus, Menura, Tetrao and Perdix; (2) Epollicati, composed of Ortygis (= Turnix) and Syrrhaptes; (3) Columbini, consisting

LIMPKIN, Aramus, also, though its position is not so decided can hardly be kept among the Rails. Mr. W. H. Hudson's notes on the habits of these birds, which he (Proc. Zool. Soc. 1876, pp. 102-109) considers to be Rails, as well as others that undoubtedly are so, deserve the best attention.

1 The most recent revision of the Rallidx is that by Dr. Sharpe (Cat. B. Br. Mus. xxiii. pp. 1-228), who has found it necessary to recognize 61 genera. 
of Columba ; (4) Crypturi of Crypturus (=Tinamus); and (5) Inepti of Didus.

RATITE, that division of the Class Ares whose sternum developing no "keel" resembles a raft or flat-bottomed boat (ratis), and accordingly so named by Merrem (Ablamll. Alatl. Wissensch. Berlin, 1812-13, Physit. Kl. p. 259) in contradistinction to his Carinate (p. 76), though to it he admitted only the single genus Struthio. The extraordinary neglect of this important distinction is elsewhere dwelt upon (IxTRODUCTION), and to Prof. Huxley (Proc. Zool. Soc. 1867, p. 418) is due the full recognition of Merrem's merits. According to the views ${ }^{1}$ adopted in this volume the Subclass Patita comprehends of existing forms the Orders Apteryges (Kiwi), Megistanes (Cassowary, Eveu), Rher (RHEA) and Struthiones (OsTrICH), together with the extinct Apyornithes (Roc) and Immanes (MOA). As regards the relation of other older forms to the Ratita it seems best at present to use reserve (see Fossil Birds, Odontorixithes and Stereorxithes).

RATTLE-IVINGS, a fowlers' name for the GOLDEN-EYE (p. $369)$.

RAVEN (Anglo-Saxon Hrafn, Icelandic Hiafn, Danish Rarn, Dutch Paaf, German Pabe), the largest of the Birds of the Order Pusseres, and probably the most highly developed of all Birds. Quick-sighted, sagacious and bold, it

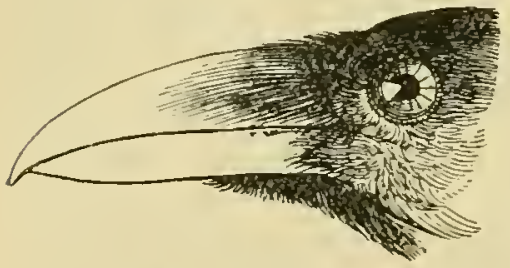

Raves. (After Swainson.) must have followed the prehistoric fisher and hunter, and generally without molestation from them, to prey on the refuse of their spoils, just as it now waits, with the same intent, on the morements of their successor's; while it must have likewise attended the earliest herdsmen, who could not have regarded it with equal indifference, since its now notorious character for attacking and putting to death a weakly animal was doubtless in those days marifested. Yet the Raven is no mere dependent upon man, being always able to get a living for itself; and moreover a sentiment of veneration or superstition has from very remote ages and among many races of men attached to it-a sentiment so strong as often to overcome the feeling of distrust not to say of hatred which its deeds inspired, and, though rapidly decreasing, even to survive in some places until the present time.?

1 See Ann. and Mag. Nat. Hist. ser. 4, xx. lpp. 499, 500.

2 There is no need to dwell on the association of this hird with well-known characters of lhistory sacred or profane-Noah or Elijall, Odin or Flokki, the last of whom by its means discovered Iceland. The Raven is even said to lave 
Notwithstanding all this, however, the Raven has now fallen upon evil days. The reverence with which it was once regarded has all but vanished, and has been very generally succeeded by persecution, which in many districts has produced actual extirpation, so that it is threatened with extinction, save in the wildest and most unpeopled districts. ${ }^{1}$

The Raven breeds very early in the year, in England resorting to its nest, which is usually an ancient if not an ancestral structure, about the middle or towards the end of January. Therein are laid from five to seven eggs of the common Corvine coloration, and the young are hatched before the end of February. In more northern countries the breeding-season is naturally delayed, but everywhere this species is almost if not quite the earliest of birds to enter upon the business of perpetuating its kind. The Raven measures about 26 inches in length, and has an expanse of wing considerably exceeding a yard. Its bill and feet are black, and the same may be said of its whole plumage, but the feathers of the upper parts as well as of the breast are very glossy, reflecting a bright purple or steel-blue. ${ }^{2}$ The species inhabits the whole of Europe, and the northern if not the central parts of Asia ; but in the latter continent its southern range is not well determined. In America ${ }^{3}$ it is, or used to be, found from the shores of the Polar

played its part in the mythology of the Red Indian; and none can wonder that all this should be so, since, wherever it occurs and more especially wherever it is numerous, as in ancient times and in thinly-peopled countries it must have been, its size, appearance and fearless habits would be sure to attract especial attention. Nor has this attention wholly ceased with the advance of enlightenment, for both in prose and verse, from the time of Shakespear to that of Poe and Dickens, the Raven has often figured, and generally without the amount of misrepresentation which is the fate of most animals which celebrated writers condescend to notice.

1 That all lovers of nature should take what steps they can to arrest this sad fate is a belief which I strongly hold. Without attempting to deny the loss which in some cases is inflicted upon the rearers of cattle by Ravens, it is an enormous mistake to suppose that the neighbourhood of a pair of these birds is invariably detrimental. On this point I can speak from experience. For many years I had an intimate knowledge of a pair occupying an inland locality surrounded by valuable flocks of sheep, and abounding in rabbits and game, and had ample opportunities, which I never neglected, of repeatedly examining the pellets of bones and exuvix that these, like all other carnivorous birds, cast up. I thus found that this pair of Ravens fed almost exclusivcly on Moles. Soon after I moved from the neighbourhood in which they lived the unreasoning zeal of a gamekeeper (against, it is believed, the orders of his master) put an end to this interesting couple-the last of their species which inhabited the county.

2 Pied examples are not at all uncommon in some localities and wholly white varieties are said to have been secn.

${ }^{3}$ American birds have been described as forming a distinct species under 
Sea to Guatemala if not to Honduras, but is said hardly to be found of late years in the eastern part of the United States. In Africa its place is taken by three allied but well-differentiated species, two of which (Corvus umbrinus, readily distinguished by its brown neck, and $C$. affinis, ${ }^{1}$ having its superior nasal bristles upturned vertically) also occur in South-Western Asia, while the third ( $C$. leptonyx or $C$. tingitanus, a smaller species characterized by several slight differences) inhabits Barbary and the Atlantic Islands. Further to the southward in the Ethiopian Region three more species appear, whose plumage is varied with white-C. scapulatus, $C$. albicollis and C. crassirostris-the first two of small size, but the last rivalling the real Raven in that respect.

RAZORBILL or RAZOR-BILLED AUK, known also on many parts of the British coasts as the Marrot, Murre, Scout, Tinker, or Willock-names which it, however, shares with the GUILLEMot, and to some extent with the PUFFIN-a common sea-bird of the Northern Atlantic, ${ }^{2}$ but not having a very high northern range, resorting in vast numbers to certain stations on rocky cliffs for the purpose of breeding, and, its object being accomplished, returning to deeper waters for the rest of the year. It is the Alca torda of Linnæus ${ }^{3}$ and most modern authors, congeneric with the GAREFowL, if not the true Guillemots, between which two forms it is intermediate-differing from the former in its small size and in retaining the power of flight, which that had lost, and from the latter in its peculiarly-shaped bill, which is vertically enlarged, compressed and deeply furrowed, as well as in its elongated, wedge-shaped tail. A fine white line, running on each side from the base of the culmen to the eye, is in the adult bird in breeding-

the name of Corvus cannivorus, C. cacolotz or C. principalis, of which there are several forms, and the myology of one, the Mexican C. sinuatus, is the subject of a volume by Dr. Shufeldt published in New York and London in 1890.

1 Dr. Sharpe (Cat. B. Brit. Nrus. iii. p. 45) separates C. affinis as forming a distinct genus Rhinocorax; but it is a liard task on any reasonable ground to break up the genus Corvus as long accepted by systematists.

2 Schlegel (Nus. des Pays-Bas, Urinatores, p. 14) records an example from Japan; but this must be an error.

3 The word Alca is simply the Latinized form of this bird's common Teutonic name, Alke, with which Auk is the English cognate term. It must therefore be held to be the type of the Linnæan genus $A l c a$, though some systematists on indefensible grounds have removed it thence, making it the sole member of a genus named by Leach, after Aldrovandus (Ornithologia, bk. xix. chap. xlix.), Utamania - an extraordinary word, that seems to have originated in some mistake from the equally mistaken Vuttamaria, given by Belon (Observations, livr. i. ch. xi. (as the Cretan name of some diving bird (which certainly could not have been the present species) and, as Mr. H. F. Tozer has kindly informed me, it should have been written Vutanaria, that being the proper transliteration

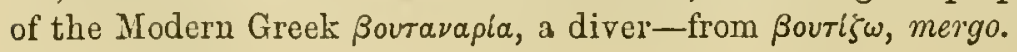


apparel (with a few very rare exceptions) a further obvious characteristic. Otherwise the appearance of all these birds may be briefly described in the same words-head; breast and upper parts generally of a deep glossy black, and the lower parts and tip of the secondaries of a pure white, while the various changes of plumage dependent on age or season are alike in all. In habits the Razorbill closely agrees with the true Guillemots, laying its single egg (which is not, however, subject to the same amazing variety of coloration that is pre-eminently the Guillemot's own) on the ledges of the cliffs to which it repairs in the breeding-season, but it is said, as a rule, when not breeding, to keep further out to sea. On the east side of the Atlantic the Razorbill has its stations on convenient parts of the coast from the North Cape to Britanny, besides several in the Baltic, while in winter it passes much further to the southward, and is sometimes numerous in the Bay of Gibraltar, occasionally entering the Mediterranean but apparently never extending to the eastward of Sicily or Malta. On the west side of the Atlantic it breeds from $70^{\circ} \mathrm{N}$. lat. on the eastern shore of Baffin's Bay to Cape Farewell, and again on the coast of America from Labrador and Newfoundland to the Bay of Fundy, while in winter it reaches Long Island.

RECOLLET, the name given by the French-speaking population of Canada to Ampelis cedrorum (CEDAR-BIRD), from the resemblance of its occipital tuft to the hood worn by members of the Franciscan order of friars.

PECTRICES, the quill-FEATHERs of the tail in Birds, so called from their action in directing FuIGHT. They grow in pairs ; ${ }^{1}$ and what seems to have been their original arrangement is shewn by Archropteryx (Fossic Birds, pp. 278, 279). ${ }^{2}$ Crowding upon a shorter basis seems to have produced the fan-shaped tail and Pygostyle of most recent birds. Absence of this last implies an irregular arrangement of the tail-feathers, which in such cases, as among the RATIT 2 and TiNaMous, can scarcely be called Rectrices; but the reverse does not always occur, as witness those of the Grebes and Penguins. The normal number of Rectrices is 6 pairs, but a few birds possess 10 or 11 ; several 9,8 or 7 ; many only 5, and Crotophaga (ANI) only 4-the diminution being brought about by the suppression of the outer pair or pairs, as is indicated by their often dwindling dimensions, as may be seen in the WoODPECKERS and WRYNECKS when compared with the BARBETS

I Where an odd number is found, as not rarely happens in Swans and some other birds, it seems not unreasonable to suppose that through an injury the germ of one of them has perished.

2 It was there incorrectly stated that each of the 20 vertebræ bore a pair of rectrices, whereas only 12 of them are so furnished. 
(Capito) on the one hand and the PuFf-BIRds (Monacha) on the other. Though the smaller number may be a later and higher stage of the tail's development, it certainly does not confer a higher morphological rank on the forms that bear it, as is shewn by the fact that the majority of PICARI e have but 5 pairs, and also some of the lower PAsseres as Acanthidositta and Xenicus, while it is certain that the possession of more than 6 pairs is not an ancestral feature, the increase being a comparatively recent acquisition. Indeed the number of Rectrices seems to have but little signification, very nearly-allied species differing in this respect. Thus of Oreocincla (ThrusH) two species have 7 pairs, and all the rest 6 . Among the Cormorants the common Phalacrocorax carbo has 7 pairs and the smaller $P$. graculus (SHAG) 6 pairs. Still greater diversity obtains among the SNIPES, the ordinary species of the Old World, Gallinago calestis, has 7, that of North America, G. wilsoni (otherwise not readily distinguished from the former) has 8 , as also has $G$. major, while G. gallinula, the Jack Snipe, but 6, though in the last two cases accompanied by osteological differences, and the Pin-tailed Snipe of Asia, G. stenura, sometimes exhibits 14 pairs. Several other similar cases are on record and many must exist that have not been detected. A difference too may depend upon sex, as with the PEACOCK, which has 10 pairs, being one more than the Peahen.

Of the varied forms and functions of the Rectrices there is little need to speak. The differences displayed by the first are obvious to all who have the least acquaintance with Birds. The forked tail of a SWALLow is proverbial, and the pointed tail of a PARAKEET hardly less familiar, while the erect tail of the Cock with its gallant streamers affords a striking contrast to the flatteued tail of the Goose that feeds beside him in the poultry-yard. Similarly as to function: in the Peacock, QuEzal and some other birds the rectrices serve but as a support to the showy train that covers and hides them: in the WoODPECKERs, TrEE-CREEPERs, and many forms not allied to either, they are of the greatest importance in the bird's economy, as without their support it would be unable to obtain a living; but many are the cases in which ingennity is at a loss to assign the reason for some remarkable peculiarity offered by the Rectrices.

RECTUM, the portion of the intestine (Digestive SYsTeM, p. 138) between the insertion of the CACA and the CLOACA. Birds, the Patitre and Palamedea excepted, have no colon, and the Rectum descending along the right KIDNEY is generally shorter than the distance from the upper end of the kidneys to the cloaca. In the Ostrich, howevel, it is of enormous length (p. 140) and width.

REDBACK, a name applied in North America to the DunLiN 
of that country, Tringa americana (p. 172); but at best only applicable to it in summer-plumage.

REDBIRD, a name of Cardinalis virginianus (CARDINAL), and with the prefix "Summer" of a species of TANAGER, Pyranga astira, since it occurs at that season only within the United States of America.

REDBREAST, the name of a bird which from its manners, no less familiar than engaging, has for a long while been so great a favourite among all classes in Great Britain as to have gained an almost sacred character. The pleasing colour of its plumage-one striking feature of which is expressed by its ancient name-its sprightly air, full dark eye, enquiring and sagacious demeanour, added to the trust in man it often exhibits, but, above all, the cheerful sweetness of its song, even "when winter chills the day" and scarce another bird is heard-combine to produce the effects just mentioned, so that among many European nations it has earned some endearing name, though there is no country in which "Robin Redbreast" is held so highly in regard as England." Well known as is its appearance and voice throughout the whole year in the British Islands, there are not many birds which to the attentive observer betray more unmistakably the influence of the migratory impulse; but somewhat close scrutiny is needed to reveal this fact. In the months of July and August the hedgerows of the southern counties of England may be seen to be beset with Redbreasts, not in flocks as is the case with so many other species, but each individual keeping its own distance from the next ${ }^{2}$ - all, however, pressing forward on their way to cross the Channel. On the European continent the migration is still more marked, and the Redbreast on its autumnal and vernal passages is the object of hosts of bird-catchers, since its value as a delicacy for the table has long been recognized. ${ }^{3}$ But even those Redbreasts which stay in Britain during the winter are subject to a migratory movement easily perceived by any one that will look out for it. Occupying during autumn their usual haunts in outlying woods or hedges, the

1 English colonists in distant lands have gladly applied the .common nickname of the Redbreast to other birds that are not immediately allied to it. The ordinary "RoBIN" of North America is a Thrush, Turdus migratorius (FieldFare, p. 250), and the Bluebirds of the same continent belonging to the genus Sialia in ordinary speech are Blue "Robins"; while the same familiar name is given in the varions communities of Australasia to several species of Petroca and its allies, though some have no red breast.

2 It is a very old saying that Unum arbustum non alit duos Erithacos-one bush does not harbour two Redbreasts.

${ }^{3}$ Of late years an additional impulse has been given to the capture of this species by the absurd fashion of using its skin for the trimming of ladies' dresses and "Cliristmas cards." 
first sharp frost at once makes them change their habitation, and a heavy fall of snow drives them towards the homesteads for such food as they may find there, while, should severe weather continue long and sustenance become more scarce, even these stranger birds disappear-most of them possibly to perish-leaving only the few that have already become almost domiciled among men. On the approach of spring the accustomed spots are revisited, but among the innumerable returning denizens Redbreasts are apt to be neglected, for their song not being powerful is drowned or lost, as Gilbert White well remarked, in the general chorus.

From its abundance, or from innumerable figures, the Redbreast is too well known to need description, yet there are very few representations of it which give a notion of its characteristic appearance or gestures-all so suggestive of intelligence. Its olive-brown back and reddish-orange breast, or their equivalents in black and white, may be easily imitated by the draughtsman; but the faculty of tracing a truthful outline or fixing the peculiar expression of this favourite bird has proved to be beyond the skill of almost every artist who has attempted its portraiture. The Redbreast exhibits a curious uncertainty of temperament in regard to its nesting habits. At times it will place the utmost confidence in man, and again at times shew the greatest jealousy. The nest, though generally pretty, can seldom be called a work of art, and is usually built of moss and dead leaves, with a moderate lining of hair. In this are laid from five to seven white eggs, sprinkled or blotched with light red.

Besides the British Islands, the Redbreast (which is the Motacilla rubecula of Linnæus and the Erithacus rubecula of modern authors) is generally dispersed over the continent of Europe, and is in winter found in the oases of the Sahara. Its eastern limits are not well determined. In Northern Persia it is replaced by a very nearly allied form, Erithacus hyrcanus, distinguishable by its more ruddy hues, ${ }^{1}$ while in Northern China and Japan another species, $E$. akahige, is found of which the sexes differ somewhat in plumage-the cock having a blackish band below his red breast, and greyish-black flanks, while the hen closely resembles the familiar British species-but both cock and hen have the tail of chestnut-red. ${ }^{2}$

1 A similar intense coloration distinguishes some of the resident Redbreasts of the Canary Islands (Tristram, Tois, 1890, p. 72), and one of them from Tenerife has been described as distinct under the name T'. superbus (König, Journ. f. Orn. 1889, p. 183, 1890, pl. iii. figs. 1, 2).

2 A beautiful bird now known to inhabit the Iroochoo Islands, the Sylvia komadori of Temminck, of which specimens are very scarce in collections, is placed by some writers in the genus Erithacus, but whether it has any affinity to the Redbreasts remains to be proved. It is of a bright orange-red above, and 
REDCAP, a local name of the GoLDFINCH.

REDHEAD, a name often given by gunners to the male of the Pochard and of the WIGEon, as well as in North America to a WooDPEckER, Melanerpes erythrocephalus.

REDLEG, in England a common rame for the French or Redlegged PArtridge (p. 695), Caccabis rufa, and occasionally of the REDSHANK (when it is generally used in plural form); but in North America said to be applied to the Turnstone.

REDPOLL, a very well-known native of Britain, the Linota rufescens of recent authors, for a long while confounded with the Fringilla linaria of Linnæus, the Mealy or Stone-Redpoll of English bird-catchers, which last is hardly more than an irregular wintervisitant to this country, while the former, often called by way of distinction the Lesser Redpoll, is resident in Scotland and a great part of England, changing its haunts, however, according to the time of year, and being moreover subject to much variability in the places it affects, without our being able to account for the fact otherwise than on the general supposition that the choice is influenced by the supply of food, just as with the Crossbills, to which in several respects the Redpolls have no small affinity. Thus this pleasing little bird may be found nesting abundantly, for it is of a social disposition, in a locality for perhaps two or three seasons in succession, and then may be altogether wanting for several years, though this is especially observable of it in the more southerly parts of its breeding-range, for in the more northerly it exhibits a greater constancy. The Lesser Redpoll is too well known to need description here, for even those who have not had the happiness of studying its habits afield, especially in the breedingseason (and there are few small birds in this country that afford the observer more enjoyment), must have seen it caged scores of times; but the lively colours which glow upon the cock-bird at liberty are in confinement lost at the first moult and never resumed, so that the very name Redpoll becomes a misnomer-the top of the head changing to dark orange, hardly visible in some lights. The geographical range of the Lesser Redpoll is apparently limited to Western Europe, and it cannot be confidently said to breed except in the British Islands. On the other hand, the Mealy Redpoll, which yearly visits us, though in variable numbers, and seems to be always distinguishable by its call-note as well as by the "mealy" appearance of its back, is much more widely distributed, breeding abundantly throughout northern Scandinavia, though, further to

white beneath, the male, however, laving the throat and breast black. Dr. Stejneger (Proc. U.S. Nat. Mus. 1886, p. 615) considers it, with another equally scarce species from Japan, to form a separate genus Icoturus. 
the eastward, what seems to be a recognizably distinct form, $L$. exilipes becomes more frequent if not wholly replacing it. Yet both these forms occur in North America, as well as another, the largest of all, L. hornemanni, which has two or three times visited England. ${ }^{1}$ A remarkable peculiarity in the Redpolls is the fact ascertained by Wolley in Lapland that the size and especially the length of the bill varies according to the food of the birds, that organ growing inordinately in summer when they are almost wholly insectivorous, and being ground short in winter by the hard seeds that then form their only fare. (See also LrNNET.)

REDSHANK, the usual name of a bird-the Scolopax calidris of Linnæus and Totanus calidris of modern authors-so called in English from the colour of the bare part of its legs, which, being also long, are conspicuous as its flies over its marshy haunts or runs nimbly beside the waters it affects. In suitable localities it is abundant throughout the greater part of Europe and Asia, from Iceland to China, mostly retiring to the southward for the winter, though a considerable number remain during that season along the coasts and estuaries of some of the more northern countries. Before the great changes effected by drainage in England it was a common species in many districts, but at the present day there are very few to which it can resort for the purpose of reproduction. In such of them as remain, its lively actions, both on the ground and in the air, as well as its loud notes, render the Redshank, during the breeding-season, one of the most observable inhabitants of what without its preserice would often be a desolate spot, and invest it with a charm for the lover of wild nature. At other times the cries of this bird may be thought too shrill, but in spring the lovenotes of the male form what may fairly be called a song, the constantly repeated refrain of which-leero, leero, leero (for so it may be syllabled)-rings musically around, as with many gesticulations he hovers in attendance on the flight of his mate; or, with a slight change to a different key, engages with a rival; or again, half angrily and half piteously complains of a human intruder on his chosen ground. The body of the Redshank is almost as big as a Snipe's, but its longer-neck, wings and legs make it appear a much

1 Full details of the Redpolls most likely to be met with by European naturalists will be found in Dresser's Birds of Europe (iv. pp. 37-57) and Yarrell's British Birds (ed. 4, ii. pp. 133-152); and, resting upon considerable experience, may be recommended as trustworthy. Dr. Sharpe (Cat. B. Br. Arus. xii. pp. 245-247) recognizes two "species" of Redpoll-Acanthis linaria, with 3 "subspecies" holbolli, rostrata and rufesecns, and $A$. exilipes with a "subspecies" hornemanni; but the reasons for taking this view of a confessedly very difficult subject are not clearly stated, and it would seem as if the specimens enumerated by him were chiefly sorted according to the length of their wing, which he is careful to give. 
larger bird. Above, the general colour is greyish-drab, freckled with black, except the lower part of the back and a conspicuous band on each wing, which are white, while the flight-quills are black, thus producing a very harmonious effect. In the breedingscason the back and breast are mottled witl dark brown, but in winter the latter is white. The nest is generally concealed in a tuft of rushes or grass, a little removed from the wettest parts of the swamp whence the bird gets its sustenance, and contains four eggs, usually of a rather warmly-tinted brown with blackish spots or blotches; but no brief description can be given that would point out their differences from the eggs of other birds, more or less akin, among which, those of the LAPWING especially, they are taken and find a ready sale.

The name Redshank, prefixed by some epithet as Black, Dusky, or Spotted, has also been applied to a larger but allied species-the T. fuscus of ornithologists. This is a much less common bird, and in Great Britain as well as the greater part of Europe it only occurs on its passage to or from its breeding-grounds, which are usually found north of the Arctic Circle, and differ much from those of its congeners - the spot chosen for the nest being nearly always in the midst of forests and, though not in the thickest part of them, often with trees on all sides, generally where a fire has cleared the undergrowth, and mostly at some distance from water. This peculiar habit was first ascertained by Wolley in Lapland in 1853 and the following year. The breeding-dress this bird assumes is also very remarkable, and seems (as is suggested) to have some correlation with the burnt and blackened surface interspersed with white stones or tufts of lichen on which its nest is made-for the head, neck, shoulders and lower parts are of a deep black, contrasting vividly with the pure white of the back and rump, while the legs become of an intense crimson. At other times of the year the plumage is very similar to that of the common Redshank, and the legs are of the same light orange-red.

REDSTART, a bird well known in Great Britain, in many parts of which it is called Firetail-a name of almost the same meaning, since "start" is from the Anglo-Saxon steort, a tail." This beantiful bird, the Ruticilla phonicurus of most ornithologists, returns to England about the middle or towards the end of April, and at once takes up its abode in gardens, orchards and about old buildings, when its curious habit of flirting at nearly every change of position its brightly-coloured tail, together with the pure white

1 On this point the articles "Stark-naked" and "Start" in Prof. Skeat's Etymological Dietionary may be usefully consulted; but the connexion between these words would be still more evident had this bird's habit of quickly moring its tail been known to the learned author. 
forehead, the black throat and bright bay breast of the cock, renders him conspicuous, even if attention be not drawn by his lively and pleasing though short and intermittent song. The hen is much more plainly attired; but the characteristic colouring and action of the tail pertain to her equally as to her mate. The nest is almost always placed in a hole, whether of a tree or of a more or less ruined building, and contains from five to seven eggs of a delicate greenish-blue, occasionally sprinkled with faint red spots. The young on assuming their feathers present a great resemblance to those of the REDBREAST at the same age; but the red tail, though of duller hue than in the adult, forms even at this early age an easy means of distinguishing them. The Redstart breeds regularly in all the counties of England and Wales; but, except in such localities as have been already named, it is seldom plentiful. It also reaches the extreme north of Scotland; but in Ireland it is of very rare occurrence. It appears throughout the whole of Europe in summer, and is known to winter in the interior of Africa. To the eastward its limits cannot yet be exactly defined, as several very nearly allied forms occur in Asia; and one, $R$. aurorea, represents it in Japan.

A congeneric species which has received the name of Black Redstart, ${ }^{1} R$. titys ${ }^{2}$ is very common throughout the greater part of the European continent, where, from its partiality for gardens in towns and villages, it is often better known than the preceding species. It yearly occurs in certain parts of England, chiefly along or near the south coast, and curiously enough during the antumn and winter, since it is in central Europe only a summer visitor, and it has by no means the high northern range of $R$. phoenicurus. The males of the Black Redstart seem to be more than one year in acquiring their full plumage (a rare thing in Passerine birds), and since they have been known to breed in the intermediate stage, this fact has led to such birds being. accounted a distinct species under the name of $R$. cairii, thereby perplexing ornithologists for a long while, though now almost all authorities agree that these birds are, in one sense, immature.

More than a dozen species of the genus Ruticilla have been described, and the greater number of them seem to belong to the Himalayan Subregion or its confines. One very pretty and interesting form is the $R$. moussieri of Barbary, which no doubt

1 The author of a popular work on British birds has suggested for this species the name of "Blackstart," thereby recording his ignorance of the meaning of the second syllable of the compound name as already explained, for the Black Redstart has a tail as red as that of the commoner English bird.

2 The orthography of the specific term would seem to be titis, a word possibly cognate with the first syllable of Titlapk and Titurodse (Ann. Nat. Hist. ser. 4, x. p. 227). 
allies the Redstart to the STone-Chats, Praticola, and of late some authors have included it in that genus. In an opposite direction the BLUfTHRoATs, Cyanecula, are apparently nearer to the Redstarts than to any other type. By the ornithologist of tolerably wide views the Redstarts and Bluethroats will be regarded as forming with the Nightingale, Redbreast, Hedge-Sparrow, Wheatear and Chats a single group of the "Family" Sylviida, which has been usually called Saxicolina, and is that which is most nearly allied to the THRushes.

In America the name Redstart has been not unfittingly bestowed upon a bird which has some curious outward resemblance, both in looks and manners, to that of the Old Country, though the two are in the opinion of some systematists nearly as widely separated from each other as truly Passerine birds well can be. The American Redstart is the Setophaga ruticilla of authors, belonging to the purely New-World Family Mniotittidx, and to a genus which contains about a dozen species, ranging from Canada (in summer) to Bolivia. The wonderful likeness, coupled of course with many sharp distinctions, upon which it would be here impossible to dwell, between the birds of these two genera of perfectly distinct origin, is a matter that must compel every evolutionist to admit that we are as yet very far from penetrating the action of Creative Power, and that especially we are wholly ignorant of the causes which in some instances produce analogy.

REDTAIL, in North America the Buteo borealis (BUzZARD).

REDTHROAT, the name in Australia for the Pyrrholimus brunneus of Gould (Proc. Zool. Soc. 1840, p. $173 ;$ B. Austral. iii. pl. 68), a little bird, akin to Acanthiza, whose habits are well described by Mr. North (Nests and Eggs of B. Austral. pp. 145, 146).

REDWING, Swedish Rödvinge, Danish Röddrossel, German Rothdrossel, Dutch Koperwiel, a species of THRusH, the Turdus iliacus of authors, which is an abundant winter visitor to the British Islands, arriving in autumn generally about the same time as the FIELDFARE does. The bird has its common English name, ${ }^{1}$ from the sides of

1 Many old writers assert that this bird used to be known in England as the "Swinepipe"; but except in books, this name does not seem to survive to the present day. There is no reason, however, to doubt that it was once in rogue, and the only question is how it may have arisen. If it has not been corrupted from the German TVeindrossel or some other similar name, it may refer to the soft inward whistle which the bird often utters, resembling the sound of the pipe used by the swineherds of old when collecting the animals under their charge, whether in the wide stubbles or the thick beech-woods; but another form of the word (which may, however, be erroneous) is "Windpipe," and this might learl to a conclusion very different, if indeed to any conclusion at all. 
its body, its inner wing-coverts and axillaries being of a bright reddish-orange, of which colour, however, there is no appearance on the wing itself while the bird is at rest, and not much is ordinarily seen while it is in flight. In other respects it is very like a SongThrush, and indeed in France and some other countries it bears the name Mauvis or Mavis, often given to that species in some parts of Britain; but its coloration is much more vividly contrasted, and a conspicuous white, instead of a light brown, streak over the eye at once affords a ready diagnosis. The Redwing breeds in Iceland, in the subalpine and arctic districts of Norway, Sweden and Finland, and thence across Northern Russia and Siberia, becoming scarce to the eastward of the Jenisei, and not extending beyond Lake Baikal. In winter it visits the whole of Europe and North Africa, occasionally reaching Madeira, while to the eastward it is found at that season in the north-western Himalayas and Kohat. Many writers have praised the song of this bird, comparing it with that of the Nightingale; but herein they seem to have been as much mistaken as in older times was Linnæus, who, according to Nilsson (Orn. Srecica, i. p. 177, note), failed to distinguish in life this species from its commoner congener T. musicus. The notes of the Redwing are indeed pleasing in places where no better songster exists; but the present writer, who has many times heard them under very favourable circumstances, cannot but suppose that those who have called the Redwing the "Nightingale" of Norway or of Sweden have attributed to it the credit that properly belongs to the SongThrush; for to him it seems that the vocal utterances of the Redwing do not place it even in the second rank of feathered musicians. Its nest and eggs a good deal resemble those of the Blackbird, and have none of the especial characters which distinguish those of the Song-Thrush.

In South Africa the name Redwing is applied to a very different kind of bird, one of the Francolins, Francolinus levaillanti, a valuable game-bird, not only for the sport it affords, but for the excellence of its flesh.

REED-BIRD, a name variously bestowed in different countries on almost any species of small bird affecting reeds. In England it is generally the Reed-WARELER or Reed-Wren, Acrocephalus streperus; in North America the BoвoLink, while the English in South Africa, in India and Australia seem to use it without much specialization. REED-BUNTING and REED-SPARROW are in England names of Emberiza schenichus often called the Black-headed Bunting; REED-THRUSH is the book-name of $A$. arundinaceus (otherwise

"Whindle" and "Wheenerd" have also been given as two other old English names of this bird (Harl. Miscellany, ed. 1, ii. p. 558), and these may be referred to the local German IVeindrustle and Winsel. 
turdoides), while REED-PHEASANT is the local name in East Anglia for the unhappily-called Bearded TiтmousE.

REEL-BIRD or REELER, a local name for what in books is called the Grasshopper-WARBLER, Locustella navia, while the prefix "Night" signified what is usually known as Savi's WARBLER, Potamodus luscinioides, in the days when it inhabited the English Fell-country. In either case the name was applied from the resemblance of the bird's song to the noise of the reel used by the handspinners of wool.

REEVE, the hen RUFF, a word that puzzles philologists as offering an apparently inexplicable vowel-change ( $c f$. Skeat, Etymol. Dict. s.v.).

REGENT-BIRD, a very beautiful and by no means abundant inhabitant of the eastern part of Australia, conspicuous for the deep golden-yellow and velvety-black of the male's plumage. Originally described in 1801 by Latham (Ind. Orn. Suppl. p. xliv.) from a specimen in Lambert's collection, as a Thrush, Turdus melinus, it was figured and again described in 1808 by J. W. Lewin (B. $N$. Holl. p. 10, pl. vi.) as Meliphaga chrysocephala, the Golden-crowned Honey-sucker; a name changed by him in the subsequent issue of his work in $1822(B . N . S$. W Wales, p. 6) to King Honey-sucker. In 1823, Quoy and Gaimard (Ann. Sc. Nat. v. p. 489), ${ }^{1}$ referred it to the Orioles as Oriolus regens. In 1825 Swainson (Zool. Journ. i. p. 476), thongh not removing it from the Orioles, perceived in it some affinities to the Birds-of-Paradise, and founded for it a new genus, Sericulus, which has since been generally accepted, while in 1845 G. R. Gray (Gen. B. i. p. 233), aided probably by access to the unpublished drawings of Lambert, was able to establish the identity of Lewin's species with Latham's (which must have been from a female specimen), and thus the bird became the Sericulus melinus of ornithology. ${ }^{2}$ Still its affinities remained in doubt until Mr. Coxen's account in 1864 of the discovery by $\mathrm{Mr}$. Waller of Brisbane that it

1 From their more elaborate account (Voy. de l'Uranie et de la Physicienne, Zool. pp. 46, 105, pl. 22) it appears that when they were in Australia in 1819 the colonists called the bird the "Prince Regent," and this indicates the origin of its present name. A few years later Lesson (Voy. de la Coquille, Zool. p. 641) confirmed their statement, but improved upon it by mistakes of his own which have gained currency in this country. He supposed it to have been discovered during the Regency (which only began in 1810), and declared that Lewin (the number" of whose plate he misquotes) had called it "King's Honey-sucker" after" a former governor of that name, whereas the change, as mentioned in the text, was doubtless due to the Regent becoming King in 1820. The earliest appearance of the name Regent-bird known to me is in the list of Australian animals included in the Geographical Memoirs of New South IVales, edited in 1825 by Barron Fieid (p. 503).

${ }^{2}$ Stephens (Gen. Zool. x. p. 240) has the name mellinus, and the spelling, 
was a Bower-bIrd (Gould, Handb. B. Austral. i. pp. 458-461)-a fact confirmed shortly after by Mr. E. P. Ramsay (Ibis, 1867, p. 456) who had really observed it earlier. The "bower" of this bird, however, does not seem to be so elaborate as are the structures raised by its allies, but it is applied to exactly the same uses, and has nothing whatever to do with the nest, which is built in a tree. The name "Mock Regent-bird" is said to be given to one of the Australian HoneY-suckers, Meliphaga phrygia, from its black and yellow plumage.

REGULUS, a genus founded in 1800 by Cuvier (Leç. d'Anat. comp. tab. ii.) for the Motacilla regulus of Linnæus (GoLDCREST), and often used as an English word; but it is to be noted that the regulus of classical or at least mediæval writers was the WREN.

REMIGES, the principal FEATHERS of the wing by which the bird is sustained and rowed forward in FLIGHT, consisting of two series-PRIMLARIES or "manuals," and CUBITALS commonly called "secondaries," according as they are borne by the bones of the manus or the ulna. 1 If the method of enumeration before recommended (pp. 118, 741) be adopted, as long ago suggested by Forbes (Proc. Zool. Soc. 1879 , p. 256, note 2), but as yet followed only by a few scientific writers, vague and often contradictory expressions are obviated. The taxonomic value of Remiges is not to be despised, being as good as that of many internal characters; but it is curious that their least important features are made most of by ordinary ornithological writers, while the really useful information they give is persistently ignored. The phylogenetic development of the Remiges furnishes an interesting problem. The late Mr. Wray (Proc. Zool. Soc. 1887, pp. 343-357, pls. xxix.-xxxii.) discovered that in the embryo the first traces of wing-feathers appear on the dorsal surface in successive rows, of which the last but one or last but two grows more rapidly than the rest, and in conjunction with the growing tendinous fascia at the posterior margin of the wing, the stronger series develops into the Remiges, while the weaker becomes the "reversed" TECTRICES.

The earliest Reptilian Birds ${ }^{2}$ most likely possessed a somewhat uniform covering of feathers on their fore limbs, those of the lower surface being softer and more downy, those of the upper firmer and smoother, while the first that grew out strong and large were those on the upper hind margin of the forearm, with the effect of protecting the sides of the body and possibly of occasionally serving as a parachute, these advantages being preserved and increased by

since adopted by G. R. Gray and Prof. Cabanis may be grammatically more correct if the word, not a common one, really signifies honey-coloured.

1 "Tertials," spoken of by many writers, have no separate existence.

2 "Herpetor"nithes," Gadow, Thicr-Ricich, Vögel, ii. p. 86. 
Natural Selection, just as the scales on the hind margin of Turtles' paddles are elongated and flattened out. Subsequently their lengthening and strengthening extended to the feathers of the metacarpus and so on to the digits, which at this stage were still free (Archropteryx). If these ancestral Birds possessed a patagium or duplication of the skin which would assist as a parachute, it was gradually restricted to the proximal region between the fore limb and the trunk, or it might interfere with the folding of the limb now become a wing. Already in the Reptiles the PoLLex had shewn a tendency to shorten, and it remained outside the series of the other fingers, taking part only to a slight extent in the formation of the wings. The metacarpals became elongated and coalesced because of their simultaneous and one-sided use. The other bones of the mid-hand and of the fifth, fourth and in part of the third digits were reduced in size and number, since the newly-gained and much-strengthened axis required their presence the less, and moreover the full development of those digits would have hindered the folding of the wing, which is effected by a strong abduction towards the ulnar side. From purely mechanical causes the primaries grew into quills stronger and larger than the cubitals. In the embryos of many Birds the Remiges of the forearm appear earlier and for some time grow more rapidly than those of the manus, until they are overtaken by the primaries - thus repeating their phylogenetic development.

After the reduction and partial ancylosis of the bones of the manus have once taken place it is as impossible to free or separate the coalesced metacarpals again as it is to restore the lost digits. Neither the soft Remiges of the Ostrich nor the vane-less quills of the Cassowaries could ever have produced their typically "Neornithic " wing-skeleton. ${ }^{1}$

1 As bearing on this important subject the following references may be of use :-E. Alix, "Sur les plumes ou rémiges des ailes des Oiseaux," Journ. Soc. Philomath. 1874, p. 10 ; J. Cabanis, "Ornithologische Notizen," Arch. f. Naturg. xiii. (1847), pp. 16, 256 ; E. Cones, "On the number of the primaries in Oscines," Bull. Nutt. Orn. Club, i. p. 60 (1876); H. Gadow, "Remarks on the numbers and on the phylogenetic development of the Remiges of Birds," Proc. Zool. Soc. 1888, p. 655 ; J. G. Goodchild, "Observations on the disposition of the cubital coverts in Birds," op. cit. 1886, p. 184 ; J. A. Jeffries, "On the number of primaries in Birds," Bull. Nutt. Orn. Club, vi. p. 156 (1881); W. P. Pycraft, "Contribution to the pterylography of Birds' Wings," Trans. Leicester Lit. and Philos. Soc. ii. pt. 3 (1890) ; C. J. Sundevall, "Om Foglarnes vingar," K. Vet.-Ak. Handl. 1843, p. 303 (Engl. transl. Ibis, 1886, p. 389); J. Vian, "De la plume bâtarde dans les Oiseanx," Rev. MFag. Zool. 1872, p. 83; A. R. Wallace, "On the arrangement of the Families constituting the Order Passeres," Ibis, 1874, p. 406 ; R. S. Wray, "On some points in the morphology of the wings of Birds," Proc. Zool. Soc. 1887, p. 343 ; witl of course the great works of Nitzsch and Prof. Fürbringer. 
REPRODUCTIVE ORGANS, or those which serve for propagation, consist of the germ-produeing glands and their efferent ducts, and are best considered according to sex.

I. In the Female, a pair of Ovaries are developed, but with rare exceptions only that on the left side becomes functional. The mass of embryonic eggs (see page 195) of which each is composed presents the appearance of a cluster of grapes, situated at the anterior end of the KIDNEY of the same side, immediately below the posterior end of the LIVER, and is separated from its fellow by the deseending AORTA, whence it receives its supply of blood,

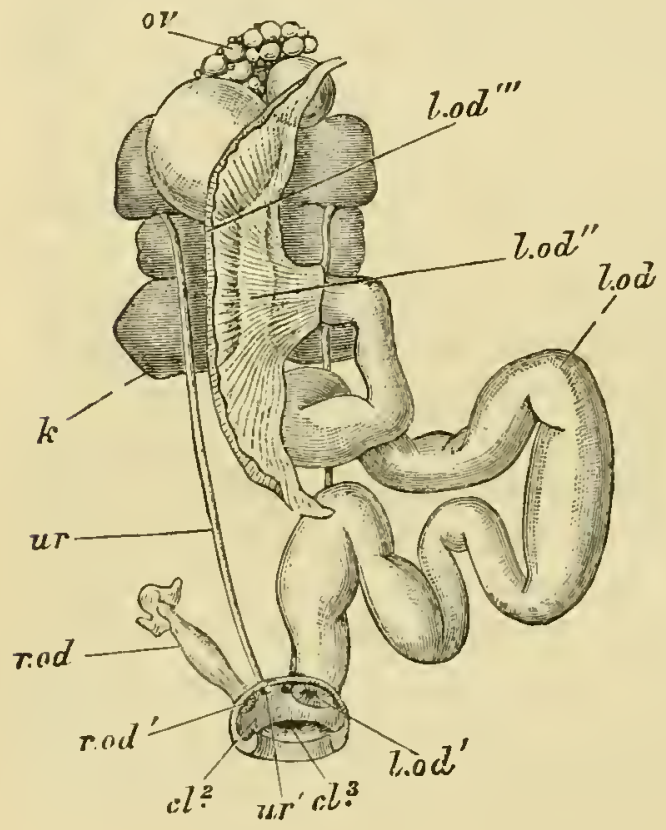

FIG. 1.

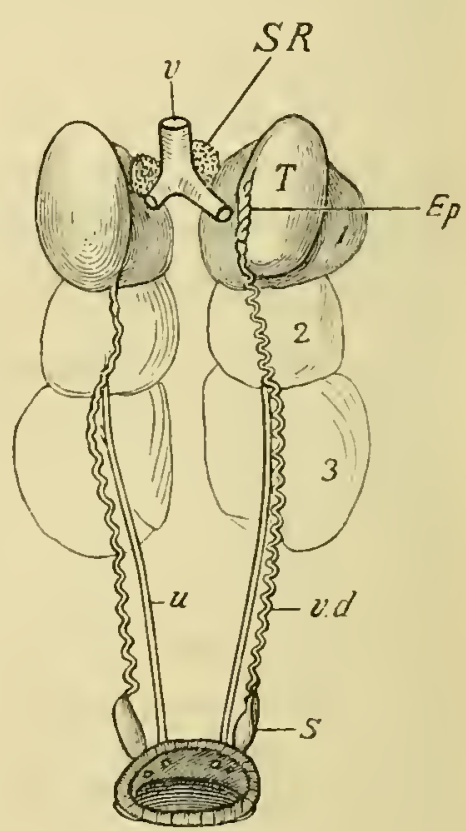

FIG. 2.

Reprodective Organs of Pigeon.

Fig. 1.-Female. $c l$, second cloacal cluanuer in urodaum; $c l^{3}$, inmost chamber; 7 ; lidney : l.ou, left oviluct; l.od', openiug of the same into the urouteum; l.od", infundibulun; l.odl" , opening of the same into the body cavity; ov, ovary; r.odl, abortive right ovicluct; $u r$, ureter' $u^{\prime}$, olening of the same iuto the urodieum. (About $2 / 3$ of the natural size. After T. J. Parker.)

Fig. 2.-Male. 1, 2,3, the three principal lobes of the lidney; $E_{P}$, epididynis ; $\$ I_{\text {, }}$ suprarenal borlies; $T$, testes; $u$, ureter ; $r$, vena cava posterior ; $v$.d, vas deferens witl a swelling at $S$. (Natural size.)

while it discharges into the posterior vena cava. The number of germs which form the ovary frequently amounts to several hundred, which during the breeding-season exhibit all stages of development from a mere microscopic object to a full-grown ripe orum, with its large amount of yolk. The germs which do not ripen during the season undergo a process of resorption, and this is accompanied by the dwindling in size of the whole ovary, so that during winter the determination of the sex of any particular bird may be a doubtful 
if not a difficult matter. ${ }^{1}$ 'The ripe eggs are received by the Oviducts, which furnish them with the "white albumen," the shellmembrane and the shell, before expelling them into the CLOACA (pp. 197, 198). In young birds both oviducts are almost equally leveloped, but the right one soon becomes reduced to an insignificant ligamentous strand along the ventral side of part of the Kidney. This one-sided suppression of the organs may possibly be referable to the inconvenience that might be caused were each oviduct to contain an egg ready to be deposited. Practically the Oviduct is a gut-like tube suspended by its own mesentery and opening by a wide slit-like infundibulum into the body-cavity near the Ovary. This upper portion of the Oviduct, corresponding with the Fallopian tube of human anatomy, has extremely thin walls, while peritoneal elastic lamellæ attach it to the hinder margin of the left LUNG in such a way as to secure the reception of any ripe egg that may burst from the Ovary. The next portion of the Oviduct is much narrower with thick glandular walls, which, twisting and turning irregularly, secrete the albumen, and it is connected by a constricted portion, the isthmus (p. 197), with a dilated "uterus," situated on the ventral and partly on the right side of the RECTUM and cloaca. The walls of the isthmus deposit the shell-membrane, while those of the uterus secrete the calcareous shell and the pigment, and the uterus leads into a rather glandless portion, the "vagina" (which in a common Fowl is about an inch, and in a Goose two inches in length) opening into the dorsal wall of the urodæum (p. 90) to the left of the urethral papilla.

Microscopically examined, the structure of the parts above mentioned is seen to be as follows-The whole duct consists of four layers: (1) an outer peritoneal, mesenteric lamella; (2) a layer of smooth unstriped muscular and, for the most part, longitudinal fibres, most numerous in the uterus and the vagina, but scanty or absent in the infundibulum; (3) connective tissue with bloodvessels; and (4) the tunica mucosa, mucous membrane, which in the infundibulum is thin and contains numerous cells with cilia, the vibrating motion of which propels the ovum downward. In the other portions of the duct the mucous membrane forms from ten to twenty or even more folds, and contains numerous secreting glands.

During the breeding-season the whole Oviduct is in a state of hypertrophic turgescence. In the common Fowl at the period of rest it will be only some six or seven inches long and scarcely a

I This is so often the case that the usual notes on the labels which collectors attach to their specimens are at that season mostly the expression of fancy. The vicinity of the suprarenal capsules, which are of a pale yellow colour and "granular" in appearance, makes them liable to be mistaken for ovaries, or more often for the testes when in a dormant and much reduced condition. 
line wide, but at the time of laying eggs it becomes more than two feet in length and nearly half an inch in width, thus increasing its volume about fifty times; and this remarkable change takes place annually.

II. In the Mule, the Testes are a pair of whitish-yellow glands, of oval or globular shape-occasionally (as in Cypselus) vermiformand lie at the anterior end of the KIDNEYS, being kept in position by an enveloping peritoneal lamella, whence septa extend into the interior. Within the meshwork thus formed are embedded the spermatic resicles or tubuli seminiferi, which combine toward the median side of each testis into wider tubes that in their turn leave it, and joining numerous convoluted canals, the whole constitute the Epididymis, which is irregular in shape and as a rule of a deeper colour. Generally the left testis is bigger than the right, although both are equally functional. During the breeding-season they are greatly enlarged, as has been most often remarked in the case of the House-Sparrow, where they increase from the size of a mustard-seed to that of a small cherry, temporarily displacing the usual arrangement of intestine, liver and stomach. The canals of each epididymis unite to form a narrow tube, the vas deferens, that, with small undulations, passes laterally along the ureter of the same side, over the ventral surface of the kidney, and opens upon a small papilla into the urodæum of the CLOACA (p. 90). The walls of the reusc deferentia are furnished with unstriped muscular fibre, but are devoid of glands, and there are no accessory glands, seminal or prostate. In many birds, especially the Passeres, the vasa deferentia increase considerably in length during the breedingseason, and form a closely convoluted mass which often causes a protrusion of the cloacal walls, a peculiarity that is particularly remarkable in some of the Ploceida, ${ }^{1}$ and has been observed in Accentor collaris.

The spermatozoa of Birds, though extremely minute, have a complicated structure, the different parts of which present so many differences of shape, size and proportion in various groups, that they may possibly afford characters of no mean taxonomic value ( $c f$. Ballowitz, Anat. Anzeiger, 1886, pp. 363-376, and Arch. mikrosk. Anat. xxxii. pp. 402-473, tabb. 14-18).

RETINA, the visual or perceptive screen formed by the terminal expansion of the optic nerve and lining the inner chamber of the EyE.

I The external protrusion thus caused in certain of the South-African Weaver-birds is often visible in their prepared skins, for it dries into a hard hook-shaped excrescence and has given rise to various absurd and speculative explanations. 
RHEA, the name given in 1752 by Möhring ${ }^{1}$ to a SouthAmerican bird which, though long before known and described by the earlier writers-Nieremberg, Marcgrave and Piso (the last of whom has a recognizable but rude figure of it) - had been without any distinctive scientific appellation. Adopted a few years later by Brisson, the name has since passed into general use, especially among English authors, for what their predecessors had called the American Ostrich; but on the European continent the bird is commonly called $N a n d u,{ }^{2}$ a word corrupted from a name it is said to have borne among the aboriginal inhabitants of Brazil, where the Portuguese settlers called it Ema ( $c f$. EMEU). The resemblance of the Rhea to the OsTrich was at once perceived, but the differences between them were scarcely less soon noticed, for some of them are very evident. The former, for instance, has three instead of two toes on each foot, it has no apparent tail, nor the showy wingplumes of the latter, and its head and neck are clothed with feathers, while internal distinctions of still deeper significance have since been dwelt upon by Prof. Huxley (Proc. Zool. Soc. 1867, pp. 420422) and the late Mr. W. A. Forbes (op. cit. 1881, pp. 784-787), thus justifying the separation of these two forms more widely even than as Families; and there can be little doubt that they should be regarded as types of as many Orders-Struthiones and Phea-of the Subclass RatiTæ. ${ }^{3}$ Structural characters no less important separate the Rheas from the Emeus, and, apart from their very different physiognomy, the former can be readily recognized by the rounded form of their contour-feathers, which want the AFTERSHAFT that in the Emeus and Cassowaries is so long as to equal the main shaft, and contributes to give these latter groups the appearance of being covered with shaggy hair. Though the Rhea is not decked with the graceful plumes which adorn the Ostrich, its feathers have yet a considerable market-value, and for the purpose of trade in them it is annually killed by thousands, so that it has been already extirpated from much of the country it formerly inlabited, ${ }^{4}$ and its total extinction as a wild animal is probably only a question of time. Its breeding-habits are precisely those which have been

1 What prompted his bestowal of this name, so well known in classical mythology, is not apparent.

2 The name Touyou, also of South-American origin, was applied to it by Brisson and others, but erroneously, as Cuvier shews, since by that name, or something like it, the JABIRU is properly meant.

3 Ann. Nat. Hist. ser. 4, xx. p. 500.

4 Mr. Harting, in his and Mr. De Mosenthal's Ostriches and Ostrich Farming, from which the woodcut here introduced is by permission copied, gives (pp. 67-72) some portentous statistics of the destruction of Rheas for the sake of their feathers, which, he says, are known in the trade as "Vautour" to distinguish. them from those of the African bird. 
already described in the case of other Ratite birds. Lilie most of them it is polygamous, and the male perforns the duty of incubation, brooding more than a score of eggs, the produce of several females-facts known to Nieremberg more than two hundred and fifty years since, but harily accepted by naturalists until recently.

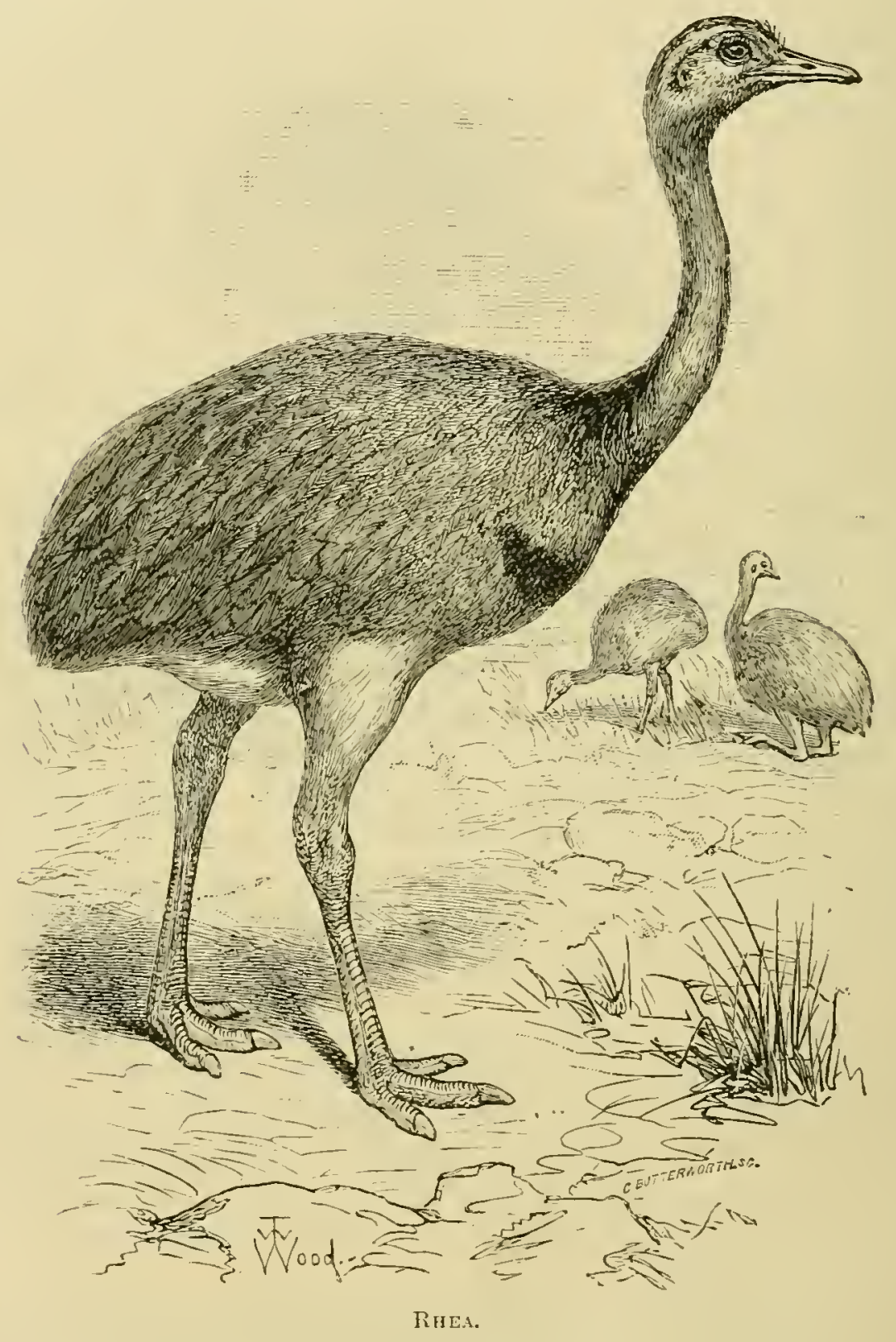

From causes which, if explicable, do not here concern us, no examples of this bird seem to have been brought to Europe before the beginning of the present century, and accordingly the descriptions previously given of it by systematic writers were taken at second hand, and were mostly defective if not misleading. In 1803 Latham issued a wretched figure of the species from a half-grown 
specimen in the Leverian Museum, and twenty years later 'said he had seen only one other, and that still younger, in Bullock's collection (Gen. Hist. B. viii. p. 379). ${ }^{1}$ A bird living in confinement at Strasburg in 1806 was, however, described and figured by Hammer in 1808 (Ann. du Muséum, xii. pp. 427-433, pl. 39), and, though he does not expressly say so, we may infer from his account that it had been a captive for some years. In England the Report of the Zoological Society for 1833 announced the Rhea as having been exhibited for the first time in its gardens during the preceding twelvemonth. Since then many other living examples have been introduced, and it has bred both there and elsewhere in Britain, but the young do not seem to be very easily leared.'

Though considerably smaller than the Ostrich, and, as before stated, wanting its fine plumes, the Rhea in general aspect far more resembles that bird than the other Ratita. The feathers of the head and neck, except on the crown and nape, where they ale dark brown, are dingy white, and those of the body ash-coloured tinged with brown, while on the breast they are brownish-black, and on the belly and thighs white. In the course of the memorable voyage of the 'Beagle,' Darwin came to hear of another kind of Rhea, called by his informants Avestruz petise, and at Port Desire on the east coast of Patagonia he obtained an example of it, the imperfect skin of which enabled Gould to describe it (Proc. Zool. Soc. 1837, p. 35) as a second species of the genus, naming it after its discoverer. Rhea daruini differs in several well-marked characters from the earlier known $R$. americana. Its bill is shorter than its head; its tarsi are reticulated instead of scutellated in front, with the upper part feathered instead of being bare; and the plumage of its body and wings is very different, each feather being tipped with a distinct whitish band, while that of the head and neck is greyish-brown. A further distinction is also asserted to be shewn by the eggs-those of $R$. americana being of a yellowish-white, while

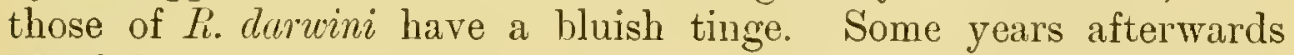
Mr. Sclater described (op. cit. 1860, p. 207) a third and smaller species, more closely resembling the $R$. americana, but having apparently a longer bill, whence he named it $R$. macrorhyncha, more slender tarsi and shorter toes, while its general colour is very much darker, the body and wings being of a brownish-grey mixed with black. The precise geographical range of these three species is still nndetermined. While $R$. americana is known to extend from Paraguay and southern Brazil through the state of La Plata to an uncertain distance in Patagonia, $R$. darwini seems to be the proper

1 The ninth edition of the Companion to this collection (1810, p. 121) states that the specimen "was brought alive" [? to England].

2 Interesting accounts of the breeding of this bird in confinement are given, with much other valuable matter, by Mr. Harting in the work already cited. 
inhabitant of the country last named, though M. Claraz asserts (op. cit. 1885 , p. 324) that it is occasionally found to the northward of the Rio Negro, which had formerly been regarded as its limit, and, moreover, that flocks of the two species commingled may be very frequently seen in the district between that rivel and the Rio Colorado. On the "pampas" R. americana is said to associate with herds of deer (Cariasus campestris), and $P$. darwini to be the constant companion of guanacos (Lama huanacus) - just as in Africa the Ostrich seeks the society of zebras and antelopes. As for $P$. macrorhyncha, it was found by Forbes (Ibis, 1881, pp. 360, 361) to inhabit the dry and open "sertoẽs" of north-eastern Brazil, a discovery the more interesting since it was in that part of the country that Marcgrave and Piso became acquainted with a bird of this kind, though the existence of any species of Rhea in the district had been long overlooked by or unknown to succeeding travellers. ${ }^{\text {I }}$

RHINOCEROS-BIRD, an old book-name for one or more of the Hornbills (p. 433), and occasionally used by modern SouthAfrican travellers for the Ox-PECKER (p. 680).

PIBS, if typically developed, have a double attachment to the vertebræ-a capitulum or "head" articulating with the centrum of a vertebra, and a tuberculum or knob movably applied to the transverse process of the same vertebra. The portion next to the "head" is known as the "neck," and to it succeeds the shaft, composed of two pieces, the dorsal or vertebral (to the posterior" margin of which is generally attached an UNCINATE Process) and the ventral, which is sometimes called the sternal or sterno-costal rib. If this ventral piece reaches and articulates with the sternum, the whole is called a "true" Rib; but if the sternum is not reached, the whole is called a "false" Rib, even if the ventral piece be present.

According to their position Ribs are usually distinguished as (1) Cervical Ribs possessing only a short shaft, while both head and tubercle are immovably fused with the vertebra; (2) Cervico-dorsal Ribs movably attached to the vertebræ, being in number from 1 to 4 on each side, with a shortened shaft which may in some cases carry a small ventral piece; (3) Thoracic Ribs, connecting the vertebral column with the sternum, from 3 to 9 in number-as

2 Beside the works above named and those of other recognized authorities on the ornithology of South America such as Azara, Prinee Max of Wied, Prof. Burmeister and others, more or less valuable information on the subjeet is to be found in Darwin's Voyage; Dr. Böcking's "Monographie des Nandu" in (Wiegmann's) Archiv für Naturgeschichte (1863, i. pp. 213-241) ; Prof. R. O. Cunningham's Natural History of the Strait of Magellan and paper in the Zoological Soeiety's Proceedings for 1871 (1). 105-110), as well as Dr. Gadow's still more important anatomical contributions in the same journal for 1885 (pp. 308 ct seqq.) 
3 or 4 in Columbidx, 4 or 5 in Passeres and most Picarix, 4 to 7 in Stegunopodes and 4 to 9 in Anseres; (4) Lumbar Ribs, following the Thoracic, and often consisting only of a short dorsal piece which is thus frequently fused with the overlapping part of the Ilius. The number of Ribs varies (not so much as a whole, but according to the regions to which they belong) among closely-allied species as well as among individuals of the same species. Usually an increased number of cervical or lumbar "false" Ribs means a reduced number of "true" or thoracic Ribs, and vice versa. Speaking generally, a greater number of Ribs, and especially of thoracic Ribs, indicates a lower and therefore phylogenetically older condition, a feature which is found in the Bird not only in its embryonic but even during its adolescent stage. From a taxonomic point of view Ribs are valueless.

RICE-BIRD, one of the many names of the BoBolink (p. 46), and perhaps locally applied in the East Indies to others not at all allied ( $c f$. PADDY-BIRD, p. 683).

RICHEL-BIRD (etymology ${ }^{1}$ and spelling doubtful) said to be a local name of the Lesser TERN.

RIFLEMAN-BIRD, or RIFLE-BIRD, names given by the English in Australia to a very beautiful inhabitant of that country, ${ }^{2}$ probably because in coloration it resembled the well-known uniform of the rifle-regiments of the British army, while in its long and projecting hypochondriac plumes and short tail a further likeness might be traced to the hanging pelisse and the jacket formerly worn by the members of those corps. Be that as it may, the cock bird is clothed in velvety-black generally glossed with rich purple, but having each feather of the abdomen broadly tipped with a chevion of green bronze, while the crown of the head is covered with scale-like feathers of glittering green, and on the throat gleams a triangular patch of brilliant bluish emerald, a colour that reappears on the whole upper surface of the middle pair of tailquills. The hen is greyish-brown above, the crown striated with dull white; the chin, throat and a streak behind the eye are pale ochreous, and the lower parts deep buff, each feather bearing a black chevron. According to James Wilson (Ill. Zool. pl. xi.),

1 "Rekels" (Cathol. Angl. p. 302), "Richelle" or "Rychelle" (Prompt. Parvul. pp. 66, 433), derived from reke or reek (smoke), is an old word for incense, but no connexion with the bird's name is apparent.

2 Its English name seems to be first printed in 1825 by Barron Field (Geog. Mem. N. S. Wales, p. 503). In 1828 Lesson and Garnot said (Voy. de la Coquille, Zool. p. 669) that it was applied "pour rappeler que ce fut un soldat de la garnison [of New South Wales] qui le tua le premier,"-which seems to be an insufficient reason, though the statement as to the bird's first murclerer may be true. The Riflenan of New Zealand is Acaththidositta chloris. 
specimens of both sexes were obtained by Sir T. Brisbane at Port Macquarie, whence, in Angust 1823, they were sent to the Edinbnrgh Museum, where they arrived the following year; but the species was first described by Swainson in January 1825 (Zool. Journ. i. p. 481) as the type of a new genus Ptiloris, more properly written Ptilorrhis, ${ }^{1}$ and it is generally known in ornithology as $P$. paradisea. It inhabits the northeru part of New South Wales and southern part of Queensland as far as Wide Bay, beyond which its place is taken by a kindred species, the $P$. victoria of Gould, which was found by John Macgillivray on the shores and islets of Rockingham Bay. Further to the north, in York Peninsula, occurs what is considered a third species, $P$. alberti, very closely allied to and by some authorities thought to be identical with the $P$. magnifica (Vieillot) of New Guinea - the "Pronerops" of many writers. From that country a fifth species, $P$. wilsoni, has also been described by Mr. Ogden (Proc. Acad. Plilad. 1875, p. 451, pl. 25). Little is known of the habits of any of them, but the Rifleman-bird proper is said to get its food by thrusting its somewhat long bill under the loose bark on the boles or boughs of trees, along the latter of which it runs swiftly, or by searching for it on the ground beneath. During the pairing-season the males mount to the higher branches and there display and trim their brilliant plumage in the morning sun, or fly from tree to tree uttering a note which is syllabled "yass" greatly prolonged, but at the same time making, apparently with their wings, an extraordinary noise like that caused by the shaking of a piece of stiff silk stuff. In February 1887 Mr. A. J. Campbell of Melbourne described (Vict. Nat. ii. p. 165) the egg of the Queensland species, $P$. victoria, which he had lately received from Rockingham Bay, being apparently the first authentic account of the nidification of any species of the genus ever given. The nest is said to have been an open one, placed in dense scrub, and containing two eggs of a light flesh-colour with subdued spots and small blotches of dull red or brown. The genus Ptilorrhis is now generally considered to belong to the Paradiseidx, or Birds-of-PARAdise, and in his Monograph of that Family all the species then known are beantifully figured by Mr. Elliot, as will doubtless be the case also in the similar work by Dr. Sharpe now in course of publication.

RING-DOVE, properly Columba palumbus, see Dove (p. 162); but a name often misapplied to the Collared or Barbary Dove (p. 165).

RING-OUSEL, Turdus torquatus, see OuseL (p. 667).

RING-PLOVER, Egialitis hiaticola, see PLover (p. 482). This

1 Some writers have amended Swainson's faulty name in the form Ptilomis, but that is a mistake. 
bird Sir Thomas Browne called "Ringlestones," the derivation of which word is open to conjecture; but Prof. Skeat thinks it may refer to the bird's habit of "ranging" (an old form of arranging) the stones for its nest.

RINGTAIL, the old name for the female HARrier (p. 410), long thought to be specifically distinct from the male; but also occasionally applied to the immature Golden EAGLE (p. 177).

RIPPOCK or RITTOCK (Icelandic Ritur), a local name for a TERN.

ROAD-RUNNER, a name for the CHAPARRAL-Cock (p. 84).

ROBIN, a well-known nickname of the REDBREAST, which in common use has almost supplanted the stock on which it was grafted, while it has been transplanted as well to the oldest as to the newest settlements of England beyond sea, as to Jamaica in the case of the Green ToDy, to North America where the Robin pure and simple is Turdus migratorius (p. 250), but with the prefix Blue signifies some nember of the genus Sialia (BLuEbird), in consequence only of their red breast, while in Australia the name is applied, irrespective of that character, to several species of Petroca, Melanodryas and others (Wheatear), and in New Zealand to some of the birds of the probably kindred genera Miro and Myiomoiva, which have no red at all about them. Robin-Snipe in North America is the KNoT in summer-plumage, when it is in winterdress the prefix White is added.

ROC, RUC and RUKH, transliterations of the name of the colossal bird celebrated in the Arabian Nights, which as everybody knows could carry off elephants in its clutch; and according to the best authorities frequented Madagascar and its neighbourhood! Discoveries of the last half-century, or thereabouts, have shewn that what so long passed for an idle tale was possibly founded on fact, however gross have been the exaggelations. In November 1849 Strickland, who had already cited (The Dodo \&c. p. 60) the testimony of Flacourt in 1658 (Histoire de la grande isle Madagascar, p. 165) as to a large bird, called "Fouron patra," a kind of Ostrich said to frequent the south of that island, published in 1849 (Ann. Nat. Hist. ser. 2, iv. p. 338) information received through $\mathrm{Mr}$. Joliffe, an English naval officer, from a French trader named Dumarele, that he had seen in Madagascar the shell of an enormous egg capable of holding 13 wine-quarts, and used as a vessel for liquor by the natives (Sakalaves), who declared that such eggs were but rarely found and the bird which laid them still more rarely seen. Strickland remarked on the coincidence of this gigantic egg being in the locality to which the great traveller Marco Polo had referred the Roc. In January 1851 Isidore Geoffroy- 
St. Hilaire exhibited to the French Academy of Sciences (Comptes Rendus, xxxii. pp. 101-107; Eng. transl. Ann. Nat. Hist. ser. 2, vii. p. 161) some fossils-two eggs and a fer fragments of bone, which had just been brought to Paris from Madagascar by Capt. Abadie, -referring them to a bird which he named Apyornis maximus and declared to be a "Rudipenne"-or allied to the Ostrich. He soon after republished (Ann. Sc. Nat. Zool. ser. 3, xiv. pp. 205-216) his original remarks, together with some additional information of considerable interest to the effect that, in 1832, Sganzin, who resided for some years in Madagascar, sent thence to Jules Verreaux, then at Capetown, a full-sized drawing of a gigantic egg, but this was lost at sea with all his collections; while in 1834, Goudot, another traveller in that island, obtained some fragments of egg-shells which Gervais had mentioned in 1841 (Dict. Sc. Nat. Suppl. i. p. 524) as resembling Ostriches'. In 1861, Prof. Bianconi (Mem. Accad. Bologna, xii. pp. 61-76) seriously took up the question of the identity of the Roc, described by some one to Marco Polo (for the great Venetian himself did not see it); of the "Chrocko" (which is only another form of the same word) mentioned on the map of Fra Mauro (1450) whose egg was as big as a butt; and of the Apyornis of ornithology, declaring the latter to be no Struthious bird but a Vulture-an opinion which he steadily maintained throughout a long series of papers. The matter has therefore attracted some scientific attention, especially as other remains have come to light; but none can doubt after the masterly treatise of MM. Alphonse MilneEdwards and Grandidier (Ann. Sc. Nat. ser. 5, xii. pp. 167-196, pls. 6-16) that the original deternination was right; and therefore, according to the views taken in the present work, a group or Order Apyornithes should be recognized as of equal rank with the

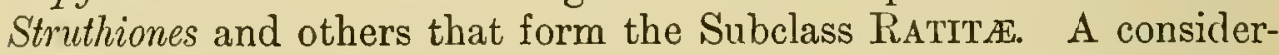
able number of eggs, which from their enormous size-being the largest eggs known-are conspicuous objects, and no small number of fossil bones have now been discovered, and have been attributed to five species of which $A$. maximus, medius and modestus are indicated by the eminent naturalists last named, who think it possible that one of the smaller species may have survived long enough for a tradition of its existence to be transmitted, especially since some of the bones found shew marks of a cutting instrument, evidently the work of a human hand and presumably made on the recently-killed bird. ${ }^{\text {I }}$ Sir Henry Yule (Book of Ser Marco Polo, ii. pp. 346-354) treated the question in his usual happy style and,

1 They cite from a French work of fiction published in 1696 under the titio of Furteriana a passage describing enormous birds inhabiting Madagascar and there carrying off sheep and human beings, so that the latter had to walk about with tame tigers for theil own protection! This modern embellishment of the old Arabian stories is hardly an improvement if probability is to be regaraed. 
acting on the hint first given by Strickland, snggested that the story of the Ruc, though it may have originated much further to the eastward, became localized in Madagascar through some rumour of Apyornis and its stupendous eggs, one of which (now in the British Mnseum, and measuring more than 13 inches by 9.5 ) lie figured of the natural size ${ }^{1}$ but there seems no doubt that the largest species of Atpyornis as yet found by no means equalled in bulk or height the larger forms of Dinornithes. Herr R. Burckhardt (Palæontol. Abhandl. vi. Heft 2, 1893) has referred some remains obtained by the late Dr. Hildebrandt to a fifth species AE. hildebrandti.

ROCKIER, the name of a Pigeon, presumably Columba livia, commonly called the Rock-Dove; but (teste Gilb. White, N. H. Selborne, Lett. xliv. to Pennant) applied to the Stock-Dove, C. cenas, so long confounded with it (p. 163).

RODE-GOOSE (Germ. Rotgans), a local name given by fowlers to the Brant-Goose (pp. 57, 375).

ROERDOMP, the Dutch name of the BITTERx (p. 40), commonly used by colonists in South Africa.

ROLLER, a very beautiful bird, so called from its way of occasionally rolling or turning over in its flight, ${ }^{2}$ somewhat after the fashion of a Tumbler-Pigeon. It is the Coracias garrulus of ornithology, and is widely though not very numerously spread over Europe and Western Asia in summer, breeding so far to the northward as the middle of Sweden, but retiring to winter in Africa. It occurs almost every year in some part or other of the British Islands, from Cornwall to the Shetlands, while it has visited Ireland several times and is even recorded from St. Kilda. But it is only as a wanderer that it comes hither, since there is no evidence of its having ever attempted to breed in Great Britain; and indeed its conspicuous appearance-for it is nearly as big as a Daw, and very brightly coloured-would forbid its being ever allowed to escape the gun of the always-ready murderers of stray birds. Except the back, scapulars and inner cubitals, which are bright reddish-brown, the plumage of both sexes is almost entirely blue- of various shades,

1 One possessed by the late Mr. Rowley was said to measure $12 \cdot 25$ by $9 \cdot 75$ inches. He referred it to a distinct species which he named $\mathcal{E}$. grandidieri. Dr. von Nathusius has described (Zeitschr. wissensch. Zool. 1871, pp. 330-334, pl. xxv.) the microscopical examination of the egg-shell in Epyornis.

${ }^{2}$ Gesner in 1555 said that the bird was thins called, and for this reason, near Strasburg, but the name seems not to be generally nsed in Germany, where the bird is commonly called Rake, apparently from its harsh note. The French have kept the name Rollier. It is a curious fact that the Roller, notwithstanding its occnrrence in the Levant and conspicuous appearance, cannot be identified witl any species mentioned by Aristotle. 
from pale turquoise to dark ultramarine-tinted in parts with green. The bird seems to be purely insectivorous. The genus Coracins, for a long while placed by systematists among the Crows, has really no affinity whatever to them, and is now properly con-

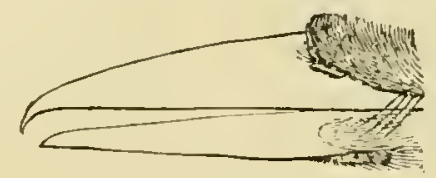

Coracias.

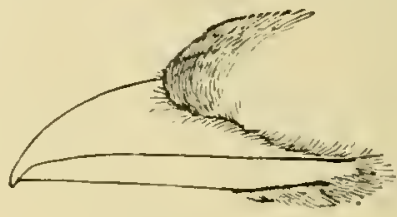

VURTSTOMUS.

(After Swainson.)

sidered to belong to the PICARIF, in which it forms the type of the Family Coraciidax; and its alliance to the Meropida (BEE-FATER) and Alcedinida (Kingfisher) is very evident. Some eleven other species of the genus have been recognized, one of which, C. leucocephalus or abyssinus, is said to have occurred in Scotland. India has two species, $C$. indicus and C. affinis, of which thousands upon thousands are amnually destroyed to supply the demand for gaudy feathers to bedizen ladies' dresses. One species, $C$. temmincli, seems to be peculiar to Celebes and the neighbouring islands, but otherwise the rest are natives of the Ethiopian or Indian Regions. Allied to Conucius is the genus Eurystomus with some eight species, of similar distribution, but one of them, E. parificus, has a wider extent, for it ranges from Celebes through New Guinea to Tasmania and strays to New Zealand. Madagasear has five or six very remarkable forms, belonging to the genera Brachypteracias, Geobiastes and Atelornis, which are considered to belong to the Family; and, according to Prof. A. Milne-Edwards, no doubt should exist on that point. Yet if donbt may be entertained it is in regard to Leptosomus discolor, with the cognate L. graitis of the Comoros, which on account of its zygodactylous feet some authorities place among the Cuculida, while others have considered it the type of a distinct Family Leptosomutidx. Brachypterucius and Atelormis present fewer structural differences from the Rollers, and perhaps may be rightly placed with them; but the species of the latter have long tarsi, and are believed to be of terrestrial habit, which Rollers generally certainly are not. These rery curious and in some respects very interesting forms, which are peculiar to Madagascar, are admirably described and illustrated by a series of twenty plates in the great work of MM. Grandidier and A. Mihne-Edwards on that island (Oisecur, pp. 223-250), while the Family Coruciulex is the subject of a monograph, published in 1893, by Mr. Dresser, as a companion volume to that on the Meropicita.

ROODEBEC (Red beak), the colonial name of a bird in South Africa, Estrilde astrill, belonging to the WEAvtri-BIRDS and akin to 
the Amidavad (p. 11), while Vidur principalis (WIDOw-BIRD) is the "Koning Roodebec" or King of the same (cf. Layard, B. S. Afr. pp. 192, 188).

ROOK (Anglo-Saxon Hróc, Icelandic Hrókr, Swedish Ricka, Dutch Roel, Gaelic Rocas), the Corvus frugilegus of ornithology, and throughout a great part of Europe the commonest and best-known of the Crow-tribe. Beside its pre-eminently gregarious habits, which dicl not escape the notice of Virgil (Georg. i. 382) ${ }^{2}$ and are so unlike those of nearly every other member of the Corvidx, ${ }^{3}$ the Rook is at once distinguishable from the rest by commonly losing at an early age the feathers from its face, leaving a bare, scabrous and greyishwhite skin that is sufficiently visible at some distance. In the comparatively rare cases in which these feathers persist, the Rook may be readily known from the black form of Crow by the rich purple gloss of its black plumage, especially on the head and neck, the feathers of which are soft and not pointed. In a general way the appearance and manner's of the Rook are so well known, to most inhabitants of the British Islands especially, that it is needless here to dwell upon them, and particularly its habit of forming conlmunities in the breeding-season, which it possesses in a measure beyond that of any other land-bird of the northern hemisphere. Yet each of these communities, or rookeries, seems to have some custom intrinsically its own, the details of which want of space forbids any attempt to set before the reader. In a general way the least-known part of the Rook's mode of life are facts relating to its migration and geographical distribution. Though the great majority of Rooks in Britain are sedentary, or only change their abode to a very limited extent, it is now certain that a very considerable number visit this country in or towards autumn, not necessarily to abide here, but merely to pass onward, like most other kinds of birds, to winter further southward; and, at the same season or even a little earlier, it cannot be doubted that a lirge proportion of the young of the year emigrate in the same direction. As a species the Rook on the European continent only resides during the whole year

1 The bird, however, does not inhabit Iceland, and the language to which the word (from which is said to come the French Freux) belongs would perhaps be more correctly termed Old Teutonic. There are many local German names of the same origin, such as Rooke, Rouch, Ruch and others, but the bird is generally knowp in Germany as the Saat-Krähe, i.e. Seed-(=Corn-) Crow. In Pomerania it was formerly Korrock (A. von Homeyer, Zeitschr. fiir Orn. xiv. p. 136).

2 This is the more noteworthy as the district in which he was born and educated is almost the only part of Italy in which the Rook breeds. Shelley also very truly mentions the "legioned Rooks," to which he stood listening "mid the mountains Euganean," in his Lines written anong those hills.

3 The winter-gatherings of one of the Americar species, though sufficicntly remarkable, seem to be in no way comparable to those of the Rook. 
throughout the middle tract of its ordinary range. More to the northward, as in Sweden and northern Russia, it is a regular summer-immigrant, while further to the southward, as in southern France, Spain and most parts of Italy, it is, on the contrary, a regular winter-immigrant. The same is found to be the case in Asia, where it extends eastward as far as the upper Irtish and the $\mathrm{Ob}$. It breeds throughout Turkestan, in the cold weather visiting Affghanistan, Cashmere and the Punjab, and .Sir Oliver St. John found a rookery of considerable size at Casbin in Persia. In Palestine and in Lower Egypt it is only a winter-visitant, and Canon Tristram noticed that it congregates in great numbers about the mosque of Omar in Jerusalem. ${ }^{1}$

There are several moot points in the natural history of the Rook which it is impossible here to do more than mention. One is the cause of the curious shedding on reaching maturity of the feathers of its face, and another the burning question whether Rooks are on the whole beneficial or detrimental to agriculture. In England the former opinion seems to be generally entertained, but in Scotland the latter has long been popular. The absence of sufficient observations made by persons at once competent and without bias compels the naturalist to withhold his judgment on the matter, but the absence of such observations is eminently discreditable to the numerous Agricultural Societies of the United Kingdom.

ROSEHILL (often corrupted by dealers into ROSELLE), an Australian PARAKEeT, Platycercus eximius, so called from the place of that name in New South Wales where, if it was not (as is possible) first obtained, it was formerly abundant. The nearly allied $P$. icterotis of Western Australia also frequently bears the same name.

ROTCHE (German or Dutch Rotges ¿ - ostensibly from its cry, "rot-tet-tet"), a bird familiar to all Arctic navigators, the Little AUK of books, and Mergulus alle of ornithology. It is, or used to be, abundant almost beyond belief at many of its breeding-haunts,

1 It is right to mention that the Canon considers the Rook of Palestine entitled to specific distinction as Corvus agricola (Proc. Zool. Soc. 1864, p. 444; Ibis, 1866, pp. 68, 69). In like manner the Rook of China has been described as forming a distinct species, mnder the name of C. pastinator (Proc. Zool. Soc. 1845 , p. 1), from having the feathers of its face only partially deciduous.

2 Thus spelt the name is given by Friderich Martens (Spitsbergische oder Groen7andische Rcise Bescheibung. Hamburg: 1675, p. 61) who voyaged to Spitsbergen in a Friesland ship in 1671, and is, like the others nsed by him, confessedly (p. 55) of Dutch origin, thongl possibly in a German form. Yet the word seems not to be recognized as Dutch by authorities on that language. An English translation of Martens's narrative appeared in London in 1694 in an anonymous volume bearing the title of An Account of several Late Voyages and Discorerics to the South and Vorth, dedicated to Samuel Pepys, Secretary of the Admiralty and author of the well-known Diary, by whom its publication was probably instigated. 
and in 1818 Beechey (Voy. Dorothen and Trent, p. 46) estimated that he frequently saw a column in Magdalena Bay which he calculated to consist of "nearly four millions of birds on the wing at one time. ${ }^{1}$ These numbers may have dwindled at the present day through the depredations of sealing and whaling crews; but some of the most recent voyagers yet speak of countless congregations, though it must be remembered that, as with the Alcidæ in general, the breeding-places are comparatively few in regard to the extent of coast, and especially so in the ease of the Rotche, which lays its bluish-white and generally spotless egg not on a ledge of rock, but in a cavity worn by the weather, or in the "scree" of loose stones at the foot of high clifts. Consequently suitable stations are by no means common, but often many miles apart, and are, moreover, not unfrequently situated at some distance from the sea, security against foxes being apparently one great object sought in their selection. In Smith Sound the Rotehe is said not to breed below lat. $68^{\circ}$ or above $79^{\circ}$, and not even to occur in the so-called Polar Basin; but it goes much further northward in the Spitsbergen seas and is included among the birds of Franz-Josef Land, as presumably nesting there. Though it frequents the shores of Nova Zembla (Proc. Zool. Soc. 1877, p. 29), it is not found east of the Kara Sea, and thus its breeding-range is not so very wide, while the most southern locality at which its eggs have been taken is Grimsey on the north coast of Iceland, an island which is just eut by the Arctic Cirele. In winter stray examples are not at all unfrequently met with on the shores of the British Islands, or are driven by stress of weather far inland, and they have occurred even in the Azores and Canaries (Godman, Ibis, 1866, p. $102 ; 1874$, p. 224), but these are mere accidental wanderers from the vast hosts that must somewhere exist, and what becomes of the enormous number of birds of this and other kindred species at that season is a problem as yet unsolved, though it is obvious that they must resort to some part of the North Atlantic when the waters near their homes are frozen.

The Little Auk is a compactly-built bird, some 8 inches in length, with the general coloration of its Family, glossy black above and pure white beneath, the latter in winter-plumage extending to the chin. The squab young, with their dark blue skin thinly clothed with black down, are strange-looking objects.

RUDDER-BIRD or -DUCK, a name for Erismatura rubida, one of the Spiny-tailed Ducks (p. 168). BREAST.

RUDDOCK, A.S. Rudduc, a well-known name for the RED-

1 This result may seem incredible ; but from my own experience (Ibis, 1865 . p. 204) I do not feel justified in doubting it ( $c f$. suprà, Puffis, p. 751, note 2). 
RUFF, so called from the very beautifnl and remarkable frill of elongated feathers that, just before the breeding-season, grow thickly round the neck of the male, ${ }^{1}$ who is considerably larger than the female, known as the REEve. In many respects this species, the Tringa pugnax of Linnæus and the Machetes pugnax of the majority of modern ornithologists, is one of the most singular in existence, and yet its singularities have been very ill appreciated by zoological writers in general. ${ }^{2}$ These singularities would require almost a volume to describe properly. The best account of them is unquestionably that given in 1813 by Montagu (Suppl. Orn. Dict.), who seems to have been particularly struck by the extra. ordinary peculiarities of the species, and, to investigate them, expressly visited the fens of Lincolnshire, possibly excited thereto by the example of Pennant, whose information, personally collected there in 1769 , was of a kind to provoke further enquiry, while Daniel (Rural Sports, iii. p. 234) had added some other particulars, and subsequently Graves (Brit. Orn. iii.) in 1816 repeated in the same district the experience of his predecessors. Since that time the g'reat changes produced by the drainage of the fen-comntry have banished this species from nearly the whole of it, so that Lubbock (Fauna Norf. pp. 68-73; ed. 2, Southwell, pp. 102, 103) and Stevenson (Birds Norf. ii. pp. 261-271) can alone be cited as modern witnesses of its habits in England, while the trade of netting or snaring Ruffs and fatteuing them for the table has for many years ceased. ${ }^{3}$

The cock-bird, when out of his nuptial attire, or, to use the fenman's expression, when he has not "his show on," and the hen at all seasons, offer no very remarkable deviation from ordinary

1 This " "uff" has been compared to that of Elizabethan or Jacobean costume, but it is essentially different, since that was open in front and widest and most projecting behind, whereas the bird's decorative apparel is most dereloped in front and at the sides and scarcely exists behind. It seems to be at present unknown whetler the bird was named from the frill, or the frill from the bird. In the latter ease the name should possibly be spelt Rough ( $f$. "rough-footed" as applied to Fowls with feathered legs), as in 1666 Mlerrett (Pinax, p. 1S2) lhad it.

2 Mr. Darwin, though frequently eiting (Descent of Man and Sexual Selection, i. 1 p. 270,306 ; ii. pp. $41,42,48,81,84,100,111)$ the Ruff as a witness in varions capacities, most unfortunately seems never to have had its peculiarities presented to him in such a form that he could fully perceive their bearings. Though the significance of the lesson that the Ruff may teach was lardly conceivable before he began to write, the fact is not the less to be regretted that he never elucidated its importanee, not only in regard to "Sexual Selection," but more especially "vith respect to "Polymorphism."

${ }^{3}$ I ean well recollect considerable numbers, both alive and dead, being annually imported from Holland; but I believe that this practice is now given ณщ. 
Sandpipers, and ontwardly ${ }^{1}$ there is nothing, except the mequal size of the two sexes, to rouse suspicion of any abnormal peculiarity. But when spring comes all is changed. In a suprisingly short time the feathers clothing the face of the male are shed, and their place is taken by pupilla or small caruncles of bright yellow or pale pink. From each side of his head sprouts a tuft of stiff curled feathers, giving the appearance of long ears, while the feathers of the throat change colom, and beneath and around it sprouts the frill or mff already mentioned. The feathers which form this remarkable adormment, almost unique among birds, are, like those

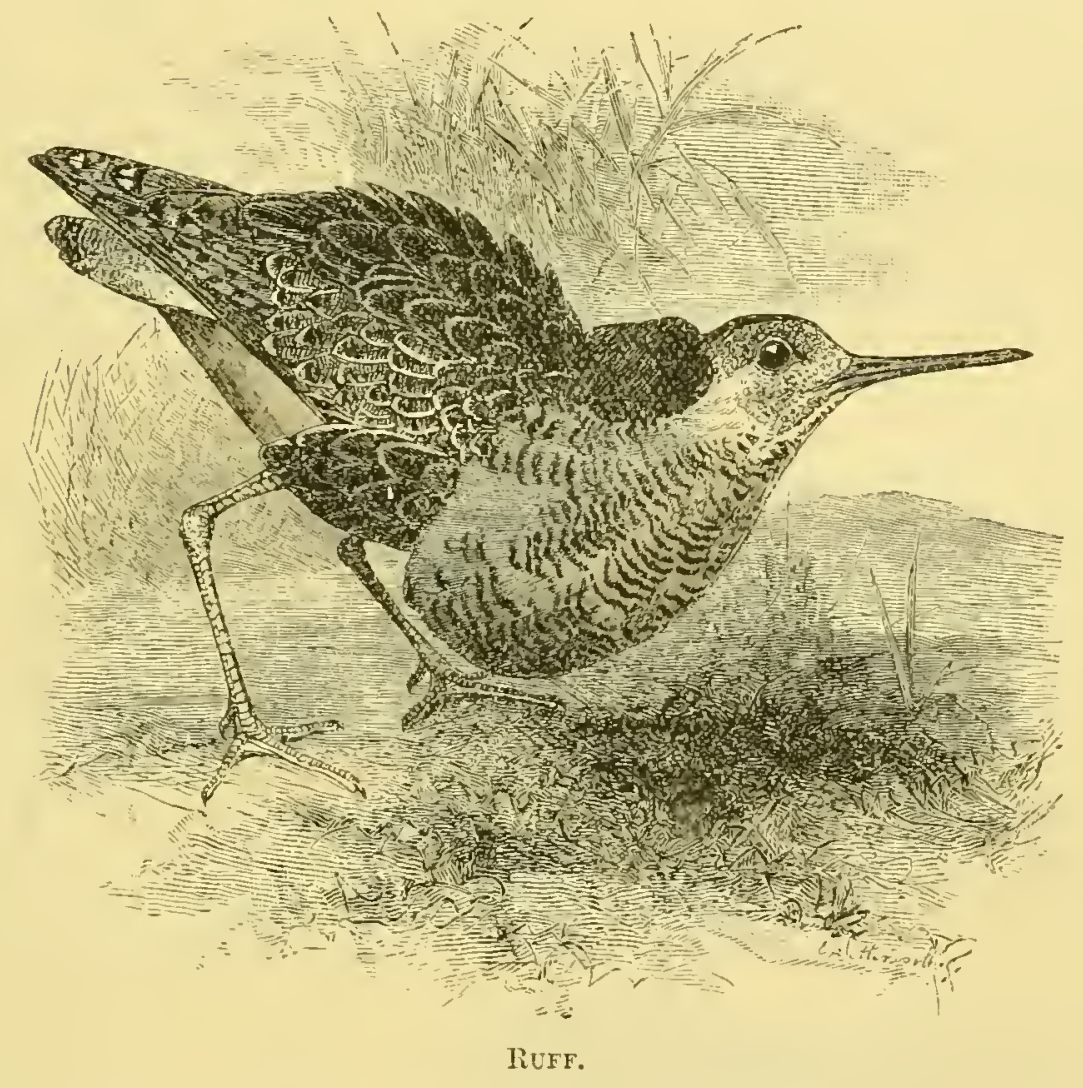

of the "ear-tufts," stiff" and incurved at the end, but much longermeasuring more than two inches. They are closely arrayed, capable of depression or elevation, and form a shield to the front of the breast impenetrable by the bill of a rival. More extraordinary than this, from one point of view, is the great variety of coloration that obtains in these temporary outgrowths. It has often been said that no one ever saw two Ruff's alike. That is perhaps an overstatement; but, considering the really few colours that the birds exhibit, the variation is something marvellons, so that fifty examples or more may be compared without finding a very close resemblance

1 Internally there is a great difference in the form of the posterior margin of the sternum, as long ago remarked by Nitzsch. 
between any two of them, while the individual variation is increased by the "ear-tufts," which generally differ in colour from the frill, and thus produce a combination of diversity. The colours range from deep black to pure white, passing through chestnut or bay, and many tints of brown or ashy-grey, while often the feathers are more or less closely barred with some darker shade, and the black is very frequently glossed with violet, blue or green - or, in addition spangled with white, grey or gold-colour. The white, on the other hand, is not rarely freckled, streaked or barred with grey, rufous-brown or black. In some examples the barring is most regularly concentric, in others more or less broken-up or undulating, and the latter may be said of the streaks. It was ascertained by Montagu, and has since been confirmed by the still wider experience and if possible more carefully-conducted observation of Mr. Bartlett, that every Ruff in each successive year assumes tufts and frill exactly the same in colour and markings as those he wore in the preceding season; and thus, polymorphic as is the male as a species, as an individual he is unchangeable in his wedding-garment -a lesson that might possibly be applied to many other birds. The white frill is said to be the rarest.

That all this wonderful "show" is the consequence of the polygamous habit of the Ruff can scarcely be doubted. No other species of Limicoline bird has, so far as is known, any tendency to it. Indeed, in many species of Limicola, as the DOTTEREL, the Godwits, Phalaropes and perhaps some others, the female is larger and more brightly coloured than the male, who in such cases seems to take upon himself some at least of the domestic duties. Both Montagu and Graves, to say nothing of other writers, state that the Puffs, in England, were far more numerous than the Reeves, and their testimony can hardly be doubted; though in Germany Naumann ( $V \ddot{o g}$. Deutschl. vii. p. 544) considers that this is only the case in the earlier part of the season, and that later the females greatly outnumber the males. It remains to say that the moral characteristics of the Ruff exceed even anything that might be inferred from what has been already stated. By no one have they been more happily described than by Wolley, in a communication to Hewitson (Eggs of Brit. Birds, ed. 3, p. 346), as follows :-

"The Ruff, like other fine gentlemen, takes much more trouble with lis courtship than with his duties as a husband. Whilst the Reeves are sitting on their eggs, scattered about the swamps, he is to be seen far away flitting about in Hocks, and on the ground dancing and sparring with his companions. Before they are confined to their nests, it is wonderful with what devotion the females are attended by their gay followers, who seem to be each trying to be more attentive than the rest. Nothing can be more expressive of humility and ardent love than some of the actions of the Ruff. He throws himself prostrate on the ground, with 
every feather on his body standing np and yuvering; but he seems as if he were afraid of coming too near his mistress. If she flies off, he starts up in an instant to arrive before her at the next place of alighting, and all his actions are full of life and spirit. But none of his spirit is expended in care for his family. He never comes to see after an eneny. In the [Lapland] marshes, a Reeve now and then flies near with a searcely audible ka-kia-liuk; but slre seems a dull bird, and makes no nois 5 attack on an invacler."

WTant of space forbids a fuller accomt of this extremely interesting species. Its breeding-grounds extend from Great Britain ${ }^{1}$ across northern Europe and Asia; but the birds become less numerous towards the east. They winter in India, reaching even Ceylon, and Africa as far as the Cape of Good Hope. The Ruff also occasionally visits Iceland, and there are several well-authenticated records of its occurrence on the eastern coast of the United States, while an example is stated (Ibis, 1875, p. 332) to have been received from the northern part of South America.

RUNNER, a local name for the Mater-RAIL (p. T63).

\section{S}

SACRUM, see SKELETON.

SADDLE-BACK, in Britain and North America, a local name for the adult of either of the Black-backed GuLLs, Larus marinus and fuscus; but in New Zealand applied to Creadion, a genus fomded in 1816 by Vieillot (Analyse, p. 34) of which the Sturmus carmnculatus of Gmelin, based on the Trattled Stare of Latham (Gen. Synops. iii. p. 9, pl. $36)$ is usually considered the type. ${ }^{2}$ Its real affinity must be regarded as doubtful; for, like several other forms of the New-Zealand Region, it does not enter

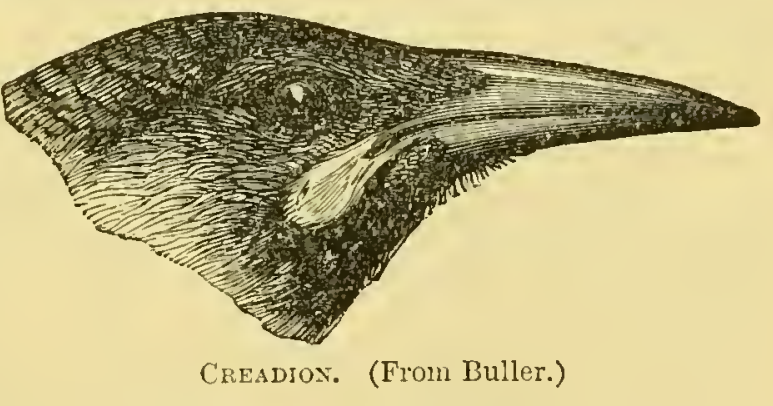
readily into any of the recognized Families of Birds, and thus has been placed among the Sturnida or Corvida, while it very possibly

1 In England of late years it has been known to breed only in one locality, the name or situation of which it is not desirable to publish.

2 This is not to be confounded with the Anthochara carnenculate, which has also been called Creadion caruncrelatus (Vieillot, Encycl. Néthod. ii. p. 874) and is a HoNEY-sucker. 
represents an earlier and more generalized form from which both may have sprung. That point must be left to future examination (which may be hoped for before extirpation has done its work), meanwhile it is enough to remark that the habits, as described by Sir W. Buller (B. New Zeal. ed. 2, i. pp. 18-20), of the Saddle-back of New Zealand shew little trace of agreement with those of either of the Families to which it has been assigned, and that the bird derives its name from the distribution of its strongly-contrasted colours, black and ferruginous, of which the latter covers the shoulders and back in a way suggestive of saddle-flaps. A second species described by Sir Walter in 1865 (Essay Orn. N. Z. p. 10), under the name of $C$. cinereus, was subsequently repudiated by him (B. N. Z. ed. 1, p. 149), but in 1888 was restored (op. cit. ed. 2, i. p. 21). It is said to be known as the Jack-bird.

SAGE-COCK, Centrocercus urophasianus (GRouse, p. 394), the "sage" being an Artemisia.

SAINT CUTHBERT'S DUCK, a local name of the EIDER (p. 192).

SAKER, Fr. Sacre-said to be from the Arabic Sagr (= Falcon) and to have no connexion, as was once thought, with the Latin Sacer, a translation of $i^{\prime} \in \alpha \xi$ ( $=\mathrm{Hawk}$ ) - a species of FALCON which was allowed to drop almost out of knowledge with the neglect of Falconry, so that though some of the older systematists recognized a Falco sacer, ${ }^{1}$ they had but little acquaintance with it, and mostly described it at second hand. It had been especially confounded with the LANNER, and figured under that name in the works of Naumann and Gould. To Schlegel, in 1844 (Rev. Crit. pp. ii. 9; Traité de la Fauconnerie, pp. 17-19, pl.), is due the disentanglement of the complication, and the placing of the species on a sound base, yet doubt may still be entertained as to the scientific name it should bear. ${ }^{2}$ In Europe it inhabits only the south-eastern portion, beginning with Bohemia, ${ }^{3}$ but in North Africa it ranges from

1 The F. sacer of J. R. Forster (Phil. Trans. lxii. p. 383) was evidently the young of the American Goshawk, and neither (as he thought) the Sacre of Brisson and Buffon, nor (as has lately been supposed) the young of $F$. gyrfalco. Schlegel took it to be the young of $F$. candicans, which he at that time believed to be brown.

${ }^{2}$ It cannot be $F$. sacer, Gmelin 1788 , since that was anticipated by Forster in 1772 (see preceding note). According to most synonymies, F. chcrrug, J. E. Gray ( $I l l$. Ind. Zool. pl. 25), is next in point of time, and perhaps should stand. It is certainly the F. cyanomus of Thienemann (Rhca, pp. 39, note, and 62, pls. i. and ii.) in 1846-49.

3 Messrs. Salvin and Brodrick (Falconry in the British Islands, p. 96) say that in $1848 \mathrm{Mr}$. A. C. Cochrane obtained breeding birds in Hungary, and twelve years later Mr. Hudleston took a nest in the Dobrudska (1bis, 1860, p. 377, pl. xii. fig. 1). 
Morocco to Egypt, and thence across Asia to north-eastern China, being highly esteemed by the falconers of that tract of country, as well as by those of India, to whom it is known as the Cherrug, though it there occurs only as a cold-weather visitant ( $c f$. Jerdon, Ibis, 1871, pp. 238-240), its place as a native being taken by its smaller relative the LUGGAR, which it a good deal resembles in its generally dull-coloured plumage. Falcons, however, are met with as large as the Saker or larger, but coloured almost like a hen KESTREL, and on such a bird was founded the $F$. milvipes of Hodgson, published as a bare name in 1844 (Zool. Miscell. p. 81). Some authors appear still to consider this a distinct species, but the late Mr. Gurney referred it to the Saker (Ibis, 1882, pp. 444-447; List Diurn. B. Prey, p. 110). In India the Saker is flown chiefly at hares, small deer and the larger birds, as Bustards, Cranes and Kites, often shewing remarkable sport with the last, yet in its wild state it preys chiefly on rats, lizards and even insects, and when trained for a more powerful quarry it has to be drugged to give it courage.

SANDERLING (Icel. Sanderla ${ }^{1}$ ), one of the commonest and most widely-ranging of the Lrificolæ that frequent our shores, and one in which great interest has been manifested, from the fact that for a very long while naturalists were unable to reach its breedinghaunts, though they were asserted to have been found in the Parry Islands; and Iceland was also suspected to be one of them. All doubt was, however, put aside when it became known that, in June 1863, its nest and eggs had been discovered near Franklin Bay by Mr. MacFarlane (Proc. U. S. Nat. Nus. xiv. p. 427), a discovery the more fortunate since the species is rare in that quarter, and he was never able to obtain a second nest. One of the eggs, on being sent to England by the Smithsonian Institution (for whom that gentleman, at the instigation of the late Prof. Baird, was collecting) was described and figured ${ }^{2}$ (Proc. Zool. Soc. 1S71, p. 76, pl. iv. fig. 2). Shortly after, the eggs collected by the German North-Pole Expedition were received in this country and among them were ten, in a more or less fragmentary condition, obtained by Dr. Pansch on the east coast of Greenland, which, by an exhaustive process, were shewn (tom. cit. p. 546; Wisscnsch. Ergebn. doutsch. Nordpolarfahrt, pp. 204, 240-242) to be those of this species, while the series also served to corroborate the suspicion before entertained of the breed-

1 A name often confounded with Sand-Zóa, the Icelandic name of the Ringed Plover, whereby several mistakes have arisen.

2 The egg had been professedly figured before both by Thienemann (Fortpfian: gesammt. Vögel, t. lxii. fig. 2) and Bædeker (Eier Europ. Vögel, t. lxxi. fig. 5), but no doubt their specimens had been wrongly assigned, as were many others in varions collections. 
ing of this species in Iceland, since they shewed that an egg which had been brought thence in 1858 could hardly belong to any other. In the Arctic Expedition of 1875-6 Col. Feilden (Ibis, 1877, p. 406, and Nares, Voyage to the Polar Sea, ii. p. 210, pl.) found a nest with two eggs, which fully agree with the rest. Thus it will appear that the breeding-range of this species, so far as is at present known with certainty, extends only from Iceland (say long. $15^{\circ} \mathrm{W}$.) to Point Barrow (say long. $155^{\circ} \mathrm{W}$.), and that interruptedly, though it is just possible that some part of the Aretic coast of Asia may have to be included, but not that of Europe, Nova Zembla or Spitsbergen. ${ }^{1}$ In autumn the Sanderling is well known to pass southward across, or along the coast of all the great continents, though it winters in no inconsiderable numbers in temperate elimes, our own, for example; but, while it reaches Patagonia in the New World and the Cape of Good Hope in the Old, it seems mostly content to stay on the northern margin of the Arabian Sea and Bay of Bengal, only rarely venturing to Ceylon or Burma; and, hitherto unknown to the Malay Peninsula, has been observed bnt on two of the islands (Borneo and Java) of that Archipelago. Yet it appears on the Chinese sea-board generally, and has even been obtained in New South Wales, while its occurrenee, perhaps more or less accidental, has been recorded at spots distant enough from its true home-such as the Sandwich Islands, the Galapagos and the Marshall group in the Pacific, the Lacdivies, Aldabra and Madagascar in the Indian Ocean, and the Canaries, Madeira and Bermuda in the Atlantic, to say nothing of the Antilles. Observation seems to shew that in such outlying places.it appears less frequently and more irregularly than several of its wandering kindred, and wherever it tarries, whether on passage or to winter, it rather prefers the drier sandy shores, where it consorts with Plovers of the genus Agialitis, to the expanses of mud or marsh that so many of its allies affect.

The Sanderling belongs to the group Tringina (SANDPIPER) but is always recognizable by wanting the small hind toe, a distinction that justifies its generic separation, and it has long been the Calidiris arenaria of ornithology. ${ }^{2}$ It undergoes a seasonal change quite as remarkable as the KNOT and some others, its winter-smit being of a beautiful silvery-grey, making the bird at times look almost wholly white, but in spring the head, back and breast become mottled with rust-colour and black, the former predominating in the form of a broad edging to the feathers; but the belly and lower parts are white all the year romnd.

1 It is pretty obvious that there must be places in high northern latitudes where the Sanderling, the Knot and sereral other allied species breed in profusion.

${ }^{2}$ Linnæus deseribed it twice, first as a Charadrius and then as a Tringa. The absence of the hallux induced many systematists to put it among the Plovers. 
SAND-GROUSE, the name ${ }^{1}$ by which are commonly known the members of a small but remarkable group of birds frequenting sandy tracts, and having their feet more or less clothed with feathers after the fashion of Grouse, to which they were originally thought to be closely allied, and the species first described were by the earlier systematists invariably referred to the genus Tetrao. Their separation therefrom is due to Temminck, who made for them a distinct genus which he called Pterocles, ${ }^{2}$ and his view, as Lesson tells us (Traité, p. 515), was subsequently corroborated by De Blainville; while in 1831 Bonaparte (Suggio \&c. p. 54) recognized the group as a good Family, Pediophili or Pteroclida. Further investigation of the osteology and pterylosis of the Sand-Grouse revealed still greater divergence from the normal GALLINE, as well as several curious resemblances to the Pigeons; and Prof. Huxley (Proc. Zool. Soc. 1868, p. 303) for sufficiently weighty reasons, proposed to regard them, under the name of PTERocLOMORPHÆ, as forming a group equivalent to the Alectoromorph $Æ$ and PeristerOMORPHE. ${ }^{3}$ The gromp consists of two genera ${ }^{4}$-Pterocles, with about fifteen species, and Syrrhaptes, with two. Of the former, two species inhabit Europe, P. arenarius, the Sand-Grouse proper, and that which is usually called $P$. alchata, the Pin-tailed Sand-Grouse. The European range of the first is practically limited to Portugal, Spain and the southern parts of Russia, while the second inhabits also the south of France, where it is generally known by its Catalan name of "Gunga," or locally as "Grandaulo," or, strange to say, "Perdrix d'Angleterre." Both species are also abundant in Barbary, and have been believed to extend eastwards through Asia to India, in most parts of which country they seem to be only winter-visitants; but in 1880 Herr Bogdanow pointed out (Bull. Ac. Sc. Petersb. xxvii. p. 164) a slight difference of coloration between eastern and western examples of what had hitherto passed as $P$. alchato; and the difference, if found to be constant, may require the specific recognition of each. India, where these birds are commonly known to sportsmen as "Rock-Pigeons," moreover, possesses

1 It seems to have been first used by Latham in 1783 (Gen. Synops. iv. p. 751) as the direet translation of the name Tetrao arenarius given by Pallas.

${ }^{2}$ He states (Man. d'Orn. ed. 2, ii. p. 474, note) that he published this name in 1809 ; but hitherto research has failed to find it used until 1815 .

3 Some more recent writers, recognizing the group as a distinct Order, have applied to it the name of "PTERocLetes," while another calls it Heteroclito. The former of these words is based on a grammatical misconception, while the use of the latter has long since been otherwise preocenpied in zoology. If there be need to set aside Prof. Huxley's term, Bonaparte's Pediophili (as above mentioned) may be accepted, and indeed has priority of all others.

- Bonaparte (Compt. rend. xiii. p. 850) proposed to separate the Pin-tailed Sand-Grouse as Pteroclurus, and therein has been followed by Mr. Ogilvie Grant (Cat. B. Br. Mus. xxii. pp. 2, 6), but this separation seems needless. 
five other species of Pterocles, of which however only one, $P$. fasciutus, is peculiar to Asia, while the others inhabit Africa as well, and all the remaining species belong to the Ethiopian Region-one, $P$. personatus, being peculiar to Madagascar, and four occurring in or on the borders of Cape Colony.

Syrhaptes, though in general appearance resembling Pterocles, has a conformation of foot quite unique among birds, the three anterior toes being encased in a common "podotheca," which is covered to the claws with hairy feathers, so as to look much like

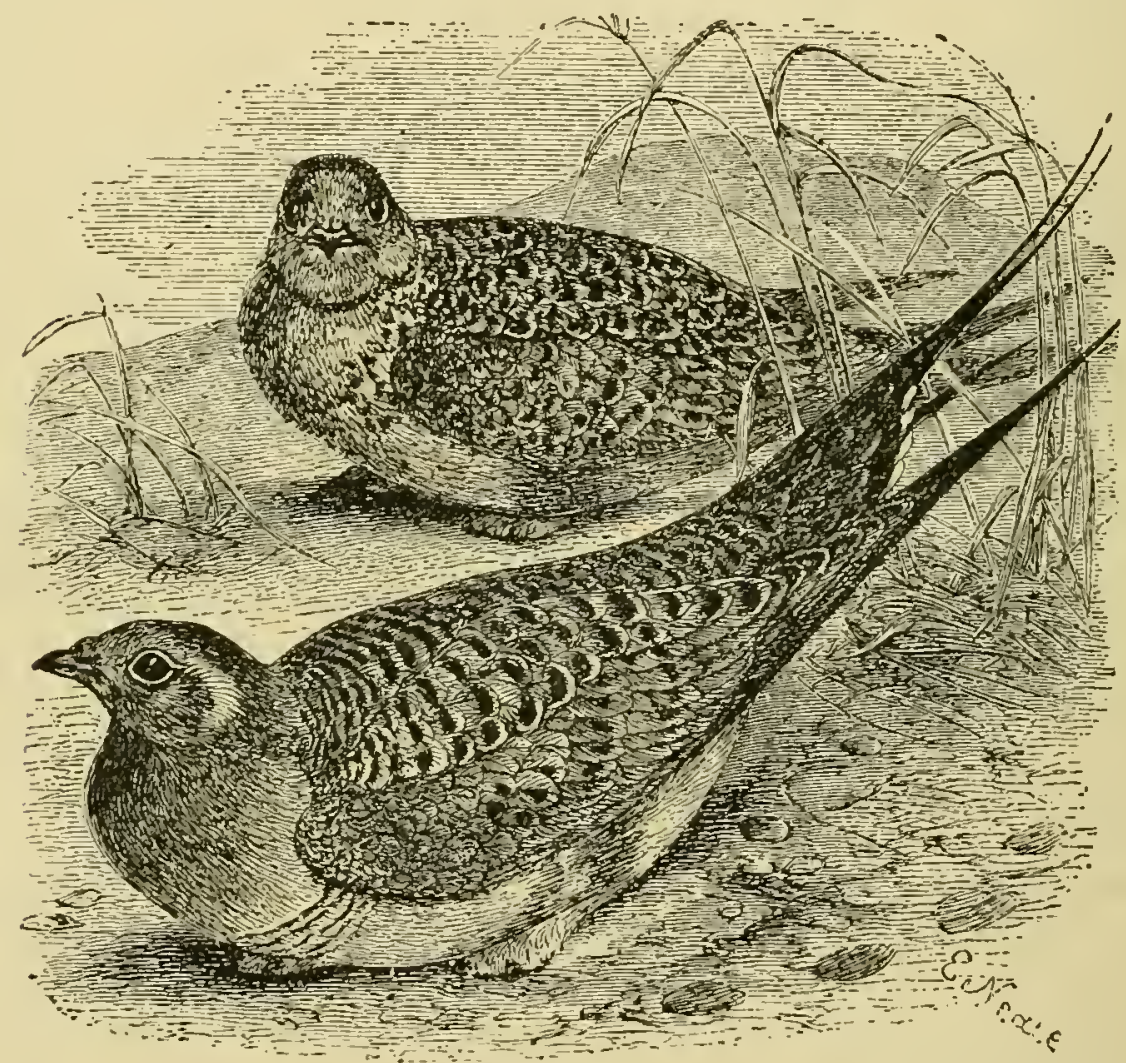

Srrriaptes Paradorus. (From the Prospectus of Yarrell's Lritish Birds, ed. 4.)

a fingerless glove, while the hind toe is wanting. The two species of Syrrhaptes are S. tibetanus-the largest Sand-Grouse knowninhabiting the conntry whence its trivial name is derived, and $S$. paradoxus, ranging from Northern China across Central Asia to the confines of Europe, which it occasionally, and in a marvellous manner, invades, as has been already mentioned (Migration, p. 571). Here the subject, which has a large literature of its own, ${ }^{1}$ must be treated very concisely. Hitherto known only as an inhabitant of the Tartar steppes, a single example was obtained at

1 Dr. Leverkühn has been at great pains to compile a bibliography of Syrrhaptes which will be found in the Monatssehrift des Deutschen Verein zum Schutze der Vogelwelt for 1888-92. 
Sarepta on the Volga in the winter of 1848 . In May 1859 a pair is said to have been killed in the Government of Vilna on the western borders of the Russian Empire, and a few weeks later five examples were procured, and a few others seen, in Western Europe -one in Jutland, one in Holland, two in England and one in Wales, beside which a sixth was killed near Perpignan at the foot of the Pyrenees in the October following (Ibis, 1871, p. 223). In 1860 another was obtained at Sarepta; but in May and June 1863 a horde, computed to consist of at least 700 birds, overran Europe - reaching Sweden, Norway, the Færoes and Ireland in the northwest, and in the south extending to Rimini on the Adriatic and Biscarolle on the Bay of Biscay. On the sandhills of Jutland and Holland some of these birds bred, but war was too successfully waged against the nomads to allow of their establishing themselves, and a few survivors only were left to fall to the gun in the course of the following winter and spring. ${ }^{1}$ In 1872 and 1876 there were two small visitations; but from the former, observed in only two localities-one on the coast of Northumberland, the other on that of Ayrshire, both in the month of June-no specimen is known to have been obtained, while the latter was observed in three localities -one near Winterton in Norfolk in May, another near Modena in Italy in June, and the third in the county Wicklow in Ireland, where at least one was killed. In 1888 occurred an irruption in numbers quite incalculable. The excess of observations over those of 1863 is no doubt due in some measure to the increased attention paid to it, mainly in consequence of a warning issued (29th April) by Prof. R. Blasius of Brunswick so soon as the movement was known to him, but still there is proof of the invasion being on a much larger scale. Most of the features of 1863 were repeated, and the general line taken was much as in that year, suggesting the same "radiant point" (to use an astronomical phrase) in both cases ; ${ }^{2}$ but, owing to the meagre reports that have reached us from the East, that point is still to seek, and its determination must await another opportunity. Some differences, however, are to be noted: the event took place nearly a month earlier in the year, and the passage across Europe soon expanded more widely. In the north-east the Gulf of Finland was crossed to Helsingfors, but the most northerly (Roraas in Norway) and westerly (Belmullet in Ireland) points reached were only a little further than the limits of 1863. Southward a great extension was shewn not only in Italy

1 Ibis, 1864, pp. 185-222. A few additional particulars which have since become known to me are here inserted.

2 But the species seems to have established itself in 1876 on the left bank of the Lower Volga (I. G. Henke, Bull. Soc. Nat. Mosc. 1877, i. p. 119), and the incursionists of 1888 may have had their origin there. South-west of the Caspian the species is a rare visitant. 
(Santa Severa, not far from Rome) but in Spain (Albufera of Valencia), that country being now invaded for the first time. If records are to be trusted, flocks of many hundreds appeared on the steppes of Orenburg at the end of February (qu. O.S. ?), all moving duc westward, and a month later a bird was killed at Saratov (Baron A. von Krïdener, Zool. Gart. 18s8, p. 282). On the 4th April, from 30 to 10 were seen at Selb on the boundary of Bohemia and Bavaria. On the 17th Husum in Sleswick was reached, and Heligoland on the Sth May-but there is reason to believe that one of the Farne Islands was visited on the 6 th, and certainly within a very few days the British Islands were completely occupied, ${ }^{2}$ while after that dates become of little value since, as before, the movement was practically unchecked, though doubtless here and there affected in some measure by local causes. Just as when a billow has broken upon the beach it is a thousand accidents that determine the way in which the spray is scattered, so was it with these birds, for no sooner had they arrived than they were hastening in one direction or another in quest of food, and with their wonderful wing-power the search was pretty easy. A suitable place being found, they occupied it in parties of from 6 to 8 , or 20 to 30 -and so far as Britain is concerned it was plain that they were nearly all paired and ready to breed. This object they effected in several localities, both here and on the continent; but many false rumours, some of them intentionally set about, were current. As regards England, two nests were certainly found in the East Riding of Yorkshire, ${ }^{2}$ and in Scotland a young bird was found by Mr. Scott, a gamelieeper, on the Culbin Sands in Moray. This was not preserved, but in the following year he obtained another, which was subsequently exhibited at the Newcastle meeting of the British Association, and from it the first description and figure of the chick were published. ${ }^{3}$ Notwithstanding the destruction carried on, small parties or even considerable flocks were observed from time to time during the autumn of $18 \mathrm{~s}$ in one part of Europe or another, but gradually their numbers dwindled, and the spring and summer of $1889^{4}$ saw but few remaining. Some,

$1 \mathrm{Mr}$. W. Evans computes the garrison of Scotland at from 1500 to 2000 birds.

${ }^{2}$ I was indebted to the kindness of Mr. J. C. Swailes for the opportunity of seeing the eggs there obtained.

${ }^{3}$ In numerons instances, especially in Germany, the young of Crex pratensis seem to have been taken for those of Syrrhaptes. Some old bircls taken alive bred in the aviary of Herr J. B. Christensen, near Copenhagen, and after an incubation of 23 days several eggs were hatched, from which, in 1891, one young bird reached maturity, as he kindly informed me. In the zoological garden of Amsterdam eggs were also laid and some hatched after an incubation of 28 days; but it does not appear that any produce was reared (Iois, 1890, p. 466).

4 In 1888 an Act of Parliament was passed to protect these birds, but as it was not to come into operation until February 1889 it was a futile measure. 
however, contrived to get through another winter in Great Britain, and if rumour may be credited, all had not disappeared even in 1892 , but this is by no means certain. The interest attaching to the several European irruptions has almost made ornithologists forgetful of the somewhat similar inroad upon the plains between Pekin and Tientsin in China in the autumn of 1860, which affords another proof of the propensity of the speeies to irregular migration. ${ }^{1}$

Externally all Sand-Grouse present an appearance so distinetive that nobody who has seen one of them can be in doubt as to any of the rest. Their plumage assimilates in general colour to that of the ground they frequent ( $c f$. Geographical Distribution, p. 336), being ahove of a dull ochreous hne, more or less barred or mottled by darker shades, while beneath it is frequently varied by belts of deep brown intensifying into black. Lighter tints are, however, exhibited by some species-the drab merging into a pale grey, the buff brightening into a lively orange, and streaks or edgings of an almost pure white relieve the prevailing sandy or fawn-coloured hues that especially characterize the group. The sexes seem always to differ in plumage, that of the male being the brightest and most diversified. The expression is decidedly Dove-like, and

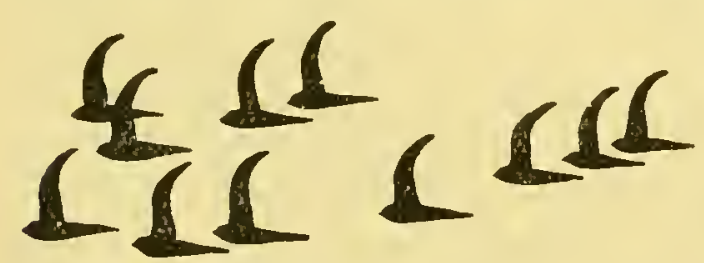

SyRRHAPTES ON THE WINA.

(Wilton, Norfolk, sth October 1sss.) so is the form of the body, but their appearanee when flying in a flock is more like that of Plovers. ${ }^{2}$ The long wings, the outermost primary of which in Syrrkuptes has its shaft produced into an attenuated filament, are in all the species worked by exceedingly powerful muscles, and in several forms the middle rectrices are likewise protracted and pointed, so as to give to their wearers the name of Pin-tailed Sand-Grouse. The nest is a shallow hole in the sand. Three seems to be the regular complement of eggs laid in each nest, but there are writers who declare (most likely in error) that the full number in some species is four. These eggs are of peculiar shape, being almost cylindrical in the middle and nearly alike at each end, and are of a pale earthy colour, spotted, blotched

I It appears to be the "Barguerlac" of Mareo Polo (ed. Yule, i. p. 239); and the "Loung-Kio" or "Dragon's Foot," so unscientifically described by the Abbé Hue (Souvenirs d"un Voyage dems la Tartarie, i. p. 244), can searcely be any thing else than this bird.

${ }^{2}$ I write with especial reference to Syrrhaptes, a flock of which may be easily mistaken for one of Golden Plovers, as the figure shews, though the former have the wing more curved and keep stroke with far more regularity, their "time" (as an oarsman would say) being absolutely perfeet. 
or marbled with darker shades, the markings being of two kinds, one superficial and the other more deeply seated in the shell. The young are hatched fully clothed in down (P. Z. S. 1866, pl. ix. fig. $2)$, and though not very active would appear to be capable of locomotion soon after birth. Morphologically generalized as the Sand-Grouse undoubtedly are, no one can contest the extreme specialization of many of their features, and thus they form a very instructive group. The remains of an extinct species of Pterocles, $P$. sepultus, intermediate apparently between $P$. alchata, and $P$. gutturalis, have been recognized in the Miocene caves of the Allier by Prof. A. Milne-Edwards (Ois. foss. France, p. 294, pl. clxi. figs. 1-9); and, in addition to the other authorities on this very interesting group of birds already cited, reference may be made to Mr. Elliot's "Study" of the Family (Proc. Zool. Soc. 1878, pp. 233-264) and Dr. Gadow, "On certain points in the Anatomy of Pterocles" (op. cit. 1882, pp. 312-332).

SANDPEEP, used in America for SANDPIPER.

SANDPIPER (Germ. Sandpfeifer), according to Willughby in 1676 the name given by Yorkshiremen to the bird now most popularly known in England as the "Summer-Snipe,"-the Tringa hypoleucos of Linnæus and the Totanus, Actitis or Tringoides hypoteucus of later writers, - and probably even in Willughby's time of much wider signification, as for more than a century it has certainly been applied to nearly all the smaller kinds of the group termed by modern ornithologists LinICOL $\approx$ which are not Plovers or SNires, but may be said to be intermediate between them. Placed by most systematists in the Family Scolopacida, the birds commonly called Sandpipers seem to form three sections, which have been often regarded as subfamilies-Totanina, Tringina and

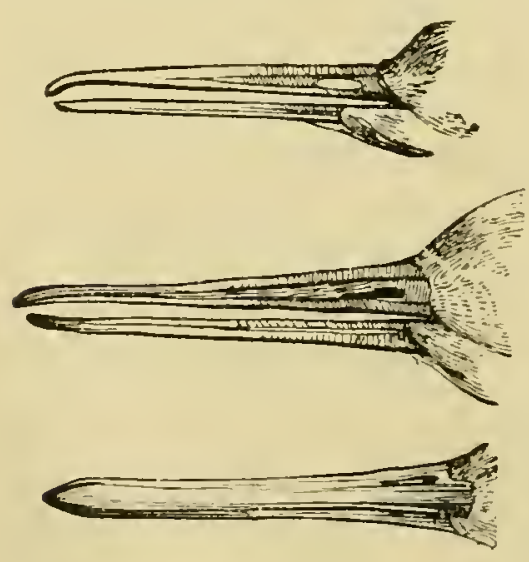

Trisga. (After Swainson.)

Phalaropodina, the last of which has already been treated (PHALAROPE), and in some classifications takes the higher rank of a Family - Phalaropodidx. The distinctions between Totanina and Tringina, though believed to be real, are not easily drawn, and space is wanting here to describe them minutely. Both of these groups have been the sport of nomenclators and systematists, so that a vast mass of synonymy, puzzling to unravel, and many superfluous genera have been introduced. The most obvious distinctions may be said to lie in the form of the tip of the bill (with which is associated a less or greater development of the sensitive nerves 
running almost if not quite to its extremity, and therefore closely connected with the mode of feeding) and in the style of plumagethe Tringina, with blunt and flexible bills, mostly assuming a summer-dress in which some tint of chestnut or reddish-brown is very prevalent, while the Totaninx, with more acute and stiffer bills, display no such lively colours.

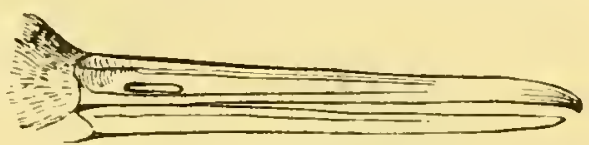

Totanus. (After Swainson.)

Furthermore, the Tringina, except when actually breeding, frequent the sea-shore much more than do the Totanina. ${ }^{1}$ To the latter belong the Greenshank and Redshank, as well as the Common Sandpiper of English books, the "Summer-Snipe" above-mentioned, a bird hardly exceeding a Skylark in size, and of very general distribution throughout the British Islands, but chiefly frequenting clear streams, especially those with a gravelly or rocky bottom, and most generally breeding on the beds of sand or shingle on their banks. It usually makes its appearance in May, and thenceforth during the summer months may be seen in pairs skimming gracefully over the water from one bend of the stream to another, uttering occasionally a shrill but plaintive whistle, or running nimbly along the margin, the mouse-coloured plumage of its back and wings making indeed but little show, though the pure white of its lower parts often renders it conspicuous. The nest, in which four eggs are laid with their pointed ends meeting in its centre (as is usual among Limicoline birds), is seldom far from the water's edge, and the eggs, as well as the newly-hatched and down-covered young, so closely resemble the surrounding pebbles that it takes a sharp eye to discriminate them. Later in the season family-parties may be seen about the larger waters, whence, as autumn advances, they depart for their winter-quarter's. The Common Sandpiper is found over the greater part of the Old World. In summer it is the most abundant bird of its kind in the extreme north of Europe, and it extends across Asia to Japan. In winter it makes its way to India, Australia and the Cape of Good Hope. In America its place is taken by a closelykindred species, which is said to have also occurred in England- $T$. macularius, the "Peetweet," or Spotted Sandpiper, so called from its usual cry, or from the almost circular marks which spot its lower plumage. In habits it is very similar to its congener of the Old World, and in winter it migrates to the Antilles and to Central and South America. Of other Totanina, one of the most remarkable is that to which the inappropriate name of Green Sandpiper has been

1 There are unfortunately no English words adequate to express these two sections By some British writers the Tringinæ have been indicated as "Stints," a term cognate with Stunt and not wholly applicable to all of them, while recent American writers restrict to them the name of "Sandpiper," and call the Totanin $x$, to which that name is especially appropriate, "Willets." 
assigned, the Totanus or Helotromas ochropus of ornithologists, which most curiously differs (so far as is known) from all others of the group both in its osteology ${ }^{1}$ and mode of nidifieation, the hen laying her eggs in the deserted nests of other birds-Jays, Thrushes or Pigeons-but nearly always at some height (from 3 to 30 feet) from the ground (Proc. Zool. Soc. 1863, pp. 529-532). This speeies occurs in England the whole year round, and is presumed to have bred here, though the faet has never been satisfactorily proved, and our knowledge of its erratic habits comes from naturalists in Pomerania and Sweden; yet in the breeding-season, even in England, the cock-bird has been seen to rise high in air and perform a variety of evolutions on the wing, all the while piping what, without any violence of language, may be called a song. This Sanclpiper is characterized by its dark upper plumage, which contrasts strongly with the white of the lower. part of the back and gives the bird as it flies away from its disturber mueh the look of a rery large House-Martin. The so-ealled IVood-Sandpiper, T. glareole, whieh, though much less common, is known to have bred in England, has a considerable resemblanee to the speeies last mentioned, but ean at once be distinguished, and often as it flies, by the feathers of the axillary plume being white barred with greyish-black, while in the Green Sandpiper they are greyish-black barred with white. It is an abundant bird in most parts of northern Europe, migrating in winter very far to the southward.

Of the section Tringina the best known are the Dunlin, the KNoT and the SANDERLING (the last to be distinguished from every other bird of the group by wanting a hind toe), while the Purple Sandpiper, Tringa striatc or maritima is only somewhat less numerous, but is especially addicted to rocky coasts. The Curlew-Sandpiper, T. subarquata, appears not unfrequently, and is of espeeial interest sinee its nest has never been discovered, and none can point even approximately to any breeding-place for it, except it be, as Von Middendorff supposed, on the tundras of the Taimyr. The Little and Temminck's Stints, T. minuta and T. temmincki, are more regular in their visits, and have been traced to their homes in the most northern part of Seandinavia and the Russian Empire, but want of space forbids more than this record of their names; and, for the same reason, no notice can be taken of many other species, chiefly American, belonging to this group, with the exeeption of $T$. maculata or pectoralis, concerning which a few words must be said on account of the extraordinary faculty, first noticed by the late Mr. Edward Adams (Proc. Zool. Soc. 1S59, p. 130), possessed by the male of puffing out its oesophagus, after the manner of a Pouter-Pigeon.

1 It possesses only a single pair of posterior "emarginations" on its sternum, in this respect resembling the RUFF. Among the Plovers and Sxipes other sinilarly exeeptional cases may be found. 
This habit, unique, so far as is known, among the group, is indulged in during the breeding-season, and the inflation is accompanied by the ntterance of a deep, hollow and resonant note, as subsequently observed by Mr. E. IT. Nelson (Auk, 1854, pp. 218-221), who afterwards figtred the bird ( 1 . H. Collect. Alasta, pp. 108, 109, pl. vii.) in this extraordinary condition, when it presents almost the appearance of a RuFF, while his experience has been corroborated by Mr. Murdoch (Rep. Internat. Pol. Eirped. Point Barrou; p. 111). Two other forms must howerer be mentioned. ${ }^{1}$ 'These are the broad-billed Sandpiper, T. platynhyncha, of the Old World, which seems to be more Snipe-like than any that are usually kept in this section, and the mavellous Spoon-billed Sandpiper, Ew?mothynchus pygmans (cf. Harting, Ibis, 1869 , pp. 426-434), the true home of which has still to be discovered, according to the experience of Baron Nordenskjöld in the memorable voyage of the 'Tega.' 2
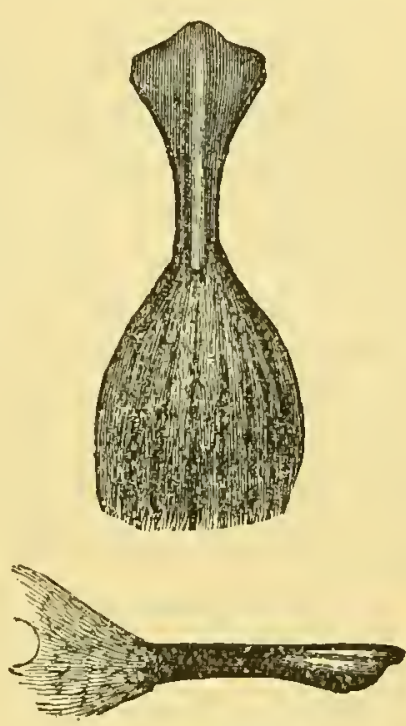

EURYNORHYNCHUS. (liom The Ibis.)

SAND-PLOVER, a name given locally to PLovers of the genus Agralitis.

SAND-RUNNER, like the foregoing, but perhaps sometimes used more for SANDPIPER.

SAPSUCKER, a common name in North America for many of the smaller Wooppeckers, Dendrocopus pubescens, villosus and others, but strictly only applicable to Sphuropicus warius, which with its local forms, muchalis and ruber, and congener thyroideus, has a lingual structure, first described by Macgillivray for Audubon (Or\%. Biogr. v. pp. 537, 53S), very different from that of most Pirilla, and a mode of feeding to correspond ( $c f$. Coures, Birds of the North West, pp. 285-289).

SARUS (Hind. Suras and Sarhans), often corrupted into "Cyrus," the ordinary name for Grus antigone, one of the finest of the Cranes (p. 112).

1 Reference has already been made to the presumably extinet Achmorhynehns (1. 712, note 2) and Prosobonia (11. 225, 226), if the latter really belonged to this group.

- MIr. Seebohm's rolume before mentioned (p. 733, note 2) The Geographical Distribution of the Family Charadriida, or the Plovers, Sandpipers, Snipes and their allies, contains an account of every speeies and figures of a great many of the Sandpipers. Yet a good work on the subject is still to be desired, especially if it will deseribe aceurately the range of the various species, distinguishing between their summer-liomes and their winter-resorts, while recording also their occasional wanderings. 
SATIN-BIRD, one of the Bowkr-BIRDS (p. 49), Ptilorhynchus violaceus or holosericeus, so-called from its glossy plumage.

SATIN-SPARROW, the name in Tasmania for Myiagra nitida, a FLYCATCher.

SAURIURA or SAURIURI, Prof. Häckel's names in 1866 (Gen. Morphol. i. p. cxxxix.) for the first of his two Subclasses of Aves, consisting so far as is at present known of Archropteryx (Fossil Birds, pp. 278-280), his second Subclass being named Ornithuræx, and composed of two "Legions," (1) Autophagæ or NIDIFUG present work (p. 635); and (2) Pædotrophæ or INsessones (p. 459), which last differs from the meaning attached to it by Vigors. Prof. Huxley having adopted the modified term SAURUR.\& as one of his Orders (Proc. Zool. Soc. 1867, p. 418), it has come into general use, while Ornithura may be said to have lapsed. ${ }^{1}$

SAUROGNATH $Æ$, the late Prof. W. K. Parker's name (Trans. R. Micros. Soc. 1872 , p. 219) for the Celeomorpha of Prof. Huxley (Proc. Zool. Soc., 1867, p. 456), consisting of the Picidx (WOODPECKER) and Iyngine (WRYNECK), thereby raising them to the same rank as the latter's other Suborders of Carinate.

SAVANNA BLACKBIRD, a common West-Indian name of Crotophaga ani (ANI).

SAWBILL, a name commonly given to the GoosANDER and Merganser, and also used in some books for the Motmots.

SAW-SHARPENER, a widlely-spread local name for the Great Tituouse, Parus major, from the peculiar song of the cock.

SAW-WHET, a little OwL, Nyctala acadica, so-called in Audubon's words (Orn. Biogr. ii. p. 567) from "the sound of its love-notes bearing a great resemblance to the noise produced by filing the teeth of a large saw."

SAYSIE, a name applied in Sonth Africa to several Finches of the genus Crithagra (Layard, B.S. Afr. ed. 2, pp. 485-487).

SCALE-DUCK, a local name for the SHELD-DRAKE.

SCAMEL, a word, used once by Shakespear (Tempest, Act II. Sc. ii., line 176), that has given rise to many conjectures ( $c f$. Wright, Cambr. Shakesp. i. p. 51); but is commonly accepted as a bird's name, a signification rendered more likely by the fact that at Blakeney, on the coast of Norfolk, it was applied to a GodwiT (Stevenson, B. Norf. ii. p. 260), though it is not to be supposed that Shakespear used it in that sense. It seems to be otherwise

1 Botanists, however, had made a prior application of Saururæ. 
unknown, and the most plausible suggestions are that the word was a misprint for "Seamel" (i.e. SEA-MEW) or for "Stannel" (a KESTREL).

SCANSORES, Illiger's mame in 1811 (Prodr. p. 194) for his First Order, made to contain 5 Families:-(1) Psittacini, with the genera Psittucus and Pezoporus; (2) Serrati, made up of Ramphastos, Pteroglossus, Pogonias, Corythaix, Trogon and Iusopharu; (3)-Amphiboli, including Crotophaga, Scythrops, Bucco, C'uculus and Centropus; (4) Sugittilingues, formed by Iynx and Picus; and (5) Symlactyli, consisting of Galbula.

SCAPULARS, a set of feather's on each side of a bird's dorsal surface, so called as lying along the scapula or shoulder-blades; but by some writers termed Humerals, since they run across the humeri. These feathers form part of the PARAPTERON of Illiger and Sundevall, and in some groups of birds are very conspicuous and characteristic.

SCARF (Icel. Skarfi), otherwise SCART, a local name for a Cormorant or SHAG.

SCAUP, the wild-fowlers' ordinary abridgment of SCAUP-DUCK, meaning a Duck so called "because she feeds upon Scuup, i.e. broken shel-fish," as nay be seen in Willughby's Ornithology (p. 365); but it would be more proper to say that the name comes from the "Mussel-scaups," or" "Mussel-scalps," 1 the beds of rock or sand on which mussels (Mytilus edulis, and other species) are aggregated - the Anus marilu of Linneus and Nyroca or Fuligula marila

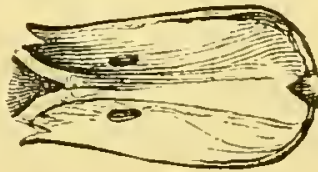

Bill of SCAUP-DUCK. (After Swainson.) of modern ornithology, a very abundant bird around the coasts of most parts of the northern hemisphere, repairing inland in spring for the purpose of reproduction, though so far as is positively known hardly but in northern districts, as Iceland, Lapland, Siberia and the fur-countries of America. It was many year's ago believed (Edinb. N. Philos. Journ. xx. p. 293) to have been found breeding in Scotland, but assertions to that effect have not been wholly substantiated, though apparently corroborated by some later evidence (Proc. N. H. Soc. Glasg. ii. p. 121, and Proc. Phys. Soc. Edint. vii. p. 203). The Scaup-Duck has considerable likeness to the POCHARD, both in habits and appearance; but it much more generally affects saltwater, and the head of the male is black, glossed with green, and hence the name of "Blick-head," by which it is commonly known in North America, where, however, a second species or race, smaller than the ordinary one, is also found, the $N$. or $F$. affinis. The

1 "Scalp" primarily signifies a shell; $c f$. Old Dutel schelpe and Old Fr. escalope (Skeat, Etymol. Dictionary, p. 528). 
female Scaup-Duck can be readily distinguished from the Dunbird or female Pochard by her broad white face.

SCAURIE or SCOREY. In Orkney the young of the HerringGuLL is so-called (Niell, Tour through Orkney and Shetland, p. 201), and the name is perhaps elsewhere applied (Montagu, Suppl. Orn. Dict.) to that of some other species.

SCHIZOGNATH $Æ$, Prof. Huxley's second Suborder of CARINaTe, composed of six groups - Charadriomorpha, Gerano-

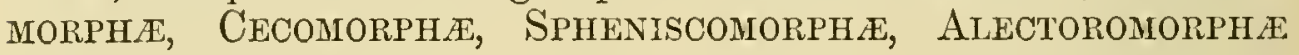
and Peristeronorphe - in all of which the vomer, however variable, always tapers to a point anteriorly, while behind it embraces the basisphenoidal rostrum between the palatals; but neither these nor the pterygoids are borne by its posterior divergent ends. The maxillopalatals are usually elongated, and, bending backward along their inner edge, leave a fissure (whence the name of the Suborder) between the vomer and themselves. In addition to these characters, the birds composing this group often want intrinsic muscles in the lower larynx, and never possess more than a single pair of them. With the exception of Podicipes (GREBE) all the genera which he had examined have two carotid arteries (Proc. Zool. Soc. 1867, pp. 426-435; 456-460).

SCHIZORHINAL, the epithet bestowed by Garrod (Proc. Zool. Soc. 1873, p. 36), in his first and crude systematic arrangement of Birds, on what appeared to him to be a "Suborder," in contradistinction to those possessing what he called the HoLORHINAL structure. This view was virtually abandoned by him within little more than twelve months (op. cit. 1874, pp. 111-123); but that fact has not hindered some writers from continuing to use these terms as if they had any taxonomic signification.

SCIZZORS-TAIL, Milvulus forficatus, one of the most beantiful of the Tyrannida (Tyrant), so called in some of the Southern States of North America from its habit of opening and closing its long and deeply-forked tail like the blades of a pair of scissors. It is only an accidental wanderer to the Northern or even the Middle States, but is or was abundant on the prairies of Texas, and inhabits Mexico and Central America as far as Costa Rica. Without possessing any tints that may be called brilliant in its plumage, the delicate harmony of lavender-grey and rose-red that it displays -and it is very fond of the display - as well as its graceful form combine to make its appearance most engaging, and almost justify its being known, according to Mr. Dresser (Ilis, 1865, p. 472), in Western Texas as the "Bird-of-Paradise"-for its long tail (10 inches) helps to give it that name, and its habits render it conspicuons. It is of a fearless disposition and quarrelsome towards its fellows, though it will join with them in playful and lofty 
flights, in which all will shoot rapidly upwards, making the strokes of their wings resound so as to be heard at a considerable distance. The same kind of behaviour has been observed in the allied $M$. tyrannus, a more soberly-coloured and even longer-tailed bird, which, though properly a native of Central and pretty generally of South America, occasionally strays to the northeru part of that continent, and has occurred more than once within the limits of the United States. Mr. Hudson (Argent. Orn. i. p. 161 ; Nat. in La Platu, pP. 271, 272) states that the birds of this species, though not gregarious, rise just before sunset to the tree-tops, and after calling to one another with loud and excited chirps, "mount upwards like rockets, to a great height in the air; then, after" whirling about for a few moments, they precipitate themselves downwards with the greatest violence, opening and shutting their tails during their wild zigzag flight, and uttering a succession of sharp, grinding notes."

SCOBBY, a north-country name for the CHAFFiNCH (p. 82).

SCOLDER-perhaps from Icel. Shjoll $\cdot$ ( $c f$. SHELD-DRAKE), ar possibly from Icel. Tjuldr; Færoese Tjaldwi-in Orkney a name for the Orster-catcher (1).681); but, according to Mr. Trumbull (Names a: Porti. B. P. 89), on the east coast of North America for the Long-tailed Duck (see HArELD, p. 406).

SCOOPER, said to hare been a local name for the ArosEr (1. 23).

SCOTER, a word of doubtful origin, perhaps a variant of SCOUT-one of the many local names shared in common by the

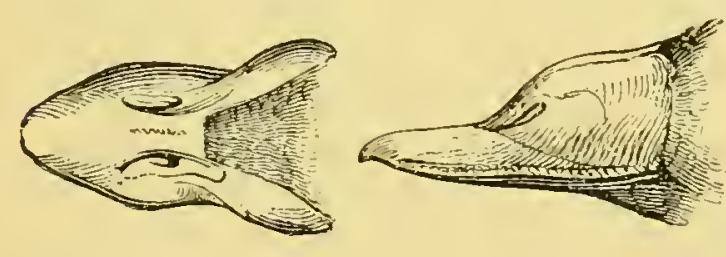

SCOTER.

(After swainson.)

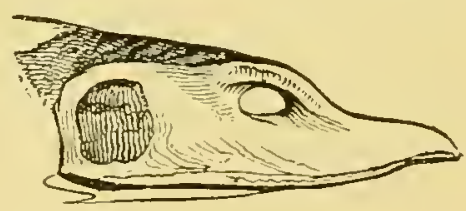

SURF-DUCK.

GuILLEIOT and the RAzorbiLl, - or perhaps primarily connected with Coot, ${ }^{1}$ - the English name of the Anas nigra of Linnaus, which with some allied species has been justifiably placed in a

1 In the former case the derivation seems to be from the O. Fr. Esconte, and that from the Latin auscultare ( $c f$. Skeat, Elymol. Dict. p. 533), but in the latter from the Dutch Koet (Coor), which is said to be of Celtic extractionCutiar (op. cit. p. 134). The French Macreuse, possibly from the Latin macer, indicating a bird that may be eaten in Lent or on the fast days of the Roman Church, is of double signification, meaning in the south of France a Coot and in the north a Scoter. By the wild-fowlers of parts of North America Scoters are commonly called Coots. 
distinct genus, Edemia (often misspelt Oidemia)_-a name coined in reference to the swollen appearance of the base of the bill. The Scoter is also very generally known around the British coasts as the "Black Duck," from the male being, with the exception of a stripe of orange ${ }^{1}$ that runs down the ridge of the bill, wholly of that colour. In the representative American form, $E$. americana, the protuberance at the base of the bill, black in the European bird, is orange as well. Of all Ducks the Scoter has perhaps the most marine habits, keeping the sea in all weathers, and rarely resorting to land except for the purpose of breeding. Even in summer small flocks of Scoters may generally be seen in the tideway at the mouth of any of the larger British rivers or in mid-channel, while in autumn and winter these flocks are so increased as to number thousands of individuals, and the water often looks black with them. A second species, the Velvet-Duck, $E$. fusca, of much larger size, distinguished by a white spot under each eye and a white bar on each wing, is far less abundant than the former, but examples of it are occasionally to be seen in company with the commoner one, and it too has its American counterpart, $\mathbb{E}$. velvetina; while a third, known only to Europe as a straggler, the Surf-Duck, E. perspicillata, with a white patch on the crown and another on the nape, and a curiously-shaped and particoloured bill, is a not uncommon bird in North-American waters. All the species of Edemia, like most of our other Sea-Ducks, have their true home in arctic or subarctic countries, but the Scoter itself is said to breed in Scotland (Zool. 1869, p. 1867 ; Vert. Faun. Sutherl. \&c. pp. 194, 195). The females display little of the deep sable hue that characterizes their partners, but are attired in soot-colour, varied, especially beneath, with brownish white. The flesh of all these birds has an exceedingly strong taste, and, after much controversy, was allowed by the ecclesiastical authorities to rank as fish in the dietary (cf. Graindorge, Traité de l'origine des Macreuses, Caen: 1680; and Correspondence of John Ray, Ray Soc. ed. p. 148).

SCOUTI-ALLEN, variously spelt, a name in Orkney for the Aretic Gull (SKUA). ${ }^{2}$

SCRABER (Gael. Sgrab), a name given in St. Kilda to the Dovekfy (Martin, St. K. p. 58); but said to be used in the other Hebrides for the Manx SHEARwater, which is possibly the more

1 This varies much in extent (J. H. Gurney, Zool. 1894, pp. 292-295).

2 The allied species known to English ornithologists as Buffon's Skua is commonly called Skaiti by Lapps and Quæns in Finmark, and the subjacent parts of Finland and Sweden, though I have not found that word in any printed book, and know not whether it can have any connexion with the Orcadian name. We are told, and doubtless rightly, that Scandinavian words beginning with Sk lose the $S$ when adopted by Finns; but for all that I have heard this uttered many times and seen it in manuscript still oftener. 
correct application since the word scems to be the same as the Norsk Shrupe (Icel. Scrofa), which in some form or other is the ordinary Scandinavian name for a Shearwater.

SCRAYE, from its cry, a name for a TEIN.

SCREAMER, ${ }^{1}$ a bird inhabiting Guiana and the Amazon valley, so called in 1773 by Penmant (Gen. Birds, p. 42) "from the violent noise it makes,"-the Palamedea " cornuta of Linnæus. First made known in 1648 by Marcgrave under the name of "Anhima," it was more fully described and better figured by Buffon under that of Kamichi, still applied to it by French writers. Of about the size of a Turkey, it is remarkable for the "hor"n" or" slender caruncle, more than three inches long, it bears on its forehead, the two sharp spurs with which each wing is armed, and its elongated toes. Its plumage is plain in colour, being of an almost uniform greyish-black above,

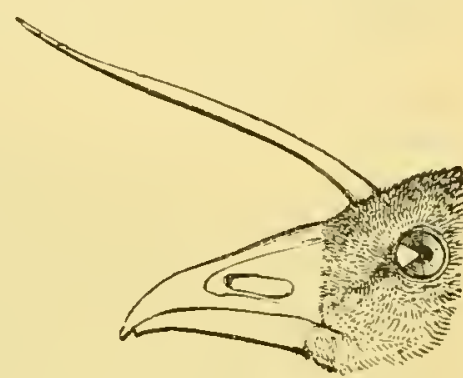

Palamedea. (After swainson.) the space round the eyes and a ring round the neck being variegated with white, and a patch of pale rufous appearing above the carpal joint, while the lower parts of the body are white. Closely related to this bird, known as the "Horned Screamer," is another first described by Linneus as a species of Parra (JACANA), to which group it certainly does not belong, but separated therefrom by Illiger to form the gems Chauna, and now known as C. chavaria, or in English very generally as the "Crested Screamer," "3 though that name was first bestowed on the Seriend. This bird inhabits the lagoons, swamps, and open level country of Paraguay and Southern Brazil, where it is caller "Chajé " or "Chaka," and is smaller than the preceding, wanting its "hol'n," but having its head furnished with a dependent crest of feathers. Its face and throat are white, to which succeeds a blackish ring, and the rest of the lower parts are white, more or less clonded with cinereons. According to Mr. Gibson (Ilis, 1880, pp. 165, 166), its nest is a light construction of dry rushes, having its foundation in the water, and contains as many as six eggs, which are white tinged with buff. The young are covered with down of a yellowish-brown colour. A most singular habit possessed by this bird is that of rising in the air and soaring in circles at an immense altitude, uttering at intervals

${ }^{1}$ In some parts of England the Swift is called "Screamer."

2 This name was adopted from Möhring; but why it was given is unknown.

3 Under this name its curious habits have been well described by Mr. W. H. Hudson (Gentleman's Ilagazine, Sept. 1885, pp. 280-287; Argent. Om. ii. pp. 119-122; Nat. in La Plate, chap. xvii.). 
the very loud cry of which its local name is an imitation. From a dozen to a score may be seen at once so occupying themselves. The young are often taken from the nest and reared by the people to attend upon and defend their ponltry, a duty which is faithfully ${ }^{1}$ and, owing to the spurs with which the Chaka's wings are armed, successfully discharged. Another very curious property of this bird, which was observed by Jacquin, who brought it to the notice of Linnæus, ${ }^{2}$ is its emphysematous condition,-there being a layer of air-cells between the skin and the muscles, so that on any part of the body being pressed a crackling sound is heard. In Central America occurs another species, C. derbiana, chiefly distinguished by the darker colour of its plumage. For this a distinct genus, Ischyrornis, was proposed, but apparently without necessity, by Reichenbach (Syst. Arium, p. xxi.).

The taxonomic position of the Palamedeida, for all will allow to the Screamers the rank of a Family at least, has been much debated, and cannot be regarded as fixed. Their Anserine relations were pointed out by Parker (Proc. Zool. Soc. 1863, pp. 511-518), and Prof. Huxley (op.cit. 1S67, pp. 436, 460) placed them among his Chenourorphe; but this view was contravened by Garrod (op. cit. 1876, pp. 189-200), to whom it seemed that "the Screamers must have sprung from the primary avian stock as an independent off'shoot at much the same time as did most of the other important families." Accordingly in 1880 Mr. Sclater regarded them as forming a distinct "Order," Palamedex, which he, however, placed next to the true Anseires, from the neighbourhood of which they can hardly be removed.

SCREECH or SCREECH-BIRD, the Mistletoe-Thrush, Turdus viscivorus ( $c f$. SHRIKE); SCREECH-OWL, properly the Barn-OwL, Aluco flammeus; but not unfrequently misapplied to the SwifT.

SCRUB-BIRD, the name (for want of a better, since it is not very distinctive) conferred upon the members of an Australian genus, one of the most curious ornithological types of the many furnished by that country. The first examples were procured by the late Mr. Gilbert between Perth and Augusta in West Australia, and were described by Gould (Proc. Zool. Soc. 1844, pp. 1, 2) as forming a new genus and species under the name of Atrichia clamosa, the great peculiarity observed by that naturalist being the absence of any bristles around the gape, in which respect alone it seemed to differ from the already-known genus Sphenura. In March $1866 \mathrm{Mr}$. Wilcox obtained on the banks of the Richmond river

"Hence Latlam's name for this species is "Faithful Jacana,"-he supposing it to belong to the genus in which Linuæus placed it.

2 "Tacta manu cutis, sub pennis etiam lanosa, crepat ubique fortiter" (Syst. Nit. ed. 12, i. p. 260). 
on the eastern sicle of Anstralia some other examples, which proved the existence of a second species, described by Mr. Ramsay (op. cit. 1866, p1. 438-440) as 4. rufescens; but still no suspicion of the great divergence of the genus from the ordinary Passerine type was raised, and it wis generilly regarded as belonging to the Muluida or Anstralian Wirblers. However, the peculiar formation of the stermum in Atrichornis-as the genus has to be called, since Atrichia had long been preoccupied in zoology -attracted the present writer's attention almost as soon as that of $A$. clamosa was exhibited in the museum of the College of Surgeons, and at

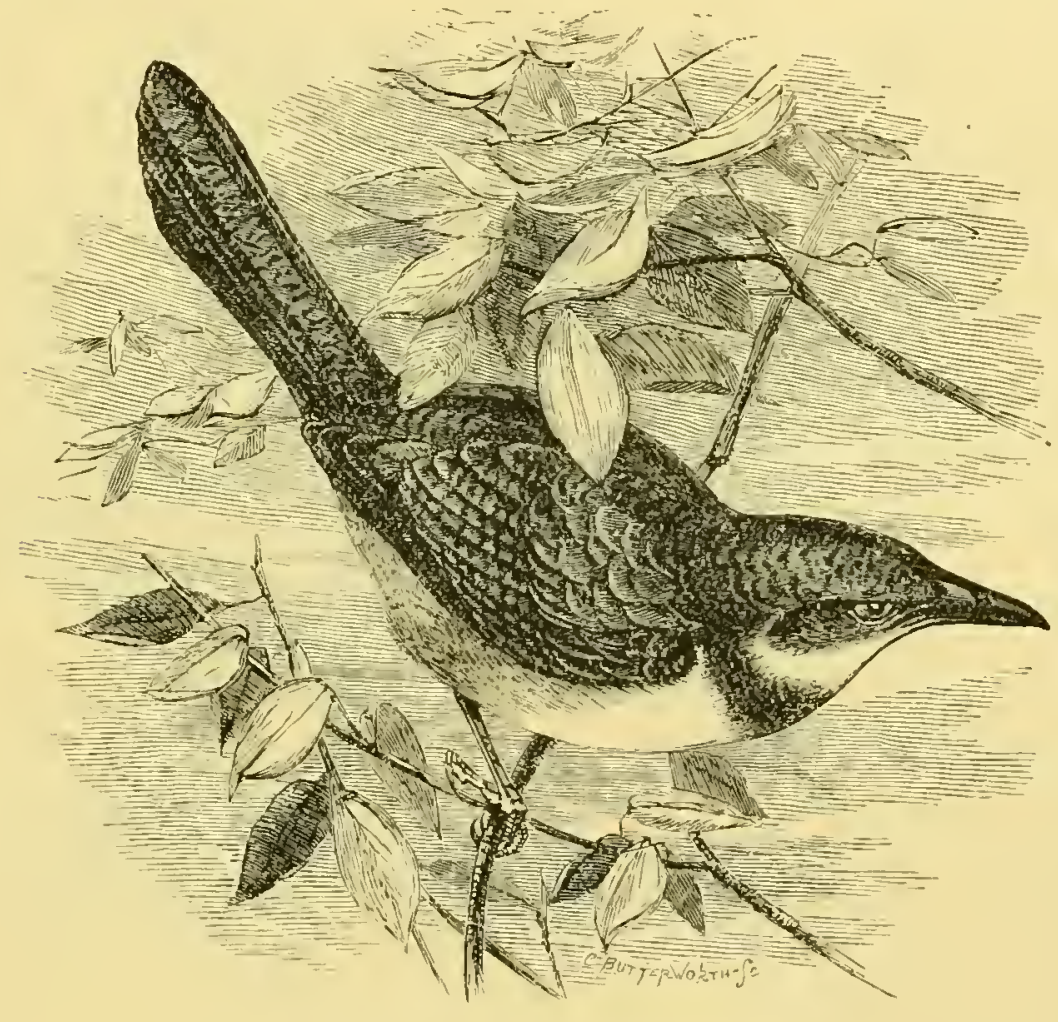

Atrichoris ciamosa. (After Gould.)

his request Mr. Rimsay a little later sent to the museum of the University of Cimbridge examples in spirit of A. rufescens, which shewed a similar structure. The Scrub-birds were consequently declared in 1875 (Encyclop. Brit. er. 9, iii. p. 741) to form a distinct Family, Atriclizid', standing, so far as was known, alone with the Lyre-prRds as "abnormal P'usseres." " Much the same view was also taken by Garrod, who (Proc. Zool. Soc. 1876, pp. 516, 518, pl. lii.

1 This fact seems to have been detected by Dr. Stejneger (Stand. Nat. Hist. iv. 11). 459,462$)$.

2 Mr. Sclater (Kois, 1874, 1. 191, note) remarked on the peenliar form of sternum ; but, writing doubtless from memory, aseribed to it two emarginations on each side of the posterior end, which it lyas not. The sternum is fairly figured and briefly deseribed by Eyton in 1874 (Ostcol. Ai. Suppl. ii. pl. 20, 
figs. 4-7), further dwelt on the taxonomic importance of the equally remarkable characters of the syringeal muscles exhibited alike by this form and Menura, which he accordingly placed together in a division of the Acromyodian Passeres, differing from all the rest and since recognized by Mr. Sclater (Iois, 1880, p. 345) as a Suborder Pseudoscrnes-the Suboscines of the present work. A detailed anatomical description of Atrichornis has, however, yet to be given, and a comparison of many other Australian types is needed ${ }^{\mathbf{l}}$ before it can be certainly said to have no nearer ally than Menura. Both the known species of Scrub-bird are about the size of a small Thrush-A. clamosa being the larger of the two. This species is brown above, each feather barred with a darker shade; the throat and belly are reddish white, and there is a large black patch on the breast; while the flanks are brown and the lower tail-coverts rufous. A. rufescens has the white and black of the fore-parts replaced by brown, barred much as is the upper plumage. Both species are said to inhabit the thickest "scrub" or brushwood forest; but little has been ascertained as to their mode of life except that the males are noisy, imitative of the notes of other birds and given to violent gesticulations. The nest and eggs seem never to have been found, nor indeed any example of the female of either species to have been procured, whence that sex may be inferred to escape observation by its inconspicuous appearance and retiring habits.

SEA- used as a prefix in more birds' names than can here be mentioned, and often without much precision. Thus in one part of the country SEA-CROW may be the CHOUGH, in another the Cormorant, and very generally (especially inland) a GULL, while in America it may mean either a Coot or a SkImmer accorcing to locality. SEA-DOTTEREL and SEA-LARK are names of the Ringed Plover, SEA-MALL, -MEL ( $c f$. ScAmEL) or -MEW have been used indifferently for GULLS: SEA-PARROT is the PUFFIN, SEA-PHEASANT the PINTAI, SEA-PIE the Oyster-CATChER, SEA-SWALLOW a Tern, and so on.

\section{SECONDARIES, see CuBITALs (p. 118).}

SECRETARY-BIRD, a very singular African form, first accurately made known, from an example living in the menagerie of the Prince of Orange, in 1769 by Vosmaer, ${ }^{2}$ in a treatise published

fig. 1, p. 29); but a fuller description is needed, and the figure in Garrod's paper, presently noticed in the text, is bad.

1 Forbes shewed (Proc. Zool. Soc. 1882, p. 544) that OrThoryx (p. 657) did not belong to the group as at one time had beeu suspected.

2 Le Vaillant (Scc. Voy. Afrique, ii. p. 273) truly states that Kolben in 1719 (Caput Bonæ Spei hodiernum, 1. 182, French version, ii. p. 198) had mentioned 
simultaneously in Dutch and French, and afterwards included in his collected works issued, under the title of Regnum Animule, in 1804. He was told that at the Cape of Good Hope this bird was known as the "Sagittarius" or Archer, from its striding gait being thought to resemble that of a bowman advancing to shoot, but that this name had been corrupted into that of "Secretarius." In Angust 1770 Edwards saw an example (apparently alive, and the survivor of a pair which had been brought to England) in the possession of Mr. Raymond near Ilford in Essex; and, being unacquainted with Vosmaer's work, he figured and described it as "of

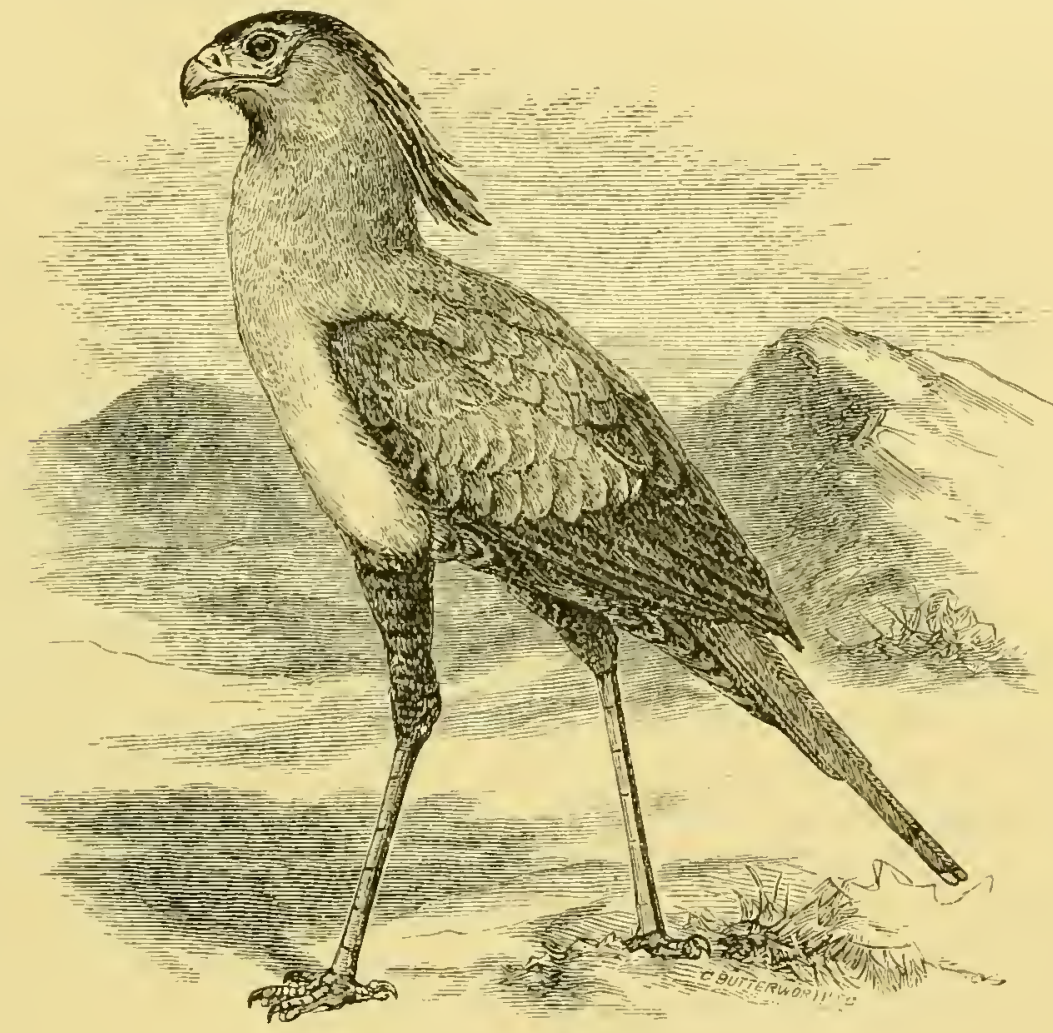

SECRETARY-EIRD.

a new genus" in the following year (Phil. Trans. 1xi. pp. 55, 56, pl. ii.) In 1776 Sonnerat (I'oy. Nouv. Guinée, p. 87, pl. 50) again

this bird uniler its local name of "Snake-eater" (Slangenvrceter, Dutch translation, i. p. 214); lout that author, who was a bad naturalist, thought it was a Pelican and also confonnded it with the Spoonbill, which is figured to illustrate his account of it. Though he donbtless had seen, and perhaps tried to describe, the Secretary-bird, he certainly failed to convey any correct idea of it. Latham's suggestion (loc. infra cit.) that the figure of the "Grus Capensis cauda cristata" in Petiver's Gazophytacium (tab. xii. fig. 12) was meant for this bird is negatived by his description of it (p. 20). The figure was probably copied from one of Sherard's paintings and is more likely to have had its origin in a Crane of some species. Vosmaer's plate is lettered "Amcrikamischen Roof-Vogel," of course by mistake for "Afrikaanischen." 
described and figured, but not at all correctly, the species as found also in the Philippine Islands, whither, if that be true, it must have been brought. A better representation was given by D'Aubenton (Pl. Enl. 721): and in 1780 Buffon (Oiseaux, vii. p. 330) published some additional information derived from Querboent, saying also that it was to be seen in some English menageries; and the following year Latham (Synops. i. p. 20, pl. 2) described and figured it from three examples which he had seen alive in England. None of these authors, however, gave the bird a scientific name, and the first conferred upon it seems to have been that of Falco serpentarius, inscribed on a plate bearing date 1779, by John Frederick Miller (Ill. Nat. Hist. xxviii.), which plate appear's also in Shaw's Cimelia Plysica (No. 28) and is a misleading caricature. In 1786 Scopoli called it Otis secretarius-thus referring it to the Bustards, ${ }^{1}$ and Cuvier in 1798 designated the genus to which it belonged, and of which it still remains the sole representative, ${ }^{2}$ Serpentarius. Succeeding systematists have, however, encumbered it with many other names, among which the generic terms Gypogeranus and Ophiotheres, and the specific epithets reptilivorus and cristatus, require mention here. ${ }^{3}$ The Secretary-bird is of remarkable appearance, standing nearly 4 feet in height, the great length of its legs giving it a resemblance to a Crane or a Heron; but the expert will at once notice that, unlike those birds, its tibiæ are feathered all the way down. From the back of the head and the nape hangs, loosely and in pairs, a series of black elongated feathers, capable of erection and dilation in periods of excitement. ${ }^{4}$ The skin round the eyes is bare and of an orange colour. The head, neck and upper parts of the body and wing-coverts are bluish-grey, but the carpal feathers, including the primaries, are black, as also are the feathers of the vent and tibiæ, - the last being in some examples tipped with white. The tail-quills are grey for the greater part of their length, then barred with black and tipped with white; but the two middle feathers are more than twice as long as those next to them, and drooping downwards present a very unique appearance.

The habits of the Secretary-bird have been very frequently

1 Curiously enough, Boddaert in 1783 omitted to give it a seientifie name.

2 Ogilby's attempt to distinguish three speeies (Proc. Zool. Soc. 1835, Pp. 104, 105) has met with no encouragement; but examples from the north of the equator are sonewhat smaller than those from the south.

${ }^{3}$ The seientific synonymy of the speeies is given at great length by Drs. Finseh and Hartlaub (Vögel. Ost-Afr. p. 93) and later by Dr. Sharpe (Cat. B. Brit. IIus. i. p. 45); but each list lias some errors in common.

+ It is from the fancied resemblance of these foathers to the pens which a elerk is supposed to stick above his ear that the bird's name of Secretary is really derived. 
described, one of the best accounts of then being by Verreaux (Proc. Zool. Soc. 1856, pp. 348-352). Its chief prey consists of insects and reptiles, and as a foe to snakes it is held in high esteem. Making every allowance for exaggeration, it seems to possess a strange partiality for the destruction of the latter, and suecessfully attacks the most venomous species, striking them with its knobbed wings and kicking forwards at them with its feet, mntil they are renclered incapable of offence, when it swallows them. The nest is a huge structure, placed in a bush or tree, and in it two white eggs, spotted with rust-colour, are laid. The young remain in the nest for a long while, and even when four months old are unable to stand upright. They are very frequently brought up tame, and become agreeable not to say useful pets about a house, the chief drawbacks to them being that when hungry they will help themselves to the small poultry, and the liability of their legs to fracture, which follows on any sudden alarm, and canses death. The Secretary-bird is found, but not very abundantly and only in some localities, over the greater part of Africa, especially in the south, extending northwards on the west to the Gambia and in the interior to Khartum, where Von Henglin observed it breeding.

The systematic position of the genus Serpentarins has long been a matter of discussion, and is still one of much interest, though of late classifiers have been pretty well agreed in placing it in the Order Accipitres. Most of them, however, have shewn great want of perception by putting it in the Family Falconida?. No anatomist can doubt its forming a peculiar Family, Serpentariuda, differing more from the Falconida than do the Vulturidx; and the faet of Prof. A. Milne-Edwards (Ois. foss. Fr. ii. pp. 465-468, pl. 186, figs. 1-6) having lecognized in the Miocene of the Allier the fossil bone of a species of this genus, $S$. rolustus, proves that it is an ancient form, one possibly carrying on a direct and not much modified descent from a generalized form, whence may have sprung not only the Falconida but perhaps the progenitors of the Ardeida and Ciconiidae, to say nothing of others.

SEDGE-BIRD, the common name for what in most books is called the Sedge- W ARBLEF.

SEGGE, Angl.-Sax. Sugge (especially in composition as Hegessugge), an old name, apparently for any small bird, that seems still to survive in places for the Hedge-SPARrow; but taking also the form Heysuck ( $c f$. HAY-JACK) and even corrupted into Isaac.

SENEGALI, a dealers' name which should properly belong to the Fringilla senegala of Linnæus, the Estrilda or Lagonosticta senegala of some modern writers, but seems to be often applied in a general way to small species of Ploceida (WEAVER-BIRD) from West Africa, or perhaps even other countries. 
SERIENIA, otherwise CARIANA, ${ }^{1}$ a South-American bird, sufficiently well described and figured in Marcgrave's work (Hist. lier. Nat. Brasilia, p. 203), posthumously published by De Laet in 1648, to be recognized by succeeding ornithologists, among whom Brisson in 1760 acknowledged it as forming a distinct genus Cariuma,

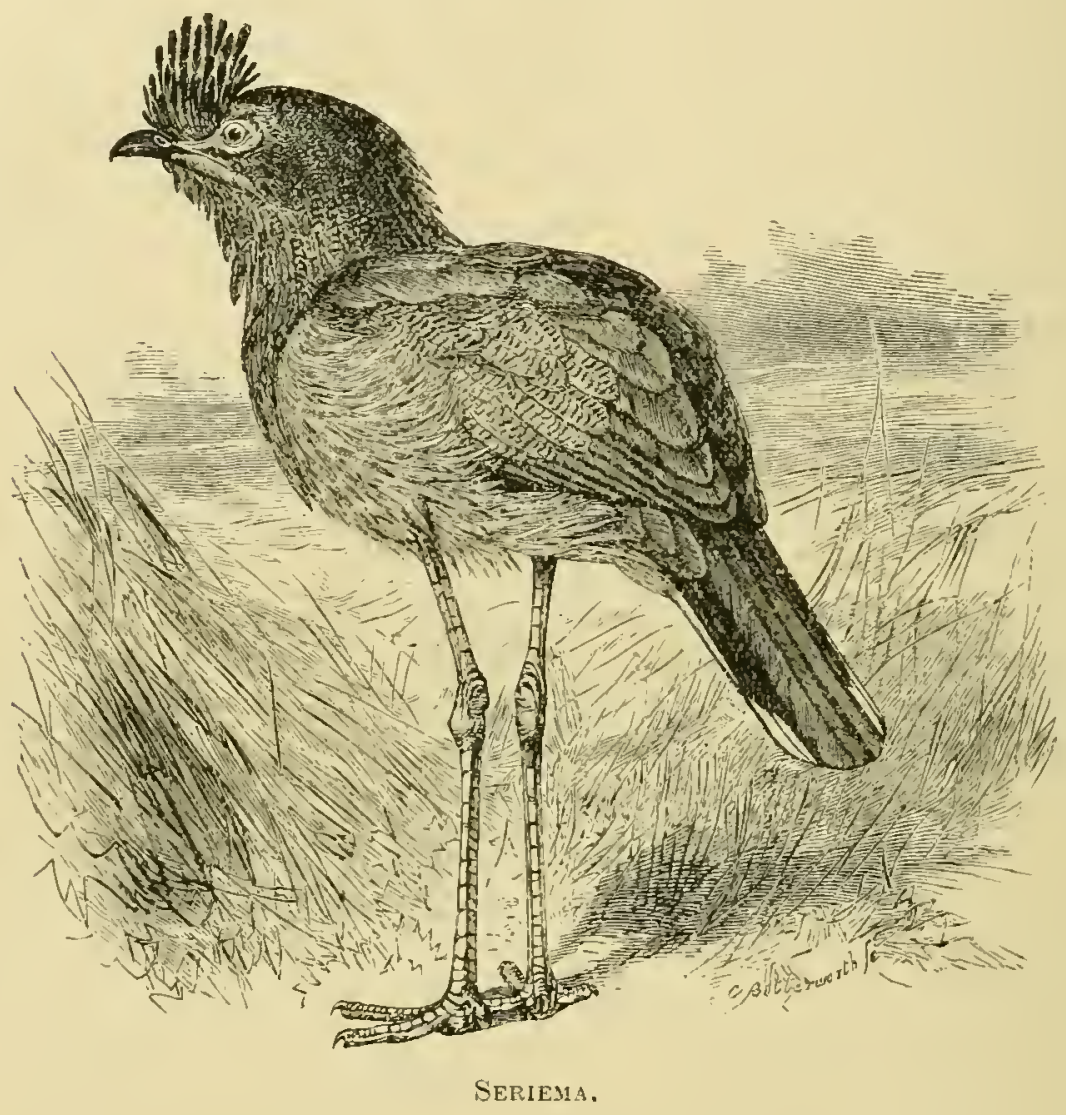

while Linnæus regarded it as a second species of Palamedea (SCrEantr, p. 819), under the name of $P$. cristata, Englished in 1785 by Latham (Gen. "Synops. v. p. 20) the "Crested Screamer,"-an appellation, as alleady observed, since transferred to a wholly different bird. Nothing more seems to have been known of it in Europe till 1803, when Azara published at Madrid his observations on the birds of Paraguay (Apuntamientos, No. 340), wherein he gave an account of it under the name of "Saria," which it bore among the Guaranis, - that of "Cariama" being applied to it by the Portuguese settlers, and both expressive of its ordinary cry." It was not, however, until 1809 that this very remarkable

I In this word the initial C, as is usual in Portugnese, is pronounced soft, and the accent laid unon the last syllahle.

2 Yet Forbes states (Ilis, 1881, 1. 358) that Scricma comes from Sivi, "a diminutive of Indian extraction," and Ema, the Portuguese name for the Fhea ( $\circ$. EMeu, P. 212, note 1), the whole thus meaning "Little Rhca." 
form came to be autoptically described scientifically. This was done by the elder Geoftroy-St. Hilaire (Ann. du Muséum, xiii. pp. 362370 , pl. 26), who had seen a specimen in the Lisbon museum; and, though knowing it had already been received into scientific nomenclature, he called it anew Microdactylus marcgravii. In 1811 Illiger, without having seen an example, renamed the genus Dicholophusa term which has since been frequently applied to it-placing it in the curious congeries of forms having little affinity which he called Alectorides. In the course of his travels in Brazil (1S15-17) Prince Max of Wied met with this bird, and in 1823 there appeared from his pen (N. Act. Acad. L.-C. Nat. Curiosorum, xi. pt. 2, pp. 341-350, tab. xlv.) a very good contribution to its history, embellished by a faithful life-sized figure of its head. The same year Temminek figured it in the Planches Coloriées (No. 237). It is not easy to say when any example of the bird first came under the eyes of British ornithologists; but in the Zoological Proceedings for 1836 (pp. 29-32) Martin described the visceral and osteological anatomy of one which had been received alive the preceding year. ${ }^{1}$

The Seriema, owing to its long legs and neck, stands some two feet or more in height, and in menageries bears itself with a stately deportment. Its bright red beak, the bare greenish blue slin surrounding its large yellow eyes, and the tufts of elongated feathers springing vertically from its lores, give it a pleasing and animated expression; but its plumage is generally of an inconspicuous ochreous-grey above and dull white beneath, - the feathers of the upper parts, which on the neck and throat are long and loose, being barred by fine zigzag markings of dark brown, while those of the lower parts are more or less striped. The wingquills are brownish-black, banded with mottled white, and those of the tail, except the middle pair, which are wholly greyish-brown, are banded with mottled white at the base and the tip, but dark brown for the rest of their length. The legs are red. The Seriema inhabits the campos or elevated open parts of Brazil, from the neighbourhood of Pernambuco to the Rio de la Plata, extending inland as far as Matto Grosso (long. $60^{\circ}$ ), and occurring also, though sparsely, in Paraguay. It lives in the high grass, running away in a stooping posture to avoid discovery on being approached, and taking flight only at the utmost need. Yet it builds its nest in thick bushes or trees at about a man's height from the ground, therein laying two eggs, which Burmeister likened to those of the Land-Rail in colour. ${ }^{2}$ The young are latched fully covered

1 The skeleton has been briefly described and figured by Eyton (Osteol. Avium, p. 190, pls. 3, K, and 28 bis, fig. 1).

2 This distinguished author twice cites the figure given by Thienemann (Fortpflanzungsgesch. gesammt. Vögel, pl. lxxii. fig. 14) as though taken from a genuine specimen; but little that can be called Ralline in character is 
with grey down, relieved by brown, and remain for some time in the nest. The food of the adult is almost exclusively animal,insects, especially large ants, snails, lizards and snakes; but it also eats certain large red berries.

Until 1860 the Seriema was believed to be without any near relative in the living world of birds ; ${ }^{1}$ but in the Zoological Proceedings for that year (pp. 334-336) Dr. Hartlaub described an allied species discovered by Prof. Burmeister in the territory of the Argentine Republic. ${ }^{2}$ This bird, which has since been regarded as entitled to generic division under the name of Chunga burmeisteri (Proc. Zool. Soc. 1870, p. 466, pl. xxxvi.), and seems to be known in its native country as the "Chunnia," differs from the Seriema by frequenting forest or bushy districts. It is also darker in colour, has less of the frontal crest, shorter legs, a longer tail and the markings beneath take the form of bars rather than stripes. In other respects the difference between the two birds seems to be immaterial.

There are few birds which have more exercised the taxonomer than this, and the reason seems to be plain. The Seriema must be regarded as the not greatly modified heir of some very old type, such as one may fairly imagine to lave lived before many of the existing groups of birds had become differentiated. Looking at it in this light, we may be prepared to deal gently with the systematists who, having only the present before their eyes, have relegated it positively to this, that or the other Order, Family or other group of birds. There can be no doubt that some of its habits point to an alliance with the BUSTARD or perhaps certain Plovers, while its digestive organs are essentially, if not absolutely, those of the Heros. Its general appearance recalls that of the SeCRETARY-BIRD ; but this, it must be admitted, may be merely an analogy and may indicate no affinity whatever. On the one hand we have had anthorities, starting from bases so opposed as Prof. W. K. Parker (Proc. Zool. Soc. 1863, p. 516) and Sundevall, placing it among the Accipitres, while on the other Nitzsch, Burmeister, ${ }^{3}$ Martin (ut sumà), and Dr. Garlow (Journ. f. Orn. 1876,

wbservable therein. The same is to be said of an egg laid in captivity at Paris ; but a speeimen in Mr. Walter's possession undeniably shews it (Proc. Zool. Soc. 1881, p. 2).

1 A supposed fossil Cariuma from the eaves of Brazil, mentioned by Bonaparte (Comptes Rendus, xliii. p. 779) and others, has since been shewn by Reinhardt (Ibis, 1882, N P. 321-332) to rest npon the misinterpretation of certain bones, which the latter considers to have been those of a Rhea.

a Near Tueuman and Catamarea (Burmeister, Reise durch dic La Plata Stacten, ii. P. 508).

3 Nitzsch, as Burmeister stated in his masterly contribution to the natural history of this bird (Abhandl. naturf. Gescllsch. Halle, i. pp. 1-68, pls. 1, 2), 
pp. 445, 446) have declared in effect that this view of its affinities camnot be taken. Prof. Huxley (Proc. Zool. Soc. 1867, p. 455) expressed himself more cantiously, and, while remarking that in its skull "the internasal septum is ossified to a very slight extent, and the maxillo-palatine processes may meet in the middle line, in both of which respects it approaches the birds of prey," added that "the ossified part of the, nasal septum does not unite below with the maxillo-palatines," and that in this respect it is unlike the Accipitres; finally he declared (p. 457) that, as Otis connects the Geranomorpha with the Charadriomorpha, so Cariama connects the former with the Aetomorpha, "but it is a question whether these two genera may be better included in" the Geranomorpha, "or made types of separate groups." The latter course is followed by Prof. Fürbringer (Untersuchungen, p. 1566) and Dr. Gadow (Thier-reich, Vögel, ii. pp. 184-186), who unhesitatingly regard the Seriema as the type of a distinct Family, whose nearest living allies may be found in the Gruidx (Crane), Psophiidx (Trunpeter) and Otidide (Bustard) - a determination which is probably final.

SERIX, F1. Serin, O.F. Serene, Provenç. Serena, supposed to be from Sirene (Lat. Siren), and applied to the bird from its agreeable song-the Fringilla serinus of Linnæus and Serinus hortulanus of recent ornithologists-a small FinCH long known to inhabit Sonthern Europe with Torthern Africa, and of late years observed to be extending its range on the continent and to have appeared in England (Yarrell, Br. B. ed. 4, ii. p. 111). Its habits have been described by Mr. Dresser (B. Eur. iii. pp. 551-553) from his personal observation, and by no one better. It is nearly allied to the CANARY-BIRD, though recognizable by its tints, its larger size, proportionally shorter wings and longer tail. Dr. Sharpe (Cut. B. Br. Mus. xii. p. 370) accounts the latter a "subspecies" of the Serin, but withont giving his reason for departing from the general practice of considering them distinct species, and thus one is unable to appreciate the validity of his judgment. He however admits 18 other species of the genus.

SHAG, the English name commonly applied all over the world to member's of the gemus Phalucrocorax in general; but specialized by British ornithological writers for P. graculus, the smaller of the two species which inhabit the coasts of these islands (CorMORANT, p. 106). In breeding-plumage the Shag, with its plumage of imiform glossy green, its tufterl crest-the feathers of which curve

in 1834 saw a defective skeleton sent to Munich by the Brazilian travellers Spix and Martius. His description of it was not, however, published until 1853. To it is appended a description by Dr. Creplin of some Entozod found in the Seriema, but this unfortunately seems to give no help as to the systematio prosition of the bird. 
forwards-the deep yellow of the bare skin about its face, and its beryl-coloured eyes, is one of the most beautiful of sea-birds.

SHEARWATER, the name of a bird first published in Willughby's Ornithologia (p. 252), as made known to him by Sir T. Browne, who sent a picture of it with an account that is given more fully in Ray's translation of that work (p. 334), stating that it is "a Sea-fowl, which fishermen observe to resort to their Vessels in some numbers, swimming ${ }^{1}$ swiftly to and fro, backward, forward, and about them, and doth as it were radere aquam, shear the water, from whence perhaps it had its name." 2 Ray's mistaling young birds of this kind obtained in the Isle of Man for the young of the Coulterneb, now usually called PUFFis, has already been mentioned (p. 752); and not only has his name Puffinus anglorum hence become attached to this species, commonly described in English books as the Manx Puffin or Manx Shearwater, but the barbarous and misapplied word Puffinus has come into regular use as the generic term for all birds thereto allied, forming a wellmarked group of the Family Procellariida (PeTrel, p. 708), distinguished chiefly by their elongated bill, and numbering some twenty species, if not more-the discrimination of which, owing partly to the general similarity of some of them, and partly to the change of plumage which others through age are believed to undergo, las taxed in no common degree the ingenuity of those ornithologists who have ventured on the difficult task of determining their characters. ${ }^{3}$ Shearwaters are found in nearly all the seas and oceans of the world, ${ }^{4}$ generally within no great distance from the land, though rarely resorting thereto, except in the breedingseason. But they also penetrate to waters which may be termed inland, as the Bosphorus, where they have long attracted attention

I By mistake, no doubt, for flying or "hovering," the latter being the word used by Browne in his Account of Birds found in Norfolk (Mus. Brit. MS. Sloane, 1830, fol. 5. 22 and 31), written in or about 1662 . Edwards (Gleanings, iii. p. 315) speaks of comparing his own drawing "with Brown's old draught of it, still preserved in the British Museum," and thus identifies the latter's "Shearwater" with the "Puffin of the Isle of Man."

${ }^{2}$ Lira, Lyra or Lyrie (all three forms being found) appears to be the most common local name for this bird in Orkney and Shetland; but SCRABER and Scraib are also used in the Hebrides. These are from the Scandinavian Skrapc or Skrofa, and considering Prof. Skeat's remarks (Etym. Diet. p. 546) as to the alliance between the words shear and scrape it may be that Browne's hesitation as to the derivation of "Shearwater" liad more ground than at first appears.

${ }^{3}$ Mr. Salvin's catalogue of the specimens of Procellariidx in the British Museum, which is understood to be in a forward condition, will doubtless throw much light on this difficult question.

4 The chief exception would seem to be the Bay of Bengal and thence throughout the western part of the Malay Archipelago, where, though they may occur, they are certainly uncommon. 
by their daily passage up and lown the strait, in numerous flocks, hardly ever alighting on the surface, and from this restless habit they are known to the French-speaking part of the population as ames damnes, it being held by the Turks that they are animated by condemned human souls. Four species of Puffinus are recorded as visiting the coasts of the United Kingdom; but the Manx Shearwater aforesaid is the only one that at present is known to occur commonly or breed in the British Islands. It is a very plain-looking bird, black above and white beneath, and about the size of a Pigeon. Some other species are considerably larger, while some are smaller, and of the former several are almost wholecoloured, being of a sooty or dark cinereous hue both above and below. All over the world Shearwaters seem to have precisely the same habits, laying their single purely white egg in a hole under ground. The young are thickly clothed with long down, and are extremely fat. In this condition they are thought to be good eating, and enormous numbers have been caught for this purpose in some localities, especially of a species commonly known as the Mutron-BIRD, $P$. brevicauda, which used to frequent the islands off the coast of Australia; but is probably meeting if it has not already met the fate of its congener $P$. auduboni in Bermuda, where the latter was known as the "Cahow" (variously spelt) and was once abundant. ${ }^{1}$

SHEATHBILL, a bird so-called in 1781 by Pennant (Gen. B. ed. 2, p. 43) from the horny case ${ }^{2}$ which ensheathes the basal part

${ }^{1}$ Details of the mournful and instructive story of the almost complete annihilation of this species on those islands can be gathered from Lefroy's Memorials \&ec. of the Bermudas or Somers Islands (i. pp. 13, 18, 35, 36, 76, $137,330,331$; ii. p. 578), where many extracts, chiefly from Purchas's Pil. grimes and Smith's Virginia, are given. The swine, let loose in early days by the original Spanish discoverers, produced the usual effect, but the birds still abounded on the smaller islets, where there were no hogs, and in 1614 (apparently) the settlers being reduced to distress by famine and fever, the English Governor sent 150 of the "most weake and sicke" to Couper's Isle, where were "infinite numbers of Birds called Cahowes." But through the "luunger and gluttony" of these poor people "those heavenly blessings they so much consumed and wasted by carelessness and surfeiting" that many died. The next Governor, in 1616 apparently, had to issue "a Proclamation against the spoile of Cahowes, but it came too late, for they were most destroyed before." Almost all knowledge of such a bird in the colony had vanished according to Mr. J. M. Jones (Nat. in Bermuda, pp. 94-96) when, in 1849, Sir John Campbell-Orde and a brother-officer visited the Black Rock, wear Cooper's Island, and found three birds, the sole remnant of those that had once crowded every available part of the group. In 1874 Capt. Reid (Zoot. 1877, p. 491) found two nests, and considered that a few pairs of the birds still frequented the islands. How many may be there now I know not.

2 A strange fallacy arose early, and of course has been repeated late, that this case or sheath was movable. It is absolutely fixed. 
of its bill. It was first made known from having been met with on New-Year Island, off the coast of Staten Land, where Cook anchored on New Year's eve 1774.1 A few days later he discovered the islands that now bear the name of South Georgia, and there the bird was again found, - in both localities frequenting the rocky shores. On his third royage, while seeking some land reported to have been found by Kerguelen, Cook in December 1776 reached the cluster of desolate islands now generally known by the name of the French explorer, and here, among many other kinds of birds, was a Sheathbill, which for a long while no one suspected to be otherwise than specifically identical with that of the western Antarctic Ocean; but, as will be seen, its distinctness has been subsequently adnitted.

The Sheathbill, so soon as it was brought to the notice of

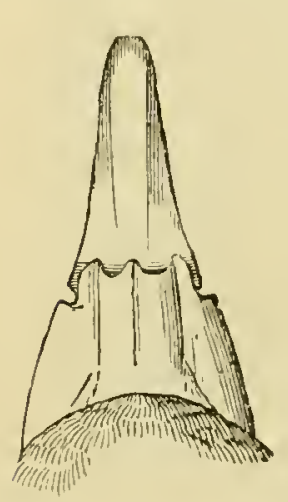

BILL OF ChIONis, from above.

(After Swainson.) naturalists, was recognized as belonging to a genus hitherto unknown, and the elder Forster in 1788 (Enchivid. p. 37) conferred upon it, from its snowy plumage, the name Chionis, which has most properly received general acceptance, though in the same year the compiler Gmelin termed the genus Fuginulis, as a rendering of Pennant's English name, and the species alba. It has thus become the Chionis alba of ornithology. It is about the size of and has much the aspect of a Pigeon ; ${ }^{2}$ its plumage is pure white, its bill somewhat yellow at the base, passing into pale pink towards the tip. Round the eyes the skin is bare, and beset with cream-coloured papillæe, while the legs are bluish-grey. The second or eastern species, first discriminated by Dr. Hartlaub (Rer. Zool.

1 Doubtless some of the earlier voyagers had encountered it, as Forster. (Deser. Anim. 1. 330) suggests and Lesson (Man. d'Orn. ii. p. 343) asserts; but for all practical purposes we eertainly owe its discovery to the naturalists of Cook's seeond royage. By some error, probably of transcription, New Zealand, instead of New-Ycar Island, alpears in many works as the place of its discovery, while not a few writers have added thereto New Holland. Hitherto there is no real evidence of the oceurence of a Sheathbill in the waters of Australia or New Zealand; but one (C. allue) was shot by the lighthonse-keeper at Carlingford in Ireland, 2 Dee. 1S92, as recorded by Mr. Barrington (Zool. 1893, 1. 28; Proc. Zool. Soc. 1893, 1. 178). Examples of this species have been often brought alive to this conntry; and the bird thus killed may' well have escaper from confinement.

"In the Falkland Isles it is called the "Kelp-Pigeon," and hy some of the earlier French narigators the "Pigeon blane antaretique." The cognate species of Kerguelen Land is named by the sealer's "Sore-eyerl Pigeon," from its prominent fleshy orbits, as well as "Paddy-bird"--the last perhaps from its white plumage resembling that of some of the smaller Egrets, often so ealled. 
1841, p. 5; $1 \$ 42$, p. 402 , pl. 2) ${ }^{1}$ as C. minor, is smaller in size, with plumage just as white, but having the bill and bare skin of the face black and the legs much darker. The form of the bill's "sheath" in the two species is also quite different, for in C. alba it is almost level throughout, while in $C$. minor it rises in front like the pommel of a saddle. Of the habits of the western and larger species not much has been recorded. It gathers its food, consisting chiefly, as Darwin and others have told us, of seaweeds and. shell-fish, on rocks at low water; but it is also known to eat birds' eggs. There is some curiously conflicting evidence as to the flavour of its flesh, some asserting that it is wholly uneatable, and others that it is palatable, - a difference which may possibly be due to the previous diet of the particular example tasted, to the skill of the cook or the need of the taster. Though most abundant as a shore-bird, it is frequently met with far out at sea, as by Fleurieu (Voy. de Marchand, i. p. 19), in lat. $44^{\circ}$ S., some 260 miles from the eastern coast of Patagonia. It is not uncommon on the Falkland Isles, where it is said to breed (Iois, 1861, p. 154), though confirmation of the report is as yet wanting, and from thence is found at both extremities of the Strait of Magellan, and southward to Louis-Philippe Land in lat. $60^{\circ} \mathrm{S}$. On the other land, thanks to the naturalists of the British and United States expeditions to Kerguelen Land for the observation of the transit of Venus in 1874, especially Mr. Eaton (Philos. Trans. clxviii. pp. 103-105) and Dr. Kidder (Bull. U. S. Nat. Mus. 1875, No. 2, pp. 1-4), much more has been recorded of the eastern and smaller species, which had already been ascertained by Mr. Layard (Proc. Zool. Soc. 1871, p. 57, pl. iv. fig. 7) to breed on the Crozet Islands, ${ }^{2}$ and was found to do so still more numerously on Kerguelen, while it probably frequents Prince Edward's Islands for the same purpose. The eggs, of which a considerable number have now been obtained, though of peculiar appearance, bear an unmistakable likeness to those of some Plovers, while occasionally exhibiting a resemblance-of little significance, however-to those of the Tropic-birds.

The systematic position of the Sheathbills has been the subject of much hesitation-almost useless since 1836, when De Blainville (Ann. Sc. Nat. ser. 2, vi. p. 97) made known certain anatomical facts proving their affinity to the Oyster-CATCHERs, though

${ }^{1}$ Lesson (loc. cit.) cites a brief but correct indication of this species as obscrved by Lesquuin (Lycée Armoricain, x. p. 36) on Crozet Island, and, not suspecting it to be distinct, was at a loss to reconcile the discrepancies of the latter's description with that given of the other species by earlier authors.

2 A previous announcement of the discovery of its egg (Ibis, 1867, p. 458) was premature, the specimen, now in my posscssion, proving to be that of a Gull-a fact unknown to the American writer named above. 
pointing also to a more distant relationship with the GuLLS. These he afterwards described more fully (Voy. 'Bonite' Zoolog. i. pt. 3, pp. 107-132, pl. 9), so as to leave no doubt that Chionis was a form intermediate between those groups. Yet some writers con. tinued to refer it to the Gallinx and others to the Columbx. The matter may now be regarded as settled for ever. In 1876 Dr. Reichenow in Germany (Jour. f. Orn. 1876, pp. 84-89) and in America Drs. Kidder and Coues (Bull. U. S. Nat. Mus. No. 3, pp. 85-116) published elaborate accounts of the anatomy of $C$. minor, the first wholly confirming the view of De Blainville, the last two ${ }^{1}$ agreeing with him in the main, but concluding that the Sheathbills formed a distinct group "Chionomorpha," in rank equal to the Cecomorphes and Charadriomorphe of Prof. Huxley, and regarding this group as being "still nearer the common ancestral stock of both." These authors also wish to separate the two species generically; but their proposals are considered needless by Garrod (Proc. Zool. Soc. 1877, p. 417) and Prof. Milne-Edwards (Ann. Sc. Nat. ser. 6, xiii. art. 4, p. 24). The osteology of $C$. minor has further received the attention of Dr. Shufeldt (Journ. Anat. \& Physiol. 1891, pp. 508-525, pls. xi. xii.) who has also (Aut, 1893 , pp. 158-165) reviewed the various opinions entertained as to the systematic position of this form. The views of De Blainville and Dr. Reichenow are borne out by the observations of Mr. Eaton (loc. cit.), and no one knowing the habits of an Oyster-catcher can read his remarks without seeing how nearly related the two forms are. Their differences may perhaps justify the separation of each form into what is vaguely called a "Family," but the differences will be seen by the comparative anatomist to be of slight importance, and the intimate affinity of the Gavia and Limicolx, already recognized by Prof. IV. K. Parker as well as by some of the best taxonomers, is placed beyond dispute.?

SHELD-DRAKE, or, as commonly spelt in its contracted form, SHELDRAKE, a word whose derivation ${ }^{3}$ has been much discussed,

1 In some details their memoir is unfortunately inaccurate.

2 The little group of very curious birds, having no English name, of the genera Thinocorys and Attagis (Plover, p. 733), which are peculiar to certain localities in South America and its islands, are by some systematists placed in the Family Chionididx and by others in a distinct Family "Thinocoridx" (more correctly Thinocorythidx). They are undoubtedly Limicoline, though having much the aspect of Sand-Grouse, but their precise pcsition and rank remain at present uncertain ( $c f$. Garrod ut suprà, and Parker, Trans. Zool. Soc. x. pp. 301 et seqq.), though it is pretty clear that they are generalized and somewhat ancicnt forms--a fact which accords with their GEOGRAPHICAL DisTribuTION (p. 324).

3 Ray in 1674 (Engl. Words, p. 76) gave it from the local "sheld" (=particoloured), which, applied to animals, as a horse or a cat, still survives in East Anglia. This opinion is not only suitable but is confirmed by the bird's 
one of the most conspicuous birds of the Duck tribe, Anatilit, called, however, in many parts of England the "Burrow-Duck" from its habits presently to be mentioned, and in some districts by the almost obsolete name of "Bergander" (Dutch, Bery-cende, Germ. Biergente), a word used by Turner in 1544. Other local names are SKEEL-DUCK and SkELDER.

The Sheldrake is the Anas taloma of Linnæus, and the Tadornu cornuta or T. vulpanser of modern ornithology a bird somewhat larger and of more upright stature than an ordinary Duck, having its bill, with a basal fleshy protuberance (whence the specific term cornuta) pale red, the head and upper neck very dark glossy green, and beneath that a broad white collar, succeeded by a still broader belt of bright bay extending from the upper back across the upper breast. The outer scapulars, the primaries, a median abdominal stripe, which dilates at the rent,

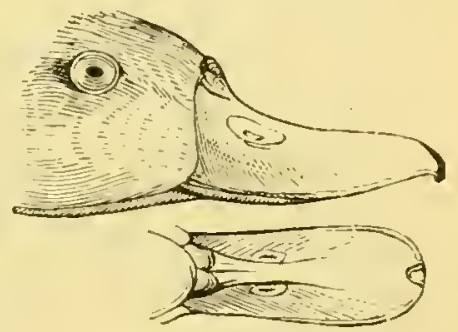

TADORNa. (After Swainsun.) and a bar at the tip of the middle tail-quills are black; the inner secondaries and the lower tail-coverts are grey; and the speculum or wing-spot is a rich bronzed-green. The rest of the plumage is pure white, and the legs are flesh-coloured. There is little external difference between the sexes, the female being only somewhat smaller and less brightly coloured. The Sheldralie frequents the sandy coasts of nearly the whole of Europe and North Africa, extending across Asia to India, China and Japan, generally keeping in pairs and sometimes penetrating to favoumble inland localities. The nest is always made under cover, usually in a rabbit-hole among sandhills, and in the Frisian Islands the people supply this bird with artificial burrows, taking large toll of it in eggs and down. Barbary, south-eastern Europe and a large part of Asia are inhabited by an allied species of more inland range and very different coloration, the $T$. casurca or Casarca ${ }^{2}$ rutila of ornithologists, the

Old Norsk name Sligöldungr, from Slijöldr, primarily a patch, and now commonly bestowed on a piebald horse, just as Skjjalda (Cleasby's Icel. Dict. sub voce), from the same sonrce, is a particoloured cow. But some scholars interpret Skjöldungr by the secondary meaning of sirjöldr, a shield, asserting that it refers to "the shield-like band across the breast" of the bird. If they be right the proper spelling of the English word would be "Shield-drake," as some indeed have it. A third suggested meaning, from the Old Norsk Skjoil, shelter, is philologically to be rejected, but, if true, would refer to the bird's liabit, described in the text, of breeding under cover.

1 This is the Latinized form of the French Tadorne, first published by Belon (1555), a word on which Littré throws no light except to state that it has a southern variant Tardone.

"Bonaparte in 1838 separated this species from the genus Tadorna, but neither he nor lis snccessors have shewn any good reason for doing so. 
Ruddy Sheldrake of English authors-for it has several times strayed to the British Islands, - and the "Brahminy Duck" of Anglo-Indians, who find it resorting in winter, whether by pairs or by thonsands, to their inland waters. This species is of an almost uniform bay colour all over, except the quill-feathers of the wings and tail, and (in the male) a ring round the neck, which are black, while the wing-coverts are white and the speculum shines with green and purple; the bill and legs are dark-coloured. ${ }^{1}$ A species closely resembling the last, but with a grey head, T. cana, inhabits South Africa, while in some of the islands of the Malay Archipelago, and in the northern parts of Australia, there is a fourth species, T. radjah, which almost equals the true Sheldrake in its brightlycontrasted plumage, but yet wants some of the lively colours the latter displays -its head, for instance, being white instead of dark green. Further to the southward in Australia occurs another species of more sombre colours, the T. tadornoides; and New Zealand is the home of a sixth species, $T$. variegata, still less distinguished by bright hues. In the last two the plumage of the sexes differs not inconsiderably, but all are believed to have essentially the same habits as the $T$. cornuta. ${ }^{2}$

It is not without a purpose that these different species are here particularized. Sheldrakes will, if attention be paid to their wants, breed freely in captivity, crossing if opportunity be given them with other species, and an incident therewith connected possesses an importance hardly to be overrated by the philosophical naturalist, though it seems not to have met with the attention it deserves. In the Zoological Society's gardens in the spring of 1859 a male of $T$. cormuta mated with a female of $T$. cana, and, as will have been inferred from what has been before stated, these two species differ greatly in the colouring of their plumage. The young of their union, however, presented an appearance wholly unlike that of either parent, and an appearance which can hardly he said, as has been said (Proc. Zool. Soc. 1859, p. 442), to be "a curious combination of the colours of the two." Both sexes of this hybrid have been admirably portrayed by Mr. Wolf (tom. cit. Aves, pl. 158); and, strange to say, when these figures are compared with equally faithful portraits by the same master (op. cit.

1 Jerdon ( $B$. Ind. iii. p. 793) tells of a Hindu belief that once upou a time two lovers were transformed into birds of this species, and that they or their descendants are condemed to pass the night on opposite banks of a river, whence they unceasingly call to one another: "Charkwa, shall I come?" "No, Charkwi." "Charkwi, shall I come?" "No, Charkwa." As to how, in these circumstances, the race is perpetuated the legend is silent.

2 The Anas scutellata of the Indo-Malay countries is by several anthorities considered to be a Tadorna, but this view is denied by others, among them by Mr. Hume (Stray Feathers, viii. p. 158). 
1864, pls. 18, 19) of the Australian and New Zealand species, $T$. tadornoides ${ }^{1}$ and $T$. variegata, it will at once be seen that the hybrids present an appearance almost midway between the two species last named-species which eertainly had nothing to do with their prorluction. The only explanation of this astomnding fact seems to be that afforded by the principle of "reversion," as set forth by $\mathrm{Mr}$. Darwin, and illustrated by him from examples of certain breeds of Doves, domestic Fowls and Dueks (Anim. anl I\%. under Domestic. i. pp. 197-200, ii. p. 40), as well as, in the matter of domestie Fowls, by Mr. Cambridge Phillips (Zool. 1854, p. 331). It is a perfectly fair hypothesis that the existing animals of New Zealand and Australia ( $c f$. Geographical Distrinution, pp. 315 317 ) retain more of their ancestral character than do those of countries in which we may suppose the struggle for life to have been fiercer and the action of natural selection stronger. Why it is so we cannot say, yet experiment proves that the most widely-different breeds of Pigeons and other poultry, when crossed, produce offspring that more resembles the ancestral wild species from which the domesticated forms have sprung than it resembles either of the immediate parents. "This mysterious ageney is known as the principle of "reversion," and the example just eited proves that the same effect is produced in species as well as in "races,"-indieating the essential identity of both, - the only real difference being that "species" are more diflerentiated than are "laces," or that the distinetion between them, instead of being (as many writers, some of the first repute, have maintained) qualitative, is merely quantitative, ol one of degree."

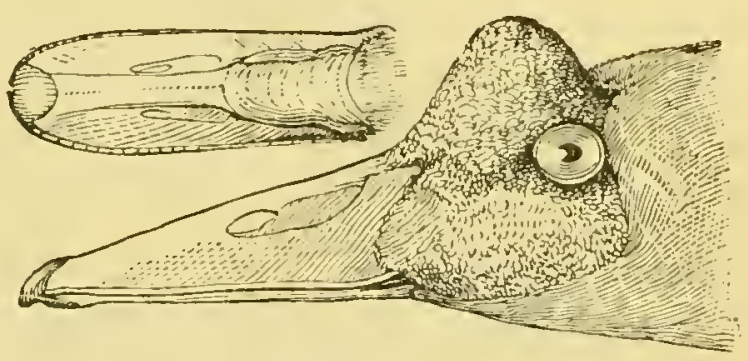

Plectropterus. (Afler Swainson.)

The genus Tudorna seems to be most nearly related to Chenalopex, containing the bird so well known as the Egyptian Goose, $C$. rgyptiuca, and an allied species $C$. jubata, from South America. As shewn by their tracheal characters, the genus Plectropterus, composed of the Spur-winged Geese of Africa, and perhaps the Australian Anseranas and the Indo-African Surcidiornis, also appear to belong to the same group, which should be referred rather to the Anatine than to the Anserine section of the Anatida.

1 By inadvertence this species was assigned $(1.600)$ to New Zealand.

2 It is further worthy of remark that the young of $T$. casarea when first hatehed closely resemble those of T. variegata, and when the latter assmme their first plumage they resemble their father more than their mother (Proc. Zool. Soc. 1866, p. 150). 
SHELDER (Icel. Skjöldr=piebald), a local name for the Oyster-CATCher ( $c f$. Scolder, p. 817, and SHELd-drake, p. 835).

SHELL-APPLF, a name for the Crossbill, but occasionally for the CHAFFINCH, though in that case SHELLY is commoner.

SHEPSTER, a local name for the STARLing ( $c f$. CHEPSTER), possibly an abbreviated form of Sheep-stare, from the bird's habit of accompanying flocks of sheep.

SHERIFF'S MAN, a nickname of the GOLDFINCH, from its gaudy colouring.

SHIRL ( = Shrill, $c f$. SHrIke), a name for the Mistletoe-THRUsh.

SHOE-BILL or SHOE-BIRD, renderings of the Arabic name Abu-markub (Father of a Shoe) that have been given by travellers to one of the most remarkable-looking of Central-African birds, Balaniceps rex, also called by some writers the Whale-headed Stork - the bird's huge bill, ${ }^{1}$ in shape not unlike a whale's head, and tipped with a formidable hook, suggesting all these names. It was first brought to Europe by Mr. Mansfield Parkyns ${ }^{2}$ from the White Nile, and was regarded by Gould (Proc. Zool. Soc. 1851, pp. 1, 2, Aves, pl. xxxv.), who described and figured it, as an abnormal Pelican. This view was disputed by Reinhardt (op. cit. 1860, pp. 377-380) and wholly dispelled by Parker (Trans. Zool. Soc. iv. pp. 269-351, pls. 64-67), though these two authors disagreed as to its affinities, the former placing it near Scopus (HAMnIER-HEAD) with the STorks, and the latter assigning it to the Herons. More recent views either halt between these two opinions (Reichenow, Journ. für Om. 1877, p. 231 ; Stejneger, Stand. Nat. Hist. iv. p. 171), or incline to the latter (Fürbringer, Untersuchungen, p. 1565 ; Beddcrd, Proc. Zool. Soc. 1888, p. 289 ; Gadow, Thier-reich, Vögel, System. Th. p. 137). There should be no hesitation in regarding it as the representative of a distinct Family Balanicipitidx, on account of its many structural peculiarities, and in singularity of aspect few birds surpass it, with its gaunt grey figure, some five feet in height, its large head surmounted by a little curled tuft,

1 Jardine (Contr. Orn. 1851, pl. 68, p. 11) gave a full-sized figure of it.

2 This traveller only incidentally mentions (Life in Abyssinia, ii. pp. 304, 305 ) the bird, and indeed was never in the country it inhabits. His specimens, according to Von Heuglin (ut infrä), were bought of a slave-dealer in Khartoum, whither they had been brought. It is reasonably supposed that to this species belonged the extraordinary bird, as big as a young Camel, with a bill like a Pelicau's, thongh wanting a pouch, which Ferdinand Werne (Exped. zur Entdeck. der Quellen des Weissen Nil, p. 143) tells us was seen by his people, 15 th December 1840, while he was asleep, and they were unwilling to awaken liim. His countryman Baron F. W. von Müller (Naumannia, 1852, i. p. 85) was more fortunate, in that in 1848 he saw two, but was unable to procure them. On his return to Khartoum he saw in a collection the twn specimens afterwards bought by Mr. Parkyns, for which a high pricc was asked. 
the scowling expression of its eyes, and above all its wonderful bill of which enough has been already said. In 1860 two living examples were brought to England by Mr. Petherick, and exhibited

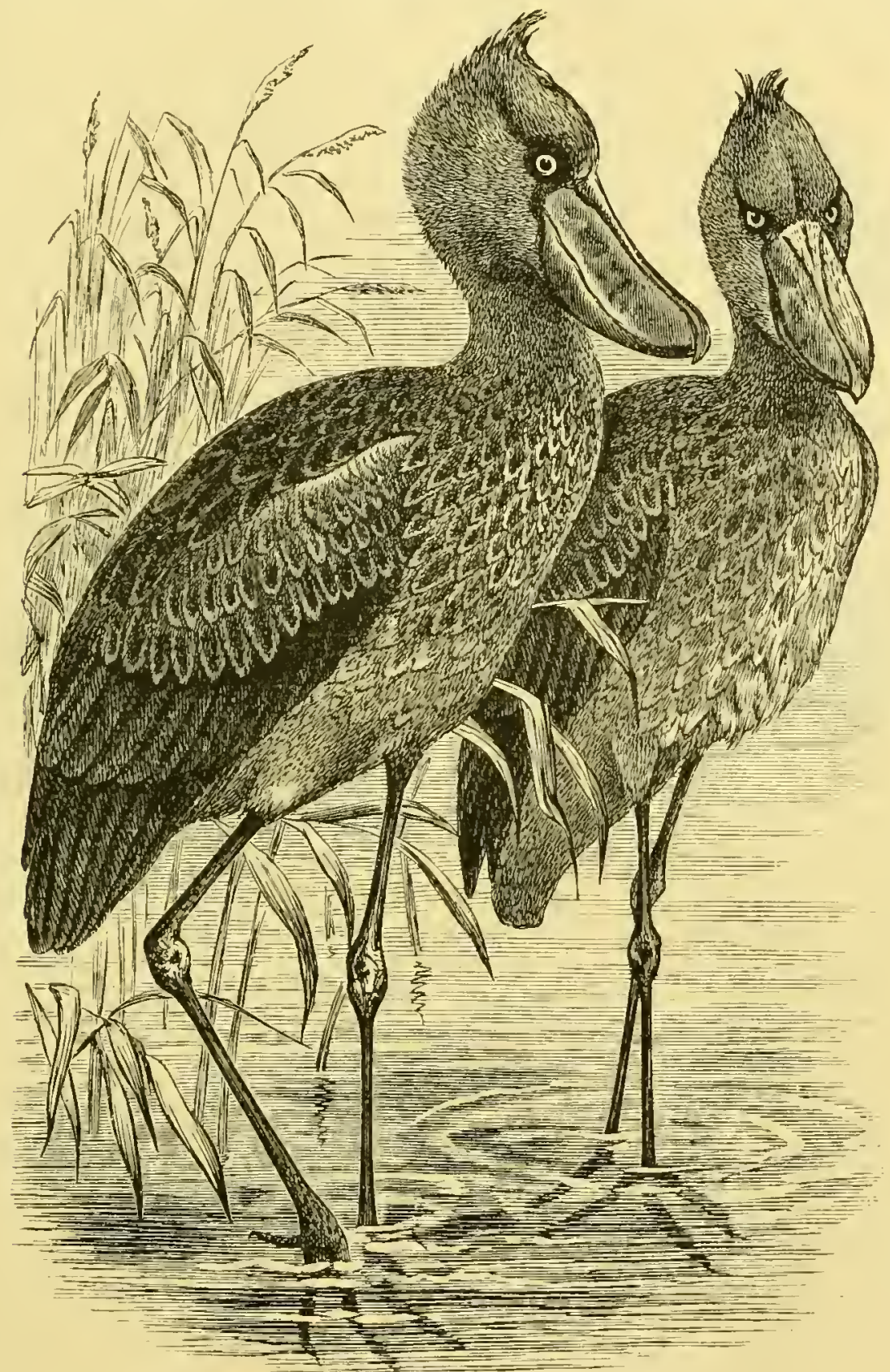

Shoz-Bill. (After Wolf in Trans. Zool. Soc.)

in the Zoological Gardens. He also discovered its mode of nidification, and obtained its eggs, which are white like those of Storks ${ }^{1}$ but the fullest account of the bird is that given by Von Heuglin (Oin. Nordost-Afritia's, pp. 1095-1099).

1 Proc. Zool. Soc. 1860, 1p. 196-199; and Egypt, the Soudan, \&e. 11. 365, 475-478 (London: 1861). 
SHOOI, a name in Shetland (Edmondston, Zetlund Islands, ii. p. 2S1) for the Arctic Gull (SKUA).

SHORT BILL, the inexpressive name given by Swainson in 1820 (Zool. Illustr. pl. 31) to a curious bird, first described by Vieillot (Analyse, P. 68) as Phibalura flariostris, one of the Cotingidar

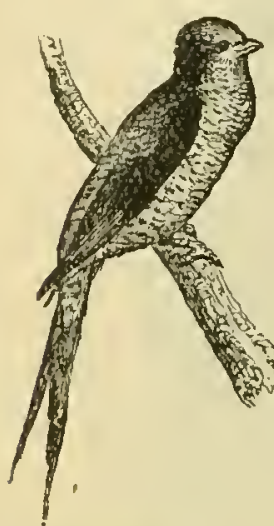

(ChatTerer), but easily recognized by its long, forked tail. Its coloration, though somewhat resembling that of Ampetion, is peculiar, the olive-green feathers of the upper parts being tipped with bright yellow, following a subterminal black bar; while those of the throat and breast are white with a similar black bar and no yellow tip: the crown of the head is crimson, more or less concealed by a thick growth of dark feathers. There is only one species of the genus which inhabits open spaces in the forests of South-eastern Brazil ; but until the

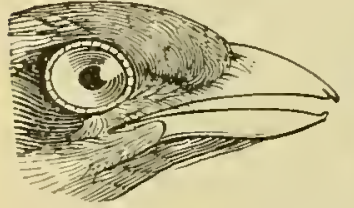

Phibalura. (After Swainson.) appearance of Dr. Göldi's notes (Ibis, 1894, pp. 484-490) next to nothing was known of its habits, and what he tells us leaves mich to be desired. He found that the bird devours enormous quantities of certain berries having a viscous pericarp, and he obtained a nest with two eggs on which the parent was sitting. 'These were of a clear greenish-blue with an irregular crown of neutrally-tinted spots at the larger end, but the illustration representing the nest, eggs and young is disappointing. The nest is almost concealed by the sawnoff branches of the tree in which it was built, the egrs from the small scale shew no characters, and the young are nearly as insignificant. ${ }^{2}$

\section{SHOVELER, formerly spelt SHovelar, and more anciently}

1 Some writers objeet to this word as senseless, so that in 1827 Gloger (Notizen a. l. Geb. r. Natur, xvi. 1. 27S) proposed Cheliclis instead, and Prof. Cabanis (Arch. f. Naturgesch. 1847, i. F. 233), thinking that too much like Chelirton, suggested Amphiboturce as an amendment, unaware that the last had been preoceupied by Wagler in Herpetology; but no change seems needed, for piparos (gracilis, exilis), though not eommonly given in lexieons, is to be found in that of Constantine (1592), and eombined with oipa is appropriate enough-. this being the very etymology Vicillet gave (N. Dict. d'hist. nat. xxiv. p. 107).

2 Many years ago MIr. A. G. More drew my attention to a figure in the Dublin Penny Journal (i. p. 253) for 2 Feh. 1833 which he had recognized as representing a bird of this species, professedly taken from one said to have been shot two or three years before at Powerscourt in Ireland, where it was flying about with some Swallows! The specimen was said to be in the possession of a gentleman at Dublin; but, though the deseription is aeenrate, the contributor did not give his name, and his statement is hard to believe. 
SHOVkLARD, a word by which used to be meant the bird now almost invariably called SPoonbru, but in the latter half of the 17 th century transferred to one litherto generally, and in these days locally, known as the Spoon-billed Duck-the Anus clypeata of Linnwens and Spatula or Rhynchaspis clypeata of modern writers. All these names refer to the shape of the bird's bill, which, combined with the remarliably long lamellex (not wholly incomparable with the "whalebone" of the toothless Cetaceans) that beset both maxilla and mandible, has been thought sufficient to remove the species from the Linnean genus Anas. Except for this exaggerated feature, which carries with it a clumsy look, the male

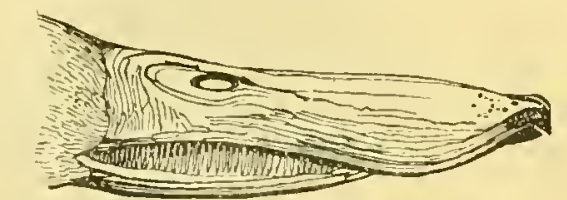
Shoveler would pass for one of the most beautiful of this generally beautiful group of birds. As it is, for bright and variegated colouring, there are few of his kindred to whom he is inferior. His golden eye, his dark green head, surmounting a throat of pure white and succeeded by a breast and flanks of rich bay, are conspicuous; while his deep brown back, white scapulars, lessel wing-coverts (often miscalled "shoulders") of a glaucous blue, and glossy green speculum bordered with white, present a wonderful contrast of the richest tints, heightened again by his bright orange feet. On the other hand, the female, except the blue wing-coverts she has in common with her mate, is habited very like the ordinary Wild Dre $A$. loscus (pp. 168-170). The Shoveler is not an abmulant species, and in Great Britain its distribution is local; but its numbers have remarkably increased since the passing of the Wild-Fow Protection Act in $1876,{ }^{1}$ so that in certain districts it has regained its old position as an indigenous member of our Famma. It has not ordinarily a very ligh northern range, but inhabits the greater part of Europe, Asia and America, passing sonthwards, like most of the Anctidx, towards winter, constantly reaching India, Ceylon, Abyssinia, the Antilles and Central America, while it is known to have occurred at that season in New Granada, and, according to Gould, in Australia. Generally resembling in its habits the other freshwater Ducks, the Shoveler has one peculiarity that has been rarely mentioned, and one that is perhaps correlated with the structure of its bill. It seems to be especially given to feeding on

1 Prior to that year there was perhaps only one distriet in Fngland wherein the Shoveler could be said to breed regularly, and thereto only a few jairs resorted. Ten years later there must have been a dozen comnties in whieh it nested, and in some of them the prairs breeding might be reekoned by the score, while at the present time the number of counties might be safely donbled. 
the surface of the water immediately above the spot where Diving Ducks (POCHARD) are employing themselves beneath. On such occasions a pair of Shovelers may be watehed, almost for the hour together, swimming in a circle, about a yard in diameter, their heads tmined inwards towards its centre, their bills immersed vertically in the water, and engaged in sifting, by means of the long lamellix before mentioned, the floating matters that are disturbed by their submerged allies and rise to the top. These gyrations are executed with the greatest ease, each Shoveler of the pair merely using the outer leg to impel it on its circular course, and to the observer the prettiest part of the performance is the precision with which each preserves its relative distance from its partıer.

Four other species of the genus Spatula, all possessing the characteristic light blue "shoulders," have been described:--one, $S$. platalea, from the southern parts of South America, having the head, neck and upper back of a pale reddish-brown, freckled or closely spotted with dark brown, and a dull, bay breast with interrupted bars; a second, S'. capensis, from Sonth Africa, much lighter in colour than the female of S. clypecter; a third and a fourth, $S$. r.mynchotis and $S$. variegute, from Australia and New Zealand respectively, - these last much darker in general coloration, and the males possessing a white crescentic mark between the bill and the eye, ${ }^{1}$ but so much resembling each other that their specific distinctness is denied by good anthority (cf. Salvadori, Cut. B. Br. Mus. xxvii. p. 315). In these last two the sexual difference is well marked by the plumage; but in the Sonth-American and SouthAfrican species it would scem that both male and female have much the same appearance, as is the case with so many species of the restricted genus Anas, though this cannot yet be asserted with certainty.

Apparently allied to the genus Spatula is Malacorhynchus

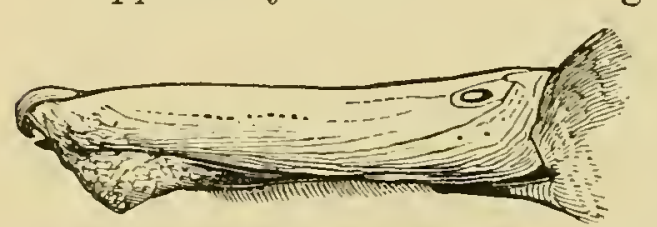

Bil. of Mlalacorhychus. (After Swainson.) membranacens, the "Pink-eye" of Australians - so called from a spot of that colour, so uncommon in birds, just behind the eye in the drakes-which has a soft and flexible maxilla, having near the end on either side a triangular cutaneous flap. It has lamella highly developed; but its fasciated plumage of greyishbrown and white has no resemblance to that of any member of the gemus sprutula. Another bird possessing somewhat similar

1 This mark is observable in several forms of Anctila, and especially in the Blue-winged and Cinnamon Trass of America, Anas or Qucrquedule discors and eyanoptera, slecies whieh not only exhibit in a still greater degree the blue "shonlders" of the Shoveler, but also have very well-dereloped lamelliz on the basal half of the hill. 
though smaller maxillary flap, and marked by a very peculiar style of coloration, is the "Blue Duck" of New Zealand, Hymenolimms mulacorhynchus, from its lobated hallux generally placed among

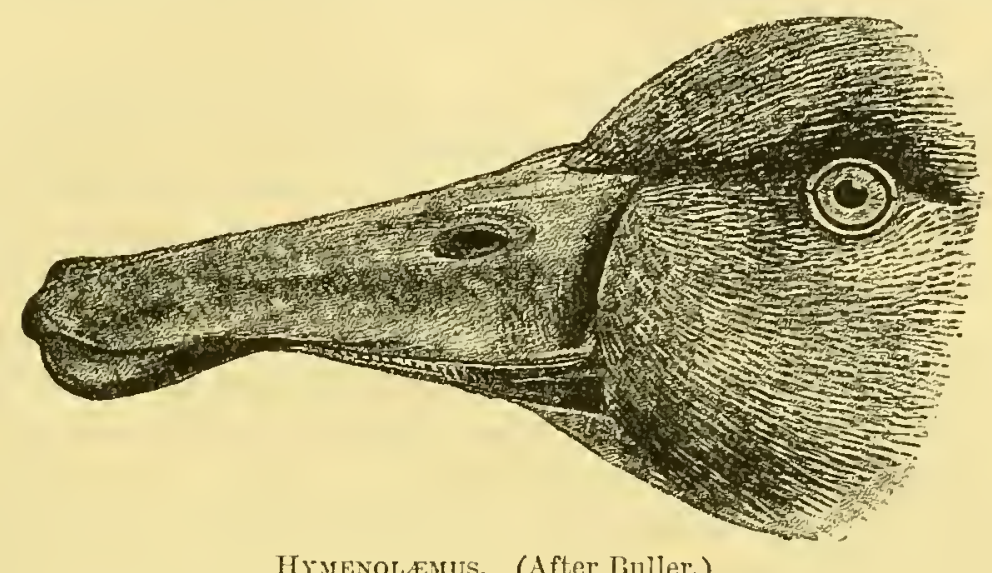

the Nyrocina or Fuligulina (Pochard), but having a tracheal conformation very similar to that of the Anatina and of Somateria. ${ }^{1}$

SHRIEKER, an old name for the GoDwIT.

SHRIKE, a bird's name so given, on the anthority of Sir Francis Lovell, by Turner (1544, sub voce Molliceps), who said he could not find any one else who so called it, and had seen the bird but twice in England, though in Germany often. There can be little doubt that Turner's informant was mistaken, and that the nane, signifying a bird that screeches or shrieks (A.-S. Scric, old Norsk Shirija, mod. Scand. Skriku-a Jay) probably applied originally to the Mistletoe-Thrush, known to Charleton in 1668 (Onomast. p. 83) as SHRELTCH, and to Willughby as SHRITE-a name it still bears in some parts of England, to say nothing of cognate forms such as SCreECH-BIRD and SHIRL. However, the word Shrike ${ }^{2}$ was caught up by succeeding writers; and, though hardly used except in books -for Butcher-BiRD (p. 66) is its popular synonym-it not only retains a position in literary English, but has been largely extended so as to apply in general to all birds of the Family Laniidx and others besides. The name Lanius, in this sense, originated with Gesner ${ }^{3}$ (1555), who thought that the birds to which he gave it had not

${ }^{1}$ As this page is passing through the press I am indebted to Capt. Hutton for a speeimen which enables me to make the above remark. G. R. Gray shewed (Ann. Nut. Hist. xi. 1p. 369-371) that it has no affinity to Malacorhynchus, to which Wagler (Isis, 1832, 1'. 1235) referred it.

2 Few lirds enjoy sneh a wealth of local names as the Shrikes. M. Rolland (Faunc Pop. France, ii. 11). 146-151) gires upwards of minety apl lied to them in France and Savoy ; but not one of these has any affinity to our word "Slırike."

${ }^{3}$ He does not seem to have known that Butcher-bird was an English name; and indeed it may have been subsequently invented ( $f$. FuUsher). 
been mentioned by the ancients. Sundevall, however, considers that the Malacocraneus of Aristotle was one of them, as indeed Turner had before suggested, though repelling the latter's supposition that Aristotle's Tyrannus was another, as well as Belon's reference of Collyrion.

The species designated Shrike by Turner is the Lanius excubitor of Linnæus and nearly all succeeding authors, nowadays ${ }^{1}$ commonly known as the Greater Butcher-bird, Ash-coloured or Great Grey Shrike, - a bird which visits the British Islands pretty regularly, though not numerously, in autumn or winter, occasionally prolonging its stay into the next summer; but it has rarely if ever been ascertained to breed here, though often asserted to have done so. This is the more remarkable since it breeds more or less commonly on the Continent from the north of France to within the Arctic Circle. Exceeding a Song-Thrush in linear measurements, it is a much less bulky bird, of a pearly-grey above with a well-defined black band passing from the forehead to the ear-coverts; beneath it is nearly white, or-and this is particularly observable in Eastern examples -barred with dusky. The quill-feathers of the wings, and of the elongated tail, are variegated with black and white, but are mostly of the former, though what there is of the latter shews very conspicuously, especially at the base of the remiges, where it forms either a single or a double patch. ${ }^{2}$ Much smaller than this is the

1 According to Charleton, Willughby and Ray, it was in their day called in many parts of England "Wierangle" (Germ. Würgengel and IVürger, the Strangler); but it is hard to see how a bird which few people in England could know by sight should have a popular name, and Chaucer's use of it in his Assemblye of Foules may be ascribed to his fondness for outlandish words.

2 On this character great store has been laid by some recent writers, who maintain that the birds presenting only a single patch, with some other minor distinctions, as the barred breast above mentioned, come from the far East and deserve specific recognition as the Lanius major of Pallas. But it is admitted that every intermediate form occurs, and Prof. Collett has now shewn (Ibis, 1886, pp. 30-40) that the typical $L$. excutbitor and typical $L$. major may be found in one and the same brood, and also that this occasional divergence is due neither to age nor sex. That it does depend to some extent on locality is allowed; for, though examples with the single patch ( $L$. major) occasionally reach Great Britain, it is asserted that nearly all the specimens from Eastern Siberia are so marked. But it is also found that by almost insensible degrees other (and sometimes more important) distinctions are manifested, and the extreme terms of the several series have been exalted to the rank of "species"-or at least local races. These are too many to be here enumerated, but it may be mentioned that the Great Grey Shrike of North America, which ordinarily has the lower plumage strongly barred, and is usually known as $L$. borealis, seems to be only one of these divergent forms, though perhaps the most divergent, as might be expected from the wholly distinct area it occupies. Yet occasionally examples occur in the old World, which there is no reason to suppose have an American origin, indis. tinguishable from the typical $L$. borealis, and an uninterrupted series from one 
Red-backed Shrike, L. collurio, the best-known species in Great Britain, where it is a summer visitor, and, though its distribution is rather local, it may be seen in many parts of England and occasionally reaches Scotland. The cock is a sightly bird with his grey head and neck, black cheek-band, chestnut back and pale red breast, while the hen is ordinarily of a dull brown, barred on the lower plumage. A more highly-coloured species is called the Woodchat, $L$. curiculatus or rutilus, with a bright bay crown and nape, and the rest of its plumage black, grey and white. This is an accidental visitor to England, but breeds commonly in many parts of Emrope.

The limits of the Family Laniida have been very variously regarded, and agreement between almost any two systematists on this point seems at present ont of the question. The latest synopsis is that by Dr. Gadow (Cat. B. Brit. Mas. viii. pp. 88-321), who frankly states that it is "quite impossible to give a concise diagnosis of what we are to understand by "the Funily. For his purpose he

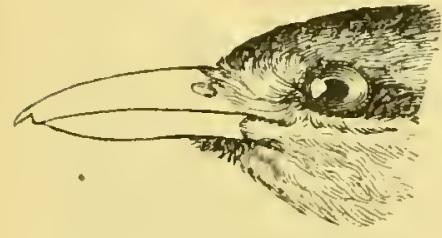

Nillaus.

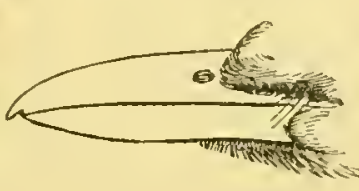

LANIARIUS

(After Swainson.)

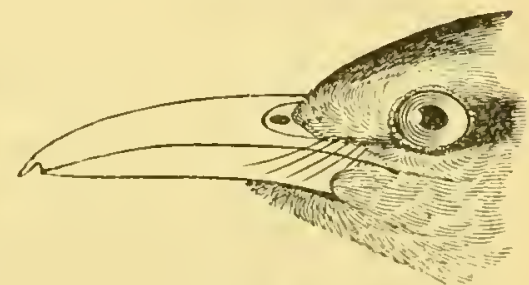

T'elepionus.

makes it to include about 250 species and divides it into five subfamilies:-Gymmorhinina, Malaconotina-inchding such forms as Nilues, Laniarius and Telephoms, Pachycephatina- of which Falcunculus nay serve as an example, Laniinx and 7 ireonina. Of these doubts may be especially entertained as to the affinity of the first and last. He, but for the crude plan to which he was compelled to conform, would not have separated Strepere from Grinorhina, but the former had been already included, to the exclusion of the latter, among the

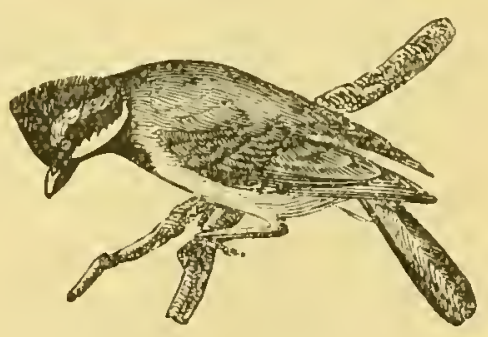

Falcunculus. (After Swainson.) Corvida, and even placed among the normal Corvina. The need of exercising reserve on this matter has been before stated (Crow, p. 116); but the number of ornithologists who think that these two genera should be placed in different Families must be small.

extreme to the other can be found. The differences when compared with those observable in other animals are, as a whole, too slight to justify the epithet "polymorphic" to $L$. excubitor as a species; but enough has been said to shew that it indicates a tendency in that direction. 
The view taken by the late Prof. Parker seems to be the most reasonable: these genera-doubtless with others and most of them Australian - are morphologically inferior to the true Corvida, and perhaps deserve some such designation as that of "NotoCoracomorpha" suggested by him (Trans. Zool. Soc. ix. p. 327). ${ }^{1}$ At the same time their relationship to the Laniida appears to be evident, and they may perhaps be best regarded as the less-altered descendants of an old type, whence both the true Crows and the true Shrikes have sprung, each to develop into higher morphological

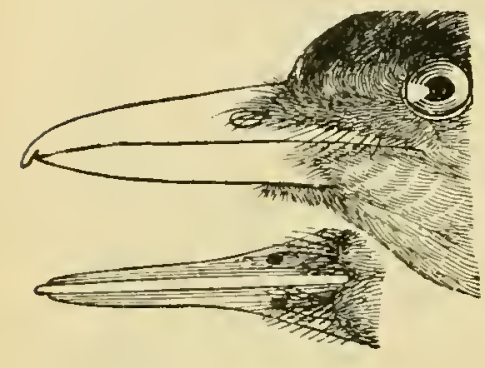

COLLTRIOCINCLA.

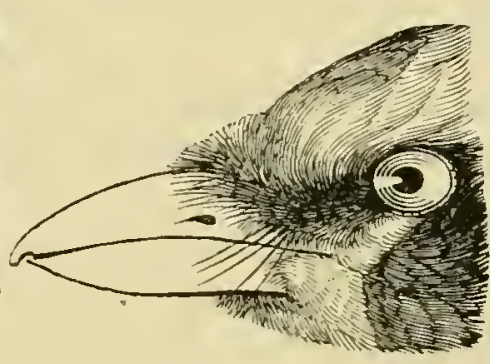

EURYCEPHALL'S.

(After Swainson.)

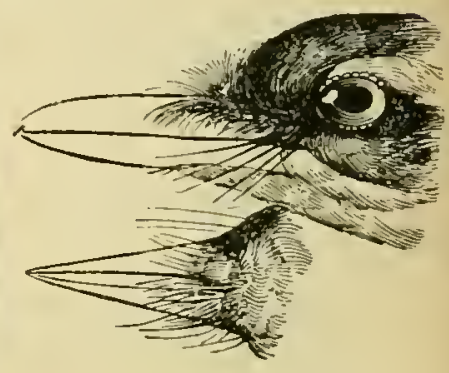

TEPHRODORNiS.

lank, and by the way to throw out numerous other branches. As to the VIreos it would seem almost certain that they have little or no connexion with the Laniidax; but on the other hand no inconsiderable number of forms, which some recent systematists have regarded as a Family, Prionopida, appear to be hardly separable from the Shrikes, and among them Collyriocincla, Eurycephalus and Tephrodornis here figured.

SHUFFLE-WING, an appropriate name for the Hedge-SPARRow, from its "peculiar shake of the wing" (Knapp, Joum. Nat. p. 151).

SILVER-EYE, the name given in New Zealand to the species of Zosterors (Z. lateralis) which was first recognized there in 1856 (Buller, Essuy on Orn. New Zeul. 1865, p. 9).

SINCIPU'T, the fore part of the head to the crown, as opposed to oCCIPUT (p. 649).

SISKIN (Dan. Sidsken; Germ. Zeisig and Zeising), long known in England as a cage-bird, since, in 1544, Turner mentioned it in that character under this name, ${ }^{2}$ and said that he had only once met with it at large-the Fringilla spimus of Linnæus, and Carduelis spinus of many modern writers. ${ }^{3}$ In some of its structural characters

'By an oversight (c.g. p. 403) this group was lesignated "A Astru-Coraces" -the term by which Prof. Parker" often spoke of it, thongh "Anstro-corvines" (Trons. Zool. Soe. x. 1. 252) is lis nearest alpuroach to it in print that I can find. In the earlier prassage eited in the text his expression is as above given.

2 It is also called by bird-fanciers "AbaldAvine" or "A BElituvine" (page 1).

: Those who would separate it from Carluclis should nse the name Spinus, not, as commonly, Chrysomitris, and then our bird becomes S. viridis. 
it is most nearly allied to the GoLDFINCH, and both are often placed in the same genus by systematists; but in its style of coloration, and still more in its habits, it resembles the REDPOLLs, though withont their slender figure, being indeed rather short and stout of build. Yet it hardly yields to them in activity or in the grace of its actions, as it seeks its food from the catkins of the alder or birch, regardless of the attitude it assumes while so doing. Of an olivegreen above, deeply tinted in some parts witl black and in others lightened by yellow, and beneath of a yellowish-white again marked with black, the male of this species has at least a becoming if not a brilliant garb, and possesses a song that is not ummelodious, thongh the resemblance of some of its notes to the rumning-down of a piece of clockwork is more remarkable than pleasing. The hen is still more soberly attired; but it is perhaps the Siskin's disposition to familiarity that makes it so favourite a captive, and, though as a cage-bird it is not ordinarily long-lived, it readily adapts itself to the loss of liberty. Moreover, if anything like the needful accommodation be afforded, it will build a nest and therein lay its eggrs, but it rarely succeeds in bringing up its young in confinement. As a wild bird it breeds constantly, though locally, throughout the greater part of Scotland, and has frequently done so in England, but more rarely in Ireland. The greater portion, howerer, of the numerous bands which visit the British Islands in autumn and winter doubtless come from the Continent-perhaps even from far to the eastward, since its range stretches across Asia to Japan, in which country it is as favourite a cage-bird as with us. The nest of the Siskin is very like that of the Goldfinch, but seldom so neatly built; the eggs, except in their smaller size, much resemble those of the Greenfinch.

A larger and more brightly coloured species, $C$. spinoides, inhabits the Himalayas, and another, C. tibetana, is found in Sikhim; but the Siskin has many more relatives belonging to the New Morld, and in them serious modifications of structure, especially in the form of the bill, occur. Some of these relatives lead almost insensibly to the Greenfinch and its allies, others to the Goldfinch, the Redpolls and so on. Thus the Siskin perhaps may be regarded as one of the less modified descendants of a parent stock whence such forms as those just mentioned have sprung. Its striated plumage also favours this view, as an evidence of permanent immaturity or generalization of form, since striped feathers are so often the earliest clothing of many of these birds, which only get rid of them at their first moult. On this theory the Yellowbird or North-American "Goldfinch," C. tristis, would seem, with its immediate allies, to rank among the highest forms of the group, and the Pine-Goldfinch, C. pinus, of the same country, to be one of the lowest,- the cock of the former being generally of a bright jonquil hue, with black 
crown, tail and wings - the last conspicuonsly barred with white, while neither lens nor young exhibit any striations. On the other hand, neither sex of the latter at any age puts off its striped garbthe mark, it may be pretty safely asserted, of an inferior stage of development. The remaining species of the group, mostly SouthAmerican, do not seem here to need particular notice.

SKART, see SCARF and SCART (p. 815).

SKEEL-DUCK, SKEEL-GOOSE, SKEELING and SKELDER (see SHelder), local names for the SHELD-Drake, the last also applied to the OxSTER-CATCHER.

SKELETON, the bony framework of a Bird or other vertebrate animal which, from the ease with which it can be freed from the more perishable soft parts of the body and durably preserved, has long attained a pre-eminent place in anatomical study. This preeminence is still further justified not only from the numerosity of the bones composing the skeleton-the very number alone affording great amplitude of differential variability-but because each individual bone is modelled by its neighbouring soft parts, and notably by the muscles, so that its shape reflects (so to speak) important features of the various organic systems (page 604). Most bones, either in their shape generally, or from the processes, tuberosities, crests or foramina they exhibit, are so characteristic that it is frequently possible to determine not only the Family but even the genus or species of Bird to which they belong. Unfortunately it often happens that the characters selected for taxonomic purposes are those which are the easiest to describe rather than those which are the most important. For convenience of treatment the Skeleton may be regarded as made up of three chief portions-the Head, the Trunk and the Limbs. Frequently a distinction is made between the Axial and the Appendicular Skeleton - the former being restricted to the Vertebral Column and the Cranim proper, while the latter comprises the RrBs, Breastbone (STERnum), Limbs and their arches, the HyoID apparatus and the Jaws.

The Vertebral Coluno has for its chief function the support of the Head and Limbs, as well as the protection of the Spinal Cord, the Vertebræ being its constituent units. These last are distinguished, according to the several regions of the trunk, as Cervical, Dorsal, Sacral or Pelvic, and Cauclal, and may be defined as follows :-

I. Cervical Vertebræ are all those that lie between the SkULL and the first vertebra which is connected with the sternum by a pair of complete ribs; but they may be subdivided into

(a) Cervical Vertebræ, in the strict sense-either without rudimentary ribs, as the Atlas, or having rudimentary ribs which are fused with the vertebra; and 
(b) Cervico-dorsal Vertebra, with movable ribs which do not reach the sternum. Their number may vary from 1 to 5 , often individually and then in smaller limits.

II. Dorsal Vertebre begin at the first that is connected with the sternum by a pair of complete ribs, and end at the last that is not fused with the ILIUM.

III. Pelvic Vertebrx are all those that are fused with the iliac portion of the PELVIS, some of the anterior of them frequently bearing long and often complete and movable ribs, occasionally reaching the sternum. Hence it follows that "Thoracic" Vertebræ, or those which are connected with the sternum, are not necessarily Dorsal Vertebræ, and therefore unless clear definitions are strictly adopted, a promiscuous application of those terms will lead to much confusion. This remark applies with still greater force to the terms "dorso-lumbar" and "lumbar" Vertebræ, which have a well-defined meaning in Mammals and in most Reptiles; but are absolutely inapplicable to Birds, as will presently be seen (page 855). ${ }^{\text {I }}$

IV. Caudal Vertebrx, those following the last, and not connected with the ilium.

A typical Bird's vertebra consists of the centrum, an arch and two ribs. Roughly speaking, the arch encloses the spinal cord, and frequently extends dorsally into a spinous process, the size and position of which vary considerably in the different regions of the vertebral column. The arch also sends out a pair of anterior and a pair of posterior oblique processes (commonly called præzygapophyses and postzygapophyses), as well as a right and a left transverse process. The oblique processes terminate in facets, which articulate with those of the adjoining vertebra, so that the facets of the præzygapophyses look upwards and forwards and are overlapped by those of the postzygapophyses of the vertebra next in front. When the vertebræ are free this rule is absolute, except in the case

1 Table shewing the Numerical Diversity of the several Vertebral Regions in some forms of Birds.

\begin{tabular}{|c|c|c|c|c|c|c|c|c|c|c|c|}
\hline & & 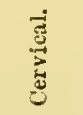 & 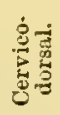 & 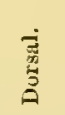 & 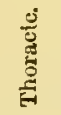 & & & 苞 & 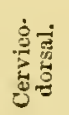 & $\begin{array}{l}\text { 范 } \\
\text { 总 } \\
\text { a }\end{array}$ & 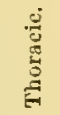 \\
\hline Apteryx & . & 16 & 1,2 & 7,8 & 4 & Treron olax. & • & 15 & 2 & 3 & 3 \\
\hline Dromæus & - & 20,21 & $2-4$ & $5-7$ & 5 & Dididæe & • & 15 & 2 & 3 & 4 \\
\hline Struthio & . & 20 & 2,3 & 5 & & Falconidx & . & 14 & 2,3 & 4,5 & 6,7 \\
\hline Anser cinereus & - & 18 & 2 & & 7,8 & Striges & - & 14 & 1,2 & 5 & 4,5 \\
\hline Cygnus olor & - & 23 & $\overline{2}$ & 4,5 & & Psittaci & 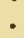 & 13,14 & 2,3 & 4,5 & 5,6 \\
\hline Sula . & - & 27 & $\overline{1}$ & & 4,5 & Coccyges & 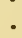 & 14,15 & 2,3 & 4,5 & 4,5 \\
\hline Ciconia & • & 17 & 2 & 4,5 & & Cypselidx . & - & 13,14 & 1,2 & 3,4 & 4,5 \\
\hline Phonicopterus & ${ }^{\circ}$ & 18,19 & 2 & 4,5 & 5,6 & Caprimulgidæe & • & 13,14 & 1,2 & 3,4 & 4,5 \\
\hline Larus . & . & 15 & 2 & 5 & 6,7 & Trnchili & • & 14 & 2 & 4 & 5 \\
\hline Alca : & 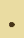 & 15 & 2 & $6-8$ & 6,7 & Buceros & . & 14 & 2,3 & 4 & 4,5 \\
\hline Limicolæe (1nost) & & 15 & 2 & 5,6 & 6 & Upupa. & - & 14 & 2,3 & 4 & 4,5 \\
\hline Otis . & - & 16 & 2 & 5 & 5 & Pici . & - & 14 & 3 & 5 & $6^{\prime}$ \\
\hline Rallidre & - & 15 & 1 & 7,8 & $5-7$ & Eurylæmus. & - & 15 & 3 & 4,5 & 4 \\
\hline Gallus. & 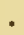 & 26 & 2 & 4 & 4 & Pitta . & & 15 & & 4,5 & 4 \\
\hline Columba livia & - & $2 \cdot 1$ & 2 & 44 & & Passeres (most) & • & 14 & 2,3 & 5 & 5 \\
\hline
\end{tabular}


of the Atlas to be mentioned presently, and the position of the facets at once distinguishes the anterior from the posterior end of the bone. 'The transverse processes articulate with the tuberculum of the corresponding rib, while the capitulum of the latter does the like with a knob or facet on the side of the anterior portion of the centrum. When the vertebre are free the centrum of each articulates with that of those next to it by complicated joints, exhibiting four kinds of configuration, in accordance with which the vertebra are distinguished as-

1. Heteroccelous, or those which have saddle-shaped articular facets. In them the anterior surface is concave in a transverse, but convex in a vertical, direction, while the posterior surface shews the condition reversed. When looked at from the ventral side the joints appear to be "procœlous," but "opisthocolous" when seen from the side. This heterocœlous formation is the most perfect one attained by the vertebral column, and is typical of, and restricted to, Birds. There are however a few exceptional cases in which the joints are not heterocœlous.

2. Amphiccelous, or those in which each end of the vertebra is concave. This is the lowest condition, and is rapidly passed through by recent Birds in the embryonic stage; but Archæopteryx seems to have had biconcave vertebræ of this kind, and the dorsal and cervico-dorsal vertebræ of Ichthyornis were undoubtedly thus, while the few well-preserved cervicals of the latter indicate transitional steps towards the heterocolous condition. Among recent Birds the caudal vertebræ alone are occasionally more or less amphicolous, but this may not be a primitive feature. Atlas.

3. Proccelous, or concave in front-a condition found only in the

4. Opisthocolous, or concave behind, so as to receive a corresponding knob on the anterior face of the following vertebra, instances of which occur in the thoracic region of the Sphenisci, and, though in a much less degree, in various Steganopodes, Lari, Limicolx, Psittaci and Steatornis.

The Procolous and Opisthocœlous types are not to be regarded as fundamentally important, as they are not primary features, but produced by adaptation to functional requirements. Neither of them necessarily indicates a Reptilian descent for Birds, nor can their modifications be used as valid characters in determining the affinities of various groups of the Class. The prevalent type among Reptiles is the Procœlous, while Opisthocolous vertebre are common among Mammals.

The articulations of the vertebra are further complicated by the presence of a ring or pad of fibrous or cartilaginous tissue interposed between the centrum of each vertebra and of that next to it. These pads vary much; when fully developed they are 
thickest on the ventral side, becoming thinner dorsally and enclosing a central opening, through which passes the ligamentum suspensorium - being the remuant of the notochord (see page 205) and its sheath -connecting the several vertebræ together. In well-macerated preparations its former existence is indicated by a pinhole-like pit exactly in the middle of the articular surface. The pad is frequently incomplete dorsally, and then being half-moon shaped, has obtained the name of meniscus, by which it is often known. It is morphologically the homologue of the pair of basiventral elements, which by their lateral extension give origin to the corresponding ribs. As in Birds, however, the ribs are removed backward on the centrum, and, attached also by the tubercle to the dorsilateral process of the dorsal arch, these basiventrals are relieved, so to speak, of their original function, and are reduced to intervertebral pads. This explains why these pads fuse with the anterior end of the vertebra to which they belong, forming there in fresh or imperfectly macerated skeletons a fibrous or cartilaginous non-ossified covering. Often, however, especially when the flexibility of the vertebral column is reduced or lost, the pads fuse with both the apposed surfaces of the adjoining vertebræ and then resemble the annulus fibrosus of the Mammalian vertebra. Lastly, when as in the sacrum the vertebræ are wholly ossified together, all trace of the intervertebral disks is lost.

Besides these primary ligaments, there is a considerable number of additional bands (probably produced by the muscles which move the vertebral column) connecting the various bony processes of successive vertebræ with eacl other. It is chiefly owing to them that Birds can retain the neck in the well-known S-shaped curve without muscular exertion.

In this place it may be more useful to treat specially the several vertebræ in succession than to enter further upon generalities respecting them.

The First Cervical, called, as in other Classes of Vertebrates, the Atlas-since it bears that important portion the Head-is the only one that retains very primitive features. It consists of three elements, each ossifying from its own centre. These are a pair of lateral pieces joining above the spinal cord to form a simple neural arch, without any spinous process, and a single ventral piece, morphologically equivalent to the pair of basiventral elements. The Atlas has no ribs, and with rare exceptions has no transverse foramina for the passage of vertebral arteries. The unpaired median piece is incompletely ossified, the rest of it standing up as a halfmoon-shaped cartilage, called the ligamentum transversum atlantis. It is really the first intervertebral meniscus clinging round the centrum of the Atlas, and fused with the two portions of the neural arch. These last display on their anterior surface a cupshaped cavity which receives the occipital condyle of the head. 
The Second C'ervical, known as the Aris or Epistropheus, as being the pivot on which the Atlas and Head turn, is composed of seven separate elements, the first of which is really the centrum of the Atlas, but fused with the second, the centrum of the Axis, so as to form the "odontoid process." The third and fourth are the pair of pieces which form the neural arch, and generally bear a prominent spinous process. The fifth and sixth are a pair of rib-elements, each of which is perforated by a transverse arterial foramen, and fuses with the antero-lateral portion of the centrum and neural arch. The seventh element is a single median piece wedged ventrally between the anterior end of the axial centrum and the Odontoid process, and is really equivalent to the second pair of basiventral elements, having formed in the embryo the intervertebral pad connecting the Odontoid with the body of the Axis, which last frequently carries on its ventral side a single hypapophysis. The neural arch of the Axis
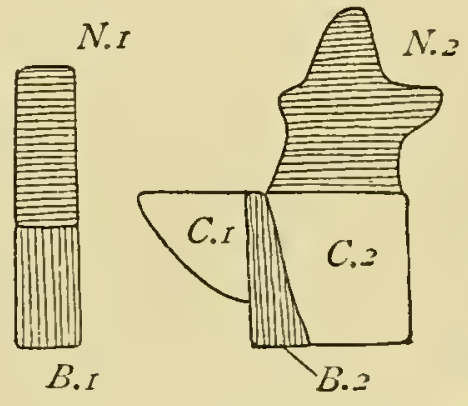

Diagraj of First Three Cervical Verterre FROM THE LEFT SIDE.

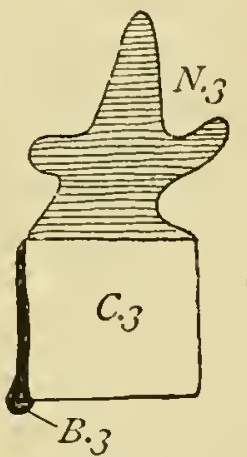

Diagram of Atlas mrom THE FRONT.

$C$. Centrum ; $C_{.1}$, Ollontoid process ; $B$. Basiventral element; $B \cdot 1$, the ventral half of the Atlas ring ; $J i$. , the first so-callel Intercentrum; $I .3$, the meniscus of Vertebra 3 ; Ch. Chorda dorsaiis; M. spinal canal ; It. Ligamentum transrersum; N. Neural arel.

possesses a pair of postzygapophyses to articulate with the præzygapophyses of the Third Vertebra, but owing to the reduced condition of the Atlas the præzygapophyses of the Axis are insignificant or aborted, and in most of the Bucerotida the Atlas is fused with the Axis. In general the Axis, which owing to the Odontoid process is really the compound of a vertebra and a half, is considerably longer and larger than any one of

The next succediny Cervical Tertebra, which have nany features in common. Each of them consists of a centrum, a right and left basidorsal piece, forming a neural arch above the spinal cord and frequently sending out a long single or short bifurcated spinous process, a pair of ribs and an intervertebral pad; but the ribs have mostly lost their shaft and are fused by their head and tubercle with corresponding short knobs of the centrum or with larger processes of the neural arch. A transverse foramen is always: present, and is a rather characteristic feature. The centra frequently 
send out paired or single ventral processes (hypapophyses), which are extremely varied in shape and size, affording valuable help in the determination of the bones. When unpaired, these hypapophyses either remain in the shape of vertical knobs, processes or blades, ${ }^{1}$ and serve for the attachment of the powerfully-developed flexor muscles of the neck, especially the m. longus colli anticus. Sometimes, as in certain vertebræ of Palumalea (SCREAnEr) and many Pusseres, they have the shape of $\perp$. When however they are paired,
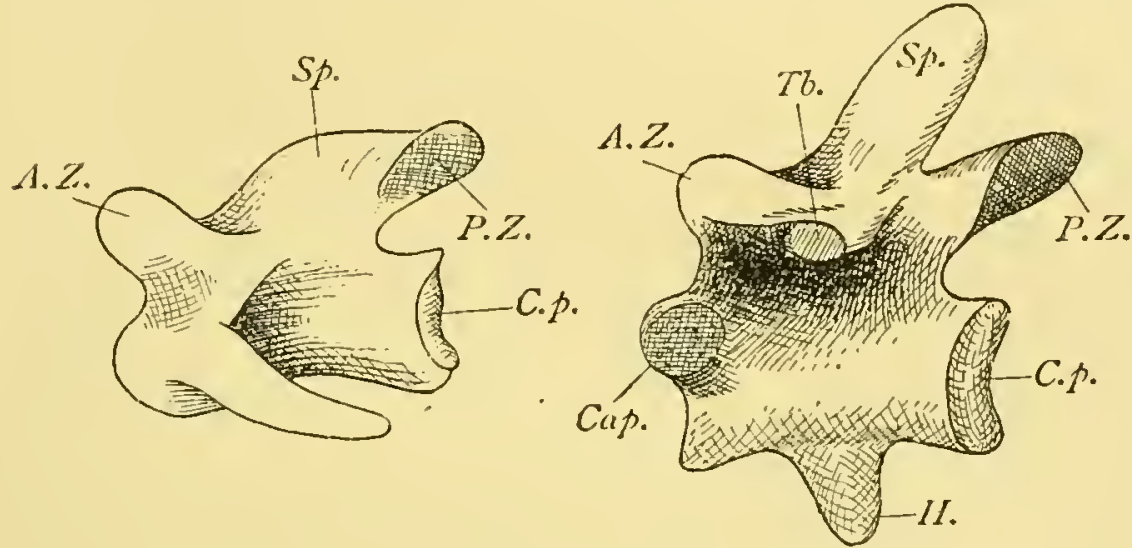

A Cervical and a Thoracic Vertebra from the Left.
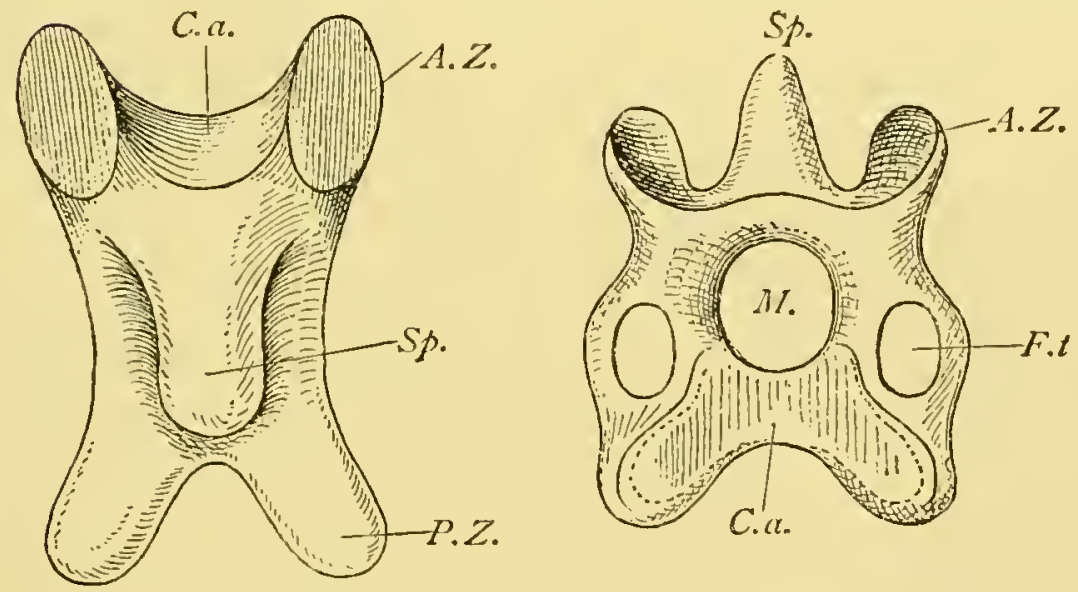

A Cervical Vefterra seex from the Dorsal axd Axterior Sine.

A.Z. Aitterior or Prezygapoplyssis ; P.Z. Posterior or Postzygapoplyysis ; C.a. anterior articulat. ing surface of the centrum; Cap. articular surface for eapitulum of rib; C.p. posterior articulating surface of the centrum ; F.t. Foramen trausversarium; H. Hyjapophysis; $M$. spinal canal ; $s p$. lorsal spinous process; $T b$. articular surface for the capitulum.

and in such cases restricted to the ends of the centra, they are utilized for the better protection of the deep CAROTIDs (page 76), as is especially shewn by the Stcganopodes, Aideida (excl. Scopus), most Ciconiidie and some Pici which possess completely closed osseous

1 They form vertical blades on some of the lower cervicals of Sphenisci, Corcciildx, Alccdinidx, Aeropidx, Todidx, Cypseli, Trogones, Galbuliulx, Bucconiulx, Pici, Capitonida and Passeres. 
canals for their arteries. Movable ribs are borne by one or more of the lower Cervical Vertebræ, thus forming a gradual transition to

The Dorsal Vertebrx, which are composed of the same elements, but are marked by the high longitudinal crest into which their spinous process rises, while each of the dorsilateral processes of the neural arch (which are mostly large) possesses an articular facet for the tubercle of the rib, and a short ventrilateral knob near the anterior end of the centrum has a similar facet for the attachment of the head of the rib. Between the head and the tubercle is a large foramen, the serial homologue of the f. transversarium, protecting a continuation of the deep lateral strand of the Sympathetic Nervous System (page 626). Dorsal vertebræ frequently exhibit a ventral ontgrowth of the centrum, very variable in shape and extent. These outgrowths (Hypapophyses) may be simple vertical blades, or $\perp$-shaped, or paired knobs-such modifications often occurring in the same bird-and they serve for the attachment of the thoracic origin of the $m$. longus colli anticus, reaching their greatest development in Spherisci and the Colymbidix. In many birds the thoracic vertebræ shew a tendency to more rigid junction, which is often effected in old individuals by the ossification of the various ligaments connecting the processes of adjoining vertebræ, or even by the ossification of the attached tendons of the spinal muscles. In other cases consolidation is carried further by the co-ossification not only of the centra but also of the spinous, tranverse and zygapophysial processes of adjoining vertebræ, so that in extreme cases the whole dorsal region may become one continuous mass of bone. The number of such synosteotically-comnected vertebræ varies considerably not only in closely-allied Families, genera and species, but even in individuals. It is however a character that with care will yield good taxonomic results, and thus may be depended upon as a common feature in many Ciconix, Gruidx, Rallidx and Podicipedidx. In most Columbx the 15 th, 16 th and 17 th vertebræ, being generally the three middle thoracics, are consolidated. In Crypturi and most Gallinx, in Phonicopterus and Pterocles the last cervical and the first 3 or 4 thoracics coalesce, and in many Accipitres the first 4 thoracics.

The Sacral Vertebræ in the widest sense are all those that are overlaid by and partly fused with the iliac bones ( $f f$. ILIUM, PELVIS) which are originally attached to not more than two of them situated just behind the Acetabulum, and are the primitive or true Sacrals. The iliac bones, however, during development extend considerably both forwards and backwards, gradually coming into contact with a variable number of others, which thus become præsacral or postsacral vertebræ, while all those that are not reached by the anterior extension of the ilia remain as Dorsals. Thus it follows that no absolute line of demarcation can be drawn in regard to these 
vertebræ, their definition being rather practical, and applicable to particular skeletons, than of general morphological value.

It has been already pointed out (p. 849) that dorsal and thoracic vertebra are not necessarily identical, and in like manner the most anterior præsacrals may bear complete ribs and thus become thoracic also, or they may bear movable ribs which, though possessing dorsal and ventral portions, do not reach the sternum, and are therefore floating or false ribs, or again ribs reduced to short dorsal pieces which may or may not fuse with the superimposed iliac bones. As a rule the centrum and the spinous process of all sacral vertebry are ossified into one continuous mass.

The most important features of the Sacrum are best seen on a ventral view and may be thus grouped:-

(1) The anterior or crural portion composed of vertebræ counected with the ilium by strong dorsilateral and ventrilateral processes. The first of these vertebre often bears a complete thoracic rib; and is followed by others bearing aborted ribs having a tendency to lose their "head" and "neck," while the shaft fuses with the ventral surface of the iliac expansions. Between the transverse processes of the successive vertebræ are foramina through which pass the spinal nerves forming the crural plexus.

(2) The second or ischiadic portion, composed of vertebræ which have neither ribs nor ventrilateral processes, but only dorsilateral, and these last reduced to thin transverse blades extending obliquely, or sometimes almost vertically, upwards, and ultimately reaching the dorsal median rim of the iliac bones. The safest guide to the number of vertebræ composing this portion is afforded by the number of foramina through which pass the nerves forming the ischiadic plexus. In most Birds the number is from 3 to 5 . Owing to the absence of ribs and ventrilateral processes, the space between the fused centra of the vertebre and the right and left iliac bones constitutes a large hollow or fovea wherein is imbedded part of the KIDNEYs.

(3) The third portion is connected with the dorsimedian rim of each ilium by transverse dorsiventral and ventrilateral bony bridges. The first two vertebræ of this portion are the primitive or true Sacrals before mentioned, and they lie just behind a line which might be drawn from one acetabulum to the other. Their lateriventral buttresses are not ontgrowths of the centra, but are ribs, though their true nature is only revealed in embryos or very young birds.

(4) The postsacral portion consists of vertebræ which in many birds, Pavo, for example, behave partly as do the primitive sacrals, and partly come by degrees to resemble the caudals. Dorsilateral and ventrilateral processes are always present, and, fusing with each other, abolish the transverse foramen, while they abut upon the dorsal rim of the postacetabular part of the ilia. The first.post- 
sacral not unfrequently retains a pair of rib-elements which either abort or form a third primary sacral vertebra, while on the other hand only one primary sacral may exist. The general tendency of modein Birds seems to be towards an increase in the number of postsacrals at the expense of the præsacrals, and especially of those of the ischiadic portion (2).

So far then the general plan of the Sacrum is easily understood, but since it is composed of numerous vertebræ and those of each of its constituent portions are variable in number, beside shewing many modifications in the development, fusion or suppression of their processes, it follows that the whole Sacrum of not only every Family but even genus and almost species of Bird may have its own characteristic points. These however are difficult to describe, and their morphological meaning is still more difficult to recognize. Thus this part of the Skeleton has hitherto escaped the pursuit of the claptrap hunter of taxonomic formulæ. The few illustrations here introduced will serve to indicate some of the differences.

The Caudal Vertebræ have strong transverse processes, and the spinous process often shews a slight bifurcation at the end. Their hypapophyses, whether double or single, are mostly restricted to the last which are free and to the first of those which fuse to form the PYGostYle (page 753). They articulate almost entirely by the centrum, which has slightly heterocœlous or concave facets, with the interposition of a fibrocartilaginous disk, the ventral side of which frequently displays in embryos, but rarely in the adult, a median osseous nodule, the last remnant of the basiventral elements commonly called the intercentrum.

The Pectoral Arch, or Shoulder-Girdle as some term it, consists of the Sternum and a pair of CoraCoIDs (page 104), Scapulæ and Clavicles (page 89), which last three meet and form the foramen triosseum, through which passes the tendon of the $m$. supracoracoideus (pages 605, 606) to the tuberculum superius of the HUMERUS (pages 439,440). The configuration of the various processes of these bones is manifold, and of great taxonomic importance, as has been exhaustively shewn by Prof. Fürbringer, in whose Untersuchungen zur Morphologie und Systematili der Vögel about one hundred figures of this articulation in different Birds are given.

The Coracoid is one of the most characteristic bones of the ornithic Skeleton. At its upper end is the Acrocoracoidal process, on the inner surface of which the proximal portion of the clavicle nearly always rests; but more important is the Præcoracoidal process, of variable size and shape, arising from the inner surface of the "neck" of the bone, and the remnant of an originally independent element, the Præcoracoid-a bone which is almost typically complete, although soon fused at either end with the 
Coracoid, in the Ostrich alone of Birds. This precoracoital process is of some taxonomic valne, ${ }^{1}$ and near its base is either a notch or a small foramen for the passage of the nervus supracoracoideus which supplies the muscle of the same name, and indicates the boundary between Coracoid and Pracoracoid. A strong ligament, sometimes partly ossified, frequently extends along the inner margin of both coracoid and precoracoid to the rostimm of the sternum. In most Birds the light and left Coracoids do not touch each other, but in some groups they meet, as in certain Tulinares, Cathartidie, some Falconidre, Luridie, Opistho-

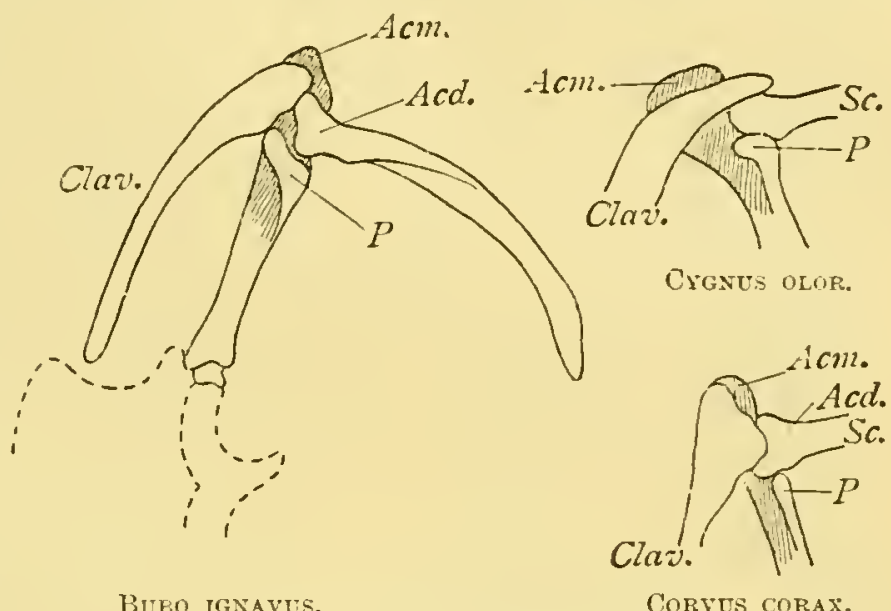

BUBO IGNAVUS. (lnner view.)

Acl. Acrocoracoid ; Acm. Acromium ; Claz. Clavicle; I. l'recoracoid process; SC. Scapula.

comus, some Gullinx, Bucerotida, Ulmure and Trogonida, while in some other groups one overlaps the other, the right lying ventrally upon the left, as Dromaus, Ichthyornis, Apatornis, certain Tulinares, some Steganopodes, Ardeidx and Ciconix, Phunicopterus, some Fulconidx, some Gallinx, Musophaga, Striges and Meropiclu. From the distal third part of the lateral margin of the Coracoid a long process often projects, overlapping the neighbonring part of the anterior margin of the sternum, examples of which may be especially seen in Tulinares and Pici.

The Scapula or shoulder-blade is more or less sabre-shaped, usually ending in a point, but its extremity being much curved in the Pici. It extends backward from the lumeral joint over the ribs, lying almost parallel to the vertebral colmm. The median anterior knob is the acromion. In the Ratitie and Didus the Scapnlar and Coracoid are fused, which might be regarded as correlative with the loss of flight, were it not that the same fusion is observable in

I It approaches the Acrocoraeoidal process in Cncmionis, Faleo, Asio, Herops, Imisor and Cuculus; fusing with it and forming a complete osseous bridge aeross the supracoraeoid sulens, in Mhesophaga, Corythaix, Mcrops, Upupa, Buceros and Alecdo; while in Dielus and Opisthocomes it fuses with the Claviele, of whieh in Hesperomis it is the sole support. In Dromaus and Casuarius it is small and bear's the clavicular remnant. It varies much in size and, as above stated, is complcte in Struthio only. It is large, though withont meeting the Claviele, in Ichthyornis, Sulu, Grus, Trichoglossus and others; but very small or absent in Apteryx, Tinamus, Steganopodes, Gallinæ and Passeres. 
a very marked way in Fregata, one of the most powerful fliers of the world (FrIGatE-BIRD, pages 293, 294).

The Clavicles when united, as is generally the case, are known as the Furcula (page 296). Their dorsal extremity may be variously attached to the Scapula and Coracoid or to one only, ${ }^{1}$ and here is a wide field for variation, which seems however constant enough in the different groups. When Clavicles do not fuse at their ventral extremity, they are occasionally joined by semiossified cartilage or fibrous tissue, admitting of slight motion, as in Hesper. ornis, Ocydromus, Cariama, Didus, Carpophaga, many Psittaci and Striges, Musophagidx, Buceros, Alcedo, Rhamphastos and Capito; but in by far the greater number of Birds the Clavicles are drawn out at their symphysis into a median projecting blade, knob or rod, the Hypocleidium, which frequently ossifies from a centre of its own. The hypocleidium often touches the keel of the Sternum, leading to a syndesmosis or even synostosis therewith, as in many Tubinares, Steganopodes, Ardex, Ciconix, Gruidx, Striges, Gypogeranus, Cuculus and Buceros. The peculiar connexion in Opisthocomus has already been mentioned (HoACTzIN, page 423). In a considerable number of Birds of various groups the Clavicles -are more or less degenerated, their dorsal portion being alone retained, while the ventral is represented by a long ligament extending to the keel of the Sternum. This condition exists both in Birds that fly and those that cannot, as in Dromaus, Casuarius, many of the Psittaci-as Stringops and nearly all the Platycercinx, Capito and, among the Passeres, Atrichornis. In extreme cases both clavicles are wholly lost, as in Dinornis, Apteryx, Struthio, Rhea and Mesites.

The Anterior Linibs or Wings are composed of three principal portions: (1) the Humerus, of which enough has been already

1 The connexion of Coracoid, Scapula and Clavicle with each other is subject to many modifications, the chief of whioh may be conveniently expressed as follows :-

Clavicle connected with-

(1) Præcoracoid process only :-Hesperornis.

(2) Præcoracoid chiefly, hardly with Acromion:-Ratitæ.

(3) Acrocoracoid only :-many Alcidx, Steganopodes, Ardex, Ciconix, Gruidx, Vultur, Gypaetus, Cathartes, Cypscluts.

(4) both Præcoracoid and $\Lambda$ crocoracoid:-some Lari, Limicola, Gruidx, Rallidæ, T'urnix, Opisthocomus, Columbæ, Psittaci, Striges, Trochilus, many Picarix and Falconidx.

(5) Acrocoracoid and Acromion-

(a) attached to the anteriol margin of the Acromion:-Sphcnisci, Tubinarcs, Crypturi, Gallinæ, Psittaci and many others.

(b) reaching further back, beyond the dorsal margin of the Acromion, and even over the neck of the Scapula:-Colymbus, Podicipcs, Anseres.

(c) attached to the inner surface of the Acromion:-Pici, Alcedinida, MLropidæ, Coraciidæ, Todidæ and all Passeres. 
said (pages 439,440$) ;(2)$ the forearm, consisting of the Radius, before mentioned (page 762) and Ulna; and (3) the Carpus (page $\tau \tau, 78$ ), Metacarpus (page 547) and Digits, which last three form the hand. According to Prof. Gegenbaur, the original arrangement of the wrist-bones consisted of (a) three proximal elements - the capale ulnure, $c$. intermedium and $c$ radiale; (b) one median element; and (c) five distal carpals, each of which carried a metacarpal with a digit. In Birds these elements are much reduced by fusion and suppression, so that there are now only two free carpals-one, generally termed the "radial," but resulting from the fusion of the $c$. radiule with the c. intermedium, and articulating with the distal end of both radius and ulna; and the other, the so-called "unar," which is really the centrale and uluare combined, and artieulates with a small portion of the ulna only. The distal carpals are now reduced to three, the fourth and fifth being lost. 'They fuse in the embryo with the proximal end of the three first metacarpals, and all trace of their originally separate existence disappear's when the hand is completely ossified.

The greatest reduction of the earpal bones prevails in the Ratita. Setting aside the Dinornithes, of

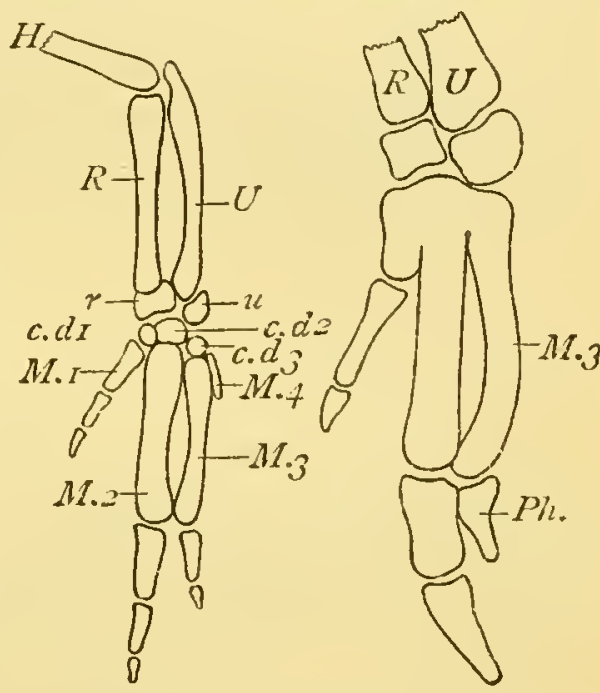

Common Fowl, Embryo and Adulf.

c.d. distal carpals 1-3; $H$. Humerus; $M$. Metacarpals $1-4$; $l$. Radius ; r radial carpal; U. Ulna; u. ulnar carpal.

which only remnants of a humerus are known, Casuarius galeatus has only one separate carpal, which is probably the c. ulnure, while in Apteryx oweni and in Dromaus even this is suppressed.

The Metacarpus is composed of three bones, the first, second and third metacarpals, while trace of a fourth has been observed in embryos. The first of these is the shortest, and bears the PoLLex (page 737). In most Birds it fuses throughout its length with the inner margin of the second, which, as well as the third, is much longer. The ends of these fuse, the proximal first and the distal later, leaving as a rule a space between the shafts. The second is by far the strongest, generally straight, and bears the INDEX (page 459), while the third is ontwardly bowed and much more slender, being in a degenerate condition. ${ }^{1}$ In embryos it sometimes still shews two phalanges, but these are soon reduced to one, which, resting closely against the proximal phalanx of the second digit, occasionally fuses with it. Curiously enough this

I Of all Birds Archropteryx alone is known to have had 3 free metacarpals, and 3 free digits, with 2,3 and 4 phalanges respectively. 
much aborted digit seems in embryonic Ostriches to bear a CLAw (page 89). In the Sphenisci the pollex is more or less completely fused with the index, which latter is made up of two long phalanges, while the third digit consists of one long phalanx. Casuarius, Dromxus and Apteryx retain only the index, the first and third digits being either lost or reduced to insignificant traces. ${ }^{1}$

The Pelvic Arch is the portion of the Pelvis (page 703) which is made up of the ILIUn (page 458), ISCHIUm (page 460) and. os PUBIs (page 748 ), the last three being paired bones which meet on each side at the acetabulum or cup that receives the head of the FEnUR (page 248), coalescing with each other at an early stage. The ilium may be conveniently divided into a præacetabular and a postacetabular part, the relative proportions of which afford some useful characters; thus in the Gallina they are nearly equal, but

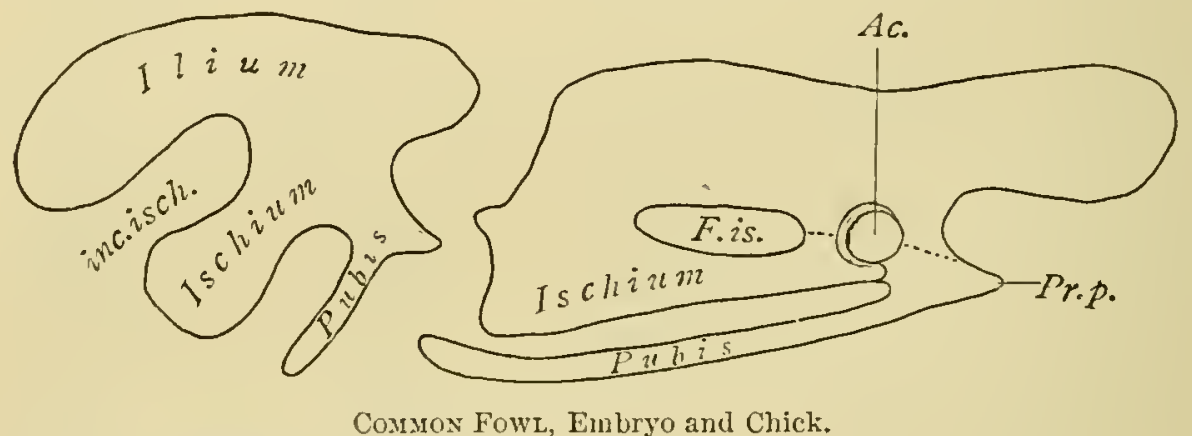

Ac. Acetabulum; $F$. is. Foramen ischiadicum; Pr.p. Processus pectinealis.

in the Accipitres the anterior is longest, while in Colymbus, where most of the pelvis is drawn out backward, it is only half the length of the posterior. To the inner surface of the ilium, and in most cases near its ventral margin, are attached the lateral processes of the cruro-sacral vertebræ (page 855), while near its dorsal rim is attached all the rest of the sacrum. The outer surface of the preacetabular portion forms a broad vertical blade with a more or less deep concavity which serves for the origin of the external iliac muscles (often mistakenly called gluteal). In rare cases the right and left præacetabular portions fuse with each other along their dorsal edge above the spinous processes of the neighbouring vertebre and enclose a canal on each side. In front of the

${ }^{1}$ As an appendix to the aecount of this part of the Skeleton, mention shonld lere be made of the Sesamoid Bones. These are not diseonnected portions of the framework, but cartilaginons or osseous formations either within the capsules of joints, as the lumero-scupular bone in the capsule of the joint of that name, or within the inserting tendons of muscles, as the patella of the knee and the patclla ulnaris of the Sphcnisci, and osseons or eartilaginous nodules in the tendons of the long museles of the toes, of the musc. cxtcnsor metacarpi radialis and of the musc. proputugialis. 
acetabulum a thick process of the ilium descends to meet the os pubis, and behind a similar process meets the ischium. Behind the acetabular rim is a considerable thickening of the ilium, which frequently bears a facet on which plays the great trochanter of the femur. The postacetabular ilium is very variable in shape, either broadened ont vertically only as in Columba and Phea, or transversely, in the latter case forming a plain dorsal surface most

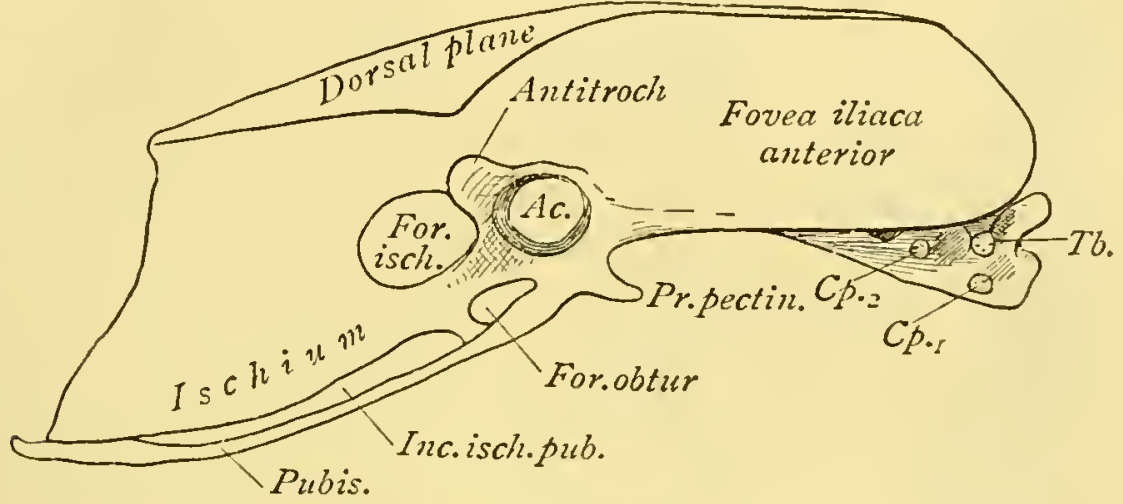

Payo cristatus.

pronounced in Paro. The ischium originally extends backward, parallel to the postacetabular ilium, ard with it encloses the ischiadic notch. Among recent Birds this primitive condition persists only in Liatito and Crypturi. In all others the distal por-

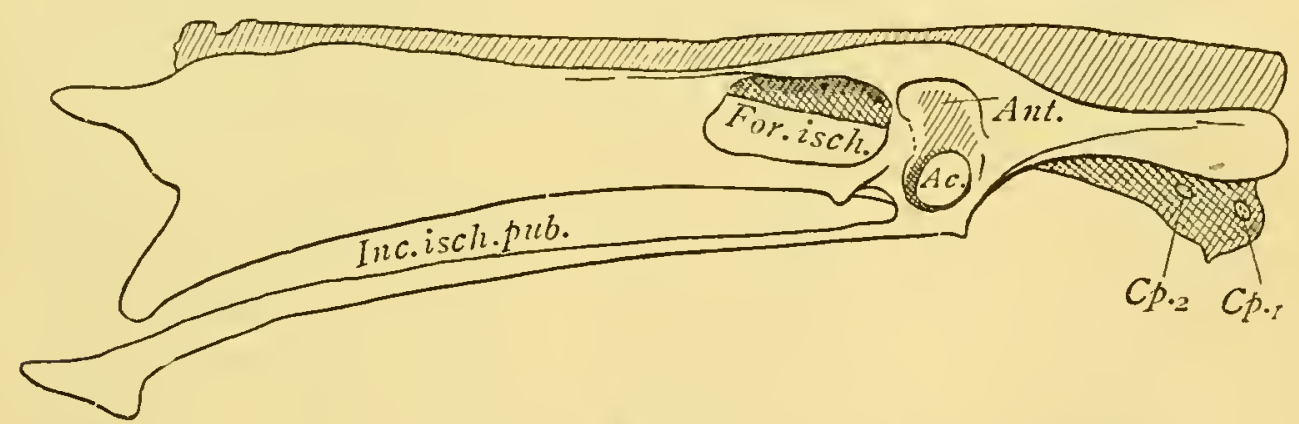

Colvabus arctrotes.

tions of the ilium and ischium meet so that this notch becomes a foramen, through which pass the big stems of the ischiadic nerves (page 625) and most of the chief blood-vessels of the hind limb. ${ }^{1}$ The os pubis consișts of an anterior and a posterior portion, the latter being long and slender, and rumning backwards more or less parallel

I A unique modification occurs in Rhco: the two ischia fuse in the middle line forming a long ischiadic symphysis which lies above the intestines separating them from the kidvers. In adults the distal ends of the ilia fuse with these united ischia, forming foramina, and herewith is correlated a still more striking feature, namely the gradual resorlotion as maturity approaches of nearly the whole postsacral vertebral column, so that the candal vertebræ seem to be attacherl to the united ischiadic and iliac ossification. 
to the ischium. The proximal portion of the space thus enclosed almost always forms a foramen, called the f. obturatum, because it serves for the passage of the tendon of the $m$. obturator and the $n$. obturatorius (page 625), which supplies that muscle, and the m. pulischio-femoralis (page 611), or principal adductor of the thigh. The rest of the opposed margins of ischium and pubis are connected with

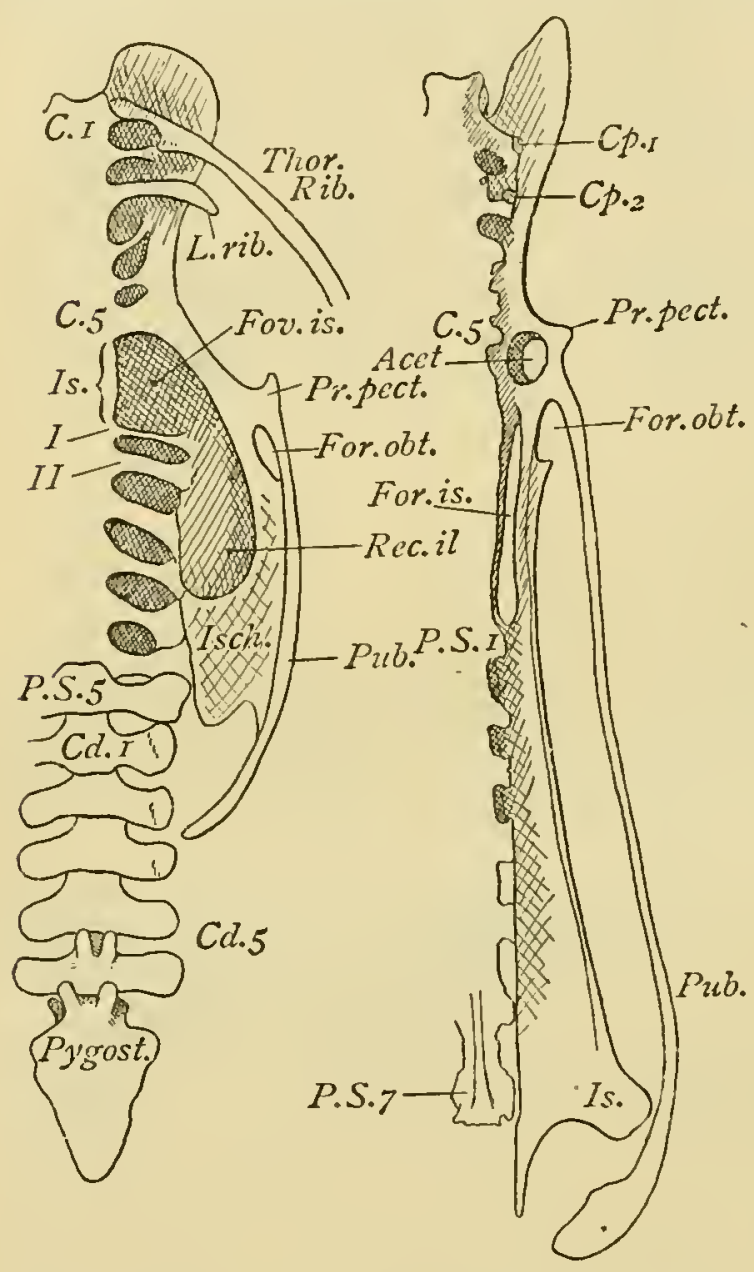

Pavo cristatus. each other to a variable extent, either by membranes only or, if the bones touch, by more or less extensive ossification, which in extreme cases, as in some Anatida, leads to the obliteration of the middle portion of the shaft of the pubis, so that its distal portion appears in a prepared skeleton as a separate bone. The distal end of the pubis is mostly bowed inwards and broadened, serving for the attachment of the lateriventral muscles of the tail (m. pubo-coccygeus). In Struthio only the end of the pubis meets that of the other side, forming a dagger-shaped symphysis upon which rests a great part of the weight of the abdominal intestines. The spina pubica or anterior 1. II. thie Sacral Vertebre; C. 1.5, Crural Vertebre; Cal. process of the os pulbis, $1-5$, Caulal; $C_{p \cdot 1} C_{p .2}$, Capitular attachment of the last often called the pectineal free ribs; Is. Ischiadic Vertebre; I'.S. Postsacral ( $f f$. p. 650, fig. $4, p$.), is Vertebre; Rec.il. Iliac recess; $T$. Tubercular part morphologically of great
of the rib.

interest, because it is the element which in Dinosaurs is described as the "prepubis," while in recent Reptiles it is represented by the pubis proper, the "pubis" of Birds being in reality homologous with the postpubis of Dinosaurs and the processus lateralis pubis of other Reptiles. It serves for the origin of the Ambinss muscle (page 11), though that not unfrequently extends to the adjoining part of ilium, or further down to the shaft of the pubis, and hence has been preserved when that muscle is present; but the process is very 
variable in extent, being comparatively largest in the Gallinx and some of the Cuculi and Musophagida, while it is hardly indicated in many Grues, Ciconix, Phonicopterus, Columba, Lari, Psittuci, Bucerotida and Pusseres. It may grow wholly from the pubis, or from that and the ilium, or in extreme cases from the last only.

The Posterion Lmibs or Legs, like the anterior, are composed of three principal portions (1) the Fenur, which has been already mentioned (pages 248, 249), and the figures here introduced will shew some of its more important features; (2) next the Tibra and Fibula; and lastly (3) the bones of the Fcet. The proximal end of the Tibia has two facets, of which the inner is concave and articulates with the inner condyle of the Femur, while the outer is convex, and partly fits into the intercondylar sulcus and partly articulates with the inside of the outer femoral condyle. It also supports the Fibula. From the anterior surface of its upper end arises a crest formed by two ridges, of which the inner is generally the more prominent. They selve for the origin of part of most of the extensor muscles of the leg, the tendon of the chief of which, musc. femori-tibiclis, is inserted on the upper part of the crest, and within this teudon is intercalated the PATELLA (page 69s). In Colymbus and Podicipes is dereloped a long triangular process which stands high above the liead of the tibia, and in the latter the almost equally-high triangular patella rests with its base on the intercondylar femoral sulcus, and its whole side against the outer surface of the crest. On the outer side of the tibia is the peroneal ridge serving for a lateral attachment to the Fibula, the fusion of which with the Tibia is generallyindicated by a similar ridge situated furtler down. The distal end of the Tibia is completely fused with several

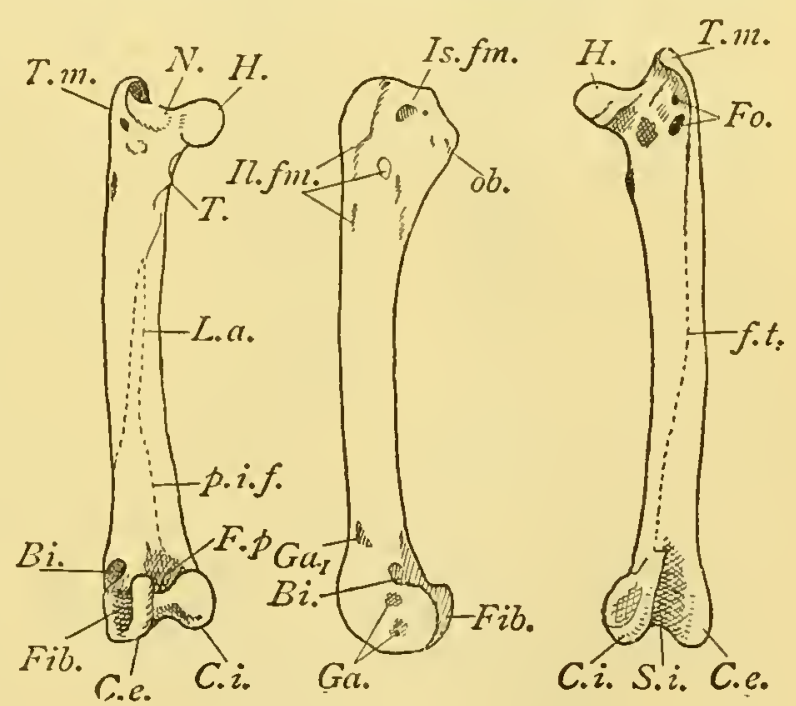

Pavo cristatus, Left Femur, back, outer und front view.

Bi. Loop for Biccps cruris; C.c. C.i. exterior and interior Condyles; F.p. Fossa poplitea; Fib. Fibular facet; f.t. Femoro-tibialattachnent; Fo. Pueunatic foramina; $G a$. Gastrocnenial tendons; $H$. liead of Feruur; $I l . f n$. ilio-femoral ; Is. $f m$. ischio-femoral ; N. Neck ; p.i.f. Pubischio-femoral muscle; ob. Obturator muscle insertion. of the proximal tarsal bones, which form an inner and an outer condyle, separated by a sulcus, and articnlate with the "tarsometatarsus." On the anterior surface a little above the sulcus just 
mentioned is a deep cavity crossed by a transverse bridge, acting as a pulley for the tendon of the musc. extensor digitorum communis (page 612) which passes beneath it. In the majority of Birds this bridge is ossified, as in Dinornithes (page 579), Phororhacos, Gastornis (page 281) and the other Carinatie not named below, but it remains tendinous or cartilaginous, and is thus often described as non-existent, in a good many, as Struthio, Rhea, Dromaus, Casuarins, Apyomis, Brontonis, Opisthocomus, striges, Todus, Buceros, Camimulgi and Trochili; while it varies, being either soft or osseous, in Apteryx, Podicipes and Psittaci. The Fibula articulates by its head with the outer condyle of the Femur, leaning also on the lateral knob on the head of the 'Tibia, and lowel' down is connected with the peroneal ridge by a rough surface. The distal end of the Fibula is always much reduced and fuses more or less conpletely with the outer sicle of the tibio-tarsus, generally ending in a sharp point. ${ }^{1}$

The Metatarsus, or "Tursus" as it is commonly but incorrectly called by ornithologists, is a compound structure made up of the second,

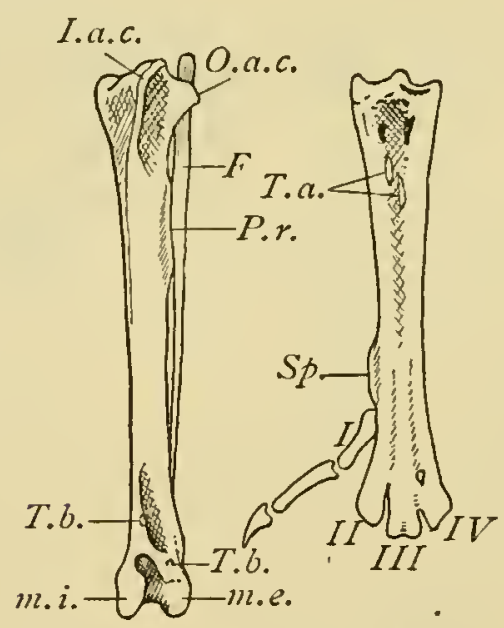

Pavo. Tibia and Tarso-metatarsus, front view.

F. Fibula; I.a.c. aud O.a.c. inner and outer anterior crest; m.i. m.e. inner and outer malleolus; $S_{\%}$. exostosis, carrying spur; T.a. insertion of Tibialis anticus.
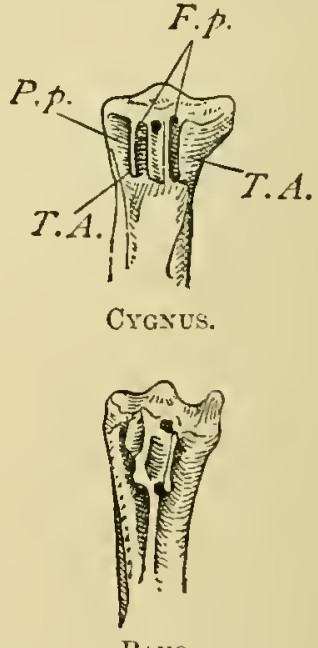

Proximal end of left Tarso-metatarsus, back view.-F.p. gloove and canal for $m$. flexor profundus; $P . p$. groove for deep peroneal ; T.A. ridge for tendo Achillis.

1 Dr. Shufcldt (Tois, 1894, p. 361) takes excep,tion to the statement previously made in this volume (page 249) describing and partly figuring some cases, that appear to me exceptional if not abnormal, in which the Fibula is "complete and reaches the tarsal epiphysis of the tibio-tarsus." But my statement appears to have been nisunderstood, and I may repeat that the ankle-joint "is never normally reached" by the Fibula, nor, for the matter of that, by the Tibia cither. A complete account of these features was published in 1891 (Thierreich, Vögel, 1p. 980, 981), wherein also exceptional occurrences of a complete Fibula in Birds are mentioned. 
third and fourth metatarsal bones, which are fused together and bear on their proximal end an epiphysis-like mass containing several of the distal tarsal bones. Except in Sphenisci and to a certain extent in Psittaci, the three netatarsals do not lie in the same plane, the middle one, which is the third, having its upper end thrust backward and its lower forward, consequently the nalleolus of the third toe is more prominent on its anterior surface than its neighbours, while on the same surface of the upper half or more of the "metatarsus" there is a deep longitudinal furrow, and on the posterior surface of the proximal end is found the "Hypotarsus." Articulation with the tibio-tarsus is effected by an inner and an outer concave facet for the corresponding "tibial" condyles, while these two facets are separated in front by a knob which fits into the intercondylar sulcus. Two rough surfaces near the upper end of the anterior metatarsal sulcus indicate the position of a transverse ligament, beneath which passes the common extensor tendon of the toes. In one section of OWLS (page 672) and in the OsPrEY (page 660) this ligament becomes a strong bony bridge. A little lower than the inner end of this ligament or bridge is a small tuberosity indicating the insertion of the musc. tibialis anticus.

The Hypotarsus is of some taxonomic value from its ridges which end in furrows or canals for the passage of the several flexor tendons, but in regarding its characters we must remember that the conversion of a furrow into a canal is often due to extended ossification progressing with age. The Hypotarsus is simple, possessing only one wide groove lying between two low ridges, in Sphenisci, Ciconiinx, Plataleinæ, Phonicopteri, Palamedex, Accipitres (excl. Pandion), Crypturi, Cariama and Rhinochetus. It is also simple, though with an additional median ridge, in Striges, Cypseli and Trochili; but complex, with high ridges and a canal or more than one in most other birds, exhibiting numerous modifications, each of them directly connected with the arrangement of the flexor tendons, and the size, pasition and function of the toes. Intermediate forms are of course numerous, and their careful study gives a valuable hint as to the group to which any particular form belongs: in the Colymbi, for instance, the two lateral ridges are very high and almost completely enclose a wide triangular space.

In the Sphenisci the three tarso-metatarsal bones are almost in the same plane and are incompletely co-ossified, a feature frequently regarded as primitive because of its likeness to embryonic and therefore phylogenetically ancestral conditions. It may, however, be reasonably conjectured that we have here a case of relapse, indeed a pseudo-archaic formation produced in adaptation to the peculiar plantigrade functions of the feet in these birds. An analogous condition obtains in Fregata. ${ }^{1}$

1 The morphological meaning of the bones of the Bird's foot is best understood 
The Toes are generally four in number, and no trace of a fifth has been or is likely to be discovered, considering the extreme reduction and ephemeral occurrence of the fifth metatarsal element. The number of phalanges typically increases in arithmetical scries from 2 on the first or HALLUX (pages 404,405) to 5 on the fourth

by a short sketeh of their development, and its comprehension may be assisted by the accompanying diagram shewing the typical plan in the pentadactyl Bird,
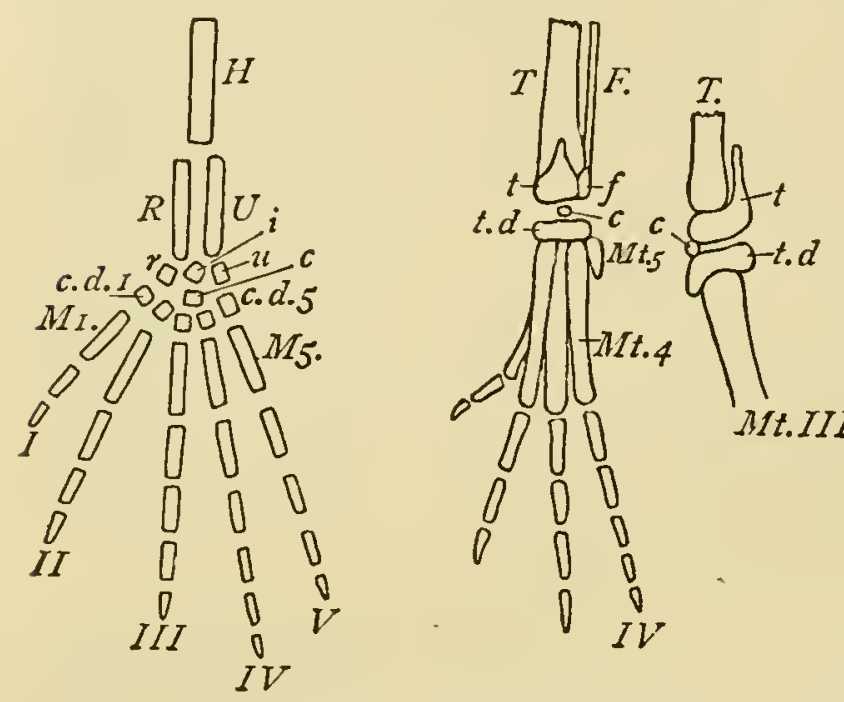
which mutatis mutandis may be made equally applicable to the Bird's "hand." There are first three proximal tarsals which fuse with each other and then with the distal end of the tibia, while that of the fibula withdraws from direct contact with the outer or fibular tarsal. The united unass of these then sends out an ascending process which fuses with the front of the tibial interconclylar furrow. At an early period the five distal tarsals fuse into one cartilaginous mass, in which only one centre of ossification appears, wherempon it fuses with the upper end of the 2 nd, $31 d$ and 4 th metatarsals. These being originally separate, soon press backwards the upper end of the $3 \mathrm{rd}$, and fuse together from above downwards. The 5th or onter metatarsal element has only been observed in early embryos, soon disappearing by lesorbtion, and the same may be said of its distal tarsal. The 1st metatarsal remains separate on the inner side of the 2ncl-a condition which persists in the Penguins; but in other 4toed Birds it does not keep up witl the lengthening growth of the 2nd, 3rd and 4 th, but loses its proximal position and thereby its connexion with the tarsal region, lying in the majority of Birds along the inner hind margin of the lower end of the united "metatarsus," retaining (or regaining) its position in their plane in Steganopodes.

Besides the 3 proximal and 5 distal tarsals just mentioned, the diagram shews a ninth element-a central tarsal, which is sometimes double. Appearing in the embryo as distinct cartilaginous nodules, tliey are soon buried in the fibrous interartieular pad, and in the majority of birds ultimately ranish. However one of them occasionally persists, as in the liatita and Crypturi, developing into a separate bone which is wedged in from behind between the tibio-tarsal and tarso-metatarsal surfaces. This bone was deseribed many years ago by Owen either as a calcaneus or calcaneal sesamoid, but now properly by Gegenbaur (Untersuchungen zur vergleichenden Anatomic, i. p. 104) and Morse (Ann. Lyc. Nat. Hist. New York, x. p. 141) as the central tarsal, the latter figuring it as found in Tyrannus. Sir WValter Buller ( $P . N$. Zeal. ed. 2. ii. p1) 333, 334 , pl. xlix.) was unfortunately induced to figure and describe it in Dinornis as "an astragalus-like bone." 
Toe; but in Cypselus the number never exceeds 3, being reduced during embryonic development. The proximal phalanx of the fourth toe is resorbed, while the 2 nd and $3 \mathrm{rd}$ phalanges of the third toe, and the original $3 \mathrm{rd}$ and 4 th of the fourth fuse together respectively. The same number of phalanges obtains in Panyptila. Further reduction in the number of toes begins with the hallux, which, as may be gathered from what has been already stated, represents almost every intermediate condition from being the strongest, as in Accipitres, to total loss. The second toe is absent in Struthio only, though its malleolus is present, but in a very degenerate condition. This Bird indeed seems to be on the way to becoming one-toed, for though the fourth still exists, long and functional, its phalanges decrease in length and strength towards the extremity, and the terminal one is frequently reduced to a mere nodule, devoid of a claw. Such an example has therefore already reached a one-hoofed condition. Cholomis, a rare form from Thibet, of doubtful affinity, seems to offer the only instance of the loss of the fourth toe, which is said to be reduced to a mere stump. The proportional length of the phalanges, especially when the reduction in length affects the basal and next following phalanges without the terminal, is of some taxonomic value, for a special account of which reference may be made to the account in Bronn's Thier-reich (pp. 508-521), but above all to Kessler's Osteologie der Togelfuisse, in the Bulletin of the Naturalists' Society of Moscow for 1841 (pp. $467,628)$.

SKELLY, or Shelly, a local name for the Chaffinch.

SKIDDAW, another form of KIDDAW (see GUILLEMIOT).

SKIDDY, otherwise SKITTY-Cock, a name applied to the Moor-Hen and Water-RAIL.

SKIMMER, the English name bestowed by Pennant ${ }^{1}$ in 1773 on a North-American bird which had already been figured and described by Catesby (B.Carol.i.pl. 90) under that of "Cut-water,"as it appears still to be called on some parts of the coast, ${ }^{2}$-renarkable for the unique formation of its bill, in which

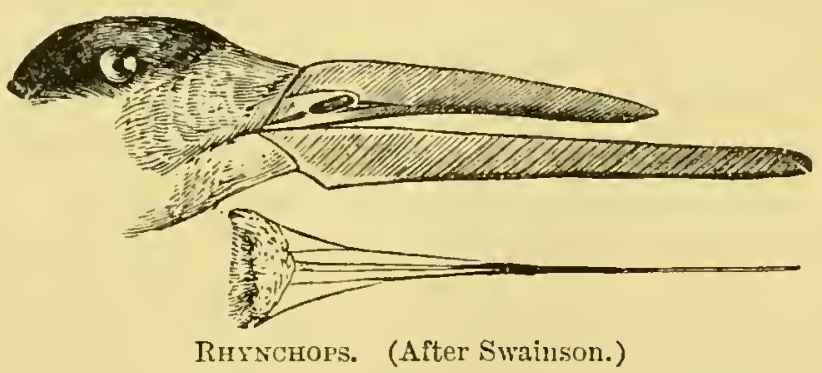
the maxilla, or so-called upper mandible, is capable of much vertical

$\therefore$ "I call it Skimmer, from the mamer of its collecting its food with the lower mandible as it flies along the surface of the water" (Gcn. of Birds, P. 57).

2 Other English names alphlied to it in America are "Razorbill," "Scissorbill," and "Shearwater." 
movement, while the lower mandible, which is considerably the longer of the two, is laterally compressed so as to be as thin as a knife-blade. This bird is the Rhynchops nigra of Linnæus; who, however, united with it what proves to be an allied species from India that, having been indicated many years before by Petiver (Gazoph. Nat. tab. 76, fig. 2), on the authority of Buckley, and named by J. R. Forster in 17S1, was only technically described in 1838 by Swainson (Anim. Menag. p. 360) as $R$. alticollis. A third species, $R$. flavirostris, inhabits Africa; and examples from South America, though by many writers regarded as identical with $P$. nigra, are considered by Mr. Saunders (Proc. Zool. Soc. 18S2, p. 522) to form a fourth, $R$. melanura of Swainson (ut supri, p. 340), and he has now separated southern examples as a fifth, $R$. intercedens. All these resemble one another very closely, and, apart from their singularly-formed bill, have the structure and appearance of TERss. Some authors make a Family of the genus, but it seems needless to remove it from the Laridæ (GULL). In breeding-habits the Skimmers agree with the Terns, the largest species of which group they nearly equal in size, and indeed only seem to differ from them in the mode of taking their food, which is well described by Mr. Darwin (Journ. of Pesearches, chap. vii.) from his own observation, and is of course correlated with the extraordinary formation of their bill.

SKOOI, see SKUA.

SKRABA, see SCRABER.

SKUA, ${ }^{1}$ the name for a long while given to certain of the Laridx, which sufficiently differ in structure, appearance and habits to justify their separation as a distinct genus, Stercorarius (Lestris of some writers), subfamily, or even, according to a late author, a Family-Stercorariidx. Swift of flight, powerfully armed and intrepid, they pursue their weakel cousins, making the latter disgorge their already-swallowed prey, which is nimbly caught. before it reaches the water; and this habit, often observed by sailors and fishermen, has made these predatory and parasitic birds locally known as "Teasers," "BoATswains," and, from a misconception of their intent, "Dunghunters." On land, however, whither they resort to breed, they seek food of their own taking, whether small mammals, little birds, insects, or berries; but even here their uncommon courage is exhibited, and they will defend their homes and offspring with the utmost spirit against any intruder, repeatedly shooting down on man or dog that invades their haunts, while

1 Thus written by Hoier (circa 1604) as the name of a Froese bird (hodie Skúir), an example of which he sent to Clusius (Exotic. Auct. p. 367). The word being thence copied by Willughby has been generally adcpted in English, and applied to all the congeners of the species to which it was originally peculiar. 
every bird ahnost, from an Eagle downwards, is repelled by buffets or something worse.

The largest European species is the Stercorarius catarihactes of ornithologists-the "Skooi" or "Bonxie" of the Shetlanders, a bird in size equalling a Herring-Guli, Larus argentatus. The sexes do not differ in colour, which is of a dark brown, somewhat lighter beneath; but the primaries have at the base a patch of white, visible even when the wings are closed, and forming, when they are spread, a conspicuous band. The bill and feet are black. This is a species of comparatively limited range, breeding only in some two or three localities in the Shetlands, about as many in the Freroes, ${ }^{1}$ and hardly more in Iceland. Out of the breeding-season it shers itself in most parts of the North Atlantic, but never seems to stray further south than Gibraltar or Morocco, and it is therefore a matter of much interest to find the Southern Ocean inhabited by a bird-the "Port Egmont Hen" of Cook's Voyages-which so closely resembles the Skua as to have been for a long while regarded as specifically identical with it, but is now usually recognized as distinct under the name of $S$. antarcticus. This bird, characterized by its stout, deep bill and want of rufous tint on its lower plumage, has an extensive range, from the Falkland Islands past I Terguelen Land to Australian waters and those of $\mathrm{New}$ Zealand, while occasionally visiting the coast of Madagascar and the Cape of Good Hope as well perhaps as Ceylon. Another allied species hitherto only met with near the sonth-polar ice is recognized by Mr. Saunders (Cat. B. Br. Mus. xxv. p. 321, pl. i.). On the western coast of South America, making its way into the Straits of Magellan, and passing along the coast so far as Rio Janeiro, is found S. chilensis, distinguished among other characters by the cinnamon tint of its lower plumage. All these are now placed by Mr. Saunders (tom. cit. p. 313) in a distinct genus-Megalestris.

Three other smaller species of Stercorarius are known, and each is more widely distributed than those just mentioned, but the home of all is in the more northern parts of the earth, though in winter two of them go very far south, and, crossing the equator, shew themselves on the seas that wash the Cape of Good Hope, Australia, New Zealand and Pertu. The first of them is S. pomatorhinus (often and originally mis-spelt pomarinus), about the

1 It has long been subjected to persecution in these islands, a reward being paid for its head, and but very few pairs now exist there. On the other hand, in the Shetlands a fine was exacted for its death, as it was believed to proteet the sheep against Eagles. Yet for all this it would long ago have been extirpated there, and have ceased to be a Britislı bird in all but name, but for the special protection afforded it by several members of two families (Edmondston of Unst and Scott of Melby), whose exertions on its behalf deserve the praise of all ornithologists, and were recognized in 1891 by the award to their representatives of the silver medal of the Zoological Society of London. 
size of a common Gull, Larus canus, and presenting, irrespective of sex, two very distinct phases of plumage, one almost wholly sooty-brown, the other particoloured-dark above and white on the breast, the sides of the neck being of a glossy straw-colour, and the lower part of the neck and the sides of the body barred with brown; but a singular feature in the adults of this species is that the two median tail-feathers, which are elongated, have their shaft twisted towards the tip, so that in flight the lower surfaces of their webs are pressed together vertically, giving the bird the appearance of having a disk attached to its tail. The second and third species so closely resemble each other, except in size, that their distinctness was for many years unperceived, and in consequence their nomenclature is an almost bewildering puzzle. Mr. Saunders (tom. cit. p. 322) thinks that the larger of them, which is about the size of a Black-headed Gull, should stand as S. crepidatus, and the smaller as S. parasiticus, though the latter name has been generally used for the larger when that is not termed, as it often is, $S$. richardsoni-a name that correctly applies only to whole-coloured examples, for this species too is dimorphic. Even its proper English name ${ }^{1}$ is dispntable, but it has been frequently called the Arctic Gull or Arctic Skua, and it is by far the commonest of the genus in Britain, and perhaps throughout the northern hemisphere. It breels abundantly on many of the Scottish Islands, ${ }^{2}$ and in most countries lying to the northward. The nest is generally in long heather, and contains two eggs of a dark olive colour, suffused with still darker brown patches. Birds of either phase of plumage pair indiscriminately, and the young shew by their earliest feathers whether they will prove whole or particoloured ; but in the immature dress of the last the upper surface is barred with pale reddish-brown. The smallest species, commonly known in English as the Long-tailed or Buffon's Skua, rarely exhibits the remarkable DinorPHISı (p. 149) to which the two preceding are subject, but one instance (Ibis, 1865, p. 217) apparently being on record. It breeds abundantly in some seasons on the fells of Lapland, its appearance depending chiefly on the presence of Lemmings, on which it mainly preys. All these three species occasionally visit the southern coasts of Europe in large flocks, but their visitations are highly irregular.

SKULL, the comprehensive word for all the bones of the head, which may be conveniently grouped as those forming the CRANIUI

1 It is the FAsceddar or Fasgadair of the Hebrides, the Shoor of the Shetlands, and the SCOUTI-ALLEN of the fishermen of Orkney and on the east coast of Scotland.

2 Pemnant was the first to discover that it bred in the British Islands, by finding it on the 1st of Jnly 1772 on Jura, which, thanks to the protection accorded to it, it still inhabits, and this must be the most sontherly point in its breeding-range. 
(p. 112), and those belonging to viscelal arches which give rise to the Hrom apparatus, the palate and the jaws (Maxilla, Mandible). Being a most complicated structure, the composition of the Skull will be better understood if the clescription of its adult condition be prefaced by a short account of its general development. The first trace of the Cranium appears towards the end of the fourth day of incubation (EMBryology, p. 209), and on the seventh (p. 211) its essential shape is completed. Roughly speaking, the ventral half of the cranial capsule consists of a mass of cartilage in which no separate clements are distinguishable, while its side-walls and roof, though continuous with that mass, are still in a membranaceous condition, being formed of indifferent connective tissue. The inmost layer of this membranaceous covering remains throughout life as the dura mater (Nervous System, p. 622), while the outer and thicker layer ossifies, of course to form membrane BONE (p. 47), and the greater part of the cartilaginous framework is likewise converted into bone. Though so unlike in their origin, it is not always easy to distinguish between these two sorts of bone, owing to the conclensed or abbreviated way in which stages of development are hurriedly passed through and to other cænogenetic changes (ANATOMY, p. 14) which obscure and sometimes completely alter the proper phylogenetic procedure. Thus bones originally cartilaginous are overlaid by direct ossification of membrane, and often have their cartilage more or less suppressed, so that they appear from the beginning as formed from membrane and not from cartilage. This applies to most of the jaw-bones, as well as those of the roof of the mouth or palate. Most of the bones of the Skull ossify each from one centre, and originally all are paired.

Analysis of the Cranium shews it to be constituted thus :-

I. The basis of the cranial capsule, composed of the following (cartilaginous) elements, which, proceeding from behind forwards, are-(1) Basioccipital ; (2) Basisphenoid; (3) Præsphenoid ; (4) continuation of the last into the interorbital and internasal Septum.

II. The right and left sides, formed by the (cartilaginous) paired -(1) Lateral Occipitals (Exoccipitals of many author's) ; (2) Periotics; (3) Alisphenoids ; (4) Orbitosphenoids; (5) Ethmoids.

III. The roof of the capsule, formed by the following (membrane) bones in pairs-(1) Supra-occipitals; ${ }^{1}$ (2 and 3) Parietals and Squamosals ; (4) Frontals ; (5) Lacrymals ; (6) Nasals.

IV. Additional (nembrane) bones on the ventral side of the base of the capsule-(1) a pair of Basitemporals, amalgamated with the Basisphenoids; (2) an unpaired investment of the likewise

1 In several species of Cormorant a peculiar, long, pyramidal sesamoid bone is loosely attached to the supra-occipital, serving apparently to increase the surface of attachment of the musc. complexus capitis and of part of the temporal muscle. 
unpaired Presphenoid, forming with it the rostrum of the busis crunii; (3) the Vomer, paired or umpaired, resting upon the septum.

$\mathrm{V}$. Bones derived from, or developed upon, visceral arches, forming the appendicular apparatus of the Skull-(1) the mpaired

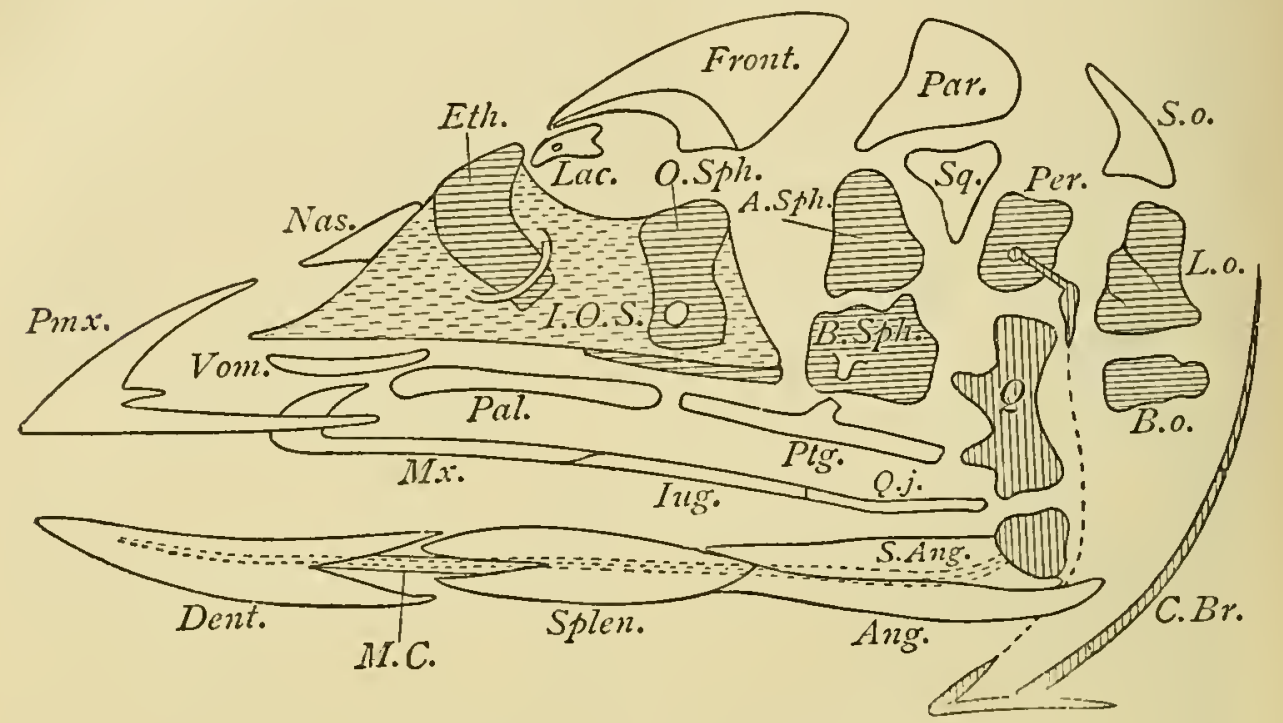

Analytical Diagrail of a`Bird's Skitut.

Præmaxilla; (2) the right and left Maxillæ; (3, 4, 5) the right and left "Palatines," Pterygoids and Quadrates-these being, as well as $(6,7)$ the right and left Jngals and Quadrato-jugals, modifications of the dorsal half of the first visceral arch; $(8)$ the bones forming the right and left Mandibula (or the lower jaw)-namely, the Dentals, Splenials, Supra-angulars, Angulars and Articulars-all these last being modifications of the ventral half of the same (first) visceral arch; (9) the ossicles of the ear, columella auris (p. 179),

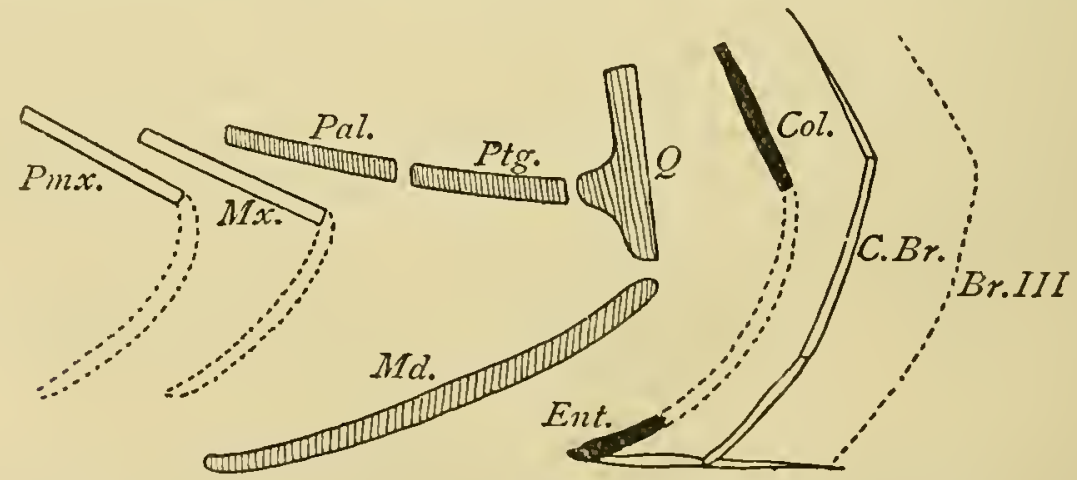

Analytical Diagram of the Visceral Arches. The dotted portions are not developed.

being the remnants of the dorsal half of the second visceral arch (=the 1 st branchial arch), while the remnant of its ventral half is transformed into the os entoglossum (p. 453); (10) the rest of the Hroid apparatus formed by the third visceral (=2nd branchial) arch. 
And now to proceed to a more detailed description of the rarions regions of the Skull. The OccIPUT proper is formed by the Basioccipital, right and left lateral and supra-occipital, all of which enelose the foramen magmum, through whieh passes the medulla oblonguta ( $\mathrm{p}$ 51), and, as in Reptiles, the Skull articulates by a single globular or kichey-shaped knob with the Atlas ( $c f$. Skzilkton, p. 848), the condyle being formed almost wholly by the basioccipital, the lateral occipitals taking but little share in it, and thus constituting a fundamental distinction between the Amphibians on the one hand and Mammals on the other, where the articulation of the head with the neck is effected wholly by the lateral occipitals.

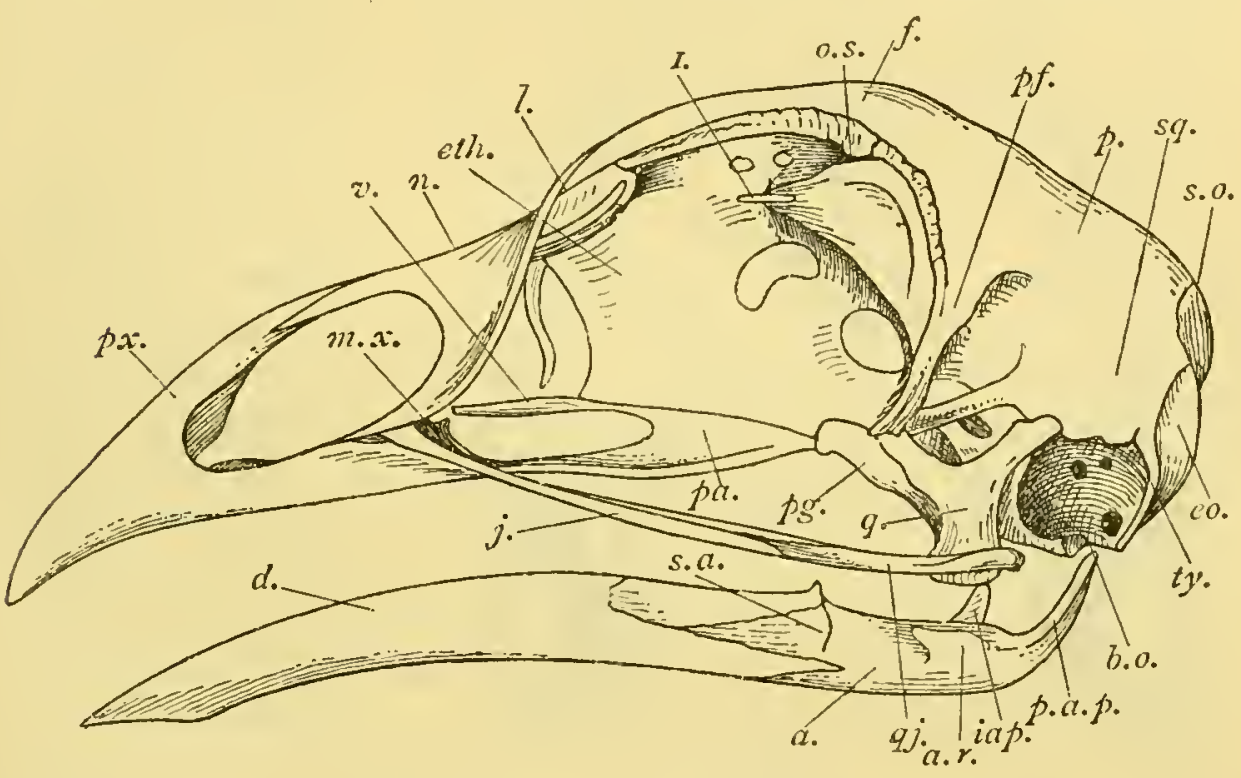

Skuld of Common Fowl from the side. (After Parker.)

Part of the nembranaceous roof between the supra-occipital and parietal bones frequently remains unossified and in the macerated Skill presents the appearance of a pair of fontanelles, which are common features in Limicole and Anseres, but of variable occurrence in closely-allied genera. In the majority of Pigeons and also in some Owls and Parrots, the supra-occipital contains a single small median foramen for the passage of a blood-vessel. Further forwards the occiput joins the Basisphenoid, Alisphenoid and Periotic bones, this portion of the Cranium being roofed-in by the Parietals and Squamosals, the latter as a rule forming the posterior outer margin of the Orbits, and frequently continued into two lateral downward processes enclosing the temporal fossa. Of these the anterior; known as proc. orbitalis posterior, frequently combines with a similar outgrowth of the Alisphenoid, and in Cockatoos and Tinamous is continued forwards so as to meet a process of the Lacrymal bone, and thus forms an infra-orbital bridge; while the posterior, known 
as proc. zygomaticus, is very variable in size, being largest in the Ostrich, Gallinx and Parrots, and smallest in Anseres. In many

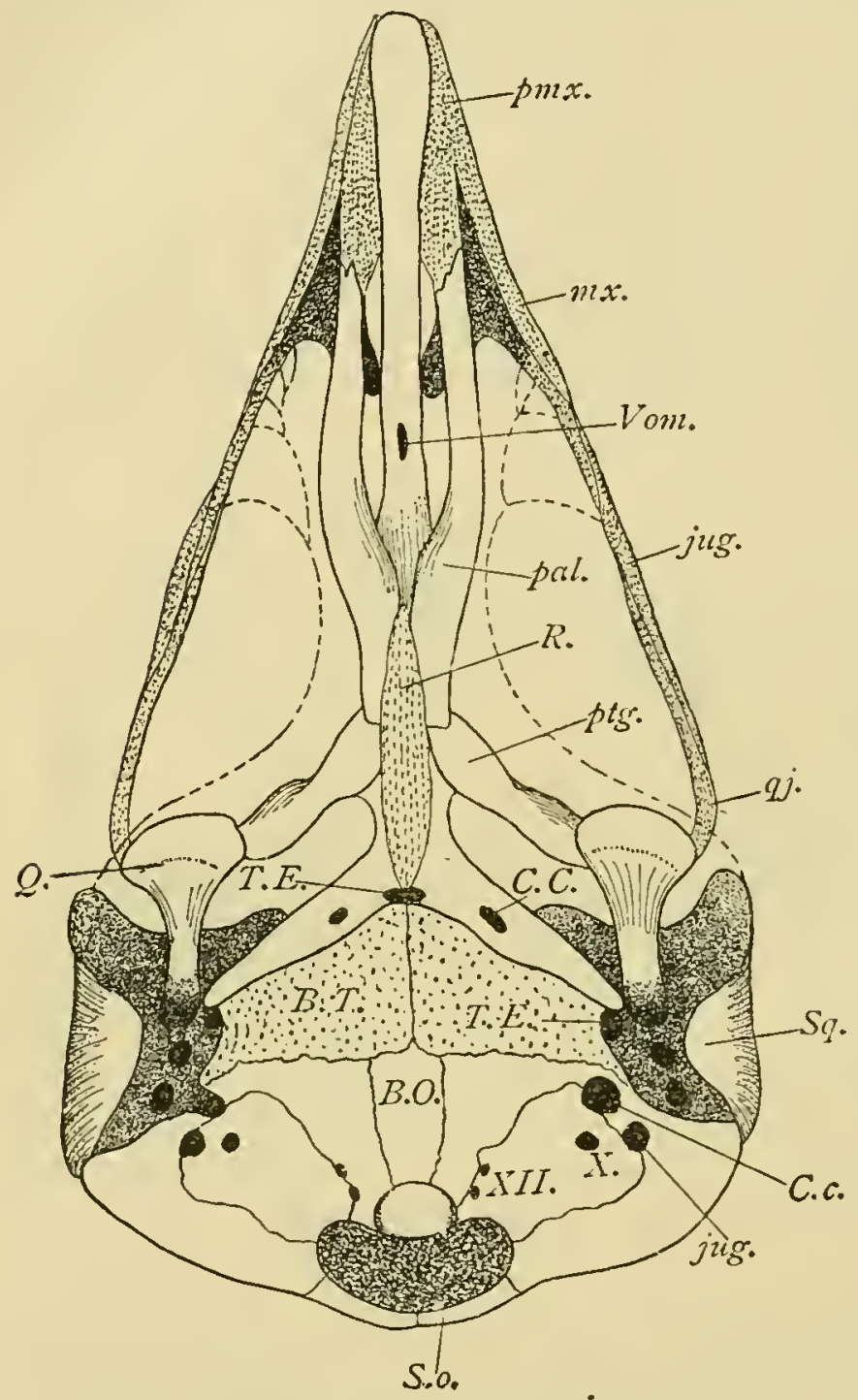

Shull of Common Fowl from beneatr. (After Parker.) Gallina both processes meet at their distal end and transform the temporal fossa into a foramen.

The Periotic Bones, enclosing the inner EAR (p. 178) occupy a space bounded beneath by the Basioccipital and Basisphenoid, in front by the Alisphenoid and Squamosal (which last to a great extent overlaps and hides them when viewed from without), behind and above by the lateral and supra-oceipitals and parietals. The Periotics consist of three distinct elements, which in size, relative position and in regard to the surrounding bones exhibit many modifieations, forming a very difficult chapter" of ornithic anatomy which as yet has been touched by few, ${ }^{1}$ though an exhaustive study of them promises results of prime taxonomic importance. The Prootic (Petrosal of some writers) abuts upon the Alisphenoid, and with the latter encloses the foramen orale, through which passes the $3 \mathrm{rd}$ branch of the nerus trigeminus, while between the posterior margin of the Prootic and the anterior borcler of the Lateral Occipitals lies the fenestra oralis, ${ }^{2}$ into which fits the base of the Columellu of the ear, and the fenestru rotunda. Dorsally the Prootic adjoins the Epiotic

1 Among them are the late Prof. W. K. Parker in several of his numerous papers, Prof. Huxley in his Elements of Comparative Anatomy and Prof. Selenka (Bronn's) Thier-Ricich.

2 Inadvertently called foramen ovale nu p. 179. 
(sometimes the Mastoid of Parker), which is often very small and only develops sereral irregular ossifications that soon fuse with the supra-occipital. The Opisthotic (Mastoid of Selenka) lies between the Epiotic and the Lateral Occipitals, with which last it ultimately fuses, and in some birds-Larus (GULL) for example-it actually helps to bound the foramen magnum.

The Basisphenoids are ventrally overlaid by a pair of membranebones, the Basitemporals of some authors, and laterally they help to form the lower and anterior border of the auditory meatus (EAR, p. 176), while each Eustachian tube (l.c.) is, roughly speaking, accompanied and partly covered by a canal for the passage of the Carotids (p. 76) and some of their branches. The Basisphenoids frequently articulate with the Pterygoids by the BASIPTERYGOID PROCESSES (p. 28), and their dorsal surface supports the greater portion of the base of the BRAIN, forming with the adjoining end of Præsphenoids the sella turcica (p. 52). Dorsi-laterally the Basisphenoid is joined by the Alisphenoid, which takes the greater share in forming the posterior wall of the orbit. Between the Alisphenoid and the Prootic the 2nd and 3rd branches of the nervus trigeminus issue through one or two foramina, and laterally the Alisphenoid joins the Squamosal, which in most cases separates it from contact with the Parietal, while dorsally it meets the Frontal. Forwards the Basisphenoid and Alisphenoid are continued into the Præsphenoid and Orbitosphenoid respectively, and these last, except at their posterior end, are practically unpaired-the right and left half being, so to say, pressed together by the extraordinarily developed eyeballs into a median interorbital septum, which is dorsally overlaid by the Frontals, while it is continued forwards as the internasal septum; but complications are produced by the development of lateral outgrowths, which as Turbinals or nasal conchæ serve partly to enlarge the surface and partly as protective chambers of the olfactory and nasal mucous membranes. There is often no sharp line of demarcation between the Orbitosphenoid and Præsphenoid, because the extent to which the cartilaginous septum ossifies is subject to individual variation ${ }^{1}$ but the foramen opticum for the passage of the optic nerve (EYE, p. 233) always lies near the base of the Orbitosphenoid. The junction of this last named with the Alisphenoid is also marked by a variable number

1 An incomplete internasal septum produces what are known as nares perviz, characteristic of Colymbus, Podicipes, Phacthon (alone among the Steganopodes), Ardeidæ (excl. Balaniceps and Cancroma) Scopus, Ciconia, Phonicopterus, Anseres, Palamedea, Cathartidæ, Rallidæ, Gruidæ, Cariama, Otis, Eurypyga, Podica, not in Rhinochetus, Limicolæ, Laridæ, Alcidæ, and varions Passeres. When the septum is complete these are of course nares impcrvix, no matter whether it remains cartilaginous or ossifies more or less, as in many Striges, Podargus, Steatornis and Trogonidæ. 
of smaller foramina for the exit of the 1st branch of the nerv. trigeminus and of the $3 \mathrm{r} d$, 4th and 6th Cranial Nerves. Frequently, however, one or more of these leave the cranial cavity together with the optic nerve, converting in such cases the optic foramen into a foramen lacerum anterius. The olfactory or 1st pair of cranial nerves leave the cranial cavity at the point where the Orbitosphenoid meets the Frontal, and reach the nasal cavities by passing above the interorbital septum.

The Frontals form the greater portion of the upper surface of the Skull, and by their forward, lateral or backward expansion come into contact with a great number of bones, such as the Parietals, Squamosal and Opisthotic, Ali-orbitosphenoid, Ethmoid, Laclymal and Nasal, Maxillary and Præmaxillary. In most embryos the Frontals and Nasals are originally separated by the upper portion of the Ethmoid, which appears on the surface, and this condition is persistent in Struthio; but otherwise the Ethmoid is overlaid by expanding growths of the Præmaxillæ and the Nasals until these reach the Frontals. Posteriorly the Frontals combine with the Squamosal and Alisphenoid in forming the postorbital process; and, as this part often ossifies from a separate centre, it possibly represents the postfrontal of other Vertebrates. The space between the Frontal, Orbitcsphenoid and Ethmoid is filled by the Lacrymal, which always forms part of the anterior border of the orbit (processus orbitalis anterior), and has a perforation through which pass the secretions of the lacrymal and various orbital glands. The Lacrymal exhibits many modifications which seem to be of some taxonomic value: most generally it fuses with the Frontal and Nasal, but it may fuse with the former and articulate with the latter, or vice versa as in Vanellus; or it may articulate with both as in Ardea, or may fuse with the much-expanded Maxilla, as in Balrniceps and Podargus; or it may fuse with the Ethmoid as in Corvus corax, or again may articulate with the Palatal as in Struthio, or with the Jugal as in Corvus, Psittaci and Accipitres. Many birds, as most Accipitres, several Gallinx, beside Grus and Struthio, possess Supraorbital bones which are loosely attached, one or more on either side, to the posterior margin of the Lacrymal and the adjoining side of the Frontal. To the same category as these belong the Infraorbitals, which join the Jugal or downward process of the Lacrymal, and protect the lower side of the eyeball.

The Nasals, which are always conspicuous, send out three processes-(1) a præmaxillary which joins laterally the posterior dorsal præmaxillary process and forms the upper margin of the nasal cavity, (2) a lateral one, descending and joining the Maxilla so as to border the nasal cavity behind, and (3) a frontal process which, uniting with its fellow on the other side, overlaps the upper surface of the Ethmoid and frequently fuses with the anterior 
median end of the Froutals. In the majority of birds the Nasals ${ }^{1}$ fuse with the Frontal, Ethmoid, Maxilla and Præmaxilla, making this part of the Skull more or less solid, though generally springy, ${ }^{2}$ but many birds possess a transverse fronto-nasal joint, often very conspicuous and admitting of the vertical movement of what is commonly known as the "upper mandible" of the bill. This joint is just anterior to the Frontals and Lacrymals, but behind the Nasals and Præmaxillæ, and is a modification that stands in direct correlation with the mode of feeding, and is consequently very variable in closely-allied groups. ${ }^{3}$

The Præmaxilla (or Intermaxilla) is in Birds an unpaired bone, its right and left component halves being fused from the beginning. It forms the anterior and largest part of the so-called "upper mandible," of which it is the most important factor, though the outward shape of the BILL (p. 32) depends chiefly on its thamphotheca, and being therefore intimately connected with the bird's economy is subject to very great variation in proportion and strength. Each half of the Præmaxilla sends out three processes-(1) one which fuses with the Maxilla and forms the anterior part of the upper jaw, (2) one which contributes to the formation of the anterior: part of the palate, and (3) one which togethel with its fellow on the opposite side forms the culmen (p. 33) and extends backward to the Frontals.

The paired Maxillaries form, as just stated, part of the upper jaw, contributing also to the floor of the nasal cavity, and always

1 The mutual relations of the processes of the Nasals to those of the neighbouring bones induced Garrod in 1893 (see INTRoDdoTion) to distingnish Birds as Holorhinal ( $p .425$ ) where the anterior margin of the Nasal is concave, and Schizorhinal (p. 816) where this posterior border of the nasal cavity is continued backward into a slit which extends beyond the frontal processes of the Præmaxilla. To use this feature as a primary taxonomic character is all error, as he himself speedily saw, but otherwise it is as good as many others, though closely-allied birds differ in this respect. The typically schizorhinal birds are the Limicolx, excluding Edicnemus but including Parra, Laridæ, Alcidæ, Pteroclida, Columbr, Turnices, Grues, including Eurypyga and Rhinochetus but not Psophia, Mesites and Ibis. An approach to the holorhine structure is present in some individuals of Platalea, and among Passercs in the Furnariidx. All schizorhinal birds are also schizognathous, of which more presently; but the reverse is by no means the case.

2 The flexible part commonly lies behind the nasal cavities, but in Trochili and Scolopacide far in front of the nostrils, so that only the anterior part of the "upper mandible" is movable, and motion can be effectel while the mouth is closed. In some Plovers and lbises, and probably a few other birds also, such a flexible region exists beside the usual fronto-nasal one.

3 The joint is most developed in certain Psittaci, Striges, Caprimulgida, Anseres, Steganopodcs, several Ciconiæ- for instance Tantalus, though not in Ibis or Platalea,-Corydon sumatranus, and is more or less developed in many other birds, among them not a few Fringillide. 
fuse with the Præmaxillary, Nasals, Palatines and Jugals, frequently also with the Vomer and Lacrymals. Each Maxillary is usually pyramidal in shape, having an outer, inner and ventral surface, the anterior corner of which joins the Præmaxilla, the posterior the Jugal. and the dorsal the descending process of the Nasal. It varies much in size: very small in the Gallinæ, it is in the Ardeæ next to the Præmaxilla the most conspicuous bone of the Skull. Inwardly each Maxilla sends out a more or less horizontal transverse process, the proc. maxillo-palatinus, of which more presently.

The so-called Palatines are long, and for the most part flat and horizontally-placed bones, always fused at their anterior end with the Præmaxilla, and frequently with the ventral surface of Maxillæ and their maxillo-palatine process, just mentioned, while posteriorly they rest movably on the Præsphenoid rostrum, articulating also, in most Birds, with the anterior end of the Pterygoids. The Palatines form the greater portion of the palatal roof of the mouth, and border the CHOAN (p. 87) or inner narial openings.

The Vomer, a median bone, rests on the Præsphenoidal rostrum, and to the ventral view appears between the Palatines. It is very variable in shape and size, being wholly absent or reduced to a mere trace in the Gallinæ, Pteroclidx, Columbæ, Psittaci, Musophagidx, Alcedinidx, Todidx, Coliidx, Upupida and Bucerotidx, while it is small in the Coraciida and Meropida. In Pici it is secondarily resolved into a right and left half, which in Galbulidx and Bucconidx are very much reduced in size. ${ }^{1}$

1 On the various bones of the palate, Prof. Huxley based his classification of Carinate, published in 1867 (see InTroduction), dividing them into four sub-orders-Dromegnathe, Schizognathe, Desmognathe and EgrthoGNATHE. As details of the cranial structure have become better known, many additions to and corrections of the original scheme have been rendered necessary, chiefly through the labours of Parker, Garrod and Forbes, Profs. Magnus and Fürbringer and Dr. Shufeldt. Doubtless the most primitive formation is the Schizognathous, whence has arisen the Desmognathous-either by direct approach of the Palatines in the middle line, or by the help of the Ethmoid and internasal septum. Desmoguathism therefore does not necessarily imply blood-relationship, lut has been reached independently in various groups, while a like consideration applies to the Egithognathous feature, which is also derived from earlier Schizognathous conditions. Thinocorys and Turnix, for instance, are incompletely Egithognathous, and the same niay be said of Mcnura, while the Indicatoridx and the Cypselidlx are as completely Egithognathous as the true Passures, exclusive of the Schizognathous Furnariinz. Among certain Passeres, such as Gymnorhina, Paradisea, Artamus, Dendrocolaptes, Thamnophiturs and Phytotoma, what may be called compound Egithognathism prevails, in that fusion of the Palatines with each other at their anterior end and with the internasal septum leads to a sort of Desmognathous condition.

According to our present knowledge, the following forms and groups are Schizognathous:-Struthio, Aptcryx, Crypuru, Sphenisci, Tubinares, Colymbi, Podicipedidx, Alcidæ, Laridx, Limicolæ (excl. Thinocorys above named), Ptero- 
The PTERYgords are rod-shaped bones articulating in front with the posterior end ${ }^{1}$ of the Palatines, or also with the adjoining part of the sphenoidal rostrum, and behind with a process of the Quadrates. In many birds an additional articulation exists between the Pterygoids and the Basisphenoid by means of the BASIPTERYgoid Procenses (p. 28).

The QUADRATES connect the lower jaw with the cranium, beside serving for the posterior end of the Pterygoids, and lastly are connected with the Maxilla and Præmaxilla by two thin rod-shaped bones-the Quadrato-jugal and the Jugal.

'The Mandibula forming the lower jaw is composed of a considerable number of bones, most of which developing from membrane invest the primitive cartilaginous portion, known as Meckel's Cartilage, and soon fuse witl each other. The os articulare forms the articulation with the Quadrate, and bears on its inner side the mocessus mandibularis internus, which serves for the insertion of part of the digastric muscle, or that which opens the mouth. The os angulare forms the posterior end of the mandible, and is frequently produced into a processus mandibularis posterior, likewise serving for the insertion of the digastric muscle. Its shape and size are of taxonomic value. The greater part of the Mandible is formed by the Dentary, so called because in it the teeth when present are lodged. In Hesperornis, Ichthyornis and apparently Gastornis the two halves of the Mandible were movably connected at the distal end : in recent birds they are fused together and ossify from the point of meeting. The Supra-angular or Coronoid element fills the space between the Articular and Dentary on the upper or anterior side, and serves for the insertion of part of the temporal or masseter

clidx, Columbæ, Turnix, Ralli, Grues (excl. Cariama and Rhinochetus, which are incompletely Desmognathous), Gallinx, Opisthocomus, Trogonidr, many' Striges, Trochili, Caprimulgus, Nyctibius, Pici, Nlegalæma and, as first mentioned, Furnariinz.

Parker drew attention to the existence of three kinds of Desmognathism :-

(1) Direct - where the maxillo-pralatine proeesses fuse direetly with each other, either ineompletely as in Cariama, or completely as in most Accipitres and Anseres, with or withont additional help from the internasal septum.

(2) Indirect-where the fusion of these proeesses is effeeted solely by that septum, either incompletely as in Megalæma, or completely as in Aquila, $V u l t u r$, several Striges and Alccdinidx.

(3) Double-where those proeesses and the palatines meet in the middle line and form a broad solid roof, as in Podargus and Buceros.

The following are Desmognathous :-Dromzus, Anseres, Stcganopodes, Herodii, Pelargi, Aceipitres, Psittaci, Coccyges, Alcedinida, Mcropida, Todidæ, Umupida, Buccrotidx, Coliida, Bucconialx, Gullulidx, Steatornis, Chordiles, Podargus and Rhamphasticle; lastly, the ineompletely Desmognathous Cracidre, Cariama, lihinochetus and various Striges.

1 At page 744 the "anterior end" was inadvertently stated. 
muscle. Additional Splint bones, the os operculare and os complementare, rest on the median side of the lower jaw, filling the gap between the Dentary and Angular, and between the Supra-angular and Articular.

SKYLARK. Alauda arvensis, see LARK, pages 507-509.

SLANGENVREETER or SLANGVRETER (Snake-eater), the Dutch name, adopted by many English residents in the Cape Colony, for the Secretary-Bird (Layard, B. S. Afr. p. 33).

SLIGHT-FALCON (Germ. schlicht, plain, simple or homely), a name once in common use (Sebright, Observations on Hawking, pp. 3, 33) for what is now called the Peregrine FALCoN. Schlegel (Traite cle Fauconnerie, p. 26) has pointed out the mistake of deriving it from the German Schlacht or schlect.

SMEW, the commonly-accepted name for the smallest of the Mergansers, M. albellus (p. 544), though not unfrequently applied in this country to some other Anatidx as the WIGEON and PoCHARD; but then generally in the form of SMEE-DUCK ( $c f$. Dutch Smiente=Wigeon) or SMETHE, while in America one or other of these variants is locally used for the Pistall (Trumbull, Names and Portr. B. p. 38). Originally it would seem to have been used for the female (Willughby, Orn. Engl. Ed. p. 337) of the species to which it is now ordinarily applied, while the male was the NuN.

SNAIL-EATER, an absurd name given to a species of Anastomus (OPEN-BILL).

SNAITH or SNYTH, Orcadian for COOT.

SNAKE-BIRD, in many parts of England a name for the WRYNECK, from the hissing noise it utters while in its nest; but applied to a very different kind of bird by the English in North America, because of its "long.slender head and neck," which, its body being submerged as it swims, "appear like a snake rising erect out of the water" (Bartram's MS., quoted by Ord in Wilson's Am. Ornithology, ix. p. 81). It is the "Darter" of many authors, the Plotus anhing ${ }^{1}$ of ornithology, and is the type of a small but very well-marked Family of Birds, Plotidx, belonging to the group STEGANOPODES, and consisting of but a single genus and three or four species. They bear a general resemblance both outwardly and in habits to CoRMorants, but are much more slender in form, and have both neck and tail much elongated. The bill also, instead of being tipped with a maxillary hook, has its edges beset with serratures directed backwards, and is sharply pointed,-in

1 "Anhinga," according to Marcgrave, who first described this bird (Hist. lier. Nat. Brasil. p. 218), was the name it bore among the natives. 
this respect, as well as in the attenuated neck, likeming the Snakebirds to the Herons; but the latter do not generally transfix their prey as do the former.

The male of the American species, which ranges from Illinois to the south of Brazil, is in full breeding-plumage a very beautiful bird, with crimson irides, the bare skin round the eyes apple-green and that of the chin orange, the head, neck and most part of the body clothed in black glossed with green; but down each side of the neck runs a row of long hair-like white feathers, tinged with

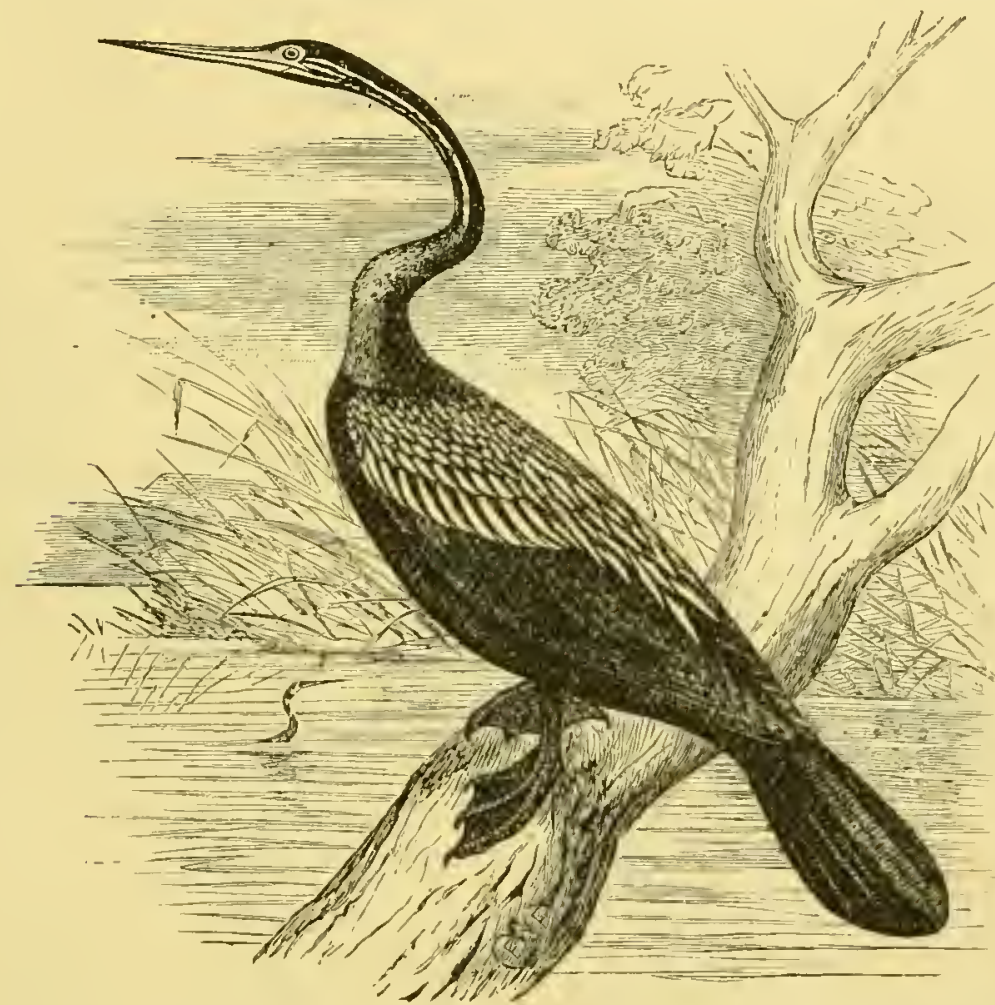

INDIAN SNaKE-BIRd. After Tickell's drawing in the Zoological Society's library.

pale lilac. The much elongated scapulars and the small upper wing-coverts bear each a median white mark, which on the former is a stripe pointed at either end, and on the latter a broad ovate patch. ${ }^{1}$ The larger wing-coverts are dull white, but the quillfeathers of the wings and tail are black, the last broadly tipped with brownish-red, passing into greyish-white, and forming a conspicnous band when the tail is spread in folm of a fan, as it often is under water. ${ }^{2}$ The hen differs much in appearance from the

1 These feathers are very characteristic of each species of the genus, and in India, says Jerdon, are among the Khasias a badge of royalty.

2 This peculiarity, first pointed out to me by Mr. Bartlett, who observed it in birds in the Zoological Society's possession, doubtless suggested the name of "Water-Turkey" by which in some places Plotus anhinga is said to be known. 
cock, having the head, neck and breast of a more or less deep buff, bounded beneath by a narrow chestnut band; but otherwise her plumage is like that of her mate, only not so bright in colour. The habits of this species have been repeatedly described by American writers, and those of its congeners, to be immediately mentioned, seem to be essentially the same. The Snake-bird frequents the larger rivers or back-waters connected with them, where it may be seen resting motionless on some neighbouring tree, generally choosing a dead branch, or on a "snag" projecting from the bottom, whence it plunges beneath the surface, in pursuit of its fishy prey, to emerge, in the manner before related, shewing little more than its slender head and neck. Its speed and skill under water are almost beyond exaggeration, and it exhibits these qualities even in captivity, taking - apparently without effort-fish after fish that may be introduced into its tank, however rapidly they may swim and twist, and only returning to its perch when its voracious appetite is for the moment appeased or its supply of food temporarily exhausted. Then, after adjusting its plumage with a few rapid passes of its bill, and often expanding its wings, as though, Cormorant-fashion, to dry them, it abandons itself to the pleasurable and passive process of digestion, reawaking to activity at the call of hunger. Yet at liberty it will indulge in long flights, and those of the male at the breeding-season are ostentatiously performed in the presence of his mate, around whom he plays in irregular zigzag courses. The nest is variously placed, but almost always in trees or bushes overhanging the water's edge, and is a large structure of sticks, roots and moss, in which are laid four eggs with the white chalky shell that is so characteristic of most Steganopodous birds. Not unfrequently several or even many nests are built close together, and the locality that suits the Snakebird suits also many of the Herons, so that these, its distant relatives, are often also its near neighbours. ${ }^{\text {I }}$ The African Snake-bird, $P$. congensis (or levaillanti of some authors), inhabits the greater part of that continent from Natal northwards; but, though met with on the White Nile, it is not known to have occurred in Egypt, a fact the more remarkable seeing that Canon Tristram found it breeding in considerable numbers on the Lake of Antioch, to which it is a summer-visitor, and it can hardly reach its home without passing over the intervening country. The male is easily distinguishable from that of the American species by its rufous coronal patch, its buff throat and its chestnut greater wing-coverts. A third species, $P$. melanogaster, ranges from Madagascar to India,

1 The curious but apparently well-attested fact of the occurrence in England, near Poole, in June 1851, of a male bird of this species (Zoologist, pp. 3601, 3654 ) has been overlooked by several writers who profess to mention all cases of a similar character. 
Ceylon, Borneo, Java and China. This so closely resembles the last-mentioned that the differences between them cannot be briefly expressed. ${ }^{1}$ 'The Australian Region also has its Snake-bird, which is by some regarded as forming a fourth species, $P$. norx-hollandia; but others unite it to that last-mentioned, which is perhaps somewhat variable, and it would seem (Proc. Zool. Soc. 1877, p. 349) that examples from New Guinea differ somewhat from those inhabiting Australia itself.

The anatomy of the genus Plotus has been dealt with more fully than that of most forms. Beside the excellent description of the American bird's alimentary canal furnished to Audubon by Macgillivray, other important points in its structure have been well set forth by Garrod and Forbes (Proc. Zool. Soc. 1876, pp. 335-345, pls. xxvi.-xxviii.; 1878, pp. 679-681; and 1882, pp. 208-212), shewing among other things that there is an appreciable anatomical difference between the species of the New World and of the Old; while the osteology of $P$. melanogaster has been admirably described and illustrated by Prof. Milne-Edwards in M. Grandidier's great work (Ois. Madag. pp. 691-695, pls. 284, 285). In all the species the neck affords a feature which seems to be unique. The first seven of the cervical vertebre form a continuous curve with its concavity forward, but the eighth articulates with the seventh nearly at a right angle, and, when the bird is at rest, lies horizontally. The ninth is directed downwards almost as abruptly, and those which succeed present a gentle forward convexity. The muscles moving this curious framework are as curiously specialized, and the result of the whole piece of mechanism is to enable the bird to spear with facility its fishy prey.

SNIPE, or SNITE-the latter being also its Anglo-Saxon form (Icel. Snipa, Dutch Snip, Germ. Schnepfe)-one of the commonest Limicoline birds, in high repute no less for the table than for the exciting sport it affords. It is the Scalopax gallinago of Linnæus, but by many later writers separated from that genus, the type of which is the WOODCOCK, and hence has been variously named Gallinago cxlestis, G. media, or G. scolopacina. Though considerable numbers are still bred in the British Islands, notwithstanding the diminished area suitable for them, most of those that fall to the gun are undoubtedly of foreign origin, arriving from Scandinavia towards the close of the summer or later, and many will outstay the winter if the weather be not too severe, while the home-bred birds emigrate in autumn to return the following spring. Of late years our markets have been chiefly supplied from abroad, mostly from Holland.

1 Remains of a still smaller species, $P$. nanus, now extinct, have been found in Mauritius (Trans. Zool. Soc. xiii. p. 288). 
The Snipe is fortunately too well known to need description, for a description of its variegated plumage, if attempted, would be long. It may be noticed, however, as subject to no inconsiderable variation, especially in the extent of dark markings on the belly, flanks and axillaries, while examples are occasionally seen in which no trace of white, and hardly any of buff or grey, is visible, - the place of these tints being taken by several shades of chocolatebrown. Such examples were long considered to form a distinct species, the $S$. sabinii, but its invalidity is now generally admitted. No fewer than 55 specimens of this abnormality have been reckoned by Mr. Barrett-Hamilton (Irish Nat. 1895, pp. 12-17), and every one as yet examined seems to be a bird of the year. Other examples in which buff or rust-colour predominates have also been deemed distinct, and to these has been applied the epithet russata. Again, a slight deviation from the ordinary formation of the tail, whose rectrices normally number 14 , and present a rounded termination, has led to the belief in a species, S. brehmi, now wholly discredited. But, setting aside two European species, to be presently noticed more particularly, there are at least a score, more or less nearly allied, belonging to various parts of the world, for no considerable territory is without its representative. Thus North America produces G. delicata or wilsoni, so like the English Snipe as not to be easily distinguished except by the possession of 16 rectrices, and Australia has $G$. austratis, a larger and somewhat differently coloured bird with 18 rectrices. India, while affording a winter resort to multitudes of the common species, which besides Europe extends its breeding-range over the whole of northern Asia, has the so-called Pin-tailed Snipe, G. stenura, in which the number of rectrices is still greater, varying from 20 to $2 S$, it is said, though 22 seems to be the usual number. This curious variability, deserving more attention than it has yet received, only occurs in the outer feathers of the series, which are narrow in form and extremely stiff, there being always 10 in the middle of ordinary breadth.

Those who only know the Snipe as it shews itself in the shooting-season, when without warning it rises from the boggy ground uttering a sharp note that sounds like scape, scape, and, after a few rapid twists, darts away, if it be not brought down by the gun, to disappear in the distance after a desultory flight, have no conception of the bird's behaviour at breeding-time. Then, though flushed quite as suddenly, it will fly round the intruder, at times almost hovering over his head. But, if he have patience, he will see it mount aloft and there execute a series of aerial evolutions of an astounding kind. After wildly circling about, and reaching a height at which it appears a mere speck, where it winnows a random zigzag course, it abruptly shoots downwards and aslant, and then as abruptly stops to regain its former elevation, and this process 
it repeats many times. A few seconds, more or less according to distance, after eacl of these headlong descents a mysterious sound strikes his ear-compared by some to drumming and by others to the bleating of a sheep or goat, ${ }^{1}$ which sound evidently comes from the bird as it shoots downwards, and then only; but how the sound is made is a question on which many persons are still undecided. There are those who maintain that it proceeds from the throat, while some declare it is produced by the wings, which sharp-sighted observers say they can see in tremulous motion. Others, again, assert that it is caused by the vibration of the webs of the outer rectrices, and these last have in support of their opinion the fact that a similar sound may be made by affixing those feathers to the end of a rod and drawing them rapidly downwards in the same position as they occupy in the bird's tail while it is performing the feat. ${ }^{2}$ But, however it be produced, the air will also ring with loud notes that have been syllabled tinker, tinker, tinker, while other notes in a different key, something like djepp, djepp, djepp rapidly uttered, may be heard as if in response. The nest is always on the ground and is a rather deep hollow wrought in a tuft of herbage, and lined with dry grass-leaves. The eggs are four in number, of a dark olive colour, blotched and spotted with rich brown. The young when freshly hatched are beautifully clothed in down of a dark maroon, variegated with black, white and buff.

The Double or Solitary Snipe of English sportsmen, S. major, a larger species, also inhabits northern Europe and may be readily recognized by the white bars on its wings and by its 16 or occasionally 18 rectrices. It has also a very different behaviour. When flushed it rises without alarm-cry, and flies heavily. In the breedingseason much of its love-performance is exhibited on the ground, and the sounds to which it gives rise are of another character; but the exact way in which its "drumming" is effected has not been ascertained. Its gesticulations at this time have been well described by Prof. Collett in a communication to Mr. Dresser's Birds of Europe (vii. pp. 635-637). It visits Great Britain every year at the close of summer, but in very small numbers, and is almost always seen singly-not uncommonly in places where no one could expect to find a Snipe.

1 Hence in many languages the Snipe is known by names signifying "Flying Goat," "Heaven's Ram," as in Scotland by "Heather-bleater." One may almost suspect that the airok't $\phi a \lambda$ os of the ancients was really this bird, though the applicability of the name would be unknown to any one unacquainted with its breeding habits.

2 Cf. Meves, EEfvers. K. Vet.-Akad. Förh. 1856, pp. 275-277 (transl. Naumannia, 1858, pp. 116, 117), and Proc. Zool. Soc. 1858, p. 202, with Wolley's remarks thereon, and Zool. Garten, 1876, pp. 204-208. 
The third species of which any details can here be given is the Jack, 1 or Half-Snipe, $S$. gallimula, one of the smallest and most beautifully colonred of the group. Without being so numerons as the common or full Snipe, it is of frequent occurrence in Great Britain from September to April (and oceasionally both earlier and later); but it breeds only, so far as is known, in northern Scandinavia and Russia; and the first trustworthy information of that subject was obtained by Wolley in June 1 $\$ 53$, when he found several of its nests near Muonioniska in Lapland." Instead of rising wildly as do most of its allies, it generally lies so close as to let itself be almost trodden upon, and then takes wing silently, to alight at a short distance (if it escape the gun), and to return to the same place on the morrow. In the breeding-season, however, it is as noisy and eonspieuous as its larger brethren while exeenting its aerial evolutions.

As a group the Snipes are in several respeets highly specialized,

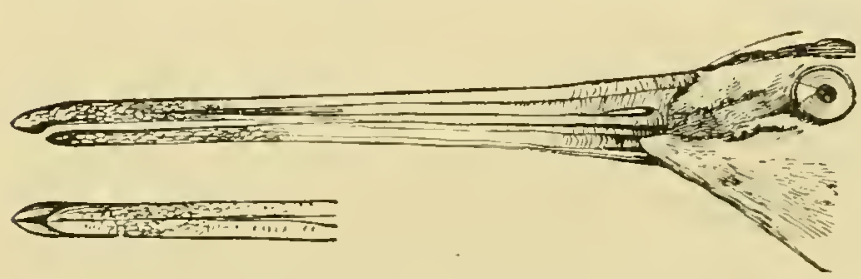

Bill of SNipe from the side and beneath.

(After Swainson.)

but here there is only space to mention the sensitiveness of tho bill, which, though to some extent noticeable in many SANDPIPERs is in Snipes earried to an extreme

by a number of filaments, belonging to the fifth pair of nerves, which run almost to the tip, and open immediately under the soft enticle in a series of cells that give this portion of the surface of the premaxillaries, when exposed, a honeyeomb-like appearance. Thus the bill becomes a most delicate organ of sensation, and by its means the bird, while probing for food, is at once able to distingrish the nature of the oljects it encounters, though these are wholly out of sight. So far as is known, the sternum of all the Snipes, except the Jaek-Snipe, departs from the normal Limicoline formation, a fact which tends to justify the removal of that species to a separate genus, Limnocryptes.

The so-called Painted Snipes, forming the genus liostratulu, or Phynchar, demand a few words. Three species are now admitted, natives respectively of South America, Africa and sonthern Asia,

1 Thongh this word is clearly not intended as a nickname, such as is the prefix which eustom has applied to many birds, one can only guess at its origin or meaning. It may lre, as in Jackass, an indieation of sex, for it is a popular belief that the Jack-Snipe is the male of the common species; or, again, it may refer to the comparatively small size of the bird, as the "jack" in the game of bowls is the smallest of the howls used, and as fishermen call the smaller Pikes Jacks. Possibly this may account for Curlew-rack as a name of the WummRis.

2 His acconnt was pmblished by Hewitson in May 1855 (Egys Rr. Birds, erl. \&, ii. 1'1, $356-358$ ). 
and Australia. In all of these it appears that the female is larger and more brilliantly coloured than the male, and in the last two

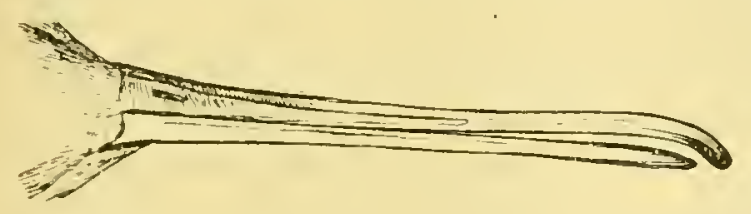

Bill of Paited Sxipe. (After Swainson.) species she is further distinguished by what in most birds is emphatically a masculine property, though its use is here unknown,namely a complex TRACHEA, while the male has that organ simple. He is also believed to undertake the duty of incubation.

SNOW-BIRD, a name variously applied in different parts of the world, but perhaps originally to the Snow-Bunting, Plectrophanes mizalis, which is also known as SNOW-FINCH (through that name being by some writers assigned to Montifringilla nivalis of the Alps, which is often mistaken for it) and SNOW-FLAKE. SNOWCOCK is an Anglo-Indian name for Tetraogallus himalayensis, which others call SNOW-PARTRIDGE or SNOW-PHEASANT, but the last is restricted by some to the birds of the beautiful genus Crossoptilum.

SOLAN-GOOSE (Icel. Sula, Gael. Sulaire), often spelt Soland, a very common name for the GANNET. The supposition that the bird takes its name from the channel known as the Solent has nothing to justify it.

SOLDIER-BIRD, a name in Australia for Myzomela sanguinoleuta, also called BLOOD-BIRD (p. 44), one of the Meliphagida (HonerEATER, p. 428).

SOLITAIRE, ${ }^{1}$ the name used by the French colonists for the Didine bird of Bourbon (Extremination, p. 217), as we learn from Du Bois (Voyages faits pur le Sieur D. B. Paris: 1674, p. 170) and Carré (Voyages dans les Indes Orientales, Paris: 1699, i. p. 12) who were there in 1668 and the following years. In 1691 Leguat arrived in Rodriguez, where he resided more than two years, and in the narrative of his adventures he applied the same name to the Didine bird he found there, of which he is the first known to have given an account. ${ }^{2}$ This was rescued from obscurity by Buffon's

1 According to Littre the first application of the word to a Bird is in the Psalter (Ps. 101, 8, or 102, 7 of the Anglican version), the species there mentioned having been long identified with the Blue Rock-Thrusn, Monticola cyanus. The name is also used in Jamaica (Gosse, B.Jam. p. 200) for Myiadectes solitarins, possibly one of the Ampclid $x$, and has been carried on by Dr. Sharpe (Cut. B. Br. Mus. vi. I' $370-377$ ) to other species of the genus.

2 I cannot but suspect there was some other, from what is said of a land-bird that could not fly by the author of The Isle of Pines, a fictitious work ascribed by Wood (Athen. Oxon. 918 ; cf. Rigg, Dict. Nat. Biogr. xl. Hl. 259, 260) to Henry Nevile, of which two editions appeared in 1668. Herbert (A lielation of some 
gleat work in 1770 , though the writer ${ }^{1}$ regarded much of it as fabulous, and hence, through Latham, Gmelin in 1788 accorded technical recognition to Lcguat's bird as Didus solitarius, while Strickland, sixty year's after, referring it to a distinct genus, Pezophaps, continued the latter's name for it as an English word.

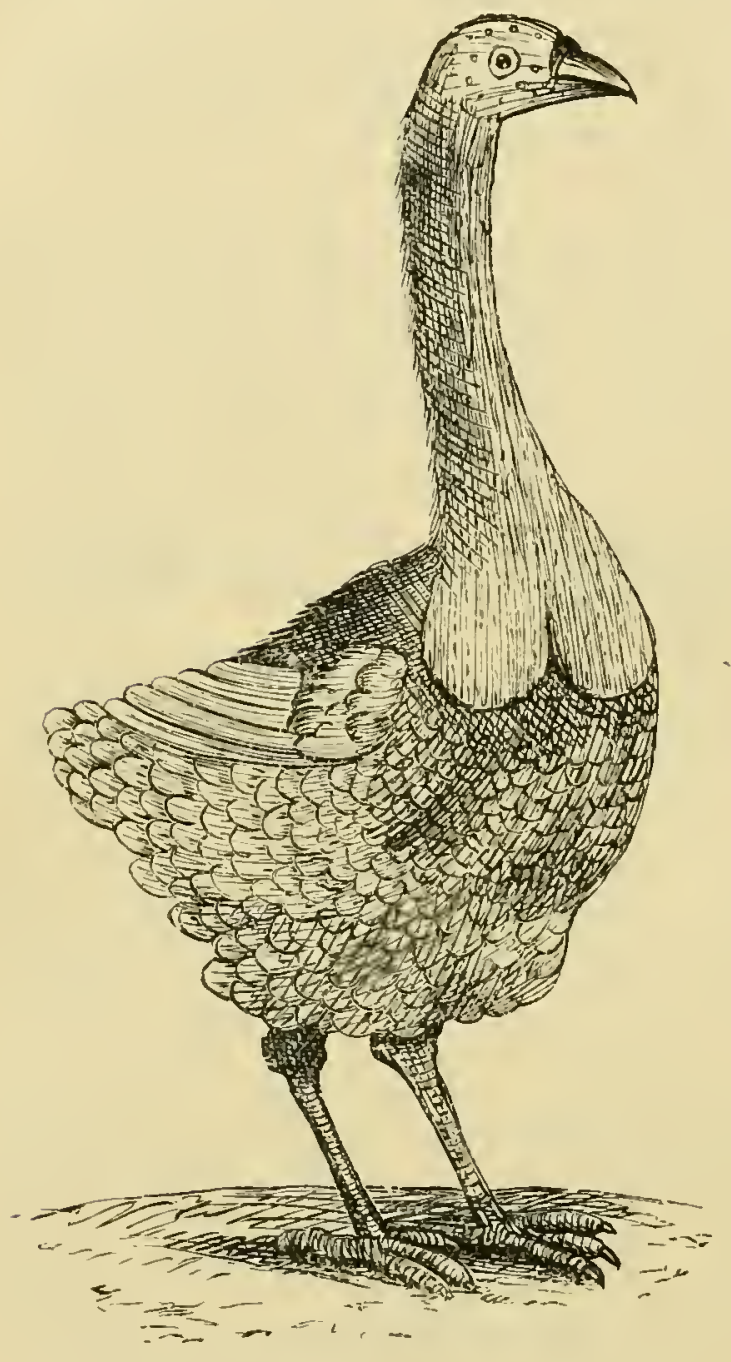

Sulitaire of Rodriguez. (After Leguat.)

For want of space the delightful accomt given by its discoverer cannot be here reproduced. ${ }^{2}$ Except a brief notice by D'Heguerty (Mém. Soc. Sc. Nancy, i. p. 79 ) in 1751 , which adds little to Leguat's account, and a manuscript report by Pingré, who observed the transit of Venus of 1761 in Rodriguez, to the effect that the bird was then supposed still to exist though withdrawn to the most inaccessible parts of the

yeeres' Travaile, p. 211) must have lieard of it in 1634 or earlier, but thought it was the Dono (p. 158), which certainly was not in "Dygarroys" (= Rodriguez), though it possibly gave the hint to Nevile.

"In the "Table" of the original edition the article is assigned to Buffon ; but Sonnini, in lis edition (iv. p. 343), says it was by Gnéneau de Montheillard.

2 Voyage et avantures de François Leguat, sie. 2 vols. Londres: 1708. An English translation, made, according to Fennell (Ficld-Nat. ii. p. 185, note), by one Thompson, appeared in London the same year ; and this has been edited for the Hakluyt Society (in 2 vols. 1891) with notes and many arlditional illustrations by Capt. Oliver. Copious extracts from both French and English versions are given by Strickland (The Dollo and its Kindred, pp. 46-50), and some passages liave often been reprinted elsewhere. A Dutch translation was published at Utrecht in 1708 , and a German at Frankfunt and Leipzig in 1709. A mutilated Frenel version appeared at Paris, without date, but after 1759, and was reissued there in 1883, with notes by M. Engène Mnnller. M. Théodore Sanzier has done a great service to the admirers of Leguat by discovering and reprinting a very rare tract to which he refers, Un projet de république (Paris : 1887), written by Du (Quesue and published anonymonsly at Amsterdam in 1689. 
island, 1 the only other documentary evidence forthcoming is in an anonymous manuscript Relation de l'Ile Rodrigue discovered, in 1874 by Mr. Rouillard of Mauritius, in the archives of the Ministry of Marine at Paris (Proc. Zool. Soc. 1875, pp. 39-42), and believed by Prof. Milne-Edwards (Comptes Rendus, 1xxx. pp. 1212-1216, and An. Sc. Nat. ser. 6, ii. art. 4) to have been written about 1729 . Even this does not say very much of the Solitaire, though a great deal concerning other birds of the island, and we are thrown back on Leguat's description, the accuracy of which, so long impugned, has been wonderfully confirmed by recent discoveries. So early as 1789 certain bones encrusted with stalagmite and obtained from a cave in Rodriguez by a resident named Labistour, came into the hands of Desjardins, who in 1830 sent five of them to Cuvier. He, believing them to be those of the Dodo, and to have been found in Mauritius under a bed of lava, laid them before the French Academy of Sciences (Rev. Bibliogr. Ann. Sc. Nat. 1830, p. 104 ; Edinb. Journ. Nat. Sc. iii. p. 31 ); but their true story was presently told to the Mauritian Society by Desjardins himself (Proc. Zool. Soc. 1832, p. 111). In 1831 Mr. Eudes, at the instance of Telfair, dug from the same cave a dozen bones (op. cit. 1833, p. 31), six of which were given to the Andersonian Museum of Glasgow, and five (now in the British Museum) to the Zoological Society, while a sixth was subsequently presented by Bojer to Strickland, together with one from the older "find" (Ann. Nat. Hist. ser. 2, iv. p. 326). ${ }^{2}$ Three other bones, more or less imperfect, probably obtained by Telfair, were in 1860 sent from the Museum at Port Louis by Bouton, who rightly determined them, to Owen, in whose possession they remained till 1877, when he handed them to Sir Edward Newton, to be returned to their proper place. ${ }^{3}$ Thus just 21 specimens of bones ascribed to this bird were known to exist when the gentleman last named visited Rodriguez, and entering a cave on the 2nd November 1864, with the intention of seeking for more, happily found two - one fragmentary the other perfect, while Capt. Barclay afterwards gave him a third which he had picked up (Proc. Zool. Soc. 1865, pp. 199-201; Ibis, 1865, p. 152). Encouraged by this discovery, Sip Edward persuaded Mr. Jenner, the resident magistrate in the island, to make further search, with the

1 This astronomer and his colleague Le Monnier dedicated a southern constellation to the Solitaire; but instead of tracing its outline, as they might well have done from Leguat's figure, they followed the ecclesiastical tradition and chose that given by Brisson (Orn. ii. fol. xxviii. fig. 1) of the Philippine RockThrush, Monticola solitariuis.

2 These two last are now in the Cambridge Museum.

3 Owen was wholly wrong in his belief (Trans. Zool. Soc. vii. 1). 519, note; Ann. Nat. Hist. ser. 4, ix. pl. 168, 211, 321) that he had returned these specimens before. 
result that 85 more specimens were obtained in the following year (Proc. Zool. Soc. 1865, pp. 715-718). Moreover, the British Association was induced by Mr. Sclater to supply Sir Edward with the means of more extended exploration, and this, carried on by $\mathrm{Mr}$. Jenner's orders, under the supervision of Sergeant Morris, produced nearly 2000 examples, which were in due time described and figured (Phil. Trans. 1869, pp. 327-362, pls. xv.-xxiv.) That the results obtained were important needs hardly to be said, but in nothing were they more striking than in the testimony they bore to the truth of Leguat's account of the bird, even in parts which had been thought too extraordinary for belief :- the rugosity at the base of the bill indicated a caruncular ridge that he likened to "a widow's peak" and represented in his figure: the curved outline of the pelvis is in accordance with the bird's "hind part" being "rounded like the crupper of a horse": the long neck and legs could not fail to produce "their fine mien" and the "stateliness and good grace" with which they walked: but, more unexpected than anything else was the "little round mass" of bone on the wing "as big as a musket ball"-largely developed in the males and forming a formidable weapon in the combats which took place among rivals. All this, together with the difference of the sexes in size $^{1}$ which, though not positively stated, may be inferred from his words, was just as he had said; and the variability of colour he had noticed in the females_- "some fail", some brown" - was paralleled by the marvellous variability displayed by almost every bone of the skeleton. Mr. Jenner was good enough to continue his services, and at least as many more specimens were obtained from the caves in 1871. On the occasion of the Transit of Venus Expedition to Rodriguez in $1874, \mathrm{Mr}$. H. H. Slater was commissioned by the Royal Society to renew the exploration, and brought back a collection as large as his predecessors had obtained, which together with the-second acquisition of Mr. Jenner was dealt with by Sir F. Newton and Mr. J.' W. Clark (Phil. Trans. clxviii. pp. 448-451), while in 1875 the late Mr. J. Caldwell visited the island (Proc. Zool. Soc. 1875, pp. 644-647) and excavated for himself not only at least two complete skeletons (since unhappily lost) but also found associated with thein 3 or 4 examples of the stone which Leguat had said the bird always bore in its gizzard (op. cit. 1878, p. 291) and thus crowned the work of establishing his veracity.

Notwithstanding Leguat's description and the fact that we know

1 This sexual inequality was first recognized by Sir E. Newton; but not until it had misled Mr. Bartlett (Proc. Zool. Soc. 1851, pp. 280-284, pl. xlv.), Strickland (Trans. Zool. Soc. iv. pp. 187-196, pl. 55) and myself. Even after my brother had shewn it, Sir R. Owen fell into the same error, which he subsequently but tacitly acknowledged (Ann. Nat. IIist. scr. 5, i. p. 94). 
almost every bone ${ }^{1}$ of the Solitaire's skeleton, it is not easy to picture its appearance in our imagination. Whatever be its source, the figure given by him, and here reproduced as the only one professing any originality, must be a caricature, ${ }^{2}$ for it wholly wants the beauty which he says was so characteristic of the bird. All that can be said with certainty seems to be that it had nothing of the clumsiness nor the prodigious beak of the Dodo, while the head was rather flat than elevated at the top. The largest males weighed from 40 to 50 lbs. and must have stood fully 2 feet 9 inches high; the females were shorter by at least six inches. The general colour of the former was brownish-grey, darker on the back; while the latter varied from blonde to brunette, with the swelling breast much whiter. The eyes were black, and according to the anonymous author of the Relation before cited the frontal band was like black velvet, and black indeed it appears in Leguat's figure, though he is commonly understood to say that it was of a tan colour, but his language seems open to the meaning that it was the bill which was of that tint. The flank feathers were thick and rounded at the end like shells, but generally the plumage must have been soft ("ni plumes ni poils") and it was kept extremely neat. So much for the appearance of the birds, of their habits it may be said that they were generally found singly or in pairs, but the young, of which only one seems to have been hatched yearly, accompanied its parents for some time. Tlie nest was a heap of palm-leaves, a foot and a half high, and therein a single egg was laid, both parents incubating it in turn. The male birds were very pugnacious, and the number of bones that had been broken and united during life contained in the collections bronght to this country is very considerable, shewing the effects of the cestus-like armature of the wing. The quarrels were no doubt between rival birds, and they indulged in curious gesticulations, whirling round 20 or 30 times in succession, during which time they made a loud noise with their wings. It wonld seem too that between the time of Leguat and that of the later observers the birds had learnt to resent injurious treatment by biting.

I The liyoids, the tip of the wing and the tail are, I think, the only exceptions.

${ }^{2}$ Leguat's figures are neither works of art nor of authority, and no doubt contributed to the ill repute under which he so long laboured. His marvellous "Geant" is obviously taken from an engraving by Francis Barlow (cf. Rowley, Orn. Niscell. ii. p. 132), which is itself but a poor copy of one by Adrian Collaert (Proc. Zool. Soc. 1875, p. 194). Schlegel's restoration of the Solitaire (Album der Natuur, 1854, Aflev. ii. p. 344) is vitiated by his mistaken belief in the Struthious affinity of the Dididx. Still it is the work of an artist and an ornithologist, which is more than can be said of one (produced, I believe, in France but by whom I know not) that lias of late years obtained a popular circulation, as often happens with inferior work, and must be at least as wide of the mark as Leguat's. 
These are meagre details, but they amount to more than we know of the Dodo, while perhaps no species has had its osteology examined on so great a scale as the Solitaire.

SONG plays a most important part in the economy of Birds, though the word in a treatise like this has to be used in a general sense, and not limited to the vocal sounds uttered by not more than a moiety of the feathered races which charm us by the strains they pour from their vibrating throat ( $c f$. SYRINX), - - strains indeed denied by the scientific musician to come under cognizance as appertaining to his art, but strains which in all conntries and in all ages have conveyed a feeling of true pleasure to the human hearer, and strains of which by common consent, in the Old World at least, the Nightingale is the consummate master. It is necessary in a scientific spirit to regard every sound made by a Bird under the all-powerful influence of love or lust as a "Song." It seems impossible to draw any but an arbitrary line between the deep booming of the EMeu, the harsh cry of the Gulluemot (which, proceeding from a thousand throats, strikes the distant ear in a confused murmur like the roar of a tumultuous crowd), the plaintive wail of the LAPwING, the melodious whistle of the WIGEON, "the Cock's shrill clarion," the Cuckow's "wandering voice," the scream of the EAGLE, the hoot of the OwL, the solemn chime of the BELLBIRD, the whip-cracking of the MANaKin, the CHAFFINCH's joyous burst, or the hoarse croak of the RAVEN, on the one hand, and the bleating of the SNIPE or the drumming of the Ruffed GROUSE, on the other. Innumerable are the forms which such utterances take. In many birds the sounds are due to a combination of vocal and instrumental powers, or, as in the cases last mentioned, to the latter only. But however produced-and of the machinery whereby they are accomplished this is not the place to speak-all have the same cause and the same effect. The former has been already indicated, and the latter is its consummation. Almost coinstantaneously with the hatching of the Nightingale's brood, the song of the sire is hushed, and the notes to which we have for weeks hearkened with rapt admiration are changed to a guttural croak, expressive of alarm and anxiety, inspiring a sentiment of the most opposite character. No greater contrast can be imagined, and no instance can be cited which more completely points out the purpose which Song fulfils in the economy of the bird, for if the Nightingale's nest at this early time be destroyed or its contents removed, the cock speedily recovers his voice, and his favourite haunts again resound to his bewitching strains. For them his mate is content again to undergo the wearisome round of nest-building and incubation. But should some days elapse before disaster befalls their callow care, his constitution undergoes a change and no second 
attempt to rear a family is madc. It would seem as though a mild temperature, and the abundance of food by which it is generally accompanied, prompt the physiological alteration that inspires the males of most birds to indulge in the Song peculiar to them. Thus after the accomplishment of the annual MouLT, the most critical epoch in the life of any bird, cock THRUSHES, SKYLarks and others begin to sing, not indeed with the jubilant voice of spring, but in an uncertain cadence which is quickly silenced by the supervention of cold weather. ${ }^{1}$ Yet some birds we have which, except during the season of moult, hard frost and time of snow, sing almost all the year round. Of these the Redpreast and the Wren are familiar examples, and the CHIFF-CHAFF repeats its twonoted cry, almost to weariness, during the whole period of its residence in this country. ${ }^{2}$

Akin to the "Song" of Birds, and undoubtedly proceeding from the same cause, are the peculiar gestures which the males of many perform under the influence of the approaching season of pairing, but these again are far too numerous here to describe with particularity. It must suffice to mention a few cases. The RufF on his hillock in a marsh holds a war-dance. The Snipe and some of his allies mount aloft and wildly execute mlooked-for evolutions almost in the clouds. The Woodcock and many of the NightJArs beat evening after evening the same aerial path with its sudden and sharp turnings. The Ring-Dove rises above the neighbouring trees and then with motionless wings slides down to the leafy retreat they afford. The CAPERCALLY and BLACKCOCK, perched on a commanding eminence, throw themselves into postures that defy the skill of the caricaturist 3 -other species of the Grouse-tribe assume the strangest attitudes and run in circles till the turf is worn bare. The PEACOCK in pride spreads his train so as to shew how nearly akin are the majestic and the ridiculous. The BowerBIRD, not content with his own splendour, builds an arcade, decked with bright feathers and shining shells, or arranges a trim garden with moss and newly-plucked flowers, through and around which he paces with his gay companions. The LARKs and PIPITS never deliver their song so well as when seeking the upper air. Rooks rise one after the other to a great height and, turning on their

1 Jenyns (Obser. Nat. Hist. pp. 86-102) has some good notes on the singing of Birds, and particularly as to the time of its beginning in the morning.

2 A curious question, which has as yct attracted but little attention, is whether the notes of the same species of Bird are in all countries alike. From my own observation I am inclined to think that they are not, and that there exist "dialects," so to speak, of the song. (Cf. Gloger, Jour. für Om. 1859, p. 39s; Allen, Bull. Mus. Comp. Zoöl. Harvard, ii. pp. 166, 167.)

3 The singular fact that during the paroxysms that attend this performance of the Capercally the bird becomes deaî has long been known to foresters, but it has been only of late explained ( $f$. F.A F, p. 178). 
back, wantonly precipitate themselves many yards towards the ground, while the solemn Raven, does not scoln a similar feat, and, with the tenderest of croaks, glides supinely alongside or in front of his mate. ${ }^{1}$

Yet there are cases in which these gestures are not confined to the males, but are shared by both sexes. Any one who has watched a pair of Wild Ducks of any species in spring can hardly fail to have been entertained by their proceedings, in which the most affectionate caresses are mingled with acts to all appearance of violence, and these last are, as often as not, begun by the female. The same may be said of GREBEs, which like Ducks will swim in circles with the head, now raised aloft, now laid flat on the water. Many of the movements are simultaneously performed by both partners, others by each alternately, and solemn bows are exchanged with ludicrous regularity. Suddenly a playful attack is made by one bird on the other, and then all the spectator sees is a splash or series of splashes in the water, while his ears are struck by the loud and harsh cries of the actors in this display. ${ }^{2}$ But there are other birds in which gesticulations are carried much further, and it would seem that JACANAS and some of the RAILS join in festive dances that can be only likened to balls, the performers becoming excited almost to frenzy, and with loud cries and outstretched wings rushing from side to side for several minutes. Still more strange are said to be some of the actions of the Cayenne LAPwing, where one bird of a pair leaving his own mate will pay a visit to a neighbouring pair, by whom he is received with ceremonious courtesy: the three form a procession, the stranger walking in front and his hosts following - all keeping step and uttering resonant drumming notes. Presently the march stops, the stranger elevates his wings, and stands motionless, while the other two, exactly abreast, halt behind him, drop their voice to a murmur, touch the ground with the bill, as thongh making obeisance, and in this posture remain for some time. Then the ceremony is over, and the visitor retires to his own ground and mate, to receive another visitor in exactly the same way. ${ }^{3}$

1 No comprehensive account of the Song of Birds seems ever to have been written. The following may be cited among the principal treatises on the subject:Barrington, Phil. Trans. 1773, pp. 249-291; Kennedy, N. Abhandl. baier. Akad. (Phil. Abrandl.) 1797, p. 169; Blackwall, Mem. Lit. and Phil. Soc. Manch. 1824, pp. 289-323 ; Savart, (Froriep's) Notizen u. s. w. 1826, pp. 1-10, 20-25 : Brehm and Hansmann, Naumannia, 1855, pp. 54-59, 96-101, 181-195, and Journ. für Orn. 1855, pp. 348-351, 1856, pp. 250-255. The notes of many of our common birds are musically expressed by Mr. Harting, Birds of Middlesex (London: 1866); and Prof. Paolucci, $I l$ Canto degli Uccelli (Milano: 187S).

${ }^{2}$ Cf. Stevenson and Southwell, B. Norf. iii. p. 239.

3 Cf. Mr. Hudson's interesting Naturalist in La Plata (chap. six.) whence are 
SORA or SOREE, the name given in North America to a RAIl, Porzana carolina.

SORE-FALCON or HAWK (Fr. sor or saure; Low Latin saurius), a bird of the first year that has not moulted, but properly applicable only to those species which in that condition have reddish plumage, and hence more often called "Red Hawks." The ordinary spelling "Soar" (as though from the French essorer and supposed Low Latin exaurare) is misleading, for the word has nothing to do with flight but only colour, and is apparently alin to "sorrel" applied to a horse. (Cf. Littré, sub vocc. citt.)

SOUTH-SOUTHERLY, one of the many names of the Longtailed Duck.

SPARLIN-FOWL, a name of the female or immature GoosANDER, as old as Willughby's time but apparently now obsolete. Spartin or Sparling is a local name of the Fish more commonly called Smelt, Osmerus eperlanus.

SPARROW (A.-S. Spearua; Icel. Spörr; Old High Germ. Sparo and Sparwe), a word perhaps (like the equivalent Latin. Passer) originally meaning almost any small bird, but gradually restricted in signification and nowadays in common English applied to only four kinds, which are further differentiated as Hedge-Sparrow, HouseSparrow, Tree-Sparrow and Reed-Sparrow-the last being a Bunting (p. 61)-though when nsed without a prefix the second of these is usually intended.

1. The HedGe-Sparrow, called DunNock in many parts of Britain, the Accentor modularis of ornithologists, is the little brownbacked bird with an iron-grey head and neck that is to be seen in nearly every garden throughout the country, unobtrusively and yet tamely seeking its food, which consists almost wholly of insects, as it progresses over the ground in short jumps, each movement being accompanied by a slight jerk or shuffle of the wings, and hence another local name, SHufflewing. Though on the Continent it regularly migrates, it is one of the. few soft-billed birds that reside thronghout the year with 11 , and is one of the earliest breeders, - its well-known greenish-blue eggs, laid in a warmlybuilt nest, being recognized by hundreds as among the surest signs of returning spring; but a second or even a third brood is produced later. The cock has a sweet but rather feeble song; and the species has long been accounted, though not with accuracy, to be the most common dupe of the Cuckow. Several other species are assigned to the genus Accentor; but all, except the Japanese $A$. rubidus, which is the counterpart of the British Hedge-Sparrow, inhabit more or less taken the particulars of the last three birds above mentioned, Parra jacana, Aramides ypecaka and Vanellus cayenncnsis, all of them being therein figured. 
rocky situations, and one, $A$. collaris or alpinus, is a denizen of the higher mountain-ranges of Europe, though it has several times strayed to England. The taxonomic position of the genus is regarded by some systematists as uncertain; but there seems no good reason for removing it from the group which contains the Thrushes and Warblers (Turdidie and Sylviidx), to which it was long referred without doubt.

2. The House-Sparrow, the Fringilla domestica of Linnæus and Passer domesticus of modern authors, is far too well known to need

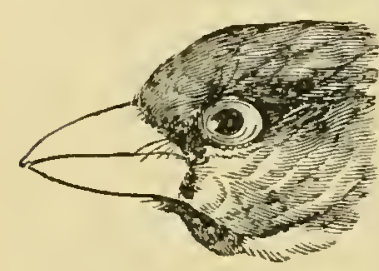

IFoUSE-SPARROF: (After Swainson.) any description of its appearance or habits, being found, whether in country or town, more attached to human dwellings than any other wild bird; nay, more than that, one may safely assert that it is not known to thrive anywhere far away from the habitations or works of men, extending its range in such countries as Northern Scandinavia and many parts of the Russian empire as new settlements are formed and land brought under cultivation. Thus questions arise as to whether it should not be considered a parasite throughout the greater portion of the area it now occupies, and as to what may have been its native country. Moreover, of late years it has been inconsiderately introdnced to several of the large towns of North America ${ }^{1}$ and to many of the British colonies, in nearly all of which, as had been foreseen by ornithologists, it has multiplied to excess and has become an intolerable nuisance, being unrestrained by the natural checks which partly restrict its increase in Europe and Asia. Whether indeed in the older seats of civilization the House-Sparrow is not decidecily injurious to the agriculturist and horticulturist has long been a matter of discussion, and no definite result that a fair judge can accept has yet been reached. It is freely admitted that the damage done to growing crops is often enormous, but as yet the service frequently rendered by the destruction of insect-pests cannot be calculated. Both fiends and foes of the House-Sparrow write as violent partisans, ${ }^{2}$ and the

1 'The onnithologists of the United states had timely warning from their English brethren to beware of this species, bnt some of them persisted in allowing or even advocating its introdnetion-the main object of which was alleged to be the destruction of "measuring worns" - the common name applied to the larve of eertain of the Gcometridx, and the bird's arrival was hailed in an ode by so distingnished a poet as Bryant. Having found their new eolonist a failure, it seems too had of them to distinguish it emphatieally as the "English" Sparrow, for we, in this country, know what feeling thist e ejithet expresses among the lesseducated class of citizens of the great Republic; and, as hinted in the text, the House-Sparrow is in all likelilood not indirenous to England. On its introduetion to America Messrs. Baird, Brewer and Ridgway gave it its correct designation.

- Some of the more recent attacks upon it are contained in several issues of 
truth will not be known until a series of experiments, conducted by scientifically-trained investigators, has been instituted, which, to the shame of our numerous agricultural and horticultural societies, has not yet been done. It is quite likely that the result will be infavourable to the House-Sparrow, from what has been said above as to its being so dependent on man for its subsistence; but, while the evil it does is so apparent, - for instance, the damage to ripening grain-crops, - the extent of the counterbalancing benefit is quite uncertain, and from the nature of the case is often overlooked. In the South of Europe the House-Sparrow is in some measure replaced by two allied species, $P$. hispaniolensis and $P$. italix, whose habits are essentially identical with its own; and it is doubtful whether the Sparrow of India, $P$. indicus, is specifically distinct; but Africa has several members of the genus which are decidedly so.

3. The Tree-Sparrow, the Fringilla montana of Linnæus, and Passer montanus of modern writers, in appearance much resembling the House-Sparrow, but easily distinguishable by its reddish-brown crown, the black patch on the sides of its neck and its doublybarred wings, ${ }^{1}$ is a much more local species, in England generally frequenting the rows of pollard-willows that line so many rivers and canals, in the holes of which it breeds; but in some Eastern countries, and especially in China, it frequents houses, even in towns, and so fills the place of the House-Sparrow. Its geographical distribution is extensive, and marked by some curious characters, among which may be mentioned that, being a great wanderer, it has effected settlements even in such remote islands as the Færoes and some of the Outer Hebrides.

That the genus Passer properly belongs to the Fringillide is admitted by most ornithologists, yet there have been some who would refer it to the Ploceida (WEAVER-BIRD), if they are to be accounted as forming a distinct Family. The American birds called "Sparrows" have little in common with the members of the genus Passer, and probably belong rather to the Family Emberizida than to the Fringillida ( $c f$. TowHEE).

SPARROW-HAWK, Sw. Sparrhök, Dutch Sperwer, Germ. Sperber, O. H. G. Sparvari, O. Fr. Esprevier, Mod. Fr. Épervier (all the Report of Observations of Injurious Insects and Common Crop Pests, annually made by Miss Ormerod, and in a little volume, with the title of The HouseSparrow, published in 1885, which consists chiefly of three essays by Mr. J. H. Gurney, jun., the late Lieut.-Col. C. Russell, and Prof. Coues, but the last has only reference to the behaviour of the bird in the United States of America, where, from the reason above assigned, its presence was expected by almost all well-informed persons to be detrimental.

1 A more important difference is that the two sexes have almost the same plumage, while in the House-Sparrow they are unlike in this respect. 
akin to the Gothic Sparva, Sparrow), perhaps the commonest Birdof-Prey now left in the British Islands, and the only one that in these days can be said to be practically detrimental to the gamepreserver. It is the Accipiter nisus of most modern authors, standing as the type of the genus of that name (HAwk, p. 412). Too well known to need description here, there must be few observers of nature who have not at one time or another witnessed the consternation that prevails among small birds on the unexpected and rapid dash among them of a Sparrow-Hawk which, still and motionless in some convenient tree or bush, has been biding its opportunity, while the victim, which the aggressor rarely misses, is

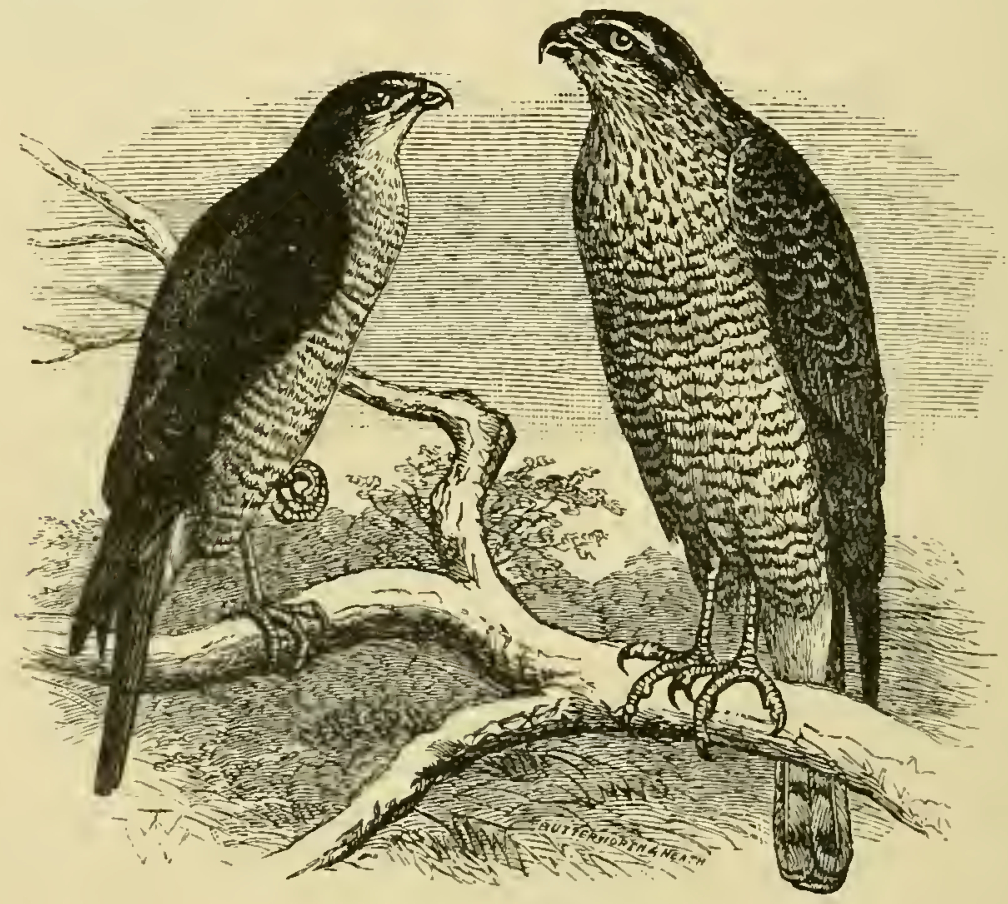

SPARRow.HAwk. MTale and female.

as speedily snatehed array to be eaten in covert seclusion, for the Sparrow-Hawk shews itself in the open as little as possible. The species is widely distributed throughont the palrearctic area from Ireland to Japan, extending also to northern India and Esypt, while a second species $A$. breripes (by some placed in the group Micronisus and by others called an Astur), only appears in the south-east of Europe and the adjoining parts of Asia Minor and Persia. In North America the place of the former is taken by two very distinet speeies, a small one, A. fuscus, known in Canada and the United States as the Sharp-shinned Hawk, and A. cooperi (by some placed in another genus, Cooperastur), which is larger and has not so northerly a range. In South America there are four or five more, including A. tinus, before mentioned (p. 412) as the smallest of all, while a species not much larger, $A$. minullus, together 
with several others of greater size, inhabits South Africa. Madagascar and its neighbouring islands have three or four species sufficiently distinct, and India has $A$. badius. A good many more forms are found in South-eastern Asia, in the Indo-Malay Archipelago, and in Australia three or four species, of which $A$. cirrhocephalus most nearly represents the Sparrow-Hawk of Europe and Northern Asia, while $A$. radiatus and $A$. approximans shew some affinity to the Gos-HAwK (p. 377) with which they are often classed. The differences between all the forms above named and the much larger number here unnamed are such as can be only appreciated by the specialist, and could not possibly be pointed out within the limits of this work. It may be observed in conclusion that the so-called "Sparrow-Hawk" of New Zealand (QUAIL-Hawk, p. 757) does not belong to this group of Falconidx, and that of America is an undoubted KESTREL (p. 477).

SPARROW-OWL, a name applied by some writers to Carine noctua, though more suited to Glaucidium passerinum, and in North America to Nyctala richardsoni.

SPECULUM (Germ. Spiegel, Fr. miroir), a long-established name for any patch of feathers on the wing of a bird differing remarkably in colour from those that are near them, and especially applied to the lustrous patch, called the "beauty spot" by some writer's and even now by gumners, formed by the cubital remiges in the freshwater-Ducks (Anatinx).

SPEICHT (Hollyband, Dict. Fr. and Engl. sub. voc. "Pie"), SPEIGHT or corruptly SPITE, generally with the prefix " Wood" (Germ. Specht, Fr. Épciche) names of a WooDPECKER, generally Gecinus viridis, but sometimes Dryocopus major.

SPEKVRETER (Fat-eater), a bird so called in South Africa as it is supposed to pick the grease from the waggon-wheels (Layard, B. S. Afr. p. 108), a species of Saxicola (WHEATEAR), for. a long while thought to be the Sylvia sperata of Latham, which is founded on the "Traquet du cap de Bonne-espérance" of Buffon (H. N. Ois. v. p. 233), but his description so ill accords with the former that Messrs. Blanford and Dresser (Proc. Zool. Soc. 1874, p. 237) referred it to the Enythropygia galtoni of Strickland (Contr. Orn. 1852 , p. 147), shewing that it cannot be the Ruticilla familiaris of Stephens, as some authors had alleged, and it now stands as S. galtoni.

SPENCY, a local name for the Storm-PeTreL (cf. p. 709).

SPERVEL (from the Dutch) the name in South Africa for a Falcon, probably Falco minor (Layard, B. S. Afr. p. 19).

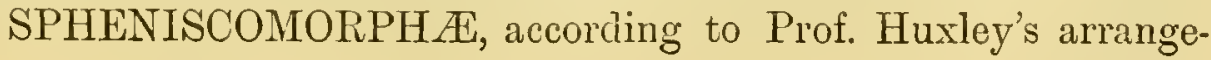


ment (Proc. Zool. Soc. 1867, pp. 456, 458) the fourth great group of Schizognathe, consisting of the birds now known as Penguins.

SPIDER-CATCHER or -HUNTER, a book-name given to the larger forms of SUN-BIRD.

SPIKE-TAIL, a local name in North America for the PINTAIL.

SPINAL CORD, see Nervous Systerr (p. 622).

SPINE-BILL, the name given in Australia to birds of the genus Acanthorhynchus, one of the Meliphagida (Honey-EATER), and in New Zealand to the very peculiar Acanthidositta.

SPINE-TAIL, as a prefix to DucK or SwIFT signifies respectively birds of the genus Erismatura, of wide distribution, and Acanthyllis, but used alone by Mr. Hudson (Argent. Orn. i. pp. 174-188) for several species of Synallaxis (Picucule, p. 719).

SPINK, a very common local name of the CHAFFINCH (p. 82).

SPIRIT-DUCK, a name widely given by gunners to species of Clangula (GoLden-Eye, p. 368), but in Canada especially to $C$. albeola, from their instantly diving at the flash of a gun or the twang of a bow ( $c f$. Richardson, Faun. Bor.-Am. ii. p. 437).

SPLEEN, a small pulpy mass of oval or worm-like shape, and generally of a bluish-led colour, which in most Birds rests upon and is loosely attached to the right side of the proventricular or glandular STOMACH; but the form, size, position and colour of this organ, which apparently plays an important part in the economy of the blood-corpuscles, vary much in different birds.

SPOONBILL. The bird now so called was formerly known in England as the PoPELER, Shovelard or Shovelar, while that which used to bear the name of Spoonbill is the SHOVELER (p. 840) of modern days-the exchange of names having been effected about 200 years ago, when the subject of the present notice, the Platalea leucorodia of ornithology, waś doubtless better known than now, since it evidently was, from ancient documents, the constant concomitant of Herons, and with them the law tried to protect it. ${ }^{1}$ The Calendar of Patent Rolls of Edw. I. shews (p. 546) the issue in 1300 of a commission to enquire who carried off the eyries of these birds ("poplorum") at several places in Norfolk, and Mr. Harting

${ }^{1}$ Nothing shews better' the futility of the ancient statutes for the protection of birds than the fact that in 1534 the taking of the eggs of Herons, Spoonbills (Shovelars), Cranes, Bitterns, and Bustards was visited by a heavy penalty, while there was none for destroying the parents in the breeding-season. All the birds just named, except the Heron, have passed away, while there is reason to think that some at least might have survived had the spirit of the Levitical law (Deut. xxii. 6) been followed. In 1894 an Act of Parliament was passed, reviving (at the will of a County Council, subject to the approval of a Secretary of State) the principle of the old law which had proved so insufficient. 
(Zool. 1886, pp. S1 et seqq.) cites a case from the "Year-Book" of 14 Hen. VIII. (1523), wherein the Bishop of London (Cuthbert Tunstall) maintained an action of trespass against a tenant at Fulham for taking Herons and "Shovelars" that made their nests on the trees there, and has also printed (Zool. 1877, p. 425) a document shewing that "Shovelers" bred in certain woods in west Sussex in 1570. In George Owen's Description of Penbrokshire, written in 1602 (ed. 1892, p. 131), the "Shovler" was stated to breed "on highe trees" in that county, and nearly sixty years later (circa 1662) Sir Thomas Browne, in his Account of Birds found in Norfolk (Works, ed. Wilkin, iv. pp. 315, 316), stated of the "Platea or Shouelard" that it formerly "built in the Hernerie at Claxton and Reedham, now at Trimley in Suffolk." This last seems to be the latest known proof of the breeding of the species in England; but that it was in the fullest sense of the word a "native" of England and Wales is thus incontestably shewn; though for many years past it has only been a more or less regular visitant, not seldom in considerable numbers, which would doubtless, if allowed, once more make their home here; but its conspicuous appearance renders it an easy mark for the gunner and the collector. What may have been the case on the continent formerly is not known, except that, according to Belon, it nested in his time (1555) in the borders of Britanny and Poitou; but as regards north-western Europe it seems of late years to have bred only in Holland, and there it has been deprived by drainage of its favourite resolts, one after the other, so that it must shortly become merely a stranger, except in Spain or the basin of the Danube and other parts of sonth-eastern Europe.

The Spoonbill ranges over the greater part of middle and southern Asia, and breeds abundantly in India, as well as on some of the islands in the Red Sea, and seems to be resident throughout Northern Africa. In Southern Africa its place is taken by an allied species with red legs, $P$. cristata or tenuirostris, which also goes to Madagascar. Japan, Corea and Eastern China possess also a smaller species, $P$. minor; while a distinct one, $P$. intermedia, is said to be found in New Guinea. Australia has two other species, $P$. regia or melanorhynchus, with black bill and feet, and $P$. flavipes, in which those parts are yellow. The very beautiful and wholly different $P$. ajaja is the Roseate Spoonbill of America, and is the only one found on that continent, the tropical or juxta-tropical parts of which it inhabits. The rich pink, deepening in some parts into crimson, of nearly all its plumage, together with the yellowishgreen of its bare head and its lake-coloured legs, sufficiently marks this bird; but all the other species are almost wholly clothed in pure white, though the English has, when adult, a fine buff pectoral band, and the spoon-shaped expanse of its bill is yellow, contrasting with the black of the compressed and basal portion. Its legs are 
also black. In the breeding-season a pendent tuft of white plumes further ornaments the head of both sexes, but is longest in the male. The young of the year have the primary quills dark-coloured.

The Spoonbills form a natural group, Plataleida, allied, as before stated (p. 456), to the Ibididx, and somewhat more distantly to the STorks. They breed in societies, not only of their own kind, but in company with Herons, either on trees or in reed-beds, making large nests in which are commonly laid four eggs, - white, speckled, streaked or blotched, but never very closely, with light red. Such breeding-stations have been several times described, and among the more recent accounts of one of them are those of Messrs. Sclater and W. A. Forbes (Tbis, 1877, p. 412), and Mr. Seebohm (Zool. 1880 , p. 457), while a view of another has been attempted by Schlegel ( $\mathrm{Vog}$. Nederland, taf. xvii.). The latest systematic revision of the group is by Mr. Grant (Ibis, 1889, pp. 32-58, pl. i.).

SPOWE, Icel. Spói, an old name, though apparently yet extant, for the WHIMBREL; but SPOIVSE is an ancient corruption of Sparlowes, i.e. Sparrows.

SPRAT-LOON, a gunner's name for a Diver in immature or winter-plumage-the Red-throated Diver, Colymbus septentrionalis, as the commonest species, being that which is generally meant.

SPRIG-TAIL, a name for the Pintail (p. 726), and perhaps also for the Long-tailed Duck (HARELD, p. 406), though that is a species much less common than the other.

SPRITE, see SPEICHT (p. 899).

SPUR-FOWL, the Anglo-Indian name for birds of the genus Galloperdix, allied to Gallus (FowL, p. 289), but remarkable for the two, or sometimes even three, pairs of spurs that the cock bears on his legs, while the hens are similarly armed. Three species are known, of which the first described is peculiar to Ceylon, and is the Perdix bicalcarata of J. R. Forster in 1781 (Ind. Zool. p. 25, pl. xiv.), the other two inhabiting the mainland of India ; but their respective range seems not to have been yet defined with precision (Hume, Nests and Eggs Ind. B. ed. 2, iii. pp. 423-425). One of them, $G$. spadicea, was originally described as from Madagascar; but, as Dr. Hartlaub shewed in 1861 (Orn. Beitr. Madag. p. 69), evidently by mistake.

SQUACCO, the mis-spelling of Latham (Gen. Synops. iii. p. 74, in place of Sguacco, the Italian name of a HEron (p. 419, note), Ardea ralloides or comatu, which was correctly given by Willughby and Ray (thongh they had not seen the bird) from Aldrovandus. The error has, however, established itself firmly.

S'TANIEL, S'TANNEL and STONEGALL (Germ. Steingall), 
variations of a local name of the Kestres, commonly, but according to Prof. Skeat (Trans. Philolog. Soc. 188S-90, pp. 20-2.2) erroneously, referred by guessing etymologists to "Stand-gale" (cf. WINDHOrer) -its real meaning being the bird that yells or cries from a stone or rock.

STARLING (A.-S. Star; Stearn and Sterlyng; Lat. Sturnus; Fr. Etourneau), a bird long time well known in most parts of Fngland, and now, through the extension of its range within the present century, in the rest of Great Britain, as well as in Ireland, where, though not generally distri. buted, it is very numerous in some districts. It is about the size of a Thrush, and, though at a distance it appears to be black, when near at hand its plumage is seen to be briglitly shot with purple, green and

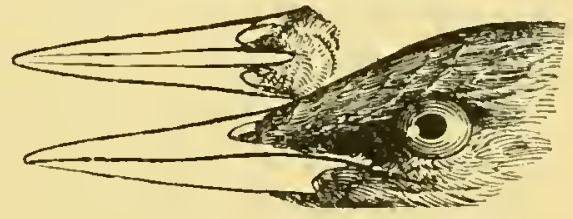

STURnis. (After Swainson.) steel-blue, most of the feathers when freshly grown being tipped with buff. These markings wear off in the course of the winter, and in the breeding-season the bird is almost spotless. It is the Sturnus vulgaris of ornithologists.

To describe the habits of the Starling ${ }^{\mathbf{1}}$ within the limits here allotted is impossible. A more engaging bird scarcely exists, for its familiarity during some months of the year gives opportunities for observing its ways that few others afford, while its varied song, its sprightly gestures, its glossy plumage, and, above all, its character as an insecticide-which last makes it the friend of the agriculturist and the grazier-render it an almost universal favourite. The worst that can be said of it is that it occasionally pilfers fruit, and, as it flocks to roost in autumn and winter among reed-beds, does considerable damage by breaking down the stems. ${ }^{2}$ The congregations of Starlings are indeed very marvellous, and no less than the aerial evolutions of the flocks, chiefly before settling for the night, have attracted attention from early times, being mentioned by Pliny (Hist. Nat. x. 24). The extraordinary precision with which the crowd, often numbering several hundreds, not to say thousands, of birds, wheels, closes, opens ont, rises and descends, as if the whole body were a single living thing-all these movements being executed without a note or cry being nttered-must be seen to be appreciated, and may be seen repeatedly with pleasure. For a

1 They are dwelt on at some length in Yarrell's British Birds, ed. 4, vol. ii. pp. 229-241.

2 A most ridiculous and unfounded charge has beèn, however, more than once bronght against it-that of destroying the eggs of Skylarks. There is little real evidence of its sncking eggs, and much of its not doing so; while, to render the allegation still more absurd, it has been brought by a class of farmers who generally complain that Skylarks themselves are highly injurions. 
resident, the Starling is rather a late breeder. The nest is eommonly placed in the hole of a tree or of a building, and its preparation is the work of some little time. The eggs, from 4 to 7 in number, are of a very pale blue, often tinged with green. As the young grow they beeome very noisy, and their parents, in their assiduous attendanee, hardly less so, thus oecasionally making themselves disagreeable in a quiet neighbourhood. The Starling las a wide range over Europe and Asia, reaching India ; but examples from Kashmir, Persia and Armenia have been considered wortly of speeific distinction, and some of them are suspected to occur oecasionally in England ( $f$. Sharpe, Cat. B. Br. Mus. xiii. pp. 26-38, and Journ. fiir Orn. 1891, pp. 307, 308), while the resident Starling of the countries bordering the Mediterranean is generally regarded as a good species, and called S. unicolor from its unspotted plumage.

Of the many forms allied to the genus sturnus, some of which have perhaps been needlessly separated therefrom, those known as Grackles (p. 378) and the beautiful PAstor (p. 698), which last,

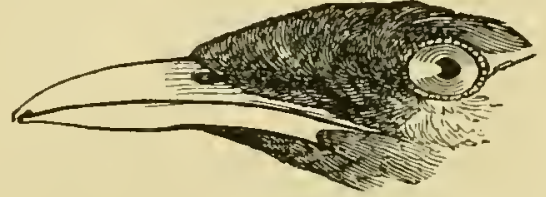

LAMPROCOLIUS.

(After Swainson.)

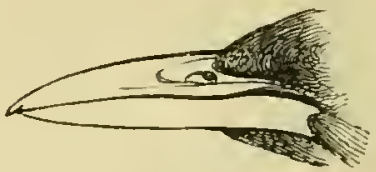

LAMPROTORNIS.

as suggested by Cuvier, seems to have been the Seleucis of the aneients, have been already mentioned; but the so-ealled Glossy Starlings of Afriea, Lamprocolius and Lamprotornis, yet need that their names should appear here.

\section{STARN or STERN, see TERN.}

STEGANOPODES, Illiger's name in 1811 for a group consisting of the genera Pelecanus (Pelican), Haleus (= Phalacrocorar, Cormorant), Dysporus ( = Sula, Gannet) Phaethon (TropiC-Bird), and Plotus (SNAKE-BIRD); by many writers reasonably regarded as a natural group or Order, though the applieation of the word can

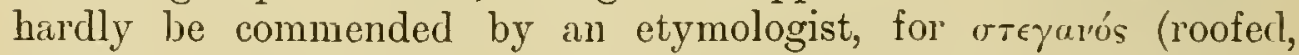
covered or, in some cases, firm) can only be forcerl to signify the connexion of all the toes by a single web. The Frigatk-BIRDs were ineluded by Illiger in the genus Haleus.

STEREORNITHES, ${ }^{1}$ the name conferred in 1891 by Señores Moreno and Mercerat (Anules del MIuseo de La Plata, Paleontología Argentinu, i. pp. 20,37) on a proposed new Order of Birds, from

1 For this artiele I am once more obliged to Mr. Lydekker, who enjoys the enviable privilege of having twice visited Sonth America to examine the marvellous fossil remains some of which are here briefly treated. $-\mathrm{A}$. $\mathrm{N}$. 
remains, mostly of gigantic size, found in the Tertiary strata of Santa Cruz in Patagonia. They were considered to combine the characters of Anseres, Herodiones and Accipitres, to shew a transition from the Anatidx to the Vulturidx, and to be separable into nine genera, which were grouped in four Families. In a critical review of this memoir, published in the same year, Dr. Florentino Ameghino (Revist. Argent. Hist. Nat. i. pp. 441-453) came to the conclusion that the whole series of remains might be referred to two genera, Phororhacos ${ }^{2}$ and Brontornis, both included in the family Phororhacidx, which he placed among the Ratitx, a third genus, named Opisthodactylus from a peculiarity in the position of the facet for the hallux, being at the same time proposed. These views were provisionally accepted by the present writer (Ibis, 1893, pp. 40-47); but an examination of the specimens in the Museum of La Plata induced him (Nat. S'c. 1894, p. 125) to consider the retention of the Order Stereornithes desirable, and also to declare that the Santa Cruz beds were in all probability not older than the Upper Oligocene; while here it may be mentioned that the group of Birds is also represented in the somewhat newer deposits of Monte Hermoso near Bahia Blanca. The most important information regarding these Birds is that given in 1895 by Dr. Ameghino (Bolet. del Inst. Geograf. Argent. xv. 11, 12), where a considerable number of their remains, obtained by his brother in Patagonia, are figured; the validity of the group Stereornithes is admitted, and nine genera ${ }^{2}$ are referred to it, Phororhacos with six species, Pelecyornis with three, Brontornis with one or two, and the others with one each; all but Opisthodactylus, which is regarded as forming a distinct Family, being grouped as Phororhacidx.

The most conspicuous peculiarity of the Stereornithes is the enormous size and ponderous structure of the skull, which is quite unlike that of any recent Bird, and seems out of all proportion to the limbs, gigantic as are some of the leg-bones. The upper jaw is remarkable for its extreme lateral compression, and yet is of great depth, its extremity terminating in a hook, while that of the mandible turus upward. ${ }^{*}$ There is no ossified interorbital septum, and the orbits apparently communicate with the preorbital vacuity, while the nostrils, which are situated high up, are pervious. The

I This, with the spelling Phorysrhacos, had been originally described in 1887 by Dr. Ameghino (Bolet. MIus. de la Plata, i. p. 24) from its mandible as an Edentate Mammal ; but its ornithic nature was declared by him four years later. (Rcvist. Argent. Hist. Nat. i. p. 255). As to the etymology of the name, conjecture only can be entertained. That which is next to it in point of time is Mesembriornis, Moreno (Progresos del MIus. la Plata, p. 29. Buenos Aires : 1889.)

2 These are by no means the same as the nine before proposed by Señores Moreno and Mercerat, all but two of which are submerged, while others are proposed.

3 Señores Moreno and Mercerat figured the mandibles as upper jaws (op. cit. pls. v. fig. 3, vi. fig. 2, viii. fig. 4, ix. fig. 2 , pp. 20,21 ). 
quadrate articulates with the squamosal by two distinct heads, a

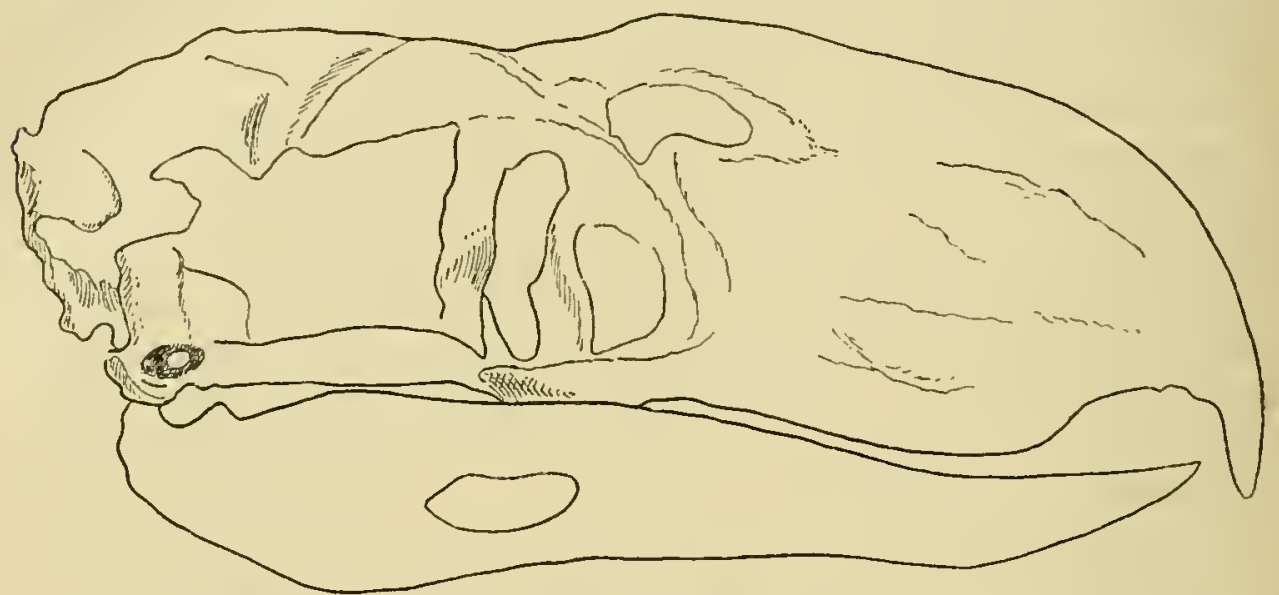

Phororkacos_inflatus. Head from the side. (After F. Ameghino.)

condition of which remnants may be traced in Rhea and Dromæxus, though not in other Ratitx, and the mandible has its hinder end

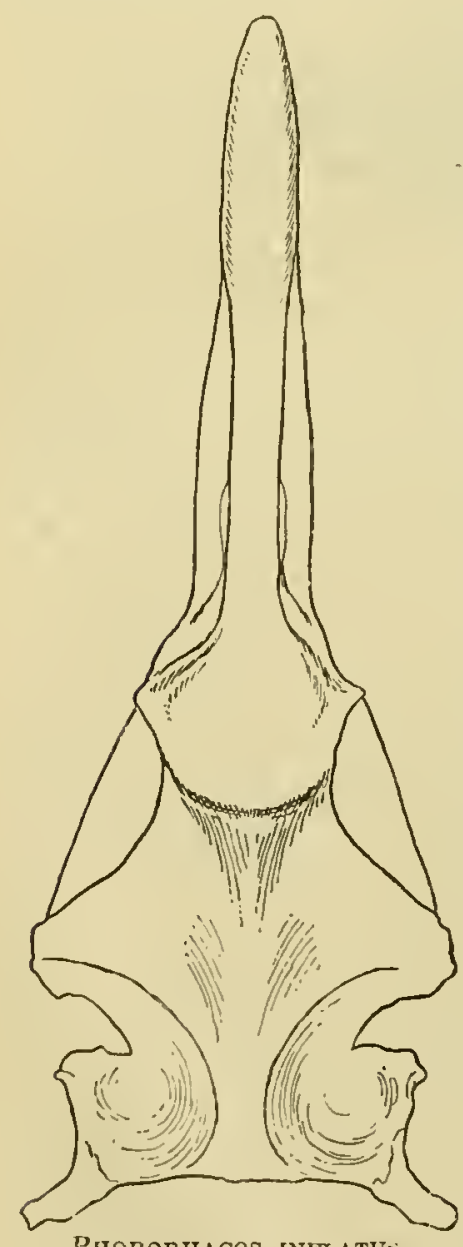

PHoRorilacos INFLATUS. Head from above. (Atter F. Aneghino.) truncated as in Phea. Unfortunately the sternum is still unknown, but the coracoid is narrow and elongated, the furcula very slender and almost rudimentary, yet the wings, though relatively small, are completely developed. The pelvis is very remarkable, being narrow and elongated, and has the ischia produced beyond the ilia, with which they are fused. Its preacetabular portion is short and the postacetabular very narrow. The tail is long with a relatively eonsiderable number of separate vertebræ. There is no pneumatic foramen in the femur. The tibio-tarsus has a prominent cnemial crest, a distal extensor bridge and a deep intercondylar groove, the condyles themselves being very prominent. The tarso-metatarse is moderately or considerably elongated, with the proximal intercotylar tuberosity strongly developed, and the upper part of the anterior surface deeply grooved. In all cases a hallux is present.

In Phororhacos the mandible is characterized by the length and narrowness of the trough-like symphysis, and the moderate divergence of the rami. In the typical $P$. longissimus the whole length of the mandible is about $21 \mathrm{in}$, and the nedium breadtl of the symphysis $2.5 \mathrm{in}$. 
In a smaller species, $P$. inflatus, of which more remains than of any other have been reeovered, the entire head measures $340 \mathrm{~mm}$., or nearly $13.5 \mathrm{in}$. The tarso-metatarsus of what Dr. Ameghino eonsiders to be a species of intermediate size, $P$. sehuensis, is about $14 \cdot 25$ in. long and $3 \mathrm{in}$. wide; and he figures an example of the tibio-tarsus of $P$. influtus which he says is $400 \mathrm{~mm}$., or say $15.75 \mathrm{in}$. in length. The femur measures 230 mm., or about $9 \mathrm{in.}$

In Brontornis the mandibular symphysis is shorter, wider and more sharply curved upward at the tip, while the rami are more divergent, their approximate length being $5 \cdot 5$ in., and maximum width 4 inches. The tarso-metatarse in this genus is relatively shorter and stouter than in Phororhacos, having a length of about 15.5 in., and a maximum distal width of $5 \cdot 25$ in. The associated tibio-tarsus of Brontornis, measures $30 \cdot 5$ in. and the former 15.5 in. The species, $B$. burmeisteri, therefore attained a stature approximately equal to that assigned to Apyornis maximus.

On the remaining nembers of this Family and of Opisthodactylus

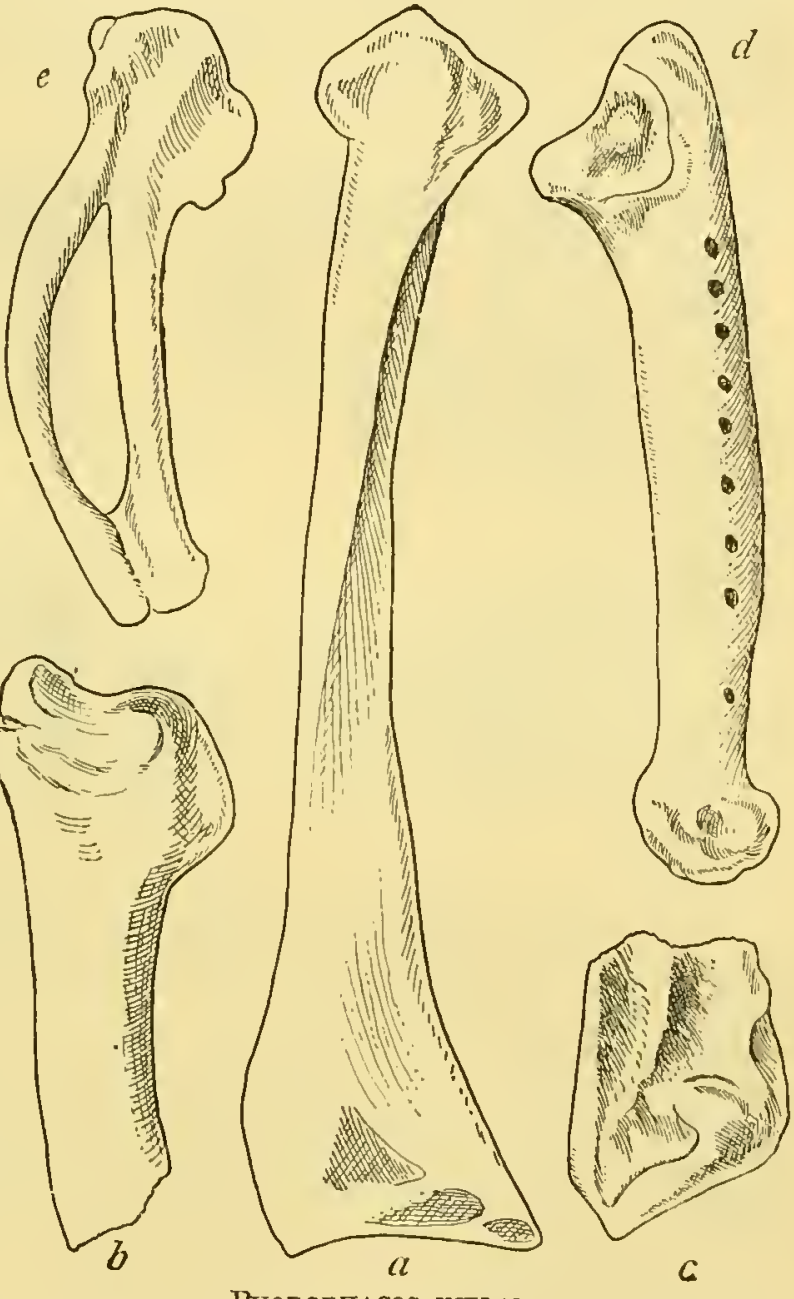

Phororaacos inflatus.

$a$, coracoid ; $b$, proximal end of scapula ; $c$, distal end of huwerus; $d$, ulna ; $c$, metacarpus. (After F. Ameghino.) there is no need now to dwell, for the remains discovered are insufficient to admit of their being considered to any useful purpose.

With regard to the general affinities of the Stereornithes it is impossible to say much at present; but more than one writer has remarked on the resemblance in several points offered to Gastonins of the European Lower Eocene, the tibio-tarsus of the latter having a distal bridge and a deep intercondylar furrow, while its tarso-metatarsus has a prominent intereotylar tuberosity, and the relative length of the distal trochlere is similar. It is true that the distal end of the tibio-tarsus is inflected in the European genus; but the example of 
the Moas (p. 579) shews that this feature may not be of more than generic value. The little that is known of the skull of Gastornis suggests - though the suggestion depends perhaps chiefly on its size - that it may have had some resemblance to that of the Phor.0rhucidx, although of a more depressed form; and the coracoid of Gastornis is as elongated and narrow as that of Phororlacos. That the Stereornithes. were flightless may be considered certain, but whether they should rank as a Subclass with the Rutita and Carinatie, or should merely form an Order in one or other of these groups cannot

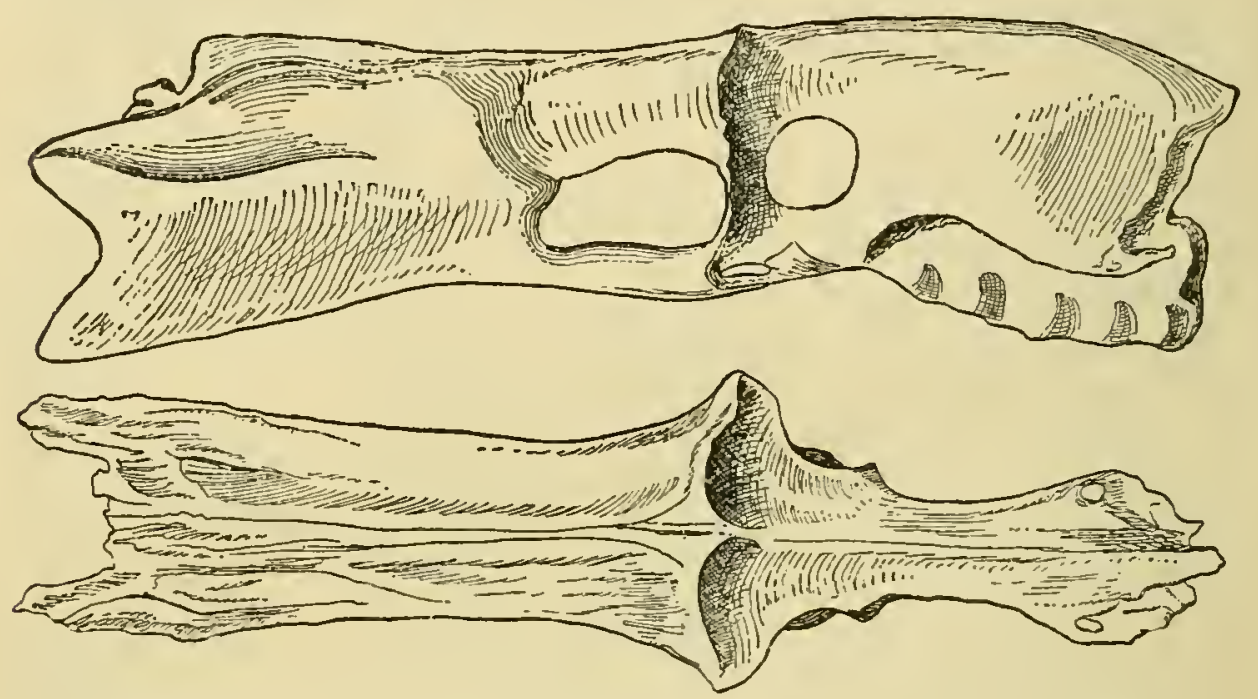

Phororhacts inflatus. Pelvis from the side and above. (After F. Ameghino.)

as yet be determined, though the view taken by Dr. Gadow (Thierreich, Tögel, Syst. Th. pp. 106-114), who has placed the European Remionis, Gastornis and Dasonnis, together with the North-American, Diatryma-all of them being Eocene forms-among the Stereornithes, ${ }^{1}$ receives support from the evident connexion between the peculiar and specialized Ungulates of South America and the Eocene Perissodactyl Ungulates of the Old World and North America.

\section{Richard LYDEKKER.}

STERNUM, or Breastbone, that part of the SrELETON which is connected with the vertebral column by the thoracic ribs and serves for the support of the coracords. Genetically it is wholly of costal origin. In the chick, towards the end of the first week of incubation (ENBryologr, p. 211), about 10 pairs of RiBs are considerably elongated, so that their free ventral half extends forward and approaches the middle line. The distal ends of each right and left series soon meet and fuse, so as to for'm a "sternal band" of

1 This alliance was first suggested by the writer, who, in 1889 (Nicholson and Lydekker, Man. Palzontol. ii. 1. 1229), referred both Diatryma and Mcsembriornis to the Gastornithida. 
cartilage on either side. Thereupon the lateral portion of the first 2 or 3 Ribs is absorbed, so that the anterior portion of each band loses its connexion with the vertebral column, and is transformed into a ribless process, the future processus lateralis anterior of the Sternum, the dorsal part of these reduced Ribs remaining as cervicodorsal Ribs (p. 788). A similar reduction or withdrawal of 2 or 3 Ribs takes place at the posterior end of each band, transforming it into the mocessus lateralis posterior. In the meanwhile both bands have met in the middle line, and fuse together, from the anterior end backward, thus forming the sternal plate or body of the Breastbone. The inner margins of the bands, however, do not unite smoothly, but turn downward, producing two

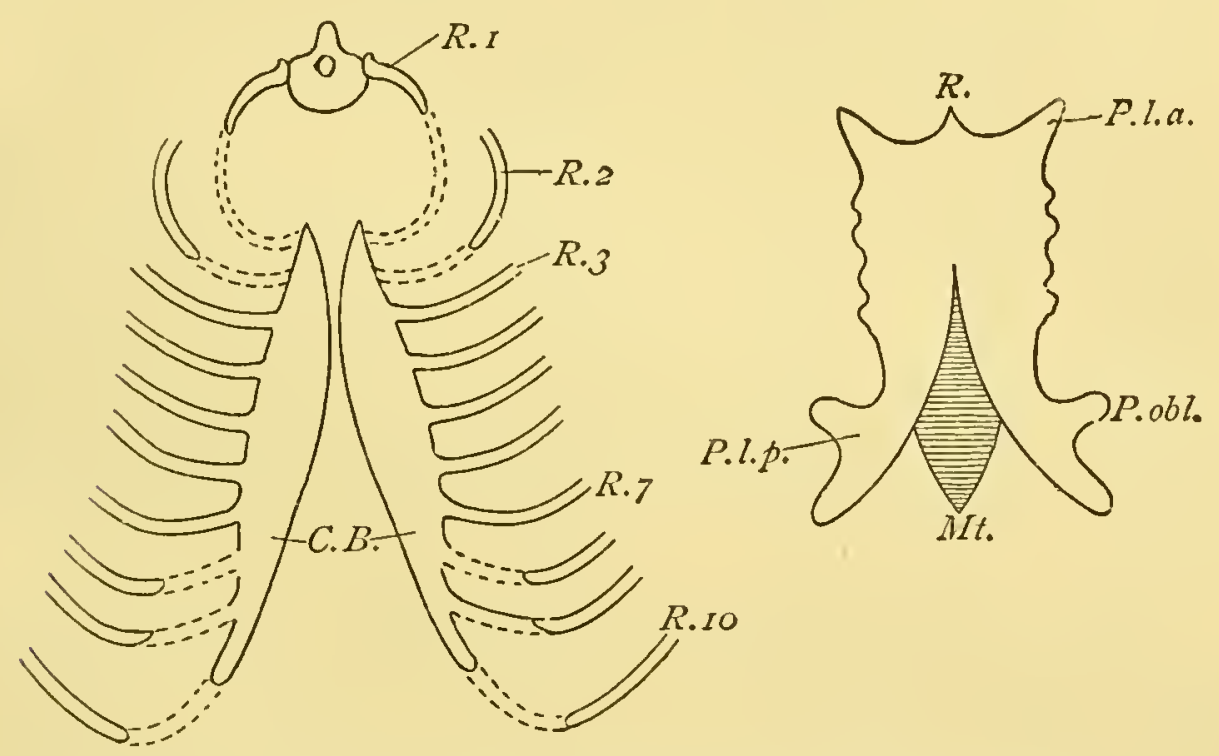

Early and Later Staoes of the Develophent of the Chick's Sternum.

C.B. sterual bands; MIt. Metasternum; P.l.a. P.l.p. and P.obl. Processus lateralis anterior posterior and obliquus ; $R$. Rostrnm; R.1-10, Ribs.

median ridges which are the foundation of the future Keel ( $c f$. CARINate, p. 76). The sternal plate now develops considerably posteriorly, forming the Metasternum, which, not being directly caused by withdrawing Ribs, is not homologous to the Xiphosternum of other Vertebrates, whose equivalent is the two posterior lateral processes. This Metasteruum grows to a great length in many Birds, so that, as in the Gallina, it may form the most conspicuous part of the whole, and the same remark applies to the posterior lateral processes from the lateral margin of which grows out in many Birds a mrocessus obliquus. The anterior end of the Sternum receives in facets the distal end of the Coracoids, between which grows out a median apophysis, the rostrum or spinu sternalis, which serves chiefly for the attachment of the ligaments which connect it with the CravicLes, and also close the whole space between them and the Coracoids, 
saving that the partition is traversed by the TRACHEA and ESOPHAGUS. The spina sternalis is not, as often stated, the homologue of the manubrium sterni of Mammals, for that is equivalent to the right and left anterior lateral processes. ${ }^{1}$ It is to be understood that so far all these structures are cartilaginous.

Ossification of the Sternum does not begin till after it has attained its final shape, and proceeds from various centres, which, notwithstanding the elaborate studies of Geoffroy St.-Hilaire, L'Herminier and Parker cannot always be recognized in the different groups of Birds, chiefly owing to the variable situation of these centres-one or another being suppressed and its place taken by the extension of its neighbours. As a rule ossification begins earliest where the greatest strength or resistance is needed. Thus in Rhea, Gallinx, Turnix, Lestris and the Passeres, each anterior lateral process has its pro-osteon (Parker), but in many other forms, as Ardea, Rallidiz and Ibis, these processes possess no special centre of ossification, and are converted into bone by the extension of the pleurostea, which last occur in the majority of Birds, though absent in Turnix and the Gallinx, and lie in the lateral margin of the Sternum, where the ribs are attached: coracostea occur sometimes at the anterior end of the Steruum, near the articulation of the Coracoids, and in some Birds metostea are the centres whence the posterior lateral processes ossify, while the lophosteon (Parker), which may be single, multiple or paired, is the centre of ossification for the keel.

The Duck and the common Fowl may be cited in particular illustration of this variability. In the former no trace of ossification is visible before the bird is about 6 weeks old, when the centres appear in the anterior lateral processes. By the end of the 7 th week ossification extends over the lateral rib-bearing margin. A few days later it reaches the coracoidal portion, and in the course of the following weeks numerous irregular patches of

1 The synonymy of the various parts of the Avine Sternum being somewhat perplexing, the following may be of some use:-

Processus lateralis anterior $=$ proc. costalis of various authors; prosternal latéral, L'Herminier ; proc. sterno-coracoïdeus or praccostalis, Fürbringer.

" $\quad$ " posterior $=$ latcral xiphisternal process, Parker ; trabecula inter . media and trab. lateralis, Fürbringer.

, obliquus = trab. lateralis, Fürbringer.

Metasternum $=$ xiphosternum of various authors; median xiphisternal process, Parker.

Spina sternalis=rostrum, wrongly called manubrium by many; episternum, Owell.

: ,, externa = manubrinm, rostrum, epistemal process, apophyse sousépisternale or supérieure, inferior rostrum.

„ " interna = apophyse sousépisternale, superior rostrum. 
calcarcous matter appear in the body of the Sternum, at the base and in the anterior part of the licel; but the whole does not become bone until about the 20th week, and even then the posterior rim may yet remain unossified. In the Chick an unpaired lophosteon in the anterior loasal portion of the keel and a pair of metosten appear a few days before emerging from the shell; and on the day of hatching a pair of pro-ostea is added, all these five centres extending so as to coalesce about 9 dilys later. On the 18 th day half of the keel is ossified, after which follows the spina; but ossification is not complete before the bird is 5 or 6 months old. A comparison of a Duck's Breastbone with that of a Fowl shews at a glance that in the latter the consolidation is much less, more than two-thirds of it being formed by the metastermum and the posterior lateral as well as the oblique processes-all of them persisting as outgrowths and being connected only by non-cartilaginous membranaceous tissue. In the macerated skeleton the spaces between these outgrowths appear as reep "notches"; or, if distally closed by bone or cartilage, as fenestra. Moreover, in many Birds an additional process appcars between

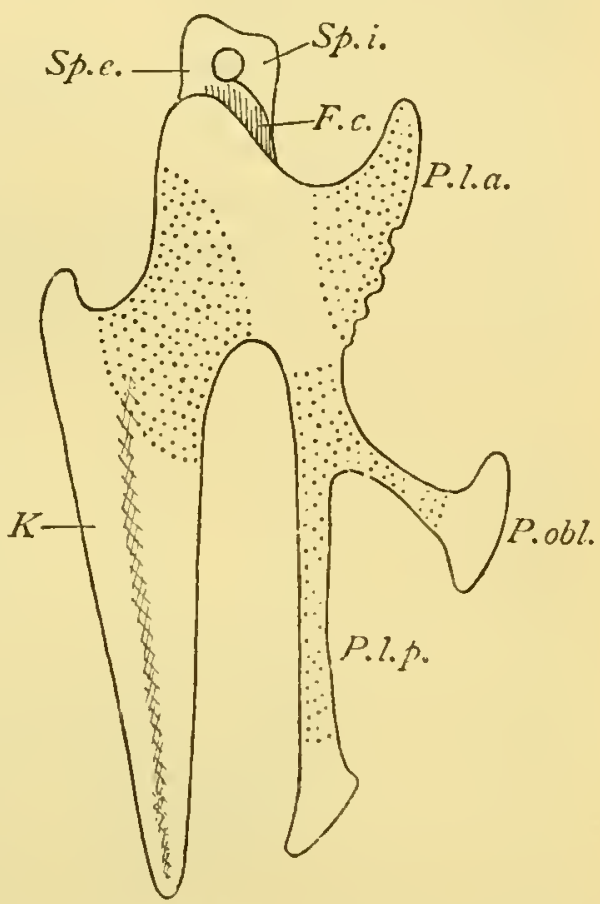

Sternum ow a loung Fowl.

$F . c$ coracoidal facet; $K$. Keel ; Sp.e. and $S p . i$. Spina exterua and interma (other letters as before).

the metasternum and the posterior lateral processes: the presence of such a processus intermedius divides each posterior " notch" into two, and when a processus olliquus is wanting it is often hard to determine whether there is such an intermediate process. These posterior "notches" and fenestra have for many years been used by the hunter for neat "characters," and undue value has been attributed to them, notwithstanding that authorities such as Parker and Prof. Selenka have insisted on the far greater taxonomic importance of the configuration of the anterior portion of the Sternum. ${ }^{1}$ The variable mode of connexion of the Furcula with the keel of the Sternum has already been dealt with (SKeleton, p. 858).

The spina sterni often consists of an inner (dorsal) and an onter (ventral) portion; but sometimes they are confluent, or one of them may be absent. The shape of the anterior free margin is

I This view has also been strongly urged in Phil. Trans. 1869, p. 337, as well as by Prof. Firbringer. 
generally of importance, and it may be pointed or truncated or bifid. Some of the more important modifications can be formulated thus:-

A spina interna is present, although very small, in Pteroclidix, Columba and Trochili.

Both a spina interna and a spina externa occur, fusing to form a spina communis, which in most cases contains a cavity into which the inner corners of the Coracoids fit, in Gallinæ, Meropidx, Bucerotidæ, Upupidx and Cypselidx.

A spina externa only, which is (1) very short, slightly $U$-shaped at its free end in Colymbi, Podicipedes, Tubinares, Ciconiidx, Plataleinie (partly), Palamedex and Accipitres; (2) $\mathrm{Y}$-shaped in Steganopodes (mostly), Phonicopterus, Coraciidx, Alcedinidx, Todidx, Trogonida, Galbulida, Pici, Menura and Passeres generally; or (3) $\perp$-shaped in Sphenisci, Ardeidx, Scopus, Plataleinx (partly), Anseres, some Cuculidx, Eurylamidx and Rhamphastida.

No spina externa in some Steganopodes, Crypturi, Turnix, some Pullidx, Otididx, Columbx (partly) and Caprimulgidx. It would, however, be a great mistake to suppose that the presence, absence or form of the spina sterni is enough to determine the systematic position of a Bird. The Breastbone taken as a whole, regard being paid more to the anterior than to the posterior portion, no doubt affords excellent taxonomic help; but it is obvious that its numerous processes and ridges are only the result of special requirements. Thus the number of Ribs naturally affects the length of the side of the Sternum, while the development of the muscles is intimately connected with the various irregularities of its surface. It is easy to make sweeping generalizations based upon a few evident facts, but such generalizations become hard when put to the crucial test of extended research. As an instance may be cited the anterior lateral processes which are scarcely developed in Dinornis, Grus, Psophia, Cathartes and Vultur, while they attain a great size in Dromæus, Apteryx, Aptenodytes, Botaurus, Rallus, Crypturi, Gallina, Cuculidx, Todus, Merops, Upupa, Buceros, Colius, Pici, Atrichornis, Menura and the Passeres. As a rule these processes seem to be smallest in the Birds which are capable of long enduring flight, and largest in those not remarkable for that power. They are obviously most intimately correlated with the development of the sternocoracoid muscles ( $c f$. p. 605) which arise from them and are inserted on the basal portion of the Coracoids, acting as levatores of the Ribs, and therefore aiding respiration; but what really determines the numerous modifications of these muscles we do not know. Birds which fly well may in a general way be said to have the Breastbone more consolidated than those which fly badly. A good instance of this is shewn by the Tubinares with their generally enormous wing-area, and above all by Fregata, which have a very short Sternum, while this is much longer in proportion 
to its breadth in the heavy-bodied and comparatively short-winged Alcidx.

STILT, Longshanks or Long-Legged Plover, a bird so called for reasons obvious to any one who has seen it, since, though no bigger than a SNIPE, the length of its legs (their bare part measuring 8 inches), in proportion to the size of its body, exceeds that of any other bird's. The first name, a rendering of the French Echasse, given in 1760 by Brisson (Orn. v. p. 33), seems to have been formally conferred by Rennie in 1831 ; but, recommended by

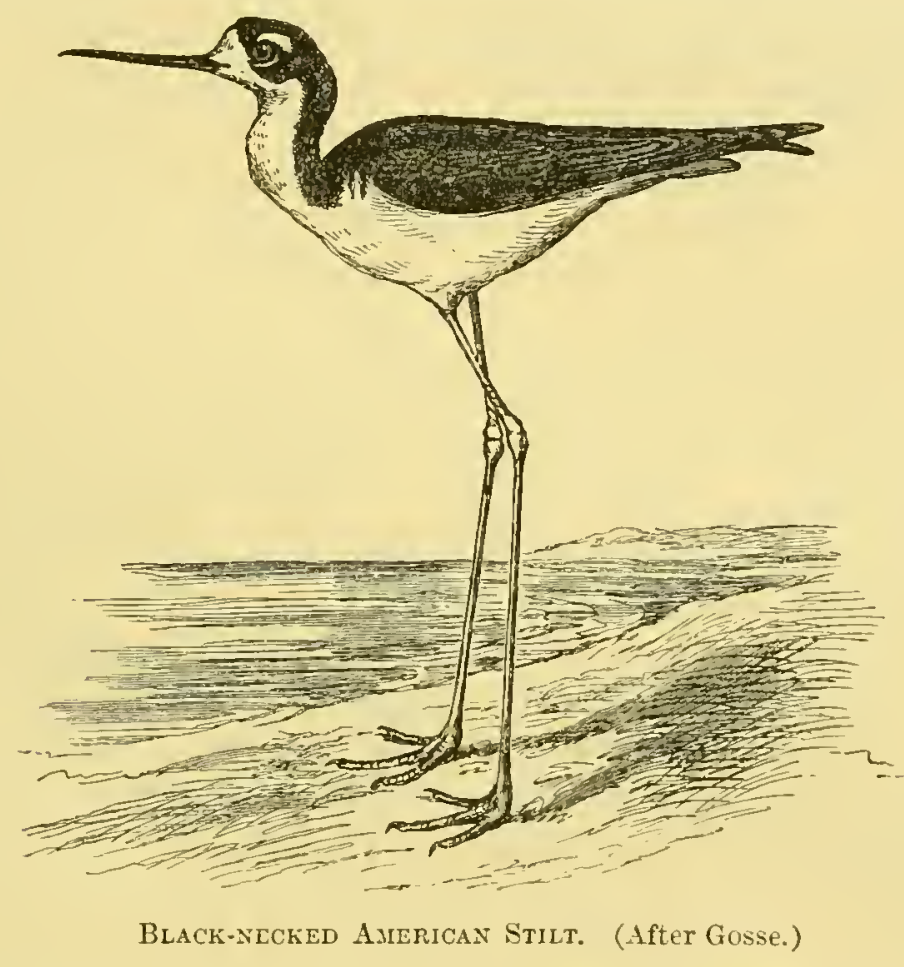

its definiteness and brevity, it has wholly supplanted the others. ${ }^{\text {I }}$ The bird is the Charadrius himantopus ${ }^{2}$ of Linnæus, the Himantopus candidus or melanopterus of modern writers, and belongs to the group Limicola, having been usually placed in the Family Scolopacida, and is certainly not very distant from Recurvirostra (AVOSET).

The very peculiar form of the Stilt naturally gave Buffon occasion (Hist. Nat. Ois. viii. pp. 114-116) to lament the shortcomings of

1 According to Wilson (Am. Orn. vii. p. 50) it was already in use in 1813 in his adopted country; but it must have been through adaptation from the French, or coincidence, and not, like Orstel-CATCIner (p. 682, note 1), an English name that had been carried thither. The old and perhaps singular application of OX-EYE to this bird has been already mentioned (p. 680, note 2).

2 The possible confusion by Pliny's transcribers of this worl with Hamatopus has been already mentioned (p. 682, note 2). Himantopus, with its equivalent Loripes, "by an awkward metaphor," as remarked by Gilbert White, "implies that the legs are as slender and pliant as if cut out of a thong of leather." 
Nature in producing an animal with such "enormous defects," its long legs in particular, he supposed, scarcely allowing it to reach the ground with its bill. But he failed to notice the flexibility of its proportionately long neck, and admitted that he was ill-informed as to its habits. No doubt, if he had enjoyed even so slight an opportunity as occurred to a chance observer (Ibis, 1859, p. 397), he would have allowed that its structure and ways were in complete conformity, for the bird obtains its food by wading in shallow water and seizing the insects that fly over or float upon its surface or the small crustaceans that swim beneath, for which purpose its slender extremities are, as might be expected, admirably adapted. Widely spread over Asia, North Africa and Southern Europe, the Stilt has many times visited Britain-though always as a straggler, for it is not known to breed to the northward of the Danube valley, - and its occurrence in Scotland (near Dumfries) was noticed by Sibbald (Scot. Illustr. II. iii. p. 18) ${ }^{1}$ so long ago as 1684 . It chiefly resorts to pools or lakes with a margin of mud, on which it constructs a slight nest, banked round or just raised above the level so as to keep its eggs dry (Ibis, 1859, p. 360); but sometimes they are laid in a tuft of grass. They are four in number, closely resembling those of the Avoset, and, except in size, the Oyster-catcher. The bird has the head, neck and lower parts white, the back and wings glossy black, the irides red and the bare part of the legs piuk. In America the genus has two representatives, one closely resembling that just described, but rather smaller and with a black crown and nape. This is $H$. mexicanus or nigricollis, ${ }^{2}$ and occurs from New Eugland to the middle of South America, beyond which it is replaced by $H$. brasiliensis, which bas the crown white. The Sandwich Islands appear to be the home of a species peculiar to them, $H$. knudseni. The Stilt inbabiting India is now recognized to be $H$. candidus, but Australia possesses a distinct species, $H$. leucocephalus or nove-hollandia, which also occurs in New Zealand, though that country has in addition a species peculiar to it, $H$. noræ-zelandix or melas, differing from all the rest by assuming in the breeding-season wholly black plumage, to say nothing of a possible third species, the H. albicollis of Sir W. Buller. Australia, however, presents another form, which is the type of the genus Cladorhynchus, and differs from Himantopus both in its style of plumage (the male having a broad bay pectoral belt), in its shorter tarsi and in having the toes (though, as in the Stilts' feet, three in number on each foot) webbed as in the Avosets.

STINK-BIRD, a naine given to the HoACTZIN (p. 421) : STINKPOT, STINKER, sailors' names for some of the Petrels (p. 710).

1 Sibbald was unfortunate in his draughtsman, who gave the bird a hind-toe.

2 This species was made known to Ray by Sloane, who met with it in Jamaica, where in his day it was called "Longlegs." 
STINT (akin to Stunt), a common name for any of the smaller SAndpipers (p. 812), but especially for the DunliN (p. 172). By British authors it is almost restricted to Tringa mimute and ' $I$ '. temmincki, both of which occur yearly on our coasts. ${ }^{1}$

STITCH-BIRD, one of the most interesting of the Meliphagida (HoNEY-EATER, p. 42S) of New Zealand, so called from uttering a "sharp clicking sound like the striking of two quartz stones together," which "has a fanciful resemblance to the word stitch," the Pogonorniscincta of ornithology. The inale is remarkable for the tuft of white feathers standing out behind each eye in contrast with his glossy black head and neck, to which succeeds a band of deep yellow,

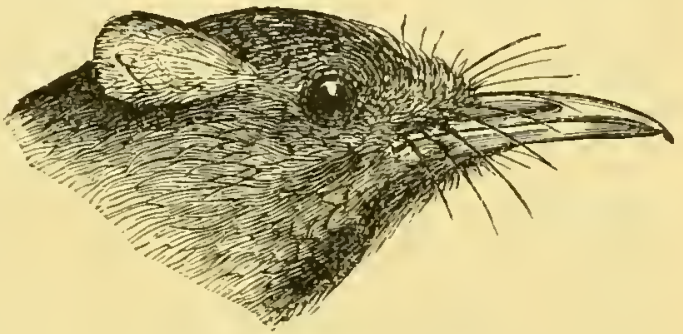

Pogononnis. (1fter Buller.) narrow in front but broadening at the sides, while the same colour is shewn in some of the wing-feathers; but for the most part the rest of the plumage is olive-brown variegated with dark streaks and a white patch on the cubitals. The species, which was only made known in 1839 , seems to have had a limited rauge on the North Island of New Zealand, where it is believed to be now extinct, and though a small number may still exist on some of the off-lying islets, its extirpation can be only a question of a few years, yet its cause one can but guess. However, before the days of colonization, the bird seems to have been a good deal persecuted for the sake of its fine yellow feathers, which were sought by the Maories to deck the robes of their chiefs, even as those of the Drepanis (p. 166) were in the Sandwich Islands (cf. Buller, B. N. Zeul. ed. 2, i. pp. 101-105).

STOCK-DOVE ( $c f$. p. 163), the Columba anas of ornithologists, most likely so called from the mistaken belief in its being the origin of the domestic Pigeon, just as for a similar reason STOCK-DUCK is a local name for the common Wild Duck (p. 169); but some suppose that the Dove has its name from its habit of frequently breeding in the stocks of trees, and it must be allowed that the German Holztaube and some other cognate names in Teutonic tongues, to say nothing of STOCK-EIKLE (a corruption of StockHiCKWALI and itself corrupted into Stock Eagle) a local name of a WOODPECKER, favour that view.

1 The first authenticated eggs of the latter were mrobably taken by Schrader in East Finmark in 1842 (Journ. für Orn. 1853, p. 308), though its breedingground was found there in 1840 by Von Mildendorff (Bcitr. Kenntn. Iiuss. Reichs, viii. p. 207), who in 1843 discovered in the Taimyr peninsula the nest of the former (Sib. Rcisc, ii. 2, 1. 221, and Proc. Zool. Soc. 1861, p. 398). 
STOMACH. This important organ in the Digestive SystexI (p. 136) consists of an anterior portion, the Proventriculus, which is glandular, and a posterior, the Ventriculus or Gizzard, which is muscular - the former being characterized by specific glands, and in size standing in inverse proportion to the latter. In many Birds, however, especially those which feed upon Fishes, both portions are wide and pass gradually into one another; but in the majority the Proventriculus is much the smaller, and is separated from the Gizzard by a marked constriction, devoid of glands. The glands themselves vary greatly in size and position, being however generally packed close together in a broad ring; but, when the Proventriculus is wide, as in Casuarius, Aptenodytes and the Tubinares, either scattered with wide interstices, or collected in patches leaving the greater part of the walls free. In Leptoptitus argala, in Phalacrocorax and in Plotus levaillanti two such patches exist, while in $P$. antinga they are gathered into one globular mass, as big as a hazel-nut, attached to the outside of the Stomach, and opening into the right dorsal wall of the Proventriculius. Phea possesses a round dorsal patch, and one similar occurs in the embryo of Struthio, but is subsequently drawn out into a dumb-bell shaped area, which, owing to the peculiar distortion of the whole Stomach, eventually occupies the greater part of the dorsal wall. In most carnivorous and piscivorous Birds, in the Laro-Limicola, Columba and Pusseres, the individual glands are small and simple; but larger and more complicated in most herbivorous and granivorous Birds, especially the Ratitxe and Gallina.

The Gizzard occupies most of the middle and left part of the abdominal cavity, its Cardia or upper end looking toward the vertebral column, and slightly inclined to the left side, while the Pylorus or lower end is turned toward the right. The surrounding muscular fibres are disposed in more or less regular spirals, possessing in their course two tendinous intersections, producing as many tendinous opercula, one on each side; and though, taken as a whole, they form only one muscle, the entire mass is generally spoken of as consisting of a right and a left muscle. The Gizzard varies greatly in size, shape, strength and position-chicfly according to the kind of food. When the organ is very muscular, as in Pigeons, Fowls and Ducks, it takes the form of a biconvex lens, with a sharp dorsal and ventral margin. On the whole the walls retain the same layer's as those of the rest of the alimentary canal ( $p$. 137 ); but the muscular layer is more strongly developed, while the tunica mucosa contains mucous glands alone, and none producing any specific or chemically-acting secretion. The function of the Gizzard, beyond serving as a receptacle of food, is therefore purely mechanical.

The Pylorus ( $c f$. p. 138, fig.) is almost always guarded by a special muscular sphincter and several inner valve-like ridges, pre- 
venting substances such as grass, fragments of bone, or sharp stones from entering the small intestine, while smooth seeds, however hard, pass freely.

What may be deemed a third compartment of the Stomach is possessed by many birds. This is the so-called pyloric bulb, belonging to the Gizzard and not to the Duodenum, since it contains the same cuticular lining as the former; and, although as regards the latter cut off by a constriction, ending towards it by the typical pyloric sphincter. This arrangement is possessed by Casuarius, Dromaus, Sphenisci, Podicipedidx, Steganopodes, Herodiones, Phonicopterus and Ciconix; and, though less apparent, by Phea, Mergus and the Pallidx. Since most of the birds thus furnished are piscirorous, it seems more reasonable to connect this arrangement with their very watery food than to regard it as a Reptilian, notably Crocodilian, feature.

Two kinds of Gizzard, the Simple and the Compound, may be conveniently distinguished, though they are connected by intermediate stages, and thus only the extreme forms are fit for generalized description.

1. The Simple Gizzard may be oval, globular or sack-shaped, each of the slightly-flattened sides containing a weak operculum, while the walls are always thin, capable of considerable distention, and mostly of a pale bluish-yellow, rarely reddish, colour. The tunica mucosa contains numerous simple glands, secreting a soft cuticular lining which is continuously renewed and easily peels off as a viscous yellow coating. Such a Gizzard is possessed by the birds that feed chiefly on fish, flesh, soft fruits and insects. In many piscivorous birds, such as Ardea and Phalacrocorax, it is transformed into a long oval sack occupying the greater part of the ventral and left space of the abdominal cavity, and reaching to the cloacal region. In other piscivorous birds, however, Phaethon, Pelecanus and Sula, as well as in Casuarius and Dromaus, and in certain Tanagers, Euphones, the Gizzard is much reduced in size, while its functions are assumed by the much enlarged Proventriculus. The relation between the strength of the Stomach and the nature of the food is clearly shewn by Manucodia, which feeds on soft fruit and has very thin walls to its Gizzard, whereas in the omnivorous Corvida they are very muscular.

2. The Compound Gizzard possesses conspicuous tendinous opercula, a pair of intermediate and a pair of strong lateral muscles. The interior is lined with a thick brownish cuticle, formed by the hardened secretion of the tunica mucosa, and consisting of numerous lamellæ, which are continuously reproduced by the secreting cells to supply those that are worn down by constant trituration of the food through the action of the lateral muscles. The cuticular covering of the middle muscular or part of each of these muscles 
forms a thickened pad which by contraction of the spirally-arranged muscular fibres presses upon and slides over the opposite corresponding pad. Ptilopus, one of the Pigeons, possesses four such pads, and the cavity of its Gizzard appears cross-shaped in a transverse section. The cuticle between the pads generally shews irregular folds which end suddenly towards the Cardia and the Pylorus. Occasionally it assumes peculiar shapes: in Carpophaga latrans, another of the Pigeons, and in some Tubinares, it forms conical processes which have been wrongly described as horny structures (p. 724); in Plotus the pyloric chamber is beset with hair-like filaments which permit nothing but fluid matter to pass into the duodenum.

As a rule the cuticle, which exists also in the Simple Gizzard, though there not hardened, is continuously wearing away and being reproduced, but many cases are known in which most of the lining is suddenly cast off and ejected through the mouth, as has been observed in Pastor roseus, Sturnus vulgaris, Turdus viscivorus, Carine noctua, Cuculus canorus, and especially in Buceros. Another peculiarity is that the Gizzard of Cuculus canorus and of Harpactes is frequently lined with the broken-off hairs of the Caterpillars swallowed, which, penetrating the cuticle, assume a regular spiral arrangement due to the rotatory motion of the muscles. The Compound Gizzard is most typically developed in Struthio, Rhea, the Anseres, Phonicopterus, Tantalus, Grus, the Columbx, Gallinx and in many Passeres, that is to say in Birds which mainly live on grass and seeds, and therefore need a mechanical apparatus to prepare the food for the action of the several digestive secretions, to aid which preparation stones are very frequently swallowed and retained in the organ. The compound muscular stomach, a substitute for the wholly lost TEETH, is a peculiarity of Birds.

STONE-CHAT, the Motacilla, Saxicola or Praticola rubicola of ornithology, one of the few "soft-billed" birds that are perenially resident as a species in this country. The black head, ruddy breast and white collar and wing-spot of the cock render him a conspicuous object on almost every furze-grown heath or common in the British Islands, as he sits on a projecting twig or flits from bush to bush, uttering a cheery song or the alarm-note whence he takes his name. This species has a wide range in Europe, and several others more or less resembling it inhabit South Africa, Madagascar, Réunion, and Asia-both the mainland and some of the islands from those of the Indian Archipelago to Japan. The genus Praticola is no doubt nearly allied to Ruticilla (REDSTART, p. 775), and only somewhat more distantly to Saxicola (WHEATEAR), though for some occult reason Dr. Sharpe (Cat. B. Br. Mus. iv. p. 113) referred it to the Muscicapidæx (FLY-CATCHER, p. 273). 
STONE-CURLEW, Edicnemus scolopax or crepitans (CURLEW, p. 129); STONEHATCH, a name for the Ringed Plover, Egialitis hiaticola, given to it in places where, breeding on the turf, it paves the hollow it makes for its nest with small stones before laying its eggs (cf. Salmon, Mag. N. H. ix. p. 521, Stevenson, B. Norf. ii. p. 85); STONERUNNER, another name for the same bird, but given to it at its seaside resorts.

STORK (A.-S. Storc; Germ. Storch), the Ciconia alba of ornithology, and, through picture and story, one of the best known of foreign birds; for, though often visiting Britain, it has never been a native or even inhabitant of the country. It is a summer-visitant to most parts of the European Continent,-the chief exceptions being France (where the native race has been destroyed), Italy and Russia,_-breeding from southern Sweden to Spain and Greece, and being especially common in Poland. ${ }^{1}$ It reappears again in Asia Minor, the Caucasus, Persia and Turkestan, but further to the eastward it is replaced by a larger, black-billed species, C. boyciana, which reaches Japan. Though occasionally using trees (as was most likely its original habit) for the purpose, the Stork most generally places its nest on buildings, ${ }^{2}$ a fact familiar to travellers in Denmark, Holland and Germany, and it is nearly everywhere a cherished guest, popular belief ascribing good luck to the house to which it attaches itself. ${ }^{3} \quad$ Its food, consisting mainly of frogs and insects, is gathered in the neighbouring pastures, across which it may be seen stalking with an air of quiet dignity; but in the season of love it indulges in gestures which can only be called grotesque,-leaping from the ground with extended wings in a kind of dance, and, absolutely voiceless as it is, making a loud noise by the clattering of its mandibles. At other times it may be seen gravely resting on one leg on an elevated place, thence to sweep aloft and circle with a slow and majestic flight. Apart from its considerable size, - and a Stork stands more than three feet in height, -its contrasted plumage of pure white and deep black, with its bright red bill and legs, makes it a conspicnous and beautiful object, especially when seen against the fresh green grass of a luxuriant meadow. In winter the Storks of Europe retire to

1 In that country its numbers are said to have greatly diminished since about 1858, when a disastrous spring-storm overtook the homeward-bound birds. The like is to be said of Holland since about 1860 .

2 To consult its convenience a stage of some kind, often a cart-wheel, is in many places set up and generally occupied by successive generations of tenants.

3 Its common Dutch name is Ooijevaar, which can be traced through many forms (Koolmann, Wörterb. d. Ostfries. Sprache, i. p. 8 sub voce "Âdebar") to the old word Odeboro ("the bringer of good"). In countries where the Stork is abundant it enters largely into popular tales, songs and proverbs, and from the days of Esop has been a favourite in fable. 
Africa, - -some of them, it would seem, reaching the Cape Colony,while those of Asia visit India. A second species with much the same range, but with none of its relative's domestic disposition, is the Black Stork, C. nigra, of which the upper parts are black, brilliantly glossed with purple, copper and green, while it is white beneath, - the bill and legs, with a patch of bare skin round the eyes, being red. This bird breeds in lofty trees, generally those growing in a large forest. Two other dark-coloured, but somewhat abnormal, species are the purely African $C$. abdimii, and the $C$. episcopus, which has a wider range, being found not only in Africa, but in India, Java and Sumatra. The New World has only one true Stork, C. maguari, ${ }^{1}$ which inhabits South America, and resembles not a little the C. boyciana above mentioned, differing therefrom in its greenish-white bill and black tail. Both these species are very like C. alba, but are larger, and have a bare patch of red skin round the eyes.

The Storks form the Pelargi of Nitzsch, as separated by him from the Herons and the Ibises, but all three are united by Prof. Huxley in his group Pelargonorphes (p. 702). The relations of the Storks to the Herons may be doubtful ; - but there is no doubt that the former include the ADJUTANT (p. 2) and JABIRU (p. 462), as well as the curious genus Anastomus (OPEN-BILL, p. 655). The relationship of two other remarkable forms, Balaniceps (SHOE-BILL, p. 838) and Scopus (Hammer-HEad, p. 405), is more questionable. ${ }^{2}$ In all the Storks, so far as is known, the eggs are white, and in most forms distinguishable by the grain of the shell, which, without being rough, is closely pitted with pore-like depressions.

STORM-COCK, the Mistletoe-THRush; STORM-FINCH, the Storm-Petrel (p. 709), but rather a landsman's than a seaman's name.

STRANY, one of the many local names of the GUILLEMot.

STRIGES, Wagler's first Order of Birds in 1830 (Natur. Syst. der Amphib. u.s.w. p. 80), composed of the OwLS (p. 671) as distinct from the ACCIPITRES (p. 1) with which they had before been united.

STRLSORES, an Order of Birds proposed by Prof. Cabanis (Arch. für Naturgesch. 1847, i. pp. 308, 345, 346) to consist of the Families Trochilidx, Cypselidx, Caprimulgidx, Opisthocomidæ and Musophagidæ (see INTRODUCTION).

STRUTHIONES, the sixth Order of Birds in the classification of Latham in 1790 (Ind. Orn. pp. xv. 662), comprehending the genera Didus, Struthio, Casuarius and Rhea.

1 This was formerly, but erroneously ( $c f$. Schlegel, Rev. Crit. p. 104), believed to have occurred in Europe.

${ }^{2}$ Cf. Beddard (Proc. Zool. Soc. 1884, pp. 543-553). Mr. Bartlett informs me that Scopus has a loud voice, while all Storks are dumb. 
SUBCLAMATORES, the name proposed in 1893 (Gadow, Thier-reich, Vögel, System. Th. pp. 273-276) for a division of Passeres formed by the Family Eurylamidæ (Broadbill, p. 57).

SUBOSCINES, proposed, like the last (iom. cit. pp. 272, 277, 278), in place of Pseudoscines (p. 743).

SUGAR-BIRD, the English name commonly given in the West India Islands to the various members of the genus Certhiola, ${ }^{1}$ generally regarded as belonging to the Family Cærebidæ (cf. GuITGUIT, p.401), ${ }^{2}$ from their habit of frequenting the curing-houses where sugar is kept, apparently attracted thither by the swarms of flies. These little birds on account of their pretty plumage and their familiarity are usually favourites. They often come into dwellinghouses, where they preserve great coolness, hopping gravely from one piece of furniture to another and carefully exploring the surrounding objects with intent to find a spider or insect. In their figure and motions they remind a northern naturalist of a NuTHATCH (p. 647), while their coloration-black, yellow, olive, grey and white -recalls to him a Titmouse. They generally keep in pairs and build a domed but untidy nest, laying therein three eggs, white blotched with rusty-red. Apart from all this the genus presents some points of great interest. Mr. Sclater (Cat. B. Br. Mus. xi. pp. 36-47) recognizes 18 "species," therein following Mr. Ridgway (Proc. U. S. Nat. Mus. 1885, pp. 25-30), of which 3 are continental with a joint range extending from southern Mexico to Peru, Bolivia and southeastern Brazil, while the remaining 15 are peculiar to certain of the Antilles, ${ }^{3}$ and several of them to one island only. Thus C. caboti is limited, so far. as is known, to Cozumel (off Yucatan), C. tricolor to Old Providence, C. flaveola (the type of the genus) to Jamaica, and so on, while islands that are in sight of one another are often inhabited by different "species." Further research is required; but even now the genus furnishes an excellent example of the effect of isolation in breaking up an original form, while there is comparatively little differentiation among the individuals which inhabit a large and continuous area. The non-appearance of this genus in Cuba is very remarkable.

1 American ornithologists have lately taken to use the name Cæreba (or Coreba, as they and others spell it) in place of Certhiola, but Mr. Sclater (Ibis, 1893, p. 247) successfully defends the older practice.

2 The Guitguit of Hernandez (Rer. Medic. N. Hisp. Thes. p. 56), a name said by him to be of native origin, cau hardly be determined, though thought by Montbeillard (Hist. Nat. Ois. v. p. 529) to be what is now known as Cæreba cærulea, but that of later writers is C. cyanea. The name is probably from the bird's note, like QUIT (p. 761), applied in Jamaica to several species.

3 More recently, in 1889, Mr. Cory (Birds of the West Indies, pp. 61-67) admitted only twelve species as Antillean. 
SUGGE (Prompt. Parvul. ed. Way, p. 483), the apparently obsolete form of SEGGE (p. 825) which still persists.

SUMMER-DUCK, a name in America for $A x$ sponsa (p. 171); -SNIPE, the commonest name of the common SANDPIPER, Actitis hypoleuca (p. 811); -TEAL, the GarGANeY (p. 309).

SUN-BIRD, a name more or less in use for many years, ${ }^{1}$ and now generally accepted as that of a group of over 100 species of small birds, but when or by whom it was first applied is uncertain. Most of them are remarkable for their gaudy plumage, and, though those known to the older naturalists were for a long while referred to the genus Certhic (TREE-CREEPER), or some other group, they are now fully recognized as forming a valid Family Nectariniida, from the name Nectarinia invented in 1811 by Illiger. They inhabit the Ethiopian, Indian and Australian Regions, ${ }^{2}$ and, with some notable exceptions, the species mostly have but a limited range. They are considered to have their nearest allies in the

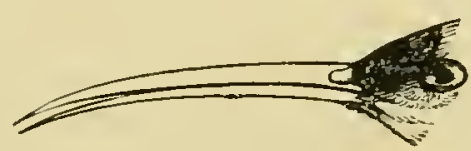

NeCtarinia

(After Swainson.)

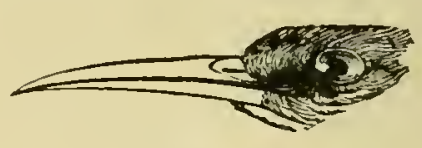

A.NTHREPTE:.

Meliphagida (HoNEY-EaTtri, p. 428) and the members of the genus ZOSTEROPS ; but their relations to the last require further investigation. Some of them are called "Humming-birds" by Anglo-Indians and colonists, but with that group, as before indicated (HumningBIRD, pp. 442, 443), the Sun-birds, being true Passeres, have nothing to do. Though part of the plumage in many Sun-birds gleams with metallic lustre, they owe much of their beauty to feathers which are not lustrous, yet almost as vivid, ${ }^{3}$ and the most wonderful combination of the brightest colours - scarlet, crimson, purple, blue, green or yellow - is often seen in one and the same bird. One group, however, is dull in hue, and but for the presence in

1 Certainly since 1826 ( $c f$. Stephens, Gen. Zool. xix. pt. 1, p. 229). Swainson (Classif. B. i. p. 145) says they are "so called by the natives of Asia in allusion to their splendid and shining plumage," but gives no hint as to the nation or language wherein the name originated. By the French they have been much longer known as Souimangas, from the Madagascar name of one of the species given in 1658 by Flacourt as Soumangha.

2 One species occurs in Beloochistan, which is perhaps outside of the Indian Region (ef. supri, p. 334), but the fact of its being found there may be a reason for including that country within the Region, just as the presence of another species in the Jordan valley induces zoographers to regard the Ghór as an outlier of the Ethiopian Region.

${ }^{3}$ Cf. suprà, pp. 97, 98, and Gadow, Proc. Zool. Soc. 1882, pp. 409-421, pls. xxvii. xxviii. 
some of its members of yellow or flame-coloured precostal tufts, which are very characteristic of the Family, might at first sight be thought not to belong here. Graceful in form and active in motion, Sun-birds flit from flower to flower, feeding chiefly on small insects which are attracted by the nectar; but this is always done while perched, and never on the wing as is the habit of IInmming-birds. The extensible TONGUE, though practically serving the same end in both groups, is essentially different in its quasi-tubular structure, and there is also considerable difference between this organ in the Nectariniuda and the Meliphagida. ' The nests of the Sun-birds, domed with a penthouse porch, and pensile from the end of a bough or leaf, are very neatly built. The eggs are generally three in number, of a dull white covered witl confluent specks of greenishgrey.

The Nectarinida formed the subject of a sumptuous Monograph by Capt. Shelley (4to, London: 1876-1880), in the coloured plates of which full justice was done to the varied beanties which these gloriously arrayed little beings display, while, almost every available sonrce of information having been consulted, and the results embodied, the text left little to be desired, and of course superseded all that had before been published about them. He divided the Family into three subfamilies :-Neodrepanina, consisting of a single genus and species peculiar to Madagascar; Nectariniina, containing 9 genera, one of which, Cinnyris, has more than half the number of species in the whole group; and Arachnotherina (sometimes known as "Spider-hunters"), with 2 genera including 11 speciesall large in size and plain in hue. To these he also added

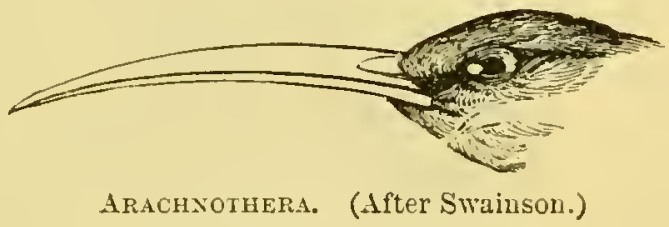
the genus Promerops (p. 743 ), the affinity of which to the rest can as yet hardly be taken as proved. According to Mr. Layard, the habits of the Cape Promerops, its mode of nidification and the character of its egrgs are very unlike those of the ordinary Nectariniida. In 1883-84 Dr. Gadow (Cat. B. Br. Mus. ix. pp. 1-126, and 291) treated of this Family, reducing the number of both genera and species, though adding a new genus discovered since the publication of Capt. Shelley's work, and additional species have since been described.

SUN-BITTERN, the Eurypyga helics of ornithology, a bird that has long exercised systematists and one whose proper place can scarcely yet be said to have been satisfactorily determined.

According to Pallas, who in 1781 gave (N. nürdl. Beytr. ii. pp. 48-54, pl. 3) a good description and fair figure of it, calling it the

$$
1 \text { Cf. Gadow, op. cit. 1883, pp. 62-69, pl. xri. }
$$


"Surinamische Sonnenreyger," Ardea helics, the first author to notice this form was Fermin, whose account of it, under the name of "Oiseau de Soleil," was published at Amsterdam in 1769 (Descr. (c. de Surinam, ii. p. 192), but was vague and meagre. In 1772, howerer, it was satisfactorily figured and described in Rozier's Observations sur la Physique, dre (r. pt. 1, p. 212, pl. 1), as the Petit Paon des roseanx-by which name it was known in Cayenne. ${ }^{1}$ A few years later D'Aubenton figured it in his well-known series $(P l$. enl. 782), and then in 1781 came Buffon (H. N. Ois. viii. pp. 169, 170 , pl. xiv.), who, calling it "Le Caurále ${ }^{2}$ ou petit Paon des roses,"

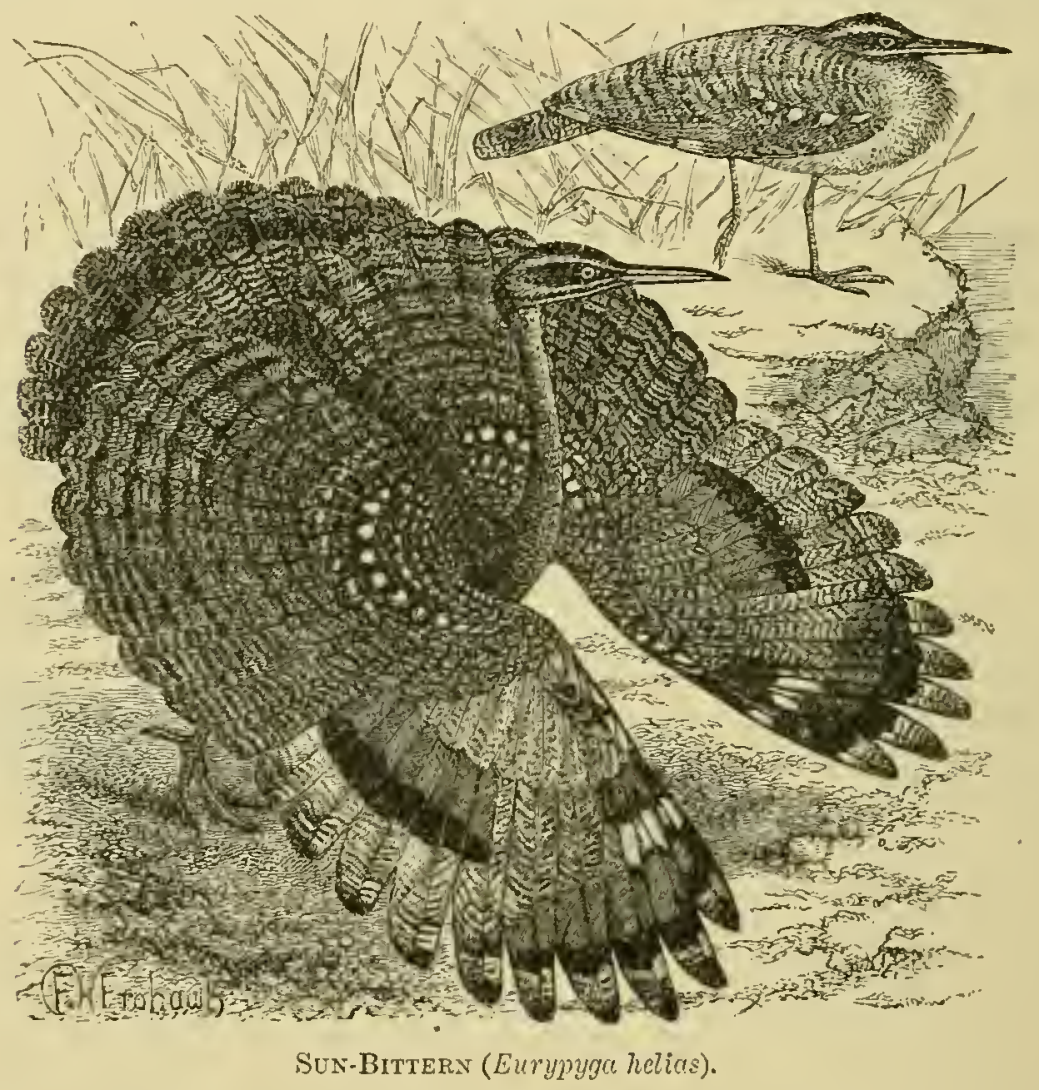

announced it as hitherto undescribed, and placed it among the Rails. In the same year appeared the above-cited paper by Pallas, who, notwithstanding his remote abode, was better informed as to its history than his great contemporary, whose ignorance, real or affected, of his fellow-countryman's priority in the field is inexplicable ; and it must have been by inadvertence that, writing "roses" for "roseanx," Buffon turned the colonial name from one that had a good meaning into nonsense. In 1783 Boddaert, equally ignorant

1 This figure and description were repeated in the later issue of this work in 1777 (i. pp. $679-681$, pl. 1).

2 The name, he says, was intended to mean Râle ì queue, that is, a tailed Rail! 
of what Pallas had done, called it Scolopax solaris, ${ }^{1}$ and in referring it to that genus he was followed by Latham (Gen. Synops. iii. p. 156), by whom it was introduced to English readers as the "Caurale Snipe." Thus within a dozen years this bird was referred to three perfectly distinct genera, and in those days genera meant much more than they do now. Not until 1811 was it recognized as forming a genus of its own. This was done by Illiger, whose appellation Eurypyga has been generally accepted.

The Sun-Bittern is about as big as a small Curlew, but with much shorter legs and a rather slender, slightly decurved bill, blunt at the tip. The wings are moderate, broad and rounded, the tail rather long and broad. The head is black with a white stripe overand another under each eye, the chin and throat being also white. The rest of the plumage is not to be described in a limited space otherwise than generally, being variegated with black, brown, chestnut, bay, buff, grey and white-so mottled, speckled and belted either in wave-like or zigzag forms as somewhat to resemble certain motlis. The bay colour forms two conspicuous patches on each wing, and also an antepenultimate bar on the tail, behind which is a subterminal band of black. The irides are red; the bill is greenish olive; and the legs are pale yellow. As in the case of most SouthAmerican birds, very little is recorded of its habits in freedom, except that it frequents the muddy and wooded banks of rivers, feeding on small fishes and insects. In captivity it soon becomes tame, and has several times made its nest and reared its young, which when hatched are clothed with mottled down (Proc. Zool. Soc. 1866, p. 76, pl. ix. fig. 1), in the Zoological Gardens, where examples are generally to be seen and their plaintive piping heard. It ordinarily walks with slow and precise steps, keeping its body in a horizontal position, but at times, when excited, it will go through a series of fantastic performances, spreading its broad wings and tail so as to display their beantiful markings. This species inhabits Guiana and the interior of Brazil ; but in Colombia and Central America occurs a larger and somewhat differently coloured form which is known as $E$. major.

For a long while it seemed as if Eurypyga had no near ally, but, on the colonization of New Caledonia by the French, an extremely curious bird, known as the $\mathrm{KAGU}$ (p. 471), was found inhabiting most parts of that island, and a few years later the affinity of the two forms, though not very close, was made manifest.

SURF-BIRD, ${ }^{2}$ Audubon's name, since generally adopted, for

a Possibly he saw in the bird's variegated plumage a resemblance to the Painted Snipes (p. 886). His specific name shews that he must have known how the Dutch in Surinam called it.

In thanking the author for this article, I must express my dissent from the proposal with which it concludes.-A. N. 
the Aphriza virgate of ornithology, a peculiar Limicoline form found on the Pacific coast of America from Alaska to Chili (Gay, Fauna Chilena, p. 408). It was referred to the genus Tringa by Latham, who in 1785 (Gen. Synops. iii. p. 180) described a specimen brought from Sandwich Sound (most likely by the survivors of Cook's last voyage), but was lost sight of for many years until Townsend obtained a single example, in November 1836, at the mouth of the Columbia River, and sent it to Audubon, who redescribed the species as 11 ew, founding thereon a new genus Aphriza. It has since been frequently observed, but the most recent explorers of north-western America have failed to find its breeding-grounds, which are probably, as the natives told Mr. Nelson (Rep. N. H. Coll. Alaska, iii. p. 128), though he mistrusted them, on the bare mountains of the interior; and little is known of its habits, except that it frequents the sea-shore, seeking its food in the surf, undeterred by the spray of the breaking waves, and hence it has received both

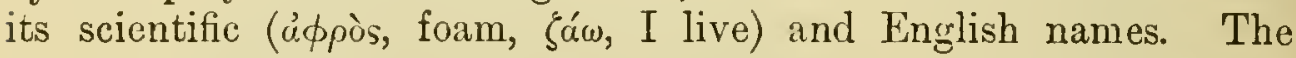
bird is about as large as a KNoT, and not unlike one in its winterdress, though much darker in colour above, with a conspicuous white bar on the wings and a white rump, and it undergoes little if any seasonal change. Its osteology, as examined by the present writer (Journ. Morphol. 18s8, pp. 311-340, pl. xxv.), shews that its affinity is rather to the smaller SANDPIPERS than to the Plovers, and still less than to the TURNstones or Oyster-CATCHERs, among which it has been generally placed, and therefore it is proposed to be regarded as in itself forming a separate Family Aphrizidx.

R. W. SHufELDT.

SIVALLOW (A.-S. Swalewe, Icel. Svala, Dutch Zwaluw, Germ. Schwalbe), the bird which of all other's is recognized as the harbinger

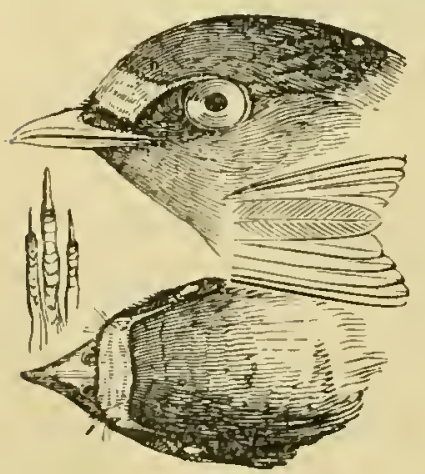

Swallow. (After Swainson.) of summer in the northern hemisphere; for, though some differences, varying according. to the meridian, are usually presented by the birds which have their home in Europe, in northern Asia and in North America respectively, it is difficult to allow to them a specific value; and consequently a zoologist of wide views, while not overlooking this local variation, will regard the Swallow of all these tracts as forming a single species, the Hirundo rustica of Linnæus. ${ }^{1}$ Returning, usually already paired, to its summer-haunts,

1 It has been already noticed that recent American authors would apply to the Swallow the generie term of Chelidon, generally accepted for the HouseMartin (p. 536), and to the latter Himundo. Herein they are technically incorreet, for one of the tirst principles of zoological nomenclature has always 
after its winter-sojourn in southern lands, and generally reaching England about the first week in April, it at once repairs to its old quarters, nearly always around the abodes of men; and about a month later, the site of the nest is chosen, resort being had in most cases to the very spot that has formerly served the same purposethe old structure, if still remaining, being restored and refurnished. So trustful is the bird, that it commonly establishes itself in any of men's works that will supply the necessary accommodation, and a shed, a barn or any building with an open roof, a chimney ${ }^{1}$ that affords a support for the nest, or even the room of an inhabited house-if chance should give free access thereto- to say nothing of extraordinary positions, may be the place of its choice. Wheresoever placed, the nest is formed of small lumps of moist earth, which, carried to the spot in the bird's bill, are duly arranged and modelled, with the aid of short straws or slender sticks, into the required shape. This is generally that of a half-saucer, but it varies according to the exigencies of the site. ${ }^{2}$ 'The materials dry quickly into a hard crust, which is lined with soft feathers, and therein are laid from four to six white eggs, blotched and speckled with grey and orange-brown deepening into black. Two broods are usually reared in the season, and the young on leaving the nest soon make their way to some leafless bough, whence they try their powers of flight, at first accompanying their parents in short excursions on the wing, receiving from them the food they themselves are as yet unable to capture, until able to shift for themselves. They collect in flocks, often of many hundreds, and finally leave the country about the end of August or early in September, to be followed, after a few weeks, by their progenitors. The Swallows of Europe doubtless pass into Africa far beyond the equator, ${ }^{3}$ and those of Northern Asia, $H$. gutturalis and $I$. tytleri, though many stop in

been that a generic term, to be valid, must be defined. In the absence of definition such a term may be, by conrtesy, occasionally accepted; but this courtesy has never been, nor except in America is likely to be, extended to the misapplication here in question.

"Hence the common English name of "Chimney-Swallow." In North America it is usually the "Barn-Swallow," as in Sweden.

2 In 1870 M. Pouchet announced to the French Academy of Science (Comptes Rendus, lxx. p. 492) that the "Hirondelles" building in the new part of Rouen had adapted themselves to the moderu style of architecture there used, and so saved much of the mud which was necessary when they built in the old part of the city, whence he inferred that they had reasoning powers. It fell to M. Noulet (op. cit. lxxi. p. 77) to shew this was an illusion: the Hirondelles of the new town were $H$. rustica, those of the old $H$. or Chelidon urbica! (Cf. Ann. N. H. sér. 4, v. p. 307 , vi. p. 270 ; and Yarrell, $B$ r. B. ed. 4, ii. p. 350 , note.)

${ }^{3}$ It must be noted that the Swallow has bcen observed in England in every month of the year; but its appearance from the beginning of December to the middle of March is an extremely rare occurrence. 
India or Burma, even further to the southward, occasionally reaching Australia, while those of North America, H. erythrogastra, extend their winter-wanderings to Southern Brazil; but, whithersoever they then resort, they during that season moult their feathers, and this fact affords one of the strongest arguments against the popular belief (which, curious to say, is still partly if not fully entertained by many who should know better) of their becoming torpid in winter, for a state of torpidity would suspend all animal functions. ${ }^{1}$ The chestnut forehead and throat, the shining steel-blue upper plumage and the dusky-white-in some cases reddening so as almost to vie with the frontal and gular patchesof the lower parts are well known to every person of observation, as is the markedly-forked tail, which is become proverbial of this bird.

Taking the word Swallow in a more extended sense, it is used for all the members of the Family Hirundinidx, ${ }^{2}$ excepting a few to which the name MarTin (p. 536) has been applied, and this Family includes more than 100 species, which have been placed in many different genera. The true Swallow has very many affines, some of which range almost as widely as itself, while others (as the form resident in Egypt, $H$. savignii) seem to have curiously restricted limits, and much the same may be said of some of its more distant relatives. But altogether the Family forms one of the most circumscribed and therefore one of the most natural groups of OsCINES, having no near allies; for, though in outward appearance and in some habits the Swallows bear a considerable resemblance to Swifts, the latter belong to a very different Order, and are not Passerine birds at all, as their structure, both internal and external, proves. It has been sometimes stated that the Hirundinidre have their nearest relations in the Muscicapide (FLYCATCHER,

i See John Hunter's Essays and Observations in Natural History, edited by Sir R. Owen in 1861 (ii. p. 280). An excellent bibliography of the Swallowtorpidity controversy, up to 1878, was given by Prof. Coues (Birds of the Colorado Valley, pp. 378-390), who seemed still to hanker after the ancient faith in "hibernation," as do apparently some other writers not so well informed.

2 An enormons amount of labour was bestowed upon the Hirundinidær by Dr. Sharpe (Cat. B. Br. Mus. x. pp. 85-210), only commensurate, perhaps, with that required for an understanding of the results at which he arrived. It was to be hoped that in the finely-illustrated Monograph of the Family which he and Mr. Wyatt hare published (2 vols. 4to, London: 1885-94), more of the many puzzles which the group offers would have been cleared up, but it still remains an intricate maze to tempt the adventurous. MIr. Wyatt's figures are very beautiful, but he is apparently one of those who believe that birds when flying at full speed do not extend their legs behind them. A curious omission of the authors is any reference in the work, with its copious bibliography, to the admirable account of the British Hirundinidæ contributed by Gilbert White to the Royal Society (Phil. Trans. lxiv. pp. 196-201; lxv. pp. 258-276) and afterwards reprinted in the Natural History of Selborne (1759). 
p. 273); but the assertion is very questionable, and the supposition that they are allied to the Ampelidx (WAXWING), though possibly better founded, has not as yet been confirmed by any anatomical investigation. An affinity to the Indian and Australian Artamus (the species of which genus are often known as Wood-Swallows, or Swallow-Shrikes) has also been suggested; and it may turn out that this genus, with its neighbours, may be the direct and less nodified descendants of a generalized type, whence the Hirundinida have diverged; but at present it would seem as if the suggestion originated only in the similarity of certain habits, such as swift flight and the capacity of uninterruptedly taking and swallowing insect-food on the wing.

Swallows are nearly cosmopolitan birds, inhabiting every considerable country except New Zealand, wherein only a stray example, presumably from Australia, occasionally occurs.

SWAN (A.-S. Swan and Swon, Icel. Svanr, Dutch Zwaan, Germ. Schwan), a large swimming-bird, well known from being kept in a half-domesticated condition throughout many parts of Europe, whence it has been carried to other countries. In England it was far more abundant formerly than at present, the young, or Cygnets, ${ }^{1}$ being highly esteemed for the table, and it was under especial enactments for its preservation, and regarded as a "Bird Royal" that no subject could possess without licence from the crown, the granting of which licence was accompanied by the condition that every bird in a "game" (to use the old legal term) of Swans should bear a distinguishing mark of ownership (cygninota) on the bill. Originally this privilege was conferred on the larger freelolders only, but it was gradually extended, so that in the reign of Elizabeth upwards of 900 distinct Swan-marks, being those of private persons or corporations, were recognized by the royal Swanherd, whose jurisdiction extended over the whole kingdom. It is impossible here to enter into further details on this subject, interesting as it is from various points of view. ${ }^{2}$ It is enough to remark that all the

I Here, as in so many other cases ( $c f$. PIGEoN, p. 723), we have what may be called the "table-name" of an animal derived from the Norman-French, while that which it bore when alive was of Teutonic origin. I find Yarrell's assertion, as to the use of $\mathrm{COB}$ and $\mathrm{PEN}_{\mathrm{EN}}$ on which I threw doubt (p. 92), confirmed by citations (N. Engl. Dict. ii. p. 559).

2 At the present time the Queen and the Companies of Dyers and Vintners still maintain their Swans on the Thames, and a yearly expedition is made in the month of July or August to take up the young birds-thence called "Swan-upping" and corruptly "Swan-hopping"-and mark them. The largest Swannery in England, indeed the only one worthy of the name, is that belonging to Lord Ilchester, on the water called the Fleet, lying inside the Chesil Bank on the coast of Dorset, where from 700 to double that number of birds may be kept-a stock doubtless too great for the area, but very small when compared with the numbers that used to be retained on various rivers in the country. The Swanpit 
legal protection afforded to the Swan points out that it was not indigenous to the British Islands, and indeed it is stated (though on uncertain authority) to have been introduced to England in the reign of Richard Coeur de Lion; but it is now so perfectly naturalized that birds having the full power of flight remain in the country. There is no evidence to shew that its numbers are ever increased by immigration from abroad, though it is known to breed as a wild bird not further from our shores than the extreme south of Sweden and possibly in Denmark, whence it may be traced, but with considerable vacuities, in a south-easterly direction to the valley of the Danube and the western part of Central Asia. In Europe, however, no definite limits can be assigned for the natural range of the species, since birds more or less reclaimed and at liberty consort with those that are truly wild, and either induce them to settle in localities beyond the boundary, or of themselves occupy such localities, so that no difference is observable between them and their untamed brethren. From its breeding-grounds, whether they be in Turkestan, south-eastern Europe or Scania, the Swan migrates southward towards winter, and at that season may be found in north-western India, in Egypt and on the shores of the Mediterranean.

The Swan just spoken of is by some naturalists named the Mute or Tame Swan, to distinguish it from one to be presently mentioned, but it is the Swan simply of the English language and literature. Scientifically it is usually known as Cygnus olor or C. mansuetus. It needs little description: its large size, its spotless white plumage, its red bill, surmounted by a black knob (technically the "berry") larger in the male than in the female, its black legs and stately appearance on the water are familiar, either from figures innumerable or from direct observation, to almost every one. When left to itself its nest is a large mass of aquatic plants, often piled to the height of a couple of feet and possibly some six feet in diameter. In the midst of this is a hollow which contains the eggs, generally from five to nine in number, of a greyish-olive colour. The period of incubation is between five and six weeks, and the young when hatched are clothed in sooty-grey down, which is succeeded by feathers of dark sooty-brown. This suit is gradually replaced by white, but the young birds are more than a twelvemonth old before they lose all trace of colouring and become wholly white. ${ }^{1}$

at Norwich seems to be the only place now existing for fattening the Cygnets for the table-an expensive process, but one fully appreciated by those who have shared the result. The English Swan-laws and regulations have been concisely but admirably treated by the late Serjeant Manning (Penny Cyclopædia, xxiii. pp. 271,272 ), and the subject of Swan-marks, elucidated by unpublished materials in the British Museum and other libraries, is one of which a compendious account, from an antiquarian and historical point of view, would be very desirable.

1 It was, however, noticed by Plot ( $N$. H. Staffordshire, p. 228) 200 years 
Thus mnch having been said of the bird which is nowadays commonly called Swan, we must turn to other species, and first to one that anciently must have been the exclusive bearer in England of the name. This is the Whooper, Whistling or Wild Swan ${ }^{1}$ of modern usage, the Cygnus musicus or C. ferus of most authors, which was doubtless always a winter-visitant to this country, and, though nearly as bulky and quite as purely white in its adult plumage, is at once recognizable from the species which has been half domesticated by its wholly different but equally graceful carriage, and its bill--which is black at the tip and lemon-yellow for a great part of its base. This entirely distinct species is a native of Iceland, eastern Lapland and northern Russia, whence it wanders southward in autumn, and the musical tolses it utters (contrasting with the silence that has caused its relative to be often called the Mute Swan) have been celebrated from the time of Homer to our own.

ago and more that certain Swans on the Trent had white Cygnets; and it was subsequently observed of such birds that both pareuts and progeny had legs of a paler colour, while the young had not the "blue bill" of ordinary Swans at the same age that has in some parts of the country given them a name, besides offering a few other minor differences. These being examined by Yarrell, led him to alnounce (Proc. Zool. Soc. 1838, p. 19) the birds presenting them as forming a distinct species, C. immutabilis, to which the English name of "Polish" Swan had already been attached by the London poulterers. There is no question so far as to the facts ; the doubt exists as to their bearing in regard to the validity of the so-called "species." Though apparently wild birds, answering fairly to the description, occasionally occur in hard winters in Britain, north-western Europe and even in the south-east (Lois, 1860, p. 351), their mother-country bas not yet been ascertained,-for the epithet "Polish" is but fanciful,-and most of the information respecting them is derived only from reclaimed examples, which are by no means common. Those examined by Yarrell are said to have been distinctly smaller than common Swaus, but those recognized of late years are as distinctly larger. The matter requires further investigation, and it may be remarked that occasionally Swans, so far as is known of the ordinary stock, will produce one or more Cygnets differing from the rest of the brood exactly in the characters which have been assigned to the so-called Polish Swans as specific -namely, their white plumage slightly tinged with buff, their pale legs and flesh-coloured bill (Zool. 1887, p. $463 ; 1888$, p. 470). It may be that here we have a case of far greater interest than the mere question of specific distinction, in some legree analogous to that of the so-called Pavo nigripennis before mentioned (PEACOCK, pp. 699, 700). The most recent authorities on the Polish Swan are Stevenson (B. Norf. iii. 111-121), and Southwell (Trans. Norf. \& Norw. Nat. Soc. ii. pp. 258-260), as well, of course, as Dresser (E. Eur. vi. pp. 429-433, pl. 419, figs. 1, 2). Gerbe, in his edition of Degland's Ornithologie Europeenne (ii. p. 477), makes the amusing mistake of attributing its name to the "fourrcurs" (furriers) of London, and of rendering it "Cygne du pôte"!

1 In some districts it is called by wild-fowlers ELK (p. 194), cognate with the Icelandic Alft and the Old German Elbs or Elps (cf. Gesner, Orn. pp. 358, 359), though by modern Germans Elb-schwan seems to be used for the preceding species. 
Otherwise in a general way there is little difference between the habits of the two, and closely allied to the Whooper is a much smaller species, known as Bewick's Swan, C. bewicki. This was first indicated as a variety of the last by Pallas, but its specific validity is now fully established. Apart from size, it may be externally distinguished from the Whooper by the bill having only a small patch of yellow, which inclines to an orange rather than a lemon tint; while internally the difference of the vocal organs is well marked, and its cry, though melodious enough, is unlike. It has a more easterly home in the north, first ascertained by Messrs. Harvie-Brown and Seebohm (Ibis, 1S76, p. 440), than the Whooper, but in severe winters frequently occurs in Britain.

Both the species last mentioned have their representatives in North America, and in each case the Transatlantic bird is considerably larger than that of the Old World. The first is the Trumpeter-Swan, C. buccinator, which has the bill wholly black, and the second the $C$. columbianus or americanus ${ }^{1}$-greatly resembling Bewick's Swan, but with the coloured patches on the bill of less extent and deepening almost into scarlet. South America produces two very distinct birds commonly regarded as Swans, the Black-necked Swan and that which is called Cascaroba or Coscaroba. This last, which inhabits the southern extremity of the continent to Chili and the Argentine territory, and visits the Falkland Islands, is the smallest species known,-pure white in colour except the tip of its primaries, but having a red bill and red feet. ${ }^{2}$ The former, C. melanocorypha or nigricollis, if not discovered by earlier navigators, was observed by Narbrough 2nd August 1670 in the Strait of Magellan, as announced in 1694 in the first edition of his Voyage (p. 52). It was subsequently found on the Falkland Islands during the French settlement there in 1764-65, as stated by Pernetty (Voyage, ed. 2, ii. pp. 26, 99), and was first technically described in 1782 by Molina (Saggio sulla Stor. Nat. del Chile, pp. 234,344 ). Its range seems to be much the same as that of the Cascaroba, except that it comes further to the northward, to the coast of southern Brazil on the east and perhaps into Bolivia on the west. It is a very handsome bird, of large size, with a bright red

1 Examples of both these species have been recorded as occurring in Britain, and there can be little doubt that the first has made its way hither. Concerning the second, more precise details are required.

2 Dr. Stejneger (Proc. U. S. Nat. NTus. 1882, pp. 177-179) lias been at much pains to shew that this is no Swan at all, but merely a large Anatine form. Further research may prove that his views are well founded, and that this, with another very imperfectly known species, C. davidi, described by Swinhoe (Proc. Zool. Soc. 1870, p. 430) from a single specimen in the Museum of Peking, should be removed from the subfamily Cygnina. Of C. coscoroba Mr. Gibson remarks (Ibis, 1880, pp. 36, 37) that its "note is a lond trumpet-call," and that it swims with "the neck curved and the wings raised after the true Swan model." 
nasal knob, a black neck and the rest of its plunage pure white. It has been introduced into Europe, and breeds freely in confinement.

A greater interest than attaches to the South-American birds last mentioned is that which invests the Black Swan of Australia. Considered for so many centuries to be an impossibility, the knowledge of its existence seems to have impressed (more perhaps than anything else) the popular mind with the notion of the extreme divergence-not to say the contrariety-of the organic products of that country. By a singular stroke of fortune we are able to name the precise day on which this unexpected discovery was made. The Dutch navigator Willem de Vlaming, visiting the west coast of Zuidland (Southland), sent two of his boats on the 6th of January 1697 to explore an estuary he had found. There their crews saw at first two and then more Black Swans, of which they caught four, taking two of them alive to Batavia; and Valentyn, who several years later recounted this voyage, gives in his work ${ }^{1}$ a plate representing the ship, boats and birds, at the mouth of what is now known from this circumstance as Swan River, the most important stream of the thriving colony of Western Australia, which has adopted this very bird as its armorial symbol. Valentyn, however, was not the first to publish this interesting discovery. News of it soon reached Amsterdam, and the burgomaster of that city, Witsen by name, himself a fellow of the Royal Society, lost no time in communicating the chief facts ascertained, and among them the finding of the Black Swans, to Martin Lister, by whom they were laid before that society in October 1698 (Phil. Trans. xx. p. 361). Subsequent voyagers, Cook and others, found that the range of the species extended over the greater part of Australia, in many districts of which it was abundant. It luas since rapidly decreased in numbers, and will most likely soon cease to exist as a wild bird, but its singular and ornamental appearance will probably preserve it as a modified captive in most civilized countries, and perhaps even now there are more Black Swans in a reclaimed condition in other lands than are at large in their mother-country. The species scarcely needs description: the sooty-black of its general plumage is relieved by the snowy white of its flight-feathers and its coral-like bill banded with ivory.

The Cygninx admittedly form a well-defined group of the Family Anatida, and there is now no doubt as to its limits, except in the case of the Cascaroba above mentioned. This bird would seem to be, as is so often found in members of the South-American fauna, a more generalized form, presenting several characteristics of the Anatinx, while the rest, even its Black-necked compatriot and the

1 Commonly quoted as Oud on Nieuw Oost Indien (Amsterdam: 1726). The incidents of the voyage are related in Deel iii. Boek i. Hoofdst. iv. (which has for its title Beschrijuinge van Band $\alpha$ ), pp. 6s-71. 
almost wholly Black Swan of Australia, have a higher morphological rank. Excluding from consideration the little-known C. davidi, of the five or six ${ }^{1}$ species of the Northern hemisphere four present the curious character, somewhat analogous to that found in certain Cranes (p. 111), of the penetration of the sternum by the TRACHFA nearly to the posterior end of the keel, whence it returns forward and upward again to revert and enter the lungs; but in the two larger of these species, when adult, the loop of the trachea between the walls of the keel takes a vertical direction, while in the two smaller the bend is horizontal, thus affording an easy mode of recognizing the respective species of each. ${ }^{2}$ Fossil remains of more than one species of Swan have been found. The most remarkable is $C$. falconeri, which was nearly a third larger than the Mute Swan, and was described from a Maltese cave by Prof. Parker (Trans. Zool. Soc. vi. pp. 119-124, pl. 30).

SWIFT, ${ }^{3}$ a bird so called from the extreme speed of its flight, which apparently exceeds that of any other British species, the Hirundo apus of Linnæus and Cypselus apus or murarius of most modern ornithologists, ${ }^{4}$ who have at-last learned that it has only an outward resemblance but no near aflinity to the SwaLlow (p. 926) or its allies. Well known as a summer-visitor throughout the greater part of Europe, it is one of the latest to return from Africa, and its stay in the country of its birth is of the shortest, for

1 The C. unwini doubtfully described by Mr. Hume (Ibis, 1871, pp. 412, 413) from India, though recognized by Dr. Stejneger (ut suprd), seems to be only the immature of the Mute Swall.

2 The correct scientific nomenclature of the Swans is a matter that offers many difficulties, but they are of a kind far too technical to be discussed here. Dr. Stejneger, in his learned "Outlines of a Monograph" of the group (ut suprà), has employed much research on the subject, with the result (which can only be decmed unhappy) of upsetting nearly all other views hitherto existing, and propounding some which few ornithologists outside of his adopted country are likely to accept. In the text, as above written, care has been taken to use mames which will cause little if any misunderstanding, and this probably is all that can be done in the present state of confusion.

3 The bird has many local names, of which perhaps Deviling and ScreechOWL are the commonest. Black MArtin, House-Martin and Martuer are also used, the last especially in Heraldry.

4 An attempt has been lately made to revive the generic name Micropus conferred in 1810 by Meyer and Wolf (Taschenb. i. p. 280), ignorant that it was already used in Botany, and by the laudable practice of those days inadmissible, as Meyer himself apparently recognized when he, in 1815 (Vög. Liv- und Esthlands, p. 143), substituted Brachypus for it ; but meanwhile Illiger had come in with his Cypselus, which Meyer in 1822, in the supplement to his former work (p. 255), accepted. Both Micropus and Brachypus have since been applied in several zoological and even ornithological groups; but the use of either is contrary to customary law. 
it generally disappears from England very early in August, though occasionally to be seen for even two months later.

The Swift commonly chooses its nesting-place in holes under the eaves of buildings, but a crevice in the face of a quarry, or even a hollow tree, will serve it with the accommodation it requires. This indeed is not much, since every natural function, except sleep, oviposition and incubation, is performed on the wing, and the easy evolutions of this bird in the air, where it remains for hours together, are the admiration of all who witness them. Though considerably larger than a Swallow, it can be recognized at a distance less by its size than by its peculiar shape. The head scarcely projects from the anterior outline of the pointed wings, which form an almost continuons curve, at right angles to which extend the body and tail, resembling the handle of the crescentic cutting-knife used in several trades, while the wings represent the blade. The mode of flight of the two birds is also unlike, that of the Swift being much more steady, and, rapid as it is, ordinarily free from jerks. The whole plumage, except a greyish-white patch under the chin, is a sooty-black, but glossy above. Though its actual breeding-places are by no means numerous, its extraordinary speed and discursive habits make the Swift. widely distributed; and throughout England scarcely a summer's day passes without its being seen in most places. A larger species, C. melba or alpinus, with the lower parts dusky white, which has its home in many of the mountainous parts of central and southern Europe, has several times been observed in Britain, and two examples of a species of a very distinct genus, Acanthyllis or Chxtura, which has its home in northern Asia, but regularly emigrates thence to Australia, have been obtained in England (Proc. Zool. Soc. 1880, p. 1).

Among other peculiarities the Swifts, as long ago described (probably from John Hunter's notes) by Home (Phil. Trans. 1817, pp. 332 et seqq., pl. xvi.), are remarkable for the development of their salivary glands, the secretions of which serve in most species to glue together the materials of which the nests are composed, and in the species of the genus Collocalia form almost the whole substance of the structure. These are the "edible" nests so eagerly sought by Chinese epicures as an ingredient for soup, and their composition, though announced many years since by Home (ut suprà), whose statement was confirmed by Bernstein (Act. Soc. Sc. Indo-Néerl. iii. Art. 5, and Journ. für Orn. 1859, pp. 111-119), has of late been needlessly doubted in favour of the popular belief that they were made of some kind of sea-weed, Alga, or other vegetable matter collected by the birds. ${ }^{\text {I }}$ It may be hoped that the examination and analysis made by Dr. J. R. Green (Journ. of Physiol. vi. pp. 40-45) have settled that question for all time. These re-

1 Hence one species has been called Collocalia fuciphaga. 
markable nests consist essentially of mucus, secreted by the salivary glands above mentioned, which dries and looks like isinglass. Their marlietable value depends on their colour and purity, for they are often intermixed with feathers and other foreign substances. The Swifts that construct these "edible" nests form a genus Collocalia, of which the number of species is uncertain; but they inhabit chiefly the islands of the Indian Ocean from the north of Madagascar eastward, as well as many of the tropical islands of the Pacific so far as the Marquesas, - one species occurring in the hill-country of Inclia. They breed in caves, to which they resort in great numbers, and occupy them jointly and yet alternately with Bats - the mammals being the lodgers by day and the birds by night. ${ }^{x}$

The genus Cypselus, as noted by Willughby, with its American ally Panyptila, exhibits a structure of the foot not otherwise observed among birds. Not only is the hind-toe constantly directed forwards, but the other three toes depart from the rule which

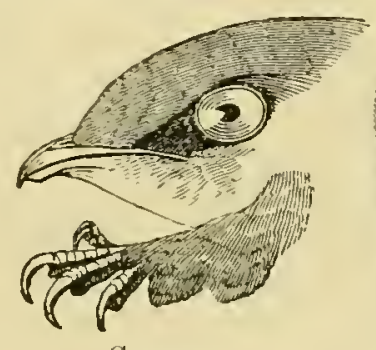

CYPSELES

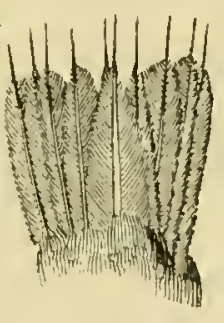

Acanthyllis. (After Swainson.)

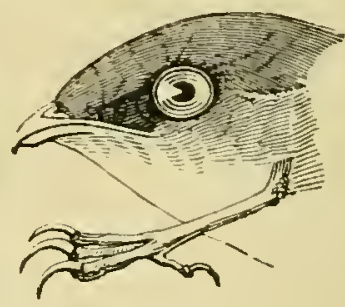

MaCRopterix.

ordinarily governs the number of phalanges in the Bird's foot,-a rule which applies to even so ancient a form as Archxopteryn (FossIL Breds, p. 278), -and in the two Cypseline genera just named the series of digital plalanges is $2,3,3,3$, instead of $2,3,4,5$, which generally obtains in the Class Aves. Other Swifts, liowever, do not depart from the normal arrangement, and the exception, remarkable as it is, must not be taken as of more value than is needed for the recognition of two sections or subfamilies admitted by Mr. Sclater in his monographical essay on the Family (I'roc. Zool. Soc. 1865, pp. 593-617). Mr. Hartert (Cut. B. Br. Mus. xvi. pp. 434-518) recognizes three subfanilies with nine genera and 78 species. Their geographical distribution is much the same as that of the Hirundinida (SwALLow, p. 926); but it should be always and most clearly borne in mind that, though so like Swallows in many respects, the Swifts have searcely any part of their structure which is not formed on a different plan; and, instead of any near affinity existing between the two groups, it can scarcely be doubted by any un-

$x$ Mr. H. Pryer has given one of the latest accounts of some of these caves in North Borneo (Proc. Zool. Soc. 1885, PI. 582-538), which may be read to advantage. 
prejudiced investigator that the Cypselidx not only differ far more from the Hirundinida than the latter do from any other Fanily of Passeres, but that they belong to what in the present state of ornithology must be deemed a distinct Order of Birds-that which in the present work has been called Picarix. That the relations of the Cypselida to the Trochilida (Humuing-BIRD, pp. 442, 443) are close, as has been asserted by L'Herminier, Nitzsch, Burmeister and Prof. Huxley, is denied by Dr. Shufeldt (Proc. Zool. Soc. 1885, pp. 886-914; Ibis, 1893, pp. 84-100), but the views of the last are controverted by Mr. Lucas (Auk, 1886, pp. 444-451; Ibis, 1893, pp. 365-371).

SWIET FOOT, Selby's name in 1825 (Brit. Orn. i. p. 334) for what was already known as the Courser (p. 107).

SWINEPIPE, an old name for the REDWING, Turdus iliacus (p. 777 , note 1 ).

SYNALLAXIS, the name of a genus instituted in 1819 by Vieillot (N. Dict. d'H. $N$. xxxii. p. 309), and used as English in 1825 by Stephens (Shaw's Zool. xiii. p. 227) ( $c$. Pscucule, p. 719).

SYNDACTYLI, one of Illiger's groups of SCANSORES (p. 815) in 1811 (Prodr. Syst. p. 207) consisting only of the genus Galbula (JACAMAR, p. 463).

SYRINX, the organ of voice, and a peculiarity of the class Aves, in so far as it is a modification of the lower end of the TracheA and adjoining parts of the BronchI (p. 58), whence it is frequently called the Lower LARYNX (p. 513). The essential features of such an organ are, first, membranes stretched between the several parts of a cartilaginous or bony framework, and next, special muscles which by their action vary and regulate the tension of the membranes.

In the majority of Birds the median wall of each bronchial tube is formed by a membrana tympaniformis interna, while a variable number of membranx tympaniformes externa exist on the outer side, either between neighbouring bronchial semirings, or between the first bronchial semiring and the last tracheal ring, or between the last two tracheal rings. The two inner tympaniform membranes mostly meet at the pessulus (p. 58), whence they often extend into the lower end of the Trachea as a semilunar fold. When there is no pessulus these two membranes meet directly and are attached to the ventral and dorsal corners of the last tracheal ring or rings. The position of the bronchidesmus (p.58) varies considerably. In Anseres it lies very near the pessulus, and is easily overlooked, while in Gallina it is placed further back and is very conspicuous: in Ardea, Buteo, Cuculus and Cypselus it is situated at the 5th pair of bronchial semirings, but at the 8 th in Picus and Podicipes.

All the muscles of the Syrinx (grouped as B. $\beta$. at p. 605) are 
supplied by a long branch of the Hypoglossal, or 12th pair of cranial nerves (xii. 2 of diagr. p. 624). A branch descends on either side of the Trachea, being often accompanied along its whole length by thin muscles which extend from the Upper Larynx and the Hyoid apparatus (p. 452) to the Syrinx, and the Syringeal muscles proper are in fact the distal portion of such a long lateral mass as in the majority of Birds is now restricted to the lower third part of the Trachea, and is there separated into a variable number of pairs; but there are also others which, though belonging to the same category, only act upon the Syrinx indirectly. Of these there is in all Birds one pair, but in Anseres, including Palamedex, two pairs, of slender muscles, which arise at about the beginning of the lower third of the Trachea and are inserted upon the arms of the Furcula or upon the lateral processes of the STERNUM (p. 909), or again, but rarely however, on neighbouring soft parts and not upon bones. These are the tracheo-clavicular and sterno-tracheal muscles.

The proper vocal muscles, being those which are inserted upon the lower end of the Trachea or upon the Bronchi, shew an extraordinary amount of modification. Their number varies from one pair to seven, and they are either inserted upon the middle or lateral portion of the bronchial semirings (MESOMYYDI, p. 546), or attached to the end of those semirings where they pass into the inner tympaniform membrane (ACROMYODI, p. 1). The former is morphologically the more primitive condition, and is found in an overwhelming majority of Birds ; while the latter, with few exceptions, is restricted to the Oscines (p. 659). But there are also other conditions"Anacromyodian," "Catacromyodian" and "Diacromyodian" according as these muscles are inserted on the dorsal, the ventral or on both ends of the semirings. Hence the distinction between Oligomyode (p. 654) and Polymyode (p. 737), depending on the presence of few or many song-muscles, even if applied to Passeres only, cannot be maintained, for that group includes forms with any number of pairs from 1 to 7 . Nor is the distinction between Mesomyodi and Acromyodi always safe. The Tyrannida for instance are anacromyodian, while the Pipridæx and Cotingidx are catacromyodian, and these modifications can be shewn to have been derived (comparatively recently) from the weak mesomyodian and oligomyodian condition which prevails in the majority of the so-called Oligomyodx. On the other hand, the diacromyodian type can only have been developed from a strong muscular basis which could split into a dorsal and a ventral mass. Moreover, there are no Passeres known to be intermediate between those that are diacromyodian and those that are not. We have therefore to distinguish between

(1) Passeres diacromyodi, in which some of the syringeal muscles. 
are attached to the dorsal and some to the ventral ends, those ends being, so to say, equally treated; this form comprises the SubOSCINES (p. 921) and Oscines; and

(2) Passeres anisomyodi, in which the muscles are unequally inserted, either in the middle, or upon only one or the other, dorsal or ventral, end of the semirings; this form comprises the Subclamatores (p. 921) and Cramatores.

In this way we can arrive at a natural classification of the Passeres, and avoid the obviously illogical shortcomings which result from attempts to sort them into two groups by the application of two distinct taxonomic principles, one being the number of the muscles and the other the mode of their insertion, in addition to the over-estimate of the tracheophonous type.

The following list shews the number of muscles attached to the lower end of the Trachea or to the Syrinx (except the tracheoclavicular and sterno-tracheal muscles) in various groups of Birds.

I. Trachea and Syrinx devoid of muscles:-Casuarius, Dromæus, Apteryx, Struthio, most Steganopodes, Ciconiidx, Cathartidx and some Gallina. This is not a primitive feature, but one brought about by loss.

II. One pair of muscles inserted on the distal end of the Trachea :-Anseres, with Palamedea, Scopus, Limosa, most Gallinæ, Columbx, Pteroclidx, Opisthocomus, Rhamphastidx, Bucconidx, Momotidx, Todida, Cypselus, some Pteroptochida and Formicariida.

III. One pair of tracheo-bronchial muscles, arising mostly from the Trachea and attached to one or more of the bronchial semirings: - Phea, Sphenisci, Colymbus, Podicipedidx, Phalacrocorax, Tubinares, Ardeidx, Phonicopterus, Ralli, Grues, Limicolæ, Lavidx, Alcidx, Megacephalon, Lophortyx, most Falconidx, Cuculidx, Coraciidx, Upupidx, Coliidx, some Trochilida, Pici, Capitonidx, Todidx, Striges, Caprimulgi, some Pteroptochidie and Fonnicariidx, Conopophagidx, Cotingidx, Pittidx, Philepittidx, Eurylamidx, various Pipridx and Tyrannidx.

IV. Two pairs of short tracheo-bronchial muscles :-Gallinago cxlestis, Falco, some Trochilidx, various Piprida and Tyrannidx, Dendrocolaptidxe and Furnariidx, and Atrichornis - the last having one pair inserted dorsally and the other rentrally, and being therefore diacromyodian.

V. Three pairs:-Psittaci, with tracheal and tracheo-bronchial muscles; Menura and Poodytes, ${ }^{1}$ with two dorsal and one ventral tracheo-bronchials.

V1. Four pairs or more:-Grallina, with two dorsals and two ventrals; Prosthematodera, with two or three dorsals and two ventrals.

1 This is the Sphenceacus of Gould and other writers; but the type of that genus is a South-African species which I can scarcely believe to be nearly allied; 1 have therefore adopted the generic name which applies to the Australian form. 'The species I examined seems to be $P$. galactodes. 
VII. Most of the Oscines seem to possess five or seven pairs of syringeal muscles-no case of six pairs being known. In the Corvida they are arranged as follows:-(1) $m$. tracheo-bronchialis ventralis, from the Trachea to the anterior ventral end of the 2nd semiring; (2) m.tr-bronch. olliquus, to the ventral end of the 3rd semiring; (3 and 1) m. tr.-bronch. dorsalis longus et brevis, to the dorsal end of the 2nd semiring, and to the inner tympaniform membrane near the pessulus ; (5) m. syringeus ventralis, to the ventral end of the 2nd semiring-shorter than and covered by No. 1 ; (6) $\mathrm{m}$. syr. ventri-lateralis, covered by No. 2, inserted on the membrane between the 2 nd and 3 rd semirings; $(T) m$. syr. dorsalis, to the dorsal end of the 2 nd semiring.

According to the position of the sound-producing membranes, three types of Syrinx are distinguishable:-Tracheal, Bronchial and Tracheo-Bronchial.
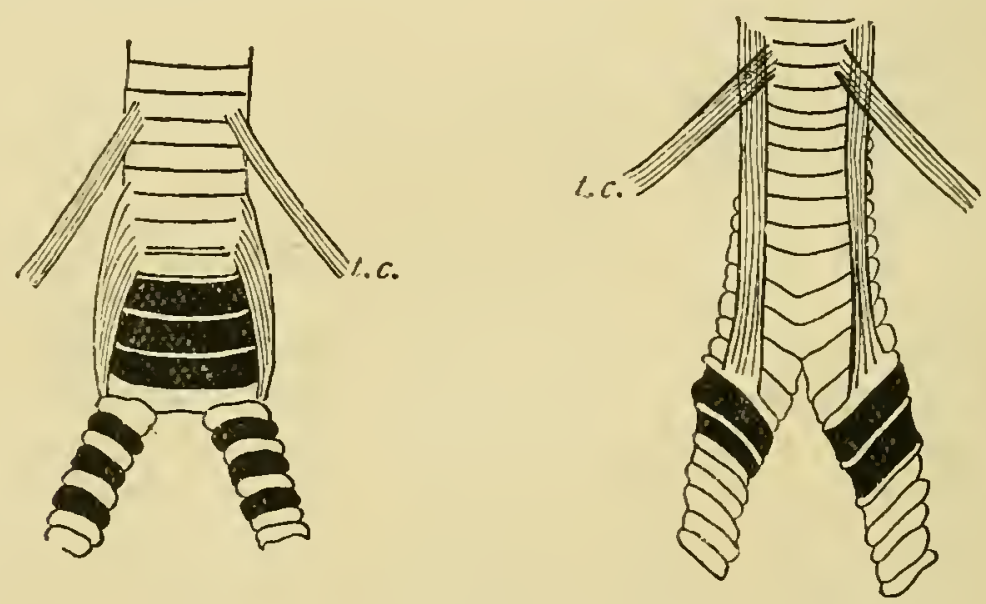

Diagray of a Tracheal and a Broxchial Syrinx. t.c. tracheo-clavicular muscle.

I. Syrimx trachealis, in which the lower portion of the Trachea consists of thin membranaceous walls, about six of the rings being extremely thin or, as often happens, deficient. Both inner and outer tympaniform membranes exist in the Bronchi as well as some vibratory tracheal membranes. The few muscles, generally but one pair, are wholly lateral. The birds this furnished are the TracheophoNe, their voice is very loud, and while it is being sounded the lower part of the throat swells out. They belong entirely to the Neotropical Region, and comprising the Dendrocolaptida, Formicariida, Pteroptochida and Conopophagida, form a tolerably well-marked group of the Passeres Clumatores. Indications of such a tracheophonous Syrinx exist in various Cotingida and Pittida, as well as in Columber and Gallina-but the last cases are clearly only analogous.

II. Syinx bronchialis, in which outer tympaniform membranes exist between two or more successive bronchial semirings, while an 
inner tympaniform membrane may also be present. In typical cases the Trachea has no solunding membranes, and to such belong Steatornis, various Caprimulgi and Cuculi-notably Batrachostomus, Podargus, Crotophaga, Piaya and Guira; but there are other members of these groups, as Egotheles, Nyctidromus, Cuculus and Centropus, in addition to certain Striges, as Asio accipitrinus, which shew stages intermediate between the typical Bronchial and Tracheo-bronchial Syrinx, in so far as the lower part of the Trachea has incomplete rings only, with no pessulus, and is, as in Centromes, split into a right and left half, so that it assumes the Bronchial character.

III. Syrinx tracheo-bronchialis, which may be regarded as the normal form, the other two being modifications of it, yet it is
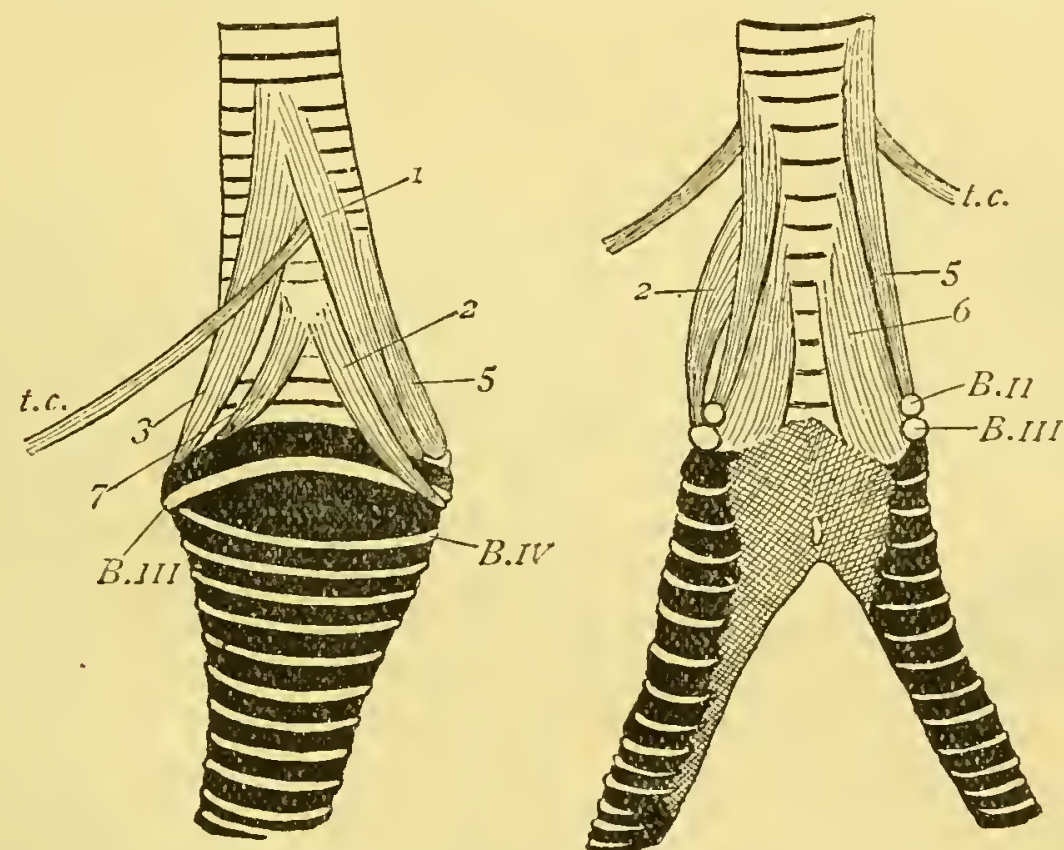

Raven. Lateral and Dorsal View of Syrinx.

B.II. IIT. IT. second, third and fourth bronchlal rings; Nos. 1-\%, as ou page 940.

difficult to give such a diagnosis of it as will apply to all its modifications. The essential feature is that the proximal end of the inner tympaniform membrane is attached to the last pair of tracheal rings. In the Oscines the four or five distal tracheal rings are solidly fused into a little box which communicates with the Bronchi; the first and second bronchial semirings are closely attached to the Trachea; and the spaces between the second and third and third and fourth semirings are generally closed by onter tympaniform membranes. Similar arrangements exist in many other birds; but the chief outer membrane is frequently formed between the last. tracheal and the first bronchial ring, as in Rhea, Anseres, Sphenisci, Perdix, Cypselus, Aluco flammeus and Rupicola. Most peculiar features are shewn by Gallus and the Psittaci; but in fact the modifications are very numerous, as may well be expected from the 
number of rings, semirings, muscles and membranes that enter. into the composition of the Syrinx. The essential requirement of a vocal organ, the presence of vibratory membranes, can be met in many ways; but how these membranes act in particular, and how their tension is modified by the often numerous muscles we do not know. Various dilatations of the Trachea no doubt assist the modulation of the voice, and the same may be said of the upper Larynx; but the Tongue plays no part in the voice of Birds, with the possible exception of Parrots, and the slitting of that member or the cutting of its frenum cannot possibly add to the faculty of articulation.

\section{$\mathrm{T}$}

TAILOR-BIRD, the Motncilla sutorie of Pennant, who in 1769 (Indian Orn. p. 7, pl. viii.) described and figured its wonderful nest, ${ }^{1}$ built in a cone which is formed by the sewing together of the leaves of plants, as may be seen in almost every museum, and read of in many books. A good summary of what has been witten on the subject is given ly Mr. Oates (Hume's Nests \& Eggs, Ind. B. ed. 2, i. pp. 231-235); but thongh the progress of building has been watched and recorded almost day by

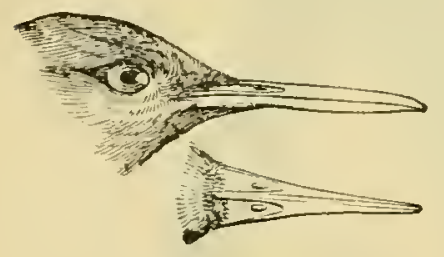

ORTHOTOMUS LONGIROSTRIS.: (After Swainson.) day, few seem to have olserved the birds at work upon their fabric, and no one has explained how they make the threads (when they do make them) with which they sew, or the bunches at the ends acting as knots to hinder the threads from being drawn ont. The briefest account must here suffice.

Of the common Indian Tailor-bird, Orthotomus sutorius or Sutoric longicauda, Jerdon (B. Ind. ii. p."166) writes that it "makes its nest of cotton, wool and various other soft materials," and "draws together one leaf or more, generally two leaves, on each sicle of the nest, and stitches them together with cotton, either woven by itself,

" He was wrongly informed as to what the bird was like, for he says it was "light yellow," whereas it has a ehestnut crown, the back of a bright olive-green, and is white beneatl.. The cock has the two middle tail-featleers elongated; but in the hen they do not surpass the rest. J. R. Forster, a dozen years later, brought out a German version of Pennant's work (the original edition of which was never completed), and therein referred (p. 17) to an earlier description of the hird and its nest by Walter Schouten (Voy. Ind. Orient. ii. 1\% 513, pl. xv.) under the name of "Tati ore Oiseau-moneche."

2 The figure was drawn from a specimen in the Paris Museum; but Dr. Sharpe (ut supric, p. 219, note) says he has "not sueceeded in identifying" the speeies to whieh it belonged. 
or cotton thread picked up; and after passing the thread throngh the leaf, it makes a knot at the end to fix it." Species of Tailorbird more or less nearly allied are found throughout the greater part of the Indian Region; but some of them would appear not always to build their nests in this fashion; and birds of the genus Cisticola, to which belongs the FANTAIL-WARBLER, C. cursilans, that inhabits the South of Europe, ply the same trade on stems of grass, confining them by stitches above the nest, which is built among them and takes a globular form. Both Orthotomus and Cisticola are remarkable for the variation in colour of the eggs they lay, which in the case of the latter is said to depend on the season of the year ( $c f$. EGGs, p. 189). All these birds are referred by most systematists to a subfanily of Sylviida (WARBLER) known as Drymocinx, but at present nothing can be said with certainty on that point. Dr. Sharpe (Cat. B. Br. Mus. vii. p. 215) places them in his Timeliidx, with the true members of which group they seem to have little in common.

TAISTEY or TYSTY (spelling uncertain), Icel. beista, the Shetland name for the DovEkEY of sailors (p. 166) and Black GUILiEMoT of books (p. 399), Uria grylle.

TAKAHE, the Maori name of Notornis (cf. Moonhen, pp. 591, 592), adopted by the settlers in the South Island of New Zealand, where it is supposed still to exist.

TALENTER, used fancifully for HAwK (Thos. Middleton, The World Tost at T'ennis, 1620), as having "talents," i.e. talons-these words being often confounded, or played upon, as by Shakespear (Love's Labour's Lost, iv. 2, 65).

TAMMY-NORIE, a northern form of TOM-NODDY, and a name for the PUFFIN (p. 750).

TANAGER, a word adapted from the quasi-Latin Tanagra of Linnæus, which again is an adaptation, perhaps with a classical allusion, of Tangara, used by Brisson and Buffon, and said by Marcgrave (Hist. Rer. Nat. Bras. p. 214) to be the Brazilian name of certain birds found in that country. From them it has since been extended to a great many others mostly belonging to the southern portion of the New World, now recognized by ornithologists as forming a distinct Family of Oscines, and usually considered to be allied to the Fringillidx (FINCH, p. 250); but, as may be inferred flom Prof. Parker's remarks (Trans. Zool. Soc. x. pp. 252, 253 and 267), the Tanagrida are a "feebler" form, and thereby bear out the opinion based on the examination of many types both of Birds and Mammals as to the lower morphological rank of the Neotropical Fauna as a whole (GEographical Distribution, pp. 321-323).

The Tanagers are a group in which Mr. Sclater has for many 
years interested himself, and his latest treatment of them (Cat. Br. Mus. xi. pp. 49-307) admits the existence of 375 species, which he arranges in 59 genera, forming six subfamilies-Procniatine, Euphoniine, Tunagrina, Lamprotina, Phonicoplitina and Pitylinx.

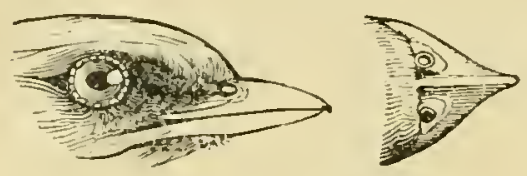

Procsias. (After Swainson.) These are of very unequal extent, for, while the first of them consists of but a single species, Procnias tersu, - the position of which may be for several reasons still open to doubt, 一 the third includes mole than 200. Nearly all are birds of small size, the largest barely exceeding a SongThrush. Most of them are remarkable for their gaudy colouring, and this is especially the case in those forming the genus called

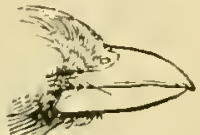

Euphosia MUSica.

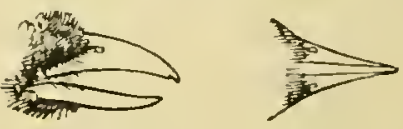

TANAGRA CYANOPTERA.

(After Swainson.)

by Mr. Sclater, as by most other authors, Calliste, a term inadmissible through preoccupation, to which the name of Tanagru of right seems to belong, while that which he names Tanagra.

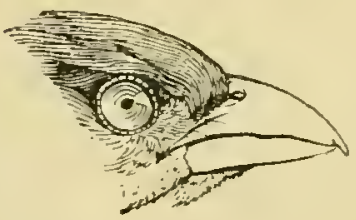

ThraUPIS EPISCOPUS.

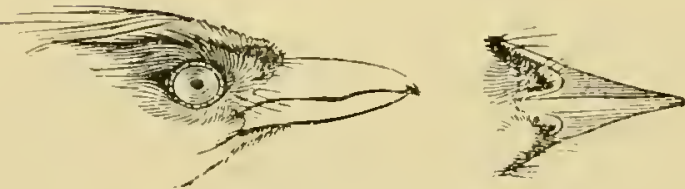

TACHYPHONUS CRISTATUS.

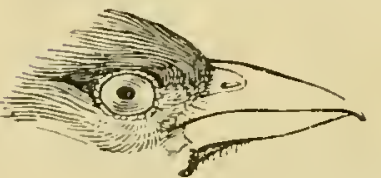

CYPSNAGRA RUFICOLLIS.

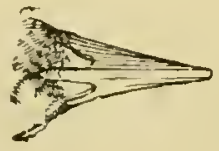

(After Swainson.)

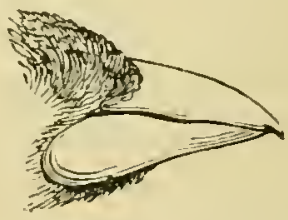

Rhamphocelus.

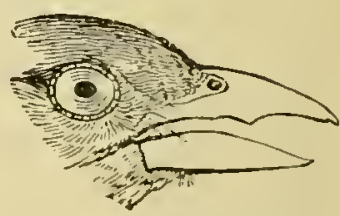

Pyranga rubra.

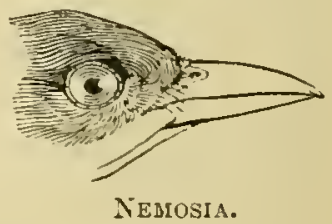

should probably be known as Thraupis. ${ }^{1}$ The whole Family is almost confined to the Neotropical Region, and there are several

1 All this appears clearly from what MIr. Sclater himself says in the Introduction (pp. vii. viii.) to his beautiful Monograph of the genus (London: 1857). 
forms peeuliar to the Antilles; but not a tenth of the speeies reach even sonthern Mexico, and not a dozen appear in the northern part of that country. Of the genus Pyranga, which has the most northern range of all, three if not four speeies are common summer immigrants to some part or other of the United States, and two of

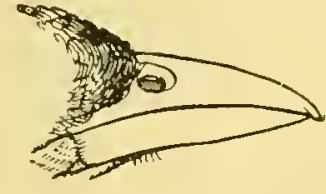

LAMPROTES.

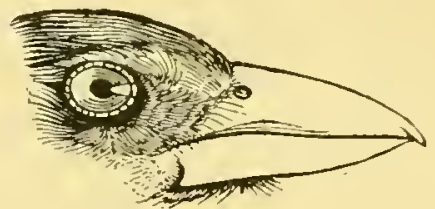

SALTATOR.

(After Swainson.)

them, $P$. rubre and $P$. astiva,-there known respectively as the Scarlet Tanager and the Summer Redrind (p. 771 ), - reach even the Dominion of Canada, visiting as well, though accidentally, Bermuda. $P$. astive has a western representative, $P$. cooperi, which by some anthors is not reeognized as a distinct species. The males of all these are clad in glowing red, $P$. rubru having, however, the wings and tail black. The remaining speeies, $P$. ludoviciana, the males of which are mostly yellow and black, with the head only

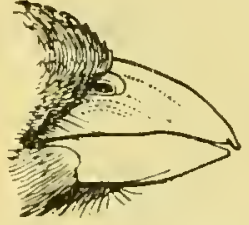

Cissopis picatus.

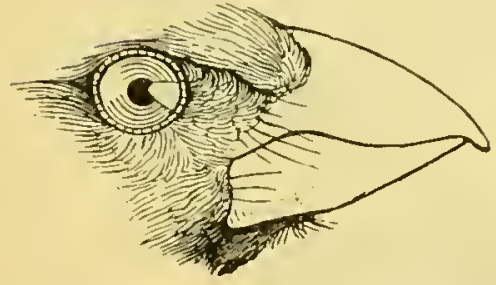

Pitylus Fuliginosus.

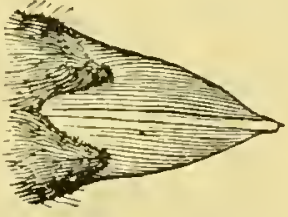

(After Swainsol.)

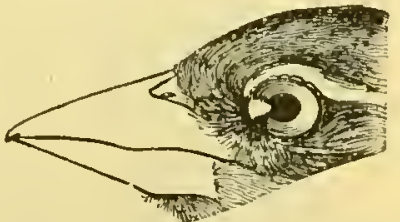

ARREMON.

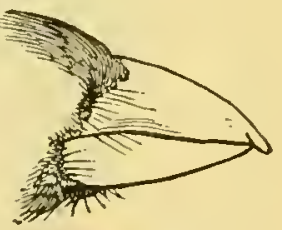

SCHISTOCHLAJIYS.

red, does not appear eastward of the Missouri plains, and has not so northerly a range. Another species, $P$. hepatica, has just shewn itself within the limits of the United States. In all these the females are plainly attired; but generally among the Tanagers, however bright may be their coloration, both sexes are nearly alike in plumage. Little has been recorded of the habits of the species of Central or Sonth America, but those of the north have been as elosely observed as the rather retiring nature of the birds renders possible, and it is known that insects, especially in the larval condition, and berries afford the greater part of their food. They have 
a pleasing song, and build a shallow nest, in which the eggs, generally three in number and of a greenish-blue marked with brown and purple, are laid.

The figures here given will shew the varied proportion of the bill in some of the genera of this Family, and as a whole the Tunugrida may perhaps be cousidered to hold the same relation to the Fringillida as the Icteridx do to the Sturmidx (STARLING), and the Mniotiltida to the Sylviida (Warbler) or Turdida (Thrush), in each case the purely New-World Family being the "feebler" type.

TAPACULO, the name ${ }^{l}$ given in Chili to a bird of singular

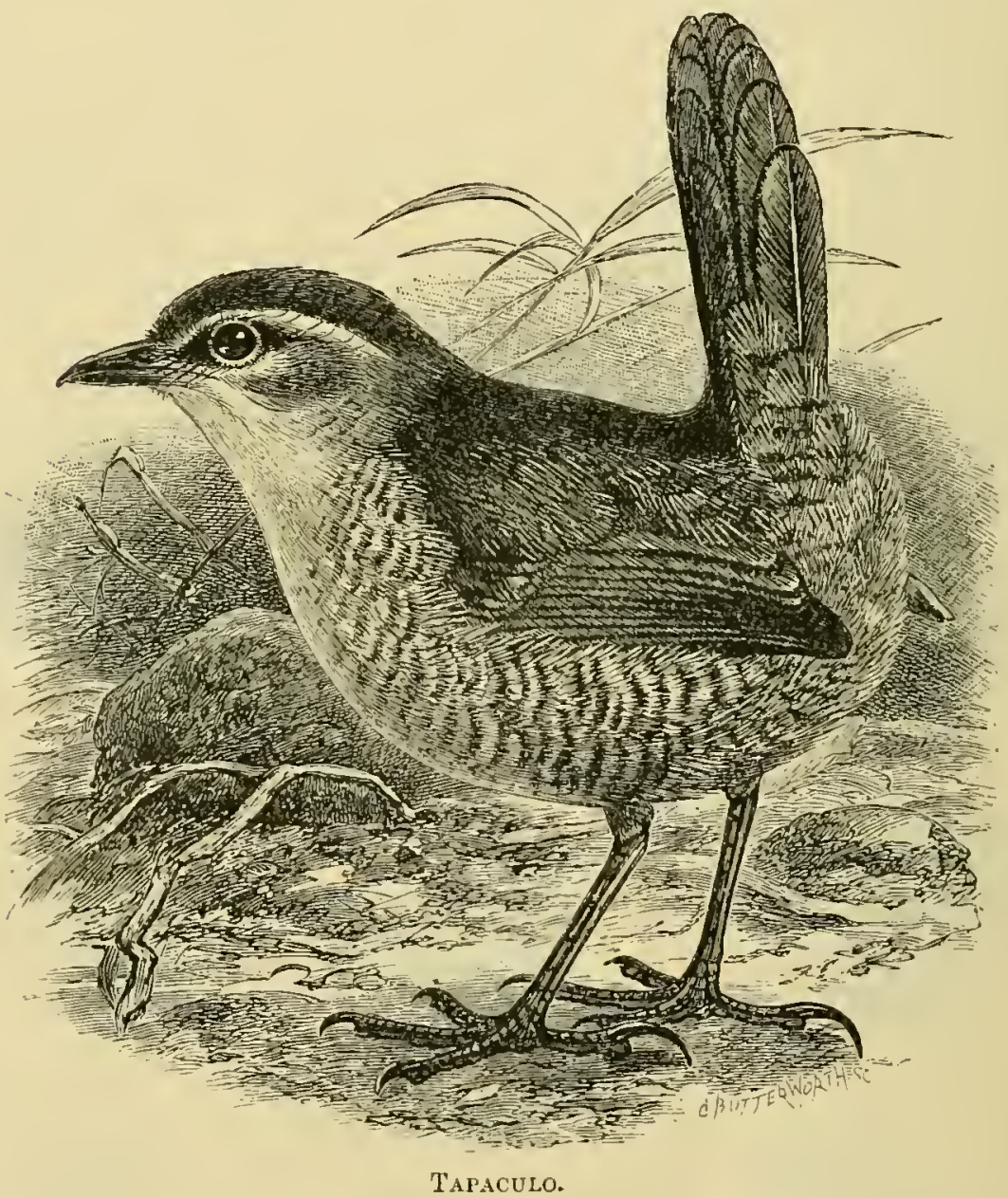

appearance,-the Pteroptochus ullicollis of ornithology, - and in this work (p. 324 and INTroduction) applied in an extended sense to

1 Of Spanish origin, it is intended as a reproof to the bird for the shameless way in which, by erecting its tail, it exposes its hinder parts. It has been sonetimes misspelt "Tapacolo," as by Mr. Darwin, who gave (Joum. Res. ehap. xii.) a short but entertaining aceount of the habits of this bird and its relative IIylactcs megapodius, called by the Chilenos "El Turco," while Mr. Hudson (Argent. Om. i. p. 206) has briefly described those of the Patagonian "Gallito" (Little Cock), Phinocrypta lanccolata. 
its allied forms, which are now found to constitute a small Family, Pteroptochida, belonging to the Tracheophonous division of Passeres, and therefore peculiar to South America. About 20 species, disposed by Mr. Selatel (Cat. B. Br. MIus. xv. pp. 337-352) in 8 genera, are believed to belong to this group.

The species of the Family first made known is Scytalopus magellanicus, originally described in 1783 by Latham (Gen. Syn. iv. p. 464) as a Warbler. Even in 1836 Gould not umnaturally took it for a Wren, when establishing the genus to which it is now referred; but some ten years after Johammes Mïller found that Scytalopus, together with the true Tapaculo, which was first described by Kittlitz in 1830, possessed anatomical characters that removed them fal from any position previously assigned to them, and determined their true place as above given. In the meanwhile a kindred form, Hylactes, also first deseribed in 1830, had been shewn by Eyton to have some very exceptional osteological features, and these were found to be also common to Pteroptochus and Scytulopus. In 1860 Professor Cabanis recognized the Pteroptochidix ats a distinct Family, but made it also include Menue (Irrebird, p. 523), while some year's later Mr. Sclater (Ibis, 1874, p. 191, note) thought that Atrichomis (SCRUB-BIRD, p. 820) might belong here. It was Garrod in 1876 and 1877 who finally divested the Family of these aliens, but, until examples of some of the other genera liave been anatomically examined, it may not be safe to say that they all belong to the Pteroptochida.

The true Tapaculo, $P$. albicollis, has a general resemblance in plumage to the females of some of the smaller SHRIkes (p. 845), and to a cursory observer its skin might pass for that of one; but its shortened wings and powerful feet would on closer inspection at once reveal the difference. In life, however, its appearance must be wholly unlike, for it rarely flies, hops actively on the ground or among bushes, with its tail erect or turned towards its head, and continually utters various and strange notes,-some, says Mr. Darwin, are "like the cooing of doves, others like the bubbling of water, and many defy all similes." The "Turco," its fellow-comntryman, Hylactes megapodius, is larger, with greatly developed feet and claws, but is very similar in colour and habits. Two more species of Hylactes are known, and one other of Pteroptoclus, all of which are peculiar to Chili or Patagonia. The species of Scytalopus are as small as Wrens, mostly of a dark colour, and inhabit parts of Brazil and Colombia, one of them occurling so far northward as Bogota. ${ }^{1}$

1 This may be the most convenient

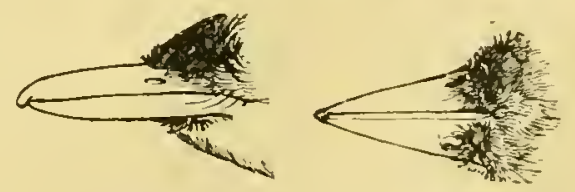

ConopophaGa. (After Swainson.) place to mention another South-American Family, Conopophagilla, suggested by Garrod (Proc. Zuol. Suc. 1877, 1. 452), and subsequently shewn by Forbes (op. cit. 
TARNEY, TARRACK and TARRET, said to be local names of the common TERN; but the second, spelt

TARROCK, is generally used for the KrTTrwake (p. 492) in immature plumage.

TARSEL and TASSEL (Romeo anel Juliet, ii. 2, 160) corruptions of Tercel.

TARSUS, in common descriptive ornithology the thind and most conspicuous portion of the Bird's leg, whence the toes spring. For its actual composite nature see SkELETon (p. 864).

TATLER, a name applied in North America to various species of SANDPIPER (p. 810); but generally with a distinetive prefix. Its first reeognition as an ornithological term seems to be in 1831 by Richardson and Swainson (Fann. Bor:-Amer. ii. p. 388), but it was probably used before colloquially ( $f$. TELLTALE).

TEAL (Old English Tele), a word of uncertain origin, but doubtless cognate with the Duteh Taling (formerly Talingh and Telingh), and this apparently with the Scandinavian Atteling-And (Briinnich, Orn. Bor. p. 18) and Atting, which it seems impossible

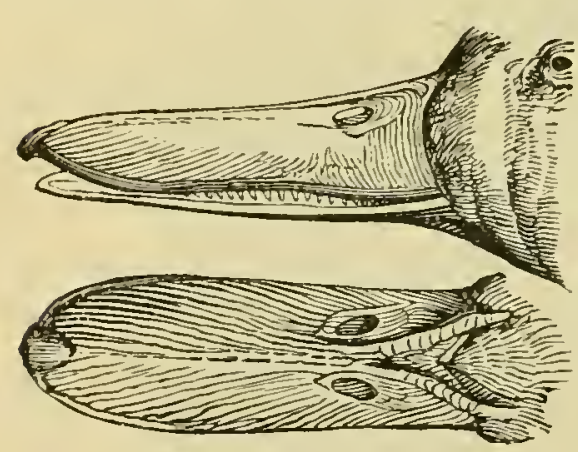

Bill of TEAL. (After Swainson.) not to connect with the Seottish AtThal (p. 22), though this last word (however it be spelt) is generally used in conjunction with Teal, as if to mean a different kind of bird; and commentators have shewn a marvellous ineptitude in surmising what that bird was.

The Teal is the Anas crecca of Linnæus, and the smallest of the European Anatida (DUCK, p. 168), as well as one of the most abundant and highly esteemed for the table. It breeds in many parts of the British Islands, making its nest in places very like those ehosen by the IVild Duck, A. boscus; but there is no doubt that by far the greater number of those that are taken in deeoys, or are shot, during the antumm and winter are of foreign origin. While the female presents the usual inconspicuous mottled plumage of the same sex in most species of Anatina, the male is one of the handsomest of his kind; but too well known to need description. It inhabits almost the whole of Europe and Asia,from Iceland to Japan,_-in winter visiting Northern Africa and India, and occasionally occurring on the western shores of the Atlantic; but its place in North Ameriea is taken by its representative, 4 . carolinensis, the male of which is easily to be recognized 1851, p. 435 ) to be suffieiently remarkable (cf. Sclater, Cat. D. Br. Mus. xv. 1'p. $329-336)$. 
by the absence of the upper buff line on the side of the head and of the white scapular stripe, while he presents a whitish crescentic bar on the sides of the lower neck just in front of the wings.

Species more or less allied to these two are found in most other parts of the world, and among such species are some (for instance, the $A$. gibberifrons of the Australian region and the $A$. eatoni of Kerguelen Island) in which the male wears almost the same inconspicuous plumage as the female. But the determination of the birds which should be technically considered "Teals," and belong to the subgenus Nettium (generally misspelt Nettion), as distinguished from other groups of Anatinx, is a task not yet accomplished, and confusion has possibly been caused by associating with them such species as the GARGANEY (p. 309) and its probable allies of the group Querquedula. Others again have not yet been discriminated from the WigEons, the Pintams (p. 726), or even from the typical form of Anas, into each of which groups Nettium seems to pass without any great break. In ordinary talk "Teal" stands for any Duck-like bird of small size, and in that sense the word is often applied to the members of the genus Nettopus, though systematists will have it that they are Geese, which the formation of their trachea shews they are not. In the same loose sense the word is often applied to the two most beautiful of the Family Anatida, belonging to the genus $A: x$ (commonly misspelt $A i x$ ) - the Carolina or Wood-Duck of North America, $A E$. sponsa (not to be confounded with the above-named Anas carolinensis or Nettium carolinense), and the Mandarin-Duck of China, AE. galericulata. Hardly less showy than these are the two species of the group named Eunettu, - the Falcated Duck, E. falcata, and the Baikal Teal, E. formosa,-both from Eastern Asia, but occasionally appearing in Europe. Some British authors have referred to the latter of these well-marked species certain Ducks that from time to time occur, but they are doubtless hybrids, though the secret of their parentage may be unknown; and in this way a so-called Bimaculated Duck, Anas bimaculata, was for many years elroneously admitted as a good species to the British list, but of late this has been properly discarded (cf. Suchetet, Hist. du Bimaculated Duck, Lille: 1894).

TEASER, a local name for the Arctic Gull (SKUA).

TECTRICES (sing. tectrix), the feathers that cover the base of the quill-feathers of the wing (REmiges, p. 780) and of the tail (RECTRICES, p. 769), in each case divisible into Upper and Lower, according to their position on the dorsal or ventral surface; but the tail-coverts need little further notice, while those of the wing deserve much attention. Setting aside the marginal feathers, each group of wing-coverts, whether Upper or Lower, comprises three series-known as the Greater, Middle and Lesser-the two first 
consisting of only one row of feathers, which in the case of the Greater agrees in number with that of the Remiges, each tectrix being placed on the proximal side of its corresponding remex. When the 11th or terminal quill is absent its Upper covert remains as a supernumerary, as for instance the well-known stiff "painter's feather" of the Woodcock. The Lower 11 th tectrix is less constant, and in the Gallina, for example, is ahsent. Similar conditions are found in the 10th Greater covert of many Passeres, and sometimes

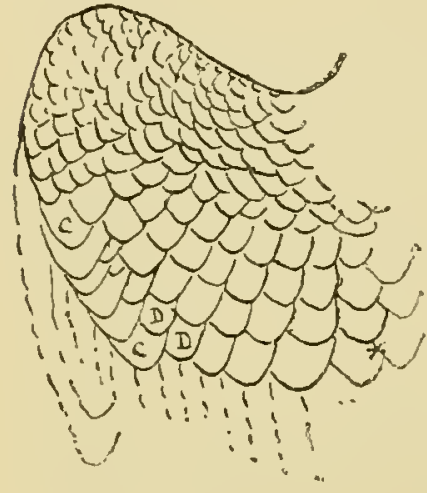

Fatco.

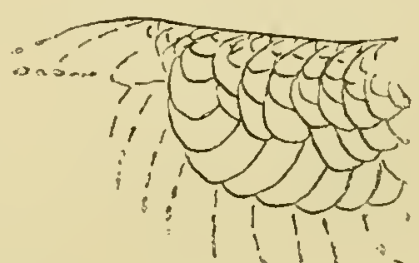

TTRDUS.

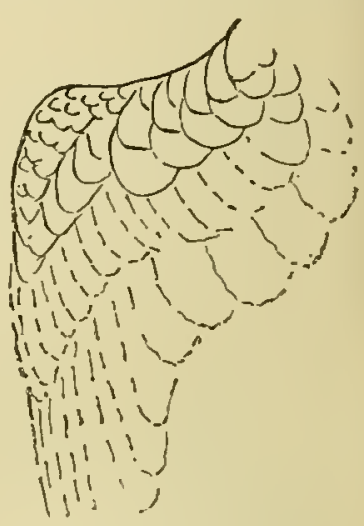

Trochilus.

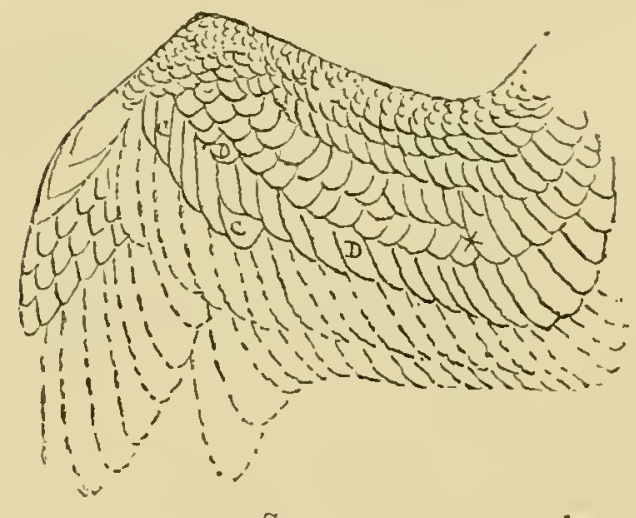

Sterna.

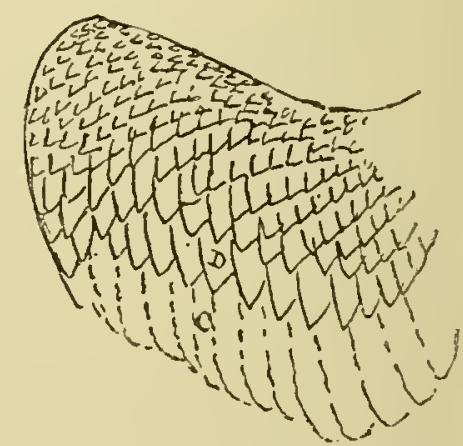

Plotus.

$C$, supplementary ; $D$, posterior row of Middle Upper wing coverts; $x$ shews the point of change in the overlap. (After Goodchilı.)

(From the Proccedings of the Zoological Society, 1856.)

the terminal Upper covert is even larger than the corresponding quill. The Upper corert of the first or proximal digital ("primary") quill is often very small or even absent, being completely overlaid or represented by the corresponding Middle covert, an arrangement probably produced by the mechanical conditions necessary to the folding of the wing. The Upper Greater coverts of the cubital ("secondary") quills likewise grow from the proximal side of their" remiges, but they cross the latter in an outward direction. The Lower tectrices are also inserted proximally, but those of the Greater series do not cross their remiges, though they are crossed inwards 
and very obliquely by those of the Middle series, which are inserted each between a remex and its corresponding Greater covert. The Lower coverts arise from the floshy part of the wing, and the marginals clothe the propatagium or anterior part of the wing to which they are restricted.

The Greater and Middle rows of Lower coverts have their concave surface downwards, thus agreeing with the remiges and with the Upper coverts. They are the tectrices aversa of Sundevall, and the explanation of the apparent anomaly they present has been given by Wray, who found that they are originally situated on the dorsal sicle of the wing, but that, during the growth of the embryo, they are gradually pushed over to the ventral side, so as to assume the position of Lower coverts (Proc. Zool. Soc. 1887, pp. 343-357). This shifting is probably initiated through the greater development of the feathers on the upper surface which become the remiges, and to the formation of the tendinous band (elast. sec. fig. p. 608) connecting their bases. ${ }^{1}$

The overlapping of wing-coverts presents some curious features. Feathers are said to overlap proximally when the inner vane or web of any one is overlapped by the outer vane of its proximal or inner neighbour. This is the case with (1) all the remiges, as well as in the so-called bastard wing, (2) all the Greater coverts, both Upper and Lower, (3) the Upper Middle coverts of the hand, and frequently those of the arm, (4) those of the PARAPTERon (p. 684) or upper humerals, and (5) the marginals, both Upper and Lower. On the other hand, feathers overlap distally when the inner vane covers the outer vane of the one next to it. Such a row of feathers therefore seems to run in a direction opposite to that of the remiges and Greater coverts, and of this kind are (1) all the Middle and Lesser Lower coverts, (2) the feathers of the HYPOPTERon (p. 454), (3) very frequently the Lesser Upper coverts, and (4) in many birds the Middle Upper coverts. The number and position of these distally-over-

1 Owing to Wray's ingenious discovery it is easier to understand the relations between remiges and tectrices majores and tectrices media in the Ratitre and Sphenisci, and moreover to arrive at a possible explanation of the development of the remiges as such. Struthio and the Oscines have only one row of inverted Lower coverts; $R h c a$ and the Sphenisci have none. In the last there are more than 30 rows of little scale-like feathers on each surface of the wing, the largest of them not being, as in most Birds, the last series, but the last series but one on the hand, and the second and third last on the dorsal side of the forearm. This suggests the probability that in the Penguins no rows of feathers have been turned ventrally round the posterior margin of the wing, which is to say, that these birds retain a condition which in the others is characteristic of embryonic life. Struthio possibly represents an intermediate stage, in which only one row has been turned ventrally, unless indeed a reduction from several rows to one row has taken place, and such a reduction has probably been effected in Rinea and the Oscines. 
lapping wing-coverts were shewn many years ago by Sundevall ${ }^{1}$ to have a taxonomic value, and the later researches of $\mathrm{Mr}$. Goodchild (Proc. Zool. Soc. 1886, pp. 184-203) have carried the matter further. The latter distinguishes seven different types of arrangement in the wing-coverts :

1. All the Upper feathers overlap proximally: only 3 or 4 transverse rows owing to the absence of the Lesser coverts, which are represented by enlarged marginals-Cypselidx and Trochiti.

2. Lesser coverts absent, marginals enlarged and overlapping proximally: Middle Upper coverts reduced to one row and overlapping distally - Oscines.

3. One row of Middle and 5 or 6 rows of Lesser Upper coverts, all overlapping proximally-Cuculidx, Musophagida, Coracias, Indicator and Caprimulgus.

4. One low of Middle and from 2 to 4 rows of Lesser coverts overlapping distally-Picidx, Rhamphastidx, Alcedinidx and Chasmorhynchus.

5. The Middle row and from 3 to 6 Lesser rows overlap distally, except the feathers toward the elbow, which overlap proximally- the meeting-place of these two differently-disposed groups being generally very conspicuous. This is the most common and possibly the most generalized type, from which all the rest may be derived, and occurs in Falconidx, Psittaci, Striges, Herodii, Phalacrocorax, Anseres, Meleagris and many Gullinæ, Goura, Rallidx, Limicolæ, Ciconia, Platalea and Ibis.

6. The whole row of Middle coverts overlaps proximally; numerous rows of Lesser, but those which overlap distally are restricted to a patch on the middle of the Upper surface-Columba, Pteroclidx, Laridx, Sula, Serpentarius.

7. Numerous rows of Upper coverts all overlapping proximally - Mycteria, Leptoptilus, Fregata, Plotus, Diomedea, Ossifraga, Puffinus, Cathartida.

Considering that all the birds of this last type are remarkable for the length of their wing-bones, and consequently the great number of remiges, as well as the fact that other Ciconia, Tubinares and Steganopodes belong to a different type, it seems reasonable to think that the character of this group is the result of specialization, and has been independently acquired, without indicating any relationship. On the other hand, the agreement between Cypselidx and Trochiti, Columbx and Pteroclidx, both indicating a reference to Limicolx, and the similarity between Cathartidx and Steganopodes as well as Pelargi are at least suggestive of taxonomic value; but for further information Mr. Goodchild's treatise, whence some figures are here introduced, should be consulted.

1 K. Vetensk.-Al. Handl. 1843, pp. 303-384. A translation of this memoir by Dallas appeared in The Tbis, 1886, pp. 389-457, pls. x. xi. 
TEETAN, TEETING, Orkney and Shetland names for the TitLARK.

TEETH are so generally possessed by Vertebrata as naturally to induce the supposition that the older Birds must have had them, and many anatomists had been looking out for their traces. Already in 1821 Etienne Geoffroy St.-Hilaire announced the discovery, on the edges of the mandible and præmaxilla in embryos of Palæornis torquatus, of papillæ, rich in blood-vessels and nerves and containing globular bodies, which he likened to dental germs. His son, Isidore, and Cuvier thought that these "germs" became suppressed by the later development of the horny sheath of the bill. In 1860 Blanchard (Comptes Rendus, 1. pp. 540-542) made microscopical investigations on Cacatua and Melopsittacus, and described plates of dentine, sent out from the edge of the underlying bone and partly surrounding the papille, which last were directly connected with the periosteum. Subsequently Prof. W. Marshall (cf. Thier-reich, Vögel, i. p. 499) examined a nestling of Nymphicus and found clusters of calcareous deposit in the papillæ of the still cartilaginous mandible. He observed similar papillæ in an embryo of Aptenodytes, and his attention was drawn to a longitudinal groove extending along the edges of both the upper and lower jaw in the adult. Dr. M. Braun (Arb. Zool. Inst. W Vürzburg, 1879, pp. 161-204, pls. viii. ix.) described and figured similar papillæ in Melopsittacus, explaining the so-called plates of dentine as calcified horn, and comparing the papillæ themselves with the horny serrations on the bill of the Anseres. In 1880 Dr. Paul Fraisse (SB. Phys. Med. Terh. IVürzburg, xv. pp. iii.-ix.) re-examined these papillæ, and concluded that they were but cutaneous outgrowths, projecting into the super imposed horny layers; which, being situated between the Malpighian layer and the periosteum, became connected with the latter, the capsule of supposed dentine consisting of peculiarly-modified anci occasionally calcified cells of the horny layer. Thus they bear a striking but only a superficial resemblance to the gerns of Teeth. After all, then, Dr. Finsch's practical suggestion (Die Papagcien, p. 138) is right, and these papillæ only ensure the firmer comnexion and better nourishment of the thick horny beak. They can be easily seen by macerating a Parrot's beak and tearing off the covering, and are comparable with the long cutaneous papillæe which extend into the hoof of a horse. They occur numerously only in Psittaci and to a lesser degree in Anseres, but not in Ratita, Gallinx, Columbx, Accipitres or Corvida, though present in the form of a single long and soft projection at the tip of the præmaxilla and mandible of many Birds with strong and hooked beaks.

The total absence of dental germs in all recent Birds is of course no proof that their ancestors did not possess such organs, 
and in fact Archropteryx (Fossic Birds, p. 278) and the Cretaceous forms of North America (ODontonnithes, p. 649) had teeth. It is highly probable that Teeth were a more or less universal feature in all Birds of that period, that their loss took place at or shortly before the beginning of the Tertiary period, and moreover that their suppression was caused by the gradually increasing strength of the holny sheath of the jaws, as in Tortoises and in young Monotremes; but it is not permissible to divide the Class Aves into Birds with Teeth (Odontornithes) and Birds without. In Hesperornis regalis there are 33 Teeth (p. 650) in each mandible and 14 in each maxilla, while the præmaxilla is toothless and was probably covered with horn. All the Teeth stand in a groove (whence Prof. Marsh's name Odontolca), but bony processes between them indicate a future alveolar condition. Each Tooth is curved backward, contains a pulp-cavity, and consists of dentine with an enamel coating just as in the case of the normal Reptilian Tooth, and another truly Reptilian character is shewn by the succession of the 'Teeth, younger and still imperfect Teeth being found on the inner side of the base of the old or functional set. The Teeth of Ichthyornis are likewise restricted to the mandibles and maxillie; but they stand each in a separate socket or alveolus (whence the name Odontotormx is applied to this group of Birds), and the young or reserve Teeth are contained in the pulp cavity of the older set, growing from the same base just as in Crocodiles and in Mammals. The much more ancient and still more Reptilian Archxopteryx had few Teetl, and those but small.

\section{TELEOPTILE, see FEATHERs (p. 243).}

TELLTALE, the name long used in North America for Totanus melanoleucus and $T$. flavipes (SANDPIPER, p. 810) from "their faithful vigilance in alarming the Ducks with their loud and shrill whistle on the first glimpse of the gunner's approach," and accordingly detested by him (Wilson, 'Am. Orn. vii. p. 57). ${ }^{1}$

TENDON, see under Muscular System ( $f f$. 602-620).

TENUIROSTRES, a French word used by Cuvier in 1805 (Leç. d'Anat. Comp. tabl. 2) for a group of Pusseres, containing the genera Sitta, Certhia, Trochilus, Upupa, Merops, Alcedo, and Todus ; ${ }^{2}$ but its Latin application seems due to Illiger in 1811, who restricted it to the genera Nectarinic (SUN-BIRD), Tichodroma and Upupa

1 For the same reason the REDshank, T. calidris, is known as Tolk (interpreter) in Danish and Swedish (cf. Turnstone).

2 In the following year Duméril (Zool. Analyt. pp. 46, 47, 64, 65, used the word (also as French) in a double sense-first almost precisely as Cuvier had done, but next for a group composed of Recurvirostra, Tringa, Charadrius, Numenius and Scolopax. 
(Hoopoe). In the Cuvierian sense it has since been largely employed, and can hardly be said to have been wholly dropped except by those who have some knowledge of real characters, for it was used in 1888 by Olphe-Galliard (Faun. Orn. Eur. occid. fasc. xxiii.), who referred to it Oriolidx, Upupida, Tichadromadidx, Certhiida and Sittidx.

TERCEL and TIERCEL (corruptly TARsel and TAssel), Fr. Tiercelet, the male of many Birds-of-Prey ${ }^{1}$ but.especially of those used in Falconry-except the Gyrfalcon, Hobby, Lanner, Merlin, SACRE and SPARROW-HAWK. It is commonly thought to signify that a Hawk of that sex was "a third part lesse then the female" (Cotgrave); but some writers, as Tardif and De Thou, maintain that it referred to a belief that every brood of Hawks consists of 3 birds, whereof 2 were females and the $3 \mathrm{rd}$ was a male, or that this was the last hatched ( $c f$. Schlegel, Trait. de la Fauconnerie, p. 1, note 3$)$.

TERMAGANT or TERMIGANT, the earliest English and Scottish forms of the name now written Ptarmigan ( $c f$. Grouse, p. 392, note).

TERN (Norsk Tarne, Tenne or Tende; Swedish Tärna; Dutch Stern $\left.{ }^{2}\right)$, the name now applied generally to a group of sea-birds, the Sternina of modern ornithology, but, according to Selby, properly belonging, at least in the Farne Islands, to the species known by the book-name of Sandwich 'Teln, all the others being those called Sea-Swallows-a name still most commonly given to the whole group throughout Britain from their long wiugs, forked tail and marine habit. In Willughby's Ornithologia (1676), however, the word Tern is used for more than one species, and, though it does not appear in the older English dictionaries, it may well have been from early times as general a name as it is now.

Setting aside those which are but occasional visitors to the British Islands, six species of Terns may be regarded as indigenons, though of them one has ceased from ordinarily breeding in the United Kingdom, while a second has become so rare and regularly appears in so few places that mention of them must for prudence sake be avoided. This last is the beautiful Roseate Tern, Sterna dougalli; the other is the Black Tern, Hydrochelidon nigra, belonging

1 Chaucer applies the name to an EAGLE (Parlement of Fowles, line 393).

2 STARN was used in Norfolk in the middle of this century for the bird known by the book-name of Black Tern, thus confirming Turner, who, in 1544, described (sub cap. "De Gavia") that species as "nostrati lingua sterna appellata." In at least one instance the word has been confounded with one of the old forms of the modern Starling (p. 903). To Turner's name, repeated by Gesner and other authors, we owe the introduction by Linnæus of Sterna into scientific nomenclature. "Ikstern" is another Dutch form of the word. 
to a genus in which the toes are only half-webbed, and the birds of small size and dark leaden-grey plumage. It is without doubt the Sterna of Turner, and in former days was abundant in many parts of the fen country, ${ }^{1}$ to say nothing of other districts. Though nearly all its ancient abodes have been drained, and for its purposes sterilized these many years past, not a spring comes but it shews itself in small companies in the eastern counties of England, evidently seeking a breeding-place. All around the coast the diminution in the numbers of the remaining species of Terns within the last 50 years is no less deplorable than demonstrable.

The Sandwich Tern, S. sandvicensis or $S$. cantiaca-named from the place of its discovery, though it has long since ceased to inhabit that neighbourhood-is the largest of the British species, equalling in size the smaller Gulls and having a dark-coloured bill tipped with yellow, and dark legs. Through persecution it has been extirpated in all its southern haunts, and is become much scarcer in those to which it still resorts. It was, kowever, never so abundant as its smaller congeners, the so-called Common and the Arctic Tern, -two species that are so nearly alike as to be beyond discrimination on the wing by an ordinary observer, and even in the hand require a somewhat close examination. ${ }^{2}$ The former of these has the more southern range, and often affects inland situations, while the latter, though by no means limited to the Arctic circle, is widely distributed over the north and mostly resorts to the seacoast. Yet there are localities where, as on the Farne Islands, both meet and breed, without occupying stations apart. The minute diagnosis of these two species camnot be briefly given. It must suffice here to state that the most certain difference, as it is the most easily recognizable, is to be found in the tarsus, which in the Arctic Tern is a quarter of an inch shorter than in its kinsman. The remaining native species is the Lesser Tern, $S$. minuta, one of the smallest of the genus and readily to be distinguished by its permanently white forehead. All the species already mentioncd, except the Black Tern, have much the same general coloration-

${ }^{1}$ It was known there as Carr-Swallow, C.smr-Crow and Blue Darr $(q u .=$ Daw?).

2 Linnæus's diagnosis of his Sterna hirundo points to his having had an "Arctic" Tern before him; but it is certain that he did not suspect that specific appellation (already used by other writers for the "Common" Tern) to cover a second species. Some modern anthorities disregard his name as being insufficiently definite, and much is to be said for this view of the case. Undoubtedly "hirundo" has now been used so indiscriminately as to cause confusion, which is a voided by adopting the epithets of Nanmann (Isis, 1819, pp. 1847, 1848), who, acting on and confirming the discovery of Nitzsch (the first detector of tlee specific difference), called the more southern species $S$. fluviatilis and the more northern $S$. macrura. Temminck's name, S. arctica, applied to the latter a year later, has been until lately most generally used for it, nutwithstanding. 
the adults in summer phumage wearing a black eap and having the upper parts of the body and wings of a more or less pale grey, while they are mostly lighter beneath. They generally breed in association, often in the closest proximity--their nests, containing three eggs at most, being made on the shingle or among herbage. The young' are hatched clothed in variegated down, and remain in the nest for some time. At this season the parents are almost legardless of human presenee and expose themselves freely.

At least half-a-dozen other speeies have been reeorded as oecuring in British waters, and among them the Caspian Tern, S. caspia, which is one of the largest of the genms and of wide distribution, though not breeding nearer to the shores of England than on Sylt and its neighbouring islands, which still afford lodging for a few pairs. Another, the Gull-billed Terı, S. anglica, has also been not unfrequently shot in England. All these species are now acknowledged, though the contrary was once maintained, to be inhabitants of North America, and many go much further.

Mr. Saunders (Cat. B. Br. Mus. xxт. pp. 4-152) recognizes 11 genera of the subfamily-Hydrochelidon with 4 species; Phaethusa, Gelochelidon, Hydroprocne and Seenc with one each-these being hitherto most generally placed in Sterna, to which last he allots 33 species, including among them 3 or 4 that ale called in books "Sooty Terns," but by sailors EGG-BIrd (p. 182), or, from their cr'y, WIDE-AWAKES, and seem as much entitled to generic separation as the four above named; Nania, a very aberrant form, consisting of but one species, the Inea Tern, peculiar to the west coast of South America; Procelsterna, Anous and Micrenous containing the various species of NoDDY (p. 643), of which he now admits but 7 ; and Gygis, composed of 2 species of purely white birds, almost restricted to the southern hemisphere.

TERTIALS, a name now almost wholly abandoned, but applied by older writers to the innermost or proximal cubital REMIGES (p. 780), especially when, as in many groups of Birds, they are distinetly longer than the more distal or outer.

TEUCHET and TEWFITT, local names of the LAPWING (p. 504) from its cry.

THICKHEAD, Swainson's rendering in 1837 (Classif. B. ii. p. 249) of his own Puchycephala, a genus named by hinı in 1824 (Trans. Linn. Soc. xiv. p. 444 , note), to which about 50 speeies, all characteristic of and mostly

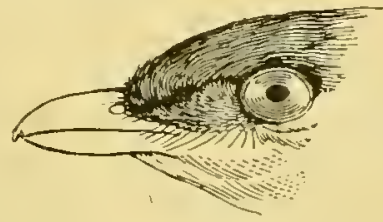

PACHYCEPHALA.

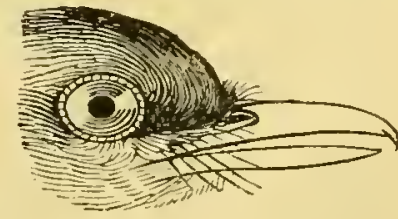

Eopsaltria.

(After Swainson.) peenliar to the Anstralian Region, have been referred, while some 
other genera as Falcunculus (SHrike), Orececa and Eopsaltria seem to be nearly allied (ef. Gadow, Cat. B. Br. Mus. viii. pp. 172-227). By many systematists they are placed among the Laniid ; but they seem to differ much in habit from the SHRIKES, of an older and more generalized form of which they may be survivors, and they certainly deserve grouping as a subfamily at least. No fewer than 12 species of Pachycephala and 4 of Eopsaltria occur in one part or another of Australia; but the latter are said by Gould (Hand-b. B. Austral. i. p. 292) to be "very nearly related" to the genus Petroca (Wheatear), while the former are described by him (tom. cit. p. 206) as differins in habit from most other insectivorous birds, "particularly in their quiet mode of hopping about and traversing the branches of trees in search of larve," caterpillars forming a large part of their food.

The name THICKHEAD is, however, given in other parts of the world to very different birds, and in South Africa especially to Edicnemus capensis (Dikkop, p. 148), the Stone-CurLEW of that country, and if not complimentary, it is at least not inaccurate, as is

THICK-KNEE, absurdly applied to our own bird by Leach in 1816 (Syst. Cot. Mamm. \& B. Br. Mus. p. 28), being an abbreviation of Pennant's still more misleading "Thick-kneed Bustard" conferred by him in 1776 (Brit. Zool. ed. 4, i. p. 244).

THISTLE-BIRD, -FINCH and -WARP, names of the GOLDFINCH (p. 370), -COCK in Orkney for the Great Bunting (p. 60).

THRASHER, THRESHER, or THRUSHER, ${ }^{1}$ names given to a bird well known in the eastern part of North America, the I'urdus fuscus of the older and Harporhynchus fuscus of later ornithologists, some of whom have dissociated it altogether from the THRUSHES, to which it was long held to belong, placing it with Mimus (MockingBIRD, pp. 582-585) among the "Troglodytina" (WREN), and those among the "Timeliidx," which is an admission of taxonomic inability. Valid reasons there may be for separating Harporhynchus, of which there are several species in North America, from the Turdidx, and the osteological grounds are temperately advanced by Mr. Lncas (Proc. U. S. Nat. Mus. xi. pp. 173-180); but little value can be attached to what had previously been urged as the strongest point, namely, that in Turdus, and its nearest allies, the tarsus is covered anteriorly with a continuous plate, while in the Mimus-group the tarsus is anteriorly scutellated, generally with 7 scales; for Baird (Rev. $A m$. B. p. 3) shewed that this might be an individual peculiarity,

1 These words are doubtless derived from Thrush, if they be not corruptions of it. An esteemed American correspondent has suggested to me that Thrusher originated in the wish to indicate that the bird so called was bigger than au ordinary Thrush, of which word it might be said to be (if the expression be allowable) the "comparative degree." In that case the other two must be regarded as corruptions. They have nothing to do with threshing. 
citing a specimen of $M$. carolinensis with a leg as much "booted" as in the true Thrushes, while in a species of Mimocichla, the divisions of the scutellie are appreciable though they are all fused into one plate. ${ }^{1}$

THRICECOCK, a local name for the Mistletoe-THrush.

THROSTLE (A.-S. prosle), now nearly obsolete, apparently the diminutive fol'm of

THRUSH (A.-S. prysce, Icel. Jröstr, Norw. Trast, O. H. Germ. Drosce, Mod. Germ. Drossel), ${ }^{2}$ the name that in England seems to have been common to two species of birds, the first now generally distinguished as the Song-Thrush, but known in many districts as the Mavis, ${ }^{3}$ the second the Mistletoe-Thrush, but having many other local designations, of which more presently.

The former of these is one of the finest songsters in Europe, but it is almost everywhere so common that its merits in this respect are often disregarded, and not unfrequently its melody, when noticed, is ascribed to the prince of feathered rocalists, the Nightingale (p. 635). The Song-Thrush is too well known to need description, for in the spring and summer there is hardly a field, a copse or a garden that is not the resort of a pair or more; and the brown-backed bird with its spotted breast, hopping over the grass for a few yards, then pausing to detect the movement of a worm, and vigorously seizing the same a moment after, is one of the most familiar sights. Hardly less well known is the singular nest built by this bird-a deep cup, lined with a thin but stiff coating of fragments of rotten wood ingeniously spread, and plastered so as to present a smooth interior-in which its sea-green eggs spotted with black are laid. An carly breeder, it builds nest after nest during the season, and there can be few birds more prolific. Its ravages on ripening fruits, especially strawberries and gooseberries, excite the enmity of the imprudent gardener who leaves his crops unprotected by nets, but he would do well to stay the hand of revenge, for no bird can or does destroy so many snails, as is testified to the curious observer on inspection of the stones that it selects against which to dash its captures, - stones that are besmeared with the slime of the victims and bestrewn with the fragments of their shattered shells. Nearly all the young Thrushes reared in the British Islands-and this expression includes the

${ }^{1}$ I have no experience of Harporhynchus, but close to it is usually placed the Antillean genus Margarops of Mr. Sclater, and no one who has made its acquaintance in life can doubt that form being a true ThuUsh.

2 For many interesting facts connected with the words "Thrush" and "Throstle" which cannot be entered npon here, the reader should consult Prof. Skeat's Etymological Dictionary.

${ }^{3}$ Its diminntive is Mauviette, the modern table-name of the Skylark, and perhaps Navis was in English originally the table-name of the Thrush. 
Outer Hebrides, though not Shetland-seem to emigrate as soon as they are fit to journey, and at a later period they are followed by most of their parents, so that many parts of the kingdom are absolutely bereft of this species from October to the end of January. On the continent of Europe the autumnal influx of the birds bred in the North is regarded with much interest, as has been already stated (Migration, p. 551), for they are easily ensnared and justly esteemed for the table, while their numbers make their appearance in certain districts a matter of great importance.

The second species to which the name applies is distinguished as the Mistletoe-Thrush, corrupted into Missel-Thlidsh (p. 575). ${ }^{1}$ This is a larger species than the last, of paler tints, and conspicuous in flight by the white patches on its outer tail-feathers. Of bold disposition, and fearless of the sleety storms of spring, ${ }^{2}$ as of predatory birds, the cock will take his stand on a tall tree, "like an enchanter calling up the gale" (as Knapp happily wrote), and thence with loud voice proclaim in wild and discontinuous notes the fervour of his love for his mate; nor does that love cease when the breedingseason is past, since this species is one of those that appear to pair for life, and even when, later in the year, it gathers in small flocks, husband and wife may be seen in close company. In defence of nest and offspring, too, few birds are more resolute, and the Daw, Pic or Jay that approaches with an ill intent specdily receives treatment that causes a rapid retreat, while even the marauding cat finds the precincts of the "master of the coppice" (Pen y llwyn), as the Welsh name this Thrush, unsuitable for its stealthy operations. The connexion of this bird with the mistletoe, which is as old as the days of Aristotle, is no figment, as some have tried to maintain. Not only is it exceedingly fond of the luscious viscid berries, but it seems to be almost the only bird that will touch them. Of other British Thrushes, the Finddfare (p. 249), Redwing (p. 777) and the Blackird (p. 42) and Ring-Ousel (p. 666), have been before noticed in these pages, as has been (under the first of those headings) the so-called "RoBIN" (pp. 250, 791) of North America.

1 There is no doubt of the bird taking its name from the plant Nistletoe (Viscum album), about the spelling of which there can be no uncertainty-A.-S. Mistcltan, the final syllable originally signifying "twig," and surviving in the modern "tine," as of a fork or of a deer's antler.

2 It is known also in many districts as the "Storm-cock," from its habit of singing in squally weather that silences almost all otler birds, and "Holm- (i.e. Holly-) Thrush," while the harsh cries it utters when angry or alarmed have given it other local names, as "Screech," "Shrite," and "Skrike," all traceable to the Anglo-Saxon Scric. And it is likely that the word SHriKe (p. 843) may have been originally applied to the Mistletoe-Thrush. In several of the AngloSaxon Vocabularics dating from the 8 th to the 11th century, as printed by Thomas Wright, the word Scric, which can be hardly anything else than the early form of "Shrike," is glossed Turclus. 
The Thrushes have been generally considered to form a distinct Family, Turdida, which is placed by some taxonomers the highest in rank among birds. The fallacy of this last view is pointed out elsewhere (INTRODUCTION). Though many modern systematists will admit the close connexion of the Turdide and some of the so-called Family Sylviida (WARBLER), the abolition or modification of the latter, by wholly or partially merging it in the former, has not yet been satisfactorily effected. Mr. Seebohm (Cat. B. Br. Mus. v. p. 1), being compelled by the conditions previously laid down by Dr. Sharpe (op. cit. iv. pp. 6, 7) to unite them, protested against doing so. His own assignment of the subfamily Turdinæ was into 11 genera, of which, however, 6 only would be commonly called Thrushes, and it must be borne in mind that in establishing these he regarded coloration as the most valid character. They are Geocichla (a phantom name) with 40 species, Turdus with 48, Merula with 52, Mimocichla with 3, Catharus with 12 and Monticola with 10. These last, well known as Rock-Thrushes, make a very near approach to the ReDstart (p. 775) and Wheatiar.

IHYMUS GLAND, a body of obscure significance; but wrongly called a gland. It is best developed in young birds, and is a yellowish mass extending on either side from each bronchus along the jugular vein and ending like a thread. In adults it becomes much reduced and is not unfrequently lost.

THYREOID GLAND, like the last, is of unknown function and wrongly called a gland. It is a small, oval, reddish-yellow body situated on either side of the root of the neck, loosely covered by the skin and attached to the carotid artery and jugnlar vein. In an adult Swan it is abont three-quarters of an inch long.

TIBIA, in common descriptive ornithology the third and generally the longest portion of the Bird's leg, intervening between the Feirur and the so-called "TARsus." For its actual composite nature see SkeLeton (p. 863).

TICHICRO, the name (given from its note) in Jamaica of is small bird, the Fringilla savannarum of Gmelin, now referred either. to the genus Coturniculus, of which the very closely allied $F$. passerina of Wilson, the Yellow-winged Bunting of North America, is the type, or to Ammodromus, founded for the Sharp-tailed Finch, A. caudacutus. Both belong to a group of New-World forms hitherto ill defined, and considered by some to be Finches and by others Buntings. Of somewhat Lark-like habit, the Tichicro is said by Grosse ( $B$. Jam. p. 245) to have the habit of running on the ground, and to perch but seldom, in which respect it differs from both normal Finches and Buntings ( $c f$. TowHEE). 
TIDEE, TIDIF, TYDIF and 'TYTYFR (spelling uncertain), obsolete names, but the second and third are used by Chaucer ( $c f$. Skeat's ed. iii. p. 76, iv. p. 479, v. p. 386), and most likely signify a Titmouse. ${ }^{1}$

TIDLY-GOLDFINCH, said to be a name for the Goldcrest.

TIMELIA, amended from Timalia, ${ }^{2}$ the generic name, since used as English, applied by Horsfield in 1820 (Trans. Limn. Soc. xiii. p. 150) to a small bird he discovered in Java, and two years

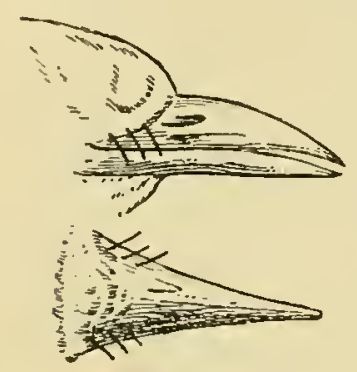

TrMelia.

(After Horsfield.) later figured and more fully described (Zool. Ries. pl. 43, fig. 1) - T. pileate. It has a strong bill, arched and much compressed, the wings short and much incurved, the plumage generally long and lax, a rather long and graduated tail and moderately stout feet. The sexes are outwardly alike, except in point of size, and it is a pretty bird with a bright bay crown, and a white line from the base of the black bill over the eye, contrasting also with the black lore, while the rest of the upper parts are olive, the rectrices darker and transversely barred by a deeper shade: the cheeks, throat and neck are white-the last with fine longitudinal black streaks, while the breast and other lower parts are of a pale tawny. The species, declared by Mr. Oates (Faun. Br. Ind. i. p. 131) to be the only one of the genus, is now admitted to have a widish range on the Asiatic continent from Cochin-China to Nepal; but the statements, though made on good authority (Jerdon, B. Indiu, ii. p. 24, and Sharpc, Cat. Br. E. vii. p. 508) of its occurrence in Malacca, are doubted by Mr. Oates (ut supri, p. 132). It has a pleasant song, and is described as affecting the neighbourhood of cultivation in Java, but in India its habits seem to be more retiring, for though said to be an active, bright bircl, it keeps creeping about the grass near the ground, and seldom shews itself. It builds a domerl nest in a lowly position and therein lays 3 eggs, white speckled with brown.

These particulars are dwelt upon because this little bird has of late year's been set in such a position as none other has ever occupied. Around it, or upon it, have been heaped, one after another, or whole groups at a time, many of the most incongruous forms of Passeres from all parts of the world, mntil the "Family Timeliida" became a confused mass, the like of which had not been seen since systematic ornithology began. The practice of referring some

1 In the eopy before mentioned (1. 680, note 2) of Belon's Portraits, the figure of Parıs major is inseribed "Collmouse, A Tydie."

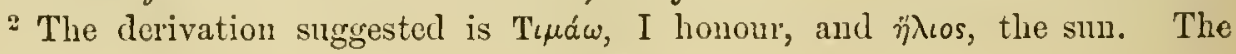
correction is Sundevall's in 1872 (Tentamen, 1. 11). 
Passerine birds whieh did not well agree with the best known European or Ameriean types to the neighbourhood of the genus Timelic, and of founding a subfamily or even a Family for them, was at first harmless, and, indeed, where new forms of the Indian Fauna like Stcchyris and other's were concerned was praiseworthy; but the practice was presently abused and its reduction to absurdity effected in the Sixth and Seventh volumes of the British Muscum Catalogue of Birds, wherein tolerably homogeneous groups of various kinds that had long been accepted by systematists were broken up and flung upon the heap-the Troglodytida (WReN), for instance, were referred to the Timelivda, whereas if their union were neeessary the

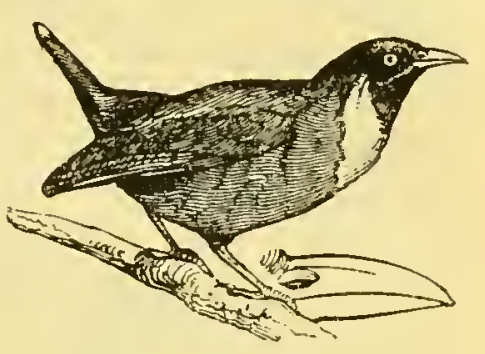

StTACHYRIS THORACICA. (After Swainson.) Timelias should have been referred to the Wrens. The sole eharacter all these birds were supposed to possess in eommon was one shared by many others that were excluded, namely, wings short, rounded and "eoncave," so as to fit close to the body, the last epithet being intended to signify that the remiges were incurved. ${ }^{1}$

'TINAMOU, the name given in Guiana to a certain bird as stated in 1741 by Barrere (France Equinoxiale, p. 138), from whom it was taken and used in a more general sense by Buffon (Hist. Nat. Ois. iv. p. 502). In 1783 Latham (Synops. ii. p. 724) adopted it as English, and in 1790 (Index, ii. p. 633) Latinized it Tinomus, as the name of a new and distinct genus. The "Tinamou" of Barrere has been identified with the "Maencagna" deseribed and figured by Marcgrave in 1648, and is the Tincmus mujor of modern authors."

1 It is due to Dr. Sharpe to observe that he indicates (op. cit. vii. p. 1) the existence of some hidden porrer against which he was helpless, and that his "Group VIII. Timelize" (p. 504) does not differ very much from that which MIr. Oates subsequently tried with some success to define as a subfanily Timclina (with 25 genera found in India alone) of Crateropodidae ; but even that "Group" still includes forms that it is impossible to believe are allied, and the Doctor, in his Address to the International Congress of 1891 (p. 87), thongh referring with approval to MIr. Oates's attempt, and adopting a few other modifications, stated that he was "not prepared at the present moment to reconsider the Timcliulx." Out of a heap of road-sweepings a skilful gardener will make a compost that shall produce fragrant flowers, while untended it remains a bed that grows nothing but noisome weeds. Let ns hope that Dr. Sharpe, with the cxtraordinary resomees at his command, will one day treat this festering mass so as to obtain from it results that will canse the former unhappy faihure to be forgotten and a crop of fair blooms secured that will be worthy of him, for a solution of the Timelian difficnlty will indeed be a great feat.

2 Brisson and after him Linmæus confomded this bird, which they lad never seen, with the TlunpeTEl. 
Buffon and his successors saw that the Tinamous, though passing among the European colonists of South Ameriea as "Partridges," could not be associated with those birds, and Latham's step, above mentioned, was generally approved. The genus he had founded was usually placed among the Gallinæ, and by many writers was held to be allied to the Bustards, which, it must bc remembered, were then thought to be "Struthions." Indeed the likeness of the Tinamou's bill to that of the RHEA (p. 785) was remarked in 1811 by Illiger. On the other hand, L'Herminier in 1827 saw features in the Tinamou's sternum that in his judgment linked the bird to the Rallidie. In 1830 Wagler (Nat. Syst. Amph. u.s.w. p. 127) plaeed the Tinamous in the same Order as the Ostrich and its allies; and, though he did this on very insufficient grounds, his assignment has turned out to be not far from the mark, as in 1862 the great affinity of these groups was shewn by Prof. Parker (Trans. Zool. Soc. v. pp. 205-232, 236-238, pls. xxxix.-xli.), and a few years later further substantiated by him (Phil. Truns. 1866, pp. 174-178, pl. xv.). Shortly after this Prof. Huxley (Proc. Zool. Soc. 1867 , pp. 425, 426) was enabled to place the matter in a clear light, urging that the Tinamous formed a very distinet group of birds which, though not to be removed from the Carinatef, presented so mueh resemblance to the RATIT\& as to indicate them to be the bond of union between those two great divisions. ${ }^{1}$ The group from the resemblance of its palatal characters to those of the Eneu (p. 212), Dromaus, he called Droneognathe, and his decision, if not his name, has since been widely accepted.

The Tinamous thus-by whatever name we eall them, Dromæognatha, Tinami or Crypturi-will be seen to be of great importance from a taxonomer's point of view, though in regard to numbers they are comparatively insignificant. In 1873 Messis. Sclater and Salvin (Nomencl. Av. Neotrop. pp. 152, 153) reeognized nine genera and thirty-nine species; but in 1895 Count T. Salvadori (Cat. B. Br. Mus. xxvii. pp. 494-569) admitting the nine genera, aeknowledged but sixty-six species. They are especially characteristie of the Patagonian or Chilian portion of the Neotropieal Region-four species only finding their way into Southern Mexieo and none beyond. Some of them inhabit forests and other's the more open eountry; but setting aside size (which in this group varies from that of a Quail to that of a large eommon Fowl) there is an unmistakable uniformity of appearanee among them as a whole, so that almost anybody having seen one species of the group would always recognize another. Yet in minor eharacters there is eonsiderable difference among them; and before all the group may be divided

1 M. Alix also has from an independent investigation of the osteology and myology of Nothura major come to virtually the same conclusion (Journ. de Zoologic, iii. pp. 169 and 252, pls. viii.-xi.) 
into two subfamilies, the first, Tinamina, having four toes, and the second, Tinamotilina, having but three-the latter containing, so fitr as is known, but two genera, Calopezus with a single species and Tinamotis with two, while the former, according to Messis. Sclater and Salvin (ut supri), may be separated into seven genera, two being I'inumus and Nothocercus, characterized by the roughness of their posterior tarsal scales, the others, Crypturus, Phynchotus, Nothoproctu, Nothure and T'coniscus, having smooth leg's.

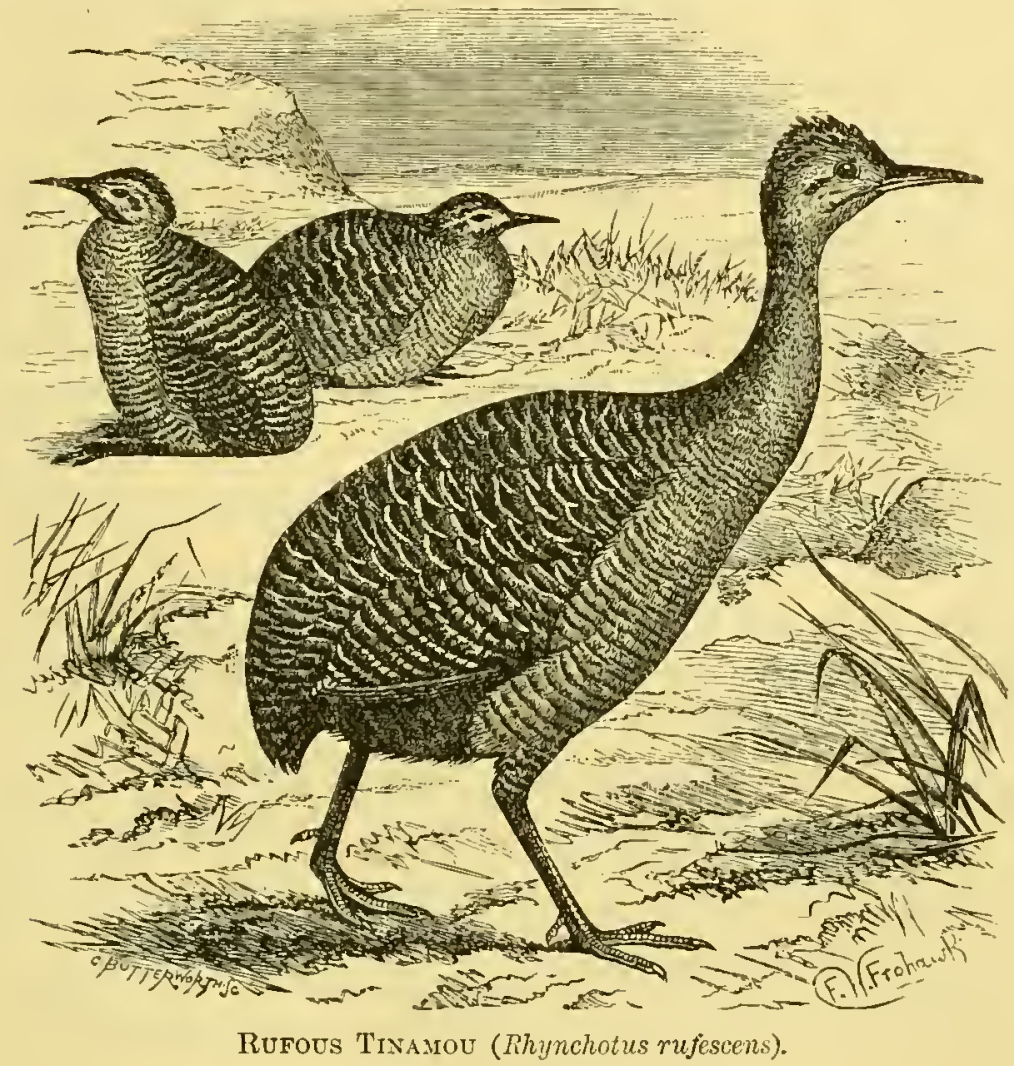

To the ordinary speetator Tinamous have mueh the look of Partridges, but the more attentive observer will notice that their elongated bill, their small head and slender neck, clothed with very short feathers, give them a different air. The plumage is generally inconspicuous: some tint of brown, ranging from rufous to slaty, and often more or less closely barred with a darkel shade or black, is the usual style of coloration; but eertain speeies are characterized by a white throat or a bay breast. The wings are short and rouncled, and in some forms the feathers of the tail, which in all are hidden by their coverts, are soft. In bearing and gait the birds shew some resemblance to theil distant relatives the Ratita, and Mr. Bartlett shews (Proc. Zool. Soc. 1868, p. 115, pl. xii.) that this is especially seen in the newly-hatched young. He also notices the still stronger Ratite character, that the male takes on himself the duty of incubation. The eggs are very remarkable objects, euriously 
unlike those of other birds; and, as before stated (p. 187), their shell ${ }^{1}$ looks as if it were of highly-burnished metal or glazed porcelain, presenting also various colours, which seem to be constant in the particular species, from pale primrose to sage-green or light indigo, or from chocolate-brown to pinkish-orange. All who have eaten it declare the flesh of the Tinamou to have a most delicate taste, just as it has a most inviting appearance, the pectoral muscles being semi-opaque. Of their habits not much has been told. Darwin (Journal, chap. iii.) has remarked upon the silliness they shew in allowing themselves to be taken, and this, being wholly in accordance with what Parker observes of their brain capacity, is an additional testimony to their low morphological rank. At least one species of Tinamou has bred not unfrequently in confinement, and an interesting account of what would have been a successful attempt by Mr. John Bateman to naturalize this species, Rhynchotus rufescens, in England, at Brightlingsea in Essex, appeared in The Field (23rd Feb. 1884 and 12th Sept. 1885). The experiment unfortunately failed owing to the destruction of the birds by foxes.

TINKER or TINKERSHIRE, one of the many names of the GuILLEMot.

TINKLING or 'TIN-TIN, the name in Jamaica for one of the American Grackles (p. 379), Quiscalus crassirostris (Gosse, B. Jam. p. 217) belonging to the Family Icteridx.

TIT, ${ }^{2}$ Icel. Titr (obsol.), Norsk Tita, Old. Engl. TIDEE and other forms (p.962), a vulgar abbreviation of TITMouse, apparently first used, except as a provincialism (when it often means the WREN and possibly gave rise to the nickname KITTY), in 1831 by Rennie (Architect. Birds, p. 134); but from its derivation, which involves the idea of something small, equally applicable to

TITLARK or TITLING, Icel. Tittingr, common names for what books call the Meadow-PIPIT (p. 727), Anthus pratensis.

TITMOUSE $^{3}$ (A.-S. Mase and Tytmase, Germ. Meise, Swed. Mes, Dutch Mees, French Mésange), the name long in use for several species of small English birds, which are further distinguished from one another by some characteristic appellation. These go to make up the genus Parus of Linnæus, and with a very uncertain

1 Herr von Nathusius has described its microscopic structure (Journ. für vissensch. Zoologie, 1871, pp. 330-355).

2 It had been thought cognate with the Greek $\tau$ itis, which originally meant a small chirping bird (Ann. Nat. Hist. ser. 4, x. p. 227) ; but Prof. Skeat informs me that no conuexion between them is possible.

${ }^{3}$ It is by false analogy that the plural of Titmouse is made Titmice ; it should he Titmouses. A nickname is very often added, as with many other familiar English birds, and in this case it is "Tom." 
number of other genera form the Family Paridx of modern ornithology. Its limits are, however, very ill-defined; and here only the species best known to English readers can be noticed.

I. The first to be mentioned is that called from its comparatively large size the Great Titmouse, $P$. major, but known also in many parts as the OX-EYE (p. 680), conspicuous by its black head, white cheeks and yellow breast, down which runs a black line, while in spring the cock makes himself heard by a loud love-note that resembles the noise made in sharpening a saw. It is widely distributed throughout the British Islands, and over nearly the whole of Europe and northern Asia. The next is the Bluc Titmouse, Blue-cap or NuN (p. 646), P. caruleus, ${ }^{1}$ smaller than the last and more common. Its names are so characteristic as to make any description needless. A third common species, but not so numerous as either of the foregoing, is the Coal-Titmouse, $P$. ater, distinguished by its black cap, white cheeks and white nape. Some interest attaches to this species because of the difference observable between the race inhabiting the scanty remnants of the ancient Scottish forests and that which occurs throughout the rest of Britain. The former is more brightly tinted than the latter, having a clear bluish-grey mantle and the lower part of the back greenish, hardly either of which colours are to be seen in the same parts of more southern examples, which last have been described is forming a distinct species, $P$. britannicus. But it is to be observed that the denizens of the old Scotch fir-woods are nearly midway in coloration between the dingy southern birds and those which prevail over the greater part of the Continent. It would therefore seem unreasonable to speak of two species only: there should be either three or one, and the latter alternative is to be preferred, provided the existence of the local races be duly recognized. Much the same thing is to be noticed in the next species to be mentioned, the Marsh-Titmouse, $P$. palustris, which, sombre as is its plumage, is subject to considerable local variation in its very extensive range, and has been called $P$. borealis in Scandinavia, $P$.alpestris in the Alps and $P$. lugubris in south-eastern Europe, to say nothing of forms like $P$. baicalensis, $P$. camchatkensis and others, whose names denote its local variations in northern Asia, while no great violence is exercised if to these be tacked on $P$. atricapilla with several geographical races which inhabit North America. A fifth British species is the rare Crested Titmouse, $P$. cristatus, only found in limited districts in Scotland, though common enough, especially in pine-woods, in many parts of Europe.

It is impossible to state how many species of Parus exist, their

1 Canon Tristram informs me that the historic bottle at Oxbridge (supri,, p. 553 , note) was reoccupied in 1895 , making a tenancy, though not quite continuous, of at least 110 years. 
recognition at present being wholly subjective to the view taken by the investigator of the group. Dr. Gadow (Cat. B. Br. Mus. viii. pp. 3-53) in 1883 recognized forty-eight, besides several subspecies, while others have since been described. ${ }^{1}$ North-American ornithologists include some fifteen as inhabitants of Canada and the United States; but scarcely two writers agree on this point, owing to the existence of so many local forms. Of the species belonging to the Indian and Ethiopian Faunas there is no space here to treat, and for the same reason the presumably allied forms of Australia and New Zealand must be left unnoticed. During the greater part of the year the various species of the genus Parus issociate in family parties in a way that has been already described (Mrgration, p. 554), and only break up into pairs at the beginning of the breeding-season. The nests are nearly alwars placed in a hollow stump, and consist of a mass of moss, feathers and hair, the last being worked almost into a kind of felt. Thereon the eggs, often to the number of eight or nine, are laid, and these have a translucent white shell, freckled or spotted with rust-colour. The first plumage of the young closely resembles that of the parents; but, so far as is known, it hās always a yellower tinge, very apparent on the parts, if there be such, which in the adult are white. Few birds are more restless in disposition, and if "irritability" be the test of high organization, as one systematist asserts, the Paridx should stand very near the top of the list. Most of the European species and some of the North-American become familiar, haunting the neighbourhood of houses, ${ }^{2}$ especially in winter, and readily availing themselves of such scraps of food, about the nature of which they are not particular, as they can get. ${ }^{3}$

Akin to the genus Parus, but in many respects differing from

I Some of the most interesting, to the European ormitholngist, of this genus, as well as of Acredula, presently to be mentioned, are figured by MIr. Dresser in the Supplement to lis Birds of Europe (pls. 655-661).

2 By gardeners every Titmouse is generally regarded as an enemy, for it is supposed to do infinite damage to the buds of frmit-trees and bushes; but the accusation is wholly false, for the buds destroyed are always found to be those to which a grub-the bird's real object-has got access, so that there can be little doubt that the Titmouse is a great benefactor to the horticulturist, and hardly ever more so than when the careless spectator of its deeds is supposing it to be bent on mischief.

3 Persons fond of watching the habits of birds may with little trouble provide a pleasing spectacle by adopting the plan, practised by the late Mr. A. E. Knox, of hanging a lump of suet or tallow by a short string to the end of a flexible rod stuck aslant in to the ground close to the window of a sitting-room. It is seldom long before a Titmouse of some kind finds the dainty, and once found visits are made to it until every morsel is picked off. The attitudes of the birds as they cling to the swinging lure are very diverting and none but a Titmouse can succeed in keeping a foothold upon it. 
it, is Acrelula, containing that curious-looking bird the Long-tailed or Bottle-Titmouse, witl its many local raees or species inlabiting various parts of the Palrearctic area, which must be here passed over withont a word. The bird itself, having its tail longer than its body, is unlike any other found in the northern hemisphere, while its nest is a perfect marvel of construction, being in shape nearly oval with a small hole in one side. The exterior is studded with pieces of lichen, worked into a firm texture of moss, wool

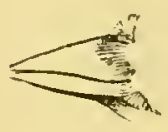

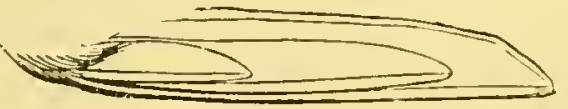

PARUS.

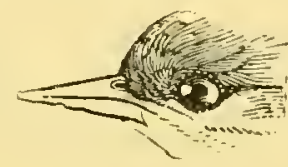

LGithalus.

(After Swainson.)

and spiders' nests, and the insirle is profusely linerl with soft feathers-2379 having been, says Macgillivray, counted in one example. Not inferior in beauty or ingenuity is the nest built by the Penduline Titmouse, Égithalus pendulinus, of the south of Europe, which differs, howevel, not merely in composition but in being suspended to a bough, while the former is nearly always placed between two or more branches.

The general affinities of the Paridiu seem to lie rather with the Sittila (Nuthatch, p. 647) and Certhiula (Tree-Creeper); and those systematists who would ally them to the Laniula (SHRIKE, p. 84.3), or still more interpose the last between the former Families, have yet to find gromnds for so doing.

II. The so-ealled "Bearded Titmouse," Panurus biamious, has habits wholly unlike those of any of the foregoing, and eertainly does not belong to the Family Puridx, though its real affinity has not yet been clearly shewn. It was formerly found in many parts of England, especially in the eastern counties, where it bore the name of Reed-Pheasant; ${ }^{1}$ but through the draining of meres, the destruction of reed-beds, and (it must be added) the rapacity of colleetors, it now only exists as a native in a very few localities. It is a beautiful little bird of a bright tawny colour, variegated with black and white, while the cock is further distinguished by a bluish-grey head and a black tuft of feathers on each side of the chin. Its ehief food seems to be the smaller kinds of freshwater mollusks, which it finds among the reed-bers it seldon quits.

TODY, Pennant's rendering in 1773 (Gen. B. p. 17) through the

1 The names given to this bird are so very inapllicable that it is almost a pity that "Silerella" (from siler, an osier) bestowed upon it by Sir T. Browne, its diseoverer ( $c f$. Ray, Collection of English Words, London : 1674), eamnot be restored, thongh it is less a frequenter of willow-garths than of reed-beds (cf. Yarrell, Brit. B. ed. 4, i. I']. 511-522). 
French Todier of Brisson (Orn. iv. p. 528) of the somewhat obscure Latin word Todus, ${ }^{1}$ not unhappily applied in 1756 by Patrick

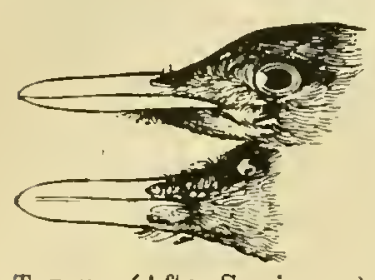

Todus. (After Swainson.) Browne (Hist. Jamaica, p. 476) to a little bird remarkable for its slender legs and small feet, the "Green Sparrow" or "Green HummingBird" of Sloane (Voy. ii. p. 306). The name, having been taken up by Brisson in 1760, was adopted by Linneus, and has since been recognized by ornithologists as that of a valid genus, though many species have been referred to it which are now known to have no affinity to the type, the T. viridis of Jamaica, and accordingly have since been removed from it. The genus, from its flat bill, was at one time placed among the Muscicapida (FLYCATCHels); but Dr. Murie's investigations (Proc. Zool. Soc. 1872, pp. 664-680, pl. lv.) have conclusively proved that it is not Passerine, and is nearly allied to the Momotida (Мотмот, p. 593) and Alcedinida (KingFisher, p. 485), though it should be regarded as forming a distinct Family Todida, peculiar to the Greater Antilles, each of which islands has its own species, all of small size, the largest not exceeding four inches and a half in length.

Of the species already named, T. viridis, Gosse (B. Jam. pp. 72-80) gives an interesting account. "Always conspicuous from its bright grass-green coat, and crimson-velvet gorget, it is still a very tame bird; yet this seems rather the tameness of indifference than of confidence; it will allow a person to approach very near, and, if disturbed, alight on another twig a few yards distant ... commonly it is seen sitting patiently on a twig, with the head drawn in, the beak pointing upwards, the loose plumage puffed out, when it appears much larger than it is. It certainly has an air of stupidity when thus seen. But this abstraction is more apparent than real; if we watch it, we shall see that the oddlooking grey eyes are glancing hither and thither, and that ever

1 In Forcellini's Lexicon (ed. De Vit, 1875) we find "Todus genus parvissimæ avis tibias habens perexiguas." Dneange in his Glossarium quotes from Festus, an ancient grammarian, "Toda est aris que non habet ossa in tibiis; quare semper est in motu, unde Todius (al. Todinus) dicitur ille qui velociter todet et movetur ad modum todx, et todere, moveri et tremere ad modum todae." The evidence that such a substantive as Todus or Toda existed seems to rest on the adjectiral derivative found in a fragment of a lost play (Symos) by Plautus, cited by this same Festus. It stands "eum extritis [extortis] talis, cum todillis [todinis] crusculis"; but the passage is held by scholars to be corrupt. Among naturalists Gesner in 1555 gave currency (Hist. Anim. iii. p. 719) to the word as a substantive, and it is found in Levins's Manipulus Vocabulorum of 1570 (ed. Wheatley, 186 $\%$, col. 225) as the equivalent of the English "Titmouse." Dueange allows the existence of the adjective todinus. Stephanus suggests that todi comes from $\tau v \tau \theta$ oi, but his view is not accepted. The verb toderc may perhaps be Englished to "toddle"! . 
and anon, the bird sallies out upon a short feeble flight, snaps at something in the air and returns to his twig to swallow it." $\mathrm{He}$ goes on to describe the engaging habits of one that he for a short time kept in captivity; which, when turned into a room, immediately began catching all the insects it could, at the rate of about one a minute. The birds of this Family also shew their affinity to the Kingfishers, Motmots and Bee-eaters by burrowing holes in the ground ${ }^{1}$ in which to make their nest, and therein

F.

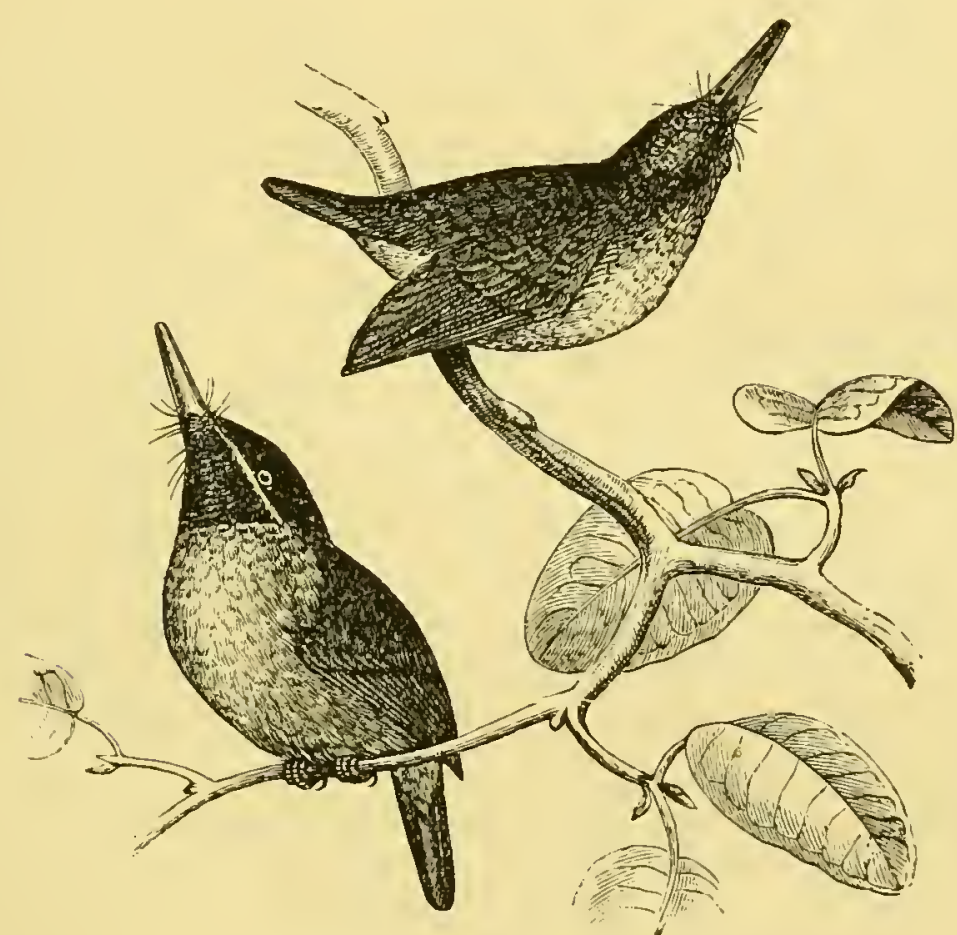

Todus viridis. (After Gosse.)

laying eggs with a white translucent shell. The sexes differ little in plumage. All the four species of Todus, as now restricted, present a general similarity of appearance, and, it may be presumed, possess very similar habits. ${ }^{2}$ Apart from their structural peculiar-

1 This habit and their green colour has given them the French name of Perroquet or Todier de terre, by which they have been distinguished from other species wrongly assigned to the genus by some systematists; and, if we may believe certain French travellers, they must in former days have inhabited some of the Lesser Antilles; but that is hardly probable.

2 Dr. Sharpe has treated of the genus (Itis, 1874, pp. 344-355 and Cat. B. Br. Afus. xvii. 11) 333-337); but he was misled by an exceptionally brightcoloured specimen to ald a fifth and bad species to those that exist-and even these, by some ornithologists, might be regarded as geographical races. The Cuban form is T. multicolor; that of Hispaniola is T. subulatus or dominicensis; and that of Porto Rico, originally named in error $T$. mexicanus, has since been called hypochondriceus. 
ities, one of the chief points of interest attaching to the Todidre is their limitation, not only to the Antillean Sub-region, but, as is now believed, to its greater islands.

TOES, forming that part of the foot on which a Bird rests, naturally exhibit countless modifications - in number, size or in the way in which they are connected by the podotheca or integument of the foot, for it is obvious that these modifications depend chiefly on the kind of life the bird leads, and whether it uses its Toes to catch prey, to perch, climb, run, scratch, wade or swim. Earlier ornithologists, having no better characters on which to rely, attached to the structure of the Toes a value ont of all proportion to their real taxonomic importance, and thus a superabundance of technical terms was created, some quite illogically, even by systematists of the modern school. ${ }^{1}$ In a great many Birds either the HALLUX (p. 404) or the Fourth Toe is reversible-the latter for instance can not only be turned back at will by the OwLS (pp. 675, 676), but is frequently so carried by some of them. To a less extent the Musophagidre (Touraco) and Leptosoma (Roller, p. 794) have the same faculty. In all these birds the feet shew a more or less temporary condition which has become permanent in groups that are called "zygodactylous" and placed together as SCANSOPES. There can scarcely be a doubt that this form of "climbing" foot has been acquired independently by several groups of birds, just as others have independently developed the webs that form a "swimming" foot, and so, regardless of essential differences of structure, have been combined as Natatores. In Colius (MoUse-BIRD) the hallux can be turned forward and the Fourth Toe backward, so that this peculiar form can put on at will the normal, the zygodactylous or the "pamprodactylous" type-the last being permanent in certain SwIFTs, and in a less degree some NightJaris.

Originally the four Toes may be presumed to be placed on the same level, and this condition prevails in most if not all of the Birds in which the hallux is large and functional, such as Palamedea, Steganopodes, Herodii, Scopus, Megapodiida, Cracidx, Porphyrio, Accipitres, Columbr, Striges, Picaria and Passeres. When, however, the hallux is reduced in size and importance it is often moved higher up, so that it does not seem to rise from the same level as the fore-toes, as is the case in Tubinures, Colymbidx, most Anseres,

1 Thus Desmodactyli (p. 134) and Eleutherodactyli (p. 194) are names given to groups, not because one has the Toes externally joined and the other Toes free to the base, but hecause one has a vinculum to the deep plantar tendons and the other has not (cf. p. 615, Type I.). Arisodactrli (p. 19), Hétérodactylcs (Blainville, Bull. Soc. Phitomat. 1816, p. 110), Panpronactyl.E (p. 684), SYNdacTYLI (p. 937) and ZYGODACTYLI, with their derivatives, are other cases in point. 
Phonicopterus, Ciconiida (less so in Ibidida), Podica, Helionnis, Fulica, Tribonyx, Ocydromus, Aramus, Grues and their allies (as Psophia, Eurypyga, Rhinochetus and Cariama), Laro-Limicole (not Dromas), Cathartidx and Gypogeranus. This modification seems to be a character easily adapted according to the nature of the bird's resting-place, and to be of as little taxonomic importance as the comparative length of the toes.

TOM, a nickname applied to several birds: In Jamaica Myiarchus stolidus is the TOMIFOOL, while a larger and a smaller species, M. validus and Contopus pallidus are respectively distinguished as the Great and Little Tomfool (Handb. of Jam. 1881, p. 107), all three belonging to the Tyrannida (TrRANT-BIRD). In the same island TOM-KELLY, or as Patrick Browne (Nat. Hist. Jam. p. 476) in 1756 has it, "WHIP-TOM-KELLY" has been said to be the creole name of Vireosylvia calidris, one of the Vireonidx (VIREo); but Gosse (B. Jam. p. 195) never heard it so called and could not believe that the bird's note could be so witten. ${ }^{1}$ TOMMY, ${ }^{2}$ and TOMI-NODDY ( $c f$. TAMny-Norie), mean the Puffix. TOMT'TT is a very common name in England for almost any kind of TITrouse, but preferably perhaps to Parus caruleus as the best known.

TONGUE, one of those organs which in Birds presents almost endless modifications, not only in size and shape, but also in gross and minute structure. As a whole it consists of the HroID (p. 452) framework, with its attached muscles (pp. 619, 620), the sensory terminal corpuscles ${ }^{3}$ of a branch of the glossopharyngeal

1 Tet March (Proc. Ac. Phitad. 1863, p. 294) nses the name, and Wilson (Am. Orn. ii. 1) 35) declares of an allied continental form, $V$. olivacca, that it "requires but little of imagination to fancy that you hear it pronounce these words "Tom-Kelly! Whip-Tom-Kelly!' very distinctly," a statement denied by Nuttall (Man. Orn. U. S. and Canada, i. p. 313), who also says (tom. cit. p. 238) that this call is nittered by Parus bicolor, the Tufted Tiтmouse.

2 Tomor, or Tymor (for both readings occur) appears to be a bird's name, and though there is nothing to shew its signification, needs mention here since it is included in several works and has been misprinted Tornor by Hartshorne (Ancient Metrical Tales, 1. 177). The authority for each form of the word is a MS. poem without title in the Public Library of the University of Cambridge (the first being given in Ff. 5. 48. fol. 69, $b$, line 6 ; the second in Ff. 2. 38. fol. 57, col. 2, line 22). They are rightly cited by Halliwell (Diet. Arch. \& Prov. Words, ii. pp. 880, 898), but Thomas Wright (Dict. Obsol. \& Prov. Engl. pp. 968, 988) wrongly assigns them to the old poem of True Thomas.

3 'The Tongue is commonly supjosed to be the chief organ of taste; but it is certainly not so in Birds, where it is, with a few exceptions, subservient to deglutition, being also in some cases (Honey-eaters, Humming-birds and Woodpeckers) the meaus of taking up the food. It is true that the Tongue of Birds is very rich in sensory bodies, the so-called Pacinian or Herbst's corpuscles, which are the terminal organs of sensory nerves; but these corpuscles are frequently imbedded deeply in and beneath the impervious horny sheath, so that they 
nerves (p. 627), together with glands, blood-vessels and the tegumentary sheath, which last is composed of horny epidermal cells, and is frequently frayed out on the margins or at the tip, in various ways according to the use to which it is put, but mainly connected with the mode of feeding. A similar if not identical modification of the Tongue seems to have been brought about in Birds belonging to widely-different groups from adaptation to the same circumstances; but here we must restrict ourselves to a notice of the more striking or aberrant types, only remarking that generalizations as well as conclusions from the shape of the bill and from the nature of the food are very unsafe.

The Tongue is frequently small in Birds which have the bill, mouth and gullet very large, so that bulky food can be swallowed whole and quickly. In Pelecanus and Sula, for instance, the free part of the Tongue is reduced to a little nodule. A similar diminution is apparent in the Ratita and Crypturi, in some Sphenisci and Tubinares, in Numenius, Ciconize, Ibidida, ${ }^{1}$ Cancroma, Bucerotida, Umupidx, Alcedinidx and Caprimulgidx. On the other hand the most marked development of the organ is found in the Anseres and Plocnicopterus. In the former it ends in a horny scoop, concave above, convex beneath, while its sides are beset with a row or rows of horny papilla like very short bristles or denticulations, which fit more or less into the similarly-serrated edges of the rhamphotheca or sheath of the BILL; but its upper surface is furnished with short and soft papillax sometimes of velvety appearance. Along the middle of the Tongue runs a furrow bordered on each side by a horny ridge, beset more or less tlickly with hard papilla which aid in swallowing the food. On the under side of the root lies a pair of cushion-like swellings, filled with fat. In most Birds-of-Prey the Tongue is thick, soft and spoon-shaped, but short; in the Pici (WOODPECKER) it is long, round, narrow, pointed at the end and, in the most insectivorous forms of the group, beset with spines or hooks directed backward. The elaborate apparatus already described (pp. 452,619) serves to protrude the organ, by means of which the bird is able to stir up and, in Mr. Lucas's neat phrase

cannot serve as organs of taste though they may act as organs of touch. Moreover, corpuscles of the same kind are generally distributed not only in the palate and bill (as in the Snipes for instance, and in the rail-like tip of the beak in Anseres), but also in great numbers in different parts of the body-as near the roots of the contonr-feathers, especially the rectrices and remiges, in the cloaca, in the mesentery and, last though not least, in the joints of the skeleton, but above all in the periosteum of the tibia. However, "taste" is one of the diffuse senses.

1 The extraordinary reduction of the Tongue in Ibis and Platalea inducen Nitzsch (Pterylographie, p. 193) to combine those genera in one group as Hemiglottides. 
(Bull. U. S. Dept. Agricult. Orn. No. 7, p. 3S), "coax" out of their hiding-places the grubs which form its food. The sides and back of the Tongue contain many Herbstian corpuscles, and according to that gentleman the number and distribution of the hooks and soft papilla vary much in closely-allied species, while the elongation of the organ and the development upon it of the spines apparently takes place during adolescence. ${ }^{1}$

In many groups of Birds, but chiefly among the Meliphagidae (HoNey-EATER), Nectariniidx (Sun-BIRD) and Trochili (HUMMINGBIRD) the horny sheath of the Tongue reaches its greatest development (cf. Proc. Zool. Soc. 1883, pp. 62-69, pl. xvi.). In the last group each side of it is bordered by a long thin lamella, the outer edge of which curls up like a roll of paper, so as to form a right and left tube; while in the second group the inner or median margin is laciniated or frayed out, and in the first group the sheath continues splitting dichotomously, producing a complicated brush. Unfortunately, and to the shame of observers, the precise way in which these tongues are used is still imperfectly known. Provided that the birds really eat honey, it is possible that the nectar of flowers is sucked up by capillary attraction, and therefore that what is thus taken is pressed out in the mouth; but the stomach of these birds almost always contains small insects and larvæ, and it seems possible that the Tongue may be used as a brush to dislodge and collect insects, which are then nipped by the jaws, the margins of which are, as in Meliphagidx and Nectariniidx, finely serrated. The same consideration applies to the Carebidæ (QUIT-QUIT, SUGARBIRD) and to the Drepanidida (Drepanis). Some of the Psittaci (LORY and NESTOR) possess a short brush-like fringe of soft papillic, which possibly act as a tactile and suctorial apparatus. The Tongue of the Phamphastida (ToUCAN) is about as long as the enormous bill, but is very slender and narrow, not protusible, and having the sides of the horny covering frayed out into numerous short bristles.

TORRENT-DUCK, a book-name given to birds of the SonthAmerican genus Merganetta and the Papuan Salvadorina, which seem doubtfully referable to the Merginx (MErganser). ( $C f$. Salvadori, who places with them Hymenolamus, suprà p. 843, Cat. B. Br. Mus. xxvii. p. 455.)

TOT-O'ER-SEAS, a name by which Regulus cristatus (GOLDCresT) is said to be known on some parts of the east coast, where it often arrives in countless numbers when on its autumnal migration.

1 A minute account of the Woodpecker's Tongue is given by Prince Ludwig Ferdinand of Bavaria (Sitzungsber. K. Bayr. Akad. 1884, pp. 183-192, figs. 1-10, and in his grand work Zur Anatomie cler Zunge, 4to, Miinchen : 1884-the part relating to Birds being pp. 67-76, and pls. xxiv. xxv.). 
TOUCAN, the Brazilian name of a bird, ${ }^{1}$ long , since adopted into nearly all European languages, and apparently first given currency in England (though not then used as an English word) in $1668^{2}$ by Charleton (Onomast. p. 115); but the bird, with its enormous beak and feather-like tongue, was described by Oviedo in his Sumario de la Natural Historia de las Indias, first published at Toledo in 1527 (chap. 42), ${ }^{3}$ and indeed so remarkable a bird must have attracted the notice of the earliest European invaders of America, the more so since its gandy plumage was used by the natives in the decoration of their persons and weapons. In 1555 Belon (Hist. Nat. Oys. p. 184) gave a characteristic figure of its beak, and in 1558 Thevet (Singularitez de la France Antarctique, pp. 88-90) a somewhat long description, together with a woodcut (in some respects inaccurate, but quite unmistakable) of the whole bird, under the name of "Toucan," which he was the first to publish. In 1560 Gesner (Icones Avium, p. 130) gave a far better figure (though still somewhat incorrect) from a drawing received from Ferrerius, and suggested that from the size of its beak the bird should be called Burhynchus or Ramphestes. This figure, with a copy of Thevet's and a detailed description, was repeated in the posthumous edition (1585) of his larger work (pp. 800, 801). By 1579 Ambroise Paré (OEuvres, ed. Malgaigne, iii. p. 783) had dissected a Toucan that belonged to Charles IX. of France, and about the same time Léry (Voy. Bresil, chap. xi.), whose chief object seems to have been to confute Thevet, confirmed that writer's account of this bird in most respects. In 1599 Aldrovandus (Orn. i. pp. 801-803), always ready to profit by Gesner's information, and generally without acknowledgment, again described and repeated the former figures of the bird; but he corrupted his predecessor's Ramphestes (which was nearly right) into Ramphastos, and in this incorrect form the name, which should certainly be Rhamphestes or Rhamphastas, was subsequently adopted by Linnæus and has since been recognized by systematists. Into the rest of the early history

1 Commonly believed to be so called from its cry; but Prof. Skeat (Proc. Philolog. Soc. 15th May 1885) adduces evidence to prove that the Guarani Tuca is from $t \tilde{\imath}$, nose, and cang, bone, i.e. nose of bone.

2 In 1656 the beak of an "Aracari of Brazil," which was a Toucan of some sort, was contained in the Musæum Tradescantianum (p. 2), but the word Toucan does not appear there.

s I have only been able to consult the reprint of this rare work contained in the Biblioteca de Autores Españoles (xxii. pp. 473-515), published at Madrid in 1852. To quote the translation of part of the passage in Willughby's Ornithology (p. 129), "there is no bird secures her young ones better from the Monkeys, which are very noisom to the Young of most Birds. For when she perceives the approach of those Enemies, she so settles her self in her Nest as to put her Bill out at the lole, and gives the Monkeys such a welcom therewith, that they presently pack away, and glad they scape so." 
of the Toucan's discovery it is needless to go. ${ }^{1}$ Additional particular's were supplier by many succeeding writers, until in 1834 Gould completed his Monograph of the family ${ }^{2}$ (with an anatomical appendix by Owen), to which, in 1835, some supplementary plates were added; and in 1854 he finished a second and improved edition. 'The latest systematic work on Toucans is by Mr. Sclater (Cat. B. Br. Mus. xix. pp. 122-160), which agrees for the most part with that of Cassin (Proc. Acad. Philad. 1867, pp. 100-124), and five genera and 59 species of the Family are recognized. There can be little doubt that the bird first figured and described by the earliest authors above named is the $P$. toco of nearly all ornithologists, and as such is properly legarded as the type of the genus and therefore of the Family. It is one of the largest, measuring 2 feet in length, and has a wide range throughout Guiana and a great part of Brazil. The huge beak, looking like the great claw of a lobster, more than 8 inches long and 3 high at the base, is of a deep orange colour, with a large black oval spot near the tip. The eye, with its double iris of green and yellow, has a broad blue orbit, and is surrounded by a bare space of deep orange skin. The plumage generally is black, but the throat is white, tinged with yellow and commonly edged beneath with red; the upper tail-coverts are white, and the lower scarlet. In other species of the genus, 14 in number, the bill is mostly particoloured-green, yellow, red, chestnut, blue and black variously combining so as often to form a ready diagnosis; but some of these tints are very fleeting and often leave little or no trace after death. Alternations of the brighter colours are also displayed in the feathers of the throat, breast and tail-coverts, so as to be in like manner characteristic of the species, and in several the bare space round the eye is yellow, green, blue or lilac. The sexes are almost alike in coloration, and externally differ chiefly in size, the males being largest. The tail is nearly square or moderately rounded. The so-called HillToucans form another genus, Andigena, and consist of 6 species

1 One point of some interest may, however, be noticed. In $1705 \operatorname{Plot}(N . H$. Oxfordsh. p. 182) recorded a Toncan found within two miles of Oxford in 1644, the body of which was given to the repository in the medical school of that university, where, he said, "it is still to be seen." Already in 1700 Leigh (Lancash. i. p. 195, Birds, tab. 1, fig. 2) had figured another which he said had been found dead on the coast of that county about two years before; but his figure is copied from Willughby. The bird is easily kept in captivity, and no doubt from early times many were brought alive to Europe. Beside the one dissected by Paré, as above mentioned, Joh. Faber, in his additions to Hernandez's work on the Natural History of Mexico (1651), figures (p. 697) one seen and described by Puteus (Dal Pozzo) at Fontainebleau.

2 Of this the brothers Sturm in 1841 published at Nuremberg a German version. 
chiefly frequenting the slopes of the Andes and reaching an elevation of 10,000 feet, though one, $A$. bailloni, remarkable for its yellow-orange head, neck and lower parts, inhabits the lowlands of southern Brazil. Another very singular form is A. laminirostris, which has affixed on either side of the maxilla, near the base, a quadrangular ivory-like plate, forming a feature unique among Birds. In Pteroglossus, the "Aracaris" (pronounced Arassarí), the sexes more or less differ in appearance, and the tail is graduated. The species are smaller in size, and nearly all are banded on tho belly, which is generally yellow, with black and scarlet, while except in two the throat of the males at least is black. One of the most remarkable and beautiful is $P$. beauharnaisi, by some authors placed in a distinct genus and called Beauharnaisius ulocomus. In this the feathers of the top of the head are very singular, looking like glossy curled shavings of black horn or whalebone, the effect being due to the dilatation of the shaft and its coalescence with the consolidated barbs. Some of the feathers of the straw-coloured throat and cheeks partake of the same structure, but in a less degree, while the subterminal part of the lamina is of a lustrous pearly-white. ${ }^{1}$ The beak is richly coloured, being green and crimson above and lemon below. The upper plumage generally is dark green, but the mantle and rump are crimson, as are a broad abdominal belt, the flanks and many crescentic markings on the otherwise yellow lower parts. ${ }^{2}$ The group or genus Selenidera, ${ }^{3}$ proposed by Gould in 1837 (Icones Avium, pt. 1), contains some 7 species, having the beak, which is mostly transversely striped, and tail shorter than in Pteroglossus. Here the sexes also differ in coloration, the males having the head and breast black, and the females the same parts chestnut; but all have a yellow nuchal crescent (whence the name of the group). The genus Aulacorhamphus, or "Groove-bills," to which 14 species are assigned, contains the rest of the Toucans.4.

1 This curious peculiarity naturally attracted the notice of the first discoverer of the species, Poeppig, who briefiy described it in a letter published in Froriep's Notizen aus dem Gebiete der Natur (xxxii. p. 146) for December 1831.

2 Readers will recollect the account and illustration given by Bates (Nat. Amaz. ii. p. 344) of his encounter with a flock of this species. His remarks on the others with which he met are also excellent.

${ }^{3}$ Some other name is needed for this genus, as Gould's was preoccupied by an entomologist.

${ }^{4}$ The monstrous serrated bill that so many Toucans possess was by Buffon, after his manner, accounted a grave defect of Nature, and it must be confessed that no one has given what seems to be a satisfactory explanation of its precise use, though none will now doubt its fitness to the bird's requirements. Solid as it looks, its weight is inconsiderable, and the perfect hinge by which the maxilla is articulated adds to its efficiency as an instrument of prehension. Swainson (Classif. Birds, ii. p. 138) imagined it merely " to contain an infiuity of nerves, 
As the foregoing shews, Toucans are a Neotropical form, and by far the greater number inhabit the northern part of Sonth America, especially Guiana and the valley of the Amazons. Some three species occur in Mexico, and several in Central America. One, $R$. vitellinus, which has its headquarters on the mainland, is said to be common in Trinidad, but none are found in the Antilles proper. The precise place of the Family in the heterogeneous group Picaria cannot yet be determined. Its nearest allies perhaps exist among the Capitonida; but none of them are believed to have the long feather-like tongue which is so characteristic of the Toucans, and is, so far as known, possessed besides only by the Momotidx (Motmo', p. 593). But of these last there is no reason to deem the Toucans close relatives, and, according to Swainson (Classif. B. p. 141), who had opportunities of observing both, the alleged resemblance in their habits has no existence. Those of the Toucans in confinement have been well described by Broderip and Vigors (Zool. Journ. i. p. 484 ; ii. p. 478), and indeed may be partially observed in many zoological gardens. Though feeding mainly on fruits, little seems amiss to them, and they swallow grubs, reptiles and small birds with avidity. They are said to nest in hollow trees, and to lay white eggs.

TOURACO, the name, evidently alleady in use, under which in 1743 Edwards figured a pretty African bird, ${ }^{1}$ and presumably disposed like net-work, all of which lead immediately to the nostrils," and add to the olfactory facnlty. This notion seems to be borrowed from Trail (Trans. Linn. Soe. xi. p. 289), who admittedly had it from Waterton, and stated that it was "an admirable contrivance of nature to increase the delicacy of the organ of smell;" but Owen's description shews this view to be groundless, and he attributes the extraordinary developnient of the 'Toncan's beak to the need of compensating, by the additional power of mastication thus given, for the absence of any of the grinding structures that are so characteristic of the intestinal tract of vegetable-eating birds-its digestive organs possessing a general simplicity of formation. The question is one worth deciding, and would not be difficult to decide by those who have the opportunity. The nostrils are placed so as to be in most forms invisible until sought, being obscured by the frontal feathers or the backward prolongation of the horny sheath of the beak. The wings are somewhat feeble, and the legs have the toes placed in pairs, two before and two behind. The tail is capable of free vertical motion, and controlled by strong muscles, so that, at least in the true Toucans, when the bird is preparing to sleep, it is thrown forward and lies almost flat on the back, on which also the huge bill reposes, pointing in the opposite direction.

${ }^{1}$ Apparently the first ornithologist to make the bird known was Albin, who figured it in 1738 firom the hife, yet badly, as "The Crown-bird of Mexico." $\mathrm{He}$ had doubtless been misinformed as to its proper country; but Touracos were called "Crown-birds" by the Europeans in West Africa, as witness Bosman's Description of the Coast of Guinea (1721), ed. 2, p. 251, and W. Smith's Voyage to Guinca (1745), p. 149, though the name was also given to the Crowned Cranks, Balcarica. 
that applied to it in Gumen, whence it had been brought alive. It is the Cuculns perse of Linnæus, and Turucus or Corythaix persu of later anthors, who perceived that it required generic separation. Cuvier, in 1799 or 1800, Latinized its native name (adopted in the meanwhile by both French and German writers) as above, for which barbarous term Illiger, in 1811, substituted a more classical word; but in 1788 Isert had described and figured a bird, also from Guinea, which he called MIusophaga violacea (PLANTaIn-Eater, p. 730), and its affinity to the original Touraco being soon recog-

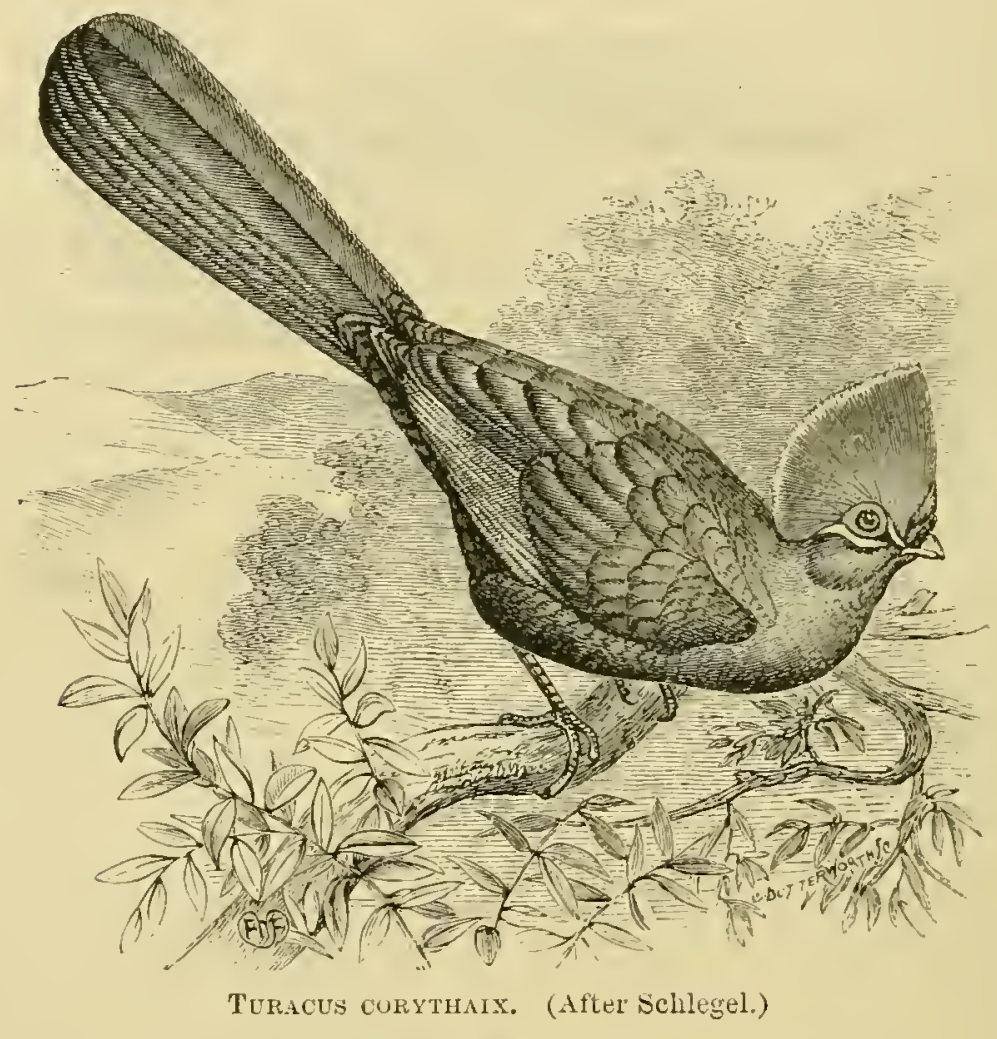

nized, both forms have been joined by modern systematists in the Family Musoplayida.

To take first the Plantain-eaters proper, or the genus Musophagu of which only two species are known. One about the size of a Crow is comparatively common in museums, and is readily recognized by having the horny base of its fine yellow bill prolonged backward over the forehead in a kind of shield. 'The top of the head, and the primaries, except their outer edge and tip, are deep crimson; a white streak extends behind the eye; and the rest of the plumage is of a rich glossy purple. The second species, $M$. rossie, which is rare, chiefly differs by wanting the white eye-streak. Then of the Touracos-the species originally described is about the size of a Jay, and has the head, erest (which is vertically compressed and tipped with red), neck and breast of a fine grass-green, 
varied by two conspicuous white streaks-one, from the gape to the upper part of the crimson orbit, separated by a black patch from the other, which runs beneath and behind the eye. The wing-coverts, lower part of the back and tail are of a bright steelpurple, the primaries deep crimson, edged and tipped with bluishblack. Over a dozen other congeneric species, more or less resembling this, have now been described, and all inhabit some district of Africa; but there is only room here to mention that found in the Cape Colony and Natal, where it is known as the "Lory" (cf. p. 519, note 2), and, though figured by Daubenton and others, was first differentiated in 1811 by Wagler as Turacus corythaix, but renamed in 1841 by Strickland (Ann. Nat. Hist. vii. p. 33) T. albicristatus-its crest having a conspicuous white border, while the steel-purple of $T$. persa is replaced by a rich and glossy bluishgreen of no less beauty. In nearly all the species of this genus the nostrils are almost completely hidden by the frontal feathers; but there are two others in which, though closely allied, this is not the case, and some systematists would place them in a separate genus Gallirex; while another species, the giant of the Family, has been moved into a third genus as Corythaola cristata. This differs from any of the foregoing by the absence of the crimson coloration of the primaries, and seems to lead to another group, Schizorrhis, in which the plumage is of a still plainer type, and, moreover, the nostrils here are not only exposed but in the form of a slit, instead of being oval as in all the rest. This genus contains four species, one of which, S. concolor, is the Grey Touraco of the colonists in Natal, and is of an almost uniform slaty-brown. Lastly a genus Gymnoschizorrhis, with a bare forehead, has also been proposed. A good deal has been written about these birds, which form the subject of one of the most beautiful monographs ever publishedDe Toerako's afgebeld en beschreven,-by Schlegel and Westerman (Amsterdam: 1860): while more recent information is contained in an elaborate essay by Herr Schalow (Jour. f. Orn. 1886, pp. 1-77), and the specimens in the British Museum were catalogued in 1891 by Capt. Shelley (Cat. B. Br. Mus. xix. pp. 435-456). Still much remains to be made known as to their distribution throughout Africa, and their habits. They seem to be all fruit-eaters, and to frequent the highest trees, seldom coming to the ground. Very little can be confidently asserted as to their nidification, but at least one species of Schizorrhis is said to make a rough nest and therein lay three eggs of a pale blue colour."

3 An extraordinary peculiarity attends the crimson coloration which adorns the primaries of so many of the Musophagidx. So long ago as 1818, Jules Verreaux observed (Proc. Zool. Soc. 1871, p. 40) that in the case of T. corythaix this beautiful hue vanishes on exposure to heavy rain and reappears only after some interval of time and when the feathers are dry. The fact of this colouring 
The Musophagida form a very distinct Family of Prof. Huxley's Coccygomorpher, having perhays the Coliulde (Mouse-BIRD, p. 600) and Cuculida as their nearest allies. ${ }^{2}$ The bill of nearly all the species is eurionsly serrated or dentiunlated along the margin, and the feet have the outer toe reversible. No member of the Family is found outside of the continental portion of the Ethiopian Region.

TOWHEE, so cillerl from one of its notes, a well-known NorthAmerican bird, Piprito erythrophthutmus, one of the "Columbian"

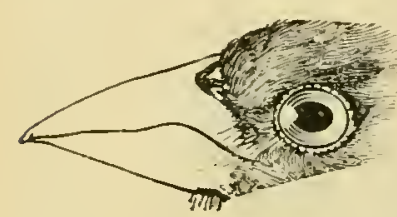

Pipizo. (After Siwainson.) forms which as yet cannot be positively assigned to the Fringillida (FINCH) or the Emberizida (Buntina), though commonly regarded as belonging to the latter group, and indeed genera presumably allied have been named Emberizoudes and Embernagra. The number of "species" of Pipilo is by 110 means certain, for many local races occur in various parts of the comntry, and it is thus a matter of opinion whether 8 or 10 or nearly twice as many should be recognizerl (cf. Cones, Key $\Lambda$. Am. B. ed. 2, pp. 395-398; Rirlgway,

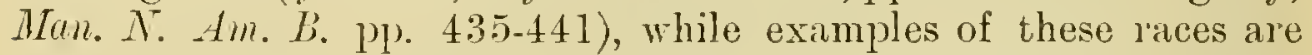
not easily distinguished. In some the sexes are nearly alike in plumage, but this is not so in the eastem bird to which the English name, now extended to all the rest, was originally given. There is also a considerable difference in their call-note, for $P$. megalonyx, the prevalent form in the south-west, is said to mew like a CATBIRI, while the more nol'thern $I^{\prime}$. arctims will octasionally utter one of the cries of $P$. erythrophthutmus, which has procured for that species the name of Chewink, by which as well as Ground-Robin it is also known. The colour of the iris too varies in some cases aceording to locality. matter being solnble in water was, by $\mathrm{Mr}$. Tegetmeicr, bronght to the notice of Prof. Chureh, who published in 1868 (Student and Intellcetual Observer, i. 1'p. 161-168) an account of it as "Turacin, a new animal pisment containing copper." He has since dealt with it more fully in two communications to the Royal Society (Phit. Trons. 1869, 1'1. 627-636, and 1893, 1'1.511-530), in the last of which he intimates a doubt as to the existence as an independent pigment of "Turaco-verdin" (of. Colot k, p). 96) as annomeed by Dr. Kurtkenberg (Vergl.physiol. Stud. ser. 2, i. 1. 151). The subject has received much attention from other's, and the peenliar property is possessed by the crimson feather's of all the birds of the Family.

1 Eyton pointel out (Am. Nat. Hist. ser. 3, ii. p. 458) a feature possessed in common by some of the Cucutid and the MFusophayidx, in the "process attached to the anterior edge of the ischimm," which he likened to the so-called "marsmpial" bones of Didelphian Mammals. J. T. Reinhardt also noticed (Vid. NTcldels. Aaturhist. Furen. 1871, 11'.326-341) another Cueuline character ofiered by the os uncinatum affixed to the lower side of the ethmoid in the Plantain-eaters and Touracos; but too much dependence must not be placed on that, since a similar strneture is presented by the FliGATE-BBliD and some PETLELS. A corresponding process seems also to be found in Trucios. 
TRACHEA or Windpipe, the flexible tube, composed of a great number of rings, originally cartilaginous but ossifying more or less with age, through which Birds breathe and utter most of their characteristic notes. Its upper end is modified into the LARYNX, and it continues subcutaneously down the neck to the thorax, which it enters between the two branches of the FURCULA, and bifurcates into the two BRONCHI, each of which passes to the LUNG of its own side. The tracheal rings frequently overlap each other in various ways, and, except a few adjoining the larynx, are dorsally complete; but in Dromæus several in the third quarter of the length of the tube are incomplete ventrally, and permit its inner mucous lining to bulge out so as to form the pouch before mentioned (EMEU, p. 214) which occurs in both sexes and may be 12 inches in length. In the Trochili, Platalea, many Tubinares and Sphenisci a great portion of the tube is divided by a median, vertical, cartilaginous septum, extending forward from the bronchial bifurcation, and consisting of rings which pass laterally into those of the walls, thus perpetuating a condition that in other Birds exists for a short time only in their embryonic development, before the septum has been reduced to the pessulus marking the beginning of the bronchi. Frequently the Trachea is depressed or flattened dorso-ventrally, as in Psittaci, Accipitres, Ciconix and Ratitx; but a very common feature, found in many groups not at all allied to each other, is the dilatation of a portion, generally near the middle, as may be seen in several Cotingidre, Channa and the males of many Anseres-some of the last-named group presenting even a second dilatation, which may be as in Edemia fusca close to the larynx, ${ }^{1}$ but is more usually near the lower end. Still further modifications are exhibited by the males of many or most of the Anseres, some 6 or 8 of the lowest rings being fused together and forming what is known as the bulba ossea or labyrinth. Its simplest form seems to be that presented, according to Eyton (Monogr. Anat. p. 125, pl. ii. fig. 2), by Anas or Querquedula formosa, where the enlargement is very slight, but essentially similar to that found generally in the genus Anas $^{2}$ and its many subdivisions, the GarGaney (p. $309^{3}$ )

1 This structure is, so far as known, quite unique: the enlargement next to the larynx surrounds the tube which communjeates with it by an aperture on each side. The lower enlargement, in shape of a flattened bulb, is formed of expanded tracheal rings firmly ossified together. It is the more remarkable since the allied $C E$. nigra has a very simple trachea. The male of Mctopiana peposaca has a bulbous enlargement just above the middle of the trachea very similar to the lower one in $E$. fusca.

2 The statement (Proc. Zool. Soc. 1871, p. 651) as to the female of $A$. punctata possessing a labyrinth originated in a mistake (op. cit. 1882, p. 454).

${ }^{3}$ Since the footnote on this page was printed Mr. Lucas has most obligingly examined the labyrinth of $A$. discors, which has nothing exceptional about it. 
excepted, a single ampulla often of considerable size being thrown out on one side-usually the left. This structure obtains apparently throughout all the "Freshwater Ducks" or Anatina, as well as in Somateria and Tachyeres, but it is subject to great exaggeration and, though occasionally absent as in Edemia, becomes very complicated in the group of "Diving Ducks," forming in many cases a tympanum, whose bony walls are fenestrated and the spaces filled with a resonant membrane, ${ }^{1}$ while it attains its greatest magnitude in the Merginx. Tadorna has two bony ampulla, one on each side, and dilatations are also present in Chenalopex, Sarcidiornis and, according to Eyton (op. cit. p. 83, pl. i. figs. 1, 2), in Chloephaga magellanica. In Dendrocygna the labyrinth is composed of two oblong chambers, and takes the form of a symmetrical shield-shaped box (Ibis, 1859, p. 366).

Quite as remarkable is the lengthening of the Trachea in some birds during adolescence, so that to be contained conveniently it is looped, and this formation is frequently, though not always, confined to one or the other sex. In the male of Tetrao urogallus (CApercally) and in the female of Anseranas there is a simple subcutaneous loop. In the female of the Old-World Painted SNIPES (p. 887), Rostrutula, the loop extends ventrally over the furcula, and mole or less over the pectoral muscles ( $c f$. WoodMason, Proc. Zool. Soc. 1878, p. 745), and a similar arrangement is found in the males of most Cracina (CURAssow), while it occurs in both sexes of Penelope jacucaca, though most of the Penelopinz (GUAN) have no loop at all. Among Passeres a series of coils is found in both sexes of Plionygama, and in the males of Manucodia (MANUCODE). In the male of Anseranas the convolutions of the Trachea lying outside the pectoral muscles are not only subject to variation in number, but they may be placed on either side of the body (cf. Yarrell, Trans. Linn. Soc. xv. pp. 383, 381, pls. xiii. xiv.), the form of the coracoid on that side being modified accordingly. A curious peculiarity is exhibited by the Crested Guinea Fowls (suprà, p. 401), in both sexes of which the symphysis of the furcula is dilated so as to lodge a short tracheal loop (tom. cit. pl. ix.).

The furcula and coracoids are not, however, the only bones which are modified by the excessive lengthening of the Trachea. As has long been known, some of the Swans and Cranes have their sternum invaded by it; but each in a different way-the

1 Very remarkable is the tracheal structure of Harelda and Rhodonessa, but want of space renders it impossible to particularize all the pecultarities in this group of Anatidx. Reference may be made to the classical papers of Latham and Yarrell (Trans. Linn. Soc. iv. pp. 90-128, and xv. pp. 378-388), as well as to Eyton's Monograph above cited, and the observations of Garrod (Proc. Zool. Soc. 1875, pp. 151-156) and Forbes (op. cit. 1882, pp. 347-353). 
looping being praclavicular in the former and postclaricular in the latter. In both sexes of Cygmus Jucrinutor, C'. musicns, $C$. americanus. and $C$. bewicki the Trachea runs ventrally beneath the symphysis of the furcula, which bends dorsally to permit its passage, to enter the swollen keel, which in old birds it penetrates to the furthest extremity, ${ }^{1}$ and thence returns, still keeping below the furcula, on its way to the thorax. In all the other Swans the Trachea is simple. Among the Crancs almost every degree of development may be found, from Balearica where there are no convolutions at all, to Authropoiles where the keel is hollowed into a cavity open at the sides, to Grus americana and $(r$. commonis where it is penetrated to its ntmost extremity by the Trachea; but no part of the Trachea passes ventrally over the furcula. Such a postclavicular loop exists in Platalea leucorodia, but not in $P^{\prime}$. "ijaj", and in the male of Tuntalus itis, but not that of $T$. loculetor. For the thoracic, voice-producing end of the Trachea see Srrivx (p.937).

TRACHEOPHONES (by some witten Tracheophona or Tracheophoni) Johannes Müiller's name (Abhemell. k. Alutel. Bertin, Phys. Kl. 1847,1 . 367) for the second of his three gromps of PASSERINI, having the trachea furnished with but one or two pairs of rocal muscles, and those lateral (of. SrTinx, p. 940).

TREE-CREEPER, one of the smallest of British birds, and, regard being had to its requirements, one very generally distributed. It is the Certhic familiaris of ornithology, and remarkable for the stiffened shafts of its long and pointed tail-feathers, aided by which, and by its comparatively large feet, it climbs nimbly in a succession of jerks the trunks or branches of trees, invariably proceeding upwards or ontwards and generally in a spiral

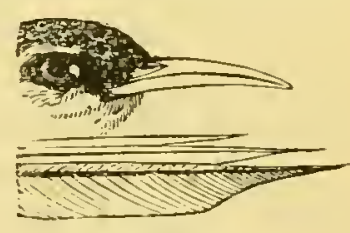

Tree-Creeprer. (After Swainsoll.) direction, as it seeks the small insects that are hidden in the bark and form its chief food. When, in the course of its search, it near's the end of a branch or the top of a trunk, it flits to another, always alighting lower down than the place it has left, and so continues its work.

Inconspicuous in colour, for its upper plumage is mostly of various shades of brown mottled with white, buff and tawny, and beneath it is a silvery white, the Tree-Creeper is far more common than the incurions suppose; but, attention once drawn to it, it can be frequently seen and at times heard, for though a shy singer its song is loud and sweet. The nest is neat, generally placed in a chink formed by a half-detached piece of bark, which secures it

I In $C$. buccinator and $C$. musicus the return loop is vertical; in $C$. bewicli and apiarently $C$. comericunes it is horizontal. 
from observation, and a considerable mass of material is commonly used to stuff up the opening partly and give a sure foundation for the tiny cup, in which are laid from six to nine eggs of a translucent white, spotted or blotched with rust-colour. The TreeCreeper inhabits almost the whole of Europe as well as Algeria, and has been traced across Asia to Japan. It is now recognized as an inhabitant of the greater part of North America, though for a time examples from that part of the world, which differed slightly in the tinge of the plumage, were accounted specifically distinct (of. Ridgway, Proc. U. S. Nat. Mus. 1882, pp. 111-116). It therefore occupies an area not exceeded in extent by that of many Passerine birds, and is one of the strongest witnesses to the inseparability of the Holarctic Fauna.

Allied to Certhia, but wanting its lengthened and stiff tailfeathers, is the genus Tichodroma, the single member of which is the Wall-Creeper, T. muraria, of the Alps and some other mountainous parts of Europe and Asia, and occasionally seen by the fortunate visitor to Switzerland fluttering like a big butterfly against the face of a rock, conspicuous from the scarlet-crimson of its wing-coverts and its white-spotted primaries. Its bright hue is hardly visible when the bird is at rest, and it then presents a dingy appearance of grey and black. It is a species of wide range, extending from Spain to China; and, though but seldom leaving its cliffs, it has wandered even so far as England. ${ }^{1}$

The genus Certhia as founded by Linnæus contained 25 species, all of which, except the two above mentioned, have now been shewn to belong elsewhere; and for a long while so many others were referred to it that it became a most heterogeneous company. At present so few are the forms left in the Family Certhiidx that systematists ( $c f$. Gadow, Cat. B. Br. Mus. viii. pp. 322-340) are not wanting to unite it with the Sittidx (NuTHaTCH), for the two groups, however much their extreme members may differ, are linked by forms which still exist, and little violence is done to the imagination by drawing upon the past for others to complete the series of descendants from a common and not very remote ancestor, one that was possibly the ancestor of the Wrens as well. Two things, however, have especially to be noticed here. The Certhiida have not the least affinity to the Picida (WOODPECKkr), but are strictly Passerine, and also that the Australian genus Climacteris may possibly not belong to them.

1 Merrett (Pinax, p. 177) in 1667 included it as a British bird, and the correspondence between Marsham and Gilbert White (Proc. Norf. and Norw. Nat. Soc. ii. p. 180) proves that an example was shot in Norfolk, 30th October 1792 ( $f f$. Stevenson and Sonthwell, $L$. Norf. iii. p. 380, pl. v.), while anotlere is reported (Zoologist, ser. 2, p. 4839) to have been killed in Lancashire, 8th May 1872. Its reputed occurrence in Abyssinia seens doubtful. 
TROCHILI, the Twelfth Order of Birds in Wagler's classification of 1830 (Nat. Syst. d. Amphib. u. s. w. p. 81) and frequently used since by those who would raise the Family Trochilidx (HunMING-BIRD) to ligher rank.

TROGON, ${ }^{1}$ a word apparently first used in English ${ }^{2}$ by Shaw (HIus. Lever. p. 177) in 1792, and for many years accepted as the name of certain birds forming the Family Trogonid $\mathscr{x}$ of ornithology, the species Trogon curucui of Linnæus being its type. ${ }^{3}$

The Trogons are birds of moderate size : the smallest is hardly bigger than a Thrush and the largest less bulky than a Crow. In most of them the bill is very wide at the gape, which is invariably beset by recurved bristles. They seize most of their food, whether caterpillars or fruits, on the wing, though their alar power is not exceptionally great, their flight being described as short, rapid and spasmodic. Their feet are weak and of a unique structure, the second toe being reverted. The plumage is very remarkable and characteristic. There is not a species which has not beauty beyond most birds, and the glory of the group culminates in the QUEZAL (p. 758). But in others golden-green and steely-blue, rich crimson ${ }^{4}$ and tender pink, yellow varying from crimson to amber, vie with one another in vivid coloration, or contrasted, as happens in many species, with a warm tawny or a sombre slatygrey - to say nothing of the delicate freckling of black and white, as minute as the marblings of a moth's wing - the whole set off by bands of white, producing an effect hardly equalled in any group. The plumage is further remarkable for the large size of its contour-feathers, which are extremely soft and so loosely seated as to come off in scores at a touch, and there is no down. The tail is generally a very characteristic feature, the rectrices, though in some cases pointed, being often curiously squared at the tip,

1 Trogonem (the oblique case) occurs in Pliny (H. N. x. 16) as the name of a bird of which he knew nothing, save that it was mentioned by Hylas, an augur, whose work is lost ; but some would read Trygonem (Turtle-Dove). In 1752 Möhring (Av. Gen. p. 85) applied the name to the "Curueui" (pronounced "Suruquá" fide Bates, Nat. Amaz. i. p. 254) of Maregrave (Hist. Nat. Brasil. p. 211), who described and figured it in 1648 recognizably. In 1760 Brisson (Om. iv. p. 164) adopted Trogon as a generic term, and, Linnæus having followed his example, it has since been universally accepted.

2 Pennant in 1769 (Ind. Zool. 1). 4) anglicized the word Curucur as Couroucou.

3 Since doubts exist as to whether this is that which was subsequently called by Vieillot T. collaris or the T. melanurus of Swainson, though evidence is in favour of the former (Cabanis, Mus. Hein. iv. p. 117, and Finsch, Proc. Zool. S'oc. 1870, p. 559), several writers have dropped the Linnæan specific term.

${ }^{4}$ M. Anatole Bogdanoff (Comptes Rendus, 2 Nov. 1857, xlv. pp. 688-690) determined the red pigment of the feathers of Pharomacrus auriceps to be a sub stance which he called "zooxanthine." (See CoLour, p. 95.) 
and when this is the case they are usually barred ladder-like with white and black. ${ }^{1}$ According to Gould, they are larger and more pointed in the young than in the old, and grow squarer and have the white bands narrower at each succeeding moult. $\mathrm{He}$ also asserts that in the species which have the wing-coverts freckled, the freckling becomes finer with age. So far as has been observed, the nidification of these birds is in holes of trees, wherein are laid without any bedding two roundish eggs, generally white, but certainly in one species (Quezal) tinted with bluish-green.

The Trogons form a very well-marked Family, belonging to the multifarious group here treated as PICARI $\mathrm{e}$; but, instead of being (so far as is known) like all the rest of them and, as Prof. Huxley believed, "desmognathous," they have been shewn by W. A. Forbes (Proc. Zool. Soc. 1S81, p. 836) to be "schizognathous"thus demonstrating, in the words of the latter, "that the structure of the palate has not that mique and peculiar significance that has been claimed for it in the classification of birds." Perhaps the explanation of this anomaly may lie in the fact that the Trogons are a very old form. The remains of one, $T$. gallicus, have been recognized by Prof. A. Milne-Edwards (Ois. foss. de la France, ii. p. 395, pl. 177, figs. 18-22) from the Miocene of the Allier, and it may not be too much to suppose that the schizognathous structure was more ancient than the desmognathous (cf. suprà, p. 878, note). Again too this fortunate discovery seems to account for the remarkable distribution of the Trogons at the present day. While they chiefly abound, and have developed their climax of magnificence, in the tropical parts of the New World, they yet occur in the tropical parts of the Old. The species now inhabiting Africa, forming the group Hapaloderma, are clearly allied to those of the Neotropical Trogon, and the difference between the Asiatic forms, if somewhat greater, is still comparatively slight. It is plain then that the Trogons are an exceptionally persistent type; indeed in the whole Class few similar instances occur and perhaps none that can be called parallel. The extreme developmerit of the type in the New World just noticed also furnishes another hint. While in some of the American Trogons (Pharomacrus, for instance) the plumage of the females is not very much less beautiful than that of the males, there are others in which the hen-birds retain what may be fairly deemed a more ancient livery, while the cocks flaunt in brilliant attire. Now the plumage of both sexes in all but two of the Asiatic Trogons resembles rather that of the young and of those females of the American species which are modestly clothed. The inference from this fact would seem to be that the general colora-

1 In the Trogon of Cuba, Prionotelus, they are most curiously scooped out, as it were, at the extremity, and the lateral pointed ends diverge in a way almost unique among birds. 
tion of the Trogons prior to the establishment, by geographical estrangement, of the two types was a russet similar to that now woln by the adults of both sexes in the Indian Region, and by at portion only of the females in the Neotropical. The Ethiopian type, as already said, very closely agrees with the American, and therefore would be likely to have been longer in connexion therewith. Again, while the adults of most of the American Trogons (Pharomacrus and Euptilotis excepted) have the edges of their bill serrated, their young have them smooth or only with a single notch on either side near the tip, and this is observable in the Asiatic Trogons at all ages. At the same time the most distinctive features of the whole group, which are easily taken in at a glance, but are difficult to express briefly in words, are equally possessed by both branches of the Family, slewing that they were in all likelihood-for the possibility that the peculiarities may have been evolved apart is not to be overlooked-reached before the geographical sundering of these branches (whereby they are now placed on opposite sides of the globe) was effected.

It remains to say that Gould in the second edition of his Monograph of the Family (1875) recognized about sixty species, dividing them into 7 genera; but Mr. Grant's revision in 1892 (Cat. B. Br. Nus. xvii. pp. 429-497, 501, 502) gives 8 genera and 49 species, though admitting several made known since his predecessor's time. Pharomacrus, Euptilotis and Trogon inhabit the mainland of tropical America, no species passing to the northward of the Rio Grande nor southward of the forest district of Brazil, while none occur on the west coast of Peru or Chili. Prionotelus and Tmetotrogon, each with one species, are peculiar respectively to Cuba and Hispaniola. The African form Hapaloderma has three species, one found only on the west coast, another on the east coast and the third of more general range. The Asiatic Trogons, Harpactes (with eleven species according to the same authority), occur from Nepal to Malacea and Cochin China, in Ceylon, and in Sumatra, Java and Borneo, while one species is peculiar to some of the Philippine Islands, and Hapalarpactus has a species in Borneo, with another in Sumatra.

TROOPIAL, from the French Troupiale ${ }^{1}$; apparently the invention of Bonaparte (Am. Orn. i. p. 27) in 1825, and used as the equivalent of Icterus.

TROPIC-BIRD, so called of sailors from early times, ${ }^{2}$ because, as Dampier (Voy. i. p. 53) among others testifies, it is "never seen far

I Brisson (Orn. ii. p. 85) in 1760 says that the word was already applied in America to some of the birds of his genus Icterus.

2 More recently sailors have taken to call it "Boatswain-bird"-a name probably first bestowed on the Aretic SkUA. 
without either Tropick," and hence, indulging a pretty fancy, Linnæus bestowed upon it the generic term, continued by modern writers, of Phaethon, in allusion to its attempt to follow the path of the sun. ${ }^{1}$ There are certainly three well-marked species of this genus, but their respective geographical ranges have not yet been definitely laid down. All of them can be easily known by their totipalmate condition, in which the four toes of each foot are united by a web, and by the great length of the two middle tailquills, which project beyond the rest, so as to have gained for the birds the names of "Rabijunco," "Paille-en-queue" and "Pijlstaart" among mariner's of different nations. These birds fly to a great distance from land and seem to be attracted by ships, frequently hovering round or even settling on a mast-head.

The Yellow-billed Tropic-bird, P. flavirostris or candidus, appears to have habitually the most northerly, as well, perhaps, as the widest range, visiting Bermuda yearly to breed there, but also accurring numerously in the southern Atlantic, the Indian and a great part of the Pacific Ocean. In some islands of all these three it breeds, sometimes on trees, which the other species are not known to do. However, like the rest of its congeners, its lays but a single egg, and this is of a pinkish-white, mottled, spotted and smeared with brownish-purple, often so closely as to conceal the ground-colour. This is the smallest of the group, and hardly exceeds in size a large Pigeon; but the spread of its wings and its long tail make it appear more bulky than it really is. Except some black markings on the face (common to all the species known), a large black patch partly covering the scapular's and wing-coverts, and the black shafts of its elongated rectrices, its general colour is white, glossy as satin, and often tinged with roseate. Its yellow bill readily distinguishes it from its larger congener $P$. aethereus, but that has nearly all the upper surface of the body and wings closely baired with black, while the shafts of its elongated rectrices are white. This species has a range almost equally wide as the last; but it does not seem to occur in the western part of the Indian Ocean. The third and largest species,

1 Occasionally, perhaps through violent storms, Tropic-birds wander very far from their proper haunts. In 1700 Leigh, in his Lancashire (i. pp. 164, 195, Birds, tab. i. fig. 3), described and figured (after Willughby) a "Tropick Bird" found dead in that county. Another is said by Mr. Lees (Zool. ser. 2, p. 2666) to have been found dead at Cradley near Malvern-apparently before 1856 (J. H. Gurney, jun. op. cit. p. 4766)-which, like the last, would seem (W. H. Heaton, op. eit. p. 5086) to have been of the species known as P. acthereus. Naumann was told (Rhea, i. p. 25) of its supposed occurrence at Heligoland, and Col. Legge ( $B$. Ceylon, p. 1174) mentions one taken in India 170 miles from the sea. The case cited by MM. Degland and Gerbe (Ornith. Europ. ii. p. 363) seems to be that of an Albatros. 
the Red-tailed Tropic-bird, $P$. rulricauda or phcenicurus, not only has a red bill, but the elongated and very attenuated rectrices are of a bright crimson-red, and when adult the whole body shews a deep roseate tinge. The young are beautifully barred above with black arrow-headed markings. This species has not been known to occur in the Atlantic, but is perhaps the most numelous in the Indian and Pacific Oceans, in which last great value used to be attached to its tail-feathers to be worked into ornaments.

That the Tropic-birds form a distinct family, Phaethontidx, of the STeganopodes was originally maintained by Brandt, and is now generally admitted, yet it cannot be denied that they differ a good deal from the other members of the group; indeed Prof. Mivart (Zool. Trans. x. p. 364) will hardly allow Fregata and Phaethon to be steganopodous at all; and one curious difference is shewn by the eggs of the latter, which are in appearance so wholly unlike those of the rest. The osteology of two species has been well described and illustrated by Prof. Milne-Edwards in M. Grandidier's fine Oiseaux de Madagascar (pp. 701-704, pls. 279-281a).

TRUMPETER, or TRUMPET-BIRD, the literal rendering in 1747, by the anonymous English translator of De la Condamine's travels in South America (p. s7), of that writer's "Oiseau trompette" (Mém. Acad. Sc. 745, p. 473), which he says was called "Trompetero" by the Spaniards of Maynas on the Upper Amazons, from the peculiar sound it utters. He added that it was the "Agami" of the inhabitants of Para and Cayenne, ${ }^{1}$ wherein he was not wholly accurate, since the birds are specifically distinct, though, as they are generically united, the statement may pass. But he was also wrong, as had been Barrere (France Equinox. p. 132) in 1741, in identifying the "Agami" with the "Macucagua" of Marcgrave, for that is a TiNauou (p. 963); and both still more wrongly accounted for the origin of the peculiar sound just mentioned, whereby Barrere was soon after led (Orn. Spec. Nov. pp. 62,63$)$ to apply to the bird the generic and vulgar names of Psophia and "Petteuse," the former of which, being unfortunately adopted by Linnæus, has ever since been used, though in 1766 and 1767 Pallas (Miscell. p. 67, and Spicileg. iv. p. 6), and in 1768 Vosmær (Descr. du Trompette Américain, p. 5), shewed that the notion it conveys is erroneous. Among English writers the name "Trumpeter" was carried on by Pennaut, Latham, and others so as to be generally accepted, though an author may occasionally be found willing to resort to the native "Agami," which is that almost always used by the French.

1 Not to be confounded with the "Héron Agami" of Buffon (Ois. vii. p. 382), which is the Ardea agami of other writers. 
Messrs. Sclater and Salvin in their Nomemclutor (p. 141) admit 6 species of Trumpet-birds-(1) the original Psophia crepitans of Guianil; (2) P. mapensis of eastern Ecuador (which is very likely the veritable "Oiseau trompette" of De la Condamine); (3) $P$. ochropterce from the right bank of the Rio Negro; (4) P. leucoptera from Pern and the right bank of the Upper Amazons; (5) $P$. virilis from the right bank of the Madeirat; and (6) P. obscura, the distinctness of which is denied by Dr. Sharpe (Cut. B. Br. Mus. xxiii. p. 281), from the right bank of the Lower Amazons near Para. And they have remarked (Proc. Zool. Soc. 1867, p.

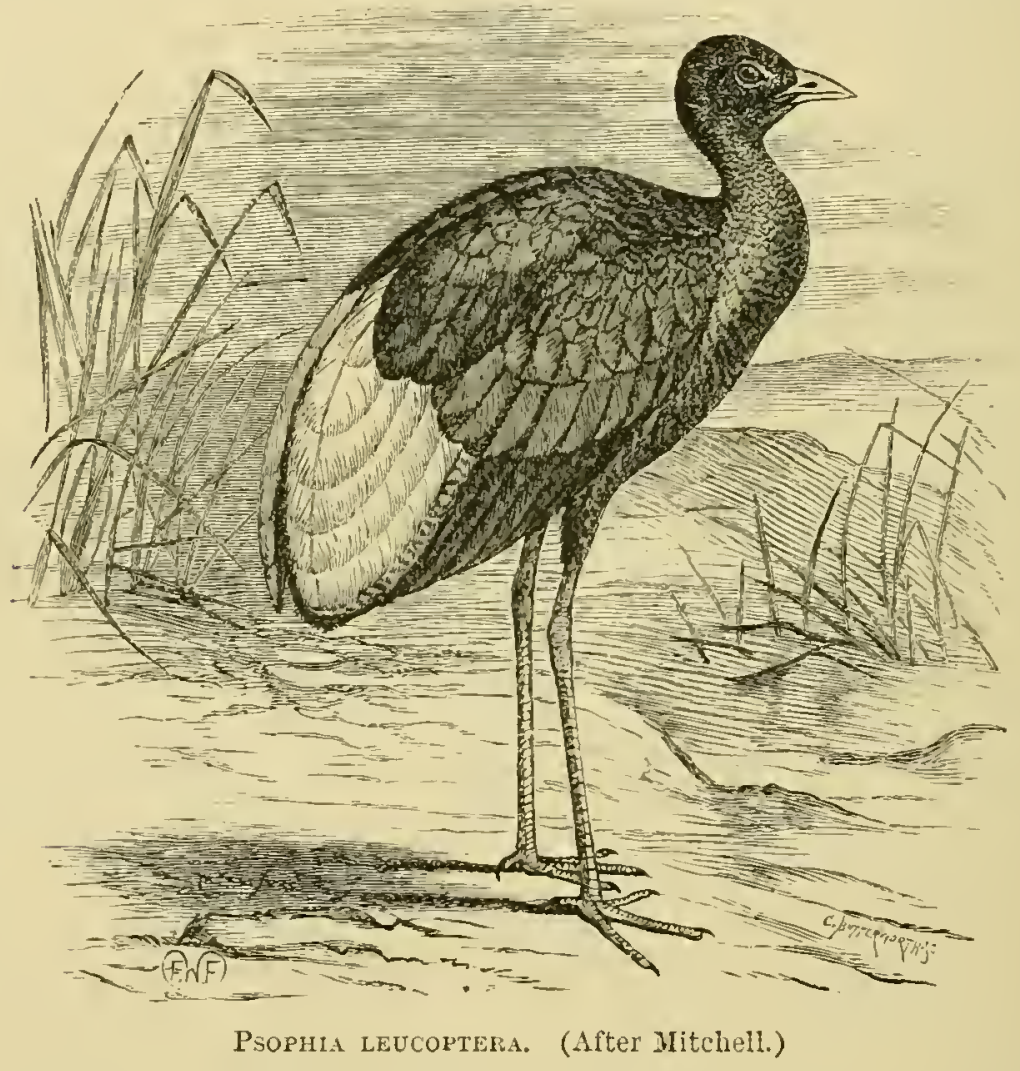

592) on the curious fact that the range of the several species appears to be separated by rivers, a stitement confirmed by $\mathrm{Mr}$. Wallace (Geogr. Distr. Anim. ii. p. 358); and in commexion therewith it may be observed that these birds have short wings and seldom fly, but run, though with a peculiar gait, very quickly. A seventh species, $P$. cantatrix, from Bolivia, has since been indicated by Prof. TI. Blasius (Journ.f. Orn. 1884, pp. 203-210), who has given a monographic summary of the whole grouls worthy of attention. The chief distinctions between the species lie in colour and size, and it will be here enough to describe briefly the best known of them, $P$. crepitans. This is about the size of a large barndoor Fowl; but its neck and legs are longer, so that it is at 
taller bird. The head and neck are clothed with short velvety feathers; the whole plumage is black, except that on the lower front of the neck the feathers are tipped with golden green, changing according to the light into violet, and that a patch of dull rusty-brown extends across the middle of the back and wingcoverts, passing into ash-colour lower down, where they hang over and conceal the tail. The legs are bright pea-green. The habits of this bird are very wonderful, and it is much to be wished that fuller accounts of them had appeared. The curious sound it utters, noticed by the earliest observers, has been already mentioned, and by them also was its singularly social disposition towards man described; but the information supplied to Buffon (Ois. iv. pp. 496-501) by Manoncour and De la Borde, which has been repeated in many works, is still the best we have of the curious way in which it becomes semi-domesticated by the Indians and colonists and shews strong affection for its owners as well as for their living property-poultry or sheep-though in this reclaimed condition it seems never to breed. ${ }^{1}$ Indeed nothing can be positively asserted as to its mode of nidification; but its eggs, according to Mr. E. Bartlett, are of a creamy-white, rather round and about the size of Bantams'. Waterton in his Wanderings (Second Journey, chap. iii.) speaks of falling in with flocks of 200 or 300 "Waracabas," as he called them, in Demerara, but added nothing to our knowledge of the species; while the contributions of Trail (Mem. Wern. Soc. v. pp. 523-532) and Dr. Hancock (Mag. Nat. Hist. ser. 2, ii. pp. 490-492) as regards its habits only touch upon them in captivity.

To the Trumpeters must undoubtedly be accorded the rank of a distinct Family, Psophiida; but like so many other SouthAmerican birds they seem to be the less specialized descendants of an ancient generalized group-perhaps the common ancestors of the Rallida and Gruide-and they therefore rightly come into Prof. Huxley's Geranomorphe. The structure of the syrinx is stated by Trail (ut suprà) to be unique; but Mr. Beddard says that no trenchant characters distinguish it from many Rails and Cranes, nor has he found any such modification of the trachea as is described by Trail (ut suprà) to exist in some but not all males (Proc. Zool. Soc. 1890, pp. 329-341).

TUBINARES, Illiger's name in 1811 (Prodr. p. 273) for the group containing the Aldatroses and Petrels, for a long while

${ }^{1}$ In connexion herewith may be mentioned the singular story, received by Montagu (Orn. Dict. Suppl. Art. "Grosbeak, White-winged"), from the then Lord Stanley, of one of these birds, which, having apparently escaped from confinement, formed the habit of attending a poultry-yard. On the occasion of a pack of hounds running through the yard, the Trumpeter joined and kept up with them for nearly three miles! 
considered to be allied to the Larida (GULL), but now regarded by the best authorities as having little to do with them.

TUI, the common name in New Zealand for the PARSONBIRD (p. 691).

TURKEY, ${ }^{1}$ an abbreviation for TURKEY-COCK or TURKEY-HeN as the case may be, a well-known, large, domestic, gallinaceous bird. How it came by this name has long been a matter of discussion, for it is certain that this valuable animal was introduced to Europe from the New World, and in its introduction had nothing to do with Turkey or with Turks, even in the old and extended sense in which that term was applied to all Mahometans. But it is almost as unquestionable that the name was originally applied to the bird which we know as the Guinea-Fowl (p. 399), and there is no doubt that some authors in the 16 th and 17 th centuries curiously confounded these two species. As both birds became more common and better known, the distinction was gradually perceived, and the name "Turkey" clave to that from the New World-possibly because of its repeated call-note-to be syllabled turk, turk, turk, whereby it may be almost said to have named itself ( $c f$. Notes and Queries, ser. 6 , iii. pp. 23,369$)$. But even Linnæus could not clear himself of the confusion, and, possibly following Sibbald, unhappily misapplied the name Meleagris, undeniably belonging to the GuineaFowl, as the generic term for what we now know as the Turkey, adding thereto as its specific designation the word gallopavo, taken from the Gallopavus of Gesner, who, though not wholly free from error, was less mistaken than some of his contemporaries and even successors. ${ }^{2}$

The Turkey, so far as we know, was first described by Oviedo in his Sumario de la Natural Historia de las Indias ${ }^{3}$ (cap. xxxvi.), said to have been published in 1527. He, not unnaturally, includes both Curassows (p. 126) and Turkeys in one category, calling both "Pavos" (Peafowls); but he carefully distinguishes between them, pointing out among other things that though the latter make a wheel (hacen la rueda) of their tail, this was not so grand or so beautiful as that of the Spanish "Pavo," and he gives a faithful though short description of the Turkey. The chief

1 For Turkey-Buzzard see Vulture.

2 The French Coq and Poule d'Inde (whence Dindon) involve no contradiction, looking to the general idea of what India then was. One of the earliest German names for the bird, Kalekuttisch Hün (whence the Scandinavian Kalkon), must have arisen through some mistake at present inexplicable; but this does not refer, as is generally supposed, to Calcutta, but to Calicut on the Malabar coast (cf. Notes and Queries, ser. 6, x. p. 185).

3 Purchas (Pitgrimes, iii. p. 995) in 1625 quoted both from this and from the same author's Hystoria General, said to have been published a few years later. I know Oviedo's earlier work only by the reprint of 1852 . 
point of interest in his account is that he speaks of the species having been already taken from New Spain (Mexico) to the islands and to Castilla del Oro (Darien), where it bred in a domestic state among the Christians. Much labour has been given by various naturalists to ascertain the date of its introduction to Europe, to which we can at present only make an approximate attempt; ${ }^{1}$ but it is plain that evidence concurs to shew that the bird was established in Europe by 1530-a very short time to have elapsed since it became known to the Spaniards, which could hardly have been before 1518, when Mexico was discovered. The possibility that it had been brought to England by Cabot or some of his successor's earlier in the century is not to be overlooked, and reasons may be assigned for supposing that one of the breeds of English Turkeys may have had a northern origin $;^{2}$ but the often-quoted distich first given in Baker's Chronicle (p. 298), asserting that Turkeys came into England in the same year-and that year by reputation 1524 -as carps, pickerels and other commodities, is wholly untrustworthy, for we know that both these fishes lived in this country long before, if indeed they were not indigenous to it. The earliest documentary evidence of its existence in England is a "constitution" set forth by Cranmer in 1541, which Hearne first printed (Leland's Collectanea, ed. 2, vi. p. 38). This names "Turkeycocke" as one of "the greater fowles" of which an ecclesiastic was to have "but one in a dishe," and its association with the Crane and Swan precludes the likelihood of any confusion with the Guinea-Fowl. Moreover the comparatively low price of the two Turkeys and four Turkey-chicks served at a feast of the serjeantsat-law in 1555 (Dugdale, Origines, p. 135) points to their having become by that time abundant, and indeed by 1573 Tusser bear's witness to the part they had already begun to play in "Christmas lusbandlie fare." In 1555 botl sexes were characteristically

1 The bibliography of the Turkey is so large that there is here no room to name the various works that might be cited. Recent research has failed to add anything of importance to what has been said on this point by Buffon (Ois. ii. pp. 132-162), Pennant (Arct. Zool. pp. 291-300), -an admirable summary,and Broderip (Zool. Recreat. pp. 120-137) -not that all their statements can be wholly accepted. Barrington's essay (Misccllanies, pp. 127-151), to prove that the bird was known before the discovery of America and was transported thither, is an ingenious piece of special pleading which his friend Pennant did him the real kindness of ignoring.

${ }^{2}$ In 1672 Josselin (New England's Raritics, p. 9) speaks of the settlers bringing up "great store of the wild kind" of Turkeys, "which renuain about their houses as tame as ours in England." The bird was evidently plentiful down to the very seaboard of Massachusetts, but it is not likely to have been domesticated by the Indian tribes there, as, according to Hernandez, it seems to have been by the Mexicans. It was probably easy to take alive, and, as we know, capable of enduring the voyage to England. 
figured by Belon (Oyseaux, p. 249), as was the cock by Gesner in the same year, and these are the earliest representations of the birl known to exist. ${ }^{1}$

The genus Meleagris is considered to enter into the Family Phasianidx, in which it forms a subfamily Meleagrina, peculiar to North and Central America. ${ }^{2}$ The fossil remains of three species have been described by Prof. Marsh-one from the Miocene of Colorado, and two, one much taller and the other smaller than the existing species, from the Post-Pliocene of New Jersey. Both the last had proportionally long and slender legs.

TURNICOMORPHA, Prof. Huxley's name (Proc. Zool. Soc. 1868 , p. 304) for the group of Birds containing the genus Turnix (HEMIPODE, p. 415).

TURNSTONE, the name long given ${ }^{3}$ to a shore-bird, from its

1 There is no need to describe here a bird so familiar and in these days so widely distributed. As a denizen of our poultry-yards there are at least two distinct breeds, though crosses between them are much commoner than purelybred examples of either. That known as the Norfolk breed is the taller of the two, and is said to be the more hardy. Its plumage is almost entirely black, with very little lustre, but the feathers of the tail and some of those of the back have a brownish tip. The chicks also are black, with occasionally white patches on the head. The other breed, called the Cambridgeshire, is much more variegated in colour, and some parts of the plumage have a bright metallic gloss, while the chicks are generally mottled with brownish-grey. White, pied and buff Turkeys are also often seen, and if care be taken they are commonly found to "breed true." Occasionally Turkeys, the cocks especially, occur with a top-knot of feathers, and one of them was figured by Albin in 1738. It has been suggested with some appearance of probability that the Norfolk breed may be descended from the northern form, Meleagris gallopavo or americana, while the Cambridgeshire breed may spring from the southern form, the $M I$. mexicana of Gould (Proc. Zool. Soc. 1856, p. 61), which indeed it very much resembles, especially in having its tail-coverts, and quills tipped with white or light ochreous,-points that recent North-American ornithologists rely upon as distinctive of this form. If this supposition be true, there would be reason to believe in the double introduction of the bird into England at least, as already hinted, but positive information is almost wholly wanting. The northern form of wild Turkey, whose habits have been described in much detail by all the chief writers on North-American birds, is now extinct in the settled parts of Canada and the eastern States of the Union, where it was once so numerous; and in Mexico the southern form, which would seem to have been never abundant since the couquest, has been for many years rare. Still further to the south, on the borders of Guatemala and British Honduras, there exists a perfectly distinct species, $M$. ocellata, whose pluniage almost vies with that of a Peacock in splendonr, while the bare skin which covers the head is of a deep blue studded with orange caruncles (Proc. Zool. Soc. 1861, pl. xl.).

2 The results of a comparison of the skulls of wild and domesticated Turkeys are given by Dr. Shufeldt in Journ. of Comp. Dredicine and Surgery, July 1887.

${ }_{3}^{3}$ The name seems to appear first in Willughby's Ornithologia (p. 231) in 
habit of turning over with its bill such stones as it can to seek its food in the small crustaceans or other animals lurking beneath them. It is the Tringa interpres ${ }^{1}$ of Linnæus and Strepsilas interpres of most litter writers, and is remarkable as being perhaps the most cosmopolitan of birds; for, though properly belonging to the northern hemisphere, there is scarcely

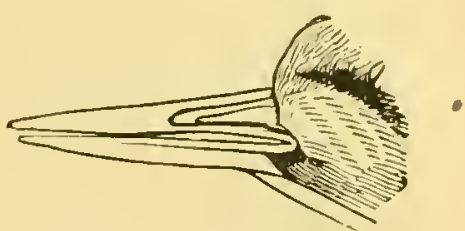

TuRrstone. (After Swainson.) a sea-coast in the world on which it may not occur: it has been obtained from Spitsbergen to the Strait of Magellan and from Point Barrow to the Cape of Good Hope and New Zealandexamples from the southern hemisphere being, however, almost invariably in a state of plumage that shews, if not immaturity, yet an ineptitude for reproduction. It also, though much less commonly, resorts to the margins of inland rivers and lakes; but it is very rarely seen except in the neighbourhood of water, and salt water for preference.

The Turnstone is about as big as an ordinary Snipe; but, compared with most of its allies of the group LIMICOLA, to which it belongs, its form is somewhat heavy, and its legs are short. Still it is brisk in its movements, and its variegated plumage makes it a pleasing bird. Seen in front, its white face, striped with black, and broad black gorget attract attention as it sits, often motionless, on the rocks; while in flight the white of the lower part of the back and white band across the wings are no less conspicuous even at a distance. A nearer view will reveal the rich chestnut of the mantle and upper wing-coverts, and the combination of colours suggests the term "tortoise-shell" often applied to it, while the quill-feathers are mostly of a dark brown and its lower parts pure white. The deeper tints are, however, peculiar to the muptial plumage, or are only to be faintly traced at other times, so that in winter the adults-and the young always-have a much plainel appearance, ashy-grey and white being almost the only hues observable. From the fact that Turnstones may be met with at almost any season in various parts of the world, ${ }^{2}$ and especially on

1676 ; but he gave as an alius that of Sea-Dottrel (i.c. Ringed Plover) under which name a drawing, figured by him (pl. 58), was sent to him by Sir Thomas Browne.

1 Linnæus (GEl. och Gothländska Resa, p. 21\%), who first met with this bird on the island of Gottland, 1st July 1741, was meler the mistaken belief that it was there called Tolk (=interpres). But that name properly belongs to the Renshank, from the cry of warning to other animals that it ntters on the approach of danger ( $f f$. Telltale).

2 The anthors of The Water Birds of North America (i. p. 123) in reference to this fact raise the pertinent question, "Do birds, after they have become old, effete, or barren, prefer to stay in a warm climate?" 
islands as the Canaries, Azores and many of those in the British seas, it has been inferred that these birds may breed in such places. In some cases this may prove to be true, but in most evidence to - that effect is wanting. In America the breeding-range of this species has not been defined. In Europe there is good reason to suppose that it includes Shetland; but it is on the north-western coast of the continent, from Jutland to the extreme north of Norway, that the greatest number are reared. The nest, contrary to the habits of most Limicolix, is generally placed under a ledge of rock which shelters the bird from observation, ${ }^{1}$ and therein are laid fonr eggs, of a light olive-green, closely blotched with brown, and hardly to be mistaken for those of any other bird. A second species of Turnstone is admitted by some anthors and denied by others. This is the $S$. melanocephalus of the Pacific coast of North America, which is said to be on the average larger than S. interpres, and it never exhibits any of the chestnut colouring.

Though the genus Strepsilas seems to be rightly placed among the Charadriida (PLOVER), it occupies a somewhat abnormal position among them, and in the form of its pointed beak and its variegated coloration has hardly any very near relative.

TURTLE or TURTLE-DOVE, Fr. Tourterclle, Germ. Turteltaube, Lat. Turtur, see Dove (p. 165). Greenland Turtle and Sea-Turtle are sailor's' names for the Black Guillemor' (p. 399).

TIVITE, the name apparently first recorded by Albin ( $N . H$. Birels, iii. pl. lxxiv. p. 69) in 1737 for what is often known as the Mountain-Linvet (p. 516).

TWOPENNY-CHICK, a creole name in Jamaica for the White-chinned Thrusi of that island, Turdus anrantius or Semimerula aurantic (cf. Latham, Gen. H. B. x. 1. 32 ; Gosse, B. Jam. p. 138).

TYRANT or TYRANT-BIRD, in its modern sense a name originating in 1731 with Catesby (N.H. Carol. i. p. 55), who applied

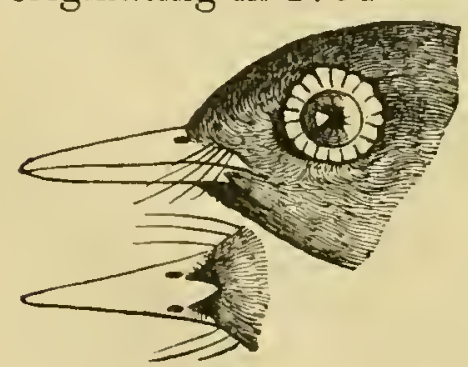

Lichexops. (After Swainson.) it solely to what is now generally known as the KING-BIRD (p. 482), of which enough has been said, but apparently as much in reference to its bright crown, resembling that of the GoLDCREST, ${ }^{2}$ as to its tyrannical behaviour to other birds. On this species, being the Mruscicapa tyranmus of Linnæus, was founded the genus Tyrannus of Cuvier, and sub-

1 There is little external difference between the sexes, and the brightly. contrasted colours of the hen-bird seem to require some kind of coneealment.

2 The rúpavvos of Aristotle was undoubtedly the Golderest, the Latin licgulus, 
sequently the Family, Tyrannida, in which Mr. Sclater (Cat. B. Br. Mus. xiv. pp. 2-280) includes over 400 species, all peculiar to the New World, and as already stated (p. 483) belonging to the group Clamatores (Tracheophona). These he provisionally arranges in four subfamilies - Taniopterinx with 21 genera of more or less terrestrial habit, including Lichenops and Copurus; Platyrhynchina with 20 genera, having very broad bills

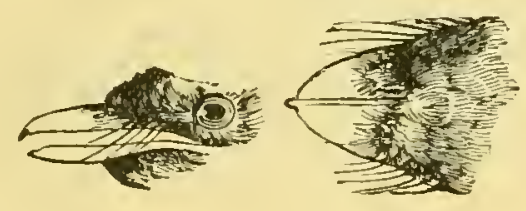

Platyrhynchus.

(After Swainson.)

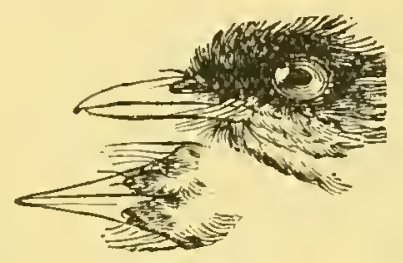

HAPALOCERCUS.

and weak feet, inchuding Platyrhynchus and Hapalocercus; Elainina having the gape withont bristles and almost confined to the Neotropical Region; and Tyranninx with 28 genera, among which he places Elacicus and Myiarchus (TONFOOL) and their near ally Contopus (PEEwEE) together with Empidias, to which he refers the well-known Sayornis fuscus (PHÆEBE) while keeping Sayomis in his first subfamily, as well as Milvulus (ScIssors-TAIL ${ }^{1}$ ) and of course Tyrannus. ${ }^{2}$

In several respects some of these birds resemble the SHRIKES; but it must be clearly understood that the likeness ${ }^{3}$ is but of analogy, and that there is no near affinity between the two Families Laniidx and Tyrannida, which belong to wholly distinct sections of PASSEREs; and, while the former is a comparatively homogeneous group, as much diversity of form and habits is found among the latter as among the Dendrocolaptida (PICUCULE), testifying to the antiquity of the Fauna of which both are so characteristic. Similarly many of the smaller Tyrannida bear some analogy to certain Muscicapida (FLycATCHER), with which they were at one time confounded; but the difference

French Roitelet, German Königlein (ef. D. W. Thompson, Gloss. Greek Birds, p. 174), and of course had nothing to do with the birds now ealled Tyrants.

1 Aceidentally misspelt ScIzzons-TaIL, p. 816.

2 Nearly akin to the King-bird is the Petchary or Chicheree, so called from its loud and petulant cry, Tyrannus dominicensis, or $T$. griseus, one of the most eharacteristic and conspicuous birds of the West Indics, and the earliest to give notice of the break of day. In habits, except that it eats a goor many berries, it is the very counterpart of its congener, and is possibly even more jealons of any intruder. At all events its pugnacity extends to animals fiom which it could not possibly receive any harm, and is hardly limited to any scason of the year.

3 It is enrious that in at least some instances this likeness extends to the eggs. 
between them is deep seated. ${ }^{1}$ Nor is this all, for out of the 80 genera, or nearly, into which the Tyrannida have been divided, a series of forms can be selected which find a kind of parallel to those found in the Oscines; and the genus Tyrannus, though that from which the Family is named, is by no means a fair representative of it; though it would be hard to say which genus should be so accounted. The birds of the genus Muscisaxicola have the habits and almost the appearance of WHEATEARS ; the genus Alectorurus calls to mind a WAGTAIL; Euscarthmus may suggest a Titmouse, Elainea perhaps a Willow-Wren; but the greater number of forms have no analogous bird of the Old World with which they can be compared; and, while the combination of delicate beauty and peculiar external form possibly attains its utmost in the long-tailed Milvulus, the glory of the Family may be said to culminate in the king of King-birds, Muscivora regia, and its three allied species.

\section{U}

ULNA, the more curved and stouter of the two bones of the forearm (the other being the RADIUS, p. 762). Its proximal end forms the OLECRANON (p. 654) process, and its distal end articulates with two bones of the CARPUS (p. 77). The attachment of the CUBITAL remiges (p. 118) often causes rugosities on its dorsal surface. (See Skeleton, p. 859.)

UMBRE, Pennant's rendering in 1773 (Gen. B. p. 44) of Brisson's Ombrette (ef. Hammer-Head, p. 405, and Stork, p. 920).

UMBRELLA-BIRD, ${ }^{2}$ the Cephalopterus ornatus of Geoffroy-St. Hilaire (Ann. Mus. xiii. p. 228, pl: 15) the "Umbrella'd Chatterer" of Shaw (Nat. Misc. xxi. pl. 897), so called from the remarkable crest of feathers it wears, the shafts of which, when it is displayed, says

I This is not the place to dwell upon the essential nature of the difference; but two easy modes of discriminating them externally may be mentioned. All the Laniidæ and Muscicapidæ have but nine primary quills in their wings, and their tarsi are covered with scales in front only; while in the Tyrannida there are ten primaries, and the tarsal scales extend the whole way round. The more recondite distinction in the structure of the trachea seems to have been first detected by Macgillivray, who wrote the anatomical descriptions published in 1839 by Audubon (Orn. Biog. v. pp. 421, 422); but its value was not appreciated till the publication of Joliannes Muiller's celebrated treatise on the vocal organs of PAsseres (Abh. $k$. Ak. Berlin, 1845, pp. 321-405).

${ }^{2}$ I find this name first in print, Proc. Zool. Soc. 1850, p. 91 ; but Gould there uses it for the bird as being "commonly so called." In 1836 Swainson (Classif. B. i. p. 41) likened its crest to an umbrella. 
Mr. Wallace (Proc. Zool. Soc. 1850, p. 206) radiate on all sides, reaching beyond the tip of the bill, and forming a perfect dome, some 5 inches in length by 4 or 4.5 in width. Another curious appendage is a cylindrical fleshy process, an inch and a half long, pendent from the front of the neck, and clothed with imbrieated feathers. The bird is about the size of a Crow, and wholly black,

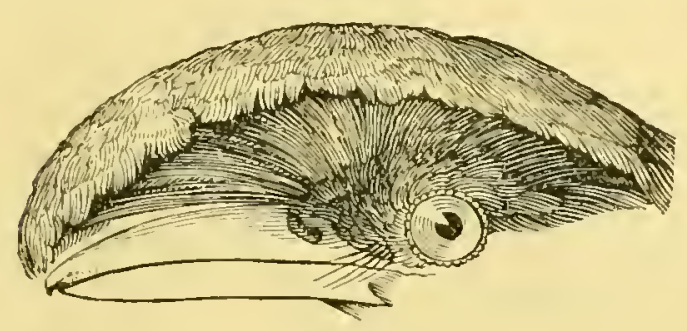

Cephalopterus.

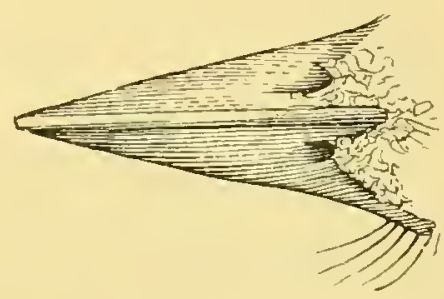

GrMiNOCEPHALES.

(After Swainson.)

glossed with blue in places and especially on the crest and dewlap. This species inhabits Colombia, Guiana, a great part of Brazil and Eucador; but, in the western districts of the country last named, a second species, $C$. penduliger, occur's, with a still more extraordinary feathered dewlap nearly as long as the whole bird (Ibis, 1859, pl. iii.); and in Veragua and Costa Rica, a third, C. glabricollis, in which the throat, of a reddish-orange, and dewlap arc bare of feathers, except at the tip of the latter (Pioc. Zool. Soc. 1850, pl. xx.), but all have the plumage black and the parasol-like crest. The genus belongs to the Cotingida (ChatTerer, p. 86), and is mearly allied to the genera Pyroderus, Gymnocephalus, Gymnodera and Chasmorhynchus (Beil-Bird, p. 80). (Cf. Selater, Cut. B. Br. Mus. xiv. pp. 397-403).

UNCINATE PROCESS, a thin bony blade attached, either movably or firmly, to the posterior margin of each of the true RiBs (p. 788) except the last. Originally cartilaginous, these processes subsequently ossify each from a special centre, and extend backward to overlap the next succeeding Rib. With the sole exception of the Palamedeida (SCREAMER) they are present in all Birds, as well as in some Reptiles, as Hatteria and the Crocodiles.

UNICORN-BIRD (Bates, Nat. Amaz. i. 27 ), a name for Palamedeu cormuta (SCREAMER, p. 819).

URETEP, the duct which conducts the urine from the KIDNEY (p. 480) to the CLOACA (p. 90), there being no urinary bladder in Birds (see also figs. pp. 138, 782).

URINATORES, Vieillot's name in 1816 (Analyse, p. 64) for a group of Birds composed of the genera Helionis, Podiceps [Podicipes] and Colymbus. 
UROIONI (properly Urconi), Owen's name in 1868 (Anat. Vertebr. iii. p. 849) for the group consisting of Archropteryx.

UROSTYLE, see Pygostyle, p. 753.

UTICK, a local name for the WHiNchat, from its call-note.

\section{V}

VALK, Dutch for Falcon or Hawk, and so used in the Cape Colony-Blaauxe Valk (Blue Hawk), being especially the name of Melierax musicus, the so-called "Chanting Falcon," which has a mellow, piping whistle (Layard, B.S.Afr. p. 31).

VARIATION is a seductive subject that must here be treated briefly and with the view of bringing forward a few only of its known facts, the consideration of its supposed causes, which are often glibly and positively assigned by some writers to account for its origin, being wholly out of place, while questions involving the definition of "species," though immediately arising, cannot be entertainedsince experience shews that they can be rarely answered to the satisfaction of any but the respondent. Presuming that readers of this article are acquainted with what has been published on the subject by Darwin and Mr. Wallace, there will be no need to enter at length on the observed facts of Variation as set down by those able naturalists. The former of them many years ago declared (Origin of Species, chap. v.), "Our ignorance of the laws of Variation is profound," and in 1894 Mr. Bateson (Materials for the Study of Variation, p. 13) had still to regret that "Darwin's first collection of the facts of Variation has scarcely been increased." 1 Yet

1 It may perhaps be convenient here to adduce in the most concise way, yet almost in Darwin's own words, what these facts- "Laws" they have sometimes been called-are as enunciated by him :-

I. (1) Wide-ranging, much diffused and common Species vary most.

(2) Species of the larger Genera in each country vary more frequently than the Species of the smaller Genera.

(3) Many of the Species of the larger Genera resemble Varieties in being very closely, but unequally, related to each other, and in having restricted ranges (Origin of Species, chap. ii.).

II. (4) Multiple, Rudimentary and Lowly-organized Structures are the most variable.

(5) A Part developed in any Species, in an extraordinary way, compared with the same Part in allied Species, tends to be highly variable.

(6) Specific characters are more variable than Generic characters.

(7) Secondary sexual characters are very variable.

(8) Distinct Species present analogous Variations; and a Variety of one 
as in times past there are endless records, among which Ornithology has its full share, ${ }^{1}$ of individual irregularities of all sorts, from those which are to be entitled Monstrosities (p. 587) down to the abnormal colouring of a single feather; but no considerable approach has been made to the methodizing of the different observations since the remarkable essays published in 1871 and 1872 by $\mathrm{Mr}$. J. A. Allen, ${ }^{2}$ which naturally attracted the attention of Mr. Wallace, who (Darwinism, chap. iii.) by means of a series of diagrams reduced to a concrete and convenient form some of the elaborate tables of measurements, for, as treated by the author, they are not very easily mastered. Few, if any other writers, however, have availed themselves of the vast store of statistics collected with enormons toil by Mr. Allen, and hence the publication of other similar series has unhappily been discouraged. Every one knows the use which has been made of facts like these, but the study of Variation has perhaps suffered from the way in which it has been connected with theories of Evolution instead of being pursued for its own sake. Whether those theories be true or not, the existence of Variation is undoubted, and it behoves ornithologists among other naturalists to learn all they can of its facts apart from any speculation that may be raised upon them. Many persons regard Variation as being so much clue to domestication that they are apt to overlook the extent to which wild creatures vary. It would be almost safe to assert that no two creatures are ever produced which are absolutely alike, however hard it may be for any one to define the difference between them; but it may be positively stated as the result of considerable experience in ornithology that the greater the number of individuals that are closely examined the more they are found to differ. ${ }^{3}$ The differences may be minute, but differences they are, and

Species often assumes some of the characters of an allied Species, or reverts to some of the characters of an early progenitor (op. cit. chap. v.).

Several modifications of the above statements seem requisite.

1 With Ornithology rests perhaps the honour of producing the earliest treatise on part, at least, of the subject, that by Gloger before cited (GEOGRaphical Distribution, p. 343).

2 To these reference has been already made (p. 343, note 2). An appreciative analysis of the first was given in The Zoological Record (viii. pp. 24, 25), and a critical notice in The Itis (1872, pp. 189-191). Mr. Ridgway followed with some good observations (Am. Journ. Sc. ser. 3, iv. pp. 454-460, v. pp. 39-44), which led to the criticism of Prof. Cones (Am. Nat. 1873, pp. 415418), and a rejoinder by the author (tom. cit. pp. 548-555).

3 As an instance I may refer to the experience gained by the study of an enormous series of bones of the Solitaire (p. 887), not one of which but was liable to greater or less individual Variation of some kind or other. This was not confined to absolute size, but extencled to the relative proportion of divers parts of the bones, to processes or depressions upon them commonly held to be 
perceptible to the carefully-trained eye. ${ }^{1}$ It is a trite remark that in a flock of sheep the ordinary man sees nothing to distinguish one animal from another, while the shepherd knows each unfailingly, and those who look after birds kept in captivity are soon able to do the same in regard to their charges, though both shepherd and bird-keeper would often find it impossible to point out wherein the difference lay. Yet because the difference cannot be expressed in words, its existence is not to be denied, and indeed for all practical purposes we may assume its existence except in rare cases. Thus, believing Variability to be general, the question naturally arises as to its limits, if it has any. Some there are who would boldly declare it to be in one sense boundless, and others would define its limits as geographical. Much is to be said for this last point of view, which was that taken by some of the earliest investigators of Variation; but then it must be admitted that those who adopt it have a very summary way of treating the subject, though it is eminently practical and perhaps at present indispensable.

When a definite structure or coloration of any form is observed to be associated with a definite area, and to cease on that area being overpassed, the systematist will generally say at once that we have two distinct species of the form; but, on the other hand, he is often puzzled how to regard a form that ranges over an area, mostly large, at one end of which it exhibits certain well-marked characters which gradually vanish as the centre is approached, and are as gradually replaced by different but equally well-marked characters, until at the other end it generally, though not always, assumes a wholly distinct appearance, the intervening space being thus occupied by individuals more or less intermediate between the extremities of the series. The reflective naturalist will perceive the probability of both these categories being reducible to the same principle-only in the latter case the Variation is continuous and in the former discontinuous; but it has takẻn ornithologists a long while to recognize this probability.

Conditions such as these are furnished in cases far too numerous to name, ${ }^{2}$ and their proper recognition and full appreciation (if that

specifically characteristic, so that it was utterly impossible to declare the limits of individual modification, while the Variability did not wholly depend on age or sex (Phil. Trans. 1369, pp. 330, 331). Subsequent examination of a still larger series of specimens confirmed the former statement (op. cit. vol. 168, p. 451). Yet all this amount of Variation was exhibited by the individuals of a single species, confined to a small island, and apparently all living at about the same period and under the same conditions.

1 The more minutely a specimen is described the less clance there is of another specimen being found to agree with it. Hence the value of a proper diagnosis, in the old sense of the word, compared with a description-a fact which some modern ornithologists are apt to overlook.

2 They are mostly found among the Oscines, but possibly because that group 
may be considered to have been reached) are, since in Europe Gloger's attempt had failed to produce any effect, ${ }^{1}$ mainly due to the ornithologists of North America, and especially to Baird as before said. Definite results soon followed, and in $1872 \mathrm{Mr}$. Allen in his summing up was able to say truly (Proc. Bost. Soc. N. H. xv. p. 218), "Gradual differentiation is now known in so many cases that it amounts to the demonstration of climatic variation as a general law by means of which a species may be safely predicted to take on a given character under certain specific climatic conditions." 2 It would be impossible here to enter into particulars, suffice it to state that species after species, as well as genus after genus, is proved to be subject to this kind of geographical Variation, which is noticeable not only in regard to the Size of the whole bird, but to the proportion of its several parts, as Bill, Claws, Tail and Wing, as also to Colour. Difference in the length of Wing had, it is true, been noted in some species of the Old World, but the results were not brought together nor their meaning made evident. As regards the geographical Variation of Colour, Mr. Allen proved that in America northward of Mexico it was reducible to two phases of modification, a general increase of intensity toward the south and development of dark markings at the expense of the light intervening spaces, so that of brightly-coloured species southern individuals are the most brightly coloured, and some tints, which to the northward cannot be called brilliant, become vivid in a lower latitude. In respect of longitude Variation occurs with like regularity, the differences appearing to hold a direct relationship to the humidity of the climate. Thus on the dry plains of the middle and western parts of the continent birds have a pallid complexion, while on the Pacific slope they resume nearly the tints of the eastern form, though further to the northward, in the rainy belt that extends along the coast of British Columbia, they acquire a depth of colour far in excess of that which they display on the Atlantic border. The value of Mr. Allen's results is very much increased when we find that similar observations had long before been made in regard to the Old World, only no one had been at the trouble of collecting them. Thus Temminck in 1835 (Man. d'Orn. iii. p. liv.) had noticed the more lively coloration of indihas immeasurably the most abundant forms. The remarkable cases offered by the geuus Colaptes have been already mentioned (FLICKER, p. 258), and others of hardly less interest occur in the RolLers (p. 793) and KaLLEGE Pheasants (p. 476).

1 The only notices of it I know are those by F. Boie (Isis, 1834, pp. 386396), and: Fries (Arsberättelse om nyare zoologiska Arbeten, 1834, pp. 38-45), the last being in Swedish.

2 He also has some remarks shewing that the usual way of accounting for such variation by hybridity is untenable, though this explanation has lately been revived in England by some writers, who substitute "interbr'eeding" for hybridity, and by the shallowness of their argument prove their small capacity for reasoning on the subject ( $c f$. suprò, pp. 344, 345). 
viduals from the south of Europe; the peculiarities of Desert-forms had been dwelt upon by Canon Tristram (suprà, p. 336, note); and the darkening tendency of a rainy climate observed by Mr. VernonHarcourt (Proc. Zool. Soc. 1851, p. 142) and Mr. Godman (suprù, p. 338); while it had even been suggested to account for the similarity between British and Japanese birds in much the same way (Ibis, 1863, p. 189).

Other and still more important modifications are connected with insulation, and we can scarcely doubt are brought about by it. Many instances could be cited of Birds in distant islands shewing a tendency to a shortening of the wing, in some to the extent of its becoming unfit for flight, while concomitantly the size of the bill increases. The DoDo may be adduced as the extreme case of this process, andit would seem excusable, as indicating the initiation of such a series of modifications as might end in something like that extinct form, to regard the Turtur rostratus peculiar to the Seychelles, but differing as yet in little more than its bigger bill and somewhat rounded wing (Ibis, 1867, p. 355) from the more widely-ranging T. picturatus. Other analogous cases could be advanced, the Lophopsittacus of Mauritius (p. 216), the Nycticorax megacephalus of Rodriguez (p. 420), the Gallinula nesiotis of Tristan da Cunha (p. 590), and perhaps the Nesonetta of the Anckland Islands, which appears to be little else than a brevipennate form of the Anas chlorotis of New Zealand ( $c f$. Salvadori, Cat. B. Br. Mus. xxvii. p. 290). This branch of the subject cannot be pursued further here; but it should be obvious that it gives rise to problems of the greatest interest, and more light is likely to be thrown on the origin and cause of Variation by studying facts of this kind than by the abstract conjectures in which so many indulge.

Remarkable as is the modification of colour exhibited by Desertforms, or by those which inhabit rainy districts, it is comparatively speaking intelligible; but so much cannot be said for the Variation that comes under the title of Dimonphism ${ }^{1}$ (p. 149), a very few cases of which have already been instanced. Many kinds of OwLS of different groups and of different countries, as before remarked (p. 675 ), are subject to this curious kind of variability, which shews itself in enduing them with a plumage in which either grey or rufous predominates (p. 678); but strange to say a precisely similar Variation in colour is found to obtain among certain NrGHTJars (p. 642). It is impossible to suggest any way of accounting for this parallelism, the nocturnal habits of the majority of each group affording the only similarity between them. An equally extraordinary Dimorphism is now known to occur in some of the Herons (p. 419),

1 This term is here used in a very wide sense, and in the cases under cousideration "Dichromatisn " would be more precise. 
especially in certain American species, where part will be arrayed in snowy white and part are deeply coloured-blue, of some shade or other, or reddish-brown as the case may be. ${ }^{1}$ In most of these examples the Variation is discontinuous, for it rarely happens that intermediate forms are found; and, in regard to these Herons, like the SkUAS before mentioned (p. 870), no question of locality has to be considered, for birds of opposite colours have been observed paired and breeding together. Variation indeed may be quite independent of locality, as shewn by the remarkable series of specimens of Lagopus scoticus collected almost entirely in one district by Mr. Buckley (Proc. Zool. Soc. 1882, pp. 112-116). The differences therein observable would almost entitle the Red Grouse in that part, at least, of Scotland to be called polymorphic, and yet in Ireland its coloration seems to be monotonous (p. 391, note). ${ }^{2}$

In regard to Colous (p. 99) Variation of a stronger kind is shewn by abnormalities which are collectively spoken of as examples of Heterochrosis (p. 420), and some of them are the delight of many collectors. The most common are those that tend to become Albinos (p. 9), which occur in almost every group of birds, and occasionally take permanent form, as the Australian Astur noræ-hollandix (Goshawk, p. 377), a species which may be properly considered dimorphic, and the extinct Notornis alba (p.592). The direct cause of Albinism is easily found, and it is not much more difficult to account for many cases of MELANism (p. 542), ${ }^{3}$ but that of ERY'THRISM

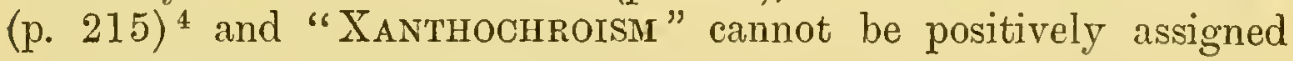

1 It had long been known that the smaller Blue Heron of America, Ardca (or Florida) exrulea, like the widely-ranging $A$. sacra of Polynesia, was white in its young state and adopted its cleep tints as it grew older; and it began to be suspected that $A$. (Demiegretta) irufa and $A$. pealii might be subject to the same change of colour, when in 1875 the late Dr. Brewer was able to prove that the latter was but a white phase of the former, and three years later Mr. Ridgway (Bull. U. S. Geol. \& Geogr. Survey, iv. pp. 219-248) shewed the same relations to exist between the North-American $A$. wierdemanni and A. occidentalis. Other writers have fully accepted this view, while Dr. Stejneger even suggests (Stand. Not. Hist. B. p. 7) the existence of a third phase in what has been called $A$. wardi, so that we should here have a case of "trichromatism" which would be very interesting if proved.

${ }^{2}$ I well remember observing at the end of two very successful days' Partridgeshooting in Suffolk, in January 1859, the extraordinary amount of Variation presented by the contents of the "bag"-approaching 500 in number, and nearly all examples of Perdix einerea. I much regret that circumstances did not permit my taking note of the details. At that season the birds had assuned their full plumage.

3 Melanism, it is well kuown, can be induced in some cage-birds by feeding them with hemp-seed. Among wild birds perhaps the best known case is that of the so-called Sabine's SNIPE (p. 884), which is almost peculiar to the British Islands and has been oftener obtained in Ireland than elsewhere.

"American ornithologists speak of the "red" form of Owls (and Nightjars) 
and it is conceivable that they may be induced in more than one way. ${ }^{1}$

$V A S C U L A R$ SYSTEM, the comprehensive term for the vessels conducting the blood and the lymph, and composed of (A) the Heart (p. 413), Arteries (p. 22) and Veins, and (B) the Lymphatic Vessels. The walls of the blood-vessels have three layers, of which the outermost consists wholly of connective tissue, the middle one is made of annular unstriped muscular fibres, interwoven with elastic bands, and is the thickest, while the inmost is a thin endothelial lining, forming the valves which are so arranged as to hinder the reflux of the blood. In considering the Vascular System it is convenient to divide it as follows:-

A. Blood-System, consisting of-

I. The Pulmonary Circulation, or that of the Lungs (p. 522). The right and left pulmonary Arteries arise with a short common stem, guarded at its base by three valves, from the right ventricle of the Heart, and each accompanied by its BRONCHUS (p. 58) enters the Lung of its own side, there breaking up into capillary vessels, which again combine and convey the arterialized blood into the right and left pulmonary veins respectively. These ultimately, as the vena pulmonalis communis, enter the left atrium.

II. The Systemic Circulation, or that of the body, divisible into Arterial and Venous.

i. Arterial. The left ventricle sends all its blood into the truncus aortx, the base of which is guarded by 3 valuula semilunares. The trunk is very short, sending off the right and left coronary arteries to nourish the heart itself, and then the left arteria anonyma or brachio-cephalica, while the rest of it, considerably thicker, divides into the right $a$. anonyma and the arcus ascendens aortx. The latter, situated between the TRACHEA and the right lung, runs headward and over the right bronchus, reaching the ventral surface of the

as coming under this term or "Erythrochroism" (Stejneger, tom. cit. p. 8); but it seems to me due to a cause of quite another kind than that which produces the change from normal yellow or orange, let alone green, to some shade of scarlet, and should therefore bear another name. Real "Erythrism" is not common in species of the Holarctic Fauna. The Crossbilu (p. 114) is partly subject to it, and then has beeu regarded as specifically distinct under the name of Loxia rubrifasciata, and the Green Woodpecker, Gecinus viridis, has been known to exhibit it (Zool. 1853 , p. $3800 ; 1854$, p. 4250); but perhaps the most abnormal case on record, if it belong to this category, is that of the pink-hcaded Pastor roscus described by Dr. A. B. Meyer (Proc. Zool. Soc. 1890, p. 590).

1 For its bearings, more or' less direct, on Variation Mr. Kecler's Essay on the Evolution of the Colors of North American Land Birds (published as No. III. of the "Occasional Papers of the Califormian $\Lambda$ cadeniy of Science." San Francisco: 1893) should also bc consulted. 
vertebral column aloug which it passes, as the aorta descendens, to the tail, where it ends as arteria coccygea.

Each brachio-cephalic artery divides and subdivides thus-

a. Truncus caroticus, further separating into

a. Arteria vertebralis, ascending the neck, running through the transverse foramina of the cervical vertebræ (SKELETON, pp. 852, 853), and anastomosing in the head with the cephalic branches of the CAro'tios (p. 76);

B. Arteria carotis communis, subdivided into the car. externa or facialis, and car. interna or cerebralis;

b. The Arteria subclavia also separating into

a. The sterno-clavicular and thoracic arteries;

$\beta$. The axillary artery, subdivided into the scapular', humeral and brachial - the last being composed of the $a$. ulnaris and a. radialis, or principal arteries of the forearm and manus.

The aorta descendens gives off in succession-

A variable number of small vessels to the cESOPHAGUS, and intercostal vessels, generally in pairs, to the RIBS and their muscles, as well as the strong unpaired cœliac artery for the STOMACH, SPLEEN, LIVER and duodenum (pp. 141, 142) beside an $a$. mesenterica superior, also unpaired, supplying most of the small intestine. To them follow the right and left principal renal arteries, and those for the REPRODUCTIVE ORGANS, while a pair of crural arteries each penetrating the first lobe of the KIDNEY and, after sending a branch (a. pelvica) in the PELVIS and some of its viscera, leaving that bone in front of the ilio-pubic spine, are continued as femoral arteries, running along the crural vein on the posterior side of the thigh and supplying chiefly the extensor muscles. Next to them come a pair of ischiadic arteries, each running ventrally past the kidneys and sending branches into their middle and lower lobes, as well as to part of the oviduct, after which it leaves the pelvis together with the ischiadic nerve through the ischiadic foramen and ultimately descends the leg, separating into the anterior and posterior tibial arteries. Lastly there are a pair of arterix pudendx communes, branches of which supply the lateriventral muscles of the tail, the CLOACA and copulatory organs, and near the place where this pair originate arises also the unpaired a. mesenterica inferior, which supplies most of the rectum, part of the CACA and part of the cloacal region-a peculiar branch, the $a$. coccygo-mesenterica, being directly connected with a branch of the superior mesenteric artery.

ii. Venous. It has been already stated (p. 414) that the venous blood is collected and conveyed to the right atrium of the heart by 3 great trunks. Thesc are composed as follows:-

Each vena cara superior consists of (1) a rena jugularis which, running subcutaneously along the trachea and osophagus, collects 


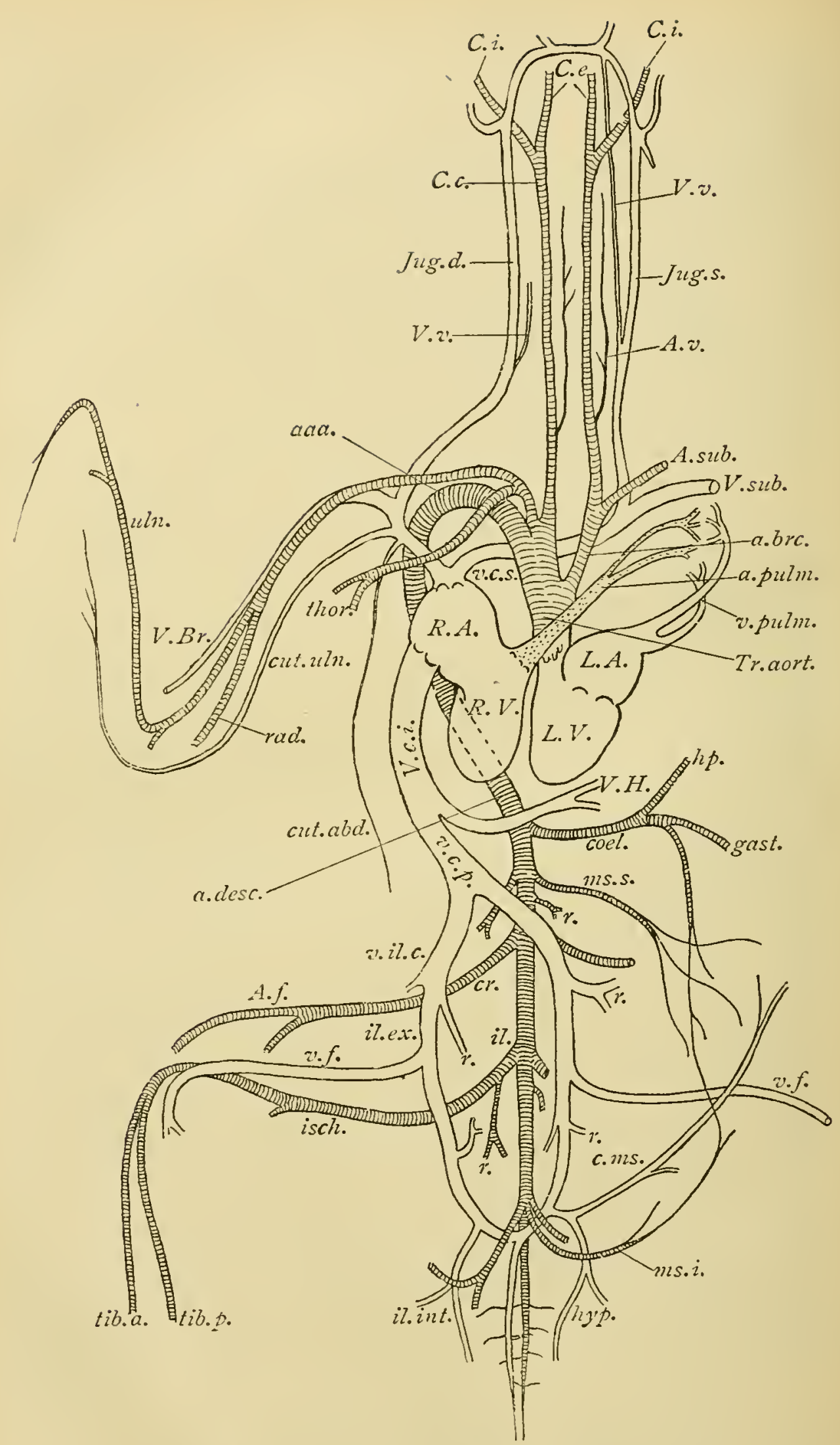

Diagrail of a Bird's Vasclear Srstem. Ventrat, Aspect.

The two halves of the Heart are clrawn as if separate to shew the complete double circulation. L.A. and L.V. Left Atrium and Ventricle; R.A. and R.V. Right Atriun and Ventricle.

The Arteries, except the Pulmonary (u. malm.) which is dotted, are shaded:-aut, arcus 
the blood from the head and neck; (2) a vena vertebralis which drains the brain, anastomoses by numerous and wide branches with the cephalic portions of the jugulars and, being lodged in the transverse foramina of the cervical vertebræ, which it also drains, runs along the neck; and (3) a rena subclavia which receives the blood from the thorax, beside a vena humeralis, $v$. radialis and $v$. ulnaris, combining to form the v. brachialis, and this again unites with the subcutaneous ulnar vein of the wing as the $v$. axillaris.

The vena cava inferior receives the blood from all the rest of the body with its viscera, entering the heart as an unpaired trunk, and close to it receiving the pair of $v$. hepaticæ magnæ which carry the blood from the liver, while the rest of the venous trunk is known as the vena cara posterior, and is formed by the two vv. iliacx communes, each of which is composed of a $v$. cruralis or itiaca externa and a $v$. hypogastrica or iliaca interna. The former of these carries the blood from the hind limb through the $v$. titialis antica and $v$. tibialis postica, as well as through a $v$. femoralis, while it also receives an epigastric vein from the walls of the abdomen and its AIR-SACS (p. 4). Immediately after the v. iliac. externa has entered the pelvis, near the pectineal process (pp. $\$ 61,862$ ) it is joined by the $v$. itiac. interna, which drains the blood from the tail, $v v$. coccygea, from the pelvis and most of the viscera therein embedded, including the kidneys. Much of the venous blood is however conveyed directly into the rena iliaca communes, and numerous veins, very variable, send blood from the generative glands, from the suprarenal capsules and from the liver into the 2 . cava posterior.

The Hepatic Portal System remains to be mentioned. A Bird's liver receives nearly all the blood from the stomach, gut, pancreas and spleen, as well as from the liver itself. This blood enters the right hepatic lobe by a $v$. portalis dextra, composed of the mesenteric and coccygeo-mesenteric veins, and those from the pancreas, duodenum, proventriculus and spleen; while the left lobe receives the $v$. portalis sinistra with blood from the stomach. Having entered the liver, both portal veins break up into innumerable small vessels which combine again within this organ, and leave it as the $v v$. hepatica magna, which, as stated before, join the $v$. cuva posterior, the

ascendens Aortse ; u.brc. Alt. braclialis; a.desc. Aorta descendens; A.f. Art. femoralis ; A.sub. Art. subclavia; A.v. Art. vertebralis ; C.c. Carotis communis; C.e. Carot. externa; C.i. Carot. interna ; c.ms. Vena coceygonesentrica; conl. Art. coliaca ; cr. Vena cruralis; cut.abd. Vena cntanea abuominalis ; cut.uln. V. cut. uhnaris ; gast. Art. gastralis; $h p$. Art. hepatica; hyp. Ven. llypogastrica; il. Art. iliaca; il.ex. Vena iliaca externa; il.int. V. il. interna; isch. Art. iscliadica ; Jug.d. V. jugnlaris dextra ; Jug.s. V. jng. sinistra ; ms.i. Art. mesenterica inferior ; $m s . s$. Art. mesent. superior ; $r$. renal arteries aud veins; rad. Art. radialis; tib.a. Art. tibialis antica; tib.p. Art. tib. postica; thor. Art. thoracica; Ir.coort. truncns Aortæ; uln. Art. nlnaris; V.Br. Vena brachialis; V.c.i., v.c.p., v.c.s. Tena cava inferior, posterior and sinistra; v.f. Vena femoralis; V.H. V. Lepatica; v.il.c. V. iliaca communis; v.pulm. V. puimonaria; V.sub. V. subclavia; V.v. V. vertebralis. 
combined trunk being then lnown as the v. cava inferior. But the left $v$. hepaticu magna receives also the $v$. umbilicalis, a long unpaired vein arising in adult birds from the walls of the abdomen and its air-sacs, and frequently anastomosing with the epigastric veins. Its

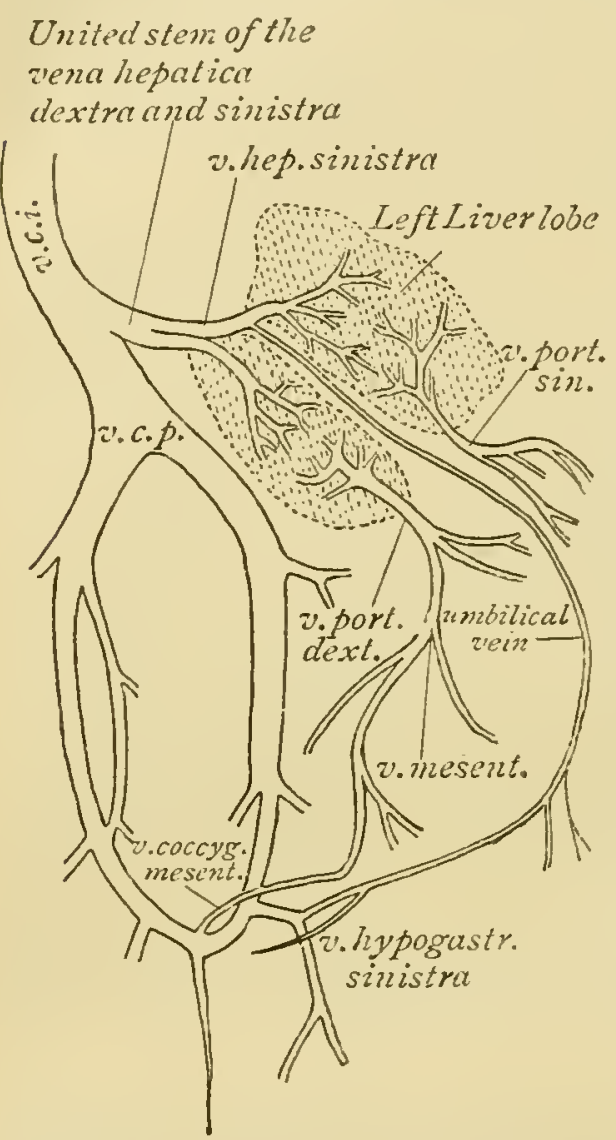

Diagram of a BrRd's Portal Vexols Srstem. Ventral Aspect. stem rums nearly midway along the visceral surface of the abdominal wall, passing first to the right of the stomach and then between the two lobes of the liver, finally joining the left hepatic vein. This peculiar vessel is the remnant of one which played an important part in the embryo, for it originally collected all the blood of the yolk-sac (p. 211) into one stem which passed along the left side of the gut; and, after receiving the mesenteric vein, entered the right auricle of the heart as the $v$. omplualomesaraica. This stem, however, soon became surrounded by the liver, and began to form the Hepatic Portal System by partly breaking up into capillaries, while the mesenteric developed more and more, nutil the primitive vessel persists only as the umbilical vein.

Owing to the numerous anastomoses set up by veins on the confines of their several districts, some of these connexions are often used by the blood as "short cuts," and then become wider channels, while the original vessels suffer atrophy, so that quite new modifications are brought about. Such rariations are so common, especially in the cervical and pelvic regions, that they deprive the Tenous System of much of its taxonomic ralue. ${ }^{1}$

B. Lynphatic System.

The Lacteal or Absorbent vessels arise in the villi of the intestine, whence they convey the chyle into the Lymphatics (p. 139), together with the white blood or lymph corpuscles (p. 43), which are produced in the follicles at the base of the villi

1 A careful, minute and amply illustrated description of the venous system of numerous hirds-"Systema venosum Avium cum eo Manmalium et inprimis Hominis collatum" - was published by Neugebaner in 1844 (Nor: Act. L.-C. Acad. xxi. pp. 517-698, tabb. xxxvi.-1.). 
(p. 139, Fig. 1, L.). Lymphatics and lacteals unite, and grenerally follow the course of the bigger arteries and veins, often surrounding them with anastomosing network. The lymph vessels of the tail and hinder parts of the body enter the hypogastric veins, and at the point of junction a small contractile "lymph-heart" is regularly developed in the embryo and persists in many forms until maturity. The lymphatic vessels of the trunk and intestines chiefly accompany the cortu descendens and the mesenteric and coeliac arteries, finally opening into the two superior venx cutx, as also do the branches of the lymphatic stems that come down from the head and neck, accompanying the jugular veins into which they partly enter.

TAS DEFERENS, sce Reproductive Organs (p. 784 and fig. p. 782$)$.

VEERY, a name in North America (Nuttall, Man. Orn. i. p. 349) for what is otherwise known as Wilson's THRusH, Turdus fuscesciens.

$T^{2} E I N$ (adj. venous). Veins are the vessels through which the blood flows into the HEART, no matter if this blood be venous, or arterial like that which returns purified from the LUNGs through the pulmonary veins. The walls of the veins are thinuer than those of the ARTERIES, and, especially toward the extremities, contain numerous valves to hinder the reflux of the blood. Similar veins guard the entrance to the heart, but there are none in the jugular, trunk and cutineous veins (see p. 1008).

\section{TERTEBR.}

YIREO, the name of a genus proposed by Vieillot in 1807, and long since nsed as English, for some North-American birds, sometimes ealled GrennLets. With some allied genera they seem to form a small but recognizahle Family, very characteristic of the "Columbian" Famna. They a]'e mostly inconspienous in their olive-green plumage, but like the Alundida (IARK) are instructive to the taxonomer, teaching him not to depend on the number of primary quills, and also shewing

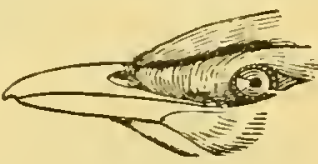

VIREOSYLVIA. (After Swainson.) a considerable amount of differentiation of form within certain limits, though some of the speeies are not easily distinguished. By most systematists they are supposed to he allied to the Laniida (SHrike), and by some are even included in that Family, but on grounds that are at least debatable. Paird in 1866 (Rev. Am. B. pp. 321-400) insisted foreihly on the distinctness of the Vireonilla, to which he assigned' $T$ genera and some subgenera, being therein followed in 1873 by Messrs. Sclater and Salvin (Nomencl. A : pp. 11-13); but Sundevall in 1872 (Tentumen, p. 13) had 
assigned another place to two of them, Hylophilus and Cyclorhis, so that the position of Vireosylviu, Vireo, Neochloe, Laletes and Vireolanius only can be regarded as undisputed; and it is in the first of these that the tenth (usually numbered the first) primary is always small and frequently wanting, ${ }^{1}$ the type species, commonly called $V$. olivacea, ${ }^{2}$ being, it is said, rariable in this respect (Ridgway, Man. N. Am. B. p. 469, note). This bird, the Red-eyed Flycatcher of many writers, is a well-known summer-immigrant to eastern North America which has even reached Greenland, and has been recorded as accidentally occurring in England (E. Brown, in Mosley's Nat. Hist. Tutbury, p. 3S5, pl. vi.). The type of Vireo, in which the wing has 10 undoubted primaries, is the White-eyed Flycatcher of many writers, $V$. noveboracensis, also a native of North America, but having a more southerly range, and being abundant all the year round in Bermuda. Of these two genera, 17 species or races were recognized as found in the teritory of the United States by Prof. Coues in 1884, and 21 by Mr. Ridgway in 1887. All seem to have much the same habits, among which must be mentioned the utterance of loud and melodious notes; in some cases sufficiently connected to form a real song, and the peculiar structure of their nests, which are built in the fork of a horizontal branch, between the prongs of which the beautifully-woven fabric is suspended, just as among the Oriolidx, and it is to be remarked that the eggs are very similar in coloration and markings to those of the true Orioles. Of the rest, Neochloe, if that really belongs here, is Mexican, and Laletes peculiar to Jamaica, each of them having but a single species, while of Vireolanius there are four ranging from Mexico sonthward to Ecuador (Cat. B. Br. Mus. viii. pp. 292-316).

VISCHFANGER (Fish-catcher), the Dutch name used in the Cape Colony for Haliaetus vocifer (Layard, B. S. Afr. p. 17), an EAGLE (p. 176).

\section{VOCAL ORGANS, see LARYNX and TracheA.}

VOLUCRES, Bonaparte's name in 1850 (Comp. Av. i. p. 57) for the first of the two "Tribus" into which he divided the Order" PASseres, the second being Oscines, making the former to include all the Picuriz of this work as well as the Tracheophone.

VOMLER, a median bone of the SKULL (p. 871 ), so called from its general resemblance to a ploughshare in shape, though varying much in that respect, as well as in comparative size and its connexion with other bones, so as to be of considerable taxonomic value.

1 On this Baird's note (op. cit. p. 325) is important, shewing a great advance on the statements of other taxonomers.

3 Whether it should bear this name is questionable. 
VULTURE, the name of birds whose best-known characteristic is that of feeding upon carcases, and, owing to this obscene habit, are regarded with favour as useful scavengers in many hot coluntries. The genus Vultur, as instituterl by Limieus, is now restricted by ornithologists to a single species, $V$. monachus, of which more presently, the other species included therein by him, or thereto referred by succeeling systematists, being elsewhere relegated; but the most important taxonomic change that has been introdnced is that by Prof. Huxley (Proc. Zool. Soc. 1867, pp. 462-464), who

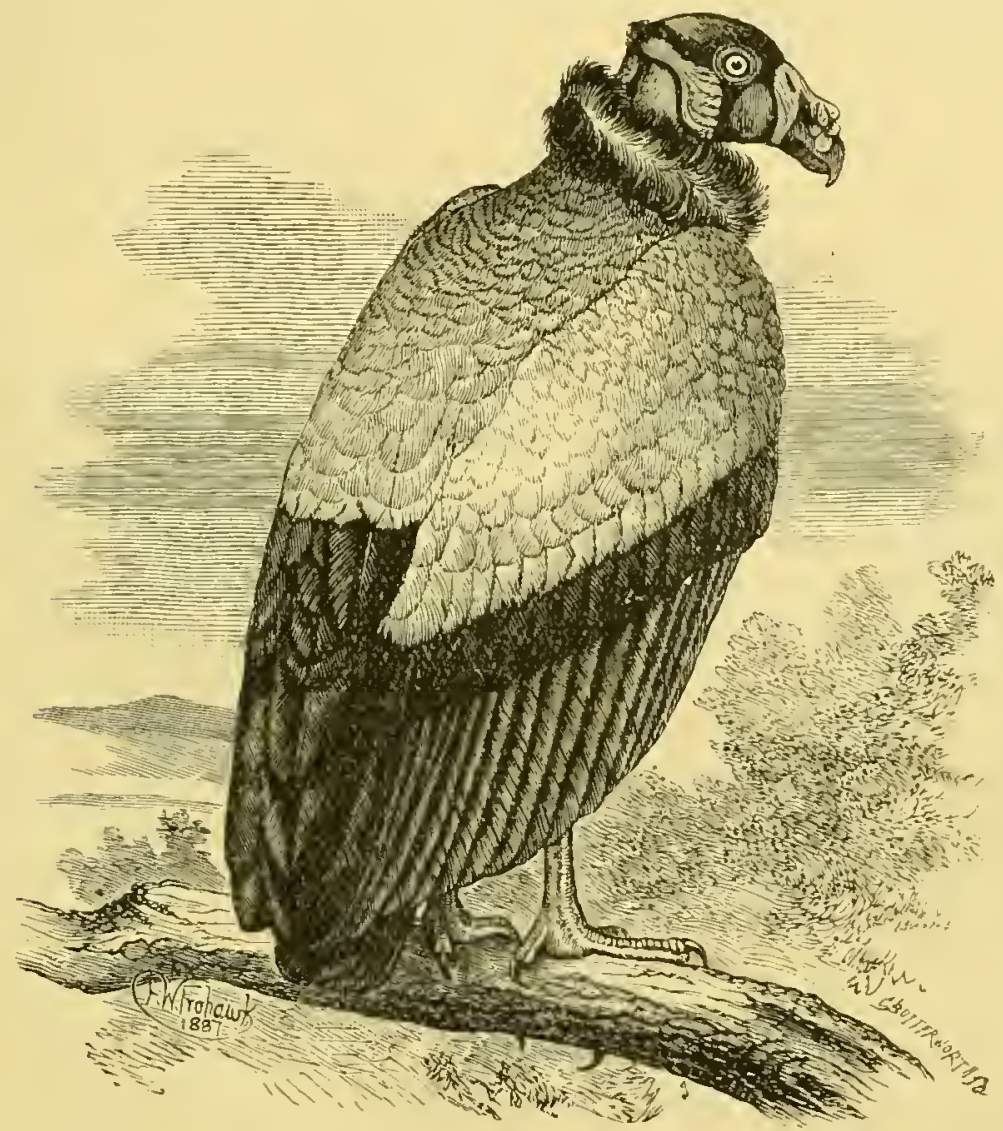

King-Vulture (Gypagus papa).

pointed out the complete structural difference between the Vultures of the New ITorld and those of the Old, regarding the former as constituting a distinct Fanily, Cuthartide (more properly named Surcorlumphida), while he mited the latter with the ordinary diurnal Birds-of-Prey as Gypaetidie (LÄMnERGEYER, p. 501, note). This arrangement overlooks the signitication of some considerable distinetions, and it would appear more reasonable to recognize the existence of a Family Tulturida, confined to the true Vultures of

1 This separation had already been made by Brandt (Journ. für Orn. 1853, p. 181), but he contented himself with dividing the Vultures into two subfamilies, Temnorhines or Sarcorhamphina and Holorhines or Vulturina. 
the Ancient Continent, equal in rank to the Falconidx, while fully admitting the claim made on behalf of the New-World forms for the same standing.

I. The American Vultures include five genera:-(1) Sarcorhamphus, the gigantic Condor (p. 101), the male distinguished by a large fleshy comb and wattles; (2) Gypagus, the King-Vulture, with its gaudily-coloured head and nasal caruncle; (3) Catharista, generally known as the Black Vulture or "Carrion Crow," C. atrata, of the warmer parts of America; (4) Cathartes, containing the so-called JoHN Crow (p. 470), or Turkey-Buzzard of English-speaking Americans, with its allies ; ${ }^{1}$ and (5) Pseudogryphus, the great Californian Vulture- of very limited range on the western slopes of North America and, through the use of poison, threatened with speedy extinction. Though all these birds are structurally so different from the true Vultures of the Old World, in habits the Vulturida and Sarcorhamphida are much alike, and of several of the latter-particularly of the Condor and the Turkey-Buzzardwe possess elaborate accounts by excellent observers, as Darwin, Alexander Wilson and Gosse-whose works are readily accessible.

II. The true Vultures of the Old World, Vulturidx in the restricted sense, are generally divided into five or six genera, of which NeopHron (p. 621) has been not unjustifiably separated as forming a distinct subfamily, Neophroninæ,-its members, of eomparatively small size, differing both in strueture and habit considerably from the rest. One of them is the so-called Egyptian Vulture or Pharaoh's Hen, $N$. percnopterus, a bird whose delicaey of build and appearance contrasts forcibly with its choice of the most filthy food. It is a well-known species in some parts of India, ${ }^{2}$ and thence westward to Africa, where it has an extensive range. It also oceurs on the northern shores of the Mediterranean, and on three occasions has strayed to such a distance from its usual haunts as to have twice suffered capture in England, and once even in Norway. Of the genera composing the other subfamily, Vulturinx, space is wanting to say much. Gyps numbers seven or eight local species and races, on more than one of which the English name GRIFFon (p. $385)$ has been fastened. The best known is G. fulvus, which by some authors is accounted "British," from an example having been taken in Ireland, though in circumstances which suggest its appearance so far from its nearest home in Spain to be due to man's intervention. The species, however, has a wider distribution on the European continent (especially towards the north-east) than the

1 The birds of these two genera are easily to be distinguished on the wing at a considerable distance (ef. Cones, B. North West, pp. 381, 382).

2 In the eastern part of the Indian peninsula it is replaced by a smaller race or (according to some authorities) species, $N$. gingianus, which has a yellow jnstead of a black bill. 
Egyptian Vulture, and in Africa nearly reaches the Equator, extending also in Asia to the Himalayas; but both in the Ethiopian and Indian Regions its range inosculates with that of several allied forms or species. Pseudogyps with two forms - one Indian, the other African-differs from Gyps by having twelve instead of fourteen rectrices. Of the genera Otogyps and Lophogyps nothing here need be said; and then we have Vultur, with, as mentioned before, its sole representative, $V$. monaclus, commonly known as the Cinereous Vulture, a bird which is found from the Strait of Gibraltar to the sea-coast of China. ${ }^{1}$ Almost all these birds inhabit rocky cliffs, on the ledges of which they build their nests. ${ }^{2}$

\section{W}

WAGELL, ${ }^{3}$ the Cornish name of a bird of which Ray and Willughby were told, 30th June 1662, on Godreve Island near St. Ives in Cornwall (Memorials of Ray, ed. Lankester, p. 188, and Ray, Collection of Words, p. 93). From what is said of it the Arctic Gull (SkUA, p. 870) seems to have been meant, but they took it to be the young of what we now know as Larus marinus, and so the name has been attached to that species by subsequent writers. ${ }^{4}$

2 The geographical range of the varions species of Vultures has been treated by Dr. Sharpe (Journ. Linn. Soc. Zool. xiii. pp. I-26, pls. i.-ix.).

2 The question whether Vultures in their search for food are guided by sight of the object or by its scent has long excited interest. Without denying to them the olfactory faculty, it is now generally admitted, notwithstanding the assertions to the contrary of Waterton and a few more, that the former is in almost every case sufficient to account for the observed facts. It is linown that directly a camel drops dead, as the caravan to which it belonged is making its way across the desert, Vultures of one sort or another appear, often in considerable numbers, thongh none had before been observed by the traveller, and speedily devour the earcase over which they are gathered together. The unode in which commmication is effected between the birds, which are soaring at an immense height, seems at first inexplicable, but Canon Tristram suggested (Ibis, 1859, p. 2S0) a simple solution of the supposed mystery:- "The Griffon who first descries his qualry descends from his elevation at once. Another, sweeping the horizon at a still greater distance, observes his neighbour's movements and follows his course. A third, still further removed, follows the flight of the second; he is traced by another ; and so a perpetual succession is kept up so long as a morsel of flesh remains over which to consort."

3 The derivation and pronumciation of this word are unknown to me. It is spelt indifferently by Ray with one $l$ or two. I preserve the latter form as possibly indicating a stress to be laid on the last syllable.

${ }^{4}$ See Additions to Borlase's Natural History (reprinted from Journ. R. Inst. Cornwall, Oct. 1865), Triro: 1865, 1. 46. 
WAGTAIL (Wagsterd and Wagstyrt, 15th cent. fide Th. Wright, Vol. Vocabul. ii. pp. 221, 253 ; Unagtale, Turner, 1544, p. 53), the little bird that delights us equally by its neat coloration, its slender form, its nimble actions and its sprightly notes. ${ }^{2}$ Since it is so generally dispersed, especially in summer, throughout the British Islands, it needs no further description.

The Pied Wagtail of authors, it is the Motacilla ${ }^{2}$ lugubris of modern ornithology, or $M$. yarrelli of some writers, and has for its very near ally -if indeed it be not merely a local race of - the $M$. alba of Linnæus, which has a wide range in Europe, Asia, and Africa, visiting England almost yearly, and chiefly differing from the ordinary British form in its lighter-coloured tints, - the cock especially having a clear grey instead of a black back. Eleven other more or less nearly-allied species are recognized by Dr. Sharpe (Cat. B. Brit. Hus. x. pp. 456-496), who has laboriously treated the complicated synonymy of this gromp of birds. Eight of them are natives of Asia, several wintering in India, and one, $M$. ocularis, even reaching Alaska, while the rest are confined to Africa. No colours but black, grey or white enter into the plumage of any of the foregoing; but in the species peculiar to Madagascar, M. flaviventris, as well as in that which it much resembles, the so-called Grey Wagtail of Britain, $M$. melanope ( $M$. boarula or sulphurea of some authors), a great part of the lower surface is yellow. This is one of the most graceful of birds, and though having a very wide range in the world at large is curiously local in its distribution in Britain, being almost wholly confined in the breeding-season to the neighbourhood of rocky streams in the west and north, and a line drawn from the Start Point, slightly curving to include the Derbyshire hills, and ending at the mouth of the Tees, will, it is believed, mark off its breeding-range in England. Then there is a section which by some systematists has been raised to the rank of a genus, Budytes, containing the Wagtails in which yellow takes a still more prominent part in their coloration. Of these, 8 species, besides several subspecies, are recognized by Dr. Sharpe (ut suprà, pp. 503 532). One of these is the common Yellow Wagtail of England,

1 It is the Dishwasher of some parts of England, in others it has the endearing nickname of Molly or Polly Washdish, with which may be compared the Icelandic Mariu-eria, and of course the French Lavandière and Batte-lessive.

2 The genus Motacilla (an exact rendering of the English "Wagtail," the Dutch Kwikstaart, the Italian Codatremola and other similar words), whieh, as originally founded by Linnæus, contained nearly all the "soft-billed" birds of early English ornithologists, was restricted by varions anthors in succession, following the example set by Scopoli in 1769 , until none bnt the Wagtails remained in it. Most of the rest are now commonly classed as Sylviidx (WARBLER), while the Wagtails with the PrPITs, and possibly some others, constitute the Family Motacillidx. 
M. raii (by some mistakenly called $M$. campestris), which, though very generally distributed throughout the country, is much less numerous than the Pied Wagtail, and more addicted to wet meadows; but, just as $M$. lugubris is regarded by some as a loeal form of the more widely-ranging $M$. alba, so does $M$. raii hold the same relation to $M$. flava, the Blue-headed Wagtail, which has a very extensive distribution in the Old World, and even erosses the Pacific to Alaska, presenting also a great number of varicties or races (most of them treated by Dr. Sharpe as real species) differing from each other chiefly, if not solely, in the colour of the head, a character which in this section can hardly be deemed speeifie, while their geographical range intersects and inosculates in a most puzzling manner. Credit is due to the author just named for the enormous trouble he has taken, after study of a vast series of specimens, to clear up the questions herein involved; but it will probably be long before ornithologists can agree on many of the disputed points, and it is certain that the last word has by no means been spoken concerning them.

WALL-BIRD, a common local name of the Spotted FLYCATCHER (p. 274); WALL-CREEPER see under Tree-Creeper (p. 986).

WARBLER, the name bestowed in 1773 by Pennant (Gen. Birds, p. 35) on the birds removed, in 1769, by Seopoli from the Linnæan genus Motacilla (IVAGTAIL) to one founded and called by him Sylvia, - the last being a word employed by several of the older writers in an indefinite way, - that is to say, on all the species of Motacilla which were not Wagtails. "Warbler" has long been used by English technical writers as the equivalent of Sylvia, and consequently generally applied to all members of the Family Sylviidx thereon raised, which has sinee been so much subdivided as to include a vast number of genera, while speeies almost innumerable have from time to time been referred to it.

Until recently ornithologists had come to agree pretty well as to which forms should be considered to belong to the Family Sylviidx, -the "American Warblers" (Mniotiltidx), to be presently considered, being therefrom segregated; but some writers, seeing the diffienlty of separating the remainder from the Turdida (THRUsH), tried to get over it by proposing to erect an intermediate Family for the WHEATEAR and some similar forms, under the name Saxicolidx. ' But the affinity, seeming or real, to the Turdidx does not

1 In truth the difficulty was thereby doubled, for, if it was before hard to dis. tingnish between Sylviide and Turdidx, it has since become harder to distinguish on the one hand between Sylviidx and Saxicolidx, and on the other between Saxicotidx and Turdidx. The confusion thus caused is chiefly due to the adoption in a more or less modified form of the views put forth by Sundevall in 1872 , and revised by him in 1874 ( $c j$. Intronuction). For him, however, it is 
offer the only difficulty. The resemblance shewn by some other forms, such as Timelia (p. 962) and its allies, often placed with the Sylvidix, is equally if not more puzzling. Again, a small group of birds, almost wholly peculiar to the Anstralian Fauna, have been sometimes separated as Maluridx, and of these more must be said presently. Lastly, there are certain genera that, though formerly included without hesitation among the Sylviidx, have lately been designated "FLY-CATCHERS," on grounds, however, that have not been explained; but to deal with this theme in satisfactory detail would require far more space than can here be allowed, for the failures of later systematists would have to be shewn by a series of minute criticisms.

I. All things considered, it would seem best at present to regard the "WARBLERS"-without pledging our faith to the recognition of a "Family" Syltiid $x$-from the point of view which obtained before the more recent and perplexing (because ill-defined) opinions were introduced. Such an aspect is afforded by the scheme furnished by Canon Tristram to Mr. Wallace (Geogr. Distr. Anim. ii. pp. 257-260); but these limits will only permit us to touch upon a few of the most prominent members in addition to those which have been or will be the subject of separate articles. In this sense then the first "Warbler's" that may be mentioned are those forming a group of more or less aquatic habit, often called Calamoherpinx, but more correctly Acrocephalinx, the commonest of which in England is the well-known Sedge-BIRd or Sedge-Warbler, Acrocephalus schoenobxnus, whose chattering song resounds in summer-time from almost every wet ditch in most parts of Britain. As is the case with so many of its allies, the skulking habits of the bird carse it to be far more often heard than seen; but, with a little patience, it may be generally observed flitting about the uppermost twigs of the bushes it frequents, and its mottled back and the yellowishwhite streak over its eye serve to distinguish it from its ally the REED-Wren or ReEd-WArbier, A. streperus, which is clad in a wholly mouse-coloured suit. But this last can also be recognized

to be said that he at least proceeded in a fashion that had long been recognized, and gave reasons, whether good or bad, for the system he propounded; but his imitators have omitted so obvious a requirement, and leave to any one who would use their results the task of discovering how they have been reached. Hence it has been suggested that some of the alterations introduced siuce Sundevall's time are purely arbitrary, if indeed they do not proceed from considerations of personal convenience, or nccasionally even through mischance. Still the greatest allowance must be made for those who attempt to reduce to order such a multitudinous assemblage of forms-forms which present an almost endless variety of small differentiating characters, pointing in numerons directions-while the essential structure of all is apparently so similar that at present there is harlly hope of assistance from the anatomist or the morphologist. 
by its different song, and comparatively seldom does it stray from the reed-beds which are its favourite haunts. In them usually it builds one of the most beautiful of nests, made of the seed-branches of the reed and long grass, wound horizontally round and round so as to include in its substance the living stems of three or four r'eeds, between which it is suspended at a convenient height above the water, and the structure is so deep that the eggs do not roll out when its props are shaken by the wind. ${ }^{1}$ Of very similar habits is the Revd-Thrush or great Reed-Warbler, A. arundinaceus, a loudvoiced species, abundant on the Continent but very rarely straying to England. Much interest also attaches to the species known in books as Savi's Warbler, Potamodus luscinioides, which was only recognized as a constant inhabitant of the Fen-district of England a few years before its haunts were destroyed by drainage. No example seems to have been obtained in this country since 1856 . Its nest is peculiar, placed on the ground and formed of the blades of Glyceria so skilfully entwined as to be a very permanent structure, and it is a curious fact that its nests were well known to the sedge-cutters of the district which it most frequented, as those of a bird with which they were unacquainted, long before the builder' was recognized by naturalists. ${ }^{2}$ In coloration the bird somewhat resembles a Nightingale (whence its specific name), and its song differs from that of any of those before mentioned, being a long smooth trill, pitched higher but possessing more tone than that of the Grasshopper-Warbler, Locustella navia, which is a widely-distributed species throughout the British Isles, not only limited to marshy sites, but affecting also dry soils, inhabiting indifferently many kinds of places where there is tangled and thick herbage, heather or brushwood. ${ }^{3}$ The precise determination of this bird-the Grasshopper-Lark, as it was long called in books, though its notes if once heard can never be mistaken for those of a grasshopper or cricket, and it has no affinity to the Larks - as an English species is due to the discernment of Gilbert White in 1768. In its habits it is one of the most retiring of birds, keeping in the closest shelter, so that it may be within a very short distance. of an eager naturalist without his being able to see it, - the olive-colour, streaked with dark brown, of its upper plumage helping to make it invisible. The nest is very artfully concealed in the thickest herbage. The foreign

1 Of late years the nearly-allied MArsh-WARbler, A. palustris, is said to have been recognized in several parts of England, but I have not seen a specimen obtained in this country or had the good fortune knowingly to hear its song, which all agree in saying is very different from that of the Reed-Wren.

${ }^{2}$ See Yarrell, Br. B. ed. 4, i. pp. 389-397, where the history of the species was first told.

3 In those parts of England where each of the two species last mentioned was formerly most abundant it was known as the Reel-bird or Reeler (p. 779). 
forms of Aquatic Warblers are far too numerous to be here mentioned.

It seems expedient to recognize a subfamily Drymcecinx, which may include some 15 genera and nearly 200 species; but about its composition and limits much doubt cannot fail to be entertained. If its existence be acknowledged, the remarkable genera Orthotomus (TAILOR-BIRD) and Cisticola (FAntaIL) may be fairly admitted as belonging to it; but of them enough has been said (pp. 238, 942) and it is obviously impossible to dwell here on the rest.

In the group Drymoecinx is placed by some authors the Australian genus Malurus, to which belong the birds aptly named as "SUPERB WARBLERS," since in beanty they surpass any others of their presumed allies. Part of the plumage of the cocks in breedingdress is generally some shade of intense blue, and so glossy as to resemble enamel, while black, white, chestmut or scarlet, as well as green and lilac, are also present in one species or another, so as to heighten the effect. But, as already stated, there are systematists who would raise this genus, which contains some 15 species, to the rank of a distinct Family, though on what grounds it is as yet hard to say.

Of the other subfamilies, Saxicolina, Sylviina and Phylloscopina will be conveniently treated under WHEATEAR, WHITETHRoAT and WiLlow-Wren, while the Ruticillina have been already mentioned under Nightingale, Redbreast and Redstart, and the Accentorina under HedGe-Sparrow (p. 895). ${ }^{1}$

II. The birds known as "AMIERICAN WARBLERS," forming what has now been long recognized as a distinct Family, ${ }^{2}$ Mniotiltilla, remain for consideration. They possess but nine instead of ten primaries, and are peculiar to the New World. More than 130 species have been described, and these have been grouped in 20 genera or more, of which members of all but three are at least summer visitants to North America. As a whole they are much more brightly coloured.than the Sylviidx (Malurus, if it bclongs to them, always excepted); for, though the particular genus Mniotilta (from which, as the fortune of nomenclature will have it, the Family takes its right name) ${ }^{3}$ is one of the most

1 It is to be hoped that before long some competent ornithologrist will take on limself the task, necessary if toilsome and perhaps ungrateful, of revising the work that has lately been donc in regard to these birds and the Thrushes, and, setting aside all preconceived notions, fixing the limits of the Family or Families, if Families they be, and at the same time adjust the relations of the hitherto indefinite group of Timelias.

"Some American authors have called the Family "Wood-Warblers", an inappropriate name, and inconvenient since it has long since been specialized in England.

${ }^{3}$ By some writers the Family is called Sylvicolidx, a practice which contra. ienes ordinary usage, since the name Sylvicola was jreoccupied in conchologi: 
abnormal-its colomrs being plain black and white, and its habits rather resembling those of a TrEE-CREEPEr-in other groups chestunt, bluish-grey and green appear, the last varying from an olive to a saffiron tint, and in some groups the yellow predominates to an extent that has gained for its wearers, belonging to the gemus Hendrece, the name of "Golden" Warblers. In the genus Setophaga, the members of which deserve to be called "Fly-catching" Warblers, the plumage of the males at least presents yellow, orange, scarlet or crimson, and recalls the ReDstarts of the Old World. Dr. Cones ( $K c y$ N. Am. Birds, ed. 2, p. 288), following on the whole the arrangement of Baird, Brewer and Ridgway ( $N$. Am. Birds, i. p. 178), separates the Family (for which he wrongly retains the name Sylvicolidx) into three subfamilies, Sylvicolina (= Mniotiltina), Icteriina and Setophagina, grouping the genera Mniotiltu, Purula and

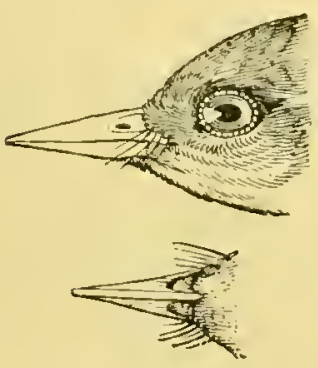

DENDRECA.

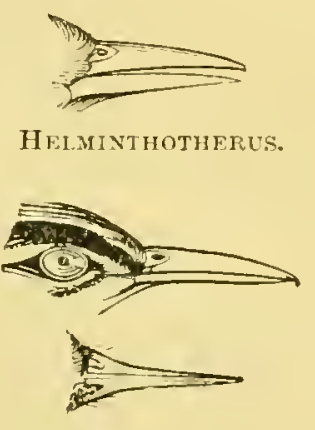

INIOTILTA. After Swainson.)

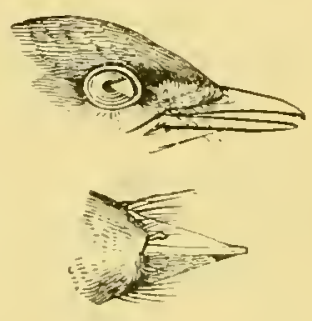

SETOPHAGA.

Peucedromms as "Creeping Warblers"; Gcothlypis, Oporornis and Siurus as "Ground-Varblers"; I'rotonoturia, IIelminthotherus and Helminthophila as "Worm-eating Wrabler's"; Setophaga, Cardellina and IIyiodioctes as "Fly-catching Warblers"; Icteria (CHAT, p. 85), which perhaps may not belong to the Family, standing alone; and Dendroece as " Wood-TTarblers." 1

The Mniotiltidx contain forms exhiliting quite as many diverse modes of life as do the Syluiida. Some are exclusively aquatic in their predilections, others affect dry soils, brushwood, forests and so on. Almost all the genera are essentially migratory, but a large proportion of the species of Dendreca, Setophuga and especially Basileuterus, seem never to leave their Neotropical home; while the genera Leucopezd, Teretristis and Nicroligia, comprising in all but 5 species, are peculiar to the Antilles. The rest are for the most part natives of North America, where a few attain a very high latitude,"

1 In 1887 Mr. Ridgway (Man. N. Am. E. 1). 480-532) recognized 20 genera as belonging to the United States, while another comes very near their southerm boundary, but he made no attempt to separate subfamilies.

- Seven species have been lecorded as wandering to Greenland, and one, Dendreca virens, is said to have occurred in Europe (Nammannia, 1858, 1). 425); Gätke, Vogelwarte Helgoland, ए. 326 ; Eng. tians. p. 315. 
penctrating in summer even beyond the Arctic Circle, and thence migrate southward at the end of summer or in the fall of the year, some reaching Peru and Brazil, but a few, as, for instance, Parula pitiayumi and Geothlypis velata seem to be resident in the country last named.

WARE-GOOSE, a name for the Brent Goose (pp. 57, 375)"ware" being a local term for some kind of seaweed.

WARIANGLE and WIERANGLE (with other variations of spelling) O.H.G. IVerkengel, mod. Germ. Würgengel and Würger (the Worrier or Throttler) an obsolete name for the Great Ash-coloured Shrike (p. 844, note ; $f$. Cotgrave, 1611, sub vocc. "Engrouée," "Escrire" and "Pie"). ${ }^{1}$

WARWINCKLE, used in 1633, by Simon Latham (Faulconry, ii. p. 144), apparently for a Pied WAGTAIL (p. 101S), as certainly are

WASHDISH and WASHTAIL (Holinshed, Descr. Engl. chap. ii. ed. 1586, p. 223): the former very frequently with the prefix "Molly" or "Polly," according to the common custom of nicknaming favourite birds.

WASKITE, ${ }^{2}$ given, with the description "from Virginia," in 1655 by Izaak Walton (Compleat Angler, ed. 2.'p. 18) as the name of a Hawk in Falconry, but otherwise unknown.

WATCHY-PICKET, a Creole name in Jamaica for Icterus leucopteryx (Sloane, Voy. Jam. ii. pp. 299, 300 ; Gosse, B. Jam. p. 226).

WATER-, a prefix to the name of many birds, especially to some of the Rallidix: thus Water-cock is Gallicrex cinerea or cristata (Jerdon, B. Ind. ii. p. 71S), Water-hen, a very common equivalent of Moor-HeN (p. 589), Water-Partridge is Porzana concolor (Gosse, $B$. Jam. p. 369, and we have Water-RAIL (p. 763); while Water-Crow and -Ousel (p. 677) are Scottish and English names for Cinclus aquaticus; the Water-Thrush of the English in North America is Siurus noveboracensis, one of the Mniotiltidæ (WARBLER, p. 1019), and the Watcr-Turkey is Plotus anhinga (SNake-BIRD, p. 880).

WATTLE-BIRD, the name given by Cook's people to a species they found during his second voyage in New Zealand (G. Forster, Voy. i. p. 148), and adopted in 1781 by both Pennant (Gen. B. ed. 2, p. 9) and Latham (Gen. Synops. i. p. 364 , pl. xiv.) for what they rightly considered a new genus, which was technically termed in

1 In the eopy of Belon's Portraits before mentioned (pp. 680, 918 notes) the figure of Lanius excubitor is named WarriangLe.

2 The Century Dictionary (1891) includes the word "Waspkite" explained as Pernis apivorus (Honey-BuzzArD, p. 67), but 110 anthority is cited for it, nor does such a name seem to be known in Eugland. There is no bird like it in America. 
1788 by J. R. Forster (Enchiridion, p. 35) Cullace, and by Gmelin (Syst. Nat. i. p. 363) Glaucopis. ${ }^{1}$ The Kokako of the Maories, it is now commonly known as the Wattle-Crow, and two species are reeognized-the original $C$. or $G$. cinerea, belonging to the Sonth Island, and the $C$. or $G$. witsoni, which represents it in the North,

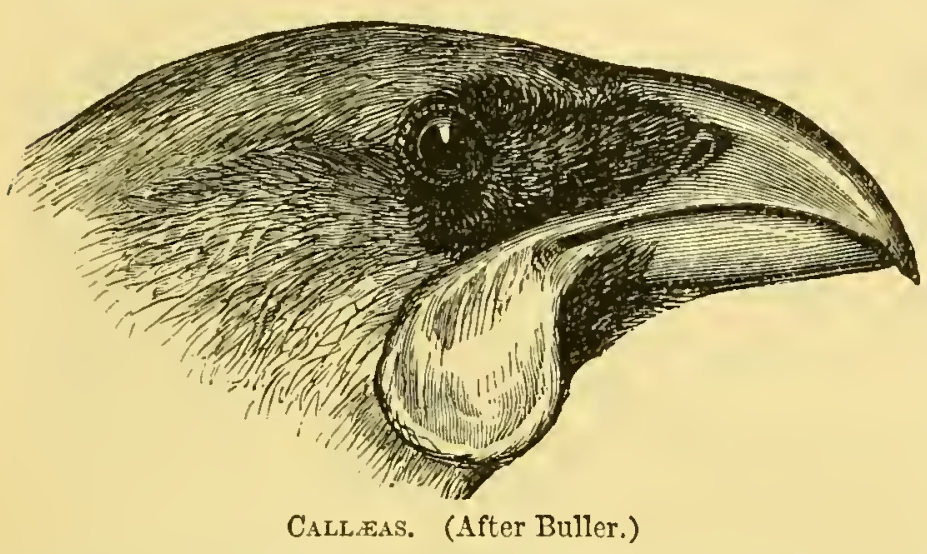

almost the sole differenee between them being the eolour of the bare lobes or wattles that depend from the gape, which in the latter are wholly blue, but in the former blue at the base only, the lest being orange. The genus is usually placed in the Corvida, but its fringed and ciliated tongue, whieh was duly noticed by the elder Forster, and is figured, though very indistinctly, by Latham, tends to throw doubt upon that assignment; yet Dr. Gadow finds ( $c f$. Buller, B. New Zeal. ed. 2, p. 4) that osteologically it is one of the Austrocoraces or Noto-Coracomorpha ( $c f$. Bird-of-PARAdise, page 39, note ; GynnoRHINA, page 403; and Shrike, page 846 , note). Both birds are about as big as a Jay, of a dark ash-eolour, inelining to brown beneath and on the lower part of the back, and have the face black. They feed mostly on berries, and are very locally distributed. The males, in each species said to be smaller than the females, have loud and varied notes, one of them of great depth and richness.

The Wattle-birds of Australia and Tasmania belong to a very different group, the Meliphagida (Honey-EATER). The first of them was diseovered at Port Jaekson, 17th April 1788, and was described in 1789 by Phillip (Bot. Buy, p. 164), as also in the next year by John White (Voy. New South IV ules, p. 144), as a Bee-eater, receiving from Latham the name of Merops curunculutus. It is now the Anthocharce carunculate of ornithology, and is widely distributed in Australia, having a comparatively short red wattle hanging below the eye, while a second species, $A$. incuris, is peculiar to Tasmania, and has a mueh longer pendant, white at the root deepening into orange. These birds are among the largest of the Meliphogida, and have a very inconspicuous plumage of dull brown streaked with white. Allied to them are two other genera, Acanthogenys with a single species, and Anellobium with two, the members of which are often

1 Forster's preface is dated 15th February, Gmelin's 16th March. One cannot but wish that priority of publication rests with the former, as one of the discoverers of the bird. 
ealled Wattle-birds though not possessing any appendage to justify the name (cf. Gould, Hund. B. Austral. i. pp. 534-544; Gadow, Cat. B. Br. Mus. ix. pp. 262-266), while the rare and apparently extinct Chatoptila angustiplume of Hawaii, though from a locality so far off, would seem to be near of kin ( $c f$. Wilson and Evans, $B$. Sanclu. Isl.).

WT AVEY, a name long used by the residents in the Hudson's Bay Territory, apparently for any species of Wild Goose (p. 374), but especially for those of the genus Chen (Hearne, Journey, p. 442).

WAXBILL, the name in use in Edwards's time (1751) for the well-known little eage-bird, the Loxic astrild of Linnæus and Estrilda ustrild of modern ornithology, one of the Ploceidx (WEaveri-Brid), but also applied to several other species, more or less allied, which have the bill like sealing-wax, though they are placed by Dr. Sharpe (Cat. B. Bi. Mus. xiii.) in almost as many distinet genera.

WAXWING, apparently first so-ealled by Stephens in 1817 (Gen. Zonl. x. 420), having been before known as the "Silk-tail"

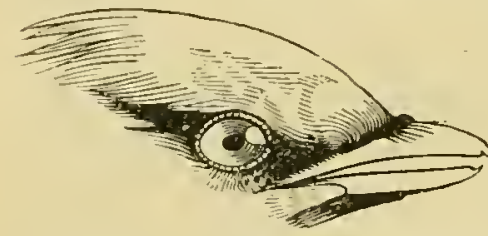

Warwing. (After Swainson.) (Phil. Truns. 1685, p. 1161) - a literal rendering of the German Scidenschwonz -or "Chatterer"- the prefix "German," "Bohemian" or "Waxen" being often also applied. Stephens's convenient name has now been generally adopted, since the bird is readily distinguished from almost all others by the curious expansion of the shaft of some of its wing-feathers at the tip into a flake that looks like searlet sealing-wax, while its exeeedingly silent habit makes the name "ChatTerer" wholly inappropriate ( $f$. page 85 ). It is the Ampelis gurvulus of Linnæus and of more reeent ornithologists. ${ }^{1}$

The Waxwing is a bird that for many years exeited vast interest. An irregular winter-visítant, sometimes in countless hordes, to the eentral and some parts of southern Europe, it was of old time looked upon as the harbinger of war, plague, or death, and, while its harmonious coloration and the grace of its form were attractive, the curiosity with which its irregular appearanees were

1 Limneus had, as is well known, no conception of what is meant by the modern idea of a "type"; but none can doubt that, if such a notion had been entertained by him, he would have declared his tyle-species to be that to whieh the name was first applied, viz. the present, and hence those systenatists are wrong who would remove this to a genus varionsly called Bombycilla, Bombiciphora, or, most absurd of all, Bombicivora. The birds which ought to be removed from his Ampelis are those whieh are now generally recognized as forming a Family Cotingida (Chatterer), allied to the Pipride (Manakin), and like them peculiar to the Neotropical Fauna, in which they constitute a very natural group (Inthoduction). 
regarded was enhanced by the mystery which enshrouded its birthplace, and until the summer of 1856 defied the searching of any explorer. In that year, however, all doubt was dispelled, through the successful sealch in Lapland, organized by the late John Wolley, as briefly described by him (Proc. Zool. Soc. 1857, pp. 55, 56 , pl. cxxii.). ${ }^{1}$ In $1858 \mathrm{Mr}$. Dresser found a small settlement of the species on an island in the Baltic near Uleaborg, and with his own hands took a nest. It is now pretty evident that the Waxwing, though doubtless breeding yearly in some parts of northern Europe, is as irregular in the choice of its summer-quarters as in that of its winter-retreats. Moreover, the species exhibits the same irregular habits in America. Mr. Drexler on one occasion, in Nebraska, saw it in "millions." In 1861 Kennicott found it breeding on the Yukon, and later Mr. MacFarlane had the like good fortune on the Anderson River.

Beautiful as is the bird with its drooping crest, its cinnamonbrown plumage passing in parts into grey or chestnut, and relieved by black, white and yellow-all of the purest tinit-the external feature which has invited most attention is the "sealing-wax" which tips some of the secondary or cubital quills, and occasionally those of the tail. ${ }^{2}$ This is nearly as much exhibited by the kindred species, A.cedrorum-the well-known CEDAR-BIRD of North America -which is easily distinguished by its smaller size, less-black chinspot, the yellower tinge of the lower parts and the want of white on the wings. In the A.phcenicoptera of south-eastern Siberia and Japan the remiges and rectrices are tipped with red in the ordinary way without dilatation of the shaft of the feathers.

Both the Waxwing and Cedar-bird seem to live chiefly on insects in summer, but are greatly addicted to berries during the rest of the year, and will gorge themselves if opportunity allow. Hence they are not pleasant cage-birds, though quickly becoming tame. The erratic habits of the Waxwing are probably due chiefly to the supplies of food it may require, prompted also by the number of mouths to be fed, for there is some reason to think that this varies greatly from one year to another, according to season. The flocks which visit Britain and other countries outside the breeding-range of the species naturally contain a very large proportion of young birds. ${ }^{3}$

1 A fuller account of his discovery, illustrated by Hewitson, is given in The Ibis (1861, pp. 92-106, pl. iv.).

2 The strueture of these appendages has been carefully described by Herr Andersen (Effvers. K. Vet.-Ak. Förhandl. 1859, pp. 219-231, pl. ii.). Their development seems chiefly due to age, though, as Wolley shewed, they are perceptible in the nestlings. Mr. Turner states (Contr. Nat. Hist. Alaska, p. 177) that the Eskimo name of the Waxwing means a "killer of small birds," these appendages being held to be "the clotted blood of its victims"!

3 The systematic position of the genus Ampelis is very doubtful. It can 
WEAVER-BIRD, the name ${ }^{1}$ by which a group of some 250 species is now usually called, from the elaborately interwoven nests that many of them build, some of the structures being of the most marvellous kind. By the older systematists such of these birds as were then known were distributed among the genera Criohus, Loxia, Emberiza and Fringille; and it was Curier who in 1817 first brought together the scattered forms, comprising them in a genus Ploceus. Others were subsequently referred to its

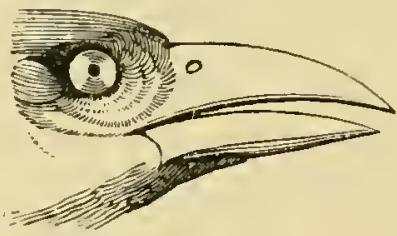

Sycobrotus.

(After Swainson.)

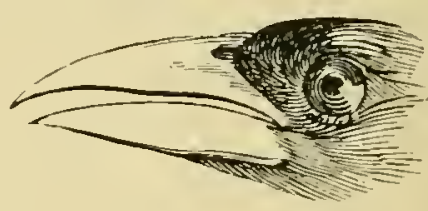

Plocets.

neighbourhood, and especially the genus Viduc (WIDow-BIRD) with its allies, so as to make of them a subfamily Ploceina, which in 1847 was raised by Prof. Cabanis to the rank of a Fanily Ploceidla, equivalent to that of Fringillide (FINCH) in which they had been included, on the ground that the Finches have but nine primary quills in their wing, while the Weaver-birds have ten. Following Sundevall, Dr. Sharpe (C'at. B. Bi. Hus. xiii. pp. 198-511) divides the Ploceida into two subfamilies-Viduina (with 42 genera and

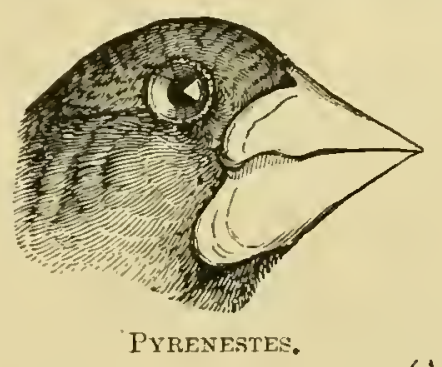

(After Swainson.)

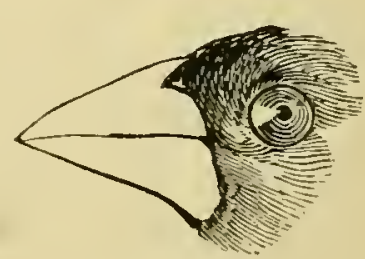

Pyroneldena.

156 species) having the outermost primary rery short, and Ploceine (with 20 genera and 92 species) in which it is large-a proceeding that is confessedly artificial and not to be recommended, since it obscures the very natural group of Viduina proper by associating harlly be said to have any near ally, for neither of the Neotropical and Antillean genera, Ptilogonys and Myiodectes (often erroneonsly spelt Myiculcstes), can as yet be safely declared of kin to it, as has been alleged.

${ }^{1}$ First bestowed in this form apparently by Stephens in 1826 (Gen. Zool. xiv. p. 34); but in 1782 Lathan (Synopsis, i. p. 435) had called the "Troupiale des Sénégal" of Buffon the "Weever Oriolo," from its habit of entwining the wires of the cage in which it was kept with such vegetable fibres as it could get, and hence in 1788 Gmelin named it Oriolus tcxtor. In 1800 Dandin used the term "Tisserin" for several species of the Limnean gemus Loxia, and this was adopted some years later by Cuvier as the equivalent of his Ploceus, as mentioned in the text. 
with them a promiscuous company far better left as it was by Gray and others in a distinct group as Spermestina, or more correctly Estrildinx, composite though this group may be and requiring the separation of its Australian members, Donacilda and Poophila, known as Grass-Finches and certainly not true Vidua, to say nothing of others often included with Estrildinx, but apparently not belonging to them, as Pyrenestes and Euplectes or Pyromelana, which seem closely to approach Ploceus and Symplectes or Sycobrotus.

Where so many forms are concerned, only a few of the most important can now be mentioned. The type of Cuvier's genus is certainly the Loxia philippina of Linnæus, so termed from the islands whence it was received but to which it is not indigenous. But the typical Weaver-bird of Lathain (not that he had the name in that precise form) is the Hyphantornis cucullata or textor of modern writers, an African species, and it is to the Ethiopian Region that by far the greatest number of these birds belong, while in it they seem to attain their maximum of development. They are all small, with, generally speaking, a Sparrow-like build; but in richness of colouring the males of some are very conspicuous-glowing in crimson, scarlet or golden-yellow, set off by jet-black, while the females are usually dull in hue. Some species build nests that are not very remarkable, except in being almost invariably domed-others (such as the Ploceus philippinus just named, or $P$. baya as some call it) fabricate singular structures ${ }^{1}$ of closely and uniformly interwoven tendrils or fine roots, that hang from the bough of a tree often over water, and, starting with a solidly-wrought rope, open out into a globular chamber, and then contract into a perpendicular tube several inches in length, through which the birds effect their exit and entrance. But the most wonderful nests of all, and indeed the most wonderful built by birds, are those of the so-called Sociable Grosbeak, Philhetrorus socius, of Africa. They are composed wholly of grass, and are joined together to the number of 100 or $200-$ indeed 320 are said to have been found in one of these aggregated masses, which usually take the form of a gigantic mushroom, ${ }^{2}$ affording a home and nursery to many pairs of the birds which have been at the trouble of building it. These nests, "however, have been so often described and figured by South-African travellers that there is no need here to dilate longer on their marvels. It may be added that this species of Weaver-bird, known to French writers as the Républicain, is of exceptionally dull plumage.

1 These differ from those built by some of the OrIOLES and other birds, whose nests may be compared to pensile pockets, while those of these Weaver-birds can best be likened to a stocking hung up by the "toe," with the "heel" enlarged to receive the eggs, while access and exit are obtained throngh the "leg."

2 But at a distance they may often be mistaken for a native hut, with its grass-roof. 
The group of Widow-birds, ${ }^{1}$ Viduina, is remarkable for the extraordinary growth of the tail-feathers in the males at the breeding-season. In the largest species, Vidua or Chere mocne, the cock-

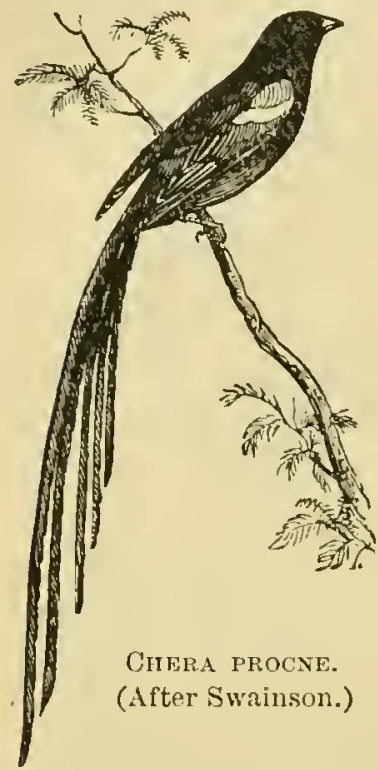
bird, which, with the exception of a scarlet and buff bar on the upper wing-coverts, is wholly black, there is simply a great elongation of the rectrices, and the same obtains in Cotiopresser or Penthetric which is now generically separated; but in $V$. puruclisew the form of the tail is quite unique. The middle pair of feathers have the webs greatly widened, and through the twisting of the shafts their inferior surfaces are vertically opposed. These feathers are comparatively short, and end in a hair-like filament. The next pair are produced to the length of about a foot-the bird not being so big as a Sparrow-and droop gracefully in the form of a sickle. But this is not all: each has attached to its base a hair-like filament of the same length as the feather, and this filament originally adhered to and ran along the margin of the outer web, only becoming detached when the feather is full grown. $^{2}$ In another species, $V$. principalis, the two middle pairs of reetrices are equally elongated, but their webs are convex, and the outer pair contains the inner, so that when the margins of the two pairs are applied a sort of cylinder is formed. ${ }^{3}$ The females of all the Widow-birds differ greatly in appearance from the

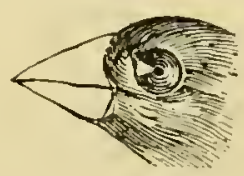

VIDUA PRIXCIPALIS.

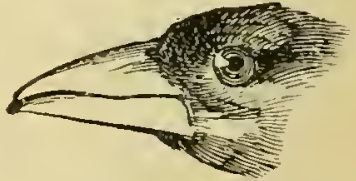

Penthetria ARDENS.

(After Swainson.) males, and are generally clothed in a plumage of mottled brown.

The vast group of small seed-eating forms that make up the true Estritdina comprehend the numerous species so commonly seen in cages, and known as AMADAVATS, CowRy or NuTnIEG-BIRDs, WAXbills, Cutthroats, Amudime fesciate, the JAva Sparrow and

1 It has been ingeniously suggested that this name should he more correctly written Whydah bird-from the place on the West Coast of Africa so named; but Edwards, who in 1745 figured one of the species, states that he was informed that "the Portuguese call this bird the Widow, from its Colour and long Train" (Nat. Hist. Birds, i. p. S6).

2 This curions structure was long ago lescribed by Brisson (Om. iii. p. 123), and again more fully by Strickland (Contr. Orm. 1850, pp. 88 and 149, pl. 59).

3 Both these species seem to have heen first described and figured in 1600 by Aldrovandus (lib. xv. capp. 22, 23) from pictures sent to him by Ferdinando de' Medici, duke of Tuseany. 
many more than can here be named. Some of these genera are common to Africa and India, and some are imputed also to Australia, but the last seems to have several genera peculiar to itself, the true affinity of which requires further investigation. ${ }^{1}$

TVEETWEET, a name in North America for the Spotted SANDPIPER, Actitis maculari.

WEKA, the Maori name, accepted in English, of some flightless New-Zealand RAILS, the first known of which was found, in March 1773 , by Cook's people on his second voyage (i. p. 97 ) to abound on the shore of Dusky Bay, and was called by them "Wood-hen." In 1785 Latham (Gen. Synops. iii. p. 229) published a description of it as the Troglodyte Rail, and it was in 1785 scientifically designated Rullus troglodytes by Gmelin. ${ }^{2}$ In 1830 Wagler (Nat. Syst. Amphib.u.s.w. p. 98) made it the type of a separate genus Ocydromus.

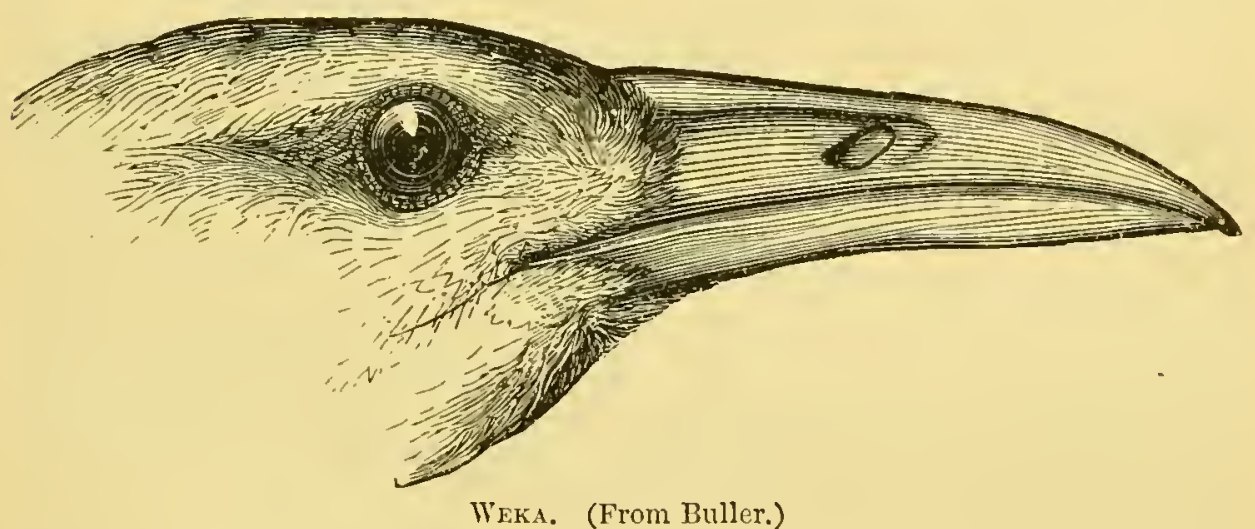

Sir W. Buller (B. N. Zeal. ed. 1, p. 174; ed. 2, ii. p. 113) declares there can be no doubt as to this species being that which, nearly 60 years after, Du Bus (Esq. Om. pl. 11) figured and described as Gallirallus fuscus, ${ }^{3}$ a specific term that has generally been preferred, in the belief that the $R$. troglodytes was identical with the $R$. australis, figured and described in 1784 by Sparrman * (Mus. Carlson. i. no. 14); but the two birds appear to be distinct, both in coloration (though this in each is variable) and habit-the former frequenting the sea-

1 A Monograph of the Weaver-Birds by Mr. Edward Bartlett was begun in 1888, but unfortunately remains unfinished.

2 A name given by J. R. Forster, from whom Latham states that his information was derived. To the shame of English authorities Forster's manuscript wạs not published until 1840 .

${ }^{3}$ In the meanwhile it had received another name, G. brachypterus, from Lafresnaye (Rcv. Zool. 1841, p. 243; Mag. de. Zool. 1842, pl. 24) the type of which has been examined by Dr. Sharpe (Cat. B. Br. Mus. xxiii. p. 67).

4 What Sparman's bird was may yet be open to doubt. His localities are not trustworthy, and his specimen differed, by its yellow legs, from all other known Ocydromi. 
shore (whence one of its names-Kelp-hen) and feeding chiefly on shell-fish and other marine products, while that which is commonly identified with the latter ranges widely through the interior of the South Island of New Zealand-examples from the western side of the Alps being however apparently distinguishable by wanting the barred flanks, and in that respect resembling another form which inhabits the North Island, and is, according to Sir WV. Buller who named it O. greyi, peculiar thereto. ${ }^{1}$ That these three or four forms should be justly considered good species is very probable; but that more species should exist in New Zealand seems unlikely. What was presumably an Ocydromus, and if so was doubtless a distiuct species, inhabited Norfolk Island, when discovered by Cook (ut suprì, ii. p. 148), but it must have been long extinct, and no specimen is known to exist. ${ }^{2}$ Another species, 0 . sylvestris, smaller and lighter in colour than any we now have, was found in 1869 to linger yet in Lord Howe Island (Proc. Zool. Soc. 1869, p. 472, pl. xxxv.), where the existence of such a bird was long ago known, and the remains of a few individuals are preserved in collections. ${ }^{3}$ A remarkable form from . New Caledonia, originally described as Gallirallus lafresnayanus, was referred by Mr. Sclater

${ }^{1}$ It was for some time called 0 . earli, the name under which Dr. Sharpe (tom. cit. p. 66) still has it, but Sir Walter (E. N. Zcal. ed. 2, ii. p. 105) states that the type of that form (Ibis, 1862, p. 238) agrees with some specimens from the Sonth Island, and he recognizes it as a distinct species. He also admits an 0. brachypterus which is certainly not that of Lafresnaye, and if distinct should probably be called $O$. hectori. An extinct species has been indicated by Mr. H. O. Forbes (Tr. N. Z. Inst. 1892, p. 188) from the Chatham Islands.

2 The subject of Sparrman's figure, above mentioned, may possibly have been from this island, the birds of which were distinguished by their bright colouring (cf. Nestor, p. 628).

3 It has lately been referred by Dr. Sharpe, though its affinity is not explained, to the genus Cabalus, the type of which is Rallus modestus, a small species

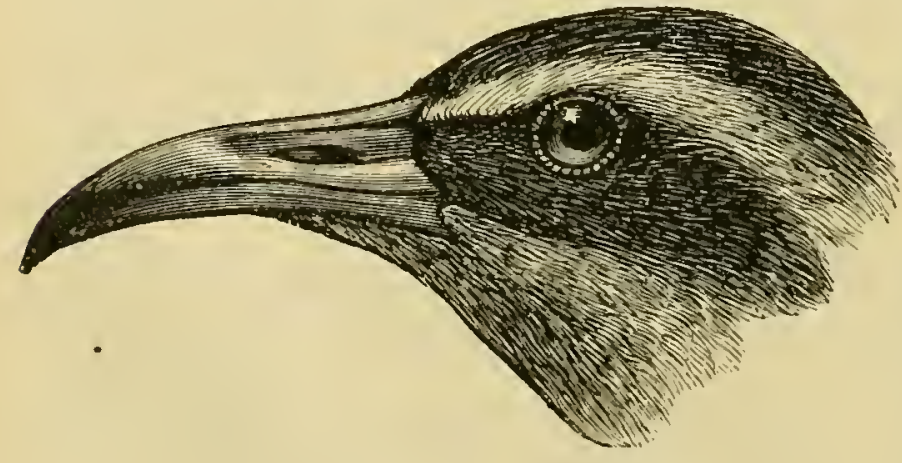

Rallus diefFenbachi. (From Buller.)

(Cat. B. Br. Mus. xxiii. p. 331 , pl. vi.) perliaps still surviving on one of the Chatham Islands, which some ornithologists have refused to acknowledge, holding it to be the young of $R$. diefforbachi (itself also referred occasionally to Ocydromus, but being apparently a modified Hypotanidia), known from the unique specimen in the British Museum; but the judgment of its original describer, Capt. Hutton, is now admitted, and should never have been doubted after lis full account of it (Iois, 1873, pp. 349-352). 
(Proc. Zool. Soc. 1869, p. 431) to Ocydromus, and has certainly some resemblance thereto ( $c f$. Layard, Ibis, 1882, p. 535). Subsequently placed by Gray in Eulabeornis (Brenchley, Cruise of the 'Curaçoa,' pl. xxi.), Dr. Sharpe has more recently proposed for it a distinct genus Tricholimnas. Akin to Ocydromus must have been Diaphorapteryx, a recently extinct form made known by Mr. H. O. Forbes from one of the Chatham Islands, where its bones were found in plenty. $\mathrm{He}$ at first referred it to the Mauritian genus Aphanapteryx (Extermination, p. 217), but subsequently (Nature, xlv. p. 416) separated it therefrom, a course which has been justified by Prof. Milne-Edwards (Ann. Sc. Nat. ser. 8, ii. pp. 117-136, pls. xi.-xv.), and Mr. Andrews (Novit. Zool. 1896, pp. 73-84, pl. iii.). ${ }^{2}$ There is a curious analogy between the two forms, but the latter, which was mentioned by Herbert, and is the Poule rouge of some of the old writers, had a slender head, a long bill, and tall, thin legs, while the head of Diaphorapteryx is large, and its bill and legs shorter and stouter in comparison, so that the appearance of the two birds must have been very unlike.

The chief interest attaching to the Ocydromes is their inability to use in flight the wings with which they are furnished, and hence an extreme probability of the form becoming wholly extinct in a short time. ${ }^{3}$ It is to be hoped that the naturalists of New Zealand will not allow this to happen if any effectual means can be taken to perpetuate it; but, should that fate be inevitable, it at least behoves the present generation to see that every possible piece of information concerning the birds be recorded, and every possible preparation illustrating their structure be made, while yet there is time; for, though much has been written on the subject, it is obvious from one of the latest papers (Trans. N. Z. Inst. x. p. 213) that there is still more to be learned, some of which may throw further light on the affinities of the extinct genus Aptornis (pages 286, 592, note).

WET-MY-FOOT, or -LIPS, names for the QUAIL (page 754), in imitation of its call-note.

WHALE-BIRD, a sailors' name for PETRELS of the genus Prion (pages 34, 742).

WHAUP, formerly Quhaip, Dutch $W u l p$, the common name in Scotland for the Long-billed CURLEW, and there accounted "uncanny" or a bird of ill-omen. ${ }^{4}$

1 This memoir was read to the Zoological Congress at Leyden, Sept. 1895.

2 I wholly concur in the general conclusions reached by this gentleman, based as they are on those of Dr. Gadow (Thier-reich, Vögel, ii. p. 101).

3 Of this inability there are other instances among the Rallidæ (see Moor-HEN, p. 590); but here we have coupled with it the curious fact that in the skeleton the angle which the scapula makes with the coracoid is greater than a right angle, a peculiarity shared only, so far as is known, among the Carinatz by the Dovo.

4 The call of the Whaup brings melancholy associations to many people, who, 
WHEATEAR, as a bird's name perhaps of doubtful meaning, ${ }^{1}$ though Taylor, the "water poet" (ob. 1654), in whose writings it seems first to occur, and Willughby explain it (in the words of Ray, the latter's translator) as given "because [in] the time of wheat harvest they wax very fat." 2

The Wheatear, the Saxicola cenanthe of ornithologists, is one of the enrliest migrants of its kind to return to its home, often reaching England at the end of February and almost always by the middle of March. The cock with his bluish-grey back and light buff breast, set off by black ear coverts, wings and part of the tail, is rendered still more conspicuous by his white rump as he takes short flights in front of those who disturb him, while his sprightly actions and gay song harmonize so well with his delicately-tinted plumage as to render him a welcome object to all who delight in an open country. When alarmed both sexes have a sharp monosyllabic note that sounds like chat; and this has not only entered into some of the local names of this species and of its allies, but has caused all to be spoken of as CHATS. The nest is constantly placed under ground; the bird taking advantage of the hole of some other

if they are imaginative, are apt to ascribe the same feelings to the bird that utters it. Thus we have writers finding in it a resemblance to "the wail of a lost spirit"-that being presumably a sound with which they are acquainted. One anthor terms Curlews "Plaintive creatures who pity themselves on moorlands" -a pretty poetic fancy maybe, but sheer nonsense as every naturalist knows. Given the moorland, the Whaup leads a happy life; without it, he would have good reason to pity himself. The unsuspecting traveller no doubt may be occasionally startled at the sudden and loud cry, especially at night when the bird is invisible, and this species is probably in many instances the cause of the widely-spread belief, if one may so call it, in the mysterious "Seven Whistlers," thongh the Golden Plover, and perlaps other night-flying Limicola on MIGliation (pages 571, 572) may contribute to the consternation of the listener.

1 The supposition that it is an euplemism of an Anglo-Saxon name ( $c f$. Bennett's ed. of White's Nat. Hist. Selb. p. 69, note) must be rejected until it be shewn that such a name ever existed. It is true that "Whittaile" ( $c f$. Dutch Witstaart and French Culblanc) is given by Cotgrave in 1611; but the older names, according to Turner, in 1544, of "Clotburd " (=Clod-bird) and "Smatch" (=Chat) do not point in that direction. "Fallow-chat" is another old name still locally in use, as is "Coney-chuek."

${ }^{2}$ It would seem also from this author to have been originally the local name for the species in Sussex, on the South Downs of which county its capture in a very simple kind of trap has been the oecupation of many generations of shepherds, who thereby have made an excellent trade, since Wheatears in their proper season, from the end of July till towards the end of September, are justly esteemed for the table and fetch a price that for many years has been continually rising owing to the failing supply, which is chiefly due to the bringing under tillage of so much of the sheep-walk, heath, down and other open country that was formerly in a natural condition. 
mimal, the shelter of a clod in a fallow-field, or a recess beneath a rock. A large amount of soft bedding is therein collected, and on it from 5 to $S$ pale blue eggs are laid. The Wheateal has a very wide range throughout the Old World, extending in summel far within the Aretic Circle, from Norway to the Lena and Yana valleys, while it winters in Africa beyond the Equator, and in India. But it also breeds regularly in Greenland and some parts of North America. Its reaching the former and the eastern coast of the latter, as well as the Bermudas, may possibly be explained by the drifting of individuals from Iceland; but far more interesting is the fact of its continued seasonal appearance in Alaska without ever shewing itself in British Columbia or California, and without ever having been observed in Kamchatka, Japan or China, though it is a summer resident in the Tehuktchi peninsula. Hence it would seem as though its annual flights across Bering's Strait must he in commexion with a migratory movement that passes to the north and west of the Stanoroi mountains, for Mr. Nelson's suggestion (C'ruise of the 'Corwen,' pp. 59, 60) of a north-west passage from Boothia Felix, where Ross observed it, is less likely. ${ }^{1}$

More than 60 other species more or less allied to the Wheatear have been described, ${ }^{2}$ but probably so many do not really exist. Some 8 are included in the European fauna; but the majority are inhabitants of Africa. Several of them are birds of the desert; and here it may be remarked that, while most of these exhibit the sand-coloured tints so commonly found in animals of like habitat, a few assume a black plumage, which, as explained by Canon Tristram, is equally protective, since it assimilates them to the deep shadows cast by projecting stones and other inequalities of the surface.

Of genera allied to, and by some writers included in, Saxicola there is only need here to mention Praticola, which comprises among others two well-known British birds, the STONECHAT and Whinchat, $P$. rubicola and $P$. rubetra.

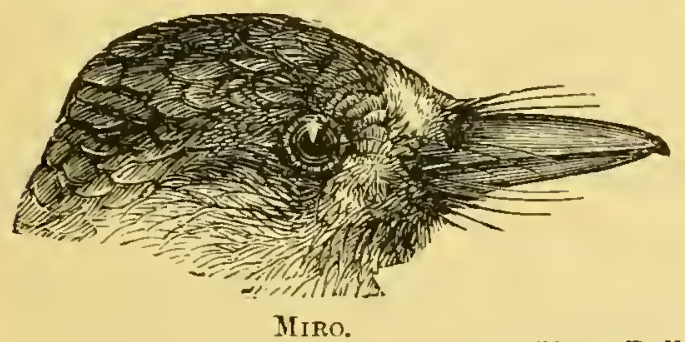

(From Buller.)

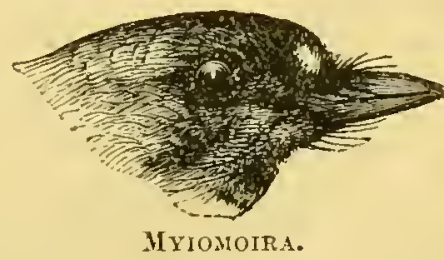

Placed near these forms by most systematists is the group containing the Australian genus Petrece, containing about a dozen

1 See Dr. Stejneger's observations in his "Ornithological Exploration of Kamtsehatka," (Bull. U. S. Nat. Mues. No. 29, p1. 349-351), and those of Prof. Palmén (Vega-Exped. Vetensk. Iakttag. v. pp. 260-262).

2 Cf. Blanford and Dresser (Proc. Zool. Soc. 1874, pp. 213-241). 
species, - the "Robins" of the colonists, some of them remarkable for their bright plumage; and possibly allied to them, as indeed is generally thought, with 5 or 6 species peculiar to New Zealand, are the genera Miro and Myiomoira. But the late Prof. Parker (Trans. Zool. Soc. v. p. 152) saw in the osteology of the first inferior characters which appeared to separate them from their presumed colleagues, and he termed them "Struthious Warblers." Like so many other forms from the same countries, they probably preserve the more generalized structure of earlier and lower types, and should possibly be distinguished as a separate subfamily Petrœcinæ.

All the birds above mentioned form the group Saxicolinx of most authors. Some, however, raise them to the rank of a distinct Family Saxicolida (cf. WARBLER, p. 1019); and Dr. Sharpe (Cat. B. Brit. Mus. iv. pp. 164-199) has placed Petrceca and Praticola in the Family Muscicapidx (FlyCATCHER).

WHEW or WHEWER, common names of the WIGEON from its call-note.

WHIMBREL, "the bird that keeps on uttering a cry imitated by whim" (Skeat, Trans. Philolog. Soc. 1888-90, p. 22), -a name made known to Willughby as being used at the mouth of the Tees, and generally adopted in English for Numenius phaopus (CurLEw, page 128 ).

WHIN-CHAT, the Motacilla, Saxicola or Praticola rubetra of ornithology, a well-known summer-visitant to this country, in many parts of which it is common, and from its call-note named Utick. It has much of the habit of the STONE-CHAT, especially in perching upon whin-bushes, though more affecting enclosed lands and fields reserved for hay; but, unlike that bird, it has no very near ally. As a species it has an extensive range, reaching India and generally wintering in Africa almost under or perhaps beyond the Equator. In spring the cock is very conspicuous with a white streak over the eye and another on the side of the throat, his back being of a mottled brown and his breast of a delicate buff colour.

WHIP-POOR-WILL, so named in North America from its cry. One of the Caprimulgidæ (NightJAR, page 640), Antrostomus vociferus.

WHIP-TOM-KELLY, see under Tou.

WHISKEY-JACK, apparently a ludicrous adaptation of the Cree name "Whiskæ-shawneesh" (Swains. and Richards. F. Bor.-Am. ii. p. 295) of Dysornithia or Perisoreus canadensis, the common JAY (page 469) of Canada, occasionally visiting the United States in winter.

WHITE-EYE, see Zosterops.

WHITEHEAD, the name in New Zealand for a little bird peculiar to the North Island, and now verging on extinction, a 
result to be especially regretted since its affinities are uncletermined. Originally described as a Fringilla, it was next placed in the genus Parus, and for a long while was supposed to belong to ORTHONYX (page 658), a purely Australian form, but is now referred, with its supposed representative in the South Island (YkLLOWHEAD), to a distinct genus Clitonyx, which the late Mr. W. A. Forbes (Proc. Zool. Soc. 1882, pp. 544-546) ascertained to be "perfectly Oscinine." The Whitehead, C.allicapilla, from being one of the commonest is now one of the rarest species in its country,

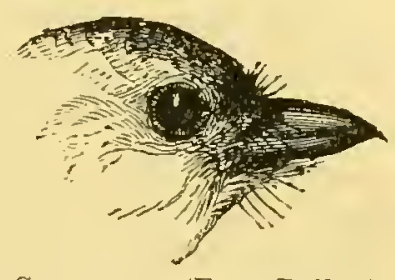

Clitonyx. (From Buller.) and its diminution ending in its inevitable destruction seems due, as Sir TV. Buller (B. N. Zeal. ed. 2, i. p. 55) suggests, to the introduction of exotic birds, which, being morphologically higher and constitutionally stronger, establish themselves at the expense of the lower, weaker and earlier, but far more instructive native forms.

WHITETHROAT, a name commonly given to two species of little birds, one of which, the Motacille sylria of Linnzeus and Sylviu ruf $a^{1}$ or $S$. cinerea of some recent authors, is regarded as the type, not only of the genus Sylvia, but of the so-called family Sylviida (WARBLER).

Very widely spread over Great Britain, in some places common, and by its gesticulations and song rather conspicnous, it is one of those bircls which has gained a familiar nickname, and "Peggy Whitethroat" is the anthropomorphic appellation of schoolboys and milkmaids, though it shares "Nettle-creeper" and other homely names with perhaps more than one congener, while in books it is by way of distinction the Greater Whitethroat. Its song, except by association with the season at which it is uttered, can scarcely be called agreeable, some of its notes being very harsh; but the performer may be seen to be always in earnest, erecting the feathers of his crown, puffing out those of his throat, shaking his wings and making other rapid movements expressive of his feelings. Occasionally he will deliver his song as he flies up in a peculiar fashion, describing small circles in the air, stopping with a jerk, and then returning to the spot whence he arose.

The Lesser Whitethroat, Sylvic curncer, ${ }^{2}$ is both in habits and plumage a much less sightly bird: the predominant reddish-brown of the upper surface, and especially the rufous edging of the wingfeathers, so distinctive of its larger congener, are wanting, and

1 This specific term has been often but inaccurately and absurdly used for a very different bird, the Chiffchaff ( $c f$. [Willow] W tion is to the Whitethroat.

2 This is not the curruce of ancient writers, that being almost certainly the Hedge-SPArrow (page 895), in England the ordinary dupe of the Cuckow. 
the whole plumage above is of a smoky-grey, while the bird in its movements is never obtrusive, and it rather shuns than courts observation, generally keeping among the thickest foliage, whence its rather monotonous song, uttered especially in sultry weather, may be continually heard without a glimpse of the vocalist being presented. The nests of each of these species are very pretty works of art, firmly built of bents or other plant-stalks, and usually lined with horsehair; but the sides and bottom are often so finely woven as to be like open basket-work, and the eggs, splashed, spotted or streaked with olive-brown, are frequently visible from beneath through the interstices of the fabric. This style of nestbuilding seems to be common to all the species of the genus Sylvia, as now restricted, and in many districts has obtained for the builders the name of "Hay-Jack," quite without reference to the kind of bird which puts the nests together, and thus is also applied to the BlackCap, S. atricapilla, and the Garden-Warbler or PetTichaps. All these four birds, as a rule, leave Great Britain at the end of summer to winter in the south. Two other species, one certainly belonging to the same genus, S. orphea, and the other, S. nisoria, a somewhat aberrant form, have occurred tiwo or three times in Great Britain. The rest, numbering perhaps a dozen, must be passed over.

Nearly allied to Sylvia is Melizophilus, which consists of two species, one of them the curious Dartford Warbler of English writers, $M$. undatus or provincialis. This is on many accounts a very interesting bird, for it is one of the few of its family that winter in England, - a fact the more remarkable when it is known to be migratory in most parts of the Continent. Its distribution in England is very local, and chiefly confined to the southern counties, where it has of late years become so scarce that its extermination seems probable. It is a pretty little dark-coloured bird, which here and there may be seen on furze-grown heaths from Kent to Cornwall. In spasmodic gesticulations the cock surpasses the Whitethroat; but these feats are almost confined to the pairing season, and at other times of the year the bird's habits are retiring. For a species with wings so feebly formed it has a wide range, inhabiting nearly all the countries of the Mediterrancan seaboard, from Palestine to the Strait of Gibraltar, and thence along the west coast of Europe to the English Channel; but everywhere else it seems to be very local.

This may be the most convenient place for noticing the small group of Warblers belonging to the well-marked genus Hypolais, which, though in general appearance and certain habits resembling the Phylloscopi ([Yrillow] WREN), would seem usually to have little to do with those birds, and to be rather allied to the Syluiina, if not to the Acrocephaline (WARBLer, page 1020). They have a 
remarkably loud song, and in consequence are highly valued on the continent of Europe, where two species at least spend the summer. One of them, $H$. icterina, has occurred more than once in the British Islands, and theil absence as regular visitors is to be regretted. Among the minor characteristics of this little group is one afforded by their eggs, which are of a deeper or paler brownishpink, spotted with purplish-black. Their nests are beautiful structures, combining warmth with lightness in a way that cannot be fully appreciated by any description.

A great number of other more or less allied forms, interesting as they are in various ways, cannot for want of space be here mentioned.

WHITWALL (spelling various), see WOODPECKER.

WHOOP, a local name for the BuLlFINCH: WHOOPER, the ordinary VVild SwaN.

WHYDAH-BIRD, by mistake for WIDOW-BIRD (see WEAVERBIRD).

WIDE-AWAKE, a seamen's name for certain 'TERNs (page 957) differing a good deal from the rest in habit and appearance-laying but a single egg in their nest and being of a sooty colour above. By some writers they have been placed in a distinct genus, Onychoprion, which Mr. Saunders (Proc. Zool. Soc. 1S76, p. 666 ; Cat. B. Br. Mus. xxv. p. 110) refuses to recognize, especially in view of the connecting link afforded by the Sterna aleutica. They form, however, an easily recognized group $-S$. lunata, hitherto found only in the Pacific Ocean, and $S$. anxstheta and $S$. fuliginosa having a very wide distribution within and near the tropics. These crowd at certain seasons in innumerable multitude to certain suitable islands, where they breed, and the wonderful assemblage at present known as "Wide-awake fair" on the island of Ascension has been more or less fully described from very ancient times. Dampier in his voyage to New Holland in 1699 particularly described and figured the Sooty Tern (Toyages, iii. p. 142), discriminating it from the Noddy, from which it had not before been distinguished.

WIDOW-BIRD, see WEAVER-BIRD (p. 1030).

WIGEON (Fr. Vigeon, Lat. Vipio ${ }^{1}$ ), the MIareca penelope of modern ornithology, one of the most abundant species of Ducks throughout the greater part of Europe and northern Asia, reaching northerm Africa and India in winter. A good many pairs breed in the north of Scotland; but the nurseries of the vast numbers which resort in

1 Just as Pigeor is from Pipio. Other French names, more or less local, are, according to M. Rolland, Vignon, Vingeon, Wagne, Woinge, Wignet, Wuiot, Vioux and Digeon. In some parts of England the small teasing flies, generally called midges, are known as "wigeons." 
autumn to the waters of temperate Europe are in Lapland or further to the eastward. Comparatively few breed in Iceland.

Intermediate in size between the TEAL and the MALLARD, and less showy in plumage than either, the drake Wigeon is a beautiful bird, with the greater part of his bill blue, his forehead cream-colour, his head and neck chestnut, ${ }^{1}$ passing into pinkish-grey below and above into lavender-grey, which last, produced by the transverse undulations of fine black and white lines, extends over the back and upper surface of the wings, except some of the coverts, which are conspicuously white, and shews itself again on the flanks. The wings are further ornamented by a glossy green speculum between two black bars; the tail is pointed and dark; the rest of the lower parts is white. The female has the inconspicuous coloration characteristic of her sex among most of the Freshwater-Ducks. In habits the Wigeon differs not a little from most of the Anatinx. It greatly affects tidal waters during the season of its southern stay, and becomes the object of slaughter to hundreds of gunners on the coasts of Britain and Holland; but, when it resorts to inland localities, as it also does to some extent, it passes much of its time in grazing, especially by day, on the pastures which surround the lakes or moors that it selects.

The Wigeon occurs occasionally on the eastern coast of North America, and frequently, it would seem, in Alaska. But the New World has two allied species of its own. One of them, $M$. americana (a freshly-killed example of which was once found in a London market), inhabiting the northern part of that continent, and in winter reaching Central America and the West Indian islands as far as Trinidad, resembles its Old-World congener wholly in habits and much in appearance. But in it the pale frontlet and the rich chestnut are mingled into, as it were, a compromise of light warm brown, the white wing-coverts are less extensive and nearly all the plumage is subdued in tone. The other species $M$. sibilatrix or chiloensis, inhabits the southern portion of South America and its islands, from Chili on the west to the Falklands on the east, and is easily recognized by its nearly white head, nape glossy with purple and green and other differences.

WILLET, a name in North America originally given, from its cry, to what is known in books as the Semipalmated Sandpiper, Symphemia semipalmata, but by recent writers of that country applied to all the Totaninx (SANDPIPER, page 811 , note).

WILLOCK, one of the many names of the GuILLEMIOT and RAZOR-BILL.

WILLOW-BITER (corruptly Billy-biter), a local name of the Blue Trrarouse (page 967) : WILLOW-IVREN, see WreN.

1 Hence come the additional local names "Bald-pate" and "Red-head." 
WINDHOVER, a common name for the KESTREL (page 477).

WINDLESTRAW, a local name for the WHITETHRoAT.

TVINDPIPE, see TRACHEA; but also, with

TVIND-THRUSH, WINE-THRUSH (Germ. Wein-drossel) and WINNARD, a name of the REDWING (page 777).

IVING, see Carpus, Cubitals, Flight, Humerus, Primaries, Radius, Remiges and Ulina.

WIRE-BIRD, a Plover of the genus Agialitis (KILLDEER, p. 482) peculiar to the island of St. Helena, on the arid plains of which, more or less covered with "wire-grass" (Cynodon dactylon), it is a resident. It is allied to and, until Mr. Harting (Ibis, 1873, pp. 266 269 , pl. ix.) shewed its distinctness, was confounded with $A E$. pecuaria, a species widely distributed in Africa. A. sancta-helenæ is however the larger of the two, and like most birds peculiar to oceanic islands has broader and comparatively shorter wings.

WITTE KRAAI (White Crow) and WITTE OOGJE (Whiteeye), Dutch names adopted by colonists in South Africa for NEoPHRON percnopterus (page 621) and ZOSTEROPS capensis respectively.

WOBBLE, a bird so called by some of the early voyagers to North America, and supposed to be the GARE-FowL, but almost as likely to refer to any other species of Alcidx which flutter their wings. (Cf. Skeat, Etymol. Dict. sub wabble, another form of the word.)

WONGA-WONGA, a large and fine PIGEON, Leucosarcia picata, inhabiting the eastern part of Australia, which from its esculent qualities would apparently be well worthy of domestication, if that end could be attained, which is not improbable seeing that the species will breed in confinement. It is said to feed mostly on the ground on the seeds and fruit-stones that have fallen from the trees among which it lives. Of a deep slaty-grey above, with a white gorget bordered above and below by deep black, black triangular spots on its white flanks, and buff lower tail coverts, to say nothing of its pink bill and legs, it is rather a noble-looking bird.

WOOD-CHAT, a name for which no earlier use can be traced than to Ray's posthumous work (Synops. Meth. Av. p. 19) published in 1713 , when it is applied to a species of SHRIKE (p. 843), Lanius auriculatus or rufus, which has since borne it, though how this bird, being only a chance visitor to Britain, came to earn a distinctive English name, and one so unmeaning, is not easily understood. ${ }^{1}$

1 Wald-Katze, is one of its German names. Ray may have rendered this literally "Wood-Cat," and his Editor (Derham), or the printer, not knowing what was intended, may have turned the last syllable into Chat. 
WOODCOCK (A.-S. $W u d e-c o c c, W u d u-c o c$ and $W u d u-s n i t e$ ), a bird as much extolled for the table, on account of its flavour, as by the sportsman, who, from its relative scarcity in regard to other kinds of winged game, ${ }^{1}$ the uncertainty of its occurrence, as well as the suddenness of its appearance and the irregularity of its flight, thinks himself lucky when he has laid one low. Yet, under favourable conditions, large bags of Woodcocks are made in many parts of Great Britain, and still larger in Ireland, thongh the numbers are trifling compared with those that have fallen to the gun in various parts of the European Continent, and especially in Albania and Epirus. In England of old time Woodcocks were taken in nets and springes, and, though the former method of capture seems to have been disused for many years, the latter was practised in some places until nearly the middle of the present century ( $c f$. Knox, Game-birds and Wild Fowl, pp. 148-151) or even later.

The Woodcock is the Scolopax rusticula ${ }^{2}$ of ornithology, and is well enough known to need no minute description. Its long bill, short legs and large eyes - suggestive of its nocturnal or crepuscular habits-have often been the subject of remark, while its mottled plumage of black, chestnut- and umber-brown, ashy-grey, buff and shining white-the last being confined to the tip of the lower side of the tail-quills, but the rest intermixed for the most part in beautiful combination-could not be briefly described. Setting aside the many extreme aberrations from the normal colouring which examples of this species occasionally present (and some of them are extremely curious, not to say beautiful), there is much variation observable in the plumage of individuals, in some of which the richer tints prevail while others exhibit a greyer coloration. ${ }^{3}$

1 In the legal sense of the word, however, Woodcocks are not "game," though Acts of Parliament require a "game liccnce" from those who would shoot them.

2 By Linnæus, and many others, misspelt rusticola: the correct form of Pliny and the older writers seems to have been first restored in 1816 by Oken (Zoologie, ii. p. 589).

3 This variation is often, but not always, accompanied by a variation in size or at least in weight, which last is very great, though it seems to have been exaggerated by some writers. A friend who has had much experience told me that the heaviest bird he ever knew weighed $16 \frac{1}{4} \mathrm{oz}$, and the lightest $9 \mathrm{oz}$. and a fraction. The paler birds are generally the larger, but the difference, whether in bulk or tint, cannot be attributed to age, sex, season or, so far as can be ascertained, to locality. It is, notwithstanding, a very common belief among sportsmen that there are two "species" of Woodcock, and many persons of experience will have it that, beside the differences just named, the "little red Woodcock" invariably flies more sharply than the other. However, a sluggish behaviour is not really associated with colour, though it may possibly be correlated with weight - for it is quite conceivable that a fat bird will rise more slowly, when flushed, than one which is in poor condition. It may suffice here to say that ornithologists, some of whom have taken a vast amount of tromble about the matter, are 
Though there are probably few if any counties in the United Kingdom in which the Woodcock does not almost yearly breed, especially since a "close time" has been established by the legislature, there can be no doubt that by far the greater number of those shot in the British Islands have come from abroad,-mostly, it is presumed, from Scandinavia. These arrive on the east coast in autumn-generally about the middle of October-often in an exhausted and impoverished state. Most of them seem to cross the sea by night, and at that season it is a brutal practice for men to go out in the morning and kill the helpless and almost starving wanderers, who are often found seeking refuge in any shelter that may present itself. If unmolested, however, they are soon rested, pass inland, and, as would appear, in a short time recover their condition. Their future destination seems to be greatly influenced by the state of the weather. If cold or frost stop their supply of food on the eastern side of Great Britain, they press onward and, letting alone Ireland into which the immigrant stream is pretty constant, often crowd into the extreme south-west, as Devonshire and Cornwall, and to the Isles of Scilly, while not a few betake themselves to the unknown ocean, finding there doubtless a watery grave, though instances are on record of examples having successfully crossed the Atlantic and reaching Newfoundland, New Jersey and Virginia. To return, however, to the Woodcocks which breed in Britain, whose habits have been much more frequently observed since the folly and cruelty of killing them in spring has been recognized, and it may be hoped abandoned. Pairing takes place very early in February and the eggs are laid often before the middle of March. These are four in number, of a yellowish cream-colour blotched and spotted with reddish-brown, and seldom take the pyriform shape so common among those of Limicoline birds. The nest-always made on the ground amid trees or underwood, and usually near water or at least in a damp locality - is at first little more than a slight hollow in the soil, but as incubation proceeds dead leaves are collected around its margin until a considerable mass is accumulated. During this season the male Woodcock performs at twilight flights of a remarkable kind (SONG, p. 893), repeating evening after evening (and it is believed at dawn also)

practically unanimous in declaring against the existence of two "species" or" even "races," and moreover in agreeing that the sex of the bird cannot be determined from its plumage, though there are a few who believe that the young of the year can be discriminated from the adults by having the outer web of the outer primary marked with angular notches of a light colour, while the old birds have no trace of this "vandyke" ormament. Careful dissections, weighings and measurings seem to shew that the male varies most in size; on an average he is slightly heavier than the female, yet some of the lightest birds have proved to be cocks. Cf. Hoffmann's Die Waldschnepfe, ed. 2, p. 35 (Stuttgart: 18s7). 
precisely the same course, generally describing a triangle, the sides of which may be a quarter of a mile long or more. On these occasions the bird's appearance on the wing is quite unlike that which it presents when hurriedly flying after being flushed, and though its speed is great the beats of the wings are steady and slow. At intervals an extraordinary sound is produced, whether from the throat of the bird, as is commonly averred, or from the plumage is uncertain. To the present writer the sound seems to defy description, though some hearers have tried to syllable it. This characteristic flight is in some parts of England called "roading," and the track talien by the bird a "cock-road." 1 In England in former times advantage was taken of this habit to catch the simple performer in nets called "cock-shutts," which were hung between trees across the open glades or rides of a wood, ${ }^{2}$ and in many parts of the Continent it still is, or was till very lately, the disgraceful habit of persons calling themselves sportsmen to lie in wait and shoot the bird as he indulges in his measured love-flight. A still more interesting matter in relation to the breeding of Woodcocks is the fact, asserted by several ancient writers, but for long doubted if not disbelieved, and yet finally established on good evidence, that the old birds transport their newly-hatched offspring, presumably to places where food is more accessible. The young are clasped between the thighs of the parent, whose legs hang down during the operation, while the bill is to some extent, possibly only at starting, brought into operation to assist in adjusting the load if not in bearing it through the air. ${ }^{3}$

I The etymology and consequently the correct spelling of these expressions seem to be very uncertain. Some would derive the word from the French rôder, to rove or wander, but others connect it with the Scandinavian rode, an open space in a wood (see Notes and Queries, ser. 5, ix. p. 214, and ser. 6, viii. pp. 523, 524). Looking to the regular rontine followed by the bird, the natural supposition would be that it is simply an application of the English word road; but of course natural suppositions are often wrong, and they always require the support of evidence before acceptance.

2 There is an interesting passage, to which Lord Lilford kindly drew my attention, in George Owen's Description of Penbrokshire, written in 1602 and printed in 1892 as No. 1 of the "Cymmrodorion Record Series" (pp. 129, 130), shewing the marvellous "plentie" of Woodcocks, from Michaelmas to Christmas, in that county, where they were taken "in cock shoote tyme (as yt is tearmed) wch is the twylight," when " $y$ t ys no strange thinge to take a hundred or sixe score in one woodd in xxiiijor houres," and another MS. speaks of one wood having 13 cock-shots. In explanation of this abundance the great extent of forest which then prevailed in England may be borne in mind. One can hardly doubt that very many more Woodcocks were then bred here than we have any notion of at present, while the birds would, as they now do, make in antumn for the western part of the island. It is expressiy stated by Owen that they were not reared in Wales, for he says that the species is "not our countryeman borne."

${ }^{3} C f$. Harting, Zoologist, 1879 , pp. 433-440, and MIr. Wolf's excellent illustra- 
The Woodcock inhabits suitable localities across the northern part of the Old World, from Ireland to Japan, migrating southward towards autumn. As a species it is said to be resident in the Azores and other Atlantic Islands; but it is not known to penetrate very far into Africa during the winter, thougl in many parts of India it is abundant during the cold weather, and reaches even Ceylon and Tenasserim. The popular belief that Woodcocks live "by suction" is perhaps hardly yet exploded; but those who have observed them in confinement know that they have an almost insatiable appetite for earthworms, which the birds seek by probing soft ground with their highly sensitive and flexible bill. ${ }^{1}$ This fact seems to have been first placed on record by Bowles, ${ }^{2}$ who noticed it in the royal aviary at San Ildefonso in Spain, and it has been corroborated by other observers, and especially by Montagu, who discovered that bread and milk made an excellent substitute for their ordinary food.

The easteru part of North America possesses a Woodcock, much smaller than though generally (and especially in habits) similar to that of the Old continent. It is the Scolopax minor of most authors; but, chiefly on account of its having the outer three primaries remarkably attenuated, it has been placed in a separate genus, Philohela. In Java is found a distinct and curiously-coloured species, described and figured many years ago by Horsfield (Trans. Linn. Soc. xiii. p. 191, and Zool. Res. pl.) as S. saturata. To this Mr. Seebohm (Geogr. Distr. Charadr. p. 506, pl.) referred the S. rosenbergi of Schlegel (Nederl. Tijds. Dierk. iv. p. 54) from New Guinea; but, as the culpable destruction of the type-specimen of the former (during its transfer from the old museum of the East India Company to the British Museum) has made a comparison of the two impossible, the identification can scarcely be said to be free from doubt. Another species is S. rochusseni from the Moluccas, but this last, though resembling the other Woodcocks in most of the characters which distinguish them from the SNIPES, has like the latter the lower part of the tibia bare of feathers.

WOOD-DUCK, AEx sponsa (page 171): WOOD-HEN (see WeKA, page 1031): WOODLARK (pages 509, 510).

WOODPECKER, a bird that pecks or picks holes in wood, and from this habit is commonly reputed to have its name; but since it is in some parts of England also known as "Woodspeight"

tion. Sir R. Payne-Gallwey, in the 'Badminton Library' (Shooting, ii. p. 118, note), states that he himself has witnessed the performance.

1 The pair of muscles said by Loche (Expl. Scient. de l'Algérie, ii. p. 293) to exist in the maxilla, and presumably to direct the movement of the bill, do not seem to have as yet been precisely described.

2 Introduccion a la Historia Natural y a la Geografia fisica de España, pp. 454, 455 (Madrid : 1775). 
(erroneously written "Woodspite") - the latter syllable being cognate with the German Specht and the French Epeiche, to say nothing possibly of the Latin Picus-the vulgar explanation seems open to doubt. ${ }^{1}$ More than 300 species of Woodpecker have been described, and they have been very variously grouped by systematists; but all admit that they form a very natural Family Picidx. Huxley (Proc. Zool. Soc. 1867, p. 467) separated the Woodpeckers still more under the name of Celeomorphx, and Prof. Parker (Trans. R. Microsc. Soc. 1872, p. 219) raised them still higher as Saurognatha. ${ }^{2}$ They are generally of bright particoloured plumage, in which black, white, brown, olive, green, yellow, orange or scarlet - the last commonly visible on some part of the head-mingled in varying proportions, and most often strongly contrasted with one another, appear; while the less conspicuous markings take the form of bars, spangles, tear-drops, arrow-heads or scales. Woodpeckers inhabit most parts of the world, with the exception of Madagascar and the Australian Region, save Celebes and Flores; but no member of the group is recorded to have occurred in Egypt.

Of the three British species, the Green Woodpecker, Gecinus viridis, though almost unknown in Scotland or Ireland, is the commonest, frequenting wooded districts, and more often heard than seen, its laughing cry (whence the name "Yaffl " or "Yaffle," by which it is in many parts known) and undulating flight afford equally good means of recognition, even when it is not near enough for its colours to be discerned. About the size of a Jay, its scarlet crown and bright yellow rump, added to its prevailing grass-green plumage, make it a sightly bird, and hence it often suffers at the hands of those who wish to keep its stuffed skin as an ornament. Beside the scarlet crown, the cock bird has a pateh of the same colour running backward from the base of the lower mandible, a patch that in the hen is black. ${ }^{3}$ Woodpeckers in general are very

1 The number of English names, ancient and modern, by which these birds are known is very great, and even a bare list of them conld not be here given. The Anglo-Saxon was Higera or Higere, and to this may plansibly be traced "Hickwall," nowadays used in some parts of the country, and the older "Hickway," corrnpted first into "Highhaw," and, after its original meaning was lost, into "Hewhole," which in North America has been still further corrupted into "Highhole" and more recently into "High-holder." Another set of names includes "Whetile" and "Woodwale," which, different as they İook, have a common derivation perceptible in the intermediate form "Witwale." The Anglo-Saxon Wodake (=Woodhack) is another name apparently identical in meaning with that commonly applied to Woodpecker ( $c f$. Yarrell, Br. B. ed. 4, ii. pp. 461-463).

2 Cf. Shufelit, Proc. Zool. Soc. 1891, pp. 122-129.

:A patch of conspicuous colour, generally red, on this part is characteristic of very many Woodpeckers, and careless writers often call it "mystacial," or some more barbarously "moustachial." Seeing that moustaches spring from above the mouth, and have nothing to do with the lower jaw, the term is misleading. 
shy birds, and to observe the habits of the species is not easy. Its ways, however, are well worth watching, since the ease with which it mounts, almost always spirally, the vertical trunks and oblique arms of trees as it searches the interstices of the bark for its food, flying off when it reaches the smaller or upper branches-either to return to the base of the same tree and renew its course on a fresh line, or to begin upon another tree near by-and the care it shews in its close examination, will repay a patient observer. The nest almost always consists of a hole, chiselled by the bird's strong beak, impelled by very powerful muscles, in the upright trunk or arm of a tree, the opening being quite circular, and continued as a horizontal passage that reaches to the core, whence it is pierced downward for nearly a foot. There a chamber is hollowed out in which the eggs, often to the number of six, white, translucent and glossy, are laid with no bedding but a few chips that may have not been thrown out. The young are not only hatched entirely naked, but seem to become fledged without any of the downy growth common to most birds. Their first plumage is dull in colour, and much marked beneath with bars, crescents and arrowheads.

Of generally similar habits are the two other Woodpeckers which inhabit Britain - the Pied or Greater Spotted, and the Barred or Lesser Spotted Woodpecker-Dendrocopus major and D. minor-each of great beanty, from the contrasted white, blue-black and scarlet that enter into its plumage. Both of these birds have an extraordinary habit of causing by quickly-repeated blows of their beak on a branch, or even on a small bough, a vibrating noise, louder than that of a watchman's rattle, and enough to excite the attention of the most incurious. Though the Pied Woodpecker is a resident in Britain, its numbers receive a considerable accession nearly every autumn.

The three species just mentioned are the only Woodpeckers that inhabit Britain, though several others are mistakenly recorded as occurring in the country-and especially the Great Black Woodpecker, the Picus martius of Linnæus, which must be regarded as the type of that genus. ${ }^{2}$ This fine species considerably exceeds

1 It often happens that, just as the Woodpecker's labours are over, a pair of STARLivgs will take possession of the newly-bored hole, and, by conveying into it some nesting-furniture, render it unfit for the rightful tenants, who thereby suffer ejectment, and have to begin all their trouble again. It lias been stated of this and other Woodpeckers that the chips made in cutting the hole are carefully removed by the birds to guard against their leading to the discovery of the nest. I have had ample opportunity of observing the contrary as regards this species and, to some extent, the Pied Woodpecker next to be mentioned. Indeed there is no surer way of finding a nest of the Green Woodpecker than by looking on the ground in the presumed locality, for the trce which holds the nest is always recognizable by the chips scattered at its foot.

${ }^{2}$ The expression Picus martius was by old writers used in a very general 
the Green Woodpecker in size, and except for its red cap is wholly black. It is chiefly an inhabitant of the fir forests of the Old World, from Lapland to Galicia, and across Siberia to Japan. ${ }^{1}$ In North America this species is replaced by $P$. pileatus, there generally known as the Logcock, an equally fine species, but variegated with white;

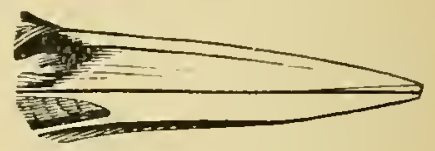

Picus. (After Swainson.) and further to the southward occur two that are finer still, $P$. or Campephilus mincipalis, the Ivory-BiLL ${ }^{2}$ (p. 460), and P. imperialis. The Picina indeed flourish in the New World, nearly one-half of the described species being American, but ont of the large number that inhabit Canada and the United States there is here room to mention only one at any length.

This is the Californian Woodpecker, Melanerpes, formicirorus, which has been said to dis-

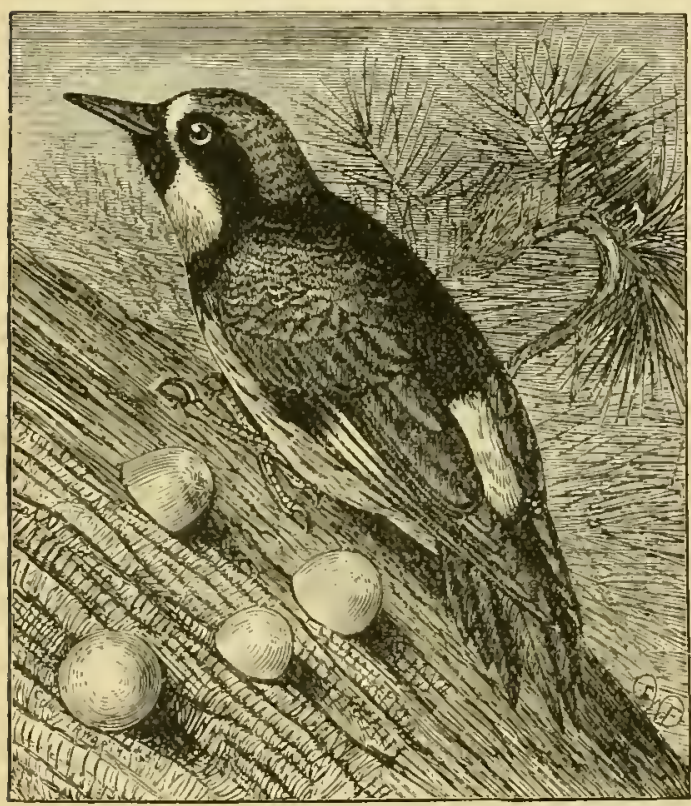

CALIFORNIAN WOODPECKER (Melanerpos formicivorus). play an amount of providence beyond almost any other bird in the number of acorns which it collects and, as shewn in the accompanying figure, fixes tightly in holes which it purposely makes in the bark of trees, and thus "a large pine forty or fifty feet high will present the appearance of being closely studded with brass nails, the heads only being visible." An extraordinary thing is that this is not done to furnish food in winter, for the species migrates, and after journeying a thousand miles or more only returns in spring to the forests where its supplies are laid up. It has been asserted that the acorns thus stored are always those which contain a maggot, and, being fitted into the sockets prepared for them cup-end foremost, the enclosed

sense for all birds that climbed trees, not only Woodpeckers, but even the Nutiatch and Tree-creeper. The adjective martins loses all its significance if it be removed from Picus, as some even respectable writers have separated it.

1 The persistency with which many writers on British birds have for years included this species among them is a marvellous instance of the durability of error, for not a case of its asserted occurrence in this conntry is on record that will bear investigation, and the origin of the mistake has been more than once shewn.

2 On the threatened extinction of this species, of. Hasbrouck, Auk, 1891, 1). $174-186$. 
insects are ruable to escape, as they otherwise would, and are thus ready for consumption by the birds on their return from the south. But this statement las again been contradicted, and moreover it is alleged these Woodpeckers follow their instinct so blindly that "they do not distinguish between an acorn and a pebble," so that they "fill up the holes they have drilled with so much labor, not only with acorns lut occasionally with stones" (cf. Baird, Brewer and Ridgway, N. Am. B. ii. pp. 569-571). Another remarkable North-American form is the genus Colaptes, of which enough has been said above (FLICKkR, pages 258-260). ${ }^{1}$

The Picida have offered a fruitful ground for taxonomical speculation; but three subfamilies are admitted by all modern systematists - the Toodpeckers proper, Picina; the Piculets, Picumnine (page 720) and the WRrnecks. The most recent examination of the Family is that by the late Mr. Hargitt (Cot. B. Br. Mus. xviii.), who admitted 45 genera and 343 species or subspecies

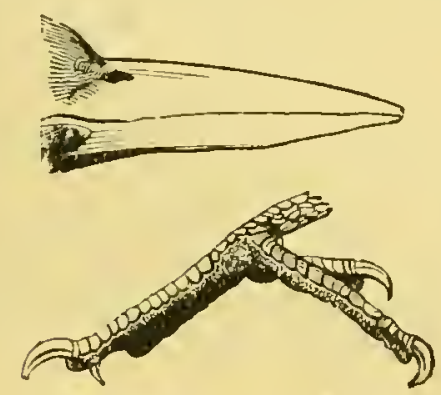

Brel and Foot of Celeus.

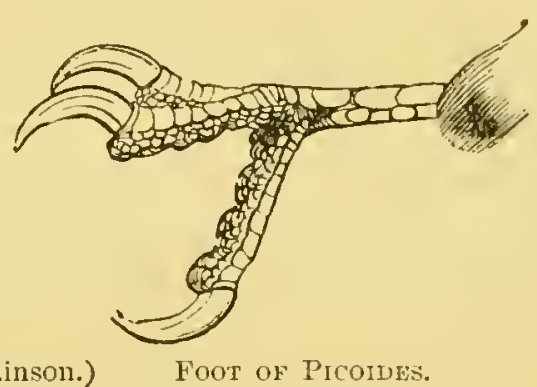

of the first group. ${ }^{2}$ Having deroted himself for many years to the study of the Picida, and laving the largest collection of them in the world to work upon, his results are doubtless more correct than those of any of his predecessors, ${ }^{3}$ but it seems obvious that until the aid of the anatomist is invoked no satisfactory arrangement can be supplied, and it is not certain that even then will the desired cud be reached, for Macgillivray, who furnished Audubon with elaborate descriptions of parts of the structure of several North-American forms, found considerable differences to exist between species which can hardly be but nearly allied. ${ }^{4}$

1 When more is known it will very likely be found that a state of things somewhat similar to that of Colaptes exists in the Paliearetie area in regard to the varions local races of, or "speeies" allied to, Dendrocopus major and D. mizor respectively.

2 That some Woodpeckers, as in the well-known genus Picoides, have only three toes is as little significant as is the same fact in certain KiNGFisHers (p. 488).

3 Malherbe, Monographie des Picidées, 4 vols. folio, Metz: 1859-62 : Cabanis, Musenm Heincanum, iv. Heft 2; Sundevall, Conspectus Avium Picinarum, Stockholm: 1866.

4 Some of the most striking of these differences often lie in the form and development of the hyoid bones, and of the museles which work the extensile 
WOOD-PIE, WOOD-SPEIGHT and WOODWALL (see WoODPECKER, page 1045); IVOOD-PIGEON (see Ring-Dove, page 162).

WOOD-SWALLOW, the name in Australia for birds of the genus Artamus, the systematic position and true affinities of which must be regarded as undetermined. Some writers place it in a Family of its own, Artumida, others refer it as a subfamily Artamina to Laniida (SHrIKE), while again some see in it a relationship to the OrIOLES, and others to the Starlings. The species of Artamus, and 17 are recognized by Dr. Sharpe (Cat. B. Br. xvii. pp. 2-21), range from India through most of the intervening countries and islands to Australia, and have many of the habits and to some extent the appearance of Swallows (not that there seems to be any affinity between the groups), passing much of their time on the wing, and taking insects as they fly. 'Two species, $A$. fuscus and A. leucorhynchus or lencogaster occur in India, the former reaching to the Philippines and Hainan, the latter from the Andamans to Queensland, and eight others are found in Australia, while one is peculiar to the Fijis. They are plain-looking birds, mostly of a slate-colour with more or less white beneath. Some forms from Madagascar, as Artamia, Oriolia and others, as well as the curious Pseudochelidon from Westem Africa, have been referred to the group, but it may be questioned whether they have anything to do with it. By AngloIndian ornithologists these birds are generally called SwallowShrikes.

\section{WRANNOCK, WRANNY, Orcadian and Cornish, for the}

WREN (A.-S. Wrænna and Wrenne, Icel. Rindill), the inquisitive and familiar little brown bird-with its short tail, cocked on highthat braves the winter of the British Islands and even that of the European continent, and, except in the hardest of frosts, will daily sing its spirit-stirring strain. ${ }^{1}$ It is the Motacilla or Sylvia troglo-

tongue. For a long while the subject was not pursued by any other investigator, but lately an excellent though too brief treatise on the subject by Mr. Lueas has been printed by the Agricultural Department of the Government of the United States, together with a valnable preliminary Report by Mr. Beal on the food of Woodpeckers (Washington: 1895), the result of whose investigations is much against the popular view of the alleged mischief done by these birds. It may be montioned that some limited researches on the pterylosis, conducted by Kessler (Bull. Soc. Nat. IFuscou, xvi. p. 285), in addition to those of Nitzsch, indicate that as being also a promising line of enquiry, though one that has scarcely been attempted by other workers.

1 The interest taken in this bird throughout all European comntries is scarcely excceded by that taken in any other, and, though in Britain comparatively few vernacnlar names have been applied to it, two of them- "Jenny" or "KittyWren" - are terms of endearment. M. Rolland records no fewer than 139 loeal names for it in France ; and Italy, Germany and other lands are only less prolific. Jany of these carry on the old belief that the Wren was the King 
dytes of the earlier systematists, and the Troglodytes parvulus, europaus or vulgaris of most later writers. ${ }^{1}$ Here it hardly needs description, and its domed nest, apparently so needlessly large for the size of the bird, is a well-known object, for it is built with uncommon care, and often (though certainly not always) in such a fashion as to assimilate its exterior to its surroundings, and so to escape observation. Very curious, too, is the equally unaccountable fact, that near any occupied nest may generally be found another nest, or more than one, of imperfect constiuction. The widespread belief concerning these unfinished fabrics is implied by their common name of "cocks' nests," but evidence to that effect is not forthcoming. The breeding-habits of the Wren were most closely studied and accurately reported by $\mathrm{Mr}$. Weir to Macgillivray (Brit. Birds, iii. pp. 23-30) in a way that leads every ornithologist to wish that the same care might be bestowed on other kinds of birds.

The range of the Wren in Europe ${ }^{2}$ is very extensive, though it secms to stop short of the Arctic Circle; but it occurs in Algeria, Madeira and, according to Bolle, in the Canaries. It also inhabits Palestine. Further to the eastward its limits are difficult to trace, because they inosculate with those of a considerable number of local races or species. As might be expected, the form inhabiting Japan, T. fumigatus, seems to be justifiably deemed a species. In North America, 1'. alascensis occurs in the extreme

of Birds, a belief connected with the fable that on one occasion the fowls of the air in general assembly resolved to choose for their leader that one of them which should mount highest. This the Eagle seemed to do, and all were ready to accept his rule, when a lond burst of song was heard, and perched upon lim was seen the exultant Wren, which unseen and unfelt had been borne aloft by the giant. The curious association of this bird with the Feast of the Three Kings, on which day in South Wales, or, in Ireland and in the sonth of France, on or about Christmas Day, it was enstomary for men and boys to "hunt the Wren," addressing it in a song as "the King of Birds," is very remarkable, and has never yet been explained ( $c f$. Yarrell, $B r . B$. ed. 4, i. pp. 465, 466).

1 A few, who ignore not only common sense but also the accepted rules of scientific nomenclature, by a mistaken vicw of Vieillot's intention in establishing the genus Troglodytes, reserve that term for some American specieswhich can hardly be generically separated from the European form,-and have attempted to fix on the latter the generic term Anorthura, which is its strict equivalent, and was proposed by Rennie on grounds that are inadmissible.

2 Some interest was excited by the discovery, announced by Mr. Seebolim (Zool. 1884, p. 333), that the Wren, for nearly 200 years known to inhabit St. Kilda, differed in hue from that of the other British Islands and of the continent of Europe, and he described it as a clistinct species, T. Tirtensis. It had for more than 20 years been known that the Wren of the Færoes and Iceland, T. borealis (Fischer, Journ. für Orn. 1861, p. 11, pl. i.), deserved separation from the ordinary $T$. parvulus, by bcing larger, and especially by having larger and stouter feet. 
north-west, and is replaced further to the southward by $T$. pacificus. Eastward of the Rocky Mountains, the form is $T$. hyemalis-the well-known Winter-Wren of Canada and the United States. The number of species inhabiting North America is, however, very considerable, though authorities are by no means agreed as to how many should be reckoned valid, and they have been segregated into six or seven genera. Here the House-Wren, $T$. domesticus or aedon, can alone be mentioned. It is a very common summer-visitant to most parts of the Eastern States, and where it occurs is of a very familiar disposition, entering into the closest relations with those that cultivate its acquaintance. It is represented in the West by $T$. parkmanni.

The Troglodytidx, regarded as a distinct Family, predominate in the New World (no fewer than 60 species being enumerated in the Nomenclator of Messrs. Sclater and Salvin as belonging to the Neotropical Region), and seem to have the Certhiidx (TREE-CREEPER, page 986) for their nearest allies. To place them among the Timeliidx, as has been done (Cat. B. Br. Mus. vi. pp. 1 et seqq.) is, as already observed (Timelia, page 963), preposteronsly unfitting, and to suppose them related to the Water-Ousel (page 688) is absurd.

The Troglodytidx, however, by no means contain all the birds to which the name "Wren" is applied. Several of the Sylviidæ (WTARBLFR) bear it, especially the beautiful little Golden-crested Wren (KINGLET) and the group commonly known in Britain as "Willow-Wrens"-forming the genus Phylloscopus. Three of these are habitual summer-visitants, which differ much more in their manners than in their look. The largest, usually called the WoodWren, $P$. sibilatrix, is more abundant in the north than in the south of England, and chiefly frequents woods of oak or beech. It has a loud and very peculiar song, like the word twe $\bar{e}$, sounded very long, and repeated several times in succession-at first slowly, but afterwards more quickly, and near the end accompanied by a peculiar quivering of the wings, while at uncertain intervals comes another note, which has been syllabled as chea, uttered about three times in succession. The Willow-Wren proper, $P$. trochilus, is in many parts of Great Britain the commonest summer-bird, and is the most generally dispersed. In spring its joyous burst of song is repeated time after time, until all around thrills with the loud and merry chorus, and yet never tires the ear. The restless but graceful activity of the bird, as it flits from twig to twig, adds to the charm of its appearance, which Hewitson so well appreciated.1 The third species, $P$. collybita or minor (frequently but most wrongly called Sylvia rufa or $P$. rufus), commonly known as the ChIFfCHAFF, from the peculiarity of its constantly repeated twonoted cry, is very numerous in the southern and western part of

1 It seems to be the "Green Linnet" of Wordsworth's poem. 
England, but seems to be scarcer northward. These three species make their nest upon or very close to the ground, and the building is always domed. Hence they are commonly called "OvenBIRDS" (page 669), and occasionally, from the grass used in their stiucture, "Hay-jacks," a name common to the WHITETHRoAT (page 1037) and its allies.

WRYBILL, Anarhynchus frontalis, one of the most singular birds known, peculiar to New Zealand and, as Mr. Harting, in an admirable account of its history (Ibis, 1869, pp. 304310 , pl. viii.), shewed, allied to the genus Agialitis (KILLDEER, page 182). It has its English name from its bill being congenitally (Proc. Zool. Soc. 1870, p. 674) bent in the middle and diverted to the right side - a formation supposed to give the bird greater facility in sceking its food, ehiefly arthropods that lurk under stones, round which it may be seen running from left to right. An excellent account of its habits as observed by the late Mr. Potts was given by Sir W. Buller (B. N. Zeal. pp. 217-219), who also asserts that the black pectoral band worn by the bird is "generally widest on the left side." Be that as it may, it does not detract from the wonderful nature of this asymmetry of the bill, which is comparable indeed with that found in so large a number of Cetaceans among mammals, but with nothing known among

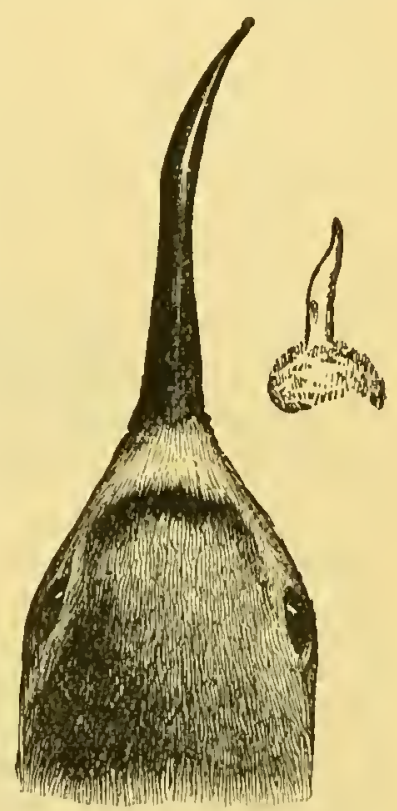

Wrybile, Adult and Chick. (From The Ibis, and Proc. Zool. Soc.) birds, for neither in the Crossbills nor the members of the genus Loxops, little birds peculiar to the Sandwich Islands, are the bones of the mandibles affected, nor is the distortion of the ear-bones in certain Owls (page 675) externally visible.

WRYNECK (Germ. Wendehals, Dutch Dranihalzen, French Torcol), so called from its wonderful way of writhing its head and neck, especially when captured, as it may easily be, on its nest in a hollow tree. The Iynx ${ }^{1}$ torquilla of ornithology, it is a regular summer-visitant to most parts of Europe, generally arriving a few days before the Cuckow, and it is in many countries known by a name associating it with that well-known bird-as in England "Cuckow's leader" and "Cuckow's mate"-but in some places it is called "Snake-bird," not only from the undulatory motions just mentioned, but from the violent hissing with which it seeks to repel an intruder from its hole. ${ }^{2}$

1 Frequently misspelt, as by Linnæus in his later years, $Y$ unx.

2 The peculiarity was known to Aristotle, and possibly led to the cruel use of 
The very unmistakable note of the Wryneck, without having any musical merit, is always pleasant to hear as a harbinger of spring. It is merely a repetition of what may be syllabled que, que, que, many times in succession, rapidly uttered at first, but gradually slowing and in a continually falling key. This, however, is only heard during a few weeks, and for the rest of the bird's stay in Europe it seems to be mute. It feeds almost exclusively on insects, especially on ants, and may often be seen on the ground, busily engaged at their nests. Somewhat larger than a Sparrow, its plumage is not easily described, being beautifully variegated with black, brown, buff and grey-the last produced by minute specks of blackish-brown on a light ground-the darker markings disposed in patches, vermiculated bars, freckles, streaks or arrow-heads-and the whole blended most harmoniously, so as to recall the coloration of a NightJAR or of a WoODCOCK. The Wryneck builds no nest, but commonly lays its translucent white eggs on the bare wood of a hole in a tree, and it is one of the few wild birds that, by abstracting its eggs day after day, will go on laying, and thus upwards of forty have been taken from a single hole-but the proper complement is from six to ten. ${ }^{1}$ As regards Britain, the bird seems to be becoming rarer, owing probably to the destruction of hollow trees in orchards, but is most common in the south-east, its numbers decreasing rapidly towards the west and north, so that in Cornwall and Wales and beyond Cheshire and Yorkshire its occurrence is but rare, while it appears only by accident in Scotland and Ireland.

Three other species of Iynx are recognized by Mr. Hargitt (Cat. B. Br. Mus. xviii. p. 560), the so-called I. japonica being indistinguishable from $I$. torquilla; while that designated, through a mistake in the locality assigned to it, $I$. indica, is identical with the I. pectoralis of South Africa. Near to this is I. pulchricollis, discovered by Emin Pasha in the east of the Bar-el-Djebel (Itis, 1884, p. 28, pl. iii.). Another distinct African species is the $I$. xquatorialis, originally described from Abyssinia. As already stated (WOODPECKER, p. 1049), they form a subfamily Iynginx of the Picidx, from the more normal groups of which they differ but little in internal structure, but much in coloration and in having the tail-quills flexible, or at least not stiffened to serve as props as in the climbing Picinx.

WYPE (Sw. Vipa) often Pie-wype, a name of the LaPwing.

the bird as a love-charm, to which several classical writers refer, as Pindar ( $P y t h$. iv. 214; Nem. iv. 35), Theocritus (iv. 17, 30), and Xenophon (Nemorabilia, III. xi. 17, 18). In one part at least of China a name, Shay-ling, signifying "Snake's neck," is given to it (lbis, 1875, p. 125).

1 Dr. Günther (Ibis, 1890, p. 411) has noticed a curions pad, beset with tubercles, on the heel of the newly-liatched bird. 


\section{$\mathrm{X}$}

XANTHOCHROISA, the abnomal replacement of another colour, generally green, by yellow, not unfrequently seen in Parrots; but said to be often induced artificially (cf. Colour, page 99).

XENICUS, the generic name ${ }^{1}$ of a little bird from New Zealand, long known as the Long-legged Warbler (Latham, Synops. ii. p. 465) or Motacilla longipes of Gmelin, and exciting little curiosity until A. W. Forbes shewed (Proc. Zool. Soc. 1882, pp. 569-571) that it, as well as Acanthidositta ${ }^{2}$ - the Rifleman of the colonists (sumic

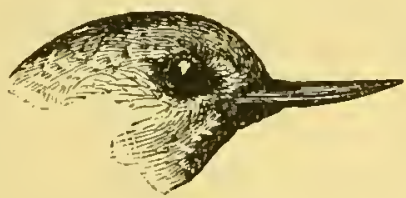

ACANTIIDOSITTA.

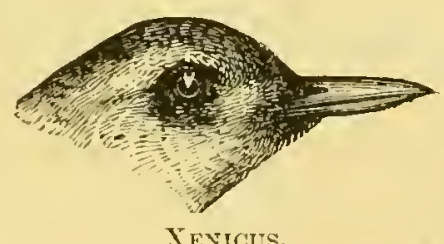

Xevicus.

(From Bıller.)

p. 789 , note), to which genus it had sometimes been referred-had not the eharacteristic vocal organs of the OsciNes, and belonged to the group which Garrod termed Mesomyod. X. longipes is the Bush-Wren of the colonists, while a seeond species, their Rock-Wren, X. gilviventris, inhabits the Sonthern Alps. The existence of these two, morphologically-low genera, forming a Family which should rightly be called Acanthidosittidx is a very significant feature in New-Zealand ornithology ( $c f$. Buller, B. N. Zeal. ed. 2, pp. 108-115).

\section{Y}

YAFFIL, YAFFINGALE, variously spelt, names of the Green WOODPECKER (page 1046).

YARWHELP, an old name for the Black-tailed GoDwrT when it inhabited this country ( $c f$. WhaUP).

YELLOW, used in combination in the name of many linds;

1 Said by G. R. Gray (Cat. Gen. B. p. 31) in 1855 to have been bestowed by him in 1853 ; but no publication at that date is known, and the genus was not really described till some years later (Tbis, 1862, $\%$. 218).

2 Originally miswritten by Lafresnaye (IKag. de Zool. 1842, Ois. 11. 27) Acanthisitte. 
thus YELLOWBIRD is the North-Ameriean SISIIN (page 84T) and perhaps more than one of the Mniotiltida? (WARBLER, page 1022): YELLOWHAMMER, Germ. Goldummer (with many variant forms, as YELLOW YELDROCK, YOLDRIN, YOWLEY and more), is the Yellow-Bunting (page 61) of this comntry, and in North Ameriea, one of the WoODPECkERs; YELLOTHHEAD in New Zealand is Clitonya ochrocephalus, the representative in the South Island of the WHitehead (page 1037) of the North; YELLOWLEGS is an American SANDPIPER, Totanus faripes; YELLOWPOLL and YELLOW-RUMP are American W ARBLers (page 1022), Dendroece astiva, coronata and maculose; while another of that group, Trichas marylandice is the YELLOWTHROAT.

YELPER, an old name for the AvosET and also for the Blacktailed GoDitT ( $c f$. YARWHELP).

YOKEL and YUKEL, local names of the Green WoODPECKER (page 1046).

\section{Z}

ZOSTEROPS, ${ }^{1}$ originally the name of a genus founded by Vigors and Horsfield (Truns. Linn. Soc. xv. p. 235) on an Australian speeies called by them $Z$. dorsalis, ${ }^{2}$ and latterly Anglicized in the same sense, being applied, whether as a scientific or a vernacular
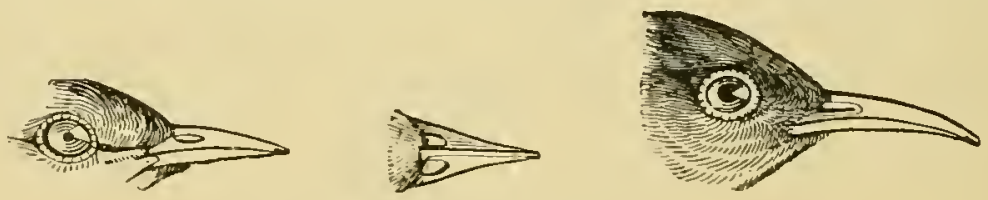

Zosterops. (After Swainson.)

term, to a great number of little birds," which inhabit for the most part the tropical districts of the Old World, from Africa to most of the islands in the Indian and Pacific Oceans, and northward in Asia through India and China to Amurland and Japan.

1 The derivation is $\zeta \omega \sigma \tau \hat{\eta} \rho$ and $\omega \psi$, whence the word should be pronounced with all the vowels long. The allusion is to the ring of white feathers round the eyes, which is very conspicuons in many species, and henee by most Engtish. speaking people in various parts of the world the prevalent Zosterops is commonly called "White-eye" ol "Silver-eye."

${ }^{2}$ Subsequently shewn to be identical with the Certhia carulescens, and also with the Sylvice lateralis, previously described by Latham.

"In 1883 Dr. Sharpe (Cat. B. Br. Mus. ix. 11). 146-203) admitted 85 species, beside 3 more which he had not been able to examine. 
The birds of this group are mostly of unpretending appearance, the plumage above being generally either mouse-coloured or greenish-olive; but some are sufficiently varied by the white or bright yeliow of their throat, breast or lower parts, and several have the flanks of a more or less lively bay, while, as the annexed figures shew, the bill often differs in form. It is remarkable that several islands are inhabited by two distinct species, one belonging to the brown and the other to the green section, the former being wholly insular. The greater number of forms seem to be confined to single islands, often of very small area, but others have a very wide distribution, and much interest has been excited by the undoubted fact that the type-species, $Z$. carulescens, has of late years largely extended its range. ${ }^{1}$

All the species of Zosterops are sociable, consorting in large flocks, which only separate on the approach of the pairing season. They build nests, described as being variously placed-sometimes suspended from a horizontal fork and sometimes fixed in an upright crotch-and lay (so far as is known) pale blue, spotless eggs, thereby differing wholly from several of the groups of birds to which they have been thought allied. Though mainly insectivorous, the birds of this genus will eat fruits of various kinds, and in such quantities as to be at times injurious. The habits of $Z$.carulescens are well described by Sir W. Buller, and those of a species peculiar to Ceylon, $Z$. ceylonensis, by Col. Legge (B. Ceylon, p. 586), while those of the widely-ranging Indian Z. palpebrosa and of the South-African

1 First described from New Sonth Wales, where it is very plentiful, it had been long known to inhabit all the eastern part of Australia. In 1856 it was noticed by naturalists as occurring in the Sonth Island of New Zealand, when it became known to the Maories by a name signifying "Stranger," and to the English settlers as the "Blight-bird," from its clearing the fruit-trees of a blight by which they had lately been affected. It soon after appeared in the North Island, where it speedily became common, and it has thence spread not only to the Chatham Islands, but, as Sir W. Buller states ( $B . N$. Zeal. ed. 2, i. p. 79), it has been met with in considerable numbers 300 miles from land, as though in search of new conntries to colonize. Yet this author believes it to be indigenous to the west coast of the Soutl Island, and Sir James Hector joins in that opinion. If they be right, it is, however, pretty certain that until the year before mentioned it must lave been confined to an extremely small district, and the only assignable canse of its spreading so rapidly, when it did extend its range, is that of a large surplus population unable to find a living at home. It is known to propagate at a high rate of increase, and at times numbers have been found dead, apparently for want of food. In any case it is obvions that this Zosterops must be a comparatively modern settler in New Zealand, though Sir W. Buller says that he and Mr. Gould were able to pick out New Zealand examples from a series otherwise made up of Australian specimens. Hence it would seem as if a slight amount of differentiation had been set up; but the variation would doubtless have been greater had the species been an ancient colonist. 
Z. capensis have been succinctly treated by Jerdon (B. Ind. ii. p. 266) and Mr. Layard (B.S. Afi. p. 116) respectively. ${ }^{1}$

The affinities of the genus Zosterops.are by no means clear. Placed by some writers, with the Parida (Trimouse), by other's among the Meliphagida (HoNEY-EATER), and again by others with the Nectariniida (SUNBIRD), the structure of the tongne, as Dr. Gadow (Proc. Zool. Soc. 1883, pp. 63, 68, pl. xvi. fig. 2) shews, wholly removes it from the first and third, and from most of the forms generally included among the second. It seems safest to regard the genus, at least provisionally, as the type of a distinct Family_Zosteropida_-as Families go among Passerine birds; but, whether the Australian genera Melithreptus and Plectrorhamphus (otherwise Plectrorhyncha) should be included under that heading, as has been done, remains to be proved, and in the meanwhile may be reasonably doubted.

ZYGODACTYLI, Vieillot's name in 1816 (Analyse, p. 25) for the birds having two toes before and two behind, which he placed as the First "trith" of his Second Order, and thus made the group practically equal to Illiger's Scansores, being composed of 7 Families-(1) Psittacini, with the genera Psittacus, Macrocercus and Plyctolophus; (2) Macroglossi, with Picus and $Y$ unx; (3 and 4) Aurcoli and Pteroglossi, consisting respectively of Galbula and Ramphastos; (5) Barbati, made up of Trogon, Pogonia, Bucco, Capito, Monasa and Phonicopluaus; (6) Imberbi, including Saurothera, Scythrops, Leptosomus, Coccyzus, Cuculus, Indicator, Corydonyx and Crotophaga; and (7) Frugivori, formed by Musoplaga and Opathus.

1 It is a remarkable and, if capable of explanation, would doubtless be an instructive fact that the largest known species of the genus, $Z$. alligularis, measuring nearly six inelies in lengtl, was confined to so small a spot as Norfolk Island, where also another, Z. tenuirostris, not much less in size, occurred; while a third, of internediate stature, $Z$. strenui , inlabited the still smaller Lord Howe Island. A fourth, Z. vatensis, but little inferior in bulk, is found on one of the New Hebrides ; but, after these giants of their kind, the rest fall off considerably, and some of the smaller species hardly exeed $3 \frac{1}{2}$ inches from end to enc? 


\section{N D E X}

OBs.--Where a name is repeated in the course of an article, reference is given only to its first use, excejt for some special reason. Families or Subfamilies of Birds shonld be sought under the genus whence their name is taken:-as Acanthidosittide uncler Acanthidositta, Alcedinide under Alcedo, Anatidæ under Anus, and so on.

\section{AASVOGEI, 1}

Abadaviue, 1

Aberduvine, 1

Abou-Hannes, 454

Abou-mengel, 455

Absorbent Vessels, 1012

Acanthiclositta, 316, 322. $406,547,648,770,789$, 900,1055

Acanthis, 515, 774

Acanthiza, 1, 777

Acanthogenys, 1025

A canthorhynchus, 92, 900

Acanthyllis, 935

Accentor, 1, 120, 697, 784, 895

Accipiter, 185, 377, 412, $491,574,898$

Accipitres, 1, 2, 11, 18, 33, $40,69,90,118,144,147$, $150,190,243,244,282$, $315,440,459,478,517$, $546,603,606,607,610$, $613,616,621,629,651$, $671,739,747,765,825$, $829,854,865,867,876$, $912,972,983$

Aceros, 435

Acetabulum, 248, 460

Acolin, 95

Acorn-Duck, 1

Acredula, 968

Acridotheres, 378, 538

Acrocephalus, 120,778 , 1020

Aclocoracoid, 856

Acromium, 857

Acromyodi, 1, 426, 547, 743,938

Acrulocercus, 167, 655

Acryllium, 400
Actinodura, 2S

Actiornis, 283

Actitis, 514, 810

Adjutant, 2, 5, 21, 271, $288,451,463,536$

Echmorhynchus, 713, \$13

Aedon, 632

सû̉ur, 192

Egialitis, 162, 171, 341, $351,481,498,512,734$, $790,804,813,919,1041$ Egialornis, 283

Egiothus, 251

Egithalus, 725, 969

Egithognathæ, 2, 130, 443

Figocephalus, 365, 885

Agotheles, 365, 638, 941

Apyornis, 2S6, 352, 791

Epyornithes, 766, 792

Epypodius, 541

Esacus, 130

Asalon, 235, 477, 546

Ethyia, 72, 734

Aetomorphæ, 2, 134, 364, 829

Ax, 1, 171, 534, 949

Aftershaft, 3,17

Agami, 991

Agapornis, 521, 689

Agelieus, 457, 530

Agelastes, 350, 401

Aghiroue, 192, 416

Agnopterus, 283

Aigle, 173

Aigrette, 192

Aigron, 192

Ailurœdns, 80

Airone, 416

Air-sacks, 3, 522

Aitliurus, 444

$\mathrm{Aix}, 49$
Alæmon, 509

Alauda, 70, 250, 353, 431, $458,475,507,559,598$, 697

Alban, 424

Albanella, 424

Albatros, 6, 45, 74, 80 $281,518,530,534,585$, 758,993

Albinism, 99

Albiuo, 9, 420, 1007

Albitross, 6

Alca, 11, 18, 22, 35, 42 $77,81,151,190,145$, $191,220,287,304,310$, $398,405,440,518,60 \tau$, $610,615,629,635,651$, $704,747,750,753,768$, $797,875,876,878,939$

Alcaduz, 6

Alcatraz, 6

Alcedo, 30, 69, 92, 118 , $144,147,463,485,593$, $601,615,616,630,718$, $746,794,853,857,858$, $879,912,952,974$

Alcyon, 404

Alcyone, 486

Alecthelia, 542

Alectorides, 9, 827

Alectoromorphæ, 9, 26, 29? $397,422,707,805,816$

Alectorurus, 1000

Alectryon, 586

Ales Jovis, 177

Aletornis, 283

Alft, 931

Algatross, 6

Alisphenoid, 871

Alk, 9, 22

Alke, 768 
Allantois, 9, 11, 13

Ailoco, 677

Alp, 10, 645, 655

Alph, 10

Altrices, 10, 154, 635, 739

Aluco, 178, 353, 364, 660, $673,820,941$

Amadavat, 11, 23

Amadina, 108

Amazon, 11

Ambiens, 11, 16, 19, 425, 608,862

Amblonyx, 277

Amblyornis, 49

Ambulatores, 459

American Warblers, 1022

Amidavad, 11, 795

Ammodromus, 961

Ammomanes, 509

Ammoperdix, 696

Amnion, 9, 11, 13, 589

Ampelion, 840

Ampelis, 58, 81, 85, 134, $571,697,719,737,769$, 1026

Amphibolæ, 12, 89

Amphiboli, 12, 815

Amphicolous, 850

Amphimorphæ, 12, 134, 254

Amphipelargus, 285

Ampulla, 983, 984

Amydrus, 348

Amytis, 57

Anabatoides, 719

Anacromyodian, 938

Anais, 362

Analogy, 15

Anarhynchus, $35,315,482$, $734,105:$

Anas, 63, 72, 86, 152, 168, $190,222,284,295,309$, $311,329,368,371,406$, $407,503,543,597,600$, $607,610,619,623,635$, $726,734,815,817,835$, $841,983,984$

Anastomus, 34, 510, 655, 741

Anatomy, 12

And, 371

Andigena, 977

Androdon, 444

Anellobium, 1025

Angulars, 872

Anhima, 19, 819

Anhinga, 19, 880

Ani, 12, 19, 42, 126, 191, $197,477,633,769,814$

Anisodactyli, 19, 972

Anisom yodi, 939
Ankle, 19, $86 \pm$

Anomalogonatx, 11, 19 , 425,609

Anomalopteryx, 578

Anorrhinus, 435

Anorthura, 1051

Anous, 643

Auser, 140, 168, 190, 285. 300,371

Anseranas, 981

Anseres, 3, 10, 11, 18, 19, $29,32,33,34,63,89$, $91,95,105,118,243$, $245,254,285,315,440$, $459,513,606,603,615$, $621,653,746,747,789$, $820,858,873,874,875$, 879, 912, 918, 937, 939, $941,952,953,983$

Anseriformes, 152

Anthochiera, 429, 801, 1025

Anthocincla, 728

Anthornis, 31, 316, 429

Anthracoceros, 435

Anthreptis, 922

Anthropoides, 133, 985

Anthus, 120, 316, 332, 475 , $598,697,727$

Anticolous, 142

Antrostomus, 88, 639, 1036

Ant-'Thrush, 20, 728, 758

Ant-Wren, 20

Aorta, 21

A patornis, 280, 652, 857

Apex, 33

Aphanapteryx, 217, 764, 1033

Aphriza, 926

Aprosmictus, 519

Aptenodytes, 458, 706, 912

Apteryges, 315, 766

Apteryx, 21, 68, 76, 90, $118,194,231,405,459$. $493,580,607,613,615$. $617,619,630,646,701$, $745,753,857,858,859$, $860,878,912$ (cf. Kiwi) Aptornis, 286, 592, 1033

Apus, 38

Aquila, 87, $173,284,879$

Ara, 96,527

Aracari, 976

Arachnothera, 96, 748, 923

Aramides, 895

Aramus, 118, 514, 765, 973

Arara, 527

Araruna, 527

Archæopteryx, 13, 21, 37, Australian Region, 317

$89,118,278,741,753$, Austro-Columbia, 313
$769,781,814,850,859$

954, 100:

Archibuteo, 67, 332

Arctogæa, 313

Ardea, 46, 111, 140, 188 $192,218,284,310,379$, $406,416,440,455,612$, $651,739,745,746,825$, $853,857,875,902,912$, $917,937,939$

Ardeacites, 285

Ardex, 615, 629, 858

Ardetta, 42, 419

Arend, 21

Argala, 21

Argillornis, 281

Argozoum, 277

Argus, 21, 100

Argusianus, 654,701

Argus-Pheasant, 701

Arremon, 945

Arses, 276

Artamia, 98, 1050

Artamus, 22, 319, 362, 739 $878,929,1050$

Arterial circulation, 1008

Arteries, 22, 1008

Articular, 872

Asio, 179, 675, 857941

Asprey, 660

Astragalus, 866

Astrarchia, 39

Astur, 140, 235, 377, 696, 898

Atelornis, 353, 794

Atlas, 851

Atling, 22, 948

Atrichia, 1, 69, 184, 320, $451,524,746,747,820$

Atrichornis, 821, 858, 939

Attagas, 696

Attagen, 696

Attagis, 68, 113, 145, 324, $733,757,831 ; 878$

Atteal, 22

Atteile, 22

Atteling, 948

Atteling.And, 22

Attila, 86

Attile, 22

Aubreau, 124

Aubrier, 424

Auk, 9, 18, 22, 81, 151, $166,198,304,310,399$, $630,704,752,769,796$

Aulacorhamphus, 978

Aureoli, 1058

Austermann, 682

Austernfischer, 68 
Austrocoraces, 39, 116, 148, $403,846,1025$

Autophagæ, 814

Antruclie, 662

Avaduvat, 11,23

Aves Diomedex, 6

Avestruz, 662, 787

Avian, 23

Avicida, 428

Avine, 23

Avis, 23

Avis Numidica, 399

Avis strutlio, 662

Avocetta, 23

Avocettula, 445

Avoset, 20, 23, 28, 34, 68, $92,109,317,379,445$, $518,733,913$

Avosetta, 23

Awbe, 10

Axilla, 25

Axis, 852

BABAGHA, 684, 738

Babbler, 25

Babelard, 26

Babillard, 26

Bacbakiri, 26

Baia, 29

Balæniceps, 34, 46, 349 , $406,739,838,875,876$

Baldpate, 26, 1040

Balearica, 112, 229, 985

Baltimore Oriole, 457, 657

Banana Quit, 761

Bantam, 27, 290

Baptornis, 280, 652

Barbati, 1058

Barbet, 12, 27, 92, 104, $319,430,749,769$

Barbu, 27

Barcud, 177

Bargander, 28

Barlker, 24, 28, 366

Barley-bird, 28

Barnacle, 31

Barnicle, 31

Baru-Ow], 261, 672, 820

Barrel, 761

Barwing, 28

Baryphthengus, 594

Basileuterus, 1023

Basioccipital, 871

Basipterygoid, 875

Basipterygoid Processes, 28

Basisphenoid, 871

Basitemporal, 871

Batara, 21

Bateleur-Eagle, 31, 717

Batracliostomus, 295, 643, 941
Batte-lessive, 1018

Baya, 29, 428

Bay-bird, 29

Beach-bird, 29

Beak, 29, 32

Beam-bird, 29

Bearcoot, 177

Bearded Titmouse, 779

Bearded Vulture, 500

Beauharuaisins, 978

Beauregard, 59

Beccafico, 250, 659

Bec-croisé, 113

Bec-figue, 250

Bec-ouvert, 655

Becquefigue, 365

Bee-eater, 29, 68, 92, 292, $463,487,593,711,743$

Beef-eater, 30

Bee-Martin, 483

Bcll-bird, 30, 80, 86, 316 , $429,892,1001$

Bengali, 31

Bennaric, 365

Bennarie, 365

Berenicornis, 435

Bergander, 28, 835

Berg-eende, 835

Bergente, 835

Berghaan, 31

Bergut, 177

Bernaca, 31

Bernacle, 31, 81, 89, 375

Bernekke, 31

Bernicla, 65, 375

Betcherrygah, 59

Bhringa, 167

Biæder, 29

Biblis, 539

Bienenfresser, 29

Bilcock, 32

Bill, 32, 134

Bill-joint, 877

Billy-biter, 1040

Bircl-Partridge, 394

Bird, 36

Bird-of-Paradise, 37,51 , $150,184,241,523,534$, $717,790,816$

Bird-of-Passage, 550

Bird-of-Prey, 1, 2, 3. 32, 40, $95,605,635,754,738$

Bishop-bird, 40

Bishop Tanager, 40

Bitorius, 40

Bittacus, 685

Bittern, 40, 310, 416, 575, 739,790

Bittour, 40

Biziura, 5, 150

Blacicus, 999
Blackbird, 36, 42, 89, 99 , $191,249,539,545,563$, 666

Blackcap, 42, 413, 582, 598

Blackcock, 43, 150, 393 , 415,893

Black Duck, 818

Black game, 388

Blackhead, 815

Blackstart, 776

Bleater, 43, 365

Blight-bird, 43, 1057

Blood, 43

Blood-bird, 44

Blood-Olph, 10, 44

Blood-Pheasant, 44

Pluebird, 44, 168, 771, 791

Bluecap, 45, 967

Blue Darr, 956

Blue Jay, 469

Blue Quit, 761

Bluethroat, 45, 566, 777

Boat-bill, 34, 45, 380, 416

Boatswain, 46, 989

Boat-tail, 46, 761

Bob-Lincoln, 46

Boblink, 46

Bobolink, 46, 61, 458, 539, $649,778,789$

Bobo, 48

Bob-White, 47, 756

Bneuf d'ean, 40

Bombiciphora, 1026

Bombycilla, 1026

Bonasa, 394, 696

Bondrée, 426

Bone, 47

Bonxie, 48, 869

Booby, 48, 80, 294

Boreal Region, 330

Botamus, 2:9, 416, 420 , 738, 744, 912

Botley-bump, 40

Botor, 40

Bottlenose, 750

Bottle-Titmonse, 632

Boudree, 426

Bower-bird, 26, 39, 48, 80 , $780,814,893$

Brachial Plexus, 623

Brachygalba, 463

Brachypteracias, 353, 794

Brachypus, 59, 934

Brachyurus, 730

Brämling, 56

Bralıminy Duck, 836

Brahminy Kite, 491

Brain, 51

Bramble-Finch, 56, 83

Brant, 57, 81, 113, 297, 375 
Branta, 375

Brant-Goose, 70̉1. 793

Breastboue, 57

Bient, 57

Brêve, 727

Brid, 36

Bristle-bird, 57

Broadbill, 57, 134, 194, 273

Bronchi, 58, 937

Brontornis, 281, 905,907

Brontozoum, 277

Bronze-wing, 58, 696, 724

Brown Owl, 672

Brubri, 58

Brush-tongued Parrots, 521

Brush-Turkey, 59, 541

Bubo, 178, 2\$3, 674, 857

Bucco, 12, 27, 92, 463, $617,630,654,717,749$, S15, 853, S79, 939

Buceros, 36, 69, 77, 84, 92, $134,144,147,432,486$, $601,615,616,630,717$, $746,747,765,852,857$, S58, $863,879,912,918$, 974

Buchanga, $16 \mathrm{~S}$

Bucorax, 433

Bucorvus, 77, 433

Budjerigar, 59, 72

Budytes, 332, 758, 1018

Buffle-head, 59, 370

Bulba ossea, 983

Bulbul, 59, 461

Bullfinch, 10, 44, 60, 99 , $250,332,338,386,587$, $645,655,737$

Bullhead, 60

Bullseye, 60

Bunting, 47, 60, 76, 124 , $182,186,250,458,45 ?$, $554,598,659$

Bunting-Lark, 61

Buntlin, 60

Buntyle, 60

Buphaga, 347, 680.717

Burhinus, 130, 517

Burhynchus, 976

Burrow-Duck, 62

Bursa Fabricii, 90

Busard, 66

Bush-Hawk, 480

Bush-Tit, 83

Bush-Wren, 1055

Bustard, 5, 9, 62, 129, 130. $150,226,273,320,364$. $380,621,666,683,803$. 828

Bustard-Quail, 415

Butalis, 275
Butcher-bird, 66, 273, 843 Campephilus, 460

Buteo, 40. 66, 426, 5S8, Campylopterus, 446 777,937

Butio, 40

Butor, 40

Butter-ball, 370

Butter-bump, 40

Button-Quail, 60,415

Buttour, 40

Buzzard, 40, 66, 173, 263, $408,409,411,426,753$, 777

Bycanetes, 386

Rycauistes, 435

Cabalus, 1032

Cacacolin, 95

Cacatelho, 92

Cacatilho, 92

Cacatua, 93, 95, 229, 299, $319,653,690,739,953$

Caccabis, 695, 773

Cacomantis, 125

Cactornis, 387

Cadran, 133

Crea, 16, 68

Cænogenetic Development, 14

Cæreba, 96, 131, 166, 326, $401,428,761,921,975$

Cahow, 831

Caille, 754

Cairina, 17]

Calander, 70

Calandra, 70

Calandre, 70

Calandrella. 509, 659

Calandria, 585

Calamus, 239

Calao, 70

Calaw, 70

Calcaneus, 866

Calendula, 511

Calico-bird, 70

Calidris, 130, 405, 517, 804

Caliology, 633

Callæas, 1025

Callisitta, 648

Callista, 944

Callocephalon, 93

Calloo, 70

Calœuas, 360, 724

Calopezus, 965

Calopsitta, 92, 93, 690

Calyptomena, 57

Calyptorhynchus, 9.3

Camarhynchus, 387

Camascelus, 284

Campanero, 30

Campephaga, 70, 273, 319. $381,575,681$
Canachites, 394

Canada Goose, 65

Canara byrd, 71

Canariebyter, 72

Canary-bird, 70, 251, 829

Canary-Parrot, 72

Caucroma, 34, 45, 390, 875 , 974

Canori, 459

Canuti aves, 498

Canvas-back Duck, 72, 735

Cape Barren Goose, 81

Cape Canary, 72

Cape Pigeon, 710, 723

Capercaillie, 72

Capercally, 72, 89, 94, 178, $226,287,394,600,892$

Capercalze, 72

Caperkellie, 72

Cape-sheep, 74

Capito, 27, 92, 147, 299, $430,617,747,749,770$, \$53, 858, 939

Caprimulgi, 629, 653, 939, 941

Caprimulgus, $32,69,8 \mathrm{~S}, 118$, $130,134,148,195,231$, $365,395,405,440,442$, $606,607,615,607,638$, $654,697,711,718,740$, $754,879,912,952,974$

Caracara, 74, 457

Carancho, 75

Carbo, 105

Carcinentes, 485

Cardellina, 1023

Cardia, 916

Cardinal, 61, 76, 381

Cardinalis, 61, 95, 387, 771

Carduelis, 251, 370, 846

Carfil, 304

Cariama, 75, 76, 324, 607, $654,826,858,865,875$, 879,973 (cf. Dicholophus)

Cariua, 476

Carinate, 2, 76, 134, 167, $242,286,315,650,688$, $704,766,814$

Carine, 674, 899, 918

Carolina Duck, 1

Carotid, 76

Carpodacus, 386

Carpophaga, 144, 154, 724, 85S, 918

Carpus, 77, 859

Carr-Crow, 7S, 956

Carr-Goose, 78

Carrier, 164

Carrion-bird, 1 
Carrion-Crow, 116

Carrion-Hawk, 75

Carr-Swallow, 78, 956

Caryocatactes, 646

Casarca, 835

Cascaroba, 932

Casera, 669

Cashew-bird, 78, 127, 656

Cassenoisette, 533

Cassicus, 457

Cassowaly, 3, 43, 78, 97, $113,130,187,212,242$, $320,543,578,592,781$, 785

Casuarius, 68, 78, 89, 90, $130,140,1 S 7,242,245$, $320,543,607,616,741$, $858,859,860,917,939$

Cata-bird, 21

Catacromyodian, 938

Cat-bird, S0, 585

Caterpillar-eater, 70

Catharista, 470, 1016

Cathartx, 629

Cathartes, 3, 29, 33, 89, $102,147,470,501,606$, $610,615,616,747,765$, $857,858,875,912,939$, $952,973,1016$

Catharus, 961

Cattiwike, 492

Caudal end, 14

Caurâle, 924

Cavalier, 733

Ceblepyris, 70

Cecomorphæ, 80, 151, 816, 834

Cedar-birl, 81, 87, 769, 1027

Cela, 21, 580

Celeonorphæ, 2, 81, 814, 1046

Celeus, 1049

Centrocercus, 93, 394, 802

Centrococcyx, 701

Centropelma, 382

Centropus, $12,10 \vec{i}, 125$, $349,473,610,815,941$

Cephalic end, 14

Cephalopterus, 1000

Ceratorhina, 23

Cerchneis, 478

Cercotrichas, 133

Cereopsis, 76, 81, 286, 315, 376

Ceriornis, 22, 587

Cerorhyncha, 23, 752

Certhia, 112, 135, 166, 648, $697,718,719,985$

Certhilauda, 431, 509

Certhiola, 921
Certliparus, 316

Cervix, 621

Ceryle, 488

Cesena, 249

Ceuthmocheres, 107

Ceyx, 486

Chachalaca, 82

Chætoptila, 225, 1026

Chxtura, 935

Chaffincl, 56, S2, 250, 411, $631,725,817,892$

Chajá, 819

Chaka, 819

Chalaundre, 70

Chalcites, 125

Chalcopsittacus, 520

Chamæa, 83, 328, 582

Chamæpelia, 659

Chamrepetes, 397

Champore cock, 27

Channel-bill, 12, S3, 125

Chanting Falcon, 1002

Chaparral-cock, 84, 126, 791

Chaptia, 167

Charadriiformes, 152

Charadriomorphx, 85,364 , $422,816,829,834$

Charadrius, 85, 107, 109, $129,130,143,162,283$, $380,405,465,481,540$, $514,517,610,682,731$, $740,745,757,804$

Clıarkwa, 836

Charmosyna, 520

Chasmorhy nchus, 30,80 , 113, 952, 1001

Cliat, 85, 777, 1034

Chat-huant, 676

Chatterer, 30, 85, 93, 107, 273, 421, 460, 532, 718, $737,1001,1026$

Chaulelasmus, 298

Channa, 9, 90, 819,983

Cheeper, 86

Cheer, 86

Chelaundre, 70

Chelidon, 189, 536, 926

Chelidoptera, 749

Chen, 300, 374, 1026

Chenalopex, 349, 376, 837 . 984

Chenomorpliæ, $86,134,820$

Chenoruis, 285

Chepster, 87

Chera, 1030

Cherrug, 803

Cherry-bird, 87

Cherry-picker, 87

Cherry-sucker, 87

Chettusia, 506
Chevêche, 679

Chèvre-volant, 365

Chewink, 982

Chiacalacca, 82

Chibia, 167

Chicheree, 999

Chickadee, 87

Chicken, 87

Chicquera, 546

Chiffchaff, $57,710,893$, 1052

Chimango, 75

Chimerina, 600

Chionis, 68, 109, 310, 324, 732,832

Chionomorphæ, 834

Chipchop, 87

Chir, 86

Chiromachreris, 533

Chiroxiphia, 53 ?

Chlamydera, 49

Chlamydochen, 376

Chloephaga, 374,984

Chloridops, 384

Chloris, 394

Choanæ, 33

Chok, 87

Cholornis, 711, 867

Chordiles, 573, 635, 639, 727,879

Chorion, 11

Chotacabras, 638

Chough, 87, 116, 132, 482, 822

Chrocko, 792

Chrysococcyx, 125, 349,567

Chrysonas, 320,723

Chrysolampis, 447

Chrysomitris, 88, 251, 258, $371,563,846$

Chrysotis, 11, 96, 99, 229, $654,690,739$

Chuck-will's-widow, 88

Chunga, 828

Chunnia, 828

Chuparosa, 442

Churn-Owl, 88, 639, 6־1

Ciconia, 91, 144, 191, 244. $416,440,456,462,517$, $559,610,651,655,741$, $746,747,825,853,854$, $875,912,919,952,973$

Ciconix, 146, 615, 629 , $857,858,863,917,939$, 974,983

Cigano, 424

Cilia, 239

Cimoliornis, 280

Cinclorhamphus, 25

Cinclus, 134, 277, 667, 698,1024 
Cinnyris, 748, 923

Circaetus, 173

Circulation, 88

Circus, 67, 408, 424, 491, 572,739

Ciridops, 645

Cirl-Bunting, 61

Cisne, 155

Cissa, 470, 722

Cissopis, 945

Cisticola, 189, 238, 725, 1022

Citril, 88

Citronenfink, 88

Cittocincla, 133

Cladorhynchus, 914

Clakis, 89

Clamatores, 21, 89, 483, 728, 939

Clangula, $59, \quad 369,407$, $544,592,900$

Clark's Crow, 647

Clavicle, 89, 296, 858, 909

Claw, 89, 393, 459, 599

Climacteris, 986

Clinker, 24

Clitonyx, 72, 316, 658, 1037, 1056

Cloaca, 90

Clotburd, 1034

Clucking Hen, 514

Clytorhynchus, 574

Cnemiornis, 76, 82, 286, $315,376,857$

Cnott, 498

Coachwhip-bird, 91

Coalfinch, 94

Coalmouse, 92, 967

Cob, 92, 703, 929

Cobbler's-awl, 24, 92

Coccothranstes, 251, 371, 384,411

Coccyges, 11, 147, 879

Coccygomorphæ, 92, 130 , $134,430,435,593,609$

Coccystes, 124

Coccyx, 119

Coccyzus, 108, 534

Coc-des-roches, 93

Cock, 892

Cockateel, 92, 690

Cockatoo, 34, 92, 93, 687

Cockatoon, 527

Cock-of-tle-Plains, 93

Cock-of-the-Rock, 86, 93, 532

Cock - of - the - Wood, 72 , 94

Codatremola, 1018

Coddy-moddy, 94

Colæus, 101
Colaptes, 258, 331, 458, 1005

Coldfinch, 94

Colemouse, 92

Colibri, 442

Colin, 94, 649, 696

Coliopasser, 1030

Coliou, 101

Colius, 12, 69, 77, 92, 101, $118,148,251,347,405$, $600,607,616,630,684$, $746,747,879,912,939$, 972

College Pheasant, 476

Collocalia, 284, 935

Collyrio, 517

Collyriocincla, 846

Coloburis, 730

Colour, 95, 99, 215, 1007

Columba, 11, 26, 118, 140, $154,160,162,188,243$, $284,299,329,378,440$, $606,612,623,697,723$, $747,766,789,790,793$, $915,939,952$

Columbæ, 18, 29, 69, I43, $145,320,517,615,621$, $651,707,724,854,863$, $876,879,912,918,940$, 953,972

Columbini, 765

Coluinella, 179, 872, 874

Coly, 101

Colymbi, $615,616,621,912$

Colymboides, 151, 283

Colymbo-Podicipites, 651

Colymbus, $11,68,81,118$, $146,151,243,244,280$, $310,398,405,440,518$, $597,606,607,610,621$, $635,651,698,745,746$, $747,753,765,854,858$, $860,861,862,863,865$, $875,878,902,939,973$

Cometes, 449

Condor, 101, 634

Coney-catcher, 132

Coney-chuck, 1034

Conirostres, 102

Conopophaga, 323, 939, 940,947

Contopus, 483, 710, 973

Conurus, 219, 528, 686

Cooperastur, 898

Coot, 27, 35, 102, 217, $380,398,517,539,711$, 817,822

Coot-footed Tringa, 711

Coppersmith, 28, 104

Coprodæum, 90

Copsychus, 133
Copurus, 999

Coq d'Inde, 994

Coq-de-roche, 93

Coraces, 148

Coracias, 25, 30, 57, 69, 92, $147,161,259,440,593$, $615,630,638,654,717$, $718,739,745,747,793$, $853,912,939,952$

Coraciiformes, 638

Coracocichla, 728

Coracoid, 104, 856, 909

Coracoideæ, 638

Coracomorphæ, 2, 104, 130, 524

Coracopitta, 728

Coracostea, 910

Corbeau, 116

Corcorax, 88

Coriphilus, 520

Corlieu, 127

Cor marin, 105

Cormorant, 33, 89, 104, $113,173,197,223,229$, 243, 283, 378, 703, 770, $815,822,829$

Corn-Bunting, 61

Corn-Crake, 68, 109, 550, 762

Corresso, 126

Corrira, 107

Corvo marino, 105

Corvus, 70, 87, 104, 114, $116,124,132,140,190$, $191,316,329,380,385$, $429,438,466,646,697$, $698,717,722,768,795$, $801,857,876,940,553$

Corvus Indicus, 433

Corydon, 877

Corydus, 509

Corythaix, 69, 140, 612, $815,857,980$

Coscaroba, 932

Cosmetornis, 641

Cosmonetta, 407

Cotile, 189, 538

Cotinga, 30, \$5, 93, 95, 107 , $134,273,323,421,532$, 718, 737, 938, 939, 940, 983,1001

Cotton-bird, 725

Coturniculus, 961

Coturnix, 283, 316, 353, $407,754,765$

Coua, 125

Coucal, 107, 125

Coucou, 119

Coulterueb, 107, 750, 830

Coure-vite, 107

Courlan, 514 
Courlis, 127

Couroucou, 987

Courser, 107, 130, 733

Coverts, 949

Cow-bird, 108, 458, 633

Cow-Blackbird, 108

Cow-Bunting, 108

Cowpen-bird, 458

Cowry-bird, 108, 648

Crab-Plover, 100, 215, 733

Cracker, 109

Crake, 109

Crane, 66, 109, 212, 226, $241,283,296,364,416$, $471,514,550,621,803$, 813,829

Cranial Nerves, 54

Cranium, 112, 870

Crateropus, 25, 45, 92, 963

Crax, 91, 126, 299, 325 , $396,535,539,607,739$. $765,808,879,972,984$

Creadion, 316, 801

Creatophora, 379, 517

Créçerelle, 477

Creeper, 112, $16 \mathrm{\jmath}$

Creeping Warblers, 1023

Cresserelle, 477

Crest, 112

Cretornis, 280

Crex, 109, 610, 762

Criniger, 26, 243

Crista sterni, 476

Cristel, 477

Crithagra, 814

Crocker, 113

Crocodile-bird, 733

Crossbill, 113, 250, 386, 571,1053

Crossoptilum, 716, 887

Crotophaga, $12, \quad 19,42$, $126,190,234,717,814$, 815,941

Crow, 70, 87, 100, 114, $116,124,132,149,190$, $231,269,430,500,565$, $647,722,795$

Crow-Pheasant, 107

Crow-Shrike, 403

Crown-bird, 118, 979

Crowned Crane, 112

Crowned Pigeon, 378, 724

Crying-Bird, 514

Cryptolopha, 276

Cryptornis, 283

Crypturi, 10, 11, 28, 68, $118,145,167,299,738$, $766,854,858,865,912$

Crypturus, 878,965

Ctenorhynchus, 298

Cubitals, 118, 741
Cucco, 119

Cuccu, 119

Cuckoo, 118

Cuckow, 12, 19, 68, 84, 92 $107,108,118,351,378$, $463,530,534,550,566$, $572,633,654,765,892$

Cuckow's Leader, 126 , 1053

Cuckow's Mate, 126, 1053

Cuculi, 745, 863, 912, 941

Cuculo, 119

Cuculus, 12, 19, 29, 84, 92, $107,118,145,147,299$, $422,463,473,429,500$, $559,612,615,617,630$, $654,717,718,747,815$, $857,858,912,918,937$, $939,941,952$

Cuetzal, 758

Cuisinier, 681

Culblane, 1034

Culmen, 33

Cuntur, 101

Curaçoa-bir'd, 126

Curassow, 78, 126, 396, $421,707,739,753,994$

Curlew, 24, 127, 161, 456, $526,565,1033,1036$

Curlew-Jack, 886

Curreso, 126

Curruca, 43, 413

Cursores, 130

Cursorius, 89, 107, 130, 517, 733

Curucui, 130, 987

Cushat, 130, 162, 758

Cushew-bird, 78

Cute, 102

Cwtiar, 817

Cyanecula, 45, 332, 567, 777

Cyanocitta, 470

Cyanocolax, 470,607

Cyanolyseus, 686

Cyanopica, 124, 342, 722

Cyanopolius, 722

Cyanorhamplius, 686

Cyanospiza, 459, 644

Cyanurus, 469

Cyclocœlous, 142

Cyclopsittacus, 690

Cyclorhis, 1014

Cyguet, 929

Cygnopsis, 376

Cygnus, 111, 168, 190, 623, 930,985

Cymindis, 428, 492, 739

Cymochorea, 710

Cypseli, 11, 18, 440, 606, $630,654,853,865,867$
Cypselomorphx, 2, 130 , $148,443,517,608,610$ 615,638

Cypselus, 69, 77, 118, 130, $140,148,229,284,405$, $442,529,557,603,616$, $617,623,638,711,718$, $742,745,858,878,912$, $934,937,939,941,952$ Cypsnagra, 944

Cyrus, 813

Cyta, 489

DABCHICK, 131, 136, 156 , 382,519

Dacelo, $465,487,617$

Dacnis, $131,401,428$

Dafila, 109, 726

Daha, 132

Daie, 540

Daker-hen, 131, 762

Dances, 894

Daption, 710, 726

Darr, 132

Darter, 132

Dartford Warbler, 1038

Dasornis, 281, 908

Dassie-vanger, 132

Dasylophus, 125

Dasypæedes, 748

Daulias, 59, 637

Daw, 87, 116, 132, 466 , 471

Dayal, 133, 134

Decoy, 170

Dei ingenium, 366

Demiegretta, 1007

Demoiselle, 111, 133

Deudragapus, 394

Dendrocitta, 722

Dendrocolaptes, 323,658 , $669,718,878,939,940$

Dendrocops, 719

Dendrocopus, 292, \$13, 1047

Dendrocygna, 171, 984

Dendrœca, 72, 1023, 1056

Dendrophila, 648

Dendroplex, 719

Dentals, 872

Dentirostres, 134

Dertrum, 33, 134

Desert-Falcon, 235, 522

Desert Forms, 336, 421

Desmodactyli, 58, 134, 194, 972

Desmognathæ, 2, 12, 86, $92,134,173,254,420$, $456,702,743,878$

Devil-bird, 134

Deviling, 134, 934 
Dhyal, 133, 134

Diablotin, 227, 395

Diacromyodian, 938

Dial-bird, 133, 134

Diamond-bird, 134, 136, 277

Diaphorapteryx, 1033

Diaphragm, 135, 413

Diatryma, 281, 908

Jicæum, 135, 273, 428

Dichoceros, 434

Dicholophus, 9, 29, 118, $145,440,603,610,616$, $635,746,747,827$ (cf. Cariama)

Dick-Cissel, 136

Dicrocercus, 30, 741

Dicrurus, 167

Didapper, 136

Didi, 725

Didunculus, 154, 320, 654, 724

Didus, 76, 154. 155, 215, $459,651,766,557,858$, SSS

Digeon, 1039

Digestive System, 136

Dikkop, 148

Dilophus, 379

Dimorphism, 36, 149, 642, 1006

Dindon, 994

Dirornis, 151, 286, 315, $575,858,866,912$

Dinornithes, 793, 859, 864

Diomedea, 6, 45, 201, 530, 708, 952

Diphlogæna, 449

Diploe, 47

Diplopterus, 126

Dipper, 151, 667

Dishwasher, 151, 276, 1018

Dissemurus, 167

Dissodectes, 478

Distal. 14

Distelfink, 370

Divedapper, 136

Diver, 4, 33, 81, 151, 194, $310,453,518,597,765$

Diverticulum, 153

Diving-Duck, 734

Diving-Petrel, 708

Dixhuit, 505

Dobchick, 131

Docimastes, 443

Dodaers, 157

Dodir, 159

Dodlet, 154, 724

Doun, 76, 80, 154, 155, $215,459,475,493,724$, 1006,1033
Doe-bird, 161

Dolichonyx, 46. 458, 588

Dolichopterus, 284

Dollar-bird, 161

Domicella, 520

Donacilda, 1029

Dorking-fowl, 587

Dorr-Hawk, 161

Dorsal side, 14

Dotterel, 150, 161, 171, $481,634,712,732,800$

Doucker, 162, 171

Doudo, 155

Dough-bird, 161

Dove, 26, 154, 162, 217, 23\&, 320, 399, 659, 723, 790

Dovekey, 166. 813

Down, 242

Draaihalzen, 1053

Drake, 168

Draw-water, 166

Drepanis, 113, 166, 182, $225,320,428,655,915$, 975

Dromæognathæ, 167, 322

Dromæus, 68, 78, 90, 167, $187,213,231,242,243$, $245,320,543,607,616$, $857,858,859,860,879$, $912,917,939,983$

Dromaieus, 213

Dromas, 89, 215, 733. 973

Dromeicus, 213

Dromornis, 286, 578

Drongo, 167

Dronte, 156

Drymœca, 354, 725, 1022

Dryocopus, 899

Duc, 671

Duck, 4, 52, 72, 86, 113, $151,168,191,194,297$, $311,368,404,406,407$, $503,518,530,534,587$, $593,597,654,726,797$, 817

Duck-antl, 168

Ducker, 162, 171

Duck-Hawli, 236

Due, 162

Dufa, 162

Dukipath, 432

Dulwilly, 171

Dunbird, 172,816

Duncur, 172

Dun Diver, 54 :

Dunker, 172

Dunlin, $149, \quad 1 \% 2,680$ $734,753,770,812,915$

Dumnock, 173, 895

Dunter, 173
Duycker, 168

Duyve, 162

Dysornithia, 468, 1036

Dysporomorphæ, 134, 173

Dysporus, 904

EAGLE, 1, 3, 21, 27, 31, $66,87,100,132,173$. 191, 215, 261, 408, 411, $500,587,632,892$

Eagle-Owl, 674

Ear, 178

Earn, 657

Earthlinger, 40

Easterling, ISI

Ebb, 182

Ebb-sleeper, 182

F́chasse, 913

Eclectus, 99, 520, 690

Ectopistes, 696, 723

Edible birds' nests, 631

Edolier, 1S?

Edolius, 134, 16 i

Ece-eve, 102

Eeude-coy, 170

Effraie, 660, 679

Egg-bird, 182

Egg-tooth, 36

Eggs, 182

Eqret, 192，241，416, 505, $660,683,683,832$

Egretta, 192

Egrettides, 505

Egritte, 192

Eider, 173, 192, 222, 633, 736,802

Eisvogel, 485

Elainea, 999, 1000

Elanoides, 491

Elanus, 491, 739

Elaphrornis, 360

EIbs, 931

Eleutheroclactyli, 194, 972

E1k, 931

Elornis, 258, 283

Elps, 931

Ema, 79, 212, 785, 826

Ember Goose, 194

Emberiza, 47, 61, 76, 124, $186,250,329,381,458$, $459,554,598,644,658$, $690,761,778$

Emberizoides, 982

Embernagra, 982

Embryology, 13, 194

Émerillon, 545

Emel, 3, 5, 78, 167, 187, $212,320,494,543,576$, 785,892

Emens, 580

Emmer, 194 
Emmet-hunter, 215

Empidias, 999

Finpidonax, 483

Enaliornis, 13, 2S0, 652

"English" Sparrow, 896

Eugrouée, 1024

Engyptila, 724

Enicurus, 276

Entomyza, 428

Eopsaltria, 957

Eos, 520

Épeiche, 1046

Epervier, 897

Ephippiorhynchus, 463

Ephouskyka, 514

Epimachus, 39

Epiotic, 874

Epiphyses, 48

Epistropheus, 852

Epithema, 432

Epollicati, 765

Epopes, 11, $14 \vec{\jmath}$

Epopomorphæ, 430

Epops, 430

Eremophila, 511

Eremnetes, 514, 734

Eriocnemis, 447

Eriodora, 20

Erismatura, 168, 338, 545, 761,797

Erithacus, 45, 122, 771

Erue, 175, 215, 657

Erodius, 416

Erody, 215

Erolia, 215

Erythra, 591

Erythrism, 99, 215, 1007

Erytlırochroism, 1008

Erythromachus, 218, 764

Erythropus, 478

Erythropygia, 899

Erythrosterna, 275

Escoute, 817

Escriere, 643

Escrire, 1024

Esmerillon, 545

Esprevier, 897

Estridge, 662

Estridger, 215

Estrilda, 11, 31, 794, 825, 1026,1029

Ethiopian Region, 345

Ethmoid, 871, 876

Eucichla, 728

Eucorystes, 457

Eudocimus, 456

Eudromias, 162, 634

Eudynamis, 125, 500, 567

Eudyptes, 529, 706

Eudytes, 151, 519, 753

Enethia, 381
Evlabeornis, 1033

Eulabia, 374

Eule, 671

Eumomota, 594

Eunetta, 949

Euornithes, 651

Eupetomena, 417

Euphones, 917

Euphonia, 656, 761, 944

Euplocamus, 259, 476, 716

Eupodotis, 77, 320, 349, $498,610,746$

Euptilotis, 989

Eurlæmus, 57

Euryapteryx, 579

Eurycephalus, 846

Euryceros, 347, 433

Eurylæmus, 134, 194, 273, $323,355,615,617,630$, $747,912,939$

Euryworliynchus, 34, 337 , 734,813

Eurypyga, 118, 252, 320, $324,440,472,615,629$, $739,746,747,765,875$, 923,973

Eurystomus, 161, 794

Euscarthmus, 1000

Euspiza, 136

Eustachian tubes, 5, 179

Eustephanus, 448

Evejar, 639

Evêque, 40

Exauthemops, 374

Excalphatoria, $756^{\circ}$

Exoccipital, 871

Extermination, 215

Extinction, 215

Extirpation, 215

Eyas, 629, 645

Eye, 229

FAISAN, 84

Falcinellus, 513

Falco, 16, 29, 33, 69, 74, $235,261,283,329,404$, $409,424,426,477,489$, $501,503,522,545,552$, $617,660,757,765,824$, $857,858,939,950,952$

Falcon, 66, 235, 410, 411, $424,477,490,503,522$, $536,632,802$

Falculia, 353, 354

Falcunculus, 845,958

Falk, 235

Fallow-Chat, 238, 1034

Falmair, 295

Fantail, 238, 276, 385, 943

Fantail (Pigeon), 164

Fantail-Warbler, 189, 631
Fasan, 713

Fasant, 713

Fasceddar, 239, 870

Fasgadair, 239, 870

Father John, 454

Father-of-tle-Sickle, 455

Fancon, 235

Fallvette, 239

Fealo-for, 249

Feather, 239, 761

Feather-poke, 239

Fedoa, 365

Feet, 863

Femur, 248, 708, 868

Fern-bird, 249, 381

Fern-OwI, 269, 629, 671

Fesaum, 713

Fesaunt, 718

Fibula, 249

Ficedula, 250, 275, 365

Fieldfare, 269, 295, 551, 633, $77 \%$

Field-officer, 530

Fig-eater, 250, 365, 659

Filoplume, 242

Finch, $61,70,76,82,88$, $102,113,250,253,319$, $411,459,516,554,563$, 814,829

Fill-foot, 184, 252, 517 , 764

Fiuk, 82, 250

Firecrest, 253

Firetal, 253, 775

Fiscal, 253

Fish-Hawk, 632, 661

Fissipedal, 194

Flamenco, 253

Flamingo, 3, 12, 20, 33, 95, $113,197,253,283,379$. $597,632,649,703$

Flanderkin, 273

Flax-bird, 258

Flercher, 273

Flesher, 273

Flicker, 258, 458, 1005, 1040

Flight, 260

Florican, 273

Florida, 1007

Flower-picker, 136, 273

Flusher, 273, 843

Flycatcher, 29, 57, 87, 92, $94,151,238,250,273$, $364,385,482,633,738$, $762,814,918$

Fly-catching Warblers, 1023

Flying Goat, 885

Fool's-coat, 276

Foramen magnum, 873

Foramen ovale, 179, 874 
Forktail, 276

Formicarius, 20, 323, 930, 940

Formicivora, 20

Forty-spot, 277

Fossil Birds, 277

Foulque, 103

Fourmilier, 20

Four-o'clock, 289, 293

Fowl, 4, 37, 53, 87, 198, $233,248,289,452,634$, 783

Francolin, 22\%, 2\%3, 291, 692,778

Fraucolino, 291

Francolinus, 227, 291, 352

Frangão, 291

Frango, 291

Fratercula, 229, 558, 597, 737,750

Free-fowl, 291

Frégate, 293, 603, 607, $745,858,865,952$

Fregilupus, 217, 353, 354

Fregilus, 87, 349

French Partridge, 695

French Pie, 292, 720

Fresaie, 660, 679

Freshwater-Duck, 734

Fressaia, 660

Freux, 795

Friar-bird, 289, 292, 429 . $513,573,587, \quad 725$. 737

Frigate-bird, $173,293,296$, 534,703

Frill-back, 164

Fringilla, $31,56,60,61,70$, $82,108,113,243,250$, $285,319,370,383,386$. $411,515,556,600,655$. $690,730,773,825,829$. 846,896

Frog-mouth, 295

Frontal, 871, 876

Fronto-nasal joint, 877

Froufrou, 442

Frowl, 398

Frugivori, 1058

Fugl, 289

Fulfer, 295

Fulica, 102, 380, 517, 631, 973

Fulicarix, 118

Fuligula, 72, 103, 151, $168,230,284,368,407$, $544,593,734,815$

Fulmaire, 295

Fulmar, 295, 471, 530

Fulmarus, 295

Furcula, 296, 401
Furnarius, 323, 632, 669, | Gardener-bird, 49, 303

$719,877,878,879,939$ Gare-fowl, 22, 220, 287, Furze-Chat, 296

\section{GabBiano, 310}

Gabble-ratchet, 297, 572

Gaddel, 297

Gadwall, 171, 297. 381

Gairfowl, 303

Galbalcyrhynchus, 463

Galbula, 30, 92, 97, 324, $403,487,617,630,654$, $747,749,815,853,879$, 912

Galeoscoptes, 582

Galerita, 509

Galgulus, 457, 463

Gall-bladder, 298, 517

Galley-bird, 299

Gallicrex, 591, 1024

Gallina, 311

Gallina Africana, 399

Gallina Numidica, 399

Gallinaceæ, 299

Gallinacei, 9, 299, 765

Gallinæ, 3, 9, 10, 11, - 18, $29,68,113,126,115$, $147,188,190,198,234$, $242,243,245,283,299$, $401,415,422,440,517$, $539,597,606,607,608$, $610,611,613,615,621$, $635,695,699,745,747$, $805,854,857,860,863$, $874,879,912,918,937$, $939,940,952$

Gallinago, 68, 770, 883, 939

Galliney, 299

Gallinula, 299, 589

Gallirallus, 1031

Gallito, 946

Gallopavus, 994

Galloperdix, 902

Gallophasis, 476

Gallus, 89, 126, 140, 285, $289,299,617,623,765$, 902,941

Gallus Mauritanus, 400

Gallus peregrinus, 156

Gambet, 299

Gambetta, 299

Gambette, 299

Gampsonyx, 492

Gander, 300, 371

Gandra, 300

Ganga, 805

Gannet, 3, 33, 48, 300, 310, $477,634,703$

Ganot, 300

Gans, 300

Garden-Warbler, 43 $303,704,768,1041$

Garganello, 309

Garganey, 171, 309, 949

Garrot, 309

Garrulus, 85, 323, 466

Gas, 371

Gasserian ganglion, 55

Gastornis, 281, 864, 907

Ganlding, 310

Gaulin, 310

Gaunt, 310, 382

Gavia, 310, 402

Gaviæ, 33, 183, 190, 310, 652

Gearbhu1, 303

Gearrabhul, 304

Gecinomorphæ, 2

Gecinus, 421, 452, 747, 899,1046

Geelbec, 311

Geier, 364, 404

Geirfugl, 303, 704

Geline, 311

Gelinotte, 311, 394

Gemitores, 311

Gennæa, 235

Gennæus, 522

Gennaia, 522

Gentoo, 471

Genys, 33

Geobates, 670

Geobiastes, 353, 794

Geocich]a, 388, 961

Geococcyx, 84, 126

Geocolaptes, 458

Geographical Distribution, 311

Geophaps, 58, 696

Geopsittacus, 475

Geositta, 670

Geospiza, 387

Geothlypis, 1023

Geranomorpliæ, 111, 363, $473,816,829$

Geranopsis, 283

Geranos, 109

Gerfalcon, 364

Geronticus, 456

Gervaisia, 133

Gerygone, 316, 364

Giant Petrel, 593

Gier-Eagle, 364

Gilly-Howlet, 364

Gizzard, 916

Gjardiniere, 49

Gjög, 119, 378

Gjök, 37s

Glada, 364
Gentle Falcon, 235 
Glareola, 9, 89, 453, 517, Gosling, 371 610,740

Glasoogje, 364

Glass-eye, 364

Glancidium, 178, 675, 899

Glaucopis, 316, 1025

Glead, 364, 459

Gled, 364, 489

Glida, 364

Globicera, 35

Glossoptila, 761

Glottis, 384

Glutt, 384

Gnat, 364, 498

Gnat-catcher, 365

Guat-snapper, 365

Gnathodon, 154

Goathead, 365

Goatsucker, 88, 130, 134, 365,638

Godwit, 24, 28, 128, 150, $161,248,365,536,566$, $634,696,712,734,800$, 814

Gök, 119, 378

Goeland, 401

Goldammer, 1056

Goldcrest, 253, 367, 489, 565

Goldeine, 310

Golden-crested Wren, 632

Golden-crowned'Thrush, 669

Golden Eagle, 176, 186, 500,791

Golden-eye, 59, 60, 261, $309,368,407,544,546$, 592,633

Golden Plover, 505, 565, 731, 734, 809

Golden Robin, 457

Goldeu Warblers, 1023

Goldfinch, 250, 258, 276, $370,489,632,773,838$

Gollfink, 370

Golding, 310, 371

Goldyn, 310

Gom-Paauw, 371

Goñabuch, 441

Gonambuch, 441

Gonys, 33

Goosander, 310, 371, 543

Goose, 32, 53, 81, 91, 168, $190,194,286,297,300$, $315,371,439,588,597$, 605,770

Gooseherd, 373

Goreock, 377

Gorfou, 304, 704

Gós, 371

Gos-Hawk, 185, 235, 377, 411, 696, 802
Gossander, 371, 814

Goulen, 401

Goura, 286, 320, 377, 654, 724, 952

Gowk, 119, 378

Gowry-bird, 109

Gozzerd, 373

Gracculus, 378

Grackle, 42, 46, 378, 457, $517,530,538,761,904$

Gracula, 133，134，350, 697, 717

Graculavus, 281

Gracnlus, 105, 37s

Grallæ, 3, 10, 11, 29, 33, $68,81,243,254,379$, 740

Grallaria, 20

Grallator, 277

Grallatores, 380

Gralliua, 25, 320, 380, 530, 939

Grandala, 44

Grandaulo, S05

Grand Duc, 677

Gräönd, 297, 381

Grape-eater, 380

Grass-bird, 380, 458

Grasshopper-Lark, 512

Grasshopper-Warbler, 779, 1021

Grassmïcke, 601

Grass-Quit, 381, 761

Graucalus, 148, 351

Gray, 297, 351

Great Auk, 220, 304, 704

Grebe, 18, 33, 78, 131, $136,151,156,191,197$, $310,381,424,518,630$, $769,816,893$

Grèbe-Foulque, 252

Greenfinch, 10, 251, 383, 655

Greenland Dove, 166, 399

Greenland Turtle, 998

Greenleek, 384

Greenlet, 384, 1013

"Green Limnet," 1052

Green 0lph, 10

Green Plover, 505

Greenshank, 28, 384, $\$ 11$

Greoche, 389

Greyback, 385

Greyhen, 385, 393, 415

Grey Partridge, 692

Grey Plover, 731

Griais, 359

Grice, 389

Griece, 389

Griesche, 389
Griffon, 385, 1016

Grinder, 276, 385

Groove-bill, 978

Grosbeak, 251，385，510, 632,637

Grosbec, 385

Ground-Parrot, 473

Ground-Robin, 982

Ground-Thrush, 388, 728

Ground-Warblers, 1023

Ground-Wren, 83

Grouse, 43, 74, 86, 89, 93, $150,283,311,341,377$, $385,388,415,599,693$, 740,802

Grows, 43, 388

Give, 109

Grues, $606,607,615,635$, $746,863,879,939,973$

Grulla, 109

Grinfink, 39 ,

Grus, 25, 68, 109, 118, 133, $145,212,240,283,299_{1}$ $416,440,514,559,610$, $612,621,747,813,829$, $854,857,858,875,876$, $912,918,985$

Grus Capeusis, 823

Gryphosaurus, 278

Gryphus, 395

Gryps, 385

Guacamayo, 528

Guacharo, 394, 638, 671

Guainumbi, 442

Guan, 82, 396, 703, 758

Guillem, 397

Guillemot, 22, 149, 166, $166,191,194,397,453$, $480,513,519,536,602$, $768,817,892$

Guinea-fowl, 296, 299, 399, 726,994

Guira, 401, 593, 941

Guiraca, 387

Guit-guit, 401, 761, 921

Gull, 3, 4, 33, 43, 81, 92 , $94,100,113,194,198$, $239,261,281,310,401$, $453,492,505,518,534$, 539, 547, 571, 631, 635, $692,710,718,801,816$, $818,822,834$

Gullet, 403

Gulönd, 310

Gum-Peafowl, 371

Gwillem, 403

Gwilym, 397

Gwylan, 401

Gymnocephalus, 1001

Gymnodera, 86. 1001

Gymnopædes, 743 
Gymnorhina, 148, 403, 656, $845,878,1025$

Gypaetus, 3, 173, 227, 404, $500,501,739,765,858$, 1015

Gypagus, 1016

Gypogeranus, 3, 765, 824, 858,973

Gypotriorchis, $42 \frac{4}{2}$

Gyps, 385, 1016

Gypsornis, 283

Gyrfalcon, 237, 404, 470, 503

Gyrofalco, 401

HABRoptila, 320, 591

Hackbolt, 404

Häger, 416

Hremantopus, 682

Hæmatopus, 109, 130, 380, $517,51 \mathrm{~s}, 610,682.725$, 734,913

Hämpling, 515

Hänfling, 515

Hagbolt, 404

Hagdown, 404

Haggard, 629, 696

Halcyon, 404, 486

Halcyones, 11, 147

Halcyornis, 281, 489

Haleus, 904

Half-bird, 404

Haliaetus, 27, 144,175, 284

Haliastur, 176, 491

Halieus, 105

Hallux, 404, 587, 972

Halodroma, 708

Hammer-head, 405, 838

Hammer-kop, 405

Hamili, 239

Hang-bird, 406

Hang-nest, 406, 457

Hanna, 424

Hapalarpactus, 989

Hapalocercus, 999

Hapaloderma, 327, 989

Hajaloptila, 750

Haploophonæ, 406, 425, 547

Harderian Glands, 55, 231

Hareld, 406, 817

Harelda, 229, 406, 984

Hargīla, 2, 21, 451

Harild, 902

Harle, 407

Harlequin-Duck, 407, 519

Harpa, 407, 757

Harpactes, 617, 918,989

Harpagornis, 286, 315

Harpagus, 412, 574

Harpe, 480, 503, 757
Halporhynchus, 582, 958

Harpy, 407

Harrier, 66, 67, 177, 226, $408,411,424,572,589$, 791

Hartlaubia, 283

Haselhuhn, 394

Havelda, 406

Hárelle, 406, 407

Haversian Canals, 47

Hawfinch, 250, 371, 384, 386,410

Hawk, 1, 3, 408, 411, 490, $549,572,629,897$

Hawk-Owl, 674

Hay-bird, 413

Hay-jack, 413, 825, 1053

Hazel-hen, 311, 394, 696

Heart, 413, 1008

Heath-cock, 415

Heath-hen, 415

Heather-bleat, 415

Heather-bleater, 885

Heather-blite, 415

Heaven's Ram, 8S5

Hedge-Sparrow, 1, 26, 120 , $173,452,637,777,825$, 895

Hedymeles, 387

Heergans, 416

Hegessugge, S25

Hegre, 416

Heiger, 416

Heigh-haw, 421

Heire, 416

Heleothreptes, 641

Helicura, 532

Heliodilus, 353, 673

Heliornis, 252 617, 629, 761,973

Helmet-Hornbill, 434

Helıninthopliila, 1023

Helminthotherus, 1023

Helodromas, 812

Helornis, $25 \mathrm{~S}$

Helotarsus, 31, 173, 717

Hemiglottides, 146,456 , 974

Hemignathus, 167

Hemipode, 66, 415, 757

Henipodius, 115

Hemixus, 461

Hen-Harrier, 408

Henicurus, 276

Hepatic Portal System, 1011

Herald, 406

Herbst's corpuscles, 973

Herle, 407

Hermit, 147

Her'n, 416
Hernser, 416

Hernshaw, 416

Herodias, 215

Herodii, 10, 11, 18, 68, 69, $76,90,118,146,243$, $517,606,607,610,613$, $615,617,879,952,972$

Herodiones, 406, 917

Heron, 3, 12, 33, 41, 98, $192,215,218,254,281$, $310,379,406,416,455$, $471,632,635,702,738$, 764,828

Heronry, 410

Heronsewe, 416

Heronshaw, 416

Herpetornithes, 780

Herring-Gull, 816

Hesperiphona, 251, 384

Hesperornis, 13, 280, 405, $477,649,699,753,754$, $857,858,954$

Heteralocha, 36, 184, 316, 438

Heterochrosis, 99, 215, 420, 1007

Heteroclitx, S05

Heterococcyx, 362

Heterocœlous, 850

Heterodactyles, 972

Heteromeri, S6, 406, 421. $425,532,547$

Heteromorpha, 322, 421, 422

Heterops, 509

Hewel, 421

Hewhole, 421, 1046

Heysuck, 825

Hibou, 677

Hickwall, 421, 915, 1046

Hickwaw, 421

Hickway, 421, 1046

Hielacidea, 757

Hierax, 685, $\mathrm{S} 02$

Hierofalco, 235, 401

Higera, 421, 1046

Highawe, 421

Highhaw, 1046

High-holder, 421, 1046

High-hole, 421, 1046

Himantopus, 100, 130, 284, $517,610,680,682,913$

Himbrim, 196

Hirondelle, 927

Hirundo, 189, 536, 559, $599,697,740,741,926$

Hirundo marina, 740

Histology, 12

Histrionicus, 407

Hjerpe, 394

Hlcápewince, 504 
Hoactzin, 9, 12, 296, 322, 421,911

Hobby, 235, 424, 477

Hobé, 424

Hobereau, 42.4

Hoberel, 421

Hocco, 421

Hoitlallotl, S4

Holarctic Region, 313, 378

Holaspidere, 431

Holm-cock, 425

Holm-Thrush, 425

Holorhinal, 425, 816, 877

Holorhines, 1015

Holzlianer, 421

Homalogonatæ, $11,19,425$, 609

Homodyuamous, 15

Homconeri, S6, 406, 421, $4 \cdot 25,547$

Homology, 15

Homolopus, 284

Homrai, 426, 434

Honey-bird, 426

Honey-Buzzard, 67, 426, 492

Honey-eater, 292, 428, 915 , 1025

Honey-guicle, 27, 429

Honey-sucker, 31, S7, 92 , $166,428,655,779, \mathrm{~S} 01$

Hoodie, 430

Hoopoe, 92, 93, 284, 430, $436,438,460,505,509$, $632,653,743$

Hoplopterus, 506, 733

Hornbill, 4, 35, 47, 70, 83, $92,112,134,234,283$, $426,432,480,601,632$, 788

Hol'ned Owls, 677

Horned Pheasant, 587

Hornero, 669

Horn-Pie, 437, 505

Hortolan, 658

House-Martin, 536

House-Sparrow, 896

Houtou, 595

Howlet, 437, 671

Hræfn, $766^{\circ}$

Hrain, 766

Hiagra, 416

Hróc, 795

Hrókr, 795

Huhola, 121

Huia, 36, 316, 437, 647

Huitrier, 682

Huin-bird, 441

\begin{tabular}{l|l} 
Humerus, 439 & Imber-Goose, 459 \\
Humming-bird, 18, 32, 43, & Immanes, 315, 76
\end{tabular}

$113,130,195,323,440$, Immer-Goose, 194, 458 638,762

Нирpe, 430

Hurgila, 451

Hyas, 732

Hydralector, 464, 5.21

Hydrobata, 667

Hyàrocheliảon, 955

Hydrocichla, 277

Hydrocorax, 434

Hydrornis, 284

Hylacola, 451

Hylactes, 946

Hyliota, 276

Hylochelidon, 5.38

Hylomanes, 594

Hylophilus, 1014

Hyoid, 452, 512

Bypapophyses, 854

Hyphantornis, 1029

Hypocleidium, 858

Hypopteron, 454

Hyporhachis, 3, 239

Hypositta, 648

Hypotarsus, 865 477

Hypselornis, 285

Hypsipetes, 230, 574

Hystornis, 654

IBIDOPODIA, 284

Tbidlopsis, 283 $754,850,859,954$

Icoturus, 773

Icteria, 85, 457, 1023 741,1024

Ictinia, 458, 491

Idle Jack, 3SI, 458

Iiwi, 182

Ikstern, 955

lleum, $45 \mathrm{~s}$

Ilium, 458

Imber, 194

Imberbi, 1058

Inber-Goose, 458
$477,529,534,594,632$, I Impennes, 11, 18, 29, 324,

Hurricane-bind, 294, 451

Hydrophasianus, 90, 461

Hymenolæmus, 843, 975

Hypolais, 12:2, 364, 1038

Hypotænidia, 764, 1032

Hypotriolchis, 235, 424,

Ibis, $34,89,95,146,283$, $349,379,454,513,610$, $702,877,952,973,974$

Ibycter, 74, 457

Ichthyornis, 281, 649, 753,

Icterus, 42, 46, 96, 329 $378,406,457,476,512$, $530,539,563,657,727$, 458,704

Impeyan Pheasant, 458, 5s6 Tmping, 596

Index, 459

Indian Cock, 586

Indian Raven, 433

Indian Region, 312, 355

Indicator, 27, 429, 617, 878, 952

Indigo-bird, $40,459,645$

Inepti, 459,766

Inertes, 459, 493

Insectivores, 459

Insessores, 312, 459, 524, 697, 698, 707, 718, 814

Intermaxilla, 877

Interpres, 997

Intestines, 459

Irena, 45, 168

Iris, 160

Irrisor, 432, 460, 617, 618, $\$ 57$

Isaac, 825

Ischium, 460

Isen, 485

Isepiptesis, 559

Isel'n, 485

Island Hen, 590

Isocœlons, 142

Ithagiuis, 44

Ivory-bill, 460

Ivory-Ciull, 575

Ixus, 59, 319, 161

Iyux, S1, 1053

JABIRU, 2, 379, 462

Jacamar, 30, 92, 463, 487, 749

Jacamaralcyon, 463

Jacameri, 463

Jacamerops, 463

Jacana, 380, 464, 521, 764, 819,893

Jackass, 465

Jack-bird, 802

Jackdaw, 132, 364, 466

Jacko, 690

Jack-Snipe, $466,8 \& 6$

Jacobin, I64

Jaggar, 522

Jaquette, $7: 0$

Jardræka, 366

Java Sparrow, 466

Jay, 116, 323, 429, 466, $592,647,722,812$

Jemuy-Wren, 470, 1050

Jerfalcon, 470

Jhagar, 522

John-Crow, 227, 470, 1016 
John-Down, 47]

Johnny, 471

Jugals, 872

Jumby-bird, 471

Jumping Jack, 465

Jungle-Fowl, 471

Jynx, 717, 814, 815

$\mathrm{KAAP}, 92$

Kackela, 460

Kae, 471

Kago, 691

Kagu, 32, 320, 471, 765, 925

Kaka, 473, 627

Kaliapo, 76, 316, 473, 477 , 686

Kakatielje, 92

Kakatua, 93

Kalekuttisclı Hün, 994

Kalij, 476

Kalkoentje, 458, 475, 575, 727

Kalkon, 994

Kallege, 476, 716, 1005

Kamichi, 819

Kapol-vogel, $\uparrow 25$

Kea, 476, 600, 627

KeeI, 476

Keel-bird, 477

Kelp-hen, 1032

KeIp-Pigeon, 832

Kentish Plover, 341

Kestrel, 89, 235, 327, 477, 815,903

Ketupa, 676

Kiddaw, 398, 480

Kidney, 361, 480

Kiebitz, 505

Kiewiet, 505

Killdeer, 481

Killigrew, 482

King-bird, 482

King-Crow, 167

King-Duck, 194

Kingfisher, 30, 92, 100, $243,281,320,404,463$, $465,485,593,601,631$, 749

King Harry, 489

Kinglet, 367, 489, 1052

King-Lory, 519

King-Vulture, 1015

Kirr-Mew, 489

Kite, $66,67,118,176$, $226,364,411,458,489$, $563,753,803$

Kittiwake, 398, 402, 492

Kitty, 493, 966

Kitty Wren, 1050

Kiwi, 3, 4, 224, 286, 315,
$459, \quad 493, \quad 578, \quad 630, \mid$ Lanner, 503, 522, 802

$646 \quad$ Laornis, 281

Knee, 498

Knorhaan, 498

Knot, 364, 385, 498, 539 $655,791,804,812$

Kobbe, 92

Koekkoek, 119

Koel, 499

Königłein, $99 ?$

Königsfischer, 485

Koet, 817

Kohlineise, 92

Koklas, 752

Koko, 691

Koning Roodebec, 795

Koperwiek, 777

Korrock, 795

Kraai, 116, 500

Kraan, 109

Krähe, 116

Kræn, 109

KramtsvogeI, 249

Kreuzschnabel, 113

Kruiper, 112

Kryber, 112

Krypare, 112

Kuckuk, 119

Kukker, 119

Kwakliel, 754

$\Pi$ wartel, 754

Kwikstaart, 1018

LABRADOR DUCK, 222, 736

Labyrinth, 984

Lacrymal, 871,876

Lacteal VesseIs, 1012

Lady-fowl, 500

Läminergeyer, 21, 101, 404, $407,500,501,1015$

Lærke, 507

Lagenoplastes, 538

Laggar, 522

Lag Goose, 371

Lagonosticta, 825

Lagopus, 89, 287, 341, 389, 597

Laletes, 1014

Lamellirostres, 503

Lampornis, 534

Lamprocolius, 229, 904

Land-Rail, 109, 131, 762

Langvia, 398

Langy, 398

Laniarius, 72, 503, 845

Lanier, 503

Lanius, 31, 66, 70, 116 , $124,134,167,253,284$, $292,362,463,483,517$, $574,575,643,681,697$, 843,1041
Lapwing, 68, 192, 310, $432,504,565,701,711$, $732,775,892,893,1054$

Lapwynches, 504

Lari, 850, 858, 863

Lark, 6, 70, 250, 431, 458, $476,507,513,539,565$, $598,659,671,726$

Lark-heeled Cuckow, 107

Laro-LimicoIæ, 118, 973

Larus, 10, 11, 29, 68, 81, $92,94,109,113,143$ $145,195,243,284,310$ $329,401,440,492,505$, $606,607,610,612,615$, $621,635,651,707,710$, $742,747,801,857,875$, $876,878,939,952$

Larynx, 512, 937

Lateral, 15

Latirostres, 513

Laughing Jackass, 465

Laurillardia, 283

Lavandière, 1018

Laverock, 513

Lavy, 398, 513

Láwerce, 507

Lazy Dick, 381

Leather-head, 293, 513

Leeuwerik, 507

Lefler, 514

Leistes, 458

Lemuria, 355

Lepelaar, 514, 733

Leplar, 514

Leptodon, 428

Leptoptilus, 2, 5, 284, 463, $536,610,741,952$

Leptosoma, 347, 638, 654, 739,972

Lerche, 507

Lerwa, 696

Lestris, 149,868

Leucocerca, 238

Leucopeza, 1023

Lencosarcia, 320, 723, 1041

Leucosticte, 251, 332, 516

Lever, 513

L'evesque, 40

Lhagar, 522

Lichenops, 998

Lichenoxauthine, 187

Licmetis, 93

Ligament, 514

Ligurinus, 251, 384

Limicole, 10, 29, 33, 68, $85,109,143,145,150$, $161,182,183,190,191$, 
$195,243,281,315,366$, $385,405,440,464,498$, $511,514,518,548,606$, $607,610,613,615,621$, $635,652,682,733,740$, $747,757,800,810,850$, $858,873,875,876,878$, 939,952

Limuatornis, 284

Limosa, 69, 128, 283, 365, $634,734,939$

Limpkin, 514, 765

Linete, 515

Linet-wige, 515

Linnet, 251, 383, 386, 515, 774

Linota, 251, 515, 773

Linotte, 515

Lintqubit, 515

Lintwhite, 515

Lipaugus, 86

Lipoa, 320, 530, 541, 621

Lipotypes, 319

Lira, 517, 523, 830

Lire, 523

Liri, 523

Lithornis, 281

Litorne, 249

Little Auk, 796

Little Bittern, 188

Little Owl, 679

Littorales, 514, 517

Liver, 513, 517

Lóa, 734

Lóarthræll, 734

Lobiophasis, 362

Lobipedes, 517

Lobipes, 712

Lobivanellus, 506

Locust-bird, 379, 517

Locustella, 779, 1021

Loddigesia, 444

Löfflar, 514

Logcock, 517, 1048

Logger-head, 517, 597, 737

Loggerhead Duck, 762

Lómr, 518

Longipennes, 310, 518

Longirostres, 85, 518

Longlegs, 914

Long-tailed Duck, 70

Loom, 151, 518, 522

Loon, 382,518

Looree, 519

Lophogyps, 1017

Lophoictinia, 491

Lopholæmus, 610

Lophophaps, 58, 320

Lophophorus, 458, 585, 716

Lophopsittacus, 216, 1006
Lophortyx, 756, 939

Lophosteon, 910

Lophotibix, 456

Lord, 519

Loriculus, 530

Lorikeet, 519, 520

Loripes, 913

Lorius, $320,520,690$

Lory, 519, 687

Lotus-bird, 464, 521

Louro, 519

Loury, 519

Lóuthræll, 734

Love-bird, 521, 689

Love-gestures, 892, 893

Lowan, 522, 541

Loxia, 114, 250, 386, 571, 698

Loxops, 1053

Luggar, 238, 522, 803

Lullula, 509

Lumme, 518, 522

Lunda, 522

Lunde, 522

Lungs, 522

Luscinia, 637

Lymphatic System, 1012

Lymphatic Vessels, 1008

Lyncornis, 639

Lynx, 717

Lyra, 523, 830

Lyre-bird, 2, 9, 92, 242, $320,523,753,821$

Lyric, 523, 830

MAAGE, 401

Macao, 527

Macaw, 527

Maccao, 527

Maccaroni, 529

Maccaw, 220, 527, 690

Machæropterus, 532

Machao, 527

Machetes, 798

Mackerel-bird, 529

Mackerel-cock, 529

Mackerel-Diver, 529

Mackerel-Gull, 529

Macreuse, 102, 817

Macrocephalon, 541

Macrocercus, 527

Macrochires, 16, 29, 442, 529

Macrodipteryx, 641

Macronyx, 458, 475, 575, 727

Macroptères, 518

Macroptery $x, 936$

Macrornis, 283

Macucagua, 963

Madge, 529, 720
Mrew, 547

Máfur, 401

Magot, 720

Magpie, 364, 403, 530, 720

Magpie-Lark, 530

Magpie-Robin, 530

Magpie-Shrike, 530

Maina, 378, 530

Maiwi, 539

Maize-bird, 530

Makavouanne, 528

Malacocercus, 25

Malaconotus, 845

Malacoptila, 750

Malacorhynchus, 842

Malart, 168, 530

Maleo, 530

Malkoha, 530

Mallard, 168, 530

Mallee-bird, 530, 541

Mallemuck, 9, 293, 530, 585

Mallemugge, 295, 530

Malleoe, 540

Malurus, 821, I022

Malvitius, 539

Mamo, 167, 225, 655

Mamuco-Diata, 38

Manacus, 533

Manakin, 85, 93, 421, 531, 892

Manchot, 704

Mandarin-Duck, 534

Mandible, 534

Mango-bird, 534

Mangrove-Cuckow, 534

Mangrove-hen, 534

Manneken, 531

Man-of-twar bird, 6, 293, 534

Manorhina, 31

Manucode, 40, 150, 534

Manucodia, 140, 144, 534, 917

Manucodiata, 38, 534

Manukdewata, 534

Manu-mea, 724

Måse, 401

Marabou-Stork, 536

Maracry, 213

Mareca, 1039

Margarops, 959

Margot, 720

Maringouin, 365, 498

Mariu-erla, 1018

Marlin, 367, 536, 545

Marlion, 545

Maroang, 2:13

Marrock, 398, 536

Marrot, 536, 750, 768

Marryang, 213 
Marsh-Harier, 409

Marsh-hen, 536

Martelet, 536

Martin, 189, 454, 536, 632, 928,934

Martin (Fr.), 538

Martiuet, 536

Martlet, 536, 934

Marvizzo, 539

Mascarin, 687

Mase, 966

Mastoid, 875

Matuitni, 750

Mauviette, 539, 959

Mauvis, 539, 778

Mâvi, 539

Mavis, 539, 7\%8, 959

Maxilla, 539

May-bird, 539

May-chick, 539

May-cock, 539

May-fowl, 539

Meadow-chicken, 539

Meadow-hen, 539

Meadow - Lark, 512, 539, 575

Median, 15

Meerelster, 682

Mees, 966

Meeuw, 401

Megacephalon, 320, 541, 939

Megalæma, 28, 319, 879

Megalapteryx, 579

Megalestris, 869

Megaloprepia, 97

Megalornis, 281, 576

Megapode, 59, 522, 530, $539,600,621,630,707$, 753

Megapodii, 118

Megapodius, $77,126,243$, $319,360,361,539,597$, 972

Meggy, 543, 601

Megistanes, 78, 320, 543, 766

Meionornis, 580

Meise, 966

Melampitta, 728

Nelanerpes, 773, 1048

Nlelanism, 99, 542, 543, 1007

Melanocorypha, 70, 510

Melanodryas, 791

Meleagris, 69, 285, 399, $610,765,952,994$

Melidor'a, 488

Melierux, 1002

Meliphaga, 31, 32, 33, 44, $92,166,292,316,428$,

573, 655, 691, 743, 779, Milhuez, 539 975

Melithreptus, 87, 429, 1058

Melittophagus, 30

Melizophilus, 1038

Mellisuga, 444

Mellopitta, 728

Melopsittacus, 59, 194, 953

Menura, 2, 9, 92, 134, 320, $453,523,607,630,746$, $747,753,765,822,878$, 912,939

Merganetta, 545, 975

Merganser, 151, 168, 369, $371,407,503,543,814$

Mergulus, 339, 796

Mergus, 168, 284, 299 , $369,371,503,543,917$, 984

Merle, 545

Merlin, 235, 477, 536, 545

Mero, 791

Meroblastic, 546

Meropogon, 30

Merops, 29, 68, 77, 92, $292,463,487,593,616$, $630,654,718,743,747$, $794,853,857,879,912$, 912

Merrythought, 296

Merry-wing, 546

Mertyn, 546

Merula, 42, 545, 961

Mes, 966

Mésange, 966

Mesembriormis, 905

Mesentery, 546

Mesites, 353, 730, 764, 858,877

Mesoblast, 546

Mesomyodi, 86, 406, 421, $426,532,546,728,938$

Mesopteryx, 580

Metacarpus, 547, 859

Netasternum, 910

Metatarsus, 547, 861

Metopia, 532

Metopiana, 736, 983

Metopidius, 464

Mietostea, 910

Meve, 401

Mew, 401, 547

Microdactylus, 827

Microglossa, 34

Microligia, 1023

Micromonacha, 750

Micronisus, 898

Micropterus, 518, 737

Micropus, 934

Micropus, 934
Migration, 547
Miliaria, 659

Miller, 572

Milnea, 284

Milvago, 74

Milvid, 539

Milvulus, 483, 816, 999

Milvus, $67,89,144,284$, 489

Mimeta, 573, 656

Mimetes, 573

Mimicry, 572

Mimocichla, 959, 961

Mimus, $80,582,958$

Mina, 575

Minivet, 575

Minor, $378,530,575$

Mirafra, 511

Mire-dromble, 40, 575

Mire-drum, 575

Miro, 316, 791, 1035

Miroir, 899

Miserythrus, 218, 764

Missel-bird, 575

Missel-Thrush, 575

Mistletoe-Thrush, 249, 425, $575,820,843,960$

Mitua, 127

Mniotilta, 85, 273, 323, $328,365,777,1022$

Moa, 3, 82, 151, 226, 286 , 315,575

Moat-hen, 582, 589

Mock-bird, 582

Mocking - bird, 26, 80 , 582

Mock-Nightingale, 582

Mock Regent-bird, 780

Moeleoe, 540

Mohoa, 655

Molenaartje, 572

Molly, 585

Molly-Mawk, 9, 295, 530, 585

Molly-Washdish, 1018

Molobrus, 108,458

Molothrus, 108

Molpastes, 59

Momotus, 30, 92, 134, $324,433,463,487,593$, $616,617,654,746,747$, 939

Monacha, 750, 770

Monal, 459, 585, 716

Monk, 293, 587

Monstrosities, 587, 1003

Monticola, 45, 887, 889, 961

Montifringilla, 251, 517, 887

Moonaul, 585 
Moor-Buzzard, 67, 409, | Muscivora, 1000 491,589

Moorcock, 589

Moore-heuue, 389

Moor-fowl, 389, 589

Moor-game, 389

Moor-hen, 299, 582, 589

Moor-poult, 589

Moor-Titliug, 595

Mooruk, 80, 592

Moose-bird, 592

Morah, 575

Morepork, 295, 592, 643, 671

Morillon, 369, 592

Mormon, 113, 753

Mosquito-Hawk, 593

Moss-cheeper, S6, 593

Motacilla, 45, 108, 120, $131,134,151,276,284$, $332,367,381,458,475$, $511,559,598,637,697$, $727,758,772,780$, 1018

Mother Carey's Chicken, 593, 709

Mother Carey's Goose, 593

Mother Carey's Hen, 593

Moth-Hawk, 593

Moth-hunter, 593

Motmot, 30, 92, 134, 463, $487,543,762,814$

Mottled Owl, 678

Mouchet, 620

Nouette, 401

Moult, 170, 393, 595

Mound-bird, 540, 600

Mountain-Bunting, 600

Mountain-cock, 31, 590, 600

Mountain-Duck, 600

Mountain-Finch, 251, 600

Mountain-Parrot, 600

Mountain-Quail, 295

Mountain-Sparrow, 600

Mouse-bird, 12, 92, 101, $251,600,684$

Nousquet, 620

Mouth, 136

Mud-Lark, 512

Muggy, 543, 601

Muisvogel, 600

Müllerchen, 572

Mullet-Hawk, 601

Mumruffin, 601

Munál, 585

Munia, 108, 466, 601, 648 Nurre, 398, 602

Muscicapa, 57, 92, 134, $238,273,316,362,364$, $3.85,697,738$
Muscular System, 602

Musk-Duck, 171

Musket-Hawk, 620

Musophaga, 12, 18， 35, $69,92,95,96,147$, $284,347,422,615,630$, $730,753,815,857,858$, $863,952,972,980$

Musquet-Hawk, 620

Mutton-bird, 620, 831

Mycteria, 4, 379, 462, 741, 952

Myiadectes, 887, 1028

Myiadestes, 1028

Myiagra, 275, 814

Myiarchus, 483, 518, 973, 999

Myiodioctes, 1023

Myiodynastes, 483

Myiomoira, 316, 791, 1035

Myiothera, 134

Myiozetetes, 493

Myna, 378

Mynah, 530

Myzomela, 44, 428, 887

NA'Ara, 212

Na'êma, 212

Nail, 89

Namaqua Duif, 724

Nandu, 620, 785

Nares perviæ, 875

Nasal Glands, 620

Nasals, 871,876

Nasiterna, 93, 687

Nasutæ, 621

Natatores, 621, 650, 972

Native - companion, 112, 621

Native-hen, 621

Native-Pheasant, 541, 621

Native-Sparrow, 621

Native-Thrush, 621

Native-Turkey, 621

Nauclerus, 491

Nearctic, 312, 329

Neck, 621

Necropsar, 353, 354

Necropsittacus, 218

Necrornis, 284

Nectarinia, 97, 349, 428, $444,743,922,975$

Nemosia, 944

Neochloe, 1014

Neocorys, 727

Neomorpha, 438

Neomorphus, 126

Neophron, 364, 606, 621. 1016

Neossoptile, 243, 629, 635
Neotropical, 312, 321

Nervous System, 621

Nesoctites, 720

Nesonetta, 1006

Nest, 630

Nestor, 223, 316, 473, $476,600,627,686$

Nettium, 949

Nettle-creeper, 1037

Nettopus, 376, 949

Neunmörder, 643

Neuntödter, 643

New-Holland Vulture, 59, 541

New-Zealand Region, 315

Nhandu-guaçú, 620

Niais, 629

Nias, 629, 645, 696

Nicobar Pigeon, 724

Nidax, 629

Nidicolæ, 10, 154, 212, $234,243,629$

Nidification, 630

Nidifugæ, 10, 153, 212, $234,243,635,814$

Night-Hawk, 635, 639

Night-Heron, 45, 416, 635, 754

Nightingale, 6, 45, 59, 339, $550,635,777,778,892$

Nightjar, $17,68,88,89$, $161,295,297,351,365$, $395,442,592,593,630$, $635,638,671,738,749$

Night-Parrot, 473

Night-Raven, 643

Nihtegale, 635

Nilaus, 58,845

Nine-killer, 643

Nine-murder, 643

Nisaetus, 178

Nisoides, 411

Nisus, 412

Noddy, 310, 643

Noira, 519

Non, 646

Nonnenmeise, 646

Nonnette, 646

Nonnula, 750

Nonpareil, 459, 644

Nope, 645, 655

Nor, 519

Norfolk Plover, 129, 645

Nori, 519

Nothocercus, 965

Nothocrax, 127

Nothoprocta, 965

Nothura, 615, 964

Noto-Coracomorphæ, 39 , 846, 1025 (cf. Austro. coraces) 
Notogæa, 314

Notornis, 286, 316, 591, 592, 1007

Nousbrecher, 646

Noyra, 519

Nucifraga, 571, 646

Nullipennes, 493, 646

Numenius, $25,68,127,145$, 146, 148, 161, 284, 299, $514,610,612,1036$

Numida, 299, 399, 765

Nun, 646, 967

Nuri, 519

Nussbrecher, 646

Nutcracker, 116, 571, 646

Nuthack, 647

Nuthatch, 112, 189, 632 647,1048

Nutjobber, 647

Nutmeg-bird, 648

Nyctala, 178, 675, 899, 814

Nyctea, 178, 287, 674

Nyctibius, 643, 738, 879

Nycticorax, 33, 45, 229, $244,416,754$

Nyctidromus, 639, 941

Nyctiornis, 30

Nyroca, 734, 815

OAT-FOWL, 649

Oatseed bird, 649

Occipitals, 870

Occiput, 649.873

Oceanites, 710

October-bird, 649

Ocydrome, 649

Ocydromus, $315,592,764$, $858,973,1031$

Ocyphaps, 58

Odontoglossæ, 649

Odontoid, 852

Odontolcæ, 640, 954

Odontophorinæ, 188

Odontophorus, 649,756

Odontopteryx, 281

Odontornithes, 281, 649, 954

Odontotormæ, $649,655,954$

Edemia, 36, 817, 983, 984

Edicnemus, 68, 129, 148 , $284,440,453,610,877$, 919,958

Ena, 371, 724

Enops, 470

Ern, 175, 215, 657

Esophagus, 653

Oestervisscher, 682

Estrelata, 227, 395, 709

Oil-bird, 394, 638, 653
Oil-gland, 653

Oiseau-de-soleil, 252, 924

Oiseau-mouche, 442

Oiseau-trompette, 992

Olaf, 655

Old man, 654

Old squaw, 654

Old wife, 654

Olecranon, 654

Oligomyodæ, 58, 323, 654, 938

Olive, 655

Olph, 10, 655

Ombre, 655

Ombrette, 406, 655, 1000

Ombria, 600

Onocrotalus, 702

Ontogeny, 13

Onychoprion, 1039

$0-0,167,655$

Oocyan, 187

Ooijevaar, 919

Oorhodeiue, 187

Ooxanthine, 187

Open-bill, 510, 655

Ophiotheres, 824

Opisthocœlous, 850

Opisthocomus, 9, 12, 29, $113,118,145,147,322$, $421,606,615,630,635$, $655,745,746,747,765$, $857,858,879,939$

Opisthodactylus, 905,907

Opisthotic, 875

Oporornis, 1023

Orange-bird, 655

Orange-Quit, 701

Orbitosphenoid, 871, 876

Orchard-Oriole, 657

Orchilus, 442

Oreocincla, 770

Oreœca, 31, 958 .

Oreophasis, 126,397

Oreopsittacus, 521

Oreoscoptes, 582

Oreotrochilus, 97, 448

Orfraie, 660, 679

Organ-bird, 404, 656

Organist, 656

Organiste, 40, 656

Oriental Region, 355

Oriol, 656

Oriole, 230, 406, 457, 463, $573,632,656,1029$

Oriolia, 1050

Oriolns, 134, 230, 457, 534 $559,574,656,697,717$, 779

Ornithichnites, 657

Ornithion, 483

Ornitholite, 657
Ornithology, 657

Ornithopus, 277

Ornithotomy, 657

Ornithuræ, 754, 814

Ortalida, 397

Ortalis, $82,325,397$

Orthocœlous, 142

Orthonyx, 77, 657, 822, 1036

Orthotomus, 942, 1022

Ortolan, 47, 61, 365, 658

Ortygis, 765

Ortygometra, 762

Ortygornis, 692

Ortyx $47,95,696$

Ortyxelus, 757

Oscines, 1, 380, 453, 617, $659,668,698,718,737$, $746,939,940,951$

Os entoglossum, 872

Osle, 666

Ospray, 660

Osprey, 178, 192, 253, $332,503,601,632,660$, 672,679

Ossification, 47

Ossifraga, 593, 660, 710, 952

Ossifrage, 503, 660, 662

Osteornis, 282

Ostrich, 3, 33, 66, 89, $91,130,190,194,197$, $212,234,285,346,380$, $630,651,662,770,781$, 785

Otidiphaps, 724

Otis, 9, 62, 77, 130, 145, $284,320,371,380,405$, $440,607,610,621,635$, $654,746,747,824,829$, 875,912

Otocorys, 511

Otogyps, 349, 1017

Otus, 678

Oubrier, 424

Ourissia, 442

Ousel, 277, 666

Ouzel, 666

Ovary, 669

Oven-bird, $632,669,1053$

Oviduct, 660

Ovum, 195

Owl, 1, 3, 16, 33, 47, 68, $178,184,188,191,218$, $287,316,353,364,409$, $437,471,529,534,565$, $592,634,638,642,671$, 892

Owl (Pigeon), 164

Owlet, 671

Owl-Parrot, 473 
Ox-bird, 680

Uren-and-Kine, 680

Ox-eye, 680, 913, 967

Ox-pecker, 30, 680, 788

Oxlophus, 125

Oxynotus, 70, 353, 681

Oxyurus, 719

Oyster-catcher, 109, 130, $380,518,565,655,681$, $725,733,817,822,833$, 838,913

PAaUW, 683, 699, 730

Pachycephala, 319, 621, 957

Pachyornis, 580

Pachyrhamphus, 325

Pacinian Corpuscles, 973

Padda, 466, 683

Paddy-bird, 683, 789, 832

Pædotrophæ, 814

Pagophila, 402

Paictes, 730

Paisano, 84

Palæarctic, 312, 329, 334

Palæeudyptes, 283

Palægithalus, 283

Palælodus, 257, 280, 284

Palælogrus, 283

Palæocircus, 283

Palæohierax, 284

Palæoperdix, 284

Palæornis, 218, 280, 354, $384,685,953$

Palæortyx, 283

Palæospiza, 283

Palæotetrix, 285

Palæotringa, 281

Palamedea, 9, 86, 113, 118 . $146,324,379,465,607$, $616,635,683,744,745$, $746,747,770,819,826$, $865,875,939,972,1001$

Palamedeæ, 853, 912

Palapteryx, 578

Palate, 683

"Palatine," 872

Pamprodactylæ, 600, 684, 972

Pancreas, 684

Pandion, 140, 144, 178, 612 $616,617,653,660,865$

Panurus, 113, 251, 337, 453,969

Panyptila, 711, 936

Paon, 699

Paon des roseaux, 924

Papagaio, 684

Papagallo, 738

Papagau, 738

Papagayo, 684, 738
Papagei, 684

Pape, 40, 645

Papegai, 738

Papegau, 738

Papegaut, 684

Papejay, 738

Paradisea, 38, 51, 148, 320, 523, 534, 681, 697, 717, 790,878

Paradise-bird, 684

Paradisornis, 39

Paradoxornis, 251, 510

Paraka, 84

Parakeet, 684, 770, 796 (cf. Parrakeet)

Parapteron, 684

Paraquito, 684

Pardalote, 684

Pardalotus, 134, 277

Pareudiastes, 320, 591

Parietal, 871

Parisomus, 58

Parkinson, 523

Parkinsonius, 523

Parra, 60, 90, 380, 464, $521,610,684,764,819$ 877

Parrakeet, 59, 218, 384 (cf. Parakeet)

Parraqua, 84

Parrot, 3, 16, 32, 54, 76, $93,96,216,229,234$, $473,521,527,534,653$, $684,738,743$

Parson-bird, 429, 691

Parson-Gull, 692

Partridge, 86, 192, 566, 633, 692, 756, 773

Partridge-Hawk, 237, 696

Partridge-Pigeon, 696

Parula, 1023

Parus, 45, 83, 92, 189, 283 , $316,329,332,367,453$, $532,648,658,697,814$, 967

Pashara boues, 48

Passage-Hawk, 696

Passenger-Pigeon, 696, 723

Passer, 140, 186, 251, 895

Passeres, 1, 3, 4, 11, 18, 19, $21,29,32,33,39,53$, $58,69,77,102,104$, $118,134,143,148,167$, $183,190,194,195,229$, $243,244,250,282,312$, $406,426,459,483,510$, $517,532,535,538,582$, $603,607,610,617,618$, $621,623,621,629,634$, $660,697,728,730,739$, $742,747,784,789,821$,
$853,858,863,875,912$,

918, 938, 972, 984

"Passeridæ," 697

Passeriformes, 697

Passerina, 459, 644

Passerinæ, 697

Passerini, 698, 718, 737

Passer muscatus, 441

Pastor, 698, 904, 918

Pasture-bird, 698

Patagona, 443

Patella, 698

Patrick, 692

Patrijs, 692

Pauwis, 739

Pauxis, 78, 127

Pavo, 363, 610, 699, 765, $855,861,862,863,864$, 994

Pavo sylvestris, 73

Pavoncella, 505

Pawe, 699

Paxaro mosquito, 441

Paxaros bobos, 48

Peacock, 21, 100, 150, 241, $699,716,739,770,931$

Peafowl, 701

Peaseweep, 505, 701, 711

Pecten, 701

Pectineal Process, 701

Pectoral Arch, 856

Pediocætes, 394, 726, 740

Pedionomus, 113, 145, 320 $517,610,757$

Pediophili, 744, 805

Peep, 702

Peetweet, 811

Peewit, 403, 505

Peggy - Whitethroat, 702 1037

Pelagornis, 280

Pelargi, 10, 11, 68, 118, $144,145,243,406,517$, $606,607,621,879,952$

Pelargodes, 284

Pelargomorphæ, 134, 420 , 456,702

Pelargopsis, 284

Pelecanoides, 708

Pelecanus, 68, 284, 293, 300, $607,702,745,917,974$

Pelican, 4, 269, 287, 599, 702

Pelicanus, 173, 702, 904

Pelidna, 283

Pellorneum, 25

Pelvic Arch, 860

Pelvis, 703, 860

Pen, 92, 703, 929

Penelope, 126, 396, 703, 765,984 
Penguin, 33, 221, 283, 458, | Phalaropus, 517, 634, 711, $471,477,493,529,596$, $646,703,769$

Penguin-Duck, 170

Penis, 91

Penthetria, 1030

Perchers, 707

Perdicula, 756

Perdix, 44, 192, 692, 765, 902,941

Perdrix, 692

Perdrix d'Angleterre, 805

Peregrine Falcon, 236, 707

Peres, 503

Pericœlous, 142

Pericrocotus, 575

Periotic, 871,874

Periquito, 684

Perisoreus, 468, 1036

Peristera, 725

Peristeromorphæ, 422, 707, 805,816

Peristeropodes, 126, 397 , $539,707,754$

Peritoneum, 707

Pernis, 67, 426, 492, 1024

Pernix, 426

Perriche, 684

Perroquet, 684

Perroquet-de-terre, 971

Perroqueto, 684

Perrot, 684

Perruche, 684

Pertriche, 692

Pessulus, 940

Petchary, 999

Petit Duc, 678

Petrel, 32, 81, 227, 295, $395,477,518,575,593$, $707,723,726,742,830$, 993

Petrœca, 771, 791，958, 1035

Petrosal, 874

Pettichaps, 710

Peucedromus, 1023

Pewee, 710, 711

Pewit, 701, 710, 716, 718

Pezophaps, 90, .150, 888

Pezoporus, 475, 815

Pfau, 699

Phænorrhina, 724

Phathon, 33, 46, 190, 607, $745,875,904,917,990$

Phaethornis, 447

Phalacrocorax, 105, 223, $283,607,651,745,770$, $829,904,917,939,952$

Phalanges, 711,866

Phalaridopus, 711

Phalarope, 150, 711, 800
810

Phaps, 58, 407, 723

Pharomacrus, 97, 760,987

Phasiana avis, 713

Phasianus, 44, 84, 86, 90, $113,259,284,319,362$, $422,586,701,713,765$

Phasidus, 350, 401

Pheasant, 21, 86, 262, 476, $478,522,523,541,566$, $586,588,633,701,713$, 752

Phegornis, 713

Phene, 503

Phibalura, 840

Philacte, 374

Philedon, 134, 292 573,656

Philepitta, 323, 347, 353, $406,547,729,939$

Philhetærus, 1029

Philip-Sparrow, 132, 716

Phillip-Island Parrot, 223

Philp, 716

Philydor, 719

Phodilus, 672

Phœbe, 483

Phœbe-bird, 711, 716

Phœbetria, 708, 758

Phœnicocercus, 94

Phœnicoparrus, 257

Phœnicophaes, 125, 530, 607

Phœnicopterus, 12, 18, 20, $29,68,76,91,145,243$, $253,284,379,440,452$, $606,607,610,616,635$, $649,741,746,747,854$, $857,863,865,875,912$, $917,918,939,973$

Phœnix, 38, 717

Phonipara, 381, 761

Phonygama, 535, 984

Phororhacos, 281, 864, 905, 908

Phorysrhacos, 905

Photodilus, 672

Phyllornis, 319, 355

Phylloscopus, 87, 332, 368, 557,1022

Phyllostrephus, 59

Phylogeny, 13

Phytotoma, 134, 730, 878

Piaya, 125, 265, 941

Pica, 124, 722

Picæ, 19, 459, 697, 717 , 720

Picaflor, 442
Phalcobænus, 75

Philemon, 289, 292, 429,
Picariæ, 20, 89, 92, 118, $190,191,243,283,312$, $440,463,593,607,611$, $616,621,718,749,770$, $789,794,858,972$

Picarii, 654, 698, 718

Piccione, 723

Pic-grimpereau, 718

Pichat, 718

Pici, 11, 29, 69, 77, 229, $440,517,607,610,630$, $718,719,853,857,879$, $912,939,974$

Picicorvus, 647

Pickcheese, 718

Pickmire, 718

Picktarn, 718

Picoides, 405, 720, 1049

Picucule, 658, 669, 718

Picule, 720

Piculet, 720, 1049

Piculule, 718

Picumnus, 720, 1049

Picus, 81, 96, 147, 195, $229,258,283,299,319$, $329,443,453,460,463$, $517,600,612,613,617$, $619,620,647,717,718$, $720,747,814,815,937$, 952,1046

Pie, 116, 429, 466, 529, 631 720,1024

Pie-de-mer, 682

Pied Duck, 222

Pierrot, 684

Piet, 720

Pie-wype, 1054

Piezorhynchus, 275

Pigeon, 3, 16, 32, 53, 58, $66,154,162,188,194$, $246,261,286,311,378$, $407,564,588,631,635$, $653,696,723,726,753$, $782,793,812$

Pigeon blanc, 832

Pilwillet, 725

Pimlico, 293, 725

Pinc, 82

Pincio, 82

Pincione, 82

Pinc-pinc, 725

Pine-Goldfinch, 847

Pine-Grosbeak, 386

Pingouin, 704

Pinicola, 143, 251, 386

Pink, 725

Pinkeye, 842

Pinson, 82

Pintado-Petrel, 710, 725

Pintail, 109, 171, 726, 822

Pin-wing, 221 
Pinzon, 82

Pionus, 521, 654, 690

Piper, 723

Pipile, 397

Pipilo, 982

Piping Crow, 116, 403, 726 Pipio, 109, 723, 726, 1039

Pipione, 723

Pipiri, 726

Pipit, 316, 475, 512, 598, 671, 726

Pipra, 85, 86, 93, 134, 323, $421,532,656,928,939$

Pique-bœuf, 680

Piramidig, 727

Pirenet, 727

Pirree, 727

Pitangus, 483, 518

Pitta, 21, 96, 148, 323, $362,388,406,547,727$, 939,940

Pitylus, 945

Pityriasis, 362

Plagiocœlous, 142

Plantain-eater, 35, 92, 288 , $730,753,980$

Plant-cutter, 134, 730

Platalea, 91, 145, 146, $379,456,607,610,615$, $629,737,746,747,865$, $877,900,912,952,974$, 983,985

Platea, 900

Platycercus, 686, 796, 858

Platyrhynchus, 999

Platysternæ, 730

Platystira, 276

Plectrophanes, 61, 189, 517, 887

Plectropterus, 90, 376, 837

Plectrorhamphus, 1058

Plectrorhyncha, 1058

Plegadis, 456

Plictolophus, 93

Ploceus, 29, 31, 72, 109, $230,250,319,386,466$, $602,784,825,1028$

Plotus, 252, 607, 745, 880, $904,918,950,952$, 1024

Plover, 32, 60, 66, 85, $130,162,171,183,284$, $308,311,380,481,504$, $539,571,631,682,730$, $740,810,828$

Plover's Page, 734

Plovers' eggs, 504

Plovier, 730

Pluvianus, 349, 442, 732

Pluvier, 730

Plyctolophus, 628
Pochard, 22, 72, 168, 172, $230,407,734,773,815$

Pocheculier, 734

Pockard, 734

Pocs, 739

Podargus, 32, 33, 69, 148, $295,592,612,638,639$, $654,737,738,875,876$, 879,941

Podica, 145, 252, 517, 615, $629,746,747,875,973$

Podiceps, 151, 310, 381

Podicipedes, 912

Podicipes, 11, 18, 68, 77, $78,89,118,131,146$, $151,156,190,243,353$, $381,440,518,607,610$, $612,615,630,635,699$, $741,745,746,747,753$, $816,854,858,863,875$, $878,917,937,939$

Podicipitiformes, 651

Podilymbus, 383

Podoa, 252

Podotheca, 511

Poe-bird, 691, 737

Pœocephalus, 686

Poes, 739

Pogonias, 815

Pogonorhynchus, 27

Pogonornis, 316, 429, 915

Poker, 734

Polioptila, 365

Pollex, 737, 741, 781

Polly Washdish, 1018

Polochion, 292

Polyborus, 74

Polymorphism, 798

Polymyodæ, 737, 938

Polymyodi, 1, 698, 737

Polyphasia, 125

Polyplectrum, 701

Polytelis, 384

Polytmus, 445

Pompadour Chatterer, 86, 737

Pona-inki, 727

Ponnunky pitta, 727

Poodytes, 381, 939

Pool-Snipe, 737

Poophila, 1029

Poor-soldier, 293, 737

Poot-Hawk, 753

Pope, 737

Popeler, 737

Popinjay, 684, 738

Porphyrio, 68, 316, 591, 972

Porphyriornis, 590

Portal Venous System, 1012
Port-Egmont Hen, 738, 869

Porzana, 68, 353, 764, 895,1024

Post-bird, 738

Potamodus, 77, 1021

Potoo, 738

Poule d'Inde, 994

Poule rouge, 1033

Poulle de la Guinée, 400

Poult-Hawk, 753

Pouter, 164

Powder-down, 420, 738

Powee, 739

Powese, 739

Poy-bird, 691

Prrecoces, 10, 635, 739

Prrecoracoid, 856

Præmaxilla, 872

Præsphenoid, 871

Prairie-Chicken, 739

Prairie-Falcon, 238

Prairie-fow1, 4

Prairie-hen, 739

Praticola, 777, 918, 1035, 1036

Pratincola, 740

Pratincole, 9, 108, 517, 733,740

Presaie, 679

Pressirostres, 85

Primaries, 741

Prion, 34, 708, 742

Prionites, 593

Prioniturus, 595

Prionodura, 51

Prionops, 380, 846

Prionorhynchus, 594

Prionotelus, 327, 988

Procellaria, 69, 81, 140, $146,295,310,707,742$, 830

Procellarieæ, 708

Procnias, 944

Procœlous, 850

Proctodæum, 91

Prodotiscus, 430

Progne, 484, 538

Progoura, 286

Proherodius, 281

Promerops, 428, 743, 790, 923

Pro-ostea, 911

Prootic, 874

Propasser, 386

Propelargus, 283

Prosobonia, 225, 713, 813

Prosthemadera, 316, 429

Prosthematodera, 691, 939

Protonotaria, 1023

Protornis, 282

Proud tailor, 743 
Proventriculus, 916

Proximal, 14

Pseudapteryx, 286

Pseudochelidon, 1050

Pseudogerygone, 364

Pseudogryphus, 102, 1016

Pseudogyps, 1017

Pseudoscines, 1, 320, 524, 743, 822, 921

Psilopædes, 743, 748

Psilorhinus, 470

Psittace, 685

Psittaci, 11, 18, 29, 34, $69,77,93,113,118,144$, $147,220,243,244,299$, $312,440,474,519,527$, $606,607,610,612,613$, $615,617,619,629,688$, $738,739,743,747,850$, $858,863,865,879,939$, $941,952,953,975$

Psittacini, 815

Psittacomorphæ, 134, 688, 743

Psittacula, 96, 521, 689

Psittacus, 286, 350, 627, $685,717,718,739,815$

Psophia, 9, 118, 145, 324, $380,473,829,912,973$, 992

Psophodes, 91

Ptarmigan, 389, 597, 744

Pteuornis, 284

Pternis, 68, 426

Pterocles, 10, 11, 29, 68, $113,118,145,191,243$, $284,440,610,611,612$, $613,615,616,635,726$, $746,747,805,854,877$, $879,912,939,952$

"Pterocletes," 744, 805

Pteroclides, 744

Pteroclomorphæ, 422, 744, 805

Pteroclurus, 805

Pteroglossus, 815, 978

Pterophanes, 447

Pteroptochus, 25, 323, 524, 939, 940, 946

Pterygoid, 744, 872, 879

Pterylosis, 744

Ptilogonys, 1028

Ptilopædes, 743, 748

Ptilopus, 563, 723

Ptilorhynchus, 49, 814

Ptiloris, 790

Ptilorrhis, 97, 790

Ptilosis, 748

Ptilotis, 319, 428

Pubis, 748

Puckeridge, 639, 748
Pucrasia, 716, 752

Pudding-poke, 749

Puet, 719

Puff-bird, 12, 92, 463, 749, 770

Puffin, 22, 35, 107, 398, $522,536,556,597,737$, $750,768,797,822,830$, 973

Puffinus, 284, 517, 620, $752,830,952$

Pukras, 716,752

Pullastræ, 753

Pulmonary Circulation, 1008

Purple Water-hen, 591

Purre, 753

Puttock, 67, 753

Pycnonotus, 59, 461, 574

Pygopodes, 10, 29, 146, $381,652,753$

Pygoscelis, 471, 706

Pygostyle, 753, 769

Pylorus, 916

Pylstaart, 754

Pyranga, 771, 944

Pyrenestes, 1028

Pyrocephalus, 483

Pyromelæna, 1028

Pyrrhocorax, 87, 134

Pyrrholæmus, 777

Pyrrhula, 60, 251，332, 338

Pyrrhulauda, 659, 510

Pyrrhuloxia, 387

Pytelia, 31

QUA-BIRD, 754

Quadrate Bone, 754, 872, 879

Quaglia, 754

Quail, 47, 66, 94, 261, 316, $389,407,415,649,754$, 761,762

Quail-Dove, 757

Quail-Hawk, 480, 757

Quail-Snipe, 757

Quaille, 754

Quailzie, 754

Quaker, 758

Quaketail, 755

Quam, 396, 758

Quan, 396, 758

Qua-qua, 21, 758

Quaquila, 754, 761

Queest, 162, 758

Quercelle, 477

Quercerelle, 477

Querquedula, 297, 309, 983,

Quesal, 758

Quetzal-tototl, 758

Quezal, 758, 770, 987
Quhaip, 1033

Quill, 761

Quill-tail Coot, 761

Quinck-Goose, 761

Quirizao, 126

Quiscalus, 46, 379, 563 . 761,966

Quisquilla, 761

Quist, 758

Quit, 401, 761, 921

$\mathrm{R}_{\triangle A \mathrm{~F}}, 766$

Rabe, 766

Rabihorcado, 293

Race-horse Duck, 518, 737, 762

Racham, 364

Rachmah, 364

Racquet-tail, 446, 594, 762

Radii, 239

Radius, 762, 859

Rafter-bird, 762

Rail, 4, 218, 286, 320, $364,380,464,473,514$, $539,563,589,621,630$, $659,742,762$

Rain-bird, 654, 765

Rain-Goose, 519, 765

Rain-Qnail, 765

Rake, 793

Râle, 762

Ralli, 615, 635, 879, 939

Rallus, 102, 109, 111, 145, $225,281,299,380,424$, $440,464,473,514,534$, $536,589,607,747,762$, $854,858,875,912,917$, 952

Rami, 239

Ramphastos, 593, 717, 815, 976 (cf. Rhampliastos)

Ramphestes, 976

Råka, 795

Rapaces, 765

Raptatores, 765

Raptores, 2, 40, 765

Rara, 730

Rasores, 9, 299, 415, 765

Rathsherr, 402

Ratitæ, 4, 10, 11, 28, 37, $53,77,78,91,145,154$, $190,234,242,245,281$, $315,405,459,477,493$, $578,604,610,621,634$, $635,650,654,665,744$, $745,746,747,753,754$, $766,769,770,785,792$, $857,859,951,953,974$, 983

Rattlewings, 369

Raven, 99, 191, 227, 269, 
$439,499,554,634,766$, 892

Ravn, 766

Razorbill, 22, 304, 398, $519,529,537,602,768$, 817,867

Recollet, 769

Rectrices, 769

Rectum, 770

Recurvirostra, 20, 23, 109, 379,913

Redback, 770

Redbeak, 794

Fedbird, 76, 771

Redbreast, 45, 122, 551, $637,771,776,791,797$, 893

Redcap, 773

Redhead, 773, 1040

Redleg, 773

Red Owl, 678

Redpoll, 251, 386, 515, 599,773

Redshank, 384, 737, 773, 774,811

Redstart, 45, 124, 253, $277,365,633,637,775$, 918,1023

Redtail, 777

Redthroat, 777

Redwing, 539, 637, 777

Reed-bird, 778

Peed-Bunting, 43, 778

Reed-Pheasant, 779, 969

Reed-Sparrow, 778

Reed-Thrush, 778, 1021

Reed-Warbler, 778

Reed-Wren, 120, 778, 1020

Peel-bird, 779, 1021

Reeler, 779, 1021

Reeve, 680, 779, 798

Regenpfeifer, 730

Regent-bird, 49. 779

Regent-Oriole, 779

Regulus, 253, 367, 780, 998

Reiger, 416

Pieiher, 416

Remiges, 780

Remiornis, 908

Reproductive Organs, 782

Républicaill, 1029

Republican Swallow, 633

Retina, 784

Rhachis, 239

Rhamphastos, $27,84,92,96$, $144,147,293,324,436$, $612,617,747,765,858$, $879,912,939,952,975$, 976 (cf. Ramphastos)

Rhamphocolus, 944
Rhamphocorys, 510

Rhamphodon, 444

Rhamphotheca, 87 7

Rhea, 3, 68, 69, 76, 89, $90,118,130,197,233$, $242,245,299,322,453$, $543,611,616,617,620$, $741,754,785,858,917$, $918,939,941,951$

Rheæ, 766, 785

Rhinoceros Avis, 433

Rhinoceros-bird, 788

Rhinochetus, $32,60,118$, $145,320,440,471,615$, $739,747,765,865,875$, 879,973

Rhinocorax, 768

Rhinocrypta, 946

Rhinogryphus, 470

Rhinoplax, 434.

Rhinopomastus, 347, 432, 460

Rhintaces, 38

Rhipidura, 238, 276, 385

Rhodonessa, 984

Rhodostethia, 402, 492

Rhopodytes, 530

Rhopotrope, 20

Rhynchæa, 150, 349, 535, 746,886 ( $c f$. Rostratula)

Rhynchaspis, 841

Rhynchops, 35, 401, 867

Phynchostruthus, 349

Rhynchotus, 965

Rib, 788

Rice-bird, 458, 789

Rice-Bunting, 46

Richel-bird, 789

Rifle-bird, 789

Rifleman-bird, 40, 789

Rindill, 1050

Ring-Dotterel, 481

Ring-Dove, 130, 162, 790

Ring-Ousel, 667, 790

Riuged Plover, 171, 48I, $732,803,822$

Ring-Plover, 790

Ringlestones, 791

Ringtail, 791

Rippock, 791

Rissa, 402, 405

Rittock, 791

Ritur, 791

Road-runwer, 84, 791

Robin, 250, 771, 791, 1036

Pobin-Redbreast, 364, 470

Robin-Snipe, 791

Roc, 286, 791

Rocas, 795

Rock-Dove, 163, 793
Rock-hopper, 529

Rockier, 793

Rock-Lark, 512

Rock-Pigeon, 723, 805

Rock-Sparrow, 251

Rock-Wren, 1055

Rode-Goose, 793

Röddrossel, 777

Rödvinge, 777

Roek, 705

Roerdomp, 793

Roi-péheux, 485

Roitelet, 999

Roller, 30, 57, 68, 92, $100,161,259,593,638$, $687,793,1005,792$

Rollier, 793

Roodebec, 794

Pook, 116, 132, 194, 504, $633,795,893$

Rooke, 795

Rosehill, 796

Roselle, 796

Rostratula, 886, 984 (cf. Rhynchæa)

Rostrhamus, 492

Rostrum, 32

Rostrum carinæ, 909

Rotche, 22, 166, 796

Rotgans, 793

Rotges, 796

Rothdrossel, 777

Rouch, 795

Rough, 798

Ruc, 791

Ruch, 795

Rudder-bird, 797

Ruddock, 797

Rudduc, 797

Rudipenne, 792

Ruff, 299, 680, 779, 798, 813,893

Ruffed Grouse, 394, 696

Rukh, 791

Runner, 801

Rupicola, 86, 93, 148, 406, 532,941

Ruticilla, 45, 124, 277, 775,899

SAAT-KRÄHE, 795

Sabine's Snipe, 884, 1007

Sabre-wing, 446

Sacer, 802

Sacral Plexus, 625

Sacre, 237, 802

Sacred Ibis, 455

Sacrum, 855

Saddle-back, 801

Sage-cock, 802

Sagittarius, 823 
Sagittilingues, 815

Saint Cuthbert's Duck, 802

Saker, 238, 522, 802

Saltator, 945

Salvadorina, 975

Sanderla, 803

Sanderling, 29, 130, 803, 812

Sand-Grouse, 191, 571, $723,744,756,805$

Sand-Lark, 512

Sand-lóa, 803

Sand-Martin, 537, 631

Sandpeep, 810

Sandpfeifer, 810,813

Sandpiper, 215, 300, 380, $631,698,702,712,713$, 733,810

Sand-Plover, 813

Sand-runner, 813

Sapsucker, 813

Saqr, 802

Saras, 813

Sarcidiornis, 376, 837, 984

Sarciophorus, 506

Sarcophanops, 58

Sarcorhamphus, 101, 470, 501,1016

Sarhans, 813

Saria, 826

Sarus, 813

Sasia, 405, 720

Satin-bird, 49, 814

Satin-Sparrow, $81 \pm$

Saulary, 133

Sauriuræ, 814

Sauriuri, 814

Saurognathæ, 81, 814, 1046

Saurothera, 84, 125, 765

Saururæ, 754, 814

Savanna Blackbird, 814

Savi's Warbler, 1021

Sawbill, 814

Saw-sharpener, 814

Saw-whet, 671, 814

Saxicola, 557, 777, 899, 918, 1022

Sayornis, 483, 711, 716, 999

Saysie, 814

Scamel, 814, 822

Scamell, 366

Scaniornis, 280

Scansores, 19, 815, 972

Scapula, 857

Scapular, 857

Scarecrow, 78

Scarf, 815

Scart, 815

Scaup-Duck, 736, 815

Scaurie, 816
Sceloglaux, 315, 674

Schistochlamys, 945

Schizognathæ, 9, 80, 85, $363,707,816,878$

Schizorhinal, $\$ 16,877$

Schmerl, 545

Schneppe, 883

Schwalbe, 926

Schwan, 929

Schwaneria, 362

Scissor-bill, 867

Scissors-tail, 816, 999

Sclerurus, 719

Scobby, 817

Scolder, 817

Scolecophagus, 379

Scolopax, 69, 85, 99, 127 $191,226,329,366,379$, $514,610,621,734,774$, $810,883,1042$

Scooper, 24, 817

Scops, 642, 678

Scoptelus, 460

Scopus, 33, 89, 405, 629, $747,838,853,875,912$, $920,939,972$

Scorey, 816

Scoter, 35, 102, 398, 736, 817

Scout, 398, 768, 817

Scouti-Allen, 818, 870

Scraber, 818,830

Scraib, 830

Scraye, 819

Screamer, 4, 9, 86, 379, $465,819,826$

Screech-bird, 820, 843

Screech-Owl, 672, 820, 934

Scríc, 843, 960

Scrofa, 819,830

Scrub-bird, 1, 320, 451, 820

Scute, 102

Scutelliplantares, 511

Scuttock, 398

Scytalopus, 947

Scythrops, 12, 84, 125, 433,815

Sea-Crow, 822

Sea-Dotterel, 822

Sea-Dottrel, 997

Sea-Duck, 734

Sea-Eagle, 174

Sea-fowl, 633

Sea-Lark, 512, 822

Sea-Mall, 822

Seamel, 815, 822

Sea-Mew, 815, 822

Sea-Parrot, 750, 822

Sea-Pheasant, 822

Sea-Pie, 681, 822
Sea-Swallow, 822

Sea-Turtle, 998

Secondaries, 118

Secretary-bird, 3, 75, 822 , 828

Sedge-bird, 351, 582, 825, 1020

Sedge-Warhler, 85, 1020

Seeelster, 682

Segge, 825, 922

Seidenschwanz, 1026

Selasphorus, 448

Selatophorus, 448

Selenidera, 978

Seleucis, 904

Semimerula, 998

Semioptera, 39

Senegali, 825

Serena, 829

Serene, 829

Sericulus, 49, 779

Seriema, .9, $75,76,364$, 819,826 (cf. Cariama)

Serilophus, 58

Serin, 70, 251, 829

Serinus, 70, 251, 829

Serpentarius, 29, 75, 284, $347,603,610,824,952$

Serrati, 815

Serratirostres, 593

Serrirostres, 503

Sesamoids, 47, 860

Setophaga, 365, 777, 1023

Seven Whistlers, 1034

Sgrab, 818

Sguacco, 419, 902

Shag, 106, 770, 815, 829

Shâma, 133

Shay-ling, 1054

Shearwater, 6, 404, 523, $529,620,708,752,818$, 830,867

Sheathbill, 109, 310, 733, 831

Sheld-drake, 28, 62, 171 . $376,600,631,727,817$, 834,838

Shelder, 838

Shell-apple, 838

Shell-eater, 655

Shell-Ibis, 655

Shelly, 838, 867

Shepster, 87, 838

Sheriff's man, 838

Shirl, 838

Shoe-bill, 406, 838

Shoe-bird, 46, 838

Shooi, 840,870

Shore-Lark, 511

Shortbill, 840

Shoulder-Girdle, 856 
Shovelard, 900

Shoveler, 34, 171, 734, 840, 900

Shreitch, 843

Shrieker, 366, 843

Shrike, 21, 25, 26, 31, 40, $58,66,70,72,116,124$, $167,182,253,273,292$, $517,574,643,681,843$, $960,999,1024,1041$

Shrite, 843

Slıufllewing, 846,895

Sialia, 44, 771, 791

Sidsken, 846

Silerella, 969

Silk-tail, 1026

Silver-eye, 846, 1056

Simorhynchus, 600

Sinciput, 649, 846

Sirène, 829

Siskin, 1, 28, 251, 258, 37I, 846, 1056

Sisura, 151, 276, 385

Sitta, 189, 283, 647, 697, 718

Sittace, 527

Sittasomus, 719

Sittella, 648

Siurus, 669, 1023, 1024

Skaiti, 818

Skarfr, 815

Skart, 848

Skeel-duck, 835, 848

Skeeling, 848

Skelder, 835, 848

Skeletou, 848

Skelly, 867

Skiddaw, 398, 867

Skiddy, $\$ 67$

Skimmer, 35, 401 518, 822, 867

Skitty-cock, 867

Skjöldr, 817

Skjöldungr, 835

Skooi, 868, 869

Skraba, 868

Skrape, 819

Skrika, 843

Skrikja, 843

Skua, 46, 68, 149, 239, $401,534,738,754,818$, $840,868,1017$

Skúir, 868

Skull, 871

Skylark, 99, 507, 880

Slangenvreeter, 823,880

Slangenvreter, 880

Slight-Falcon, 880

Smatch, 1034

Smee-Duck, 880

Smew, 544, 646, 880
Smirill, 545

Smirlon, 545

Snail-eater, 655,880

Snaith, 880

Snake-bird, 132, 173, 252, $703,880,1053$

Snake-eater, 823,880

Snake's neck, 1054

Snipa, 883

Snipe, 43, 55, 85, 99, 151, $183,191,365,415,466$, $733,770,810,883$

Snite, 883

Snow-bird, 887

Snow-Bunting, 61, 189, 517, 649,887

Snow-cock, 887

Snow-Finch, 517, 887

Snowflake, 887

Snow-Goose, 374

Snow-Partridge, 696, 887

Snow-Plieasant, 696, 887

Snowy Owl, 674

Snyth, 880

Sociable Grosbeak, 633

Soland, 887

Solan-Goose, 300, 887

Soldier-bird, 428

Solitaire, 161, 217, 887, 1003

Somateria, 192, 222, 736

Song, 892

Song-Thrush, 26, 551, 636, 959

Sonnenreyger, 924

Sonne-Vogel, 252

Sonoran Region, 330

Sora, 659, 895

Soree, 895

Sore-eyed Pigeon, 832

Sore-Falcon, 895

Souimanga, 922

South-southerly, 895

Sparlin-fowl, 895

Sparo, 895

Sparrhök, 897

Sparrow, 132, 195, 232, $251,262,587,716,784$, 895

Sparrow-Hawk，66，185, $188,377,411,479,574$, 620,897

Sparrow-Owl, 899

Sparva, 897

Sparvari, 897

Sparwe, 895

Spathura, 762

Spatula, 841

Spearwa, 895

Specht, 1046

Speculum, 899
Speicht, 899

Speight (Wood-), 899

Spekvreter, 899

Spency, 899

Sperber, 897

Spermestinæ, 1029

Spervel, 899

Sperwer, 897

Sphecotheres, 657

Sphenisci, 10, 68, 629 $741,744,745,746,747$, $850,853,854,858,861$, $865,912,917,939,941$, 951, 983

Spheniscomorphæ, 899

Spheniscus, 140, 146, 152, $242,243,405,440,465$, $610,615,704,878$

Sphenceacus, 381, 458, 939

Sphenoproctus, 447

Sphenura, 57, 820

Sphyropicus, 813

Spider-catcher, 900

Spider-hunter, 900, 923

Spiegel, 899

Spike-tail, 900

Spiloglaux, 592

Spilornis, 173

Spina externa, 912

Spina interna, 912

Spina sternalis, 909, 911

Spinal Cord, 622

Spinal Nerves, 622

Spinclalis, 655

Spindasis, 655

Spinebill, 92, 316, 648, 900

Spink, 725, 900

Spinus, 846

Spirit-Duck, 370, 900

Spite (Wood-), 899

Spiza, 40, 136, 459, 644

Spizaetus, 173

Spiziaptery $x, 412$

Spleen, 900

Splenials, 872

Spói, 128, 902

Spoonbill, 226, 254, 379, $456,513,514,702,734$, 737,900

Spörr, 895

Spowe, 128, 902

Sprat-Loon, 519, 902

Sprig-tail, 902

Sprite, 902

Sprosser, 637

Spruce-Partridge, 394

Spur-Fowl, 902

Squacco-Heron, 419, 902

Squamosal, 871, 876

Squatarola, 539, 731

Stachyris, 963 
"Stand-gale," 477, 903

Staniel, 477, 902

Stannel, 477, 815, 902

Stare, 801

Starling, 87, 102, 194, 217 , $316,438,458,565,633$, $680,698,903,1047$

Starn, 904, 955

Starnœnas, 757

Steamer-Duck, 518, 737 , 762

Steatornis, 58, 324, 394, $606,607,638,653,654$, $850,875,879,941$

Steganopodes, 3, 10, 11, 29, $33,68,69,77,90,105$, $118,146,173,191,243$, $281,293,310,405,440$, $453,517,606,608,610$, $613,615,629,653,703$, $707,746,747,789,850$, $853,857,858,875,879$, $904,912,917,939,952$, 972

Steganopus, 712

Stegnolæma, 397

Steinfalk, 546

Steingall, 902

Stercorarius, 46, 48, 401, 868

Stereornithes, 904

Stern, 904, 955

Sterna, 143, 145, 182, 401, $610,643,950,955,1039$

Sternum, 908

Stieghitz, 370

Stilt, 24, 109, 130, 680, $682,733,913$

Stiltia, 741

Stink-bird, 914

Stink-pot, 710, 914

Stinker, 914

Stint, 539, 698, 702, 811, 915

Stitch-bird, 316, 429, 915

Stock-Dove, 163, 793, 915

Stock-Duck, 915

Stock Eagle, 915

Stock-Eikle, 915

Stomach, 916

Stone-Chat, 43, 85, 296, 777,918

Stone-Curlew, 66, 128, 130, $148,284,553,630,645$, 733,919

Stonegall, 902

Stonehatch, 919

Stonerunner, 919

Storc, 919

Storch, 919

Stork, 2, 4, 12, 18, 33, 46, Supraoccipital, 871
58, 113, 190, 254, 284, Surf-bird, 925

$406,416,456,462,517$, Surf-Duck, 817

$550,635,655,702,919$

Storm-cock, 920,960

Storm-Finch, 920

Storm-Petrel, 708, 920

Strany, 398, 920

Strepera, 116, 148, 403

Strepsilas, 68, 514, 588, 610,997

Striges, 11, 18, 29, 118, $148,195,243,315,395$, $409,603,606,607,610$, $612,615,629,671,747$, $857,858,865,875,879$, $920,939,941,952,972$

Strigops, 76,473

Stringops, 316, 473, 477, 688,858

Strisores, 920

Striz, 3, 134, 178, 191, 284, $332,642,765$

Struthio, 68, 69, 79, 89, $90,100,118,130,140$, $212,231,242,245,285$, $299,346,380,517,543$, $613,616,662,741,745$, $857,858,862,867,876$, $878,918,939,951$

Struthiolithus, 285, 666

Struthiones, $665,766,785$, 920

Struthious Warblers, 1036

Sturnella, 457, 476, 539, 575,727

Sturnornis, 360

Sturnus, 97, 316, 378, 438, $458,680,697,698,801$, 903,918

Subbuteo, 424

Subclamatores, 743,921

Suboscines, 743

Succiacapre, 638

Suckervogel, 71

Sugar-bird, 761, 921

Sugge, 825, 922

SuIa, 48, 244, 284, 300, $453,607,621,745,857$, $887,904,917,952,974$

Sulaire, 887

Sultana, 591

Summer-Duck, 922

Summer-Snipe, 810, 922

Summer-Teal, 309, 922

Sun-bird, 428, 444, 743, 922

Sun-Bittern, 252, 472, 765, 923

Superb Warblers, 1022

Supra-anguIar, 872 765,805

\section{Surnia, 178, 332, 674}

Surniculus, 125

Sutoria, 941

Suwari, 78

Svala, 926

Svanr, 929

Svartfugl, 42

Swalewe, 926

Swallow, 184, 261, 454, $538,549,599,632,770$, 926

Swallow-Shrike, 22, 1050

Swan, 4, 35, 92, 100, 111, $155,168,190,296,597$, $634,703,769,929$

Swan-Goose, 376

Swedish Nightingale, 637

Swift, 4, 18, 130, 134, 195, $288,442,477,529,558$, $631,638,697,819,820$, 934

Swiftfoot, 937

Swinepipe, 777, 937

Swon, 929

Sycobrotus, 1028

Sylvia, 1, 42, 45, 57, 133, $239,243,250,283,316$, $364,365,367,413,582$, $598,637,697,710,772$, $777,1019,1022,1037$

Sylviæ, 143

Sylvicola, 1022

Syma, 488

Sympathetic System, 626

Symphemia, 725

Symplectes, 1029

Synallaxis, 719, 937

Syndactyli, 815, 937, 972

Synœcus, 756

Syrinx, 546, 937

Syrnium, 134

Syrrhaptes, 140, 338, 571 ,

Systemic Circulation, 1008

TACHYDROMUs, 130

Tachyeres, 518, 597, 737

Tachyphonus, 944

Tadorna, 171, 600, 835, 984

Tadorne, 835

Tärna, 955

Tærne, 955

Tafelente, 735

Tailor-bird, 631, 941

Taistey. 943

Takahe, 943

Talegallus, 59, 320, 541

"Talenter," 943 
Talgoxe, 680

Taling, 22, 948

Tamatia, 750

Tammy-Norie, 750, 943

Tanager, 76, 250, 459, 644, $655,761,771,943$

Tanagra, 40, 134, 250, 323, 730,943

Tangara, 943

Tannenheher, 646

Tantalus, $146, \quad 349,379$, $454,514,741,877,918$, 985

Tanypus, 380

Tanysiptera, 595

Taoniscus, 965

Taoperdix, 283

Tapaculo, 946

Tapun, 540

Tardone, 835

Tarmachan, 392, 744

Tarney, 948

Tarret, 948

Tarrock, 492, 948

Tarsel, 948

Tarsus, 864, 948

Tassel, 948

Taste, 973

Tati, 942

Tatler, 948

Taube, 162

Tauch-ente, 168

Taucher, 162

Taureau-d'étang, 40

Tavon, 540

Tawny Owl, 672

Tchitrea, 275

Teal, 22, 171, 297, 309, $404,842,948$

Teaser, 949

Tectonarchus, 39

Tectrices, 949

Teetan, 953

Teeth, 453

Teeting, 953

Tele, 948

Teleoptile, 243, 629, 954

Telephonus, 26, 845

Telltale, 954

Telmatornis, 281

Telogyrous, 142

Temenuchus, 378

Temnorhines, 1015

Temnotrogon, 327

Tende, 955

Tendon, 954

Tenne, 955

Tenuirostres, 954

Tephrodornis, 846

Teracus, 284

Teratology, 588
Tercel, 955

Teretristis, 1023

Termagant, 392,955

Tern, 4, 78, 109, 132, 182, $252,310,401,482,489$, $518,529,571,643,727$, $789,791,819,822,955$

Terpsiphone, 275

Tertials, 957

Tetrao, 72, 93, 95, 191, 283, 287, 291, 329, 389, 599, $765,805,984$

Tetraogallus, 696,887

Tettechèvre, 638

Teuchet, 957

Teuchit, 505

Tewfitt, 957

Textor, 680

Thalassiarche, 708

Thamnobia, 632

Thamnophilus, $20,758,878$

Thaumalia, 716

Thaumastura, 449

Theista, 943

Thickhead, 621, 957, 958

Thick-knee, 129, 498, 958

Thinocorys, $68,113,145$, $324,733,757,834,878$

Thinornis, 482

Thistle-bird, 958

Thistle-cock, 958

Thistle-Finch, 370, 958

Thistle-warp, 958

Thrasaetus, 407

Thrasher, 582, 958

Thraupis, 944

Thresher, 958

Thricecock, 959

Thröstr, 959

Throsle, 959

Throstle, 959

Thrush, 21, 25, 45, 133, $249,388,425,539,582$, $728,770,771,777,812$, 958,959

Thrush-Nightingale, 637

'I'hrusher, 958

Thryothorus, 582

Thrysce, 959

Thymus, 961

'Thyreoid, 961

Tibia, 961

Tichicro, 961

Tichodroma, 697, 986

Tidee, 962,966

Tidif, 962

Tidly-Goldfinch, 962

Tiercel, 955

Tiga, 405

Tijuca, 85

Timalia, 25
Timelia, 25, 28, 45, 51, 57, $59,133,277,316,381$, $574,658,962,1020$, 1022,1052

Tinamomorphæ, 422

Tinamotis, 965

Tinamou, 33, 299, 579, 738, $769,963,991$

Tinamus, 69, 91, 167, 187, $190,322,325,440,606$, $607,610,615,635,745$, 747, 753, 754, 766, 857, 963

Tinc-tinc, 725

Tinker, 398, 768, 966

Tinkershire, 398, 966

Tinkling, 966

Tinnunculus, 235, 327, 477

Tin-tin, 966

Tisserin. 1028

Tit, 966

Tita, 966

Titis, 966

Titlark, 86, 120, 507, 592, $593,727,776,966$

Titling, 966

Titlingr, 966

Titmouse, 43, 45, 83, 87, $92,189,239,251,283$, $316,342,367,553,601$, $631,646,648,680,718$, $725,749.766,814,966$, 973

Titr, 966

Tityra, 86

Tjaldr, 22, 817

Tjaldur, 817

Tmetotrogon, 989

Toccus, 435

Todier, 442, 970

Todus, 273, 324, 327, 593, $616,630,718,746,747$, $853,858,879,912,939$, 970

Tody, 69, 273, 791, 970

Toerako, 981

Toes, 866,972

Tolk, 997

Tomfool, 973

Tomia, 33

Tominejo, 442

Tom-Kelly, 973

Tom-Noddy, 973

Tommy, 973

Tomor, 973

Tomtit, 364, 966, 973

Tongue, 973

Topau, 433

Torcol, 1053

Torillo, 416

Torrent-Duck, 545, 975 
Totanus, 28, 68, 284, 384, $734,774,810$

Totipalmi, 310

Tot-o'er-seas, 975

Toucan, 27, 34, 35, 84, 92 , 436,976

Touraco, 12, 92, 118, 519, 730,979

Touyou, 785

Towhee, 982

Trachea, 937, 983

Tracheophonæ, 323，406, $425,547,670,718,940$, 985

Tracheophones, 698, 718, 985

Tracheophoni, 985

Tragopan, 22, 432, 587

Tree-creeper, 112, 189, 332, $648,770,985,1048$

Tree-Duck, 171

Tree-Lark, 512

Tree-Sparrow, 186, 897

Treron, 654, 723

Triarctic, 313

Tribonyx, 320, 591, 621, 973

Trichas, 1056

Trichoglossus, 320, 521, 857

Tricholestes, 26

Tricholinumas, 1033

Tringa, 150, 172, 215, 283, $299,379,380,498,504$, $514,610,712,734,771$, $790,804,810$

Tringoides, 810

Trochili, 18, 118, 606, 865, $879,912,952,975,983$, 987

Trochilus, 69, 130, 148, 299, $323,442,529,534,603$, $615,617,620,630,638$, $718,733,747,858,939$, 950

Troglodytes, 83, 329, 582, 668,1050

Trogon, 11, 77, 92, 130, $148,284,325,327,618$, $630,654,717,746,747$, $758,815,875,879,912$, 987

Trogones, 853, 857

Trompetero, 991

Trompette, 991

Troopial, 457, 989

Tropic-bird, 46, 173, 703, 754,989

'ropidorhyuchus, 292, 573, 656

Troupiale, 457, 989
Trumpet-bird, 991

Trumpeter, $9,164,380,473$, 963,991

Trupialis, 457, 458

Tubinares, 6, 10, 11, 29, $32,118,146,405,440$, $453,517,606,610,616$, $621,634,629,635,653$, $708,747,857,858,878$, $912,918,939,952,973$, $974,983,993$

Tucã, 976

Tufted Duck, 936

Tui, 429, 691, 994

Tumbler-Pigeon, 164, 276

Turacin, 95, 982

Turacoverdin, 96, 982

Turacus, 980

Turbit, 164

Turco, 946

Turdoïde, 461

Turdus, 20, 22, 42, 45, 133, $134,191,243,249,277$. $319,329,364,461,539$, $557,574,583,666,668$, $697,698,771,779,791$, $820,918,950,961$

Turkey, 198, 400, 588, 994

Turkey-Buzzard, 68, 470, 994,1016

Turnagra, 316

'Turnices, 29, 118, 145, 517, 607,635

Turnicomorphæ, 415, 422, 996

Turnix, 66, 68, 77, 150 , $320,415,440,610,616$, $747,757,765,858,879$

Turnstone, 29, 70, 351, 588, $733,773,996$

Turtle-Dove, 165, 566, 998 Turtur, 165, 557, 998

Turumti, 546

Twin-structures, 589

'Twite, $99 \mathrm{~S}$

Twopenny-chick, 998

Tydie, 962

Tydif, 962

'Tylas, 574

Tylopteryx, 580

'lymor, 973

'I'ympanuchus, 394, 740

Tympanum, 984

Tyrannus, 273, 323, 329, $482,710,718,726,816$, $866,938,939,998$

Tyrant-bird, 482, 518, 711 , $716,726,816,973,998$

Tysty, 399, 943

Tytmase, 966

Tytyfi, 962
UGGLA, 671

Ule, 670

Ulna, 859,1000

Ulula, 671

Umbre, 405, 1000

Umbrella-bird, 86, 1000

Uncinate Process, 788, 1001

Unicorn-bird, 1001

Upucerthia, 671

Upupa, 69, 77, 92, 147, $284,430,436,438,460$, $505,510,607,615,617$, $618,629,718,743,747$, $857,879,912,939,974$

Urægnathus, 31

Uragus, 386

Ureter, 1001

Uria, 68, 149, 166, 285, 398,753

Urinator, 151

Urinatores, 310, 1001

Urochroma, 521

Urodæum, 90

Urœoni, 1002

Urogalba, 463

Uroioni, 1002

Urospatha, 594

Urostyle, 1002

Utamania, 768

Utick, 1002

Uuagtale, 1018 ( $c f$. Wagtail)

VAGINALIS, 832

Vagtel, 754

Valk, 1002

Valken, 235

Vanellus, 504, 610, 876 , 895

Variation, 342, 1002

Vascular System, 1008

Vas defereus, 782, 784, 1013

Vautour, 7\$5

Veery, 1013

Veins, 10cs, 1013

Veldjakker, 249

Veld-lyster, 249

Velvet-Duck, 818

Venous Circulation, 1009

Ventral side, 14

Ventriculus, 916

Venturon, 88

Verreauxia, 720

Vertebræ, 848

Vestiaria, 167, 182

Vidua, 795, 1028

Vigeon, 1039

Viguon, 1039

Vinago, 723

Vingeon, 1039

Vioux, 1039 
Vipa, 505, 1054

Vipio, 1039

Vireo, 273, 326, 329, 384, 973,1013

Vireolanius, 1014

Vireosylvia, 1013

Virginian Nightiugale, 61, 76,637

Virginian Quail, 188

Vischfanger, 1014

Vocal Orgaus, 1014

Togel, 299

Volucres, 104, 1014

Vomer, 871, 872, 878, 1014

Vourun patra, 791

Vultur, 33, 101, 319, 470, $501,621,739,765,825$, $858,879,912$

Vulture, 1, 2, 4, 68, 173, $227,261,364,385,411$, $470,500,1015$

Vutanaria, 768

Vuttamaria, 768

WACHHOLDERDROSSEL, 249

Wachtel, 754

Wagell, 1017

Wagne, 1039

Wagsterd, 1018

Wagstyrt, 1018

Wagtail, 29, 108, 120, 151, $276,332,458,551,598$, $649,727,758,1018$

Wald-Katze, 1041

Waldschnepfe, 1042

Walghvogel, 155

Wallace's Line, 317, 363

Wall-bird, 1019

Wall-creeper, 986, 1019

Waracaba, 993

Warbler, 1, 25, 45, 72, 85, $133,239,239,250,273$, $283,351,364,365,367$, $413,563,598,632,710$, $779,825,1019$

Ware-Goose, 1024

Wariangle, 1024

Warriangle, 1024

Warwinckle, 1024

Washdish, 1024

Washtail, 1024

Waskite, 1024

Wasphite, 1024

Watchy-picket, 1024

Water-cock, 1024

Water-Crow, 66\%, 1024

Water-hen, 589, 1024

Water-Ousel, 26, 151, 667, 1024

Water-Partridge, 1024

Water-Quail, 95
Water-Rail, 762, 1024

Water-Thrush, 728, 1024

Water-Turkey, 881, 1024

Wattle-bird, 429, 1024

Wavey, 374, 1026

WVawa, 374

Waxbill, 1026

Waxwing, 58, 81, 85, 242, 571,1026

Wearer-bird, 11, 29, 31, 72 , $76,109,250,253,387$, $466,602,621,633,680$, $794,825,1028$

Weetweet, 1031

Weever-Oriole, 1028

Weindrossel, 777

Weindrustle, 778

Weissbäcklein, 424

Weka, 224, 315, 475, 764, 1031

Wendehals, 1053

Werkengel, 1024

Wet-my-feet, 755

Wet-my-foot, 1033

Wet-my-lips, 755

Whale-bird, 34, 1033

Whaup, 24, 128, 1033

Wheatear, 238, 557, 671, $777,918,1034$

Wheel-bird, 639

Wheenerd, 778

Whekau, 674

Whetile, 1046

Whew, 1036

Whimbrel, 34, 128, 351, $539,886,1036$

Whin-Chat, 85, 1036

Whindle, 778

Whip-poor-will, 88, 1036

Whip-Tom-Kelly, 973, 1036

Whiskæ-shawneesh, 1036

Whisky-Jack, 469, 1036

White-eye, 1036, 1056

Whitehead, 657, 1036

Whitethroat, $26,43,89$, $543,572,598,601,702$, 1037

Whittaile, 1034

Whitwall, 1039

Whoop, 1039

Whooper, 931, 1039

Whydah-bird, 1030, 1039

Widdehop, 93

Wide-awake, 1039

Widow-bird, 1030

Wierangle, 844, 1024

Wigcon, 171, 181, 500, 773, 892,1039

Wignet, 1039

Wild l'igeon, 696
Willet, 725, 811, 1040

Willock, 398, 750, 768, 1040

Willow-biter, 1040

Willow-Grouse, 389

Willow-Wren, 87, 351, 413, $557,669,1040,1052$

Windhover, 777, 1041

Windlestraw, 1041

Windpipe, 777, 1041

Wind-Thrush, 1041

Wine-Thrush, 1041

Wiug, 1041

Wiunard, 104]

Winsel, 778

Wire-bird, 351, 482, 1041

Wishbone, 296

Witstaart, 1034

Witte Klaai, 1041

Witte oogje, 1041

Witwall, 1046

Wobble, 1041

Wodake, 1046

Woinge, 1039

Wonga-wonga, 723, 1041

Wood-Chat, 1041

Woodcock, 379, 551, 696, 1042

Woodcock-Owl, 678

Woodcocks' Pilot, 368

Wood-Duck, 1, 171, 1045

Wood-Grouse, 72

Woodhack, 1046

Wood-hen, 1031, 1045

Woodhewer, 718

Woodlark, 507, 1045

Woodpecker, 3, 81, 243, 258, 283, 292, 299, 319 $421,443,460,463,517$, $563,600,631,647,718$, $720,738,765,769,773$, $813,814,915,1045$

Wood-Pie, 1050

Wood-Pigeon, 130, 162 , 1050

Wood-speight, 1045, 1050

Woodspite, 1046

Wood-Swallow, 22, 929, 1050

Woodwall, 1046, 1050

Wood-Warbler, 1022

Wood-Wren, 1052

Worm - eating Warblers, 1023

Wrænna, 40, 1050

Wrannock, 1050

Wranny, 1050

Wreu, 21, 26, 40, 83, 189 , $367,441,470,493,582$, $893,966,1050$

Wronue, 1050 


\begin{tabular}{|c|c|c|}
\hline \multirow{4}{*}{$\begin{array}{l}\text { Wrybill, } 35,315,482,1033 \\
\text { Wryneck, } 28,81,126,215 \text {, } \\
\quad 384,529,718,769,814 \\
\quad 1053\end{array}$} & Xenopirostris, 574 & Yokel 1056 \\
\hline & Xenorhynchus, 463 & Yoldrin, 1056 \\
\hline & Xipholena, 86,737 & Yowley, 1056 \\
\hline & Xiphorhynchus, 719 & Yrđ̈ling, 40 \\
\hline Wude-cocc, 1042 & Xiphosternum, 910 & Yukel, 1056 \\
\hline Wudu-coc, 1042 & & Yunx, $717,718,1053$ \\
\hline Wudu-Snite, 1042 & YAFFIL, 1046,1055 & \\
\hline Würgengel, 844, 1024 & Yaffingale, 1055 & ZANCLOSTOMA, 125,530 \\
\hline Würg & Yaffle & Zap \\
\hline Wuio & Yarwhelp, 24, 366, 1055 & Zeisig, 846 \\
\hline 33 & Yal & Ziegenmelker, 638 \\
\hline $\mathrm{Wy}$ & $\begin{array}{l}\text { Yeldrock, } 1056 \\
\text { Yellow-bird, 258, } 1056\end{array}$ & $\begin{array}{l}\text { Zonæginthus, } 253,621 \\
\text { Zooerythrin, } 95\end{array}$ \\
\hline XanthoChroIsm, 99,1007 , & Yellow-Bunting, 1056 & Zoomelanin, 95 \\
\hline Xantholæma, 28, 147 & niner, 01 , & $\begin{array}{l}\text { Zooxantnin, } 95 \\
\text { Zooxanthine, } 987\end{array}$ \\
\hline Xanthomelas, 96 & Yellowhead, 658,1037, 1056 & Zosterops, $43,316,364$, \\
\hline Xantl & & $380,428,1056$ \\
\hline Xem: & $\mathrm{Y}$ & Zwaan, 929 \\
\hline $\begin{array}{l}\text { Xenicus, } 316,406,648,770 \text {, } \\
1055\end{array}$ & $\begin{array}{l}\text { Yellowrump, } 1056 \\
\text { Yellowthroat, } 1056\end{array}$ & $\begin{array}{l}\text { Zwaluw, } 926 \\
\text { Zygodactyli, 19, } 89,972,\end{array}$ \\
\hline Xenocichla, 26 & Yelper, 1056 & 1058 \\
\hline
\end{tabular}

THE END 




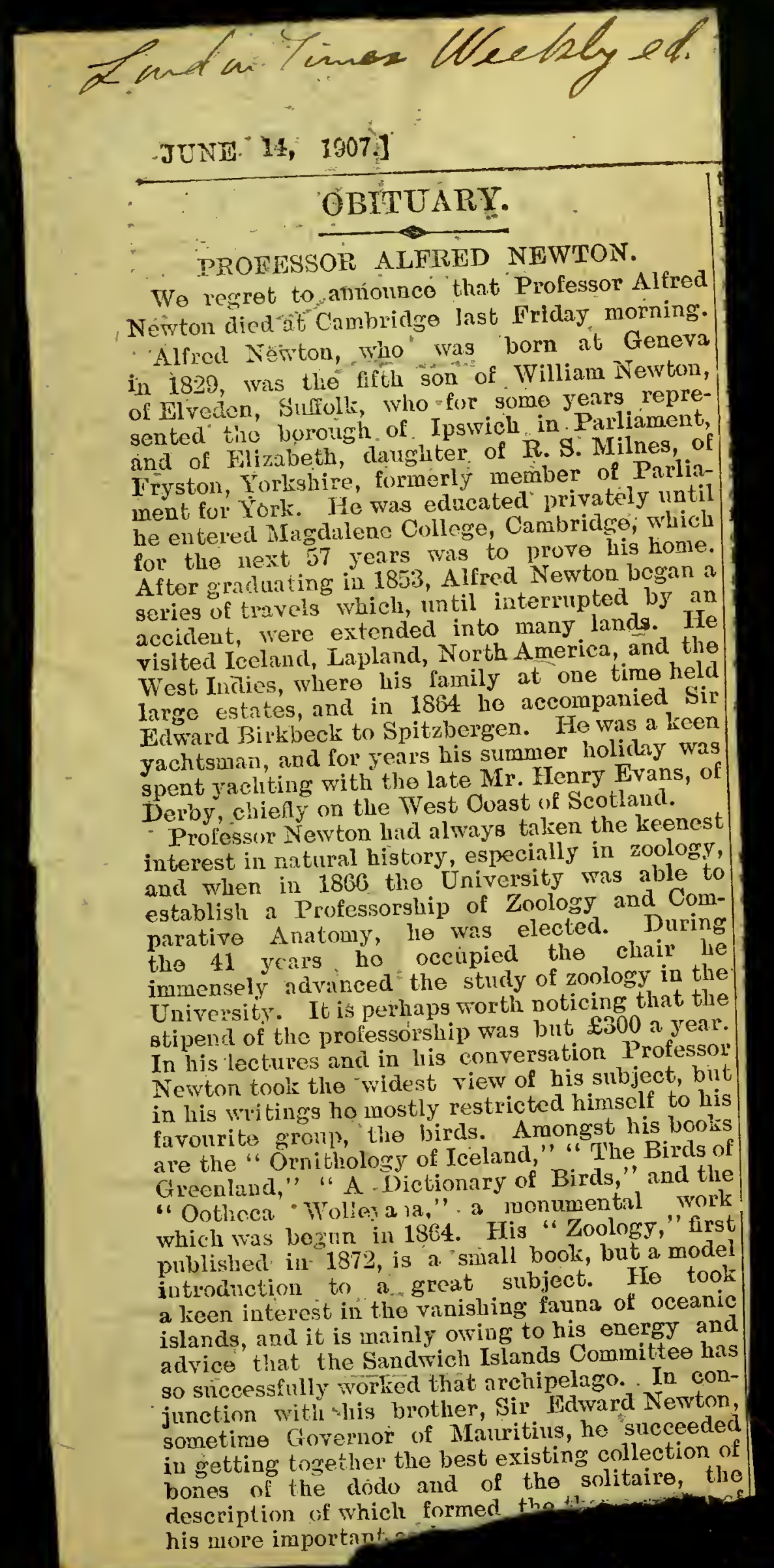


(1) 